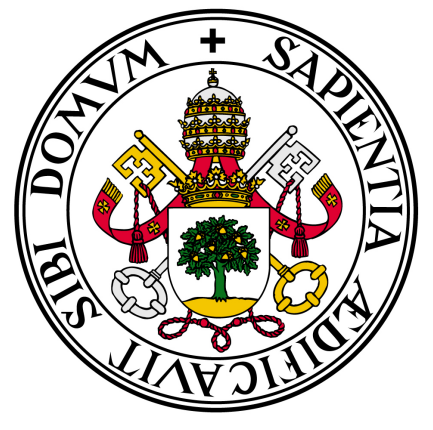

UNIVERSIDAD DE VALLADOLID

FACULTAD DE FILOSOFIA Y LETRAS

TESIS DOCTORAL

EVOLUCIÓN DEL PATRIMONIO RELIGIOSO EN CARRIÓN DE LOS CONDES, PALENCIA, DESDE LA BAJA EDAD MEDIA HASTA NUESTROS DÍAS

LORENA GARCIA GARCIA 
A mis padres, a Silvia y a Sergio 


\title{
EVOLUCIÓN DEL PATRIMONIO ARTÍSTICO DE CARÁCTER RELIGIOSO EN CARRIÓN DE LOS CONDES, PALENCIA, DESDE LA EDAD MEDIA HASTA NUESTROS DÍAS
}

\author{
LORENA GARCÍA GARCÍA
}

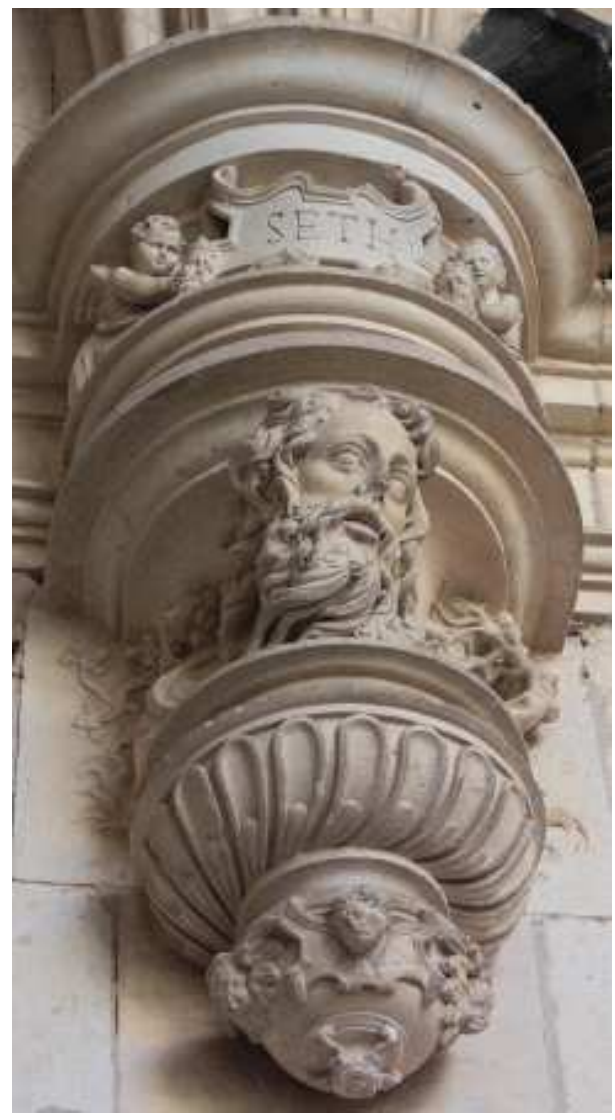

Ménsula representando Seth en el claustro del monasterio de San Zoilo.

\section{TOMO 1}

TESIS DOCTORAL DIRIGIDA POR EL DR. JESÚS Mª PARRADO DEL OLMO 


\title{
EVOLUCIÓN DEL PATRIMONIO ARTÍSTICO DE CARÁCTER RELIGIOSO EN CARRIÓN DE LOS CONDES, PALENCIA, DESDE LA EDAD MEDIA HASTA NUESTROS DÍAS
}

\author{
LORENA GARCÍA GARCÍA
}

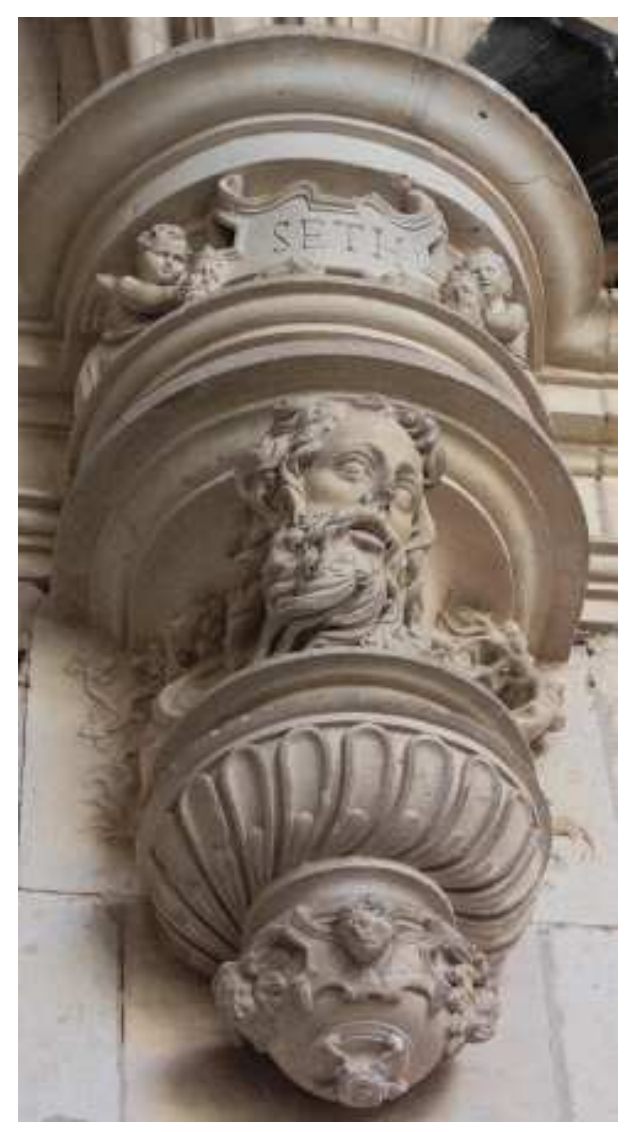

Ménsula representando Seth en el claustro del monasterio de San Zoilo.

\section{TOMO II}

TESIS DOCTORAL DIRIGIDA POR EL DR. JESÚS Ma. PARRADO DEL OLMO 


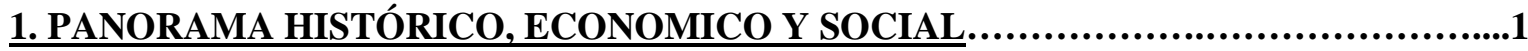

1. 1 CARRIÓN HASTA LA EDAD MODERNA..........................................3

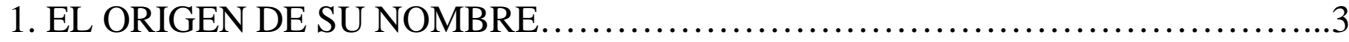

2. El ESCUDO DE ARMAS ................................................. 6

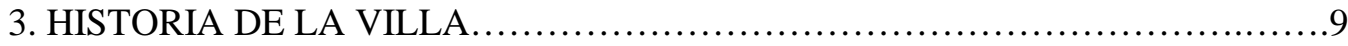

1. 2. CARRIÓN DEL SIGLO XVI A LA ACTUALIDAD.................................18

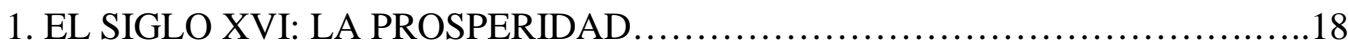

2. LOS SIGLOS XVII Y XVIII: DECADENCIA Y ESTABILIZACIÓN..............20

3. DEL SIGLO XIX EN ADELANTE: UNA VILLA MEDIA CASTELLANA........27

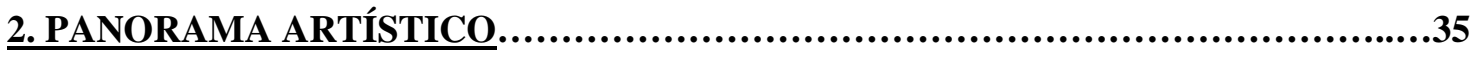

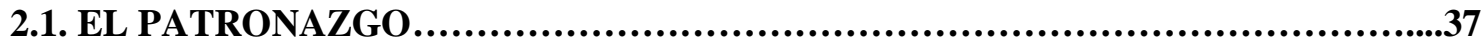

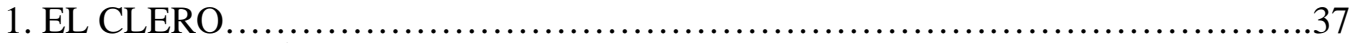

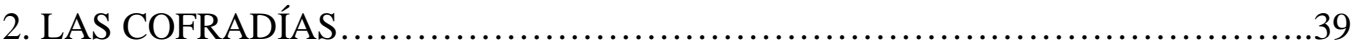

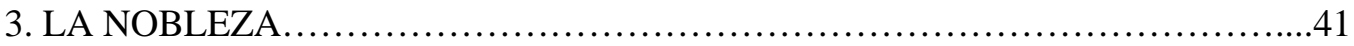

2.2. LA ARQUITECTURA................................................................50

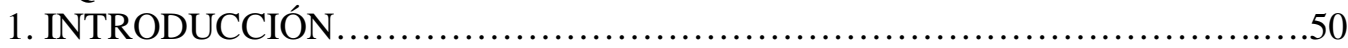

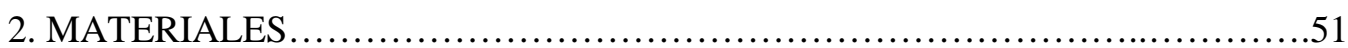

3. LA IDIOSINCRASIA DEL TRABAJO ARQUITECTÓNICO ....................53

3.1 La Edad Moderna: las agrupaciones canteriles............................53

3.2 La situación a partir de 1752: la Academia..............................58

4. LOS ARTÍFICES DE LAS OBRAS ARQUITECTÓNICAS .....................61

4.1 Artífices cántabros.......................................................61

Juan de Nates...............................................64

Felipe de la Cajiga..............................................66

Juan de la Cuesta..............................................69

Domingo de Cerecedo Pierredonda..................................73

Toribio de la Cuesta.......................................... 75

Francisco Martínez de Bálcava....................................78

Francisco del Río Pontecillas.................................... 82

Domingo del Río Pontecillas........................................ 85

Francisco de Buega.................................................99

Jerónimo Avendaño............................................92

Juan de Cajigosa................................................97

Francisco de la Maza.............................................99

Juan de Trujeda.............................................101

Pedro Ruiz Solano............................................. 102

Juan Gutiérrez del Pozo..........................................104

Juan de la Lastra.............................................. 106 
Andrés de Zorlado Ribero......................................109

Diego de Zorlado Ribero........................................111

Juan de Solana..................................................

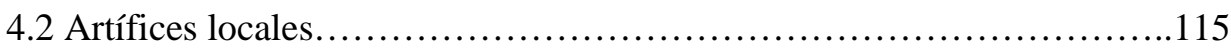

Francisco Rabín............................................... 117

Marcos de la Torre ............................................. 118

Santiago Díaz de Sigüenza.......................................124

Antonio de Cuéllar.............................................128

Bernardo Sánchez.............................................132

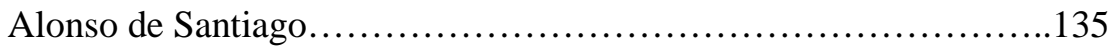

Juan González de la Mata.....................................137

Hernando de Inestrosa........................................ 146

Julián de León.................................................147

Felipe Berrojo de Isla........................................151

Francisco Prieto Gómez.........................................157

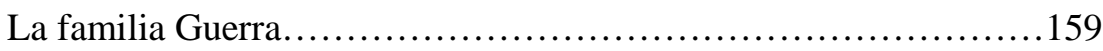

La familia Iglesias......................................... 160

La familia Rodríguez...........................................163

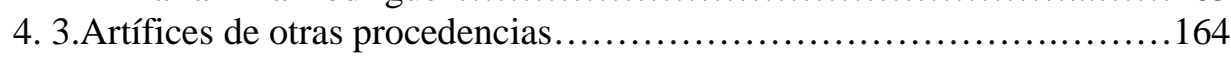

Rodrigo Gil de Hontañón........................................ 165

Juan de Badajoz “el Mozo"..........................................168

Juan de Celaya..................................................170

Alonso de Tolosa...........................................173

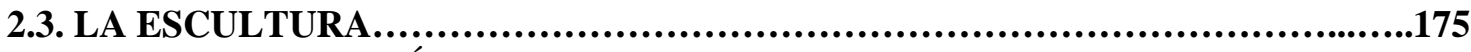

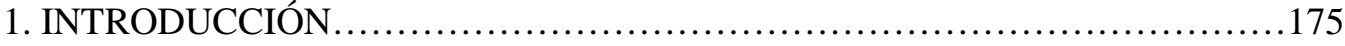

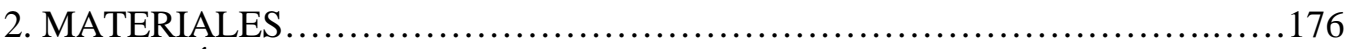

3. LOS ARTÍFICES DE LAS OBRAS ..................................... 178

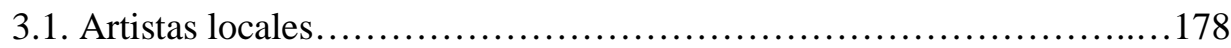

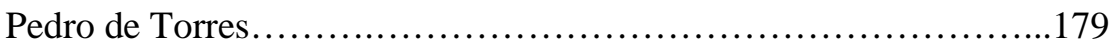

Nicolás de Vega................................................ 181

Pedro Santos............................................... 182

La familia Infante: Hernando, Lope y Santiago.....................183

Manuel de Salceda o Salcedo......................................188

Juan Bautista Pérez..............................................190

Santiago Carnicero...........................................192

Pablo de Villazán.................................................194

Juan Manuel Becerril............................................195

3.2. Artistas de otras procedencias..................................... 197

Miguel de Espinosa.................................................197

Antonio Morante ...........................................200

Gregorio Fernández...............................................201

Alonso Fernández de Rozas........................................203

Tomás de Sierra..................................................205

Blas Martínez de Obregón...........................................208

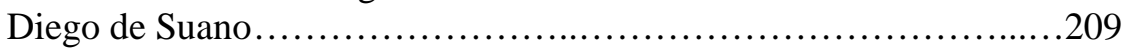

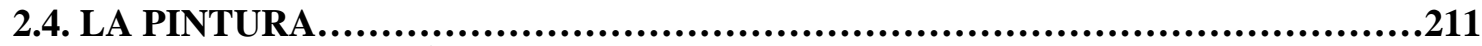

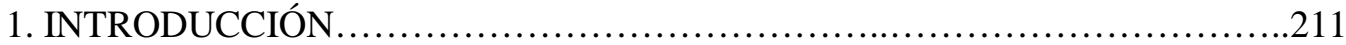

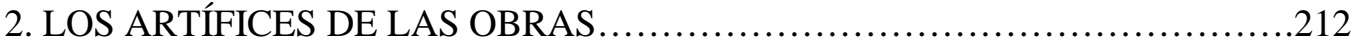




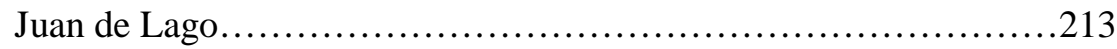

Miguel del Val................................................215

Bartolomé Medina................................................217

Francisco Gutiérrez...........................................221

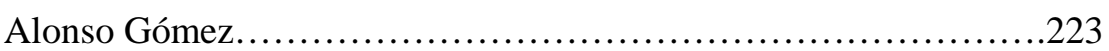

Ramón Canedo................................................225

3.1. ANTECEDENTES: SITUACIÓN EN LA EDAD MEDIA..................................231

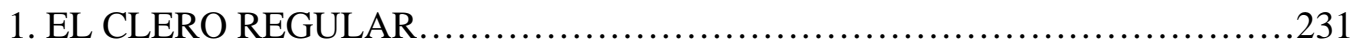

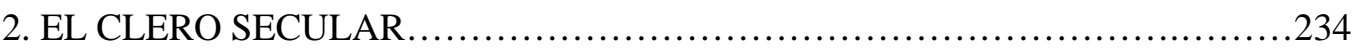

3.2. EL SIGLO XVI: NUEVAS FUNDACIONES Y FÁBRICAS EXTINTAS..............237

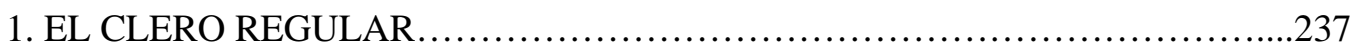

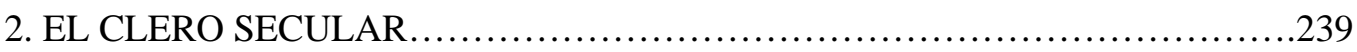

3.3. PERÍODO BARROCO: RECONSTRUCCIÓN EX NOVO Y RUINAS..................242

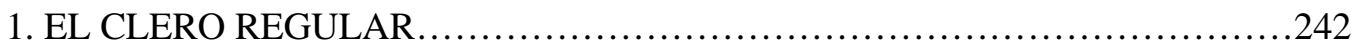

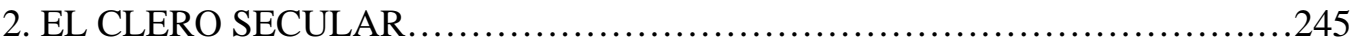

3.4. DEL SIGLO XIX HASTA NUESTROS DÍAS: LA GRAN PÉRDIDA...................249

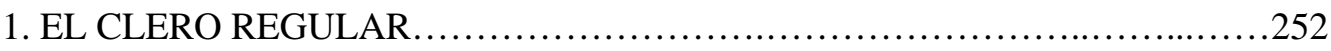

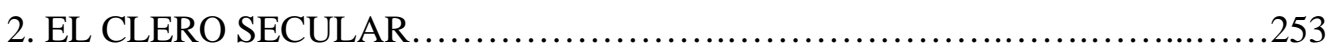

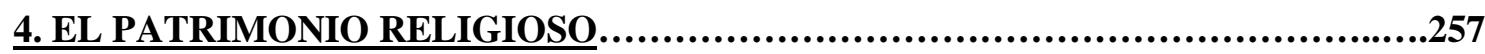

4. 1. MONASTERIOS Y CONVENTOS CONSERVADOS..................................257

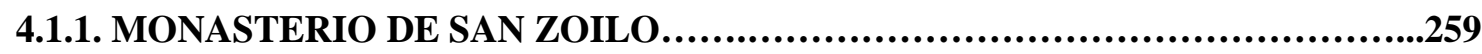

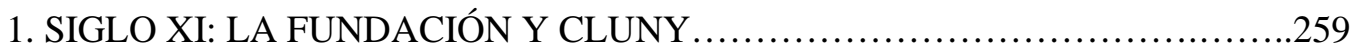

1.1. PRIMER ASENTAMIENTO: SAN JUAN BAUTISTA....................259

1.2. REFUNDACIÓN CONDAL: SAN ZOILO..............................260

El traslado de las reliquias desde Córdoba............................262

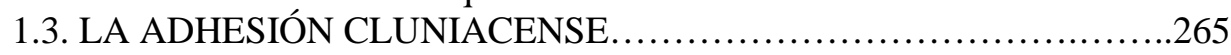

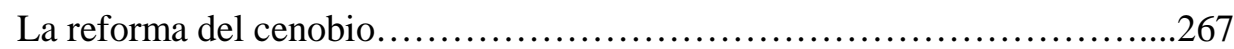

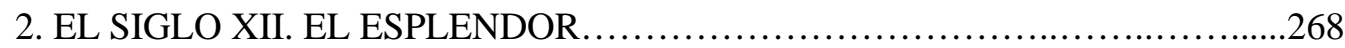

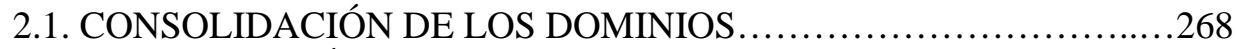

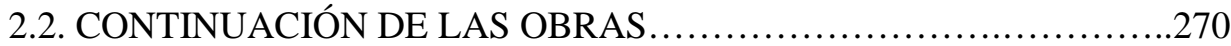

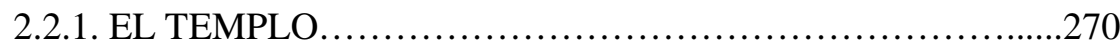

2.2.2. LA GALILEA O CAPILLA CONDAL ...........................276

Sepulcros de los siglos XI-XII..............................279 
Sepulcros del siglo XIII..................................292

Las telas ubicadas en la sacristía............................297

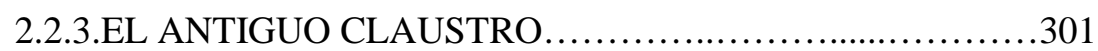

3. LOS SIGLOS XIII y XIV: PERIODO DE CRISIS .............................302

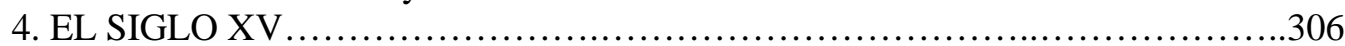

4.1 EL FUNCIONAMIENTO DEL MONASTERIO............................306

4.2 LA ANEXIÓN DE LA PARROQUIA DE LA MAGDALENA..............308

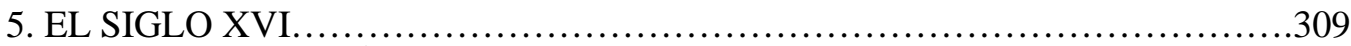

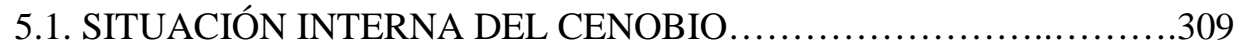

5.2. EL CLAUSTRO RENACENTISTA...................................

5.2.1. EL CLAUSTRO BAJO ....................................

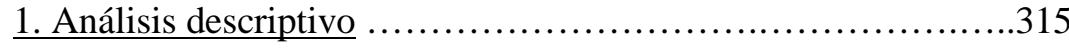

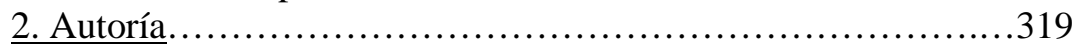

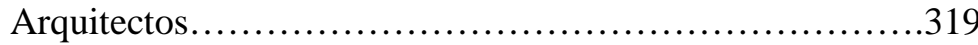

Escultores.................................................

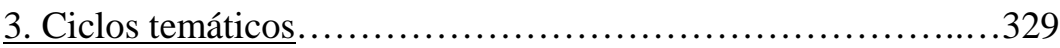

Antes de Cristo....................................................

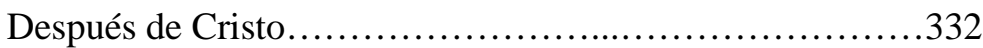

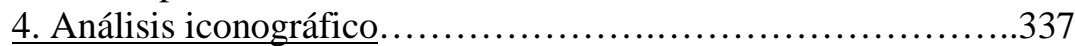

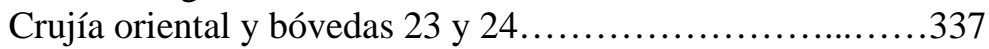

Crujía meridional........................................ 362

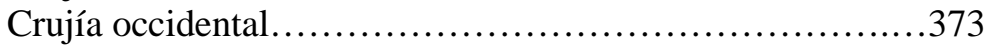

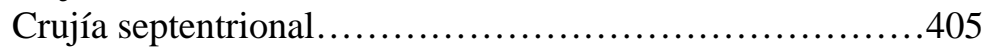

5. Policromía original .........................................425

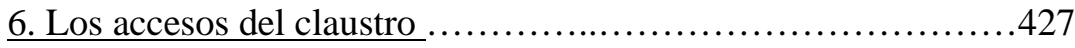

7. Nichos de los muros....................................... 435

Nicho de Alonso Barrantes y Díaz.........................435

Cristo atado a la columna.................................439

5.2.2. EL CLAUSTRO ALTO.....................................442

1. Análisis descriptivo ..........................................442

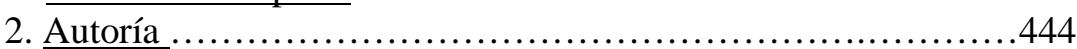

Arquitectos............................................ 444

Escultores..............................................445

3. Análisis iconográfico.....................................446

5.2.3. CONSIDERACION A LO LARGO DE LA HISTORIA........450

5.2.4. ASPECTOS INTERESANTES DEL CICLO..................451

Interpretación universal del programa.........................452

El papel de la mujer en el ciclo...........................453

Curiosidades y relaciones historiográficas................455

5.3. OTRAS REFORMAS DE MENOR ENTIDAD ........................460

6. EL SIGLO XVII..........................................................463

6.1 LA CAPILLA DE DOÑA CONSTANZA...........................464

6.2. RENOVACIÓN DE LAS DEPENDENCIAS CLAUSTRALES.......466

Enlosado del claustro.........................................466

Almacén de leña..............................................467

La sacristía y la librería........................................468

Mayordomía y celdas.........................................470

Otras reformas............................................473

6.3. LA CONSTRUCCIÓN DEL NUEVO TEMPLO........................474

6.4. LOS RETABLOS DE LA CAPILLA MAYOR Y DE LA

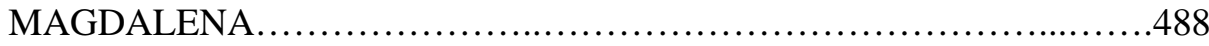


$\mathrm{El}$ antiguo retablo mayor.......................................488

El retablo procedente de Baquerín de Campos......................490

El retablo de la Magdalena........................................501

6.5. LA FACHADA BARROCA.........................................505

7. EL SIGLO XVIII......................................................... 512

Retablos de Santa Gertrudis y Santo Cristo el Real..........................513

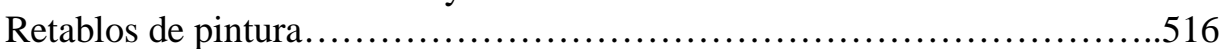

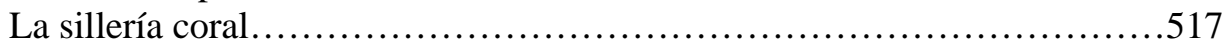

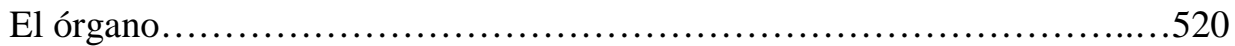

La decoración de la sacristía.........................................522

Reformas generales..................................................525

Patio neoclásico..................................................5. 527

8. EL DEVENIR A PARTIR DEL SIGLO XIX ..............................5529

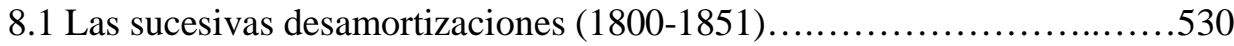

8.2 El colegio del Sagrado Corazón de Jesús (1852-1868)..................535

8.3 Multiplicidad de usos civiles $(1868-1877) \ldots \ldots \ldots \ldots \ldots \ldots \ldots \ldots \ldots \ldots . \ldots \ldots 43$

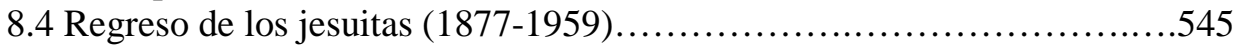

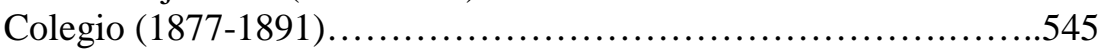

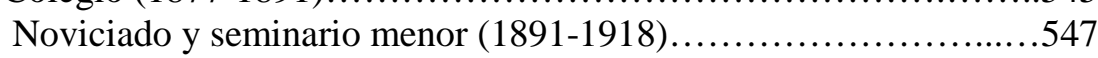

Escuela apostólica (1918-1959)...............................551

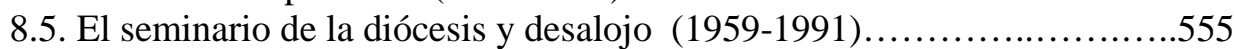

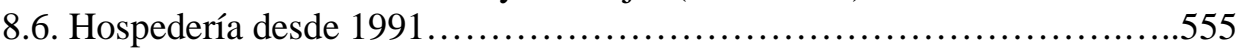

9. LA DECLARACIÓN DE MONUMENTO NACIONAL ..........................556

4.1.2. CONVENTO DE SANTA CLARA...........................................561

1. LA FUNDACIÓN Y LOS PRIMEROS SIGLOS .................................561

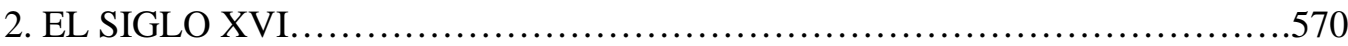

El sepulcro de doña Aldonza Manrique.................................5570

Lápida sepulcral de doña Isabel de Velasco...............................577

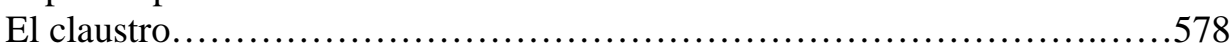

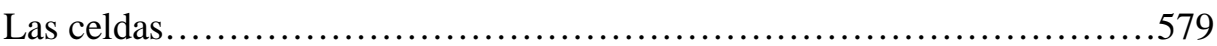

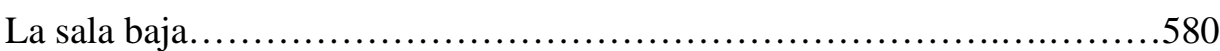

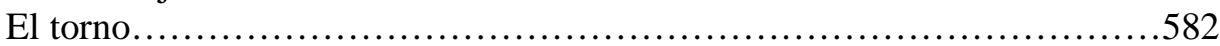

Los coros bajo y alto.................................................. 583

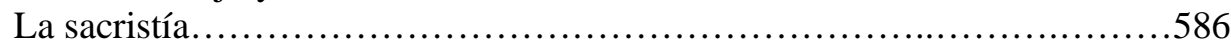

Retablos de San Blas y del Espíritu Santo................................586

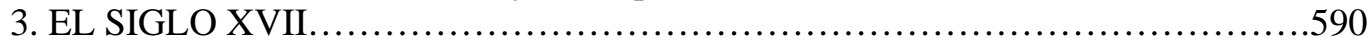

3.1 LOS LIENZOS DEL REFECTORIO...............................591

3.2. LA MADRE LUISA DE LA ASCENSIÓN ............................593

3.3. OBRAS PROMOVIDAS POR LA MADRE LUISA.....................597

La ermita de San Juan Bautista....................................598

La ermita de María Luisa...........................................599

Reconstrucción íntegra del templo..................................601

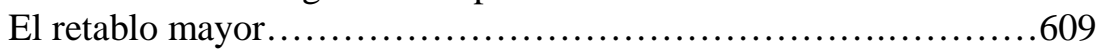

Los lienzos del presbiterio....................................622

Crucificado de Gregorio Fernández................................624

Imagen de Nuestra Señora de la Consolación........................626

Piedad de Gregorio Fernández.....................................626

Frontis de azulejería talaverana del coro..........................628

La fachada y reja exterior del templo............................6631

Las tapias del convento........................................6. 634

3.4. LAS INTERVENCIONES POSTERIORES.........................635 
Patio reglar y Hospedería...........................................635

Biblioteca musical..........................................636

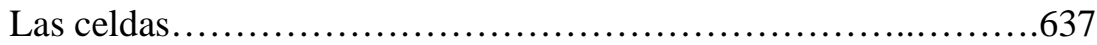

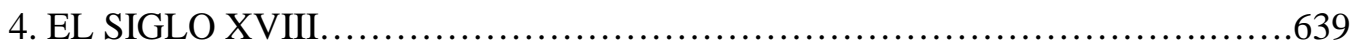

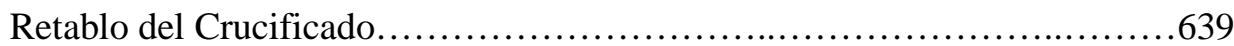

Retablo de Nuestra Señora de la Consolación................................640

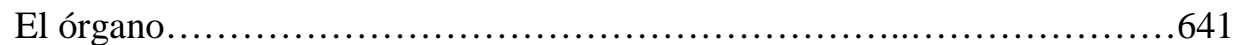

El antiguo sagrario del retablo mayor...................................643

El retablo del coro bajo............................................644

Mejoras de carácter general...........................................645

5. EL DEVENIR A PARTIR DEL SIGLO XIX .............................6646

6. EL MUSEO: OBRAS ARTÍSTICAS..........................................649

Obras de época fundacional..............................................650

Imágenes de Santa Clara y de clarisas..................................651

Imágenes de San Francisco.............................................652

Representaciones de Cristo............................................654

Representaciones de la Virgen..........................................656

Representaciones del Niño Jesús.......................................658

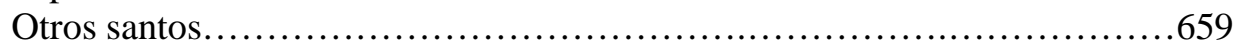

Sor Luisa y la talla de cruces.......................................660

La colección de belenes..............................................663

\section{TOMO 2}

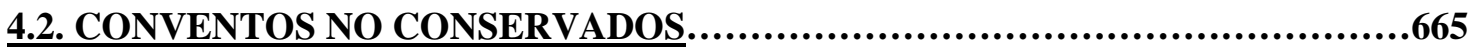

4.2.1 CONVENTO DE SANTA $M^{\mathrm{a}}$ DE BENEVÍVERE...............................667

1. EL SIGLO XII. LA FUNDACIÓN...........................................667

Las armas de la familia fundadora.......................................671

2. LA EXPANSIÓN DURANTE LOS SIGLOS XII Y XIII........................673

3. LOS SIGLOS XIV Y XV ...............................................676

4. EL CONJUNTO CONVENTUAL DURANTE LA EDAD MEDIA................677

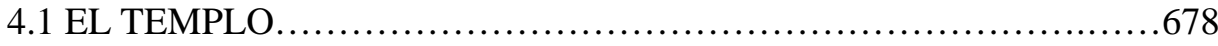

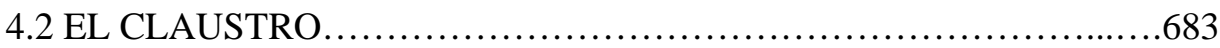

4.3 LA SALA CAPITULAR............................................685

El fundador Don Diego Salvador de Villamayor....................687

El Abad Domingo..............................................690

Don Pedro Fernández.............................................690

Don Diego Pérez de Sarmiento.....................................691

Don Fadrique de Castro...........................................691

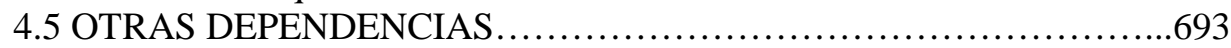

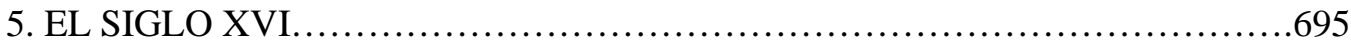

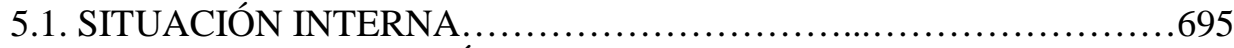

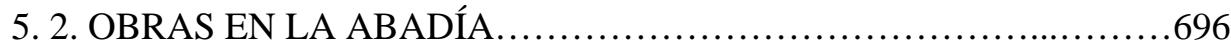

La portada principal de acceso................................696

El primer retablo conocido...................................699 
Otras intervenciones................................................. 700

5. 3. MONUMENTOS FUNERARIOS......................................701

Don Pedro Ruiz Sarmiento......................................... 701

El Abad don Juan Sarmiento........................................702

Los patronos del linaje Sarmiento...................................707

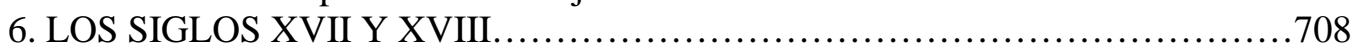

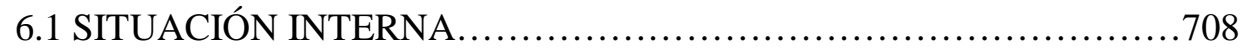

6.2 OBRAS EN LA ABADÍA..........................................710

La capilla mayor........................................... 710

El retablo mayor.............................................711

Intervención en el claustro alto..................................712

Sepulturas en la abadía.........................................714

7. EL DEVENIR A PARTIR DEL SIGLO XIX ............................... 715

4.2.2. EL CONVENTO DE SAN FRANCISCO........................................723

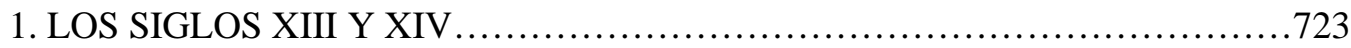

1.1 EL PROCESO FUNDACIONAL .....................................

1.2 LA ERECCIÓN DEL CONJUNTO CONVENTUAL ......................726

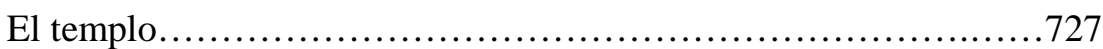

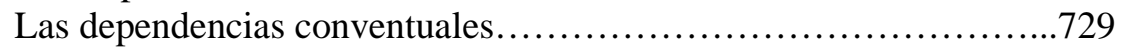

El claustro principal............................................ 730

2. EL SIGLO XV. CREACIÓN DE NUEVOS ESPACIOS ......................731

3. EL SIGLO XVI...................................................... 735

Reconstrucción del templo........................................735

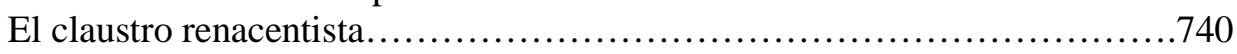

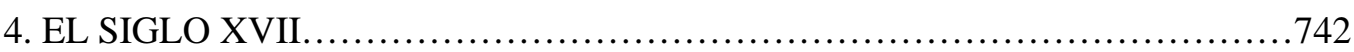

Intervenciones de reedificación y mejoras.............................742

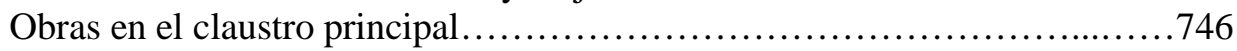

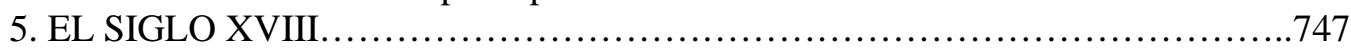

Reedificación general del templo.....................................747

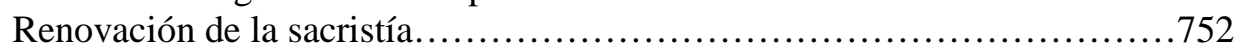

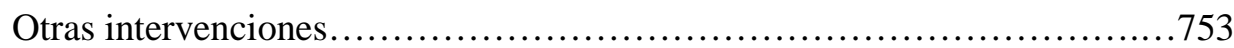

6. EL DEVENIR A PARTIR DEL SIGLO XIX ................................ 754

7. LAS CAPILLAS, ESPACIOS DE CULTO ......................................763

7.1. La Capilla Mayor, de los Marqueses de Aguilar.............................764

Los diversos retablos.............................................768

7.2. Capilla de los Duques del Infantado o de los Mendoza............................771

7.3. Capilla de los Camporredondo.........................................773

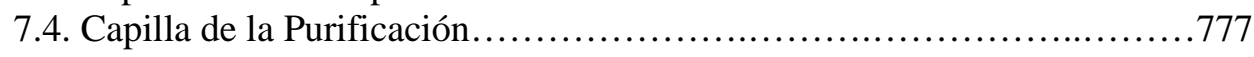

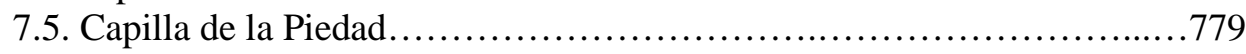

7.6. Capilla de las Once Mil Vírgenes........................................782

7.7. Nuestra Señora de Mirabueno o Crucifijo. San Antonio .....................786

7.8. Capilla de San Pedro Regalado y San Cristóbal.............................789

7.9. Capilla de La Virgen del Pópolo, Santa Brígida .............................793

7.10. Capilla del Crucifijo y Capilla de San Antonio .............................793

7.11. Capilla de San Luis de Anjou...............................................795

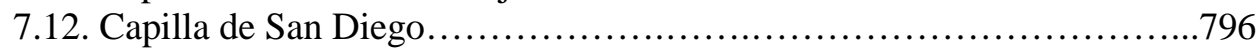

7.13. Capilla de Nuestra Señora.......................................... 798

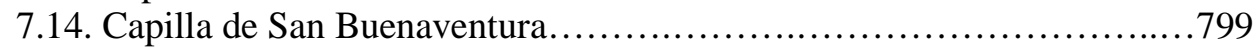

7.15. Capilla de La Resurrección...............................................800

7.16. Capilla de La Cofradía de la Concepción..............................801 


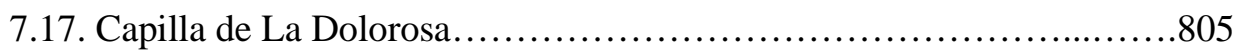

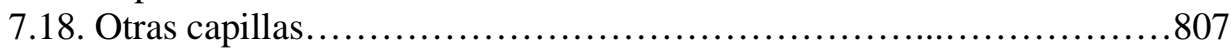

4.2.3 CONVENTO DE SAN MIGUEL Y SANTA ISABEL ...............................809

1. EL ORIGEN: EL HOSPITAL DE SAN MIGUEL..................................809

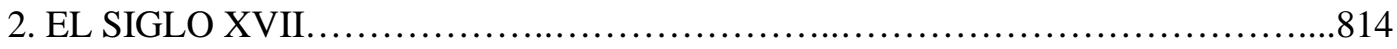

2.1. DECRETO DE CLAUSURA ..................................... 814

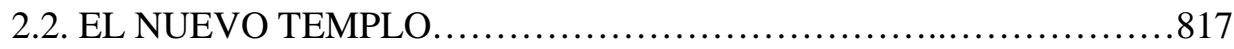

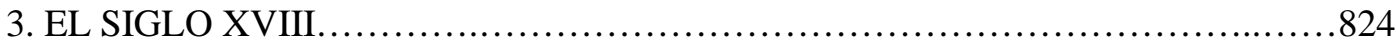

4. EL DEVENIR A PARTIR DEL SIGLO XIX ............................... 824

La construcción del fuerte.......................................... 825

La ruina posterior...................................................... 829

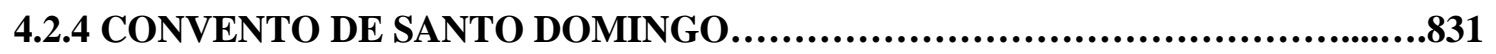

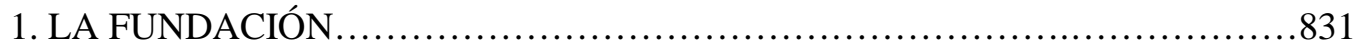

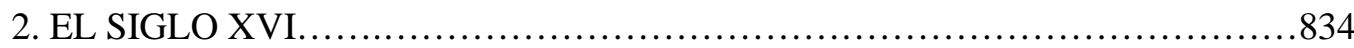

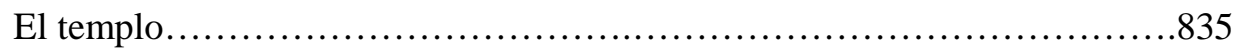

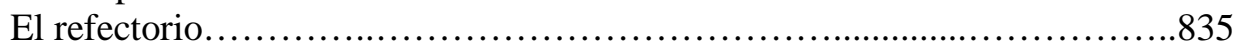

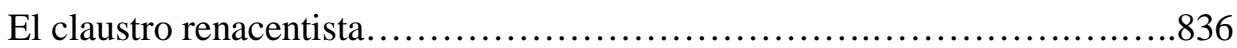

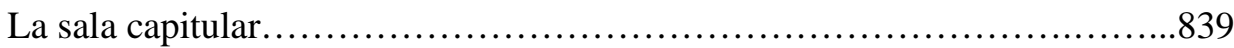

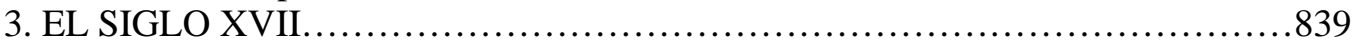

Reedificación del templo............................................. 840

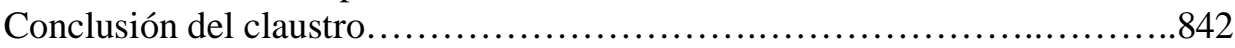

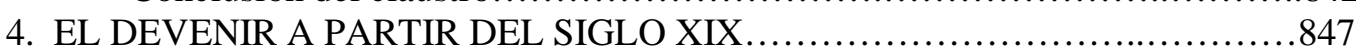

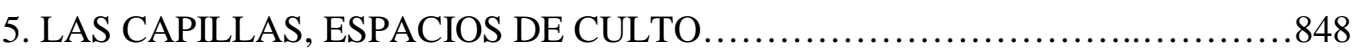

5.1 La capilla mayor................................................ 848

Capilla de la Virgen del Rosario..................................850

Capilla de los Mendoza o La Piedad................................852

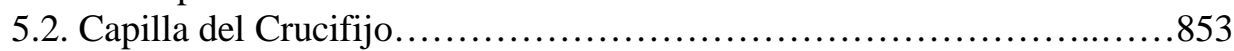

5.3 Capilla de la Cofradía de San Pedro y San Ildefonso.......................854

5.4 Capilla del Dulce Nombre de Jesús................................. 855

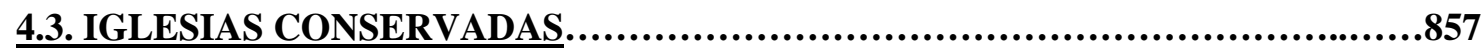

4.3.1. IGLESIA DE SANTA MARÍA DEL CAMINO......................................859

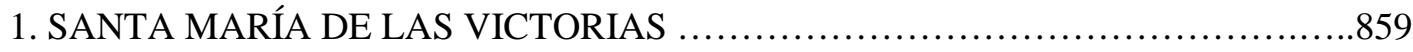

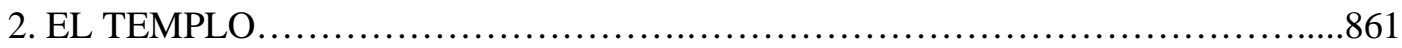

1. La portada románica.............................................. 865

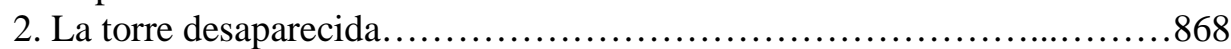

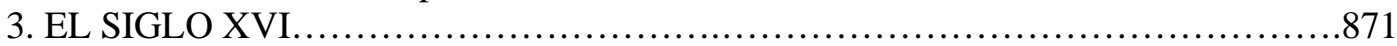

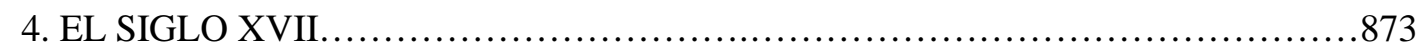

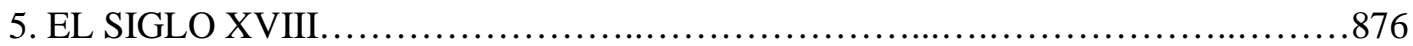




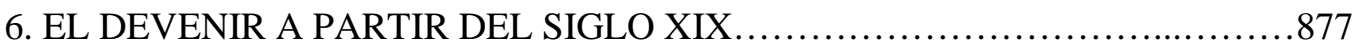

1. Reconstrucción de los tejados y otras obras...........................877

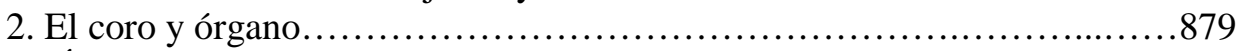

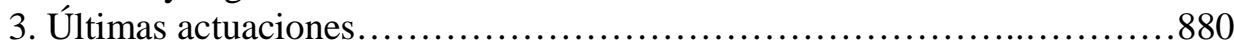

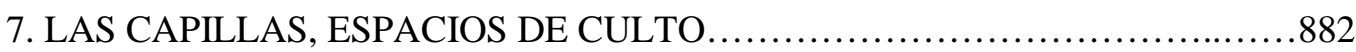

7.1 LA CAPILLA MAYOR ........................................... 882

1. El monumento funerario del Obispo don Juan de Molino

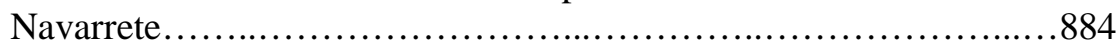

2. El retablo mayor precedente............................... 887

3. El retablo mayor actual.................................... 890

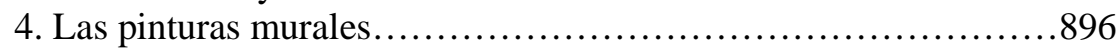

7.2. LA CAPILLA DE SAN NICOLÁS O DE LOS PAZ .....................898

1. Sepulcro de Don Juan de Paz........................................898

2. Lápida sepulcral de don Francisco de Paz.........................900

3. Reconstrucción de la capilla....................................901

4. El retablo de San Nicolás o de Nuestra Señora.........................903

7.3. LA CAPILLA DEL LICENCIADO PASTOR.............................908

1. El retablo de la Virgen del Pópolo....................................911

2. Los antiguos retablos colaterales..............................915

3. Las actuales obras colaterales.................................9917

7.4. LA CAPILLA DEL CRISTO DEL AMPARO ........................918

1. Retablo del Santo Cristo del Amparo.............................9921

2. Retablo de San Antonio de Padua...............................9921

3. Retablo de la Virgen de la Paz................................ 925

7.5 OTRAS OBRAS DEL TEMPLO...................................927

1. Obras de las naves laterales...............................9927

2. Obras de la sacristía........................................930

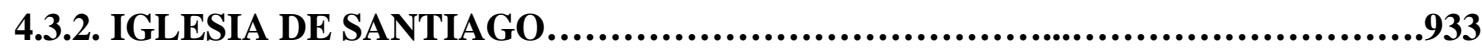

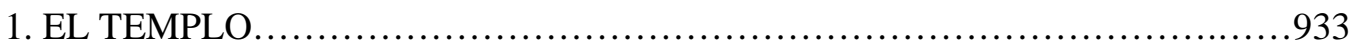

1. La portada románica................................................ 934

2. EL ANTIGUO CONVENTO DE SANTIAGO .............................. 936

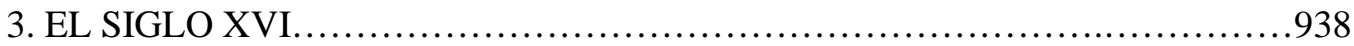

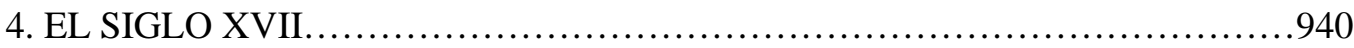

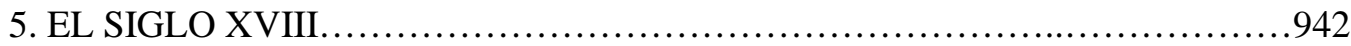

6. EL DEVENIR A PARTIR DEL SIGLO XIX .................................944

7. LAS CAPILLAS, ESPACIOS DE CULTO....................................998

7.1 La capilla mayor o de los Ponce de León................................948

7.2. Capilla del Dulce nombre de Jesús....................................953

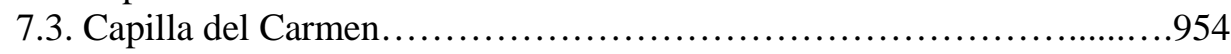

7.4. Capilla de San Agustín................................................954

7.5. Capilla de san Juan o del bautismo..................................... 959

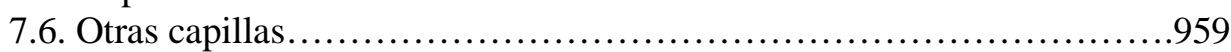

8. EL MUSEO DE ARTE SACRO ............................................. 960 


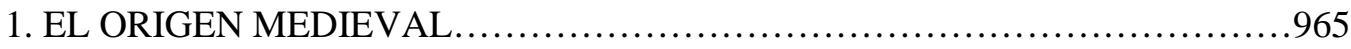

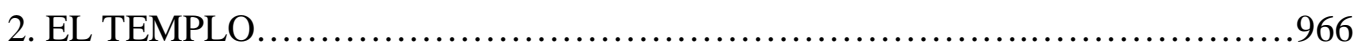

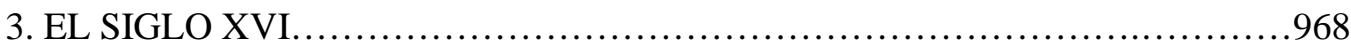

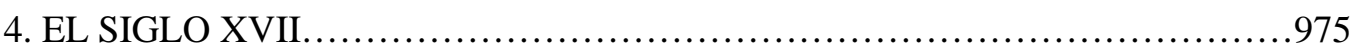

1. Continuas intervenciones de refuerzo.................................... 975

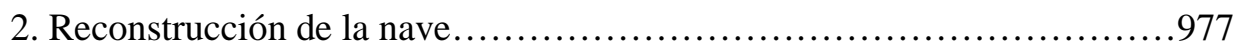

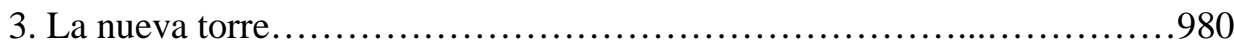

4. El camarín de la Virgen.......................................... 982

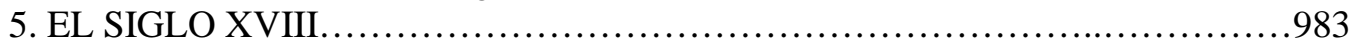

6. EL DEVENIR A PARTIR DEL SIGLO XIX ................................. 984

1. La construcción del fuerte..........................................984

2. Otras intervenciones............................................. 986

7. LAS CAPILLAS, ESPACIOS DE CULTO_................................... 987

7.1 LA CAPILLA MAYOR ............................................... 987

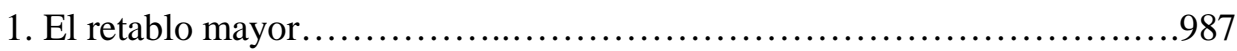

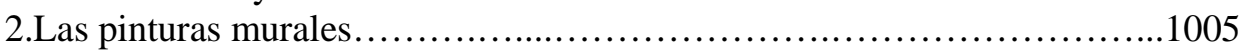

3. El retablo de San José ..................................................1006

4. El retablo de San Isidro Labrador......................................1008

7.2. CAPILLA DE SAN GREGORIO...................................1011

1. Retablo del Santo Cristo........................................ 1013

2. Sepulcro de arcosolio del doctor Fernando Díez...................1015

7.3 ANTIGUAS CAPILLAS DEL TEMPLO..............................1016

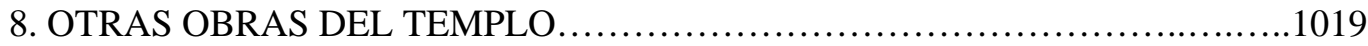

4.3.4. IGLESIA DE SAN ANDRÉS...............................................1023

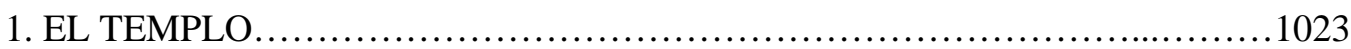

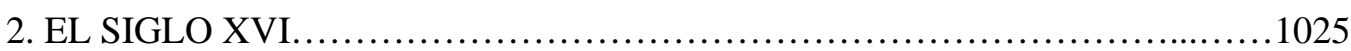

1. El proyecto de Rodrigo Gil de Hontañón...............................1025

2. El mantenimiento de los principios de Rodrigo Gil......................1027

3. El fortalecimiento de la torre......................................... 1030

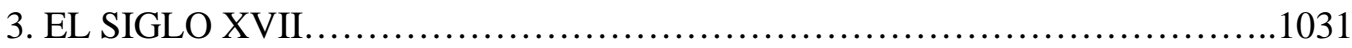

1. Finalización de la capilla mayor.....................................1031

2. Reconstrucción íntegra del resto del templo...........................1031

2.1 El proyecto de 1608: Francisco Bálcava.......................1031

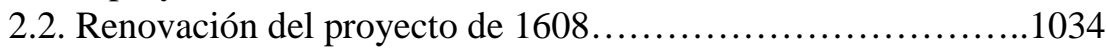

2.3. El lento transcurrir de las obras...........................1036

2.4. Conclusión de los trabajos.................................1038

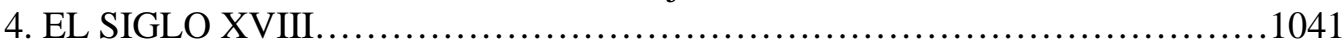

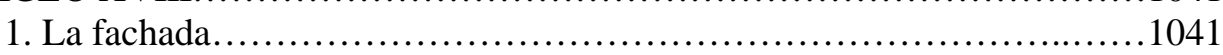

2. Obras de pequeña entidad...........................................1043

5. EL DEVENIR A PARTIR DEL SIGLO XIX ................................ 1044

1. Incendio de la torre y reconstrucción...................................1044

2. La construcción del fuerte..............................................1046

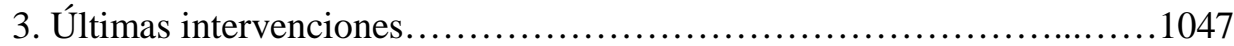

6. PRINCIPALES OBRAS DEL TEMPLO................................... 1047

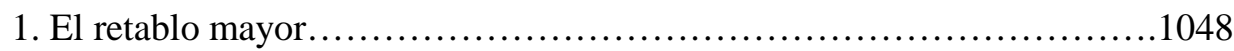

2. Retablos del testero de las naves..................................1055

2.1 Retablo de Santa Catalina, hoy de San Francisco Javier..........1058

2.2. Retablo de Nuestra Señora, hoy de San José.....................1063 
3. El monumento del Obispo don Pedro Cantero............................ 1068

4. El púlpito neogótico..............................................1068

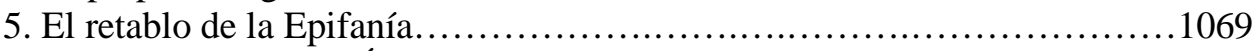

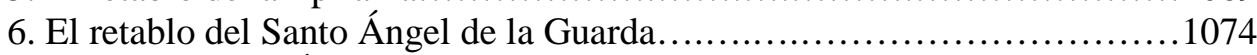

7. El lienzo de las Ánimas....................................................1076

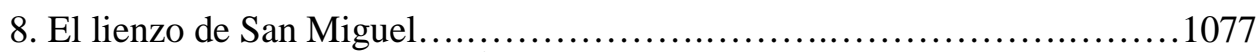

9. El monumento de Melchor Álvarez de Vozmediano...........................1079

10. El retablo de la Virgen del Rosario..........................................1082

11. La Virgen de la Herrada y los Santos Juanes................................1084

12. El coro: la sillería coral y el órgano..................................1086

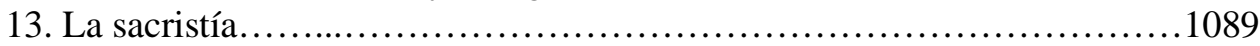

7. LAS ANTIGUAS CAPILLAS, ESPACIOS DE CULTO........................1090

7.1. La capilla mayor................................................. 1091

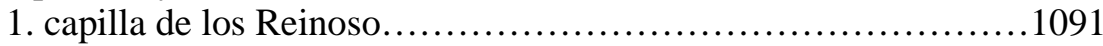

2. capilla de San Miguel........................................1092

7.2. Capilla de San Antolín................................................1093

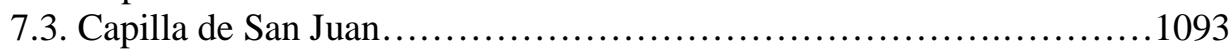

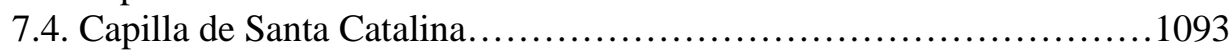

7.5. Capilla de Nuestra Señora de las Velaciones..............................1094

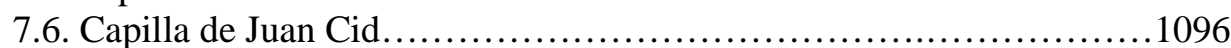

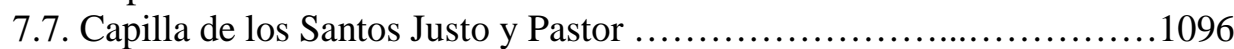

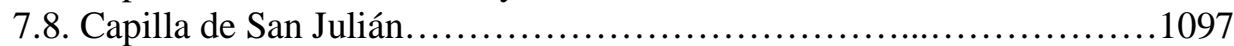

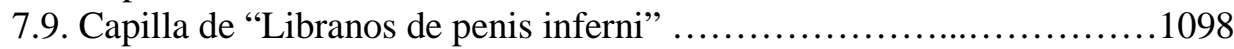

7.10. Capilla de Santa Martina la Vieja..................................1099

4.3.5. IGLESIA DE SAN JULIÁN........................................................1101

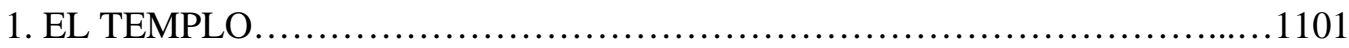

2. ORIGEN DEL PATRONAZGO .......................................... 1103

1. El fundador: don Hernando de Berrio.....................................1103

2. La voluntad testamentaria de don Hernando.............................1104

2.1. Principales disposiciones del testador........................1104

2.2 Deseo frustrado: Nuestra $S^{a}$ de las Capillas.....................1105

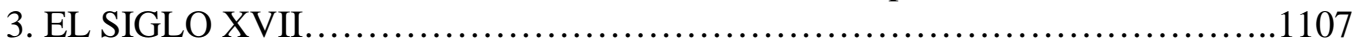

1. El origen de San Julián...........................................1107

2. Construcción del nuevo templo.......................................1109

2.1. Trazas de Juan Gutiérrez del Pozo............................1109

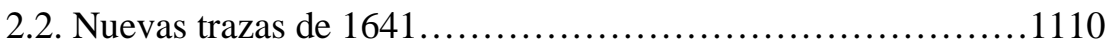

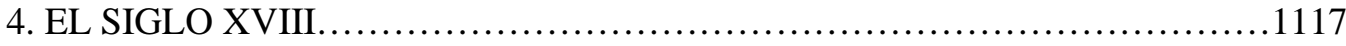

1. La ejecución de los retablos.....................................1117

1.1. El retablo mayor.........................................1121

1.2. Los retablos colaterales..................................1128

Retablo de San Pedro, hoy de San Antonio......................1130

Retablo de San Jerónimo, hoy de San José.....................1134

5. EL DEVENIR A PARTIR DEL SIGLO XIX................................1134

6. OTRAS OBRAS DEL TEMPLO .......................................... 1135 
4.4.1. SAN JUAN DEL MERCADO........................................................1139

1. ALGUNOS DATOS DE SU CONSTRUCCIÓN.................................1141

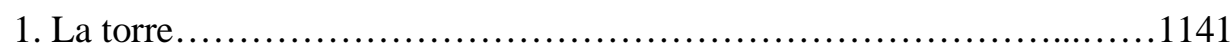

2. Reparos del templo................................................1141

2. OBRAS DEL TEMPLO .................................................. 1142

1. El retablo mayor.............................................. 1142

2. Otras obras..................................................... 1146

4.4.2. SAN BARTOLOMÉ...........................................................1149

1. ALGUNOS DATOS DE SU CONSTRUCCIÓN.............................1150

2. OBRAS DEL TEMPLO ....................................................1151

4.4.3. SAN VICENTE Y SANTA EULALIA.........................................1153

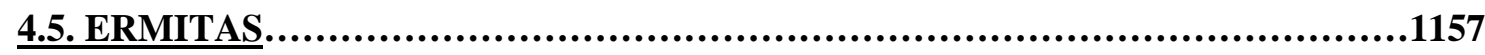

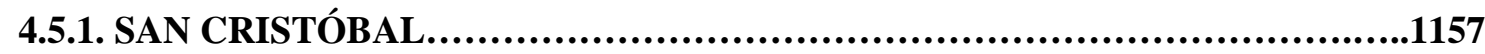

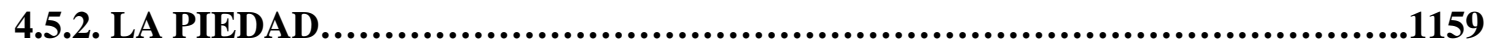

El retablo................................................................ 1162

Obras conservadas en el Museo de Arte Sacro....................................1166

4.5.3. SAN JUAN DE CESTILLOS............................................. 1167

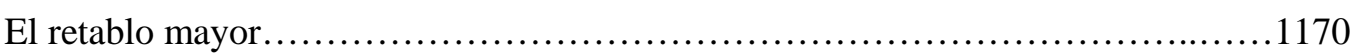

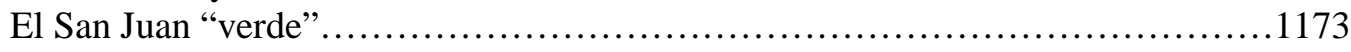

4.5.4. LA VERA CRUZ ...............................................................1175

1. ESTRUCTURA DE LA ERMITA.................................... 1176

El salón parroquial..................................................1177

La capilla de la Vera Cruz..............................................1179

2. LAS OBRAS ARTÍSTICAS ........................................... 1182

Retablo del Santo Cristo de la Cruz.......................................1182

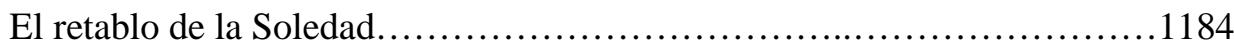

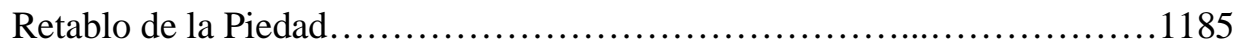

Nuestra Señora de los Dolores...........................................1185

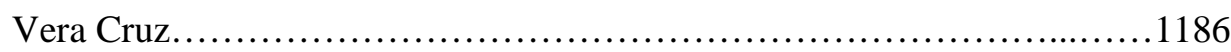

Santo Sepulcro.................................................... 1186

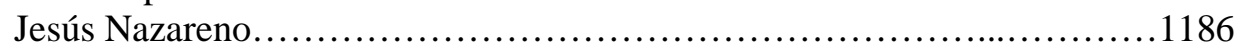

Cristo de los Azotes..................................................... 1186

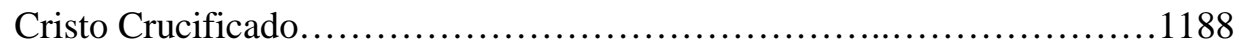

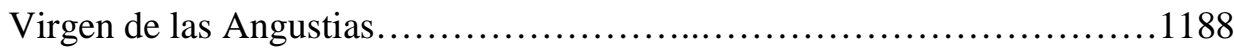

La oración en el Huerto.............................................1188

El descendimiento................................................... 1188 


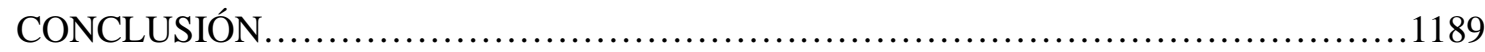

ABREVIATURAS DE LAS FUENTES DOCUMENTALES..............................1193

ABREVIATURAS DE REVISTAS Y OTRAS ABREVIATURAS .......................1194

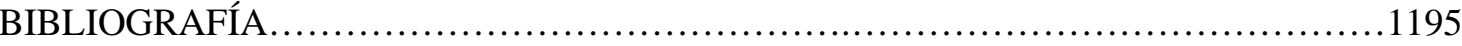


1. PANORAMA HISTÓRICO, ECONÓMICO SOCIAL 


\section{PANORAMA HISTÓRICO, ECONÓMICO SOCIAL}

\subsection{CARRIÓN HASTA LA EDAD MODERNA}

\section{EL ORIGEN DE SU NOMBRE}

El nombre de Carrión se configuraría, según Carrión Gutiez, en el siglo IX, en los años de reinado de Alfonso II, Ordoño I y Alfonso III. A lo largo de esta centuria descienden desde el norte de la Península, diversos caballeros y monjes aprovisionados, con la intención de establecerse definitivamente en los territorios que tras la invasión árabe y el consecuente refugio de la población de la meseta en la vertiente cantábrica, quedaron casi desiertas. Estas gentes, o bien trajeron el nombre consigo o más probablemente, se encontraron con un topónimo prerromano familiar $^{1}$.

Así, Ortega Aragón, nos explica que cuando se decide dotar de un nuevo nombre a los nuevos poblados que se van creando, los grupos repobladores eligen caminos diferentes para bautizar el lugar atendiendo a cualquiera de estas opciones:

-El nombre del repoblador, fundador o dueño, que puede ser de origen germánico, romano o árabe, y en cualquiera de los casos, puede aparecer en su forma original o ya pasada al romance.

-La situación geográfica.

-La producción concreta del suelo.

-Algún suceso relevante acaecido en esa zona.

-El Santo o la Virgen que es titular de la iglesia principal o monasterio.

-El diminutivo o derivado de un poblado anterior y mayor cercano, y de alguna manera dependiente de él.

-El grupo repoblador o lugar de origen de dicho grupo

\footnotetext{
${ }^{1}$ CARRIÓN GUTIEZ, Manuel. "Carrión de los Condes" en Apuntes Palentinos. Villas Palentinas, fascículo 4. Obra Cultural, Caja de Ahorros y Monte de Piedad. Palencia, 1983, pág. 5.
} 
-La palabra villa (cuyo origen procede de las fundaciones aisladas de granjas o caseríos de explotación agrícola ya existentes en época romana) junto a un nombre de persona o adjetivo ${ }^{2}$.

Con respecto a Carrión de los Condes, la leyenda, que algunos dan por veraz, cuenta que las tropas de Alfonso II El Casto, para vencer a los moros emplearon algo parecido a la estrategia del Caballo de Troya, entrando en la ciudad con unos carros cargados de carbón bajo los cuales iban los soldados que abrirían las puertas y asaltarían la ciudad, derrotando a sus adversarios y destruyendo su lugar de refugio, el castillo de Monte Argel ${ }^{3}$. Son pocos los que piensan que el nombre de Carrión pudiera motivarse por el hecho de esta hazaña. A Ponz esta leyenda le parece ridícula, al igual que otra que afirma que "el nombre de Carrión procede de los Cares, habitantes de Caria, región de Asia, que vinieron muchos siglos antes del Nacimiento de Christo á poblarla"4.

Carrión Gutiez no admite el origen legendario de Carrión de los Condes a pesar de no poder justificar la aparición de los carros en diversa documentación de la villa cuya presencia es constante en sellos de plomo que se remontan a $1234 \mathrm{y}$ $1258^{5}$. Quadrado también habla de esta leyenda pero la considera falsa y expresa que tal vez los blasones de Carrión han tomado origen de una arbitraria etimología. Defiende que fue Alfonso III quien conquistó Carrión, y que en dicha villa se encontraba cuando su servidor Adanino intentó matarle, por lo cual fue ajusticiado ${ }^{6}$. El mismo Gutiez ha encontrado los topónimos Carrio, La Carriona y Carriedo en Asturias, y aporta una explicación que atenderá al significado en latín medieval, según las Glosas Isidorenses, de la palabra "carrio", que quiere decir, dividir. Su razonamiento sería lógico, pues el río Carrión dividió barrios de la ciudad en época medieval ${ }^{7}$.

\footnotetext{
2 ORTEGA ARAGÓN, Gonzalo. "Cuestiones de toponimia mayor palentina. Algunos topónimos tradicionalmente mal interpretados" en PITTM, no 70. Palencia, 1999, pp. 519-521.

${ }^{3}$ NIPHO, Francisco Mariano. Descripción natural, geográfica y económica de todos los pueblos de España. Tomo 3. Madrid, 1771, pág. 369.

${ }^{4}$ PONZ, Antonio Viaje de España. 3. Tomos IX-XIII. .Atlas. Madrid, 1988, pág. 203.

${ }^{5}$ CARRIÓN GUTIEZ, Manuel. “Carrión de los Condes”...Op.cit, pp. 5-6.

${ }^{6}$ QUADRADO; José María y PARCERISA, Francisco J. Recuerdos y bellezas de España. Palencia. $1^{a}$ Edición: Palencia, 1861. Edición facsímil de Editorial Ámbito. Valladolid, 1989, pág. 123.

${ }^{7}$ CARRIÓN GÚTIEZ, Manuel. “Carrión de los Condes”...Op.cit, pp. 5-6.
} 
Gordaliza y Sánchez Pagín han encontrado el topónimo aún más cerca de Carrión; por ejemplo en Carrioncillo en Terradillos, Carriona en Támara, San Román de la Cuba y Villamuriel, Carrionda en Villamartín, Frechilla y Arroyo, lo que les lleva a descartar que se trate de divisiones de la Reconquista. Se postulan por la creencia de que carriona procede del latín "caryon", que significa "nuez ferreña, dura y desmedrada", relacionándolo con un terreno pedregoso o de cascajos ${ }^{8}$.

La opinión más extendida entre los historiadores, defendida entre otros por Gonzalo Ortega Aragón, es que el nombre de Carrión deba su origen al primitivo asentamiento que se limitaba al río, justo donde éste presenta una "carria" o vado que enlaza el costerón con las vías hacia tierras leonesas. Esta “carria” que identificaría la población, daría el nombre de Carrión ${ }^{9}$. Así, en algunos documentos de Sahagún, del siglo X, se aplica el nombre de Carrión a la ciudad y al territorio circundante: "in territorio de Carrione". Al convertirse este poblado en cabeza de condado y centro de expansiones, terminaría por dar el nombre al río.

Sin embargo, existen controversias en relación a esta afirmación, pues muchos historiadores creen firmemente que fue precisamente el río, el que dio nombre a la población y no al revés. Así, en el documento de donación del monasterio de San Zoilo a Cluny, en 1076, la condesa Teresa expresa que la ciudad se llamaría Santa María de Carrión: “...in urbe Sancte Marie et rivulo currente Carrione $^{10, \text {, }}$

El padre Yepes es otro de los máximos defensores de esta teoría, la cual demuestra citando un privilegio hallado en San Benito de Sahagún, según el cual el rey Don Alfonso VI designa al río con el nombre de Carrión y al núcleo primitivo de población como Santa María de Carrión ${ }^{11}$. Por tanto, atendiendo a estos documentos,

\footnotetext{
${ }^{8}$ GORDALIZA APARICIO, F. Roberto y CANAL SÁNCHEZ-PAGIN, José Ma . Toponimia palentina: nuestros pueblos, sus nombres y sus orígenes. Caja España. Palencia, 1993, pág. 111 y GONZÁLEZ, Julio. "Siglos de reconquista” en Historia de Palencia, 1. Palencia, 1990, pág. 158.

${ }^{9}$ ORTEGA ARAGÓN, Gonzalo. Op.cit, pp. 529-530.

${ }^{10}$ BERNARD, Auguste. Recueil des chartes de l'Abbaye de Cluny. Tomo IV. $1^{\text {a }}$ Edición, París, 1876. Revisada por BRUEL, Alexandre. Frankfurt, 1988, pp. 622-625.

${ }^{11}$ YEPES, Fray Antonio. Crónica General de San Benito. Volumen 3. Estudio preliminar y edición por JUSTO PÉREZ DE URBEL, Fray Justo. Atlas. Madrid, 1960, pp. 48-49.
} 
la villa habría tomado su nombre del río adyacente ${ }^{12}$. No se ha llegado a un acuerdo y, consecuentemente, la duda continúa hoy día.

En cuanto al apelativo de "los Condes" que ha venido dándose hasta la actualidad, éste no aparece en la documentación hasta el siglo XVI, concretamente en el testamento de Aldonza Manrique, condesa de Castañeda, ${ }^{13}$ dictado en 1522. El linaje Castañeda-Manrique tuvo una importancia decisiva en la villa, pues la primera condesa de Castañeda, Aldonza Tello y su marido Don García Manrique, fundaron el Hospital de la Trinidad. Sus descendientes, los hermanos Juan Manrique, conde de Castañeda y Gabriel Manrique, conde de Osorno, crearon junto al conde de Treviño, Diego Gómez, una hermandad en 1462 para proteger la villa y mantenerla bajo la corona real ${ }^{14}$. Los presupuestos establecidos en este "pleito homenaje", como así denomina la documentación, se confirmaban periódicamente, como así sucedió en $1506^{15}$. Así bien, todas estas relaciones señoriales con la villa pudieron ser decisivas para la actual denominación del núcleo urbano con el apelativo condal ${ }^{16}$.

\section{EL ESCUDO DE ARMAS DE CARRIÓN}

Para conocer el origen del escudo de armas de esta villa, debemos remontarnos al siglo VIII. Siguiendo la leyenda, ya relatada previamente, las tropas de Alfonso II el Casto entraron en la ciudad en el año 796 con sus armas escondidas en carretas de carbón, y así, con esta estrategia, se apoderaron del castillo de Monte Argel donde se cobijaban los sarracenos y levantaron la población de Santa María, Carrión hoy día ${ }^{17}$. Uno de sus más valientes luchadores, fue al parecer Alonso Carreño, caballero asturiano gracias al cual los cristianos lograron la victoria ${ }^{18}$.

\footnotetext{
${ }^{12}$ GORDALIZA APARICIO, F. Roberto y CANAL SÁNCHEZ-PAGIN, José Ma . Op. cit, pág. 111.

${ }^{13}$ De quien se hablará con posterioridad en el convento de Santa Clara, en el que está enterrada

${ }^{14}$ PERAL VILLAFRUELA, Santiago. San Francisco. Op.cit, pág. 290.

${ }^{15}$ CISNEROS Y TAGLE, Juan. Historia de las grandezas y antigüedades de la villa de Carrión de los Condes. Palencia, 1629, en AHN, Códices, Libro 336, fol 136 v y ss y en CASTRO, Lázaro de. Breve Historia de Carrión. Carrión, Palencia, 1779, s/f.

${ }^{16}$ PERAL VILLAFRUELA, Santiago y GÓMEZ PÉREZ, Enrique. Carrión, la ciudad de los Condes.

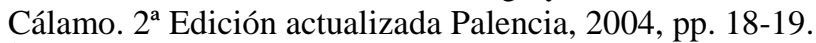

${ }^{17}$ MOGROVEJO, E. Diccionario hispanoamericano de Heráldica, Onomástica y Genealogía. V, 34. Bilbao, 1995, pág. 76.

${ }^{18}$ SÁNCHEZ BADIOLA, Juan José. "Símbolos locales en los sellos de tinta palentinos durante el siglo XIX” en PITTM, no 79. Excelentísima Diputación de Palencia, 2008, pp. 378.
} 
Parece ser que gracias a este personaje o la táctica empleada se decidió incluir los carros en el escudo de Carrión, los cuales podrían ser interpretados como sendos elementos parlantes, obviando cualquier otro origen.

Sin embargo Cisneros y Tagle informa que reinando Alonso VI, con motivo de un privilegio dado por el monarca a Sahagún en 1068, indica que las armas de Santa María de Carrión, al tomar su origen del río junto al que se ubica, llevaba en su campo unas ondas de aguas blancas. En su orla se ubicarían una "coponada" de castillos colorados y carros en campo verde ${ }^{19}$. No consta fehacientemente que este escudo existiese en el siglo XI, pues la imagen que reproduce el cronista pertenece al siglo XVII.

Hasta el siglo XIII no aparecen las primeras manifestaciones sigilográficas en Castilla. Son sellos, en su mayoría, de doble impronta y moldeados con cera natural $^{20}$. Concretamente el primer testimonio en Carrión es de 1234, a través de la donación que realiza Juan Galindo al Monasterio de San Zoilo. En el anverso de dicho sello de cera se nos muestra una carreta de bueyes sin yunta acompañada de la inscripción "SIGIL [LVM: CONCILII DE CA] RRIONIS ${ }^{21}$.". Seguramente la representación de un carro obedezca a su carácter de elemento parlante y no al suceso legendario, inventado por los cronistas para enaltecer el espíritu épico de la villa. Este proceso es común a un gran número de municipios españoles, que han optado por elegir un objeto homófono como blasón con el fin de ser fácilmente identificados. El escudo de Cuenca, por ejemplo es un cuenco, en el de Aguilar de Campoo o Aguilar de Marañón figura el águila, en el de Cifuentes, en Guadalajara, unas rocas de las que manan sendas fuentes, y como éstos, muchos más; la lista es interminable ${ }^{22}$. Respecto al anverso, el sello de Carrión contenía un castillo con tres torres almenadas, elemento propio del reino de Castilla, como así presentaba gran parte de los sellos medievales pertenecientes a este amplio territorio ${ }^{23}$.

\footnotetext{
${ }^{19}$ CISNEROS Y TAGLE, Juan de. Op.cit, fol 211v, 212.

${ }^{20}$ GONZÁLEZ, Julio. Los sellos concejiles de España en la Edad Media. Instituto Jerónimo Zurita. Madrid, 1945, pp. 12-13.

${ }^{21}$ CISNEROS Y TAGLE, Juan de. Op.cit, pp. 377-378.

${ }^{22}$ GONZÁLEZ, Julio. Los sellos concejiles...Op.cit, pp. 32-33.

23 Aguilar de Campoo o Ampudia en Palencia, Cuéllar, en Segovia, Castrojeriz, en Burgos y las propias Burgos, Palencia, Valladolid, Segovia, son algunos ejemplos que contenían idéntica imagen al reverso de Carrión. En la actual Castilla la Mancha, perteneciente al reino castellano, sucedía lo
} 
En el siglo XVI conformará su estructura cuartelada: El primero, de gules, un castillo de oro aclarado de azur (Castilla), segundo y tercero, de azur con carretas dorada, cuarto, de planta, león rampante de gules coronado de oro (León), entado en punta una granada y timbrado con corona real.

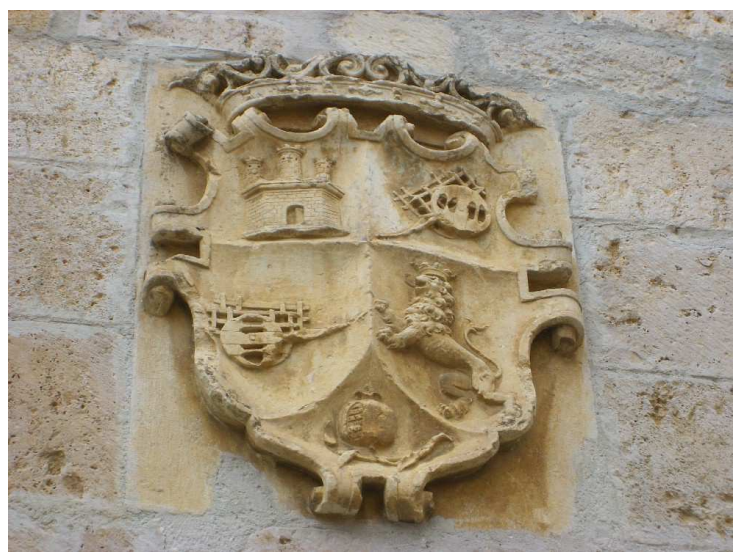

Escudo de Carrión en la Casa de Cultura. 1568.

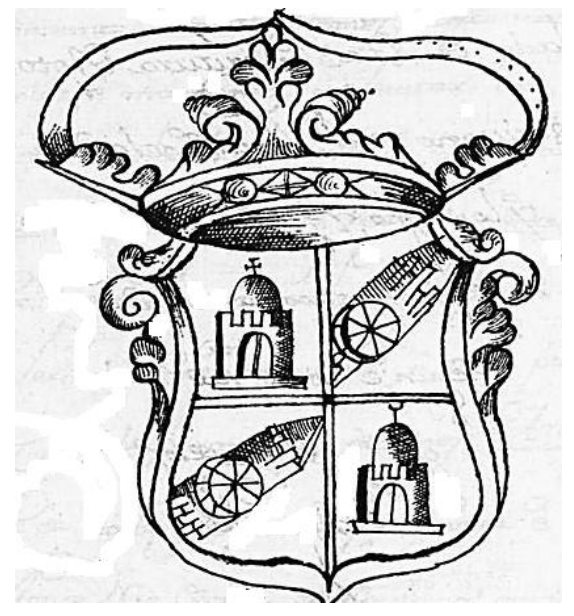

Escudo de Carrión que publicó Juan de Cisneros y Tagle en 1619.

A finales de esta centuria perderá el león y no lo volverá a recuperar en 300 años, por lo que, aunque continúa cuartelado, varía ligeramente: primero y cuarto: carro, segundo y tercero: castillos $^{24}$. Ramírez de Helguera crea un escudo inventado: En la punta baja del escudo hay una rosa, emblema de valor demostrado por el ejército del monarca. Su corona condal de 18 perlas y círculo de pedrería, tiene la significación de haber sido población del condado de Castilla y señorío de los muchos que tuvo ${ }^{25}$. A partir de 1928, siguiendo la moda basada en que los dominios reales usasen en su escudo el Toisón de Oro, éste pasó a formar parte del mismo desde entonces, sin ser justificada tal condecoración, propia de un título concedido a nivel personal. El escudo actual, modificado en el presente año de 2012, ha suprimido ambos elementos - la corona y el Toisón- con el fin de ajustarse al rigor histórico que debe prevalecer en cualquier armería municipal.

mismo. Es el caso de Cuenca, Hita o Cifuentes, en Guadalajara o Illescas, en Toledo. GONZÁLEZ, Julio. Los sellos concejiles...Op.cit, pp. 40.

${ }^{24}$ PIFERRER, F. Nobiliario de los reinos y señoríos de España. vol, I. Madrid, 1860, pp.10-11.

${ }^{25}$ RAMIREZ DE HELGUERA, Martín. El libro...Op.cit, pp. 194-195. 


\section{HISTORIA DE LA VILLA}

Ubicada en el centro geográfico de la provincia de Palencia, dentro de la comarca de Tierra de Campos y como resulta inherente a todos los municipios de este territorio, Carrión de los Condes está conformado por amplias extensiones de fértiles llanuras y prados que han propiciado una próspera economía basada en la producción cerealista y ganadera, complementada con el cultivo de los viñedos ${ }^{26}$.

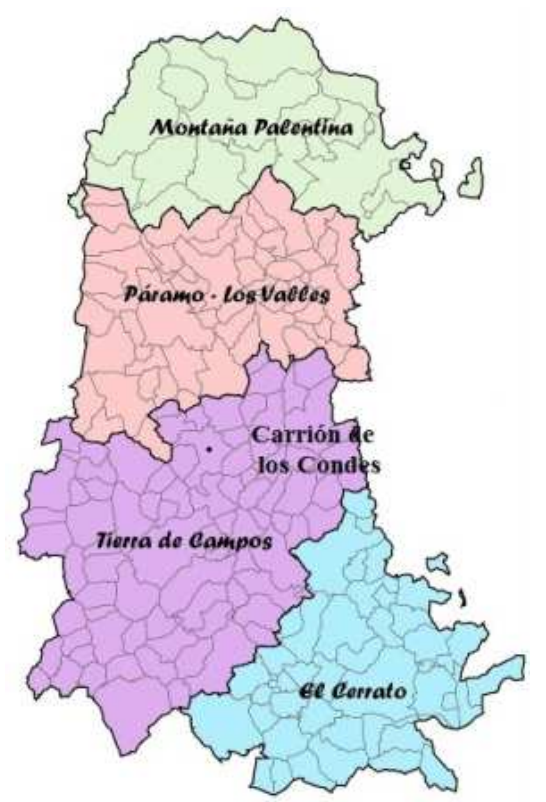

Comarcas de la provincia de Palencia.

Resulta ineludible repasar brevemente la historia de esta villa, cuyo patrimonio artístico no sería tal de no haber confluido en la misma factores de diversa índoles, tales como una adecuada situación geográfica dentro de la ruta

\footnotetext{
${ }^{26}$ A través de los fueros se constata la importancia de esta producción. GONZÁLEZ MíNGUEZ, César. "Aspectos económicos del espacio palentino en la Edad Media: Estructura productiva, vías de comunicación y ejes mercantiles (siglos X-XIII) en Actas del III Congreso de Historia de Palencia, volumen II. Palencia, 1995, pp. 347-369 y en RODRÍGUEZ FERNÁNDEZ, Justiniano. Palencia: panorámica foral de la provincia. Merino. Palencia, 1981, pp. 254-262. El estatuto que el Cabildo palentino emitió en 1359 sobre el cultivo de las viñas pone de relieve la importancia de esta producción la provincia palentina. VACA LORENZO, Ángel. "La peste negra en Castilla. Aportación al estudio de algunas de sus consecuencias económicas y sociales" en Stvdia Historica. Historia Medieval, n². Salamanca, 1984 pp. 103-107. Como ejemplo específico, se puede consultar un inventario de las rentas del monasterio de San Zoilo para comprobar la relevancia de la cebada, y el trigo, en mayor medida, además de la cría de ganado y explotación del monte. PÉREZ CELADA, Julio A. Documentación...Op.cit, pp. 132-138.
} 
jacobea y una tierra llana y fértil que motivó la prosperidad de la población y la convirtieron en corte de reyes y señorío de condes en la Edad Media. Aquí se fundaron abadías, se celebraron concilios, asambleas y se organizaron municipios, por lo que es interesante hacer un recorrido de su evolución hasta el momento presente, deteniéndonos en los siglos XI y XII que marcan la prosperidad de esta comarca palentina.

Se identifica comúnmente a Carrión con Lacóbriga, asentamiento de los vacceos desde el siglo V-III a.C que se integraría en el triángulo territorial constituido por Pallantia e Intercatia, situada ésta última cerca de Villalpando, que se extendería hasta el alto valle del Carrión ${ }^{27}$. Prueba del paso de estos pueblos es la caja celtíbera decorada geométricamente en todas sus caras que, procedente de Carrión, se halla en el Museo Arqueológico Nacional desde $1944^{28}$. Posteriormente, hacia el siglo II.a.C, Carrión fue seguramente un territorio bajo dominación romana que vería pasar las legiones que ascendían a Reinosa y Astorga para someter a los cántabros y astures ${ }^{29}$. Las monedas de plata y cobre halladas junto a algunos esqueletos en las excavaciones arqueológicas de 1896 entre la calle San Pedro y la extinguida de Santo Domingo evidencian su asentamiento ${ }^{30}$. La romanización quedó cortada con la llegada de los visigodos a la zona de Tierra de Campos, donde extendieron sus dominios a partir del 456, en que asaltaron Palencia contra el emperador Avito. Esta es la razón por la que este territorio pasó a denominarse "Campos Góticos" o tierra de los godos, extendiendo posteriormente sus dominios al vencer a los suevos y cántabros ${ }^{31}$. La presencia de estos pueblos no tuvo demasiado protagonismo en Carrión, pues no se han hallado restos arqueológicos en la villa ni alrededores.

\footnotetext{
${ }^{27}$ MONTENEGRO DUQUE, Ángel. "La toponimia palentina prerromana y la definición del componente étnico vacceo" en Historia de Palencia, I. Palencia, 1990, pp. 55-56.

${ }^{28}$ ORTEGA MATEOS, Lourdes. "Cajita excisa procedente de Carrión de los Condes" en BSAA, $\mathrm{n}^{\circ}$ 48.Valladolid, 1982, pp. 93-96. En Astudillo, Palenzuela o Calzadilla se han hallado este tipo de cajas. PÉREZ GONZÁLEZ, Cesáreo. "Cajitas celtibéricas de la provincia de Palencia. Aportaciones, síntesis y localización” en PITTM, n 48. Palencia, 1983, pp. 7-25.

${ }^{29}$ PÉREZ CELADA, Julio A. "Sobre el origen de Carrión de los Condes y sus funciones en la articulación territorial: Del poblamiento vacceo a la configuración medieval" en Los orígenes de la ciudad en el noroeste hispánico. Actas del Congreso Internacional. Lugo 15-18 de mayo de 1996. vol 2. Lugo, 1999, pp. 1411-1413.

30 ÁLVAREZ SANCHÍS, Jesús y CARDITO MARÍA, Luz. Comisión de Antigüedades de la Real Academia de la Historia. Castilla y León. Catálogo e Índices. Madrid, 2000, pág. 197.

31 MOLINA, Montserrat. "Las tierras de Palencia durante la monarquía goda" en Historia de Palencia, I. Palencia, 1990, pp. 129-130. Sobre la historia de los campos góticos, véase SIMÓN Y NIETO, Francisco. Los antiguos campos góticos. Palencia, 1971.
} 
Con la llegada de la Reconquista, Carrión vuelve a tener su lugar en las Crónicas, dada su relevancia estratégica y militar. Alfonso III ordena en el año 903 la repoblación de los Campos Góticos y ajusticia en Carrión a su hijo y a su servidor Addanium por conjurar contra él. Otro hecho destacado ocurrido en Tejar, junto a Carrión, refiere el encarcelamiento ordenado por Ordoño II de los condes castellanos Nuño Fernández y Fernando Ansúrez por no haber asistido a la batalla de Valdejunquera, librada en el año 929 y en la que Abderramán III logró una incuestionable victoria ${ }^{32}$.

Ramiro II llega al trono tras Alfonso IV en el 931. Sus hechos más significativos son la derrota de Abderramán III en Simancas y la creación del condado de Monzón para Asur Fernández contra la voluntad de Fernán González, que tenía el de Saldaña. Las luchas por el dominio de estas tierras entre los ríos Cea y Pisuerga, serán continuas entre los reino de Castilla y León hasta que los BeniGómez, se apoderan en el 952 del condado de Saldaña y Carrión, y tratarán de que se convierta en hereditario. Uno de los miembros más destacados de este linaje, con el que Carrión alcanza su época más próspera es Don Gómez Díaz, hijo de Don Diego Fernández, quien entronca con el linaje regio leonés a través de su enlace con la condesa Teresa Peláez, hija del infante Pelayo y de Doña Aldonza Ordoñez ${ }^{33}$. Don Gómez, de la familia de los Beni- Gómez, influyente en la corte de Fernando I, desempeñará junto a su esposa y su hijo primogénito Fernando Gómez, un papel importantísimo en el impulso de Carrión, a través, como veremos, de su intervención en el monasterio de San Zoilo.

Carrión figura con el nombre de ciudad en los años 1037 y 1059, cuando Fernando I restableció la silla episcopal de Palencia al indicar que la ciudad de Santa María, junto al río Carrión, se encontraba incluida entre sus poblaciones. En la carta de donación que hizo Pedro Ansúrez a la iglesia de Santa María de Valladolid en 1095 se confirma, al igual que en tantos otros escritos, esta consideración de

\footnotetext{
${ }^{32}$ PÉREZ DE URBEL, Fray Justo. Historia...op.cit, pp. 62-64 y CARRIÓN GUTIEZ, Manuel. "Carrión de los Condes"...Op.cit, pág. 6.

${ }^{33}$ PÉREZ CELADA, Julio A. "Notas sobre la ampliación del patrimonio condal en el siglo XI: Una operación múltiple de compraventa y permuta protagonizada por Don Gómez Díaz y Doña Teresa en 1057" en AIICHP, tomo 2. Palencia, 1990, pp. 416-417. Sobre esta familia véase el capítulo relativo a la fundación de San Zoilo.
} 
ciudad $^{34}$. La villa fue testigo de primera línea del enfrentamiento en la batalla de Golpejera o Volpejar de 1071 entre Don Alfonso VI, acompañado de su valiente caballero Don Pedro Ansúrez, y Sancho II, de cuya parte venía El Cid. Fue el monarca castellano quien resultó victorioso al hacer rendirse al leonés, que se había refugiado en el templo de Santa María ${ }^{35}$. Hay que destacar la importancia de Pedro Ansúrez como gobernador del condado de Carrión, siendo los señores territoriales del mismo, los hijos del conde de Don Gómez. A partir de este momento, el poder de los condes empezará a mermar, convirtiéndose en simbólico.

Muerto Alfonso VI sin descendencia varonil, será Doña Urraca quien ocupe el trono, casando primero con Raimundo de Borgoña y con Alfonso I de Aragón después, a quien se enfrentará en 1110. Por requerimiento de un legado de Roma, Urraca y Alfonso firmaron las paces en 1111, fijando la reina su residencia en Carrión. Para gobernarla, designó conde a Bernal de Risnel, su primo y así se establecieron los aragoneses en la villa condal hasta que, al fallecer doña Urraca, se marcharon con la proclamación de rey de su hijo Alfonso VII. Éste concedió privilegios a la villa, de la cual se ausentaría un tiempo con motivo de la guerra de los sarracenos. En 1130 se celebró un solemne concilio en la villa reunido por el cardenal Humberto en el que se depusieron a varios prelados como Diego de León y Juan de Salamanca. Alfonso VII no faltó a esta asamblea, que fue dirigida por el arzobispo Gelmírez ${ }^{36}$. Durante los reinados de Sancho III y Fernando II no se menciona nada relevante que sucediera en Carrión.

Alfonso VIII trató con predilección a esta villa otorgándola privilegios como la concesión a San Zoilo, donde fue investido caballero cuando contaba con catorce años, de una feria anual de un mes de duración en $1169^{37}$. Gracias a ellas proliferó significativamente la actividad comercial y artesanal en la villa, que, en palabras del

\footnotetext{
${ }^{34}$ RAMIREZ DE HELGUERA, Martín. El libro...Op. cit, pp. 34 y 35.

35 QUADRADO, José María y PARCERISA, Francisco J. Recuerdos...Op.cit, pág. 125. Sobre la célebre batalla véase ANGUITA JAÉN, José $\mathrm{M}^{\mathrm{a}}$. "La batalla de Golpejera. Historia, literatura y toponimia" en Iacobus: revista de estudios jacobeos y medievales, n ${ }^{\circ} 7-8,1999$, pp. 141-184.

${ }^{36}$ QUADRADO, José María y PARCERISA, Francisco J. Recuerdos...Op.cit, pp. 125-126.

${ }^{37}$ PALACIO SÁNCHEZ IZQUIERDO, María Luisa. "El monasterio de San Zoilo de Carrión: jurisdicción, franquezas y privilegios" en AICHP, tomo 2. Palencia, 1987, pág. 71.
} 
Codez Calixtinus, era “...próspera y excelente, abundante en pan, vino, carne y todo tipo de productos..."

Además celebró cortes en las que admitió al pueblo llano como la de 1188, en las que el monarca designó caballero a su primo Alfonso IX de León, celebrándose, según se cree, el enlace de doña Berenguela, hija del rey castellano, con Conrado de Alemania ${ }^{39}$. Por esta época, y bajo el poder del monarca, la autoridad real de los condados recaerá, no en los condes, cuyo título es más bien honorífico y simbólico, sino en merinos, que las dividirán en tenencias, siendo dos las de Carrión desde 1156, las de Saldaña y Carrión, encomendadas a los hermanos Ruiz Girón.

En el terreno de lo eclesiástico, se constituyó en 1190 en Arcedianato, cabeza de la cuarta parte del Obispado de Palencia. Alfonso VIII y su predecesor, Alonso VII fueron, entre los monarcas hispanos, los grandes benefactores de monasterios, aunque no privilegiaron a los cistercienses por encima de otros, como hasta entonces se había creído ${ }^{40}$.

Durante este período Carrión se convierte en uno de los focos neurálgico de la actividad artística de la provincia, propiciada, entre otros factores, por la presencia del Camino de Santiago desde mediados de siglo $\mathrm{XI}^{41}$. En la villa también convergía la cañada leonesa, así como las vías romanas de Herrera de Rio Pisuerga y Saldaña,

\footnotetext{
${ }^{38}$ BRAVO LOZANO, Millán. Guía del peregrino medieval: 'Codex Calixtinus'. Centro de Estudios del Camino de Santiago. Sahagún (León), 1989, pág. 23.

39 RAMIREZ DE HELGUERA, Martín. El libro...Op. cit, pp. 64- 67, MARTÍNEZ DÍEZ, Gonzalo. "Curia y Cortes en el Reino de Castilla" en Las Cortes de Castilla y León en la Edad Media. Actas del Congreso sobre la Historia de las cortes de Castilla y León, Burgos, 30 de septiembre a 3 de octubre de 1986, Vol. 1, Burgos, 1988, pp. 142-144 y VALLE CURIESES, Rafael de. A orillas del Carrión. Destellos de un pasado entrañable: acontecimientos históricos, personajes memorables, arte. Caja de Ahorros y Monte de Piedad. Palencia, 1989, pp. 103-107.

${ }^{40}$ Alfonso VII fundó los centros de Sobrado, Valparaíso, Cántavos y reformó el de San Vicente de Segovia. A Alfonso VIII le corresponden los de Óvila, Gumiel, las Huelgas de Burgos y San Clemente de Toledo. De ahí que siempre se halla creído que tenían predilección por los cistercienses. A la luz de las colecciones diplomáticas se demuestra que no es así. GARCÍA FLORES, Antonio. Arquitectura de la Orden del Císter en la provincia de Valladolid (1147-1515). Valladolid, 2010, pág. 46, a su vez de PORTELA SILVA, E. La colonización cisterciense en Galicia. Santiago de Compostela, 1981, pág. 59 y PÉREZ EMBID WAMBA, J. El Císter en Castilla y León. Monacato y dominios rurales (ss. XII-XIV). Salamanca, 1986, pp. 36-37.

${ }^{41}$ Es por ello que núcleos como Villafranca del Bierzo, Burgos, Logroño o Santiago de Compostela acogieron desde fecha muy temprana a los frailes franciscanos. A este respecto, un estudio sobre la formación de estos núcleos en GAUTIER DALCHÉ, Jean. Historia urbana de León y Castilla en la Edad Media (siglos IX-XIII). Traducción de PÉREZ SEDEÑO, Encarnación. Madrid, 1979.
} 
lo que la convertía en foco neurálgico de comunicaciones ${ }^{42}$. Por entonces Carrión había pasado de ser un simple burgo a considerarse un núcleo urbano, de hecho en la documentación figura como "ciudad de Santa María" por la iglesia homónima en torno a la cual se asentó la población en un primer momento ${ }^{43}$. La villa condal se había convertido en un lugar habitado por una masa heterogénea de mercaderes, comerciantes, jornaleros y peregrinos que conformaba una sociedad activa, reuniendo además las condiciones propicias para obtener una cálida acogida por los fieles.

A principios del siglo XIII la autoridad de los condes será prácticamente nula y Carrión se quedará sin el título de ciudad, mención que recuperará y perderá nuevamente en el siglo XIV, convirtiéndose en una más de las 19 merindades menores de Castilla, hasta que recupere dicho título, como veremos, en el siglo XIX. Al morir Alfonso VIII en 1214, heredó la corona el joven príncipe Enrique I bajo la regencia de su hermana Doña Berenguela, la cual otorga la tutoría del rey a Núñez de Lara desatándose una serie de protestas por parte de otros miembros de la nobleza, algunas de las cuales tuvieron Carrión como escenario, que no están de acuerdo con la nueva tutoría. Sucedió en el trono Fernando III, quien confirmó los fueros concedidos en la villa por Alfonso VII y realizó diversas donaciones a San Zoilo, al igual que Alfonso X, que hizo merced a Carrión con la renta del Portazgo en 1235, la exención de tributo real en 1277 y la confirmación del privilegio de libertad por los servicios que le había prestado esta villa a la Corona ${ }^{44}$.

Sancho IV guardaría todas estas exenciones y privilegios concedidos con anterioridad y concedió a la villa, además, una feria anual de ganados. Fallecido en 1295, le sucedió Fernando IV quien ordenó, a petición de los carrionenses, que la villa no saliera de manos de la Corona.

Ocupó posteriormente el trono Alfonso XI, cuya minoría de edad ocasionó diversas reyertas por su tutela entre el Infante Don Juan de Castilla, tío de su padre, su abuela, doña María de Molina y su tío, Don Pedro de Castilla y Molina. Tras la

\footnotetext{
${ }^{42}$ VACA LORENZO, Ángel. "La estructura socioeconómica de Tierra de Campos a mediados del siglo XIV. Parte I” en PITTM, n 39. Diputación Provincial. Palencia, 1977, pág. 371.

${ }^{43}$ RAMIREZ DE HELGUERA, Martín. El libro...Op. cit, pp. 34 y 35.

${ }^{44}$ QUADRADO, José María y PARCERISA, Francisco J. Recuerdos...Op.cit, pág. 127.
} 
muerte de Fernando IV, los tres fueron regentes. Rindieron cuentas en las Cortes celebradas en Carrión en 1317, siendo aún menor el monarca, con el fin de examinar la administración de sus rentas, de las que no se halló fraude alguno. Los setenta y cinco capítulos contenidos en este acuerdo reiteran los acuerdos que los tres tutores debían mantener para conservar su cargo, como el castigo de aquellos que perturbasen la paz o impusieran penas arbitrarias, la protección de las tierras de "ricoshombres" y caballeros y el mantenimiento de los privilegios otorgados a los $\operatorname{mismos}^{45}$. Una vez alcanzada la mayoría de edad, Alfonso XI no volvió a Carrión.

En el ámbito religioso, Carrión continúa a la cabeza de los cuatro arcedianazgos del Obispado de Palencia, a mediados del siglo XIV, como así certifica la Estadística de la Diócesis realizada en 1345, que manifiesta la supremacía sobre los de Cerrato, Campos y el Alcor, no sólo por la superioridad en el número de parroquias sino por los privilegios de que carecían estos tres ${ }^{46}$.

Con Pedro I comienza un período poco afortunado para algunos personajes de Carrión, pues, haciendo mención a su sobrenombre, "el Cruel", el monarca mata a Alfonso Téllez por servir a María de Portugal, despoja de todos sus bienes a un tal Juan Estébanez por ser traidor y a Diego Pérez de Sarmiento, Adelantado Mayor de Castilla, por llegar tarde, al parecer, a una batalla. A pesar de los castigos que imponía el rey Pedro, es cierto que mantuvo los privilegios y exenciones concedidas con anterioridad y establece en 1389 un código civil y penal para algunas poblaciones, entre las que se halla, por supuesto, Carrión. Al monarca castellano le debemos además la realización en 1351 de un valioso inventario de las diecinueve merindades del reino de Castilla, entre las que figura Carrión, que era por entonces señorío de realengo ${ }^{47}$.

\footnotetext{
${ }^{45}$ ASCV. Manuscritos. Cortes y ordenamientos. Tomo V, fol 15-73. Es una traslación literal escrita en el siglo XVIII en la que se incluyen, entre otras, las peticiones y respuestas de las Cortes celebradas en Carrión en 1317, cuyo original, según se indica, se conserva en el Archivo de Talavera ${ }^{46}$ SAN MARTÍN PAYO, Jesús. "La más antigua estadística de la Diócesis Palentina (año 1345)" en PITTM, no 7. Palencia, 1949-1950, pág. 4.

${ }^{47}$ MARTÍNEZ DÍEZ, Gonzalo. "Años de crisis. (1252-1369)" en Historia de Palencia, I. Palencia, 1990, pág. 251. Nos referimos al célebre manual del que este mismo autor realiza un estudio: Libro Becerro de las Behetrías (1351-1352). 3 volúmenes. Centro de Estudios e Investigación San Isidoro. León, 1981.
} 
Las malas relaciones entre Enrique II y Pedro I y el trato poco modélico del segundo con la población carrionesa, provocó el favor del Conde de Trastámara entre los habitantes de la villa. Éstos le siguieron a pesar de que Enrique, una vez en el trono, olvidó la prohibición de Fernando IV de que la villa no saliera de la Corona, concediéndosela a un caballero que ni siquiera era castellanos como Hugo de Caureley, o a Don Juan Sánchez Manuel. Cuando sube al trono Juan I, Carrión ve disminuida su población y con su sucesor, Enrique III, que entrega a Catalina de Lancaster, su futura esposa, el condado de Carrión en 1393, regresando así, la villa a la corona. Excepto Palencia, todas las localidades acogidas en la Diócesis de Palencia eran villas de realengo en el siglo XIV, por las cuales el monarca respectivo recaudaba suculentos impuestos, lo que provocaba la codicia de otros sectores de la población por ejercer el poder como el concejo y el poder señorial e incluso religioso ${ }^{48}$.

Al llegar Juan II al poder, renovó los privilegios de Carrión en 1415. Durante su reinado es ineludible mencionar a un insigne carrionés, don Iñigo López de Mendoza, que ostentó el título de Marqués de Santillana desde 1445 por su fidelidad a la corona ${ }^{49}$. En 1454, Enrique IV concede a Carrión el privilegio de no pagar portazgos en todo el reino y lo incorpora a la corona de Castilla. Durante este período, la jurisdicción de la villa oscila entre las manos de diversas dignidades señoriales, Don Pedro Manrique, Conde de Treviño y Rodrigo Pimentel, Conde de Benavente $^{50}$. El sitio de la fortaleza ubicada en la parte alta de Carrión llevado a cabo por ambos desde 1474 finalizó en 1509, en que la villa volvió a ser independiente y fue destruido el castillo próximo a la iglesia de Belén ${ }^{51}$.

\footnotetext{
${ }^{48}$ VACA LORENZO, Ángel. “La estructura socioeconómica...Op.cit, pp. 372-373.

49 Sobre este noble literato, véase PÉREZ BUSTAMANTE, Rogelio. El marqués de Santillana: biografía y documentación. Fundación Santillana. Santillana del Mar, 1983 y SUÁREZ FERNÁNDEZ, Luis y VV.AA. El Marqués de Santillana (1398-1458): los albores de la España Moderna. 5 volúmenes. Nerea. Guipúzcoa, 2001.

50 Debió tratarse de un período bastante agitado, como así manifiesta un censo que otorga el monasterio de Benevívere en 1466, firmado en el portal del hospital de la Herrada, a unos kilómetros de Carrión, en lugar de en la villa “...porque estaban ayantadas muchas gentes de a pie y de a caballo para ir sobre la dicha villa de Carrión a la combatir...”. FERNÁNDEZ MARTÍN, Luis. La Abadía...Op.cit, pág. 74. Sobre este período, véase BECEIRO PITA, Isabel. "Luchas políticas y nobiliarias y resistencia antiseñorial en el reinado de Enrique IV: los conflictos de Castromocho y Carrión" en El pasado histórico de Castilla y León. Actas del I Congreso de Historia de Castilla y Léón (1-4 de diciembre de 1982). volumen 1. Valladolid, 1983, pp. 151-159.

${ }^{51}$ Quadrado asegura que fue Enrique IV quién devolvió la independencia a la villa, pero es imposible, pues había fallecido en 1474. QUADRADO, José María y PARCERISA, Francisco J. Recuerdos...Op.cit, pág. 128.
} 
Con la llegada de los Reyes Católicos desaparece la figura del señor particular de Carrión y el gobierno del mismo será regido por el alcalde ordinario, el corregidor con gobierno real en posesión de alcabalas y sisas $^{52}$ que se extendían a ciento cincuenta lugares, un teniente corregidor, un alférez, un alguacil mayor, doce regidores, doce escribanos y seis procuradores. El siglo $\mathrm{XV}$ se convierte en un período de notable impulso de la nobleza, propiciado por la monarquía, que, consciente de la influencia ejercida en la sociedad por algunos linajes, como los Mendoza, establece relaciones de connivencia con el fin de lograrse aliados de peso $^{53}$.

\footnotetext{
${ }^{52}$ Tributo del tanto por ciento del precio que pagaba al fisco el vendedor en el contrato de compraventa y ambos contratantes en el de permuta. En su origen era un impuesto local, administrado por los concejos, hasta que en 1342 fue concedido a Alfonso XI por un período de tres años. En 1349 fue cedido a perpetuidad, decisión que lo convirtió en impuesto permanente y de libre disposición del rey, lo que le permitió usarlo como parte de su patrimonio, situando deuda sobre las rentas de alcabalas, vendiéndolas o haciendo donación de ellas en favor de particulares. La capacidad fiscal de cobrar alcabalas se transfirió bajo la dinastía Trastámara, bien por compra o donación (las famosas mercedes enriqueñas de Enrique II), bien por usurpación, sobre todo durante el reinado de Enrique IV. Información extraída de Internet. Sisa: Impuesto que se cobraba sobre géneros comestibles, menguando las medidas.

${ }^{53}$ SUÁREZ FERNÁNDEZ, Luis. Nobleza y monarquía: puntos de vista sobre la historia política castellana del siglo XV. Universidad de Valladolid. Valladolid, 1959, pp. 168-169.
} 


\subsection{CARRIÓN DEL SIGLO XVI A LA ACTUALIDAD}

\section{EL SIGLO XVI: LA PROSPERIDAD}

El auge experimentado por la villa de Carrión durante en el siglo XVI y, más concretamente en las décadas centrales de la centuria, se hace extensivo a toda la Corona de Castilla, tanto en el ámbito rural como en el urbano. Asistimos a una época de expansión económica con un marcado protagonismo de las poblaciones pertenecientes a la cuenca del Duero ${ }^{54}$. El aumento de la producción agraria, de la demanda y de los precios no se basó en la renovación de los aperos o del sistema de regadío, que se mantuvieron inalterables, sino que fue motivado por la extensión de los cultivos a los pastizales, la sustitución de los bueyes por mulas como ganado de labor pero sobre todo, la reorganización de las tierras en "suelos" y de las viñas en "pagos". Este período de bonanza económica vino acompañado de un notable crecimiento demográfico, pues desde el siglo precedente, su población registra un aumento considerable -densidad de 25 habitantes por kilómetro cuadrado- dado que las pestes mermaron las regiones periféricas con una mayor agresividad que en el corazón peninsular ${ }^{55}$. El elevado índice de pobladores de algunas localidades de Tierra de Campos como Carrión de los Condes, que alcanza su cota máxima en este período, debe su razón de ser a la concentración de sus moradores a lo largo de las riberas fluviales, el río Carrión, en nuestro caso. El resultado en Tierra de Campos es la creación de núcleos no demasiado grandes y muy continuados -cuya distancia máxima es la de una legua- en los que se establece una jerarquización que termina de forjarse hacia $1530^{56}$. En este sentido, Carrión se mantenía a la cabeza dentro del conjunto territorial palentino, situación forjada desde la Baja Edad Media con la

\footnotetext{
${ }^{54}$ Sobre este tema, son bastante clarificadores los artículos CASTILLO PINTADO, Álvaro. "Population et richesse en Castille durant la seconde moitie du XVI ${ }^{\mathrm{e}}$ siécle" en Anales Economies, Societés, Civilisations, nº4, 1965, pp. 719-733 y SUÁREZ FERNÁNDEZ, Luis. "Aristocracia, señorío y crecimiento económico en Castilla. en Revista de Historia Económica, n³, 1985, pp. 443471.

${ }^{55}$ GARRIDO REDONDO, Javier. "Introducción histórico-social a los siglos XVI-XVII y XVIII" en Arquitectura civil de los siglos XVI, XVII y XVIII de la provincia de Palencia (inventario). Diputación Provincial de Palencia. Palencia, 1988, pp. 27-34. Para una visión general sobre la situación económica y social en Castilla dentro del ámbito rural en este período, SALOMÓN, Nöel. La vida rural castellana en tiempos de Felipe II. Barcelona, 1982.

${ }^{56}$ YUN CASALILLA, Bartolomé. Sobre la transición al capitalismo en Castilla: economía y sociedad en Tierra de Campos (1500-1830). Valladolid, 1987, pp. 57-59. En el caso de Carrión, se constata esta teoría, pues los pueblos más cercanos: San Mamés de Campos, Calzada de los Molinos y Villalcázar de Sirga distan a 3, 5 y 6 kilómetros, respectivamente.
} 
obtención de privilegios y exenciones y la posesión de un mayor número de parroquias de la Diócesis que la sitúan en cabeza de los cuatro arcedianazgos ${ }^{57}$. Incluso cuando con el Obispo Don Alonso de Burgos (1486-1499) se crea el Arcedianazgo de Palencia y con ello la máxima dignidad del cabildo tras el deán, el arcediano de Carrión gozaba de una situación de privilegios tal, que en las Constituciones Sinodales del Obispo Cabeza de Vaca continúa siendo el primero ${ }^{58}$.

En Carrión, esta pujanza económica fue posible gracias a su estratégica situación, como así señalaba el maestro al mando de las obras del puente en 1594, señalando la necesidad de reconstruirlo con la mayor brevedad posible, dado que es “...paso muy común para todos los mercados y ferias de Villalón, Villada, Rioseco, León, Saagún y Zamora y todas las montañas de Aguilar, San Vizente, Arenillas y Santander... ${ }^{59 " . ~ E s t e ~ p e r i ́ o d o ~ c r i s t a l i z o ́ ~ e n ~ l a ~ r e v i t a l i z a c i o ́ n ~ d e l ~ r e ́ g i m e n ~ a r i s t o c r a ́ t i c o, ~}$ que se convertirá, como veremos en el gran patrocinador de obras de arte. Igualmente, esta época de vigorización económica influyó decisivamente en el florecimiento de la actividad artística que posibilitó la afluencia masiva de artistas cántabros en la provincia de Palencia, convirtiéndose la villa carrionesa en uno de los focos donde se registra una mayor concentración de canteros ${ }^{60}$.

Desde un punto de vista histórico, no ocurren sucesos reseñables en la villa, exceptuando las poco entusiastas revueltas antiseñoriales que tuvieron lugar en 1520 y 1521 con el comunero Juan de Mendoza a la cabeza. La mayor parte de los carrioneses se mantuvieron fieles a la corona y en la junta que se celebró en Palencia poco antes de la batalla de Villalar, se comprometieron a abstenerse en participar en los levantamientos. Con motivo de este comportamiento favorable al poder real, Carlos I confirmó los privilegios que le habían sido concedidos a la villa con anterioridad y dispone que la villa rinda pleitesía solamente a los monarcas ${ }^{61}$.

\footnotetext{
${ }^{57}$ SAN MARTÍN PAYO, Jesús. "La más antigua estadística...Op.cit, pág. 4.

${ }^{58}$ FERNÁNDEZ DE MADRID, Alonso. Silva Palentina. Volumen 1. Palencia, 1932, pág. 496.

${ }^{59}$ AHN. Leg. 24676.

${ }^{60}$ Sobre este tema profundizaremos en el apartado relativo a los maestros de cantería.

${ }^{61}$ VALLE CURIESES, Rafael de. A orillas...Op.cit, pp. 112-117. Un estudio profundo sobre el movimiento comunero en la comarca terracampina en FERNÁNDEZ MARTÍN, Luis. El movimiento comunero de los pueblos de Tierra de Campos. León, 1979.
} 
En lo que a las relaciones sociales se refiere, durante toda la época moderna e incluso hasta bien entrado el siglo XIX, se dio un Carrión un fenómeno muy llamativo, no tanto por el hecho en sí mismo, pues ocurría sino por el sector al que afectó, dada su aparente tendencia hacia la concordia y su promulgación de ejemplaridad entre los fieles. Nos referimos a las continuas disputas y pleitos que enfrentaron entre sí, a diversos miembros del clero, particularmente a las dos parroquias con mayor número de fieles en Carrión: Santa María y San Andrés. En todos ellos siempre subyace un trasfondo de animadversión, cuya razón de ser verdadera es la ambición de supremacía por parte de ambas. Sirva como muestra de la situación referida un contencioso de 1543 interpuesto por el cura y beneficiados de San Andrés contra el de Santa María por el robo de los sambenitos promulgados en la villa “...an estado de tiempo inmemorial...” en el templo susodicho ${ }^{62}$. San Andrés defiende su preponderancia basándose en el hecho de que Santa María fue primeramente ermita, mientras que San Andrés siempre fue templo parroquial. Alega además que se ubica en mejor lugar, que tiene mayor número de fieles, que en su iglesia se reciben a los arciprestes y que desde este templo se reparten los óleos y crismas al resto de templos de la villa. Continúan las alegaciones basadas en que desde San Andrés se llama al Cabildo por campana tañida, que se realizan las exequias de los personajes más relevantes, que reciben la bula de la Santa Cruzada, que reciben la primera visita del obispado de Palencia, que sus eclesiásticos encabezan la mayor parte de las procesiones. Todos estos argumentos coadyuvaron favorablemente en San Andrés, que logró la restitución de los sambenitos.

\section{LOS SIGLOS XVII Y XVIII: DECADENCIA Y ESTABILIZACIÓN}

En el siglo XVII la expansión demográfica y económica se atenúa sustancialmente y la Corona de Castilla se ve arrastrada hacia una grave situación de decadencia cuyos orígenes debemos buscarlos en el lastre del sistema financiero desde Carlos $\mathrm{I}^{63}$. El aumento de los tributos y la creación de otros nuevos

\footnotetext{
${ }^{62}$ ADP. Carr. San Andrés. Legajos. 93.3.

${ }^{63} \mathrm{La}$ recesión económica de Castilla en este período ha sido objeto de numerosos estudios. YUN CASALILLA, Bartolomé. "La crisis del siglo XVII en Castilla: indicadores, cronología y factores en la Tierra de Campos (1580-1640)" en El pasado histórico de Castilla y León: [actas del I Congreso de Historia de Castilla y León celebrado en Valladolid, del 1 al 4 de diciembre de 1982, vol. 2,
} 
repercutieron directamente en aquellos que mantenían el sector de la producción, quienes debido a la agobiante presión fiscal, interrumpieron sus inversiones y mermaron la producción agrícola. Paralelamente, la población desciende vertiginosamente por los casos de peste y otras enfermedades vinculadas a la miseria como difteria, tifus o paludismo, y los reclutamientos de soldados ordenados por Felipe IV, registrándose un descenso demográfico de un treinta por ciento respecto al siglo anterior y un aumento del número de despoblados ${ }^{64}$. En Carrión, podemos verificar estos fenómenos, acontecidos durante la primera década del siglo. Precisamente en 1614, en la plaza de Santa María, se demuelen unas viviendas particulares con el objeto de disponer la denominada "Casa del Capitán" en su solar “...para la possada de los capitanes que en nombre de su magestad vienen a levantar jente de ynfantería en esta dicha billa...”, llevadas a cabo el año posterior $^{65}$. Por otro lado, las epidemias de 1615 y 1616 redujeron a la población a seiscientos vecinos y el receso experimentado por la actividad comercial a consecuencia de la excesiva fiscalización real, produjo cierta recesión en la villa.

Sin embargo, y aunque no frenó el descenso de la población que venía acusando Carrión, la concesión del mercado franco por Felipe III en 1618 coadyuvó significativamente en la inyección económica de la localidad. Celebrado se celebra cada jueves en la plaza de Santa María, fue una de las iniciativas llevadas a cabo por la monja clarisa María Luisa de la Ascensión, quien en 1617 solicitó al monarca, al que le unían vínculos amistosos, el permiso necesario para su establecimiento dentro de la villa ${ }^{66}$. Su majestad se lo concedió el 14 de febrero del año siguiente para que

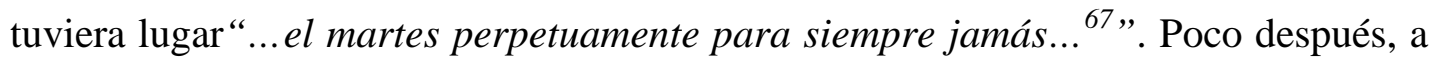
finales 1619 se solicitó el cambio de día por resultar más conveniente a los vecinos, lo cual fue concedido en febrero de 1620, en que pasó a celebrarse los jueves, y

Valladolid,1983, pp. 257-278, GARCÍA SANZ, Ángel. "Auge y decadencia en España en los siglos XVI y XVII: economía y sociedad en Castilla" en Revista de Historia Económica, nº 1, 1985, pp. 11-27, SUÁREZ FERNÁNDEZ, Luis. "Aristocracia, señorío y crecimiento económico en Castilla. en Revista de Historia Económica, n³, 1985, pp. 443-471.

${ }^{64}$ GARRIDO REDONDO, Javier. "Introducción...Op.cit, pp. 29-30.

${ }^{65}$ VIGURI, Miguel de y SÁNCHEZ, José Luis. Arquitectura en la Tierra de Campos y el Cerrato. Colegio Oficial de Arquitectos de León. Palencia, 1993, pp. 169-170, a su vez de AHPP. Carr.Prot 5211, Jerónimo López (1615), s/f.

${ }^{66}$ Se comienza la sesión con la lectura de dicho privilegio real. AMCC. Libro 1, Sesiones municipales (1618-1638). Sesiones municipales, 1617, s/f.

${ }^{67} \mathrm{La}$ fecha de dicha concesión se refiere en Sesión de 21 de febrero de 1626. AMCC. Libro 1, Sesiones municipales (1618-1637), fol 353. También en CISNEROS Y TAGLE, Juan de. Op.cit, fol $172 \mathrm{v}$. 
hasta la fecha ${ }^{68}$. Resulta una fecha de concesión un poco tardía, si se tiene en cuenta que Palencia obtiene el permiso para instalar el mercado franco por privilegio de Carlos V en $1529^{69}$. No obstante, hay que señalar que Carrión contaba ya con un mercado anual desde 1295, concedido por el rey Sancho IV desde Toledo ${ }^{70}$. Desde su creación y hasta su concentración en la plaza de Santa María, los puestos de las mercadurías se establecieron en un lugar determinado según el género:

-El ganado mayor y menor en la plaza de San Andrés y del Marqués de Santillana.

- Pescado, sedas, objetos de mercería y joyería en la plaza de Santiago y del Infantado

-Leña, carbón y madera en la Puerta de Santa María.

-Vidrio y lino en la plaza del Duque de Nájera, que llaman de Manose.

-Los cereales -trigo, cebada, centeno y avena- en la plaza del Mercado, que por entonces se encontraba extramuros de la villa.

Del mismo modo, existían ferias de ganado, con periodicidad anual, celebradas igualmente en la plaza de Santa María y en las eras aledañas. Las de tipo mular, caballar y asnal tuvieron lugar, hasta finales del siglo XIX el 21 y 22 de septiembre y del 27 al 30 de octubre y los ganados lanar, vacuno y cabrío, del 24 al 27 de octubre ${ }^{71}$. Con el paso del tiempo, los productos comienza a venderse en cualquier parte de la villa, lo que conduce en 1788 a la promulgación de un edicto municipal por el cual se prohíbe “...la reprobada costumbre que hastta aquí ha hauido..." de vender hortalizas y otros géneros a la puerta de los templos, especialmente el de Santiago, bajo pena de excomunión ${ }^{72}$.

Desde un punto de vista social, la progresiva desaparición de la burguesía y el mantenimiento del sistema del Antiguo Régimen basado en la percepción de

\footnotetext{
${ }^{68}$ AMCC. Libro 1, Sesiones municipales (1618-1637). Sesión municipal de 6 de diciembre de 1619 y de 19 de febrero de 1620 , fol 57 y $76 \mathrm{v}$.

${ }^{69}$ VALLE CURIESES, Rafael del. "El mercado franco de la ciudad de Palencia y sus papeles" en Actas del II Congreso de Historia de Palencia, tomo 2. Palencia, 1989, pág. 337.

${ }^{70}$ GARCIA BARRIUSO, Patrocinio. Op.cit, pág. 151, a su vez de RAH. Colección Salazar y Castro, O-24, fol 97-101.

${ }^{71}$ RAMÍREZ DE HELGUERA, Martín. El libro...Op.cit, pág. 134. Desconocemos a qué época remonta la existencia de estas ferias, pero si nos referimos a Castilla, existían ferias muy célebres desde el siglo XV, como las de Villalón, Medina del Campo o Medina de Rioseco que comerciaban sus productos a nivel internacional. YUN CASALILLA, Bartolomé. Sobre la transición...Op.cit, pp. 182-186.

${ }^{72}$ ADP. Iglesia de Santiago. Libro $1^{\circ}$ de Cuentas de Fábrica (1778-1849), fol 65 y ss.
} 
rentas y en la venta de títulos supusieron un lastre en la evolución económica y técnica de la agricultura, propiciando además, un aumento de la mendicidad general. A pesar de ese período de crisis que aquejó a la aristocracia durante esta centuria y que se hizo extensiva en Castilla $^{73}$, el patrocinio de obras artísticas no se vio demasiado condicionado, pues continuaron estableciéndose obras pías y el auge constructivo de este período fue posible a los préstamos, limosnas y censos concedidos al clero regular, que en la figura de sus párrocos, impulsaron la renovación de sus fábricas.

Por su parte, el clero regular continuó ejerciendo su papel de estamento privilegiado como absoluto señor de un extenso monopolio con poderes jurisdiccionales. Treinta de las cincuenta y cinco instituciones de clero regular que llegaron a existir en Palencia, se concentraban en tan sólo nueve localidades Palencia, Carrión, Dueñas, Aguilar de Campoo, Villada, Frómista, Herrera de Pisuerga, Paredes de Nava y Bárcena de Campos- situándose Carrión de los Condes entre los enclaves de primera magnitud, tan sólo por detrás de la capital. Esta situación se ve refrendada por el control ejercido entre los seis cenobios carrioneses que llegaron a acaparar el veinte por ciento, tanto de la producción agraria, como de los réditos de censos a nivel provincial ${ }^{74}$. De todos ellos, San Zoilo figuraba a la cabeza de todos ellos y su influencia era tal, que cuando en 1641, Urbano VIII expidió una Bula por la que instaba a que a partir de entonces todas las poblaciones fueran dotadas de un patrón que las representara en las fiestas, el glorioso mártir cordobés resultó elegido por unanimidad en el sorteo celebrado dos años más tarde, descartando las candidaturas de San Andrés, y Nuestra Señora de Belén ${ }^{75}$.

\footnotetext{
${ }^{73}$ Sobre este tema DOMÍNGUEZ ORTIZ, Antonio. "La desigualdad contributiva en Castilla durante el siglo XVII" en Anuario de Historia del Derecho Español, 1951-1952, pp. 1222-1268 y del mismo, Crisis y decadencia de la España de los Austrias. Barcelona, 1971, JAGO, Charles. "La crisis de la aristocracia en el siglo XVII en Castilla" en Poder y sociedad en la España de los Austrias. Barcelona, 1982, pp. 248-286 y YUN CASALILLA, Bartolomé. Sobre la transición...Op.cit, pp. 228-244, ATIENZA HERNÁNDEZ, Ignacio. "La quiebra de la nobleza castellana en el siglo XVII: Autoridad real y poder señorial en Hispania, n¹56, 1984, pp. 49-82, COLÁS LATORRE, Gregorio y SERRANO MARTÍN, Eliseo. "Nobleza en España en la Edad Moderna” en Manuscrits, n¹4, 1996, pp. 15-38.

${ }^{74}$ LÓPEZ GARCÍA, José Miguel y VILLA MATEOS, Javier. "Los informes de bienes nacionales y desamortización: una aproximación al estudio del clero regular en las provincias de Valladolid y Palencia a finales del Antiguo Régimen" en Congreso de historia rural: siglo XV al XIX. Actas del coloquio celebrado en Madrid, Segovia y Toledo del 13 al 16 de octubre de 1981. Madrid, 1984, pp. 545-554.

${ }^{75}$ BECERRO DE BENGOA, Ricardo. "El monasterio...Op.cit, pág. 89, VALLE CURIESES, Rafael de. A orillas...Op.cit, pág. 100. El testimonio de la elección que hizo el Cabildo eclesiástico se otorgó
} 


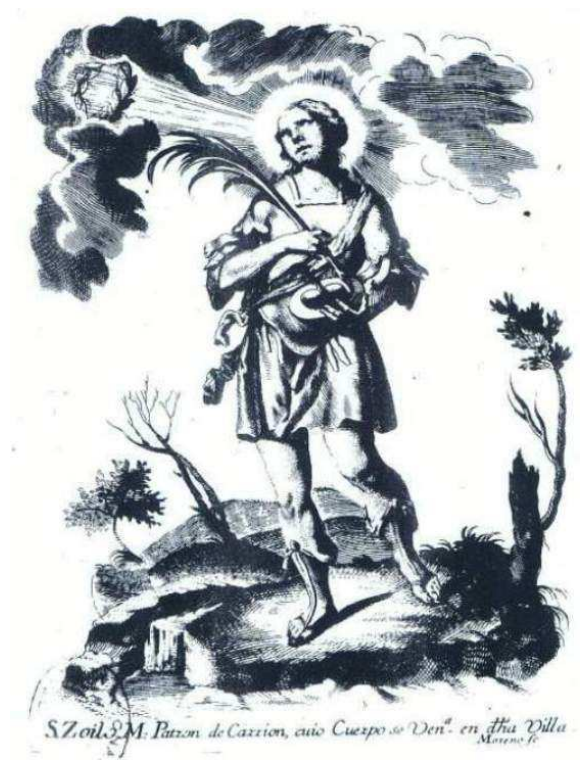

Grabado calcográfico de San Zoilo, patrón de Carrión de los Condes. Juan Moreno Tejada (1739-1805). AHN. Sala Goya. Inventario 32487.

De las tres casas de mendicantes existentes en Carrión, las monjas de Santa Clara fueron sin duda las más poderosas. Parece que desoyendo la máxima de pobreza que caracterizaba a la orden en sus orígenes, las clarisas percibían una jugosa fuente de ingresos por el capital invertido que ascendía a 837.292 reales en el siglo XVII. San Zoilo y Santa Clara se erigieron en los cenobios con mayores ingresos no sólo de Carrión, sino de toda la provincia, superados solamente por las dominicas de la Piedad en Palencia. Los agustinos de Benevívere también gozaron de una privilegiada situación, pues ocupaban el quinto lugar entre los principales rentistas del clero regular palentino, por detrás de Santa Clara de Calabazanos ${ }^{76}$.

Durante este período, las relaciones entre los diversos sectores de carácter religioso asentados en la villa se recrudecen notablemente. Así lo colegimos en base a las múltiples referencias relativas a la "falta de entendimiento", por emplear un eufemismo, que hallamos en la documentación de los siglos XVII y XVIII. Las órdenes mendicantes, que, como ya referimos, contaron con la aceptación de la mayor parte de la población, dado su carácter asistencial y su desinterés por los bienes materiales, no gozaron de la misma acogida entre el clero secular y el obispado. La razón fundamental hunde sus raíces en la predilección otorgada a las

en Carrión el 5 de octubre de 1643. AHPP. Desamortización 112. Índice del Archivo de San Zoilo. Caja 5 ${ }^{\text {a }}$ San Andrés. Legajo 2. Cuaderno A. nº 13.

${ }^{76}$ LÓPEZ GARCÍA, José Miguel y VILLA MATEOS, Javier. “Los informes”...Op.cit, pp. 545-554. 
mismas por el papado, que permitió a los frailes predicar en las parroquias sin permiso del obispo dado que en sus inicios estos frailes no contaban con un templo propio $^{77}$. No debemos pensar que este un hecho aislado sino la tendencia generalizada en territorio hispano y por extensión en ámbito occidental europeo ${ }^{78}$. Otro motivo que ocasionó la férrea oposición de los clérigos y obispos y que lejos de aminorarse, resultó vigorizada en este período, fue el reclamo de los frailes por parte de los fieles para que actuasen no sólo de predicadores, sino de albaceas testamentarios o intercesores en asuntos públicos. Los sacerdotes veían cómo su protagonismo y el de sus parroquias, se había visto minado progresivamente, hasta el punto que las capillas de las iglesias habían dejado de ser lugares de preferencia para enterramiento, prefiriéndose en muchos casos las de los templos conventuales, por su acogida a todos los sectores de la sociedad. Tenían que reaccionar, no podían mantenerse impasibles y cualquier excusa resultaba apta para desencadenar una trifulca o interponer un pleito. Sirva como ejemplo el litigio desencadenado el 11 de septiembre de 1636 por los clérigos de Santa María y San Andrés contra los frailes de Santo Domingo durante el sepelio de doña María del Campo, mujer del regidor perpetuo de la villa, que dispuso su entierro en la casa de predicadores. La procesión funeral, precedida como era habitual por las cuatro grandes iglesias de Carrión: Santa María, San Andrés, Santiago y Belén, era seguida por un acólito de la parroquia a la que estaba adscrita la difunta, en este caso San Juan del Mercado, templo del que partía la comitiva, y dos frailes mendicantes, uno de San Francisco y otro de Santo Domingo. Los familiares y el resto de vecindario asistente desfilaban en último lugar. Llegados a la puerta del templo dominico, los frailes esperaban a la puerta para recibir el cuerpo del difunto y trasladarlo a su respectiva capilla. Pese a la solicitud de que se marchasen, los presbíteros se negaron, pues arguiían que debían someterse al edicto emitido por Clemente VIII en 1601 y confirmado en 1603, por el cual disponía que, en todo acto público, procesión o entierros, el clero eclesiástico

\footnotetext{
77 MOLINER, José María. Espiritualidad medieval: Los mendicantes. Monte Carmelo. Burgos, 1974, pág. 91.

78 CUADRADO SÁNCHEZ, Marta. “Arquitectura franciscana...Op.cit, pp. 40-46. Un caso particular en el que se analiza el conflicto de los mendicantes de Haro con el cabildo de Santo Tomás en GOICOLEA JULIÁN, Francisco Javier. "La influencia de las órdenes mendicantes en la religiosidad de los fieles de la villa de Haro en la Edad Media" en VI semana de Estudios Medievales. Nájera, 31 julio-4 de agosto, 1995. Nájera, 1995 pp. 255-270. En Francia se daba la misma oposición. DOSSAT, Yves. "Opp.osition des anciens ordres à l'installation des mendiants" en Cahiers de Fanyeux, no 8. Fanyeux, 1973, pp. 263-306.

GLORIEUX, Paul. "Prélats français contre religieux mendiants" en Revue d'histoire de l'église de France, volumen 11, no 53, Lion, 1995, pp. 471-495.
} 
precediese a los monjes y religiosos de cualquier orden sin excepción ${ }^{79}$. La falta de respeto mostrada por los clérigos, quienes se negaron a continuar con la celebración hasta que el prior dominico y sus acólitos les permitieron el paso, indica la enconada confrontación que la pérdida progresiva de su autoridad y prestigio en la villa había desencadenado.

Otro motivo de repetida disputa entre ambos sectores eclesiásticos fue el tema de la libre elección de sepultura. El clero carrionés no se mostraba demasiado conforme con un edicto promulgado por Bonifacio VIII en 1298 que otorgaba autorización expresa a los franciscanos y dominicos de enterrar en sus templos conventuales a los fieles que así lo solicitasen ${ }^{80}$. Ilustra su descontento y malestar ante los mendicantes una querella de 1742 interpuesta por la comunidad eclesiástica carrionesa a los herederos de todos aquellos feligreses que siendo parroquianos de una iglesia determinada hubieran decidido ser sepultados en los templos conventuales de Santo Domingo o San Francisco. Los clérigos pretendían incrementar los costes de las exequias a los familiares de estos difuntos. Sin embargo, gracias a la intervención del regimiento y diputados de las seis cuadrillas de la villa que trataron de impedirlo, la justicia dio la razón al sector civil ${ }^{81}$. En todo este conflicto subyace un trasfondo de cariz eminentemente económico, pues el clero local al perder una sepultura obtenía menos aportaciones derivadas de la fundación de misas y donaciones realizadas por el difunto en su testamento.

Incluso entre el Cabildo y el clero secular carrionés se produjeron desavenencias respecto al protocolo a seguir en la celebración de los óbitos. Era habitual en este tipo de solemnidades, que los párrocos, al salir de las iglesias en busca de los parientes de los difuntos, fuesen ataviados con sobrepellices, de manera que enviaban las capas y cetros con los sacristanes a las casas de los difuntos, donde se las ponían para volverlos a acompañar hasta la iglesia, “...siendo ésta costumbre antigua, sin que jamás hayan ido ellos con las capas y cetros puestos desde la iglesia...”. En 1627, el obispo de Palencia vigente, don Miguel de Ayala pone pleito

\footnotetext{
${ }^{79}$ AHN. Clero Secular-Regular, Legajo 5358 s/f, Expediente 6, Iglesia de Santiago, Documentos eclesiásticos.

${ }^{80}$ ORLANDIS ROVIRA, José. "Sobre la elección de sepultura en la España medieval" en Anuario de Historia del Derecho español, n²0, 1950, pág. 39.

${ }^{81}$ 1742. ACP. Provisorato. Legajo 399, pieza $2^{\mathrm{a}}$.
} 
para que salgan directamente vestidos pero el fallo da la razón a los beneficiados de San Andrés ${ }^{82}$.

Durante el período progresista de Carlos II, la inflación se sitúa bajo control y no se crean nuevos impuestos, por lo que a partir de la década de los ochenta se observa un una tímida recuperación en Tierra de Campos gracias al alza de la renta de la tierra motivada por una óptima selección de los suelos y un ajuste de la producción a la población existente. Este período de recuperación perdura en el siglo XVIII, si bien persiste la sociedad del Antiguo Régimen en Castilla. Además se mantiene la agricultura tradicional de baja productividad, el crecimiento industrial es débil, de carácter artesanal y las comunicaciones no se desarrollan. Durante este período nada especial ocurrió en la villa. Tan sólo, en 1717 se recogieron franquicias $\mathrm{y}$ privilegios otorgadas por Felipe $\mathrm{V}$ y se formaron las ordenanzas municipales indispensables para el buen gobierno de la ciudad condal. La villa contaba por entonces con 3.500 habitantes $^{83}$.

\section{DEL SIGLO XIX EN ADELANTE: UNA VILLA MEDIA CASTELLANA}

Por abdicación de Carlos IV, la corona recayó en Fernando VII en 1808, con tan mala fortuna que los franceses invadieron España poco después. En Carrión, existía una amenaza inminente de ocupación, de ahí que las fuerzas militares planteasen una defensa en la villa ante posibles ataques, como así lo muestra un Croquis de 1812 que estudia una posible posición militar en la que se explica la posibilidad de acceder por el río, plenamente vadeable, incluso en invierno. No obstante, la desventaja numérica y sus deficientes medios de defensa les hicieron desistir de su empresa, sometiéndose, no sin ciertos enfrentamientos, a las órdenes de los recién llegados hasta que en 1813 volvió a gobernar el monarca español. Carrión, como el resto de villas, debía entregar los alimentos y otros objetos que les fuesen requeridos. Debía además, prestar asistencia para el cuidado de los heridos de

\footnotetext{
${ }^{82}$ AHN. Clero Secular-Regular, Legajo 5357 s/f. Expediente 1,Iglesia de San Andrés, Papeles religiosos.

${ }^{83}$ CARRIÓN GUTIEZ, Manuel. "Carrión de los Condes"...Op.cit, pág. 18.
} 
guerra, y en este sentido, el Hospital de Santa María fue el centro más importante de la provincia para la acogida de los mismos ${ }^{84}$. La invasión provocó el incendio voluntario de algunos edificios para evitar que fuesen ocupados por las huestes francesas, lo que provocó la pérdida de un valioso patrimonio arquitectónico además de todos los archivos que se guardaban en la casa consistorial ${ }^{85}$.

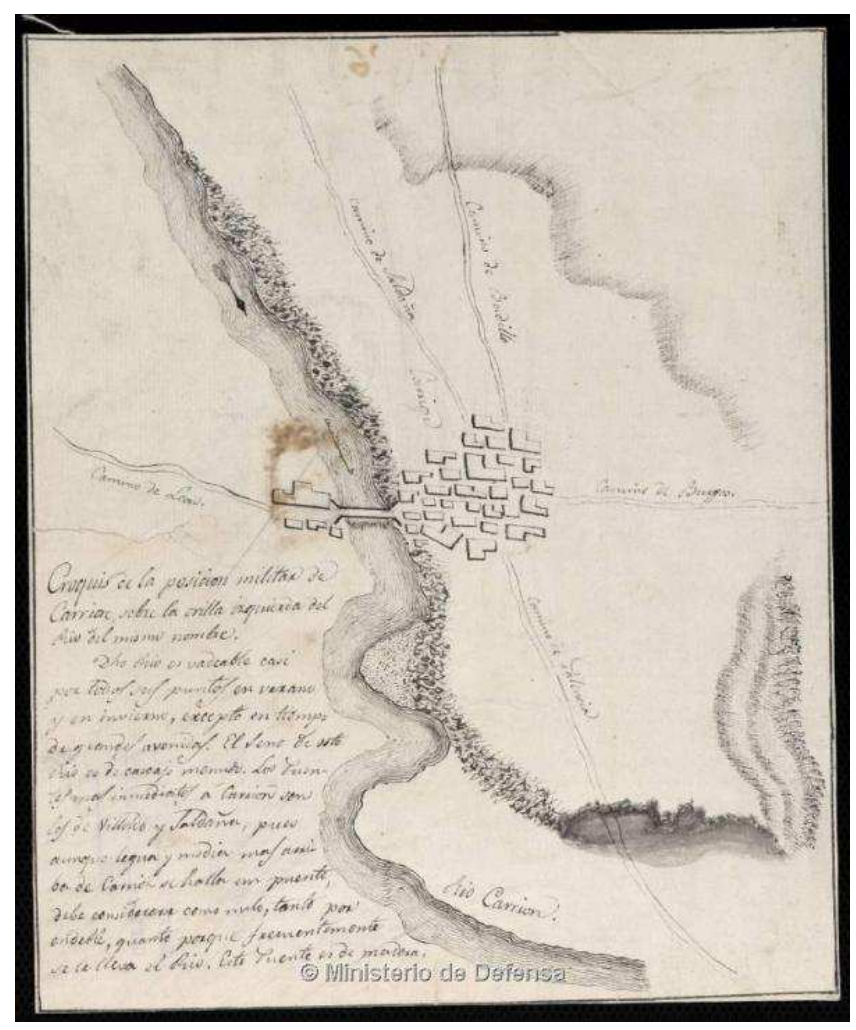

Croquis de la posición militar de Carrión sobre la orilla izquierda del mismo nombre. 1812. Cartoteca del Centro Geográfico del Ejército. Colección SG. Ar. Et7 C1-288. Biblioteca Virtual del Patrimonio Bibliográfico.

Concluida la guerra, con la proclamación de Fernando VII, Carrión verá aumentar su población, impulsarse su economía y actividad política, viviendo una época de calma hasta su muerte en 1833 en que, aparte de sufrir los efectos del cólera morbo, se verá afectada por la lucha política nacional entre los partidarios

\footnotetext{
${ }^{84}$ OLLERO DE LA TORRE, Alfredo. La guerra de la Independencia y la crisis del Antiguo Régimen en Palencia” en Historia de Palencia, 2, pág. 162.

${ }^{85}$ Acerca de las consecuencias de la guerra de la Independencia en los monumentos de Carrión, véase el apartado relativo a la "Evolución del patrimonio".
} 
carlistas e isabelistas, aunque es cierto que no fue escenario de grandes acontecimientos bélicos ${ }^{86}$. Con la llegada de la primera guerra carlista, en la que Carrión se mostró partidaria de don Carlos, se realizó en 1838 un fuerte que estudiaremos posteriormente, que nos muestra, una vez más, el apoyo carrionés a los sectores más conservadores. Este conjunto defensivo abarcó la zona noroeste de la villa, por considerarse la más segura, al situarse en ella los edificios más elevados, como los templos de Belén, y San Andrés. El fuerte se completaría con un área que abarcaría el antiguo convento de San Miguel y Santa Isabel, dada su posición preeminente sobre el río ${ }^{87}$. En 1839, Carrión recuperó la tranquilidad, pero este hecho no impidió que la disminución de habitantes continuara su curso. La segunda guerra carlista, desarrollada a mediados de siglo tuvo partidarios de Carlos VII en Carrión, si bien los enfrentamientos no adoptaron un cariz demasiado radical.

En este período el consistorio pretendía mejorar las comunicaciones de la villa a través del ferrocarril que, con salida en Alar del Rey unía las ventas de San Isidro de Dueñas. Por ello, en sesión de 15 de abril de 1856 solicitó a las Cortes constituyentes que Carrión de los Condes fuera lugar de parada de dicho tramo ferroviario $^{88}$. Dicha concesión llegó por intervención de Agustín Esteban Collantes, Ministro de Fomento pocos meses más tarde ${ }^{89}$. Pero no llegó a materializarse, resultando Frómista, la villa afortunada. Para enlazar con la misma, se decidió construir una carretera, cuya subasta sería conseguida en marzo de $1861^{90}$. Se había pensado la inauguración para la mañana del 13 de junio de dicho año, sin embargo, dado que era día de mercado y festividad en algunos pueblos, se planteó posponer el acto al día 15 o 16, optándose finalmente por este último. Tan "fausto acontecimiento" traería consigo una gran festejo cuyo programa incluía fuegos artificiales, la invitación a una comida para las corporaciones militares, eclesiásticas y civiles más destacadas, una ceremonia religiosa, encendido de una hoguera,

\footnotetext{
${ }^{86}$ CARRIÓN GUTIEZ, Manuel. “Carrión de los Condes”.... Op.cit, pág. 19.

${ }^{87}$ Será debidamente estudiado al referirnos a Belén, San Andrés y Santa Isabel.

${ }^{88}$ AMCC. Libro 5, Sesiones municipales (1850-1857), fol 33v-34. A este respecto DE LA MADRIZ MANRIQUE, Manuel. Breves reflexiones sobre que es más ventajosa: la dirección del camino de hierro de Palencia a Alar del Rey pasando por Carrión de los Condes que por Frómista. Imprenta y Librería de Mariano García y Gervasio Santos. Palencia, 1856.

${ }^{89}$ AMCC. Libro 5, Sesiones municipales (1850-1857), fol 77.

${ }^{90} \mathrm{La}$ preocupación por mejorar el aspecto general de la villa se hace patente en la puesta de las cartelas con el nombre y número de las calles, solicitada en 1859. AMCC, Libro 6, Sesiones municipales (1858-1862), Sesión de 26 de abril de 1859, fol 51.
} 
colocación de "hachas de viento y pipotes" por las calles, baile con diversos danzantes y dulzaineros, novillos y organización de juegos tradicionales como el del árbol de la cucaña. No faltaría pan para los pobres y limosna para los presos, enfermos y sacristanes. Incluso se planteó construir en las inmediaciones de la nueva obra pública un pabellón que alojara un altar para bendecir las herramientas destinadas a tal fin ${ }^{91}$. En julio de 1864 el ayuntamiento intentó nuevamente que la línea que unía Alar con Palencia fuera dotada con una parada en Carrión, pues sería conveniente para la villa no sólo por la extracción de sus productos agrícolas sino también por la promoción de material industrial ${ }^{92}$. Otro intento en vano para conseguir la llegada del ferrocarril a Carrión llegó en 1883, de modo que el proyecto que enlazaba Astudillo con Saldaña tuviera parada en las proximidades de la fábrica de harinas de San Zoilo ${ }^{93}$. Pero los costes eran excesivos y tampoco se llevó a cabo. Sin cesar en sus intentos, en 1894 el ayuntamiento pretendía que el ferrocarril de línea estrecha que, según el proyecto de Pedro Romero Herrero, uniría Palencia con Guardo, pasara por Carrión ${ }^{94}$.

En el ámbito político, durante estos años nada destacable sucedió, salvo la llegada de Cánovas del Castillo como refugiado político desde diciembre de 1867 hasta febrero del año siguiente. En septiembre de ese mismo año, la revolución destronó a Isabel II y los vecinos de Carrión proclamaron la libertad ${ }^{95}$. La aplicación de los decretos de 12 y 18 de octubre de 1868, supusieron la supresión de la Compañía de Jesús y la reducción de los conventos femeninos. De este modo, los jesuitas de San Zoilo y las monjas de Santa Clara se vieron obligados a abandonar sus moradas, regresando éstas últimas, al año siguiente, en $1869^{96}$. Carrión será dividida a finales de 1871 en dos distritos cuya denominación corresponderá a su

\footnotetext{
${ }^{91}$ Se acordó dicho día para inauguración tres días antes, en sesión extraordinaria de 10 de junio de 1860. AMCC, Libro 6, Sesiones municipales (1858-1862) s/f.

${ }^{92}$ AMCC. Libro 7, Sesiones municipales (1863-1867). Sesión de 12 de julio de 1864, s/f.

93 AMCC. Libro 11, Sesiones municipales (1879-1885), Sesión de 27 de mayo de 1883, fol 206 v.

${ }^{94}$ AMCC. Libro 14, Sesiones municipales (1892-1896). Sesión de 19 de octubre de 1894, s/f.

${ }^{95}$ CARRIÓN GUTIEZ, Manuel. "Carrión de los Condes”...Op.cit, pág. 20.

${ }^{96}$ Explicado en los capítulos relativos a ambos cenobios. En Palencia, el gobernador civil, pese a las protestas del Obispado, suprimió el convento de Santa Clara de Palencia, que, al transformarse en hospital, sus monjas se unieron a las de Calabazanos. En la capital, también se suprimieron los conventos de agustinas y bernardas. Por su parte, las benedictinas del Moral fueron trasladadas a Paredes de Nava. REVUELTA GONZÁLEZ, Manuel. "Un siglo de crisis y restauración en la iglesia palentina” en Historia de Palencia, 2. Palencia, 1990, pp. 228-229.
} 
ubicación en la villa: el de "Mediodía y Oriente" con un colegio en el consistorio, y el distrito del "Norte y de Poniente", que contará con la escuela de párvulos ${ }^{97}$.

Nombrado rey Amadeo de Saboya, se produjo, entre los años 1872 y 1876, la tercera guerra carlista para apoyar a Carlos María de Borbón, y en Carrión de los Condes no faltaron partidarios del mismo, muchos de los cuales murieron o fueron exiliados. En estos años setenta, se puede decir que la vida municipal fue intensa: se encauza el río, se fomentan los regadíos, se cuida la asistencia pública, se atiende el pósito y se ordenan los pastos, entre otras intervenciones ${ }^{98}$. Con la restauración borbónica en 1875 y Alfonso XII en el poder, los jesuitas regresaron a San Zoilo para ejercer de profesores de segunda enseñanza.

A finales de 1877 por consenso general se establecen dos sedes del Tribunal del Partido en la Provincia: uno en Palencia con la circunscripción de Palencia, Baltanás y Frechilla, presentando un total de 89 ayuntamientos y rondando los 85.000 habitantes; y otro en Carrión de los Condes, con las demarcaciones de Carrión, Cervera de Pisuerga, y Astudillo, alcanzando 158 ayuntamientos y algo más de 100.000 habitantes $^{99}$.

A este acuerdo se habían llegado no sin cierta discusión por parte de la villa, pues en el anteproyecto se planteaba la posibilidad de establecer tan solo un Tribunal de Partido en toda la provincia. De ahí que los carrioneses, en caso de que debiera elegirse una sede, preponderaran cuestiones históricas, posesión de recursos de todo género y su situación central en el territorio, descartando Palencia como posible elección. Para curarse en salud, los carrioneses manifestaban la necesidad de establecer más de un tribunal de Partido, basándose en la extensión y el número de habitantes de la provincia. Esta normativa de la división territorial comenzó a aplicarse en 1878, junto a la implantación paralela del sufragio censitario, las cuales

\footnotetext{
${ }^{97}$ Sesión municipal de 6 de noviembre de 1871 AMCC. Libro 8, Sesiones municipales (1868-1871), s/f.

${ }^{98}$ CARRIÓN GUTIEZ, Manuel. “Carrión de los Condes”...Op.cit, pág. 21.

${ }^{99}$ Información remitida en la sesión de 25 de noviembre de 1877. AMCC. Libro 9, Sesiones municipales (1872-1877), s/f.
} 
perduraron durante la Restauración ${ }^{100}$. Entre las décadas de transición entre los años ochenta a los noventa, la llegada del telégrafo y la línea telefónica, el establecimiento de la imprenta, la creación de la banda municipal, la construcción del hospital municipal, la plaza de toros, el casino y la protectora, germen del actual teatro municipal, revitalizó sensiblemente a Carrión ${ }^{101}$. Por entonces continuaba siendo una villa de cierto prestigio, pues cuando Alfonso XII murió en 1885, Carrión celebró sus funerales en la iglesia de Santa María.

Siendo regente María Cristina por la minoría de edad de Alfonso XIII, la villa condal tuvo el privilegio de ser elegida para instalar la Audiencia Provincial de Palencia en el consistorio con motivo de una huelga de abogados en la ciudad palentina en 1893. El júbilo duró poco, pues ese mismo año se promulgó la supresión de los juzgados de primera instancia. Debido al aumento de la población y el auge de la industria, aunque lejos ya del esplendor que experimentó en los siglos precedentes, María Cristina, en nombre del futuro Alfonso XIII, expidió en 1894 un decreto por el cual Carrión recuperó el título de "Muy noble y leal villa" que llevaba solicitando desde $1887^{102}$. El decreto concedido por la reina regente se hace público el 26 de diciembre de 1899, y por el mismo conceder a su regidor el tratamiento de "Ilustrísima ${ }^{103,}$.

En lo que a la estructura social de Carrión se refiere, la pérdida progresiva de poder de la nobleza y la supresión de gran parte de las órdenes religiosas a lo largo del siglo XIX, propició la supresión de los estamentos privilegiados y por tanto, una repartición equitativa de las tierras entre los carrioneses. Desaparecido casi

\footnotetext{
${ }^{100}$ Esta época viene caracterizada por el caciquismo y fraude electoral. GARCIA TORRELLAS, Julián. "Reflejo social, económico y político de Palencia durante la Restauración (1875-1923) en Historia de Palencia, 2. Palencia, 1990, pp. 212-216.

${ }^{101}$ La banda de música pasó a denominarse banda municipal en 1881. AMCC. Libro de Ordenanzas municipales de 187? y otros reglamentos. Archivo Sección 1-2 B, Legajo 10, Carpeta, 2, s/f. El casino fue creado en 1883, al sur de la plaza mayor y desapareció en 1895. La línea telefónica llegó en 1890. AMCC. Libro 13, Sesiones municipales (1887-1892). Sesión de 30 de mayo de 1890, s/f. El establecimiento de la estación de telégrafos se planteó en 1878 pero no llegó hasta 1904. AMC, Libro 9, Sesiones municipales (1872-1878).Sesión de 13 de enero de 1878, s/f. Respecto al hospital municipal, fue concluido en 1884 junto al convento de San Francisco y la protectora data de 1894. RAMÍREZ DE HELGUERA, Martín. El libro...Op.cit, pp. 142,201, 202.

${ }^{102}$ AMCC. Libro 13, Sesiones municipales (1887-1892), Sesión de 29 de julio de 1887, fol 32 (solicitud al gobernador civil de Palencia) y Libro 14, Sesiones municipales (1892-1896). Sesión de 27 de noviembre de 1894, fol 92 (concesión del título).

103 AMCC. Copia de la hoja del periódico "el Carrionés" publicado el 4 de enero de 1900 en la primera pág.ina de las sesiones correspondientes al año 1900 y referido en la sesión municipal de 5 de enero de dicho año. Libro 16. Sesiones municipales (1899-1900).
} 
íntegramente el clero regular, las desavenencias entre los miembros del clero secular persistieron, e incluso se intensificaron con la designación de la parroquialidad única en 1894 , continuándose hasta nuestros días ${ }^{104}$.

Con la llegada del siglo XX, las ferias anuales, las antiguas tenerías y los tejidos de lana, quedan suprimidos, si bien continúa el mercado semanal, todos los jueves en la plaza de Santa María. Como no podía ser de otro modo, prevalece la tradición ganadera y agrícola, apoyada por la Cooperativa Agrícola Regional, la única de las tres agrupaciones que existían anteriormente, aunque con menos jornaleros y mayor número de propietarios ${ }^{105}$. La enseñanza se vio impulsada con la creación en 1900 del colegio de Maristas de San Antonio y, ha terminado por ser pública al fundarse un colegio nacional en el antiguo solar de Santa Isabel y un Instituto en la zona de la ermita de la Piedad. Nada más relevante acontece en el plano económico y social en este villa media castellana, que ronda hoy día, los dos mil trescientos habitantes.

\footnotetext{
${ }^{104}$ Abordaremos este tema al referirnos a la evolución del patrimonio carrionés.

${ }^{105}$ Sobre este tema MARTÍNEZ FERNÁNDEZ, Mateo. "Las aportaciones: técnica financiera de las cooperativas agrícolas de Tierra de Campos (1917-1936)" en El pasado histórico de Castilla y León. Actas del I Congreso de Historia de Castilla y León celebrado en Valladolid, del 1 al 4 de diciembre de 1982, vol. 3. Valladolid, 1983, pp. 215-226.
} 
2. PANORAMA ARTÍSTICO 


\section{PANORAMA ARTÍSTICO}

\subsection{EL PATRONAZGO}

Las obras de arte y los edificios de carácter religioso que llegaron a existir en Carrión, fueron posibles gracias al patrocinio de diversos sectores de la población, pertenecientes tanto al clero -entre ellas, los parroquias, el clero regular y el Obispado- como al sector civil -las cofradías y la nobleza-.

La puesta en marcha de una obra arquitectónica o el encargo de una escultura, una pintura o un retablo, respondía normalmente a una cuestión de índole pragmática, la de satisfacer las necesidades generadas por el culto, además de una preocupación estética, la de adecentar y embellecer el lugar para el que están destinadas. Sin embargo, en algunos casos, como el del alto clero o la nobleza, observamos que el mecenazgo, aparte de responder a una práctica devota, tiene como objetivos primordiales la perpetuación de la memoria, la ostentación del poder y sobre todo, la salvación eterna de sus protagonistas a través de una relación directa con la divinidad y la devoción manifiesta a la misma. La privilegiada situación de la que gozaron ambos estamentos les permitió adquirir la posesión de capillas propias donde fundar capellanías, memorias y obras pías traducidas en suculentas dádivas destinadas a diversos destinos. Las más usuales eran la práctica de misas, el mantenimiento de los espacios de culto, la dotación de doncellas o la alimentación de pobres y huérfanos, actos de piedad mediante los cuales los fieles creían asegurarse su sino celestial en el más allá.

\section{EL CLERO}

Como observamos con anterioridad, en el período que abarca la Edad Moderna, el clero regular, con el monasterio de San Zoilo y el convento de Santa Clara a la cabeza, se constituyeron como los centros religiosos más poderosos de Carrión y por extensión de toda la provincia. Sin duda, el señorío clerical obtuvo 
pingües beneficios procedentes de sus posesiones y exenciones, muy superiores, como sucedió en otras villas castellanas, a las del señorío laico ${ }^{106}$. Este hecho motivaría que se erigiesen en los principales comitentes de obras durante este período, con la ventaja que suponía la autonomía de las órdenes religiosas respecto al clero secular para tomar la iniciativa a la hora de acometer empresas de índole artística.

Las iglesias, en cambio, estaban aquejadas de ciertas restricciones, emanadas, no sólo de sus limitaciones económicas, sino además de su subordinación al Obispado. Sus párrocos eran quienes, estimando necesaria y en ocasiones, de extrema urgencia, la realización de una obra concreta en sus templos, nombraban al mayordomo y clérigos en su nombre para que se encargasen de la gestión de las mismas. Para ello debían contar con la aprobación de la Diócesis de Palencia, que si las consideraba oportunas, concedía licencia para las mismas ${ }^{107}$. Dado que en la mayor parte de las ocasiones no se disponía de fondos suficientes para abordarlas, se establecían censos, se solicitaban préstamos, procediendo algunas sumas de generosas donaciones particulares. Consecuencia directa de la carestía económica de las iglesias parroquiales es el lento proceso constructivo, del que se deriva directamente el escaso sentido unitario de la mayor parte de las fábricas. Aparte de convivir espacios de la edificación primitiva con la fábrica moderna en un mismo templo, como es el caso de de Santa María -donde las naves románicas preceden a la capilla mayor barroca-, también observamos una evolución en las cubiertas respecto a la nave, como así constatamos en San Andrés, por citar algún ejemplo, donde las bóvedas de arista apean sobre pilares cilíndricos. Este fenómeno, lejos de ser focal, se hace extensible a todo el ámbito rural palentino ${ }^{108}$.

\footnotetext{
${ }^{106}$ En el Catastro de la Enseñada, tomando cien localidades de Tierra de Campos, se muestra cómo los monasterios y cabildos acaparaban un tercio del total de las propiedades, es decir, aproximadamente un $15 \%$ de la producción agraria, sin contar el diezmo y otros derechos, que aumentarían esta cifra al 30\%. YUN CASALILLA, Bartolomé. "Aristocracia, señorío y crecimiento económico en Castilla. Algunas reflexiones a partir de los Pimentel y los Enríquez (siglos XVI y XVII)" en Revista de Historia Económica, n³, 1985, pp. 443-444.

107 Tenemos constancia de licencias en la construcción de San Andrés en 1594. AHPP. Carr.Prot 5673. Andrés Sánchez (1594), s/f.

${ }^{108}$ ZALAMA, Miguel Ángel. La arquitectura del siglo XVI en la provincia de Palencia. Diputación Provincial de Palencia, 1990, pág. 29.
} 
El tercer sector del clero que, si bien con un alcance minoritario, promovió ciertas obras en Carrión fueron algunos obispos a título personal. La obra cumbre la constituye la reconstrucción de la capilla mayor de la iglesia de Santa María, promovida por el Obispo de Palencia y fraile franciscano de dicha ciudad, Fray Juan del Molino Navarrete en 1682, aunque no falleció hasta 1685. La sustitución de la capilla románica por la actual barroca fue encomendada al arquitecto Felipe Berrojo, quien también se encargaría de concertar la ejecución de los monumentos funerarios del finado y de sus progenitores, rindiéndoles homenaje eternamente por el cariño que les profesaba. Incluso, aunque el retablo de la capilla mayor era de factura reciente, concretamente de 1648, proveyó la ejecución de uno nuevo, y acorde al gusto del momento, ejecutado por Santiago Carnicero. Mucho más discreto fue el arcosolio funerario del Obispo de Guadix y prior de Aroche, don Melchor Álvarez de Vozmediano, fechado en 1636, coetáneo a su óbito. La iglesia de San Andrés, en su muro de la Epístola, acoge el monumento pétreo del religioso, espacio que otrora se hallaba bajo la advocación de Nuestra Señora de las Velaciones. La remembranza de su patronazgo se reseña en sus armas, que campean sobre su sepulcro y en el retablo dedicado hoy día a San José. El pincel del vallisoletano Ramón Canedo, dejó un retrato del prelado conservado hoy día en el Salón de plenos del consistorio. En la abadía de Benevívere aún se conserva un testimonio gráfico en forma de escudo, que prueba la protección del linaje Sarmiento y más concretamente de uno de sus más ilustres miembros, el Obispo de Palencia, de Tuy, Badajoz y cardenal de Santiago de Compostela, don Pedro Ruiz Sarmiento. Gracias a su intervención fue posible la cesión de la iglesia de San Pedro para la fundación del convento de Santo Domingo de Carrión en 1527. Si bien falleció en Luca en 1541, sus restos fueron trasladados a la casa agustina, depositándose en un magnífico sepulcro con estatua genuflexa, según describían los miembros de la Comisión de Monumentos de Palencia, cuando aún se conservaba, al igual que otros enterramientos que ornaron su espléndida sala capitular, oculto entre la vegetación.

\section{LAS COFRADÍAS}

En todos los templos carrioneses existieron un sinfín de capillas patrocinadas en algunos casos por cofradías, cuyos miembros depositaban su confianza en el 
mayordomo, quien se encargaba, entre otros asuntos, de establecer los contratos con los artífices que intervendrían en la mejora de las mismas. En Carrión proliferaron un gran número de ellas, cuya creación se origina a lo largo del siglo XVI y su punto álgido se produjo en las dos centurias posteriores. Cada templo contaba, al menos, con una hermandad situada bajo la advocación homónima. Las de mayor arraigo en la villa condal fueron la del Santísimo Sacramento, establecida en los templos de Nuestra Señora de Belén, Santa María, San Andrés y San Juan del Mercado y la de “Las Ánimas del Purgatorio”, representativa de los templos anteriores, salvo Belén, asentándose además en Santiago. A este listado se suman otras, como "San Antonio", "Las Brígidas" y "San Justo" de San Andrés, "Nuestra Señora de la Paz” y "San Antonio Abad”, de San Juan del Mercado, "Santo Tomás” en Santiago y "El Santo Cristo del Amparo” o "Los Veinte Clérigos”, originalmente "Los Veinticinco Clérigos", en Santa María ${ }^{109}$. De todas ellas, ésta última merece especial atención, pues además de encargarse de la obra pía del clérigo Antonio Pastor en la iglesia de Santa María, fueron patrones de la de don Gonzalo Gallo, fundador del Hospital de San Miguel, en adelante convento de Santa Isabel.

Este tipo de hermandades también hallaron cabida en las ermitas, de ahí que existieran las de San Cristóbal, Nuestra Señora de la Piedad, San Juan de Cestillos y la "Vera Cruz", la más antigua de la villa, y la única que, paradójicamente subsiste de todas ellas, al cargo de las procesiones de Semana Santa. Remonta sus orígenes a finales del siglo XV, cuando por entonces se hallaba vinculada al convento de San Francisco, hasta que erigió una sede independiente en la centuria siguiente ${ }^{110}$. En efecto, el asentamiento de cofradías en conventos de órdenes mendicantes resulta muy frecuente, para lo cual, el síndico respectivo debía obtener la autorización del Ministro de la Provincia. Tras la Vera Cruz, una de las cofradías más antiguas de la casa terciaria, fue "la Concepción” fundada en 1524, cuando Carlos V emitió una cédula real por la que “...en todas las villas y lugares de sus reinos y señoríos...”

\footnotetext{
${ }^{109}$ A este respecto, véase Archivo Diocesano de Palencia. Libros de Cofradías de cada templo.

${ }^{110}$ En Palencia, la vinculación de las cofradías de la Vera Cruz a las órdenes mendicantes era usual. Estos y otros datos proceden de un interesante estudio acerca de estos lugares de culto. PÉREZ DE CASTRO, Ramón. "Manifestaciones artísticas de la Cofradía de la Vera Cruz en Palencia: Palacios, Casas de la Cruz, Ermitas y Humilladeros" en IV Congreso Internacional de Hermandades y Cofradías de la Santa Vera Cruz. Zamora, 2008, pp. 283-339.
} 
debía establecerse una bajo dicha advocación ${ }^{111}$. Pese a que la declaración del dogma de la Inmaculada Concepción no llegará hasta mucho tiempo después, su devoción y protección fue promovida desde sus orígenes por los franciscanos ${ }^{112}$. Posteriormente, en 1751, el gremio de los Sastres estableció su cofradía en la capilla de San Antonio ${ }^{113}$. Por su parte, en el convento de Santo Domingo, fueron fundadas durante el siglo XVII las cofradías del Dulce Nombre de Jesús, Nuestra Señora del Rosario y San Pedro y San Ildefonso, siendo trasladadas las dos primeras a la iglesia de San Andrés con la Desamortización.

\section{LA NOBLEZA: LINAJES DESTACADOS}

Constituyendo una minoría las mencionadas cofradías, la nobleza se erige en el mecenas primordial para el mantenimiento de los espacios de culto. Desde principios del siglo XV se hallaba asentada en Carrión una clase social media, emancipada de la nobleza y vinculada con la Corona en calidad de vasallaje. Asistimos al surgimiento de una nueva burguesía a quienes los pecheros pagaban tributos, que paulatinamente van subiendo escalafones en la sociedad ${ }^{114}$.

Si bien la mayor parte de los monumentos carrioneses remontan su origen al medievo, no es menos cierto que a lo largo del siglo XVI se llevan a cabo renovaciones íntegras de muchos de ellos, además de efectuarse nuevas fundaciones religiosas. Las causas de esta prolífica actividad se hallan en íntima relación con la óptima situación que se vivía en la capital palentina. Como sede del Obispado y sin competencia aún con Valladolid, la ciudad del Carrión y sus provincias más destacadas fueron sede de un pujante mecenazgo que posibilitó una ingente cantidad de encargos artísticos. Así, en Dueñas, diversos miembros del linaje de los Acuña, condes de Buendía, patrocinaron las obras de la capilla mayor de Santa María, de su hospital o del convento de San Agustín. Por citar otros ejemplos, en Paredes de

\footnotetext{
${ }^{111}$ Informaciones diversas sobre fundaciones y misas. ADP. Religiosos. Franciscanos (1616-1774), s/f.

${ }^{112}$ Sobre este tema, véase STRATTON, Suzanne. La Inmaculada Concepción en el arte español. Madrid, 1988.

${ }^{113}$ Permiso otorgado el 23 de julio de 1751. AHPP. Carr.Prot 5885. Manuel Vega (1749-1751), fol 125 y ss.

${ }^{114}$ FRANCIA LORENZO, Santiago. Gentes de estas tierras. Notas de Archivo, 2. Palencia, 1987, pág. 41
} 
Nava se asentaron los Manrique, en Ampudia gozaron de gran prestigio los Ayala ${ }^{115}$ y desde el siglo XV, estuvo bajo el dominio de los Sandoval y Rojas, condes de la villa y duques de Lerma. Más al norte, Aguilar de Campoo fue señorío de los marqueses de Aguilar, en cuya iglesia de San Miguel dispusieron su enterramiento don Luis Fernández Manrique y su mujer, doña Ana de Aragón ${ }^{116}$.

Carrión, dada su relevancia histórica y su estratégica situación en el centro de la provincia, fue testigo del asentamiento de un sector importante de la nobleza castellana y de la pervivencia de otras familias cuyas generaciones continuaron residiendo en la villa condal, a los cuales debemos el patrocinio de numerosas obras. Si bien el origen y punto álgido de la institución señorial remite directamente a las centurias medievales, no debemos desdeñar el impulso de la nobleza en la Edad Moderna. En Carrión gozaron de gran prestigio, los marqueses de Aguilar, cuyo foco neurálgico se hallaba situado en Aguilar de Campoo desde la creación de su señorío en $1339^{117}$. La categoría de Marquesado fue otorgada por los Reyes Católicos en 1484 hasta su extinción en 1662, figurando posteriormente integrados en el marquesado de Villena ${ }^{118}$. Sin embargo también contaban con viviendas en Carrión, pues a ellos pertenecía la casa del Águila, ubicada frente a la iglesia de Santa María, así denominada por la forma del escudo que preside la fachada. Al menos desde el siglo XV adquirieron el patronazgo de la capilla mayor del convento de San Francisco, cuyos miembros se vieron envueltos en diversos litigios por el descuido de la misma. También el convento de Santa Clara gozó de su protección, pues las armerías de este linaje, junto a las de los condes de Osorno y Castañeda, campean en los escudos de los Manrique de Lara, que ostentaron todos estos títulos ${ }^{119}$.

\footnotetext{
${ }^{115}$ LUENGAS OTAOLA, Vicente Francisco. "Tierra de Ayala: cómo la Casa de Ayala perdió el Señorío de Ayala y Mayorazgo de Ampudia" en Boletín de la Real Sociedad Vascongada de Amigos del País, tomo 46, nº 1-2, 1990, pp. 155-174.

${ }^{116}$ MARTín GONZÁLEZ, Juan José. "Arte y territorio en la provincia de Palencia durante el siglo XVI" en AIIICHP, nº 4. Diputación Provincial. Palencia, 1995, pp. 406-412.

${ }^{117}$ HUIDROBO Y SERNA, Luciano. "Breve historia de la muy noble villa de Aguilar de Campoo" en AIICHP, tomo 3. Palencia, 1989, pp. 64-67 y PALENCIA HERREJÓN, Juan Ramón. "Fundación y consolidación del Marquesado de Aguilar de Campoo a través de los pleitos de Garci Fernández Manrique (140-1499) en AIICHP, tomo 2. Palencia, 1995, pp. 787-794.

${ }^{118}$ ABAD MARTÍN, Ángel Santos. "Los señoríos en la montaña palentina: El marquesado de Aguilar" en Actas del III Congreso de Historia de Palencia, vol. 2. Palencia, 1995, pp. 527-550.

${ }^{119}$ Sobre los Manrique, consúltese MONTERO TEJADA, Rosa María. Nobleza y sociedad en Castilla: el linaje Manrique (siglos XIV - XVI). Caja Madrid. Madrid, 1996.
} 
Los Mendoza, sobradamente conocidos en Castilla, constituyen otro de los linajes con fuerte presencia en Carrión, a través de algunas ramas procedentes del tronco común de la familia principal. El referente primordial es don Íñigo López de Mendoza, nombrado en 1445 Marqués de Santillana, por la ayuda prestada a la corona $^{120}$, cuya casa conserva su escudo en la calle de la Rúa. En el convento de San Francisco, poseían, desde al menos el siglo XV, la capilla del Infantazgo, colateral del lado del Evangelio ${ }^{121}$. La predilección de los Mendoza por las órdenes mendicantes explica que también adquiriesen el patronazgo de la capilla de la Piedad en el cenobio dominico ${ }^{122}$. Don Luis Hurtado de Mendoza, hermano del conde de Castro funda en 1492 el hospital de Nuestra Señora de la $\mathrm{O}^{123}$, próximo al monasterio de San Zoilo donde desempeñaría el cargo de abad comendatario al sustituir a Pedro González de Mendoza ${ }^{124}$. También fue mayorazgo de los Mendoza la casa del Águila, pues perteneció al virrey de Nueva España don Luis de Velasco Mendoza y a sus sucesores ${ }^{125}$. En la entrada de la capilla colateral de la Epístola de la iglesia de Santa María, uno de los cuartelados del escudo de don Antonio de Paz de la Serna es el de los Mendoza, que constituía su ascendente genealógico y daba de este modo prestancia a sus armas cuando en 1620 ordena introducirlas por las obras ejecutadas $^{126}$. La impronta de este linaje se mantiene en el siglo XVIII, por ejemplo en el tercer cuartelado del escudo del retablo mayor de la iglesia de San

${ }^{120}$ Sobre este noble literato, véase PÉREZ BUSTAMANTE, Rogelio. El marqués de Santillana: biografía y documentación. Fundación Santillana. Santillana del Mar, 1983 y SUÁREZ FERNÁNDEZ, Luis. El Marqués de Santillana (1398-1458): los albores de la España Moderna. 4 volúmenes. Nerea. Guipúzcoa, 2001.

${ }^{121}$ RAMÍREZ DE HELGUERA, Martín. El libro...Op.cit, pp. 178-179 y también en PERAL VILLAFRUELA, Santiago. "San Francisco de Carrión de los Condes (siglos XIII-XIX). Aproximación al conocimiento de un convento de menores en la Diócesis de Palencia" en Archivo Ibero-Americano: Revista franciscana de estudios históricos. no 262-263. LXIX. Enero-Agosto 2009, pp. 294-295.

${ }^{122}$ AHPP. Carr.Prot 5655. Pedro Saldaña (1596), s/f.

${ }^{123}$ YEPES, Fray Antonio. Crónica General de San Benito. vol 3, pág. 73. No se debe confundir con su contemporáneo, don Luis Hurtado de Mendoza y Pacheco, 1489- Mondéjar, 19 de diciembre de 1566), tercer conde de Tendilla y segundo marqués de Mondéjar, hijo de Iñigo López de Mendoza y Figueroa.

${ }^{124}$ VV.AA. Diccionario de historia eclesiástica de España. II. Instituto Enríquez Flórez. Madrid, 1972, pp. 1036-1038.

125 SARABIA VIEJO, María Justina. Don Luis de Velasco: virrey de Nueva España: 1550-1564. Escuela de Estudios Hispano-Americanos. Sevilla, 1978, pp. 2,3. Otro estudio monográfico en RUBIO MAÑÉ, Jorge. Don Luis de Velasco, el virrey popular. México, 1946.

${ }^{126}$ AHPP. Carr.Prot 4820. Francisco Cuetos (1619), fol 150 y ss. 
Julián, promovido por Manuel de Berrio, cuya presencia es debida a que era hijo de doña Josefa de Colmenares y Mendoza ${ }^{127}$.

Los Herrera Calderón también gozaron de espacios privilegiados en Carrión desde el siglo XVI y su recuerdo aún pervive en los escudos conservados en la capilla del Cristo del Amparo de la iglesia de Santa María y en la capilla del Dulce Nombre de Jesús de la iglesia de Santiago, ambas en el lado del Evangelio, próximas a la capilla mayor. Bajo esta última advocación también poseyeron un espacio de culto en el extinguido convento de Santo Domingo. En San Francisco no tenemos constancia de que llegaran a disponer enterramientos; sí observamos, en cambio, un interés y devoción por la protección de los terciarios, pues el caballero de la orden de Alcántara, don Rodrigo de Herrera y Rojas les traspasó su herencia en $1662^{128}$. Una casa solariega donde residieron algunos de los miembros de los Calderón unidos al mayorazgo de los Ayala, se situaba en la plazuela de Belén, junto a la cabecera de San Andrés. El alfiz que perfila el arco señala una datación en el siglo XV y la pervivencia de este linaje en la villa está constatada hasta finales del siglo XIX en que el edificio funciona como cuartel ${ }^{129}$.

Otro destacado linaje, con presencia destacada en la villa condal, fue el de los Enríquez Cisneros. Surgido en el siglo XIV con don Pedro Enríquez, esposo de doña Mencía de Cisneros, fundadores de la capilla de Santa Ana, una de las colaterales de la capilla mayor en el convento de San Francisco. Don Pedro Enríquez Cisneros, primer señor de Camporredondo, era el primogénito de los diez hijos extramatrimoniales que tuvo el poderoso Conde Don Tello, señor de Aguilar, Lara, Vizcaya y Castañeda. Seguramente su devoción franciscana le vino precisamente de su padre, quién se enterró en la iglesia de San Francisco de Palencia ${ }^{130}$. Desde entonces los sucesivos patronos de esta capilla adoptarán el título de señores de

\footnotetext{
${ }^{127}$ VIGURI, Miguel de. Heráldica palentina. volumen 2. Palencia, 2005, Árbol genealógico, pp. 7172.

${ }^{128}$ AHPP. Carr.Prot 5696. Norberto de Sandoval y Guevara (1662), fol 590 y ss.

${ }^{129}$ AMCC. Libro 14, Sesiones municipales (1892-1896), Sesión de 10 de mayo de 1895, fol 24v.

${ }^{130}$ Don Tello (1337-1370) poseía los títulos mencionados porque estaba esposado con Juana Núñez de Lara. Recibió el señorío de Aguilar gracias a su padre Alfonso XI y el de Castañeda por su hermano Enrique II, de ahí el apellido Enríquez que don Pedro heredó. Su sepulcro no fue descubierto hasta 1978, lo que arrojó datos esclarecedores sobre la heráldica familiar. RIVERO SIERRA, Borja del. "Heráldica de los Enríquez de Cisneros en Cantabria" en Ascagen. Revista de la Asociación Cántabra de Genealogía, nº 1 . Santander, 2009, pp. 55-56.
} 
Camporredondo, y el apellido Enríquez en recuerdo de su descendencia del linaje real. El último patrón conocido de la misma es don Francisco Enríquez Calderón, a quien el síndico del convento conmina en 1789 al reparo de su capilla, a lo que se niega en rotundo dadas las sumas donadas una décadas atrás. Nuevamente se observa la devoción de este linaje por las órdenes terciarias, pues don Francisco era patrón de la capilla de los Santos Reyes de San Francisco de Segovia.

Menos célebre en Carrión, aunque consolidado firmemente fue la casa de los Berrio Colmenares, linaje que emerge en tierras vascas a mediados del siglo $\mathrm{XIV}^{131}$. Su presencia se constata a partir de mediados del siglo $\mathrm{XV}$, cuando don Hernán García Pachistre, camarero de la esposa del rey Juan II, funda la iglesia de Nuestra Señora de las Capillas, junto al templo de Santiago ${ }^{132}$. Este lugar será el enterramiento escogido por los Berrio hasta 1794 en que fue demolido. No obstante, uno de sus miembros más destacados, el maese de campo y regidor perpetuo de Panamá, don Hernando de Berrio y Ribera Colmenares, no descansará en esta ermita a pesar de que en su testamento, dictado en 1598 era su opción preferente. Su voluntad de ampliar el espacio y disponer coro y sacristía fue determinante para que su testamentario, don Antonio de Berrio, descartase Nuestra Señora de las Capillas y optase por edificar el actual templo de San Julián, cuya erección no tendrá lugar hasta 1623. Poseía unas casas cerca de la iglesia de Santa María, pues en 1630, su hijo, don Manuel de Berrio, encarga su reparación al trasmerano Domingo de la Maza, indicando que se ubican linderas a la calle de Padierno ${ }^{133}$.

En la iglesia de San Andrés, los Berrio también estuvieron presentes desde principios del siglo XVI a través del patronazgo de la antigua capilla de la Magdalena, también denominada de "libranos de penis inferni", fundada por un miembro cuyo nombre desconocemos de la familia Alarcón, que se esposó con Doña María de Berrio, quien adquirió el patronato al sobrevivirle unos años. Ambos linajes -Berrio y Alarcón se fundieron y pervivieron, al menos, según nos consta documentalmente, hasta finales del siglo XVIII, en que este espacio de culto

\footnotetext{
${ }^{131}$ TORAL PEÑARANDA, Enrique. Los Berrio y sus enlaces. Diputación Provincial de Jaén, 2000, pág. 9.

${ }^{132}$ VIGURI, Miguel de. Heráldica... 2. Op.cit, pág. 62, a su vez de AHPP. Carr.Prot 5446. Gregorio Movilla (1574-1576), s/f.

${ }^{133}$ AHPP. Carr.Prot 4856. Juan Díaz Pajaza (1630), s/f.
} 
figuraba bajo la protección de Manuela Antonia de Berrio y Ribera, que testó en 1788, extinguiéndose el linaje Berrio en su persona, pues los hijos de sus hermanos varones no tuvieron descendencia. Su matrimonio con Juan de Vozmediano, señor de Calzadilla y Bustocirio, posibilitó el acceso de esta casa a la posesión de San Julián y de la capilla de San Andrés, continuándose la línea generacional por el matrimonio de su hija Josefa de Vozmediano y Berrio con Juan Teijeiro, entroncando así, con los marqueses de Villasante, con presencia en Carrión hasta mediados del siglo $\mathrm{XIX}^{134}$.

Los Vozmediano, por su parte, se vinculan a Carrión desde, al menos, mediados del siglo XV, en que don Mosén Rodrigo de Vozmediano figura como patrón de la capilla de la Resurrección del convento de San Francisco, ubicada a los pies del templo ${ }^{135}$. Desde principios del siglo XVII los Vozmediano, en la figura de don Pedro Barba, adquieren la tutela del hospital desaparecido de don Gonzalo o la Herrada, a las afueras de Carrión, dado su enlace en 1612 con María Ortega de Velasco, última de su linaje al cual se debe la fundación de obras pías en el mismo desde sus comienzos ${ }^{136}$. Con su fallecimiento, adquiere simultáneamente la posesión de la capilla de Santa Catalina o de la Concepción, ubicada precisamente junto a la mencionada de la Resurrección.

Sabemos que en el siglo XVII poseían varias casas en la plaza de Santiago, actual plaza mayor, cuando en 1668 se inventarían los bienes de Don Juan Barba de Vozmediano, señor de Calzadilla y Bustocirio. Fueron necesarios cinco días para contabilizar todos los enseres, de lo que colegimos su acomodada situación económica $^{137}$.

Por sus lazos de consanguineidad de algunos de sus miembros con el célebre San Ignacio de Loyola, merecen mención los Díez. El primer testimonio de su presencia en Carrión es la fundación de la capilla de San Gregorio en la iglesia de Nuestra Señora de Belén por parte del doctor en teología y canónigo de Alcalá de

\footnotetext{
${ }^{134}$ Véase cuadro genealógico en VIGURI, Miguel de. Heráldica...2. Op.cit, pp. 71-72.

135 Así se indica en el inventario de los bienes de Don Juan Barba de Vozmediano, entre cuyos papeles figura la escritura de traspaso de esta capilla a dicho fundador. AHPP. Carr.Prot 5713, Norberto Sandoval y Guevara (1668), fol 1137 y ss.

${ }^{136}$ AHPP. Carr.Prot 5018, Agustín García Miranda (1696-2698), s/f.

${ }^{137}$ AHPP. Carr.Prot 5713. Norberto Sandoval y Guevara (1668), fol 1174 y ss.
} 
Henares, don Fernando Díez, cuyo sepulcro, levantado en 1556, preside el muro norte de este espacio. El enlace de su hermano, Julián Díez con doña María de Loyola, posibilitó la fusión de las dos casas en la figura de su primogénito don Juan Díez de Loyola, cuyo grado de parentesco con el santo vasco, le correspondía por vía materna, siendo probable que doña María fuese su prima carnal o segunda ${ }^{138}$. La heráldica de los Díez está presente en una vivienda con balcón esquinado de la actual calle de José Antonio Girón, en las que se mezclan con las de los Monroy, pues pertenecieron a don Ignacio Díez de Monroy, patrón desde al menos 1615 de la capilla que, bajo la triple advocación de la Virgen del Pópolo, Santa Brígida y San Juan se situaba en el brazo norte del crucero, en el templo de San Francisco. Sus armas figuran en la vivienda con balcón esquinado situada en la calle de don José Antonio Girón, lo que señala la residencia de los Díez en Carrión. Con el paso del tiempo, el vínculo es traspasado a mediados del siglo XVII a los Serna, marqueses de Villasinda y posteriormente los condes de San Rafael hasta mediados del siglo $\mathrm{XIX}^{139}$.

Los Ponce de León se asientan en Carrión a lo largo del siglo XVI. Se trata de una estirpe andaluza de ilustre abolengo, dado que sus miembros descendían de Pedro Ponce, alférez mayor de Alfonso IX de Castilla, y de su mujer Aldonza Alonso, hija del monarca. Si bien, la mayor parte de su hacienda abarca las provincias de Sevilla, eminentemente, Málaga y Cádiz, en menor medida, algunos de sus miembros tuvieron cierta presencia en territorio palentino ${ }^{140}$. Los descendientes masculinos del linaje lograron su ascenso social conjugando la vida laica y religiosa. Sin ir más lejos, los primeros patrones conocidos de la capilla mayor de la iglesia de Santiago, fueron los canónigos Sebastián y Gaspar Ponce de León, quienes, además de desempeñar el cargo de maestreescuelas, detentaron la canonjía de Sevilla. Asimismo, Don Gaspar llegó a ocupar la de Palencia.

\footnotetext{
${ }^{138}$ FERNÁNDEZ MARTÍN, Luis. "Voces de dentro y de fuera: Familiares de San Ignacio de Loyola en tierras palentinas" en PITTM, n Palencia, 1984, pp. 351-364.

${ }^{139}$ VIGURI, Miguel de. Heráldica...2. Op.cit, pág. 60.Véase el árbol genealógico en pág. 60.

${ }^{140}$ CARRIAZO RUBIO, Juan Luis. "Dos siglos de estudios sobre los Ponce de León: historiografía de un linaje medieval" en Historia, instituciones, documentos, n²9, 2002, pp. 9-11. Sobre este linaje y su ascendencia, véase del mismo autor La memoria del linaje: los Ponce de León y sus antepasados a fines de la Edad Media. Universidad de Marchena. Sevilla, 2002, sobre todo pp. 21-64.
} 
Algunos de sus miembros también participaron en la vida política de la villa, ocupando regidurías ${ }^{141}$. Adquirieron unas viviendas ubicadas muy próximas al templo de Santiago, en su lado meridional, separadas del mismo por la ermita de Nuestra Señora de las Capillas. De este modo podían atender las necesidades derivadas del mantenimiento del espacio de culto con total inmediatez. Sin embargo, los Ponce no mostraron análoga disposición y entrega para la atención de la capilla de San Antolín que poseían en la iglesia de San Andrés, tal vez por tratarse de un espacio mucho más modesto ${ }^{142}$. A mediados del siglo XVII, concretamente en 1642, con la transmisión del mayorazgo que don Manuel Ponce de León a su primo, Manuel de Berrio, ambos linajes vinculan su pertenencia a la capilla, hasta las postrimerías del siglo XVIII.

Los Paz de la Serna poseían desde 1512 un lugar privilegiado dentro de la iglesia de Santa María: la capilla de San Nicolás, colateral de la capilla mayor por el lado de la Epístola. Su fundador, don Juan de Paz, quiso perpetuar su recuerdo a través de un sepulcro pétreo, trasladado a los pies del templo, erigido en 1513. Cuando en 1735 doña Lorenza Manrique y Paz contraiga matrimonio con don Francisco Jofre de Villegas, entroncará con este linaje de regidores perpetuos, que continuará con el patronato durante buena parte del siglo XIX.

Los Paces podían haber accedido al patronato de la capilla de la Piedad del convento de San Francisco. Sin embargo, uno de sus miembros, don Antonio de Paz, como hijo político de doña Lucía de la Carrera, asumió su deuda y cedió una sepultura de su propiedad para que Los Carrera pudiesen proseguir con el patronazgo, como así sucedió ${ }^{143}$. También los Paz de la Serna alcanzaron cargos de regidores en la villa, siendo sintomático de la confianza que despertaban el hecho de que algunos de sus descendientes actuaron como testamentarios, a pesar de no poseer ninguna relación de consanguineidad con el difunto Jacques de la Vega, primer patrón conocido de la capilla del Rosario del convento de Santo Domingo ${ }^{144}$.

\footnotetext{
${ }^{141}$ Así figura en el contrato para la ejecución de la casa del Capitán en 1615, que son regidores de Carrión, don Alonso Díaz de la Serna y Hernando Ponce de León. AHPP. Carr.Prot 5211, Jerónimo López (1615), s/f.

${ }^{142}$ Incluso llegaron a pleitear con el mayordomo, que les instaba a que hiciesen los reparos convenientes, hasta que la capilla se derribó. 1593 ACP. Provisorato. Legajo 5. nº449.

${ }^{143}$ AHPP. Carr.Prot 5411. Francisco Moro Saldaña (1628), s/f.

${ }^{144}$ AHPP.Carr.Prot 5410. Francisco Moro Saldaña (1627) s/f.
} 
Si bien existieron, como resulta obvio, otras muchas familias asentadas en Carrión de los Condes, las referidas con anterioridad son las que gozaron de mayor reconocimiento. El siglo XVI, constituye, como hemos podido colegir de los datos apuntados, la época dorada de la nobleza, que comienza a desvanecerse paulatinamente a lo largo de los siglos posteriores ${ }^{145}$. La prohibición expresa de sepultarse en los presbiterios según “...decrettos dados por los sumos pontífices y repetidas providencias del Triuunal eclesiástico de la ciudad de Palencia...”, a la que se refiere un documento fechado en $1783^{146}$, justifica que no poseamos referencias de titularidad de la capilla mayor a partir de ese momento, lo cual se hace extensible al resto de espacios de culto, a mediados del siglo XIX, en que asistimos al ocaso de esta arraigada clase privilegiada ${ }^{147}$.

\footnotetext{
${ }^{145}$ Ya hicimos referencia a la crisis de la aristocracia en el apartado precedente relativo a la sociedad y economía carrionesas, y la ingente bibliografía existente sobre el tema.

${ }^{146}$ La petición de sepultura en la capilla mayor por parte de don José Jofre de Villegas en la iglesia de San Andrés, refiere la prohibición mencionada. El documento data de 1783, si bien desconocemos en qué fecha comenzó a aplicarse tal decreto. AHPP. Desamortización. Legajo 104, s/f.

147 Sobre este tema, véase MOXÓ, Salvador de. La disolución del régimen señorial en España. Madrid, 1965.
} 


\subsection{LA ARQUITECTURA}

\section{INTRODUCCIÓN}

De entre las artes mayores, podemos afirmar que en Carrión, la arquitectura gozó de mayor prestigio que la escultura y la pintura durante la Edad Moderna, a tenor, no sólo, del número de edificaciones realizadas en este período sino de la concentración de artistas de cierta relevancia en la villa y su entorno. Sin duda el período de mayor auge constructivo fueron los siglos XVI y XVII, situándose Carrión a la cabeza de la provincia por detrás de Palencia, que a su vez cederá su protagonismo a Valladolid con la creación de su Obispado en $1595^{148}$.

La pervivencia de las soluciones estructurales del estilo gótico en las fábricas carrionesas renovadas en la centuria décimo sexta, resulta la tendencia generalizada extensible a todo el ámbito hispano, como manifiestan la iglesia de Nuestra Señora de Belén o el primitivo templo de San Francisco ${ }^{149}$. Conforme avanzan las décadas, se van introduciendo los nuevos planteamientos del Renacimiento, superándose paulatinamente la herencia medieval arraigada secularmente. A lo largo del siglo XVII, asistimos a la erección de edificaciones de corte clasicista, en consonancia con la moda imperante en Valladolid, foco del nuevo gusto artístico en la Meseta Norte, emanado a su vez, del Escorial ${ }^{150}$. La manifestación más pura de esta corriente se percibe en la iglesia conventual de Santa Clara, en la monasterial de San Zoilo y en el templo de San Julián. La centuria posterior, caracterizada por las intervenciones de carácter general, nos legará, no obstante, algunos guiños neoclásicos de excepción en el patio de San Zoilo, las capillas laterales de San Francisco, desafortunadamente todas ellas desaparecidas, salvo la portada en el caso

\footnotetext{
${ }^{148}$ Un estudio reciente en DELICADO BAEZA, José. Historia de la Diócesis de Valladolid. Valladolid, 2006.

${ }^{149}$ Sobre este tema, MARÍAS, Fernando. El siglo XVI: Gótico y Renacimiento. Sílex. Madrid, 1992, GÓMEZ MARTÍNEZ, Javier. El gótico español de la Edad Moderna. Bóvedas de crucería. Secretariado de Publicaciones e Intercambio Científico. Valladolid, 1998 y AÚREA DE LA MORENA, Bartolomé. "Reflexiones en torno a la arquitectura religiosa castellana en el siglo XVI" en Arquitectura religiosa del siglo XVI en España y Ultramar. Abril, 2003. Actas del Curso de la Cátedra de Goya. Institución Fernando el Católico. Zaragoza, 2004 (actas), pp. 159-188.

${ }^{150} \mathrm{Al}$ respecto, BUSTAMANTE GARCÍA. La arquitectura clasicista del foco vallisoletano (15611640). Valladolid, 1983.
} 
del cenobio benedictino, y la fachada lateral de la parroquia de San Andrés, conservada, aunque de somera ejecución.

El letargo constructivo de la centuria decimonónica y la inmediata a ésta, vendrá acompañado de intervenciones discretas consistentes en labores de reconstrucción y rehabilitación de las fábricas, despuntando excepcionalmente las reformas de San Zoilo para el asentamiento de los Padres jesuitas o la construcción de la linterna de San Andrés, una de las edificaciones más elevadas de la villa.

\section{MATERIALES}

Sucede normalmente, que los materiales utilizados en un determinado lugar para las construcciones son los que se hallan en el entorno. En Carrión, dada su ubicación en la comarca de Tierra de Campos, una gran llanura arcillosa, es comprensible que el ladrillo, el tapial o el adobe resultaran bastante recurrentes en la arquitectura popular, en la construcción de ermitas o en intervenciones concretas de refuerzo, dado su bajo coste.

Sin embargo y a pesar de su elevado precio, la arquitectura religiosa privilegiará el empleo de la piedra para sus muros, dada su resistencia y mejor apariencia. Los cantos rodados o ripios se destinan a los cimientos mientras que los paramentos van dotados de sillares labrados o un aparejo de mampostería. Tradicionalmente la piedra se extraía de "los términos de la villa 151 ”, notablemente de las canteras de la Pedrería, en Villasirga, que sería utilizada, por ejemplo en la fábrica del puente y de la iglesia de San Andrés ${ }^{152}$. En ciertas ocasiones, para lugares precisos como portadas, zócalos, esquinas o aquellos que se determinase, se precisaba la adquisición de piedra procedente de Palacios del Alcor, cuyas canteras se ubicaban en Astudillo, a una treintena de kilómetros al suroeste de Carrión. La relativa cercanía del lugar posibilitó su empleo en prácticamente todas las fábricas carrionesas. De manera excepcional, cuando el comitente así lo solicitaba, los carros de piedra eran transportados desde Villaescusa, localidad cántabra ubicada a unos

\footnotetext{
${ }^{151}$ AHPP. Carr.Prot 5161. Jerónimo Laso (1616), s/f.

152 AHPP. Carr.Prot 4842. Juan Díaz Pajaza (1615), fol 399 y ss.
} 
175 kilómetros de nuestra villa condal, lo que encarecía significativamente la suma total de la obra ${ }^{153}$.

Respecto a la madera, dada la deforestación de la comarca, tampoco abundaba este material pero resultaba imprescindible en las cubiertas, para situarlas sobre las bóvedas, de modo que aunque las armaduras no iban a ser vistas, se procuraba que fuesen de buena calidad para que perdurasen. Solía importarse de la comarca de Pinares, un territorio fuertemente accidentado que acoge dos provincias castellanas, pues se extiende entre el noroeste de Soria y al sureste de Burgos, formando parte de las Sierras de Urbión y de la Demanda. La madera de pino se extraía sobre todo de los municipios de Quintanar de la Sierra o Canicosa de la Sierra, dos de los veintidós municipios que integraban esta área, lo cual ha permitido una pujante economía basada principalmente en la explotación forestal y en la transformación de la madera. Estos pueblos de Pinares pertenecían a la Real Cabaña de Carreteros, corporación económica creada en 1497 para el transporte de mercancías en tierra destinada al abastecimiento de clientela privada y de la Corona. La institución, que se agrupaba por hermandades y estaba sostenida por una jurisdicción específica desde finales del siglo XVI, vio su triste final con la llegada de la desamortización de $1836^{154}$.

En la mayor parte de los casos, los materiales eran proporcionados por el mayordomo del templo, excepto las sogas y el agua necesaria, que lo suministraba el maestro a cargo de la obra ${ }^{155}$. Cuando los materiales debía ponerlos el artífice de la

\footnotetext{
${ }^{153}$ En el primer proyecto del templo de San Andrés, Rodrigo Gil de Hontañón precisaba la utilización de piedra de Villaescusa en los cascos de las bóvedas y en los capiteles de los soportes. ZALAMA, Miguel Ángel. "Documentos de Historia del Arte en Palencia, 1. Arquitectos y edificios del siglo XVI" en PITTM, n 66. Diputación Provincial. Palencia, 1995, pp. 252-256, a su vez de AHPP. Carr.Prot 5663, Andrés Sánchez (1562-1564), s/f. El extinto convento de Santo Domingo poseyó un magnífico claustro renacentista en cuyos arcos y columnas se utilizó piedra de Villaescusa. GARCÍA CHICO, ESTEBAN. "El claustro de Santo Domingo de Carrión de los Condes" en BSAA, n 10. Valladolid, 1944, pp. 212-215.

${ }^{154}$ Sobre este tema. GIL ABAD, Pedro. Quintanar de la Sierra: un pueblo burgalés de la comarca de pinares. Diputación Provincial de Burgos. Burgos, 1980 y SÁNCHEZ REY, Agustín. "Los caminos y el transporte terrestre durante el reinado de Isabel La Católica, en su quinto centenario" en Revista de Obras Públicas, no 3452, 2005, pp. 41-52.

${ }^{155}$ Las referencias son múltiples. Por ejemplo 1671. Condiciones de la obra de la iglesia establecidas por Francisco Reinaldos y Manuel de Salceda. ACP. Provisorato. Legajo 164, s/f.
} 
obra, se le abonaba un pago al comienzo de la misma para que pudiese $\operatorname{adquirirlos}^{156}$.

\section{LA IDIOSINCRASIA DEL TRABAJO ARQUITECTÓNICO}

\subsection{La Edad Moderna: las agrupaciones canteriles}

Desde la Edad Media, los oficios se encontraban agrupados en gremios y la enseñanza de los mismos se daba en el taller del maestro. La costumbre residía en el establecimiento de contratos de aprendizaje con una duración que oscilaba entre los tres y cuatro años de duración, por los que el maestro además de instruir al neófito en el oficio debía proporcionarle ropas y alimento.

Respecto a los artífices de las obras, a pesar de la aparente claridad de la acepción de arquitecto desde la Antigüedad, proporcionada por Vitrubio y retomada por Diego de Sagredo en pleno Renacimiento ${ }^{157}$ en la práctica, el término no estaba nada claro ${ }^{158}$. Para éstos, el arquitecto era reconocido como el "principal fabricador" de una obra en el sentido de creador, que sólo trabaja con su espíritu e ingenio, dejando el trabajo físico, realizado con las manos, para el maestro de obras y sus oficiales. La diversidad de nominativos entre los miembros del gremio de artistas durante la Edad Moderna -aparejador, maestro de obras, maestro de cantería- conlleva en muchos casos la confusión acerca de las funciones que llegó a desempeñar cada uno. La primera mención que hemos hallado de arquitecto en Carrión, data de 1599 y se aplica a Santiago de Sigüenza y Marcos de la Torre cuando se les reclama para redactar un informe sobre el estado de Nuestra Señora de

\footnotetext{
${ }^{156}$ Así sucede en la obra que el maestro de cantería Marcos de la Torre realiza en la torre de Santa María en AHPP. Carr.Prot 5671 Andrés Sánchez (1567-1568), s/f.

${ }^{157}$ SAGREDO, Diego de. Medidas del romano. Toledo. 1526. Edición actualizada a cargo de Fernando Marías. Toledo, 2000.

${ }^{158}$ En este sentido, existen numerosos estudios que intentan diferenciar a los diversos artífices. MARTÍN GONZÁLEZ, Juan José. El artista en la sociedad española del siglo XVII. Madrid, 1974. MARÍAS, Fernando. "El problema del arquitecto en la España del siglo XVI" en Academia, n48, 1979, pp. 175-232, GARCÍA MORALES, Ma Victoria. La figura del arquitecto en el siglo XVII. Madrid, 1991.
} 
las Capillas, un pequeño eremitorio que se ubicaba junto al templo de Santiago ${ }^{159}$. En realidad, el propio documento los designa además como maestros de carpintería y cantería, respectivamente y en base a los trabajos que estos artífices carrioneses ejecutaron en Carrión, manifiesta que el término no se empleaba en sentido estricto con cariz humanista sino como un modo de engrandecer a meros ejecutores de obras. En definitiva, la principal denominación que veremos durante los siglos XVI a XVIII será la de maestro de cantería para el principal "hacedor" de una obra, tanto si diseñaba el edificio como si se encargaba de su ejecución, citándose esporádicamente para el mismo fin, el término aparejador o maestro de obras.

Para llegar a ejercer cualquiera de los oficios de manera profesional, era necesario pasar un período de aprendizaje que comenzaba normalmente a temprana edad y tenía una duración habitual de cuatro años, pudiendo prolongarse una anualidad. El maestro además de la enseñanza del oficio, se comprometía con el futuro "alumno" a hacerse cargo de su manutención, a cambio de una cantidad que dependía en cada caso del estatus del artífice. Conservamos algunos contratos de aprendizaje, como el establecido entre Jerónimo de Avendaño y María de Hano, madre de Domingo del Río, en 1643 para que le capacitara como maestro de cantería $^{160}$ o el que acuerda Felipe Berrojo con Julián de León para enseñarle el oficio de maestro de albañilería en $1652^{161}$. Un contrato que nos resulta muy curioso es el que firma Santiago de Sigüenza en 1587 con uno de los criados del monasterio de San Zoilo, Rodrigo Juárez, para enseñarle el oficio de carpintero ${ }^{162}$. Nos llama la atención por dos motivos: el primero es que el dicho Rodrigo no debía ser precisamente un zagal, dado que es él mismo quien solicita los servicios de Sigüenza y en segundo lugar, el hecho de querer iniciar un aprendizaje cuando ya poseía otro oficio, parece indicar que su permanencia en el cenobio benedictino no era definitiva, ya que descartamos que en aquella época, en la que satisfacer las necesidades primarias era el objetivo primordial, la decisión de aprender un nuevo oficio respondiese a una pura motivación personal. La formación que adquirían era eminentemente práctica, pues no hallamos inventarios de libros entre las posesiones

\footnotetext{
${ }^{159}$ FERRERO MAESO, Concepción. "El mecenazgo de la familia Berrio en la iglesia de San Julián de Carrión de los Condes" en Actas del III Congreso de Historia de Palencia. Tomo 4. Diputación Provincial. Palencia, 1995, pág. 587, a su vez de AHPP. Carr.Prot 5324, s/f.

${ }^{160}$ VV.AA. Artistas cántabros...Op.cit, pág. 62.

161 AHPP. Carr.Prot 5689. Norberto Sandoval y Guevara (1656), fol 587.

${ }^{162}$ AHPP. Carr.Prot 5671. Andrés Sánchez (1578-1579), s/f.
} 
de los artífices. Es más, muchos de ellos eran analfabetos, por lo que a la hora de firmar un contrato, una persona de su confianza lo hacía en su nombre. Es el caso del maestro de cantería cántabro Francisco del Bado, quien a través de la rúbrica de un tal Andrés Sánchez, aceptó la cesión de una tercera parte de la obra del claustro del convento de Santo Domingo en $1579^{163}$.

Mientras una obra se realizaba, así como una vez finalizada, la supervisión de su ejecución recaía en la figura de los veedores, cuya labor, en el caso de Palencia, se ejercía dentro de los límites de su Obispado. Dada la multiplicidad de obras que se realizaban simultáneamente, se nombraba más de uno. Se trataba de una profesión que gozaba de gran prestigio, a tenor de su labor eminentemente intelectual. Sin embargo, pese a la aparente liberalidad de su profesión, artistas reconocidos como Alonso de Tolosa o Juan de Escalante y otros menos célebres como Jerónimo Avendaño o Francisco del Río Pontecillas, nombrados veedores en diferentes períodos, participaron activamente al pie de las obras que se encontraban bajo su mando. Nuevamente observamos el fenómeno en que se entremezclan las profesiones e incluso, en infinitud de casos, artífices que no habían sido nombrados oficialmente veedores, actuaban como tales tasando el valor de una obra. Generalmente se nombraban dos maestros, "peritos en el arte", uno de parte del mecenas -la parte contratante- y otro de parte del artista -la parte contratada- con el fin de que estipularan un precio equitativo, en la medida de lo posible.

\section{El sistema tradicional de contratación de obras}

Existían dos sistemas de contratación de las obras que se aplica en todas las localidades del Obispado de Palencia. El más singular y menos conveniente era el denominado "de maestría", por el que los artífices reciben una porción de los ingresos basada en sus rentas que se abonaba fundamentalmente en especie. Resultaba poco eficaz para ambas partes, pues los pagos, en muchas ocasiones, no mantenían una correspondencia real con lo edificado y, por otro lado, la retribución no siempre era monetaria, sino que se efectuaba un pago en especie, cuyo precio era

${ }^{163}$ AHPP. Carr.Prot 5668. Andrés Sánchez (1577-1579), s/f. 
susceptible de variación ${ }^{164}$. El párroco de Santa María aplicó este sistema en 1613, cuando contrató a Francisco Reinaldos y Juan González de la Mata para los reparos de la torre, los cuales recibieron treinta cargas de trigo por los trabajos ${ }^{165}$. Lo mismo sucede en la reconstrucción de la ermita de San Cristóbal que tiene lugar en 1622, en cuyo contrato se señala que el maestro “... a de tomar y cobrar de las rrentas de trigo y dinero que la dicha cofradía tiene... a los prezios de mayo de cada un año, en los mercados d'esta uilla ${ }^{166}$. Estos datos corroboran una vez más la base cerealística de la economía terracampina.

Sin embargo, el sistema habitual era el llamado "contractual", por el que la obra se contrata en un precio y duración determinados. Las obras podían adjudicarse directamente a un maestro conocido o de cierto renombre en la villa, pero si el comitente no tenía demasiado clara la elección o quería abaratar el coste de la obra, la opción más recomendable y en consecuencia más recurrente, era el sistema de subasta. Si bien el proceso era mucho más farragoso, el mecenas se aseguraba un precio mucho más competitivo y ajustado al valor real del trabajo.

El edicto de la nueva obra quedaba fijado en la esquina de las puertas principales de las casas de ayuntamiento y si se quería pujar para hacer baja los interesados debían presenciarse ante el corregidor en la puerta de la iglesia el día del remate $^{167}$. En un caso excepcional, observamos que el remate se lleva a cabo en la casa de un particular, como en la obra de fortificación de la torre de Santa María que en 1586 fue concertada con Marcos de la Torre. En diciembre de aquel año, se reunieron en la vivienda del juez de la comisión de la obra, don Lorenzo de Avia, el cura, el beneficiado y el mayordomo del templo, además de los oficiales interesados en la misma, incluidos algunos feligreses de Santa María ${ }^{168}$. La subasta tenía una duración variable, dependiendo en muchos casos del tiempo que durase una vela encendida “...e no mas e acabada la bela la quedaría hecho el rremate en quien la

\footnotetext{
${ }^{164}$ ZALAMA, Miguel Ángel. La arquitectura...Op.cit, pág. 35.

165 AHPP. Carr.Prot 5396 Francisco Moro de Saldaña (1613), s/f.

${ }^{166}$ AHPP. Carr.Prot 5405. Francisco Moro Saldaña (1622), s/f.

${ }^{167}$ Concierto con Francisco Martínez de Bálcava para la ejecución de las obras del templo de San Andrés de Carrión. 18 de febrero de 1608. AHN. Clero Regular-Secular, Legajo 5356, Expediente 2, Iglesias de San Andrés y San Pedro, Obras.

${ }^{168}$ AHPP. Carr.Prot 5671. Andrés Sánchez (1567-1568), s/f.
} 
tubiese puesta... ${ }^{169}$ " Se marcaba un precio de salida y si se hacían bajas, el pujador obtenía un prometido, esto es, un tanto por ciento sobre la cuantía de cada una de las bajas con el que se obsequiaba a quienes las hacían. La obra quedaba rematada en el maestro que estuviera dispuesto a realizar la obra por menor precio. En alguna ocasión, si se quería abreviar el proceso de subasta, el que encargaba la obra establecía un precio final de remate y aquel que lo aceptara, se llevaba la obra ${ }^{170}$.

Una vez adjudicada la obra, se procedía a tramitar el contrato de obligación entre la parte contratante -el mayordomo de un convento, su patrono, el ayuntamiento, un particular- y la parte contratada -un albañil, maestro arquitecto, carpintero, serrano, etc. En el mismo quedaban establecidas las condiciones de la obra, con los plazos, la paga, la fecha y el compromiso de ambos de respetar su contenido. No podían faltar los fiadores, amigos o familiares del artífice, que se comprometían bajo juramento a avalarle en caso de incumplimiento de alguna cláusula. Para ello se presentaban fianzas bajo la clásica fórmula de "legas, llanas y abonadas", esto es, que los bienes que presentaban como garantía no gozaran de fueros eclesiásticos o nobiliarios y que tuvieran la solvencia suficiente para correr con los gastos derivados de la obra ${ }^{171}$.

En algunos casos el artista podía llegar a ser encarcelado, como sucedió con Juan de la Cuesta en la obra del claustro del convento de San Francisco en 1589, ya que no cumplió con los plazos establecidos ${ }^{172}$. Para acordar la finalización de la obra, se establecía que debía estar acabado antes de un día señalado, que se marcaba según la efeméride, sin mencionar en el contrato a qué día correspondía, dado que en una sociedad de arraigada religiosidad como la española en los siglos XVI a XVIII, el conocimiento de las celebraciones estaba al orden del día. Las referencias más usuales correspondían al día de Nuestra Señora (La Asunción, el 15 de agosto), San Juan (24 de junio) o Pascua de Flores (Domingo de Resurrección, en una fecha que oscila según el año entre el 22 de marzo y el 25 de abril). Aunque existen algunas

\footnotetext{
${ }^{169}$ Este modo de subastarse una obra, figura, por ejemplo en la adjudicación de los reparos del puente de Carrión en 1595. AHPP. Carr.Prot 5286. Pascual López (1595), s/f.

${ }^{170}$ Así sucedió con la obra de refuerzo de la torre de Santa María. Tras varias pujas, el vicario y mayordomo ofrecieron mil cuatrocientos ducados, que fueron aceptados por Francisco del Bado y Marcos de la Torre. AHPP. Carr.Prot 5671 Andrés Sánchez (1567-1568), s/f.

${ }^{171}$ VIGURI, Miguel de y SÁNCHEZ, José Luis. Arquitectura...Op.cit, pág. XXVI.

172 Amigos de profesión del maestro pagaron las fianzas. AHPP. Carr.Prot 4980, Sebastián García, (1588-1590), fol 672.
} 
excepciones que se refieren a las festividades del Apóstol Santiago ${ }^{173}$ (25 de julio), San Andrés ${ }^{174}$ (30 de noviembre) o Todos los Santos (1 de noviembre $)^{175}$.

Si el artífice introducía alguna mejora en la obra que no estuviera contenida en las condiciones del contrato, el artista debía recibir una cuantía a mayores por dichas “demasías". Podemos constatar demasías en la obra que Francisco Reinaldos realizó junto a Manuel Salceda en la iglesia de San Andrés hacia 1671, que fueron abonadas en $1674^{176}$. Otro ejemplo es la construcción del hospital de Santa María, comenzado en 1626 por Juan González de la Mata. Aún en 1653 no lo había finalizado, por lo que la cofradía del nosocomio le denuncia a la justicia. El maestro se compromete a finalizar las obras, pero deben abonarle cuatro mil reales en concepto de demasías ${ }^{177}$.

\subsection{La situación a partir de 1752: la Academia de Bellas Artes}

La Real Academia de Bellas Artes de San Fernando, fundada en 1744 y cuya puesta en marcha tuvo lugar en 1752, provocó el desvanecimiento paulatino del secular sistema gremial ${ }^{178}$. Desde 1757 una Real Cédula permitía el libre ejercicio de la profesión, por lo que la Academia decide aglutinar el monopolio de la expedición del título de arquitecto a partir de 1764, lo que restringe la independencia de los artistas, que deben formarse en el seno de la institución. Por entonces, Carrión figuraba entre los focos constructivos periféricos de la extensa comarca de Tierra de Campos, junto a Palencia, Medina de Rioseco, Valderas y Sahagún cuya situación facilita las comunicaciones con otras regiones limítrofes. Entre todos ellos engloban

\footnotetext{
${ }^{173}$ AHPP. Carr.Prot 5181. Jerónimo Laso (1635), s/f.

${ }^{174}$ AHPP. Carr.Prot 5018. Agustín García Miranda (1696-1698), s/f.

175 AHPP. Carr.Prot 5689. Norberto Sandoval y Guevara (1656), s/f.

${ }^{176}$ Actuaron como tasadores Santiago de Pedrosa y Domingo de Lovizera en 330 reales, de los cuales aceptaron 234, cediendo el resto como limosna al templo AHPP. Carr.Prot 5776 Andrés Simón Aguilar (1672), fol 326 y ss.

${ }_{177}$ AHPP. Carr.Prot 5763. Andrés Simón Aguilar (1653-1654), s/f.

${ }^{178}$ Sobre los requisitos de los futuros arquitectos para su nombramiento. BALSALOBRE GARCÍA, Juana María. "El aspirante a arquitecto y la Real Academia de Bellas Artes de San Fernando" en Arquitectura y ciudad en España de 1845 a 1898. Actas de la I Jornada de Arquitectura histórica y urbanismo Cádiz, 1998, pp. 135-148
} 
más de un centenar de artífices dedicados a la construcción, calificados catastralmente como operarios de oficios mecánicos ${ }^{179}$.

Por sesión municipal de 30 de agosto de 1789, el concejo de Carrión acordó que desde ese momento, siempre que se hubiera de ejecutar una obra pública de cualquier entidad en la ciudad, habría que emitir un informe a la Real Academia de Bellas Artes de San Fernando que contuviese “... una explicación por escrito, los dibujos de los planos y costes de las fábricas que se ideen..." con el fin de que dicha institución resolviese si lo consideraba oportuno. A partir de aquel momento, expedía los títulos de arquitectura, labor que hasta entonces había ejercido el Consejo de Castilla ${ }^{180}$.

Esta nueva situación provoca que los maestros de cantería pierdan progresivamente su protagonismo, dado que además a partir de entonces no se levantan grandes fábricas, sino que se efectúan reconstrucciones de pequeña entidad. Por ello, serán los maestros alarifes, que conjugan en su persona las labores de albañilería y carpintería, quienes tomen el testigo de las intervenciones en este período. Destacan fundamentalmente tres familias -los Guerra, los Rodríguez y los Iglesias- cuyos miembros desarrollan su labor desde los años treinta del siglo XVIII y los primeros años de la centuria decimonónica ${ }^{181}$.

Se conservan algunos datos correspondientes a mediados del siglo XVIII, acerca del personal cualificado que tenía contratado la villa destinado a socorrer las necesidades de obra que pudieran surgir en toda la jurisdicción. Así Carrión contaba con cuatro maestros de obras acompañados de dos oficiales que siendo hijos de aquéllos les ayudaban en las labores que requerían menor especialización. En función de ello recibían su salario, correspondiendo a los maestros seis reales diarios y cuatro sus colaboradores. El número de alarifes ascendía a doce; no obstante había tan sólo un oficial, siendo correlativo el sueldo de maestros y colaboradores, de

${ }^{179}$ Otros centros importantes son el triángulo que en el interior forman Paredes de Nava, Becerril y Fuentes de Nava, además de otras localidades más aisladas de este núcleo como Frómista, Villalpando o Villalón de Campos. VIGURI, Miguel de y SÁNCHEZ, José Luis. Arquitectura...Op.cit, pág. XIX.

${ }^{180}$ Sobre el nuevo sistema de aprendizaje, véase NAVARRETE MARTÍNEZ, Esperanza. "La enseñanza fuera del taller del maestro: la Real Academia de Bellas Artes de San Fernando" en El arte del siglo de las luces. Barcelona, 2010, pp. 255-276.

${ }^{181}$ Sobre estas familias, véase el apartado dedicado a la biografía de los maestros locales. 
nuevo seis y cuatro reales, respectivamente. Considerados de menor rango, los carpinteros en número de dos, recibían un estipendio de cuatro reales y medio ${ }^{182}$.

\section{El nuevo sistema de contratación de obras}

Con la llegada de la Academia, los artistas tuvieron que plegarse al gusto de raigambre clásica de la nueva organización ${ }^{183}$. Por otro lado, el sistema tradicional fue sustituido por otro más rígido que se mantuvo durante todo el siglo XIX ${ }^{184}$. Para que una obra se contratara legalmente, se realizaba una doble subasta anunciada durante treinta días que se celebraba simultáneamente en el Gobierno Civil de Palencia y en el Ayuntamiento de Carrión. El presupuesto al que se deberán ceñir será marcado por el arquitecto de provincia y debidamente anunciado.

Los artistas que se presentaran debían proporcionar los planos de la futura obra en pliegos cerrados. Dado que partir del siglo XVIII existe un mayor afán estético en la creación de los mismos, éstos irán provistos de varios colores planos y gran cantidad de detalles. El sistema de posturas continúa, pero el "prometido" es sustituido por un depósito de diez mil reales reales en metálico que cada artista debía ingresar en la Caja sucursal, bien de Palencia o Carrión. Esta cantidad sería devuelta una vez concluido el remate, excepto en el caso del mejor postor, que quedaría en modo de fianza hasta la conclusión de la obra. Este método, como puede deducirse, resultaba bastante selectivo, pues aquellos artistas que carecieran de medios, no podían siquiera presentarse a la subasta.

Antes de adjudicar la obra, el mejor postor era sometido a una rueda de preguntas y respuestas que juzgase conveniente el consistorio. En caso de coincidir dos pujadores en un precio, ambos eran sometidos a un cuarto de hora de licitación verbal, uno contra otro, defendiendo su propuesta. Notificada la aprobación, en el

\footnotetext{
${ }^{182}$ AHPP. Catastro del Marqués de la Ensenada. Respuestas dadas a las preguntas generales por los nombrados en dicha villa para la operación de única contribución en la Villa de Carrión, provincia de Toro. 12 de febrero de 1753. Microfilm 335, Libro 629, fol 224v.

${ }^{183}$ Acerca de la estética vigente por entonces, véase MARTíN GONZÁLEZ, Juan José. "El gusto clásico en los comienzos de la Real Academia de Bellas Artes de San Fernando" en La visión del mundo clásico en el arte español. Madrid, 1993, pp. 305-312

${ }^{184}$ AMCC. Libro 6, Sesiones municipales (1858-1862), Sesión municipal de 6 de septiembre de $1861, \mathrm{~s} / \mathrm{f}$
} 
plazo máximo de un mes, el artista elegido debía entregar la escritura de aprobación de la obra que debía ser comenzada en treinta días a partir de aquel momento.

El sistema de pagos era muy semejante al aplicado tradicionalmente; en cuatro plazos, en este caso iguales: el primero, reunidos los materiales y sacados los cimientos; el segundo, levantados los pisos; el tercero, hecha la fachada y el tejado; y por último, seis meses tras ser concluida y aprobada la obra. Tras esto, el cantero quedaba eximido de cualquier daño a posteriori.

\section{LOS ARTÍFICES DE LAS OBRAS}

\subsection{Artífices cántabros}

Desde finales del siglo XV se observa una emigración masiva de canteros, arquitectos, escultores y albañiles provenientes de la merindad de Trasmiera, comarca ubicada en el litoral oriental de Cantabria, hacia los territorios de la Corona de Castilla. Allí existía una larga tradición en el trabajo de la piedra que remonta sus orígenes a la Edad Media. La abundancia de este material, junto a la imperiosa necesidad de construir edificios sólidos para sobrellevar el clima invernal, justifica, en buena parte, la especialización en la cantería. A pesar de la pericia de estos maestros, la pobreza de la tierra y derivada de ésta, la escasez de encargos en un entorno eminentemente rural como el cántabro, motivó la búsqueda de nuevos horizontes donde labrarse un futuro ${ }^{185}$. Resulta paradójico que artistas de la talla de Juan de Herrera, Diego de Praves o Juan Gil de Hontañón tuvieran que marcharse de sus villas natales para obtener un reconocimiento a nivel nacional y alcanzar un estatus social elevado.

Carrión de los Condes, fue uno de los focos de asentamiento de estos artistas que llegaron a crear la llamada Escuela Montañesa, pero la afluencia de los mismos en nuestra villa no se produciría hasta mediados del siglo XVI, intensificándose durante las primeras décadas de la centuria décimo séptima. Los motivos del

${ }^{185}$ VV. AA. Cantabria a través de su historia: la crisis del siglo XVI. Institución cultural de Cantabria. Santander, 1979, pp. 197-202. 
prestigio y renombre que alcanzaron muchos de ellos hay que buscarlos en su estructurada organización y en la complicidad que siempre manifestaron, llegando a conformarse verdaderos clanes. La fórmula del éxito se deriva básicamente de las siguientes actuaciones clave:

-El mantenimiento de vínculos familiares estrechos. Los progenitores transmitían a las siguientes generaciones el oficio de la cantería, con lo que las familias obtenían un renombre, derivado de su larga experiencia en el gremio. En el caso de Carrión destacan los Cuesta, los Zorlado, los Avendaño, los del Río Pontecillas, entre otros.

-En segundo término, la endogamia canteril era una práctica muy habitual, es decir, las hijas o hermanas de los maestros de cantería contraían matrimonio con hombres dedicados a la cantería. De este modo, la proliferación de este fenómeno afianzó la relación entre diversos clanes a la par que los volvía más fuertes. Ejemplo de ello Jerónimo de Buega, que hace las trazas de San Julián, era hijo de un maestro de cantería, Domingo de Zorlado, y se esposó con Catalina de Naveda, hermana de Juan de Naveda, también dedicado al mismo oficio ${ }^{186}$. Análogo caso es el de Francisco del Río Pontecillas, cuñado de Andrés de Zorlado, con el que asocia para lograr la adjudicación de la mayor parte de los puentes de la provincia de Palencia $^{187}$.

-El establecimiento de acuerdos previos a la contratación de una obra. Un maestro concreto pactaba el remate y posteriormente se cedían las partes para que trabajara el mayor número de trasmeranos en la obra. Esta táctica de la subcontratación resultó de gran utilidad para que Toribio de la Cuesta se repartiera la obra de la iglesia del nuevo proyecto de la iglesia de San Andrés con Francisco Bálcava en $1608^{188}$.

\footnotetext{
${ }^{186}$ VV.AA. Artistas...Op.cit, pág. 96.

${ }^{187}$ Ibídem, pág. 572.

${ }^{188}$ AHN. Clero Regular-Secular, Legajo 5356, Expediente 2, Iglesias de San Andrés y San Pedro, Obras.
} 
-Para comunicarse tenían una jerga específica heredada de sus antepasados. Celosos de su profesión, los canteros trasmeranos, como los de otros lugares como Galicia o Burgos, crearon un lenguaje que en Cantabria se denominó "la Pantoja", gracias al cual mantenían el secreto profesional del labrado de la piedra ${ }^{189}$.

Todas estas estrategias corporativas coadyuvaron significativamente en su éxito, pues consiguieron el remate de una parte importante de las obras que se llevaron a cabo en Carrión durante la Edad Moderna. Un dato ilustrativo de la monopolización de los montañeses en la arquitectura palentina, es el hecho de que en el período comprendido entre 1575 y 1650, de los 130 maestros que figuran trabajando en las edificaciones religiosas de la provincia, sólo son locales nueve $\operatorname{artistas}^{190}$. La falta de maestros especializados en el trabajo de la piedra en Carrión, dada la escasez del material en la localidad, fue la clave del éxito de todos estos maestros de cantería formados desde temprana edad en el corte de la piedra, que constituyeron, como así refiere Aramburu Zabala, una verdadera "mafia" a la que difícilmente se le podían arrebatar las obras, logrando en ocasiones apartar de competencia incluso a otros maestros norteños, como el vasco, Juan de Celaya ${ }^{191}$.

De algunos de ellos, dedicamos un apartado relativo a sus datos biográficos menos conocidos e inéditos relativos a Carrión y el entorno palentino, reseñando sus intervenciones fuera de estos límites a través de la bibliografía existente ${ }^{192}$.

\footnotetext{
${ }^{189}$ Acerca de este lenguaje, véase SOJO Y LOMBA, Fermín. La Pantoja: jerga de los maestros canteros de Trasmiera. Segovia, 1947.

190 ARAMBURU- ZABALA HIGUERA, Miguel Ángel. "Los maestros canteros en Palencia (15751650)" en AIICHP, tomo V. Palencia, 1990, pág. 165. Un estudio sobre la intervención trasmerana en los puentes castellanos, del mismo autor. Las obras públicas de la Corona de Castilla entre 1575 y 1650: los puentes. Madrid, 1989.

191 Ibídem, pág. 164.

${ }^{192}$ Así actuaremos con el resto de artistas de otras procedencias para evitar repeticiones innecesarias. El orden de aparición de los artistas obedece a la cronología de su actividad artística, situándose en primer lugar los maestros del siglo XVI y así, sucesivamente.
} 


\section{Juan de Nates}

\section{Maestro arquitecto procedente de Secadura}

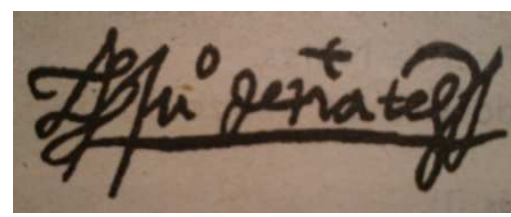

De entre todos los maestros cántabros, sin duda Juan de Nates es uno de los que más prestigio llegó a alcanzar y sobre el que más atención ha merecido, al centrar su radio de acción en Valladolid y provincia, convirtiéndose en uno de los maestros introductores del clasicismo en este foco. Nacido hacia 1547 de padres cuyos nombres permanecen anónimos hoy día, tuvo varios hermanos, de los cuales los varones, Juan y Andrés, también se convirtieron en arquitectos ${ }^{193}$. La intensa y prolífica actividad de corte herreriano que desarrolló a partir de los años 70 y durante la primera década del siglo XVII en obras como la Colegiata de San Luis de Villagarcía de Campos, la catedral, el puente mayor o la iglesia de San Nicolás de la capital vallisoletana ha merecido que Juan de Nates haya sido objeto de numerosísimos estudios ${ }^{194}$. Nuestro objetivo, en este caso, al abordar la figura del artista trasmerano, y con el fin de evitar repeticiones innecesarias, reside en entresacar su actividad en Carrión y por extensión, en la provincia de Palencia, en la que, a diferencia de Valladolid, destaca por su labor de tasador o veedor, más que como proyectista.

193 SOJO Y LOMBA, Fermín. Los maestros...Op.cit, pp. 112-118, BUSTAMANTE GARCÍA, Agustín. La arquitectura...Op.cit, pág. 218. Sobre los vínculos familiares de Juan de Nates, ALONSO RUIZ, Begoña. "Datos para el estudio de la organización familiar en los canteros de Trasmiera: Las familias Nates, Vega y Secadura en Príncipe de Viana, $n^{\circ} 12,1991$, pp. 111-127

${ }^{194}$ Sobre Juan de Nates véanse pp. GARCÍA CHICO, Esteban. Documentos...Arquitectos...Op.cit, pp. 64-85 y del mismo, "Una nueva obra de Juan de Nates" en BSAA, no 15, 1948-1949, pp. 251-251, PEREDA DE LA REGUERA, Manuel. Juan de Nates. Librería Moderna. Santander, 1953, PARRADO DEL OLMO, Jesús María. "Noticias sobre Juan de Nates" en BSAA, n45, Valladolid, 1979, pp. 443-448, BUSTAMANTE GARCÍA, Agustín. La arquitectura...Op.cit, pp. 218-273, ALONSO RUIZ, Begoña. "Datos para el estudio de la organización familiar en los canteros e Trasmiera: Las familias Nates, Vega y Secadura en Príncipe de Viana. Anejo 10-91 Jornadas Nacionales sobre el Renacimiento español, 1991, pp. 111-127, VV.AA. Artistas...Op.cit, pág. 184, FERNÁNDEZ DEL HOYO, Ma Antonia. "Juan de Nates y la portada de la Vera Cruz de Valladolid" en BSAA, n52. Valladolid, 1986, pp. 396- 401, VV.AA Artistas cántabros...Op.cit pág. 447-452, GÓMEZ MARTÍNEZ, Javier. "Juan Gómez de Nates y Fernández de Albear: Juan de Nates” en Juan de Herrera y su influencia. Actas del simposio de Camargo, 14-1 de julio de 1992, Santander, 1993,

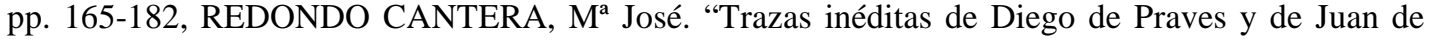
Nates para el convento de Sancti Spiritus de Valladolid (1592-1596)" en Juan de Herrera y su influencia. Actas del simposio de Camargo, 14-17 de julio 1992. Santander, 1993, pp. 361-370, del mismo "Juan de Nates, entre las influencias de Ribero Rada y Herrera" en Altamira, no 52, 1996, pp. 167-204 y VASALLO TORANZO, Luis. "La contestación de Juan de Nates y Felipe de la Cajiga al magisterio de Juan del Ribero" en De Arte, nº7. Universidad de León. León, 2008, pp. 113-128. 
La primera referencia del artista en la capital del Carrión es bastante temprana, concretamente de 1576, cuando toma como fiador a Hernando de Pumar en la obra de la iglesia de Nuestra Señora de la Calle ${ }^{195}$. Al frente de las obras del puente de Husillos figura a partir de 1580, actuando sus hermanos en 1583 en nombre del trasmerano, lo que refleja cómo Juan de Nates se fue apartando progresivamente de la obra hasta traspasarla en $1588^{196}$.

En la iglesia de San Pedro de Amusco, proporcionó las trazas de su construcción, que serían posteriormente revisadas por Alonso de Tolosa ${ }^{197}$. Con éste último arquitecto tendrá una breve participación en Carrión en el año 1585 para tasar la parte de la torre que Juan de Celaya había edificado en la iglesia de Belén, por cuya intervención emitirían carta de pago un año más tarde. Nates recibe ocho ducados y por entonces ya era veedor de las obras del Obispado de Palencia ${ }^{198}$. No obstante, como analizaremos posteriormente, el templo será reedificado por completo hacia 1646 y la torre, aunque estaba arruinada desde 1632, no verá su reconstrucción hasta 1663.

Corría el año 1592 cuando se presencia en Baltanás, junto a Felipe de la Cajiga, con el fin de tasar la obra que otro compañero trasmerano, Francisco del Río, había ejecutado en el monasterio de Santa Ana de dicha localidad. Dos años más tarde se traslada a Villamuriel de Campos para ocuparse de la obra de su torre, dando poder a Juan de la Lastra para tomarle como fiador. Después, en 1595, es reclamado en Palencia para actuar como testigo ${ }^{199}$. También se hizo cargo de la obra del puente de Herrera de Pisuerga por la cesión que en él hizo Felipe de la Cajiga cuando testó en noviembre de $1598^{200}$. Por último, en 1603, participó como fiador de Francisco de Buega en la obra que éste realizaba junto a su hermano Felipe de Buega en la iglesia de San Esteban de Villoldo ${ }^{201}$.

\footnotetext{
195 ZALAMA, Miguel Ángel. La arquitectura...Op.cit, pág. 289.

${ }^{196}$ BUSTAMANTE GARCÍA, Agustín. La arquitectura...Op.cit, pág. 219 y ZALAMA, Miguel Ángel. La arquitectura...Op.cit, pág. 290.

${ }^{197}$ PEREDA DE LA REGUERA, Manuel. Juan de Nates...Op.cit, pág. 240.

${ }^{198}$ ZALAMA, Miguel Ángel. La arquitectura...Op.cit, pp. 92-93 y 290.

${ }^{199}$ ZALAMA, Miguel Ángel. La arquitectura...Op.cit, pp. 290-291.

${ }^{200}$ MARTÍ Y MONSÓ, José. Estudios...Op.cit, pág. 633.

${ }^{201}$ ZALAMA, Miguel Ángel. La arquitectura...Op.cit, pág. 291.
} 


\section{Felipe de la Cajiga}

\section{Maestro arquitecto natural de Rada}

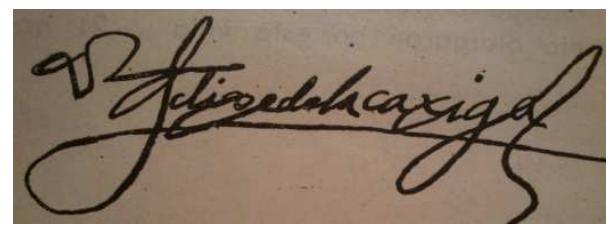

Pertenecía a una familia de canteros, pues su progenitor lo era, al igual que sus dos hermanos, Leonardo y Diego ${ }^{202}$. Hijo de Juan Sanz de la Cajiga y de su mujer Catalina Fernández de Velasco, nació en Rada en 1557, localidad de la Junta de Voto de donde procedía también su gran amigo y colaborador en muchas obras, Juan de $\mathrm{Nates}^{203}$. Los estrechos vínculos establecidos entre ambos se ponen de manifiesto en el hecho de que Nates actuó como su testamentario, cediéndole sus dos esclavos y fue quien se responsabilizó de la educación de su hija, Catalina de Velasco. Su último deseo fue sepultarse en la iglesia de San Andrés de Valladolid, localidad a la que emigró tempranamente y en la que se registra buena parte de su obra $^{204}$. En la ciudad del Pisuerga se convertiría en uno de los artistas más afamados del célebre foco clasicista, actuando como ingeniero y proyectista Desde 1575 en que figura su primera participación como aparejador de Nates en el puente de Mojados, hasta finales de siglo no cesaron los encargos en Valladolid y provincia, destacándose entre los más prestigiosos, su participación en las capillas funerarias de San Pablo o el porche del convento de San Francisco en la capital, o los puentes de Mayorga, Olivares y Quintanilla y las iglesias de los Santos Juanes de Nava del Rey o de Santa María de Tordesillas, entre sus encargos provinciales ${ }^{205}$.

En 1584 está en Palencia al cargo del puente mayor ${ }^{206}$. Entre 1589 y 1590 se encuentra en León, trabajando primero en la iglesia de San Marcelo, siguiendo las trazas que él y su maestro Juan de Ribero Rada habían elaborado. Precisamente, a consecuencia de esta obra se desencadena un pleito entre ambos, en el cual nuestro artista acabará por recibir las cuantías que se le adeudaban ${ }^{207}$. Un año después está

\footnotetext{
${ }^{202}$ VV.AA. Artistas cántabros...Op.cit, pág. 109.

${ }^{203}$ En 1591, declara se de edad de treinta y cuatro años. ALONSO CORTÉS, Narciso. "Datos para la biografía artística de los siglos XVI y XVII” en BRAH. Tomo XXX. Madrid, 1922, pág. 103.

204 MARTÍ Y MONSÓ, José. Estudios histórico-artísticos relativos principalmente a Valladolid: basados en la investigación de diversos archivos. Valladolid, 1898-1901, pp. 395 у 633.

${ }^{205}$ BUSTAMANTE GARCÍA, Agustín, La arquitectura...Op.cit, pp. 488-495.

${ }^{206}$ GARCÍA CHICO, Esteban. Documentos...1. Arquitectos...Op.cit, pp. 87.

${ }^{207}$ VASALLO TORANZO, Luis. "La contestación de Juan de Nates...Op.cit, pp. 113-128.
} 
realizando unos capiteles en el convento de San Claudio de León ${ }^{208}$, por cuya obra otorga una carta de poder en 1591 para recibir los pagos concernientes, siendo sus fiadores los maestros de cantería Francisco del Río y Domingo de Cerecedo, procedentes del valle de $\operatorname{Aras}^{209}$.

En relación con Carrión, resulta de gran interés el contencioso que se desata en abril de 1585, cuando logra adjudicarse unos cuartos nuevos del monasterio de San Zoilo, en los cuales se comprometía a seguir las trazas de Juan de Ribero Rada. Felipe de la Cajiga, aliado con otros canteros trasmeranos -Juan de Alvear, Pedro Prieto, Pedro de Nates, Hernando de Ocejo, Juan de Ortega Castañeda, Alonso de Tolosa, Juan de la Cuesta, Juan de Mazarredonda y su hermano, Andrés de Mazarredonda- pretendía que la obra les fuese rematada en alto precio y por eso, querían evitar que los carpinteros y albañiles locales pujaran en la subasta. Así es que los artífices cántabros ofrecieron a los artistas carrioneses la mitad del dinero que ganasen en los prometidos, aparte de asalariarles cuando la obra diese comienzo. Éstos aceptaron y para hacerlo oficial, Pedro de Nates preparó un papel en blanco en el que firmaron todos sus compañeros. Una vez finalizado el remate en Felipe de la Cajiga, los maestros locales se dieron cuenta que el mencionado escrito tan sólo recogía que los maestros carrioneses recibirían el salario que correspondiese exclusivamente a su trabajo. Este sucio ardid les valió el encarcelamiento a todos los cántabros. No obstante, los locales no salieron impunes del contencioso, pues fueron acusados de ser cómplices de los anteriores ${ }^{210}$. Felipe de la Cajiga pudo continuar la obra tras el litigio y por tanto la mayor parte de los cuartos referidos fueron ejecutados a lo largo de $1594^{211}$. La Comisión de Monumentos de Palencia emite un

${ }^{208}$ GARCÍA CHICO, Esteban. Documentos...1. Arquitectos...Op.cit, pp. 88-89 y también, VALDÉS FERNÁNDEZ, Manuel y LLAMAZARES RODRÍGUEZ, Fernando. Notas para el estudio del arte en León (VIII): Trazas de los siglos XVI, XVII y XVIII en el Archivo Histórico Provincial de León (II), Juan de Nates y Felipe de la Cajiga en el Monasterio de San Claudio de León" en Tierras de León, n³9, 1980, pp.119-132.

${ }^{209}$ AHPP. Carr.Prot 5650, Pedro Saldaña (1591), fol 421 y ss.

${ }^{210}$ Este contencioso se incluye en el pleito suscitado en 1586 entre Don Juan de Leguizamo, alcalde mayor de los Obispados de Badajoz y Coria, y patrón de la capilla mayor de San Benito el Viejo de Valladolid, contra Juan de Mazarredonda, maestro de cantería a cuyo cargo estuvo la construcción de la misma. Leguizamo se negaba a pagar a Mazarredonda los últimos 650 mil maravedís del precio ajustado en el remate por considerar que no había obrado de acuerdo a las condiciones el mismo. En su defensa sobre las malas artes de los canteros, saca a colación el pleito de San Zoilo. GÓMEZ MARTÍNEZ, Javier. “Obras en San Benito el Viejo (Valladolid) y San Zoilo de Carrión (1583-1594). Buenas y malas artes en el foco clasicista" en BSAA. Tomo LVIII. Universidad de Valladolid. Valladolid, 1992, pp. 333-348.

${ }^{211}$ MARTÍ Y MONSÓ, José. “Menudencias...Op.cit, pág. 539. 
informe en el que afirmaba que hacia 1584 se llevaron a cabo las obras de las habitaciones superiores de Oriente, que duraron hasta $1596^{212}$, así que con toda probabilidad se identifican con los trabajos en los que intervendría Felipe de la Cajiga, que corresponderían a las celdas del claustro alto contiguas a la cabecera del templo. Esta intervención, aunque breve, pone de relieve el conocimiento que se tenía del artista en la provincia de Palencia. Aprovechando su estancia carrionesa, en 1595 se presenta en la subasta de la obra del puente, cuyas condiciones habían sido redactadas por el maestro avecindado en León, Pedro Álvarez de la Torre, con la intención de adjudicársela. Marcos de la Torre y Francisco del Río establecieron un precio de salida de 6.000 ducados que Buega bajó en 5.000. Sin embargo, la cifra era demasiado elevada y el corregidor la bajó a 3.000, pero ante la falta de pujadores ofreció 4.000, aceptando Marcos de la Torre la obra, que la compartió con Francisco del Río ${ }^{213}$.

Su último trabajo fue la reconstrucción de las casas de la Inquisición de Valladolid, ubicadas en la calle de la Peña de Francia, para las que redactó las condiciones que entregó al inquisidor Alonso de Gaitán en 1597 y que realizaría Juan de Mazarredonda ${ }^{214}$. Dictó testamento el 24 de noviembre de 1598, falleciendo dos días después, a los 41 años de edad ${ }^{215}$. Este dato nos permite descartar la identificación de Felipe de Buega con otro artista homónimo que en 1627, junto a Juan de Cajigosa, tasan la obra que en la celda mayordomía del monasterio de San Zoilo habían ejecutado Veintemillas y Domingo de Bustos ${ }^{216}$.

\footnotetext{
${ }^{212}$ ARASF. Leg.5-282-1

${ }^{213}$ AHPP. Carr.Prot 5286. Pascual López (1595), s/f.

${ }^{214}$ FERNÁNDEZ MARTÍN, Luis. "La casa de la Inquisición de Valladolid" en Investigaciones Históricas, nº10, 1990, pp. 199-200.

${ }^{215}$ SOJO Y LOMBA, Fermín. Los maestros canteros...Op.cit, pág. 41.

${ }^{216}$ AHPP. Carr.Prot 5410, Francisco Moro Saldaña (1627), s/f.
} 


\section{Juan de la Cuesta}

\section{Maestro de cantería de Secadura}

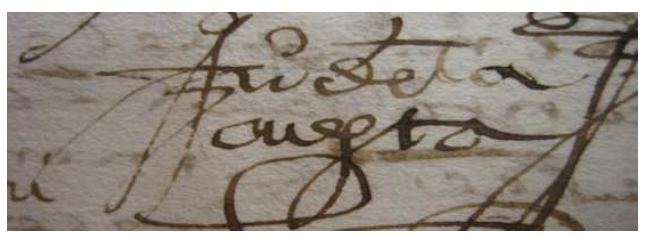

Este maestro trasmerano procedente del Valle de Aras, trabaja intensamente en Carrión y el entorno durante un breve período que transcurre durante poco más de una década, desde 1579 a principios de 1592 en que ya había fallecido. Es probable, por tanto, que estableciera su lugar de residencia en la villa condal en una etapa madura de su vida, a tenor de un documento de 1549 que lo sitúa en la iglesia de Santa María de Villamelendro, en que aparece citado ya como maestro, lo que permitiría retrasar su nacimiento, al menos a $1530^{217}$. Desarrolla una actividad ambivalente, tanto como tracista, como de "hacedor" de varias obras bajo el mando de otros maestros. Probablemente tuvo un descendiente del mismo nombre que continuó la tradición cantera, el cual hace acto de presencia en 1654, al figurar como veedor y tasador de la obra ejecutada en el templo de San Julián por Jerónimo de Avendaño ${ }^{218}$.

Hasta ahora se había creído que la primera relación contractual de Juan de la Cuesta en Carrión de los Condes, había sido establecida con los frailes franciscanos. Sin embargo, hallamos en la documentación que el primer proyecto del claustro del extinto convento de Santo Domingo fue firmado el 31 de enero de 1579 con el prior Fray Juan de Salvatierra ${ }^{219}$. Es entonces cuando se establecen las condiciones que prevalecen después y cuando de la Cuesta, cede una tercera parte al maestro cántabro Francisco del Bado, pues además de figurar como tracista, está al cargo de las obras. El contrato con fecha de 1 de octubre de 1585 que sacó a la luz García Chico $^{220}$ no era más que la actualización del anterior entre los maestros señalados con el prior de entonces, Fray Antonio de San Pablo, dado que los dos paños que habían sido realizados hasta el momento presentaban ciertas carencias en la cimentación y tuvieron que ser demolidos. Tal vez por ello y con el fin de motivar

\footnotetext{
${ }^{217}$ Hay que tener en cuenta que al menos debía tener 20 años para poder desempeñar el oficio de cantero. ZALAMA, Miguel Ángel. La arquitectura...Op.cit, pp. 260 y 263.

${ }^{218}$ AHPP. Carr.Prot 5436. Francisco Moro Saldaña (1654), s/f.

219 AHPP. Carr.Prot 5668. Andrés Sánchez (1577-1579) s/f

${ }^{220}$ GARCÍA CHICO, ESTEBAN. "El claustro de Santo Domingo...Op.cit, pp. 212-215.
} 
significativamente hacia una óptima ejecución de la nueva obra, el montante final respecto al contrato anterior resultó ser más del doble ${ }^{221}$. No obstante, cuando en 1586 Pedro de Naveda y Juan Pérez de Rozpe bajen la cifra a la cuarta parte, la obra quedará adjudicada en estos maestros, si bien Juan de la Cuesta continuará en la dirección de las obras hasta 1591 en que, dada la lentitud de las mismas, es desplazado por Marcos de la Torre ${ }^{222}$.

El encargo que sin duda más quebraderos de cabeza le ocasionó y el que mayor desgaste físico le produjo, fue la fábrica del convento de San Francisco, donde pone de manifiesto una formación intelectual tomando como referentes a Serlio y Vitrubio, pero manteniéndose fiel a la tradición goticista a través del uso de bóvedas de crucería. Desde 1581, no sólo estuvo al mando de las obras del claustro $^{223}$, sino que además nos consta que dirigía la fábrica del templo, encargo que se prolongaría hasta el fin de sus días ${ }^{224}$. El incumplimiento de los contratos motivó su encarcelamiento, al menos en dos ocasiones, una en 1588 y otra el año de su muerte, en $1592^{225}$. Sabemos de la existencia de un hermano, Francisco de la Cuesta, en virtud del poder que le otorga para que revise la obra ejecutada en 1589 y quien actúa en su nombre para todos sus negocios ${ }^{226}$. Veremos cómo a partir de 1590 y hasta su fallecimiento, su intervención en la fábrica franciscana no es directa, pues aunque mantiene la titularidad de la obra, efectúa cesiones y se desvincula progresivamente de la misma, aunque excepcionalmente deba acudir cuando se le reclama por algún problema estructural.

Paralelamente a las obras de los cenobios mendicantes carrioneses, desarrolló su actividad en distintos lugares, siempre dentro del ámbito palentino. En 1582 se encargaba de las trazas de la casa de Juan de Valderrábano, en la plaza de San Andrés $^{227}$. En Fuentes de Nava, llegado el año 1583, figura nuevamente junto a

\footnotetext{
${ }^{221}$ El contrato de 1579 establecía 1.600 ducados, que equivalen a 17.600 reales y el de 1585 ascendía a 47.832 reales.

${ }^{222}$ VIGURI, Miguel de y SÁNCHEZ, José Luis. Arquitectura en Tierra de Campos...Op.cit, pp. 221223, a su vez de AHPP. Carr.Prot 5670. Andrés Sánchez (1585-1586), fol 300 y ss y Protocolo 5650, Pedro Saldaña (1591), fol 564 y ss.

${ }^{223}$ ZALAMA, Miguel Ángel. La arquitectura...Op.cit, pág. 260.

${ }^{224}$ AHN. Clero Secular-Regular Franciscanos, 5355, s/f.

225 AHPP. Carr.Prot 5648. Pedro Saldaña (1588), s/f y AHPP. Carr.Prot 4982. Sebastián García (1592-1594), fol 87 y ss.

226 AHPP. Carr.Prot 8712. Sebastián García (1588-1590), fol 952 y 953.

${ }^{227}$ AHPP. Carr.Prot 5669. Andrés Sánchez (1581-1584), s/f.
} 
Francisco del Bado en la construcción de una capilla de la iglesia parroquial de San Pedro, promovida por don Juan Rodríguez de Cisneros, deán de Charcas, en Perú ${ }^{228}$. Un año después, la iglesia de San Agustín de Capillas fue testigo de la presencia de dos artistas, Juan de la Cuesta en las trazas y Diego de Praves en la ejecución de la capilla de Don Francisco Blanco Salcedo, arzobispo de Santiago de Compostela, que encargaría su heredero en mayo de dicho año, fallecido el finado ${ }^{229}$.

Como tracista, en 1585 diseñaría las reformas de la vivienda del regidor perpetuo de Carrión, don Antonio Doro Campoo, célebre por ser el comitente de la custodia del Corpus Christi ${ }^{230}$. Esta intervención sería ejecutada por el maestro de cantería carrionés Marcos de la Torre, que recibiría un total de sesenta ducados ${ }^{231}$. En la iglesia de Belén, realizó un proyecto de fortalecimiento ese mismo año, que revisaría Alonso de Tolosa ${ }^{232}$. Además nos consta que participaba activamente en el mismo, pues en 1591 Marcos de la Torre le vende unas losas procedentes del puente para que las emplee en la iglesia en la obra que allí se hacía ${ }^{233}$. Incluso un año después aún le requiere el mayordomo del templo para que tase la parte ejecutada por Juan de Buega, artista igualmente procedente de Secadura ${ }^{234}$. Si bien el proyecto en Belén no lo realiza hasta 1585, previamente se registra su intervención en este templo, colaborando con Juan de Celaya, pues en 1581 recibe cuatro ducados “...como nombrado por su parte para la obra de la iglesia... ${ }^{235, "}$

A principios de 1587 se encuentra trabajando en la reparación del puente de Osorno y exactamente un año después Juan de Nates cede el puente de Husillos a Francisco de Hontañón especificando que se siga lo dictado por Cuesta, quien por tanto habría participado como tracista. A finales de 1588 sus encargos se extienden más allá de los límites de la provincia de Palencia, pues redacta condiciones para el puente cántabro de Reinosa junto a Francisco del Río y en Valladolid se

\footnotetext{
${ }^{228}$ ZALAMA, Miguel Ángel. La arquitectura...Op.cit, pág. 265.

${ }^{229}$ Ibídem, pp. 260-261 y del mismo, "Documentos...Op.cit, pp.. 236-243.

${ }^{230}$ A este respecto, URREA FERNÁNDEZ, Jesús. "La custodia de Carrión de los Condes (Palencia): una obra del siglo XVI hecha con dinero americano" en Homenaje al Profesor Hernández Perera. Madrid, 1992, pág. 765-770.

${ }^{231}$ AHPP. Carr.Prot 5619, Melchor de la Rúa (1585-1587), s/f.

232 ZALAMA, M. Ángel. La arquitectura...Op.cit, pp. 92-93.

${ }^{233}$ AHPP. Carr.Prot 4981, Sebastián García (1590-1592), fol 352-353

${ }^{234}$ ADP. Carrión. Iglesia de Belén. Libro 15, $3^{\circ}$ de Cuentas de Fábrica (1584-1599), fol 76, 77.

${ }^{235}$ Ibídem. Libro 14. Inventario de los bienes parroquiales (1568-1586), fol 183.
} 
compromete a levantar la sacristía de la iglesia de San Martín en Gallegos de Hornija $^{236}$. Su incesante actividad le conduce en 1589 a Palencia, donde tomó parte en la ejecución de la Casas Episcopales y en la apertura de dos claraboyas en el claustro franciscano ${ }^{237}$.

Junto a Francisco del Río, en 1590 tenía a su cargo la obra de la iglesia y torre palentina de San Mamés, pero decide traspasar su parte a Antonio de Cuéllar y a Marcos de la Torre, por las trazas de la misma. En una de las cartas de pago no precisa el motivo de la cesión, indicando simplemente “...por motivos que le mueven...”, sin embargo en la otra explica: “...porque tengo necesidad de me hallar presente a otras obras que tengo y porque la dicha torre se haga con la puntualidad

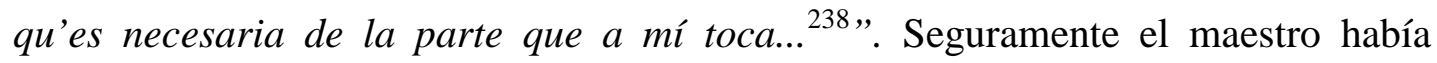
escarmentado tras haber estado encarcelado el año antes y no quería repetir la experiencia, de la que, lamentablemente, no podría eximirse dos años después. No nos extraña que se viese incapacitado a cumplir con los plazos establecidos, pues como hemos visto, aceptó varias obras simultáneamente no sólo en la misma localidad, sino en lugares separados por más de un centenar de kilómetros.

La última referencia al maestro trasmerano es posterior a su muerte. El 8 de mayo de 1594, el heredero de Cuesta, Hernando del Río, cede la obra del puente de Osorno a Pedro de Solares ${ }^{239}$.

\footnotetext{
${ }^{236}$ ZALAMA, M. Ángel. La arquitectura..Op.cit, pp. 263-266.

${ }^{237}$ Ibídem, pág. 266.

${ }^{238}$ AHPP. Carr.Prot 4981. Sebastián García (1590-1592), fol 103 y ss y fol 354 y ss.

239 ZALAMA, M. Ángel. La arquitectura...Op.cit, pág. 267.
} 


\section{Domingo de Cerecedo Pierredonda \\ Maestro de cantería \\ de San Miguel de Aras}

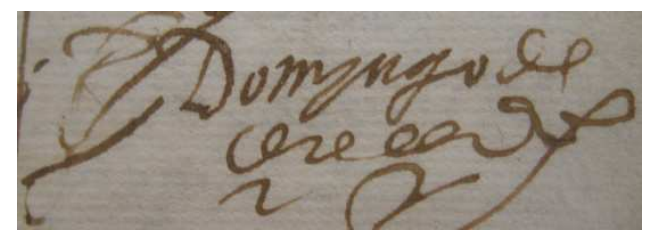

Este maestro cántabro, del cual se conoce un número muy reducido de obras, procedía de San Miguel de Aras, en la comarca trasmerana de Voto, como otros miembros de esta dinastía canteril cuyo recuerdo pervive hoy día en el escudo de su iglesia parroquial donde los Cerecedo poseían capilla propia ${ }^{240}$. En su primera etapa de formación aparece vinculado a Rodrigo Gil de Hontañón y a partir de entonces trabajará notablemente en la zona riojana y soriana ${ }^{241}$. Su actividad palentina enlaza dos siglos, pues abarca desde la penúltima década de la centuria décimo sexta hasta la primera de la siguiente.

En 1586 se le menciona por primera vez en la provincia de Palencia, concretamente en Fuentes de Nava, donde es reclamado como testigo de Felipe de la Cajiga en la obra del puente vallisoletano de Mayorga. Tres años después ya figura al cargo de la la construcción del templo parroquial de Fuentes de Valdepero ${ }^{242}$. Fue uno de los quince maestros que se personaron en la subasta de la obra del puente palentino de Herrera de Pisuerga el 4 de diciembre de $1590^{243}$. Junto a Francisco del Río, actúa como fiador en las obras que Felipe de la Cajiga efectuaba en 1591 en el convento leonés de San Claudio ${ }^{244}$.

Recibió el 14 de diciembre de ese mismo año de 1591 un poder otorgado por Juan de la Cuesta para cobrar veinte ducados que se le debía por la traza del puente cántabro de Cartes, la cual había realizado junto a Francisco de la Aza ${ }^{245}$. La obra

\footnotetext{
${ }^{240}$ La posesión de espacios de culto entre el gremio de canteros, así como la adquisición de un mayorazgo, es un fenómeno muy habitual en Cantabria. GONZÁLEZ ECHEGARAY, M ${ }^{\mathrm{a}}$ DEL Carmen. Escudos de Cantabria. Santander, 1969, pág. 224. Sobre la familia, GARCÍA CUETOS, P. Arquitectura en Asturias, 1500-1580. La Dinastía de los Cerecedo. Oviedo, 1996.

${ }^{241}$ ALONSO RUIZ, Begoña. El arte de la cantería...Op.cit, pág. 146 y sobre esta etapa VV.AA. Artistas cántabros...Op.cit, pp. 159 y 160.

${ }^{242}$ ZALAMA, Miguel Ángel. La arquitectura...Op.cit, pág. 256.

${ }^{243}$ ARAMBURU-ZABALA, Miguel Ángel. Las obras públicas...tomo II. Op.cit, pág. 870.

${ }^{244}$ AHPP. Carr.Prot 5650, Pedro Saldaña (1591), fol 421 y ss.

${ }^{245}$ AHPP. Carr.Prot 5650, Pedro Saldaña (1591), fol 420.
} 
del puente había sido rematada en Pedro de la Peña, pero éste cedió parte de la misma a los dichos Juan de la Cuesta, Francisco de Alvarado y Juan Gil de Zorlado $^{246}$.

Su amistad con Juan de la Cuesta se corrobora en enero de 1592, cuando el maestro trasmerano recurre a su colega para que actúe como tasador de la obra que había ejecutado en dos capillas del convento de San Francisco de Carrión que se habían hundido, situadas bajo la advocación de San Bernardino y los Santos Cosme y Damián. El patrón de las mismas, el Licenciado Díaz Flores, requiere a Juan de Celaya para que valore los daños y entre ambos maestros determinan que Juan de la Cuesta le abone doscientos ducados ${ }^{247}$. Precisamente esa cantidad es la que Domingo de Cerecedo adeudaba a Juan de Nates y Felipe de Cajiga en 1593, comprobándose una vez más los lazos de amistad entre los maestros trasmeranos ${ }^{248}$.

También está documentada su participación en la iglesia de la Asunción de Autilla del Pino, cuando en 1593, Domingo de Cerecedo otorga poder a Juan de la Lastra para que presente una carta de pago en virtud de lo que se le adeuda ${ }^{249}$. Ese mismo año aparece trabajando en la iglesia de San Hipólito de Támara, donde es posible que residiera intermitentemente hasta 1600 en que volvemos a localizarle, realizando su sacristía y unos años más tarde, concluyendo la cabecera de la iglesia de Santa Eugenia de Becerril ${ }^{250}$. A principios del siglo XVII está documentada su participación, junto a Alonso de Santiago y Pedro de la Sierra en la iglesia de Santa Eugenia de Becerril de Campos ${ }^{251}$ En 1607 se instala en la Rioja y allí recibe en cesión la obra del monasterio de Moya, de la que se hará cargo junto a Valentín de Vallesteros $^{252}$. Será una intervención de pequeña entidad, pues poco más tarde, en 1608, le localizamos en Cordovilla la Real, donde levanta la torre de la iglesia de la Asunción junto a Juan de Cerecedo y Rodrigo de la Pasadilla ${ }^{253}$.

\footnotetext{
${ }^{246}$ AHPP. Carr.Prot 4981, Sebastián García (1590-1592), fol 424 y ss.

${ }^{247}$ ZALAMA, Miguel Ángel. La arquitectura...Op.cit, pág. 256. También en AHPP. Carr.Prot 5651, Pedro Saldaña (1592), fol 881 y ss.

248 ZALAMA, Miguel Ángel. La arquitectura...Op.cit, pág. 290.

${ }^{249}$ Ibídem, pág. 256.

${ }^{250}$ Ibídem, pág. 257.

${ }^{251}$ URREA GONZÁLEZ, Jesús y MARTÍN GONZÁLEZ, Juan José. Inventario...I, Op.cit, pág. 99.

${ }^{252}$ VV.AA. Artistas cántabros...Op.cit, pág. 632.

${ }^{253}$ URREA GONZÁLEZ, Jesús y MARTÍN GONZÁLEZ, Juan José. Inventario...I, Op.cit, pág. 146.
} 


\section{Toribio de la Cuesta}

\section{Maestro de cantería natural de Penagos}

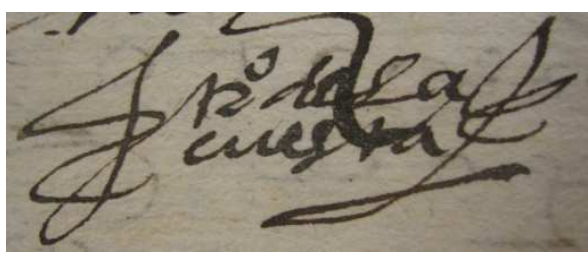

Desconocemos si existieron vínculos de consanguinidad entre Toribio y Juan de la Cuesta, si bien está constatada su común dedicación a la cantería y su procedencia cántabra aunque Toribio no era trasmerano, pues Penagos, ubicada a una treintena de kilómetros al occidente de Secadura, pertenece a la comarca de Santander. La naturaleza de las intervenciones en las que llegó a participar nuestro artista en la provincia de Palencia se reducen al abanico de la primera década del siglo XVII. Éstas fueron de la misma índole de las que realizaría Juan de la Cuesta dos décadas antes, desempeñando labores de tasador y de tracista, pasando por la ejecución directa de obras de carácter público y religioso. Probablemente después regresaría a su tierra natal.

En la provincia de Segovia se sitúa la primera referencia documental del artista, donde figura realizando una pared de cantería en el convento de Santa Cruz la Real, obra que le había cedido en febrero de 1605 el trasmerano Francisco del Río $^{254}$. Pese a lo nimio de la intervención, quizá en la misma se encuentre la clave de la rápida aceptación de este artista en Carrión, si tenemos en cuenta que el cenobio segoviano pertenecía a la orden dominica y su primera obra en la villa condal sea precisamente el convento de Santo Domingo. Las relaciones entre las dos casas mendicantes eran estrechas, lo que ratificamos en la aceptación del establecimiento de los dominicos en Carrión que tuvo lugar en la casa segoviana el 24 de enero de $1529^{255}$. El convento de Santo Domingo encargó a Toribio de la Cuesta en octubre de 1605 la ejecución de la panda que quedaba por hacer en el claustro de Santo Domingo, que comenzara Juan de la Cuesta en 1579, así como la construcción de

\footnotetext{
${ }^{254}$ AHPP. Carr.Prot 4832, Juan Díaz Pajaza (1605), fol 223 y ss.

${ }^{255}$ HOYOS, Manuel María, O. P. Registro documental hispano-dominicano. Tomo III. Editorial Sever-Cuesta. Valladolid, 1963, pág. 207.
} 
una escalera de comunicación entre la iglesia y el claustro alto ${ }^{256}$. Parece que las obras se prolongaron hasta 1607, aunque un año después no había recibido la suma acordada $^{257}$. La razón del retraso de las mismas, que debían haber sido finalizadas en la Navidad de 1605 o a lo sumo a comienzos del año siguiente, la hallamos en la simultaneidad compartida con las obras del convento de Santa María de Benevívere. Don Diego Sarmiento de Silva y Mendoza, descendiente de los Sarmiento, el linaje benefactor de la abadía, encomendó al artista la ejecución de la cripta de la capilla mayor en la cual se sepultarían a partir de entonces los condes de Salinas ${ }^{258}$. Dicho encargo vendría motivado seguramente por la necesidad de encontrar un espacio adicional de enterramiento en un lugar privilegiado, pues la sala capitular, que había funcionado como panteón desde su fundación, albergaba ya demasiados monumentos funerarios en su interior.En 1606, hallamos a Toribio en la localidad palentina de Villamuriel de Cerrato, que dista medio centenar de kilómetros de Carrión. En ella, el carrionés Antonio de Cuéllar le cede la obra de su iglesia parroquial, consistente en la realización de algunas tapias ${ }^{259}$. En este caso, adopta la faceta de albañil, demostrando las buenas relaciones que mantenía en su lugar de residencia, incluso con los maestros locales.

De nuevo en Carrión, logra adjudicarse el proyecto de reconstrucción del nuevo templo que debía levantarse en San Andrés, ya que todo lo edificado previamente siguiendo a Rodrigo Gil de Hontañón, a excepción de la capilla mayor, presentaba una pésima cimentación a comienzos del siglo. De este interesante proyecto, que fue entregado el 18 de febrero de 1608, se encargaría junto a Francisco Bálcava, arquitecto trasmerano que estudiaremos a continuación, con el que colaborará repetidamente ${ }^{260}$. Precisamente, las obras habían sido rematadas en Bálcava, la mitad de las cuales, en virtud de un acuerdo previo que existiría entre ambos artistas, cedería a favor de Toribio $^{261}$. Por tanto, ambos ejercen simultáneamente de arquitectos y maestros de obras en una obra que tuvieron que ejecutar ex novo, derrumbando el viejo templo. No obstante, respetaron en buena

\footnotetext{
${ }^{256}$ AHPP. Carr.Prot 4832. Francisco Moro Saldaña (1605), fol 521 y ss.

257 AHPP., Carr.Prot 4772. Martín Cisneros (1607-1609), s/f.

${ }^{258}$ AHPP. Carr.Prot 4708. Pedro Carrión (1605), s/f.

${ }^{259}$ AHPP. Carr.Prot 4833. Juan Díaz Pajaza (1606), fol 209 y ss.

${ }^{260}$ AHN. Clero Regular-Secular, Legajo 5356, Expediente 2, Iglesias de San Andrés y San Pedro, Obras.

${ }^{261}$ AHPP. Carr.Prot 4835. Juan Díaz Pajaza (1608), fol 288 y ss.
} 
medida las condiciones planteadas por el maestro de Rascafría. Unos meses después, concretamente en junio de dicho año, Bálcava cede dos terceras partes de la obra que realizaba y asimismo dirigía en el puente de Carrión a favor de Toribio de la Cuesta y del trasmerano Pedro Yáñez, vecino de $\operatorname{Rada}^{262}$. No obstante, de la Cuesta renunció poco después, probablemente acuciado por las obligaciones del templo de San Andrés y seducido por otra obra, que, aunque de pequeña entidad, le permitiría trabajar con total libertad. Nos referimos a la construcción de la iglesia parroquial de Villarmentero, localidad muy próxima a Carrión, que hasta el momento ejecutaba Juan Ortiz. Fallecido repentinamente, las obras fueron rematadas en el artista en octubre de $1608^{263}$.

El 16 de mayo de 1609 suscribió un contrato de aprendizaje con Francisco García de la Penilla, padre de un joven oriundo de Penagos, llamado como su progenitor, por espacio de tres años. De no resultar suficiente este período para ganarse un jornal como oficial, debía emplear “...todo el tiempo que tardare en acauar de aprender el dicho oficio..." En el documento se le nombra maestro arquitecto, tal vez para otorgar mayor relevancia a su persona, aunque se indica que le va a enseñar el oficio de cantero, además de proporcionarle “...vestido y calçado que ubiere menester exceto camisas... ${ }^{264}$ ". Ese mismo año es cuando Toribio de la Cuesta vuelve a participar en el puente de Carrión, que continuaba supervisando Bálcava, cuando Felipe de Buega le traspasa su parte, por la que se comprometía a encañar los huecos de sus siete $\operatorname{arcos}^{265}$.La obra de la iglesia de San Miguel en Tariego de Cerrato que ejecutaron los tres Juanes, Juan Gil de Ramales primero y Juan de la Lastra y Juan de Gabanes a partir de 1604, fue tasada tras su conclusión en 1610 por Toribio de la Cuesta ${ }^{266}$. El mismo papel desempeña en 1611, en la iglesia de Villanueva de la Cueza, valorando la obra que llevó a cabo el maestro cántabro Pedro de Carandil, procedente del Valle de Penagos ${ }^{267}$. Esta será la última referencia documental del artista.

\footnotetext{
262 AHPP. Protocolo Carrión 4835. Juan Díaz Pajaza (1608), fol 240 y ss.

${ }^{263}$ Ibídem.

${ }^{264}$ AHPP. Carr.Prot 4578. Juan Aranda Treceño (1608-1609), s/f.

${ }^{265}$ AHPP. Protocolo. Carrión 5392. Francisco Moro Saldaña (1609), s/f.

${ }^{266}$ ZALAMA, M. Ángel. La arquitectura...Op.cit, pp. 200, 335, 343.

${ }^{267}$ AHPP. Carr.Prot 4579. Juan Aranda Treceño (1610-1611), s/f.
} 


\section{Francisco Martínez de Bálcava Maestro arquitecto de Bádames}

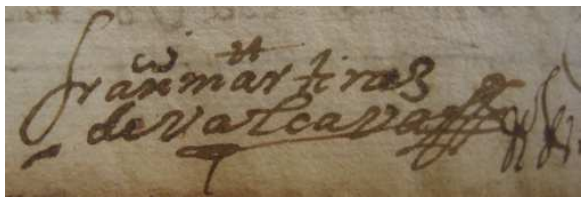

Era el hijo único de María Fernández de Pontecillas, la cual le traspasa todos sus bienes por vía de mayorazgo en $1613^{268}$ y primo, por vía materna, de los maestros de cantería trasmeranos Francisco y Domingo del Río Pontecillas, a los que nos referiremos seguidamente ${ }^{269}$. Su trayectoria artística, que se prolonga hasta los años treinta del siglo XVII, comprende las dos últimas décadas del siglo XVI, en que figura al cargo del puente palentino de Guardo desde 1590, y de la erección de la capilla mayor de la iglesia parroquial de la Asunción en 1596 junto a otros maestros de albañilería, carpintería y cantería ${ }^{270}$. A su mano se deben la construcción de la iglesia monasterial de San Miguel de Villamayor de Treviño, en Burgos y la iglesia de Labastida, en Álava, lo que le sitúa recorriendo diversos puntos de la geografía del norte español ${ }^{271}$. Este artista, que trabajó paralelamente como maestro de cantería y arquitecto, figura avecindado desde 1605, en la localidad de San Quirce, en Herrera de Pisuerga, donde le encargan la ejecución de su puente, al que regresará en 1616 para efectuar unos reparos ${ }^{272}$.

Desde febrero de 1608, dirige las obras de rehabilitación del puente de Carrión, en mal estado por entonces debido a las crecidas, a consecuencia de las cuales se había derrumbado uno de sus arcos y un pilar. También participaba activamente en el mismo, pues dos terceras partes de la obra se las cede en junio a Pedro Yáñez y Toribio de la Cuesta ${ }^{273}$. Dado el estado de ruina del puente, se le vuelve a requerir en 1619, en que proyecta una presa hacia el convento de San Zoilo

\footnotetext{
268 AHPP. Carr.Prot 4841. Juan Díaz Pajaza (1614), s/f.

${ }^{269}$ AHPP. Carr.Prot 4855. Juan Díaz Pajaza (1629), s/f.

${ }^{270}$ VAQUERIZO GIL, Manuel. "Tipología documental para la Historia del Arte en Protocolos Notariales" en Publicaciones del Instituto de Etnografía y Folclore Hoyos Sainz, vol XII. Santander, 1976, pág. 159.

${ }^{271}$ VV.AA. Artistas cántabros...Op.cit, pp. 387-388.

${ }^{272}$ Así se puede comprobar por una carta de poder en la que se le rrequiere para "fabricar el rreparo y nuevo rompimiento y añadimiento que se ha de açer en la puente de la uilla de Herrera de Rrío Pisuerga...”. AHPP. Carr.Prot 4818. Francisco Cuetos (1616), fol 412 y ss.

${ }^{273}$ AHPP. Carr.Prot. 5392. Francisco Moro Saldaña (1609), s/f.
} 
para frenar el daño sufrido por las aguas, la cual ejecutará junto a Felipe de Rivas, con el que volverá a trabajar en el puente de Villaescusa de Ecla, al norte de Palencia, en $1620^{274}$. Ese mismo año, que estaba concertado en la fábrica del puente de Lantadilla y los reparos del puente de Guardo, cede su parte a Domingo del Río y Pedro de la Torre ${ }^{275}$, pues como veremos a continuación, estaba comprometido con otros trabajos en Carrión.

Durante este intervalo de tiempo, transcurre más de una década durante la cual Bálcava se adjudica las obras más importantes de Carrión y participa en otras que, sin serlo tanto, avalan la experiencia del artista, que se presencia solícito, en calidad de tasador. Resulta de vital trascendencia la ejecución del proyecto de reconstrucción del templo de San Andrés de 1608, ejecutado junto a Toribio de la $\mathrm{Cuesta}^{276}$, dado que, salvo la capilla mayor, el resto de la iglesia es fruto de las reformas llevadas a cabo siguiendo sus trazas. Por ello, el proyecto que planteara Rodrigo Gil de Hontañón casi un siglo antes, sirvió de inspiración para éste pero no resultó el definitivo como se había pensado dada la recurrencia al tipo de iglesia columnaria o el esquema de tres naves a la misma altura, propio del siglo $\mathrm{XVI}^{277}$. Ante la lentitud con que marchan las obras, el proyecto de Bálcava es renovado en 1613, estableciéndose un nuevo plazo límite en 1626, que no se cumplirá, pues las obras se prolongarán hasta el último cuarto de siglo, cuando ya Bálcava había fallecido tiempo atrás ${ }^{278}$. En esta obra además de estar al mando de la misma, encargado de la supervisión, participaba activamente en ésta, junto a Toribio de la Cuesta, a quien le traspasa la mitad, como había sucedido en la obra del puente de Carrión. Esta cesión le proporciona la libertad suficiente para poder abordar otros proyectos paralelamente, como la dirección de las obras del nuevo templo del convento de Santa Clara en $1616^{279}$.

\footnotetext{
${ }^{274}$ AMCC, Libro 1, Sesiones municipales (1618-1637). Sesión de 25 de agosto y de 12 de septiembre de 1619, fol 46 y 47, AHPP. Carr.Prot 5215. Jerónimo Laso (1619), fol 153 y ss y VV.AA. Artistas cántabros...Op.cit, pp. 387-88.

${ }^{275}$ AHPP. Carr.Prot 5508. Sebastián Peláez (1607-1610), s/f.

${ }^{276}$ AHN. Clero Regular-Secular, Legajo 5356, Expediente 2, Iglesias de San Andrés y San Pedro, Obras.

${ }^{277}$ ZALAMA, Miguel Ángel. La arquitectura...Op.cit, pp. 89-91.

${ }^{278}$ AHPP. Carr.Prot 4840. Juan Díaz Pajaza (1613), fol 290 y ss.

${ }^{279}$ AHPP. Carr.Prots 4843. Juan Díaz Pajaza (1616), fol 592 y ss.
} 
En estos años también figura en la documentación en calidad de fiador, como en 1614, en que se erige como máximo responsable de la obra que ejecuta Pedro del Arenal en el convento de San Zoilo, consistente en la fábrica de un cuarto inmediato a la huerta, en el lado sur, junto al río ${ }^{280}$. En la plaza de Santa María, el linaje Villasante poseía unas viviendas que, dado su lamentable estado, son derruidas para edificar sobre su solar la Casa del Capitán, destinada a la residencia eventual de capitanes para reclutar soldados en nombre del rey. Bálcava será uno de los artífices que tase en septiembre de 1614 los despojos del derrumbe y plantee la ubicación de la nueva edificación para que esté alineada con el resto del conjunto. En 1615, Bálcava actuará como veedor de la obra que se estaba ejecutando, que había sido rematada en Juan Carnicero, determinando que efectúe algunos cambios como la disminución del tamaño de la puerta principal, la sustitución de soleras de roble por las de pino en las cubiertas, así como la ejecución de las bóvedas del zaguán en forma de medio punto, lo que prolongará la obra hasta $1617^{281}$. Ese mismo año 1616 Bálcava es requerido por Bartolomé de Villegas, a cuya cuenta estaba el puente palentino de Lantadilla, localidad palentina en la que, como referimos, había trabajado con anterioridad. Debía continuar las obras del mismo en la que ya había participado, pues Francisco Gómez del Río había renunciado a ellas ${ }^{282}$. Ante tal exceso de trabajo, otorga poder al trasmerano Andrés de Zorlado Rivero, avecindando en Saldaña, por entonces perteneciente a la Diócesis de León, para que se encargue de la obra de la iglesia de Salas, situada en dicha localidad palentina ${ }^{283}$. Como fiador de Domingo del Río en la obra de la iglesia parroquial de San Esteban de Villoldo, Bálcava se obliga a que este la finalice en los períodos establecidos ${ }^{284}$.

Regresa a su villa natal en 1618, pues en septiembre de dicho año, proporciona las trazas de una de las capillas de la iglesia parroquial de Santiago de Bádames, para cuya ejecución contrata al maestro trasmerano, vecino de Carasa, Juan de Rioseco Agustina. Ubicada en lado del Evangelio de la capilla mayor, debía estar finalizada en el plazo de un año, finalizado el cual Rioseco recibiría la última paga que completaría los 300 ducados estipulados por ambas partes. Los arcos de

\footnotetext{
${ }^{280}$ AHPP. Carr.Prot 5397. Francisco Moro Saldaña (1614), s/f.

${ }^{281}$ VIGURI, Miguel de y SÁNCHEZ, José Luis. Arquitectura en la Tierra...Op.cit, pp. 169-170, a su vez de AHPP. Carr.Prot 5211, Jerónimo López (1615), s/f.

${ }^{282}$ AHPP. Carr.Prot 4818. Francisco Cuetos (1616), fol 376 y ss.

${ }^{283}$ AHPP. Carr.Prot 4843. Juan Díaz Pajaza (1616), fol 409 y ss.

${ }^{284}$ AHPP. Carr.Prot 5161. Jerónimo Laso (1616), fol 16 y ss.
} 
medio punto, las cornisas y basas toscanas, las molduras bien labradas, la presencia de una claraboya para aportar diafanidad y la extrema atención a las proporciones son elementos que revelan un pleno conocimiento del lenguaje renacentista ${ }^{285}$. En agosto de 1619 se había rematado en Juan de Santiago la obra del convento de San Miguel y Santa Isabel de Carrión, pero el contrato no se firma hasta 1620 porque era necesario presentar un fiador y hasta noviembre, Bálcava se presenta como tal. Por otro lado se encontraba por entonces en Herrera de Pisuerga, por lo que emite un poder a su primo, Domingo del Río, para que actúe en su nombre, de ahí la demora de la firma ${ }^{286}$.

En noviembre de 1621, Andrés de Zorlado, como cesionario en nombre de los herederos de Domingo de Argos, abona 1.452 reales a Francisco Martínez de Bálcava en concepto de haber fiado la obra del convento de San Juan de Coria, en Asturias, rematada en el dicho Argos. Ese mismo año, salió como fiador junto a su primo Domingo del Río de la obra del puente de Olivares que había sido rematada en Andrés de la Cajiga por 6.800 ducados, nada menos ${ }^{287}$. El mismo papel desempeñará al menos en dos ocasiones más, ambas en 1622. En mayo de dicho año, fía a Juan Gutiérrez del Pozo en los reparos del puente de Reinoso de Cerrato y en octubre avala a Domingo del Río, en la obra que éste ejecutaba en el puente leonés de Sahagún desde $1615^{288}$. En 1624, el regidor de Carrión, vuelve a solicitar la presencia de Bálcava para dirigir las obras del puente “...con todo cuidado y brebredad... ${ }^{289, "}$.

El artista fallecerá hacia 1634 en que se nombran maestros de cantería, albañilería y carpintería para tasar todo lo que Bálcava ha ejecutado y determinar aquello que queda por hacer ${ }^{290}$. Dado que la iglesia estaba lejos de ver su finalización y por tanto, Bálcava había incumplido el contrato, en julio de 1635, el

\footnotetext{
${ }^{285}$ AHPP. Carr.Prot 5214. Jerónimo López (1618), fol 623 y ss.

${ }^{286}$ AHPP. Carr.Prots 5403, Francisco Moro Saldaña (1620), fol 194 y ss.

287 AHPP. Carr.Prot 4848. Antonio Orejón “el Viejo” (1621-1622), fol 415 y fol 533.

288 AHPP. Carr.Prot 4849. Juan Díaz Pajaza (1622-1623), fol 91 y ss, 177 y ss y 228 y ss.

${ }^{289}$ AMCC. Libro 1, Sesiones municipales (1618-1637). Sesiones de 9 de marzo y de 6 de junio de 1624 , fol 273 y 286.

${ }^{290}$ AHN. Clero Regular-Secular, Legajo 5356, Expediente 2, Iglesias de San Andrés y San Pedro, Obras.
} 
mayordomo de San Andrés incoa un pleito contra los herederos y fiadores ${ }^{291}$. A finales de 1649 se menciona por última vez al maestro trasmerano, en que Juan de Trujeda, como cesionario de sus herederos, tasa en 3000 reales su intervención en la obras de finalización de la capilla mayor de la iglesia parroquial de Santa María de Lantadilla, que aún no se le habían abonado ${ }^{292}$.

\section{Francisco del Río Pontecillas \\ Maestro de cantería de}

Bádames

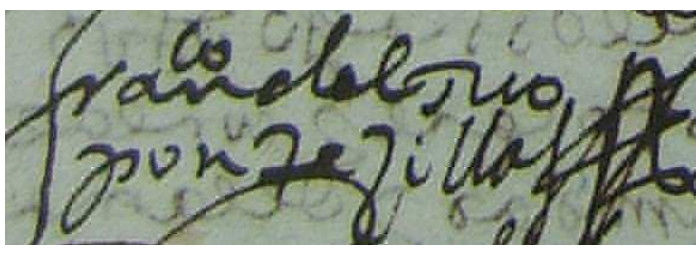

Era hijo de Rodrigo Gutiérrez del Río y Catalina Fernández de Pontecillas, dato que conocemos gracias al testamento de su hermano, Domingo del Río Pontecillas, maestro igualmente cántabro que trabajó en numerosas ocasiones en la villa $^{293}$. No debe confundirse con el también trasmerano Francisco del Río, vecino de San Miguel de Aras, que trabaja también en la provincia de Palencia, en Carrión concretamente, en la edificación de su puente pétreo $^{294}$. Podemos certificar que no se trata de la misma persona, pues trabajan juntos en la ejecución de la iglesia parroquial de Cevico de la Torre ${ }^{295}$. La clave para diferenciarlos es que nuestro Francisco del Río figura siempre con el patronímico añadido de Pontecillas y es el sobrino de su homónimo. Sucede a su tío dentro de la cuadrilla de canteros que en los años cuarenta y cincuenta del siglo XVII realiza la mayor parte de los puentes de la meseta norte, junto a Andrés de Zorlado, que era su cuñado ${ }^{296}$. Gracias al hallazgo

\footnotetext{
${ }^{291}$ AHN. Clero Regular-Secular, Legajo 5357, Expediente 1, Iglesias de San Andrés y San Pedro, Obras.

${ }^{292}$ AHPP. Carr.Prot 5193. Aso (1649-1650), fol 154.

293 AHPP. Carr.Prot 4842. Juan Díaz Pajaza (1615), fol 399 y ss.

${ }^{294}$ No abordaremos la personalidad de este artista, pues no participa en obras religiosas carrionesas. Sobre el mismo, SOJO Y LOMBA, Fermín. Los maestros canteros de Trasmiera. Madrid, 1935, pp. 161-163, GARCÍA CHICO, Esteban. Documentos...Arquitectos...Op.cit, pp. 23-25, LLAGUNO Y AMIROLA, Eugenio. Noticias de los arquitectos y arquitectura de España desde su restauración, Ilustradas y acrecentadas con notas, adiciones y documentos por Juan Agustín Ceán Bermúdez. Editorial Turner. Madrid, 1977, tomo 1, pág. 319, tomo 2, pág. 125, tomo 3, pp. 16-17. ZALAMA, Miguel Ángel. La arquitectura...Op.cit, pp. 304-311, VV.AA. Artistas cántabros...Op.cit, pp. 29 y 572.

${ }^{295}$ GARCÍA CHICO, Esteban. Documentos...Arquitectos, Op.cit, pp. 23-25.

${ }^{296}$ ALONSO RUIZ, Begoña. El arte de la cantería...Op.cit, pp. 159.
} 
de su testamento, sabemos de su participación junto a éste en la fábrica de los puentes de Saldaña, Velilla de Guardo, o el de Prioro, en León, por cuya intervención se le debían 8000 reales. Así mismo ambos participan junto a Jerónimo de Avendaño en el puente de Cea, gracias a la cesión de una parte de la obra que en ellos hizo Pedro Cayón, en quien se había rematado en fecha indeterminada. Cayón y Pontecillas no habían ajustado cuentas, como tampoco habían acordado la suma que aquel debía a Francisco por la parte correspondiente al puente de Sahagún. Pero estos no son los únicos casos de impagos a Francisco del Río Pontecillas. Así, se pueden enumerar diversas sumas pendientes de pago correspondientes a la mitad del puente de Monzón, Palencia, rematada en Juan Gutiérrez del Pozo, vecino de dicha ciudad o la cuarta parte del puente de Melgar de Yuso, en Palencia ${ }^{297}$.

Además de maestro de cantería, llegó a desempeñar el cargo de "familiar" del Santo Oficio de la Inquisición. De su matrimonio con doña Catalina del Río Rivero nacieron Francisco, María, Catalina, María, Francisca y Simón del Río, del cual se sabe que se convirtió en clérigo y cura de la iglesia de Belén de Carrión.

Figura como veedor de las obras de Palencia en 1594, cuando valora la intervención realizada por el trasmerano Juan de la Lastra para la nueva sede de la cofradía de Nuestra Señora del Rosario, junto al convento dominico de San Pablo ${ }^{298}$. En 1619 actúa junto a su hermano Domingo como fiador de Francisco de Buega en la obra que éste ejecuta en la capilla de San Nicolás de la iglesia de Santa María de Carrión ${ }^{299}$.

La obra del puente de Saldaña, que estaba a cargo del maestro Domingo Vélez de Argos, queda momentáneamente paralizada cuando, en marzo de 1620, fallece repentinamente. Tal y como figuraba en su testamento, de la finalización de las obras que estuviesen a su cargo y no pudiese finalizar, se harían cargo los maestros que contratasen sus herederos. En este caso, la obra es traspasada por su

\footnotetext{
${ }^{297}$ AHPP. Carr.Prot 5466. Francisco Ochoa (1648-1650), fol 229 y ss

${ }^{298}$ Declaración de Francisco del Río a 25 de mayo de 1594. AHPP. Varios. Protocolo 10895. Varios años y escribanos, s/f.

${ }^{299}$ AHPP. Carr.Prot 4820. Francisco Cuetos (1619), fol 150.
} 
hermano y albacea testamentario, el Licenciado Martín Vélez de Argos a Andrés de Zorlado, quien cede a su vez, su mitad, a Francisco del Río ${ }^{300}$.

No se vuelve a tener noticias de Francisco del Río hasta 1636 en que el maestro trasmerano, de Bádames como él, Domingo de la Puente, le nombra su testamentario y le cede la parte que tiene en el puente de Monzón, para que la prosiga $^{301}$. En 1637 tenía a su cargo la obra de los puentes de Vega y la Oz de la localidad palentina de Cardaño de Arriba, cuyas dos terceras partes cede a favor de Zorlado y Jerónimo de Avendaño ${ }^{302}$. En julio del año siguiente, la obra estaba concluida, como así lo prueba la carta de pago por 30.000 reales que se le otorga, un tercio del montante total de la obra ${ }^{303}$.

A partir de 1640 interviene en la reedificación del puente de Carrión, en compañía de Andrés de Zorlado y Jerónimo de Avendaño ${ }^{304}$. Sus buenas relaciones con estos maestros vuelven a ser ratificadas dos años después, cuando se remate en Avendaño la fábrica del templo de San Julián y salgan por fiadores Pontecillas y Zorlado $^{305}$. Entre 1645 y el año siguiente, toma parte nuevamente en obras públicas palentinas, como son los puentes de Palenzuela y Quintana del Puente ${ }^{306}$.

Dictó testamento el 30 de octubre de 1648 disponiendo ser enterrado en la iglesia de Santiago de Bádames, si bien su cuerpo debía ser depositado previamente en la iglesia de Belén, donde yacían los restos de su difunto hermano, que, habiendo sido trasladados por las obras de reconstrucción llevadas a cabo, dispone vuelvan a depositarse en su ubicación original. Aparte de estar aquejado de una grave enfermedad, como él mismo indica, la incapacidad de terminar la firma del documento, manifiesta que Francisco del Río se encontraba ya en una edad avanzada. Por otro lado, podemos constatar algunos lapsus de memoria, que el propio testador reconoce, como sucede cuando se refiere a su participación en los

\footnotetext{
${ }^{300}$ AHPP. Carr.Prot 4821. Francisco Cuetos (1620), s/f.

${ }^{301}$ SOJO Y LOMBA, Fermín. Los maestros...Op.cit, pp. 145 y 164.

302 AHPP. Carr.Prot 5183. Jerónimo Laso, (1637), fol 502 y ss.

${ }^{303}$ AHPP. Carr.Prot 4826. Francisco Cuetos (1637), s/f.

${ }^{304}$ VV.AA. Artistas cántabros...Op.cit, pág. 572.

${ }^{305}$ FERRERO MAESO, Concepción. "El mecenazgo... Op.cit, pp. 591, a su vez de AHPP. Carr.Prot 4829. Francisco Cuetos (1641-1642), s/f.

${ }^{306}$ ARAMBURU-ZABALA, Miguel Ángel. Las obras públicas...Tomo I, Op.cit, pág. 234.
} 
puentes de Astudillo y Castrojeriz, de los que se le debe la suma correspondiente a la cuarta parte del total, de lo que se retracta unas líneas más abajo, pues “...se me ha uenido a la memoria que está ajustada.${ }^{307}$." Aún estaba vivo en 1656, cuando se presenta como testigo de un poder otorgado por el trasmerano Andrés de la Maza a su mujer ${ }^{308}$.

\section{Domingo del Río Pontecillas Maestro de cantería de Bádames}

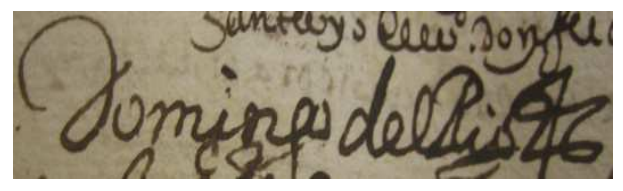

Hermano de Francisco del Río Pontecillas, también le unían lazos de consanguinidad con otros maestros trasmeranos, pues era primo de Francisco Martínez de Bálcava, a cuyo lado ejecutará varias obras, el primero como maestro arquitecto y éste, a sus órdenes como maestro de obras. Contrajo matrimonio con doña Isabel Gómez de la Madrid con la que tuvo tres hijos, de nombre Manuel, María y Teresa del Río Pontecillas, a cuyo cargo quedarían a raíz del fallecimiento del artista en $1634^{309}$. El enlace tuvo que producirse a partir de 1615, conclusión que extraemos del hecho de que este año, en que dicta testamento, designa como única y universal heredera a su madre, doña Catalina Fernández, residente en Bádames, pues su padre Rodrigo Gutiérrez, había fallecido por entonces ${ }^{310}$. Además debía ser muy joven, dado que ni siquiera había comenzado a trabajar en Carrión, aunque ya se denominaba a sí mismo "maestro arquitecto", lo que revela la utilización aleatoria del término e igualmente un afán de ascenso en la escala social.

A través de su testamento colegimos su religiosidad, pues además de ser cofrade la Vera Cruz de San Quirce del Río Pisuerga, en Palencia, y de la cofradía del Sacramento de la iglesia de Belén de Carrión, deseaba ser sepultado con el paño de Nuestra Señora de la O, advocación bajo la cual se hallaba un hospital próximo a San Zoilo. El hecho de que fuera cofrade en San Quirce, localidad donde precisamente estaba avecindado su primo, apunta hacia la posibilidad de que sus

\footnotetext{
${ }^{307}$ AHPP. Carr.Prot 5466. Francisco Ochoa (1648-1650), fol 229 y ss.

${ }^{308}$ VV.AA. Artistas cántabros...Op.cit, pág. 579.

${ }^{309}$ AHPP. Carr.Prot 5692. Norberto Sandoval y Guevara (1659), fol 419 y ss.

${ }^{310}$ AHPP. Carr.Prot 4842. Juan Díaz Pajaza (1615), fol 399 y ss.
} 
primeros años de formación se gestasen de la mano de Bálcava en aquella localidad palentina. Desarrolla su actividad principalmente en las provincias de León y Palencia durante las tres primeras décadas del siglo XVII, constatándose su avecindamiento en Carrión.

Vivía, como así constata un protocolo fechado en 1629 , en la calle de Castillería, corredera de la iglesia de Belén ${ }^{311}$. Ésta era su residencia desde al menos 1625, en que el propio Domingo del Río accede, con el fin de evitar pleitos, a reparar los desperfectos que había ocasionado el derrumbe de un colgadizo de la casa aledaña de doña Mencía de la Serna, poseedora del mayorazgo de don Gaspar de Guevara, debiendo ésta abonarle el gasto correspondiente a los materiales y trabajo. Asimismo, el artífice aprovechó la ocasión favorable para solicitar a su vecina la venta del suelo de esa parte, aún sabiendo que estaba prohibida la venta de los bienes pertenecientes a un mayorazgo heredado ${ }^{312}$. Debió existir otro Domingo del Río que también se dedicó a la cantería, pero no fue coetáneo de nuestro artista sino posterior, pues el que referimos, ya había fallecido en 1643 cuando éste otro se inicia junto a Jerónimo de Avendaño, gracias al contrato de aprendizaje que suscribe su madre, María de Hano ${ }^{313}$.

Su primo, Bálcava, es quien le proporciona los trabajos más tempranos, que, como es usual en los maestros trasmeranos, se producen en las obras públicas. En este caso se trata de la fábrica del puente de Lantadilla y el reparo del puente de Guardo, cuya ejecución compartirá con Pedro de la Torre, en quien igualmente se produce la cesión en $1608^{314}$. También al lado de Bálcava, siguiendo sus trazas, actúa como maestro del puente de Carrión en 1609, en el que participaba por entonces el maestro de Secadura, Felipe de Buega ${ }^{315}$. Está documentada su participación en la iglesia palentina de Santa María de Villasarracino, concertada a partes iguales con el carrionés Juan González de la Mata desde 1614, en la que participará más de una década después ${ }^{316}$.

\footnotetext{
${ }^{311}$ AHPP. Carr.Prot 4855. Juan Díaz Pajaza (1629), s/f.

AHPP. Carr.Prot 4852. Juan Díaz Pajaza (1625), s/f.

${ }^{313}$ ALONSO RUIZ, Begoña. El arte de la cantería, Op.cit, pág. 179.

${ }^{314}$ AHPP. Carr.Prot 5508. Sebastián Peláez (1607-1610), s/f.

315 AHPP. Carr.Prot. 5392. Francisco Moro Saldaña (1609), s/f.

316 AHPP. Carr.Prot 4842. Juan Díaz Pajaza (1615), fol 399 y ss.
} 
Gracias al hallazgo del codicilo de Agustín de la Cajiga, otro maestro trasmerano perteneciente a una familia de larga tradición en el mundo de la cantería, conocemos algunos de sus trabajos de su época leonesa, que se debieron producir coetáneamente a la fecha del documento, 1614, pues por entonces se documenta su participación en Sahagún. En él se menciona la ejecución de las obras de la iglesia de Santa Catalina de la Vega de Almanza y el campanario de la iglesia de San Pedro de Foncollada, que se hallaba aún en proceso de construcción ${ }^{317}$. La siguiente intervención de Domingo del Río le sitúa en Sahagún, en las obras del puente, rematado en 1614 en Francisco de Praves por seis mil ducados. Éste cedió la mitad de su obra a Pedro Yañez, "maestro arquitecto" de León, y éste su mitad a Domingo del Río a cambio de 125 ducados, tomando como fiadores a su inseparable Bálcava y a Felipe de Buega ${ }^{318}$. Dejó esta obra inconclusa, para volver a participar en la misma en $1619^{319}$.

En 1615 figura por primera vez avecindado en Carrión y es ese año cuando dicta testamento ante la posibilidad de fallecer, pues se encontraba aquejado de una enfermedad de la que se recuperará completamente, desarrollando sus trabajos eminentemente en la villa y en el entorno. Decide entonces ceder las obras de los templos palentinos de Villasarracino y Villoldo a su hermano Francisco, lo que no se hará efectivo posteriormente ${ }^{320}$. La obra de la iglesia de San Esteban de Villoldo suscitó un pleito desde 1614 en que Felipe de Buega, al fallecer su hermano Francisco, le cedió su parte a Domingo del Río. Al parecer, “...lo que toca a la albañería y texados están en letixio..." pero se le permitía continuar en las partes concernientes a la cantería. El restablecimiento total del artista no tarda mucho en producirse, ya que ese mismo año aparece trabajando en el templo de San Andrés y un año después en la iglesia conventual de Santa Clara, reedificados siguiendo los proyectos de Bálcava, proporcionados en 1608 y 1616, respectivamente. Domingo del Río se encarga de subcontratar maestros de cantería, encargar la adquisición de materiales, esto es, actúa como maestro de obras, bajo la dirección de su primo, que encarna la figura del arquitecto. En la casa clarisa sólo está documentada su participación en 1616, pero en San Andrés continúa al menos hasta 1619 y una

\footnotetext{
317 AHPP. Carr.Prot 4841. Juan Díaz Pajaza (1614), s/f.

${ }^{318}$ Ibídem, fol 415.

319 AHPP. Carr.Prot 5242. Laurencio López (1619-20), fol 129.

${ }^{320}$ AHPP. Carr.Prot 4842. Juan Díaz Pajaza (1615), fol 399 y ss.
} 
década después, reclamará, en nombre de Bálcava, los pagos que la iglesia le $\operatorname{adeuda}^{321}$.

También es muy interesante su participación en la construcción del puente leonés de Sahagún. Las obras habían sido rematadas en 1615 en el maestro clasicista vallisoletano Francisco de Praves y en Pedro de Llánez, maestro avecindado en Palencia, por seis mil ducados. Éste último decidió ceder su parte, esto es, la mitad de la obra a Domingo del Río. Praves continuaría en la misma hasta abril de 1619, en que le cedió su mitad a nuestro artista “...porque está ocupado en esta ciudad (Valladolid) en las obras de su magestad y en otras de yglesias y monasterios d emucha importancia...”, quedándose con el total de la obra. No será hasta octubre de 1622 cuando Bálcava se erija como fiador de su primo, por lo que es posible que las obras se mantuvieran paralizadas durante este espacio de tiempo ${ }^{322}$.

Intenta, sin éxito, adjudicarse la obra de la construcción ex novo de la iglesia y dependencias conventuales de la casa terciaria de San Miguel y Santa Isabel, cuyo pregón tiene lugar en agosto de 1619, resultando el máximo pujador el maestro de albañilería Juan de Santiago ${ }^{323}$. Como fiador, actúa en 1619, junto a su hermano, Francisco del Río Pontecillas en la obra que Francisco de Buega ejecutaba en la capilla Santa María de Carrión, situada bajo la advocación de San Nicolás ${ }^{324}$. Este favor le valió un año después la cesión de una parte de las obras de la iglesia palentina de San Miguel en Becerril de Campos, que Buega hizo además a favor del carrionés Juan González de la Mata, en relación a unas capillas que debían finalizarse $^{325}$. El hermanamiento entre artistas trasmeranos se hace patente una vez más en 1621, en que Domingo del Río, junto a Bálcava, fían a Andrés de la Cajiga en la obra del puente vallisoletano de Olivares, que se había subastado por 6.800 ducados $^{326}$.

\footnotetext{
${ }^{321}$ Ibídem, fol 163 y ss., Protocolo 5485. Antonio Orejón (el Viejo) (1616-1617), s/f, Prot. 4821.Francisco Cuetos (1620), s/f y Prot. 4855. Juan Díaz Pajaza (1629), s/f.

${ }^{322}$ La referencia a todo el proceso, con las copias de los documentos originales en AHPP. Carr.Prot. 4849. Juan Díaz Pajaza (1622-1623), fol 91 y ss.

${ }^{323}$ VIGURI, Miguel de y SÁNCHEZ, José Luis. Arquitectura en la Tierra de Campos...Op.cit, pp. 197-199, a su vez de AHPP. Carr.Prot 5403, Francisco Moro Saldaña (1620), fol 194 y ss.

${ }^{324}$ AHPP. Carr.Prot 4820. Francisco Cuetos (1619), fol 150.

${ }^{325}$ AHPP. Carr.Prot 4757. Gregorio Cisneros (1619-21), fol 279 y ss.

${ }^{326}$ AHPP. Carr.Prot 4848. Juan Díaz Pajaza (1621), fol 533.
} 
Para el convento de Santa Clara de Carrión, realizó entre 1626 y 1627, unas tapias correspondientes a la cerca que separaba la casa clarisa del cenobio franciscano $^{327}$, trabajos que constatan las múltiples facetas de Domingo del Río, en este caso, como mero constructor en labores de albañilería. Durante ese intervalo, el burgalés Domingo de Bustos realizaba un cuarto y celdas en el monasterio de San Zoilo, para cuyo contrato actuó Domingo del Río en calidad de testigo ${ }^{328}$.

La iglesia de Santa María de Villasarracino la tenía concertada, como indicamos, junto a Juan González desde 1614. Pues bien, en agosto de 1627, Alonso Santiago, vecino de Támara, revisó la obra, confirmó las condiciones y añadió ciertas modificaciones, tales como derruir el arco toral que está arruinado hace mucho tiempo y rehacer dos arcos colaterales por ser muy bajos. Asimismo, se debían rehacer las alas de los tejados de dichas naves, más altos y reforzados con estribos y se compele a que el crucero no fuera reconstruido por el momento para que los feligreses tuvieran donde desempeñar los oficios. Además se dispone que la cubierta se haga “...cerrado en óbalo todo lo que se pudiere subir de alto y se guarnezcan con sus fajas y requadratura...". Para que no quedase desprotegida la iglesia, no debían deshacer los tejados viejos hasta que subiesen los andamios para cerrarles y una vez cerrados, proceder a la fabricación de los nuevos ${ }^{329}$. Ambos maestros, de la Mata y del Río, continúan en los reparos de la iglesia en 1630 contratando para la parte de carpintería a Toribio Escandón, vecino de Saldaña, quien recibiría por la ejecución de los tejados 3.300 reales $^{330}$. Aún en abril de 1636, fallecido ya Domingo del Río la obra continuaba, como así declara su viuda, doña Isabel, quien recibió por cuenta de la tasación de lo allí realizado 2.300 reales. Igualmente recibió 1.135 reales en concepto de las obras del puente de Sahagún ${ }^{331}$. Otra deuda que el clero contrajo con Domingo del Río fue la concerniente a los reparos de San Esteban de Villoldo, encargo al que se había dedicado entre 1614 y 1631, con períodos de paralización, sin recibir la suma acordada por parte del cura. Hay que señalar que la obra está plagada de infortunios, pues se había rematado en nuestro maestro porque en 1613 habían fallecido Pedro del Val de Lastra y

\footnotetext{
AHPP. Carr.Prot 5222. Jerónimo López (1626), s/f.

${ }^{328}$ AHPP. Carr.Prot 5410, Francisco Moro Saldaña (1627), s/f.

${ }^{329}$ AHPP. Carr.Prot 4854. Juan Díaz Pajaza (1628), s/f.

${ }^{330}$ AHPP. Carr.Prot 5175. Jerónimo Laso (1630), fol 336 y ss.

${ }^{331}$ AHPP. Carr.Prot 4825 Francisco Cuetos (1636), fol 282 y ss.
} 
Francisco de Buega, los maestros que desde 1608 se encontraban al cargo de la misma, debido precisamente a que los canteros al cargo de la obra hasta entonces, Juan de la Cuesta y Francisco Gómez, habían fallecido igualmente. Pues bien, desde 1631 a 1634, del Río había decidido detener la obra conminando de este modo a la iglesia, a que le abonase la suma acordada.

Con la experiencia que le avalan sus casi treinta años de profesión, es requerido por su amigo Juan González de la Mata para que tase la parte que él ha ejecutado en la capilla de San Ildefonso del cenobio de Santo Domingo de Carrión que se hallaba en mal estado en $1630^{332}$.

La muerte le sorprende en 1634, de ahí que tenga que ser su mujer, en su nombre, quien interponga un pleito ante el provisor de Palencia para que dos maestros visiten el templo y a estipulen una justa cantidad concerniente a las obras ejecutadas $^{333}$. Doña Isabel quedó como legítima administradora de sus tres hijos, hasta su muerte, que si bien se produjo en fecha incierta, poseemos como referencia, la de redacción de su testamento el 20 de enero de $1659^{334}$.

\section{Francisco de Buega}

\section{Cantero y albañil de Secadura}

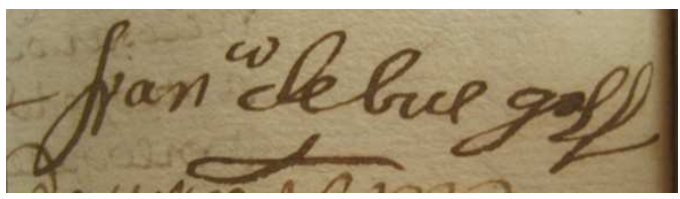

Es muy fácil confundir a este artista con su homónimo, también trasmerano, que estuvo avecindado en el municipio vallisoletano de Cabezón de Pisuerga, donde aquel realizaría a partir de 1608 la obra de la capilla mayor de la iglesia de Nuestra Señora de la Asunción, cedida por Alonso de Tolosa ${ }^{335}$. Aparte del nombre común, les une su participación en obras dentro del ámbito palentino, si bien aquel trabaja sólo hasta 1614, contándose entre sus aportación más significativa, la finalización de la cabecera de la iglesia de San Esteban de Villoldo, adjudicada en 1603 tras el

\footnotetext{
${ }^{332}$ AHN. Clero Secular-Regular 5352. Santo Domingo, Obra, s/f.

${ }^{333}$ Ibídem, fol 292 y ss.

${ }^{334}$ AHPP. Carr.Prot 5692. Norberto Sandoval y Guevara (1659), fol 419 y ss.

${ }^{335}$ CASTÁN LANASPA, Javier. "Nuevas noticias sobre la iglesia de Nuestra Señora de la Asunción en Cabezón de Pisuerga (Valladolid)”en BSAA, nº 54. Valladolid, 1988, pp. 351-360, pág. 356.
} 
fallecimiento de Pedro de Valdelastras ${ }^{336}$. Nos consta que eran artistas diferentes porque precisamente en 1615 en que dicta testamento Domingo del Río, declara que los hermanos Felipe y Francisco de Buega habían estado al cargo de las obras del templo referido de Villoldo, hasta que, con el fallecimiento de Francisco, Felipe de Buega le había cedido su mitad. No refiere cuando se produjo la muerte del trasmerano pero constata estar pleiteando por esta obra desde septiembre de $1614^{337}$.

Partiendo de este dato, podemos asegurar la autoría de las obras ejecutadas a partir de entonces por nuestro maestro, que probablemente estaría emparentado con el anterior. Descartamos con toda certeza que fuera su hijo, pues los padres del Francisco de Buega que tratamos eran Antonio de Buega y Catalina de la Vega. Se esposó en Secadura, en 1658, de cuyo matrimonio tuvo dos hijos, Catalina y Jerónimo. Probó hidalguía en Rada en dos ocasiones, 1641 y 1674, dictando testamento este último año ${ }^{338}$. El hecho de que Francisco de Buega figure en su región natal durante el tercer cuarto del siglo XVII y la época carrionesa diste temporalmente en más de tres décadas respecto a la posterior, apuntan hacia un artista de gran longevidad que pasó su juventud en la localidad palentina, efectuando obras de cantería pero sin proporcionar ninguna traza que nos permita elevarle más allá de la mera condición de cantero.

Pujó con ciento ochenta ducados en la obra del convento de San Miguel y Santa Isabel de Carrión en 1619, resultando finalmente rematada en Juan de Santiago por ciento treinta ducados ${ }^{339}$. Logra, sin embargo, adjudicarse dicho año una obra interesante en Carrión, como es la reforma de la capilla de San Nicolás en la iglesia de Santa María ${ }^{340}$. En ella debía sustituir los tejados arruinados existentes en el tramo de acceso, que posteriormente serían ocultados por la bóveda de arista que luce este espacio hoy día. En julio de ese año participa como fiador de Juan de Cajigosa en la ejecución de unos pilares que el maestro trasmerano debía edificar en el convento de Santo Domingo de Carrión ${ }^{341}$. En Frechilla, participó a partir de 1620, en la ejecución de las obras de la iglesia parroquial de Santa María, siguiendo

\footnotetext{
336 ZALAMA, Miguel Ángel. La arquitectura...Op.cit, pp. 210 y 333, 342.

${ }^{337}$ AHPP. Carr.Prot 4842. Juan Díaz Pajaza (1615), fol 399 y ss.

338 DE CADENAS Y VICENT, Vicente. Caballeros de la orden de Calatrava que efectuaron su ingreso en el siglo XVIII. tomo 3. Hidalguía. Madrid, 1987, pág. 87.

339 VIGURI, Miguel de y SÁNCHEZ, José Luis. Arquitectura...Op.cit, pp. 197-199, a su vez de AHPP., Carr.Prot 5403.Francisco Moro Saldaña (1620), fol 194 y ss.

${ }_{340}$ AHPP. Carr.Prot 4820. Francisco Cuestos (1619), fol 150 y ss.

${ }^{341}$ AHPP. Carr.Prot 5164. Jerónimo Laso (1619), fol 387 y ss.
} 
las trazas proporcionadas por Francisco de Praves que posteriormente ampliaría Juan Gutiérrez del Pozo ${ }^{342}$.

Actúa en 1621 como fiador de Francisco Reinaldos en la obra de la iglesia de Torre de los Molinos junto al carrionés Juan Santos ${ }^{343}$. Junto a Reinaldos y Pedro Ruiz Solano, en enero de 1622 actúa como fiador de Hernando del Arco en la obra que realizaba en el convento de Santo Domingo de Carrión. Concertada en enero de 1622 consistía en la ejecución de unos pilares en el templo ${ }^{344}$. En abril de ese mismo año toma a su cargo, junto a Diego de Mazarredonda la obra de cantería de la sacristía y librería del monasterio de San Zoilo, ocupándose Juan González de la Mata de lo concerniente a la albañilería ${ }^{345}$. Con este maestro carrionés se concierta en 1626 para finalizar las capillas de la iglesia San Miguel en Becerril de Campos por 2.800 reales $^{346}$. Ese mismo año, junto a Domingo del Río y Juan Santos tasa la obra que debe realizarse en el desaparecido Hospital de la Herrada de Carrión figurando para nuestra sorpresa, como maestro de carpintería ${ }^{347}$.

\section{Jerónimo de Avendaño}

Maestro de cantería y arquitecto

de San Pantaleón de Aras

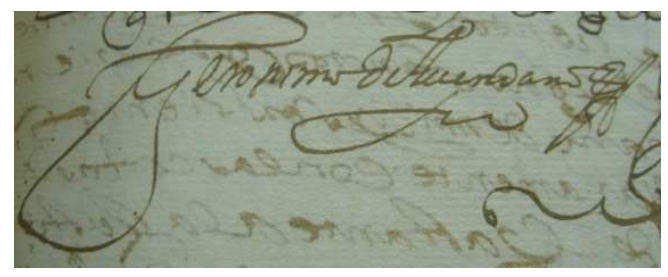

Jerónimo de Avendaño desarrolla una incesante actividad a lo largo de las tres décadas que transcurren entre 1640 y 1670, dentro de la provincia de Palencia. Fuera de este ámbito, tan sólo se le ha atribuido la ejecución de la calzada y puente de Castrojeriz, en Burgos. Nunca le faltaron los encargos; de hecho, se dedicó a varios simultáneamente y la incapacidad para abordarlos le ocasionó varios careos con la justicia. De hecho, no hay prácticamente un monumento carrionés en el que Avendaño no haya intervenido. No llevaba una vida demasiado acomodada, como colegimos de sus escasos bienes y de las deudas que dejó a sus herederos. Pese a su

\footnotetext{
${ }^{342}$ HERREROS ESTÉBANEZ, Francisco. Historia de Frechilla. Palencia, 1984, pág.. 259.

${ }^{343}$ AHPP. Carr.Prot 5166, Jerónimo Laso (1621) s/f.

${ }^{344}$ AHPP. Carr.Prot 4822 Francisco Cuetos (1621-1622), s/f.

${ }^{345}$ AHPP. Carr.Prot 5405 Francisco Moro Saldaña (1622), s/f.

${ }^{346}$ AHPP. Carr.Prot 5409. Francisco Moro de Saldaña (1626), fol 303.

${ }^{347}$ AHPP. Carr.Prot 4852, Juan Díaz Pajaza (1626), s/f.
} 
origen trasmerano, no regresará a su tierra natal para ser enterrado, como se hacía frecuentemente, sino que decidió sepultarse en Carrión de los Condes. Se casó con Francisca del Río Cubillas, con la cual tuvo tres hijos: Luis, Andrés, que se convertiría en cura asentado en San Pantaleón y el maestro de cantería Francisco Antonio de Avendaño ${ }^{348}$.

Participó activamente en la construcción de puentes, mayormente palentinos. En 1640 figura trabajando en el puente de Amusco $^{349}$. A finales de ese año, el 1 de noviembre de 1640 se remata en su persona el puente de Astudillo por ocho mil ducados. Dos días más tarde decide ceder buena parte a varios maestros trasmeranos Tomás Pantaleón y Juan de Ribas, vecinos de Pantaleón como él; Hernando de la Lastra, vecino de Agüero y Juan de la Torre, vecino de Otides, en el valle de Carranza, quedándose eso sí con la quinta parte de la misma ${ }^{350}$. Ésta será cedida igualmente casi dos años más tarde, en abril de 1642 a Hernando de Inestrosa "teniendo atención a sus ocupaçiones preçisas en otras obras del dicho su offiçio y que por esta causa no puede asistir a trauaxar en la obra de la dicha puente...", abonándole 1500 reales por el dicho traspaso ${ }^{351}$. Volvió a encargarse de la obra, pues en 1655 el procurador general de la villa le interpone pleito para que lo acabe ${ }^{352}$. Es seguro que esas ocupaciones a las que hace referencia sean las concernientes a la obra de mayor calibre a la que consagró gran parte de su vida: la construcción de la iglesia de San Julián, en la que reveló sus profundos conocimientos sobre los principios clasicistas. Rematada en su persona el 24 de junio de 1642 por nada menos que 7550 ducados, le acarreó muchos problemas con la justicia ${ }^{353}$. A tal empresa se dedicaría, incumplido su compromiso de finalizarla en cuatro años, hasta 1658 en que el patrón de la obras, don Antonio de Berrio y Ribera le interpuso un pleito $^{354}$. Se había comprometido a realizar este encargo en exclusividad, pero su afán de monopolizar el mayor número de construcciones, le llevó a contratar múltiples obras de las que no podía ocuparse y acabará siendo encarcelado.

\footnotetext{
${ }^{348}$ VV.AA. Artistas cántabros...Op.cit, pág. 62.

${ }^{349}$ IbIbídem, pág. 62.

${ }^{350}$ AHPP. Carr.Prot 5170. Jerónimo Laso (1625 y otros años), fol 369 y ss.

${ }^{351}$ AHPP. Carr.Prot 5188. Jerónimo Laso (1642), fol 369 y ss.

${ }^{352}$ AHPP. Carr.Prot 5764. Andrés Simón Aguilar (1655), fol 530 y ss.

${ }^{353}$ MARTÍNEZ GONZÁLEZ, Rafael. "Notas para el estudio del patronazgo de indianos palentinos" en Actas del V Simposio Hispano Portugués de Historia del Arte. Valladolid, 1990, pág. 164.

${ }^{354}$ No nos extenderemos más, pues todos los datos referentes a las condiciones, contrato, remate y devenir de la fábrica de San Julián figuran en el apartado correspondiente a dicho templo.
} 
Enseñó todos los entresijos de su oficio al trasmerano Domingo del Río, quien como indicamos, no debe confundirse con el homónimo de Bádames al que nos referimos con anterioridad, que ya había fallecido. Su padre, Mateo del Río, había fallecido en 1643 y su madre, María de Hano, considera que la mejor opción para el futuro de su vástago es que se convierta en maestro de cantería ${ }^{355}$.

También se hizo cargo de los reparos de los dos puentes burgaleses de la villa de Castrojeriz, denominados de Bárcena y Tavanera, obras adjudicadas en octubre de 1643 por once mil rreales ${ }^{356}$. Puja en 1649 en el puente de Cervatos de la Cueza y dos años después, en 1651 se remata en su persona y en Diego de Zorlado la factura del puente cántabro de May, cerca de Toranilla ${ }^{357}$. Ambos decidieron, de mutuo acuerdo, ceder a finales de 1654 parte de la obra a Andrés de Zorlado y a Francisco Falla de la Vega ${ }^{358}$. A partir de ese contrato, Avendaño, Andrés de Zorlado y Juan de Trujeda establecieron un contrato de compañía para las obras de puentes que se remataran en cualquiera de ellos ${ }^{359}$. Observamos por tanto, esos vínculos estrechos que mantenían los maestros trasmeranos y que les permitía rematarse un buen número de las obras carrionesas, eminentemente aquellas en las que se requería un exhaustivo conocimiento del trabajo de la piedra, como en el caso de la construcción de puentes. Ese mismo año de 1654, junto a Pedro de Carandil y Felipe Berrojo se comprometió en la fábrica de la torre de la iglesia de Santa Ana en Herrera de Río Pisuerga, de cuya traza se había encargado Francisco Cavanzo, por treinta mil reales ${ }^{360}$. En la obra del puente de Amusco ya había participado en 1640, pero volverá a participar a partir de la Navidad de 1654, cuando tome el relevo de Juan González de la Mata, ya difunto, y se ponga al mando, junto a Francisco de Cabanzo, vecino de Noja, en los reparos del mismo, siendo éste quien proporcione los materiales necesarios para dicha obra $^{361}$. En ella ya aparece designado como maestro arquitecto, lo que revela su status social. Por estas fechas se encargaría de las trazas para la vivienda situada en la calle de la Rúa, destinadas a residencia del

\footnotetext{
${ }^{355}$ ALONSO RUIZ, Begoña. El arte de la cantería, Op.cit, pág. 179.

${ }^{356}$ AHPP. Carr.Prot 5189. Jerónimo Laso (1643), fol 257 y ss.

${ }^{357}$ VV.AA. Artistas cántabros...Op.cit, pág. 62.

${ }^{358}$ AHPP. Carr.Prot 5196. Jerónimo Laso (1654), s/f.

${ }^{359}$ Así se establece en el poder otorgado por Andrés de Zorlado a su hijo Diego y a su yerno Juan de la Maza. AHPP., Varios, Protocolo 5858 (1520-1654), fol 693 y ss.

${ }_{360}$ AHPP. Carr.Prot 5687. Norberto Sandoval y Guevara (1654), s/f.

${ }^{361}$ AHPP. Carr.Prot 5196. Jerónimo Laso (1654), s/f.
} 
ilustre matrimonio formado por Doña Francisca de Bustamante y don Diego Velarde Calderón, caballero de la Orden de Santiago, cuya ejecución había recaído en Juan Fernández de Bustillo, al ser el único postor ${ }^{362}$. Sin poder precisar en qué período, Avendaño participó junto a Diego de Zorlado en los reparos del puente de Carrión, a tenor de la solicitud que ambos emiten en 1657 ante La Chancillería de Valladolid, solicitando el cobro de 8.400 ducados que se les debía por su participación en el mismo $^{363}$. No obstante, en base al elevado montante podemos determinar que trabajaron varios años en el mismo.

Entre todos estos encargos civiles, efectúa en 1645 una tasación del nuevo templo de San Zoilo que se estaba edificando por entonces, correspondiente a la capilla mayor y la cúpula del crucero, siendo elegido de parte de los maestros vecinos de Valladolid, Melchor Ruiz, Tomás García y Domingo Ponce, que se habían encargado de su ejecución. Por parte del cenobio, escogieron al carrionés Juan González de la Mata ${ }^{364}$. De nuevo es requerido por el monasterio benedictino en 1651, para realizar otra tasación, en este caso de los daños de la ruinosa capilla de doña Constanza, hoy desaparecida, que se ubicaba junto a la capilla mayor ${ }^{365}$. Junto a Juan de Trujeda, valora la parte relativa a la cantería, mientras que de la carpintería se ocupan Santiago Pedrosa y Juan Vicente González.

También lo vemos ejerciendo como tracista, pues fue quien redactó en 1656 las condiciones para la reedificación de la capilla del Licenciado Pastor, situada sobre la antigua capilla de San Pedro, en la iglesia de Santa María del Camino ${ }^{366}$. Figura como veedor de obras del Obispado de Palencia en 1658, según consta en una deuda de 388 reales contraída con el maestro campanero trasmerano como él, Mateo Arnuero ${ }^{367}$. Por entonces, en compañía de Felipe Berrojo y Pedro de Carandil, reedifica la torre de la iglesia parroquial de Santa Ana en Herrera de Pisuerga $^{368}$. En 1662, vuelve a enfrentarse con la justicia, pues estaba condenado a

\footnotetext{
${ }^{362}$ Ibídem.

363 AHPP. Protocolo. Carrión 5207 Antonio López (1657-1659), s/f.

${ }^{364}$ AHPP. Carr.Prot 5427. Francisco Moro Saldaña (1645), s/f.

365 AHPP. Desamortización. Legajo 110 y Legajo 112. Índice del Archivo de San Zoilo. Caja 5a: San Andrés. Leg. 4. Capilla de doña Constanza. No 25.

${ }^{366}$ AHPP. Carr.Prot 5689. Norberto Sandoval y Guevara (1656), s/f.

${ }^{367}$ AHPP. Carr.Prot 5691. Norberto Sandoval y Guevara (1658), fol 66 y ss.

${ }^{368}$ AHPP. Carr.Prot 5767. Andrés Simón Aguilar (1659), fol 861 y ss.
} 
abonar 2.874 reales, deuda que saldó Don Andrés Ordóñez de la Real, clérigo abogado de Carrión ${ }^{369}$.

En el extinto convento de Santo Domingo de Carrión, se le encarga la redacción de las trazas para la reparación de la capilla del sotocoro del templo en $1663^{370}$. Con Santiago de la Lastra Díez, maestro de cantería trasmerano como él, oriundo de Ceneyo, establece a finales de dicho año, un contrato de compañía por el que ambos se comprometen a ejecutar conjuntamente los puentes palentinos de Monzón, Lantadilla y el burgalés de Ruyales. Con dicho acuerdo se obligaban a asumir tanto las pérdidas como a recibir las ganancias que produjeran dichas obras a partes iguales en ambos casos. Para las diligencias tocantes al Real Consejo de Madrid acudiría de la Lastra y en las de Carrión y Palencia se personificaría Avendaño ${ }^{371}$.

En el lugar de Villaturde, jurisdicción de Carrión, le había sido rematada en 1664 la fábrica de la torre de la iglesia de Nuestra Señora de la Asunción ${ }^{372}$. Un año después la obra seguía su curso, pues Avendaño requiere al cura y mayordomo del templo para que traigan al pie de la obra 200 varas de piedra de las canteras de Valdespina, ya extraída y preparada para ser porteada, y de este modo se evite que pueda ser robada y al mismo tiempo puedan proseguir con normalidad ${ }^{373}$. La torre sería finalizada, como ambas partes acordaron, en 1666, sin embargo aún en 1668 no se le había abonado el importe íntegro de los trabajos ${ }^{374}$. Repara algunas casas de propiedad privada, como la de Alonso de la Serna en 1667 por la que recibe 1500 reales, ocupándose de la parte relativas a la carpintería Francisco de Reinaldos ${ }^{375}$.

Dicta testamento en 1668, disponiendo ser enterrado preferentemente en la iglesia de San Julián con la pertinente autorización de la por entonces patrona doña

\footnotetext{
3699 de noviembre de 1662. AHPP. Carr.Prot 5769, Andrés Simón Aguilar (1662-1663), fol 434.

370 AHPP. Carr.Prot 5201. Jerónimo Laso (1663-1664), fol 643 y ss.

371 Escritura de compañía firmada el 3 de diciembre de 1663. AHPP. Carr.Prot 5697, Norberto Sandoval y Guevara (1667), fol 196 y ss.

372 AHPP. Carr.Prot 5201. Jerónimo Laso (1663-1664), fol 293 y ss.

${ }^{373}$ Carta de obligación de 25 de abril de 1665. AHPP. Protocolo 5700. Norberto Sandoval y Guevara (1665), fol 283.

${ }^{374}$ Información contenida en su codicilo de 19 de julio de 1668. AHPP. Carr.Prot 5703, Norberto Sandoval y Guevara (1668) fol 592 y ss.

${ }^{375}$ Las trazas y condiciones de la obra en AHPP. Carr.Prot 5773, Andrés Simón Aguilar (1667), fol $230 \mathrm{y}$ ss.
} 
Josefa de Colmenares, o, de no ser posible, en la iglesia de Santa María del Camino $^{376}$. Nombra como testamentarios a Manuel del Río Pontecillas, cura de Santa Eulalia e hijo del cantero trasmerano Domingo del Río y a Diego de Zorlado, maestro igualmente cántabro, y, como herederos a su mujer y tres hijos ${ }^{377}$. El 19 de julio de dicho año, redacta su codicilo, pues había olvidado indicar que fueran revisadas las cartas de pago referentes a la obra de la torre de Villaturde, pues no sabía cuánto se le adeudaba. Aparte de dicha suma, se deben 576 reales por la extracción que hicieron sus hijos de 30 varas de piedra para dicha obra y otras cantidades relativas a la traza, condiciones y alquiler de la maroma. Cuatro días después se realiza el inventario de sus bienes, constatándose a través de sus escasas pertenencias en la casa que poseía en la calle de la Tejada, que el maestro trasmerano vivía humildemente ${ }^{378}$. De hecho, el patrón por entonces de la capilla de San Buenaventura del convento de San Francisco de Carrión, al dictar testamento en 1661 decide perdonarle una paga "por constarle su pobreza",379. Otra prueba más de su carestía, es un poder de 1669 emitido por dos de sus hijos Andrés y Francisco por el que subastan la vivienda de su padre para saldar una deuda por la obra de San Julián y por la de una casa de un particular ${ }^{380}$.

\section{Juan de Cajigosa o Cajigojo Maestro de cantería de Penagos}

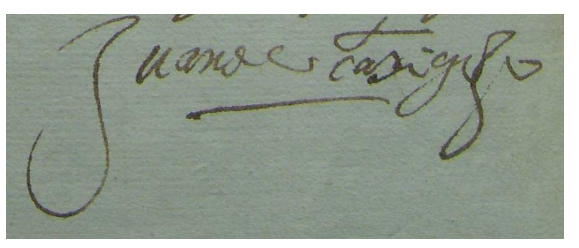

Estaba casado con María de la Cuesta, con la que tuvo cuatro hijos de nombre Juan, Pedro, Mateo y el mayor, Francisco ${ }^{381}$. Al parecer, emigró a Carrión en una etapa madura de su vida, pues desde la intervención más temprana hasta que

\footnotetext{
${ }^{376}$ AHPP. Carr.Prot 5703. Norberto Sandoval y Guevara (1668), fol 592 y ss.

${ }^{377}$ VV.AA. Artistas cántabros...Op.cit, pág. 62.

${ }^{378}$ Ibídem, pág. 62 . Se recogen ciertos muebles, utensilios del oficio de cantero así como otros enseres que: una mesa de pino, una sartén, un asador, un cazo de hierro, un cofre con ropilla de paño plateado, un calzón, dos pares de calcetas, un par de jubones, dos almohadas, una escuadra, una escoda, un mazo, una manta vieja, un cántaro de tierra, una cama de pino, etc.

379 AHPP. Carr.Prot 5695, Norberto Sandoval y Guevara (1661), fol 561.

${ }^{380}$ VV.AA. Artistas cántabros...Op.cit, pág. 62.

${ }^{381}$ Datos obtenidos de su testamento, dictado en 1632. AHPP. Carr.Prot 4858. Juan Díaz Pajaza (1632-1633), s/f.
} 
dicta testamento, transcurren un par de décadas. Aunque sus trabajos son muy puntuales, participa en buena parte de los monumentos carrioneses.

La primera mención de Cajigosa en Carrión, data de 1618 en que se le remata la reparación de la torre de Santiago, pero decide ceder la obra al carrionés Juan González de la Mata ${ }^{382}$. No vuelve a aparecer hasta 1620 en que, junto al trasmerano Diego de Mazarredonda realiza dos pilares para la sacristía del nuevo templo de San Andrés ${ }^{383}$. En junio de 1621 Cajigosa se concierta con Pedro Ruiz Solano para adecentar el molino de Guzmán, en la ribera del barrio de San Zoles, ubicado junto al monasterio de San Zoilo, al otro lado del núcleo urbano, pasando el río. Es una intervención sin importancia, pues recibe tan sólo 260 reales $^{384}$.

Junto a Francisco Martínez de Bálcava construye parte de la torre de San Andrés, cuyo pago les abonan en $1625^{385}$. Ese mismo año las clarisas requieren sus servicios para que rehaga la vieja cerca del convento de Santa Clara, lo que nos muestra el conocimiento en el trabajo de otros materiales, ya que debía utilizar tapial y mampostería ${ }^{386}$. Además de participar activamente en las obras, también actuó como veedor, al menos en 1627, cuando tasó la ejecución de la mayordomía y celdas que en el lienzo occidental del claustro de San Zoilo habían llevado a cabo el burgalés Domingo de Bustos y Juan de Veintemillas ${ }^{387}$.

Al parecer en 1628, regresa a su tierra natal, pues figura tasando unos bienes junto a Pedro de Gandarillas, natural de Penagos, con quien compartía oficio y probablemente les unían lazos de amistad ${ }^{388}$. Esta estancia fue bastante breve, ya que un año después interviene en la reparación de dos pilares del puente de Carrión ${ }^{389}$.

Dicta testamento el 15 de diciembre de 1632, gracias al cual conocemos a sus familiares directos, pero sobre todo es interesante para recomponer los lugares en los

\footnotetext{
${ }^{382}$ AHPP. Carr.Prot 5401. Francisco Moro de Saldaña (1618), s/f.

${ }^{383}$ AHPP. Carr.Prot 4821.Francisco Cuetos (1620), s/f.

${ }^{384}$ AHPP. Carr.Prot 5217. Jerónimo López (1621), s/f.

${ }^{385}$ ADP. Carrión. Iglesia de San Andrés. Libro $2^{\circ}$ de cuentas de fábrica (incompleto, cuadernillos sueltos, 1614-1637).

${ }^{386}$ AHPP. Carr.Prot 5221. Jerónimo López (1625), s/f.

${ }^{387}$ AHPP. Carr.Prot 5172. Jerónimo Laso (1627), fol 653.

${ }^{388}$ VV.AA. Artistas cántabros...Op.cit, pág. 116.

${ }^{389}$ AMCC. Libro 1, Sesiones municipales (1618-1637). Sesión de 7 de julio de 1630, fol 571v, 572.
} 
que intervino gracias al dinero que admite se le dejó a deber en dichas obras. Estas revelan su actuación dentro de un radio de pocos kilómetros en torno a Carrión, como la iglesia de Villarmentero, de la que no se llegó a “...hacer cuenta...”, cien reales del puente de Villasirga, otros trabajos de orden menor en casas privadas y 800 reales del convento de San Zoilo, suponemos que procedentes de la tasación mencionada $^{390}$.

\section{Francisco de la Maza \\ Maestro arquitecto de Bádames}

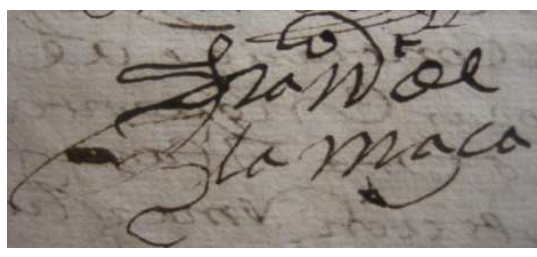

No debe confundirse a nuestro arquitecto con el escultor homónimo del siglo $\mathrm{XVI}^{391}$. Nuestro maestro, aunque avecindado en Paredes de Nava, era de procedencia trasmerana, como manifiesta su patronímico, pudiendo unirle lazos de consanguinidad con Andrés y Juan de la Maza.

En la iglesia vallisoletana de Matapozuelos se encarga de reforzar la cimentación y muros de la primitiva torre en 1595. La tasación de estos trabajos desencadena un pleito en el que testifican algunos de los maestros más conocidos del momento, como Juan de Celaya, Juan de la Lastra o Pedro de Naveda ${ }^{392}$.

A principios de siglo ya se encuentra avecindado en Paredes de Nava y figura como maestro arquitecto, lo que revela que se trataba de un artista de sobrada experiencia, dado que esta nomenclatura, como hemos podido comprobar, no la adoptaban en virtud de sus conocimientos sino de su experiencia. En Carrión, la primera vez que aparece, es al mando de la reforma de la capilla mayor de la iglesia conventual de San Francisco, perteneciente a los marqueses de Aguilar, obra

\footnotetext{
${ }^{390}$ AHPP. Carr.Prot 4858. Juan Díaz Pajaza (1632-1633), s/f.

391 MARTÍ Y MONSÓ, José. "Menudencias biográfico-artísticas" en BSCE, tomo II. Caja de Ahorros Provincial de Valladolid 1905-1906, pp. 172-173.

${ }^{392}$ URREA FERNÁNDEZ, Jesús. "El templo, la torre y el retablo de Matapozuelos" en BSAA, nº53, Valladolid, 1987, pág. 262.
} 
comenzada en $1611^{393}$. Debía contar con buenas referencias para logar adjudicarse una obra tan relevante como ésta, en la que, como veremos, se produjeron los hallazgos de los sepulcros ocultos, hoy desaparecidos, de la infanta Doña Juana y su esposo $^{394}$. Esta intervención le valió el reconocimiento de su labor en otro cenobio franciscano, el convento de Santa Clara, que requirió al maestro para dirigir la nueva iglesia en 1615, ejecutada por Alonso de Santiago ${ }^{395}$. Pero también trabaja activamente en otras obras, como maestro de cantería, pues se le conoce su participación en 1613 junto a Pedro del Arenal en las labores de reedificación de la casa blasonada conocida del "Águila" por ser éste el animal que sustenta con sus garras el escudo de su fachada ${ }^{396}$. Esta vivienda ubicada frente a la iglesia de Santa María, pertenecía a los Velasco de Mendoza. Tras esta intervención, el mismo año, acordó con el trasmerano Domingo del Río la baja de la obra de los puentes de Logroño y de Villalonquéjar, en la jurisdicción de Burgos, para que en caso de adjudicarse las obras, ambos la ejecutaran juntos ${ }^{397}$.

En 1615 y siguiendo trazas de Juan Gutiérrez del Pozo, de la Maza estaba concertado en la ejecución de aderezar y lucir la capilla mayor y las dos colaterales de la iglesia parroquial de Santa María en Autillo de Campos, a cuarenta kilómetros al suroeste de Carrión ${ }^{398}$. El último dato sobre Francisco de la Maza lo ubica en la prisión de Carrión en febrero de 1619, cuando el ensamblador Lope Infante y el albañil Francisco Rodríguez abonan su fianza. Había sido encarcelado por haber derribado la vivienda de Alonso Pérez Carretero situada junto a la plaza de los Caldereros, comprometiéndose, en recompensa, a rehacerla tal y como se encontraba previamente $^{399}$.

\footnotetext{
${ }^{393}$ AHPP. Carr.Prot 5156. Jerónimo Laso (1611), s/f.

${ }^{394}$ AHPP. Desamortización Legajo 105. Legajo $n^{\circ} 1$.

395 AHPP. Carr.Prot 4842. Juan Díaz Pajaza (1615), fol 183 y ss.

${ }^{396}$ Contrato de la obra en AHPP. Carr.Prot 4840. Juan Díaz Pajaza (1613), fol 466 y ss.

${ }^{397}$ Ibídem, fol 572.

${ }^{398}$ AHPP. Carr.Prot 4967. Alonso García (1614-1615), fol 378.

399 AHPP. Carr.Prot 5215. Jerónimo López (1619), s/f.
} 


\section{Juan de Trujeda Valle \\ Maestro de cantería de Herrada}

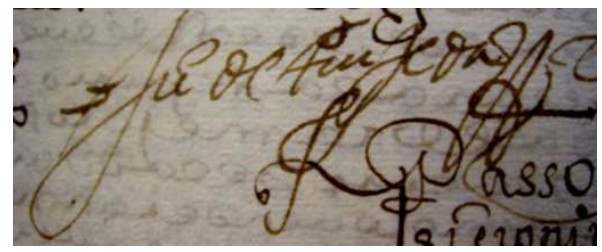

Se esposó en segundas nupcias con María Vélez de Herrada, quien, como señala su apellido, procedía de la misma localidad trasmerana que nuestro maestro, situada en la Junta del Voto. Fruto de este matrimonio fue María de Trujeda, que estaba esposada con Sebastián de Zorlado, probablemente emparentado con el gremio de canteros trasmeranos con este patronímico. Estaba integrado completamente en la vida social carrionesa. Así lo constata su ingreso en la cofradía de la Vera Cruz, la más antigua de Carrión, cuya elección resulta lógica si tenemos en cuenta que en la población cántabra de Bárcena de Cicero fue cofrade de la hermandad homónima. Asimismo tenía buena relación con los maestros de su profesión, pues según afirmaba en su testamento, Jerónimo de Avendaño tenía en su casa unas herramientas suyas de su oficio que le había prestado ${ }^{400}$.

La mención más temprana de Juan de Trujeda data de 1641 en que ejerce como fiador, junto a Jerónimo de Avendaño y Francisco del Río, de Juan Gutiérrez del Pozo en la obra del puente de Torquemada ${ }^{401}$. De nuevo junto a Francisco del Río, figura como fiador en la erección del templo de San Julián, rematado en Avendaño en $1642^{402}$. Su primera y más importante intervención en Carrión es la que realiza junto a Juan González de la Mata desde 1642: la construcción del nuevo templo de Belén, que cambiaría su orientación hacia el sur a partir de entonces ${ }^{403}$. Sin abandonar esta obra, en 1645, es llamado por el mayordomo del convento de Santo Domingo para que tase la parte ejecutada en la capilla mayor de su iglesia por Juan González de la Mata ${ }^{404}$.

\footnotetext{
${ }^{400}$ AHPP. Carr.Prot 5691. Norberto Sandoval y Guevara (1658), fol 492 y ss.

401 AHPP. Carr.Prot 5187, Jerónimo Laso (1641), fol 515 y ss.

${ }^{402}$ FERRERO MAESO, Concepción. "El mecenazgo... Op.cit, pp. 591, a su vez de AHPP. Carr.Prot 4829. Francisco Cuetos (1641-1642), s/f.

${ }^{403}$ ADP. Carrión. Iglesia de Belén. Libro 16, 4 de Cuentas de Fábrica (1616-1646), fol 301v.

${ }^{404}$ AHN. Clero secular-regular 5352. Obras, s/f.
} 
En noviembre de 1649 figura como cesionario de los herederos de Francisco Martínez de Bálcava fiándole para ello, Jerónimo de Avendaño ${ }^{405}$. Junto a éste último tasaría las obras de rehabilitación de la capilla de doña Constanza del monasterio de San Zoilo en $1651^{406}$. Por la redacción del informe relativo a la cantería, que le llevó quince días, no recibió un solo maravedí y por ello lo reclama en 1658 indicando: “...me ocupé y trauajé en la obra del dicho conuento, quiero se ajuste la quenta... ${ }^{407}$ ”. Estableció junto a sus compañeros trasmeranos Jerónimo de Avendaño y Andrés de Zorlado un contrato de compañía para las obras de puentes que se remataran en cualquiera de ellos desde $1654^{408}$. Dictó testamento en 1658 disponiendo ser enterrado en la iglesia de Belén de la villa en la que había residido hasta entonces ${ }^{409}$.

\section{Pedro Ruiz Solano \\ Maestro de carpintería del Valle de Hoz}

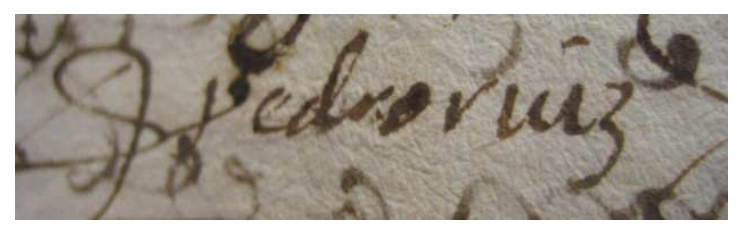

Constituye un caso excepcional dentro de los artistas trasmeranos, puesto que es el único de todos ellos que en lugar de formarse como maestro de cantería, se especializó en el trabajo de la madera. No conservamos demasiados datos de su actividad, aunque podemos afirmar que no llega a establecerse permanentemente en Carrión, ya que en la documentación, aún figurando como residente de la villa condal, se mantiene avecindado en el Valle de Hoz, también conocido como Hoz de Anuero, antigua capital de la Merindad de Trasmiera. La sospecha de que pivota entre las dos localidades, es el hecho de que la primera vez que se le menciona en Carrión es en los primeros años del siglo XVII pero se le pierde la pista hasta el período comprendido entre 1618 a 1623 en que vuelve a reaparecer. No obstante, a finales de esta década, está documentada su participación en tierras cántabras, sin

\footnotetext{
${ }^{405}$ AHPP. Carr. Prot 5193. Jerónimo Laso (1649-1650), fol 154.

${ }^{406}$ AHPP. Desamortización. Legajo 110 y Legajo 112. Índice del Archivo de San Zoilo. Caja $5^{\text {a }}$ : San Andrés. Leg. 4. Capilla de doña Constanza. No 25.

${ }^{407}$ AHPP. Carr.Prot. 5691. Norberto Sandoval y Guevara (1658), fol 496.

${ }^{408}$ AHPP. Varios. Prot. 5858 (1520-1654), fol 693 y ss.

${ }^{409}$ AHPP. Carr. Prot. 5691. Norberto Sandoval y Guevara (1658), fol 492 y ss.
} 
que se le vuelva a mencionar desde ese momento, a partil del cual presuponemos que desarrolle su actividad en aquella zona, falleciendo en su lugar natal.

La primera aparición en Carrión de Solano se produce en 1604 en que acomete, junto a otro maestro trasmerano, Hernando Cidrón, la obra de la grada y casa del horno del convento de San Miguel y Santa Isabel, el mismo año que había solicitado su clausura ${ }^{410}$. Juntos vuelven a participar en la ejecución de los reparos del monasterio palentino de Santa María de Arconada, concretamente en la capilla mayor, torre de la iglesia y en el granero, a partir de $1618^{411}$. En febrero de 1620 paga la fianza de Pedro de Prasmanes, un maestro de carpintería trasmerano como él, procedente de Sajano, por un pleito que tenía con un vecino “...sobre cierta pesadumbre y palabras que dizen le dijo... ${ }^{412}$ ". En abril de dicho año Solano toma a Juan del Cañizo, un joven de 25 años procedente de Trasmiera para enseñarle su oficio y le ayude en su casa, pagándole al mes una cuantía de 33 reales ${ }^{413}$. Por estas fechas, es llamado ante la justicia junto a Francisco de Reinaldos por no haber cumplido con el contrato que firmaron con el regidor por entonces de Carrión, don Blas Ruiz de Reinoso, en razón de la obra de la casa perteneciente a los herederos de Gaspar de Campo. Por ello se les obliga a finalizar los aleros en quince días y en caso de no cumplirlo, pagar 800 reales correspondientes al coste de los reparos ${ }^{414}$.

En 1621 se concierta para ejecutar unas casas junto a la iglesia de Santiago para los clérigos de dicha parroquia ${ }^{415} \mathrm{y}$, unos meses más tarde, junto al trasmerano Juan de Cajigosa, trabajará en los reparos del molino de Guzmán, en la ribera del barrio de San Zoles por 260 reales $^{416}$. A comienzos de 1622, Solano figura como fiador junto al maestro de carpintería Francisco de Reinaldos, en la obra de cantería que realiza Hernando del Arco para la iglesia conventual del convento de Santo Domingo $^{417}$. En junio de 1622 contrata a Hernando de Acebo, vecino de la localidad cántabra de Pámanes, para que le ayude en las obras en que éste trabajare hasta

\footnotetext{
${ }^{410}$ AHPP. Carr.Prot 5387. Francisco Moro Saldaña (1604), s/f.

411 AHPP. Carr.Prot 5401. Francisco Moro Saldaña (1618), s/f.

${ }^{412}$ AHPP. Carr.Prot 5165. Jerónimo Laso (1620), fol 396.

${ }^{413}$ Ibídem, fol 380.

${ }^{414}$ Ibídem, fol 612.

415 AHPP. Carr.Prot 4848. Juan Díaz Pajaza. (1621), fol 471.

416 AHPP. Carr.Prot 5217. Jerónimo López (1621), s/f.

${ }^{417}$ AHPP. Carr.Prot 4822 Francisco Cuetos (1621-1622), s/f.
} 
noviembre de dicho año a cambio del sustento del mismo ${ }^{418}$. Es probable entonces que colaborasen juntos cuando la cofradía de San Cristóbal contrata ese año a Solano para que efectúe los reparos convenientes en su ermita ${ }^{419}$. También actúa como tasador, pues en 1623 redacta un informe sobre la valoración del molino de San Cebrianeja, finca perteneciente a Santiago del Val, en el municipio palentino de Santoyo y unas casas aledañas valoradas en 56.000 maravedíes $^{420}$.

Debió regresar posteriormente a su región natal, pues en 1628, figura trabajando junto a otro maestro de carpintería llamado Fernando de Prasmanes en la "torre y casa baja" que el Obispo don Francisco González de Acevedo mandó construir en la localidad cántabra de Hoznayo, como parte de su palacio, al mando de cuyas obras se encontraba Juan de Naveda ${ }^{421}$. Desde entonces, no se vuelve a saber nada más de él.

\section{Juan Gutiérrez del Pozo \\ Maestro de cantería del Valle de Aras}

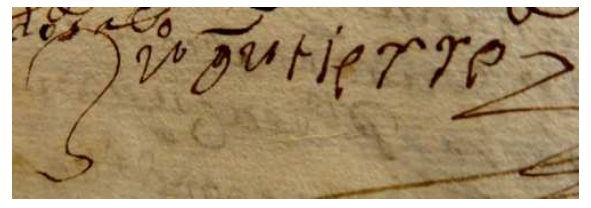

Este maestro trasmerano procedente de la Junta del Voto, figura no obstante la mayor parte de su vida como vecino de Palencia, donde se han documentado varias obras de su mano ${ }^{422}$. El artista desarrolló su labor en Palencia, Burgos y Valladolid, en torno a la corriente clasicista de Francisco de Praves y Juan de Nates, que le influyeron decisivamente. Pertenecía a la cuadrilla de Juan González de Cisniega, junto al que ejecutará el puente de Dueñas y con el cual colaborará en San Isidoro de León ${ }^{423}$. De su actividad burgalesa podemos destacar la ejecución de un cuarto del lado sur del monasterio de la Vid en 1607, la capilla del Santo Cristo de Campillo en 1618 y la ampliación de la iglesia de Fuentespina a partir de 1620, pero

\footnotetext{
418 AHPP. Carr.Prot 5218. Jerónimo López (1622), s/f.

${ }^{419}$ AHPP. Carr.Prot 5405. Francisco Moro Saldaña (1622), s/f.

${ }^{420}$ AHPP. Carr.Prot 4970. Alonso García (1622-1624), s/f.

${ }^{421}$ LOSADA VAREA, Celestina. La arquitectura en el otoño...Op.cit, pág. 228.

${ }^{422}$ VV.AA. Artistas cántabros...Op.cit, pág. 291.

${ }^{423}$ ALONSO RUIZ, Begoña. El arte de la cantería...Op.cit, pág. 146.
} 
las dejó sin finalizar ${ }^{424}$. Tampoco finalizaría la iglesia conventual de Santo Domingo de Lerma $^{425}$.

Su primera intervención data de 1585, en que, al enfermar Diego de Praves, le encarga que prosiga la iglesia vallisoletana de Villanubla ${ }^{426}$. También efectúa labores de aparejador, como sucede en la iglesia parroquial de Gallegos de Hornija, donde trabaja desde $1590^{427}$.

Su actividad palentina se desarrolló a partir de la segunda década del siglo XVII. En 1615 participó en las obras de la iglesia de San Bernardo de Palencia junto a Francisco de Praves y también se le debe la ejecución del segundo cuerpo, con la espadaña de la iglesia de Nuestra Señora de la Calle, para la que siguió trazas de Francisco de Praves ${ }^{428}$. En 1622, las obras del puente palentino de Reinoso fueron rematadas en 7.500 ducados en Gutiérrez del Pozo y en el trasmerano Simón Muñoz. No obstante, seguidamente del Pozo bajó la obra en cinco mil ducados y fue aceptada su propuesta. Como eran necesarias nuevas fianzas, el trasmerano Francisco Martínez de Bálcava ejerció como su avalista otorgando poder desde Carrión, “...porque personalmente no puedo yr en persona a la dicha ciudad de

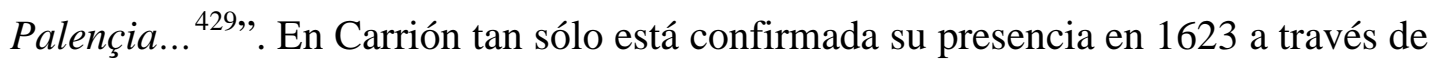
una referencia indirecta, pues cuando Pedro de Quintana logra hacerse con la obra de construcción de la iglesia de San Julián, se remite a Gutiérrez del Pozo como tracista de la misma. Si bien la lentitud de las obras provocó la realización de un nuevo proyecto en 1641 proporcionado por Jerónimo de Buega y Bartolomé Lechuga, la referencia a las primeras trazas proporcionadas por el maestro trasmerano pone de relieve que del Pozo sentó las bases de la iglesia que se erigió ${ }^{430}$. Se trata de un templo que sigue los postulados clasicistas de los que se nutrió Juan

\footnotetext{
${ }^{424}$ ZAPARAIN YÁÑEZ, M ${ }^{\mathrm{a}} \mathrm{J}$. “Aportación a la biografía del arquitecto palentino Juan Gutiérrez del Pozo. Su actuación en la zona de Aranda de Duero (Burgos) en AIICHP, tomo 5. Palencia, 1990, pp. $155-161$.

${ }^{425}$ CERVERA VERA, Luis. El convento de Santo Domingo de Lerma. Valencia, 1969, pp. 44 y 67.

${ }^{426}$ GARCIA CHICO, Esteban. Documentos...Arquitectos. Op.cit, pág. 113.

427 PARRADO DEL OLMO, Jesús María. Catálogo monumental del Antiguo Partido Judicial de Mota del Marqués. Valladolid, 1976, pp. 55 y 61-65.

${ }^{428}$ BUSTAMANTE GARCÍA, Agustín. La arquitectura...Op.cit, pp. 281 y 467.

${ }^{429}$ AHPP. Carr.Prot 4849. Juan Díaz Pajaza (1622-1623), fol 177 y ss y 228 y ss.

430 FERRERO MAESO, Concepción. "El mecenazgo...Op.cit, pp. 585-590, a su vez de AHPV. Protocolo 148, José de Frías Sandoval (1623) fol 819 y ss. Las condiciones de la nueva obra, firmadas en 1641 en AHPP. Carr.Prot 4829. Francisco Cuetos (1641-1642), fol 279 y ss.
} 
Gutiérrez a lo largo de su vida, patentes tanto en el alzado, a través del uso de bóvedas de arista, arcos termales o la cornisa encapitelada del perímetro, así como en la planta de cruz latina y testero plano, que remite al modelo utilizado en los templos vallisoletanos de las Descalzas Reales o San Quirce. Dentro de Palencia el referente más inmediato lo hallaríamos en las Agustinas Recoletas de Palencia, donde también se emplearon las capillas hornacina de poca profundidad.

Regresa a Valladolid posteriormente, pues en 1635 estaba trabajando en la fachada de los pies de la Catedral del Pisuerga, concluida tres años más tarde ${ }^{431}$. Después volvemos a encontrarle en Palencia, en la obra del puente de Torquemada que logró adjudicarse en 1641 por 23.400 reales, ejerciendo de fiadores Francisco del Río Pontecillas, Juan de Trujeda y Jerónimo de Avendaño ${ }^{432}$. En esta localidad se erige como el autor del proyecto de la fachada y espadaña de la iglesia de Santa Eulalia, obra materializada entre 1647 y el año posterior por Martín de los Cuetos ${ }^{433}$. La última vez que aparece citado es en 1650, en que se afirma que ha inspeccionado la obra del puente palentino de Saldaña ${ }^{434}$.

\section{Juan de la Lastra \\ Maestro arquitecto de Argoños}

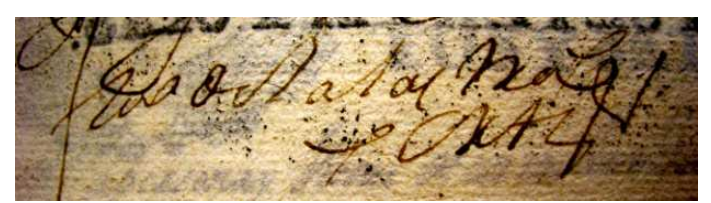

Este artista trasmerano desarrolló una triple faceta de cantero, veedor y tracista entre las provincias de Madrid, Valladolid y Palencia. Sus primeros trabajos los desarrolló en sede de la corte, como oficial de cantería en la obra del Escorial, concretamente en el Patio de la Reina, entre los años 1582 a 1584, período que condicionaría su formación clasicista ${ }^{435}$. Después se traslada a la capital castellana donde figura vinculado a Pedro de Espinosa y su mujer, María de Salazar, quienes

\footnotetext{
${ }^{431}$ BUSTAMANTE GARCÍA, Agustín. La arquitectura... Op.cit, pág. 250.

${ }^{432}$ AHPP. Carr.Prot 5187. Jerónimo Laso (1641), fol 515 y ss.

${ }^{433}$ MARTÍN GONZÁLEZ, Juan José y URREA FERNÁNDEZ, Jesús. Inventario...1, Op.cit, pág. 261.

${ }^{434}$ ARAMBURU-ZABALA, Miguel Ángel. La arquitectura de puentes...II, Op.cit, pág. 899.

${ }^{435}$ ANDRÉS, Gregorio de. Inventario de documentos sobre la construcción y ornato del Monasterio del Escorial existentes en el Archivo de su Real Biblioteca. Instituto Diego Velázquez. Madrid, 1972.
} 
solicitan sus servicios para que levante el patio de su vivienda particular, de lo cual otorga carta de pago en diciembre de $1591^{436}$.

La primera vez que figura en Palencia, es tomando parte en una obra importante como era el monasterio de San Isidro de Dueñas, en cuya fábrica intervino en 1592, si bien no sabemos qué papel desempeñó ${ }^{437}$. Cedió parte de la obra a Francisco Negrete, probablemente para hacerse cargo desde ese año y hasta 1594 de las trazas y supervisión de la obra del palacio de la cofradía de Nuestra Señora del Rosario situada junto al convento dominico de San Pablo, en la calle Manflorido, cuyo solar ocupa hoy día la iglesia de San Bernabé. De dichas obras fue veedor Francisco del Río, quien las aprobó en $1594^{438}$. Entre estos encargos, en agosto de 1593 figura ejecutando la fachada de los pies del convento palentino de San Isidro de Dueñas ${ }^{439}$. Estuvo un breve período en Carrión, siendo requerido en 1593 por el mayordomo del templo de Santiago, para que emitiese un informe en el que se hiciesen constar los daños que sufrían las cubiertas, así como un peritaje de los mismos ${ }^{440}$.

Un año después, Juan de la Lastra se halla en Villamuriel de Cerrato ofreciendo una postura para la ejecución de la torre de la iglesia de Santa María, que logra adjudicarse a finales del mismo, en la que participa intermitentemente hasta $1601^{441}$. En los últimos años del siglo, se registra su participación en las obras de corte clasicista más punteras de la capital del Carrión, como la iglesia de la Compañía de Jesús, el templo de las canónigas Agustinas, siguiendo trazas de Diego de Praves y el convento de San Pablo, donde abre un acceso a su claustro ${ }^{442}$. Ya en los primeros años de la centuria décimo séptima, reaparece en diversas localidades

\footnotetext{
${ }^{436}$ Nuestro Juan de La Lastra sería el que García Chico titula "el Mozo". No debe confundirse con otro Juan de la Lastra que desarrolla su actividad anteriormente y que participa en la construcción del Palacio de Fabio Nelli y que dicta testamento en 1582. GARCÍA CHICO, Esteban. Documentos. Arquitectos...Op.cit, pp. 61-64 y SOJO Y LOMBA, Fermín. Los maestros...Op.cit, pp. 95-96.

${ }^{437}$ GARCÍA CHICO, Esteban. "Celdas y refectorio de la Abadía de San Isidro de Dueñas" en BSAA, no14.Valladolid, 1947-1948, pp. 238-239.

${ }^{438}$ Declaración de Francisco del Río a 25 de mayo de 1594. AHPP. Varios. Prot. 10895. Varios años y escribanos, s/f.

${ }^{439}$ ZALAMA, Miguel Ángel. La arquitectura...Op.cit, pág. 276.

${ }^{440}$ AHPP. Carr.Prot 4595. Juan Birtus (1592-1594), s/f.

${ }^{441}$ ZALAMA, Miguel Ángel. La arquitectura...Op.cit, pág. 276

442 RAMOS DE CASTRO, Guadalupe. "La iglesia del convento de las Agustinas Canónigas de Palencia" en AICHP, vol 1, Palencia, 1987, pp. 179-188 y ZALAMA, Miguel Ángel. La arquitectura...Op.cit, pp. 276-277.
} 
de la provincia interviniendo en la reparación de algunos templos como San Agustín de Dueñas o San Miguel de Ampudia, donde arreglaba su torre, realizada casi un siglo antes, hacia $1513^{443}$ Igualmente interviene en la construcción de otros, como la torre de Nuestra Señora de Arbis en Baquerín de Campos o la iglesia de San Miguel en Tariego de Cerrato ${ }^{444}$. Posteriormente, entre 1608 y 1614, afirma residir en Támara de Campos, donde está documentada su participación en la torre de la iglesia parroquial de San Hipólito ${ }^{445}$.

En la documentación posterior figura otro Juan de la Lastra, también trasmerano, con el patronímico añadido de Ortiz, que se intitula maestro arquitecto. Sabemos que no eran la misma persona, pues en 1640, María González de la Lastra, su mujer, suscribe un contrato de aprendizaje con Juan de Rivas del Río para que enseñe el oficio a su hijo Juan Fernández de la Lastra, indicando que es viuda ${ }^{446}$. Por otro lado, el abanico temporal comprendido entre la primera y última referencia nos situaría ante una persona centenaria, lo cual descartamos rotundamente en un período en el que la esperanza de vida era mucho más corta.

Este otro Juan de la Lastra procedía de Agüero, núcleo poblacional ubicado en el municipio de Marina de Cudeyo. Tenemos un par de datos que lo relacionan con la ejecución de puentes. En agosto de 1666 se obliga a devolver el préstamo de 10.000 reales que le hizo el escribano Andrés Martínez para ganar las provisiones del remate del puente palentino de Lantadilla y sacar su ejecutoria ${ }^{447}$. Se remató en su persona la obra del puente de Gradefes, en tierra de Rueda (León) pero el defensor de puentes Isidro de Bezerrero le interpuso pleito el 6 de septiembre de 1676 porque el río había desviado su curso y el puente que se estaba construyendo no iba a tener utilidad ${ }^{448}$.

\footnotetext{
443 AZCÁRATE RISTORI, José María de. "El brote del Renacimiento en Palencia" en AICHP, volumen1. Palencia, 1987, pp. 65.

${ }^{444}$ ZALAMA, Miguel Ángel. La arquitectura...Op.cit, pág. 277.

${ }^{445}$ MARTÍN GONZÁLEZ, Juan José y URREA FERNÁNDEZ, Jesús. Inventario...I. Op.cit, pág. 255.

${ }^{446}$ ALONSO RUIZ, Begoña. El arte de la cantería...Op.cit, pág. 76.

447 AHPP. Carr.Prot 5133. Juan de la Hesa (1673-1678), s/f.

${ }^{448}$ AHPP. Carr.Prot 5733. Juan Santiago (1676-1677), fol 389 y ss.
} 
Andrés de Zorlado Ribero

Maestro procedente de Bádames

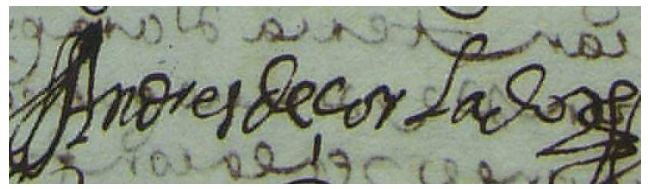

Pertenece a una familia de canteros que ostentan el apellido Zorlado como señal de pertenencia al barrio homónimo, en la localidad trasmerana de Bádames. Era hijo de Andrés de Zorlado, maestro de cantería como él, procedente de la misma localidad. La posesión de una amplia formación se evidencia a través del inventario de sus bienes, entre los cuales se recoge un ejemplar de Cristóbal de Rojas y otro de Alberti, dato nada baladí si se tiene en cuenta que entre los maestros trasmeranos no se recoge ningún libro entre sus posesiones salvo en casos excepcionales como Juan de Ribero Rada ${ }^{449}$. Formó parte de la cuadrilla de canteros que en los años cuarenta y cincuenta del siglo XVII realiza la mayor parte de los que se erigían en la meseta norte como Astudillo, Guardo, o Saldaña, entre otros ${ }^{450}$. Esta última localidad palentina, fue su lugar de residencia para las obras que realizaba en el entorno, concretamente las casas de su cuñado, donde afirmaba tener unas arcas con herramientas de su oficio ${ }^{451}$.

Sus primeros años de formación transcurrirían en el entorno natal, figurando a partir de la última década del siglo XVI en la provincia de Palencia. La primera mención a nuestro maestro data de abril de 1594, en que se presencia en Madrid para actuar como testigo del procurador de Carrión, junto a Francisco del Río, Pedro de Palacios y Pedro de la Torre para prestar juramento sobre la urgente necesidad de actuación sobre el puente de la villa condal ${ }^{452}$. La licencia de las obras será concedida y los tres maestros mencionados participarán en las mismas: Pedro de la Torre, maestro de cantería avecindado en León, lo hará desde $1595^{453}$ y Zorlado intervendrá a partir de mayo de 1596 en virtud de un poder otorgado por Francisco

\footnotetext{
${ }^{449}$ Una rara excepción entre los maestros del Voto es Juan de Ribero Rada, que poseyó una amplia biblioteca. Este hecho pone de manifiesto su rango social, dado que era arquitecto, y éste fue un medio de diferenciación con el resto del gremio cantero. ALONSO RUIZ, Begoña. El arte de la cantería...Op.cit, pág. 106.

${ }^{450}$ En este grupo figuraban Jerónimo de Avendaño, Juan de Trujeda y Francisco del Río. ALONSO RUIZ, Begoña. El arte de la cantería...Op.cit, pp. 90, 113, 159 y 171-172.

451 Ibídem, pág. 86.

452 AHN. Consejos.Leg.24676.

${ }^{453}$ AHPP. Carr.Prot 5286. Pascual López (1595), s/f.
} 
del Río que le facultaba para poder participar $^{454}$. Mientras tanto, en la ciudad del Carrión colaborará junto a Francisco del Río y Juan de Buega en la construcción de las casas episcopales, cuyos gastos fueron aprobados en 1595, así como en Lantadilla, en la fábrica de la iglesia de la Asunción, en 1596, gracias a un poder emitido nuevamente por Francisco del Río ${ }^{455}$. A comienzos de la siguiente centuria continúa en tierras palentinas, pues se tasan las obras que había realizado en Villaproviano, en el templo de San Martín ${ }^{456}$.

Aparece nuevamente en Carrión en 1616 para actuar como testigo de la entrega de varios carros de madera a Francisco Martínez de Bálcava, a cuyo cargo se encontraba la obra del convento de Santa Clara ${ }^{457}$. Su siguiente intervención la encontramos en el puente palentino de Saldaña, que había sido rematado en el maestro trasmerano Domingo Vélez de Argos, quien debía encontrarse en una edad avanzada o aquejado de alguna enfermedad grave, pues se compromete a que, en caso de no finalizar la obra, respondan por él sus herederos. En marzo de 1620, fallecido Argos, el Licenciado Martín Vélez de Argos, como curador de sus hijos Pedro, Martín y María Vélez de Argos, traspasa la obra a Zorlado, para que la fenezca, quien a su vez, cede su mitad al trasmerano Francisco del Río Pontecillas $^{458}$.

En la reconstrucción de la iglesia de San Julián de Carrión, que fue rematada en Jerónimo de Avendaño en 1642, se erigió Andrés de Zorlado como fiador, además de otros artistas dedicados a la construcción como Juan de Trujeda, Francisco del Río y Juan González de la Mata. Tal vez se hubieran pensado dos veces avalar a Avendaño con sus bienes si hubieran sabido que el maestro no cumpliría con el contrato y sería encarcelado por su falta de seriedad ${ }^{459}$.

\footnotetext{
${ }^{454}$ VAQUERIZO GIL, Manuel. “Tipología...Op.cit, pág. 159.

455 ZALAMA, Miguel Ángel. La arquitectura...Op.cit, pág. 382.

${ }^{456}$ Ibídem.

${ }^{457}$ AHPP. Carr.Prot 4843 Juan Díaz Pajaza (1616), fol 592 y ss.

${ }^{458}$ AHPP. Carr.Prot 4821. Francisco Cuetos (1620), s/f.

${ }^{459}$ FERRERO MAESO, Concepción. "El mecenazgo... Op.cit, pp. 591, a su vez de AHPP. Carr.Prot 4829. Francisco Cuetos (1641-1642), fol 279 y ss.
} 
Dicta testamento en $1655^{460}$, falleciendo poco después, pues en 1656, su hijo, Diego de Zorlado, interpone pleito a los artistas que desde 1642 construían la vivienda de Andrés de Zorlado, que habían dejado sin concluir ${ }^{461}$.

\section{Diego de Zorlado Ribero Maestro arquitecto de Bádames}

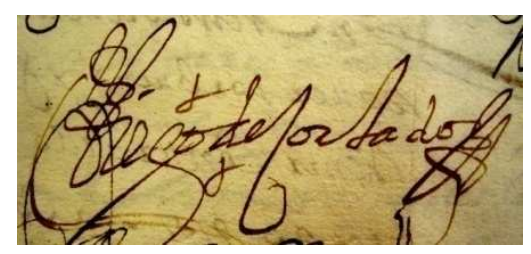

Este maestro constituye el último eslabón de las tres generaciones consagradas a la cantería procedentes de la Junta del Voto ${ }^{462}$. De su padre, Andrés de Zorlado, hereda el mayorazgo establecido en San Pantaleón de Aras, aunque ambos procedían de la cercana localidad de Bádames, donde regresará cuando fallezca para cobrar con su primo Juan de la Maza, también maestro de cantería, las deudas y bienes de Saldaña, León y Palencia ${ }^{463}$. El patente interés personal que puso de relieve Andrés de Zorlado por la formación no sólo práctica sino también teórica ${ }^{464}$, posibilitará a su vástago el acceso a los conocimientos más relevantes de ingeniería y arquitectura. Por otro lado, la experiencia avalada por su progenitor, le brindará los contactos precisos que le permitirían contratar ciertas empresas de carácter civil repartidas por la zona norte de la península, ya fuera en localidades cántabras o palentinas. La etapa más temprana de su producción artística la pasaría en la zona cántabra, de ahí que no tengamos noticia de su actividad hasta los años cuarenta del siglo XVII. Por entonces ya no se declara vecino de Bádames, sino de Matienzo, en el valle de Ruesga, otra localidad cántabra, ubicada a una veintena de kilómetros de su villa natal, donde probablemente conocería a su esposa, Ana de Matienzo $^{465}$.

\footnotetext{
${ }^{460}$ VV.AA. Artistas cántabros...Op.cit, pág. 83.

${ }^{461}$ Ibídem.

${ }^{462}$ Desde Andrés de Zorlado, vecino de Bádames, le suceden en el oficio sus dos hijos Andrés y Juan de Zorlado Ribero y por último Diego de Zorlado, hijo del segundo Andrés. Además existen otros Zorlado procedentes de Trasmiera cuya vinculación con éstos resta desconocida. VV.AA. Artistas cántabros...Op.cit, pp. 709-710.

${ }^{463}$ VV.AA. Artistas cántabros...Op.cit, pág. 709.

${ }^{464}$ Una rara excepción entre los maestros del Voto es Juan de Ribero Rada, que poseyó una amplia biblioteca. Este hecho pone de manifiesto su rango social, dado que era arquitecto, y éste fue un medio de diferenciación con el resto del gremio cantero. ALONSO RUIZ, Begoña. El arte de la cantería...Op.cit, pág. 106.

${ }^{465}$ AHPP. Carr.Prot 5701. Norberto Sandoval y Guevara (1666), fol 499.
} 
En 1648 le encontramos en tierras leonesas haciendo postura en la obra del puente de Sahagún. Cuatro años después se encargará, junto a Jerónimo de Avendaño, de las obras del puente cántabro de May, en Toranilla, donde actuará su padre, entre otros, como fiador. Igualmente en Cantabria, dos años después figura como veedor de Rocamundo en Polientes ${ }^{466}$. Desde 1642, su padre había encargado a los cántabros Juan de la Carrera y Juan de Bayas que levantasen unas viviendas cuyo proyecto había proporcionado él mismo. Transcurrida más de una década, la obra continuaba sin finalizar y Diego de Zorlado decide intervenir en 1656, interponiéndoles pleito ${ }^{467}$.

La siguiente referencia sobre Zorlado, lo sitúa en Carrión de los Condes. En virtud de la instancia remitida conjuntamente por éste y Jerónimo de Avendaño ante la Chancillería de Valladolid en 1657, colegimos un largo período de dedicación en las obras de su puente, pues ambos maestros afirman que se les debía nada menos que 8.600 ducados por su participación, cifra que sólo habría podido acordarse en una intervención de cierta entidad o proporcionando algún diseño de reconstrucción que no descartamos dado que el puente presentaba muchas carencias $^{468}$. Continuando con las obras públicas, llegó a alcanzar la consideración de tracista, al encargarse en su persona el proyecto del camino de Ramales, en Cantabria ${ }^{469}$.

La obra de mayor relevancia de la que tenemos constancia documental, fue la finalización del templo monasterial de San Zoilo. El 11 de junio de 1666 suscribe el contrato con el mayordomo para ejecutar “...la obra del lienzo, pórttico, capillas, coro y pilares...”, proporcionando las trazas y comprometiéndose a finalizar la obra en dos años ${ }^{470}$. Su intervención consistía en la ejecución de los dos últimos tramos del templo, esto es, el del coro con dos niveles y el contiguo, provisto de dos tribunas, con una cubrición de bóvedas de arista con puntas de diamante para mantener la uniformidad con el resto del templo. A medida que se iba avanzando en la nueva obra, se debía demoler el templo anterior. En el lado del Evangelio se abriría un acceso correspondiente a la portada pétrea que vemos hoy día, cuya

\footnotetext{
466 ARAMBURU-ZABALA, Miguel Ángel. Las obras públicas...Tomo II, Op.cit, pp. 581 y 778.

${ }^{467}$ VV.AA. Artistas cántabros...Op.cit, pág. 83.

${ }^{468}$ AHPP. Carr. Prot 5207 Antonio López (1657-1659), s/f.

${ }^{469}$ VAQUERIZO GIL, Manuel. “Tipología documental...Op.cit, pág. 164.

${ }^{470}$ AHPP. Carr.Prot 5701. Norberto Sandoval Y Guevara (1666), fol 499 y ss.
} 
autoría se vinculó a Felipe Berrojo ${ }^{471}$, la cual, sin embargo, salvo la parte escultórica, también debemos a su mano. El empleo de pilastras cajeadas o las bolas escurialenses revelan la herencia clasicista del artista, si bien otros detalles anticlásicos como el rompimiento de frontones, los elementos apiñonados o los aletones avolutados manifiestan un gusto por la profusión ornamental del barroco imperante.

Junto a Manuel del Río, actúa como testamentario del trasmerano Jerónimo de Avendaño en $1669^{472}$. Zorlado continuaría por entonces adscrito a Matienzo y así lo declara ese mismo año cuando otorga fianzas para la ejecución del puente cántabro de Tama, en el municipio de Liébana, última referencia del artista que le sitúa próximo ya a Bádames ${ }^{473}$.

\section{Juan de Solana Quintanilla Maestro arquitecto vecino de Liaño}

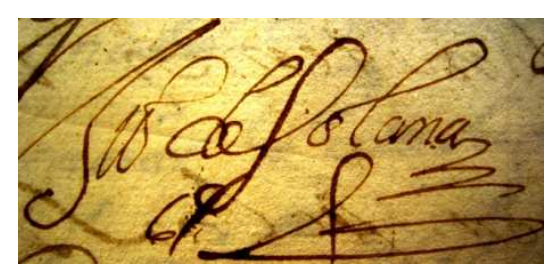

Desconocemos su lugar de procedencia, aunque sospechamos que Juan de Solana procedía de Liaño, localidad cántabra ubicada en el valle de Villaescusa, provincia de Nueve Valles, donde siempre se mantuvo avecindado nuestro artista. Desarrolla la mayor parte de su actividad en la provincia de Palencia durante la última década del siglo XVII y la primera de la siguiente centuria.

La referencia documental más temprana lo sitúa en 1693 en Palencia, abriendo los cimientos del coro y sacristía de la nueva iglesia conventual de las Agustinas Recoletas, junto a Bernardo Soto ${ }^{474}$. En 1695 se encarga de redactar las condiciones para fabricar la toma que se arruinó en el puerto de Zapardiel situado en la Ribera de Torre de los Molinos, por lo que recibirá 20 reales. Los 830 reales

\footnotetext{
${ }^{471}$ URREA FERNÁNDEZ, Jesús y MARTÍN GONZÁLEZ, Juan José. Inventario...II. Op.cit, pág. 58 y siguiendo a éste ANDRÉS ORDAX, Salvador. La iglesia de Santa María de Carrión de los Condes. Diputación Provincial. Palencia, 1994, pág. 33.

${ }^{472}$ AHPP. Carr.Prot 5703. Norberto Sandoval y Guevara (1668), fol 592 y ss.

${ }^{473}$ ALONSO RUIZ, Begoña. El arte de la cantería...Op.cit, pág. 49, a su vez de AHRC. Protocolo 1167 , fol 81.

${ }^{474}$ RAMOS DE CASTRO, Guadalupe. "El convento...Op.cit, pág. 627.
} 
restantes en que fue rematada la obra serían repartidos entre Andrés de Naveros, Antonio Martín, Juan Ruiz, Nicolás Delgado e Isidro Martínez, los maestros de Carrión que llevaron a cabo dicho reparo ${ }^{475}$. En 1696, fiado por Tomás Herrero, Leonardo de Salinas y José Pérez se encarga de la obra de la cárcel real de Carrión, ubicada tras el consistorio y convertida en Casa de Cultura. La subasta se celebró en abril de dicho año y se remató en su persona por 8.735 reales, incluidos en esa cantidad los 672 reales que importó la cuantía de 2.687 reales que hizo de baja ${ }^{476}$. Ese mismo año Solana se obliga a construir la torre de la iglesia de Santa María de Riberos de la Cueza, para sustituir a la anterior, derruida, que al parecer era de tierra. Se compromete a ejecutar el encargo en tres años, hasta octubre de 1699. El primer año levantará hasta diez y ocho pies sobre la superficie y lo dejará cubierto para que las aguas no hagan perjuicio. En los dos siguientes ejecutará la obra restante, recibiendo por la misma seis mil reales ${ }^{477}$.

Proporciona las trazas para la reconstrucción de la torre de la iglesia de la Asunción de Baltanás en 1698, obra rematada en Francisco del Valle ${ }^{478}$. Ese año también está al cargo de otra obra, la reedificación de la capilla arruinada de la Piedad, perteneciente al convento de Santo Domingo de Carrión, colateral del lado del Evangelio ${ }^{479}$. En 1700 ejecuta el pedestal para asentar el retablo de la iglesia de Santa María la Mayor de Villamuriel de Cerrato ${ }^{480}$. Paralelamente a este encargo, desarrolla otros en la villa de Carrión de los Condes, como es el caso de la iglesia de San Juan del Mercado, cuyos reparos ejecuta por catorce mil quinientos reales ${ }^{481}$. En mayo de 1701 se compromete junto a Francisco de Viñas Octavilla a fabricar treinta mil ladrillos para la obra de San Andrés, lo que nos sitúa ante su faceta más

\footnotetext{
${ }^{475}$ Las condiciones se firmaron el 7 de junio de 1695 y el contrato de la obra, seis días después. AHPP. Carr.Prot 5756, Juan de la Serna Reinaltos, (1694-8), s/f.

${ }^{476} \mathrm{La}$ escritura se firma el 2 de abril de 1696. AHPP. Carr.Prot 5027, Gregorio García de Miranda (1696-1699), fol 112.

${ }^{477}$ Las condiciones se firman el 25 de julio de 1696 y la escritura del contrato, el 21 de octubre de 1696 en Hacen baja José de Solaesa, residente en Palencia y maestro de cantería, Francisco de Quintana Ocejo, arquitecto que asiste en Villanueva del Rebollar, Pedro de Rebollar, maestro de cantería y asistente en el lugar de Villaturde, Miguel de la Cuesta, asistente en Villamuera, Jerónimo Fernández, residente en Carrión, José de Arenal, asistente en Paredes de Nava. AHPP. Carr.Prot 5634, Francisco Ruiz Sandoval (1696-1697), fol 126 y ss.

${ }^{478}$ GONZÁLEZ ECHEGARAY, Mª del Carmen. Artistas...Opcit, pág. 577.

${ }^{479}$ AHPP. Carr.Prot 5018, Agustín García Miranda (1696-1698), s/f.

480 CLEMENTINA GIL, Julia Ara. Villamuriel de Cerrato. Iglesia de Santa María la Mayor. Palencia, 1992, pág. 37.

${ }^{481}$ La escritura de obligación se firma el 19 de abril de 1700. AHPP. Carr.Prot 5019, Agustín García Miranda, (1699-1700) s/f.
} 
$\operatorname{artesanal}^{482}$. El 24 de noviembre de dicho año el mayordomo de Santa Inés de Villambroz, jurisdicción de Saldaña, le encarga la terminación de la obra de su iglesia $^{483}$.

La última referencia a una obra del artista está documentada en Carrión, y data de 1702, cuando se concierta con el mayordomo de San Andrés de Carrión para ejecutar la portada, ubicada en su lienzo meridional ${ }^{484}$. Se trata de una sobria fachada integrada dentro de un gran arco de triunfo, donde el artista recurre a un repertorio clásico de pilastras, bolas y puntas de diamante. Gracias a la carta de pago que emite en 1704, sabemos que esta obra se ejecutó con la piedra obtenida del despojo de la desaparecida iglesia de Santa Eulalia, ubicada al norte de la villa condal y que además en San Andrés también se ocupó de ampliar la sacristía y la panera, adosadas en el lado del Evangelio ${ }^{485}$.

\subsection{Artífices locales}

Como en el caso de los artistas cántabros, los maestros locales también mantenían vínculos familiares, por los que el oficio se transmitía a través de sucesivas generaciones como es el caso de los Reinaldos, en la carpintería. Este sistema lógicamente se hace extensivo a toda la Corona de Castilla, pero nos interesa constatarlo específicamente en el caso de Palencia y su provincia. Por ejemplo en Villalpando, resaltaron especialmente los Allende, los Emperador en Paredes de Nada o los Sipos y Yenes en Palencia ${ }^{486}$.

Existía cierta rivalidad entre los maestros comarcanos y los trasmeranos. Los locales observaban con recelo cómo los forasteros se adjudicaban las obras de cantería, ya que en ese sector todos ellos habían adquirido una óptima formación, motivada en parte por la abundancia de piedra en Cantabria. Sin embargo cuando se

\footnotetext{
${ }^{482}$ AHPP. Carr.Prot 5020. Agustín García Miranda (1701-1704), s/f.

${ }^{483}$ AHPP. Carr.Prot 4897. Santiago Duque Estrada (1699-1704), fol 108 y ss.

484 PERAL VILLAFRUELA, Santiago y GÓMEZ PÉREZ, Enrique. Carrión...Op.cit, Edición actualizada, 2003, pág. 62.

${ }^{485}$ AHPP. Carr.Prot 5020. Agustín García Miranda (1701-1704), s/f.

${ }^{486}$ VIGURI, Miguel de y SÁNCHEZ, José Luis. Arquitectura en la Tierra de Campos y el Cerrato. Colegio Oficial de Arquitectos de León. Palencia, 1993, pág. XIX.
} 
trataba de la realización de obras en las que no se requería especialización en el trabajo de la piedra, los maestros locales necesitaban de dicha rivalidad para encontrar un incentivo que les motivase a participar en las pujas. A este respecto existe un documento muy interesante fechado en 1603 por el que el cura y mayordomos del templo de Santa María deliberan sobre qué maestro es más conveniente para ejecutar las obras de albañilería que allí iban a realizarse. Barajando los artífices disponibles en la villa, se hace referencia a Francisco Rodríguez y Juan González, dos oficiales carrioneses jóvenes y carentes de experiencia. Linares y Cuéllar, maestros de cierto rango en la villa, seguramente no querrían hacer la obra y Santiago de Sigüenza, daría las trazas pero no ejecutaría la obra. Una de las posibles soluciones que se plantea es "que vengan maestros de fuera, que mandando vuestra merced poner çédulas en hesa çiudad o en otra parte no faltarían y acaso saldría alguno de los dos que aquí algo saben, en espeçial Cuéllar ... ${ }^{487, " . ~ D e ~ l o ~ c o n t e n i d o ~ c o l e g i m o s ~ q u e ~ l a ~ c o m p e t i t i v i d a d ~ c o n ~ a r t i ́ f i c e s ~}$ foráneos suponían un incentivo para motivar a los maestros locales a pujar en las subastas que se realizaban en su villa natal. De hecho, la obra fue rematada en el citado Antonio de Cuéllar.

En más de una ocasión, las estrategias corporativas de los artistas cántabros para hacerse con una obra se traducen en viles artimañas que dan lugar a careos judiciales $^{488}$. Un pleito que ilustra a la perfección el ambiente de desconfianza e indignación vivido por los miembros del foco local, se produjo a raíz de las obras de un cuarto nuevo en el monasterio de San Zoilo a partir de abril de 1585, y fue promovido por Felipe de la Cajiga ${ }^{489}$. No obstante, las relaciones entre los maestros cántabros y los artífices locales eran de recelo y desconfianza. Buena muestra de ello es el trato de amistad que llegó a entablar el carrionés Marcos de la Torre con los trasmeranos Francisco del Río y Juan de la Cuesta, como tendremos ocasión de comprobar.

\footnotetext{
${ }^{487}$ AHPP. Carr.Prot 5078. Pedro Guerra Cervantes (1603-1604), s/f.

${ }^{488}$ Un estudio profundo sobre el tema en ARAMBURU-ZABALA, Miguel Ángel. Fraude y corrupción en la arquitectura del siglo de Oro. Santander, 2001.

${ }^{489}$ Ya se explicó en la biografía de Felipe de la Cajiga por ser éste el promotor de la artimaña y también nos referiremos al mismo en las obras de San Zoilo, dentro del capítulo dedicado al siglo XVI.
} 
En este apartado hemos incluido a aquellos artistas denominados "maestros de cantería", que, si bien no innovan demasiado arquitectónicamente, confirmamos su presencia en numerosas obras, para las cuales emplearían soluciones técnicas tradicionales. Dada su participación en una gran parte de los monumentos carrioneses, también se contienen aquí los maestros de carpintería y albañilería, que, si bien de menor trascendencia, desempeñan labores de maestros de cantería e incluso son nombrados en ocasiones arquitectos, comprobándose una vez más cómo se entremezclan los apelativos profesionales en la Edad Moderna.

\section{Francisco Rabín \\ Maestro de cantería}

Estaba casado con María de Castañeda, con la que tuvo dos hijos varones, ambos registrados en la parroquia desaparecida de San Bartolomé de Carrión, por lo que, es probable que él también procediera de la villa condal. El primogénito, del que no se indica el nombre fue bautizado el 7 de agosto de 1543 y el menor, llamado Francisco, el 31 de julio de $1556^{490}$. Otra noticia relativa a su familia directa se relaciona con su sobrino, que además del nombre, compartió el mismo oficio que su tío ${ }^{491}$.

La referencia más temprana al artista remite al año 1543, cuando figura trabajando en Villacuende, en la iglesia de la Asunción, cuyos pagos, algunos de los cuales cobró su sobrino Juan Rabín en su nombre, se prolongaron hasta $1561^{492}$. Posteriormente se constata su colaboración en 1547 en las obras de la iglesia parroquial de Villanueva del Río, un pequeño pueblo ubicado a seis kilómetros al sur de Carrión ${ }^{493}$. Por entonces ya debía estar concertado en la obra de la iglesia de Belén. El visitador general del Obispado requirió sus servicios para llevar a cabo la “...capilla ${ }^{494}$, torre y sacristía...” En 1552 ya se realizan los primeros pagos por sus trabajos pero no podemos determinar cuando tiene comienzo su intervención en este

\footnotetext{
${ }^{490}$ ASMC. San Bartolomé. Libro $1^{\circ}$ de Bautizados (1545-1574) fol 13v y fol 19v.

${ }^{491}$ ZALAMA, Miguel Ángel. La arquitectura...Op.cit, pág. 362.

492 Ibídem.

493 AHPP. Carr.Prot 5603. Melchor de la Rúa (1545-1550), s/f.

${ }^{494}$ Entiéndase este término en un sentido más amplio, como tramo o sector en una determinada obra arquitectónica.
} 
templo ${ }^{495}$, la cual, a tenor del hecho de que tenía tomada la obra “...ha muchos años...", quizá debamos situarla hacia 1540 en que podemos datar las parte más antigua de la iglesia, correspondiente a la capilla mayor y la capilla de San Gregorio. El finiquito de estas obras data del año 1562, en que, con los 16.095 maravedíes que se le abonan “...se le acabaron de pagar los maravedís que se le debían... ${ }^{496 ” . ~}$

La siguiente obra documentada fue su participación en la iglesia parroquial de Villacuende, en Palencia, tasada por Juan de Escalante en $1554^{497}$. Debió comenzarla hacia 1536 , pues se le abonan pagos desde este año hasta $1562^{498}$. En 1563, su viuda se erige como fiadora de Juan de Aras cuando éste se compromete a respetar las condiciones dadas por Rodrigo Gil para la iglesia de San Andrés de Carrión, siendo la última vez que se menciona al cantero ${ }^{499}$.

\section{Marcos de la Torre Maestro de cantería}

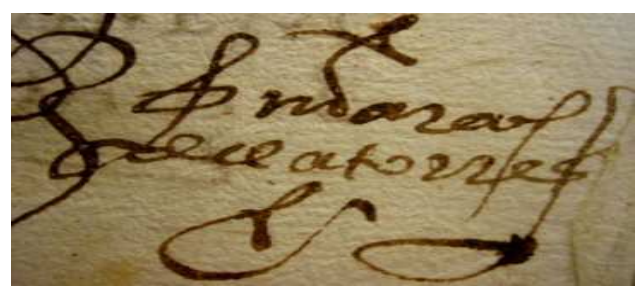

Este cantero procedente de Carrión de los Condes era hijo de Pedro de la Torre, dedicado al mismo oficio, quien al dictar testamento en 1564 le convierte en su único heredero ${ }^{500}$. Probablemente fue su progenitor quien se encargase de su formación, sin ser necesario el establecimiento de un contrato cuando se trataba de familiares directos. Esto debió ocurrir igualmente con uno de sus hijos, Pedro Álvarez de la Torre con quien trabajó en el puente de Carrión, y quien continuaría las obras de la iglesia de Santa María de la Serna. Fruto de su matrimonio con María Álvarez de Sigüenza, también lo fueron Gregorio de la Torre, también llamado

\footnotetext{
${ }^{495}$ ZALAMA, Miguel Ángel. La arquitectura...Op.cit, pág. 341, a su vez de ADP. Iglesia de Belén. Libro $3^{\circ}$ de Cuentas de Fábrica (1549-1566), fol 24v.

${ }^{496}$ ADP. Iglesia de Belén. Libro $3^{\circ}$ de Cuentas de Fábrica (1549-1566), fol 119.

${ }^{497}$ ZALAMA, Miguel Ángel. La arquitectura...Op.cit, pág. 270.

498 VV.AA. Artistas...Op.cit, pág. 208, a su vez de ADP. Villacuende. Libro $1^{\circ}$ de Cuentas de Fábrica (1534-1584), s/f.

${ }^{499}$ ZALAMA, Miguel Ángel. La arquitectura...Op.cit, pp. 256-258, a su vez de AHPP. Carr.Prot 5663 , s/f.

${ }^{500}$ ZALAMA, Miguel Ángel. La arquitectura...Op.cit, pág. 377.
} 
Gregorio de Castañeda e Isabel de Castañeda ${ }^{501}$. Tal vez este patronímico correspondiese a otro familiar, descartando que se hubiese esposado en segundas nupcias, pues en su testamento declara que continúa con la mencionada María Álvarez. Desarrolló su actividad dentro de los límites de la provincia de Palencia, eminentemente durante las dos últimas décadas del siglo XVI abarcando su producción los primeros años de la centuria posterior. Es probable, por tanto, que naciese a hacia 1560. Se trata de uno de los pocos especialistas en el trabajo de la piedra que veremos en Carrión, interviniendo como ejecutor, solventando problemas constructivos de índole técnica, no en calidad de proyectista, de ahí que no exista prácticamente una fábrica en Carrión, tanto civil como religiosa, que éste exenta de su participación.

Estos encargos le dejaron el tiempo suficiente para llevar a cabo una labor que tildaríamos de escultórica como es la ejecución de sepulturas, labor que llevó a cabo al menos en tres ocasiones. Las dos primeras se producen en 1584, cuando en mayo de dicho año Cristóbal de Herrera como patrón de la capilla del Crucifijo de la iglesia de Santa María, quería disponer unas losas pétreas para sus padres y $\operatorname{abuelos}^{502}$. Asimismo, el Licenciado don Cristóbal Brasas le encarga labrar la sepultura de don Antonio Velasco de Avendaño, para disponerla en la sacristía del convento de San Francisco de Carrión ${ }^{503}$. Dado que estos trabajos no requerían de un trabajo exhaustivo eran usualmente los canteros quienes se encargaban de las mismas, como expertos en el corte de la piedra, siendo un entallador el que cincelara el escudo y los motivos decorativos de los que fuera provisto. Precisamente en este encargo se especifica que los leones que debían disponerse bajo la losa y las armas del comitente no debía hacerlas Marcos de la Torre. De nuevo, en 1594, el patrón de la capilla mayor de la iglesia de Santiago, don Gaspar Ponce, le encarga otras sepulturas destinadas a sus descendientes ${ }^{504}$. Otros trabajos que ponen de relieve la versatilidad del artífice, en el manejo de los metales como si de un artesano se tratase, fue la ejecución del encadenado que debía separar la capilla mayor del resto del templo conventual de San Francisco. Pedro Navero, como mayordomo de los

\footnotetext{
501 Ibídem, pág. 318.

502 Ibídem, pág. 320.

${ }^{503}$ AHPP. Carr.Prot 5730. Lázaro Santacruz (1585-1590), s/f.

${ }^{504}$ AHPP. Carr.Prot 4595. Juan Birtus (1592-1594), s/f.
} 
marqueses de Aguilar, patronos de este privilegiado espacio de culto, se encargó de contratar a Pedro de la Torre en $1598^{505}$.

Su primera participación documentada le sitúa en su villa natal, en el templo de Nuestra Señora de Belén. La inestabilidad que siempre aquejó a la fábrica, dada su endeble cimentación por su proximidad al río Carrión, motivó una sucesión de labores de fortalecimiento que no evitarían la ruina y posterior reedificación de la iglesia. De estos trabajos se hizo cargo Marcos de la Torre en 1584, sucediéndole a partir de 1585 Juan de la Cuesta ${ }^{506}$.

Fue requerido por don Antonio Doro Campoo, regidor de Carrión y comerciante de las Américas, para que realizara unas tareas de fortificación en sus viviendas, siguiendo las trazas que Juan de la Cuesta había proporcionado en $1585^{507}$. Este encargo refleja el prestigio que el artífice había alcanzado en la villa, al ser contratado por una figura célebre como era don Antonio, conocido por ser el comitente de la Custodia del Corpus Christi que procesiona anualmente ${ }^{508}$. Así sucede en 1594 cuando el representante de Don Luis de Velasco, sabedor del buen hacer del cantero, le contrata para que levante un muro de cantería y unas pilastras en el patio de la casa del Águila, ubicada frente a la iglesia de Santa María, en la parte más cercana a la escalera principal $^{509}$.

En Quintanar de la Vega trabaja en los refuerzos de la torre desde 1587 junto a Santiago de Sigüenza, prolongándose su participación hasta 1591, en que “...por mucha ocupación que tienen y por causas que les mueven no pueden fenecer y acauar...” y optan por traspasársela a Antonio de Cuéllar en abril de dicho año ${ }^{510}$.

De regreso a Carrión, junto a la antigua puerta de Padierno, también denominada de Santa María, que se ubicaba junto al templo homónimo, la encomienda y hospital de las Tiendas poseía unas viviendas que necesitaban ser

\footnotetext{
${ }_{505}^{50}$ AHPP. Carr.Prot 5289. Pascual López (1598) s/f.

506 ADP. Carrión de los Condes. Iglesia de Belén. Libro 14 de Fábrica (1584-1599), fol 9 y ZALAMA, Miguel Ángel. La arquitectura...Op.cit, pág. 93.

507 Ver condiciones de la obra en AHPP. Carr.Prot 5619, Melchor de la Rúa (1585-1587), s/f. Sobre Juan de la Cuesta, véase el apartado relativo a su biografía.

${ }^{508}$ Sobre este tema URREA FERNÁNDEZ, Jesús. "La custodia de Carrión...Op.cit, 765-770.

${ }^{509}$ AHPP. Carr.Prot 5653. Pedro Saldaña (1594), s/f.

${ }^{510}$ AHPP. Carr.Prot 4981. Sebastián García (1590-1592), s/f.
} 
rehabilitadas. Por ello, su mayordomo, en nombre del administrador, solicita en 1588 a Marcos de la Torre que refuerce uno de sus muros con la piedra procedente del templo de Santa María, en el que trabajaba por entonces ${ }^{511}$. Efectivamente, en enero de 1587 se había logrado adjudicar, junto a Francisco del Vado, la obra de fortalecimiento del presbiterio, concretamente de la capilla absidal de la Epístola de dicho templo, debido a la ruina que presentaba la torre, que, ubicada sobre el crucero, afectaba a toda la zona de la cabecera. Sin embargo el trasmerano decidió cederle la obra, quedando de la Torre como único responsable hasta 1589 en que se comprometió a finalizar la obra ${ }^{512}$. No dejan de sucederse los encargos, ya que a apenas comenzado el año 1590, el trasmerano Francisco del Río le cede la obra de la torre de la iglesia parroquial de San Mamés de Campos, por cuya intervención recibiría pagos en los años posteriores, incluso cobrándolos sus herederos en 1608 cuando ya había fallecido ${ }^{513}$.

Concertado con Pedro de la Vega en el puente palentino de Raveros, debía derribar cinco arcos que se encontraban dañados, dejando solo uno y rehacer dicha parte a comienzos de $1591^{514}$. Seguidamente lo encontramos en Quintanadiez para levantar la torre de su iglesia parroquial ayudado por su aparejador Pedro Díez. Las trazas habían sido proporcionadas por Baltasar Gutiérrez ${ }^{515}$.

En octubre de dicho año, Juan de la Cuesta otorga un poder a su hermano Francisco y a Marcos de la Torre para que comprobaran las cuentas de la obra que hacía en el convento de San Francisco ${ }^{516}$. Este hecho trasluce la connivencia existente entre el maestro trasmerano y el artífice carrionés, dado que este era un momento difícil para Juan de la Cuesta, pues la obra de la casa franciscana le estaba ocasionando muchas dificultades. Esta no era la primera ocasión en que Marcos de la Torre le prestaba su apoyo, pues en febrero de 1591 le devolvió un préstamo y aún antes, en junio de 1589 abona junto a otros artífices, la fianza para sacarle de

\footnotetext{
511 AHPP. Carr.Prot 5671. Andrés Sánchez (1577-1578), s/f.

512 Ibídem.

${ }^{513}$ ZALAMA, Miguel Ángel. La arquitectura...Op.cit, pág. 310, 318-319.

${ }^{514}$ AHPP. Carr.Prot 4981. Sebastián García (1590-1592), fol 77 y ss.

515 MARTÍN GONZÁLEZ, Juan José y URREA FERNÁNDEZ, Jesús. Inventario...2. Op.cit, pág. 148.

516 ZALAMA, Miguel Ángel. La arquitectura...Op.cit, pág. 266.
} 
prisión $^{517}$. Otro caso que manifiesta el trato favorable mantenido entre los dos maestros es el hecho de que ese mismo año de 1591 Marcos de la Torre le facilita a de la Cuesta las losas sobrantes del puente de Carrión para que los empleara en los templos de Belén y San Andrés ${ }^{518}$. Se había logrado adjudicar esta obra pública, no sin ciertos problemas, concertándose para ello con el trasmerano Francisco del Río para pujar por ambos en la subasta de $1590^{519}$. El cantero Diego Prieto, maestro de cantería cántabro oriundo de Penagos, que había pujado también a la baja estableció un pleito contra Marcos de la Torre y su hijo, Pedro Álvarez de la Torre por la adjudicación de la misma. En julio de 1591 la justicia les dio la razón, quedando rematada en ellos la obra, debiendo éstos compensar a Diego Prieto con treinta ducados por los gastos de la postura que había realizado en el Real Consejo ${ }^{520}$. Sin embargo el puente se encontraba arruinado y fue necesario un nuevo proyecto, presentado ante el Consejo Real, que fue rematado nuevamente en Marcos de la Torre en febrero de 1595, comprometiéndose a seguir las trazas proporcionadas por su primogénito ${ }^{521}$. En esta obra continuaría al menos el año siguiente en que Francisco del Río se desvincula de la obra y admite estar trabajando con el carrionés $^{522}$.

A partir de 1591 en que el mayordomo del convento de Santo Domingo aparta de la obra del claustro renacentista a Juan de la Cuesta, dada la lentitud de las obras, Marcos de la Torre se compromete a ejecutar los tres paños que quedaban por hacer, tomando como modelo la crujía realizada por el maestro trasmerano ${ }^{523}$. Una vez más, constatamos el papel de nuestro cantero como mero ejecutor, sin innovar en las obras, quien no conseguirá cumplir con su contrato, pues aún en a comienzos del siglo XVII quedaba un paño por levantar. En Villalcázar de Sirga, a escasos kilómetros de Carrión, se ocupa de la obra de cantería concerniente a la ermita de Santa María del Río, por la que recibe pagos entre 1593 y $1599^{524}$. El 1 de febrero de

\footnotetext{
517 AHPP. Carr.Prot 4980. Sebastián García (1588-1590), fol 672 y Protocolo 4981. Sebastián García (1590-1592), fol 352.

518 AHPP. Carr.Prot 4981, Sebastián García (1590-1592), fol 352-353.

${ }^{519}$ AHPP. Carr.Prot 5851. Nicolás Vallejo (1584-1591), s/f.

${ }^{520}$ ZALAMA, Miguel Ángel. La arquitectura...Op.cit, pág. 318, a su vez de AHPP. Carr.Prot 5650. Pedro Saldaña (1591), fol 232 y 520 y ss.

${ }^{521}$ AHN. Consejos. Legajo 24676 y AHPP. Carr.Prot 5286. Pascual López (1595), s/f.

${ }^{522}$ VAQUERIZO GIL, Manuel. "Tipología...Op.cit, pág. 159.

${ }^{523}$ AHPP. Carr.Prot 5650. Pedro Saldaña (1591), fol 564 y ss.

${ }^{524}$ ZALAMA, Miguel Ángel. La arquitectura...Op.cit, pág. 320.
} 
1594 se compromete a finalizar la capilla mayor de la iglesia parroquial de la Serna, resultando elegido Baltasar Gutiérrez maestro de las obras ${ }^{525}$. Al concluir estos trabajos, toma la obra de reparo del casco de la capilla mayor de San Cristóbal de Lomas $^{526}$. Junto al maestro de carpintería Santiago de Sigüenza, actúa como veedor en diciembre de 1599, cuando el párroco de la iglesia de San Julián les solicita que redacten un informe sobre la viabilidad de la ubicación del panteón del maese de campo Don Hernando de Berrio, regidor de Panamá, en la iglesia de Nuestra Señora de las Capillas. El dictamen resulta a todas luces desfavorable dada la pésima ubicación de la ermita y la imposibilidad de ampliarla por flanquearla varios edificios, entre ellos, la iglesia de Santiago ${ }^{527}$. Un año después, toma como aprendiz del oficio de cantero a Domingo de Mogrobejo ${ }^{528}$. De nuevo la iglesia de Santa María le reclama para realizar unas labores de fortificación en el primer tramo del templo, específicamente en el coro. La carta de pago emitida en marzo de 1601 señala que la obra había dado comienzo un año antes ${ }^{529}$. Trabajó junto a Pedro de Carandil en las obras de la iglesia de San Juan Bautista de Cardeñosa de Volpejera según declara el propio Carandil en su testamento. No se especifica cuando tiene lugar dicha intervención, si bien reciben cartas de pago entre 1599 y $1603^{530}$.

Dictó testamento el 23 de marzo de 1601, haciéndolo unos meses más tarde su mujer. A través del mismo, conocemos su participación en las iglesias parroquiales de otras localidades palentinas que se suman a la larga lista de aportaciones. Refiere a las mismas para que se efectúe la tasación de la parte que ha realizado y se abone a sus herederos. Entre las mismas figuran los templos de San Pedro de Villasirga, Nuestra Señora de Villovieco, el cementerio y la iglesia de San Juan de Revenga, la torre de Cardeñosa, el puente de Cea, la portada y torre de San Mamés, la torre de Cardeñosa ${ }^{531}$. Continuaba trabajando por entonces, pues ese año está documentada su participación en la construcción de la sacristía de la iglesia

\footnotetext{
${ }^{525}$ AHPP. Carr.Prot 5053. Alonso Gómez Guillén (1595-1603), fol 33 y ss.

${ }^{526}$ AHPP. Carr.Prot 5389. Francisco Moro Saldaña (1606), s/f.

${ }^{527}$ FERRERO MAESO, Concepción. “El mecenazgo...Op.cit, pág. 587.

${ }^{528}$ AHPP. Carr.Prot 5291, Pascual López (1600), s/f.

529 AHPP. Carr.Prot 5384. Francisco Moro de Saldaña (1601), s/f.

${ }^{530}$ ZALAMA, Miguel Ángel. La arquitectura...Op.cit, pp. 216, 243.

${ }^{531}$ AHPP. Carr.Prot 4965, Alonso García (1601), s/f.
} 
parroquial de Villovieco, en la cual ya había intervenido unos años antes, en 1592, para reconstruir su nave ${ }^{532}$.

La última referencia al artista vivo, data de junio de 1602 en que actúa como testigo en el contrato que Bartolomé de Medina establece con la cofradía de Santo Tomás del templo de Santiago para la ejecución de un retablo ${ }^{533}$. Debió fallecer en 1605, pues ese año sus herederos se erigieron como los responsables de cobrar por los trabajos que se le adeudaban ${ }^{534}$.

\section{Santiago Díaz de Sigüenza Maestro de carpintería y cantería}

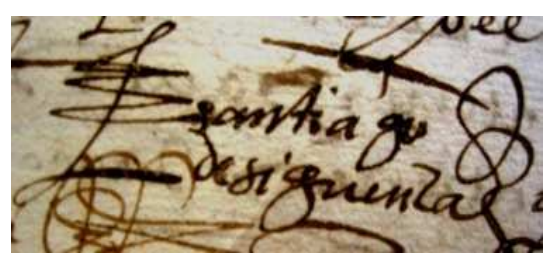

Coetáneo de Marcos de la Torre fue Santiago de Siguienza, con quien figura colaborando en algunas ocasiones. Es posible que entre ambos existiera algún lazo de parentesco, dado que la esposa del maestro de cantería, María Álvarez, tildaba Sigüenza como segundo apellido. Estaba casado con Isabel de la Vega y su hijo mayor se llamaba Juan Díez de Sigüenza, y el menor Blas.

$\mathrm{Su}$ actividad se desenvuelve fundamentalmente durante las dos últimas décadas de la centuria decimosexta, desarrollando su labor al servicio de la madera, por eso siempre figura como maestro de carpintería. Sin embargo, el hecho de que se le encargue la redacción de condiciones de algunas obras en las que participarían maestros de cantería y se ponga al mando de ciertas construcciones, revela un conocimiento de los principios técnicos del trabajo de la piedra y una capacidad de organización que manifiesta su faceta de maestro de obras y tracista, aunque en la documentación como mucho, figura excepcionalmente como maestro de cantería. Esta doble formación y carácter tan versátil, lejos de resultar excepcional, es un hecho constatado en otros maestros que trabajan en el siglo XVI en la provincia de

\footnotetext{
${ }^{532}$ MARTÍN GONZÁLEZ, Juan José y URREA FERNÁNDEZ, Jesús. Inventario...2. Op.cit, pág. 288.

${ }_{533}^{53}$ AHPP. Carr.Prot 5053. Alonso Gómez Guillén (1595-1603), fol 347 y ss.

${ }^{534}$ ZALAMA, Miguel Ángel. La arquitectura...Op.cit, pág. 319.
} 
Palencia, como es el caso de Luis de Rebanal, vecino de la capital del Carrión, o Mateo del Solar, avecindado en la localidad cántabra de Pontones ${ }^{535}$.

En abril de 1584 se le abonan los pagos concernientes a la ejecución de la armadura de la capilla mayor de la iglesia de San Andrés, previa conformidad de su antiguo patrón don Nicolás de Reinoso ${ }^{536}$. Suponemos que esta era la prueba que necesitaba el párroco y mayordomo del templo del buen hacer de Sigüenza, para depositar su confianza en este prometedor maestro pese a la escasa experiencia demostrada. Por ello, pocos meses más tarde le encargaron que proporcionase las trazas que permitieran reconstruir la torre arruinada del templo. No obstante, el deseo de asegurar que sus propuestas eran adecuadas, motivó la solicitud de una segunda traza a otro maestro y una revisión de ambas por el maestro Alonso de Tolosa que determinó “...que las que más conbiene haçerse por ellas es la del señor Santiago de Çiquença... ${ }^{537, "}$

En 1586 se concierta con Pedro de Cisneros para construir su casa ${ }^{538}$, trasladándose puntualmente a Villasarracino, ubicada a una decena de kilómetros, para tasar la obra que el carpintero Luis de Rebanal había realizado en su iglesia parroquial, labor que efectuaría junto al maestro trasmerano Pedro de la Peña ${ }^{539}$. Enseña el oficio de carpintero al criado del monasterio de San Zoilo, Rodrigo Juarez, natural de Monforte de Lemos, el cual será su aprendiz desde 1587 durante cuatro $\operatorname{años}^{540}$. Ese mismo año, se remata en él y en Marcos de la Torre la obra de la iglesia de Quintanar de la Vega que aún no habían finalizado en 1591, por lo que deciden traspasársela a Antonio de Cuéllar ${ }^{541}$.

La primera vez que el síndico de San Francisco requiere a Sigüenza en la casa terciaria carrionesa se remonta a 1588 , en que debía reconstruir los tejados correspondientes a la librería, aledaña al coro y a tres capillas colindantes con la misma, según las trazas que él mismo había entregado, todo bajo la dirección de

\footnotetext{
${ }^{535}$ ZALAMA, Miguel Ángel. La arquitectura...Op.cit, pp. 363, 373.

${ }^{536}$ AHPP. Carr.Prot 5729. Lázaro Santacruz (1579-1584), s/f.

537 AHPP. Carr.Prot 5600. Francisco de Rojas (1580-1589), fol 387-392.

${ }^{538}$ AHPP. Carr.Prot 5670. Andrés Sánchez (1585-1586), fol 301 y ss.

539 ZALAMA, Miguel Ángel. La arquitectura...Op.cit, pág. 359.

${ }^{540}$ AHPP. Carr.Prot 5671, Andrés Sánchez (1578-1579), s/f.

${ }^{541}$ AHPP. Carr.Prot 4981. Sebastián García (1590-1592), s/f.
} 
Juan de la Cuesta $^{542}$. En junio de 1589, junto a los artífices carrioneses Rodrigo de Losada, Antonio de Cuéllar, Marcos de la Torre y Gonzalo de Albear, abonó la fianza impuesta a Juan de la Cuesta por los incumplimientos en la fábrica de la casa franciscana, comprometiéndose los mismos a llevarle de nuevo a prisión cuando les fuera solicitado ${ }^{543}$. Este acto de generosidad contradice la tendencia general de la mala relación entre los artistas cántabros y los locales fundamentada en la competitividad a la hora de adjudicarse una obra. A partir de 1590 y en los años posteriores recibe diversos pagos en concepto de la ejecución del chapitel de la torre de la iglesia de Santa Cruz de Grijota ${ }^{544}$.

De nuevo es requerido para participar en el cenobio franciscano en 1594. En esta ocasión no es el síndico quien le reclama sino el marqués de Cenete, patrón de la capilla del Infantazgo, colateral de la capilla mayor, para que reparase su tejado sin modificar la bóveda de crucería existente. Además debía abrir una claraboya para permitir el paso de la luz desde el muro del Evangelio ${ }^{545}$. La prueba inequívoca del conocimiento de Sigüenza en el corte de la piedra es el encargo de realizar unas sepulturas ese mismo año, junto a Marcos de la Torre, para disponerlas en la capilla mayor del templo de Santiago ${ }^{546}$. El otro cenobio mendicante masculino de Carrión, el convento de Santo Domingo, no quería ser menos y también deseaba probar la valía de Sigüenza. El prior le requiere en 1596 para que sustituya las cubiertas del paño del claustro donde se ubicaba la sacristía, obra en la que casualmente también trabajaba Marcos de la Torre ${ }^{547}$. Su intervención se prolonga durante varios años, registrándose los pagos en 1607, en que se le abonan 1400 reales por la traza y otros quinientos por la obra de cantería del claustro ${ }^{548}$. Así parece que quedó concluida la obra que comenzara Juan de la Cuesta en 1585.

Su faceta de tasador la conocemos a través de la valoración favorable que realiza en 1594 del escritorio de nogal que había ejecutado Hernando Infante para el templo de San Julián y por una carta de pago de 1597 en razón de su valoración del

\footnotetext{
${ }^{542}$ AHPP. Carr.Prot 5620. Melchor de la Rúa (1588), s/f.

${ }^{543}$ AHPP., Carr.Prot 4980. Sebastián García (1588-1590), fol 672.

${ }^{544}$ ZALAMA, Miguel Ángel. La arquitectura...Op.cit, pág. 138.

545 AHPP. Carr.Prot 5623. Melchor de la Rúa (1594), s/f.

${ }^{546}$ AHPP. Carr.Prot 4595. Juan Birtus (1592-1594), s/f.

547 AHPP. Carr.Prot 5655. Pedro Saldaña (1596) s/f.

${ }^{548}$ AHPP. Carr.Prot 4772. Martín Cisneros (1607-1608) fol 521 y ss.
} 
precio del molino que el convento de Santa Clara poseía en Ribera de Calzada. Para las hermanas terciarias, además, ejecuta el paño del claustro coincidente con las celdas entre julio de 1597 y febrero del año posterior, levantando las columnas y efectuando las armaduras, lo que avala su doble función de cantero y carpintero ${ }^{549}$. También le correspondió la reparación de la sacristía vieja y dos estancias ubicadas junto al coro en 1600. Sigüenza debe sustituir las cubiertas por un armazón de tijera, aprovechando las vigas que pudieran resultar útiles ${ }^{550}$.

Participó como proyectista nada menos que en el monasterio de San Zoilo cuando en mayo de 1598 proporcionó "las trazas y el alçado" en la obra de cantería que Pedro de Verdes y Juan de Solórzano tenía tomada en la sacristía y la librería, ubicada encima de ella ${ }^{551}$. También actúa como mero carpintero, pues una vez que la obra estuvo concluida la arquitectura, se encargó de la ejecución de las puertas y ventanas que articulaban ambas estancias ${ }^{552}$. Por entonces proporcionó las trazas que debía seguir el albañil Marcos Santiago para finalizar la torre de la iglesia de San Juan del Mercado, ubicada en la calle homónima, que se hallaba en proceso de construcción desde al menos $1566^{553}$.

Está constatado el perfil de Sigüenza como veedor, cuando en 1599 junto a Marcos de la Torre emite un dictamen desfavorable sobre la adecuación del establecimiento de la capilla de don Hernando de Berrio en la ermita de Nuestra Señora de las Capillas ${ }^{554}$. Incluso se le intitula arquitecto cuando en 1600 es requerido por el regidor de la villa para valorar la obra del consistorio, proporcionando una traza con las modificaciones pertinentes ${ }^{55}$. En 1601, según declara Marcos de la Torre en su testamento, estaba trabajando con Sigüenza en las obras de la iglesia parroquial de Santervás de la Vega ${ }^{556}$.

\footnotetext{
${ }^{549}$ AHPP. Carr.Prot 4595. Juan Birtus (1592-1594), s/f y Prot 4700. Pedro Carrión (1597), s/f.

${ }^{550}$ Contrato de las dos piezas del convento a 26 de septiembre de 1600. AHPP. Carr.Prot 4703. Pedro Carrión (1600), s/f.

${ }^{551}$ AHPP. Carr.Prot 5657. Pedro Saldaña (1598), s/f.

552 AHPP. Carr.Prot 5382. Francisco Moro Saldaña (1599), s/f.

${ }^{553}$ AHPP. Carr.Prot 4701. Pedro Carrión (1598), fol 365 y ss.

${ }^{554}$ FERRERO MAESO, Concepción. “El mecenazgo...Op.cit, pág. 587.

${ }^{555}$ AHPP. Carr.Prot 5291. Pascual López (1600), s/f.

${ }^{556}$ AHPP. Carr.Prot 4965. Alonso García (1601), s/f.
} 
Una obra que resulta trascendental dentro de su trayectoria fue su participación en la iglesia carrionesa de Santa María del Camino desde agosto de 1603 a 1606, que fue rematada en Antonio de Cuéllar. Nos parece muy interesante pues a través de la misma podemos apreciar cómo conjugó en una sola obra las diversas facetas que desarrolló el carrionés así como la óptima consideración del artista en la villa condal avalada por su experiencia. Tres meses antes de la subasta existió una deliberación sobre quién debía encargarse de los trabajos y el mayordomo y párroco del templo, debidamente informados, determinan que Sigüenza es el adecuado para dirigir las obras. Queda determinado que el maestro “... asistirá con su persona al azer las çimbrias y andamios en lo que conbiniere su maestramiento y lo que a de aber por su trabaxo, por traza y condiçiones y

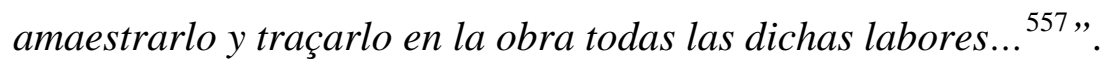

Nada más se vuelve a saber del polifacético artista, que, a tenor de la reducida horquilla de años en la que trabaja, debió fallecer a una edad temprana.

\section{Antonio de Cuéllar}

\section{Maestro de albañilería}

No se conocen datos acerca de su familia e ignoramos si tuvo esposa e hijos. En cualquier caso, la documentación trasluce algunos rasgos de su persona, como su carácter afable, pues siempre mantuvo buenas relaciones con todos los artífices, independientemente de su procedencia. Sabemos además que no poseía ninguna formación cultural, pues no sabía firmar los contratos, por lo que es probable que además de no saber escribir, no supiera leer. En ocasiones contrató varias obras a la vez para procurarse una vida más desahogada, de lo cual se arrepentiría cuando resultó encarcelado por no cumplir con los plazos. Si bien siempre aparece citado como maestro albañil, sus actuaciones van más allá de las obligaciones de un mero artífice del yeso, interviniendo mayoritariamente en reparaciones de torres de iglesias. No obstante, tampoco es autor de ningún proyecto.

${ }^{557}$ AHPP. Carr.Prot 5078. Pedro Guerra Cervantes (1603-1604), s/f. 
Al igual que sus compañeros Marcos de la Torre y Santiago Sigüenza, su actividad se desarrolla a caballo entre las últimas décadas del siglo XVI y los primeros años del XVII en Carrión y alrededores. Excepcionalmente sale de la provincia en 1575, cuando obtiene licencia para reforzar la torre de la iglesia de Arconada, en Sahagún ${ }^{558}$. No obstante, hay que tener en cuenta que la villa leonesa dista a una treintena de kilómetros de la villa carrionesa, por lo que su radio de acción resulta muy reducido.

No volvemos a saber nada del artista hasta mayo de 1580 en que se concierta con el párroco de la iglesia de Santiago de Carrión para construir el remate de la torre, encargo que no cumplió y que pagó con su ingreso en prisión, de la que saldría en septiembre de $1581^{559}$. Esta es la primera ocasión en que se menciona la torre de este templo, cuando por entonces se conservaría la edificación románica. El documento señala que poseía una elevada aguja y estaba dotada de almenas, lo que proporciona una idea del aspecto defensivo de la construcción. Cuando Cuéllar estaba al cargo de estas obras, se encontraba realizando el reparo de la torre de la iglesia de Santiago de Arconada, que también presentaba daños ${ }^{560}$, por lo que es probable que la simultaneidad de varias obras le impidiese cumplir los plazos de la fábrica carrionesa. A partir de 1589, Cuéllar figura trabajando en la fábrica del convento carrionés de San Francisco, cuya iglesia y claustro dirigía Juan de la Cuesta, a quien había pagado, junto a otros artífices carrioneses la fianza para que saliera temporalmente de prisión en junio de dicho año ${ }^{561}$. En compensación, Juan de la Cuesta cedió dos terceras partes de la obra del sotocoro y coro alto a Cuéllar y a Gonzalo Albear, que también había participado en la dicha fianza ${ }^{562}$. Albear debió ceder inmediatamente su parte a Cuéllar, pues en los pagos tan sólo figura éste como beneficiario. En marzo de 1590, le encargan la ejecución de única capilla del templo que quedaba por hacer, próxima a la cabecera. Siguiendo las condiciones de Juan de la Cuesta, efectúa una labor propia de un maestro de cantería, ya que debía reforzar el acceso a la capilla mayor con su arco, pilastras y capiteles, manteniendo la

\footnotetext{
${ }^{558}$ ZALAMA, Miguel Ángel. La arquitectura...Op.cit, pág. 342.

559 Ibídem, pág. 343.

${ }^{560}$ AHPP. Carr.Prot 5616. Melchor de la Rúa (1578-1580), s/f.

${ }^{561}$ AHPP. Carr.Prot 4980. Sebastián García (1588-1590), fol 672.

${ }^{562}$ Ibídem, fol 666.
} 
armonía con el resto de la fábrica ${ }^{563}$. Juan de la Cuesta vuelve a confiar en el carrionés y a mediados de año le traspasa a él y a Marcos de la Torre la parte que tenía tomada en la obra de la torre e iglesia de San Mamés ${ }^{564}$. Un año después, en abril de 1591, Marcos de la Torre y Sigüenza le ceden la obra de la finalización de la torre de la iglesia de Quintanar de la Vega, pues, como ya apuntamos, llevaban trabajando en la misma desde hacía cuatro años y no había conseguido concluirla porque estaban demasiado ocupados con otros encargos ${ }^{565}$. Liberado de este encargo, en diciembre de 1592 es nuevamente requerido por el cenobio franciscano carrionés. En 1591 se había hundido la capilla de San Bernardino, que había erigido Juan de la Cuesta. Su patrón, el Licenciado Díaz Flores, le demanda y acaba en la cárcel, falleciendo en enero de 1592. Es entonces cuando Cuéllar retoma los trabajos, comprometiéndose a reedificarla y cubrirla con una bóveda de arista realizada en ladrillo y guarnecida de yeso ${ }^{566}$. En Calzadilla de la Cueza toma la obra de la iglesia de San Martín en 1594 y a comienzos del siguiente reconstruye la torre de la iglesia de la Asunción de Villanueva de los Nabos ${ }^{567}$.

En abril de 1595 logra adjudicarse la obra de la cárcel de Carrión por quince mil maravedíes y otros mil que había ganado en concepto de prometido. La intervención consistía en el “... preparamento e fortificación...” de la pared de las letrinas y de la contigua, para evitar posibles fugas de presos. Las condiciones de la obra, cuyo autor se desconoce por no estar firmadas, revelan que el maestro carrionés debía encargarse de las labores propias de su oficio de albañil, además de las relativas a la carpintería ${ }^{568}$. No sabemos cuánto tiempo dedicó a esta obra, dado que no se especifican los plazos, pero creemos que fue una intervención rápida, ya que desde ese año y hasta 1597 se encuentra en Villalcázar de Sirga, trabajando en la iglesia de Santa María ${ }^{569}$.

El mayordomo del extinto templo de San Juan Bautista o del Mercado requiere la intervención de Cuéllar a comienzos de 1600 para que finalice su torre,

\footnotetext{
${ }^{563}$ AHPP. Carr.Prot 4981. Sebastián García (1590-1592), fol 57 y ss.

${ }^{564}$ AHPP. Carr.Prot 4981. Sebastián García (1590-1592), fol 103 y 354.

565 AHPP. Carr.Prot 4981. Sebastián García (1590-1592), s/f.

${ }^{566}$ AHPP. Carr.Prot 4982. Sebastián García (1592-1594), fol 113 y ss.

${ }^{567}$ ZALAMA, Miguel Ángel. La arquitectura...Op.cit, pág. 343, a su vez de AHPP. Carr.Prot 5654. Pedro Saldaña (1595), s/f.

${ }_{568}$ AHPP. Carr.Prot 5459. Francisco Obeso de Buelna (1594-1596), s/f.

${ }^{569}$ ZALAMA, Miguel Ángel. La arquitectura...Op.cit, pág. 343.
} 
que se venía edificando desde 1566. Para ello debía seguir las trazas de Santiago Sigüenza, realizando toda la obra en ladrillo ${ }^{570}$. A finales del año siguiente los trabajos debían haberse concluido, por lo que llegado el año 1602, la iglesia apremia a su pronta finalización ante la inminente llegada de las nevadas que impedirán continuar los trabajos ${ }^{571}$. En el antiguo ayuntamiento de Carrión se encargaría paralelamente de reforzar la arquería contigua al patio, siguiendo las condiciones proporcionadas por Santiago de Sigüenza, que se encontraba bastante deteriorada ${ }^{572}$. En 1601 realiza diversos reparos en la torre y fortaleza de Fernando de la Riva

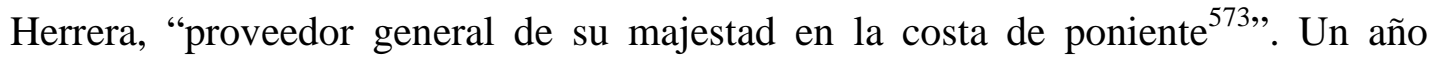
después, trabajará nuevamente por encargo de la nobleza, en este caso en la vivienda del don Luis de Velasco, propietario de la casa del Águila, ubicada frente a Santa María. Cuéllar se encarga del socalzado de la parte trasera del edificio ${ }^{574}$.

La obra de mayor responsabilidad que contrató Cuéllar fue la que llevó a cabo entre 1603 y 1606 en la iglesia de Santa María de Carrión. En principio se había concertado con su mayordomo para levantar las cubiertas correspondientes a los tres primeros tramos del templo, donde se dispondría una bóveda de lunetos en el coro alto, y en las dos secciones restantes, bóvedas de arista con lunetos “...con sus filetes y requadraturas...”. En el cuarto tramo y en el siguiente no debía intervenir por el momento, pues el cimborrio presentaba problemas de estabilidad y debía intervenirse previamente en este sector ${ }^{575}$. Cuando en 1606 le abonan varias cartas de pago, se indica que el montante se aplica en concepto de cuatro capillas y el coro $^{576}$. Esto señala que el cuarto tramo, cubierto con una bóveda de arista y el inmediato, previo al crucero, se deben a su mano. En esta última parte tan sólo blanqueó la plementería de la bóveda de crucería existente, manteniendo intactos los dos nervios pétreos.

\footnotetext{
${ }^{570}$ AHPP. Carr.Prot 5291. Pascual López (1600), s/f.

571 AHPP. Carr.Prot 5077. Pedro Guerra Cervantes (1602), s/f.

572 AHPP. Carr.Prot 5291. Pascual López (1600), s/f.

573 AHPP. Carr.Prot 5076. Pedro Guerra Cervantes (1600-1601), s/f.

${ }^{574}$ AHPP. Carr.Prot 5385. Francisco Moro Saldaña (1602), s/f.

${ }^{575}$ AHPP. Carr.Prot 5078. Pedro Guerra Cervantes (1603-1604), s/f.

${ }^{576}$ AHPP. Carr.Prot 5080. Pedro Guerra Cervantes (1606-1608), fol 160.
} 
En 1605 está comprometido en la obra de albañilería de San Pedro de Saldaña junto a Pedro de Linares ${ }^{577}$. Además realiza junto al albañil carrionés Pedro González el aderezo del Palacio de la marquesa de Aguilar situado en Avia de las Torres en $1606^{578}$. Los encargos no dejan de sucederse uno tras otro y en la iglesia de San Pedro de Villasirga se encarga en 1607 de hacer la bóveda de la capilla mayor en ladrillo guarnecida de yeso, enlucir la nave y hacer un altar para disponer el retablo ${ }^{579}$.

No será hasta septiembre de 1609 cuando Cuéllar tome parte en las obras de socalzo de la capilla mayor, incluyendo los espacios incluidos en la misma, como la capilla de Juan Moro y de Gaspar de los Ríos Campoo ${ }^{580}$. Se comprometió a finalizar los trabajos en junio del año siguiente y al no poder cumplir con los plazos, continúa la obra Francisco de Arce ${ }^{581}$.

\section{Bernardo Sánchez \\ Maestro de cantería}

Sin temor a equivocarnos, podemos situar su nacimiento en el año 1615, pues en febrero de 1647 participa como veedor de las capillas de Santa Catalina y la Resurrección, ubicadas a los pies del templo de San Francisco de Carrión, declarando ser de edad de 32 años, además de no saber escribir. Gracias a este documento también sabemos que, al menos en esta ocasión, redactó las condiciones de reedificación de estos espacios que estaban arruinados junto a Hernando de Inestrosa, de modo que, aunque excepcionalmente, además de cantero, también actuó como tracista ${ }^{582}$. Los años que permanece avecindado en Carrión abarcan un amplio abanico de algo más de un par de décadas que transcurren desde mediados del siglo XVII. Sin embargo, el hecho de no poseer ninguna mención anterior del artista nos hace pensar que fuese oriundo de alguna localidad cercana donde pasaría

\footnotetext{
577 AHPP. Carr.Prot 4832, Juan Díaz Pajaza (1605), s/f.

${ }^{578}$ AHPP. Carr.Prot 5296. Pascual López (1606), fol 606.

${ }^{579}$ AHPP. Carr.Prot 5508. Sebastián Peláez (1607-1610), s/f.

${ }^{580}$ Según Zalama, Cuéllar tomó parte en las obras del templo en 1571, pero en esas fechas no hemos hallado que participara en el mismo. La obra por entonces estaba al cargo de Juan de Celaya (véase la Voz Celaya). ZALAMA, Miguel Ángel. La arquitectura...Op.cit, pág. 342.

${ }^{581}$ AHPP. Carr.Prot 5508. Sebastián Peláez (1607-1610), s/f.

${ }^{582}$ AHPP. Desamortización. Leg. 105, s/f.
} 
los primeros años de formación. Debía poseer suficiente experiencia contratada por otras obras anteriores para que en 1647 fuese llamado para una labor de aquella índole como la referida.

El maestro de carpintería Francisco de Reinaldos requiere su presencia para que actúe como testigo en la firma del contrato de 1654 con el mayordomo del desaparecido Hospital de Santa María, que se situaba en la plaza homónima $^{583}$.

El 1 de mayo de 1656 había fallecido el clérigo don Antonio Pastor, patrón de la capilla colateral del lado del Evangelio de la iglesia de Santa María. Allí dispuso que reposaran eternamente sus huesos, por lo que se ordenó derruir la capilla de San Pedro y erigir una de nueva planta adecuada para el finado. Sin más dilación, en junio de dicho año, ajustándose a las trazas de Jerónimo de Avendaño, Bernardo Sánchez, al cargo de la cantería y Julián de León, en las labores de albañilería, acometieron el encargo ${ }^{584}$. Se habían comprometido a finalizarlo el día de Todos los Santos aunque dudamos que cumplieran con el plazo estipulado, pues debían reformar íntegramente el espacio de culto. Concretamente Bernardo Sánchez debía disponer un zócalo pétreo en todo el perímetro, abrir un arco de acceso de medio punto, reforzar las esquinas de mampostería y cubrir el espacio con la bóveda de arista que se conserva en la actualidad. Dos años después, concretamente el 30 de mayo de 1658 y de nuevo en compañía de Julián de León, toma la obra de reedificación de la capilla de la ermita de la Vera Cruz. Las obras se finalizaron, tal y como se acordó, en septiembre de 1660, como se deduce de las cartas de pago. La ermita quedó estructurada mediantes dos tramos iguales separados por un arco fajón de medio punto y cubierta de bóvedas de cañón rebajadas con lunetos a ambos lados, tapiados ${ }^{585}$. En las dimensiones de la misma se les exigía tomar como referente las dimensiones de la sacristía de San Zoilo, cenobio que conocerían de primera mano por ser residentes de la villa. Además, Julián de León estuvo

\footnotetext{
${ }^{583}$ AHPP. Carr.Prot 5763. Andrés Simón Aguilar (1654-1654), s/f.

${ }^{584}$ AHPP. Carr.Prot 5689. Norberto Sandoval y Guevara (1656), s/f.

${ }^{585}$ PÉREZ DE CASTRO, Ramón. "Manifestaciones...Op.cit, pág. 292 a su vez de AHPP. Carr.Prot 5691. Norberto de Sandoval y Guevara (1658), fol 176 y ss.
} 
trabajando en el monasterio benedictino en mayo de 1659 cuando tomó a hacer las tapias de cantería que cercaban la huerta ${ }^{586}$.

En noviembre de 1659 logra adjudicarse un pequeño encargo que, si bien pequeño, resulta curioso, pues trasciende las actuaciones más usuales del maestro de cantería. Se trata de la colocación de las campanas y la ejecución del telar de la iglesia de San Julián, actuación de la que se eximía Jerónimo de Avendaño, que estaba al cargo de las obras desde 1642, a través de una requisitoria emitida en septiembre de $1659^{587}$. El 10 de noviembre de 1660 se presencia como uno de los múltiples testigos presentados por Felipe Berrojo en la obra que iba a realizar para el convento de San Francisco ${ }^{588}$.

En 1662 se remata en su persona y en la del maestro de carpintería y molinos Pascual García, carrionés como éste, la obra del pisón de Francisco de Barrio de la Vega $^{589}$ en Calzada de los Molinos ${ }^{590}$. Dicho año se encarga además de la reparación del molino de Torre, por lo que recibe de la Cofradía de los Veinte Clérigos de Carrión 1316 reales $^{591}$. También ese año participa como testigo de una partida de cien carros procedentes de Villamorco, Nogal y Población de Campos, destinados para la obra de San Zoilo ${ }^{592}$.

A partir de 1665 y hasta 1670, recibe varios pagos en concepto de su maestría en las obras de la nueva torre que se estaba edificando en la iglesia de Belén ${ }^{593}$. La ejecución del proyecto de la misma fue encargada a Andrés Díaz Cabanzo, maestro de cantería vecino de Piña de Campos, que proporcionó las trazas

\footnotetext{
${ }^{586}$ La escritura y condiciones se firman en San Zoilo, el 10 de mayo de 1659. AHPP. Carr.Prot 5692. Norberto Sandoval y Guevara (1659), fol 340 y ss.

${ }^{587}$ FERRERO MAESO, Concepción. "El mecenazgo...Op, cit, pp. 591-592. La requisitoria en la que Avendaño se exime de la obligación de las campanas tiene fecha de 6 de septiembre de 1659. AHPP. Carr.Prot 5767. Andrés Simón Aguilar (1659), s/f. Las condiciones, postura y remate para hacer el telar y colocar las campanas en AHPP. Carr.Prot 5767. Andrés Simón Aguilar (1659), fol 1002 y ss.

${ }^{588}$ AHPP. Carr.Prot 5693 Norberto Sandoval y Guevara (1660), fol 481 y ss.

${ }^{589}$ Fue un ilustre carrionés poseedor de la capilla de San Buenaventura en el monasterio franciscano de la villa, en la cual dispuso enterrarse cuando dictó testamento en 1661. AHPP. Carr.Prot 5695. Norberto Sandoval y Guevara (1661), fol 555 y ss.

${ }^{590}$ Escritura del contrato y condiciones de la obra en AHPP. Carr.Prot 5696. Norberto Sandoval y Guevara (1662), s/f.

${ }^{591}$ Cartas de pago en 4 de febrero y 8 de diciembre de 1662. AHPP. Carr.Prot 5696, Norberto Sandoval y Guevara (1662), s/f.

592 AHPP. Carr.Prot 5696. Norberto de Sandoval y Guevara (1662), fol 1.

${ }^{593}$ ADP. Carrión. Iglesia de Belén. Libro 17, $5^{\circ}$ de Cuentas de Fábrica (1653-1783), fol 50, 62.
} 
en junio de 1663 y que se mantuvo al mando de la obra durante dos años ${ }^{594}$. Es entonces cuando Sánchez toma el relevo de la construcción que se ha conservado hasta hoy día, con su base cuadrada, y estructura maciza de zócalo, dos cuerpos y campanario con tejado a cuatro aguas.

\section{Alonso de Santiago \\ Maestro de albañilería y cantería}

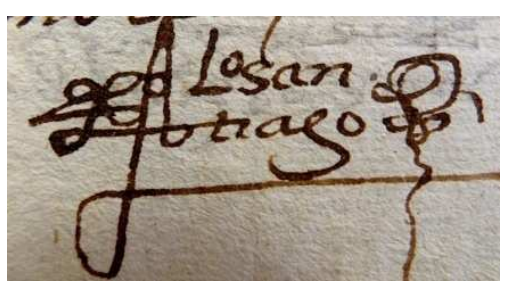

El lugar de nacimiento no es seguro, pero dado que siempre se declara vecino de Támara de Campos, es probable que la localidad palentina fuese su villa natal. Por los datos que poseemos, desarrolló su actividad en el ámbito provincial palentino figurando como maestro albañil aunque sus actuaciones sobrepasaban los límites de un mero albañil, como se puede apreciar en el convento de Santa Clara, donde actúa como un verdadero maestro de cantería. Ejerce su oficio en una horquilla de años bastante amplia, pivotando entre los años ochenta del siglo XVI y la segunda década de la centuria posterior. Tuvo un hijo llamado Juan de Santiago, dedicado igualmente a la albañilería, que trabajó con él esporádicamente y que, probablemente gracias a la experiencia avalada por su progenitor, logró adjudicarse la obra del convento de Santa Isabel en 1619.

En la primera obra documentada conocida Alonso de Santiago se autodenomina maestro carpintero, cuando en 1584 revisa las condiciones establecidas por Santiago de Sigüenza en la reedificación de la torre de San Andrés en Carrión ${ }^{595}$. En efecto, debía tener nociones del trabajo de la madera, pues los dos memoriales que le entregan refieren las condiciones de una obra de carpintería. Cuando Santiago escoge el proyecto de Sigüenza, establece algunas modificaciones, como el empleo de soleras enteras en lugar de fragmentadas para afianzar la obra o

\footnotetext{
${ }^{594}$ La escritura se firma el 14 de junio de 1663 en AHPP. Carr.Prot 5201. Jerónimo Laso (16631664), fol 638 y ss. La planta y alzado de la torre que se proyecta se halla en AHPP. Sección de dibujos. Signatura 45.

${ }^{595}$ ZALAMA RODRIGUEZ, Miguel Ángel. La arquitectura...Op.cit, pág. 326, a su vez de AHPP. Carr.Prot 5600. Francisco de Rojas (1580-1589), fol 387-392.
} 
la apertura de una ventana en lugar de dos en cada cuerpo, para mayor estabilidad, que señalan un conocimiento adecuado de las estructuras y materiales, más allá del yeso, el ladrillo y la cal. Junto a su hijo, entre 1586 y 1590 se ocupa de finalizar la torre de la iglesia de Santa Eufemia en Autillo de Campos. A partir de 1591 en que el templo es reconstruido desde sus cimientos, figura Alonso de Santiago como el maestro principal al cargo de las obras, trabajando conjuntamente con el cántabro Pedro de la Sierra, que se hará cargo de las partes relativas a la cantería. Cuando en 1597 ya estaba prácticamente levantado el templo, Santiago tasará las obras junto al tracista jesuita Juan de Bustamante, oriundo de Burgos aunque no quedarán concluidas hasta $1603^{596}$.

Por aquel año de 1591, un artífice llamado Marcos de Santiago rehacía junto a Sigüenza la sacristía antigua del convento de clarisas ${ }^{597}$. Tan sólo tres años antes se encontraba este último trabajando en las labores de albañilería de San Francisco, también en Carrión, conjuntamente con Francisco de la Calzadilla y Diego Estébanez $^{598}$. Probablemente existían lazos de consanguinidad entre aquel y este maestro albañil asentado en Carrión, que pudiera ser su padre, con quien podría haber aprendido el oficio e incluso haber facilitado el acceso de Alonso a la casa conventual a través de su intervención en los cenobios franciscanos de Carrión.

En 1603 se le encarga seguidamente la construcción de la capilla mayor y las colaterales en Santa Eugenia de Becerril de Campos. De nuevo le acompaña Pedro de la Sierra, ambos en estrecha colaboración junto a Domingo de Cerecedo ${ }^{599}$. Las obras quedaron finalizadas en 1613, contratando acto seguido las labores de albañilería en la iglesia de Villasarracino con Juan González de la Mata. Suponemos que abandonó esta obra para dedicarse enteramente a la gran empresa del cenobio de Santa Clara de Carrión en la que participaría desde el 25 de noviembre de dicho año como "maestro principal" tras serle adjudicada la construcción del templo por dos mil novecientos ducados. Debía demoler el antiguo templo y sobre el mismo

\footnotetext{
${ }^{596}$ Ibídem, pp. 70, 334 y 370 y del mismo, "Arquitectos y edificios del siglo XVI" en PITTM, nº 66. Diputación Provincial. Palencia, 1995, pp. 216-217.

${ }^{597}$ El contrato y las condiciones de la sacristía en AHPP. Carr.Prot 5731. Lázaro Santacruz (15891591), s/f.

${ }^{598}$ ZALAMA RODRIGUEZ, Miguel Ángel. La arquitectura...Op.cit, pág. 266, a su vez de AHPP. Carr.Prot 5648, Pedro Saldaña (1588), fol 135 y 136.

${ }^{599}$ PEREDA DE LA REGUERA, Manuel. "Artistas montañeses en la villa de Becerril de Campos" en Altamira, revista de estudios montañeses. N ${ }^{\circ}$. Santander, 1951, pp. 175-205.
} 
edificar el nuevo desde sus cimientos, comprometiéndose a finalizarlo en marzo de 1615. Se trata de una obra de gran envergadura que trasciende las competencias que hasta ahora pensábamos que no poseía Alonso de Santiago, sin embargo creemos presuntuosa la denominación de "maestro arquitecto" que se otorga cuando emite la carta de obligación y fianza por la que se compromete a realizar la obra ${ }^{600}$. El templo no responde a las expectativas por resultar demasiado estrecho y en agosto de 1614 llegan nuevas trazas desde Madrid, en las que además se incorporan capillas hornacina en el lado de la Epístola. Alonso de Santiago continuará trabajando en la obra, si bien bajo las órdenes del trasmerano Francisco de la Maza ${ }^{601}$.

No será hasta 1628 cuando, libre de éste y otros encargos, retome la obra de Villasarracino, donde se encargará de revisar la obra realizada hasta el momento por Juan González, confirmar las condiciones y añadir ciertas modificaciones ${ }^{602}$.

\section{Juan González de la Mata \\ Maestro de cantería y albañilería}

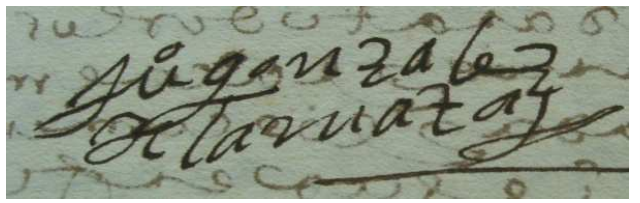

De todos los artífices que trabajan en Carrión, es sin duda del que más datos conocemos a tenor de su participación en prácticamente la totalidad de las fábricas carrionesas. En la mayor parte de la documentación figura como maestro albañil, no obstante sus intervenciones en muchos casos, comprenden las labores propias de un maestro de cantería. Excepcionalmente le veremos nombrado como maestro arquitecto $^{603}$ e incluso se le menciona en alguna ocasión como maestro de obras ${ }^{604}$.

\footnotetext{
${ }^{600}$ AHPP. Carr.Prot 4840. Juan Díaz Pajaza (1613), s/f.

${ }^{601}$ AHPP. Carr.Prot 4842. Juan Díaz Pajaza (1615), fol 183 y ss.

${ }^{602}$ Entre ellas, propone derruir el arco toral que estaba arruinado hacía mucho tiempo y rehacer dos arcos colaterales por ser muy bajos, reconstruir las alas de los tejados de dichas naves más altos y reforzados con estribos y el crucero “...cerrado en óbalo todo lo que se pudiere subir de alto y se guarnezcan con sus fajas y requadratura...” Para que no quedase desprotegida la iglesia no debían deshacer los tejados viejos hasta que suban los andamios para cerrarles y una vez cerrados se procediera a la fabricación de los nuevos. AHPP. Carr.Prot 4854, Juan Díaz Pajaza (1628), s/f.

${ }^{603}$ Sobre esto hablaremos a continuación. AHN. Clero Regular-Secular, Legajo 5356, Expediente 2, Iglesias de San Andrés y San Pedro, Obras.

${ }^{604}$ AHPP. Carr.Prot 5196. Jerónimo Laso (1654), s/f.
} 
Su actividad artística abarca toda la primera mitad del siglo XVII, por lo que nos hallamos ante una figura de larga trayectoria que podría haber nacido hacia 1585, dado que su primera intervención data de 1606. Estaba casado con María de Rebanal, con la que tuvo tres hijos, de los cuales dos niñas y un varón ${ }^{605}$. Una de ellas se llamaba María González, casada en dos ocasiones, la primera con un tal Andrés de Quintanilla, fruto de cuyo matrimonio es Andrés de Quintanilla, y de segundas nupcias se esposó con Roque García. La segunda de sus hijas se llamaba Catalina, mujer del ensamblador vecino de Paredes de Nava, Antonio Salomón, cuyo único descendiente fue su homónimo varón. Por último Gregorio González de la Mata, consagrado al oficio de escribano de la merindad de la villa, como así consta en la fianza de 500 reales que en 1635 hizo éste a favor de su padre en razón de los diezmos foráneos pertenecientes al cabildo de la villa ${ }^{\mathbf{6 0 6}}$. La escritura de compra de dicho oficio se produjo en agosto de 1633 a Pedro Moro de Solórzano por 9900 reales a pagar en tres años, saliendo por fiadores sus padres, de ahí que en 1636 se otorgará la última carta de pago a razón de 3300 reales ${ }^{607}$. Gregorio pasaría a residir posteriormente a Madrid, regresando a su villa natal de la que se convertiría en su regidor perpetuo, figurando con este cargo, al menos desde $1659^{608}$.

Vivía en unas casas encima de la Puerta de Canto, junto a la callejuela que iba hacia el puente, es decir en la parte norte de la villa ${ }^{609}$. Sin embargo este no fue su único lugar de residencia, pues, en la misma zona, al menos en 1629, residió en la calle Castillería, junto al templo de Belén, como así declara Domingo del Río, que dice ser su vecino ${ }^{610}$. Fue miembro de varias hermandades en su villa natal carrionesa, pues en 1623 ingresa como miembro de la cofradía del Santísimo Sacramento de la iglesia de San Andrés y en tres años después pertenecía a la cofradía de San Ildefonso del convento de Santo Domingo ${ }^{611}$. Además de su

\footnotetext{
${ }^{605}$ Los datos familiares son conocidos gracias a su testamento, dictado en 1647, al que nos referiremos con posterioridad. AHPP. Carr.Prot 5237. Jerónimo López (1647), fol 456v.

${ }^{606}$ AHPP. Carr.Prot 5418. Francisco Moro de Saldaña (1635), s/f.

${ }^{607}$ AHPP. Carr.Prot 5419. Francisco Moro de Saldaña (1636), s/f.

${ }^{608}$ Figura con tal cargo de regidor en una obligación otorgada por dos vecinos de Villanueba del Río, jurisdicción d Carrión, Santos Pérez y Santiago de Arconada AHPP. Carr.Prot 5531. Tomás Pérez (1659), fol 89.

${ }^{609}$ Escritura de arriendo de las casas de Joan Linazero, zapatero AHPP. Carr.Prot 5243. Laurencio López (1620-22), fol 576.

${ }^{610}$ AHPP. Carr.Prot 4855. Juan Díaz Pajaza (1629), s/f.

${ }^{611}$ ADP. Carrión. Iglesia de San Andrés. Libro 82 de Cuentas. Cofradía del Santísimo (1625-1659), fol 9 y AHPP. Carr.Prot 5408, Francisco Moro de Saldaña (1625), s/f.
} 
consabido oficio, desempeñó entre 1627 y 1628, el cargo de la mayordomía de la iglesia de San Andrés de Carrión en la que había trabajado con anterioridad ${ }^{612}$. Además ejerció como tesorero de las rentas y alcabalas reales de la villa, labor que desempeñaba desde hacía varios años hasta al menos $1647^{613}$.

La primera intervención del artista en es su villa natal y data de 1606, cuando el mayordomo del templo de San Andrés le encarga guarnecer y lucir las cubiertas, enladrillar el suelo y aderezar las cornisas de la capilla mayor, obra que debía finalizar en un mes ${ }^{614}$. Posteriormente volverá a intervenir en el templo como tasador.

En 1610 se encarga de derribar y reedificar una casa de Carrión situada en la calle Santa Olalla pertenecía al Bachiller Antonio Fernández de Cisneros ${ }^{615}$. Bajo la dirección del trasmerano Francisco de la Maza, se encargó de las obras de la cubierta de la capilla mayor del convento de San Francisco. Debía sustituir la vieja cubierta por una bóveda de casco de ochavo, a imitación de la del templo de San Andrés ${ }^{616}$. En 1612 se compromete con el cura de a rehacer tres capillas que se encontraban en mal estado de Nuestra Señora de Villasarracino ${ }^{617}$. Estableció un año después un pleito contra Domingo del Río por la adjudicación de dicha obra, cuyo fallo resolvió que lo ejecutaran ambos canteros a partes iguales. En 1613 contrata el reparo de la iglesia parroquial de Villoldo, pues urgía la ejecución de unos estribos para reforzar los arcos de las naves. Ese mismo año intentó adjudicarse las intervenciones de la casa carrionesa del Águila, residencia de los marqueses de Aguilar, cuya obra fue rematada en Pedro del Arenal y Francisco de la Maza tras bajar la puja de Juan González $^{618}$. También está documentada por entonces, su participación en las obras de refuerzo de la torre desaparecida de la iglesia de Santa María de Carrión, junto a Francisco de Reinaldos, que se ubicaba en el crucero del templo ${ }^{619}$.

\footnotetext{
612 AHPP. Carr.Prot 5172. Jerónimo Laso (1627), fol 707 y Prot 4761. Gregorio Cisneros (16271628), fol 333.

${ }^{613}$ AHPP. Carr.Prot 5237. Jerónimo López (1647), fol 455 y ss.

${ }^{614}$ AHPP. Carr.Prot 4833 Juan Díaz Pajaza (1606), s/f.

${ }^{615}$ AHPP. Carr.Prot 5393.Francisco Moro de Saldaña (1610), s/f.

${ }^{616}$ AHPP. Carr.Prot 5207. Jerónimo López (1611), s/f.

${ }^{617}$ AHPP. Carr.Prot 5395. Francisco Moro de Saldaña (1612), s/f.

${ }^{618}$ AHPP. Carr.Prot 4840. Juan Díaz Pajaza (1613), s/f.

${ }^{619}$ AHPP. Carr.Prot 5396. Francisco Moro de Saldaña (1613), s/f.
} 
Para el convento carrionés de San Miguel y Santa Isabel, ejecuta en 1614 unos cuartos sin especificar por los que otorga carta de pago en $1615^{620}$. Ese año, junto a Francisco Martínez de Bálcava y Juan Santos, ya nombrado como maestro arquitecto, fueron designados veedores de la casa del Capitán que había realizado el carpintero Juan Carnicero como residencia temporal de los oficiales que debían reclutar soldados en la villa ${ }^{621}$. De nuevo es reclamado por el cenobio terciario en 1620 para proporcionar las trazas y condiciones del nuevo templo, que ejecutaría Juan de Santiago ${ }^{622}$. Poco después, en 1621, el convento reclama sus servicios para que repare las cercas linderas a río y un año más tarde para que ejecute unas "casas secretas" y una estancia para el horno ${ }^{623}$. De nuevo, en 1635 , las isabelas solicitan que intervenga sobre unas tapias que se habían derrumbado ${ }^{624}$.

Su participación en otro cenobio mendicante carrionés también fue reiterada y se prolongó durante bastantes años. En septiembre de 1616, Juan González de la Mata es requerido por el deán de Cuenca, don Juan Bautista de Espinosa, para reconstruir la capilla de Nuestra Señora del Rosario, ubicada en la capilla mayor del convento de Santo Domingo, de la que era patrón desde $1580^{625}$. Su actuación se prolongó a los espacios colindantes, interviniendo en la rehabilitación de la arruinada capilla de San Ildefonso, de la que precisamente era cofrade, obras que finalizaría en $1626^{626}$. Sin embargo, el avanzado deterioro de la capilla provoca que el mayordomo de la cofradía denuncie al maestro en 1630, resolviéndose en 1638 que Juan González abone 300 ducados. A pesar de estos problemas, el convento le requiere nuevamente en 1642, nombrándolo maestro de obras en la ejecución del coro $^{627}$. Su vinculación con el convento se dará por concluida en 1645 cuando

\footnotetext{
${ }^{620}$ AHPP. Carr.Prot 5397. Francisco Moro de Saldaña (1614), s/f.

${ }^{621}$ AHPP. Carr.Prot 5211. Jerónimo López (1615), s/f.

622 “...el maestro en quien se rrematare, ha de dar y pagar luego zinquenta rreales por la ocupación y trauaxo de traza y condiziones a quien las hizo que fue Joan González de la Mata, albañil...” AHPP. Carr.Prots 5403. Francisco Moro Saldaña (1620), fol 194 y ss.

${ }^{623}$ La escritura y condiciones del cerco en AHPP. Carr.Prot 5404. Francisco Moro Saldaña (1621), fol 56 y ss. Se puede ver un dibujo en AHPP. Sección de Mapas, planos y dibujos. Cerca del convento de San Miguel y Santa Isabel de Carrión de los Condes. 1621. La intervención de las casas secretas en AHPP. Carr.Prot 5405, Francisco Moro Saldaña (1622) s/f.

${ }^{624}$ AHPP. Carr.Prot 5418. Francisco Moro de Saldaña (1635), s/f.

${ }^{625}$ AHPP. Carr.Prot 5161. Jerónimo Laso (1616), s/f.

${ }^{626}$ AHPP. Carr.Prot 5408, Francisco Moro de Saldaña (1625), s/f y Prot. 5409. Francisco Moro de Saldaña (1626), fol 851.

${ }^{627}$ AHPP. Carr.Prot 5188. Jerónimo Laso (1642), fol 62.
} 
Francisco del Río y Juan de Trujeda valoran positivamente lo realizado por el carrionés $^{628}$.

Simultaneando los trabajos de las casas carrionesas, se compromete a realizar otros encargos, no sólo en la villa condal sino en las localidades vecinas. Se concierta en 1617 con Francisco Rodríguez, carrionés como él, en la calzada de subida a la iglesia de San Cristóbal de Lomas, tramo destinado a facilitar el acceso a dicho templo a los parroquianos, pues está situado en una elevación, como su nombre indica ${ }^{629}$. Entre 1618 y 1619 figura trabajando en las obras de fortalecimiento del templo de Santiago de Carrión, obra que le había traspasado el maestro de cantería cántabro, Juan de Cajigosa. La intervención afectó a los pies del templo, donde reforzó el coro y la torre colindante a la misma ${ }^{630}$. No era la primera vez que intervenía en esta iglesia, ya que en 1612, se le requiere para reconstruir la bóveda de la capilla del Bautismo, que se hallaba junto a la torre, donde apuntaló su tejado con el de la torre para lograr mayor firmeza ${ }^{631}$. Solicita en 1620 al mayordomo de la iglesia de Nuestra Señora de Ballarna 107 reales por su intervención, que por la deuda, se deduce que fue mínima, pero desconocemos cual $^{632}$.

En abril de ese mismo año se presenta en la subasta de la obra de reedificación del hospital de Santa María de Carrión, que se ubicaba en la plaza homónima, frente a la iglesia del mismo nombre. Las obras son rematadas en el maestro de carpintería trasmerano Francisco de la Riva, quien se compromete a concluirlas en dos años. A pesar de no haber logrado la adjudicación de la obra, Juan González logra participar en la misma en calidad de veedor “...para que asista a la

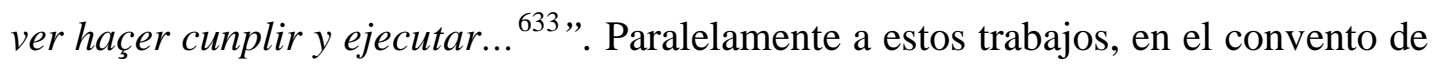
Santa Clara de Carrión, realiza en abril de 1622 el antepecho pétreo que se encuentra frente a la portada del templo, precedido de un encadenado ${ }^{634}$. Ésta fue una de las

\footnotetext{
${ }^{628}$ Vista de la obra de la capilla mayor por Juan González de la Mata. 1645. AHN. Clero secularregular 5352. Obras, s/f.

${ }^{629}$ AHPP. Carr.Prot 5400. Francisco Moro de Saldaña (1617), s/f.

${ }^{630}$ La escritura de traspaso de la obra en AHPP. Carr.Prot 4756. Gregorio Cisneros (1612-1618), fol 511 y ss.

631 AHPP. Carr.Prot 4768. Martín Cisneros (1598-1599), s/f.

${ }^{632}$ AHPP. Carr.Prot 5403. Francisco Moro de Saldaña, (1620), s/f.

${ }^{633}$ Ibídem.

${ }^{634}$ AHPP. Carr.Prot 5218. Jerónimo López (1622), s/f.
} 
tantas intervenciones promovidas por la venerable monja sor Luisa de la Ascensión, cuyo recuerdo se mantiene en la inscripción de una de las piedras de este sector. Entre 1622 y 1624, participa junto a Diego de Mazarredonda y Francisco de Buega en la ejecución de la sacristía y la librería del monasterio benedictino de San Zoilo. Estas dos estancias superpuestas, se hallaban en el lienzo este del cenobio, aledaños al templo ${ }^{635}$. Francisco de la Riva fallece en 1625 sin haber concluido el hospital de Santa María referido y la obra es retomada por Juan González en junio de dicho año, abandonándola un año después ${ }^{636}$. Si bien no expuso los motivos por los que difería la obra, el 10 de noviembre de 1626, tres días después de la renuncia, se compromete a reparar la iglesia de Nuestra Señora de la Antigua de Población por mil reales, siendo el único postor para dicha obra ${ }^{637}$. El motivo del abandono de las obras vino probablemente motivado por una oferta de trabajo más suculenta a escasos kilómetros de su villa natal. También contrata simultáneamente la obra de las capillas de la iglesia San Miguel en Becerril de Campos, en la que se concierta con el trasmerano Domingo del Río por 2800 reales $^{638}$.

Vuelve a encargarse de los reparos de la iglesia de Santa María de Villasarracino en 1630, esta vez junto a Domingo del Río, con quien colaborará en las labores de albañilería y cantería, contratando para la parte de carpintería a Toribio Escandón, vecino de Saldaña, quien recibiría por la ejecución de los tejados 3.300 reales $^{639}$. Aún en 1647 se le debían 6.000 reales por esta obra ${ }^{640}$. El mayordomo de la iglesia de Belén escogió a Juan González y Bartolomé Lechuga para que redactasen las condiciones de la nueva torre que debía edificarse a partir de $1632^{641}$, pero la falta de fondos impidió su materialización, por lo que, como veremos, no se proporciona un nuevo proyecto hasta 1663. En la capilla de la cofradía de la Vera Cruz de Bahíllo ejecuta unos reparos de emergencia a mediados de $1633^{642}$.

\footnotetext{
${ }^{635}$ AHPP. Carr.Prot 5405. Francisco Moro Saldaña (1622), s/f.

${ }^{636}$ AHPP. Carr.Prot 5408. Francisco Moro de Saldaña (1625), s/f y 5409. Francisco Moro de Saldaña (1626), s/f.

${ }^{637}$ AHPP. Carr.Prot 4757 Gregorio Cisneros (fol 279.

${ }^{638}$ AHPP. Carr.Prot 5409. Francisco Moro de Saldaña, (1626), fol 303.

${ }^{639}$ AHPP. Carr.Prot 5175 Jerónimo Laso, fol 336.

${ }^{640}$ AHPP. Carr.Prot 5237. Jerónimo López (1647), fol 456v.

${ }^{641}$ ADP. Carrión. Iglesia de Belén. Libro 16, $4^{\circ}$ de Cuentas de Fábrica (1616-1646), fol 183v.

${ }^{642}$ AHPP. Carr.Prot 4765. Gregorio Cisneros (1633-1634), fol 206 y ss.
} 
El proyecto y construcción del templo de San Andrés que hoy conocemos, fue posible gracias a la dedicación de Francisco Bálcava desde 1608 a 1634, en que, fallecido el artista, se decide tasar lo que había ejecutado, valorando asimismo lo que quedaba por hacer. Para ello se nombran tres maestros por parte del corregidor y otros tantos por la iglesia, esto es un total de seis, de los cuales dos maestros de cantería, dos de albañilería y dos de carpintería. Uno de los artífices escogidos por el templo fue Juan González ${ }^{643}$. Hasta aquí todo normal, si no fuera porque fue escogido como experto de cantería y designado "maestro arquitecto", al mismo nivel que el trasmerano, Andrés Gómez de Cisniega, que fue elegido por el consistorio. También actúa como supervisor de la demolición de los dos cuerpos superiores de la torre de la iglesia de Santiago, que a consecuencia de un fuerte vendaval y lluvias torrenciales acaecidos en 1635, se hallaba en ruina. Uno de los cuerpos fue derribado con la ayuda de maromas y otro se hizo a mano, todo “...a vista...” de Juan González de la Mata en $1636^{644}$.

A finales de 1644 actúa como fiador, junto a otro vecino de Carrión, de nombre Matías Martínez en un proceso judicial contra el alguacil de la villa Tomás de Ondatigui, pagando en su nombre una pena de 7500 maravedíes que se debían al corregimiento de la villa ${ }^{645}$. Es probable que por entonces ya estuviera participando, junto al maestro de cantería Juan de Trujeda, en la erección del templo que hoy conocemos de Belén, con su nueva orientación al sur. Ambos otorgan sendas cartas de pago en 1646, por lo que es probable que se concertasen con el mayordomo de la iglesia varios años antes ${ }^{646}$. Su intervención se extiende a la fábrica del siglo XVI, pues refuerza los muros de la capilla de San Gregorio en $1648^{647}$. En mayo de 1645, es reclamado por el síndico del monasterio de San Zoilo para actuar como veedor de las obras del nuevo templo, junto a Jerónimo de Avendaño, que fue designado por los maestros que habían trabajado en el mismo ${ }^{648}$.

\footnotetext{
${ }^{643}$ AHN. Clero Regular-Secular, Legajo 5356, Expediente 2, Iglesias de San Andrés y San Pedro, Obras. Las cartas de pago en ADP. Carrión. San Andrés. Libro $2^{\circ}$ de Cuentas de Fábrica (16141637), fol 159.

${ }^{644}$ AHPP. Carr.Prot 5182. Jerónimo Laso (1636), fol 380 y ss.

${ }^{645}$ AHPP. Carr.Prot 5190. Jerónimo Laso (1644), s/f.

${ }^{646}$ ADP. Carrión. Iglesia de Belén. Libro 16, 4 de Cuentas de Fábrica (1616-1646), fol 301v.

${ }^{647}$ AHPP. Carr.Prot 5430. Francisco Moro de Saldaña (1648), s/f.

${ }^{648}$ AHPP. Carr.Prot 5427. Francisco Moro Saldaña (1645), s/f.
} 
Juan González dicta testamento el 17 de julio de 1647, disponiendo ser sepultado en la iglesia de San Andrés, donde era parroquiano ${ }^{649}$. De su última voluntad se extraen además interesantes datos acerca de otras intervenciones por las que se le debían ciertas sumas, como es el caso de la obra de Vega de Doña Limpia. De las obras que realizó en el convento de Santo Domingo de Carrión se le debían, en virtud de poderes que había otorgado, a saber, 7.000 reales en Cabañas, en Benavente 1.647 reales y en Bodón, nada menos que 100 ducados. Le debía el maestro cantero Juan de Trujeda 500 reales “... que yo le presté para entrar a trabaxar en la obra de Nuestra Señora de Belén...." Asimismo, la propia iglesia le debía la paga correspondiente al jornal de 108 días.

En septiembre de 1647 la obra estaba en proceso, como así lo indica el requerimiento presentado por ambos maestros ante Alonso Pardo, arrendatario del molino de Cerones. Este molino, situado en la Ribera de Calzada, era propiedad del templo, y en este sentido Trujeda y González de la Mata instan al molinero a retrasar la entrega de las cargas de trigo que debía con el fin de que el mayordomo de Belén saldara la deuda que con ellos había contraído ${ }^{650}$. Prueba de su magnificencia fue el perdón de la deuda que el hospital había contraído con su persona como “...ayuda a curar los pobres enfermos de el dicho hospital...”. De los 200 ducados correspondientes a la ejecución de la escalera del convento de Benevívere, la casa agustina tan solo le había abonado la ridícula suma de 200 reales. La morosidad debía ser una moda, pues de los reparos llevados a cabo en el puente de Amusco no se le había abonado ni un real.

Había designado como sus testamentarios a su mujer y a dos de sus tres hijos, Gregorio y María, tal vez porque Catalina, al estar desposada con un escultor llevaba una vida más desahogada que sus hermanos, o quizá, como apuntamos más adelante, mantuviese una relación distante con ella ${ }^{651}$.

\footnotetext{
${ }^{649}$ AHPP. Carr.Prot 5237. Jerónimo López (1647), fol 455 y ss.

${ }^{650}$ AHPP. Carr.Prot 5192. Jerónimo Laso (1647-1648), fol 997 y ss.

${ }^{651}$ Apuntamos esta hipótesis apoyándonos tanto en el hecho de no ser designada como cesionaria de los bienes de su padre, como en la anulación inserta en el codicilo de su madre de 1659 de las cesiones otorgadas por su madre en su testamento. AHPP. Carr.Prot 5689. Norberto Sandoval y Guevara (1656), fol 840 y ss y Protocolo 5692. Norberto Sandoval y Guevara (1659), fol 451 y ss.
} 
Su muerte debió producirse a finales de 1654, dato que conocemos gracias a una escritura de contrato de la obra del puente de Amusco, concertada entre Jerónimo de Avendaño y Francisco de Cabanzo el 24 de diciembre de dicho año. En ella, Juan González, figura como “...diffunto maestro de obras”, que hasta entonces se encargaba de esta obra pública ${ }^{652}$.

Tan solo un año después de la muerte de Juan González, en 1655, su viuda, María de Rebanal y dos de sus hijos, Gregorio y María González, vendieron el solar en el que hasta entonces habían vivido, situado en la Castillería, junto a la iglesia de Belén $^{653}$. María de Rebanal al caer enferma, dictaría testamento poco después, el 10 de septiembre de 1656, dejando la posesión de su casa a su hija María, quien había vivido con sus padres desde que falleció su marido ${ }^{654}$.

Por esta fecha, la viuda había cobrado ya algunas de las sumas correspondientes a las obras ejecutadas por de la Mata en el convento de Santo Domingo de Carrión y en la iglesia de Vega de Doña Limpia, las cuales declara “...he gastado en cossas necessarias para mi perssona y cassa...”. Un tiempo después, concretamente el 1 de diciembre de 1659 en que María de Rebanal redacta su codicilo, reconoce haber seguido cobrando durante estos tres años algunas partidas de maravedíes correspondientes a dichas obras. Además, anula, quizá por un enfriamiento de la relación entre ambas, las cesiones concedidas a su hija Catalina y al único hijo de ésta, su nieto Antonio ${ }^{655}$.

\footnotetext{
${ }^{652}$ AHPP. Carr.Prot 5196. Jerónimo Laso (1654), s/f.

${ }^{653}$ AHPP. Carr.Prot 5688. Norberto Sandoval y Guevara (1655) fol 135.

${ }^{654}$ AHPP. Carr.Prot 5689. Norberto Sandoval y Guevara (1656), fol 840 y ss.

${ }^{655}$ El pago correspondiente a la iglesia de Vega de Doña Limpia es de 700 reales, mientras que del concejo de Cabañas había recibido 1960 reales de los intereses del censo del convento de Santo Domingo de Carrión, quedando pendiente una deuda que ascendía a unos 400 euros. Por otra parte, doña María revoca la siguiente manda: un manto de tafetán, tres cabezales de lino con su pluma, dos sábanas, dos almohadas, una manta, un panel de diez varas de lienzo. Codicilo de María de Rebanal. AHPP. Carr.Prot 5692. Norberto Sandoval y Guevara (1659), fol 451 y ss.
} 


\section{Hernando de Inestrosa o de la Nestosa Maestro de cantería}

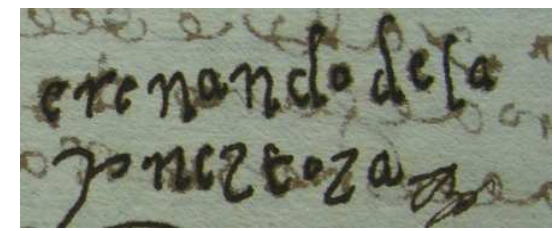

No debe confundirse con el escultor homónimo nacido hacia 1530, que también desarrolla su actividad en la provincia de Palencia ${ }^{656}$, si bien podría haber existido entre ambos algún tipo de parentesco. Sin descartar que su nacimiento tuviese lugar en la municipio burgalés de Hinestrosa, a sesenta kilómetros de Carrión, resulta igualmente probable que su villa natal fuese Astudillo, localidad palentina donde se mantuvo avecindado tempranamente y donde se le atribuye la realización de la sacristía de la iglesia de Santa María y es probable que también se deba a su mano la erección del templo de Santa Eugenia, concluido en $1598^{657}$.

Transcurren varias décadas sin saberse nada del mismo hasta que reaparece avecindado en Carrión durante la década de los treinta y cuarenta de la centuria siguiente.

Las monjas del convento de San Miguel y Santa Isabel se conciertan con Inestrosa en 1633 para que socalce de canto tosco, cal y arena en el sector occidental, en la calle que va a Belén, y realice tapias de cuatro pies de alto ${ }^{658}$. Probablemente realizaría posteriormente labores similares, pues en marzo de 1637 recibe 822 reales por ocho tapias de cantería y tres de tierra ${ }^{659}$. En 1635 se le abonan 850 reales por la ejecución de unos pilares en la iglesia del convento de Santo Domingo de Carrión. En dichas labores es contratado por Juan González de la Mata, quien estaba al cargo de las obras del templo por entonces ${ }^{660}$. En el convento de San Francisco de la villa, el mayordomo de la cofradía de la Concepción solicita la intervención urgente de Inestrosa en la capilla homónima del templo, ubicada a los pies, en el lado del Evangelio. El contrato entre ambas partes se firma el 15 de

${ }^{656}$ PORTELA SANDOVAL, Francisco José. La escultura del siglo XVI en Palencia. Palencia, 1977, pp. 360-370.

${ }^{657}$ OREJÓN CALVO, Anacleto. Historia documentada de la villa de Astudillo. Palencia, 1928, pág. 37.

${ }^{658}$ AHPP. Carr.Prot 5416, Francisco Moro Saldaña (1633), s/f.

${ }^{659}$ ASCC. Santa Isabel. Leg XII. Cartas de pago (1493-1797), s/f y también en AHPP. Carr.Prot 5183. Jerónimo Laso (1637), s/f.

${ }^{660}$ AHPP. Carr.Prot 5181. Jerónimo Laso (1635), fol 773 y ss. 
octubre de $1639^{661}$. No obstante, las medidas de fortalecimiento no fueron definitivas, pues a finales de 1646, vuelve a ser requerido junto al maestro Bernardo Sánchez, para que cada uno redacte independientemente sus condiciones -Inestrosa las relativas a la cantería y Sánchez en las labores de carpintería- comprometiéndose a reedificar la capilla para evitar el derrumbe del coro ${ }^{662}$.

En 1641 se encuentra trabajando en la iglesia de San Andrés, concretamente en la torre, donde erige el cuerpo de campanas, acompañado en estas labores por los maestros locales Juan Vicente González y Jerónimo de Linares, que se encargarán, respectivamente, de las labores concernientes a la carpintería y albañilería ${ }^{663}$.

También participa en obras públicas, como es el caso del puente de Astudillo, que había sido rematado en el maestro cántabro Jerónimo de Avendaño el 1 de noviembre de 1640. Sin embargo, este cede cuatro quintas partes a diversos maestros trasmeranos, quedándose con la quinta parte de la obra. Ésta será finalmente cedida en 1642 a Inestrosa ${ }^{664}$, a tenor de la dedicación que Avendaño debía consagrar a la ejecución de la iglesia de San Julián de Carrión, en cuya subasta había pujado precisamente Inestrosa sin lograr adjudicársela ${ }^{665}$.

\section{Julián de León}

\section{Maestro de albañilería}

Incluimos este maestro de albañilería por su relación con Felipe Berrojo de Isla, al que nos referiremos posteriormente. Su escasa formación cultural se manifiesta en el hecho de que no sabía firmar. Sus padres se llamaban Juan de León y Catalina de Castellanos. Estaba casado con Felipa de la Calle, a la que nombró testamentaria. Fruto de este matrimonio nacieron sus ocho herederos: Julián, Mateo,

\footnotetext{
${ }^{661}$ AHPP. Carr.Prot 5422. Francisco Moro de Saldaña (1639), s/f.

${ }^{662}$ AHPP. Desamortización, Legajo 105, s/f.

${ }^{663}$ AHPP. Carr.Prot 4828. Francisco Cuestos (1640-1641), fol 321 y ss y AHPP. Carr.Prot 5188, Jerónimo Laso (1642), fol 255 y 297.

${ }^{664}$ AHPP. Carr.Prot 5188. Jerónimo Laso (1642), fol 369 y ss.

${ }^{665}$ FERRERO MAESO, Concepción. "El mecenazgo... Op.cit, pp. 591, a su vez de AHPP. Carr.Prot 4829. Francisco Cuetos (1641-1642), fol 279 y ss.
} 
Francisco, Blas, Juan, Isabel, María y Jacinta de León ${ }^{666}$. Uno de ellos, Juan de León, se dedicó al mismo oficio que su padre pero no fue él quien se lo enseñó, como sucedía normalmente, sino Felipe Berrojo, con quien estableció un contrato de aprendizaje de cuatro años de duración en agosto de $1651^{667}$. Gracias a éste, logró convertirse en maestro de albañilería. En su testamento, dictado el 30 de noviembre de 1695, Juan de León, dona sus herramientas a uno de sus hijos Santiago de León, “...por el buen servicio que me ha hecho y por lo que me ha ayudado a trabajar en dicho oficio...", que igualmente siguió los pasos de su padre ${ }^{668}$.

La primera obra que se le conoce data de 1656 , en que junto al maestro de cantería carrionés, Bernardo Sánchez, se compromete a reedificar la capilla del Licenciado Pastor, ubicada en el ábside del Evangelio de la iglesia de Santa María del Camino. El finado había fallecido el uno de mayo de dicho año, por lo que la intervención vino motivada para disponer sus restos en un lugar acorde a su elevada condición. Ambos artífices convinieron la finalización de la obra a finales del año mencionado, siguiendo para ello las trazas proporcionadas por el maestro cántabro, Jerónimo de Avendaño ${ }^{669}$. Volvieron a trabajar juntos en 1658, cuando el mayordomo de la cofradía de la Vera Cruz les encargó la edificación de su capilla imitando las dimensiones que poseía la sacristía de San Zoilo ${ }^{670}$. Fruto de esta intervención, finalizada en 1660, son los dos tramos con bóveda de arista que presenta hoy día la edificación.

En la obra de albañilería del convento de Santa María la Real de Aguilar de Campoo, que había sido rematada en Felipe Berrojo, Julián de León toma parte en abril de 1659, fecha en que firma con el maestro de Paredes un contrato de compañía “...ambas las dichas parttes se conformaron y conbinieron que ttodas las obras de albañería que desde oy día en adelante se içieren de cualquier forma que sse'assí en

\footnotetext{
${ }^{666}$ AHPP. Carr.Prot 5009. Laureano García de la Llana (1678-1681), s/f.

667 AHPP. Carr.Prot 5689. Norberto Sandoval y Guevara (1656), fol 587. El documento, de 1656, señala que ya han transcurrido cuatro de los cinco años del contrato, finalizando el acuerdo entre ambos en 1657.

${ }^{668}$ Estaba casado con Catalina Pérez, con la que tuvo tres hijos, el mencionado Santiago, Tomás y Manuel. AHPP. Carr.Prot 5756. Juan de la Serna Reinaltos (1694-1698), s/f.

${ }^{669}$ AHPP. Carr.Prot 5689. Norberto Sandoval y Guevara (1656), s/f.

${ }^{670}$ PÉREZ DE CASTRO, Ramón. "Manifestaciones...Op.cit, pp. 292 y 327-329, a su vez de AHPP. Carr.Prot 5691. Norberto de Sandoval y Guevara (1658), fol 174 (Escritura del ladrillo para la obra) y fol 176 y ss (Concierto entre Julián de León y Bernardo Sánchez).
} 
esta uilla como fuera d'ella, aunque sse a bisto rremattarse en qualquiera de los dichos maestros... ${ }^{671}$. Por ello no resulta extraño que en las obras consecutivas figuren trabajando juntos, como así sucede en el claustro alto del convento extinguido de Santa María de Benevívere. Los trabajos se llevaron a cabo durante el trienio desempeñado por Fray Francisco Antonio de Medina Nuño de Reinoso, inaugurándose éstos en $1660^{672}$. Consistían en la reedificación de unos aposentos situados en el espacio existente entre el coro alto y la escalera principal, es decir, los situados en el paño occidental del claustro.

Esta obra se comprometieron a finalizarla en septiembre de 1660 y tan sólo dos meses más tarde, Berrojo y Julián de León se conciertan con el síndico del convento de San Francisco de Carrión, con el fin de que edifiquen de nueva planta un cuarto nuevo de dos pisos en el claustro principal del convento de San Francisco, en la misma panda de la cocina, "de profundis" y refectorio, los cuales debía demoler por estar afectados por las aguas, pero manteniendo sus dimensiones. En el nivel superior, debía rehacer las nueve celdas de los frailes que antes había con su corredor $^{673}$. La obra se estaba ejecutando conforme a lo previsto según se indica en la partida de madera que, para la misma, se trae al convento en agosto de $1661^{674}$. En marzo de 1662, prosiguen los trabajos como se había acordado en el contrato, pues el convento recibe la herencia de don Rodrigo de Herrera y Rojas, caballero que fue de la Orden de Alcántara, indicándose que tal suma se destinase “...para la reedificación de sus casas y habitación de sus religiosos... ${ }^{675}$ ". En agosto de dicho año recibirán doce mil reales de los quince mil en que se remató la obra, tal y como figuraba el contrato de 1660, abonándose los tres mil reales a la finalización de las $\operatorname{mismas}^{676}$.

\footnotetext{
${ }^{671}$ La escritura se firma el 14 de abril de 1659. AHPP. Carr.Prot 5531. Tomás Pérez (1659-1660), fol 142 y ss.

${ }^{672}$ CASADO IZQUIERDO, $\mathrm{M}^{\mathrm{a}}$ de los Ángeles. El arquitecto...Op.cit, pág. 60, a su vez de AHPP. Carr.Prot 5693. Norberto Sandoval y Guevara (1660), fol 438 y ss.

${ }^{673}$ Ibídem, pág. 62. Escritura y condiciones del mismo en AHPP. Carr.Prot 5693. Norberto Sandoval y Guevara (1660), fol 481 y ss.

${ }^{674}$ AHPP. Carr.Prot 5532. Tomás Pérez (1661), fol 284.

${ }^{675}$ Por la posesión de dicha herencia se establece un pleito con la hermana del difunto, religiosa del convento de Santa Úrsula de Toledo. AHPP. Carr.Prot 5696, Norberto de Sandoval y Guevara (1662), fol 590 y ss.

${ }^{676}$ AHPP. Carr.Prot 5695. Norberto de Sandoval y Guevara (1662), fol 516.
} 
En 1661 estaba a cargo de la obra de la iglesia del lugar de Villacuende, como así se deduce del pago por la partida de canto procedente de las canteras de Nogal $^{677}$. Desde entonces no vuelve a participar con Berrojo, pues éste traslada su residencia a Medina de Rioseco. De nuevo en Carrión, el 10 de enero de 1663, el prior del convento de Santo Domingo, Fray Domingo Rubio, le contrata para “...fenezer y acauar en toda perfeción la obra y capilla que está deuajo del gueco del coro...”, esto es, el sotocoro, disponiendo una bóveda de cañón con lunetos análoga a las capillas contiguas que él mismo había realizado. En las labores de carpintería participaría el maestro carrionés Francisco Reinaldos, con quien se comprometió a tener finalizada la obra para el domingo de Resurrección de ese año. Nuevamente, como sucedió en la iglesia de Santa María, se siguieron las condiciones establecidas por Jerónimo de Avendaño ${ }^{678}$.

Dicta testamento el 25 de agosto de 1671, fecha en la cual la cofradía de la Vera Cruz de Carrión adeudaba 500 reales correspondientes a la obra de su ermita $^{679}$. Aún vivía en 1674 , pues en febrero de dicho año se comprometió a reparar la bóveda quebrada por las aguas de la bodega de la casa perteneciente a Doña Juana Osorio Valderrábano, religiosa profesa de Santa Clara, por 2000 reales ${ }^{680}$. Sin embargo, unos meses después continúa la obra Francisco de Reinaldos, apartándose de la misma Julián de León ${ }^{681}$. En la iglesia de Belén, se encarga entre 1683 y1684 de cubrir el camarín de la Virgen con una cúpula sobre pechinas ${ }^{682}$. Una veintena de años después, concretamente el 2 de junio de 1691 redacta un nuevo testamento, añadiendo como herederos a Francisco Julián y Leonardo de Medina ${ }^{683}$.

\footnotetext{
${ }^{677}$ La carta de pago es de 26 de mayo de 1661. AHPP. Carr.Prot 5200. Jerónimo Laso (1661-1662) fol 366 y ss.

${ }^{678}$ AHPP. Carr.Prot 5201. Jerónimo Laso (1663-1664), fol 643 y ss.

${ }^{679}$ AHPP. Carr.Prot 5009. Laureano García de la Llana (1678-1681), s/f.

${ }^{680}$ AHPP. Carr.Prot 5709. Norberto Sandoval y Guevara (1674), fol 331 y ss.

${ }^{681}$ Ibídem, fol 364 y ss.

${ }^{682}$ ADP. Carr. Iglesia de Belén. Libro 17, 5 de Cuentas de Fábrica (1653-1783), fol 131.

${ }^{683}$ AHPP. Carr.Prot 5755. Juan Serna Reinaltos (1687-1693), s/f.
} 
Felipe Berrojo de Isla

Maestro arquitecto

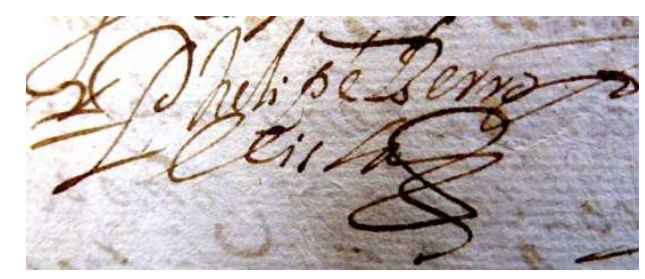

Este arquitecto nacido al parecer en 1628 en Paredes de Nava, fue el iniciador, según García Chico, del barroco en Castilla ${ }^{684}$. Su labor se desarrollará en esta villa, en la cual vivirá durante los veinticinco años gozando de la confianza y predilección de sus habitantes por ser persona, según dicen

Paredes de Nava fue testigo del nacimiento, hacia 1628, de uno de los arquitectos castellanos más influyentes en Castilla durante la segunda mitad del siglo XVII: Felipe Berrojo de Isla. La ingente cantidad de obras documentadas repartidas eminentemente por las provincias de Valladolid -con Medina de Rioseco a la cabeza- y Palencia, sin olvidar Sahagún y Zamora, lo señalan como un artista que evolucionó desde los presupuestos clasicistas imperantes hacia mediados de la centuria hasta una tendencia más ornamental caracterizada por las yeserías, propia de las décadas posteriores. No vamos a insistir en su prolífica actividad, sobradamente conocida, como arquitecto, veedor de obras, tracista y decorador ${ }^{685}$.

\footnotetext{
${ }^{684}$ Se sabe gracias a un documento fechado en 1676 en el que el artista reconoce unas casas para el convento de Trinitarias en Medina de Rioseco. En él, nuestro arquitecto declara tener 48años. Véase GARCÍA CHICO, Esteban. "Algunos datos sobre Felipe Berrojo, arquitecto" en BSAA, n¹1, Valladolid, 1934-1935, pág. 263.

${ }^{685}$ Sobre el mismo, GARCÍA CHICO, Esteban. “Algunos datos...Op.cit, pp. 263-270, del mismo, Documentos...Arquitectos. Op.cit, pp. 186-214 y Catálogo Monumental de la Provincia de Valladolid. Medina de Rioseco. Valladolid, 1956, pp. 37,52-54, 60 y 103. LEÓN, Teresa. "Historia de Paredes de Nava" en PITTM, no 27. Palencia, 1968, pp. 130-132. GARCÍA CUESTA, Timoteo. "El Santuario de Nuestra Señora de la Calle en Palencia" en PITTM, n³1. Palencia, 1971, pp. 39192. HERAS GARCÍA, Felipe. Felipe Berrojo y la portada de la iglesia del Monasterio de Sahagún en BSAA, n³6. Universidad de Valladolid, 1970, pp. 503-505. URREA FERNÁNDEZ, Jesús y MARTÍN GONZÁLEZ, Juan José. Inventario...1, Op.cit, pp. 48, 66 y 283 e Inventario... 2, Op.cit, pp. 58 y 63. MARTÍNEZ GONZÁLEZ, Rafael. Las cofradías penitenciales de Palencia. Caja de Ahorros y Monte de Piedad. Palencia, 1979, pp. 57-58 y del mismo, "El Obispo de Palencia Fray Juan del Molino y la capilla Mayor de la iglesia de Santa María de Carrión de los Condes" en PITTM, n56, Palencia, 1987, pp. 249-275, DOMINGUEZ CASAS, Rafael. "Significado de la portada de Felipe Berrojo en el Real Monasterio de San Benito de Sahagún” en Iacobus, no 3,4, 1997. Sahagún, León, 1997, "La portada de Felipe Berrojo y la fachada de la portería en el monasterio de San Benito de Sahagún. Estructura e iconografía" en Anales de Arquitectura, no 8, 1998 pp. 45- 64 y "El arco de San Benito de Sahagún: Restauración y hallazgos artísticos" en Restaurar la memoria. Congreso Internacional Valladolid ARPA 2000 (actas). Valladolid, 2001, pp. 557-574. MARTÍNEZ AGUADO, Inmaculada. "Reformas en el convento de San Francisco de Sahagún (León): una obra con trazas de Felipe Berrojo" en BSAA, n 67, Valladolid, 2001, pp. 213-228. PÉREZ DE CASTRO,
} 
La primera ocasión en que Felipe Berrojo aparece mencionado como vecino de Carrión data del año 1652 en que redime un censo de sesenta mil maravedíes establecido por su padre, Pedro Berrojo, a favor del convento de Santa Clara ubicado en esta localidad ${ }^{686}$. Por entonces contaba tan sólo con veinticuatro años, durante los cuales habría completado su etapa de formación en su villa natal y había alcanzado el grado de maestro de albañilería. La prueba fehaciente de su saber hacer es el contrato que establece con el artífice carrionés, Julián de León, dedicado a su mismo oficio. En lugar de ocuparse él mismo de la formación de su hermano, Juan de León, depositó su confianza en el artista paredeño para que se encargase de su aprendizaje, de cuatro años de duración, que había dado comienzo en el mes de agosto de 1652. Llegado el año de 1656, ambos artistas se reúnen nuevamente para prolongarlo un año más ${ }^{687}$. Integrado plenamente en la vida religiosa de la comunidad carrionesa, ingresa como miembro de la cofradía del Santísimo Sacramento de la iglesia de San Andrés en $1657^{688}$.

La primera obra documentada de Berrojo le sitúa en la localidad palentina de Herrera de Pisuerga, donde, junto a los maestros de cantería cántabros, Jerónimo de Avendaño y Pedro de Carandil, reedificaría la torre de su iglesia parroquial, bajo la advocación de Santa Ana, en $1658^{689}$. La siguiente intervención del palentino tampoco la realiza para Carrión. Se trata de la obra de albañilería relativa al convento de Santa María la Real de Aguilar de Campoo en la que participa junto al mencionado Julián de León, en cuya persona se había rematado la obra en abril de 1659. Desconocemos qué labores específicas desarrollaron en la abadía premostratense. No obstante, este contrato resulta relevante en tanto en cuanto, por el mismo, ambos artistas establecen un contrato de compañía ${ }^{690}$. Entre 1660 y 1662,

Ramón. "Un dibujo de Felipe Berrojo para la portada de San Benito de Sahagún” en De arte, n¹, 2002, pp. 75-80. También resulta ineludible una Memoria de Licenciatura inédita, dirigida por el Doctor Jesús Urrea sobre el artista. CASADO IZQUIERDO, $\mathrm{M}^{\mathrm{a}}$ de los Ángeles. El arquitecto Felipe Berrojo de Isla. Universidad de Valladolid, 1985.

${ }^{686}$ AHPP. Carr.Prot 5204. Antonio López (1652), s/f.

${ }^{687}$ AHPP. Carr.Prot 5689. Norberto Sandoval y Guevara (1656). fol 587 y ss.

${ }^{688}$ ADP. Carrión. Iglesia de San Andrés. Libro 82 de Cuentas. Cofradía del Santísimo (1625-1659), fol $272 v$.

${ }^{689}$ URREA FERNÁNDEZ, Jesús y MARTÍN GONZÁLEZ, Juan José. Inventario...2. Op.cit, pág. 95. El 20 de agosto de 1658 se abonan diferentes cartas de pago a Felipe Berrojo y Francisco Cillero como veedores. AHPP. Carr.Prot 5767. Andrés Simón Aguilar (1659), fol 861 y ss.

${ }^{690} 14$ de abril de 1659. AHPP. Carr.Prot 5531 Tomás Pérez, fol 142 y ss. 
como referimos al estudiar la figura de Julián de León, interviene junto a éste en las obras de los conventos desaparecidos de Santa María de Benevívere y San Francisco de Carrión.

Paralelamente a estos trabajos, al menos durante los años de 1661 y 1662 Berrojo había desempeñado el cargo de mayordomo de la cofradía de Santa Brígida de Carrión, establecida en la iglesia de San Andrés, dato que conocemos gracias al poder que otorga a una persona de su confianza, Toribio Francisco para que se le abone lo que le corresponde por dicho cargo ${ }^{691}$. En aquel momento ya estaba esposado con Ana Rodríguez Vallesteros, figurando como su fiadora en la documentación. Si bien desconocemos donde se produjo el enlace, podemos descartar Carrión como lugar del feliz acontecimiento, produciéndose probablemente en alguna localidad palentina de la que procedería su mujer ${ }^{62}$. La última referencia que sitúa a Felipe Berrojo en Carrión de los Condes antes de trasladar su residencia a Medina de Rioseco, es de principios de 1662. El 2 de enero de dicho año se le menciona como fiador de un vecino de Vilviestre del Pinar, al sudeste de Burgos, de nombre Juan de Martín Serrano, para traer unas vigas y machones al templo desaparecido de San Juan del Mercado, ubicado primitivamente en la plazuela homónima. Aún por entonces figura como maestro de albañilería y ya nunca más va a figurar vinculado a Julián de León, dado su cambio de vecindad ${ }^{693}$. El motivo de la ausencia documental sobre el artista en la villa condal, en el intervalo que oscila entre estos dos años, radica en el hecho de que fue reclamado por el monasterio leonés de San Benito de Sahagún para ejecutar la portada meridional de la abadía benedictina ${ }^{694}$.

Atraído por su pujanza artística y económica, y probablemente en busca de un ascenso profesional que finalmente logró, se estableció en la ciudad de los Almirantes. La primera obra que se le conoce son las bóvedas de la iglesia de Santa Cruz que llevó a cabo en 1664 al ponerse al cargo de los trabajos con motivo del

\footnotetext{
${ }^{691} 14$ de abril de 1663. AHPP. Carr.Prot 5769. Andrés Simón Aguilar (1662-1663), fol 565.

${ }^{692}$ No hemos hallado ninguna mención al matrimonio en los Libros de Matrimonios de Carrión.

${ }^{693} 2$ de enero de 1662. AHPP. Carr.Prot 5696, Norberto Sandoval y Guevara (1662), fol 378.

${ }^{694} \mathrm{Se}$ documenta por primera vez en MARTín GONZÁLEZ, Juan José. Escultura barroca castellana. Valladolid, 1959, pág. 53.
} 
fallecimiento del maestro de albañilería Francisco Cillero ${ }^{695}$. Sin embargo no se le conoce la propiedad de una vivienda en la localidad vallisoletana hasta el año 1669 en que adquiere unas casas en la calle del Pescado, por lo que podemos pensar que no había abandonado Carrión definitivamente ${ }^{696}$.

Durante estos años, concretamente entre 1665 y 1669, bajo el primer abadiato de don Bernardo de Estúñiga, se emprendió “...la obra del pórtico de la iglesia, de piedra de sillería, vistosamente ejecutada, con sus efigies y escudos... ${ }^{697,}$, perteneciente al monasterio benedictino de San Zoilo de Carrión. Concretamente el impulso de estas obras, como las de finalización del templo, fue posible gracias a las donaciones que Juan Aguado, monje de Carrión, efectuó antes de fallecer en $1666^{698}$. A tenor de la vinculación de Felipe Berrojo a la villa y en virtud de la tipología clasicista de la misma, esta fachada había sido atribuida al artista palentino ${ }^{699}$. Sin embargo la obra fue rematada en un artista trasmerano Diego de Zorlado, perteneciente a una familia de larga tradición en el sector canteril, quien realizaría además los dos últimos tramos del templo paralelamente en los dos años consecutivos $^{700}$. En realidad, Berrojo se hallaba por entonces en Valladolid, al cargo del segundo cuerpo de la fachada de la iglesia penitencial de la Pasión y las bóvedas de la iglesia de San Lorenzo en 1666, regresando de nuevo a Medina de Rioseco para cerrar la nave central y laterales de la iglesia de Santiago, en cuyas cúpulas desarrollaría una floridas labores de yesería alusivos a la advocación del templo, una de sus obras más destacadas. Por entonces ya se le consideraba maestro arquitecto $^{701}$.

${ }^{695}$ GARCÍA CHICO, Esteban. Catálogo...Rioseco. Op.cit, pág. 40.

${ }^{696}$ CASADO IZQUIERDO, $\mathrm{M}^{\mathrm{a}}$ de los Ángeles. El arquitecto...Op.cit, pág. 15.

${ }^{697}$ ZARAGOZA PASCUAL, Rafael. "Abadologio del Monasterio de San Zoilo de Carrión de los Condes (siglos XI-XIX). Libro de Gradas de los monjes que profesaron en él (1593-1833)" en PITTM, $\mathrm{n}^{\circ}$ 64. Palencia, 1993, pp. 299-300.

${ }^{698}$ BECERRO DE BENGOA, Ricardo. "El monasterio....Op.cit, pág. 89.

${ }^{699}$ URREA FERNÁNDEZ, Jesús y MARTÍN GONZÁLEZ, Juan José. Inventario...II. Op.cit, pág. 58 y siguiendo a éste ANDRÉS ORDAX, Salvador. La iglesia...Op.cit, pág. 33.

${ }^{700}$ Escritura de concierto y condiciones, firmada en Saldaña el 11 de junio de 1666. AHPP. Carr.Prot 5701. Norberto Sandoval y Guevara (1666), fol 499 y ss.

${ }^{701}$ La fachada de la Pasión fue documentada por Monsó como obra de Berrojo pero García Chico descartó la autoría de la obra íntegra. MARTÍ Y MONSÓ, Estudios histórico-artísticos relativos

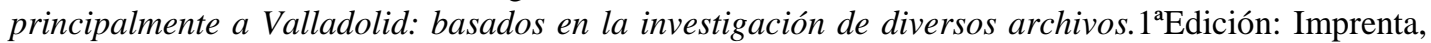
litografía, encuadernación y fábrica de libros rayados de Leonardo Miñón. Valladolid, 1898-1901, pp. 499-500, GARCIA CHICO, Esteban. Papeletas de Historia y Arte. Valladolid, 1958, pp. 55-57. Lás bóvedas de San Lorenzo, documentadas en CASADO IZQUIERDO, $\mathrm{M}^{\mathrm{a}}$ de los Ángeles. $E l$ arquitecto...Op.cit, pág. 76. Respecto a las bóvedas de Santiago de Rioseco, véase GARCÍA CHICO, Esteban. Catálogo...Op.cit, pág. 189. 
El regreso a Carrión de los Condes se produce en 1672, en que proporciona las trazas de la sacristía de la iglesia de Nuestra Señora de Belén. Ésta se ubicaba al nivel de la nave del templo, dentro de la torre, cuyo proyecto de reedificación había proporcionado en 1663 el maestro Andrés Díaz Cabanzo, avecindado en Piña de Campos $^{702}$. Las obras transcurrían con gran lentitud, y una década después no se había llegado al primer piso, por lo que se requiere al maestro de Paredes, cuyas condiciones siguió el maestro de carpintería carrionés Francisco Reinaldos para llevarla a cabo ${ }^{703}$. Uno de los lados es liso, el otro contiene la portezuela con la escalera de acceso al piso superior, que también se edificó por entonces, y en los lienzos restantes se halla una pareja de sencillos arcos de medio punto. Probablemente el entramado de madera, y las cupulillas de yeso dispuestas entre viga y viga sean fruto de esta intervención. Felipe Berrojo aprovecharía el viaje para trasladarse a la cercana localidad de Paredes de Nava, donde residiría temporalmente trabajando en la iglesia conventual de las Brígidas, en calidad de tracista y ejecutor de las obras ${ }^{704}$.

La siguiente ocasión en que figura desarrollando su actividad en Carrión, remonta al año 1679 en que redacta las condiciones necesarias para la realización de la vivienda particular del comisario del Santo oficio de la Inquisición, don Francisco Fernández de Mier, situadas en la puerta del Canto ${ }^{705}$. El maestro encargado de llevarlas a cabo, fueron Ignacio de Ceballos, vecino de Revenga y Francisco de Reinaldos, nuevamente vinculado a nuestro $\operatorname{artista}^{706}$. Por entonces, Berrojo se había convertido en Maestro general de obras del Obispado de Palencia, título que le otorgaría el Obispo de Palencia, Fray Juan del Molino Navarrete en 1675. Precisamente para el prelado carrionés ejecutó la reedificación de la capilla mayor de la iglesia románica de Santa María ayudado por el maestro local Juan de Páramo.

\footnotetext{
${ }^{702}$ La escritura de la obra de la torre se firma el 14 de junio de 1663 en AHPP. Carr.Prot 5201. Jerónimo Laso (1663-1664), fol 638 y ss. La planta y alzado de la torre que se proyecta se halla en AHPP. Sección de dibujos. Signatura 45.

${ }^{703}$ ADP. Carrión de los Condes. Iglesia de Nuestra Señora de Belén. Libro 17. $5^{\circ}$ de Cuentas de Fábrica (1653-1783), fol 84v.

${ }^{704}$ LEÓN, Teresa. "Historia de Paredes...Op.cit, pág. 86.

${ }^{705}$ Se trata de una de las puertas situadas entre la muralla medieval, a través de las cuales se accedía a la villa. Todas ellas han desaparecido hoy día. La puerta del Canto se ubicaba al inicio de la calle Esteban Collantes.

${ }^{706}$ Las trazas y condiciones de la obra de esta casa en AHPP. Carr.Prot 5889.Blas Vela Álvarez (1679-1681), fol 254 y ss.
} 
El 8 de enero de 1682 hicieron postura de la obra en 7.000 ducados, rematándose en los mismos el 25 de junio de dicho año tras una baja de mil ducados ${ }^{707}$. Aludimos a esta obra, no sólo por figurar entre sus más insignes encargos, sino porque su consecución fue posible gracias a la intervención de un carrionés llamado Pedro de Villalón, quien se responsabilizó de su fianza cuando fue encarcelado en las casas del ayuntamiento de la villa el 2 de noviembre de 1682, mientras trabajaba en la iglesia mencionada. Juan de Medina Argüelles y Felipe Berrojo, habían contraído una deuda de cinco mil y setenta y nueve reales con Juan Tejedor, arquitecto vallisoletano con el cual ambos habían trabajado en la construcción del Archivo de la Chancillería de Valladolid entre 1675 y $1679^{708}$. En junio de dicho año, en que Juan de Medina ya había fallecido ${ }^{709}$, Tejedor reclama esa cantidad a sus herederos y al maestro de Paredes a tenor de “...los gastos y materiales que se gastaron en la fábrica...". El embargo de algunos de sus bienes -una calesa de un asiento de vaqueta, una mula parda de siete años y una yegua castaña de seis años-, no impidieron el internamiento de Berrojo en prisión, de la que por fortuna salió un día más tarde, pudiendo de este modo abordar la obra que sin duda, le catapultó a la fama en la villa carrionesa ${ }^{710}$. No era la primera vez que Berrojo se veía envuelto en problemas con la justicia por motivos profesionales, pues el 22 de marzo de 1670, en que debía haber concluido las bóvedas de la iglesia vallisoletana de San Lorenzo, fue encarcelado por haber sobrepasado el plazo para cumplir el contrato. Precisamente fue el arquitecto Juan de Medina quien pagó su fianza cuatro días más $\operatorname{tarde}^{711}$.

Dictó testamento en enero de 1694 en Medina de Rioseco, localidad que le vio fallecer tras más de un cuarto de siglo asentado en la villa de los Almirantes ${ }^{712}$.

\footnotetext{
${ }^{707}$ MARTÍNEZ GONZÁLEZ, Rafael. “El Obispo...op.cit, pp. 251-269. La referencia documental en AHPP. Carr.Prot 5716 Norberto Sandoval y Guevara (1681-1682), fol 122 y ss.

${ }^{708}$ GARCIA CHICO, Esteban. Documentos...Arquitectos. Op.cit, pp.201-202 y 229. Sobre la historia de su construcción SOTERRAÑA MARTÍN, María de la. Historia del Archivo de la Real Chancillería de Valladolid. Valladolid, 1979.

${ }^{709}$ Argüelles falleció el 23 de agosto de 1681. MARTíN GONZÁLEZ, Juan José. Escultura...Op.cit, pág. 358.

${ }^{710}$ AHPP. Carr.Prot 5008. Diego García de la Llana (1675-1683), s/f.

${ }^{711}$ CASADO IZQUIERDO, $\mathrm{M}^{\mathrm{a}}$ de los Ángeles. El arquitecto...Op.cit, pp. 76-77.

${ }^{712}$ LEÓN, Teresa. "Historia de Paredes...Op.cit, pp. 130-132.
} 


\section{Francisco Prieto Gómez Maestro arquitecto y escultor}

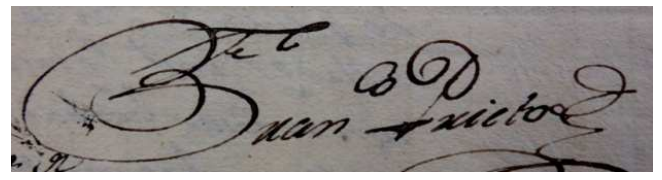

Es el hijo del maestro arquitecto y escultor asentado en Palencia, Tomás Prieto, con quien se forma. Probablemente gracias a su participación en los retablos colaterales de la capilla de Antonio Pastor ${ }^{713}$, su hijo pudo tener acceso a los diversos encargos carrioneses. Francisco Prieto estuvo avecindado toda su vida en Palencia, por lo que es probable que la localidad del Pisuerga fuese su villa natal. Se presentó en 1778 a los premios generales de la Real Academia de Bellas Artes de San Fernando y estuvo bajo la protección de don José Luis Mollinedo, obispo de Palencia desde $1780^{714}$.

A partir de 1777 sigue las directrices neoclásicas promovidas por la Academia, muestra de lo cual fue la ejecución en 1784 de la nueva Puerta del Mercado, que, derruida en 1909, constituía una de las excepciones de monumento público de este estilo en la capital palentina ${ }^{715}$. Junto a González Ortiz interviene en 1788 en el planteamiento del templo de Guaza de Campos $^{716}$.

Como su padre, también es autor de retablos como uno sin especificar en Dueñas, de 1783, dos retablos colaterales de Villamartín de Campos, de 1787, el retablo mayor de Villajimena, de 1792 y su última obra escultórica, el retablo mayor de Alba de Cerrato, en los que sigue los preceptos académicos ${ }^{717}$.

Sus intervenciones en Carrión son relativas a proyectos arquitectónicos, interviniendo a principios del siglo XIX en diversas obras de carácter religioso. En 1804, Prieto proporciona las trazas para la reedificación de la torre de San Andrés,

\footnotetext{
713 AHPP. Carr.Prot 4656. Juan Cano Guijelmo (1770-1775), s/f.

${ }^{714}$ PONZ, Antonio. Viaje...tomo XI. 1783. Op.cit, pág. 167.

715 Este y otros datos de Francisco Prieto en URREA FERNÁNDEZ, Jesús y MARTÍNEZ, Rafael. "Construcción, proceso y derribo del arco del Mercado de Palencia (1784-1909)" en BSAA, n44. Valladolid, 1978, pp. 510-516.

${ }^{716}$ URREA FERNÁNDEZ, Jesús y MARTÍN GONZÁLEZ, Juan José. Inventario...1, Op.cit, pág. 173.

${ }^{717}$ ALARIO TRIGUEROS, Teresa. "La introducción...Op.cit, pp. 686-689. El dato de Villajimena en URREA FERNÁNDEZ, Jesús y MARTÍN GONZÁLEZ, Juan José. Inventario... I, Op.cit, pág. 284.
} 
que se refuerza con sillares traídos de Palacios del Alcor ${ }^{718}$. Posteriormente, con motivo del incendio que provocaron las huestes de Santos Padilla en 1811, a raíz de los asaltos de las tropas francesas, algunos edificios resultaron incendiados. Se encargará, por tanto, de elaborar los proyectos de reedificación de los templos de Santa María y Santiago. En el primero de ellos, las brasas habían reducido a escombros la torre y las cubiertas. De la torre, ubicada en el crucero, nada quedaba, pues se había desplomado por completo y se decidió que no fuese reconstruida ${ }^{719}$. Sin embargo, se intervino sobre la nave central, reconstruida por los hermanos Carniago y Pablo Salomón, alarifes carrioneses, con los materiales procedentes del despojo del convento desamortizado de Santo Domingo. Francisco Prieto elabora una memoria en la que recoge los desperfectos del templo a finales de $1811 \mathrm{y}$ unos meses después, el 24 de febrero de 1812 proporciona el proyecto de reconstrucción ${ }^{720}$.

En el caso del templo de Santiago, la torre no resultó afectada, al contrario que la cubierta, que tuvo que ser completamente reconstruida. La falta de fondos retrasó las intervenciones, y no fue hasta 1813 cuando la comunidad de feligreses solicitó al consistorio que le proporcionase la madera procedente del convento de Santa María de Benevívere ${ }^{721}$. Obtenidos los materiales, Prieto reconoce el templo en 1814 , en que fue restituida la armadura de la nave central ${ }^{722}$.

\footnotetext{
${ }^{718}$ ADP. Carrión. San Andrés. Libro 6º de Cuentas de Fábrica (1796-1850), fol 104 y 105.

${ }^{719}$ Puede verse un dibujo a pluma de la misma, realizado por Valentín Carderera que podemos datar a finales del siglo XVIII o principios del siglo XIX. FLG. Iglesia de Santa María de las Victorias. Fondo Carderera 9138.

${ }^{720}$ ASMCC. Libro $3^{\circ}$ de Fábrica (1805-1850), fol 70v, 124v y 132.

${ }^{721}$ RUIZ SALCES, Roberto y PEÑIL MINGUEZ, Javier. "La excavación de la iglesia románica de Santiago: Aportaciones al urbanismo medieval de Carrión de los Condes" en XX Congreso Nacional de Arqueología. Zaragoza, 1991 pág. 486, a su vez de AMCC, Libro 2, Sesiones Municipales (17591814), fol 23 y v.

${ }^{722}$ ADP. Iglesia de Santiago. Libro $1^{\circ}$ de Cuentas de Fábrica (1778-1849), fol 246.
} 


\section{La familia Guerra}

\section{Maestros alarifes}

Como referimos con anterioridad, a partir del siglo XVIII, ya realizadas las obras de entidad en Carrión de los Condes, no hallamos maestros de cantería destacados en la villa, máxime a partir de la creación de la Academia de Bellas Artes, que seleccionaba sus propios arquitectos para la elaboración de los diversos proyectos.

En Carrión van a destacar tres familias de maestros alarifes -Los Guerra, los Iglesias y los Rodríguez- de los que conservamos algunos datos extraídos de la documentación. En el caso de los primeros, hallamos cuatro miembros dedicados al oficio -Esteban, Manuel, José y Simón cuyos lazos de parentesco desconocemos. No obstante, en base a los años en que trabajan, Esteban Guerra podría ser el progenitor de Manuel y José, siendo Simón Guerra el más joven, probablemente hijo de uno de los dos anteriores.

Esteban Guerra tan sólo figura en una ocasión en Carrión, recomponiendo el maderaje de la torre de Belén en $1739^{723}$.

\section{Manuel Guerra}

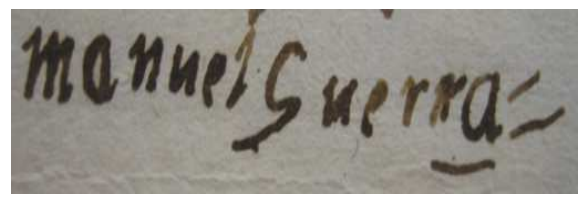

Se concierta en 1759 en los reparos de la iglesia parroquial de Cardeñosa ${ }^{724}$. En febrero de 1761 se compromete por 14.600 reales a reconstruir la torre de San Lorenzo de Fuente- Andrino, pedanía de la localidad palentina de Villaherreros ${ }^{725}$.

En noviembre de dicho año se concierta con el mayordomo de la iglesia de Santa María de Arconada a finalizar los reparos que en 1759 había realizado Pedro Calderón de los Ríos ${ }^{726}$.

ADP. Carrión. Iglesia de Belén. Libro 17, $5^{\circ}$ de Cuentas de Fábrica (1653-1783), fol 353, 354.

${ }_{725}^{724}$ AHPP. Carr.Prot 4652. Juan Cano Guijelmo (1758-1759), fol 168.

${ }^{725}$ AHPP. Carr.Prot 4741. Gabriel Ceano Vivas (1760-1762), s/f.

${ }^{726}$ AHPP. Carr.Prot 4609, Francisco Blanco Manuel (1761-1762), fol 128. 


\section{José Guerra}

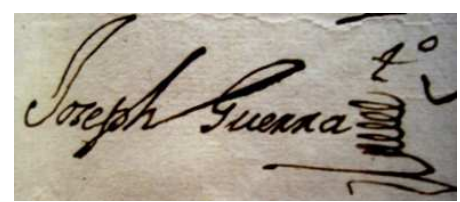

Coetáneo de Manuel Guerra, trabaja junto a éste en la iglesia de Santa María de Carrión. Reciben del mayordomo 2.932 reales en 1762, correspondientes al trabajo de tres meses y medio, por los trabajos realizados, consistentes en lucir la iglesia, sacristía y capilla de San Nicolás ${ }^{727}$.

Por último, de Simón Guerra tan sólo se sabe que reteja la nave de la iglesia de Belén de Carrión en $1814^{728}$.

\section{La familia Iglesias}

\section{Maestros alarifes}

\section{José Iglesias}

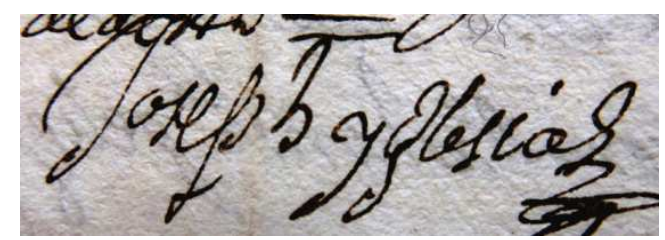

Era natural de Tordesillas, pero estaba avecindado en Carrión. Fruto de su matrimonio con Felipa Polvorosa, natural de Población de Campos, tuvo tres hijos: Leonardo, Lorenzo y Josefa ${ }^{729}$. Sus dos vástagos varones siguieron la tradición del oficio de su padre.

Participa en 1735 en el derribo de la iglesia ruinosa de San Bartolomé y en el traslado de sus materiales a la iglesia de San Juan del Mercado ${ }^{730}$. Reconstruye las bóvedas de la iglesia de Santiago en 1738, disponiendo cinco bóvedas de arista con lunetos que no se han conservado, pues fueron sustituidos por la cubierta moderna

ASMCC. Libro $2^{\circ}$ de Fábrica (1762-1804), fol 13.

ADP. Carrión. Iglesia de Belén. Libro 18, $6^{\circ}$ de Cuentas de Fábrica (1784-1852), fol 211v.

${ }^{729}$ AHPP. Carr.Prot 5781, José Tablares del Val, (1784-1785), fol 140 y ss y ASMCC. Libro $4^{\circ}$ de Bautizados y confirmados (1702-1756) fol 218v y 219.

${ }^{730}$ ASMCC. Libro $4^{\circ}$ de Bautizados y confirmados (1702-1756) fol $218 \mathrm{v}$ y 219 . ACP. Provisorato. Legajo $319, \mathrm{n}^{\circ}$ 54799, s/f. 
que presenta hoy día el templo ${ }^{731}$. No fue ésta la única ocasión en que interviene en el mismo, pues en 1759, tras reconocer junto a Manuel de Cieza la ruina del último cuerpo de la torre, elabora un proyecto para la misma consistente en una cornisa de ladrillo en forma de gola, que sobresalía de un tejado a cuatro aguas con veleta ${ }^{732}$. Este sistema es idéntico al que había empleado al reconstruir, junto a Eugenio Rodríguez, el cuerpo de campanas de la torre de la ermita de San Juan de Cestillos en 1740, tras elaborar un informe sobre el estado del anterior en $1739^{733}$.

Entre 1753 y 1757, José y sus dos hijos, Leonardo y Lorenzo, otorgan diversas cartas de pago a la iglesia de San Andrés de Carrión por la reedificación del muro occidental del templo y los retejos generales de la misma ${ }^{734}$. En 1759 , junto a Manuel de Cieza realiza un proyecto para la reconstrucción de la torre de dicha iglesia $^{735}$. De nuevo en la iglesia de San Andrés, se encarga de reforzar el último cuerpo de la torre, correspondiente a las campanas, donde colocó un nuevo esquilón fundido por el campanero palentino Juan Sierra ${ }^{736}$. Figura como fiador de Leonardo Iglesias en la obra de la antigua cárcel, hoy casa de cultura, el 26 de junio de $1771^{737}$.

Dicta testamento el 19 de septiembre de 1784. Por el mismo sabemos que se esposó en segundas nupcias con doña Catalina Nogales ${ }^{738}$. Fallece poco después, el 30 de septiembre de 1784, disponiendo ser enterrado en la iglesia de Santa María del Camino $^{739}$.

\footnotetext{
${ }^{731}$ AHPP. Carr.Prot 5880. Manuel Vega (1738-1739), s/f.

${ }^{732}$ VIGURI, Miguel de y Sánchez, José Luis. Op.cit, pp. 371-373. El diseño de la torre puede verse en ACP. Provisorato. Legajo 491 (1751-1756).

733 VIGURI, Miguel de. Heráldica...2. Op.cit, pp. 280 y ss, a su vez de AHPP. Carr.Prot 5881, Manuel Vega. (1740-1741), fol 148 y ss.

${ }^{734}$ ADP. Carrión. San Andrés. Libro 5º de Cuentas de Fábrica (1753-1795), fol 7v, 97v, 102.

${ }^{735}$ Las condiciones para la ejecución de la torre en VIGURI, Miguel de y Sánchez, José Luis. Op.cit, pp. 371-373.

${ }_{736}$ Ibídem, fol $157 \mathrm{v}$ y 191.

${ }^{737}$ AHPP. Carr.Prot 5456, Andrés Núñez Castelo (1770-1773) fol 111 y ss.

${ }^{738}$ AHPP. Carr.Prot 5781, José Tablares del Val, (1784-1785), fol 140 y ss.

739 ASMCC. Libro 16, $1^{\circ}$ de difuntos y testamentos (1617-1701), fol 225.
} 


\section{Leonardo Iglesias}

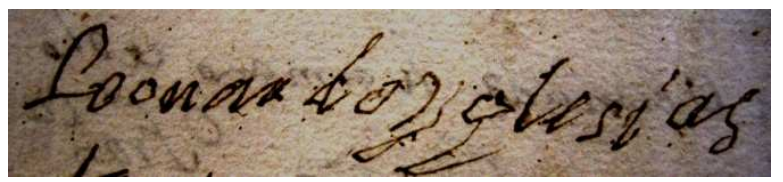

Nació en Carrión de los Condes, siendo bautizado en la iglesia de Santa María del Camino el 6 de noviembre de $1734^{740}$. Estaba casado de primeras nupcias con doña Ángela Bahíllo. Viudo de ésta, el 29 de enero de 1785, firma capitulaciones matrimoniales con la viuda Catalina de Medina ${ }^{741}$.

En 1763 ejecuta los reparos de la torre de la iglesia de Villota del Duque, en Saldaña, que por entonces pertenecía al obispado de León $^{742}$. En 1764 se encarga junto a Manuel de Becerril, vecino de Paredes de Nava, de materializar el proyecto de José Iglesias para el último cuerpo de la torre de la iglesia de Santiago de Carrión, modificando el tejado propuesto a cuatro aguas, por una cúpula con linterna ${ }^{743}$. Repara la antigua cárcel y ayuntamiento de Carrión, ubicada tras el consistorio actual en 1771, fiándole su padre, José Iglesias ${ }^{744}$. Fallece el 25 de mayo de 1787, siendo su voluntad ser sepultado en su parroquia natal de Santa María ${ }^{745}$.

Lorenzo Iglesias, al igual que su hermano Leonardo, también debió nacer en Carrión. Si bien no hemos hallado su partida de bautismo, siempre se declara vecino de la villa. No se conocen demasiados datos del mismo. Compone en la iglesia de Nuestra Señora de Belén unas gradas de la entrada y realiza el antepecho del desaparecido pórtico en $1772^{746}$. Junto a otro alarife carrionés, llamado Antonio Fernández, interviene en 1784 en los reparos de la vivienda de los Calderón-Ayala ubicada en la plazuela de Belén, en Carrión ${ }^{747}$.

Ramón Iglesias también figura trabajando en Carrión como maestro de albañilería, pero desconocemos qué vínculos de consanguinidad le unía al resto de artífices. Por sus tardías intervenciones respecto a los demás, es probable que fuese

\footnotetext{
${ }^{740}$ ASMCC. Libro $4^{\circ}$ de Bautizados y confirmados (1702-1756) fol 218v y 219.

${ }^{741}$ AHPP. Carr.Prot 5781, José Tablares del Val, (1784-1785), fol 407 y ss.

${ }^{742}$ AHPP. Carr.Prot 4723, Antonio Ceano Vivas (1763-1767), s/f.

${ }^{743}$ VIGURI, Miguel de y SÁNCHEZ, José Luis. Op.cit, pp. 371-373.

${ }^{744}$ AHPP. Carr.Prot 5456, Andrés Núñez Castelo (1770-1773) fol 111 y ss.

${ }^{745}$ ASMC. Libro 16, $1^{\circ}$ de difuntos y testamentos (1617-1701), fol 234 y 234v.

${ }^{746}$ ADP. Carrión. Iglesia de Belén. Libro 17, $5^{\circ}$ de Cuentas de Fábrica (1653-1783), fol 600.

${ }^{747}$ AHPP. Carr.Prot 5781, José Tablares del Val, (1784-1785), fol 49 y ss.
} 
hijo de Leonardo o Lorenzo Iglesias. En la iglesia de San Andrés, embaldosa la nave mayor en las postrimerías del siglo XIX, concretamente en $1797^{748}$. En 1800 el mayordomo del templo de Santiago le abona 820 reales por un retejo general, denominándole en la carta de pago "maestro de obras ${ }^{749}$ ". Ese mismo año recibe del mayordomo del hospital desaparecido de la Herrada, ubicado en las afueras de Carrión, 1.658 reales por haber desmontado el palomar, la sacristía y volverlos a reedificar, además de tapiar la huerta ${ }^{750}$ Vuelve a trabajar en Santiago en 1814, cuando recompone la escalera que da acceso a la torre ${ }^{751}$.

\section{La familia Rodríguez}

\section{Maestros alarifes}

Tres son los maestros alarifes conocidos con este patronímico: Pedro, José y Eugenio Rodríguez.

Pedro y José Rodríguez trabajan junto a Manuel Guerra en los reparos de la iglesia parroquial de Cardeñosa en $1759^{752}$. En 1761 Pedro, José y Eugenio Rodríguez toman parte en el desmonte y posterior reedificación de la capilla de Mirabueno en el convento de San Francisco de Carrión junto al riosecano Melchor García $^{753}$.
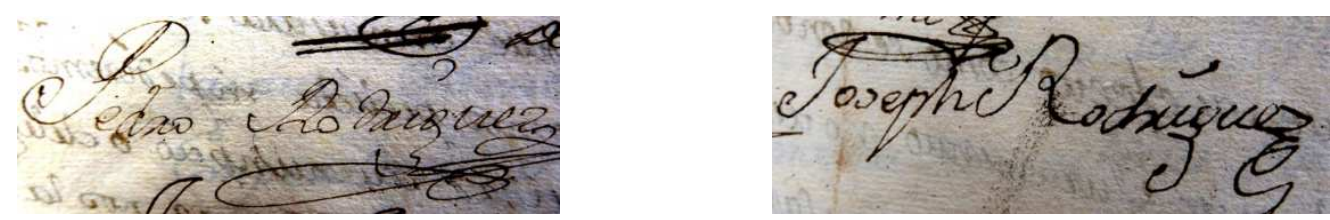

\footnotetext{
ADP. Carrión. San Andrés. Libro 6º de Cuentas de Fábrica (1796-1850), fol 20.

ADP. Iglesia de Santiago. Libro $1^{\circ}$ de Cuentas de Fábrica (1778-1849), fol 158.

${ }^{750}$ AHPP. Desamortización. Legajo 105.

${ }^{751}$ ADP. Iglesia de Santiago. Libro $1^{\circ}$ de Cuentas de Fábrica (1778-1849), fol 247.

${ }^{752}$ AHPP. Carr.Prot 4652. Juan Cano Guijelmo (1758-1759), fol 168.

${ }^{753}$ AHPP. Carr.Prot 4653. Juan Cano Guijelmo (1760-1761) fol 235 y ss.
} 


\section{Eugenio Rodríguez}

Es quien posee menor formación cultural, pues no sabía escribir. Recibe doscientos reales en 1732 por los reparos ejecutados en la iglesia de Nuestra Señora de Belén ${ }^{754}$. La casa del Águila, ubicada frente a Santa María, era propiedad del templo en 1739. Por ello, fueron el cura y mayordomos del mismo quienes contrataron a Eugenio Rodríguez para remodelarla ${ }^{755}$. Junto a José Iglesias, se encarga del proyecto de reconstrucción del templo de San Juan de Cestillos en 1740, que se comprometen a finalizar en un año ${ }^{756}$. Dicta testamento el 10 de junio de 1763 y en el mismo declara que tan sólo tiene un hijo, llamado Pedro Rodríguez, que posiblemente sea el mencionado con anterioridad ${ }^{757}$.

\section{3. Artistas de otras procedencias}

Incluimos en este grupo a todos aquellos artistas que participaron al menos en una obra carrionesa, siendo la villa condal un lugar de paso, salvo en el caso de Felipe Berrojo que se asentó en Carrión durante décadas. Se trata de maestros de reconocido prestigio y amplia formación cuyo foco de influencia se extiende por los territorios de la Corona de Castilla, sin ser Palencia se centro principal de acción. Llegaron a alcanzar los más altos grados dentro de la arquitectura, siendo veedores o maestros arquitectos, aunque también ejecutaron gran número de obras, supliendo las carencias de los maestros locales e introduciendo formas nuevas aprendidas de otros focos.

La mayor parte de estos artistas desarrollaron su actividad durante el siglo XVI, siendo los únicos que realmente podían competir de un modo efectivo con los maestros cántabros que a la hora de adjudicarse las obras, al poseer una amplia

\footnotetext{
${ }^{754}$ ADP. Libro 17. $5^{\circ}$ de Cuentas de fábrica (1653-1783), fol 333.

755 AHPP. Carr.Prot 4877. Agustín Díez de Castro (1739-1742), fol 92 y ss.

${ }^{756}$ VIGURI, Miguel de. Heráldica...2. Op.cit, pp. 280 y ss, a su vez de AHPP. Carr.Prot 5881, Manuel Vega. (1740-1741), fol 148 y ss.

${ }^{757}$ AHPP. Carr.Prot 4723. Antonio Ceano Vivas (1763-1767), s/f.
} 
formación en el manejo de la piedra. A partir del siglo XVII, en que la afluencia de artistas trasmeranos se convierte en un fenómeno masivo, su protagonismo eclipsa al de estos maestros, cuya presencia está confirmada, como hemos tenido oportunidad de comprobar, en la mayor parte de las obras públicas y religiosas de la villa condal.

\section{Rodrigo Gil de Hontañón \\ Arquitecto de origen madrileño}

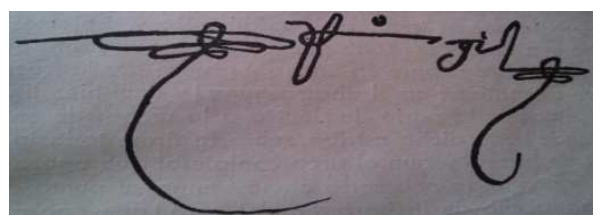

Hijo de Ana Sanz y del arquitecto Juan Gil de Hontañón, que se convertiría en su maestro, Rodrigo Gil de Hontañón nació en 1500 en la población madrileña de Rascafría. Fue un artista longevo para su época, pues falleció en Segovia en 1577, ciudad para cuya catedral trabajarían ambos artistas, pues Rodrigo Gil sucedería a su progenitor como maestro mayor a tenor de su fallecimiento en $1526^{758}$. Formado en los principios del estilo gótico, Hontañón enlazaría con las nuevas formas renacentistas que, llegadas desde Italia, se estaban aplicando en Castilla a partir de las primeras décadas del siglo XVI. Su sorprendente capacidad de crear un estilo híbrido, lo convierten en una figura que ha despertado gran interés entre los historiadores, con obras tan destacadas como la iglesia vallisoletana de Santiago en Medina de Rioseco, la portada de la Universidad de Alcalá de Henares o la dirección de la construcción de la Catedral de Plasencia ${ }^{759}$. Todas esas monografías y estudios

\footnotetext{
${ }^{758}$ LLAGUNO Y AMIROLA, Eugenio. Noticias de los arquitectos...I, Op.cit, pp. 318-319 y CASASECA CASASECA, Antonio. "Trazas para la Catedral de Segovia" en $A E A, n^{\circ} 51$. Madrid, 1978, pp. 29-62.

${ }^{759}$ AGAPITO Y REVILLA, Juan. "Un laborioso arquitecto castellano del siglo XVI: Rodrigo Gil” en Arquitectura, n47, 1923, pp. 57-63, ORTIZ DE LA TORRE, Elías. "Arquitectos montañeses: Juan y Rodrigo Gil de Hontañón en Boletín Biblioteca Menéndez Pelayo, 1923, pág.s. 215-240 y una revisión del mismo, "Sobre los arquitectos Juan y Rodrigo Gil de Hontañón y Juan de Rasines" en AEA,Tomo XIV. 1940-41. pp. 315-317, SOJO Y LOMBA, Fermín. Los maestros...Op.cit, pp. 79-84, GARCÍA CHICO, ESTEBAN. Documentos...Arquitectos, Op.cit, pp.13-20, CHUECA GOITIA, Fernando. La Catedral nueva de Salamanca. Salamanca, 1951, CAMÓN AZNAR, José. La arquitectura y la orfebrería españolas del siglo XVI. Summa Artis. Volumen 17. Espasa Calpe. Madrid, 1959, pp. 168-202, PEREDA DE LA REGUERA, Manuel. Rodrigo Gil de Hontañón. Librería Moderna. Madrid, 1951, HOAG, JOHN D. "Rodrigo Gil de Hontañón: gótico y renacimiento en la arquitectura española del siglo XVI”. Traducción: Pilar Navascués Benlloch.Xarait. Madrid, 1985. CASASECA CASASECA, Antonio. Rodrigo Gil de Hontañón (Rascafría 1500-Segovia 1577). Valladolid, 1988, VV.AA. Artistas cántabros...Op.cit, pp. 247-261, VV.AA. "Rodrigo Gil de Hontañón. Un arquitecto entre el gótico y el Renacimiento. Exposición conmemorativa del quinto centenario de su nacimiento. Madrid, 2000.
} 
han sido debidamente revisados y actualizados mediante artículos especializados que lo sitúan trabajando por toda la geografía española, como tracista y arquitecto, y poseedor de grandes conocimientos matemáticos ${ }^{760}$.

Dentro del ámbito palentino, aparece por vez primera proporcionando las trazas de la iglesia de Santa Eugenia de Becerril de Campos, cuyas obras dirigiría a partir de 1536 durante casi diez años, traspasándolas entonces a Alonso de Pando, maestro de cantería avecindado en Palencia ${ }^{761}$.

En Carrión, la única intervención documentada de la que tenemos noticia gracias a una referencia indirecta, es su participación en la iglesia parroquial de San Andrés, proporcionando las trazas del nuevo templo que debía reedificarse. En 1563, debido al repentino fallecimiento de Pedro de Castrillo que se ocupaba de las obras por entonces, toma el relevo Juan de Aras, comprometiéndose a seguir las pautas marcadas por el maestro de Rascafría ${ }^{762}$. El modelo de cabecera ochavada rememorando esquemas del tardogótico y el recurso de la planta de salón sobre pilares cilíndricos muy macizos fue la tipología más recurrente de Rodrigo Gil para

\footnotetext{
${ }^{760}$ GARCÍA SIMÓN, Agustín. Compendio de architectura y simetría de los templos conforme a la medida del cuerpo humano con algunas demostraziones de geometría, año de 1681. Estudios introductorios, BONET CORREA, Antonio y CHANFÓN OLMOS, Carlos. Valladolid, 1990GARCÍA-MURGA ALCÁNTARA, Juan. "La intervención de Rodrigo Gil de Hontañón en la iglesia de Santa María de Guareña" en Goya, n¹44, 1978, pp. 314-323 y del mismo, "Documento para la Historia del Arte de Extremadura: directrices de Rodrigo Gil de Hontañón para la iglesia de Santa María de Guareña" en Actas del VII Congreso de Estudios Extremeños, $\mathrm{n}^{\circ} 1,1983$, pp. 119-128, IBÁÑEZ PÉREZ, Alberto Cayetano. "Rodrigo Gil de Hontañón y la iglesia colegial de Peñaranda de Duero (Burgos), BSAA, n55, Valladolid, 1989, pp. 398-40, CADIÑANOS BARDECI, Inocencio. "Nuevos datos sobre la Iglesia de San Martín de la Mota del Marqués, obra de Rodrigo Gil de Hontañón” en Academia, n76, 1993, pp. 461-472, VASALLO TORANZO, Luis. "Una nueva obra de Rodrigo Gil de Hontañón en Zamora: la reforma de la iglesia de San Juan de Puerta Nueva" en $B S A A, n^{\circ} 59,1993$, pp. 313-320 y del mismo, "Rodrigo Gil de Hontañón en Valladolid. La iglesia de La Mota del Marqués para Constantino del Castillo y otras obras" en BSAA, $\mathrm{n}^{\circ} 77$. Valladolid, 2011, pp. 39-62, CASTRO SANTAMARÍA, Ana. "Aportaciones al epistolario de Rodrigo Gil de Hontañón sobre la Catedral de Coria y la catedral de Villafranca del Bierzo" en Norba, nº17, 1997, pp. 41-52, RUPÉREZ ALMAJANO, María Nieves. "El colegio de niños huérfanos: la intervención de Rodrigo Gil de Hontañón y otras aportaciones a la historia de su construcción" en Estudios Históricos Salmantinos: homenaje al P. Benigno Hernández Montes. Salamanca, 1999, pp. 129-156, REDONDO CANTERA, M ${ }^{a}$ José. "Los arquitectos y canteros del entorno de Rodrigo Gil de Hontañón en Castilla y León: la herencia paterna" en El arte de la cantería, Santander, 2003, pp. 1576, TOVAR MARTÍN, Virginia. "La cantería en la época de Rodrigo Gil de Hontañón" en El arte de la cantería, Santander, 2003, pp. 77-90, ARAMBURU- ZABALA HIGUERA, Miguel Ángel. "De Rodrigo Gil de Hontañón a Juan de Herrera" en El arte de la cantería, Santander, 2003, pp. 91-112, ALONSO RUIZ, Begoña."Diego de Riaño y los maestros de la Colegiata de Valladolid" en De arte. n³. Universidad de León. León, 2004, pp. 39-54, PASCUAL MOLINA, Jesús Félix. "Rodrigo Gil de Hontañón y el contrato para la iglesia parroquial de Laguna de Duero (Valladolid)" en BSAA, nº71. Valladolid, 2005, pp. 89-98.

${ }^{761}$ PEREDA DE LA REGUERA, Manuel. Rodrigo...Op.cit, pág. 123.

${ }^{762}$ ZALAMA RODRÍGUEZ, Miguel Ángel. La arquitectura...Op.cit, pp. $89-90$ y del mismo, "Documentos...Op.cit, pp. 248-252.
} 
sus templos parroquiales. Son iglesias columnarias, por ejemplo, la iglesia parroquial de Meco en Madrid, la iglesia de Santiago en Cigales, la Colegiata de Tendilla en Guadalajara, o la Iglesia de San Martín en Mota del Marqués, cuyo emplazamiento responde en todas ellas a un emplazamiento de alta concentración demográfica en la época, de economía saneada o de residencia de destacadas familias, como es el caso de Carrión ${ }^{763}$. Esta tipología no era nueva en absoluto, pues tenía el referente más directo en su padre, Rodrigo Gil, que la empleó en la colegiata de San Antolín en Medina del Campo.

Además de introducir los principios arquitectónicos del gótico, la concepción espacial y la introducción de motivos clásicos lo convierten en un artista del Renacimiento. Si bien no consta la fecha de las trazas, podemos apuntar hacia una datación aproximada de 1530 a 1540, abanico durante el cual levanta la mayor parte de sus iglesias parroquiales de tres naves con bóvedas de crucería. Pese a los esfuerzos de los canteros que trabajaron sucesivamente en el templo, éste tuvo que ser reconstruido desde sus cimientos a partir de 1608, gracias al proyecto de Francisco Bálcava, que siguió los principios fundamentales de Hontañón.

Puede que ésta no fuese la única ocasión en que Rodrigo Gil fuese reclamado en la villa condal. Dentro de su jurisdicción, la abadía de Santa María de Benevívere, poseyó, al menos hasta 1861 en que ya se hallaba en ruinas, una portada de acceso renacentista ${ }^{764}$ que hoy día tan sólo se conserva fragmentariamente. La recurrencia al arco de medio punto flanqueado por pilastras y medallones en las enjutas, remite a la portada que Rodrigo Gil ejecutó para la iglesia zamorana de Villamor, en Zamora en 1552, así como el repertorio pagano del segundo cuerpo, presenta una gran remembranza de las fachadas del Colegio de Alcalá de Henares o el templo vallisoletano de San Martín en Mota del Marqués, concluidas en $1553^{765}$. De modo que esta portada habría que situarla a mediados de la centuria y dado que el artista estaba al cargo de otras obras paralelamente, puede que proporcionase el diseño de la misma.

\footnotetext{
${ }^{763}$ CASASECA, CASASECA, Antonio. “Rodrigo Gil...Op.cit, pp. 44-48.

${ }^{764}$ QUADRADO; José María y PARCERISA, Francisco J. Recuerdos...Op.cit, $1^{\text {a }}$ Edición: Palencia, 1861. Edición facsímil. Valladolid, 1989, pág. 345.

${ }^{765}$ HOAG, JOHN D. "Rodrigo Gil...Op.cit, pp. 87-95, 157-161 y CASASECA CASASECA, Antonio. Rodrigo Gil...pp. 55-57, 124-127, 241-252.
} 
A través de un poder emitido en 1591 en el que Rodrigo Gil reclamaba ciertas cantidades a los herederos de Alonso de Pando, sabemos que había participado, sin saber el momento exacto, en la ejecución de la fachada de la iglesia de San Esteban de Castromocho y en la capilla mayor de la iglesia de San Juan de Villaumbrales ${ }^{766}$.

\section{Juan de Badajoz "el Mozo" \\ Maestro arquitecto y escultor}

Pese a lo que pueda indicar su patronímico, Juan de Badajoz nació posiblemente en León, donde su padre, el arquitecto homónimo apelado "el Viejo", estableció su residencia desde 1498, lugar que se convertiría en el foco principal donde su primogénito desarrollaría la mayor parte de su actividad artística, con participación en obras como el claustro y dependencias de la Catedral, el convento de San Marcos o la librería de San Isidoro ${ }^{767}$. Ese año pudo haber nacido Badajoz, pues en la declaración que prestó en 1548, cuatro años antes de su muerte, durante el célebre pleito de la Antigua de Valladolid, declara tener cincuenta años aproximadamente $^{768}$.

En Carrión, la huella de Juan de Badajoz el Mozo perdura imborrable en las piedras del claustro bajo del monasterio benedictino de San Zoilo, joya renacentista que ha merecido el elogio de un sinfín de historiadores ${ }^{769}$. Las obras fueron comenzadas el 7 de marzo de 1537 y no finalizaron hasta el 27de marzo de 1604, tal y como reza la inscripción ubicada en el plemento de la primera bóveda de la crujía oriental. Probablemente la proximidad con la capital leonesa y la experiencia avalada por el artista, motivaron la elección del mismo para inaugurar una obra de tal calibre, cuya labor desconocemos cuánto tiempo se prolongó. El punto de partida

\footnotetext{
${ }^{766}$ PEREDA DE LA REGUERA, Manuel. Rodrigo...Op.cit, pp. 249-251.

${ }^{767}$ CAMPOS SÁNCHEZ-BORDONA, María Dolores. "Proyectos urbanísticos de Juan de Badajoz y Juan del Ribero Rada para la ciudad de León” en ADHTA, n²4, 1992, pp. 145-150 y sobre todo Juan de Badajoz y la arquitectura del Renacimiento en León. Universidad de León. León, 1993, sobre todo pp. 153-167

${ }^{768}$ MARTÍN GONZÁLEZ, Juan José. Juan de Juni. Madrid, 1974, pág. 34.

${ }^{769}$ LLAGUNO Y AMIROLA, Eugenio. Noticias...Op.cit, pág. 210.
} 
lo constituyó la bóveda mencionada, denominada fundacional, por ser el soporte en el que se esculpieron los bustos de la familia Beni-Gómez, linaje benefactor del monasterio, que correspondería a la parte esculpida por Miguel de Espinosa ${ }^{770}$. Continuaría por ese lado, ejecutando todas las bóvedas de la crujía oriental, esto es de la primera a la sexta ${ }^{771}$. Además, creemos que se le deben atribuir las dos bóvedas contiguas del lado septentrional, esto es la vigésimo tercera y vigésimo cuarta, puesto que, como indicamos el claustro fue finalizado en la bóveda vigésimo segunda, siendo las dos mencionadas, parte del programa inicial. Los tres modelos de bóvedas de crucería con nervios combados que aplicó Badajoz en el claustro, están presentes en sus obras leonesas del claustro de la catedral y de la primera sacristía del convento de San Marcos. Las ménsulas molduradas unidas por el friso corrido de la capilla de don Juan Manuel del convento de San Pablo de Peñafiel, obra atribuida a Badajoz y realizada en 1536 según consta en la inscripción que recorre los muros ${ }^{772}$, constituyen, a nuestro parecer, el precedente inmediato de las que Badajoz concibió en los muros del claustro carrionés. Podemos comprobar y tendremos ocasión de analizar detenidamente, cómo a pesar de su breve intervención, Badajoz marcó la pauta de las directrices arquitectónicas que debían seguirse en cada una de las crujías, de manera que en su intervención conjugó a partes iguales la labor de cantero con la de proyectista, como buen arquitecto que era.

Por otro lado y a tenor de la similitud estilística entre la portada del crucero de la iglesia del convento leonés de San Marcos, que Badajoz proyectaría entre 1528 y 1538 y la puerta de acceso desde la iglesia al claustro del monasterio benedictino, apoyamos la tesis de Bordona sobre la autoría de Badajoz, que efectuaría esta obra plateresca poco después de comenzar las obras del claustro, hacia $1538^{773}$. La intervención en la abadía benedictina se convierte así en el crisol en el que confluye su labor arquitectónica antecedente.

\footnotetext{
${ }^{770}$ CEÁN BERMÚDEZ, Agustín. Diccionario...Op.cit, pp. 44-45.

${ }^{771}$ DÍAZ NAVA, Adolfo F. "Un claustro plateresco: San Zoilo de Carrión de los Condes" en PITTM, $\mathrm{n}^{\circ}$ 23. Diputación Provincial. Palencia, 1963, pág. 102.

772 CHUECA GOITIA, Fernando. Arquitectura del siglo XVI. Ars Hispaniae, Tomo XI. Plus Ultra. Madrid, 1953, pág. 316.

${ }^{773}$ CAMPOS SÁNCHEZ-BORDONA, María Dolores. Juan de Badajoz...op.cit, pp. 83-84.
} 


\section{Juan de Celaya \\ Maestro de cantería natural de Vizcaya}

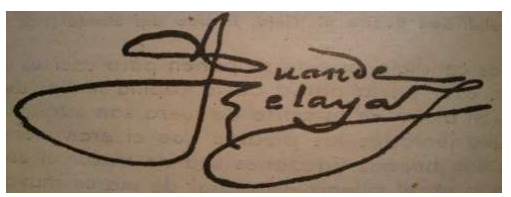

Vizcaya fue la cuna natal de este artista, que le vería nacer hacia 1550, aunque la mayor parte de su vida permaneció avecindado en Palencia y Carrión ${ }^{774}$. Se trata de una figura no demasiado estudiada, cuyo foco de acción se extiende durante el último tercio del siglo XVI y las primeras décadas de la centuria posterior entre las provincias de Palencia y Valladolid, en este último foco de acción, relacionado con los artistas clasicistas. La diversa participación en obras tanto góticas como clásicas nos sitúa ante un artista de difícil clasificación en torno al cual siempre circuló la polémica ${ }^{775}$. Su capacidad como arquitecto está probada como lo está también su irresponsabilidad profesional en relación al incumplimiento de sus contratos. A consecuencia de este comportamiento, Celaya se vio envuelto en gran número de pleitos, acabando con sus huesos en la cárcel en varias ocasiones e incluso huyendo de la justicia refugiándose en un monasterio ${ }^{776}$.

Durante la década de los setenta está documentada su actividad en el foco palentino. Podemos testimoniar su presencia en Carrión a partir de 1570 en que proporciona las trazas de la torre de la iglesia de Nuestra Señora de Belén. Recibe pagos por la misma hasta 1579, que señalan su participación directa como ejecutor, siendo apartado ese año por abandono del trabajo, tras un pleito con la iglesia ${ }^{777}$. No obstante, nada se conserva de esta fortificación, pues la que existe hoy día parte de un proyecto de 1663, como tendremos ocasión de analizar. Durante este intervalo de tiempo, participa en las obras de la iglesia de San Miguel en Magaz de Campos y en

\footnotetext{
${ }^{774}$ En 1586 declara tener aproximadamente 35 años. ZALAMA, Miguel Ángel. La arquitectura...Op.cit, pág. 246.

${ }^{775}$ LLAGUNO Y AMIROLA, Eugenio. Noticias...Tomo III. Op.cit, pp. 29-30. MARTÍ Y MONSÓ, José. Estudios...Op.cit, pp. 395, 488, 489, 503, 543, GARCÍA CHICO, Esteban, Documentos. Arquitectos, Op.cit, pp. 42-45, MARTÍN GONZÁLEZ, Juan José. Arquitectura barroca vallisoletana. 1967, HERAS GARCÍA, Felipe. Arquitectura religiosa del siglo XVI en la primitiva diócesis de Valladolid. Valladolid, 1975, BARRIO LOZA, J.A. y MOYA VALGAÑÓN, José G. Los canteros vizcaínos (1500-1800). Diccionario biográfico. Bilbao, 1981, BUSTAMANTE GARCÍA, Agustín, La arquitectura...Op.cit, pp. 501-502. PARRADO DEL OLMO, Jesús María. "Datos para el estudio de la arquitectura del siglo XVI en Palencia” en BSAA, nº52. Valladolid, 1986, pp. 384-392.

${ }^{776}$ ARAMBURU-ZABALA, Miguel Ángel. "Los maestros...Op.cit, pág. 164.

${ }^{777}$ ZALAMA, Miguel Ángel. La arquitectura...Op.cit, pág. 96.
} 
el coro de la iglesia de Santa María en Villamuriel de Cerrato ${ }^{778}$. Regresa a Carrión en 1575 para hacerse cargo de la obra de la iglesia de San Andrés, que se hallaba en proceso de reconstrucción. Pedro Castrillo había fallecido en 1563, sucediéndole Juan de Aras hasta finales de 1572 en que la iglesia se quedó sin maestros ${ }^{779}$. Tras más de dos años de paralización, en agosto de 1575 Celaya toma el relevo comprometiéndose a levantar los pilares cilíndricos y la bóveda de crucería de la capilla mayor $^{780}$, pero nuevamente desatiende este encargo, siendo denunciado ante la Chancillería de Valladolid en 1577. El fallo de 1581 resulta benevolente, pues tan sólo es compelido a finalizar la parte que había pactado ${ }^{781}$. No sabemos si cumplió o no con el trato; en cualquier caso de esta intervención sólo se conservó la capilla mayor, siendo reedificado el resto del templo a partir de 1608. Hasta ahora no se sabía, pero también participó en la reconstrucción del desaparecido templo carrionés de San Bartolomé, hasta 1579 en que el mayordomo decidió apartarle de la obra por incumplimiento del contrato, a pesar de que Celaya argüía que había realizado más de lo estipulado ${ }^{782}$.

Entre 1574 y 1577 está probada su participación en el claustro renacentista de San Zoilo, a tenor de las inscripciones que se conservan en los plementos de las bóvedas de crucería correspondientes a los tramos décimo quinto a vigésimo segundo $^{783}$. Su autoría de ocho de las veinticuatro bóvedas del claustro está avalada por una carta de pago de enero de $1582^{784}$. A través de otra, emitida un mes más tarde, Jesús Parrado constata la participación en la construcción de la noria del jardín que estaba en el claustro de este convento benedictino e intuye, antes de que compruebe documentalmente, la participación de Celaya en los templos carrioneses de Belén y San Andrés, dado que Celaya afirma haber llevado piedra desde estas iglesias para la construcción del claustro ${ }^{785}$.

\footnotetext{
778 PARRADO DEL OLMO, Jesús María. "Datos...Op.cit, pág. 246 y GARCÍA GUINEA, Miguel Ángel. "La iglesia de Santa María la Mayor de Villamuriel de Cerrato (Palencia)" en BSAA, n 18. Valladolid, 1952, pp. 40-43.

${ }^{779}$ ZALAMA, Miguel Ángel. La arquitectura...Op.cit, pág. 90.

${ }^{780}$ AHPP. Carr.Prot 5667. Andrés Sánchez (1575-1576), s/f.

${ }^{781}$ La ejecutoria que lo condena el 4 de noviembre de 1581 en ARCHV. Registro de Ejecutorias. Caja 1439,7 .

${ }^{782}$ AHPP. Carr.Prot 5729. Lázaro Santacruz (1579-1584), s/f.

${ }^{783}$ LLAGUNO Y AMÍROLA, Eugenio. Noticias...Tomo 1, Op.cit, pág. 211.

${ }^{784} \mathrm{Se}$ le abonan por las ocho capillas 51.368 maravedíes. ZALAMA, Miguel Ángel. $L a$ arquitectura...Op.cit, pág. 96, “Documentos...Op.cit, pp. 266-267.

${ }^{785}$ PARRADO DEL OLMO, Jesús María. “Datos...”. Op.cit, pp. 391-392.
} 
Simultaneando estas obras, Celaya había contratado la ejecución del cuerpo de la iglesia colegial de Roa, en Burgos, perteneciente al Obispado de Osma. Sin embargo, en agosto de 1576 decide ceder la obra a Juan de Naveda, maestro procedente de Aranda de Duero, seguramente para ocuparse de pleno en los trabajos carrioneses que le acuciazaban, pues el documento de traspasación se emitió desde la villa de Carrión y dice: "por ciertas causas e ocupaciones que tiene de presente, hizo dexaçión, çesión e trespasazión de toda la dicha obra ...el dicho Juan de Nabeda le dio e pagó al dicho Juan de Çelaya mill e çiento e sesenta rreales en dineros contados por el dicho dinero de la dicha obra y por todos los ofiçiales y obreros y de otro cualquier trabajo que en la dicha obra haya puesto hasta el día de oy... ${ }^{786 ” .}$

Llegada la década de los ochenta, Celaya viaja hasta Valladolid en 1581 para revisar la obra que Juan de Nates y Mateo Elorriaga habían realizado en el monasterio cisterciense de las Huelgas Reales, coincidiendo su dictamen favorable con el que dos años después emitiría Alonso de Tolosa ${ }^{787}$. Precisamente este maestro es quien proporciona las trazas de la iglesia palentina de San Mamés en Magaz de Pisuerga que Celaya acuerda finalizar ${ }^{788}$. Después pasaría a Palencia, donde desarrolló su trabajo hasta finales de siglo. El 4 de enero de 1584 se subasta la reparación del puente mayor de la capital palentina, para cuya intervención debían seguirse las trazas proporcionadas por Alonso de Tolosa, Juan de Ribero, Francisco del Río y Francisco de la Puente. Más de medio centenar de artistas se presentaron a la subasta, rematándose la obra en Juan de Celaya por 7.000 ducados. Sin embargo, se celebró nuevo remate y Felipe de la Cajiga se la adjudicó por mil ducados menos, cediéndole la mitad al maestro vizcaíno con el que se habría confabulado previamente. Ante el desconcierto de ambos, el arquitecto montañés Juan de Ribas solicita se reconsidere un nuevo remate menos costoso, logrando resultar el elegido. $\mathrm{Su}$ atrevimiento desencadena un contencioso con Celaya que en 1587 se desenvuelve a favor del vizcaíno, si bien no tuvo tanta suerte en el pleito contra el cantero Pedro Teruba, quien le denunció en razón de las deudas contraídas en la obra

\footnotetext{
${ }^{786}$ AHPP. Carr.Prot 5667. Andrés Sánchez (1575-1576), s/f.

${ }^{787}$ GARCÍA CHICO, Esteban. Documentos...Arquitectos, Op.cit, pp. 42-43.

788 MARTÍ Y MONSÓ, José. Estudios...Op.cit, pág. 543 y MARTÍN GONZÁLEZ, Juan José y URREA FERNÁNDEZ, Jesús. Inventario...2.Op.cit, pág. 188.
} 
del monasterio de San Isidro de Dueñas, finalizando Celaya en prisión en $1592^{789}$. El 1 de enero de dicho año, había regresado a Carrión para realizar una tasación en el convento de San Francisco, por las capillas arruinadas de San Bernardino y los Santos Cosme y Damián que Juan de la Cuesta había edificado y que pertenecían al Licenciado Díaz Flores. Celaya es elegido por el patrón, mientras que el maestro trasmerano escoge a su compatriota, Domingo de Cerecedo, determinándose el pago de doscientos ducados al comitente ${ }^{790}$.

Los años posteriores, hasta la primera década de la centuria posterior en que fallece, transcurren en la provincia de Valladolid, eminentemente en la capital, donde además de participar en las obras de la iglesia de las Angustias, diseña un escudo para el monasterio de San Benito ${ }^{791}$.

\section{Alonso de Tolosa \\ Maestro de cantería madrileño}

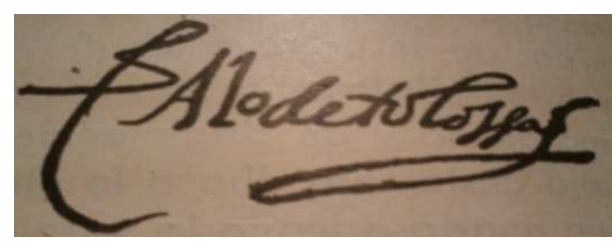

Único hijo varón del arquitecto Pedro de Tolosa, Alonso de Tolosa era oriundo de la población madrileña de San Martín de Valdeiglesias, que le vio nacer hacia 1549 y en cuya localidad dio las trazas para la remodelación de la capilla mayor de su ermita de Nuestra Señora de la Nueva antes de $1585^{792}$. Continuará la estela de su progenitor, por quien fue recomendado para ser contratado como aparejador en el Alcázar de Madrid y del Escorial desde 1583, así como del Alcázar de Segovia tras su muerte ${ }^{793}$.

\footnotetext{
${ }^{789}$ BARRIO LOZA, J.A. "Juan de Celaya y el puente mayor de la ciudad de Palencia" en PITTM, no 46 . Palencia, 1982, pp. 163-170.

${ }^{790}$ AHPP., Carr.Prot 5651. Pedro Saldaña (1592), fol 881 y ss.

${ }^{791}$ MARTÍ Y MONSÓ, José. Estudios...Op.cit, pp. 488-489, 503 y GARCÍA CHICO, Esteban. Documentos...Arquitectura, Op.cit, pp. 43-45.

${ }^{792}$ SÁNCHEZ ESTEBAN, Natividad. "Pedro y Alonso de Tolosa: un plano y nuevos datos" en ADHTA, nº3, 1991, pp. 316-320.

${ }^{793}$ LLAGUNO Y AMIROLA, Eugenio. Noticias...Tomo III. Op.cit, pág. 229.
} 
Se le atribuye la iglesia de Nuestra Señora de las Vacas en Ávila y en Toledo continuó las obras comenzadas por su padre en Navamorcuende ${ }^{794}$. Pero sin duda el grueso de su actividad artística y su labor de veedor la desarrolló en Valladolid, capital ésta última en la que residió, convirtiéndose en el introductor del estilo herreriano. Así, participó en las obras de la traída de las aguas de Argales para el Concejo de Valladolid, actuó como veedor de varias obras como la iglesia de las Huelgas Reales o la capilla mayor de San Benito el Viejo y fue aparejador en las obras de la seo de la capital desde 1582 hasta su muerte, continuadas posteriormente por Diego de Praves ${ }^{795}$.

Refiriéndonos a Palencia, en 1585 proporcionó las trazas de la iglesia de San Millán de Baltanás, rematada en Francisco del Río, de la capilla mayor de San Esteban de Villoldo, de la que se ocuparía Pedro de Mazuecos y de la torre de Santa María de Dueñas, cuya materialización fue posible gracias a la intervención de Juan de Mazarredonda y Pedro del Río ${ }^{796}$. En Carrión se ocupó ese mismo año de revisar el fortalecimiento que Juan de la Cuesta había realizado en el templo de Nuestra Señora de Belén y tasar con Juan de Nates la parte de la torre ejecutada por Juan de Celaya, cuya carta de pago emitió en marzo de $1586^{797}$. Probablemente gracias a la intervención del que por entonces era veedor oficial del Obispado de Palencia y criado de su majestad, su hermano, Juan de Tolosa tuvo acceso a este templo un año después, actuando igualmente como veedor de la inestable fábrica ${ }^{798}$.

Testó en diciembre de 1587 en Valladolid, donde falleció poco después, en enero de 1588, disponiendo como última voluntad ser enterrado en el convento franciscano de la capital ${ }^{799}$.

\footnotetext{
${ }^{794}$ CHUECA GOITIA, Fernando. Invariantes castizos de la arquitectura española. Madrid, 1947, pág.74 y SÁNCHEZ ESTEBAN, Natividad. "Pedro y Alonso de Tolosa...Op.cit, pág. 321.

${ }^{795}$ GARCÍA CHICO, Esteban. Documentos...Arquitectos. Op.cit, pp. 45-56 y BUSTAMANTE GARCÍA, Agustín. La arquitectura...Op.cit, pp. 168-169,213. El patrón de la obra de San Benito, don Juan Leguizamo, recurrió a Alonso de Tolosa pensando que hablaría en su favor, pues se entabló un pleito en 1585 entre aquel y Juan de Mazarredonda, del que salió victorioso el arquitecto trasmerano. GÓMEZ MARTÍNEZ, Javier. "Obras en San Benito el Viejo...Op.cit, pp. 333-348. Otros datos de Tolosa en URREA FERNÁNDEZ, Jesús. Catálogo monumental del antiguo Partido Judicial de Valoria la Buena. Valladolid, 1978, pp. 101, 131.

${ }^{796}$ GARCÍA CHICO, Esteban. Documentos...Arquitectos. Op.cit, pp. 26, 32, 52-57.

${ }^{797}$ ZALAMA, Miguel Ángel. La arquitectura...Op.cit, pág. 93 y los documentos transcritos en "Documentos...Op.cit, pp. 245-246.

${ }^{798}$ ADP. Carrión. Iglesia de Belén. Libro 15, 3º de Cuentas de Fábrica, (1584-1599), fol 24.

${ }^{799}$ SÁNCHEZ ESTEBAN, Natividad. "Pedro y Alonso de Tolosa...Op.cit, pp. 319-320.
} 


\subsection{LA ESCULTURA}

\section{INTRODUCCIÓN}

En los albores de la Edad Moderna, la escultura comenzó a jugar un papel significativo en el medio artístico carrionés, si bien no equiparable al de la arquitectura, cuyo éxito se basó en dos factores decisivos. El primero de ellos, fue el establecimiento en Carrión de los Condes de una clase noble e hidalga, a la que debe su apelativo la villa, así como el enriquecimiento progresivo del clero regular, que posibilitaron un pujante mecenazgo artístico laico y clerical, a partes iguales ${ }^{800}$.

El segundo agente debemos buscarlo en la tradición secular que existía en relación al asentamiento de talleres escultóricos en la villa desde la Edad Media. El referente más antiguo hunde sus raíces a mediados del siglo XII, en que un grupo de escultores de origen francés, influidos unos por las formas languedocianas y otros por las borgoñonas, cincelaron las portadas románicas de los templos de Santa María y Santiago ${ }^{801}$. Éste sería el precedente de otro taller, que se remonta a las décadas que pivotan entre los años 1230 y 1260, cuya producción fundamental consistió en la ejecución de sepulcros en la villa y su entorno, que siguen la tipología de los conservados en el monasterio burgalés de las Huelgas Reales. El exponente más significativo en Carrión lo constituyen el grupo de sarcófagos con decoración escultórica de la galilea del monasterio de San Zoilo, que revelan en su naturalismo una clara herencia francesa, notablemente de la catedral de Amiens ${ }^{802}$. Con semejantes antecedentes medievales, alcanzamos la Edad Moderna, a comienzos de la cual, asistimos a la proliferación de un taller de escultores durante el primer cuarto del siglo XVI, que, si bien conformado por artistas locales, estaba comandado a

\footnotetext{
${ }^{800}$ Sobre el patronato artístico, remítase al capítulo correspondiente.

${ }^{801}$ De consulta obligada sobre este tema es GARCÍA GUINEA, Miguel Ángel. El arte románico en Palencia. Palencia, 1961. Edición actualizada, Palencia, 1991.CUADRADO LORENZO, M ${ }^{\mathrm{a}}$ Flora. "La iglesia de Santa María de Carrión de los Condes y su programa escultórico" en PITTM, no 57. Diputación Provincial. Palencia, 1987, pp. 260-261.

${ }^{802}$ ARA GIL, Clementina-Julia. "Un grupo de sepulcros palentinos del siglo XIII: los primeros talleres de Carrión de los Condes, Pedro Pintor y Roi Martínez de Bureva" en II Curso de Cultura Medieval: Alfonso VIII y su época. Centro de Estudios del Románico. Aguilar de Campóo (Palencia), 1990, pp. 21-52 Y REVILLA VIELVA, Ramón. "Sepulcros de los Beni-Gómez" en PITTM, n 1. Diputación Provincial de Palencia. Palencia, 1949, pp. 39-51.
} 
partir de 1522 por un artista de origen francés llamado Jacques Bernal, bajo cuya supervisión debieron ser realizadas las tallas más antiguas del retablo plateresco de la iglesia de Belén, a tenor de la semejanza estilística con otras obras documentadas del escultor en la comarca de Tierra de Campos donde se manifiestan los ecos de la escultura burgalesa ${ }^{803}$. En líneas generales, el panorama escultórico de la provincia de Palencia está dominado por los testimonios románicos en la mitad norte, mientras que la parte sur es feudo de la escultura renacentista ${ }^{804}$. La ubicación de Carrión de los Condes en el Camino de Santiago, referente fronterizo entre ambos territorios, conjuga de manera equilibrada ambas manifestaciones, cuyos ejemplos más significativos tendremos oportunidad de analizar debidamente.

El barroco constituye el período en que los antiguos retablos son sustituidos por obras nuevas de muy variados estilos según su datación: desde las más sencillas obras clasicistas a otras neoclásicas, pasando por las propiamente churriguerescas. Igualmente, el sepulcro con el orante arrodillado se erige como la tipología más habitual de monumento funerario palentino a lo largo del siglo XVII, con ejemplos tan significativos en Carrión, como los arcosolios del Obispo Juan Molino Navarrete y sus progenitores en la iglesia de Santa María, el arcosolio del obispo de Guadix, Don Melchor Álvarez de Vozmediano, en San Andrés, el lucillo sepulcral de la condesa Teresa Peláez en la iglesia monasterial de San Zoilo o los nichos de los abades Alonso Barrantes y Juan Díaz Lavandero en el claustro del referido cenobio $^{805}$.

\section{MATERIALES}

En nada difieren los materiales empleados en Carrión de los de otros territorios hispanos. Como es usual, se recurre a la madera para la realización de tallas, bultos redondos, retablos, púlpitos o sillerías, siendo las más frecuentes las de

\footnotetext{
${ }^{803}$ CUESTA SALADO, Jesús. Jacques Bernal, Benito Elías y los Giralte de Villalpando. Aportaciones a la escultura del siglo XVI en el occidente de Tierra de Campos. Valladolid, 2011, pp. 13-21 y sobre obras de Jaques Bernal documentadas y atribuidas, consúltense pp. 23-94. Acerca del retablo, véase el capítulo relativo al templo de Belén.

${ }^{804}$ Resulta ineludible para estudiar ésta última, PORTELA SANDOVAL, Francisco José. La escultura...Op.cit.

${ }^{805}$ Sobre este tema, CASTRO MARTíN, Pablo L. "Arte funerario del siglo XVII en Palencia" en AIIICHP, tomo IV. Palencia, 1995, pp. 601-617.
} 
pino y nogal. De entre ambos, el primero resultó el material predilecto por su bajo coste, ligereza y fácil talla, muy empleado, como vimos, en la arquitectura. Se extraía fundamentalmente de la Comarca de Pinares de Soria, cuyo nombre señala la excelente calidad de su madera, siendo la más requerida la de Canicosa y Quintanar de la Sierra. Igualmente, el nogal, muy recurrente en las sillerías, procedía de Nogal de las Huertas, una población que distaba tan sólo ocho kilómetros de Carrión, ubicada en la margen izquierda del río homónimo y cuyo nombre, del mismo modo, indica la abundancia que se tenía de este material. El olmo y el aliso también se emplean, aunque de manera ocasional. Con independencia de la madera que se utilizase, este material debía presentarse “...seco, linpio, de buena ley y bien acondiçionado... ${ }^{806 " . ~ T a m b i e ́ n ~ s e ~ e s p e c i f i c a b a ~ q u e ~ l a ~ m a d e r a ~ “ . . . n o ~ s e a ~ c a ́ r d e n a ~ n i ~}$ yzquierda... ${ }^{807}$," esto es, que fuese de buena calidad y no tuviese una coloración gris azulada, pues cuando esto sucede significa que está infectada por hongos, si bien la resistencia y propiedades del material no se ven afectadas ${ }^{808}$ Para ocultar los nudos del material y producir un mayor deleite estético, las obras eran posteriormente policromadas y doradas ${ }^{809}$, excepción hecha del retablo de la capilla de San Nicolás en la iglesia de Santa María, que se dejó “en blanco", posiblemente por falta de medios.

Debido a los elevados costes, así como la escasez del material en el término, la piedra no se empleaba demasiado, salvo en la arquitectura funeraria, especialmente el alabastro. No obstante, en algún caso, como los sepulcros del obispo Navarrete y sus padres, el prelado optó por la madera policromada imitando la piedra, dado que ya había invertido una suma muy elevada en la reconstrucción de la capilla mayor y la ejecución del nuevo retablo. Un caso singular dentro de la estatuaria carrionesa lo constituye el Cristo atado a la columna del claustro del

\footnotetext{
${ }^{806}$ Así se indica, por ejemplo, en las condiciones para la ejecución del primer retablo documentado de la capilla mayor de Santa María (no el que la preside actualmente) contratado en 1648. AHPP. Carr.Prot 5238. Jerónimo López (1648), fol 130 y ss.

${ }^{807}$ Para ejecución del púlpito y reja de San Zoilo se precisa esta condición. AHPP. Carr.Prot 5692, Norberto de Sandoval y Guevara (1659), fol 346 y ss.

${ }^{808}$ CAPUZ LLADRÓ, Rafael. Materiales orgánicos. Maderas. Universidad Politécnica de Valencia, 2005, pág. 114.

${ }^{809}$ Sobre este tema, GÓMEZ-MORENO, María Elena. La policromía en la escultura española. Madrid, 1943, GÓMEZ-MORENO, Manuel. "La policromía en la escultura castellana" en AEA. Madrid, 1953, pp. 295-311y ECHEVARRÍA GOÑI, Pedro Luis. Policromía renacentista y barroca. Historia 16. Madrid, 1992.
} 
monasterio de San Zoilo, realizado en piedra caliza, tal vez con el fin de asegurar la perpetuidad de tan bella obra.

\section{LOS ARTÍFICES DE LAS OBRAS}

En este capítulo englobaremos a todos aquellos artistas que consagraron su vida a la escultura y participaron en alguna obra carrionesa, aunque su autoría en algunos casos no esté documentada, sino basada en principios estilísticos. Forman parte integrante del mismo tanto los imagineros, quienes, como su nombre indica, se encargaban de tallar imágenes, así como los entalladores, quienes, efectuaban figuras en relieve. Igualmente se incluyen a los ensambladores, aquellos artistas encargados de materializar la parte arquitectónica de los retablos, hecho que condujo a que en muchos casos se autodenominasen "maestros arquitectos", fenómeno muy extendido a lo largo de los siglos XVII y XVIII ${ }^{810}$. Todos estos artistas, que en ocasiones desempeñan varias de éstas competencias, se agrupaban en un taller dentro del gremio de carpinteros donde trabajaban en calidad de $\operatorname{artesanos}^{811}$. Conforme avanza el tiempo, advertimos que los contratos contemplan un mayor número de condiciones, especificando incluso los detalles ornamentales más nimios, lo que nos lleva a pensar que en el siglo XVIII disminuye la libertad de improvisación respecto a las centurias precedentes, al mismo tiempo que se engrandece proporcionalmente la figura del tracista de la obra.

\subsection{Artistas locales}

Salvo en el caso que se indique lo contrario, los artistas que figuran en este apartado se mantuvieron avecindados en Carrión a lo largo de su vida. Por ello, aunque no hemos hallado un documento que alegue su procedencia, el hecho de que su lugar de residencia se sitúe en la villa condal y que la actividad artística de todos

${ }^{810}$ COVARRUBIAS OROZCO, Sebastián de. Tesoro de la Lengua castellana o española. “. 2 volúmenes. Madrid, 1673-1674.

${ }^{811}$ Sobre este tema, PARRADO DEL OLMO, Jesús María. Talleres escultóricos del siglo XVI en Castilla y León: arte como idea, arte como empresa comercial. Colección Acceso al saber. Arquitectura y urbanismo, 2. Universidad de Valladolid. Valladolid, 2002. 
ellos no supere los límites exclusivamente jurisdiccionales de la misma, apunta a que eran carrioneses. La excepción en este grupo la constituye Pedro de Torres, artista palentino, de mayor renombre que sus compañeros, lo cual se justifica a tenor de la ejecución de trabajos en otros ámbitos fuera de la localidad que avalan su valía y reconocimiento.

\section{Pedro de Torres}

\section{Escultor y maestro de cantería palentino}

No debe ser confundido con el maestro de cantería trasmerano, Pedro de la Torre Bueras ni con el arquitecto y ensamblador madrileño Pedro de la Torre ${ }^{812}$. Vecino de Carrión de los Condes, este artista aparece vinculado a Adrián Álvarez y Pedro de la Cuadra en Valladolid, donde mezcla las tendencias romanistas de uno con las formas tardomanieristas del otro ${ }^{813}$.

En el monasterio de San Zoilo de Carrión, participó como arquitecto y escultor en la ejecución de su claustro alto, datándose su intervención entre 1577 en que fue finalizado el claustro bajo y 1604 en que se concluyen las obras de este sector. La participación de otros escultores como Bernardino Ortiz o Juan de Bobadilla dificulta la atribución de los doce medallones situados entre las arquerías renacentistas $^{814}$. Además de las arquerías de medio punto rebajadas que compartimentan las crujías, podría deberse a su mano los bustos de San Zoilo y San Benito, e incluso San Ildefonso, dado su carácter potente y la sobriedad de sus rostros de perfil cuadrático. Destacamos su actividad en el cenobio carrionés por el carácter temprano de la misma pero su excelente calidad que le facilitará el acceso a

\footnotetext{
${ }^{812}$ Sobre el mismo, CÁMARA FERNÁNDEZ, Carmen. “Arquitectura clasicista en Castilla. En torno a la figura del trasmerano Pedro de la Torre Bueras y sus obras de carácter religioso" en Juan de Herrera y su influencia. Actas del simposio. Camargo, 4-7 julio, 1992, pp. 251-257. Tampoco es el arquitecto y ensamblador madrileño Pedro de la Torre. Sobre el artista madrileño GARCIA CHICO, Esteban. Documentos...Escultores. Op.cit, pp. 312-315 y TOVAR MARTÍN, Virginia. "El arquitecto ensamblador madrileño Pedro de la Torre" en AEA, no 183, 1973, pp. 261-297.

${ }^{813}$ PORTELA SANDOVAL, Francisco José. La escultura...Op. cit, pág. 383. Al parecer, colaboró con el primero de ellos en la ejecución del retablo de la iglesia de San Miguel de Valladolid, donde trabajaría en 1595. CAMÓN AZNAR, José. La escultura y rejería...Op.cit, pág. 323.

814 CEÁN BERMÚDEZ, Agustín. Diccionario...Op.cit, pág. 44 y LLAGUNO Y AMIROLA, Eugenio. Noticias...Tomo I. Op.cit, pp. 211.
} 
otras obras promovidas por casas benedictinas como San Esteban de Ribas en Orense $^{815}$ o San Benito de Valladolid ${ }^{816}$.

Probablemente aprovechó su estancia carrionesa para realizar otras obras en la localidad, pues podemos vincular estilísticamente al escultor dos obras, que podemos datar en el último tercio de siglo. Una de ellas es una talla de San Juan Evangelista de un metro de altura ubicada en el retablo de la Epístola de la iglesia de San Andrés, antiguamente bajo la advocación de Nuestra Señora y hoy día dedicado a San José. Se trata de una figura de corte romanista, dotada de amplios mantos, que resalta entre las imágenes más tardías del resto del retablo, para el cual fue reaprovechada. La otra obra es una Inmaculada ubicada en el museo de Santa Clara que hemos atribuido al círculo del artista, a tenor de la rotundidad de la simétrica figura y la geometría y rigidez de sus facciones.

En Palencia están documentadas muchas de sus obras, como es el caso de la remodelación de las capillas del crucero de la iglesia de San Juan Bautista de Santoyo y la contratación con Don Fausto Ruiz de Montoya del retablo de la capilla de la Epístola bajo la advocación de Juan Bautista en el monasterio de Santa Clara de Palencia, en $1599^{817}$. También debemos a Pedro de la Torre la tasación que hizo del retablo mayor de la iglesia de Santa Eulalia de Palenzuela, ejecutado por Hernando de la Nestosa entre 1595 y 1600 . Fue elegido por la iglesia mientras que de parte del escultor figuró García de Arredondo. Para las Agustinas Canónigas, llevó a cabo en 1604 la ejecución de los retablos colaterales ${ }^{818}$. En el antiguo convento de jesuitas de la capital del Carrión, actual iglesia de Nuestra Señora de la Calle, realizó una obra magnífica: el retablo de San Jerónimo, en el que estaría

\footnotetext{
${ }^{815}$ DURO PEÑA, Emilio. El monasterio de San Esteban de Ribas de Sil. Instituto de Estudios Orensanos "Padre Feijoo". Orense, 1977, pp. 91,92.

${ }^{816}$ WATTEMBERG SAMPERE, Federico. Museo Nacional de Escultura de Valladolid. Aguilar. Madrid, 1966, pág. 176, MARTÍ Y MONSÓ, José. Estudios...Op.cit...pág. 554, RODRÍGUEZ MARTÍNEZ, Luis. Historia del Monasterio de San Benito el Real de Valladolid. Valladolid, 1981, pp. 270 y ss. Otras fuentes afirman que Pedro de Torres finalizó el retablo de San Benito de Valladolid en 1596. WATTEMBERG SAMPERE, Federico. Museo Nacional de Escultura de Valladolid. Aguilar. Madrid, 1966, pág. 176.

${ }^{817}$ PORTELA SANDOVAL, Francisco José. Escultura...Op.cit, pág. 383 y URREA FERNÁNDEZ, Jesús y MARTÍN GONZÁLEZ, Juan José. Inventario...Volumen 1. Op.cit, pág. 41.

${ }^{818}$ PORTELA SANDOVAL, Francisco José. Escultura...Op.cit, pp. 365 y 384.
} 
trabajando hacia $1606^{819}$. Está documentada su participación en 1607 en el sagrario de la Catedral de Palencia, pero fue obra conjunta con Juan Sanz de Torrecilla y su yerno Alonso Núñez ${ }^{820}$. En 1609, cuando el escultor se encontraba en el último tramo de su vida, el monasterio de Sahagún le contrató para la traza del nuevo retablo mayor, encargo que no pudo concretarse al fallecer poco después, encargándose del proyecto Fray Pedro Sánchez ${ }^{821}$.

\section{Nicolás de Vega}

\section{Ensamblador carrionés}

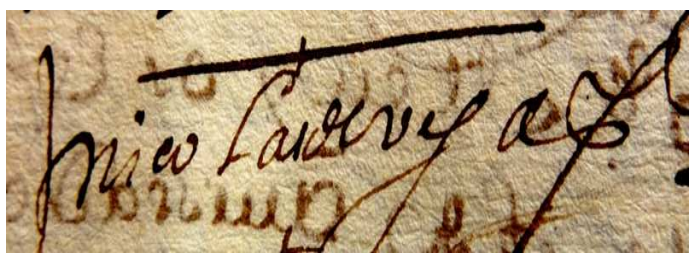

No se conocen demasiados datos de este ensamblador, cuya actividad se centró en el entorno carrionés a lo largo del segundo tercio del siglo XVII.

Su figura resulta relevante para el patrimonio de Carrión, en tanto en cuanto a él se debe la ejecución del retablo mayor de la iglesia conventual de Santa Clara, que llevaría a cargo junto a los ensambladores carrioneses Pedro Santos y Pedro López en 1633. Los tres artistas se ocuparían de asentar el antiguo retablo de la casa clarisa en la capilla mayor de la iglesia del convento de San Francisco, cuyos frailes no podían costearse una obra nueva ${ }^{822}$. El retablo de la casa clarisa se ajusta a la tendencia pujante de corte clasicista en el primer tercio del siglo XVII en Castilla, al mismo tiempo que conjuga la tipología de relicario que tanto reclamo comenzó a tener en Valladolid por estos años. Esta obra fue promovida, como tantas otras del convento, por la venerable monja Sor Luisa de la Ascensión, que debió costear la obra con una donación del rey Felipe IV, pues precisamente en 1632, el monarca le

\footnotetext{
${ }^{819}$ GARCIA CUESTA, Timoteo. "El primitivo santuario de Nuestra Señora de la Calle" en $B S A A$, tomo 33. Valladolid, 1967, pp. 115-142 y "La cofradía de Jesús Nazareno en Palencia" en BSAA, tomo 36. Valladolid, 1970, pp. 11-112.

${ }^{820}$ GARCÍA CUESTA, Timoteo. "La Catedral de Palencia según los Protocolos" en BSAA, n⿳19. Valladolid, 1952-1953, pág. 72.

${ }^{821}$ PÉREZ DE CASTRO, Ramón. "Precisiones...Op.cit, pp. 401-402.

${ }^{822}$ AHPP. Carr.Prot 5229. Jerónimo López (1633), s/f.
} 
envió dos mil ducados ${ }^{823}$. De nuevo los tres ensambladores carrioneses se erigieron como fiadores del dorador vallisoletano Gaspar Díaz del Pozo, cuando éste doró y estofó el retablo referido en $1641^{824}$.

Junto al carrionés José Infante realiza el retablo mayor de la iglesia de San Pedro de Frómista en 1636, cuya traza había sido proporcionada por Francisco Trejo. En la iglesia parroquial de Nuestra Señora de las Nieves de Villamuera de la Cueza, realiza el ensamblaje de su retablo mayor junto a Manuel de Salceda, siguiendo el proyecto que Domingo de Ciruelo entregó en 1649. Ambas obras fueron doradas por Gaspar Díaz del Pozo, que figura nuevamente vinculado a Nicolás de $\mathrm{Vega}^{825}$.

A este ensamblador carrionés se le debe la ejecución de un tabernáculo desaparecido para la iglesia conventual de Santo Domingo de Carrión, que realiza en 1652 junto al carrionés Juan Bautista Pérez ${ }^{826}$. La última referencia del artista data de 1654 en que ejerce como fiador de Gaspar Díaz del Pozo cuando éste se compromete a dorar el retablo mayor de la iglesia de Santa María, conservado actualmente en la capilla mayor de la iglesia de San Andrés ${ }^{827}$.

\section{Pedro Santos}

\section{Ensamblador carrionés}

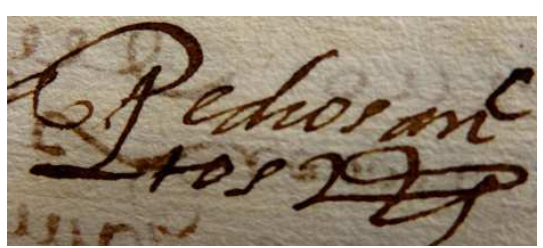

Coetáneo del referido Nicolás de Vega, también resultan exiguos los datos conocidos del mismo, pero su referencia resulta obligada por las obras en las que participa. Como señalamos con anterioridad, fue uno de los ejecutores del actual retablo que preside la capilla mayor del convento de Santa Clara, del que recibió

\footnotetext{
${ }^{823}$ La carta, fechada el 25 de febrero de 1633 fue encontrada en la huerta del convento cuando fue restaurada en 1763. Está transcrita en GARCÍA BARRIUSO, Patrocinio. La monja de Carrión...Op.cit, pp. 71-72.

${ }^{824}$ AHPP. Carr.Prot 5234. Jerónimo López (1641-1642), s/f.

${ }^{825}$ URREA FERNÁNDEZ, Jesús y MARTÍN GONZÁLEZ, Juan José. Inventario...II, Op.cit, pp. 84 y 259 .

${ }_{826}$ AHPP. Carr.Prot 5525. Tomás Pérez, (1652), s/f.

${ }^{827}$ AHPP. Carr.Prot 5527. Tomás Pérez (1654), fol 108.
} 
carta de pago en 1633 y participó como fiador de Gaspar Díaz del Pozo cuando éste lo doró en $1641^{828}$. Tal vez esta obra sirviese como modelo del retablo de la capilla mayor del extinto convento de Santa María de Benevívere, concertado entre Pedro Santos y el también carrionés Blas Ibáñez en 1647 por 2.800 reales ${ }^{829}$. A través de las condiciones podemos determinar que se trataba de una obra clasicista de dos cuerpos divididos en tres calles con lienzos, y ático provisto de Calvario, con la imagen de Nuestra Señora presidiendo el conjunto.

Es uno de los fiadores de Bernardo Sánchez y Julián de León, maestros de cantería y albañilería respectivamente, en la construcción de la capilla del Licenciado Pastor de la iglesia de Santa María de Carrión en $1656^{830}$. La última vez que Pedro Santos figura en la documentación es en calidad de fiador, con Pedro López, del maestro arquitecto Felipe Berrojo, en la obra que, junto a Julián de León realiza en el claustro de Benevívere ${ }^{831}$.

\section{La familia Infante}

\section{Ensambladores carrioneses}

Con este nombre conocemos a tres artistas carrioneses que trabajaron en la villa y alrededores: Hernando, Santiago y Lope Infante, cuyos lazos de consanguinidad desconocemos. E incluso se conserva una referencia de un ensamblador que posiblemente estuviese relacionado con ellos, llamado José Infante, que en 1636, ensambla el retablo de la capilla mayor de San Pedro de Frómista junto a Nicolás de Vega, se declara vecino de Carrión ${ }^{832}$.

\footnotetext{
${ }^{828}$ AHPP. Carr.Prot 5229. Jerónimo López (1633), s/f y Prot 5234, Jerónimo López (1641-1642), s/f.

${ }^{829}$ Contrato y condiciones en AHPP. Carr.Prot 5429. Francisco Moro Saldaña (1647), s/f.

${ }^{830}$ AHPP. Carr.Prot 5689. Norberto Sandoval y Guevara (1656), s/f.

${ }^{831}$ AHPP. Carr.Prot 5693. Norberto Sandoval y Guevara (1660) fol 438 y ss.

${ }^{832}$ URREA FERNÁNDEZ, Jesús y MARTÍN GONZÁLEZ, Juan José. Inventario...II, Op.cit, pág. 84.
} 


\section{Hernando Infante.}

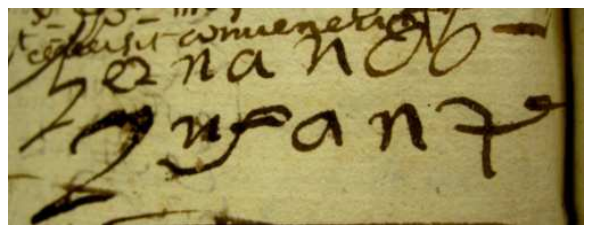

Debemos situar su nacimiento en torno a 1557, ya que cuando en 1607 testifica en favor del síndico del convento de San Francisco en el pleito que mantuvo contra los marqueses de Aguilar por tener desatendida la capilla mayor, de la que eran patrones, declara ser de edad de cincuenta años ${ }^{833}$. Se esposó con María de Colindres, perteneciente con toda probabilidad a la familia de ensambladores con ese patronímico, oriundos de la localidad cántabra homónima. Con ella tuvo al menos tres hijos que bautizó en la iglesia de Santa María: Juan, Antonio y Felipe, bautizados en 1597,1604 y 1605 , respectivamente ${ }^{834}$.

En 1594 se data su primera obra documentada, lamentablemente no conservada: un escritorio de nogal para la iglesia de San Julián que se encarga de tasar el maestro de carpintería carrionés Santiago Díaz de Sigüenza ${ }^{835}$. En cambio, sí ha dejado testimonio gráfico del retablo que ensambló en 1600 para la capilla mayor de la ermita de San Juan de Cestillos, pintado por el maestro de Boadilla del Camino, Pedro de Pedrosa. La obra se expone en el museo de arte sacro de Santiago, del que forma parte desde que en 1993 fuese robado el banco, conformado por el sagrario, seis pinturas de los Apóstoles y cuatro Virtudes ${ }^{836}$. Se trata de una obra de gran sencillez y líneas clásicas, presidida por la imagen de San Juan Bautista y coronada por una Inmaculada gótica, reaprovechada probablemente del retablo anterior.

Además de ensamblador, pudo ejercer como escultor, pues en uno de sus contratos, concretamente el que concierta en julio de 1607 con la iglesia palentina de San Miguel de Gozón de Ucieza, se compromete a realizar el retablo colateral dedicado a la Virgen del Rosario “de talla y escultura, ensanblaxe y architetura"837. No obstante, también podría ser uno de tantos casos en que el ensamblador

\footnotetext{
${ }^{833}$ ARCHV. Pleitos Civiles. Quevedo (F) 1557. Expediente 1, fol 82.

${ }^{834}$ ASMCC. Libro $1^{\circ}$ de Bautizados (1595-1617), fol 12,55 y 65.

${ }^{835}$ AHPP. Carr.Prot 4595. Juan Birtus (1592-1594), s/f.

${ }^{836}$ FRANCIA LORENZO, Santiago. Gentes de estas tierras. Notas de Archivo, 2. Palencia, 1987, pp. 284-285. El documento original en AHPP. Carr.Prot 5382. Francisco Moro Saldaña (1599), s/f.

${ }^{837}$ AHPP. Carr.Prot 5297. Pascual López (1607), s/f.
} 
subcontrata el resto de labores con otros artistas. Un año después de que se finalizase la parte escultórica del retablo, se contrató su policromía y dorado con Justo de Espinosa, pintor avecindado en Palencia. Por la misma escritura se compromete también a dorar y estofar el retablo que Hernando Infante había realizado para la cofradía de la Vera Cruz de Villamorco ${ }^{838}$.

Participa como testigo en enero de 1608 de la venta de un buey de siete años entre dos vecinos carrioneses, previa licencia concedida por el anterior poseedor del animal (procedente de Villanueva del Río) para que se produzca la transacción, pues aún no había recibido los 14 ducados que debía abonarle en agosto de $1609^{839}$. De nuevo en enero de dicho año es testigo del concierto entre el carpintero Juan de la Maza y su cliente, Francisco Álvarez de la Vega, para que derribe su vivienda de Cestillos y levante otra de nueva planta por cien reales y un carro de leña vieja ${ }^{840}$.

En 1613 junto a Ambrosio de Buega, Juan de la Maza y Juan Santos, participa como veedor de las condiciones redactadas para las obras de fortalecimiento de la torre desaparecida de Santa María que debían ejecutar los carrioneses Francisco de Reinaldos y Juan González de la Mata, maestros de carpintería y albañilería, respectivamente. Todos ellos aceptaron las condiciones establecidas introduciendo, eso sí, algunas modificaciones en lo que se refiere al número de tirantes, además del refuerzo de las tornapuntas y la colocación de unas cuñas en el primer arco del paño nuevo que mira a Santa Clara ${ }^{841}$.

Junto al maestro de cantería cántabro Francisco de Bálcava y el carpintero Juan Santos, el 4 de septiembre de 1614 efectúa una tasación de “...lo que bale y mereze el sitio que se dexa para cuadrar la plaza de Santa María de las casas que se compraron de Billasante y de Jerónima de Aguilar..." donde se construiría la Casa del Capitán, una vivienda destinada a la residencia eventual de oficiales enviados a Carrión para reclutar soldados. Una vez valorado el solar en seiscientos

\footnotetext{
${ }^{838}$ AHPP. Carr.Prot 5391. Francisco Moro Saldaña (1608), fol 337 y ss.

${ }^{839}$ AHPP. Carr.Prot 5392. Francisco Moro Saldaña (1609), s/f.

${ }^{840}$ AHPP. Carr.Prot 4578. Juan Aranda Treceño (1608-1609), s/f.

${ }^{841}$ AHPP. Carr.Prot 5396. Francisco Moro de Saldaña (1613), s/f.
} 
reales, el carpintero Juan Carnicero, avecindado en Cisneros se compromete a levantar la edificación, firmándose el contrato en marzo de $1615^{842}$.

La última mención del artista nos sitúa en 1618, año en que el mayordomo del templo de Belén le abona sesenta y seis reales en concepto del “...adereço que hiço del rretablo de la dicha yglesia que estaua para se caer e indecentemente... ${ }^{843}$,"

\section{Lope Infante.}

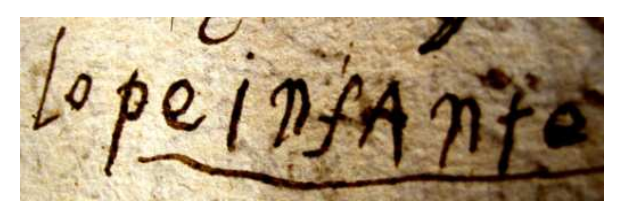

Sabemos que era ensamblador por las menciones documentales, si bien no tenemos constancia de su participación directa en ninguna obra.

Estuvo casado con una tal María Aguada, con la que al menos tuvo un hijo llamado Antonio, bautizado en la iglesia de Santa María de Carrión el 8 de agosto de $1604^{844}$. Esto nos permite retrasar el nacimiento del artista, al menos a 1580.

En 1618, junto a otros vecinos de Carrión, actúa como fiador del maestro de cantería cántabro Juan de Cajigosa y de Juan González de la Mata, maestro albañil y cantero carrionés, en la obra del reparo de la torre de la iglesia de Santiago ${ }^{845}$. En 1619 el maestro trasmerano Francisco de la Maza había sido encarcelado por haber derribado la vivienda de Alonso Pérez Carretero situada junto a la plaza de los Caldereros, obligándose, en recompensa, a rehacerla tal y como se encontraba previamente. Este compromiso fue posible gracias al pago de la fianza por parte de Lope Infante y el albañil carrionés Francisco Rodríguez ${ }^{846}$. Parece ser que era una persona fiable, pues En 1621 ejerce como avalista de Juan González de la Mata, en este caso en la obra del cerco del convento de San Miguel y Santa Isabel ${ }^{847}$.

\footnotetext{
${ }^{842}$ AHPP. Carr.Prot 5211. Jerónimo López (1615), s/f.

${ }^{843}$ ADP. Carr. Iglesia de Belén. Libro 16, 4 de Fábrica (1616-1646), fol 44.

${ }^{844}$ ASMCC. Libro $1^{\circ}$ de bautizados (1595-1617), fol 60.

${ }^{845}$ AHPP. Carr.Prot 5401. Francisco Moro de Saldaña (1618), s/f.

${ }^{846}$ AHPP. Carr.Prot 5215. Jerónimo López (1619), s/f.

${ }^{847}$ AHPP. Carr.Prot 5404. Francisco Moro Saldaña (1621), fol 56 y ss.
} 


\section{Santiago Infante}

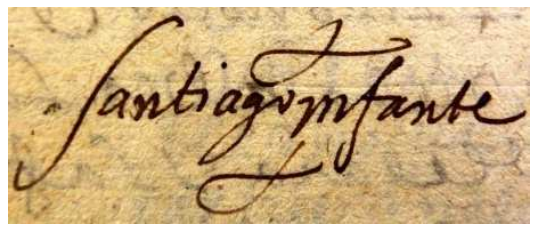

Estaba esposado con una carrionesa llamada Lucía Pérez, quien, a pesar de ser analfabeta, lucha con todas sus fuerzas por sacar de la cárcel a su marido, que se encontraba preso en 1622 por haber contraído algunas deudas que le demandaba María Martín, viuda de Pedro Cicero. Doña Lucía, solicita permiso a Santiago Infante, del que declara ser "hijodalgo", para presentarse en el juicio con su dote y arras “...y lo que más me comvenga...”, en concepto de fianza, pero no sabemos qué desenlace tuvo el litigio ${ }^{848}$

La iglesia desaparecida de San Juan Bautista o del Mercado, que se ubicaba en la plaza homónima, extramuros de la villa, poseyó una capilla bajo el patronato del linaje Barrio. Uno de sus miembros, don Juan de Barrio de la Vega, encargó en 1617 a nuestro ensamblador, la ejecución de un retablo dedicado a San Juan, de traza clasicista y gran sencillez. Su hijo, Francisco de Barrio contrató una década más tarde a Santiago Infante, para que tallase un calvario en madera de nogal o peral, que suponemos constituiría el remate de la obra precedente. Lamentablemente la obra se perdió; sin embargo, para nuestra fortuna, se realizó un bosquejo del mismo a continuación de la redacción de las condiciones del contrato. A través del mismo observamos que se trata de una pieza de un solo cuerpo dividido en tres calles separadas por columnas dóricas y un remate con aletones avolutados muy simples $^{849}$.

Para la completa reedificación del templo de San Andrés que tuvo lugar a partir de 1608 y que fue dirigida por el trasmerano Francisco Martínez de Bálcava, el retablo mayor tuvo que ser desmontado. No volvió a ser asentado hasta 1619 en que este sector estaba completamente finalizado, y fue Santiago Infante quien se hizo cargo de esta labor ${ }^{850}$.

\footnotetext{
${ }^{848}$ AHPP. Carr.Prot 4849. Juan Díaz Pajaza (1622-1623), fol 191 y ss.

${ }^{849}$ Sabemos del contrato porque se realiza un traslado de la escritura original en 1627, cuando se vuelve a contratar a Santiago Infante. AHPP. Carr.Prot 5172. Jerónimo Laso (1627), fol 865 y ss. ${ }^{850}$ ADP. Carr. San Andrés. Libro $2^{\circ}$ de Cuentas de Fábrica (1614-1637), s/f.
} 


\section{Manuel de Salceda o Salcedo Ensamblador carrionés}

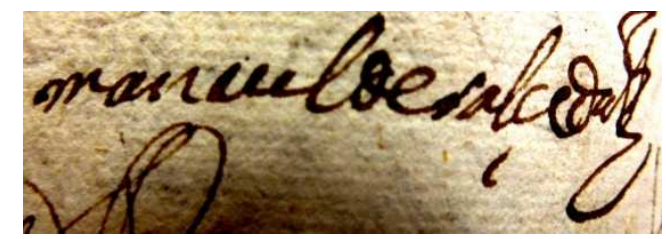

Desarrolla su actividad durante el tercer cuarto del siglo XVII en Carrión y los alrededores. Si bien en la documentación figura como maestro ensamblador, también ejecuta labores de carpintero. En cualquier caso observamos que dominaba el corte y la unión de piezas de madera, aplicadas tanto en labores arquitectónicas como de índole escultórica.

En 1649 localizamos a Salceda en Villamuera de la Cueza, ensamblando el retablo mayor de la iglesia parroquial de Nuestra Señora de las Nieves junto a Nicolás de Vega y Domingo Ciruelo ${ }^{851}$. En el convento de Santo Domingo, tasa el tabernáculo que habían realizado los carrioneses Juan Bautista Pérez y Nicolás de la Vega para el retablo mayor en 1652. Salceda es designado por parte del cenobio mientras que el artista escoge al maestro de carpintería Juan de Inestrosa. Ambos, de mutuo acuerdo, certifican que la obra se ajusta a las condiciones establecidas ${ }^{852}$. Interviene en 1656 en las obras de reconstrucción de la capilla del licenciado Pastor de la iglesia de Santa María, ejecutando una reja de madera que ya no se conserva ${ }^{853}$. Durante el cuatrienio del abad de San Zoilo, don Plácido Quirós, desempeñado entre 1657 y 1661, se decidió adaptar la zona presbiterial del nuevo templo a través de la ejecución de un enrejado que separase la capilla mayor de la nave, y hacer un púlpito para dirigir las oraciones. El encargado de realizar ambas obras, en madera, fue Manuel de Salceda, quien se comprometió con el mayordomo del cenobio el 29 de junio de 1659. Los trabajos debían finalizarse en tres meses, durante los cuales daría entregada una reja de pino decorada con balaustres y jalonada por tres puertas de nogal, material en que debía estar constituido el púlpito, de ambón ochavado y entrepaños almohadillados ${ }^{854}$.

\footnotetext{
${ }^{851}$ URREA FERNÁNDEZ, Jesús y MARTÍN GONZÁLEZ, Juan José. Inventario...II, Op.cit, pág. 259.

${ }^{852}$ AHPP. Carr.Prot 5525. Tomás Pérez (1652), s/f.

${ }^{853}$ AHPP. Carr.Prot 5689. Norberto Sandoval y Guevara (1656), s/f.

${ }^{854}$ AHPP. Carr.Prot 5692. Norberto de Sandoval y Guevara (1659), fol 346 y ss.
} 
En Paredes de Nava se le encarga en 1666 la ejecución del retablo presbiterial de la iglesia de Santa María, dedicado a Nuestra Señora de Cantomenudo, situada en el camarín ${ }^{855}$. En 1671 junto a Francisco Reinaldos, se compromete a ejecutar los reparos de la iglesia que poseía el antiguo hospital de la Herrada, ubicado extramuros de Carrión, en la real calzada ${ }^{856}$. A mediados de ese mismo año y de nuevo en compañía de Reinaldos, se compromete a reconstruir todas las cubiertas a par y nudillo que faltaban de ejecutar en las naves del templo de San Andrés ${ }^{857}$. La carta de pago data del 29 de mayo de 1672, correspondiente a la obra “... de cantería y carpintería el año passado de setenta y vno..." en que se abonan 5.034 reales incluidas las demasías, establecidas por los maestros Santiago de Pedrosa y Domingo de Lovizera en 330 reales, de los cuales aceptaron 234, cediendo el resto como limosna al templo ${ }^{858}$.

Cuando dicta testamento en 1679, asegura que la iglesia de San Julián le había abonado casi dos mil reales por la obra ejecutada “...del altar mayor y colaterales de la dicha yglessia... ${ }^{859}$. No podemos determinar qué tipo de intervención realizó, pero descartamos que se tratara del ensamblaje de los retablos, pues éstos no serían contratados hasta 1699. Debía encontrarse enfermo por entonces, pues en 1682 ya había fallecido y sus herederos se ven obligados a devolver ciertas sumas al templo por el dinero adelantado ${ }^{860}$.

El hallazgo del documento referido nos permite diferenciar a nuestro Manuel de Salceda de otro artífice homónimo que pudiera ser su hijo y que igualmente desempeñaría la doble faceta de ensamblador y maestro de carpintería. De él

${ }^{855}$ URREA FERNÁNDEZ, Jesús y MARTÍN GONZÁLEZ, Juan José. Inventario...I, Op.cit, pág. 219.

${ }^{856}$ Escritura y condiciones de la obra en AHPP. Carr.Prot 5775. Andrés Simón Aguilar (1670-1671), fol 655 y ss.

${ }^{857}$ Las condiciones, firmadas el 14 de marzo de 1671 en ACP. Provisorato. Legajo 164. El concierto de la obra entre ambos maestros se firma el 24 de mayo de 1671, fijándose una cantidad por el total de la misma que ascendía a 4800 reales. AHPP. Carr.Prot 5775. Andrés Simón Aguilar (1670-1671), fol 649 y ss.

${ }^{858}$ La carta de pago es de 29 de mayo de 1672, correspondiente a la obra “... de cantería y carpintería el año passado de setenta y vno..." en que se abonan 5034 reales en que se incluyen las demasías. AHPP. Carr.Prot 5776. Andrés Simón Aguilar (1672), fol 326 y ss. Ambos artistas habían denunciado al mayordomo de San Andrés a comienzos de 1672 para que se les abonase lo correspondiente. ACP. Provisorato. Carrión. Legajo 147-198, nº 26425.

${ }^{859}$ AHPP. Carr.Prot 5889, Blas Vela Álvarez (1679-1681), fol 274 y ss.

${ }^{860}$ Quentas y partixas de los vienes muebles y rraízes que dejó Manuel de Salçeda, difunto, vecino que fue d'esta uilla Carrión, entre su muger y herederos, año de 1682. AHPP. Carr.Prot 5897. Blas Vela Álvarez (1686-1705), s/f. 
conservamos algunas referencias. En 1685 asentó el retablo procedente de la iglesia de Santa María en la capilla mayor de la iglesia de San Andrés, ensamblado por el carrionés Juan Bautista Pérez en $1648^{861}$. Con Alonso de Reinaldos, vástago del referido Francisco Reinaldos, que siguió el oficio de su padre, se encarga de la obra de la iglesia de Santo Tomás en Villaturde por 1.015 reales, bajando todos los prometidos que diferentes maestros como los hermanos Rebollar, ganaron en las posturas y mejora. El remate de la misma se produce el 12 de junio de $1695^{862}$.

\section{Juan Bautista Pérez \\ Ensamblador y entallador carrionés}

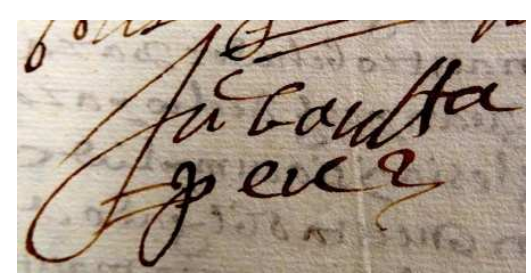

Al igual que Manuel de Salceda, del que fue coetáneo, Juan Bautista Pérez trabajó igualmente como ensamblador y como maestro carpintero. Se esposó con doña Ana de Reinaldos, quien actuó como su fiadora en algunas de sus obras ${ }^{863}$. Posiblemente ésta sería hija del maestro de carpintería carrionés Francisco de Reinaldos, con quien trabajaría nuestro artista en alguna obra. Su religiosidad se manifiesta a través de su pertenencia a la cofradía de San Ildefonso, ubicada en la capilla homónima del convento de Santo Domingo de Carrión, de la que era miembro al menos desde 1630.

Ese año es designado por el prior del cenobio para que valore los daños de la mencionada capilla, que se habían producido a raíz de la intervención del carrionés Juan González de la Mata en la misma, motivo que desencadenó un farragosos litigio. El maestro albañil escogió a los maestros trasmeranos Juan de Cajigosa y Domingo del Río para que tasasen la obra ${ }^{864}$. Si bien Juan Bautista Pérez no debía poseer demasiados conocimientos en el ámbito de la cantería, es seguro que su declaración sería favorable al cenobio por su vinculación al mismo, que era, en definitiva, lo que realmente importaba. De hecho el fallo resolvió en julio de 1638

\footnotetext{
${ }^{861}$ ADP. Carrión. San Andrés. Libro $3^{\circ}$ de Cuentas de Fábrica (1672-1718), fol 75.

${ }^{862}$ AHPP. Carr.Prot 5756. Juan de la Serna Reinaltos (1694-8), s/f.

${ }^{863}$ AHPP. Carr.Prot 5238. Jerónimo López (1648), fol. 130 y ss.

${ }^{864}$ AHN. Clero Secular-Regular 5352 s/f. Santo Domingo, Obra y también en AHPP. Carr.Prot 4858. Juan Díaz Pajaza (1632-1633), fol 230.
} 
que Juan González de la Mata debía abonar trescientos ducados a la casa mendicante. Su actuación en el pleito propició la elección del artista para la ejecución del sagrario de la capilla mayor del templo en 1652 junto a Nicolás de Vega $^{865}$.

Asentó en 1632 los retablos que se habían caído en la iglesia de Belén, a consecuencia de los derrumbes producidos por la mala cimentación del templo ${ }^{866}$. Junto al maestro de carpintería Francisco Reinaldos y el cantero Santiago de Pedrosa repara en 1643 las casas del conde de Osorno en Carrión ${ }^{867}$.

La única obra conservada del artista en Carrión -al menos que tengamos constancia- es el retablo mayor de la iglesia de Santa María, concertado el 8 de noviembre de 1648 para ser finalizado en un plazo máximo de dos años ${ }^{868}$. No obstante, como explicaremos en su debido momento, esta obra clasicista se conserva en la iglesia de San Andrés desde 1685, presidiendo su capilla mayor, modificada parcialmente por la sustitución de la escultura de la Virgen entronizada por el santo apóstol y la adición del tabernáculo que lo cobija y las tres Virtudes que lo rodean. Dada la semejanza estilística entre el retablo referido y el que, procedente del desaparecido hospital de Santa María, se ubica hoy en la capilla mayor de la ermita de la Piedad -un cuerpo de tres calles, hexástilo, columnas de fuste entorchado, aletones y frontones curvos-, podemos atribuir la ejecución de esta obra al ensamblador carrionés, que la realizaría por los mismos años.

En 1654 era miembro de la ermita de la Vera Cruz de Carrión, pues dicho año se desencadena un litigio entre el abad y algunos cofrades por el nombramiento de los mismos, entre los que figura nuestro $\operatorname{artista~}^{869}$. Entre 1655 y 1657 se encarga de la ejecución del retablo mayor de la iglesia de Santiago, desarrollando simultáneamente el oficio de mayordomo del templo. De este modo compensaría el bajo precio en que se remató la obra -2.650 reales- en comparación con los

\footnotetext{
${ }^{865}$ AHPP. Carr.Prot 5525, Tomás Pérez (1652), s/f.

866 GÓMEZ PÉREZ, Enrique. GÓMEZ PÉREZ, Enrique. El Belén, sus personajes y sus símbolos, N5, Palencia, 2009, pág. 16, a su vez de ADP. Carrión. Iglesia de Nuestra Señora de Belén. Libro $4^{\circ}$ de Cuentas de Fábrica (1616-1646), fol 182.

${ }^{867}$ AHPP. Carr.Prot 5235. Jerónimo López (1644), fol. 323 y ss.

${ }^{868}$ AHPP. Carr.Prot 5238. Jerónimo López (1648), fol. 130 y ss.

${ }^{869}$ ACP. Provisorato. Carrión. Legajo 1106-146, nº 17705.
} 
quinientos ducados -5.550 reales aproximadamente- que recibió del mayordomo de Santa María, es decir, casi el doble de la mencionada cantidad ${ }^{870}$.

Si bien es cierto que las dimensiones de aquél -ocho metros de altura y más de seis de ancho- no tenían parangón con esta obra más modesta- siete metros de altura por cuatro metros de anchura-. Siguiendo esquemas clasicistas como sus obras anteriores, el retablo estaría presidido por la imagen de la Virgen y coronado por la escultura ecuestre de Santiago, el único testimonio gráfico que se ha conservado del conjunto.

\section{Santiago Carnicero}

\section{Ensamblador de Villada}

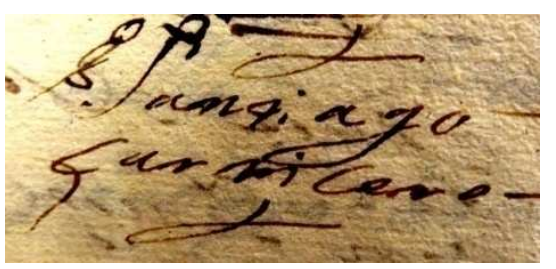

Yerno del ensamblador Pablo Villazán ${ }^{871}$, pertenecía a una familia de artistas originarios de la localidad palentina de Villada, muy próxima a Frechilla, donde estableció su taller, integrado, entre otros, por su sobrino, Carlos Carnicero ${ }^{872}$. Santiago Carnicero trabajó en el Obispado palentino durante las últimas décadas del siglo XVII y las primeras de la centuria siguiente tanto de ejecutor, como de tracista, e incluso de veedor a partir de 1687 , en que fue nombrado por el obispo Pedraza “...maestro maior y veedor general architecto en el arte de fabricar retablos de ensanblage y talla... ${ }^{873, "}$

Su obra más célebre y la más temprana de las que efectuó en Carrión, fue la ejecución del retablo mayor de la iglesia de Santa María, que preside actualmente la capilla mayor. La reconstrucción de este sector fue promovida por el obispo don Juan de Molino Navarrete, quien al adquirir su patronazgo decidió remodelar la cabecera románica y sustituirla por una barroca, dotando a este espacio de

\footnotetext{
${ }^{870}$ AHPP. Carr.Prot 5206. Antonio López (1655-1656), s/f.

${ }^{871}$ GARCÍA CUESTA, Timoteo. "La cofradía de Jesús Nazareno en Palencia" en BSAA, no 36. Valladolid, 1970, pág. 92.

872 PÉREZ DE CASTRO, Ramón. "Un retablo en Boadilla de Rioseco (Palencia) de Santiago Carnicero y Tomás de Sierra” en BSAA, nº71. Valladolid, 2005, pág. 243.

${ }^{873}$ PÉREZ DE Castro, Ramón “Un retablo en Boadilla...Op.cit, pág. 244.
} 
monumentos funerarios y como no, de retablo ${ }^{874}$. Si bien la obra, prototipo de un barroco exhuberante, fue ejecutada en 1684, el ensamblador contrató un carretero para el porte de la madera procedente de los pinares de Soria en septiembre del año precedente ${ }^{875}$. A pesar de su corta experiencia, el artista dio buena muestra de su saber hacer, cuidando hasta el más nimio detalle, todo provisto de una rica ornamentación a base de motivos cactiformes, angelillos y voluminosos pámpanos. Concluido el retablo, Alonso Campos, dorador avecindado en Mazuecos de Campos, se encargó de dorarlo y estofarlo, concertándose para ello con el mayordomo del templo en mayo de 1685 y fue Carnicero quien actuó como fiador del artista ${ }^{876}$.

En 1688 ejecutó el retablo mayor de la iglesia de Santa Eugenia de Becerril de Campos ${ }^{877}$. También en 1688 ejecuta el retablo de la iglesia parroquial de Meneses de Campos y en 1692 el de Piña de Campos ${ }^{878}$. En 1689 realizó la caja del órgano de la catedral de Palencia ${ }^{879}$. Conocemos otras obras en las que proporciona trazas, como en el retablo mayor de San Hipólito de Támara, de 1689 o el de Autilla del Pino, dos años después, sin olvidar las modificaciones que introdujo en 1703 en el retablo de Santiago de Medina de Rioseco, trazado por Joaquín de Churriguera y esculpido por el escultor del Bierzo, Tomás de Sierra ${ }^{880}$.

Cuando en 1699 se contrata la ejecución de los retablos de la iglesia de San Julián, Carnicero se encarga de realizar el diseño del tabernáculo del retablo mayor, coincidiendo nuevamente en esta obra con Diego de Suano, que proporcionó la traza así como con Tomás de Sierra, a quien se propuso como tasador ${ }^{881}$. No obstante, en

\footnotetext{
${ }^{874}$ MARTÍNEZ GONZÁLEZ, Rafael. “El Obispo de Palencia Fray Juan del Molino y la capilla mayor de la Iglesia de Santa María de Carrión de los Condes” en PITTM, n 56. Palencia, 1987, pp. 260 y ss.

${ }^{875}$ AHPP. Carr.Prot 5890. Blas Vela Álvarez (1682-1685), fol 395 y ss.

${ }^{876}$ Ibídem, fol 575 y ss.

877 REDONDO AGUAYO, Anselmo "Monografía histórica de la villa de Becerril de Campos y noticia biográfica de sus hijos más ilustres" en PITTM, n9. Palencia, 1953, pág. 145.

${ }^{878}$ URREA, Jesús y MARTÍN GONZÁLEZ, Juan José. Inventario.1. Op.cit, pág. 100, 201, 230. También en PARRADO DEL OMO, J. Ma . Piña de Campos...Op.cit, pág. 16.

${ }^{879}$ LÓPEZ CALO, José. LÓPEZ CALO, José. La música en la Catedral de Palencia. II, Actas capitulares (1685-1931), apéndices documentales. Palencia, 1981, pág. 17. pág. 17.

${ }^{880}$ GARCÍA CHICO, Esteban. Documentos...Escultores. Op.cit, pág. 396 y PÉREZ DE CASTRO, Ramón. "Un retablo...Op.cit, pág. 244. En 1699 volvieron a verse las caras en Herrera de Valdecañas, Palencia, perteneciente por entonces al Obispado de Burgos, donde Suano realizaba su retablo mayor y Carnicero acudió en calidad de veedor. PAYO HERNÁN, Jesús. El retablo barroco en Burgos...volumen 2.Op.cit, pág. 289.

${ }^{881}$ FERRERO MAESO, Concepción. "El mecenazgo en Actas...Op.cit, pág. 595, a su vez de AHPP. Carr.Prot 5019. Agustín García Miranda (1699-1700), s/f.
} 
lugar de respetar su plan original de doce columnas, el artista concibió una estructura de tan sólo tres lados cuya visión frontal semeja un templete hexástilo. También se encargó de la traza de los retablos colaterales, donde, a pesar de su preferencia mostrada por la columna salomónica, a la que recurre en la mayor parte de sus obras, optó por el estípite, si bien es cierto que esto fue por deseo expreso del patrón, para que ambos retablos quedasen acordes al retablo mayor ${ }^{882}$. En 1703 se hizo cargo del retablo vallisoletano de Castroponce de Valderaduey, donde también volvió a intervenir el artista berciano ${ }^{883}$.

Su última obra fue el retablo de la ermita del Amparo en Boadilla de Rioseco, cuya escultura corrió a cargo de Tomás de Sierra. Si bien se desconoce su fecha de ejecución, de la tasación que del mismo hizo en 1719 el ensamblador Gabriel Pérez colegimos una datación algo anterior, pues dicho año Carnicero ya había fallecido $^{884}$.

\section{Pablo de Villazán \\ Ensamblador palentino}

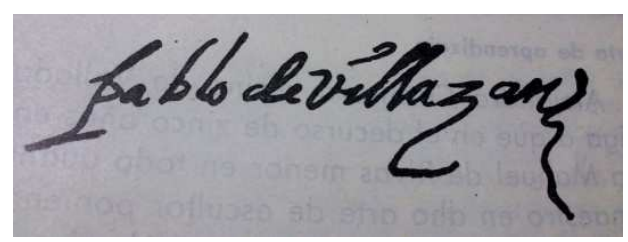

El hecho de que se mantenga avecindado en Palencia nos permite sospechar que ésta fuera su ciudad natal ${ }^{885}$. Su actividad abarca el primer tercio del siglo XVIII, siempre dentro de la provincia de Palencia. Una prueba de la endogamia de artistas a la que ya nos referimos al estudiar a los maestros de cantería, es que su hija contrajo matrimonio con el ensamblador palentino Santiago Carnicero ${ }^{886}$.

Su obra más temprana es la talla que realiza en una de las puertas de la nave de la iglesia de San Miguel de Ampudia, hacia 1701, con un copete de talla abultada

\footnotetext{
882 “...Es condiçión que el cuerpo segundo se a de executar con toda la talla que tiene la dicha traza, quitando las colunas y poniendo los estípittes que correspondan a la rretablo principal...” AHPP. Carr.Prot 5019. Agustín García Miranda (1699-1700), s/f.

${ }^{883}$ URREA FERNÁNDEZ, Jesús y BRASAS EGIDO, José Carlos. Catálogo provincial de la provincia de Valladolid. Antiguo Partido judicial de Villalón. Palencia, 1993, pág. 16.

${ }^{884}$ PÉREZ DE CASTRO, Ramón. "Un retablo...Op.cit, pp. 241-258.

${ }^{885}$ AHPP.Carr.Prot 5023. Francisco Ruiz Sandoval (1713-15), s/f.

${ }^{886}$ GARCÍA CUESTA, Timoteo. "La cofradía...Op.cit, pág. 92.
} 
y hojarasca ${ }^{887}$. Está documentada su participación en retablos palentinos como el de la iglesia parroquial de Magaz en 1709 o el retablo mayor de la iglesia de la Cofradía de Jesús Nazareno en la misma capital, de $1716^{888}$. También se encargó de realizar en 1718 el tabernáculo desaparecido del retablo de la iglesia de Santa Eulalia de Paredes de Nava, que no fue asentado hasta $1732^{889}$. En Medina de Rioseco, intentó adjudicarse dos retablos: el de la ermita de Castilviejo en 1714 y el de la Capilla de la Concepción de la iglesia de Santiago en 1720, siendo ambos rematados en Carlos Carnicero. Junto a José Díaz de Matías, realizó las trazas del retablo mayor y los colaterales de la iglesia de Santa Eufemia de Autillo, obras materializadas por Pedro Bahamonde en $1732^{890}$.

En Carrión tan sólo está documentada su participación en las trazas de los retablos colaterales de la iglesia de San Andrés, cuyas condiciones proporciona en septiembre de 1714. De tipología churrigueresca, ambos fueron ejecutados por el ensamblador de Laredo, Pedro Alvo Cavada. Los retablos debían seguir el modelo de los que se conservaban en la capilla mayor del monasterio de San Zoilo, hoy desaparecidos $^{891}$. De modo que, aunque Villazán proporcionó la traza de los mismos, se vió restringida su libertad creativa a la hora de diseñar estas magníficas obras.

\section{Juan Manuel Becerril}

\section{Ensamblador y escultor avecindado en Palencia}

Becerril desarrolla su labor en la provincia de Palencia durante la segunda mitad del siglo XVIII como retablista y escultor. En algunas ocasiones aparece denominado bajo el título de "maestro arquitecto", término que, si bien se utilizaba para otorgar prestancia a un artista que ejecutaba la arquitectura de los retablos, en este caso también se refiere a un artífice vinculado a las labores arquitectónicas de

\footnotetext{
${ }^{887}$ PARRADO DEL OLMO, Jesús. Ampudia: Iglesia de San Miguel. Palencia, 1991, pág. 28.

${ }^{888}$ URREA, Jesús y MARTÍN GONZÁLEZ, Juan José. Inventario...1, Op. cit, pp. 44 y 191.

889 ZALAMA RODRÍGUEZ, Miguel Ángel. "El retablo mayor de la iglesia de Santa Eulalia en Paredes de Nava (Palencia)" en BSAA, n ${ }^{\circ} 54$, Valladolid, 1988, pág. 372.

${ }^{890}$ GARCÍA CHICO, Esteban. Medina de Rioseco...I. Edición 1979, Op.cit, pág. 190 y del mismo Documentos...Escultores...Op.cit, pp. 426-429 y 384-385.

${ }^{891}$ AHPP.Carr.Prot 5023. Francisco Ruiz Sandoval (1713-15), s/f.
} 
carpintería. En este sentido, en 1764 colabora junto al alarife Leonardo Iglesias en la plasmación del proyecto del último cuerpo de la torre de la iglesia de Santiago de Carrión, trazada por José Iglesias, consistente en la ejecución de una cúpula con linterna. Por entonces, aparece avecindado en Paredes de $\mathrm{Nava}^{892}$.

Para la capital del Carrión ejecuta el grupo del Nacimiento ubicado en las paredes del coro del lado de la Epístola de la Catedral y el retablo mayor del convento de las Agustinas Canónigas. También debemos a su mano el retablo mayor de la ermita de Nuestra Señora de Revilla, en Baltanás, obra de $1768^{893}$. Uno de sus mejores trabajos lo constituye el retablo mayor de Frechilla, realizado en 1771 y se le atribuye el retablo de Villasarracino de 1799, con un gran número de relieves de la vida de Cristo $^{894}$.

Tan sólo está documentada una obra suya en Carrión de los Condes, que fue ejecutada a raíz de la visita del obispo de Palencia Juan de Mollinedo a la villa en 1781, quien hizo constar que la imagen de San Andrés que presidía la hornacina central del retablo mayor no tenía “...más que el pecho, caueza y espalda de su ymagen”, por lo que instó a su mayordomo a la ejecución de una nueva escultura y tabernáculo barroco para albergar la misma. Además de estas obras, Becerril realizó las tres Virtudes teologales que circundan al apóstol, por las cuales se le otorgó carta de pago en $1782^{895}$. La escultura de San Andrés, de un metro y medio de altura,

${ }^{892}$ VIGURI, Miguel de y Sánchez, José Luis. Op.cit, pp. 371-373.

${ }^{893}$ URREA, Jesús y MARTÍN GONZÁLEZ, Juan José. Inventario...1, Op. cit, pp. 17, 32, 93.

${ }^{894}$ MARTÍN GONZÁLEZ, Juan José. Escultura...Op.cit, pp. 77,138 y 406 y URREA, Jesús y MARTÍN GONZÁLEZ, Juan José. Inventario...2, Op. cit, pág. 276-277.

${ }^{895}$ Reproducimos los gastos referidos: “...de los jornales de sesenta y seis días de quattro ofiziales vno a seis reales y medio, ottro lo mismo, otro, seis rreales, y otro, cinco, que cada día componen veintte y quattro rreales y multtiplicados por sesentta y seis días, hazen mill quinientos ochentta y quattro rreales por los mismos sesentta y seis días, jornales del maestro. Por su personal ttrabajo y disposición de la obra, a quinze rreales suman nueuecienttos y nobentta, de matteriales de madera, cola, clauos y demás, doscienttos y cincuenta rreales. Por el herraje de la puertta del sagrario y cascarón, veintte y quattro rreales, por la figura del pastor con el cordero en dicha puertta, quarentta, por los dos niños de los lados de San Andrés con los attributtos, cien rreales, por las ttres figuras de las virttudes fee, esperanza y charidad, ttrescientos rreales. Por la hechura de San Andrés, ttrescienttos cincuenta rreales, por estofarle, quinienttos y cincuentta, por grattificazión a dos ofiziales que vinieron de Palencia a asenttar la obra 425 ochentta rreales, por los alquileres de ttres cauallerías del maestro y ofiziales y gasto de zeuada en los días que estubieron en el mesón, cincuentta rreales, enttendiéndose sólo del gasto de dichas cauallerías, pues la manuttención de dicho maestro y oficiales la suplió dicho Don Antonio Pérez, y nada cuentta a la yglesia en los cinco días que comieron, zenaron y durmieron en su casa, según que ttodo consta en el rreziuo que a conttinuación de la cuentta dio dicho maestro con fecha ttres de octtubre de el corriente año de ochentta y dos...". ADP. Carrión. San Andrés. Libro 5º de Cuentas de Fábrica (1753-1795), fol 424v, 425 y 447. 
destaca por su ejecución y recuerda en la oscilación de la pierna elevada sobre el tronco nudoso de su cruz a la imagen homónima del retablo de Frechilla.

\subsection{Artistas de otras procedencias}

Dentro ámbito hispano, trabajaron en Carrión otros artistas de gran calidad técnica, consecuencia de la cual fue el prestigio del que gozaron. Su foco de acción es muy variado por lo que las intervenciones en la villa palentina se producen de manera puntual.

\section{Miguel de Espinosa}

\section{Escultor e imaginero burgalés}

Hijo del dorador Andrés de Espinosa, nació en Burgos hacia 1510, capital de su formación artística ${ }^{896}$. Se sabe por la documentación, que hacia 1528 trabajaba para Diego de Siloé en la portada de la sacristía de la Catedral de Granada, cuya influencia marcará su estilo caracterizado por una energía desbordante ${ }^{897}$. Entre 1535 y 1537 se encontraba realizando dos retablos en San Francisco de Medina de Rioseco, obras contratadas por Cristóbal de Andino pero ejecutadas por el insigne Espinosa dada la falta de pericia del arquitecto, escultor y rejero burgalés ${ }^{898}$. También por estos años de 1535 a 1537, sin que podamos determinar la fecha exacta, participó en la decoración de los medallones de parte inferior de la fachada de San Marcos de León y en dos de las crujías de su claustro ${ }^{899}$. En enero de 1539, se le abonan 2.720 maravedíes por la talla de los tondos bajos de la galería

\footnotetext{
${ }^{896}$ Sobre este escultor pueden consultarse tres obras fundamentales AGAPITO Y REVILLA, Juan. "El escultor en piedra: Miguel de Espinosa en Rioseco y otras partes" en Boletín del Museo Provincial de Bellas Artes de Valladolid, nº16. Valladolid, 1929, pp. 21-32, MARTÍN GONZÁLEZ, Juan José. "Miguel de Espinosa: escultor e imaginero en Goya, n²1, 1957, pp. 145-152, PORTELA SANDOVAL, Francisco José. La escultura...Op.cit, pp. 208 y ss.

${ }^{897}$ CAMÓN AZNAR, José. La escultura y rejería españolas del siglo XVI. Summa Artis. Volumen 18. Madrid, 1961, pág. 223.

${ }^{898}$ DOMÍNGUEZ BORDONA, Jesús. Proceso inquisitorial...Madrid, 1933, pág. XIV, MARTÍN GONZÁLEZ, Juan José. "Miguel de Espinosa...Op.cit, pp. 148, CAMÓN AZNAR, José. "La escultura...Op.cit, pág. 147.

${ }^{899}$ SÁNCHEZ BORDONA, Ma Dolores. Juan de Badajoz....Op.cit, pp. 197 y 296-297.
} 
plateresca de la Catedral nueva de Salamanca ${ }^{900}$. Estos diez bustos, caracterizados por la viveza y perfección del modelado, los habría realizado, por tanto, hacia 1538.

Por entonces Espinosa ya había fijado su residencia en Palencia y estaría participando simultáneamente en la ornamentación de las bóvedas del claustro de San Zoilo, concretamente en la panda oriental, lo cual se corresponde con la parte arquitectónica ejecutada por Juan de Badajoz "el Mozo", incluida la portada plateresca, en la que Espinosa tallaría el Crucificado que la preside. Su intervención se iniciaría hacia 1537, con la inauguración del claustro, sin poder concretar cuánto tiempo se prologó ésta. La impronta de Miguel de Espinosa, patente en ménsulas y plementos y claves de las bóvedas es inconfundible por la expresividad y movimiento que infunde a los rostros de pómulos marcados presentes en los personajes bíblicos, insuflándoles vida, tal y como plasman las figuras de Adán y Eva. La variedad de gestos y actitudes es infinita y el gusto por el detalle se manifiesta en el repertorio ornamental de grutescos y niños afrontados que hacen de esta panda un lienzo tupido de piedra, mucho más rico que el resto.

Muy discutida es la autoría del Cristo atado a la columna ubicado en el nicho del lienzo oriental del claustro y que se hallaba originalmente en la galilea o capilla condal hasta al menos los años sesenta. Ponz, Azcárate o Camón Aznar defienden su atribución, datándola como obra de hacia 1535, como muestra de su pericia técnica para su posterior participación en el claustro ${ }^{901}$.

A partir de 1540 en que Rodrigo Gil de Hontañón dirige la obra de la capilla del Colegio de Fonseca, proyectada por Diego de Siloé y materializada por Pedro de Ibarra, Miguel de Espinosa intervendrá en la decoración de la parte interna de su cimborrio $^{902}$. Junto a los Aguirre, es responsable de la ejecución de ocho medallones donde figuran los bustos de Evangelistas y Padres de la Iglesia, temática de la misma índole que desarrollaba en el claustro de San Zoilo por estos años. La

${ }^{900}$ CHUECA GOITIA, Fernando. La Catedral Nueva de Salamanca: historia documental de su construcción. Universidad de Salamanca. Salamanca, 1951, pp. 146-147.

${ }^{901}$ PONZ, Antonio. Viaje...Tomo XI. Op.cit pág. 200 y AZCÁRATE RISTORI, José María de. Escultura...Op.cit, pág. 182. A este respecto, Camón Aznar dice: "Se le atribuye... [a Miguel de Espinosa]", pero no añade ninguna opinión al respecto. CAMÓN AZNAR, José. "La escultura...Op.cit, pág. 224.

${ }_{902}$ SENDÍN CALABUIG, Manuel. El Colegio mayor del arzobispo Fonseca. Universidad de Salamanca. Salamanca, 1977, pág. 75. 
actividad de Espinosa en obras castellanas por estos años es imparable, por lo que resulta harto complicado determinar si por entonces continuaría plasmando su genio en el cenobio benedictino, donde también está documentada la fugaz participación de su hermano y Esteban Jamete en estrecha colaboración, como ya había sucedido en los retablos riosecanos.

Posteriormente, es posible que se trasladase de nuevo a Carrión para esculpir el sepulcro de la condesa Doña Aldonza, ubicado en la capilla mayor de la iglesia conventual de Santa Clara. Se relaciona estilísticamente con la portada de Santiago de Medina de Rioseco, que efectuaría el burgalés en $1548^{903}$. Si bien la condesa de Osorno había fallecido en la localidad madrileña de Pinto en 1542, sus restos no fueron trasladados hasta 1547 a la ciudad condal ${ }^{904}$. Por ello, debemos pensar que la obra de alabastro debió ser encargada en el transcurso de estos cinco años. Donde mejor se puede admirar el cincel del artista es el frente del sepulcro, donde figuran los bustos de los Santos Juanes, primorosamente labrados, flanqueando la heráldica de los Osorno. En ellos se conjuga el expresionismo y la elegancia clásica propios de Siloé, con quien se formó el artista.

Por último, ha sido atribuido a su taller, a nuestro parecer acertadamente, el sepulcro- retablo del abad don Juan Sarmiento que se ubicaba originalmente en la sala capitular del extinto convento de Santa María de Benevívere, parte del cual se conserva en la iglesia del antiguo priorato de San Torcuato ${ }^{905}$. Según la descripción proporcionada por la Comisión de Monumentos palentinos en 1852, la monumental obra, de casi nueve metros de altura, habría sido realizada en 1568. El recurso siloesco de las eses avolutadas y la fuerza expresiva del Padre Eterno permiten vincularlo a los bustos que Espinosa realiza en San Zoilo, así como a otras obras

\footnotetext{
${ }^{903}$ PARRADO DEL OLMO, Jesús María. “El renacimiento...”. Op.cit, pág. 763.

904 AHPP. Legado Simón Nieto 19. Rollo 827. Trascripción del documento de cómo se efectuó el traslado de los huesos de doña Mencía y el poder otorgado por las clarisas a Fray Luis de Siles para efectuar el traslado en GARCÍA BARRIUSO, Patrocinio. La monja de Carrión: Sor Luisa de la Ascensión Colmenares Cabezón: Aportación documental para una biografía. Madrid, 1986, pp. 5558 .

905 PERAL VILLAFRUELA, Santiago. Estudio para la puesta en valor del patrimonio cultural de Carrión de los Condes como fuente de desarrollo rural. Monasterio de Benevivere-San Torcuato. Inédito. Depositado en el Ayuntamiento de Carrión de los Condes, 2007, pp. 24 y 41.
} 
atribuidas a su mano, como el Padre Eterno de la Ermita del Otero de Frómista y otra imagen del mismo tema en Boadilla del Camino ${ }^{906}$.

\section{Antonio Morante}

\section{Escultor y entallador de origen zamorano}

Se conocen muy pocos datos de este artista, por lo que resulta harto complicado perfilar su figura. Según Ceán Bermúdez procedía de la localidad zamorana de San Cebrián de Castro, a unos veinte kilómetros de la capital, donde se mantuvo avecindado ${ }^{907}$. De este entallador, bastante desconocido, tenemos noticias gracias a Martí y Monsó que recoge la escritura de demanda que presentó Inocencio Berruguete a Pedro González de León -para quien estaba realizando su sepulcro y el de su mujer, María Coronel- por no pagarle el importe que había estimado el tío del artista, Alonso Berruguete, como habían acordado en el contrato. Antonio Morante, vecino por entonces de Medina de Rioseco, se erige como testigo presentado por Inocencio Berruguete. El litigio tuvo lugar en 1553, y por entonces Morante dice tener veintiséis años, por lo que nacería hacia $1527^{908}$.

Este historiador, asegura, según consultó en el archivo desaparecido del monasterio de San Zoilo, que Morante participó en la ejecución de las tallas de su claustro renacentista, en el sector correspondiente a las bóvedas realizadas por Juan de Celaya, desde el tramo quince en adelante ${ }^{909}$. De modo que le correspondería el sector dedicado a la descendencia benedictina, en el que se aprecia una gran pericia técnica, casi comparable a la de Miguel de Espinosa, si bien sin su fuerza expresiva. Igualmente se le atribuye la talla del Cristo atado a la columna del claustro, al que nos referimos con anterioridad como posible obra de Espinosa. Se erigen como partidarios de su autoría Paul Lafond, Jesús Urrea, Martín González con Ceán Bermúdez a la cabeza de esta teoría, que la data hacia 1575, vinculándola estilísticamente con lo realizado por Morante en el lienzo norte del claustro, que fue

\footnotetext{
${ }^{906}$ Estas últimas obras han sido estudiadas en PARRADO DEL OLMO, Jesús María. "Sobre algunas esculturas del siglo XVI" 1999 en BSAA, n 69-70. Valladolid, 2003-2004, pp. 311-312.

${ }^{907}$ CEÁN BERMÚDEZ, Agustín. Diccionario Histórico...Volumen 3.Op.cit, pág. 192.

${ }^{908}$ DOMÍNGUEZ BORDONA, Jesús. Proceso inquisitorial contra el escultor Esteban Jamete. Blass. Madrid, 1933 y MARTÍ Y MONSÓ, José. Estudios...Op.cit, pp. 174-178.

${ }^{909}$ Ibídem.
} 
finalizado precisamente en $1577^{910}$. Portela Sandoval, manteniendo la autoría de Morante, considera ciertamente tardía una obra como la referida, en la que observa cierta herencia siloesca ${ }^{911}$.

\section{Gregorio Fernández}

\section{Escultor de Sarria (Lugo)}

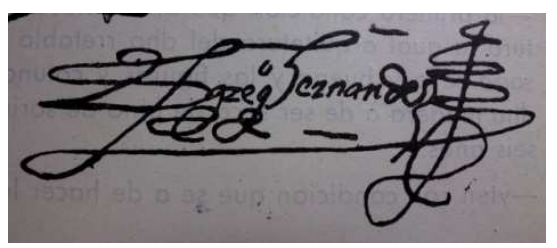

Conocidísima por cualquier historiador que se precie, es la figura del escultor gallego, nacido en la localidad lucense de Sarria en 1575. Es por ello que no vamos a incidir en aspectos sobradamente conocidos de su actividad artística, desarrollada fundamentalmente en Valladolid hasta 1636, donde se convirtió en el referente más imitado de escultura barroca de carácter religioso ${ }^{912}$. En Palencia están atribuidas a Fernández y su taller algunas obras interesantes como la Inmaculada de tamaño natural ubicada en el retablo colateral de la iglesia de Santa Eulalia en Paredes de Nava, una imagen de San Isidro Labrador ubicado en un retablo de la nave del

910 CEÁN BERMÚDEZ, Agustín. Diccionario Histórico...Volumen 2.Op.cit, pág. 45. LAFOND, Paul. Op.cit, pág. 142, MARTÍN GONZÁLEZ, Juan José. "Miguel de Espinosa...Op.cit, pág. 149 y URREA FERNÁNDEZ, Jesús y MARTÍN GONZÁLEZ, Juan José. Inventario....2, Op.cit, pág. 63.

${ }^{911}$ PORTELA SANDOVAL, Francisco José. La escultura...Op.cit, pág. 392.

${ }^{912}$ Sobre Gregorio Fernández, remitimos algunos de los estudios más interesantes. GARCÍA CHICO, Esteban. "Tres obras de Gregorio Fernández" en BSAA, n 6. Valladolid, 1939-1940, pp. 93-110 y del mismo, Gregorio Fernández. Escuela de Artes y Oficios Artísticos. Valladolid, 1952, TRIVIÑO MÉNDEZ, Ramón. Gregorio Fernández: su persona y su obra. Lugo, 1976, URREA FERNÁNDEZ, Jesús. "En torno a Gregorio Fernández" en BSAA, n³9, Valladolid, 1973, pp. 245-260, del mismo "Gregorio Fernández en Sahagún de Campos. Notas para el estudio del arte en León (IV); homenaje en el IV centenario de la muerte de Juan de Juni” en Tierras de Léon, n²7. León, 1977, pp. 41-45, “Acotaciones a Gregorio Fernández y su entorno artístico" en BSAA, nº46, Valladolid, 1980, pp. 375-396, Gregorio Fernández. Valladolid, 1983, "Gregorio Fernández y el modelo icónico de Valladolid" en Juan de Mesa (1627-202). III Jornadas de Historia del Arte celebradas en Córdoba del 28 al 30 de noviembre de 2002. Córdoba, 2003, pp. 169-184, MARTIN GONZALEZ, Juan José. Escultura barroca castellana, 1, Op.cit, pp. 143-245 y del mismo, El Escultor Gregorio Fernández. Patronato Nacional de Museos. Madrid, 1980, OLIVÁN JARQUE, María Isabel. "Gregorio Fernández y el retablo mayor de la iglesia de las Fecetas de Zaragoza" en Boletín del Museo e Instituto Camón Aznar, nº10, 1982, pp. 94-104, FERNÁNDEZ DEL HOYO, Ma Antonia. "Oficiales del taller de Gregorio Fernández y ensambladores que trabajaron con él" en BSAA, n⿳ 49, Valladolid, 1983, pp. 347-374, VÁZQUEZ SANTOS, Rosa. "Gregorio Fernández y Sarria: nuevas claves del taller familiar y su obra" en Goya, n³22, 2008, pp. 47-52 y del mismo, "Gregorio Fernández, un entallador sarriano del siglo XVI. Nuevos datos sobre el origen y familia de Gregorio Fernández" en $B S A A, n^{\circ} 65$. Valladolid, 2009, pp. 259-262, VV.AA. Gregorio Fernández: antropología, historia y arte en el Barroco. Valladolid, 2008, VÁZQUEZ GARCÍA, Francisco. "La obra del escultor Gregorio Fernández en Ávila” en Cuadernos abulenses, n40, Ávila, 2011, pp. 211-218. 
Evangelio de la iglesia de Santa María de Dueñas o la Inmaculada del convento de las Claras ${ }^{913}$.

En Carrión están documentadas dos obras de magnífica ejecución, conservadas en la iglesia del convento de Santa Clara. Ambas se vinculan con la célebre monja de la casa clarisa Sor Luisa de la Ascensión, la cual se relacionó con los personajes más importantes del momento, e incluso con la realeza ${ }^{914}$. En este sentido, es probable que ambas obras fueran donaciones y que por tanto, el artista las esculpiera en su taller de Valladolid. La más temprana de las dos es una Piedad, tema muy cultivado por Fernández, ubicada en la primera capilla de lado de la Epístola procedente de la ermita que la madre Luisa mandó edificar en la huerta del convento $^{915}$. Se vincula estilísticamente con la obra homónima de San Martín de Valladolid, si bien ésta, es algo anterior, de hacia 1620, por la composición más movida, frente a la obra vallisoletana, de factura clásica ${ }^{916}$. En el transepto norte, en su lado oriental, formando parte de un retablo barroco posterior, se ubica un Crucificado de gran calidad. Es una obra encargada por la condesa de Triviana, doña Mariana Vélez Ladrón de Guevara poco antes de 1627, año en que el administrador de la comitente ya difunta, declara que la condesa, cliente habitual del escultor, se la había enviado a la monja de Carrión ${ }^{917}$. La escultura, considerada hasta entonces del mismo período del Cristo de la Luz, ejecutado hacia 1631, por la idéntica disposición de los pliegues alatonados y el tratamiento similar de la delicada anatomía ${ }^{918}$, resulta, a la luz de la documentación señalada, una obra más temprana.

La remembranza del escultor gallego también se manifiesta en un lienzo del presbiterio de este mismo templo, dedicado a la Inmaculada, copia de la escultura desaparecida que realizara Fernández para el convento vallisoletano de San

\footnotetext{
913 MARTIN GONZALEZ, Juan José. Escultura barroca... 2, Op.cit, pág. 214 y PÉREZ DE CASTRO, Ramón. "Una Inmaculada de Gregorio Fernández en el convento de Santa Clara de Palencia" en EHA. Homenaje al Profesor de la Plaza Santiago. Universidad de Valladolid. Valladolid 2009, pp. 173-178.

${ }^{914}$ Sobre la misma, GARCÍA BARRIUSO, Patrocinio. La monja de Carrión...Op.cit.

915 GÓMEZ PÉREZ, Enrique. El Museo del Real Monasterio de Santa Clara de Carrión. Cálamo. Palencia, 2004, pág. 90 y del mismo, "La piedad de Gregorio Fernández de las clarisas de Carrión de los Condes (Palencia)” en Pasos de arte y cultura. Valladolid, 2008, pp. 32-33.

${ }^{916}$ MARTÍN GONZÁLEZ, Juan José. Escultura barroca en España. 1660-1770. Madrid, 1983, pág. 62.

${ }^{917}$ URREA FERNÁNDEZ, Jesús. "Cristo crucificado", ficha no 4 en Memorias y esplendores. Las Edades del Hombre. Catedral de Palencia, 1999, pág. 337.

${ }^{918}$ MARTÍN GONZÁLEZ, Juan José. El escultor...Op.cit, pág. 182.
} 
Francisco $^{919}$. La obra probablemente fuese pintada en 1619, al igual que el Calvario frontero que conserva una inscripción de dicho año, en consonancia con la creación de la hermandad de Defensa de la Purísima Concepción de la Virgen, jurada el 10 de enero ${ }^{920}$. No existía mejor modo de honrar su veneración que con una reproducción del prototipo iconográfico por excelencia, obra realizada por el escultor activo en Valladolid, Domingo de la Fuente ${ }^{921}$.

Por último, el influjo de Gregorio Fernández se deja sentir en el retablo mayor de la iglesia monasterial de San Zoilo, obra procedente de la capilla mayor de la iglesia palentina de Santa María de Arbis, en Baquerín de Campos. Los relieves de este retablo contrarreformista debieron ser ejecutados por un fiel seguidor del gallego hacia 1640. Si bien fueron contratados por Antonio de Ribera, finalmente éste sólo se encargaría del Calvario ${ }^{922}$.

\section{Alonso Fernández de Rozas Escultor de origen gallego}

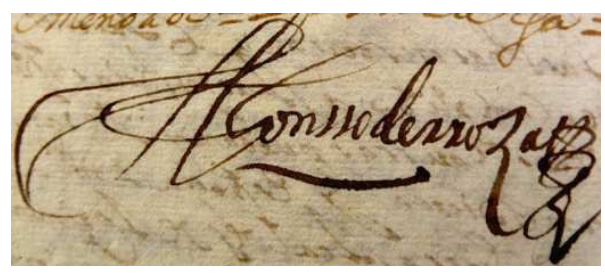

Entre los seguidores de Gregorio Fernández figura el escultor de la escuela vallisoletana Alonso de Rozas, cuya gubia sigue la estela del gallego, sin llegar a proporcionar obras creativas. Como aquél, también era de origen lucense, o al menos así parece indicarlo que sus padres, Amaro de Rozas e Inés Fernández, se declarasen residentes de Santa María de Termar, en el obispado de Mondoñedo. Desarrolló su actividad durante el último cuarto del siglo XVII eminentemente en las provincias de Palencia y Valladolid, ciudad ésta última donde contrajo nupcias con Isabel Fernández en $1656^{923}$.

\footnotetext{
${ }^{919}$ URREA FERNÁNDEZ, Jesús y MARTÍN GONZÁLEZ, Juan José. Inventario...2. Op.cit, pág. 62.

${ }^{920}$ AMCC. Libro 1 de Actas (1618-1637), fol 12.

${ }^{921}$ GÓMEZ PÉREZ, Enrique. El Real...Op.cit, pp. 84-85.

${ }^{922}$ MARTíN GONZÁLEZ, Juan José. La escultura...1, Op.cit, pág. 266, URREA FERNÁNDEZ, Jesús y MARTÍN GONZÁLEZ, Juan José. Inventario...tomo 1. Op.cit, pág. 97 y FERNÁNDEZ DEL HOYO, Ma Antonia. "Oficiales...Op.cit, pág. 356, a su vez de AHPV. Leg. 2089, Matías Pérez, fol 679.

${ }^{923}$ GARCÍA CHICO, Esteban. Documentos...Escultores. Op.cit, pág. 331.
} 
No se conoce ninguna obra del artista antes de que firmase sus capitulaciones matrimoniales. De su mano son parte de las esculturas del retablo mayor de la iglesia de Santa María de Tordesillas, cuya traza es debida al ensamblador Pedro de la Torre, que concluyó en $1660^{924}$. Este encargo resultaría la "carta de presentación" que posibilitaría el reclamo del artista por los monjes benedictinos de San Zoilo para que se hiciese cargo de la talla de su retablo mayor. El concierto con Alonso de Rozas fue firmado el 7 de agosto de $1661^{925}$. Por el mismo se comprometía a realizar seis esculturas de bulto redondo correspondientes a la Asunción, San Juan, San Bartolomé, San Benito, San Féliz y San Zoilo por mil cuatrocientos reales. Desafortunadamente, nada se conserva de este retablo, que sería sustituido en los años ochenta del siglo XX por el retablo de la iglesia de Santa María de Baquerín de Campos. Este mismo año, Rozas se erigió, junto a otros artistas, como vencedor del pleito "del soldado", en el que defendió los intereses de los escultores ${ }^{926}$.

Está documentada su participación en la parte escultórica del retablo mayor del convento de las clarisas de Medina de Rioseco, con las que se concertó en 1663, cuyo ensamblaje corrió a cargo de los riosecanos Francisco Rodríguez y Lucas González $^{927}$. Del mismo, sólo se conservan el Crucificado, San Francisco y la Asunción, observándose en esta última la herencia de Fernández de la imagen homónima de la Catedral de Plasencia ${ }^{928}$. Más de una década después, concretamente el 25 de octubre de 1674, se comprometió con la cofradía de las Angustias de Valladolid, de la que era cofrade, a ejecutar dos ángeles y cuatro soldados durmiendo para que formaran parte del paso del Santo Sepulcro. El cumplimiento de Rozas con estos trabajos sirvió para compensar a la hermandad vallisoletana por haber rechazado, dadas las ocupaciones que requería su oficio, el

\footnotetext{
${ }^{924}$ PARRADO DEL OLMO, Jesús María. "Nuevos datos sobre el retablo mayor de Santa María de Tordesillas" en BSAA, $\mathrm{n}^{\circ}$ 48. Valladolid, 1982, pág. 435.

925 Escritura y condiciones firmadas en Carrión. AHPP. Carr.Prot 5768. Andrés Simón Aguilar (1660-61), fol 1011 y ss.

${ }^{926}$ CEÁN BERMÚDEZ, Agustín. Diccionario...tomo IV, Op.cit, pág. 255.

${ }_{927}$ GARCÍA CHICO, Esteban. Documentos...Escultores. Op.cit, pp. 332-333.

${ }^{928}$ MARTÍN GONZÁLEZ, Juan José. La escultura...1, Op.cit, pág. 299.
} 
cargo de alcalde en la misma ${ }^{929}$. También está atribuido a Alonso de Rozas un Crucifijo en la parroquia de Villasexmir ${ }^{930}$.

$\mathrm{Su}$ radio de actividad se extiende a la provincia de Zamora, para cuya catedral realiza en 1671 la imagen del rey San Fernando, semejante a la que realizara poco antes para el cabildo palentino, a raíz de la canonización del santo castellano. También son de su mano las esculturas de los retablos que en 1678 ejecuta para la capilla funeraria del maestre de campo don Gabriel López de León en la iglesia zamorana de San Pedro ${ }^{931}$. Fuera de Castilla, concretamente en Madrid, figura como ayudante en la ejecución de los arcos de triunfo que para la llegada de la Reina María Luisa de Orleans se levantaron en $1679^{932}$. En 1680 se traslada a Oviedo para ejecutar junto al maestro asturiano Antonio de Borja, la escultura del retablo de San Pelayo para su Catedral, obra desgraciadamente perdida ${ }^{933}$.

\section{Tomás de Sierra \\ Escultor leonés}

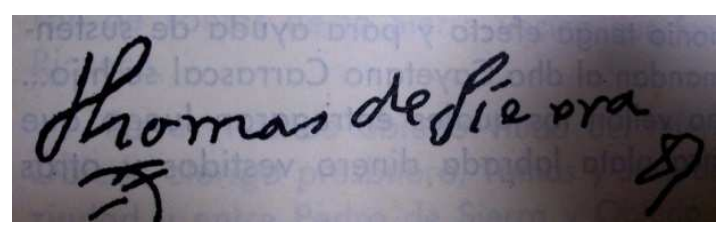

Este escultor de origen berciano pertenece a una familia de artistas, de la cual, junto a sus hijos José y Francisco de Sierra, fue uno de sus más dignos representantes. Su fecunda actividad, que abarca un amplio abanico comprendido entre los años ochenta del siglo XVII y el primer cuarto de la centuria posterior, emerge de su taller radicado en Medina de Rioseco, desde donde realizó encargos

\footnotetext{
${ }^{929}$ GARCÍA CHICO, Esteban. Documentos...Escultores. Op.cit, pp. 333-335.

930 PARRADO DEL OLMO, Jesús María. Catálogo monumental de Mota del Marqués. Valladolid, 1976, pág. 296. También se le atribuyen otras obras palentinas como un busto de Ecce Homo situado en el presbiterio de la iglesia de San Pedro de El Campo, una imagen del mismo tema en la iglesia de San Lorenzo de San Llorente del Páramo y una escultura de la Inmaculada ubicada en la nave del Evangelio de la iglesia de San Pedro de Frómista pp. 49, 84 y 185.

931 Estos y otros datos que complementan la biografía del artista se recogen en URREA FERNÁNDEZ, Jesús. "La capilla de don Gabriel López de León en la iglesia de San Pedro de Zamora" en BSAA, n51. Valladolid, 1985, pp. 505-506. Podemos mencionar, entre otras, la Inmaculada, copia de Gregorio Fernández, que ejecutó para la iglesia de Villagarcía de Campos en 1666 -atribuidas hasta ahora a un tal Alonso Fernández, sin identificarlo con nuestro escultor- o las esculturas conservadas en la iglesia palentina de San Cebrián de Campos en Palencia -consideradas hasta ahora de su hijo José de Rozas.

${ }^{932}$ CONDE DE POLENTINOS. "La Plaza Mayor y la Real Casa de la Panadería" en BSCE, 1913, pág. 47.

${ }^{933}$ MARTÍN GONZÁLEZ, Juan José. Escultura barroca en España....Op.cit, pág. 76.
} 
para todo el área castellana, destacándose los relieves y esculturas del retablo mayor de Santiago, en la villa de los Almirantes. Su herencia juniana y la dulzura de sus rostros, son dos de los rasgos distintivos del prolífico artista ${ }^{934}$. En Palencia concretamente, destaca la imagen de San Juan Bautista de la iglesia de San Fructuoso de Villada, datable hacia el último tercio del siglo XVII, las esculturas de San Antolín y San Francisco del retablo de Santa María de Villamuriel de Cerrato y el San Agustín, Santa Rita y Santa Mónica que el artista talló para el retablo mayor del convento de las Agustinas Recoletas, todas ellas realizadas en los albores del siglo $\mathrm{XVIII}^{935}$. Al taller del artista se atribuye una obra de buena calidad que representa a San Antonio de Padua, ubicado sobre el tabernáculo del retablo mayor de la iglesia de San Cristóbal en Vega de Doña Olimpa, obra de hacia 1560 cercana a Juan de Angés ${ }^{936}$.

En Carrión, proceden de su cincel algunas esculturas del retablo que preside la capilla mayor del monasterio de San Zoilo, pieza trasladada desde el templo palentino de Santa María de Arbís, en Baquerín de Campos, que podemos datar hacia 1640. Se deben a su mano las cuatro imágenes de casi dos metros de altura que representan a los Padres de la Iglesia occidental, así como las esculturas desaparecidas del tabernáculo, de casi medio metro de altura, en cuyas hornacinas se hallaban San Pedro, San Pablo, San Jerónimo, Santo Domingo de Guzmán y San Esteban, todas ellas integradas en el retablo en las postrimerías del siglo XVII ${ }^{937}$. Podemos vincular estilísticamente las esculturas mencionadas con las que realizase

\footnotetext{
${ }^{934}$ GARCÍA CHICO, Esteban. Documentos...Escultores. Op.cit, pp. 392-416, MARTÍN GONZÁLEZ, Juan José. La escultura...1, Op.cit, pp. 362-383, del mismo "Escultores del barroco castellano: Los Sierra" en Goya, no 107, 1972, pp. 282- 289, URREA FERNÁNDEZ, Jesús y MARTÍN GONZÁLEZ, Juan José. Inventario...I, Op.cit, pp. 33, 40, 41, 44, 60, 63, 69, 99, 100, 151, 163, 187, 213,215-216, 277,283, 294, 300, 307, 310 y de los mismos Inventario...II, Op.cit, pp. 8,226,281, NIETO GONZÁLEZ, José Ramón. "Nuevas obras de Tomas de Sierra” en Homenaje al profesor Martín González. Valladolid, 1995, pp. 391-394, PARRADO DEL OLMO, Jesús María. "La colaboración entre ensambladores en los proyectos de retablos de finales del siglo XVII y unas obras inéditas de Tomás de Sierra" en BSAA, n52. Valladolid, 1996, pp. 401-420, LLAMAZARES RODRÍGUEZ, Fernando. "Alonso del Manzano y Tomás de Sierra en tierra sorianas" en RAHA, $\mathrm{n}^{\circ} 15,2009$, pp. 40-55.

935 URREA FERNÁNDEZ, Jesús y MARTÍN GONZÁLEZ, Juan José. Inventario...I, Op.cit, pp. 33 y 283 y 300.

${ }_{936}$ Ibídem,...II, Op.cit, pp. 226.

${ }^{937}$ MARTÍN GONZÁLEZ, Juan José. Escultura...tomo 1, Op.cit, pp. 266 y 371.
} 
el artista hacia 1692 para el relicario de la colegiata vallisoletana de Villagarcía de Campos $^{938}$.

Cuando en 1706, el patrón de la iglesia de San Julián, don Manuel de Berrio y Ribera, se concierta con el trasmerano Pedro del Mazo Vélez en la ejecución de las treinta esculturas correspondientes al retablo mayor y los dos colaterales, se propone que todas ellas sean revisadas por Juan Antonio de la Peña, avecindado en Valladolid o por Tomás de Sierra “...qualquiera de los dos, el que eliguiere dicho señor... ${ }^{939 " . ~}$. No obstante, a falta de una carga de pago, no podemos determinar si nuestro artista llegó a participar en el mismo. Asimismo podemos datar en el primer tercio del siglo XVIII una escultura de San Juan Bautista conservada en la sacristía de la iglesia de San Andrés, que podemos relacionar con el estilo de Tomás de Sierra. De menos de un metro de altura, el movimiento cadencioso de los pliegues y el carácter lánguido del rostro del santo eremita permite vincularlo con su estilo.

También se puede atribuir al artista berciano una imagen de vestir de San Antonio de Padua que, ubicada hoy día en la tribuna del lado de la Epístola de la iglesia conventual de Santa Clara, procede del coro bajo de este cenobio. Datable hacia 1720, su rostro y manos, policromados a pulimento, se relacionan con la imagen homónima que Sierra realizara para el retablo de la ermita del Otero en la localidad palentina de Boadilla de Rioseco ${ }^{940}$. Ensamblado poco antes de 1719 por Santiago Carnicero, con el que trabajaría en el retablo de Santiago de Rioseco o los retablos de Castroponce de Valderaduey, son suyas las imágenes de San Vicente Ferrer, hoy día decapitado y el relieve de San Isidro labrador ${ }^{941}$.

\footnotetext{
938 MARTÍN GONZÁLEZ, Juan José. "El relicario de la Colegiata de Villagarcía de Campos" en $B S A A, n^{\circ} 18$. Valladolid, 1951-1952, pp. 43-52 y del mismo "Documentación de las obras de escultura de la capilla del Relicario de la Colegiata de Villagarcía de Campos en BSAA, n⿳20. Valladolid,1953-1954, pp. 206-209, “Tomás de Sierra en la capilla del noviciado de la Colegiata de Villagarcía de Campos en BSAA, nº55, Valladolid,1989, pp. 478-480.

939 FERRERO MAESO, Concepción. "El mecenazgo...Op, cit, pp. 596-598. La escritura para la realización de estas esculturas en 1706 la encontramos en AHPP. Carr.Prot 5021. Agustín García Miranda (1705- 1709) s/f.

${ }_{940}$ GÓMEZ PÉREZ, Enrique. El real...Op.cit, pp. 132-133.

${ }^{941}$ Sobre el mismo, PÉREZ DE CASTRO, Ramón. “Un retablo en Boadilla...Op.cit, pp. 241-258.
} 


\section{Blas Martínez de Obregón Ensamblador montañés}

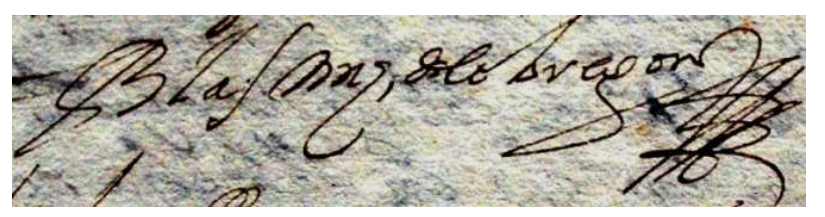

Su patronímico permite establecer una vinculación directa con la provincia de Santander, donde probablemente tendría lugar su formación. Su actividad artística como "creador de retablos", se desarrolla fundamentalmente en el foco vallisoletano, si bien, excepcionalmente figura trabajando en la localidad segoviana de Cuéllar, concretamente en el retablo de la iglesia de Santa María ${ }^{942}$. Los trabajos documentados de Obregón abarcan una horquilla de tres décadas, transcurridas entre el último tercio del siglo XVII y los primeros años del siglo XVIII.

En 1678 realiza el retablo de la capilla lateral de Nuestra Señora de la Consolación de la iglesia de San Juan de Valladolid. Junto a Antonio Álvarez, en 1689 realizó el túmulo para el funeral de María Luisa de Orleans ${ }^{943}$. Entre 1689 y 1691 ensambló los retablos colaterales de la iglesia vallisoletana de San Quirce ${ }^{944}$. En la iglesia palentina de Nuestra Señora del Tovar de Meneses de Campos, proporciona en 1690 la traza del tabernáculo que ejecutaría Juan Fernández para su retablo mayor ${ }^{945}$ Además de ensamblador, se le denomina maestro arquitecto, como así figura en las condiciones que establece para el retablo de la capilla mayor de la iglesia de Villalón de Campos, asignada al ensamblador vallisoletano Alonso de Manzano en $1693^{946}$. En 1694 se encarga de realizar el retablo mayor de la iglesia de Santiago de Villalba de los Alcores, en Valladolid, pero por entonces bajo la jurisdicción del Obispado palentino ${ }^{947}$. En el retablo desaparecido de la iglesia de San Ildefonso de Valladolid, realizado en 1648 por Bernardo Rincón, se encargó de realizar unas cartelas para los pedestales, sustituir las columnas estriadas por salomónicas y añadir otros ornamentos como festones y copetes hacia $1698^{948}$. En 1699 se concierta para la realización del retablo mayor de la iglesia vallisoletana de

942 ARRIBAS, Miguel María. "Retablo de Juan Correas y Blas Martínez de Obregón en Cuéllar" en Estudios Segovianos, no 25, 1973, pp. 556-560.

${ }^{943}$ MARTÍ Y MONSÓ, José. Estudios...Op.cit, pág. 498.

${ }^{944}$ MARTÍN GONZÁLEZ, Juan José. Escultura...1, Op.cit, pág. 308.

${ }^{945}$ URREA, Jesús y MARTÍN GONZÁLEZ, Juan José. Inventario...I, Op.cit, pág. 201.

${ }^{946}$ PARRADO DEL OLMO. Jesús María. “La colaboración...Op.cit, pp. 407-409.

${ }_{947}$ GARCÍA CHICO, Esteban. Catálogo de Medina...Op.cit, pp. 171 y 173.

${ }^{948}$ MARTÍN GONZÁLEZ, Juan José. Escultura...1, Op.cit, pág. 319. 
Villanueva de Duero, que quedó asentado en $1702^{949}$. Ese mismo año de 1699, tasa el retablo mayor de Pozaldez que había ejecutado el ensamblador Francisco Billota.

En la iglesia de San Julián de Carrión, simultanea los trabajos mencionados con la ejecución del retablo mayor y los colaterales de su presbiterio, en los que se concierta junto al montañés Pedro de Solana, el 11 de febrero de 1699 con Don Manuel de Berrio y Ribera, patrón del templo. El fallecimiento repentino del artista cántabro conlleva la responsabilidad total de las obras en Obregón, quien los había finalizado cumpliendo los plazos estipulados, como así manifiestan las cartas de pago emitidas en diciembre de $1701^{950}$.

Las últimas obras que figuran asociadas a Blas Martínez Obregón lo sitúan de nuevo en la capital del Pisuerga, pues en 1701 actúa como veedor, junto a Juan de Ávila del retablo mayor de Villanubla, ejecutado por Francisco Billota y Gregorio Díaz de la Mata ${ }^{951}$. En 1702 se concierta con la cofradía de Jesús Nazareno de Valladolid para la traza y ensamblaje de su retablo ${ }^{952}$.

\section{Diego de Suano}

\section{Ensamblador de origen cántabro}

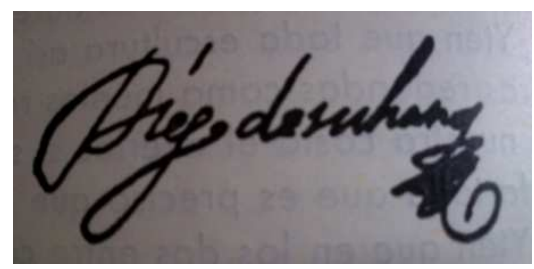

Natural de Isla, este longevo retablista trabajó principalmente en la comarca burgalesa desde los años ochenta del siglo XVII y durante la mitad del siglo siguiente. Sin embargo, ampliará sus expectativas en busca de otros mercados, estableciéndose en Carrión, según algunos historiadores, hacia $1702^{953}$. Su obra

\footnotetext{
${ }^{949}$ GARCÍA CHICO, Esteban. Documentos...Escultores. Op.cit, pp. 355-357.

${ }^{950}$ FERRERO MAESO, Concepción. "El mecenazgo...Op, cit, pp. 594, a su vez de AHPP. Carr.Prot 5019. Agustín García Miranda (1699-1700), s/f y Prot 5020. Agustín García Miranda (1701-1704), s/f.

${ }^{951}$ MARTÍN GONZÁLEZ, Juan José. Escultura...1, Op.cit, pp. 305-306, 308.

${ }^{952}$ MARTÍ Y MONSÓ, José. Estudios...Op.cit, pág. 498.

953 PAYO HERNÁN, Jesús. "El retablista barroco trasmerano: Diego de Suano" en BIFG, no 206. Burgos, 1996, pp. 159-182. La primera obra que se conoció de Suano fue el retablo burgalés de la iglesia de la Asunción parroquial de Villasandino, que ejecutó en 1693. CASTRO GARCÍA, Lázaro y ORCAJO DÍEZ, Jesús. "Noticias sobre algunas obras de arte de Villasandino" en BIFG, n¹83. Burgos, 1974, pág. 278. En Lerma, se debe el retablo mayor, de 1694, trazado por Manuel Martínez de Estrada. CERVERA VERA, Luis. La iglesia colegial de Lerma. Burgos, 1981, pág. 155.
} 
maestra fue la ejecución del retablo mayor de la iglesia de Santiago de Medina de Rioseco, obra que le catapultaría a la fama ese mismo año, cuando la ejecutó junto a Francisco Pérez, siguiendo las trazas del prolífico Joaquín de Churriguera ${ }^{954}$.

En este artista se puede apreciar una clara evolución desde presupuestos prechurrigurescos con esquemas rígidos, aprendidos de Fernando de la Peña, pasando por un período intermedio con nuevos modelos compositivos cuyo punto de partida es el retablo de Lerma de 1690, hasta llegar a una fase plenamente churrigueresca, en la que abandona la columna salomónica, recurre a la decoración de cortinajes y la talla vegetal se estiliza, como sucede en el retablo medinense, que supondrá un antes y un después en la retablística castellana ${ }^{955}$. En Palencia sólo se le conoce la ejecución del retablo mayor de la iglesia de Santa Cecilia de Valdecañas de Cerrato, localidad perteneciente al partido judicial de Baltanás ${ }^{956}$.

A pesar de establecer su residencia en la villa condal, tan sólo está documentada una obra suya en la villa palentina, cuando aún ni siquiera residía en la misma. Se trata de las trazas que proporciona para la ejecución del retablo mayor de la iglesia de San Julián, cuyo contrato, firmado el 11 de febrero de 1699 comprometía a los ensambladores Blas Martínez Obregón y Pedro de Solana en la ejecución de la obra, que se hallaba bajo el patronazgo de don Manuel de Berrio y Ribera $^{957}$. La fusión de los soportes como la columna salomónica y el estípite y el recurso de los entablamentos partidos, permite situar esta obra en una etapa intermedia dentro de la trayectoria artística del montañés, con gran herencia de los retablos burgaleses precedentes, como los de los templos parroquiales de Villalbilla o Villalmanzo, en los que ya se advierte la presencia de los motivos cactiformes y los ángeles atlantes, propios de la escultura retablística del foco vallisoletano en las últimas décadas del siglo XVII.

\footnotetext{
${ }^{954}$ Esta obra, que ejecutó junto a Francisco Pérez en 1702, está documentada en GARCIA CHICO, Esteban. Catálogo de Medina...Op.cit, pp. 102, 106 y 111.

955 Una evolución de su obra burgalesa en PAYO HERNÁN, Jesús. El retablo barroco en Burgos...Op.cit, pp. 141-161.

${ }^{956}$ URREA, Jesús y MARTÍN GONZÁLEZ, Juan José. Inventario...I, Op.cit, pág. 179.

${ }^{957}$ De las dos ocasiones en que se le nombra en la documentación, en una de ellas aparece por error como Antonio de Suano. FERRERO MAESO, Concepción. "El mecenazgo...Op, cit, pág. 595, a su vez de AHPP. Carr.Prot 5020. Agustín García Miranda (1701-1704), s/f.
} 


\subsection{LA PINTURA}

\section{INTRODUCCIÓN}

Durante la Edad Moderna y en menor medida en el siglo XIX, la hegemonía de la arquitectura y muy por detrás de ella, la escultura, van a eclipsar íntegramente a la producción pictórica, que se mantuvo siempre al margen de sus dos compañeras artísticas, lo que motivó la escasa calidad general de las obras conservadas en el medio carrionés. Obras eminentemente de carácter religioso, dado el rechazo de los temas profanos en consonancia a los presupuestos emanados del Concilio de Trento, fenómeno que se hace extensible en todo el territorio hispano. El resurgir de la espiritualidad popular está vinculado del mismo modo a la decadencia del imperio español durante el siglo XVII, que provocará una ambiente de recelo y desconfianza en el poder y en lo frugal de la vida, derivando paulatinamente en la proliferación de un sentimiento de profundo fervor ${ }^{958}$.

En consecuencia, a las demandas pictóricas provenientes de las instituciones eclesiásticas, se suman los encargos particulares por parte de fieles devotos que solicitan obras con temas piadosos y exvotos cuya posesión repercutirá favorablemente en la salvación de sus almas. El objetivo primordial reside en la obtención de una imagen de veneración, ya sea por su santidad o por sus milagros, y no de una obra de arte a la que admirar, lo que redundará en la escasa calidad técnica de las obras, que se encargan para cumplir un fin devocional.

El repertorio iconográfico habitual abarca los temas de la vida de Cristo, hagiografías y, en mayor medida, la Virgen en sus diferentes variantes -Inmaculada, Misericordia, del Socorro y de la Soledad, entre otras-, recurriendo para ello al uso de estampas o a la reproducción de obras célebres. Si bien no hemos hallado ningún inventario en que figurasen los bienes de los pintores que trabajaron en Carrión, debemos descartar a tenor de su carácter exclusivamente local, la posesión de libros

\footnotetext{
958 Este fenómeno irradia directamente de Valladolid, donde se establece temporalmente la Corte. VALDIVIESO GONZÁLEZ, Enrique. La pintura en Valladolid...Op.cit, pp. 12-23. Para el caso palentino MARTÍNEZ, Rafael. La pintura del siglo XVII en Palencia. Palencia, 1986.
} 
de perspectiva o geometría como era propio en artistas consumados cuyo radio de acción o clientela alcanzaban cotas más ambiciosas ${ }^{959}$.

El carácter anónimo de la inmensa mayoría de las pinturas repartidas por los museos e iglesias carrionesas, pone de relieve el exiguo florecimiento de artistas de talento en la villa. El recurso a fórmulas y estereotipos preestablecidos procedentes de las estampas y la desmotivación que produciría la escasa compensación económica que los pintores recibían por sus trabajos -si se compara con el precio que alcanzaba cualquier escultura de pequeño tamaño- limitó considerablemente la libertad de los artistas.

Respecto a la técnica y materiales empleados, se recurre al óleo sobre tabla de manera generalizada hasta los albores del siglo XVII, recurriéndose al lienzo a partir de entonces.

\section{LOS ARTÍFICES DE LAS OBRAS}

El oficio de pintor, tal y como lo entendemos hoy día, abarcaba el extenso abanico de actividades relativas al manejo del pincel o la brocha, lo que entrañaba la policromía de las esculturas de los retablos y el dorado y estofado de los mismos, salvo cuando estos trabajos eran efectuados por los propios doradores, quienes, del mismo modo realizan en algunos casos, pinturas de mediocre calidad. Ese carácter ambivalente de los oficios- como vimos que sucedía en el ámbito arquitectónicoestá presente en Juan de Lago, que, siendo pintor, dora las obras en las que participa, o, a la inversa, Francisco Gutiérrez y Alonso Gómez, que se denominan doradores pero ejercen en algunas ocasión de pintores.

Si bien hemos de reconocer que la categoría de estos maestros dista de ser trascendental, también es cierto que su conocimiento coadyuva a crear una visión conjunta del panorama artístico de los siglos XVI al XIX. La excepción dentro de estas pequeñas biografías la constituye el pintor vallisoletano Ramón Canedo, el más

\footnotetext{
${ }^{959}$ Sobre el repertorio temático empleado en España en este período. BROWN, Jonathan. Imágenes $e$ ideas en la pintura española del siglo XVII. Alianza. Madrid, 1980, pp. 57 y ss.
} 
célebre de los artistas que se incluyen en este apartado, con un área de acción que supera los límites territoriales palentinos y un repertorio iconográfico más amplio que incluye el retrato.

\section{Juan de Lago \\ Pintor vecino de Carrión}

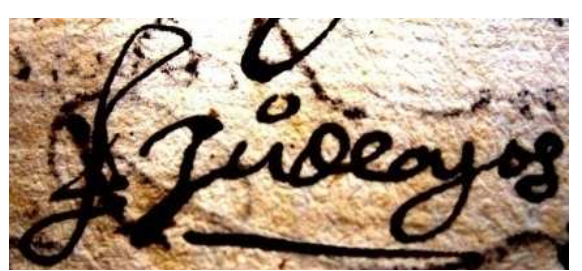

Dentro del foco carrionés, donde trabajó la mayor parte de su vida, gozó de cierto reclamo. Su foco de acción sobrepasó los límites de la localidad, si bien trabajando dentro del entorno palentino a lo largo del tercer cuarto de la centuria decimosexta. Debió fallecer poco después de 1572, pues en esa fecha otorga una carta de poder a su hijo homónimo, apelado "el Mozo", para que cobre en su nombre 31.000 maravedíes del retablo de la iglesia de Cuerno, pueblo palentino que ha mutado su nombre por el de Santana ${ }^{960}$.

En 1554 junto a otro pintor, Juan Gutiérrez de Cabiedes, vecino de Saldaña, participa en el retablo de Villanuño de Valdavia ${ }^{961}$. El trabajo de talla había sido realizado hacia 1536 por el entallador Juan de Solaje, vecino de Cisneros. Por eso no casa bien la estructura del retablo con el estilo de las pinturas, que son más avanzadas y de estilo berruguetesco ${ }^{962}$.

En el convento de San Francisco de Carrión, del que tan sólo subsiste el templo sin cubiertas, existió un retablo pintado por nuestro artista, cuya ejecución fue encargada a un ensamblador carrionés llamado Alejo de Lago, que podría ser pariente suyo. El comitente de esta obra fue un ilustre carrionés, Don Beltrán de Guevara, quien la encarga el 6 de agosto de 1557 para que fuese concluida para el

960 CHICO, Esteban. Documentos...Pintores I, Op.cit, pág. 92. Al parecer el gentilicio de los habitantes de El Cuerno, era objeto de chanzas, lo que motivó la modificación del nombre del pueblo.

${ }^{961}$ ADP. Villanuño de Valdavia. Iglesia de Santa Eugenia. Libro $1^{\circ}$ de Cuentas, 1525-1555, fol 27 a 34.

${ }^{962}$ CUESTA SALADO, Jesús. Jacques Bernal...Op.cit, pág. 23. 
Domingo d Resurrección del año siguiente ${ }^{963}$. La capilla donde iría asentado el retablo, situada en el lado de la Epístola, muy próxima al altar mayor, se hallaba bajo la advocación de las Once Mil Vírgenes. Pertenecía a los Mújica desde el siglo $\mathrm{XV}$, y había accedido a su propiedad don Beltrán tras haber contraído nupcias con doña Isabel de Mújica ${ }^{964}$. Cuando éste dispuso su enterramiento, al dictar testamento en 1620, ordenó finalizar el arcosolio que hoy se conserva, vacío, en este antiguo lugar de culto 965 .

También es suya la pintura del retablo mayor de la iglesia parroquial de Villaproviano que realiza junto a Juan de Toranzo, un pintor de Saldaña. De la tasación se encargó otro pintor vecino de Carrión, llamado Antonio de Paredes. Se recogen pagos en diferentes años, hasta $1562^{966}$.

Para la desaparecida iglesia de San Juan del Mercado en Carrión, realizó la pintura de su retablo mayor, que sustituiría al que hasta entonces presidía la capilla mayor, según contrato firmado el 6 de enero de 1564 con el mayordomo del templo, don Francisco de Lomas ${ }^{967}$. Por el mismo, Lago se comprometió a finalizar la obra en dos años, pintando para ello las historias que se estimasen convenientes e incluyéndose el dorado y estofado de los dos bustos del banco, la imagen de San Juan Bautista y la Asunción del ático. Al inicio de la obra, Lago recibiría cuarenta ducados -unos 14.960 maravedíes- y diez mil maravedíes cada año “...asta que el dicho rretablo sea acabado...”. Quizá esta condición motivó al artista a sobrepasar el plazo estipulado, ya que en 1568 la obra se hallaba sin concluir y el mayordomo, suplica al comendador del Hospital desaparecido de la Herrada que compela a Juan de Lago a su finalización. Por evitar pleitos, volvió a contratar a Lago y a “...otros dos ofiçiales que residen en esta villa..." con el fin de que se finalizase en un corto período. La suma de lo que quedaba por hacer ascendía a trescientos ducados, a juicio del pintor Luis de Villoldo. Los dos artistas escogidos fueron Miguel del Val y Gonzalo Gutiérrez y a cada uno, incluido Juan de Lago, el mayordomo se obligó a

\footnotetext{
963 GARCÍA CHICO, Esteban. Documentos...Pintores I, Op.cit, pp. 89 y 90, a su vez de AHPP. Carr.Prot 5597. Francisco Rojas (1553-1562), fol 24 y ss.

${ }^{964}$ PERAL VILLAFRUELA, Santiago. "San Francisco de Carrión... Op.cit, pp. 295-296.

965 Testamento de Don Gaspar de Guevara en AHPP. Carr.Prot 5403. Francisco Moro Saldaña (1620), s/f.

${ }_{966}$ ADP. Villaproviano. Libro $1^{\text {o }}$ de Cuentas, 1550-1630, fol 11, 11v, 12, 13 y 44.

967 AHPP. Carr.Prot 4675. Juan Cantoral, (1563-1568), s/f.
} 
abonarles más de cuarenta mil maravedíes ${ }^{968}$. En 1570 debían haberlo finalizado, pues Gonzalo Gutiérrez y Juan de Lago otorgan un poder a Cristóbal de la Serna, bordador carrionés, para que cobre los 88.666 maravedíes que el templo les debe ${ }^{969}$. Éste sería el segundo de los cuatro retablos que llegaron a asentarse en este espacio, pues entre 1617 y 1627, el ensamblador Juan Bautista Pérez realizó uno de traza clasicista y posteriormente, Ramírez de Helguera afirma que en 1895 se conservaba una obra churrigueresca con la imagen de San Bartolomé en el ático ${ }^{970}$.

La obra más tardía que se conoce del artista es de 1571, cuando pinta el retablo del desaparecido convento de Santa María de Benevívere, a cinco kilómetros de Carrión ${ }^{971}$. Debía tratarse de una pieza que ornamentaría alguna capilla particular, pues en el conciso contrato establecido con Pedro de Herrezuelo, canónigo de la abadía y prior del cenobio de Mañinos, dependiente de Benevívere, se señala el pequeño formato de la obra y el coste total de nueve mil maravedíes, una suma ciertamente baja para tratarse de un retablo importante.

\section{Miguel del Val \\ Pintor vecino de Dueñas}

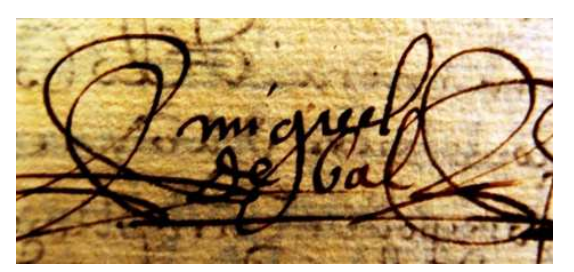

Es probable que perteneciese a una familia de artistas dedicados a la pintura, pues al menos se sabe de la existencia de un Santos del Val, igualmente avecindado en Dueñas, que se encarga en 1591 de la pintura del retablo mayor, dedicado a San Torcuato, procedente del hospital y priorato homónimo, dependiente de la abadía de Benevívere $^{972}$. Este retablo no se ha conservado, pues fue sustituido por una obra barroca, que es la que preside actualmente la capilla mayor del templo. La vida de

\footnotetext{
968 AHPP. Carr.Prot 4676. Juan Cantoral (1569-1573), s/f.

969 AHPP. Carr.Prot 5665. Andrés Sánchez (1569-1572). Segundo cosido, no 1353, s/f.

970 AHPP. Carr.Prot 5172. Jerónimo Laso (1627), fol 865 y ss y RAMÍREZ DE HELGUERA, Martín. El libro...Op.cit, pág. 163.

${ }^{971}$ GARCÍA CHICO, Esteban. Documentos...Pintores I. Op.cit, pág. 91, a su vez de AHPP. Carr.Prot 4676. Juan Cantoral. (1569-1573), s/f.

${ }^{972}$ AHPP. Carr.Prot 5731. Lázaro Santacruz (1589-1591), s/f.
} 
Miguel del Val transcurre en el entorno carrionés, donde están documentadas diversas participaciones durante el último tercio de la centuria décimosexta.

A las afueras de Carrión, junto al monasterio de San Zoilo, al cual pertenecía, se hallaba un hospital bajo la advocación de Nuestra Señora de la O. Su iglesia fue dotada con un retablo que contrató el entallador carrionés Martín de Esquicios en enero de 1565 y que se comprometió a finalizar tres meses después ${ }^{973}$. El retablo constaría de banco, donde figuraría la inscripción con la fecha de ejecución y el tabernáculo en la parte central. En la hornacina del cuerpo principal se situaría la talla de Nuestra Señora de la O, flanqueada por dos columnas y dos medias tallas. El ático estaría presidido por las armas de don Luis Hurtado de Mendoza, fundador del hospital. Es muy probable que se retrasara en su conclusión, o quizá, que el nosocomio no dispusiera de fondos suficientes para proceder a su pintura, ya que ésta no fue contratada hasta abril de 1568, estipulándose que colaborasen en dicha empresa Miguel del Val y el pintor Gonzalo Gutiérrez, vecino de la localidad burgalesa de Melgar de Fernarmental. El contrato incluía el dorado y estofado del retablo, el cual, rematado en ciento veinte ducados, debía finalizarse antes del 15 de agosto de 1569. En caso de incumplimiento de los plazos, ambos artistas determinan que sus bienes sean vendidos en pública almoneda en cualquiera de las ferias que se celebran en “...Medina del Canpo, Villalón, Medina de Rioseco, Valladolid, Madrid, Alba, Uejar, Aria, Carrión, Saldaña, Castillo, como en otra qualquier feria e pate que sea... ${ }^{974,}$.

Como señalamos previamente al referirnos a Juan de Lago, Miguel del Val colaboró junto a él y nuevamente con Gonzalo Gutiérrez en la finalización del retablo mayor de la iglesia de San Juan del Mercado a partir de 1569, pues se había rematado en Juan de Lago cinco años antes y aún no había sido finalizado ${ }^{975}$.

En el convento de Santo Domingo de Carrión, existió una capilla bajo la advocación del Dulce Nombre de Jesús que perteneció a don Rodrigo de Herrera,

\footnotetext{
${ }^{973}$ AHPP. Carr.Prot 5443. Gregorio Movilla (1564-1567), s/f.

974 ARCHV. Pleitos Civiles. Zarandona y Balboa (Olv) Caja 604, exp3. Sobre este ensamblador GARCÍA GARCÍA, Lorena. "El retablo de San Roque en la iglesia parroquial de Villamorco (Palencia)" en BSAA, no74, 2008, pp. 285-290.

${ }^{975}$ AHPP. Carr.Prot 4676. Juan Cantoral (1569-1573), s/f.
} 
poseedor igualmente de un espacio de culto en la iglesia de Santa María dedicado al Santo Cristo. Sus testamentarios se comprometieron a finalizar el retablo del cenobio dominico, que ya estaba realizado en 1569. La pintura, dorado y estofado se concretó con Miguel del Val, que debía concluirlo en dos años, comenzados a contar desde el quince de agosto de dicho año. Los doscientos ducados acordados serían abonados “...en çinco mill maravedies de çenso, alquiler y rréditos...” pertenecientes a la hacienda del mencionado patrón ${ }^{976}$.

A lo largo del siglo XVI, antes de que la iglesia de San Andrés fuese reedificada por completo, poseía una capilla bajo el coro dedicada a San Julián que pertenecía a los Colmenares. En 1589 Guión de Colmenares contrata a Miguel del Val para que dore y estofe el retablo dedicado al santo que había ensamblado con toda probabilidad Martín de Colindres. En las condiciones se determina que sea el ensamblador cántabro quien realice los pedestales, por lo que es posible que el resto de la obra se subcontratara a este artista. Miguel del Val debía pintar la escultura de San Julián, con su alba blanca, la casulla colorada, mitra y báculo de oro bruñido y el rostro encarnado a pulimento. El retablo estaba compuesto por columnas estriadas que se pintarían de verde y azul y en el remate campeaban las armas de la familia fundadora, que igualmente debían ser policromadas, todo ello por doce mil maravedíes $^{977}$.

\section{Bartolomé de Medina Pintor vecino de Carrión}

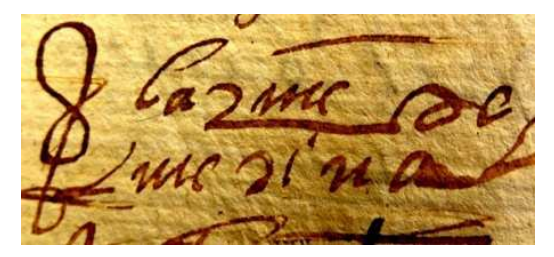

Desconocemos si el patronímico señala una posible procedencia de las localidades vallisoletanas de Medina del Campo o Rioseco. En cualquier caso, este artista se mantuvo avecindado en Carrión, donde trabajó durante los últimos años del siglo XVI y primeras décadas del siglo XVII. Sus tres obras conservadas nos remiten a un artista de carácter local, gustoso de colores artificiales y contrastados, propios del manierismo, que no se mantenía, sin embargo, ajeno a las corrientes del

\footnotetext{
${ }^{976}$ AHPP. Carr.Prot 5444. Gregorio Movilla (1568-1569), s/f.

${ }^{977}$ AHPP. Carr.Prot 4980. Sebastián García (1588-1590), fol 651 y ss.
} 
momento, inspirándose en grabados italianos. No obstante, habitualmente emplea los mismos tipos físicos.

El convento de Santa Clara custodia dos obras de este artista que ya figuran inventariadas en 1980, ambas dedicadas a la Virgen de la Misericordia, iconografía medieval de gran reclamo entre las órdenes mendicantes. Una de ellas, ubicada en la sala baja, contiene una inscripción con la fecha de 1599, y otra, que se encuentra en el refectorio, la firma y la datación: "BARme MEDna FACIEBAT AÑO 1608 978". La más temprana es también obra de Bartolomé de Medina, como así constata el hallazgo del contrato de la obra, efectuado en mayo de dicho año $(194 \mathrm{~cm} \times 154 \mathrm{~cm})^{979}$. Por el mismo se precisaba la inclusión de dos ángeles flanqueando a la Virgen y bajo ella, en tamaño reducido, San Francisco, San Agustín, San Gregorio -a la izquierda- y Santa Clara y Santa Catalina -a la derecha, dejando el resto de personajes a elección del artista. Efectivamente, los personajes que acompañan a la Virgen son fieles anónimos, acogidos bajo su manto azulado tachonado de estrellas. La Virgen porta una corona sobre su velo, con el rostro ladeado y una túnica larga que le cubre los pies, ceñida bajo su pecho con una cinta anudada. Los ángeles cobran gran protagonismo en esta imagen, no sólo por su gran tamaño sino por su actitud, pues aparte de portar una palma en la mano derecha, sostienen una corona de flores en la otra como si fueran a colocársela a la Virgen.

El lienzo del refectorio, que le supera en dimensiones, $(223 \mathrm{~cm} \times 153 \mathrm{~cm})$, es una copia del anterior, pues presenta idéntica composición aunque, en este caso, los ángeles son de menor tamaño, el fondo neutro ha sido sustituido por un rompimiento de gloria centrado por la paloma y ha incluido un mayor número de fieles. Éstos se sitúan incluso flanqueando a la Virgen, en menor tamaño, a modo de donantes, pues, a diferencia de la otra obra, que fue encargada por la abadesa Doña Ana de Guardo, ésta pudo haber sido una donación privada a la monja sor Luisa de la Ascensión. A pesar de las evidentes semejanzas de ambas obras, es evidente la evolución del artista en la década que transcurre entre ellas. En las postrimerías del siglo XVI, Bartolomé de Medina manifiesta una mayor simplicidad de la composición para

\footnotetext{
${ }^{978}$ URREA FERNÁNDEZ, Jesús y MARTÍN GONZÁLEZ, Juan José. Inventario...2.Op.cit, pág. 60.

${ }^{979}$ AHPP. Carr.Prot 5290. Pascual López (1599), s/f.
} 
adoptar un mayor dominio de los volúmenes, patente en el uso del claroscuro a finales de la década siguiente.

En 1602 figura vinculado a la iglesia carrionesa de Santiago. Una de sus antiguas capillas, sede de la cofradía de las Ánimas, le encarga el diez de junio de dicho año que pinte y dore el retablo de Santo Tomás ${ }^{980}$. Debía pintar la talla del apóstol de esmaltes azules y estofarla de oro mate, además de policromar la caja, peana y las dos columnas que flanqueaban la escultura. A los lados debía pintar una Inmaculada y el Bautismo de Cristo y el ático iría presidido por una pintura del Juicio Final con las almas del purgatorio. Medina también debía incluir una inscripción en la cornisa donde figurase el nombre de la cofradía y en la peana, las palabras de la Consagración entre dos tableros que representasen a los Apóstoles Santiago y San Juan. Para la entrega de la obra, Bartolomé de Medina tenía como plazo el día de Santo Tomás de ese año, esto es, el 21 de diciembre. Como compensación de su trabajo recibiría setenta y dos ducados y el privilegio de acceder como cofrade de la hermandad de las Ánimas. Podemos identificar este retablo con uno de los que se conservan actualmente en este templo, formando parte de su museo, a tenor de la inscripción relativa a la transubstanciación de Cristo en la parte baja y la tipología de columnas entorchadas que nos permite datar la obra a principios del siglo XVII. Lo que sucede es que el retablo fue dorado en 1679, como figura en una inscripción del mismo, y es entonces cuando se debieron sustituir las pinturas de las calles laterales por los motivos florales que vemos hoy día, la pintura de las Ánimas por una talla de un Crucificado y la imagen de Santo Tomás por una escultura de San Basilio del siglo XVIII.

La Cofradía de la Vera Cruz le encargó en 1603 la talla de un Cristo de pequeño tamaño, de menos de una vara de altura -unos $80 \mathrm{~cm}^{-981}$. Descartamos que desempeñara el oficio de escultor, ya que en ninguna de sus obras figura como tal. Posiblemente se trate de una pieza que el pintor debía policromar y cuya ejecución subcontrató.

\footnotetext{
${ }^{980}$ AHPP. Carr.Prot 5053. Alonso Gómez Guillén (1595-1603), fol 347 y ss.

${ }^{981}$ AHPP. Carr.Prot 5386. Francisco Moro Saldaña (1603), s/f.
} 
En la iglesia de Nuestra Señora del Camino, cobijada en una hornacina en el lado de la Epístola, se conserva la talla pétrea del mismo nombre, imagen que ha gozado siempre de gran veneración entre los carrioneses por su mediación en el milagro de las cien doncellas ${ }^{982}$. La devoción que despertaba motivó el encargo de una pintura de la imagen a Bartolomé de Medina en 1614, que desafortunadamente no se ha conservado. La reproducción pictórica de esculturas en este período no constituye un fenómeno aislado y suponen, en algunos casos, una fuente gráfica de primera mano para conocer la escultura original. Sirvan como ejemplo los múltiples lienzos que se conservan de la Inmaculada desaparecida que Gregorio Fernández talló para el convento de San Francisco de Valladolid, una de cuyas copias se conserva en el convento de Santa Clara de Carrión. El mayordomo del templo abonó a Medina ocho ducados por este óleo de finos colores, además de tres varas de anjeo o lienzo basto, en especias ${ }^{983}$.

El lienzo que representa a San Miguel ubicado en la iglesia de San Andrés, es obra de Bartolomé de Medina, como así consta en la inscripción de la parte inferior del lienzo, donde consta su fecha de ejecución en $1617^{984}$. La imagen efigia al santo arcángel atacando a las hordas infernales en una actitud muy elegante propia de las composiciones rafaelescas. La escena se desenvuelve en una bicromía contrastada entre la carnación de los cuerpos de los caídos y los azules del cielo y de la indumentaria de San Miguel, conformando una composición manierista, que parece haberse inspirado en algún grabado de Raimondi. Hoy se sitúa en la subida al coro y a este lugar fue trasladado desde la capilla que los Bobadilla poseían en el crucero del lado de la Epístola, donde se sitúa el retablo de San José. No obstante, el templo de San Andrés no fue su ubicación primitiva, pues procede del extinto convento de Santa María de Benevívere ${ }^{985}$.

En la iglesia de Nuestra Señora de Belén, Medina se encargó de pintar en 1618 el fondo de la caja de la hornacina del retablo mayor donde hasta entonces se

\footnotetext{
982 Sobre el mismo, remítase al capítulo dedicado a la iglesia de Santa María donde referimos la célebre leyenda.

983 AHPP. Carr.Prot 5397. Francisco Moro Saldaña (1614), s/f.

${ }^{984}$ PERAL VILLAFRUELA, Santiago y GÓMEZ PÉREZ, Enrique. Carrión...Op.cit, pág. 63.

${ }^{985}$ ADP. Carr. San Andrés. Libro 43 del Inventario de todos los ornamentos y alhajas de San Andrés (1833-1930), fol 14.
} 
ubicaba la imagen de vestir de la Virgen ${ }^{986}$, sustituida en 1684 por unas puertas que comunican con el camarín que existe en la parte trasera. Esta es la última referencia que poseemos del artista.

\section{Francisco Gutiérrez \\ Dorador y pintor de Cisneros}

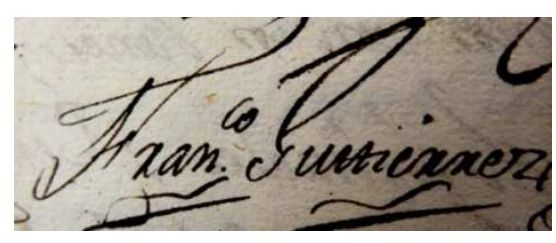

Se denomina en este orden, "maestro dorador, pintor y estofador", lo cual nos indica que detentaba los tres oficios y la medida en que desempeñaba una actividad sobre otra. De hecho, son mucho más numerosos los trabajos en los que ejerce como dorador que el resto. Conocemos su actividad desde mediados del siglo XVIII hasta la década inmediatamente posterior.

La mención documental más temprana de nuestro artista se remonta al 20 de febrero de 1749 y lo sitúa en la iglesia parroquial de Santiago de Carrión, donde acuerda con el mayordomo de la cofradía de las Ánimas dorar el retablo que dicha hermandad poseía en una de las antiguas capillas del templo. Dedicado a la advocación del apóstol Santo Tomás, el retablo debía ser dorado siguiendo como modelo el de Nuestra Señora del Carmen, que no se conserva. El contrato establecía que ambos artistas recibirían mil setecientos cincuenta reales si finalizaban el encargo antes de finales de junio de dicho año ${ }^{987}$.

Simultaneando esta obra, en abril de dicho año, Francisco Gutiérrez se compromete a realizar las "colgaduras" de la capilla mayor de la iglesia de Santa María junto al dorador carrionés José Cosgaia. Por la excepcionalidad dentro de su producción constituye su aportación más original al arte carrionés. No obstante, no se trata de una obra original de Gutiérrez, pues sigue un diseño proporcionado por otro dorador del lugar, Juan López. Las vistosas pinturas, que incluían un nutrido repertorio de frutas, colgantes y graciosos amorcillos, debían recubrir por entero el

\footnotetext{
${ }^{986}$ ADP. Carr. Iglesia de Belén. Libro 16, 4 de Fábrica (1616-1646), fol 44.

${ }^{987}$ AHPP. Carr.Prot 5142. Martín Izquierdo (1748-1749), fol 55 y ss.
} 
presbiterio “...desde las cornisas grandes hasta el piso de ella, yncluyendo los nichos y pantteones en donde esttán el Ilustrísimo señor Fray Juan del Molino Nauarrette... ${ }^{988 ” . ~ S a l v o ~ l o s ~ m o t i v o s ~ d e ~ p u n t i l l a ~ d o r a d a ~ q u e ~ r e c u b r i r i ́ a n ~ l o s ~ m u r o s, ~}$ que fueron sustituidos posteriormente por unos motivos geométricos con rombos inscritos en ellos, se ha conservado la policromía en las cornisas y en los arcosolios del obispo y sus progenitores. La suma acordada por esta obra ascendió a dos mil cuatrocientos reales. No obstante, en una carta de pago otorgada en 1750, ambos artistas recibieron casi el doble, pues habían intervenido también sobre el retablo ${ }^{989}$, probablemente recomponiendo alguna parte del dorado que se habría desprendido desde que fuera realizado en 1685 .

El visitador del Obispado de Palencia, determinó en 1751 que el retablo mayor y los dos colaterales de la iglesia de San Julián, que habían sido finalizados en 1702, fuesen dorados y estofados con la hacienda de su fundador, el maese de campo don Hernando de Berrio. Esta labor se realiza por partes, pues dicho año tan sólo se dora el tabernáculo y se estofan y encarnan las imágenes de los tres retablos $^{990}$. No será hasta 1755 cuando Gutiérrez se concierte para dorar la parte arquitectónica del retablo mayor y ya en 1759 se estofaron los angelillos de los retablos colaterales y se doraron sus guarniciones ${ }^{991}$.

Entre 1753 y 1754 dora dos retablos en la iglesia de San Andrés de Carrión junto a Juan López, quien recordemos, también intervino en las colgaduras de Santa María. Estos dos retablos eran el de Nuestra Señora de las Velaciones, hoy de San José y el de San Francisco Javier, colaterales de la capilla mayor, situados en el muro oriental del crucero bajo el patronato de don Juan Álvarez de Bobadilla, mecenas del encargo ${ }^{992}$. El contrato incluía la pintura del fondo de todas las hornacinas, donde debía disponer una gloria con árboles en las dos principales y un

\footnotetext{
${ }^{988}$ AHPP. Carr.Prot 4735. Gabriel Ceano Vivas (1748-1749), fol 18 y ss.

${ }^{989}$ La carta de pago asciende exactamente a 4.641 reales. AHN. Clero Secular-Regular Libro 9606, Cuentas de Fábrica de Santa María desde 1733.

990 FERRERO MAESO, Concepción. "El mecenazgo...Op.cit, pág. 598, a su vez de ADP. San Julián, Libro 17 de Cuentas de Fábrica (1747-1849), fol 12v.

${ }^{991}$ Escritura y contrato firmado el 16 de marzo de 1755. AHPP. Carr.Prot 4606. Francisco Blanco Manuel (1755), fol 112 y ss y los diferentes pagos por la obra, por valor de 5.700 reales en ADP. Carr. San Julián. Libro 17 de Cuentas de Fábrica (1747-1849), fol 12,12v y 44 y 79.

${ }^{992}$ El contrato se firma el 9 de abril de 1753. AHPP. Carr.Prot 4605. Francisco Blanco Manuel (17531754), fol 19 y ss.
} 
cielo nuboso con “...rrompimiento de luminar....”, en las demás. Aunque no de modo íntegro, esta policromía ha pervivido hasta nuestros días.

Posteriormente, todas las intervenciones en las que participa le sitúan fuera de Carrión, si bien dentro de las poblaciones pertenecientes al término de la villa. En 1761 en la iglesia de San Lorenzo de Revenga dora el retablo de San Juan y paralelamente el ensamblador José López de la Mata ejecuta un retablo colateral de dicho templo, por cuyo trabajo se les abona conjuntamente 1275 reales ${ }^{993}$. Dora en 1762 el retablo de Nuestra Señora de la Asunción de la iglesia de Villamuriel de Cerrato junto a Cayetano Bodigos ${ }^{994}$. Precisamente este dorador carrionés había participado también en el dorado de los retablos de San Julián, pues en 1757 se le abona la suma correspondiente por haber estofado las cuatro tallas de los retablos laterales y haber encarnado los serafines ubicados en los mismos ${ }^{995}$. Esta no será la última obra que haga en compañía de Bodigos, pues volverá a ser reclamado por la iglesia de San Andrés de Carrión. Ambos se comprometen a dorar de "corlea dura" y pintar la caja de su órgano “...con los ocho cañones de las conttras y mascarones que para éstos y cañones de prespecttiua pusieron..." recibiendo 1.432 reales en $1765^{996}$.

\section{Alonso Gómez \\ Dorador de Mazuecos de Campos}

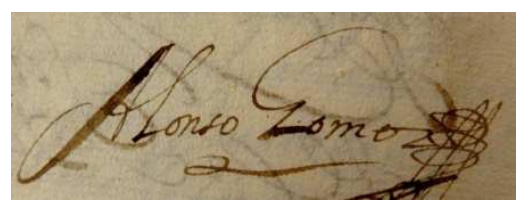

Como sucede con Francisco Gutiérrez, Alonso Gómez ejerció fundamentalmente como dorador, si bien se conoce alguna obra en la que participa como pintor, donde, seamos sinceros, no se muestra muy ducho. En 1685, admite estar esposado con una tal María Ercera ${ }^{997}$, lo que nos permite retrasar su nacimiento al menos una veintena de años. La prolijidad de detalles sobre el modo de

\footnotetext{
${ }_{993}$ AHPP. Carr.Prot 4653. Juan Cano Guijelmo (1760-1761), s/f.

${ }_{994}$ AHPP. Carr.Prot 4722. Antonio Ceano Vivas (1759-1762), fol 29.

995 También se contrata al ensamblador Bernardo de Triana, vecino de Carrión para que ejecutara dos alas y dedos de los ángeles que se habían desprendido y otras partes quebradas. ADP. San Julián. Libro 17 de Cuentas de Fábrica (1747-1849), fol 60v.

${ }_{996}$ ADP. Carr. San Andrés. Libro $5^{\circ}$ de Cuentas de Fábrica (1753-1795), fol 246.

997 AHPP. Carr.Prot 5890. Blas Vela Álvarez (1682-1685), fol 575 y ss.
} 
policromar las obras que refiere en las condiciones de los contratos, remiten a un artista concienzudo que no dejaba nada al $\operatorname{azar}^{998}$. El dorador palentino, que vive a caballo entre los siglos XVII y XVIII, se mantendrá activo durante las dos últimas décadas de la primera centuria y al menos las dos siguientes.

El retablo barroco que preside la capilla mayor de la iglesia de Santa María de Carrión es obra del ensamblador palentino Santiago Carnicero, quien precisamente se erigió como fiador de nuestro artista el 5 de mayo de 1685 cuando se le encargó el estofado y dorado del mismo por trece mil reales. Debía realizar una fina labor de escarchado, esto es, una especie de bordado con el oro bruñido aplicándolo en las hornacinas, pedestal y ornamentación. Por la obra recibiría mil trescientos reales, incluyéndose la pintura de la puerta del Sagrario con el cordero pascual o el pelícano, símbolos del sacrificio de Cristo. No obstante, la escena que existe hoy día es la tradicional de Cristo resucitado, una pintura reaprovechada del siglo XVI que sustituiría en algún momento a la imagen precedente. Por entonces tampoco estaban asentadas las esculturas, pues Alonso Gómez afirma estar eximido de dicho trabajo, ya que debían tallarse “...todos los Santos...” y sugería que tal vez don Manuel Aguado Molino, sobrino del fundador de la capilla, el obispo Juan de Molino Navarrete, traería “...dorados y estofados de Valladolid o de otra parte... ${ }^{999, "}$.

Precisamente el retablo mayor de Santa María sustituyó a otro realizado no hacía mucho, en 1647, que fue trasladado por entonces a la iglesia de San Andrés. Los ensambladores Manuel de Salceda y Gabriel Martínez se encargaron de asentarlo en la capilla mayor aquel año de 1685. Además de sustituir la imagen de la Virgen por la del Apóstol San Andrés, se tallaron unas cajas de reliquias para formar parte del retablo, tal y como vemos hoy día, que fueron talladas por el mencionado Gabriel Martínez y doradas por Alonso Gómez ${ }^{1000}$.

\footnotetext{
998 Así se muestra al redactar las condiciones para el retablo de la ermita de Boadilla de Rioseco. PÉREZ DE CASTRO, Ramón. “Un retablo en Boadilla...Op.cit, pág. 248.

999 AHPP. Carr.Prot 5890. Blas Vela Álvarez (1682-1685), fol 575 y ss.

1000 ADP. Carr. San Andrés. Libro $3^{\circ}$ de Cuentas de Fábrica (1672-1718), fol 75.
} 
En 1689 doró la caja del órgano de la catedral de Palencia ${ }^{1001}$. En 1699 doró el retablo de la iglesia de San Pedro de Villalón de Campos, en Valladolid, trazado por Blas Martínez de Obregón y ejecutado por Alonso Manzano ${ }^{1002}$. En Villamuriel de Cerrato está documentada su participación en el retablo mayor de su iglesia parroquial dedicada a Santa María la Mayor, para la cual proporcionó las condiciones del dorado encargándose asimismo de su ejecución en $1712^{1003}$. También proporcionó las pautas para el dorado del retablo palentino de la ermita de Boadilla de Rioseco en 1725, las cuales seguiría Santiago Montes, a quien le fue adjudicada su policromía y estofado ${ }^{1004}$.

También es autor de una obra muy particular, en el sentido que es pictórica: las cuatro Virtudes Cardinales del retablo mayor de la iglesia monasterial de San Zoilo. Martín González afirma que se deben a la mano de Alonso Gómez, que fueron realizadas después que el resto del retablo, sin precisar cuándo ${ }^{1005}$. La pieza procede de la iglesia parroquial de Santa María de Arbís en Baquerín de Campos desde donde fue trasladado en 1986 debido al ruinoso estado del templo. Alonso Gómez, por tanto, debió trasladarse hasta la mencionada localidad palentina para decorar el banco del retablo con las cuatro tablas de la Prudencia, la Justicia, la Templanza y la Fortaleza, excesivas en su corporeidad, ciertamente encorsetadas y de rostros poco favorecedores. Cuatro tablas dispuestas horizontalmente $(69 \mathrm{~cm}$ x147 $\mathrm{cm})$ que ponen de relieve la falta de destreza del dorador en este arte.

\section{Ramón Canedo \\ Pintor de Valladolid}

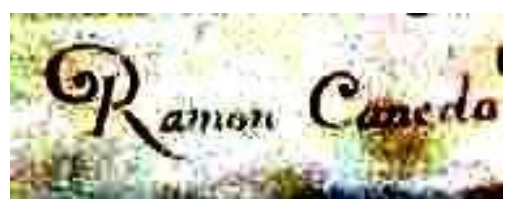

Hijo del pintor Joaquín Canedo, fue, como él, miembro de la Real Academia de Bellas Artes de Valladolid. Si bien no fue un pintor que pudiéramos tachar de eminente, debemos admitir que centró la actividad del foco vallisoletano en el siglo XVIII, donde se mantuvo activo durante el último tercio de la centuria, siendo

\footnotetext{
${ }^{1001}$ LÓPEZ CALO, José. La música...2 Op.cit, pág. 17.

${ }^{1002}$ PARRADO DEL OLMO. Jesús María. "La colaboración...Op.cit, pp. 407-416.

${ }^{1003}$ GARCÍA CHICO, Esteban. "Artistas que trabajan en la iglesia de Villamuriel de Cerrato" en $B S A A, \mathrm{n}^{\circ} 18$, Valladolid, 1951-1952, pág. 133.

${ }^{1004}$ PÉREZ DE CASTRO, Ramón. "Un retablo en Boadilla...Op.cit, pág. 248.

${ }^{1005}$ MARTÍN GONZÁLEZ, Juan José. Escultura...Op.cit, pág. 266.
} 
calificado en 1760 como un "oficial nuevo" de la ciudad ${ }^{1006}$. Esta denominación manifiesta la reciente formación académica del artista neoclásico, recurriendo a los convencionalismos propios de la institución. Su pintura está caracterizada por el empleo de figuras estáticas y un dibujo esquemático, con fondos repetitivos, sobre todo cuando se trata de retratos, género que cultivó abundantemente.

Una obra atribuida al artista en base a su vinculación con otras obras del pintor neoclásico es el retrato del Padre jesuita Francisco Suárez ubicado en las dependencias del edificio central de la Universidad de Valladolid, donde se conservan otras obras suyas ${ }^{1007}$. Tuvo que ser realizada antes de la expulsión de los jesuitas de 1767, de modo que, de corroborarse su autoría sería la obra más temprana de Canedo ${ }^{1008}$.

Su primera obra documentada le sitúa en Carrión de los Condes en cuyo consistorio se conservan al menos seis lienzos del artista, tres imágenes de los apóstoles San Pedro, San Pablo y San Andrés -estos dos identificados erróneamente por Martínez de Helguera como San Juan y Santiago- y tres retratos de ilustres carrioneses: don Melchor Álvarez de Vozmediano, obispo de Guadix, Don Andrés de Bustamante, obispo de Palencia y don Antonio Pastor, clérigo de menores ${ }^{1009}$. Dado que en la margen inferior derecha de este último lienzo figura la fecha de ejecución de 1768, es lógico pensar que el resto tengan análoga datación, siendo muy probable que la cofradía de los Veinte Clérigos, fundada por Don Antonio Pastor y a la que pertenecían los otros dos personajes, encomendara estas obras al pintor vallisoletano, todas ellas del mismo formato $(1,46 \mathrm{mtrs} \times 2,11 \mathrm{mtrs})$ salvo la del clérigo benefactor que posee mayores dimensiones (2,96mtrsx $2,07 \mathrm{mtrs})$, a tenor de

${ }^{1006}$ URREA FERNÁNDEZ, Jesús. La pintura, la rejería y la platería en Valladolid en el siglo XVIII, no5. Valladolid, 1984, pp. 353-364. En 1787, Ramón Canedo renuncia a la tenencia de dibujo que hasta entonces detentaba su padre y solicita la expulsión de la Academia, por el agravio realizado a su progenitor. CAAMAÑO MARTÍNEZ, Ma Jesús. "Datos para la historia de la Real Academia de la Purísima Concepción de Valladolid (1786-1797) en BSAA, n²9, Valladolid, 1963, pág. 92. Otros datos de Canedo en MARTíN GONZÁLEZ, Juan José y PLAZA SANTIAGO, Francisco Javier. Monumentos religiosos de la ciudad de Valladolid, volumen 2. Valladolid, 1987, pág.161.

1007 Para el retablo mayor pinta un lienzo dedicado a San Juan Evangelista, a San Jerónimo y San Agustín y en la sacristía había cuadros suyos con el tema de la Ascensión y la Última Cena. MARTÍN GONZÁLEZ, Juan José. Monumentos civiles de la ciudad de Valladolid. Valladolid, 1976, pág. 30 y URREA FERNÁNDEZ, Jesús. La pintura...Op.cit, pág. 360.

${ }^{1008}$ La obra documentada más precoz es el retrato PARRADO DEL OLMO, Jesús. "Una atribución a Ramón Canedo en la Universidad de Valladolid" en Memoria Artis, Santiago de Compostela, 2003, pp. 441-444.

${ }^{1009}$ RAMÍREZ DE HELGUERA, Martín. El libro...Op.cit, pág. 139-140. 
su protagonismo. La devoción de la hermandad por la Virgen del Pópolo, justificaría su inclusión en el fondo de los tres lienzos, a imitación de la pintura que preside el retablo que don Antonio Pastor posee en su capilla propia de la iglesia de Santa María $^{1010}$. Precisamente en esta iglesia tenía su sede la mencionada cofradía, con archivo propio. Cuando en 1867 se construyó el nuevo ayuntamiento, los lienzos fueron trasladados a su Salón de Plenos con el fin de perpetuar la memoria de tan caritativos hijos de la población ${ }^{1011}$.

Ramón Canedo aprovechó su estancia en Carrión para pintar el lienzo de las Ánimas del Purgatorio que se conserva en el muro del evangelio de la iglesia de San Andrés. La obra estaba atribuida al artista y datada en el siglo XVIII ${ }^{1012}$. Gracias a los Libros de Fábrica del templo podemos confirmar su autoría y su fecha de ejecución, ya que por la pintura el artista recibió 620 reales según carta de recibo del ocho de agosto de 1768, sin incluir el arco tallado que se hizo “...para coger la circunferencia de dicho cuadro... que presenta forma de hornacina. Este dato nos permite suponer que la obra sería ejecutada unos meses antes ese mismo año. Nos consta además que ocupó el lugar donde se ubicaba el retablo de San Ramón, junto a la sacristía, situándose hoy día a los pies del templo ${ }^{1013}$. El lienzo presenta la clásica compartimentación en dos partes: celeste y terrenal. En la margen superior preside la composición Cristo triunfante, sobre el orbe, flanqueado por la Virgen y un santo franciscano, sobre un manto de nubes. Debajo, San Miguel pesa las almas mientras es ayudado por dos querubines a seleccionar a aquellos bienaventurados que obtendrán primero la salvación. Todas las almas aguardan impacientes su pronta liberación, redimiendo sus pecados entre las llamas del purgatorio.

La idéntica representación del fuego y la tipificación de los rostros remite a otra obra del mismo tema que forma parte de la colección del museo sacro de Santiago. En este caso el artista ha prescindido de la representación del ámbito celestial, centrándose en la imagen del Purgatorio. Este lienzo, pintado por ambos lados, pertenecía al estandarte de este templo y ya había sido atribuida precisamente

\footnotetext{
${ }^{1010}$ ANDRÉS ORDAX, Salvador. "El pintor Ramón Canedo: Algunos retratos y lienzos religiosos" en $B S A A, \mathrm{n}^{\circ} 60$. Valladolid, 1994, pp. 515-520.

${ }^{1011}$ AMCC. Libro 7, Sesiones municipales (1863-1867), Sesión de 14 de septiembre de 1867, s/f.

1012 PERAL VILLAFRUELA, Santiago y GÓMEZ PÉREZ, Enrique. Carrión...Op.cit, pág. 63.

1013 ADP. Carr. San Andrés. Libro 5º de Cuentas de Fábrica (1753-1795), fol 282.
} 
a Canedo. En su parte posterior figura Santiago Apóstol en su iconografía de Matamoros, que también se vincula al artista neoclásico ${ }^{1014}$. Presenta una atmósfera irreal y un movimiento congelado a pesar de que el caballo galopa sobre los cuerpos tendidos de los infieles. Las tres imágenes probablemente coetáneas, manifiestan la escasa creatividad del artista, que repite esquemas compositivos en los que las figuras, algo envaradas, pecan de cierta inexpresividad.

Precisamente en el museo de Santiago existe otro lienzo que representa a San Andrés $(72,5 \times 53 \mathrm{~cm})$ que ha sido señalada, a nuestro juicio acertadamente, como obra “...cercana al estilo de Ramón Canedo... ${ }^{1015}$ ”. El tipo físico empleado remite al que observamos en la representación del apóstol homónimo ubicado en el ayuntamiento, por lo que la obra debe enmarcarse dentro de la misma cronología, siendo probablemente un encargo del templo de San Andrés.

Canedo regresaría a Carrión mucho tiempo después para cumplir un pequeño encargo. Está documentada su autoría en una pintura de la Espíritu Santo que realizó para ornamentar el copete del púlpito de San Andrés, obra no conservada que realizaría el tallista carrionés Fabián Martín en 1784. El pago emitido ese mismo año al pintor “...de diez y seis rreales y medio de dos baras de lenzarico y los sesentta rreales restanttes pagados” en moneda, revelan la modestia de la obra ${ }^{1016}$. El púlpito $\mathrm{y}$, consecuentemente la pintura, no se han conservado al ser sustituido por la obra neogótica de Timoteo Martín que se conserva actualmente en el lado del Evangelio.

Como venimos constatando en el resto de artistas, además de su actividad pictórica, también está constatada, al menos en una ocasión, su faceta de policromador, pues en 1793 pinta una escultura de San Francisco no conservada, para el convento homónimo de Tordesillas ${ }^{1017}$.

\footnotetext{
${ }^{1014}$ GÓMEZ PÉREZ, Enrique y MARISCAL, José. Iglesia de Santiago...Op.cit, pág. 45.

1015 Ibídem, pág. 37.

1016 ADP. Carrión. San Andrés. Libro 5º de Cuentas de Fábrica (1753-1795), fol 405 y 447v.

${ }^{1017}$ PARRADO DEL OLMO, Jesús María y ARA GIL, Clementina Julia. Catálogo Monumental del Antiguo Partido Judicial de Tordesillas. Valladolid, 1980, pág. 298.
} 


\section{EVOLUCIÓN DEL PATRIMONIO CARRIONÉS}




\section{EVOLUCIÓN DEL PATRIMONIO CARRIONÉS}

\subsection{ANTECEDENTES. LA EDAD MEDIA}

El hecho de que una villa cuya población rondaba los tres mil vecinos llegase a contener nada menos que cuatro centros monásticos, doce templos parroquiales y tres ermitas a finales de la Edad Media, nos transmite inmediatamente el esplendor que experimentó la que fue, después de Palencia, segunda cabeza de provincia.

\section{CLERO REGULAR}

El esplendor alcanzado por Carrión motivó una pluralidad de asentamientos en la villa y alrededores de hasta cuatro órdenes religiosas diferentes, acorde al espíritu eminentemente religioso que caracterizó la Edad Media en territorio castellano $^{1018}$. De ellas, dos eran monacales, los benedictinos de San Zoilo y los agustinos de Benevívere-, y dos mendicantes, perteneciendo a éstas los padres predicadores de Santo Domingo y los franciscanos en sus tres ramas, a saber: los frailes de San Francisco, la orden femenina de Santa Clara y las terciarias de Santa Isabel.

La fundación de cada uno de estos conventos o monasterios se debió a circunstancias particulares que analizaremos seguidamente en sus respectivos capítulos, entendiendo fundación como el proceso inicial de la vida en comunidad. En este sentido, como bien explica Marta Cuadrado Sánchez, resulta equivocado ceñirse a un instante concreto, ya que existen diferentes fases incluidas en este amplio término que responden a momentos bien distintos separados en el tiempo ${ }^{1019}$.

\footnotetext{
${ }^{1018}$ Sobre este tema LINAGE CONDE, Antonio. "De los monjes a los frailes: notas sobre la implantación de la vida religiosa medieval en el territorio castellano-leonés" en El pasado histórico de Castilla y León. Actas del I Congreso de Historia de Castilla y León celebrado en Valladolid, del 1 al 4 de diciembre de 1982, vol. 1, 1983, pp. 263-274.

${ }^{1019}$ El convento de San Francisco de Pamplona ilustra este caso. Los frailes se asentaron en las primeras décadas del siglo XIII en unos terrenos junto al río Arga pero no fue hasta 1245 cuando Inocencio IV concedió el permiso necesario para erigir un convento, llegando la erección del mismo un tiempo más tarde. CUADRADO SÁNCHEZ, Marta. "Arquitectura franciscana en España" en Archivo Ibero- Americano. Revista de Estudios Franciscanos. n 201-202. Enero-Junio 1991, pp. 28 30.
} 
Diferenciamos por tanto el momento de introducción de una orden en la villa, estableciéndose provisionalmente en un espacio existente de aquélla en que la comunidad decide ampliar el lugar existente o trasladarse del mismo. En este proceso interviene el papado otorgando los permisos convenientes y un miembro o familia destacada de la nobleza o la monarquía que, como patrono, se ofrece a correr con los gastos que ocasionan la cesión de los terrenos y la construcción del cenobio. En último caso, la fundación queda establecida con la colocación de la primera piedra, transcurriendo por ende, varios años, incluso décadas en los que se desarrolla todo el mecanismo fundacional. De este complicado proceso inferimos la divergencia respecto a la fecha de origen propuesta por los cronistas para las diversas comunidades puesto que cada uno toma como referente una etapa diversa de la fundación. Nosotros trataremos de establecer una evolución lógica de todas ellas desde sus orígenes, distinguiendo debidamente cada fase con el único fin de evitar confusiones.

El establecimiento más antiguo y sin duda, más insigne de Carrión de los Condes corresponde al de los benedictinos de San Zoilo, quienes originalmente acogidos a la protección de Cluny pasarían a depender posteriormente de la congregación vallisoletana. Los monjes escogieron para su asentamiento una ermita dedicada a San Juan Bautista, ubicada a las afueras de Carrión, en su parte noroeste, atravesando el río homónimo. Se trata del último enclave que halla el peregrino antes de continuar su camino hacia Calzadilla de la Cueza. Posteriormente, alrededor de este centro de vida espiritual se asentó una gran parte de la población, conformando el barrio de San Zoles, separado del resto de la villa a través de un gran puente. Su origen se remonta al siglo $\mathrm{X}$ aunque los restos conservados de época más temprana se remontan al románico. Los sepulcros de la galilea pertenecientes a los fundadores del templo, el linaje Beni- Gómez y las telas islámicas de la sacristía constituyen las piezas más destacadas de este período.

El siglo siguiente fue testigo de la fundación de una abadía en Benevívere, un arrabal perteneciente a Carrión, distando unos pocos kilómetros del mismo. Por aquel año de 1165 en que don Diego Salvador de Villamayor realizó su fundación, el convento era lugar de paso obligado del Camino de Santiago, hasta que posteriormente la ruta fue desplazada, quedando la abadía apartada de la actividad 
precedente. De este modo, Calzadilla no era la parada inmediata a Carrión, como lo es hoy día, sino que la ruta, ocupada actualmente por una carretera, se desviaba hacia el sur en dirección a Calzada de los Molinos, atravesando seguidamente Cervatos y Quintanilla de la Cueza antes de llegar a este punto. Su sala capitular albergaba los enterramientos de los miembros más destacados de los Sarmiento, de los cuales perviven tan sólo los sepulcros góticos de los museos de León y Palencia. Una pieza muy representativa de época fundacional es una estela pétrea que aunaba las funciones de reloj solar, calendario y estela conmemorativa. Forma parte de los fondos del Museo Diocesano de la capital palentina. Los moradores de esta abadía, un grupo de agustinos regulares, poseyeron además un priorato aledaño al convento denominado de San Torcuato cuya función fundamental era la de hospital de peregrinos. Su iglesia barroca, único edificio conservado enteramente, junto a los escasos restos repartidos en los alrededores ofrecen claros indicios acerca de la configuración del citado conjunto y la gran extensión que llegó a ocupar.

Por su parte, la orden franciscana gozó de gran aceptación entre los vecinos de la villa a través de la fundación de tres conventos. Frente al monacato tradicional, los mendicantes establecían una nueva religiosidad más humana y social, en contacto directo con el fiel. La predicación en lengua romance y la introducción del canto litúrgico fueron claves fundamentales para la rápida captación de una religiosidad basada en la pobreza ${ }^{1020}$. A partir de ahora, la celebración de la liturgia adoptará un carácter más abierto, pues el fiel tenía total visibilidad no sólo del predicador, ubicado en el púlpito, sino del oficiante, situado en el altar ${ }^{1021}$.

De los tres cenobios franciscanos de Carrión, dos de ellos, San Francisco y Santa Clara, son fundaciones medievales. Ambas comenzaron su andadura a lo largo del siglo XIII y se establecieron muy próximos entre sí, extramuros de la villa ${ }^{1022}$.

\footnotetext{
${ }^{1020}$ CUADRADO SÁNCHEZ, Marta. “Arquitectura franciscana en España” en Archivo IberoAmericano. Revista de Estudios Franciscanos. no 201-202. Enero-Junio 1991, pp. 19-20.

${ }^{1021}$ La liturgia tradicional no permitía la visión del oficiante, manteniéndose el cariz mistérico en las celebraciones. BANGO TORVISO, Isidro. "La vieja liturgia hispana y su interpretación funcional del templo prerrománico" en VII Semana de Estudios Medievales, Nájera, 29 julio a 2 de agosto, 1996. Actas, Logroño, 1997, pp. 98-102. Otro estudio sobre este tema en RODRIGUEZ GUTIÉRREZ CEBALLOS, A. "El reflejo de la liturgia visigótico-mozárabe en el arte español de los siglos VII al X" en Pontificia Universitas Comillensis, 1965, pp. 3-35.

1022 Sobre la instalación de los mendicantes en Castilla PEÑA PÉREZ, Javier. "Expansión de las órdenes conventuales en León y Castilla: franciscanos y dominicos en el siglo XIII" en III Semana de Estudios medievales. Instituto de Estudios Riojanos. Logroño, 1993, pp. 179-198.
} 
Del primer convento tan sólo se mantiene en pie su iglesia, fruto de diversas épocas, aunque desprovista íntegramente de su cubrición. De su patrimonio mueble se ha salvado una Piedad del siglo XV procedente de la capilla homónima, de origen flamenco, conservada entre los fondos del Museo Marés de Barcelona. La casa clarisa ha corrido mejor suerte, pues funciona hoy día con un total de ocho internas. Todo el cenobio fue reformado con posterioridad, manteniéndose las vigas del siglo XIII con escudos pertenecientes a doña Mencía de Haro y un artesonado del siglo $\mathrm{XV}$ con las armas de los Osorno como los únicos testimonios gráfico que perviven de este período.

\section{CLERO SECULAR}

En lo que al patrimonio de carácter secular se refiere, Carrión de los Condes también contó con un gran número de templos y conventos. En la primera estadística de la Diócesis palentina, que data de 1345, se recogen doce iglesias, el número más elevado de todo el territorio, regentadas por cuarenta y nueve clérigos. De ellas, nueve eran parroquiales: San Bartolomé, San Pedro, San Andrés, San Julián, San Juan del Mercado, Santiago, Nuestra Señora de Belén, Santa María del Camino y la Magdalena, dentro de la iglesia de San Zoilo. Las tres restantes no lo eran: Santa Eulalia, San Vicente y Sancti Espíritus ${ }^{1023}$. Ésta última fue anexionada a la iglesia de Santa María en $1468^{1024}$. A este recuento hay que añadir las ermitas de San Juan, en el arrabal de Cestillos, la Piedad y San Cristóbal ${ }^{1025}$, pues la Vera Cruz aún no estaba construida, pues la cofradía homónima poseía un pequeño espacio en el convento de San Francisco.

\footnotetext{
${ }^{1023}$ SAN MARTín PAYO, Jesús. "La más antigua estadística...Op.cit, pp. 10-13. Este manual lo mandó redactar el Obispo don Vasco (1344-1352) para trazar con exactitud los lugares por donde se extendía la Diócesis palentina. Había un total de 576 parroquias repartidas en cuatro arcedianazgos: Carrión, el más importante de todos por número de parroquias y posesión de privilegios, Campos, Cerrato y Alcor. Sobre este Obispo, véase VACA LORENZO, Ángel. "Don Vasco, el muy buen perlado de Palencia: su vida y obra al frente de este Obispado" en AIIICHP, tomo 2. Palencia, 1995, pp. 437-482.

${ }_{1024}$ ARCHV. Patronato Eclesiástico, Legajo 203.Traslado de petición y cesión de la iglesia de Sancti Spiritus en 1468, expedido por mandato de las religiosas clarisas en 1628.

${ }_{1025}$ CARRIÓN GUTIEZ, Manuel. "Carrión de los Condes" en Apuntes Palentinos. Tomo VI, Villas Palentinas, nº 4. Palencia, 1983, pág. 24.
} 
Entre el patrimonio mueble de estos templos, no podemos eludir dos piezas góticas ubicadas en Santa María: la Virgen de piedra policromada del segundo cuarto del siglo XIII que preside la hornacina del muro de la Epístola y el Crucifijo doloroso de la Capilla del Cristo del Amparo, de hacia 1330-1360. Conservada en el Museo de Santiago se halla una Piedad de la primera mitad del siglo XV, procedente de la ermita homónima, de tipo horizontal. De la iglesia de Nuestra Señora de Belén merece mención el Cristo de la Salud, obra del siglo XIV ubicada en la capilla de San Gregorio, en la hornacina principal de un retablo dieciochesco sin policromar.

Todos estos templos diseminados por la villa, se hallaban integrados en un gran núcleo urbano denominado "Gran Carrión” que alcanzó por su parte más septentrional la iglesia de Belén recorriendo paralelamente el curso del río hasta la zona del mercado en su zona más meridional ${ }^{1026}$. El Gran Carrión estaba a su vez dividido en dos castros: al norte, el castro de San Andrés o Castillería, al sur, el de Santa María, ambas separados por la puerta del Canto, ubicada al finalizar la calle Esteban Collantes ${ }^{1027}$. Cisneros y Tagle las denomina, por su situación "media villa arriba" y "media villa abajo"1028. De acuerdo a su ubicación, el primer sector, correspondiente a la zona septentrional abarcaría las iglesias de Belén, San Andrés, San Vicente, Santa Eulalia y la ermita de la Cruz y al otro le corresponderían los templos de Santiago, Santa María, San Juan de Cestillos y San Bartolomé. Este núcleo poblacional estaría limitado por una muralla, extramuros de la cual se hallarían los templos de Belén, dada su defensa propia por ubicarse en altozano, San Juan del Mercado, que se hallaba en línea con la misma, junto a la puerta homónima y los monasterios y conventos con sus respectivas ermitas, por su situación más apartada. Tan sólo se conserva un pequeño lienzo de esta defensa junto a la iglesia de Santa María, en la actual Avenida de Don Ramírez de Helguera.

\footnotetext{
${ }^{1026}$ VALLE CURIESES, Rafael de. A orillas del Carrión. Destellos de un pasado entrañable: acontecimientos históricos, personajes memorables, arte. Caja de Ahorros y Monte de Piedad. Palencia, 1989, pág. 95.

${ }^{1027}$ CADIÑANOS BARDECI, Inocencio. "Fortificación y castillos de los siglos románicos" en Palencia en los siglos del románico. Fundación Santa María la Real de Aguilar. Palencia, 2002, pp. 184-185.

${ }^{1028}$ CISNEROS Y TAGLE, Juan de. Historia de las grandezas y antigüedades de la muy noble villa de Carrión. Frómista, Palencia, 1629. fol 224v y 225.
} 


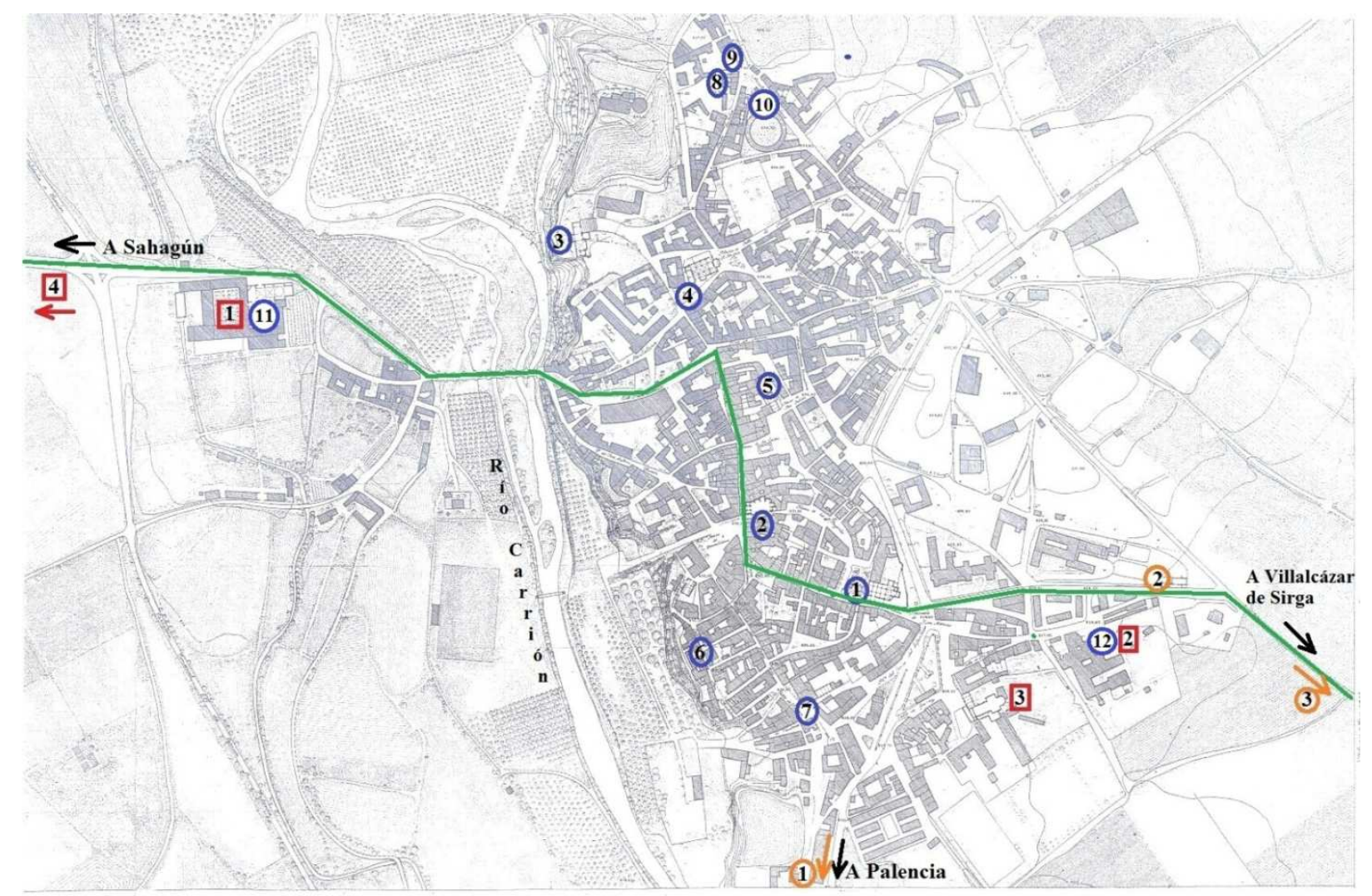

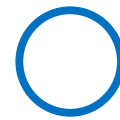

\section{Iglesias}

1. Sta. María

2. Santiago

3. Nuestra Señora de Belén

4. San Andrés

Benevívere

5. San Julián

6. San Bartolomé

7. San Juan del Mercado

8. Santa Eulalia

9. San Vicente

10. San Pedro

11. La Magdalena

12. Sancti Espíritus

homónima)

\section{Monasterios y Conventos}

1. Monasterio de San Zoilo

2. Convento de Santa Clara

3. Convento de San Francisco

4. Convento de Sta. María de

(a $5 \mathrm{~km}$ en la carretera de Villotilla)

\section{Ermitas}

1.San Juan de Cestillos (a 2km)

2. La Piedad

3. San Cristóbal (en la cuesta

Patrimonio religioso de Carrión de los Condes en el siglo XV. 


\subsection{EL SIGLO XVI: NUEVAS FUNDACIONES Y FÁBRICAS EXTINTAS}

Todos los factores analizados con anterioridad propiciaron el asentamiento de nuevas instituciones religiosas en la villa. Igualmente, a lo largo del siglo XVI el patrimonio del clero secular sufre notables alteraciones. Se construyen edificios ex novo y se producen intervenciones en otros tantos.

Entre las artes figurativas, destaca la escultura, pues prolifera de un modo significativo la ejecución de sepulcros y retablos, no conservados éstos últimos en su mayor parte al ser renovados con posterioridad, además de otras obras de carácter exento para ornamentar los espacios de culto.

\section{CLERO REGULAR}

En lo que a la arquitectura del clero regular se refiere, en 1537 dieron comienzo las obras del célebre claustro de San Zoilo, que se prolongaron hasta 1604. El Cristo atado a la columna atribuido a Miguel de Espinosa es la obra renacentista por excelencia custodiada actualmente en una hornacina del claustro bajo. En el convento de San Francisco, su iglesia fue reedificada y se construyó un nuevo claustro durante el último tercio de la centuria, obras llevadas a cabo en su mayoría por el trasmerano Juan de la Cuesta. La reconstrucción del templo, con la consecuente reforma de algunas de sus capillas, trajo consigo el encargo de algunas obras que las ornamentasen, como los dos retablos de la capilla de la Piedad, uno de escultura y otro de pintura encargados en 1575 y 1590, respectivamente, el retablo de la capilla de las Once Mil Vírgenes, de la mano de los Lago, el Cristo yacente conservado en el museo de Santa Clara, que, originariamente ubicado en la capilla de Mirabueno, podemos fechar hacia 1500 y una talla Virgen de la O, del círculo de Juan de Valmaseda, procedente de la capilla de Nuestra Señora y trasladada al Museo de Santa Cruz de Toledo. De finales de la centuria es la Inmaculada del Museo de Santa Clara primitivamente ubicada en la capilla de la Concepción. 
Santa Clara, por su parte, aprovecha el momento de bonanza económica para reconstruir parte del convento: el claustro, las celdas, la sala baja y el coro. En lo que al patrimonio mueble se refiere, el sepulcro de Doña Aldonza Vivero, atribuido a Miguel de Espinosa y los retablos de San Blas y del Espíritu Santo, encargados en 1596, constituyen las joyas escultóricas de este período.

También se produjeron dos nuevas fundaciones, pues en 1515 don Gonzalo Gallo dona sus casas para que se fundase el hospital de San Miguel, que escogió para su asentamiento unos terrenos situados junto a la iglesia de San Andrés, en la plazoleta homónima. Funcionó paralelamente como casa conventual a partir de 1532, cuando don Gonzalo dispone en su testamento que cinco beatas de San Francisco se encarguen de su atención. Tan sólo unos años después, concretamente en 1527, vería su instalación la orden dominica en Carrión, eligiendo como sede el solar de la iglesia de San Pedro, a medio camino entre dos edificios hoy día desaparecidos, la iglesia de San Juan del Mercado, ubicada en la plaza homónima y el hospital de Santa María, frente a la iglesia del mismo nombre. A lo largo de la centuria, se fueron construyendo los espacios necesarios para la vida en comunidad, como su claustro renacentista, la sala capitular o la reforma del templo precedente.

Al igual que sucedió con sus compañeros franciscanos, los dominicos fueron cálidamente acogidos por la población, e incluso por la nobleza y la monarquía que encontraron en ellos un gran apoyo. La aceptación del sector civil, resulta por tanto, lógica, máxime teniendo en cuenta que en algunos casos las dependencias conventuales fueron cedidas puntualmente para la celebración de acontecimientos políticos y sociales, algo que venía sucediendo desde tiempo inmemorial ${ }^{1029}$. En el caso carrionés, el convento franciscano fue el lugar donde ocasionalmente se firmaban los contratos de obras concernientes al cenobio vecino de clarisas ${ }^{1030}$. Al

\footnotetext{
1029 Sirva como ejemplo. extrapolable a Carrión, el hecho de que el Consejo de los Cientos de Cataluña que administraba la ciudad desde 1274, utilizaba el convento de San Francisco como sede para sus reuniones periódicas CUADRADO SÁNCHEZ, Marta. "Arquitectura franciscana...Op.cit, pág. 534.

${ }^{1030}$ Sirvan como ejemplos los siguientes: La firma en 1597con Santiago Sigüenza de las condiciones para realizar el paño del claustro donde se ubican los dormitorios. AHPP. Carr.Prot 4700, s/f Pedro Carrión (1597). Igualmente las condiciones de 1613 para la nueva obra del templo que realzaría Alonso de Santiago se firmaron en San Francisco. AHPP. Carr.Prot 4840. Juan Díaz Pajaza (1613), s/f.
} 
adquirir esta dimensión social carente en los centros monásticos, los mendicantes recibieron muestras de gratitud general traducidas, en muchos casos, en generosas aportaciones económicas.

En lo que respecta a la abadía de Benevívere, los agustinos encargaron la ejecución de su portada de acceso al recinto conventual, semejante en su tipología a las fachadas que Rodrigo Gil de Hontañón ejecutaba. Por su parte, la sala capitular engrosó el número de enterramientos con los que contaba a través de diversos monumentos funerarios pertenecientes a los miembros del linaje Sarmiento, cuya magnificencia podemos imaginar a través de las descripciones conservadas de los mismos.

\section{CLERO SECULAR}

De las iglesias existentes en Carrión en el siglo XVI, debemos realizar una distinción, creada en la documentación, entre las de Santa María, Santiago, Nuestra Señora de Belén y San Andrés, los denominados "templos mayores" y el resto, que no recibía ninguna nomenclatura especial. Los primeros eran así considerados, no sólo a tenor de su tamaño respecto al resto, sino de su antigüedad y relevancia dentro de la villa. La ambición de supremacía entre todos sus clérigos desencadenó un ambiente plagado de hostilidades que alcanzará su punto álgido en el siglo posterior.

En cuanto a las intervenciones relativas a estos cuatro templos, en la iglesia de Santa María se interviene sobre su lienzo norte, reconstruyéndose la sacristía y edificándose la capilla de los Herrera. Santiago experimenta una remodelación completa a consecuencia de la pésima cimentación, y por razones de la misma índole, Belén se reconstruye por completo a partir de mediados de siglo, conservándose de este período la capilla mayor y la de San Gregorio. Respecto a San Andrés, que comparte la advocación con San Pedro por la adhesión de sus feligreses a este templo, le sucede lo mismo que a sus compañeros, y es reedificado siguiendo el proyecto de Rodrigo Gil de Hontañón, que, en contra de lo que se pensaba, no es el definitivo, ya que se proporcionará otro a posteriori. 
Entre las obras más destacables de este período custodiadas en estos templos figura el sepulcro del fundador de la capilla de los Paces o de San Nicolás, don Juan de Paz, fallecido en 1514, de la iglesia de Santa María. De la iglesia de Santiago, formando parte del museo de Navarra, procede una talla de Santo Obispo atribuible al taller de Alonso Berruguete. En su antigua capilla de la Concepción, fue encargado en 1569 un retablo de pintura al carrionés Miguel del Val, que no se ha conservado. De la iglesia de Belén, su retablo mayor se erige entre los tesoros artísticos del plateresco castellano, obra atribuible al taller escultórico establecido en Carrión durante el primer tercio del siglo XVI y declarada Monumento Histórico artístico en 1960. También en este templo y conservado en buen estado dentro de la capilla de San Gregorio, se halla el sepulcro de su mayor benefactor, el canónigo de Alcalá don Fernando Díez, a quien sobrevino la muerte en 1556. San Andrés, por su parte atesora una pequeña pintura de un Ecce Homo, situada en el banco del retablo de la Adoración de los Reyes, que atribuimos al círculo de Juan de Juanes.

Por su parte, San Bartolomé y San Juan del Mercado experimentan reedificaciones, correspondiéndole al primero la capilla mayor y la nave y la torre, al segundo. En este último templo, procedente de la capilla mayor, resulta ineludible un tondo de alabastro desaparecido que representaba un Llanto sobre Cristo muerto y que podemos datar en el segundo tercio del siglo XVI. San Vicente, que desaparecerá en las postrimerías del siglo XVI, siendo reaprovechados su materiales en la fábrica de Santa Eulalia. Puesto que Sancti Espíritus había sido anexionada en 1468 a la iglesia de Santa María y el templo de San Pedro desapareció al convertirse en el convento de Santo Domingo, como señalamos, en 1527, de los doce templos existentes desde 1345, nos encontramos con nueve a finales de la centuria decimosexta.

De las cuatro ermitas existentes en la villa, exceptuando las dos de la clausura de Santa Clara, no se registra ningún dato relevante sobre las mismas a lo largo del siglo XVI, a excepción de la Vera Cruz, cuya cofradía se traslada desde el convento de San Francisco a su sede actual, entre los templos de Belén y San Andrés, hacia las primeras décadas, datándose de este período, la estancia que funcionó como salón, provista de un artesonado. 


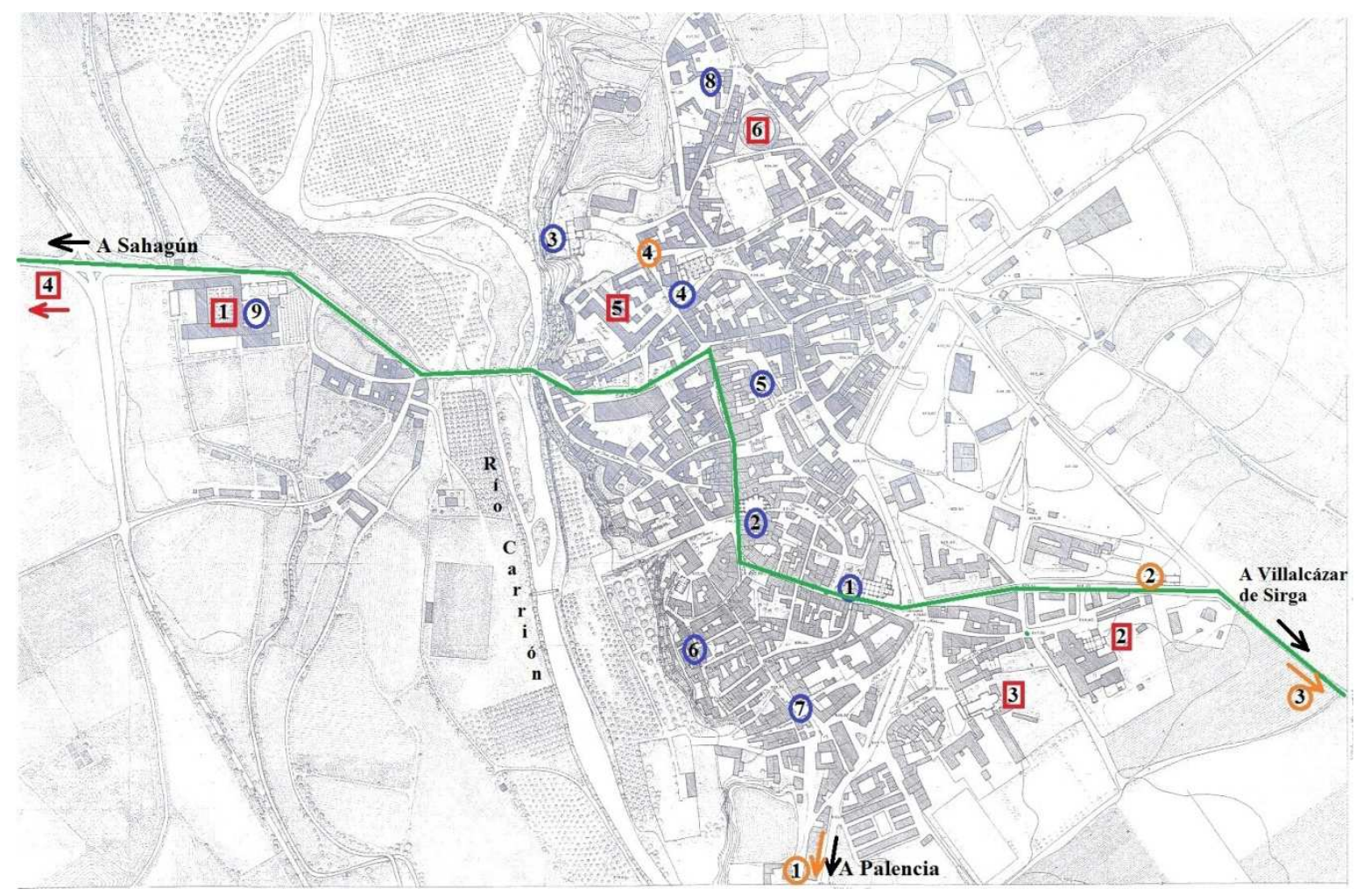

\section{Iglesias}

1. Sta. María

2. Santiago

3. Nuestra Señora de Belén

4. San Andrés

5. San Julián

6. San Bartolomé

7. San Juan del Mercado

8. Santa Eulalia

9. La Magdalena

\section{Monasterios y Conventos}

1. Monasterio de San Zoilo

2. Cvto. de Santa Clara

3. Cvto. de San Francisco

4. Cvto. de Sta. María de Benevívere (a $5 \mathrm{~km}$ en la carretera de Villotilla)

5. Cvto. de San Miguel y Santa Isabel

6. Cvto. de Santo Domingo

\section{Ermitas}

1. San Juan de Cestillos (a2km)

2. La Piedad

3. San Cristóbal (en la cuesta homónima)

4. La Vera Cruz

Patrimonio religioso de Carrión de los Condes a finales del siglo XVI. 


\subsection{EL PERIODO BARROCO: RECONSTRUCCIÓN EX NOVO DE ANTIGUAS FÁBRICAS Y RUINA DE OTRAS}

Si tuviéramos que resumir lo que sucede durante este largo período, podríamos afirmar, que el siglo XVII resulta un período de auge, constructivamente hablando, pues muchas de las fábricas existentes se renuevan por completo desde los cimientos, optándose por edificaciones de raigambre clasicista, moda imperante por entonces. En la centuria posterior no se realizan grandes obras, pues los edificios ya estaban totalmente construidos, de modo que asistimos a una etapa en la que tan sólo se registran intervenciones de retejos y otros reparos de pequeña entidad. En suma, el siglo XVII es a reedificación como el XVIII a rehabilitación. No obstante, desaparecen otras fábricas que se hallaban en ruinas, siendo sus feligreses agregados a los templos más cercanos. Por tanto, en realidad, se pierde parte del patrimonio existente sin crearse nuevas fábricas.

Respecto a las artes figurativas, la escultura cobra un protagonismo equiparable al de la arquitectura, prolongándose durante el siglo XVIII, mientras que la pintura se mantiene a la sombra de sus compañeras.

\section{CLERO REGULAR}

Comenzado por San Zoilo, durante este período se renuevan las dependencias claustrales pero lo más interesante es la erección del nuevo templo sobre la antigua fábrica románica, cuyas obras se prolongaron desde 1633 hasta 1668 en que la fachada se encuentra en fase de ejecución, finalizándose su último cuerpo en 1693 tras un largo período de paralización de las obras. En las postrimerías del siglo posterior se ejecuta el patio neoclásico, del que tan sólo se conserva su fachada. La obra más significativa de su templo, procedente de la iglesia de Santa María de Baquerín Campos, es su retablo mayor, obra del segundo tercio del siglo XVII atribuible a un seguidor de Gregorio Fernández. Del siglo XVIII son los retablos gemelos de Santa Gertrudis y de Cristo el Real, los cuatro retablos 
neoclásicos con las pinturas de San Gregorio, San Benito, la Anunciación y San Leandro y la sillería de nogal del coro alto.

La abadía beneviverense se centra durante este período en la resolución de algunos conflictos con el concejo e incluso la realeza por la provisión de la misma, por lo que su reparo y embellecimiento resulta la menor de sus preocupaciones, realizándose tan sólo algunas reparaciones urgentes en el claustro alto y la cripta de la capilla mayor a partir de 1605, por deseo expreso del conde de Salinas. Por su parte, la iglesia de San Pedro sobre la que se asentó el convento dominico, presentaba enormes deficiencias y se hizo necesaria una reedificación durante la primera mitad del siglo XVII, cuando además se concluyen las obras del claustro alto. En la iglesia de San Andrés se conservan dos de los testimonios gráficos de estos conventos: la sillería coral de Benevívere, obra del primer tercio del siglo XVII, trasladada en 1894 y el retablo churrigueresco de Nuestra Señora del Rosario, que, procedente de la capilla homónima de la casa dominica, podemos datar en el segundo cuarto del siglo XVIII.

En los conventos franciscanos se emprenden obras de reconstrucción total con carácter definitivo. La revitalización de la casa clarisa en este período se produce por impulso de Sor Luisa de la Ascensión, popularmente conocida como "la monja de Carrión", gracias a cuya intervención durante el primer tercio del siglo XVII, fue posible la creación de las dos ermitas de la huerta, el levantamiento de un nuevo templo con su frontis de azulejería talaverana y la dotación de nuevas obras de arte. Entre todas ellas, resultan ineludibles la Piedad y el Cristo Crucificado debidas a la mano de Gregorio Fernández. De gran calidad es el retablo mayor, obra clasicista que contiene cuatro lienzos napolitanos, que fue asentada en 1633, momento en que su antiguo retablo pasó a presidir la capilla mayor del convento de San Francisco. Los dos lienzos del presbiterio también se deben a la iniciativa de la venerable sor Luisa. Son dos obras de 1619 que representan un Calvario y una Inmaculada, copia de la talla desaparecida que Gregorio Fernández realizó para el convento de San Francisco de Valladolid. Salvo algunas reformas de carácter general, durante la centuria posterior no se emprenden grandes obras, dada la fiebre constructiva precedente, encargándose tan sólo nuevos retablos como el que acoge el 
Cristo Crucificado de Fernández, y su frontero, bajo la advocación de Nuestra Señora de la Consolación, además del órgano neoclásico del coro bajo.

En Santa Isabel, el decreto de clausura de 1604 con el consecuente cambio de función del centro, desde entonces exclusivamente religioso, motiva la puesta en marcha de nuevas obras adaptadas a la reciente situación que no se materializan hasta 1620. Por último, en el convento de San Francisco, las obras de reedificación de su capilla mayor, sacan a la luz en 1612 los sepulcros pétreos, no conservados actualmente, de los benefactores de la casa franciscana entre los siglos XIII y XIV: la infanta doña Juana Manzanedo y su esposo don Luis de Ponthieu, vástago del rey Fernando III. Desde las primeras décadas del siglo XVIII, asistimos a la reconstrucción parcial del templo, -capilla mayor, sacristía y algunas capillasfenómeno que resulta excepcional dentro de la villa por el retraso de las obras, aplicándose en este caso una estética neoclásica. El retablo mayor, procedente de Santa Clara, fue sustituido a mediados del siglo XVIII por otro, igualmente desaparecido, presidido por la imagen de la Purísima. Por fortuna, otras obras de este templo han corrido mejor suerte, como las tallas barrocas de San Pedro de Alcántara, San Francisco de Asís, San Diego de Alcalá o San Luis Obispo que, reubicadas en el museo de Santa Clara, presidían los retablos neoclásicos aún adosados en los muros del templo franciscano.

Un censo relativo al número de internos de cada cenobio realizado en 1753 constituye una interesante fuente a la hora de interpretar la preponderancia de unas órdenes sobre otras dentro de la villa. La cifra de miembros de una comunidad es directamente proporcional al grado de aceptación de cada orden por los sectores más elevados en la escala social -papado, monarquía, obispado y nobleza- plasmado en una serie de privilegios, donaciones y exenciones concedidos según preferencia personal. Todos estos favores y mercedes que recibe en mayor o menor medida una casa conventual se traducen tangiblemente en una inmensa posesión de heredades, en la ampliación de los cenobios o edificación de otros mejores y consecuentemente en la posibilidad de aumentar el número de internos en el seno de esa comunidad. Corresponde a San Zoilo, dada su entidad, la cifra más elevada, al contar con 34 frailes en clausura y 29 entre miembros del Colegio y administrativos. Le siguen las clarisas con 38 hermanas, número elevado sí, pero lejano a la cincuentena que poseía 
hacia el siglo XIV. Por detrás de Santa Clara, los otros dos grupos mendicantes alcanzan cifras parejas, contando los franciscanos con 29 , tres de los cuales eran donados y sus compañeras terciarias de Santa Isabel que alcanzan los 26. Los otros dos cenobios no llegaban a la veintena de religiosos, pues Santo Domingo tenía 18 y los regulares agustinos reunían por entonces a 11 canónigos y tres fámulos en clausura $^{1031}$.

\section{CLERO SECULAR}

En lo que se refiere a los principales templos carrioneses, asistimos a un período de prolífica actividad artística, pues bien se reedifican íntegramente o como mínimo, se sustituyen sus cubiertas. La iglesia de Santa María derruye la bóveda de cañón románica de su nave central a partir de 1603 . No obstante, la reforma de la capilla mayor llevada a cabo entre 1682 y 1685 por Felipe Berrojo, es sin lugar a dudas, la obra trascendental de este momento, dejando para la centuria posterior el aderezo de las capillas laterales con retablos barrocos: el de la capilla de don Antonio Pastor, obra clasicista del segundo tercio del siglo XVII y del primer cuarto de la centuria siguiente el de San Nicolás, realizado en madera sin policromar y los retablos de San Antonio y de la Virgen de la Paz de la capilla de los Calderones.

En Santiago se consolida el templo debido a su inestabilidad, además de reformarse parcialmente la capilla mayor a partir de 1607, respetando los ábsides románicos. Hacia 1738, una serie de bóvedas de arista no conservadas, suplen las cubriciones de la nave del siglo XVI. Entre las obras que custodiaba el templo, figuraba su retablo mayor, concertado con el ensamblador carrionés Juan Bautista Pérez en 1655, o el retablo de pintura que la cofradía de las Ánimas encargó a Bartolomé de Medina, vecino de Carrión, en 1602 y que podemos identificar con el retablo que preside San Basilio el Grande en su museo sacro.

\footnotetext{
${ }^{1031}$ AHPP. Catastro del Marqués de la Ensenada. Respuestas dadas a las preguntas generales por los nombrados en dicha villa para la operación de única contribución en la Villa de Carrión, provincia de Toro. 12 de febrero de 1753. Microfilm 335, Libro 629, fol 224v.
} 
En Belén, a mediados del siglo XVII se levanta la nave del templo que hoy conocemos, y su torre aledaña, modificándose su orientación hacia el sur, debido a la proximidad de la primitiva iglesia al acantilado del río. Por entonces también se realiza el retablo de San Isidro Labrador, a tenor de la canonización del santo madrileño en 1622. De la centuria posterior es el retablo sin policromar del Cristo de la Salud, al que hicimos referencia con anterioridad por la talla gótica que alberga y un grabado de San Pedro Regalado, datable hacia el tercer cuarto del siglo, ubicado en el antiguo camarín de la Virgen y actual sacristía.

San Andrés, por su parte, asiste a la reconstrucción completa de su templo a partir de 1608, según un proyecto proporcionado por el maestro trasmerano Francisco Bálcava, que respeta algunos de los principios básicos propuestos por Rodrigo Gil de Hontañón, de ahí que se pensara que pertenecía al siglo XVI, cuando en realidad las obras se prolongaron hasta bien entrada la década de los ochenta del siglo posterior, con la ejecución de la cúpula como broche final. Quedaba aún por ejecutar la fachada, encargada a principios del siglo XVIII. Este templo es, con diferencia, el que mayor número de obras de arte atesora, la mayor parte de las cuales fueron ejecutadas entre los siglos XVII y XVIII. Destacamos entre ellas el retablo mayor, obra clasicista procedente de Santa María, los retablos gemelos del presbiterio, obras churriguerescas del ensamblador palentino Pablo Villazán, iniciadas en 1714, el retablo de la Epifanía, que contiene un lienzo de gran calidad, copia de Rubens y el sepulcro del Obispo de Guadix, don Melchor de Vozmediano, fallecido en 1630.

El templo de San Julián que se conserva actualmente es el resultado de las obras ejecutadas a partir de 1623, siguiendo las trazas de Juan Gutiérrez del Pozo, respetadas en el proyecto presentado por el trasmerano Jerónimo de Buega en 1641. Desde el punto de vista constructivo, nada especial acontece en esta iglesia durante el siglo XVIII, a principios del cual se concluyen el retablo mayor y los colaterales, cuyo ensamblaje se debe al maestro vallisoletano Blas Martínez de Obregón. Durante este período finalizaron su andadura los templos de Santa Eulalia y San Bartolomé, que fueron demolidos en 1721 y 1735, respectivamente. Su curato y feligreses fueron agregados al templo de San Andrés e igualmente fueron trasladados al mismo sus bienes muebles. 
En lo que se refiere a la iglesia de San Bartolomé, desaparece a mediados del siglo XVIII, siendo agregados sus feligreses al templo de Santiago.

Respecto a las ermitas, la de San Cristóbal debió desaparecer a finales del siglo XVIII, pues la última referencia documental conservada data de 1779 en que se hallaba en estado de completa ruina. Por su parte, la Piedad, por situarse bajo la jurisdicción de la casa clarisa, fue reedificada a expensas de la Madre Luisa hacia 1625. Su retablo mayor, de mediados de esta centuria, procede del extinto hospital de Santa María. Respecto a la ermita de San Juan de Cestillos, la iglesia que se conserva hoy día es fruto de las reformas que, requeridas desde el siglo precedente, no se ponen en marcha hasta 1740. Procedente de este templo y trasladado en 1993 al museo sacro de Santiago, es el retablo mayor, obra de hacia 1595 debida a un ensamblador local llamado Hernando Infante. La configuración de la capilla de la ermita de la Vera Cruz responde a dos etapas, una de las cuales fue comenzada en 1658, resultado de la cual son dos de sus tres tramos. En su interior se custodian los pasos de Semana Santa, destacando entre todos ellos el Cristo de los Azotes, obra de 1739 del escultor Melchor García, perteneciente a la escuela riosecana.

Para clausurar el siglo, remitimos una referencia extraída de la visita Provincial a Carrión en 1799, que ilustra a la perfección el ambiente de religiosidad y decoro impuesto desde el Concilio de Trento en las obras de arte. Por la misma, el visitador insta que a cualquier talla del templo, ya fuera de procesión o de simple veneración, se le quitasen las vestiduras “...prohiuiendo igualmentte los de zinttas, vuelos, manillas, collares y otras qualesquiera ridiculeces...” por no respetar éstas la modestia y sencillez que deben presentar las imágenes ${ }^{1032}$.

${ }^{1032}$ IbIbídem, fol 148. 


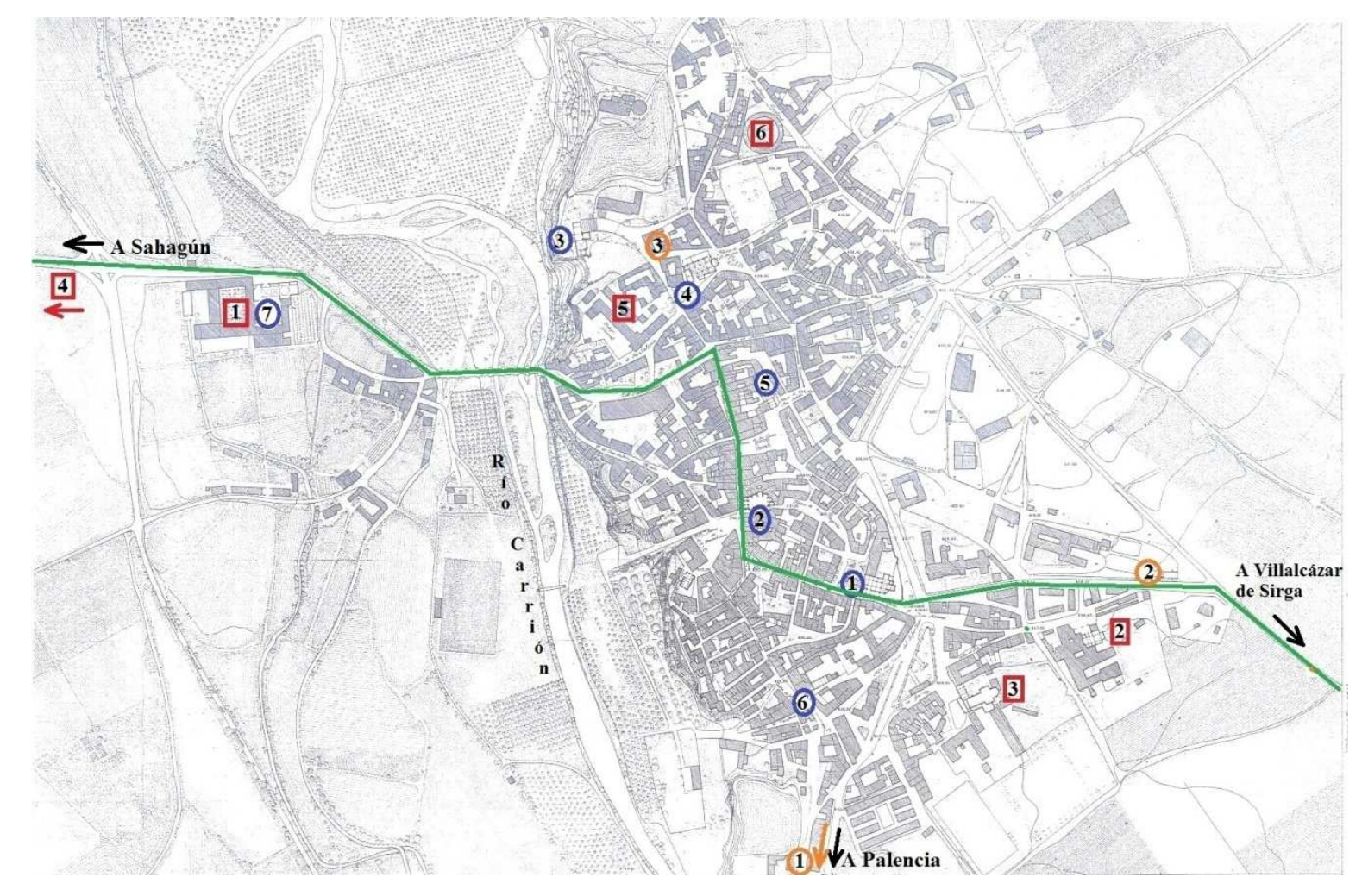

\section{Iglesias}

1. Sta. María

2. Santiago

3. Nuestra Señora de Belén

4. San Andrés

5. San Julián

6. San Juan del Mercado

7. La Magdalena
Monasterios y Conventos

1. Monasterio de San Zoilo

2. Cvto. de Santa Clara

3. Cvto. de San Francisco

4. Cvto. de Sta. María de Benevívere (a $5 \mathrm{~km}$ en la carretera de Villotilla)

5. Cvto. de San Miguel y Santa Isabel

6. Cvto. de Santo Domingo

\section{Camino de Santiago}

\section{Ermitas}

1. San Juan de Cestillos (a 2km)

2. La Piedad

3. La Vera Cruz

Patrimonio religioso de Carrión de los Condes a finales del siglo XVIII. 


\subsection{EL DEVENIR A PARTIR DEL SIGLO XIX: LA GRAN PÉRDIDA}

Un bello grabado datado hacia 1800 y realizado por el burilista carrionés Guillermo Orejón y Lamas resulta muy valioso a la hora de contabilizar el patrimonio carrionés conservado hasta el siglo $\mathrm{XIX}^{1033}$. El dibujo fue realizado desde las Vargas, una zona de vegetación situada en la ribera, al sudoeste de la villa. La exactitud del mismo en la disposición de los edificios cotejándolo con una fotografía actual tomada desde la misma ubicación, lo convierten en una fuente fiable y un testimonio gráfico de excepción.

El artista ha prescindido de la representación del convento de Santa Clara, y la ermita de la Piedad, por no haber cabida para los mismos en el dibujo, dada su ubicación más apartada, en el extremo oriental. Por otro lado, la omisión de la ermita de la Cruz viene justificada por impedir su visión los templos de San Andrés y Santa Isabel. Tampoco se han señalado, como resulta lógico, la abadía de Benevívere ni la ermita de San Juan de Cestillos, por hallarse en arrabales fuera de este ámbito.

Desde el lado más occidental de la villa, donde emerge el monumental San Zoilo, atravesando el puente sobre el río Carrión, avistamos los templos de Belén y San Andrés, entre los cuales emerge tímidamente la espadaña del convento de Santa Isabel. A continuación, pasando por los templos de Santiago y San Julián, llegamos a la parroquia de San Juan del Mercado, se otea la torre de Santo Domingo a lo lejos y la iglesia de Santa María en un plano más cercano, concluyendo en el lado este de la villa, con el convento de San Francisco.

\footnotetext{
1033 AHN. Sala Goya. Dib/18/1/616. Ya publicado por la autora en GARCIA GARCÍA, Lorena. "Aportaciones a un convento palentino desaparecido: Santo Domingo en Carrión de los Condes, Palencia” en PITTM, nº8. Diputación Provincial de Palencia, 2009, pp. 465-480.
} 


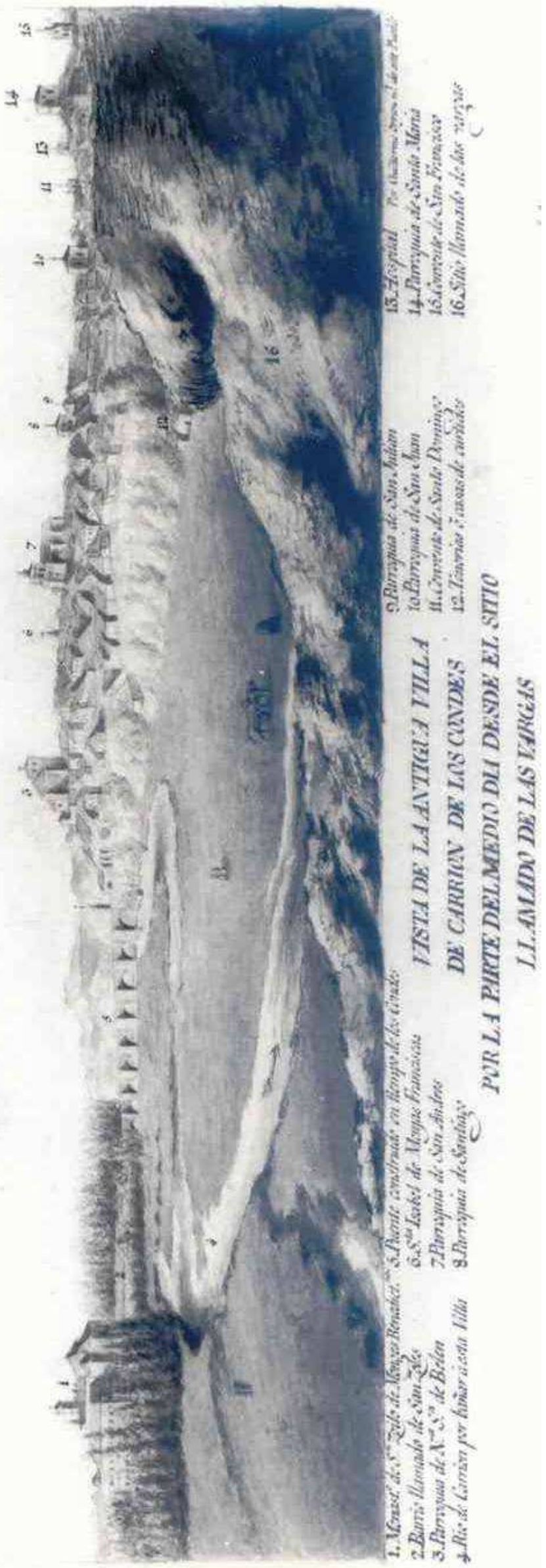

BN. Sala Goya.

Dibujos. 18/1/616.

Guillermo Orejón

y Llamas

(hacia 1800). 
Otra fuente gráfica posterior, que ilustra el patrimonio carrionés existente en 1852, lo constituye el mapa de Palencia realizado por el teniente coronel y capitán de ingenieros, don Francisco Coello, en el que se incluyen varios planos de los núcleos más relevantes, entre los que se incluyen Astudillo, Dueñas, Paredes de Nava, Becerril de Campos y, por supuesto, Carrión de los Condes. El dibujo del núcleo urbano de la villa condal comprende, además de los hospitales existentes por entonces y las tres casas terciarias, las siete parroquias conservadas -Belén, San Andrés, Santa María, Santiago, San Julián, San Juan del Mercado y la Magdalena, ubicada en el cenobio de San Zoilo-, si bien prescindiendo de las ermitas ${ }^{1034}$. La casa dominica no figura en la imagen puesto que se había extinguido por entonces. Hay que pensar que todas estas edificaciones poseían en origen mayor altura, a consecuencia del alzado de la cimentación de las calles para evitar los barrizales.

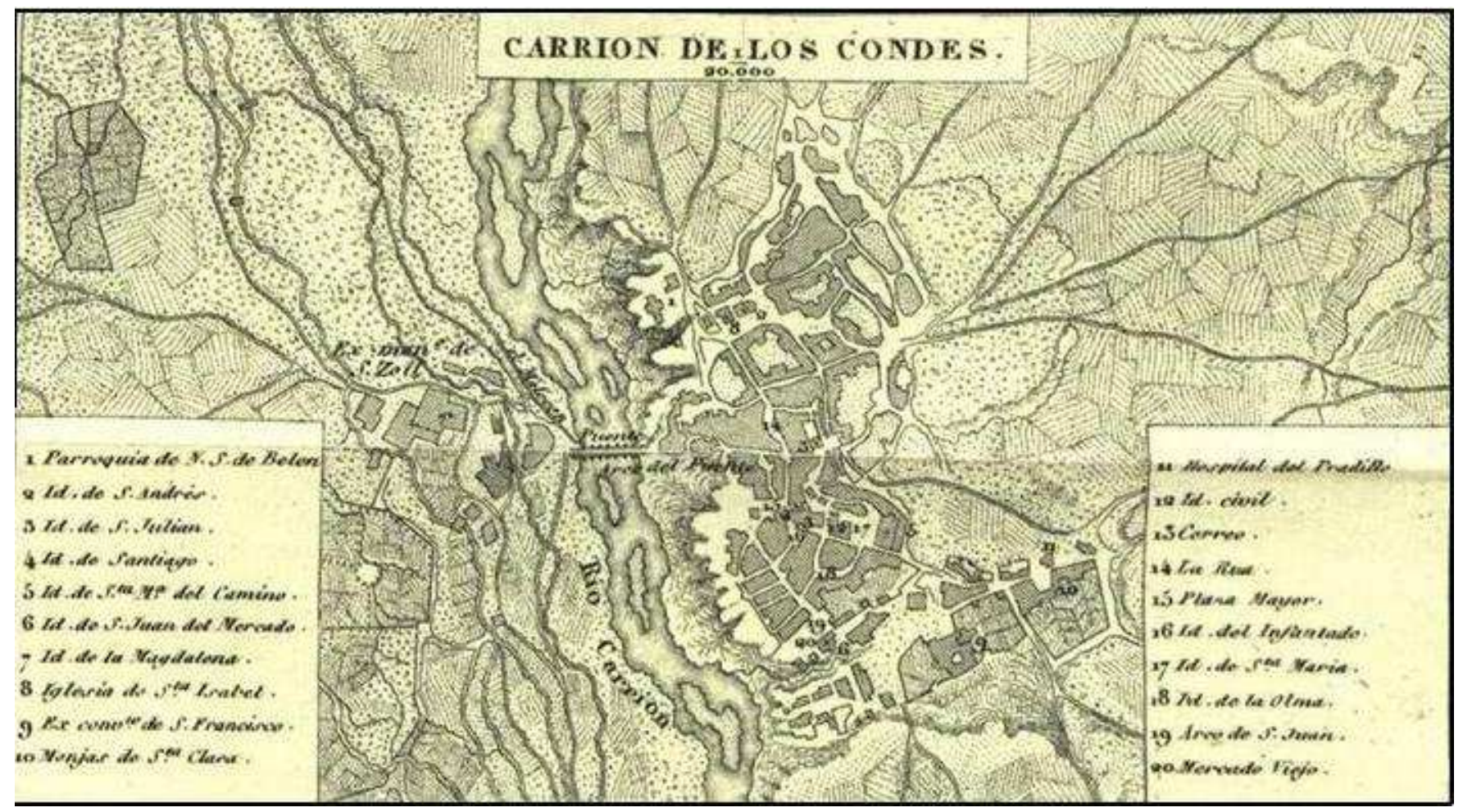

Mapa de Palencia de 1852 creado por el teniente Francisco Coello.

Detalle del núcleo urbano de Carrión de los Condes.

\footnotetext{
${ }^{1034}$ Consulta virtual en el Catálogo Digital de la Biblioteca Digital de Castilla y León. Material Cartográfico. Notas de MADOZ, Pascual, contorno de LECLERQ, topografía de ALABERN, Camilo. Madrid, 1852.
} 


\section{CLERO REGULAR}

Las seis fundaciones de clero regular que existieron en Carrión convivieron simultáneamente durante sólo tres centurias, resultando desamortizados según decreto de José I de 1809 los conventos pertenecientes a órdenes religiosas de varones, que en Carrión afectaba a los de Santa María de Benevívere, Santo Domingo, San Francisco y San Zoilo ${ }^{1035}$.

El primero en extinguirse fue el convento dominico, pues fue víctima de un incendio provocado en 1811 por las huestes del rebelde Santos Padilla para evitar su ocupación por las tropas napoleónicas. Por sesión municipal de 24 de enero de 1814 se realizó un informe sobre el estado de los tres conventos masculinos situados en el casco urbano: San Zoilo, San Francisco y Santo Domingo. De los dos primeros se indica que se habían conservado perfectamente. Así indican: “...que dichas yglesias y todo lo anexo a ellas está corriente y sin desfalco alguno en los edificios y ornamentos, como que han servido y sirven actualmente de parroquias y las oficinas de los dos conventos habitables para más de doce religiosos, sin necesidad de obra alguna...”. Santo Domingo, en cambio, estaba completamente demolido ${ }^{1036}$. Sus despojos se emplearon para la construcción del fuerte carlista edificado en 1838 en el sector noroccidental de la villa, sobre los templos de San Andrés, Belén y el convento de Santa Isabel.

Benevívere sobrevivió a este primer golpe, resultando subastado en 1821, durante el Trienio Liberal y nuevamente en 1835, pero se hallaba ya en ruina hacia $1843^{1037}$. San Francisco, por su parte, se salvó de la supresión de 1820 pero a raíz de la Desamortización de Mendizábal el declive fue imparable, salvándose de la ruina su templo, gracias a los esfuerzos de la Venerable Orden Tercera que mantuvo su culto hasta 1977, en que el abandono produjo su progresivo deterioro y la pérdida de las cubiertas. No pudieron impedir sin embargo, la utilización de sus dependencias

\footnotetext{
${ }^{1035}$ FERNÁNDEZ MARTÍN, Luis. "La diócesis de Palencia durante el reinado de José Bonaparte 1808-1813" en PITTM, nº44. Palencia, 1980, pp. 234-235 y 254-255.

${ }^{1036}$ AMCC. Libro 2, Sesiones municipales (1759-1814), s/f.

${ }^{1037}$ RAMÍREZ DE HELGUERA, Martín. El Libro...Op.cit, pág. 166.
} 
como cantera, para las obras del Seminario de los Jesuitas de San Zoilo en 1854 y del nuevo consistorio a partir de 1868 .

Mejor suerte corrió para el monasterio de San Zoilo, pues, si bien sufrió las sucesivas desamortizaciones de sus compañeros, siempre mantuvo una multiplicidad de funciones que impidió su abandono y facilitó su espléndida conservación hasta nuestros días. Funcionó como fábrica de harinas desde 1842 hasta 1850 en que fue ocupado fugazmente por una comunidad agustina que lo abandonó un año después. Desde 1852 y durante una centuria, exceptuando el Sexenio Revolucionario en que adoptó usos civiles de cárcel y posteriormente de colegio privado, los hermanos jesuitas permanecieron en San Zoilo, construyendo nuevas dependencias y manteniendo primorosamente las existentes. En 1952 se asentó el Seminario Menor de la Diócesis y aunque el monasterio fue desocupado, la preocupación por su patrimonio, de singular mérito artístico, propició la puesta en marcha de múltiples restauraciones. Desde 1991, a excepción del templo y el claustro, todas las dependencias fueron convertidas en Hospedería, función que viene desempeñando hasta la actualidad.

Los conventos terciarios de Santa Isabel y Santa Clara, como órdenes femeninas, resultaron excluidas de la Desamortización de 1809. Las monjas isabelas resistieron hasta 1836 en que fueron trasladadas, dado su reducido número de internas, al convento de Santa Clara. Las beatas clarisas fueron trasladadas a Astudillo en 1868 cuando, por decreto ley se ordenó reducir los conventos de la provincia a la mitad. Por fortuna, regresaron a Carrión en 1870, continuando su andadura hasta nuestros días, aunque sufriendo una gran merma respecto al número de internas, que no alcanzan la decena. Además de cumplir con sus deberes espirituales se encargan de gestionar el hostal de peregrinos existente en el patio de su hospedería.

\section{CLERO SECULAR}

En lo que respecta a las parroquias, los enfrentamientos que tuvieron lugar a raíz de la Guerra de la Independencia, desencadenaron incendios premeditados que arrasaron parte del patrimonio carrionés. Tuvieron lugar en agosto de 1811, período 
de mayor agitación en la villa condal y fueron provocados por los guerrilleros españoles con el fin de evitar el asedio de la villa por parte de las huestes francesas. Con todo, fue inevitable la pérdida de la torre de Santa María y el reparo de las cubiertas. En Santiago, las brasas no afectaron a la torre, sin embargo, la iglesia quedó arruinada, sobre todo las bóvedas, que fueron completamente arrasadas y su reconstrucción definitiva no se materializó hasta 1981.

Dado el elevado número de parroquias en relación a los habitantes de la villa y la dificultad de disponer un párroco para atenderlas a todas, a finales de 1894 se plantea reducirlas a una sola. El 31 de diciembre de dicho año fue redactado un escrito en Palencia para que el templo matriz fuese el de Santa María de las Victorias, argumentando que a partir de dicho templo y por impulso de Alfonso el Casto comenzó a repoblarse la villa, denominada desde entonces como Santa María de Carrión. Además de justificar su antigüedad, defendían su primacía sobre San Andrés a lo largo de la historia ${ }^{1038}$. Como ya referimos en capítulos anteriores, la rivalidad entre los dos templos y el afán de superioridad de ambos, remonta desde muy antiguo, constando documentalmente al menos desde el siglo XVI.

Poco influyó este alegato de defensa en el ánimo de los eclesiásticos, pues por acuerdo general de 1895 se funden todas las de la población alta en una sola parroquia matriz bajo la advocación de San Andrés y Santa María, quedando al otro lado del río como filial, la parroquia de la Magdalena, perteneciente a San Zoilo ${ }^{1039}$. No obstante, a efectos prácticos continuaban existiendo dos parroquias San Andrés y Santa María ${ }^{1040}$, pues dos párrocos diferentes atendían el culto de cada una de ellas, cuya extensión fue delimitada a través de una línea divisoria ubicada en la plaza de los Caídos y conocida por todos los vecinos para determinar su pertenencia, según la

\footnotetext{
${ }^{1038}$ Se repasan todos los acontecimientos históricos guardan relación con el templo de Santa María y la villa que lleva su nombre. De esta iglesia partían todas las procesiones y en ella radicaron las obras pías más destacadas. GÓMEZ CASADO, Pantaleón. Defensa de la subsistencia de la parroquialidad única de Carrión mediante el arreglo parroquial en la iglesia matriz de Santa María de la Victoria. Palencia, 1895.

${ }^{1039}$ Este acuerdo, fue un "negro nubarrón" para la que siempre fue iglesia matriz de todas las de la villa, la iglesia de Santa María, preeminencia y dignidad que ha conservado hasta el año de 1894. MERINO REVUELTA, Félix. Por Santa María. Una lección de historia carrionesa. Carrión de los Condes, Palencia, 1911, pág. 7.

${ }^{1040}$ Incluso los templos de Santiago y San Julián siguieron abiertos al culto posteriormente: el primero hasta los años cincuenta y el segundo al menos hasta los 70. Agradezco estos datos a Enrique Gómez Pérez, historiador carrionés.
} 
situación de su vivienda, a una u otra iglesia. De este modo, San Andrés, acogía las iglesias de Belén, la ermita de la Cruz, San Julián, la Magdalena de San Zoilo y el hospital de San Torcuato, y por otro lado, a cargo de Santa María de la Victoria, corrían el templo de Santiago y las ermitas de Cestillos y de la Piedad. En este recuento no se incluye San Juan del Mercado, pues sería demolida hacia 1937. En San Andrés fue demolido el segundo cuerpo de la torre y Belén se salvó de las llamas, registrándose tan sólo algunos robos de las vidrieras, en este caso, perpetrados por las tropas napoleónicas para servirse del hierro y fundirlo posteriormente. Estos dos templos, fueron adaptados como fuerte en 1838, ante los posibles ataques de las tropas liberales durante la Guerra Carlista $^{1041}$.

El 7 de septiembre de 2004, se intenta de nuevo adoptar la parroquialidad única bajo la misma denominación anterior, situándose el templo de San Andrés a la cabeza $^{1042}$. Sin embargo, sucedió exactamente lo mismo que en el período anterior, que en realidad existían dos parroquias, pues las Juntas y libros respectivos se mantuvieron independientes en lugar de unificarse. Desde junio de 2011, con la instalación del párroco actual y la marcha coetánea de los dos anteriores, existe verdaderamente una sola parroquialidad y se rinde culto en los dos templos mencionados. Sin duda, el acontecimiento más destacado del siglo XX lo constituye la Declaración de Monumento Nacional de las iglesias de Santa María, Santiago y el monasterio de San Zoilo el 3 de junio de $1931^{1043}$. En este último, resultó de vital importancia el hallazgo de la portada románica del primitivo templo, a raíz de las obras de acondicionamiento de la fachada 1993, a la que siguieron las labores de desenfoscado de los muros de 1999 y las excavaciones de 2008, gracia a las cuales se descubrieron otras piezas del mismo período. Incluso en los últimos años, el patrimonio carrionés ha resultado vigorizado gracias a las obras de la galilea de la abadía benedictina comenzadas en 2011, así como el descubrimiento de las pinturas murales de la ermita de la Piedad, y el más reciente hallazgo fortuito de otras pinturas en la capilla mayor de la iglesia de Belén.

\footnotetext{
${ }^{1041}$ AMS. Proyecto del fuerte de Carrión. Sección 3a , División 3a , Leg 99, nº11.

${ }^{1042}$ La salida de Carrión de su antiguo párroco José Mariscal en esta fecha, señala el inicio de la parroquialidad única. Este hecho se indica en una placa conmemorativa de la iglesia de Santiago.

${ }^{1043}$ VV.AA. Catálogo monumental de Castilla y León. Bienes inmuebles declarados. Primera Parte. Junta de Castilla y León. Salamanca, 1995, pp. 461-462.
} 


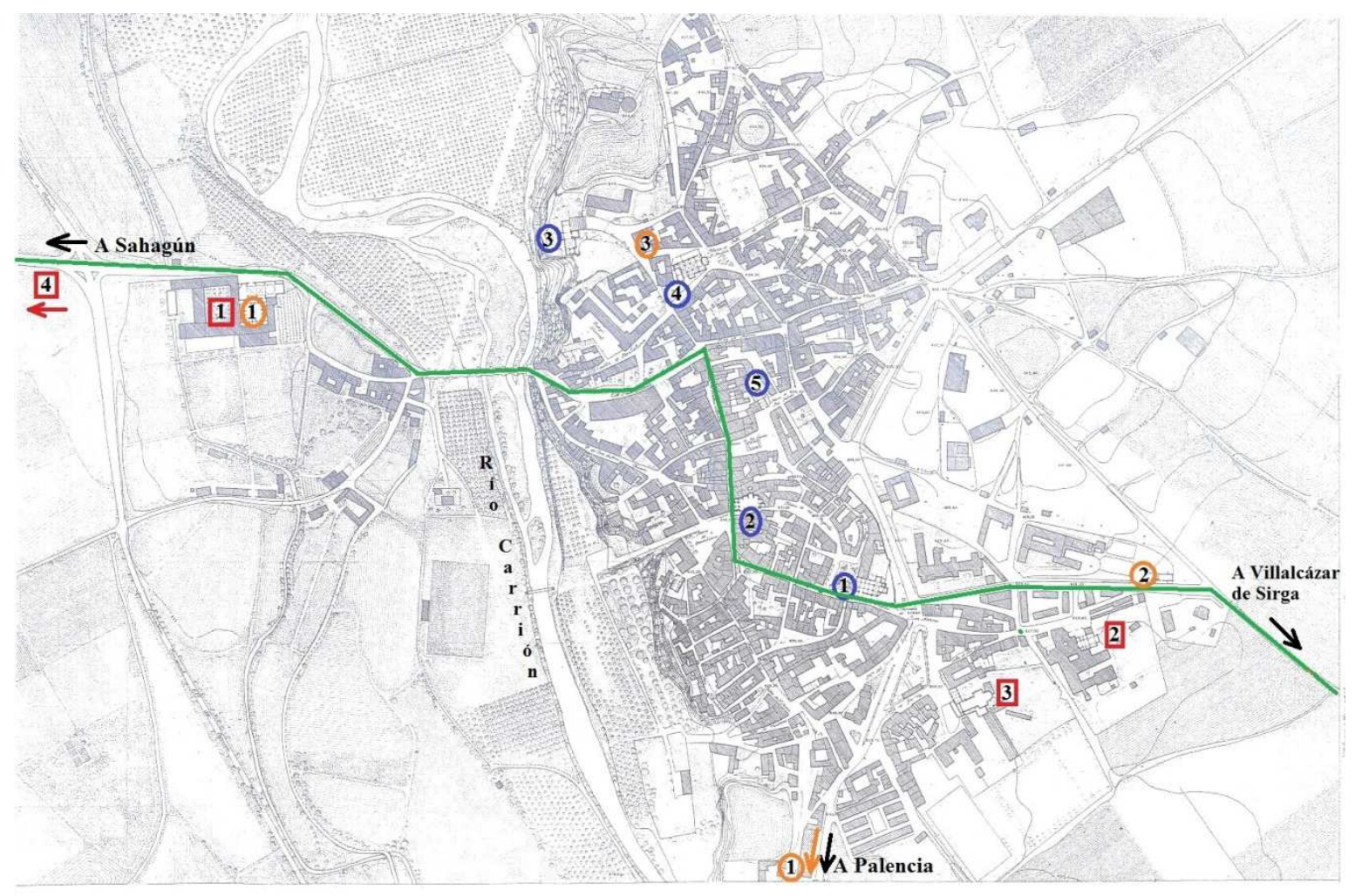

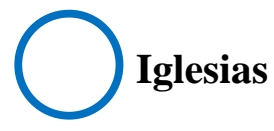

1. Sta. María

2. Santiago

3. Nuestra Señora de Belén

4. San Andrés

5. San Julián

\section{Camino de Santiago}

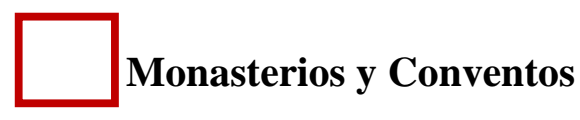

1. Monasterio de San Zoilo

2. Cvto. de Santa Clara

3. Cvto. de San Francisco (ruinas)

4. Cvto. de Sta. María de Benevívere

(ruinas)

Patrimonio religioso de Carrión de los Condes en la actualidad. 
4. EL PATRIMONIO RELIGIOSO

4.1 MONASTERIOS Y CONVENTOS CONSERVADOS 


\section{EL PATRIMONIO RELIGIOSO}

\subsection{MONASTERIOS Y CONVENTOS CONSERVADOS}

Al igual que en el caso de los templos parroquiales, para el estudio del patrimonio del clero regular hemos seguido un orden fundacional de los cenobios conservados, esto es, San Zoilo y Santa Clara, para a continuación, proceder con los cuatro conventos extintos, siguiendo el mismo criterio. De modo que, si bien la casa franciscana masculina precede en unos años al establecimiento de las monjas clarisas en la villa carrionesa, éstas anteceden a sus compañeros terciarios en nuestro análisis, dada su pervivencia en nuestros días. Encabezando la lista de los conventos extintos, se sitúa la abadía de Benevívere, dada su fundación en el siglo XII, precediendo a los franciscanos, que anteceden a su vez a las fundaciones más tardías de Santa Isabel y Santo Domingo.

\subsubsection{EL MONASTERIO DE SAN ZOILO}

\section{SIGLO XI. LA FUNDACION Y LA SUJECCIÓN A CLUNY}

\subsection{PRIMER ASENTAMIENTO: SAN JUAN BAUTISTA}

El monasterio aparece al oeste de la población, al otro lado del puente que cruza el río Carrión, con dirección a Sahagún, en la ruta del camino de peregrinación no por casualidad, sino cumpliendo una de las normas benedictinas como es la hospitalidad, acogiendo al peregrino en el cercano hospital de la Herrada.

Respecto al origen del cenobio, El libro de Concilios en pergamino escrito en el año 948 en un cenobio carrionés permite extraer la antigüedad aproximada del primitivo asentamiento ${ }^{1044}$. En esta época se habría escrito además un antifonario

${ }^{1044}$ YEPES, Fray Antonio. Op.cit, pág. 49. Otros autores están a favor de esta hipótesis. Véase SENRA GABRIEL Y GALÁN, José Luis. "Algunas notas sobre la desaparecida iglesia románica del priorato cluniacense de Carrión de los Condes" en AIIICHP, tomo 4. Palencia, 1995, pág. 440. 
visigótico-mozárabe cuyo fragmento se conserva en la Biblioteca Nacional correspondiendo, por su analogías textuales con el códice de León, al mediados del siglo X. La conservación de estos testimonios gráficos confirma la existencia de un cenobio en Carrión, pero no se corresponde con el monasterio cluniacense, creado posteriormente. Más bien, creemos que existiría un primer asentamiento mozárabe en esta época bajo la advocación de San Juan Bautista, habitado por monjes cordobeses asentados en un primer momento en el monasterio leonés de San Miguel de Escalada ${ }^{1045}$.

Esta primera fundación pudo seguir el patrón neoasturiano ejemplificado en la basílica regia de San Pelayo y San Juan Bautista de León, consagrada a San Isidoro de Sevilla en 1063. En este fervor por los mártires, San Juan Bautista de Carrión sería dotado posteriormente con las reliquias de San Zoilo para así revitalizar su culto ${ }^{1046}$.

\subsection{REFUNDACIÓN CONDAL: SAN ZOILO}

El documento más antiguo en que el monasterio figura bajo la advocación de San Zoilo es del año 1095. Se trata de una permuta entre Pedro Ansúrez y don Hugo, el prior del cenobio, por la que se cambian las posesiones del primero en Villaomez, Frechilla y Villavieco por las que el monasterio poseía en Poza y Poutes ${ }^{1047}$. La nota del reverso indicando: "48 años después que se acabó de fundar este monasterio" nos hace remontar su origen al año 1047, fecha en la que aún el cenobio estaría dedicado a San Juan, pues las reliquias de San Zoilo no habían sido traídas.

1045 SANTOS URBANEJA, Fernando. San Zoilo: un mártir cordobés en el Camino de Santiago. Centro de Estudios y Documentación del Camino de Santiago. Carrión de los Condes, Palencia, 2003, pág. 45.

${ }^{1046}$ SENRA GABRIEL Y GALÁN, José Luis.“Algunas notas...” Op.cit, pp. 441-443.

1047 YEPES, Fray Antonio. Crónica...Tomo VI. Op.cit, pág. 74. Hoy día el documento se conserva en AHN. Clero. Carpeta $\mathrm{n}^{\circ} 1700, \mathrm{n}^{\circ} 6$. Algunos historiadores lo consideran un diploma falso que realmente fue escrito en la Schuola en el siglo XII. PÉREZ CELADA, Julio A. El Monasterio de San Zoilo de Carrión. Formación, estructura y decurso histórico de un señorío castellano-leonés (siglos XI al XVI). Universidad de Burgos, 1997, pág. 77 y éste, a su vez, de PÉREZ CELADA, Julio A. Documentación del Monasterio de San Zoilo de Carrión (1047-1300). Fuentes Medievales Castellanoleonesas. Garrido. Palencia, 1985,doc 1 y PALACIO SÁNCHEZ IZQUIERDO, María Luisa. San Zoilo de Carrión (siglo XI-XIV) Diputación Provincial de Palencia. Departamento de Cultura. Palencia, 1990, pág. 12. 
Por tanto, admitimos 1047 como la fecha en que don Gómez Díaz, conde de Carrión, Saldaña y Liébana, recibió el monasterio existente gracias a una donación de Fernando I de León, que habría que considerar, por tanto, una refundación ${ }^{1048}$. Don Gómez Díaz, que accedió al condado en 1032, tras la caída de su padre Diego Fernández, se había convertido en un poderoso magnate de la corte que prestará su apoyo desde su posición en Tierra de Campos al monarca leonés ${ }^{1049}$. Este conde no vería finalizada la reedificación del monasterio, pues falleció antes de que fuera concluido, continuándolo su mujer Doña Teresa ${ }^{1050}$. Era una mujer de insigne abolengo, pues su abuelo materno, el infante Ordoño, era hijo de Ramiro III y su abuela materna, la infanta Doña Cristina, era hija del rey Vermudo II $^{1051}$. Resultaba por tanto, que la condesa Teresa era la biznieta de dos monarcas leoneses. Los BaniGómez, de origen asturiano, monopolizarán el título condal hasta el siglo XII, dominando los territorios de Saldaña, Entrepeñas y Carrión ${ }^{1052}$. Las crónicas indican que desde 1057 en que fallece el conde Don Gómez, la condesa Teresa ingresa como religiosa en San Zoilo ${ }^{1053}$. Resulta del todo factible, dado que era una práctica común en la Edad Media. La normativa restringía el acceso conventual a las viudas

\footnotetext{
${ }^{1048}$ RAMIREZ DE HELGUERA, Martín $O p$, cit, pp. 169 y 170. Sobre la importancia del indiscutible apoyo prestado por el monarca de León para la posterior adhesión a la casa francesa, véase BISHKO, Charles Julián. "Fernando I y los orígenes de la alianza castellano-leonesa con Cluny" en Cuadernos de Historia de España, no 47-48, 1968, pp. 31-135. Algunos historiadores consideran que este, como muchos otros documentos, son copias de los originales realizadas en la escuela monástica. PALACIO SÁNCHEZ IZQUIERDO, María Luisa. El monasterio de San Zoilo de Carrión: jurisdicción, franquezas y privilegios en AICHP,tomo 2. Palencia, 1987, pág. 67.

${ }^{1049}$ PÉREZ CELADA, Julio A. "Notas sobre la ampliación...Op.cit, pp. 416-417. El centro neurálgico de todas las posesiones de la familia condal residía en Carrión, denominada por entonces la población como "Santa María". MARTíNEZ DÍEZ, Gonzalo. "La familia condal de Carrión y Monzón: sus fronteras" en AICHP, tomo 2. Palencia, 1985, pp. 580-582. Un repaso de la ascendencia genealógica de don Gómez Díaz en PÉREZ CELADA, Julio A. El Monasterio de San Zoilo de Carrión...Op.cit, pp. 71-76. Cuando en 1037 Fernando I asciende al trono leonés, asistiremos a la abolición de los condados, que serán sustituidos por tenencias de origen navarro, por las que el monarca pasará a tener más poder sobre los señores que hasta el momento. MARTíNEZ DÍEZ, Gonzalo. "Palencia en Castilla o la castellanidad de Palencia" en Palencia en la Historia. Palencia, 1982, pp. 81-82.

${ }^{1050}$ BERNARD, Auguste. Recueil des chartes...Tomo IV. Op.cit, pág. 623.

1051 Para mayor aclaración, véase el gráfico de los antepasados de Doña Teresa en MARTínEZ DÍEZ, Gonzalo. "La familia...Op.cit, pág. 583

${ }^{1052}$ PÉREZ CELADA, Julio A. "La explotación de los recursos hidráulicos en el curso medio del río Carrión en la Edad Media" en PITTM, n71, Palencia, 2000, pp. 116-117. Sobre el origen del condado de Carrión y sus dominios MARTíNEZ DÍEZ, Gonzalo. "Los Condados de Carrión y Monzón: sus fronteras" en AICHP, no 2. Palencia, 1985, pp. 246-274.

${ }^{1053}$ YEPES, Fray Antonio. Crónica...Tomo VI. Op.cit, pág. 77-79, CIRIA RAXIS E INOJOSA, Pedro de. Vidas...Tomo III. Op.cit...pp. 137-139.
} 
que tuvieran familia que se hiciera cargo de ellas, salvo cuando se hacían generosas donaciones, como es nuestro caso ${ }^{1054}$.

En estos años y hasta el momento de su adhesión a la casa madre cluniacense, San Zoilo configurará parte del patrimonio, que comprende la zona terracampina, cuyo proceso concluiría a mediados del siglo XIII ${ }^{1055}$. Entre otras, gracias las libertades concedidas por los monarcas a los vasallos del abad de San Zoilo, el monasterio consiguió anexionarse el barrio aledaño de San Zoles bajo su jurisdicción, que Alfonso VI declaró inmune en $1073^{1056}$.

\section{El traslado de las reliquias desde Córdoba}

Don Fernando Díaz, primogénito de los condes, es igualmente relevante en la historia de la fundación del cenobio. Fue enviado a la guerra en Córdoba que se lidiaba entre el rey Mahomat, hijo de Abderramán III y Alfonso VI ${ }^{1057}$. Agradecido por su participación, el rey moro quería concederle todo tipo de mercedes, pero el conde no pensaba aceptar ni dinero ni bienes temporales ${ }^{1058}$. Don Fernando regresó a Carrión con las reliquias de los mártires hispanorromanos Zoilo y Félix, y del obispo Agapio hacia el año $1070^{1059}$.

\footnotetext{
${ }^{1054}$ KLEINSCHMIDT, Harald. Comprender la Edad Media. La transformación de ideas y actitudes en el mundo medieval. Akal. Madrid, 2009, pp. 359-360.

${ }_{1055}$ El amplio abanico geográfico comprenden propiedades en Baños, Villarmienzo, Cea, Castromuza, Cervazos, Villalcón. Añoza, Fuentes de Valdepero, Mayorga, Cisneros, Villaverde de Volpejera, Bolaños, Aguilar de Campos, Fuentes de Nava, Villabaruz, Zalengas, Villalpando, Coreses, Cabañas, Villafrechós y Toro, además de derechos en iglesias de algunas de estas localidades. Un resumen aclaratorio de los contenidos de las operaciones de adquisición entre los siglos XI y XIII, así como un análisis de las unidades físicas que conforman el dominio (tierras, huertas, montes, villas, coto monástico,etc) y su estructura social (campesinos, servidores, etc) en PEREZ CELADA, Julio A. El monasterio de San Zoilo...Op.cit, pp. 84-86 y 99-269.

${ }^{1056}$ CISNEROS Y TAGLE, Juan de. Historia de las grandezas y antigüedades de la muy noble villa de Carrión. Frómista, Palencia, 1629, fol 192 v y PEREZ CELADA, Julio A. El monasterio de San Zoilo...Op.cit, pág. 85.

${ }^{1057}$ MORALES, Ambrosio de. Viaje por orden del Rey Felipe II a los reinos de Castilla, León, Galicia y Principado de Asturias. Texto recuperado por Enrique Flórez. 1ª Edición, Madrid, 1765. Junta de Castilla y León, 2004, pág. 74. Se trataría de Mohamed ben Jehwar, que reinó entre 1044 y 1061. QUADRADO; José María y PARCERISA, Francisco J. Op.cit, pág. 134.

${ }^{1058}$ SANDOVAL, Prudencio de. Primera parte de...Op.cit, pág. 74 y YEPES, Fray Antonio. Crónica...Tomo IV. Op.cit, pág. 74.

${ }^{1059}$ YEPES, Fray Antonio. Crónica...Tomo III. Op.cit, pág. 53-55.
} 
San Zoilo: Fue un noble cristiano cordobés que fue cruelmente azotado, despedazado con garfio y finalmente degollado en el año 306, siendo muy joven, por haber renegado de la idolatría pagana ${ }^{1060}$. Cuentan las crónicas que era tal su valor y aguante, que, consciente de todo, decía el mártir: “Cuanto más maltrates mi cuerpo que tienes ahora en tu flaco poderío, tanto crece más mi verdadero bien, que no teme tus tormentos...los que tú has de padecer, cuando comenzaren nunca han de acabar”. Su verdugo, al oír esto, abrió el cuerpo de San Zoilo por la espalda y extrajo sus riñones, cortándole después la cabeza. Para que no pudieran encontrarle, su cuerpo fue despedazado y sepultado en un campo yermo junto al de algunos peregrinos $^{1061}$.

San Agapio: Cuenta la leyenda que San Zoilo en el año 589 se apareció en una visión a San Agapio, revelándole donde estaba enterrado. Fue éste un caballero ilustre favorecido por los reyes godos que abandonó su riqueza para tomar el hábito de San Benito en Córdoba, donde ostentó la dignidad de Obispo. Fue quién se encargó de trasladar en procesión el cuerpo de San Zoilo a una iglesia sobre la que posteriormente erigió un monasterio bajo la advocación del mártir cordobés, donde el propio Agapio fue sepultado ${ }^{1062}$.

San Félix: Se trata de un personaje de gran controversia, pues su identidad no está demasiado clara ${ }^{1063}$. La opinión generalizada relata que se trataba de un monje benito natural de Alcalá de Henares, hijo de ricos y nobles africanos que abandonó su holgada vida para ingresar como benedictino en un convento asturiano, trasladándose posteriormente a Córdoba para predicar su doctrina. En el año 853 fue degollado y su cuerpo clavado a un palo. Unos días después se quemó su cuerpo

${ }^{1060}$ CASTRO, Lázaro de. Breve Historia de Carrión. Carrión, Palencia, 1779, s/f.

1061 OCAMPO, Florián de. La Coronica general de España / que continuaua Ambrosio de Morales...Libro X, capítulo XV. Op.cit, pág. 611.

${ }^{1062}$ SANDOVAL, Prudencio de. Primera parte de...Op.cit, pág. 75.

${ }^{1063}$ Hacia el 850, año de la persecución en Córdoba de los mártires, existían dos con el mismo nombre. Unos, como Morales, defendían que se trataba del marido de Santa Liliosa, pues el otro San Félix, natural de Alcalá de Henares, había sido quemado y sus cenizas arrojadas al río, imposibilitando el transporte de sus reliquias a San Zoilo. Sin embargo, el rezo de los libros del monasterio y la Universidad de Alcalá de Henares defienden que las reliquias del cenobio pertenecían a éste segundo San Félix, pues al parecer, algunos huesos del mártir fueron arrojados al río a medio quemar y pudieron ser recuperados por los fieles, siendo ésta la opinión que comentamos, más generalizada. Cuadrado propone además otro San Félix, del que habla el Cronicón Cerratense, que sería anterior a los otros Félix referidos y que había erigido un templo en época de los godos. QUADRADO; Op.cit, pág. 134. 
junto al de otros mártires y sus huesos y cenizas se arrojaron al río Gualdalquivir. Serían algunos devotos seguidores del santo quienes recuperaron sus restos llevándolos al cenobio de San Zoilo, donde reposaban los cuerpos de sus dos compañeros $^{1064}$. La historia entrelazada de estos tres personajes justifica el traslado conjunto de sus reliquias al cenobio benedictino carrionés. El monasterio, conocido entonces como de San Juan de la Puente, compartiría desde entonces su advocación con la de San Zoilo y San Félix ${ }^{1065}$.

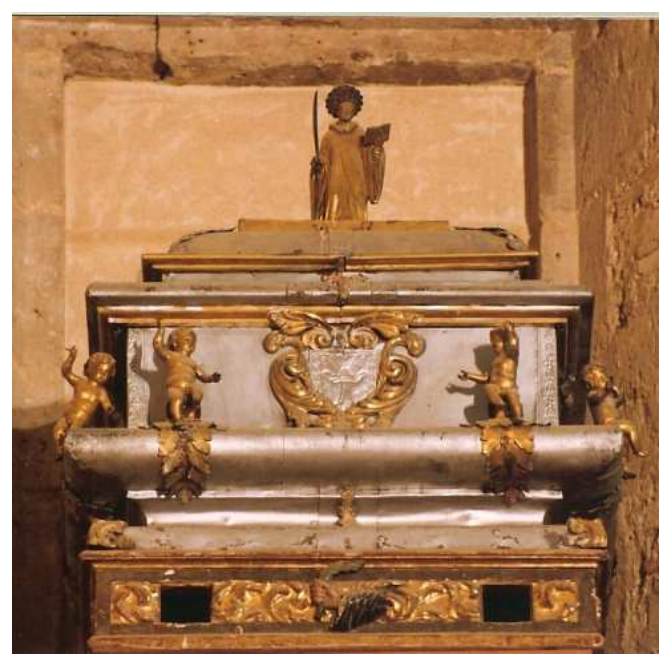

\section{Urna con las reliquias de San Félix en un nicho del altar mayor del templo.} $190 \mathrm{~cm} \times 130 \mathrm{~cm} \times 60 \mathrm{~cm}$. Anónimo. 1697.

Desde que fueron traídas a Carrión las reliquias de San Zoilo, San Félix y San Agapio permanecieron en dos nichos del altar mayor, flanqueando a la imagen de San Juan Bautista, dentro de cajas de madera cubiertas de plata con imágenes talladas de querubines y la figura del santo correspondiente en la parte superior ${ }^{1066}$. Algunos relicarios tenían talladas imágenes en relieve y algunos engastes de piedras en sus frentes ${ }^{1067}$. Sabemos por Ambrosio de Morales que sobre el arca de San Zoilo existía otra arca más pequeña de marfil que contenía “...reliquias de San Pelayo y de San Juan Bautista, y éstas de este Santo tienen mucha autoridad, pues parece

\footnotetext{
1064 YEPES, Fray Antonio. Crónica...Tomo IV. Op.cit, pág. 127 y Tomo VI, pp. 76-77, CASTRO, Lázaro de. Breve historia... s/f.

${ }^{1065}$ Con la triple advocación figura en 1076: “...in honore Sancte Trinitatis et Sancti Johannis Babtiste consecratum, et corporibus Santorum martirum cordobensium decoratum Zoyli atque Felicis...”. PÉREZ CELADA, Julio A. Documentación... (1047-1300) Op.cit, pág. 19.

1066 OCAMPO, Florián de. La Coronica general de España / que continuaua Ambrosio de Morales...Libro X, capítulo XV. Op.cit, pág. 612.

${ }^{1067}$ MORALES, Ambrosio de. Viaje por orden del Rey...2004, Op.cit, pp. 75-76.
} 
serán las de sobre que se fundó el monasterio, a la santa costumbre de entonces... ${ }^{1068,}$,

A raíz de las obras que llevaron a cabo los Padres jesuitas para dotar de calefacción al cenobio, se descubrió un relicario, que se hallaba completamente enterrado $^{1069}$. Podemos identificarlo con la arqueta eboraria que, procedente de Carrión, se halla en el Museo Arqueológico Nacional. De taller fatimí, esta caja prismática responde a las siguientes medidas: altura, 24 centímetros, anchura, 42 centímetros y profundidad, veinte centímetros. Salvo las abrazaderas de los ángulos y las asas de sus frentes, que son de hierro, está formada por nueve tableros de marfil con placas policromadas con motivos ondulantes. Según los expertos, debemos adscribirla al tercer cuarto del siglo $X$, datación que correspondería a la fundación del primer cenobio. Es probable que contuviera las reliquias de San Juan Bautista, pues fue la primera advocación que tuvo el templo. La arqueta, elaborada en el norte de África, pasaría posteriormente a Córdoba, desde donde Fernando Díez la trasladó al convento carrionés.

\subsection{LA ADHESIÓN CLUNIACENSE}

En 1076 el monasterio de San Zoilo fue donado por Doña Teresa, junto con sus hijos, a San Pedro de Cluny, alineándose a la política reformadora de Alfonso $\mathrm{VI}^{1070}$. Seguramente a partir de la adhesión, la condesa Teresa, que, como apuntamos, había ingresado como monja en 1057, se trasladara a una vivienda particular fuera del recinto monástico, sin tener que mantener clausura ${ }^{1071}$.

\footnotetext{
1068 Ibídem, Op.cit, pág. 77.

${ }^{1069}$ El ex alcalde don José Ramón Blanco Merino fue testigo del hallazgo, el cual me ha transmitido la información.

${ }^{1070}$ La confirmación de la donación fue en 1077. BERNARD, Auguste. Recueil des chartes....Tomo IV, Op.cit, pp. 604-607 y PÉREZ CELADA, Julio A. Documentación... (1047-1300) Op.cit, doc 7, pp. $15-18$.

${ }^{1071}$ No es el único caso en que una viuda fundadora goza del privilegio de vivir junto al cenobio, incluso en su interior, pues cuando falleció Guillermo de Aquitania, su viuda, doña Agnes, se retiró a Notre Dame de Saintes, que ella misma había fundado. SENRA GABRIEL Y GALÁN, José Luis. "Aproximación a los espacios litúrgicos-funerarios en Castilla y León: pórticos y galileas" en Gesta. $\mathrm{n}^{\circ}$ 36. Internacional Center of Medieval Art. New York, 1997, pp. 243-244 y 260, nota al pie $\mathrm{n}^{\circ} 61$. Otros historiados consideran que ingresó en el priorato borgoñón de Marcigny, dado que fue fundad por la hermana de Don Hugo, prior de San Zoilo, de ahí las relaciones con este cneobio. Además en el necrologio del cenobio, figura una "condesa Teresa" que falleció en la misma fecha que la que se
} 
$\mathrm{El}$ asentamiento de los monjes bajo la nueva orden parece fue facilitado por uno de los hijos de los condes Beni Gómez, Don García Gómez, quien se encargó solicitar al abad borgoñón que les proporcionara un grupo de monjes para proceder a su traslado ${ }^{1072}$. La mayor de las hijas del matrimonio, llamada doña Mayor, hará donación de un tercio de sus heredades al cenobio en 1077, lo cual se haría efectivo en 1097 , cuando ella ya había fallecido ${ }^{1073}$.

Cluny será un instrumento al servicio del Papado, pero su influencia fuera de Francia dada la distancia y la precariedad de las comunicaciones, será limitada, lo que permitirá a los monjes, sin ser los de San Zoilo una excepción, de cierta libertad, ajustándose a normas preestablecidas ${ }^{1074}$. El proceso de "benedictinización" de la zona de Tierra de Campos es paulatino ${ }^{1075}$. Hasta entonces, los cenobios familiares se regían por la Regula visigótica que más que regla sería un "modus vivendis" propio $^{1076}$. La orden borgoñona encontró en la realeza a su gran aliado, su instrumento para lograr el establecimiento de núcleos de población feudal en torno a los cenobios pertenecientes a su orden ${ }^{1077}$. Por su parte, la realeza fomentará el establecimiento cluniacense por motivos políticos, al hallar en la orden francesa a un potente aliado abierto a las reformas.

indica en los cenotafios de San Zoilo para la fundadora. SEGL, Peter. Königtum und klosterreform in Spanien : Untersuchungen über die cluniacenserklöster in kastilien-León vom Beginn des 11. bis zur mitte des 12. Jahrhunderts. Verlag Michael Lassleben. Kallmünz, 1974, pp. 131-133.

${ }^{1072}$ YEPES, Fray Antonio. Crónica...Tomo VI. Op.cit, pág. 74. Toda la documentación que relaciona a San Zoilo con la casa madre de Cluny comprendida entre los años 802 y 1300 se encuentra en BERNARD, Auguste. Recueil des chartes....Op.cit. Concretamente la donación de la que hablamos se halla en el Tomo IV, pp. 622-625. Sobre la penetración cluniacense en la cuenca del Duero, véase PÉREZ CELADA, Julio A. El Monasterio de San Zoilo de Carrión...Op.cit, pp. 55-66.

${ }^{1073}$ En la relación de hijos de los condes, entre las mujeres no figura ninguna doña Mayor, por ello Celada considera que no descendía directamente de ellos. PÉREZ CELADA, Julio A. El Monasterio de San Zoilo de Carrión...Op.cit, pág. 89. Sin embargo, habría que identificar a doña Mayor con doña María, denominada en ocasiones del oro modo por ser la primogénita. La transcripción de su epitafios en San Zoilo y su presencia con la respectiva cartela en la bóveda primera del claustro, avalan nuestra afirmación.

${ }^{1074}$ Para una explicación más amplia, pero clara del proceso de introducción de Cluny en España, véase PALACIO SÁNCHEZ IZQUIERDO, María Luisa. "Monasterio de San Zoilo y monasterios palentinos" en Palencia en la Historia. Caja de Ahorros y Monte Piedad, 1982, pp. 145-155.

${ }^{1075}$ SIMÓN Y NIETO, Francisco. Los antiguos campos góticos: excursiones histórico-artísticas a la Tierra de Campos. Región Editorial. Palencia, 2006, pp. 5-6.

${ }^{1076}$ LINAGE CONDE, Antonio. Los orígenes del monacato benedictino en la Península Ibérica.2. La difusión de la "Regula Benediciti”. Centro de Estudios e Investigación San Isidoro. León, 1973, pp. 1001-1032.

1077 VV.AA. La comunicación en los monasterios medievales: XV centenario de San Benito: exposición itinerante. Dirección General del Patrimonio Artístico, Archivos y Museos. Madrid, 1980, pág. 50. 
El sucesor de Fernando I, Alfonso VI, duplicó el censo primitivo de su predecesor convirtiendo a Cluny en el mayor inyector de oro en Francia, hecho que se justifica por el apoyo decisivo del abad Hugo al monarca en la crisis sucesoria.

\section{La reforma del cenobio}

A falta de documentación que pruebe una renovación del templo y una ampliación de las dependencias conventuales hacia el último cuarto del siglo XI, se puede recurrir al contexto de reforma litúrgica cluniacense a partir de 1080. Por una parte, dicho año dan comienzo las obras de San Pedro de Arlanza, y tan sólo unos años después, en 1088, se consagra Silos y Sahagún en 1099. La privilegiada posición de San Zoilo en el ámbito socio-económico que experimenta la villa en estos momentos, hace pensar que la comunidad carrionesa no quedaría al margen de estas iniciativas renovadoras, materializándose en una sustitución de la vieja fábrica $^{1078}$. Apoyan esta afirmación su epitafio -del que hablaremos posteriormentey el soneto dedicado a la condesa Teresa que recogió Ciris e Hinojosa en el que quedan manifiestas las tres grandes aportaciones de la benefactora: “Amplísimo hospital la clara infanta, y el monasterio de San Iuan fabrica, al puente su cuidado

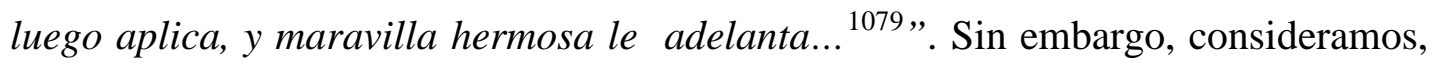
que más que una sustitución de la vieja fábrica, las intervenciones de la condesa Teresa continuaron las que había comenzado su difunto esposo, el conde Gómez Díaz a mediados de siglo. Gracias a ella el cenobio gozó de un gran prestigio, llegando incluso a adquirir un sistema propio de irrigación y molienda ${ }^{1080}$. Doña Teresa, que había profesado como monja, al morir en 1093, fue enterrada junto a su esposo en el pórtico occidental. A raíz de una leyenda milagrosa que tomó fuerza, empezó a ser considerada como santa ${ }^{1081}$. Su sepultura fue entonces introducida en la capilla mayor hasta 1570, en que el abad Sebastián de Encinas, la trasladó al lado

\footnotetext{
1078 SENRA GABRIEL Y GALÁN, José Luis “Algunas notas sobre la desaparecida...” Op.cit, pág. 445.

${ }^{1079}$ CIRIA RAXIS E INOJOSA, Pedro de. Vidas de santas y mugeres ilustres de el orden de San Benito, patriarca de los monges. Tomo III. Granada, 1691, pp. 137-139.

${ }^{1080}$ PÉREZ CELADA, Julio A. “La explotación de los recursos...Op.cit, pág. 122.

1081 MORALES, Ambrosio de. Viaje de Ambrosio...Op.cit, pág. 354, YEPES, Fray Antonio. Crónica...Tomo VI. Op.cit, pág. 79 y CIRIA RAXIS E INOJOSA, Pedro de. Vidas...Tomo III. Op.cit...pp. 137-139.
} 
de la epístola del templo románico ${ }^{1082}$. La condesa, por tanto, vio materializada tan sólo una parte de las obras románicas que se llevarían a cabo durante los años venideros, en la centuria posterior.

\section{EL SIGLO XII. EL ESPLENDOR}

\subsection{CONSOLIDACIÓN DE LOS DOMINIOS}

Durante este siglo, la comunidad benedictina consolida los dominios adquiridos entre los márgenes de los ríos Cea y Pisuerga, a través de la adquisición de bienes y derechos, y así mismo, extiende su jurisdicción por otros, conformando la práctica totalidad de su ingente patrimonio ${ }^{1083}$.

Una de las hijas de los condes fundadores, doña Aldonza, donará e 1109, además de ciertos bienes a la casa madre, una heredad situada en Villamayor a San Zoilo, colaborando así en el incremento patrimonial cluniacense ${ }^{1084}$. Bajo el dominio de Pedro Ansúrez la población de Santa María de Carrión prosiguió su desarrollo. Precisamente dicho año, en que falleció Alfonso VI, Carrión de los Condes protagonizará las revueltas surgidas tras el matrimonio de la heredera en el trono, Doña Urraca, con Alfonso I el Batallador ${ }^{1085}$. La reina contó con el apoyo de la comunidad cluniacense y recompensó al prior de San Zoilo con la entrega en 1118 de San Martín de Frómista y la jurisdicción sobre dicho barrio, quedando éste constituido como una entidad diferenciada del resto de la villa dependiente tan sólo de la comunidad cluniacense de Carrión ${ }^{1086}$. La jurisdicción de Frómista será el factor desencadenante de varios conflictos entre el señor de dicha villa y el Abad de

\footnotetext{
${ }^{1082} \mathrm{Al}$ sustituirse el edificio a mediados del siglo XVII, la tumba se trasladó a un arcosolio situado en lo alto del presbiterio con una estatua orante de estuco, donde continúa en la actualidad. Véase SENRA GABRIEL Y GALÁN, José Luis. "Dos telas islámicas encontradas en el Monasterio e San Zoilo de Carrión" en Goya: Revista de Arte. no 303. Madrid, 2004, pp. 333 y YEPES, Tomo VI, Op.cit, pág. 56.

${ }^{1083}$ PÉREZ CELADA, Julio A. El monasterio de San Zoilo...Op.cit, pp. 86-87.

${ }^{1084}$ PÉREZ CELADA, Julio A. Documentación ...(1301-1400), Op.cit, Addenda, pp. 283-284

1085 FALQUE, Emma. Historia compostelana: Introducción, traducción, notas e índices. Akal. Madrid, 1994, pp. 204-206.

${ }^{1086}$ MARTÍNEZ SOPENA, Pascual. El camino de Santiago en Castilla y León. Valladolid, 1990, pág. 88 .
} 
San Zoilo ${ }^{1087}$. Además, el prior obtuvo una recompensa personal, pues fue designado camerario de la Orden de Cluny en España ${ }^{1088}$. La reina vendió además, en 1120, todas sus heredades en la villa de Arconada. En 1130, San Zoilo acogió a los participantes de un concilio que trataría de asentar las bases para proceder a la recuperación económica y social de los reinos muy afectados por el conflicto civil y deponía al obispo Pelayo de Oviedo. Se supone que en estas fechas, al menos la iglesia monástica se encontraría finalizada ${ }^{1089}$.

A lo largo del segundo tercio del siglo, Alfonso VII, hijo de Doña Urraca y Don Raimundo de Borgoña, consolida el poder señorial de la comunidad a través de la concesión de franquezas y privilegios al monasterio estableciéndose como pionero de estas cesiones ${ }^{1090}$. Muerto éste, y separadas las dos coronas nuevamente, Alfonso VIII adopta medidas para que los derechos del cenobio sean respetados y les atribuye otros nuevos como la capacidad jurídica para organizar una feria, eso sí, por propio interés de la monarquía garantizando así el comercio en el territorio situado bajo su soberanía. Sus antagonistas leoneses, Fernando II y Alfonso IX adoptan medidas análogas en dicha zona.

Durante el último cuarto del siglo XII el monasterio asistiría a un período de auge correspondiendo con el gobierno del prior Humberto, quien, no sólo logró de Alfonso VIII, la concesión de una feria de quince días en el barrio de San Zoles en 1169, sino que consiguió además ser nombrado Camerario de Cluny, en 1174, en reconocimiento de la cálida acogida y favores prestado al monarca ${ }^{1091}$. Pero no quedan aquí sus logros, pues logró la adhesión al cenobio benedictino, que ya contaba con Frómista y San Román de Entrepeñas, los de Gañinas, Revenga y

${ }^{1087}$ ARROYO PUERTAS, Carlos. San Martín de Frómista. Editorial Cálamo. Palencia, 2002, pp. 16,17 y PERAL VILLAFRUELA, Santiago. "Frómista y San Martín en la Edad Media: una relación .conflictiva" en Actas de las Jornadas celebradas en Frómista: San Martín de Frómista, ¿paradigma o historicismo? Fundación del Patrimonio Histórico de Castilla y León. Valladolid, 2005, pp. 11-36. ${ }^{1088}$ VALLE CURIESES, Rafael de. A orillas del Carrión....Op.cit, pág. 88.

${ }^{1089}$ SENRA GABRIEL Y GALÁN, José Luis. "Algunas notas sobre la desaparecida...” Op.cit, pág. 449.

${ }^{1090}$ PALACIO SÁNCHEZ IZQUIERDO, María Luisa. El monasterio de San Zoilo...Op.cit, pp. 6970. La mayor parte de las donaciones, cédulas y confirmación de privilegios reales desde el siglo XI al XVI se conservan en copias en AHN. Clero Secular-Regular 5531 s/f. Documentos reales.

${ }^{1091}$ Ser camerario implicaba una gran responsabilidad, al representar a la orden encargándose de la disciplina. Sobre este tema, BISHKO, Julián. "El abad Radulfo de Cluny y el prior Humberto de Carrión, "camerario" de España: tres cartas inéditas de hacia 1174" en Anuario de Estudios Medievales,I. Madrid, 1964, pp. 197-215. 
Golpejera $^{1092}$. Posteriormente, en 1188 , el monarca castellano celebrará una curia regia en San Zoilo para armar caballero a su primo Alfonso IX ${ }^{1093}$. No quedan aquí los privilegios concedidos por el monarca al monasterio, pues en 1203 le otorgó la jurisdicción sobre un tercio de las aguas del río Carrión, si bien, prohibía la construcción de presas en el entorno ${ }^{1094}$.

Fernando II llevará a cabo varias permutas con la comunidad carrionesa, siendo Fernando III quien manifestará su interés por salvaguardar los derechos de San Zoilo a través de la exención del portazgo y la prohibición de ser objeto de embargos arbitrarios.

El cenobio por entonces había ampliado sus dominios, que, aparte de los centros de Frómista y Entrepeñas, se había anexionado las casas de san Andrés en Villagonzalo, San Facundo de Arconada, Santa María de Villaomet, Santa María de Villaturde, San Juan de Cestillos, a una legua de Carrión, Santa María de Trigueros en Valladolid, Santa María de cardeñosa, San Salvador de Villalumbos, San Román de Fuentes de don Vermudo, San Martín de Villavaruz, San Vicente de Autello y la iglesia de Villamuera ${ }^{1095}$. Un listado en el que se recogen las piezas artísticas y el ornamento litúrgico que poseía San Zoilo, nos da la idea del esplendor que alcanzó el cenobio durante el siglo XII ${ }^{1096}$.

\subsection{CONTINUACIÓN DE LAS OBRAS}

\subsubsection{EL TEMPLO}

De acuerdo a las excavaciones, se cree que la primitiva iglesia románica de San Zoilo era de planta basilical de unos 35 metros de longitud y 16 metros de

\footnotetext{
1092 VALLE CURIESES, Rafael de. A orillas del Carrión. Destellos de un pasado entrañable: acontecimientos históricos, personajes memorables, arte. Caja de Ahorros y Monte de Piedad. Palencia, 1989, pág. 104.

${ }^{1093}$ RAMIREZ DE HELGUERA, Martín. El libro...op. cit, pp. 64- 67 y VALLE CURIESES, Rafael de. A orillas del Carrión...Op.cit, pp. 103-107.

${ }^{1094}$ 5SIMÓN Y NIETO, Francisco. Los antiguos...Op.cit, pp. 134-135.

${ }^{1095}$ PALACIO SÁNCHEZ IZQUIERDO, María Luisa. Monasterio de San Zoilo...Op.cit, pp. 150151.

${ }^{1096}$ Ibídem, pág. 151.
} 
anchura, sin transepto acusado en planta, tres ábsides semicirculares y cubrición con bóvedas de medio cañón, pues existen claras huellas de curvatura de las bóvedas laterales en el templo actual. Por tanto, las relaciones tipológicas con Frómista y Dueñas son evidentes. José Luis Senra señala un hermanamiento de proyectos arquitectónicos impuesto por el priorato cluniacense entorno al 1100, en consonancia a la dependencia institucional de ambos centros a San Zoilo ${ }^{1097}$. Doña Teresa, por tanto, habría impulsado las obras del cenobio románico que serían finalizadas en esta época.

En 1993, gracias a unas obras de acondicionamiento en la fachada de la iglesia, apareció en un estado de conservación increíble, la portada occidental de la primitiva iglesia románica emparedada desde al menos 1786 bajo el coro alto ${ }^{1098}$. Esta fecha se conoce gracias a la inscripción que figura en la rosca del arco: "REEDIFICOSE ESTA CAPILLA Y SE COLOCARON LOS SEPULCRALES QUE SE HALLARON EN SU PAVIMENTO BAJO LOS ARCOS COLATERALES DE ELLA A ${ }^{\circ} 1786 ”$.

La portada se compone de una serie de arquivoltas de medio punto de mediadas proporciones -1,50 metros de luz y 2,50 metros de altura hasta la imposta-, que alterna la rosca plana con dos gruesos boceles. Conserva en una de sus arquivoltas los restos de una inscripción de contenido bíblico en capitales romanas alusiva a San Juan Bautista. Tan sólo es legible su parte central, pues ha sido borrado completamente el resto, pero lo que se conserva: “...PILIS CAMELORVM ET ZONAM PELI[...]AM...” es suficiente para saber que se trata de una cita bíblica proveniente del Evangelio de San Mateo en la que se refiere a la predicación de San Juan Bautista en el desierto. Describe la vestimenta del precursor de Cristo: “Juan tenía una túnica de pelos de camello y un cinturón de cuero ${ }^{1099}$ ". Podríamos

\footnotetext{
${ }^{1097}$ SENRA GABRIEL Y GALÁN, José Luis. “Algunas notas sobre la desaparecida...” Op.cit, pág. 445 y del mismo autor, "La puerta como dogma: A propósito de un nuevo descubrimiento de la iglesia románica de San Zoilo de Carrión de los Condes (Palencia)" en AEA, n 322. Abril-Junio, 2008, pág. 143-144.

${ }^{1098}$ Estas intervenciones fueron posibles gracias a la reciente adquisición de la empresa "Hospederías Españolas San Zoilo" del conjunto al Obispado palentino a finales de 1991. SENRA GABRIEL Y GALÁN, José Luis "La portada occidental recientemente descubierta en el monasterio San Zoilo de Carrión de los Condes" en AEA, tomo 67, n²95. Madrid, 1994, pp.. 57-72

1099 San Mateo, 3,4: "Ipse autem Ioannes habebat vestimentum de pilis camelorum, et zonam pelliceam circa lumbos suos". Agradezco la traducción a doña Avelina Carrera, profesora del
} 
pensar que el pasaje hace referencia a la advocación original del templo, sin embargo, esta inscripción no es tan antigua, sino que, probablemente, como señala José Luis Senra, fue realizada a finales del siglo XVI, cuando este espacio pasó a denominarse capilla de San Juan ${ }^{1100}$.

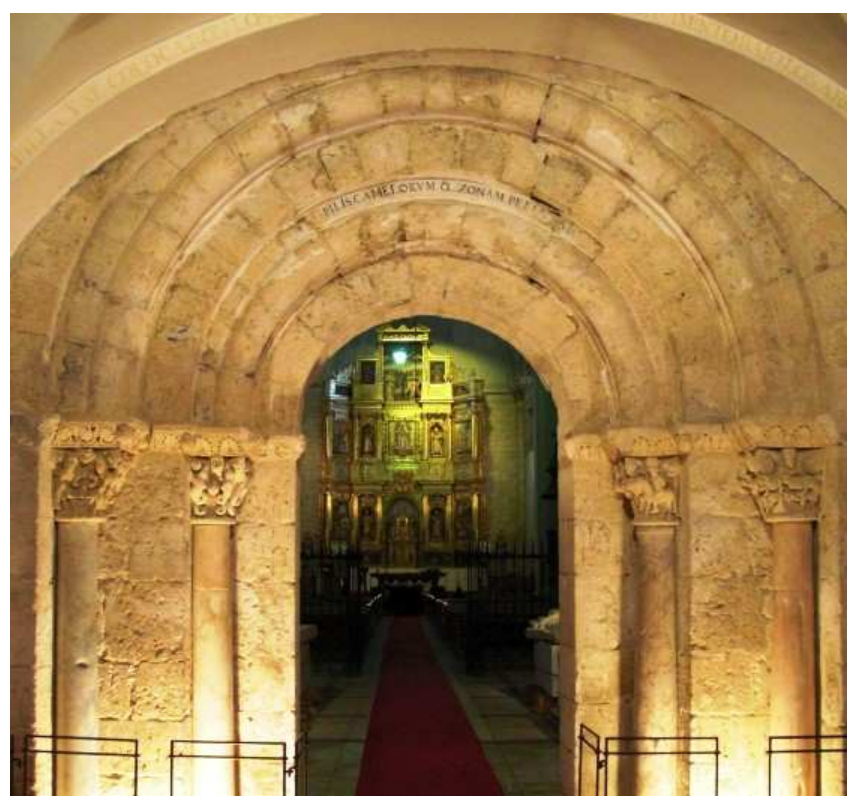

\section{Portada occidental del templo románico, descubierta en 1993}

La ausencia de tímpano, al igual que en Frómista, San Isidoro de Dueñas o San Pedro de Arlanza, todas ellas de la segunda mitad del siglo XII, junto a algunas similitudes estilísticas respecto a éstas, hace suponer una fecha similar a los templos citados con anterioridad ${ }^{101}$. Las cuatro columnas acodilladas de mármol reaprovechado descansan sobre basas con decoración de bolas. Sobre sus desnudos fustes, los capiteles historiados con cimacios adoptan forma de mastaba invertida. Encima de los mismos, los cimacios se resuelven a modo de una imposta

Departamento de Filología Clásica de la Facultad de Filosofía y Letras de la Universidad de Valladolid.

${ }^{1100}$ SENRA GABRIEL Y GALÁN, José Luis "La portada occidental...Op.cit, pp. 60-61, a su vez de YEPES, Fray Antonio. Crónica...Tomo VI, Op.cit, pág. 79 y JOVELLANOS, Gaspar Melchor, Diarios...Tomo III, Op.cit, pág. 290.

${ }^{1101}$ CASTÁN LANASPA, Javier. "Una portada románica con capiteles historiados en Carrión de los Condes (Palencia)” en Homenaje al profesor Martín González. Valladolid, 1995, pág. 306. 
ornamentada con palmetas entrelazadas que recorre las jambas, interrumpiéndose en el vano para continuar en el lado contiguo. A excepción del primero, presentan en sus dos caras representaciones historiadas típicas de los focos del camino jacobeo, que revelan la existencia de un nuevo taller escultórico palentino desde finales del siglo $\mathrm{XI}^{1102}$. Son característicos sus rostros ovalados, la mandíbula prominente y la ausencia de pupila, además de las cabelleras lanosas y las vestiduras de amplios pliegues. Entre las figuras se despliegan una serie de volutas de gran desarrollo, características de otros focos como San Isidro de Dueñas.

Los capiteles interiores adolecen de cierto deterioro y presentan además, una connotación negativa; en cambio, los exteriores, mejor conservados y tallados con mayor delicadeza, simbolizan la obra del buen cristiano, resultando así, un programa que versa sobre la Salvación. Los temas representados serían, siguiendo un eje norte-sur, las que siguen a continuación:

-Capitel exterior izquierdo: Presenta cuatro figuras dispuestas por parejas que portan bandejas sobre las que se asientan bustos. Estos personajes sostienen un libro con una mano y alzan la otra en actitud de bendición. Podemos relacionar la significación de esta iconografía con el tránsito del alma justa, tema salvífico que se observa en uno de los capiteles de la iglesia de Santiago de la misma villa ${ }^{1103}$. Las cabezas de leones, que se alzan sobre los personajes, pueden interpretarse como una exhortación al fiel para que se comporte adecuadamente. La presencia de estos felinos a la entrada de los templos románicos como símbolos de protección y advertencia, son recurrentes en territorio hispano. En este caso, se muestran mansos, mientras que existen otros ejemplos en que estos felinos se convierten en bestias antropófagas, aludiendo al destino ineludible que espera a los pecadores. Sirvan como exponente los templos de San Esteban de Otazu y la Purificación de Gazolaz, en Navarra ${ }^{1104}$.

\footnotetext{
${ }^{1102}$ CASTÁN LANASPA, Javier. “Una portada...Op.cit, pág. 308.

${ }^{1103}$ GARCIA GUINEA, Miguel Ángel. El arte románico...Op.cit, pp. 125-30 y CASTÁN LANASPA, Javier. "Una portada...”. Op. cit, pág. 310. Sobre este tema HERRERO ROMERO, LUCRECIA "Notas iconográficas sobre el tránsito del alma en el románico español" en Estudios de Iconografía Medieval Española. Bellaterra, 1984, pp. 13-51.

${ }_{1104}$ ARAGONÉS ESTELLA, Esperanza. La imagen del mal en el románico navarro. Gobierno de Navarra. Pamplona, 1996, pp. 117-119.
} 
-Capitel interior izquierdo: Introduce parejas de reptiles alados semejando dragones en posición vertical, de cola serpenteante y boca abierta amenazadoramente, separados por elementos vegetales. A algunos de ellos les falta algún miembro. Estos seres monstruosos, híbridos imaginarios creados a partir de la naturaleza, resultan pragmáticos para crear la imagen demoníaca, un referente visual muy eficaz para dogmatizar al fiel ${ }^{1105}$. En la cara oculta, se representa una serpiente, que con los elementos anteriormente citados, complemente el carácter maléfico del capitel. La flor con motivos estriados que figura en la parte superior del capitel es un recurso común en los repertorios románicos del siglo XII como Frómista, Dueñas, Santiago de Compostela o Loarre ${ }^{1106}$.

-Capitel interior derecho: Nos muestra en su cara interna, un ángel empuñando un cuchillo y con la otra mano, señala hacia el personaje dispuesto en la cara frontal, un jinete sobre un asno. Representa la escena de Balaam sobre la burra, el cual fue enviado a Israel para traer la idolatría, símbolo, por tanto, de los que se apartan del buen camino, y el águila tallado en la tercera cara, prefiguración de Dios ${ }^{1107}$. Respecto al motivo de volutas de gran desarrollo que separan a los personajes, es un recurso muy utilizado en el románico, muy característico en centros tan renombrados como la catedral de Jaca, de la que pudo influenciarse el artista que los talló $^{1108}$.

-Capitel exterior derecho: En cada cara sitúa a un hombre vendimiando, muy encorvado, como requiere la actividad, sobre el cual se sitúa una enigmática figura reducida a rostro y manos, de hierática expresión, cuyo cabello se dispone con una raya en medio y mechones estrictamente simétricos. Los focos palentinos de Frómista, Santa María de Mave presentan en alguno de sus capiteles, la escena de la recogida de la uva con las viñas de tallos vegetales enroscados rematados en racimos. La imagen de los viticultores, podando las viñas o aireando las cepas es entendida como el monje que recoge con esfuerzo los frutos de su buen hacer,

${ }^{1105}$ En una sociedad como la medieval, los conceptos del bien y del mal están muy marcados a través del arte, donde el carácter moral se extraía fácilmente, de ahí su carácter dogmático. Un estudio sobre este tema en RUIZ LLAMAS, María Gracia. "El arte de enseñar a través del arte: el valor didáctico de las imágenes románicas" en Educatio siglo XXI, n²0-21, Murcia, 2003, pp. 227-248.

${ }^{1106}$ SENRA GABRIEL Y GALÁN, José Luis "La portada occidental...Op.cit, pág. 62.

${ }^{1107}$ CASTÁN LANASPA, Javier. "Una portada...”. Op. cit, pág. 308.

${ }^{1108}$ GAILLARD, Georges. Les débuts de la sculpture romane espagnole: León, Jaca, Compostelle. Paul Hartmann. París, 1938, pp. 97-98. 
desdeñando la herejía. Aparte del referente más próximo de Frómista, esta temática presenta múltiples ejemplos en ámbito hispano, como la iglesia segoviana de la Asunción de Duratón o San Nicolás de El Frago, en Zaragoza ${ }^{1109}$.

En el año 1995, aparecieron dos ejemplares vinculados estilísticamente con la portada occidental pero con un tratamiento más tosco. El primero representa un músico tocando una vihuela y el segundo contiene volutas y elementos vegetales entrelazados, muy frecuentes en Jaca o Frómista.

Prosiguiendo las investigaciones, en esta ocasión a través de unas labores de desenfoscado que tuvieron lugar en octubre de 1999, vieron la luz algunos restos románicos correspondientes al muro sur de la iglesia barroca que llegaban hasta el arranque de la bóveda de cañón que cubría la nave ${ }^{1110}$. Entre los pilares contiguos al crucero actual, se contabilizan dos capiteles cuyas cestas representan, en un caso, un complejo entrelazo, en otro, un capitel figurado que entronca con las tallas del pórtico occidental. En él se representa a un león en posición de avance cuya cabeza converge en el ángulo derecho donde un personaje barbado aferra con ambos brazos la cabeza el animal. Sobre éste se alzan dos pequeñas aves, águilas seguramente, unidas por la cola. En el espacio de la cara derecha aparece un personaje con toga y libro cuya identificación nos es desconocida.

$\mathrm{Al}$ exterior del templo, en el ángulo noroccidental, se conservan restos de la primitiva torre románica, cuyas molduras presentan semejanzas con San Martín de Frómista $^{1111}$. Presenta en su parte superior de ladrillo una rama de paraboloide cóncava en dirección al pueblo para que el sonido de la campana no se vea afectado por la corriente transversal del río ${ }^{112}$. A esta torre se accedía por una escalera helicoidal embutida en el muro, que, aunque reformada en el barroco, nos permite comprobar que continuaba hacia la zona sur del hastial. Las obras de rehabilitación han permitido certificar la existencia de otra torre, de forma cilíndrica, en el ángulo

\footnotetext{
${ }^{1109}$ Los ciclos temáticos dedicados a las diversas actividades agrarias son muy recurrentes en la escultura románica. Un interesante estudio sobre este tema en HERNANDO GARRIDO, José Luis. "Estampas del mundo rural: la imagen del campesino en el arte románico hispano" en Poder y seducción de la imagen románica. Aguilar de Campoo, Palencia, 2006, pp. 159-189.

1110 SENRA GABRIEL Y GALÁN, José Luis "Nuevos hallazgos románicos en el monasterio de San Zoilo de Carrión de los Condes (Palencia), en AEA. Madrid, 2001, pp. 88-95.

1111 SENRA GABRIEL Y GALÁN, José Luis “Monasterio de San Zoilo". Op.cit, pp. 1023-1032.

1112 RAMÍREZ DE HELGUERA, Martín. El real monasterio...Op.cit, pág. 105.
} 
sudoeste. También existió un pórtico occidental, desaparecido, alineado con la fachada que conformaba el panteón funerario de los Condes de Carrión ${ }^{1113}$.

Las excavaciones de 2008 pusieron de manifiesto la presencia de un acceso a este torreón situado en la nave del Evangelio, concretamente en el ángulo de los pies del templo, oculto hasta hoy por un potente machón ${ }^{1114}$. El tímpano de dicho acceso contiene un crismón flanqueado por sendos tallos vegetales que la conectan directamente con el que poseía, ubicado igualmente en la puerta de la torre norte, el cercano templo de San Martín de Frómista ${ }^{1115}$. Este acceso comunicaba además con un pasillo que permitía el acceso a la tribuna y altar de la galilea de los pies ${ }^{1116}$. El proceso conformado por el ascenso al pórtico, la parada en el altar para realizar los oficios de Pascua y el descenso hacia el templo por la torre pareja, constituirían liturgia conmemorativa cluniacense en consonancia a triunfo simbólico sobre la muerte $^{1117}$.

\subsubsection{LA GALILEA O CAPILLA CONDAL}

El primitivo panteón condal se ubicó, en origen “...en una pieça que ni es

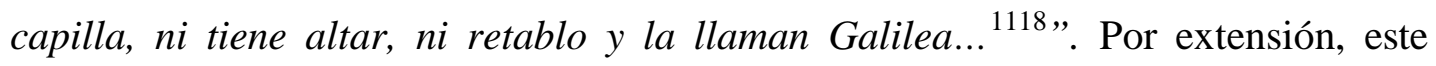
término se utiliza para designar el pórtico occidental de las iglesias monasteriales, especialmente las cluniacenses ${ }^{1119}$. En su nombre permanece el recuerdo de la región de Israel por el sentido de lugar de tránsito que tuvo en la vida de Cristo, como igualmente lo es el pórtico al que nos referimos ${ }^{1120}$. Se trataba de un lugar

${ }^{1113}$ SENRA GABRIEL Y GALÁN, José Luis. "La realidad material Op.cit, pp. 45,46.

${ }^{1114}$ SENRA, GABRIEL Y GALÁN, José Luis. La puerta como dogma...Op.cit, pág. 140-149.

${ }^{1115}$ Ya confrontada estilísticamente con nuestro templo e igualmente estudiado por el mismo autor. Véase SENRA GABRIEL Y GALÁN, José Luis. "La realidad material... Op.cit, pp. 55-57.

${ }^{1116}$ La galilea o capilla condal está explicada en el apartado correspondiente.

${ }^{1117}$ La metáfora ascensional ligada al sentido de Resurrección ya está presente en la literatura benedictina, en el pasaje de la escalara mística de Jacob, el pasaje del ascenso de los ángeles de Yahvé, etc. Así cita SENRA, GABRIEL Y GALÁN, José Luis. La puerta como dogma...Op.cit, pág. 142-143.

${ }^{1118}$ YEPES, Fray Antonio. Crónica...Op.cit, pág. 79.

1119 SENRA GABRIEL Y GALÁN, José Luis. "La realidad material...", Op.cit, pág. 48 y "Aproximación a los espacios....Op.cit, pp. 122-124.

${ }^{1120}$ Las comunidades de San Vicente de Cardona, Santa María de Ripoll, San Salvador de Oña o San Facundo y San Primitivo de Sahagún tuvieron galileas de este tipo para enterramiento noble. BANGO TORVISO, Isidro. "El espacio para enterramientos privilegiados en la arquitectura medieval española" en ADHTA, nº 4, 1992, pp. 108-109. 
privilegiado de enterramiento para las familias nobles, el más cercano al templo para asegurarse "la entrada en la otra vida" y paso obligado para los fieles, que contemplarían admirados los sepulcros que allí se encontraban. Hay que señalar que aún en el siglo XI, tan sólo los mártires o personas de conocida santidad tenían el honor de recibir sepultura en el interior de los templos. A partir del siglo XVII, este espacio ubicado a los pies del templo se denominaba capilla de los Condes o de San Juan, antigua advocación del templo ${ }^{1121}$.

Los sepulcros, conservados hoy día en el sotocoro del templo, pertenecieron a la familia Beni-Gómez y otros nobles destacados. Los sucesivos traslados que han experimentado a lo largo de los siglos han erosionado considerablemente sus inscripciones. En 1570 fue electo abad Fray Sebastián de Encinas y durante los seis años que detentó el cargo, se ocupó de adecentar la capilla, y enterró los sepulcros dejando las laudas a ras de suelo con el fin de desembarazar este espacio ${ }^{1122}$. El sepulcro de la condesa Teresa, que se situaba en el crucero, lo trasladó a la capilla mayor, situándolo en el lado de la Epístola. Para adecentarlo, hizo construir un arcosolio con un bulto de su imagen, pues de entre todos los miembros del linaje, era la única considerada santa, de ahí su preeminente ubicación ${ }^{1123}$. En 1631, con las obras del nuevo templo, sus restos fueron trasladados al lado del Evangelio, donde descansan desde entonces ${ }^{1124}$. El resto de las laudas se mantuvieron ocultas hasta que en 1786, sin cambiar su ubicación, se levantaron del pavimento, se revocaron de yeso y se apilaron en las paredes en dos bloques de cuatro ${ }^{1125}$. Debido a esta intervención, los restos óseos y las cubiertas de los sarcófagos se mezclaron ${ }^{1126}$.

A través de una abertura en el muro, Valentín Carderera y Parcerisa, como miembros de la Comisión Provincial de Monumentos, descubrieron los sepulcros 1836, aconsejando encarecidamente su extracción, que no tenía visos de llevarse a

\footnotetext{
${ }^{1121}$ YEPES, Fray Antonio. Crónica...Tomo VI, Op.cit, pág. 79.

1122 SENRA GABRIEL Y GALÁN, José Luis. "Mio Cid es de Bivar e nos de los condes de Carrión. Los Banu- Gómez de Carrión a la luz de sus epitafios" en Quintana, n 5. Santiago de Compostela, 2006, pág. 236.

${ }^{1123}$ YEPES, Fray Antonio. Crónica...Tomo VI. Op.cit, pág. 79.

${ }^{1124}$ CASTRO, Lázaro de. Op.cit, s/f.

1125 QUADRADO; José María y PARCERISA, Francisco J. Op.cit, pág. 133 y NAVARRO GARCÍA, Rafael Op.cit, pág. 12.

${ }^{1126}$ MARTÍNEZ DÍEZ, Gonzalo. "La familia condal de Carrión” en AIIICHP, tomo 2. Palencia, 1995, pág. 601.
} 
cabo, al menos, por el momento ${ }^{1127}$. Unas décadas más tarde, Quadrado preludiaba que el hallazgo de los sepulcros prometía resultados satisfactorios y que su compañero Parcerisa tenía la intención de regresar a Carrión pero no se le había presentado la ocasión ${ }^{1128}$.

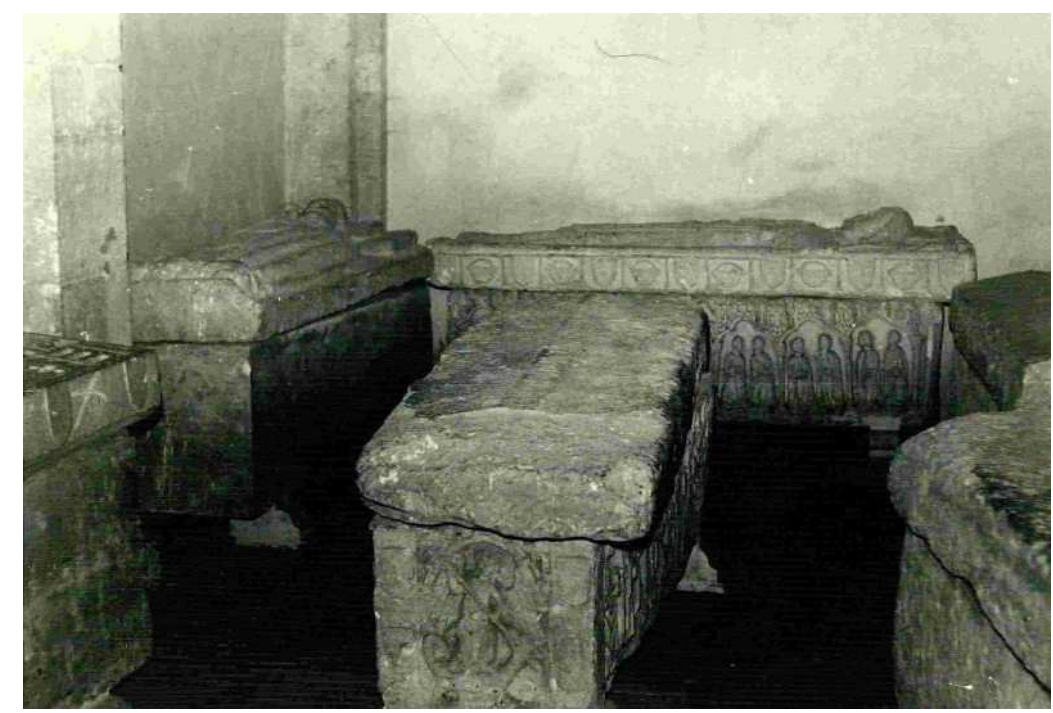

Sepulcros ubicados en la galilea.

Fotografía hallada entre los fondos del Archivo Consitorial de Carrión.

Corría el 8 de julio de 1948 cuando “...A las 10.30 de la mañana se dieron los primeros golpes en los muros que tapiaban las tumbas..." Así comenzaba la noticia del esperado acontecimiento. Por vez primera fueron mostrados los once sarcófagos bajo la atenta presencia del alcalde de Carrión, Don Martín Molina. Asistieron al acto, además, los siguientes miembros de la Comisión Provincial de Monumentos: Ramón Revilla, secretario de la misma, comisario de excavaciones arqueológicas y académico de la Real Academia de la Historia, Antonio Font, arquitecto diocesano y el coleccionista de antigüedades Arcadio Torres ${ }^{1129}$. A pesar de la mortaja de yeso que recubría los sepulcros, el paso del tiempo no pudo evitar el deterioro de los signos gráficos de algunos de ellos, hoy ilegibles, que permitirían

\footnotetext{
${ }^{1127}$ En el informe que en 1860 realizó la Comisión de monumentos palentinos sobre los monumentos notables de la provincia de Palencia, se hace referencia al descubrimiento del Panteón Condal. ARASF, Palencia, Comisión Monumental, Leg, 2-7-7, Monumentos en general.

${ }^{1128}$ QUADRADO; José María y PARCERISA, Francisco J. Op.cit, pág. 135.

${ }^{1129}$ Publicada en la revista Carrión en agosto de 1948, pp. 23 y ss. ACJAH. C11. Carrión de los Condes. 12. Publicaciones de Carrión.
} 
identificar a los personajes enterrados en los mismos. Por fortuna, Yepes transcribió algunas de las que menos afectadas se encontraban ${ }^{1130}$.

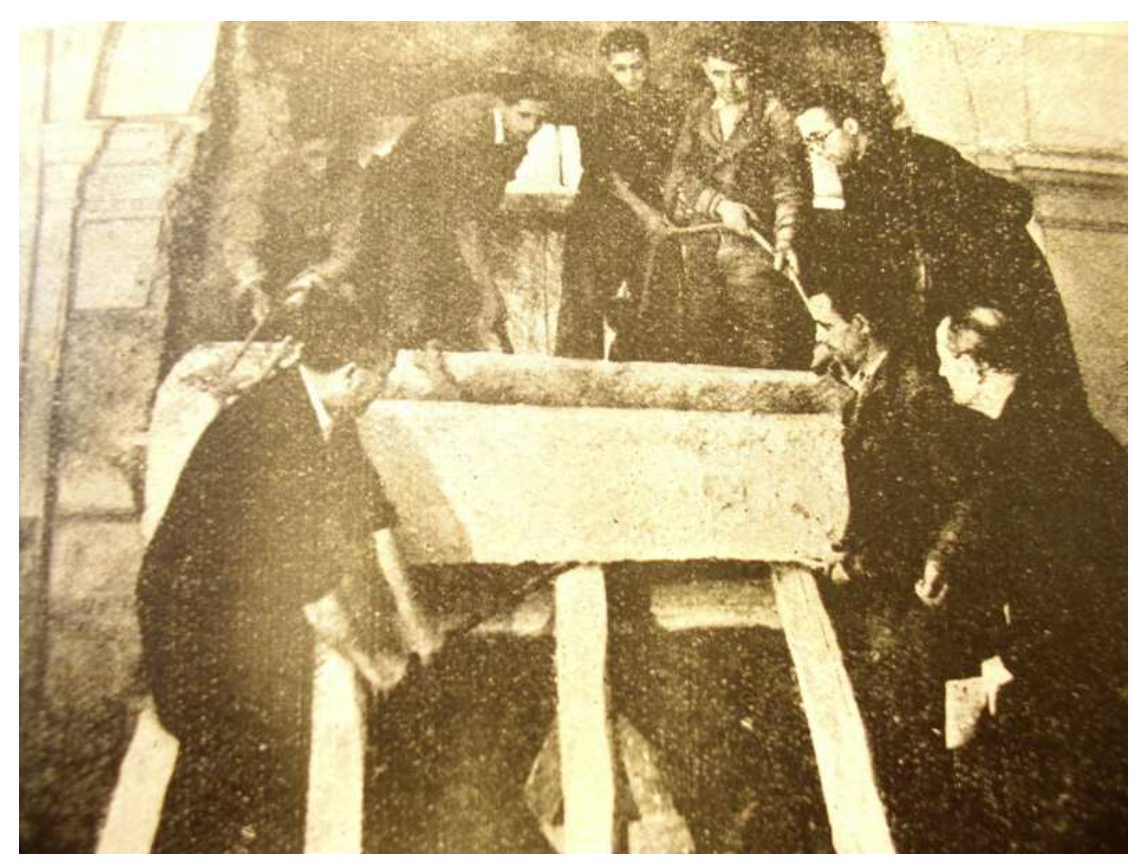

Hallazgo de los sepulcros de los Beni-Gómez en 1948.

ACJAH. C.11. Carrión. Publicaciones Periódicas.

Sin contar con el de la condesa del presbiterio, se extrajeron de la capilla un total de once sepulcros, cuya cronología oscilaba entre los siglos XI y XIII. De ellos, ocho eran lisos y tres presentaban relieves. De acuerdo a su datación, los clasificaremos en dos grupos diversos.

\section{Sepulcros de los siglos XI-XII}

En esta clasificación se insertan ocho sarcófagos altomedievales, de los cuales siete poseen forma antropoide con un hueco adaptado a la cabeza. Presentan tapas de doble vertiente, piramidales y planas, sin decoración alguna ${ }^{1131}$. Llevan talladas, eso sí, sendas inscripciones que contienen los nombres de la familia

\footnotetext{
${ }^{1130}$ Hay que ser cauteloso a la hora de manejar esta fuente, pues en algunos casos no coincide con otros autores. YEPES, Fray Antonio. Crónica...Tomo VI. Op.cit, pp. 79-80.

${ }^{1131}$ GABRIEL Y GALÁN, José Luis. "Mio Cid es de Bivar...Op.cit, pág. 239.
} 
fundadora de los Beni- Gómez y otros miembros, así como la fecha de su fallecimiento. Estos sepulcros románicos, fechables hacia finales del siglo XI, principios del XII, son contemporáneos a los de los Condes de Castilla, los más antiguos, con decoración escultórica, si bien éstos, carecen de ornamentación. Por orden cronológico, sin incluir los de los vástagos de los condes, son tres:

-Doña María (1043) Fue una dama ilustre que podría identificarse, según apunta José Luis Senra, con la Marina de la documentación, madre del conde Gómez Díaz $^{1132}$.

En su epitafio se puede leer la inscripción siguiente:

"Domina Maria, stirpe clara hic jacet humata de carne mortali fideliter migravit exuta, ea propter in celum ejus anima sit lecta. Obiit, era MLXXXI V kalendas octobris $^{1133,}$.

“Aquí yace enterrada doña María, mujer de preclara estirpe. Fortalecida con la fe, emigró de su carne mortal. Que libre ya de ésta, su alma sea recogida a las puertas del cielo. Murió el 27 de septiembre del año $1081^{1134,}$

-Don Gómez Díaz (1057) No se conserva ningún testimonio gráfico del epitafio del refundador y la inscripción conservada fue realizada en un momento posterior, pues a mediados del siglo XI, la epigrafía funeraria no presentaría una composición versificada $^{1135}$.

La transcripción del epígrafe es:

"Inclitus qui quodam fuit Didaci comes Gometius religione, atque militia splendidus lampade morte felici in matrem piam receptus, hic jacet corpore polorum

${ }^{1132}$ GABRIEL Y GALÁN, José Luis. "Mio Cid es de Bivar...Op.cit, pág. 259 (nota al pie nº36).

${ }^{1133}$ YEPES, Fray Antonio. Crónica...Tomo VI. Op.cit, pp. 79.

1134 Agradezco sinceramente esta y las siguientes traducciones así como sus comentarios a Doña Avelina Carrera, profesora de Filología Latina de la Facultad de Filosofía y Letras de Valladolid ${ }^{1135}$ Ibídem, pág. 239. 
transmitens, spiritum, arce, fidei, spei et charitatis turme refertus dapsilis benignus nunc gaudet numine faetus, ocasum adiit februari lucae nona, era MXC juncta $\mathrm{V}^{1136}$,

“Aquí yace sepultado el cuerpo del que fuera ínclito conde Gómez Díaz, ilustre religioso y soldado, acogido junto a su dilecta madre tras el resplandor de una muerte fecunda. Mientras, su espíritu recorre la fortaleza de los cielos, equipado con el batallón de la fe, la esperanza y la caridad; siendo rico y benigno, ahora se alegra sostenido por la Divinidad. Le llegó la muerte un lunes, 5 de febrero del año 1095"

Existe un error en la datación de la defunción, 5 de febrero de 1057, pues el conde estaba vivo por aquellas fechas, ya que a finales de dicho año emitió una carta de compra, último documento en que figura ${ }^{1137}$.

-Doña Teresa Peláez (1093). La lauda original conservada en el presbiterio, está oculta en parte bajo la estatua orante de la condesa, realizada en el siglo XVII ${ }^{1138}$. La primera trascripción de dicho epitafio, se lo debemos a Ambrosio de Morales en la segunda mitad del siglo XVI. Pero yerra en la datación:

"Faemina chara deo, jacet hoc tumulata sepulchro quae comitisa fuit nomine Taresia. Haec mensis junii sub quinto transiit idus. Omnis eam merito plangere debet homo. Ecclesiam ponte peregrinis optima tecta. Parca sibi struxit largaque pauperibus donet ei regnum quod permanet omne per aevum. Qui manens trius regnat ubique deus. Obiit era $\mathrm{MXCV}^{1139}$."

\footnotetext{
1136 YEPES, Fray Antonio. Crónica...Tomo VI. Op.cit, pág. 79 y QUADRADO; José María y PARCERISA, Francisco J. Recuerdos...Op.cit, pág. 136.

${ }^{1137}$ GABRIEL Y GALÁN, José Luis. "Mio Cid es de Bivar...Op.cit, pág. 239, a su vez de PÉREZ CELADA, Julio A. Documentación... (1047-1300) Op, cit, doc 6-10.

${ }^{1138}$ José Luis Senra pudo acceder a la misma gracias a la ubicación de unos andamios que estaban ubicados con motivo de unas reparaciones de iluminación en esa zona. GABRIEL Y GALÁN, José Luis. "Mio Cid es de Bivar...Op.cit, pp. 240-241.

${ }^{1139}$ OCAMPO, Florián de. La Coronica general de España / que continuaba Ambrosio de Morales... prosiguiendo adelante de los cinco libros que el Maestro Florián de Ocampo... dexo escritos... Alcalá, 1574, capítulo 17. Traducción: "Aquí yace enterrada en esta sepultura, la condesa doña Teresa, amada de Dios. Murió a los nueve días del mes de junio y con razón la deben llorar todos: edificó esta iglesia, la puente y el muy buen hospital para los peregrinos, siendo escasa para sí misma y muy liberal con los pobres. Dios que siendo trino reina en toda parte, le de el reino que dura por todos los siglos. Falleció en la era de 1095".
} 
"En este sepulcro yace enterrada la condesa Teresa, mujer amada por Dios. Murió el 9 de junio. Merece que todos la lloren. Mujer austera consigo misma y generosa con los pobres, erigió una iglesia y un puente, soberbia edificación para los peregrinos. Dios, trino y rey del universo, le dará el reino que permanece por siempre. Murió en el año 1095"

Por su parte Yepes, aunque recoge la misma fecha, advierte acertadamente, que la condesa falleció en la era de MCXXXI, esto es, año 1093, perteneciendo la datación de 1057 propuesta por Morales a su marido, el conde don Gómez ${ }^{1140}$.

Don Gómez Díaz y doña Teresa Pélaez tuvieron siete hijos: tres varones y cuatro mujeres, como así figura en el documento de adhesión de San Zoilo a Cluny en el año 1076, en que todos ellos aparecen mencionados ${ }^{1141}$. Los varones del linaje fueron:

-Don Fernando Gómez (1085?). Fue el primogénito de los condes Beni-Gómez, y el primero de los hijos en fallecer. En contra de lo que se pueda creer, no llegó a ostentar el condado de Carrión, como su padre, recayendo este título en su primo, Pedro Ansúrez, hijo de Ansur Díaz ${ }^{1142}$.

De su epitafio, cuyo principio y final nos ha llegado en un estado de deterioro tal que impide la lectura del año del óbito, se puede extraer lo siguiente:

“...Fredinando Gómiz qvi obiit die III F(eria) III ID(us) M(a)RCII ERA ..CXX ${ }^{1143}$ :”

Contrastando las transcripciones epigráficas, hallamos que los cronistas divergieron en la lectura de la datación del óbito del primogénito, con variantes entre el 13 y 14

\footnotetext{
${ }^{1140}$ YEPES, Fray Antonio. Crónica...Tomo VI. Op.cit, pág. 79.

1141 PÉREZ CELADA, Julio A. Documentación... (1047-1300) Op.cit, doc 7, pp. 15-18. Existen controversias sobre esta afirmación, pues Yepes defiende que fueron ocho los vástagos del linaje, incluyendo a Diego Gómez. YEPES, Fray Antonio. Crónica...Tomo VI. Op.cit, pp. 78-79.

1142 RODRÍGUEZ FERNÁNDEZ, Justiniano "En torno a la lauda sepulcral del conde Pedro Ansúrez" en BSAA, no 27, 1961, pp. 337-342 y MARTÍNEZ MARTÍN, Manuel. "Un promotor de obras del s. XI. El conde Pedro Ansúrez” en Aparejadores, n71, 2006, pp. 66-78.

${ }^{1143}$ El Libro Misceláneo ofrece el 14 de marzo de 1083, frente a Yepes, que lo retrasa un día. SENRA GABRIEL Y GALÁN, José Luis. "Mio Cid es de Bivar...Op.cit, pág. 259.
} 
de marzo, coincidiendo, eso sí, en el año. Gracias a ellos, eso sí, podemos reproducir la totalidad de la lauda, aunque con ligeras variantes de interpretación:

"Hoc tumulo iacet famulus Dei miles Ferdinandus Gomez, qui obiit die tertia feria tertio idus Martii era MCXXI Christus perducat animan ejus in paradisum ${ }^{1144,}$

"Hoc in tumulo requiescit famulus Dei comite Fredinando Gomez, qui obiit die 3 feria pridie idus marcia, era millesima centesima vigesima prima. Christus in quo credidit, sucurrat ei ${ }^{1145,}$.

La traducción, similar para ambos, podría unificarse en la siguiente: "En este túmulo yace el soldado, siervo de Dios, Fernando Gómez, que murió un martes, 13 de marzo, del año 1121. Que Dios conduzca su alma al Paraíso"

A pesar de lo que puedan indicar las fuentes, José Luis Senra demuestra que hay que tomar con cautela los datos que nos proporcionan. Don Fernando vivía aún en 1085, fecha en que confirma junto a Pelayo, su hermano pequeño una venta de Pedro Ansúrez ${ }^{1146}$.

-Don García Gómez (1083), fue el segundo hijo varón de los condes, que, recordemos, se encargó de traer a partir de 1076 los monjes necesarios desde Cluny para el priorato de San Zoilo ${ }^{1147}$. El epitafio, que tampoco ha llegado a nuestros días, lo conocemos gracias a los cronistas:

"Hoc in tumulo jacet famulus Dei, Garcias Gomez, qui occisus fuit a sarracenis pridie kalendas decembris, era MCXXI ${ }^{1148,}$

"En este túmulo yace el siervo de Dios, García Gómez, asesinado por los sarracenos el día 30 de noviembre del año $1121 "$

\footnotetext{
1144 YEPES, Fray Antonio. Crónica...Tomo VI. Op.cit, pág. 79.

1145 SANDOVAL, Prudencio de. Cinco Reyes, 1615 1792, pág. 205. Las dos versiones son recogidas por Quadrado. QUADRADO; José María y PARCERISA, Francisco J. Recuerdos...Op.cit, pág. 136

1146 SENRA GABRIEL Y GALÁN, José Luis. "Mio Cid es de Bivar...Op.cit, pág. 246.

1147 YEPES, Fray Antonio. Crónica...Tomo VI. Op.cit, pág. 74.

${ }^{1148}$ Ibídem, pp. 79-80 y QUADRADO; José María y PARCERISA, Francisco J. Recuerdos...Op.cit, pág. 136.
} 
Probablemente, don García, hombre de armas como sus hermanos, murió en el campo de batalla en 1083. Pudiera ser, como sugirió Menéndez Pidal, que falleciese en las campañas que Alfonso VI lanzó contra el califa Motamid de Sevilla ${ }^{1149}$.

-Don Pelayo (1101), fue, como así nos remite la transcripción de su epitafio y la cartela del claustro de San Zoilo, el tercero de los varones del matrimonio. No se conserva ningún testimonio del mismo, por lo que remitimos a Yepes para la información relativa al mismo, el cual dice:

"Pelagius tertius hujus coenobii fundatorum filius fuit hic honorifice iacet humatus cum Dei sanctis computetur et ipse beatus obiit era MCXXXVIIII decimo nono kalendas februaris ${ }^{1150}$.

"Pelayo fue el tercer hijo de los fundadores de este cenobio. Aquí yace enterrado con todos los honores. Que sea bendecido y contado entre los santos de Dios. Murió bienaventurado el día 14 de enero del año 1139”

La nomenclatura numeral "tertius hujus" de este epitafio pone de manifiesto, según los expertos, que esta dedicatoria se hizo en una fecha muy posterior a la muerte de don Pelayo ${ }^{1151}$. Se sabe que llegó a ostentar el título condal y se esposó con una noble gallega, que pudiera identificarse con doña Elvira Muñoz, hija del magnate Munio Rodríguez ${ }^{1152}$.

En cuanto a las hijas de don Gómez Díaz y doña Teresa Pélaez, éstas fueron las siguientes condesas:

Doña Mayor (1108?). Condesa primogénita de los Beni-Gómez, se llamaba realmente doña María, como así figura en el documento de cesión de San Zoilo a

\footnotetext{
${ }_{1149}^{1150}$ MENÉNDEZ PIDAL, Ramón. La España...vol. II. Op.cit, pág. 542.

1150 YEPES, Fray Antonio. Crónica...Tomo VI. Op.cit, pp. 79-80 y QUADRADO; José María y PARCERISA, Francisco J. Recuerdos...Op.cit, pág. 136.

${ }^{1151}$ SENRA GABRIEL Y GALÁN, José Luis. "Mio Cid es de Bivar...op.cit, pág. 246.

${ }^{1152}$ Ibídem, pág. 246 y 261, nota 84.
} 
Cluny en $1076^{1153}$. El hecho de que doña Mayor no figure como tal en la documentación, ha llevado a negar su vinculación directa con los condes don Gómez y Teresa, pero es como indicamos, un modo de denominar a la mayor de las mujeres de la estirpe condal ${ }^{1154}$. Figura junto a su madre, con la cartela: "HIJA PRIMOGÉNITA DE LOS FUNDADORES”. La transcripción de su epitafio, del que tenemos noticias indirectas, es el siguiente:

"Hic dormit sepulta feminam que obtulit multa cometissa Mayor Gomez sacro huic monasterio cui merces donetur in celo. Obiit era millesima MCXLVI nonas januarii ${ }^{1155,}$,

“Aquí sepultada duerme la condesa Mayor Gómez, mujer que otorgó muchas mercedes a este sagrado monasterio. Que se le otorgue su recompensa en el cielo. Murió el 5 de enero. Año 1146”

-Doña Sancha (1084?), segunda de las hijas de los fundadores, como así figura en el claustro benedictino, fue la primera de las mujeres de la familia en fallecer. Los datos biográficos conocidos son realmente exiguos. Según parece hizo donación de una heredad en San Mamés y de la iglesia palentina de Santa Cruz ${ }^{1156}$.

Transcribimos el contenido de su lauda, no conservada, gracias a los cronistas que nos aportan esta valiosa información:

"Domina Santia Gomez comitiva humus coenobii adiutrix magnifica hic jacet etiam sepulta coelica ut credimus sede foelici possessa. Obiit era MCXII quarto kalendas aprilis ${ }^{1157,}$

“Aquí yace la condesa Sancha Gómez, que ayudó grandemente a este cenobio. Creemos que ya ocupa una morada feliz en el cielo. Murió el 29 de marzo del año $1112 ”$

${ }^{1153}$ PÉREZ CELADA, Julio A. Documentación...(1047-1300) Op.cit, doc 7, pp. 15-18.

${ }^{1154}$ PÉREZ CELADA, Julio A. El Monasterio de San Zoilo de Carrión...Op.cit, pág. 89.

1155 QUADRADO; José María y PARCERISA, Francisco J. Recuerdos...Op.cit, pág. 137. Yepes utiliza el término "hera" en vez de "feminam". YEPES, Fray Antonio. Crónica...Tomo VI. Op.cit, pp. 79-80.

${ }^{1156}$ SENRA GABRIEL Y GALÁN, José Luis. "Mio Cid es de Bivar...Op.cit, pág. 248.

${ }_{1157}$ YEPES, Fray Antonio. Crónica...Tomo VI. Op.cit, pág. 79 y QUADRADO; José María y PARCERISA, Francisco J. Recuerdos...Op.cit, pág. 136. 
-Doña Elvira (1087?). De las cuatro hijas de los condes, es de la única de la que se ha conservado su lauda sepulcral. Esto ha posibilitado una lectura reciente, que ha permitido a su vez, poner de relieve la escasa credibilidad de los cronistas.

José Luis Senra recogía una fecha de fallecimiento correspondiente al 22 de diciembre de 1087:

"Hic aicet in sarcofago isto comitissa Gelvira Gomiz, q[ui] obit die III f(eria) XI $\mathrm{k}(\mathrm{ale}) \mathrm{d}(\mathrm{a}) \mathrm{s}$ ianuar(i)s era MCXXV XPS in [quo cr] edit susurra(t) illiam $^{1158,}$

"En este sarcófago descansa la condesa Elvira Gómez, que murió el miércoles 22 de diciembre del año 1125. Que Cristo, en quien creyó, la socorra”

Prudencio de Sandoval establece el óbito en esta misma fecha, no así Yepes, que lo pospone al 23 de diciembre de 1104, lo que nos lleva a dudar de la fiabilidad que merecen respecto a las otras transcripciones de las que no conservamos otro testimonio $^{1159}$. Ya Quadrado se extrañaba de tal discordancia en las fuentes que manejaba, destacando además, el hecho de que ninguna de estas dos fechas cayó en martes, como indicaban ${ }^{1160}$.

Doña Aldonza (1112? $)^{1161}$, es la única de los hijos de los condes que no figura, seguramente por falta de espacio, en la bóveda primera del claustro bajo ni tampoco entre los medallones del sobreclaustro. El documento de 1076 por el que se anexiona San Zoilo a Cluny hace mención a esta condesa como fruto del matrimonio BeniGómez ${ }^{1162}$. Estuvo casada al parecer con el magnate de Toro y Zamora, don Munio Fernández ${ }^{1163}$. Atendiendo a las cartelas del claustro, se trataría de la más pequeña

${ }^{1158}$ SENRA GABRIEL Y GALÁN, José Luis. "Mio Cid es de Bivar...Op.cit, pp. 248-249.

1159 SANDOVAL, Prudencio de. Historia de los Reyes de Castilla y de León don Fernando el Magno, don Sancho, don Alonso Sexto,doña Urraka., don Alonso Séptimo. Carlos de Labayen. Madrid, 1615. 2a Edición, Madrid, 1792, pág. 205, YEPES, Fray Antonio. Crónica...Tomo VI. Op.cit, pp. 79-80.

${ }^{1160}$ QUADRADO; José María y PARCERISA, Francisco J. Recuerdos...Op.cit, pp. 136-137.

1161 YEPES, Fray Antonio. Crónica...Tomo VI. Op.cit, pág. 79.

1162 BERNARD, Auguste. Recueil des chartes....Tomo IV, Op.cit, pp. 604-607 y PÉREZ CELADA, Julio A. Documentación... (1047-1300) Op.cit, doc 7, pp. 15-18.

${ }^{1163}$ No obstante, la afirmación no es concluyente, pues en su testamento a favor del priorato, fechado en 1109, doña Aldonza expresa, refiriéndose a don Munio “aui mei” SENRA GABRIEL Y GALÁN, 
de las infantas, pues la primogénita, segunda y tercera ya figuran en el mismo. La transcripción de su epitafio, del que no queda testimonio, nos ha llegado, una vez más, gracias al célebre cronista benedictino:

"Comitisa Alonsa electa hic iacet, quodque sepulta. Locetur Regina judicis ad dexteram Christi. Ingentia quae dona Dei templo contulit isto. Quae regia extra duce, Solaria defungitur luce/ era MCXXXXIIII idibus iunii ${ }^{1164,}$

“Aquí yace Aldonza, condesa predilecta. Que sea colocada como reina a la derecha de Cristo cuando la juzgue a ella, que proporcionó ingentes dones al templo de Dios. Ésta, como reina y señora, dejó de ver la luz del sol el 13 de junio. Año 1143.”

El propio Yepes indicaba, no obstante, que la fecha que recogía no era acertada, puesto que constaba por un privilegio que la condesa vivía catorce años después ${ }^{1165}$. No sabemos a qué privilegio se refiere, si bien es cierto que, efectivamente, doña Aldonza fue más longeva de lo que figura en estas y otras inscripciones, que incluso llegan a adelantar su muerte a $1095^{1166}$. Las donaciones que realizó en 1109 y 1112 con el fin de incrementar el patrimonio de San Zoilo evidencian la falsedad de la datación $^{1167}$.

Existe un personaje bastante controvertido, dado el desconocimiento general sobre el mismo:

-Don Diego Gómez (1107?) Algunos autores lo consideran hijo de los condes BeniGómez, como así defiende Quadrado, que se basa en fuentes anteriores, dada la inscripción del epitafio, hoy día no conservado:

José Luis. "Mio Cid es de Bivar...Op.cit, pág. 248 y 263, nota 107, a su vez de PÉREZ CELADA, Julio A. Documentación... (1301-1400). Op.cit, Addenda, pp. 283-284.

${ }_{1164}$ YEPES, Fray Antonio. Crónica...Tomo VI. Op.cit, pág. 79.

1165 Ibídem, pag 79. Así lo recoge también QUADRADO; José María y PARCERISA, Francisco J. Recuerdos...Op.cit, pág. 137.

${ }^{1166}$ Así figura en el Libro Misceláneo: "era millesima C ${ }^{a}$ XXXIII", idus iunii” en SENRA GABRIEL Y GALÁN, José Luis. "Mio Cid es de Bivar...Op.cit, pág. 248.

${ }^{1167}$ PÉREZ CELADA, Julio A. Documentación...(1301-1400), Op.cit, Addenda, pp. 283-284. 
"Didacus Gomeci quartus hujus cenobii fundatorum filius fuit, qui ipse etiam hic habetur sepultus: obiit era MCXLV quarto kalendas junii ${ }^{1168}$.

"Yace también aquí Diego Gómez, cuarto hijo de los fundadores de este cenobio. Murió el 29 de diciembre de 1145"

Prudencio de Sandoval y Yepes lo incluyen en el cómputo de vástagos que formarían parte de los miembros descendientes de los Beni-Gómez, haciendo un total de ocho ${ }^{1169}$.

A pesar de lo expuesto, hay que señalar, una vez más, la dudosa fiabilidad de las crónicas a este respecto, añadiendo el hecho de que la designación numeral del abolengo condal "quartus hujus" no es coetánea a la fecha del óbito, sino muy posterior $^{1170}$. En este sentido consideramos que el listado contenido en el documento de anexión de la orden en 1076 en que se enumeran solamente siete hijos, tiene un peso fundamental, que descarta la veracidad de las anteriores afirmaciones ${ }^{1171}$. Partimos de la base de que no fue el hijo pequeño de los condes, pero, cabe preguntarse qué relación tuvo con ellos. A este respecto, y dado que el nombre del ascendente directo de este personaje debe responder a su patronímico, José Luis Senra apunta la posibilidad de que fuera el primogénito de don Gómez Martínez, a quien aludiremos posteriormente, hijo éste de alguna de las condesas, bien Sancha, bien Elvira ${ }^{1172}$. Aún presuponiendo la longevidad de doña Teresa Pélaez, hasta 1093, y dando por hecho una muerta prematura de su presunto biznieto, don Diego Gómez en 1107 no nos parece plausible este vínculo genealógico, dado el escaso lapso de tiempo transcurrido entre ambas muertes. Es más posible que Diego Gómez, coetáneo de los hijos del conde, fuera un primo de los mismos y que junto a estos, colaborara en las campañas militares del sur de España. Era un hombre de armas, pues este personaje aparece representado en uno de los nueve medallones del claustro alto del monasterio con coraza, casco y portando una alabarda. La

\footnotetext{
1168 QUADRADO; José María y PARCERISA, Francisco J. Recuerdos...Op.cit, pág. 136.

1169 SANDOVAL, Prudencio de. Primera parte...Op.cit, pp. 80 y YEPES, Fray Antonio. Crónica...Tomo VI. Op.cit, pág. 74.

${ }^{1170}$ Senra señala este dato, como vimos, para el epitafio de Pelagio. SENRA GABRIEL Y GALÁN, José Luis. "Mio Cid es de Bivar...Op.cit, pág. 246.

${ }^{1171}$ PÉREZ CELADA, Julio A. Documentación... (1047-1300) Op.cit, doc 7, pp. 15-18.

${ }^{1172}$ SENRA GABRIEL Y GALÁN, José Luis. "Mio Cid es de Bivar...Op.cit, pág. 254.
} 
indumentaria y atributos guerreros es común a todos los varones del clan BeniGómez, como así muestran don Fernando y don García Gómez, ubicados en la primera bóveda del claustro bajo, y el hermano de éstos don Pelayo Gómez y su padre, don Gómez Díaz, cuya presencia, además de en el lugar mencionado, se reitera en el sobreclaustro. Este insigne espacio en el que tiene destacado protagonismo don Diego Gómez, es además compartido con la condesa doña Teresa, los santos relacionados con la advocación del cenobio -San Juan Bautista, San Zoilo y San Félix- y algunos santos benedictinos insignes que coadyuvaron significativamente al esplendor de la abadía. Debió tratarse, por tanto, de una figura muy próxima al linaje Beni-Gómez, dada su presencia, en dos ámbitos de preeminencia destacada en el convento desde un punto de vista no sólo funcional sino propagandístico.

Don Diego Gómez y el primogénito de los condes, don Fernando Gómez, han sido frecuentemente relacionados con los hermanos infantes de Carrión del episodio de la afrenta del Corpes, perteneciente al el célebre Cantar del Mío Cid. Según el mismo, habrían deshonrado a las hijas del Campeador, doña Elvira y doña Sol, abandonándolas en unos prados, tras haberlas azotado ${ }^{1173}$. La identificación de estos personajes con los hijos del conde Gómez Díaz, no tiene ningún atisbo de credibilidad histórica, pues como venimos indicando, don Fernando y don Diego no fueron hermanos ${ }^{1174}$. Yepes, Quadrado y Ramírez de Helguera, entre otros, justifican su falsedad con el hecho de que en la época de las supuestas bodas hacia el año 1094, en que fue tomada Valencia, ya había fallecido al menos uno de los dos infantes ${ }^{1175}$. Dado que los infantes del relato figuran con el patronímico Fernández y dicen ser hijos de don Gonzalo ${ }^{1176}$, queda descartada la identificación con los hijos de Gómez Díaz, desviando la atención otros autores hacia los vástagos de Gonzalo Ansúrez, condes de Carrión entre los siglos X y XI ${ }^{1177}$. Tampoco podría establecerse una relación directa con aquellos personajes, pues no existió ningún Diego ni

\footnotetext{
${ }^{1173}$ SIMÓN Y NIETO, Francisco. Los antiguos...Op.cit, pág. 46.

${ }_{1174}^{1175}$ PÉREZ CELADA, Julio A. Documentación... (1047-1300) Op.cit, doc 7, pp. 15-18.

1175 Véanse YEPES, Fray Antonio. Op.cit, pág.s 59-63, QUADRADO; José María y PARCERISA, Francisco J. Op.cit, pp. 124-125 y RAMIREZ DE HELGUERA, Martín. El libro... Op.cit,, pp. 50 y 51

${ }^{1176}$ ANÓNIMO. Cantar del Mío Cid. Edición, prólogo y notas de MONTANER, Alberto; con un estudio preliminar de Francisco Rico. Crítica. Barcelona, 1993, versos 2267 y 2282.

${ }_{1177}$ MENÉNDEZ PIDAL, Ramón. La España del Cid, II volúmenes. Plutarco, Madrid, 1969, pp. $556-557$ y $817-819$.
} 
Fernando González en la familia de los Beni-Gómez ${ }^{1178}$. Probablemente, el autor del poema, dejando de lado el rigor histórico, se sirvió de estos personajes del clan de los Beni-Gómez como recurso literario para expresar en último término la traición que este linaje había hecho a los castellanos al aliarse con los monarcas leoneses ${ }^{1179}$.

Aparte de las sepulturas y epitafios relativos al linaje condal, entre los sepulcros mejor conservados figura el de don Fernando Malgraliense (1126), cuyo epitafio reza:

"Pulvis in haec fossa pariter tumulantur et ossa consulis illustris Fernandi Malgradiensis, positus letetur in arce polorum quo gaudet Zoilus Felix et turma bonorum. Centies uncena sexta decima quater era ${ }^{1180 \text {," }}$

"En este sepulcro está sepultado Fernando Malgraliense, ilustre cónsul/conde, ahora polvo y huesos. Que, situado en la región del cielo en la que ya están gozando Zoilo, Félix y la legión de varones virtuosos, experimente su mismo gozo. Año 1164"

Se trataba de un conde, como así indica Quadrado, pues este término se utilizaba como sinónimo de cónsul en época de Alfonso VII para identificar a un caudillo militar con jurisdicción regia ${ }^{181}$. En efecto, poseía su tenencia en Tierra de Campos, en un territorio denominado Malgrad, a corta distancia de Benavente, de ahí el apelativo del difunto ${ }^{1182}$. José Luis Senra ha logrado desentrañar interesantes datos sobre este personaje, que fue, según muestra la documentación, muy próximo al círculo cortesano de doña Urraca. Se llamaría Fernando Fernández, conde de Campos en 1119, de Carrión en 1125, sucesor por tanto, de Pedro Ansúrez en el

\footnotetext{
${ }^{1178}$ Existieron dos hijos del conde de Carrión Ansur Díaz, de nombre Diego y Fernando, pero se apellidaban lógicamente Ansúrez. Existieron a finales del siglo XI dos personajes llamados Diego y Fernando González, como los del poema, que figuran como confirmantes de diplomas regios, pero ni fueron condes ni tuvieron parentesco alguno con los Beni-Gómez. De este modo, queda fundamentada la falta de veracidad del poema. MARTÍNEZ DIEZ, Gonzalo. "Los infantes de Carrión del cantar cidiano y su nula historicidad" en Historia, instituciones, documentos, no 34. Sevilla, 2007, pp. 213-223.

1179 RIAÑO RODRÍGUEZ, Timoteo. "Propósito de Pero abat al escribir el Cantar de Mío Cid: motivaciones geopolíticas" en El Cid: poema e historia: Actas del Congreso Internacional (1216julio, 1999). Burgos, 2000, pp. 279-282.

${ }^{1180}$ SENRA GABRIEL Y GALÁN, José Luis. "Mio Cid es de Bivar...Op.cit, pág. 250.

${ }^{1181}$ QUADRADO; José María y PARCERISA, Francisco J. Recuerdos...Op.cit, pág. 137.

1182 SENRA GABRIEL Y GALÁN, José Luis. "Mio Cid es de Bivar...Op.cit, pág. 250.
} 
cargo y en 1124 figura como "comes Fernandus in Malgrado ${ }^{1183 "}$ ". El privilegio de descansar junto al linaje Bani-Gómez radica en la segura parentela con la familia condal. Se trataría de uno de los hijos de doña Aldonza Gómez, nieto por tanto de doña Teresa y Don Gómez Díaz, dada su presencia en un documento de donación de 1087 emitido por la propia doña Aldonza en que se indica: "cum filiis meis Ferrando Ferrandez et Elvira Monioz ${ }^{184,}$.

Otra de las laudas conservadas corresponde a don Gómez Martínez (1090?) que Quadrado transcribe del modo siguiente:

"Gomez Martinus jacet hac sub rupe sepultus qui fuit mucrone diro maurorum occisus III kalendas junii era MCXXVIII ${ }^{185, "}$.

"Yace sepultado bajo esta lápida Gómez Martín, que murió atravesado por una sanguinaria espada mora el 30 de mayo de 1128."

Dada la escasa fiabilidad que en ocasiones presentan las fuentes modernas, cabe la posibilidad plantear la identificación de este personaje con el magnate leonés, tenente de Simancas y Cea, que habría fallecido en la batalla de Uclés en 1108. Este conde sería el hijo de un destacado cortesano llamado Martín Alfonso, de quien se sospecha haber contraído matrimonio con una de las condesas BeniGómez $^{1186}$. De este modo, quedaría perfectamente justificada su presencia en la galilea, como nieto de los condes de Carrión, pero es algo que no podemos asegurar.

\footnotetext{
${ }^{1183}$ Su cercanía al entorno regio lo demuestra el hecho de figurar como testigo de dos importantes donaciones que la reina Urraca realiza a prioratos cluniacenses: a a San Isidoro de Dueñas le cede unas propiedades y a San Zoilo le dona San Martín de Frómista en 1118. Además, se esposó en 117 con una hermanastra de la reina, con la infanta Elvira Alfonso, de la que posteriormente se separó, hecho que justificaría que ella se encuentra enterrada en Sahagún y no en Carrión. Ibídem, pp. 251252

${ }^{1184}$ Ibídem, pág. 251.

${ }^{1185}$ QUADRADO; José María y PARCERISA, Francisco J. Recuerdos...Op.cit, pág. 137.

${ }^{1186}$ SENRA GABRIEL Y GALÁN, José Luis. "Mio Cid es de Bivar...Op.cit, pág. 253.
} 


\section{Sepulcros del siglo XIII}

Existe una diferencia, cronológica y estilística entre estos sepulcros lisos, y los que contiene decoración escultórica. Estos últimos son del siglo XIII y pertenecen a otros benefactores no tan claros de identificar. Fechables entre $1230 \mathrm{y}$ 1260, se adscriben a la mano de los denominados "primeros talleres de Carrión", pues entorno a la villa se localizan una serie de sepulcros de la misma tipología y datación $^{1187}$. Siguen la estructura de los sarcófagos de las Huelgas Reales de Burgos, fechados los más antiguos a finales del siglo XII, que constituyen el primer testimonio de escultura funeraria en forma de sarcófago decorado del reino de Castilla $^{1188}$. Poseen una serie de rasgos comunes que los caracterizan, y que serán homogéneos en la escultura funeraria nobiliar de los siglos XIII y XIV: los frentes decorados con arquerías y estructuras defensivas, urna sobreelevada por figuras animales, usualmente leones, y temas historiados, siendo los más recurrentes como el Pantocrátor, el Apostolado, San Miguel y el dragón, la Anunciación o los funerales del difunto ${ }^{1189}$. Las figuras representadas son toscas en sus actitudes y plegados, y las superficies son planas perviviendo en ellos los ecos de la última fase de la escultura románica, pero se adscriben al gótico en su voluntad por plasmar un mayor naturalismo en los rostros. Los artistas que desarrollaron su actividad en el foco carrionés, cuya procedencia es desconocida, denotan un conocimiento de los modelos coetáneos franceses, particularmente de la catedral de Amiens, lo que apunta hacia artistas extranjeros o bien, hispanos, capaces de asimilar las tendencias del momento ${ }^{1190}$.

\footnotetext{
${ }^{1187}$ Tomamos como referencia un estudio excelente sobre los mismos. ARA GIL, Clementina-Julia. "Un grupo de sepulcros...Op.cit, pp. 21-52.

${ }^{1188}$ Una de las pocas excepciones de sarcófago con decoración escultórica en fechas anteriores, es el sepulcro de Alfonso Ansúrez en el monasterio benedictino de Sahagún. Del mismo, FERNÁNDEZ RODRÍGUEZ, Manuel. "La laude sepulcral del infante Alfonso Ansúrez" en BSAA, tomo 1-2, Valladolid, 1932-1933, pp. 140-143. Sobre los sarcófagos de las Huelgas Reales, CALVO, José María. Apuntes históricos sobre el celebre monasterio de Santa Maria La Real de las Huelgas. Imprenta y Litografía de Villanueva. Burgos, 1846. GÓMEZ MORENO, Manuel. El Panteón Real de las Huelgas de Burgos. Instituto Diego Velázquez. Madrid, 1946. VV.AA. El Panteón Real de las Huelgas de Burgos. Los enterramientos de los Reyes de Castilla. Catálogo de la Exposición. Burgos, 1988.

${ }^{1189}$ ARA GIL, Clementina-Julia. "Un grupo de sepulcros...Op.cit, pág. 21.

${ }^{1190}$ Ibídem, pág. 27.
} 
El taller carrionés presenta una novedad respecto al taller de las Huelgas, y es el hecho de presentar figuras yacentes en relieve sobre la tapa ${ }^{1191}$. Este conjunto, conformado por un sepulcro completo, una caja y dos tapas, que analizamos a continuación:

-Sepulcro de Alvar Fernández "Podestat". La efigie del difunto está enmarcada por un arco trilobulado en cuya rosca se conserva una inscripción muy particular, que indica el nombre del artesano que lo ejecutó: "Don Pedro el pintor me fiço este mio monumento Alvar Fernández Podestat", de lo que podemos colegir la doble dedicación del artista, que se encargaría de esculpir y policromar el sepulcro. El personaje yacente, cuya cabeza reposa sobre una almohadón, mantiene sus ojos abiertos y tiene una cabellera lisa, con sus mechones finamente cincelados, pulcramente dispuesta tras sus orejas. Vestido con una elegante túnica y capa, elementos de su alta alcurnia- presenta, tumbado bajo sus puntiagudos zapatos, un perro como símbolo inequívoco de fidelidad hacia su amo. Gracias al análisis de algunos elementos del sepulcro, se han extraído datos importantes acerca de la identificación de este personaje. La heráldica conservada -calderas, lobos y bandajunto a la denominación de "Podestat" permiten establecer que se trata de un magnate perteneciente a los Lara, una de las familias castellanas más poderosas del momento. Hasta ahora, las fuentes genealógicas sostenían que aquí yacía el hijo del conde don Fernando Núñez, aristócrata del reinado de Alfonso VIII, fallecido hacia 1240, datación que se correspondía a la del sepulcro, según el análisis de su decoración ${ }^{1192}$.

Barón Faraldo, basándose en la documentación del Hospital de la Herrada de Carrión de los Condes, identifica al difunto con otro aristócrata desconocido hasta el momento y perteneciente igualmente a la parentela de los Lara, aunque de otra rama y fallecido posteriormente, hacia $1262^{1193}$. Apoyándose en los documentos

\footnotetext{
${ }^{1191}$ Ibídem, pág. 25.

1192 TORRES SEVILLA-QUIÑONES DE LEÓN, Margarita. Linajes nobiliarios de León y Castilla. Siglos IX-XIII. Salamanca, 1999, pp. 219-236. Para el linaje de los Lara, véase SALAZAR Y CASTRO, L. de. Historia genealógica de la Casa de los Lara.4 vol. Madrid, 1697. Se establece una datación en torno a 1240 y 1242. ARA GIL, Clementina-Julia. "Un grupo...Op.cit, pág. 26.

${ }^{1193}$ Por razones de carácter biológico no puede tratarse del vástago del conde don Fernando Núñez nieto del conde Pedro González y Eva Pérez- pues el hijo de éste, don Alvar Fernández, no podría haber vivido hasta 1262. El Alvar Fernández que surge en la documentación posterior, debía pertenecer a otra rama, también surgida del conde Pedro González pero en este caso con la reina doña
} 
conservados en los conventos de Entrepeñas y Aguilar de Campoo, elabora un árbol geneálogico de los Podestat, determinando que el personaje de tal controversia era hijo de Fernán Pérez Podestad y Teresa Vermúdez, propietarios éstos de grandes terrenos en Tierra de Campos y como tal, poseía ascendencia regia ${ }^{1194}$.

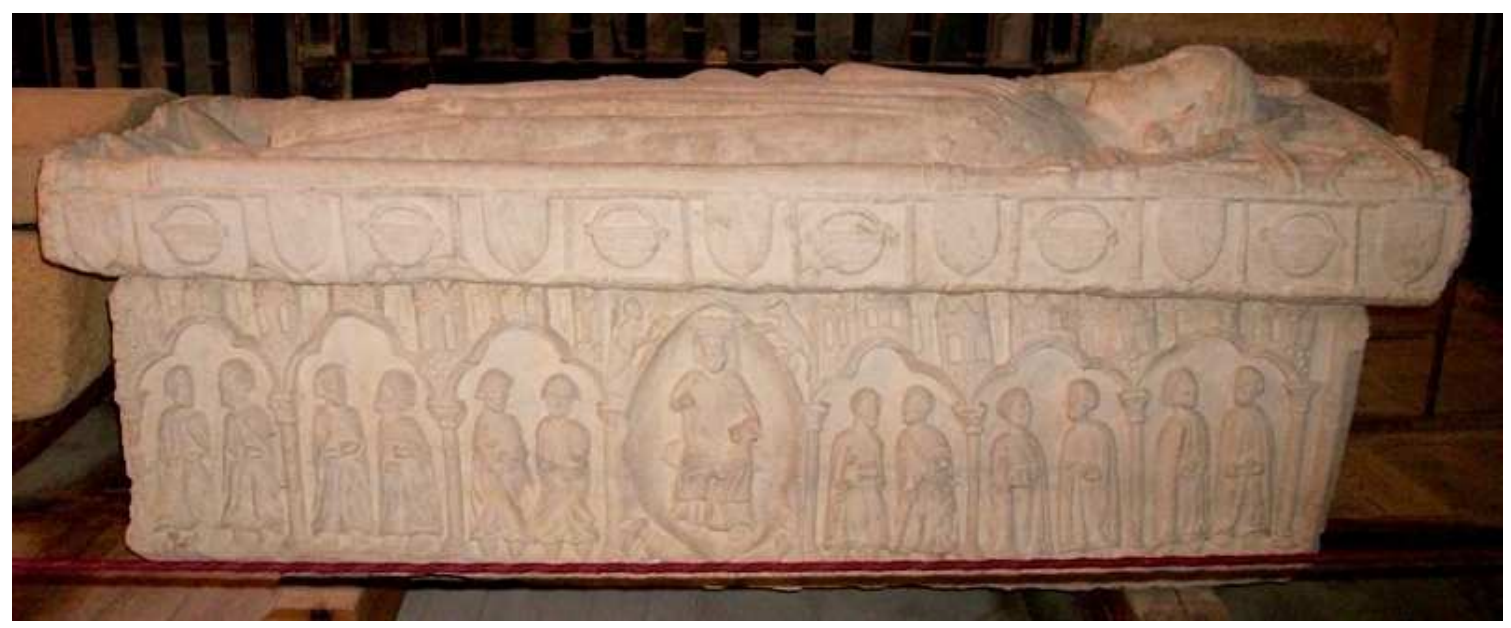

Sepulcro de Alvar Fernández Podestat.

Frente con el Apostolado y el Pantocrátor.

Paul Lafond coincide en la cronología propuesta por Baraldo hacia 1262 en que dicho Pedro Pintor, quién también sería escultor, labraría este sepulcro ${ }^{1195}$. La Comisión de Monumentos de Palencia, en un informe emitido a comienzos de 1944 indica que el autor de este último sepulcro era el antecesor de Antón Pérez de Carrión, de cuya mano salieron los sepulcros de Villasirga y quien, por otro lado, restauró los de Quintanilla de Las Viñas, en Burgos ${ }^{1196}$. La caja sobre la que se asienta esta tapa, no parece corresponderle en sus dimensiones, a lo que se suma el hecho de que la escultura tallada en tres de sus lados sería anterior, hacia 1230, a la ejecución del relieve que cubre el sepulcro ${ }^{1197}$. En su cabecera presenta una Déesis y

Urraca, a través de los cuales, llegaríamos directamente a Fernando Pérez, padre del personaje de controversia en este estudio. BARÓN FARALDO, Andrés. "Un magnate del siglo XIII: Alvar Fernández Podestat. Problemática y posibilidades sobre su origen y su parentela en PITTM, $\mathrm{n}^{\circ} 73$. Palencia, 2005, pp. 256-257.

1194 Ibídem, pp. 243-259.

1195 LAFOND, Paul. La scuplture spagnole. Dirección de Jules Compte. Librairie d'Éducation Nationale. Paris, 1908, pág. 30.

${ }_{1196}$ ARASF, Leg. 5-282-1.

${ }^{1197}$ ARA GIL, Clementina-Julia. "Un grupo de sepulcros...Op.cit, pág. 25. 
figura la Visitación a los pies. Centra la composición del frente del sepulcro un Cristo en majestad con Tetramorfos, que se complementa con el Apostolado que le flanquea a ambos lados ${ }^{1198}$. Dispuestos formando parejas, estos santos aparecen cobijados bajo sendos arcos trilobulados separados por estilizadas columnas con capiteles vegetales muy esquemáticos. La superficie que se despliega sobre estos vanos está animada por una serie de formas acastilladas provistas de almenas y ventanas con una decoración de orificios a trépano, elementos comunes a otros sepulcros salidos del mismo taller. Es el caso de los tres sarcófagos del Museo Arqueológico de Palencia, el del Museo Arqueológico Nacional procedente de Palencia o el de San Pedro de Cisneros, que como indica Julia Ara, habría que situar en el mismo contexto dadas las analogías de todos ellos ${ }^{1199}$. Este tema, tan recurrente en el románico, encuentra su análogo a pocos metros, en el friso de la iglesia de Santiago de la localidad carrionesa.

-Caja con decoración en sus cuatro frentes. No se conserva la tapa, así que es imposible identificar al personaje que pertenecía, máxime cuando no hay elementos heráldicos ni otros más específicos que revelen su identidad.

Como en el caso precedente, lleva en su cara anterior la representación del Calvario junto a la Virgen y San Juan, disponiéndose a los pies a San Miguel venciendo al demonio, ambas escenas cobijadas por un sencillo arco apuntado. En lo que a los frentes se refiere, en uno de los lados se encuentra el mismo tema del Pantocratos con Tetramorofos y los Apóstoles bajo arquerías que veíamos en el sepulcro precedente. En el otro costado, se representa, igualmente enmarcados en arquerías trilobuladas, la Anunciación y la Adoración de los Reyes Magos, cuya composición centra la Virgen en majestad, en posición frontal con el niño Jesús en su regazo. A su lado izquierdo, relegado a un plano secundario, San José, que se adormece sobre su vara. A pesar de la rudeza de la talla, los pliegues de las vestimentas y la expresión más avanzada de los rostros, permiten establecer una datación aproximada a mediados del siglo XIII ${ }^{1200}$.

\footnotetext{
1198 Podemos identificar a San Pedro y San Pablo, los personajes más inmediatos a Cristo, pues portan como atributos la llave y la espada, de ahí la identificación del Apostolado.

1199 Como indicamos previamente, todos estos sepulcros se analizan debidamente en ARA GIL, Clementina-Julia. "Un grupo de sepulcros...Op.cit, pp. 21-52.

1200 Ibídem, pág. 26.
} 
-Cubierta de sepulcro con la representación de un caballero. En actitud de reposo figura el yacente, sobre doble almohadón, con un perro a los pies, como el Podestat Alvar Fernández. Su rostro es sereno, porta bigote y sombrero que recoge su cabellera rizada y deja sus orejas al descubierto, como en el caso del magnate, pero los ojos de éste se mantienen cerrados. El atuendo de ambos es similar, con túnica larga, capa y calzas, lo que permite identificarlo con un caballero o personaje de cierta nobleza. La posición de sus manos, sin embargo, diverge de la de su compañero., pues mientras una reposa sobre su vientre, con la otra sostiene el broche de su capa. Ha desaparecido el marco arquitectónico que veíamos en el rostro de sepulcros, pero el tratamiento sencillo de los volúmenes y su tipología permiten datarlo hacia $1240^{1201}$.

-Cubierta de sepulcro con la representación de otro caballero. Esta tapa, como en los casos anteriores, presenta a un personaje de ilustre abolengo, reconocible por la disposición de la cabellera detrás de las orejas, que dejan entrever las patillas y su atuendo compuesto por túnica, manto y calzas puntiagudas. En actitud orante, mantiene los ojos cerrados y su cabeza queda enmarcada en un arco, túmido esta vez, adornado por las clásicas torres y otros elementos acastillados presentes en los otros ejemplos. Esta estructura es sostenida por dos estilizadas columnas con capiteles vegetales que flanquean hasta los pies, al joven difunto. Los pequeños cuadrifolios cincelados a ambos lados de la testa del yacente, son un recurso ornamental ya utilizado en el sepulcro del Museo Arqueológico de León, procedente de Benevívere. También están presentes en el sepulcro, que, procedente de Villafilar, se ubica en la iglesia de San Pedro de Cisneros, lo que manifiesta una autoría común del taller carrionés del que venimos hablando.

${ }^{1201}$ Ibídem, pág. 27. 


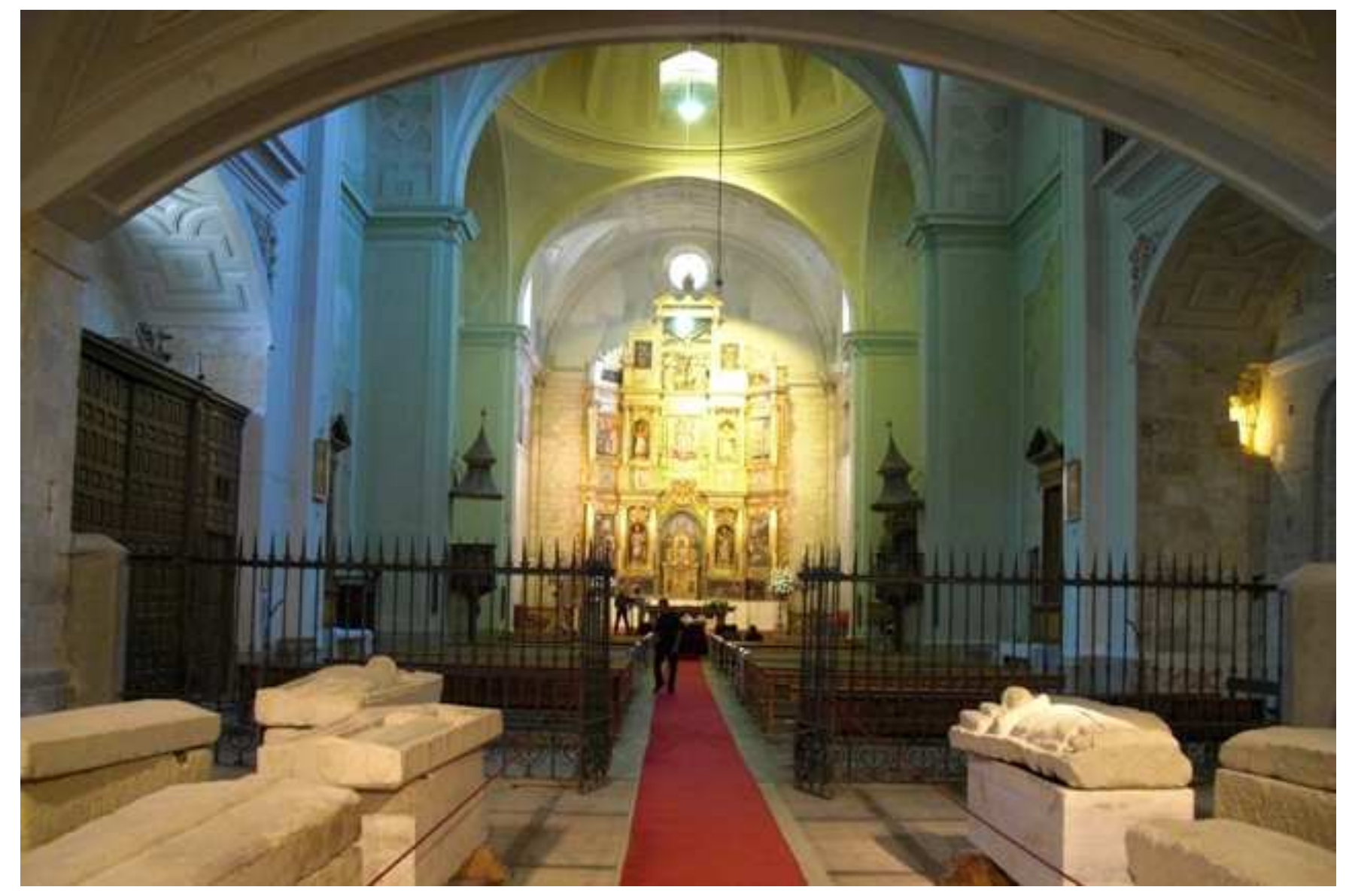

Sepulcros de los Beni Gómez en el coro bajo del templo de San Zoilo.

\section{Las telas ubicadas en la sacristía}

A raíz de la apertura de una de las dos arcas de la iglesia en 2004, aparecieron dos grandes telas de época medieval en un excelente estado de conservación $^{1202}$. En los mismos años en los que Yepes transmite la historia sobre el origen legendario de San Zoilo gracias a la condesa Teresa, dos testimonios nos hablan de un paño de seda asociado a la condesa ${ }^{1203}$. Uno es el archivero de Sahagún Juan Benito Guardiola donde se cuenta que un paño de seda cubría la tumba de

\footnotetext{
${ }^{1202}$ El estudio más completo dedicado a las telas islámicas en SENRA GABRIEL Y GALÁN, José Luis. "Dos telas islámicas encontradas...Op.cit, pp. 332-340.

${ }^{1203}$ YEPES, Fray Antonio. Crónica...Op.cit,pág. 56.
} 
Doña Teresa ${ }^{1204}$. El otro, de Juan Cisneros, de 1629, relata cómo el manto con el que supuestamente la condesa atravesó el río se conservaba entre las reliquias del monasterio. No es posible determinar cuando llegaron estas telas a San Zoilo pero son claras las relaciones de la familia Beni-Gómez con el Califato y los reinos de taifas posteriormente y por lo tanto, podemos colegir la familiaridad con los tejidos islámicos ${ }^{1205}$. Además, el hecho de que el priorato cluniacense fuese un centro político-religioso privilegiado, no extraña que recibiera donaciones de instituciones laicas para engalanar los espacios monásticos cuando tuviese lugar una determinada ceremonia, como es el caso de los concilios que se celebraron en el cenobio ${ }^{1206}$. La identificación de los objetos que conformaban el patrimonio del monasterio deviene una tarea harto complicada debido a la falta de documentación. Existe, sin embargo un listado del tesoro del priorato a principios del siglo XIII en el que se hace mención a una capa y una cortina, que tal vez, pudieran identificarse con dichas telas ${ }^{1207}$. En el siglo XIV y como tendremos oportunidad de ver, la comunidad de San Zoilo se sumerge en una gran crisis que le obliga a empeñar algunos objetos litúrgicos. En el capítulo de 1392 se ordena la restitución de todos ellos, entre los que figura, además de dos incensarios de plata, una valiosa capa: “...Praecipiunt diffinitores priori in virtute sanctae obedientiae et sub poena excommunicationis quatenus redimat et restituiat ecclesiae dicta duo thuribula et cappam intra festum omnium Sanctorum proxime futurum et revocet admodiationem factam... ${ }^{1208,}$

La asociación de telas con reliquias, es, a juicio de José Luis Senra, muy posible, dada la veneración que se tiene de las mismas desde tiempos inmemoriales. Concretamente, el arca que contiene los restos del mártir Zoilo, albergaba en su interior, según consta en la documentación del siglo XVII, una tela que cubría su cuerpo $^{1209}$. A principios del siglo XIX, con la amenaza de las tropas napoleónicas,

\footnotetext{
${ }^{1204}$ La leyenda en CIRIA RAXIS E INOJOSA, Pedro de. Vidas de santas...Tomo III. Op.cit, pp. 137139 y YEPES, Fray Antonio. Crónica...Tomo VI. Op.cit, pág. 79.

1205 SENRA GABRIEL Y GALÁN, José Luis. "Dos telas islámicas encontradas...op.cit, pp. 334335

${ }^{1206}$ Remitimos, a este respecto, a la historia de Carrión en la Edad Media. SENRA GABRIEL Y GALÁN, José Luis. "Dos telas islámicas encontradas...Op.cit, pág. 335.

${ }^{1207}$ PÉREZ CELADA, J. L. Documentación... (1301-1400). Op.cit, Palencia, 1987, pp. 246-247.

${ }^{1208}$ ROBERTS, Ulysses. "État des monastères espagnols de l'Ordre de Cluny aux XIIIİme et XVème siècles, d'après les actes des Chapitres Généreux" en BRAH. Tomo XX. Madrid, 1892, pp. 408-409.

${ }^{1209}$ Como ha sido ya explicado con anterioridad, fue Fernando, hijo de Doña Teresa y Gómez Díaz, quien trajo las reliquias de los mártires San Zoilo, Félix y Agapio desde Córdoba a Carrión, recibidas como obsequio por la valentía demostrada en el enfrentamiento que hacia 1070 tenía ligar entre el
} 
los monjes decidieron ocultar el contenido de las urnas bajo el pavimento del altar mayor, antes de ser trasladado a Santa María en 1814, año en que se produjo un reconocimiento de las reliquias y entre ellas se nombran: “...una cortina pintada que hacia el medio tenía un agujero bastante grande...Otra que es como una especie de banda de iglesia..."1210. Todo lo señalado, permite a Senra extraer la posibilidad de que una de las piezas textiles, la de color azul, que se guardaba en las arcas del monasterio, procediera del sepulcro de la condesa Teresa y la otra, de color rojo, podría haber sido encontrada junto a las reliquias de los mártires titulares del monasterio. Las marcas de la parte superior de ambas sargas, conducen a la creencia firme de su uso como colgaduras y las amplias dimensiones de las mismas anulan su utilización como capa. La finalidad original de las mismas sería la de envolver las reliquias del priorato ${ }^{1211}$.

Ambas telas presentan una composición semejante basada en la combinación simétrica de águilas y flores sin enmarcaciones, cuya descripción es la siguiente ${ }^{1212}$ :

-La tela de menor tamaño (1.38mtrs x 2.30mtrs), presenta fondo rojo con águilas amarillas afrontadas con las cabezas vueltas, separadas por un vástago y enmarcadas por óvalos perlados. La parte superior e inferior de la tela va recorrida por anchas bandas decorativas. Su composición apunta, en principio, un estilo que corresponde al período almohade de finales del siglo XII, que había prosperado bajo los califas fatimíes de Siria y había sido traído al Al- Andalus posteriormente.

-La otra tela (2,04mtrs x 2,68mtrs), se compone de treinta y seis águilas explayadas, $\mathrm{y}$, entre ellas, rosetas, todo sobre fondo azul oscuro. La definición de las líneas del dibujo, los detalles ornamentales de carácter vegetal, el repliegue de las patas hacia el vientre, la presencia de orejas y la expresividad de los ojos del águila, son elementos destacables de la tela. La banda roja que atraviesa horizontalmente el textil, contiene una serie de caracteres cúficos que tal vez recojan una exaltación a

reino taifa y los reinos e Toledo y Sevilla. Remitirse a la historia del monasterio para obtener estos datos. SENRA GABRIEL Y GALÁN, José Luis. "Dos telas islámicas encontradas...Op.cit, pág. 336. ${ }^{1210}$ Podrían tratarse de las mismas telas de las que hablamos, pues, ciertamente, una de ellas, presenta una rotura longitudinal en el lado izquierdo del eje central, tal vez debido a que sobre ella yaciese un cadáver. SENRA GABRIEL Y GALÁN, José Luis. "Dos telas islámicas encontradas...Op.cit, pág. 336.

${ }^{1211}$ Ibídem, pág. 332.

1212 Ibídem, 337-338. 
Allah. Esta capa presenta algunas concomitancias con diversos tejidos que llevan a pensar en la mima datación de éstos. Así, en un fragmento conservado en el Museo de los Tejidos de Lyon, fechado en el siglo XII se detecta la presencia de orejas y el desarrollo de la cola en abanico del águila como sucede en nuestra sarga.
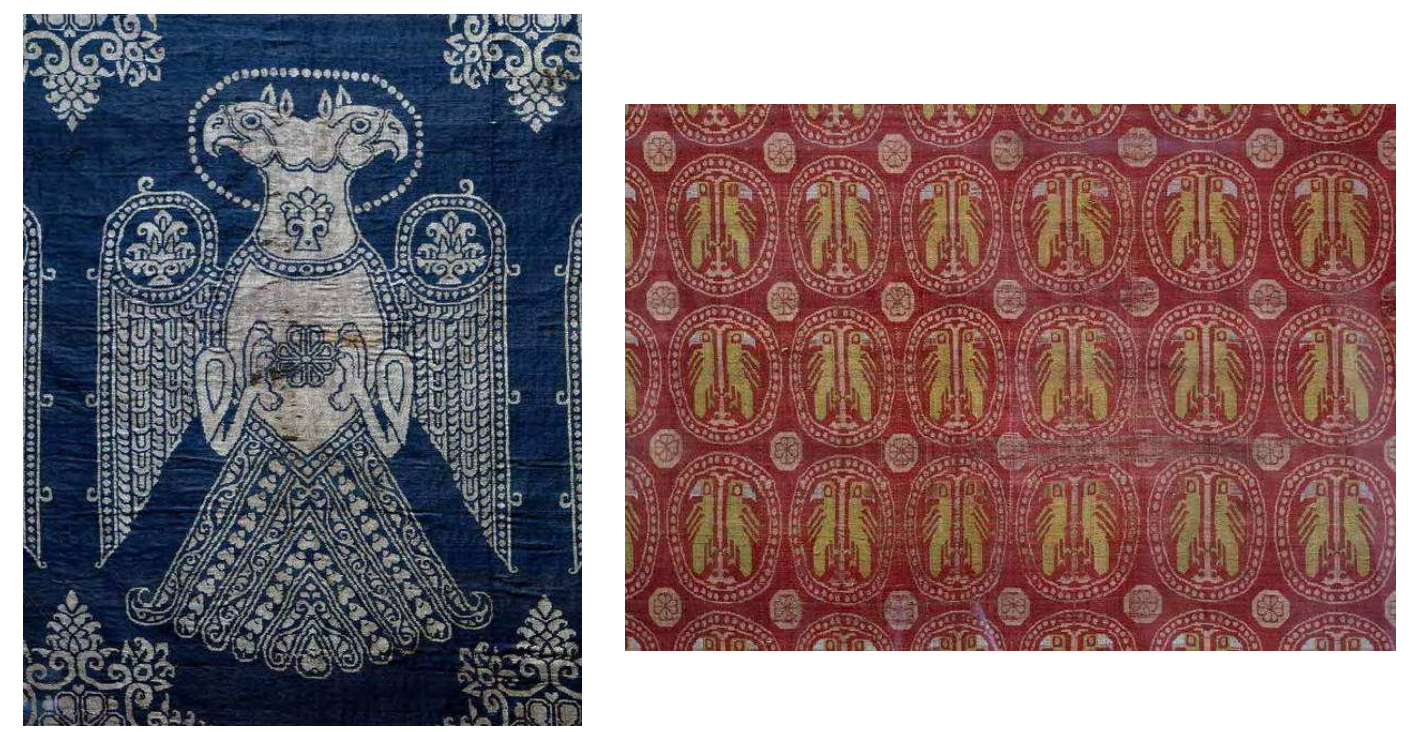

\section{Detalle de las sargas medievales expuestas en la sacristía del templo.}

El forro del relicario de Santa Librada, en Sigüenza, fechado entre finales del siglo XI y principios del siguiente, utiliza igualmente el espacio superior de las alas para producir un motivo ornamental. Las flores situadas entre las águilas se relacionan con las del relicario de San Isidoro de León que se fecha ates de 1063, pero existen también coincidencias con la casulla de Saint-Sernin de Toulouse, del siglo XII, en cuanto al fondo azul, las calles perladas y las escamas se refiere. A la espera de un próximo examen exhaustivo, por el momento, la datación de esta espléndida tela islámica oscilaría en una fecha indeterminada entre los siglos XI y $\mathrm{XII}^{1213}$.

\footnotetext{
${ }^{1213}$ Si se identificara la tela como la perteneciente a la condesa Teresa Peláez, habría que fechar su ejecución antes de 1093, año en el que falleció la misma, pero es algo que no se puede afirmar con seguridad pues la leyenda relatada por Yepes se llega a entremezclar con la historia sin que se pueda discernir con claridad, lo falso de lo que no lo es.
} 
Desde que fueron encontradas, las telas fueron depositadas en la sede de la Fundación Edades del Hombre, hasta que en junio de 2006 se trasladaron al centro de Simancas para proceder a su restauración ${ }^{1214}$. Desde el mes de julio de 2010, se exponen en la sacristía dentro de unas vitrinas especialmente acondicionadas en relación a factores lumínicos y ambientales ${ }^{1215}$.

\subsubsection{EL ANTIGUO CLAUSTRO}

Parece ser que en la época en que los condes Beni-Gómez reedificaron el monasterio, se encargaron, entre otras cosas, de dotarlo de claustro. En el capítulo de la Orden de 1387 se informa al prior que el claustro, además de la granja, se encontraban en estado total de ruina. Por entonces el monasterio contaba con quince monjes $^{1216}$. Tal situación podría deberse a una antigüedad de, al menos, un par de centurias. Unos años después, en 1392, se informa de su reconstrucción, por lo que el claustro románico ya no existía a finales del siglo XIV ${ }^{1217}$.

A finales de 1991 en el rellano del refectorio, aparecieron algunos capiteles que fueron extraídos y depositados en el zaguán de la hospedería. Se desconoce su ubicación original pero la diferencia que presentan en su concepción, apunta a una localización amplia, tal vez una galería claustral cuyos restos se conservan, en directa conexión con la escultura de la torre norte. El modo de converger de los tallos o la disposición plana de las volutas, son elementos que permiten a Senra vincular estrechamente estos capiteles con algunos de los de Jaca o Frómista ${ }^{1218}$. Serafín Moralejo Álvarez apoya esta afirmación, estableciendo los centros de Frómista y Carrión de los Condes dentro del ambiente renovador que Cluny

\footnotetext{
${ }^{1214}$ Norte de Castilla. 18 de junio de 2006.

1215 Diario Palentino. 29 de julio de 2010.

${ }^{1216}$ Además acusa al prior de llevar mala vida e introducir a mujeres en el monasterio. ROBERTS, Ulysses. "État des monastères espagnols de l'Ordre de Cluny aux XIIIème et XVème siècles, d'après les actes des Chapitres Généreux" en Boletín de la Real Academia de la Historia. Tomo XX. Madrid, 1892, pp. 405-406.

${ }^{1217}$ Ibídem, pág. 408.

${ }^{1218}$ Uno representa en cada uno de sus cuatro lados, un personaje sentado que sujeta las orejas de animales que le flanquean, que sujetan con sus garras el collarino. Otro de los capiteles representa a dos cuadrúpedos de difícil identificación dándose la espalda. Los otros dos capiteles no son figurados. Presenta elementos vegetales, como hojas y tallos entrelazados el primero y volutas y hojas anchas el más arcaico de ellos. Sobre estos restos escultóricos descontextualizados, véase SENRA GABRIEL Y GALÁN, José Luis "La portada occidental...Op.cit, pp. 64-67.
} 
representó para tierra de Campos ${ }^{1219}$. Asimismo, se pueden establecer relaciones con otros focos, pues el tratamiento clásico de los paños o la esquematización de las manos y pies de los cuatro personajes de uno de estos capiteles encontrados, recuerdan a los ángeles del sepulcro de Alfonso Ansúrez en Husillos ${ }^{1220}$.

\section{LOS SIGLOS XIII y XIV: PERIODO DE CRISIS}

La comunidad benedictina culmina a mediados del siglo XIII el proceso de configuración patrimonial comenzado en el siglo XI con los condes de Carrión ${ }^{1221}$. A partir de este momento, dará comienzo una crisis en todas las escalas, acentuada hasta el extremo en el siglo XIV, como así figura en los informes de las abadías cluniacenses. Las Actas del Capítulo General de la orden francesa así como las visitas a las diversas filiaciones desde 1259, recogen la grave situación que atravesaba el cenobio, por lo que resultan una fuente ineludible para documentar este agitado período $^{1222}$. Esta situación se incluye como un caso más dentro del proceso generalizado de declive en las abadías dependientes de la casa madre francesa ${ }^{1223}$.

Observamos, en primer lugar, una crisis de valores en la vida monacal. La progresiva relajación de costumbres y la falta de disciplina provocaron la decadencia espiritual de la orden en España, acentuada en el siglo XIV. De fecha muy temprana, 1247 concretamente, se conserva una bula emitida por Inocencio IV en que insta al prior de San Zoilo a rendir pleitesía a Cluny ${ }^{1224}$. En las visitas de la orden que se suceden a lo largo de doscientos años, encontramos una treintena de casos en que, tanto los monjes como los priores son blanco de alarmantes acusaciones, siendo el

\footnotetext{
1219 MORALEJO ÁLVAREZ, Serafín. "San Martín de Frómista, en los orígenes de la escultura románica europea" en Jornadas sobre el románico en la provincia de Palencia. Palencia, 1985, pp. 27-37.

${ }^{1220}$ VV.AA. Memorias y esplendores. Las Edades del Hombre. Catedral de Palencia, 1999, pp. 37 y38.

${ }_{1221}$ PÉREZ CELADA, Julio A. El monasterio de San Zoilo...Op.cit, pág. 87.

1222 ROBERTS, Ulysses. "État des monastères espagnols...Op.cit, pp. 321-431.

1223 A este respecto, RICHE, Denise. L'Ordre de Cluny à la fin du Moyen âge: "le vieux pays clunisien", XIIe-XVe siècles. Saint-Étienne, 2000.

${ }^{1224}$ PALACIO SÁNCHEZ IZQUIERDO, María Luisa. "Monasterio de San Zoilo...op.cit, pp. 155. A su vez de AHN. Clero. Carpeta 1702, nº20.
} 
más usual el concubinato ${ }^{1225}$. Algunas de estas ovejas negras rigieron eventualmente San Zoilo, como figura en el Capítulo de 1387: "Prior est malae vitae et malae conversationis et introducit mulieres quotidie causa incontinentiae Infra prioratum publice...et fecit tres monachos non de legitimo matrimonio procreatos... ${ }^{1226 ” . ~ Y ~}$ decimos eventualmente, porque tan sólo diez años antes se destaca su modélico comportamiento: "Prior de Carrione spiritualiter et temporaliter bene regit; quare merito debet commendari ${ }^{1227, "}$. Parece que una de las causas de este descontrol general era la posesión arbitraria de las abadías por parte de altos cargos tanto eclesiásticos como civiles, quienes, considerándolas feudo propio, designaban arbitrariamente a los priores. Los abades de Cluny se quejaban a los monarcas españoles de esta “desposesión”, contra la que lucharon inútilmente ${ }^{1228}$.

Por otro lado, la crisis espiritual trajo aparejada una crisis de carácter económico general. De las actas capitulares podemos colegir una falta notable de fondos en todos los prioratos españoles, sin constituir el de Carrión una excepción, factor que se traduce en el deplorable estado que presenta la mayoría. La exención del pago del portazgo, privilegio que, concedido por Alfonso X, fue confirmado por su nieto, Fernando IV, el 20 de julio de 1302 no fue óbice para el progresivo deterioro de la casa benedictina ${ }^{1229}$.

En muchos casos, la desesperación conlleva a la venta de bienes muebles para conseguir ingresos. En 1387, la precaria situación de la casa de San Zoilo conduce a su prior a empeñar dos cálices y un incensario y a deshacerse por un ínfimo precio, de la madera destinada a reparar la iglesia, y, de este modo, poder resolver las necesidades alimenticias básicas. Poco después, en 1392, se repite la situación, esta vez con dos incensarios y una valiosa capa ${ }^{1230}$. Los cenobios de San

\footnotetext{
${ }^{1225}$ En el capítulo de 1349 el visitador informa cómo en San Isidoro de León el subprior y algunos monjes educaban a sus propios hijos en el monasterio. El caso más extremo es el del prior de San Vicente Pombeiró, en Lugo, que fue denunciado por polígamo en el capítulo de 1393. ROBERTS, Ulysses. "État des monastères espagnols...Op.cit, pp. 330 y 398.

${ }^{1226}$ Ibídem, pp. 405-406.

1227 Ibídem, pág. 402.

${ }^{1228}$ Sirva de ejemplo el monasterio de Budiño que entre 1314 y 1317 estuvo en manos del obispo de Tuy, pasando después al cardenal Guillaume, que poseía ya el de Nájera. Algunos nobles se hicieron con el control de varios cenobios como Santa Colomba de Burgos, San Isidoro de León o San Vicente de Salamanca entre 1288 y 1310. Ibídem, pág. 329.

${ }^{1229}$ SIMÓN Y NIETO, Francisco. Los antiguos...Op.cit, pág. 135.

${ }^{1230}$ ROBERTS, Ulysses. "État des monastères espagnols...Op.cit, pp. 405 y 408.
} 
Vicente de Salamanca y San Isidoro de León certifican que no se trata de un hecho aislado, actúan de modo idéntico, llegando incluso a despojarse de la indumentaria liturgia $^{1231}$.

Dos son las causas que pudieron desencadenar esta situación que se prolongó durante casi dos siglos:

En primer lugar hay que destacar los conflictos en territorio hispano. Entre ellos, la guerra que Alfonso XI mantuvo contra los sarracenos en 1344 no favoreció demasiado las rentas monasteriales, que se vieron mermadas por los gastos invertidos en las mismas ${ }^{1232}$. Las revueltas en este período estuvieron a la orden del día, y con ello, aflora un sentimiento de inseguridad general que desencadena consecuencias desastrosas para la comunidad, pues los labriegos abandonan los campos y propiedades quedando éstas al antojo de los saqueadores. San Zoilo concretamente registra una pérdida de cuatro heredades en el siglo XIV, si bien otros cenobios, como el de Oña, salieron peor parados, con una expropiación doble a la de Carrión ${ }^{1233}$. Ante esta situación, se opta por contratar mano de obra que defienda las cosechas, con lo que el endeudamiento monástico, lejos de encontrar solución, se ve incrementado.

Pero sin duda, la causa fundamental de tal deterioro hunde sus raíces en a descuidada administración interna, que condujo a hipotecar propiedades. A este respecto, no existe capítulo en que no se recoja un dato relativo a la pésima gestión de los priores cluniacenses que, a pesar de las reprimendas y castigos que recibían de los visitadores, reiteraban una y otra vez el mismo comportamiento. Consecuencia directa de la misma, es la progresiva disminución del número de monjes, que nunca supera la veintena, así como los pleitos por la ambiciosa posesión de dominios y por los abusos en los impuestos a los vasallos ${ }^{1234}$. Las malas cosechas y el canon que

\footnotetext{
${ }^{1231}$ El prior de Salamanca vende una campana en 1310 y en 1345 otros ornamentos litúrgicos. San Isidoro vende varias tierras, cálices, una cruz y algunas vestimentas sacerdotales en 1336. Ibídem, pp. 364, 383, 395.

1232 Ibídem, pág. 329.

${ }^{1233}$ GARCÍA GONZÁLEZ, Juan José. Vida económica de los monasterios benedictinos en el siglo XIV. Universidad de Valladolid. Valladolid, 1972, pp. 115-117.

${ }^{1234}$ La comunidad de San Zoilo fue pionera en la adopción de censos para rentabilizar sus viñedos, pero en algunos casos las cosechas no fueron las esperadas. Esto unida a la excesiva ambición de
} 
debían abonar anualmente a Cluny, incentivaron un mayor deterioro, que condujo, en algún caso, a arrendamientos de larga duración, como el que realizó la comunidad en 1325 al particular don Juan Padilla sobre el barrio de Frómista ${ }^{1235}$. Sin duda el síntoma más evidente del deterioro sea la ruina de las edificaciones monasteriales, las cuales, a pesar de las continuas intervenciones que experimentaban, tenían carácter provisional. En 1276 San Zoilo amenazaba con derrumbarse y se interviene con carácter urgente, pero en 1308 volvía a encontrarse en mal estado, pues el presupuesto sólo permitía inversiones modestas traducidas en pésimas reparaciones ${ }^{1236}$. Los capítulos de 1337, 1349, 1387 confirman el estado ruinoso del cenobio, amenazado además por las frecuentes crecidas del río Carrión $^{1237}$.

En los diversos capítulos que se suceden a lo largo de la primera mitad del siglo XIV, observamos cómo los priores se excusan de la falta de fondos culpando a sus respectivos predecesores. Así, en 1314, el camarero había entregado en arrendamiento una casa de Toro al obispo de Coria dando como razón las deudas contraídas anteriormente. El visitador cluniacense muestra su descontento con el camarero de San Zoilo ante la penosa situación que atravesaba el monasterio: “...refutavit michi ospicium, nec voluit michi providere, ita quod oportuit quod jacerenm in dormitorio et famuli mei in villa cum equitaturis et quia bestie mee erant fesse, steti ibi per tres dies ad expensas monachorum loci erant amici mei et noti... ${ }^{1238,}$. La situación se repite en 1336, cuando el monje limosnero basa la escasez de ingresos en la enajenación que algunos predecesores han hecho de las rentas del lugar ${ }^{1239}$. Idénticas circunstancias aunque en diverso contexto, acontecen en 1349. El abad culpa a su predecesor de la ruina del templo, ya que el río había

acaparar dominios, conllevó muchas discordias con los vecinos. PALACIO SÁNCHEZ IZQUIERDO, María Luisa. "Monasterio de San Zoilo y monasterios...Op.cit, pp. 153- 155.

${ }^{1235}$ PALACIO SÁNCHEZ IZQUIERDO, María Luisa. "El monasterio de San Zoilo de Carrión: jurisdicción...Op.cit, pág. 68.

${ }_{1236}$ RAMIREZ DE HELGUERA, Martín El libro...Op, cit, pág. 174.

${ }^{1237}$ ROBERTS, Ulysses. "État des monastères espagnols...Op.cit, pp. 384, 398, 405.

1238 “....rehusó darme alojamiento, y no quiso darme provisiones, hasta el punto de que yo tuve que dormir en un dormitorio y mis criados en la villa, con las cabalgaduras. Como mis bestias estaban cansadas, estuve allí tres días a expensas de los monjes del lugar, que eran amigos míos y conocidos...”. Ibídem, pág. 369. Agradezco la traducción a la profesora de Filología Clásica, doña Avelina Carrera, de la Facultad de Filosofía y Letras de la Universidad deValladolid.

${ }^{1239}$ Ibídem, pág. 384. 
inundado las cercas porque las viñas que resistían la fuerza de las aguas habían sido $\operatorname{arrancadas}^{1240}$.

Durante estas dos centurias, el monasterio alcanzará un máximo de veinticinco monjes, nada despreciable pero reducido si se compara con su época de adhesión a Cluny. Aún habiendo perdido algunas heredades, mantenía, no obstante, la jurisdicción en los siguientes territorios: barrio de San Zoles, San Martín de Frómista, Arconada, Villanueva del Río, Riberos de la Cueza, Villamuera de la Cueza, Villarmienzo, además de en los siguientes territorios, hoy despoblados: Villaverde de Volpejera (en Villamuera), Villamez (en Carrión), Valcavado y Villaires (en Saldaña), Revilla (en Santa Olaja de la Vega) ${ }^{1241}$.

Parece que al finalizar la centuria se observa una cierta recuperación pues en 1392 se rehizo el claustro y el resto de edificaciones, incluida la iglesia “...sont in bono statu ${ }^{1242, "}$. El claustro plateresco que estudiaremos debidamente, sustituyó nuevamente a éste, adaptándose a su perfil, de ahí que no se conserve ningún testimonio gráfico que avale su existencia. Existen, sin embargo, en el lienzo norte, dos ventanas, cuyas molduras, si bien pertenecen al siglo XVI, son una trasposición de las ventanas románicas que hoy día cegadas, iluminarían el templo, con cuyos muros limitan.

\section{EL SIGLO XV}

\subsection{EL FUNCIONAMIENTO DEL MONASTERIO}

Hasta el 5 de junio de 1430 fue un priorato sujeto a Cluny, año en que Eugenio IV eleva San Zoilo a abadía mediante una bula expedida tras la petición de Juan II de que así fuera. El primer abad electo fue don Gonzalo Martínez de Ceballos, previo prior en Entrepeñas, que detentó el cargo en San Zoilo hasta $1440^{1243}$. Entre los años 1439 y 1444 , se produce una primera fase de

\footnotetext{
${ }^{1240}$ Ibídem, pág. 398.

${ }^{1241}$ MARTÍNEZ DÍEZ, Gonzalo. “Años de crisis. ..Op.cit, pág. 251.

${ }^{1242}$ ROBERTS, Ulysses. "État des monastères espagnols ...Op.cit, pág. 408.

${ }^{1243}$ ZARAGOZA PASCUAL, Ernesto. “Abadologio...Op.cit, pág. 283.
} 
independización, pero esto supuso a su vez, la subordinación directa a Roma a través de la encomienda, la cual empobreció el convento. Las entidades de las que San Zoilo dependía, eran quienes nombraban superiores sin tener en cuenta la capacidad de quien iba a ejercer el cargo. En vez de regirse por los priores temporales, a partir de 1430 y durante una centuria, el monasterio estaría gobernado por abades consistoriales o comendatarios, esto es, elegidos por el Papado o nombrados por los soberanos $^{1244}$. Así, durante el siglo XV y parte de la centuria siguiente, la abadía estuvo en manos de abades de ilustre abolengo entre los que podemos destacar a Pedro González de Mendoza, primer abad comendatario desde 1469 a 1482, cardenal y arzobispo de Sevilla ${ }^{1245}$. Su sucesor, don Luis Hurtado de Mendoza, hermano del Conde de Castro y administrador anteriormente de las rentas de San Zoilo, logró durante su mandato, desarrollado entre 1482 y 1507, la adhesión del cenobio palentino de Nuestra Señora de Brezo ${ }^{1246}$.

Esta libertad de la que hablamos fue tan solo aparente, pues a todos los efectos, San Zoilo seguía siendo jurisdicción de la casa madre francesa, como así lo transmiten las actas de los capítulos generales. Una de las más curiosas se remonta al año 1460 , en que se relata el ceremonial de recepción de los visitadores cluniacenses. A su llegada, el abad y la comunidad benedictina se arrodillaban al son de las campanas de la iglesia, saludaban a los recién llegados y solamente el abad besaba las cartas traídas por los mismos. Seguidamente, el cortejo se dirigía a la iglesia para entonar bien el "Te Deum", bien el "Veni Creator" y los visitadores pronunciaban un discurso y hacían un interrogatorio general, tras el cual, el abad juraba obediencia a la orden. Solo entonces, comenzaba la visita al cenobio ${ }^{1247}$.

Durante este siglo, continuando un proceso que comenzó en a finales de la centuria precedente, aumenta el número de cesiones de bienes inmuebles -tierras y explotaciones familiares-. Lo más usual es que se trate de contratos de arrendamiento temporal, aunque tampoco faltan los traspasos vitalicios que afectan a dos generaciones como máximo y las cesiones perpetuas, constituyendo todas ellas suculentas rentas para la comunidad benedictina. El número de propiedades, se

\footnotetext{
${ }^{1244}$ Ibídem, pág. 276.

1245 Su biografía en VV.AA. Diccionario de historia eclesiástica... II, pp. 1036-1038.

${ }^{1246}$ ZARAGOZA PASCUAL, Ernesto. “Abadologio....Op.cit, pág. 284.

${ }^{1247}$ ROBERTS, Ulysses. "État des monastères espagnols...Op.cit, pp. 327 y 424.
} 
mantiene más o menos estable respecto a los siglos anteriores en que quedó configurado el patrimonio de San Zoilo ${ }^{1248}$. La anexión más relevante de este período fue la del priorato de San Román de Entrepeñas en 1443. El por entonces abad de San Zoilo, Gonzalo Martín de Cervatos lejos de estar guiado por afanes expansionistas, buscaba, a través de la adhesión, enmendar la grave crisis en que se hallaba inmersa el cercano convento palentino ${ }^{1249}$.

\subsection{LA ANEXIÓN DE LA PARROQUIA DE LA MAGDALENA}

En la Estadística de 1345 sobre los de los templos que conforman la Diócesis Palentina ya se menciona esta parroquia ${ }^{1250}$. Don Pedro González de Mendoza, primer abad comendatario de San Zoilo la incorporó al monasterio en 1479 con permiso de Paulo II $^{1251}$. Dicha parroquia, ubicada junto al monasterio, subsistiría como tal dentro de la iglesia del monasterio a partir de entonces hasta el siglo XIX, ubicada bajo el coro ${ }^{1252}$.

Si bien la ermita se hallaba dentro de las propiedades de la comunidad benedictina, por entonces y durante todo el siglo XVI eran las monjas zamoranas del monasterio de San Juan de la Horta -hoy iglesia de Santa María- quienes, con permiso del abad de San Zoilo, se encargaban de sus reparos ${ }^{1253}$.

La única intervención de entidad en esta época de la que da fe la documentación es la ejecución de una sacristía en el lado del Evangelio del templo, cuya ejecución autorizan los Reyes Católicos en 1490. Hasta el momento, lo

\footnotetext{
${ }^{1248}$ La transcripción completa del Libro de Apeos -deslindes de las propiedades- del monasterio de San Zoilo entre los años 1410 y 1516 cuyo origen es AHPP. Desamortización, 107, se encuentra en BEJARANO RUBIO, Amparo y MOLINA MOLINA, Luis. El Monasterio de San Zoilo a finales de la Edad Media: propiedades y rentas. Universidad de Murcia. Murcia, 1999.

${ }^{1249}$ Sobre este proceso RUIZ ASENCIO, José Manuel. "Documentos bajomedievales del monasterio de San Román de Entrepeñas" en AIIICHP, n 2. Palencia, 1995, pp. 14-18.

${ }^{1250}$ SAN MARTÍN PAYO, Jesús. "La más antigua...Op.cit, pp. 10-12.

${ }^{1251}$ AHN. Clero Secular-Regular Legajo 5334 s/f Visitas.

${ }^{1252}$ MADOZ, Pascual. Diccionario...Palencia. 1984. Op.cit, pág. 69. Incluso la mantuvo el arreglo parroquial de 1895. RAMIREZ DE HELGUERA, Martín. El libro...Op.cit, pág. 151. Veáse a este respecto, del mismo autor Ordenanzas municipales de la muy noble y leal ciudad de Carrión de los Condes. Gutiérrez, Líter y Herrero. Carrión, Palencia, 1911.

${ }^{1253}$ Un estudio sobre el convento de San Juan de la Horta, de la Orden de Malta en FERNÁNDEZ PRIETO DOMÍNGUEZ, Enrique. "El monasterio de religiosas de San Juan de Jerusalén" en Hidalguía, no 274-275, 1999, pp. 337-368. Sobre las obras llevadas a cabo en el siglo XVI, consúltese el aaprtado relativo.
} 
ornamentos y alhajas se guardaban en la iglesia, y debido a ellos se habían producido algunos robos. Además, el sacristán no disponía de un lugar decente para su preparación ${ }^{1254}$. Esta dependencia se encontraba en mal estado, al menos desde 1476, en que Fray Zoil del Nogal, sacristán mayor del monasterio expide una misiva al Papa Sixto IV para que la capellanía que estaba fundada en el altar de la Magdalena, en el interior del templo, fuese incorporada a la sacristía, para así, con los beneficios obtenidos, proceder a su reedificación. Dos años después el Papa emitía un edicto favorable, y la capellanía quedo anexionada a partir de entonces ${ }^{1255}$.

\section{EL SIGLO XVI}

\subsection{SITUACIÓN INTERNA DEL CENOBIO}

Cuando en 1507 Fernando el Católico visitó las dependencias del monasterio, lo encontró en tan malas condiciones que decidió unirlo a la Congregación de Valladolid previo acuerdo con el abad de la capital Fray Pedro de Nájera. Éste requirió al alcalde carrionés Ronquillo, que intercediera para la adhesión. A pesar de la resistencia de los monjes de San Zoilo, el cenobio quedó sujeto a la reforma el 28 de septiembre del citado año ${ }^{1256}$. Sin embargo no nombró abad alguno, sino un presidente, hasta que Julio II ratificara el mandato. Pero no lo hizo y concedió la abadía en 1508 a Bernardino de Carvajal, sobrino del cardenal Juan de Carvajal y obispo de Astorga, Badajoz y Cartagena ${ }^{1257}$. A pesar de la solicitud de dimisión que don Fernando emitió en 1509, don Bernardino continuó en su cargo hasta 1516 en que fue sucedido por otro abad comendatario, don Juan Rodríguez de Fonseca, que lo fue paralelamente de los cenobios castellanos de Parraces, en Segovia y de San

\footnotetext{
${ }^{1254}$ AHPP. Desamortización 112. Índice del Archivo de San Zoilo. Caja 5a: San Andrés. legajo 4. Capilla de doña Constanza. Esta información se ubica en este apartado porque posteriormente esta sacristía será convertida en la capilla de doña Constanza.

${ }^{1255}$ Ibídem, Legajo 1. Cuaderno A. no 1 y 2.

${ }^{1256}$ AHPP. Desamortización. Legajo 112. Caja 4a. San Pedro. Legajo 1.14. También en CAMPOS SÁNCHEZ-BORDONA, María Dolores, HERRÁEZ ORTEGA, M ${ }^{\text {a }}$ Victoria, VALDÉS FERNÁNDEZ, Manuel. "El origen histórico y social de las reformas en los monasterios benedictinos durante el siglo XVI" en Actas del VIII Congreso Nacional de Historia del Arte, II. Comité español de historia del Arte. Universidad de Extremadura. Mérida, 1993, pp. 811 y 813.

${ }^{1257}$ ZARAGOZA PASCUAL, Ernesto. "Abadologio...Op.cit, pp. 284-285. Julio II, el mismo que lo desgnó abad, fue quien le destituyó del cargo por su deslealtad, pues favoreció a Carlos VIII de Francia. ZARAGOZA PASCUAL, RAFAEL. Los Generales de la Congregación de San Benito de Valladolid. Los abades trienales. (1499-1568) Vol 2. Monasterio de Santo Domingo de Silos, Burgos, 1976, pp. 104,105.
} 
Isidoro de León Además detentó los Obispados de Badajoz, Córdoba, Palencia y Burgos, falleciendo el 4 de noviembre de $1524^{1258}$. Le sucedió don Francisco de Atienza, natural de la localidad homónima y profeso de Carrión ${ }^{1259}$. Pocos días después, el 10 de noviembre, la comunidad benedictina solicitó al rey Don Carlos para que intercediera en su favor, instando a que el nuevo abad no tomara posesión de las encomiendas que le concederían desde Roma, pues el precedente se había quedado con “...los frutos e rrentas d'ella enteramente sin haver hedificado ni rreparado en el dicho monasterio cosa alguna...", por lo que el cenobio se encontraba en mal estado ${ }^{1260}$.

Tan sólo un año después falleció don Juan Fonseca pero sucedió otro abad comendatario entre 1525 y 1533, Diego de Sahagún, quien mantuvo serios enfrentamientos con el clérigo de Burgos, Juan Bautista Ugochoni, que intentó tomar posesión del monasterio, sin conseguirlo, pero llevándose, al renunciar a la mismas, dos tercios de las rentas del cenobio ${ }^{1261}$. Este acuerdo quedó ratificado por Bula de Clemente VII, el 16 de agosto 1532, en que San Zoilo quedó definitivamente unido a la Congregación y obtuvo el permiso para elegir a sus superiores, nombrando primer abad trienal de la reforma a Fray Alonso de Virués en $1533^{1262}$. Desde entonces hasta 1610, los abades electos fueron trienales, a excepción el período comprendido entre 1563 y 1575 , en que se fueron constituidos en sexenales $^{1263}$.

Comenzó a partir de este momento un nuevo período de esplendor para el convento, que a mediados de siglo tenía bajo su jurisdicción los prioratos palentinos

\footnotetext{
${ }^{1258}$ ZARAGOZA PASCUAL, Ernesto. “Abadologio...Op.cit, pp. 285-286.

1259 Ibídem, pág. 286.

1260 AGS. Registro General del Sello, 1524 s/f. Posteriormente figura recogido en ZARAGOZA PASCUAL, Ernesto. “Abadologio...Op.cit, pp. 286-287 y trascrito en ZALAMA, Miguel Ángel. "Documentos de Historia del Arte en Palencia, 1. Arquitectos y edificios del siglo XVI" en PITTM, $\mathrm{n}^{\circ}$ 66. Diputación Provincial. Palencia, 1995, pp. 264-265.

${ }^{1261}$ ZARAGOZA PASCUAL, Ernesto. “Abadologio...Op.cit, pp. 287 y GARCÍA ORO, José. “El Rey aprueba la elección de Fray Diego de Sahagún como abad de San Zoilo de Carrión” Liceo Franciscano, año 53, nº160-162, 2001, pp. 464-467.

${ }^{1262}$ LINAGE CONDE, Antonio. "Un caso de sucesión de familias religiosas en una misma sede: benedictinos y jesuitas en San Zoilo de Carrión de los Condes" en AIICHP.3, 2. Palencia, 1990, pág. 786. Bula original en AHN. Pergaminos. Carpeta 3487, nº. ZARAGOZA PASCUAL, Ernesto. Los Generales...Volumen 2. Op.cit, pág. 181.

${ }^{1263}$ ZARAGOZA PASCUAL, Ernesto. “Abadologio...Op.cit, pág. 276. La solicitud al embajador de Roma para la concesión de abadiatos trienales y la respectiva provisión en GARCIA ORO, José. "Al embajador en Roma para que Su Santidad conceda que la provisión de la abadía de San Zoilo de Carrión sea trienal y no perpetua" en Liceo Franciscano, año 53, nº160-162, 2001, pp. 467-468.
} 
de San Román de Entrepeñas, San Facundo y Primitivo de Arconada -fundado como San Zoilo por el conde don Gómez Díaz- San Pedro de Recuevas, Santa María del Brezo, San Martín de Frómista y Valcavado, hoy desaparecido, ubicado cerca de Saldaña. En Valladolid, San Zoilo poseía las filiaciones de San Juan de Aguilar de Campos y en Zamora, San Pelayo de Toro ${ }^{1264}$.

La Congregación de Valladolid se dividía en tres distritos, en cada uno de los cuales debían vivir tres definidores, sin coincidir dos de ellos en la misma casa conventual. San Zoilo pertenecía al distrito de Campos, que además acogía los monasterios de San Benito de Valladolid, Salamanca, Madrid, Sevilla, León, Sopetrán, en Guadalajara, el palentino de Dueñas, los leoneses Eslonza, El Bueso, Espinareda y San Pedro de Montes y en Valladolid, Vega de la Serrana ${ }^{1265}$. Mantuvo bajo su yugo catorce monasterios y posesiones en más de cincuenta pueblos entre de Palencia, en su mayor parte, Valladolid y Zamora.

La jurisdicción sobre el barrio de San Zoilo fue vendida por Benito de Sahagún (1564-1570) al Ayuntamiento en 1564 y la propiedad sobre el cuérnago continuó hasta la desamortización. El monasterio, además de poseer una gran cantidad de molinos, tenía un canal propio que nacía cerca de Población del Soto y se unía en Carrión al río homónimo ${ }^{1266}$.

Durante el Concilio de Trento, por bula Papal otorgada por Pío V el 22 de septiembre de 1571 se le concedió al monasterio el privilegio de exención de visita del ordinario, provisión de la que se sirvió el convento para impedir la pretensión del Obispo de Palencia de acceder a la misma ${ }^{1267}$.

\footnotetext{
1264 YEPES, Fray Antonio. Crónica...Tomo VI. Op.cit, pp. 83-85.

1265 ZARAGOZA PASCUAL, Ernesto. Los Generales...Volumen 3. Op.cit, pág. 271.

1266 Existía además un canal secundario que regaba las huertas del monasterio, el famoso Arroyo Forero. PÉREZ CELADA. Julio A. "La explotación de los recursos...Op.cit, pág. 128. ${ }^{1267}$ AHN. Clero Secular-Regular Legajo 5334 s/f Visitas.
} 


\subsection{EL CLAUSTRO RENACENTISTA}

El claustro que sustituiría al que se reconstruyó totalmente a finales del siglo XIV, se comenzó, según reza la inscripción de la esquina del claustro el 7 de marzo de 1537 y fue concluido el 27 de marzo de 1604. Las primeras noticias del mismo las recoge el Padre Yepes, que transmitía el lento transcurrir de la obra: “...Fray Gaspar de Villarroel fue electo abad de San Zoil el año de mil quinientos y treynta y cinco...Dio principio al claustro principal...por el año de mil quinientos y treynta y siete. Cuéntase d'él que había comenzado una obra ordinaria, y que, habiendo murmurado algunos de que en monasterio tan rico hiciese edificios tan pobres, fabricó el que ahora, que en riqueza de imaginería y molduras no se haya ninguno mejor en España...Comenzó una fábrica costosísima...y no se acabó el claustro bajo en los cuarenta años siguientes y el abad que podía proseguir con tres o cuatro capillas le parecía que acometía una gran hazaña... ${ }^{1268, .}$

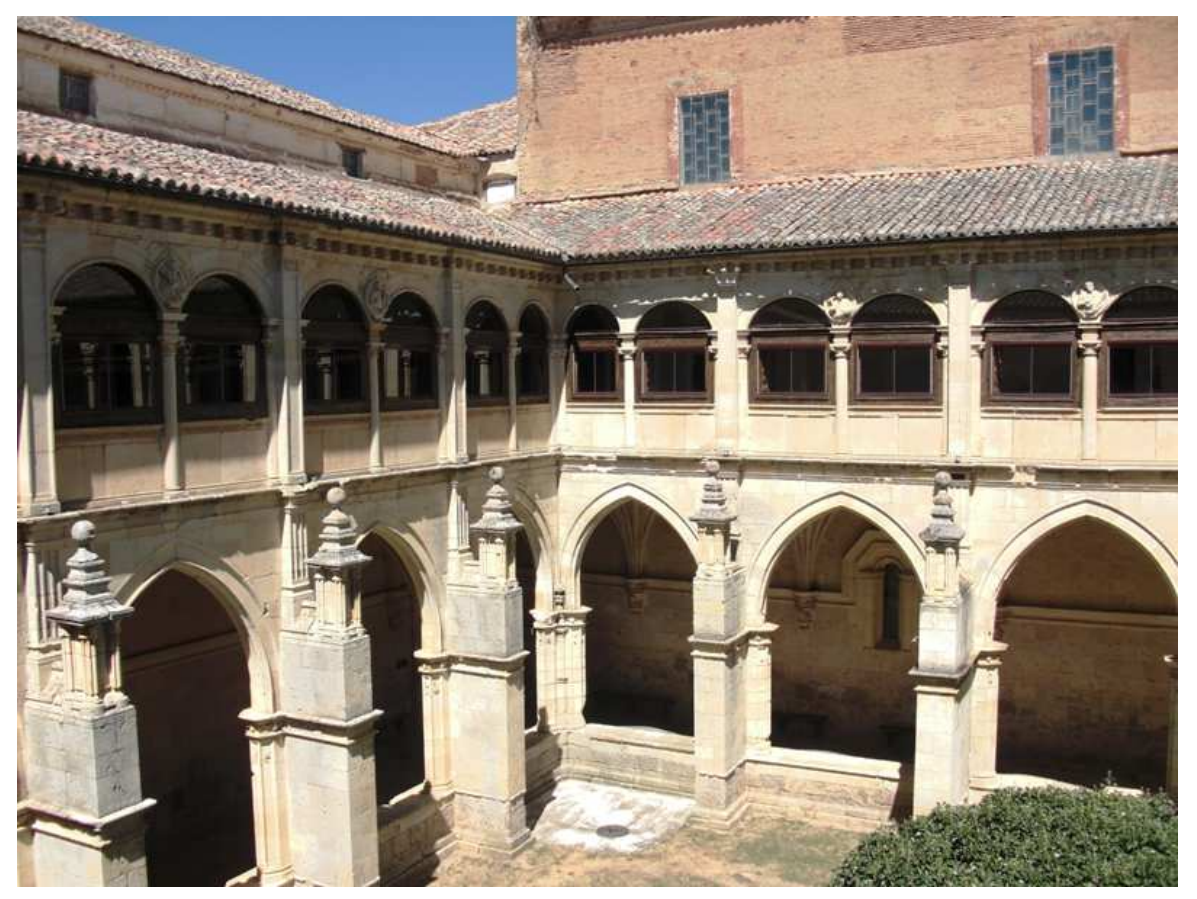

Aspecto actual del claustro renacentista de San Zoilo.

${ }^{1268}$ YEPES, Fray Antonio. Crónica...Tomo VI. Op.cit, pág. 88. 
Las obras, por tanto, comenzaron por la crujía oriental gracias al impulso de Fray Gaspar de Villarroel, profeso del monasterio de San Benito de Sahagún, donde había sido abad en dos ocasiones ${ }^{1269}$. La relativa proximidad del convento leonés, donde Juan de Badajoz el Mozo era el arquitecto principal, a la capital condal, de la que dista un centenar de kilómetros, hace plausible la elección del mismo en la intervención del claustro ${ }^{1270}$. Entre 1544 y 1553, fue abad de San Zoilo Fray Juan de Santa María, escritor que profesó en Valladolid y con sobrada experiencia previa a su paso por cinco cenobios benedictinos ${ }^{1271}$. A lo largo de su mandato, las obras fueron paralizadas, hasta que se continuaron en 1550, dando fin a las obras de la primera crujía $^{1272}$.

El insigne matemático, astrónomo y físico, Rodrigo de Corcuera, sucedió a Santa María en el trienio siguiente. Bajo su mandato y el de los tres abades siguientes, el Visitador de León y Castilla y definidor general, Juan Vaca (15561559), el primer visitador general de la Congregación y hermano de don Rodrigo, Juan de Corcuera (1559-1563) y el primer abad sexenal, don Gaspar Becerril (15631564), se realizó parte de la crujía occidental ${ }^{1273}$. La prolongación de los trabajos para ejecutar una sola panda hace pensar en una nueva parada de las obras por falta de ingresos ${ }^{1274}$. Los trabajos fueron reanudados en 1564 con el abad Fray Benito de Sahagún, quien ostenta el cargo hasta 1570, durante cuyo abadologio se llega a la crujía occidental. Para evitar conflictos de carácter jurisdiccional, vendió el barrio de San Zoles y la mitad del puente de Carrión, cuya posesión había acarreado muchos pleitos $^{1275}$. Con Sebastián de Encinas (1570-1576), profeso de Montserrat y último abad sexenal, se completa el lado oeste. Las obras del claustro bajo se concluyen en 1577 con Cristóbal de Agüero por la bóveda vigésimo segunda, en el ándito septentrional, como así reza la inscripción ubicada en el muro. De noble familia

\footnotetext{
${ }^{1269}$ Fue elegido para el cargo de abad de San Zoilo en 1535. 288-289.

${ }^{1270}$ LLAGUNO Y AMIROLA, Eugenio. Noticias...Op.cit, pág. 210.

${ }^{1271}$ De San Isidro de Dueñas, en Palencia fue abad en dos ocasiones (1534-1537, 1556-1559), en San Esteban de Ribas de Sil, lo fue entre 1541 y 1543 y en los leoneses de San Andrés de Espinareda en 1555 a 1556 y San Pedro de Eslonza de 1559-1562. Por último, entre 1563 y 1566 fue abad de San Juan de Poyo, Pontevedra. ZARAGOZA PASCUAL, Ernesto. "Abadologio del monasterio...Op.cit, pág. 289.

1272 Véase más adelante el apartado de autoría.

1273 ZARAGOZA PASCUAL, Ernesto. “Abadologio del monasterio...Op.cit, pp. 289-291

${ }^{1274}$ BECERRO DE BENGOA, Ricardo. El libro de Palencia. Hijos de Gutiérrez. Palencia, 1874.

Edición facsímil, Caja España. Palencia, 1993, pág. 206, PONZ, Antonio. Viaje..Tomo X. Op.cit, pág. 198.

${ }^{1275}$ ZARAGOZA PASCUAL, Ernesto. “Abadologio del monasterio...Op.cit, pp. 291.
} 
palentina, había tomado el hábito en San Benito de Valladolid. En Carrión tan sólo estuvo de 1576 a 1577, pues su nombramiento como General de la Congregación le impidió completar el trienio ${ }^{1276}$.

Aunque existieron otros factores determinantes para la ejecución de las obras, no hay que olvidar que la razón fundamental de las mismas fue una situación económica desahogada. Basta recordar, que, exceptuando Sahagún, no existió en Castilla otra fundación de la que dependiera un mayor número de prioratos ${ }^{1277}$. Pero además, la ejecución de este claustro coincide en su cronología con las reformas impulsadas en los centros incorporados a San Benito de Valladolid por los abades generales, destacando la labor del primer Abad General, Fray Pedro de Nájera y continuada por sus sucesores en el cargo. En este sentido, hay que señalar que aunque San Zoilo recibió la observancia de San Benito en 1507, no ingresó en la Congregación vallisoletana hasta pocos años antes, exactamente $1532^{1278}$. Los cenobios de Santa María la Real de Nájera, el cenobio burgalés de Oña, el navarro de Santa María la Real de Irache, o el de Celanova, en Orense, experimentaron ampliaciones, modificaciones y mejoras de cierta entidad en esta época. Por tanto, lejos de ser una excepción, San Zoilo, constituye una pieza más de todo este engranaje reformador del que entró a formar parte. La justificación de tales cambios hunde sus raíces en el proceso de renovación espiritual que experimentaba por entonces la orden benedictina, la cual, al aceptar la clausura perpetua, necesitaba recintos más adecuados para la oración y el estudio ${ }^{1279}$. Para acometer las obras organizadamente se elegían cada trienio cuatro casas - junto a San Zoilo, fueron escogidas las de San Millán de la Cogolla, San Juan de Burgos y San Claudio de León- de tal modo que durante los trabajos en estos centros se reducía a siete el número de monjes de las mismas y el resto se repartía por las casas de la Congregación hasta que finalizasen las obras.

\footnotetext{
${ }^{1276}$ Ibídem, pág. 292.

1277 YEPES, Fray Antonio. Crónica...Tomo VI. Op.cit, pp. 83-85 y siguiendo a éste QUADRADO; José María y PARCERISA, Francisco J. Op.cit, pág. 133.

${ }^{1278}$ ZARAGOZA PASCUAL, Ernesto. “Abadologio..... Op.cit, pp. 275-276.

${ }^{1279}$ CAMPOS SÁNCHEZ-BORDONA, María Dolores, HERRÁEZ ORTEGA, M ${ }^{\mathrm{a}}$ Victoria, VALDÉS FERNÁNDEZ, Manuel. "El origen histórico y social de las reformas en los monasterios benedictinos durante el siglo XVI" en Actas del VIII Congreso Nacional de Historia del Arte, II. Comité español de historia del Arte. Universidad de Extremadura. Editora Regional de Extremadura. Mérida, 1993, pp. 812-815.
} 
Todas ellas debían obtener la aprobación del capítulo General y ser realizadas bajo la mano de maestros renombrados, siguiendo un "modelo único para todas las casas de la Congregación, variable sólo en cuanto a las medidas, pero no en el estilo”, de ahí la similitud de todas ellas ${ }^{1280}$. Por otro lado, la construcción de esta notable obra se produjo gracias a la liberación e independencia administrativa del convento del yugo impuesto por las altas esferas eclesiásticas ${ }^{1281}$. Desde sus orígenes se mantuvo bajo la jurisdicción de los abades de Cluny, pasando a manos de Roma en 1435. Afortunadamente, en 1532, las Cortes del Reino acordaron que las piezas eclesiásticas no se cedieran a ningún extranjero, por lo que San Zoilo fue incorporado a la Congregación benedictina vallisoletana, abandonando su condición de priorato y con capacidad para elegir a sus superiores ${ }^{1282}$. Así se explica, cómo al conseguir tal emancipación fue posible llevar a cabo una obra de tal envergadura.

\subsubsection{EL CLAUSTRO BAJO}

\section{Análisis descriptivo}

Cada panda está constituida por cinco arcos apuntados con molduras planas, apoyados sobre pilastras cajeadas que se alzan sobre un basamento corrido de piedra. Al exterior, flanquean los arcos una serie de contrafuertes de sección rectangular que culminan en sendas columnillas estriadas, que a su vez, sustentan pirámides con bolas cuya altura alcanza el friso que separa ambos cuerpos del claustro. Las cuatro galerías del claustro, que conforman un total de veinticuatro tramos, se cubren con bóveda de crucería entre arcos ojivales cuyos nervios cruceros arrancan de cuatro ménsulas muy desarrolladas. Todas ellas son estrelladas de cuatro puntas con terceletes y sin ligaduras, pero dentro de esta tipología, podemos establecer tres variantes según el diseño central:

-Bóvedas de los ángulos 1, 7, 13, 19: Un cuadrifolio central enlaza, mediante combados, los nervios de los terceletes.

\footnotetext{
${ }^{1280}$ ZARAGOZA PASCUAL, Ernesto. Los Generales... Vol 2...Op.cit, pp. 208-209.

${ }^{1281}$ ARASF, Leg.5-282-1.

1282 ZARAGOZA PASCUAL, Ernesto. Los Generales...Vol 2. Op.cit, pág. 181.
} 
-Bóvedas 2, 4, 6, 14: Los nervios interiores forman un cuadrado perfecto en cuyos ángulos se ubican las cuatro claves secundarias. Del punto medio de cada lado de este cuadrado parte un nervio que conforma un cuadrante combado dispuesto en sentido inverso al que le rodea.

-Bóvedas restantes: Existen dos variantes dentro del mismo tipo. El primero, que corresponde a las bóvedas 3, 5, 15 a18 y 20 a 22, donde los nervios que parten de los vértices de los terceletes son combados, conformando un rombo de lados curvos. En el otro caso, presente en las bóvedas 8 a 12, 23 y 24, las ojivas son rectas, de ahí que en el centro de la estructura conformen una estrella de cuatro puntas.

En todas ellas, el perfil de los nervios se forma a partir de una serie de molduras con baquetones donde los nervios diagonales presentan una terminación en bocel mientras que el resto son planos. Los puntos de intersección están constituidos como mínimo, por cinco claves labradas con bustos, la central de mayor tamaño. Es el caso de las cubiertas de los tramos angulares. El resto de bóvedas, aparte de los cinco clípeos presenta un mayor número de claves, en algunos casos pinjantes con motivos, y en otros, planas, decoradas con testas de angelillos, y tarjetas con inscripciones diversas. Los plementos se transforman en el soporte perfecto para desarrollar un repertorio escultórico de jarrones y cabezas de angelillos flanqueados por bandas rematadas en volutas y otros elementos de diversa índole inspirados en la naturaleza. En los pilares, los motivos escultóricos se traducen en escudos, bucráneos, medallones y otros ornamentos de filiación plateresca ${ }^{1283}$. Sin embargo, en el plano arquitectónico, como sucede en la mayor parte de los edificios del territorio hispano de este período, se observa una pervivencia de elementos medievales mientras se van incorporando detalles del nuevo estilo. Así, entre los soportes y cubiertas de raigambre gótica de las bóvedas, aparecen toda una serie de molduras y pilastras que traslucen la impronta característica de nuestro Renacimiento $^{1284}$.

\footnotetext{
1283 Para comprender mejor el plateresco, COLLAR DE CÁCERES, Fernando. "El plateresco". Historia 16. $\mathrm{n}^{\circ}$ 8. Madrid, 1992 y CHUECA GOITIA; Fernando. El plateresco: imagen de una España en tensión. Ávila, 1998.

${ }^{1284}$ Esta dualidad conceptual se explica en NIETO ALCAIDE, Víctor y CHECA CREMADES, Fernando. Arquitectura del Renacimiento en España: 1488-1599. Cátedra. Madrid, 1989 y MARÍAS, Fernando. El siglo XVI: Gótico y Renacimiento. Sílex. Madrid, 1992
} 

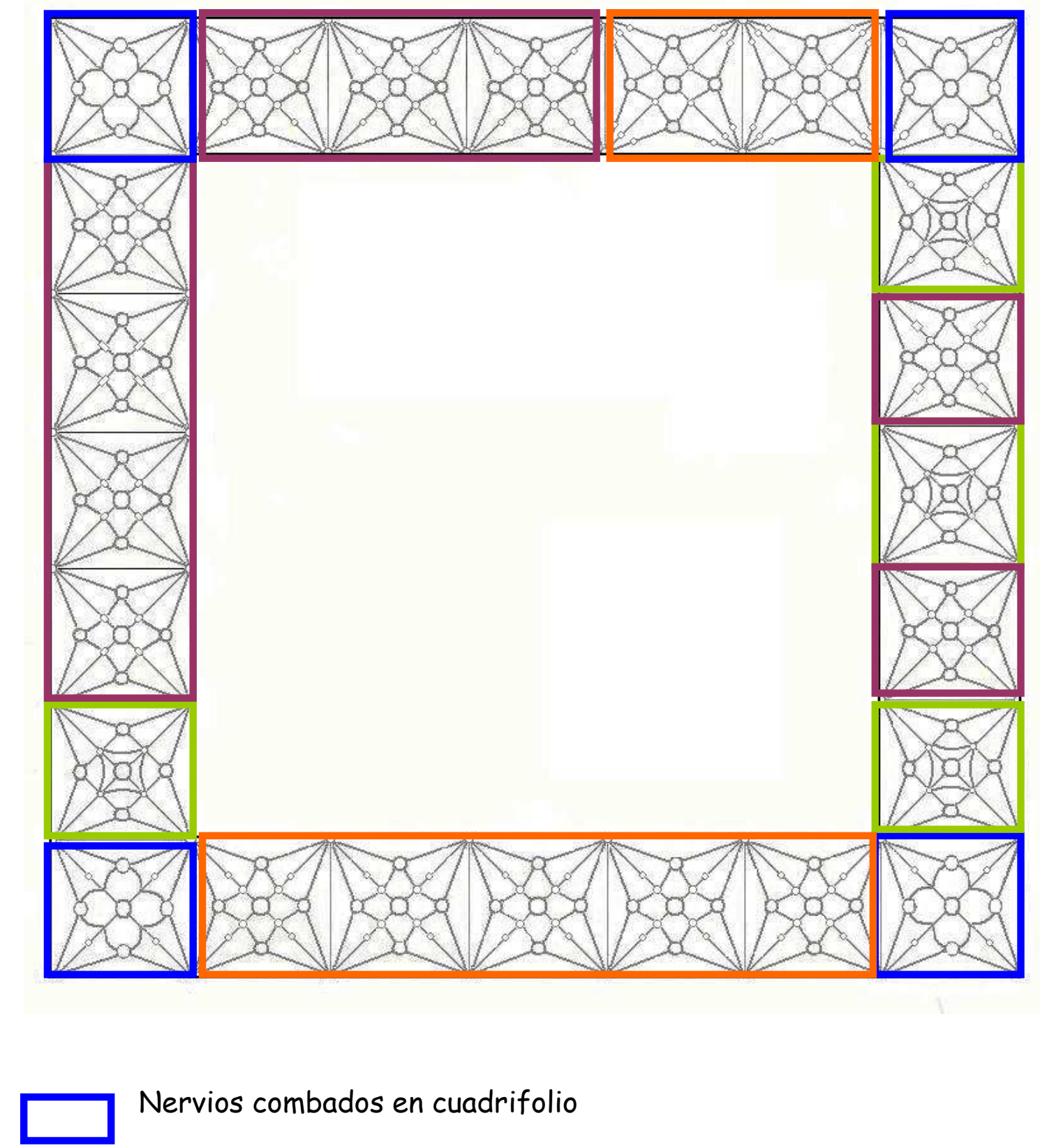

Nervios combados en cuadrifolio

Cuadrado de combados sobre su base inserto en otro cuadrado dispuesto en sentido contrario

Estrella de cuatro puntas

Cuadrado de combados dispuesto sobre uno de sus vértice

Modelos de las bóvedas de crucería estrellada según su motivo central. 
En las esquinas de cada uno de los veinticuatro cuadrantes se encuentra una ménsula: dos adosadas al muro que interrumpen la cornisa que lo recorre y las otras dos, se adosan a las pilastras de la parte externa. Presentan una fina labor escultórica y se dividen en tres partes diferenciadas que a su vez, se subdividen:

-Parte superior. Está compuesta a su vez por tres elementos:

-Una gola y dos listeles

-la parte central, en un plano más hondo, contiene bien una tarjeta con inscripción latina para los personajes representados o bien angelillos unidos por las alas en el caso que acompañen a calaveras.

-Un listel y un cuarto bocel seguido de otros dos listeles.

-Parte central. Dividida igualmente en tres partes:

- Dos listeles, gola y listel

-La parte central ocupada por un personaje bíblico con sus atributos o varias calaveras

-La parte de abajo, superpone las mismas molduras de la parte superior pero los elementos dispuestos a la inversa para crear simetría, es decir, listel, gola $\mathrm{y}$ finalmente, dos listeles.

-Parte inferior. Dividida en tres partes:

-Un cuarto de bocel muy desarrollado ornamentado a base de acanaladuras en forma de pétalos

-Una gola y un filete

-Elementos vegetales diversos que se estrechan conforme descienden.

Esta disposición tripartita de las ménsulas fue empleada por Juan Badajoz "el Mozo", artista que comenzó el claustro, en otras edificaciones del momento, como la sacristía del convento de San Marcos de León y la capilla de don Juan Manuel en el convento de San Pablo de Peñafiel, en Valladolid 

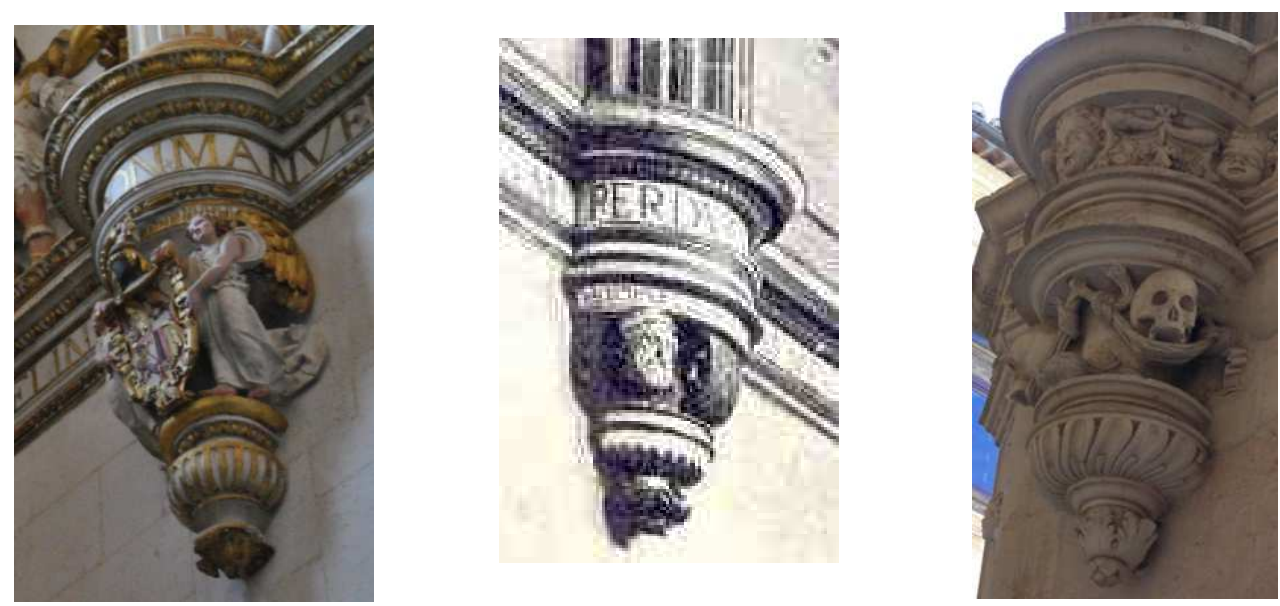

Esquema compositivo similar de las ménsulas de tres obras de Juan Badajoz "el

Mozo": La capilla de Don Juan Manuel en el convento dominico de Peñafiel, Valladolid (izq), la sacristía del convento de San Marcos, en León (medio) y el claustro de San Zoilo (dcha).

\section{Autoría}

\section{Los arquitectos}

Las obras las inició Juan de Badajoz el Mozo por el ángulo nororiental, que da acceso al templo ${ }^{1285}$. El maestro del Renacimiento introduce tendencias lombardas y francesas afincadas en León, desde donde las importó, pues allí trabajó gran parte de su vida ${ }^{1286}$.

Según Díaz-Nava, Badajoz, artista favorito de los benedictinos, se encargó de la realización de las seis primeras bóvedas ${ }^{1287}$. Sin embargo, a Badajoz debe adscribírsele la autoría de ocho, contando con la vigésimo tercera y vigésimo cuarta,

\footnotetext{
${ }^{1285}$ LLAGUNO Y AMIROLA, Eugenio. Noticias...Tomo I. Op.cit, pp. 210-211.

${ }^{1286}$ RIVERA, Javier. "Tradición y modernidad en la arquitectura palentina de los comienzos de la Edad Moderna" en Jornadas sobre el renacimiento en la provincia de Palencia. Diputación Provincial de Palencia. Palencia, 1986, pág. 33.

${ }^{1287}$ DÍAZ NAVA, Adolfo F. "Un claustro plateresco...Op.cit, pág. 102.
} 
que se integran, como veremos, en el ciclo iconográfico inicial. Datos contundentes ponderan esta afirmación. En primer lugar, las inscripciones que figuran en las bóvedas decimoquinta y vigésimo segunda indican donde dieron comienzo y finalización las obras efectuadas por Juan de Celaya ${ }^{1288}$. La ejecución del maestro vizcaíno comprende por tanto, ocho bóvedas, redundando en este hecho la carta de pago que otorgó Celaya en 1582, por la cual se le abona el trabajo correspondiente a ocho capillas ${ }^{1289}$. Por tanto, las dos bóvedas restantes, no son obra de Celaya, sino que forman parte de la primera fase de la construcción, atribuida a Badajoz.

Existe una clara relación entre el diseño de las bóvedas de crucería con nervios combados de Badajoz el Mozo y su padre, apodado "El Viejo" cuya formación toledana debió influirle ${ }^{1290}$. Creemos que las tres tipologías que presenta el claustro fueron creadas por el arquitecto leonés y a partir de ellas, se trasladaron a las cubiertas restantes. Los diversos modelos están presentes en otras obras suyas como en la primera de las sacristías del convento leonés de San Marcos, donde recurrió a la bóveda de cuadrifolios. Intervino en la misma entre 1528 y 1537, justo antes de ser requerido para las obras del claustro carrionés ${ }^{1291}$. La sección central de los otros dos tipos es una trasposición literal de los modelos que usará en el claustro de la catedral leonesa, donde participa a partir de $1537^{1292}$. La intervención de Badajoz en el claustro podemos reducirla a los años que transcurren desde 1537 a 1540, pues a partir de entonces, y durante dicha década, su foco de actividad se traslada a Oviedo, donde ejecuta otro claustro benedictino, el de San Vicente ${ }^{1293}$.

\footnotetext{
${ }^{1288}$ Véanse más adelante los detalles de esta inscripción. Sobre el arquitecto, véanse los datos relativos en el capítulo correspondiente.

${ }^{1289} \mathrm{Se}$ le abonan por las ocho capillas 51.368 maravedíes. ZALAMA, Miguel Ángel. La arquitectura...Op.cit, pág. 96, "Documentos...Op.cit, pp. 266-267. En esta carta de pago se indica la participación de Celaya en la construcción de la noria del jardín que estaba en el claustro de San Zoilo. Véase PARRADO DEL OLMO, Jesús María. “Datos...”. Op.cit, pág. 391.

${ }^{1290}$ GÓMEZ MARTÍNEZ, Javier. El gótico español....Op.cit, pág. 91.

${ }^{1291}$ Las inscripciones de la fachada, sala capitular y otras dependencias indican que en 1538 ya se habían finalizado la sala capitular, la sala del Museo Arqueológico, dos paños del claustro y el lienzo inferior de la fachada de San Marcos. CHUECA GOITIA; Fernando. Arquitectura del siglo XVI. Ars Hispaniae, Tomo XI. Plus Ultra. Madrid, 1953, pág. 312. La historia del proceso constructivo de la sacristía de San Marcos en CAMPOS SÁNCHEZ BORDONA, $\mathrm{M}^{\mathrm{a}}$ Dolores. Juan de Badajoz...Op.cit, pp. 213-223.

${ }^{1292}$ La historia del proceso constructivo de la catedral en CHUECA GOITIA; Fernando. Arquitectura monumental en la provincia de León. Santiago García. León, 1991, CAMPOS SÁNCHEZ BORDONA, M ${ }^{a}$ Dolores. Juan de Badajoz...Op.cit, pp. 349-373, del mismo autor, La catedral de León. Colegio de España. Salamanca, 1994.

${ }^{1293}$ En esta autoría coinciden CAMÓN AZNAR, José. "La arquitectura y la orfebrería...Op.cit, pág. 210 y PASTOR CRIADO, Isabel. Arquitectura purista en Asturias. Oviedo, 1987, pág. 124.
} 
Quizá en estos diez años se produjo la primera paralización de las obras, lo cual permitiría el traslado temporal del artista a la capital ovetense. Pero no fijó allí su residencia habitual, pues sabemos que en 1544 trabajaba en la sacristía de la Catedral de León ${ }^{1294}$. Según el capítulo general de 1550, siendo abad Juan de Santamaría, se aprobó la realización de obras durante el trienio que daba comienzo, lo que parece indicar una reanudación de las obras ${ }^{1295}$. Probablemente Badajoz alternase su actividad en el claustro carrionés, con períodos intermitentes de trabajo en otras localidades hasta 1552 en que finaliza su intervención en el mismo.

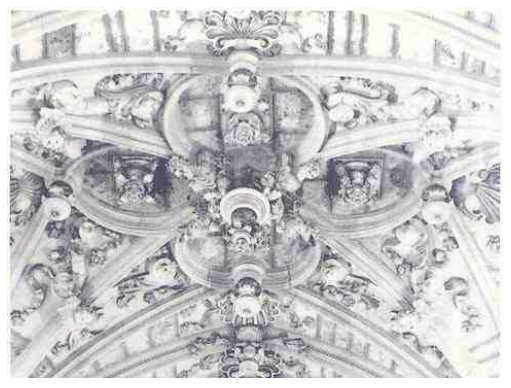

Sacristía del convento de San Marcos (León).

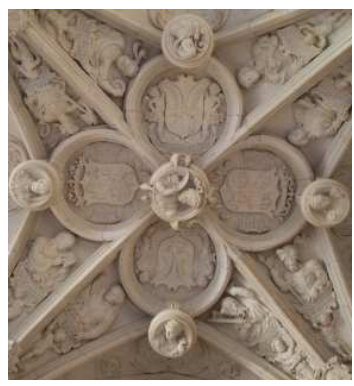

Claustro de San Zoilo.
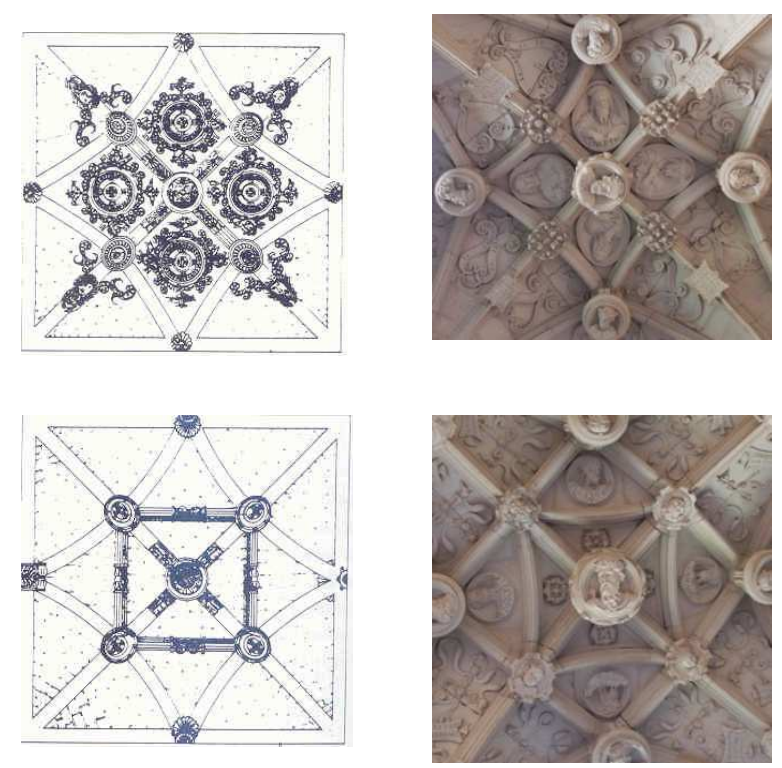

Bóvedas de la Catedral de León (izquierda) y bóvedas del claustro de San Zoilo (derecha).

${ }^{1294}$ SÁNCHEZ BORDONA, Ma Dolores. Juan de Badajoz...Op.cit, pág. 165.

1295 ZARAGOZA PASCUAL, Ernesto. “Abadologio....Op.cit, pág. 289. 
El cantero carrionés Pedro de Castrillo, discípulo de Badajoz, será quien continúe la labor de su maestro desde 1552 hasta 1574, realizando la panda sur y buena parte de la oeste -desde el tramo sexto al decimocuarto, en que de nuevo se observa menor calidad $^{1296}$. Al parecer, Castrillo no pudo proseguir las obras por las penurias económicas que atravesaba el convento, y la lentitud de las mismas provocó que no pudiera ver concluido el claustro ${ }^{1297}$. En este período trabajó un tal Juan de Palacios, del que tan sólo tenemos noticia por su mención en un documento de 1562, por el que como “...maestro de cantería de la obra de San Zoil desta villa...”, debía tasar la parte realizada por el carrionés Pedro de Torre en la capilla de los Herrera de la iglesia de Santa María del Camino ${ }^{1298}$

Ese lado occidental fue culminado por Juan de Celaya, quien había comenzado a trabajar en 1575, según consta, escrito en tinta roja, bajo la bóveda decimoquinta del lado occidental: “EBRH $19,1575^{1299}$ ”. Este maestro de obras de Palencia, fue quien concluyó las obras del claustro, que quedarían finalizadas en la bóveda vigésimo segunda, como así reza la inscripción "Este claustro se acabó ha trece de julio, año del señor de 1577, siendo abad F. Ambrosio de Nájera. Salió de ésta general, siendo abad, F. Cristóbal de Agüero. El arquitecto Juan de Celaya lo acabó”. Es decir, las dos últimas bóvedas de este tramo, la vigésimo tercera y la contigua, fueron las primeras en ser ejecutadas, debiéndose como indicamos previamente a la mano de Juan de Badajoz el Mozo. El abad Fray Sebastián de Encinas, profeso de Monserrat, fue quien impulsó desde 1570 las obras del claustro $^{1300}$.

\footnotetext{
${ }^{1296}$ CEÁN BERMÚDEZ, Agustín. Diccionario...op.cit, pág. 45, JOVELLANOS, Gaspar Melchor de. Obras publicadas e inéditas de Don Gaspar Melchor de Jovellanos. 2. Colección hecha e ilustrada por Don Cándido Nocedal. Biblioteca de Autores Españoles. Rivadeneira. Madrid, 1952, pág. 365.

1297 CEÁN BERMÚdEZ, Agustín. Diccionario Histórico... Volumen 2. Op.cit, pág. 44 y LLAGUNO Y AMIROLA, Eugenio. Noticias... Tomo 3.Op.cit, pág. 30. Conservamos el testamento de Pedro de Castrillo, dictado en Palencia el 14 de agosto de 1556, cuatro años después de emprender las obras del claustro y catorce antes de su fallecimiento. Su mujer se llamaba Beatriz Cañizales y el hijo de ambos, Ambrosio Castrillo, a quien dejó como universal heredero de sus bienes. AHPP. Palencia, Protocolo 10563. Andrés Sánchez de Villadiego (1552-1556), s/f.

${ }^{1298}$ AHPP. Carr.Prot 5440. Gregorio Movilla (1561-1562), s/f.

${ }^{1299}$ LLAGUNO Y AMIROLA, Eugenio. Noticias...Tomo III. Op.cit, pp. 29-30.

${ }^{1300}$ RAMIREZ DE HELGUERA, Martín. El Real monasterio... Op.cit, pág. 52.
} 
En resumen, los trabajos se dividieron entre tres maestros principales que ejecutaron cada uno ocho bóvedas:

-Juan de Badajoz, bóvedas 1-6 y 23 y 24

-Pedro Castrillo: Bóvedas 7 al 14

-Juan de Celaya: Bóvedas 15 a 22
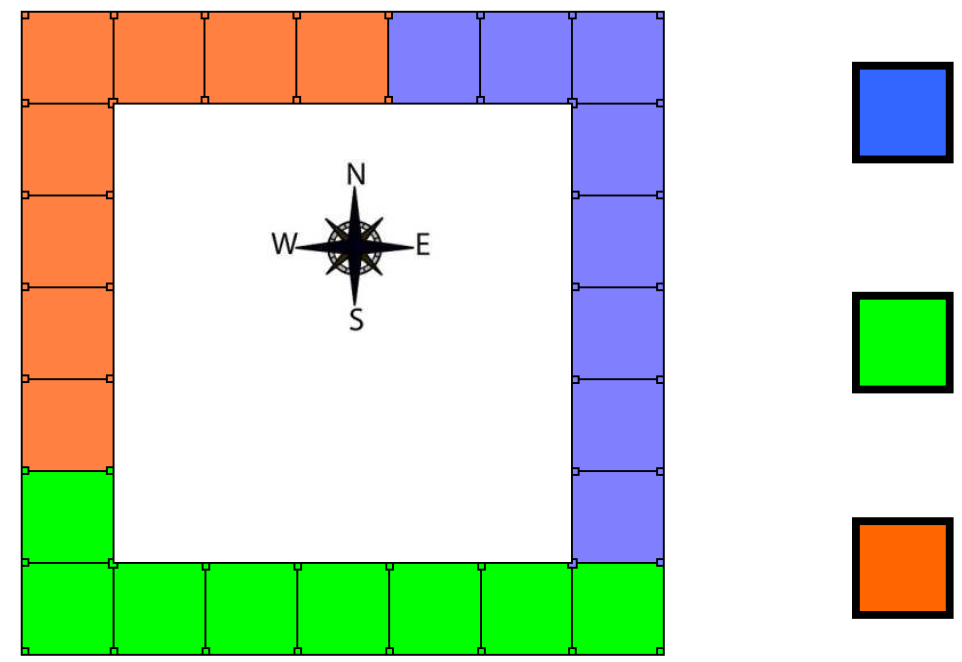

Juan de Badajoz "el

Mozo" (1537- 1552, con

períodos de paralización

y trabajos paralelos)

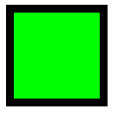

Pedro de Castrillo

(1552-1574 con períodos de paralización)

Juan de Celaya (1575-

1577)

Participación estimada de los arquitectos del claustro bajo.

\section{Los escultores}

Paralelamente a las labores arquitectónicas, se llevaron a cabo las escultóricas, pudiéndose establecer una participación coetánea entre los unos y los otros. Es decir, siguiendo parámetros estilísticos, pues carecemos de documentación, comprobamos que a cada maestro de obras le acompaña un escultor o escultores determinados; de tal modo que cuando se interrumpen las obras, ambos las traspasan a otros artistas diferentes. Veamos cómo sucedió.

Conviene señalar que Juan de Badajoz, además de arquitecto, trabajó como proyectista en San Zoilo. No cabe duda de que fue quien ideó la elaborada, a la par que elegante estructuración de las casi cincuenta ménsulas que sustentan las bóvedas del claustro. Basta observar las de la sacristía del convento de San Marcos, donde 
trabaja casi paralelamente, recurriendo a la triple partición de inscripción, retrato y gola inversa con florón ${ }^{1301}$. Para la representación de los personajes contenidos en las mismas, tuvo dos magníficos colaboradores, Juni y Doncel, que tallaron primorosamente las figuras del Antiguo y Nuevo Testamento, desarrollando como en San Zoilo, la idea del Árbol de Jesé, además de la del Templo de Salomón como morada celestial $^{1302}$. En nuestro claustro se plasman elementos frecuentes de su obra a los que recurrió para la decoración de la sacristía leonesa, como los motivos avolutados "en ese" plasmados en las bóvedas o las calaveras a los lados del retablo del testero ${ }^{1303}$.

En la capilla plateresca de don Juan Manuel del convento dominico de San Pablo, atribuida a Juan de Badajoz, observamos el mismo tipo de ménsulas, en este caso policromadas, divididas en varias partes con diversas molduras, enhebradas todas ellas por una imposta que recorre el perímetro del muro. Precisamente el homónimo biznieto del infante, encargó en 1536 la construcción de esta capilla funeraria, atribuida a Juan de Badajoz. Ubicada en el lado del Evangelio del templo, serviría como panteón de la familia Manuel, cuyo recuerdo está presente en la heráldica e inscripciones de la misma ${ }^{1304}$. Las obras de estos años treinta, realizadas tanto en Valladolid como en León, presentan evidentes analogías estilísticas con el claustro carrionés, estableciéndose como fuente directa de inspiración para el artista. La intervención de Badajoz en San Zoilo es, desde nuestro punto de vista, la más interesante en su doble faceta arquitectónica a la par que escultórica, pues establece en ambos campos el patrón a seguir en el resto del claustro.

Miguel de Espinosa es el artista que acometió la ejecución de la parte escultórica correspondiente al sector de Juan de Badajoz, la de mayor calidad, donde los rostros, las posturas, las vestimentas, no se repiten ${ }^{1305}$.

\footnotetext{
${ }^{1301}$ La sacristía alberga una de las salas del museo arqueológico. Sobre el mismo, donde se incluyen magníficas fotografías de las ménsulas, DÍAZ JIMÉNEZ Y MOLLEDA, Eloy. Historia del Museo arqueológico de San Marcos de León. Apuntes para un catálogo. Librería de Victoriano Suárez. Madrid, 1920.

${ }^{1302}$ SÁNCHEZ BORDONA, Ma Dolores. Juan de Badajoz....Op.cit, pp. 223.

${ }^{1303}$ Este tipo de ornamentación tiene su origen en la obra de Diego de Siloé, presente en la escalera dorada de la catedral burgalesa.

${ }^{1304}$ CHUECA GOITIA, Fernando. Arquitectura...Op.cit, pag 316.

${ }^{1305}$ Sobre este escutor e imaginero, véase el capítulo dedicado a su biografía dentro del apartado general de escultura.
} 
Otros oficiales le habrían ayudado en la obra, como es el caso del francés Esteban Jamete, quien, según su propio testimonio, trabajó durante un breve período de cuatro meses en Carrión, en el monasterio "de San Gil, que es de benitos ${ }^{1306 ” . ~ N o ~}$ existe en esta villa otro cenobio benedictino que el de San Zoilo, pero aparte existen otros documentos en que se emplea esta denominación, aunque no sea lo más usual $^{1307}$. Con toda probabilidad podemos precisar su actividad en el claustro hacia 1537 en que se casó con María González, que procedía del cercano pueblo de Becerril de Campos ${ }^{1308}$. Pero no será hasta 1545 en que logre fama reconocida, y establezca su taller en Cuenca, en cuya catedral realizará destacados trabajos como el trascoro o la portada de acceso al claustro, conocida como "Arco de Jamete", donde se percibe la influencia de Diego de Siloé ${ }^{1309, " . ~ L a ~ v i d a ~ p e r s o n a l ~ d e l ~ e s c u l t o r ~}$ de Orleans dista de ser modélica, pues es conocido su carácter agresivo, su afición por la bebida y sus problemas con la justicia, hasta el punto de sufrir un proceso inquisitorial en 1557 para defenderse de diversas acusaciones de herejía, apostasía y encubrimiento ${ }^{1310}$. Bien diferente es su faceta artística, de quien dice Camón Aznar: “...su labor como tallista es tan fecunda y selecta, con los grutescos más bellos de

${ }^{1306}$ DOMÍNGUEZ BORDONA, Jesús. Proceso...Op.cit, pág. 25. También figura esta atribución en CAMÓN AZNAR, José. La arquitectura plateresca... Op.cit, pág. 316.

${ }^{1307}$ El uso indistinto de los nombres de San Gil y San Zoilo para designar este monasterio carrionés lo demuestra un pleito acaecido entre la dicha casa conventual y el marqués de Aguilar a mediados del siglo XVI., en el que dichos términos se emplean indiferentemente. ARCHV. Pleitos Civiles Alonso Rodríguez (Fenecidos) Caja 1247. Expediente 3.

${ }^{1308}$ ROKISKI LÁZARO, M ${ }^{a}$ Luz. Escultores del siglo XVI en Cuenca. Cuenca, 2010, pág. 125. Este libro constituye la publicación más actualizada sobre el artista. Véanse pp. 125-206. Otros datos biográficos de Jamete en DOMÍNGUEZ BORDONA, Jesús. Proceso inquisitorial...Op.cit, pp. V-XV (notas premilitares). AZCÁRATE RISTORI, José María de. "Escultura...Op.cit, pp. 233 y ss y ROKISKI LÁZARO, Ma Luz. Arquitectura...Op.cit, pp. 145 y ss. Del mismo autor, contratos de obra en Documentos sobre escultura del siglo XVI en Cuenca. Volumen 1. Cuenca, 1988, pp. 62-65, 73 y 75 y Volumen 2. Cuenca, 1989, pp. 227-229, 290-300, 302-304, 335-337, Documentos sobre escultura del siglo XVI en Cuenca. Cuenca, 2001, pp. 114-120, 245, 323-332, 336, 338-344, 346-350, 353, 360, 411, 453-455,554.

${ }^{1309}$ Había trabajado junto al arquitecto burgalés en la capilla del Salvador, de Úbeda, durante dos años, cuyo estilo se deja sentir en el pórtico de Cuenca. ALLENDE SALAZAR, Juan. "Excursión a Cuenca y Uclés" en BSCE, vol 13, n 149. 1905, pp. 142.

${ }^{1310}$ Finalmente le libraron de la excomunión pero fue condenado a cárcel y a portar el San Benito durante tres años, con la obligación de asistir a misa y sermón e ir en romería, confesarse, etc. Todo el proceso en DOMÍNGUEZ BORDONA, Jesús. Proceso inquisitorial...Op.cit, pp. 1-72. TURCAT, André. Etienne Jamet, alias Esteban Jamete: sculpteur français de la Renaissance en Espagne condamné par l'Inquisition. Picard. París, 1994, THOMAS, Werner. Los protestantes y la Inquisición en España en tiempos de Reforma. Leuven University Press. Lovaina, 2001, pp. 125-126, 248249,341-342, 399-414 y 636-638. 
nuestro arte, que puede decirse que gran número de monumentos platerescos están en su órbita ${ }^{1311,}$.

En esta primera fase de las obras también intervendría como colaborador, el hermano del escultor palentino, Sebastián de Espinosa ${ }^{1312}$. En el pleito de 1537 entre Cristóbal de Andino y el Almirante de Castilla, en el que testifica a favor del artista, se declara como imaginario y vecino de Burgos ${ }^{1313}$. Pudiera tratarse, según información de Portela Sandoval, del artista que vivía en la actual calle Mayor, en su día, Pan y Agua, según los censos llevados a cabo en los años 1557 y $1561^{1314}$.

No era la primera vez que Esteban Jamete y Sebastián de Espinosa participaban en una obra común junto a Miguel de Espinosa. Entre 1535 y 1537 en que el palentino ejecuta los retablos de San Francisco de Medina de Rioseco, le ayudaron en la misma los dos oficiales durante un breve lapso de tiempo, que en el caso de Jamete fue solamente un mes ${ }^{1315}$. Esta experiencia previa, garantía de la capacidad de entendimiento y afinidad entre los tres artistas profesionalmente, justificaría su intervención conjunta en el claustro carrionés. Dada la escasa participación de estos artistas en el claustro resulta imposible determinar exactamente la mano de cada uno. Siguiendo a Ceán Bermúdez, podemos establecer la participación de dos entalladores poco conocidos: Juan Bello, vecino de Sahagún, que participaría en 1543 y Juan Mián o Millán, vecino de León que lo haría el año siguiente $^{1316}$. Con tan escasa participación, no obstante, resulta imposible atribuir alguna imagen a la mano de estos colaboradores. Podemos identificar con mayor facilidad, dada su amplia intervención en el claustro, la impronta de Miguel de Espinosa.

Las ménsulas de Adán, Eva, Seth y Élbora son seguras del maestro burgalés, con la expresión desolada, boca reducida y salientes pómulos característicos del estilo de Siloé. Introduce un elemento innovador copiado por Giralte en el retablo de

\footnotetext{
${ }^{1311}$ CAMÓN AZNAR, José. La arquitectura y la orfebrería...Op. cit, pág. 262

${ }^{1312}$ MARTÍN GONZÁLEZ, Juan José. "Miguel de Espinosa...Op.cit, pág. 148, AZCÁRATE RISTORI, José María de. "Escultura...Op.cit, pág. 221.

${ }^{1313}$ MARTÍN GONZÁLEZ, Juan José. “Miguel de Espinosa...Op.cit, pág. 148.

${ }^{1314}$ PORTELA SANDOVAL, Francisco José. La escultura...Op.cit, pág. 221.

${ }^{1315}$ MARTÍN GONZÁLEZ, Juan José. "Miguel de Op.cit, pp. 147-149.

${ }^{1316}$ CEÁN BERMÚDEZ, Agustín. Diccionario Histórico... Volumen 2. Op.cit, pág. 44.
} 
la capilla del Obispo: niños desnudos afrontados o de espaldas a un motivo, sea un mascarón o una tarjeta ${ }^{1317}$. Hará uso de un repertorio de grutescos avolutados que también serán un recurso de Manuel Álvarez para la ornamentación ${ }^{1318}$.

Este sector presenta una gran calidad técnica, donde los tipos son muy expresivos y variados, cambian los tocados y los atuendos e incluso la posición anatómica cuando se retratan figuras de medio cuerpo. Obsérvese la diversa ejecución que presentan los bustos de dos de los personajes ubicados en los plementos de la bóveda quinta. Eliachim aparece como un hombre maduro que, complacido, pliega sus labios en un atisbo de sonrisa. En la cabeza porta un tocado inserto en una corona y viste una túnica abotonada al frente y una capa que cubre su hombro izquierdo, mientras que con la mano derecha recoge la parte de la misma que ha caído. Frente a él, descubrimos en su tataranieto Aquim a un joven imberbe de facciones afeminadas que contrastan con la coraza con flecos que porta. Luce una espesa cabellera con bucles que asoman a través de una especie de capucha o cota de malla que protegería su cabeza. Su postura es bien diferente a la de su antecesor, apoyando su mano derecha sobre el pecho, en tanto que la otra sostiene delicadamente la tarjeta que lo identifica.

Por otro lado, no se deja ningún hueco desprovisto de ornamentación, con el fin de dotar de la mayor riqueza posible al programa escultórico. Para ello se recurre a querubines, tarjetas, cintas, flores, guirnaldas, motivos vegetales que se entrelazan entre sí creando un juego de formas diversas que aportan un guiño armónico al conjunto. Se atiende además al más mínimo detalle, jugando incluso con el carácter anecdótico, como es el caso del animal monstruoso que muerde las posaderas de uno de los querubines que amordazan a la calavera de la ménsula angular ubicada en el primer tramo.

En el resto de ménsulas parece adivinarse la mano de colaboradores como en las de Abraham, Isaac, Sara, Rebeca, Jacob y Raquel, de menor calidad técnica. Las claves y plementos de esta panda oriental no parecen haber contado con el cincel de 
Espinosa. Después, a medida que se va recorriendo este lado oriental, su impronta se va perdiendo.

Entre 1552 y 1574 Pedro de Castrillo ejecuta todas las bóvedas del lado meridional hasta el tramo décimo cuarto, segundo del tramo occidental. En el plano escultórico, merma la calidad, y se observa una disminución de la expresividad y detallismo, pudiendo deberse esta parte a la mano de artistas de menor entidad cuya identidad desconocemos. Toda la crujía meridional despliega en los plementos un motivo de jarrones con flores que se repiten con escasa variedad en su composición a lo largo de este tramo y que además, no llegan a cubrir la amplia superficie en su totalidad, aportando una sensación de pobreza general que se acentúa en la bóveda décimo cuarta, donde los plementos están íntegramente desprovistos de ornamentación. A favor de esta afirmación tenemos la homogeneidad ornamental en este lado, extendiéndose a la bóveda décimocuarta. El número de retratos ubicados en las crucerías se ha reducido a las claves dado que la talla de las figuras requiere una mayor habilidad técnica que el resto de ornamentación de la que estos escultores carecerían. Frente a los nueve personajes bíblicos que protagonizan cada tramo en el resto del conjunto, este tramo presenta cinco: cuatro ubicados en los medallones de los terceletes y entre ellos, el personaje principal en la clave central. Todos los antecesores de Cristo presentan características similares. Fijémonos en los protagonistas de cada bóveda: Eliud, Abiud, Amón, Osías, Roboam e Isaí. Se trata de hombres de edad muy avanzada, con cabeza cuadrada, cuello reducido y una expresión desoladora en sus rostros que se traduce en el entrecejo fruncido, ojos caídos y nariz arrugada. Por tanto, colegimos que el escultor de este área ha recurrido a la utilización de un mismo tipo humano, variando ligeramente la posición de la boca o el tipo de tocado, según el caso.

A continuación, a partir de la bóveda décimo quinta, intervendría el escultor Antonio Morante, en la parte que, arquitectónicamente, correspondió a Juan de Celaya. Se observa una mayor calidad técnica respecto a la parte precedente, casi equiparable a la de las primeras bóvedas ejecutadas por el binomio Badajoz y Espinosa. Morante era vecino de San Cebrián de Castro, a pocos kilómetros de 
Zamora, siendo palentino de origen ${ }^{1319}$. Sin embargo, descartamos que a cargo de Morante, escultor como indicamos de calidad destacada, corriera el trabajo de las bóvedas vigésima a vigésimo segunda, en las que se observa un cincel mucho menos diestro, posiblemente de oficiales de menor entidad. Nos basamos para ello en la idéntica disposición de las bóvedas, con tan sólo cuatro personajes en las claves secundarias, donde se reitera la pobreza ornamental a base de jarrones de flores y los motivos de eses avolutados con cintas. Estos últimos elementos se inspiran claramente en los que Juan de Badajoz plasmó en las bóvedas de la sacristía del convento de San Marcos de León, en la que trabajó justo antes, en los años treinta.

En la bóveda vigésimo segunda, finaliza el ciclo iconográfico con la inscripción mencionada de Celaya en 1577.

J uan de Badajoz y Miguel de Espinosa

Colaboradores: Esteban Jamete, Sebastián de Espinosa, Juan Bello, Juan Mián

Escultores anónimos de menor pericia técnica

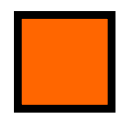

Antonio Morante

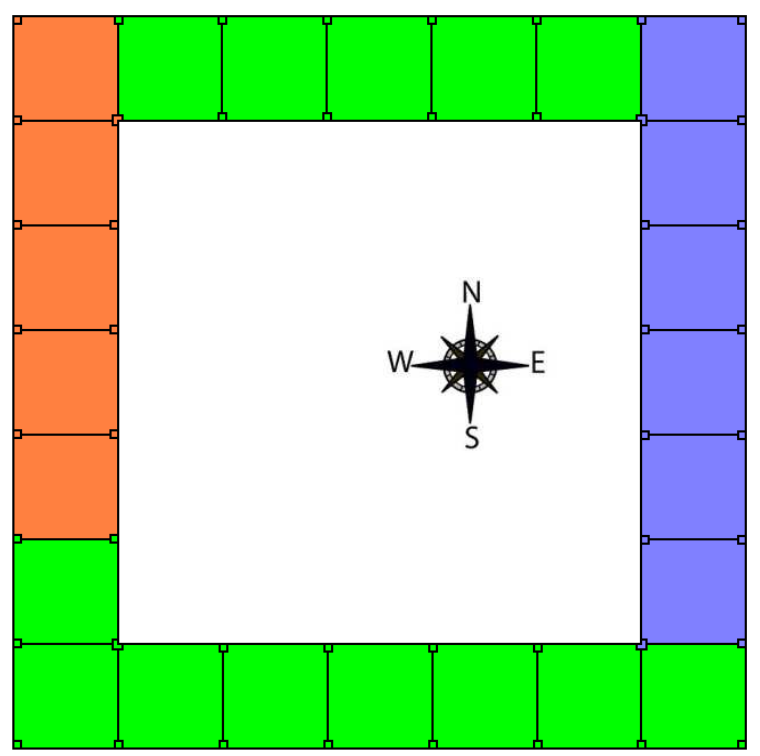

Participación estimada de los escultores del claustro bajo.

\section{Ciclos temáticos}

El conjunto está formado por doscientas cincuenta figuras de diversa índole, que conforman dos núcleos temáticos principales: las dos grandes genealogías de Cristo y San Benito, basada la primera en relaciones de parentesco y la segunda en vínculos espirituales con la orden benedictina con otros temas secundarios.

${ }^{1319}$ CEÁN BERMÚDEZ, Agustín. Diccionario Histórico... Volumen 3. Op.cit, pág. 192. 


\section{Antes de Cristo}

1. La genealogía de Cristo. Bóvedas $23 \mathrm{~A} 12^{1320}$. El primero de los temas, y el que posee un mayor protagonismo, dada su extensión desde la bóveda vigésimo tercera hasta la bóveda décimo cuarta, es la genealogía de Cristo. Para ello se ha utilizado como fuente el Nuevo testamento, tomando como referencia mayormente el Evangelio de San Mateo, salvo en una parte, donde se remite a San Lucas. Del primero se ha extraído la genealogía desde Abraham que abarca desde las bóvedas segunda a sexta. Respecto a San Lucas, que remonta el origen genealógico de Cristo a Adán, hijo de Dios, se han tomado los personajes posteriores al Diluvio Universal, es decir anteriores a Abraham, que hallamos en las bóvedas vigésimo tercera y su sucesiva $^{1321}$. La lectura iconográfica comienza, por tanto, en Adán y Eva, ubicados en las ménsulas que flanquean la Puerta principal por la que se accede al templo. Siguiendo el Evangelio de San Lucas en sentido inverso, la ascendencia de Jesús continúa precisamente en las ménsulas, a través de Seth y Élvora y su hijo Enós, tras los cuales, haciendo un salto generacional -pues se han omitido en el programa por falta de espacio a Malaleel, Jaret, Henoc, Matusalén y Lamec- se sigue el orden cronológico en la bóveda vigésimo tercera con Sem, hijo de Noé. Sigue la disposición bíblica en la bóveda vigésimo cuarta con Thera en el centro de la clave, que es padre de Abraham, de ahí que continúe la genealogía en las ménsulas de esta crujía con éste, su hijo Isaac, el hijo de éste, Jacob y las respectivas esposas de todos ellos. Judá, como hijo de Jacob, continuaría la sucesión familiar en la bóveda segunda y así, hasta la bóveda sexta, en que finaliza la genealogía en María, como madre de Cristo, hallándose éste en el acceso a la iglesia, crucificado ${ }^{1322}$.

\footnotetext{
${ }^{1320}$ Exceptuamos la bóveda primera en que figura la fundación del cenobio, formando, como indicamos posteriormente, un tema independiente.

${ }^{1321}$ Lucas, 3 y Mateo, 1. El Evangelio de Lucas contiene antecedentes de Cristo diversos al de Mateo por una sencilla razón. José tuvo dos padres, uno natural, que fue Jacob y un padrastro, proveniente del primero de los matrimonios de Iesca, la madre de Jacob, que fue Elí. Lucas remonta la genealogía del padre que llamaríamos legal, mientras que Mateo lo hace de Jacob. En un cierto punto, los personajes del linaje de Cristo coinciden porque los dos maridos que tuvo Iesca, Mathat y Mathan, descendían de David. ROCA Y CORNET, Joaquín. Historia de los hechos y doctrina de Nuestro Señor Jesucristo desde su venida al mundo hasta su gloriosa ascensión al cielo. Biografía Eclesiástica. Barcelona, 1857, pp. 128-130.

${ }^{1322}$ Lucas, 3. Para poder apreciar con claridad el orden exacto de los personajes en el tiempo, ordenados numéricamente, es excelente el gráfico contenido en REDONDO CANTERA, Ma José. "El programa...Op.cit, pp. 147-149.
} 
A partir de ésta y hasta la bóveda décimo segunda se repite el mismo tema de la ascendencia de Cristo, siguiéndose en este caso el Árbol de Jesé, según la Profecía de Isaías: "Saldrá un vástago del tronco de Isaí (Jesé), y un retoño de sus raíces brotará $^{1323 ” . ~ L a ~ i c o n o g r a f i ́ a ~ d e l ~ A ́ r b o l ~ d e ~ J e s e ́ ~ h a ~ s i d o ~ m u y ~ r e c u r r e n t e ~ a ~ l o ~ l a r g o ~ d e ~}$ la Edad Media; y es Suger, el abad de Sanint Denis, quien le da forma definitiva en el siglo XI, a través de un hombre recostado de cuyo pecho surgen las ramas donde se sitúan sus descendientes ${ }^{1324}$. Los personajes representados son los mismos que en la otra genealogía, residiendo la diferencia en la introducción de Isaí o Jesé, en vez de Adán, como punto de partida de la misma, omitido en el programa anterior ${ }^{1325}$.

2. El pueblo hebreo y sus oponentes. Sus miembros aparecen representados en las bóvedas 13 y 14. Finalizada la genealogía de Cristo, los personajes ubicados en las dos bóvedas contiguas, conforman un ciclo independiente en sí, al representar en la bóveda décimo cuarta a los seleúcidas, pueblo hostil al judío, con el que lucharon sin lograr sus propósitos. Comandados por Antíoco, pretendían someterles bajo su yugo obligándoles a adorar a sus dioses paganos. En férrea oposición a éstos, figuran en la bóveda décimo tercera los macabeos, liderados por Matatías, que defendieron el judaísmo con su vida y vencieron con la ayuda de Dios.

3. Personajes del Antiguo Testamento. Corresponden a las ménsulas de las bóvedas 7 a 14, protagonizadas por figuras que pasaron igualmente su vida en la defensa de los hebreos. Jacob, ubicado junto a su esposa Raquel en la bóveda séptima, tuvo doce hijos de los que nacerían los patriarcas de las doce tribus de Israel, a quienes Josué, representado en una de las bóvedas, repartiría la Tierra prometida. Los miembros claves de las mismas figuran en esta panda, como

\footnotetext{
${ }^{1323}$ Isaías, 11:1.

${ }^{1324}$ CORBLET, J. "Étude iconographique sur l'Arbre de Jessé" en Revue de l'art Chretien. No4. Paris, 1860, pp. 49-61. Su representación ha sido muy recurrente en el arte. A este respecto, la iconografía en España es muy usual, presente por ejemplo en la catedral de Pamplona o en edificios románicos como Silos, Santo Domingo de la Calzada o Santiago de Compostela. Aunque en el Renacimiento se recurre menos a este tema, no faltan los ejemplos, como dos obras granadinas, la vidriera de la catedral o el retablo del monasterio de San Jerónimo. MARTíNEZ JUSTICIA, María José. "La simplificación del Árbol de Jesé y otros temas genealógicos marianos en la escultura granadina" en Cuadernos de Arte iconografía, tomo 2, nº4, Valladolid, 1989, pp. 9-19.

${ }^{1325}$ A los personajes de la bóveda quinta, corresponden los de las bóvedas séptima y octava, a los de la bóveda cuarta, con los de las bóvedas novena y décima. Por último, las figuras de la tercera bóveda, salvo por la omisión de Jesé, se corresponden con las de las bóvedas undécima y décimo segunda. En estas bóvedas del lado oriental (2-5) se representan a nueve personajes, mientras que en la panda meridional, tan sólo a cinco, de ahí la extraña correspondencia.
} 
Gedeón, de la tribu de Manasés, o Moisés, Aarón y Samuel, de la tribu de Leví, la cual no poseía tierras porque sus miembros se dedicaban al sacerdocio. Los descendientes de la tribu de Judá, a la que pertenecieron David y Salomón, se ubican en las claves de las bóvedas de esta panda, de donde parte la genealogía de Cristo. A la muerte de Josué, representado en la ménsula interna de la bóveda décima, el pueblo de Israel fue gobernado por Jueces, líderes militares que salvaron de la opresión y la idolatría al pueblo judío. Los más destacados figuran en este ciclo, como Débora y Barac, que lucharon contra los cananeos; Gedeón, que lo hizo contra los madianitas; Sansón, que venció a los filisteos, y el último de ellos, Samuel, engendrado por Ana, y educado por Elí, también juez, que cerraría el ciclo de personajes veterotestamentarios en la bóveda décimo quinta, donde precisamente comienza otro de los programas ${ }^{1326}$.

En estrecha relación con el tipo de representación de los personajes ubicados en las claves de las bóvedas hallamos Promptuarii iconum, impreso por el francés Guillaume Roville en Lyon, en $1553^{1327}$. Incluye una selección de personajes insignes de la historia desde Adán y Eva dispuestos cronológicamente. Cada página esta compuesta por una xilografía que contiene el medallón de dos personajes de frente o de perfil con su respectiva identificación latina, a los que les sigue una breve biografía de los mismos.

\section{Después de Cristo}

1. La descendencia espiritual de San Benito. Comprende las bóvedas 15 a 22. Desde el tercer tramo de la crujía occidental hasta la bóveda vigésimo segunda en que finaliza el ciclo, los personajes de estos dos lienzos presentan vínculos amistosos o de protección hacia el santo fundador de la Orden benedictina.

Dado su protagonismo a lo largo del ciclo, resulta ineludible dedicar unas breves líneas a su persona. San Benito (540-604) nació en el seno de la familia Anicia, ilustre abolengo afincado en Nursia. Fue enviado a Roma para cursar sus estudios a edad temprana pero optó por una vida más espiritual y se retiró a una cueva de las

\footnotetext{
1326 Jueces, 4-13.

${ }^{1327}$ BHSCV. Promptuarii iconum insigniorum a seculo hominum, subiectis eorum vitis, per compendium ex probatissimis autoribus desumptis es su título completo.
} 
montañas de Subiaco, tomando el hábito de San Basilio. Perseguido por un monje envidioso, se refugia en Montecassino, cerca de Nápoles, donde fundó la célebre abadía, cabeza de la Congregación benedictina, donde está hoy día sepultado el santo $^{1328}$. Próximas a este monte, estableció otras once fundaciones más, siendo su principal aportación la redacción de la regla benedictina en el año 540, basada en la obediencia al abad y el "ora et labora". Durante varios siglos este compendio de setenta y tres normas espirituales convivió con otros, pero desde el siglo VIII alcanzó la supremacía dentro del monacato occidental. Mantuvo esta privilegiada posición hasta el siglo XII, en que paralelamente a la orden cisterciense, derivada de la benedictina, se impusieron otras como la premostratense, relevadas posteriormente por la dominica y franciscana, ramas de predicadores ${ }^{1329}$.San Benito es, dada su relevancia en el cenobio, la figura que preside la clave principal de este ciclo. Se le representa como a un hombre de mediana edad, que viste el hábito benedictino, cuya cogulla permite entrever su amplia tonsura monacal. Porta en sus manos la Regla Benedictina y el báculo como estandartes de su consagración pastoral. En la bóvedas de los tramos décimo quinto a décimo séptimo figura además con la inscripción: “GRATIA BENEDICTUS ET NOMINE”. La pertenencia del monasterio de San Zoilo a la orden benedictina, justifica el despliegue de hijos ilustres de la misma en su doble vertiente, temporal y espiritual. Se ofrece, por un lado, un despliegue de personajes eclesiásticos en sus diversos rangos, desde abades a Sumos Pontífices pasando por cardenales y Padres de la Iglesia que contribuyeron a otorgar el máximo esplendor a la Iglesia. No faltan, por otro, los máximos exponentes del poder terrenal como emperadores bizantinos, emperatrices, escritores y monarcas occidentales que se vincularon, a través de sus actos, al espíritu benedictino o fueron ejemplo de virtud cristiana.

Todos ellos están personalizados a través de su tarjeta correspondiente, aunque esto no ha evitado que se produzcan confusiones y dudas en algunas atribuciones debido a la repetición onomástica de algunas de ellas.

\footnotetext{
${ }^{1328}$ BHSCV. SANDOVAL, Fray Prudencio de. Primera parte de las fundaciones de los monasterios del glorioso Padre San Benito. Madrid, 1601, pp. 12-18.

${ }^{1329}$ LÓPEZ AMAT, Alfredo. El seguimiento radical de Cristo. Volumen 1. Madrid, 1987, pp. 95154.
} 
La elección de los diversos personajes no fue fruto de una selección al azar de los más importantes de la historia por parte del abad y monjes de San Zoilo, sino que utilizaron como fuente directa la Aprobación de la Regla y orden del gloriosísmo Padre San Benito. La Regla propiamente dicha fue escrita por el monje de Nursia, pero el catálogo de Príncipes eclesiásticos y seglares, doctores y santos que militaron en ella es lógicamente muy posterior, pues se incluyen personajes de la Baja Edad Media ${ }^{1330}$. Los listados que incluye este manual coinciden con los personajes representados en cada bóveda, separados, como veremos, por categorías. Los monjes benedictinos confiaron ciegamente en la fiabilidad de este manual que en algunos casos otorga dignidades que ciertamente no alcanzaron sus personajes. Por otro lado, es imprescindible tomar con cautela las dataciones que establece relativas a la vinculación a la orden benedictina, pues aunque algunas son exactas, otras yerran en varios siglos ${ }^{1331}$. Son, sin embargo, muy útiles a la hora de identificar los personajes contenidos en las bóvedas. En esta misma tendencia de explicar la historia, partiendo desde sus orígenes y estableciendo árboles familiares de los personajes que se sucedieron a lo largo de la misma, se encuentra el Liber Chronicarum, obra del alemán Hartmann Schedel, que fue publicada en Nuremberg en $1493^{1332}$. Contiene una serie de representaciones esquemáticas de las ciudades más emblemáticas como Roma, Constantinopla o Nuremberg siendo la parte más destacada un repertorio de grabados conformado por las figuras más destacadas de todos los tiempos, tanto de carácter religioso como profano, debidamente identificadas -Sibilas, líderes del pueblo judío, Papas, emperadores- que ilustran el panorama sociológico del mundo conocido hasta finales del siglo XV.

\footnotetext{
${ }^{1330}$ La edición más antigua en castellano que hemos encontrado es anónima. Aprobación de la regla y orden del gloriosísimo Padre San Benito, maestro de los religiosos, en algunos Concilios, lugares de derecho y letras apostólicas. Prólogo de Fray Juan de Castañiza. Salamanca, 1583. En latín encontramos Regula Sanctissimi Benedicti monachorum omnium patrius de Antonio Ribeiro, editada en Lisboa en 1586 que incluye a partir del folio 51 el catálogo mencionado. Tuvo que existir una versión anterior, a tenor de la coincidencia temática con el programa de San Zoilo.

${ }^{1331}$ Por citar algunos ejemplos que explicaremos posteriormente, en una de las bóvedas figura Hugo, imperator, que tan sólo fue rey de Italia o Juan Eunuco, imperator, que nunca fue así designado aunque hizo las veces de emperador. Vemos cómo si en el manual un personaje figuraba con una dignidad, en la bóveda se talla del mismo modo. En cuanto a las dataciones de este manual, contrastando las mismas con monografías especializadas, advertimos su escasa fiabilidad en algunos casos. Por ejemplo, este manual señala que Constancia tomó el hábito hacia 1195, mientras que nuestras fuentes indican que hacia esa fecha ya estaba esposada, como comprobaremos más adelante. ${ }^{1332}$ REDONDO CANTERA, Ma José. “El programa...Op.cit, pág. 144.
} 
La traslación literaria del ciclo iconográfico benedictino figura en Brieve dechiaratione dell'arbore monastico benedictino intitolato Legno della vita, cuyo autor, Arnoldo Uvion, monje de San Benito de Mantua, nos explica la estructuración en seis niveles de “...gli uomini illustri e famosi, cosí in santitá \& lettere come in ogni altra attione, che ha prodotto cosí Benedetto... ${ }^{1333 ” . ~ S o b r e ~ u n ~ m o n t e ~ e s t a ́ ~}$ plantado un árbol de cuya raíz nace San Benito. En su cabeza, una corona de doce estrellas, alusivas a los doce órdenes de la vida, seis espirituales y seis temporales. Los personajes de carácter espiritual -Papas, cardenales, arzobispos, obispos, doctores y santos- se situarán a la derecha del Santo, porque con la mano diestra trabajaban, mientras que en el lado izquierdo blandían la espada con la sinistra los emperadores, emperatrices, reyes, reinas, los hijos de todos ellos, los dogos de Venecia, los señores y por último en otro grupo los duques, condes y marqueses. Doce es igualmente el número de ramas que posee este árbol, en alusión a los dones del Espíritu Santo a los que remite el capítulo 12 de la primera carta a los Corintios y el cuarto de los efesios ${ }^{1334}$.

2. Personajes del Nuevo Testamento. Se encuentran en las ménsulas de las bóvedas 15 a 22. Paralelamente a este ciclo, en las ménsulas donde comienza el mismo, se inaugura el Apostolado, comenzando por Matías, que sustituye a Judas Iscariote y por ello éste no aparece, seguido por Simón el Cananeo o Zelote, Felipe de Betsaida, Andrés, Santiago el Menor, Bartolomé, Santiago el Mayor, Pedro, Mateo y Juan. Éstos dos últimos además forman parte del ciclo de Evangelistas que se cierra con Marcos y Lucas, los cuatro en las ménsulas del muro norte. Se han incluido además a San Pablo, que aunque no lo fue, siempre fue considerado "El Apóstol", San Sebastián, mártir del siglo III y ejemplo de buen cristiano y San Juan Bautista, precursor de Cristo. Por último, San Agapio justificaría su presencia porque sus huesos fueron traídos desde Córdoba, con los de sus compañeros Zoilo y Félix, conservándose en unas urnas dentro del templo ${ }^{1335}$.

\footnotetext{
${ }^{1333}$ BSCV. UVION, Arnoldo. Brieve dechiaratione dell'arbore monastico benedictino intitolato Legno della vita. Venecia, 1594, pág. 3.

${ }^{1334}$ Ibídem, pp. 3-6.

${ }^{1335}$ ANÓNIMO. Aprobación de la regla...Op.cit, pág. 106.
} 


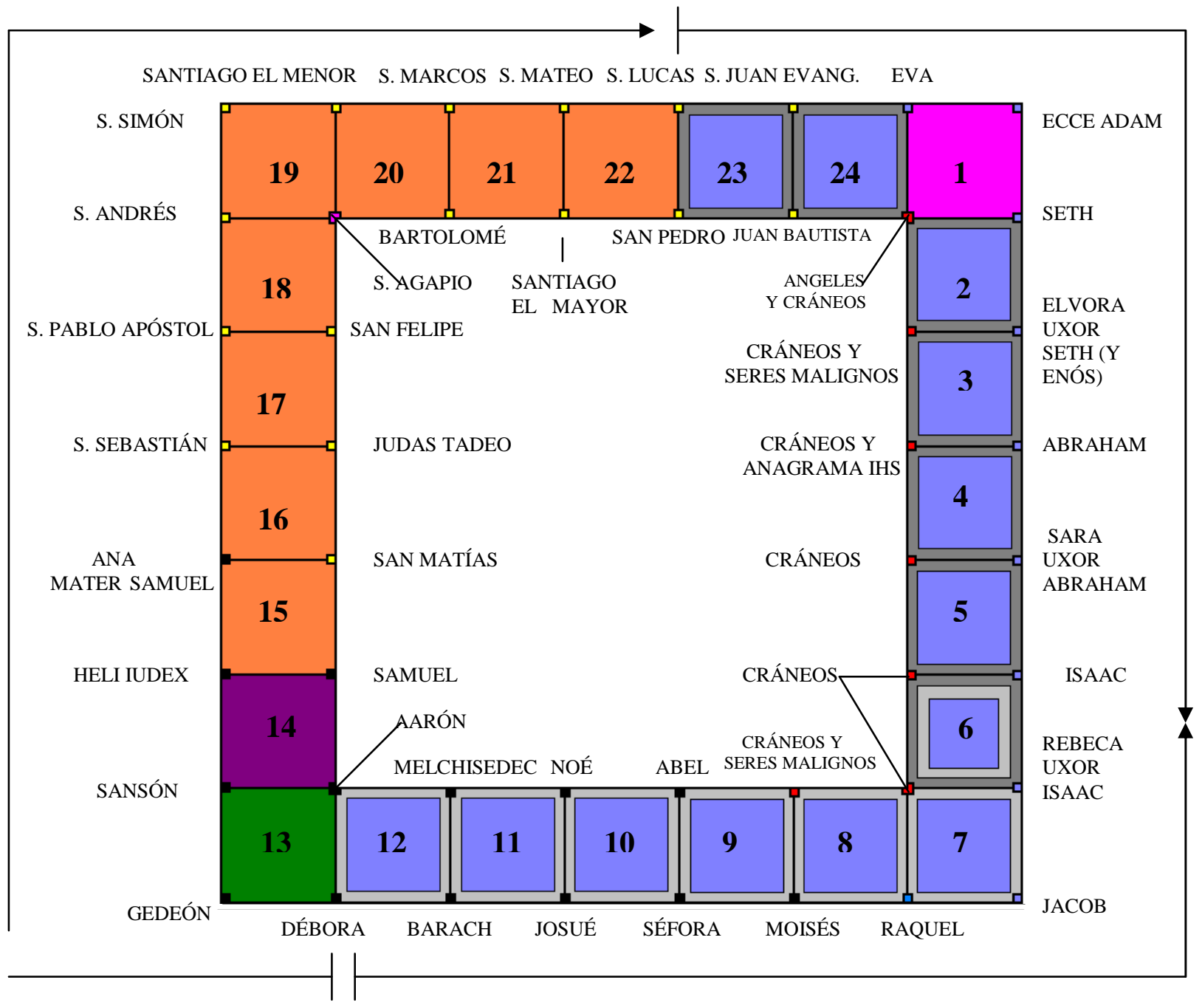

Fundación de San Zoilo

Genealogía de Cristo

-según San Lucas (ménsulas de Adán, Eva y Seth, continuando por bóvedas 23,24

-según San Mateo (Abraham, Isaac, Jacob y bóvedas 2 a 6)

Genealogía de Cristo: Árbol de Jesé, según Isaías (bóvedas 12 a 6)

Caudillos del pueblo judío: macabeos

Personajes hostiles al pueblo judío: seleúcidas y pecadoras

Genealogía espiritual de San Benito

Personajes del Antiguo Testamento: Jueces y Profetas

Personajes del Nuevo Testamento: Apóstoles, Evangelistas y otros santos

Apoteosis de la Muerte

$\longrightarrow$ Sentido de la lectura del ciclo

Núcleos temáticos del claustro. 


\section{Análisis iconográfico de las bóvedas}

La lectura iconográfica del claustro se realizará siguiendo el orden en la ejecución del mismo, es decir, comenzando por la bóveda primera, en el ángulo nororiental y siguiendo por las bóvedas vigésimo tercera y vigésimo cuarta, que enlazan con la segunda bóveda, en el tramo oriental, donde continúa el recorrido con normalidad siguiendo el sentido de las agujas del reloj hasta el lado norte. Para ello tomamos como referente los artículos de Díaz Nava, Becerro de Bengoa, y el más reciente de Redondo Cantera, estableciendo las correcciones oportunas respecto a la identificación de los personajes y completando información relevante relativa a los mismos y a otros aspectos omitidos en estos estudios ${ }^{1336}$. Asimismo aportaremos nuevos datos extraídos de las fuentes y de los testimonios gráficos que completarán el sentido final del programa iconográfico.

\section{Crujía oriental y bóvedas 23 y 24}

Es necesario indicar, para evitar repeticiones continuas, que todas las ménsulas correspondientes a las pilastras ubicadas en la parte externa del tramo oriental, contienen en su parte superior testas de querubines unidos por sus alas, en vez de las tarjetas con inscripciones del resto de ménsulas. Su parte principal la protagonizan diversas representaciones de calaveras, motivo que se reitera hasta la bóveda octava, la segunda de la panda meridional. Estos cráneos pueden ir exentos, con una ornamentación de cintas, tarjetas o el anagrama IHS, como así vemos en la confluencia de las bóvedas tercera con la cuarta, la cuarta con la quinta y ésta con la contigua. Igualmente los cráneos pueden aparecer flanqueados de otras figuras, como los angelillos que sostienen con firmeza la calavera en la pilastra angular de las bóvedas primera y segunda. Como nota anecdótica, un animal monstruoso con cabeza de dragón y cuerpo aquiliforme que identificamos con el mal, muerde el trasero de uno de estos querubines, probablemente con el fin de que suelte el objeto

\footnotetext{
${ }^{1336} \mathrm{El}$ primer análisis iconográfico sobre este claustro en DÍAZ NAVA, Adolfo F. "Un claustro...Op.cit, pp. 93-120, BECERRO DE BENGOA, Ricardo. "El monasterio de Carrión" en La España Moderna, Revista Ibero-Americana, $n^{\circ} 7$, Madrid, 1889, pp. 55-96, y por último REDONDO CANTERA, M ${ }^{\mathrm{a}}$ José. "El programa iconográfico del claustro bajo del monasterio de San Zoilo en Carrión de los Condes (Palencia)" en AIICHP, nº 5. Palencia, 1990, pp. 129-154.
} 
que tiene entre manos. En otros dos casos, a los lados de las calaveras aparecen figurillas desnudas, que, si bien podrían semejar angelillos, no lo son. Una mirada más atenta nos permite desechar esta identificación, pues estos personajes carecen de alas y sus rostros hacen una perversa mueca. Además no sujetan, sino al contrario, son ellos los retenidos contra su voluntad por sus malas acciones, castigados a perecer entre las fauces de la calavera.

Todas estas apoteosis de la muerte harían referencia al tránsito de la vida y el final inherente a todo ser humano, sea cual fuera su condición. La insistencia de este tema en este lienzo del claustro, e incluso, como indicamos, en parte del posterior, se explica por ser este tramo paso obligado de los monjes con los cadáveres de los hermanos que fallecían para hacerles las exequias en el templo ${ }^{1337}$. Esta teoría se refuerza con la presencia del acceso al "De profundis" ubicada originalmente en este lado, pues en esta dependencia que antecede al refectorio, se rezaba el salmo homónimo con el fin de desear un reposo eterno a los difuntos. La inspiración directa de las calaveras hay que buscarla en la sacristía leonesa de San Marcos, donde unos años antes Juan de Badajoz las ornamentaba con idénticos elementos de lazos colgados de argollas.

Bóveda 1: El punto de partida, por tanto, lo constituye la bóveda nororiental correspondiente a la puerta plateresca que nos presenta el tema de la fundación del monasterio. En el centro, San Zoilo, el mártir cordobés, representando anacrónicamente a la moda del XVI, con chaqueta abotonada que acaba en una especie de gorguera y tocado con una gorra con plumas.

Los nervios combados conforman una bella flor de cuatro pétalos en cuyo interior se despliegan cuatros blasones que se repiten. Dos de ellos son cuartelados, cuya lectura es la siguiente: 1 y 3, león rampante, 2 y 4, castillo. Timbrado con corona. Se trata del escudo que adoptaron los Beni Gómez en referencia a sus territorios castellanos. Ambos son idénticos salvo en el lema que se inscribe en las tarjetas que los acompañan.

${ }^{1337}$ DÍAZ NAVA, Adolfo F. “Un claustro...Op.cit, pág. 102. 


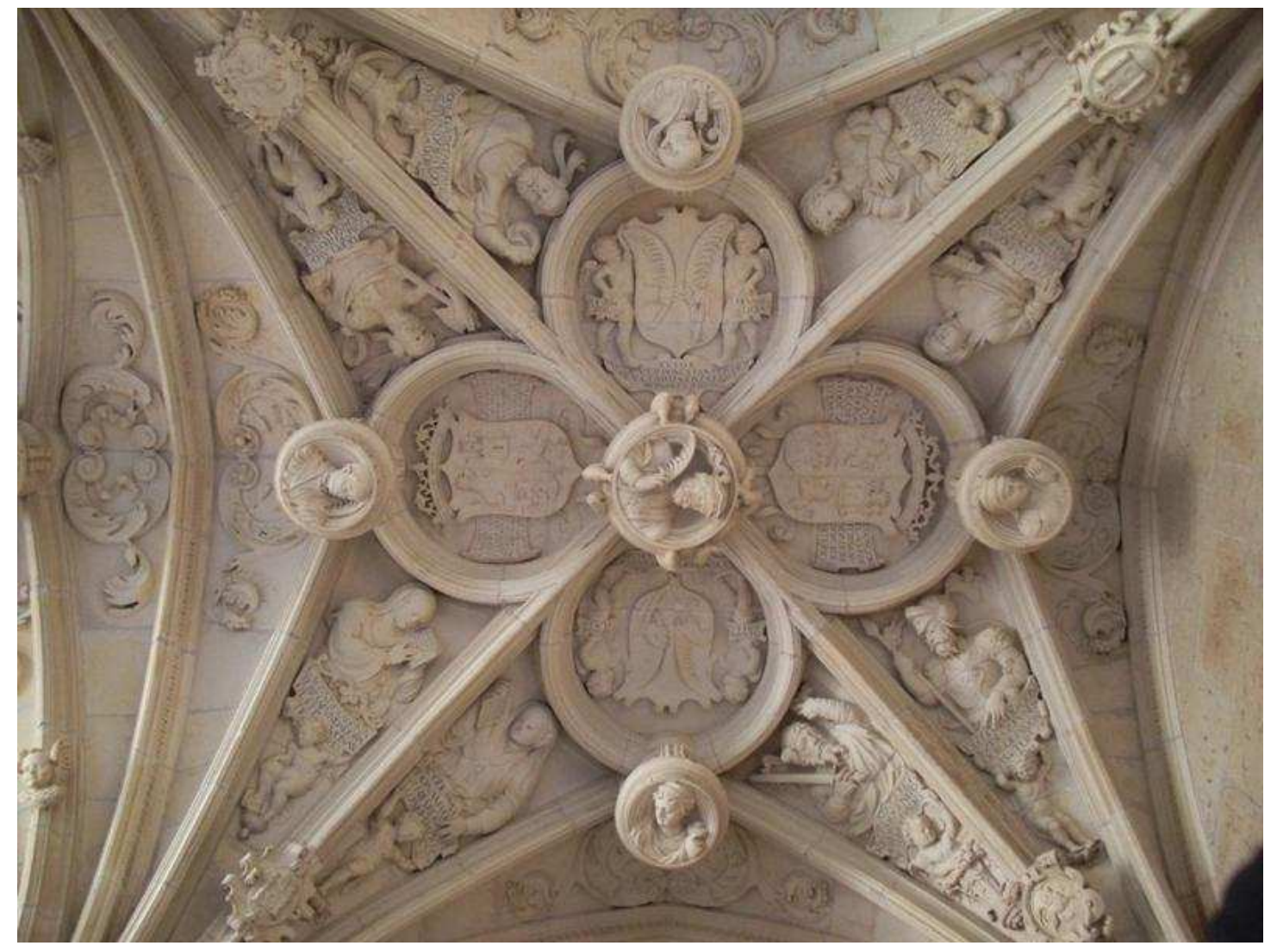

Bóveda 1. Fundación del monasterio de San Zoilo

Uno de ellos identifica a los bienhechores del cenobio: "DEL CONDE DON GOMEZ DIAZ Y DE LA CONDESA DOÑA TERESA, SV MVGER, FUNDADORES Y DOCTADORES DESTE MONASTERIO”.

El otro pone de relevancia los orígenes reales de la condesa Teresa:

"ESTAS ARMAS SON DEL CONDE DON GOMEZ DIAZ Y DE LA CONDESA DOÑA TERESA, SV MVGER, QUE FVE HIJA DEL INFANTE DON ORDOÑO, HIJO DEL REI DON RAMIRO DE LEON Y DE LA INFANTA DOÑA CHRISTINA, HIJA DEL REI DON VERMVDO DE LEON, FUNDADORES DESTE MONASTERIO ${ }^{1338,}$.

${ }^{1338}$ En realidad, doña Teresa era la biznieta y no la nieta de los reyes leoneses. Tal vez se haya omitido voluntariamente a sus padres, el conde Pelayo y doña Aldonza, con el fin de aproximar a la condesa al linaje real o por un simple error de los copistas. Véase MARTÍNEZ DÍEZ, Gonzalo. "La familia...Op.cit, pág. 582-583. 
Los otros dos escudos identifican la abadía carrionesa a través de dos palmas del martirio que se refieren a la advocación del cenobio. El escudo va sustentado por una pareja de graciosos angelillos dispuestos de cuerpo entero que sujetan, con la otra mano, las tarjetas identificativas de los mártires hispanorromanos: "DE SAN ZOIL" y "DE SAN FELICES”. Bajo sus pies, continúa la inscripción que justifica la doble advocación del cenobio: "CUYOS CUERPOS ESTÁN SEPULTADOS EN ESTE MONASTERIO”. El primogénito de los condes, don Fernando Gómez, como premio a los servicios militares prestados en Córdoba, trajo en 1070 las reliquias de los dos mártires, junto a las del Obispo Agapio ${ }^{1339}$. San Zoilo, como indicamos, protagoniza la bóveda, pues aunque originalmente se designó el cenobio bajo la doble advocación, con el tiempo solamente la mantuvo San Zoilo.

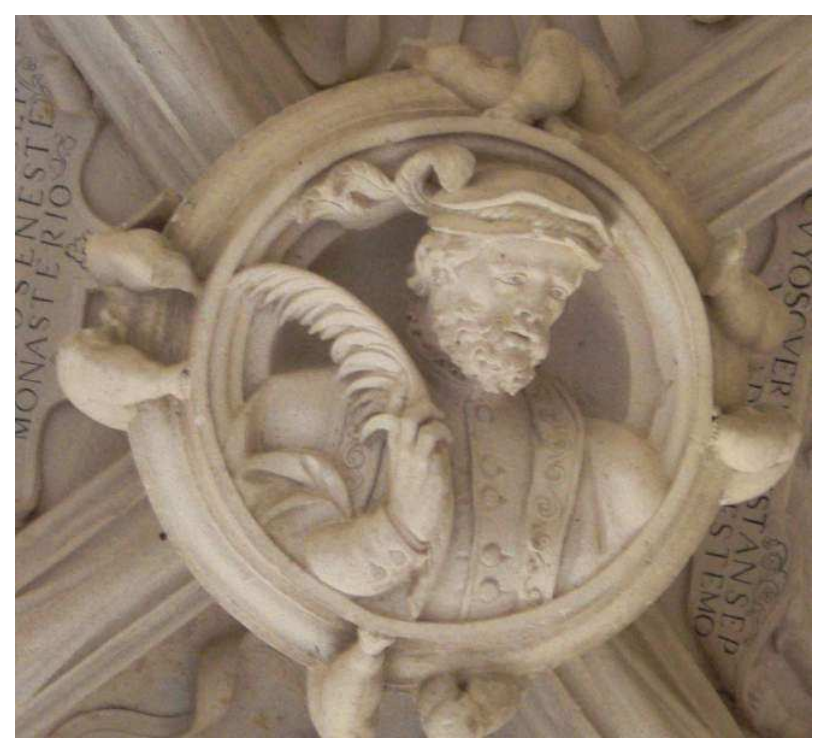

Bóveda 1. San Zoilo en la clave central.

Por su parte, San Félix, figura en una de las claves secundarias, acompañado nuevamente por la palma del martirio. En éstas además se representan a María Magdalena, modelo de conversión cristiana y titular del templo parroquial que fue incorporado a San Zoilo por Pedro González de Mendoza en $1479^{1340}$. Junto a ella, un frasco de perfume, en recuerdo a la unción de los pies de Jesús en casa de Simón,

${ }_{1339}^{133}$ ANDRÉS ORDAX, Salvador. Iconografía...Op.cit, pág. 23.

${ }^{1340}$ AHN. Clero Secular-Regular. Legajo 5334 s/f. Visitas. 
objeto que también llevaría a su sepulcro ${ }^{1341}$. En las otras dos claves, San Benito, fundador de la Orden benedictina a la que pertenece el templo, que sujeta el báculo y Santa Escolástica, su hermana, con quien fundó Montecassino, que sostiene en su mano la Regla Benedictina ${ }^{1342}$.

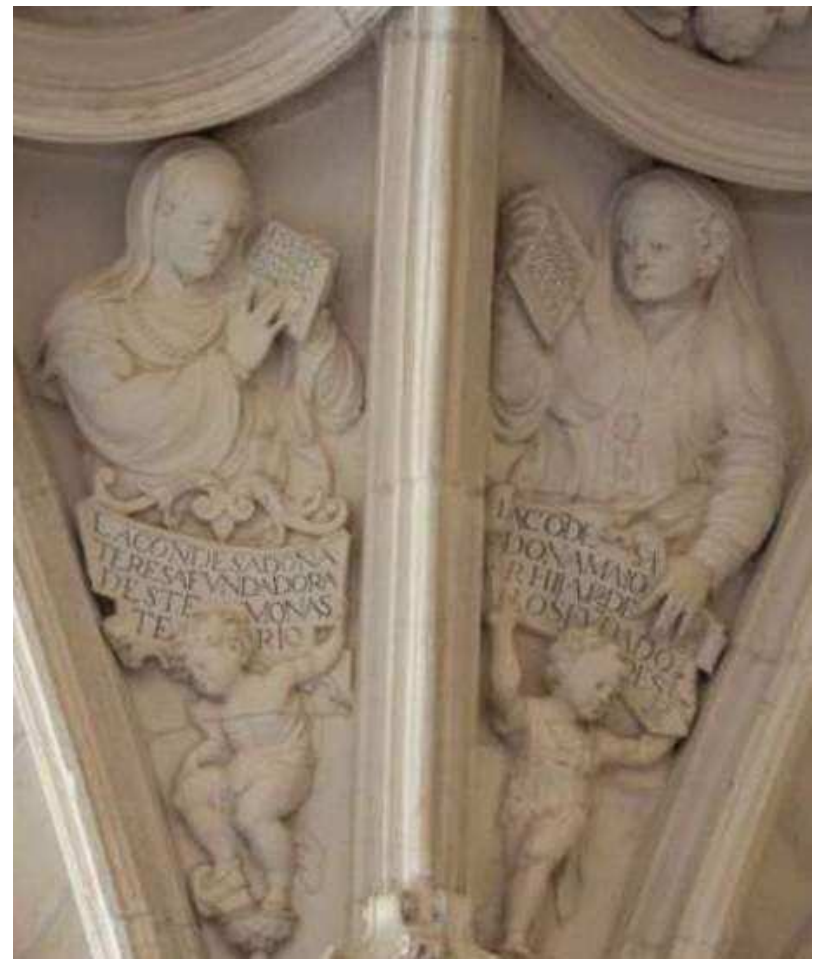

En los plementos se concreta la representación de los miembros fundadores del cenobio, fácilmente identificados a través de su respectiva tarjeta. La condesa Teresa, fundadora del cenobio, porta un libro que contiene las palabras del Anuncio a la Virgen: "AVE MARÍA GRATIA PLENA $^{1343, "}$. A su lado, la mayor de sus hijas, su hija, Doña Mayor, que también sostiene un libro que reza en castellano: "SEÑOR, ABRÍAS

\section{Bóveda 1. La condesa Doña Teresa y su hija doña Mayor.}

LOS MIS LABRIOS E MI BOCA ANUNCIARÁ”. Se han omitido por falta de espacio las palabras que finalizan la frase: "Tu alabanza"1344. Ambos textos, junto a la presencia de los personajes benedictinos, nos permite identificar a la familia BeniGómez como siervos de Dios y devotos de la fe cristiana. Doña Sancha y Doña Elvira, hijas segunda y tercera de la condesa, que portan igualmente un libro, van vestidas anacrónicamente, como su hermana pequeña. En lugar de mostrar una vestimenta propia del siglo XI, podemos observar las gorgueras con lechuguino, así como el uso de joyas, visibles en la cadena de perlas que lleva doña Mayor a modo de cinta, elementos propios de la suntuosidad de la nobleza siglo XVI. Sin embargo

\footnotetext{
${ }^{1341}$ DUCHET-SUCHAUX, Gaston y PASTOUREAU, Michel. Guía iconográfica de la Biblia y los santos. Alianza Editorial. Madrid, 1996, pág. 266.

${ }^{1342}$ HEREDIA, Fray Antonio de. Vidas... Tomo primero, Op.cit, pp. 559-561.

${ }^{1343}$ Lucas, 1.

1344 “Domine labia mea aperies et os meum adnuntiabit laudem tuam” Salmos, 50:17
} 
todas ellas cubren sus cabelleras rizadas con una toca, acorde al decoro de una dama devota.

Entre los miembros masculinos del linaje, hallamos al conde don Gómez, fundador del monasterio y tres de sus hijos, su primogénito, don Fernando Gómez, don García y don Pelayo, que lucen elementos acordes a su dedicación guerrera. Recordemos que la tradición identifica a don Fernando como la figura que trajo de Córdoba las reliquias de San Zoilo, Félix y Agapio a Carrión hacia $1070^{1345}$. De su hermano don García, se dice que trajo a los monjes de Cluny necesarios para la fundación ${ }^{1346}$. Don Gómez y don Pelayo -de quienes nada relevante destacan las crónicas- figuran vestidos con armadura y portan diversas armas, el primero una lanza y el segundo un hacha. Por su parte, don García porta un yelmo con lambrequines y su hermano mayor, Fernando, un casco y una espada. Ambos van vestidos con sendas túnicas y sostienen en su mano izquierda una bolsa de tela que podemos identificar con el botín obtenido de la victoria. Todos ellos, hombres y mujeres, protegerían la casa benedictina haciendo ostentación de su insigne abolengo $^{1347}$.

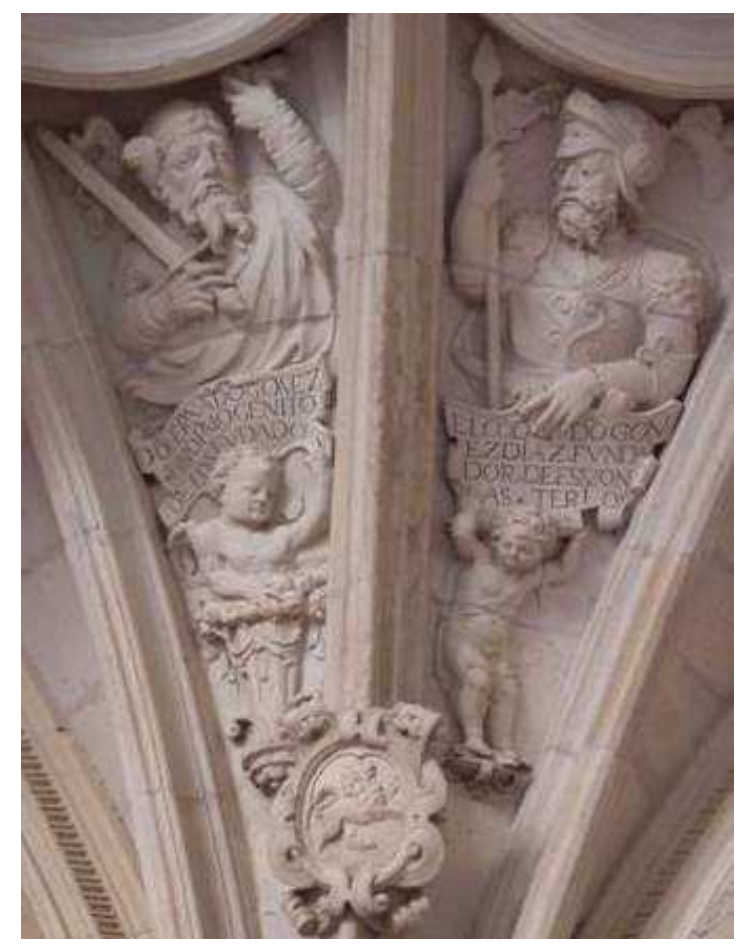

Bóveda 1. El Conde don Gómez Díaz y su primogénito don Fernando Gómez.

\footnotetext{
${ }^{1345}$ YEPES, Fray Antonio. Crónica...volumen III, Op.cit, pp. 53-55.

1346 SANDOVAL, Prudencio de. Primera parte...Op.cit, pp. 79.

${ }^{1347}$ De todos estos personajes se habla en el apartado correspondiente a la historia del cenobio.
} 
La familia de los Beni- Gómez, era más numerosa de lo que nos muestra la bóveda, pues por motivos espaciales se ha omitido al vástago menor del linaje: doña Aldonza, benefactora de la orden cluniacense que fue enterrada junto al resto del linaje condal en la galilea dispuesta a tal efecto a los pies del templo ${ }^{1348}$. El artista, en este caso Miguel de Espinosa, nos muestra en un espacio reducido, todo un abanico de rostros e indumentarias en los personajes, sin que ninguno se repita, así como las posturas de los ángeles que sustentan sus tarjetas, todos diversas entre sí.

En las ménsulas de esta primera bóveda, concretamente en las que flanquean la Puerta de las Procesiones, se sitúan Adán y Eva. Atendiendo a todas estas representaciones, bien podría llamarse ésta la "Bóveda del Origen", en un doble sentido, pues figuran los descendientes directos de Dios que inaugurarían el ciclo de la Ascendencia de Cristo. Por otro lado, la presencia de la condesa doña Teresa y el conde Gómez Díaz, dan inicio a la andadura del cenobio benedictino.
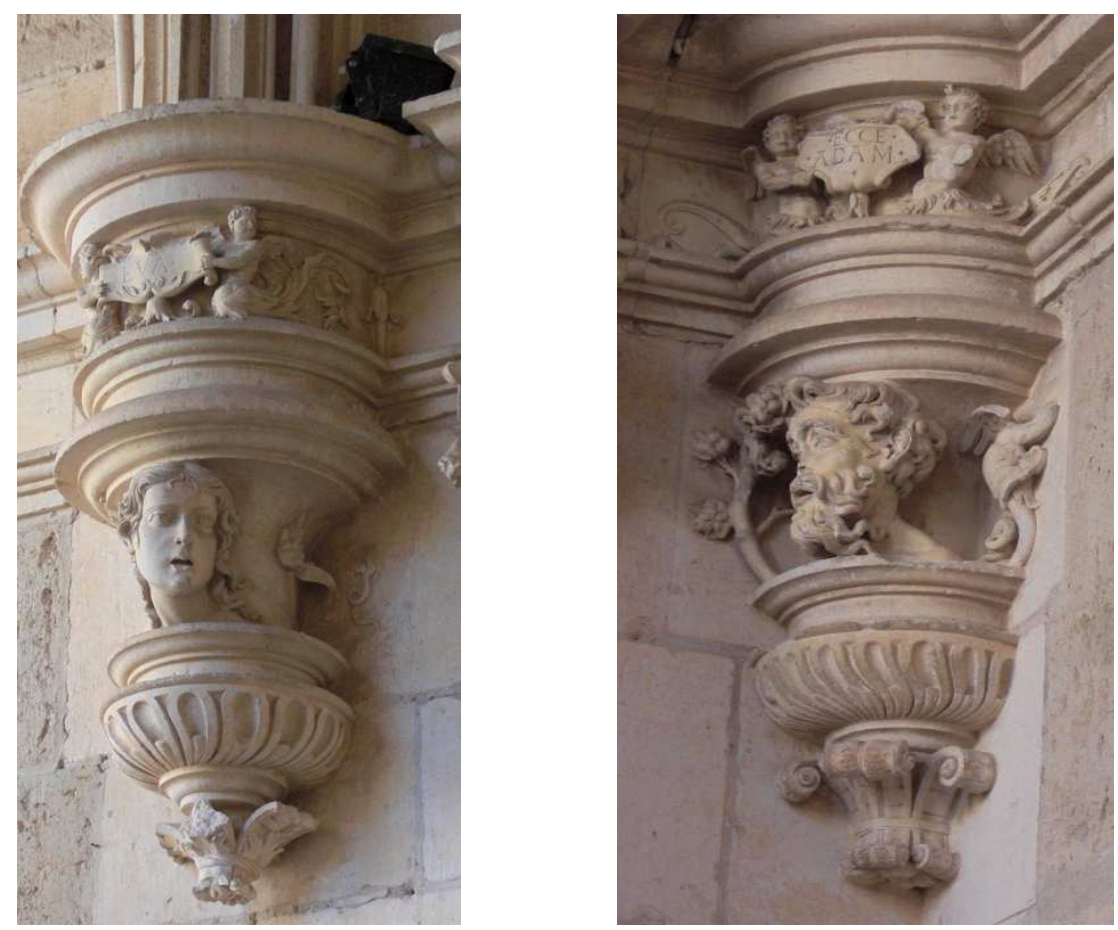

Ménsulas que representan a Eva y Adán.

${ }^{1348}$ Sobre la misma, remítase al apartado relativo a la fundación y los sepulcros condales. 
Bóveda 23: La ascendencia de Cristo continúa tras el Diluvio Universal con los personajes situados en las dos últimas bóvedas de la panda septentrional bóvedas 23 y 24 - que enlazarían con los personajes de las ménsulas de la primera bóveda, que serían Adán, Eva y Seth. Se continúa seguidamente por los personajes contenidos en el Evangelio de San Lucas, omitiendo, con un fin eminentemente pragmático, las generaciones existentes entre Cainám y Noé.

El personaje más antiguo se ubica en la clave central, con Sem, hijo de Noé. Representa la virtud, pues cubre a su padre cuando se emborracha con el vino procedente de la viña que había plantado tras salvarse del Diluvio, por eso éste le bendice $^{1349}$. Le flanquean Arphaxad, padre de Cainam, Cainam, padre de Sela, Sela, padre de Heber, y por último Heber, padre de Peleg, de quien tomaron su nombre los hebreos, sus descendientes, por sus buenas costumbres y hechos loables ${ }^{1350}$. En este caso la lectura se hace de dentro hacia fuera, es decir, de Sem descienden el resto de personajes que figuran a continuación.

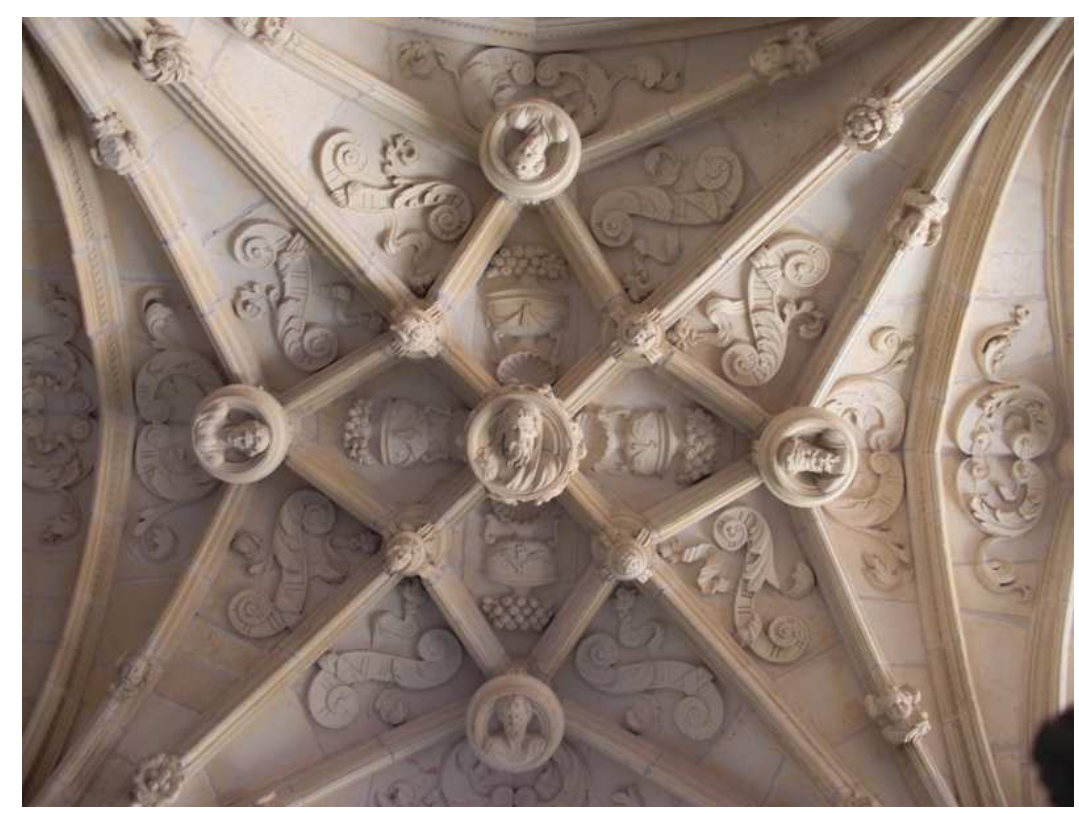

Bóveda 23. Ascendencia de Cristo

\footnotetext{
1349 Génesis, 9, 18-29.

${ }^{1350}$ MARTELL, Carlos. Anales del mundo desde la creación de él y un tratado del origen de las poblaciones de toda la Europa. Iván de Ibar. Zaragoza, 1664, pág. 28.
} 
En las ménsulas, San Juan Bautista, predicador y asceta judío que, si bien, no forma parte del ciclo de Apóstoles al que acompaña, su razón de ser radica en ser precursor de Cristo por su predicación en el desierto antes de la llegada del Mesías. Su cabeza expirante reposa sobre un plato en el que figura la inscripción: "CAPVT IVANIS", en relación al episodio de su decapitación por orden de Herodes Antipas bajo el deseo de Salomé en la fortaleza de Maqueronte ${ }^{1351}$. En la ménsula frontera, en el muro interno se ubica su homónimo, que cerraría tanto el ciclo de Evangelistas como el de Apóstoles de las ménsulas precedentes.
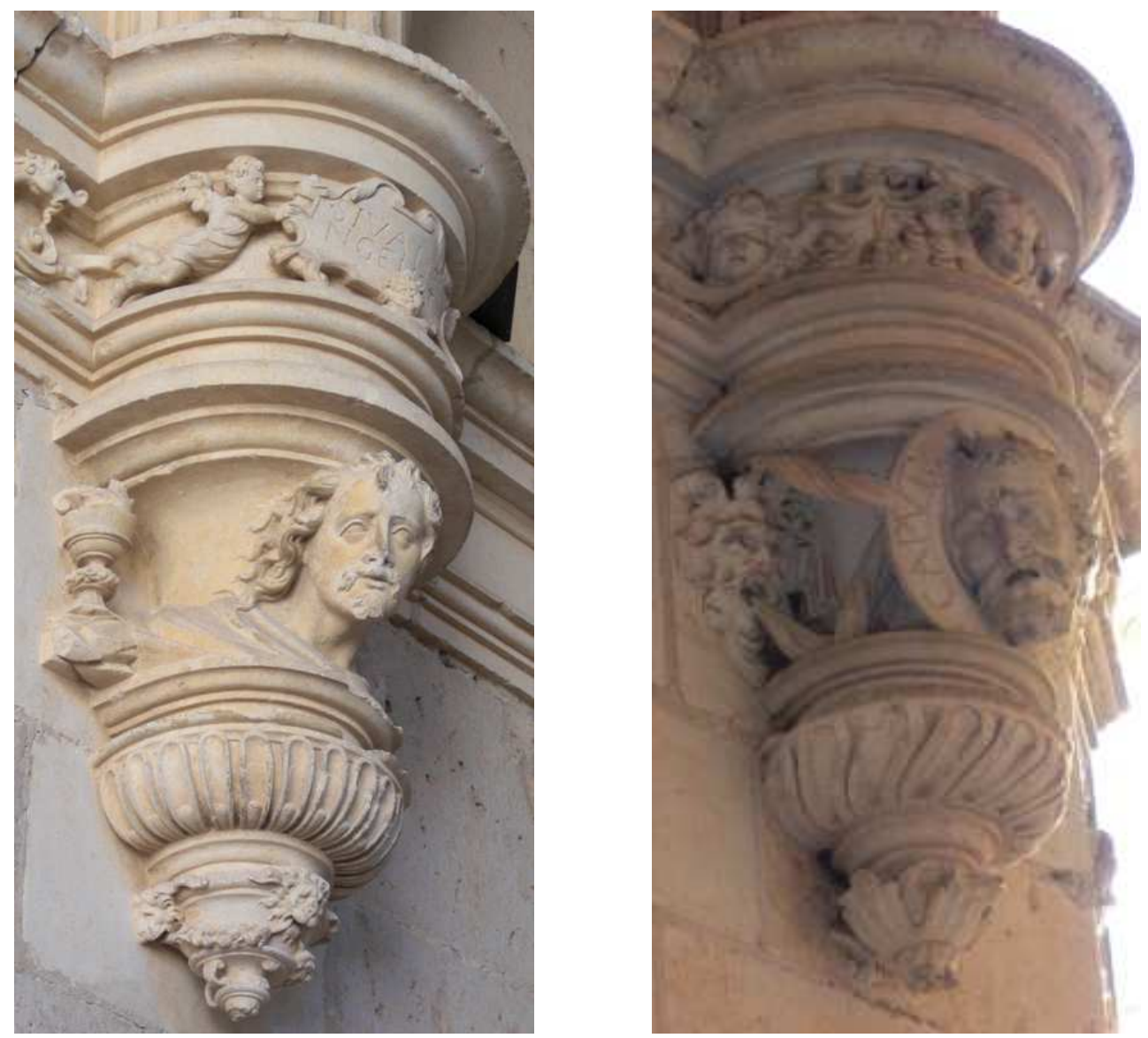

\section{Ménsulas que representan a San Juan Evangelista y San Juan Bautista.}

Bóveda 24: Continúa la genealogía de Cristo siguiendo el mismo orden que en la bóveda precedente, es decir, partiendo de los personajes ubicados en las claves

${ }^{1351}$ Marcos 6,16-29 y Mateo 14, 3-12. 
ubicados en la confluencia de los nervios terceletes y combados donde se sitúan Peleg, padre de Ragau, Ragau padre de Séruj, Séruj, padre de Najor, Najor, padre de Tera o Thare, que aparece en el centro. Al parecer fue idólatra durante gran parte de su vida hasta que se convirtió al judaísmo, sufriendo la persecución de los caldeos $^{1352}$. Tera fue el padre de Abraham, a quien acompañó hasta la salida de Haran, para que peregrinase hasta Canaán. Enlazará con su primogénito, ubicado en la ménsula de la tercera bóveda por donde continuaría el ciclo, con Isaac y Jacob, en las ménsulas sucesivas que explicaremos a continuación, pues éste último es padre de Judá, representado en la segunda bóveda.

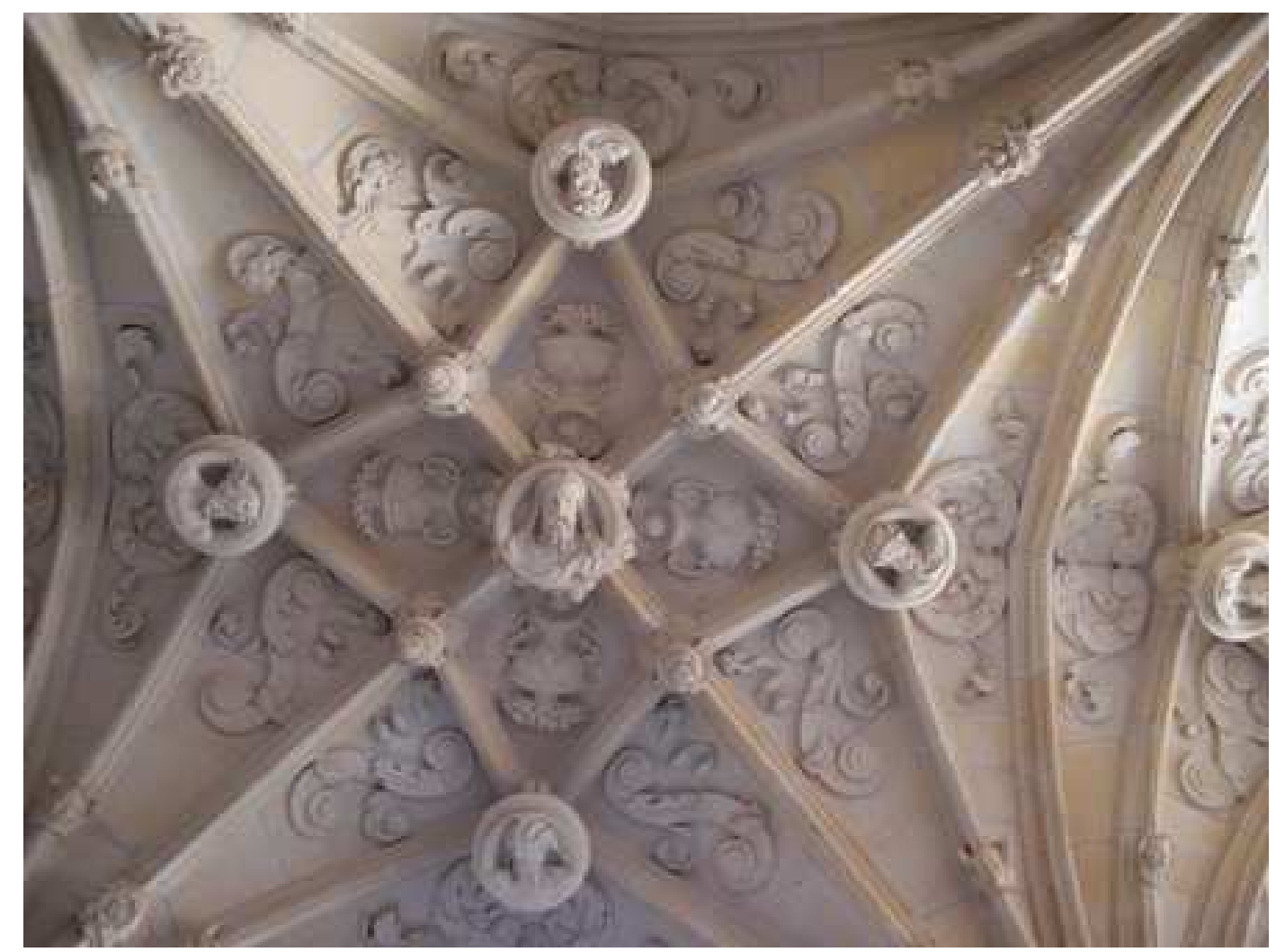

Bóveda 24. Ascendencia de Cristo.

Bóveda 2: El acceso a la sacristía se ubica en este tramo. Continúa la genealogía en los plementos adyacentes al medallón central con Judá, de quién se relata el célebre episodio con su nuera Tamar, ubicada en la bóveda décimo-cuarta,

${ }^{1352}$ MARTELL, Carlos. Anales...Op.cit, pág. 64. 
entre las mujeres pecadoras ${ }^{1353}$. En el tondo contiguo, el fruto de este matrimonio, Phares, del linaje de los parsitas que se trasladó a Egipto con las doce tribus, estableciéndose en Jerusalén tras el destierro. En su viaje le acompañó su hijo Esrom, ubicado junto a él en la bóveda, que se quedó finalmente en Trasnjordania ${ }^{1354}$. Por último figura el hijo de éste, Aram.

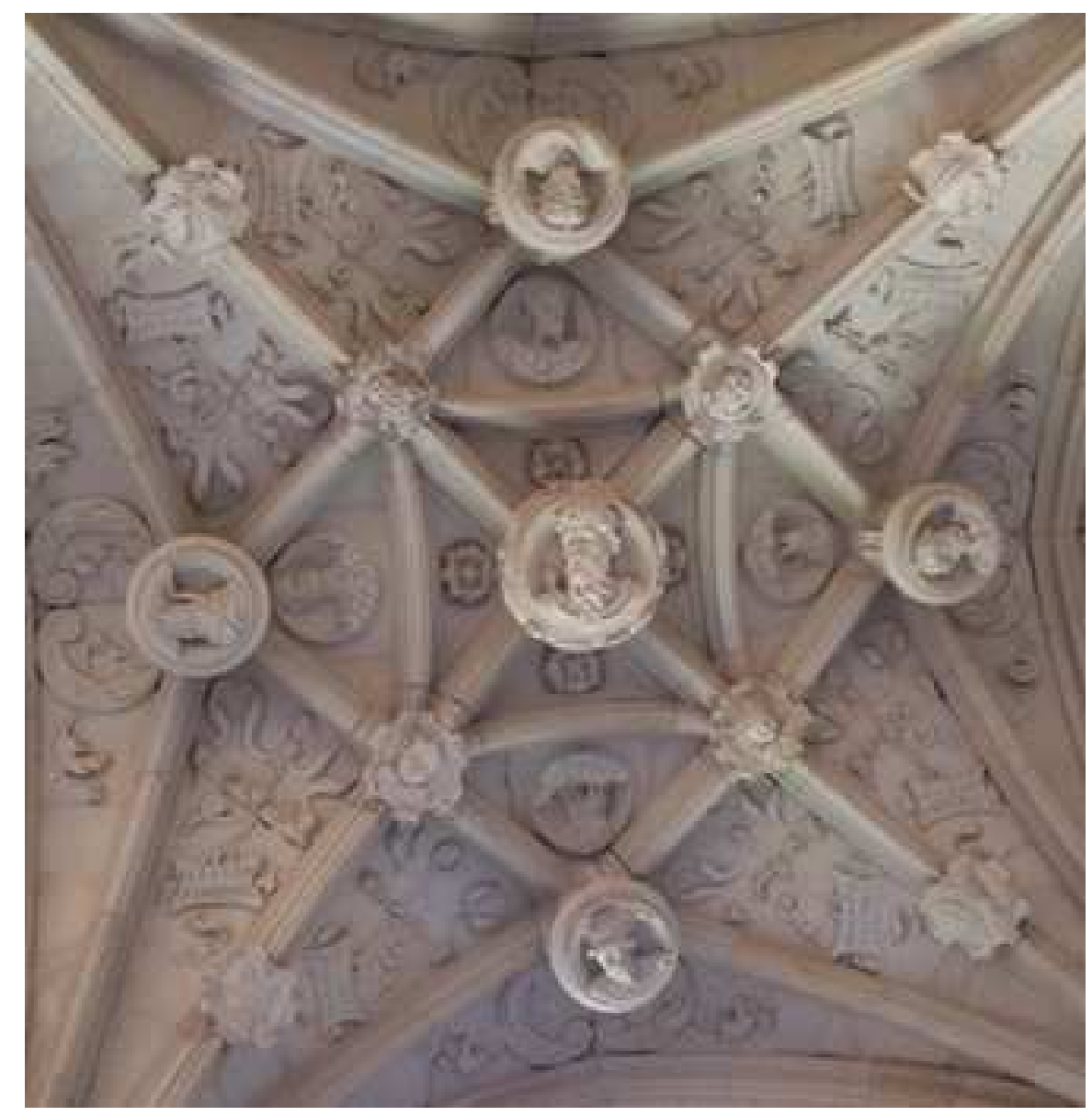

Bóveda 2. Ascendencia de Cristo.

En las claves de los nervios terceletes prosigue la línea familiar a través del hijo de Aram, de nombre Aminadab y padre de Naasón, junto a quien figura. Naasón era "príncipe de los hijos de Judá" y ayudó a Moisés a elaborar el censo de las

1353 Génesis, 38.

${ }^{1354}$ Algunos datos de los personajes bíblicos en Cristo TENA BELTRÁN, Silvia. "Los antepasados de Cristo en la escalera del coro de la Basílica de Morella" en Ars Longa. Cuadernos de Arte. n³. Valencia, 1992, pp. 156-157. 
tribus que regresaron de Egipto ${ }^{1355}$. Las representaciones se completan con el primogénito de éste, de nombre Almón o Salmón, y con Booz, hijo de Almón y padre de Obed. Siguiendo este orden lógico, Obed debería figurar en la clave principal; sin embargo, dada la relevancia de su biznieto, se hace un salto generacional, concediendo el justo protagonismo a Salomón. Hijo de David y Betsabé, no podía faltar en este ciclo de personajes representativos de la historia judía, no sólo por ser un icono de sabiduría sino por ser autor de tres de los libros del Antiguo Testamento: el Eclesiastés, Proverbios y Cantar de los Cantares. La construcción del Templo que lleva su nombre fue su aportación más significativa al pueblo judío ${ }^{1356}$. De rostro bello y facciones idealizadas como una divinidad olímpica, porta una corona y luce una capa anudada al hombro.

Los cuatro cueros recortados que, precediendo a las cabezas de querubines, interrumpen los nervios diagonales de la bóveda, nos recuerdan a través de sus palmas de martirio, la doble dedicación del cenobio a San Zoilo y San Félix, como vimos en la bóveda precedente.

Contiguos a los nervios diagonales, los plementos presentan diversas tarjetas, engalanadas con sendos lazos y cintas. Uniendo sus textos, forman el capítulo uno del versículo 14 del Libro de Isaías: "PROPE EST UT VENIAT TEMPUS EIUS ET DIES EIUS NON ELONGABUNTUR MISEREBITUR ENIM DOMINUS IACOB ET ELIGET ADHUC DE ISRAHEL ET REQUIESCERE EOS FACIET SUPER HUMUM SUAM TEMPVS EIVS ET DIES DOMINUS IACOBET”. Estas palabras inician la profecía acerca del regreso del pueblo del cautiverio de Babilonia ${ }^{1357}$.

\footnotetext{
1355 Ibídem, pág. 157.

${ }^{1356}$ GASTON y PASTOUREAU, Michel. Guía iconográfica...Op.cit, pp. 339-340. Sobre Salomón, THIVOLLIER, Pierre. Salomón: rey sabio y famoso, constructor del templo de Jerusalén. Verbo divino. Navarra, 1985.

1357،Próxima está a llegar éste su tiempo y sus días no están remotos, porque al fin, el Señor tendrá compasión de Jacob y todavía escogerá algunos de Israel y hará que reposen en su nativo suelo. Se juntará con éstos el extranjero y se incorporará con la casa de Jacob" El texto del Evangelio reproduce estas palabras excepto en la parte "tempvs eivs et dies" que es sustituido por "adiungetur advena ad eos et adherebit” TORRES AMAT, Félix. La Sagrada Biblia nuevamente traducida de la Vulgata Latina al español. Tomo III del Antiguo Testamento que contiene el libro de los Salmos, Proverbios, Ecclesiastés, Cantar de los Cantares, el Libro de la Sabiduría y la Profecía de Isaías. Imprenta de Miguel de Burgos. Madrid, 1834, pág. 519.
} 
Seth y su esposa Élvora aparecen en las ménsulas y en la pilastra continuando la ascendencia comenzada con Adán y Eva. Ambas figuras contrastan en su ejecución: los cabellos alborotados de Seth, como si una ráfaga le hubiera sorprendido, frente a la fragilidad y delicadeza soberbia de Élvora.
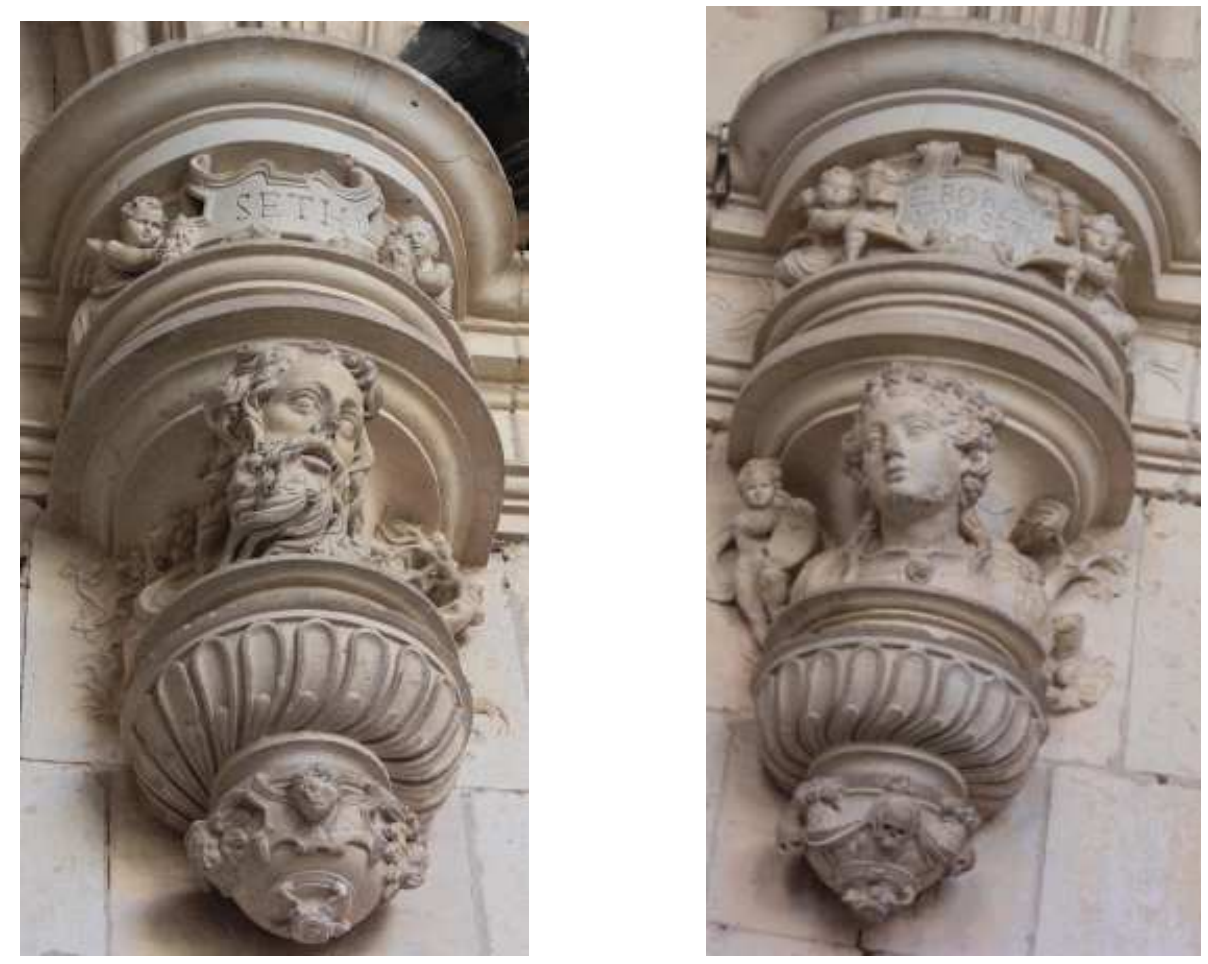

Ménsulas que representan a Seth y su esposa Élbora.

La cabeza de Seth compendia las características estilísticas de Miguel de Espinosa, como son la fuerza expresiva a través de sus pómulos salientes, la boca entreabierta y el entrecejo fruncido. Los ojos están esculpidos con globos oculares que sobresalen de sus cuencas, como si se tratase de la figura de un invidente. En algunos de su trabajos, Espinosa dejaba sin cincelar el iris de sus personajes para que fuera la policromía la que fingiese sus rasgos anatómicos como así hizo en la figura del Padre Eterno de la ermita de la Virgen del Otero de la cercana población de Frómista, con el cual podemos relacionar estilísticamente a Seth ${ }^{1358}$. Los bucles ondulados y los mechones de la cabellera aportan un gran dinamismo a esta suprema figura, considerada una de las mejores tallas de todo el claustro. De los tres hijos de

${ }^{1358}$ PARRADO DEL OLMO, Jesús María. "Sobre algunas esculturas del siglo XVI...op.cit, pp. 311312. 
Adán, solo Seth fue engendrado a su imagen y semejanza, en quién a su vez estampó Dios la suya. Por eso en él se continuó tras el Diluvio “...la línea del Mesías que avía de redemir el mundo... ${ }^{1359}$ ",

Bóveda 3: En esta bóveda nuevamente se efectúa una digresión del orden lógico en beneficio del personaje ubicado en la clave central, desencadenando un cierto desorden generacional. Es decir, Obed, bisabuelo de Salomón, a quien cedió su puesto en la bóveda precedente, se reubica en uno de los plementos que rodean la clave central. Era padre de Jesé, omitido en esta bóveda, y abuelo del rey David, que protagoniza el medallón central. Segundo rey de Israel después de Saúl, arpista y autor de los Salmos, es uno de los personajes más célebres del Antiguo Testamento. Aparte del célebre episodio de la lucha contra Goliat, interpretada tradicionalmente como la prefiguración del triunfo de Cristo sobre el mal, hay que destacar su papel de unificador del reino judío que estableció la capital en Jerusalén, a donde trajo el $\operatorname{arca}^{1360}$. Se le considera un rey modélico a pesar de haber conjurado la muerte de Urías, el esposo de su amante ${ }^{1361}$. Coronado como su hijo, de su cuello cuelga un gran medallón, atributo que corresponde más bien a Salomón, como vemos en los relieves de la escalera del coro de Morella, en Valencia ${ }^{1362}$.

Los bustos que acompañan a Obed, enmarcados en óvalos continuarían la lógica sucesión, En ellas se representan a los cuatro descendientes directos: al hijo de Salomón, llamado Roboam, éste padre de Abías, Abías, padre de Asaf y por último a Asaf, padre de Josafat.

Los plementos que rodean estas figuras contienen una ornamentación de carácter renacentista, a través de los motivos en ese avolutados unidos por alguno de sus lados, acompañados por unas cintas que se despliegan colgando de argollas. Esta rica ornamentación de raigambre siloesca deja paso a los medallones de las claves

\footnotetext{
${ }^{1359}$ MARTELL, Carlos. Anales...Op.cit, pág. 6.

${ }^{1360}$ DUCHET-SUCHAUX, Gaston y PASTOUREAU, Michel. Guía iconográfica...Op.cit, pp. 124-

127 Toda su vida en el Antiguo Testamento, Samuel I y II.

${ }^{1361}$ El episodio de la traición en LOZANO, Cristóbal. El rey penitente David arrepentido. Historia sagrada autorizada con lugares de escritura, morales y ejemplos. Madrid, 1690.

${ }^{1362}$ TENA BELTRÁN, Silvia. "Los antepasados de Cristo en la escalera del coro de la Basílica de Morella" en Ars Longa. Cuadernos de Arte. n³. Valencia, 1992, pág. 57.
} 
secundarias donde se representan a Josafat, padre de Jorám, Jorám, padre de Ozías, Ozías, padre de Jonatás.

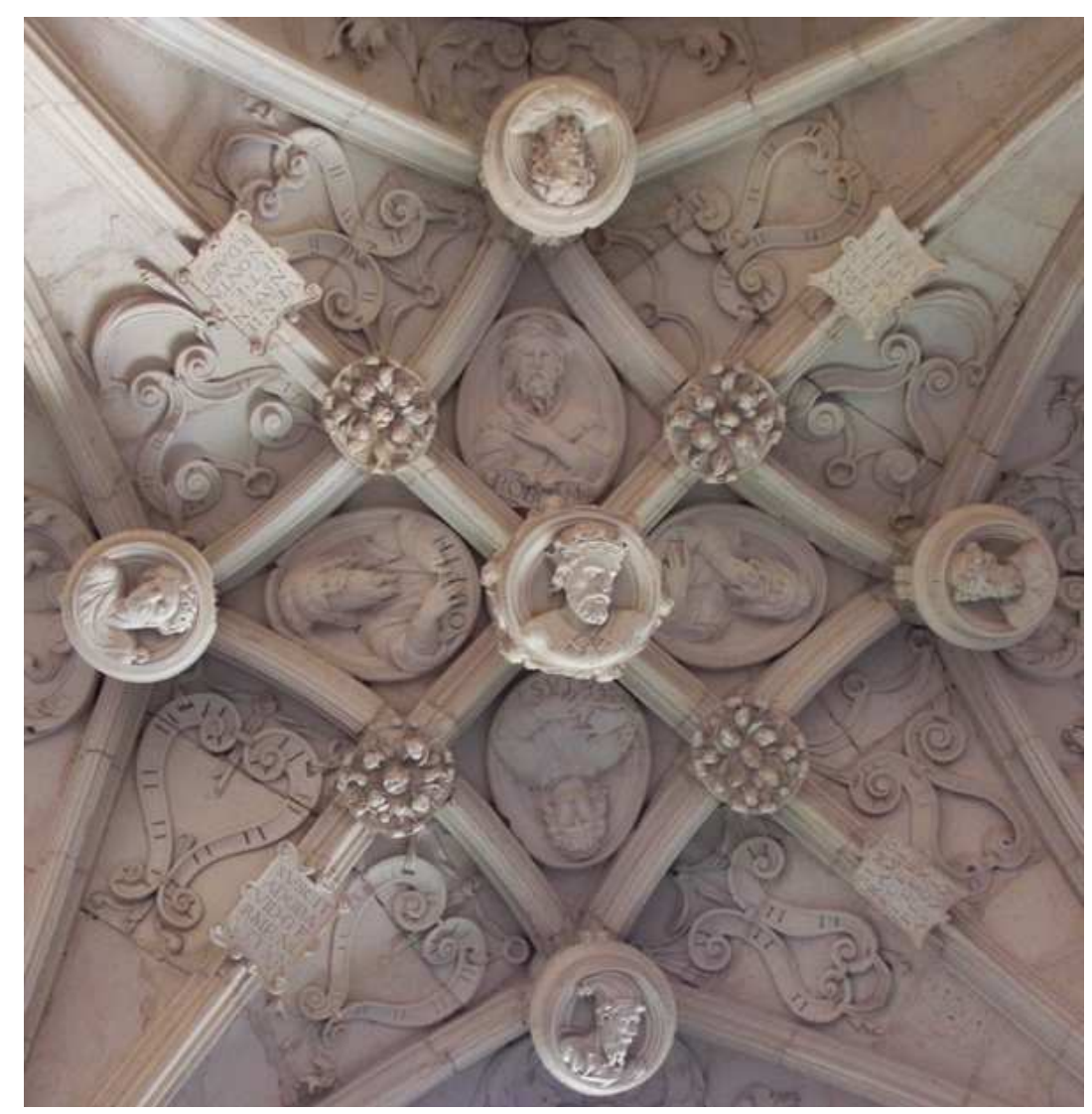

Bóveda 3. Ascendencia de Cristo.

Los nervios diagonales de la crucería se hallan interrumpidos por un ramillete de flores inserto en un óvalo, seguido de una tarjeta que contiene profecías mesiánicas extraídas de Isaías: "VENIEN SUENIET ET NON TARDABIT ET SUSCITABO DAVID GERMEN IUSTUM, ET REGNAVIT REX, ET SAPIENS ERIT; SI MORAM FECCERIT EXPECTA EUM ${ }^{1363 ”, ~ I s a i ́ a s ~ p r o n o s t i c o ́ ~ l a ~ l l e g a d a ~ d e ~ u n ~}$ Mesías nacido del tronco de David, es decir, de un descendiente de éste, con varios siglos de antelación, mensaje que, por otra parte, viene a transmitirnos la doble naturaleza de Cristo. La última de las frases inscrita en la bóveda no se recoge en el libro de Isaías. Posiblemente fue deseo del abad de San Zoilo modificar la cita con

1363 "Tiempo vendrá y no tardará en que salga de David un germen (pimpollo) justo que reinará y será sabio. Si tardara, espéralo”.HERDECK, Juan José. Defensa de la religión christiana. Imprenta Real. Madrid, 1797, pág. 92. 
una frase concisa, un mensaje directo que alentara a la comunidad a mantener la fe en la llegada próxima del Salvador, como así hicieron los judíos.

En la segunda mitad del siglo VIII a. C, época en que vivió Isaías, se desarrolló un conflicto entre Asiria y Egipto por el control de Oriente Medio. En torno a ese caos, pequeños estados como el de Judá, sufren esta situación. Durante el reinado de Ozías (767-739) se vivió una época de esplendor, comenzando las hostilidades con Asiria cuando su hijo Jotam se niega a pagarles el tributo que se les imponía. En este ambiente de sumisión, Isaías ofrece el consuelo para el pueblo judío, convirtiéndose en el profeta que, según San Ambrosio, mejor prepara para el Evangelio $^{1364}$.

Bóveda 4: Ajustándose perfectamente a la sucesión del parentesco de María, figuran, en los plementos que rodean la clave central y dispuestos en medallones, Achaz, el hijo de Jonatás, con quien concluimos en la bóveda precedente. A éste le acompañan su hijo Ecequías, padre de Manasés, Manasés, padre de Amón o Amós, y Amón, padre de Josías.

Más alejados, ubicados en las claves secundarias de la crucería, se hallan el hijo de Amós, de nombre Josías, su hijo Jeconías, con el cual llega el destierro en Babilonia. Completan el ciclo Salathiel, hijo de Jeconías y padre de Zorobabel. Figura en la clave central Zorobabel, flanqueado por cuatro bucráneos, relegando a la clave secundaria a su hijo Abiud. Cuatro calaveras sobre cueros recortados ubicadas en los nervios diagonales, nos recuerdan, una vez más en esta crujía, la fugacidad de la vida y el final inminente de cualquier ser humano. En los plementos de mayor tamaño conformados por la confluencia de los nervios terceletes, nos encontramos ocho parejas de serpientes, alusivas al mal, retenidas con cintas que penden de varias argollas. Todas ellas, dispuestas simétricamente, se encuentran afrontadas, salvo dos parejas, ubicadas en el mismo tramo de la plementería, que miran en direcciones opuestas.

1364 JIMÉNEZ HERNÁNDEZ, Emiliano. Isaías, el Profeta de la consolación. Madrid, 2007, pp. 913. 
Las inscripciones ubicadas en los extremos de las bóvedas contienen un versículo de respuesta de la Virgen María a la Anunciación del ángel: "ECCE ANCILLA DOMINI. FIAT MIHI SECUNDUM VERBUM TUUM""1365. Tras recibir la feliz noticia, llena de alegría, la Virgen entona un canto, reproduciéndose una de sus estrofas: "BEATAM ME DICENT OMNES GENERATIONES ${ }^{1366 ”, ~}$

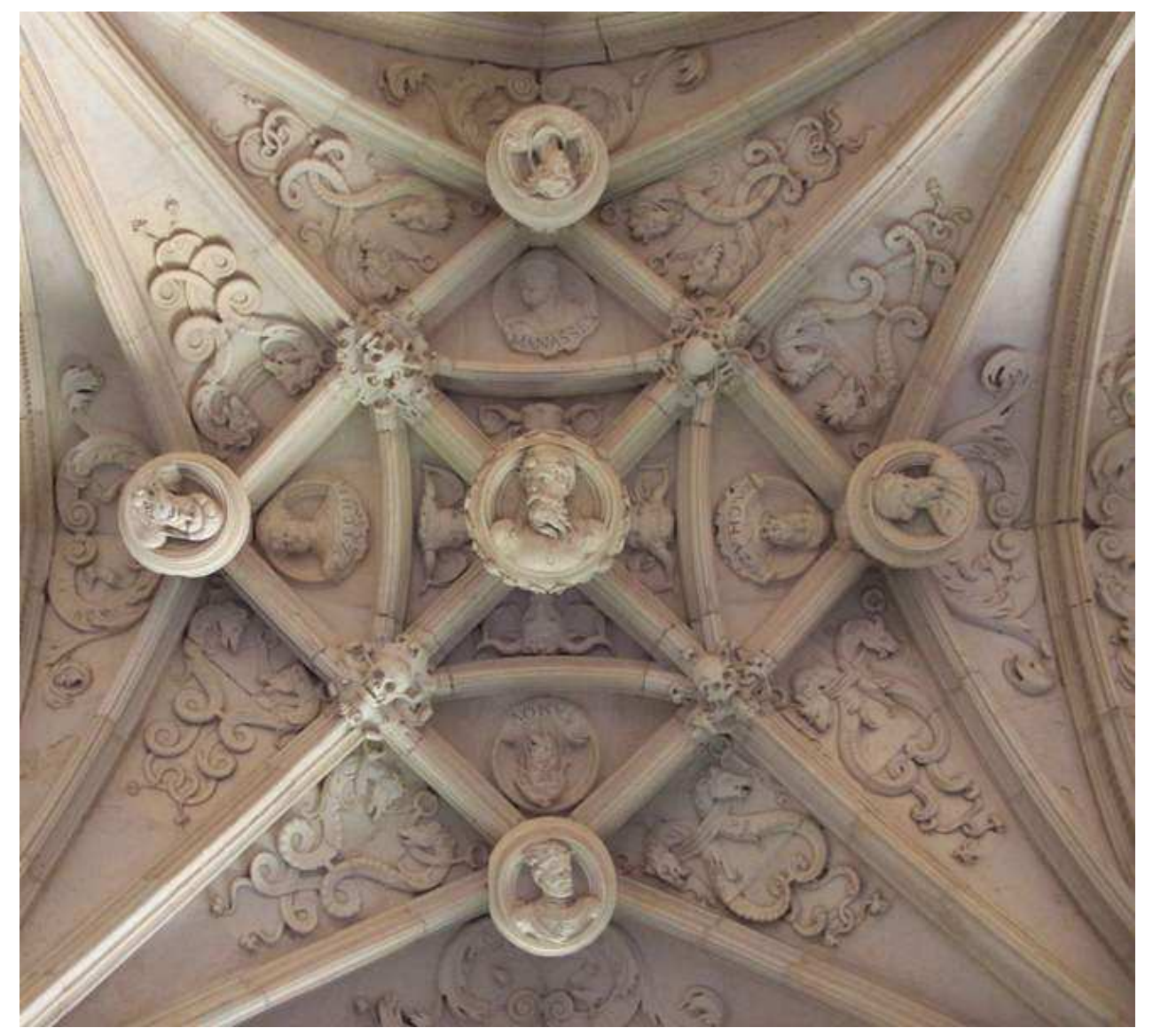

Bóveda 4. Ascendencia de Cristo.

Las ménsulas, de clara filiación renaciente, representan a Abraham, patriarca de Israel y a Sara, su obediente y hermosa esposa. Abraham figura como un anciano barbado de gran expresividad, que entreabre su boca al recibir el Anuncio de su esperada paternidad de un niño llamado Isaac. Representado a su izquierda, el ángel se presencia en la puerta de su casa y da la feliz noticia del milagro al anciano, que ya contaba con noventa y nueve años de edad. Su esposa Sara aparece representada

1365 "He aquí la esclava del Señor. Hágase en mí según tu palabra” Lucas, 1, 38.

1366 "En adelante todas las generaciones me llamarán beata” Lucas, 1,48. 
como una mujer de edad avanzada y tocada de un turbante acorde a la moda de la época. Frunce el ceño y arruga su frente, tal vez mostrando la sorpresa ante la noticia de su fertilidad a los noventa años de edad ${ }^{1367}$. El tema doble de la concepción representado en esta bóveda transmite el mensaje cristiano de mantener siempre la fe en Dios y la esperanza de bien depositada en los futuros primogénitos.
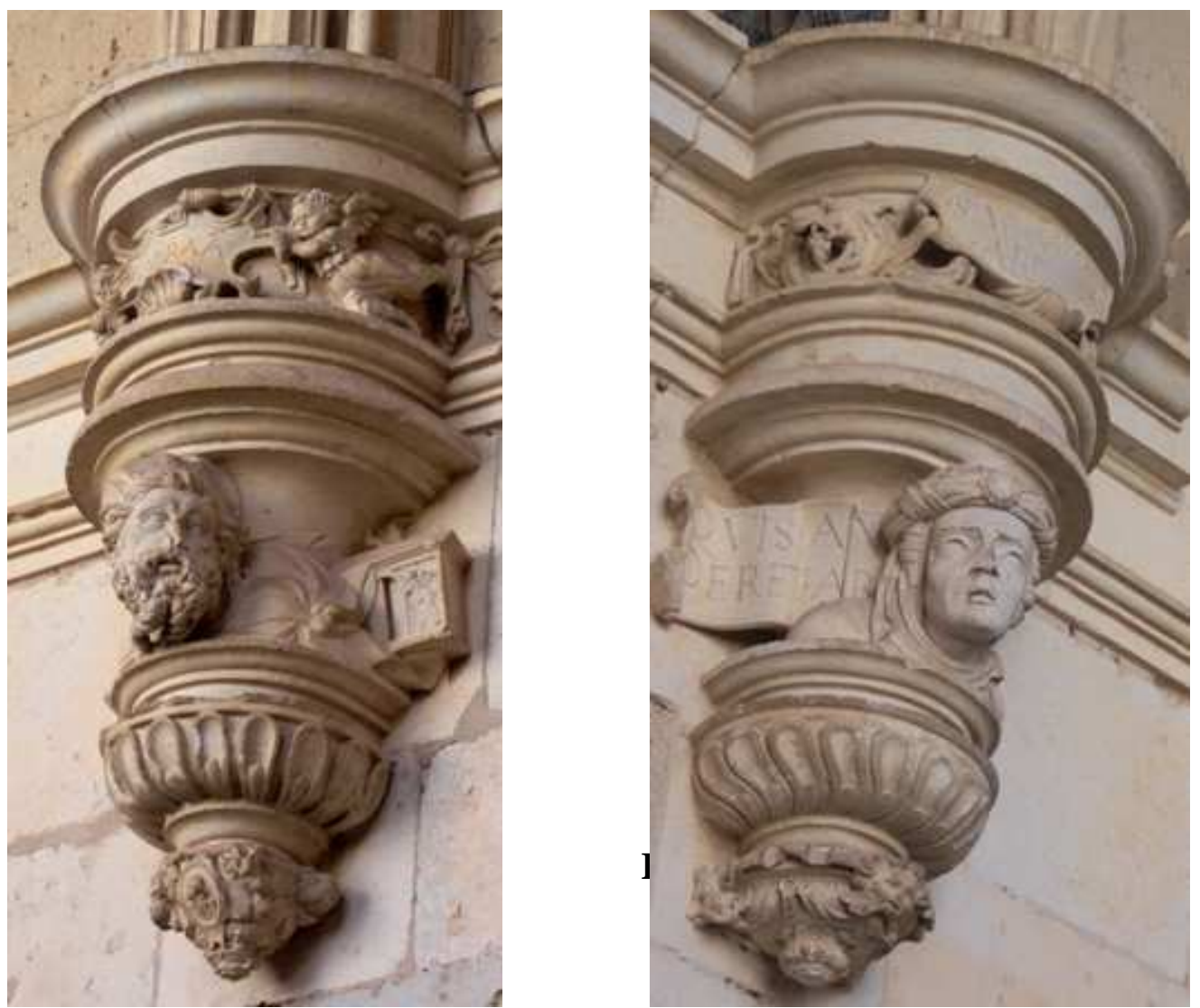

Bóveda 4. Ménsulas que representan a Abraham y a su esposa Sara.

Bóveda 5: En este tramo finaliza la ascendencia de Jesús según San Mateo, donde figura el sucesor de Abiud con quien finalizamos la bóveda anterior: Eliacím, padre de Azor. Le siguen: Azor, padre de Sadoc, Sadoc, padre de Aquím y Aquím, padre de Eliud. Estos personajes, circunscritos en óvalos, se ubican en la plementería

${ }^{1367}$ Génesis, capítulos 11-25. 
contigua a la clave central. La genealogía prosigue en las claves secundarias a través de Eliud, padre de Eleazar, éste, que lo es de Matham, que a su vez lo es de Jacob, el padre de José, éste último ubicado en la clave central.

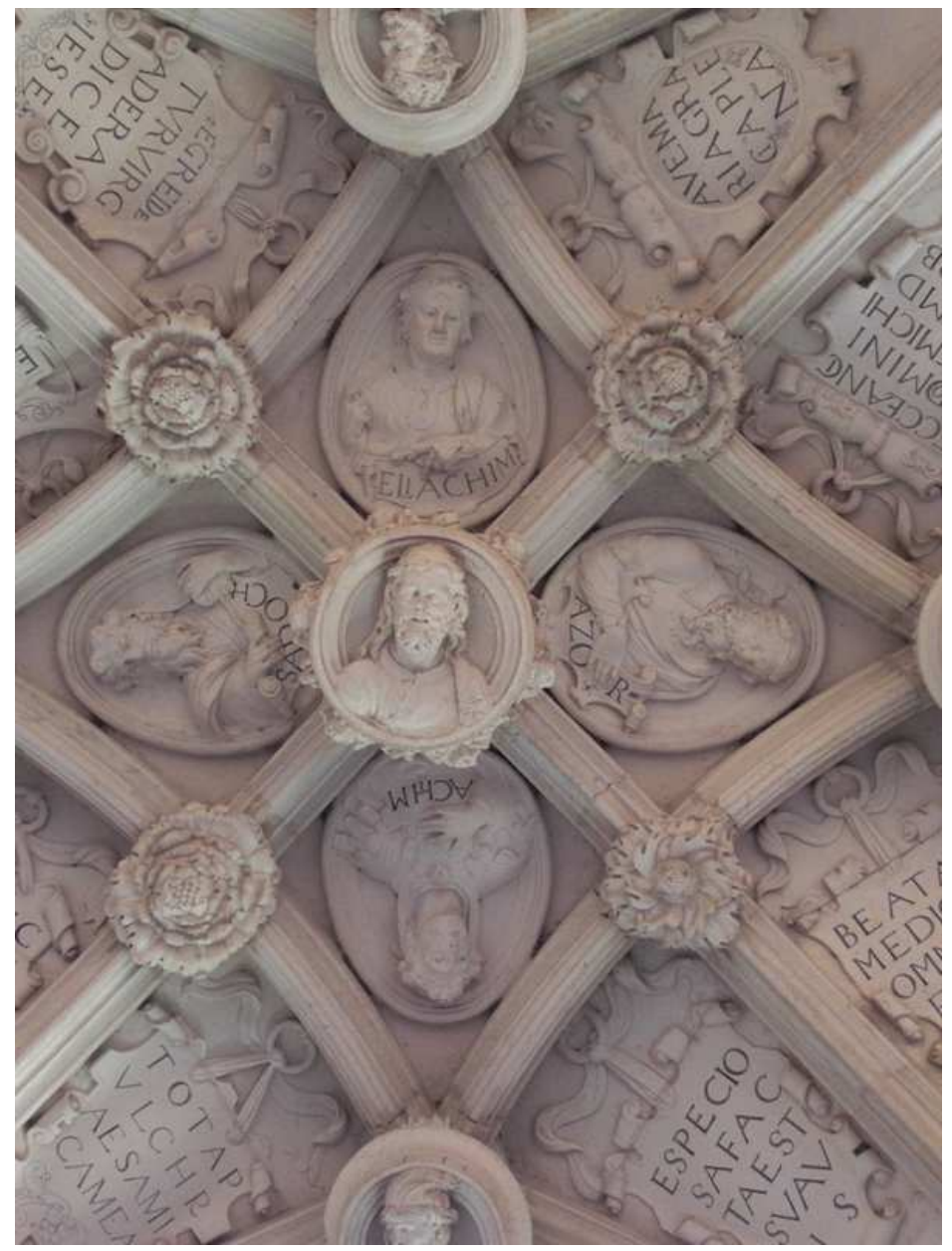

\section{Bóveda 5.}

Ascendencia de Cristo.

La ornamentación de los plementos en esta bóveda está formada por diversas tarjetas de cueros recortados que presentan inscripciones relativas a la Virgen María procedentes de la Biblia. Su lectura lógica se haría siguiendo la dirección de las agujas del reloj. El comienzo, si bien no está claro, podría comenzar en las palabras que la propia Virgen emite de sí misma: "AB INITIO ANTE SECULA CREATA SUM”. Se trata del inicio del versículo 14 del capítulo XXIV del libro del Eclesiástico, que continuaría "ET USQUE AD FUTURUM SAECULUM NON DESINAM ET IN HABITATIONE SANCTA CORAM IPSO MINISTRAVI"1368.

\footnotetext{
1368 "Al principio de los siglos fui engendrada y no faltaré por todo el siglo futuro, y ministré delante de él en la morada santa” El libro Eclesiástico o de la Sabiduría fue escrito por Sirácides, un sabio de Jerusalén hacia el 190.ac. Contiene preceptos éticos como los Proverbios y no debe confundirse por
} 
A continuación, un vaticinio sobre su maternidad: "ECCE VIRGO CONCIPIET ET PARIET FILIUM EGREDIETUR VIRGA DE RADICE JESSE ${ }^{1369, \text {, }}$

Las dos leyendas siguientes repiten el mensaje de la Anunciación de la bóveda precedente: “AVE MARIA GRATIA PLENA. ECCE ANCILLA DOMINI. FIAT MIHI SECUNDUM VERBUM TUUM. BEATAM ME DICENT OMNES GENERATIONES ${ }^{1370,}$,

En los dos plementos siguientes se proclaman y alaban las cualidades de la elegida por Dios. Uno de ellos dice así: "ESPECIOSA FACTA ES ET SUAVIS ${ }^{1371 ” . ~ E l ~ o t r o, ~ “ T O T A ~ P U L C H R A ~ E S T ~ A M I C A ~ M E A ”, ~ r e m i t e ~ a l ~ c a p i ́ t u l o ~}$ 4, versículo 7 contenidos en el Cantar de los Cantares, frase interpretada generalmente como la firma de Dios en la creación perfecta de la Virgen. Otros estudiosos identifican este ente femenino con la iglesia, como esposa de Cristo que acoge la idea de santidad, pureza y plenitud definitivas ${ }^{1372}$. La plena dedicación de todos los versículos de esta bóveda a María nos conduce a pensar que estas palabras harían referencia directa a la misma, más que a la iglesia. En cualquier caso, ambas posturas enlazan con el mensaje de ensalce de la religión cristiana que se pretende transmitir en todo el programa iconográfico. De todas estas tarjetas, la única que es diferente a todas es la que inscribe "AVE MARIA, GRATIA PLENA". Al contener el nombre de la protagonista de este espacio, el artista ha circunscrito la leyenda en un espejo ovalado, remarcando así su relevancia.

En las ménsulas del muro se representa a Isaac, hijo de Sara y Abraham. Le flanquean el trozo de leña con el pebetero para el sacrificio y el carnero que le sustituyó en su tormento ${ }^{1373}$. Se representa como un hombre maduro, barbado y

el nombre con el Eclesiastés, que como él, forma parte del Antiguo Testamento. SCIO DE SAN MIGUEL, don Felipe. (Obispo de Segovia). La Biblia. Vulgata Latina traducida en español. Tomo VIII del Antiguo Testamento. Los Proverbios, el Eclesiastés, el Cantar de los Cantares, la Sabiduría y el Eclesiástico. Imprenta de la Hija de Ibarra. Madrid, 1808, pág. 439.

1369 "Esta Virgen concebirá y parirá un hijo,, rama insigne de la raíz de Jesé” Isaías, 11:1.

1370 “En adelante todas las generaciones me llamarán beata” Lucas, 1,48.

1371 “Justa y agradable es” Salmo 126 Nisi dominus.

1372 MADRIGAL TERRAZOS, Santiago. La eclesiología de Juan de Ragusa O.P (1390/95-1443). Universidad Pontificia Comillas. Madrid, 1995, pp. 326-328.

${ }^{1373}$ Ambos elementos figuran en la narración bíblica: "Y tomó Abraham la leña del holocausto, y la puso sobre Isaac su hijo, y él tomó en su mano el fuego y el cuchillo; y fueron ambos juntos. Entonces habló Isaac a Abraham su padre, y dijo: Padre mío. Y él respondió: Heme aquí, mi hijo. Y 
ataviado a la moda del siglo XVI, con la casaca con solapas y la gorra doblada de un pico. Los artistas se permiten licencias anacrónicas realizadas expresamente como sucede en la bóveda de los fundadores del cenobio, para acercar la historia al momento actual.
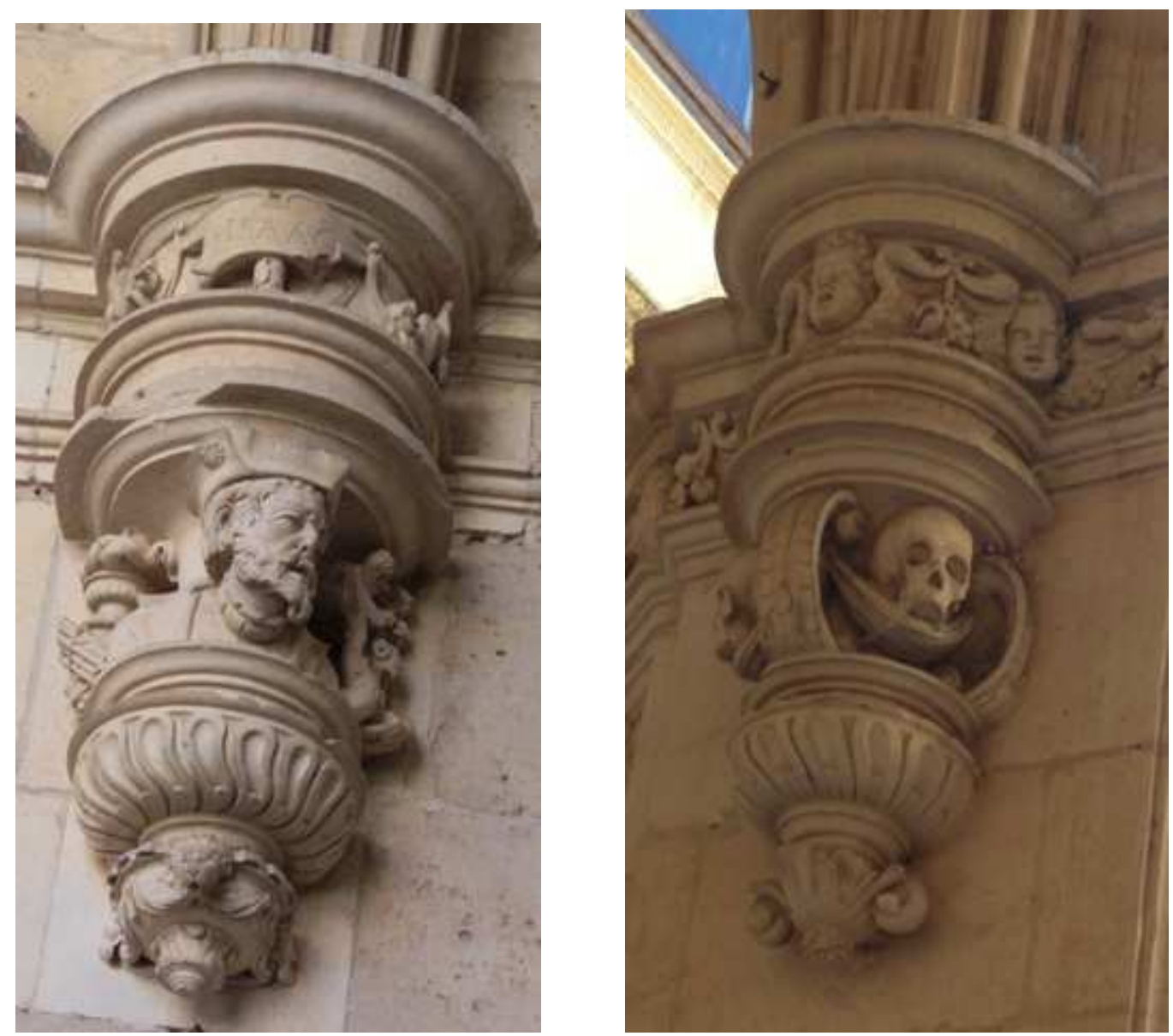

\section{Ménsulas que representan a Isaac y a la muerte.}

Bóveda 6: Tras la veneración de María, que preludiaba su aparición en la bóveda precedente, finalmente protagoniza la clave central de ésta, coronada y rodeada de querubines. Sus padres y abuelos se ubican en las claves secundarias:

él dijo: He aquí el fuego y la leña; mas ¿dónde está el cordero para el holocausto? Y respondió Abraham: Dios se proveerá de cordero para el holocausto, hijo mío. E iban juntos. Y cuando llegaron al lugar que Dios le había dicho, edificó allí Abraham un altar, y compuso la leña...” Génesis 22: 6-13. 
San Joaquín, Santa Ana, y sus abuelos maternos, Isachab y Emerencia ${ }^{1374}$. Es importante destacar la relevancia de estos cuatro personajes como los antepasados más directos de la madre de Dios y sin embargo, no aparecen siquiera mencionados en la Biblia. Santa Ana y San Joaquín sí que figuran al comienzo del Protoevangelio de Santiago, considerado apócrifo, en el relato del dolor que siente la pareja por no haber tenido descendencia, hasta que milagrosamente, Dios se le concede ${ }^{1375}$.

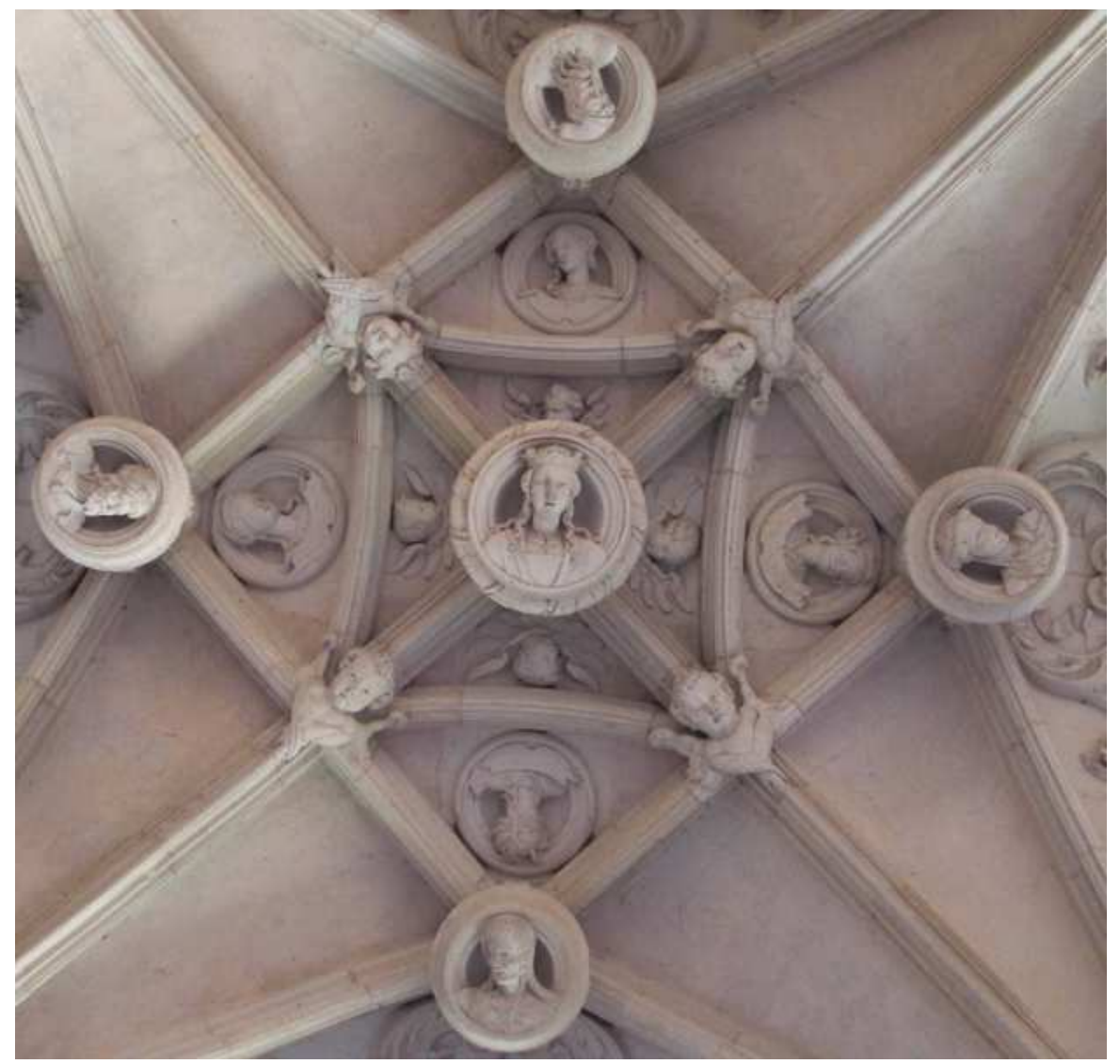

Bóveda 6. Ascendencia de Cristo.

En los plementos se han incluido cuatro bustos de las Sibilas Eritrea, Délfica, Agripina y Líbica, en cuya serie se añadiría la Sibila Europa de la puerta por la que se accede al claustro, que, junto al Profeta Daniel, flanquean a Cristo Redentor. En realidad, el nombre de Sibila proviene de la cultura helénica, pues así se llamaba la hija de Dárdano, gobernante troyano que alcanzó grandísima fama por sus profecías,

${ }^{1374}$ Sin embargo, el venerable Beda, cuando relata la ascendencia de Santa Ana, dice que sus padres se llamaban Estolano y Emerencia, naturales de Belén, que tuvieron dos hijas, Ana e Ismara. ROCA Y CORNET, Joaquín. Historia de los hechos...Op.cit, pp. 127.

${ }^{1375}$ DUCHET-SUCHAUX, Gaston y PASTOUREAU, Michel. Guía...Op.cit, pág. 17. 
extendiéndose esta denominación a las mujeres con este don ${ }^{1376}$. Por su carácter pagano, no figuran en el Antiguo Testamento, pero pudieron introducirse posteriormente en los programas cristianos gracias a la acogida de San Pablo, que abrió la puerta a los gentiles ${ }^{1377}$. Las diversas profecías que hicieron sobre Cristo y la Virgen justifican su presencia en el programa escultórico. Sus nombres proceden de los lugares en que vivieron. La más antigua de todas es la Sibila de Eritrea arrabal de Troya-, una de las dos conocidas hasta el siglo XV, con la Sibila Tiburtina. La tradición la asocia con el vaticinio de la Anunciación y el Juicio Final. Estas jóvenes vírgenes se multiplicaron a finales de la Edad Media, pasando a ser doce, en equivalencia a los doce profetas de Israel. En este ciclo se ha optado por una selección de todas ellas, entre las que figuran las Sibila Délfica, Agripina y Líbica, que prefiguraron la Coronación, la Flagelación y el Advenimiento del Mesías, respectivamente ${ }^{1378}$.

\section{Bóveda 6. Clave central.} La Virgen María.

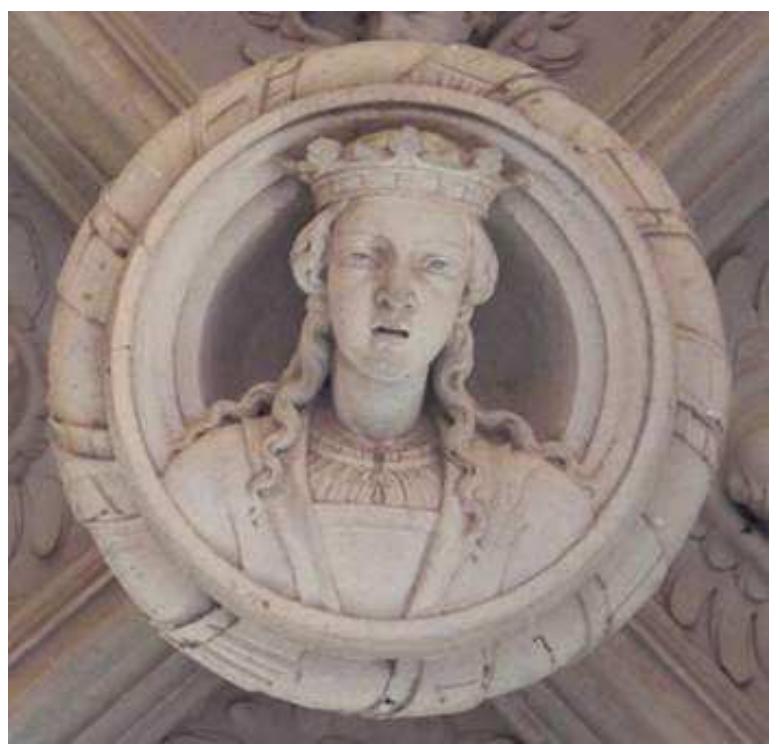

La ménsula contiene el busto de Rebeca, esposa de Isaac, mencionado con anterioridad. A pesar de presentar varios desconchones, advertimos un rostro bello y facciones redondeadas en esta elegante figura. Recoge su melena según la moda del

\footnotetext{
${ }^{1376}$ RAMOS CRUZ, Guillermina. "La otra cara de Eva: Diosas, sacerdotisas, sibilas, orishas. La mujer y lo sagrado" en Oráfrica, revista de oralidad africana, n5, abril 2009, pp. 166-167.

${ }^{1377}$ REAU, Louis. Iconografía del arte cristiano. Iconografía de la Biblia. Tomo 1, volumen 1, no4. Barcelona, 1996, pág. 477.

${ }^{1378}$ REAU, Louis. Iconografía...Op.cit, pp. 477- 485.
} 
siglo XVI, con una toca sujetada con cintas y un broche central, mientras su ondulado cabello cae suavemente sobre sus hombros formando bucles. Aparte de la tarjeta que lo identifica, le flanquean los objetos de la historia bíblica: el camello en el que llegó Isaac hasta Harán, el pozo en el que se detuvo y el ánfora del que bebió cuando Rebeca se lo ofreció, señal de que se convertiría en su futura esposa ${ }^{1379}$.

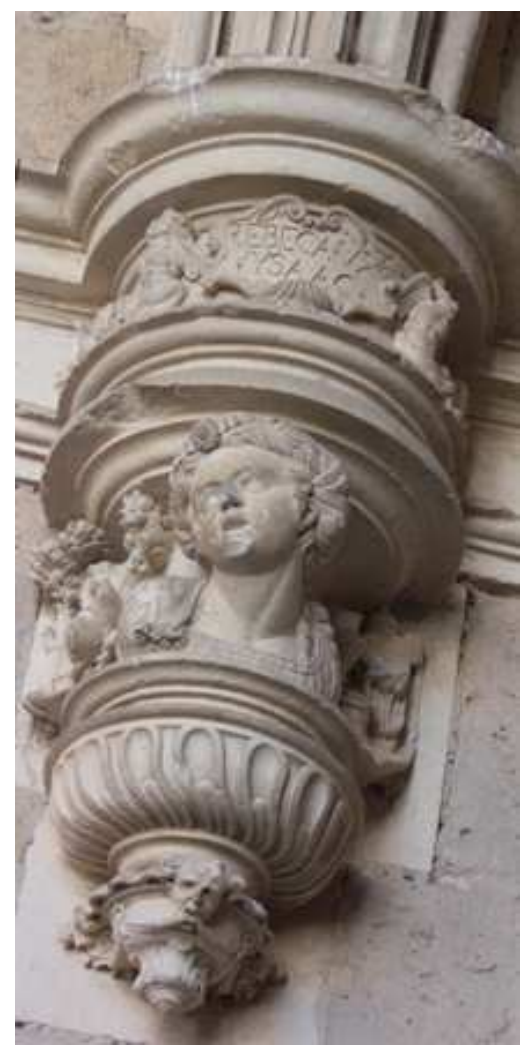

Ménsula que representa a Rebeca, esposa de Isaac.

Podemos observar claramente un cambio en la ejecución de la bóveda, de ornamentación mucho menos rica que las anteriores, pues los plementos que unen las claves secundarias con las ménsulas están desprovistos de todo adorno, dando la sensación de que este sector no está concluido. Todo parece indicar el relevo de los arquitectos y entalladores, pasando de Badajoz y Espinosa, que ceden su testigo a Pedro de Castrillo y otros escultores anónimos de menor pericia técnica. Además observamos una calidad inferior en la ejecución de las ménsulas, precisamente, las que presentan un mayor deterioro de todo el conjunto.

${ }^{1379}$ Génesis, 24. 


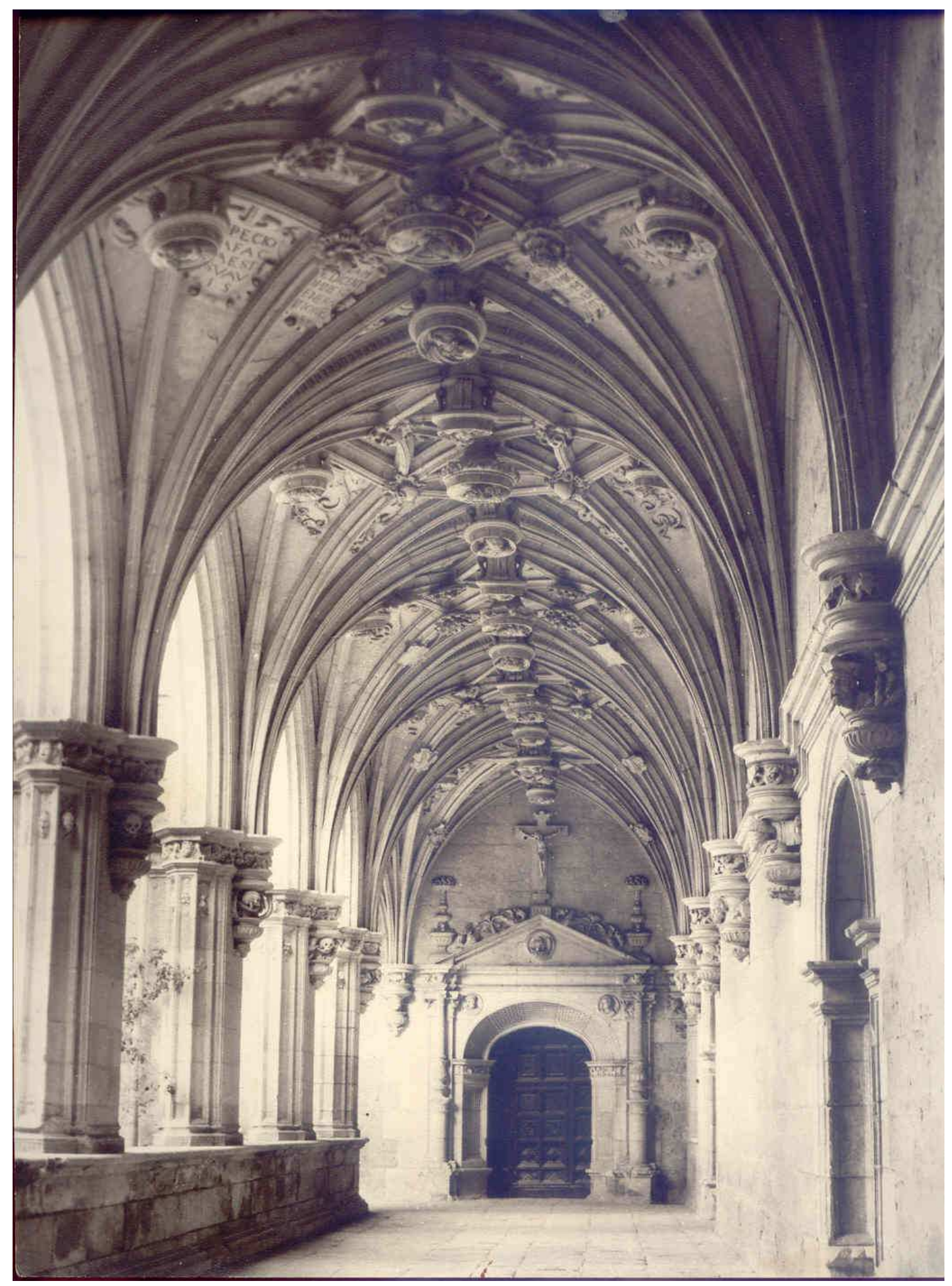

Crujía oriental del claustro de San Zoilo con la Puerta de las Procesiones al fondo de la imagen. 


\section{Crujía meridional}

En este tramo ilustra nuevamente la ascendencia de Cristo, basándose en los personajes propuestos por los Evangelios de Mateo y Lucas, pero haciéndolos partir de Jesé, como profetizaba Isaías ${ }^{1380}$. Tenemos ante nosotros el Árbol de Jesé, genealogía incansablemente reproducida a lo largo de la Edad Media, de tal manera que los personajes más lejanos cronológicamente a la Virgen se ubican en la bóveda décimosegunda, y convergen hacia ella, situada, como indicamos, en la clave de la bóveda 6. Los plementos inmediatos a la clave central, presentan en esta panda, cuatro jarrones con flores, idénticos en cada bóveda. Varían, no obstante, de una bóveda a otra en los motivos ornamentales que los conforman. En 1550 quedaría finalizada esta crujía siendo abad Fray Juan de Santa María.

Bóveda 7: Aquí comienza la ascendencia de Cristo siguiendo el Evangelio de San Mateo pero desde el final, es decir, desde José, que se muestra en la clave lateral y le acompañan, su padre Jacob, el padre de éste, Mathán, hijo de Eleazar y éste hijo de Eliud, figura protagonista de la clave central e hijo de Aquim.

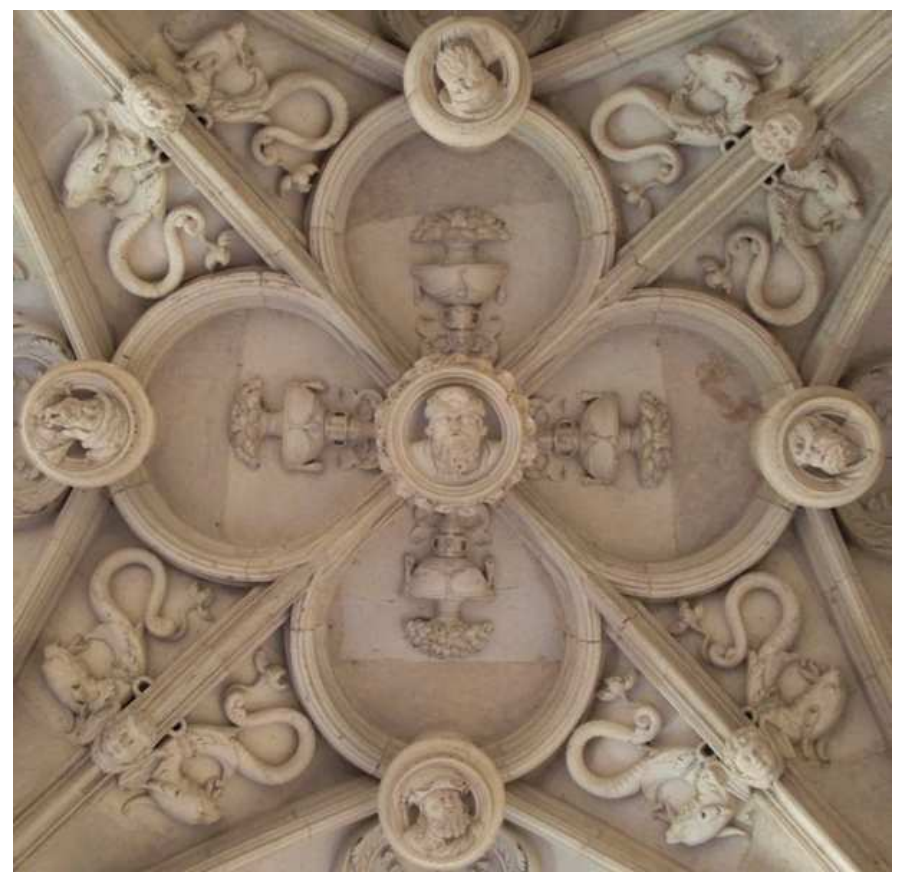

Bóveda 7.

Ascendencia de Cristo.

${ }^{1380}$ Isaías, 11:1. 
Los plementos inmediatos a la clave central conforman una flor de cuatro pétalos, en cada uno de los cuales se inserta un jarrón de cuyos lados manan caprichosos motivos elementos vegetales. Éste sirve de base a otro recipiente, semicircular y engalanado con cintas, que sostiene a su vez, un tercer jarrón del que brota un gran ramo de rosas. La ornamentación de los espacios secundarios consiste en parejas de serpientes con cabeza de dragón encadenadas a unas argollas que son custodiadas por una cabeza de querubín, como guardiana del bien.

En la convergencia de ambos lienzos del muro se sitúa la ménsula de Jacob, hijo de Abraham, de hacia el siglo XIV a. C, a quien no debe confundirse con el Jacob de la bóveda, ascendiente de Cristo, por ser padre de José. Junto a él, su esposa Raquel entre árboles y corderos. Su rostro compungido corresponde al "Rachel plorans filios suos" de las Escrituras. Se interpreta en un amplio sentido como una súplica a Dios para poner fin al sufrimiento de su pueblo y a los exilios posteriores a la destrucción del Templo de Jerusalén ${ }^{1381}$.
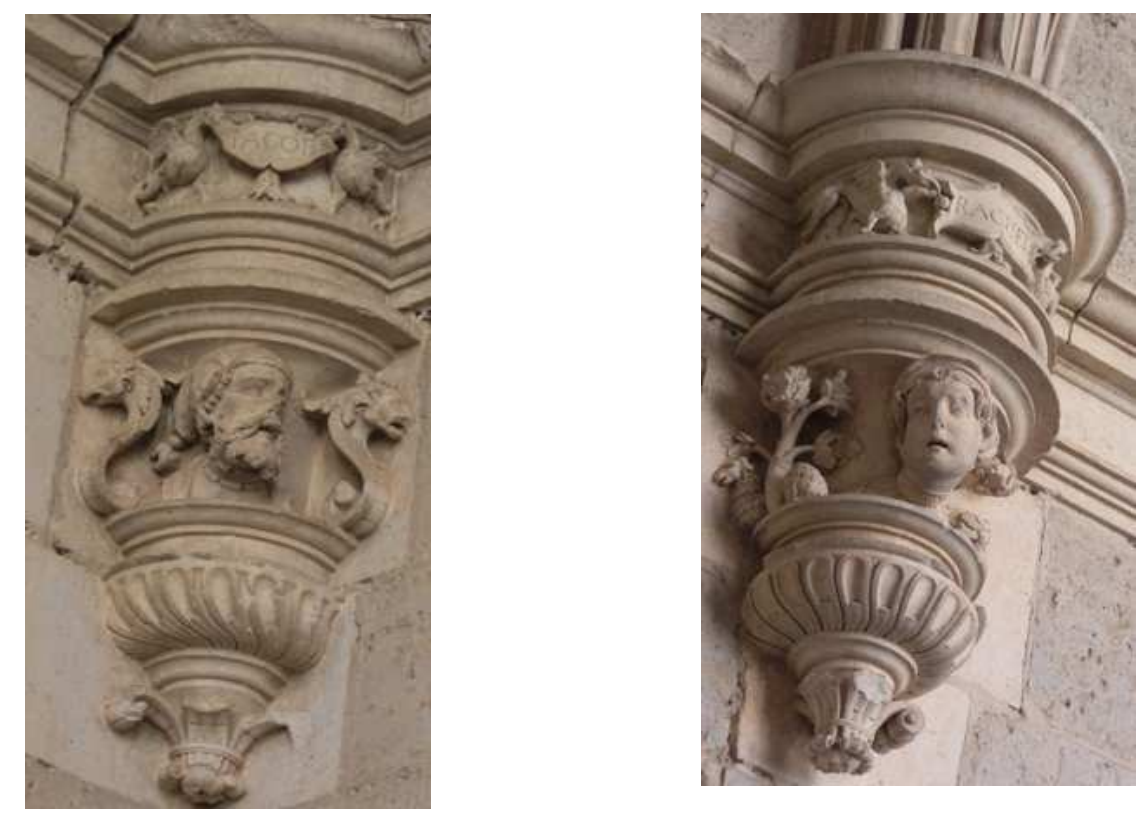

\section{Ménsulas que representan a Jacob y a su esposa Raquel.}

\footnotetext{
1381 "Rachel, que llora a sus hijos”. Raquel habló ante Dios: "Traje a mi rival (Lea) a mi casa, ¿no puedes Tú perdonar a tus hijos, que trajeron un simple ídolo de madera y piedra a tu casa (el Templo de Jerusalén)?”. Dios aceptó su súplica y prometió que, finalmente, el exilio terminaría y los judíos regresarían a su tierra. Jeremías 31,15.
} 
Bóveda 8: La segunda bóveda del lado sur continúa el retroceso generacional a con Aquim, hijo de Sadoc, Sadoc, hijo de Azor, Azor, hijo de Eliachim y Eliachim, hijo de Abiud. Todos ellos rodean a la clave central, donde se sitúa como cabría esperar, Abiud.

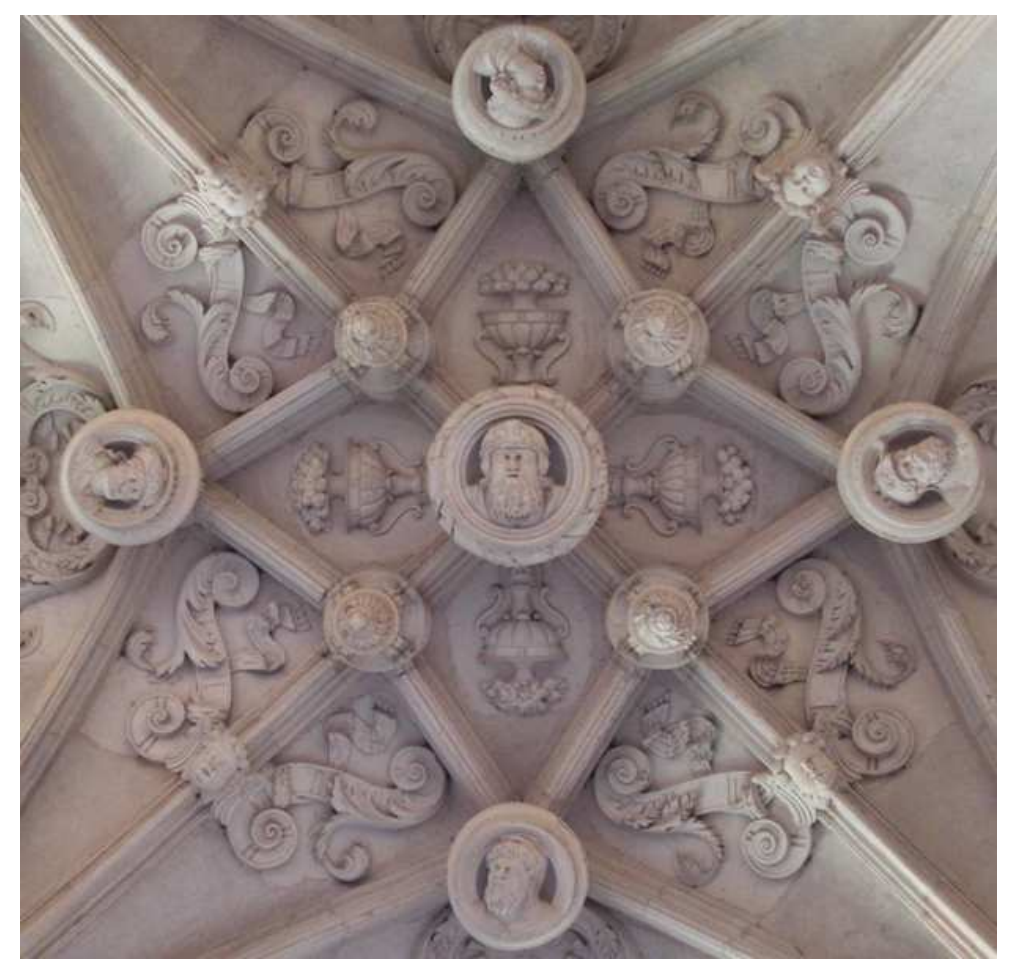

\section{Bóveda 8. Ascendencia de Cristo.}

Los plementos que forman una estructura romboidal en torno a la figura de Abiud, presentan la ornamentación de jarrones, similares a los de la bóveda anterior, salvo en la fragmentación en gajos de la superficie del recipiente principal y la unión a la base, aquí de forma antropomorfa, mediante motivos de eses avolutados. Precisamente estos elementos se repiten en la plementería contigua, repertorio ornamental al que aludimos en la bóveda tercera. En este caso, no se presentan a pares, sino uno en cada plemento, por lo que adquieren mayores dimensiones y van decorados con una especie de hojarasca.

En esta segunda bóveda del lado sur las calaveras figuran por última vez en todo el conjunto, situándose, como en las ménsulas de la parte externa, como lo hacían en la panda oriental. En la parte interna, continuando la figura de Raquel, 
aparece Moisés. La talla ha sufrido graves daños en la barba y labio, que se muestran incompletos y sobre todo en la nariz, que ha quedado seccionada. Probablemente este y otros deterioros que presentan las ménsulas, fueron originados a raíz de la utilización de claustro como patio de recreo para los internos del Colegio de San Zoilo a lo largo del siglo XIX. No obstante, su identificación es indudable, no sólo por la inscripción que lo acompaña, sino por la prolongación de su cabellera haciendo alusión a los cuernos o haces de luz de la tradición Bíblica. El texto original utiliza el término hebreo "querens" para referirse a estas protuberancias. Si bien, ambas traducciones son posibles, desde San Pablo a nuestros días, la iconografía de Moisés resplandeciente fue la más aceptada a partir de la Contrarreforma. Por cuestiones de decoro y basándose en San Pablo, se prefería la versión más "celestial ${ }^{1382 ", ~ O t r o ~ d e ~ s u s ~}$ atributos más característicos son las Tablas de la Ley entregadas por Dios, que figuran a su margen izquierda. Contienen la inscripción latina: "Ne ivres vana per

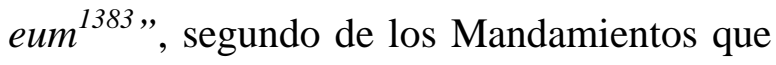
prohibe blasfemar de Dios. La tabla que le precede seccionada íntegramente, aludiría con seguridad al primero de los preceptos: "Unum cole deum”.

Ménsula que representa a Moisés.

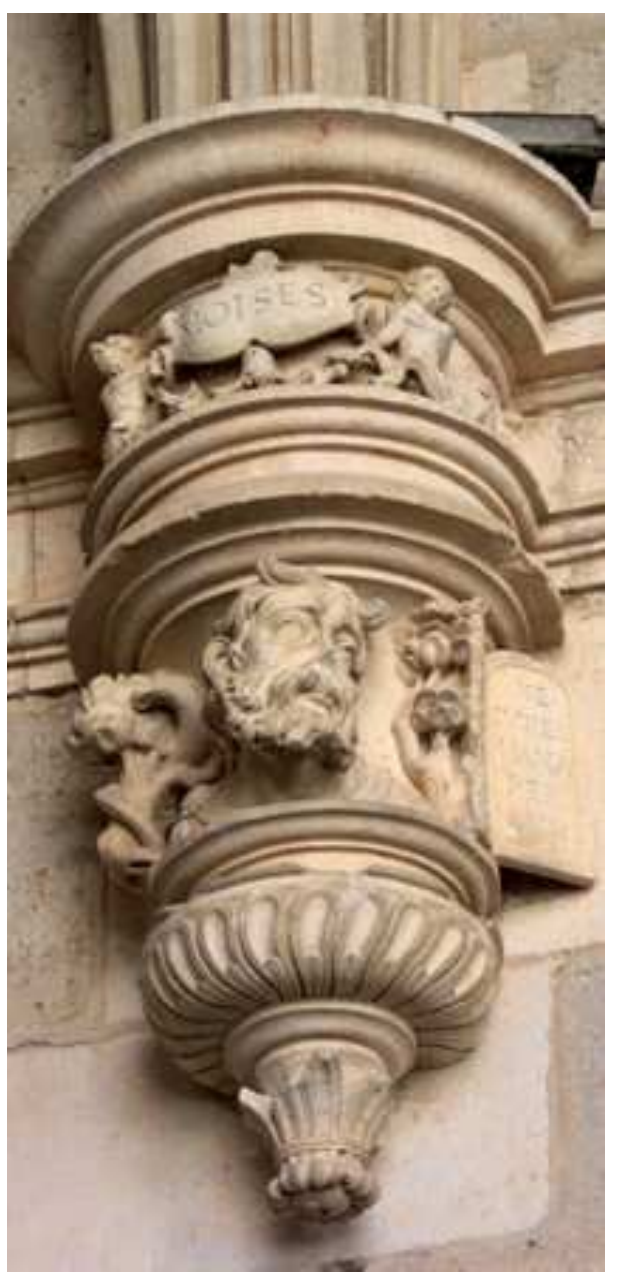

\footnotetext{
${ }^{1382}$ RUIZ DE ELVIRA, Antonio. "Los "hermanos" de Jesús y la iconografía de Moisés" en Epos: Revista de Filología. No $^{\circ} 10,1994$, pp. 60-67.

1383 "No tomarás el nombre de Dios en vano" Éxodo, 20,7 y Mateo 5,33.
} 
Bóveda 9: Continuamos la genealogía de Cristo en retroceso con el padre de Abiud, llamado Zorobabel, hijo de Salathiel, éste hijo de Jeconías y finalmente éste era el hijo de Josías, hijo éste de Amón o Amós, que es quien preside la clave central. Los jarrones con flores en esta bóveda son similares a los de la bóveda procedente salvo en la adición de una cabeza de león que con su boca sostiene un segundo recipiente ornamentado a base de acanaladuras.

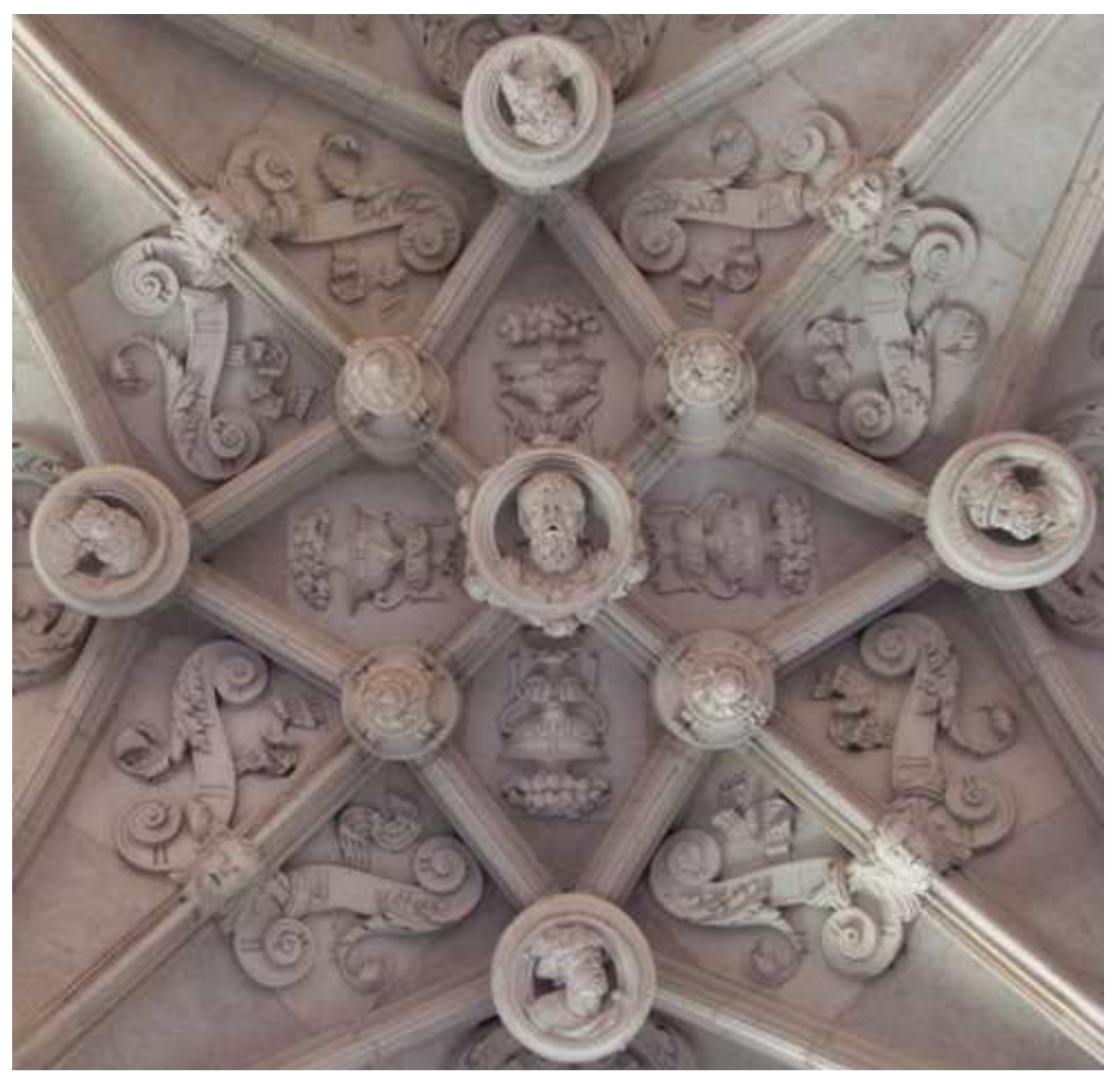

Bóveda 9. Ascendencia de Cristo.

En la ménsula interna se representa a Séphora, esposa de Moisés, a la que flanquean dos ángeles decapitados. Uno de ellos sostiene la tarjeta que contiene el nombre del primogénito del matrimonio, Gersan, por lo que el otro querubín portaría la tarjeta, hoy desaparecida, correspondiente a Eliezer, el segundo de los hijos. En la pilastra aparece "El Iusto Abel" de soberbia ejecución, sobre todo si atendemos al 
detalle con que el artista ha cincelado el pelaje de los corderos, de una calidad suprema. A un lado, estos bóvidos, junto al perro, simbolizan la dedicación de Abel al pastoreo, mientras que el cordero sobre la mesa de altar indica el sacrificio, pues éste ofreció una selección de su rebaño como dádiva a Dios, obteniendo de este modo su favor ${ }^{1384}$.
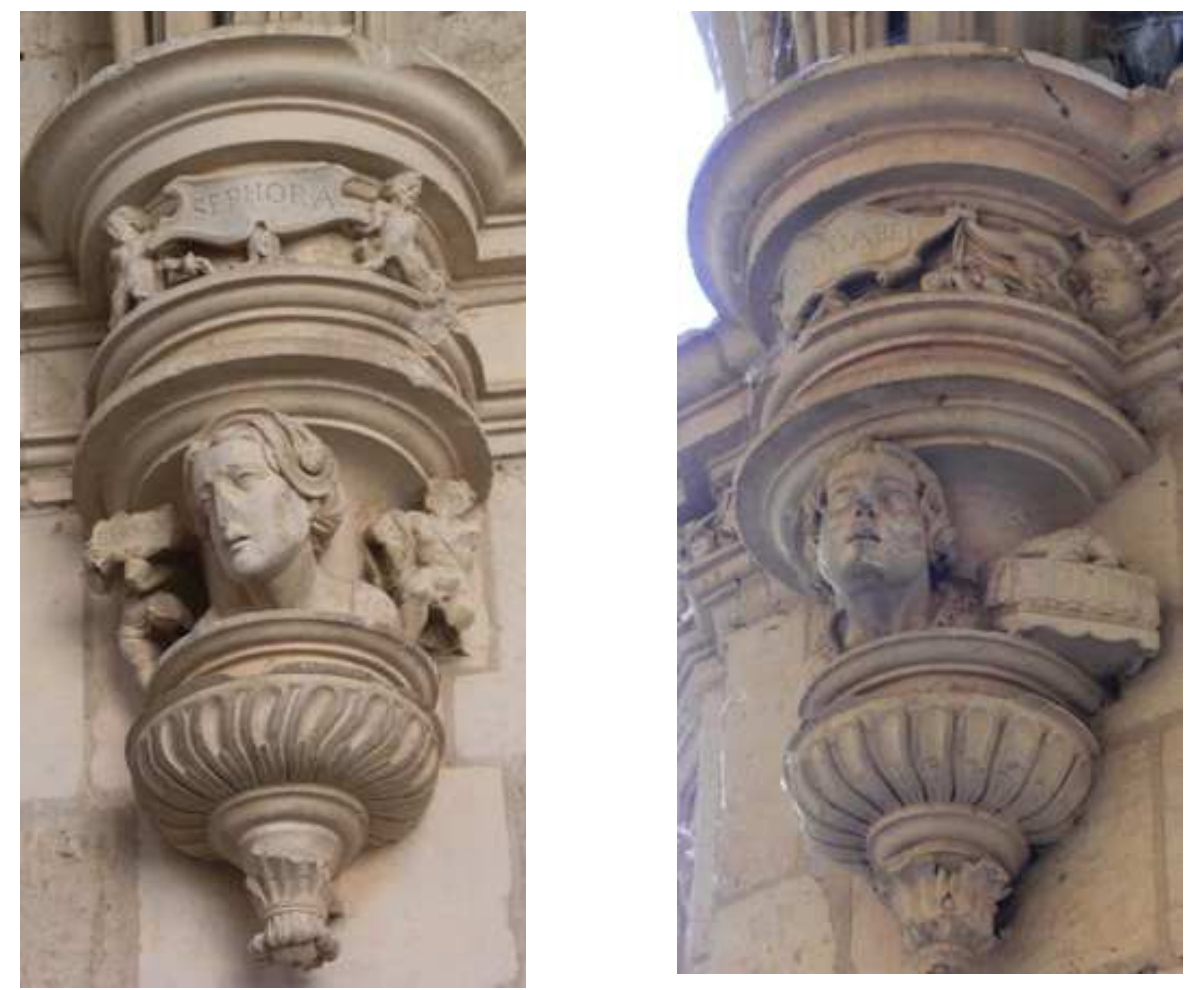

Ménsulas que representan a Séfora, esposa de Moisés y el Justo Abel.

Bóveda 10: La bóveda siguiente presenta en las claves secundarias al padre de Amón, de nombre Manasés, hijo de Ecequías, Ecequías, hijo de Acaz, Acaz, hijo de Joatám y Joatám, hijo de Ozías u Osías, que preside la parte central de la crucería. En este caso, los jarrones ubicados en los plementos son muy sencillos e imitan las ánforas clásicas. Presentan una estructura campaniforme invertida con dos asas en forma de eses semejando hojarasca.

${ }^{1384}$ La denominación de justo, frente a su hermano maligno, procede de Juan, 3:12. 


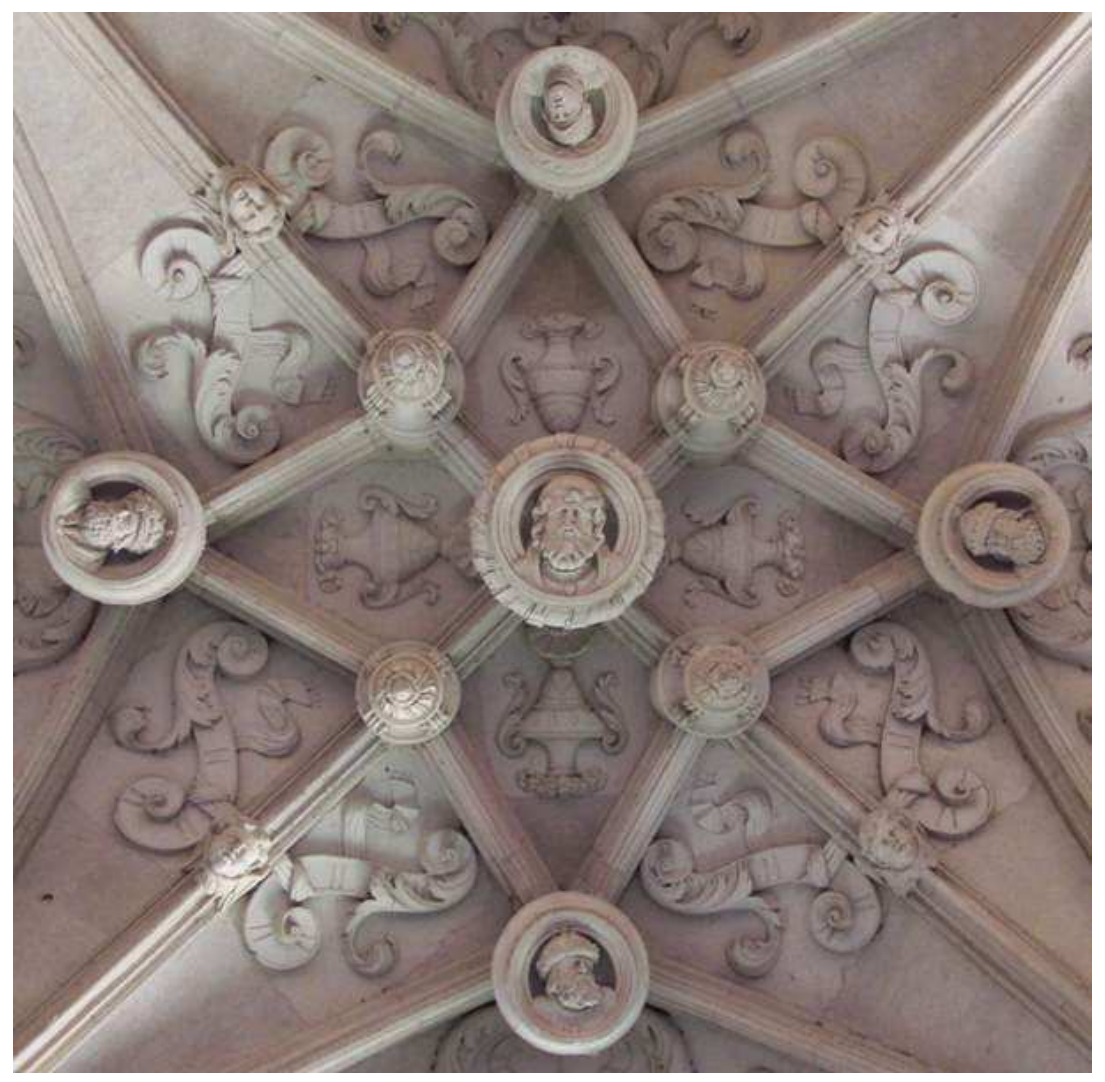

Bóveda 10. Ascendencia de Cristo.

En la parte interna, sustentando la cubierta, figura la ménsula de Josué, personaje barbado tocado de casco guerrero. Junto a él, el Arca de la Alianza con la inscripción que lo identifica "Arca faederis Domini”. Su presencia aquí guarda relación directa con el episodio del paso del Jordán, ocurrido cuando Josué fue nombrado sucesor de Moisés en su misión de alcanzar la Tierra Prometida. Josué consiguió, a través del valioso objeto, dividir las aguas para permitir el paso del pueblo israelita hacia Canaán ${ }^{1385}$. Frente a Josué, en la pilastra frontera, se sitúa Noé, que enlazaría con la bóveda 23, pues era padre de Sem, representado en la clave central de la misma. Las vides que le acompañan hacen referencia al final del Diluvio Universal. Tras 40 días con sus noches en el arca, Noé rehizo su vida en la Tierra como agricultor comenzando por plantar una viña ${ }^{1386}$. El vino, por tanto, será la bendición de Dios por la obediencia de su siervo.

\footnotetext{
1385 Josué, 3.

${ }^{1386}$ Génesis, 9,18-29.
} 

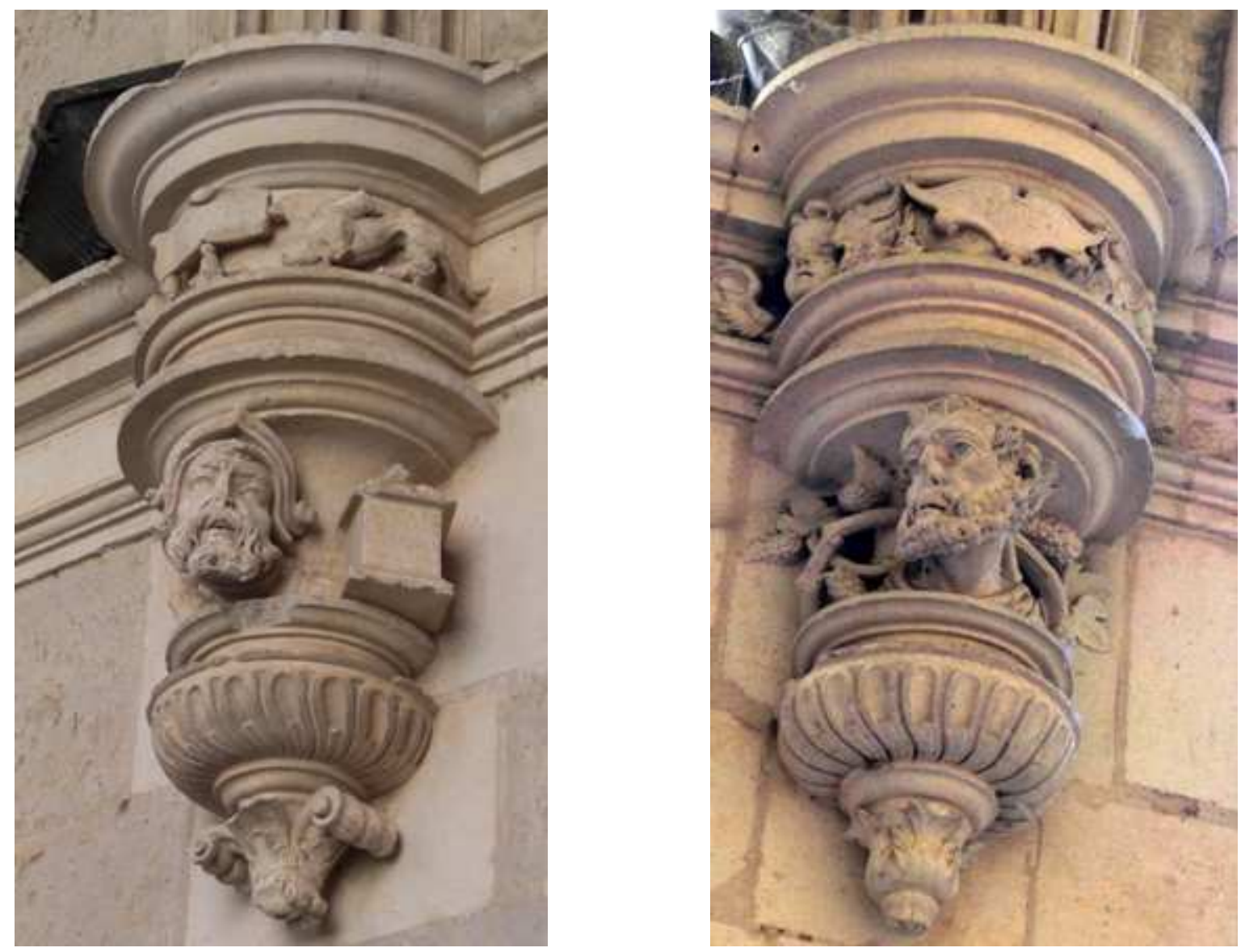

Ménsulas que representan a Josué y Noé.

Bóveda 11: La genealogía de Cristo prosigue por Joram, padre de Osías, a quien vimos en la clave de la bóveda precedente. Le acompañan su padre Josafat, éste, hijo de Asaz, Asaz, hijo de Abías y Abías, hijo de Roboam. Todos estos personajes confluyen en Roboam, que centra la composición de la cubierta.

En la parte más externa, junto a Noé, el profeta Melquisedec. Ciñéndose al pasaje bíblico, dos atributos de la Eucaristía le identifican, de ahí su presencia: "Melquisedec, rey de Salem, sacando pan y vino, como era sacerdote del Dios Altísimo, bendijo a Abram, diciendo: Bendito Abram del Dios Altísimo, el dueño de cielos y tierra. Y bendito el Dios Altísimo, que ha puesto a tus enemigos en tus $\operatorname{manos}^{1387, \text {. }}$

${ }^{1387}$ Génesis 14, 18-20. 


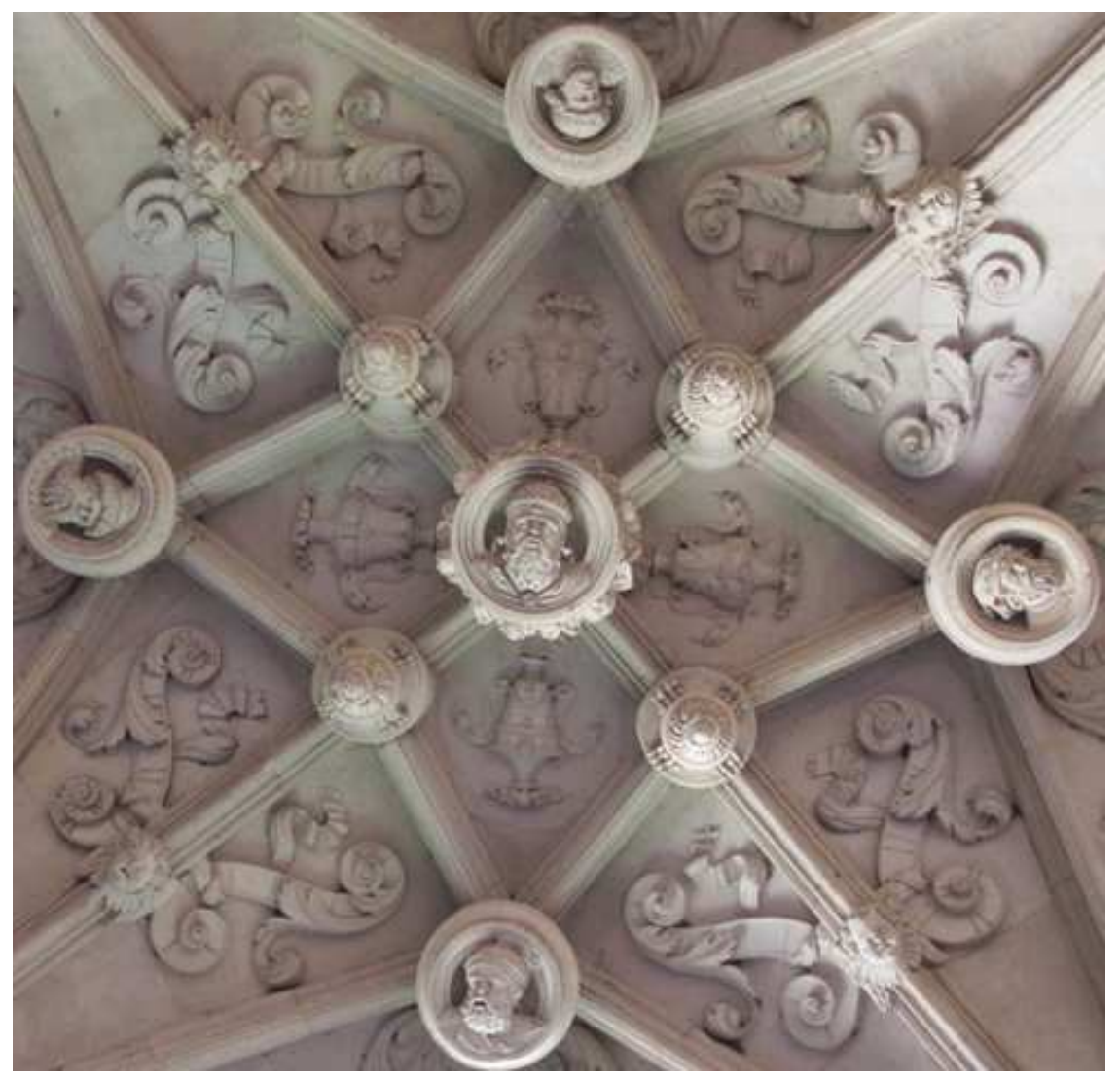

Bóveda 11. Ascendencia de Cristo.

Ménsula que representa al profeta Melchisedec.

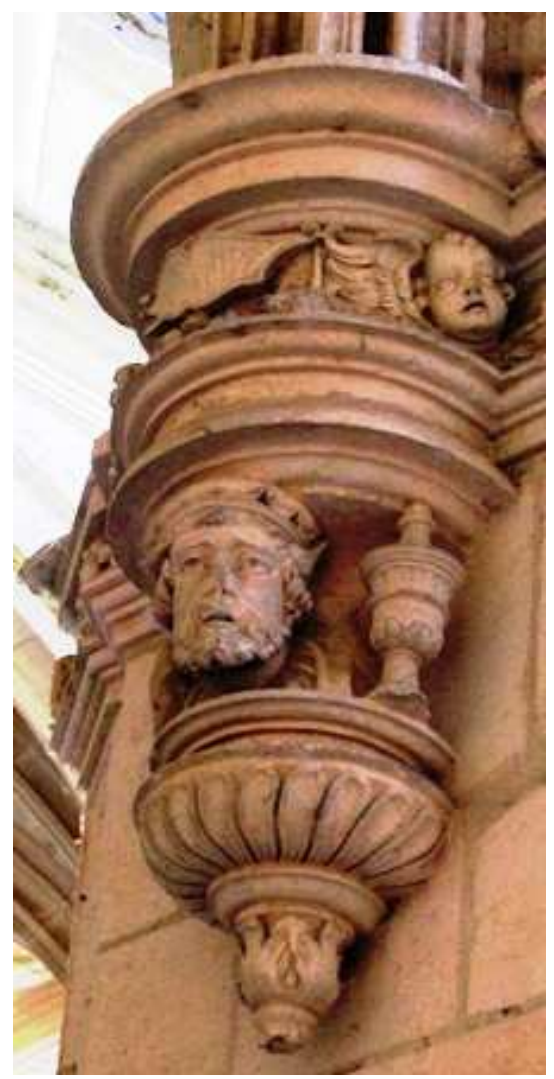


Bóveda 12: Salomón, padre de Roboam, es uno de los personajes de esa bóveda, junto a su padre David, cerrándose el ciclo en el medallón central, que contiene el busto de Isaí, que no es otro que Jesé, padre de David, de quien parte el ciclo genealógico de Cristo, siguiendo una lectura en el sentido contrario a las agujas del reloj. El resto de personajes que lo acompañan se relacionan directamente con los anteriores. Saúl, fue el primer rey de Israel, cuyos sucesores fueron David, y después Salomón, los tres reyes del Israel unificado. Jonatám, hijo de Saúl, mantuvo, al contrario que su padre, una gran amistad con David cuando éste fue nombrado heredero en el trono de Judá. Jonatám murió junto a Saúl y sus dos hermanos en la batalla que los israelitas libraron contra los filisteos en Gilboa ${ }^{1388}$.

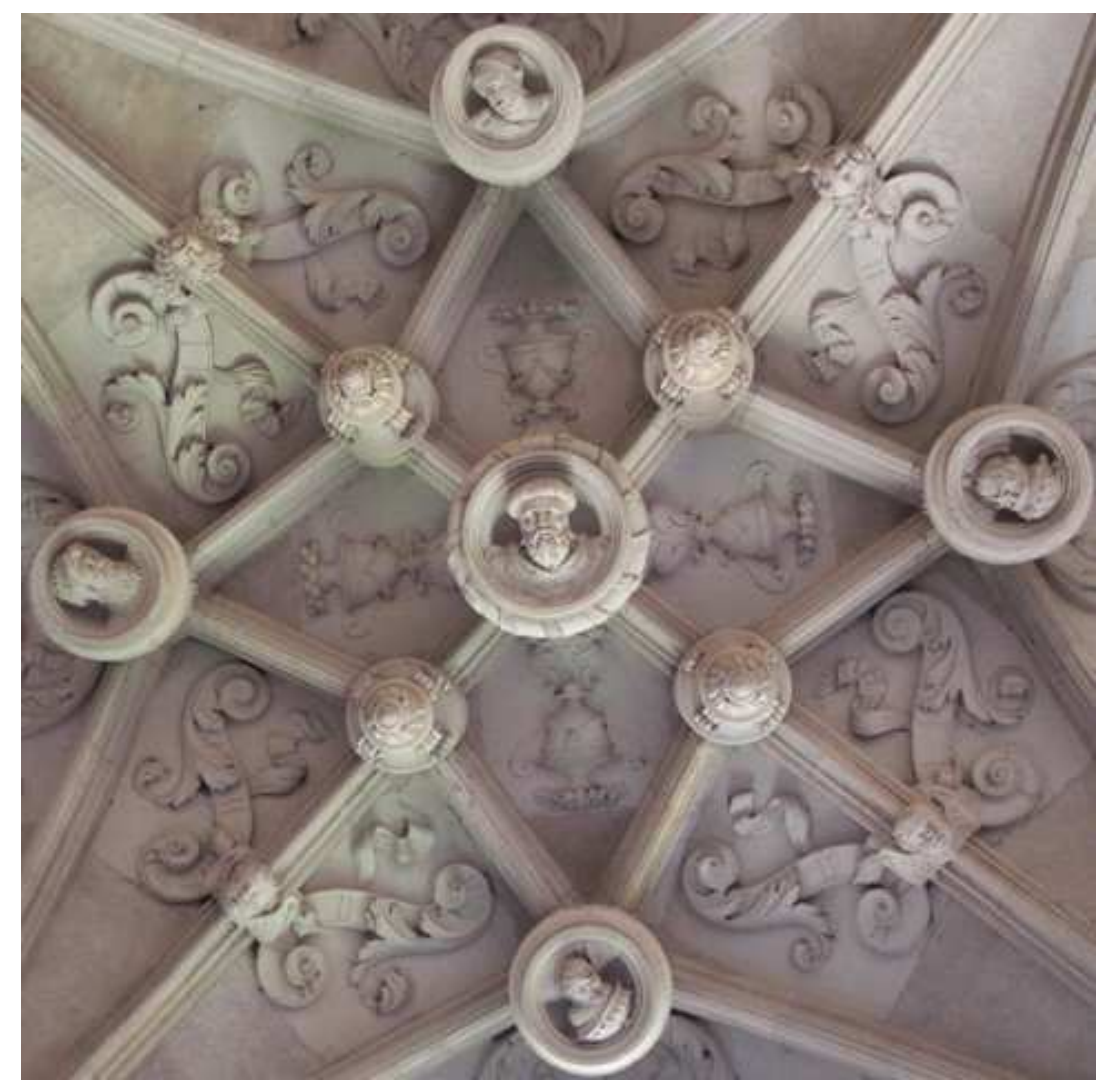

Bóveda 12. Ascendencia de Cristo.

${ }^{1388}$ I, Salomón, 31. 
En esta panda se halla el acceso al refectorio, conformado por un sencillo arco de medio punto y un alfiz moldurado que recorre el muro. El ingreso está flanqueado por dos personajes interrelacionados por la batalla del relato bíblico: Barac, rey de Israel y Débora, esposa de Lepidor. En el siglo XIII A.c., tras la muerte de Ehud, esta profetisa gobernaba Israel. Mandó llamar a Barac para que reuniera diez mil hombres en el Monte Tabor y así derrotar a la armada enemiga comandada por Sísara. Barac accedió a cambio que ésta le acompañase y así todo el ejército cayó a sus pies ${ }^{1389}$. El lugar en que aconteció la victoria explica la presencia de la inscripción "Mons Tabor" que acompaña a la figura de Débora. Barac, por su parte, va identificado con un escudo en el que se representan, una alabarda, un hacha y una cimitarra entrecruzadas, armas utilizadas para la consecución de la victoria. Este personaje junto a las figuras de Moisés o Josué tienen en común su pertenencia al pueblo judío como caudillos del mismo contra los ejércitos rivales.
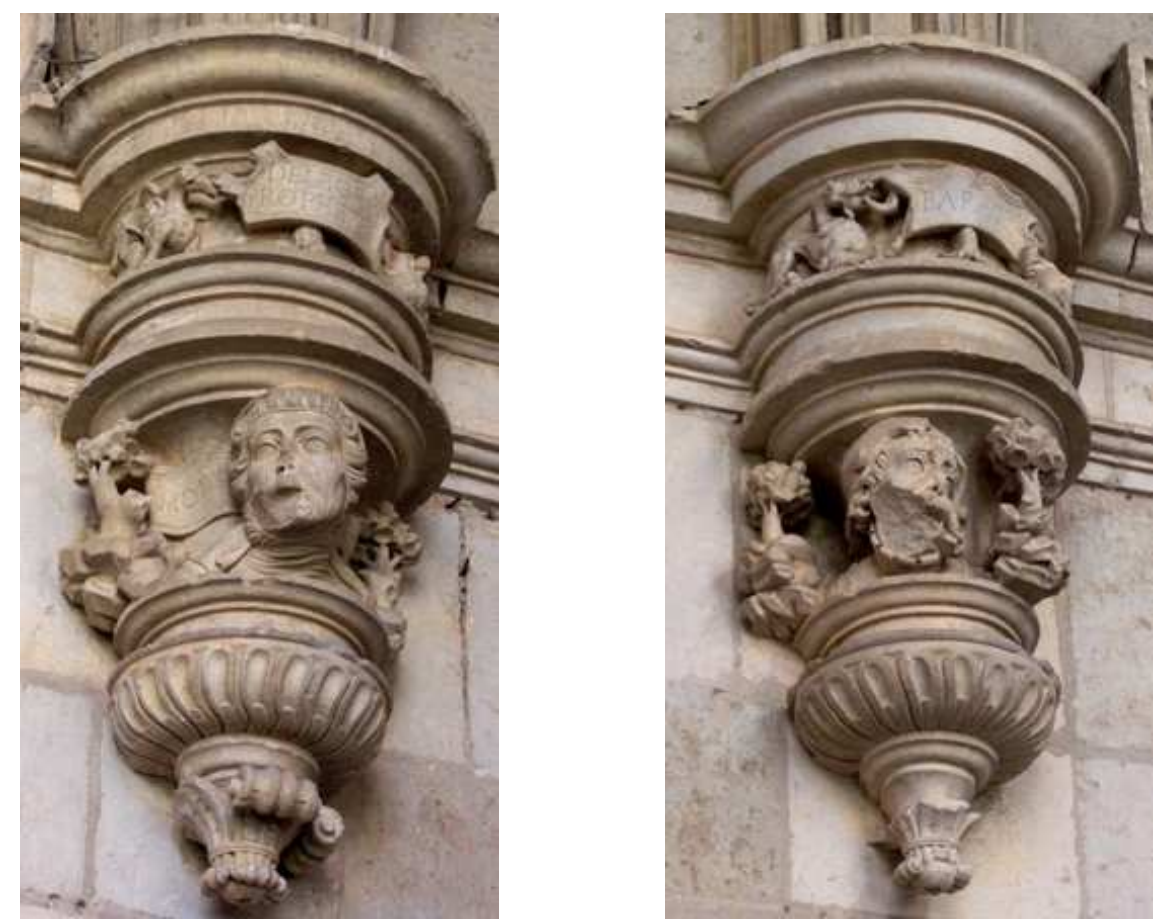

Ménsulas que representan a la profetisa Débora y Barac, rey de Israel.

1389 Jueces, 4-5 
Ambas figuras tienen los rostros desfigurados, consecuencia probable de alguno de las pedradas lanzadas por alguno de los colegiales que permanecieron en el colegio en época de los jesuitas.

Los jarrones de esta bóveda son similares a los del tramo décimo, salvo en la parte inferior, donde unos motivos vegetales de hojarasca se ensancha conforme alcanzan la base del florero.

\section{Crujía occidental}

Bóveda 13: Corresponde al ángulo sur-oeste. Aparecen representados los macabeos, mártires del pueblo de Israel que rehusaron adorar los dioses griegos que les impusieron los seleúcidas en el año 164 a. C. Dios los tomó por instrumento para librar de la opresión al pueblo judío. Lograron mantener la independencia hasta el año 63 a. C en que quedaron bajo el yugo de Roma, a las órdenes de Pompeyo. En el centro figura Matatías, primer mártir de la lucha que, al asesinar a un idólatra, desencadenó la cruenta guerra. En las claves restantes, cuatro de los cinco hijos que secundaron su hazaña. El primero de ellos fue Judas Macabeo, de quien proviene el nombre de este grupo de caudillos. A éste le siguieron sus hermanos Simón, Jonatàs y Eleazar que lideraron la rebelión contra Antíoco Epifanes y sus lacayos ${ }^{1390}$.

Su razón de ser es servir como modelo de actuación por su fiel observancia de la ley y su defensa de la religión cristiana frente a la idolatría sea cual fuere el precio a pagar, incluso si es la muerte.

Esta bóveda, que cierra el lado meridional, presenta exactamente la misma estructura y ornamentación que la bóveda séptima, que inauguraba este tramo sur. Como en aquella, una flor de cuatro pétalos emerge de la clave central hasta los medallones secundarios. Los plementos conformados a partir de esta flor contienen un jarrón con flores sobre una fuente semicircular ornamentada con cintas y base de

${ }^{1390}$ SCIO DE SAN MIGUEL, don Felipe. La Biblia. Vulgata Latina traducida en español. Tomo VIII. Los doce Profetas menores y los libros I y II de los Macabeos. Valencia, 1793, pp. 257-259 
hojarasca, completamente igual al de la otra bóveda. Igualmente se repite en la plementería adyacente el motivo de las parejas de serpientes con cabeza de dragón encadenadas a unas argollas que son vigiladas por la atenta mirada de una testa de ángel. Como ya señalamos previamente, esta panda, de menor calidad técnica que la precedente y la que le sigue, fue realizada por escultores de menor pericia técnica.

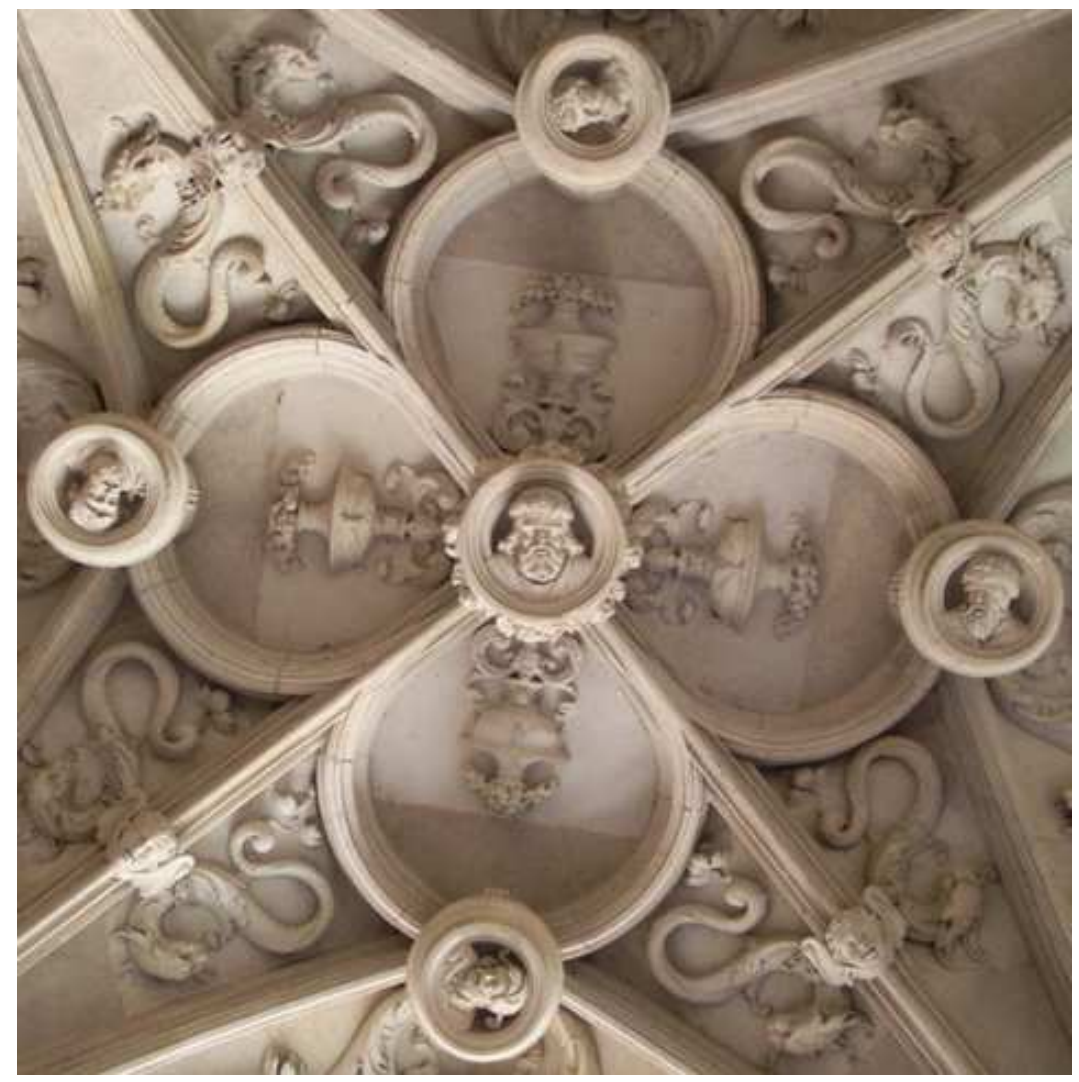

Bóveda 13. Caudillos del pueblo judío: los macabeos.

Converge en la esquina externa la ménsula de Aarón, hermano de Moisés y primer sumo sacerdote de los judíos. Le acompaña a un lado el tabernáculo que contenía el Arca de la Alianza, relacionado directamente con Aarón, pues uno de los objetos sagrados que en ella se guardaban era la vara que hizo florecer. En el otro lado se sitúa el incensario, pues Aarón se serviría de él en las ceremonias religiosas. En el ángulo interno del claustro se ubica Gedeón, hijo de Joás, perteneciente a la tribu de Manasés, una de las doce de Israel, donde ejerció además de juez. Destacó 
por sus victorias militares, sobre todo contra los madianitas ${ }^{1391}$. Junto a él figura un cordero sobre un altar, en relación al milagro del vellocino. Gedeón, incrédulo, pide a Dios dos pruebas de su elección como liberador de Israel: debía caer el rocío solamente sobre el vellocino dejando seca toda la era y viceversa ${ }^{1392}$. En el muro occidental, junto a Gedeón, el busto de Sansón flanqueado por la quijada de león y las puertas abatidas, aludiendo a su don principal, su fortaleza hercúlea. El primero de los atributos hace referencia al pasaje en el que Sansón extrae un panal de miel de las fauces del león, hecho que San Isidoro vincula con la liberación de los Justos del inframundo. El segundo de los objetos se relaciona con el episodio de Gaza, por el que Sansón arranca las puertas de sus goznes para huir de los filisteos y las transporta hasta la cima de una montaña. En esta proeza se ha querido ver una prefiguración de la Resurrección de Cristo, pues del mismo modo que Sansón se libera de esta prisión, Jesús levanta la piedra de su tumba ${ }^{1393}$.
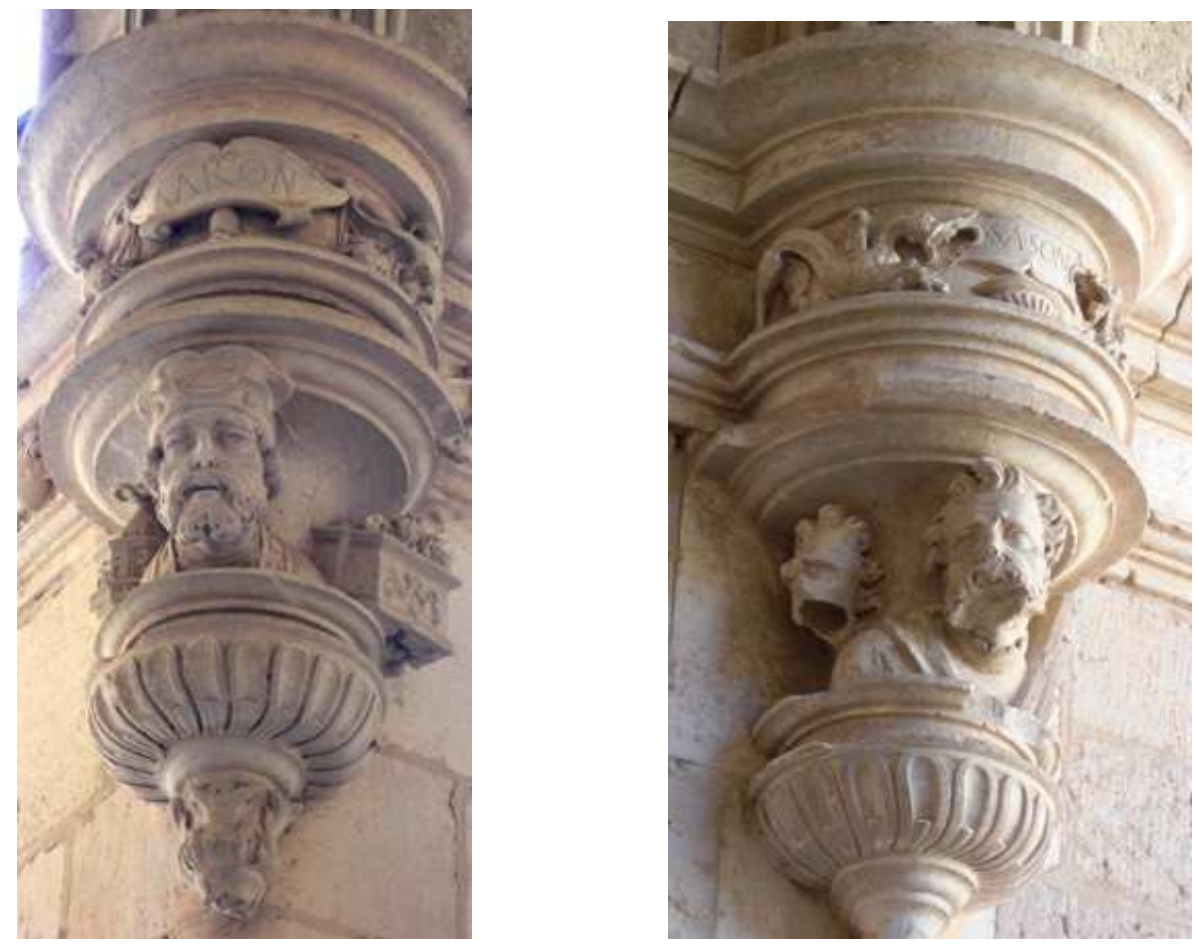

Ménsulas que representan a Aarón y Sansón.

\footnotetext{
${ }^{1391}$ Salmo 83, 12 y Jueces, 6-8.

1392 REAU, Louis. Iconografía...Tomo 1, volumen 1, Op.cit, pág. 273. El pasaje bíblico se relata en Jueces, 6: 36-40.

${ }^{1393}$ Ibídem, pp. 286-289. El primero de los relatos lo hallamos en Juces, 14:8 y el pasaje de las puertas en Juces, 16.
} 
Bóveda 14: La clave de la bóveda cerraría el ciclo del tramo anterior al ser ocupada por el quinto hijo de Matatías y jefe de los Macabeos, de nombre Jojanán o Juan.

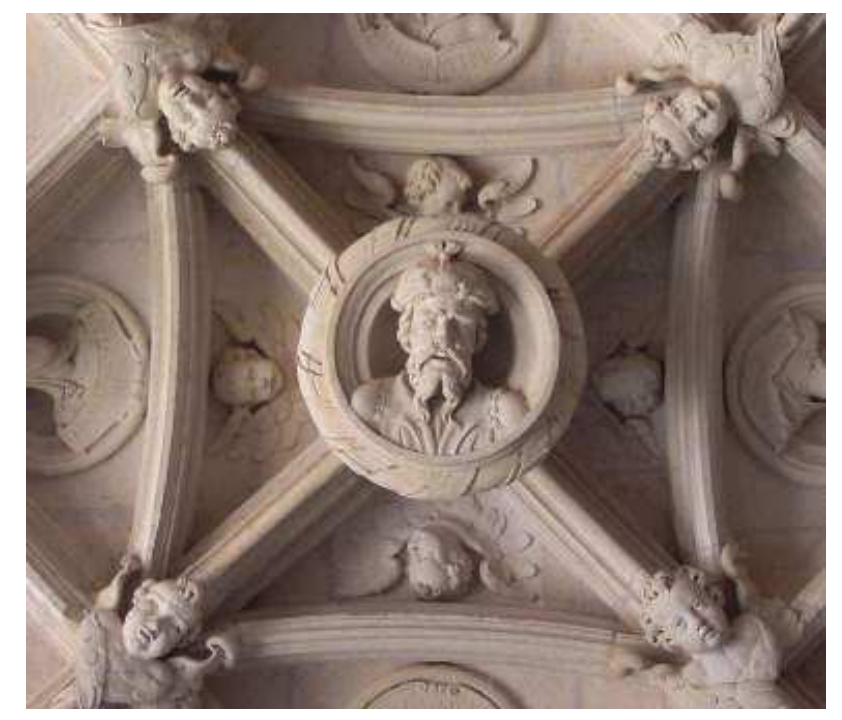

\section{Bóveda 14. Juan Macabeo en la clave central.}

Veamos ahora que no solamente en este claustro se esculpieron a los personajes “...que de voluntad trocaron la púrpura por el hábito...”, sino también “...los que tuvieron el claustro por prisión, destronados violentamente... ${ }^{1394 ” . ~ E n ~}$ este sentido, a excepción de la clave, la bóveda está dedicada a ocho personajes de connotación negativa que vendrían a reforzar el carácter ejemplar del resto de protagonistas del ciclo escultórico. Los cuatro personajes situados en las claves de las bóvedas secundarias representan la contrapartida de los macabeos, con quienes lucharon por incorporarles al pueblo seleúcida: Demetrius rex, Alcimus sacerdos, Nicanor dux y Báquides dux.

Demetrio I sube al trono tras Ptolomeo y tras establecer alianzas con los macabeos, las acabó incumpliendo, siendo derrotado por Simón. Designó a Alcimus como Sumo Sacerdote. En realidad este personaje es Eliachim, antecesor de Cristo que figura en las bóvedas quinta y octava, pero en este caso, no figura con el nombre hebreo sino con el equivalente griego, pues traicionó al pueblo judío al idolatrar a

${ }^{1394}$ ARASF, Palencia, Comisión Provincial de Monumentos, Leg. 4-46-3. 
los dioses helénicos. Súbdito de Demetrio era Báquides, que es enviado a matar a Judás, quien fallece en la batalla, siendo sucedido por su hermano Jonatám. Al no poder vencerle ni por fuerza, ni por engaño, establece un acuerdo con él de no volver más a Judea. A Jonatám, le sucede Simón, que gozará de una gran paz, al vencer como dijimos, a Demetrio.

Por lo que respecta a Nicanor, éste es enviado por Demetrio bajo la sugestión de Alcino para que mate a Judas. Con un mensaje de paz engañoso se presentó ante el Macabeo, que sabedor de su treta, estaba preparado para la lucha, de la cual Nicanor salió huyendo con los hombres que le quedaban ${ }^{1395}$.

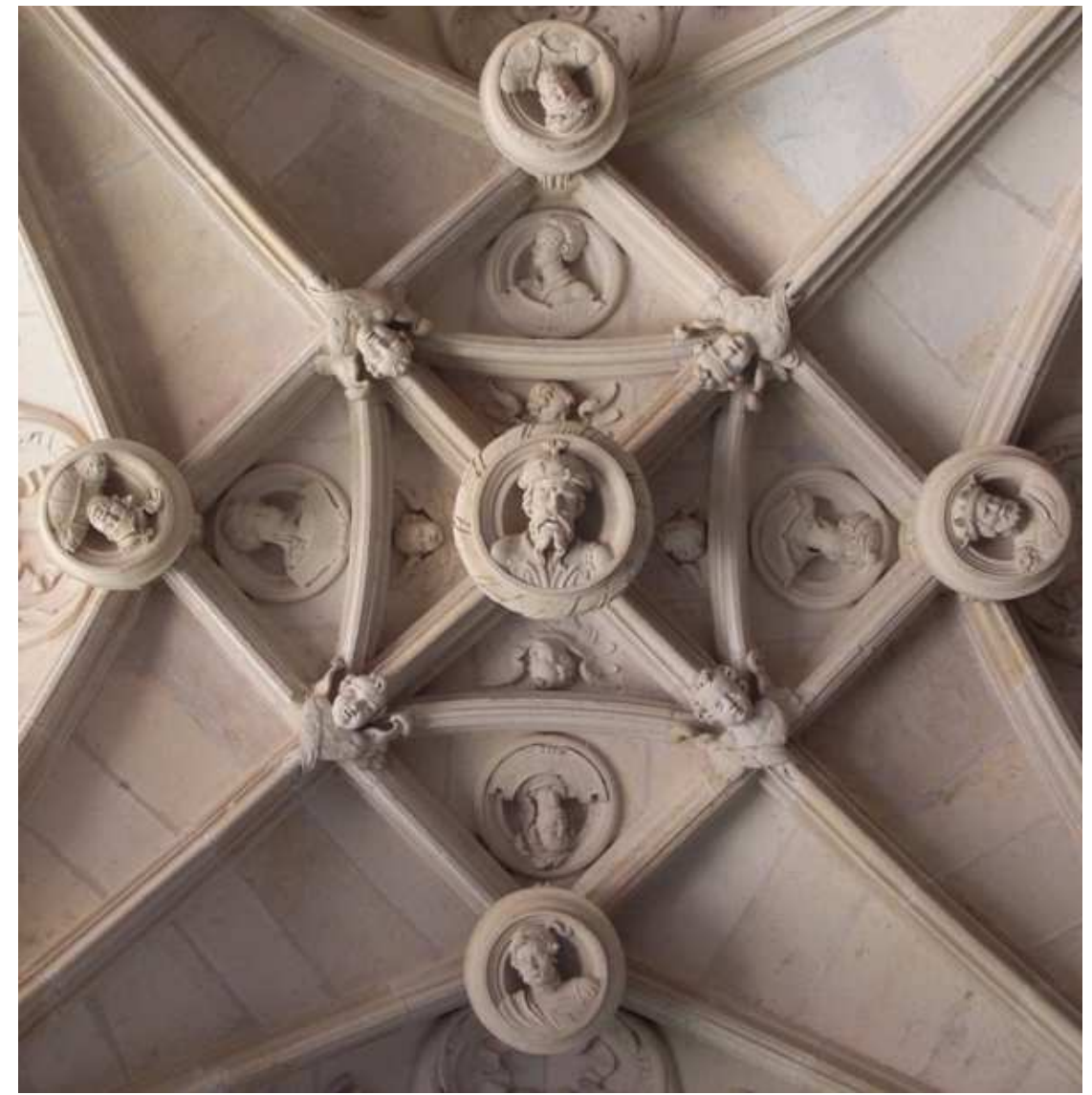

Bóveda 14. Personajes hostiles al pueblo judío: seleúcidas y pecadoras.

\footnotetext{
${ }^{1395}$ SCIO DE SAN MIGUEL, don Felipe. La Biblia...Macabeos, Op.cit, pp. 314-318, 380-390, 467-
} 471. 
Las cuatro figuras restantes, ubicadas entre los personajes previamente analizados y la clave central, representan a mujeres pecadoras del Antiguo Testamento. Una de ellas es Rahab, la meretriz, una prostituta de la ciudad cananea de Jericó que traicionó a su pueblo ocultando a dos espías de las huestes de Josué que la salvarían de una muerte segura ${ }^{1396}$. Betsabé, esposa de Urías, cometió adulterio con el rey David, por lo que su esposo fue asesinado para ocultar su culpa $^{1397}$. Las otras dos mujeres representadas se llaman Thamar. Una es la hija de David que fue mancillada por su hermano Amnón al obligarla a yacer con él cuando fingía estar enfermo. El hermano de ambos, Absalón, vengó el ultraje cometido ordenando el asesinato de Amnón ${ }^{1398}$. La otra Thamar, madre de Phares y Zara, se disfrazó de prostituta y engañó a su suegro, Judá, para yacer con él y así poder tener descendencia, ya que éste no le había entregado a su hijo Sela por esposo ${ }^{1399}$.

A partir de la bóveda siguiente y en las ocho restantes de las crujías septentrional y occidental se desarrolla el ciclo relativo a la descendencia espiritual benedictina.

Bóveda 15: Encontramos una representación de Sumos Pontífices, identificados todos ellos con su tarjeta correspondiente y acompañados de la tiara papal, bien sobre la cabeza o reposando junto a ellos. Están dispuestos siguiendo un sentido cronológico, de tal modo que en esta bóveda asistimos a la representación de los más antiguos, aquellos que detentaron el Papado entre los siglos II al IX.

En el centro, San Benito, porta un libro, que identificamos claramente con la Regula Benedicti, pues palabras inscritas en el mismo inauguran el prólogo contenido en dicho manual: "AUSCULTA, O FILI, PRAECEPTA MAGISTRI ET INCLINA

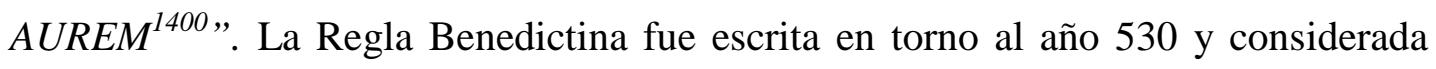
como el modelo de vida de muchas órdenes monásticas, además de la benedictina, que se reconocían en ella. A través de estas líneas, los monjes de San Zoilo reconocen a su fundador como su modelo espiritual a seguir.

\footnotetext{
1396 Josué, 2.

1397 Samuel, 11 y 12.

${ }^{1398}$ Samuel II, 13.

1399 Génesis, 38.

1400 "Escucha, oh, hijo, las enseñanzas del maestro e inclina el oído de su corazón”. Prosigue, "Recibe con gusto el consejo de un padre piadoso y cúmplelo verdaderamente...". BENITO DE NURSIA. $L a$ Regla de San Benito. Introducción y cometario por COLOMBAS GARCIA M. Traducción y notas por ARANGUREN; Iñaki. 2ª Edición. Biblioteca de Autores Cristianos. Madrid, 1993, pág. 65.
} 


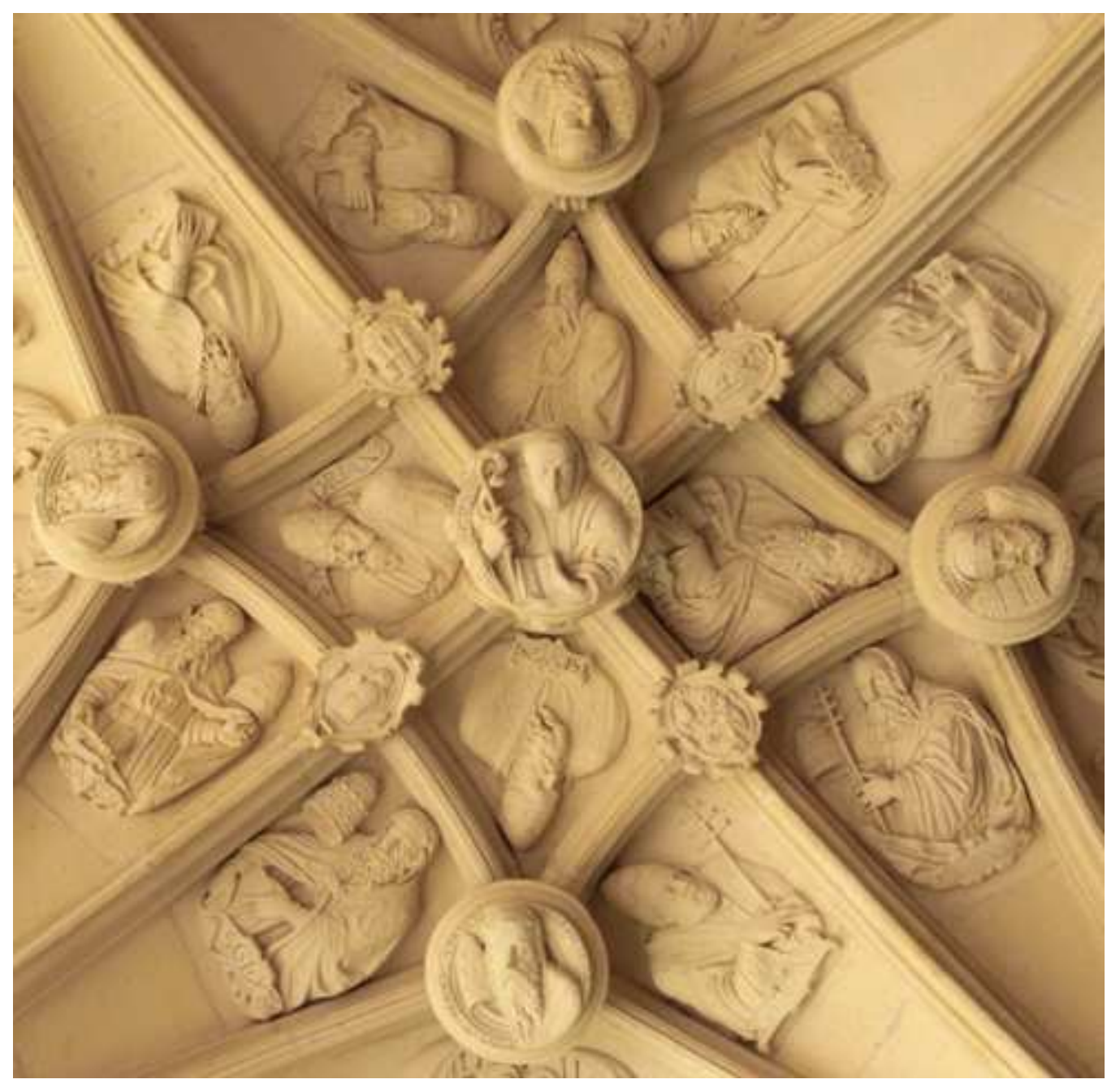

Bóveda 15. Descendencia espiritual de San Benito. Los Papas.

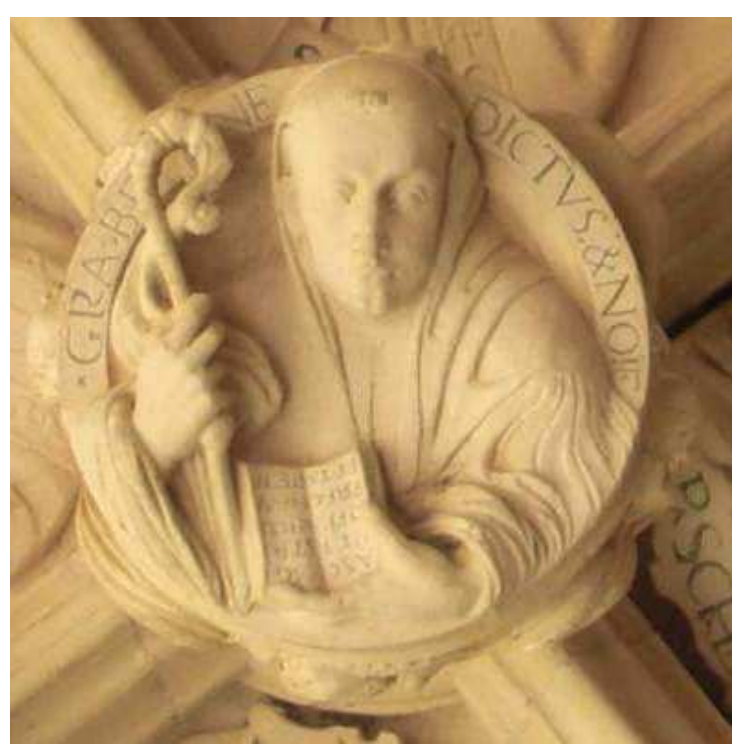

Bóveda 15. Clave central representando a San Benito. 
Las más antiguas dignidades, comprendidas entre los siglos II al VI, se ubican en los plementos comprendidos entre los nervios diagonales, donde se disponen los bustos formando parejas, que enumeramos según el orden cronológico en que ostentaron el papado. A San Alejandro (109-119) se debe el uso de agua bendita como práctica purificadora y la adopción del pan y el vino en la Eucaristía $^{1401}$. A su lado, San Calixto (219-222), esclavo liberado de origen griego y primer mártir romano después de San Pedro, que fue asesinado a golpe de bastón en el lugar donde hoy se alza la basílica romana de Santa María in Trastévere. Le sucedió San Urbano (223-230) quien tuvo que hacer frente al cisma que produjo el antipapa Hipólito de Roma. Junto a éste, San Estéfano (253-257), que defendió la validez del bautismo administrado por los lapsi o cristianos que apostataron ante las persecuciones romanas. Sin embargo, rechazó la posterior reintegración de éstos en el seno de la iglesia, lo cual motivó una lucha ideológica con San Cipriano, Obispo de Cartago. San Silvestre (314-336) celebró el Primer Concilio Ecuménico en Nicea en el año 325, condenando el arrianismo, que negaba la divinidad de Cristo. San Anastasio (399-402) apoyó fervientemente el donatismo, doctrina contra la

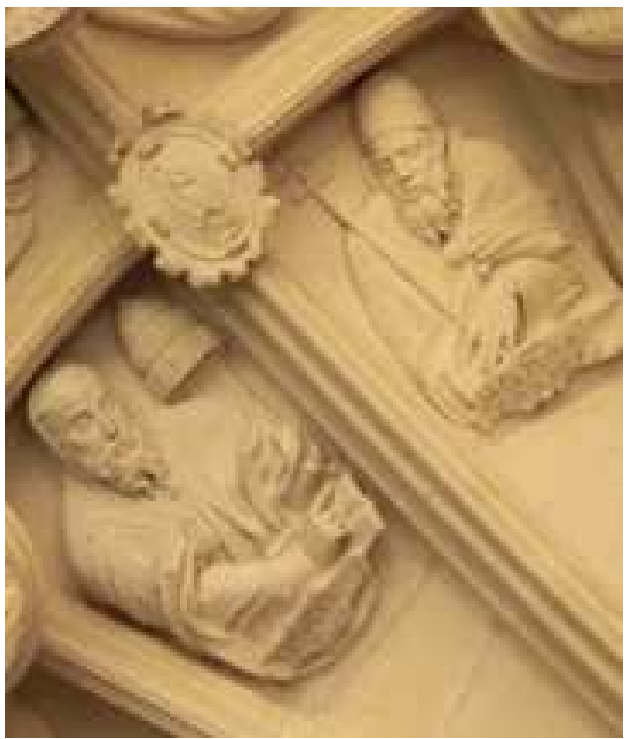
relajación de las costumbres entre los fieles. San Bonifacio (418-422) hizo frente al antipapa Eulalio y apoyó a San Agustín en su lucha contra el pelagianismo, herejía que negaba la existencia del pecado original. Finaliza la lista el Pontífice Juan I, Toscano (523-526), que fue fraile antes de su elección de Pontífice y negoció con Justino I, aunque sin éxito, el cese de las persecuciones de los $\operatorname{arrianos}^{1402}$.

\section{Bóveda 15. San Esteban y San Bonifacio en los plementos.}

\footnotetext{
1401 SCORZA BARCELLONA, Francesco. "Alejandro I, santo" en Enciclopedia dei Papi. Istituto della Enciclopedia italiana. Roma, 2000, pp. 213-215.

1402 CAMPANY Y DE MONTPALAU, Antonio de. Compendio cronológico- histórico de los soberanos de Europa. Primera parte. Real Compañía de impresores y libreros. Madrid, 1792, pp. 3-9.
} 
En la confluencia de los nervios combados y terceletes, se ubican las cuatro claves secundarias que alojan a cuatro Papas de los siglos V y VI:

-San Celestino (422-432), hizo frente a las doctrinas heréticas como el pelagianismo y el nestorianismo -que admitía a María como Madre de Cristo pero no como madre de Dios- prohibidas definitivamente en el Concilio de Éfeso del año 431.

-León el Magno (440-461) es trascendental para la historia de la iglesia, pues durante su pontificado se celebró el Concilio de Calcedonia (451), que proclamó la humanidad y divinidad consustanciales de Cristo.

-Por su parte, Benedicto Bonoso (574-578), fue designado pontífice 11 meses tras la muerte de su antecesor Juan III debido a la invasión lombarda que impedía cualquier comunicación entre Roma y Constantinopla. También fue un gran combatiente de las herejías emergentes ${ }^{1403}$.

-Gregorio Magno (590-604), además de ser uno de los cuatro Padres de la Iglesia Latina, fue monje benedictino, el primero en alcanzar la dignidad pontificia. Escribió Regula Pastoralis, un manual de predicación para los obispos ${ }^{1404}$.

A esta larga lista de eminencias se suman los papas dispuestos en torno a San Benito, ocupando los plementos inmediatos al fundador e insertos en un romboide. Son los Pontífices más relevantes entre los siglos VII al IX:

- Eugenio I, fue un arcediano romano que detentó el Papado durante tres años, desde el 654.

-Respecto a San Sergio I, elegido al trono pontificio a la muerte de Conón, en el 687, fue quien introdujo el Agnus Dei en la liturgia de la misa y extinguió el Cisma de los Obispos de Istria.

-Adriano I, fue electo papa en el 772 y logró, gracias a la ayuda de Carlomagno, trasladarse a Roma con la ayuda de su ejército. Por ello, aumentó las donaciones hechas por Pipino a la iglesia.

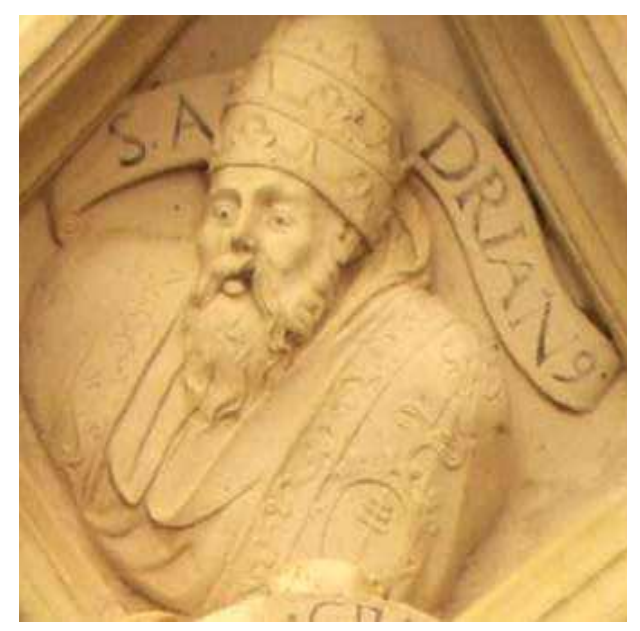

Bóveda 15. El Papa Adriano I.

\footnotetext{
${ }^{1403}$ Ibídem, Op.cit, pp. 7,10.

${ }^{1404}$ HERNANDO PÉREZ, José. "En las raíces de Europa, San Gregorio Magno: perfiles de su persona” en Salmanticensis, vol 51, fasc,3. Salamanca, 2004, pp. 579-598.
} 
-Pascual I, finaliza esta serie. Duró su pontificado desde el 817 al 824, realizando por entonces el traslado de muchas reliquias de mártires a las iglesias romanas, además de prestar ayuda a los cristianos en sus luchas contra los sarracenos ${ }^{1405}$.

En las ménsulas encontramos a Elí, Ana y su hijo Samuel, personajes íntimamente relacionados en un pasaje del Libro de Reyes. Ana no había tenido descendencia, y desesperada se fue al templo de Silo y prometió a Dios que si cumplía su deseo, entregaría a su hijo para que fuera adoctrinado. Su deseo fue concedido y nació Samuel, que se convertiría en el último juez de Israel. Ana, como prometió, presentó a la criatura ante Elí, sacerdote de dicho templo que se encargaría de educar a Samuel en el seno de la religión, po lo cual la iglesia le acompaña como atributo. Tras el sacrificio de un becerro, Ana exclamó agradecida: "Yo soy aquella mujer, que estuve aquí, orando al señor, delante de ti”. Precisamente estas palabras figuran en la inscripción que le acompaña: "EGO SVM QUAE STETI CORAM ${ }^{1406 ” . ~}$
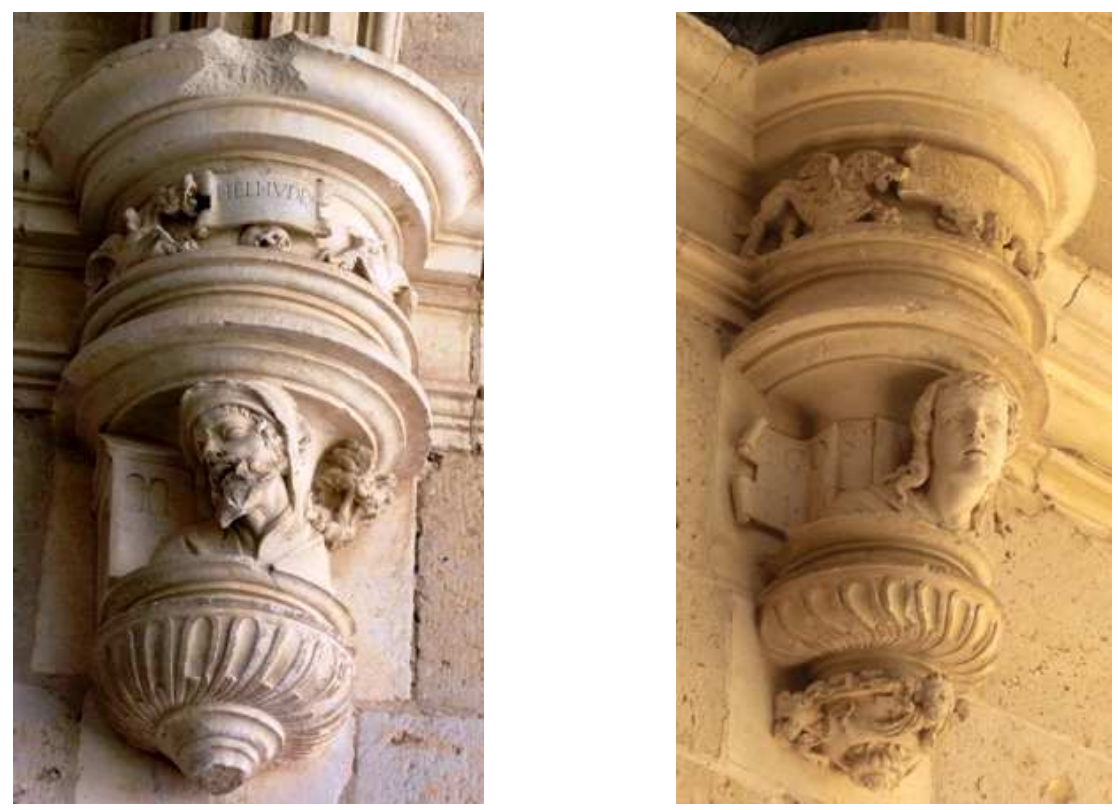

Ménsulas que representan al Juez Helí y a Ana, madre de Samuel.

\footnotetext{
${ }^{1405}$ CAMPANY Y DE MONTPALAU, Antonio de. Op.cit, pp. 12-16

${ }^{1406}$ La frase completa sería "Ego sum illa mulier, qua steti coram te hic orans Dominum". Este pasaje se relata en el primer capítulo del Primer libro de Reyes. SCIO DE SAN MIGUEL, don Felipe. (Obispo de Segovia). La Biblia. Vulgata Latina traducida en español. Tomo IV del Antiguo Testamento. Josué, Jueces, Ruth y Primero de los Reyes. Imprenta de Don Benito Cano. Madrid, 1795 , pp. 343-350.
} 
Su hijo, Samuel se convirtió en profeta, y fue quien eligió a Saúl como primer rey del pueblo judío ${ }^{1407}$. Va acompañado por una cimitarra, pues defendió Israel de las tribus sublevadas. Examinados estos tres personajes, nos falta por mencionar la ménsula ubicada en la pilastra externa, frente a Ana, mater Samuel, que representa a San Matías, acompañado de un libro. Inaugura el ciclo de Apóstoles, siendo éste quien fue elegido por Dios como sustituto de Judas Iscariote al preferirlo al otro candidato, José, al que llamaban Barsabás ${ }^{1408}$. Porta como atributo personal una alabarda, pues fue ésta el arma que le causó la muerte, por decapitación, siendo martirizado previamente con lapidación por orden de Ananías ${ }^{1409}$.
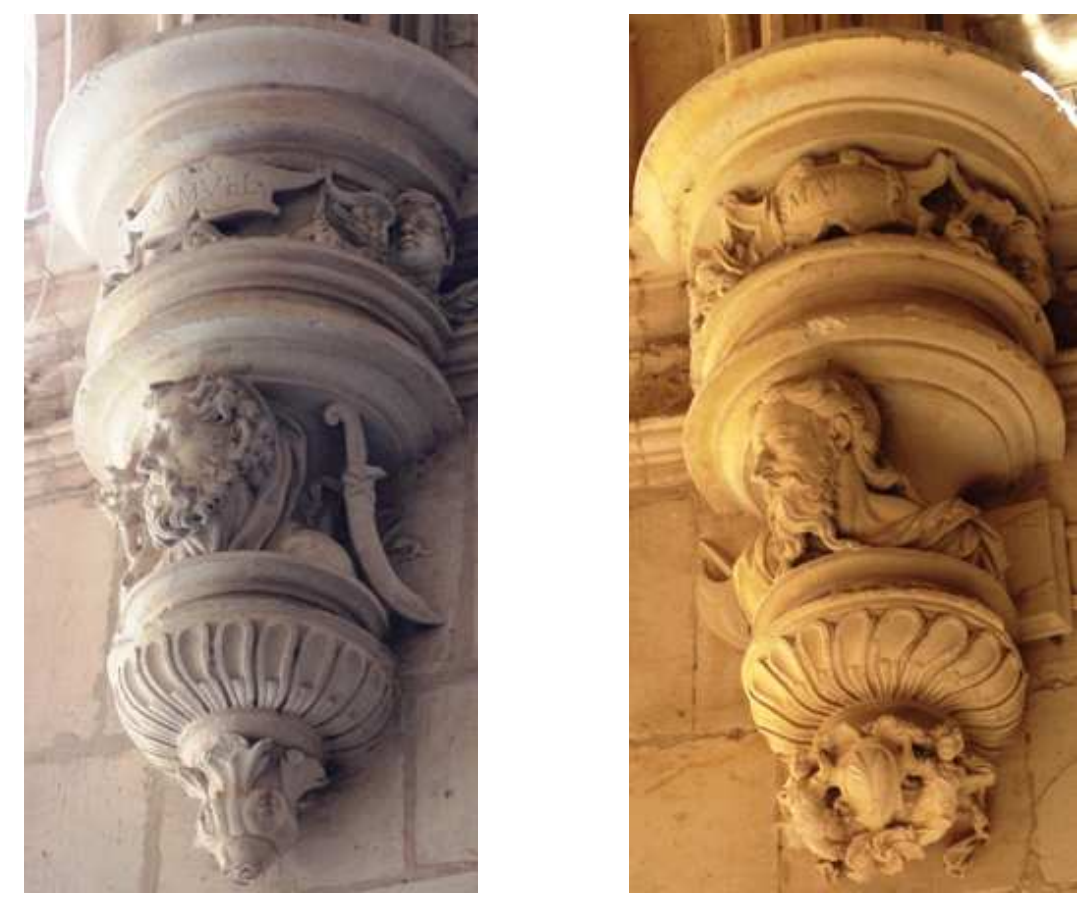

Ménsulas que representan al profeta Samuel y a San Matías.

En la parte superior de este muro figura una inscripción en uno de los sillares que junto a la marca del cantero dice: "FEBRERO 19, 1575”. En este tramo parece

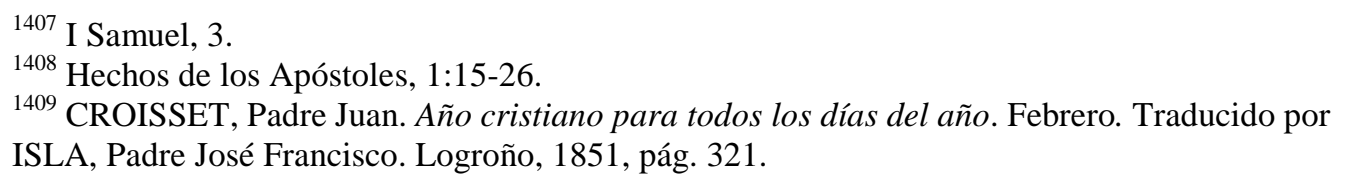


que se hizo el contrato con Juan de Celaya, que sustituye a Pedro de Castrillo en la ejecución de las bóvedas, mientras que la parte escultórica la ejecuta Antonio Morante $^{1410}$.

Bóveda 15. Clave representando a Gregorio Magno y bajo la misma, la inscripción de la conclusión de ese sector.

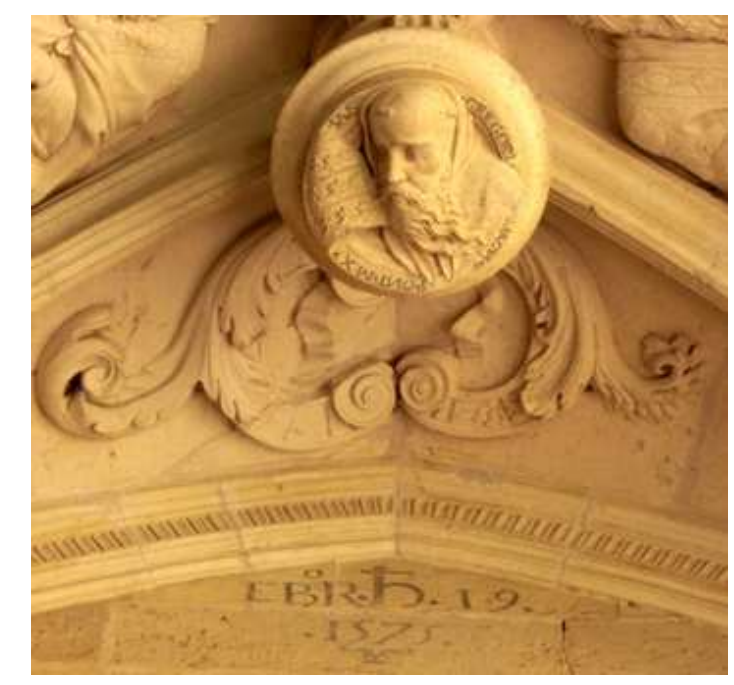

Bóveda 16: Del poder espiritual hallado en la bóveda anterior, pasamos, en las tres bóvedas siguientes, con diversos representantes del poder temporal, la mayor parte de los cuales fueron fundadores de cenobios. Contiene exactamente el listado incluido en la Aprobación de la gloriosísima regla de San Benito: "Césares que

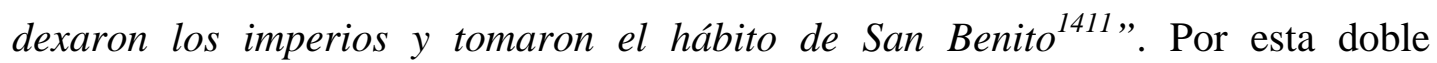
condición que detentaron a lo largo de sus vidas, visten el hábito benedictino y todos ellos portan cetro y corona, a excepción de Isacio que no lleva el bastón de mando y su corona se dispone a un lado.

La mayor parte de los personajes son emperadores bizantinos, de los siglos VII al XI que no figuran en orden cronológico. Asimismo tienen cabida dos monarcas europeos que aunque no alcanzaran la distinción de emperadores, así figuran en las tarjetas y así les denominan, como veremos, las fuentes benedictinas.

\footnotetext{
${ }^{1410}$ PONZ, Antonio. Viaje...tomo XI, carta VI, y de éste ARASF. Fondo Antiguo de Revistas, 708 : BECERRO BENGOA, Ricardo. "El monasterio... Op.cit, pág. 71.

${ }^{1411}$ ANÓNIMO. Aprobación de la regla. Op.cit,, pág. 67.
} 


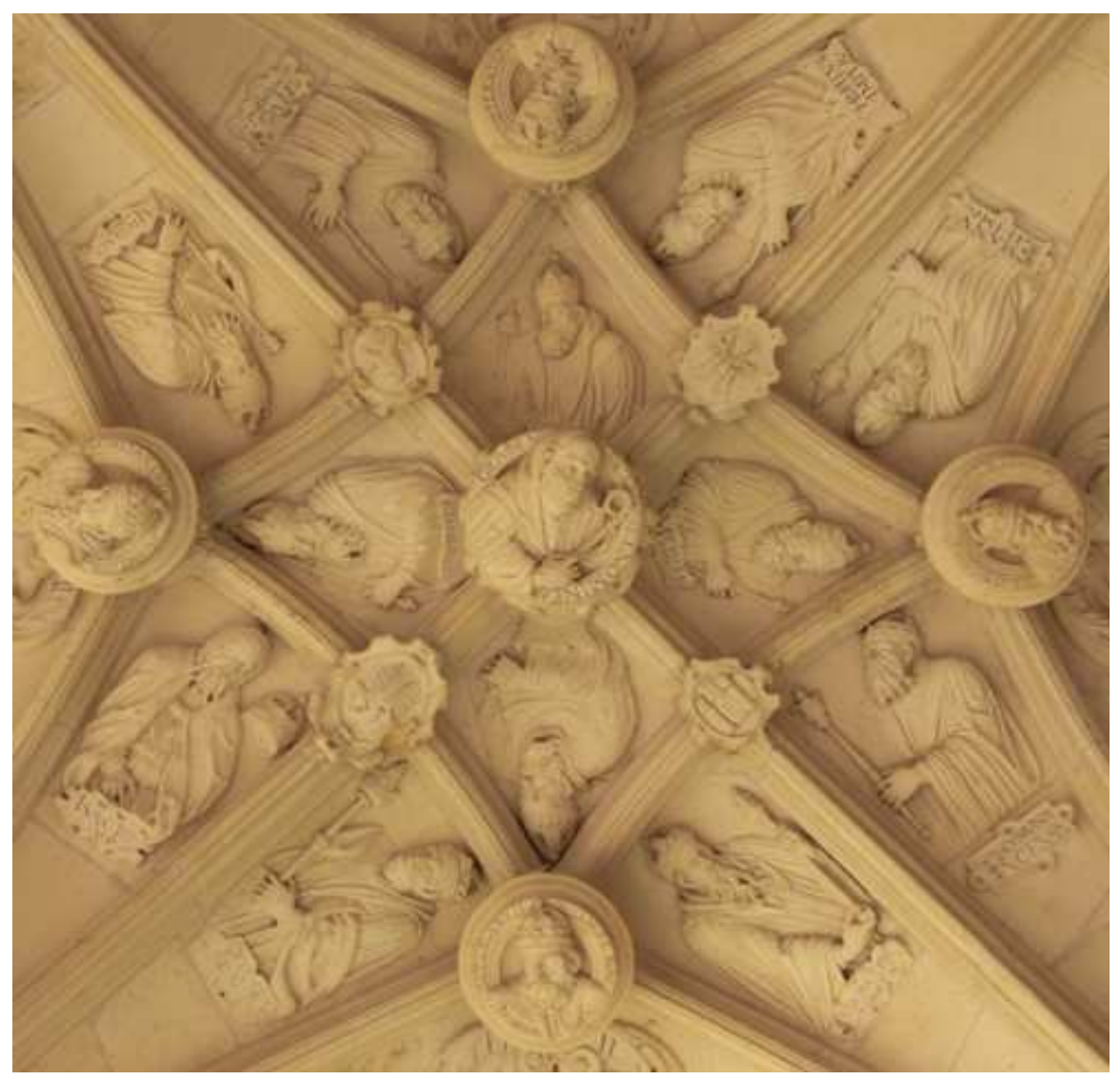

Bóveda 16. Descendencia espiritual de San Benito. Monarcas y emperadores.

En torno a la figura de San Benito, se disponen en las cuatro claves secundarias: Teodosio, imperator. Siguiendo los nombres que establece la Regla, se refiere a Teodosio III, electo entre el 715 y 717. La revuelta promovida por León el Isaurio, futuro León III, le llevó a renunciar al trono, y tomar el hábito. Participó en el Concilio Iconoclasta. Poco después se convirtió en Obispo de Éfeso ${ }^{1412}$.

-Lotario I, emperador carolingio, fue nieto de Carlomagno. Despojó a su padre, Luis I, más conocido como Ludovico Pío, de sus insignias imperiales y le hizo prisionero durante un año ${ }^{1413}$. Arrepentido, restituyó a su padre en el poder y tomó el hábito en el monasterio Pruniense ${ }^{1414}$.

-Constantino César, más célebre como Constantino X Monómaco, fundó entre 1048 y 1050 los monasterios de San Jorge y Energites en Constantinopla, que decoró

\footnotetext{
1412 GEORG MAIER, Franz. Bizancio. Siglo XXI de España Editores. Argentina, 2002, pp. 83-84.

1413 ANÓNIMO. Aprobación de la regla. Op.cit,, pág. 67.

${ }^{1414}$ HEREDIA, Fray Antonio de. Vidas...Tomo 4. Op.cit, pág. 7.
} 
lujosamente. Bajo su mandato se produjo el Cisma entre Oriente y Occidente $(1054)^{1415}$.

- “BULGARIUM IMPERATOR”. Así reza la tarjeta que contiene la figura que completa la cuarta de las claves de la crucería, cuya identidad permanece anónima ante la cantidad de emperadores búlgaros que existieron. Aparte de esto, no figura en el catálogo de la Regla benedictina, por lo que no poseemos ningún dato del mismo. No podemos afirmar tampoco que se trate de Isaac, como señala Becerro de Bengoa, pues éste figura en uno de los plementos y además no alcanzó la dignidad mencionada $^{1416}$. Entre estas cuatro claves y ubicadas en la convergencia de los nervios combados con los diagonales, se disponen cuatro cueros recortados en los que se han tallado un león y un castillo, alusivos al linaje fundador y los otros dos, que se repiten, representan dos palmas del martirio que nos recuerdan a San Zoilo y San Félix ${ }^{1417}$.

Próximos al santo de Nursia, en los plementos que le circundan, se ubican cuatro figuras de medio cuerpo, correspondientes a cuatro emperadores:

-Alejo César, tuvo que afrontar un período de crisis política motivado por las sucesivas invasiones en la Península Balcánica y el progresivo deterioro de la influencia de Bizancio en Asia Menor. Gracias a sus múltiples apoyos, consiguió controlar la situación, consolidando el poder imperial. Dos décadas después de su fallecimiento en 1118, su hija Ana escribió en su memoria la célebre Alexíada, principal fuente sobre la época bizantina ${ }^{1418}$.

-Miguel IV, apodado "Paflagonio", gobernó entre 1034 y 1041. Delegó el poder en manos de su hermano, Juan Eunuco, gracias al cual logró numerosas victorias. Aquejado de hidropesía, se retira de la vida política y funda un monasterio dedicado a los Santos Cosme y Damián, en la orilla este del Bósforo ${ }^{1419}$.

-Miguel V "Calafates", sobrino de Miguel IV, le sucedió solamente un par de años, hasta 1042, en que subieron al trono Teodora y Zoe. Ésta última figura en una de las claves de la bóveda décimo séptima. Zoe era su madre adoptiva, a la que expulsó, provocando un levantamiento que conllevó su huida al monasterio de Studio, al

\footnotetext{
${ }^{1415}$ GEORG MAIER, Franz. Bizancio...Op.cit, pp. 221-224.

${ }^{1416}$ BECERRO BENGOA, Ricardo. "El monasterio...Op.cit, pág. 71.

1417 Ya tuvimos oportunidad de analizar todos estos elementos en la primera bóveda del conjunto.

${ }^{1418}$ OSTROGORSKY, Georges. Historia...Op.cit, pp. 350-370.

${ }^{1419}$ PSELO, Miguel. Vida de los Emperadores de Bizancio. Introducción y traducción por Juan Signes Codoñer. Biblioteca universal Gredos. Madrid, 2005, pp. 137-174.
} 
suroeste de Constantinopla. Pero el pueblo le encontró y le castigó con la ceguera $^{1420}$.

- La tarjeta del último de los emperadores de este espacio está completamente borrada y ante la ausencia de atributos específicos, resulta imposible su identificación. No obstante, dado que todos estos personajes coinciden con el listado propuesto por la Aprobación de la Regla benedictina y el único que no figura es Anastasio II, bien podríamos atribuir a su persona esta tarjeta ${ }^{1421}$. Reinó brevemente, entre los años 713 y 715, momento en que el imperio estaba amenazado por los sarracenos. Fue derrocado por Teodosio III, retirándose a un monasterio en Tesalónica. Posteriormente quiso recuperar el trono resultando traicionado y decapitado $^{1422}$.

Bóveda 16. El emperador Miguel IV.

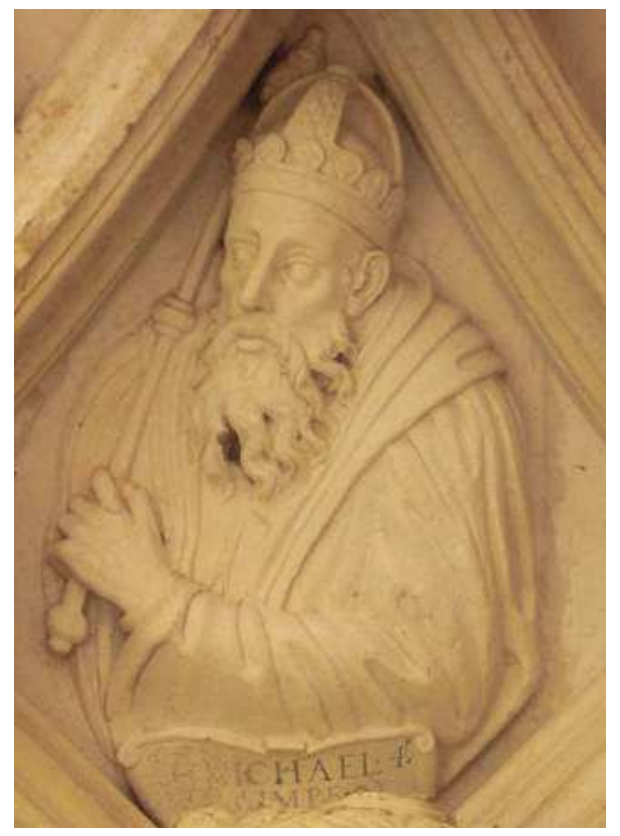

Por último, finaliza la serie de emperadores bizantinos en los ocho plementos que conforman los nervios terceletes:

-Miguel I fue un soberano débil pero fiel servidor de la Iglesia que reinó entre el 811 y 813. Rechazaba la iconoclastia, luchando fervorosamente contra sus líderes. Cuando fue derrocado por León $\mathrm{V}$ en el 813, ingresó en un convento benedictino

\footnotetext{
${ }^{1420}$ Ibídem, pp. 175- 208.

${ }^{1421}$ ANÓNIMO. Aprobación de la regla. Op.cit, pág. 67.

1422 PAULA MELLADO, Francisco de. Diccionario de historia y de geografía. Tomo I. Madrid, 1846, pág. 145 .
} 
hasta su fallecimiento en el $845^{1423}$. Junto a él se ubica Hugo, proclamado “emperador" de Italia en el 926. Huyó del país y se refugió en Borgoña, donde fundó un monasterio benedictino bajo la advocación de San Pedro ${ }^{1424}$.

- Emanuel o Manuel I Comneno fue elegido emperador en 1143. Fundó un monasterio en la embocadura del Ponto Euxino, dando a los monjes la renta del tesoro real. En su lecho de muerte se lamentó de haber confiado ciegamente en las supersticiones de unos astrólogos que le vaticinaron una prolongada vida, decidiendo que le pusieran el hábito antes de fallecer en $1180^{1425}$. Le sigue Teófilo, sucesor de Miguel II, cuyo reinado abarcó entre los años 829 y el 842 . Fue un acérrimo defensor de la iconoclastia y dedicó sus esfuerzos a la guerra contra los califas de Bagdad hasta que su salud fue debilitándose progresivamente, ingresando en un monasterio hasta el final de sus días ${ }^{1426}$.

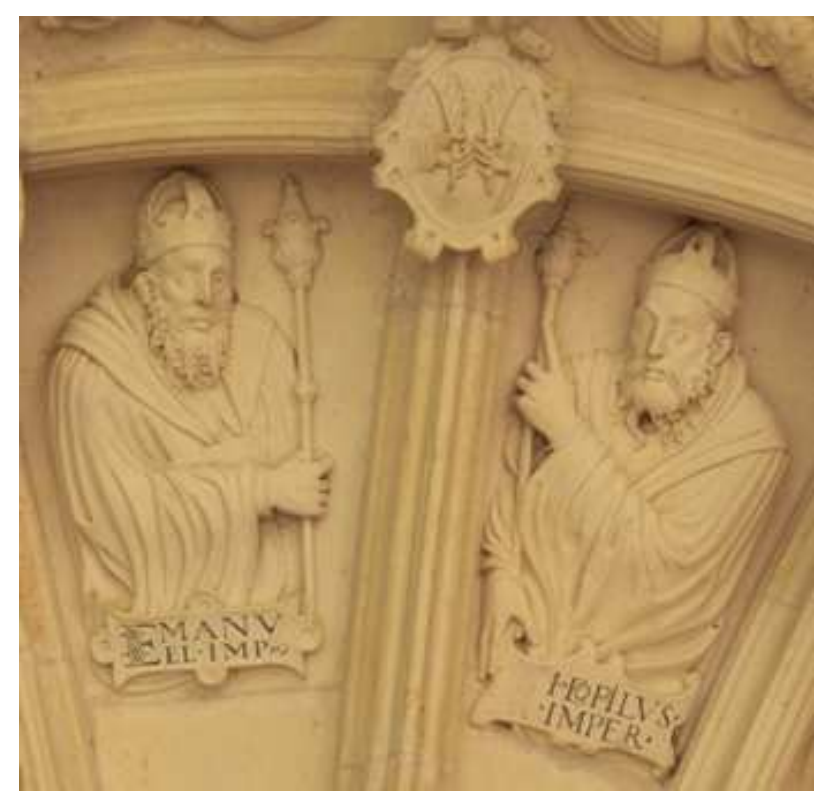

Bóveda 16. Plementos representando a los emperadores Emanuel I y Teófilo.

\footnotetext{
${ }^{1423}$ OSTROGORSKY, Georges. Historia del Estado bizantino. Akal. Madrid, 1983, pp. 204-207.

${ }^{1424}$ Yepes le denomina emperador, aunque no lo sea de Bizancio, por descender del mejor linaje europeo. Explica el monje benedictino que algunos le consideran sólo rey, porque los emperadores eran los de Alemania. YEPES, Antonio de. Crónica... Volumen V. Op.cit, pp. 70-72.

${ }^{1425}$ BERAULT-BERCASTEL, Antoine-Henri. Historia general de la Iglesia desde la predicación de los Apóstoles hasta el Pontificado de Gregorio XVI. Tomo III. Traducida por Epifanio Díez Iglesias. Madrid, 1852, pág. 470.Un amplio estudio sobre el período de su mandato en MAGDALINO, Paul. The Empire of Manuel I Komnenos: 1143-1180. Cambridge, 1993.

${ }^{1426}$ OSTROGORSKY, Georges. Historia...Op.cit, pp. 212-215.
} 
-Ludovico Pío, hijo de Carlomagno, se casó sin el permiso del Papa con Iudic, la hija del duque de Baviera con quien tenía lazos de consanguinidad. Purgó su castigo tomando el hábito de San Benito en Suecia ${ }^{1427}$. Junto a él, se sitúa Romano César, imperator, al cual Becerro de Bengoa identifica con Carlomagno, quien ya tiene protagonismo en la bóveda décimo octava ${ }^{1428}$. Se trata de Romano I Lecapene, que ostentó el trono de Bizancio entre el 929 y el 944, compartido simultáneamente con. Constantino VII e incluso con sus tres hijos. Tras una serie de intrigas, Romano huyó a la isla de Prote, donde falleció en calidad de monje ${ }^{1429}$.

-Isacio o Isaac I Conmeno, emperador en el breve período de 1057 a 1059, tras el cual tomó el hábito en Studion para consagrarse a los escritos. En su breve reinado se ganó la enemistad de la aristocracia y el clero por emprender una justa política de expropiación ${ }^{1430}$. Por su rechazo inmediato de la política y su mayor vinculación a la religión, es el único de los soberanos que relega la corona a un lado, portando tan sólo el hábito benedictino. Como bien explica el monje benedictino Arnoldo Urvión: “...sprezzando questo mondo \& suoi honori, offeriscono le corone temporali al P.S Benedetto, per riportarne poi una perpetua nel Cielo ${ }^{1431}$ ”. Culmina esta serie con Juan Eunuco, imperator, que fue ministro con Romano III, pero no llegó a alcanzar tal dignidad. Se le considera emperador, y así lo transmiten las fuentes, pues su hermano el emperador Miguel IV, delegó sus asuntos en éste ${ }^{1432}$.

Cobra el protagonismo de las ménsulas Judas Tadeo, que continúa el ciclo del Apostolado. A pesar de que la tarjeta que contiene a este personaje dice que se trata de Simón Thadeo y además va acompañado de la sierra de su martirio, no puede tratarse de éste, pues Simón aparece representado posteriormente, en la bóveda décimo novena y además, el único apóstol con el sobrenombre de Tadeo es Judas, quien por otra parte, faltaba en el programa. La confusión se deba posiblemente a que estos hermanos eran compañeros de viajes que predicaron juntos y fueron martirizados conjuntamente, de ahí que las crónicas los presenten formando

\footnotetext{
${ }^{1427}$ ANÓNIMO. Aprobación de la regla.. Op.cit, pp. 67-68.

${ }^{1428}$ BECERRO BENGOA, Ricardo. "El monasterio...Op.cit, pág. 71.

1429 MORENO CEBADA, Emilio. Historia de la Iglesia, 2: desde su establecimiento hasta el pontificado de Pío IX. Barcelona, 1867, pp. 559-560.

${ }_{1430}$ PSELO, Miguel. Vida de los Emperadores...Op.cit, pp. 383- 416.

${ }^{1431}$ UVION, Arnoldo. Brieve dechiaratione... Op.cit, pág. 69.

${ }^{1432}$ BERAULT-BERCASTEL, Antoine-Henri. Historia...Tomo III. Op.cit, pp. 226-227.
} 
pareja, en ocasiones ${ }^{1433}$. Por su parte, San Sebastián, mártir del siglo III, aunque no forma parte de este ciclo, es ejemplo de virtud cristiana por negarse a idolatrar a los dioses paganos. Además, después de San Pedro y San Pablo es considerado como el tercer patrón de Roma, cuna del poder Papal, de ahí su presencia en este ciclo ${ }^{1434}$.
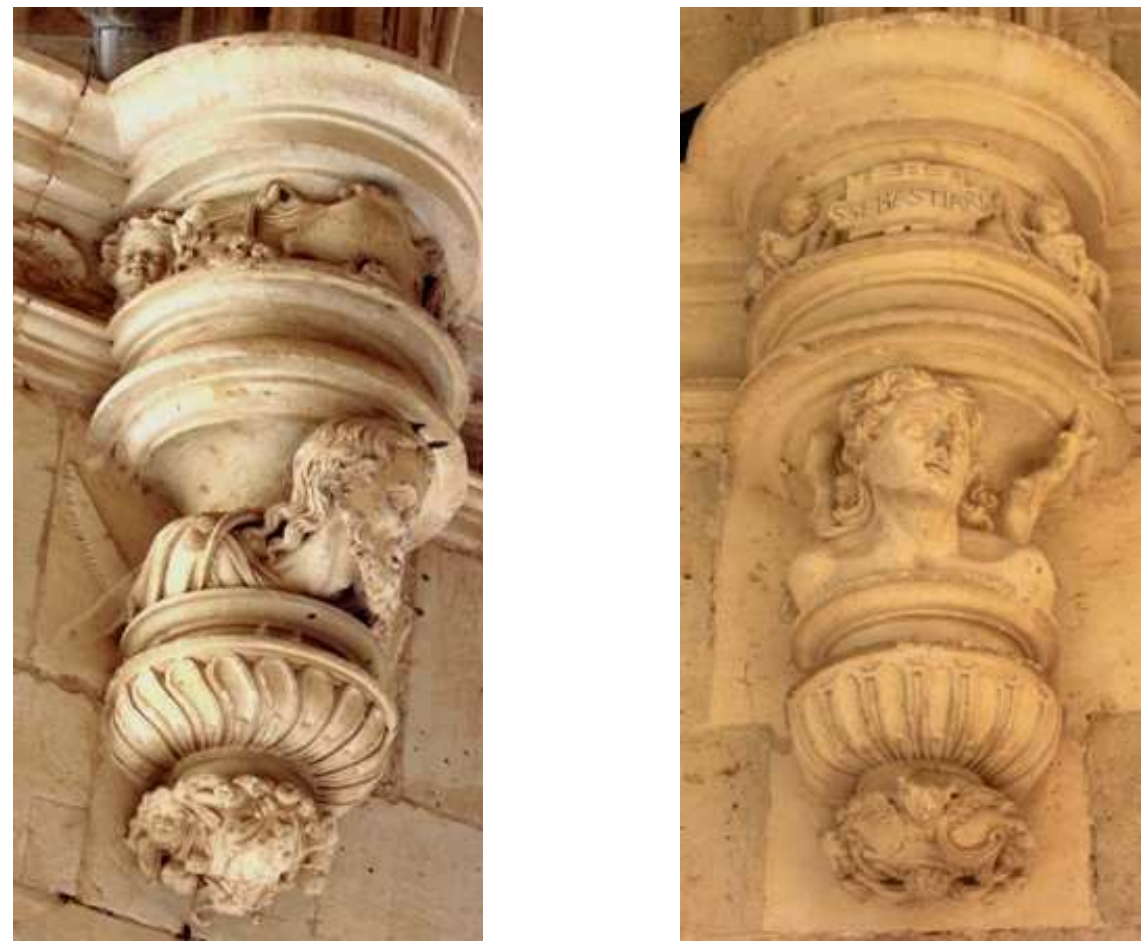

Ménsulas que representan a Judas Tadeo y a San Sebastián.

Bóveda 17: En esta bóveda aparecen representados diversas personalidades de la realeza, que corresponde a un nutrido grupo de emperatrices y reinas vinculadas a la orden benedictina, de ahí que porten corona y hábito, por su doble condición ${ }^{1435}$. Todas ellas, además, llevan un libro, que identificamos con la Biblia, pues aún se pueden llegar a leer algunas de las inscripciones contenidas en los mismos que remiten a versículos del Testamento.

\footnotetext{
1433 A este respecto, CASTELLANOS DE LOSADA, Basilio Sebastián. Biografía eclesiástica completa: vida de los personajes del Antiguo y Nuevo Testamento, de todos los santos que venera la Iglesia, papas y eclesiásticos célebres por sus virtudes y talentos. Tomo XXVII. Madrid, 1867, pp. 346-350.

${ }^{1434}$ DUCHET-SUCHAUX, Gaston y PASTOUREAU, Michel. Guía...Op.cit, pág. 351.

${ }^{1435}$ Todas ellas se incluyen en un listado con el que coinciden exactamente. ANÓNIMO. Aprobación de la regla y orden de... Op.cit, pp. 73-74.
} 


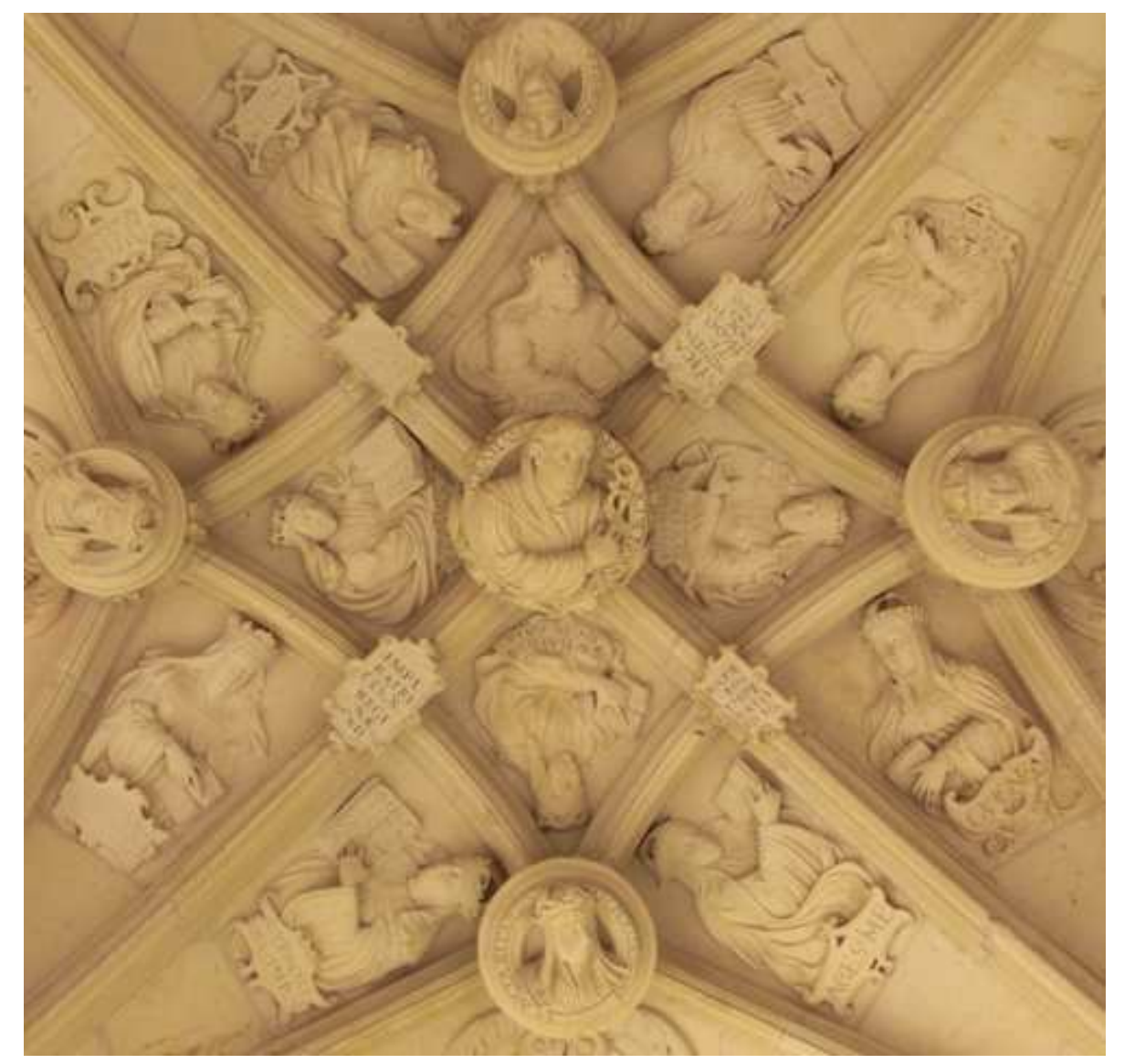

Bóveda 17. Descendencia espiritual de San Benito. Reinas y emperatrices.

Las mujeres representadas en las claves que enlazan los nervios combados y los terceletes no llevan libro, pues por motivos espaciales, tan sólo se representa su rostro. Fueron no obstante, devotas cristianas y fieles seguidoras de la Regla benedictina:

-Zoe no figura en la biografía de santas benedictinas ilustres, pues aunque pasó parte de su vida en un cenobio, fue en contra de su voluntad, encerrada por considerarla culpable de asesinato ${ }^{1436}$. Hija de Constantino VIII, llegó a reinar junto a su hermana Teodora durante menos de un año, en 1042. Se cree que mató a su marido Romano III para esposarse con su amante, Miguel IV, por lo que éste, ante la sospecha, la privó de libertad $^{1437}$.

${ }^{1436}$ REDONDO CANTERA, Ma José. “El programa...” Op.cit, pág. 139.

${ }^{1437}$ PSELO, Miguel. Vida de los Emperadores...Op.cit, pp. 128-134, 209-221. 
- Ricarda fue expulsada de su casa por su marido Carlos el Craso, marchando a Pavía mientras se construía el convento de Andelao, en Alsacia ${ }^{1438}$.

-María emperatriz de Bohemia con grandes dotes diplomáticas, convenció al Pontífice Juan XIII para que su reino se desmembrase del de Ratisbona y así elegir Obispo propio. Tras ello, ingresó en el convento de San Jorge de Praga, convirtiéndose en su abadesa en el $986^{1439}$.

-Cunegunda de Luxemburgo era emperatriz del Sacro Imperio Germánico y descendiente de Carlomagno. Su marido fue Enrique II, a cuya muerte, adoptó la regla benedictina en el monasterio alemán de San Salvador de Kagungen, en Esse, donde permaneció hasta su fallecimiento hacia el año 1040, siendo enterrada en la catedral de Bamberg ${ }^{1440}$.

Las soberanas más próximas a San Benito, dispuestas en los plementos del primer cuadrante fueron cuatro insignes reinas:

-Etelburga reina de Wessex, en Sajonia, mujer del rey Ina, a quien sirvió con devoción. Tras su muerte, hacia el año 740 decidió apartarse de la vida política y tomó el hábito benedictino en Berecingio, Inglaterra ${ }^{1441}$.

-Matilda, "Regina Aengliae", ostentó el título de soberana tan sólo nueve meses, de abril a noviembre de 1141. Su incapacidad de gobernar la llevaron a dimitir como soberana para residir en Normandía, donde era duquesa desde 1135. Se vinculó precozmente a la orden benedictina, pues fue criada en el monasterio de Ubintonia $^{1442}$. El libro que sostiene en sus manos confirma su defensa de la fe cristiana, pues en la página por la que está abierto está inscrita la leyenda: "REGNUM DEUM NON EST HIC ${ }^{1443, ", ~ q u e ~ f o r m a ~ p a r t e ~ d e ~ l a ~ d e f e n s a ~ d e ~ C r i s t o ~}$ ante Pilatos. Su reino es eterno, no pertenece a este mundo, pues si así fuera, habría sido defendido por los que se hallaban a su servicio.

\footnotetext{
${ }^{1438}$ YEPES, Fray Antonio. Crónica...Tomo IIII. Valladolid, 1613,Op.cit, pág. 213.

${ }^{1439}$ CIRIA RAXIS E INOJOSA, Pedro de. Vidas...Tomo III. Op.cit, pp. 367-369.

1440 LEONARDI, Claudio, RICCARDI, Andrea y ZARRI, Gabriella. Diccionario de los Santos. Volumen 1. Centro Iberoamericano de Editores Paulinos. Madrid, 2000, pág. 594. Estudio monográfico de la santa en LÓPEZ MELÚS, Rafael Ma. Santa Cunegunda, emperatriz. Apostolado mariano. Madrid, 1988.

${ }^{1441}$ DIEZ CANSECO, Vicente. Diccionario biográfico universal de mujeres célebres. Tomo II. Madrid, 1844, pp. 49 y 50 y YEPES, Fray Antonio. Crónica...Tomo IIII. Valladolid, 1613, Op.cit, pág. 185.

${ }_{1442}$ YEPES, Fray Antonio. Crónica...Tomo IIII. Valladolid, 1613,Op.cit, pág. 185.

1443 "Mi reino no es de aquí” Juan 18,36.
} 
-Batilda, Regina Gaeiliae, natural de Sajonia, fue mujer del rey Clodoveo II. Cuentan que era de una generosidad sin igual y una humildad suprema, de modo que siempre estaba ocupada con menesteres ajenos a la corona, bien visitando hospitales, ayudando a los más desfavorecidos o concediendo limosnas a diversos monasterios franceses, algunos de los cuales, como Corbie y Chelles, le deben su fundación. Al morir su esposo, tomó el hábito en Santa María de Cala, en las cercanías de París, donde moró hasta el fin de sus días, hacia el año $680^{1444}$.

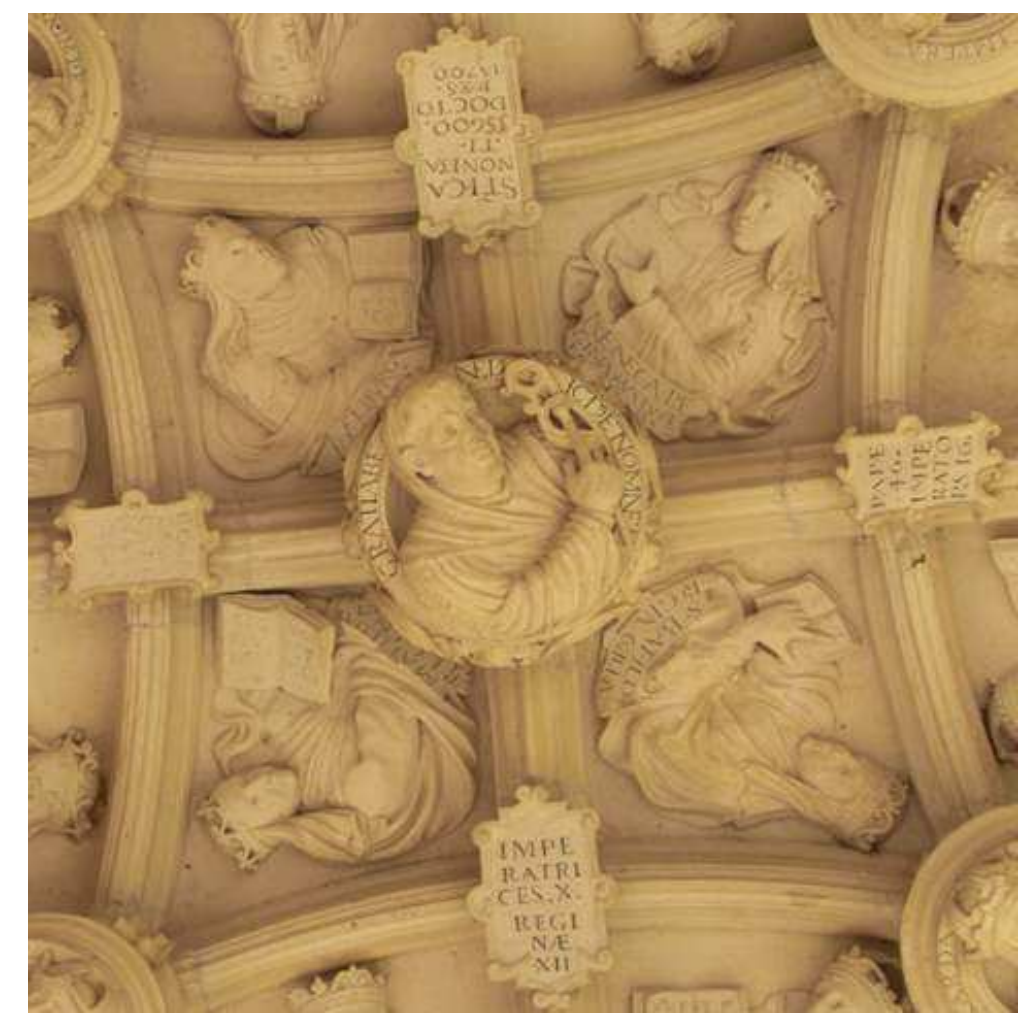

\section{Bóveda 17. Detalle del sector central que representa a las reinas Etelburga, Matilda, Batilda y Nuenega en torno a San Benito.}

-La identificación de la última de las mujeres de esta zona, Nuenega, Regina Avsturum, ha planteado muchas hipótesis. Díaz Nava y Sainz de Robles, siguiendo a Quadrado, se decantaban por la reina de León, doña Iñiga, mientras que $\mathrm{M}^{\mathrm{a}}$ José

${ }^{1444}$ CIRIA RAXIS E INOJOSA, Pedro de. Vidas...Tomo 1. Op.cit, pp. 96-98. 
Redondo proponía a doña Nuña, esposa de Sancho el Mayor de Navarra ${ }^{1445}$. Nosotros nos inclinamos por otra atribución, la reina Nugnesa, mujer de Vermudo I, rey de Asturias. Creemos que se refiere a ella, pues el monje de Mantua, Arnoldo Uvión, la incluye en el árbol benedictino dentro de los personajes temporales de segundo orden, es decir, reinas y reyes junto a la datación "788”. Concretamente figura entre las soberanas que acogieron la orden de San Benito, "delle quali non si sà il monasterio particolare ${ }^{1446, "}$. Efectivamente, las crónicas la denominan Ozenda Nunilona y reinaría junto a su esposo hacia el 789 durante un breve período de tres años. Ambos fueron sepultados en Asturias, pero los huesos de la reina descansan en la ermita de Ciella, mientras que los de don Vermudo se cree que reposan en el monasterio de San Juan de Coria ${ }^{1447}$.

Prosigue la serie de emperatrices en los plementos, donde las figuras de medio cuerpo se encuentran separadas por los nervios diagonales de la crucería.

-Comienza la serie con Gunegunda, de la cual nos informa la inscripción que la acompaña que fue emperatriz. Según la Aprobación de la Regla y orden del gloriosísimo San Benito, falleció en $1039^{1448}$. Efectivamente, se llamaba Gunilda o Cunilda y era hija de Canuto el Grande, rey vikingo de Noruega, Suecia e Inglaterra. Se casó con el emperador germano Enrique III, apodado "el Negro", al que abandonó poco después para convertirse en monja de un cenobio italiano, donde fallecería pocos años después ${ }^{1449}$. Unos años después, en 1043, Enrique III se casó en segundas nupcias con Inés de Poitiers, que figura junto a Gunegunda. Hija del duque Guillermo V de Aquitania, la vida de doña Inés presenta grandes analogías con la de su compañera, pues además de haberse esposado con el mismo hombre y haber llegado a ser emperatriz del Sacro Imperio Germánico como aquella -hasta 1056 en que enviudó y hasta 1062 como regente de su hijo Enrique IV- se retiró a Italia para convertirse en monja, donde fallece en $1077^{1450}$.

\footnotetext{
${ }^{1445}$ QUADRADO; José María y PARCERISA, Francisco J. Op.cit, pág. 139, SAINZ DE ROBLES, Federico Carlos. Monasterios...Op.cit, pág. 107, DÍAZ NAVA, Adolfo F. "Un claustro...Op.cit, pág. 117 y REDONDO CANTERA, Ma José. "El programa...” Op.cit, pág. 139.

${ }_{1446}$ BSCV. UVION, Arnoldo. Brieve dechiaratione dell'arbore..Op.cit, pág. 84.

${ }^{1447}$ FLÓREZ, Enrique. Memorias de las Reynas Cathólicas...Tomo 1.Op.cit, pp. 56-61.

${ }^{1448}$ ANÓNIMO. Aprobación de la regla y orden del...Op.cit, pp. 73.

${ }^{1449}$ UVION, Arnoldo. Brieve dechiaratione...Op.cit, pág. 72.

${ }^{1450}$ LES BLAS, Philipp.e. Historia de la Alemania. Tomo 1. Traducida al castellano por una sociedad literaria. Imprenta del Nacional. Barcelona, 1841, pp. 223-225.
} 
-Santa Eteldreda, "Regina Merciae", que abandonó su cargo para tomar el hábito en el monasterio de Croilanda, en Inglaterra en el año $740^{1451}$. Le acompaña Eufrosina, esposa de Alejo III Ángelo, emperador bizantino. Llegó a ser abadesa en Brabante hacia el $815^{1452}$. En la Biblia que porta se pueden leer las palabras de la Anunciación “AVE MARÍA GRATIA PLENA" que, como hemos señalado, se repiten en varias ocasiones en las bóvedas, reforzando el protagonismo de la Virgen.

-Santa Alfreda, figura como reina de Northumbria, al noreste de Inglaterra. Era mujer de Etelberto, rey de los Anglos orientales, asesinado cruelmente por el padre de ésta, el perverso Ossa, rey de los Mercios. A su muerte, en el 975, se dedicó a la vida religiosa ${ }^{1453}$. A su lado, Isabel, emperatriz. En un principio con esta dignidad pensamos que hacía referencia a la reina consorte de España, esposa de Carlos V, y por tanto, emperador del Sacro Imperio Germánico. Sin embargo, en el listado donde se incluyen todas estas soberanas, se indica que tomó el hábito hacia $1290^{1454}$. Con estas fechas aproximadas, seguramente se refiera a otra soberana española, doña Isabel de Aragón y Sicilia, reina de Portugal entre 1282 y 1325 por su matrimonio con Dionisio I. Su precoz devoción la condujo a la fundación de varios conventos y al ingreso en un cenobio en Coimbra a la muerte de su esposo ${ }^{1455}$.

- Constancia, era la única heredera del reino de Sicilia, pues su padre Ecogerio no había tenido descendencia. Sin embargo, decidió internarla en el monasterio de San Salvador de Palermo. Tras cincuenta años viviendo como monja, decide abandonar el hábito y se esposa en 1185 con Enrico VI de Italia ${ }^{1456}$. Sostiene un libro en el que se pueden identificar las siglas de Jesucristo, en alusión a su vocación cristiana: "IHS XRS". Por último figura Augusta, emperatriz, que con este nombre bien pudiera referirse a cualquier soberana, pues esta denominación, que indica respecto y veneración, la poseyeron prácticamente todos los emperadores romanos, y por extensión, sus mujeres, a partir de César Octaviano, a quien el Senado le otorgó

\footnotetext{
${ }^{1451}$ CIRIA RAXIS E INOJOSA, Pedro de. Vidas...Tomo III. Op.cit, pp. 14-15. No debe confundirse con otra Eteldreda, esposa del Rey Efrido de Inglaterra, que tomó el hábito en el monasterio Hilgense o Eliense hacia el 680.

${ }^{1452}$ Ibídem,Tomo I. pp. 69- 72.

1453 Ibídem, Tomo III, pp. 432-435.

1454 ANÓNIMO. Aprobación de la regla...Op.cit, pág. 73.

${ }^{1455} \mathrm{Si}$ bien, doña Isabel tomó el hábito de clarisa y no el benedictino, no hemos hallado, como sucede en otros casos, una soberana de finales del siglo XIII con este nombre que tuviera vinculación directa con la orden de San Benito. DIEZ CANSECO, Vicente. Diccionario...Op.cit, pp. 297-299.

${ }^{1456}$ Ibídem, pág. 27.
} 
tal dignidad en el año 27.a.C ${ }^{1457}$. Según la Aprobación de la Regla y orden del gloriosísimo San Benito, esta emperatriz se consagró a la vida religiosa en $1190^{1458}$. Ante la escasez de datos y dada la escasa fiabilidad de esta datación, no podemos adivinar de quién puede tratarse. Ahora bien, descartamos la identificación con la emperatriz Livia Augusta, la primera en ostentar tal dignidad, pues dudamos que el cronista errase en más de doce siglos ${ }^{1459}$.

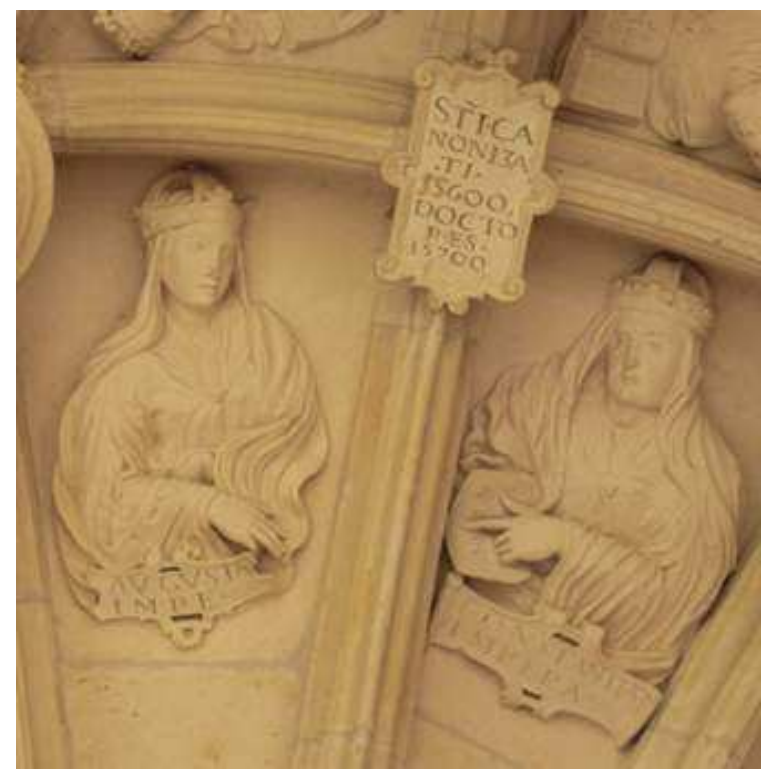

Bóveda 17. Las emperatrices Augusta y Constancia.

El Apóstol que figura en la ménsula contigua es Felipe, ubicado en la parte externa, al que identifica la cruz de sus suplicio y, enfrente, San Pablo, con su espada, que a pesar de no formar parte del ciclo de los Apóstoles y ni siquiera haber conocido a Cristo, recibe comúnmente tal calificativo. De hecho en la tarjeta, figura: “Pavlus Ap.”. El motivo de tal denominación reside en su insistente predicación itinerante por el mundo griego y romano durante cerca de un cuarto de siglo ${ }^{1460}$. Según los papeles del monasterio que Ceán Bermúdez tuvo ocasión de consultar,

\footnotetext{
${ }^{1457}$ YÁÑEZ DE AVILÉS, Fray Pablo. De la era y fechas de España. Chronología española. Tomo segundo. Imprenta de José González. Madrid, 1732, pp. 404-410.

${ }^{1458}$ ANÓNIMO. Aprobación de la regla...Op.cit, pág. 73.

${ }^{1459}$ REDONDO CANTERA, Ma José. "El programa...Op.cit, pág. 139.

${ }^{1460}$ DUCHET-SUCHAUX, Gaston y PASTOUREAU, Michel. Guía... Op.cit, pp. 299-300.
} 
ésta imagen y la de San Sebastián fueron retocadas por Bernardino Ortiz, escultor palentino que trabajó en el claustro alto hacia $1581^{1461}$.
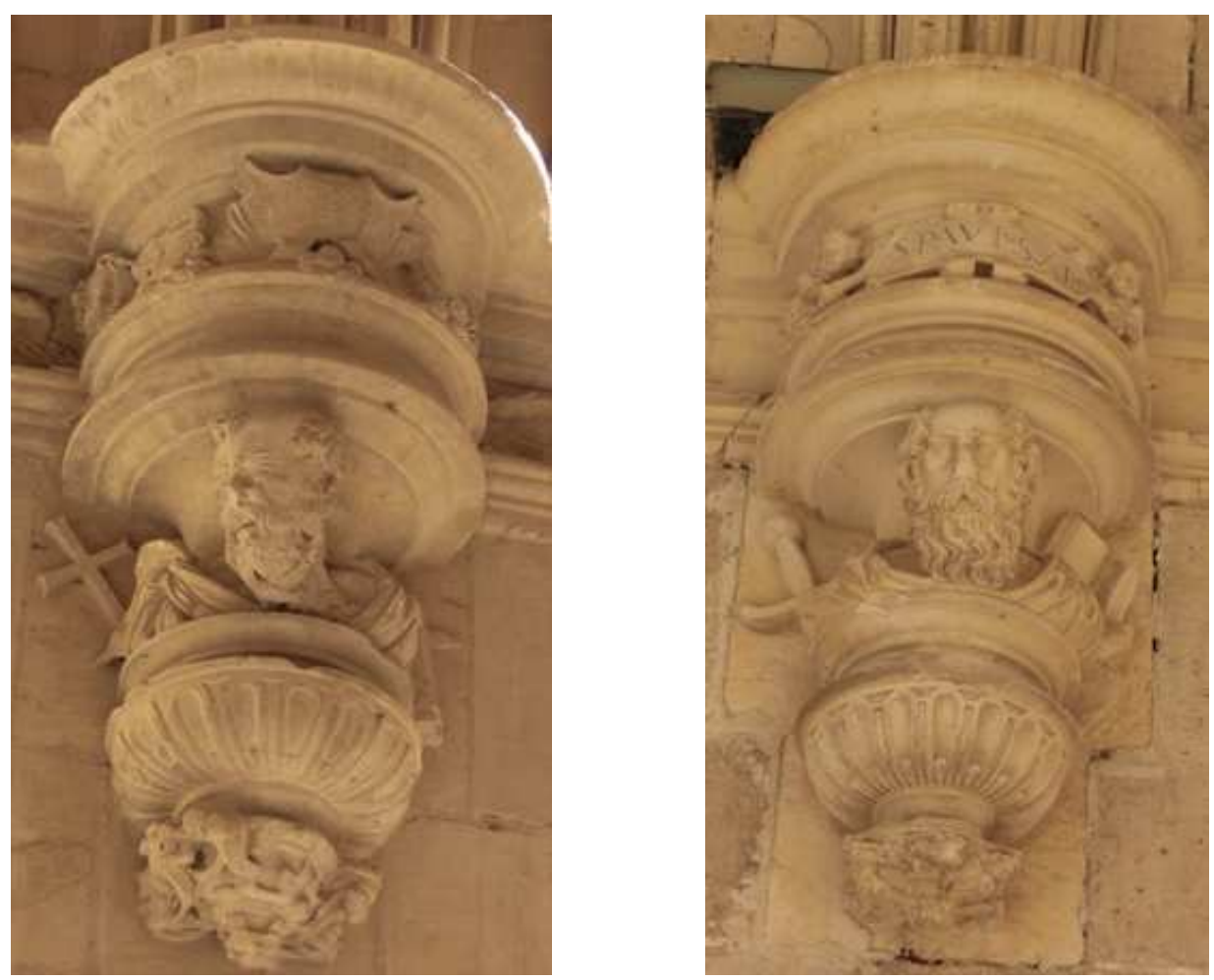

Ménsulas representando a San Felipe y San Pablo.

Resulta de gran interés la información contenida en los cuatro cueros recortados ubicados en los nervios diagonales. Conforman un censo histórico de vital importancia para establecer una cuantía aproximativa de los personajes eminentes de la sociedad hasta el siglo XVI. Reza así:

-“SANTOS CANONIZADOS, $15.6000^{1462}$. DOCTORES, 15.700”.

-"PAPAS, 46. EMPERADORES, 16”.

-“EMPERATRICES, X. REINAS, XII”.

- REYES, 29(?). CARDENALES $200(?)^{1463}$.

${ }^{1461}$ CEÁN BERMÚDEZ, Agustín. Diccionario Histórico... Volumen 2. Op.cit, pág. 45.

${ }^{1462} \mathrm{Si}$ nos fijamos en esta placa, parece que originalmente contenía otra cifra: 55.600, que viene a coincidir con la que proponen algunos autores. Véase CIRIA RAXIS E INOJOSA, Pedro de. Vidas...Tomo II, pág. 173. Posteriormente observaron otras fuentes que consideraron más ajustadas y modificaron la cifra. 

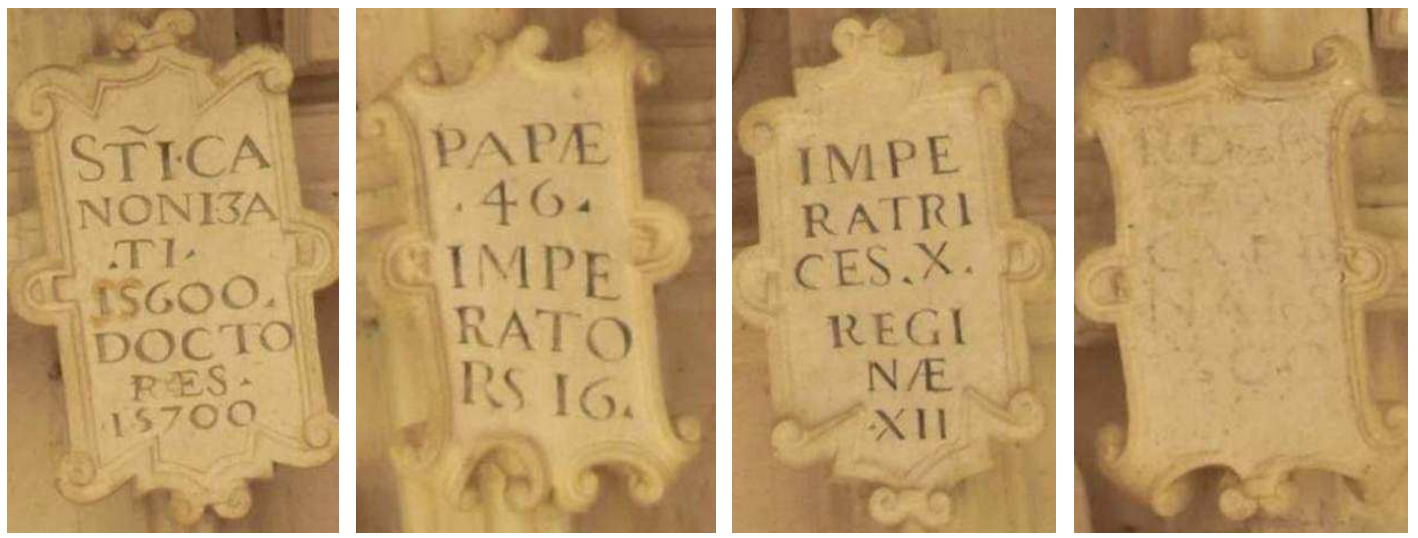

Bóveda 17. Inscripciones de los cueros recortados (uno de ellos casi ilegible).

Bóveda 18: Representa a monarcas que desde la Edad Media, reinaron en los principales países de Europa. La presencia de todos estos personajes del poder se justifica en función de la vida virtuosa que les caracterizó y su vinculación a la orden benedictina en algún momento de sus vidas. Conforman, aunque no están todos, el listado que incorpora la Aprobación de la Regla de San Benito como "Reyes que dexados sus estados profesaron el hábito de San Benito”, a los que se unen nuestros monarcas hispanos bajo el título: "Vlltra d'estos, hay otros muchos que los imitaron en nuestra España ${ }^{1464, "}$.

Junto a San Benito, cuatro monarcas de busto, que cambiaron el cetro y corona -dispuesto a un lado de ambos- por el hábito benedictino que portan todos ellos:

- Simeón I, proclamado zar de Bulgaria, fue un gran protector de las letras y las artes. Dado que era el pequeño de los dos hijos de Boris I, no heredaría el trono, por lo que su padre le reservó una educación teológica, ingresando seguidamente en un monasterio de Constantinopla. En el 888 regresó a Bulgaria pero continuó la vida monástica en un cenobio de Preslav. Tuvo que cambiar por obligación el hábito por

${ }^{1463}$ Las tarjetas han sido traducidas de su inscripción latina: "STI CANONIZATI 15.600, DOC 15700. PAPAE, 4, IMPERATORS, 16, IMPERATRICES, X. REGINAE, XII. REGUM 79(?). CARDENALIS 700 (?)". Esta última tarjeta está tan borrada que perfectamente podría leerse Reyes 79 y Cardenales 700. Coincidimos en la lectura con Helguera, que vio las bóvedas hacia 1895. RAMIREZ DE HELGUERA, Martín. El libro...Op.cit, pág. 175.

${ }^{1464}$ ANÓNIMO. Aprobación de la regla...Op.cit, pág. 68-70. 
la corona, pues su hermano Vladimir pensaba introducir el paganismo en el reino, algo que su padre no permitió, designando a Simeón como heredero en el $893^{1465}$. -Offa I de Mercia, fue el primer anglosajón en ostentar el título de rey de Inglaterra desde el 757 al 796. A imitación de Carlomagno, promovió la creación de escuelas regidas por eruditos para formar a los clérigos. Consiguió el apoyo de la iglesia a través de la destinación a la misma del diezmo de sus bienes y la realización de múltiples donaciones a la catedral de Hereford $^{1466}$. Su vinculación con la orden benedictina se establece en el año 794, en que, siguiendo a Yepes, fundó bajo su protección, previo permiso del papado, el monasterio de San Albano en Inglaterra ${ }^{1467}$.


Bóveda 18. El rey Offa, de Mercia.

- Radrix, rex Italie. El hallazgo de su identidad ha sido todo un reto, pues con este nombre no hallábamos ningún monarca medieval. Repasando la historia de Italia descubrimos que se trata de Rotaris, duque de Brescia, convertido en rey de los lombardos en el año 636. Su legado fundamental fue la creación del Edicto de Rotario, un código de leyes lombardo que abolía el derecho romano ${ }^{1468}$.

\section{Bóveda 18. El rey Radrix, de Italia.}

\footnotetext{
${ }^{1465}$ OTFINOSKI, Steven. Bulgaria. Nations in transition. $1^{\text {a }}$ Edición, Bulgaria, 1999. 2ª Edición, Nueva York, 2004, pp. 5-6.

${ }^{1466}$ HUME, David. Historia de Inglaterra desde la invasión de Julio César hasta el fin del reinado de Jacobo II. Traducida por Eugenio Ochoa. Imprenta de Francisco Oliva. Tomo I. Barcelona, 1842, pp. 35-37.

1467 YEPES, Fray Antonio de. Crónica....Tomo III. Op.cit, pp. 318-319.

${ }^{1468}$ Ibídem, Tomo IV, pág. 81.
} 
-Ivanes, rex Lusianiae, no es otro que Juan I de Portugal, hijo bastardo de Pedro I que reinó entre 1383 y 1433. Su vinculación a la orden benedictina radica en la fundación que hizo de la Orden militar de Évora, denominada posteriormente de Avis, que se regía de acuerdo a la regla cisterciense ${ }^{1469}$.

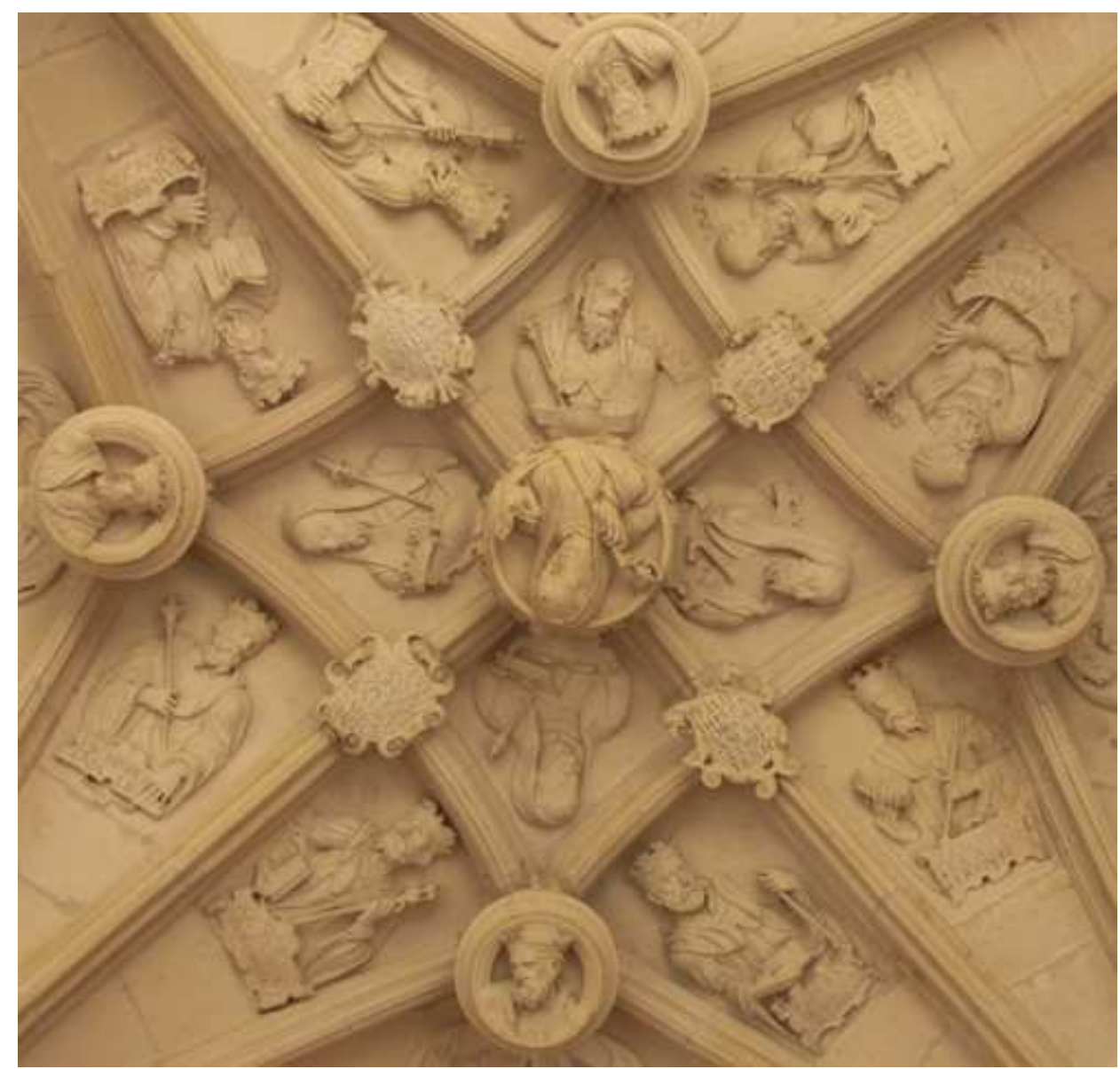

Bóveda 18. Descendencia espiritual de San Benito. Monarcas.

Los ocho personajes dispuestos en la plementería formada a partir de la unión de los nervios terceletes y combados se disponen en parejas, aunque se hallan separados por los nervios diagonales. Estos son:

-Carlomagno, rex Germaniae, llegó a erigirse en emperador del Imperio romano de Occidente entre los años 800 y 814. Hijo del rey Pipino el Breve, mantuvo una

${ }^{1469}$ ORTIZ DE LA VEGA, Manuel. Los héroes y las grandezas de la tierra. Tomo VI. Madrid, 1856, pág. 290. 
fuerte alianza con la iglesia, gracias a la provisión de monjes benedictinos en tierra de infieles, fundación de monasterios, la creación de concilios y el fomento de la literatura y cultura cristianas. Las fuentes antiguas benedictinas certifican que tomó el hábito benedictino en un cenobio italiano del monte Soracte, en la Toscana, hacia el año 747, pasando después a Montecassino, viviendo con tal humildad que cuenta una anécdota que se dejó abofetear en tres ocasiones por un cocinero del monasterio ${ }^{1470}$. No existe un atisbo de credibilidad en estos datos teniendo en cuenta que su nacimiento se estima precisamente hacia ese año y ninguna monografía hace alusión a su vida cenobítica ${ }^{1471}$. Junto a Carlomagno se sitúa Casimiro I, rey de Polonia que, retirado en San Pedro de Cluny, volvió a su país natal a requerimiento del pueblo, para ser coronado en $1041^{1472}$. Apodado “el Restaurador", realizó una serie de reformas que restablecieron el orden, acabó con el feudalismo e impuso el cristianismo en todo el reino $^{1473}$.

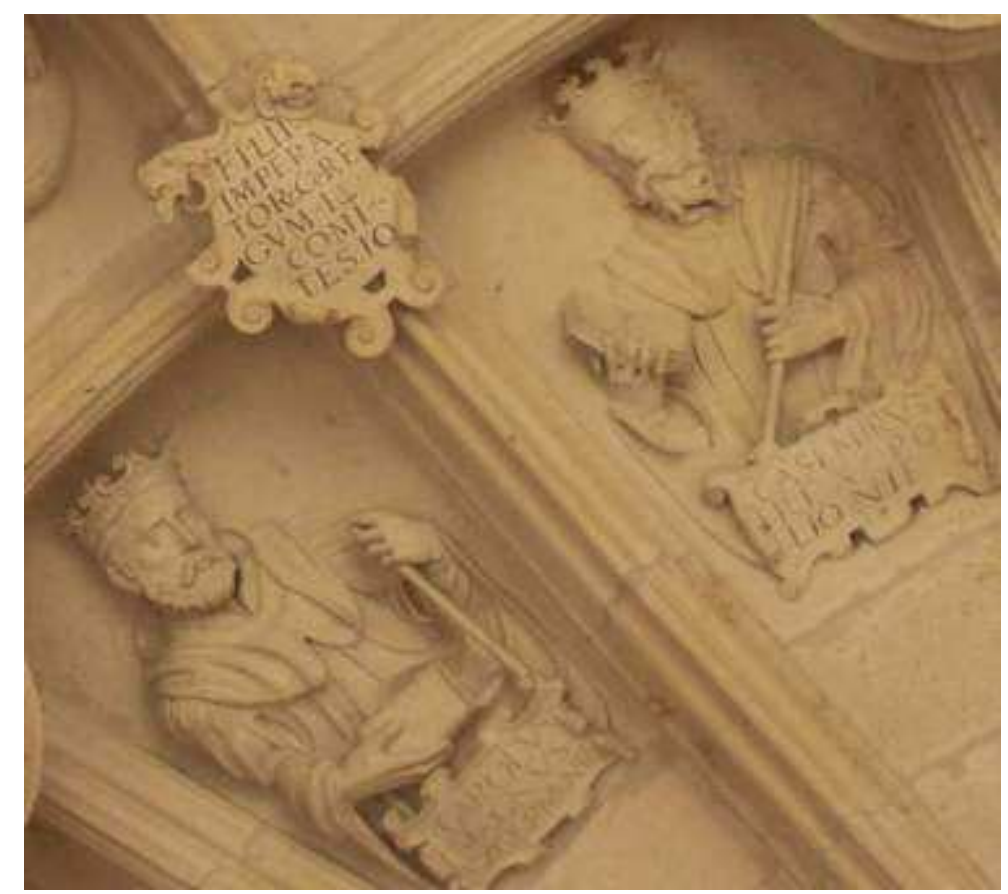

\section{Bóveda 18. Plementos donde figuran Carlomagno de Germania y Casimiro de Polonia.}

\footnotetext{
${ }^{1470}$ HEREDIA, Fray Antonio de. Vidas...Tomo tercero. Op.cit, pp. 250-263.

${ }^{1471}$ A este respecto existen multitud de estudios sobre este monarca que no hacen referencia a su vida monástica. Entre ellas HALPHEN, Louis. Carlomagno y el imperio carolingio. Traducción de José Almoina. México, 1955, CALMETTE, Joseph. Charlemagne. Presses Universitaires de France. Paris, 1951 o BARBERO, Alessandro. Carlomagno. Ariel. Barcelona, 2001.

1472 HEREDIA, Fray Antonio de. Vidas...Tomo cuarto, Op.cit, pág. 335.

${ }^{1473}$ FORSTER, Charles. Historia de la Polonia. Traducida al castellano por una Sociedad Literaria. Imprenta de A. Frexas. Barcelona, 1850, pág. 35.
} 
- Segismundo fue rey de Burgundia entre el 516 y el 524. Arriano como el resto de su familia, se convirtió al catolicismo gracias a San Avito, Obispo de Viena. En busca de un retiro espiritual, hizo vida eremítica en las montañas catalanas de Montseny, pero tuvo que volver a Borgoña para suceder en el trono a su padre ${ }^{1474}$. A su lado, Rachís, rex Italiae, se refiere a Rachisio o Ratquis de Friuli, que reinó en Lombardía, con sede real en Pavía. Invadió Perugia, por lo que el Papa Zacarías le persuadió para que presentase su renuncia al trono e ingresara como benedictino en Montecassino, como así hizo en el $742^{1475}$.

- Sigisberto, rey de Nothumbia, en Inglaterra, extendió el cristianismo, continuando la labor comenzada por Eorpwald, su difunto hermano. Hacia el 630 se retiró de la vida política e ingresó en un monasterio inglés ${ }^{1476}$. Junto a él, figura Pipino, que fue rey de Italia desde el 781 al 810, actuando Carlomagno, su padre, como consorte. Fundó el monasterio benedictino de de San Cenón, pero no se cree que llegara a tomar el hábito ${ }^{1477}$.

- Alfonso VI, rex Hispaniae, llegó a ser rey de León, de Galicia y de Castilla hasta su muerte en 1109. Las proezas más insignes del "Rey Bravo" consistieron en el refuerzo de la seguridad en el camino jacobeo, la introducción de la liturgia romana y la expansión de la reforma cluniacense en sus reinos. Fue bienhechor del monasterio leonés de San Benito de Sahagún, donde está enterrado junto a sus esposas $^{1478}$. A su lado, Ramiro II, rey de Aragón entre 1134 y 1157. Llegó a ser abad en Sahagún y Obispo de Burgos, Pamplona y Roda- Barbastro, en Huesca. Fue

\footnotetext{
${ }^{1474}$ CROISSET, Padre Juan. Año cristiano... Mayo. Op.cit, pp. 11-15.

1475 ANÓNIMO. Aprobación de la regla.... Op.cit, pág. 69.

1476 MELLADO, Francisco. Enciclopedia moderna. Diccionario universal de literatura, ciencias, artes, agricultura, industria y comercio. Complemento Tomo II. Madrid, 1864, pág. 180.

${ }^{1477}$ En realidad, cuando nació se llamó Carlomán, tercer hijo legítimo de Carlomagno, siendo Pipino "El Jorobado", el primogénito bastardo. Deseoso de obtener el poder, Pipino traicionó a su padre Carlomagno, por lo que desapareció para él como hijo, adoptando el nombre de Pipino su otro hijo, el pequeño Carlomán. El verdadero Pipino, se reclutó en un monasterio benedictino en Sal Salvador de Prumia, Alemania. CASTELLANOS DE LOSADA, Basilio Sebastián. Biografía eclesiástica...Tomo XVIII. Op.cit, pp. 636-637.

${ }^{1478} \mathrm{Al}$ parecer tuvo cinco esposas: doña Inés, doña Jimena, doña Constanza, doña Berta y doña Isabel, antes Zaida. De todas ellas, la única que no está sepultada en Sahagún es doña Jimena, que se hizo enterrar en el cenobio leonés de San Andrés de Espinareda. SALAZAR Y HACHA, Jaime de. "Contribución al estudio del reinado de Alfonso VI de Castilla: algunas aclaraciones sobre su política matrimonial" en Anales de la Real Academia matritense de heráldica y genealogía. Volumen II. Madrid, 1992, pp. 299-335. Existen gran cantidad de monografías sobre el monarca castellano. Algunas de las más completas y actualizadas MARTÍNEZ DIEZ, Gonzalo. Alfonso VI: señor del Cid, conquistador de Toledo. Madrid, 2003, PALOMERO ARAGÓN, Félix. Alfonso VI: del ocaso de lo hispano al mundo romano francés. Dykinson. Madrid, 2009.
} 
elegido sucesor de Alfonso I, por lo que fue obligado a salir del monasterio francés de San Ponce de Tomeras, regresando a la vida monacal posteriormente ${ }^{1479}$.

Completan el programa de esta bóveda las cuatro figuras ubicadas en las cuatro claves secundarias que rodean a San Benito:

-Wamba (692), rey de los visigodos por la fuerza, y monje tanto en San Pedro de Arlanza como en Pampliega ${ }^{1480}$.

- Salomón, fue rey de Hungría desde 1065 a 1074 en que tras ser vencido en una batalla huyó a Presburgo con su mujer ${ }^{1481}$.

-Vermudo I, rey de Asturias, apodado el Diácono, pues fue ordenado como tal a edad precoz. Retirado de la vida mundana, fue coronado contra su voluntad y obligado a esposarse con Nunilona. A los tres años de mandato, en el 791, cedió el trono a su sobrino Alfonso II para regresar a la vida anterior ${ }^{1482}$.

-Alfonso IV, rey de León y de Galicia, renunció al poder tras la muerte de su mujer delegándolo a favor de su hermano Ramiro II, para ingresar en San Benito de Sahagún en el $927^{1483}$. Al parecer, intentó recuperar el poder con la ayuda de sus primos, pero Ramiro al enterarse, los cegó y dispuso su traslado al cenobio leonés de Ruiforco, donde fallecieron poco después ${ }^{1484}$.

Los cuatro cueros recortados que interrumpen los nervios diagonales continúan el censo de personajes honorables comenzado en la bóveda precedente:

-“HIJOS DE EMPERADORES O REYES, 14. CONDES, 10”

-"MUJERES ESCRITORAS Y ERUDITAS, 6"

-“MUJERES ILUSTRES QUE ALCANZARON LA SANTIDAD, 30. MONJES DUQUES, 13"

\footnotetext{
1479 ANÓNIMO. Aprobación de la regla...Op.cit, pág. 70.

1480 HEREDIA, Fray Antonio de. Vidas...Tomo 1. Op.cit, pp. 357-358.

${ }^{1481}$ CAPMANY Y DE MONTPALAU, Antonio. Compendio cronológico histórico de los soberanos de Europa. Primera Parte. Madrid, 1784, pp. 71-72

${ }^{1482}$ FLÓREZ, Enrique. Memorias de las Reynas Cathólicas...Tomo 1.Op.cit, pp. 57 y 60

${ }^{1483}$ AYGUALS DE IZCO, Wenceslao. Galería regia o biografías de los reyes de España desde el primero de los godos hasta Isabel II. Tomo I. $3^{\text {a }}$ Edición. Madrid, 1848, pp. 271-272

${ }^{1484}$ FLÓREZ, Enrique. Memorias de las reynas cathólicas, 1: historia genealógica de la casa real de Castilla y León. Madrid, 1790, pp. 93-94
} 


\section{-"MUCHAS REINAS CONVERTIDAS A LA FE DE JESUCRISTO POR NUESTROS MONARCAS ${ }^{1485, "}$}

San Andrés aparece representado en una de las ménsulas junto a un monje muy vinculado al convento. El Apóstol solamente aparece identificado por la tarjeta, pues sus atributos han sido arrancados del muro. San Agapio, ubicado en el ángulo externo, luce tonsura monacal y porta el hábito, pues fue, como ya indicamos, un monje del siglo VII cuyos restos fueron traídos desde Córdoba junto a los de San Félix y San Zoilo ${ }^{1486}$. Por ello en su inscripción figura: “S. AGAPP, MOACHUS CUI OSSA HIC SUNT TVMVLATA”.
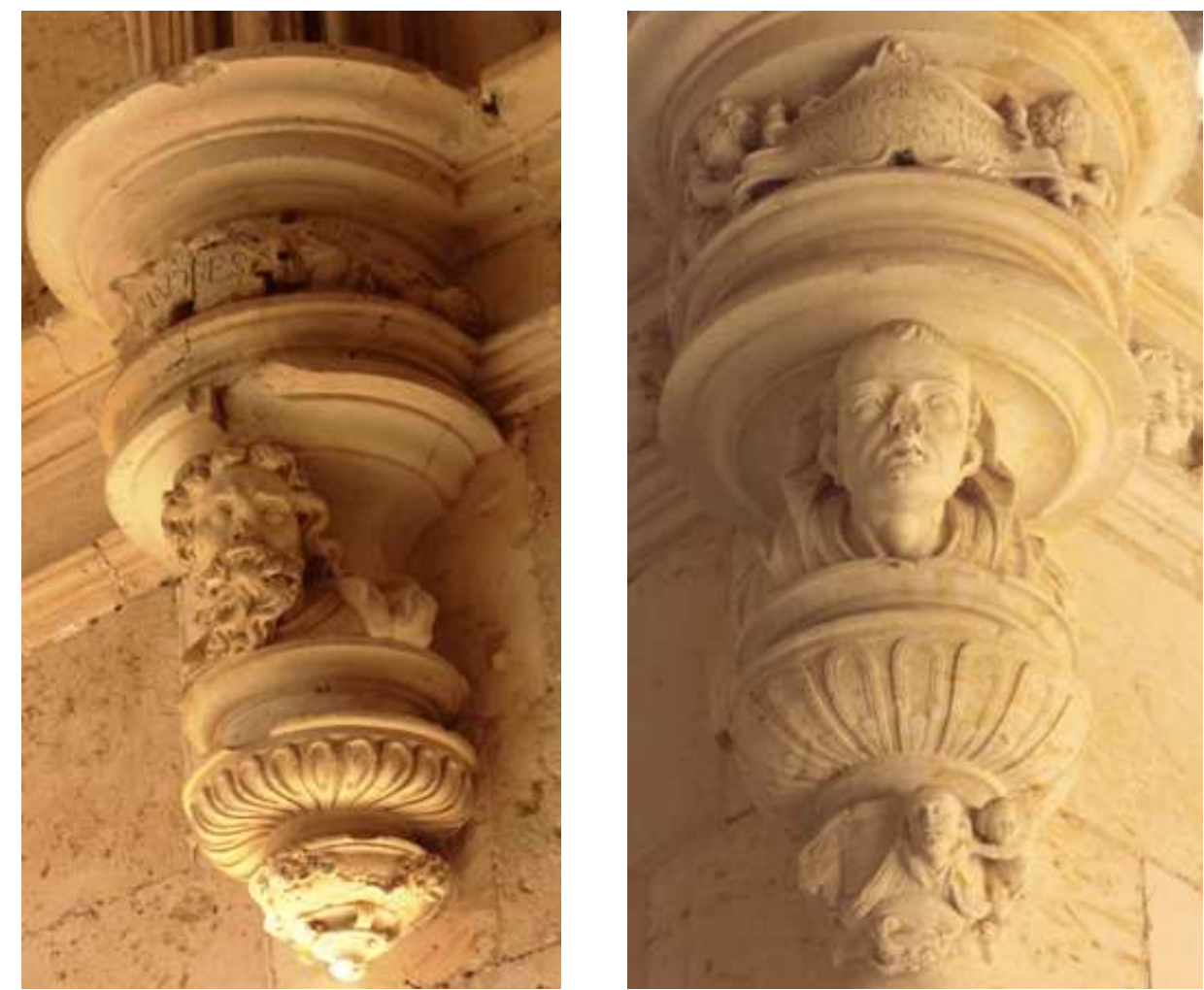

Ménsulas que representan al Apóstol San Andrés y al monje San Agapio.

\footnotetext{
${ }^{1485}$ Las tarjetas han sido traducidas de su inscripción latina: "FILII IMPERATOR ET REGVM, 14. COMITES, 10. PRAECLARAE ERVDITIONE ET SCRIPTIS FOEMINAE, 6. PER ILLVSTRES FEMINETAM SANCTITATE QUAM GENERE, 30. DVCES MONACHI, 13. AD H(A)EC QUA PLVRA REGNA AD FIBÍDEM XRI PER MONACHOS NROS CONVERSA"

${ }^{1486}$ Consúltese a este respecto la historia de la fundación del cenobio.
} 


\section{Crujía septentrional}

Los cuatro tramos que prosiguen, correspondientes a la panda norte del claustro, cerrarían el ciclo de la apoteosis gloriosa benedictina y, consecuentemente, el análisis iconográfico ${ }^{1487}$. Esta última parte va dedicada a la glorificación intelectual de la orden de San Benito, y éste, como figura protagonista, aparece nuevamente representado en la clave central de cada una de ellas. En lo que se refiere a los medallones, éstos adolecen de cierto hieratismo y falta de expresión contrastando con las dos últimas bóvedas de este tramo, que como apuntamos, se deben a una mano mucho más diestra, la de Miguel de Espinosa.

Bóveda 19: Como en el resto de bóvedas ubicadas en las esquinas, adopta una estructura en forma de flor, en la que los nervios combados se despliegan formando cuatro pétalos que convergen en la clave central. De este modo los cuatro puntos angulares del claustro marcan el inicio de una nueva crujía a través de este rasgo distintivo.

En ella se disponen dieciséis figuras de Padres de la Iglesia, doctores y escritores dedicados a la vida monacal, de ahí la tonsura de todos ellos. Todos ellos sostienen un libro, símbolo de su erudición, de ahí que la mayoría sujete una pluma, con su mano derecha, porque fue ésta su dedicación vital. A cada personaje le acompaña, aparte del libro, dos atributos de entre los siguientes: la mitra, la birreta, el capelo, el báculo y la cruz patriarcal. La mitra, que figura junto San Anselmo, San Remigio y San Bruno, es signo de dignidad episcopal en tanto que el capelo es distintivo de los cardenales, como así lo fueron San Pedro Damiano y el abad Panormitano ${ }^{1488}$. Por su parte, la birreta, puede asociarse a diversos rangos eclesiásticos, según si su color es rojo, que corresponde a cardenales, morada a los obispos y negra al resto del clero ${ }^{1489}$. En nuestro caso, los que la portan, fueron,

\footnotetext{
${ }^{1487}$ Los dos últimos tramos correspondientes a las bóvedas vigésimo tercera y vigésimo cuarta ya se habían comentado previamente por pertenecer, junto a las del lado oriental y meridional al núcleo temático de las Ascendencia paterna de Cristo.

1488 VV. AA. Tratado de genealogía, heráldica y derecho nobiliario. Tercera edición. Instituto Salazar y Castro. Madrid, 2001, pp. 178-80.

${ }^{1489}$ FATÁS, Guillermo y M. BORRÁS, Gonzalo. Diccionario de términos de arte y elementos de arqueología, heráldica y numismática. Madrid, 2000, pág. 51.
} 
como así indica su tarjeta, doctores de la iglesia, grado que alcanzaron por su contribución a la teología y doctrina cristiana. Bien sobre la cabeza, bien a un lado, todos los personajes de esta bóveda, exceptuando San Benito, San Ruperto y San Bruno, en las claves y los dos cardenales mencionados, lucen sendos gorros. En cuanto a los bastones, el báculo pastoral no es exclusivo de los obispos, pues también lo reciben los abades en su investidura y ciertos prelados, de ahí que lo porten San Benito, el abad Panormitano, Alcuino y Ricardo ${ }^{1490}$. Para finalizar esta serie de atributos, la cruz patriarcal o de doble traversa la portan San Isidoro, San Alfano, San Leandro y San Ildefonso en su condición de arzobispos ${ }^{1491}$.

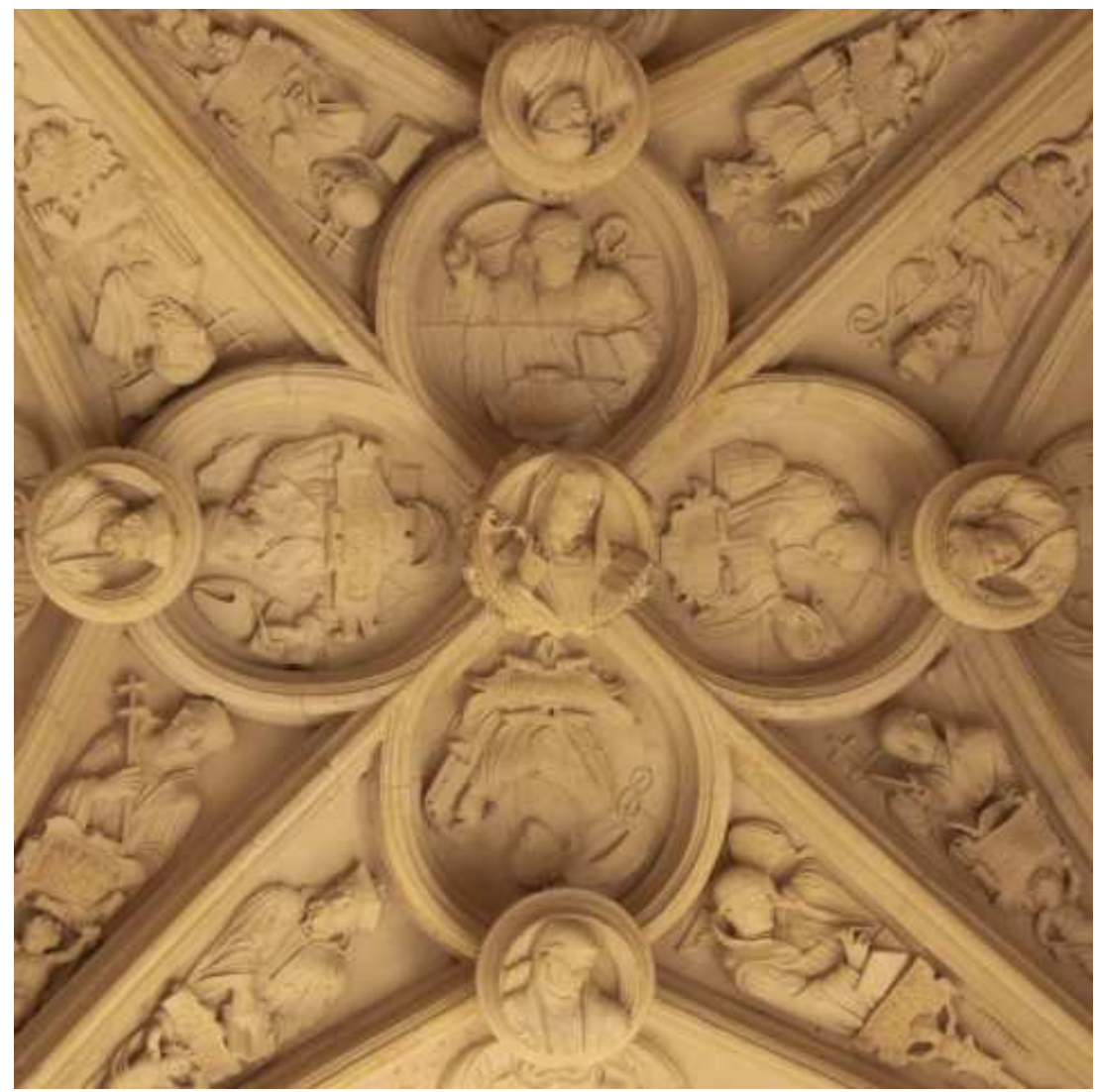

Bóveda 19. Ascendencia espiritual de San Benito.

Padres de la Iglesia, doctores y monjes escritores.

\footnotetext{
${ }^{1490}$ VV. AA. Tratado de genealogía...Op.cit, pág. 179.

${ }^{1491}$ Una curiosidad de esta cruz es que su doble travesaño proviene de la tabla que portaban los condenados y se clavaba posteriormente en la cruz, en la que se exponía el motivo de la condena. Estos y otros datos sobre su introducción en España en DE LA FUENTE, Vicente. "La cruz patriarcal o de doble traversa y su antigüedad y uso en España; A propósito de la cruz de Caravaca" en $B R A H$, Tomo 9. Madrid, 1886, pp. 177-188.
} 
Abordamos seguidamente el análisis de las figuras de las bóvedas, comenzando por los cuatro que figuran en las claves, rodeando a san Benito:

- Juan Damasceno, hoy doctor de la Iglesia, fue un teólogo y erudito sirio que vivió entre el 675 y el 749. La gran parte de su vida la pasó en el monasterio de San Sabas, en Cisjordania, dedicado al estudio. Es célebre por su férrea defensa de las imágenes, lo que le ocasionó que el terrible León el Isaúrico le cortase una mano para evitar que escribiera ${ }^{1492}$.

-San Bernardo, es el fundador del monasterio cisterciense de Claraval, donde fue designado abad y contribuyó notablemente a la expansión de la orden en Europa, llegando a fundar cerca de setenta monasterios en la segunda mitad del siglo XII. Fomentó la creación de la Orden Templaria, basada en la regla del Cister y es autor de obras como De consideratione, dirigida a su discípulo Enrique III $^{1493}$.

-San Ruperto fue un monje alemán formado espiritualmente en la abadía de Worms. Se trasladó a Baviera en el año 700, donde fundó un monasterio dedicado a San Pedro, núcleo de la nueva Salzsburgo, de la que fue su primer Obispo ${ }^{1494}$.

- En último lugar, tenemos a San Rhabano Mauro, doctor, arzobispo de Maguncia y prolijo escritor de temas bíblicos que falleció en el $856^{1495}$.

El cuadrifolio que conforman los nervios combados de la bóveda, integran en su interior a los siguientes cardenales y doctores:

-El abad Panormitano es el sobrenombre con que se conoce a Nicolás de Tudeschis (1386-1445) por el hecho de haber detentado el arzobispado de Palermo ${ }^{1496}$. Profesó en el monasterio benedictino de Santa María Novae Lucis, pasando posteriormente a

\footnotetext{
1492 Cuenta la leyenda que le rogó a la Virgen su restitución y ésta obró el milagro para que continuara escribiendo y dedicándola himnos. PALAU, José. La leyenda de oro para cada día del año. Vida de todos los santos que venera la iglesia. Tomo II. Madrid, 1844, pp. 150-153.

${ }^{1493}$ ZOLA, Ellémire. Los místicos de Occidente II. Místicos medievales. Barcelona, 2000, pp. 21-22. Una biografía completa de San Bernardo en 3 volúmenes la realiza el ex general de la Congregación cisterciense de Castilla y León. CORRAL, Eugenio del. Vida y milagros del dulce doctor y Padre de la iglesia, San Bernardo, abad de Claraval. Imprenta de Isidoro Hernández Pacheco. Madrid, 1782

${ }^{1494}$ SGARBOSSA, Mario y GIOVANNINI, Luis. Un santo para cada día. Traducida por Justiniano Beltrán. Bogotá, 2007, pp. 104-105.

1495 HEREDIA, Fray Antonio de. Vidas...Tomo 1. Op.cit, pp. 496-502.

${ }^{1496}$ REDONDO CANTERA, M José. “El programa...Op.cit, pág. 137.
} 
Bolonia para cursar derecho. Fue abad en Santa María de Maniaco desde 1425 y cardenal en 1440, de ahí el capelo y la birreta que le acompañan ${ }^{1497}$.

- Le sigue San Bruno, que no es el fundador de los Cartujos, pues al figurar junto a la mitra y birreta, nos indica que se refiere al homónimo y contemporáneo doctor, canónigo de Siena y obispo de Segni, en el Lacio ${ }^{1498}$. Dedicó todo su esfuerzo en la reforma de la iglesia y sin abandonar esta tarea ingresó en Montecassino, donde fue designado abad en 1107. La pluma que le acompaña le señalan como el autor de obras de teología como Expositio in Pentateuchum ${ }^{1499}$.

-San Pedro Damiano, cardenal de Ostia y doctor, quedó huérfano muy temprano pero fue ayudado por su hermano Damián, de ahí el apelativo. Tras ejercer de profesor en Parma, ingresó en el convento de Fonte Avellana, en la falda de los Apeninos, llegando a fundar varios prioratos italianos, donde adquirió fama singular. Se erige como el gran reformador del siglo XI gracias a obras como Libro Gomorriano, donde critica los excesos de la época ${ }^{1500}$.

-Finaliza esta serie San Remigio, obispo de Reims, además de doctor y confesor (437-533). Expandió el cristianismo y en este sentido es célebre una anécdota que relata que bautizó al rey franco Clodoveo I y se convirtió poco después en su confesor $^{1501}$.

En la parte externa, insertos en los plementos de mayores dimensiones, figuran, separados por los nervios diagonales:

-San Anselmo, doctor y arzobispo de Canterbury. Nacido en Aosta, Piamonte, se trasladó siendo adolescente a Normandía, en busca de las enseñanzas de Lanfranco e ingresó en la abadía de Bec, donde éste era abad. Anselmo le sucedió en la dignidad, pasando después a Inglaterra, donde adquirió fama sin igual. Se le

\footnotetext{
${ }^{1497}$ En este manual confirmamos la veracidad del sobrenombre "Panormitano". ORELLA UNZUÉ, José Luis. Partidos políticos en el primer Renacimiento (1300-1450). Fundación Universitaria Española. Madrid, 1976, pág. 486.

${ }^{1498}$ REDONDO CANTERA, Ma José. “El programa...Op. cit, pág. 137.

1499 SARANYANA, José Ignacio. La discusión medieval sobre la condición femenina (siglos VIIIXIII). Universidad Pontificia de Salamanca. Salamanca, 1997, pp. 63-64. Varios estudios monográficos en RÉGINALD, Grégoire. Bruno de Segni, exégète medieval et théologian monastique. Spoleto, 1965 y NAVARRA, Bruno. San Bruno Astense, vescovo di Segni e abate di Montecassino. Centro Studi del Lazio. Roma, 1980.

${ }^{1500}$ SGARBOSSA, Mario y GIOVANNINI, Luis. Un santo...Op. cit, pág. 65.

${ }^{1501}$ COSTA Y BORRÁS, Domingo. La leyenda de oro para cada día del año. Tomo 3. Madrid, 1853 , pp. 144 y ss.
} 
considera el padre de la escolástica y fue un gran defensor de la Inmaculada ${ }^{1502}$. Le acompaña la mitra, pues en numeras crónicas y manuales figura como obispo ${ }^{1503}$. Inmediato a San Anselmo, otro doctor y arzobispo, San Isidoro, (556-636) sucesor de Valerio III en la cátedra de Sevilla. Luchó contra la herejía arriana, lo que le valió su asesinato ${ }^{1504}$. Destacó por su erudición, fruto de la cual son sus célebres Etimologías, enciclopedia del conocimiento desde la antigüedad al siglo VII ${ }^{1505}$.

-A continuación el diácono inglés Alcuino de York, abad de San Martín de Turone y primer doctor de la Escuela de París. Fue el maestro intelectual de Carlomagno, bajo cuyas órdenes impartió sus enseñanzas en la Escuela Palatina ${ }^{1506}$. Su prolífica actividad literaria abarcó un amplio abanico de géneros, desde obras hagiográficas, didácticas y morales, pasando por poemas y epístolas, entre las que podemos citar De Vitiis et virtutibus o De dialectica ${ }^{1507}$. Junto a él, Ricardo, doctor. Se le ha identificado con el abad del monasterio francés de San Vannes de Verdún, atribución que consideramos acertada, dado que no hallamos otro homónimo medieval que alcanzara tal dignidad ${ }^{1508}$. San Ricardo (991-1024) fue educado en Reims, donde alcanzó el grado de archidiácono. Recibió el sobrenombre de "Gracia de Dios" y debe su fama a la reforma ejercida en una gran cantidad de cenobios franceses y belgas como San Vicente de Metz y San Pedro de Gante ${ }^{1509}$.

-Por último, San Ildefonso, prolífico escritor y discípulo de San Isidoro; a él le debemos la fundación del monasterio benedictino de San Julián de Samos o Agaliense, donde fue abad ${ }^{1510}$. Fue convertido en arzobispo de Toledo, su ciudad natal. Está enterrado en la iglesia de Santa Leocadia de Toledo desde su fallecimiento, en torno al 696. Junto a él, San Leandro, hermano de San Isidoro, que, como aquel, tomó el hábito benedictino para ser elegido después arzobispo de

\footnotetext{
1502 CROISSET, Padre Juan. Año cristiano...Abril. Op.cit, pp. 359-367.

${ }^{1503}$ Sirvan como ejemplos VILLEGAS, Alonso de. Flos sanctorum: historia general de la vida y hechos de Jesu-christo, Dios y señor nuestro y de los santos. Barcelona, 1794, pág. 290 y OLIVAR DAYDÍ, Alexandre. El santoral del calendario, Barcelona, 1999, pág. 71.

${ }^{1504}$ CROISSET, Padre Juan. Año cristiano....Enero. Op.cit, pp. 31-33.

${ }^{1505}$ Precisamente por su gran capacidad mental, que todo lo contiene, ha sido elegido como patrón de los internautas. ROS CARBALLAR, Carlos. San Isidoro de Sevilla: el obispo sabio. Colección Santos y Santas, 115. Barcelona, 2006, pág. 22.

${ }^{1506}$ BSCV. UVION, Arnoldo. Brieve dechiaratione...Op.cit, pág. 139.

${ }^{1507}$ MARTÍNEZ GÁZQUEZ, José y FLORIO, Rubén. Antología del latín cristiano y medieval: introducción y textos. Bahía Blanca, Argentina, 2006, pág. 49.

${ }^{1508}$ REDONDO CANTERA, Ma José. "El programa...Op.cit, pág. 137.

${ }^{1509}$ ROHRBACHER, René François. Storia universale della chiesa cattolica dal principio del mondo sino ai di nostri. Tomo XIII.Traducida al italiano por L. Toccagni. Milano, 1847 pp. 363-364.

${ }^{1510}$ SANDOVAL, Prudencio de. Primera parte...Op.cit, pp. 27-30.
} 
Sevilla ${ }^{1511}$. Desempeñó esta dignidad hasta su fallecimiento en el año 600 en que murió $^{1512}$.

-Los dos últimos personajes son el polifacético San Alfano y "el Venerable” Beda. San Alfano fue un prestigioso médico, abad benedictino, arzobispo y doctor que desarrolló gran parte de su ferviente actividad en Salerno hasta que falleció en el 1085. Gracias a su dominio del árabe tradujo al latín un gran número de tratados y es autor de obras de medicina como De quattuor humoribus corporis humanis o Experimenta archiepiscopi salernitani ${ }^{1513}$. Concluye esta serie Beda, monje benedictino inglés del siglo VIII. Es autor del Templo Salomonis Liber, donde establece una serie de alegorías místicas de los constructores de este sagrado templo. Gracias a Alcuino de York, su discípulo, sus escritos llegaron a manos de Carlomagno que los difundió por todo el imperio ${ }^{1514}$.

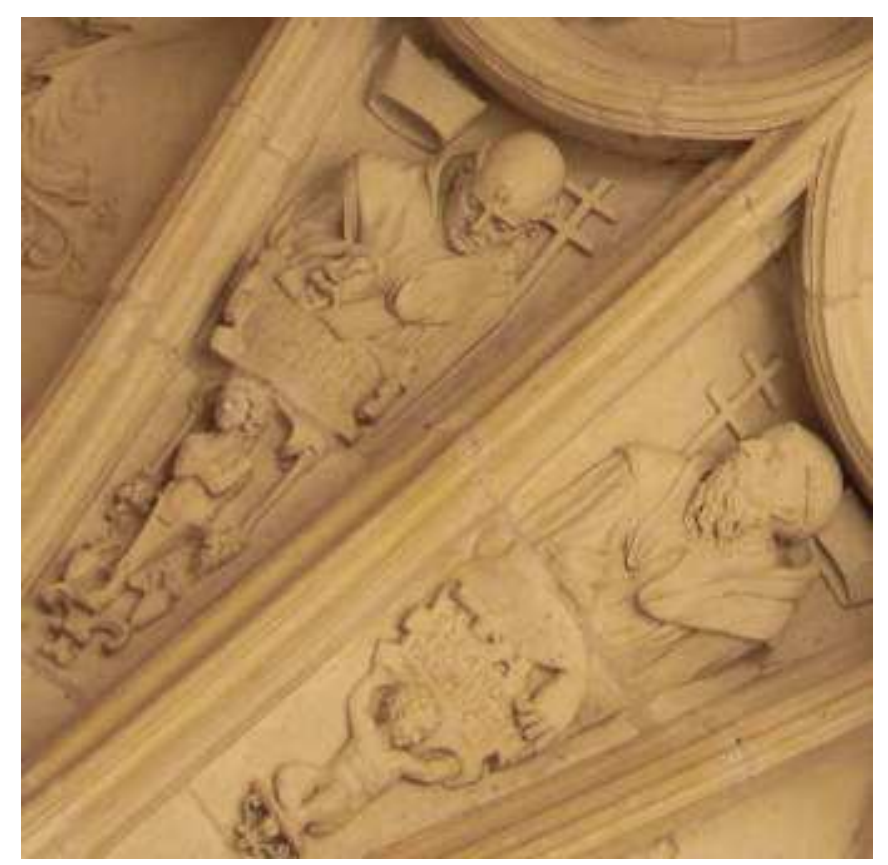

Bóveda 19. Plementos que representan a San Leandro y San Ildefonso.

\footnotetext{
1511 Ibídem, pág. 11.

${ }^{1512}$ HEREDIA, Fray Antonio de. Vidas...Tomo primero. Op.cit, pp. 417-421.

${ }^{1513}$ FUIANO, Michelle. La cultura a Napoli ne'll alto medioevo. Giannini. Nápoles,1961, pp. 173 y SS

${ }^{1514}$ CALLAEY, Eduardo. El otro imperio cristiano. De la Orden del Temple a la francmasonería. Colección Historia Incógnita. México, 2006, pág. 41.
} 
En las ménsulas continúan los Apóstoles San Simón, apodado "El cananeo" o "el Zelote", que figura en el ángulo interno, acompañado de un libro y una lanza $^{1515}$. Su atributo más usual es una sierra, pero al ser aquella utilizada para Judas Tadeo, se ha buscado otro instrumento asociado a su martirio ${ }^{1516}$. A su lado, Santiago el Menor portando el libro de las Epístolas. Ha desaparecido el otro objeto que le acompañaba, podría ser la maza, alusiva al batanero que le aplasta el cráneo cuando predicaba a los judíos ${ }^{1517}$.
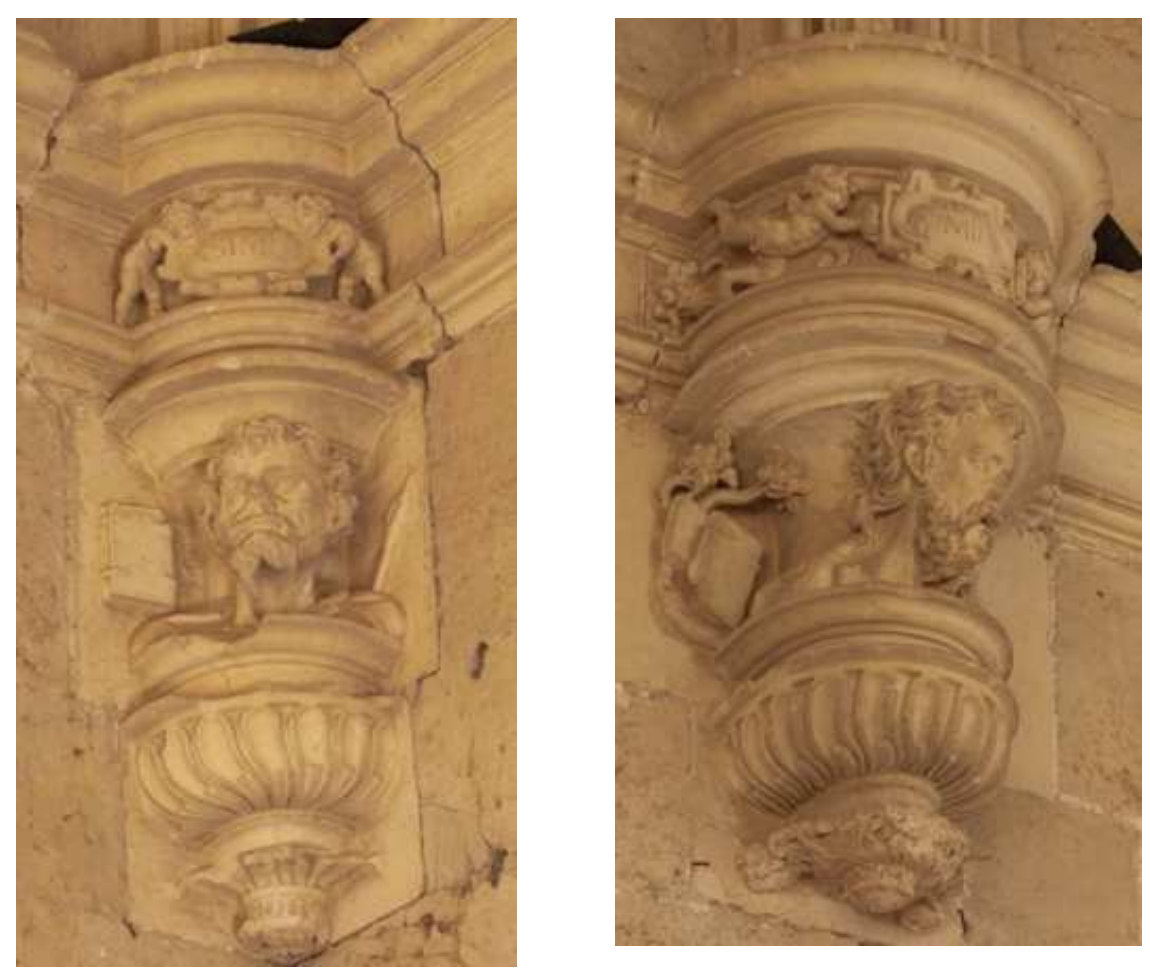

\section{Ménsulas que representan a San Simón y Santiago El Menor.}

\footnotetext{
${ }^{1515}$ El apelativo de "el Cananeo", se le otorgó por su procedencia de Canaán. Así figura en Mateo 10:4 y Marcos, 3:18. Sin embargo, en Lucas 6: 15 se le denomina "El zelote", traducción griega del hebreo "Caná". Estos apelativos se utilizaban para evitar confusiones con el otro apóstol, Simón Pedro, aunque éste haya pasado a la historia con el nombre de Pedro. CASTELLANOS DE LOSADA, Basilio Sebastián. Biografía eclesiástica...Tomo XXVII, Op.cit, pp. 346.

${ }^{1516}$ Con la lanza se representa a Simón, por ejemplo en la portada sur de la Catedral de Chartres 1210-1215), aunque no es lo más usual. GOOSEN, Louis. De Andrés a Zaqueo. Temas del Nuevo Testamento y la literatura apócrifa en la religión y las artes. Akal. Madrid, 2008, pág. 307. La lanza ha servido más bien para identificar a Santo Tomás, quien por otra parte, no figura en el programa iconográfico. Estaba evangelizando diversos territorios de la India y provocó la ira de los sacerdotes del lugar, que le atravesaron con una lanza. Fue enterrado con un trozo de la misma para que se recordase su martirio. COSTA Y BORRÁS, Domingo. La leyenda...Tomo 3. Op.cit, pág. 564.

${ }^{1517}$ DUCHET-SUCHAUX, Gaston y PASTOUREAU, Michel. Guía...Op.cit, pág. 349.
} 
Bóveda 20: A partir de esta bóveda y hasta que finaliza el ciclo en la bóveda décimo segunda, observamos una menor calidad técnica en las tallas que viene acompañada por una mayor pobreza en la ornamentación, por lo que descartamos la atribución a Morante. Podemos establecer analogías estilísticas con las bóvedas 23 y 24 y con las de la crujía meridional, pudiéndose atribuir, si no a los mismos artífices, pues su participación dista en el tiempo, a artistas de menor pericia. Se repite además la decoración a base de jarrones con flores en los plementos de los nervios combados. Igualmente, en la plementería de los nervios diagonales con los terceletes se disponen idénticos motivos de la crujía mencionada: una serie de eses avolutadas engalanadas con cintas que se enroscan caprichosamente.

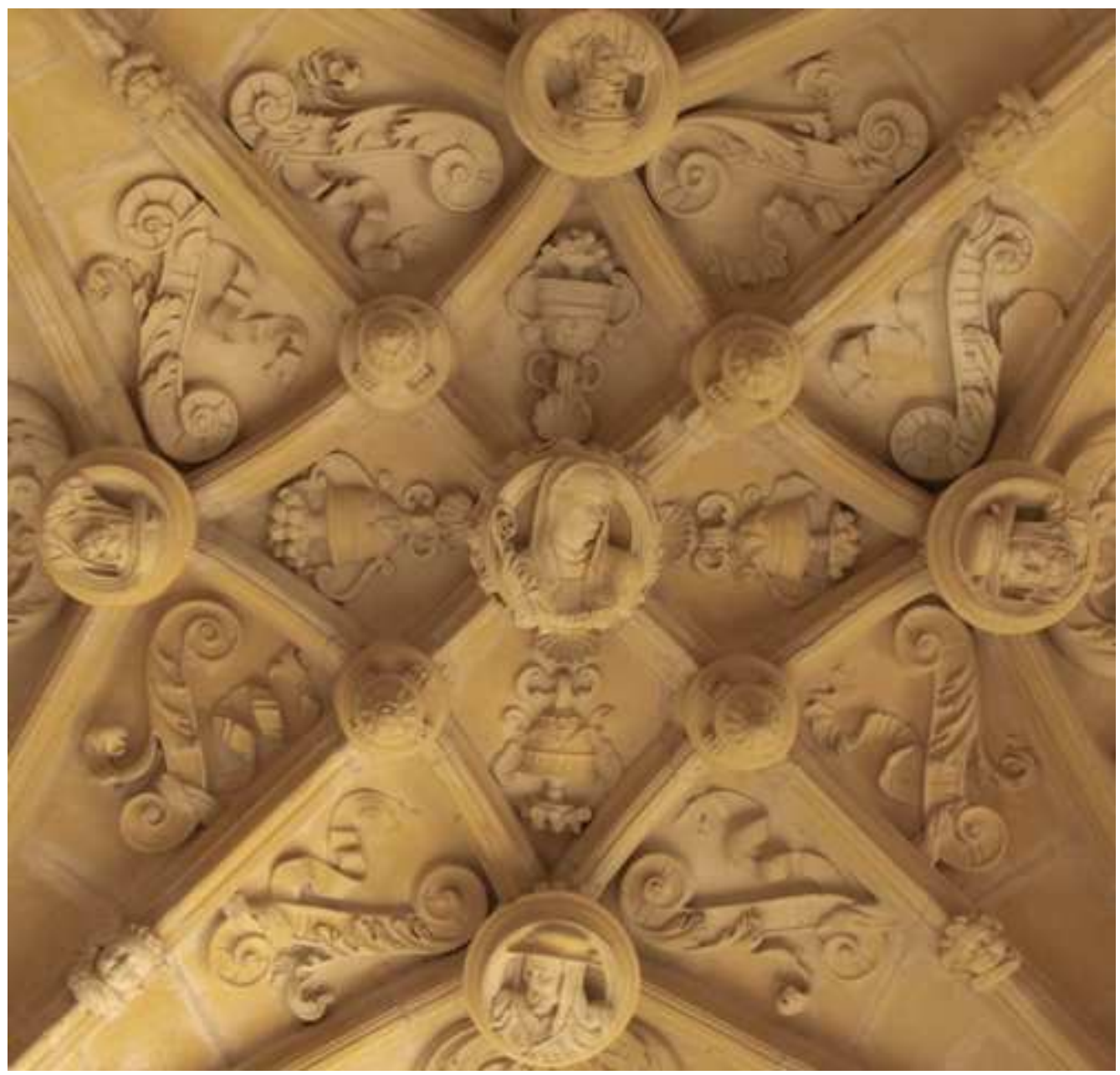

Bóveda 20. Descendencia espiritual de San Benito. Cardenales. 
San Pedro Damiano y Nicolás Tudeschi inauguraron en la bóveda precedente la serie de cardenales que prosigue a continuación, en las cuatro claves secundarias de la bóveda, todos ellos tocados de su respectivo capelo:

- En primer lugar, San Gregorio Ostiense, así denominado por haber sido ordenado cardenal de Ostia, cerca de Roma en el año 1004. Precisamente en la capital italiana pasó su juventud, como monje de San Cosme y San Damián, donde fue elegido abad. El episodio más célebre de su vida le sitúa en España, donde puso fin a la plaga de langostas que asolaba Pamplona y Navarra. En estas tierras le sorprendió la muerte, falleciendo en Logroño en $1044^{1518}$.

-Alberico, monje en Montecassino, presenta analogías con el personaje precedente, pues como él, fue abad benedictino, en este caso en el cenobio francés de Vezelay, siendo posteriormente nombrado obispo y cardenal de Ostia en 1138. Fue además legado de la Santa Sede en Inglaterra, Escocia y Francia ${ }^{1519}$.

-A continuación figura el patriarca de Constantinopla, Juan Besarión. Pasó más de veinte años en un monasterio de la orden de San Basilio en el Peloponeso hasta que en 1438, el emperador Juan Paleólogo le obligó a abandonarlo para nombrarlo obispo de Nicea. Favoreció la unión entre la iglesia griega y latina, por lo que agradecido, Eugenio IV le nombró cardenal presbítero de los Santos Apóstoles un año después ${ }^{1520}$.

-Por último, San Bernardo, a cuyo nombre y ostentando la dignidad cardenalicia responden dos monjes del siglo XII. Pudiera tratarse, como propone $\mathrm{M}^{\mathrm{a}}$ José Redondo, del italiano Bernardo, cartujano de Vallumbrosa perteneciente a la noble familia Toscana de los Uberti ${ }^{1521}$. Urbano II le nombró cardenal de la Santa Iglesia Romana y en los últimos años de su vida detentó el obispado de Parma, hasta que falleció en $1033^{1522}$. Por otro lado, proponemos al francés Bernardo de Rennes, discípulo de San Bernardo en la abadía de Claraval. Fue nombrado cardenal

\footnotetext{
1518 ARANGUREN ROLDÁN, Jimeno. “Configuración de una identidad hagiográfica popular: la leyenda de San Gregorio Ostiense" en Zainak. Cuadernos de Antropología-Etnografía. No 22. Bilbao, 2003, pp. 91-93.

1519 CASTELLANOS DE LOSADA, Basilio Sebastián. Biografía eclesiástica... Op.cit, Tomo I. Madrid, 1848, pág. 307. Un estudio de su prolífica actividad intelectual en LENTINI, Anselmo. "Alberico di Montecassino nel quadro della Riforma Gregoriana" en Studi Gregoriani, n IV. Roma, 1952, pp. 55-109.

${ }^{1520}$ CASTELLANOS DE LOSADA, Basilio Sebastián. Biografía eclesiástica... Op.cit, Tomo II. Madrid, 1849, pág. 673-674.

${ }^{1521}$ REDONDO CANTERA, Ma José. “El programa.....Op.cit, pág. 137.

1522 CASTELLANOS DE LOSADA, Basilio Sebastián. Biografía eclesiástica...Tomo 2, Op.cit, pág. 578.
} 
presbítero del título de San Clemente por Eugenio III en $1145^{1523}$. Ambas atribuciones son posibles, de hecho figuran en las hagiografías benedictinas, y ante la falta de datos, resulta imposible decantarse por uno de ellos ${ }^{1524}$.

En el muro aparece la ménsula de San Marcos con el libro y el león y en la parte correspondiente a la pilastra, San Bartolomé, junto al cual figura un cuchillo, en alusión al martirio que sufrió en Armenia por orden del rey Astiajes: ser desollado vivo ${ }^{1525}$. Al otro lado un demonio encadenado, que fue el motivo de su condena. Este ídolo, de nombre Astarot, profetizaba falsos oráculos, por lo que Bartolomé le expulsó del templo y le obligó a destruir el resto de ídolos paganos de la ciudad ${ }^{1526}$.
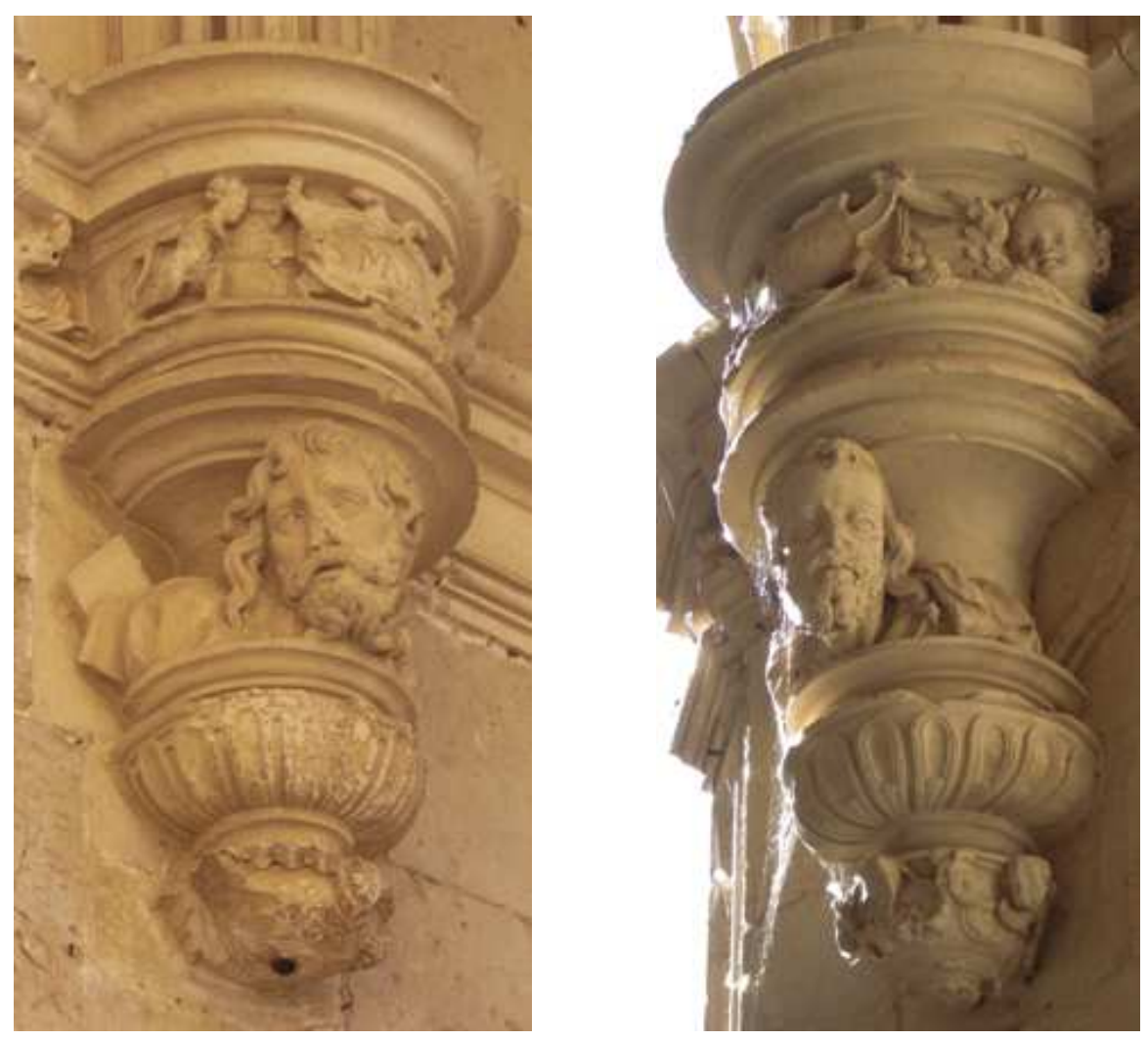

Ménsulas que representan a San Marcos y a San Bartolomé.

\footnotetext{
${ }^{1523}$ Ibídem, pp. 591-592.

${ }^{1524}$ San Bernardo Uberti figura en el listado de cardenales, mientras que Bernardo de Rennes lo hace en otro más específico de monjes cardenales nombrados por Papas. BSCV. UVION, Arnoldo. Brieve dechiaratione dell'arbore...Op.cit, pp. 22 y 117.

${ }^{1525}$ DUCHET-SUCHAUX, Gaston y PASTOUREAU, Michel. Guía...Op.cit, pp. 56-57.

${ }^{1526}$ CROISSET, Padre Juan. Año cristiano...AGOSTO. Op.cit, pp. 440-442.
} 
Bóveda 21: No insistimos en los motivos escultóricos de esta bóveda, pues presenta idéntica disposición a la precedente. Tan sólo difieren los cuatro personajes de los medallones que, flanqueando a San Benito, lucen como aquel la cogulla.

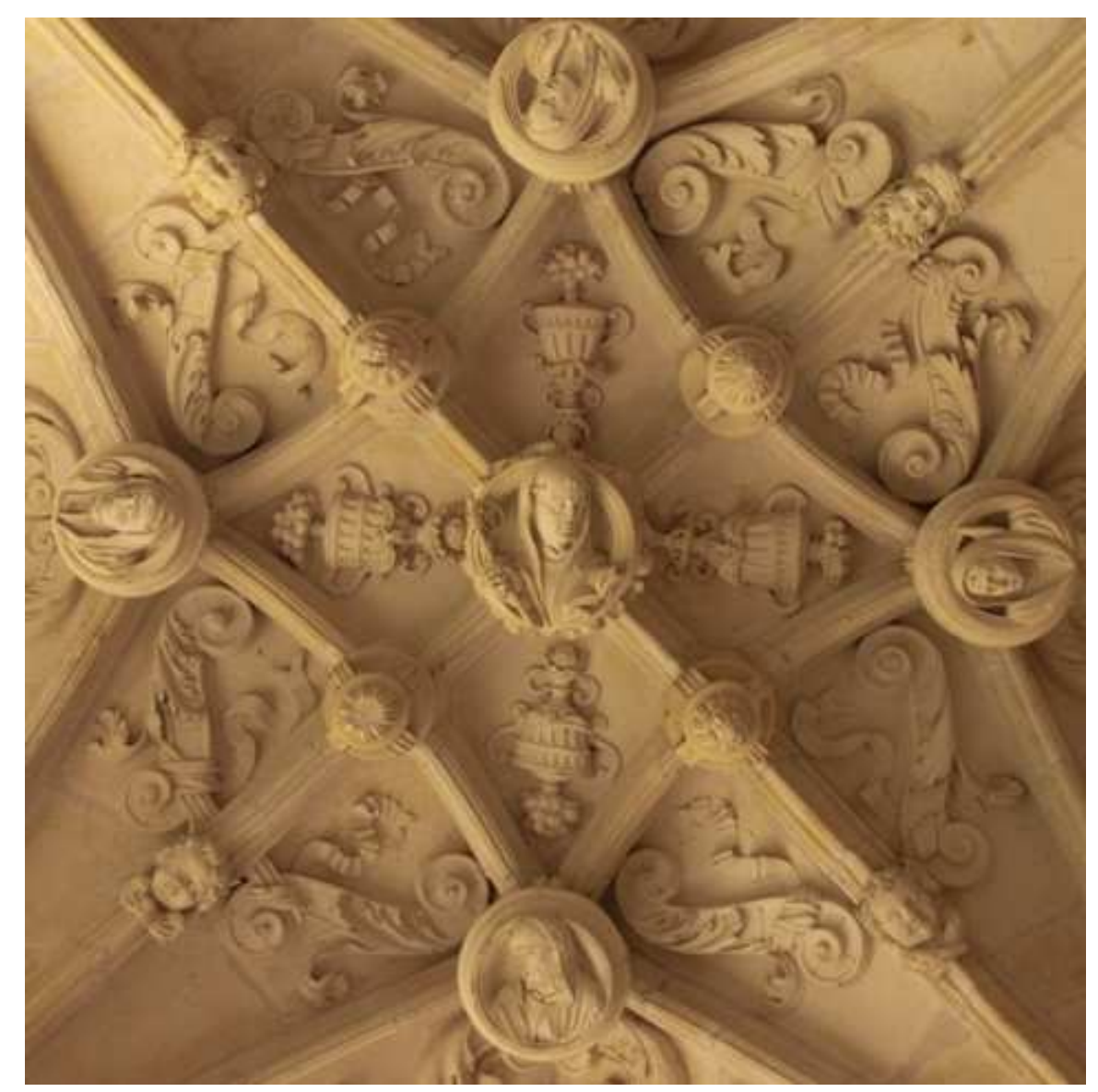

\section{Bóveda 21. Descendencia espiritual de San Benito. Monjes y abades.}

Aunque todos los personajes representados sufrieron martirio, sólo a dos de ellos acompañan las palmas:

-El obispo San Leodegario fue abad en el monasterio francés de Majencia y posteriormente obispo de la comuna borgoñona de Autun. Su irrupción en la corte de Teodorico suscitó la envidia de su mayordomo, que le cortó la lengua y le degolló en el $679^{1527}$.

${ }^{1527}$ HEREDIA, Fray Antonio de. Vidas...Tomo 4. Op.cit, pág. 9-13. 
-A continuación hallamos a Santo Tomás Becket, célebre arzobispo de Canterbury, junto al que figura la palma del martirio. Su política basada en la supresión de la jurisdicción civil sobre la iglesia provocó la enemistad con Enrique II Plantagenet. Toda la comunidad eclesiástica fue testigo de su asesinato, perpetrado en 1170 en el atrio de la catedral inglesa ${ }^{1528}$.

-San Plácido, monje desde los siete años, extendió la orden benedictina en Sicilia por orden de San Benito, a cuyo cargo quedó el joven monje por ser su sobrino en tercer grado ${ }^{1529}$. Junto a él figura la palma, aunque seccionada, señal del martirio que sufrió en el 541 por negarse a adorar ídolos paganos ${ }^{1530}$.

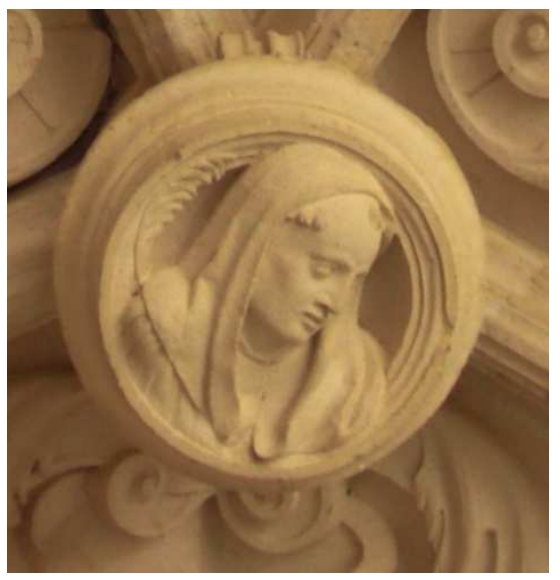

-Respecto al último de ellos, San Vicente, existió un elenco de homónimos en España, como el santo de Colibre o el diácono de Zaragoza ${ }^{1531}$. Sin embargo, bajo la dignidad abacial solamente hallamos al monje del siglo VI que ingresó desde muy joven en el cenobio benedictino leonés de San Claudio $^{1532}$.

\section{Bóveda 21. San Vicente abad.}

En las ménsulas, sigue a San Marcos el apóstol San Mateo en su iconografía habitual, acompañado de un angelillo, que se encuentra algo deteriorado y fragmentado. De frente, Santiago el Mayor, con los clásicos atributos del peregrino: el sombrero de ala ancha con una concha por adorno y la calabaza. Yepes asegura que, entre los papeles del monasterio, existió un documento que certificaba la guarda y custodia de la cabeza del apóstol en San Zoilo. Basándose en el último libro de la Historia Compostelana, el cronista benedictino ofrece testimonio expreso de estas

\footnotetext{
${ }^{1528}$ MARQUÉS, Ignacio. Santo Tomás Becket, arzobispo de Canterbury. № 95 . Centro de Pastoral Litúrgica. Barcelona, 2004, pp. 10-20.

${ }^{1529}$ SANDOVAL, Fray Prudencio de. Primera parte...Op.cit, pág. 12.

${ }^{1530}$ UVION, Arnoldo. Brieve dechiaratione dell'arbore...Op.cit, pág. 106.

${ }^{1531}$ También se enumeran los mártires de Gerona, Évora o Ávila, entre otros. CROISSET, Padre Juan. Año cristiano... Abril. Op.cit, pp. 332-333 y RIBADENEIRA, Pedro de. Flos Sanctorum...Tomo I. Op.cit, pp. 52-53.

${ }^{1532}$ Tampoco se debe confundir a este mártir y abad, primero con ese nombre en San Claudio, con otro prelado de dicha casa que alcanzó tal dignidad, pero no fue mártir sino confesor, un siglo más tarde. ARGAIZ, Gregorio de. La soledad laureada por San Benito y sus hijos en las iglesias de España. Tomo VI. Madrid, 1675, pp. 110-111.
} 
reliquias, afirmando que llegaron desde Jerusalén a principios del siglo XII. Dado que el cuerpo del santo se hallaba en Compostela, doña Urraca decidió donar el tesoro al arzobispo Diego Gelmírez para que todas las reliquias reposaran en un mismo lugar ${ }^{1533}$.
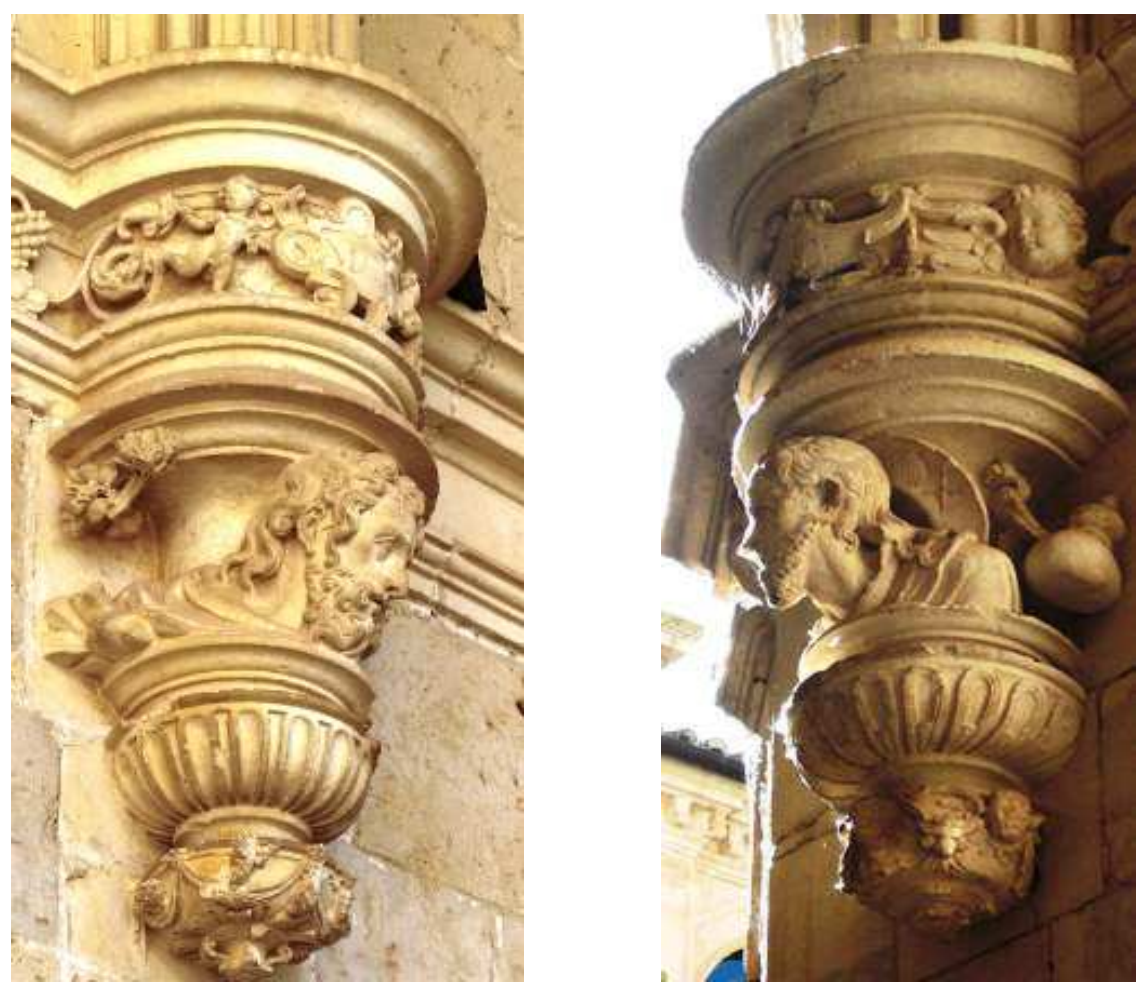

\section{Ménsulas que representan a San Mateo y Santiago el Mayor.}

Bóveda 22: Culmina el recorrido de esta secuencia de eruditos y mártires con cuatro escritoras benedictinas alemanas que vivieron entre los siglos X y XIV. Estas "Sanctas religiosas que en las letras diuinas y erudición de la Sagrada Escritura florecieron" son las siguientes ${ }^{1534}$ :

-Rosvita, primera poeta medieval germana cuya vida transcurre en el monasterio de Gandersheim entre el 935 y 973, donde adquiere su formación intelectual. Su actividad literaria estuvo estrechamente ligada a la corte, pues la abadesa del cenobio era nieta de Otón I. Fruto de la misma son sus "Dramas" y su "Gestas

${ }_{1534}^{1533}$ YEPES, Fray Antonio. Crónica...Tomo VI. Op.cit, pág. 78.

${ }^{1534}$ ANÓNIMO. Aprobación de la regla... Op.cit, pp. 76-77. 
sajonas" donde se observa que la Santa bebió tanto de los escritos de los Padres de la Iglesia y de otros doctores cristianos como de las fuentes clásicas ${ }^{1535, "}$.

-Gertrudis, su hermana pequeña, apodada "La Magna”, da redacción definitiva a las revelaciones que Matilde mantuvo ocultas durante muchos años, siendo resultado la versión latina "Liber specialis gratiae ${ }^{1536 "}$. Después de treinta años como monja en el monasterio de Rodersdof, en Sajonia, fue elegida abadesa y allí murió en $1334^{1537}$. -Matilde nació en el Ducado de Sajonia y fue la hermana mayor de Santa Gertrudis, junto a la cual pasó su vida, pues fue ingresada en el mismo convento con siete años. Fue una figura de primer orden en la literatura medieval y modelo de vida espiritual $^{1538}$.

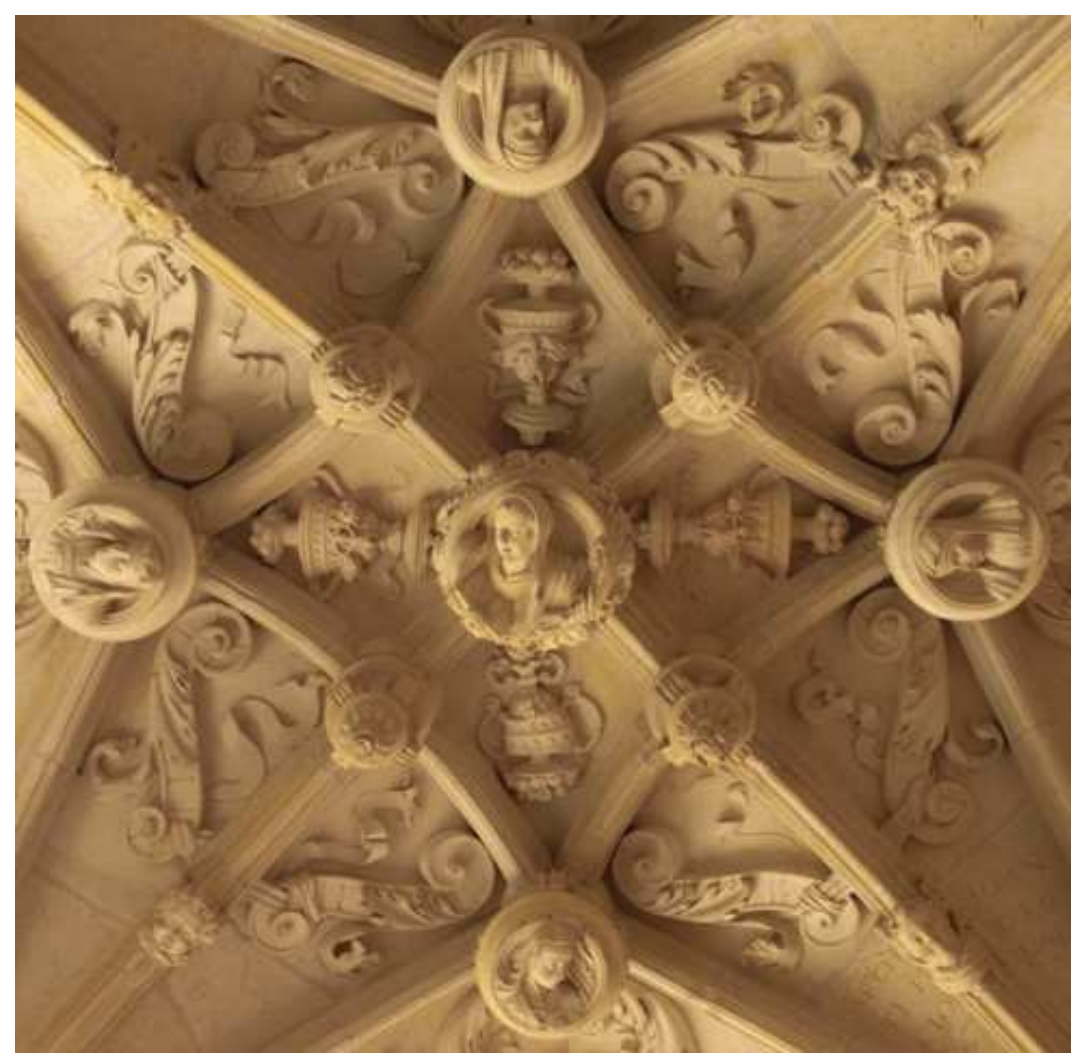

\section{Bóveda 22. Descendencia espiritual de San Benito. Monjas escritoras.}

\footnotetext{
1535 ZOTTO, Carla del. Rosvita: la poetessa degli imperatori sassoni. Jaca Book. Milano, 2007, pp. 7-10 у 33-36.

1536 DALMAU, Bernabé. Lèxic d'espiritualitat benedictina. Publicaciones de la Abadía de Montserrat. Montserrat, Barcelona,1987, pág. 154.

${ }^{1537}$ VICENTE, Fray Plácido. Vida en compendio de la prodigiosa Virgen Santa Gertrudis la Magna. Imprenta de Espinosa. Madrid, 1807, pp. 7-10, 19.

${ }^{1538}$ CIRIA RAXIS E INOJOSA, Pedro de. Vidas...Tomo I. Op.cit, pp. 330-332.
} 
-Por último, Hildegarda, la décima de sus hermanos, fue entregada al monasterio alemán de San Ruperto de Disibodenberg, su ciudad natal, con tan sólo catorce años, trasladándose posteriormente a San Ruperto, donde llegó a ser abadesa y allí fallece en 1179. Pronto comenzó a tener revelaciones místicas, llegando a ser conocida como "la Sibila del Rhin". Escribió tanto en alemán como en latín, que dicen aprendió precozmente. Entre sus obras principales destacan sus obras teológicas Scivias o Liber vitae meritorum- científicas -Liber medicinae, entre las más destacadas- e incluso es autora de varias composiciones musicales ${ }^{1539}$. La maestría del lenguaje literario, así como su espíritu de entrega y deseo de amor místico, le han valido la consideración de "trovadora de Dios ${ }^{1540 ", ~}$

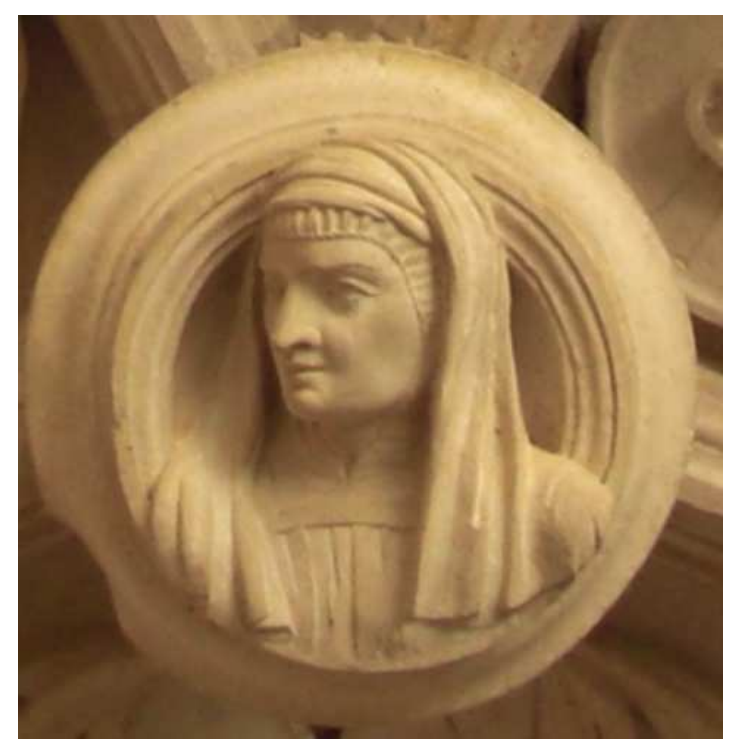

\section{Bóveda 22. Clave representando a Santa Hildegarda.}

San Lucas y San Pedro con sus respectivos atributos cierran el conjunto de Apóstoles y evangelistas que se sitúan en las ménsulas de las crujías septentrional y occidental. La ausencia de Judas Iscariote, motivada por su traición, y Santo Tomás, a causa de su falta de fe, la suplen las figuras de San Pablo y San Matías, conformando así, el grupo de doce seguidores de Cristo.

\footnotetext{
${ }^{1539}$ VON VINGEN, Hildegarda. Vida y visiones de Hildegard von Vingen. Traducción, notas y epílogo de Victoria Cirlot Valenzuela. Madrid, 2009, pp. 25-28 y CIRIA RAXIS E INOJOSA, Pedro de. Vidas...Tomo III. Op.cit, pp. 110-114.

${ }^{1540}$ ÉPINEY BURGARD, Georgette. Mujeres trovadoras de Dios: una tradición silenciada de la Europa medieval. Paidós. Barcelona, 1988, pág. 238.
} 
En este tramo central de la crujía, se conserva, además, la inscripción algo borrosa, que notifica acerca de la conclusión de las obras de edificación: "Este claustro se acabó ha trece de julio, año del señor de 1577, siendo abad F. Ambrosio de Nájera. Salió de ésta general, siendo abad, F. Cristóbal de Agüero. El arquitecto Juan de Celaya lo acabó”.
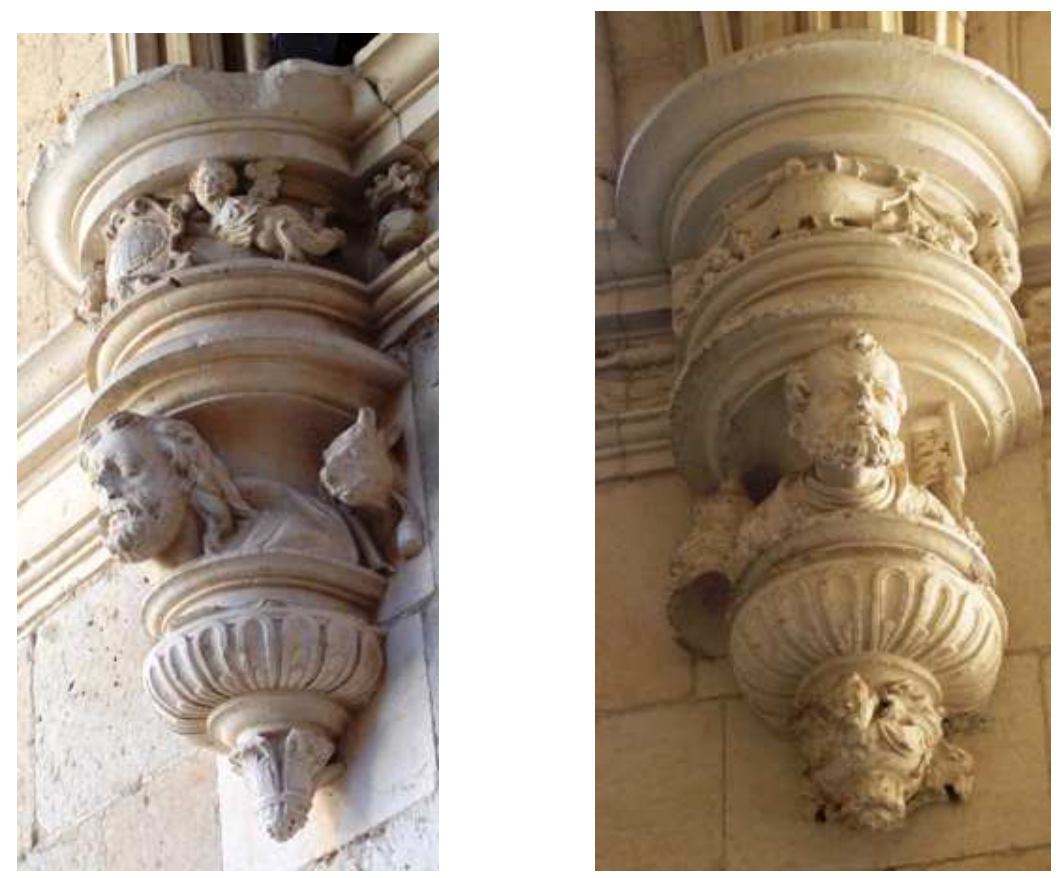

Ménsulas que representan a San Lucas y San Pedro.

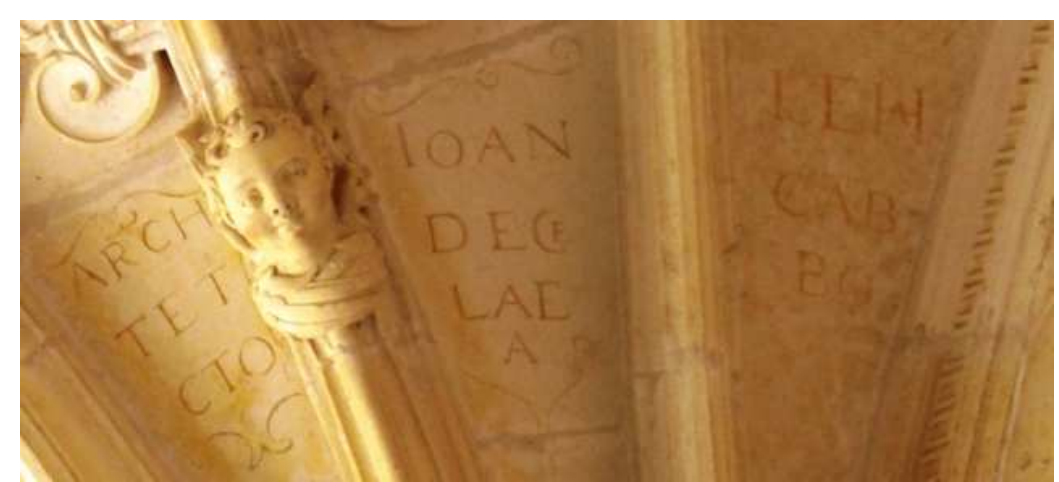

Bóveda 22. Inscripción de los plementos en la que figura: “ARCHITETCTO IOAN DE CELAEA LE HACABBO”. 
Esquema de cada bóveda con los personajes representados en ellas.

ADÁN

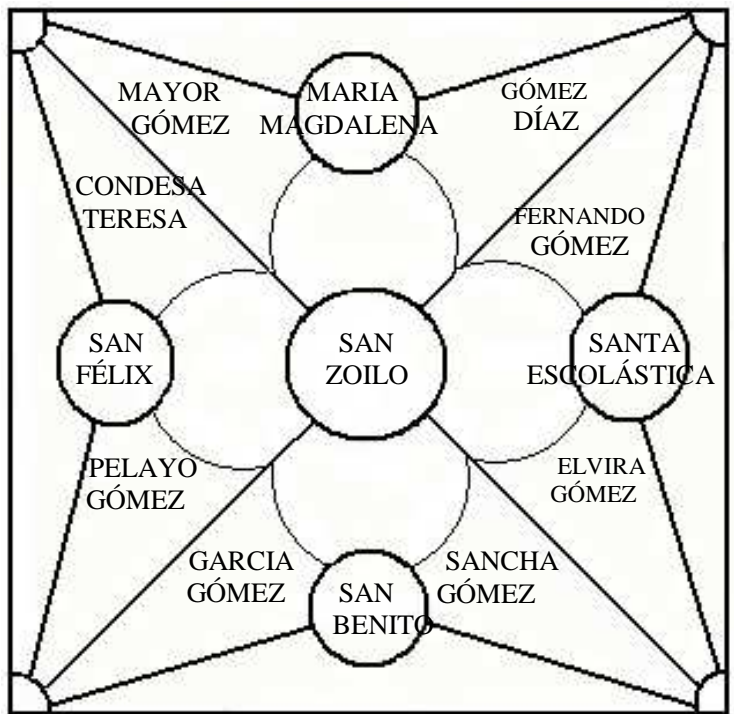

CRÁNEO

\section{BÓVEDA 1}

SAN JUAN EVANGELISTA

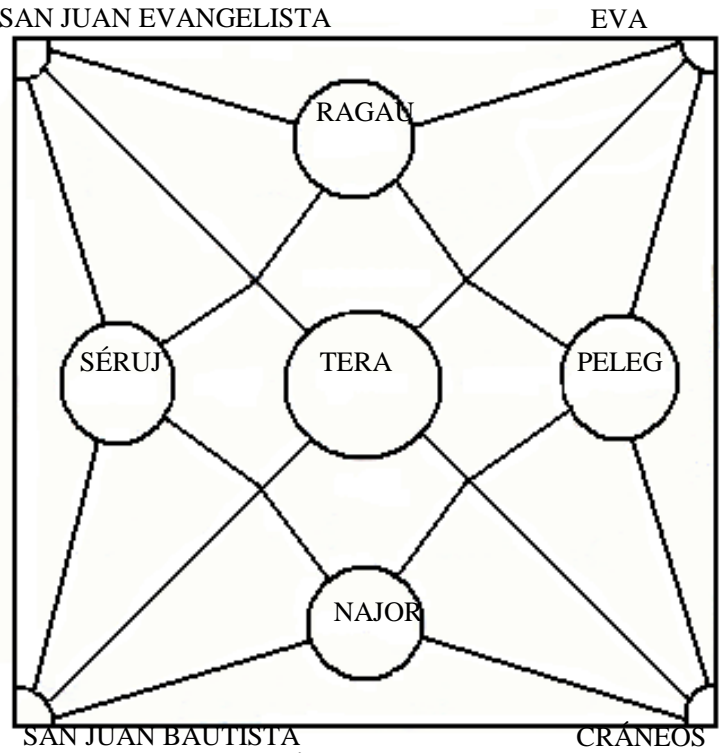

CRÁNEOS BÓVEDA 24

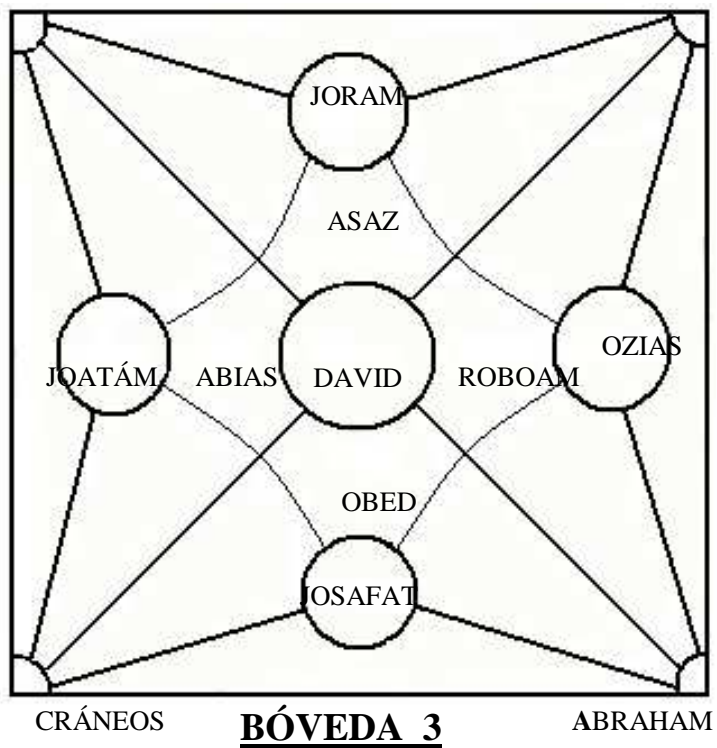

SAN LUCAS SAN JUAN EVANGELISTA

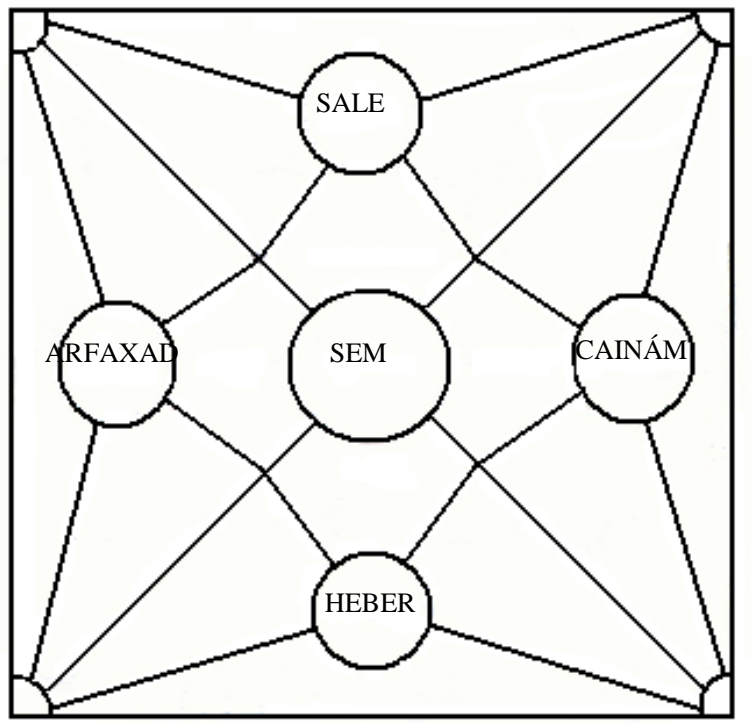

SAN JUAN BAUTISTA

BÓVEDA 23

SETH

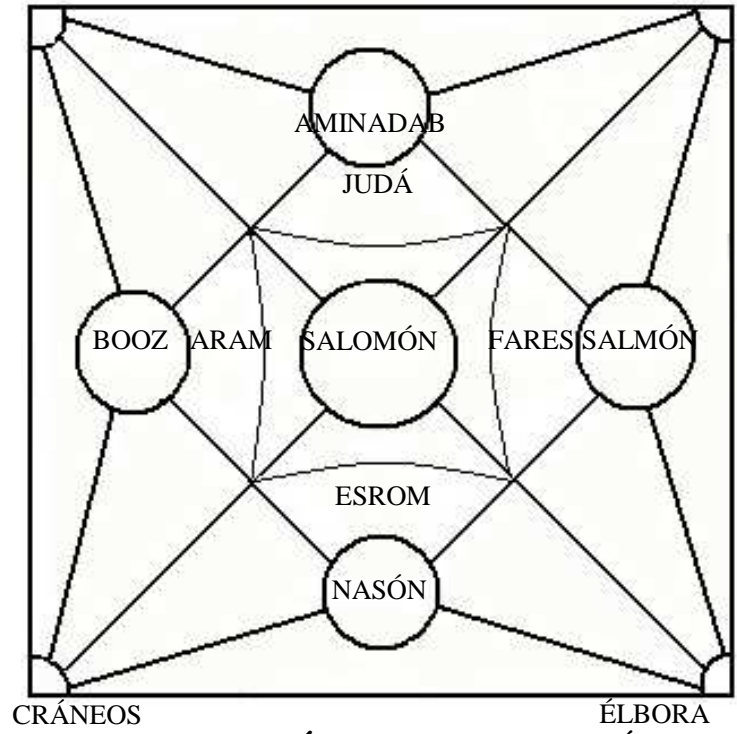

BÓVEDA 2

ABRAHAM

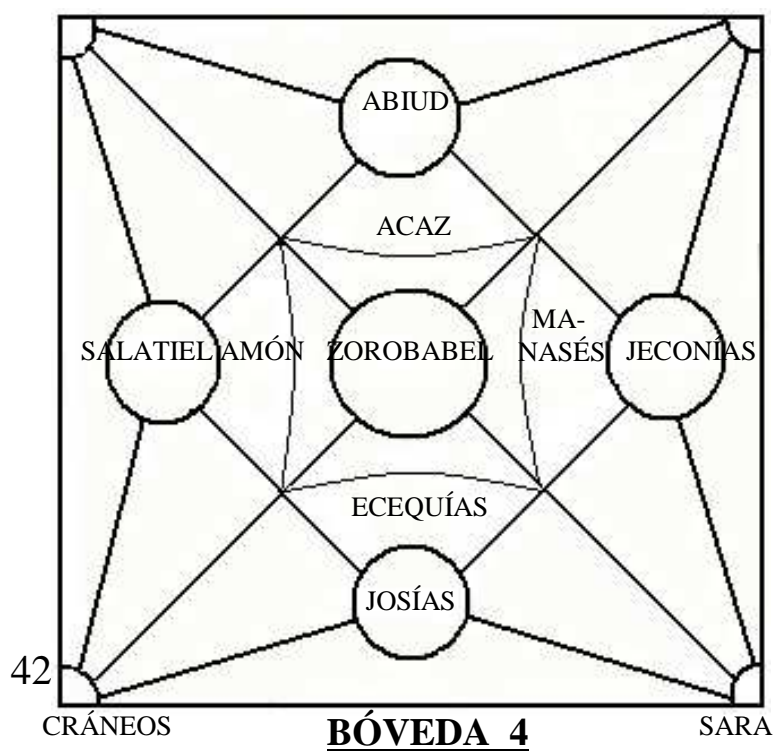



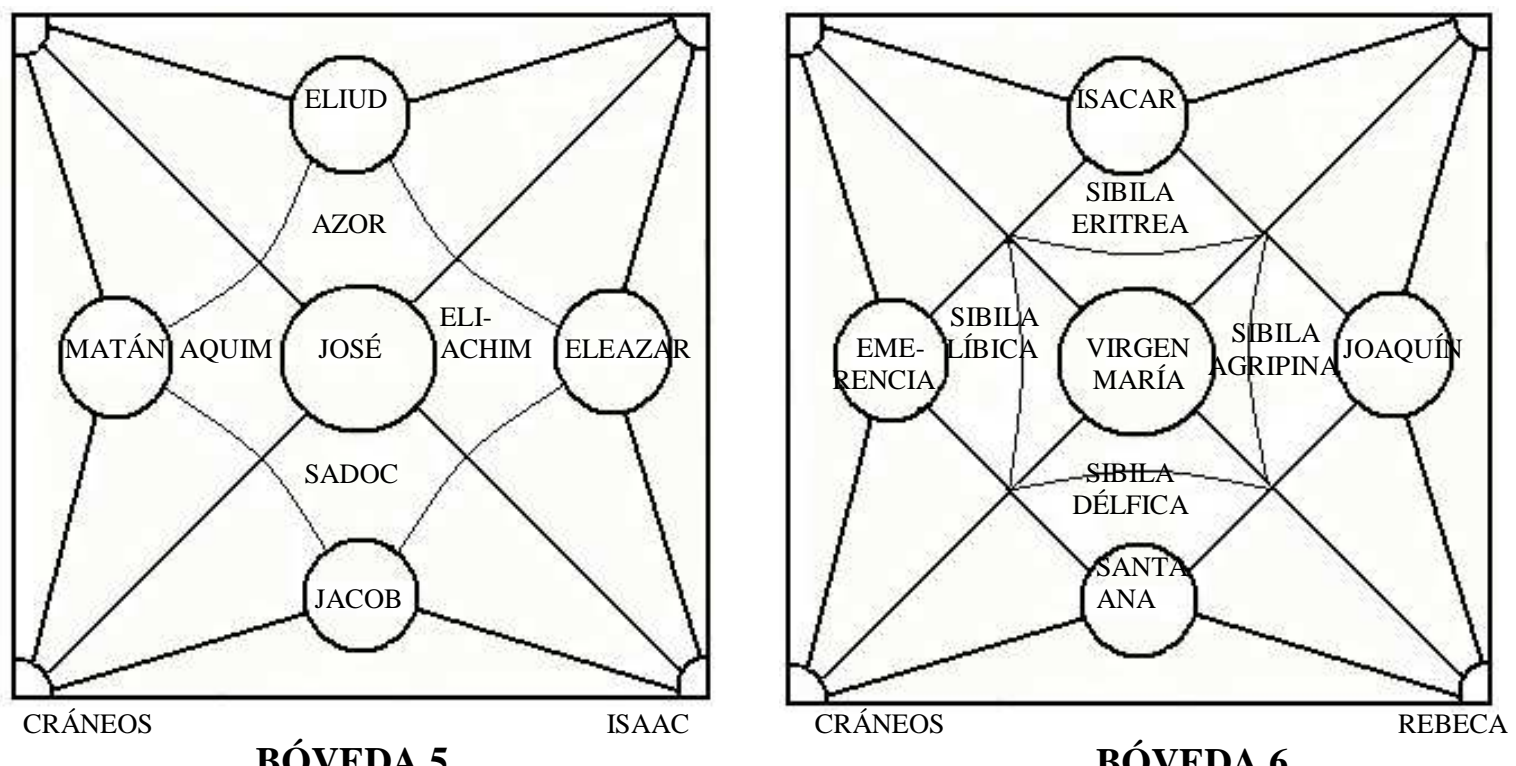

CRÁNEOS

ISAAC
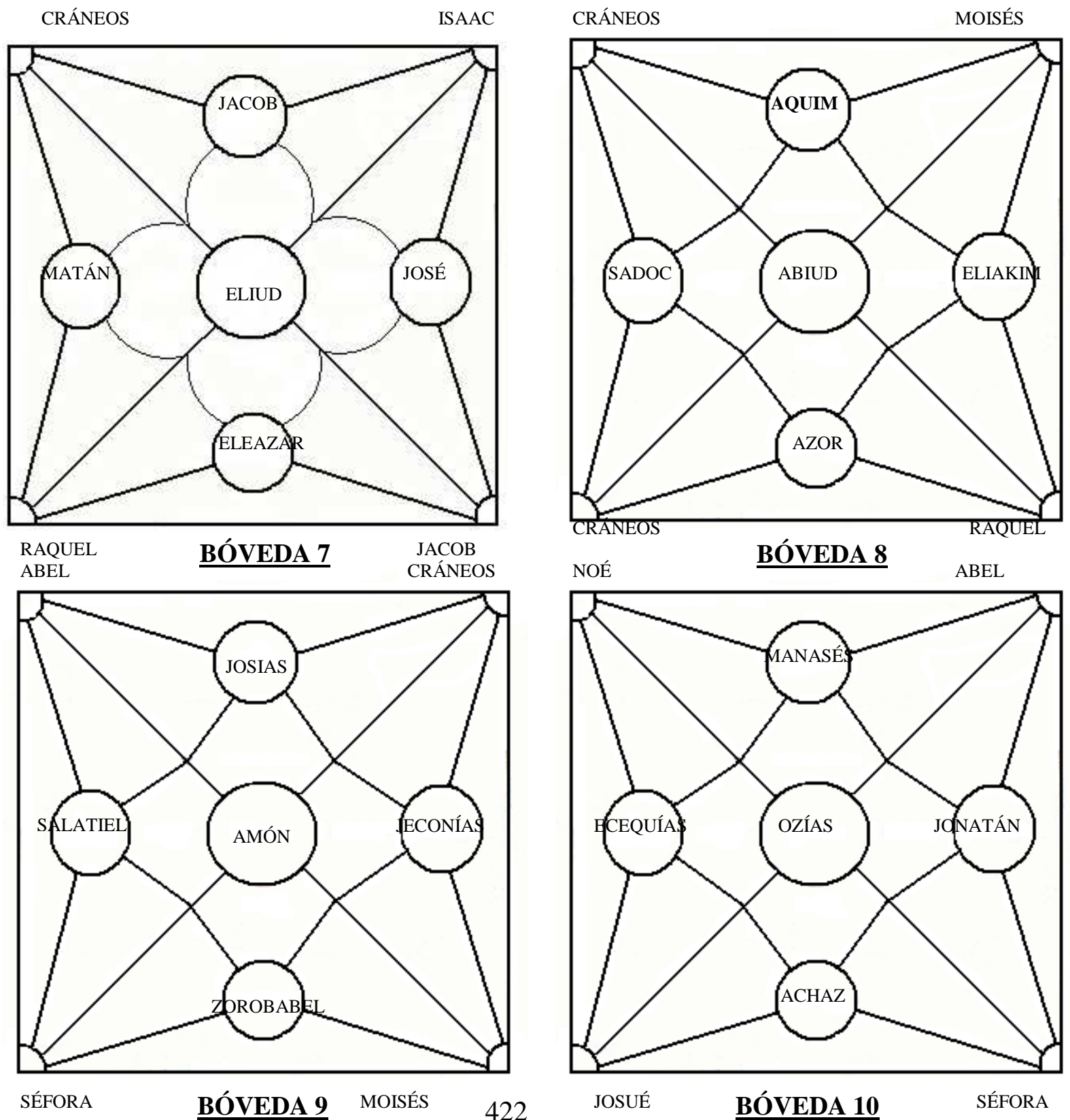


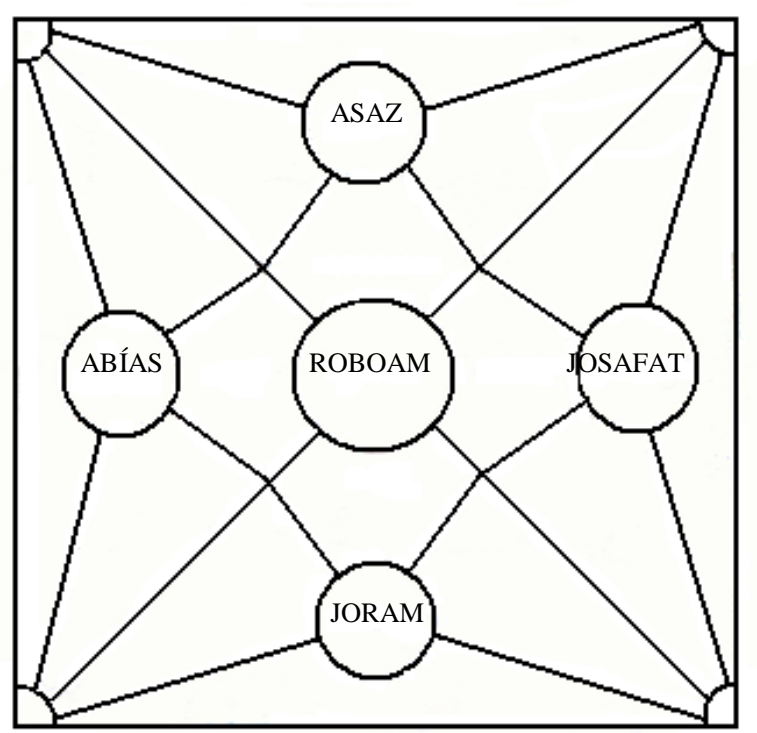

NOÉ GEDEÓN
MELCHISEDECH SANSÓN

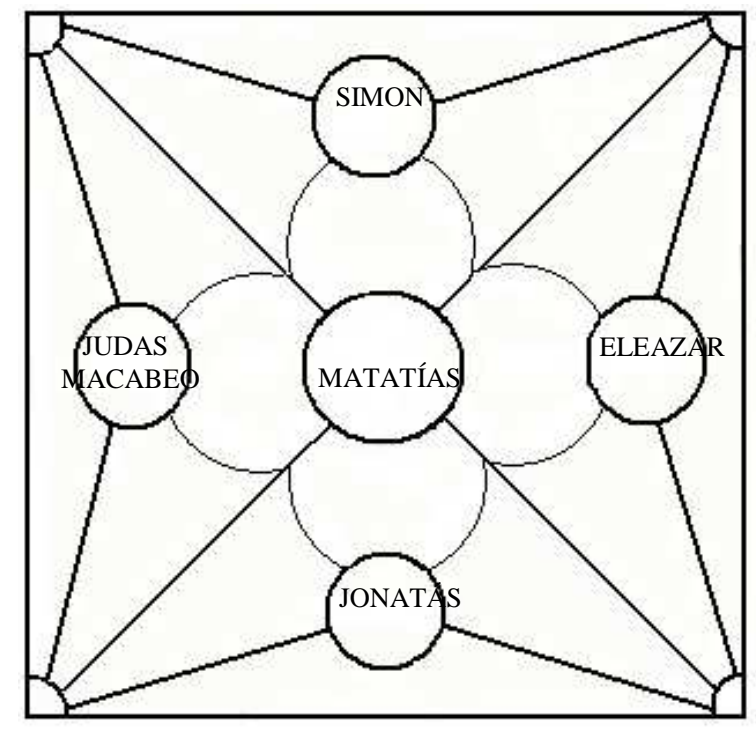

DÉBORA
BARACH DÉBORA

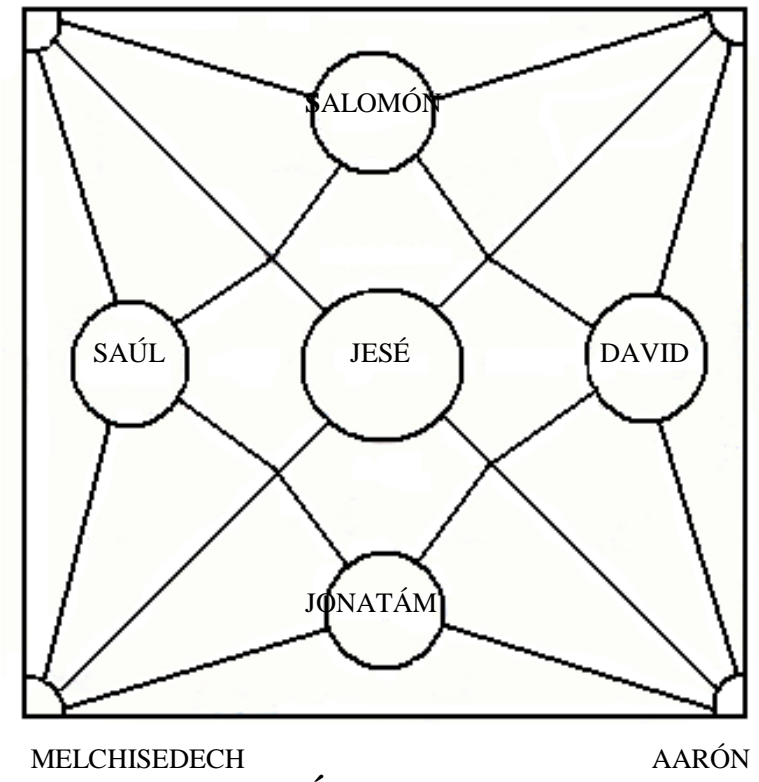

HELI IUDEX BÓVEDA 12 SAMUEL

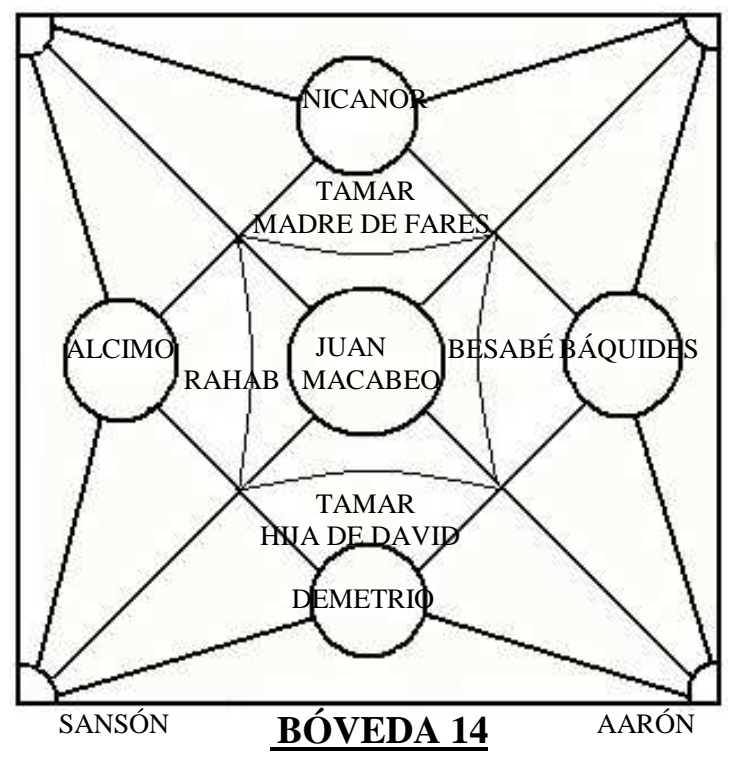

JUDAS TADEO

SAN SEBASTIÁN
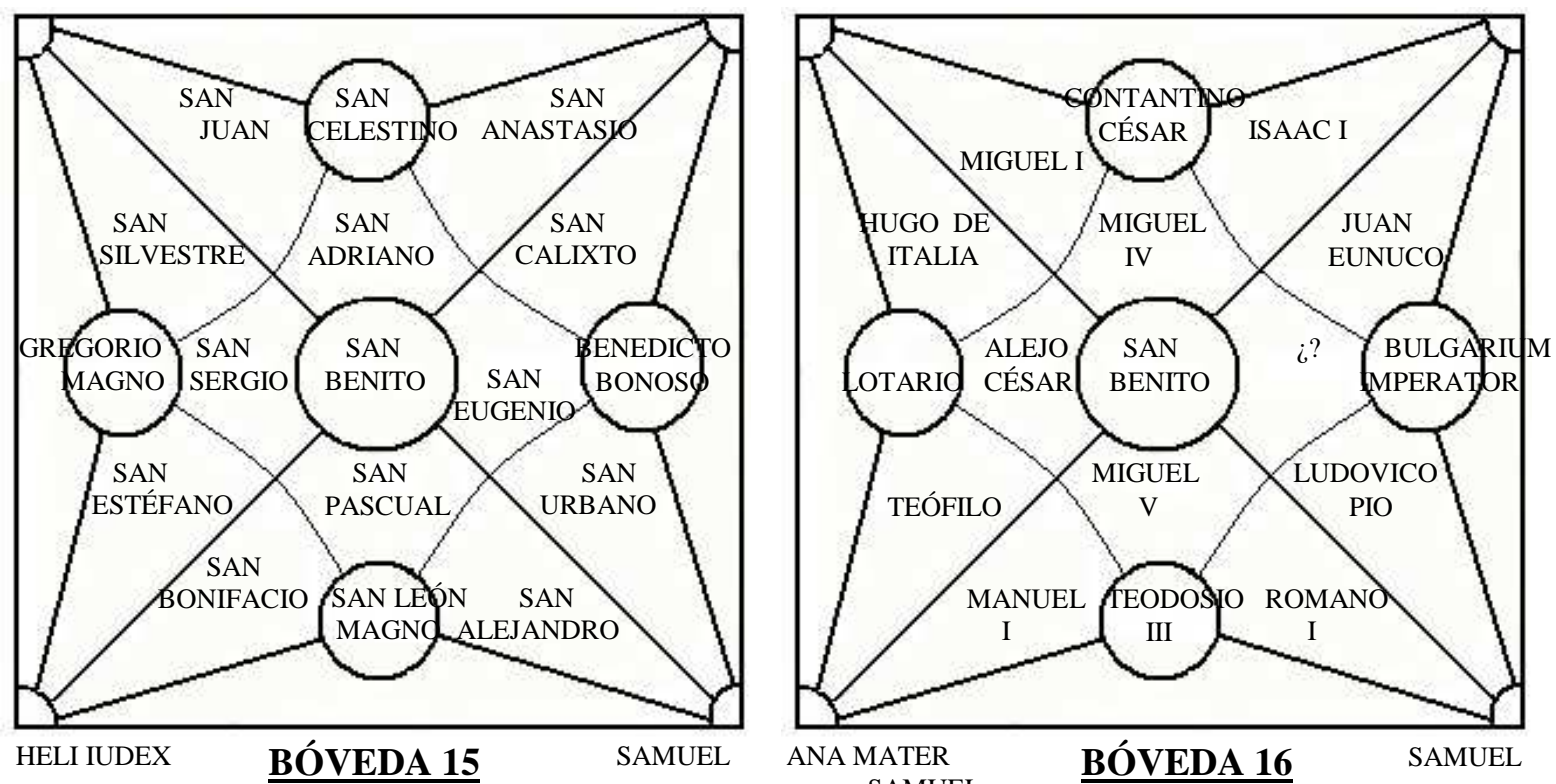


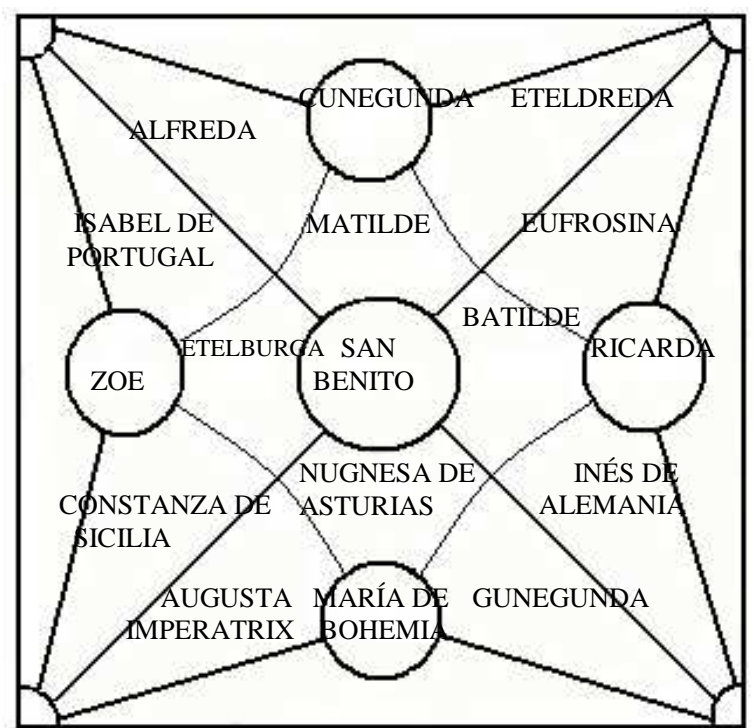

SAN SEBASTIÁN

BÓVEDA 17

SAN SIMÓN SANTIAGO EL MENOR

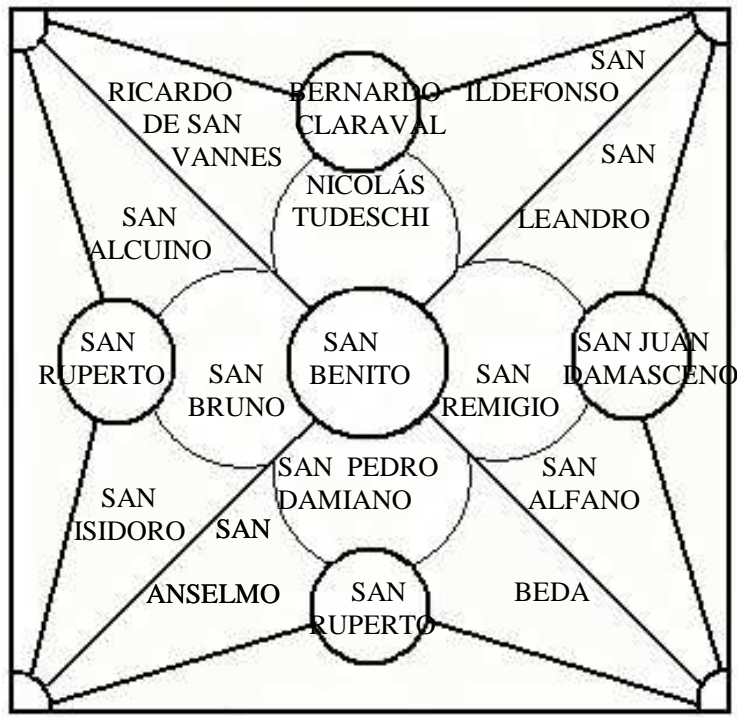

SAN ANDRÉS

SAN MARCOS BÓVEDA 19 SAN MATEO

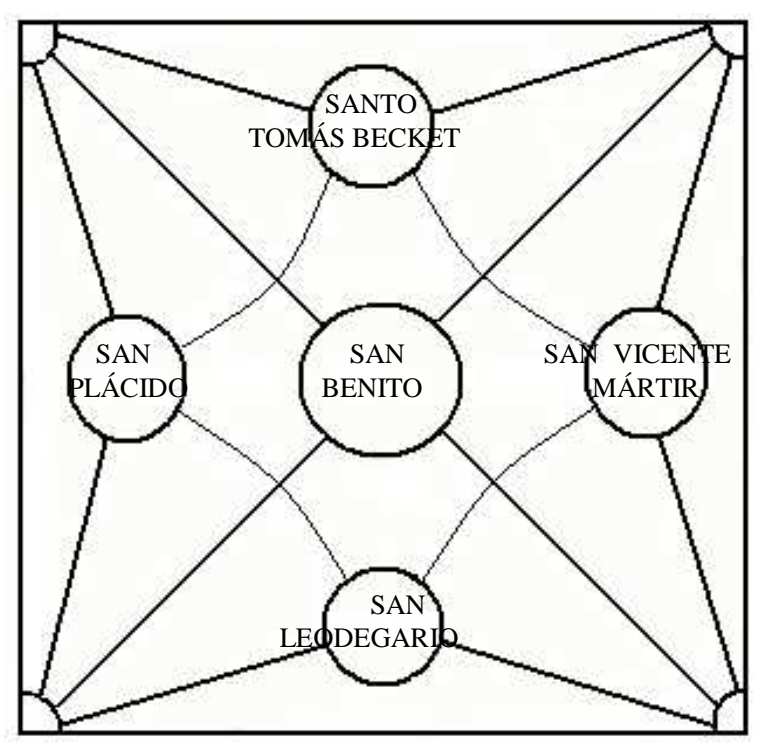

SAN BARTOLOMÉ

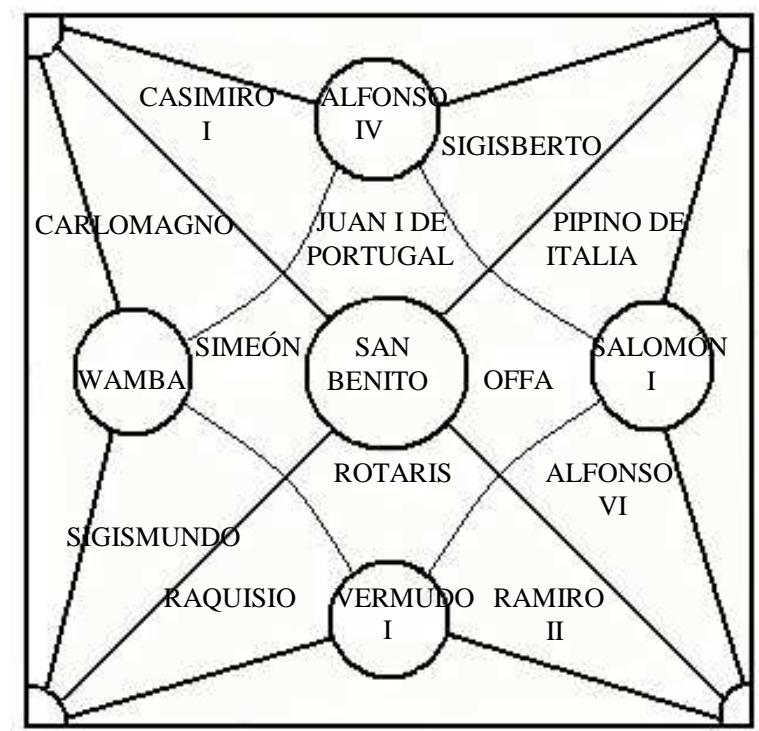

SAN FELIPE

BÓVEDA 18

SANTIAGO EL MENOR SAN MARCOS

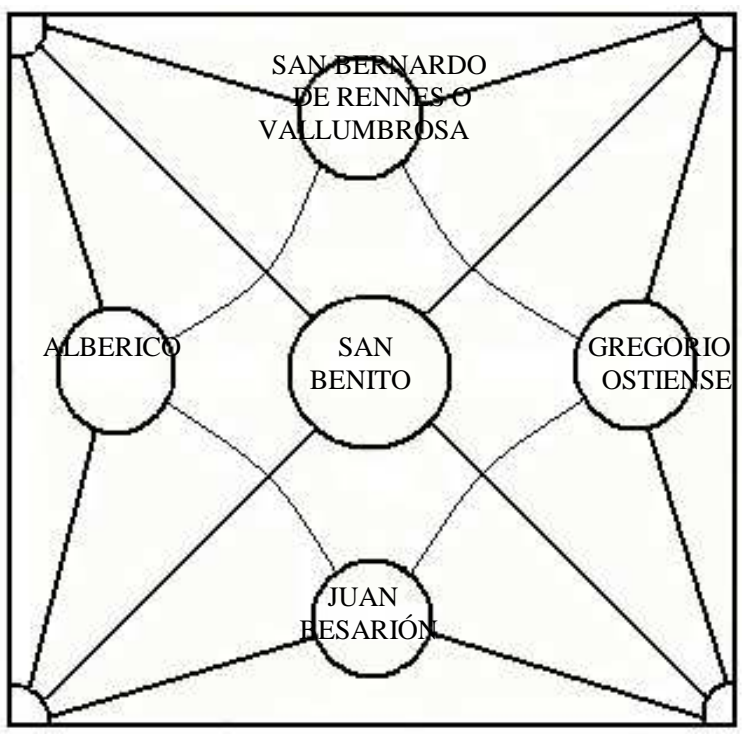

SAN AGAPIO

BÓVEDA 20

SAN LUCAS

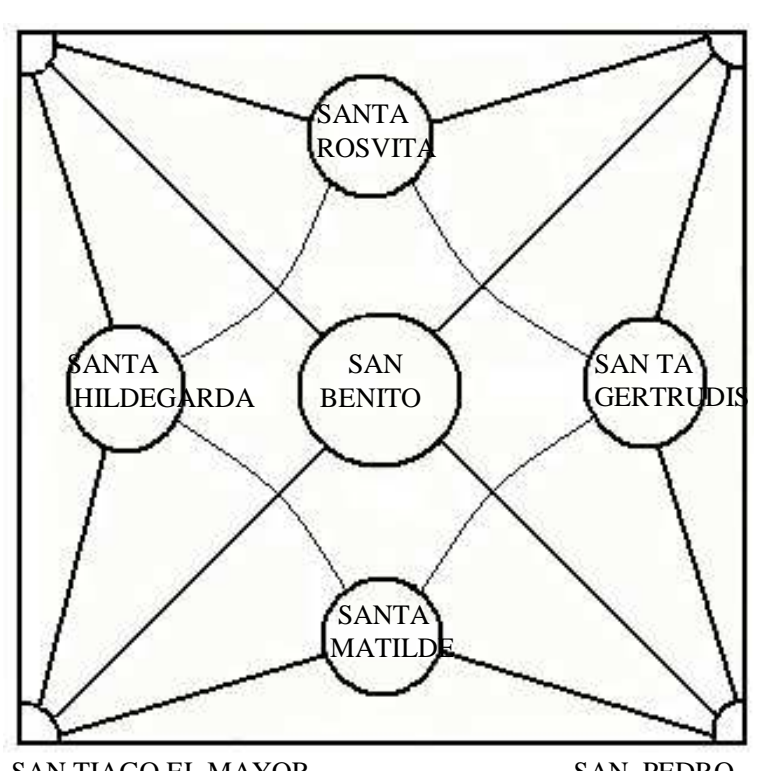

SAN TIAGO EL MAYOR

BÓVEDA 22 


\section{La policromía original}

Salvo la pintura negra con que están remarcados todos los caracteres latinos cincelados en los cueros recortados y plementos de cada una de las bóvedas, a simple vista el ojo humano no percibe otro color en el claustro bajo que no sea el de la piedra. Sin embargo, al realizar el análisis más exhaustivo de sus elementos, percibimos restos de pigmentos que, lejos de poseer un carácter puntual, se constatan repetidamente permitiéndonos afirmar, que, en origen, el programa escultórico del claustro bajo estuvo policromado.
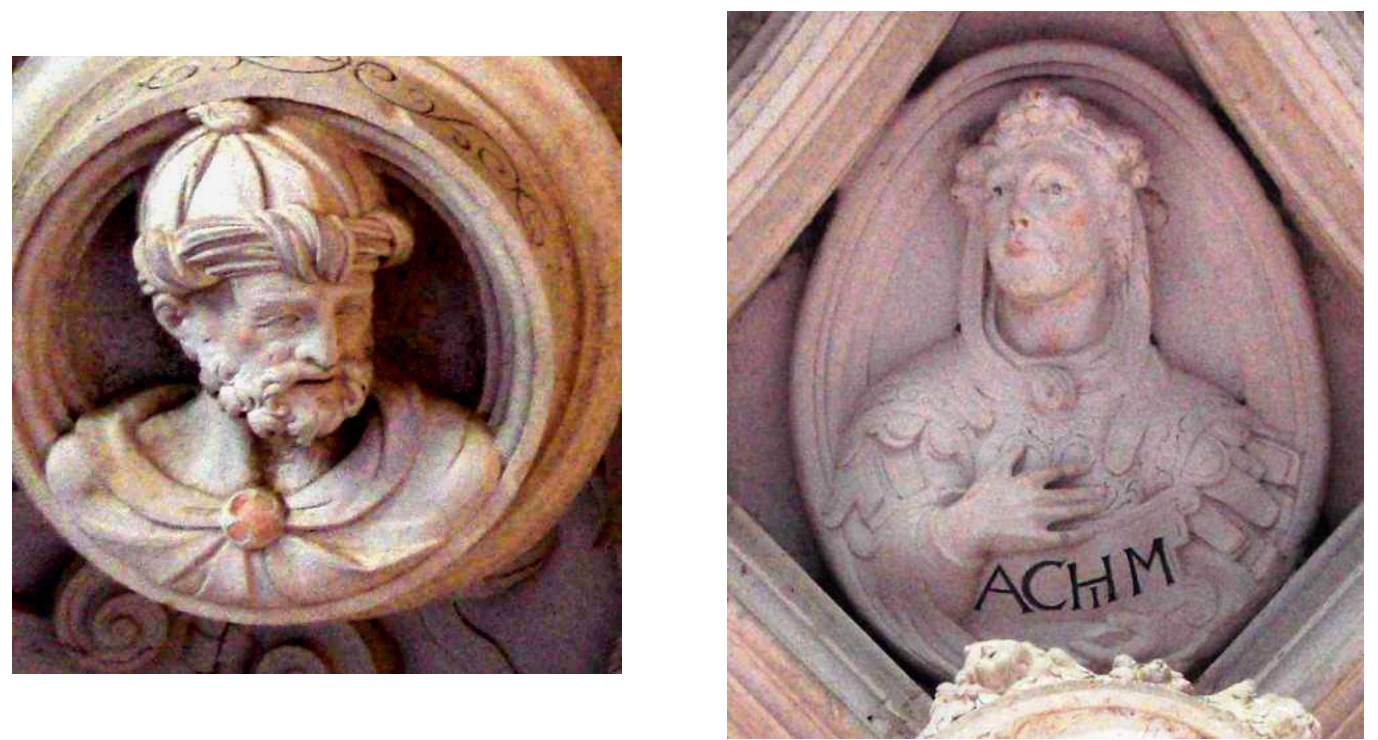

Restos de policromía en los rostros y broches de los personajes.

Bóveda 2. Medallón que representa a Nasón (izq).

Bóveda 5. Plemento que contiene el busto de Achim (dcha).

Sospechábamos que así era por el hecho de que todos los rostros, sin excepción, en lugar de tener cincelados los ojos, presentan los globos oculares desnudos, dando la impresión de ser invidentes. Creíamos posible que el escultor así lo hizo con el propósito de que dichos detalles fuesen delineados a posteriori mediante una capa pictórica, como así sucede en las ménsulas y bóvedas de la sacristía leonesa de San Marcos, en León, obra que, precisamente, realizó Juan de 
Badajoz en los años precedentes a su intervención en este claustro ${ }^{1541}$. En Valladolid, la capilla funeraria de don Juan Manuel de San Pablo de Peñafiel, está igualmente conformada por una serie de ménsulas molduradas recorridas por una amplia imposta que sustentan las bóvedas de crucería. Como ya señalamos, se atribuye a Juan de Badajoz y fue finalizada, según reza una inscripción que recorre el muro, en 1536, justo antes de su participación en el claustro ${ }^{1542}$. Puesto que ambas obras se ubican en un espacio cerrado han conservado la policromía original, no así el claustro de San Zoilo, sometido constantemente a las inclemencias del tiempo. Sin embargo, los fuertes contrastes cromáticos y el pan de oro presentes en los edificios mencionados no nos parece acorde al espíritu de la orden benedictina, cuyos monjes seguramente habrían optado por unas tonalidades más discretas como las que muestran los tondos de la plaza mayor de Salamanca o los medallones de la galería de la catedral de dicha capital, más acordes a la discreción monacal.

Afortunadamente conservamos algunos ejemplos en los que la pupila ha sido rellenada de negro, perfilándose del mismo color el contorno del iris, para rellenarlo posteriormente del color que convenga. De este modo las figuras adquieren mayor expresividad y un carácter más realista. Es el caso de los rostros de los hermanos Don García y Don Pelayo, en la primera bóveda, de Noé, ubicado en la ménsula de la bóveda décima o de la Virgen y los querubines que la flanquean en el sexto tramo.

Por otra parte la imitación de la carnación de los rostros a través de un color rosáceo está presente en varias figuras, como en Judá, padre de Phares, en la clave adyacente de la segunda bóveda o Eliachim, en uno de los plementos del quinto tramo. Incluso percibimos el rojizo de los labios, otrora más intensos, en Achim, a quien hallamos en el quinto tramo, los angelillos de cuerpo entero que sustentan el escudo del cenobio en punto de partida del ciclo, o la figura de Sem, que preside la bóveda vigésimo tercera.

El fondo de las claves sobre el que sitúan los personajes iba policromado de un gris marino o azul oscuro sin que podamos precisar su tonalidad aunque tenemos

\footnotetext{
${ }^{1541}$ Sobre la sacristía véase, SÁNCHEZ BORDONA, Ma Dolores. Juan de Badajoz...Op.cit, pp. $213-$ 223. Hoy día es una de las salas del Museo arqueológico. Historia del mismo y excelentes fotografías en DÍAZ JIMÉNEZ Y MOLLEDA, Eloy. Historia del Museo...Op.cit, s/f.

${ }^{1542}$ CHUECA GOITIA, Fernando. Arquitectura...Op.cit, pag 316.
} 
la certeza de que era oscura cercana al negro, con el fin de hacer destacar las figuras. Los ejemplos mejor conservados los encontramos en las bóvedas de la crujía meridional. Excepcionalmente hallamos una bicromía de granate y verde, presente en los florones que rodean la clave de la segunda crucería y un verdoso amarillento en el clípeo que acoge el busto de San Benito en el acceso ubicado en la panda suroeste. La humedad, las lluvias y la erosión producida por el viento fueron, posiblemente, los factores determinantes para la progresiva desaparición de la policromía. A ello se sumó, con toda probabilidad, la escasa calidad de los pigmentos empleados, pues de lo contrario y a pesar de los ataques de los agentes externos mencionados, una óptima preparación del muro hubiera garantizado la conservación, al menos parcial, de la pintura de las bóvedas.

Aun siendo escasos los testimonios gráficos, son suficientes para concluir que hace más de cuatro siglos el claustro de San Zoilo luciría, gracias a su colorido, una imagen mucho más vivaz y realista que la que presenta hoy día, más discreta, a la par que sencilla.

\section{$\underline{\text { 6. Accesos del claustro }}$}

Respecto al número de puertas que da salida al claustro, éstas son seis; dos en el lado oriental, dos en el occidental, una en la crujía norte y otra en la sur.

Crujía oriental. En el muro correspondiente a las bóvedas segunda y quinta se encuentran dos puertas sencillas, carentes de labor escultórica. Se estructuran con un arco de medio punto sustentado sobre sendas pilastras. El único ornamento de las mismas lo constituye la imposta moldurada que enmarca la parte superior, la cual continúa por ambos lados recorriendo todo el perfil del claustro, a la altura de las ménsulas. De estas dos puertas, la primera da paso a la sacristía y por la otra se accede a la sala capitular, parte de la cual conformaría el antiguo "De Profundis", que justificaría, como indicamos, la presencia de las calaveras en esta panda.

Crujía meridional. Al llegar a la bóveda décimo segunda del programa hallamos la puerta que comunica con el refectorio. Como sucedía en los accesos 
precedentes, éste, si bien más amplio, se compone de un arco de medio punto apoyado en pilastras sobre las cuales se despliega un ancho friso moldurado. El vano, en este caso es abocinado y presenta, en su dovela central, un motivo en forma de ese avolutado en sus extremos y ornamentado con hojarasca. Las ménsulas de los jueces Barach y Débora que flanquean la puerta, son atravesadas por una imposta, que interrumpiendo su recorrido lineal, se alza para enmarcar el acceso.

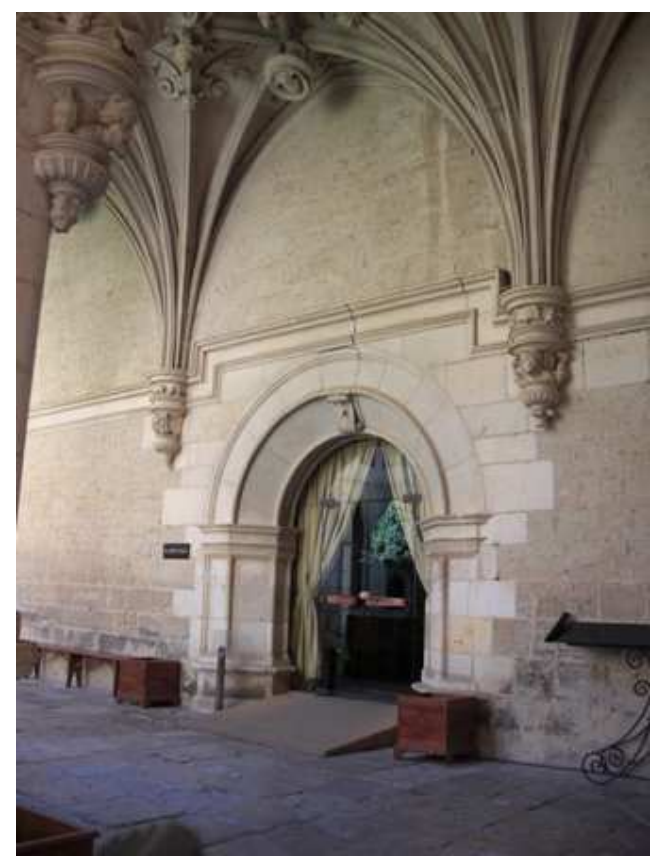

Puerta de acceso al antiguo refectorio, hoy comedor de la hospedería.

Crujía occidental. En los extremos de esta panda se encuentran dos accesos, correlativos respectivamente a las bóvedas décimo-tercera y décimo-novena. El primero de ellos comunica con la escalera que da acceso al claustro alto y dependencias que se encuentran en torno al mismo. Esta escalera fue ejecutada en 1566, pues en diciembre del año anterior, el por entonces abad, Fray Benito de Sahagún, abona una partida de piedra procedente de Villaescusa para el antepecho de la misma ${ }^{1543}$. Podemos establecer una relación con la datación de la portada, pues además coincide con los trabajos escultóricos que se realizaban paralelamente en las bóvedas. Por otro lado, las características de este acceso se hallan en consonancia a la tipología arquitectónica de esta época. Se compone de un arco carpanel abocinado

\footnotetext{
${ }^{1543}$ Escritura de obligación fechada a 10 de diciembre de 1565. AHPP. Carr.Prot 5443. Gregorio
} Movilla (1564-1567), s/f. 
ornamentado por finas molduras que apoyan sobre dos pares de pilastras cajeadas. Del ángulo suroeste, donde se ubica la ménsula que representa al juez judío Gedeón, arranca la imposta moldurada que enmarca este acceso. Entre la misma y el vano se encuentran dos medallones con su tarjeta respectiva, cuya orla está formada por una corona de laurel, o en todo caso, vegetal. Contienen las efigies de San Gregorio, que porta la tiara y la cruz patriarcal, y San Benito, identificado por el báculo abacial y la cogulla monacal, dejando entrever, bajo la misma, su amplia tonsura.

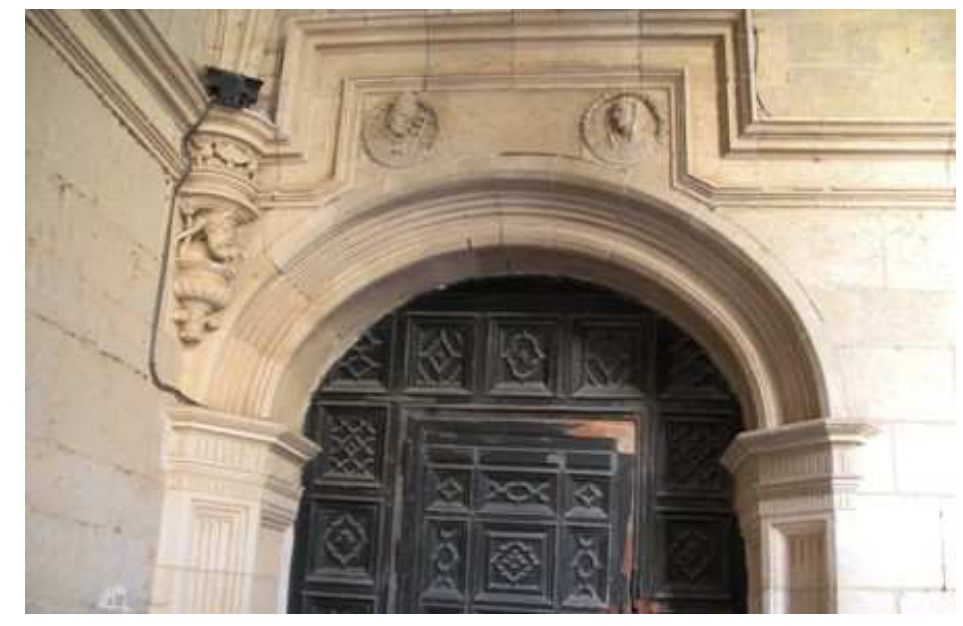

\section{Puerta de acceso a la escalera.}

Del fundador de los benedictinos, hemos hecho repetidas alusiones dado su protagonismo en el ciclo iconográfico. Respecto a San Gregorio, apodado "el Magno", figura en una de las claves secundarias de la bóveda décimo-quinta, dedicada a los Sumos Pontífices más ilustres de la Edad Media. Su reiterada presencia en un lugar preeminente como éste, viene motivada por su supremacía dentro de la orden benedictina, dado el impulso que dio a la misma y el hecho de ser el biógrafo directo del Santo de Nursia. San Gregorio nació en el año 540, en el seno de una familia patricia, gracias a la cual detentó la prefectura romana. Antes de alcanzar ese rango, consagró su vivienda, ubicada en el monte Celio a monasterio, e ingresó en el mismo, enviando monjes por toda Italia, Inglaterra y España para realizar fundaciones e imponer en ellas la regla benedictina, cuya publicación aprobó en el sínodo del año 594, cuarto de su pontificado ${ }^{1544}$. Durante el tiempo que

${ }^{1544}$ Así se relata en una misiva dirigida por San Gregorio a San Honorato, abad de Montecassino. SANDOVAL, Fray Prudencio de. Primera parte de...Op.cit, pp.21-22. 
desempeñó el mismo escribió, entre otros, los Diálogos, estructurado en cuatro volúmenes, uno de los cuales está dedicado a la vida de San Benito ${ }^{1545}$. Gracias a San Gregorio, el santo de Nursia fue consagrado como patriarca de los monjes occidentales, hecho que justifica sobradamente su presencia en esta portada.

Al finalizar este tramo hallamos el otro acceso mencionado, muy somero, que comunica directamente con el pasillo que separa este claustro del patio neoclásico aledaño. La puerta se compone, como su compañera de crujía, por un vano carpanel apoyado en pilastras. Estos soportes, que descansan en amplios plintos, alcanzan la altura de la imposta que recorre el muro. Remata la composición un sencillo frontón triangular.

Crujía septentrional. Al final de esta panda se ubica la denominada puerta de las Procesiones, que da acceso a la iglesia ${ }^{1546}$. Cuando fallecía un monje, el cortejo fúnebre formado por la comunidad benedictina, desfilaba con el difunto por el claustro hasta la iglesia ${ }^{1547}$. Celebrada la misa, el desfile salía por este acceso hasta el De profundis, donde reposaría el cuerpo. En algún caso figura también como Puerta de las Profesiones, haciendo referencia tal vez a algún ceremonial concreto por el que el monje, una vez ingreso en la orden, debía realizar un recorrido determinado saliendo por este acceso ${ }^{1548}$.

La puerta está flanqueada por las ménsulas de Adán y Eva, que, como apuntamos, inauguran el ciclo iconográfico en la bóveda primera y a su vez participan del sentido general de la portada. Ellos simbolizan el pecado inherente a la condición humana, por el cual pagará Cristo a través de su crucifixión. El hecho de tratarse de la única vía de paso hacia el templo explica su refinada ejecución, sin

\footnotetext{
${ }^{1545}$ MASOLIVER, Alejandro. Historia del monacato benedictino II. De San Gregorio Magno al siglo XVIII. Traducción del catalán por M ${ }^{a}$ Sira Carrasquer. $1^{a}$ Edición, Barcelona, 1980. Madrid, 1994, pp. 9-13.

${ }^{1546}$ AZCÁRATE RISTORI, José María de. "Escultura...Op.cit, pág. 182 y PORTELA SANDOVAL, Francisco José. La escultura...Op.cit, pág. 221.

1547 En la crujía norte del claustro del Escorial, también se advierte la presencia de esta puerta. MADOZ, Pascual. Diccionario...Tomo VII,Op.cit, pág. 538. La finalidad funeraria de la puerta se advierte en el funeral de Felipe II. QUEVEDO, José. Historia del real monasterio de San Lorenzo, llamado comúnmente del Escorial, desde su origen y fundación hasta fin del año de 1848. Madrid, 1849, pág. 91.

${ }^{1548}$ También podría ser un error del autor al copiar el nombre. Como Puerta de las Profesiones figura en SAINZ DE ROBLES, Federico Carlos. Monasterios... Op.cit, pág. 105.
} 
parangón desde el punto de vista artístico con las otras puertas del claustro. Realizada en piedra caliza, presenta una decoración típicamente plateresca.

El acceso está compuesto por un arco carpanel sustentando sobre pilastras dóricas ornamentadas, como su intradós, que a través de su tramado reticulado concede un guiño al medievo. El despliegue de motivos ornamentales se traduce en dos medallones situados en las enjutas que representan al profeta Daniel y la sibila Europa. Daniel, modelo de sabiduría y justicia, ha sido considerado como la prefiguración de Cristo, el alma salvada del mal, en alusión al episodio del foso de los leones ${ }^{1549}$. Europa, joven virgen como las once sibilas restantes, es una profetisa que vaticinó el episodio de la Huida a Egipto ${ }^{1550}$. A pesar de que las Sibilas, por su carácter pagano, no figuran en el Antiguo Testamento, gozaron de gran aceptación en el cristianismo por su don de adivinación, de ahí su presencia, como vimos, en los plementos de la bóveda sexta.
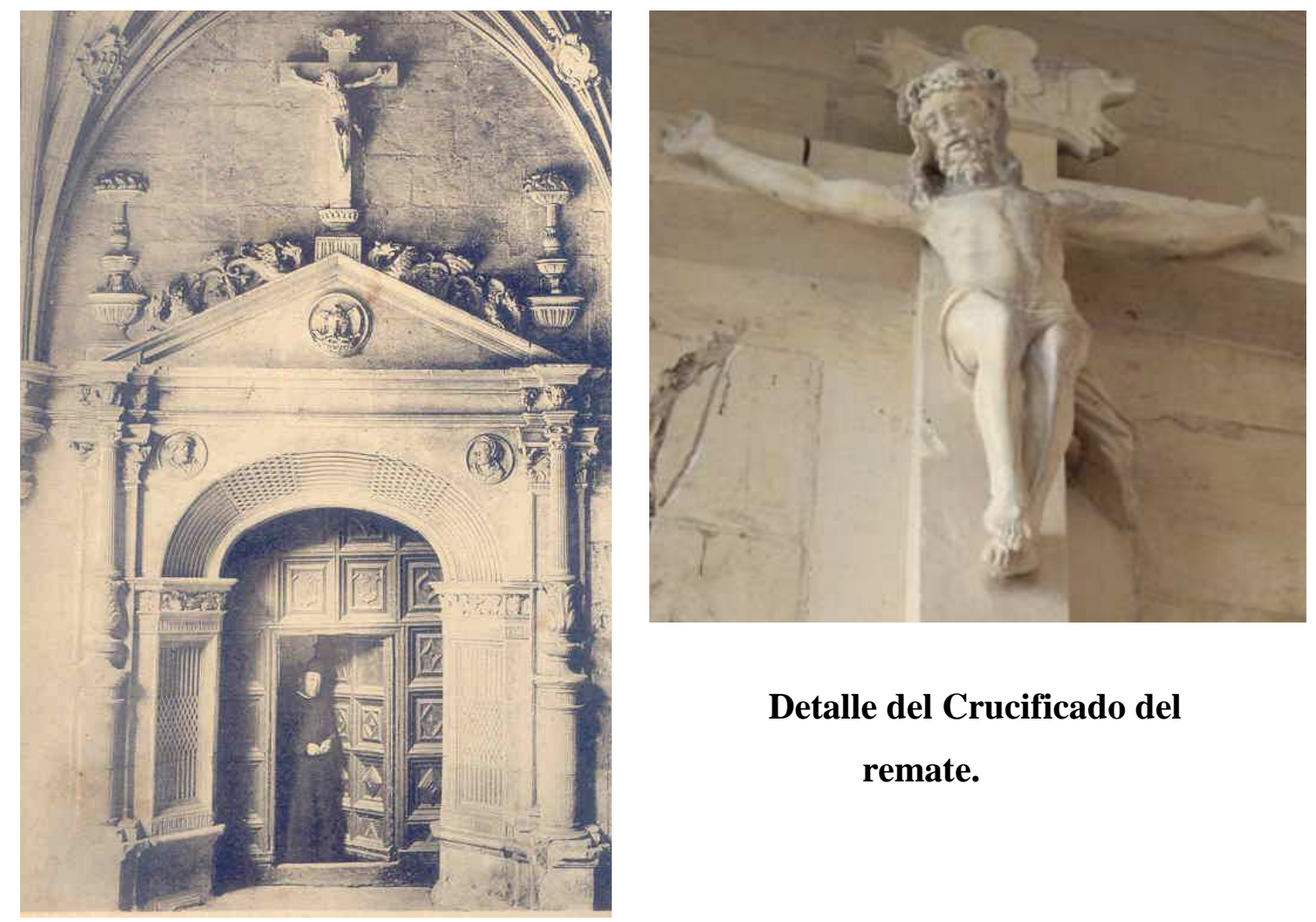

Detalle del Crucificado del remate.

Puerta de las Procesiones que da acceso al templo de San Zoilo.

\footnotetext{
${ }^{1549}$ REAU, Louis. Iconografía....Tomo 1, volumen 1. Op.cit, pp. 446-447 y 457-459.

${ }^{1550}$ Ibídem, pág. 485.
} 
Ambos personajes, a pesar de ser anteriores a Cristo, se representan anacrónicamente, siguiendo la moda del siglo XVI. En el caso de Europa, algunos elementos como las joyas adornando los vestidos remiten a la centuria mencionada. Por su parte, el profeta Daniel, en vez de ser el joven imberbe tocado con gorro frigio de su habitual iconografía, luce un elegante bigote que le convierte en un hombre maduro, con sombrero corto y, en el cuello, una fina gorguera.

Centrando el frontón clásico, decorado con una crestería de flameros flanqueados por dragones alagados de gran elegancia, se sitúa el pelícano, emblema eucarístico por excelencia con cuya sangre se alimentan sus crías. Sobre éste, lindos flamígeros que parecen alumbrar el Crucifijo que remata la composición. De correctas proporciones, esta pequeña talla muestra un Cristo de rostro dulcificado, expirante pero sin atisbo de sufrimiento. Más bien, parece estar adormecido, en estado de tránsito hacia un descanso eterno, como así lo muestran sus ojos entreabiertos y sus facciones relajadas. Ambos elementos iconográficos, Cristo y el pelícano, representan la salvación del ser humano, al que redimen de sus pecados mediante sus respectivos sacrificios. Podemos establecer importantes analogías iconográficas entre esta portada y la coetánea de la iglesia del convento dominico de Nuestra Señora de la Piedad en Casalarreina, en La Rioja ${ }^{1551}$. Igualmente plateresca, aunque dotada de un programa escultórico de mayor desarrollo, la fachada-retablo riojana presenta idénticos referentes cristianos para configurar el sentido salvífico: Adán y Eva en las pilastras que flanquean el acceso, la Piedad, en lugar de la crucifixión en el tímpano para expresar el sacrificio (en lugar de la Crucifixión, dada la advocación del cenobio) y por último, en una de las enjutas, el pelícano, empleado para reforzar el carácter expiatorio y misericordioso de la salvación.

Como vimos, en Cristo finalizaba la descendencia, el árbol genealógico que partía del Padre Eterno, pero éste, a su vez, es generador de vida. A través de su muerte y posterior Resurrección, se crea un nuevo "Lignum vitae" del que brotan los

${ }^{1551}$ Realizada hacia 1530, en ella participaron Juan de Balmaseda, Cristóbal de Forcia y Juan de Cabreros y se relaciona estilísticamente con Vigarny. ESTEBAN LORENTE, Juan Francisco. "La portada de la Piedad de la iglesia de Casalarreina (La Rioja)" en Cuadernos de Investigación, tomo 10, fascículo 2, Universidad de La Rioja, 1984, pp. 95-105. 
“fructus desideratus ${ }^{1552 "}$. Un referente medieval muy claro de este manantial de vida espiritual lo hallamos en San Buenaventura, quien en su obra Arbor Vitae, los ilustra a través de la Crucifixión y el pelícano que se alza sobre él "similis factusum".

A pesar de la belleza sin igual de esta portada, algunos, como Quadrado, se muestran nada convencidos por este tipo de ornamentación. En estos términos se expresa el historiador : “...no se desdeñaron los artistas del renacimiento de afectar al gusto gótico cruzando en figura de rombos las estrías, de lo cual si resultó más bien una parodia que una imitación, acredita de todos modos su buena voluntad $^{1553, "}$.

Este tipo de portada se integra dentro del tipo al que recurre Juan de Badajoz el Mozo entre 1534 y 1550, en el que utilizan elementos italianos a base de molduras, casetones y motivos geométricos y, en muchos casos además, al abocinamiento del arco de entrada, ya sea carpanel, de medio punto o rebajado. Seguimos la atribución de Sánchez Bordona para la autoría, basándonos en la semejanza estilística de las jambas, rosca e intradós con la puerta del crucero que da acceso a la sacristía, en la iglesia del convento leonés de San Marcos, obra del arquitecto entre 1528 y $1538^{1554}$. Inmediatamente después, hacia 1538 , y poco después de inaugurarse el claustro, se ejecutaría esta portada. Otras obras del mismo autor relacionadas estilísticamente con esta aunque no de un modo tan directo, son la puerta acceso al claustro de San Pedro de Eslonza (1547) o la de la librería de San Isidoro de León $(1534)^{1555}$. Otros motivos ornamentales empleados precedentemente por Juan de Badajoz en tierras vallisoletanas señalan, a nuestro parecer, una fuente directa de inspiración. Es el caso de los pebeteros del remate de la portada, presentes en la imposta que recorre el muro de la capilla de don Juan Manuel del convento dominico de San Pablo de Peñafiel, realizada en $1536^{1556}$.

\footnotetext{
1552 También se denomina "Fons vitae" o Fons pietatis", tema al que se recurre para evidenciar al espectador la compasión aten el acto de entrega de Cristo, que el pelícano realiza paralelamente. SÁNCHEZ LÓPEZ, Juan Antonio. "Iconografía e iconología del pelícano: un ensayo sobre la reconversión del concepto de filantropía” en Boletín de Arte, $\mathrm{n}^{\circ} 12$. Universidad de Málaga. Málaga, 1991, pp. 133-134.

${ }^{1553}$ QUADRADO; José María y PARCERISA, Francisco J. Recuerdos...Op.cit, pág. 140.

${ }^{1554}$ CAMPOS SÁNCHEZ-BORDONA, María Dolores. Juan de Badajoz..Op.cit, pp. 83-84.

1555 Ibídem, pp. 407-420.

${ }^{1556}$ CHUECA GOITIA, Fernando. Arquitectura...Op.cit, pag 316.
} 
Admitiendo que Badajoz el Mozo sea el arquitecto de la portada, y que ésta se realizó por tanto en el primer proceso constructivo del claustro, apuntamos la autoría de la escultura figurativa de la misma hacia Miguel de Espinosa, como así propusieron Martín González y Portela Sandoval ${ }^{1557}$. Siguiendo a Ceán Bermúdez, tanto Azcárate como Paul Lafond atribuyen esta portada a Antonio Morante ${ }^{1558}$. Sin embargo, el hecho de que éste se incorporara al trabajo del claustro en un momento posterior de la ejecución -como vimos, en el tramo occidental- distancia su intervención en esta portada, que sería más temprana. Por otro lado, la talla exquisita de los medallones de Europa y Daniel, llenos de expresividad y realismo, encuentran su análogo en las ménsulas de Adán y Eva, inmediatas a éstas y atribuidas igualmente al cincel de Espinosa.

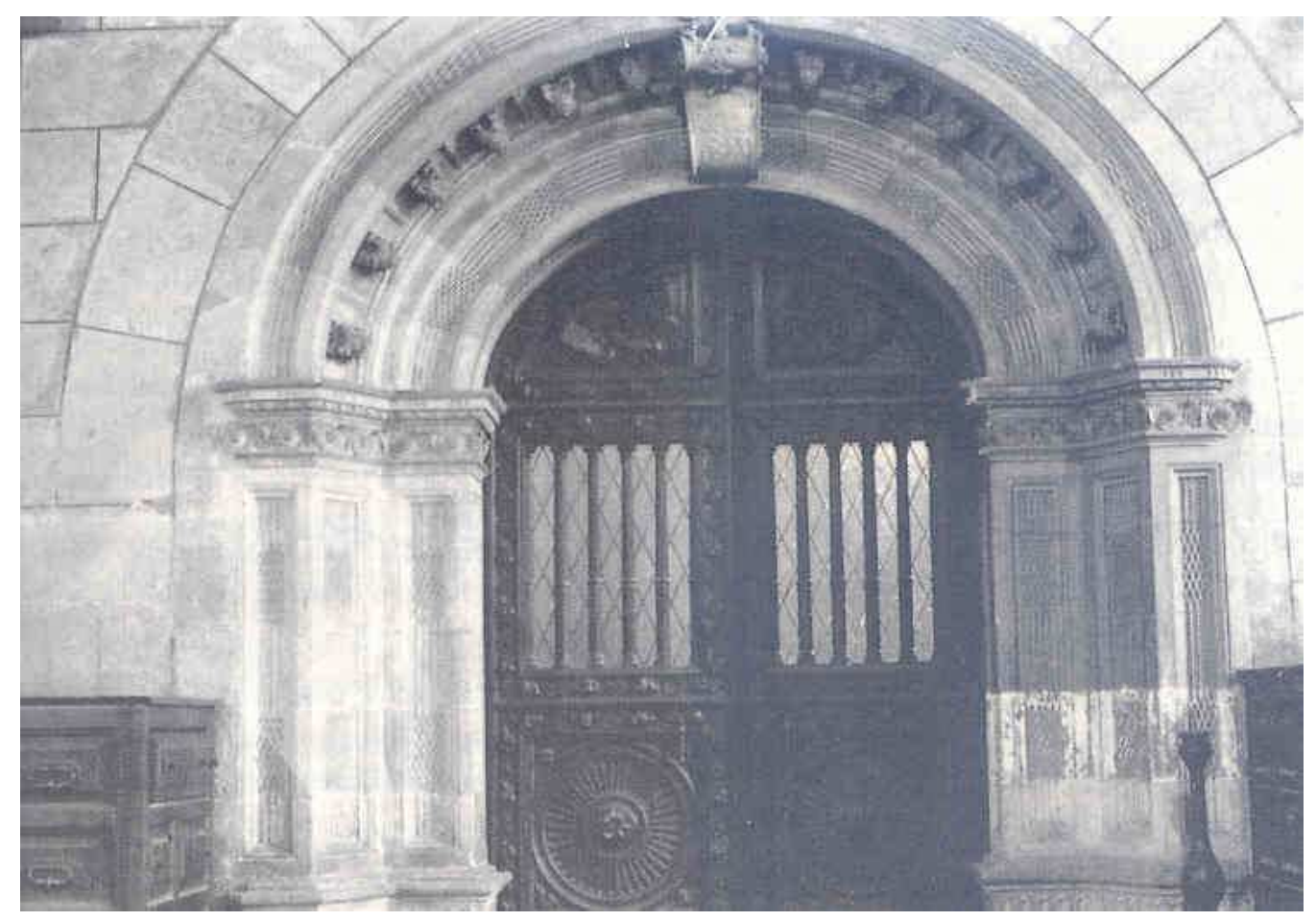

Portada de la sacristía de la Catedral de León. Juan de Badajoz “el Mozo”.

\footnotetext{
${ }^{1557}$ MARTÍN GONZÁLEZ, Juan José. "Miguel...” Op.cit, pág. 149, y PORTELA SANDOVAL, Francisco José. La escultura...Op.cit, pág. 211.

${ }^{1558}$ CEÁN BERMÚDEZ, Agustín. Diccionario Histórico... Volumen 3. Op.cit, pág. 192, LAFOND, Paul. Op.cit, pág. 142, AZCÁRATE RISTORI, José María de. "Escultura...Op.cit, pág. 182.
} 


\section{$\underline{\text { 7. Nichos del claustro }}$}

A ambos lados de la puerta plateresca, se encuentran dos nichos pertenecientes a diversas crujías, dada la ubicación de este acceso en la confluencia de los tramos septentrional y oriental. En el lado norte, coincidiendo con la bóveda vigésimo cuarta, hallamos el nicho de los abades Alonso Barrantes y Juan Díaz. En la bóveda contigua, la primera del ciclo iconográfico, se encuentra el nicho que cobija la escultura de Cristo atado a la columna.

Nicho de los abades Barrantes y Díaz. Bajo arco rebajado sobre pilastras, se disponen los nichos de los Abades y generales de la Orden, Alonso Barrantes y Juan Díaz de Lavandero. Fallecidos en 1627 y 1631, respectivamente, fueron reunidos en dichos nichos el 21 de marzo 1633, según consta en la inscripción.

Alonso Barrantes, abad n ${ }^{\circ} 62$ de San Zoilo, era natural de Cáceres. Antes de profesar como monje en la abadía, desempeñó simultáneamente los cargos de maestro y lector entre 1592 y 1595 en el monasterio orensano de San Esteban de Ribas. Colaboró activamente en la organización de la comunidad benedictina inglesa y en redacción de las Constituciones de $1612^{1559}$.

Por su parte, el palentino Juan Díaz de Lavandero fue el abad número 65 del cenobio carrionés. Nació en Boadilla del Camino y tomó el hábito en San Zoilo en 1592. Entre 1601 y 1604 ejerció de profesor de Arte en el colegio ovetense de San Vicente De las cuatro veces que, como Alonso Barrantes, desempeñó el cargo de abad, la segunda, entre 1613 y 1617, aceptó el cargo para que aquel pudiera dedicarse plenamente a las responsabilidades que conllevaban ser General de la Congregación ${ }^{1560}$.

\footnotetext{
${ }^{1559}$ ZARAGOZA PASCUAL, Ernesto. “Abadologio...Op.cit, pág. 295- 296. Su biografía completa en, mismo autor, Los Generales de la Congregación...Volumen 4. Op,cit, pp. 33-58. En la inscripción de su lápida, que transcribimos a continuación, se revelan más datos sobre su vida.

${ }_{1560}$ Ibídem, pp. 296-297. Su biografía completa en ZARAGOZA PASCUAL, Ernesto. Los Generales de la Congregación...Volumen 4. Op, cit, pp. 117-122.
} 
En el hueco del arcosolio podemos observar un escudo sobre una placa de cueros recortados, muy semejante al que campea en la fachada del templo y en el sotocoro salvo que en este caso se omite el cuervo con el pan en el pico aludiendo a San Benito. Su lectura es la siguiente: cuartelado, con la partición vertical formada por el báculo abacial: 1, castillo, 2, vacío, tan sólo ocupa una parte el cayado o voluta del báculo mencionado, 3, mitra trozos de columna, 4, león y trozos de columna. Podemos afirmar con total seguridad que estamos ante el escudo general de las abadías benedictinas, pues el mismo figura en la portada de los diversos tomos de la Crónica General de la orden de San Benito del Padre Yepes, impreso en Irache en 1609. En aquel caso, se añade además el lema latino: "IN ETERNUM ET ULTRA $^{1561,}$

Gracias a esta ilustración conocemos al artífice del grabado: “Jacob Neran $f[$ ecit]". Podemos identificarlo con toda seguridad con un grabador de buril de

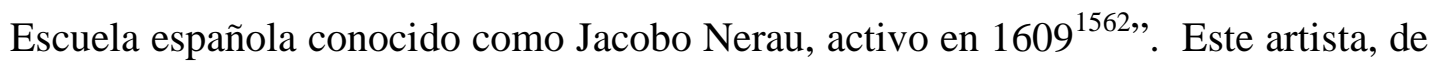
posible origen flamenco ya había trabajado para otra obra benedictina en $1604, L a$ Laurea Salamantina de Antonio Pérez, impresa en Salamanca por Artus Tabernier ${ }^{1563}$.

El 5 de junio de 1430, meses antes de ascender al papado, Eugenio IV concedió, por petición de don Juan II, el título de abadía al hasta entonces priorato cluniacense de San Zoilo. Desde esa fecha, en que fue elegido primer abad don Gonzalo Martínez de Ceballos, hasta 1835, en que, con motivo de la exclaustración cierra el ciclo don Plácido Trevijano, el cenobio ostenta orgullosamente la posesión de mitra y báculo ${ }^{1564}$. Por ello estas armas campearán en la heráldica abacial comprendida en estas fechas.

\footnotetext{
1561 "EN LA ETERNIDAD Y MÁS ALLA".

1562 BÉNÉZIT, Emmanuel. Dictionnaire critique et documentaire des peintres, sculpteurs, dessinateurs et graveurs. Tomo 6. Librairie Grund. París, 1976, pág. 332.

${ }^{1563}$ GARCÍA VEGA, Blanca. El grabado del libro español: siglos XV-XVI-XVII. Aportación a su estudio con los fondos de las bibliotecas de Valladolid. 2 volúmenes. Instituto Cultural Simancas. Valladolid, 1984, pág. 237 y RODRÍGUEZ PELAZ, Celia. "El grabado barroco en los impresos vasco-navarros" en Ondare, 19, 2000, pp. 155-156.

${ }^{1564}$ ZARAGOZA PASCUAL, Ernesto. "Abadologio...Op.cit, pág. 283. Yepes establece la fecha en 1479, cuando Eugenio IV había fallecido.YEPES, Fray Antonio. Crónica...Tomo VI. Op.cit, pág. 84.
} 


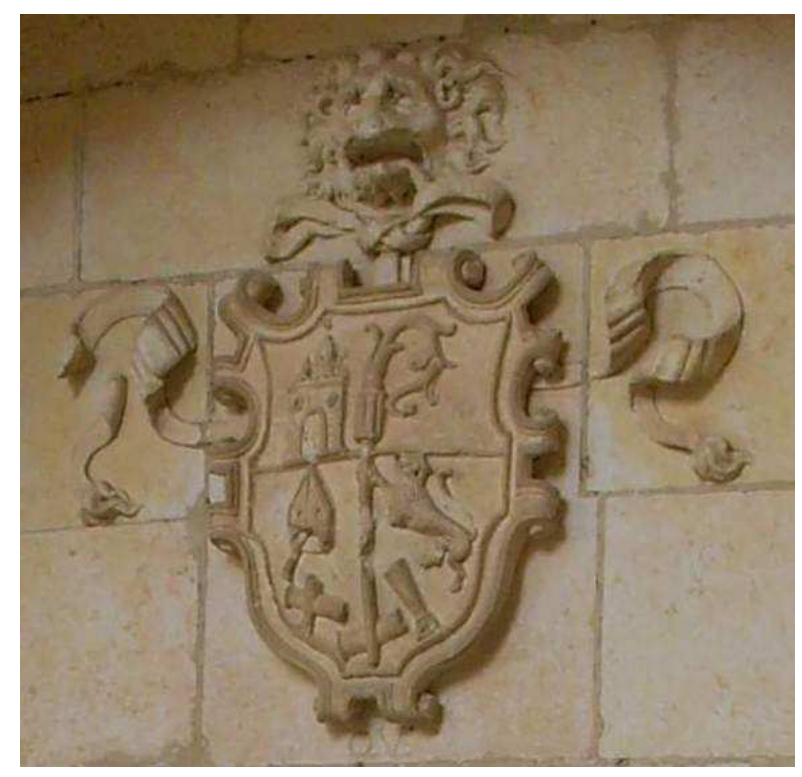

Escudo del muro del nicho de los abades

Alonso Barrantes y Juan Lavandero en el claustro.

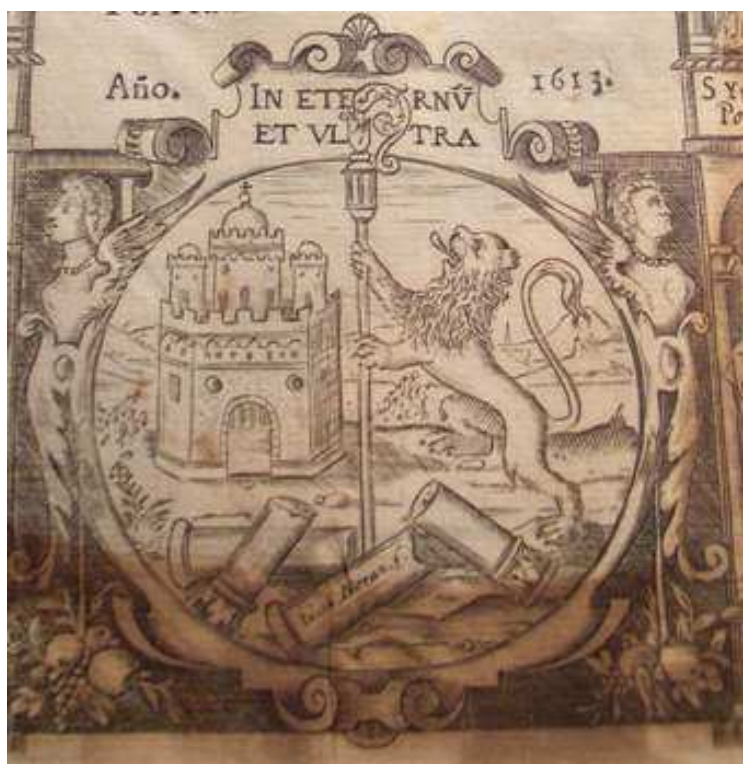

Portada de la Crónica General de San Benito del Padre Yepes. Tomo 3. Año 1613.

Bajo este escudo figura la siguiente inscripción latina:

"BARRANTESQVE DIAZQVE VNA CONDVNTVR IN VRNA QVOS DECVS IN MERITIS VNAQUE FAMA CANIT. SVSCITAT OSSA PATRVM VIRTVS. ARS MARMORA CLAVSTRI, SAXA LOQVVNTVR OPES, OSSA LOQVVNTUR OPVS".

Podríamos traducirla del siguiente modo:

“EN ESTE SEPULCRO YACEN JUNTOS BARRANTES Y DÍAZ,

A QUIENES CANTAN A UNA SU FAMA Y GLORIA EN HONOR DE SUS MÉRITOS. ENSALZA LA VIRTUD LOS HUESOS DE ESTOS PADRES. EL ARTE ERIGE LOS MÁRMOLES DEL CLAUSTRO, LAS PIEDRAS PREGONAN SU PODER, SUS HUESOS, HABLAN DE SU OBRA ${ }^{1565, "}$.

\footnotetext{
${ }^{1565}$ Agradezco la traducción a los profesores Avelina Carrera y José Antonio Izquierdo, del Departamento de Filología Latina de la Facultad de Filosofía y Letras de Valladolid.
} 
En el frente del nicho, en la parte inferior, se hallan dos placas conmemorativas que acogen los restos mortales de los abades mencionados. En este caso las inscripciones están en castellano:

“AQVI YAÇE NVESTR ${ }^{\mathrm{O}}$ PADRE REVERENDISIMO MAESTRO FR ${ }^{\mathrm{A}}$ $\mathrm{AL}^{\mathrm{O}}$ BARRANTES, HIJO PROFESO DESTA CASSA Y ABBAD DELLA 4 VECES $^{1566}$ Y GRAN BIENHE ${ }^{\mathrm{C}} \mathrm{H}^{\mathrm{O}} \mathrm{R}$ SVYO Y QVIEN LA COMENÇO ACREDITAR EN OBSERBANÇIA ${ }^{Y}$ GRANDEÇA AVMENTANDO SVS RENTAS Y EDIFIÇIOS. FVE EL PRIMER GENERAL QVADRIENAL QVE VBO Y DOS VECES PRESIDENTE DE LA CONGREGACION ${ }^{1567}, 4$ VEÇES $^{15}$ DIFINIDOR $^{1568}$ Y GRAN DEFENSOR SVY ${ }^{\mathrm{O}}$. MVRI ${ }^{\mathrm{O}}$ SIEND $^{\mathrm{O}}$ ABAD DE $S^{\mathrm{O}}$ PETRAN, EN MADRI [D] A 15 DEL M ${ }^{\mathrm{ES}}$ DE MA ${ }^{\mathrm{IO}}$ [1627].

“AQVI YAÇE NVESTR ${ }^{\circ}$ REVERENDISIM PADRE MAESTRO FRAI JOAN DIAZ, HYJ ${ }^{\circ}$ PROFESSO DESTA CASSA Y ABBAD DELLA 4 VECES $^{1569}$, GRAN BIENHCEHOR ${ }^{1570}$ SVYO AVMENTANDOL ${ }^{\text {A }}$ CON OBRAS Y RENTA ${ }^{\text {S. }}$ FVE OBSERBANTISSIM ${ }^{\circ}$ RELIGVIOSO Y CELOSO DE LA OBSERBANÇIA REGVLAR. FVE TRES VECES DIFINIDOR DE LA $\mathrm{C}^{\mathrm{O}} \mathrm{NGREGACIO}^{\mathrm{N}} \mathrm{Y}$ GENERAL DELLA $^{1571}$. MVRIO SEGVND ${ }^{O}$ AÑO DE SV OFIÇIO ESTAND ${ }^{O}$

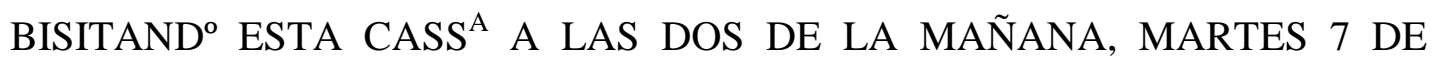
HENER $^{\circ}$ DE $1631 \%$.

Dentro de la arquitectura funeraria palentina, pertenece a la misma tipología que éste, el sepulcro de don García Mazo de la Vega, fallecido en 1614, que se ubica en la nave del Evangelio de la iglesia de Santa Eulalia en Paredes de Nava ${ }^{1572}$. Se estructura igualmente en un nicho de la misma profundidad que el muro sobre el que se adosa, en cuyo hueco figura una inscripción bajo escudo. En la parte inferior,

\footnotetext{
1566 1598-1601, 1607-1610, 1610-1613 y la última el año de 1613. Ibídem, pág. 295.

1567 Fue Presidente de la Congregación entre 1625 y 1626, ostentando paralelamente la dignidad abacial en Sopetrán, en Guadalajara. Ibídem, pág. 295.

1568 1598-1601, 1607-1610,1613, 1621-1625. Ibídem, pág. 295.

1569 1607-1610, 1613-1617, y la tercera y cuarta vez solamente en un breve período de 1621 y 1625 , respectivamente. En 1629 volvió a resultar elegido pero no aceptó el cargo. Ibídem, pág. 296.

${ }^{1570}$ Quería decir "Bienhechor".

${ }^{1571}$ Fue definidor en 1617-1621, 1625-1629 y otro breve período en 1629. Murió siendo General de la Congregación, dignidad que detentó entre 1629 y 1631. ZARAGOZA PASCUAL, Ernesto. “Abadologio...Op.cit, pág. 296.

1572 CASTRO MARTÍN, Pablo L. “Arte funerario...Op.cit, pág. 605.
} 
enmarcado por una sobria moldura, se dispone la urna del difunto a modo de pedestal.

Nicho de Cristo atado a la columna. Flanqueada por las ménsulas de Adán y Seth se halla esta magnífica talla de 1.75 metros de altura, realizada en piedra caliza. Para la Comisión de Monumentos de Palencia, se trata de una escultura de gran calidad. Se objeta, no obstante, alguna incorrección en el dibujo y cierta sensación de pesadez en las extremidades ${ }^{1573}$.
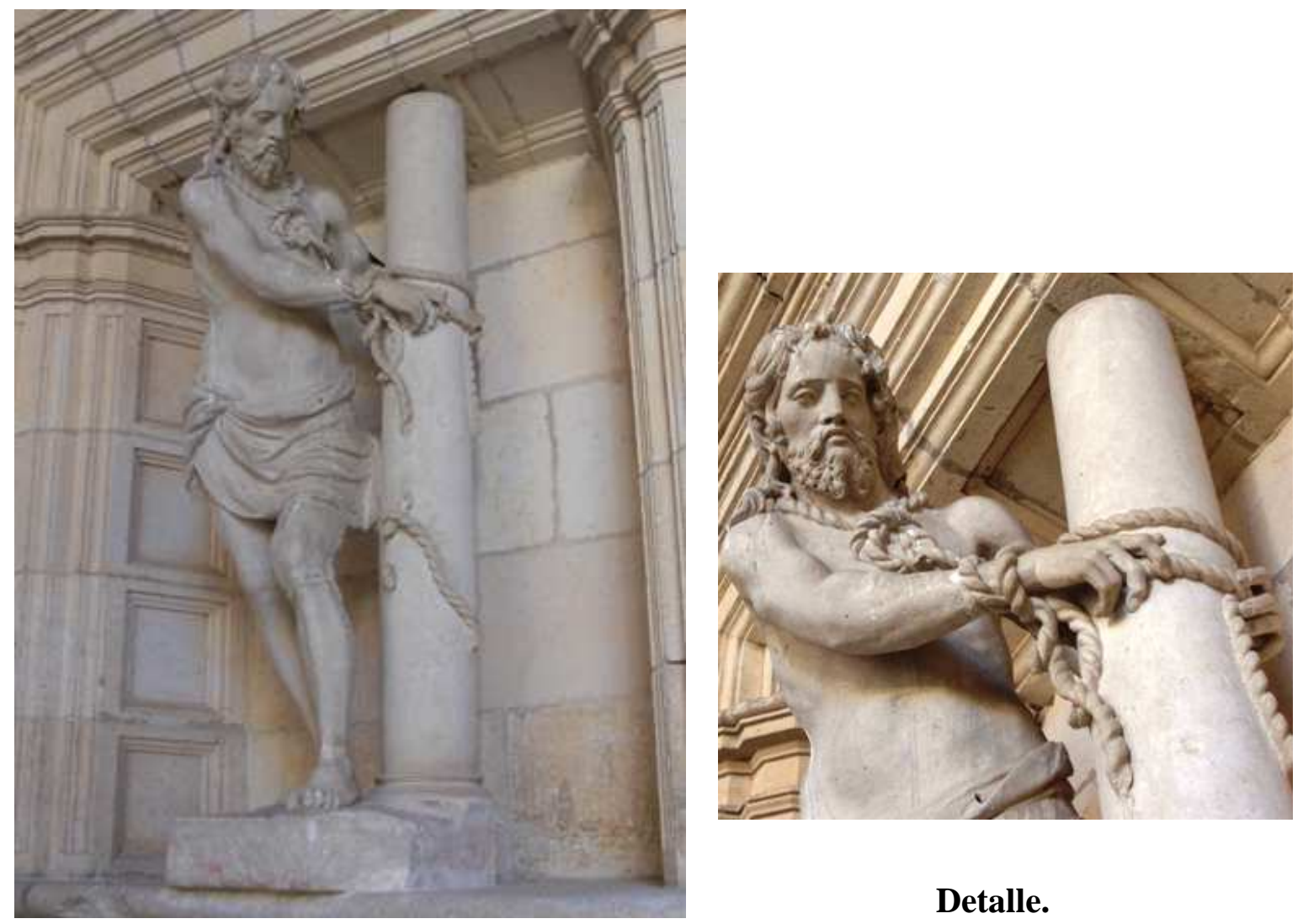

\section{Detalle.}

\section{Cristo atado a la columna atribuido a Miguel de Espinosa y Antonio Morante.}

Su autoría ha sido muy discutida sin haberse descubierto hoy día el enigma. Pudiera tratarse de una muestra que le fue encargada a Miguel de Espinosa hacia 1535, como prueba decisoria de su intervención en el claustro, como así señala Ponz

1573 Así consta por petición de junio de 1844 emitida por la Comisión de Monumentos palentinos en la que se insta a la gobernación de la capital a que vele por la conservación de los conventos suprimidos. ARASF. Palencia, Comisión de Monumentos, Leg. 2-7-7, Monumentos en general. 
o, siguiendo a éste, Azcárate ${ }^{1574}$. Frente a éstos, figuran los partidarios de Morante, cuya autoría defienden, entre otros, Paul Lafond, Martín González o Jesús Urrea, quienes, siguiendo a Ceán Bermúdez, posponen la datación en $1575^{1575}$. Portela apoya la atribución de Morante, pero duda que la imagen se realizara en una fecha tan $\operatorname{tardía}^{1576}$.

Se trata de una obra magistral y de gran elegancia que nos muestra a Cristo atado con una soga enroscada a una columna alta, siguiendo la tradición del siglo XVI, elevado sobre un pequeño pedestal. Su posición en contraposto permite la contemplación íntegra de su fornida anatomía, cubierta por un perizonium de ondulantes pliegues recogido en la cadera derecha. La inestabilidad somática de la figura se contrapone a la expresión distante de su rostro, que con la mirada fijada en el bajo, junto a los labios plegados y el mentón elevado, refleja una actitud imperturbable nada propia de un momento de tensión como el representado.

La ubicación precedente de este Cristo fue la denominada galilea o capilla de los Condes, donde estuvo al menos hasta $1963^{1577}$. Con las recientes obras que tuvieron lugar en 2011, salió a la luz el retablo neoclásico que cobijaba la figura. Se adosa al muro oriental del patio jesuita erigido hacia 1864, construcción que provocó la destrucción parcial del retablo, debido a la coincidencia con uno de los ventanales. De sencilla estructura y realizado en yeso, constaría de un pedestal de ladrillo que sustenta dos pares de pilastras desnudas entre las cuales emerge el hueco de la hornacina. El entablamento dórico y el frontón triangular de remate conservan aún hoy día una policromía en tonos rojizos, otrora mucho más intensos, que permiten adivinar una cruz pintada flanqueada por dos ángeles en el remate. Esta

1574 PONZ, Antonio. Viaje...Tomo XI. Op.cit pág. 200 y AZCÁRATE RISTORI, José María de. "Escultura...Op.cit, pág. 182. A este respecto, Camón Aznar dice: "Se le atribuye... [a Miguel de Espinosa]", pero no añade ninguna opinión al respecto. CAMÓN AZNAR, José. "La escultura...Op.cit, pág. 224.

${ }^{1575}$ CEÁN BERMÚDEZ, Agustín. Diccionario Histórico...Volumen 2.Op.cit, pág. 45. LAFOND, Paul. Op.cit, pág. 142, MARTÍN GONZÁLEZ, Juan José. "Miguel de Espinosa...Op.cit, pág. 149 y URREA FERNÁNDEZ, Jesús. Y MARTÍN GONZÁLEZ, Juan José. Op.cit, pág. 63.

${ }^{1576}$ PORTELA SANDOVAL, Francisco José. La escultura...Op.cit, pág. 392.

${ }^{1577}$ Aún en 1963 continúa en la galilea, pues se indica que en el claustro existe un nicho vacío en forma de ventanal cegado, es decir, que aún no se había realizado el traslado. DIAZ NAVA, Adolfo. "El claustro...Op.cit, pág. 104. ARASF. Fondo Antiguo de Revistas, 708: BECERRO BENGOA, Ricardo. "El monasterio...Op.cit, pág. 90. 
intervención quedó oculta tras una pared de yeso que como indicamos, ha salido a la luz recientemente

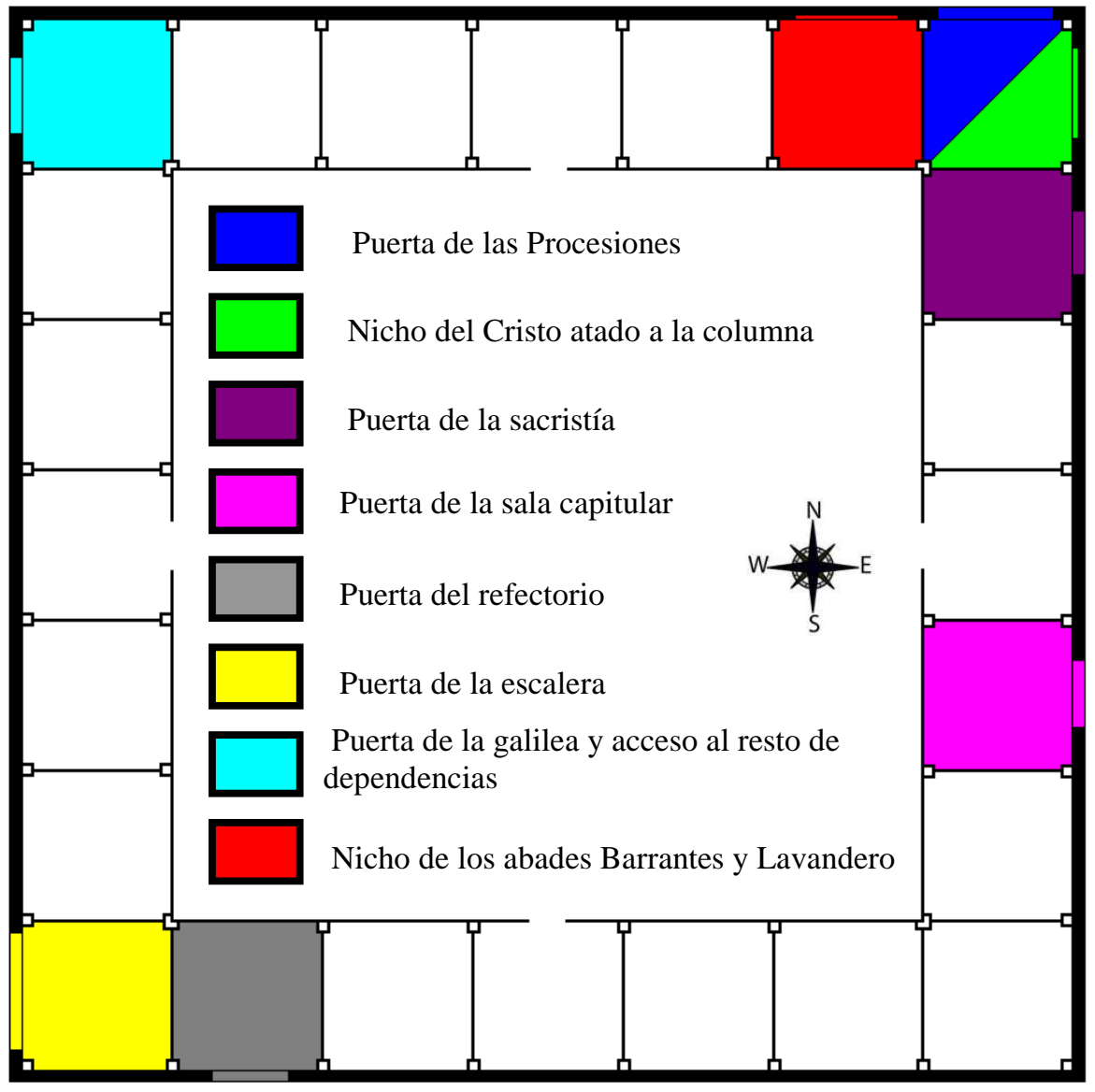

Esquema de los accesos y nichos del claustro bajo de San Zoilo. 


\subsubsection{EL CLAUSTRO ALTO}

\section{$\underline{\text { 1. Análisis descriptivo }}$}

A él se accede por una sólida escalera de hierro ubicada en el ángulo suroeste del claustro bajo, tras la puerta donde se ubican los medallones de San Gregorio y San Benito. De menor altura y calidad que el inferior, y separados por una cornisa, el claustro alto fue construido entre 1578 y 1604. Mientras se efectuaban las obras en la parte alta fue ejecutado el pozo que se ubica en el centro del claustro ${ }^{1578}$.

Como indican las inscripciones del claustro bajo, aquel fue finalizado en 1577 y seguidamente darían comienzo las obras bajo el abadologio de Fray Ambrosio de Nájera, lector de artes y teología, que ostentó el cargo hasta 1583. Tras el trienio de Fray Antonio Perroto, durante el cual paralelamente fue prior en San Martín de Frómista, San Román de Entrepeñas y Nuestra Señora de Brezo, además de definidor general, volvió a ser electo Fray Ambrosio de Nájera. No obstante fue depuesto en 1587 por su pésima gestión y se retiró al cenobio vallisoletano de Aguilar de Campos, sustituyéndole en el cargo Fray Martín de Sahagún. Entre 1589 y 1601 se sucedieron cuatro abades provenientes de tierras norteñas: los riojanos Plácido de Huércanos (en dos ocasiones,1589-1592 y 1598-1601) y Pedro de Torrecilla (1597-1598); entre ellos los cántabros, Toribio de Santander (1592-1595) y Pedro de Santillana (1595-1597). Las obras concluyeron en 1604 con Alonso Barrantes, cuya lápida, como estudiamos con anterioridad, se sitúa en un nicho del claustro bajo $^{1579}$.

Cada uno de los tramos del sobreclaustro está subdividido en dos por una columna con capitel sin un orden claro, que calificaríamos de pseudo-corintio, donde se despliega un amplio repertorio de animales fantásticos. Sobre este capitel se dispone un ancho entablamento para aportar mayor altura a la arquería, recurso empleado por primera vez en Florencia por Brunelleschi. Sobre él se sustentan dos arcos de medio punto rebajados que, en sus extremos, apoyan en medias columnas adosadas a pilastras cajeadas. A cada arco del piso inferior, corresponden dos del

${ }^{1578}$ ARASF. Leg.5-282-1.

1579 ZARAGOZA PASCUAL, Ernesto. “Abadologio...Op.cit, pp. 292-295. 
superior. Las arcadas van recorridas por un antepecho de piedra macizo. Las contraventanas de madera que tenía el claustro alto hasta finales del siglo XIX fueron sustituidos por cristaleras para evitar la entrada del frío cuando el convento fue rehabilitado para albergar el Seminario Menor de la Diócesis, función que desarrollaría entre 1891 y $1918^{1580}$.

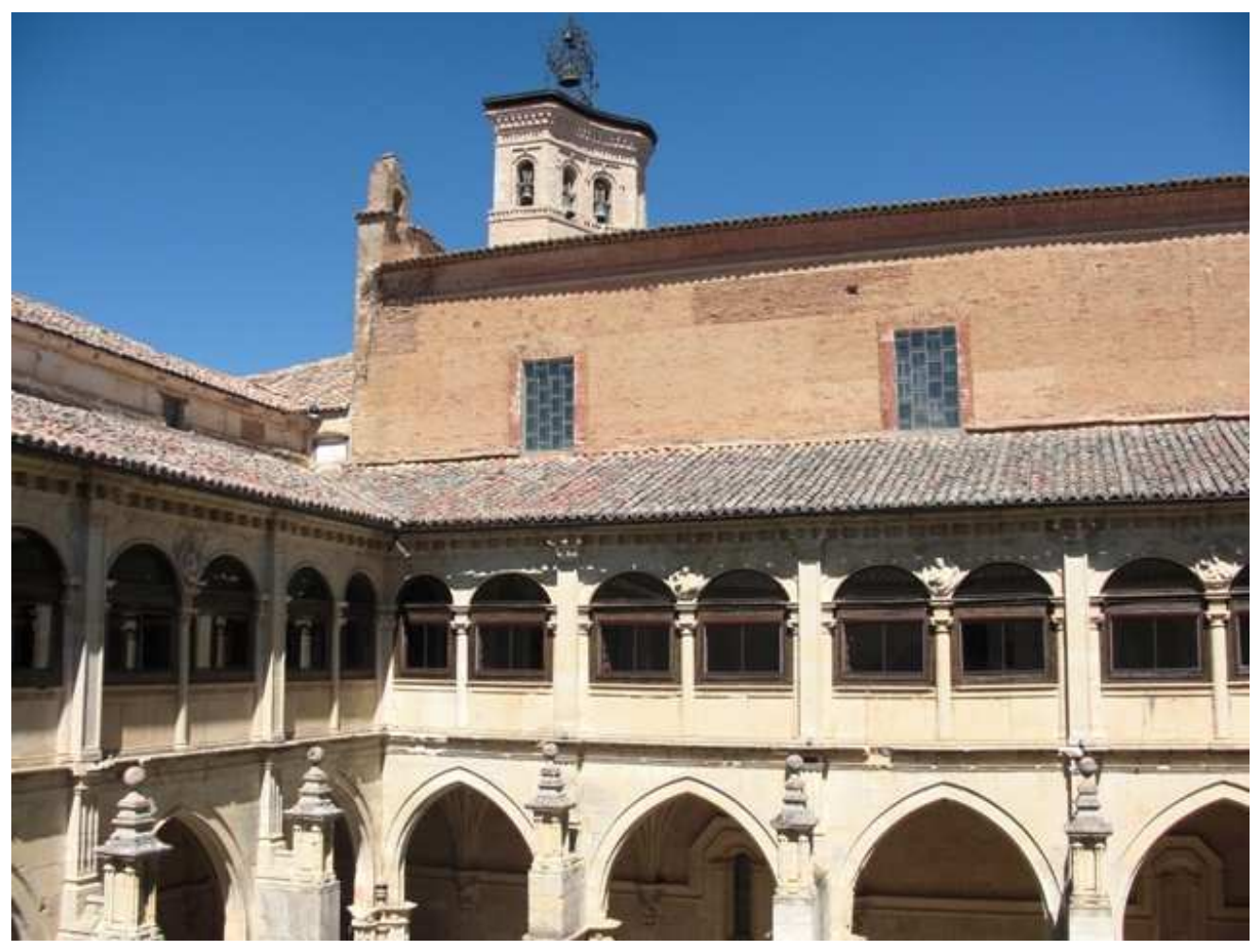

Claustro alto.

Crujías norte y oriental con la torre del templo en la parte superior.

No son sólo los elementos arquitectónicos y ornamentales los que convierten al sobreclaustro en renacentista, sino, como indica Miguel Ángel Zalama Rodríguez, este estilo está presente en las proporciones empleadas en el claustro, al presentar cuatro crujías de 33 metros cada una y una anchura de 4,5 metros, siendo cada uno de los siete tramos en que se divide cada lado, un cuadrado perfecto de 4,5 metros $^{1581}$. Llaguno y Amírola dice textualmente al hacer referencia al claustro: " $E s$

\footnotetext{
${ }^{1580}$ AHJAH. C11. Carrión de los Condes. 10. Historia, fondo benedictino, visitas, inventarios. $\mathrm{N}^{\mathrm{o}}$ 8760015.

${ }^{1581}$ ZALAMA, Miguel Ángel. La arquitectura...Op.cit, pág. 94.
} 
de orden dórico y los arcos de medio punto subido; pero sus dimensiones son defectuosas $" 1582$. No deja claro si, al hablar de defectuosas, se refería a las medidas del claustro, con lo cual presenta una clara oposición respecto a la perfección defendida por Zalama, o, en cambio, a las dimensiones de los arcos.

\section{Autoría}

\section{Los arquitectos}

El claustro alto se atribuye al palentino Pedro de Torres, arquitecto y escultor que desarrolló su actividad entre el último cuarto del siglo XVI y los primeros años de la siguiente centuria y que por tanto, podría haber intervenido en el claustro carrionés desarrollando ambas actividades en el intervalo que oscila desde la finalización de la parte baja en 1577 hasta 1604 en que se finaliza el claustro alto ${ }^{1583}$. Este encargo avaló la pericia del artista para que otros cenobios benedictinos conntrataran al $\operatorname{artista}^{1584}$. Aparte de las arquerías, de entre todos los medallones, podríamos atribuir a su mano las figuras de San Zoilo y San Benito a tenor de la cuadratura que presentan sus rosotros y el porte rotundo de sus torsos.

Javier Gómez Martínez replantea la autoría de este sobreclaustro basándose en la presencia de Ribero Rada dando trazas en el monasterio de San Zoilo, ya que, según la documentación, realiza la obra de "un cuarto de casa”, desaparecido, por estar situado en una parte remodelada después, que remata con Felipe de la Cajiga en $1585^{1585}$. Gómez Martínez defiende que este maestro, aparte de ser un arquitecto clasicista, se había formado en la tradición gótica del Renacimiento hispano, tal y como avala su labor en San Pedro de Eslonza, el convento de San Francisco de Medina de Rioseco, la Catedral Nueva y San Esteban de Salamanca y que, por tanto, dominaba este lenguaje y pudo plasmarlo en este claustro. Había trabajado en gran

${ }^{1582}$ LLAGUNO Y AMIROLA, Eugenio. Op.cit, pág. 210. Algunos datos biográficos se recopilan en AZCÁRATE RISTORI, José María de. "Escultura...Op.cit, pág. 383.

1583 CEÁN BERMÚDEZ, Agustín. Diccionario...Op.cit, pág. 44 y LLAGUNO Y AMIROLA, Eugenio. Noticias...Tomo I. Op.cit, pp. 211.

${ }^{1584}$ Sobre Pedro de la Torre, véase el capítulo dedicado a las biografías de los escultores.

1585 GÓMEZ MARTÍNEZ, Javier. “Obras en San Benito...Op.cit, pág. 340. 
número de monasterios benedictinos como San Pedro de Cardeña, San Pedro de Arlanza, San Millán de la Cogolla o San Benito de Valladolid ${ }^{1586}$.

\section{Los escultores}

La talla de las esculturas corrió a cargo del palentino Juan de Bobadilla ${ }^{1587}$, a cuyo trabajo se incorporó, en los últimos tramos, el carrionés Pedro de Cicero, quien llevaría a cabo tanto la labor arquitectónica como escultórica ${ }^{1588}$. Era por entonces abad Fray Alonso Barrantes, que lo fue tres veces de San Zoilo y en 1613, se convertiría en Prior General de San Benito.

Bernardino Ortiz, escultor natural de Palencia, trabajó en la decoración del claustro en el año $1581^{1589}$. Perfeccionó las imágenes de San Pablo y San Sebastián porque éstas no se correspondían con la calidad del resto de la obra. Era hijo del entallador palentino Juan Ortiz el Viejo II y Juana López, y tuvo siete hermanos, de los cuales se desconoce si alguno llegó a ser entallador como afirma Portela Sandoval ${ }^{1590}$. Se sabe que en 1570 se encontraba trabajando junto a su padre en Becerril, realizando unos añadidos para el retablo para la iglesia de Nuestra Señora. Desarrolló su labor en el entorno de Tordesillas. Así en 1577 contrató junto al pintor Hernando de Ayala, el retablo de la iglesia de Santiago de Bercero en Valladolid, que no se llegó a hacer. En 1592 se concierta con el pintor Francisco de Baeza para la ejecución de los relicarios en Velilla, Villavieja y un lienzo para Berceruelo. A partir de dicho año, desarrollaría su labor en Tordesillas hasta $1592^{1591}$.

\footnotetext{
${ }^{1586}$ En uno de estos cenobios, concretamente en San Pedro de Eslonza, también había trabajado Juan de Badajoz el Mozo y Ribero continuó su obra. Dado que el de Carrión también había sido iniciado por Badajoz, podría ser viable que este arquitecto participara en el claustro alto. GÓMEZ MARTÍNEZ, Javier. “Obras...” Op.cit, pp. 339-340.

${ }^{1587}$ Consta como Juan de Padilla en una petición de la Comisión de Monumentos de Palencia dirigida al Ministro de Fomento en 23 de marzo de 1871 para que el claustro y monasterio de San Zoilo sea declarado monumento nacional y se exceptúe de la venta. ARASF, Palencia, Comisión de Monumentos, Leg. 2-7-7, Monumentos especiales.

${ }^{1588}$ Ibídem, pág. 383.

${ }^{1589}$ CEÁN BERMÚDEZ, Agustín. Diccionario Histórico... Volumen 2. Op.cit, pág. 45 y PORTELA SANDOVAL, Francisco José. La escultura... Op.cit, pág. 210.

${ }^{1590}$ En realidad Portela Sandoval cae en un error de atribución al confundir a Juan Ortiz Fernández imaginario con este Juan Ortiz el Viejo que Parrado del Olmo tilda II para diferenciarlo de otro entallador homónimo (Juan Ortiz el Viejo I). El entallador Juan Ortiz que Portela asigna como hermano de Bernardino Ortiz, no es tal, sino su padre, Juan Ortiz el Viejo I. PARRADO DEL OLMO, J.M. Los escultores...Op.cit, pp. 367-369.

${ }^{1591}$ Ibídem, pág. 349 y éste a su vez de CEÁN BERMÚDEZ, Agustín. Diccionario...Op.cit, 3, pág. 281.
} 


\title{
3. Análisis Iconográfico
}

Las tres columnas exentas de cada lienzo llevan en sus enjutas un medallón ovalado, siendo por tanto, tres las representaciones correspondientes a cada lienzo:

\author{
-Crujía oriental: Don Fernando Gómez, San Juan Bautista y Don Diego Gómez \\ -Crujía meridional: Don Gómez Díaz, Doña Teresa y Don Pelayo Gómez \\ -Crujía occidental: San Félix, San Benito y San Leandro \\ -Crujía septentrional: San Ildefonso, San Zoilo y San Agapio
}

Todos estos personajes, ya representados en el claustro bajo, intensifican su relevancia en el ciclo a través de esta doble representación. Don Diego Gómez, personaje controvertido dado los exiguos datos que poseemos del mismo, no fue hijo de los condes Gómez Díaz y doña Teresa Peláez, sino un pariente con vínculos de sangre estrechos que no podemos determinar, quizá hijo de una de las hijas de los condes ${ }^{1592}$. Por eso, no figura junto al resto de varones en la primera bóveda del claustro. Su participación en las hazañas bélicas junto al resto de varones del clan Beni-Gómez, dado su atuendo guerrero a base de coraza, casco y alabarda, justificaría su presencia en un lugar tan destacado.

Puesto que la identidad de todos ellos ha sido debidamente analizada previamente, tan sólo explicaremos las razones de su presencia en el sobreclaustro. Podemos establecer que su elección gira en torno a tres núcleos temáticos:

-Familia fundadora del cenobio: Simbolizada en los condes don Gómez y doña Teresa, sus hijos varones y Gómez Díaz, que colaboraría conjuntamente con ellos en las conquistas del sur peninsular ${ }^{1593}$. Todos los varones portan atributos militares, pero presentan diversa iconografía respecto a la primera bóveda del claustro bajo. Don Fernando, lleva capa y espada en ambos casos; sin embargo, en este caso, porta un sombrero con pluma, típico del siglo XVI, en vez del casco con la quijada del

\footnotetext{
${ }^{1592}$ Sobre este personaje, remítase al apartado relativo a la capilla condal donde se explica su posible identificación.

${ }^{1593}$ Ya apuntamos su identificación al referirnos a los sepulcros de la galilea.
} 
león. Frente al aspecto maduro que presenta en la parte inferior, con larga barba, en el medallón del sobreclaustro figura como un joven imberbe. Don Pelayo, por su parte, ha sustituido la coraza, el casco y la alabarda por el sombrero, la capa y la espada. El conde don Gómez Díaz porta el mismo atuendo, constituido por coraza y casco pero ha reemplazado la lanza por la espada.

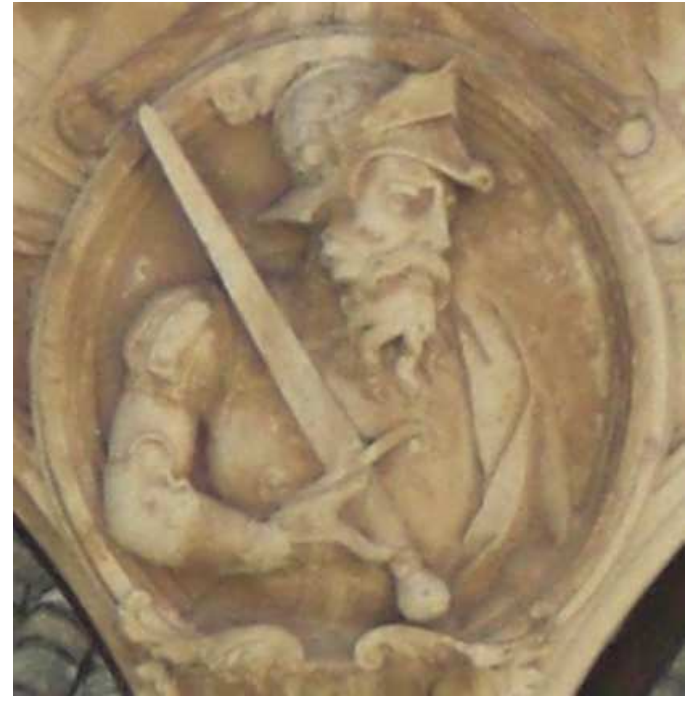

El conde don Gómez Díaz.

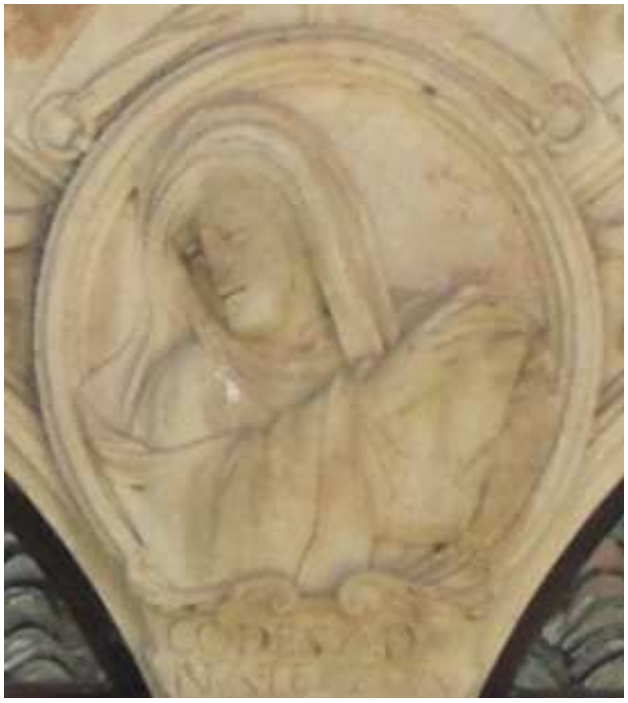

La condesa doña Teresa Peláez.

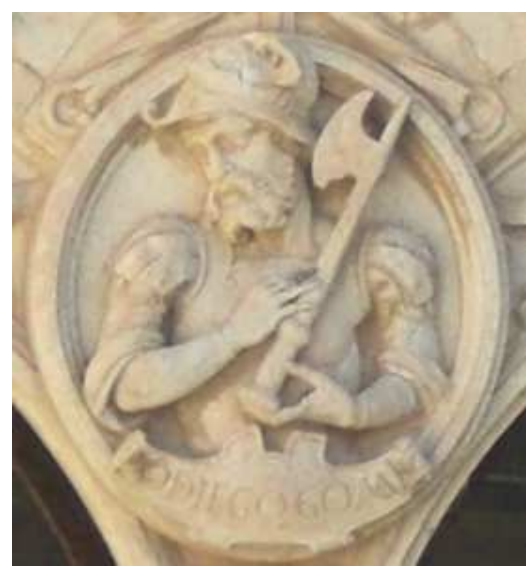

Don Diego Gómez.

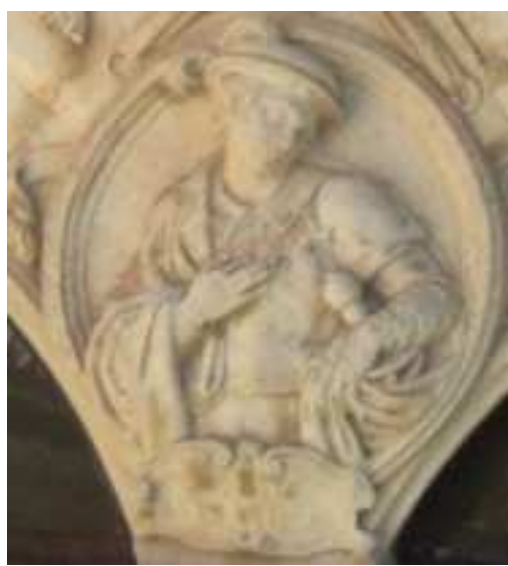

Don Fernando Gómez.

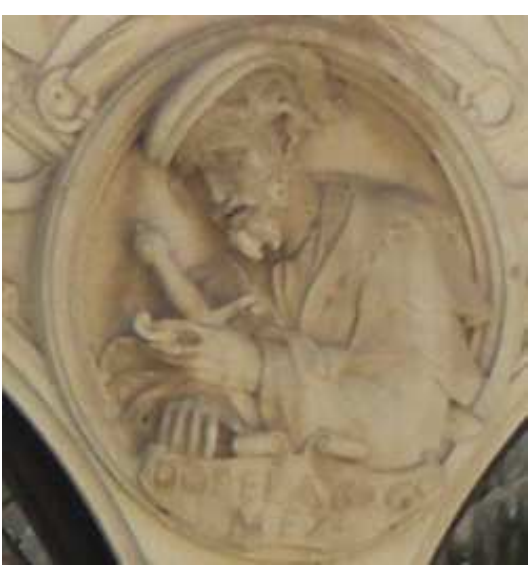

Don Pelayo Gómez. 
-La advocación del cenobio: Las reliquias de San Zoilo, Félix y Agapio fueron traídas desde Córdoba por don Fernando Gómez para fundar un cenobio sobre una ermita precedente dedicada a San Juan Bautista, de ahí que la dedicación inicial del monasterio fue de "San Juan, San Zoilo y San Félix""1594. Respecto a la iconografía de todos ellos, San Félix mantiene la que presentaba en la parte baja, como monje, con la palma del martirio, el resto han sufrido ligeras modificaciones. Mientras que en la primera bóveda del programa, San Zoilo portaba una indumentaria anacrónica, propia del siglo XVI, en este caso luce una túnica romana, vestimenta acorde a la época de Diocleciano, en los albores del siglo IV. En la ménsula común a las bóvedas vigésimo terca y cuarta, San Juan figura con la cabeza cortada, habiéndose optado en este caso por otra iconografía igualmente célebre, la del carnero y el libro como atributos. Frente al hábito benedictino y la tonsura que luce San Agapio en la ménsula del ángulo noroeste, en el medallón hace ostentación de sus atributos de obispo, pues detentó tal cargo en Córdoba en la segunda mitad del siglo VI ${ }^{1595}$. Como tal, aparece tocado con la mitra, porta la capa pluvial y el báculo pastoral.

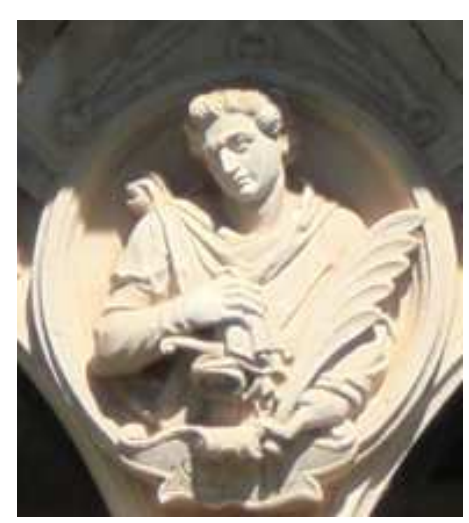

San Zoilo.

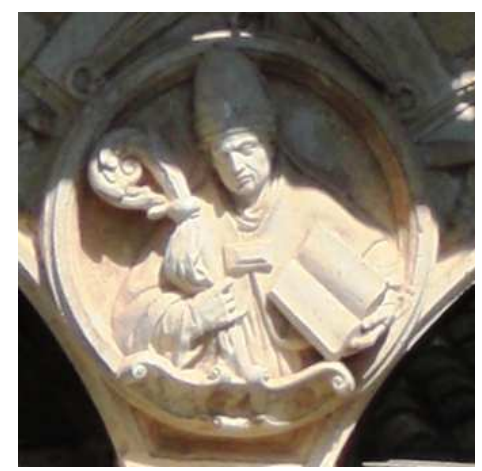

San Agapio.

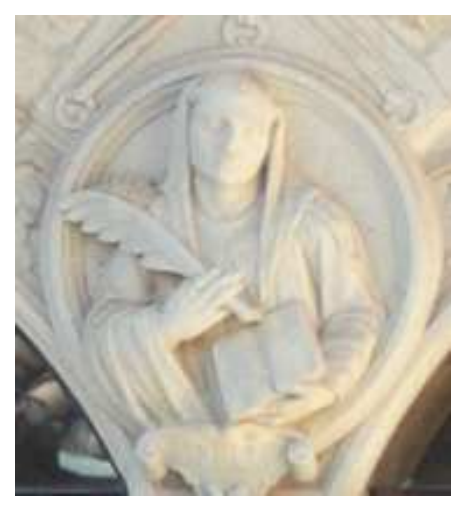

San Félix.

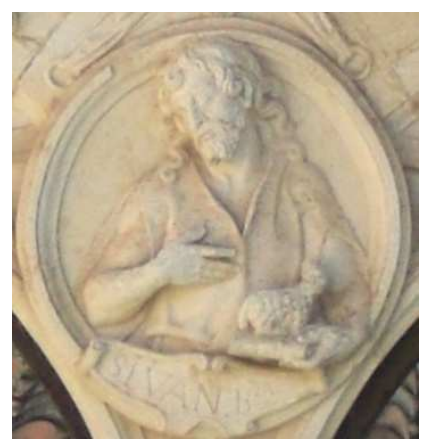

San Juan Baustista.

\footnotetext{
${ }^{1594}$ Sobre sus inicios, BHSCV. PRUDENCIO DE SANDOVAL. Primera parte...Op.cit, pp. 74-85.

1595 Ibídem, pág. 75.
} 
-La espiritualidad benedictina: Se encarna en primer lugar a través de su fundador, que, como es usual, porta la cogulla, el báculo y la Regla benedictina. Como no podía ser de otro modo en un claustro castellano, dos arzobispos hispanos, San Leandro y San Ildefonso, completan el ciclo, representando a todos los hijos ilustres que forman parte del árbol benedictino.

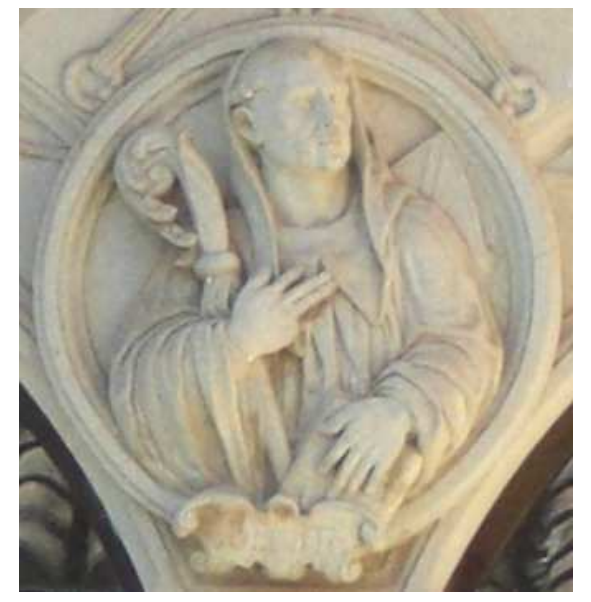

San Benito.

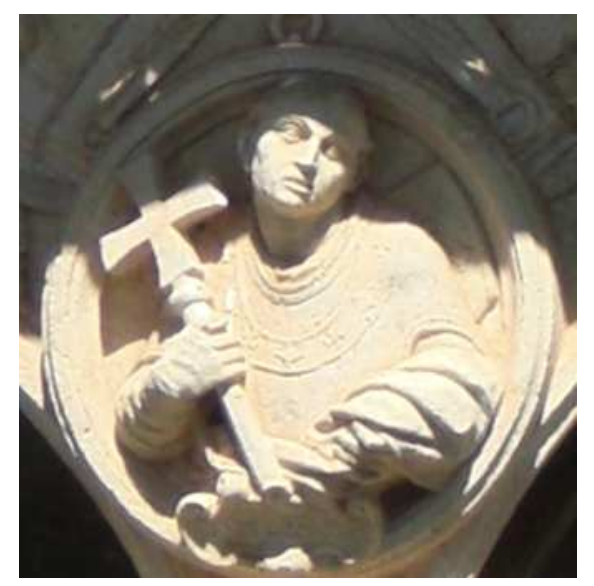

San Ildefonso.

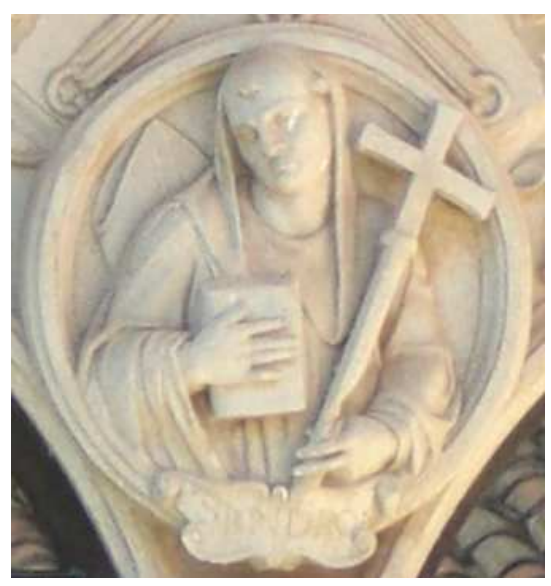

San Leandro.

Las paredes de este claustro alto contienen retratos de mártires y santos de la Compañía de Jesús de escaso mérito. A través de ellas se accedía a los dormitorios, capilla del abad, gabinetes de música, Historia Natural, Física, Química, dibujo, al coro de la iglesia y escalera del tercer piso, enfermería y botiquín ${ }^{1596}$.

${ }^{1596}$ A este respecto, consúltese el apartado relativo a la historia del Colegio de Jesuitas. 


\subsubsection{CONSIDERACIONES A LO LARGO DE LA HISTORIA}

Este claustro ha despertado la admiración de gran número de artistas, historiadores y eruditos. Para hacernos una idea de los elogios que se desprenden de algunos comentarios, reproducimos las impresiones de Ramírez de Helguera al observarlo: ... "es verdad, justo decir y mantener que casi es seguro que, ni en España, ni en el extranjero, exista una obra artística ni más elegante, ni más perfecta, ni de más variada construcción, ni de más belleza que la plateresca que contiene el claustro bajo de este tan citado monasterio de San Zoilo de Carrión, hasta el extremo de confundirse sus bustos con la realidad, como es tradicional referirse, que visitando un médico aquella majestuosa composición del Renacimiento, llegó a asegurar y creer que una calavera, que el capricho del escultor colocó sobre el capitel de una columna, era un despojo humano.."1597. A este respecto se ha popularizado otra anécdota que cuenta que el propio Felipe III, en su visita al claustro en 1612 ordenó a uno de los palaciegos que le acompañaban que golpeara uno de los cráneos, el cual fue puesto en manos del confundido monarca $^{1598}$.

Si bien estas y otras historias carecen de base documental, ilustran a la perfección la calidad técnica alcanzada en el mismo.

Incluso ha llegado a encandilar al visitante extranjero. Así lo demuestran las palabras de un estudioso de la escultura española, Paul Lafond, que reproducimos a continuación: "Chaque partie de ce cloître est décorée de bas-reliefs et de médaillons d'une rare délicatesse et d'une exécution superbe ${ }^{1599, "}$.

\footnotetext{
${ }^{1597}$ RAMIREZ DE HELGUERA, Martín. El Real monasterio de San Zoilo de la muy noble y leal ciudad de Carrión de los Condes ante la Historia y el Arte. $1^{a}$ Edición: Gutiérrez, Líter y Herrero, 1900. Reproducción facsímil de la Diputación Provincial. Palencia, 1997, pp. 42 y 43.

${ }^{1598}$ CASTRO, Lázaro de. Breve Historia de Carrión. Carrión, Palencia, 1779, s/f, también reproducida en BN. Hemeroteca. Prensa y Revistas. "La Esfera", n¹13. Artículo de CRESPO, Esteban. "Monumentos españoles. El monasterio de San Zoil", pág. 19 y SAINZ DE ROBLES, Federico Carlos. Monasterios...Op.cit, pág. 108.

1599 "Cada parte de este claustro está decorada de bajorrelieves y de medallones de gran delicadeza y soberbia ejecución”. LAFOND, Paul. La scuplture spagnole. Dirección de Jules Compte. Librairie d'Éducation Nationale. Paris, 1908, pág. 142.
} 
Fray Justo Pérez de Urbel establece similitudes entre el trazado del claustro de San Zoilo y el de la abadía benedictina de Santa María la Real de Nájera, en La Rioja y considera que la escultura del primero es "una enciclopedia escrita en la piedra" mientras que la segunda es una manifestación espontánea del arte puro, menos científica que la abadía carrionesa ${ }^{1600}$.

La Comisión de Monumentos de Palencia en 1942 al solicitar la protección de tan grandioso claustro ratifica nuestra afirmación: “...tan poco original, atrevido y grandioso en su conjunto y en sus líneas fundamentales como espléndido, valiente, revolucionario y bello en sus detalles...". Califica el conjunto como "Colección de páginas de magistral enseñanzal ${ }^{1601, "}$

En esta magnífica obra se deja sentir el espíritu italiano, palpita a través de todos y cada uno de sus ornamentos trabajados con mimo para el deleite del espectador: las bandas de flores, los bustos exquisitamente diferenciados, un sinfín de geniecillos y motivos caprichosos de grutescos de gran virtuosismo, donde el escultor trabaja al detalle hasta la nimiedad, prescindiendo en algunos casos del factor distancia.

\subsubsection{ASPECTOS INTERESANTES DEL CICLO}

Los dos grandes ciclos iconográficos, el de la genealogía bíblica de Cristo a partir de San José y de la Virgen, y el de los hijos ilustres de la Orden benedictina, no se pueden entender como dos temas independientes entre sí, sino como dos genealogías que componen una Crónica Universal en el que sobresalen dos figuras principales: Cristo, que preside el conjunto a través de su crucifixión en la puerta de acceso al claustro, y San Benito, como modelo de perfección de la orden, dando pie a la equiparación de ambas figuras. La relevancia de las dos figuras queda patente en la incidencia de sus representaciones. Cristo figura en la hornacina de la primera bóveda, atado a la columna, mientras que San Benito protagoniza las bóvedas de todo su ciclo, aparte de figurar en el claustro alto.

\footnotetext{
1600 PÉREZ DE URBEL, Fray Justo. Las grandes abadías benedictinas. Su vida, su Arte y su Historia. Ediciones Ancla. Madrid, 1928, pág. 245.

${ }^{1601}$ ARASF, Leg. 5-282-1.
} 
El ciclo genealógico de Cristo, se representa dos veces, una desde Adán, que comprende los tramos 23, 24 y segundo al sexto, y otra desde Jesé con el resto de descendencia en las bóvedas de la crujía meridional. Dos versiones diversas-la una fusión del Evangelio de Mateo y Lucas; la otra, el Árbol de Jesé contenido en Isaíascon un mismo protagonismo, pues ambas ocupan un total de siete tramos, confluyendo unánimemente en la sexta bóveda, presidida por la Virgen, quien, esposada con José, al que le unían vínculos de consanguinidad. Estos esposos eran primos hermanos, puesto que el padre de cada uno de ellos, Jacob y Joaquín, eran hermanos. Colegimos entonces que los abuelos paternos eran comunes, Mathan y Iesca, de quienes proviene la línea de David. Por tanto, hablar de la genealogía de Cristo implica remitirnos a los ascendientes paternos tanto de José como de la Virgen $^{1602}$. La Madre de Dios es venerada con hiperdulía, por ser la persona en quien Dios depositó toda su gracia y amor para que engendrara a Cristo, de ahí la supremacía en el conjunto.

\section{Interpretación universal del programa}

Todos los personajes analizados hasta el momento conformarían el ciclo de las ocho edades en que, según el Cronicón de Adricomio de Delfo se divide el mundo desde sus inicios hasta nuestros días. Además de otros gobernantes de carácter profano, este libro contiene básicamente los mismos personajes de la ascendencia de Jesús, incluyendo además a los personajes de las ménsulas hasta la bóveda décimo cuarta, que sin embargo en la Biblia no formaban parte de la ascendencia ${ }^{1603}$. La suma de las seis edades hasta el nacimiento de Cristo abarca un total de 3.960 años y a partir de entonces se suceden otras dos, que sumarían un total de ocho edades. He aquí una correspondencia entre cada una de ellas y las bóvedas respectivas:

-Primera Edad: Desde la creación del mundo hasta Noé. Bóveda 1. 1.656 años. -Segunda Edad: Tras el Diluvio, desde Sem a Thare. Bóvedas 23 y 24. 292 años.

\footnotetext{
1602 ROCA Y CORNET, Joaquín. Historia de los hechos...Op.cit, pp. 126-129.

1603 ADRICOMIO DELFO, Cristiano. Cronicón. Traducido al español por Lorenzo Martínez Marcilla. Zaragoza, 1631. El libro desarrolla esta idea de las seis edades pero la tabla que aclara su contenido se ubica en las pp. 407-420.
} 
-Tercera Edad: Se incluyen aquí todos los personajes desde Abraham hasta Samuel, es decir las figuras representadas en las ménsulas comprendidas entre la bóveda primera y la decimocuarta, donde figuran los jueces y sacerdotes de Israel. 942 años. -Cuarta Edad: De David a la destrucción del Templo de Jerusalén y la consecuente cautividad de Babilonia, en que se insertan todos los personajes de las bóvedas desde David hasta Jeconías, es decir la ascendencia de Cristo. Bóvedas 2 a 5 y 8 a 12. 486 años.

-Quinta Edad: Con el regreso de los judíos a Jerusalén, comienza a gobernar Zorobabel. Se incluyen los gobernantes que se suceden en la reedificación del templo por Herodes. Se incluye al pueblo macabeo y sus opositores (Bóvedas 13 y 14) y la ascendencia directa de Cristo (Bóvedas 5 a 7). Este período finaliza con el nacimiento de Cristo. 586 años.

-Sexta Edad: El nacimiento de Cristo inaugura esta etapa y transcurre hasta el fin del mundo, cuyo término está reservado a Dios. En este período se incluiría toda la ascendencia espiritual de San Benito, los monarcas, escritores, y los personajes de las ménsulas en que figura el Apostolado y los Evangelistas, aparte de los medallones del claustro alto, que representarían a la humanidad. (Bóvedas 15-22).

-Séptima edad: El descanso de las almas en el cielo y los cuerpos en las sepulturas se correspondería con las ménsulas que efigian calaveras en la crujía oriental. (Ménsulas interiores de bóvedas 1-8).

-Octava Edad: La Resurrección, en la cual reinarán Dios y los Santos, la cual anhelan todos los personajes representados.

\section{El papel de la mujer en el ciclo}

Enlazando con la idea precedente del papel de Madre de Dios otorgado a la Virgen, de quien partía la genealogía de Cristo, debemos subrayar la singular relevancia otorgada a las mujeres en este ciclo iconográfico.

La condesa doña Teresa, es, en este sentido la primera protagonista del programa. Junto a su marido, el conde don Gómez Díaz, reconstruyó la abadía benedictina, pero en la bóveda tan sólo se hace referencia a sus raíces por ser de abolengo real. Su relevancia queda plasmada en el hecho de figurar dos veces en el 
ciclo, una en el claustro bajo y otra en el alto. Al quedar viuda, tomó el hábito benedictino, continuó las obras del cenobio y además promovió la construcción de un hospital para peregrinos y el puente, única vía de acceso a la villa ${ }^{1604}$. De todos los miembros de la familia sepultados en la galilea, fue la única que, por sus milagros y vida ejemplar, alcanzó fama de santidad, ocupando un lugar privilegiado en el templo ${ }^{1605}$. Fray Sebastián de Encinas, impulsor de las obras del claustro entre 1570 y 1576 , se encargó de trasladar su sepulcro a la capilla mayor ${ }^{1606}$. Este carácter destacado de una mujer ilustre que actúa como principal benefactora de un monasterio en una sociedad eminentemente patriarcal, no fue un hecho aislado, pues por los mismo años, la reina doña Sancha en San Isidoro de León, doña Elvira en San Salvador de Nogal o doña Mayor en San Martín de Frómista, posibilitaron el engrandecimiento de sus respectivos cenobios, dando lugar a lo que se ha denominado como el "románico de las domnas ${ }^{1607}$ ".

El séquito de féminas prosigue en las ménsulas, donde figuran Eva, Élvora, Sara, Rebeca, Raquel y Séfora. Si bien todas ellas, excepto Eva, acompañan al apelativo "UXOR" que las relega a un papel secundario respecto al de sus maridos, no figurarían al mismo nivel que éstos de no ser por haber engendrado a los sucesivos miembros del linaje de Cristo. Sin ellas, tal sucesión no hubiera sido posible y, en este sentido, observamos un ensalzamiento de la maternidad, encarnada en primer lugar en la figura de María como Theotokos, título que adoptó a partir del Concilio de Éfeso en el año 431. Muchas de ellas, de hecho, no lograron engendrar ningún hijo hasta que, ya en edad avanzada, Dios obró el milagro por la fe que le profesaban. Así sucedió con Sara, mujer de Abraham, Raquel, esposa de Jacob o Ana, madre de Samuel, último juez de Israel. A fuerza de oraciones, lograron poner fin a su esterilidad, convirtiéndose en modelos de virtud cristiana.

\footnotetext{
${ }^{1604}$ A este respecto existe un soneto anónimo: "Amplísimo hospital la clara infanta, y el monasterio de San Iuan fabrica, al puente su cuidado luego aplica, y maravilla hermosa el adelanta. El cristal firme puente fue a su planta, pisada el agua se ufanó más rica, la solidez su rendimiento explica, siendo alcatisa hermosa de su planta. Tres obras de piedad maravillosas hizo su calidad y desvelo: el convento dio a Christo y sus esposas, el hospital a pobres por consuelo y el puente quiso en sendas misteriosas le fuesse passadizo para el cielo" CIRIA RAXIS E INOJOSA, Pedro de. Vidas...Tomo III. Op.cit...pp. 137-139.

1605 YEPES, Fray Antonio. Crónica...Tomo VI. Op.cit, pág. 79.

1606 RAMIREZ DE HELGUERA, Martín. El Real monasterio... Op.cit, pág. 52.

${ }^{1607}$ Significa dómina o señora de un lugar. MAISO GONZÁLEZ, José y LAGUNILLA ALONSO, J. Ramón. San Zoilo de Carrión en el origen del románico pleno. El románico de las donnas. Palencia, 2010.
} 
No debemos olvidar la presencia en el conjunto de Débora, a quien se nos presentó en su doble condición de profetisa y juez. El pueblo se enfrentaba a la desintegración religiosa, la derrota militar y la falta de liderazgo político adecuado. La respuesta de Dios a su clamor, en una sociedad eminentemente patriarcal, fue una mujer, bajo cuyo mandato el pueblo de Israel gozó de casi medio siglo de paz.

Las cuatro mujeres pecadoras que se ubican entre los dos grandes ciclos genealógicos, contrastan con la moralidad del resto de personajes del programa iconográfico. La presencia de todas ellas refuerza el carácter magnánimo de Dios para con sus hijos. A pesar de sus comportamientos mezquinos, las dos Thamar, Betsabé y Rahab, obtuvieron el perdón tras mostrarse arrepentidas, de ahí su inclusión en la bóveda decimocuarta. Enlazan de este modo con María Magdalena, situada en el punto de partida, pues de ella se decía que "habían salido siete demonios", en referencia a su vida anterior de prostituta ${ }^{1608}$. Posteriormente se convirtió en la más distinguida discípula de Jesús de Nazaret, siendo hoy día considerada santa.

En lo que a la descendencia de San Benito respecta, de las siete bóvedas consagradas al mismo, dos están protagonizadas por entero a un elenco de reinas, emperatrices y eruditas medievales que por su vocación religiosa, alcanzaron la dignidad de Santas. Todas ellas contribuyeron, en mayor o menor grado, a la expansión de la orden benedictina gracias a la fundación de cenobios. La humildad, la paciencia y el rechazo de los bienes materiales constituyen los rasgos afines a esta pléyade femenina, que se erigen, de este modo, en iconos universales de espiritualidad cristiana.

\section{Curiosidades y relaciones historiográficas}

Los personajes que completan la genealogía de Cristo en las ménsulas proceden de una esmerada selección de las figuras más destacadas del Antiguo y Nuevo Testamento, que con sus vidas sirvieron como ejemplo de buena conducta, como son los Sumos sacerdotes, los Jueces, los Apóstoles o los Evangelistas. Por

${ }^{1608}$ Lucas, 8:2. 
tanto, el mensaje unificador del conjunto lo constituye la glorificación y defensa del cristianismo como única religión posible para adoctrinar al fiel. La veneración que en este programa iconográfico se hace de las reliquias -San Zoilo y San Félix en la primera bóveda-, de la Virgen como madre de Dios -bóvedas quinta y sexta- y de los Santos -repartidos en todo el ciclo tanto en ménsulas como en cubiertassintoniza con el espíritu de reafirmación de las figuras principales de la religión cristiana promovido por la iglesia católica a raíz del Concilio de Trento. Este fue uno de los acuerdos tomados en la sesión vigésimo quinta. Los eclesiásticos reunidos determinaron: “...que por medio de las historias de nuestra Redención expresadas en pinturas y otras copias, se instruye y confirma el pueblo recordándoles los artículos de la fe y recapacitándoles continuamente en ellos... ${ }^{1609, "}$.

El otro gran programa, protagonizado por la genealogía de San Benito encuentra sus antecedentes en las miniaturas medievales y en los grabados del Renacimiento ${ }^{1610}$. Cada bóveda se estructura a modo de árbol genealógico en el cual la figura de San Benito es la protagonista, empapándose de su espiritualidad el resto de personajes que le circundan.

A este respecto es preciso hacer una aclaración sobre algunos de los personajes de las bóvedas, concretamente reyes y emperadores medievales cuyas conductas distaron de resultar modélicas. En el análisis de los diversos tramos, justificamos su presencia a través de la vinculación que establecieron con la orden benedictina, olvidando por motivos obvios, los datos comprometidos en torno a su conducta. En efecto, al contrastar varios estudios monográficos e históricos, no percibimos ningún atisbo de santidad en algunos de ellos. Miguel IV, emperador bizantino del siglo XI, fue según relata un cronista de la época, un hombre dominado por la bebida. Ascendió al trono gracias a su relación con Zoe, la viuda de su antecesor y posteriormente la encerró. Aunque había fundado varios monasterios, fue el último día de su vida cuando decide consagrarse a la vida espiritual, falleciendo en esta condición ${ }^{1611}$. De Offa de Mercia, algunos historiadores afirman que sobresalió en la misma medida por sus obras que por sus crímenes, siendo el

${ }^{1609}$ LÓPEZ DE AYALA, Ignacio. El sacrosanto y ecuménico Concilio de Trento. $1^{\mathrm{a}}$ Edición, Roma, 1564. Traducido al castellano. Madrid, 1785, pp. 450-451.

${ }^{1610}$ REDONDO CANTERA, M. José. "El programa...Op.cit, pp. 140-141 y 144.

${ }^{1611}$ PSELO, Miguel. Vida de los Emperadores...Op.cit, pp. 137-174. 
más destacado el asesinato de Etelberto, marido de su hija ${ }^{1612}$. Incluso hallamos casos en que no existe ninguna relación con la vida cenobítica. Sirva de muestra Carlomagno, de quien Heredia asegura su abandono de la vida política y su posterior ingreso en la abadía de Montecassino. Nos cuesta creer que un hombre con carácter libertador y espíritu conquistador como el rey lombardo, se convirtiese en el humilde monje que se dejó abofetear por el cocinero del monasterio italiano hasta en tres ocasiones ${ }^{1613}$. Pero lo que más nos sorprende es que incluso algunas cronistas cristianos incluyan como santos a personajes de este calibre y acepten sin objeción la mezquindad de los mismos. Nos relata el jesuita Juan Croisset cómo Segismundo, rey de Borgoña, con el fin de evitar que su primogénito le relevara del trono, ordenó a sus pajes que le ahogasen mientras dormía. Arrepentido, se retiró al monasterio de San Mauricio y alcanzó el perdón, siendo premiado con la corona del martirio ${ }^{1614}$.

En el transcurso de las obras del claustro bajo, los escultores que cincelaron los rostros de todos ellos, lo hicieron bajo la atenta mirada de los monjes benedictinos y contando con el beneplácito de los abades sucesivos que tuvo San Zoilo. Éstos confiaron ciegamente en la veracidad de las noticias que les relataban las crónicas, las cuales, en un intento de aproximar a los soberanos más célebres de la historia al espíritu de una orden monástica concreta, falsearon la realidad en su favor. La ingente cantidad de investigaciones llevadas a cabo hasta el presente, nos permiten un acercamiento a las figuras históricas con una visión más objetiva con la que no contaron los monjes carrioneses.

Realizadas las puntualizaciones convenientes sobre estos personajes, por el resto, el programa adquiere el sentido de glorificación del Santo y de la orden que se pretendía. El tema es muy acorde a la mentalidad Contrarreformista del momento, a través de la presencia papal como máxima autoridad espiritual o la representación de soberanos ejemplares o escritores cuyos textos se habían ajustado a la ortodoxia religiosa, los cuales proliferaron a partir de la celebración del Concilio. Como

${ }^{1612}$ HUME, David. Historia de Inglaterra...Op.cit, pp. 35-37.

${ }^{1613}$ HEREDIA, Fray Antonio de. Vidas...Tomo tercero. Op.cit, pp. 250-263. Los estudios monográficos sobre Carlomagno, aunque relatan la buena relación que mantuvo con la iglesia, no hacen referencia a su vida monástica. Entre ellas HALPHEN, Louis. Carlomagno... Op.cit CALMETTE, Joseph. Charlemagne. Op.cit, o BARBERO, Alessandro. Carlomagno. Op.cit.

${ }^{1614}$ Por si fuera poco, los Prelados de España conceden 2480 días de indulgencia a todos los que lean algún fragmento de los mismos, como así figura en la anteportada. CROISSET, Padre Juan. Año cristiano... Mayo. Op.cit, pp. 13-14. 
relatamos al comienzo, la fama de San Benito dio origen a la creación de numerosos escritos que reproducían un árbol genealógico del que descendían espiritualmente los personajes vinculados con él. Pues bien, también se aplica esta estructuración arbórea para los cenobios que siguieron la Regla Benedictina, como ramas de un firme tronco en cuya base se encuentra el santo italiano. Así lo vemos en Las fundaciones de los monasterios del glorioso Padre San Benito, impresa en Madrid en1601. Fue un encargo del rey Felipe III a su cronista, Fray Prudencio de Sandoval, prior de San Juan el Real de Naranco.

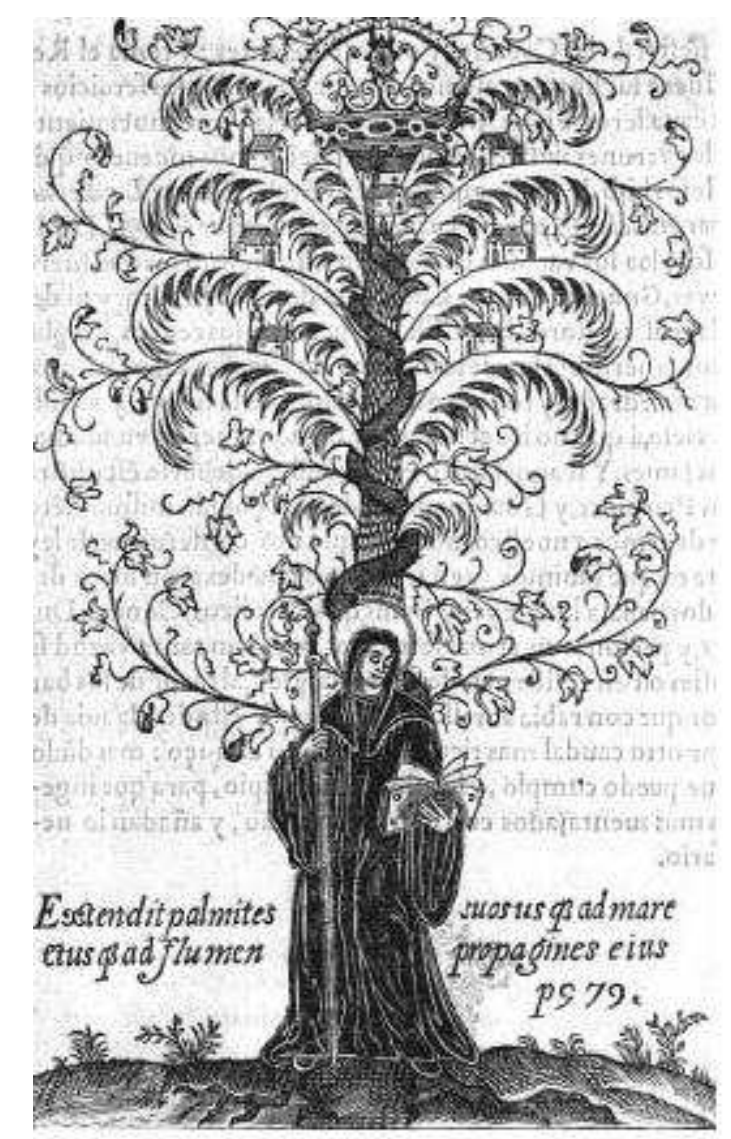

\section{Árbol benedictino. Las fundaciones de los monasterios del glorioso Padre San Benito, escrito por Fray Prudencio de Sandoval. Madrid, 1601.}

En la tónica de esta producción literaria benedictina, si bien posterior a la ejecución del cluastro de San Zoilo, se encuentran escritos tan relevantes como Aquila Imperii Benedictina, publicada en Venecia por Gabriel Bucelino en 1650 donde se ofrece un repertorio de personajes insignes relacionados con San 
Benito $^{1615}$. Resulta ineludible dentro de esta oleada de escritos insignes, La soledad laureada por San Benito y sus hijos en las iglesias de España, de la pluma del cronista Gregorio de Argaiz, predicador del monasterio cántabro de Santa María la Real de Nájera. Esta obra, impresa en Madrid en 1675, se divide en seis tomos, cada uno de los cuales corresponde a un distrito provincial, según la estructuración de Hispania realizada por Diocleciano a finales del siglo III: Gallaecia, Tarraconensis, Cartaginensis, Bética y Lusitania, más otro dedicado a las provincias de Asturias y Cantabria. A su vez, cada provincia establece una división jerárquica, partiendo de las sedes metropolitanas y continuando por las capitales sufragáneas, relatando en todas ellas la fundación de la Iglesia con los Santos y Obispos principales y su relación con San Benito.

Cristo y San Benito, grandes protagonistas del ciclo, son, asimismo los referentes espirituales de la Regla Benedictina, escrita por el Santo de Nursia en el siglo VI y cuyas pautas acataron fervorosamente los monjes de San Zoilo ${ }^{1616}$. Sus preceptos transmiten que Dios está siempre presente en la vida monástica y a él sirven en todo momento: en su obediencia al abad, en la ayuda a los enfermos o en sus rezos diarios. Muchos eruditos ya elogiaron la perfección de la norma benedictina. Así, San Antonio de Florencia, dominico italiano del siglo XV, criticaba la dificultad de comprensión de la regla de San Basilio, la generalidad de la regla de San Agustín y la brevedad de la de San Francisco. Concluía con estas palabras: "Si quieres no errar en el camino de la gloria, sigue la doctrina de los Santos. Principalmente estudia en la Regla de San Benito, no te apartes de ella nunca ni la quites una letra, ni la añadas una coma, que a esta santa regla nada le falta, ni le sobra nada ${ }^{1617,}$.

Los benedictinos y los personajes de la historia que fueron afines a ellos, son dignos modelos de comportamiento cristiano, de ahí su presencia en el ciclo. Como explica el monje benedictino Juan Castañiza: “...es justo sacar en público y descubrirles sus vidas, sus guerras, sus victorias, escudriñarles los pasos que dan y desenterrarles sus pensamientos y vidas para que guiándose por ellos, el pueblo

\footnotetext{
1615 BECERRO DE BENGOA, Ricardo. Op.cit, pág. 75.

${ }_{1616}^{16}$ BENITO DE NURSIA. La Regla.... Op.cit, pág. 64.

${ }^{1617}$ CIRIA RAXIS E INOJOSA, Pedro de. Vidas..Tomo III. Granada, 1691.Op.cit,pág. 369.
} 
Christiano sepa cómo ha de viuir y que no es imposible el cielo a los que ahora viuen como los que agora le gozan... ${ }^{1618, "}$

Por todo ello, no cabe duda de que el claustro de San Zoilo fue concebido en aras de lograr no tanto un deleite estético, ni una enseñanza universal, propósitos que por otro lado logró sobradamente, sino de modo más específico, con el fin de erigirse en icono de la de la fe católica con un sentido triunfante y glorificador de la misma. El ciclo, se inserta de este modo, en el agitado período de la lucha ideológica trentina, reafirmando su fe frente al dogma protestante.

Cerramos así este “...álbum de recuerdos sagrados...”, como tan acertadamente denominó a este claustro el insigne carrionés don Martín Ramírez de Helguera ${ }^{1619}$.

\section{3 OTRAS REFORMAS DE MENOR ENTIDAD}

Además de la ejecución del claustro, la solvencia económica del convento durante el siglo XVI permitió la ejecución paralela de otras intervenciones de cierta entidad. Así, durante el abadiato de Benito de Sahagún (1564-1570), se concertó la ejecución de unas vidrieras en el refectorio y en las tres ventanas del coro con el maestro vidriero Juan de Arce, vecino de Burgos, quien se encargó de la obra en el verano de $1569^{1620}$.

En abril de 1585 se remata en el maestro trasmerano Felipe de la Cajiga ${ }^{1621}$ unos cuartos nuevos por 16.000 ducados, para cuya ejecución se comprometía a seguir las condiciones suministradas por Juan de Ribero Rada ${ }^{1622}$. Es lógico que este

\footnotetext{
${ }^{1618}$ ANÓNIMO. Aprobación de la regla...Prólogo de Juan Castañiza. Op.cit, pág. 2.

${ }^{1619}$ RAMIREZ DE HELGUERA, Martín. El Real monasterio...Op.cit, pág. 56.

${ }^{1620}$ Contrato en AHPP. Carr.Prot 5444, s/f. Gregorio Movilla (1568-1569)

${ }^{1621}$ Datos biográficos en el apartado dedicado a los artistas cántabros.

${ }^{1622}$ GÓMEZ MARTÍNEZ, Javier. “Obras en San Benito...Op.cit, pág. 338. Acerca de Juan de Ribero Rada, véase LLAGUNO Y AMÍROLA, Eugenio. Noticias...Tomo II. Op.cit, pp. 62-65, CAMPOS SÁNCHEZ-BORDONA, María Dolores. "Proyectos...Op.cit, pp. 145-150, del mismo autor "Los órdenes clásicos en la arquitectura de Juan de Ribero Rada" en Los clasicismos en el arte español, Actas del X Congreso Español de Historia del Arte, 1994, pp. 467-474, "Juan del Ribero Rada y el orden dórico" en Boletín de la Real Academia de Bellas Artes de San Fernando, n81, 1995, pp. 517 542, "Juan del Ribero Rada, arquitecto clasicista" en Altamira, n52, 1996, pp. 127-166, "Arte y
} 
representante del clasicismo vallisoletano, que contaba con gran aceptación en la capital castellana fuera llamado para tomar parte en uno de los grandes conjuntos monasteriales de la región ${ }^{1623}$. Sin embargo, las obras no se llegan a comenzar, pues se suscita un pleito a partir de la subasta entre los maestros cántabros, entre los que se encontraba Felipe de la Cajiga y los artítices locales, quienes les denuncian por fraude. Efectivamente, los trasmeranos se habían comprometido a porporcionarles la mitad de la cantidad obtenida en los prometidos y a subcontratarles en la obra una vez que éstos se la adjudicaran, haciéndoles firmar un papel en blanco en el que Cajiga y sus compañeros escribieron a posteriori que solamente les abonarían una parte. Finalmente todos los artistas cántabros fueron encarcelados y los artistas locales, acusados de complicidad ${ }^{1624}$. Este contencioso motivó el retraso de las obras, pues Felipe de la Cajiga intervendrá finalmente en el monasterio benedictino en $1594^{1625}$, finalizándolas casi una década después de haberla comenzado.

Un informe emitido por la Comisión de Monumentos de Palencia en 1942 nos informa que a partir de 1584 se llevaron a cabo las obras de las habitaciones superiores de Oriente, y que se prolongaron hasta $1596^{1626}$. Este dato nos permite identificar estas obras con las que le encargarían a Felipe de la Cajiga. Por la ubicación, probablemente se trate de las celdas del claustro alto, contiguas a la cabecera, que se reformarían posteriormente en el siglo XVIII y en la centuria posterior cuando se establecieron los jesuitas.

Por estas fechas se emprenden las obras de la sacristía del templo, pues en 1596, se indica que ya habían dado comienzo. Es entonces cuando Juan de la Sierra, en quien se remató su ejecución, cede la mitad de la obra a Pedro de Verdes, ambos

cultura en la biblioteca de Juan del Ribero Rada” en Humanismo y tradición clásica en España y América, Universidad de León, 2002, pp. 311-332.

${ }^{1623} \mathrm{La}$ aceptación de este maestro entre la clientela vallisoletana y sobre todo entre los canteros de la época es palpable en el pleito que mantiene con su antiguo maestro y oriundo igualmente de Rada, Juan de Ribero por su participación en las trazas de San Marcelo de León, por las que acabó recibiendo las ganancias correspondientes. VASALLO TORANZO, Luis. "La contestación...pp. 113-128.

${ }^{1624}$ El pleito aparece en GÓMEZ MARTÍNEZ, Javier. “Obras en San Benito...Op.cit, pp. 333-348. Sobre este pleito, véase el capítulo introdcutorio sobre la procedencia de los artistas.

${ }^{1625}$ MARTÍ Y MONSÓ, José. “Menudencias...Op.cit, pág. 539.

${ }^{1626}$ ARASF, Leg.5-282-1. 
maestros de cantería procedentes de Secadura ${ }^{1627}$. Por entonces la sacristía era más amplia de lo que es hoy día, pues cuando se redactan las condiciones para la erección de la ermita de la Cruz en 1658, se indica que se copien las dimensiones de este espacio, que tendría 8,5 metros de largo x 7 metros de ancho ${ }^{1628}$.Finalizadas las obras en la sacristía se procede a la ejecución de la dependencia ubicada sobre la misma, la librería. De la parte relativa a la cantería se encarga el propio Pedro de Verdes junto al también trasmerano Juan de Solórzano, quienes realizarían las pilastras, esquinas y molduras en mampostería procedente de la población palentina de Palacios del Alcor. Seguirían para ello las condiciones establecidas por el maestro de carpintería Santiago de Sigüenza ${ }^{1629}$. El carrionés se encargaría de realizar las diez ventanas y cinco puertas con sus pernos del “..quarto que nuevamente se ha hecho...", lo que indicaría que en 1599 la librería estaba finalizada ${ }^{1630}$.

Durante al menos esta centuria, las obras ejecutadas en el monasterio de San Zoilo corrían a cargo de los monjes, pero no sucedía lo mismo en su iglesia, denominada parroquia de la Magdalena desde que fue anexionada en 1479 a San Zoilo. Las monjas zamoranas del monasterio de San Juan de la Horta, eran quienes, con permiso del abad, se hacían cargo de sus reparos ${ }^{1631}$. Así lo verificamos en el contrato que establecen con los carpinteros carrioneses Rodrigo de Losada y Santiago de Sigüenza, quienes se comprometen a reparar la parte hundida del tejado $^{1632}$. Esta intervención no solucionó el deterioro que sufría la capilla, pues poco después, en octubre de 1592, por medio de un abogado de la villa, el Licenciado Zoil Díez Flores, las monjas firman nuevas condiciones con otro carpintero, Francisco Hordas para proceder a una rehabilitación general. Este maestro, vecino de Carrión, se hizo cargo tanto de recomponer el tejado a cuatro

1627 El acuerdo lo firman ambas partes el 4 de agosto de 1596 en Carrión. AHPP. Carr.Prot 5655.Pedro Saldaña (1596), s/f.

${ }_{1628}$ AHPP. Carr.Prot 5691. Norberto de Sandoval y Guevara (1658), fol 176 y ss.

${ }^{1629}$ Las condiciones se firman en San Zoilo el 1 de mayo de 1598 en AHPP. Carr.Prot 5657. Pedro Saldaña (1598), s/f.

${ }^{1630}$ AHPP. Carr.Prot 5382. Francisco Moro Saldaña (1599), s/f.

${ }^{1631}$ Un estudio sobre el convento de San Juan de la Horta, de la Orden de Malta en FERNÁNDEZ PRIETO DOMÍNGUEZ, Enrique. "El monasterio de religiosas de San Juan de Jerusalén" en Hidalguía, no 274-275, 1999, pp. 337-368. Sobre las obras llevadas a cabo en el siglo XVI, consúltese el aaprtado relativo.

${ }^{1632}$ Les veremos participar en gran parte de las obras de carpintería de la zona. Carta de poder a 9 de julio de 1584. AHPP. Carr.Prot 4957.Juan Galarán (1582-1586), s/f. 
aguas como estaba en origen, a par y nudillo, así como de reforzar los muros con ladrillo, aderezar el altar y puerta de acceso y lucirlo todo de yeso ${ }^{1633}$.

\section{EL SIGLO XVII}

El cenobio de San Zoilo estuvo regido a lo largo de la historia por priores temporales, para pasar en el siglo XV a ser gobernado por abades comendatarios y finalmente, con la unión a la Congregación vallisoletana en 1532, los abades electos tendrían carácter trienal. Desde 1610 en adelante y hasta la llegada de la desamortización, se adoptará el sistema cuatrienal, siendo don Alonso de Barrantes quien lo inaugure ${ }^{1634}$. Es curioso observar cómo para la toma de hábito, los novicios debían proporcionar información sobre su vida y costumbres a través de una serie de testigos a los que se les interrogaba sobre la vida y costumbres del futuro monje, como si de un proceso judicial se tratase, de tal modo que certificaban su honradez y buen comportamiento ${ }^{1635}$. La vastedad de los bienes raíces repartidos a lo largo y ancho de las llanuras terracampinas provoca que en junio de 1670 el rey Carlos II, bajo la regencia de Mariana de Austria, responda una requisitoria del convento para que los dueños vecinos apeasen y deslindasen sus terrenos con el fin de esclarecer cual era el alcance de las posesiones del convento ${ }^{1636}$. En general, salvo períodos en que por falta de fondos se paralizan algunas obras, el monasterio atraviesa un período fructífero durante el cual se configura la mayor parte de las dependencias conventuales en torno al claustro renacentista y se construye el templo desde sus cimientos.

\footnotetext{
${ }^{1633}$ El contrato, firmado en Carrión, el 13 de octubre de 1592 en AHPP. Carr.Prot 5651, Pedro Saldaña (1592), s/f.

${ }^{1634}$ ZARAGOZA PASCUAL, Ernesto. “Abadologio...Op.cit, pp. 276 y 296.

${ }^{1635}$ Se conserva la información relativa a futuros internos de los cenobios bajo jurisdicción de San Zoilo correspondiente al siglo XVII. AHN. Clero Secular-Regular 5334 s/f. Toma de hábito e información de vida y costumbres.

${ }^{1636}$ Se enumera alfabéticamente el listado de pueblos en los que San Zoilo posee alguna heredad, prado, viña, soto, olivar o cualquier tipo de bien raíz. AHPP., Carr.Prot 5715, Norberto Sandoval y Guevara (1680), fol 183 y ss. La misiva real es de 21 de junio de 1670, cuya copia se inserta en otra carta de 20 de enero de 1680, de ahí la fecha del legajo.
} 


\subsection{LA CAPILLA DE DOÑA CONSTANZA}

Doña Constanza Enríquez de Almansa, vecina de Carrión de los Condes, fundó y dotó en marzo de 1602, una capilla en el templo de San Zoilo bajo la advocación de Nuestra Señora para enterrar a sus familiares ${ }^{1637}$. La voluntad de su viudo, don Antonio Doro Campoo, era ser sepultado en Carrión, pero la iglesia benedictina no figuraba entre sus preferencias. Así, en su testamento de 1591, encargó a sus descendientes que adquiriesen, a ser posible, la capilla mayor de San Julián, o bien una capilla en Santo Domingo “...o si no gustare aquí, en cualquier iglesia de la villa...", dejando para ello un juro de 48.000 ducados sobre las alcabalas de la villa y en caso de necesitarse, mil ducados de sus frutos y rentas ${ }^{1638}$. A este rico comerciante de las Américas, deben los carrioneses la ejecución de la custodia que procesiona en el Corpus Christi ${ }^{1639}$.

La capilla, conocida a partir de entonces con el nombre de doña Constanza, se ubicaría en el lado del Evangelio, junto al altar mayor, en el lugar que hasta entonces ocupaba la vieja sacristía ${ }^{1640}$. Las condiciones de la dotación de este lugar de culto, firmadas en junio de 1602, establecían el derecho perpetuo de enterramiento al linaje Doro Enríquez, que podía “...hacer altar con gradas, poner retablo, asientos, reja, puerta, llaves, escudos de armas dentro de la capilla y en la reja d'ella...”. De igual modo se proveía que si había que realizar reparaciones, el coste derivado de las mismas, correría a cargo de los patronos, salvo si se trataba de ejecutar retejos, que los abonaría el cenobio. En caso de que la iglesia sufriera alguna modificación, como efectivamente sucedió poco después, la capilla debía mantener su ubicación junto al altar mayor “...de suerte que los patronos puedan abrir arco en su capilla de veinte pies de largo para poner reja, sin que delante

\footnotetext{
${ }^{1637}$ AHPP. Desamortización. Legajo 112. Índice del Archivo de San Zoilo. Caja 5 ${ }^{\text {a }}$ San Andrés. Leg. 4. Capilla de doña Constanza. $\mathrm{N}^{\mathrm{o}} 2$.

1638 AHN. Clero Secular-Regular Legajo 5331 s/f. Documentos eclesiásticos y papeles de carácter religioso.

${ }^{1639}$ Sobre la misma, remítase al apartado correspondiente. Otros datos biográficos de Don Antonio Campoo pueden consultarse en URREA FERNÁNDEZ, Jesús. "La custodia...Op.cit. pp. 766-767 y LORENZO SANZ, E. "Palentinos en el nacimiento y formación de América" en AICHP, no 4. Palencia, 1987, pág. 454.

${ }^{1640}$ La sacristía vieja ya no servía, pues en 1596 se había realizado la nueva en el lugar que hoy ocupa. Remítase al siglo XVI.
} 
pueda haber altar ni embarazo ${ }^{1641 "}$. Dado que hasta aquel momento los restos de don Antonio Doro Campoo reposaban en la capilla mayor de la iglesia de Santa María, doña Constanza había solicitado el traslado de los mismos a la nueva ubicación. Puesto que las autoridades hacían caso omiso de su petición, una noche exhumó el cadáver de su difunto marido, lo que le valió un careo judicial en junio de $1603^{1642}$.

Al fallecer ambos cónyuges, el patronazgo lo hereda el primogénito, don Antonio Doro Enríquez, alférez de la villa como su padre, de quien recibe además el mayorazgo fundido con el del linaje Vozmediano ${ }^{1643}$. Dispone por testamento, dictado en 1619, que se traspase la propiedad de la capilla a sus hijos, aún menores de edad, y a su mujer, doña Teresa de Cárdenas y Toledo ${ }^{1644}$. Será ella y el primogénito del matrimonio, don Francisco Doro, quienes se vean envueltos entre 1620 y 1622 en un litigio con la comunidad benedictina, que les requiere mil ducados de los réditos del censo por la compra de la capilla que hizo Don Antonio Doro Campoo ${ }^{1645}$. Ellos se defienden de las acusaciones, alegando que la adquisición es nula porque no la hizo su abuelo, sino doña Constanza, y que en todo caso, el monasterio deberá cobrar el importe de los bienes de aquel, no de sus herederos ${ }^{1646}$.

No sabemos cómo se resolvió el pleito, pero debieron llegar a un acuerdo, pues a mediados de siglo seguía perteneciendo a la misma familia. Por entonces, la capilla seguía estando en el lado del Evangelio, pero integrada dentro del altar mayor, respetando el deseo de la antigua patrona. Recordemos que doña Constanza, en una de las cláusulas de la dotación, había dispuesto la permanencia de la ubicación preferente de su capilla si el templo sufría modificaciones. Pues bien, cuando la iglesia fue reedificada a partir de 1642, quedó contemplado en las

\footnotetext{
${ }^{1641}$ AHPP. Desamortización. Legajo 112. Índice del Archivo de San Zoilo. Caja 5a: San Andrés. Leg. 4. Capilla de doña Constanza. $\mathrm{N}^{\circ} 4$.

${ }_{1642}$ AHN. Clero Secular-Regular, Leg, 5358. Expediente 2 Santa María, Papeles judiciales, s/f.

1643 ALONSO CORTÉS, Narciso. Miscelánea Vallisoletana, tomo II. Valladolid, 1955, pp. 276-277

1644 Testamento dictado el 9 de septiembre de 1619. AHPP. Carr.Prot 4846. Juan Díaz Pajaza (1619), fol 507 y ss. Inventario de sus valiosos e innumerables bienes en AHN Clero Secular-Regular, Legajo 5358 s/f, Expediente 7, Varios.

${ }^{1645}$ AHPP. Desamortización. Legajo 112. Índice del Archivo de San Zoilo. Caja 5a: San Andrés. Leg. 4. Capilla de doña Constanza. $\mathrm{N}^{\mathrm{o}} 19$ y $\mathrm{N}^{\mathrm{o}} 21$.

${ }^{1646}$ Requerimiento del monasterio de San Zoilo en AHPP. Carr.Prot 5403. Francisco Moro Saldaña (1620), fol 2168 y ss.
} 
condiciones el mantenimiento de la misma ${ }^{1647}$. La capilla se encontraba en estado ruinoso en 1651 por lo que la comunidad de San Zoilo solicita al patrono por entonces, don Antonio Fernando Doro Enríquez, que intervenga con celeridad en la reparación de la misma, pues se estaba hundiendo el tejado y las paredes se habían resquebrajado, lo cual podía desencadenar daños colaterales en la capilla mayor. Los benedictinos escogieron como maestros para tasar los daños, a los carpinteros locales Santiago Pedrosa y Juan Vicente González, y en la parte relativa a la cantería, a los trasmeranos Juan de Trujeda y Jerónimo de Avendaño ${ }^{1648}$. Los problemas no finalizan aquí, pues entre 1658 y 1661, doña Leonor de Quiñones, en calidad de viuda del último poseedor de la capilla, don Antonio Francisco Enríquez, es responsable de las deudas acumuladas por la posesión del mayorazgo. La comunidad le obliga a abonar tres mil reales de un total de quinientos ducados que debían los fundadores, doña Constanza Enríquez y don Antonio Doro ${ }^{1649}$. Probablemente fue por estos años cuando la capilla de Doña Constanza, al encontrarse en tan mal estado fuese derruida, aprovechando las obras que se estaban llevando a cabo en el templo. De este modo, su patronazgo fue traspasado a un espacio ubicado los pies del templo pero fuera del mismo, junto a la entrada ${ }^{1650}$.

\subsection{RENOVACIÓN DE LAS DEPENDENCIAS CLAUSTRALES}

\section{Enlosado del claustro}

La situación favorable que atraviesa San Zoilo desde mediados del siglo XVI continúa en esta centuria, como así manifiesta el nutrido número de intervenciones de entidad que se realizan en el cenobio desde la finalización de las obras del

\footnotetext{
1647 “...Yten, es condiçión que los huecos que ay entre los quatro arcos de la dicha capilla mayor que es, el vno, que está sobre la capilla de Antonio Doro Campoo... los an de çerrar los susodichos de media asta de ladrillo y su yelsso y los enjutarán conforme lo demás a niuel de los arcos por la parte de abajo...”, AHPP. Carr.Prot 5424. Francisco Moro Saldaña (1641-1642), s/f.

${ }^{1648}$ La petición, dirigida por Don Juan Aranda, en nombre del abad y monjes de San Zoilo, se efectúa el 11 de agosto de 1651. AHPP. Desamortización. Legajo 110 y Legajo 112. Índice del Archivo de

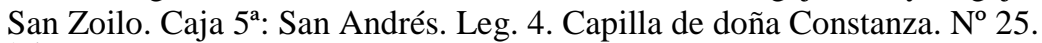

${ }^{1649}$ Los autos y diligencias llevados a cabo por el monasterio de San Zoilo en AHPP. Desamortización. Legajo 110. Cajón San Andrés. Legajo 5 y AHPP. Desamortización. Legajo 112. Índice del Archivo de San Zoilo. Caja 5ª : San Andrés. Leg. 4. Capilla de doña Constanza. No 26.

${ }^{1650}$ Véase el apartado relativo al siglo XVIII en que, además de cambiar de ubicación, la ostentan otros patronos.
} 
claustro alto, en 1604, que pusieron fin a casi setenta años de incesantes trabajos en el mismo. Señal inequívoca de esta prosperidad es patente en la renovación de dependencias que habían sido reedificadas un par de décadas antes.

La primera intervención de esta centuria consistió en enlosar ambos pisos del claustro, tarea que recayó en el cantero Pedro del Arenal, residente en Carrión. El contrato firmado con el abad Alonso Barrantes a finales de 1612, establecía que las obras debían comenzarse en enero de 1613 y que acabado el mes de abril, dos de los paños debían estar perfectamente empedrados. El plazo para el resto de la obra se decidiría conforme se fuera ejecutando y el convento acordó abonarle trescientos ducados por los trabajos ${ }^{1651}$.

\section{Almacén de leña}

En estos años la casa benedictina se mantuvo bajo el mando del abad Juan Díaz Lavandero, salvo el período de 1617 a 1621 en que estuvo al cargo Fray Miguel de Castro, definidor general de la Congregación, oriundo de Frómista ${ }^{1652}$. En el lado meridional, en la pared aledaña al refectorio y mirando a la huerta, se realizó un cuarto nuevo. Estaría destinado como depósito de madera, pues se precisa en las condiciones que “...aya de pasar por el claro del arco baxo un carro cargado de leña...”. Para su ejecución, comenzada en 1614 y completada en el transcurso de un año, la comunidad recurrió de nuevo a Pedro del Arenal, que se comprometió a realizar una estancia de dos niveles, con fuertes cimientos para protegerla del río. El primer piso estaría formado por cuatro arcos con pilastras y el segundo por una azotea con dos arcos sobre columnas, todo en mampostería ${ }^{1653}$.

\footnotetext{
${ }^{1651}$ Además, la comunidad debía abonar cien reales a la mitad de la obra y otros cien acabada la misma. El contrato y condiciones se firman en Carrión, el 10 de diciembre de 1612. AHPP. Carr.Prot 5395.Francisco Moro Saldaña (1612), s/f.

${ }^{1652}$ ZARAGOZA PASCUAL, Ernesto. “Abadologio...Op.cit, pág. 296. De Juan Díaz Lavandero ya hablamos en el apartado relativo a los nichos del claustro bajo.

${ }^{1653}$ La escritura se firma en San Zoilo, el 30 de julio de 1614, figurando como fiador de Pedro de Arenal, el arquitecto trasmerano Francisco de Bálcava, que participó en las obras de Santa Clara. Por la ejecución de este cuarto recibió cuatro mil reales. AHPP. Carr.Prot 5397. Francisco Moro Saldaña (1614), s/f.
} 


\section{La sacristía y la librería}

La sacristía y librería del convento, ubicadas en el lienzo este, linderas al templo, fueron realizadas a finales del siglo XVI. Tan sólo había transcurrido un cuarto de siglo y se decide renovarlas por completo en 1622. Por entonces, y hasta 1625, ocupaba el abadiato por tercera vez Juan Díaz de Lavandero, quien lo había aceptado por obediencia cuatro años antes ${ }^{1654}$.

Forman parte de un ambicioso proyecto concretado a mediados de dicho año con Juan González de la Mata, en la albañilería y con Diego de Mazarredonda, y el trasmerano Francisco de Buega ${ }^{1655}$, en la cantería ${ }^{1656}$. El primero, maestro de albañilería local, era muy apreciado en su trabajo, de ahí que consiguiera adjudicarse la mayor parte de las obras que se realizaron en Carrión a lo largo de la centuria ${ }^{1657}$. Respecto a Mazarredonda, procedía de San Pantaleón de Aras, en la Junta del Voto, localidad donde existe una gran tradición de canteros con este apellido, que además trabajaron en Castilla desde finales del siglo XVI, por lo que es posible que existieran vínculos familiares con éstos ${ }^{1658}$. Los datos que se conocen de su trayectoria artística, lo sitúan trabajando en el foco burgalés en la primera década del siglo XVII. Así, en octubre de 1614 se concierta con Pedro de Ruseco para hacer un entierro en la capilla mayor de Santa María la Blanca ${ }^{1659}$. En 1615, figura como fiador de Pedro de Chiprestúa en la sillería de coro de la iglesia de San Pedro de Lerma, y un año después se compromete a continuar la obra del convento de la

\footnotetext{
${ }^{1654}$ ZARAGOZA PASCUAL, Ernesto. “Abadologio...Op.cit, pág. 296.

${ }^{1655} \mathrm{Al}$ mismo nos referiremos en el capítulo dedicado a sus datos biográficos.

${ }^{1656} \mathrm{La}$ escritura de contrato se firma en el monasterio de San Zoilo el 6 de mayo de 1622. AHPP. Carr.Prot 5405.Francisco Moro Saldaña (1622), s/f.

1657 Dedicamos un capítulo biográfico y analizaremos su intervención en los distintos templos carrioneses.

1658 Los canteros más destacados con este apellido son Juan de Mazarredonda y su sobrino homónimo, ambos trabajaron en Valladolid, formando parte del foco clasicista. Sobre ellos, MARTÍ Y MONSÓ, José. "Menudencias...Op.cit, pp. 537-538, SOJO Y LOMBA, Fermín. Los maestros...Op.cit, pp. 104-106, GARCÍA CHICO, Esteban. Documentos...1 Arquitectos...Op.cit, pp. 86-87 y BUSTAMANTE GARCÍA, Agustín. La arquitectura...Op.cit, pp. 495-500 y ALONSO RUIZ, Begoña. El arte de la cantería...Op.cit, pp. 91,99-100, 126,133,146 y 183.

1659 POLANCO MELERO, Carlos. Muerte y sociedad en Burgos en el siglo XVI. Diputación Provincial de Burgos. Burgos, 2001, pág. 292.
} 
Merced de Burgos por un poder que le otorga su anterior maestro, Silvestre de la Torre $^{1660}$.

La obra que estos tres maestros ejecutaron, consistió en la ejecución de una sacristía en el piso principal del monasterio, adosada al templo por su lado sur. Se trata de una estancia rectangular de pequeñas dimensiones, compartimentada en sus lados longitudinales por tres amplios arcos de medio punto apoyados en macizos pilares, sobre los que se dispone una sencilla imposta moldurada de sección cuadrangular. El espacio entre las jambas de los arcos laterales acoge la cajonería del siglo XVI, mientras que en la parte central se ubica una puerta. La del lado norte, da acceso al crucero del templo, mientras que a través de su frontera se pasa a la antigua sala capitular. Los otros dos muros, que presentan lisas sus paredes, están provistos igualmente de cajonería. El lado occidental además, comunica directamente con el claustro, concretamente con la segunda bóveda del lienzo oriental, lo que daría un total de tres accesos en la sacristía. Los tres muros que les corresponden están realizados en ladrillo y guijarros recubiertos por sillería en sus dos terceras partes, creando un vivo contraste con el enlucido que presentan las cubiertas y el lado oriental. Esta parte "del solano" se aprovechó para disponer tres ventanas, la central de mayores dimensiones, con cierto abocinamiento, para dotar de luz natural a este espacio. Como cubrición se optó por una bóveda de cañón separada por fajones que coinciden en sus extremos con el arranque de lar tres arcadas de los muros. Sobre ellas, tres lunetos en cada lado, cegados, “...de mиy

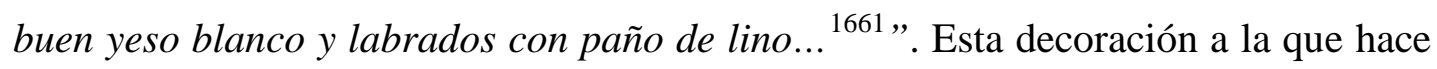
referencia la documentación consiste en dos sencillos listeles dispuestos verticalmente, que animan la superficie gracias a la división tripartita del luneto. El espacio que separa la cubierta de los muros, aparte del contraste visual que marcan la propia piedra y el yeso, se decidió señalarlo con una imposta “...la qual tendrá pie y quarto de grueso y medio pie de salida, digo un quarto... ${ }^{162, " . ~ P a r a ~ l a ~}$ ornamentación de la bóveda de cañón se optó por la disposición de puntas de diamante en las partes laterales. En la sección central, se dispone una yesería

\footnotetext{
${ }^{1660}$ LOSADA VAREA, M ${ }^{a}$ Celestina. La arquitectura en el otoño del Renacimiento: Juan de Naveda (1590-1638). Universidad de Cantabria. Santander, 2007, pág. 174.

${ }^{1661}$ Así se indica en la segunda de las condiciones. AHPP. Carr.Prot 5405. Francisco Moro Saldaña (1622), s/f.

${ }^{1662}$ Ibídem, cuarta condición.
} 
romboidal tangente a otra cuadrangular, ambas completamente lisas, al contrario que el caprichoso repertorio de florones vegetales y rameados tallados a trépano que observamos en el interior.

Habrá que esperar al siglo siguiente para proveer este espacio de una exquisita selección de cuadros religiosos que desaparecieron con la Desamortización ${ }^{1663}$. También se desconoce el paradero de una cruz de plata que ejecutó el platero de Sahagún Pedro de Bedoya, entre los meses de noviembre del año 1600 y febrero del año siguiente. Constaba de esmaltes pintados para acoger nada menos que cuarenta y ocho reliquias repartidas por el pie y la cruz y por ambos lados de la misma ${ }^{1664}$.

Respecto a la librería, se ubicaría en el primer piso, ocupando la misma superficie que la sacristía sobre la que se asienta. En ella se aplicarían los mismos principios arquitectónicos, de corte clasicista, “...guardando el orden que se seguirá bajo en la sacristía de suerte que los güecos se correspondan unos con otros y los maçizos a los maçizos ${ }^{1665, " . ~ L a ~ u ́ n i c a ~ s a l v e d a d ~ e s ~ q u e ~ l a s ~ p i l a s t r a s ~ d e ~ e s t a ~}$ dependencia, decoradas con roleos y cartelas, serían más estrechas, con vistas a que la estructura fuese más liviana. Por encima de la cubierta, se cerraría el tejado con sus nudillos y soleras asentado "a la morisca", sobre la que iría la azotea. Para el suelo de ambas estancias se optó por el ladrillo, pues la piedra aumentaría los costes.

\section{Mayordomía y celdas}

Posteriormente se procedió a ejecutar las dependencias ubicadas en el lienzo occidental, aledañas al patio neoclásico ${ }^{1666}$. Estas obras tuvieron lugar durante el cuatrienio de don Juan Cortés, comprendido entre 1625 y 1629, año en que falleció durante la Celebración del capítulo general en Valladolid ${ }^{1667}$. Efectivamente nos consta que las obras de este lienzo fueron subastadas en diciembre de 1626, pujando

\footnotetext{
${ }^{1663}$ Véase el apartado relativo al siglo XVIII

${ }^{1664}$ La cruz pesaría ocho marcos de plata, por la cual el abad Plácido de Huercanos le abonaría treinta y dos ducados. El contrato se firma el 25 de noviembre de 1600 en el convento de San Zoilo. AHPP. Carr.Prot 5076, $\mathrm{n}^{\circ}$ 666. Pedro Guerra Cervantes (1600-1601), fol 69 y ss.

${ }_{1665}$ AHPP. Carr.Prot 5405, s/f. Francisco Moro Saldaña (1622).

1666 BECERRO DE BENGOA, Ricardo. "El monasterio...Op.cit, pág. 88.

1667 ZARAGOZA PASCUAL, Ernesto. “Abadologio...Op.cit, pág. 297.
} 
en ellas Juan González de la Mata, albañil local, con 3.000 ducados, y Juan de Veintemillas, vecino de Burgos, que la bajó a 2.000 ducados. El remate recayó sobre Domingo de Bustos, maestro de cantería procedente de Burgos, que ofreció la postura menor, en 20.100 reales, unos 1.830 ducados. Las condiciones del proyecto, fijadas un mes antes de la subasta, establecían la ejecución de un cuarto destinado a mayordomía y varias celdas repartidas entre el piso principal y el sobreclaustro ${ }^{1668}$. En la parte baja, en el espacio existente entre la escalera, situada en el extremo sur del lienzo y la capilla de los Condes, ubicada en el lado contrario, se dispondría la mayordomía. Para ello, se demolió la pared del archivo, que se ubicaba en el ángulo, trasladándolo, como veremos al piso superior. Por su parte, en la galilea se levantó otro muro recolocando el retablo del Ecce Homo ${ }^{1669}$. La mayordomía fue dividida en tres cuartos de veinte pies de largo en los que se dispuso, bajo sólidos cimientos, unos zócalos de piedra sobre los que se asentaron pilares en sillería ornamentados con sendas impostas ${ }^{1670}$. Dos arcos de medio punto "con buenas dovelas de a dos pies de lecho" compartimentan cada lado, de los cuales parten las cubiertas, pequeñas bóvedas de arista, tal y como vemos hoy día. La diferencia es que actualmente no persiste la triple compartimentación original de esta dependencia, transformada en un largo pasillo que comunica la hospedería con el lienzo de la actual portería, ubicada en el lado septentrional, en línea con la fachada del templo. En el hueco que queda junto a la escalera del claustro, se dispondrán dos pequeños cuartos para oficinas, a los que se bajará por unas gradas que se construirán a tal efecto. Cada una de estas dependencias iría provista de un par de ventanas de cuatro pies y medio de ancho y tres de largo, en piedra de Palacios de Alcor, con un motivo de orejetas en su marco ${ }^{1671}$. La capilla de los Condes, se iluminaría de igual modo, para regularizar este ala. En el piso superior, comenzaron las obras por el ángulo noroccidental, donde se abrió una puerta, frontera a la de la librería, ubicada en el otro extremo, es decir, en el ángulo nororiental. En el espacio situado entre este acceso y la escalera principal, coincidente con la mayordomía del nivel inferior, se dispusieron tres celdas, con sus puertas respectivas en el sobreclaustro, siguiendo la

\footnotetext{
${ }^{1668}$ Las condiciones se firman en el monasterio de San Zoilo el 28 de noviembre de 1626 y el contrato, el 22 de enero de 1627. AHPP. Carr.Prot 5410. Francisco Moro Saldaña (1627), s/f.

${ }^{1669}$ Nos referimos al Cristo atado a la columna, que, antes de ser trasladado en los años ochenta al nicho del lienzo oriental del claustro bajo, presidía el retablo de la capilla condal.

${ }^{1670}$ Dado que un pie castellano son 0.2786 centímetros, cada estancia alcanzaría una longitud de unos cinco metros y medio.

${ }^{1671}$ Las ventanas tendrían unas dimensiones de 1.25 metros de largo y 83 centímetros de ancho.
} 
disposición de aquella dependencia. Se construyó una sala entre la puerta angular y la pared del coro, situado a los pies del templo, que serviría de sala- recibidor para la hospedería, y junto a la misma, un pequeño espacio para el archivo, que previamente se ubicaba en el espacio inferior coincidente con éste. La altura de estas nuevas dependencias y del coro quedaría nivelada con una cornisa de ladrillo "de orden toscana" y sobre ésta, armaduras de tijera. Todas irían debidamente iluminadas con dos ventanas, como en las estancias inferiores, sin ser excepción el coro, donde se practicarían sendos ojos de buey. Las condiciones determinan que el suelo de toda la obra debe estar realizado en ladrillo “...rraspado, cortado en el tejar, y cuando no sea rraspado, por lo menos será cortado...” y que todas las piezas deben ser lucidas de yeso. Por último se establece que en la parte aledaña a la torre “...para la buena correspondencia de dicho cuarto..." se tapiarán las ventanas que ahora existen y sobre éstas se elevará un cuerpo de ladrillo donde se dispondrán arcos de medio punto entre dos líneas de imposta. La campana del reloj será alojada por una pequeña ventana, cuyas esquinas se ornamentarán con bolas sobre pedestales y rematarán el conjunto cruz y una veleta. Hoy día esta campana del reloj se inserta en un balaustre de hierro con labor de forja que se construyó en $1824^{1672}$.

Como ayudante en las obras de cantería, Domingo de Bustos contrató a su paisano, Juan de Veintemillas, quien, recordemos, había pujado en la subasta de la obra, aunque no logró adjudicársela. Los maestros Felipe de la Cajiga y Juan de Cajigosa $^{1673}$ se encargarán de tasar la parte ejecutada en el lienzo occidental. Las obras prosiguen a buen ritmo a finales de 1627, como así se deduce de la carta de pago que se otorga al maestro burgalés el 20 de noviembre ${ }^{1674}$. Las últimas intervenciones, realizadas en la torre, brindaron la ocasión idónea para contratar en 1630 el arreglo de su reloj, para lo cual intervino el relojero de Palencia, José Ruiz Mancio $^{1675}$.

\footnotetext{
1672 Monasterio de Santo Domingo de Silos. ACSBV. Documentos, Volumen 33, $\mathrm{n}^{\circ}$ 1187. 1824. Estado general del monasterio de San Zoil de Carrión, fol 319-324v. La torre igualmente, ha sufrido modificaciones en su apariencia, fruto del último cuarto del siglo XVIII, como tendremos oportunidad de ver.

1673 Sobre el mismo, véanse los datos relativos en su apartado biográfico.

${ }^{1674}$ Se le abonan 1183 reales. AHPP. Carr.Prot 5172. Jerónimo Laso (1627), fol 653.

1675 Por carta de pago de 4 de diciembre de 1630, se le abonan 220 reales. AHPP. Carr.Prot 5413. Francisco Moro Saldaña (1630), s/f.
} 


\section{Otras reformas de menor entidad}

En los años siguientes, durante los cuales todos los esfuerzos fueron dedicados a la construcción, como veremos, del nuevo templo, no se llevaron a cabo intervenciones en las dependencias conventuales. Sólo después de finalizadas las obras, se reformaron el refectorio y cocina, en el lienzo meridional, durante el segundo abadiato de Plácido del Río, entre 1649 y $1653^{1676}$. Unos años más tarde, en 1659, Bernardo Sánchez, maestro de cantería carrionés, será requerido por el convento para hacer las tapias del monasterio por la parte de la huerta ${ }^{1677}$. Por la fotos y dibujos que conservamos de la época en que los jesuitas se asentaron en San Zoilo, deducimos que, al igual que aquéllos, los benedictinos debieron poseer grandes parcelas para todo tipo de cultivo en la parte meridional, que aprovechaban la vega fértil del cuérnago, cuyo cauce atravesaba el cenobio de norte a sur.

La última intervención en las dependencias conventuales en este siglo tiene lugar en 1662. La carta de obligación de la que obtenemos este dato tan sólo indica que se habían de traer “...100 carros de piedra tosca de las canteras de Villamorco, Nogal y Población... 1678". Es probable que los trabajos afectaran fundamentalmente a la sacristía, pues durante el abadiato del cántabro don Juan González se nos indica que hizo allí “...diversas obras... ${ }^{1679 ” . ~ N o ~ t e n e m o s ~ m a ́ s ~ d a t o s ~ s o b r e ~ e s t a ~ o b r a ~ d e ~}$ cantería. Puede que se llevaran a cabo labores de refuerzo de sus muros. Hay que tener en cuenta que aunque esta dependencia había sido renovada cuarenta años antes, la edificación del nuevo templo con el derribo consecuente del anterior, aledaño a este sector, habría causado daños cuya reparación fue posible al finalizar las obras del mismo.

\footnotetext{
${ }^{1676}$ En 1650 las obras sufrieron nuevamente un alto debido a una plaga de langosta BECERRO DE BENGOA, Ricardo. "El monasterio...Op.cit, pág. 89.

${ }^{1677}$ La escritura y condiciones se firman en San Zoilo, el 10 de mayo de 1659. AHPP. Carr.Prot 5692. Norberto Sandoval y Guevara (1659), fol 340 y ss.

${ }^{1678} \mathrm{La}$ obligación se firma el 9 de enero de 1662. AHPP. Carr.Prot 5696. Norberto de Sandoval y Guevara (1662), fol 1.

${ }^{1679}$ Profesó en Carrión en 1632 y fue abad en cuatro ocasiones (1653-1657, 1661-1665, 1669-1673, 1677-1680). ZARAGOZA PASCUAL, Ernesto. “Abadologio...Op.cit, pág. 299-300.
} 


\section{3. LA CONSTRUCCIÓN DEL NUEVO TEMPLO}

Bajo el mandato de don Antonio del Valle, fue derribada la antigua iglesia románica, pero sólo en parte, como veremos ${ }^{1680}$. Corría por entonces el año 1633, pero el abad asturiano no pudo ver continuada su labor al fallecer un año después de ser elegido para el cargo ${ }^{1681}$. Éstas fueron continuadas con Bernardo de Santisteban (1634-1637), que funda los cimientos para erigir del nuevo templo y Francisco de Lemos (1637-1641), a cuyo impulso se debió la capilla mayor, interrumpida en 1640 por la llegada de unas fuertes fiebres ${ }^{1682}$. Don Plácido del Río, predicador palentino electo en 1641 retomó las obras paralizadas, que transcurrían muy lentas ${ }^{1683}$.

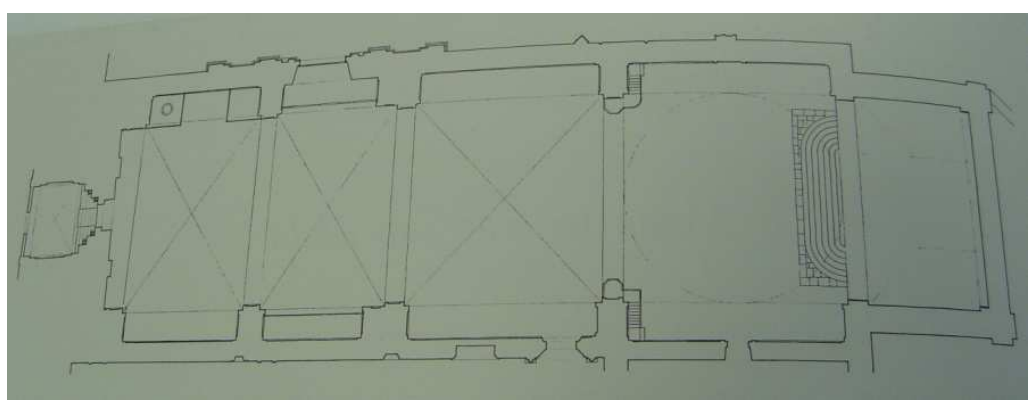

Planta del templo de San Zoilo con la galilea a los pies.

En una década, por tanto, se habían realizado solamente los muros del presbiterio. Llegado el verano de 1642 se firmaron nuevas condiciones, contratándose a los maestros de albañilería, también denominados maestros de obras, Melchor Ruiz, Tomás García y Domingo Ponce para que continuasen las obras comenzadas ${ }^{1684}$. Estos artífices, vecinos de Valladolid, se encargaron de realizar tres tramos del nuevo templo: la capilla mayor, el crucero y el tramo contiguo $^{1685}$. Se desconoce el tracista de la nueva obra, pero dada la fisonomía del templo, se trataría de un miembro de la escuela clasicista palentina o vallisoletana.

\footnotetext{
${ }^{1680}$ BECERRO DE BENGOA, Ricardo. "El monasterio...Op.cit, pág. 88.

${ }^{1681}$ ZARAGOZA PASCUAL, Ernesto. “Abadologio.... Op.cit, pág. 297.

${ }^{1682}$ Los dominicos fueron los encargados de cuidar a los benedictinos que enfermaron. BECERRO DE BENGOA, Ricardo. "El monasterio...Op.cit, pág. 88.

${ }^{1683}$ Fue abad durante los cuatrienios de 1641 a 1645 y 1649 a 1653. ZARAGOZA PASCUAL, Ernesto. “Abadologio...Op.cit, pág. 298.

${ }^{1684}$ Las condiciones se firman el 6 de agosto de 1642 en el monasterio de San Zoilo. Se acuerda abonar a los artífices veintitres mil reales si cumplen con lo estipulado. AHPP. Carr.Prot 5424. Francisco Moro Saldaña (1641-1642), fol 1.

${ }^{1685}$ Se dispone que se realicen siete arcos y medio, es decir, cuatro correspondientes al crucero, tres del tramo consecutivo y medio del testero de la capilla mayor, de menor grosor que el resto. Ibídem
} 
Para acometer el nuevo encargo se derruyó parte de la vieja iglesia, dejando en pie sus dos primeros tramos, dado que en esta fase no se iba a alcanzar esa parte. La primera intervención consistió en levantar los muros de la capilla mayor, donde dispusieron el sepulcro de la condesa doña Teresa, en un nicho ubicado en alto, del lado del Evangelio ${ }^{1686}$. En efecto, cuando posteriormente se efectúen las tasaciones de la obra, una de las labores que no figuraban en el contrato y que hicieron a su costa los maestros fue “...subir y assentar los dos escudos y haçer la peana de yesso

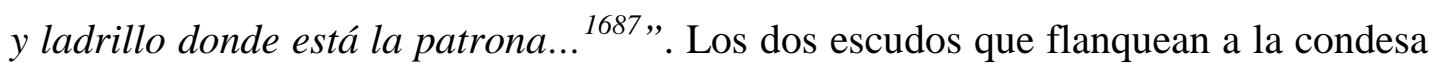
son los mismos que vemos en la fachada del templo y que analizaremos posteriormente. El de la derecha, cuartelado, es el emblema general de las abadías benedictinas y el otro el escudo propio del monasterio de San Zoilo. La escultura orante de doña Teresa, arrodillada y vestida de religiosa con hábito y toca fue colocada en dirección al altar mayor, una vez realizado el arcosolio. Dentro de esta tipología funeraria, recurrente en Palencia para enterramientos de cierto rango, se conservan en Carrión otros dos ejemplares. El más inmediato cronológicamente se halla en la iglesia de San Andrés, correspondiente al sepulcro del obispo Don Melchor Álvarez de Vozmediano, fallecido en 1630 y en la iglesia de Santa María se hallan los dos arcosolios del Obispo Navarrete y sus padres, encargados con motivo de la reforma llevada a cabo en 1685 en la capilla mayor por Felipe Berrojo ${ }^{1688}$.

\section{Sepulcro de la Condesa doña \\ Teresa en el presbiterio. Piedra calcárea.Escultura orante $(125 \mathrm{~cm} \times 45 \times 30 \mathrm{~cm})$.}

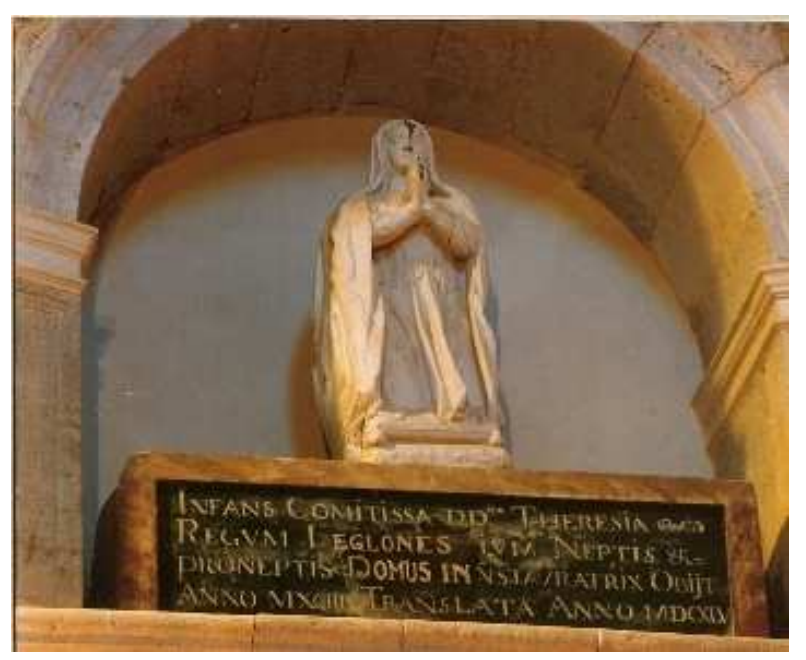

\footnotetext{
${ }^{1686}$ ZARAGOZA PASCUAL, Ernesto. “Abadologio...Op.cit, pág. 298.

${ }^{1687}$ Declaración de Juan González de la Mata y Jerónimo de Avendaño como veedores de las obras, firmada en Carrión a 9 de mayo de 1645. AHPP. Carr.Prot 5427. Francisco Moro Saldaña (1645), s/f. Sobre la condesa doña Teresa y su enterramiento ya se habló en el apartado relativo a la capilla condal.

${ }^{1688}$ Sobre estos sepulcros véanse los capítulos relativos a los templos en los que se ubican.
} 
La cabecera quedó conformada a través de un espacio cuadrangular más estrecho que el resto del templo, con acceso a través de un gran arco de medio punto, unido a otro, ubicado en el testero del templo, a través una bóveda de cañón con lunetos. No se determinó la decoración que debía lucir, si bien quedó precisado que “... se a de echar una lavor muy buena...”. Se optó por puntas de diamante en los laterales, dejando en la franja central dos molduras cuadrangulares con sus ángulos escalonados y dos diamantes tangentes a ellas. Desde este espacio, elevado respecto al resto del templo, se accedía a la nave mediante cinco gradas realizadas en piedra de Palacios del Alcor, de dos pies de ancho cada una, cuya amplitud abarcaba todo el ancho de la capilla mayor. Los siete escalones que encontramos hoy día no son originales, son de menor amplitud y presentan forma de medio óvalo.

En el crucero se dispusieron cuatro arcos de medio punto sustentados sobre pilastras cajeadas con lunetos cegados, dado que la luz se filtraría por la gran cúpula que se alza sobre ellos. Se convino que la media naranja quedase asentada sobre una serie de molduras a base de collarino, friso y cornisa de orden dórico; de las tres, ésta última no se hizo finalmente, lo cual penalizó a los maestros. La cúpula contiene ocho vanos cuadrangulares capialzados, adornados con sendas orejetas. Solamente cuatro de ellos filtran la luz solar, estando el resto cegados. Podríamos pensar que es resultado de una intervención posterior, sin embargo, las condiciones establecían la disposición comentada, de modo que “...en las ventanas se a de dar luz a las que fueren neçessarias...”.

Para la ornamentación de los espacios comprendidos entre ellas se dio libertad a los artífices vallisoletanos, que optaron por unos listeles que se estrechan conforme convergen en la clave, guarnecida con un amplio bocel, tal y como se especificaba. En torno al mismo, se despliegan ocho molduras cuadrangulares con sus ángulos cortados en redondo que se amplían según se aproximan a las ventanas que les corresponden. 


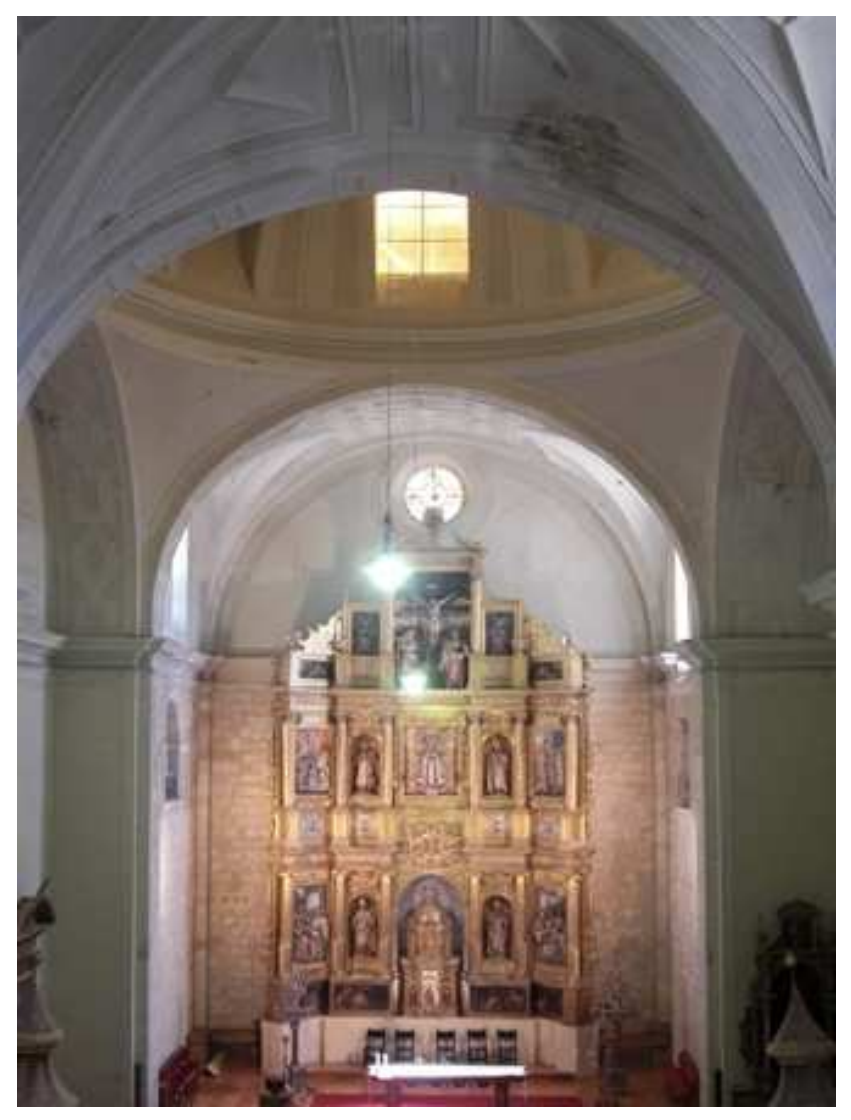

Iglesia de San Zoilo desde el coro, con el retablo mayor al fondo.

Respecto al tramo restante de la nave, más estrecho que los dos anteriores, contiene en sus lados un par de lunetos que voltean en una bóveda de arista en la que se han tallado ocho puntas de diamante. El pavimento de los tres tramos se acordó que fuera enladrillado. La ejecución de las ventanas correspondientes a los vanos de los tres tramos mencionados corrió a cargo del vidriero palentino don Cristóbal Álvarez. El monasterio le contrató en septiembre de 1643 para ejecutar un total de ocho vidrieras cuadradas: dos en el presbiterio, cuatro en la cúpula del crucero y dos en el tramo de la nave, además de la claraboya del testero, ubicada sobre el ático del retablo mayor ${ }^{1689}$. Dado que el artesano vivía y poseía su taller en la capital palentina, la comunidad convino suministrarle carros y caballos para desplazarse hasta el convento una vez lista la obra, prevista para Pascua de 1644, además de proporcionarle alojamiento y víveres para el tiempo que tardase en asentarla.

${ }^{1689}$ Las condiciones se firman en el monasterio de San Zoilo el 23 de septiembre de 1643. AHPP. Carr.Prot 5425. Francisco Moro Saldaña (1643), s/f. 
Las obras correspondientes a esta mitad del templo debían quedar finalizadas en dos años, esto es, en agosto de 1644. No obstante, sospechamos que se retrasaron hasta finales de año, pues no es hasta principios del siguiente cuando se contrata la decoración pictórica de la cúpula del crucero, y se habla ya de "iglesia nueva". Francisco Ruiz de la Cámara, pintor vallisoletano de edad aproximada de veinticinco años, se comprometió a policromar la clave “...comforme lo pidiere la architettura..." y realizar una especie de trampantojo en los vanos de esta cubierta, de manera que los que poseían ventanas, debían prolongarse con vidrieras fingidas y las cuatro que decidieron cegarse, incluirían representaciones de Santos, de medio cuerpo, en perspectiva de sotto in $\mathrm{su}^{1690}$. Se eligieron a San Ildefonso, San Isidoro, San Leandro y San Fulgencio, que irían vestidos con casullas de monacales y palio, acompañados de la cruz de doble asta, dado que detentaron el arzobispado -San Leandro y San Isidoro, el de Sevilla, San Fulgencio el de Cartagena y por último, el arzobispado de Toledo correspondió a San Ildefonso. Todos ellos vivieron en el siglo VII y además les unen vínculos muy estrechos, pues San Fulgencio, San Leandro y San Isidoro, eran hermanos y San Ildefonso se convirtió tempranamente en discípulo de éste último. Todos ellos fueron grandes eruditos y fundadores de un nutrido grupo de cenobios benedictinos.

El contrato incluía además la pintura de las cuatro pechinas. Completarían el ciclo San Juan, bajo cuya advocación se situó la primera comunidad, San Zoilo y San Félix, cuyas reliquias fueron traídas al templo en el siglo XII, motivando la nueva dedicación del priorato y San Benito, fundador de la orden bajo la que se situó el monasterio a partir del siglo XV. Se representan así, los tres diferentes estadios que atravesó el cenobio desde su asentamiento hasta su pertenencia a la Congregación vallisoletana. Las condiciones especifican que todos ellos vayan acompañados de sus atributos respectivos, y además, de una tarjeta con las armas de Castilla y León, especificando que en la de San Benito, debía figurar un báculo entre el castillo y el león, y, sobre ellos, una estrella.

\footnotetext{
${ }^{1690}$ La escritura de contrato y condiciones fueron firmadas con Fray Plácido del Río el 2 de enero de
} 1645. AHPP. Carr.Prot 5427. Francisco Moro Saldaña (1645), s/f. 
En una fotografía antigua, correspondiente a la época de los jesuitas, se pueden apreciar aún las pinturas de las pechinas, que por tanto se conservaron hasta el siglo $\mathrm{XX}$.

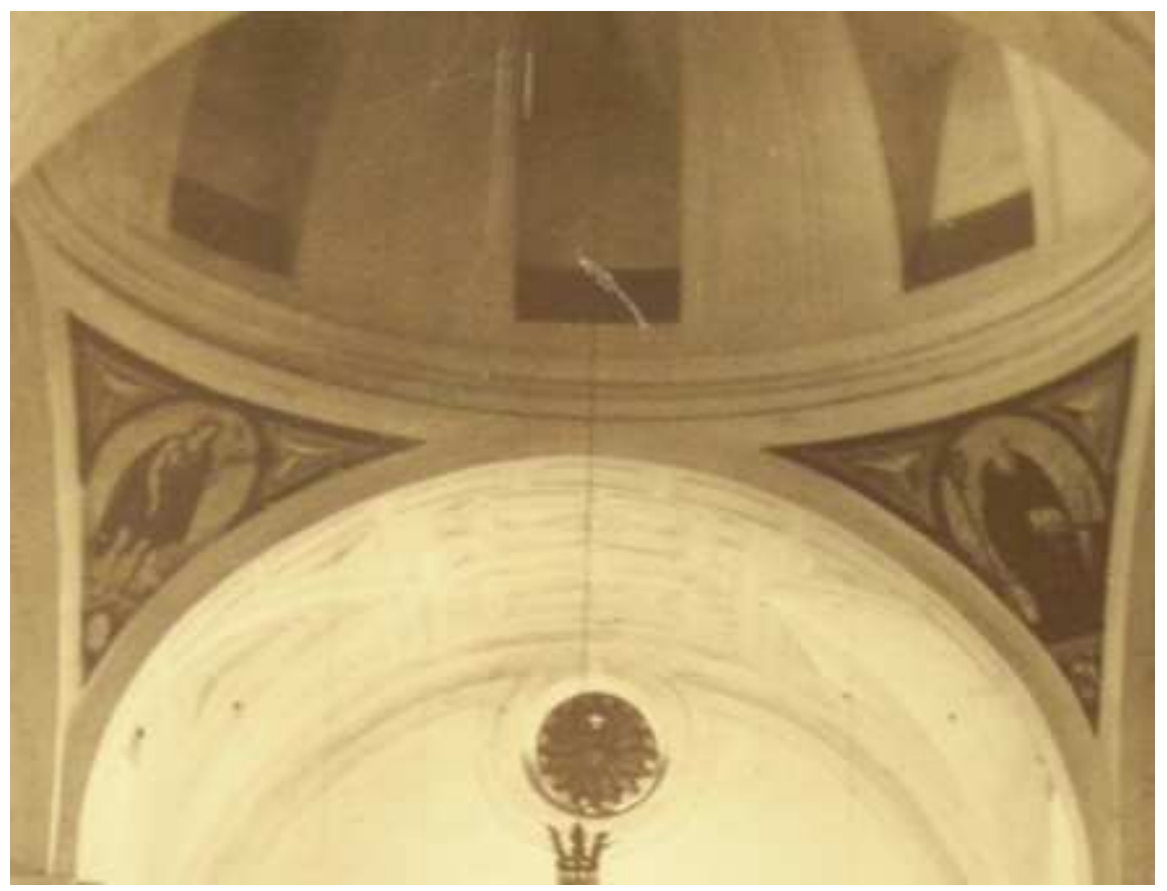

Pechinas de la cúpula representando a San Juan Bautista y San Benito. ACJAH. C11. Fotografías antiguas.

La elección de estos ocho santos, por tanto, no es arbitraria, sino que se integra en un programa iconográfico bien meditado. Asistimos nuevamente a la rememoración de la fundación del cenobio y a la exaltación de los santos hispanos más insignes de la orden benedictina, como sucedía en el caso de los personajes representados en los medallones del claustro alto. El recuerdo de la familia fundadora, los Beni-Gómez, se mantenía vivo en la galilea, a través de sus cenotafios, por lo que no era necesario reiterar su presencia en las bóvedas. Todas estas pinturas existieron al menos hasta mediados del siglo $\mathrm{XX}$, pues algunas fotografías tomadas en la época en que los jesuitas ocuparon el colegio testimonian su existencia. Enlucidas posteriormente, sólo se conservan hoy día los vivos colores de la moldura estrellada de la clave de la bóveda. 
Otro indicio que señala una demora en las obras es el hecho de que hasta mayo de 1645 no se solicita el informe de dos maestros ajenos a la obra para ver y tasar las faltas y mejoras de la misma ${ }^{1691}$. Por parte de la comunidad benedictina, se persona Juan González de la Mata, maestro de albañilería local y por tanto, seguramente conocedor de los monjes. Del lado de los vallisoletanos se presentó Jerónimo de Avendaño, cantero trasmerano, en quien encontraron a un maestro ajeno al entorno palentino, como lo eran ellos. Ambos veedores, de mutuo acuerdo, tasaron las faltas halladas en la obras en 2.168 reales. Por un lado, el hecho de no haber realizado el tejaroz indicado de la cúpula central o no haber comunicado la sacristía y el coro mediante una escalera fueron dos omisiones severamente penalizadas para los artífices. Por otro lado, los monjes no proporcionaron los andamios convenidos, que los vallisoletanos tuvieron que poner por su cuenta y además, hicieron una serie de mejoras a las que no estaban obligados, como el haber lucido los tabiques de la iglesia antigua, blanqueado todas las cornisas del templo y refajado las pilastras, lo que ascendía a un total de 1.778 reales en "demasías". A la luz de los resultados, los tasadores convinieron que se les descontase a los maestros la diferencia entre ambos montantes ${ }^{1692}$.

No se llevaron a cabo más intervenciones en el templo hasta el abadiato del burgalés don Plácido de Quirós (1657-1661) ${ }^{1693}$. Entre los meses de junio y noviembre de 1659, Manuel de Salceda, que por entonces era vecino de la villa carrionesa, ejecutó la reja que separaba el presbiterio y crucero del resto del templo, así como el púlpito situado sobre la misma ${ }^{1694}$. La reja, de madera de pino, estaba formada por balaustres de una sola pieza rematados por arquitrabe, friso y cornisa. La ornamentación se complementaba por las armas que determinase el abad. Se asentaba sobre un pretil de cantería y contaba con tres puertas, una en cada lado y la

\footnotetext{
${ }^{1691}$ Además se otorga la última carta de pago en junio de 1646. AHPP. Carr.Prot 5428. Francisco Moro Saldaña (1646), s/f.

${ }^{1692}$ Declaración de Juan González de la Mata y Jerónimo de Avendaño como veedores de las obras, firmada en Carrión a 9 de mayo de 1645. AHPP. Carr.Prot 5427. Francisco Moro Saldaña (1645), s/f. ${ }^{1693}$ Tras este período, se trasladó al colegio de San Vicente de Oviedo en calidad de lector de teología entre 1661 y 1665 y abad en el mismo durante los cuatro años siguientes. ZARAGOZA PASCUAL, Ernesto. “Abadologio...Op.cit, pág. 298.

${ }^{1694}$ La escritura y condiciones de la obra fueron firmadas el 29 de junio de 1659 en el monasterio de San Zoilo. AHPP. Carr.Prot 5692, Norberto de Sandoval y Guevara (1659), fol 346 y ss. Sobre Manuel de Salceda, remítase al capítulo dedicado a los escultores y ensambladores locales.
} 
central, todas en madera de nogal, que aún subsistían en 1817, cuando Madoz visitó el templo ${ }^{1695}$. Del mismo material eran los púlpitos que Salceda realizó, pegados a la pared, en los extremos de la reja, por encima de ésta. El ambón debía ser ochavado, con sus entrepaños almohadillados y remate de cartelas y “...el buelo de la dicha cubierta se le a de dar conforme paresçiere al padre abbad...", lo que indica que quedaba por determinar ${ }^{1696}$. Los púlpitos sin embargo continúan hoy día en el mismo lugar para el que fueron realizados. Para el tornavoz se optó por una estructura campaniforme probablemente para favorecer la sonoridad, cuya parte superior la interrumpe un amplio bocel del que parte un elemento cónico rematado en una bola.

La segunda etapa correspondiente a la terminación de las obras del templo correspondió al primero de los tres abadiatos del palentino don Bernardo de Estúñiga, desarrollado en el cuatrienio que dio comienzo en 1665. Fue un personaje polifacético, gran amante de la poesía, autor de una crónica del monasterio, predicador de los monarcas Felipe IV y Carlos II, además de docente en teología ${ }^{1697}$. Estas obras fueron posibles gracias a la cuantiosa donación que legó a San Zoilo el monje benedictino Juan Aguado cuando falleció en $1666^{1698}$. Precisamente don Bernardo se concierta dicho año con el maestro cántabro Diego de Zorlado Ribero para finalizar el templo ${ }^{1699}$. Este artista además de tomar la obra, proporcionó la traza, pues además de figurar como "maestro arquitecto", en las condiciones declara que cerrará un arco toral según “...demuestra en ssu planta la letra B...”, que nos permite presuponer que habría entregado un proyecto previo. En el tiempo que ejecutó la obra, creemos que debió alojarse en la localidad palentina de Saldaña, donde residía el cuñado de Andrés de Zorlado, donde ya se alojó éste cuando realizó

\footnotetext{
${ }^{1695}$ MADOZ, Pascual. Diccionario...Palencia, 1984, Op.cit, pág. 69.

1696 Algunas fotografías de la época en la que los jesuitas estuvieron en el convento, se conserva todavía la reja pero debió de sustituir a la de madera, pues era de hierro. Así lo confirma Helguera, indicando que dicha reja preservaba el acceso de las mujeres al presbiterio. RAMÍREZ DE HELGUERA, Martín. El libro...Op.cit, pág. 152.

${ }^{1697}$ También fue abad en 1673-1677 y entre 1680 y 1685. ZARAGOZA PASCUAL, Ernesto. “Abadologio...Op.cit, pág. 299.

1698 BECERRO DE BENGOA, Ricardo. “El monasterio...Op.cit, pág. 89.

1699 Escritura de concierto y condiciones, firmada en Saldaña el 11 de junio de 1666. AHPP., Carr.Prot 5701. Norberto Sandoval y Guevara (1666), fol 499 y ss. Sobre este artista, véase el apartado dedicado a sus datos biográficos.
} 
obras para esta localidad ${ }^{1700}$. Además, a Diego de Zorlado se le pagan cada día 500 maravedíes por la “...yda, estadía y vuelta...”, lo que indica que no viviría en Carrión en el tiempo de la obra, siendo con toda seguridad Saldaña el lugar escogido, pues allí tomó a sus fiadores y firmó el contrato con el monasterio ${ }^{1701}$.

Diego de Zorlado se comprometió a realizar los dos últimos tramos del templo, de idénticas dimensiones, entre los que se incluía la ejecución del coro, así como su portada. La demolición del templo antiguo no se llevaría a cabo “...hasta

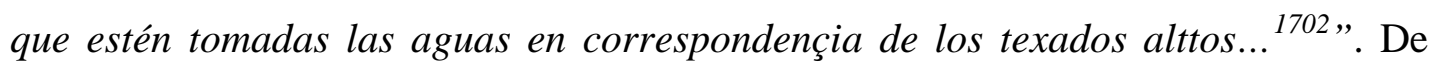
este modo, el lienzo septentrional del claustro quedaría más seguro y además la comunidad benedictina podría seguir haciendo uso del viejo coro en tanto se ejecutaba la nueva obra. Los dos tramos que debían ejecutarse, ocuparían el espacio existente entre el ámbito ubicado junto al crucero, y la capilla de los Condes, ubicada en el extremo occidental. Las pautas venían establecidas de la obra precedente, que había que seguir, en favor de la uniformidad del templo. Por ello se recurrió a pilastras cajeadas que voltean sobre bóvedas de arista adornadas con puntas de diamante y provistas de lunetos.

El primer tramo, ocupado por el coro, presentaba cegado su muro occidental, pues no fue hasta 1993 cuando se descubrió la portada románica que permitió la comunicación entre la galilea y el templo ${ }^{1703}$. Este fue dividido en dos niveles: el sotocoro, al que se accedía por un arco rebajado cuyas pechinas recibieron una tupida ornamentación de hojarasca. En su centro, se dispusieron las armas de la abadía de San Zoilo. Su lectura es partido por báculo, cordero con la cruz y mitra: 1, castillo y una mano con la palma. 2, león y mano con la palma. Timbrado con corona. Bajo su cubierta, formada por una bóveda de arista, se ubican los sepulcros procedentes del panteón condal, separados por una reja del resto de la iglesia.

\footnotetext{
1700 ALONSO RUIZ, Begoña. El arte de la cantería...Op.cit, pág. 86, a su vez de AHRC. Protocolo 1190, fol 417.

${ }^{1701} \mathrm{El}$ poder para tomar fiadores, indicando las pertenencias que el maestro ofrece como aval, se firman en Saldaña a 21 de mayo de 1666, siendo testigos Francisco Díez de Rabago, Alonso de Villota y Tomás de Minguera, ante Manuel de Soto. AHPP. Carr.Prot 5701. Norberto Sandoval y Guevara (1666), fol 507.

1702 Ibídem, fol 500.

${ }^{1703}$ Sobre los hallazgos, remítase al capítulo relativo a la fundación del cenobio.
} 
El retablo de la Magdalena, hoy en la nave de la Epístola, se ubicaba en este espacio, como así testimonia una fotografía de los años cuarenta en que se pueden ver que estaba flanqueado por dos santa Benedictinas, hoy ubicadas en el Museo Diocesano de Palencia. A los lados de este espacio, bajo arcos escarzanos, se conservan aún las ventanas abocinadas y las impostas de billetes procedentes del templo románico, cuyo perfil coincidiría con el de la nueva iglesia.

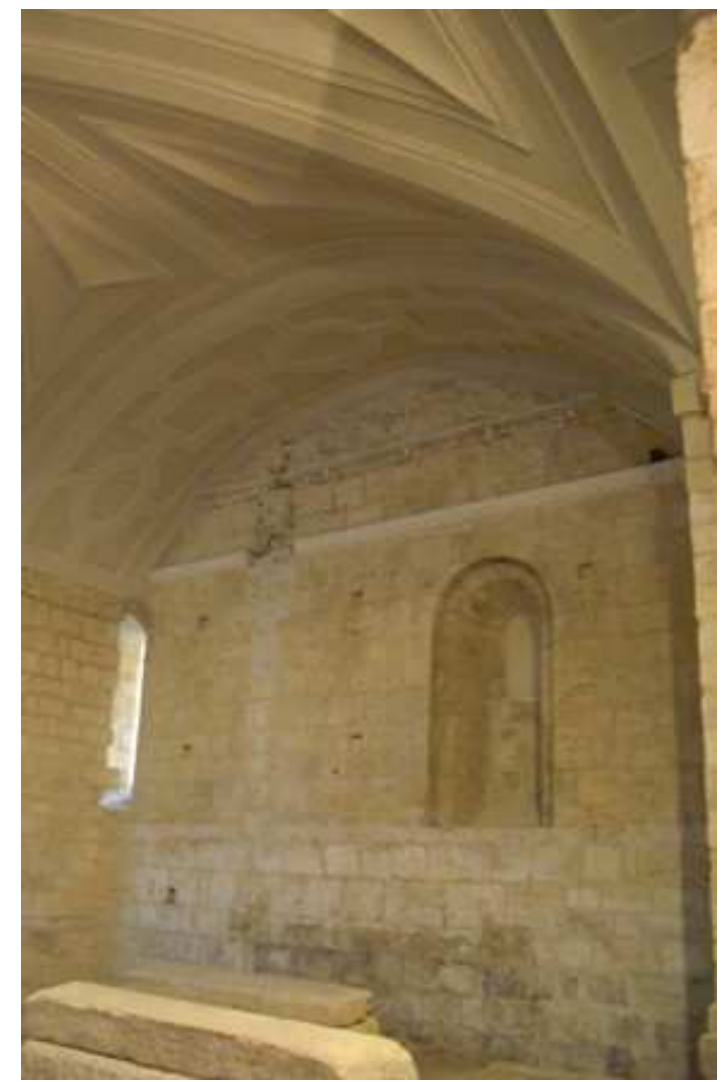

El coro bajo con la ventana abocinada del primitivo templo románico.

En el lado del Evangelio se dispuso una reja provista de dos escudos policromados: uno cuartelado de Castilla y otro es el escudo general de una abadía benedictina, que se repite en la fachada del templo, en el nicho presbiterial de la condesa Teresa y en el sepulcro del Abad Barrantes en el claustro. La única salvedad es que éste no es de piedra sino de hierro, como la reja y va policromado. ${ }^{1704}$.

\footnotetext{
${ }^{1704}$ Para no repetirnos, estudiaremos los elementos de este escudo cuando analicemos la portada del templo.
} 

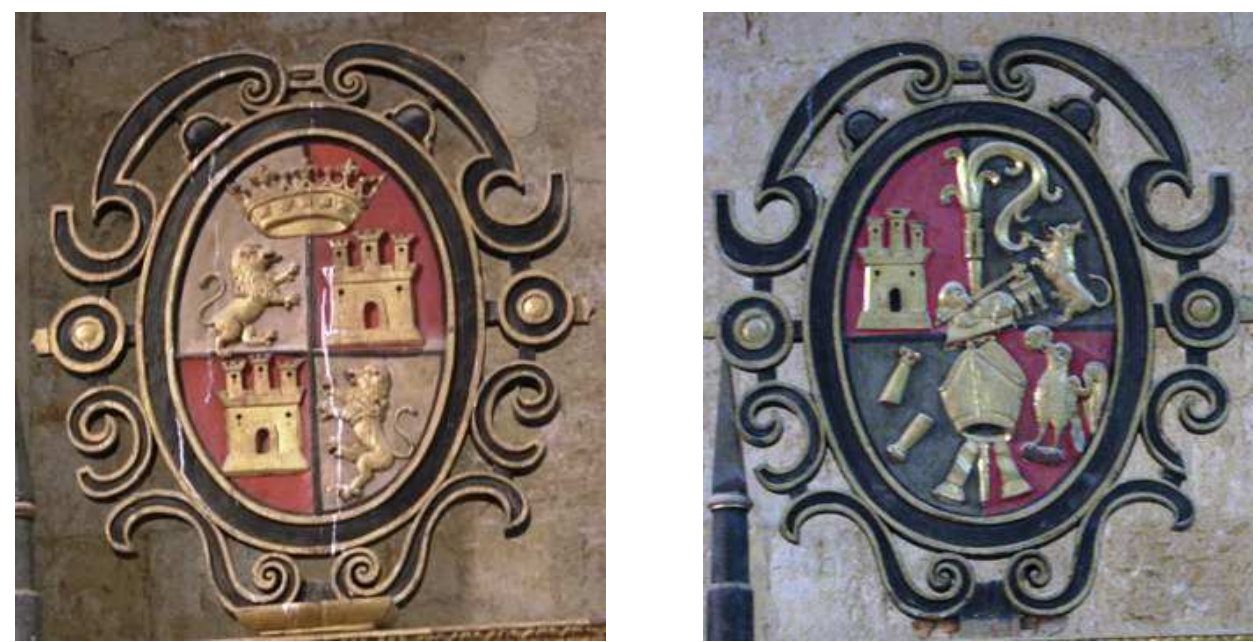

\section{Escudos de la reja del coro. Emblema de Castilla y León (izquierda) y escudo general de una abadía benedictina (derecha).}

Respecto al segundo tramo, de idénticas dimensiones que el precedente, va provisto, como aquél de una bóveda de arista con puntas de diamante talladas en la misma. Los laterales se compartimentan en dos niveles de una anchura aproximada de un metro, el primero de los cuales, a la misma altura que el sotocoro, se abre a la nave a través de un arco escarzano cuyas pechinas están provistas de unos "cogollos de talla”, traducidos en motivos de hojarasca. Sobre éstos, una cornisa de finísimas molduras a base de dentellones y elementos vegetales que se repiten, recorre estas dos alas y el sotocoro conformando una "U" que mira al presbiterio. El lado del Evangelio, que limita con la portada del templo, está abierto para acceder al mismo, donde se han colocado las puertas de doble batiente. El muro de la Epístola, por su parte, es soporte de restos pertenecientes al templo románico. En él se pueden observar una puerta de pequeñas dimensiones por la que se pasaría al claustro, una ventana abocinada con sus dovelas, de doble moldura, que comunicaría igualmente con esta dependencia, iluminando así el templo. Junto a la misma, se conserva una pintura mural en la que puede adivinarse el perfil de un cuadrante doble en el que se inserta una rueda, perfilada de negro, que nos habla de la antigua policromía que revestía las paredes. Encima de estos elementos se dispone una imposta de billetes enlucida de yeso para optimizar su conservación. Por último, en el ángulo, un capitel 
figurado hallado a raíz de unas labores de desenfoscado que tuvieron lugar en octubre de 1999, muestra una figura con toga y libro en la cara frontal y en la lateral, un hombre barbado mostrando las fauces de un león, tema repetido en Jaca o Loarre y referencia probable a la hazaña de Sansón o Hércules como prefiguraciones de Cristo $^{1705}$. En el piso superior, al mismo nivel del coro, Zorlado se comprometió a disponer “...dos tribunas en la capilla consecutiva...con los huecos de las salidas de los pilares..." que se cubren con bóveda de cañón ornamentadas con molduras geométricas. El hueco del Evangelio alberga el órgano barroco mientras que su frontero, que permanece vacío, ilumina la nave por medio de una lucerna abierta en el arco de medio punto del muro.

Zorlado se comprometió a finalizar las obras en mayo de 1668, recibiendo por su trabajo 65.000 reales, en cuya suma se incluía la ejecución de la portada ${ }^{1706}$. $\mathrm{Al}$ año siguiente, el maestro trasmerano se hallaba en Cantabria, otorgando finazas para la ejecución del puente de Tama, en Liébana ${ }^{1707}$. De su regreso a tierra natal podemos colegir la finalización de las obras. Sin embargo, Becerro de Bengoa señala que esta parte, incluida la fachada, no quedaron concluidas hasta 1693, en que el obispo de Tuy, don Anselmo de la Torre concedió al monasterio un generoso donativo con el que se saldaron las deudas contraídas y pudieron retomarse los trabajos tras un largo período de paralización ${ }^{1708}$. En aquel año fue nombrado abad don Jerónimo Ruiz, natural de la comarca palentina de Cerrato, que lo fue hasta 1697. Entre 1685 y 1686 había desempeñado el cargo de predicador en San Benito de Valladolid, así como el de secretario de la Congregación desde 1689 a $1693^{1709}$. El maestro habría quedado libre del trabajo en el año establecido de 1668, y algún otro cantero que desconocemos, se encargaría de rematar la parte que faltaba.

Podemos resumir, por tanto, la construcción del templo en varias fases: -1633-1641: Cimentación y muros de la capilla mayor.

\footnotetext{
1705 SENRA GABRIEL Y GALÁN, José Luis "Nuevos hallazgos románicos...Op.cit, pp. 88-95. Se analiza en el apartado relativo al siglo XII, a la que pertenecen estos restos.

1706 AHPP., Carr.Prot 5701. Norberto Sandoval y Guevara (1666), fol 499 y ss.

1707 ALONSO RUIZ, Begoña. El arte de la cantería...Op.cit, pág. 49, a su vez de AHRC. Protocolo 1167 , fol 81.

${ }^{1708}$ BECERRO DE BENGOA, Ricardo. "El monasterio...Op.cit, pág. 89.

${ }^{1709}$ ZARAGOZA PASCUAL, Ernesto. “Abadologio...Op.cit, pág. 301.
} 
-1642-1645: Melchor Ruiz, Tomás García y Domingo Ponce ejecutan la cubierta de la capilla mayor, crucero y tramo contiguo.

-1645-1666: Paralización intermitente de las obras.

-1666-1668: Diego de Zorlado finaliza los dos tramos restantes y ejecuta la portada. -1693: Se finalizan las obras tras un largo período de paralización de las mismas.

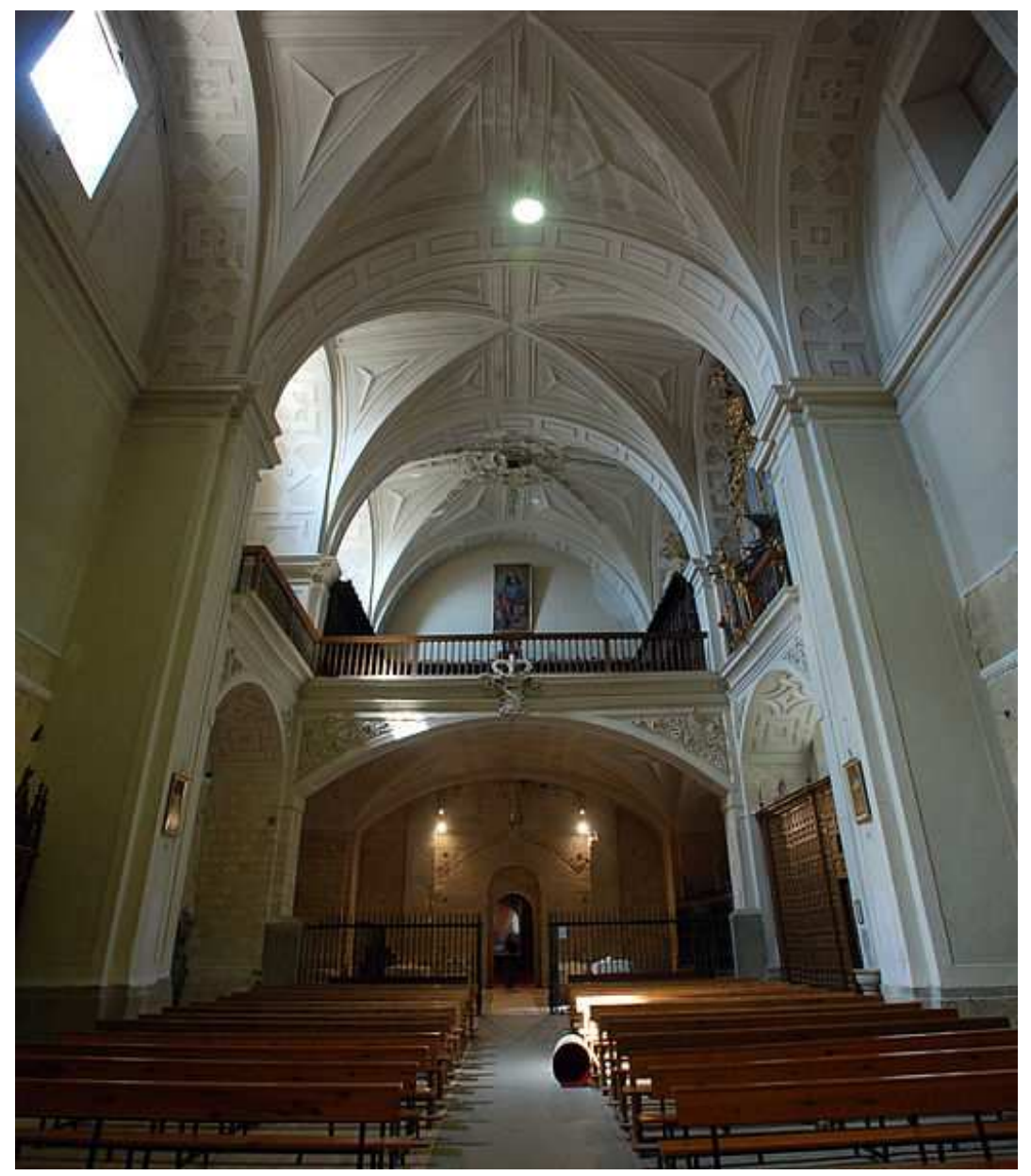

Iglesia de San Zoilo desde la cabecera.

Queda de este modo conformado un templo de una sola nave, dividida en cinco tramos, tres de ellos cubiertos con bóveda de arista, amplio crucero no marcado en planta y presbiterio más estrecho que el resto de la nave, con testero plano. Se trata, de una iglesia tipo sala, de corte clasicista, gran amplitud y altura, 
que se encuentra coronada por una media naranja trasdosada mediante un tejado a cuatro aguas $^{1710}$.

La Comisión de Monumentos palentinos habría deseado que el templo hubiera sido reconstruido en la misma época que su claustro porque en el siglo XVII "el arte clásico de Herrera llegó degenerado" o en todo caso que se hubiese optado por mantener la iglesia original, ya que “...a poca elegancia y carácter propio valdría más como curiosidad artística..."1711. El cambio de gusto respecto a los estilos a lo largo del tiempo es patente en los textos que algunos autores dejaron escritos sobre la iglesia de San Zoilo. La admiración que el templo despertó en Jovellanos, quien en 1795 expresaba: ... "grande y bella iglesia de una nave, bello retablo mayor de arquitectura....." dista ampliamente de los desdeñosos juicios emitidos a los largo del siglo XIX. Quadrado prefería que la autoría del templo permaneciese anónima para evitar el desprecio posterior del artista. En su opinión: “...La iglesia de San Zoilo no es simplemente grecorromana, ni barroca, ni de un dórico mal entendido en expresión de Ponz; ningún género de arquitectura deshonra porque a ningún género pertenece... más que iglesia, parece sala destinable a cualquier objeto menos al culto..."1712. Igualmente de estos años, la opinión de Becerro de Bengoa en la que expresa su rechazo: “...Corresponde, pues, la obra de este templo, en su interior y en su vulgar aunque vanidosa fachada, a aquella época...en que se hicieron toda suerte de innovaciones y variantes, dentro de la tendencia greco-romana, que nada notable dejó en las iglesias de nuestra patria... ${ }^{1713 ” . ~ A n a ́ l o g a s ~ a ~ e ́ s t a s, ~ e n c o n t r a m o s ~ m u c h a s ~ o t r a s ~ n o t i c i a s ~ m a n i f i e s t a s ~ d e l ~}$ desprecio que durante la centuria decimonónica despertó el estilo barroco en su tendencia clasicista.

\footnotetext{
${ }^{1710}$ No debemos denominarla iglesia de planta salón, pues ésta presenta una disposición basilical y debe poseer tres naves a la misma altura, y por tanto la iluminación proviene de los laterales. También puede que las naves no sean iguales, pero siempre que la diferencia de alturas no permita abrir vanos en la nave central, hablaremos de iglesia salón. PANO GRACIA, José Luis. "El modelo de planta de salón: origen, difusión e implantación en América" en Arquitectura religiosa del siglo XVI en España y Ultramar. Curso de la Cátedra de Goya en abril de 2003. Institución Fernando el Católico. Zaragoza, 2004 (actas), pág. 38.

${ }_{1711}$ ARASF, Leg.5-282-1, pág. 84.

${ }^{1712}$ QUADRADO; José María y PARCERISA, Francisco J. Op.cit, pp.132-133.

${ }^{1713}$ BECERRO DE BENGOA, Ricardo. "El monasterio...Op.cit, pp. 89-90.
} 


\subsection{LOS RETABLOS DE LA CAPILLA MAYOR Y LA MAGDALENA}

Antes de que se efectuase la remodelación completa del nuevo templo a partir de 1633, no sabemos el tipo de retablo que ornamentaría la capilla mayor de la iglesia románica precedente. A partir de entonces, y hasta el presente, han sido cuatro los retablos que han presidido la cabecera, dos de los cuales, que comentamos seguidamente, fueron realizados en el siglo XVII, pero se hizo uso de ellos en momentos muy diferentes. Los otros dos, en cambio, llegaron de la mano de los Padres Jesuitas, como tendremos oportunidad de ver posteriormente.

\section{El antiguo retablo mayor}

Las fuentes indican que durante uno de sus cuatrienios, don Juan González

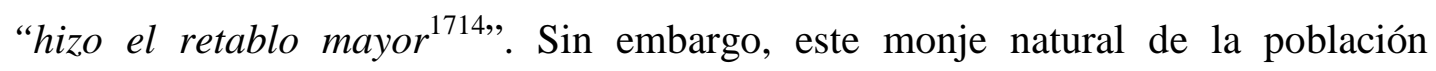
cántabra de Ruiloba, fue abad de San Zoilo hasta en cuatro ocasiones, de 1653 a 1657, de 1661 a 1665, desde 1669 a 1673 y por último, de 1677 a 1680, lo que ofrece un posible abanico de ejecución que oscilaría en torno al tercer cuarto de siglo $^{1715}$.

La documentación, en cambio, precisa que la escultura del retablo fue contratada el 7 de agosto de 1661 con el escultor gallego Alonso Fernández de Rozas, vecino por entonces de Valladolid ${ }^{1716}$. De este escultor, seguidor de Gregorio Fernández, tan sólo se conserva una obra documentada previa a este encargo: las esculturas del retablo mayor de Santa María de Tordesillas, trazado por Pedro de la Torre, realizadas en $1660^{1717}$. No obstante, los monjes benedictinos conocerían otras obras del escultor gallego que habrían justificado la elección, para nada arbitraria, de

\footnotetext{
${ }^{1714}$ Había sido abad en el cenobio gallego de San Pedro de Tenorio, en Pontevedra y en el asturiano de Obona, además de procurador de la Congregación (1629-1633). Su abadiato fue tan breve porque falleció en 1634. ZARAGOZA PASCUAL, Rafael. “Abadologio...Op.cit, pp. 298-299.

1715 Ibídem, pág. 299.

${ }^{1716}$ Escritura y condiciones firmadas en Carrión. AHPP. Carr.Prot 5768. Andrés Simón Aguilar (1660-61), fol 1011 y ss.

${ }^{1717}$ PARRADO DEL OLMO, Jesús María. "Nuevos datos....Op.cit, pág. 435.
} 
un artista que les asegurase una total satisfacción en el resultado. De todos modos, su trayectoria artística no podía ser demasiado prolongada, dado que por entonces contaba con unos treinta y cinco años de edad ${ }^{1718}$. A partir de este momento, se suceden un sinfín de encargos, la mayor parte en ámbito castellano, que avalan su pericia técnica, convirtiéndose en el escultor más afamado de Valladolid en el último cuarto del siglo XVII.

Debía ejecutar un total de seis esculturas de bulto redondo y entregarlas a finales de 1662. Entre ellas figuraban una Asunción rodeada de siete ángeles y “...quatro cauezas de seraphines en el trono y con su corona...”, San Juan, San Bartolomé, San Benito, San Félix y San Zoilo. Aunque el contrato no especifica más que los personajes que deben ir representados y la iconografía que ha de emplearse, podemos imaginar la disposición de cada uno de ellos dentro del retablo, dado el orden y modo con que se citan y la vinculación con el cenobio. Imaginamos que se compondría de dos cuerpos, divididos en tres calles. La imagen de Nuestra Señora centraría la composición del primero, pues se cita en primer lugar. A continuación se indica que deberán tallarse dos imágenes de San Juan y San Bartolomé. Puesto que el precursor de Cristo se ubica a la derecha, no cabe duda que el apóstol sería su frontero en el lado opuesto. San Benito y San Félix se citan seguidamente, pues irían sobre los santos previamente mencionados.

La advocación primera del cenobio al Bautista, las reliquias traídas desde Córdoba de San Félix, y la fundación de la orden benedictina a la que pertenece el monasterio por el santo nursiano, justifican su protagonismo en el retablo. En cuanto a San Bartolomé, si bien no tiene una vinculación específica con el cenobio, su elección no resulta baladí, pues en él se compendia la doble condición de Apóstol de Cristo y mártir cristiano, referentes clave en el Barroco desde que el concilio Trentino avivase su veneración. Finalmente, San Zoilo, como advocación principal del cenobio y patrón de Carrión centraría la composición en la parte superior. Por su trabajo, el maestro arquitecto Manuel de Salceda “...como perssona que tiene

\footnotetext{
${ }^{1718}$ Nació hacia 1625 como parroquiano de Santa María de Germán, en el Obispado de Mondoñedo, Lugo. Se esposó en 1656 con doña Isabel Fernández de Montoya en Valladolid, su lugar de residencia. GARCIA CHICO, Esteban. Documentos....Escultores...Op.cit, pág. 331. Sobre este escultor, remítase al apartado dedicado a los escultores.
} 
tomada la obra del rretablo mayor..." abonaría a Alonso de Rozas cuatro mil cuatrocientos reales.

A comienzos del siglo XVIII, el retablo debió experimentar alguna reforma o adición, pues Zaragoza Pascual señala que bajo el mandato del asturiano don Pedro de Granda, desarrollado entre 1701 y 1705, se “adornó el retablo mayor "1719", Nada más se supo a partir de entonces de este retablo. Quizá por encontrarse en pésimas condiciones fue sustituido a mediados del siglo XIX por el tabernáculo moderno que encargaron los jesuitas por entonces, también reemplazado por otro posteriormente $^{1720}$.

\section{El retablo actual, procedente de Baquerín de Campos}

El retablo que se conserva en la actualidad, datable como veremos entre 1642 y 1647, procede de la iglesia de Nuestra Señora de Arbás de Baquerín de Campos, de donde fue trasladado hacia 1986 por el Obispado de Palencia. La razón de dicho desplazamiento se debió a la ruina inminente que presentaba el presbiterio del templo palentino, que de hecho, se hundió poco después. Había que tomar medidas preventivas antes de que sobreviniese la catástrofe, y no había demasiados templos en Palencia capaces de alojar una pieza de semejantes dimensiones. Fue trasladado provisionalmente a San Zoilo, donde se depositó un tiempo hasta que se decidió que lo mejor era proceder a su montaje, dado que el retablo que por entonces presidía el presbiterio, realizado por los jesuitas, no era una pieza de demasiada calidad ni valor artístico $^{1721}$.Dorado y policromado, el retablo está compuesto de un banco, dos grandes cuerpos divididos en cinco calles y ático. Adopta una estructura de tríptico, con los laterales oblicuos, que se adaptarían al espacio ochavado del ábside de la iglesia de la cual procede ${ }^{1722}$.

\footnotetext{
1719 ZARAGOZA PASCUAL, Ernesto. “Abadologio...Op.cit, pág. 302

${ }^{1720}$ Sobre la época jesuita, ver el apartado relativo a los siglos XIX y XX.

${ }^{1721}$ Se trataba del retablo de época de los jesuitas que veremos en el apartado relativo a los siglos XIX y XX.

${ }^{1722}$ Actualmente la iglesia de Arbís de Baquerín de Campos se encuentra en estado de total abandono ocasionado por el derrumbe de las cubiertas pero puede apreciarse su ábside poligonal reforzado con contrafuertes. Un dibujo de la planta del mismo en ADP. Baquerín de Campos. Iglesia de Nuestra Señora. Libro 1.
} 


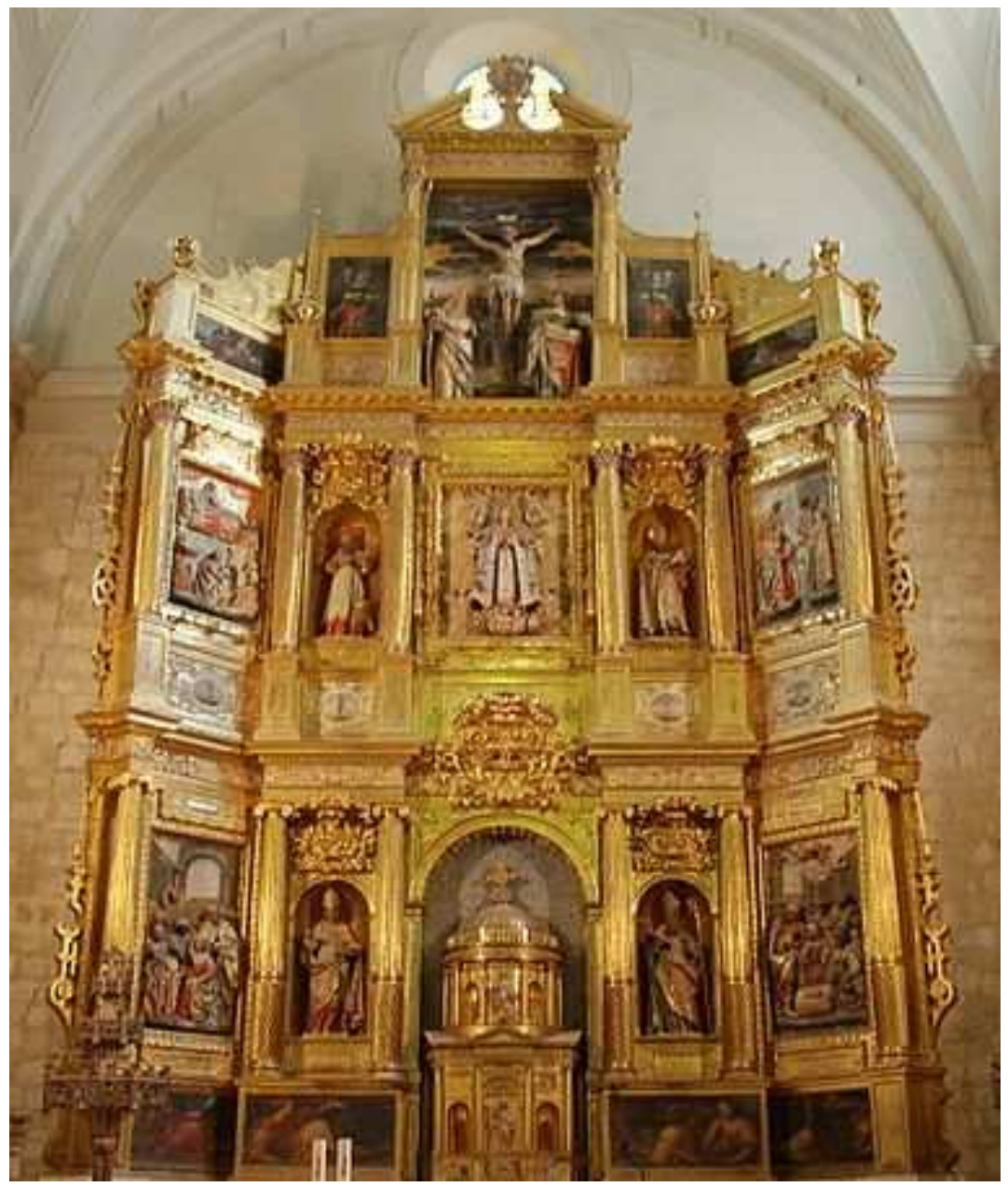

Retablo mayor de San Zoilo, procedente de Baquerín de Campos, Palencia.

La predela está constituida por cuatro tablas de mediana calidad y formato apaisado cuyo protagonismo lo detentan las Virtudes cardinales. Se disponen recostadas, monumentales, destacándose sobre un fondo neutro siguiendo este orden desde el lado izquierdo: La Prudencia, melancólica, se aparta del espejo, pues es ella quien debe discernir con precaución entre el bien y el mal, y no siempre este refleja la realidad tal y cómo es. Le acompaña la Justicia, sostiene firmemente la balanza, mientras que con la otra mano blande la espada, ambos atributos ya presentes en la diosa Themis, como referentes de la aplicación de la autoridad con equidad ${ }^{1723}$. En el

${ }^{1723}$ SÁNCHEZ PRIETO, Sara. "El espejo de la justicia: acercamiento a sus principales símbolos e imágenes” en Lex Nova, n59, 2010, pág. 40. 
lado derecho la Templanza lucha racionalmente contra los placeres mundanos, de ahí que aparezca representada sosteniendo una jarra volcada y un plato vacío. Por último, la Fortaleza sostiene el peso de una gran columna evidenciando su energía física y en último sentido, intelectual. Estas pinturas fueron realizadas con bastante posterioridad a la ejecución del retablo, correspondiendo su factura a Alonso Gómez $^{1724}$. La profesión en la que verdaderamente destacó fue en la de dorador, lo que justificaría su falta de pericia en la ejecución de estas pinturas.

En el primer cuerpo, bajo un arco de medio punto centra la composición un tabernáculo a modo de templete renacentista formado por dos cuerpos sobre un zócalo sustentado por columnas torsas corintias. En él se representan en bajo relieve a los cuatro evangelistas recostados, en actitud de escribir, acompañados por sus respectivos atributos. En los extremos, San Lucas, en el lado izquierdo y San Marcos, en el lado derecho, mientras que San Juan y San Mateo se hallan en la parte central, uno frente al otro. Sobre ellos, en el primer nivel y bajo un frontón clásico, un Cristo redentor custodia la puerta de este templo. Un cuerpo circular cupulado remata el conjunto, en cuyo centro se sitúa Santo Toribio de Liébana, identificado con su cartela, que porta mitra, báculo y libro. Las calles laterales van separadas por columnas de orden jónico que combinan las formas estriadas en los dos tercios superiores del fuste, siendo torsa su parte inferior.

Este elegante tabernáculo, exponente de la sobriedad escurialense, presenta hoy día sus hornacinas vacías. Contenía las imágenes de pequeño formato de San Esteban, San Jerónimo, Santo Domingo de Guzmán, de 47 centímetros de altura y las de San Pablo, San Pedro de 42 centímetros. Se desconoce el año exacto de su desaparición, pero es seguro que se produjo cuando el retablo ya había sido trasladado al monasterio benedictino, es decir, después de 1986, pero no fueron denunciadas hasta dos décadas después ${ }^{1725}$. Las esculturas de estos Santos según nos informa Martín González, se debían a la mano de Tomás de Sierra ${ }^{1726}$.

\footnotetext{
${ }^{1724}$ MARTÍN GONZÁLEZ, Juan José. Escultura...Op.cit, pág. 266. Sobre Alonso Gómez, remítase al capítulo dedicado a los pintores locales.

${ }^{1725}$ El propio Presidente de la Delegación Diocesana de Patrimonio Cultural de Palencia, don José Luis Calvo Calleja, me mostró muy amablemente la denuncia de 2006 y me proporcionó la información expuesta.

${ }^{1726}$ MARTÍN GONZÁLEZ, Juan José. Escultura...Op.cit, pág. 266. Sobre Tomás de Sierra, remítase al capítulo dedicado a la biografía de los escultores.
} 

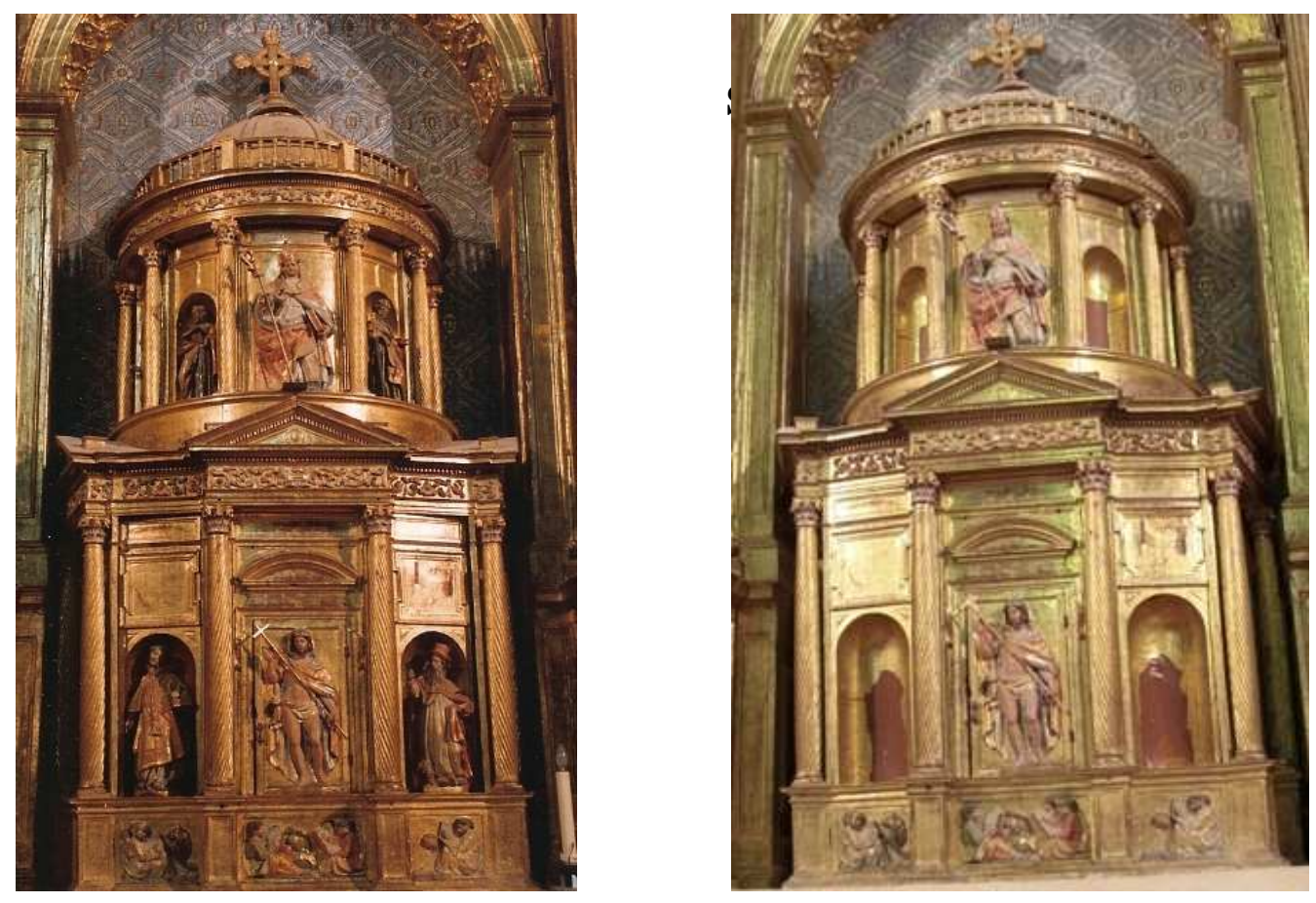

Sagrario del retablo mayor de San Zoilo antes y después del robo de las esculturas. (3,35metrosx 1,75metrsx 0,7 metros).
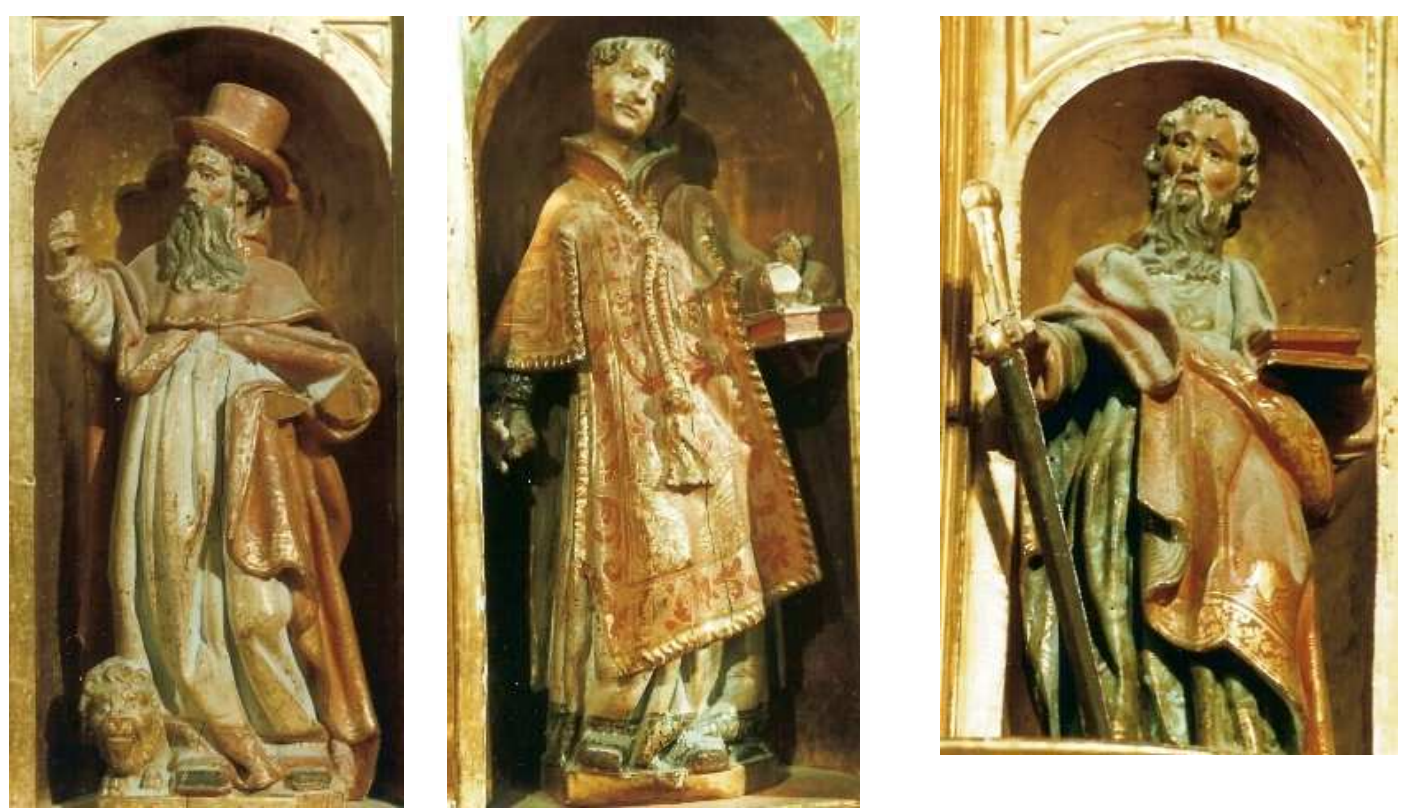

San Jerónimo (47cmx21cm). San Esteban $(47 \mathrm{~cm} x 23 \mathrm{~cm})$. San Pablo $(42 \mathrm{~cm} \times 17 \mathrm{~cm})$.

Algunas de las imágenes que se perdieron en el robo de hacia 1986, atribuidas a Tomás de Sierra. 
El segundo cuerpo, emplea como soportes seis columnas corintias torsas entre las cuales figura una talla de la Asunción, cuya ejecución es alabada por Jovellanos cuando visita el cenobio el 20 de abril de $1795^{1727}$. Responde a la tipología de Inmaculadas de Gregorio Fernández, reconocible por la clásica cadencia acartonada de los pliegues y la caída simétrica de la cabellera, dividida en cuatro largos mechones ondulados a cada lado. La Virgen porta una amplia túnica con repintes florales del siglo XVIII, atada en la cintura con una lazada y cubre sus hombros con un manto azul tachonado de estrellas en cuya orla se superponen varios capullos en flor de los que brotan termes que sustentan cartelas con cueros recortados. Su rostro de facciones redondeadas, se aleja ya de los tipos más ovalados del escultor gallego. En torno a la misma, seis angelillos colocados simétricamente en dos grupos de tres, adoptan idéntica pose los de un lado a los de su frontero. Los querubines de la parte superior, sentados sobre algodonosas nubes, alzan sus brazos para coronar a la Virgen; los de la parte central, dispuestos de perfil uno mirando al otro, la sostienen por los hombros y en postura de tres cuartos, a los pies de Nuestra Señora, le flanquean otros dos, asiendo su manto.

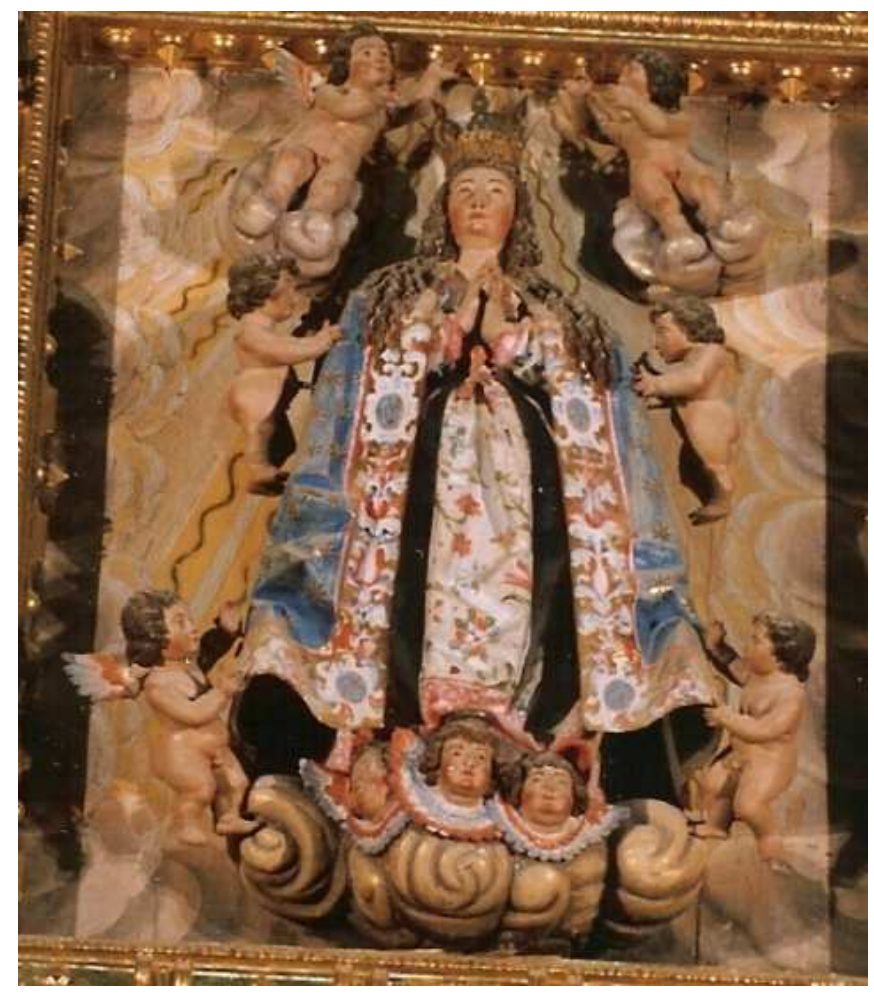

Inmaculada del retablo mayor. $190 \mathrm{~cm} \times 85 \mathrm{~cm}$. Seguidor de Gregorio Fernández.

${ }^{1727}$ JOVELLANOS, Gaspar Melchor de. Diarios, 2. Instituto de Estudios Asturianos. Oviedo, 1594, pág. 31 
Los bultos de los cuatro Padres de la iglesia occidental, de unos dos metros de altura, se disponen en ambos cuerpos flanqueando la hornacina central. Estas cuatro imágenes pertenecen igualmente a la mano de Tomás de Sierra. San Gregorio Magno y San Ambrosio se sitúan en el nivel inferior, mientras que San Jerónimo y San Agustín figuran junto a la Virgen. Éste último recuerda vivamente a la figura homónima de pequeño formato que se ubica en el relicario de la Colegiata vallisoletana de Villagarcía de Campos de cuya obra se encargaría el escultor berciano hacia $1692^{1728}$. Los rostros de todos ellos irradian una gran serenidad y los pliegues de las capas pluviales, en especial la de San Gregorio y San Agustín se sostienen ingrávidos en torno a los personajes creando una gran sensación de volumen. Presentan, sin embargo, una apariencia metálica y perfiles afilados que les dota de cierta rigidez. El modo de recoger los paños, en el caso de San Gregorio, es muy similar al que presenta la escultura de Santa Ana procedente del Hospital de Medina de Rioseco, de la misma época que nuestra escultura. Los cueros recortados que se ubican sobre las cuatro imágenes fueron añadidas en las postrimerías del siglo XVII tal vez por Pedro Solana ${ }^{1729}$.

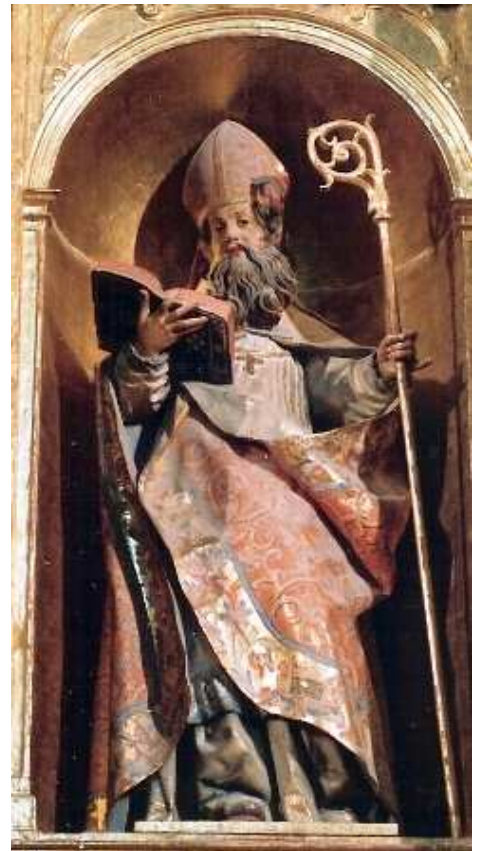

San Agustín $(165 \mathrm{~cm} \times 65 \mathrm{~cm})$.

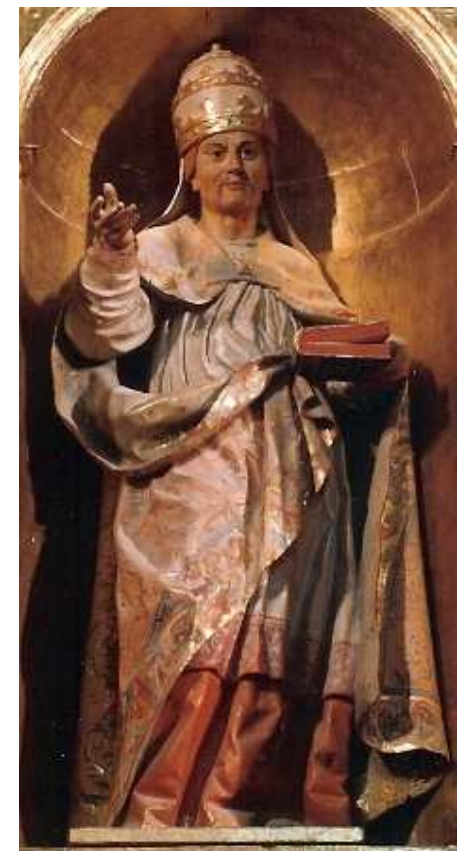

San Gregorio Magno $(163 \mathrm{~cm} \times 64 \mathrm{~cm})$.

\footnotetext{
${ }^{1728}$ MARTÍN GONZÁLEZ, Juan José. "El relicario de la Colegiata...op.cit, pp. 43-52.

${ }^{1729}$ MARTÍN GONZÁLEZ, Juan José. Escultura...pág. 266.
} 
En lo que a las calles laterales respecta, hay en ellas cuatro escenas en bajorrelieves de remarcable factura, que adolecen, sin embargo, de cierta ingenuidad. Los dos del cuerpo superior representan el Nacimiento de la Virgen y la Visitación. En la primera de estas escenas hallamos la clásica compartimentación en dos niveles: en la parte superior, sobre un cortinaje pintado, Santa Ana, recostada en una cama, es asistida por una partera, mientras San Joaquín presencia el feliz acontecimiento. Bajo ésta, varias mujeres se encargan de los cuidados de la recién nacida. Una de ellas se distrae contemplando lo que ocurre en la habitación, mientras la mujer del centro acaba de lavar a la Virgen en la pila dispuesta a tal efecto y otra acude presurosa a secarla. En la Visitación, aparte de las figuras de la Virgen y su prima Isabel en primer término, figuran sus respectivos maridos, en segundo plano y bajorrelieve. San José, detrás de María, avanza decidido hacia Zacarías, reconocible por su poblada barba canosa, que alza su sombrero en actitud de júbilo. El perfil de ambos varones se recorta sobre un fondo donde nuevamente la arquitectura y el paisaje han sido fingidos a través de la pintura.

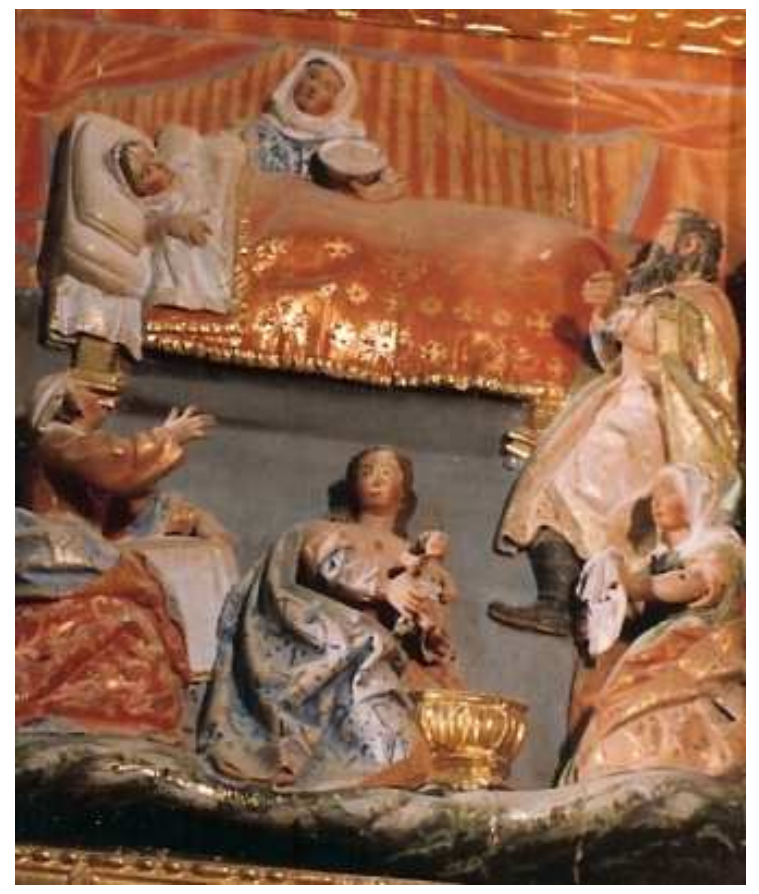

El Nacimiento de la Virgen. $(170 \mathrm{~cm} \times 110 \mathrm{~cm})$.

\section{La Visitación.}

$(170 \mathrm{~cm} x 110 \mathrm{~cm})$.

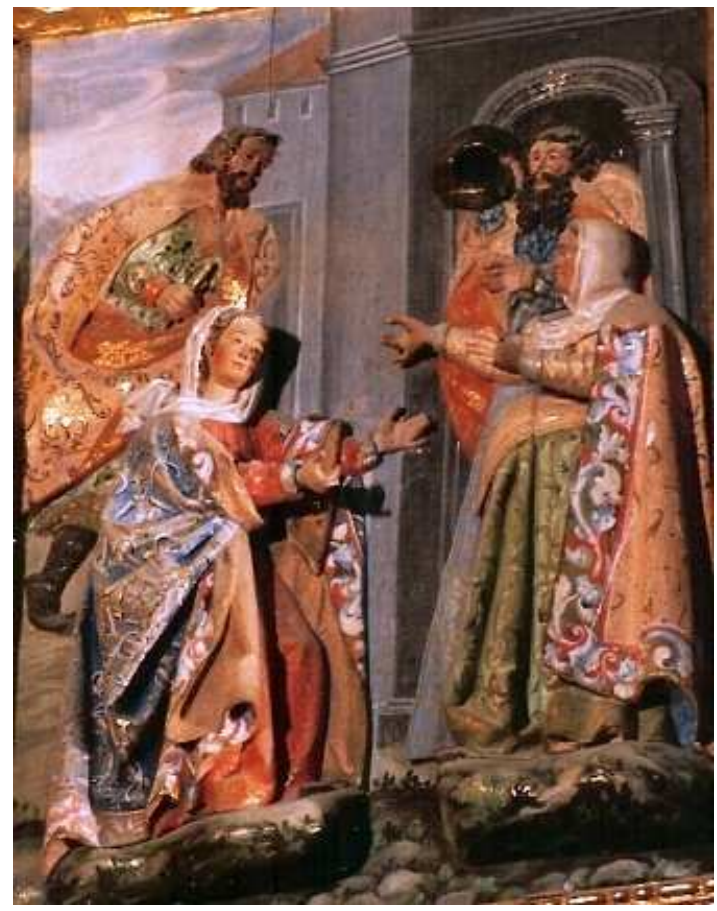




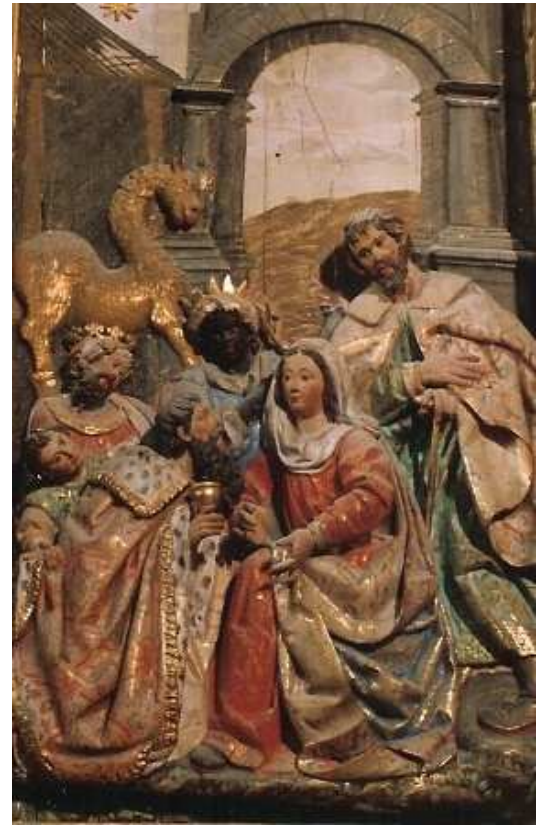

Adoración de los Reyes. $(170 \mathrm{~cm} \times 110 \mathrm{~cm})$.

En la escena de los Pastores, la Virgen, arrodillada entre ellos frente al Niño Jesús, peca de cierto hieratismo. San José, situado detrás de ella, de bellas facciones, asiste complacido a la escena. Su iconografía, que podemos contemplar mejor si cabe en la Adoración de los Reyes Magos, dada su representación de cuerpo entero, responde al modelo establecido por Gregorio Fernández. La devoción josefina del maestro

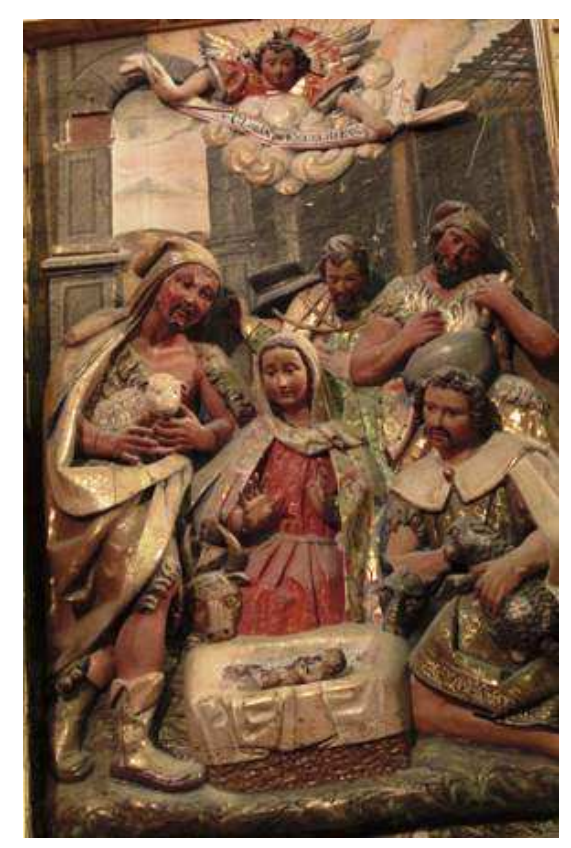
lucense conllevó la fijación de un tipo repetido Adoración de los pastores. incansablemente durante el siglo XVII en $(170 \mathrm{~cm} \times 110 \mathrm{~cm})$. la Meseta Norte, frente al prototipo montañesino del sur peninsular. San José figura como un hombre maduro, rejuvenecido respecto a la tradicional representación de anciano, que luce una generosa cabellera peinada hacia delante y barba hirsuta. Los dos elementos característicos de su vestimenta los constituye el manto, anudado al cuello, crea dos pliegues en forma apuntada y los borceguíes de cuero ${ }^{1730}$.

\footnotetext{
${ }^{1730}$ ARRIBA CANTERO, Sandra de. "San José en la obra de Gregorio Fernández: un estudio iconográfico" en Gregorio Fernández. Antropología, historia y estética en el Barroco. Valladolid, 2008, pp. 457-462.
} 
Remata la composición un grupo escultórico del Calvario. San Juan es una figura de gran teatralidad, que mira a Cristo mientras lleva una mano a su pecho y despliega la otra hacia el espectador, para convertirle en parte integrante de la escena. Bajo sus brazos, un amplio y voluminoso manto rojo, en relación al martirio, flota ajeno a las leyes de la gravedad en torno al cuerpo del Bautista. Por su parte, la Virgen está dotada de la gestualidad patente en las Dolorosas de Fernández, que alzan sus brazos, en este caso cruzados delante de su pecho con las manos extendidas. El rostro afligido, se gira levemente hacia un lado y el manto se quiebra en los clásicos pliegues acartonados de Fernández. No obstante, la imagen carece de la expresividad y el dramatismo del maestro. El Crucificado, si bien ha perdido la corona de espinas, muestra otros signos evidentes de su sufrimiento, como la sangre que mana de sus heridas, los cardenales de sus rodillas o la caja torácica excesivamente marcada. La expresión de su rostro, con la mirada dirigida al bajo y la boca entreabierta en actitud clamorosa denotan la agonía de quien está a punto de expirar. A ambos lados de la Déesis, dos pinturas de formato cuadrangular que representan dos ángeles portando las arma christi.

Cierra el ático un frontón partido que aloja una cartela de cueros recortados en cuyo interior se ha pintado el busto del Padre Eterno. Jesús Urrea señaló al círculo del toresano Antonio Ribera como autor posible del Calvario ${ }^{1731}$. Esta atribución queda probada con el hallazgo del testamento del escultor, dictado el 11 de marzo de 1647 en que se declara que ya había tallado el Cristo y estaba trabajando en las otras dos figuras ${ }^{1732}$.

${ }^{1731}$ URREA FERNÁNDEZ, Jesús y MARTÍN GONZÁLEZ, Juan José. Inventario...tomo 1. Op.cit, pág. 97. Por estas fechas ejecutaría un retablo en la iglesia de Gallegos de Hornija, probablemente el del Descendimiento, copia del paso que Fernández ejecutó para la Vera Cruz de Valladolid. PARRADO DEL OLMO, Jesús María. Catálogo monumental del Antiguo Partido Judicial de Mota del Marqués. Valladolid, 1976, pág. 56. Sobre Antonio de Ribera FERNÁNDEZ DEL HOYO, Ma Antonia. "Oficiales del taller de Gregorio Fernández y ensambladores que trabajaron con él" en $B S A A$, n $^{\circ} 49$, Valladolid, 1983, pp. 355-357.

1732 “...declaro que yo tomé una obra en la villa de Baquerín de Campos en cierta cantidad de maravedies concertado por primer y tengo entregada... una echura de un santo Cristo crucificado de seis pies de alto y por esta dicha echura me pagó 50 reales de que le dí recibo... y ansimismo declaro tengo comenzado azer para la dicha obra un San Juan al pie de la cruz y una ymaxen de nuestra señora, mando se acave de azer dichas dos figuras y se cobre lo que yo hubiere trabajado en dichas dos figuras y lo demás que se montare en acavarles se pague al que acavare y se cobre todo.." FERNÁNDEZ DEL HOYO, $\mathrm{M}^{\mathrm{a}}$ Antonia. "Oficiales...Op.cit, pág. 356, a su vez de AHPV. Leg. 14067, Matías Pére, fol 17y ss. Debemos pensar que Ribera finalizaría las dos esculturas que ya había comenzado, dado que no falleció entonces, sino más tarde. 
Respecto a la autoría del retablo, se atribuye a un seguidor de Gregorio de Fernández ${ }^{1733}$. Precisamente un oficial del gallego, Antonio de Ribera, había otorgado carta de pago en el mes de octubre de 1641 “.... a quenta de la obra que tiene obligación de hacer en la dicha yglessia de Baquerín de Campos, de los santos y etorias que ffabrica para el altar mayor ${ }^{1734, "}$. Según parece, tenía concertada la obra y sin embargo no se encargó de la misma como se deduce de su propia declaración en 1647 como autor tan sólo del Calvario, además de la atribución de algunas tallas del retablo a Tomás de Sierra ${ }^{1735}$. La ejecución de la obra debe oscilar con toda seguridad en este intervalo de años si tenemos en cuenta que en 1647 Ribera realizaba las esculturas del remate, parte final de la pieza, contratada seis años antes ${ }^{1736}$.

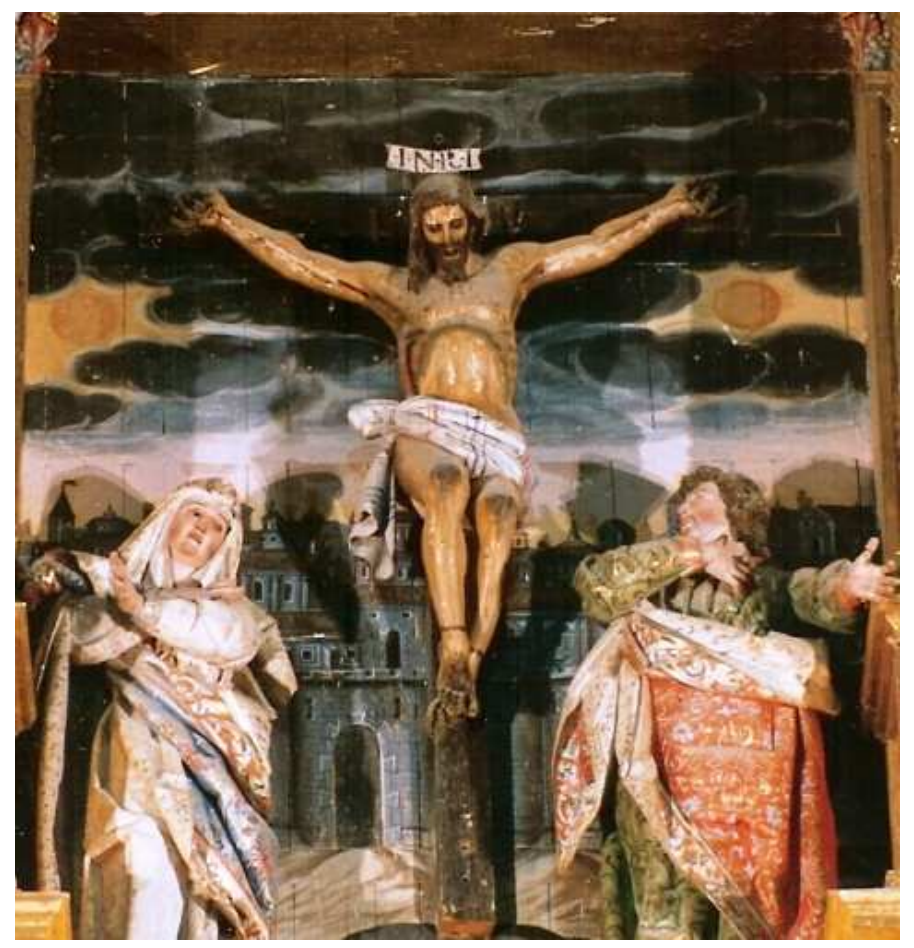

Calvario atribuido a Antonio de Ribera. $(140 \mathrm{~cm} x 160 \mathrm{~cm})$.

\footnotetext{
${ }^{1733}$ MARTÍN GONZÁLEZ, Juan José. Escultura...Op.cit, pág. 266. Urrea retrasa la fecha a 1647, pero somos partidarios de una fecha anterior, dado que de tratarse de esta fecha, figuraría su ejecución en los Libros de Fábrica que comienzan en 1646. URREA FERNÁNDEZ, Jesús y MARTÍN GONZÁLEZ, Juan José. Inventario...tomo 1. Op.cit, pág. 97.

${ }_{1734}^{17 E R N A ́ N D E Z ~ D E L ~ H O Y O, ~ M}{ }^{a}$ Antonia. "Oficiales...Op.cit, pág. 356, a su vez de AHPV. Leg. 2089, Matías Pérez, fol 679.

1735 Ibídem.

${ }^{1736}$ Además el libro de Cuentas de Fábrica más antiguo que se conserva de Baquerín de Campos comprende los años de 1646 a 1680 y en él no figura nada sobre el retablo, que tuvo que ser ejecutado, en base por otro lado a su estilo, con anterioridad.
} 
Jovellanos califica el retablo de bello, aunque las esculturas, excepción hecha de la Asunción, poco proporcionadas ${ }^{1737}$. Diversa opinión le merece a su ilustrado coetáneo, don Antonio Ponz, quien se expresa al respecto en estos términos: “...de razonable arquitectura, pero la talla de mal gusto, lo desterraría para siempre a la Sitia, o a la región de los Cafres" ${ }^{1738 .}$.

Tras el retablo, en el lado del Evangelio se encontraban las reliquias de San Zoilo $^{1739}$ y a la derecha del altar mayor, en una arqueta, las de San Agapio y San Félix $^{1740}$, todas ellas desaparecidas en el expolio de la Guerra de la Independencia $^{1741}$. La importancia de la posesión de reliquias es patente en la petición que desde Córdoba se hace de las de San Zoilo en 1600. Al abrir la arqueta de las reliquias del santo patrón, el abad halló su cabeza partida en dos fragmentos, muchos huesos, ropajes y una bolsa grande de cuero envuelta en un almaizal o gorro que contenía la siguiente inscripción: “Aquí yace el cuerpo de San Zoilo todo, e la camisa e la saya en que fue martirizado, e la su cinta, e la tierra de huesos menudos en otro palio e las candelas que ardían sobre la fuera. Por la gracia de Dios porque los cuendes hallaron el cuerpo de San Zoilo ${ }^{1742, " . ~}$

Unos años después, por mediación de Felipe III, la villa de Alcalá de Henares solicitó al convento de San Zoilo la restitución de las reliquias de San Félix. El por entonces abad Alonso Barrantes, entregó la mayor parte de ellas -se quedó con algunos huesos y cenizas- el 29 de diciembre de 1606, depositándose en la iglesia de los Santos Justo y Pastor de la célebre villa madrileña en enero del año

\footnotetext{
1737 JOVELLANOS, Gaspar Melchor de. Diarios, 2...Op, cit, pág. 31.

${ }^{1738}$ Es sabido el desprecio del viajero por toda manifestación artística de barroca, estilo al que critica, fundamentalmente, por su carácter recargado. PONZ, Antonio. Op.cit, pág. 200.

${ }^{1739}$ En 1600,Fray Plácido de Huercanos, abad de San Zoilo, Fray Juan de los Arcos, maestro general de la Congregación de San Benito y Fray Alonso Barrantes, definidor de la dicha congregación y predicador de San Zoilo fueron testigos de la apertura de la arqueta en que se encontraban las reliquias de San Zoilo para su certificación. AHN Clero Secular-Regular Legajo 5331. Documentos eclesiásticos y papeles de carácter religioso, s/f.

1740 VICENTE GONZÁLEZ, José de y AZORES TORRES, Mariano. Monasterios, cartujas y conventos en las rutas compostelanas españolas. TresCtres Editores. A Coruña, 2004, pp.. 170, 171

${ }^{1741}$ PERAL VILLAFRUELA, Santiago y GÓMEZ PÉREZ, Enrique. Op.cit, pág. 75.

1742 BNM. LLORENTE DE ALCÁZAR Y MENDIZÁBAL, Juan Antonio. Noticias históricas de la villa de Carrión de los Condes esparcidas en diversos historiadores y recopiladas para su instrucción particular. 1802, Fol. 13v y 14 y QUADRADO; José María y PARCERISA, Francisco J. Op.cit, pág. 134.
} 
siguiente ${ }^{1743}$. Igualmente el cabildo de la localidad zaragozana de Sangüesa requirió sin éxito a la comunidad benedictina una reliquia de San Zoilo en 1657, basándose en la tradición que afirma la aparición del Santo en aquella villa y la fundación de su iglesia $^{1744}$. En 1697, por iniciativa del procurador de Roma, Fray Alonso de Mier, se encargó en Madrid la ejecución de dos nuevas urnas de plata y piedras preciosas para disponer las reliquias ${ }^{1745}$. La petición de reliquias de San Zoilo, no finaliza aquí, y en 1708 se le concede al obispo de Córdoba la canilla de un brazo de San Zoilo, dado el nacimiento del mártir en la ciudad andaluza ${ }^{1746}$.

\section{El retablo de la Magdalena}

En el brazo sur del crucero, adosado en el muro oriental, se halla un retablo del primer tercio del siglo XVII dedicado a la Magdalena, titular de la parroquia de San Zoilo. Ha sufrido modificaciones, pues carece de elementos que antes tenía y añadidos posteriores, aparte de haber sido trasladada de lugar, aunque siempre dentro del templo. Sobre un amplio banco ornamentado con sendas molduras en tonos mostaza que imitan jaspes, se asienta el cuerpo del retablo, de menor anchura que su pedestal. Cuatro columnas torsas sustentadas por ménsulas se ubican en los extremos. Los soportes internos se adelantan, creando el retranqueo del arquitrabe dispuesto sobre los mismos. Bajo la hornacina central, cuyas pechinas se ornamenta a través de puntas de diamante, se dispone una escultura de bulto redondo, pieza que no forma parte del retablo original. Se trata de una copia de la Magdalena Penitente de Pedro de Mena, realizada en 1803 por la Academia Vallisoletana ${ }^{1747}$. Belleza y espiritualidad se muestran en igual medida en el prototipo del escultor granadino. Si bien en Andalucía las réplicas de esta versión resultan exiguas, el prototipo sí gozó de una mayor aceptación en Castilla, donde se realizaron varias versiones. Una

\footnotetext{
${ }^{1743}$ YEPES, Fray Antonio. Crónica...Tomo VI. Op.cit,pág. 77 y AHPP. Desamortización 112. Índice del Archivo de San Zoilo. Caja 5a . San Andrés. Legajo 2. Cuaderno A. no 5.

${ }^{1744}$ AHPP. Desamortización 112. Índice del Archivo de San Zoilo. Caja 5a . San Andrés. Legajo 2. Cuaderno A. $\mathrm{n}^{\circ} 14$.

${ }^{1745}$ BECERRO DE BENGOA, Ricardo. "El monasterio...Op.cit, pág. 89 y VALLE CURIESES, Rafael de. A orillas del Carrión...Op.cit, pág. 100. El sermón dado por Fray Jacinto Díez, abad del monasterio con motivo de la entrega de las reliquias en DÍEZ, Fray Jacinto (O.S.B). Sermón historial gratulatorio en la entrada de dos urnas de plata para colocar los cuerpos de los gloriosos martyres y patronos de Carrión S. Zoil y S. Félix. Oficina de Eugenio Antonio García. Salamanca,1707.

${ }_{1746}$ El testimonio de la apertura de la caja se firma el 21 de diciembre de 1708. AHPP. Desamortización 112. Índice del Archivo de San Zoilo. Caja 5a . San Andrés. Legajo 2. Cuaderno A. $\mathrm{n}^{\circ} 21$.

${ }^{1747}$ MADOZ, Pascual. Diccionario...Palencia. 1984. Op.cit, pág. 69.
} 
réplica de la misma de los mismos años de la nuestra que evidencia el gusto por este tipo iconográfico, la realizó Claudio Cortijo en 1797 para la iglesia de Santa María Magdalena de la localidad vallisoletana de Castrillo-Tejeriego. En el ático, unos aletones avolutados sostienen un frontón triangular partido adornado por una serie de dentículos. Cobija en su centro un lienzo que representa un bodegón que remata en un frontón curvo. Esta pintura, que representa un jarrón con azucenas está fechada en el último tercio del siglo XVII y por tanto, no formaba parte del retablo original $^{1748}$. Esta representación se vincula directamente con la pureza de la Virgen María y prueba de ello es el anagrama "AM" inserto en el florero ${ }^{1749}$.
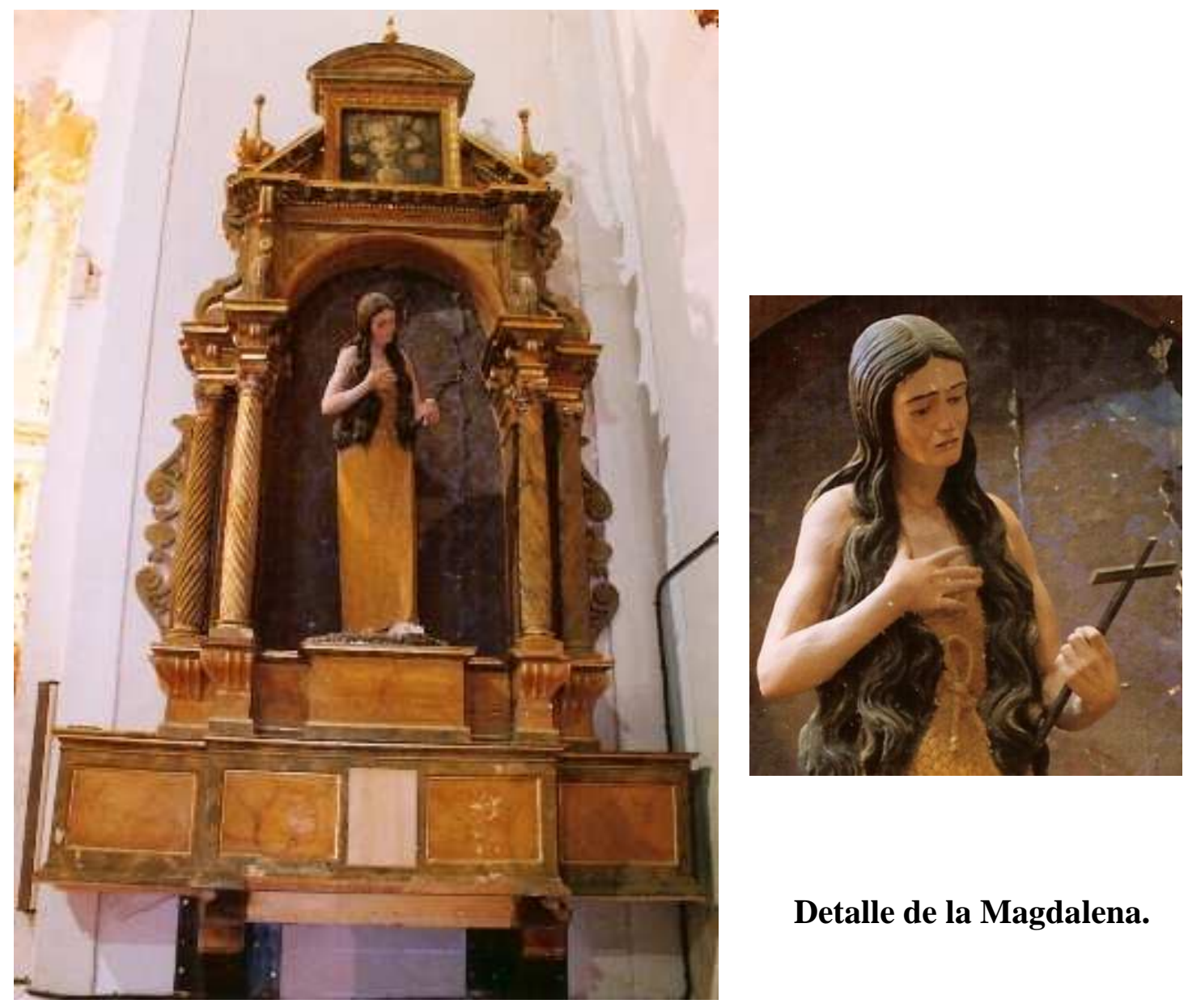

\section{Retablo de la Magdalena en el brazo sur del crucero de la iglesia de San Zoilo. $(150 \mathrm{~cm} \times 54 \mathrm{~cm} \times 56 \mathrm{~cm})$.}

\footnotetext{
${ }^{1748}$ URREA, Jesús. Y MARTÍN GONZÁLEZ, Juan José. Inventario...I. Op.cit, pág. 63.

${ }^{1749}$ Las letras mayúsculas A y M se cruzan, indicando así “Ave María”.
} 
El retablo se encuentra hoy día adosado al muro, elevado del nivel del suelo porque en origen se asentaba sobre una mesa de altar semejando las vetas del mármol y asentada sobre estilizadas columnillas. En época jesuita se ubicaba a los pies del templo, adosado en el lado del Evangelio del coro bajo, donde estuvo al menos hasta los años ochenta. Gracias a una fotografía de hacia 1940, tenemos constancia de que sobre la mesa de altar se hallaba el sagrario barroco procedente del retablo mayor de Santa Clara, hoy ubicado sobre la cajonería de la sacristía ${ }^{1750}$.

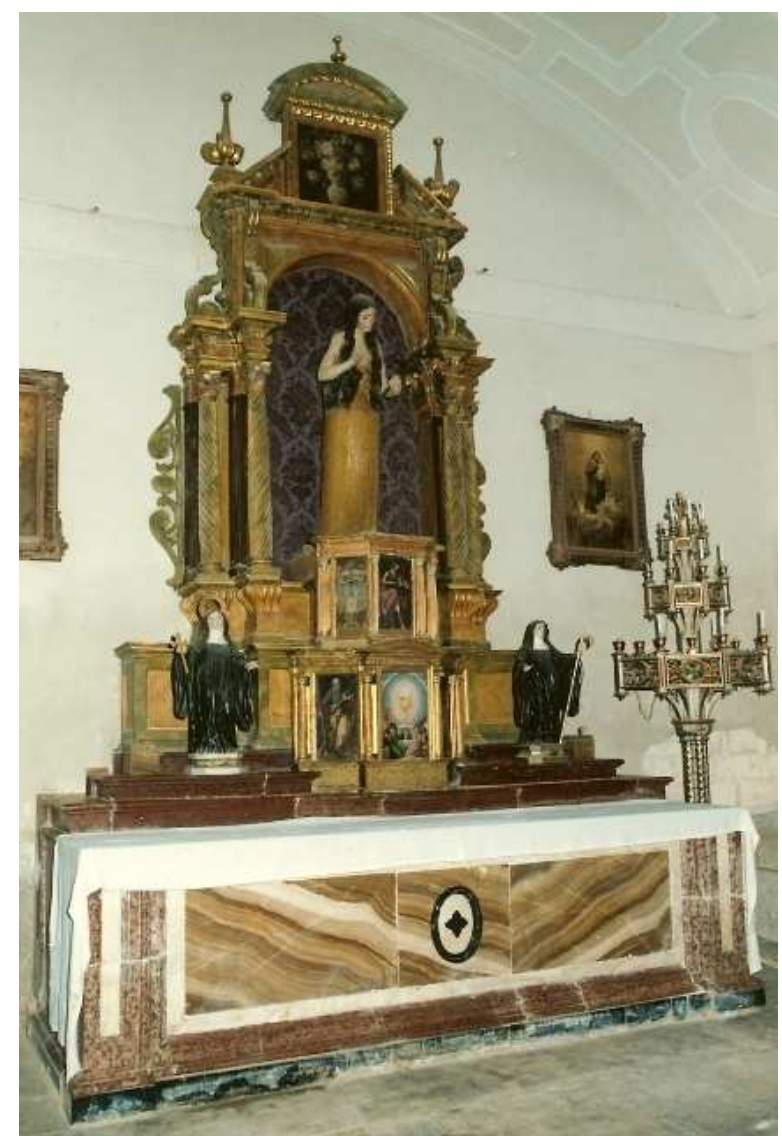

\section{Retablo de la Magdalena cuando se ubicaba en el coro bajo.}

Además acompañaban a la Magdalena las esculturas de dos santas de notable factura en buen estado de conservación. Se trata de dos santas vinculadas a la orden Benedictina, con el hábito tachonado de florecillas doradas y aureola de latón, también dorada. Son idénticas en sus rostros nacarados, que miran al cielo, e incluso

\footnotetext{
${ }^{1750}$ Al mismo nos referiremos en el capítulo dedicado al retablo mayor de Santa Clara, donde se encontraba en origen.
} 
en su pose, con los brazos abiertos y una pierna ligeramente adelantada. Tan sólo se diferenciaban por el atributo: un báculo y una cruz trebolada. Los plegados voladizos de las vestiduras de ambas santas con los contornos creando vivos perfiles nos señalan una datación de la primera mitad del siglo XVIII. La caída paralela de los pliegues de las túnicas y su tratamiento blando evoca la época más avanzada de Juan de Ávila, concretamente la Virgen de la Anunciación del convento vallisoletano de las Brígidas ${ }^{1751}$. Probablemente del segundo cuarto de la centuria, si se tiene en cuenta además la dulzura que emanan los rostros de ambas figuras. Las tallas fueron trasladadas al despacho del Delegado Diocesano de Patrimonio Cultural de Palencia, donde se conservan hoy día. La peana sobre la que se sitúan está provista de cartelas que las identifica como Santa Escolástica, hermana de San Benito, que ha perdido su aureola. Junto a ella, Santa Matilde, que carece del bastón pastoral. Con toda probabilidad se trata de la mística alemana del siglo XIV ya representada en las bóvedas del claustro bajo de San Zoilo, conocida como Matilde de Hefta o de Hackeborn. Aunque fue una monja cisterciense, tal vez fue su vida modélica la que justificó su inclusión entre las biografías de santas benedictinas ${ }^{1752}$.

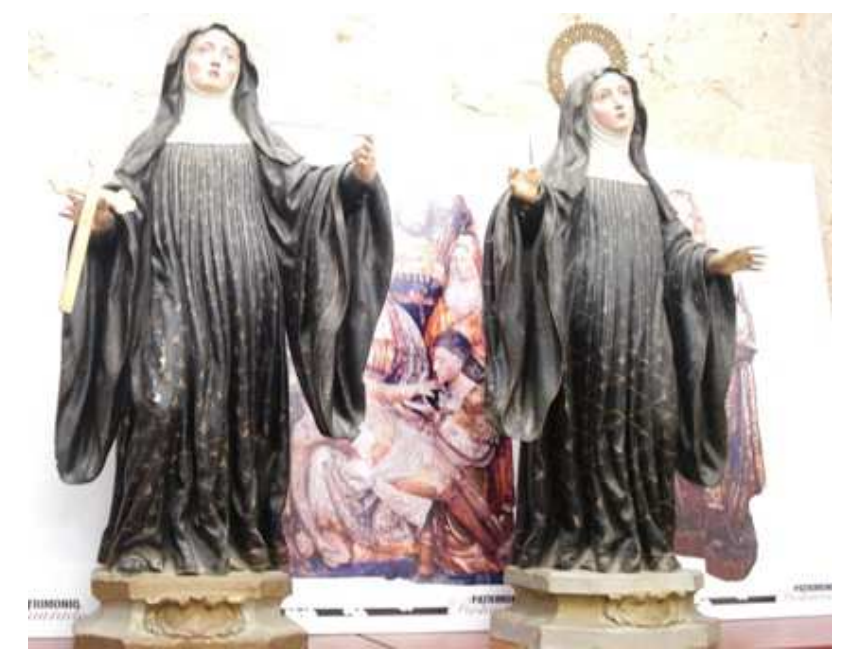

\section{Santa Escolástica y Santa Matilde en la Delegación Diocesana de Patrimonio de Palencia procedentes del retablo de la Magdalena de San Zoilo.}

\footnotetext{
${ }^{1751}$ Juan de Ávila talló dicha Virgen de la Anunciación hacia el año 1700. MARTíN GONZÁLEZ, Juan José. Escultura...Op.cit, pp. 323-324.

${ }^{1752}$ Sobre la misma, CIRIA RAXIS E INOJOSA, Pedro de. Vidas...Tomo I. Op.cit, pp. 330-332.
} 


\subsection{LA FACHADA BARROCA}

Ubicada en el hastial norte de templo, junto a la torre románica se yergue la imponente fachada pétrea de San Zoilo, desplazada al lado derecho del mismo. El resto de la edificación está realizada eminentemente en ladrillo, a excepción de la parte inferior de sillería y algunos fustes embutidos en el muro, ya que, ante la escasez de sillería en la zona, se opta por el aprovechamiento del perímetro del templo precedente.

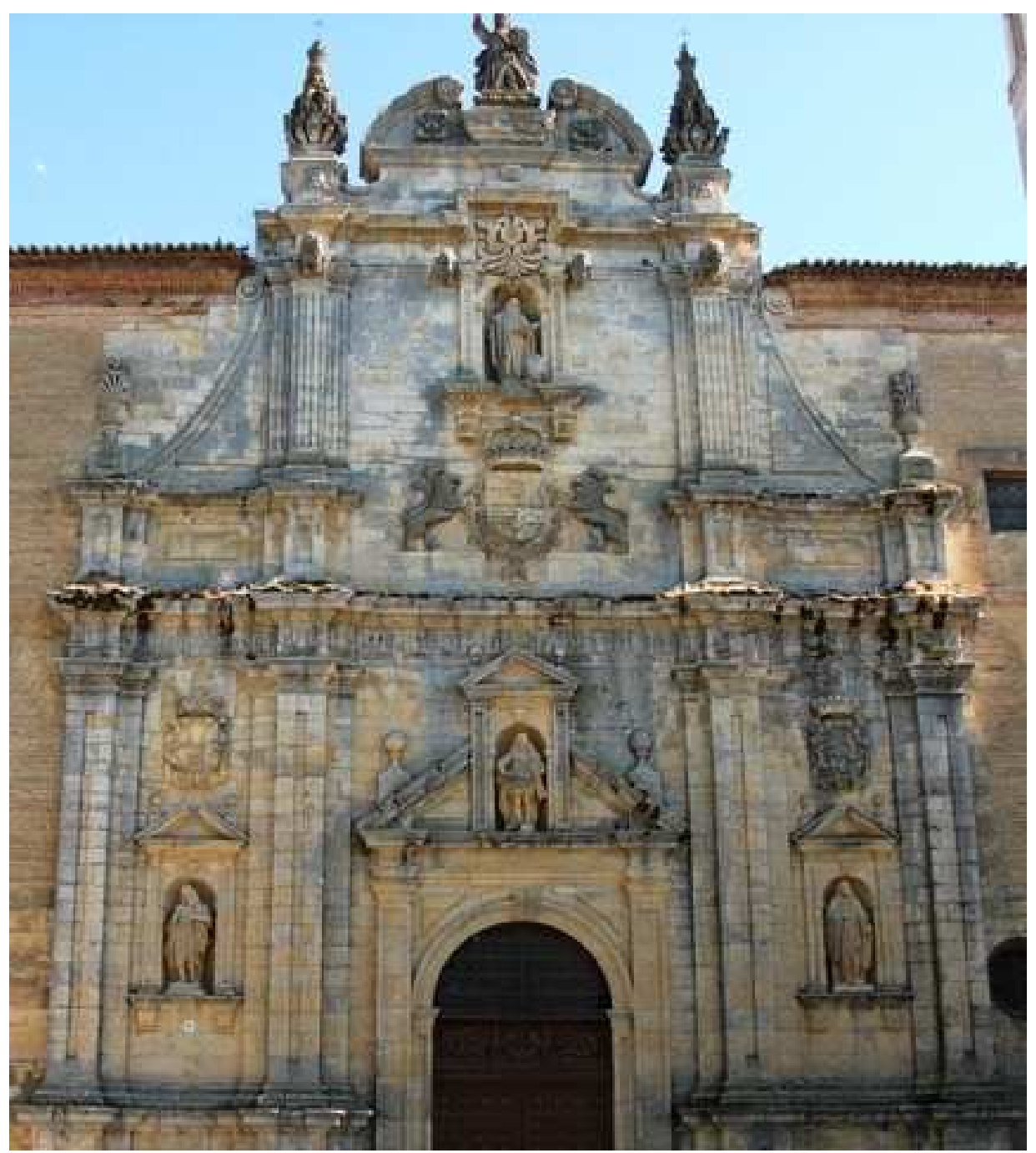

Fachada del templo de San Zoilo. 
La portada se articula en dos niveles, el inferior, de mayor desarrollo y piñón que sobresale de la línea de fachada. Sobre un plinto de notable altura, se elevan cuatro pilastras cajeadas que dividen el primer cuerpo en tres partes. A cada lado se disponen dos hornacinas flanqueadas por pilastras cajeadas que asientan sobre una pareja de repisas. Los soportes sustentan un frontón triangular partido de doble moldura a cuyos lados se disponen dos bolas sobre pedestales, motivo eminentemente herreriano.

San Juan Bautista, en la parte izquierda, es fácilmente identificado por su atuendo exiguo de piel de camello, a pesar de que su brazo derecho, con el que sostendría la cruz con filacteria o el cordero, ha sido amputado. Un amplio manto, aludiendo a su martirio, cubre tan sólo su hombro izquierdo, mientras el resto de su juvenil anatomía asoma de sus vestiduras de asceta. La figura, muy expresiva, entorna su cabeza hacia el alto, con su boca entreabierta, de gran fuerza comunicativa. Se puede ver con claridad que su mano izquierda, a pesar de que carece de tres de sus dedos, está extendida sobre su pecho. La iconografía habitual que le representa señalando con el dedo índice, en calidad de predicador o anunciador o con el dedo índice y anular extendido para bendecir, ha sido suplantada por otra, menos usual ${ }^{1753}$. En este caso, como en la representación del medallón del claustro alto, el Precursor de Cristo se erige más que como emisor, como receptor de un mensaje que emerge de las alturas.

En el lado derecho, San Félix, en actitud más reposada, porta el hábito benedictino, con la capucha que permite entrever la tonsura monacal del santo alcalaíno. De las amplias mangas emergen tímidamente sus manos, la una sostiene un libro, probablemente la Regla Benedictina; la otra, fragmentada, posiblemente sujetara la palma de martirio que sufrió en Córdoba, como es usual en su iconografía.

\footnotetext{
${ }^{1753}$ El dedo índice, en sus variantes de anunciador, acusador o señalador, es, desde un punto de vista teológico, el elemento más relevante del Bautista. Sobre este tema, GONZÁLEZ REGLERO, Juan José y CAMPO Y FRANCÉS, Ángel del. "En torno al lenguaje del dedo índice en la iconografía del Bautista" en Cuadernos de Arte e iconografía, tomo 4, nº , 1991, pp. 223-234.
} 

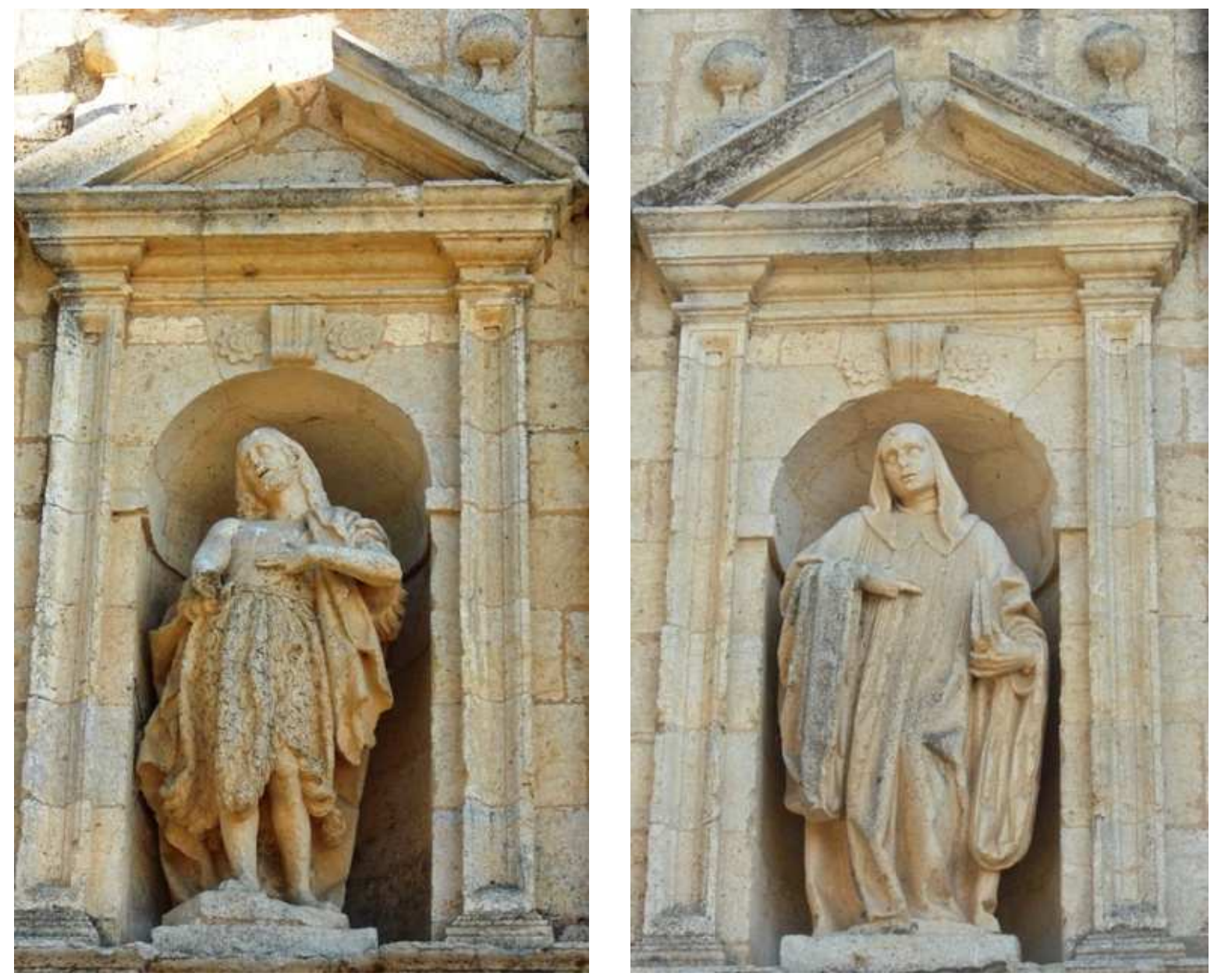

San Juan Bautista y San Félix en el cuerpo principal de la fachada.

Sobre estas imágenes se sitúan dos escudos ovalados, enmarcados por una espesa orla de hojarasca. El de la izquierda, es el escudo real del monasterio: dos brazos sosteniendo las palmas del martirio; en la siniestra, el de San Zoilo, identificado por su camisa abotonada de soldado, mientras que el brazo de San Félix se adivina por las mangas del hábito. Bajo ellos, el cordero, aludiendo a San Juan Bautista, acompañado de una banderola, y bajo él, un puente sobre el río, identificado con el de Carrión. El blasón de la derecha es cuartelado, y la partición vertical la constituye un báculo de oro: 1 , de gules con castillo de oro. 2 , de sinople con un león de oro coronado. 3, de azur con trozo de una columna, 4 de gules con un cuervo de oro que lleva un pan en el pico, relacionado tradicionalmente con la iconografía de San Benito. Abismo con cordero con la banderola y bajo él, mitra de oro. Este escudo ha sido identificado ocasionalmente con las armas del abad Alonso 
Barrantes $^{1754}$. Sin embargo, no puede ser asociado al mismo, pues las obras no se hicieron bajo su mandato, y ni siquiera este escudo se corresponde con una dignidad concreta. Es idéntico al de la reja lateral del coro e igualmente se repite, con algunas variantes, en el acceso al sotocoro, en el arcosolio del claustro bajo y en el nicho de la condesa Teresa en el presbiterio. Su presencia en dependencias ejecutadas en diversas épocas así como los elementos característicos que lo conforman, permiten identificarlo con el emblema general de cualquier casa benedictina ${ }^{1755}$. De hecho, salvo por la omisión del cuervo que alude a San Benito, este mismo escudo aparece por primera vez en 1609 para ilustrar, precisamente, la portada de la Crónica de San Benito, del Padre Yepes. El autor de la empresa es un grabador de origen flamenco llamado Jacobo Nerau, familiarizado con las obras de esta orden, pues en 1608 había ilustrado una crónica de Antonio Pérez, la Laurea Salamantina ${ }^{1756}$. Respecto a la bandera con dos pendones que figura en el blasón, es un distintivo heráldico que se emplea para poner de relieve que la mitra y báculo que figuran junto a él, responden a una abadía y no a una dignidad episcopal ${ }^{1757}$.

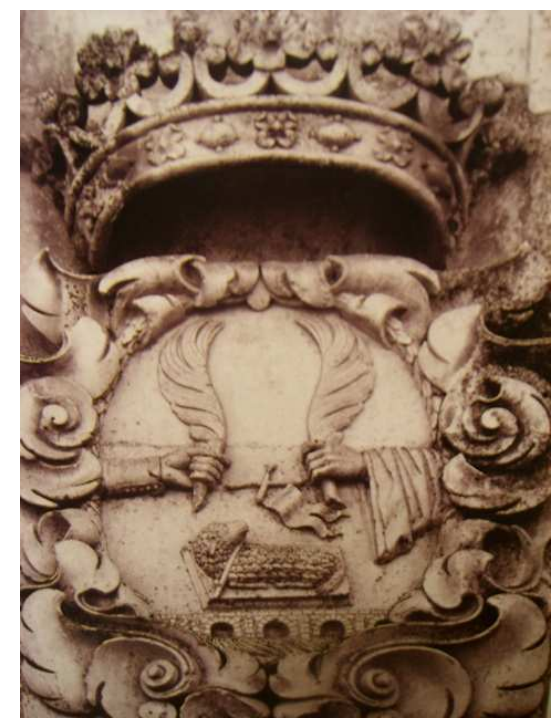

Escudo del monasterio de San Zoilo en la fachada del templo.

La puerta de acceso, formada por un arco de medio punto flanqueado por pilastras cajeadas, se sitúa, a su vez, entre estos mismos soportes de dimensiones

${ }^{1754}$ VIGURI, Miguel de. Heráldica...2, Op.cit, pág. 67.

${ }^{1755}$ El escudo específico de San Zoilo, como indicamos, es el que figura junto a él.

1756 GARCÍA VEGA, Blanca. El grabado... Op.cit, pág. 237 y RODRÍGUEZ PELAZ, Celia. "El grabado barroco...Op.cit, pp. 155-156.

1757 VV. AA. Tratado de genealogía, heráldica y derecho nobiliario. Tercera edición. Instituto Salazar y Castro. Madrid, 2001, pág. 179. 
dobles, sobre los cuales se desarrolla el frontón decorado con bolas, repitiéndose así, el esquema de los laterales, sólo que a gran escala. El frontón, en este caso, se parte para repetir la misma estructura clasicista de los laterales. Algunos historiadores han identificado erróneamente la imagen que alberga su hornacina con San Luis, rey de Francia $^{1758}$. Sin embargo, dada la advocación del cenobio, así como la indumentaria del personaje, no cabe duda de que se trate de San Zoilo. El mártir cordobés figura como un joven de generosa melena, vestido con coraza, falda de flecos y sandalias, a la usanza de soldado romano. Con una mano recoge un voluminoso manto, añadido efectista y anacrónico del patrón carrionés. Carece del otro brazo, que sostendría la palma o la bandeja con dos riñones, alusivas a su martirio ${ }^{1759}$.

Separado del primer cuerpo por un friso dórico, se alza el segundo, presidido por el escudo de los Austrias, concretamente de Carlos II, dada la fecha de ejecución de la portada, flanqueado por leones tenantes ${ }^{1760}$. Sobre éste, cobijado por una hornacina a la que flanquean pilastras ornamentadas con una sucesión de minúsculas bolas, el patrón por antonomasia de la Orden benedictina. Representado como un anciano barbado y amplia tonsura, San Benito, sostiene con su mano extendida la Regla benedictina abierta, mientras que con el otro brazo sujeta el báculo abacial, de hierro. A sus pies, sobre un elegante cojín con borlas en sus esquinas, la mitra episcopal a la que renunció el santo de Nursia a favor de la consagración fundacional. Los cuatro santos mencionados, tan vinculados con el cenobio,

1758 RIVERA BLANCO, Javier. "Palencia" en Catálogo Monumental de bienes inmuebles declarados. Primera parte. Valladolid, 1995, pág. 463.

${ }^{1759}$ De este modo aparecía representado en una de las pechinas de la cúpula central previamente comentadas, que lamentablemente no se conserva, pero así lo estipulaban las condiciones de las pinturas. Hemos hallado un grabado calcográfico de Juan Moreno Tejada (1739-1805) en el que San Zoilo figura con ambos atributos, uno en cada mano. AHN. Sala Goya. Inventario 32487.

${ }^{1760}$ La lectura del escudo cuartelado con su policromía correspondiente sería la siguiente:

1. Cuartelado de Castilla y León: 1 y 3 . En campo de gules, castillo de oro con tres torres, aclarado de azur, 2 y 4. En campo de plata, león de gules rampante coronado de oro, linguado y uñado de gules

2. Partido: 1. Aragón: En campo de oro, cuatro palos gules. 2. Cuartelado en sotuer, 1 y 3: Aragón, 2 y 4, Dos Sicilias: en campo de plata, águila explaya da de sable - Granada: De plata, entada y caída en punta, granada de oro, tallada y foliada de sinople -Portugal: De plata y cinco escudetes en azur puestos en cruz con cinco bezantes o dineros en plata puestos en sotuer, bordura de gules con siete castillos de oro. 3. Cortado. 1. Hagsburgo: En campo gules, faja de plata, 2, Borgoña antigua: Bandado de oro y azur, en órdenes de 3 y 3 . Bordura componada de plata y gules. 4. Cortado. 1. Borgoña moderna: En campo azur, sembrado de flores de lis de oro. Bordura componada de plata y gules. 2. Bravante: En campo de sable, león rampante de oro, linguado y uñado de gules. En medio de ambos cuartelados, escudo partido: 1. Flandes: En campo de oro, león rampante sable. 2. Tirol: En campo de plata, águila exployada de gules, coronada y picada de oro. Collar de la orden del Toisón: collar de oro, compuesto de eslabones dobles, entrelazados de pedernales o piedras centelleantes, inflamadas de fuego con esmaltes de azul y los rayos de gules; en el cabo tiene una piel de cordero, con su lana y extremidades, adornada de oro, liada por el medio y suspendida del collar. 
coinciden con los que protagonizan las pinturas de las pechinas de la cúpula central del crucero o los del retablo que por entonces presidía la iglesia. Se incide nuevamente, sobre la fundación del cenobio en relación a sus diversas advocaciones y a la adhesión de San Zoilo en el siglo XVI a la Congregación Vallisoletana ${ }^{1761}$. A los lados de este eje central, se elevan, sobre amplios pedestales cajeados, una pareja de pilastras estriadas, superpuestas, a su vez, a pilastras más amplias. De sus capiteles parten dos aletones avolutados que confluyen en jarrones floreados, dispuestos igualmente sobre pedestales. Las cuatro gárgolas que, ubicadas a la altura de los tejados de la nave, rematan este cuerpo, cumplen así su finalidad estética y funcional. Por encima, el entablamento de orden jónico se alza en su parte central para acoger la ornamentación que se despliega por encima de San Benito, conformada a base de un nutrido grupo de lambrequines que rodean una venera.

El ático sobresale por encima del edificio, tal y como especificaban las condiciones: “...enllegando la pared de la yglessia al alto que biene la del edifiçio nuevo, a de caminar el pórtico sólo hastta lo que pidiere el frontispiçio de él...”. En cambio, a los lados del remate, se optó por disponer elementos apiñonados, en lugar de las bolas acordadas, ya empleadas en el cuerpo bajo. El plinto sobre el que se asientan está decorado con tres mascarones; sobre éste se eleva un frontón avolutado partido donde se sitúa la imagen de San Miguel. La figura, un tanto andrógina, se alza triunfante, avanzando con una pierna, mientras extiende su brazo derecho hacia el cielo, hoy día seccionado, con el que blandiría la espada. Aunque no figura el demonio a los pies, podemos identificar al arcángel a través de la divisa latina inscrita en el escudo que sostiene con su mano izquierda "QVIS SICVT DEVS", aludiendo así su preeminencia en el ejército celestial.

Aunque dotada de ciertos elementos clasicistas, la portada se nutre ya de todas las exuberancias propias del barroco. El desprecio que este estilo despertó en la estética neoclásica, queda manifiesto en la selección de opiniones que recogemos a continuación sobre la portada. Las palabras de Ponz son bastante comedidas: “...es

\footnotetext{
${ }^{1761}$ No insistimos sobre este asunto, ya sobradamente tratado en los capítulos respectivos de la fundación del cenobio, las bóvedas y medallones del claustro y las pechinas de la media naranja del templo.
} 
cosa rematada, pero que habrá costado muchos miles" $" 1762$. Más agresivas son las críticas posteriores, como la de Garrachón Bengoa: "la portada de la iglesia, churrigueresca...desconsolando nuestro espíritu, saber que tan importante recinto románico fue destruido por capricho por desgracia y reedificado malamente a

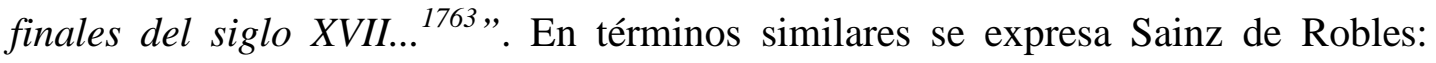
“...es churrigueresca. Es decir, moderna, fea, absurda. En ella contemplamos entre otras cosas ridículas, éstas: San Zoil, mártir cordobés de la España romanizada...vestido a la moda de Luis XV; San Félix y san Juan Bautista -a sendos lados de aquel-, con atuendos de melodrama pastoril; San Miguel Arcángel, de gran prosopopeya bélica, surgiendo de unos cogollos y de unas hojarascas como

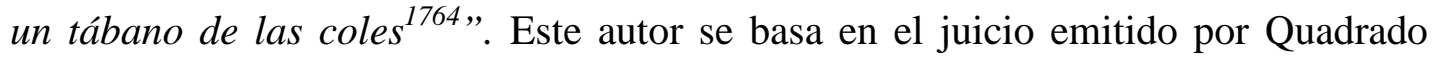
casi una centuria antes ${ }^{1765}$. Sin embargo aquel opinaba con mayor acierto, al equiparar la vestimenta de San Zoilo a la moda de Luis XIV, dado que el otro monarca francés vió la luz en el siglo XVIII.

Hasta el momento la fachada había sido atribuida al maestro palentino Felipe Berrojo de Ysla, dadala vinculación del artista a la villa condal y su actividad en la misma ${ }^{1766}$. Sabemos, sin embargo, que bajo el primer abadiato de don Bernardo de Estúñiga, detentado entre 1665 y 1669, se emprendió “...la obra del pórtico de la iglesia, de piedra de sillería, vistosamente ejecutada, con sus efigies y escudos ${ }^{1767, "}$ El impulso de estas obras, como las de finalización del templo, fue posible gracias a las donaciones que Juan Aguado, monje de Carrión, efectuó antes de fallecer en $1666^{1768}$. En efecto, el abad Estúñiga se concertó en junio de dicho año con maestro de cantería Diego de Zorlado para su ejecución, quien realizaría los dos últimos tramos del templo paralelamente en dos años ${ }^{1769}$. Tan sólo era responsable de la parte arquitectónica y de la talla de ornamentos, pues “...toda la escultura de los

\footnotetext{
1762 PONZ, Antonio Op.cit, pág. 200.

${ }^{1763}$ GARRACHÓN BENGOA, Ambrosio. Palencia y su provincia. Guía, catálogo prontuario del turista. Biblioteca palentina. Valladolid, 1920, pág. 200.

${ }^{1764}$ SAINZ DE ROBLES, Federico Carlos. Monasterios...Op.cit, pp. 102-103.

1765 QUADRADO; José María y PARCERISA, Francisco J. Recuerdos...Op.cit, pág. 132.

1766 URREA FERNÁNDEZ, Jesús y MARTÍN GONZÁLEZ, Juan José. Inventario...II. Op.cit, pág. 58 y ANDRÉS ORDAX, Salvador. La iglesia...Op.cit, pág. 33.

${ }^{1767}$ Sobre este abad, ZARAGOZA PASCUAL, Rafael. “Abadologio...Op.cit, pp. 299-300.

${ }^{1768}$ BECERRO DE BENGOA, Ricardo. "El monasterio...Op.cit, pág. 89.

${ }^{1769}$ Escritura de concierto y condiciones, firmada en Saldaña el 11 de junio de 1666. AHPP. Carr.Prot 5701. Norberto Sandoval y Guevara (1666), fol 499 y ss. Sobre Diego de Zorlado, véase el caítulo dedicado a los maestros de arquitectura cántabros.
} 
quatro cuerpos de Santtos que sse an de poner en la dicha obra y lo mismo los tres escudos de armas..." era responsabilidad del monasterio, que debía contratar un escultor, encargándose Zorlado tan sólo de asentar las piezas en el lugar señalado.

A pesar de las sumas invertidas, las obras fueron paralizadas por falta de fondos, lo cual debió suceder hacia 1668 en que Zorlado ya se encontraba en Trasmiera, su comarca natal ${ }^{1770}$. Gracias a la donación que don Anselmo de la Torre, Obispo de Tuy, versó a la comunidad en 1693, fue posible concluir las obras ${ }^{1771}$. Efectivamente, dicho año fue nombrado abad el palentino Jerónimo Ruiz, bajo cuyo mandato, indican las fuentes, se “acabó el pórtico de la iglesia ${ }^{1772 ” . ~ D e ~ t o d o s ~}$ modos, las obras debían estar prácticamente finalizadas. Para ello, nos basamos en un detalle tan principal como la presencia de las armas de Portugal en el escudo real del segundo cuerpo, incluidas en el escudo de los Austrias desde que en 1580 Felipe II conquistase el reino luso. Sin embargo, en 1668, reinando Carlos II, quedó reconocida la independencia del territorio vecino. Este singular dato, evidencia que, desde que dan comienzo las obras en 1666 hasta 1668, la fachada estaba prácticamente finalizada, y por tanto, lo que se hizo en 1693, debió corresponder al remate del segundo cuerpo y ático.

\section{EL SIGLO XVIII}

La presencia de la vega del río Carrión junto al monasterio de San Zoilo y el intenso provecho que ha obtenido del cuérnago para el regadío de sus cultivos, explica, en parte, la riqueza generada por la abadía a lo largo de los siglos. Por ello, resultaba ineludible en este capítulo hacer mención a la redacción de unas ordenanzas sobre la distribución de las riberas de San Zoilo y Cestillos, aprobadas el 15 de marzo de 1715 por el rey Felipe $\mathrm{V}^{1773}$. La relevancia de este documento radica en el hecho de que es ésta la primera vez que se actualizan las antiguas ordenanzas,

\footnotetext{
1770 Efectúa una fianza para un puente de Liébana. ALONSO RUIZ, Begoña. El arte de la cantería...Op.cit, pág. 49, a su vez de AHRC. Prot. 1167, fol 81.

${ }^{1771}$ BECERRO DE BENGOA, Ricardo. "El monasterio...Op.cit, pág. 89.

1772 ZARAGOZA PASCUAL, Ernesto. “Abadologio...Op.cit, pág. 301.

${ }^{1773}$ LALANDA CARROBLES, Pablo. "Las vegas de Saldaña y Carrión: antecedentes históricos de sus regadíos" en PITTM, n 36. Palencia, 1975, pp. 144, 158-160 y el despliegue de los artículos en pp. 186- 203.
} 
de más de cinco siglos de antigüedad ${ }^{1774}$. Lo más destacado es la creación del cargo de "alcalde de agua" que debe asistir a la toma de aguas de cada una de las riberas para evitar fraudes. Dichos estatutos reales han seguido en vigor, incluso respetados en la redacción de la Ley de Aguas de $1871^{1775}$.

En lo que se refiere a cuestiones de índole artística, tras la fiebre constructiva experimentada en el siglo XVI con la ejecución del claustro y en el siglo XVII, con la renovación de las dependencias conventuales y la edificación del nuevo templo, podríamos pensar que la nueva centuria sería más tranquila desde el punto de vista arquitectónico. Sin embargo se decidió dotar de un nuevo patio al cenobio, en torno al cual se ampliarían los espacios habitables del mismo. Asímismo se renovaron algunas dependencias existentes, deterioradas con el transcurso de los años y sobre todo se dotó de obras de arte al templo y a la sacristía, que estaban desprovistas de ornamentos.

\section{Retablos de Santa Gertrudis y el Cristo Real}

En el tercer tramo de la nave, inmediato al crucero, se ubican dos retablos gemelos de sencilla estructura. Asentados sobre unas sencillas mesas de altar, se componen de banco con los frentes moldurados y un solo cuerpo rematado en frontón flanqueado por dos elementos campaniformes. En el centro, flanqueando la imagen principal, dos columnas jónicas de fuste liso alineadas en segundo término, más al fondo, lo que ocasiona el retranqueo de la cornisa. La única concesión efectista que se aparta de la sobriedad neoclásica de estas piezas es la policromía a base de ocres y granates que imita jaspes.

\footnotetext{
${ }^{1774}$ Recordemos que el 14 de agosto de 1203, el rey Alfonso VIII ratificó un privilegio emitido por Alfonso VII -desconocemos la fecha, pero nos remontamos por tanto al siglo XII- sobre la distribución de aguas que discurrían por el río Carrión. Por el mismo, concedía la tercera parte de las aguas al monasterio de San Zoilo, otra para Nogal de las Huertas y otra "para las damas de Carrión". SIMÓN NIETO, Francisco. Los antiguos...Op.cit, pág. 127. En las ordenanzas de 1715 se mantiene esta división.

${ }^{1775}$ LALANDA CARROBLES, Pablo. "Las vegas...Op.cit, pp. 159-160.
} 
En el lado de la Epístola, presidía el retablo el Cristo Real, una obra del siglo XVI y "de maravillosa escultura"1776. La escultura que mencionan las fuentes no debe haberse conservado, pues la que hoy día ocupa el retablo, si bien bajo la misma advocación, es una escultura de mediocre calidad y marcado patetismo que luce una larga y espesa cabellera postiza. Presenta unas carnaciones oscurecidas y unos repintes de dudoso gusto. Podría datarse hacia finales del último tercio del siglo XVI, si bien presenta reminiscencias del gótico por los brazos tan alargados, delgados y extremadamente rígidos. Esta representación tan patética parece rememorar la tipología de Cristos Dolorosos, como el que se conserva en la iglesia de Santa María.

La imagen del lado del Evangelio, es, en cambio, una obra de buena calidad y casi dos metros de altura. Representa a Santa Gertrudis, mística y prolífica escritora alemana del siglo XIV cuyo protagonismo es igualmente patente en una de las bóvedas del claustro bajo. Atribuida como obra del siglo XVIII ${ }^{1777}$, parece que esta imagen de dulce expresión y excelentes paños fue adquirida en Madrid hacia 1699-1700 por el abad del convento y Obispo de Tuy, Fray Jacinto Díez, pagándose por ella 17 doblones ${ }^{1778}$. Este dato concordaría con la información proporcionada por Zaragoza Pascual, quien señala que dicho abad "adornó la iglesia con retablos” durante su mandato ${ }^{1779}$. Puesto que el primero de sus abadiatos se desarrolló precisamente entre 1697 y 1701, es probable que la ejecución del retablo para disponer en un lugar adecuado la reciente adquisición fuera inmediata. Aunque ha desaparecido, sabemos que era gemelo a otro, dedicado a San Gregorio, ambos ubicados en la capilla mayor. En el contrato de los retablos colaterales de la iglesia de San Andrés, encargados al maestro cántabro Pedro Alvo en 1714, se especifica repetidamente que se ejecuten “...conforme están ejecutados otros dos en el

\footnotetext{
${ }^{1776}$ MADOZ, Pascual. Diccionario...Palencia, Op.cit, pág. 69 y URREA, Jesús y MARTÍN GONZÁLEZ, Juan José. Inventario..1.Op.cit, pág. 63.

${ }^{1777}$ URREA FERNÁNDEZ, Jesús. Y MARTÍN GONZÁLEZ, Juan José. Op.cit, pág. 63.

${ }^{1778}$ El delegado de la Academia de la Comisión de Monumentos de Palencia en su petición dirigida al Ministro de Fomento en 23 de marzo de 1871 para que San Zoilo sea declarado Monumento Nacional, indica sin ninguna certeza, que la figura podría proceder de Italia. ARASF. Palencia, Comisión de Monumentos, Leg. 2-7-7, Monumentos especiales. Becerro, en cambio, aporta datos específicos, indicando además que las urnas de los mártires San Zoilo y San Félix, fueron igualmente adquiridas en la capital en esta fecha. BECERRO DE BENGOA, Ricardo. "El monasterio..." Op.cit, pág. 91.

${ }^{1779}$ Detentó tres veces el cargo, entre 1697 y 1701, de 1705 a 1709 y de 1713 a 1717. ZARAGOZA PASCUAL, Ernesto. “Abadologio...Op.cit, pág. 301.
} 
conuento de San Zoil de esta uilla de Carrión, que son, el uno en donde está Santa Gertrudis, y el otro correspondiente a él... ${ }^{1780 " .}$
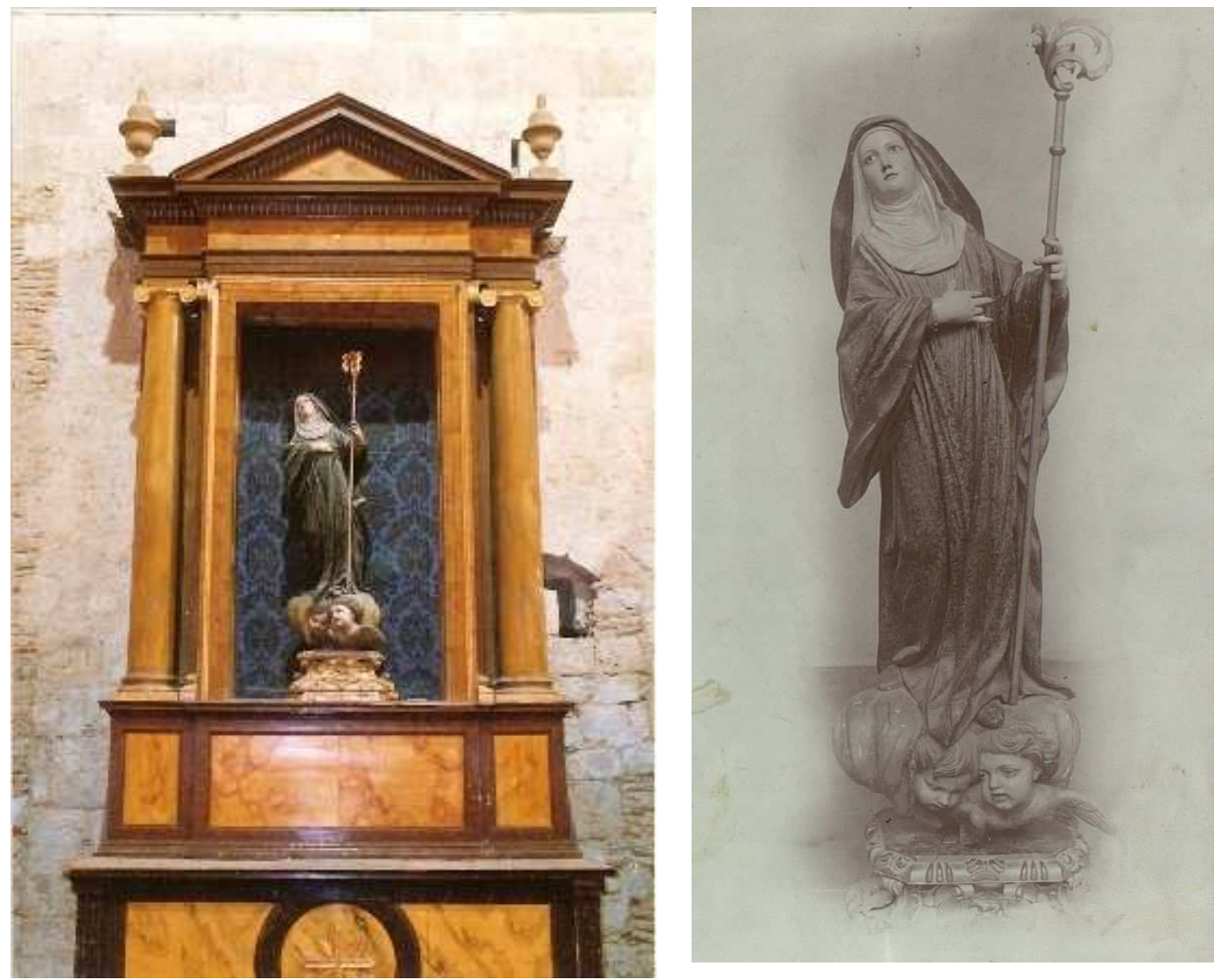

\section{Retablo de Santa Gertrudis e imagen homónima en el lado del Evangelio} de San Zoilo. (4,5mtrx2,75mtrx0,8mtr).

La conservación de estas obras de San Andrés permite adivinar la fisonomía de los dos retablos barrocos desaparecidos, sustituidos en el último tercio del siglo XVIII por otros neoclásicos trasladados a la nave del templo. Policromados y dorados, constarían de banco para disponer el sagrario, cuerpo principal sustentado por columnas salomónicas y estípites y ático con aletones. Cartelas, orejeras, hojarasca y un nutrido repertorio de motivos vegetales conformarían la ornamentación del retablo como un tupido manto donde ninguna superficie permanece desnuda.

\footnotetext{
${ }^{1780}$ El contrato y condiciones de los retablos colaterales de San Andrés en AHPP. Carr.Prot 5023. Francisco Ruiz Sandoval (1713-1715), s/f.
} 


\section{Retablos de pintura}

Adosados en los brazos del crucero, hallamos cuatro retablos, dos a cada lado, de idéntica estructura. Estas piezas, de factura neoclásica, se alzan sobre unas sencillas mesas de altar con dos columnillas dóricas de carácter ornamental a ambos lados. Los retablos se componen de un solo cuerpo que se asienta sobre un amplio banco cuya única decoración la constituyen tres placas rectangulares: dos en los extremos conformando los pedestales y una en el frente. Sobre la predela, un par de pilastras cajeadas con capiteles corintios cobijan un gran lienzo central. Encima del sobrio arquitrabe apoya un frontón curvo jalonado por una serie de dentículos y en el remate, un haz de finísimos rayos emerge del sol central. Este elemento que corona la composición, junto a los capiteles y el marco de la pintura han sido dorados, contrastando así con la policromía en tonos granates y mostaza del resto del retablo, donde se ha intentado semejar el veteado de los jaspes.
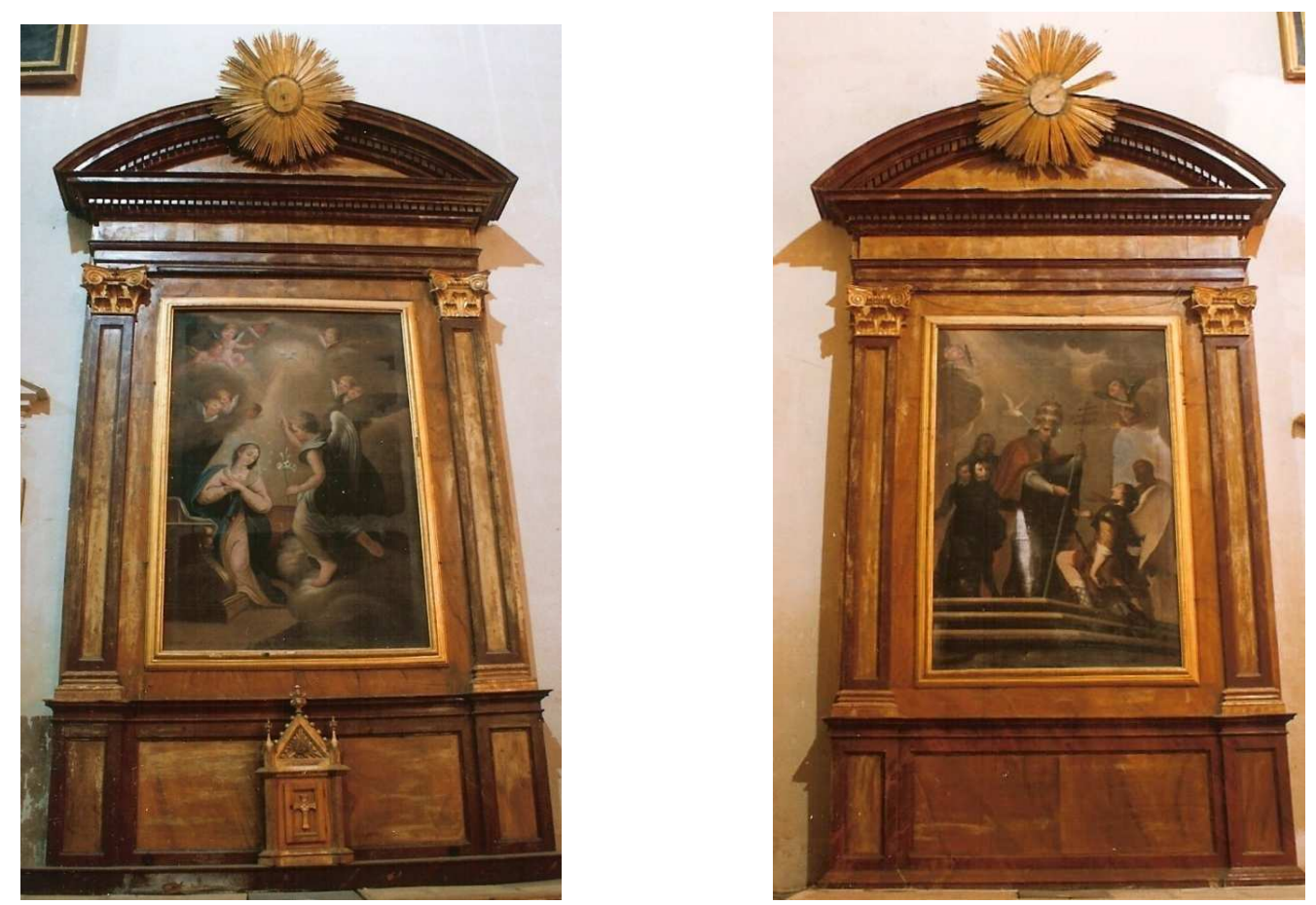

Retablo de la Anunciación y de San Gregorio Magno.

Lado del Evangelio. (5,2 metros x3,2 metros). 
Estos sencillos retablos serían ejecutados hacia el último tercio del siglo XVIII, época en que también se inscriben las cuatro pinturas de algo más de cinco metros de altura ubicadas en cada uno de ellos. Se trata de anónimos castellanos que representan, los del brazo norte, a San Gregorio repartiendo limosnas y la Anunciación; mientras que en los del transepto meridional figuran San Benito orando ante el crucifijo bajo la atenta mirada de un cuervo y San Leandro sobre los herejes. Según Helguera, para los rostros de estos dos santos "el esclarecido pintor" se inspiró en los de dos monjes benedictinos ${ }^{1781}$. La iconografía aquí representada del obispo de Sevilla es muy ilustrativa de su férrea defensa de la divinidad de Cristo. En lugar de la clásica representación sosteniendo el pergamino con las palabras: "CREDITE OGOTHI CONSVBS TANTIALEM PATRI", nos encontramos con que el santo cartaginés empuña una pluma y es a través de la misma cómo logra vencer a los arrianos tendidos a sus pies estando presente el ojo de Dios, que todo lo ve.

\section{La sillería coral}

En origen el coro se ubicó detrás del altar mayor hasta que con la reedificación del templo a partir de 1642, pasó a los pies del templo, donde se ubica desde entonces ${ }^{1782}$. Durante el cuatrienio transcurrido entre 1713 y 1717 , el mismo abad que se encargó la ejecución de los retablos del templo, don Jacinto Díez, "hizo la sillería y el órgano ${ }^{1783}$ ". Predicador de la Congregación vallisoletana, de San Claudio de León y de San Martín de Santiago de Compostela, detentó el abadiato en los cenobios de San Salvador de Lorenzana y San Esteban de Ribas de Sil. A él se debe el traslado de las reliquias de San Zoilo y San Félix que se llevó a cabo en 1697 , en presencia de los abades de Sahagún y Oviedo ${ }^{1784}$. Fueron dispuestas en dos urnas de plata que a tal efecto se realizaron en Madrid, costeadas por el procurador de Roma, Fray Alonso de Mier ${ }^{1785}$.

\footnotetext{
${ }^{1781}$ RAMÍREZ DE HELGUERA, Martín. El libro...Op.cit, pág. 153.

1782 IbIbídem, pág. 152.

${ }^{1783}$ ZARAGOZA PASCUAL, Ernesto. “Abadologio...Op.cit, pág. 303.

${ }^{1784}$ Ibídem, pág. 301.

${ }^{1785}$ BECERRO DE BENGOA, Ricardo. "El monasterio...Op.cit, pág. 89.
} 
Ubicada en el coro alto, la sillería coral se adosa en los tres lienzos del muro, formando una " $U$ " en dirección al presbiterio y alcanza una altura de tres metros y medio. Está compuesta por once sitiales en el frente y nueve en los laterales en madera de nogal separados por estilizadas columnas salomónicas de gran movimiento que descansan sobre sencillas ménsulas. Este tipo de soporte, si bien con un menor número de espiras en su fuste, fue utilizado en otra sillería castellana coetánea, la del convento franciscano de Medina de Rioseco, hoy en la iglesia de Santa María de la misma localidad ${ }^{1786}$. A excepción de las sillas centrales, los respaldos presentan tan sólo un ornamento muy simple a base de moldura rectangular. Las dos puertas de este espacio, situadas a los pies del templo en el lado occidental, se integran a la perfección en la estructura de la sillería por estar realizadas en el mismo material. Ambos accesos presentan una serie de listeles geométricos, alternándose los rectángulos y cuadrados en sus batientes. Todo el contorno está remarcado por sendas orejetas y sobre éstas, una cartela con letras doradas.

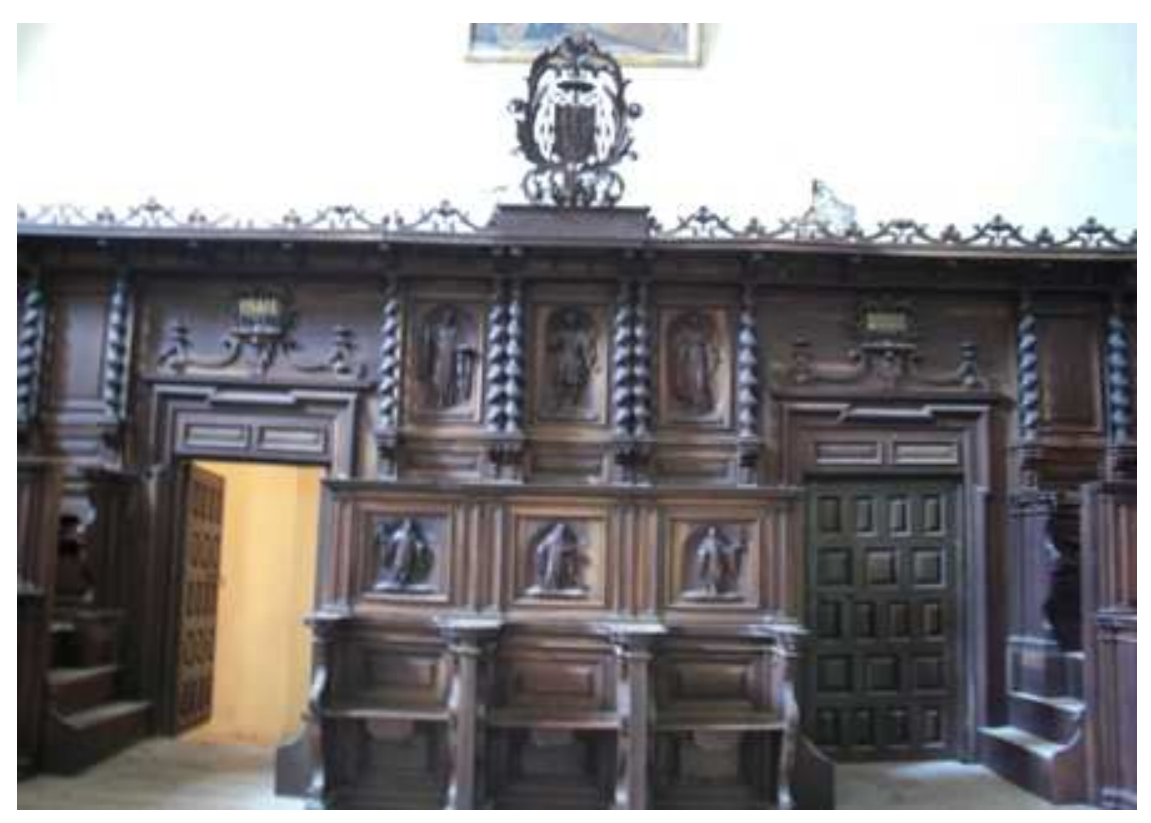

Sillería de San Zoilo en el coro alto.

Entre las dos puertas, los frentes de los seis sitiales están provistos de relieves de santos de cuerpo entero bajo hornacinas aveneradas. San Zoilo es

${ }^{1786}$ Es una obra de 1708. MARTÍN GONZÁLEZ, Juan José. Escultura...Op.cit, pág. 84. 
flanqueado por San Félix y San Agapio en la parte superior, mientras que los tres sitiales inferiores, de menor tamaño, muestran a San Benito en el centro y dos figuras de dudosa identidad a ambos lados. San Pablo pudiera ser el personaje que se encuentra a su derecha y la figura femenina que aparece a su izquierda la vinculamos con Santa Gertrudis o Santa Escolástica, las santas benedictinas más representativas de la orden que porta el báculo. Remata la composición una sencilla crestería de tallos afrontados que conforman una suave ondulación. Por último, en el centro sobresale, envuelto en una corona de hojarasca, el escudo del monasterio de San Zoilo. El timbre eclesiástico que lo corona, conformado por el capelo cardenalicio y dos cordones de los cuales penden tres borlas a cada lado del mismo, corresponden a la dignidad que ostentó el abad, pues llegó a ser Obispo de Tuy ${ }^{1787}$.

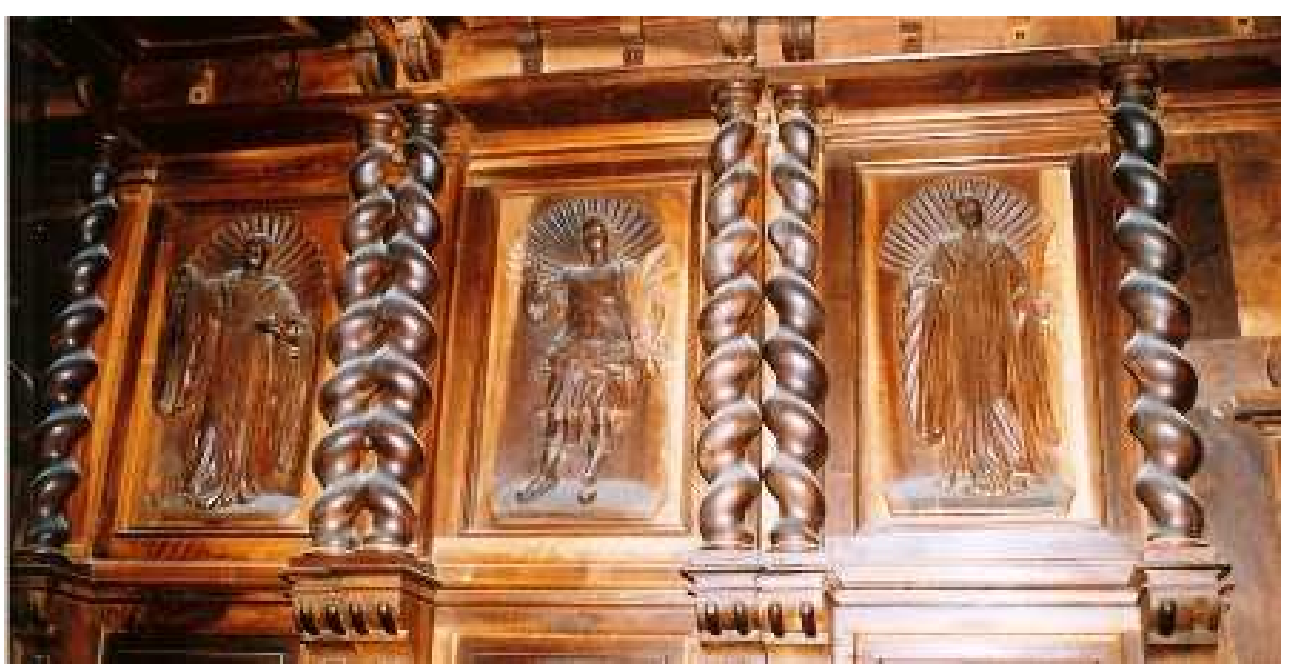

Detalle de la sillería. San Félix, San Zoilo y San Agapio.

Disposición análoga a la de esta sillería es la que se ubica en el también palentino monasterio cisterciense de San Andrés de Arroyo, en Santibáñez de la Ecla. Se trata de una obra realizada igualmente en madera de nogal y contemporánea a la San Zoilo, concretamente en 1714 bajo el abadiato de Juana de la Campa y $\operatorname{Cos}^{1788}$. Presenta la misma disposición de columnas salomónicas, repertorio de ménsulas y crestería en el remate, en este caso, las rocallas se hallan jalonadas por

\footnotetext{
${ }^{1787}$ BECERRO DE BENGOA, Ricardo. "El monasterio...Op.cit, pág. 91.

1788 YÁÑEZ NEIRA, Fray María Damián y TOBÍO CENDÓN, Rafael. San Andrés de Arroyo: ochocientos años de fidelidad. Trobajo del Camino, León, 2001, pp. 32-33.
} 
pináculos. Esta abadía dista poco más de medio centenar de kilómetros de nuestra abadía, así que por semejanzas estilísticas bien pudieron compartir autoría las dos obras, anónimas en ambos casos.

Al menos hasta 2005, como indican las fotografías, se ubicaba en la pared occidental, sobre el escudo de la sillería, una pintura del último tercio del siglo XVII que representaba la Defensa del Dogma de la Inmaculada. El lienzo presentaba la doble compartimentación de lo terreno y lo celeste. En la parte inferior, El Papa Alejandro VII, rodeado de algunos Santos como Santo Domingo, escribe, inspirado por el Espíritu Santo la proclamación de esta devoción mariana, según estableció la bula de 1661 .

\section{El órgano}

En la tribuna del lado del Evangelio que hay junto al mismo existe un interesante órgano barroco que, como indicamos, fue costeado por el entonces abad de San Zoilo, don Jacinto Díez durante su tercer mandato, entre 1713 y $1717^{1789}$. Su ejecución fue encargada al maestro organero vallisoletano, Gregorio González Roldán, el cual recibió por ello la elevada suma de 13.800 reales ${ }^{1790}$. La fecha exacta del órgano es 1716, como así lo verifica no sólo la documentación sino la inscripción situada en una cornucopia en la caja. Se estructura en dos cuerpos, distribuyéndose la tubería en el segundo, de mayor tamaño, organizado de forma escalonada. La abigarrada ornamentación a base de talla vegetal dorada que cubre los tubos como si de un cortinaje se tratase, crea un drástico contraste con la vívida policromía de los paneles en tonos rojizos, otorgando a la pieza un carácter teatral acentuado aún más si cabe con la presencia de multitud de cabezas de querubines soplando en los tubos y otros cinco ángeles con trompetas rematando el conjunto. Pueden establecerse analogías estilísticas con otros órganos de iglesias parroquiales palentinas ejecutados en las décadas posteriores como el de Nuestra Señora de Tovar en Meneses de Campos (1732), Santa Cecilia de Espinosa en Villagonzalo (1759),

\footnotetext{
${ }^{1789}$ Ibídem, pág. 91.

${ }^{1790}$ La escritura de contrato y condiciones de la ejecución del órgano con fecha 28 de febrero de 1716, en AHPP. Carr.Prot 4657. Francisco Cano Núñez (1715-1718), fol 136 y ss.
} 
San Millán de Baltanás (1795) ${ }^{1791}$. Si bien de autorías diversas, todos ellos son barrocos y presentan la estructura piramidal mencionada junto a un manto de follaje dorado en la decoración de los tubos. La originalidad de este órgano reside en la ubicación de algunos de ellos detrás del lugar donde se situaría el organista, con el fin de que éste pueda escuchar mejor la pieza que interpreta.

Según los expertos, su deteriorado estado general requiere una restauración profunda e inmediata ${ }^{1792}$.

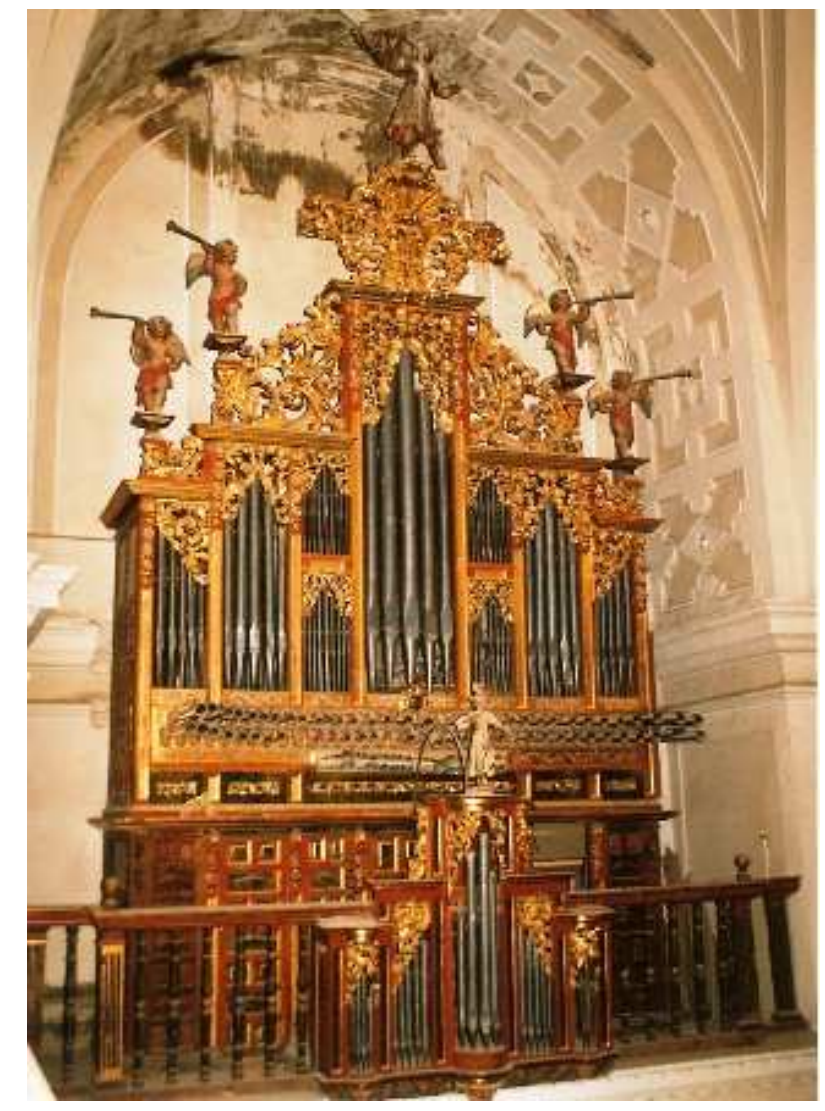

\section{Órgano de la iglesia de San Zoilo en la tribuna del lado del Evangelio.}

(8,5metros x5,5 metros).

\footnotetext{
${ }^{1791}$ Especializado en este tipo de órganos, véase LAMA GUTIÉRREZ, Jesús. El órgano barroco español. Registro I, Registros II. Junta de Castilla y León. Asociación Manuel Marín de Amigos del Órgano. Valladolid, 1995.

${ }^{1792}$ VV.AA. Inventario...Op.cit, pág. 168,170.
} 


\section{La decoración de la sacristía}

Aunque edificada en el siglo precedente, el aderezo íntegro de la misma no se produjo hasta 1705 en que Fray Alonso de Mier, procurador general de la orden y allegado del Papa Clemente XI, donó a la abadía algunos cuadros "copias de Anibal

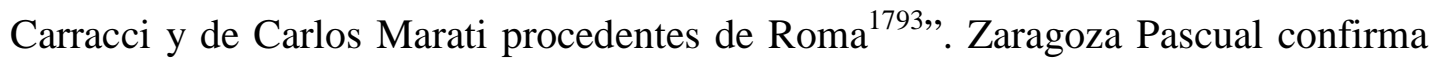
esta provisión de obras para la sacristía, siendo abad Pedro de Ganda, entre 1701 y 1705. Indica que además de las copias de los artistas mencionados, existían otras reproducciones de Ribera y Van Dyck ${ }^{1794}$.

Un informe de 1846 emitido por la Comisión de Monumentos de Palencia nos informa de las pinturas que, depositadas en el convento de San Buenaventura de la capital, procedían de esta dependencia del templo. En dicho catálogo, en que se recomienda la restauración de estas obras, figuran las siguientes: San Benito de Mateo Cerezo, San Pedro ad Víncula, del estilo de Guido Reni, La Virgen con el niño, copia de Anibal Carracci, San Bruno, San Bernardo, Tobías, Santo Tomás, San Jerónimo, San Francisco de Asís, Santo Domingo de Guzmán, San Ignacio de Loyola, San Francisco de Paula, San José, San Juanito y San Jerónimo del estilo de Jordán, San Gregorio, El rey David, San Francisco y paisajes con santos anacoretas $^{1795}$.

Todas estas pinturas no regresaron a su lugar de origen, hallándose hoy día en paradero desconocido. Los seis lienzos anónimos que podemos admirar hoy día no poseen el mérito artístico del que parecían estar dotados los anteriores. En el lado norte de la sacristía, por el que se accede al lado sur del crucero, se hallan un San Benito entre ángeles, de finales del XVII y una Magdalena Penitente, de la segunda mitad de esta centuria que se ubican flanqueando la puerta, sobre la cajonería. En el lado frontero, a los lados, se ubican dos retratos. El de la izquierda, adscribible al último tercio del siglo XVII representa al Papa Alejandro VII escribiendo su encíclica "De Ligno Vitae", en defensa de la Inmaculada y el de la derecha, de factura más reciente, de la primera mitad del siglo XIX, es protagonizado por el

\footnotetext{
${ }^{1793}$ BECERRO DE BENGOA, Ricardo. “El monasterio...Op.cit, pág. 89-91.

${ }^{1794}$ ZARAGOZA PASCUAL, Rafael. “Abadologio...Op.cit, pp. 301 y 302.

1795 ARASF, Palencia, Comisión Provincial de Monumentos, Leg. 2-7-7.
} 
abad Fray Fulgencio del Campo, que fue, según reza la inscripción bajo el cuadro: "Hijo de este monasterio de San Zoil de Carrión, dos veces Abad del dicho, otro del de San Vicente de Salamanca y General de toda la Congregación en cuya Prelacía murió el día tres de abril del año 1832”. En el centro, un lienzo de San Francisco de Paula, del siglo XVII y de pequeño formato, pues debe adaptarse al reducido espacio que hay sobre el acceso. De tonalidades oscuras y muy sobrio en su representación, el eremita italiano nos muestra la hoja con la palabra en mayúscula "Charitas".

El lado oriental está ornamentado por un lienzo de mayor tamaño que el resto, de casi dos metros de altura, probablemente del último cuarto del siglo XVI. Relata el momento en el que San Zoilo es martirizado con la extracción de sus riñones mientras el santo cordobés se retuerce encadenado de pies y manos.

Estos lienzos han sido eclipsados por la presencia desde el verano de 2010 de dos piezas de gran tamaño ubicadas en el centro de la sala. Se trata de dos telas islámicas medievales restauradas y recuperadas para el monasterio, debidamente protegidas por un cubo de cristal con el fin de permitir la visibilidad de las sargas por ambas caras ${ }^{1796}$.

No podemos dejar de aludir a otro de los bienes muebles más destacados de la sacristía, un sagrario clasicista procedente del convento de Santa Clara de la misma villa, que fue sustituido por el tabernáculo barroco que ocupó su lugar en el banco del retablo mayor. Presenta una estructura en dos cuerpos tripartitos sobre amplio zócalo. En el inferior, separados por columnas entorchadas corintias, dos pinturas de San Pedro y San Pablo que flanquean la tabla central en la que dos ángeles sujetan el cáliz con la sagrada forma. Las columnas estriadas del segundo cuerpo contienen igualmente tres óleos, el central protagonizado por San Juan Bautista y a los lados el Escudo de la Orden Franciscana y San Juan Bautista. Este orden, a simple vista, no es lógico, pues la composición debería centrarla el emblema terciario, para que quedasen ambos Santos en los laterales. Y así fue su disposición original, como se deduce de la lectura posterior de las tablas en que figura el orden en que deben situarse ${ }^{1797}$. Esta pieza fue un regalo de la madre sor

\footnotetext{
${ }^{1796}$ De ellas se habla en el apartado relativo a la fundación de San Zoilo.

1797 Detrás del escudo franciscano se lee: "la de en medio" y tras la tabla del Bautista. "evangelio". GÓMEZ PÉREZ, Enrique. El Real...Op.cit, pág. 101.
} 
Luisa de la Ascensión, como consta en la inscripción ubicada en la peana del segundo cuerpo, casi oculta por el frontón triangular que remata el primero. Fue trasladada a San Zoilo entre finales del XIX y principios del XX y se ubicó bajo el coro, al menos hasta los años cuarenta, como así lo indican las fotografías tomadas hacia esos años. Se situaba entre las gradillas laterales de una mesa de altar de mármol rojo, bajo el retablo de la Magdalena, para lo cual fue necesario serrar el sagrario longitudinalmente. Nuestro tabernáculo pasó posteriormente a situarse en la peana del retablo de San Benito, en el brazo sur del crucero, donde estuvo al menos hasta 2005 como así vemos en algunas fotografías, y finalmente, fue traspasado a la sacristía.
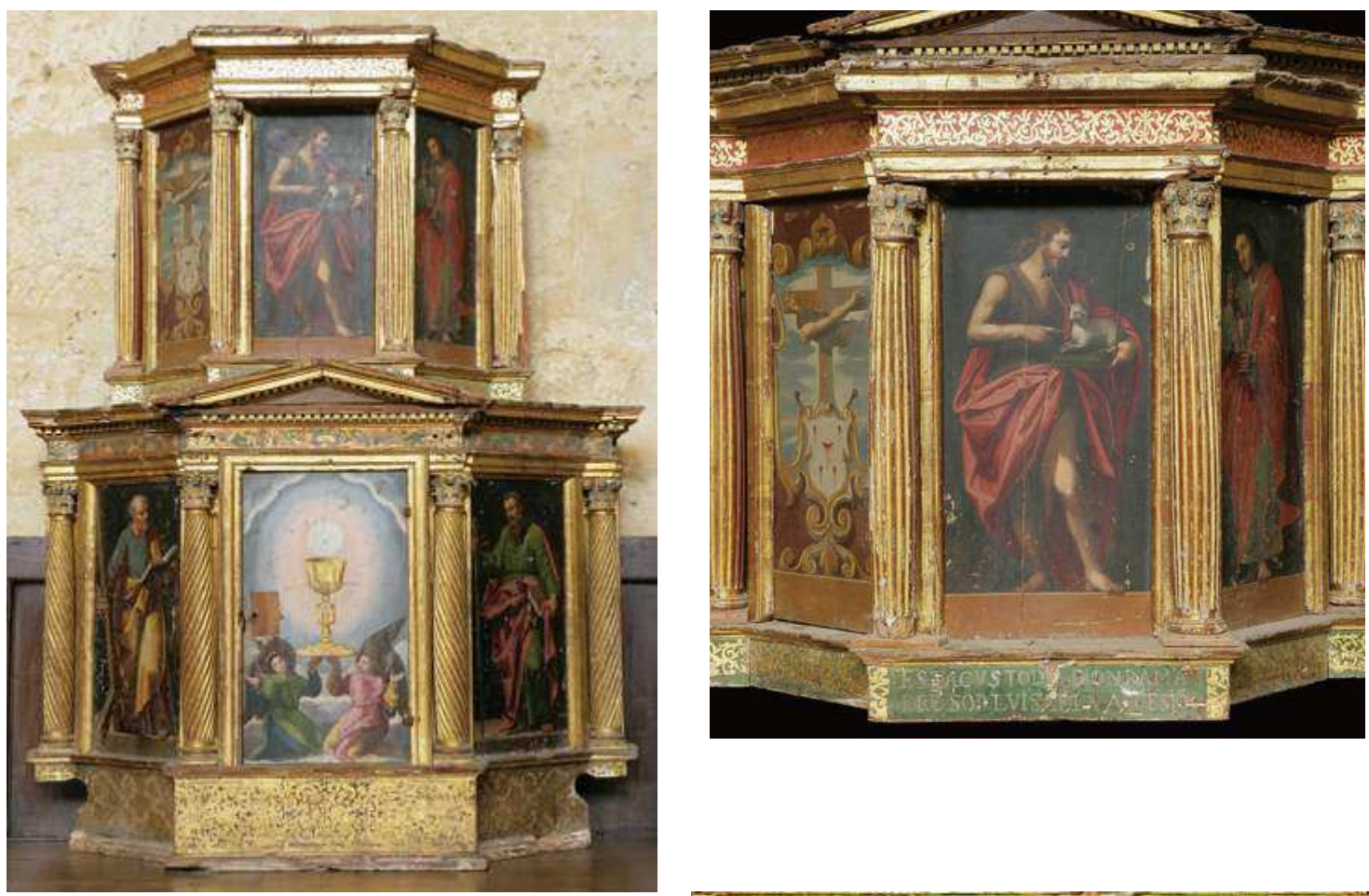

Sagrario procedente de Santa Clara, hoy en la sacristía de San Zoilo. Detalle e inscripción: ESTA CVSTODIA DIO NRA MADRE SOR LVISA DE LA ASCENSIÓN”. (142cm x114cm). 


\section{Reformas generales en el monasterio}

Además del órgano mencionado, la espadaña, reloj y campanas de la torre románica fueron ejecutados bajo el tercer abadiato de Fray Jacinto Díez, en $1713^{1798}$.

La comunicación que hoy existe entre el coro y la capilla de los Condes fue fruto de las obras que se realizaron en 1773, bajo el abadiato de Martín Basco, demoliéndose un año después la capilla de doña Constanza, ubicada al pie de la torre $^{1799}$. Esta capilla, fundada por Doña Constanza Enríquez y ubicada en origen junto a la capilla mayor del templo fue desplazada a finales del siglo XVII a los pies del mismo. Se ubicaba ahora junto a la fachada del templo y el patronazgo de la misma lo ostentaba el conde de Superunda, sucesor del mayorazgo de Don Antonio Doro Campoo. Podemos identificar al conde con la figura de don José María Manso de Velasco del Águila y Chaves, que obtuvo el título en 1757 hasta que murió en 1795, siendo sucedido por su hijo don José ${ }^{1800}$. Antes de derruirla, el mayordomo puso en conocimiento al patrono de la ruina de la capilla a través de una carta emitida en julio de 1772, instándole a que la mandase reparar, recordándole asimismo el abono de los pagos por posesión del espacio de culto. La respuesta no se hizo esperar y el conde se desvincula del patronato y por ende, de cualquier reparación que se solicite ${ }^{1801}$.

El monasterio de San Zoilo comienza en enero de 1773 los trámites para rescisión de la capilla que continúan el año siguiente ${ }^{1802}$. La demolición de la capilla tuvo lugar en marzo de 1774, unos días después de que Cornelio Alario y Manuel

\footnotetext{
${ }^{1798}$ BECERRO DE BENGOA, Ricardo. “El monasterio...Op.cit, pág. 89.

1799 Ibídem,pág. 91.

${ }^{1800}$ El título de conde de Superunda fue creado por el rey don Fernando VI de España, por real cédula de 8 de febrero de 1748, para agraciar a don José Antonio Manso de Velasco a los mejores y más honestos funcionarios españoles en la América colonial. Probablemente el documento se refiera al tercer Conde de Superunda, José María, pues obtuvo el título en 1757 hasta que murió en 1795, siendo sucedido por su hijo don José.

${ }^{1801}$ AHPP. Desamortización. Legajo 111. 8 de julio de 1772, s/f.

${ }^{1802}$ Primera respuesta de San Zoilo con la solicitud de rescisión AHPP. Desamortización. Legajo 111.28 de enero de 1773. s/f. Poder de 8 de enero de 1774 solicitando de nuevo la rescisión. AHPP. Carr.Prot 5134. Francisco Ignacio (1772-1774), s/f. Este documento deja constancia de la escasa relación que en ocasiones mantenían el convento y sus patronos, sobre todo cuando estos vivían fuera, como en el caso del conde de Superunda, en Madrid. El mayordomo se dirige a don Antonio Manso de Velasco y Samaniego, caballero de Santiago y coronel de ejército, que fue primer conde de Superunda y había fallecido en 1744. El actual conde era el tercero de su nombre, don José María Manso, como indicamos.
} 
Salomón emitieran una escritura de obligación en que se comprometían a desmontarla. Estos maestros arquitectos, oriundos de la localidad palentina de Amayuelas y vecinos de Carrión, erigirían en el mismo lugar y frente a la fachada un atrio empedrado de su misma anchura ${ }^{1803}$. Se planteó una estructura en forma de media luna con un pretil jalonado por columnas y tres accesos de escaleras. Si se llegó a construir -algo que nos parece poco probable dado que no se menciona en ningún documento posterior ni figura en las fotografías más antiguas- no se ha conservado.

Gracias a un informe de 1785 sobre el estado del monasterio custodiado en el Monasterio de Silos, sabemos que hacia esta fecha se realizaron obras de mejora de cierta entidad $^{1804}$. Zaragoza Pascual ratifica estas intervenciones, que precisa fueron ejecutadas entre los años 1781 y 1785. En primer lugar se puso en la capilla mayor un frontal de piedra ágata con marco, costados y seis gradas de jaspe sobre la mesa del altar, a cuya espalda se hizo también una escalera de piedra ágata con dos ramos para subir a la custodia y se adquirió un gran número de vestiduras litúrgicas entre dalmáticas, capas y casullas. Además se desmontaron y renovaron los tejados de la capilla mayor, gran parte de la nave, la torre y los cuatro paños del claustro, el estudio, los dos salones y el de un cuarto nuevo donde se dispusieron dos nuevas alcobas. Se construyeron dos escaleras para subir a los dormitorios y una para bajar al archivo, del cual se copiaron los documentos más antiguos y en peor estado con el fin de perpetuar su contenido. Además se hizo un noviciado con cinco celdas y una con estudio situada en el claustro ${ }^{1805}$.

En la librería se llevó a cabo una reforma general, optándose por un techo raso de madera con una cenefa en su perímetro y piso de tabla. Alrededor de la estancia se dispusieron grandes estantes, separados los más altos por una balaustrada, que quedarían ordenadamente completados con obras eminentemente

${ }^{1803}$ Por la obra recibirían 2.380 reales. Escritura y condiciones en AHPP. Carr.Prot 5457. Andrés Núñez Castelo (1774-1775), fol 34 y ss. En el fol 42 los vecinos de la villa se encargan de retirar los escombros a la puerta de la iglesia, verificando que se llevó a cabo la demolición de la capilla. ${ }^{1804}$ Monasterio de Santo Domingo de Silos. ACSBV. Documentos, Volumen 29, no 847. 1785. Estado general del monasterio de San Zoil de Carrión.1785, fol 46-46v.

1805 ZARAGOZA PASCUAL, Rafael. Los Generales de la Congregación de San Benito de Valladolid. Los abades trienales. (1701-1801) Vol 5. Monasterio de Santo Domingo de Silos, Burgos, 1984, pág. 236. 
devocionarias de San Agustín, San Jerónimo, San Juan Crisóstomo, el Padre Flórez y de diversa temática como los viajes de Bawles ${ }^{1806}$.

En estas intervenciones de 1785, debió ejecutarse también la denominada capilla del abad, ubicada en el lienzo septentrional del sobreclaustro, contigua a la pared del coro alto, a los pies del templo. Se trata de un espacio estrecho y alargado dividido en dos tramos cubiertos con bóveda de arista y cúpula sobre pechinas. Dos ojos de buey abiertos en el centro de cada tramo iluminan cenitalmente este espacio. El retablo moderno, de escaso mérito que conserva hoy día, se debe a la mano de los jesuitas, cuando el monasterio se convirtió en Noviciado y Seminario menor ${ }^{1807}$.

\section{Patio neoclásico}

Bajo el segundo abadiato de don Leandro Pérez, desempeñado entre 1793 y

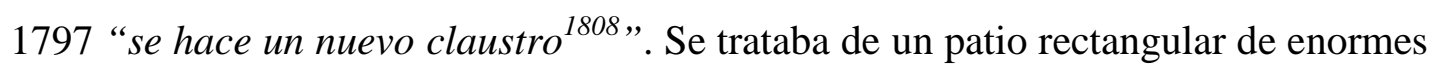
dimensiones -casi el doble del claustro renacentista- en torno al cual se dispondrían nuevas celdas para los monjes. Se ubicaba a los pies del templo, en la parte occidental del monasterio y paralelo al claustro. En el lugar que ocupaba, los Padres de la Compañía de Jesús erigieron hacia 1864 el que vemos actualmente para disponer en torno a él las nuevas dependencias del colegio ${ }^{1809}$.

En cambio, sí se conservó la fachada principal del patio, ubicada en el centro del lienzo oriental, que proporciona el acceso al ándito que comunica con el claustro. A ambos lados de la puerta, enmarcada por sendas orejetas, dos parejas de pilastras cajeadas sobre pedestales sustentan un friso con la clásica molduración de triglifos entre los cuales, en este caso, en lugar de metopas, se disponen rosetas. Una fila de dentículos se dispone en la parte inmediatamente superior dejando paso a un frontón partido conformado por un par de aletones avolutados. Estos elementos de gran dinamismo convergen en el centro, cobijando un escudo con cueros recortados

\footnotetext{
${ }^{1806}$ Monasterio de Santo Domingo de Silos. ACSBV. Documentos, Volumen 29, $\mathrm{n}^{\circ}$ 847. 1785. Estado general del monasterio de San Zoil de Carrión.1785, fol 46-46v.

${ }^{1807}$ Véase a este respecto el apartado pertinente de San Zoilo en los siglos XIX y XX.

${ }^{1808}$ ZARAGOZA PASCUAL, Rafael. "Abadologio...Op.cit, pp. 306

${ }^{1809}$ Sobre el mismo, remítase a la historia del Colegio.
} 
identificativo del monasterio. Sobre éstos se yerguen dos pares de plintos rematados en bolas con pináculos que flanquean el balcón principal. En esta portada, como vemos, se asimilan ciertas reminiscencias tardobarrocas propias del neoclasicismo español.

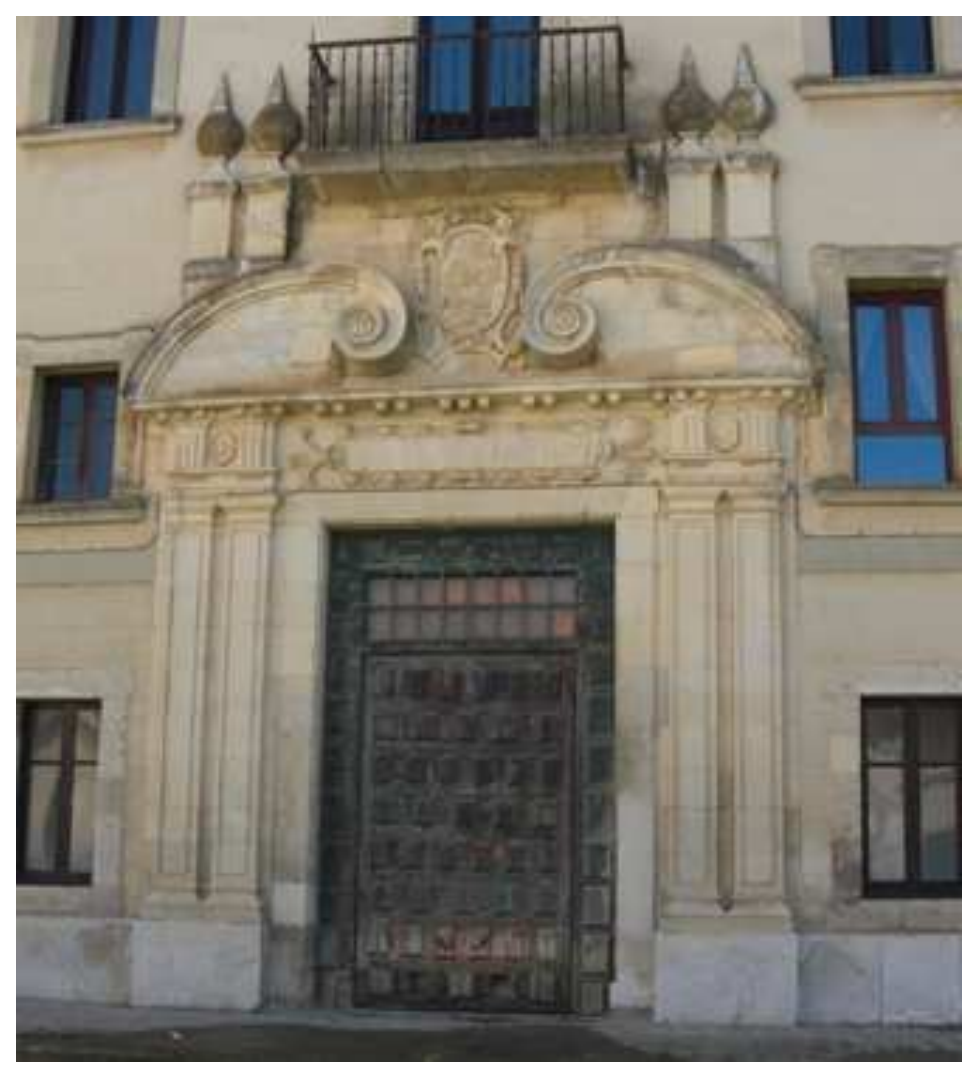

\section{Portada del patio neoclásico de San Zoilo.}

Un pleito que interpuso el monasterio al tejero Blas Bázquez entre 1796 y 1798 por incumplimiento del contrato, hace referencia con toda seguridad a los problemas que surgieron con la construcción de este patio. En la declaración se menciona un contrato que firmó el dicho Blas Vázquez, vecino de Paredes de Nava con San Zoilo en diciembre de 1794 para proporcionar "...la cantidad de ladrillo de alzar, solar y jabonero que necesiten para la obra empezada en el referido monasterio... ${ }^{1810 " .}$. Los precios, cantidades y condiciones quedaban estipulados con claridad en el mismo pero parece que el tejero palentino no cumplió con su palabra. Los benedictinos se quejaban de que habiéndosele adelantado cierta suma para que

${ }^{1810}$ Es la única obra de la que tenemos constancia que estuviese comenzada por estas fechas. Escritura y condiciones en ARCHV. Pleitos Civiles Pérez Alonso (F) caja 3581. Exp $33^{\circ}$. 
la obra no se dilatase “...ha abandonado el trabajo al mejor tiempo y estación retirándose, y a los demás travajadores sin ánimo de continuar en la obra de ladrillo...”. A ello se sumaba el hecho de que los monjes se habían visto obligados a adquirir casi un millar de ladrillos por su cuenta procedentes de los tejares de Carrión, San Mamés y Villaverde ya que Vázquez no les había proporcionado los que había prometido traer de Villaverde. Los argumentos poco convincentes expuestos por el tejero le valieron una justa indemnización al convento por la paralización y retraso de las obras ${ }^{1811}$.

\section{EL DEVENIR A PARTIR DEL SIGLO XIX}

A las fructíferas centurias precedentes les siguió un período bastante desafortunado motivado por las sucesivas desamortizaciones decimonónicas. Ambas desencadenaron una pérdida progresiva del patrimonio del monasterio, que resultó irrecuperable.

La multiplicidad de funciones que a partir de mediados del siglo XIX comenzó a desempeñar San Zoilo, evitó la ruina de las edificaciones, destino final de otros cenobios benedictinos que no corrieron la misma suerte de su compañero carrionés. Sobre todo gracias a la iniciativa y los esfuerzos nada desdeñables de los Padres de la Compañía de Jesús, las diferentes dependencias conventuales se mantuvieron en buen estado e incluso hubo construcciones de nueva creación para adaptarse a los usos docentes. Asimismo, la creación del Colegio del Sagrado Corazón (1852-1868 y después en 1878-1991), el Noviciado y Seminario Menor (1891-1918) y la Escuela Apostólica finalmente (1918-1959) avivaron sin duda la religiosidad cristiana en la villa, convirtiéndose igualmente en foco de atracción para la enseñanza en el entorno palentino. Los Jesuitas fueron testigos de un hecho célebre para la historia de San Zoilo: la Declaración de Monumento Nacional el 3 de junio de 1931. Recuerda Cuadrado con palabras de admiración, la labor ejercida por la Compañía en Carrión: "Sin los jesuitas, cuya modestia y sólida enseñanza vienen a

\footnotetext{
${ }^{1811}$ Admitía que los monjes habían adquirido ladrillos pero ignoraba el motivo y confesaba que le habían adelantado dinero pero no había podido emprender las obras. ARCHV. Pleitos Civiles Pérez Alonso (F). Caja 3581. Exp $33^{\circ}$.
} 
buscar en aquel escondido rincón numerosos alumnos de todos los rincones de España, el monasterio de San Zoilo yacería probablemente confundido en un montón de ruinas ${ }^{\prime 1812}$.

El declive del monasterio llegaría en los años ochenta en que fue totalmente desocupado hasta que en 1991 se creó la Hospedería de San Zoilo adquiriendo las edificaciones del monasterio salvo el claustro y la iglesia, que son visitados independientemente.

\subsection{LAS SUCESIVAS DESAMORTIZACIONES (1800-1851)}

Pocos cenobios podían presumir de haber llegado a principios del siglo XIX con el monopolio de San Zoilo. En 1804 se contabilizan más de medio centenar de posesiones repartidas entre pueblos de Valladolid, Zamora y sobre todo, de Palencia. Los diezmos anuales ascendían por entonces, a nada menos que 520 fanegas de trigo, 220 de cebada y 50 de centeno y los censos de sus heredades producían 23600 reales anuales ${ }^{1813}$. Aún así corrió la misma suerte que las casas conventuales de la provincia. San Zoilo fue suprimido por decreto del 18 de agosto de 1809. Don Plácido Emelgo, último abad del cenobio, que quedó como párroco de la iglesia, se vio envuelto en graves acusaciones, tales como sustracción de fondos, desobediencia a la autoridad y ocultación de bienes. Fue destituido del cargo en junio de 1810 y rehabilitado unos meses después, tras probarse su inocencia. Todos los libros, alhajas y demás efectos que faltaban, los habían extraído los monjes benedictinos que huyeron a Asturias antes de que se produjese un saqueo de los franceses, acto que fue encubierto por Don Manuel Merino de Castro, administrador de bienes nacionales ${ }^{1814}$.

Este suceso ilustra a la perfección el ambiente de hostilidad que se respiraba durante la ocupación de José Bonaparte. El desfalco de piezas artísticas y mobiliario

\footnotetext{
${ }^{1812}$ REVUELTA GONZÁLEZ, Manuel. “Orígenes...Op.cit. Palencia, 1992, pág. 80.

${ }^{1813}$ FRANCIA LORENZO, Santiago. Anecdotario para la pequeña historia de un pueblo. Notas de Archivo, 1. Palencia, 1985, pág. 36.

1814 FERNÁNDEZ MARTÍN, Luis. "La diócesis de Palencia durante el reinado de José Bonaparte 1808-1813” en PITTM, n44. Palencia, 1980, pp. 248-254.
} 
litúrgico de valor durante este período es sobradamente conocido ${ }^{1815}$. Sin embargo, algunos datos recabados de los archivos apuntan un expolio de idéntica magnitud en las sucesivas desamortizaciones de la primera mitad del siglo XIX -del período liberal, de Espartero después y de Mendizábal, posteriormente-. Un inventario realizado en 1809, previo a su llegada nos permite comprobar la existencia de varios lienzos, hoy perdidos, copias de artistas italianos que estaban ubicados en la sacristía $^{1816}$. Podríamos pensar que se pierden en este momento, mas vuelven a figurar en el catálogo que en junio de 1846 envía la Comisión de Monumentos de Palencia de las pinturas que encuentran depositadas en el convento de San Buenaventura de Palencia, procedentes de San Zoilo, y es a partir de entonces cuando se les pierde la pista $^{1817}$.

El recelo y la desconfianza de los monjes a la llegada de los franceses motivan el traslado que de las reliquias de los Santos Zoilo y Félix al templo de Santa María el 5 de mayo de $1810^{1818}$. La veneración y estima que siempre habían tenido las mismas justifica la insistente petición emitida unos años antes por el antiguo abad de San Zoilo, don Bernardo Soto Cabiedes, para recibir una reliquia de San Zoilo y llevársela a una de las iglesias del Principado de Asturias, región que le vio nacer. El acta de donación de la canilla de un brazo del mártir cordobés por parte del abad tuvo lugar en mayo de 1803 en presencia de todos los monjes ${ }^{1819}$. El 13 de agosto de 1814, considerando seguro su regreso, las reliquias fueron llevadas a San Zoilo. Efectivamente por entonces los franceses habían abandonado Carrión y los monjes habían regresado al convento dos meses antes, celebrándose el acto de entrega y posesión del mismo el 23 de junio de $1814^{1820}$.

1815 VALLE CURIESES, Rafael de. A orillas del Carrión...Op.cit, pág. 100 y SANTOS URBANEJA, Fernando. Op.cit, pág. 78. El caso concreto de Palencia en ANTIGÜEDAD DEL CASTILLO-OLIVARES, Dolores. “Aportación documental sobre la enajenación de obras de arte en Palencia durante el gobierno intruso" en AIICHP, n 5. Palencia, 1990, pp. 261-276.

${ }^{1816}$ Inventario de los bienes muebles en AHPP. Desamortización. Leg. 435 s/f.

1817 BECERRO DE BENGOA, Ricardo. "El monasterio..." Op.cit, pág. 91 y ARASF, Palencia, Comisión Provincial de Monumentos, Leg. 2-7-7.

${ }^{1818}$ VALLE CURIESES, Rafael de. A orillas del Carrión...Op.cit, pág. 102 y AHPP. Desamortización 112. Índice del Archivo de San Zoilo. Caja 5a. San Andrés. Legajo 2. Cuaderno A. $\mathrm{n}^{\circ} 25$.

${ }^{1819}$ La solicitud de la reliquia y el acto de donación de la misma en AHPP. Desamortización. Legajo 111.

${ }^{1820}$ La solicitud del abad Fray Fulgencio del Campo al Intendente de la Provincia de Palencia para la reinstalación se fecha en 21 de junio de 1814, haciéndose la entrega dos días después. AHPP. Desamortización. Legajo 56. 
Por decreto de 11 de octubre de 1820 todos los monasterios quedarían suprimidos hasta que en 1823 fuese restablecido el poder absoluto de Fernando VII $^{1821}$. Así, el 9 de marzo de 1820 se procedió diligentemente a la ocupación formal del monasterio, sustrayendo por este orden los libros de cuentas, el archivo, los libros de la librería, el contenido de la bodega, las fincas y propiedades contenidos en los libros de hacienda y apeos. Por último se requisaron todos los bienes muebles inventariados correspondientes a cada uno de los cuartos ${ }^{1822}$. El convento quedaría suprimido en septiembre de dicho año y los cenobios palentinos de Cardeñosa, Benavides, San Pablo de Palencia, Benevívere o Arenillas de San Pelayo, entre otros, sufrieron el mismo destino. Al finalizar el Trienio Constitucional, la ley obligaba a restituir todos los bienes y propiedades incautados sin recibir los compradores de los mismos compensación alguna. Los monjes pudieron recuperar sólo una parte de los bienes de mayor entidad y consideración que habían sido enajenados por el crédito público interponiendo una ejecución judicial por los que aún no habían sido reintegrados ${ }^{1823}$. Se trató de un breve pero agresivo período en el que, según relata el abad Plácido Emelgo, las pérdidas fueron incalculables: las pinturas del archivo, biblioteca, sacristía e iglesia importadas de Roma y Nápoles a principios del siglo XVII fueron irrecuperables ${ }^{1824}$. Sus declaraciones evidencian el deterioro general que sufrió el convento: “...todas sus riquezas, grandezas y consideración desde lo material al edificio hasta la principal forma de su perfección, adorno y hermosura, todo lo perdió en los tres años de la rebelión ${ }^{1825, "}$ De vuelta a la casa conventual, en 1824, los benedictinos pusieron manos a la obra para habilitar nuevamente el edificio procediendo con un retejo general del mismo y

\footnotetext{
${ }^{1821}$ ZARAGOZA PASCUAL, RAFAEL. "Relación de los daños sufridos por algunos monasterios benedictinos españoles durante el Trienio Constitucional (1820-1823)" en Stvdia Monástica, $\mathrm{n}^{\circ} 30$, fascículo 1. Barcelona, 1988, pág. 121

${ }^{1822}$ AHN. Clero Secular-Regular Legajo 5334. Papeles de desamortización, s/f.

${ }^{1823}$ Incluso rescataron el reloj de la torre que fue incautado durante la Guerra de la Independencia y llevado a Palencia. Fue colocado nuevamente, reforzándose al mismo tiempo el remate del campanario con una base de madera y balaustre de hierro. Se construyó incluso un cuarto específico para la maquinaria, en la misma torre, con el fin de preservarla de la humedad y las aguas. Monasterio de Santo Domingo de Silos. ACSBV. Documentos, Volumen 33, n 1187. 1824. Estado general del monasterio de San Zoil de Carrión, fol 319-324v.

${ }^{1824}$ Las obras de arte que atesoraba la biblioteca se recogen en el inventario que en 1820 , fueron incautadas a consecuencia de la exclaustración del convento. Se contabilizan un total de 50 lienzos, todos ellos de temática religiosa, que van desde retratos de Santos a escenas de martirios la vida de Cristo y de la Virgen. AHN Clero Secular-Regular Legajo 5334 s/f Papeles de desamortización 1825 A ello se suman los robos que los comisionados del Crédito Público realizaron al falsear los inventarios y guardar para sí cuantos objetos querían, sometiendo al abad a todo tipo de amenazas. ZARAGOZA PASCUAL, RAFAEL. "Relación...Op.cit, pp. 153-158. A su vez de Monasterio de Santo Domingo de Silos. ACSBV. Documentación varia, XXXII, fol 724-725.
} 
una reforma de las casas del barrio de San Zoles y prioratos dependientes. El número de internos se vio sustancialmente reducido, pues contaban con quince monjes y dos legos, sin incluir el personal especializado -médico, abogado, cirujano- y los mozos de cada oficio -herrero, cubero, etc.--

El golpe más duro llegaría en noviembre de 1835, con la desamortización de Mendizábal, cuando, al parecer, quedaban treinta monjes en el monasterio ${ }^{1826}$. Con arreglo al decreto de 25 de julio de dicho año, se habían inventariado todos los bienes de biblioteca, archivo y pinturas, reservándose, en cambio, los ornamentos litúrgicos, ya que la parroquia se mantenía al culto divino ${ }^{1827}$. En marzo de 1837 las pinturas y libros pertenecientes a los veintidós conventos desamortizados en la provincia de Palencia, incluidos entre estos los de Carrión, pretendían trasladarse a la librería del convento franciscano de la capital palentina. Sin embargo, este edificio presentaba cierta inseguridad dados los acuartelamientos de la milicia nacional, que había sustraído algunos objetos. La Comisión Provincial de Monumentos propone en julio de 1838 la habilitación de una Biblioteca y Museo público en San Zoilo. Éstas contarían con un total de tres salas, dos para galerías de pinturas y una para albergar libros y documentos. Para ello se hacía necesario el derribo de los tabiques pertenecientes a las celdas de los religiosos, destinando para ello una inversión de cerca de nueve mil maravedíes. El proyecto queda en un fracasado conato imposibilitado por la falta de fondos de la Junta científica y artística de Palencia ${ }^{1828}$.

Durante la regencia del General Espartero en el trienio de 1841 a 1843, se decidieron subastar los conventos y monasterios exclaustrados de las provincias, pues los de la capital corrieron mejor suerte al ser entregados a instituciones civiles que les dieron un destino público. A instancias de la Comisión de Monumentos de Palencia, el Ministro de la gobernación accede a la conservación de San Zoilo en una carta con fecha de 3 de julio de 1842 “...por el sin igual mérito artístico de su

1826 RAMIREZ DE HELGUERA, Martín. El libro...Op.cit, pág. 176. El cenobio contaba con cincuenta monjes según otras fuentes LINAGE CONDE, Antonio. Op.cit., pág. 788.

${ }^{1827}$ Carta de Isidro Pérez Roldán enviada Palencia el 18 de octubre de 1835 al convento de San Zoilo comunicándole la enajenación. ACJAH. C11. Carrión de los Condes. 10. Historia, fondo benedictino, visitas, inventarios.

${ }^{1828}$ ARASF, Palencia, Comisión Provincial de Monumentos, Leg. 2-7-7. Veremos cómo muchos de estos bienes pasan a la Sociedad económica palentina a espaldas de la Comisión de Monumentos y al convento de San Buenaventura de la capital castellana. 
claustro bajo...", instando a la contratación de un arquitecto que realice dibujos así como una memoria del mismo. Además dispone se de aviso al intendente de rentas para que no se proceda a la venta del convento hasta nueva disposición ${ }^{1829}$. San Zoilo constituirá, por tanto, un caso singular dentro de los monasterios provinciales pues fue arrendado y parcialmente convertido en fábrica de harinas. Su antiguo abad, fray Plácido Trevijano, quedó como cura de la parroquia de la Magdalena ubicada dentro de la iglesia ${ }^{1830}$.

Respecto a los bienes muebles desamortizados, en junio de 1844 y tras una larga investigación, la Comisión de Monumentos emite un informe en el que revela que en la Sociedad Económica de Amigos del País de Palencia "se hallan en depósito muchos libros, algunos procedentes de conventos" y algunas piezas de valor, sin que nadie lo supiera. El gobierno aseguraba que dicha institución se encontraba abierta al público desde 1839 pero lo visitaban solo ciertos aficionados a la lectura y que desde finales del año siguiente se trataba de un depósito "sin interés” ${ }^{\prime 1831}$. En cuanto a las pinturas, a finales de 1844 se pretende catalogar las que se hallaban en la Catedral de Palencia, sin obtener el consecuente permiso del Cabildo eclesiástico, quien finalmente cedió al solicitárselo el gobierno central. Las pinturas procedentes de la sacristía de San Zoilo estaban depositadas en el convento de San Buenaventura de Palencia y fueron catalogadas en junio de $1846^{1832}$.

La Comisión ruega que todos ellos sean restaurados, pues están "llenos de agujeros y malos pegotes". Reiteran en el intento de que se luche por conservar los monumentos y se hagan dibujos de los mismos "antes que sucumbieren al efecto de las estaciones ${ }^{1833}$ ". La restauración de algunas de estas piezas se estaba llevando a cabo en la sede de la Sociedad económica palentina gracias a la Comisión de Instrucción Pública, como así consta por informe de la Comisión Central de

\footnotetext{
${ }^{1829}$ De todo esto se informa en una carta que don Jacinto Manrique envía al convento el 8 de agosto de 1842.ACJAH. C11. Carrión de los Condes. 10. Historia, fondo benedictino, visitas, inventarios. $\mathrm{N}^{\circ}$ 8400002.

1830 Ibídem.

${ }^{1831}$ ARASF.Palencia, Comisión Provincial de Monumentos, Leg. 2-7-7.

1832 Ibídem. La mayor parte de estos lienzos fueron un regalo traído de Roma por Fray Alonso de Mier, procurador general de la Orden, quien pertenecía al círculo de Clemente XI, por quien era muy estimado. BECERRO DE BENGOA, Ricardo. "El monasterio..." Op.cit, pág. 91.

${ }^{1833}$ ARASF. Palencia, Comisión Provincial de Monumentos, Leg. 2-7-7. La Central de Monumentos acoge favorablemente la petición de las intervenciones más urgentes, descartando la ejecución de restauraciones completas.
} 
Monumentos con fecha 6 de noviembre de $1851^{1834}$. No se vuelve a saber nada de las pinturas de la sacristía, de hecho cuando Ramírez de Helguera visita San Zoilo hacia 1895 afirma que no existía nada de interés salvo "sus ricas y hermosas ropas y ornamentos sagrados $^{1835}$.

\subsection{EL COLEGIO DEL SAGRADO CORAZÓN DE JESÚS (1852-1868)}

En 1850 el gobierno había cedido el monasterio de San Zoilo a la diócesis de Palencia, la cual, dos años más tarde, a través de su obispo se la cede a una comunidad de la orden de San Agustín. Al encontrar el inmueble en un estado no demasiado bueno, los frailes agustinos desistieron de su intención y abandonaron inmediatamente el monasterio ${ }^{1836}$.

Tras la fugaz ocupación de estos religiosos, el 25 de Octubre de 1852, la Compañía de Jesús obtuvo el permiso para fundar un colegio seminario, comunidad restablecida dicho año por el Gobierno de Isabel II desde que los benedictinos fueran expulsados en $1835^{1837}$. Este centro de segunda enseñanza, primero de su género en España, no empezó a funcionar como tal hasta $1854^{1838}$. El fundador y primer rector de este centro religioso fue el Padre Pedro Picazo, que llegó desde Orán, en Lyon, donde era superior de una residencia convertida en colegio. Ardua debió de ser su labor, pues además de reunir un cierto número de jesuitas con quien repartir la docencia, se hizo cargo del ingreso de los alumnos que allí se formasen, que llegarían a ser cerca de sesenta. Para dotar al centro de un nuevo nombre, el Padre Picazo se debatía entre su devoción a San Luis y al Sagrado Corazón de Jesús y al echarlo a suertes, resultó el segundo afortunado, por lo que “...entendió ser de beneplácito divino el que condecorase el futuro seminario con tal dulce y glorioso

\footnotetext{
${ }^{1834}$ Ibídem.

${ }^{1835}$ RAMIREZ DE HELGUERA, Martín. El libro...Op.cit, pág. 153.

${ }^{1836}$ AHJAH. C11. Carrión de los Condes. 10. Historia, fondo benedictino, visitas, inventarios. $\mathrm{N}^{\circ}$ 9540235.

1837 Toda la información acerca del establecimiento de los jesuitas en Carrión se ha extraído de ABAD, Camilo María. Historia del Colegio del Sagrado Corazón de Jesús de Carrión de los Condes (1854-1918). Palencia, 1946.

1838 REVUELTA GONZÁLEZ, Manuel. La Compañía de Jesús en la España Contemporánea. Supresión y reinstalación (1868-1883). Tomo 1.Universidad Pontificia de Comillas. Comillas, 1984, pág. 577.
} 
nombre ${ }^{1839}$ ". La nueva institución tenía como precepto la admisión exclusiva de niños en edades comprendidas entre los ocho y los doce años sujetos a un examen previo a su ingreso, conformándose la repartición en las aulas no en función de su edad, sino en el grado de instrucción de cada uno de ellos ${ }^{1840}$. Los internos debían acatar una serie de normas cuyo incumplimiento comportaría su inmediata expulsión ${ }^{1841}$. Además se reservaba un número de plazas para alumnos externos, los cuales no debían mezclarse en ningún momento con el resto. Todos ellos debían presentarse convenientemente uniformados ${ }^{1842}$.

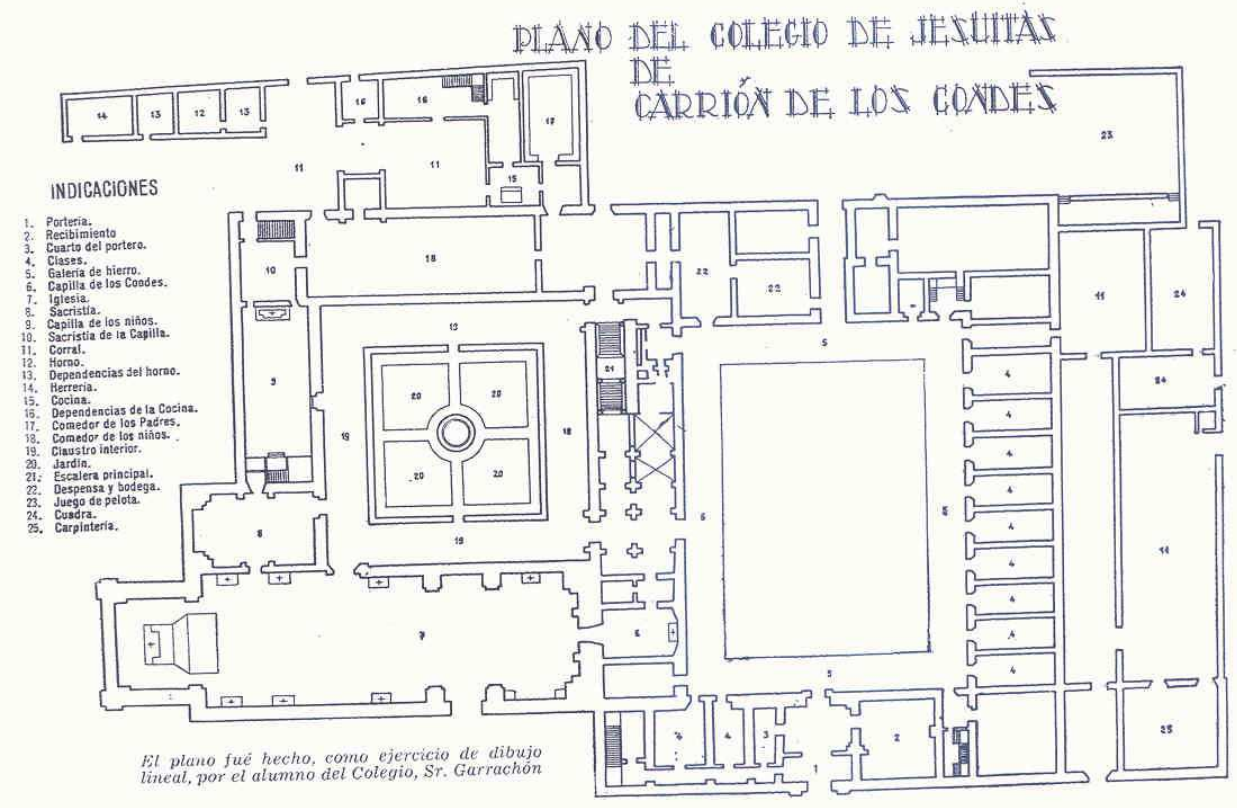

Plano del Colegio de Jesuitas. Extraído del libro del Padre Camilo Abad. Historia del Colegio del Sagrado Corazón de Jesús de Carrión de los Condes (1854-1918). Palencia, 1946.

\footnotetext{
1839 AHJAH. C11. Carrión de los Condes. Historia. ANÓNIMO. Historia del Seminario Menor de Palencia en Carrión de los Condes bajo la invocación del Sagrado Corazón de Jesús. Palencia, 1943, pág. 8. Consúltese este manual para conocer a fondo la organización interna del Seminario ${ }^{1840}$ Normativa del Colegio de la Compañía de Jesús, impresa a máquina en AHPP. Varios. Protocolo 12468. Varios años y escribanos, s/f

${ }^{1841}$ Ibídem. Para muestra del rigor de las mismas, por ejemplo, estaba prohibido comer fuera de los horarios establecidos, recibir visitas previamente autorizadas, o escribir y recibir cartas sin consentimiento del director.

${ }^{1842}$ Ibídem. El equipo de los alumnos consistía en una chaqueta o levita azul con cuello vuelto de terciopelo negro, un pantalón negro de paño fino, un corbatín negro, un chaleco de paño con solapa, una gorra azul con galón de oro y un chaleco de piqué blanco para el verano. Aparte de los recambias, debían proporcionar su ropa de cama (incluido colchones y almohadas) y cubertería.
} 
En el primer año de su andadura, el número de alumnos en el colegio fue bastante elevado, sumando un total de ciento ochenta, de los cuales, ciento doce eran internos y cincuenta y ocho, externos. Éste se redujo al año siguiente debido a la dudosa legalidad del Colegio, pues, ante la falta de profesores con titulación académica dentro del mismo, se ignoraba si los estudios allí cursados eran válidos a efectos académicos.

En 1854 el cólera asoló la villa de Carrión y todos los internos fueron enviados a sus casas. Cuando la situación se normalizó, al año siguiente, los jesuitas vuelven a emprender su labor con la intención de impartir Segunda Enseñanza. El Real Decreto promulgado en Septiembre de 1855, prohíbe que ésta se imparta en los Seminarios. Así, a finales de dicho año, el Gobernador Provincial pretendía clausurar el colegio, sin embargo el empeño del ayuntamiento y de diversos miembros destacados de la comarca se reunieron para impedirlo ${ }^{1843}$. Lograron su propósito al conseguir la autorización, estrictamente concedida a los centros religiosos en septiembre de $1857^{1844}$. E n diciembre de 1858 , se promulga un decreto por el que se convalidan todas las materias siempre y cuando los alumnos se examinasen en el Instituto Provincial de Palencia. A partir de entonces el centro vuelve a experimentar una marcha ascendente.

Hay que destacar la ingente labor realizada para habilitar el centro, pues se hallaba por entonces en un estado totalmente ruinoso y carente de todo lo imprescindible ${ }^{1845}$. La actuación más inmediata consistió en dotar al centro de un mejor aspecto conforme a las nuevas necesidades. Entre estas intervenciones figura la adaptación de la capilla privada para los alumnos en la antigua sala capitular de los benedictinos, esto es, en la parte baja del lienzo oriental del claustro. Los jesuitas construyeron un modesto retablo en uno de los lados cortos de la sala, adaptándose en la medida de lo posible, a la bóveda de cañón existente. Constaba de un solo cuerpo dividido en cinco calles separadas por columnas corintias sobre amplios

\footnotetext{
${ }^{1843}$ Nota cosida sin foliar. Libro 5, Sesiones municipales (1850-1857).

1844 ACJAH. C11. Carrión de los Condes. 10. Inventario histórico-índice del Seminario Menor de Carrión de los Condes de la Provincia de León por el P. Martínez. Nº 9280141 y ss, fol 24.

${ }^{1845}$ Valga como muestra que en la primera cena de alumnos, el día de la inauguración del colegio, a falta de lámpara se improvisó una formada por velas clavadas sobre patatas, a modo de candelabro. ACJAH. C11. Carrión de los Condes. 10. Historia, fondo benedictino, visitas, inventarios. $\mathrm{N}^{\circ}$ 8760015 .
} 
pedestales. A los lados figuraban dos esculturas de santos jesuitas ataviados con túnica blanca y el roquete blanco. El de la izquierda, que porta el crucifijo entre sus manos, lo identificaríamos con San Luis Gonzaga.

Respecto a la figura de la derecha, sin atributos reconocibles, se encuentra actualmente formando parte de los bienes muebles de la iglesia de Santa María, con la indumentaria renovada y luciendo además, manípulo y estola. Entre estos santos, dos lienzos de formato ovalado representan en busto a la Virgen y el Sagrado Corazón de Jesús. Estas pinturas flanqueaban la hornacina central donde una imagen de vestir de la Inmaculada lo presidía, dada la reciente aceptación de su dogma en 1854, defendido por los jesuitas. Atribuida al sevillano Manuel Gutiérrez Reyes Cano, esta imagen, conocida como Madre del Amor Hermoso o Inmaculada de las Congregaciones Marianas pasó posteriormente al templo de Santa María, donde se conserva hoy día ${ }^{1846}$.

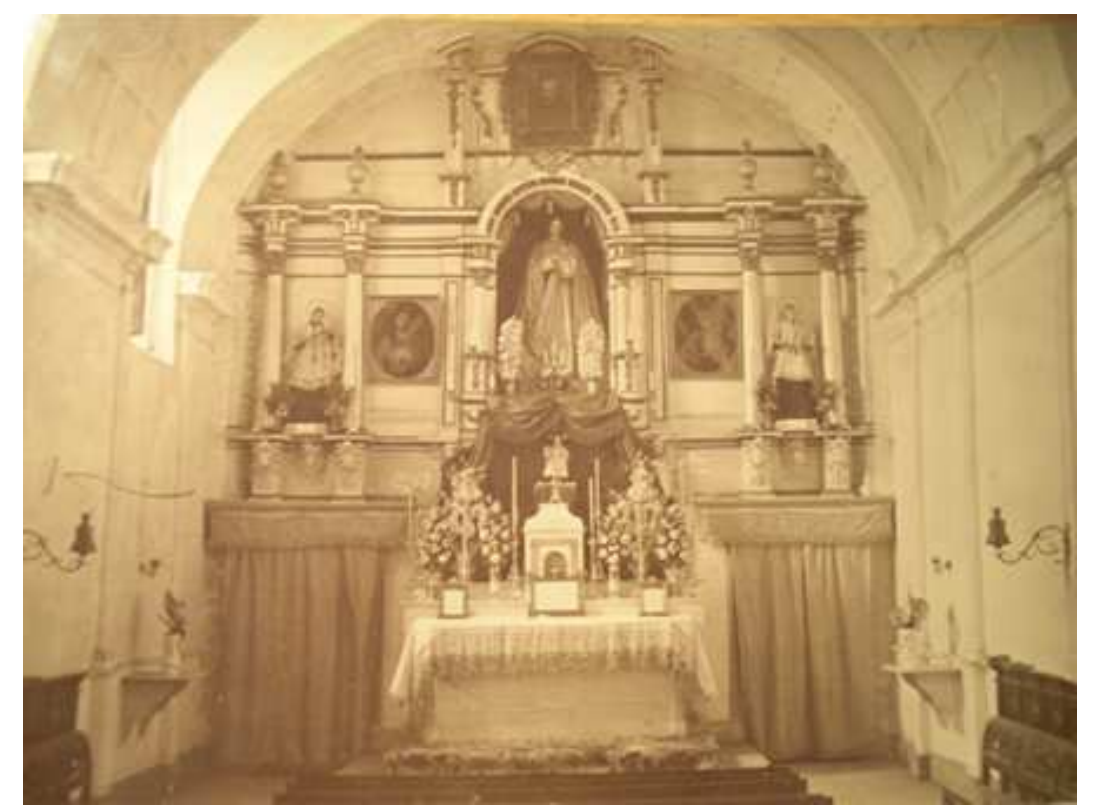

\section{Capilla de los Colegiales en la antigua sala capitular del monasterio con retablo} dedicado a la Inmaculada. ACJAH. Carrión. Fotografías.

\footnotetext{
${ }^{1846}$ LUNA MORENO, Luis. "Madre del Amor Hermoso" en Iconografía Mariana: La Inmaculada. Catálogo de la exposición del 31 de octubre al 12 de diciembre en el RR.MM. Clarisas de Carrión de los Condes. Carrión de los Condes, Palencia, 2004, pág. 62. Las ropas que hoy lleva fueron donadas por la célebre mística de Carrión, Francisca Javiera del Valle. DIEGO SÁNCHEZ, Manuel. Fuentes históricas para la biografía de Francisca Javiera del Valle (1856-1930). Palencia, 1991, pág. 171.
} 
El remate albergaba un pequeño retrato de San Ignacio de Loyola con el emblema de los jesuitas en la parte superior. Bajo el mismo se podía leer la siguiente inscripción: "EL VERDADERÍSIMO RETRATO DE DE SAN IGNACIO DE LOIOLA, FVNDADOR DE LA COMPAÑÍA”. Atribuido a un seguidor de Claudio Coello, este lienzo proviene del Colegio de Jesuitas de Madrid ${ }^{1847}$. A continuación de la capilla, se hallaba el antiguo refectorio que fue destinado como comedor de los colegiales, pues los Padres tenían un espacio para este fin ubicado más al sur, entre el juego de pelota y la huerta. En el primer piso, también en torno al claustro se dispusieron diversos estudios para los niños y los aposentos de los Padres en el lado meridional. En el segundo piso, sobre el espacio de la sacristía se dispuso la biblioteca, comunicada con la sacristía del piso bajo a través de una escalera de servicio que también se levantó. En ella se guardaban obras antiquísimas que se tenían en gran estima ${ }^{1848}$. También en este lado oriental se ubicaban los aposentos de los profesores, que continuaban por el lado meridional y en éste además se hallaban las dependencias de la enfermería ${ }^{1849}$.

En la iglesia, el retablo barroco fue desmontado y reemplazado por una obra moderna de dudoso gusto cuya apariencia conocemos a través de unas fotografías antiguas. Por la referencia al mismo por parte de Quadrado, sabemos que en 1861 ya estaba instalado ${ }^{1850}$. Se trataba de una especie de tabernáculo rectangular dispuesto sobre la mesa de altar que sobresalía de la misma por ambos lados y desprovisto de imágenes. Estaba decorado con gran cantidad de cirios e iluminado por una serie de grandes lamparones que colgaban del techo, delante de un cortinón que hacía las veces de telón de fondo, cubriendo así el espacio vacío del muro oriental, dado el pequeño tamaño del altar.

Para todas estas obras se sirvieron en muchos casos de cascote, madera y otros materiales procedentes del derruido convento de San Francisco. Cuando la noticia llegó a oídos de don Pedro Merino, recién nombrado en el cargo de

\footnotetext{
${ }^{1847}$ ACJAH. C11. Carrión de los Condes. Fotografías. Nota en reverso.

${ }^{1848}$ Entre ellas, el Libro primero de Concilios en letra gótica, las Epístolas de Montano, arzobispo de Toledo, la homilía de San Leandro o el Concilio Emeretense. RAMIREZ DE HELGUERA, Martín. El libro...Op.cit, pág.. 177.

${ }^{1849}$ Para mayor aclaración, visualizar los planos existentes de este período en ABAD, P. Camilo María. Historia...Op.cit.

${ }^{1850}$ QUADRADO; José María y PARCERISA, Francisco J. Op.cit, pág. 133.
} 
administrador de bienes nacionales, éste se presenció en el colegio para realizar un inventario de todo lo que el Obispo había ordenado extraer para las obras del colegio, según él sin permiso. Tras una trifulca escandalosa, quedó sin esclarecer en qué grado se habían incautado materiales del convento terciario, pues Merino fue llamado a resolver una contienda entre los milicianos, desistiendo así, en sus indagaciones $^{1851}$.

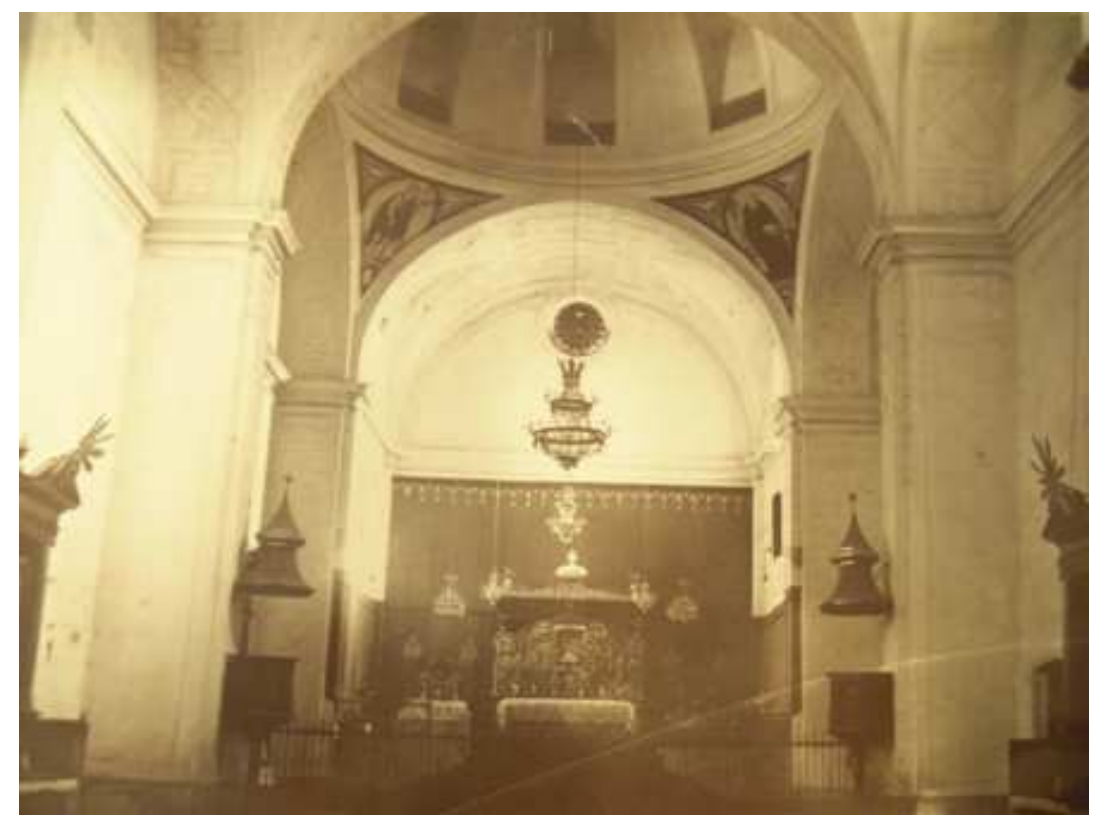

\section{Aspecto del templo desde 1861. ACJAH. C11. Fotografías antiguas.}

La prosperidad condujo a la ejecución de una serie de reformas y mejoras. Para empezar se compró en 1862 la huerta contigua al monasterio en su lado sur, la cual había sido propiedad del mismo hasta 1836 en que fue enajenada a un particular. Dicha huerta, "hermosísima, frondosa y abundante en frutas y hortaliza” ocupaba una extensión de cuatro hectáreas y media. En ella se levantó el espacio para los juegos de pelota y junto a ellos, dependencias para el ganado, gallineros, lavadero, entre otros ${ }^{1852}$.

${ }^{1851}$ ACJAH. C11. Carrión de los Condes. Historia. Historia del Seminario...Op.cit, pág. 17-19.

${ }^{1852}$ RAMÍREZ DE HELGUERA, MARTÍN. El libro...Op.cit, pág. 177. 
En torno a 1864, se procedió a la edificación de un gran patio abierto entre cuatro lienzos de cátedras para más de 240 internos. En línea con el carácter riguroso de los jesuitas, presenta una sencilla estructuración en cuatro pisos de ventanales dispuestos alineadamente, aportando una sensación de armonía y sencillez propios del estilo. Enmarcando los vanos se dispone una sencilla moldura con orejetas en los ángulos, de raigambre barroca. Entre el nivel a ras de suelo y el resto de pisos se existe una cornisa rodeando todo el perímetro del patio que refuerza su carácter horizontalista.

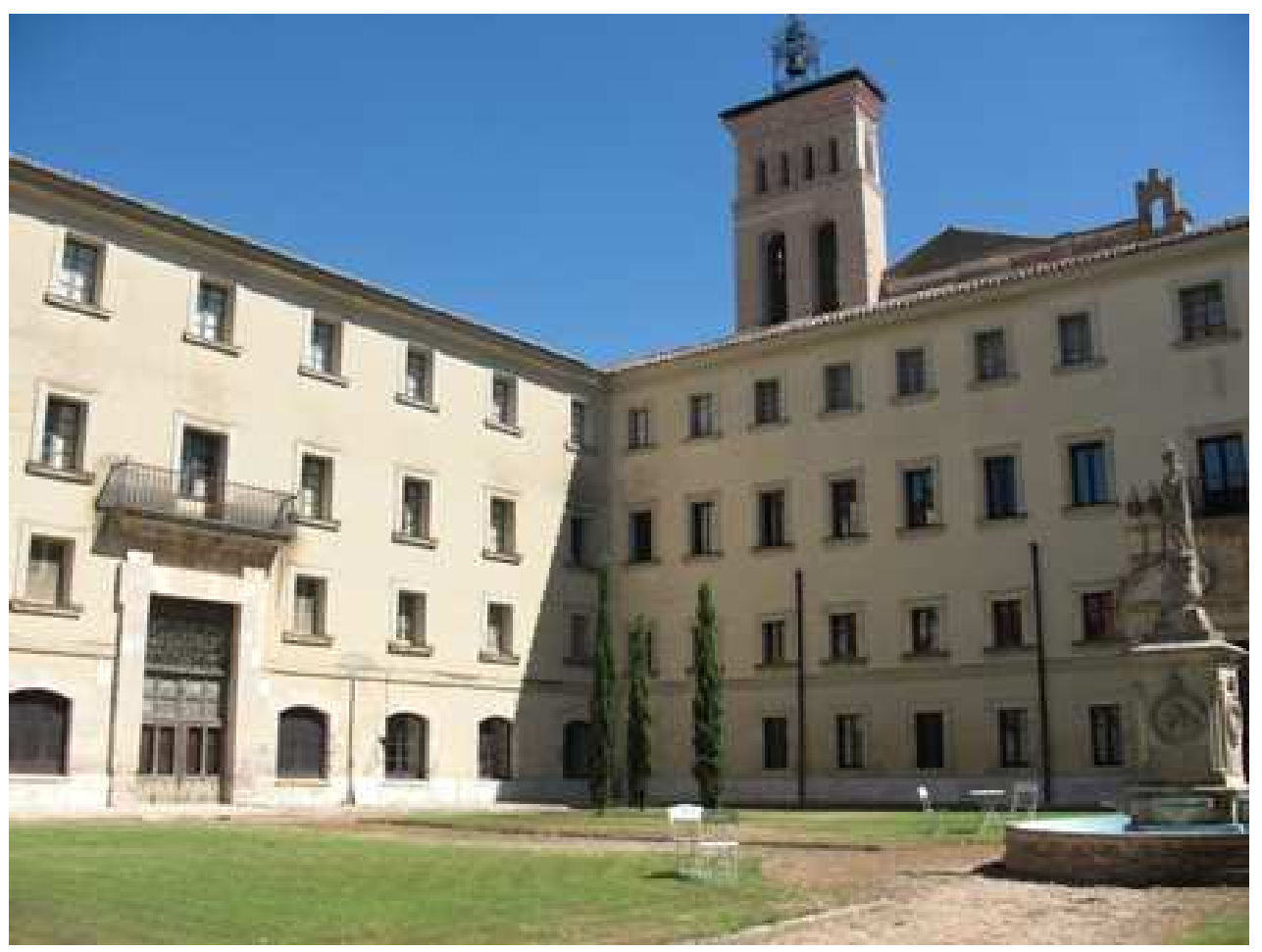

Patio de los jesuitas, construido hacia 1864.

En torno a este patio, en la planta baja, se situaban la portería al norte, las clases en el lienzo occidental y la despensa y bodegas en el lado sur, quedando en la parte oriental la consabida escalera principal y el espacio de comunicación con el claustro. El piso principal alojaba en la parte que caía sobre la portería, un depósito de baúles, en el lado este un teatro y en la parte meridional se hallaban los Gabinetes de Física e Historia Natural y el Laboratorio de Química. Por último, el segundo piso. Los dormitorios de los colegiales se disponían en todo el perímetro de la 
segunda planta $^{1853}$. Con el fin de proteger de la lluvia y del calor a los colegiales, en 1865 se trajo desde Bélgica un cobertizo de hierro y zinc para el patio que se derrumbaría veinte años más tarde, muriendo cuatro alumnos bajo sus cascotes ${ }^{1854}$.

De esta época es la fachada del monasterio. Todo el perímetro del conjunto está desprovisto de ornamentación. Tan sólo existe una organizada compartimentación de los ventanales, dispuestos en línea, que corresponderían a las diversas habitaciones de los colegiales y estancias respectivas. En palabras de Quadrado: “...vasto y regular como un cuartel, presenta en sus líneas la más insípida igualdad y la más completa desnudez en todo su esterior... ${ }^{1855}$ ". La portada “simple y de gran carácter ${ }^{1856 "}$ se compone de un sencillo acceso entre dos pares de columnas jónicas sobre el cual puede leerse "COLEGIO DE CARRIÓN DE LOS CONDES". Sobre el mismo descansa un entablamento, igualmente de orden jónico y remata en un frontón triangular ornamentado de dentellones en el cual figura el escudo real.

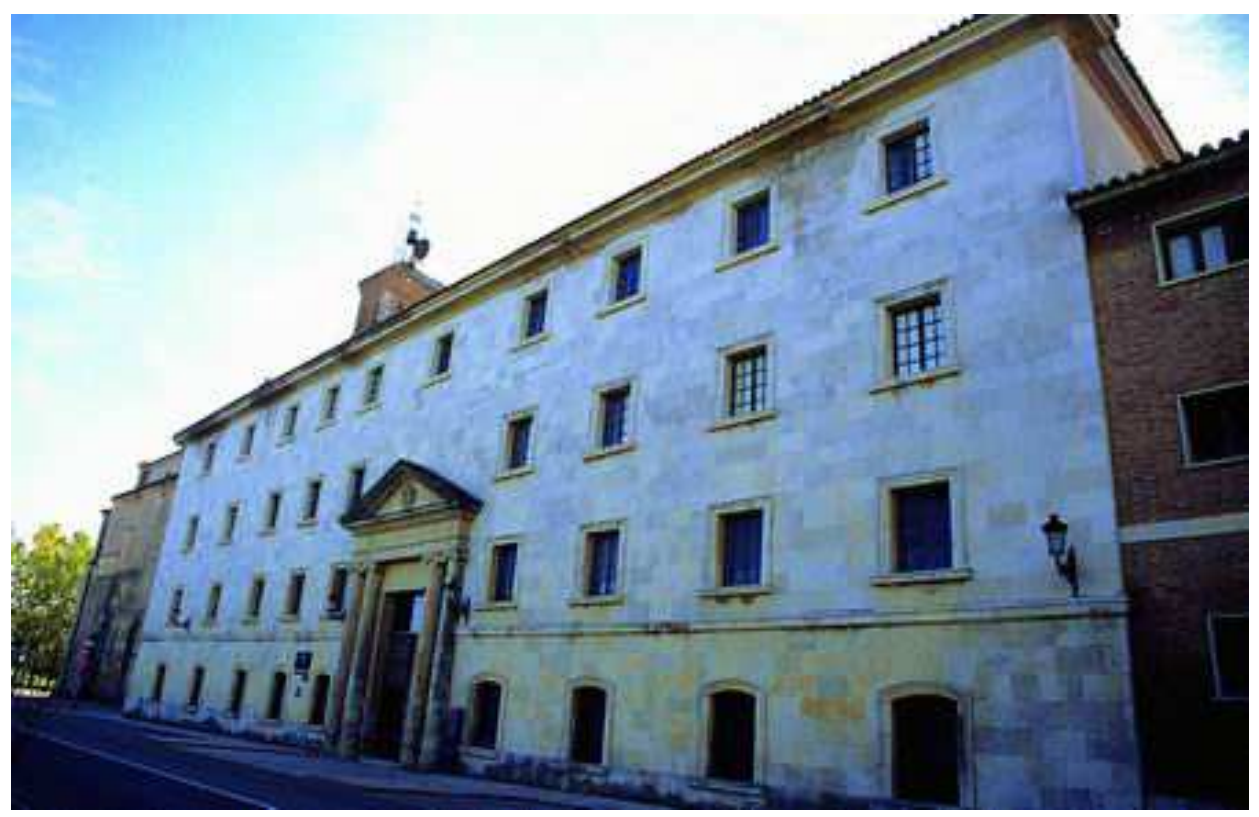

Fachada del Colegio de los Jesuitas.

\footnotetext{
${ }^{1853}$ Para mayor aclaración, visualizar los planos existentes de este período en ABAD, P. Camilo María. Historia...Op.cit.

${ }^{1854}$ Conservamos fotografías donde se puede ver dicha marquesina.

${ }^{1855}$ QUADRADO; José María y PARCERISA, Francisco J. Op.cit, pág. 132.

${ }^{1856}$ ZARAGOZA PASCUAL, Rafael. “Abadologio...Op.cit, pp. 306.
} 


\subsection{MULTIPLICIDAD DE USOS CIVILES (1868-1877)}

La llegada del Sexenio Revolucionario supuso la expulsión de los jesuitas de Carrión. El 18 de octubre de 1868 se envía una misiva al director del colegio de San Zoilo para que sus integrantes abandonen el centro en un plazo máximo de dos meses, incautándose todo el mobiliario y material científico ${ }^{1857}$.

Para un pueblo de cinco mil habitantes como era Carrión, sustentado básicamente en la agricultura y el comercio, el colegio aportaba unos recursos económicos importantes, lo cual, sumado al ambiente religioso y favorable a la comunidad jesuita, condujo a que su marcha repercutiera negativamente en la misma. A pesar de los esfuerzos de las junta carrionesa, que llegó a enviar una solicitud al gobierno y proponer la gestión del colegio por un grupo de profesores laicos, nada pudo evitar el cierre del mismo ${ }^{1858}$.

Con la expulsión de la Compañía, los hermanos coadjutores se dirigieron a Francia y los padres se repartieron por España. En el colegio permaneció al cuidado del mismo únicamente El Hermano José Alberdi, en calidad de servidor del que fue último abad benedictino, Don Plácido Trevijano. El rector del Colegio solicitó que fuera éste último junto con su hombre de confianza, don Matías Caballero, quienes se encargasen de custodiar los bienes inventariados con anterioridad por la Junta Revolucionaria ${ }^{1859}$. Sin embargo, al traspasarse la propiedad del convento a manos del ayuntamiento, el gobierno civil designó al administrador de hacienda pública para que desempeñase dicho cargo ${ }^{1860}$. Las consecuencias de dicha expulsión, sumadas a las cosechas recientes de pésimo resultado, pronto se dejarían notar en la villa, produciéndose la emigración de más de una quinta parte de la población hacia

\footnotetext{
1857 ACJAH. C11. Carrión de los Condes. 10. Historia, fondo benedictino, visitas, inventarios. $\mathrm{N}^{\mathbf{0}}$ 8680007.

${ }^{1858}$ Incluso los miembros de la junta de Carrión llegaron a reunirse con Cánovas del Castillo para ver si éste cedía a sus pretensiones, pues cuando estuvo desterrado en la villa en 1868 había trabado amistad con algunos de los comisionados. Éste les aconsejó que si querían mantener abierto el colegio, lo pusieran a cargo de seglares o escolapios, no de jesuitas. REVUELTA GONZÁLEZ, Manuel. La compañía de Jesús...Tomo 1.Op.cit, pp. 119-120.

${ }^{1859}$ La relación de los utensilios entregados en virtud de la autorización del Gobernador Civil de la Provincia en 1869 en ACP. Documentación del Hospital de Santa María de Carrión. Legajo 3, nº16. Inventarios generales del hospital (1862-1941), s/f.

${ }^{1860}$ AMCC. Libro 8, Sesiones municipales (1868-1871). Sesión de 26 de octubre de 1868, fol 5v.
} 
medios más favorables ${ }^{1861}$. Los jesuitas no poseían ninguna pertenencia en muebles ni raíces, pues todo lo que existía era propiedad del Obispado quien se lo había cedido cuando se establecieron, de ahí que fueran obligados a devolver todo una vez inventariado $^{1862}$.

Desde abril de 1869 hasta finales de dicho año el colegio fue usado como cárcel. Los presos fueron alojados en el patio principal y cátedras de la parte sur para evitar sufrir el contagio por fiebres tifoideas que habían infectado el local utilizado hasta entonces ${ }^{1863}$. La venta de San Zoilo fue planteada en 1871, pero la Real Academia de Bellas Artes de San Fernando emite un informe favorable sobre el monumento al Ministro de Hacienda demandando una excepción ${ }^{1864}$. Un mes después, en abril el ayuntamiento solicita el uso del cobertizo de hierro del patio grande de San Zoilo como mercado y el resto de la edificación como hospital, basándose en que no se disponía de lugares convenientes a tal efecto ${ }^{1865}$. Denegada la petición, en septiembre de 1871, el Gobierno provincial decidió destinar el edificio a Instituto libre de segunda enseñanza ${ }^{1866}$. Parece ser que fue durante estos años cuando se produjeron las mutilaciones de algunas de las esculturas del claustro que se encontraban al alcance de las manos de los alumnos ${ }^{1867}$.

Tan sólo tres años habían transcurrido desempeñando esta función y el ayuntamiento decide que el mantenimiento del mismo resulta imposible, optándose

\footnotetext{
${ }^{1861}$ Ibídem. Sesión de 14 de noviembre de 1868, fol 14v.

${ }^{1862}$ Salvo la huerta, que pertenecía a los herederos del particular que la había cedido, y algunos muebles, que trajeron los colegiales, el resto del edificio pertenecía a la mitra. El inventario fue realizado el 16 de octubre de 1868. AHPP. Varios. Protocolo 12468, s/f.

1863 AMCC. Libro 8, Sesiones municipales (1868-1871), s/f. En sesión de 22 de abril de 1869 se ordena el traslado de los presos al ex convento y en sesión de 21 de noviembre de 1869 se informa que los presos han sido trasladados a la nueva cárcel. El ayuntamiento financia la instalación con fondos municipales. AHPP. Desamortización. Legajo 66, s/f.

${ }^{1864}$ ARASF. Palencia, Comisión de Monumentos, Leg. 2-7-7, Monumentos especiales.

1865 Sesión municipal de 16 de abril de 1871 AMC. Libro 8, Sesiones municipales (1868-1871), s/f y también en AHPP. Desamortización. Legajo 66, s/f.

${ }^{1866}$ AMCC. Libro 8, Sesiones municipales (1868-1871). Sesión municipal de 27 de agosto de 1871 y de 28 de septiembre de 1871 , s/f.

${ }^{1867}$ En 1872 el gobernador provincial de Palencia ordena a la Comisión de Monumentos Artísticos llevar a cabo un recuento de los desperfectos causados en el convento y le responden en estos términos: "Han sido inutilizados los bustos de personajes de la Sagrada Escritura que adornan las ménsulas donde arrancan los arcos del claustro, que éstas y más obras de arte que constituyen la ornamentación de la repisa y otros caprichos que dan fisionomía especial están al alcance de la mano, han sido destruidos a martillazos causando un daño que sobre no proporcionar provechos al que lo ha verificado, demuestra una criminal complacencia al inferirlo”. AHPP. Desamortización. Legajo 66. (1871-1872), s/f.
} 
por establecer un colegio privado ${ }^{1868}$. Para la nueva función se hizo imprescindible intervenir en el edificio para realizar las reparaciones convenientes, que estuvieron al cargo de Gaspar del Campo, albañil palentino que igualmente participó en algunas de las obras del nuevo consistorio ${ }^{1869}$. Desempeñó esta función por tanto desde 1874 hasta 1877.

\subsection{REGRESO DE LOS JESUITAS (1877-1959)}

\section{Colegio (1877-1891)}

Con la restauración borbónica de 1874 y la proclamación de la Constitución en 1876, los jesuitas fueron readmitidos nuevamente, siendo el Obispo de Palencia, Don Juan Lozano, quien entrega San Zoilo a la Compañía en junio de 1877 para que instale un colegio de bachillerato formado por internos y externos, único por entonces en Castilla.

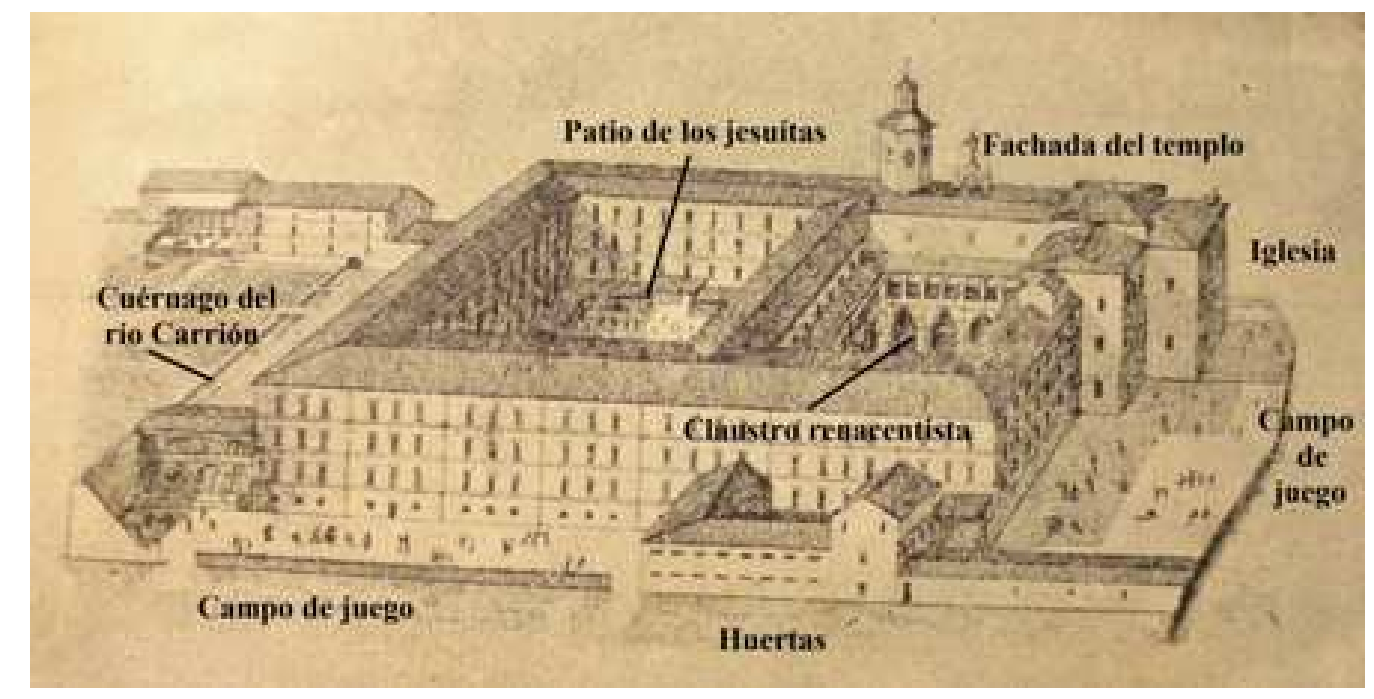

Dibujo aéreo del Monasterio de San Zoilo en la época del Colegio de Jesuitas.

\footnotetext{
${ }^{1868}$ AMCC. Libro 9, Sesiones municipales (1872-1877). Sesión extraordinaria de 6 de septiembre de 1874 , s/f.

${ }^{1869}$ Ibídem. Sesión de 6 de de 1874, s/f.
} 
Paralelamente desempeñó la función de filosofado, pues los jesuitas procedentes de la de Poyanne, huían de las pésimas condiciones climatológicas de la casa aquitana. Fueron acogidos en San Zoilo pero desarrollaban sus funciones separadamente de los colegiales. Fue una época de gran esplendor para Carrión, pues entre ambos grupos sumaban trescientos setenta y ocho miembros ${ }^{1870}$.

Se habilitó una capilla en el coro de los monjes, a los pies del templo, en su parte alta. Gracias a una fotografía podemos ver la adaptación que hicieron los jesuitas de este espacio, disponiendo un alto panel de madera que impedía la visualización del templo. Adosado al mismo se colocó una mesa de altar que sustentaba un pequeño retablo de un cuerpo que cobijaba una imagen de vestir de la Inmaculada con pelo postizo de factura moderna. Sin embargo el retablo -aunque no podemos verlo con claridad- parece ser una obra de principios del siglo XVIII por las amplias columnas salomónicas ornamentadas de vides y el acentuado retranqueo de la cornisa.

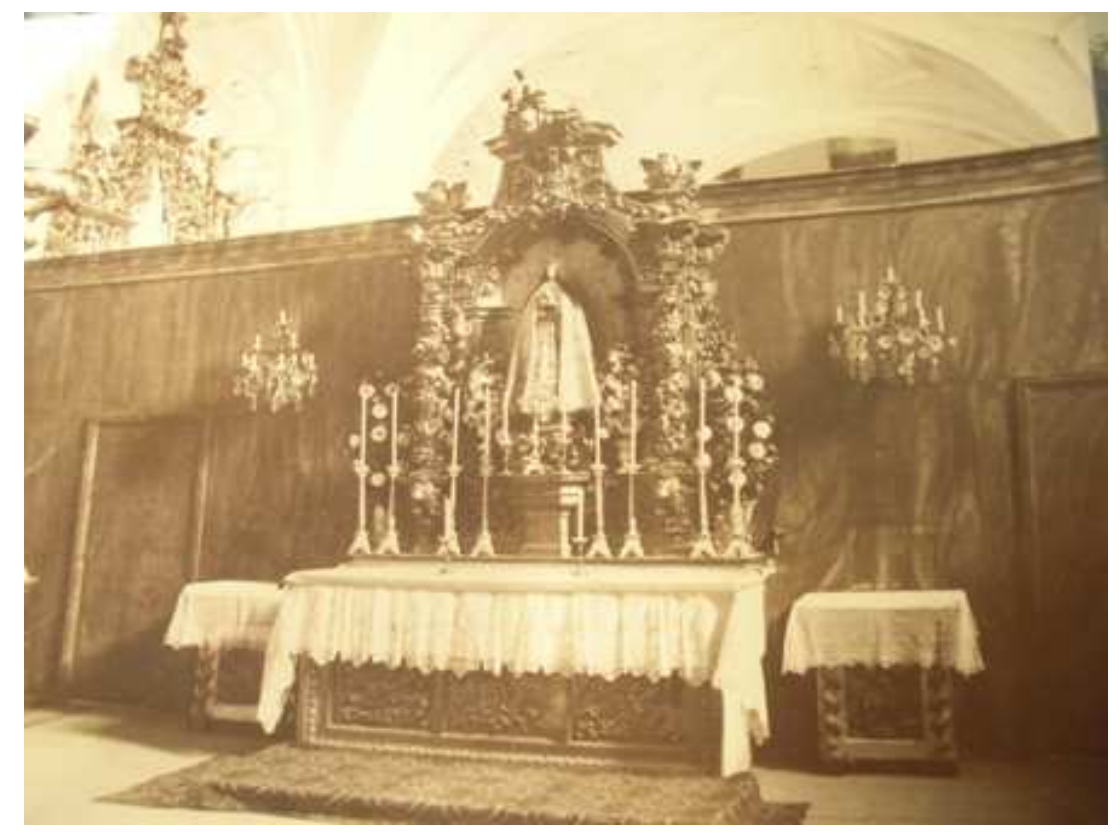

Adaptación del coro alto como capilla de la Inmaculada para los Colegiales. ACJAH. C11. Carrión. Fotografías.

\footnotetext{
${ }^{1870}$ REVUELTA GONZÁLEZ, Manuel. La Compañía de Jesús...Tomo 1.Op.cit, pp. 580-581 y 730-
} 733. 
La apertura del colegio de Valladolid en 1883, y del de Gijón cuatro años más tarde, condujo a una considerable disminución del número de internos en el de Carrión y a la posterior clausura del mismo en 1891, al ser considerada innecesaria su existencia. Se acuerda asimismo trasladar a San Zoilo la mitad del Noviciado de Loyola e impartir clases gratuitas de todas las materias para los escolares externos que deseen frecuentarlas ${ }^{1871}$. El caso de Carrión y el barcelonés de San Ignacio de Manresa constituyen las dos excepciones de colegios peninsulares que tras la revolución se instalaron en el mismo edificio que ocuparon anteriormente. Además en ambos la vida colegial vio su final en la misma fecha, cuando el colegio catalán fue trasladado a Barcelona ${ }^{1872}$.

\section{Noviciado y Seminario menor (1891-1918)}

Desde finales de 1890 los superiores del centro se venían replanteando el próximo destino de San Zoilo, y dado que hacía años que era necesario dividir a los internos de Loyola, se planteó el destino de noviciado para Carrión. Existía no obstante, la posibilidad de instalarlos en La Merced de Burgos, en proceso de restauración por aquel tiempo. En septiembre de 1891 se decantaron por la casa de Carrión, que se transformó, por tanto, en Noviciado y Seminario Menor diocesano (juniorado). El Seminario fue también conocido con los nombres de Escuela de Gramática o "Externado" porque la mayor parte del mismo estaba formado por miembros que acudían al colegio sin vivir internados y pertenecían a familias acomodadas, siendo éstas quienes se responsabilizaban de su manutención ${ }^{1873}$. La minoría restante, formada por alumnos internos destinados a ser novicios, se hospedaba en "la Fonda", una finca cercana que pertenecía a San Zoilo compuesta por una casa, huerta y almacenes. Éstos conseguían la manutención gracias a las becas y ayudas de los jesuitas.

\footnotetext{
${ }^{1871}$ ACJAH. C11. Carrión de los Condes. 10. Historia, fondo benedictino, visitas, inventarios. N ${ }^{\mathbf{~}}$ 8760015.

${ }^{1872}$ Hay que tener en cuenta que una parte de los internos de Carrión procedían de Asturias, y al tener noticia de la apertura del colegio en Gijón, es lógico que marcharan allí. A ello hay que sumar el descuido de algunas partes del edificio de Carrión, la escasez de personal y el derrumbe en 1884 del cobertizo que, al causar la muerte a cuatro alumnos, produjo una gran desconfianza entre los familiares de los internos. REVUELTA GONZÁLEZ, Manuel. La Compañía de Jesús...Tomo 1.Op.cit, pág. 731-736.

${ }^{1873}$ REVUELTA GONZÁLEZ, Manuel. La Compañía de Jesús...tomo 2. Op.cit, pp. 1148-1153.
} 
Para adaptar el centro a su nuevo destino, se llevaron a cabo ciertas modificaciones. Se pavimentó el refectorio, se reformó la cocina y se ampliaron los dormitorios de los colegiales. El cambio más evidente lo experimentaron los Gabinetes de Historia Natural, los cuales se transformaron en enfermería.

La capilla de los novicios se ubicó en un principio en la que habían usado los colegiales, en la planta baja, en el antiguo capítulo. Sus paredes fueron revestidas con los respaldos de la sillería del coro bajo y se abrieron dos entradas en el muro del retablo, por debajo del mismo, que al parecer contenían pinturas con el tema de la Pesca milagrosa ${ }^{1874}$. Esta capilla se mantuvo; Sin embargo en 1893 se establecería otra en el antiguo salón de actos y teatro del Colegio, que se inauguraría tres años después. Estaría ubicada, por tanto en el lienzo occidental del claustro alto ${ }^{1875}$.

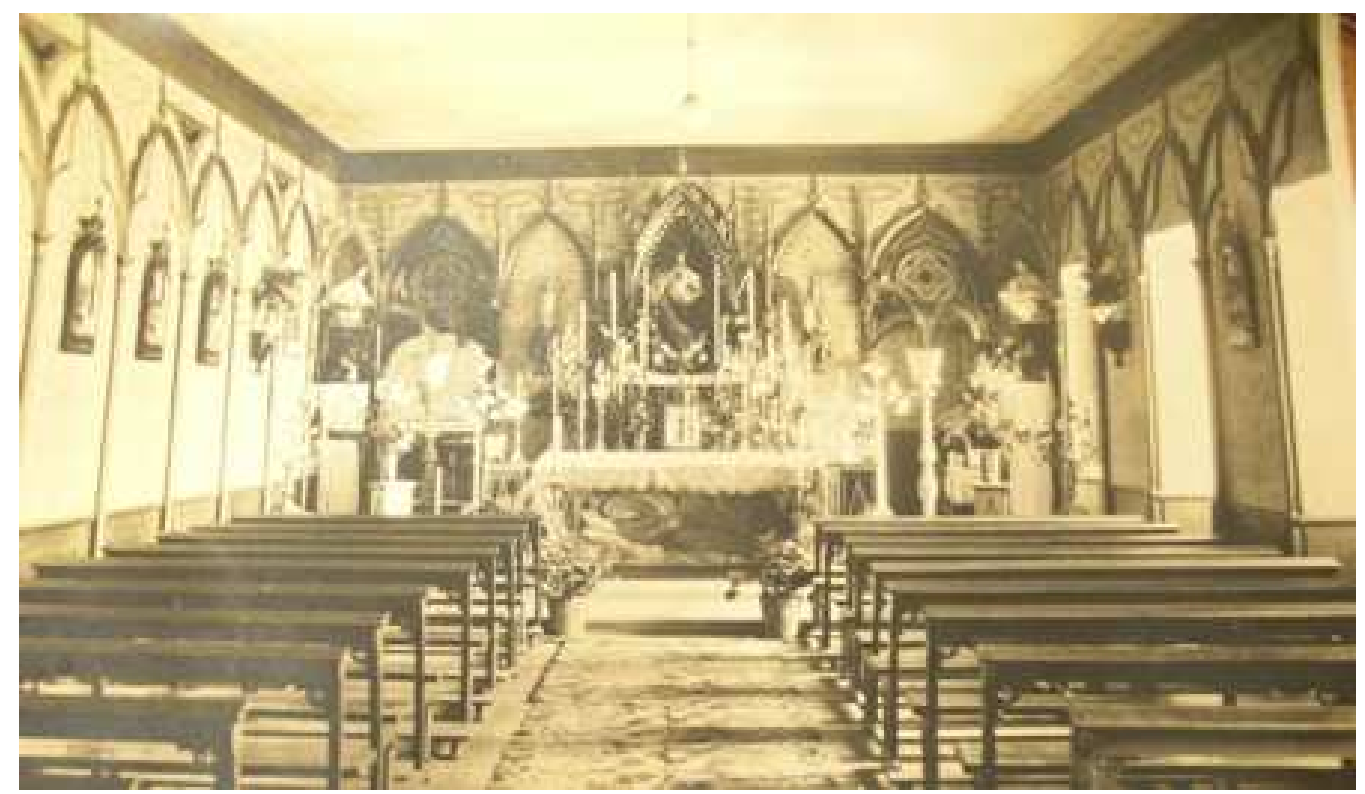

Capilla de los Novicios en el lienzo occidental del claustro alto. ACJAH. C11. Carrión de los Condes.

\footnotetext{
1874 MARTÍN MÍNGUEZ, Bernardino. Catálogo... vol 3. Op.cit, pág. 104. Puede verse la sillería y los huecos abiertos tapados con cortinajes en una fotografía antigua.

${ }^{1875}$ Esta capilla existió hasta el año 2000 en que, por obras de ampliación del hotel, lo convirtieron en habitaciones. Las arcadas neogóticas estuvieron colocadas decorando el pasillo que se dirige hacia la actual discoteca. Las imágenes se guardaron en un armario ubicado frente a la iglesia del que se deshicieron cuando se descubrió el capitel románico. Información cortesía de Ángel Luis Barreda Ferrer, director del Centro de Estudios y Documentación del Camino de Santiago, Enrique Gómez Pérez, historiador y autor de varios libros y artículos sobre el patrimonio de Carrión.
} 
Se dispuso en todo el perímetro de la estancia rectangular una arquería compuesta por una conjunción de arcos ojivales sobre columnillas estilizadas en madera, que apenas sobresalen unos centímetros de la pared. En el lado oriental, una imagen del Sagrado corazón de Jesús preside la hornacina central. Le flanquean dos pequeñas esculturas -apenas visibles en la fotografía- que parecen ser una Inmaculada y San José con el niño. En los laterales figuraban las imágenes de los jesuitas que se ubicaban en la capilla del primer colegio jesuita, hoy en la iglesia de Santa María.

De esta época también son las cristaleras de las ventanas del claustro alto que hasta entonces se cerraban con contraventanas de madera, el entarimado de la mayor parte del edificio y el retablo mayor ${ }^{1876}$. Según parece, esta pieza fue un regalo de una señora de San Sebastián a los jesuitas, que sustituyó al anterior retablo, el cual fue retirado ${ }^{1877}$.
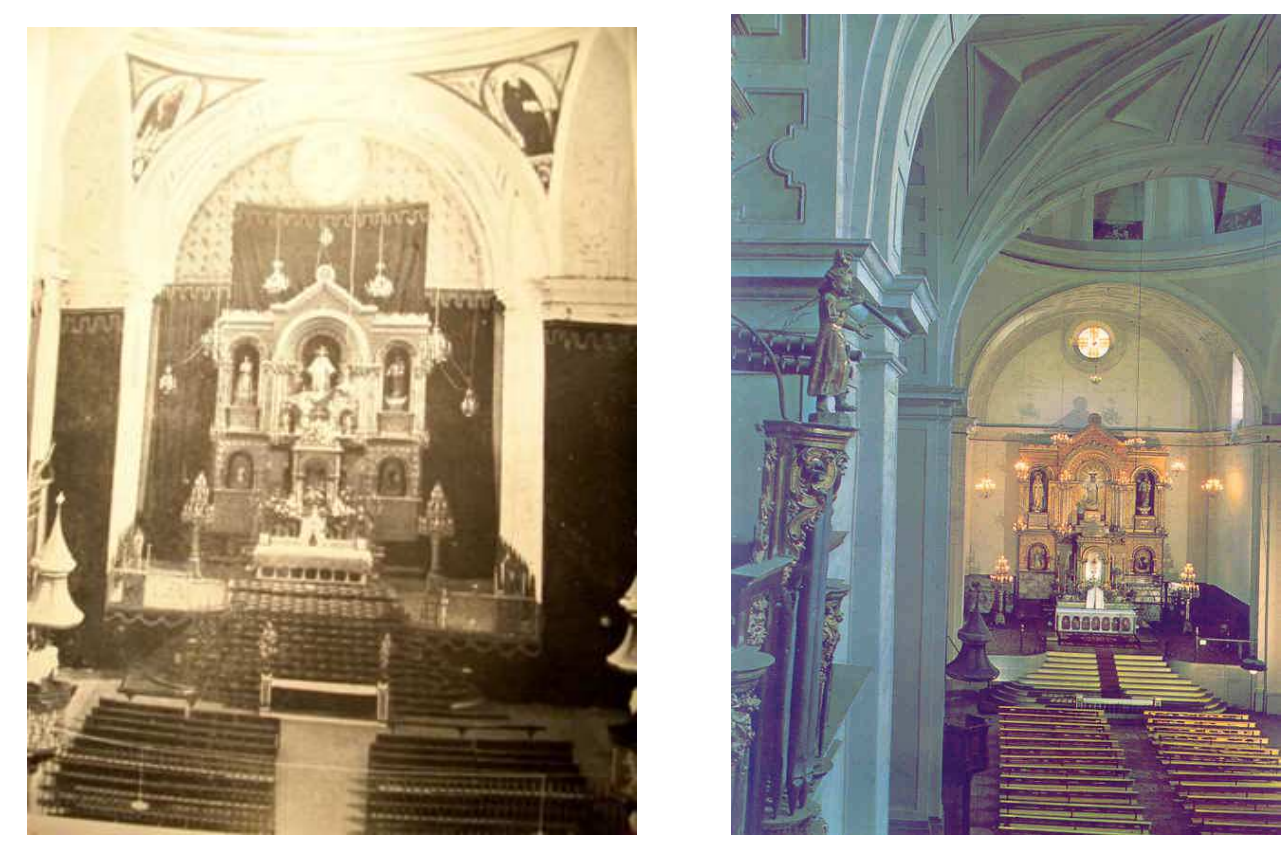

\section{Aspecto del templo en la época del Noviciado y Seminario con el retablo} neorrománico. ACJAH. C11. Fotografías.

\footnotetext{
${ }^{1876}$ ACJAH. C11. Carrión de los Condes. 10. Historia, fondo benedictino, visitas, inventarios. $\mathrm{N}^{\mathrm{o}}$ 8760015.

${ }^{1877}$ MARTÍN MÍNGUEZ, Bernardino. Catálogo...Op.cit, volumen 3, pp. 99-100.
} 
A través de una foto de pésima calidad podemos ver que se trataba de una obra de estilo neorrománico y dorada íntegramente, conformada por dos cuerpos divididos en tres calles. El cuerpo inferior contenía dos pequeñas hornacinas que flanqueaban un tabernáculo central coronado por una cúpula de media naranja. En el cuerpo principal se ubicaban tres imágenes, La Purísima y San José con el niño a los lados y en la parte central, el Sagrado Corazón de Jesús ${ }^{1878}$. Esta escultura se integraba en un vano de medio punto con columnillas y arquivoltas, una especie de intento de reproducción de una portada románica. Cuando el retablo fue desmontando para ubicar el barroco que, procedente de Baquerín de Campos, preside actualmente la capilla mayor, el cuerpo central se conservó y hoy día decora una de las salas de estar del hotel San Zoilo ${ }^{1879}$.

La capilla que utilizaba el Provincial para uso personal es la que conocemos con el nombre de capilla del abad, ubicada en el lienzo norte del claustro alto, inmediata al coro ${ }^{1880}$. Aún hoy día se conserva el retablo de yeso de escaso mérito artístico que encargaron los jesuitas. Dispuesto sobre una mesa de altar, consta de un solo cuerpo cuya superficie imita las vetas del mármol. Se divide de un modo sencillo a través de tres calles separadas por dobles pilastras. En los lados, una escultura moderna de San José con el niño, y un Santo jesuita, probablemente San Ignacio de Loyola, escultura reaprovechada de otro retablo, pues es una obra del siglo XVII. En el centro, dispuesta en una hornacina tachonada con estrellas negras sobre un manto azul, se dispone la Inmaculada, una imagen de vestir con cabellos postizos que se ubicaba en el retablillo del coro alto que usaron los colegiales.

Con posterioridad a estas obras, constatamos otras de menor entidad entre 1890 y 1916 consistentes en la reparación del tejado y la ejecución del entarimado del templo, además del arreglo de la torre ${ }^{1881}$.

\footnotetext{
${ }^{1878}$ En la fotografía no podemos llegar a distinguir de quién se trata, de ahí la importancia de la información aportada por Helguera. RAMIREZ DE HELGUERA, Martín. El libro...Op.cit, pág. 152. ${ }^{1879}$ Está realizado en escayola y cubierto de purpurina. Información cortesía de Ángel Luis Barreda Ferrer.

${ }^{1880}$ MARTÍN MÍNGUEZ, Bernardino. Catálogo...Op.cit, volumen 3, pág. 106.

${ }^{1881}$ ADP. Carrión. La Magdalena. 24. 3 cosidos de papeles y obras de fábrica entre 1879 y 1960.

Primer cosido. 8 junio de 1896,17 mayo de 1900, 7 de mayo de 1901 y 30 de junio de 1902 . Segundo cosido. 15 de noviembre de 1917, 25 de noviembre de 1915, septiembre de 1916, octubre 1916.
} 
En el centro del patio, dentro de una fuente circular, se levantó en 1914 el Monumento al Sagrado Corazón de Jesús, encargo que corrió a cargo del escultor valenciano, Modesto Pastor y Juliá ${ }^{1882}$. Para celebrar el centenario del Restablecimiento de la Compañía de Jesús, se levantó en el jardín esta solemne figura de más de cuatro metros y medio de altura, en cemento que preside el patio. Lleva una inscripción en el frente del pedestal que dice: Sacratissimum Jesu Cor. Semper. Societatem Iesu. Numine ac nomine. Insignivit. VII Agusti MCMXIV. A restituta societate Iesu. Saeculari primo. A. M.D. G. En los lados restantes se representan en relieve a los Papas de mayor trascendencia para la compañía jesuita: Paulo III, que fue quien la aprobó, Pío VII, que la restauró y León XIII que confirmó sus privilegios ${ }^{1883}$.

\section{Escuela Apostólica (1918-1959)}

En 1918 pasó a convertirse en Escuela Apostólica. Aunque formalmente se constituyó en dicho año, el origen de esta escuela se encuentra en el grupo de niños externos que, formando parte del Seminario Menor desde sus inicios (1891), se preparaban para el sacerdocio. Con la conversión del Seminario en Escuela Apostólica, los nuevos alumnos pasaban a vivir dentro del edificio del colegio en clausura, junto a los novicios y júniores. Esta es la única diferencia entre Seminario y Escuela, tratándose en ambos casos de un centro de preservación y cultivo de vocaciones religiosas.

Para poder ingresar en la Escuela, además de poseer vocación jesuita, los solicitantes debían tener cumplidos los once años y demostrar haber adquirido cierta base de gramática, catecismo, aritmética y escritura. Igualmente eran requisitos indispensables el gozar de un buen estado de salud y provenir de familias honradas. En este centro cursaban tres años de latín y griego, un año de retórica, sin faltar la geografía e historia, pasando posteriormente a estudiar Filosofía y Teología en el Seminario Menor ${ }^{1884}$.

\footnotetext{
1882 PLAZA SANTIAGO, Francisco Javier. Op.cit, pág. 366.

${ }^{1883}$ ABAD CAMILO, Jose $\mathrm{M}^{\mathrm{a}}$. Op.cit, pág. 175.

${ }^{1884}$ BN.VC 15696-4, Escuela Apostólica del Sagrado Corazón de Jesús de Carrión de los Condes. Palencia, 1919, pp. 13, 14 y 23.
} 
Entre las mejoras más importantes realizadas al comienzo de la instauración de la Escuela Apostólica, figura la instalación de dos hornos de aire caliente, uno en el ángulo noreste y otro en la fachada de levante. Por otro lado, la estancia que cae inmediatamente sobre la sacristía se adecuó como biblioteca y la iglesia fue retejada $^{1885}$

Para el Juniorado se adecuó toda la crujía occidental del patio como cuartos dobles separados por un pasillo central. En el lienzo meridional se desplegarían la enfermería, en el piso principal y los aposentos de profesores en el segundo piso, por poseer la mejor orientación. Se hizo además otra nueva enfermería nueva y más amplia, que, tras muchos tanteos y dudas en cuanto a su ubicación, se optó por situarla en la planta superior, encima de las habitaciones del juniorado ${ }^{1886}$.

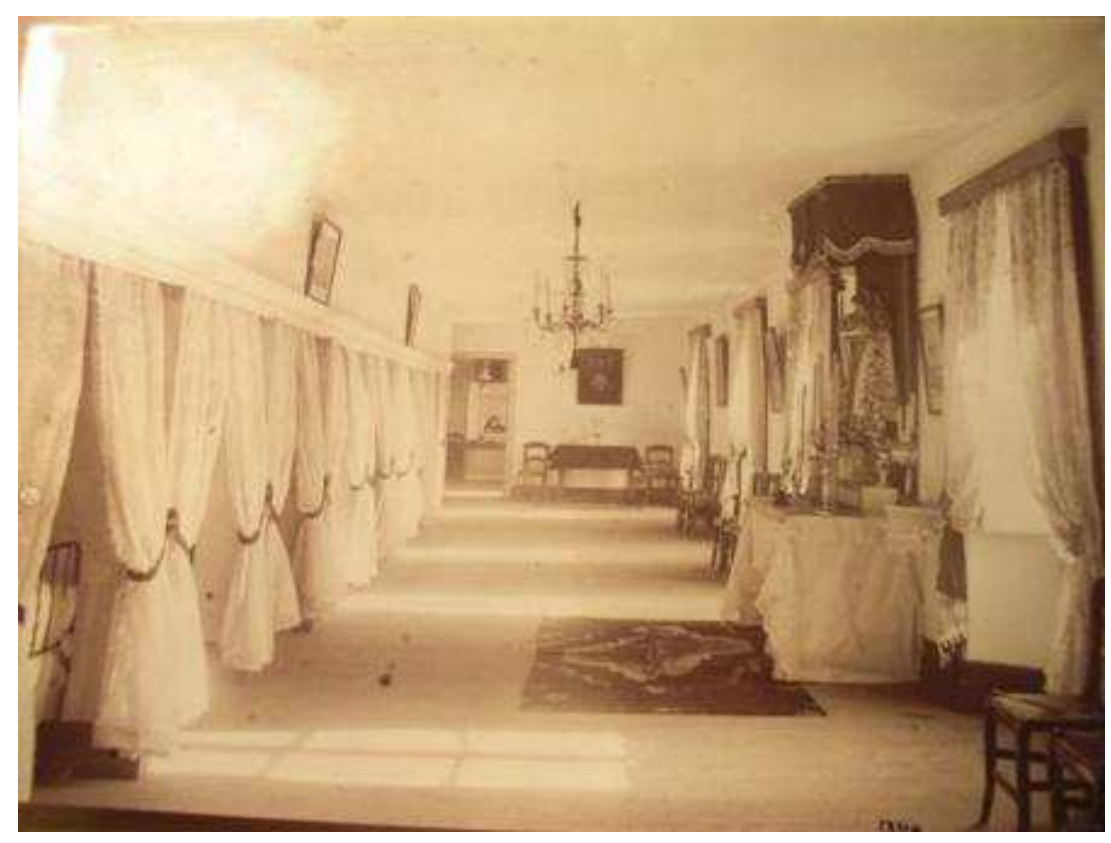

\section{Enfermería del Juniorado en el piso alto del patio de los jesuitas.}

Se aprovechó la capilla doméstica que había utilizado el Noviciado pero también desempeñó la misma función la antigua sala capitular del monasterio. El retablo existente fue sustituido por otro de estilo ecléctico, de madera sin policromar

1885 ACJAH. C11. Carrión de los Condes. 10. Historia, fondo benedictino, visitas, inventarios. $\mathrm{N}^{\mathrm{o}}$ 8760015.

${ }^{1886}$ ACJAH. C11. Carrión de los Condes. 10. Inventario histórico-índice del Seminario Menor de Carrión de los Condes de la Provincia de León por el P. Martínez. № 9280141 fol 26 y ss. 
estructurado en un solo cuerpo. En la parte inferior tan solo se ubican las puertas para acceder al refectorio. Se cierra en semicírculo para adaptarse a la bóveda de cañón existente en esta capilla. Las imágenes de escayola que poseía el retablo se disponían escalonadamente, ocupando la hornacina principal la Inmaculada, San Ignacio de Loyola y San Francisco Javier en un nivel inferior y en la parte más baja, en los laterales, San José con el niño y probablemente San Luis Gonzaga, pues en vez del tradicional Crucifijo, lleva al niño Jesús en sus brazos. Este retablo sigue instalado en su lugar original y al parecer fue una obra del carpintero carrionés Timoteo Martín Valiente. Sin embargo todas las imágenes del mismo se las fueron llevando progresivamente cuando la Hospedería San Zoilo adquirió el conjunto en 1991 y por ello se desconoce su actual paradero ${ }^{1887}$.

Los novicios y júniores de Carrión fueron trasladados en 1926 a San Estanislao de Kostka, el nuevo noviciado que se había inaugurado en Salamanca, quedando en San Zoilo los alumnos de la Escuela Apostólica ${ }^{1888}$.

Respecto al estado de San Zoilo por estos años, el 9 de noviembre de 1942 se solicita una inspección técnica por el peligro que presenta la pared medianera del claustro y el templo. La Academia de San Fernando emite un comunicado justo un año después en el que considera necesario reafirmar la solidez de ambas edificaciones y a su vez, proceder al registro de sepulcros ocultos en la capilla condal y su consecuente ordenación. ${ }^{1889}$. Los contrafuertes de este lienzo norte habían sido desplazados por el empuje de la bóveda y muros del templo ya que estaban edificados sobre cimientos románicos muy superficiales.

El proyecto de consolidación, formulado por Anselmo Arenillas en 1944, consistió en el atirantado del arco del coro, sin que esta intervención fuera visible al exterior. Tras un farragoso e interminable proceso burocrático de concesión de

\footnotetext{
${ }^{1887}$ Agradezco la información proporcionada sobre esta capilla a Enrique Gómez, Ángel Barreda y José Luis Calvo Calleja. La familia de Timoteo Martín proporcionó el dato sobre la autoría del retablo al propio Barreda aunque no exista ningún documento.

${ }^{1888}$ ACJAH. C11. Carrión de los Condes. 10. Inventario histórico-índice del Seminario Menor de Carrión de los Condes de la Provincia de León por el P. Martínez. N 9280141 fol 26 y ss.

${ }^{1889}$ ARASF, Leg. 5-282-1.
} 
permisos y demás papeleo, las obras se terminaron en $1953^{1890}$. Dos años más tarde se rehicieron los antepechos y las limas de la cubierta, se reforzaron los arranques de los arcos y fueron consolidados los zócalos ${ }^{1891}$.

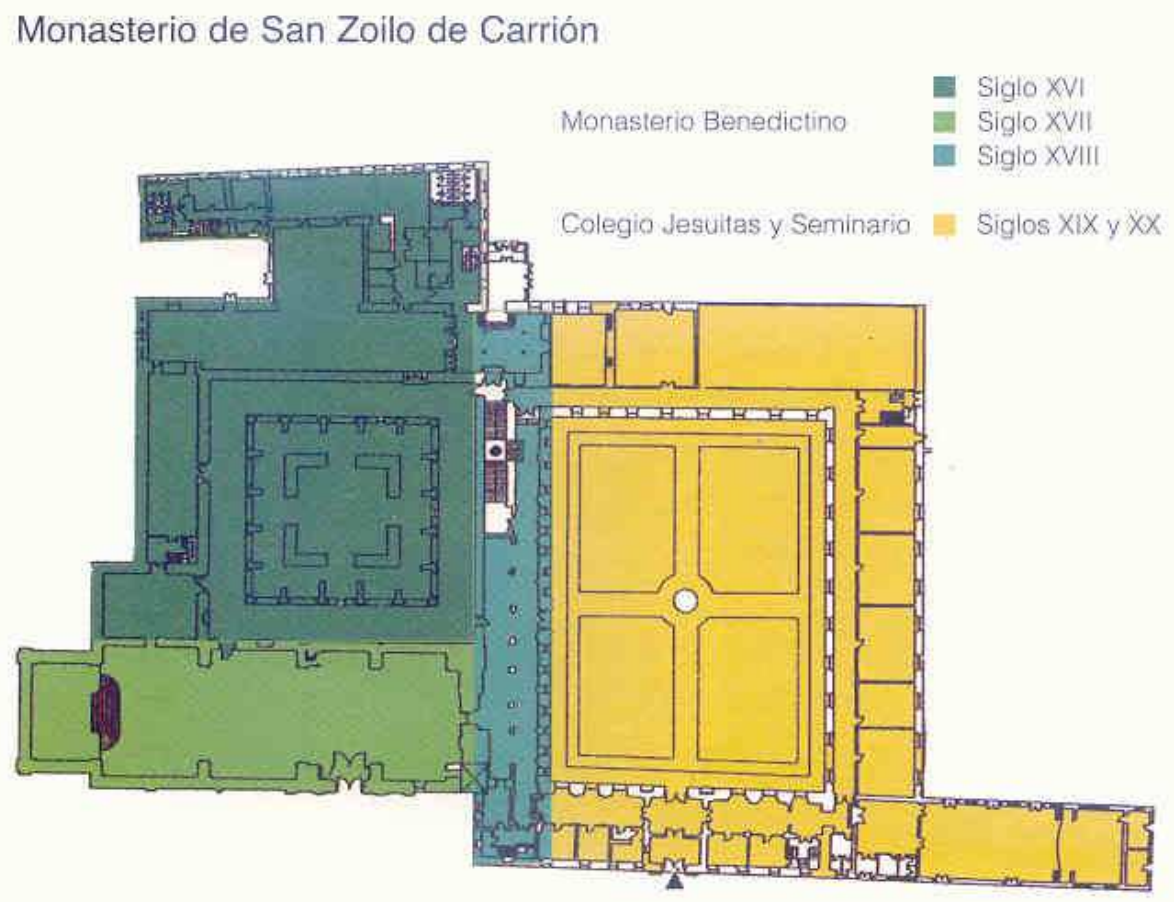

Evolución del monasterio de San Zoilo desde el siglo XVI hasta la actualidad.

Extraído de San Zoilo de Carrión, en el origen del románico pleno, de Maiso

González y Lagunilla Alonso.

\footnotetext{
${ }^{1890}$ AGA. Expedientes de restauración de monumentos. (3) 5 Caja 51/11284. Condiciones y presupuesto en Caja 26/347. También se hace referencia a estas obras en ADP. Carrión. La Magdalena. 24. 3 Cosidos de papeles y obras de fábrica entre 1879 y 1960. Tercer Cosido. 17 de octubre de 1947, 8 de marzo de 1952 y 24 junio de 1952.

${ }^{1891}$ Se emplea un criterio de similitud con la obra original para no desentonar con ella, pero diferenciándose ligeramente para no falsificarla. Los materiales nuevos (tejas, pizarras, baldosines, azulejos) irán señalados en su parte posterior con una marca que las identifique. El plano, condiciones y detalles del presupuesto concernientes a esta intervención en. AGA (3) 115. Expedientes de restauración de monumentos Caja 26/380 y Caja 26/298.
} 


\subsection{EL SEMINARIO DE LA DIÓCESIS Y DESALOJO (1959-1991)}

Con esta última dedicación persistió hasta 1959 fecha en la que fue desalojado por los jesuitas instalándose el Seminario Menor de la Diócesis palentina. La Escuela Apostólica fue trasladada a León, donde poco después se transformó en colegio de segunda enseñanza ${ }^{1892}$.

El Seminario fue trasladado a Palencia a comienzos de los años ochenta quedando el edificio desocupado. Se aprovechó entonces para realizar, partiendo de un proyecto de 1980, algunas obras de restauración en el claustro consistentes en la sustitución de los tejados deteriorados y el zunchado y atirantado de los mismos, quedando finalizada la intervención en $1982^{1893}$.

\subsection{HOSPEDERÍA DESDE 1991}

1991 fue el año en que el conjunto, exceptuando el claustro y la iglesia, fue vendido por la Diócesis palentina a una empresa privada para convertirlo en Hospedería de San Zoilo. El proyecto comenzaría a fraguarse un año antes y gracias al mismo se potenció el conocimiento del conjunto ${ }^{1894}$. Para ello se realizaron obras de acondicionamiento a raíz de las cuales salieron a la luz la portada occidental de la primitiva iglesia románica emparedada desde al menos $1786^{1895}$.

En unas salas ubicadas según se entra a mano derecha por la puerta grande, se creó el Centro de Estudios y Documentación del Camino de Santiago, dotada de

\footnotetext{
${ }^{1892}$ GONZÁLEZ, Manuel. La Compañía de Jesús...tomo 1.Op.cit, pág. 578.

${ }^{1893}$ Luis Arranz Algueró fue el arquitecto al cargo del proyecto. El informe de la realización en AGA. Expedientes de restauración de monumentos. (3) 115 Caja 51/11361. Planos, condiciones, historial y presupuesto en (3) 115 Cajas 26/1677 y 26 1782. Liquidación de las obras en (3) 115 26/1783. La memoria de las obras realizadas y el anexo del proyecto repetido nuevamente en (3) 115 26/1682 y en (3) $11526 / 1542$.

${ }^{1894}$ En 1989 visitaron San Zoilo 3.500 turistas frente a los casi 50000 que lo hicieron una década después, ayudado por otros factores como la celebración de Año Santo y PERRINO DÍEZ, José Antonio. "San Zoilo (1992-2002). La memoria recuperada" en Sentir y potenciar Palencia. FUNDEPA. Madrid, 2004, pp. 286-287.

${ }^{1895}$ Estas intervenciones fueron posibles gracias a la reciente adquisición de la empresa "Hospederías Españolas San Zoilo" del conjunto al Obispado palentino a finales de 1991. SENRA GABRIEL Y GALÁN, José Luis "La portada occidental recientemente descubierta en el monasterio San Zoilo de Carrión de los Condes” en AEA, n 67, n²95. Madrid, 1994, pp.. 57-72.
} 
una espléndida biblioteca jacobea. El germen de la misma se halla en la Asociación de Amigos del Camino de Santiago de Palencia, cuya andadura comenzó en 1987. Se trata de un punto de encuentro, de estudio e intercambio de propuestas con actividades programadas para fomentar la cultura y conocimiento. Esta idea es germen del éxito cosechado por la exposición itinerante que tuvo lugar entre 1998 y 1999 bajo el lema: "Camino de Santiago, mil años de historia, mil libros para conocerla" 1896 .

Las coloristas pinturas murales que conserva este espacio y la portería son obra del dibujante italiano Bruno Mefredi ${ }^{1897}$. Debieron realizarse cuando llegaron los jesuitas a Carrión, hacia 1852, pues en estos años el artista se encontraba en la villa $^{1898}$.

Entre los años 1993 y 1994 se tiran tabiques de todo el pasillo entre los claustros desde el vestíbulo de la hospedería en el lado meridional hasta el lado opuesto, unificando todo este espacio. A mediados de marzo del año 2011 se comenzaron unas obras en esta misma parte, levantando el suelo y picando las paredes. El objetivo primordial consistía en renovar el pavimento y dejar la piedra vista en los muros que se encontraran. El problema es que los materiales hallados fueron mayormente adobe y ladrillo, que evidenciaron intervenciones más modernas de lo que se auguraba. Los trabajos continúan hasta marzo del año venidero. Fue durante estas obras cuando se descubrió el retablo neoclásico en el que estaba colocado el Cristo atado a la columna que hoy se ubica en el claustro ${ }^{1899}$.

\section{LA DECLARACIÓN DE MONUMENTO NACIONAL}

La relevancia que para el monasterio de San Zoilo supuso la declaración de Monumento Nacional justifica un capítulo aparte que recogiese resumidamente el proceso para dicho nombramiento. El primer paso lo da la la Academia de la

\footnotetext{
${ }^{1896}$ SANTOS URBANEJA, Fernando. Op.cit, pp. 100 y ss.

1897 ARASF, Fondo Antiguo de Revistas, 708: BECERRO BENGOA, Ricardo. "El monasterio de Carrión” en La España Moderna, Revista Ibero-Americana, no 7, 31 de julio de 1889, pp. 55-96.

${ }^{1898}$ En 1859 pintó un escudo con las armas reales dedicado a la reina Isabel para el Consistorio de Carrión. Sesión extraordinaria de 7 de febrero de 1859. AMCC, Libro 6, Sesiones municipales (18581862), s/f.

${ }^{1899}$ Véase el apartado referente al Cristo atado a la columna, en la fase relativa al siglo XVI.
} 
Comisión de Monumentos en marzo de 1871 al emitir un escrito al Ministro de Fomento y Hacienda solicitando que el convento y claustro de San Zoilo se exceptúe de la venta y sea declarado Monumento Nacional ${ }^{1900}$.

En 1900 el Ayuntamiento de Carrión de los Condes solicita a la Comisión mixta de las Reales Academias de la Historia y de Bellas Artes de San Fernando que el claustro y monasterio de San Zoilo sea declarado Monumento Nacional ${ }^{1901}$. En su petición, el alcalde elogia la belleza del claustro a través de calificativos como "joya artística", "preciosa reliquia" y "verdadera maravilla del arte del Renacimiento". Asimismo, enumera a los artífices creadores y se remite a la opinión de escritores para ensalzar nuevamente sus cualidades. Exalta por otra parte, el patrimonio de la villa, aludiendo escuetamente a los pórticos de las iglesias de Santa María y Santiago, reiterando la petición mencionada ${ }^{1902}$.

Fueron necesarios tres años para que la Comisión solicitara al ayuntamiento de Carrión los motivos de la disociación entre monasterio y claustro, tratándose de un mismo conjunto monumental ${ }^{1903}$. En respuesta, el Corregimiento carrionés, tras realizar un repaso de la historia del cenobio, concluye en la desestimación del deseo manifestado por la proclamación del monasterio, justificada en la escasa conservación de restos originales de relevancia, considerando lo más conveniente a los intereses del arte la propuesta del claustro ${ }^{1904}$.

Después no se conserva más correspondencia hasta que es declarado Monumento Nacional el 3 de junio de 1931, título que detenta desde entonces junto a las iglesias de Santiago y Santa María de la misma villa ${ }^{1905}$.

\footnotetext{
1900 ARASF. Palencia, Comisión de Monumentos, Leg. 2-7-7, Monumentos especiales. ${ }^{1901}$ AMCC. Libro 16. Sesiones municipales (1899-1900). Sesión de 26 de enero de 1900, fol 11 y ss. ${ }^{1902}$ ARASF, Legajo 4-46-3. El expediente sobre la solicitud del Ayuntamiento de Carrión de los Condes para que el Monasterio de San Zoilo sea declarado Monumento Nacional tiene fecha de 19/6/1900 en RAH. CAP/9/7967/25 (3), pág. 204.

${ }^{1903}$ Se tiene noticia de que la comunicación de la Real Academia de Bellas Artes de San Fernando se demoró más de lo esperado. AMCC. Libro 18. Sesiones municipales (1902-1903), Sesión municipal de 10 de mayo de 1903, fol 106v.

1904 Tanto en la misiva del Ayuntamiento, como en el informe de la Comisión que copia los datos de aquella se dice que el claustro tiene cuatro arcos en vez de cinco.

${ }^{1905}$ AZCÁRATE RISTORI, José María de. Monumentos españoles...Op.cit, pp. 440-441. La fecha exacta de la declaración, que no constaba en el manual anterior, figura en VV.AA. Catálogo monumental...Op.cit, , pp. 463-464.
} 
Luis Hurtado de Mendoza (1482-1507)

Bernardino López de Carvajal (1508-1516)

Juan Rodríguez de Fonseca (1516-1524)

Francisco de Atienza (1524-1525)

Diego de Sahagún (1525-1533)

Alonso Ruiz de Virúes (1533-1535)

Gaspar de Villarroel (1535-1538)

Juan de Santa María (1544-1553)

Rodrigo de Corcuera (1553-1556)

Juan Vaca (1556-1559)

Juan de Corcuera (1559-1563)

Gaspar de Becerril (1563-1564)

Benito de Sahagún (1564-1570)

Sebastián de Encinas (1570-1576)

Cristóbal de Agüero (1576-1577)

Ambrosio de Nájera (1577-1583)

Antonio Perroto (1580-1583)

Ambrosio de Nájera (1586-1587)

Martín de Sahagún (1587-1589)

Plácido de Huércanos (1589-1592)

Toribio de Santander (1592-1595)

Pedro de Santillana (1595-1597)

Pedro de Torrecilla (1597-1598)

Plácido de Huércanos (1598-1601)

Alonso Barrantes (1601-1604)

Hernando de Sarabia (1604)

Alonso Barrantes (1604-1607)

Juan Díaz de Lavandero (1607-1610)

Alonso Barrantes (1610-1613)

Juan Díaz de Lavandero (1613-1617)

Miguel de Castro (1617-1621)

Juan Díaz de Lavandero (1621-1625)

Juan Cortés (1625-1629)

Bernardo Santisteban (1629-1633)

Antonio del Valle (1633-1634)

Bernardo Santisteban (1634-1637)

Francisco de Lemos (1637-1641)

Plácido del Río (1641-1645)

Francisco de Lemos (1645-1649)

Plácido del Río (1649-1653)

Juan González (1653-1657)

Plácido de Quirós (1657-1661)

Juan González (1661-1665)

Bernardo de Estúñiga (1665-1669)

Juan González (1669-1673)

Bernardo de Estúñiga (1673-1677)

Juan González (1677-1680) 
Bernardo de Estúñiga (1680-1685)

Francisco Turzeta (1685-1689)

Diego de Fonseca (1679-1683)

Gregorio Ruiz (1693-1697)

Jacinto Díez (1697-1701)

Pedro de Granda (1701-1705)

Jacinto Díez (1705-1709)

Mateo Quijano (1717-1721)

Plácido Flórez (1721-1725)

Jacinto Díez de Angulo (1725-1729)

José Iglesias (1729-1733)

Jacinto Díez de Ângulo (1733-1737)

Juan Vaca (1737-1731)

Manuel Ordóñez (1741-1745)

Félix Rodríguez (1745-1749)

Benito Iglesias (1749-1751)

Manuel Ordóñez (1751-1753)

Ildefonso Bárcena (1753-1757)

Ildefonso Mier (1757-1761)

Bernardo Morante (1761-1765)

Ildefonso Mier (1765-1769)

Agapio Franco (1769-1773)

Martín Basco (1773-1777)

Ildefonso Mier (1777-1781)

Martín Basco (1781-1785)

Leandro Pérez (1785-1789)

Martín Basco (1789-1793)

Leandro Pérez (1793-1797)

Fulgencio Campo (1797-1801)

Leandro Pérez (1801-1805)

Plácido Emelgo (1805-1814)

Fulgencio Campo (1814-1818)

Plácido Emelgo (1818-1824)

Isidro López (1824-1828)

Bernardo García (1828-1832)

Plácido Trevijano (1832-1835) 


\subsubsection{EL CONVENTO DE SANTA CLARA}

\section{LA FUNDACIÓN Y LOS PRIMEROS SIGLOS}

El monasterio de Santa Clara de Carrión fue fundado, según la tradición, por dos discípulas españolas que tras haber convivido cierto tiempo en el cenobio de San Damián de Asís, retornaban a su país de origen con diversas s pontificias para realizar fundaciones, siendo su primera parada Santiago de Compostela, donde obtendrían el jubileo en el año $1232^{1906}$. No nos parece plausible afirmar que se trataba de monjas italianas enviadas por Santa Clara desde su comunidad para fundar monasterios por Italia, Francia y España, pues el número inicial de seguidoras en esta comunidad no sería tan elevado ${ }^{1907}$.

Parece que en 1231 las dos "damas pobres" o "damianitas" se hospedaron en la ermita de Santa María del Páramo, una población cercana a Carrión y Calzada de los Molinos, donde las beatas españolas las acogieron hospitalariamente ${ }^{1908}$. Pudo ser que los relatos de las monjas acerca del cenobio de San Damián entusiasmaran tanto a las religiosas leonesas, que, en su recuerdo, años más tarde, pidieran al Papa Alejandro IV establecerse en un centro espiritual que se adaptara a la nueva vida religiosa.Estos hechos explican que el Padre Francisco Calderón afirme que cuando falleció Santa Clara en 1253, ya estaba fundada la casa clarisa, aunque no estaba establecida en la villa carrionesa ${ }^{1909}$. Carrión Gutiez establece como fecha clave la segundo año del pontificado de Alejandro IV, esto es, hacia 1256, cuando, como explica Omaechevarría, por Breve del 3 de junio de dicho año Su Santidad se dirige a Doña Mencía López de Haro, reina consorte del rey de Portugal Sancho II "el Capelo" para que intercediera ante la penosa situación que sufrían las monjas

\footnotetext{
${ }^{1906}$ OMAECHEVARRÍA, Ignacio. Santa Clara en Carrión de los Condes. Colección Espíritu y vida, 10. Monte Casino. Zamora, 1986, pp. 4 y ss. Sobre las primeras fundaciones franciscanas ROJAS, Francisco de (OFM). Anales de la orden de los Menores: donde se tratan las cosas más memorables de personas insignes de santidad y letras de las tres órdenes que institvyó sv gran fundador San Francisco. 3 tomos. Málaga, 1652.

${ }^{1907}$ CASTRO, Manuel de. "Monasterios hispánicos de clarisas desde el siglo XIII al XVI" en Archivo Ibero-americano, $\mathrm{n}^{\circ}$ 193-194, 1989, pp. 80-82.

1908 PERAL VILLAFRUELA, Santiago. "El convento de Santa Clara de Carrión y su archivo" en Archivo Ibero-Americano, no 213-214. LXIX. Enero-Junio, 1994, pág. 97.

1909 CALDERÓN, Padre Francisco. Op.cit. Archivo de la Iglesia franciscana de San Antonio de Valladolid. Carpeta 1.Caja 1, Legajo 1, III Fol 247 y OMAECHEVARRÍA, Ignacio. Op.cit, pág. 4.
} 
damianitas construyendo un nuevo monasterio ${ }^{1910}$. Doña Mencía era hija de Don Lope Díaz de Haro, XI Señor de Vizcaya y de Doña Urraca Alfonso de León, hermana del rey Fernando el Santo y nieta de Alfonso IX de León. Esta dama vizcaína nacida en 1215 había enviudado de don Alvar Pérez de Lara "el Castellano" en 1234, de ahí que se esposara varios años después -en una fecha comprendida entre 1242 y 1245- con el monarca luso. Fallecida el 15 de enero de 1272, sus restos descansan en el sepulcro que había mandado realizar para este fin, en la capilla de la Vera Cruz del claustro de los Caballeros de Santa María de Nájera en La Rioja, el pueblo que la había visto nacer hacia 1215. Como vemos, el apoyo de la monarquía fue decisivo para la implantación de las clarisas a la par que la tendencia generalizada en las fundaciones castellanas durante la Edad Media. Los reyes, aliados con la alta nobleza realizaron concesiones decisivas para el óptimo desarrollo de un régimen de clausura que, dado el elevado número de internas, requería la posesión de un amplio patrimonio ${ }^{1911}$.

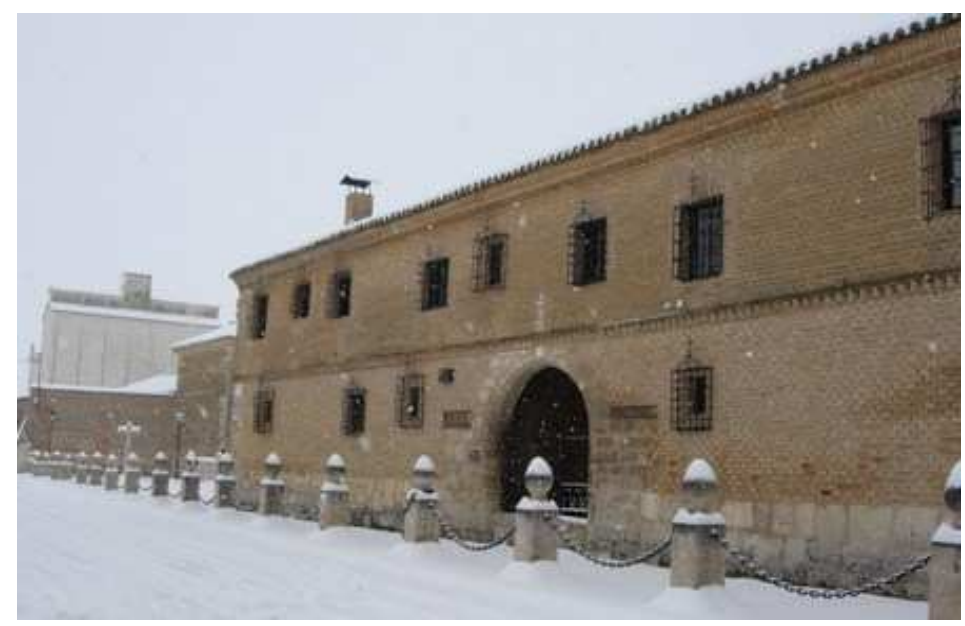

Aspecto exterior del convento de Santa Clara. Acceso al patio de la hospedería.

\footnotetext{
${ }^{1910}$ La traducción del latín de dicho Breve, cuyo original está en el archivo conventual, en OMAECHEVARRÍA, Ignacio. Op.cit, pág. 14. El dato también en CARRIÓN GUTIEZ, Manuel. Op.cit, pág. 27. También apodado "el Piadoso", el rey Sancho II era hijo del rey Alfonso II "el Gordo" y su esposa, la infanta castellana, Urraca de Borgoña. Había nacido en 1207 en Coimbra, ascendiendo al trono de Portugal en 1223. No consiguió descendencia con su esposa doña Mencía.

${ }^{1911}$ En nuestro caso se trata de la intervención directa de una nobleza de "ricoshombres", pues el linaje Haro había sido enaltecido a través de sus respectivos matrimonios, primero doña Mencía casó con Alvar Pérez de Castro, en cuya persona se hallaban familias de abolengo como los Lara y Castro. En segundas nupcias, emparentó con la realeza a través de Sancho II de Portugal. CAVERO DOMINGUEZ, Gregoria. "Monarquía y nobleza: su contribución a las fundaciones de clarisas en Castilla y León (siglos XIII-XV)" en Archivo Ibero- Americano, n 213-114, Enero-Junio 1994, pp. 258-263.
} 
Doña Mencía erigiría la casa clarisa hacia 1256, junto al priorato de Sancti Espíritus que los agustinos canónigos regulares tenían en Carrión desde el siglo XI y que dependían de la abadía aquitana de San Román de Blaye desde el último cuarto de la centuria posterior ${ }^{1912}$. Desde el año 1263, las monjas, por indicación del papa Urbano IV, modificaron los antiguos apelativos de "damianitas" o menoretas, descalzas o frairas, por la denominación universal de clarisas ${ }^{1913}$.

La convivencia de los dos centros religiosos duró poco y dada la debacle experimentada por los clérigos agustinos en aquellos años, en 1265 doña Mencía compra el priorato de Sancti Espíritus para anexionarla a las propiedades de las monjas $^{1914}$. Relata el Padre Francisco Calderón que aquel lugar no era adecuado: “...la fábrica estaba imperfecta y corta, por no tener los espacios que la piadosa reina quisiera dar a sus religiosas para su mejor conveniencia...". Los primeros años de andadura fueron dedicados por tanto a optimizar el estado de este convento, además del templo, que sabemos contaba con altares dedicados a Santa Clara y Santa María ${ }^{1915}$. Las clarisas por tanto, poseían templo propio y junto a él, aunque desprovisto de canónigos, la iglesia de Sancti Espíritus, con altares dedicados a San Blas y Santo Espírito, era atendida por un capellán otorgado por la diócesis ${ }^{1916}$.

\footnotetext{
${ }^{1912}$ De este santuario, ubicado al sudoeste de Francia en el departamento de la Gironda empezó a depender el priorato de Sancti Spiritus de Carrión hacia 1170. Las razones hay que buscarlas en las estrechas relaciones establecidas entre las delegaciones conformadas por clérigos y nobles castellanos y aquitanos que participaron en la comitiva que llevaría a Leonor de Aquitania hacia Carrión para esposarse con Alfonso VIII dicho año. Un estudio profundo del tema en PERAL VILLAFRUELA, Santiago. De Aquitania a Carrión: El priorato de Sancti Spiritus en el camino de Santiago Palentino. Diputación Provincial de Palencia. Palencia, 2011, pp. 33-63.

${ }_{1913}$ CASTRO, Manuel de. "Monasterios...Op.cit, pág. 81.

${ }^{1914}$ La venta de la iglesia de Sancti Espíritus por su sacristán en ARCHV. Patronazgo Eclesiástico. Legajo 203 y el acta de donación y ratificación por el Papa Clemente IV en GARCÍA BARRIUSO, Patrocinio. La monja de Carrión: Sor Luisa de la Ascensión Colmenares Cabezón: Aportación documental para una biografía. Madrid, 1986, pp. 48-49. Todo el proceso del abandono de Sancti Spiritus por los canónigos y su traspaso a las clarisas se detalla en PERAL VILLAFRUELA, Santiago. De Aquitania...Op.cit, pp. 109-124. La ratificación de dicha venta entre el abad Arnalt y el priorato de Blaye se produjo el 27 de julio de 1268, fecha que en una copia de este documento emitida en 1618 (ASCC, Leg.9, 592), se transcribe equivocadamente por 1260. PERAL VILLAFRUELA, Santiago. De Aquitania...Op.cit, pág. 121, nota 9. Este hecho explicaría qué la monja de Carrión al consultar el archivo de clarisas, tomase esta fecha como referencia de la fundación del convento. CLARISA DE CARRIÓN DE LOS CONDES. El convento de Santa Clara y la Virgen de la Piedad de Carrión de los Condes. Apuntes para la historia. Palencia, 1946, pág. 6. 1915 ASCCC. Legajo 1, nº52.

${ }^{1916}$ La veneración por el Espíritu Santo hunde sus raíces en la época más remota de los agustinos canónigos, ligada estrechamente a la peregrinación compostelana como así lo demuestran otros enclaves del camino jacobeo como la iglesia de Roncesvalles. PERAL VILLAFRUELA, Santiago. De Aquitania...Op.cit, pág. 125-127.
} 


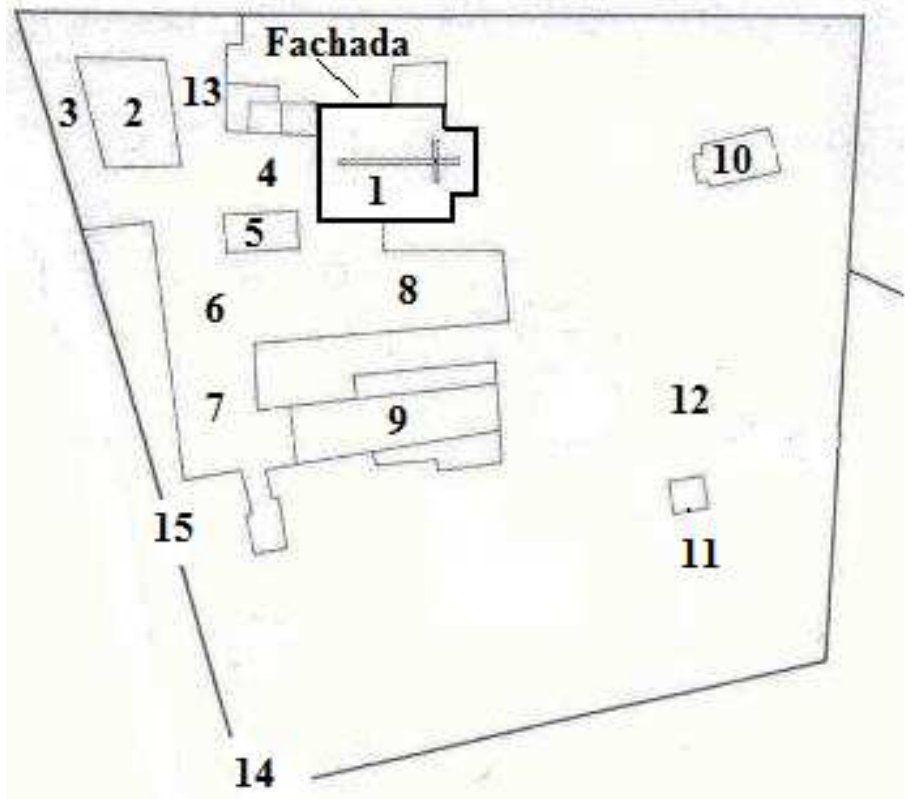

1. Iglesia

2. Patio de la Hospedería

3. Casa de la demandadera, actual refugio de peregrinos

4. En planta baja, antecoro y coro bajo. En planta alta antecoro y coro alto.

5. Claustro

6. Sala Baja

7. Refectorio

8. En planta baja, claustro, obrador y biblioteca-sala capitular. En planta alta Pasillo de las Celdas

9. Posible ubicación de la antigua iglesia conventual, hoy cuadras, carpintería y almacenes.

10.Ermita de la Piedad o de la madre Sor Luisa

11. Ermita de San Juan

12. Huerta

13. En planta baja Museo y en planta alta Hospedería casa del capellán

14. Antigua Puerta de Carros.

15. Actual Puerta de Carros

Plano actual del convento de Santa Clara. 
Seguramente a finales de este siglo estaba conformado el aspecto del templo de clarisas, llegando por entonces a contar con el nada despreciable número de cincuenta religiosas. Por entonces, la administración de los bienes del convento no era solamente comunal, sino que gracias al edicto de Clemente IV podían heredar propiedades a nivel personal, de ahí la consecuente diferenciación social entre las internas $^{1917}$.

Conforme a la tendencia general, esta primitiva iglesia constaría de una sola nave sin crucero ni capillas y cabecera poligonal de piedra de mejor fábrica que el resto del templo. Por tanto, se trata de un espacio sencillo para una comunidad que realiza la mayor parte de sus rezos en el coro. Debido a la pobreza, el ladrillo, tapial y madera serían los materiales constructivos empleados de manera general ${ }^{1918}$. Como sucede con la mayor parte de cenobios palentinos de esta orden, el templo se adscribiría seguramente al estilo mudéjar, pues era éste el gusto personal de los comitentes, además de la tendencia más acorde a la austeridad franciscana ${ }^{1919}$.

En el museo del monasterio se exponen varias tablazones que probablemente procedan de este primer templo conventual. Se trata de unas vigas del siglo XIII reutilizadas posteriormente en la grada del locutorio que muestran las armas de doña Mencía López de Haro. La madera está bastante carcomida y se ha perdido la intensidad original de la policromía. No obstante, observamos con claridad los símbolos de la reina que se repiten alternativamente, pero no dispuestos en escudos sino encuadrados en las estrechas vigas. De este modo se representan los castillos dorados campeando sobre gules y los lobos de sable sobre plata, cuya identificación con el linaje de Haro sería más correcta si fueran cebados de un carnero.

Les suceden las tablas en las que se representa de sable, león rampante de oro y finalmente en campo de oro, águila explayada de sable, haciendo referencia a los reinos de Castilla y León, por su descendencia regia. Asimismo procedería de este

\footnotetext{
${ }^{1917}$ PERAL VILLAFRUELA, Santiago. "El convento de Santa Clara...Op.cit, pp. 98-99.

${ }^{1918}$ ANDRÉS GONZÁLEZ, Patricia. Los monasterios de Clarisas en la provincia de Palencia. Palencia, 1997, pp. 32-34.

1919 PARRADO DEL OLMO, Jesús María. "El renacimiento y la modernización de las formas artísticas en los conventos de Santa Clara de Palencia: Los conventos de Santa Clara en Astudillo y Carrión de los Condes” en Verdad y Vida. Tomo LII. Madrid, 1994, pág. 763.
} 
primer templo la imagen gótica de una Virgen mutilada que igualmente se expone en el museo y que ha perdido el Niño Jesús ${ }^{1920}$.

El siglo XIV transcurre sin grandes acontecimientos para la casa clarisa, que ve cómo se consolida la vida conventual gracias a la adquisición de nuevos terrenos y a la concesión de ciertos privilegios reales que la eximen de ciertos pagos anuales. Destaca el privilegio concedido por Enrique II en 1366 por el que los empleados de la casa clarisa quedan exentos de abonar los pechos anuales ${ }^{1921}$.

1380 será una fecha clave para las clarisas por su adhesión a la familia de monasterios de Tordesillas, lo que implicaba la creación de un visitador propio, independiente del de los franciscanos ${ }^{1922}$.

Aparte de contar con los favores del rey, el convento recibió la gracia del Papado, quien concedió al convento un sinfín de indultos apostólicos, 13 bulas pontificias, 45 privilegios y otros tantos decretos ${ }^{1923}$. Se sumaron a la causa diversos miembros de la nobleza que gracias a la donación de limosnas, heredades y mandas piadosas nos legaron la impronta de sus escudos en algunas salas del convento como la biblioteca y la sala capitular. Es el caso del patronato de los condes de Osorno ${ }^{1924}$, linaje de ilustre abolengo en Castilla que protegió durante el siglo XV el cenobio y cuyo recuerdo perdura en el artesonado de las estancias mencionadas en sus tres $\operatorname{armerías}^{1925}$ :

\footnotetext{
1920 GÓMEZ PÉREZ, Enrique. El Real monasterio de Santa Clara de Carrión de los Condes. Palencia. Cálamo. Palencia, 2010, pág. 12.

1921 GARCÍA ORO, José. Francisco de Asís en la España medieval. C.S.I.C. Santiago de Compostela, 1988, pág. 309. Enrique II y su consorte Juana Manuel, ofrecieron su apoyo incondicional a la orden franciscana a través de un programa de reforma de los cenobios existentes, nuevas fundaciones y dotación de mercedes varias. MARTíN PRIETO, Pablo. "Sobre la promoción regia de la orden franciscana en la Corona de Castilla durante el primer reinado Trastámara" en Hispania Sacra, vol. 59, nº119. Madrid, 2007, pp. 51-83.

${ }^{1922}$ YARZA LUACES, Joaquín. "Las clarisas en Palencia" en Jornadas sobre las Órdenes Religiosas en Palencia. Palencia, 1989, pág. 155.

${ }^{1923}$ Por citar algún ejemplo, El Cardenal Cervini emitió en 1768 desde Siena un decreto por el que autentificaba las reliquias que las clarisas custodiaban pertenecientes al confesor San Francisco de Siena. ASCC. Legajo XI, $\mathrm{n}^{\circ} 62$.

${ }^{1924}$ Un estudio sobre la genealogía y orígenes del linaje en RODICIO GARCÍA, Sara. "Osorno y su condado. El señorío del condado de Osorno" en PITTM, n 62. Diputación Provincial de Palencia. Palencia, 1992, pp. 337- 484.

${ }^{1925}$ VIGURI, Miguel de, Op.cit, pág. 65.
} 
-Cuartelado de Manrique de Lara, condes de Castañeda y marqueses de Aguilar: 1 y 4, de gules con castillo de oro, 2 y 3, de oro, un águila de sable. Bordura general de oro con nueve armiños de sable.,

-De Lara: de gules, dos calderas de oro fajadas de gules

-De Zúñiga: de oro con una banda de sable y alrededor, una cadena de gules brochante.

Todos los escudos vienen acompañados de unos motivos geométricos policromados en rojo, blanco y negro, desarrollándose un repertorio vegetal más naturalista y colorido en la viga madre.

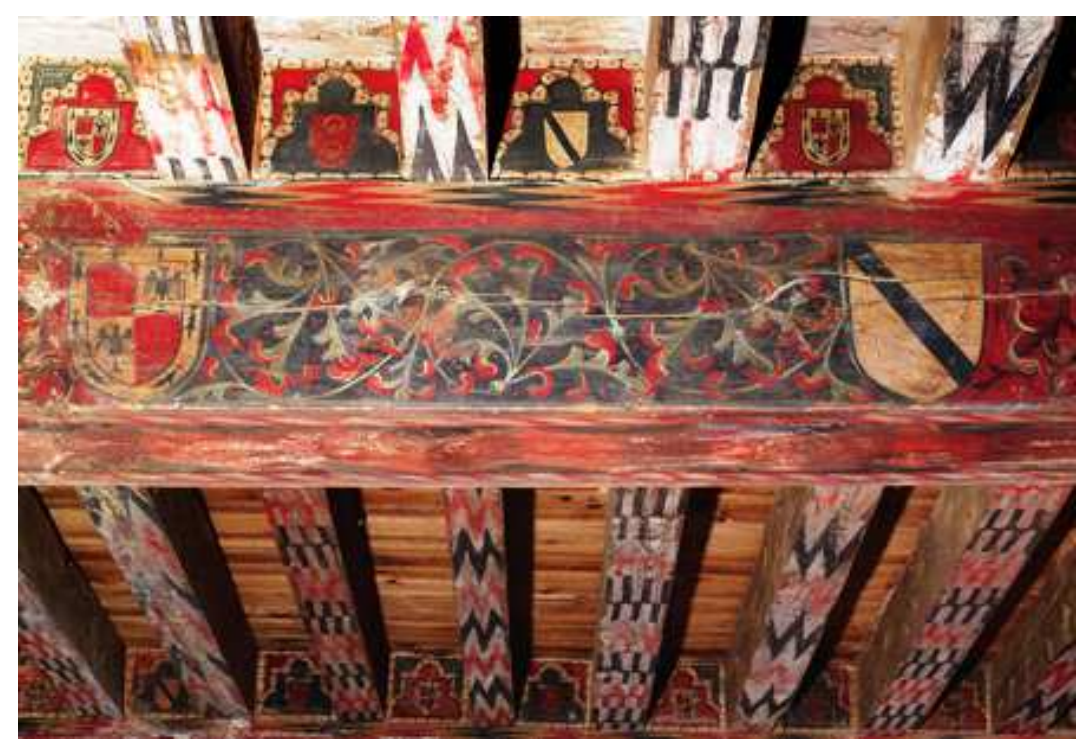

\section{Artesonado de la sala capitular con los escudos de los condes de Osorno en sus diversas armerías.}

La mujer de don Gabriel de Manrique, conde de Osorno, será sin lugar a dudas la figura protagonista de este período. Hablamos de Doña Aldonza de Vivero, condesa de Castañeda, quien en 1438 donó sus bienes a favor del convento y ordenó construir un nuevo templo que conviviría con el primitivo de Sancti Spiritus ${ }^{1926}$. Para ello se adquiriría un corral cercano que, si bien hoy día está transformado en

${ }^{1926}$ PERAL VILLAFRUELA, Santiago. Lo hospitales de Carrión y los Condes de Castañeda en la Edad Media. Cálamo. Palencia, 1998, pág. 63. 
almacén, mantiene una estructura, dimensiones y orientación que permiten relacionarlo con la que pudo ser la denominada "iglesia de la condesa". Expuestas en el museo de las clarisas se conservan dos piedras de similar tamaño que presentan sendas tracerías góticas con decoración de bolas que posiblemente pertenecieron a este templo $^{1927}$. La condesa, como así la llamaban las monjas, no sólo impulsó las obras de un nuevo templo, sino que participó activamente en la dotación de los objetos litúrgicos necesarios para el culto divino. Así, en 1453 intercedió para que el prior de San Benito de Valladolid las entregase un cáliz de plata, una cruz, también de plata y dos arcas de reliquias ${ }^{1928}$.

El templo de Sancti Espíritus, anejo a la iglesia de la condesa se encontraba desde mediados del siglo XV en un estado de deterioro imparable, hasta tal punto que el peligro de desprendimientos impedía la celebración de la misa en su interior. Por un lado, los parroquianos no disponían de caudales para su reparación; por otro, las clarisas necesitaban este espacio para poder agrandar el templo que poseían.

Así, con el fin de aprovechar este espacio litúrgico, la casa terciaria solicitó la anexión del templo al monasterio en 1468, consiguiendo la propiedad un año más $\operatorname{tarde}^{1929}$. Los feligreses que por entonces pertenecían a dicha parroquia fueron trasladados por petición de las clarisas a la iglesia de Santa María del Camino, quienes convencieron al obispo de estar mejor acondicionada que la de San Juan del Mercado, por la que éste se había decantado en un principio. Por otra parte, tenía más clérigos disponibles para la administración de los oficios divinos y estaba mejor situada. La parroquia de Sancti Espíritus quedó así resumida en la iglesia de Santa Clara “...con sus reliquias y devociones...” el 21 de junio de 1468 gracias a la intervención del obispo de Palencia, don Gutierre de la Cueva ${ }^{1930}$. El documento fue firmado en la fortaleza de Magaz de Pisuerga, en el Cerrato palentino, residencia por entonces del prelado hasta que falleciera un año más tarde.

\footnotetext{
1927 GÓMEZ PÉREZ, Enrique. El Real... Op.cit, pp. 27-29.

${ }^{1928} 12$ de diciembre de 1453. Recibo de alhajas para el convento de Santa Clara de Carrión. AHPV. Sección Clero, 242-12.

${ }^{1929}$ Traslado de petición y cesión de la iglesia de Sancti Spiritus en 1468, expedido por mandato de las religiosas clarisas en 1628. ARCHV. Patronato Eclesiástico, Legajo203.

${ }^{1930}$ El documento original titulado: "Resumpción de Santi Espíritus, oi iglesia de Santa Clara, monjas de San Francisco a la parroquia de Santa María del Camino por el Ilustrísimo Don Gutierre de la Cueva, Obispo de la ciudad de Palencia..." y su respectivo traslado en ADP. Carrión de los Condes. Santa María. Libro 78. Escrituras antiguas, nº11. También en ASCC, Leg.2, 73-B. Todo el proceso de la anexión en FRANCIA LORENZO, Santiago. Anecdotario...Op.cit, pp. 63-64 y en PERAL VILLAFRUELA, Santiago. De Aquitania...Op.cit, pp. 131-135.
} 
Ese mismo año de 1468 el Licenciado don Fernando Ortega ${ }^{1931}$ ordenó erigir una capilla de enterramiento, junto a las dedicadas al Santo Espíritu y San Blas bajo las trazas del maestro Juan Gutiérrez, vecino de Carrión de los Condes. Para su ejecución se toma como modelo la arquería gótica de la iglesia del aledaño convento franciscano ${ }^{1932}$. Tan sólo un año después, una vez finalizada la capilla, se procedió a dotarla de retablo no conservado hoy día, cuya ejecución fue encomendada a dos pintores asentados en Becerril, Gonzalo de Torres y Pedro Palacios.

Éste se compondría de un banco sobre el que se acordaron disponer los bustos de cuatro Apóstoles, encima de los cuales se situarían la imágenes de la Virgen y San Juan Evangelista, bajo cuya advocación estaba el retablo. Flanqueándolos, cuatro escenas de la vida de ambos, dos de cada uno, cerrarían la composición de este altar de madera dorado, cuyo coste total alcanzó 9.500 maravedíes ${ }^{1933}$. La estrecha relación de los condes de Osorno y Castañeda con el convento continuará a través de Beatriz Manrique, hija ésta de doña Aldonza de Vivero, condesa de Castañeda y don Gabriel Manrique, quien en 1475 ingresó como monja en el convento, del que sería abadesa posteriormente, donando todas las heredades que sus padres poseían en Villanueva de Sanabria ${ }^{1934}$.

Desde sus orígenes y como sucedió con el convento de franciscanos de la misma villa, las clarisas alternaron períodos en que acataron la conventualidad y otros en que fue un convento de clausura. Desde los inicios de su fundación hasta mediados del siglo XV, las monjas vivieron como claustrales hasta que, por intervención de Doña Aldonza Manrique, enriqueció el convento “...de grandes heredades y dio gran suma de dinero para su socorro, solo con fin de que se

\footnotetext{
${ }^{1931}$ Fue precisamente él quien hizo entrega de las alhajas procedentes de San Benito a las monjas clarisas en 1453.El árbol genealógico de este personaje figura junto al de la familia de Hernán García Pachistre y Leonor de Berrio, marqueses de Villasante, pues en el siglo XVII se establecen lazos entre ambos linajes, dado que doña Manuela Antonio de Berrio se esposa con Juan de Vozmediano, fruto del matrimonio entre doña María Ortega de Velasco y Pedro Barba de Vozmediano. Gracias al gráfico podemos comprender el traspaso del patronazgo de la capilla de los Berrio en la iglesia de San Julián de Carrión, que explicaremos debidamente. VIGURI, Miguel de. Heráldica...Op.cit, pp. 71 y 72.

${ }^{1932}$ GÓMEZ PÉREZ, Enrique. El Real... Op.cit 38-43. , a su vez de ASCCC. Legajo XI, no27, bis.

${ }^{1933}$ Condiciones del mismo en Ibídem, pp. 43-46, a su vez de ASCCC. Legajo XI, nº28.

${ }^{1934}$ No sería el único miembro del linaje Manrique que ostentó el cargo de abadesa, como es el caso de doña Antonia Manrique en el último cuarto del siglo XVI. La relación de los Osorno con el convento será continuado en el siglo XVI Doña Aldonza Manrique, como veremos posteriormente.
} 
reformase a vida más estrecha en la observancia, que ya por este tiempo resplandecía en España con gran perfección, guardando perpetua clausura, como la observaba el Real Monasterio de Tordesillas" ${ }^{1935}$. Así, por Bula apostólica de Eugenio IV emitida el 21 de octubre de 1438, comenzó la observancia en este monasterio. Ésta se mantuvo, no sin grandes disturbios, pues como indica el Padre Calderón: “...Veinte y un años después desta reforma excitó el espíritu inquieto de algunas monjas, que acordándose del Egipto de la claustra, aclamaron boluer a ella y destruir la observancia regular que tanto florecía". El conflicto finalizó con la salida del monasterio de aquellas religiosas que lo habían ocasionado. Desde comienzos del siglo XVII las clarisas guardarán clausura, acatando lo dispuesto en el Breve emitido por Clemente VIII en 1604, aunque no se las obligaba a hacer voto de ello ${ }^{1936}$.

\section{EL SIGLO XVI}

Como hemos visto, doña Beatriz Manrique había tomado el hábito de clarisa en 1475. Fallecería en el convento el 5 de septiembre de 1517, adquiriendo para su entierro una sepultura dentro del mismo ${ }^{1937}$. Pues bien, su hermana, doña Aldonza Manrique, escogería la capilla mayor de la iglesia para su reposo eterno ${ }^{1938}$.

\section{El sepulcro de doña Aldonza Manrique}

Es, sin lugar a dudas, la obra más importante de este siglo y se ubica en el crucero sur del templo, próximo al altar mayor. Doña Aldonza Manrique era hija de los primeros condes de Osorno, don Gabriel Manrique y Doña Aldonza Vivero, y nieta tanto del segundo conde de Castañeda, García Fernández Manrique y su mujer Aldonza como del contador mayor de Castilla, Alonso Pérez de Vivero ${ }^{1939}$.

${ }^{1935}$ CALDERÓN, Padre Francisco. Op.cit. Archivo de la Iglesia franciscana de San Antonio de Valladolid. Carpeta 1.Caja 1, Legajo 1, III Fol 321.

${ }^{1936}$ ASCCC. 1604. Legajo XI, n³5

${ }^{1937}$ GARCÍA BARRIUSO, Patrocinio. Op. cit, pág. 55, a su vez de ASCC. Legajo 2 , nº1

${ }^{1938}$ Véase el linaje de la misma en PERAL VILLAFRUELA, Santiago y GÓMEZ PÉREZ, Enrique. Op.cit, pp. 52-91

${ }^{1939}$ No se debe confundir a esta Aldonza Manrique con Aldonza de Mendoza, fallecida ésta última en 1435 y enterrada en el monasterio de Lupiana y casada con Fadrique de Castro, duque de Arjona, 
Falleció en 1542 en la localidad madrileña de Pinto, lugar donde su marido, el conde don Gómez Carrillo, tenía señorío ${ }^{1940}$. Por su testamento, dictado en 1522, la condesa de Castañeda dispuso que su cuerpo fuera depositado provisionalmente en el convento de San Francisco de aquella villa hasta que fuera trasladado a la casa clarisa carrionesa ${ }^{1941}$. Con su generosa aportación, derivada de una vida desahogada, doña Aldonza disponía que se construyera una capilla nueva para su enterramiento $^{1942}$.

Sus restos fueron llevados en 1547 al convento de Santa Clara de Carrión de los Condes por el franciscano de dicha villa, Fray Luís de Siles ${ }^{1943}$. El mausoleo se colocó en la capilla mayor de la anterior iglesia de Santa Clara, pero al rehacerse el nuevo edificio, se trasladó al brazo del crucero del lado del Evangelio, donde al menos se encontraba hasta 1917, “...en lo alto, debajo de un arco hecho en el muro...” junto a la sacristía, que ha sido cegado ${ }^{1944}$. Hoy día se ubica justo en el lado frontero, adosado al muro de la Epístola.

muerto en 1430 y trasladado al convento agustino de Benevívere poco después. .GIRONELLA, Gervasio. Semanario pintoresco español. Tomo II. Madrid, 1844, pp. 1,2.

${ }^{1940}$ Traslado de su testamento en ASCC. Legajo II, $n^{\circ} 92$. Desea ser sepultada en el convento a cambio de una cuantiosa donación y rezo de misas diarias.

1941 El Condado de Castañeda fue concedido en 1430 por don Juan II de Castilla a don Garci Fernández Manrique de Lara, ricohombre de Castilla y Capitán General de la frontera de Jaén. Era éste el bisabuelo de doña Aldonza Manrique. ALONSO DE CADENAS Y LÓPEZ, Ampelio, y CADENAS Y VICENT, Vicente de. Elenco de grandezas...Op.cit, pág. 292.

${ }^{1942}$ Hemos extraído un párrafo que ilustra muy bien las comodidades de las que disfrutaba, como era la posesión de esclavo y el cariño que profesaba a los mismos: "Por el amor que yo he tenido a mis esclavitos Antonio, Perico y Mariquita, que de aquí adelante los hago para syenpre jamás libres de mi parte e de la parte de Gómez Carrillo, mi señor..." Traslado del testamento en ASCCC. Legajo 9, $\mathrm{n}^{\mathrm{o}} 592$.

${ }^{1943}$ AHPP. Legado Simón Nieto 19. Rollo 827. Trascripción del documento de cómo se efectuó el traslado de los huesos de doña Mencía y el poder otorgado por las clarisas a Fray Luis de Siles para efectuar el traslado en GARCÍA BARRIUSO, Patrocinio. ob.cit., pp. 55-58.

${ }^{1944}$ Así nos lo indica el historiador Martín Mínguez cuando visitó la iglesia por vez primera para catalogar sus obras. MARTÍN MÍNGUEZ, Bernardino. Catálogo monumental de Palencia.19071909, inédito.Volumen 3, pág. 42. 


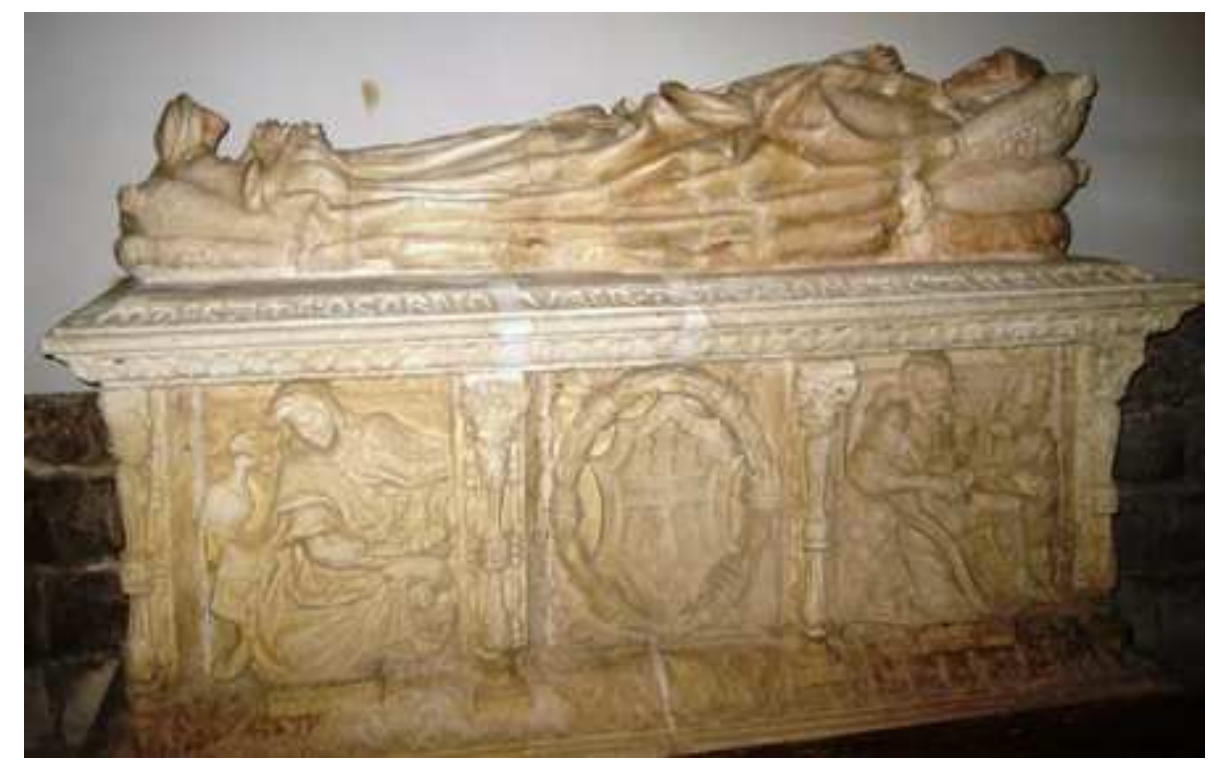

\section{Sepulcro de Doña Aldonza Manrique en la capilla mayor de Santa Clara. Entre 1542 y 1547. Atribuido a Miguel de Espinosa.}

En su epitafio podemos leer: ... “[AQVI] YACE LA M...CONDESA DE OSORNO, MUJER DEL SEÑOR GÓMEZ CARRILLO. En el museo de Santa Clara se conserva una piedra que constituiría la moldura de una pequeña parte perdida del sepulcro cuando éste fue trasladado desde el muro frontero. Conserva la siguiente inscripción que completa perfectamente la parte que falta, identificando a la yacente: [M]ANIFICA SEÑORA DOÑA AL[DONZA] ${ }^{1945}$.

El matrimonio entre doña Aldonza Manrique con el dicho Gómez Carrillo, es el único que hallamos entre estos dos linajes, por lo que es segura su identificación con la difunta ${ }^{1946}$. A favor de ello, además, está la fecha de la muerte de de Doña Aldonza, que se corresponde con el estilo del sepulcro. Si todavía quedaba alguna duda al respecto, con motivo de la presentación de la capellanía que quedó vacante por muerte de Santiago Gutiérrez, cura de San Juan del Mercado, en octubre de 1591 se dice: “..la capellanía que dejó y doctó doña Aldonza Manrique, señora que fue

1945 GÓMEZ PÉREZ. Enrique. El Real Monasterio...Op.cit, pág. 53.

${ }^{1946}$ QUADRADO; José María y PARCERISA, Francisco J. Op.cit, pág. 132. 
del lugar de Pinto y Carazena y que dotó, dejó y fundó en la iglesia del dicho monasterio en la capilla mayor del dicho monasterio, donde está el cuerpo de la susodicha enterrado... ${ }^{1947, "}$.

Tan sólo la estatua yacente es de alabastro, siendo de piedra primorosamente tallada el sepulcro sobre el que reposa la condesa. Su estilo está cercano al de Miguel de Espinosa, maestro burgalés que había trabajado en el claustro de San Zoilo desde $1537^{1948}$. El sepulcro habría sido realizado antes de 1548 , en que se le encarga realizar la portada lateral de Santiago en Medina de Rioseco, con la que se relaciona estilísticamente ${ }^{1949}$. Pero podemos precisar aún más teniendo en cuenta que falleció en 1542 y el traslado de los restos de la difunta desde el convento franciscano de Pinto fue efectuado en el año 1547. Los huesos, una vez extraídos de su sepultura, fueron depositados en una caja de pino, y a su vez metida en otra de cobre y entregada acto seguido a Fray Luis de Siles. Por tanto, en esta horquilla de cinco años pudo haberse ejecutado la obra, de modo que a la llegada de los restos de doña Mencía, estos pudieran reposar definitivamente en la iglesia carrionesa.

El frente del sepulcro consta de tres partes separadas a través de balaustres a los que acompañan unos motivos a base de cuerda con bolas que podríamos relacionar con un cordón franciscano o incluso un rosario, afín a la religiosidad de la difunta. Las dos figuras de los extremos presentan una técnica de ejecución contrastada. A la izquierda, San Juan Evangelista, porta en su mano derecha las Escrituras, mientras que en su rodilla derecha se apoya el águila, que dirige su mirada hacia el Santo. Se trata de una figura de aspecto juvenil que porta un amplio manto de múltiples pliegues sobre el cual se dispone una túnica unida al pecho a través de un broche triangular. Las facciones de San Juan son sumamente delicadas, hasta tal punto que, de no ser por la musculatura que entrevemos en su brazo izquierdo, y los atributos que presenta, podríamos identificarlo con una bella mujer.

\footnotetext{
1947 AHPP. Carr.Prot 4981, Sebastián García (1590-1592), fol 412.

1948 Sobre Miguel de Espinosa, véase el capítulo dedicado al mismo en los escultores.

${ }^{1949}$ En el siglo XVI, los conventos de clarisas de la provincia de Palencia se engalanan de obras de arte costeadas por personajes particulares que buscan buenos artistas para la ejecución de sus sepulcros. Véase PARRADO DEL OLMO, Jesús María. "El renacimiento...”. Op.cit, pág. 763. Se suma, además el hecho de que Carrión de los Condes es un centro de peregrinación, cuya pujanza se acentúa en este siglo. PARRADO DEL OLMO, Jesús María. “"A propósito del Camino de Santiago palentino. En torno a varias obras de escultura el siglo XVI" en $B S A A$, n ${ }^{\circ}$ LXI. Universidad de Valladolid. Valladolid, 1995, pág. 315.
} 
Su espesa cabellera de mechones ondulados deja paso a un rostro melancólico de gran elegancia cuyos ojos se inclinan hacia abajo, en actitud de recogimiento. El artista nos muestra el momento en que San Juan, apoyado sobre un tronco nudoso, dirige su mirada al suelo percibiendo el arrastre de sus voluminosas vestiduras, las cuales recoge delicadamente con su mano derecha.

En el otro lado San Juan Bautista aparece representado como hombre maduro acompañado del cordero y el lábaro, en su papel de intercesor ante Cristo. En este caso el maestro ha tallado al Santo ermitaño en una actitud más dinámica, pues éste apoya su codo en una superficie rocosa para hincar su rodilla derecha en la tierra. $\mathrm{Su}$ otra pierna en posición adelantada forma un ángulo recto, dejando entrever su fornida musculatura. La perfección anatómica del profeta, heredera de modelos italianos, se completa con un torso desnudo por cuyo hombro se desliza la piel de camello que porta habitualmente el profeta mientras señala con su dedo índice al cordero de Dios.

En lo que al rostro se refiere, podemos establecer claros paralelismos estilísticos con las tallas que el maestro realiza en el claustro del convento de San Zoilo, notablemente con la ménsula que representa a Seth. En ambos casos la figura gira cabeza hacia un lado mientras sus cabellos ondulados se agitan hacia el sentido contrario. Asimismo, la boca entreabierta es de una gran fuerza comunicativa y los ojos de grandes globos oculares aportan gran expresividad a su mirada. A ello se suma la prominencia de los pómulos y el ceño fruncido que acentúan el impulso vital que respiran gran parte de las obras de la mano de Espinosa. Es el caso de otra obra palentina, como es Padre Eterno que procedente de la fachada de la ermita del Otero en Frómista se sitúa hoy día al interno de la misma ${ }^{1950}$. De la soberbia ejecución de ambos santos podemos colegir una alianza entre la herencia clásica y el expresionismo característicos del estilo de Diego de Siloé, con el que apuntamos se formó Espinosa ${ }^{1951}$. En el caso de San Juan Evangelista, la monumentalidad de la figura y el tratamiento de los paños evidencian la elegancia del arte italiano asimilado por el arquitecto y escultor burgalés. Por su parte, el Bautista ilustra los

\footnotetext{
${ }^{1950}$ PARRADO DEL OLMO, Jesús María. “Sobre algunas esculturas...Op.cit, pp. 311-312.

${ }^{1951}$ Para un estudio profundo sobre Diego de Siloé, véase GÓMEZ MORENO, Manuel. Diego Siloé. Universidad de Granada. Granada, 1988. Del mismo autor, Las águilas del renacimiento español: Bartolomé Ordóñez, Diego Silóe, Pedro Machuca, Alonso Berruguete. Xarait. Madrid, 1983.
} 
preceptos del arte clásico a través de la idealización anatómica de su figura. Estas figuras flanquean un escudo central, que acogido por una gran corona de laurel, representa las armas del condado de Osorno: cortado: 1, Castilla, de gules, un castillo de oro. 2, Aguilar, águila de sable explayada y coronada de oro. Por último presenta una bordura general de armiños por ser la condesa de Castañeda.
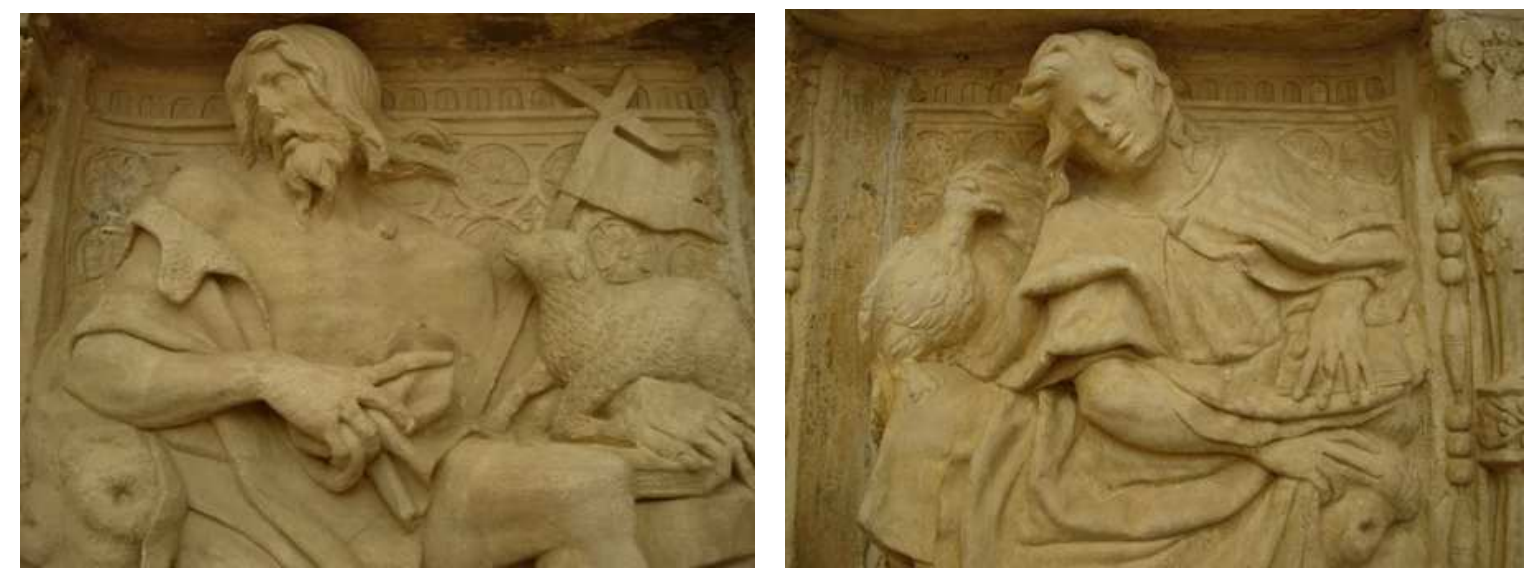

\section{San Juan Bautista y San Juan Evangelista en el frente del sepulcro.}

En los lados menores se representan dos figuras ataviadas a la manera italiana, con sendas túnicas de amplias mangas hasta las rodillas. Ambos tenantes sostienen el escudo de los Osorno, en sus diversas armerías. Uno de ellos, de Lara, dos calderas con sierpes y bordura con diez armiños (de Castañeda), y, el otro, es partido: 1, de Vivero, sobre ondas de agua tres rocas con tres matas de ortiga. 2, de Lara, dos calderas. Bordura de diez armiños. Les flanquean dos columnas abalaustradas decoradas con motivos vegetales y junto a éstos soportes, se dispone un motivo colgante jalonado por bolas agrupadas de tres en tres, aludiendo probablemente al cordón franciscano. 

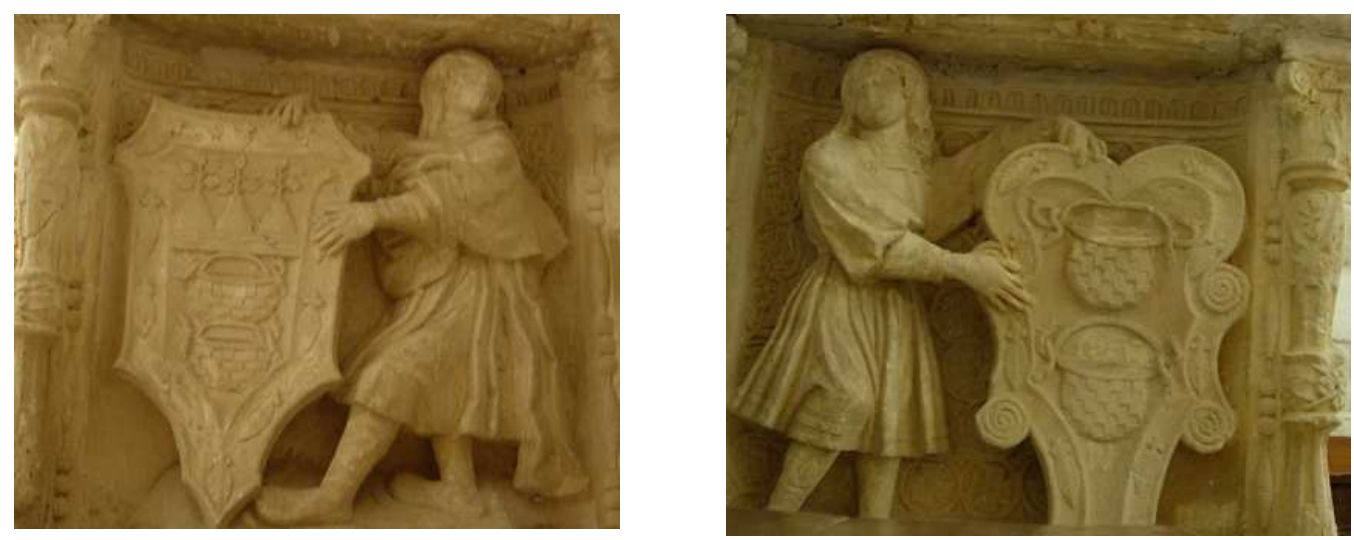

\section{Lados cortos del sepulcro de Doña Aldonza con los escudos de los condes de \\ Osorno.}

Doña Aldonza, con rostro sereno, parece estar sumiéndose en un dulce sueño, sus párpados le pesan, y aún entrevemos sus ojos a medio abrir. Está cubierta con una toca, y su cabeza reposa sobre tres almohadones, con las manos en actitud de oración, y envuelta en grandes pliegues. A sus pies, sobre dos almohadones y a escala inferior, descansa su doncella, sumisa y serena, sosteniendo el libro devocional de la condesa ${ }^{1952}$. La gran calidad en el trabajo técnico del sepulcro es indiscutible y probablemente algunas zonas estaban policromadas, como atestigua la pintura negra que hallamos en sus ojos. Tanto estos relieves como los de los lados cortos, se recortan sobre un fondo de círculos tangentes en los que aparece inscrita una especie de cruz griega o flor de cuatro pétalos.

En origen, el sepulcro, iría exento, pues contiene relieves en el lado que hoy día está adosado a la pared ${ }^{1953}$. El sepulcro se ubicaba en la capilla mayor de la primitiva iglesia, trasladándose a un lateral de la misma con la construcción de la nueva, en las primeras décadas del siglo XVII.

${ }^{1952}$ ANDRÉS GONZÁLEZ, Patricia. Op.cit, pp. 79,80.
${ }^{1953}$ PARRADO DEL OLMO, Jesús María. "El renacimiento...”. Op.cit, pág. 768. 


\section{Lápida sepulcral de doña Isabel de Velasco}

Una religiosa que ocupó el cargo de vicaria en la época del traslado de los restos de doña Aldonza Manrique a Carrión, hacia 1547 fue enterrada poco después en la clausura, a la entrada del convento ${ }^{1954}$. Al pie de una de las cruces de piedra que se yerguen en el edificio, se sitúa una lápida sepulcral, bastante deteriorada correspondiente a Isabel de Velasco, lo cual se deduce del escudo de dicha familia y de la inscripción iniciada en el borde: “AQVI YACE LA ILVSTRE SEÑORA DOÑA ISABEL DE... QUE FVE EN ESTA CASA DE BVENA MEMORIA HYIA Y NATURAL DEL MVI ILLVSTRE SEÑOR DON ANTONIO DE VELAS[CO]”. En 1558 recibe del virrey de Perú y Nueva España don Luís de Velasco, una renta de 6.000 maravedíes. Éste poseía un palacete en Carrión, la casa denominada del Águila, ubicada frente a la iglesia de Santa María. Pudiera tratarse de su tío, pues el hermano de don Luis, responde al mismo nombre. Por otra parte nuestro virrey mantenía una estrecha vinculación con Carrión, donde había nacido y poseía la célebre casa del Águila, por lo que la relación entre ambos es plausible. El escudo es de Velasco con jaquelado de quince piezas ilustrado con veros, con bordura de cuatro castillos y cuatro calderas alternando ${ }^{1955}$.

Como vemos, el vínculo entre los condes de Osorno y el convento fue muy estrecho, lo cual no fue óbice para que en ocasiones las buenas relaciones se viesen truncadas por los clásicos pleitos en los que cada parte cree ser la poseedora por derecho de una propiedad o fuero determinado. Es el caso del litigio que enfrentó en 1547 a las monjas clarisas con don Juan Fernández Manrique, marqués de Aguilar. El motivo de tal disputa se basaba en la posesión de treinta cargas de trigo de fuero y censo perpetuo que el convento tenía sobre el marqués y sobre ciertas rentas suyas posesión. Don Juan Rodríguez de Castañeda, comendador del hospital de la Herrada -extramuros de Carrión-, como juez y árbitro dictó la sentencia favorable para las monjas $^{1956}$.

\footnotetext{
${ }^{1954}$ ANDRÉS GONZÁLEZ, Patricia. Op.cit, pp. 80,81.

${ }^{1955}$ VIGURI, Miguel de. Heráldica ...2, Op.cit, pág. 78.

${ }^{1956}$ SNT, Villena, Carpeta, 7, Doc.19.
} 
El patrocinio de la alta nobleza se mantiene, como así continúan confirmándose los privilegios reales durante esta centuria que tanto favorecieron a la casa clarisa. Por citar algún ejemplo, Felipe II concedió 21700 maravedíes de juro al convento en $1562^{1957}$. En la segunda mitad del siglo XVI se registra una gran actividad constructiva. En líneas generales se produce una reforma de algunas de las estancias medievales, procediéndose a su ampliación. Además se procede a la edificación de otras nuevas.

\section{El claustro}

En el caso de las clarisas este espacio no es el núcleo del convento pues la vida no se desarrollaba en común, sino que la cédula vital era la celda donde dedicarse a la oración y contemplación. El claustro de Santa Clara es rectangular y consta de dos pisos de gran sencillez, con arcos de medio punto, dos en los lados cortos y cuatro en los largos, y cubierta de madera decorada con estrellas. Por su fisonomía, este claustro podría haberse realizado a mediados del siglo XVI. En el nivel inferior, los vanos son ciegos, con un ventanal en medio de cada uno de los arcos para evitar demasiada oscuridad en el recinto; y en el superior, los pilares que sostienen los arcos son bastante achatados, dando la sensación que en vez de arcos de medio punto, se traten de arcos peraltados que continúan hasta el suelo.

Las obras de este claustro finalizaron en 1597 con el cierre de las cubiertas del paño de los dormitorios que llevó a cabo el carpintero Santiago de Sigüenza, quien intervendría en las obras del convento al comenzar la siguiente centuria ${ }^{1958}$. El empedrado del claustro se efectúa en $1676^{1959}$. Hasta el año 2000 este piso estaba abierto con una barandilla de madera, momento en que decidió acristalarse.

\footnotetext{
${ }^{1957}$ ACSCC. Legajo IX, nº585.

${ }^{1958}$ Escritura y condiciones firmadas a dos de julio de 1597 en AHPP. Carr.Prot 4700. Pedro Carrión (1597), s/f.

${ }^{1959}$ ASCCC. Libro 8. Cuentas del convento (1675-1704), fol 137v.
} 

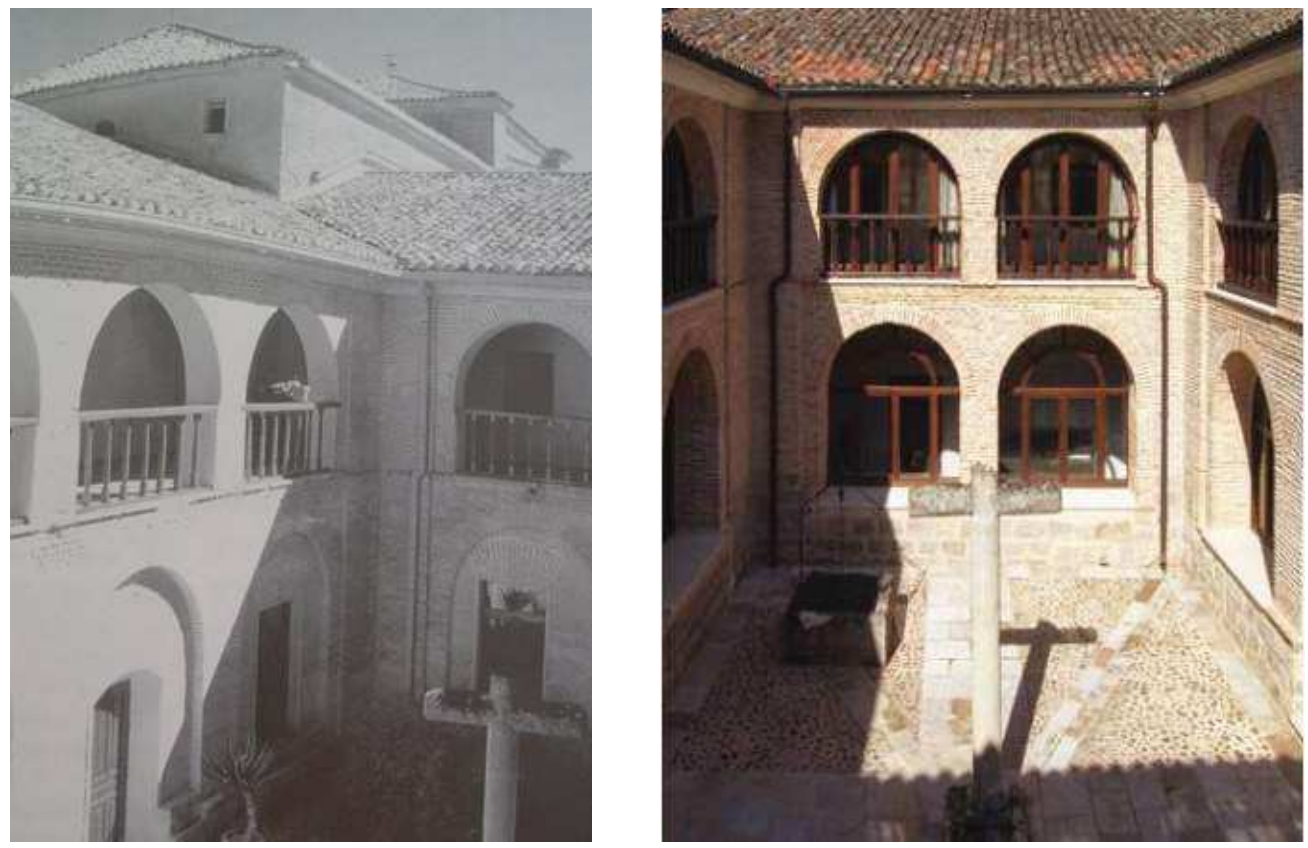

\section{El claustro de Santa Clara antes y después de que fuera acristalado en el año}

2000.

\section{Las celdas}

En 1557, siendo abadesa doña Isabel de Granada, las clarisas contrataron a los carpinteros Juan de Lomas y Jorge de Toledo ${ }^{1960}$, vecinos de la villa de Carrión, para que derribaran los dos paños del claustro que hasta entonces se habían hecho ${ }^{1961}$, el coincidente con la nave de la iglesia y el contiguo, para que así rehicieran los dormitorios de las monjas ${ }^{1962}$.

Las celdas, de gran importancia entre las Órdenes mendicantes, se distribuyen normalmente alrededor del claustro superior y están formadas por una

\footnotetext{
${ }^{1960}$ Se conocen pocos datos sobre este carpintero local. En 1542 figura ejecutando una tribuna en la iglesia de Santa María de Villalcázar de Sirga. ADP. Villalcázar de Sirga. Legajo con restos de un Libro de Cuentas, 1533-1535 y 1540-1542, s/f. Realiza diferentes retejos y reparaciones en la iglesia parroquial de Bahíllo a partir de 1562, cuyo pagó recibirá entre 1564 y 1565ADP. Bahíllo. Libro $1^{\circ}$ de Cuentas de Fábrica (1562-1581), fol 22, 130v, 131.

${ }^{1961}$ Se indica por tanto que las obras del claustro ya habían comenzado sin dar buenos resultados, por lo que se derribe derribar lo hecho hasta el momento.

${ }^{1962}$ Por el trabajo se les abonará 60 mil maravedíes. Escritura y condiciones en AHPP. Carr.Prot 5597. Francisco Rojas (1153-1562), fol 41 y ss.
} 
serie de naves alargadas sin ningún detenimiento constructivo, que, en el caso de Carrión, además, se distribuyen sin seguir orden lógico alguno, pues los huecos son de diversas alturas y la pared está sin plomar. Esta disposición responde a las obras ejecutadas en este momento, en que se ensancharon las celdas existentes del siglo $\mathrm{XV}$, disponiéndose solamente un total de diez -cinco a cada lado-, con ventana y puerta, separadas por el corredor. En la parte que da hacia el patio, ordenan que se haga una armadura de buena madera sobre postes de roble o pilares de canto, decantándose, como podemos observar hoy día por el segundo tipo de soporte. Estos irán reforzados por canecillos que sobresalgan de canes y cuartones tallados "al romano ${ }^{1963}$ ". La armadura recuerda en su estructura al del convento de Nuestra Señora de Calabazanos, no siendo ésta la única similitud estilística con este cenobio de clarisas palentinas ${ }^{1964}$.

En su parte externa los muros de ladrillo de los dormitorios presentan una disposición a soga y tizón en las que se desmarcan las rejas que protegen las ventanas, sobre las cuales una serie de coronas animan la sobriedad del conjunto. Además de las celdas, alrededor del claustro se disponen el resto de dependencias conventuales, situándose en la parte inferior la sala baja, la sala capitular -antes cementerio-, el zaguán o sala de San Miguel y en torno a la parte superior las celdas, -entre ellas la de la Madre Luisa- el coro alto y las oficinas.

\section{La sala baja}

Se trata de un espacio de grandes dimensiones y forma rectangular que según la tradición, era el dormitorio de las criadas. Comunica con las celdas de las monjas a través de una sencilla escalera con una puerta en su tramo medio que se cierra por la noche para quedar aislado de la clausura.

\footnotetext{
${ }^{1963}$ El término supone la asimilación de los fundamentos en los que se basa el Renacimiento y supone el abandono de los repertorios góticos, que en España se dio tardíamente, desde finales del siglo XV. Un estudio en profundidad sobre sus repercusiones en la pintura aragonesa en IBÁÑEZ FERNÁNDEZ, Javier. "La introducción del ornato al romano en el primer renacimiento aragonés. Las decoraciones pictóricas" en Artigrama, n¹8, Universidad de Zaragoza. Zaragoza, 2003, pp. 293340 .

${ }^{1964}$ Sobre este convento, véase GÓMEZ PÉREZ, Enrique y SANCHO CAMPO, Ángel. El Real Monasterio de Nuestra Señora de Calabazanos. Palencia. Cálamo. Palencia, 2009.
} 
En sus muros, esta sala cuenta con varias alacenas recubiertas de azulejos del siglo XVII que se adscriben al mismo autor del frontis existente a los pies del templo, Alonso de Figueroa Gaitán ${ }^{1965}$. Este ceramista estuvo trabajando en los cenobios de Porta Coeli y Santa Catalina, con cuyo estilo pueden establecerse claras relaciones. Los revestimientos cerámicos de este espacio están formados por azulejos de arista presentan motivos diversos como lazos formando abalorios geométricos, círculos de vegetales y flores o un diseño polícromo muy original en el que se trata de representar un espacio en perspectiva. Son diseños que se repiten en otros lugares de Castilla como en los conventos de Santa Clara de Salamanca o San Salvador de Oña, en Burgos ${ }^{1966}$.

En el lado que corre paralelo al claustro se dispone un arco apuntado cegado con sencillo dovelaje que apoya sobre dos esquemáticos pilares. Seguramente se tratara de un acceso creado hacia el siglo XIV que daría paso a otras estancias medievales y que posteriormente fue cegado para ser utilizado como hornacina.

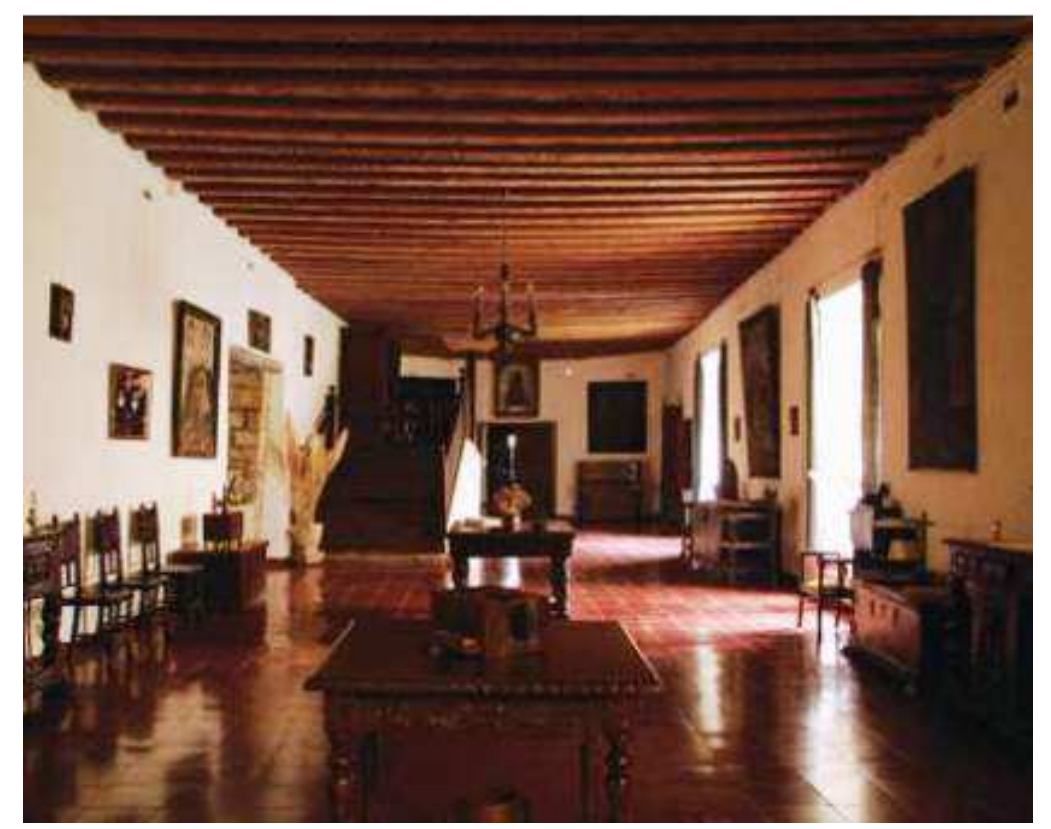

Sala baja del convento de Santa Clara.

\footnotetext{
1965 Sobré el se hablará en el apartado relativo al siglo XVII, en el capítulo dedicado al frontis de azulejería del templo, realizado entre 1614-1619.

1966 MALO CERRO, Mónica. Azulejería en Castilla y León. De la Edad Media al Modernismo. Universidad de Valladolid. Valladolid, 2002, pp. 62 y 611-614.
} 
Presenta un sencillo pero bello artesonado datable en el siglo XVI, en buen estado de conservación. Está formado por una multiplicidad de vigas transversales cuya longitud es equivalente a la anchura de la estancia. En su frente exterior, estos soportes de madera están decorados pictóricamente a través del cordón franciscano, motivo muy recurrente en los cenobios terciarios como recuerdo al Santo fundador de la Orden franciscana. El cordón se entrelaza caprichosamente, destacando vivamente sobre la madera al estar pintada de blanco. Esta ornamentación aparece nuevamente en el de Profundis", el espacio contiguo a la Sala baja. Se llamaba así por ser el lugar en el que los religiosos, antes de pasar al comedor para la refacciones del mediodía y de la noche, rezaban el salmo 129, titulado "de Profundis" como responsorio por el eterno descanso de los hermanos difuntos.

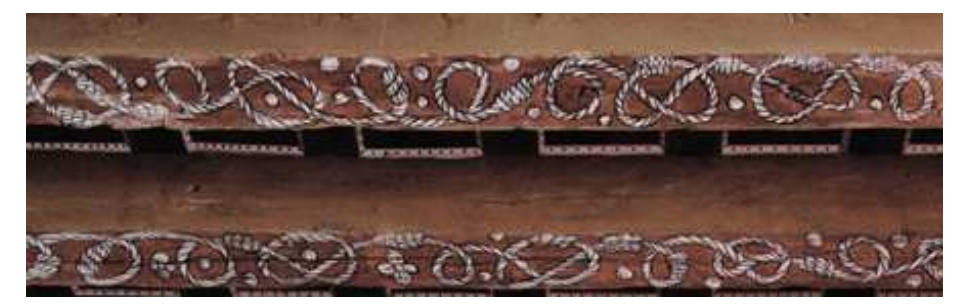

Detalle del artesonado de la sala baja.

En la puerta de acceso a esta estancia existe una vitrina del siglo XVIII donde se expone la Virgen "Quemadilla". Esta talla del primer tercio del siglo XVII recibe esta advocación por presentar chamuscados sus cabellos cuando, según cuenta la tradición, durante una noche de tormenta, un rayo en la sala baja produjo el desprendimiento de una de las vigas de madera del techo. Se trata de una imagen de vestir pero completamente tallada, que presenta los brazos articulados ${ }^{1967}$.

\section{El torno}

Durante la segunda mitad de siglo se llevan a cabo diversas obras en el convento, correspondientes las primeras a la ejecución del torno que, ubicado en el patio reglar está presidido por un escudo franciscano con la inscripción "SIGNA

${ }^{1967}$ Más datos en GÓMEZ PÉREZ, Enrique. El Real...Op.cit, pp. 67 y 68. 
REDENPTIONIS NRE” y la fecha de 1563 que confirma la datación de estas obras $^{1968}$.

\section{Los coros bajo y alto}

Conservamos varias cartas de obligación fechadas justo un año después, en 1564, por las que la por entonces abadesa doña Leonor de Prado, dispone la entrega de gran cantidad de madera y carros de piedra de sillería del lugar de Palacios del Alcor en el monasterio de Santa Clara. Se indica asimismo que el cantero Juan Antonio de Castillo y el carpintero Pedro González de Saldaña, vecino de Carrión estaban realizando una obra para el convento, sin especificar cual ${ }^{1969}$. Probablemente se trate, como indica Enrique Gómez, de las obras de los coros bajo y alto.

El coro bajo va cubierto con una serie de bóvedas de arista formadas por nervios muy amplios y marcados que nos hace pensar que nos hallamos ante una bóveda de crucería. Entre los mismos se disponen sendos lunetos. Cada uno de los tramos que separa las cubiertas va reforzada por anchos fajones acasetonados con una cabeza de querubín por adorno, campeando nuevamente el escudo de lo Osorno el recuadro central ${ }^{1970}$. Hoy día toda la cubierta presenta una bicromía en amarillo para los $\operatorname{arcos}$ y blanco en la plementería, fruto de los enlucidos que ha experimentado esta sala desde el siglo XVII.

La sillería del coro, que podemos datar del primer tercio del siglo XVI, ha sido muy restaurada ${ }^{1971}$. Está estructurada de un modo sencillo, a través de un solo piso en forma de U, salvo en su parte frontera, la más estrecha, que presenta dos, disponiéndose seis sitiales en su parte inferior. Tres de estas sillas y tan sólo uno de los paneles del lado de la Epístola presentan una ornamentación típicamente renacentista a base de labores de candelieri, mientras que en el resto de sitiales, desprovistos por otro lado de adorno alguno, palpita el recuerdo del pasado. La separación de los respaldos, modelada a través de unos pliegues rectilíneos y

\footnotetext{
1968 GÓMEZ PÉREZ, Enrique. El museo...Op.cit, pp. 13,14.

1969 AHPP. Carr.Prot 5663. Andrés Sánchez (1562-1564), s/f y Protocolo 4675. Juan Cantoral (1563$1568), \mathrm{s} / \mathrm{f}$.

${ }^{1970}$ GÓMEZ PÉREZ, Enrique. El Real...Op.cit, pág. 57.

1971 PARRADO DEL OLMO, Jesús Mª “El Renacimiento...”Op.cit, pág. 767.
} 
cortantes denota cierta raigambre gótica, como así entrevemos en los pomos de los sitiales. En el remate de la sillería se superponen ambos estilos sin entremezclarse, pues sobre un friso corrido de fina tracería una crestería de dobles volutas afrontadas concede un guiño clasicista al conjunto.

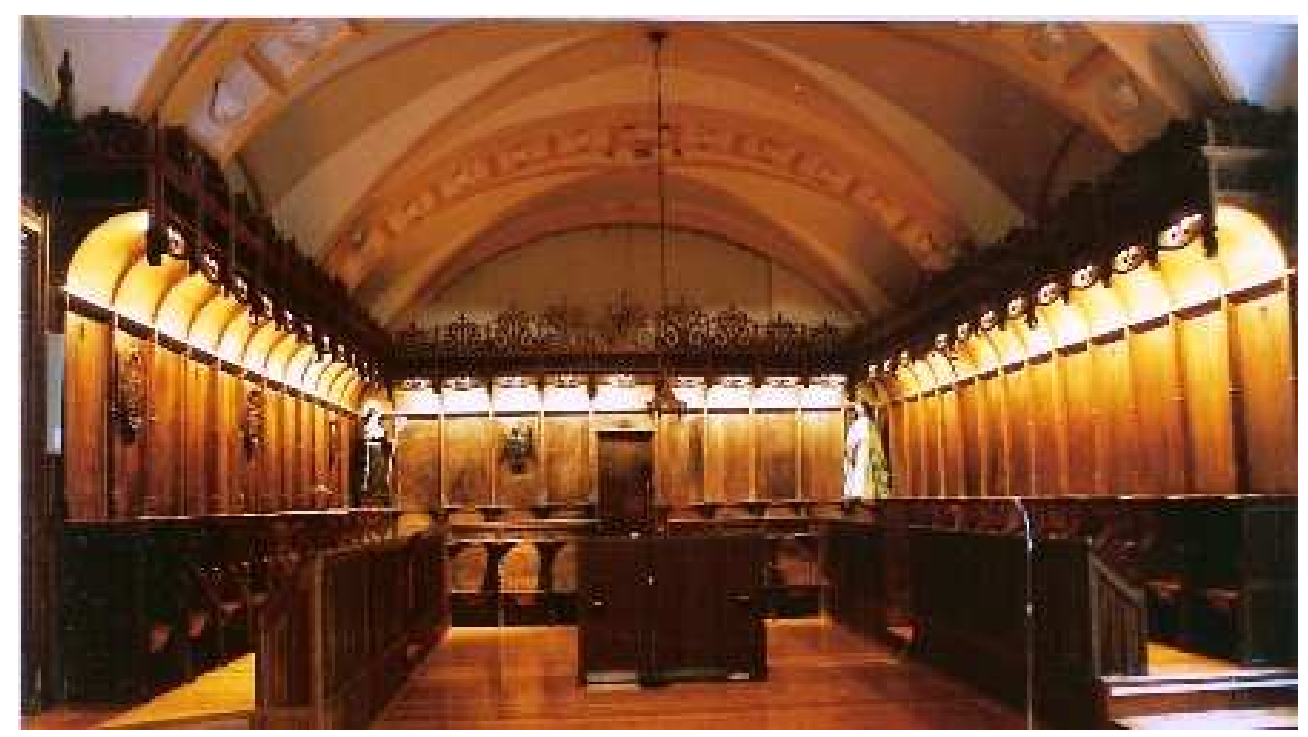

Coro bajo y sillería del convento de Santa Clara.

(Alto 3,24mtrs x Ancho 6,95metros x Profundidad 8,5 metros).

Los cuatro escudos que campean en algunos de los respaldos del lado de la Epístola constituyen la única concesión decorativa en la madera desnuda. Un águila explayada sujeta con sus garras el blasón de los Osorno, redundando una vez más en la protección y los favores de este linaje para con la casa clarisa. Su lectura, figurándonos que fuera policromado como corresponden a la heráldica convencional sería partido: 1, Lara, de gules, dos calderas de oro con sierpes de sinople dispuestas en palo ${ }^{1972}$. Abismo, de León, de plata, león rampante de púrpura. 2 cortado 1, Castilla, de gules, castillo de oro aclarado de azur, 2, de Aguilar, de plata, águila de sable. Por último, bordura de plata con ocho armiños de sable rememorando a los condes de Castañeda ${ }^{1973}$.

\footnotetext{
${ }^{1972}$ Las calderas, en vez de ir fajadas, deberían ir jaqueladas, pues de este modo parecen representar al linaje Herrera, en vez de a la familia Lara. Creemos que se deba a una confusión, pues no existen miembros Herrera entre los condes de Osorno ni su parentesco directo.

${ }^{1973}$ RIVERO SIERRA, Borja del. "Heráldica...Op.cit, pág. 59.
} 
En lo que se refiere al coro alto, superpuesto al bajo e idéntico originalmente en cuanto a sus proporciones, ha sido muy reformado a lo largo de los siglos, habiéndose reducido significativamente sus dimensiones para acoger el antecoro que se situaba en el piso inferior. Originalmente constaría de un alfarje de parhilera conformado por una serie de listeles clasicistas que remitirían a finales del XVI. Precisamente en 1691, aprovechando otras intervenciones de mejora en el convento como el blanqueo del refectorio, se enladrillan sus paredes ${ }^{1974}$. Fruto de una reforma efectuada entre 1715 y 1717 fue la ejecución de un tragaluz con cinco ventanas y un techo raso, enmascarados por las obras posteriores. Asimismo la sillería y el facistol, que no se conservan, fueron realizados en el transcurso de estas intervenciones ${ }^{1975}$.

El aspecto que presenta hoy día, con una cúpula central enlucida, se debe a una intervención del siglo XX en que se bajaron los techos de esta sala, quedando oculto bajo las yeserías el antiguo artesonado. Además se adquirió una sillería moderna de treinta y dos sitiales y se abrió la comunicación con la tribuna de los Condes de Osorno, ubicada en el lado del Evangelio del templo, sobre el portal de acceso $^{1976}$

La obra más destacada de este espacio es un retablo del siglo XVIII de reducidas dimensiones en cuya hornacina se sitúa un tabernáculo dorado de factura moderna. De sencilla estructura y dorado, está formado por un solo cuerpo donde el hueco central deja paso a dos estilizadas columnas corintias que lo flanquean. Dispuestas sobre amplios plintos, estos soportes presentan en su primera mitad un motivo ondulante caprichoso, mientras que la parte restante de los fustes aparecen estriados. Sobre ambos capiteles, un grueso entablamento sostiene la cornisa en cuyo centro un elemento avenerado remata la hornacina central. Originalmente acogía la imagen de Santa Clara portando un báculo de plata. Hoy día esta obra del siglo XVIII, perteneciente al taller de los Sierra, se ubica en el coro bajo ${ }^{1977}$.

A los pies del coro se alza el campanario, una especie de torre cuadrada que sobresale con un cuerpo hexagonal que remata en forma de chapitel.

1974 ASCC. Libro 8. Cuentas del convento (1675-1704), fol 47.

1975 ASCC. Libro 30. Cuentas de cargo y descargo (1815-1817), fol 49 y 50.

1976 Ibídem, pág. 61.

${ }^{1977}$ GÓMEZ PÉREZ, Enrique. El Real...Op.cit, pág. 61. 


\section{La sacristía}

Por su parte, la sacristía se encontraba arruinada a finales del siglo XVI. Ante semejante situación, se optó por derribar la dependencia vieja y aprovechar ciertos materiales para la nueva fábrica. De la obra se encargaron en 1591 el carpintero y ensamblador Lucas de Castillo y el albañil Marcos de Santiago, vecinos de Carrión, bajo la supervisión de Santiago de Siguënza, recibiendo por la misma mil cuatrocientos reales $^{1978}$. Esta sacristía, situada junto al coro bajo era de planta rectangular, de algo más de 20 pies de largo, 15 de ancho, y 25 de alto, y se accedía desde la iglesia a través de una grada. Su altura era menor que la del resto del templo, si bien, en las condiciones del contrato se especificaba que se igualara al mismo a través de un tejado de madera “..azer el zielo de madera y de yeso, conforme lo muestra la traza, y enzima su texado de buena madera y forma que si es posible benga con el de la yglesia bien texado y revocado con cal.”. Quedaba precisada además la ornamentación "al romano", es decir, de raigambre clasicista, para lo cual se realizaría un arquitrabe, friso y cornisa “...con mui buena gracia, polizia y belleza cual es lugar lo pido bien labrados y concertados..."

De ningún modo resultó definitiva esta sacristía, pues a comienzos de la centuria siguiente se intervendría sobre esta estancia, siendo derruida al construirse el nuevo templo en 1614.

\section{Retablos de San Blas y del Espíritu Santo}

De la antigua iglesia construida sobre el solar de Sancti Spiritus, se convino conservar los altares de las capillas de la Epístola, dedicados al Espíritu Santo y a San Blas ${ }^{1979}$. La anexión de este viejo templo al convento en 1468, exigía esta condición, la cual fue respetada sólo durante algún tiempo ${ }^{1980}$.Es por ello que los

\footnotetext{
${ }^{1978}$ El contrato y las condiciones de la sacristía en AHPP. Carr.Prot 5731. Lázaro Santacruz (15891591), s/f.

1979 ANDRÉS GONZÁLEZ, Patricia. Los monasterios...Op.cit, pp. 90,91.

1980 Traslado del documento de anexión de la iglesia de Santi Espítirus en 1468. ARCHV. Patronato Eclesiástico, 203.
} 
retablos actuales sustituyeron a los de la primitiva iglesia, pues, como indica la inscripción del retablo de San Blas, fueron finalizados en septiembre de 1596 gracias a las limosnas que Don Andrés de Espinosa, deán de Cuenca y camarero de Clemente VIII concedió a sus hermanas, religiosas de la casa clarisa ${ }^{1981}$. Probablemente, el insigne prelado dispusiera su sepultura en este convento por su vinculación familiar al mismo. Recordemos que no era la primera vez que un deán de Cuenca carrionés decide que sus restos reposen en su villa natal ${ }^{1982}$.

Se trata de dos piezas de sencilla estructura y pequeñas dimensiones que siguiendo una traza clásica se componen de banco, cuerpo principal en tres calles separadas por columnas de orden toscano y ático desarrollado que posee la misma altura que la parte central. En la parte inferior de ambos retablos se representan cuatro santos de medio cuerpo en posición de tres cuartos. La hornacina principal va flanqueda por cuatro tablas, dos que representan figuras completas de Santos, y por encima de ellas, dos pequeñas pinturas de formato cuadrado. El friso de las dos piezas va decorado con los anagramas de IHS y María y sobre ellos, un piñón rematado en un frontón clasicista con aletones que sirven de unión al cuerpo principal.

El retablo de San Blas contiene en la hornacina central la representación en altorrelieve de dicho santo sentado sobre un trono que se adosa a un manto celeste de soles dorados. Porta la capa pluvial y la mitra, propias de su condición de obispo de Sebaste, hoy día Sivas, en Turquía. Sostiene un libro en su mano izquierda mientras que con la otra señala al cielo. Su rostro cuadrado, de facciones duras nos remite a un posible seguidor del estilo de Juan Ortiz Fernández. De esta iconografía, no demasiado habitual en el entorno palentino, encontramos otro ejemplo en la iglesia de Terradillos de los Templarios. En el banco se representan pequeños lienzos de santos, siendo San Pedro Mártir y San Jerónimo los personajes centrales, disponiéndose un Santo Obispo y San Bruno en los laterales. En el cuerpo principal,

\footnotetext{
${ }^{1981}$ Todavía vivía en 1611, pues ejerce testamentario del inquisidor apostólico Claudio de la Cueva, que falleció el 27 de abril de dicho año. CEBRIÁN GARCÍA, José. Estudios sobre Juan de la Cueva. Sevilla, 1991, pp. 48-49.

${ }^{1982}$ Don Juan Bautista de Espinosa se convirtió en patrón de la capilla mayor del convento de Santo Domingo desde 1580. AHPP. Carr.Prot 5461. Lázaro Santa Cruz (1579-1584) s/f .En 1615 se encargó de reedificar toda la capilla mayor para acondicionarla y disponer su sepultura. AHPP. Carr.Prot, 5161. Jerónimo Laso (1616) s/f.
} 
flanqueando a San Blas, se disponen Santo Domingo de Guzmán y San Diego de Alcalá. Sobre éstos se superponen dos pinturas de pequeñas dimensiones que representan, la de la izquierda a la Virgen del entregando su rosario a Santo Domingo y al otro lado la representación de la Magdalena ante el sepulcro vacío. En el remate se representa la Visitación, con la presencia de San José y San Zacarías. Todas estas pinturas de mediana calidad, son obras de un pintor palentino manierista de finales del siglo XVI ${ }^{1983}$. Esta capilla presentaba ciertas deficiencias el mismo año en que se ejecutó su retablo, por lo que intervino en su arreglo el carpintero Juan de Herrera ${ }^{1984}$.
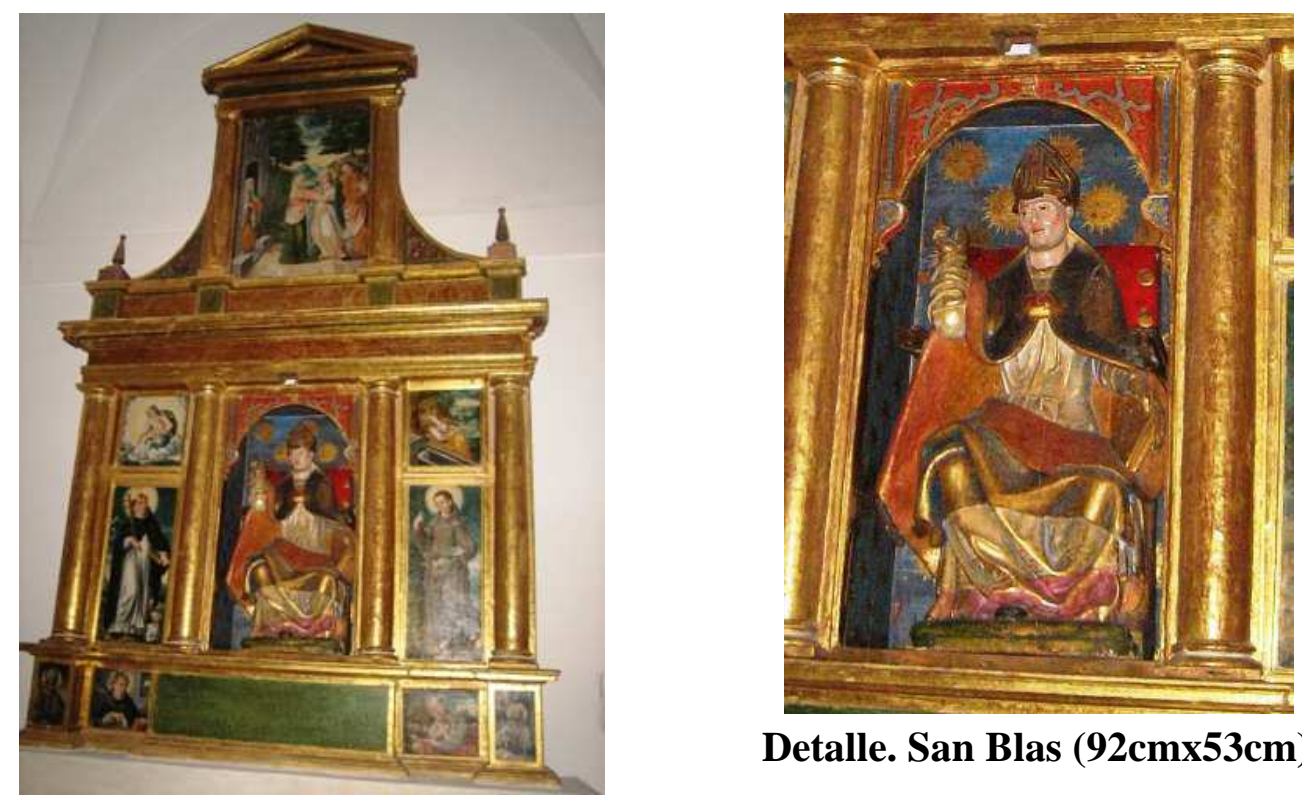

Detalle. San Blas $(92 \mathrm{~cm} \times 53 \mathrm{~cm})$

\section{Retablo de San Blas en el lado de la Epístola del templo de Santa Clara. $(3,1 \mathrm{mtrx} 1,95 \times 0,48 \mathrm{mtr})$.}

El retablo del Espíritu Santo, en cambio, no contiene ninguna talla. En el banco se sitúan cuatro pinturas que representan, de izquierda a derecha, Santo Domingo rezando ante un niño muerto, Santa Catalina de Alejandría, Santa Catalina de Siena y santo cardenal. La presencia de un difunto en la iconografía de Santo Domingo no es muy usual, siendo más recurrente que figuren el rosario, la iglesia o

\footnotetext{
1983 PARRADO DEL OLMO, Jesús María. “El renacimiento...”. Op.cit, pág. 771.

${ }^{1984}$ AHPP. Carr.Prot 5655. Pedro Saldaña (1596), s/f.
} 
el perro con antoncha como atributos ${ }^{1985}$. Sin embargo, no es el único caso, pues hallamos en Lerma, en Burgos, una pintura sobre tabla del siglo XVII ubicada en el monasterio de San Blas, donde se muestra a Santo Domingo en actitud de bendecir, para resucitar milagrosamente al personaje yacente a sus pies. En este caso es el joven Napoleón Orsini, que había tenido un fatal accidente al caerse de su caballo.

En el centro del banco, como en el retablo de San Blas, figura en letras capitales doradas las palabras de la consagración del pan y del cáliz en la Eucaristía: "HOC EST ENIM CORPVS MEVM, HIC EST ENIM CALIX SANGVINIS MEI, NOVI ET AETERNI TESTAMENTI, MISTERVM FIDEI, QVI PRO VOBIS ET PRO MVLTIS EFFVNDETVR IN REMISSIONEM PECATORUM ${ }^{1986, "}$
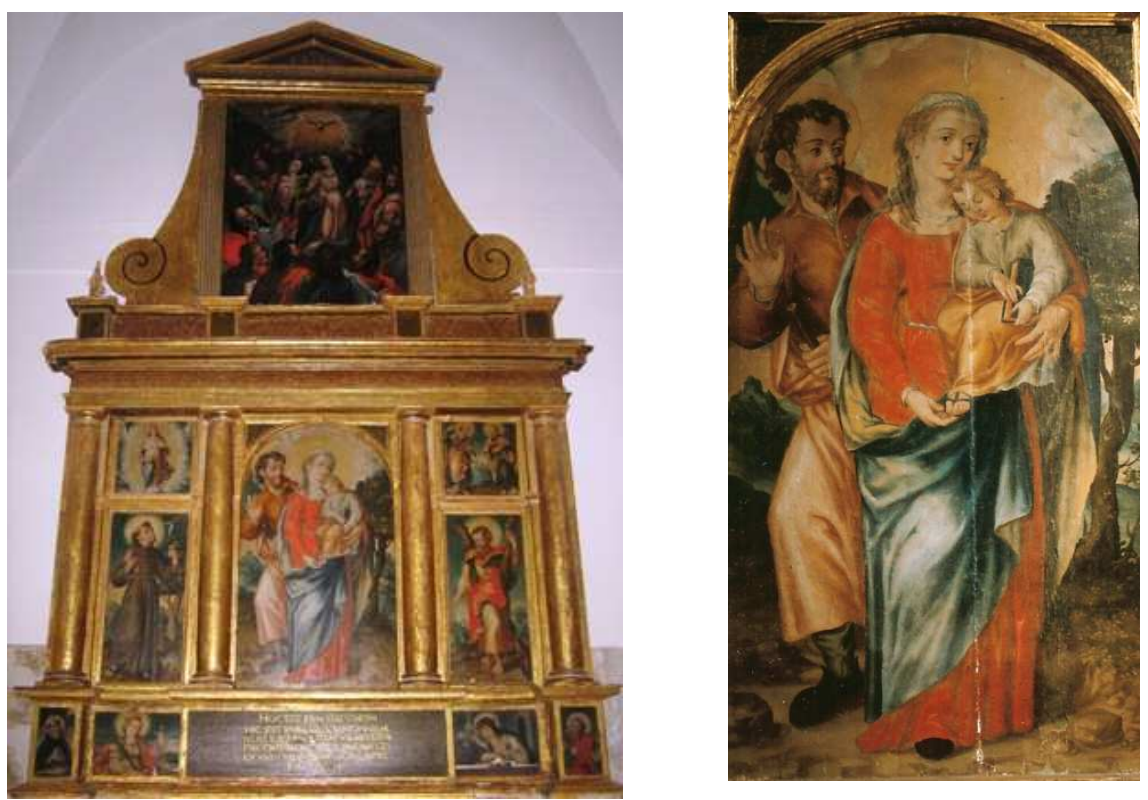

\section{Retablo del Espíritu Santo (3,28mtrx2,02mtr x0,26mtr) y detalle de la pintura de la Sagrada Familia $(99 \mathrm{~cm} \times 56 \mathrm{~cm})$.}

En la hornacina central figura una tabla de la Sagrada Familia, siendo ésta la pintura de mayor calidad del conjunto. San José, en segundo plano, saluda al Niño Jesús mientras la Virgen, ajena a su presencia, sostiene al Salvador, excesivamente grande a nuestro parecer, a la par que adelanta suavemente su pierna derecha para equilibrar el peso. La languidez de las expresiones y la gracilidad de la composición

\footnotetext{
1985 A este respecto, véase ALONGO GETINO, Luis G. (O.P). Santo Domingo de Guzmán. Biblioteca Nueva. Madrid,1939.

1986 “Este es mi cuerpo, este es el cáliz de la nueva y eterna alianza, que será entregada por todos vosotros para el perdón de los pecados”.
} 
indican un conocimiento de la pintura vallisoletana de finales del siglo XVI por parte de nuestro pintor anónimo.

A los lados del cuerpo principal, aparecen San Francisco y San Andrés y, en la parte superior, dos pequeñas imágenes, la de la izquierda de La Inmaculada Concepción, acorde a la devoción franciscana por este tema desde época medieval, y San Pedro y San Pablo.

El remate, unido al cuerpo principal a través de aletones cuyas volutas han sido fingidas mediante unas líneas pintadas, representa la venida del Espíritu Santo centrada por la Virgen. Apoyamos la tesis que sostiene Enrique Gómez Pérez acerca de la no pertenencia del remate al resto del retablo puesto que no se adecúa al mismo, ya que las pilastras no coinciden con sus plintos. A esto se suma el hecho de que la pincelada del lienzo no es como la del resto de cuadros del conjunto ${ }^{1987}$.

\section{EL SIGLO XVII}

El nuevo siglo se inaugura con nuevas obras en el convento. En el mes de septiembre de 1600, el mayordomo del convento, don Alonso de Cerecedo, se concierta con el carpintero Santiago de Sigüenza, vecino de Carrión, para que repare los tejados de las dos estancias superpuestas situadas junto a los coros alto y bajo y la escalera principal. Una de las salas sobre las que debe intervenir era la sacristía vieja, que, como vemos, cambiará de ubicación cuando se realicen las obras del nuevo templo. Sigüenza debe desmontar el maderaje desgastado y montar un armazón de tijera, aprovechando las vigas que pudieran resultar útiles ${ }^{1988}$.

Otra intervención relativa a la carpintería es ejecutada poco después por Juan González quien en 1603 se encargará de retejar todo el convento, incluida la iglesia, el cerco, las casas, corrales y paneras recibiendo quince ducados y medio y una carga de trigo cada año con carácter perpetuo ${ }^{1989}$.

\footnotetext{
1987 GÓMEZ PÉREZ, Enrique. Op.cit, pág. 90.

${ }^{1988}$ Contrato de las dos piezas del convento a 26 de septiembre de 1600. AHPP. Carr.Prot 4703. Pedro Carrión (1600), s/f.

${ }^{1989}$ AHPP. Carr.Prot 5386. Francisco Moro Saldaña (1603), s/f.
} 


\subsection{LOS LIENZOS DEL REFECTORIO}

Siguiendo un orden lógico de intervenciones o encargos de obras, destacaremos un gran tabla del refectorio $(223 \mathrm{~cm} \times 153 \mathrm{~cm})$ que representa la Virgen de la Misericordia flanqueada por San Joaquín y Santa Ana, que acoge bajo su manto a diversos fundadores de órdenes religiosas como Santa Clara, Santo Domingo o San Francisco dispersos entre otras figuras religiosas y fieles devotas que se reúnen bajo su protección. Éstos se sitúan incluso flanqueando a la Virgen, en menor tamaño, a modo de donantes, ya que pudo haber sido una donación privada a la monja sor Luisa de la Ascensión. En la parte superior, inmersa en un rompimiento de gloria, emerge la paloma del Espíritu Santo acompañada de dos ángeles que unen sus manos en el pecho, mostrando una actitud contemplativa. La firma indica el

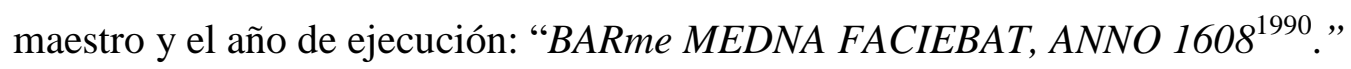

Existe una tabla de la misma temática y de menor tamaño $(194 \mathrm{~cm} \times 154 \mathrm{~cm})$ que, realizado en 1599 según consta en la inscripción que bordea el lienzo, está ubicado en la sala baja ${ }^{1991}$. Además de la fecha, esta orla contiene los cuatro primeros versos del himno "Iesu corona Virginum", atribuido a San Ambrosio: “IESV CORONA VIRGINUM, QVEM MATER ILLA CONCIPIT, QUA SOLA VIRGO PARTVRIT, HAEC VOTA CLEMENS ACCIPE ${ }^{1992 ", ~ L a ~ d a t a c i o ́ n ~ d e ~ l a ~}$ obra viene confirmada por el hallazgo del contrato de la obra, cuya autoría corresponde igualmente a Bartolomé de Medina ${ }^{1993}$. Ha sufrido numerosos repintes por parte de una de las monjas de la comunidad lo que impide apreciar la calidad original de la pintura ${ }^{1994}$. Se trata de un encargo de doña Ana de Castañeda, monja profesa de Santa Clara en el que se precisaba que el pintor debía representar dos ángeles flanqueando a la Virgen y bajo ella, en tamaño reducido Santa Clara y Santa Catalina -a la derecha- y San Francisco San Agustín, San Gregorio -a la izquierda,

\footnotetext{
${ }^{1990}$ URREA FERNÁNDEZ, Jesús y MARTÍN GONZÁLEZ, Juan José. Inventario...2.Op.cit, pág. 60. Sobre esta obra VV.AA. Iconografía Mariana: Real Monasterio de Santa Clara. RR. MM. Clarisas de Carrión de los Condes. Carrión de los Condes, Palencia, 2004, pág. 24.

${ }^{1991}$ URREA FERNÁNDEZ, Jesús y MARTÍN GONZÁLEZ, Juan José. Inventario...2.Op.cit, pág. 60.

1992 “Jesús, Gloria de las Vírgenes, concebido de la beata madre, la única que parió Virgen y que acogió clemente a todos los fieles".

1993 AHPP. Carr.Prot 5290. Pascual López (1599), s/f.

${ }^{1994}$ Así me informa el historiador carrionés Enrique Gómez.
} 
siendo el resto de personajes elección del artista. Esta iconografía, de raigambre medieval, gozó de gran aceptación entre cofradías de penitentes, disciplinantes y en mayor medida, entre las órdenes mendicantes, dada su defensa de la concepción inmaculada de la Virgen, de ahí que no resulte extraña la repetición de esta iconografía $^{1995}$. Comparando estilísticamente ambas obras, a pesar de sus evidentes analogías, se observa una clara evolución en el artista, patente en la representación más bella de la Virgen, frente al rostro plano de la obra de 1599, y la utilización del claroscuro para marcar los volúmenes, como sucede en el manto de la Virgen.

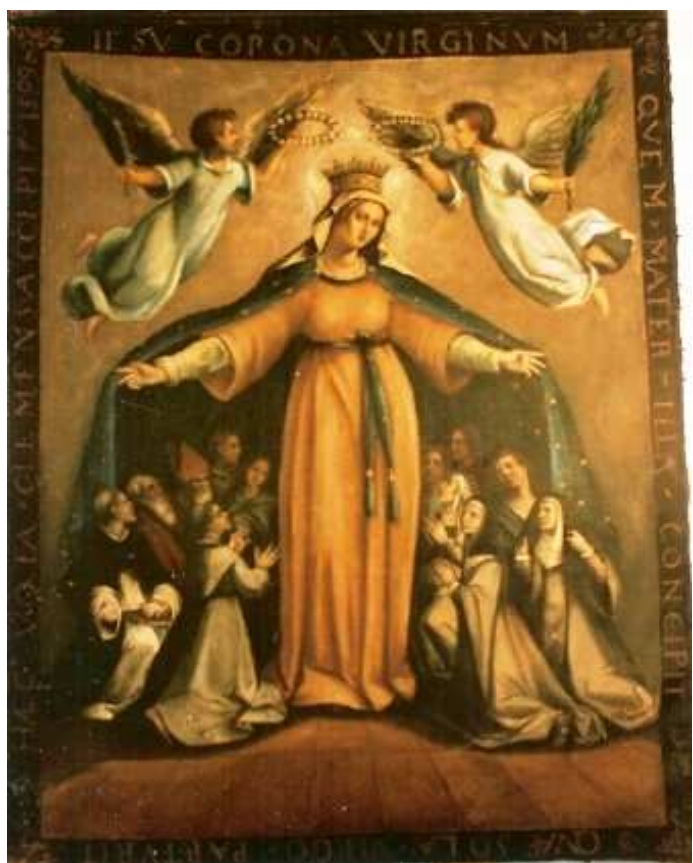

Sala Baja. (194cm x $154 \mathrm{~cm}) .1599$.

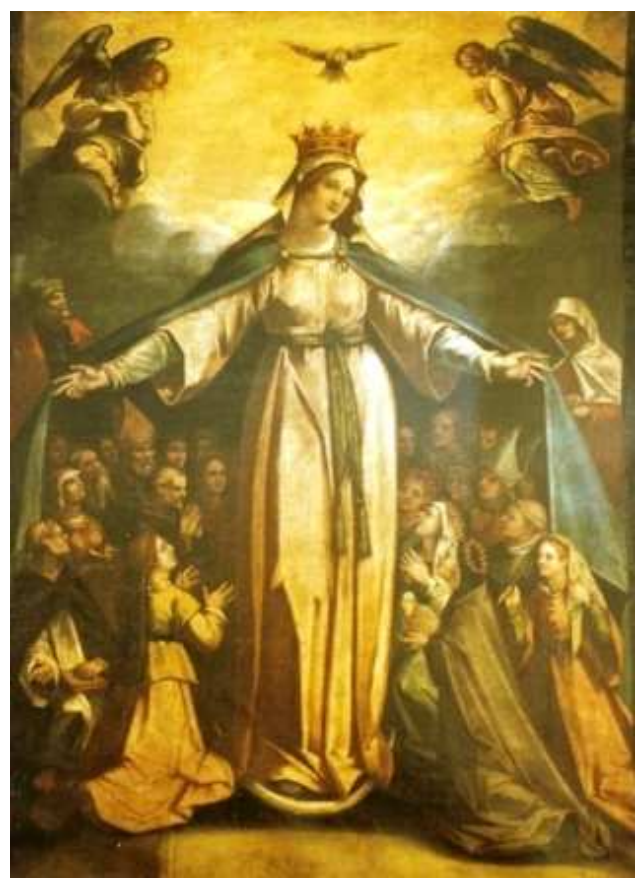

Refectorio. $(223 \mathrm{~cm} \times 153 \mathrm{~cm}) .1608$.

Pinturas de la Virgen de la Misericordia pintadas por Bartolomé Medina.

En la misma pared del refectorio, haciendo pareja con la Virgen de la Misericordia, existe un lienzo anónimo de cierta calidad que escenifica a San Joaquín y Santa Ana con la Virgen niña. Ese cuadro, fue ejecutado por las mismas fechas que el anterior, pues en el ángulo inferior derecho puede leerse que la

${ }^{1995}$ Una pintura muy célebre de esta iconografía se ubicaba en el convento de Santa Clara de Palencia, hoy trasladada al Museo Arqueológico Nacional. FRANCO MATA, Ángela. "Precisiones sobre algunas obras góticas del Museo Arqueológico Nacional" en Boletín del Museo Arqueológico Nacional, nº16, 1998, pp. 187-189. 
Madre Luisa de la Ascensión mandó poner este lienzo en $160 ?^{1996}$. La composición sigue modelos manieristas de finales del siglo XVI, del tipo de Barocci, por lo que el autor pudo haber recurrido a la utilización de grabados como fuente de inspiración.

El refectorio ha sido modificado a lo largo de los siglos, siendo la última intervención en el siglo XX, en que se abrieron nuevas ventanas y se elevó del nivel original para evitar la humedad.

\subsection{LA MADRE LUISA DE LA ASCENSIÓN}

No podemos obviar a un personaje que dentro de la casa clarisa, marcó la historia del convento, manteniéndose vivo su recuerdo hoy día. Hablamos de la abadesa Sor Luisa Ruiz de Colmenares y Solís, más conocida como La Madre Luisa de la Ascensión o más familiarmente "La monja de Carrión ${ }^{1997, " . ~ H i j a ~ d e ~ J u a n ~ R u i z ~}$ de Colmenares y Jerónima Solís de Cabezón, nació en Madrid el 16 de mayo de 1565. Contaba con 17 años cuando fue llevada a Carrión por petición de una tía suya donde permanecería al ser su voluntad ingresar en la casa clarisa, profesando en 1584, tras un año de noviciado ${ }^{1998}$.

Como buena franciscana se distinguió por su devoción de la Concepción Inmaculada de la Virgen ${ }^{1999}$. Juró su defensa en Carrión en enero de 1619, llegando a crear incluso una hermandad entre cuyos miembros figuraban la realeza, obispos y otros altos cargos ${ }^{2000}$. Alcanzó gran celebridad por sus grandes dones y milagros como la bilocación, la capacidad para extinguir incendios, sanar enfermos o amansar

\footnotetext{
${ }^{1996}$ GÓMEZ PÉREZ, Enrique. El Real...Op.cit, pp. 73-74. Por su relevancia dentro de la historia del convento, dedicamos a continuación un capítulo a la célebre monja.

1997 Acerca de la biografía de esta monja, véase GARCÍA BARRIUSO, Patrocinio. La monja...Op.cit y GORDALIZA APARICIO, F. Roberto. Historias y leyendas palentinas. Saber Palencia, Volumen 5. Cáñamo. Palencia, 2001, pp. 126-129 y CALDERÓN, Padre Francisco. Op.cit. Archivo de la Iglesia franciscana de San Antonio de Valladolid. Carpeta 1.Caja 1, Legajo 1, III Fol 322 y ss.

1998 ASCCC. Legajo 29. Traslado de un cuaderno manuscrito en el que se refieren las mercedes y favores que Nuestro Dios y Señor se dignó hacer a la Madre Sor Luisa de la Ascensión. Sebastián Martín Perrote. 1772, fol 32 y ss.

1999 Sobre esta devoción, STRATTON, Suzanne. La Inmaculada Concepción en el arte español. Madrid, 1989.

${ }^{2000}$ La copia del relato sobre el voto, juramento de la Inmaculada y fiestas que con dicho motivo se celebraron en GARCÍA BARRIUSO, Patrocinio. Op.cit, pp. 156-173.
} 
animales salvajes. A ella se le atribuye la participación en conflictos bélicos acudiendo en ayuda de los católicos alemanes contra los herejes de Praga o del rey de Polonia contra el Gran Kan de los tártaros en los campos de Balaquia ${ }^{2001}$.

Durante todo el tiempo que permaneció en clausura, sin ser necesariamente abadesa, no solo dedicó sus esfuerzos a la atención espiritual, sino que además impulsó las obras dentro del monasterio invirtiendo en dichas obras más de treinta mil ducados que obtuvo de limosnas ${ }^{2002}$.

Para ello contó con los favores de Felipe III, el cual, a través de su secretario, enviaba generosas sumas en concepto de limosna al regidor de Carrión para que fueran depositadas en el convento de clarisas ${ }^{2003}$. Este monarca fue quien en 1617 le concedió perpetuamente un mercado franco “...el martes perpetuamente para siempre jamás..." mutándolo poco después al jueves por ser el día del mercado por tradición en la villa ${ }^{2004}$. Es comprensible que, dados los privilegios otorgados por los monarcas, el corregimiento defendiera a la Madre Luisa y venerase su modo de vida. Sus virtudes se hicieron generales hasta en el extranjero, conocidas de viva voz y por escrito, por lo que fue visitada por ilustres personajes quienes confiaban ciegamente en ella para alcanzar todo tipo de favores celestiales ${ }^{2005}$.

${ }^{2001}$ Traslado de un cuaderno manuscrito en el que se refieren las mercedes y favores que Nuestro Dios y Señor se dignó hacer a la Madre Sor Luisa de la Ascensión. Sebastián Martín Perrote. 1772. ASCC. Legajo 29.

${ }^{2002}$ Para conocer una relación detallada de los milagros de la monja, conviene consultar EGIDO, Teófanes. "Religiosidad popular y taumaturgia del Barroco. Los milagros de la Monja de Carrión" en AIICHP, tomo 3. Vol, 1. Palencia, 1990, pp. 11-39.

2003 “..Su Majestad, por rreal título firmado de su nombre a echo merced a esta dicha villa de Carrión de la perpetuar los dos ofiçios de fieles ejecutores que tiene en ssu cabeza porque esta dicha billa le sirviese con ochenta mill marabedís, los quales manda se paguen y den de limosna a la dicha Madre Luissa de la Axzensión como consta por certificación de Tomás Angulo, secretario del rrey..." Ver carta de pago completa en AHPP. Carr.Prot 5216. Una carta emitida por la madre Luisa pidiendo limosna al rey en AHN. Inquisición, Legajo 3708, caja 1. El monarca otorgó en 160421.222 maravedíes situados en la renta de los diezmos de lanar de Castilla. ACSCC. Legajo IX, nº586. Se cuenta que ella a cambio, asesoraba al rey en todo que podía y en su lecho de muerte, estuvo junto a él para sacar su alma y la de la reina Margarita del purgatorio. ASCC. Legajo 29. Traslado...Op.cit, fol 71 y ss.

${ }^{2004}$ Se comienza la sesión con la lectura de dicho privilegio real. Sesiones municipales, 1617. AMCC. Libro 1, Sesiones municipales (1618-1638) s/f.

${ }^{2005} \mathrm{La}$ enumeración de estos personajes y otras notas bibliográficas de la religiosa pueden verse en RAMIREZ DE HELGUERA, Martín. El libro...Op. cit, pp. 182-184. 


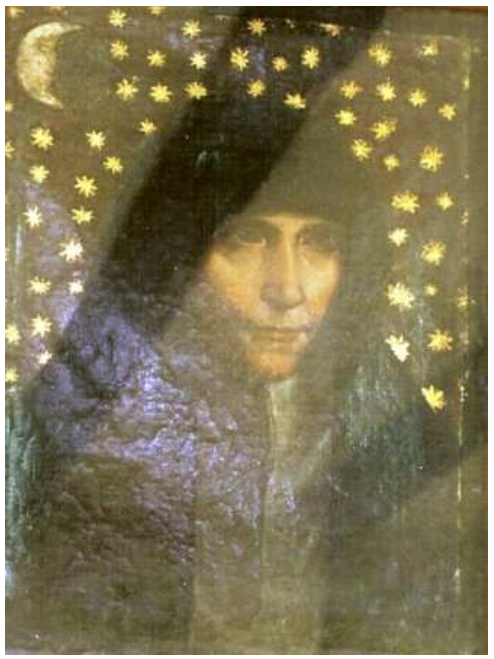

\section{La Venerable Sor Luisa de la}

Ascensión. Óleo sobre tabla de escuela

vallisoletana. Primer tercio del siglo XVII.

Museo de Santa Clara.

El recelo que despertó la fama alcanzada por la Madre Luisa entre algunas monjas y predicadores eclesiásticos, acérrimos opositores de la doctrina de la Inmaculada, trajo consigo la intervención del Santo Oficio. Desde en 27 de marzo de 1635 quedó apartada de su hasta ahora comunidad carrionesa, siendo trasladada al convento de la Encarnación de las Agustinas Recoletas de Valladolid, en tanto se constatasen los hechos atribuidos a la célebre monja ${ }^{2006}$.

Tanto el visitador y ministro de la Provincia de la Concepción, Fray Luis Fernández como las monjas profesas de la casa clarisa emitieron dicho año diversas requisitorias al secretario del Tribunal del Santo Oficio, don Juan Encrena solicitando que doña Luisa regresara al convento “...donde a estado de más de çinquenta años a esta parte... ${ }^{2007}$." Haciendo oídos sordos a sus súplicas, la Inquisición mantuvo una postura tajante, aún cuando ya había fallecido la Madre Luisa, el 28 de octubre de $1636^{2008}$. Llegó incluso a prohibir a través de un

\footnotetext{
${ }^{2006}$ GARCIA BARRIUSO, Patrocinio. Op.cit. pp. 267-290.

2007 AHPP. Carr.Prot 5231. Jerónimo López (1635), s/f.

${ }^{2008}$ El Padre Villacastín emite un comunicado el 1 de noviembre que dice así: "Nuestro Señor se ha llevado para sí a la Madre Luisa de la Ascensión, o de Carrión, día de los Apóstoles San Simón y Judas, en el convento de las Madres Recoletas Agustinas Descalzas, donde estaba depositada por la Suprema, las cuales avisaron luego al señor Obispo y a los señores inquisidores. Acudió el prelado y un inquisidor, y sin hacer demostración alguna exterior, dentro de tres horas la sepultaron allá dentro, donde le dijeron la misa de cuerpo presente y la dieron tierra, y tomaron por fe que quedaba allí depositada y viniéronse a sus casas. Los Padres Franciscos, que estaban muy desconsolados, quisieron hacerla unas honras muy suntuosas con misa y sermón y sólo pudieron recavar y no con pequeña dificultad, que aquel día por la tarde se convocasen de todas las religiones seis Padres de casa una y se juntasen en la iglesia de las Madres par asistir a la vigilia que todo el convento de los Padres Franciscos había de cantar con su responso. Fuimos como nos lo pidieron y hallamos en la capilla mayor de la iglesia una humilde tumba con paño negro de bayeta, catorce velas de cera
} 
comunicado con fecha 10 de enero de 1637, la posesión de todos aquellos bienes que tuvieran relación directa con la monja, así como escritos relacionados con su vida, bajo pena de excomunión “... porque así conuiene a la pureza de Nuestra Santa Fe en materia de la dotrina y al desengaño de las almas senzillas... ${ }^{2009 " .}$ Incluso el concejo y los vecinos de Carrión fueron partícipes de la causa actuando en defensa de la monja ${ }^{2010}$.

Pero sin duda, su más insigne defensor fue Fray Pedro de Balbás, calificador de la Inquisición, lector jubilado y procurador en su causa. Habitaba en el convento franciscano de Medina de Rioseco y contaba con 39 años cuando se trasladó a Madrid para defender incansablemente a Sor Luisa desde 1636 hasta 1650, cuando ya había fallecido. Su aportación más significativa fue el memorial completo presentado en 1643 ante la Suprema Inquisición con toda una serie de argumentos contra los cargos de la acusación ${ }^{2011}$. Las clarisas apoyaron la causa en todo momento, pues fueron quienes corrieron con los gastos ocasionados en la defensa de la monja ${ }^{2012}$. Sin embargo, estos intentos resultaron en vano, pues Doña Luisa fue recluida en la cárcel de Valladolid, ciudad en la que falleció al año siguiente. En una época de exaltación religiosa y fragor inmaculista, como la que atravesaba la capital del Pisuerga por entonces, otras monjas milagrosas como Luisa de Carvajal o Marina de Escobar gozaron del favor de la nobleza y la realeza e igualmente de una gran devoción popular ${ }^{2013}$.

amarilla, encima una cruz y un hábito de monja francisca con un bulto a la cabecera que tenía una calavera, y a los lados dieciséis pedazos de hachas amarillas. Este era todo el aparato y para misa y sermón el día siguiente no nos convidaron ni hubo nada y es de creer no se les daría licencia ni se la darán hasta que hayan concluido con su causa pendiente”. ANÓNIMO. Memorial Histórico Español. Colección de documentos, opúsculos y antigüedades que publica La Real Academia de la Historia. Volumen 13. Imprenta Nacional. Madrid, 1861, pág. 521.

${ }^{2009}$ SNT, Osuna, Car. 844, Doc. 21.

${ }^{2010}$ AMCC. Libro 1, Sesiones municipales (1618-1637). Sesión de 12 de abril de 1635. s/f.

2011 ASCC. Memorial informativo en defensa de Sor Luisa de la Ascensión, monja de Santa Clara de Carrión, hecho por Fray Pedro de Balbás.1643 y Traslado del mismo realizado en 1772.

${ }^{2012}$ Factura de los años 1635 a 1637 en que se le abonan al Padre Balbás 500 reales en gastos. ASCC. Libro de cuentas 1633-1655, fol 47v.

${ }^{2013}$ Sobre las mismas, véase PUENTE, Luis de la. Vida maravillosa de la venerable Virgen Doña Marina de Escobar natural de Valladolid, sacada de lo que ella misma escriuio de orden de sus Padres espirituales. Francisco Nieto. Madrid, 1665-1673, ABAD, Padre Camilo María. Una misionera española en la Inglaterra del siglo XVII: Doña Luisa de Carvajal y Mendoza. (1566-1614) Universidad Pontificia de Comillas. Santander, 1966, FERNÁNDEZ DEL HOYO, M ${ }^{\mathrm{a}}$ Antonia. Marina de Escobar. Caja de Ahorros Popular de Valladolid. Valladolid, 1984, PINILLOS IGLESIAS, Ma de los Hoyos. Hilando oro: Vida de Luisa de Carvajal. Laberinto. Madrid, 2000, BURRIEZA SÁNCHEZ, Javier. Los milagros de la corte: Marina de Escobar y Luisa de Carvajal en la historia de Valladolid. Valladolid, 2002. 
Tras la muerte de sor Luisa el 28 de octubre de 1636, el proceso inquisitorial continuó, resultando absuelta de todas las causas impuestas el 3 de mayo de $1648^{2014}$. Su cuerpo sería trasladado a Santa Clara de Carrión en 1655, para disponerlo en un arca situada en el muro de la Epístola del coro bajo, frente al órgano. Algunos restos de la Madre sor Luisa se conservan hoy día en la iglesia parroquial de San Nicolás de Tellego, en Asturias, dentro de la capilla de las Santas Reliquias $^{2015}$.

\subsection{LAS OBRAS PROMOVIDAS POR LA MADRE LUISA}

Desde la primera década del siglo hasta que Sor Luisa fue trasladada contra su voluntad a Valladolid, tanto las intervenciones que se llevaron a cabo en el convento como las obras de arte que fueron traídas al mismo, se debieron a la iniciativa de la monja. No sólo la documentación sino las inscripciones que acompañan a todas sus obras avalan la incansable labor de esta abadesa a lo largo de su vida.

Sor Luisa fue nombrada varias veces vicaria pero solamente llegó a desempeñar el cargo de abadesa durante el trienio de 1609 a 1611 y parece que lo rechazó en dos ocasiones que fue elegida. García Barriuso apuntaba que también estuvo al cargo entre 1615 a 1617, sin llegar a finalizarlo, contando por entonces el convento con sesenta monjas ${ }^{2016}$. Sin embargo, ni siquiera se le puede atribuir su mandato en 1615, pues en agosto de dicho año figura ocupando tal puesto la madre Francisca María de Lerma ${ }^{2017}$.

\footnotetext{
${ }^{2014}$ Todo el proceso y causas finales en GARCIA BARRIUSO, Patrocinio. Op.cit. pp. 323-424.

2015 En dicha capilla se veneran además las reliquias de la Madre Ágreda, los sudarios de San Diego de Alcalá y Santa Teresa, el hábito de San Pedro Regalado, partes del pesebre y la cruz de Cristo y otras reliquias de San Blas, Santa Juliana, San Juan Bautista, San Andrés, San Eusebio, San Victor, Santa Eulalia, San Jerónimo, San Gregorio Magno y Santo Tomás de Aquino. HEVIA VALLINA, Agustín y MARTÍNEZ VEGA, Andrés. "Reliquias y relicarios en la Archidiócesis de Oviedo" en Memoria Ecclesiae, ${ }^{\circ} \mathrm{XXV}, 2004$, pág. 509.

${ }^{2016}$ GARCÍA BARRIUSO, Patrocinio. Op.cit, pág. 64.

${ }^{2017}$ Así figura en una carta de obligación sobre un préstamo con fecha 23 de agosto de 1615. AHPP. Carr.Prots 5211. Jerónimo López (1615) fol 34 y ss.
} 
El número de ocasiones en que la madre Luisa fue abadesa se torna en este caso una cuestión baladí pues el hecho de ser una monja como las otras del cenobio no fue óbice para el papel destacado y activo que desempeñó en todo momento. $\mathrm{Su}$ figura trasciende fuera de la clausura gracias a la devoción hacia ella profesada por personalidades de diversos rangos. Desde la realeza, pasando por los nobles y el alto clero hasta el propio vecindario de Carrión, todos ellos, en mayor o menor medida, contribuyeron a través de la intercesión de la monja a forjar el esplendor del cenobio en lo que a obras y aportaciones se refiere ${ }^{2018}$. Repasemos ahora todas las aportaciones de la Madre Luisa al convento ${ }^{2019}$.

\section{La ermita de San Juan Bautista}

Es una de las dos que se encuentran en clausura, en la misma huerta, y fue edificada en 1611 para conmemorar el milagro de la serpiente, ocurrido en este lugar, por el cual, son Luisa logró expulsar al terrible animal que las amenazaba ${ }^{2020}$. De hecho queda recogida en la documentación como ermita "de la sierpe"2021, aunque considerarla como ermita es mucho decir, pues apenas cabe una persona en su interior.

Se trata de un pequeño cubículo de ladrillo con una cubrición exterior a cuatro aguas e interior de bóveda de cañón. Debe su advocación a una pequeña escultura de San Juan Bautista de no muy buena calidad que está dispuesta en la única hornacina del oratorio. San Juan, de aspecto maduro, porta la barba y le acompaña el cordero. Se trata de una talla romanista de finales del siglo XVI, que ha sufrido numerosos repintes ${ }^{2022}$. Adosada en la pared derecha del cubículo, se sitúa

\footnotetext{
${ }^{2018}$ El siglo XVII sería por un lado el de máximo esplendor del convento pues se renueva casi enteramente, sin embargo puntualizamos, pues como sabemos, también se desarrolló todo el proceso inquisitorial durante el cual sor Luisa acabará falleciendo.

${ }^{2019}$ Aparte de las dos ermitas que aquí se tratan, reformó la ermita de la Piedad, que por situarse fuera del convento se tratará en el consabido capítulo de las ermitas.

${ }^{2020}$ El relato de la serpiente que María Luisa echó de la huerta en ASCC. Memorial informativo en defensa de Sor Luisa de la Ascensión, monja de Santa Clara de Carrión, hecho por Fray Pedro de Balbás. 1643 Punto 66, fol 176 y Traslado de 1779 del Memorial informativo en defensa de Sor Luisa de la Ascensión de 1643. Documentos María Luisa, 4, fol 38 y ss y fol 276.

${ }^{2021}$ La denominación la encontramos en ASCC. Libro 31. Asientos de cuentas de cargo y data de maravedíes. (1817-1820), fol 49.

${ }^{2022}$ GÓMEZ PÉREZ, Enrique. El Real...Op.cit, pág. 76.
} 
una cruz de madera con una inscripción tallada que hace alusión a la Madre Luisa, como promotora de este espacio.

La cubierta y las paredes de este espacio están completamente recubiertas de azulejos. La presencia de revestimientos cerámicos en el convento, como es el caso de la sala baja o el muro situado a los pies del templo, son ilustrativos de la buena situación económica que atravesaban las monjas entre los años 1614 y 1619 en que se llevaron a cabo todos ellos gracia a la iniciativa de la monja de Carrión. Los motivos representados en los azulejos de arista son muy diversos, destacando el florón escurialense, ornamento al que se recurre en el frontis del coro ${ }^{2023}$. Igualmente son muy utilizados los elementos florales y abalorios geométricos, decoración de inspiración manierista que se repite en el templo.

Esta obra se atribuye al ceramista talaverano Alonso Figueroa Gaitán, a quien se adscriben las otras piezas del convento ${ }^{2024}$.

\section{La ermita de María Luisa}

Fue edificada por María Luisa de la Ascensión en el siglo XVII con el fin de llevar a cabo sus ejercicios espirituales. Se trata de un edificio sencillo, con una nave dividida en dos tramos, el primero cubierto con cúpula sobre pechinas que contiene una inscripción alusiva a la Madre Luisa. En el segundo, que vendría a ser el presbiterio, hay una bóveda de cañón con lunetos. Exteriormente es bastante sencillo; presenta contrafuertes y un pórtico de entrada a los pies.

La propia monja encargó de acondicionar este espacio con obras artísticas entre las que destacaba una espléndida Piedad de Gregorio Fernández ${ }^{2025}$ que se conserva en el convento de Santa Clara y cuya ubicación original era la hornacina de la cabecera. En torno a ésta figura, el cordón franciscano y protegida por este, una

\footnotetext{
${ }^{2023}$ Uno de los mejores clientes de cerámica talaverana fueron los jerónimos de San Lorenzo del Escorial, quienes desde 1570 solicitaron encargos de loza destinados fundamentalmente a la botica. MARTÍNEZ CAVIRÓ, Balbina. Cerámica de Talavera. Instituto Diego Velázquez. Madrid,1969, pp. 33 y 34 .

${ }^{2024}$ MALO CERRO, Mónica. Azulejería...Op.cit, pág. 617.

${ }^{2025}$ Comentada posteriormente, entre las obras del templo promovidas por la Monja Sor Luisa.
} 
orla con una inscripción sobre la pureza de la Virgen: “...TOTA PVLCRA S MARIA ET MACvLa ORIGINALiS NON EST IN TE ORA PRONoBIS INTERCeDE PrONoBIS AD DoMINVM IES...”. Esta inscripción es muy acorde al espíritu inmaculista de la época, defendido como indicamos por la monja de Carrión, hasta el punto de fundar una hermandad en su defensa.

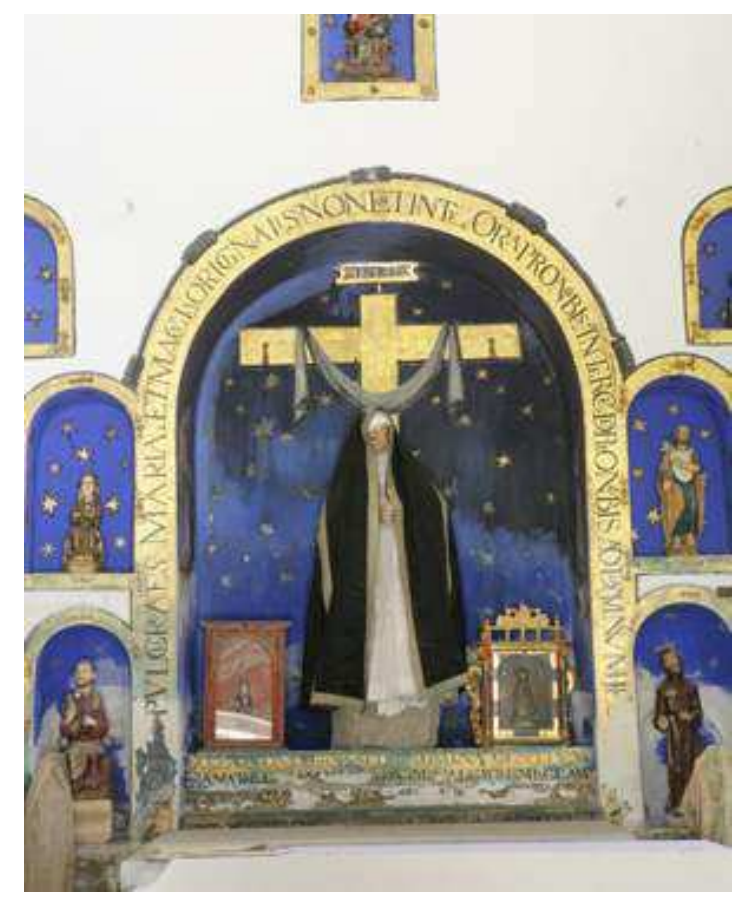

\section{Interior de la ermita que albergaba orginalmente la Piedad de Gregorio} Fernández ubicada en el templo.

Bajo la imagen de la Piedad se encontraba otra inscripción, hoy en parte perdida, que Enrique Gómez ha podido recomponer gracias a las fotografías antiguas en las que todavía el grupo escultórico presidía el hueco central. En ella se reproducen algunos fragmentos del Stabat Mater, himno dedicado a la Dolorosa ${ }^{2026}$. Asimismo, nos informa que en su interior existen varias obras de calidad, como un Apostolado completo y un Crucificado ${ }^{2027}$. Todas estas obras, pertenecientes al siglo XVII, constituyen uno de los programas iconográficos más recurrentes en las salas capitulares y sacristías de las casas conventuales.

\footnotetext{
${ }^{2026}$ El texto, escrito en latín con varias abreviaturas se transcribe y traduce en GÓMEZ PÉREZ, Enrique. El Real...Op.cit, pág. 112.

${ }^{2027}$ Ibídem, pág. 113.
} 
Al exterior de la ermita existen una serie de cruces pétreas formando un via Crucis, que fueron allí colocadas por iniciativa de la monja Sor Luisa. También gracias a su intervención se reconstruyó la ermita de la Piedad, frontera al convento y perteneciente al mismo ${ }^{2028}$.

\section{Reconstrucción íntegra del templo}

La construcción del nuevo templo, construido entre 1614 y 1619, se debió a la iniciativa de la Madre Luisa de la Ascensión, quien, según relata el Padre Calderón: “...derribó la iglesia vieja de Santi Spiritus, que estaba mui mal tratada con la antigüedad, y fabricó otra de fundamentos, con dos grandes coros principales que gozan los monasterios de la provincia”. Precisamente se conserva una carta sin fechar emitida por el convento y dirigida al rey que por la grafía, cotejada con las de la época, correspondería al reinado de Felipe III $^{2029}$. Seguramente fuese escrita en los años precedentes a la construcción del nuevo templo, hacia 1613, en que las monjas piden auxilio al monarca para que sufrague los gastos necesarios, pues “...el combento es tan pobre, que con tener muchos días ha abierto todo el lienço de la pared de la parte del euangelio de la yglesia del dicho combento y con notable peligro de caerse toda, no han podido ni pueden remediallo... ${ }^{2030 "}$.

El templo fue construido en tan sólo cinco años como así indica la inscripción que recorre un friso la sacristía: “AD VOS SCERDOTES LAVAMNET MVNDI ESTOTE. QVI FERTIS VASA DOMINI. ESTA SACRISTIA Y LAVATORIO CON SV ORNATO Y LA PORTADA CON SV CORONACIÓN DE CRVCES ESCRIPTAS Y ESTE SANTO TEMPLO, CAPILLAS Y SVS IMÁGENES I PARED DE CHORO, REJA MAYOR Y AÇULEJOS, HIÇO HACER LA MADRE LVISA DE LA ASCENSIÓN. COMENÇOSE A 9 DE MARÇO DE 1614. ACABÓSE A 7 DE HENERO DE 1619. PASOSE EL SSMO SACRO A 13 DE HENERO DE 1619”.

\footnotetext{
${ }^{2028}$ De la misma se hablará en el apartado correspondiente.

${ }^{2029}$ Así nos lo confirma la archivera de Simancas.

${ }^{2030}$ AGS. Cámara de Castilla. Pueblos. Legajo 5, n²04.
} 


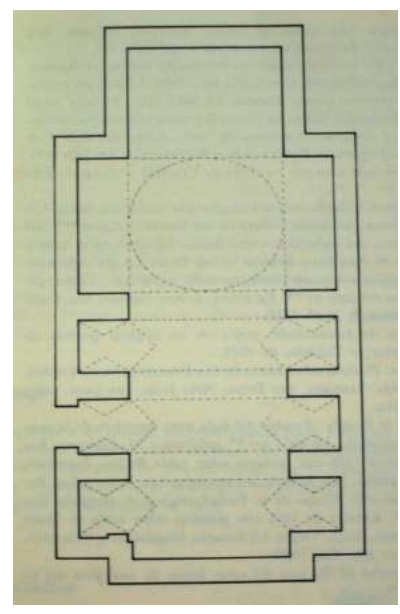

\section{Planta del templo de Santa Clara.}

Extraído del Inventario de la provincia de Palencia, 2 de los profesores Martín González y y Jesús Urrea.

Como indica el profesor Urrea, esta sacristía contenía pinturas sobre lienzo del siglo XVII, dedicadas a San Francisco, Santo Toribio, Santo Tomás, Santiago, San Pedro y San Juan ${ }^{2031}$. Efectivamente, estas imágenes ubicadas en el muro norte, fueron realizadas en el primer tercio de la centuria, como consta por una inscripción “AÑO DE 1620”. De todos ellos, hoy día solo en la sacristía sólo figuran las de San Francisco, en actitud contemplativa y Santo Tomás de Aquino, acogidos en sendas pinturas murales de cueros recortados. Estos mismos motivos que albergarían las obras mencionadas, acogen en su espacio un espejo y un crucifijo de factura moderna. En el centro, sobre la actual cajonería, una inscripción pintada sobre el muro reza lo siguiente: "CONSCIENTIA EXAMINATA/SEMPER ACCEDE AD SACRV $V^{M}$ CHRISTI CORPV $V^{S .}$ NON EXPECTES FESTOS DIES. AMBLIB S. DE SACRAM ${ }^{\text {TIS }}$. C.4.Q. ${ }^{\text {VO TIDIE COMMUNICARE. NECL }}{ }^{A}$ V: $D^{O}$ : Enc TV PERO. AVGUSTINVS”. La sacristía sufrió una remodelación en el siglo XVIII, dividiéndose en dos niveles con la creación de un piso alto que fue derruido en las reformas de $2002^{2032}$.

Volviendo a las obras del templo, no solamente la inscripción que recorre el muro de la sacristía confirma la fecha de finalización de las mismas, sino que conservamos una carta de acuerdo entre las monjas clarisas y el sobrino y heredero de don Luis Sánchez Caballero expedida unos días después, el 22 de enero de 1619, en la que se indica que la iglesia “...se a buelto a hacer y fabricar toda de nuevo,

${ }^{2031}$ URREA FERNÁNDEZ, Jesús y MARTÍN GONZÁLEZ, Juan José. Inventario...Op.cit, pág. 62.

${ }^{2032}$ GÓMEZ PÉREZ, Enrique. El Real...Op.cit, pág. 91. 
de sus principios... ${ }^{2033}$ ". Hasta ahora, a falta de documentación sobre los autores de esta obra, se había barajado la participación de arquitectos regios o que mantuvieran contactos con el círculo cortesano, teniendo en cuenta las estrechas relaciones mantenidas por la Madre Luisa con varios monarcas. Sin embargo, nada más lejos de la realidad, pues fue en el entorno palentino y en los maestros procedentes de Trasmiera, donde las monjas hallaron a los artífices del nuevo templo.

Aunque la iglesia no se comienza hasta el mes de marzo de 1614, será a finales del año precedente, el 25 de noviembre de 1613, cuando, por orden de la Madre Luisa, se produzca la firma del contrato con las condiciones en el aledaño convento de San Francisco. Fue el padre Antonio Daza, Visitador Provincial de Palencia, guardián de San Francisco de la ciudad homónima y gran amigo de la monja de Carrión la figura presente en la aceptación de condiciones, establecidas unos días antes, el diez de noviembre, cuando fue rematada la obra tras varias pujas, en dos mil novecientos ducados ${ }^{2034}$. La obra se la adjudicó el maestro de albañilería Alonso de Santiago, vecino de Támara, localidad ubicada a casi una treintena de kilómetros al sureste de Carrión de los Condes $^{2035}$. Se comprometió a derribar el antiguo templo de Sancti Espíritus, mantenido la pared del coro, que debía tan solo ser enlucida y el muro del brazo del crucero, que serviría de estribo para el nuevo templo. Las paredes del cuerpo de la vieja iglesia y toda su techumbre debían ser derribadas, reaprovechando eso sí, los materiales que se encontraran en buen estado. Una vez demolido el templo, Alonso de Santiago reforzó los cimientos de mampostería con piedra de Támara, su localidad, ahondado un pie más sobre la superficie de la tierra en todo el contorno. Quedaría el cuerpo de la iglesia con cuatro pies de grosor mientras que en el lado del Evangelio, donde se ubica la puerta principal y la sacristía, tan sólo se hundiría tres. Seguidamente se levantarían los

\footnotetext{
203322 de enero de 1619. Don Francisco Sánchez Caballero debe abonar la suma que le corresponde a su difunto tío, don Luís, para que las sepulturas y retablo que poseía en el antiguo templo vuelvan a disponerse en el nuevo templo. Su heredero no había pagado lo que le correspondía según una cláusula del testamento y por tanto las clarisas se negaban a volver a disponer la sepultura. AHPP. Carr.Prot 5215. Jerónimo López (1619), fol 346 y ss.

${ }^{2034}$ Fue confesor ocasional de la madre Luisa y le ayudó en varios asuntos. Escribió una biografía inédita en el Archivo Nacional titulada Vida que fue presentado en el proceso inquisitorial, tomando parte en su defensa ante las calumniosas acusaciones de las que fue víctima. Todo ello justifica su presencia en una cuestión tan relevante como las trazas del templo. GARCIA BARRIUSO, Patrocinio. Op.cit. pp. 5, 11, 87, 181.

${ }^{2035}$ Condiciones en AHPP. Carr.Prot 4840. Juan Díaz Pajaza (1613), s/f. Sobre Alonso de Santiago, véase el apartado relativo a los maestros locales.
} 
muros de tapial, reforzados de ladrillo en el lado del acceso, disponiendo tres pilastras con una cornisa corrida a lo largo de la nave. A los pies del templo, en el coro, añadiría una puerta a la ya existente para acceder a las partes altas. Suponemos que sería ésta la que iría conformada por un torno, como así indican las trazas, pues éste no tendría sentido en otro lugar que no fuera la entrada a la clausura. En el crucero, acordó abrir cuatro grandes pilares que, que gracias a sus cinco pies de hondo, sustentarían la cúpula de media naranja. La sacristía tenía dos pisos, siendo en realidad dos estancias diferentes más antesacristía pues era “...donde se an de vestir los relijiosos y por donde an de dar el rrecado las religiosas...”. En ellas se abrirían tres ventanas y una puerta, cubriéndose todas las estancias con un artesonado. Se comprometió a finalizarla en dos años, es decir, en marzo de 1615, debiéndose contratar más oficiales en caso contrario. Pero sucedió algo inesperado. El templo que se estaba construyendo no cumplía las expectativas por resultar demasiado angosto, por lo que el 25 de agosto de 1614 se llegan nuevas trazas de Madrid, con un coste adicional de ochocientos ducados, que sumados a los dos mil novecientos de partida, ascendieron a una suma de tres mil setecientos ducados. Continúa trabajando en el templo Alonso de Santiago, pero se sitúa al mando de las obras el cántabro Francisco de la Maza, maestro arquitecto vecino de Paredes de $\mathrm{Nava}^{2036}$.

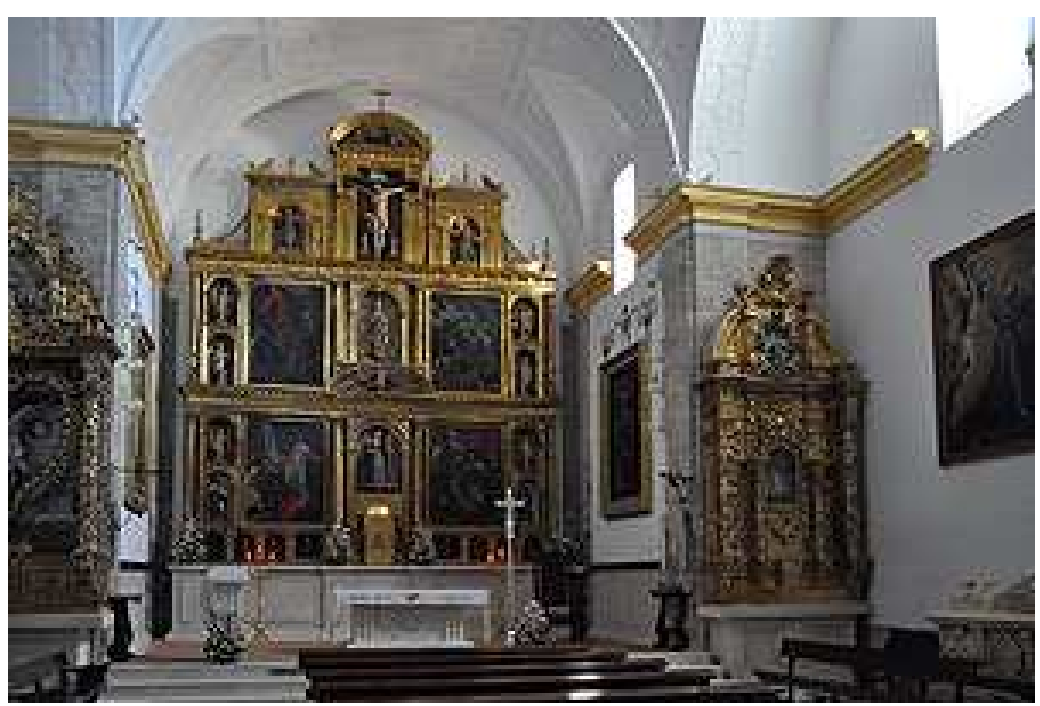

Interior del templo hacia la capilla mayor.

\footnotetext{
${ }^{2036}$ Nuevo contrato y condiciones en AHPP. Carr.Prot 4842. Juan Díaz Pajaza (1615), fol 183 y ss. Sobre Francisco de la Maza, véase el apartado relativo a los maestros cántabros.
} 
Para la ejecución del templo se sigue el mismo proceso comentado previamente introduciendo eso sí, notables modificaciones. Aparte de las dimensiones, la diferencia más notoria estriba en la creación de capillas en la parte de la Epístola, que la anterior traza omitía. Para la cubrición de la nave se optó por bóveda de cañón con lunetos de ladrillo jabonero cuya altura alcanza hasta el mismo nivel de las celdas aledañas. En el lado contiguo a la clausura, estos lunetos irían cegados, ya que “...por aquel lado no le caue luz...”. La cúpula del crucero precisa que tenga forma "aobada", la cual como podemos observar, presenta una deformación en su lado más próximo a la cabecera. La cúpula de forma oval fue utilizada por vez primera en la arquitectura religiosa por Vignola en la iglesia de San Andrés en vía Flaminia ${ }^{2037}$.

Precisamente en las trazas que sigue Francisco de la Maza se admiten seguir los principios arquitectónicos del gran tratadista italiano, como así veremos en la fachada del templo. Esta cubrición queda trasdosada al exterior a través de una estructura cúbica, como así sucede en otros templos clasicistas castellanos, como en San Pedro mártir de Medina de Rioseco, Santa Clara de la misma villa o los jesuitas de Valladolid y Palencia ${ }^{2038}$.

En las pechinas de esta cúpula dispuso cuatro espejos para que las monjas los adornasen por su cuenta con pinturas de santos. Y así lo hicieron, pues en la parte más cercana al altar mayor se representa la Anunciación, con la Virgen en el lado del Evangelio y el arcángel Gabriel frontero a ella. Frente a María se sitúa San Luís Obispo, con las coronas como atributo y en la pechina de la Epístola, un santo franciscano con la mitra en el suelo que se ha identificado con San Buenaventura ${ }^{2039}$. En lo que respecta a la sacristía, se adosará en el brazo norte del crucero, de gran amplitud, guarnecida de ventanas con sus rejas de hierro y suelo empedrado con motivos de lazos y huesos. La cubierta quedará conformada a través de dos bóvedas de arista separadas por un arco fajón de medio punto.

${ }^{2037}$ Fue el primer encargó eclesiástico independiente de Vignola y uno de los pocos edificios iniciados y terminados bajo su directa supervisión entre 1552 y 1554 . La integración de la cúpula elíptica constituye la principal empresa creativa del arquitecto en este templo. Los precedentes de iglesias ovales se encuentran en diseños de Peruzzi y Serlio, pero en aquellos casos se desarrollan sobre muros curvos, siendo éste innovador por partir de un espacio cuadrado. VV.AA. Jacopo Barozzi da Vignola. Electa. Milán, 2002, pp. 60 y 248-250.

${ }^{2038}$ BUSTAMANTE GARCÍA, Agustín. La arquitectura...Op.cit, pág. 543.

${ }^{2039}$ GÓMEZ PÉREZ, Enrique. “El real...Op.cit, pág. 86. 
Las obras continuaban a buen ritmo en 1615; proseguía la llegada de nuevos materiales y por tanto, aumentaban los gastos, de ahí que las monjas se vieran obligadas a solicitar diversos préstamos con carácter urgente a diversos miembros de la villa carrionesa. Tenemos constancia de una petición de 400 ducados al clérigo de San Juan del Mercado, suma que se comprometían a devolver en marzo del año siguiente. Se indica explícitamente que dicha cantidad será destinada “... a la fábrica

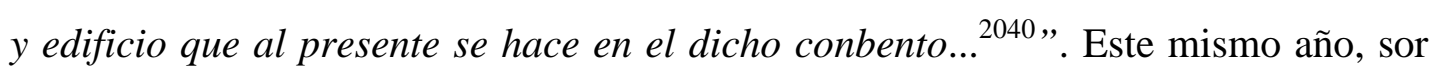
Luisa se personó ante el procurador general de la villa solicitándole otros 400 ducados para hacer frente a los gastos de la obra, pues había que abonar una partida de madera solicitada por Francisco de la $\mathrm{Maza}^{2041}$. Alonso de Santiago quedó apartado de las obras al menos desde 1616 o incluso, tal vez antes. En dos cartas de obligación fechadas el 18 de mayo, Francisco Martínez de Bálcava realiza una compra de ladrillos y vigas y en ambas se indica: “... a cuyo cargo está la obra del

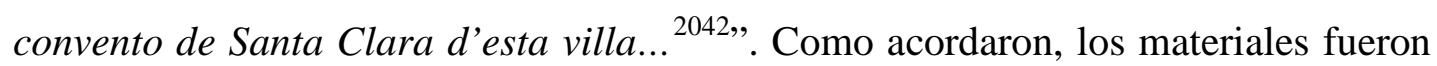
traídos tres meses más tarde cuando Bálcava abonó la suma correspondiente ${ }^{2043}$.

La mayor parte de las obras del templo ya se habían realizado en 1617, pues en la puerta de la tribuna de la Epístola, se puede leer la siguiente inscripción: “Acabóse esta ermita i la iglesia de Sta. Clara año del Señor de 1617, siendo Abadesa segunda vez IO Indignisima Sor Luisa de la Ascensión, esclava de mi dulcísimo IHS M⿻. Indigna Abadesa conmigo mi dulcísimo IHS $m^{a}$ S. Gabriel S. Joseph $^{2044, \text {. }}$

\footnotetext{
${ }^{2040}$ Carta de obligación fechada a 23 de agosto de 1615. AHPP. Carr.Prot 5211. Jerónimo López (1615), fol 34 y ss.

${ }^{2041}$ Son dos cartas, una fechada a 7 de marzo de 1615 en que Francisco de la Maza abona a Juan López Serrano 400 reales por la madera traída al convento. Seguidamente, una carta de pago fechada en 5 de agosto de 1615 en que por cédula de Madre Luisa se abonan a Alonso Gómez Guillén los 400 ducados prestados. AHPP. Carr.Prot 5211.Jerónimo López (1615), fol 259 y ss.

${ }^{2042}$ En una de las cartas, Bálcava se concierta con el tejero Juan Ochoa para que le traiga 27.000 ladrillos, la mitad jaboneros y la otra mitad de los anchos de marco que hace dicho tejero en Villasirga. En la otra obligación se concierta con Alonso Cicero para que le traiga al convento 31 vigas de diversas larguras, 80 machones, 56 sesenes y 200 catorzales. AHPP. Carr.Prot 4843, Juan Díaz Pajaza (1616), fol 592 y ss. Aparte de estas dos cartas, existe otra fechada el 2 de mayo de 1616 por la que Domingo del Río adquiere 400 fanegas de cal viva para el convento. AHPP. Carr.Prot 5485. Antonio Orejón, el Viejo (1616-1618), s/f.

${ }^{2043} 18$ de agosto de 1616. AHPP. Carr.Prot 4843. Juan Díaz Pajaza (1616), fol 267 y ss.

${ }^{2044}$ GÓMEZ PÉREZ, Enrique. El Real...Op.cit, pág. 79.
} 


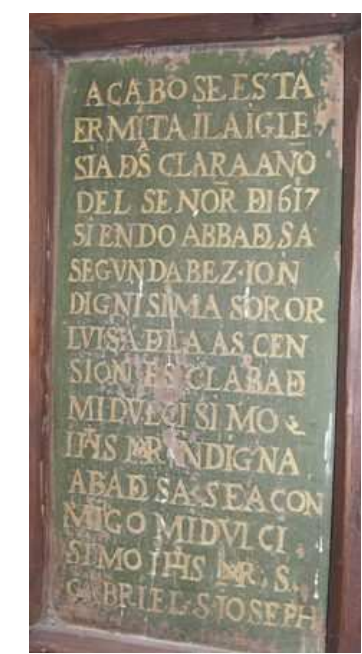

\section{Inscripción del oratorio de la Madre}

Luisa que refiere la finalización de las

obras.

Esta ermita era en realidad un estrecho y alargado oratorio comunicado con la clausura al que sor Luisa se retiraba en soledad, pues a través de una ventana con reja dispuesta al fondo de la estancia, podía dirigir sus rezos hacia el altar mayor sin necesidad de bajar a la iglesia. Allí tuvieron lugar, según relatan las crónicas, gran parte de las apariciones de Santos y es igualmente en esta capilla donde se disciplinaba la monja ${ }^{2045}$.

En el lado del Evangelio, en la línea de la fachada, se dispone otra tribuna de similares características a la frontera, que se comunica con el coro alto. No existe testimonio gráfico ni documental que justifique la creencia de que los condes de Osorno, impulsores de las obras del antiguo templo, continuaran su patronazgo a lo largo de los siglos posteriores. La presencia de este espacio puede deberse a razones de simetría acordes al rigor clasicista que marca las directrices del templo. Pero sobre todo, responde a la necesidad de crear un lugar privilegiado para las visitas de los diversos miembros de la alta nobleza que tanto habían favorecido a la casa clarisa y con los que la madre Luisa guardaba estrechas relaciones.

En 1619 quedaría conformado este sobrio pero elegante templo clasicista, muy acorde a la modernidad estética desde finales del XVI irradiada por el grupo de maestros de obras asentados en el foco vallisoletano. Exento de ornamentación

${ }^{2045}$ ASCC. Legajo 29. Traslado de...Op.cit.1772, fol 73. 
salvo en la cornisa que recorre el contorno, está constituido por una amplia nave dividida en tres tramos con tres capillas en el lado de la Epístola, mientras que en el lado del Evangelio el triple acceso del templo ocupa este espacio, marcándose en planta como si tuviera tres a cada lado. La cabecera es plana, reforzada con contrafuertes, y crucero que no sobresale en planta. Tiene adosado en su brazo norte la sacristía, que exteriormente está en línea con el atrio de entrada al templo. Se cubre con bóveda de cañón con lunetos y cúpula en el centro con yeserías planas.

La primera traza del templo, cuya ejecución corrió a cargo de Alonso de Santiago, era muy similar a la que resultó finalmente, llevada a cabo por Francisco de la Maza, salvo en las dimensiones y la ubicación de la sacristía. Quienquiera que fuese el autor de los proyectos de la obra de Santa Clara, tomó como precedente para inspirarse la iglesia conventual de Santa Eufemia de Autillo de Campos, construida entre 1591 y 1603 . No debe ser casual que el "principal hacedor de las obras" de este templo fuese precisamente Alonso de Santiago ${ }^{2046}$ ni que Francisco de la Maza participase precisamente en 1615, cuando trabajaba en Santa Clara, en las obras de un templo de Autillo, el de Santa María ${ }^{2047}$, prueba de que ambos artífices conocían este templo, cuyo tracista pudo ser la misma persona ${ }^{2048}$. Ambas son el resultado de la aplicación de idénticos presupuestos clasicistas. Si se observan sus respectivas plantas, concluimos instantáneamente que una es la reproducción de su compañera -una nave dividida en tres tramos, con tres capillas rectangulares, crucero que no se marca en planta y testero plano. La única salvedad radica en que la sacristía se adosa en el brazo norte del transepto en la casa clarisa mientras que en Autillo se ubica en el lado frontero. Igualmente en el alzado se recurren a los mismos elementos estructurales como es la cubrición de bóveda de cañón con lunetos, cúpula con pechinas, uso de pilastras y arcos de medio punto en las hornacinas. Asimismo la ornamentación se reduce a las sencillas molduras de las cubiertas y el friso que recorre el perfil del templo, unificando el conjunto.

\footnotetext{
${ }^{2046}$ ZALAMA RODRIGUEZ, Miguel ángel. La arquitectura...Op.cit, pp. 69-71.

2047 AHPP. Carr.Prot 4967. Alonso García (1614-1615), fol 378.

${ }^{2048}$ Zalama plantea la posibilidad de que fuse Diego de Praves el autor del proyecto de Santa Eufemia de Autillo en base a que Francisco de Reinoso, que costeó parte de las obras, le llamó a Córdoba para que hiciese la cúpula de la catedral, por lo que pudiese existir alguna relación. También propone al jesuita Juan de Bustamante por su presencia como tasador de la parte edificada en 1597. ZALAMA RODRIGUEZ, Miguel ángel. La arquitectura...Op.cit, pp. 71-72.
} 
Tanto en la primera traza, en la que la ordenación de todos los elementos del templo se realiza “...según la doctrina de Sebastiano...” como en la segunda, donde las pilastras y cornisa dórica encapitelada siguen “...el orden sacado de Vignola..." queda manifiesto el conocimiento y la asimilación de los principios manieristas italianos. La concepción lógica y racional del espacio y el lenguaje ornamental tremendamente depurado señalan hacia una formación clasicista de los proyectistas, con gran influencia del foco vallisoletano. Así la planta, conformado por una cruz latina inscrita en un rectángulo similar a la de las Huelgas Reales de Valladolid o Nuestra Señora de la Calle, en Palencia, siguiendo el prototipo creado por la Colegiata de Villagarcía de Campos. También del templo cisterciense vallisoletano hereda el sentido orgánico y unitario del mismo, con la nave entre capillas laterales que se abren con un arco de triunfo y el recurso de arcos termales $^{2049}$.

\section{El retablo mayor}

El retablo mayor que vemos hoy día no es el que tuvo originalmente. En unas obras de limpieza de 2002 durante las cuales se puso al descubierto el muro del presbiterio sobre el que se adosa el retablo actual, se hallaron las marcas de lo que pudo ser un tabernáculo triangular flanqueado por tarjetas, que sería el altar primitivo del nuevo templo. Cuando las obras del templo finalizaron en 1619, se mantiene la iglesia con el retablo viejo. Pasará más de una década hasta que se recauden fondos suficientes y se contrate la realización del retablo actual. Los maestros ensambladores de Carrión Nicolás de Vega, Pedro López y Pedro Santos $^{2050}$ recibieron en 1633 de la Madre Luisa 541 reales por su ejecución y por asentar el viejo retablo en la capilla mayor del convento aledaño de San

${ }^{2049}$ BUSTAMANTE GARCÍA, Agustín. La arquitectura...Op.cit, pp. 86-87.

${ }^{2050}$ Pedro Santos ejecuta el retablo mayor de Santa María de Benevívere en 1647. AHPP. Carr.Prot 5429 Francisco Moro de Saldaña (1647), s/f. Es uno de los fiadores de Bernardo Sánchez y Julián de León, maestros de cantería y albañilería respectivamente, en la construcción de la capilla del Licenciado Pastor de la iglesia de Santa María de Carrión en 1656. AHPP., Carr.Prot 5689, Norberto Sandoval y Guevara (1656), s/f. Pedro Santos y Pedro López figuran como fiadores del maestro Felipe Berrojo, en la obra que junto a Julián de León realizaba en el claustro del convento de Santa María de Benevívere hacia 1660. AHPP. Carr.Prot 5693 Norberto Sandoval y Guevara (1660), fol 438 y ss. 
Francisco ${ }^{2051}$. Por ello hay que pensar que el retablo pudo comenzarse un año antes. Parece que la monja de Carrión volvió a contar con el apoyo de la realeza, siendo en este caso Felipe IV quien sufragó los gastos de esta y otras obras a través de los dos mil ducados que envió al convento precisamente dicho año ${ }^{2052}$. La estrecha vinculación de la monja clarisa con la realeza, nos permite asimismo apuntar una traza madrileña del retablo, muy cercano en su tipología al estilo emanado de la Corte.

Presenta una estructura reticulada que sirve de soporte a esculturas y pinturas como es común en los retablos barrocos clasicistas de principios del siglo XVII aunque algunas esculturas del siglo precedente han sido reaprovechadas para el mismo $^{2053}$. Podemos adherirlo a la tipología de retablo relicario, pues aunque está conformado además por esculturas y lienzos, los relicarios cobran un marcado protagonismo en esta obra, conformando un total de trece: en el banco se disponen ocho, uno en el primer cuerpo, dos en los extremos del segundo y otros dos en el remate. Este modelo gozó de de gran repercusión durante la Contrarreforma, en consonancia a la proliferación que experimentó el culto de las reliquias a partir del Concilio de Trento. El prototipo castellano de bustos con sus tecas insertos en hornacinas halló una gran acogida en Valladolid, figurando entre los primeros ejemplos los retablos laterales de la iglesia de San Miguel contratados por los ensambladores Cristóbal, Francisco y Juan Velázquez en $1613^{2054}$. Coetáneo al de Carrión es el de la iglesia de Santiago de Medina del Campo, localidad en que esta tipología alcanzó su grado máximo, en la iglesia de Agustinas Recoletas, hoy de Padres Carmelitas y en la de Santiago el Real ${ }^{2055}$.

2051 AHPP. Carr.Prot 5229. Jerónimo López (1633), s/f. Los tres ensambladores figuran como fiadores cuando en 1641 Gaspar Díez del Pozo dora el retablo de Santa Clara. AHPP. Carr.Prot 5234, Jerónimo López (1641-1642), s/f.

${ }^{2052}$ La carta, fechada el 25 de febrero de 1633 fue encontrada en la huerta del convento cuando fue restaurada en 1763. Está transcrita en GARCÍA BARRIUSO, Patrocinio. La monja...Op.cit, pp. 7172.

2053 PARRADO DEL OLMO, Jesús María. “El renacimiento...”. Op.cit, pág. 769.

${ }^{2054}$ MARTÍN GONZÁLEZ, Juan José. Escultura...Op.cit, pp. 78-84.

2055 Otro ejemplo vallisoletano de excelente factura, se ubica en la colegiata de Villagarcía de Campos, donde existen tres retablo relicarios de hacia mediados del siglo XVII. A este respecto MARTÍN GONZÁLEZ, Juan José. "El relicario de la Colegiata...Op.cit, pp. 43-52. Entre los primeros ejemplos de retablo relicario en España, se halla el del monasterio sevillano de Nuestra Señora de Gracia en Villamanrique de la Condesa, trazado en 1612 por Juan de Oviedo el Mozo y ejecutado por Diego López Bueno. MARTíN GONZÁLEZ, Juan José. El retablo barroco en España. Alpuerto. Madrid, 1993, pág. 18. 


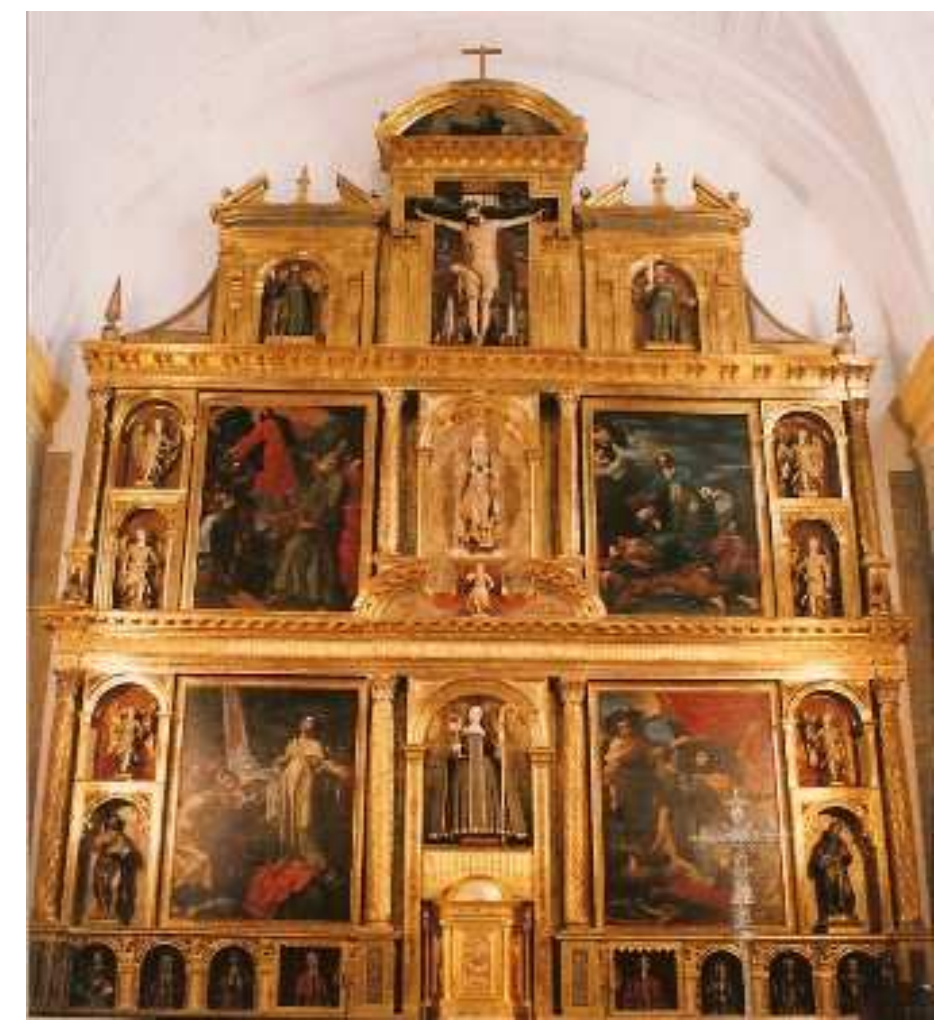

Retablo mayor del templo de Santa Clara. (8,5mtrx7,3mtrx0,7mtr).

Se compone de banco, dos cuerpos iguales divididos en cinco calles de diversa anchura y ático tripartito. No obstante, dentro de la claridad compositiva reinante se conceden ciertas licencias acordes al gusto barroco como el uso de columnas entorchadas de ambos cuerpos, la cornisa avolutada que centra el retablo y los frontones curvos del ático que se unen al cuerpo del retablo a través de pequeños aletones.

Comenzando por la parte inferior, en el banco se disponen ocho bustos relicarios, seis de ellos dentro de hornacinas y dos en cubículos rectangulares, todos ellos con su reja respectiva. Santa Águeda, representada en la margen izquierda es imagen del siglo XVII que contiene la reliquia de las Once Mil Vírgenes. El busto relicario que le sigue, del siglo XVI podría identificarse con la Virgen, pues en su peana puede leerse: Veni sponsa chisti accipe coronam $^{2056}$, siendo éste el título de

2056 "Ven, prometida de Dios, recibe la corona". 
un canto latino dirigido a la misma. Esta inscripción puede leerse igualmente en el tercero de los relicarios del lado derecho, comenzando la lectura de derecha a izquierda. La única diferencia es que las reliquias que contienen son diferentes, correspondiendo a la primera los huesos y cráneo de las Once Mil Vírgenes y a la otra la reliquia de San Pablo Apóstol. Después aparece Santa Úrsula, del siglo XVII, cuya imagen se repite en el lado derecho, siendo aquélla de finales del siglo XVI y contienen las reliquias de las Vírgenes.

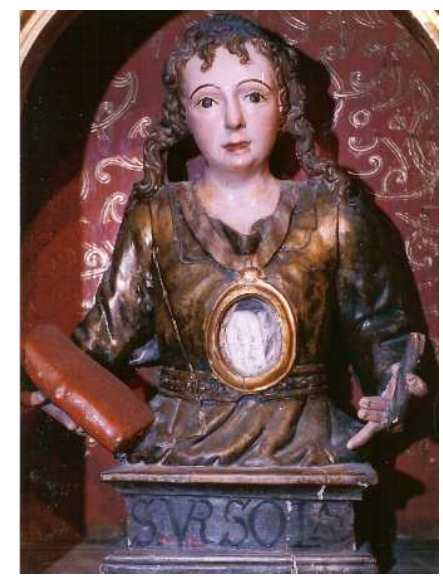

$(48 \mathrm{~cm} \times 32,5 \mathrm{~cm})$. Siglo XVII.

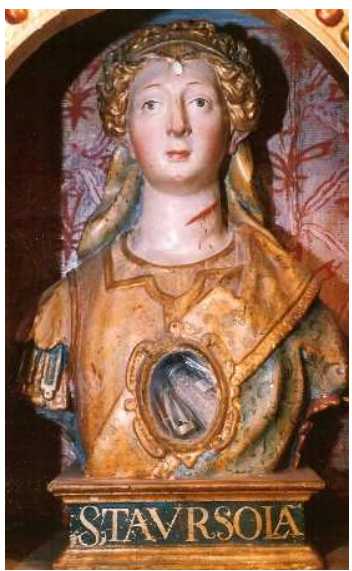

$(52 \mathrm{~cm} \times 34 \mathrm{~cm})$. Siglo XVI.

\section{Bustos relicarios de Santa Úrsula en el retablo de Santa Clara.}

A continuación, también del mismo siglo y flanqueando el sagrario, aparecen dos figuras femeninas sin identificar con una particularidad, pues ambas tienen uno de sus ojos pintado mientras el otro es una incrustación de cristal. Tan sólo nos queda mencionar el busto relicario situado en el lado derecho, entre Santa Úrsula y la Virgen. Se trata de un santo mártir de Cardeña, como así le identifica su peana, probablemente San Pedro. Esta imagen del santo benedictino podemos datarla en el siglo XVI y contiene el manípulo de San Luis, Obispo de Tolosa ${ }^{2057}$.

${ }^{2057}$ GÓMEZ PÉREZ, Enrique. El Real...Op.cit, pág. 99. 

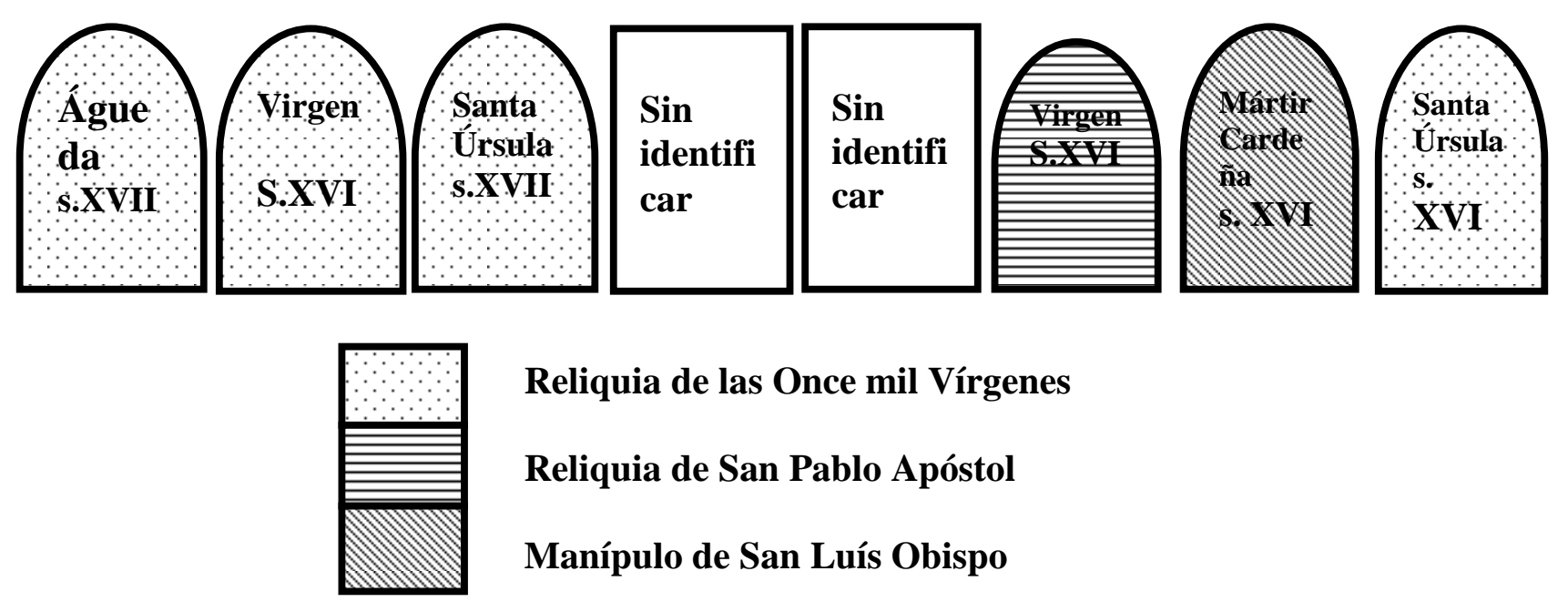

\section{Esquema del banco con los bustos relicario del retablo de Santa Clara.}

Algunas de estas pequeñas piezas, de cronología anterior a la de la ejecución del retablo fueron reaprovechadas del antiguo altar, como así se hizo con otras imágenes del cuerpo superior como veremos a continuación. El sagrario, al que flanquean los ocho bustos relicario del banco es actual, pues sustituyó en 2002 al anterior, barroco, que a su vez sustituyó al primitivo. Este primer sagrario, original del retablo, fue donación de la monja Sor Luisa, según consta figura en la inscripción del segundo cuerpo. Presenta una estructura en dos cuerpos tripartitos sobre amplio zócalo, siguiendo el mismo rigor clasicista del retablo. En el inferior, separados por columnas entorchadas corintias, dos pinturas de San Pedro y San Pablo que flanquean la tabla central en la que dos ángeles sujetan el cáliz con la sagrada forma. Las columnas estriadas del segundo cuerpo contienen igualmente tres óleos, el central protagonizado por San Juan Bautista y a los lados el Escudo de la Orden Franciscana y San Juan Evangelista. Este orden, a simple vista, no es lógico, pues la composición debería centrarla el emblema terciario para que quedasen ambos Santos en los laterales. Y así fue su disposición original, como se deduce de la lectura posterior de las tablas en que figura el orden en que deben situarse ${ }^{2058}$. El cambio de las tablas se justifica por su ubicación actual en el convento de San Zoilo

${ }^{2058}$ Detrás del escudo franciscano se lee: "la de en medio" y tras la tabla del Bautista. "evangelio". GÓMEZ PÉREZ, Enrique. El Real...Op.cit, pág. 101. 
que, como ya señalamos, tuvo su antigua advocación de San Juan Bautista. En 1777 este sagrario fue sustituido por un tabernáculo dorado ${ }^{2059}$. Del mismo, en el actual retablo, tan sólo permanece la pequeña figura de la Fe ubicada a los pies de la Inmaculada que constituía el remate de dicho baldaquino. Como indicamos, a comienzos del siglo XXI será remplazado por el sagrario actual, en el cual aparecen representados, como lo estaban en el primer sagrario, las figuras de los Apóstoles San Pedro y San Pablo.

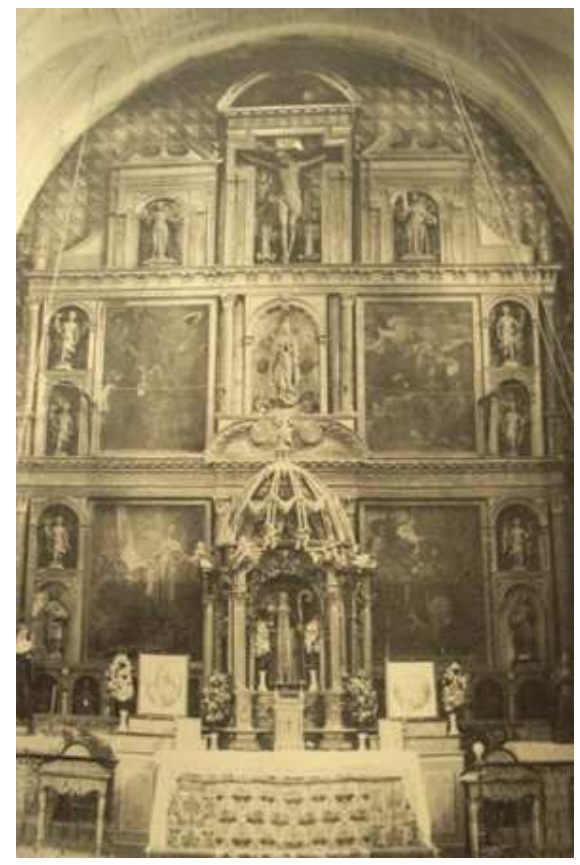

\section{Retablo mayor de Santa Clara.}

con el antiguo sagrario que hoy se encuentra en el museo homónimo.

En el primer cuerpo, sobre el sagrario y bajo arco de medio punto, se yergue la fundadora de la segunda orden franciscana, obra coetánea a la ejecución del ensamblaje del retablo. Se trata de una Santa Clara de rostro muy joven, ataviada con el clásico sayal marrón y velo negro propio de las clarisas que contrasta vivamente con la custodia y báculo dorados que porta orgullosa en cada mano.

Sobre la santa italiana, se halla una escultura de la Virgen de en torno al 1500 y por tanto, reaprovechada tal vez del anterior altar. Tradicionalmente se ha venido admitiendo que se trataba de una Inmaculada Concepción y no era de extrañar

${ }^{2059}$ Sobre él se hablará en el apartado relativo al siglo XVIII. 
teniendo en cuenta la acérrima devoción de Sor Luisa de la Ascensión por la Inmaculada y la defensa que de la misma hizo a lo largo de su vida. Sin embargo una foto antigua muestra un séquito de ángeles en torno a su figura, propio por tanto,

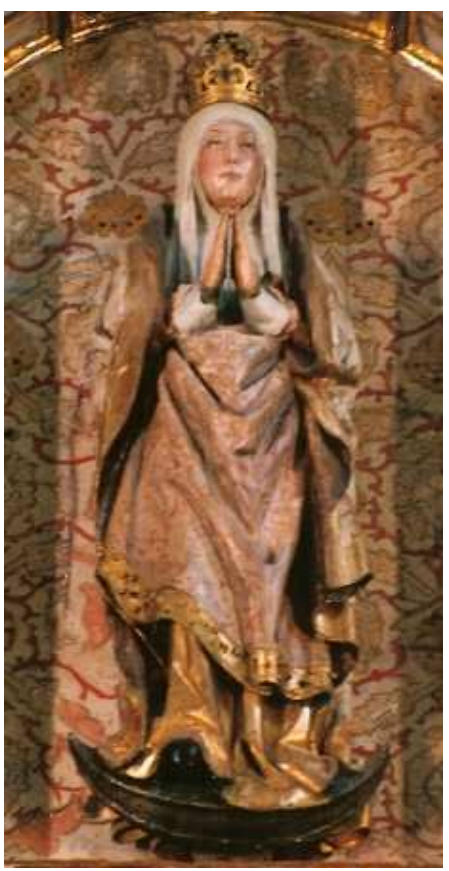
de la iconografía de la Asunción. Esta bella imagen, si bien peca de cierto hieratismo en la expresión y simetría en su conjunto, es una figura de gran elegancia. Su rostro ovalado y el tratamiento quebrado de los pliegues permiten relacionarlo con modelos de Alejo de Vahía, quien se encontraba trabajando en Tierra de Campos por estos años ${ }^{2060}$. Tal vez esta imagen fuera ejecutada por el maestro de Becerril por las mismas fechas que el San Antonio Abad conservado en el museo de Santiago, siendo trasladadas conjuntamente a Carrión desde su taller $^{2061}$.

\section{Asunción. (120cm x40cm).}

Hacia 1500.

Al menos hasta principios del siglo XX y como así atestiguan las fotografías, bajo la Virgen se disponían dos bustos relicario de pequeño tamaño, uno a cada lado. Se trata de dos santos varones, uno es un joven imberbe con melena, mientras que el otro es barbado y ambos portan un libro en la mano. Sin otro atributo ni inscripción que los acompañe no podemos aventurarnos en la identificación de estas piezas que actualmente han sido desplazadas a los extremos de este cuerpo central.

Flanqueando las dos figuras protagonistas del retablo se disponen cuatro grandes lienzos de gran calidad y factura napolitana que llegarían al convento en la misma fecha que se ejecutaba el retablo, hacia 1632. Estas pinturas representan en el cuerpo bajo a David adorando la calavera ante un ángel y Santa Úrsula acompañada

${ }^{2060}$ PARRADO DEL OLMO, Jesús María. “El renacimiento...”. Op.cit, pág. 770.

2061 Dado que se trata de una imagen castellana, descartamos la atribución de la misma como la Virgen de la Guía, procedente de la India que nos indica Martín Mínguez, acogiéndose a alguna leyenda o tradición recogida en su viaje por la provincia de Palencia que indicaba que la trajeron misioneros franciscanos. MARTÍN MÍNGUEZ, Bernardino. Catálogo...Op.cit, volumen 3, pág. 37. 
de las Vírgenes mártires, ocupando el cuerpo superior. La oración en el huerto y la Ascensión del Señor. Durante el siglo XVII, Nápoles acogerá en su seno todo un cúmulo de manifestaciones y pensamientos contrarreformistas que se plasmarán en el arte a partir de los años veinte, cuando el fragor antiluterano estaba casi extinguido. La década de los años treinta en que se incluye el encargo de estas obras, es un período interesantísimo para la pintura napolitana, pues en la ciudad convergen artistas de diversas procedencias, tanto de Italia como de Flandes, atraídos por el esplendor de la capital, muchas de cuyas obras tendrán la Península como destino final $^{2062}$.

Enrique Gómez Pérez ha puesto en relación todas estas obras de la capital de la Campania -muy acertadamente desde nuestro punto de vista- con su posible comitente, el virrey de Nápoles, don Manuel de Fonseca de Zúñiga ${ }^{2063}$. No sólo su vinculación política con la ciudad italiana sino los estrechos lazos de amistad que mantuvo con sor Luisa de la Ascensión -a quien defendió ante la Inquisiciónpermiten establecer que sufragase todos estos encargos, sin cuya ayuda, el convento no podría haber logrado su adquisición. Precisamente Fonseca ostentó el virreinato napolitano entre 1631 y 1637, oscilando entre estas fechas la datación de los $\operatorname{lienzos}^{2064}$. Se sabe además que este conde de Monterrey era un ávido coleccionista de pintura napolitana, figurando como asiduo cliente de Ribera, Viviano Codazzi, Aniello Falcone, Mássimo Stanzione o Domenico Lanfranco, quienes, emigrados de sus respectivos lugares de procedencia, desarrollaron su actividad en la capital napolitana logrando así una clientela prestigiosa ${ }^{2065}$. Lamentablemente no pueden

\footnotetext{
${ }^{2062}$ Con motivo de la exposición de pintura napolitana organizada por el Prado en 1985, se publicó un libro en el que se hace referencia al mecenazgo español en Nápoles -los virreyes serán los grandes protectores de las artes -así como los artistas más solicitados por esta clientela -Ribera, Lanfranco, Domenichino, Caravaggio, Castiglione. Igualmente se elabora un catálogo con las obras importadas en los fondos del museo. PÉREZ SÁNCHEZ, Alfonso Emilio. Pintura napolitana. De Caravaggio a Giordano. Museo del Prado. Madrid, 1985.

${ }^{2063}$ GÓMEZ PÉREZ, Enrique. "El real...”Op.cit, pág. 94.

2064 También conocido como Manuel de Acevedo y Zúñiga, este personaje fue Grande de España, II conde de Fuentes de Valdepero, en Palencia y desempeño los cargos de embajador en Florencia y Roma. Se casó con Leonor de Guzmán, hermana del conde de Olivares, quien a su vez estaba esposado con la hermana de éste, Inés de Zúñiga y Velasco. Un repaso de la biografía y actuación de los sucesivos virreyes napolitanos en PARRINO, Domenico Antonio. Teatro eroico e politico de governi de Vicerè del regno di Napoli. Nápoles, 1692.

${ }^{2065}$ VV.AA. Barocco mediterraneo: Genova, Napoli, Venecia nei musei di Francia. Electa. Napoli, 1989, pp. 28-31.
} 
establecerse paralelismos estilísticos entre los lienzos de Santa Clara y el estilo de ninguno de estos pintores que trabajaban por entonces en la ciudad italiana.

Nuestro artista se caracteriza por el uso de una viva policromía que crea fuertes contrastes en las túnicas de los personajes, decantándose por los azules, rojos y amarillentos. Recurre a los tipos de composición barroca por excelencia como el esquema triangular empleado en la Ascensión y la Oración en el huerto, optando por la línea diagonal en los dos lienzos del cuerpo inferior. Asimismo emplea algún recurso artificioso para aportar dinamismo al conjunto, como el manto del señor que asciende a los cielos con un movimiento caprichoso o más aún el cortinaje que nos descubre al Rey David, a modo de telón de teatro. No obstante, a pesar de estos guiños efectistas, el pintor concentra la atención sobre los personajes que reducidos a los imprescindibles se tornan monumentales en un sentido de síntesis escenográfica.

Sus rostros se iluminan intensamente gracias a foco de luz cenital cuyo origen no parece ser otro que el celestial, destacándose sobre un fondo que queda relegado a un plano secundario, bien un cielo poblado de nubes amenazantes o una arquitectura anónima. El personaje que yace a los pies de Santa Úrsula, así como el San Pedro recostado que duerme a los pies de Cristo, ambos recortados en la parte inferior de sus respectivos lienzos, denotan la destreza del artista en la recreación de los escorzos.

De los cuatro lienzos, quizá el que más llame la atención en cuanto a su icnografía es el del rey David. Su presencia en el retablo puede venir justificada por la dedicación a la música del abuelo de la madre Sor Luisa. Antonio Cabezón fue organista de la Capilla Real en la corte de Felipe II y además compuso varias obras para ser tocadas, entre otros instrumentos, con el arpa, principal atributo del rey David $^{2066}$. En este caso, el monarca ha dejado su corona y se arrodilla ante la

\footnotetext{
${ }^{2066}$ Una obra del artista en CABEZÓN, Antonio de. Antonio de Cabezón 1510-1566: obras de música para tecla, arpa y vihuela.1 / Primera edición por Felipe Pedrell. Nueva edición corregida por Higinio Anglés. Barcelona, 1982. Biografía sobre el mismo en ANGLES, Higinio. "Antonio de Cabezón, organista de Carlos V y de Felipe II: en el cuarto centenario de su muerte: 1510-1566" en Cuadernos Hispanoamericanos, n²03, 1966, pp. 257-272, MAURINO, Alonso. El organista ciego de Felipe II: Antonio Cabezón. Madrid, 1977, CAPDEPÓN VERDÚ, Paulino. "Vida y obra de Antonio Cabezón: 1510-1566" en López de Gámiz: Boletín del Instituto Municipal de la Historia, 1986, pp. 59-64, y
} 
calavera para hacer penitencia, mostrando de este modo al espectador, su lado más humano, consciente de la frugalidad de la vida.

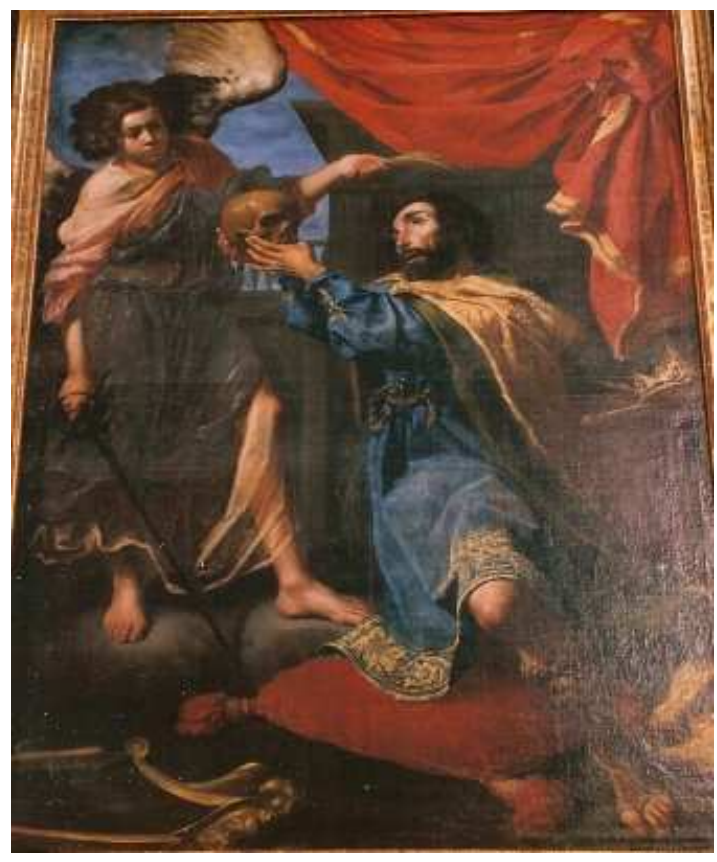

EI Rey David orando.

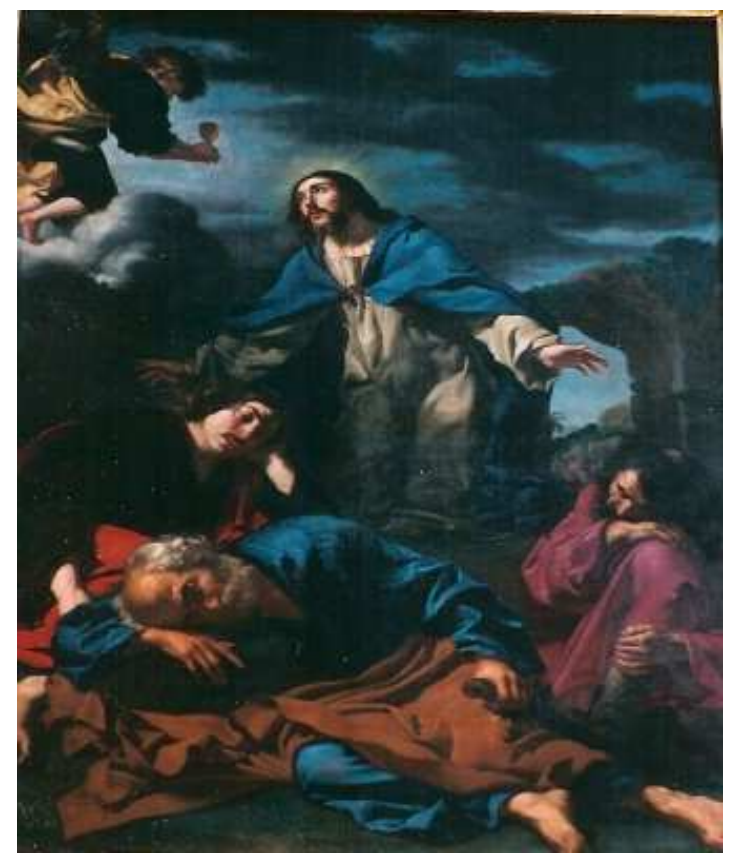

La Oración en el huerto.

\section{Lienzos napolitanos del retablo de Santa Clara. Siglo XVII $(189 \mathrm{~cm} x 143 \mathrm{~cm}$.}

Las entrecalles laterales de ambos cuerpos representan bajo hornacinas a seis ángeles ceroferarios de gran finura en el rostro y gracia en su movimiento. Todas ellas dirigen su mirada hacia el alto, como queriendo iluminar el mundo celestial con los candeleros en forma de cuerno de la abundancia que sostienen delicadamente en una de sus manos. En ocasiones, como en este caso, los ángeles, en vez de portar túnica, llevan una indumentaria militar, dada su pertenencia a los ejércitos celestiales.

Por eso, aparte de la camisa anudada a la cintura, viste una especie de faldellín, típicamente romano, que deja entrever la pierna que figura en posición

más recientes, VEGA CERNUDA, Daniel S. "La música de Antonio de Cabezón y el repertorio organístico europeo de la época" en Nasarre: Revista aragonesa de musicología, vol 18, nº1-2. 2000. pp. 41-60. 
adelantada. Son esculturas de pequeño tamaño y elegancia exquisita que presentan facciones redondeadas, ciertamente dulcificadas, efecto que se acentúa al observar el carmín de sus labios, la finura de sus cejas y el tono rosáceo que emerge de sus pómulos. Una rica policromía dorada, que cubre su espesa cabellera rizada, al igual que su vestimenta, las alas desplegadas y el candelabro que portan estas figuras, contrasta vivamente con el encarnado de su piel nacarada, que semeja la porcelana. La connotación ambigua de estas imágenes, en las que se recurre a un prototipo afeminado con indumentaria típicamente masculina, refleja a la perfección una de las características inherentes a los ángeles, y es su carácter asexuado. Así quedó establecido a partir del II Concilio de Nicea (787), dado que, como bien explica Alice de Saint André, si son espíritus llenos de pureza “...à quoi pourraient-ils bien accrocher un sexe...? ${ }^{2067 ", ~ C o m o ~ l o s ~ l i e n z o s, ~ p o d r i ́ a n ~ t r a t a r s e ~ d e ~ u n a ~ i m p o r t a c i o ́ n ~}$ napolitana.

Bajo los ángeles candeleros, igualmente en las entrecalles laterales y bajo hornacinas, existen dos esculturas reaprovechadas de buena calidad, datables en el último tercio del siglo XVI que representan a San Francisco y San Juan Bautista. Con relicario en su pecho. Conformarían, junto a los bustos relicarios del banco de esta centuria, piezas procedentes de otro retablo que podrían adscribirse, siguiendo a Parrado del Olmo, a Manuel Álvarez ${ }^{2068}$, pues este escultor se caracteriza por sintetizar los rasgos de Juni, patentes en la monumentalidad y expresividad de la figura del Bautista, y los de Berruguete, presentes en la melancolía del rostro y la estilización del cuerpo de San Francisco ${ }^{2069}$. Ambas tallas presentan claros vínculos estilísticos con otras realizadas por Manuel Álvarez para poblaciones cercanas a Carrión. Es el caso del retablo de Santoyo, realizado entre los años 1562 a 1573, que

2067 ¿...A qué sexo se aproximarían entonces? SAINT-ANDRÉ, Alix de. Archives des anges. Gallimard. Paris, 2000, pág. 88. Una clasificación de las jerarquías angélicas en GIORGI, Rosa. "El ejército del cielo" en Ángeles y demonios. Traducción de CLAVEL, Teresa. Electa. Barcelona, 2004, pp. 279-372.

${ }^{2068}$ Más datos biográficos sobre Manuel Álvarez en PARRADO DEL OLMO, Jesús María "Manuel Álvarez" en Jornadas sobre el renacimiento en la provincia de Palencia. Diputación Provincial de Palencia. Departamento de Cultura. Palencia, 1986, pp. 95-106.

2069 PARRADO DEL OLMO, Jesús María. Los escultores seguidores de Berruguete en Palencia. Universidad de Valladolid. Valladolid, 1981, pp. 194-281. Más datos biográficos sobre Manuel Álvarez en PARRADO DEL OLMO, Jesús María "Manuel Álvarez" en Jornadas sobre el renacimiento en la provincia de Palencia. Palencia, 1986, pp. 95-106. 
puede relacionarse con la imagen de San Juan Bautista, o la escultura de San Román en Villaherreros, similar formalmente a nuestro San Francisco ${ }^{2070}$.

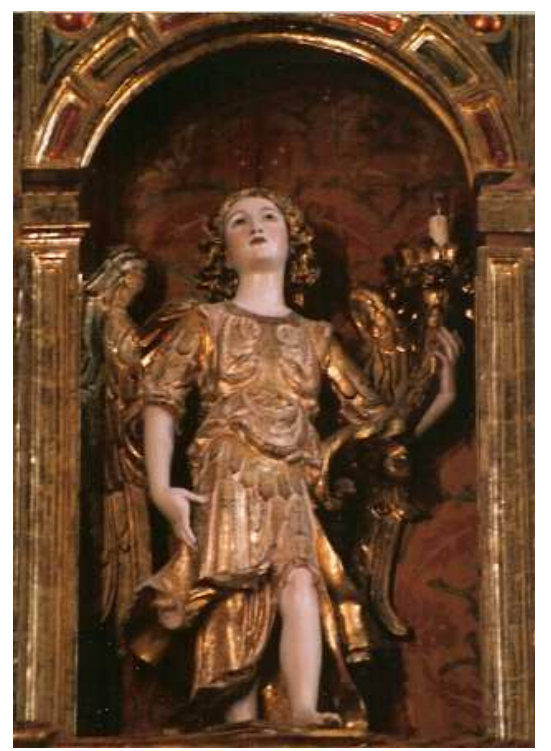

Ángel ceroferario del retablo de Santa Clara. $(69 \mathrm{~cm} \times 44 \mathrm{~cm})$.

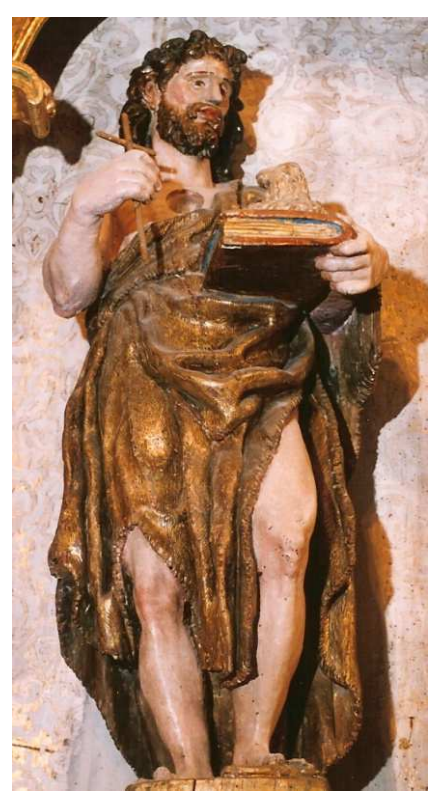

San Juan Bautista $(90 \mathrm{~cm} \times 32 \mathrm{~cm})$.

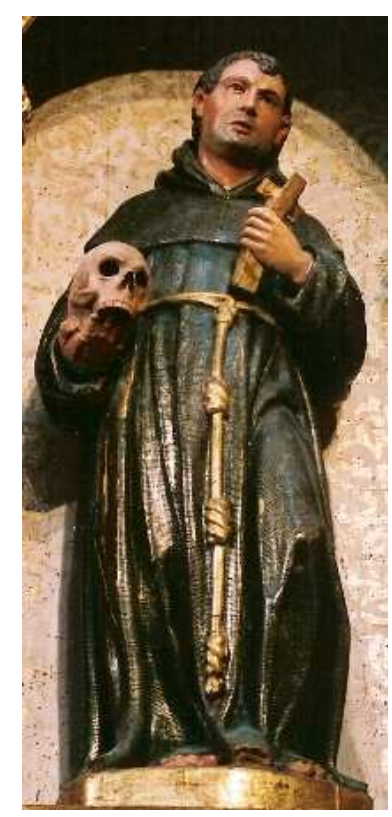

San Francisco de Asís $(92 \mathrm{~cm} \times 34 \mathrm{~cm})$.

Esculturas reaprovechadas para el retablo mayor de Santa Clara cercanas a Manuel Álvarez.

${ }^{2070}$ PARRADO DEL OLMO, Jesús María. “El renacimiento...”. Op.cit, pág. 770. 
El ático está rematado por un calvario de hacia $1590-1600^{2071}$. El crucificado se adapta perfectamente a la original hornacina cruciforme que lo cobija, en cuyo fondo se dispone una pintura que, representando una ciudad en llamas, acentúa el dramatismo de la escultura que la acompaña. Este elegante Cristo de bellas proporciones, ya expirante, reposa su cabeza sobre el lado derecho, el mismo en el que un grueso nudo, sujeta el amplio paño de pureza. A los pies de esta figura, se disponen dos relicarios piramidales en cuyo interior se conservan las tibias de San Cosme y San Benito ${ }^{2072}$. Bajo frontones rotos con decoración de bolas, flanquean a Cristo dos santos franciscanos. Cobijados en hornacinas, en la parte izquierda San Francisco, con los brazos abiertos en el momento de la estigmatización, mientras que al otro lado, San Antonio de Padua muestra la palma del martirio. De acuerdo a su estilo, podemos datar ambas imágenes hacia 1633, fecha de ejecución del ensamblaje del retablo y por tanto talladas expresamente para el mismo, como los ángeles candeleros y la imagen de Santa Clara. La utilización de pliegues quebrados de los mantos de ambos Santos, influenciados por Gregorio Fernández, apuntan esta datación aproximada.

Dentro en un frontón semicircular, un lienzo del busto Padre Eterno que bendice sujetando el orbe, corona la composición. Esta pintura fue realizada varios años después de haberse finalizado el retablo, pues se le encarga su factura al maestro vallisoletano Gaspar Díez del Pozo en 1641, cuando se contrata el estofado y dorado del mismo ${ }^{2073}$. Los mismos ensambladores que ejecutaron el retablo en 1632 actuaron como fiadores del maestro dorador, rematándose la obra en ochocientos ducados. Por entonces, ya fallecida doña Luisa de la Ascensión, era abadesa Mariana de Valderrábano, quien se comprometió a cumplir

${ }^{2071}$ URREA FERNÁNDEZ, Jesús y MARTÍN GONZÁLEZ, Juan José. Inventario...op. cit, pág. 62. ${ }^{2072}$ GÓMEZ PÉREZ, Enrique. “El real...”Op.cit, pág. 105.

${ }^{2073}$ Contrato y condiciones de la obra a 17 de junio de 1641 en AHPP. Carr.Prot 5234. Jerónimo López (1641-1642), s/f. Este dorador se encarga en 1643 de la pintura y dorado del retablo mayor de la iglesia de San Pedro de Frómista y hacia 1649 del dorado del retablo mayor de la iglesia de Nuestra Señora de las Nieves en Villamuera de la Cueza, ambos ensamblados por el carrionés Nicolás de Vega. URREA FERNÁNDEZ, Jesús y MARTÍN GONZÁLEZ, Juan José. Inventario...II, Op.cit, pp. 84, 259. Pertenecía en 1657 a la cofradía de San Lucas de Valladolid. MARTI Y MONSÓ, José. Estudios...pág. 15. Sobre pintura en este siglo véase VALDIVIESO GONZÁLEZ, Enrique. La pintura...Op.cit. En 1676, dora el retablo mayor de la iglesia parroquial de Cevico de la Torre, labrado entre 1666y 1671 por Cristóbal de Andino y Francisco de Villota. URREA FERNÁNDEZ, Jesús y MARTÍN GONZÁLEZ, Juan José. Inventario...II, Op.cit, pág. 136. 
escrupulosamente con los pagos, abonándose el importe integral el mismo año del contrato, antes incluso de la fecha acordada ${ }^{2074}$.

\section{Los lienzos del presbiterio}

Analicemos ahora, siguiendo un orden espacial, partiendo del presbiterio en dirección a los pies, las obras artísticas que se debieron igualmente a la intervención de la Madre Luisa. En las paredes laterales del presbiterio se sitúan dos lienzos encargados por la madre Luisa en el mismo año. En el lado de la Epístola se representa un Calvario con la Magdalena arrodillada y San Juan. Cristo aparece vivo y aunque presenta una anatomía correcta, adolece de una gran rigidez en los brazos. Entorna los ojos al cielo, en el momento en que recita las siete últimas palabras. Esta última plegaria antes de expirar, figura en latín en el marco, al igual que otra frase muy célebre de Cristo en la Cruz tomada de San Lucas: "PATER DIMITTE ILLIS NON ENIM SCIVNT QUID FACIVNT ${ }^{2075 ", ~ D e b a j o ~ d e l ~ c u a d r o ~ s e ~ p u e d e ~ v e r ~ l a ~}$ inscripción: "MADRE LVISA DE LA ASCENSION PVSO AQVI ESTE QVADRO. ANO DE 1619”. Se trata de una pintura de mediana calidad artística que además ha perdido la intensidad de los colores originales.

El lienzo del lado del Evangelio es una copia de la Inmaculada Concepción esculpida por Gregorio Fernández ${ }^{2076}$. Ubicada originalmente en el convento de San Francisco de Valladolid, desapareció posteriormente, siendo éste el único testimonio gráfico de la afamada escultura. Podemos relacionar ambas imágenes por la leyenda que figura bajo la peana de la Virgen que dice así: "RETRATO DE NVESTRA $S^{A} D E$ LA CONCEPCIÓN DE S. FRN CO DE LA CIVDAD DE VALLADOLID”. La importancia de esta imagen radica en el hecho de erigirse como el tipo iconográfico a seguir en el barroco castellano ${ }^{2077}$. Además figura la firma del artista, si bien un poco escondida

\footnotetext{
${ }^{2074}$ Sabemos la equivalencia exacta de los ducados por entonces porque el propio documento del contrato expresa "a once reales cada uno". Se acordó una suma de 800 ducados, esto es, unos 9.000 reales -teniendo en cuenta que no se expresarían en el documento las particiones, por ejemplo si fuera 11,3 u 11.4 reales-que sería abonada en tres pagos en 1641 y el último pago en junio de 1642, ya finalizada la obra. Dado que se abonaron 9198 reales en 1641, la deuda quedó saldada dicho año. GÓMEZ PÉREZ, Enrique. “El real...”Op.cit, pág. 105, a su vez de ASCC. Libro de Cuentas 16331655 , fol $125 \mathrm{v}$.

${ }^{2075}$ Lucas 23,34.

${ }^{2076}$ URREA, Jesús y MARTÍN GONZÁLEZ, Juan José. Inventario...2. Op.cit, pág. 62.

${ }^{2077}$ Sobre este tema, PÉREZ DE CASTRO, Ramón. "Una Inmaculada...Op.cit, pp. 174-175.
} 
en un lateral de la peana, que nos indica que fue Domingo de la Fuente, pintor activo en Valladolid en la primera mitad del XVII, quien ejecuta la obra ${ }^{2078}$. La devoción de Sor Luisa por la Inmaculada Concepción, por entonces discutida, justifica plenamente la presencia de esta iconografía, pues, como indicamos, fue la promotora de la hermandad de los Defensores de la Purísima Concepción de la Virgen, cuya defensa se juró en Carrión, el 13 enero de $1619^{2079}$, precisamente el mismo año de la ejecución de este lienzo. Aparte de contar con el apoyo de un sinfín de fieles de todas las clases sociales, se sumaron a la causa entre otros, Felipe III, diversos cardenales, obispos y algunos nobles, hasta llegar los 80.000 miembros $^{2080}$.

La creación de esta hermandad no es, ni mucho menos, un hecho aislado en España, pues numerosos eruditos habían hecho alarde de su fervor inmaculista en estos años a través de numerosos escritos de defensa ${ }^{2081}$. Por otro lado, la orden Franciscana en cualquiera de sus vertientes, se erigió en adalid de la defensa de la pureza virginal de María, recurriendo al escultor gallego en al menos siete ocasiones $^{2082}$.

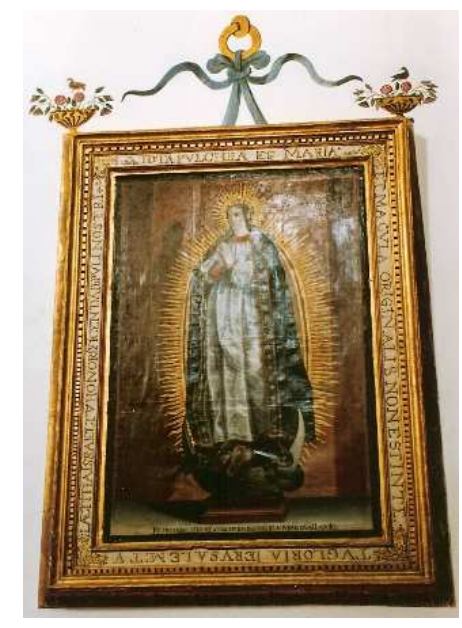

\section{Lienzo de la Inmaculada, copia de Gregorio Fernández. (2,25mtrsx 1,60metrs).}

\footnotetext{
${ }^{2078}$ GÓMEZ PÉREZ, Enrique. El Real...Op.cit, pp. 84-85.

2079 AMCC. Libro 1 de Actas (1618-1637), fol 12.

${ }^{2080} \mathrm{La}$ copia del relato sobre el voto, juramento de la Inmaculada en GARCÍA BARRIUSO, Patrocinio. Op.cit, pp. 156-173.

${ }^{2081}$ A este respecto, gran parte de ellos proceden del foco sevillano. SOBRINO, Alonso. Tratado de la Inmaculada Concepción de la Virgen Maria N. S. Gabriel Ramos Vejarano. Sevilla, 1615, ANTIST, Vicente Justiniano. Tratado de la Immaculada Concepción de Nuestra Señora. Gabriel Ramos Vejarano. Sevilla, 1615, OJEDA, Pedro de. Información eclesiástica en defensa de la limpia concepción de la Madre de Dios. Sevilla, 1616. CERVANTES, Gonzalo. Parecer de S. Augustin en favor de la concepcion purissima de la Virgen Maria Madre de Dios, sin pecado original. Gabriel Ramos Vejarano. Sevilla, 1618.

${ }^{2082}$ Sobre este tema. MARTÍN GONZÁLEZ, Juan José. "Imágenes de escultura de la Concepción en Castilla y León, en los siglos XVI al XVIII" en Actas del I Congreso Internacional. La Orden Concepcionista, volumen 2. León, 1990, pp. 15-24 y del mismo, El escultor...Op.cit, pp. 224-234.
} 


\section{Crucificado de Gregorio Fernández}

En el brazo del crucero del Evangelio encontramos un retablo barroco del siglo XVIII de un solo cuerpo, con columnas cubiertas de decoración y remate en forma de ático semicircular con hornacina central. Contiene un Crucificado de Gregorio Fernández de tamaño inferior al natural, con encarnación mate, relacionado estilísticamente con el Crucifijo de la Luz ubicado hoy día en el Colegio de Santa Cruz de Valladolid. Ambos se caracterizan por el cuerpo delicado, el tórax delgado, el vientre hundido y el paño de pureza a bases de pliegues quebrados o alatonados tan característicos del escultor. Igualmente el gusto en mostrar la sangre que mana de las heridas es acorde al espíritu contrarreformista de la época, en la que el dramatismo y la cruda realidad se tornan en armas extremadamente valiosas para conmover al fiel.

Por tanto, se consideraba, como la obra mencionada, una talla perteneciente al período final del artista, entre 1631 y $1636^{2083}$. Sin embargo, el profesor Jesús Urrea aporta un interesantísimo documento del pago de dicha escultura, fechado en marzo de 1627, cuya comitente era Doña Mariana Vélez Ladrón de Guevara, condesa de Triviana, en Vitoria. A consecuencia de la muerte de la condesa, cliente usual de Gregorio Fernández, su administrador ajustó las cuentas de la difunta y se pagaron un total de 1750 maravedíes a Gregorio Fernández por la "hechura de un Cristo que envió mi señora a nuestra madre Luisa de Carrión”. Las pequeñas dimensiones del crucifijo, hacen suponer que la obra, cuya ejecución no requeriría demasiado tiempo, habría sido encargada poco antes, a finales de 1626 o comienzos de 1627, y por tanto, sería el precedente del Cristo de la Luz ${ }^{2084}$. Si bien de mayor corpulencia, nuestro Crucificado no resulta muy similar al que talló el artista lucense para el convento vallisoletano del Carmen extramuros ${ }^{2085}$, concretamente en la forma elíptica de la caja torácica y la consecuente prominencia del vientre.

\footnotetext{
${ }^{2083}$ MARTÍN GONZÁLEZ, Juan José. El escultor...Op.cit, pág. 182.

${ }^{2084}$ URREA FERNÁNDEZ, Jesús. “Cristo crucificado”, Op.cit, pág. 337.

${ }^{2085}$ MARTÍN GONZÁLEZ, Juan José. La escultura..1, Op.cit, pág. 152.
} 
El corazón flamígero de tonos dorados que envuelve al Cristo, está decorado con piedras preciosas fingidas, cuya fuente de inspiración podría ser un grabado de los hermanos Wierix realizado contemporáneamente a nuestro crucificado ${ }^{2086}$. Fue nombrado altar privilegiado en 1749 por decreto del papa Benedicto XIV ${ }^{2087}$.
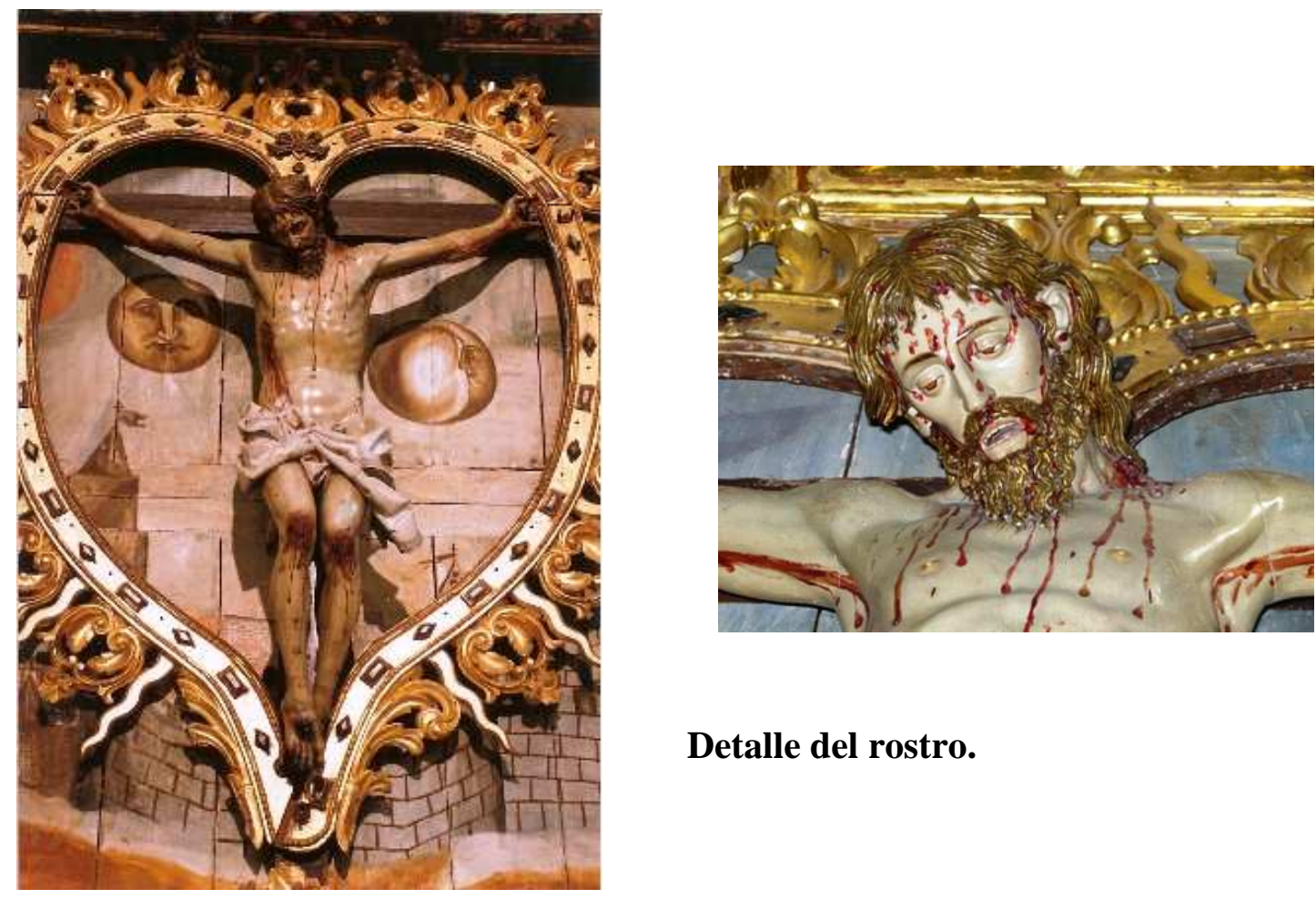

Detalle del rostro.

Cristo Crucificado de Gregorio Fernández en el retablo del crucero norte. (1,50 mtrsx 1,26mtrs).

Junto al Crucificado de Gregorio Fernández se conserva una representación de San Buenaventura sentado ante el scriptorium con el hábito franciscano bajo sus vestiduras episcopales con manto púrpura y capelo de cardenal en la pared. Sobre la mesa, el roquete y un libro y a los pies de ésta, la mitra episcopal. Se trata de una obra de artista anónima datable en el siglo XVIII.

${ }^{2086}$ URREA FERNÁNDEZ, Jesús. "Cristo crucificado”, Op.cit, pág. 338.

${ }^{2087}$ ASCC. Legajo 1, nº56. 


\section{Imagen de Nuestra Señora de la Consolación}

El retablo de la Epístola inmediato al altar mayor está dedicado a la advocación de Nuestra Señora de la Consolación. Tan sólo la imagen que alberga en su vitrina pertenece al siglo XVII, correspondiendo el retablo a la centuria posterior $^{2088}$. En la hornacina central se dispone una imagen de vestir oriunda de las Indias que Fray Benigno de Génova, general de la Orden franciscana, regaló a la Madre Luisa, como ella misma relata en una de sus declaraciones ante la Inquisición $^{2089}$. En 1726 Benedicto XIII le concede el privilegio perpetuo de misa para todos los viernes del año por los religiosos de la orden ${ }^{2090}$.

\section{Piedad de Gregorio Fernández}

Sin duda la obra más interesante del convento, trasladada desde la ermita de la huerta o de la madre Luisa ${ }^{2091}$, es la que se sitúa en la nave de la Epístola de una de las capillas donde se venera una Piedad de Gregorio Fernández ${ }^{2092}$. Se trata de un tipo iconográfico muy usado por el maestro. Concretamente en Castilla llevó a cabo otras cuatro Piedades, lo que ocurre es, que en este caso, la Virgen se representa significativamente más joven que en el resto.

El conjunto está destinado para una exclusivamente visión frontal, pues su parte posterior es plana, como la del convento de San Francisco de Valladolid -hoy en la iglesia de San Martín- con la que puede relacionarse estilísticamente y que sería de los mismos años. Quizá la de Carrión sea anterior, de hacia 1620, pues la de San Francisco, que podría fecharse en 1625, muestra un avance en el rostro. De todos modos, ambas Piedades debieron ser ejecutadas, según Martín González, en un corto lapso de tiempo; si bien, la Piedad de San Martín figura entre lo más delicado que esculpiera Fernández, conservando la elegancia del clasicismo ${ }^{2093}$. En cambio, la Piedad de Carrión muestra cierto desequilibrio a través de la adopción de

\footnotetext{
${ }^{2088}$ Analizado en el apartado relativo al siglo XVIII.

${ }^{2089}$ AHN. Inquisición. Legajo 3704, caja 2, fol 405.

2090 ASCCC. Legajo 1, no56.

${ }^{2091}$ Los retablos de las otras dos capillas de la Epístola dedicados a San Blas y El Espíritu Santo son tratados en el apartado relativo al siglo XVI.

${ }^{2092}$ Sobre este escultor, remítase al capítulo dedicado a los escultores.

${ }^{2093}$ MARTÍN GONZÁLEZ, Juan José. Escultura barroca en España...Op.cit, pág. 62.
} 
la dirección oblicua, tal y como se desarrolla la composición en la Sexta Angustia del Museo Nacional de Escultura de Valladolid.

El cuerpo de Cristo, redondeado, macizo y elegante contrasta con el trato anguloso de los pliegues de la Virgen. Fernández pretendió ofrecer una visión profunda de su piedad a través de la colocación en escorzo del cuerpo de Cristo. Se puede observar un cuidadoso empleo del color apreciable en la encarnación del cuerpo se ha conseguido una tonalidad mortuoria muy realista Se desconoce cómo llegó este grupo escultórico hasta el convento. Tal vez fuese un regalo de Felipe III a María Luisa, lo cual no consta documentalmente, o que la abadesa la encargara personalmente por su devoción al tema de la Piedad. En cualquier caso, el artista probablemente realizó las obras desde su taller de Valladolid, sin tener que trasladarse a Carrión para entregarlas, pues, como indicamos, el Crucificado fue una donación y esta obra probablemente también.
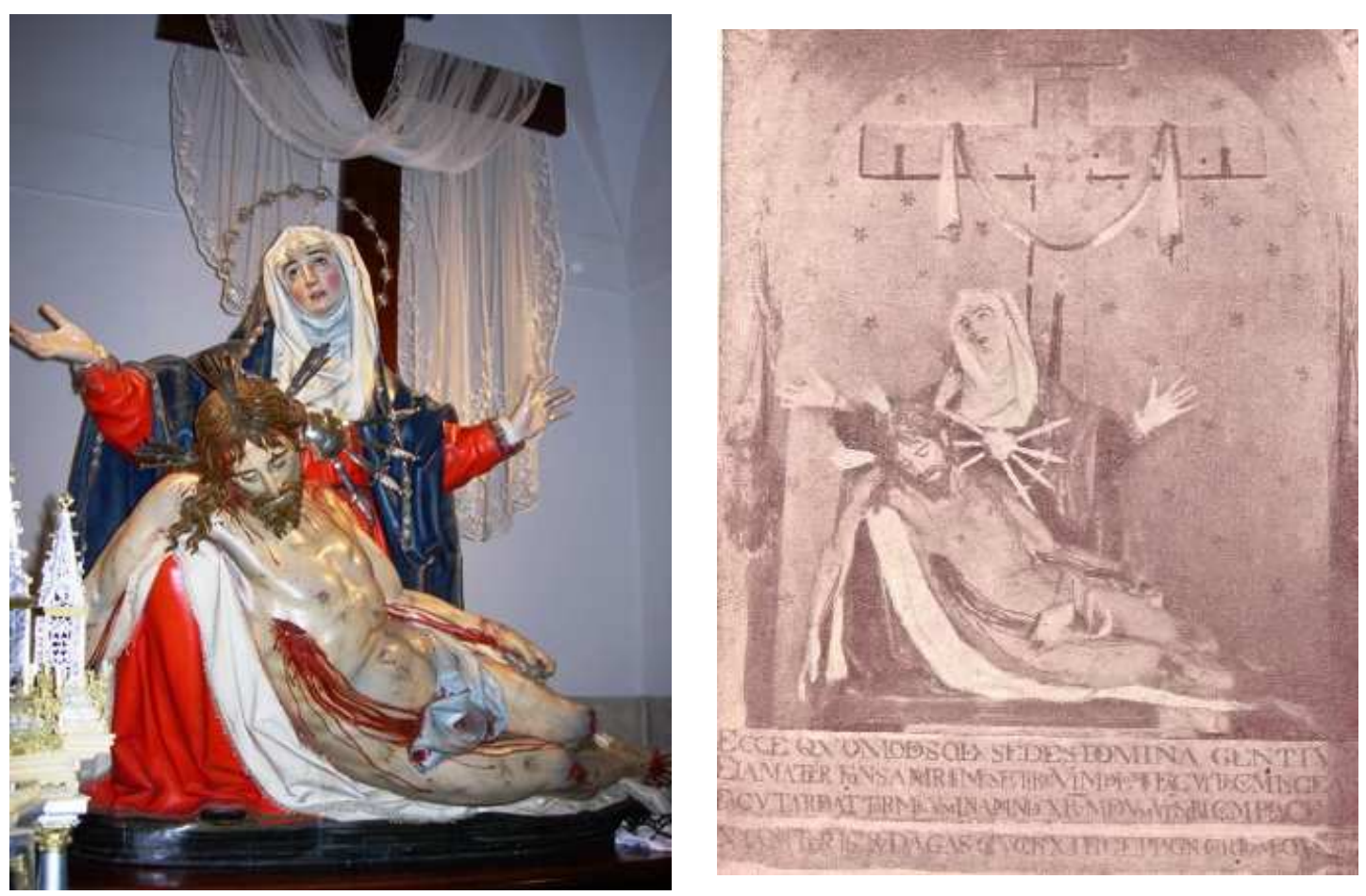

Piedad de Gregorio Fernández $(1,20 \mathrm{~cm} \times 1,70 \mathrm{~cm})$ en el lado del Evangelio del templo (izquierda) y en la hornacina de la ermita de la madre Luisa (derecha). 
Esta obra permaneció en la hornacina de la cabecera de la ermita de María Luisa hasta 1968 en que fue trasladada al templo. La Cofradía de la Vera Cruz procesionó ocasionalmente la imagen, siendo la última vez en $1998^{2094}$. Se incumple así lo contenido en el Breve de Urbano VIII emitida en 1630 para otorgar indulgencias a la ermita, por el cual se prohíbe taxativamente extraer cualquier objeto sagrado de la misma ${ }^{2095}$.

\section{Frontis de azulejería talaverana del coro}

A los pies del templo, el muro que contiene las cratículas de los coros alto y bajo, está cubierto con una ornamentación a base de azulejería de Talavera de la Reina, en Toledo, donde predomina la bicromía azul y blanca con algunos detalles en amarillo.

La parte inferior del revestimiento está formado por el clásico florón escurialense, motivo manierista del que conservamos muchos ejemplos en Castilla y León, como en San José de Ávila, Las Huelgas Reales de Burgos, o Santa María de Valbuena en Valladolid, entre otros. La fuente de inspiración para el artista parece provenir de las estampas del Tratado de Serlio ${ }^{2096}$.

En el espacio intermedio entre las dos ventanas del coro, un par de pilastras cajeadas dotadas de un amplio cimacio, sustentan un frontón avolutado que acoge en su centro una tarjeta de cueros recortados en la que figura el escudo de la orden franciscana, con el brazo de Cristo y el de San Francisco -en bicromía azul y blancaantepuestos a la cruz -en ocre- sobre fondo amarillo. Sobre el frontón citado se sitúan dos bolas escurialenses de las que pende una cinta amarilla a la que se han atado ramilletes de hojas y frutos, sujetados en los extremos por cuatro angelillos. Este tipo de ornamentación, a diferencia de la que hallamos en el resto del revestimiento, es de carácter eminentemente barroco.

\footnotetext{
${ }^{2094}$ GÓMEZ PÉREZ, Enrique. El museo...Op.cit, pág. 90.

2095 Ibídem, pág. 110.

${ }^{2096}$ MALO CERRO, Mónica. Azulejería...Op.cit,, pp. 603-604.
} 
Enmarcada por azulejos de grecas vegetales se representa el hermanamiento de las dos ramas franciscanas a través de las figuras de los santos fundadores de la orden, San Francisco y Santa Clara. De rodillas y afrontados, veneran el crucifijo existente entre ambos, que se destaca sobre un copioso manto de nubes, brillando con luz propia, como así lo hacen los nimbos de ambos Santos. La cruz contiene una dedicatoria en letras capitales doradas sobre fondo azul -bicromía típicamente toledana- mandada inscribir por la Madre Luisa en 1619:

“O CRUZ SANTÍSIMA, O CRUZ ENAMORADÍSIMA MÍA, LUZ DE MI ALMA, FAVORECE A ESTE INDINA SOPOR LUISA DE LA ASCENSIÓN, ESCLABA DE MI DULCE JHS MARÍA 2097 ",

En las composiciones figuradas, como es nuestro caso, este tipo de producción tiene un acento ingenuo; no así cuando se representan motivos heráldicos o florales en los que el naturalismo y la vivacidad están siempre presentes. Se ve que nuestro ceramista estaba mucho más familiarizado con los motivos decorativos; de hecho es el único caso en que representa escenas.

El motivo central descrito, ornamentado con aletones laterales cual remate de un retablo, se une a través de ellos con los motivos idénticos que se representan en los laterales. Flanqueando las dos puertas que dan acceso al coro, se dispone idéntico revestimiento. La azulejería representa dos columnas corintias en cuyo fuste se despliega toda una serie de motivos floreados de los que surgen roleos vegetales. Se asientan sobre grandes plintos en cuya parte central se delinean unas placas rectangulares amarillas -como lo son también el capitel y la basa- imitando jaspes, a la manera italiana. Este tipo de ornamentación la hallamos en numerosos edificios castellanos, notablemente en Valladolid, como por ejemplo en el Palacio Nelli, Las Descalzas Reales o los monasterios de Nuestra Señora de Prado y San Benito ${ }^{2098}$.

\footnotetext{
${ }^{2097}$ Cruces de todos tipos y materiales se reparten en el conjunto conventual, obra igualmente de la madre Luisa: de piedra en el patio de la hospedería, huerta y delante de la fachada de la iglesia, de madera en la hospedería y varias pintadas, conservadas en el museo con la misma dedicatoria mencionada.

${ }^{2098}$ MALO CERRO, Mónica. Azulejería...Op.cit, pág. 605.
} 
Los dos soportes mencionados sostienen un friso de elementos vegetales, posiblemente vides, en cuyo centro se dispone el anagrama IHS. Por encima, un frontón quebrado acoge un gran piñón formado por pilastras cajeadas con decoración vegetal que, soporta sendas ménsulas, sobre las cuales, a su vez, se dispone un frontón curvo. El remate de la composición lo compone una cruz en el centro flanqueada por dos bolas de tipo escurialense. El centro de este panel lo protagoniza una escena celestial donde dos ángeles en posición de tres cuartos rodeados de unas nubes espesas portan, al igual que lo hace Santa Clara, la custodia del Santísimo.
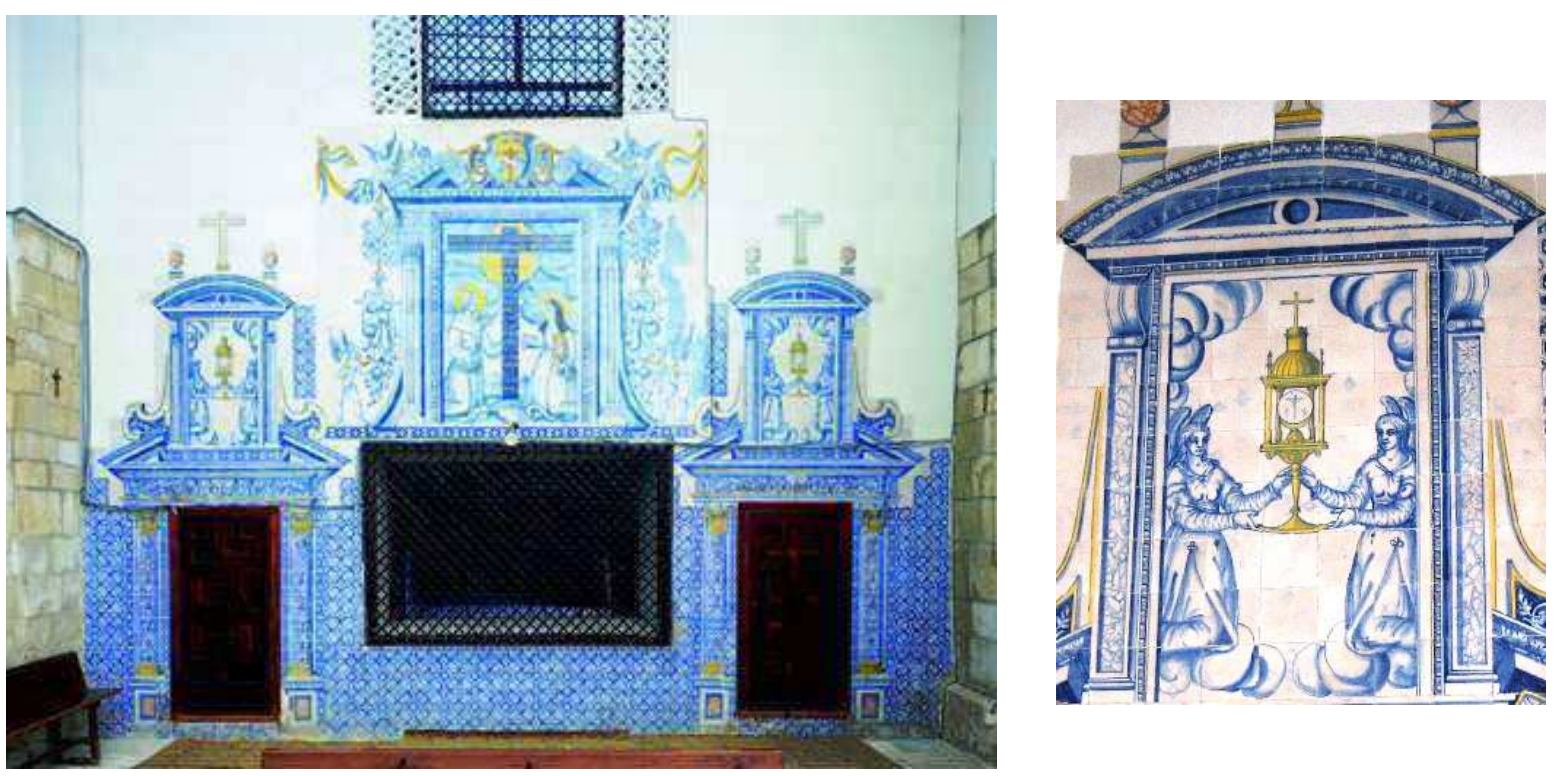

Detalle. Ángeles

portando la custodia.

\section{Frontis de azulejería talaverana a los pies del templo de Santa Clara.}

La recreación de arquitecturas clasicistas es un recurso habitualmente empleado en la azulejería sevillana del siglo XVI; sirva como muestra la casa de la Condesa de Lebrija ${ }^{2099}$. Este revestimiento se llevaría a cabo hacia 1619, cuando se estaban finalizando las obras del nuevo templo, como así consta por la inscripción cerámica de la sacristía.

${ }^{2099}$ Ibídem, pág. 607. 
Por los motivos y la policromía empleada, la obra se atribuye al ceramista Alonso de Figueroa Gaytán. Perteneciente a una conocida familia de ceramistas, nació hacia 1576 en Talavera de la Reina ${ }^{2100}$. Se sabe además que nuestro artista era morisco, interesante dato que confirma, una vez más, la tendencia generalizada por la azulejería acaparada por este sector de la población ${ }^{2101}$. Por las fechas en que participa en el convento carrionés, se encontraba trabajando en la capital vallisoletana, lo que concuerda con el dato aportado por Bernardino Martín Mínguez, que aseguraba que esta obra había salido de los hornos de Valladolid $^{2102}$. Esta obra pudo ser sufragada por Felipe III, quien tanto favoreció a la monja de Carrión. En este sentido el monarca corrió con los gastos de los revestimientos cerámicos que para los refectorios de los conventos vallisoletanos de Santa Catalina y Porta Coeli realizaría este artista talaverano y por tanto, bien pudo ser la realeza la benefactora de esta obra ${ }^{2103}$.

\section{La fachada y reja exterior del templo}

Para la realización de la fachada se siguieron las trazas dadas por Francisco de la Maza, quien como apuntamos, modificó las condiciones establecidas por Alonso de Santiago por motivos de espacialidad. Ambos, siguen los preceptos de los manieristas italianos en pleno siglo XVII, integrándose de este modo en la corriente clasicista imperante en estos años. Del mismo modo que Santiago había recurrido a los principios de Serlio en sus primeras trazas, de la Maza dispondrá todos los elementos de acuerdo al orden de Vignola en este segundo y definitivo proyecto $^{2104}$.

\footnotetext{
${ }^{2100}$ Fallece en 1653, heredando su alfar Juan Echevarría .VACA GONZÁLEZ, Diodoro y RUIZ DE LUNA ROJAS, Juan. Historia de la cerámica talaverana. Editora Nacional. Madrid, 1943, pág. 200. ${ }^{2101}$ Se dice así en un pleito de 1604 entre los Figueroa y la Cofradía de Nuestra Señora de Prado en Talavera que les negaba el acceso a la misma por ser moriscos. Finalmente los ceramistas ganaron el litigio. GONZÁLEZ MUÑOZ, $\mathrm{M}^{\mathrm{a}}$ del Carmen. "Algunas notas sobre la cerámica de Talavera" en $A E A$, tomo $53, \mathrm{n}^{\circ} 211$. Madrid, 1980, pág. 358.

${ }^{2102}$ MARTÍN MÍNGUEZ, Bernardino. Catálogo...Op.cit, pág. 38.

${ }^{2103}$ GÓMEZ PÉREZ, Enrique. El real...Op.cit, pág. 82. Este artista fue un cliente asiduo de la realeza, pues revistió hacia 1601 los zócalos y pavimento del oratorio de la reina en el Palacio Real de Felipe III. Fue elegido tras una visita al alfar de Figueroa por los monarcas junto a su hijo, el futuro Felipe II. Tras la visita el artista colocó una placa conmemorativa del suceso. MALO CERRO, Mónica. Azulejería...Op.cit, pp. 83 y 84 y 120.

${ }^{2104}$ AHPP., Carr.Prot 4842. Juan Díaz Pajaza (1615) fol 183 y ss.
} 
Esta sobria portada fue realizada íntegramente con piedra traída de Támara y está constituida por una estructura triple en dos pisos, dotados de cuatro pares de soportes cada uno. Las pilastras adosadas del piso inferior llevan basa toscana y “...cornija dórica encapitelada...”, esto es, el capitel está incluido en la misma línea del friso que separa ambos cuerpos. De los tres accesos originales, el del extremo derecho, que comunicaba con la tribuna del Evangelio ha sido tapiado. Los tres arcos de medio punto que alojan las puertas en su interior, cobijan en su parte superior tres hornacinas, en cuyo centro se dispone la fundadora de la orden clarisa. El nivel superior está formado igualmente por cuatro pares de pilastras, en este caso corintias, entre las cuales se disponen tres hornacinas con esculturas y tres vanos rectangulares de pequeña dimensiones para iluminar el templo.

En los laterales, dos Santos franciscanos, San Francisco mirando en alto con la mano en el pecho y otro sin identificar que tan solo porta un libro. La defensa de Sor Luisa de la Purísima concepción queda patente incluso en la fachada, pues en la parte central sobre la figura de Santa Clara del primer cuerpo, aparece representada la Inmaculada, con el fin de que entrasen los fieles “...confesando su preservación y pureza... ${ }^{2105 "}$. En el remate, sobre una cornisa doble con cuatro acanaladuras para la caída del agua, se alza un plinto moldurado con cuatro pares de bolas al estilo herreriano. Todos los elementos señalados evidencian la adquisición de un lenguaje depurado en el que los excesos ornamentales no tienen cabida. La disposición triple se trasluce al interior a través de tres arcos de medio punto que se corresponden con las capillas hornacinas en el lado frontero de la epístola. El desarrollo de esta portada, que se extiende desde los pies del templo hasta el crucero, constituye un caso excepcional entre los templos clasicistas de la Meseta norte, en los que, la fachada ubicada en este sector no suele adquirir tal protagonismo, como es el caso de las Huelgas Reales de Valladolid o la iglesia de los Santos Juanes de Nava del Rey. El amplio desarrollo de la cornisa, el uso de pilastras pareadas o el recurso de

\footnotetext{
${ }^{2105}$ Extendió su devoción por todo el territorio hispano, creando una congregación de adeptos a la misma Los cinco preceptos de esta hermandad eran: la admisión de la concepción sin mácula de la Virgen, satisfacer las culpas ajenas como si fuesen propias, preservar los caudales que se dedican para buenas obras en nombre de la Virgen y aumentarlos en la medida de lo posible y por último la devoción perenne por la Virgen, incluso tras la muerte. Tal fue el éxito de esta hermandad, que en vida de María Luisa contó con más de ochenta mil integrantes, entre ellos obispos, cardenales, monarcas y conventos. ASCCC. Traslado de 1779 del Memorial informativo en defensa de Sor Luisa de la Ascensión, monja de Santa Clara de Carrión, hecho por Fray Pedro de Balbás. 1643. Documentos María Luisa, 4, fol 38 y ss.
} 
las bolas recuerda otros templos del clasicismo palentino como la iglesia palentina de la Asunción de Lantadilla en Palencia, sin llegar la nuestra a la monumentalidad de sus compañeras ${ }^{2106}$. Este modo de hacer clasicista irradia sin duda del foco vallisoletano, donde algunos artistas como Francisco de Praves, asumieron los principios de Vignola o Palladio y los aplicaron en obras castellanas como la fachada de San Ambrosio de Valladolid, la de Nuestra Señora de la Calle, en Palencia o el Hospital de la Concepción de Burgos ${ }^{2107}$.

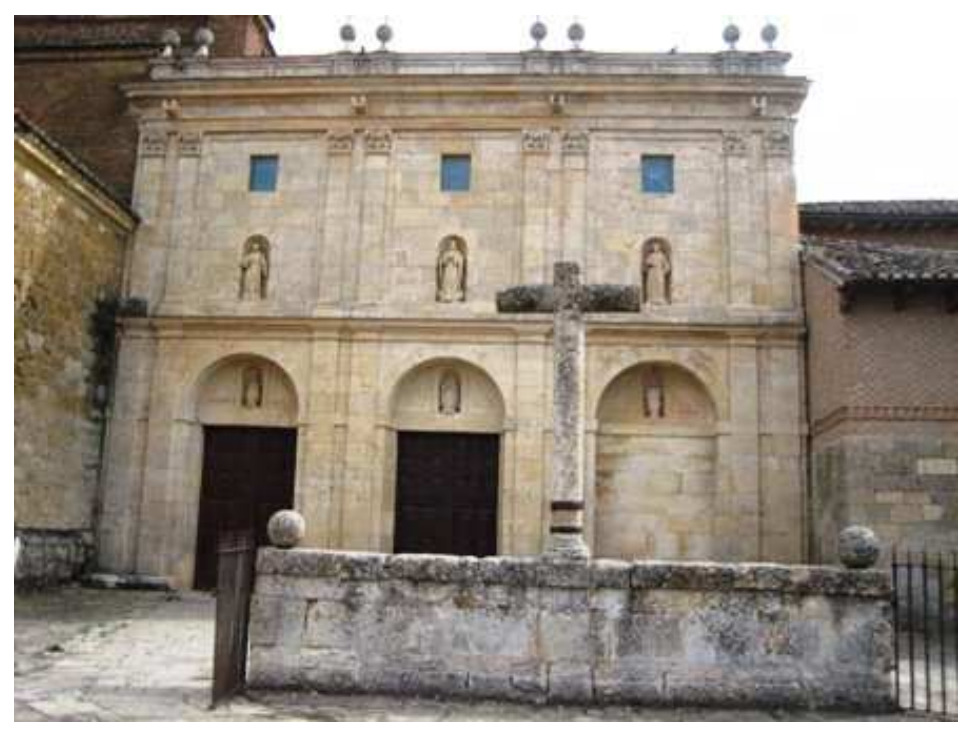

Fachada del templo de Santa Clara y antepecho pétreo del atrio.

La fachada, restaurada entre 1774 y 1776, va precedida de una reja interrumpida por un antepecho pétreo en el cual se conserva una inscripción conmemorativa de la Madre Luisa $^{2108}$. Su presencia viene justificada por ser ella quien, en abril de 1622, finalizadas las obras del templo en su totalidad, dispone “... açer un petril y encadenado a la entrada de la yglesia del dicho convento”. La obra será llevada cabo por Juan González de la Mata, maestro albañil oriundo de Carrión, que se basó en las condiciones firmadas por el vicario del convento, Fray Pedro de Castro $^{2109}$. Sobre el antepecho se dispuso una cruz dotada de basa y

2106 BUSTAMANTE GARCÍA, Agustín. La arquitectura...Op.cit, pp. 79-80, 547 y ZALAMA, Miguel Ángel. Arquitectura... Op.cit, pág. 142.

${ }^{2107}$ BUSTAMANTE GARCÍA, Agustín. "El siglo XVII. Clasicismo y barroco" en Manual del arte español. Madrid, 2003, pág. 541.

${ }^{2108}$ La intervención en ASCC. Libro 15. Cuentas del convento (1759-1777), s/f.

${ }^{2109}$ Concierto y condiciones firmadas a 25 de abril de 1622 en AHPP. Carr.Prot 5218. Jerónimo López (1622), s/f. Sobre Juan González de la Mata, véase el apartado relativo a los maestros locales. 
pedestal, flanqueada por bolas, todo ello realizado en piedra procedente de Palacios del Alcor, célebre por su excelente calidad. La distancia existente entre el petril y la portada debía empedrarse igualmente con motivos de lazos y "...motivos agradavles..." que posteriormente fue sustituido por un pavimento de losas rectangulares. El encadenado debía abarcar desde la pared de la sacristía hasta lo que era el cuarto del padre Vicario, convertido en museo, conformando una especie de atrio de entrada como podemos ver hoy día. En 1994 se amplía el número de bolas de tipo herreriano con sus pedestales a lo largo de la fachada del convento alternándose con sus correspondientes cadenas, en sintonía a la disposición de la fachada del templo ${ }^{2110}$.

\section{Las tapias del convento}

Exteriormente, el convento aparece rodeado por unos muros de ladrillo y tapial recubiertos de mampostería de cuyas intervenciones tenemos noticia desde el siglo XVII. Su antigua fábrica correspondió a la iniciativa de la monja María Luisa, quien contrató en 1625 a Juan de Cajigosa, maestro trasmerano vecino de Carrión, para rehacer la vieja cerca a medida que iba construyendo la nueva, a razón de 72 reales por cada tapia de dos pies y medio de grosor $^{2111}$.

Se comprometió a participar en la edificación de este cerramiento hasta diciembre del año posterior, de ahí que en abril de 1616 figure participando en el mismo, esta vez junto a Diego de Mazarredonda. Ambos continuarán la obra por la parte de la huerta, debiendo comenzar por la callejuela que separaba los dos cenobios franciscanos y proseguir por la correspondiente a la ermita de la Piedad. Sin embargo, la ejecución la llevaría finalmente a cabo Domingo del Río ${ }^{2112}$, quien firmando las condiciones en julio de 1626 se comprometió a concluirla en septiembre del año posterior. Se dispuso reforzar la cerca con un total de cien tapias de tres pies de grosor frente a los dos y medio de la otra parte, salvando la diferencia a través de una pilastrilla o talud en la esquina hacia la parte interior. Se utilizaría

\footnotetext{
${ }^{2110}$ El taller de cantería de Aguilar de Campoo se encargó de las labores en piedra. GÓMEZ PÉREZ, Enrique. El real monasterio...Op.cit, pág. 189.

${ }^{2111}$ Concierto y condiciones firmadas a 11 de mayo de 1625 en AHPP. Carr.Prot 5221.Jerónimo López (1625), s/f.

${ }^{2112}$ Datos biográficos en el apartado relativo a los maestros de obras.
} 
mampostería asentada a plomo y cordel y ligada con cal y arena bien batida, debiendo finalizarse las obras en septiembre de $1627^{2113}$. Aún faltaba por finiquitar una parte del cerco a finales de 1627 en que se contrata nuevamente a Juan de Cajigosa para dicho trabajo, concluyéndose definitivamente los trabajos ${ }^{2114}$.

\subsection{LAS INTERVENCIONES POSTERIORES}

\section{Patio reglar y Hospedería}

Es el patio externo desde el cual se accede a las partes públicas del convento como los talleres, locutorios, la portería o el torno. En uno de sus laterales conserva una interesante pieza del siglo XVII, el Pozo de la Salud o de los Peregrinos. El primero de sus nombres se debe a la cabeza de carnero del siglo XIII que lo corona en relación a la leyenda del Vellocino de Oro, como si de la Fuente de las curaciones se tratase. El segundo de ellos, como es obvio, viene justificado por ser lugar en el que los caminantes hacían una parada para beber agua. El pozo conserva una doble reja, la interna del siglo XVIII y la externa del siglo XX.

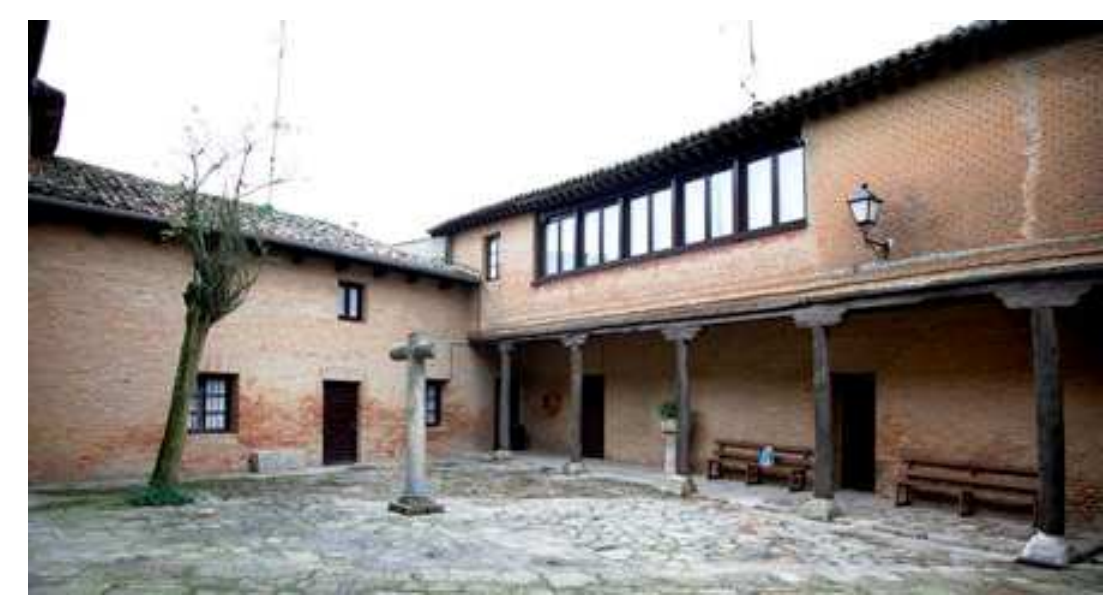

Patio de la Hospedería.

\footnotetext{
${ }^{2113}$ Escritura de contrato y condiciones firmadas a 26 de julio de 1626 en AHPP. Carr.Prot 5222. Jerónimo López (1626), s/f.

${ }^{2114}$ AHPP. Carr.Prot 5223.Jerónimo López (1627), s/f.
} 
La Hospedería del Monasterio, de gran sencillez, situada frente a dicho pozo, ofrece alojamiento desde el siglo XVII. La casa del capellán es hoy día un lugar de retiro espiritual con capilla en su interior. El albergue de peregrinos está situado en la antigua casa de la demandadera. Junto a éste, se ubica el locutorio bajo (uno de los cinco con los que el convento contaba) donde las monjas reciben las visitas. Lo que era otro locutorio, se ha convertido en una modesta tienda.

En 1884 el albañil carrionés Nicolás Herrero se encargó de realizar los últimos arreglos del patio ${ }^{2115}$.

\section{Biblioteca musical}

La presencia de la música en la liturgia es común a todas las órdenes religiosas, pero en el caso de las clarisas, adquiere un papel fundamental, pues desde la admisión de las monjas hasta su fallecimiento está presente en multitud de ceremonias religiosas ${ }^{2116}$. Se sabe que el monasterio poseyó una importante biblioteca musical, que no se conserva, construida seguramente en una época anterior, pero nos remitimos a ella en este momento puesto que se conservan varios ejemplares destacados de esta centuria.

Existen dos volúmenes, ambos encuadernados en madera recubierta de cuero repujado y con herrajes en los cuatro ángulos en que se contiene la polifonía necesaria para la liturgia conventual. La recopilación, probablemente de composiciones de los siglos XVI y XVII, fue de Martín de Galdámez, vecino de Alfaro y músico de la iglesia colegiata de Santa María de la ciudad de Viana, en Navarra. Este códice fue regalado a la Madre María Luisa por Melchor Torres y Carrillo en 1633 por haber acogido a su hermana, tras la muerte de su padre, en la casa conventual $^{2117}$. Éste fue capitular de la misma colegiata que Galdámez. Seguramente este personaje guarde alguna clase de parentesco con Gómez Carrillo,

${ }^{2115}$ ASCCC. Libro 44. Cuentas del convento (1863-1900), s/f.

${ }^{2116}$ En Palencia, concretamente, adquiría gran protagonismo en la toma del hábito, la profesión solemne, la renovación de votos, la elección de abadesa, en la ceremonia de "Santo y alma", entre otras. VIRGILI BLANQUET, María Antonia y CABEZA RODRÍGUEZ, Antonio. Jornadas sobre el de las Órdenes Religiosas en Palencia. Palencia, 1989, pp. 221-223.

2117 GONZÁLEZ BARRIONUEVO, Herminio. El códice polifónico de Santa Clara la Real de Carrión de los Condes. Antología de obras para la misa y el oficio. $1^{\text {a }}$ Edición: 1633. Edición facsímil de Editorial Alpuerto, Madrid, 2004, pp. 25-28. 
marido de Doña Aldonza Manrique, la condesa enterrada en este convento.También se conservan algunos cantorales procedentes del convento de Santa Isabel de Carrión que fueron trasladados al convento con la Desamortización, trayendo todo su archivo. Destaca uno realizado por Fr. Pedro Gutiérrez dedicado a Doña Ana Pimentel en $1698^{2118}$. Incluso existían varios libros de villancicos, cuyo canto fue prohibido a partir de 1683 por Fray Marcos Zarzosa, comisario general de la Orden franciscana, dada la relajación de costumbres “...que se venía dando en los últimos tiempos...”, permitiendo tan sólo el canto gregoriano y las letanías de Nuestra Señora $^{2119}$.

Con motivo de su reciente restauración, destacaremos dos cantorales expuestos en el museo conventual desde el 13 de julio hasta el 1 de septiembre de 2012, enmarcándose dentro de la celebración del vigésimo quinto aniversario de su apertura. El más antiguo de ellos, que se ha utilizado hasta los últimos años, es un libro de música gregoriana que data de 1512. Procedente de la localidad italiana de Turín, no conserva las páginas iniciales ni finales, lo cual, no obstante, no resta su interés. La otra obra, más tardía, remonta su ejecución a 1616. Se trata de un Vesperal de Santos por la Madre Luisa de la Ascensión ${ }^{2120}$.

\section{Las celdas}

Como vimos, la fisonomía de las celdas quedó conformada a mediados del siglo XVI. No obstante se produciría un cambio fundamental en las mismas, a consecuencia de una orden emitida en 1683 por Fray Marcos Zarzosa, desde el convento de San Francisco de Medina de Rioseco. Conforme a la misma todos los conventos de la comunidad debían disponer celosías en sus celdas bajo pena de ser tabicadas las ventanas que no las tuvieran ${ }^{2121}$. Merece mención de este siglo un lienzo de la Inmaculada firmada por Clemens Sánchez que se dispuso en la celda de $M^{\mathrm{a}}$ Luisa en el año $1647^{2122}$.

\footnotetext{
${ }^{2118}$ ANDRÉS GONZÁLEZ. Patricia. Los monasterios...Op.cit, pp. 183-185.

${ }^{2119}$ ASCC. Legajo XI, nº57.

${ }^{2120}$ En prensa: Revista Ecclesia, 11 de julio de 2012 o El Norte de Castilla, 12 de julio de 2012.

2121 Ibídem.

${ }^{2122}$ ANDRÉS GONZÁLEZ. Patricia. Op.cit, pág. 60.
} 


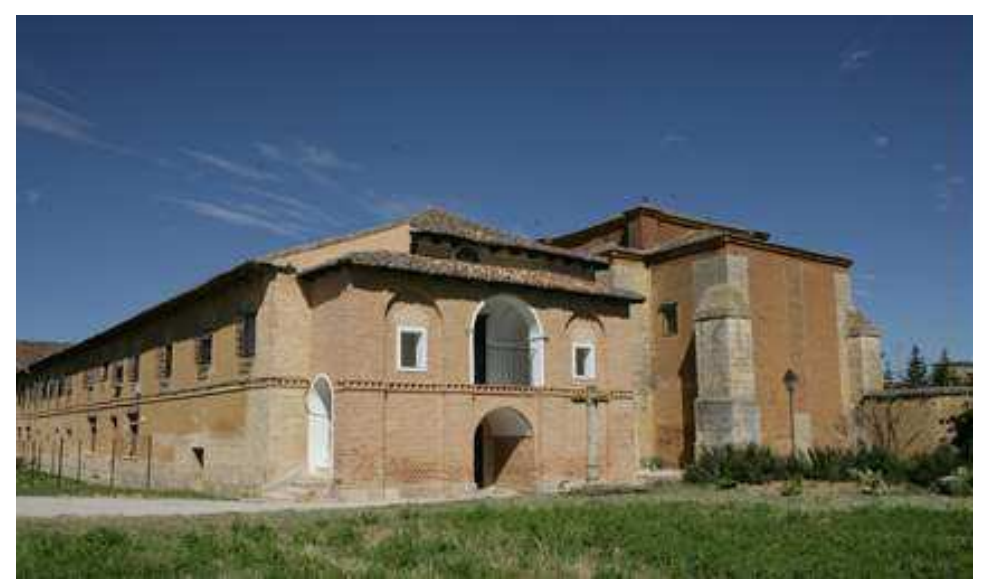

\section{Celdas reformadas en el siglo XVIII y la cabecera del templo de Santa Clara al fondo.}

El convento sufrió un incendio hacia 1675, pues en esa fecha se reconstruyen las partes deterioradas afectadas por el mismo, invirtiendo una suma de siete mil reales $^{2123}$. A pesar de este pésimo incidente, el número de intervenciones comentadas hasta ahora es signo indicativo de la prosperidad que atravesaba el convento. Redundan en esta afirmación los datos concernientes a una carta de pago de 1681 sobre la refacción de las cuatro especies -vino, vinagre, aceite y carnes consumidas dicho año, donde se registra un total de 49 religiosas, confesor, sacristán, siete novicias y dos demandaderas, cifra elevadísima y solamente comparable a la época fundacional del cenobio $^{2124}$. Dicho año, en las cuentas del convento figura un cargo por la ejecución de una custodia del Santísimo Cristo, cuyo paradero es desconocido pero que se conservaba al menos hasta $1907^{2125}$. Fue ejecutada a partir de la fundición de tres alhajas de la sacristía gracias además a la aportación significativa de diversos particulares. El viril era de oro y el resto de plata $\operatorname{dorada}^{2126}$.

\footnotetext{
${ }^{2123}$ ASCC. Libro 8. Cuentas del convento (1675-1704), s/f.

${ }^{2124}$ La refacción consistía en una restitución que se hacía al estado eclesiástico de la porción con que había contribuido a los derechos reales, de los cuales estaba exento. AHPP. Carr.Prot 5004, Diego García de la Llana (1679-1685), s/f.

${ }^{2125}$ MARTíN MíNGUEZ, Bernardino. Catálogo...op.cit, pág. 44.

${ }^{2126}$ ASCC. Libro 8. Cuentas del convento (1675-1704), fol 175 y 199.
} 


\section{EL SIGLO XVIII}

Tras un agitado siglo XVII, la centuria posterior transcurrirá sin hechos destacados para el convento mientras se mantiene viva la memoria de la Monja de Carrión. A partir de 1620 en que quedaron finalizadas las obras del templo, todos los esfuerzos fueron dedicados a dotar este espacio del ornato adecuado a través del retablo mayor, la azulejería del coro, los lienzos del altar, las esculturas de Gregorio Fernández o la decoración pictórica de las pechinas de la cúpula. No obstante, en el siglo XVIII se completa con otras obras artísticas de gran relevancia que señalamos a continuación.

En los brazos del crucero del templo se ubican dos obras ejecutadas en los años veinte del siglo XVII, como es el caso del Crucificado de Gregorio Fernández y la imagen de vestir de Virgen de la Consolación, ya estudiadas con anterioridad. No obstante, los retablos que acogen ambas obras debemos adscribirlos a esta centuria. Son obras estructuradas en un solo cuerpo cuya gran sencillez contrasta con una ornamentación abigarrada en extremo, siguiendo una tipología churrigueresca.

\section{Retablo del Crucificado}

En el lado del Evangelio, un amplio banco con tarjetones deja paso en los extremos a dos plintos que se retranquean mostrando en sus frentes un par de testas de querubines que se entrelazan con los motivos vegetales circundantes. Sobre estas plataformas se despliegan dos columnas pseudocorintias de fuste liso dorado en cuyo contorno se adosan en altorrelieve toda una serie de guirnaldas, angelillos y otros motivos caprichosos en tonos rojizos y azules, creando un vivo contraste con el dorado de ambos soportes. Entre ellos, se sitúa el Cristo doliente de Gregorio Fernández analizado previamente. Aparece rodeado de un gran corazón flamígero de tonos dorados y decorado con piedras preciosas fingidas. Su fuente de inspiración podría encontrarse en un grabado de los hermanos Wierix que habría sido realizado contemporáneamente a nuestro crucificado ${ }^{2127}$. El fondo de este cuerpo principal lo

${ }^{2127}$ URREA FERNÁNDEZ, Jesús. “Cristo crucificado...” Op.cit, pág. 338. 
constituye una pintura de escasa calidad, donde se ha representado escuetamente una ciudad amurallada cualquiera sobre la cual se alzan el sol y la luna flanqueando a Cristo, como figura que domina sobre todas las cosas, incluso las celestes. Al igual que sucede en el banco, la cornisa superpuesta se retranquea en los extremos, otorgando dinamismo al conjunto. Deja paso así a un remate semicircular sobre el que se adosa una pareja de estípites que cobijan una hornacina en cuyo perímetro se ha dispuesto una corona vegetal interrumpida por querubines. En ella se ubica la imagen de San Francisco de Asís cuya datación, en la segunda mitad del siglo XVIII también correspondería al santo del remate en el altar correlativo.

Fue nombrado altar privilegiado en 1749 por decreto del papa Benedicto XIV ${ }^{2128}$.

\section{Retablo de Nuestra Señora de la Consolación}

Por su parte, el retablo de la Consolación, presenta igualmente una estructura muy sencilla, a base de banco, cuerpo muy desarrollado y remate semicircular. La simplicidad arquitectónica del retablo contrasta con el dorado y la abigarrada decoración de sus superficies que lo cubren todo. El banco esta formado por cuatro cuadrantes con bajorrelieves, los de los extremos representan jarrones con flores y los centrales, cabezas de angelillos que flanquean una portezuela que daría acceso al sagrario. Entre estos cuatro elementos se disponen los plintos de las cuatro columnas que conforman el retablo, dos a los extremos, de grandes dimensiones, y dos de menor tamaño, flanqueando la hornacina central. Los cuatro soportes están dotados de una profusa ornamentación donde guirnaldas de tipos variados se entremezclan con un sinfín de testas de querubines. Sobre la escultura de la Virgen, entre dos pilastras, se ha tallado un espejo ovalado con las llagas de San Francisco acompañado de un repertorio de motivos vegetales y hojarasca. Por encima, se dispone un bambalinón de telón con pasamanería de borlas que, cerrando este cuerpo permite separarlo del ático, al mismo tiempo que aporta un toque efectista y teatral al conjunto.

${ }^{2128}$ ASCC. Legajo 1, nº56. 


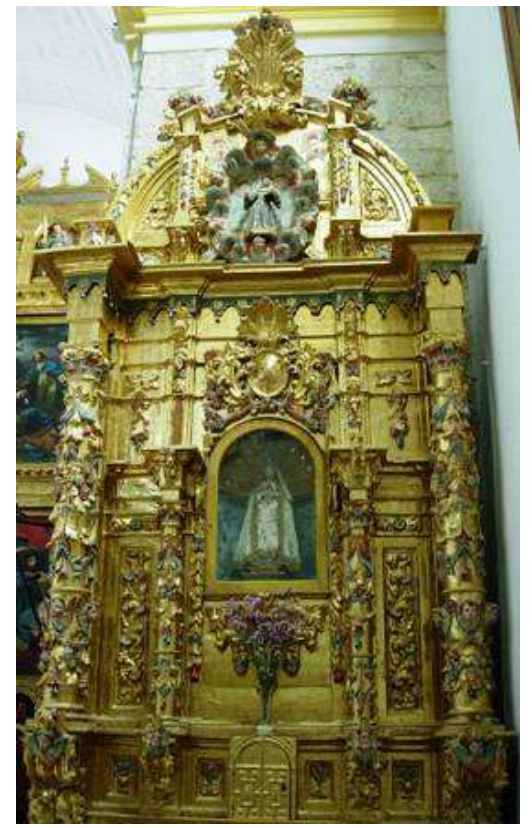

Detalle del ático. San Antonio de Padua $(45 \mathrm{~cm} \times 20 \mathrm{~cm})$.

\section{Retablo de Nuestra Señora de la Consolación (5,5 mtrsx2,5 mtrs).}

Igualmente del siglo XVIII es la pequeña escultura de San Antonio de Padua que cierra la composición. La imagen de este santo franciscano y la de San Francisco del retablo del Cristo de Gregorio Fernández, pueden adscribirse a la misma mano, anónima por el momento. Inserto en una orla celestial conformada por un coro de querubines y nebulosas, la imagen presenta, al igual que su compañera, multitud de orificios, fruto de la acción de los xilófagos. En 1726 Benedicto XIII concede a este altar el privilegio perpetuo de misa para todos los viernes del año por los religiosos de la orden ${ }^{2129}$.

\section{El órgano}

Situado en el lado del Evangelio dentro del coro bajo de la iglesia, se ubicaba un órgano más antiguo que el que se conserva hoy día, pues en 1645, José Martínez se encargaba de su aderezo ${ }^{2130}$. Según el Padre Barriuso, esta pieza musical había sido ejecutada poco antes por encargo de la Madre Luisa, ubicándose, al menos

${ }^{2129}$ GÓMEZ PÉREZ, Enrique. El real...Op.cit, pág. 120, a su vez de ASCCC. (1726-1749) Legajo 1, $\mathrm{n}^{\circ} 56$.

${ }^{2130}$ ASCC. Libro de cuentas 1633-1655, fol 248v. 
hasta los años ochenta en la ermita de la huerta, en un gran estado de abandono ${ }^{2131}$.

El órgano que hoy existe es neoclásico, del siglo XVIII. Conservado en óptimo estado, su estilo musical es barroco ${ }^{2132}$. La caja de cinco metros de altura presenta una sencilla estructura en dos cuerpos, estando el inferior adornado por casetones de jaspes en tonos pastel y el superior por los tubos dispuestos horizontal y verticalmente y una pequeña cornisa con florones en el remate. Se trata de un encargo realizado al maestro organero palentino Don Gaspar de Salazar el 8 de septiembre de 1734 y finalizado un año después, de ahí que en las compras del convento figure la adquisición del nuevo instrumento ${ }^{2133}$.

Varios decenios después, fue Juan Francisco de Toledo quien se ocupó de su reparación y puesta a punto, entre los años 1765 y $1767^{2134}$. No pudo ver finalizado este encargo, ni el del órgano de Villasirga del que se ocupaba simultáneamente, pues murió poco después, designando sus albaceas testamentarios a su discípulo, Tadeo Ortega, para que las llevase a cabo desde $1768^{2135}$. Éste iba a contraer matrimonio con la hija de uno de los albaceas, el organista de la iglesia de San Andrés de Carrión, de ahí la lógica elección del pupilo de Francisco de Toledo paraqué continuase la obra inconclusa del maestro ${ }^{2136}$. Este organero, activo desde el último cuarto del siglo XVIII en Palencia, construye además el órgano nuevo para el convento de clarisas de la capital ${ }^{2137}$.

\footnotetext{
${ }^{2131}$ GARCÍA BARRIUSO, Patrocinio. Op.cit, pp. 84 y 85.

${ }^{2132}$ VV.AA. Inventario de los órganos de la Provincia de Palencia. Cálamo. Palencia, 2008, pág. 149.

${ }^{2133}$ La escritura y condiciones del mismo en AHPP. Carr.Prot 4730, fol 119 y ss.

${ }^{2134}$ VV.AA. Inventario de los...Op.cit, pp. 148-152. También son obras suyas los órganos palentinos de la iglesia de la Asunción de Villasarracino, de 1761, de San Miguel de Piña de Campos y San Andrés de Carrión, ambos de 1766, el de la Asunción de Lantadilla, de 1767. Ibídem, pp. 154, 297, 524, 424-426.

${ }^{2135}$ Juan Francisco de Toledo fallece el 20 de enero de 1768, sepultándose junto a su mujer en la iglesia parroquial de San Andrés de Carrión. FRANCIA LORENZO, Santiago. Por tierras...Op.cit, pp. 152-154, a su vez de ADP. Carr. San Andrés. Libro 24 de defunciones, 1742-1774.

${ }^{2136}$ VV.AA. Inventario de los...Op.cit, pág. 152, a su vez de ASCCC. Libro de fábrica, 156-77. Para conocer más datos sobre el maestro organero véase CASTRO MATÍA, Santiago de y BIROUSTE, Daniel. La organería en Tierra de Campos. La obra de Tadeo Ortega. Diputación Provincial de Palencia, 1979.

2137 VIRGILI BLANQUET, María Antonia y CABEZA RODRÍGUEZ, Antonio. "La música...Op.cit, pág. 227.
} 


\section{El antiguo sagrario del retablo mayor}

En 1777 se extraen 300 ducados del arca del convento para realizar el tabernáculo y su dorado ${ }^{2138}$. Esta pieza remplazará, como apuntamos, al sagrario del siglo XVII que fue trasladado a la sacristía del convento de San Zoilo, donde se encuentra desde entonces. Este tabernáculo barroco será sustituido a su vez en el año 2002 por el nuevo sagrario que desde entonces se sitúa sobre el banco del retablo.

Desde entonces, nuestro tabernáculo se dispondrá en una de las salas del museo de clarisas, junto a la colección de belenes y acogiendo una Natividad. Cuando se hallaba en el retablo, era la imagen de Santa Clara la que se disponía en su interior. Se trata de un templete dorado de base irregular y caprichosa, abierto por sus cuatro lados sobre el que se yergue un sinfín de columnas estriadas con amplio plinto decorado a base de tarjetones. Los capiteles corintios dejan paso a sendos cimacios sobre los que se asientan frontones de formas inverosímiles que se rompen para dejar paso a los arcos de medio punto que cobijan bustos en altorrelieve de querubines. Estas figurillas aladas parecen estar sosteniendo la banda de elementos vegetales que enmarca el acceso principal de medio punto.

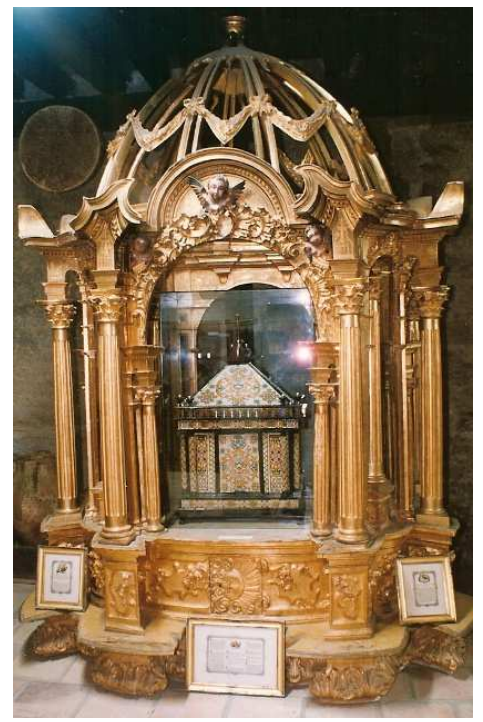

Sagrario del retablo mayor, hoy en el museo de Santa Clara.

(3,2 metrsx 2,35metrs).

\footnotetext{
${ }^{2138}$ GÓMEZ PÉREZ, Enrique. El real...Op.cit, pág. 132, a su vez de ASCC. Legajo XIV. Papeles dispersos. 1780.
} 
Remata la composición una cúpula calada, formada tan sólo por su nervatura doble y una serie de guirnaldas en su parte central recorriendo todo su contorno. El único testimonio de este tabernáculo presente en el actual retablo lo constituye la minúscula figura de la $\mathrm{Fe}$ que situada entre elementos avolutados a los pies de la Virgen, coronaba el mencionado baldaquino.

\section{El retablo del coro bajo}

Gracias a Enrique Gómez Pérez, quien ha tenido el privilegio de acceder a la clausura en varias ocasiones, conocemos la existencia de un retablo neoclásico realizado hacia 1786 en el que se disponían hasta principios del siglo XX tres esculturas de vestir sustituidas por tres imágenes modernas de la Inmaculada, San Francisco y San José con el niño. Una de ellas, de mediana calidad representa una Santa Inés del siglo XVII, pero las otras dos están atribuidas a dos grandes escultores del siglo XVIII. En primer lugar, destaca un San Antonio de Padua, obra atribuible Tomás de Sierra, aunque de menor calidad que el resto de sus obras ${ }^{2139}$. Realizada hacia 1720, guarda semejanzas estilísticas con la imagen homónima de talla completa del retablo de Bobadilla de Rioseco. Conserva sus vestiduras originales y sobre la mano que sujeta el libro se dispone, como sucede tradicionalmente, un Niño Jesús de bulto que ha sido vestido, sobre cuya rodilla apoya el peso del mundo.

La otra pieza es un San José articulado del taller de Juan de Ávila. Está acompañado de un Niño Jesús que no se correspondería con el mismo autor, sino que se trataría de una pieza procedente de una peana, como así lo testimonian las oquedades de sus pies. Al parecer la figura de San José fue serrada en un momento determinado, sustituyéndose el bastidor inicial de la parte inferior por otro, con calzado y faldilla tallados. Así lo evidencia la diversa policromía de esta parte con la del tronco superior y los brazos movibles.

Hoy día estas imágenes se encuentran en la tribuna de la Epístola del templo, en lo que originalmente fue el oratorio de la madre Luisa ${ }^{2140}$.

${ }^{2139}$ Sobre Tomás de Sierra, remítase al capítulo dedicado a las biografías de los escultores.

${ }^{2140}$ GÓMEZ PÉREZ, Enrique. El real...Op.cit, pp. 132-133. 


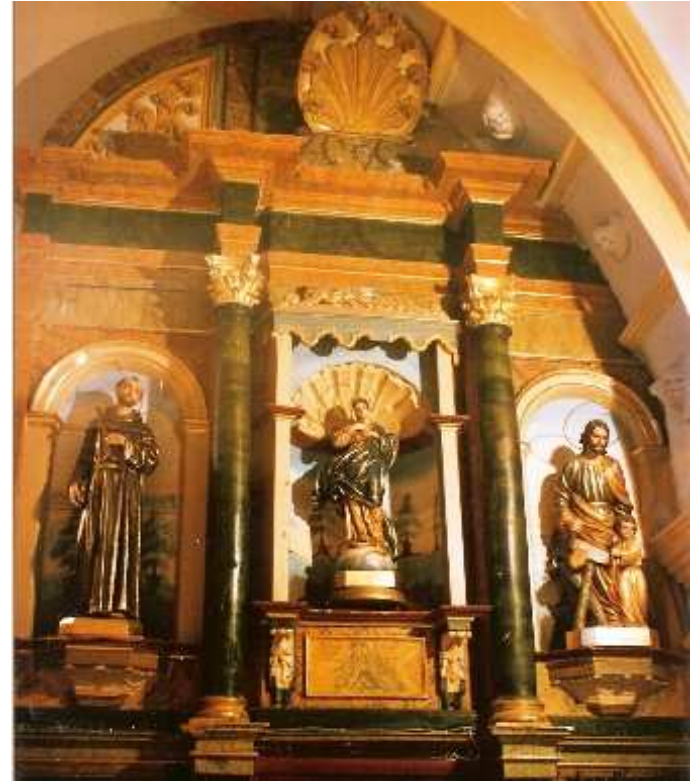

Retablo de la Inmaculada en el coro bajo. (2,9mtrsx2,35mtrs).

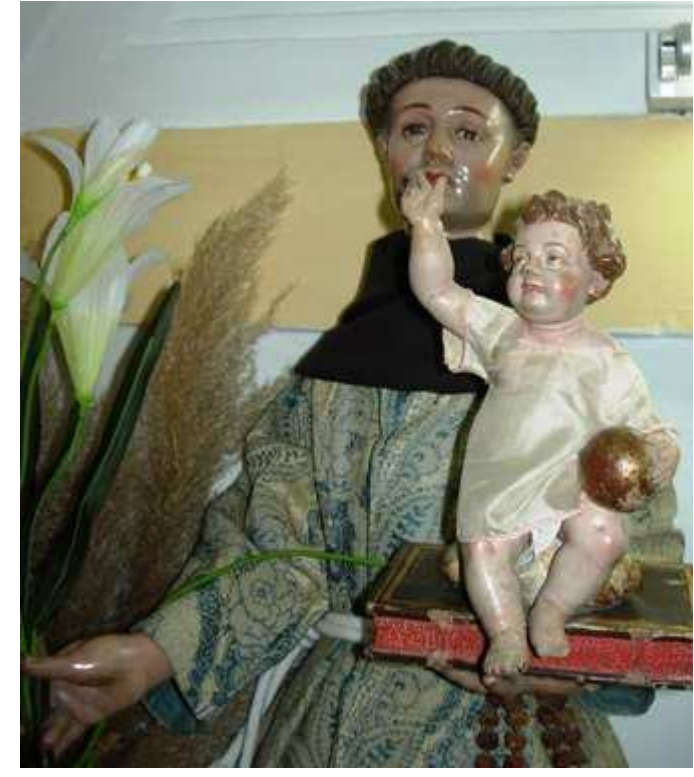

Imagen de vestir de San Antonio de Padua que se hallaba en el retablo de la Inmaculada.

\section{Mejoras de carácter general}

Es completamente lógico que, tras dos siglos de renovación íntegra de las distintas estancias del cenobio, no se registren obras de entidad a lo largo de esta centuria. Conviene, sin embargo, señalar, las intervenciones de mejora que fueron llevadas a cabo a partir de la segunda mitad de siglo.

Así, entre 1756 y 1758 se construye la celda del vicario, y tan sólo dos años después, refectorio de los padres. Entre 1762 y 1765 se reedifica la ermita de la madre Luisa, la ubicada en la huerta. Por otro lado se reforma tanto el coro alto, donde se colocan puertas y ventanales, como el coro bajo, que se aboveda, además de dotarle de nuevo retablo y entablado nuevo para la sillería. Dos años después, entre 1765 y 1767, se emprenden nuevas obras, pues se desmonta el claustro y se rehacen las escaleras de las celdas. y el pasillo entre éstas se amplía dotándole de un 
testero con balconada externa que mira a la huerta ${ }^{2141}$. Una inscripción ubicada en uno de los arcos de la escalera confirma estas intervenciones: "HÍZOSE ESTA OBRA EL AÑO DE 1767 SIENDO ABADESA M S $S^{A} D^{A} R^{A} B E L A S C O^{2142, ” . ~}$

Entre 1776 y 1778 las clarisas obtienen permiso del visitador provincial para sacar de su archivo trece mil reales, de los cuales cuatro mil serían destinados para finalizar la obra comenzada, reservando nueve mil para la colgadura de la iglesia. Por último se extraen ocho mil reales para hacer dos celdas nuevas ${ }^{2143}$. Por último en 1780, las monjas solicitan permiso para extraer del arca 3500 reales destinados a la ejecución del noviciado ${ }^{2144}$.

\section{EL DEVENIR A PARTIR DEL SIGLO XIX}

La centuria decimonónica será muy agitada para la casa clarisa, pues en 1808 será ocupada por los franceses, pero solamente en la parte de la hospedería, por lo que el resto del monasterio no sufrió daños ${ }^{2145}$. Durante este período, existió, al parecer, un acuerdo entre las monjas y los soldados de Napoleón que se denominó "Pacto del Chocolate", por el cual las religiosas se comprometían a servirles chocolate a la caída de la tarde a cambio del respeto de la clausura ${ }^{2146}$.

El respeto mostrado por las huestes francesas no es comparable al lamentable comportamiento adoptado por los soldados españoles. La falta de armamento entre los soldados fue de tal calibre que se llegaron a tomar medidas extremas, como la incautación de la plata labrada del convento por tropas armadas apostadas a la puerta

\footnotetext{
${ }^{2141}$ ASCC. Libro 15. Cuentas del convento (1759-1777) s/f.

2142 GÓMEZ PÉREZ, Enrique. El real...Op.cit, pág. 129.

${ }^{2143}$ Cartas con fecha 19 de junio de 1776 y 15 de junio de 1777,7 de agosto de 1777,8 de junio de 1778, 27 de enero de 1778 ASCC. Legajo XIV. Autorizaciones para sacar dinero del arca. 17701789.

${ }^{2144}$ ASCC. Legajo XIV. Papeles dispersos. 1780.

${ }^{2145}$ CLARISA DE CARRIÓN DE LOS CONDES. Op. cit. pp. 12-13. Se desconoce hasta qué punto los hechos relatados por la monja respecto a la providencia divina que velaba sobre el convento son totalmente ciertos y no están exagerados por la ferviente religiosidad de la declarante.

${ }^{2146}$ En el museo del convento se conservan diferentes utensilios de cocina en los que se servía el dulce GÓMEZ PÉREZ, Enrique. El Museo... Op.cit, pp. 11 y 35.
} 
del mismo ${ }^{2147}$. Situación semejante tuvo lugar con la Primera Guerra Carlista, momento en que la Compañía de Caballería de Palencia, en la figura de su brigadier insta a los patriotas que apoyan a Isabel II a que les auxilien "voluntariamente" a través de sus donaciones ${ }^{2148}$. En el coro, dormitorios y claustros se realizan obras de mejora entre 1832 y 1835, lo cual indica su permanencia aún en el siglo XIX.

Según decreto desamortizador de 8 de marzo de 1836, las clarisas de Carrión incorporarán la comunidad de religiosas del convento de San Miguel de la orden de Santa Isabel. Fue el único convento de monjas de Palencia que fue suprimido, pues la Junta Diocesana respetó el resto, aunque sí se incautaron sus propiedades ${ }^{2149}$.

De acuerdo a la ley de Regulares de 29 de junio de 1837 por la que se suprimían los conventos de monjas, se permitía la permanencia en los mismos, sobreviviendo a través de las mínimas aportaciones estatales ${ }^{2150}$. Llegado el año 1843, la casa clarisa continuaba asistiendo a las isabelas de Carrión con comida, botica, y criada, recibiendo como compensación las pensiones de dichas religiosas $^{2151}$.

Con el fin de evitar el cierre inmediato de su convento, en 1854 fueron obligadas a dedicar una parte de su tiempo a la enseñanza femenina desde las gradas

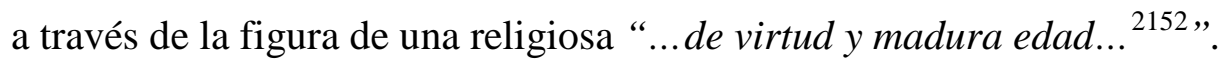

Por decreto de 17 de octubre de 1868 se ordenó reducir los conventos de monjas a la mitad en cada provincia. Todas las clarisas de Carrión, excepto la abadesa que permaneció en el monasterio, serían enviadas a Astudillo, al igual que las hermanas de Aguilar. Por misiva del Gobernador Provincial, la abadesa queda informada de que el día 9 de diciembre tendrán dispuestos diversos carruajes a la puerta del convento para proceder al traslado de las monjas ${ }^{2153}$. Al parecer, dicho

${ }^{2147}$ GÓMEZ PÉREZ, Enrique. El real...Op.cit, pp. 138-139. Carta de 11 diciembre de 1811. ASCCC. Legajo XIV. Correspondencia y recibos (1763-1933).

${ }^{2148}$ Carta con fecha 23 de enero de 1835. ASCC. Legajo XIV. Correspondencia y recibos (17631933)

${ }^{2149}$ REVUELTA GONZÁLEZ, Manuel. Op.cit, pp. 75 y 76.

${ }^{2150}$ GÓMEZ PÉREZ, Enrique. El real...Op.cit, pág. 149.

${ }^{2151}$ ASCC. Correspondencia. (1843-1869)Legajo XI, nº59 s/f.

${ }^{2152}$ GÓMEZ PÉREZ, Enrique. El real...Op.cit, pág. 150. ASCC. Correspondencia. (1843-1869) Legajo XI, n ${ }^{\circ} 59$ s/f.

${ }^{2153}$ Carta emitida el 8 de diciembre de 1868. ASCC. Legajo XIV. Papeles referentes a la salida de las monjas del convento. 
convento ni reunía las condiciones de salubridad mínimas ni poseía celdas suficientes para todas las religiosas, por lo que el ayuntamiento gestiona el regreso de las clarisas junto con otras procedentes de conventos suprimidos a la villa ${ }^{2154}$.

El 25 de mayo de 1870 el ayuntamiento realiza una comunicación sobre el regreso de las monjas el día anterior, relatando la cálida acogida del vecindario que salió a recibirlas a las afueras de la villa “...haciendo que recorriesen los carruages que las conducían las calles más principales de la población, antes de ingresar en su tan suspirada morada... ${ }^{2155}$ ". De nuevo en Carrión, en agosto de dicho año dieron hospedaje a una comunidad palentina procedente de San Salvador del Moral, cuyas religiosas permanecerían en la casa clarisa durante dos años ${ }^{2156}$.

El siglo XIX se cierra con la llegada desde Roma en 1897 de las reliquias de San Francisco y Santa Clara, que serán veneradas por el pueblo carrionés en sus respectivas festividades. Durante el tiempo restante permanecen en clausura, ubicadas en un relicario en el muro del coro bajo ${ }^{2157}$.

Sin grandes acontecimientos para el convento se desarrollará el siglo venidero. Hay que lamentar, no obstante, algunas ventas de objetos artísticos, en la mayoría de los casos a precios bajos, motivadas por la escasez de medios. Esta crítica situación económica se vincula directamente a la progresiva disminución del número de internas desde principios de la centuria, en que la casa contaba con 22 hermanas a las 16 de los años treinta ${ }^{2158}$.

Como hecho destacable del siglo XX, se produce en 1960 la adhesión de un grupo de monjas procedentes del monasterio del Sagrado Corazón de Jesús de Cantalapiedra, Salamanca, incrementándose en veintidós el número de clarisas. Es este mismo año cuando se colocan las rejas en las ventanas exteriores de la fachada de entrada al convento y se amplía significativamente el espacio dedicado a museo

\footnotetext{
${ }^{2154}$ AMCC. Libro 8, Sesiones municipales (1868-1871), Sesión de 13 de diciembre de 1868. fol 26.

${ }^{2155}$ Información adjunta a las actas a posteriori mediante grapa AMC. Libro 8, Sesiones municipales (1868-1871), s/f.

${ }^{2156}$ Se ordena el traslado de las mismas en AMCC. Libro 8, Sesiones municipales (1868-1871), Sesión de 14 de agosto de 1870, s/f.

${ }^{2157}$ GÓMEZ PÉREZ, Enrique. El real...Op.cit, pág. 155. La llegada de las reliquias queda confirmada por documento en ASCC. 1897. Legajo XI, nº61.

${ }^{2158}$ Ibídem, pp. 164-165.
} 
Al finalizar la centuria, en 1999, se lleva a cabo una restauración y reestructuración del conjunto, consistente en la colocación de una cámara perimetral a los muros para la ventilación y una limpieza de las fachadas. El año 2000 se inauguró con un saneamiento de los pavimentos del templo y consiguiente soterramiento la calefacción, razón por la cual se guardaron las esculturas y pinturas del retablo mayor hasta el final de las obras ${ }^{2159}$. A mediados del año 2012, gracias al refuerzo proporcionado por la llegada de cinco monjas procedentes del monasterio mexicano de Nuestra Señora del Refugio de San Diego, en Texcoco, el número de internas de la casa clarisa ha alcanzado la docena. De este modo, se garantiza la permanencia de la comunidad clarisa carrionesa ${ }^{2160}$.

\section{EL MUSEO: OBRAS ARTÍSTICAS}

La iniciativa de abrir un museo en el convento surgió en 1987, año desde el cual permanece abierto al público. Para ello se escogió uno de los cinco locutorios del convento, una sala que estaba dividida por siete arcos de medio punto. De éstos, decidieron derribarse dos, de los cuáles tan sólo se conservan sus arranques. Unos años más tarde, concretamente en 1993, decidió ampliarse con una nueva sala para poder albergar un mayor número de obras. Por otra parte, en 2002, se incorporaron nuevas vitrinas para exponer entre otras obras, una serie de Belenes del Mundo. Las piezas que se exponen, proceden, además del propio convento, de los desaparecidos de San Francisco y Santa Isabel, además de algunas donaciones particulares ${ }^{2161}$.

En el primer ámbito se encuentran piezas de tipo religioso tanto escultóricas como pictóricas relacionadas con la Orden clarisa, además de obras de la época de fundación de la casa conventual. No podemos hacer mención a todas ellas, analizándose a continuación las más interesantes. Seguiremos para ellos un orden

\footnotetext{
${ }^{2159}$ VV.AA. Arquimilenios. Arquitectura entre dos milenios (1999-2000). Junta de Castilla y León. Valladolid, 2000, pp. 67-68.

${ }^{2160}$ Diario Palentino. Jueves, 28 de junio de 2012.

${ }^{2161}$ Dedica un extenso apartado al análisis iconográfico de las obras artísticas de los monasterios palentinos de clarisas entre los que se encuentra el de Santa Clara de Carrión. ANDRÉS GONZÁLEZ, Patricia. Los monasterios...Op.cit, pp. 103-164 y GÓMEZ PÉREZ, Enrique. El museo...Op.cit, pp. 15-86.
} 
temático de las mismas con el fin de ofrecer una visión clara de lo que aquí se expone.

\section{Obras de época fundacional}

Como obras del siglo XIII correspondientes a la época de fundación del convento, se conserva una imagen gótica de la Virgen en madera policromada, de hacia 1250 que podría identificarse con la imagen que desde Santa María del Páramo trasladaron las monjas damianitas. Era una talla de cuerpo entero, que fue usada como imagen de vestir hasta el 2002. Ese año se la despojó de su traje de abadesa del siglo XVIII y se pudo comprobar su antigüedad además del deterioro de la madera.

Junto a esta talla se conservan varios fragmentos de artesonados de las mismas fechas, que aparecieron repartidos por el convento y que formarían parte del palacio de doña Mencía López de Haro, el cual había donado la benefactora del convento a las monjas venidas de Santa María del Páramo para que se asentaran en Carrión. Así lo prueba la heráldica representada en las tablas que hacen referencia a la dicha Mencía:

-el castillo: Al ser hija de la infanta Urraca, se hace referencia al reino de Castilla

-el león: Representa al reino de León, pues era nieta de Alfonso IX -el lobo: Se identifica con la familia de los Haro, pues su padre era don Lope Díaz de Haro. La iconografía correcta de este linaje llevaría el lobo cebado de un carnero, pero lo entendemos igualmente.

Se conservan otros restos de artesonado de fecha más tardía, procedentes de la sala capitular y la biblioteca. Presentan una viva policromía con decoración de ataurique, flores de lis y motivos geométricos que acompañan a escudos de los Lara -dos calderas de oro fajadas de gules-, Zúñiga -banda de sable y cadena de gules brochante- y Manrique, que como condes de Castañeda y Marqueses de Aguilar, portan un escudo cuartelado de castillos y águilas con bordura de nueve armiños. Todos estos blasones pertenecen a los protectores del convento a lo largo del siglo 
$\mathrm{XV}$, los condes de Osorno ${ }^{2162}$.El resto de obras artísticas repartidas a lo largo del museo, todas ellas de carácter religioso, las hemos agrupado por núcleos temáticos para seguir un orden lógico.

\section{Imágenes de Santa Clara y de clarisas destacadas}

Se conservan múltiples representaciones de Santa Clara en el monasterio, por la obvia razón de ser la fundadora de la Orden que lleva su nombre.

Del siglo XVII es la pintura de la sala baja donde la fundadora sostiene el ciborio sobre un paño blanco delante de un fondo donde se mezclan arquitectura y paisaje. Parece ser copia de una obra de Scipione Pulzone. En una vitrina del museo se conserva una imagen de vestir de la Santa con relicario en el pecho, fechada hacia 1600. También del siglo XVII, en concreto, del primer cuarto es una pintura de escuela toledana en la que la Santa sostiene el ostensorio en relación al episodio en el cual la Santa evita el asalto del convento mostrando dicho objeto ${ }^{2163}$. Viste el hábito pardo con velo negro, de ahí que a las clarisas se las denomine "monjas de velo prieto". La imagen, monumental, de medio cuerpo, se destaca sobre un fondo neutro. El artista ha querido mostrar a una Santa Clara joven, de rostro dulce y facciones delicadas que dirige su melancólica mirada hacia la Sagrada Forma. La piel blanquecina de su rostro contrasta con sus labios rosáceos, que permanecen cerrados en actitud de sumisión.

Además de la fundadora, Santa Clara, entre las clarisas que alcanzaron la santidad, destacaron Santa Catalina de Bolonia y Santa Rosa de Viterbo. De ésta última, se conserva un lienzo del siglo XVII donde la santa aparece representada con el hábito de franciscana, sin toca, con corona de flores, sosteniendo al Niño Jesús, ambos llevando un ramo de flores ya que la tradición cuenta que los mendrugos de pan de su mesa se transformaban en rosas.

${ }^{2162}$ GÓMEZ PÉREZ, Enrique. El Monasterio...Op.cit, pág. 25.

${ }^{2163}$ Sobre pintura toledana del siglo XVII, consúltense ANGULO IÑIGUEZ, Diego y PÉREZ SÁNCHEZ, Alfonso E. Historia de la pintura española. Escuela toledana de la primera mitad del siglo XVII. Vol 1 y 2. Instituto Diego Velázquez. Madrid, 1972, REVENGA DOMINGUEZ, Paula. Aproximación a la pintura toledana de la segunda mitad del siglo XVII. Caja de Ahorros. Toledo, 1988. 


\section{Imágenes de San Francisco}

San Francisco aparece representado en la clausura en numerosas ocasiones, por los lazos establecidos entre la orden que lleva su nombre y la de las clarisas. Destacan entre ellas dos pinturas, una ubicada en el locutorio en la que el Santo se arrodilla ante el crucifijo, con el libro apoyado sobre un cráneo imitando la iconografía de San Jerónimo; la segunda, en la sacristía, de medio cuerpo, igualmente con la calavera.

En el zaguán del convento se conserva la escena de la estigmatización o imprimación de las llagas, obra del siglo XVII, dentro de un tenebrismo naturalista en que San Francisco aparece arrodillado mirando al crucifijo, similar al que existe en la iglesia, en el brazo de la epístola del crucero. En este lienzo, Cristo aparece, a gran escala, como serafín, con seis alas, de acuerdo al episodio acaecido el día de la Exaltación de la Cruz de 1224. Se trata de una obra barroca en la que se observa el contraste cromático y el uso de la diagonal en la posición de la cruz, elementos propios de este período.

Dentro del museo, junto a unas basas de piedra aparecidas en 1987 en lo que era antiguo locutorio, se encuentra una imagen exenta de San Francisco del siglo XVI. (72cm). Esta escultura de pequeño formato podemos atribuirla a la escuela palentina, realizada hacia 1590. Representa al Santo invocando al cielo mientras muestra sus llagas. Conserva todavía su dorado y estofado originales, y muestra un San Francisco maduro, pero más joven de lo habitual, barbado y dotado de una espesa cabellera de bucles que entreabre su boca aportando una mayor fuerza comunicativa.

Todavía más interesantes son dos piezas de mayor tamaño que la anterior que, a pesar de sus diferencias estilísticas presentan algunos rasgos comunes. En ambas representaciones, San Francisco gira su cabeza hacia un lado entornando sus ojos hacia el cielo, mientras cruza sus brazos en el pecho para sostener la cruz. Por el resto, son dos tallas de diversa calidad. La de mejor ejecución, datable hacia $1600(57 \mathrm{~cm})$ presenta al Santo barbado y enjuto con una magnífica policromía en su hábito, pues conserva su estofado auténtico. Descalzo, se asienta sobre una amplia 
peana de base cuadrangular, igualmente policromada. Ésta y la imagen anterior deben corresponderse con las esculturas que al menos hasta 1980 se ubicaban en el claustro de la casa clarisa ${ }^{2164}$.

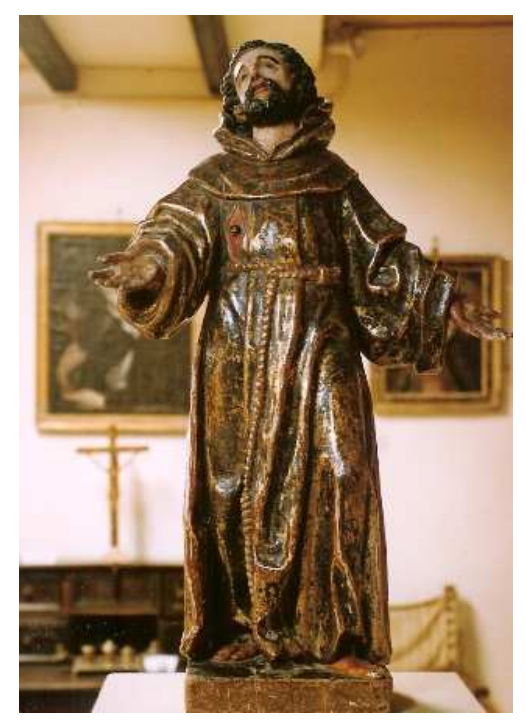

San Francisco de Asís.

$(72 \mathrm{~cm} \times 44 \mathrm{~cm})$. Hacia 1600.

Museo de Santa Clara.

La otra talla es un San Francisco del siglo XVIII. De tamaño mayor del natural, presenta un rostro imberbe de gran realismo en el que contrastan sus pómulos rosados con el tono grisáceo que se adivina en el contorno de su boca, en recuerdo de una barba anterior. Sus amplias vestiduras, en un monócromo marrón, han perdido parte de su policromía. Tan sólo una franja en tonos amarillos situada en la parte inferior y mangas del hábito, restan un poco de sobriedad a la pieza. Apoyado sobre una minúscula peana circular, va calzado con unas sencillas sandalias de cuero de acuerdo al precepto de pobreza de la orden terciaria. Esta otra imagen, sin embargo, procedería del aledaño convento de San Francisco, traída al museo con motivo del cierre del templo terciario con el fin de evitar que se extraviara $^{2165}$.

${ }^{2164}$ URREA, Jesús y MARTÍN GONZÁLEZ, Juan José. Inventario...2. Op.cit, pág. 60.

${ }^{2165}$ Ibídem, pág. 60. 


\section{Representaciones de Cristo}

Al taller de Luis de Morales podemos atribuir una tabla de "Ecce Homo" en la que Cristo aparece representado de busto, con vara y soga al cuello, muy similar a otras obras del mismo tema que el pintor ejecutó durante el tercer cuarto del siglo $\mathrm{XVI}^{2166}$. El artista pacense llegó a crear una iconografía particular de marcado patetismo acorde a la devoción popular del momento. La figura de Cristo se recorta sobre un fondo neutro, el torso de frente y la cabeza gira a un lado, el rostro enjuto y como atributos, la caña, la soga, luciendo en ocasiones, la corona y capa ${ }^{2167}$. Se atribuyen al pintor, aunque algunas se deban posiblemente al taller, casi una treintena de obras del mismo tema como la conservada en Nueva York, en la Hispanic Society of America o la tabla central del tríptico del Museo de Cádiz ${ }^{2168}$. De características formales similares a la nuestra, aunque mostrando todo el torso, es la tabla de la sacristía de la iglesia de San Andrés de Calahorra, en Logroño ${ }^{2169}$. Los objetos de dolor que acompañan al Cristo, unidos al ceño fruncido y la boca entreabierta de su rostro acentúan el carácter emotivo del lienzo, reforzando su fuerza comunicativa. Esta obra, antes de ser instalada en el museo, se ubicaba en la sala baja del convento $^{2170}$.

\section{Ecce Homo. Óleo sobre tabla}

$(31 \mathrm{~cm} \times 22,5 \mathrm{~cm})$. Seguidor de Luis de Morales. Museo de Santa Clara.

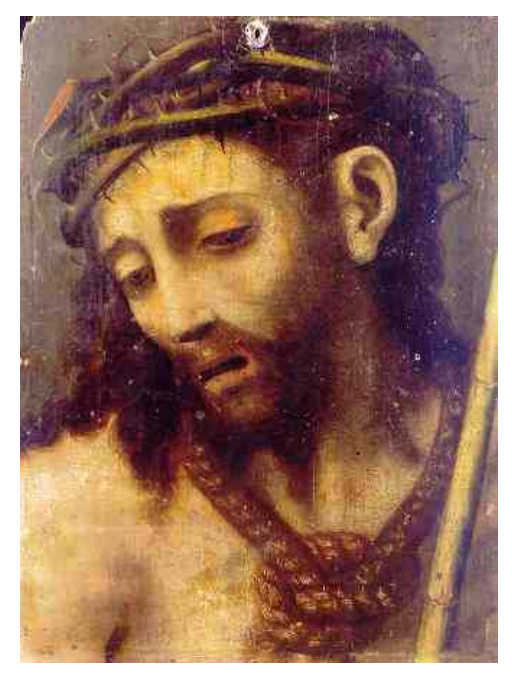

${ }^{2166}$ GÓMEZ PÉREZ, Enrique. El museo...Op.cit, pág. 29. Datos biográficos del artista siguiendo un orden cronológico en PÉREZ SÁNCHEZ, Alfonso Emilio. El retablo de Morales en Arroyo de la Luz. Salas de Exposiciones de la Dirección General de Bellas Artes. Madrid, 1974, pp. 10-11.

${ }^{2167}$ PIZARRO GÓMEZ, Javier. "El Ecce Homo de Luis de Morales del Museo de Bellas Artes del Museo de Chile" en Norba, n' 11. Badajoz, 1991, pp. 179-181.

${ }^{2168}$ BACKSBACKA, Ingjald. Luis de Morales. Helsinki, 1962, pp. 153 y ss. Sobre el pintor, GAYA NUÑO, Juan Antonio. Luis de Morales. Instituto Diego Velázquez. Madrid, 1961 y MARÍAS, Fernando. "Luis de Morales "El Divino" en Historia 16, n68. Madrid, 1992.

${ }^{2169}$ La restauración de esta obra, que condujo al estudio de la misma, dio como resultado la atribución a Luis de Morales. Guadalupe. CARRAMIÑANA PELLEJERO, "Proceso de restauración de una obra manierista de la iglesia de San Andrés de Calahorra" en Kalakorikos, nº, Calahorra, 2001, pp. 283-292

${ }^{2170}$ URREA FERNÁNDEZ, Jesús y MARTÍN GONZÁLEZ, Juan José. Inventario...2. Op.cit, pág. 60. 
En el museo se conserva también un tríptico de Ecce Homo datable hacia finales del siglo XVI, o según Urrea, de la siguiente centuria ${ }^{2171}$. Su marcado patetismo viene reforzado en este caso, por el contraste entre la sangre de su frente y sus ojos enrojecidos con el color blanquecino de la carne. Cristo, coronado de espinas aparece ataviado con un manto de un vívido rojo que se delinea sobre un fondo dorado sobre el que se delinea la figura, creando un marcado simbolismo de la Pasión. Las alas laterales de la pieza muestran una inscripción latina de un salmo en letras capitales doradas que se destacan sobre un fondo negro. Es una copia del original de Albert Bouts conservado en la Nacional Gallery de Londres ${ }^{2172}$. Esta obra, antes de su exposición, se ubicaba en uno de los frentes de la sillería del coro bajo del convento, como así lo muestra una fotografía tomada en los años cincuenta.

Merece mención el grabado del Cristo de las Claras de Palencia, realizado por Tomás Solares en 1818. En él aparece representada dicha imagen con la iconografía habitual, sobre un sepulcro de carey y bronce. En este caso se ha simplificado su representación, pues se ha omitido la reja que lo protege normalmente y en vez de dos almohadones, nuestro Cristo reposa tan sólo sobre uno. Las ovas que lo rodean representan la historia de la llegada de esta imagen a Palencia y los milagros de la misma y se acompañan de su respectiva leyenda explicativa.

En varias ocasiones Cristo, en vez de ser una figura exenta, centra la composición de una escena determinada. La Oración en el Huerto es un cobre flamenco del siglo XVII, que nos presenta la escena dentro de un bosque frondoso. Cristo aparece en un claro, a la derecha, mientras San Pedro, San Juan y Santiago aparecen dormidos en primer plano.

La escena homónima aparece en otra ocasión en el museo a través de un conjunto procedente de la ermita de la Madre Luisa. Es una obra que podemos fechar entre 1570 y 1590. El ángel, de pequeñas dimensiones, esta tallado

\footnotetext{
2171 Ibídem, pág. 62.

${ }^{2172}$ Acerca de las pinturas flamencas en tierras castellanas, SILVA MAROTO, M ${ }^{\mathrm{a}}$ Pilar. Pintura hispanoflamenca castellana: Burgos y Palencia. Obras en tabla y sarga. 3 vol. Junta de Castilla y León. Valladolid, 1990.
} 
enteramente y porta en sus manos un cáliz y una cruz. Arrodillado sobre una nube parece flotar en el aire mientras dirige su mirada a la figura del Señor. Es ésta una imagen de vestir con cabello postizo y carnación rosácea que alude a la sangre.

\section{Representaciones de la Virgen}

En lo que a escultura se refiere, dentro del museo se conservan dos interesantes tallas ejecutadas a finales del siglo XVI pero de factura completamente diversa.

Una de ellas, de hacia 1590, procede del convento de San Francisco de Carrión donde se le denominaba Virgen de los Ángeles, pues probablemente iría acompañada de un coro de querubines hoy perdidos. Es una imagen muy bella de madera policromada en la que la Virgen, de rostro sereno y mirada ensimismada, porta una corona por cuyos laterales caen los pliegues de la capucha. La Virgen mantiene unidas sus manos en actitud de rezo, mostrando sumisión a través de un lazo dorado que se anuda en sus muñecas. La amplia túnica deja adivinar la anatomía de la Virgen cuando ésta adelanta su pierna izquierda, adhiriéndose los pliegues en esta zona y creando un suave dinamismo. La imagen presenta los típicos repintes de mediados del siglo XVIII aproximadamente, característicos por la carnación blanquecina del rostro y los motivos de florecillas brillantes en el manto.

La otra talla del museo es una Inmaculada romanista del último cuarto del siglo XVI. Su ubicación original era el coro bajo del convento ${ }^{2173}$.

En este caso, la ejecución es más tosca, el rostro acusa cierta geometría y peca de inexpresividad, motivada ésta por la mirada perdida en el infinito de la Inmaculada. Presenta una composición totalmente simétrica, disponiéndose sus brazos en actitud de rezo, con las manos mirando hacia el frente, lo cual no es demasiado habitual en este tipo de representaciones. Debió perder los dedos en algún momento, pues hoy día aparecen sustituidos por otros, señalándose esta intervención a través de una diversa policromía. El autor de esta imagen, probablemente de origen palentino, se

${ }^{2173}$ VV.AA. Iconografía Mariana...Op.cit, pág. 40. 
encuentra cercano al círculo de Pedro de Torres, con ese rostro cuadrático que se en enmarca dentro de la producción del escultor palentino ${ }^{2174}$.

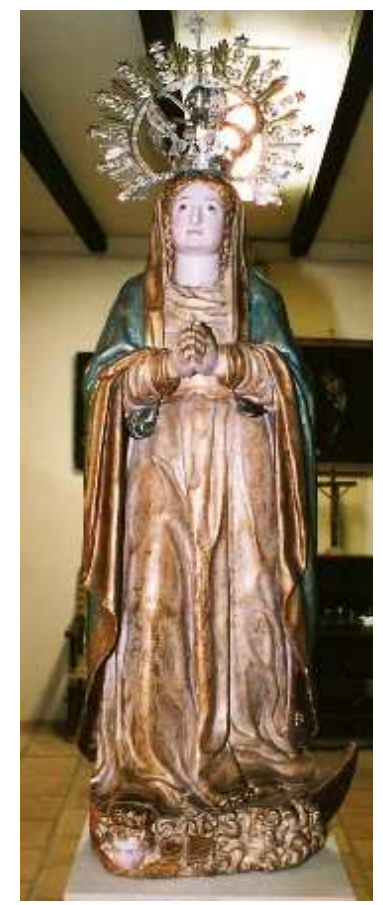

\section{Inmaculada romanista procedente del coro de} Santa Clara, hoy en el museo homónimo $(106 \mathrm{~cm} \times 46 \mathrm{~cm})$.

También existe un lienzo dedicado a La Virgen de los Ángeles, o de la Hoz, de la segunda mitad del siglo XVIII, de la que se desconoce cómo llegó desde el convento de Duruelo Sotillo, según narra la inscripción. Sólo muestra el rostro y la manos sosteniendo con la mano derecha un ramillete y con la izquierda al Niño Jesús, y como corresponde a su iconografía, aparecen dos esculturas de ángeles colgando de unas cuerdas. La obra, de evidente teatralidad reflejada en la presencia de los cortinajes, está firmada por un tal Quintanilla en 1770, del que poco se sabe, que podría relacionarse con un Nicolás de Quintanilla que trabaja por estos años en la zona de Cuéllar. Podría tratarse de este artista, o de un familiar suyo, pues encontramos un lienzo de la Virgen del Henar de Cuéllar, de estas fechas, que presenta ciertas similitudes con el nuestro.

Pero sin duda la pintura de mayor calidad artística dentro de la iconografía de la Virgen, es un lienzo de pequeño formato en el que María, como esposa de Cristo, porta una suntuosa corona de piedras preciosas adornada con diversos tipos

${ }^{2174}$ Sobre Pedro de Torres, véase el capítulo dedicado a las biografías de los escultores. 
de flores. La Virgen, de rostro dulce y rosáceo, entorna sus ojos hacia el bajo en señal de humildad. Esta imagen es una copia de la Virgen del tríptico del Cordero Místico de San Bavón de Gante, obra de los hermanos Van Eyck, de las que hay varias repartidas por la Península. Gómez Pérez atribuye esta imagen flamenca a Michiel Coxcie, que la ejecutaría a mediados del siglo XVI. A este pintor de Malinas se le encargaron varias réplicas de obras flamencas como la Deposición de la Cruz de Van der Leiden cuando no se podían conseguir los originales ${ }^{2175}$. Este artista, que residió nueve años en Roma, absorbió la estética clásica de Rafael, de ahí que sus obras se encuentren más próximas al estilo atemperado de los italianos que al más realista de los flamencos ${ }^{2176}$.

\section{Representaciones del Niño Jesús}

Existen diversas variantes iconográficas para el Niño Jesús ${ }^{2177}$. Destaca por su belleza una imagen de escuela sevillana de principios del siglo XVII que representa al Niño Majestad o Emperador, que al parecer fue un regalo de Felipe III a María Luisa $^{2178}$. La peana y las potencias que lo coronan pertenecen a la misma centuria. En cambio los ropajes son del siglo XIX. Según Patricia Andrés González, está realizada en madera, con las manos y cara de plomo, pero Enrique Gómez Pérez asegura que es de plomo enteramente ${ }^{2179}$. Imita el modelo creado por Martínez Montañés de este tipo iconográfico, de gran elegancia.

Otra escultura muestra un Niño de la Pasión con las arma Christi bordadas en su túnica, que duerme apoyado sobre su brazo derecho mientras sujeta la bola del mundo con la otra mano. Esta escultura del siglo XVII se conoce vulgarmente "Niño

${ }^{2175}$ GÓMEZ PÉREZ, Enrique. El museo...Op.cit, pág. 68-69.

2176 Sobre la gran aceptación de este pintor en la península, véase OLLERO BUTLER, Jacobo. "Michel Coxcie y su obra en España" en AEA, tomo 48, no 190-191. CSIC. Madrid, pp. 165-198 y FERNÁNDEZ SORIANO, Victor. "Michel Coxcie, pintor grato a la Casa de Hagsburgo" en $A E A$, tomo 81, no 322. CSIC. Madrid, 2008, pp. 165-196.

${ }^{2177}$ Un estudio acerca de la variedad iconográfica de la imagen del Niño Jesús en VEGA GIMÉNEZ, $\mathrm{M}^{\mathrm{a}}$ Teresa de. Imágenes exentas del Niño Jesús. Historia, iconografía y evolución. Catálogo de la Provincia de Valladolid. Valladolid, 1984.

${ }^{2178}$ Un estudio sobre la pintura sevillana de este siglo en VALDIVIESO GONZÁLEZ, Enrique. Historia de la pintura española. Escuela sevillana del primer tercio del siglo XVII. Centro de Estudios Históricos. Madrid, 1985.

${ }^{2179}$ ANDRÉS GONZÁLEZ, Patricia. Los monasterios...Op.cit, pág. 150 y GÓMEZ PÉREZ, Enrique. El museo...Op.cit, pág. 39. 
Jesús con dolor de muelas", pues bien puede parecer que el infante, aquejado por el sufrimiento, cierra los ojos mostrando paciencia, llevando su mano hacia el flemón derecho $^{2180}$. Sentado sobre un sillón frailero, esta imagen presenta una gran semejanza con la imagen conservada en Frechilla, Palencia ${ }^{2181}$.

En pintura, se conserva una representación de este mismo tipo, pero, en este caso, carga con la Cruz camino del Calvario. También se conserva un Niño Jesús dormido acompañado por San Juan semejante al que se conserva en el Monasterio de Santa Clara de Lerma y procedente de nuestro convento, Santa Clara de Carrión. San Juan hace un gesto de silencio para evitar que se despierte al Niño Jesús, quien duerme sobre una calavera. Según recoge una copia en una nota manuscrita, la imagen formaba parte de los objetos personales de la monja María Luisa siendo ésta contemporánea a la monja y por tanto, del primer tercio del siglo XVII.

Incluso el Museo alberga un Niño Jesús peregrino, pequeña talla del siglo XVII cuyo sombrero y esclavina pertenecen al siglo siguiente ${ }^{2182}$. La túnica que lleva es de factura moderna y porta un gran sombrero al que se ha cosido la insignia que lo identifica como caminante, una concha de nácar, motivo que se repite en la esclavina. Además, en su mano derecha, si cabía alguna duda de su condición, lleva una calabaza de plata, acompañada de un bastón para ayudarse en el camino.

\section{Otros Santos}

San Pedro Regalado aparece representado en dos pinturas mediocres: en una, calvo y enjuto, con el libro en la mano; en la otra, del siglo XVIII, vestido de observante franciscano, con bastón, un gran sombrero de ala ancha a la espalda y con un libro. En el paisaje del fondo se vislumbran los dos conventos vallisoletanos de la orden terciaria, El Abrojo y La Aguilera. Su presencia en este convento puede justificarse por la defensa de la reforma franciscana que se había comenzado en

${ }^{2180}$ GÓMEZ PÉREZ, Enrique, El museo...Op.cit, pág. 43.

2181 La ficha de esta obra en FERNÁNDEZ GONZÁLEZ, Rosario. "Niño Jesús dormido" en Catálogo de las Edades del Hombre de Palencia. Salamanca, 1999, pp. 337-338.

${ }^{2182}$ ARRIBAS, Carmen y GÓMEZ PÉREZ, Enrique. "Iconografía jacobea en el Camino de Santiago a su paso por la provincia de Palencia" en Actas del VI Congreso Internacional de Asociaciones Jacobeas. Logroño, 2002. 
1334 para proteger la Observancia ante la relajación de costumbres que se acentuó con el Cisma de Occidente.

También existen algunas esculturas que representan a diferentes Santos, que proceden del convento de San Francisco y fueron traídas al museo tras la desaparición del cenobio para evitar su ruina. Dada su primitiva ubicación en la casa terciaria masculina, las analizaremos cuando abordemos el estudio de las capillas donde se ubicaban estas imágenes originalmente.

\section{Sor Luisa y la talla de cruces}

No podían faltar igualmente representaciones de la monja más importante que profesó en el convento. La Madre Luisa de la Ascensión alcanzó una fama que llegó incluso a la corte de Felipe III. Su vida singular, con hechos milagrosos, hizo confluir en el convento de Santa Clara, la devoción popular y la curiosidad de nobles y teólogos. Sin embargo, el recelo de sus compañeras de clausura, que le acusaban de "alumbrada ilusa", la llevó ante el Tribunal de la Santa Inquisición en un proceso que se prolongó durante catorce años, incluso tras su muerte, declarando indemne la memoria de esta monja cuya fama llegó a extenderse por toda Europa. Se la representa de 3 modos:

Retratos. Existen dos en el museo. En uno, de busto, con el gesto bastante conseguido en cuyo reverso figura una $\mathrm{S}$ atravesada por un clavo, símbolo de “esclava de Jesús" con el que la monja solía firmar ${ }^{2183}$. Realizada en el siglo XVII, está atribuida a Felipe Gil de Mena y se ubicaba anteriormente en la ermita de la Madre Luisa ${ }^{2184}$. El artista palentino residía en esta época en Valladolid realizando encargos de conventos franciscanos en Cuéllar, Medina del Campo y la capital vallisoletana, por lo que no sería extraño que el pintor realizara esta obra ${ }^{2185}$. Su

\footnotetext{
${ }^{2183}$ GÓMEZ PÉREZ, Enrique. El museo...Op.cit, pág. 38.

${ }^{2184}$ URREA FERNÁNDEZ, Jesús y MARTÍN GONZÁLEZ, Juan José.Inventario, 2, Op.cit, pág. 60. Sobre el artista, con gran cantidad de ilustraciones, véase URREA FERNÁNDEZ, Jesús. Felipe Gil de Mena (1603-1673): del 2 al 21 de noviembre de 1985. Valladolid, 1985 y del mismo autor "Blas de Cervera y Felipe Gil de Mena, pintores palentinos" en AICHP, tomo 1. Palencia, 1987, pp. 241250.

${ }^{2185}$ GÓMEZ PÉREZ, Enrique. El museo...Op.cit, pág. 38.
} 
formación con Diego Valentín Díaz, quien mantuvo vínculos afectivos con la esfera eclesiástica de Valladolid y alrededores, pudo haberle facilitado el contrato de esta pieza. La Madre Luisa negó haber posado para el retrato, por lo que se cree que la firma sea falsa o que la pintura no se hiciera del natural sino que su autor se basara en las descripciones que de ella hacían las crónicas. La otra es una miniatura en cobre en la que la abadesa aparece orante ante la cruz y llevando el crucifijo en las manos. El retrato parece ser que se realizó en el siglo XVII, pero el marco de madera con motivos florales, es probablemente del siglo XVIII.

Alegoría: "La Monja de Carrión" lleva un dragón a sus pies. Existen dos representaciones de este tipo: una en el locutorio, y otra, más interesante iconográficamente en la que María Luisa sostiene un libro sobre el que se asienta una capilla y a sus pies un dragón aparece dominado por el cordón franciscano que cae de la cintura de la monja. Desde el cielo, un ángel porta un crucifijo. La capilla se ha interpretado como alusión a la reedificación del convento por parte de la abadesa. Es una imagen del siglo XVII que ilustra uno de tantos milagros atribuidos a la Monja de Carrión, quien consigue dominar a todo tipo de criaturas expulsándolas del convento, como fue el célebre episodio de la "domesticación de la serpiente" que tuvo lugar en la huerta del convento ${ }^{2186}$.

Visión de Dios Padre entregando la bola del mundo a Jesucristo. El lienzo realizado en el siglo XVII ${ }^{2187}$, de notables dimensiones, se encuentra en el zaguán. María Luisa aparece representada en un extremo en actitud de oración mientras Cristo, arrodillado sobre la cruz, extiende los brazos hacia el Padre. Curiosamente en el coro bajo se conserva una obra parecida pero se excluye la presencia de la monja. Este hecho nos lleva a pensar que la visión de la religiosa clarisa no fuera tal, sino que por devoción fuera voluntad de la monja aparecer representada en dicha escena.

En relación con María Luisa de la Ascensión, existe en el Museo un retrato de su confesor, Fray Pedro de Castro, yacente, en su lecho de muerte y vestido de

\footnotetext{
${ }^{2186}$ En este sentido, este cuadro guarda una gran relación con el milagro de la sierpe que consiguió expulsar de la huerta. Fue uno de los motivos por los que la Inquisición la acusó en el largo proceso que contra ella se desarrolló en Valladolid, por considerarlo una invención. Estos y otros milagros en ASCCC. Memorial informativo...Op.cit, s/f.

${ }^{2187}$ URREA, Jesús y MARTÍN GONZÁLEZ, Juan José. Inventario...2 Op.cit, pág. 60.
} 
franciscano con el crucifijo entre los brazos. Había fallecido en el año 1636.Otra obra de iconografía clarisa en el Museo es la representación de la Venerable Juana de la Cruz en éxtasis presenciando cómo un ángel entrega a Jesús una serie de rosarios para que los bendiga. En la parte izquierda del lienzo, la comunidad de clarisas se percata de la desaparición de los rosarios al abrir el baúl que los contenían. Finalmente, en la parte inferior, una serie de personajes diminutos salen de cántaros y piedras representando a las almas del purgatorio.

Respecto a las cruces, existe un inusitado número de ellas de la primera mitad del siglo XVII, pintadas sobre madera dentro del monasterio, cuya presencia se puede asociar con la devoción profesada por la Madre Luisa a la cruz. La tradición asegura que fue precisamente ella la autora de estas cruces, pero es algo improbable. En las vitrinas del museo aparecen separadas las cruces "auténticas" de las "falsas", pero como decimos, incluso las que se creen realizadas por la monja pueden no serlo. De especial interés es una cruz de madera en la que se ha pintado al óleo a Cristo y, por debajo se representan, superpuestos, La Inmaculada, y un rey, seguramente San Luis, rey de Francia, quien fue terciario de la Orden franciscana y era, además, devoto de la Pasión como lo demuestra su atributo personal.

Otra de las cruces conservadas nos presenta las "arma Christi” distribuidas por los brazos de la cruz. En otra ocasión nos encontramos sólo con la imagen del Crucificado, muerto, con su cabeza caída sobre el pecho acompañado de una inscripción. Interesante es una cruz con el Crucificado de gran dramatismo, que mira al espectador y la imagen de la Inmaculada debajo, por ser esta cruz de las únicas que lleva ésta la firma: “Clemens Sanchez fa/ciebat 1647”. Esta firma se identifica con una de las monjas que profesó en el monasterio, procedente de Toro, y de nombre Isabel. Existe además una interesante cruz-relicario del siglo XVII, pieza de factura vallisoletana, realizada en plata sobredorada. Presenta vínculos formales con la de Ampudia, contratada por Juan de Najéra en 1612, aunque la de Santa Clara es de menor calidad ${ }^{2188}$.

${ }^{2188}$ BRASAS EGIDO, José Carlos. La platería vallisoletana...Op.cit, pág. 93. 


\section{La colección de belenes}

La colección de casi un centenar de Belenes que se conservan en las dos últimas estancias del museo, viene justificada porque la tradición que asocia a San Francisco como iniciador de este gusto. Los conservados son de diferentes épocas, materiales y procedencias. Entre los más famosos se pueden citan el Belén Monumental, que es el más antiguo, compuesto por imágenes de los siglos XVI a XVIII con ciertas semejanzas al Belén de las Descalzas Reales de Valladolid, el Belén Napolitano obra de Concetta Fusco o el Belén de cristal de Murano, realizado por Fratti en el año 2003.

También en el museo se conserva un realejo de escuela castellana, cuya fecha de ejecución y autoría es desconocida, si bien el estilo de la caja puede adscribirse al siglo XVII ${ }^{2189}$. El pedestal, con paneles policromados que simulan las vetas de la madera, contiene los fuelles y sobre éste se dispone la consola, y encima de la misma, la tubería, resguardada por dos puertas con celosías. Similar disposición presenta algunos órganos palentinos de finales del siglo XIX, como el de la iglesia parroquial de Santa María de Arconada o el de Nuestra Señora del Carmen, en Palencia.

El convento además poseyó un clavicémbalo; podemos constatar su existencia gracias los arreglos que experimentó entre 1693 y 1695, para cuya acción fue trasladado hasta Ampudia, al taller del organista Juan García ${ }^{2190}$.

${ }^{2189}$ VV.AA. Inventario...Op.cit, pp. 171-172.

${ }^{2190}$ ASCC. Libro 8. Cuentas del convento (1675-1704), fol 513. 
4.2. CONVENTOS NO CONSERVADOS 


\subsection{CONVENTOS NO CONSERVADOS}

\subsubsection{EL CONVENTO DE SANTA Ma DE BENEVÍVERE}

\section{EL SIGLO XII. LA FUNDACIÓN}

La Abadía de Santa María de Benevívere fue un monasterio de Canónigos regulares situado en un paraje frondoso de la carretera a Sahagún, a la espalda de la modesta iglesia de San Torcuato, a unos tres o cuatro kilómetros de Carrión de los Condes. Constituye uno de los establecimientos del entramado hospitalario en el Camino jacobeo palentino, formando parte de su antiguo itinerario ${ }^{1}$. El nombre de Benevívere, procede del latín y significa "vivir bien”, o más exactamente, "vivir recta y

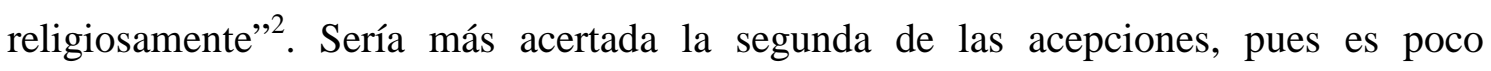
probable que en este entorno los monjes llevasen una vida muy cómoda, dado que, "por las muchas aguas que le bañan y humedades de que participa”, resultaban vulnerables a un sinfín de enfermedades ${ }^{3}$.

El centro monástico se constituyó desde sus orígenes en orden propia bajo la regla agustina y supeditada solamente a la autoridad de la Santa Sede de Roma. Fue Don Diego Martínez Salvador de Villamayor y Sandoval su fundador, noble castellano del siglo XII, perteneciente a la casa de los condes de Bureba y consejero de Alfonso VII y Sancho III $^{4}$. Era uno de los cuatro hijos de Martín Díaz ${ }^{5}$, rico hombre de Castilla y

\footnotetext{
${ }^{1}$ En Carrión existieron otros centros agustinos como el Priorato de Sancti Spiritus, San Torcuato y quizá la desaparecida ermita de San Cristóbal. Sobre este tema PERAL VILLAFRUELA, Santiago. De Aquitania...Op.cit, sobre todo pp. 137-173. No se debe olvidar el protagonismo de la orden de San Juan, otra de las órdenes hospitalarias de mayor reconocimiento en Palencia. BARQUERO GOÑI, Carlos. "Los hospitalarios en la Diócesis de Palencia durante los siglos XII y XIII" en ACHP, tomo 2, Palencia, 1995, pp. 681-691.

${ }^{2}$ GORDALIZA APARICIO, F. Roberto y CANAL SÁNCHEZ-PAGIN, José Ma . Op.cit, pág. 112.

${ }^{3}$ CASTRO, Lázaro de. Op.cit, s/f.

${ }^{4}$ FERNÁNDEZ, Luis. Colección diplomática de la Abadía de Santa María de Benevívere (Palencia) 1020-1561. Escuela Gráfica Salesiana. Madrid, 1961, doc.19.

${ }^{5}$ Era un magnate con territorios en Palencia con gran vinculación a la realeza. SANDOVAL, Fray Prudencio de. Crónica del ínclito emperador de España don Alfonso VII. Madrid, 1600, pág. 148. Martín Díaz falleció en 1161, dejando cuatro descendientes: Diego Martínez, Rodrigo Martínez, García Martínez y una mujer de la que no se menciona más que era abadesa. FERNÁNDEZ, Luis. Colección...Op.cit, doc. 19 .
} 
criado de Alfonso VII, perteneciente a la casa de los Salvadores, señor de los Estados de Pancorbo, Cerezo, Tordevanca, Tordemora, y Celada, y de María García, heredera de las casa burgalesa de Villamayor de los Montes y las palentinas de Carrión y Benevívere $^{6}$. Con su esposa, María Ponce de Minerva, don Diego tuvo cuatro vástagos, todos varones excepto uno, de nombre María García, la cual se convirtió en heredera de sus dominios al perecer sus tres hermanos en el campo de batalla. Como su padre, don Diego fue un hombre de armas y estuvo al servicio del rey, convirtiéndose en valido del rey Alfonso VIII, que le concede algunos privilegios ${ }^{7}$. Fue don Diego un noble caballero que, cansado de las batallas y probablemente decepcionado por la suerte que corrieron sus tres hijos en la guerra, opta por una vida más tranquila dedicándose a la fundación de cenobios ${ }^{8}$.

La primera gran concesión del monarca la constituye la donación del monasterio benedictino de San Andrés de Valvení de Valladolid en 1165. Una vez recuperado, Diego Martínez se comprometió a restablecer la vida monástica y velar por la seguridad del centro. Para ello, se lo entrega al abad de Valbuena de Duero, guardándose a partir de entonces la regla cisterciense ${ }^{9}$. A continuación se trasladó con algunos de los miembros de la comunidad trashumante de Valvení a la localidad vallisoletana de Ceinos de Campos, donde los Martínez de Villamayor poseían propiedades. Allí se estableció sobre una antigua capilla que llamó Santiago de la Tola ${ }^{10}$. Hacia 1168

\footnotetext{
${ }^{6}$ Más datos acerca de su ascendencia paterna y materna. PELLICER Y OSSAU, J. Informe del origen, antigüedad, calidad y sucesión de la excelentísima Casa de Sarmiento de Villamayor. Madrid, 1663 y FERNÁNDEZ MARTÍN, Luis. La abadía...Op.cit, pp. 16-18.

${ }^{7}$ MORALES, Ambrosio de. Viaje por orden...Op.cit, pág. 78. También se dice que sirvió también a Alfonso VII y a Fernando el Deseado. PONZ, Antonio. Viaje...1 $1^{a}$ Edición, Op.cit, pág. 188. PÉREZ VILLAAMIL, Genaro. España artística y monumental: vistas y descripción de los sitios y monumentos más notables de España. Tomo 1. Alberto Hauser, París, 1845, pág. 19. Aunque no se puede negar la vinculación con el monarca de las Navas, no existe ningún diploma real en que aparezca el nombre de Diego Martínez en relación a algún cargo desempeñado para la monarquía. FERNÁNDEZ, Luis. La abadía de Santa María de Benevívere durante la Edad Media: su historia, su regla. Universidad Pontificia de Comillas. Santander, 1962, pág. 20.

${ }^{8}$ La metamorfosis de Diego Martínez queda reflejada en el poema escrito por el primer abad, don Pascual en honor a Diego Martínez, una vez fallecido éste. FERNÁNDEZ MARTÍN, Luis. "Un poema latino medieval" en Humanidades, XIII, nº30. Universidad Pontificia de Comillas, 1961, pp. 275-321. Este poema ha sido comentado recientemente por MARTÍNEZ SOPENA, Pascual. "Aristocracia, monacato y reformas en los siglos XI y XII" en El monacato en los reinos de León y Castilla (siglos VII-XIII).X Congreso de Estudios Medievales. León, 2007, pp. 92-95 y en PÉREZ RODRÍGUEZ, Estrella. Poema sobre el fundador de Benevívere. Estudio y edición crítica con traducción del poema y de los diplomas relacionados. Universidad de León. León, 2008.

${ }^{9}$ El convento había sido asaltado por malhechores, por lo que fue necesaria su restauración. En 1166 Alfonso VIII confirma la donación a los cistercienses. FERNÁNDEZ MARTín, Luis. La Abadía...Op.cit, pp. 22-24.

${ }^{10}$ Ibídem, pág. 25.
} 
edificaría otro monasterio, en Mansilla de las Mulas, provincia de León, llamado de Nuestra Señora de Sandoval, donde también vivió algún tiempo con algunos monjes cedidos del monasterio cisterciense de la Santa Espina ${ }^{11}$.

Finalmente se asienta junto a sus compañeros en Benevívere, propiedad de su madre y erige hacia 1170 un hospital y monasterio bajo la advocación de Nuestra Señora, donde murió, en $1176^{12}$.

La escritura de fundación data del año 1175, en que Don Diego dona la casa y hospital de Benevívere al abad Don Pascual o Pascasio Rustán, monje francés originario de Gascuña, y a los canónigos presentes y futuros, y se reserva su patronato ${ }^{13}$. Transcurrieron, por tanto, varios años entre la fecha de asentamiento en Benevívere del conde junto a los caballeros que lo acompañaban y la de fundación del convento. Este hecho fue debido a los pleitos que mantuvieron con los monasterios de Sahagún y Nogal de las Huertas por la propiedad de aquellos terrenos que pertenecían entonces, a dichos centros benedictinos, los cuales, finalmente, se los cedieron, como apuntamos, en $1175^{14}$. Una vez organizada la abadía, Diego Martínez se procuró el apoyo de los obispos más cercanos, Don Raimundo de Minerva de Palencia y don Juan de León, respectivamente, consiguiendo la condonación de los diezmos perpetuamente a ambas diócesis ${ }^{15}$. Se fue poco a poco conformando el patrimonio del monasterio, a través de heredades en Trianos ${ }^{16}$, León y la de Villalbura, en Burgos y se hizo con el control de otras en Palencia, donadas por Alfonso VII entre 1173 y 1175, como Amusquillo, Poza, Saldaña, Villota del Páramo, Celadilla con su iglesia y arroyos ${ }^{17}$.

\footnotetext{
${ }^{11}$ CASTÁN LANASPA, Guillermo. Documentos del Monasterio de Villaverde de Sandoval (siglos XII$X V)$. Universidad de Salamanca. Salamanca, 1981, pp. 12-13.

RAMIREZ DE HELGUERA, Martín. El libro...Op.cit, pp. 232-233.

${ }^{12}$ PONZ, Antonio. Castilla y León en el siglo XVIII a través de los viajes de Antonio Ponz. Selección y prólogo de VALDEÓN, Julio. Valladolid, 1987, pág. 88.

${ }^{13}$ La elección de abad se realizó antes de 1173 , pues existe documentación de este año firmada por Don Pascual como abad. La importancia de éste se refleja en el hecho de que es quien firma la paz de Medina de Rioseco ente Alfonso VIII y Fernando II. Véase FERNÁNDEZ, Luis. La Abadía...Op.cit, pág. 33

${ }^{14}$ Ibídem, pág. 20.

${ }^{15}$ Recordemos que la abadía pertenecía a la diócesis palentina pero contaba con territorios ubicados en el seno de la mitra leonesa, de ahí la búsqueda de estos aliados. FERNÁNDEZ MARTÍN, Luis. La Abadía...Op.cit, pág. 34.

${ }^{16} \mathrm{La}$ documentación medieval del cenobio en CASTÁN LANASPA, Guillermo. Documentos del Monasterio de Santa María de Trianos: (Siglos XII-XIII). Universidad de Salamanca. Salamanca, 1992.

17 SIMÓN Y NIETO, Francisco. Los antiguos...Op.cit, pág. 140. Sumados a éstos, existían otros dominios bajo su jurisdicción, cuyo listado podemos consultar en PERAL VILLAFRUELA, Santiago. Estudio...Op.cit, pp. 6 у 7.
} 
Diego Martínez falleció el cinco de noviembre de 1176 pero citó testamento quince días antes $^{18}$. Parece ser que el rey Alfonso VIII se presentó en el convento para dar consuelo a los canónigos, no sólo “de presencia y de palabra, sino de mercedes ${ }^{19}$ ”. Gracias al Poema que le dedicó el primer abad, don Pascual, sabemos que don Diego fue siempre un hombre generoso con los pobres y enfermos. Incluso en los últimos momentos de su vida, aquejado de una enfermedad que le había provocado un entumecimiento progresivo de todo el cuerpo que le impedía caminar, dedicó a los monjes unas palabras acerca de la frugalidad de la vida ${ }^{20}$.

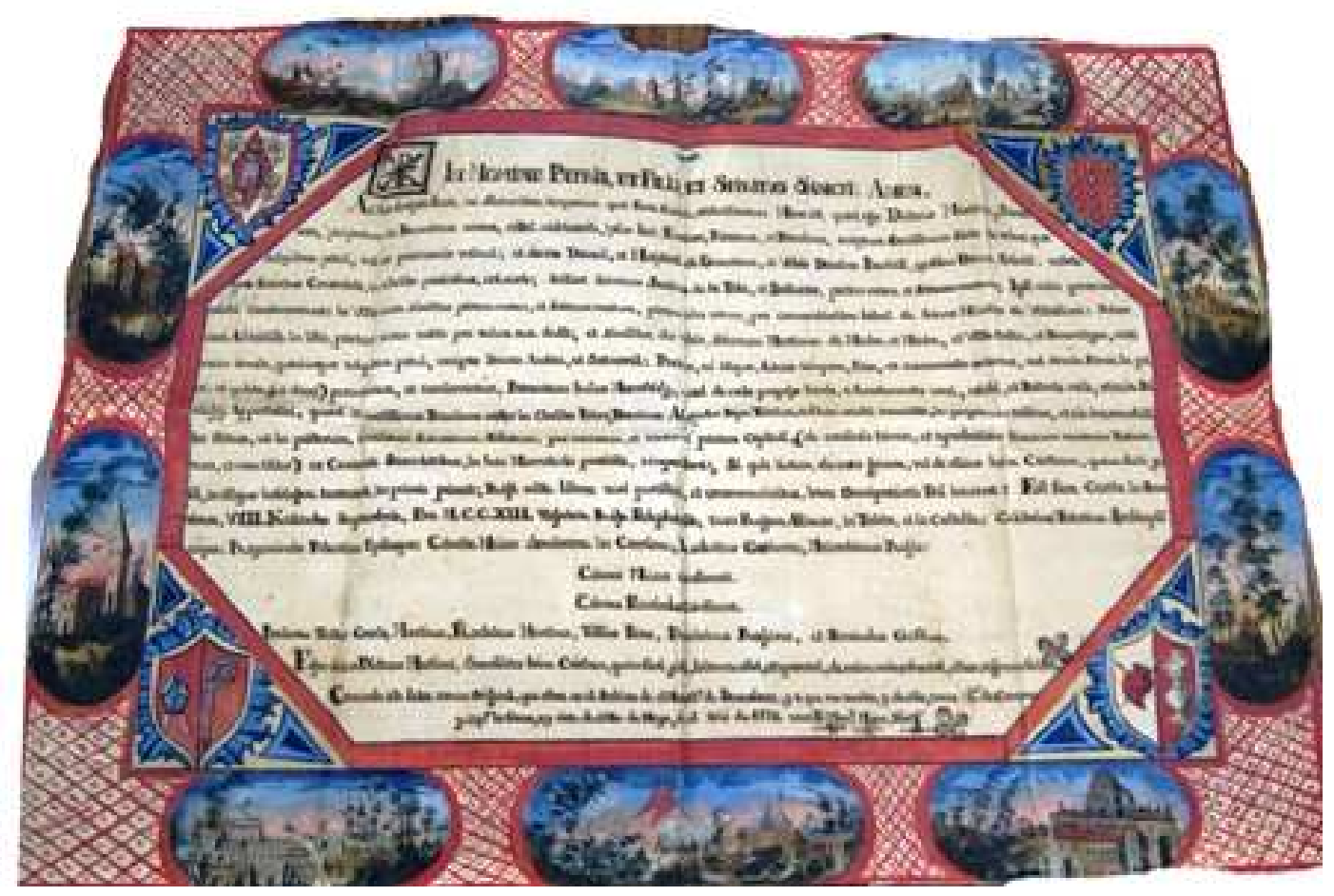

Copia de 1774 del testamento original de Don Diego Martínez Sarmiento, fundador de Benevívere en la era 1213, año 1175. AHPZ. Casa del Duque de Híjar 496-1.

\footnotetext{
${ }^{18}$ La fecha de su muerte figura en FERNÁNDEZ MARTÍN, Luis. "Un poema...Op.cit, versos 533-535 y su testamento original en AHN. Benevívere 1691/3.

${ }^{19}$ CASTRO, Lázaro de. Op.cit, s/f y RAMÍREZ DE HELGUERA, Martín. El libro...Op.cit, pp. 232-233

${ }^{20}$ FERNÁNDEZ MARTÍN, Luis. La Abadía..Op.cit, pág. 35.
} 


\section{Las armas de la familia fundadora}

A pesar de la escasez de restos conservados, algunos escudos del priorato de San Torcuato y de la sillería de coro perteneciente a la abadía testimonian la presencia del linaje de los Sarmiento en Benevívere: trece roeles de oro sobre campo de sangre. Sobre el proceso de adopción de estas armas existen numerosas versiones fundamentadas en la tradición, asociadas a distintos personajes. Las leyendas sobre la fundación de cenobios

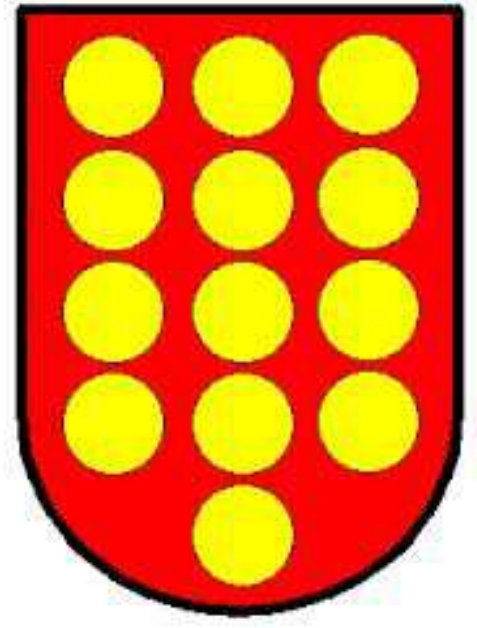
han sido siempre muy recurrentes. Se busca vincular los orígenes a un hecho maravilloso, a un signo venido del cielo o a un personaje célebre, como es nuestro caso, con el fin de explicar de algún modo el surgimiento de una comunidad ${ }^{21}$. La búsqueda de los orígenes de un determinado linaje en figuras de grandes caballeros, reales o imaginarios, pone de manifiesto la imperiosa necesidad de linajes secundarios ascendidos paulatinamente por justificar su distinción social ${ }^{22}$. Recogemos las más extendidas ${ }^{23}$ :

\section{Escudo del linaje Sarmiento.}

-La más antigua de todas las leyendas, remonta al período altomedieval. Según las Bienandanzas e Fortunas del cronista vizcaíno Lope García de Salazar, tras la batalla de Alarcos del año 1195, recogió Alfonso VIII a muchos huérfanos de los caballeros castellanos muertos en combate. A uno de ellos, que servía al monarca, le dijo un día: "Buen sarmiento se cría aquí para los moros ${ }^{24 ” . ~ E s t e ~ r e l a t o ~ n o ~ h a c e ~ r e f e r e n c i a ~ d i r e c t a ~ a ~}$

\footnotetext{
${ }^{21}$ DIMIER, Anselme. "Quelques légendes de fondation chez les cisterciennes" en Studia Monastica, $\mathrm{n}^{\circ} 12$, 1, 1970, pág. 97.

${ }^{22}$ Sobre este tema, véase el prólogo del siguiente manual, realizado por Reyna Pastor. DUBY, Georges. Hombres y estructuras de la Edad Media. Siglo XXI de España Editores. Madrid, 1978 y BECEIRO PITA, Isabel. "La conciencia de los antepasados y la gloria del linaje en la Castilla Bajo imperial" en Relaciones de poder, de producción y parentesco en la Edad Media y Moderna. Madrid, 1990, pp. 333335.

${ }^{23} \mathrm{Si}$ bien existen otras, que se pueden consultar en FERNÁNDEZ SUÁREZ, Gonzalo Francisco. La nobleza gallega entre los siglos XIV-XV: Los Sarmiento Condes de Ribadavia. Santiago de Compostela, 2002, pp. 57-60.

${ }^{24}$ GARCÍA CARRAFA, Alberto y Arturo. Diccionario heráldico y genealógico de los apellidos españoles americanos. Apellido Sarmiento. Imprenta Antonio Marzo. Madrid, 1920, s-a, pág. 151, a su vez de GARCIA DE SALAZAR, Lope. Las Bienandanzas e fortunas. Códice IV. No se hace referencia a
} 
ningún miembro concreto, si bien debe tratarse de algún sucesor de don Diego Martínez, pues éste había fallecido en 1175. En este sentido hallamos un manuscrito con base documental que recoge como protagonista a un hijo de Ruy García, nieto éste de don Diego Martínez ${ }^{25}$.

-Alfonso VII, estando a punto de luchar contra los moros, sirvió a sus soldados una fuente con buñuelos, previniéndoles que debían comer tantos como cabezas de moros pensasen presentar ante el rey. Se dice que Don Juan Martínez de Villamayor, familiar del fundador, comió trece y el número equivalente presentó al monarca, el cuál complacido, expresó: “De tal cepa, tal sarmiento”. Así quedó su escudo, simbolizando los trece buñuelos de la historia ${ }^{26}$.

-Por último tenemos una hipótesis planteada desde la historia. Las constituciones monásticas del archivo abacial del año 1631 relataban cómo Don Diego Martínez “...se retiró a este convento, dejando las pompas y banidades del mundo con doçe caballeros y deudos que le siguieron...". Los trece caballeros se identificarían con cada uno de los roeles existentes en el escudo ${ }^{27}$.

La introducción de los trece roeles en el escudo de los Sarmiento, no sucedió en ningún caso en época del fundador don Diego Martínez Salvador de Villamayor. De hecho los motivos representados al menos hasta 1666 en las claves de la capilla mayor y crucero eran la imagen del Salvador acompañado de un cordero con bandera, de lo que

ningún nombre concreto pero debe vincularse a un sucesor de Diego Martínez de Villamayor, ya que éste falleció, como indicamos en 1175.

${ }^{25}$ No se dice su nombre. URCELAY GAONA, Egoy. Los Sarmiento, condes de Salinas: orígenes y elevación de una nueva clase señorial: Siglos XII-XVI. Universidad del País Vasco. Bilbao, 2009, pp. 2829, a su vez de BN, Mss 8631. La fundación de los Sarmientos.

${ }^{26}$ RAMIREZ DE HELGUERA, Martín. El libro...Op.cit, pág. 235. El informe de 1666 coincide con esta versión, salvo que fue un descendiente de Diego Martínez, llamado Juan, el protagonista de la historia. ADP. Religiosos. Abadía de Benevívere (1475-1808), s/f. Esta leyenda es la copia de otra versión en la que los protagonistas son el rey Fernando y Gonzalo Salvadores. Esta sucedería en 1093, lo cual es imposible, pues Fernando fallece en 1065. BN. Mss. 8631. Prólogo para haber de tratar de la nobleza y real sangre del linaje y armas de los Sarmientos y Acuñas, fol 53 y 54.

${ }^{27}$ PERAL VILLAFRUELA, Santiago. Estudio para la puesta en valor del patrimonio cultural de Carrión de los Condes como fuente de desarrollo rural. Monasterio de Benevivere-San Torcuato. Inédito. Depositado en el Ayuntamiento de Carrión de los Condes, 2007, pág. 3, a su vez de ADP. Conventos dispersos. Benevívere. Libro 1. 1631. Constituciones y estatutos, tratado 1. Un resumen de la información contenida en las mismas y otra documentación conservada en HERREROS ESTÉBANEZ, Francisco. "Las constituciones monásticas de los canónigos regulares de San Agustín de Benevívere, según un libro manuscrito del Archivo Diocesano de Palencia” en Memoria ecclesiae, №. 6, 1995, pp. 177-182. 
colegimos que se trata de un emblema parlante del fundador ${ }^{28}$. Por tanto, la utilización de los roeles en el escudo debe corresponder, si aplicamos la lógica, al momento en que se adopta el patronímico de Sarmiento por vez primera. Esto ocurre, como indicamos previamente, con el primogénito de Rodrigo Martínez, sobrino del fundador, don Pedro Ruiz Sarmiento ${ }^{29}$. Las referencias al mismo oscilan en un abanico de años entre 1230 y $1250^{30}$. En cuanto a la conexión que podemos establecer entre la nomenclatura "sarmiento" y los trece discos de oro, Urcelay plantea una posibilidad plausible; podría tratarse de una adaptación esquemática del racimo de uva que pende de casa sarmiento $^{31}$.

\subsection{LA EXPANSIÓN DURANTE LOS SIGLOS XII Y XIII}

La ubicación en un lugar apartado de la villa, asistiendo eso sí, a los peregrinos, el trabajo manual tanto de clérigos como de legos o la advocación a la Virgen María, son algunos de los preceptos que comparten los agustinos de Benevívere con los centros de la orden cisterciense ${ }^{32}$. Precisamente esta aproximación hacia el modo de vida de los monjes bernardos coincide con su período de máxima expansión por la Península en el segundo tercio del siglo XII. La estrecha vinculación de Benevívere con la Orden del Císter queda corroborada cuando en 1179 Alejandro III redacta las constituciones de la abadía bajo la regla de San Agustín pero con el decreto de Citeaux y de las iglesias cistercienses $^{33}$. Éstas serían confirmadas por los Papas sucesivos ${ }^{34}$. Hasta la muerte del

\footnotetext{
${ }^{28}$ ADP. Religiosos. Abadía de Benevívere (1475-1808), s/f. Helguera sostiene que los Salvadores tenían el escudo comentado pero que éste se trocó por el de los Sarmiento con la anécdota de Alfonso VII y Diego Martínez que relatamos previamente. RAMIREZ DE HELGUERA, Martín. El libro...Op.cit, pp. 235-236.

${ }^{29}$ Para el autor, el uso de este patronímico es un síntoma claro de la preponderancia en la región de diversas familias aristocráticas. URCELAY GAONA, Egoy. Los Sarmiento...Op.cit, pág. 62.

${ }^{30}$ Algunas de ellas en AHN. Clero. Benevívere, 1693/6 y GONZÁLEZ, Julio. Repartimiento...Op.cit, pág. 42.

${ }^{31}$ Esta referencia directa figura en el escudo de don Juan Sarmiento en la capilla de esta familia ubicada en el convento de San Francisco de Palencia, donde aparecen los roeles acompañados de racimos de uva. URCELAY GAONA, Egoy. Los Sarmiento...Op.cit, pág. 179.

${ }_{32}$ Estos y otros aspectos de la vida monacal beneviverense son recogidos en el "Incipet Liber II Consuetudinum Eclesiae Beatae Marieae de Benevivere". Redactado hacia el año 1207 es brevemente resumido en FERNÁNDEZ MARTÍN, Luis. La Abadía...Op.cit, pp. 84-88.

${ }^{33}$ FERNÁNDEZ MARTín, Luis. Colección diplomática de la Abadía de Santa María de Benevívere (Palencia): 1020-1561. Escuela Gráfica Salesiana. Madrid, 1961, doc 21, pág. 23, y del mismo La Abadía...Op.cit, pp. 45-49.

${ }^{34}$ Lucio III en 1183, Inocencio IV en 1249, Alejandro IV en 1256, Eugenio IV en 1443 - quien nos muestra la decadencia de Benevívere en este siglo al ordenar a los abades de San Zoilo de Carrión y San Isidoro de León que defiendan las posesiones de la abadía, pues algunas habían sido retenidas- , Paulo III
} 
fundador, don Diego Martínez, sucesivos benefactores -condes, señores y familiaresconfiguraron, a través de la provisión de donaciones, permutas, y en menor medida compraventas, el patrimonio casi definitivo de la abadía. Lo más relevante lo constituye sin duda, la provisión, título y colación de seis prioratos en las provincias de Palencia, León y Zamora, que permitieron a los monjes gozar de una vida desahogada:

-Santiago de la Tola en Ceinos de Campos (Valladolid)

-Santa María de la Puente de Dios o de Rianso, en la diócesis de Astorga cerca de Benavente (Zamora). Pertenecía a la diócesis de Astorga y fue anejado por Bula de Clemente XIII en 1760 debido al despoblamiento de sus términos ${ }^{35}$.

-San Martín de Pereda en Riaño (León) ${ }^{36}$

-San Salvador de Villarramiel (Palencia).

-Nuestra Señora de Mañino en el Valle del Boedo (Palencia).

-San Torcuato, hospital de peregrinos junto a la Abadía de Benevívere ${ }^{37}$.

Todos ellos eran controlados por el abad, encargado de visitarlos y conceder licencias para confesar y administrar los sacramentos ${ }^{38}$.

A través de las donaciones, el fundador y sus sucesores se reservaban algunos derechos, tales como la gestión del patrimonio a un solo miembro de la familia. Eliminando los repartos entre diversos miembros, se evitaba la disgregación de sus monopolios, consolidándose paulatinamente el linaje en el seno de la alta nobleza castellana ${ }^{39}$. Si bien la abadía beneviverense se encargaba de elegir a los abades de los otros prioratos, en su propio caso, el cargo de abad tuvo desde sus orígenes hasta el siglo XVI un carácter perpetuo y comendatario $^{40}$. Teóricamente su cometido era regir el

en 1464, Alejandro VI en 1499, León X en 1519, Paulo III en 1545, Pío IV en 1564 y Pío V el 15 de Octubre de 1575. Todas las bulas y confirmación de privilegios en AHN. Clero Secular-Regular, Carpeta 1699, Microfilm Positivo, 234.

${ }_{35}$ ACP. Sección Histórica. Armario XIV. Legajo 8, nº 2866.

${ }^{36}$ Fue donada por la condesa doña Urraca González, señora de dominios en la ribera del Esla, en 1189.

Concedió una veintena de heredades en la montaña leonesa, siendo ésta la donación más cuantiosa de la historia del priorato. FERNÁNDEZ MARTíN, Luis. La Abadía...Op.cit, pág. 62.

${ }^{37}$ Para más datos sobre la hacienda de la abadía en la Edad Media, consúltese FERNÁNDEZ MARTín, Luis. La Abadía...Op.cit, pp. 3, 49, 60- 78.

${ }^{38}$ FRANCIA LORENZO, Santiago. Por tierras palentinas. Palencia, 1991, pág. 174.

${ }^{39}$ URCELAY GAONA, Egoy. Los Sarmiento, condes de Salinas: orígenes y elevación de una nueva clase señorial: Siglos XII-XVI. Universidad del País Vasco. Bilbao, 2009, pp. 46-47.

${ }^{40}$ ADP. Conventos dispersos. Benevívere. Libro 1. 1631. Constituciones y estatutos, fol 91v y 92. 
funcionamiento de su abadía, a efectos prácticos, todas las decisiones se tomaban bajo el consentimiento del benefactor ${ }^{41}$.

Al fallecer el fundador don Diego Martínez en 1176, sucede en el mayorazgo su hermano Rodrigo Martínez ${ }^{42}$. El "segundo edificador del monasterio" anexionó la iglesia de San Martín de Valdesalce en Palencia en 1202 y adquirió unas propiedades en Villaturde tres años después. Con el hijo de Rodrigo Martínez podemos decir que da comienzo la estirpe de los Sarmiento, pues su primogénito, Pedro Ruiz es el primero que adopta dicho sobrenombre ${ }^{43}$. En la documentación, Pedro Ruiz Sarmiento figura como mesnadero del infante Alfonso X tomando parte en el asedio de Sevilla hacia $1247^{44}$. Con esta ya son tres generaciones de caballeros en la familia vinculados estrechamente a la realeza.

Durante el siglo XIII, el patrimonio de los Sarmiento no crece sustancialmente, pues las cesiones y donaciones de la centuria anterior dan el relevo a la reclamación de derechos sobre algunas tierras y a la adquisición de otras ya integradas en Benevívere ${ }^{45}$. Por su parte, la abadía sigue ampliando sus dominios, con la adquisición de heredades en Palencia -Mayorga, Villamuza, Cisneros, Bustocirio- León -Riaño, Primajas, Mental y Zamora -Ferreruela- entre otras ${ }^{46}$.

\footnotetext{
${ }^{41}$ Así queda reflejado: “...cum communi consensu et voluntate uenerabilis frais nostri Didacis Martini...” FERNÁNDEZ, Luis. Colección...Op.cit, doc 13,14,15 y 18.

${ }^{42}$ URCELAY GAONA, Egoy. Los Sarmiento...Op.cit, pág. 59, a su vez de FERNÁNDEZ MARTín, Luis. La abadía...Op.cit, apéndice documental.

${ }^{43}$ Rodrigo Martínez siempre figura en la documentación con el apelativo de Rodericus Martini. FERNÁNDEZ MARTÍN, Luis. Colección...Op.cit, doc 19.

${ }^{44}$ Los mesnaderos eran vasallos del rey que velaban por su vida, incluso cuando dormía. URCELAY GAONA, Egoy. Los Sarmiento...Op.cit, pp. 63-64, a su vez de GONZÁLEZ, Julio. Repartimiento de Sevilla, 2. Escuela de Estudios Medievales. Madrid, 1951, pág. 42. No se debe confundir con un personaje homónimo, posterior, repostero de Juan II de Castilla.

${ }^{45}$ Así sucedió por ejemplo con Villaturde y Villarramiel, donde tanto el abad como Pedro Ruiz eran los "señores", es decir, podemos hablar de condominio sobre la aldea. A partir de este momento y hasta la creación del Becerro de las Behetrías a mediados del siglo XIV existe un vacío documental absoluto sobre los Sarmiento. URCELAY GAONA, Egoy. Los Sarmiento...Op.cit, pp. 60-67.

${ }^{46}$ FERNÁNDEZ MARTÍN, Luis. La Abadía...Op.cit, pp. 66-70.
} 


\section{LOS SIGLOS XIV Y XV}

En el siglo XIV se reflejan tan sólo algunas permutas y ventas de territorios “...por la gran carestía..." produce una recesión de las rentas que conlleva a una crisis generalizada de todos los conventos, acentuada por la peste negra, por lo que la hacienda se ve menoscabada ${ }^{48}$. La suerte de los Sarmiento, sin embargo, no corre paralela a la del cenobio, pues experimentan un gran empuje en este período. En el Becerro de las Behetrías se observa cómo el núcleo de los Sarmiento, ubicado en Carrión, Saldaña, Monzón y Campos se extiende por Burgos gracias a la alianza internobiliaria del cabeza de linaje, Diego Pérez Sarmiento (fallecido en 1363) con María de Velasco ${ }^{49}$. Se había aliado con Pedro El Cruel, quien por los servicios prestados en la guerra, le otorgó en 1355 uno de los

principales cargos de la corona, el de Adelantado Mayor de Castilla ${ }^{50}$. Sin embargo, a partir de la derrota de Araviana, Diego Pérez se cambió al bando de Enrique de Trastámara, lo que resultó determinante para el devenir del linaje. Con su hijo, Diego Gómez Sarmiento se fragua paulatinamente el ascenso familiar dentro del seno de la alta nobleza castellana gracias a su enlace con doña Leonor de Castilla, sobrina de Enrique II y a la magnitud de las mercedes otorgadas por el monarca ${ }^{51}$.

Durante la centuria posterior, la situación tampoco es demasiado halagüeña para el monasterio, dado que se producen robos y ocupación de tierras por parte del concejo y ciertos nobles. Tal es así que, a instancias de la abadía, el papa Eugenio IV otorga una Bula en 1443, por la que concede una serie de jueces defensores de las propiedades de Benevívere a los abades de San Isidoro de León y San Zoilo de Carrión ${ }^{52}$. La unidad económica del convento, otrora indiscutible, se resquebraja irremediablemente porque los canónigos, en lugar de explotar sus propiedades, recurren al establecimiento de foros y censos con diversos concejos palentinos. Así sucede en 1438 con las villas de Ledigos

\footnotetext{
${ }^{47}$ Ibídem, pp. 70-72.

${ }^{48}$ Sobre este fenómeno consúltense los estudios VALDEÓN BARUQUE, Julio. "La crisis del siglo XIV en la Corona de Castilla" en Homenaje a Marcelo Vigil Pascual: la historia en el contexto de las ciencias humanas y sociales.Salamanca, 1989, pp. 217-236, VACA LORENZO, Ángel. "Recesión económica y crisis social de Castilla en el siglo XIV” en Las crisis en la historia.Salamanca, 1995, pp. 33-56.

${ }^{49}$ URCELAY GAONA, Egoy. Los Sarmiento...Op.cit, pp. 85-106.

${ }^{50}$ DÍAZ MARTÍN, Luis Vicente. Los oficiales de Pedro I de Castilla. Valladolid, 1987, pp. 23-30.

${ }^{51}$ El proceso detallado se examina en URCELAY GAONA, Egoy. Los Sarmiento...Op.cit pp. 109- 129

${ }^{52}$ FERNÁNDEZ MARTÍN, Luis. La Abadía...Op.cit, pp. 73-75.
} 
y Palacio, en 1443 con Carrión, en 1463 con San Martín de Pereda, en 1466 con Villarramiel y finalmente en 1478 con el priorato de San Salvador de Villarramiel ${ }^{53}$.

No todo son malas noticias para Benevívere. Según Bula emitida por el Papa Sixto IV en 1473 , se le concede al abad el uso de mitra y báculo ${ }^{54}$. Aún así, la abadía conserva posesiones en casi un centenar de lugares, que se concentran en su mayor parte en la provincia de Palencia ${ }^{55}$.

En lo que se refiere a los Sarmiento, con Juan II asistimos a un fortalecimiento del linaje a través de la figura de Pedro Ruiz de Sarmiento, repostero mayor del monarca, con la obtención del título de I conde de Salinas en $1445^{56}$. El Señorío de las salinas de Añana, en Álava, lo obtuvo su primogénito, Diego Gómez Sarmiento, por donación de Enrique IV en 1464, además del control de los principales pasos del Ebro, mediante los portazgos de las localidades burgalesas de Miranda y Pancorvo y la alavesa de Puentelarrá en 1473. De este modo, queda consolidado el linaje hasta el fallecimiento de don Diego en $1505^{57}$.

\section{EL CONJUNTO CONVENTUAL DURANTE LA EDAD MEDIA}

Desde sus inicios, la abadía de Benevívere contó con una muralla que cercaba el perímetro del conjunto. Cabría pensar que fueron los monjes, buscando su protección, quienes dispusieron la erección de tal fortificación ${ }^{58}$. Sin embargo, del poema que el abad Pascual dedica a Don Diego Martínez, se colige que fue una iniciativa del propio fundador, al poco tiempo transcurrido desde la edificación ${ }^{59}$. Si bien reedificada con

\footnotetext{
${ }^{53}$ Ibídem, pp. 76-77.

${ }^{54}$ RAMIREZ DE HELGUERA, Martín. El libro...Op.cit, pág. 235.

${ }^{55}$ Véase el elenco de todas ellas en FERNÁNDEZ CANTÓN, José María. Catálogo del Archivo Histórico Diocesano de León, II. León, 1986, pp. 331-362.

${ }^{56}$ Diego Sarmiento, tercero de su nombre se esposó con una hija de Diego López Estúñiga, naciendo de este matrimonio Pedro Ruiz Sarmiento, el primer conde de Salinas. GARCÍA CARRAFA, Alberto y Arturo. Op.cit, pág. 151. Sobre este personaje LÓPEZ DE HARO, Alonso. Nobiliario genealógico de los Reyes y Títulos de España. $2^{\circ}$ v. 1622. Edición facsímil, Navarra, 1996, pp. 530 y ss y BENITO RUANO, Eloy. "Don Pedro Sarmiento, repostero mayor de Juan II de Castilla. Datos biográficos documentales" en Hispania, $\mathrm{n}^{\circ}$ LXIX. 1957, pp. 483-504 y del mismo "El origen del Condado de Salinas" en Hidalguía, V, no 20,1957 , pp. 41-48.

${ }^{57}$ URCELAY GAONA, Egoy. Los Sarmiento...Op.cit, pp. 132-158.

${ }^{58}$ No hay que olvidar que entre 1157 y 1230 en que, a instancias de Alfonso VII, Castilla quedó separada de León, ésta era una zona fronteriza en la que los leoneses obtuvieron por entonces, su soberanía. GONZÁLEZ, Julio. Fijación de la frontera castellano-leonesa en el siglo XII. Valladolid, 1982, pp. 411424.

${ }^{59}$ URCELAY GAONA, Egoy. Los Sarmiento...Op.cit, pág. 49, a su vez de FERNÁNDEZ MARTín, Luis. "Un poema...Op.cit, versos 305-308.
} 
posterioridad, hoy día se mantiene un fragmento de ese cerco interpuesto a modo de icono de poder sobre el territorio aledaño.

\subsection{EL TEMPLO}

La primera edificación se realizaría en torno al año 1161 en que Diego Martínez de Villamayor y sus caballeros se asientan en Benevívere. A juzgar por la datación, debió tratarse de un templo románico que, según parece, no quedó concluido a la muerte de su fundador. Continuó con las obras su hermano Rodrigo Martínez hasta principios del siglo XIII, quien figura en la documentación como segundo edificador siendo priores sucesivamente Don Pedro (1203-1205) y Don Juan (1206- 1220) ${ }^{60}$. Un documento firmado por el abad don Pedro en 1203 aporta un interesante dado acerca de la obra que se estaba realizando en la abadía. Se trata de una donación a Benevívere de una heredad en Villacuende en la que figuran como testigos, entre otros, un fraile de nombre Mamelio, y el prior de Sahagún, don Pelayo ${ }^{61}$. Ambos son denominados "edificator operis", de modo que bien pudieron ser estos frailes los artífices o al menos manos partícipes de esta gran empresa ${ }^{62}$.

El templo por tanto, comenzado en el último cuarto del siglo XII, se iría configurando a lo largo de la centuria siguiente. Una bellísima aguada de color realizada por Valentín Carderera en 1838 nos permite visualizar la fisonomía de la capilla mayor, correspondiente efectivamente, al siglo $\mathrm{XIII}^{63}$. El dibujo muestra cómo en la cabecera poligonal del templo una bóveda radial se ramifica en ocho nervios finísimos que voltean sobre una serie de baquetones estilizados entre los cuales se ubican los vanos practicados en el muro. Dispuestos a cierta altura del nivel del suelo, a unos dos metros, se disponen siete arcos abocinados de medio punto, de los cuales dos, parecen estar

\footnotetext{
${ }^{60}$ FERNÁNDEZ MARTÍN, Luis. La abadía...Op.cit, pág. 38, 56.

${ }^{61}$ Ibídem, pp. 64-65.

${ }^{62} \mathrm{La}$ intervención de los monjes como operarios, maestros de obras o arquitectos en los conjuntos monásticos, sobre todo en el caso de la Orden del Císter, es sobradamente conocida. AUBERT G. L'architecture cistercienne en France. París, 1947, pp. 95 y ss, DIMIER, Anselme. Les moines battîsseurs: architecture et vie monastique. París, 1964, ASCANI, V. "Cisterciensi. Architettura" en Enciclopedia dell'arte medievale, vol.IV. Roma, 1993, pp. 817-835. Otros estudios más recientes y específicos en PITA GALÁN, Paula. "Monjes capitulares y frailes arquitectos: dos aspectos de la maestría de obras en el monasterio de San Martín Pinario (siglos XVI-XVIII)" en Galica monástica, Santiago de Compostela, 2009, pp. 537-560, GARCÍA FLORES, Antonio. Arquitectura de la Orden del Císter en la provincia de Valladolid (1147-1515). Junta de León. Valladolid, 2010.

${ }^{63}$ FLG. Interior de la iglesia de Benevívere. Fondo Carderera. N ${ }^{\circ} 9813$.
} 
tapiados. La luz de los cinco restantes resulta tan estrecha que los vanos recuerdan en su estructuración a las saeteras o aspilleras de las fortalezas medievales. Si bien no podemos verlo a través de la imagen, sabemos que en la clave de la capilla mayor figuraba la imagen del Salvador y en el crucero, un cordero con bandera como estandarte del fundador, don Diego Martínez Salvador ${ }^{64}$. En el siglo XIX la iglesia no tenía retablo, por eso tan sólo una mesa de altar con una cruz de pie en su centro preside la capilla mayor. El tramo precedente al del ábside, correspondiente al del presbiterio presentaba una cubrición de bóveda de crucería sexpartita con nervios de sección redondeada, igualmente sustentada sobre baquetones, de mayor altura que los de la capilla mayor. Estos soportes salvaban la diferencia de altura existente por la presencia de una escalinata para acceder al altar cobijada por un gran arco triunfal apuntado de sección prismática y aristas vivas.

La distribución de la capilla mayor con la bóveda radial, los arcos abocinados, el tramo recto precediendo al polígono absidal guarda gran analogía con la que presentan las iglesias de los monasterios de Santa María de Palazuelos, en Valladolid y más aún con San Andrés de Arroyo en Palencia, con la que comparte la distribución en siete paños con dos ventanas cegadas. La salvedad la constituye la disposición de arquivoltas y jambas en los arcos abocinados en el caso de los cenobios cistercienses, en lugar de hallarse éstos embebidos en el muro. Si Benevívere y las casas del Císter compartían rigor de observancia y análogos libros eclesiásticos ${ }^{65}$, no nos debe extrañar que todas ellas recurriesen a patrones constructivos análogos.

Según estos datos, el resto del templo poseería la misma cubrición y soportes que el altar mayor. Respecto al número de naves que tendría el templo, Quadrado dice al respecto: “...todavía se demarca el recinto de la iglesia, que era de tres naves no tal como fundó hacia 1165 el conde Diego Martínez de Villamayor... ${ }^{66 " . ~ E l ~ a ́ b s i d e ~ s e ~}$ encontraba flanqueado por dos capillas colaterales, una de las cuales pervivió al menos hasta 1861, pues Quadrado la conoció. Un dibujo de Carderera realizado en 1858 de los restos de abadía, cuando la iglesia había perdido sus cubiertas, confirma la presencia de

\footnotetext{
${ }^{64}$ La descripción de la clave corresponde al año 1666. ADP. Religiosos. Abadía de Benevívere (14751808), s/f.

${ }^{65}$ Alejandro III confirma en 1179 las constituciones de la abadía con el decreto de Citeaux. FERNÁNDEZ MARTÍN, Luis. Colección... doc 21, pág. 23.

${ }^{66}$ PONZ, Antonio. Viaje...1 $1^{a}$ Edición, Op.cit, pág. 189, QUADRADO, José $\mathrm{M}^{\mathrm{a}}$ y PARCERISA, Francisco, J. $1^{\text {a }}$ Edición. Op.cit, pág. 345.
} 
una capilla en el lado del evangelio ${ }^{67}$. En la misma y adosado al muro se dispone un acceso conformado por un arco de medio punto con doble moldura de base prismática, un añadido de época moderna. El arranque de un arco formero en un nivel superior respecto a la capilla mayor indica una mayor altura de la nave principal.
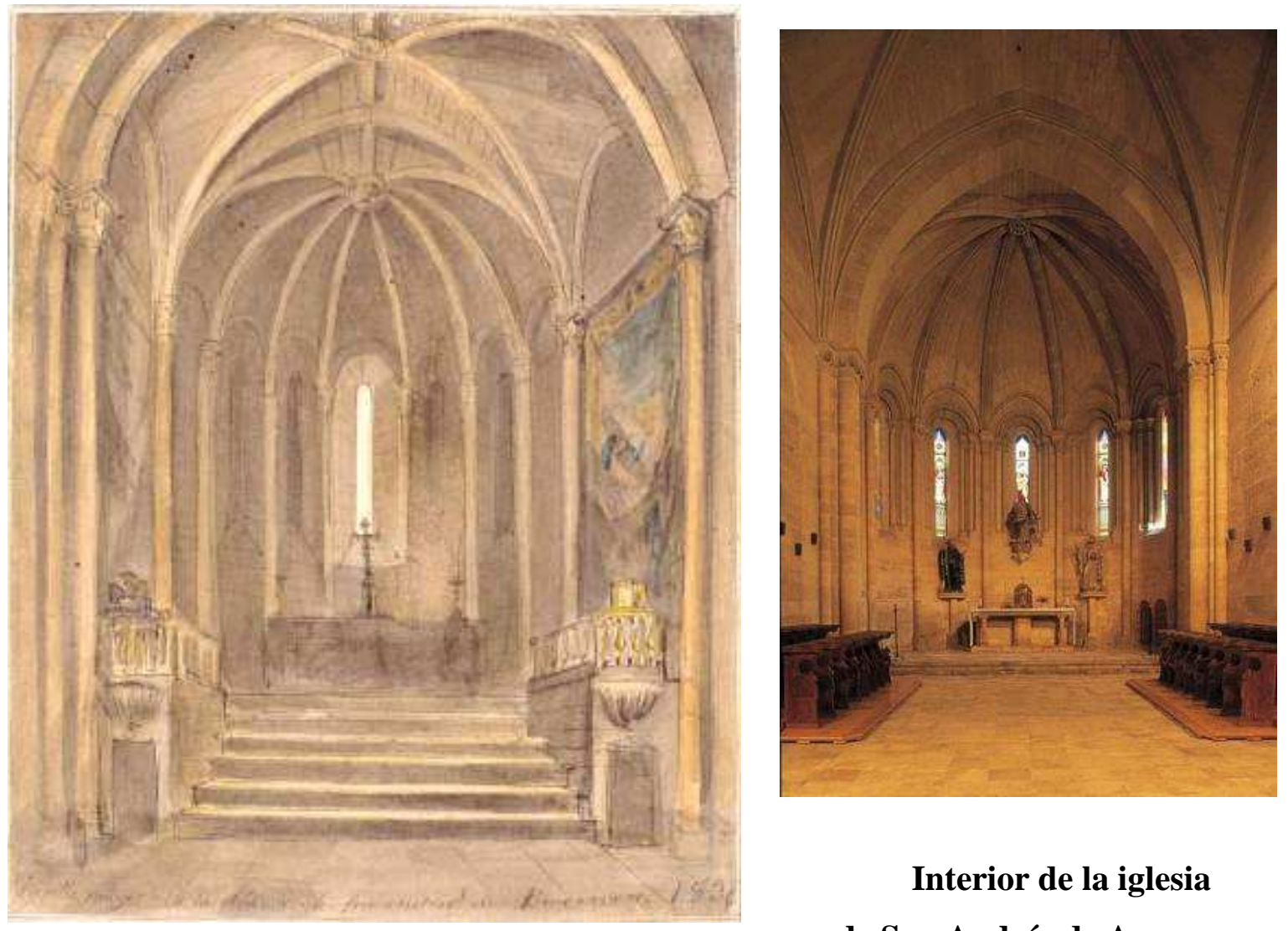

Interior de la iglesia

de San Andrés de Arroyo.

\section{Interior de la iglesia de Benevívere.}

Aguatinta de 1838. Fundación Lázaro Galdiano.

Fondo Carderera 9813.

La descripción del conjunto del templo transmitida por Quadrado de 1861 coincide exactamente con la visión ofrecida: “...ojivas no muy pronunciadas, sus capiteles entre góticos y bizantinos, sus cinco angostas y prolongadas lumbreras

\footnotetext{
${ }^{67}$ FLG. Ruinas de la abadía de Benevívere. Fondo Carderera. № 9814.
} 
semicirculares y los arcos que irradiando de la clave, bajan a descansar sobre delgadas columnas ${ }^{68,}$.

En la aguatinta de Carderera, se observa además la ornamentación de los muros del tramo recto del presbiterio recubiertos de dos amplias sargas. A los pies de éstas, hallamos dos tribunas conformadas por una sencilla balaustrada para dirigir los rezos y cantos diarios a la comunidad monástica. Frente a la capilla mayor se hallaba el coro, cuyos sitiales se conservan íntegramente en la iglesia de San Andrés de Carrión ${ }^{69}$. A juzgar por la cantidad de cargos y oficios que se detallan en el Libro de Costumbres y por la cantidad de prioratos dependientes del mismo, se cree que la comunidad agustina fue bastante numerosa ${ }^{70}$. Las constituciones de 1631 revelan que el total de cátedras del coro era de veinticuatro:

-el abad

-trece canónigos claustrales que asistían al coro y demás ejercicios religiosos. Por regulación de quinquenio, nunca superaron este número ni fueron menos de once para el buen mantenimiento de la comunidad ${ }^{71}$. También cabe pensar en la simbología de este número vinculada a los roeles del escudo de los Sarmiento.

-siete canónigos no claustrales que sólo acudían a las festividades principales y a la elección canónica del abad

-tres o cuatro canónigos estudiantes en otras partes como Trianos y Salamanca

Además se reservaba un asiento para el patrono ${ }^{72}$.

El abad, como es sabido se reservaba el sitial central y el resto se disponían según la dignidad de los religiosos. En las congregaciones con el resto de prioratos dependientes de la abadía, los priores se ubicaban según la antigüedad de cada una de ellas. Así, al lado derecho del abad se ubicaba el prior de claustro e inmediatamente el de Villarramiel y al lado contrario, el prior mayor y seguidamente los de la Puente y

\footnotetext{
${ }^{68}$ QUADRADO, José $\mathrm{M}^{\mathrm{a}}$ y PARCERISA, Francisco, J. $1^{\text {a }}$ Edición. Op.cit, pág. 345. Esas cinco lumbreras se corresponden con las ventanas abocinadas de la cabecera.

${ }^{69}$ Sobre la sillería se hablará en el apartado consignado a este templo.

${ }^{70}$ Es el libro en el que puede verse cómo de realizaba la vida monacal en la abadía y las ceremonias litúrgicas que en ella se celebraban. El códice original se ubica en el Archivo Histórico Nacional y se escribió al parecer entre 1206 y 1220. Véase FERNÁNDEZ, Luis. Colección...Op.cit, pág. 79-250.

${ }^{71}$ Informe de 1666 ADP. Religiosos. Abadía de Benevívere (1475-1808), s/f.

72 ADP. Conventos dispersos. Benevívere. Libro 1. 1631. Constituciones y estatutos, fol 92.
} 
Mañino. Además de éste, existía otro coro alto, utilizado para la ceremonia de la toma del hábito de los novicios ${ }^{73}$.

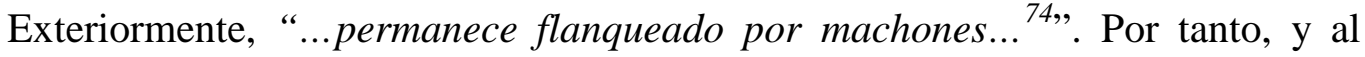
igual que otras iglesias conventuales de la época, poseería un ábside poligonal reforzado a través de contrafuertes, del mismo modo que en el primitivo templo de San Francisco de Carrión.

Hacia 1382 se llevó a cabo la reedificación que dotaría al templo de su aspecto definitivo exceptuando, eso sí, las transformaciones barrocas posteriores ${ }^{75}$. Esta reconstrucción fue comandada por un descendiente de Diego Martínez, llamado Don Diego Gómez Sarmiento, quien se convertirá en patrono en 1371 a partir de una donación de Enrique II $^{76}$. Ésta viene justificada por los estrechos lazos familiares entre ambos, dado que la esposa de Don Diego, doña Leonor de Castilla, era sobrina del monarca $^{77}$. Hijo de Diego Pérez Sarmiento y doña María de Velasco, ostentó el título de I señor de Salinas y Mariscal de Castilla.

Acerca de la portada, que se mantuvo en pie hasta el siglo XVIII, se conservan algunas descripciones que apuntan a una iconografía típicamente románica al tratarse probablemente de la portada de la primitiva de la iglesia. En la puerta estaba esculpido un Apostolado que flanquea el carro de Ezequiel ocupado por Cristo y tirado por los animales del Apocalipsis ${ }^{78}$. En realidad, el carro de Ezequiel no es tal objeto; la interpretación más razonable lo vincularía con la mandorla del Pantocrátor rodeado del

\footnotetext{
${ }^{73}$ ADP. Conventos dispersos. Benevívere. Libro 1. 1631. Constituciones y estatutos, fol 77-78.

${ }^{74}$ QUADRADO, José M ${ }^{\mathrm{a}}$ y PARCERISA, Francisco, J. Op.cit, pág. 141.

${ }^{75}$ PONZ, Antonio. Op.cit, pp. 204-205, LLAGUNO Y AMIROLA, Eugenio. Noticias...Tomo I, Op.cit, pág. 70 y FERNÁNDEZ, Luis. La Abadía...Op.cit, pág. 38. No sabemos si por error, otros autores probablemente por equivocación, invierten la fecha de la reedificación y proponen 1328. RAMIREZ DE HELGUERA, Martín. El libro...Op,cit, pág. 166. Dice que la toma de Quadrado, y éste en su descripción se refiere efectivamente al año 1382. QUADRADO, José Mª y PARCERISA, Francisco, J. Op.cit, pág. 141.

${ }^{76}$ Don Diego Gómez Sarmiento dicta testamento en 1385 estando en la villa de Peñacerrada, en el Obispado de Calahorra, dictó testamento y dispuso su enterramiento en este lugar BN. Manuscritos. LLORENTE DE ALCÁZAR Y MENDIZÁBAL, Juan Antonio. Noticias...Op.cit, fol 13v.

${ }^{77}$ BN. Manuscritos. LLORENTE DE ALCÁZAR Y MENDIZÁBAL, Juan Antonio. Noticias históricas de la villa de Carrión de los Condes esparcidas en diversos historiadores y recopiladas para su instrucción particular. 1802, fol 13.

${ }^{78}$ PONZ, Antonio. Viaje...1 ${ }^{a}$ Edición, Op.cit, pág. 189, RAMIREZ DE HELGUERA, Martín. El Real monasterio... Op.cit, pág. 95.
} 
Tetramorfos $^{79}$. La similitud con la portada de Santiago es bastante evidente, siendo anterior al menos de una década la de nuestra abadía. Hernando Garrido defiende que un fragmento tardo-románico representando un hombre barbado que se conserva en el Museo Arqueológico Nacional, pertenecería al Apostolado de la portada ${ }^{80}$. Esta cabeza, que Martín Mínguez identifica con la del Salvador, se encontraba en 1907 en la casa de don Gregorio Obeso, capellán de la iglesia de Santiago, figurando entre los escasos bienes que se pudieron salvar del conjunto ${ }^{81}$.

Se desconoce en qué año fue derruida esta fachada, pero fue probablemente durante las sucesivas desamortizaciones decimonónicas, pues los viajeros que durante este siglo visitaron el convento, se lamentaban de su pérdida. Así indica Quadrado en 1861: "Ha desaparecido empero sin dejar rastro toda la parte primitiva del siglo XII...que según los testimonios de Ponz estaban esculpidos sobre la puerta del templo",82.

\subsection{EL CLAUSTRO}

Dataría del siglo XII, de los orígenes de la abadía, y por tanto su estilo sería románico. En primer plano del grabado de 1842 que Villaamil reproduce de la sala capitular tomando como referencia el dibujo de Pérez Villaamil de 1842, se observa un arco y la continuación de otro, de tipo carpanel con moldura de bolas, que pertenece a este claustro. La aparición de este tipo de arco indica una remodelación hacia el siglo $\mathrm{XV}$, conservándose, eso sí, las columnas de mármol con sus capiteles vegetales de muy diversas labores en cada uno, probablemente de la fábrica original. Sobre este piso, se situaría otro, cuya estructura desconocemos. La cubrición se realizaba mediante un alfarje al que se superponían listones de madera dispuestos paralelamente a lo ancho de la crujía. En el dibujo, además se puede apreciar que el pavimento, que podría ser de mosaico, está compuesto por una serie de círculos tangentes que contiene otros motivos

\footnotetext{
${ }^{79}$ PERAL VILLAFRUELA, Santiago. Estudio...Op.cit, pág. 8.

${ }^{80}$ HERNANDO GARRIDO, José Luis. "Benevívere..”. Op.cit, pág. 995.

${ }^{81}$ MARTÍN MÍNGUEZ, Bernardino. Catálogo...Op.cit, volumen 3, pág. 56 bis.

${ }^{82}$ QUADRADO, José M ${ }^{\mathrm{a}}$ y PARCERISA, Francisco, J... $1^{\text {a }}$ Edición. Op.cit, pág. 345.
} 
geométricos. Este recinto se usaba como lugar de congregación de los monjes antes de ser llamados a la misa.

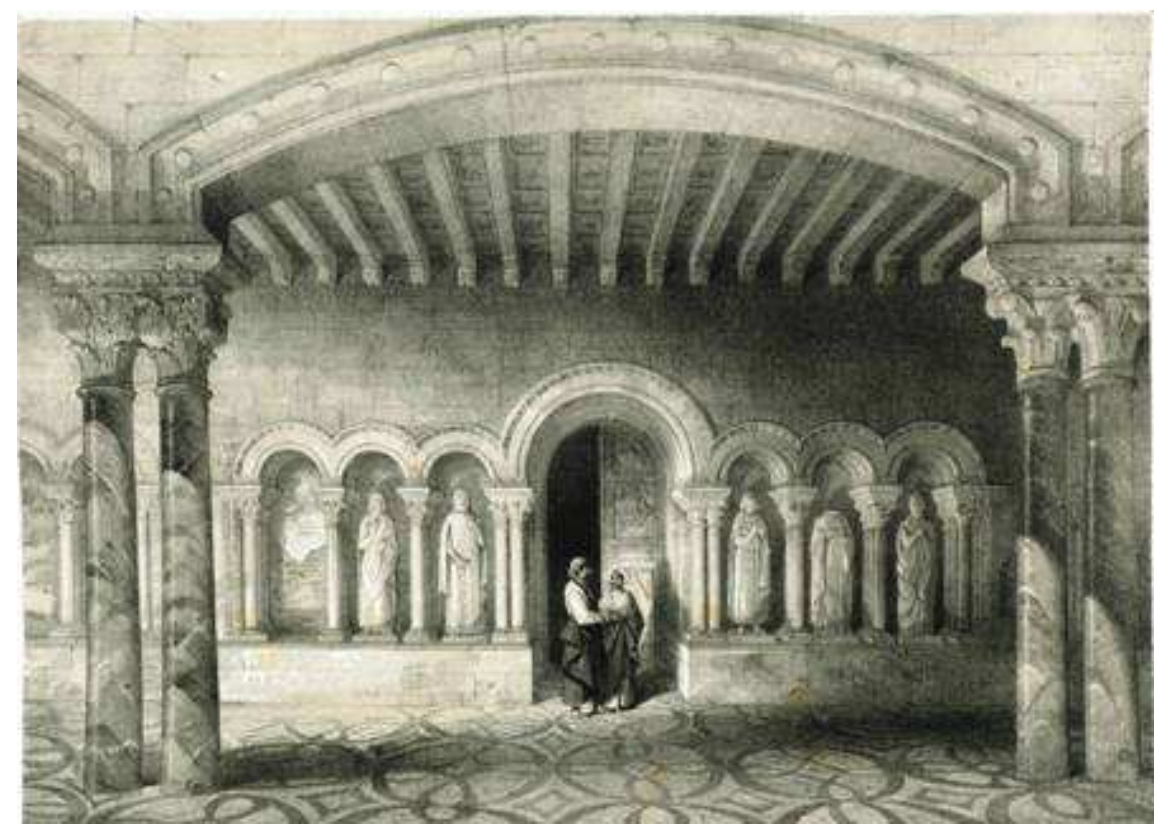

Claustro y entrada a la sala capitular de Benevívere.

Grabado de Genaro Pérez Villaamil de 1842 en España Artística y

Monumental.

En el informe que realizó la Comisión de monumentos palentinos sobre los monumentos notables de la provincia de Palencia en 1860 se recogen entre otros, los sepulcros de Benevívere y una estela de piedra que se halló en el claustro, junto al capítulo, situada sobre un pedestal ${ }^{83}$. Allí estuvo desde hacía siglos pues en 1593, se indica que en un pilar del claustro “...un odre de rrelox y alrededor della unas letras [sic: antiguas] góticas que dizen aber sido el dicho Diego Martínez, fundador del dicho monasterio... ${ }^{84,}$.

Ubicada hoy día en el museo Diocesano de Palencia, y cedida temporalmente para la exposición "Monacatus" de las Edades del Hombre celebrada en el monasterio de Oña (22 de mayo-4 de noviembre de 2012), esta losa pétrea con inscripciones realizada en tiempos del primer abad Pascual, conmemoraba efectivamente la muerte del fundador Diego Martínez de Villamayor en 1176. Su singularidad estriba en el

\footnotetext{
${ }^{83}$ ARASF. Palencia, Comisión de Monumentos, Leg. 2-7-7, Monumentos en general.

${ }^{84}$ AHPP. Desamortización. Legajo 118, №4.
} 
hecho de que los dos círculos que conforman esta lápida hacen las funciones un calendario litúrgico con las horas canónicas y el inferior, un reloj solar con las doce horas del día ${ }^{85}$. Debido a los desprendimientos y roturas, la pieza ha sido sometida a una restauración reciente ${ }^{86}$.

\subsection{LA SALA CAPITULAR, PANTEÓN DE HOMBRES ILUSTRES}

Desde el siglo XVI se le denominaba Capilla de San Miguel por la presencia en su interior de un altar dedicado al Arcángel, originariamente bajo la advocación de Santa María. En el capítulo, además de celebrarse la elección del abad y tratarse los asuntos referentes a la comunidad monástica, se realizaban misas cantadas a las que podían asistir las mujeres ${ }^{87}$.

La apariencia del acceso a esta capilla la conocemos gracias a un grabado que realizó en 1842 Pérez Villaamil tomando como referencia para el mismo, un dibujo que Carderera hizo en su excursión a la abadía en 1836. En él se contenía una portada sobre un podio compuesta por un arco de medio punto flanqueada por dos arcadas de tres arcos ciegos de menores dimensiones a cada lado que cobijaban esculturas pétreas de tamaño natural. Representarían a personajes regios o de rango nobiliario, dada la posesión de espada, la capa larga y la melena recta al nivel del cuello, propia de la moda medieval. Ya por entonces no se conservaban íntegramente, pudiéndose observar que de las tallas estaba decapitada y una de las hornacinas se encontraba vacía. Las figuras se hallaban separadas por tres columnas dispuestas en fila con fustes de mármol, capiteles con hojas de acanto muy variadas y cimacios labrados a trépano. En la parte izquierda del grabado, un arco de medio punto nos indica que la estancia continuaba, al menos, por ese lado, de lo que se extrae que era un espacio de grandes dimensiones. Confirmamos que se trata de la sala capitular con las palabras de Quadrado: “una majestuosa entrada a la sala capitular, consistente en un severo arco bizantino a cada

\footnotetext{
${ }^{85}$ SANCHO CAMPO Ángel. Guía del museo diocesano de Palencia. Origen, formación y estado actual. Palencia, 1999, pp. 367-368.

${ }^{86}$ La trascripción latina de sus inscripciones en HERNANDO GARRIDO, José Luis. "Benevívere", pp. 1263-1264.

${ }^{87}$ PERAL VILLAFRUELA, Santiago. Estudio...Op.cit, pág. 15.
} 
lado del cual había otros tres conteniendo estatuas, decorados con columnas del mismo género ${ }^{88, "}$

Su altura alcanzaba 36 pies de altura, lo que equivaldría a nada más ni menos que 9,5 metros. Estos datos nos los proporciona la Comisión provincial de monumentos de Palencia al describir el monumento del abad Juan de Sarmiento, que debía tener la misma altura. Dicha comisión encontró en este acceso una lápida de tres cuartas de alto datada en 1074 en cuyo centro estaba esculpido un florón ${ }^{89}$. No se transcribe la inscripción, por lo que no podemos saber a quién pertenecería. En todo caso, se trataría de un personaje desvinculado de la abadía, dado que corresponde a una fecha muy anterior a la de su fundación. Recorriendo los muros de la sala capitular se disponían los bancos para asiento de los canónigos. Pero lo más importante del capítulo es el hecho de que fue usado como panteón para albergar los sepulcros de algunos miembros del linaje de los Sarmiento y de ciertos abades del convento que lamentablemente no se conservan $^{90}$.

En el informe que realizó la Comisión de monumentos palentinos sobre los monumentos notables de la provincia de Palencia en 1844 se recogen los sepulcros de Benevívere, gracias a cuya descripción podemos imaginar cual fue su fisionomía ${ }^{91}$. En la siguiente visita del cenobio, realizada en 1858 se constata con desolación que los sepulcros han desaparecido y que toda el área está sembrada de hortalizas y árboles ${ }^{92}$. Además de otros que se realizaron con posterioridad, se tiene constancia de que se conservaban los sepulcros medievales de los personajes relatados a continuación.

\footnotetext{
${ }^{88}$ QUADRADO, José M ${ }^{\mathrm{a}}$ y PARCERISA, Francisco, J.. $1^{\text {o }}$ Edición, Op.cit, pág. 345.

${ }^{89}$ PERAL VILLAFRUELA, Santiago. Estudio...Op.cit, pág. 16.

${ }^{90}$ Además de en el Capítulo, os miembros del linaje Sarmiento se enterraban además bajo la capilla mayor. Por su parte, los abades, lo hacían en la capilla de San Pedro. ADP. Conventos dispersos. Benevívere. Libro 1. 1631. Constituciones y estatutos.

${ }^{91}$ ARASF. Palencia, Comisión de Monumentos, Leg. 2-7-7, Monumentos en general.

${ }^{92} \mathrm{El}$ estado de total abandono del convento lo ilustra un aguatinta de 1858 realizado por Carderera. Se puede observar cómo han crecido los arbustos en el interior de la iglesia y las ramas de los árboles penetran por las ventanas de la capilla mayor. FLG. Ruinas de la abadía de Benevívere. Fondo Carderera. $\mathrm{N}^{\circ} 9814$.
} 


\section{El fundador Don Diego Martínez Salvador de Villamayor}

Se situaba en el centro del capítulo y se componía de sarcófago con la tapa labrada con la estatua del yacente. Un dibujo a color que en 1836 realizó Valentín Carderera nos permite conocer la apariencia del fundador ${ }^{93}$. A pesar de que nos lo describe de aspecto bárbaro y terrible, su dibujo, sin embargo, no se corresponde demasiado con la representación, si bien es cierto que el ceño se frunce, como si el yacente estuviera siendo víctima de un mal sueño. Presentaba barba larga en punta y prolongadas cabelleras al modo de un rey godo o franco. Además portaba una túnica ancha y manto cerrado con un broche a modo de púrpura imperial. Portaba un azor - en su mano izquierda, -decapitado en la imagen- como también lo tenían algunos de los yacentes del capítulo, pues así nos lo remite Ambrosio de Morales:

“...está allí enterrado con muchos de su linage, y él y los más en los vultos, tienen halcones en la mano”.

Portar este ave rapaz, era signo de los derechos jurisdiccionales de la nobleza en la Edad Media $^{94}$.

Los pliegues del manto pecaban de cierto acartonamiento. Remataba el conjunto una gran arcada o nicho. Con sus pies, el difunto pisa un león, símbolo del triunfo sobre la muerte, en referencia al pasaje bíblico del Salmo 91 que conmina a caminar sobre el león, el dragón, el basilisco o el escorpión ${ }^{95}$. Otros ejemplos castellanos del siglo XIII en que los yacentes figuran acompañados de estos animales, son los del arcediano y maestro Facundo o el canónigo Pedro Yáñez, fallecido en 1250 y 1258, respectivamente ${ }^{96}$.

En el testero del sepulcro, dispuesta en varias líneas, figuraba la siguiente inscripción, que no aparece en el dibujo:

\footnotetext{
${ }^{93}$ CARDERERA Y SOLANO, Valentín. Iconografía española: colección de retratos, estatuas, mausoleos... de reyes, reinas, grandes capitanes... desde el siglo XI hasta el XVII. Madrid, 1855-1864.

${ }^{94}$ FERNÁNDEZ, Luis. La Abadía...Op.cit, pág. 36.

${ }^{95}$ FRANCO MATA, Ángela. "Iconografía funeraria gótica en Castilla y León (siglos XIII y XIV)" en De arte. $\mathrm{n}^{\circ}$ 2. Universidad de León. León, 2003, pág. 73.

${ }^{96}$ FRANCO MATA, Ángela. Escultura gótica en León y provincia (1230-1530). León, 1998, pp. 266268.
} 
"HIC JACET VENERABILIS MEMORIAE DIDACUS MARTINEZ, DOMUS BENEVIVERENSIS AEDIFICATOR, PATRONUS EJUSDEM DOMUS, CUJUS ANIMA REQUIESCAT IN PACE. OBIIIT ERA MCCXIIII. NON. NOVEMBR ${ }^{97, "}$

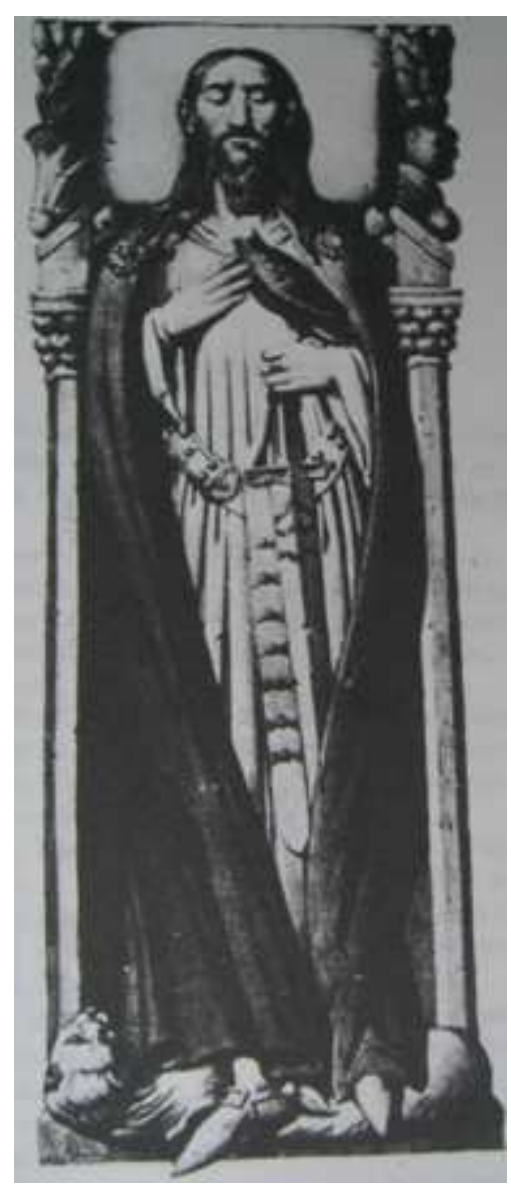

Fernández del Pulgar añade el nombre del abad por entonces, y primero que tuvo el convento: "Existente Domino Paschasio i Abbate"

Carderera altera la transcripción.: "HIC JACET VENERABILIS DOMINUS DIDACUS MARTINEZ DE SARMIENTO BENEVIVERENSIS AEDIFICATOR, PATRONUS ET DOMINUS, OBIT ERA 1214”. Añade el patronímico Sarmiento, que como apuntamos no lo tenía el fundador y sustituye la numeración romana por la arábiga.

Tapa del sepulcro de Don Diego Martínez.

Extraído de Carderera Solano, Valentín.

Iconografía Española.

Curiosamente, Carderera nos habla de que existía una "arcada o nicho que rodea la efigie de Don Diego sobre su tumba...práctica que se remonta a principios del siglo XII”. Añade que sepulcro estaba asentado sobre leones. Se trataría por tanto de un monumento funerario tipo baldaquino, una tipología que, sin embargo, no aparece en Castilla hasta finales del siglo XII. Los primeros ejemplares de estos monumentos funerarios decorados los mandó ejecutar Alfonso VIII en las Huelgas Reales de Burgos ${ }^{98}$. La llegada de este modelo a Carrión tuvo lugar, según indica Julia Ara, entre 1230 y 1270 . El taller aquí asentado llevaría a cabo los sepulcros más tardíos de la galilea del monasterio de San Zoilo ${ }^{99}$.

\footnotetext{
${ }^{97}$ La era 1224 se corresponde con el año 1178. PONZ, Antonio. Viaje...1 $1^{a}$ Edición, Op.cit, pág. 189.

${ }^{98}$ Sobre el mismo PÉREZ MONZÓN, Olga. "Iconografía y poder real en Castilla: las imágenes de Alfonso VIII" en ADHTA, n 14, 2002, pp. 19-41.

${ }^{99}$ ARA GIL, Clementina-Julia. "Un grupo de sepulcros... Op.cit, pág. 21.
} 
Esto nos lleva a plantear que, por una parte, la lápida pudiera haber sido realizada poco después de la muerte de don Diego Martínez. El hecho de que el epitafio no envolviese la lauda, sino que apareciera concentrado en este espacio del sarcófago con un relieve apenas destacado, permite fecharla a finales del siglo XII o principios del siguiente. Posteriormente, en el siglo XIII con el establecimiento del taller carrionés es probable que se decidiera añadir el mencionado ciborio y los leones. De este modo, la comunidad monástica engrandecería la figura del fundador destacando su presencia en el centro del capítulo con un monumento acorde a su relevancia dentro del mismo. Por eso, incluso Quadrado, en su visita a las ruinas del monasterio se extraña de la diferencia que presentan unas partes del sepulcro con otras: "tumba magnífica para aquella edad aunque con sencillo y modesto epitafio ${ }^{100,}$.

En el Museo Arqueológico Provincial de Palencia se conserva una urna sepulcral del siglo XIII que podría corresponderse con la de Diego Martínez. Algunos historiadores, basándose en una lista remitida por la Comisión de Monumentos Histórico Artísticos que el diario de Palencia publicó en 1899, aseguraban que eran tres los sarcófagos procedentes de Benevívere. Habían sido utilizados como abrevaderos cuando la abadía se utilizaba como granja ${ }^{101}$. Sin embargo, estos datos no parecen ser demasiado fiables, como así revela un informe remitido por dicha Comisión a la Real Academia de Bellas Artes de San Fernando en 1860. En el mismo queda reflejado el estado de los monumentos palentinos y sus bienes y se hace constar que dos de ellos provienen del monasterio de Santa María de Vega y sólo uno de la abadía Agustina.

En la cabecera de este sepulcro se representa un Calvario con cierta tendencia naturalista en el tratamiento de la anatomía. A los pies un tema medieval muy recurrente, el óbito de un noble asistido por dos acólitos, pues la tradición exigía que los miembros de cierto rango, como es nuestro caso, no murieran en soledad ${ }^{102}$. En la cara de la izquierda, aparecen representados personajes del Antiguo Testamento. Tal vez, los dos primeros de ellos, sean Moisés y Aaron. En la cara lateral derecha se representa el clásico Apostolado bajo arquerías y el Pantocrátor presidiendo el conjunto con los

\footnotetext{
${ }^{100}$ QUADRADO, José M ${ }^{\text {a }}$ y PARCERISA, Francisco, J. $1^{\text {a }}$ Edición. Op.cit, pág. 346.

${ }^{101}$ NAVARRO GARCÍA, Rafael y REVILLA VIELVA, Ramón. Op.cit, pp. 14 y 15 y GARCÍA CHICO, Esteban. "Documentos...Tomo III, 1, Pintores". Op.cit, pág. 92.

${ }^{102}$ PÉREZ MONZÓN, Olga. "La procesión fúnebre como tema artístico en la Baja Edad Media" en ADHTA, $\mathrm{n}^{\circ} 20,2008$, pp. 21-22.
} 
símbolos de los Evangelistas, esquema que se repite en los sepulcros de Cisneros y Sahagún, con los que se relaciona además por la composición análoga de las tracerías góticas $^{103}$.

\section{El Abad Domingo}

En 1895 fueron encontrados en una propiedad particular cuatro sepulcros pétreos cubiertos con tapa que aseguraban procedían de Benevívere. Sólo uno llevaba el siguiente epitafio: "HIC JACET ABBATIS PRIMI SACER OS PIETATIS NOMINE DOMINICUS DOMINICE VERO AMICUS. ERA MCCXXXIII"), Este abad Domingo falleció, como indicamos en 1194. Sin embargo, el primer abad de Benevívere que consta documentalmente, fue don Pascual, que detentó el cargo desde 1173 a 1202 y no figura ningún abad con el nombre de don Domingo, hasta 1221, siendo el cuarto de su cargo $^{105}$. Por entonces sólo estaba fundado el monasterio de San Zoilo y tampoco allí aparece este nombre en el abadologio benedictino ${ }^{106}$. Si bien pudiera proceder de un cenobio del entorno, como Santa María de la Vega, debemos descartar la procedencia carrionesa de esta lauda, hoy desaparecida.

\section{Don Pedro Fernández}

Ponz afirma, con no demasiada seguridad, que este personaje, según él Primer maestre de la Orden de Santiago, está enterrado en este monasterio, sin precisar dónde $^{107}$. Luis Fernández, gran estudioso de la documentación medieval de la abadía, defiende que este personaje podría identificarse con Pedro Fernández de la Fuente Encalada, hijo de la condesa Doña Estefanía Armengol, fundadora de la Abadía de Valbuena de Duero. Habría colaborado en 1166 con Diego Martínez, benefactor de Benevívere, en la seguridad de peregrinos, desde que el monasterio benedictino de San Andrés de Valvení fue asaltado por unos bandoleros ${ }^{108}$.

\footnotetext{
103 ARA GIL, Clementina-Julia. “Un grupo...”. Op.cit, pág. 35.

${ }^{104}$ RAH, CAP/9/7967/15 (1) (2). Expediente sobre el hallazgo de varios sepulcros en Benevívere. Oficio en el que se comunica el hallazgo de sepulcros 16/11/1895 p. 196.

${ }^{105}$ FERNÁNDEZ MARTÍN, Luis. La Abadía...Op.cit, pág. 56.

106 ZARAGOZA PASCUAL, Ernesto. “Abadologio...Op.cit, pp. 280-281.

${ }^{107}$ PONZ, Antonio. Viaje... $1^{a}$ Edición, Op.cit, pág. 190.

${ }^{108}$ FERNÁNDEZ MARTÍN, Luis. La Abadía...Op.cit, pp. 22, 23.
} 


\section{Don Diego Pérez de Sarmiento}

Se tiene noticia del sepulcro de Don Diego Pérez Sarmiento gracias al informe redactado por la Comisión de Monumentos Palentinos en 1845 que decía lo siguiente:

"En su centro tiene un escudo con trece círculos; a los lados de éste, año de 1435; alrededor de la piedra y en caracteres romanos se lee: Aquí yaze el esforzado caballero Don Diego Gómez Sarmiento, el cual mataron en Aragón en un combate de un hachazo en la cabeza ${ }^{109, "}$.

Como vemos, la Comisión muta el apellido Pérez por el de Gómez, lo cual conlleva a pensar que se trata del I señor de Salinas, esposo de Doña Leonor de Castilla, sobrina de Enrique II y patrón de Benevívere desde el año 1371, como apuntamos previamente. Sin embargo aquel falleció en 1385. Se trata de su nieto, Diego Pérez Sarmiento, III señor de Salinas y padre del I conde de Salinas, don Pedro Ruiz Sarmiento. Éste dictaba testamento en 1433, disponiendo como última voluntad ser sepultado “...donde es el

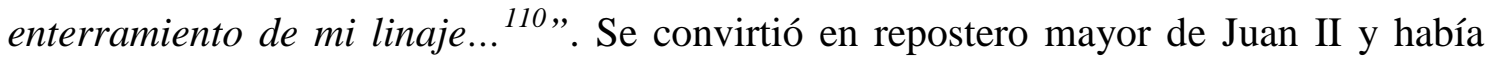
jugado un papel importante en la guerra castellano-navarra cuando en 1429 apresó en La Bastida al mariscal del rey de Navarra, don Sancho de Londoño ${ }^{111}$. Se hallaba en estos territorios conflictivos en los años en los que le sobrevino la muerte, por lo que es probable que falleciera en algún combate al servicio del rey castellano.

\section{Don Fadrique de Castro}

Hijo de don Pedro Enríquez, segundo Condestable de Castilla y conde de Trastámara, por sus venas corría sangre real, pues era primo segundo de Enrique III. Se

\footnotetext{
${ }^{109}$ PERAL VILLAFRUELA, Santiago. Estudio...Op.cit, pág. 21.

${ }^{110}$ URCELAY GAONA, Hegoi. Los Sarmiento...Op.cit, pág. 186. Para mayor claridad, véanse el árbol genealógico en 122. El testamento de Diego Pérez Sarmiento, dictado el 17 de marzo de 1433 en Archivo Municipal de Miranda de Ebro, 62-39.

${ }^{111}$ Sobre el conflicto en este territorio a partir de 1429 véase, DIAGO HERNANDO, Máximo. "Política y guerra en la frontera castellano-navarra durante la época de los Trastámara” en Príncipe de Viana, 203, 1994, pp. 525-548.
} 
esposó con Doña Aldonza de Mendoza, hija del Almirante don Diego Hurtado de Mendoza, y nieta de Enrique II, con la cual nunca tuvo descendencia ${ }^{112}$.

Fue nombrado duque de Arjona por merced de Juan II en 1423, el mismo que le mandó apresar en el castillo de Peñafiel en $1429^{113}$. Su cuerpo fue trasladado a la abadía beneviverense por un pariente cercano suyo, Don Pedro Ruiz Sarmiento ${ }^{114}$.

La comisión de monumentos palentinos nos indica que el sepulcro medía seis pies de largo por tres de ancho y en su centro ostentaba un escudo cuya lectura sería de campo dorado, seis roeles azur, correspondiente al linaje Castro ${ }^{115}$.

Ponz nos trascribe la inscripción que contenía:

"Aquí yace el esforzado caballero Don Fadrique de Castro, Duque de Arjona. Trájole a esta casa Pedro Ruiz Sarmiento, su sobrino, primer conde de Salinas; que finó en el castillo de Peñafiel en prisión, año de MCCCCXLII ${ }^{116 ", .}$

Se cree que esta fecha de 1442 fue mal copiada, pues en el testamento de su esposa, fechado en 1435, se refiere al duque en estas palabras: “cuya ánima Dios aya ${ }^{117}$ ”. De hecho Quadrado afirma que el duque falleció en 1430, sin embargo yerra al asegurar que don Pedro Ruiz Sarmiento no fue el primero que ostentó el condado de Salinas, otorgando su posesión a don Diego Sarmiento ${ }^{118}$. La inscripción probablemente fue realizada con posterioridad a la fecha del óbito de don Fadrique, pues el título de conde de Salinas -sustituido por el de señor- figura por vez primera en una misiva fechada en 9 de mayo de $1445^{119}$.

\footnotetext{
${ }^{112}$ MORALES TALERO, Santiago de. "Don Fadrique de Castilla y Castro, duque de Arjona" en Boletín del Instituto de Estudios Giennenes, n ${ }^{\circ} 40,1964$ pp. 19 y 32.

113 VV.AA. "Sepulcro de Doña Aldonza de Mendoza" en Semanario pintoresco español. Dirigido por GIRONELLA, Gervasio. Tomo II. Madrid, 1844, pp. 1,2. Parece que la causa del encierro fue el retraso intencionado del duque a la llamada del rey, aunque también se habla de la infidelidad a sus compatriotas. Sobre este tema y un poema que relata el asunto MORALES TALERO, Santiago de. "Don Fadrique...Op.cit, pp. 27-29.

${ }_{114}^{11}$ QUADRADO, José M ${ }^{a}$ y PARCERISA, Francisco, J.. Op.cit, pág. 142.

${ }^{115}$ ARASF. Palencia, Comisión de Monumentos, Leg. 2-7-7, Monumentos en general

${ }^{116}$ PONZ, Antonio. Viaje... $1^{a}$ Edición, Op.cit, pág. 190, Por tanto no fallece en 1430, como indican otras fuentes QUADRADO, José $\mathrm{M}^{\mathrm{a}}$ y PARCERISA, Francisco, J. Op.cit, pág. 141 y VV.AA. "Sepulcro...Op.cit, pág. 2.

${ }^{117}$ MORALES TALERO, Santiago de. "Don Fadrique...Op.cit, pp. 31-32.

${ }^{118}$ QUADRADO, José M ${ }^{a}$ y PARCERISA, Francisco, J.. $1^{\mathrm{a}}$ Edición. Op.cit, pp. 172, 345-346.

${ }^{119}$ URCELAY GAONA, Egoy. Los Sarmiento...Op.cit, pág. 149 y gráfico familiar en pág. 157.
} 
Aunque la losa con la inscripción se conservaba en el capítulo de Benevívere en 1835, los restos de don Fadrique no se encontraban allí desde hacía mucho tiempo como algún historiador indica ${ }^{120}$. Se tiene noticia de que estaba enterrado en el convento de Santa Clara de Toledo al menos desde el siglo XVII ${ }^{121}$.

\subsection{OTRAS DEPENDENCIAS}

Los datos que se conocen acerca de otras dependencias monásticas, provienen del Libro de Costumbres de la abadía, redactado hacia el año $1207^{122}$. Otra fuente ineludible resultan las Constituciones monásticas de 1631, que hablan de aspectos de que regían la vida monacal desde sus orígenes ${ }^{123}$.

Al sur de la sala capitular se encontraba el archivo, la librería y el escriptorio. Al cuidado de este lugar estaban dos archiveros, uno de los cuales era el secretario del capítulo, que debían custodiar un registro de préstamos comúnmente denominado "Libro del conocimiento". Aquel que no anotase en este registro el documento que se llevaba para consulta, aparte de hacer constar el motivo y la promesa de devolverlo, podría resultar excomulgado ${ }^{124}$.

Junto a la crujía sur del claustro, se situaba el refectorio. En él las sillas se disponían siguiendo una jerarquía como en el caso del coro. Quedaban excluidos de este comedor los seglares, siendo excepción que el médico o el escribano tuvieran acceso en caso de tener que ejercer su oficio en ese momento y lugar ${ }^{125}$. Los hermanos

\footnotetext{
${ }^{120}$ En contra de lo que otros piensen, como que que fueron trasladados a partir de entonces, hacia 1835 PERAL VILLAFRUELA, Santiago. "Estudio...Op.cit, pág. 21.

${ }^{121}$ SALAZAR DE MENDOZA, Pedro (1549-1629). Origen de las dignidades seglares de Castilla y Leon: con relacion sumaria de los reyes de estos reynos con un resumen al fin de las mercedes que su magestad ha hecho de marqueses y condes desde el año de 1621 hasta fin del de 1656. Oficina de Don Benito Cano. Madrid, 1794, pp. 220 y 302.

122 "Incipet Liber II Consuetudinum Eclesiae Beatae Marieae de Benevivere", un libro de Costumbres del cenobio escrito hacia el año 1207 y conservado en el AHN. Códice 1281. Se compone de cuatro partes: la primera se dedica a los clérigos, la segunda a los legos, la tercera a las relaciones entre la Abadía madre y las sufragáneas y la cuarta es una mezcla de diversas temáticas. El libro en latín figura en FERNÁNDEZ MARTÍN, Luis. La Abadía...Op.cit, pp. 84-247.

${ }^{123}$ Un compendio de las mismas aparecen recogidas en PERAL VILLAFRUELA, Santiago. "Estudio...Op.cit, pp. 31-34, a su vez de ADP. Conventos dispersos. Benevívere. Libro 1.1631. Constituciones y estatutos, fol 81-89.

${ }_{124}^{124}$ PERAL VILLAFRUELA, Santiago. "Estudio...op.cit, pág. 31.

${ }^{125}$ Ibídem, pág. 131.
} 
recibían en la comida dos platos de la cocina, es decir, calientes -normalmente legumbres y hortalizas, además de pescado cuatro días semanalmente- y uno de la despensa, reservándose la carne sólo para los enfermos ${ }^{126}$. Durante la misma se leían los inventarios relativos a las propiedades del convento o diversos fragmentos en latín y romance que consideraban de interés para los frailes.

La cocina se situaba a continuación del refectorio, y, seguidamente dos despensas, una más pequeña unida al claustro viejo, para los productos de consumo reciente y otra de mayor capacidad, ambas controladas por el mayordomo, quien además dispensaba las limosnas de vianda ${ }^{127}$. Las donaciones de aquellos que deseaban recibir sepultura en el monasterio se destinaban a la cocina en el caso de que no rebasaran tres áureos. Si se trataba de cantidades superiores, un tercio iría destinado al priorato de San Torcuato ${ }^{128}$.

Siguiendo dirección norte, se disponía la cárcel o cadena para encerrar a aquellos canónigos que hubiesen tenido una fuerte disputa, se hubieran saltado la clausura o hubieran incumplido alguna norma. A su cargo estaba el alcalde eclesiástico nombrado por el abad, que portaba una vara con un casquillo de plata y algunas cadenas como símbolo del cargo que desempeñaba. Junto a la cárcel se disponía la puerta que daba al claustro viejo por un lado y por el otro conducía al pasillo de entrada al convento ${ }^{129}$.

La entrada de seculares y mujeres en el recinto monástico era permitido excepcionalmente, mas nunca en la clausura. A los monjes les estaba permitido salir hasta el muro que delimitaba el coto de la abadía. Sufrirían pena de excomunión si traspasaban esos límites, quedando exentos en esta normativa los monjes de más de treinta años de antigüedad, el prior mayor, el mayordomo y el abad o ex abades ${ }^{130}$.

\footnotetext{
${ }^{126}$ FERNÁNDEZ MARTÍN, Luis. La Abadía...Op.cit, pág. 32.

${ }^{127}$ PERAL VILLAFRUELA, Santiago. “Estudio...Op.cit, pp. 31-32.

${ }^{128}$ FERNÁNDEZ MARTÍN, Luis. La Abadía...Op.cit, pág. 32.

${ }^{129}$ PERAL VILLAFRUELA, Santiago. "Estudio...Op.cit, pág. 32.

${ }^{130}$ Ibídem, pág. 34.
} 


\section{EL SIGLO XVI}

\subsection{SITUACIÓN INTERNA}

Asistimos a una época caracterizada por la cantidad de pleitos y litigios que entabla la abadía con diversos particulares por impagos o posesión de propiedades. Por citar algunos ejemplos, en 1532 acusan a la viuda de Juan Marqués, vecino de Becerril, de negarse a abonar la renta del molino de los bienes del difunto ${ }^{131}$. En 1547, un vecino de Moratinos, Andrés Olías, es acusado de no querer abonar el tercio del arrendamiento de unos molinos que el monasterio poseía en Becerrilejos ${ }^{132}$. La usurpación de dos tierras de la abadía en 1570 conlleva que García de Aguilar sea obligado a pagar una indemnización por el perjuicio al arrendatario de las mismas ${ }^{133}$. Junto al priorato de San Torcuato, la abadía pleitea con el escribano de Carrión, Juan de Cantoral sobre el pago de ciertos maravedíes como cesionario de los mismos ${ }^{134}$. Más que el resultado de estos procesos, de los que tan sólo hemos referido una pequeña porción, nos interesa constatar cómo la comunidad de Benevívere lucha con todo su ímpetu por mantener su hacienda, que se había visto menoscabada desde el siglo XIV.

Pero sin duda la causa más trascendental de todas y la que se prolongó durante más tiempo, fue la que enfrentó a la abadía con el doctor Bargundia entre 1593 y 1625 por el patronato de la misma ${ }^{135}$. Don Juan Bargundia, canónigo de Jaén y prior de Nuestra Señora de la Puente, filiación del convento agustino, había acudido ante Su Majestad, Felipe III y el Obispo de Palencia, Fernando Miguel de Prado, con el fin de que le otorgasen la posesión de la abadía al hallarse vacante su patronazgo desde la muerte de su último abad, don Pedro Sarmiento, Presidente de la Hacienda de Felipe II, prior y canónigo de Osma ${ }^{136}$.

\footnotetext{
${ }^{131}$ ARCHV. Pleitos Civiles Fernando Alonso (F),Caja 317,3.

${ }^{132}$ Ibídem, Caja 65, 4.

${ }^{133}$ Ibídem, Caja 306, 4.

${ }^{134}$ Ibídem, 1452,34.

135 ARCHV. Patronato eclesiástico. 177. Algunos autos de 1599-1600 del pleito en AHN. Clero SecularRegular 5321. Papeles judiciales, s/f.

${ }^{136}$ No se debe confundir a este abad con el cardenal homónimo cuyos restos descansan en la sala capitular.
} 
Desde su fundación el convento había estado regido por abades perpetuos comendatarios hasta que don Pedro se trasladó a Roma y por mediación de Pío V, hizo posible, que el cargo de abad comenzase desde 1571 a tener una periodicidad trienal ${ }^{137}$. Esto sucedería tras la muerte del último abad vitalicio, don Juan Sarmiento en $1563^{138}$. Bargundia argumentaba que la abadía era consistorial “...por ser monasterio de varones conforme a la regla de cançelería, y exceder la suma de duçientos florines, y como tal, tocar a vuestra magestad la presentación della...”. El convento alegó que la abadía no era una fundación real sino nobiliar, pues los condes de Salinas la habían dotado. Además el cargo de abad era elegido por los religiosos y tan sólo se hallaban bajo obediencia de Su Santidad. Pasaron muchos años de farragosos trámites y presentación de documentos: indultos y autos por parte del doctor y bulas y ejecutoriales de manutención por parte del convento, aparte de la asistencia a Roma por ambas partes. Finalmente el pleito dio la razón a la abadía. El fallo determinó que el patrón único y verdadero era don Rodrigo Sarmiento, conde de Salinas.

\section{2. OBRAS EN LA ABADÍA}

\section{La portada principal de acceso}

De esta época debe ser la puerta principal de acceso a la misma. Denominada "puerta del arco", estaba conformada por un arco renacentista sostenido por cuatro columnas y sobre éste, un nicho que albergaba una imagen de la Asunción ${ }^{139}$. Cuando Quadrado visita la abadía en 1861, el conjunto había sido demolido en su mayor parte, de ahí estas palabras de clara decepción: “...No despierta el mayor interés la portada

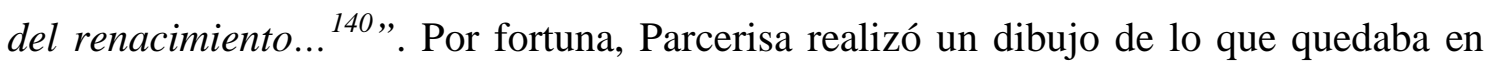
pie y aunque no se percibe con claridad, se puede observar efectivamente un acceso de medio punto flanqueado por columnas o pilastras en cuyas enjutas se disponen dos medallones que contienen bustos.

\footnotetext{
${ }^{137}$ ADP. Conventos dispersos. Benevívere. Libro 1. 1631. Constituciones y estatutos, fol 91v y 92 . No se debe confundir este Pedro Sarmiento, con el cardenal Pedro Ruiz Sarmiento.

${ }^{138}$ NÚNẼZ MARQUÉS, Vicente. Guía de la S.I. Catedral de Burgo de Osma y breve historia del Obispado de Osma. Soria, 1949, pág. 156.

${ }^{139}$ PONZ, Antonio. Viaje...1 $1^{a}$ Edición, Op.cit, pág. 188.

${ }^{140}$ QUADRADO, José M ${ }^{\mathrm{a}}$ y PARCERISA, Francisco, J.. $1^{\mathrm{a}}$ Edición. Op.cit, pág. 345.

HUIDROBO Y SERNA, Luciano. Las peregrinaciones...Op.cit, pág. 545.
} 
Sobre el acceso se dispone un amplio friso retranqueado, cuyas labores no llegamos a apreciar, pero pudieran ser amorcillos y guirnaldas, propios del repertorio ornamental de este período. Sobre este cuerpo se ubicaba un nicho avenerado vacío, que probablemente cobijaría la imagen de la Asunción mencionada, dada la dedicación del cenobio a Santa María. Flanqueando esta hornacina se yerguen dos columnas que presentan el primer tercio del fuste con bajo relieves y en los extremos se distinguen dos figuras que parecen estar empujando el soporte que tienen delante. La de la izquierda se halla de pie, haciendo fuerza a través de la disposición abierta y flexionada de sus piernas y la del lado derecho, es una figura sedente que parece sustentar una voluta en perspectiva. Por último, en la parte superior distinguimos una representación de un Padre Eterno, dirige su mano derecha hacia el alto, mientras que con la otra se apoya en una especie de jarrón sobre una peana, lo cual resulta muy singular, ya que tradicionalmente sostiene la bola del mundo.

La disposición de esta portada mantiene grandes analogías con la del monumento funerario del abad don Juan Sarmiento que analizaremos a continuación. La semejanza con la obra plateresca nos permite establecer una cronología aproximada dentro de la primera mitad de la decimosexta centuria. El esquema compositivo utilizado rememora algunas portadas de Rodrigo Gil de Hontañón ${ }^{141}$ como la puerta norte de la iglesia parroquial de Villamor, en Zamora, fechada hacia 1552. Además se observa el mismo repertorio iconográfico de figuras de carácter pagano ornamentando el primer cuerpo que utiliza Hontañón en la portada de la iglesia vallisoletana de San Martín en Mota del Marqués o en la fachada del Colegio de San Ildefonso de Alcalá de Henares, ambas finalizadas hacia $1553^{142}$. El maestro de Rascafría se había trasladado a Carrión unas décadas antes para proporcionar las trazas del templo de San Andrés y por tanto, ésta pudo ser la segunda ocasión en que visitaba la villa condal, inspirando el repertorio iconográfico de esta fachada.

\footnotetext{
${ }^{141}$ Sobre el mismo, véase el apartado dedicado a su persona en los artífices de las obras.

${ }^{142}$ HOAG, JOHN D. "Rodrigo Gil...Op.cit, pp. 87-95, 157-161 y CASASECA CASASECA, Antonio. Rodrigo Gil...pp. 55-57, 124-127, 241-252.
} 


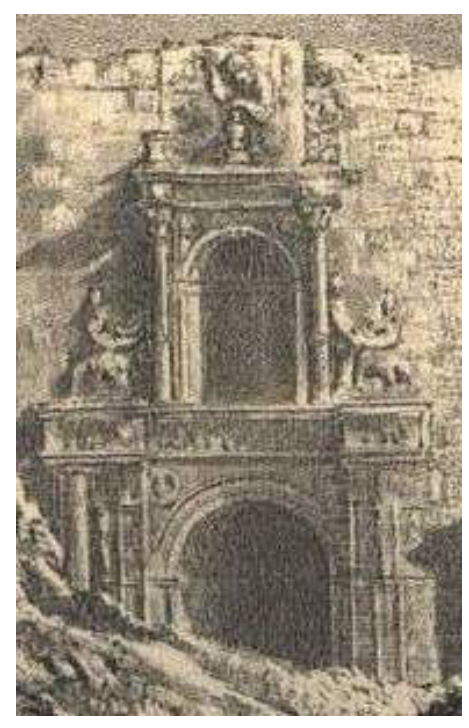

\section{Puerta de acceso a la abadía de Benevívere.}

Detalle del grabado realizado por Parcerisa en 1861, extraído de Recuerdos y bellezas de España.

Esta puerta de acceso a la abadía parece corresponderse con un fragmento de muro conservado hoy día, que conforma un portalillo aislado. En él hay practicado un sencillo arco de medio punto provisto de doble moldura con el despiece del dovelaje en cada una de ellas: la primera de ellas es fina y de sección circular; la segunda, más ancha, está embebida en el muro de sillería, sin sobresalir del mismo. Este acceso, cubierto hoy día por un tejadillo, correspondería a las obras ejecutadas en el siglo XVI. Sobre el arco se ubica el emblema agustino: un corazón atravesado por varias flechas. A los lados, podemos ver las armas de don Pedro Ruiz Sarmiento, cuyos restos fueron depositados en la abadía ${ }^{143}$. Se trata de un escudo partido: 1 , trece bezantes de oro en tres palos y uno en el jefe, 2, losange de Castilla cantonado de cuatro leones rampantes. Esta representación de Castilla vestida de León, proviene de las armas de doña Leonor de Castilla, nieta de Alfonso XI y sobrina de Enrique II y los roeles, de su esposo, Diego Gómez Sarmiento. Pero la unión de estas armas en un escudo no se efectúa hasta sus descendientes, los condes de Salinas ${ }^{144}$. Por tanto, la heráldica de esta portada nos permite fechar las obras antes de 1541 en que fallecería el prelado, tal y como habíamos apuntado. Estas mismas armas también podemos apreciarlas en algunos monumentos palentinos como la capilla mayor del convento de San Pablo, en el Palacio episcopal, en la clave de la bóveda de la capilla mayor de la Catedral de San Antolín y en la capilla de

\footnotetext{
${ }^{143}$ A Pedro Ruiz Sarmiento nos referiremos posteriormente.

${ }^{144}$ MENÉNDEZ PIDAL DE NAVASCÚES, Faustino. Heráldica medieval española, I. La casa Real de León y Castilla. Madrid, 1982, pp. 154-155.
} 
San Pedro y San Pablo de dicha seo, dada la condición de obispo de la ciudad castellana de don Pedro Sarmiento ${ }^{145}$.
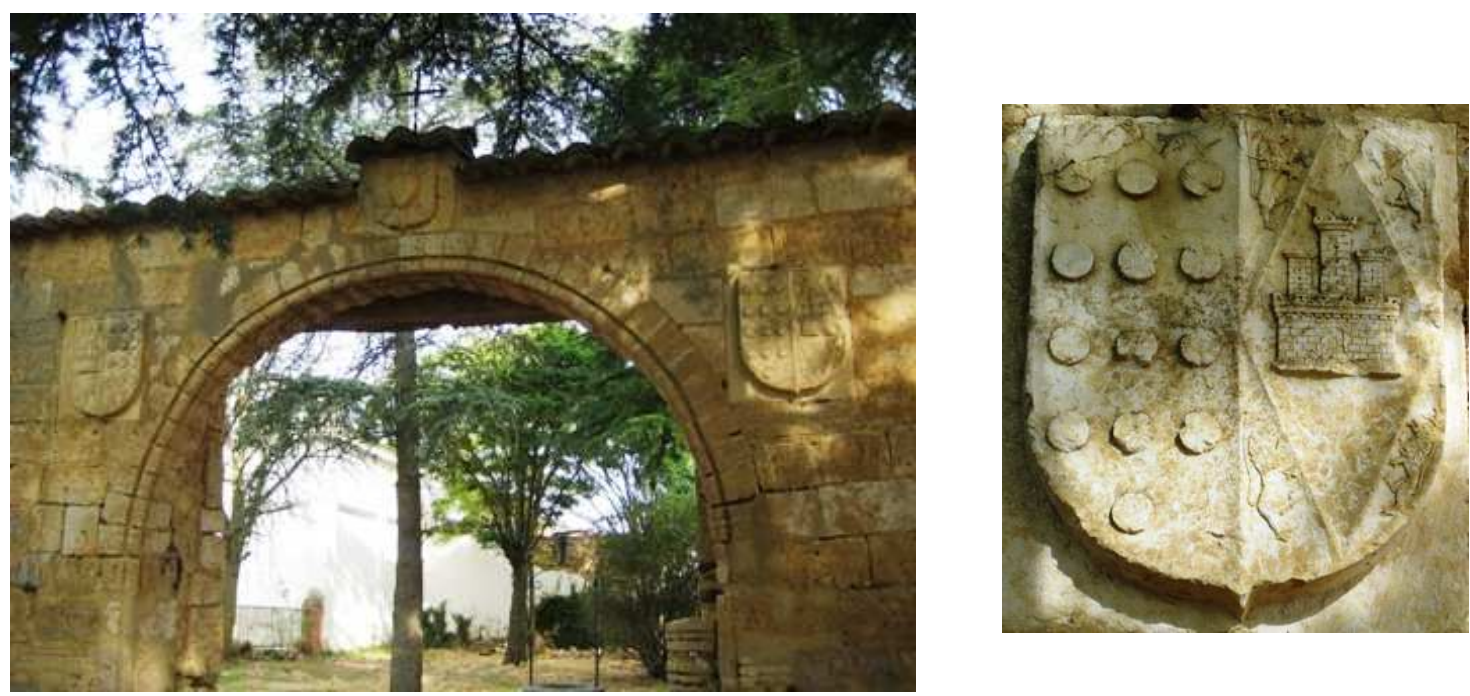

\section{Antiguo acceso a la abadía con el escudo de Don Pedro Ruiz Sarmiento.}

Junto a este acceso se encontraba la despensa y la portería. A partir de este sector comenzaba la clausura, donde ninguna mujer de más de siete años, podía entrar, excepto para la misa, que la oían desde la capilla de San Miguel y para procesiones eventuales que hubiese en el claustro. Este segundo acceso daba paso al claustro, donde había un enrejado y cadena, desde cuyas puertas se accedía al templo y sacristía ${ }^{146}$.

\section{El primer retablo conocido}

El primer retablo del que se tiene constancia es una obra de factura renacentista conformado por seis tableros y pilares, cuya "pintura y doradura" correspondió a Juan de Lago conforme a una traza que quedaba en su poder. En el contrato, fechado en 1571, el canónigo de Benevívere y prior de Mañinos, Pedro Herrezuelo, se comprometía a pagar a Lago nueve mil maravedíes por la hechura y pintura del mismo ${ }^{147}$. No debía tratarse del retablo mayor, puesto que en el contrato se señala que se trata de una obra

\footnotetext{
145 VIGURI, Miguel de. Heráldica. 1...Op.cit, pp. 21-22.

${ }^{146}$ ADP. Conventos dispersos. Benevívere. Libro 1. 1631. Constituciones y estatutos, fol 79.

${ }^{147}$ GARCÍA CHICO, Esteban. Documentos. Pintores I. Op.cit, pág. 91, a su vez de AHPP. Carr.Prot 4676. Juan Cantoral, (1569-1573), s/f. Sobre Juan de Lago, remítase al capítulo dedicado a los pintores.
} 
de pequeño formato, por lo que es probable que fuese una obra de alguna capilla el templo.

\section{Otras intervenciones}

Por el tiempo en que se ejecutaba la portada principal, se estaban realizando algunas mejoras en el templo. En 1566 consta documentalmente la adquisición de una cantidad importante de madera de distintos cortes y tamaños procedente de Quintanar de la Sierra, municipio de la provincia de Burgos ${ }^{148}$. El hecho de requerir el material de la zona de Pinares, conocida por su calidad, pero bastante distante de la abadía y el montante abonado que ascendía a seis ducados, permite suponer una obra de cierta relevancia, quizá una rehabilitación completa de las cubiertas de la iglesia.

En 1590 el albañil Pedro Gutiérrez se comprometió a finalizar un cuarto nuevo que había dejado sin acabar el maestro de albañilería carrionés Bartolomé Alejo ${ }^{149}$ siguiendo las trazas del carpintero carrionés Santiago Sigüenza ${ }^{150}$. No se especifica a qué obra corresponde esta intervención aunque se menciona que se trata de una alcoba frontera al cuarto de la chimenea, por lo que pudiera tratarse de la celda del abad. Pedro Gutiérrez realizaría las tapias de hormigón y adobes y toda la obra de yesería correspondiente. Un año después en que el albañil carrionés firma su testamento al hallarse enfermo, declara que continúa trabajando en el monasterio y que ha realizado algunas demasías que tiene convenientemente apuntadas en un memorial para que las cobre su mujer del canónigo del convento y tesorero de Villaherreros, don Miguel de Campoo $^{151}$.

\footnotetext{
${ }^{148}$ La escritura de contrato entre el abad y Llorente Calvo Serrano se firma el 23 de septiembre de 1566. AHPP. Carr.Prot 5610. Melchor de la Rúa (1565-1566), s/f.

${ }^{149}$ En su persona se rematan la obra de la torre de San Andrés, consistente en reparar los desperfectos del último cuerpo en colaboración con Juan Antonio González en 1584. AHPP. Carr.Prot. 5600 Francisco Rojas (1580-1589), s/f. En 1622 puja en la obra del casco de la capilla mayor de la iglesia de Belén con 18 ducados, pero finalmente se remata en Bartolomé del Campo por 11 ducados. AHPP. Carr.Prot 4849. Juan Díaz Pajaza (1622-1623), s/f. En 1632 se le abona una carta de pago por participar con Francisco Rodríguez, en la ejecución de la nave del templo de Santo Domingo de Carrión. AHN. Clero SecularRegular 5352 s/f .Santo Domingo, Obra. Allí además se encargó de lucir y rehacer la bóveda de la capilla del nombre de Jesús. AHN .Clero Secular-Regular 5352. Papeles judiciales, s/. Junto a Antonio del Tejo repara en 1636 la iglesia de Santiago de Calzada de los Molinos. AHPP. Carr.Prot 5182, Jerónimo Laso (1636), s/f.

${ }^{150}$ El contrato y condiciones de esta obra en AHPP. Carr.Prot 4681. Juan Cantoral (1589-1594), s/f.

${ }^{151}$ Testamento de Pedro Gutiérrez en AHPP. Carr.Prot 5601. Francisco Rojas (1590-1605), fol 59 y ss.
} 


\section{3. MONUMENTOS FUNERARIOS}

Como referimos anteriormente, los miembros más destacados de la abadía de Benevívere, como los abades y aquellos personajes que tuvieron una especial vinculación con el cenobio, dispusieron ser enterrados en el convento.

La capilla mayor era lugar de sepultura de los Sarmiento, mientras que las dos capillas del templo eran exclusivas de la comunidad monástica: una bajo la advocación de San Pedro, en la que se enterraba a los monjes, y otra la del Santo Cristo, destinada para la sepultura del abad. Incluso, por cuestiones de espacialidad, también existían sepulturas alrededor del templo ${ }^{152}$.

Además, se tiene constancia documental de que los restos de algunos miembros tanto del clero como de los Sarmiento reposaron en la sala capitular. En su interior se custodiaban, las reliquias de San Mauricio, Santa Úrsula y las de San Torcuato, éstas últimas repartidas entre esta capilla y el priorato cercano bajo la advocación de este santo. Las urnas de madera sólo podían ser abiertas conjuntamente por el abad y el sacristán mayor, pues cada uno poseía una de las dos llaves necesarias para las dos cerraduras de cada receptáculo. Dichas reliquias habían sido enviadas por el rey Francisco I de Francia y por Brianda de la Cerda ${ }^{153}$

\section{Don Pedro Ruiz Sarmiento}

Obispo de Tuy, Badajoz, Palencia y Cardenal de Compostela, era hijo de Diego Pérez de Sarmiento, segundo conde de Salinas y doña María de Villandrando, segunda condesa de Ribadeo. Cursó sus estudios de derecho en Salamanca y Valladolid. Aparte de los cargos ya citados, fue capellán de los Reyes Católicos, sacristán mayor de Carlos V y cardenal por disposición de Paulo III. El fue quien cedió la iglesia de San Pedro para la fundación del convento de Santo Domingo de Carrión en 1527. Prestó servicios en la empresa contra los turcos y presenció el desafío que el Rey de Francia, por mandato del Príncipe de Guyena trajo a Carlos V en 1528. Acompañó a Italia a la princesa Margarita para presenciar la boda de ésta con un pariente del pontífice, siendo

\footnotetext{
${ }^{152}$ ADP. Religiosos. Abadía de Benevívere (1475-1808), s/f.

${ }^{153}$ PERAL VILLAFRUELA, Santiago. Estudio...Op.cit, pág. 16.
} 
en este país donde recibió el cardenalato. Detentó el cargo de cardenal hasta que murió en Luca el 13 de octubre de 1541. Su cadáver fue depositado en el convento de Santo Domingo de esta ciudad italiana, para ser posteriormente trasladado a Benevívere por Juan Sarmiento, abad del convento y deudo suyo ${ }^{154}$.

Según señala Ponz y confirma Quadrado, el sepulcro era de mármol y presentaba la imagen esculpida del cardenal arrodillado ${ }^{155}$. El orante estaba cobijado bajo un nicho en el que había un niño con una mitra en la mano. La Comisión Monumental de Monumentos se equivocó al afirmar que el sepulcro de este cardenal era el del fundador, pues como vimos, Diego Martínez de Villamayor, presentaba una estatua yacente y no orante. Así afirma dicha comisión: "el bulto o estatua del fundador está enterrado y tirado en el suelo, sin cabeza ni manos, su actitud, de rodillas ${ }^{156 " .}$ Probablemente, el hecho de que todos los sepulcros se encontrasen tirados por el suelo, llevó a establecer atribuciones equivocadas en algunos de los enterramientos.

De conservarse el sepulcro de Don Pedro de Sarmiento, los escudos que contendría su monumento serían idénticos a los que comentamos previamente, ubicados en el acceso a la abadía.

\section{El Abad don Juan Sarmiento}

El abad don Juan Sarmiento, miembro de la familia fundadora, fue quien, como deudo de Don Pedro Ruiz Sarmiento, se encargó del traslado de su cuerpo desde Lucca al convento ${ }^{157}$. Figura en 1561 como el último de los abades vitalicios de la comunidad, sucedido por Pedro Sarmiento, primer abad trienal ${ }^{158}$.

La Comisión de Monumentos Palentinos realizó un informe sobre el sepulcro del abad en el que se aportan detalles sobre la estructura del mismo, cuyo “...mérito y gusto

\footnotetext{
${ }^{154}$ ORTEGA GATO, Esteban. "Blasones y mayorazgos de Palencia" en PITTM, $\mathrm{n}^{\mathrm{o}}$ 3. Diputación Provincial de Palencia. Palencia,1950, pp. 204-206.

${ }^{155}$ PONZ, Antonio. Viaje... $1^{a}$ Edición, Op.cit, pág. 188.

${ }^{156}$ ARASF. Palencia, Comisión de Monumentos, Leg. 2-7-7, Monumentos en general.

${ }^{157}$ QUADRADO, José $\mathrm{M}^{\mathrm{a}}$ y PARCERISA, Francisco, J.. Op.cit, pág. 142 y ORTEGA GATO, Esteban. "Blasones...Op.cit, pág. 206.

${ }^{158}$ FERNÁNDEZ MARTÍN, Luis. La Abadía...Op.cit, pág. 57.
} 
compite con el magnífico claustro de San Zoilo de Carrión... ${ }^{159 " . ~ S e ~ t r a t a r i ́ a ~ d e ~ u n ~}$ suntuoso monumento funerario configurado al modo de una fachada plateresca, cuya altura, de unos nueve metros, igualaría a la de la sala capitular. En 1852, dado el deterioro del sepulcro y la imposibilidad de trasladarlo por sus enormes dimensiones, la Comisión propuso a la Central de Monumentos elaborar una copia “...pues dejará de existir muy luego por hallarse hace tiempo a la intemperie, sirviendo de blanco a las piedras que barabara mano quieran asentarle... ${ }^{160 " . ~ D e s g r a c i a d a m e n t e, ~ q u i z a ́ ~ p o r ~ l a ~}$ negativa del permiso, la copia no se llegó a realizar, pero al menos contamos con una descripción, si bien bastante desordenada, resulta muy significativa sin duda a la hora de elaborar la configuración hipotética del sepulcro ${ }^{161}$.

Se compondría de dos cuerpos, como si se tratase de la estructura de un retablo, sustentados sobre un gran pedestal en cuyos extremos se ubican angelillos portando escudos, suponemos que los del abad. El primer cuerpo se compone de dos columnas de orden corintio a los lados cobijando en su primer tercio los relieves de dos virtudes teologales: la Fe y la Caridad con sus respectivas tarjetas y dos virtudes cardinales: la Fortaleza y la Justicia. Entre ellas, un nicho de escasa profundidad cobija dos figuras cuya identificación resulta imposible al no poseer ni cabeza ni manos ni describirse el atuendo que portan. Posiblemente se trate del abad don Juan, y el otro personaje, tal vez el obispo don Pedro Ruiz Sarmiento, dada la vinculación existente entre ambos prelados. Sobre los mismos, dentro del nicho, se ubica un relieve de la Inmaculada, igualmente sin manos y decapitada. Sobre este primer cuerpo se dispone un friso en el que figuran angelillos que portan una tarjeta que nos permite fechar el sepulcro: "Esta obra se hizo año de 1568”. La obra fue realizada unos años después del óbito de don Juan Sarmiento, el 5 de julio de $1563^{162}$.

El segundo cuerpo estaría conformado por dos columnas corintias en cuyo primer tercio figuran relieves y el resto se halla estriado. En la hornacina central se indica que "nada existe”, por tanto, a mediados del siglo XIX ya no se conservaba. Sí se indica la decoración de la parte superior del nicho avenerado en el que se disponen una serie de

\footnotetext{
${ }^{159}$ ARASF. Palencia, Comisión de Monumentos, Leg. 2-7-7, Monumentos en general.

${ }^{160}$ Ibídem.

${ }^{161}$ Debo la elaboración del dibujo a mi compañero de carrera, Eduardo Ochoa, quien se prestó solícito a elaborarlo.

${ }^{162}$ NÚÑEZ MARQUÉS, Vicente. Guía...Op.cit, pág. 156.
} 
pilastras superpuestas jalonadas por cabezas de querubines. En las enjutas, sendos medallones contienen el corazón atravesado de flechas, emblema agustino y la mitra, cuya presencia se debe a que el Papa Sixto IV le concede su uso al abad, en el año $1473^{163}$. Un entablamento quebrado ornamentado con relieves de ángeles dormidos sobre calaveras se dispone a continuación. Sobre el mismo y rematando el conjunto, la figura del Padre Eterno flanqueado por dos eses avolutadas y dos jarrones en los extremos.

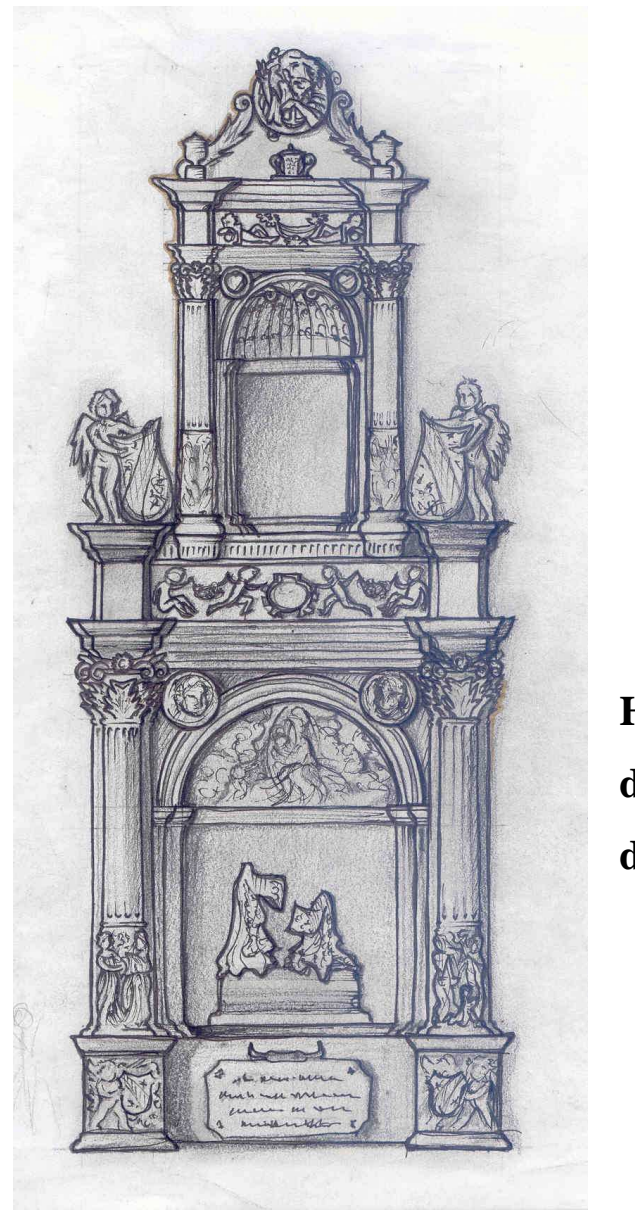

Hipótesis del aspecto del monumento funerario del Abad don Juan Sarmiento según las descripciones.

Se halló además una piedra medio enterrada y en parte destruida, que contenía un letrero en caracteres mayúsculos romanos donde puede leerse: "Aquí yace el Señor Don Juan Sarmiento, Abad de Benevívere, dignidad de (borrado), Presidente del Consejo (borrado ${ }^{164}$ )... ndas.. tauro, electo Obispo de Osma..”. Probablemente iría ubicada en la parte inferior del retablo, donde existiría un hueco a tal efecto.

${ }_{163}$ RAMIREZ DE HELGUERA, Martín. El libro...Op.cit, pág. 235.
164 "de Indias". 
Efectivamente fue designado Obispo de Osma, pero no llegó a ser consagrado en el cargo por su fallecimiento repentino ${ }^{165}$.

Santiago Peral Villafruela identifica el segundo cuerpo del sepulcro con el retablo de la Purísima de la iglesia que fue del priorato de San Torcuato. Este fragmento pétreo, atribuido al taller de Miguel de Espinosa, pudo ser trasladado para evitar que se perdiera para siempre entre las ruinas ${ }^{166}$. Nos parece muy acertada la tesis de Villafruela, no sólo por la coincidencia exhaustiva con la descripción de la Comisión sino porque dicha delegación proponía ya por entonces el traslado del sepulcro en fragmentos en estos términos: "podrían desmontarse...los cornisamentos y columnas con inteligencia y cuidado... ${ }^{167}$,. Dicho traslado justificaría el inadecuado ensamblaje de algunas piezas y los cortes laterales que indican que faltan algunos elementos $^{168}$.

La atribución al círculo de Espinosa resulta igualmente plausible, sobre todo si observamos el remate del sepulcro. La utilización de las eses avolutadas, muy recurrentes en el repertorio siloesco, lo vinculan a su maestro. Por otro lado, el busto del Padre Eterno posee las características inherentes al estilo del artista. Se trata de una figura de gran fuerza expresiva que fiel a la iconografía habitual de esta representación, porta el orbe en su mano derecha mientras bendice con la mano izquierda. El anciano, representado con gran humanismo, lleva la característica melena larga y barba de mechones que se ondean al viento. Los ojos muestran unos globos oculares salientes y una boca semiabierta en actitud de comunicar que aportan una gran fuerza expresiva al rostro, muy definitoria del maestro. Se puede relacionar estilísticamente con otra obra del mismo autor en Carrión, como es el caso de las tallas del claustro de San Zoilo de Carrión, en especial la ménsula de Seth. Asimismo se pueden establecer paralelismos con otras obras palentinas del autor de idéntica iconografía, como son dos Padres

\footnotetext{
${ }^{165}$ NÚÑEZ MARQUÉS, Vicente. Guía...Op.cit, pág. 156.

${ }^{166}$ PERAL VILLAFRUELA, Santiago. “Estudio...Op.cit, pp. 24 y 41. Ramírez Helguera considera erróneamente que este altar es de yeso en vez de piedra y que su fecha de ejecución es 1864. Es evidente que no tocó la pieza para comprobar su material y que creyó que la imagen del siglo XIX que se ubica hoy día en la hornacina principal era de la misma época que el resto de la obra. RAMIREZ DE HELGUERA, Martín. El libro...Op.cit, pp. 167-168.

167 Se recogen estos datos en el informe emitido en abril de 1845 por la Comisión de monumentos palentinos sobre los trabajos realizados en los monumentos notables de la provincia de Palencia en 1860. ARASF. Palencia, Comisión Monumental, Leg. 2-7-7, Asuntos de carácter general.

${ }^{168}$ PERAL VILLAFRUELA, Santiago. “Estudio...Op.cit, pág. 41.
} 
Eternos, uno situado en la ermita del Otero de Frómista y otro del retablo de Boadilla del Camino ${ }^{169}$. En Valladolid, el remate de uno de los retablos laterales del convento franciscano de Medina de Rioseco, también de la mano de Espinosa, conserva idéntica fuerza y viveza. El retablo estaba originalmente policromado, como así lo demuestran los toques rojizos de las guirnaldas que acompañan a los angelillos en el friso de la parte inferior.
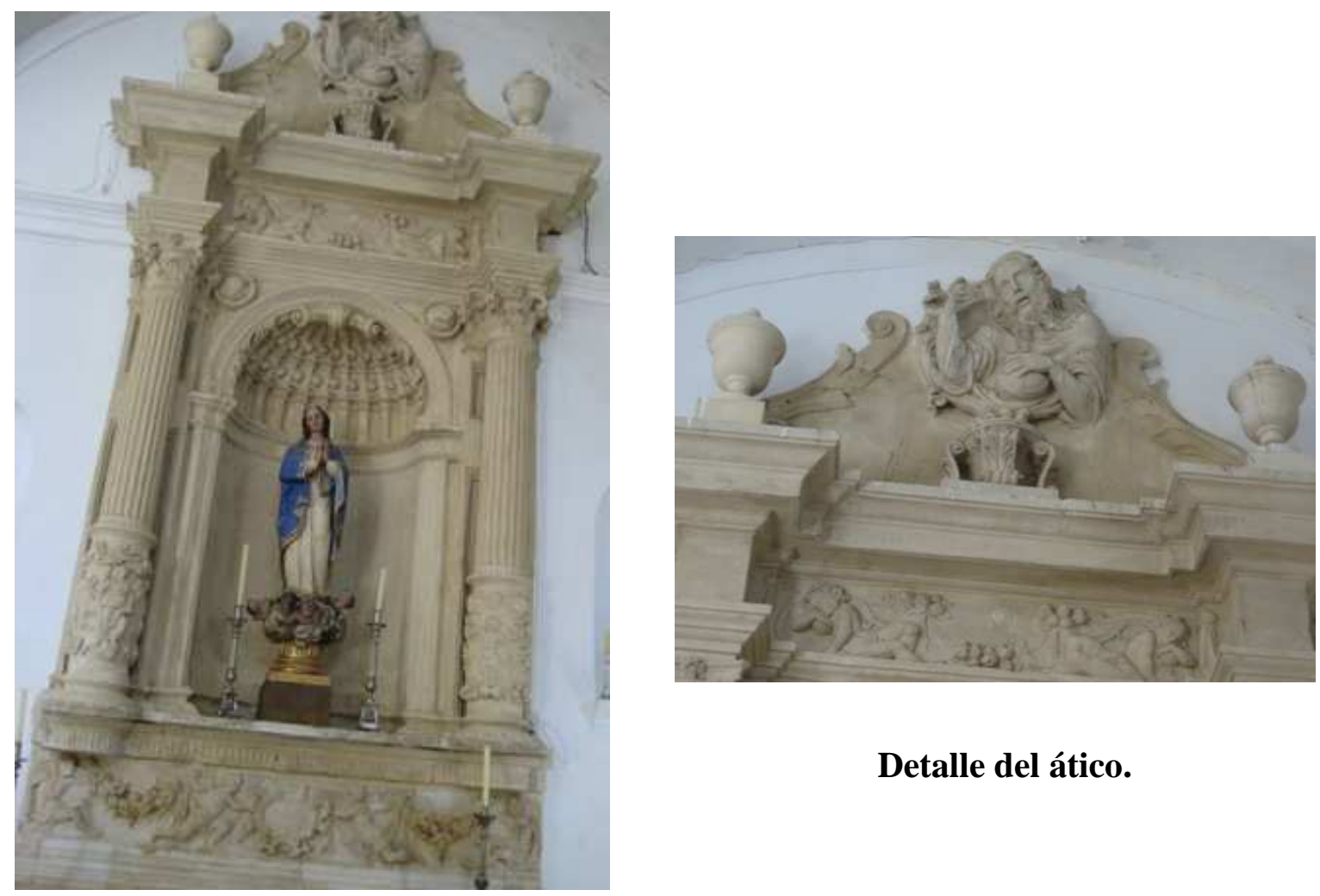

\section{Detalle del ático.}

Retablo de la Purísima en la iglesia del antiguo priorato de San Torcuato correspondiente al ático del monumento del Abad Sarmiento.

Algunos restos aislados procedentes de este sepulcro se trasladaron a la huerta del monasterio de San Zoilo, como una cabecilla de ángel o algún que otro capitel, piezas de las que nada se volvió a saber. En 1907 pasaron a ser propiedad de los Padres Jesuitas gracias a la intervención del encargado de inventariar los bienes de la provincia,

\footnotetext{
${ }^{169}$ Sobre estas esculturas PARRADO DEL OLMO, Jesús María. "Sobre algunas esculturas del siglo XVI...Op.cit, pp. 311-312.
} 
Martín Mínguez, quien se lo solicitó a Acisclo Piña Merino, fundador del Antiguo Hospital Municipal ${ }^{170}$.

\section{Los patronos del linaje Sarmiento}

Como señalan las constituciones monásticas de 1631, además de los abades y la familia del fundador, en el capítulo disponían su sepultura “...muchos condes, duques, marqueses y personas ylustres, assí en armas como en letras, y juntamente el eminentísimo s[eñ] or cardenal Sarmiento, arçobispo de Toledo, deudos todos del dicho fundador, en donde dejaron sus memorias, doctaciones y anibersarios ${ }^{171 "}$.

Ambrosio de Morales afirma que algunos de los sarcófagos pertenecientes al linaje Sarmiento eran de mármol -aunque probablemente el viajero las confundiese con el alabastro- y presentaban estatua orante ${ }^{172}$.

Entre los miembros cuya voluntad fue la de sepultarse en la abadía, figuran don Diego Gómez Sarmiento, II conde de Salinas, hijo de Pedro Ruiz Sarmiento, I conde de Salinas ${ }^{173}$. Dictó testamento el 11 de diciembre de 1505 , pero no dispuso enterrarse en la sala capitular, sino en la capilla mayor del templo ${ }^{174}$.

Su nieto, don Diego Gómez Sarmiento de Villandrando, III conde de Salinas (1500-1563) encargaba en 1551 una serie de misas en el monasterio por su madre, doña María de Ulloa y por su mujer, doña Brianda de la Cerda y Mendoza ${ }^{175}$. Doña Brianda, hija de don Luis de la Cerda y doña Francisca de Mendoza, era señora de los lugares de Miedes y Mandayona, en Guadalajara. Fue quien, como apuntamos, dotó el convento de algunas reliquias, por lo que, independientemente de su vinculación con el linaje Sarmiento, se ganó por derecho propio la sepultura en la abadía.

\footnotetext{
${ }^{170}$ MARTÍN MÍNGUEZ, Bernardino. Catálogo...Op.cit, volumen 3, pág. 57.

${ }^{171}$ ADP. Conventos dispersos. Benevívere. Libro 1. 1631. Constituciones y estatutos.

${ }^{172}$ ARA GIL, Clementina-Julia. "Un grupo...” Op.cit, pág. 34.

${ }^{173}$ No se trata del cardenal homónimo, que por supuesto, no tuvo descendencia.

${ }_{174}^{174}$ URCELAY GAONA, Hegoi. Los Sarmiento...Op.cit, pág. 186, a su vez de AHPZ. CDH, IV- 37-54

${ }^{175}$ Ibídem, pág. 186.
} 


\section{LOS SIGLOS XVII Y XVIII}

\subsection{SITUACIÓN INTERNA}

Conforme avanzamos en el tiempo, la comunidad monástica de Benevívere se reduce paulatinamente, hasta tal punto que en 1785 los canónigos que profesaban coro eran tan sólo nueve o diez ${ }^{176}$. No obstante, la jurisdicción eclesiástica de la abadía se mantiene inalterable, y por tanto los monjes se sujetan tan sólo a la autoridad papal, tal y como nos indican las Constituciones y Estatutos de $1631^{177}$.

En teoría, sólo existía sujeción a la silla apostólica, mas en la práctica, el patrón del convento tenía la última palabra sobre determinados aspectos de la vida monacal. Por ejemplo, la elección del abad requería el beneplácito del patrón, en cuya ausencia, acudía en su nombre una persona de confianza, dado que la residencia habitual de los mismos se hallaba en Madrid. En este sentido, dos cartas de poder emitidas en el primer tercio del siglo XVII nos remiten el citado procedimiento. La primera, fechada en 1616 y otorgada por Don Diego de Silva, duque de Francavila, Conde de Salinas y de Ribadeo y capitán general del reino de Portugal, en nombre y como administrador de su hijo y patrón de la abadía, Rodrigo de Sarmiento Villandrando de la Cerda. En ella dispone que envía al doctor Don Diego Vela, deán de Lugo y canónigo de la Catedral de Palencia al acto de designación del nuevo abad, dado el fallecimiento del anterior, don Francisco Gómez de Espinosa ${ }^{178}$. En la segunda carta de poder, emitida en 1628, don Rodrigo Sarmiento concede licencia para el mismo fin a don Melchor de Paz y Mendoza por haber finalizado el trienio del Licenciado Pedro Pérez ${ }^{179}$.

La autonomía de Benevívere ya había sido puesta en entredicho con el pleito del doctor Bargundia desarrollado entre 1593 y 1625. El Licenciado pretendió, sin éxito, convertirla en consistorial, reservándose su patronato ${ }^{180}$. Incluso la realeza pretendió

\footnotetext{
${ }^{176}$ La noticia proviene del Padre Sobreira, un monje que vivió durante un tiempo en el monasterio de San Zoilo. FERNÁNDEZ MARTÍN, Luis. La Abadía...Op.cit, pág. 58.

${ }_{177}$ ADP. Conventos dispersos. Benevívere. Libro 1. 1631. Constituciones y estatutos, fol 93 y ss.

${ }^{178} 6$ de abril de 1616. AHPP. Carr.Prot 5399, Francisco Moro Saldaña (1616), s/f

${ }^{179} 30$ de agosto de 1628. AHPP., Carr.Prot 5411. Francisco Moro Saldaña (1628), s/f. Otras ceremonias para La elección de abad en ADP. Libro de Cuentas y Profesiones d'este convento de Nuestra Señora de Benevívere, año 1628, fol 240-241 (se refiere al año 1675) y fol 11-16 (año de 1695)

${ }^{180}$ ARCHV. Patronato eclesiástico. 177. Algunos autos de 1599-1600 del pleito en AHN. Clero SecularRegular 5321. Papeles judiciales, s/f. Ya hicimos referencia al mismo en el apartado precedente.
} 
hacerse con el control de Benevívere, como así refieren las Constituciones monásticas de 1631: “...los reyes Felipe III y IV, que pretendieron hacerle patrimonio suyo, y que la abadía fuese perpetua. Y sobre defenderse el convento pleiteando con tan poderosos contrarios, gastó y se empeñó en muchos ducados... ${ }^{181}$ ". Hallamos efectivamente entre los protocolos una carta de obligación expedida por el convento en 1635 que hace relación del pleito que les enfrentaba con Felipe IV por la provisión de la abadía. El Tribunal de la Sacra Rota, les había otorgado la razón pero el Consejo de la Cámara determinó quedar al margen del litigio, por lo que el abad de Benevívere propone a la corona que renuncie a la posesión del monasterio “...porque la dicha abbadía se a probeydo de más de quatroçientos y sessenta años a esta parte por elección del dicho conbento con assensso de los patronos, y que nunca fue consistorial ni pudo ser comprendida en el dicho yndulto por ser rregular...". Como contrapartida, el monarca solicita tres mil ducados en concepto de los gastos ocasionados a lo cual accede voluntariosa la comunidad agustina, que lo entrega “...por donativo gratuyto y espontáneo para ayuda a los gastos de las guerras y ocasiones presentes... ${ }^{182 " .}$ Podemos leer entre líneas que convenía evitar un conflicto a toda costa para evitar granjearse enemigo demasiado poderoso.

No acaban aquí las luchas por la posesión de la abadía. En 1679, pleitea con la villa de Carrión para eximirse de la jurisdicción de ella, litigio al que se sumarían, en clara oposición a la casa agustina, los feligreses de las diversas parroquias de Carrión establecidos por cuadrillas. Cada una de ellas otorga un poder a un vecino de Carrión para que les represente en la causa judicial. Primero lo hacen los de San Bartolomé, seguidamente los de Santiago y San Julián, más tarde los de San Andrés, Santo Domingo y finalmente los de Santa María del Camino. El caso fue llevado ante el Consejo Real de Castilla de la villa de Madrid que falló a favor de la abadía ${ }^{183}$.

Esta no fue la única ocasión en que los agustinos tuvieron que hacer frente al Concejo de Carrión; está documentada otra en 1765. En esta ocasión, la rivalidad radicaba en la propiedad del término de Benevívere, pues al no tratarse de un lugar coto y redondo, con sus límites claramente establecidos, no podía considerarse con

\footnotetext{
${ }^{181}$ HERREROS ESTÉBANEZ, Francisco. "Las constituciones monásticas...Op.cit, pp. 180-181.

183 AHPP. Carr.Prot 5735. Francisco Santos (1679-1680), fol 360 y ss.
} 
independencia de los pueblos vecinos. La Audiencia otorgó la jurisdicción compartida, pues existían heredades pertenecientes a dueños particulares, otras compradas, cedidas o heredadas por ambas partes ${ }^{184}$.

\subsection{OBRAS EN LA ABADÍA}

\section{La capilla mayor}

La primera intervención de este período se produce a comienzos de siglo. En 1605 el maestro de cantería trasmerano Toribio de la Cuesta $^{185}$ se compromete con el patrón del convento, don Diego Sarmiento de Silva y Mendoza, a ejecutar un espacio con bóveda “...debajo del altar mayor y gradas de la dicha capilla mayor... ${ }^{186 ” . ~ E s t e ~}$ contrato pone de manifiesto la existencia de una cripta donde se enterrarían los condes de Salinas, como así refería Ponz ${ }^{187}$. Toribio de la Cuesta debía desmontar las gradas existentes, extraer la tierra de debajo, construir un "arco de bóveda" y empedrar el suelo de este espacio. Posteriormente reconstruiría la escalinata con un adorno de bocel y practicaría un acceso “...para el seruicio de la bóbeda por el lado del altar mayor o por la parte que más convenga...”. Se comprometió a finalizar la obra a finales de dicho año de 1605 por ciento cincuenta ducados, lo cual manifiesta la intensidad con que trabajó el artista, máxime si se tiene en cuenta que a partir de octubre de dicho año trabajaba paralelamente en el paño del claustro aledaño a la iglesia del convento de Santo Domingo de Carrión ${ }^{188}$.

Un interesantísimo dibujo que Valentín Carderera realizó en 1838, cuando aún la iglesia se hallaba en buen estado, reproduce una vista de la capilla mayor desde la nave central $^{189}$. En él se aprecian dos pequeñas puertas laterales por las que se accedería a este espacio subterráneo del templo, que flanquean una escalinata de seis peldaños, que también sería ejecutada en esta época. La parte restante, analizada previamente

\footnotetext{
${ }^{184}$ AHN. Consejo de Castilla, Leg. 27136, $\mathrm{n}^{\circ} 1$

${ }^{185}$ Sobre el mismo, véase su capítulo biográfico.

${ }^{186}$ AHPP. Carr.Prot 4708. Pedro Carrión (1605), s/f.

187 “...en la bóveda que estaba debajo del altar mayor...”. PONZ, Antonio. Viaje...1 $1^{a}$ Edición, Op.cit,

pág. 188 y también RAMIREZ DE HELGUERA, Martín. El libro..Op.cit, pág. 236.

${ }^{188}$ El contrato y condiciones en AHPP. Carr.Prot 4708. Pedro Carrión (1605), s/f.

${ }^{189}$ FLG. Interior de la iglesia de Benevívere. Fondo Carderera. № 9813.
} 
correspondería al siglo XIII. Esta cripta, por tanto, serviría para los condes de Salinas, pero en el templo existían otras dos capillas de enterramiento, destinadas en este caso, a la comunidad monástica; una dedicada al Santo Cristo, para los canónigos y otra para los abades, bajo la advocación de San Pedro ${ }^{190}$.

\section{El retablo mayor}

Debió existir un retablo de factura gótica correspondiente a la primera fábrica que fue sustituido por el que ahora se ejecuta. En 1647 el abad y canónigos de Benevívere se conciertan con el ensamblador carrionés, Pedro Santos para la ejecución de un retablo que debía finalizar al año siguiente ${ }^{191}$. La obra, de madera de pino, mediría siete metros y medio de alto y cuatro y medio de ancho ${ }^{192}$. Según las condiciones, el retablo constaría de banco, dos cuerpos divididos en tres calles, y ático. La parte inferior sería completamente lisa, tan sólo ornamentada con una moldura de media caña y partida en el centro para albergar "una custodia", esto es, un tabernáculo. El primer cuerpo se compondría de ocho columnas pareadas entorchadas y capitel corintio entre los cuales se situarían dos lienzos. En la hornacina principal figuraría la imagen de la Virgen. Se trataba, como así indica un informe sobre la abadía redactado en 1666, de Nuestra Señora de Benevívere, que junto a las reliquias de San Torcuato, era la pieza de mayor devoción para los visitantes ${ }^{193}$. Una cornisa lisa “... sin cartelas ni talla...” daría paso al segundo cuerpo donde se dispondrían otras dos pinturas flanqueando una escultura de la Asunción. El número de soportes en esta parte se reduce a la mitad, optándose por cuatro columnas de orden compuesto. Otro friso similar al anterior, situado sobre este cuerpo precedería al remate, con la clásica representación del Calvario. Del análisis de esta obra artística colegimos que se trataba de una obra clasicista, semejante en su estructura al retablo mayor del convento de Santa Clara de Carrión, si bien de menor riqueza, pues en éste no existían ni los bustos relicarios del banco ni los ángeles

\footnotetext{
${ }^{190}$ Suponemos que la sala capitular y la capilla mayor no resultaban suficientes para todos los miembros vinculados al convento cuyo último deseo era sepultarse en la abadía. ADP. Conventos dispersos. Benevívere. Libro 1. 1631. Constituciones y estatutos. Podemos constatar la existencia de estas capillas pues se nombran en las intervenciones del claustro entre 1660 y 1661. AHPP. Carr.Prot 5693 Norberto Sandoval y Guevara (1660), fol 438 y ss y 5695, Norberto Sandoval y Guevara, (1661), fol 352 y ss.

${ }^{191}$ Recibiría por su ejecución 2.800 reales. Contrato y condiciones en AHPP. Carr.Prot 5429. Francisco Moro Saldaña (1647), s/f. Sobre Pedro Santos, remítase al capítulo dedicado a los escultores y ensambladores locales.

${ }^{192}$ "veynte y siete pies de alto y ancho diez y seis pies y medio". Hemos tomado como referencia la medida de un pie castellano, equivalente a 0.2786 metros.

${ }^{193}$ ADP. Religiosos. Abadía de Benevívere (1475-1808), s/f.
} 
ceroferarios de los extremos. Las columnas entorchadas referidas, deben entenderse, por la época en que se hace la obra, no como salomónicas, sino más clásicas, esto es, torsas, con su fuste estriado helicoidalmente. El retablo de la casa clarisa lo había ejecutado precisamente el propio Pedro Santos junto a otros dos ensambladores de Carrión, Pedro López y Nicolás de Vega en 1633, así que pudo haberle servido de modelo ${ }^{194}$.

Este retablo debió ser reemplazado por otro barroco churrigueresco en el siglo XVIII como podemos colegir de las palabras que le dedica Ponz cuando visita la abadía hacia 1783: “...dichosa talla y follajes de nuestro siglo, según cuyos cánones se hizo el retablo mayor, sin que se olvidasen de hacerle sus transparentes... ${ }^{195, "}$

\section{Intervención en el claustro alto}

Las obras que afectaron al claustro alto se llevaron a cabo durante el trienio de don Francisco Antonio de Medina Nuño de Reinoso. En 1660 Felipe Berrojo se concierta junto al carrionés, Julián de León, en la ejecución de cuatro aposentos correspondientes al sobreclaustro. Estos maestros de albañilería habían establecido un contrato de compañía desde que trabajaran juntos un año antes en la abadía premostratense de Santa María la Real de Aguilar de Campoo ${ }^{196}$. En esta ocasión debían intervenir en la reedificación de unos cuartos ubicados desde el coro alto a la escalera principal, es decir, los situados en el paño occidental del claustro ${ }^{197}$. Debían demoler todo ese ángulo aledaño también a otro patio "jarreando paredes, blanqueándolo todo y echando sus tejados y lima oya" tal y como se hallaba previamente. Los tejados y suelos de toda esta zona debían ser armados nuevamente, utilizando para ello la madera extraída en la obra de otro paño del claustro que había sido renovado recientemente por Jerónimo de Avendaño ${ }^{198}$. A la entrada de la iglesia, en el hueco donde se hallaban las pesas del reloj, se practicaría un acceso, en el tabique de entrada del coro “...para el

\footnotetext{
${ }^{194}$ AHPP. Carr.Prot 5229. Jerónimo López (1633), s/f. El retablo al que sustituyó, fue trasladado al convento de San Francisco para ser colocado en la capilla mayor de su templo.

195 PONZ, Antonio. Viage...Op.cit, pág. 204.

19614 de abril de 1659. AHPP. Carr.Prot 5531. Tomás Pérez (1659-1660), fol 142 y ss. Sobre Felipe Berrojo y Julián de León, remítase al capítulo dedicado a los maestros locales.

${ }^{197}$ CASADO IZQUIERDO, $\mathrm{M}^{\mathrm{a}}$ de los Ángeles. El arquitecto...Op.cit, pág. 60. Escritura y condiciones del contrato en AHPP. Carr.Prot 5693. Norberto Sandoval y Guevara (1660), fol 438 y ss.

${ }^{198}$ Sobre Jerónimo de Avendaño, véanse los datos relativos al mismo en el apartado dedicado a los maestros cántabros.
} 
usso y sserviçio de ello...”. La obra incluiría la reedificación de la fachada de ladrillo de la portería que limitando con la del templo, precedía al patio mencionado ${ }^{199}$. Para ello se dispondrían “...nuebe postes de piedra de Palacios de Alcor...”, de orden toscano, con su basa y capitel de sección circular y en el acceso, un arco capialzado con un alféizar.

Esta obra, que se comprometieron a finalizarla en septiembre de 1660, daría relevo a otra al año siguiente, a cargo del maestro de carpintería Francisco de Reinaldos ${ }^{200}$. La reforma afectaría a los dos paños del claustro que faltaban por renovar, en los que existían ocho columnas de orden toscano, como así refieren las condiciones, lo cual aporta una idea del mismo ${ }^{201}$. Uno de estos lienzos era el del lado oriental, dada la referencia a la sala capitular, en la que se debía construir una techumbre a par hilera con tejado a dos aguas cuyos paños tuvieran una vertiente hacia el claustro y otra hacia la huerta. Contigua a esta, se ubicaba la librería. En ella se reconstruirían las paredes, donde se dispondrían dos órdenes de estantes, se solaría el pavimento con ladrillo en labor de lazo, se abriría una ventana con un arco y se cerrarían bóvedas de buen yeso blanqueadas posteriormente. En el otro paño se debía construir una cochera y una estancia dividida en tres partes para vivienda de los mozos.

También se debía intervenir en el lienzo realizado un tiempo atrás por Jerónimo de Avendaño, que era el contiguo al templo, es decir, el septentrional, donde había que demoler los tejados del crucero, asentados sobre la "media naranja". Por tanto, ya estaba construida la cúpula perforada por ventanas de medio punto adornadas de mascarones a la que se refiere Quadrado en 1861, cuando ya no se conservaba más que un lienzo de la misma ${ }^{202}$.

Asimismo se hacen referencias a otras dependencias como caballeriza, colgadizo de carros, pajar, aposento de harina, lavadero y huerta que constituyen un testimonio

\footnotetext{
${ }^{199}$ Para que comprendamos la distribución del convento, la ubicación del claustro, el patio, el coro alto, la iglesia y la portería sería similar a la del monasterio de San Zoilo, con la salvedad de que la fachada del templo, en lugar de ubicarse en el lado norte del templo, se ubicaría en su lado occidental, a los pies del coro, de ahí que limitase con la de la portería.

${ }^{200}$ Es hijo del maestro de carpintería homónimo, de quien hablaremos en un apartado dedicado a su persona.

${ }^{201}$ Escritura y condiciones firmadas el 3 de febrero de 1661 en AHPP. Carr.Prot 5695. Norberto Sandoval y Guevara, (1661), fol 352 y ss.

${ }^{202}$ QUADRADO, José M M $^{\mathrm{a}}$ PARCERISA, Francisco, J. $1^{\text {a }}$ Edición. Op.cit, pág. 345.
} 
valioso sobre los principios de provisión y autoabastecimiento que regían la vida de la comunidad monástica.

Las obras, comenzadas en febrero de 1661, debían estar finalizadas en agosto de dicho año. Aunque desconocemos si se finalizaron en el tiempo estipulado, proseguían a buen ritmo, ya que en el mes de mayo se indica que Francisco Reinaldos ejecutaba un paño “...en correspondenzia de las tres (alas) que están fabricadas... ${ }^{203}$ ”. El claustro bajo no se modificó, sino que mantuvo los arcos rebajados con molduración de bolas propios del siglo XV, tal y como lo muestra el dibujo que Parcerisa realizó en 1842 del acceso de la sala capitular, en el que se aprecia uno de estos arcos que conformaban el claustro.Varios años más tarde, en 1668, algunos cuartos del convento sin especificar, son retejados por los maestros locales Lázaro Vicente González y Francisco de Valles $^{204}$.

\section{Sepulturas en la abadía}

La costumbre de disponer de la sala capitular como panteón de la estirpe de los Sarmiento fue continuada a través de los siglos. Así se puede observar que en 1630, Don Rodrigo Sarmiento de Villandrando y de la Cerda, conde de Salinas y Belchite y Aliaga La Bureba y Ribadeo, Duque y señor de Hijar, siendo administrador su padre Diego de Silua y Mendoza, marqués de Alenquer, duque de Francavila. Tenía dos hijos, Jaime Fernández de Hijar y Silva, su primogénito y Rui Gómez de Silva, a quienes otorga poder en 1649 para que le representen en cualquier causa jurídica ${ }^{205}$. Dona el cuerpo de su padre Don Diego de Silva y Mendoza al convento en el que ya estaban enterrados otros familiares:

\footnotetext{
${ }^{203}$ AHPP. Carr.Prot 5768, Andrés Simón Aguilar (1660-61), fol 826 y ss. 20427 de mayo de 1668. AHPP. Carr.Prot 5535, Tomás Pérez (1667-1672), fol 225.

${ }^{205}$ Los títulos nombrados son lo más representativos, siendo su denominación completa la siguiente: Duque de Lecera, Marqués de Alenquer, Príncipe de la Portella, Conde de Baltogona, Altaza, Castellot, Velchite y Gulmatán, Vizconde de Illa y de Canete, de Ebol, Flacie y Anor, Loquerfordat, Noble Varón de Vinot, Bafaninfa y Luca, Mataplana, Rocafort, Peramola, Vulcano, La Otilla y Zurita, Adelantado Mayor de la mar, repostero mayor de la Real Casa de Castilla, Capitán General del reino de Navarra y de las provincias de Álava y Guipúzcoa, Alcalde perpetuo de las Fortalezas de Miranda de Ebro y Pancorvo, señor de la Casa fuerte de Puentelarad, señor de las villas de la Chamusca y Ulme, Peñacerrada y sus aldeas, Lagran y sus aldeas, Ocio, Puentelarad, La Bastida y Hallercuanas, Villarrubia de los Ojos, de Trosa de los Reguengos, de Guimarais y Nespeira, de las Capillas de Coruche y Soure, Comendador de San Vicente de Pereira y de Acebuesem de la Orden de Cristo, gentilhombre de la cámara de Su Magestad y de su Consejo de Estado. AHPP. Carr.Prot 5432. Francisco Moro de Saldaña (1650) s/f.
} 
“Amortajado con el hábito de Alcántara, descubierto el rostro, en un ataúd con las llaves, guarnecido y cubierto de terciopelo negro y oro, con dos cerraduras y llaves doradas, para le enterrar conforme a su voluntad y última disposición en el dicho convento, en medio de los cuerpos de las señoras condesas de Salinas y Ribadeo, doña Ana Sarmiento y doña María Sarmiento, sus mujeres, que están sepultadas en el dicho convento" ${ }^{206}$.

La relación entre el Duque de Hijar y el convento permanece durante siglos, pues así lo manifiesta la carta de pago del conde de Ribadeo al tesorero de Benevívere fechada en 1697 “...por las misas dotadas que se dieren por el dicho prior mayor y capellanes todos los días de Nuestra Señora... ${ }^{207, "}$

\section{EL DEVENIR A PARTIR DEL SIGLO XIX}

En un informe de 1845 redactado por Comisión provincial de monumentos sobre la abadía, se indica que en el claustro principal ya demolido, se conserva un pórtico jónico con columnas pareadas que data de 1805. Esta arquería neoclásica podría identificarse con algunos pilares decorados las armas del linaje Sarmiento conservados en el acceso y capilla del cementerio de Carrión de los Condes. Parece ser que en las obras ejecutadas en la década de 1890 para la ejecución del camposanto ${ }^{208}$, fueron reaprovechados algunos elementos de la derruida abadía ${ }^{209}$.

El mismo año de 1805, se intervino sobre el coro de la iglesia, concretamente se desmontó la claraboya del lado meridional que daba luz a este espacio por el peligro de derrumbe que presentaba, sustituyéndose por otra “...con arreglo al orden dórico...”. Además fue reforzada la estructura de dicho muro y se colocó una reja de separación con el resto del templo. De las obras que se prolongarían durante poco más de tres meses, se encargó el maestro cantero Lorenzo Regaliza, vecino de Becerril de Campos,

\footnotetext{
${ }^{206}$ AHPP. Carr.Prot 5413, Francisco Moro de Saldaña (1630), s/f.

${ }^{207}$ AHPP. Carr.Prot 5018, Agustín García Miranda (1696-1698), s/f.

${ }^{208}$ La construcción del nuevo cementerio fue propuesta a mediados de 1885 y se hizo cargo de la obra el maestro Pedro Rey, vecino de Castrillo de Villavega, que la finalizó en 1902. AMC. Libro 11, Sesiones municipales (1879-1885) fol 38.

${ }^{209}$ PERAL VILLAFRUELA, Santiago. Estudio...Op.cit, pág. 30.
} 
quien para ello seguiría las trazas del arquitecto Manuel Rodríguez Rascado ${ }^{210}$. Este artista vallisoletano fue miembro de la Real Academia de la Purísima Concepción de Valladolid, en la que ingresó como alumno de dibujo en mayo del año $1787^{211}$.

Como sucedió en otros edificios palentinos y por extensión, en la inmensa mayoría de los conventos y monasterios españoles, las sucesivas desamortizaciones decimonónicas conllevaron la ruina de la abadía de Benevívere. La primera de ellas se produjo en 1809, según el Decreto emitido por José Bonaparte de 18 de agosto, por el que se suprimían todas las órdenes religiosas de varones. El último abad de Benevívere, don Juan Ignacio Barbán emitió una misiva al rey con el objetivo de que excluyeran la abadía de la exclaustración, pues sus miembros eran canónigos, no monjes. Así se expresaba el prelado: “...no debe estar comprendida en la generalidad por ser su cabildo el único en el reino compuesto por el abad y diecisiete canónigos que no están sujetos a jurisdicción eclesiástica alguna ni a otra potestad sino a la de Vuestra Majestad; viven bajo la antigua Regla de San Agustín, como algunos Cabildos catedrales, visten hábitos clericales como ellos y aunque tienen vida común hacen suyos los bienes que adquieren por sus dignidades y salen a canónigos de Santas Iglesias de real presentación y hacen oposiciones a prebendas de oficio a las que no tienen opción los regulares, tienen a su cargo la cura de almas y sus jóvenes individuos van a la Universidad de Valladolid a cursar estudios que costea la casa y se mantienen en casa particulares... ${ }^{212 ” . ~ A u n q u e ~ n o ~ l o g r o ́ ~ s u ~ p r o p o ́ s i t o, ~ a l ~ m e n o s ~ l o s ~ r e l i g i o s o s ~}$ obtuvieron el derecho a la percepción de pensiones que asignaba el gobierno por su conducta política favorable durante la guerra y la posibilidad de ocupar canongías en catedrales o colegiatas ${ }^{213}$. Los objetos de oro y plata fueron un botín muy preciado tanto para los soldados franceses como para los guerrilleros de la provincia y los conventos de Carrión y el de Benevívere resultaron algunos de los más afectados. El monasterio había sufrido algunos desperfectos fácilmente reparables; la iglesia en cambio, si bien cerrada al culto, se conservaba en buen estado ${ }^{214}$.

\footnotetext{
${ }^{210}$ Escritura y condiciones del contrato en AHPP. Carr.Prot 5264, Miguel López (1804-1805), fol 7 y ss.

${ }^{211}$ CAAMAÑ̃ MARTÍNEZ, M ${ }^{a}$ Jesús. "Datos para la historia de la Real Academia de la Purísima Concepción de Valladolid (1786-1797) en BSAA, n²9, Valladolid, 1963, pág. 106.

${ }^{212}$ Como vemos, los canónigos habían dejado de depender de la Santa Sede, pero desconocemos cuando se produce este cambio.

${ }^{213}$ FERNÁNDEZ MARTÍN, Luis. "La diócesis...Op.cit, pp. 234-235 y 254-255.

${ }^{214}$ AGS. Gracia y Justicia. Papeles del Gobierno intruso. Asuntos civiles y eclesiásticos. 1210. Palencia, 7 de julio de 1810 .
} 
Durante el trienio liberal de 1820 a 1823 , se vendieron en Palencia gran número de conventos a grandes propietarios e industriales de la ciudad. La subasta pública de Benevívere se produjo en 1821, figurando a partir de entonces bajo el apelativo de ex monasterio $^{215}$. Un inventario de dicho año aporta una interesante descripción general sobre la abadía, que aún se hallaba en perfectas condiciones. En el mismo se indica que todo el perímetro tenía un zócalo de piedra y el resto del muro era de ladrillo jalonado por sendas rejas. En total existían tres accesos, el principal se ubicaba a mediodía, lienzo en el que en lugar del enrejado existían balcones y dos torres de piedra, una de las cuales aún subsiste, aunque fragmentada. La portada renacentista aún se conservaba con la Asunción presidiendo en la hornacina principal. Una vez dentro del recinto, reseña la existencia de dos patios, uno con antepecho de hierro y ventanas y otro de menor tamaño, junto al templo, es decir, el claustro, “cuya fábrica es antiquísima” . Contaba con dos espadañas, una de piedra para las campanas y otra de ladrillo para contener el reloj. Finalmente se hace referencia al resto de dependencias como corrales, cuadras, pajares y demás necesario para el mantenimiento del ganado ${ }^{216}$.

Cuando en 1823, Fernando VII regresó al poder tras ser destituido por el Consejo de Regencia, los religiosos recuperaron el convento pero nadie reintegró la suma abonada por su compra al antiguo poseedor ${ }^{217}$.

Los monjes volvieron a recibir un duro golpe con la desamortización de 1835 , pues se determinó que aquellos conventos con menos de doce individuos debían ser suprimidos. Al contar solamente con diez, Benevívere fue uno de los dieciséis cenobios de la provincia de Palencia afectados por el decreto, resultando subastado en junio de $1841^{218}$. Por entonces Benevívere aún se conservaba en buen estado. El dibujo de la capilla mayor del templo, realizado por Carderera en 1838 nos muestra cómo efectivamente se había mantenido intacto desde el siglo XIII ${ }^{219}$. Lamentablemente, poco tiempo después, en 1843 ya se había demolido “...quedando sólo sus paredes, que todavía demuestran la majestad y hermosura de aquel tiempo... 220 ". No cabe duda de que hubo un derribo deliberado por el dueño de entonces. Tal vez se trataba de una

\footnotetext{
${ }^{215}$ Se anuncia su venta en La Gaceta de Madrid, 1821, nº 166, 168, 169, 176. El 24 de julio de 1821 se saca a crédito público la finca de Villaherreros que pertenecía a Benevívere. En este documento ya figura con el apelativo de ex monasterio. AHPP. Carr.Prot 10706, Carlos Vázquez (1821-1832), fol 3

${ }^{216}$ AHPP. Desamortización. Legajo 436. Inventario de Santa María de Benevívere.

${ }^{217}$ REVUELTA GONZÁLEZ, Manuel. "Origen, ocaso...op.cit, pp. 67.

${ }^{218}$ Ibídem, pp. 68 y 77.

${ }^{219}$ FLG. Interior de la iglesia de Benevívere. Fondo Carderera. № 9813.

${ }^{220}$ RAMÍREZ DE HELGUERA, Martín. El Libro...Op.cit, pág. 166.
} 
mezquina táctica para sortear la posibilidad de que la propiedad regresara a los monjes, como así había sucedido durante el Trienio Liberal ${ }^{221}$. Acaso la verdadera pretensión era su aprovechamiento como cantera, pues nos consta que la piedra fue destinada para otros $\operatorname{usos}^{222}$. En cualquier caso observamos que la propiedad recayó en manos equivocadas, con una carencia total de sensibilización por el patrimonio artístico.

Cuando la Comisión provincial de monumentos palentinos visitó el convento en 1845 con miras de redactar un informe sobre el estado del mismo, encontró que muchas esculturas, mayoritariamente las de la capilla de San Miguel, se hallaban tiradas por el suelo, fragmentadas y cubiertas de tierra, por lo que el reconocimiento de algunas se hizo imposible. El propietario particular del convento había retirado el tejado y a consecuencia de ello, la capa de tierra que lo reforzaba se derrumbó, resultando de esta caída el destrozo referido. Otro posible factor añadido a esta caótica disposición puede responder a expoliaciones en busca de objetos preciosos ${ }^{223}$.

Los miembros de la comisión, avergonzados ante esta situación, deciden recurrir al jefe provincial para que impida al dueño hacer uso de los bienes histórico artísticos, por no hallarse éstos incluidos en la compra del convento. Además, solicitan fondos al gobierno provincial para el mantenimiento y mejora del monumento, recibiendo diversas negativas basadas en la necesidad de autorización gubernamental o la falta de caudal. En otra misiva, de junio de 1844, la Comisión de monumentos de Palencia emite al gobernador principal una catalogación de los monumentos que, pertenecientes al Estado, aún existen en la provincia y son dignos de conservación. Entre ellos se describe in situ el convento de San Pablo de Palencia, destacando el sepulcro de los marqueses de Poza, los sepulcros del infante Felipe y doña Inés de Castro en Villalcázar de Sirga, el sepulcro de Husillos ${ }^{224}$ y como no, el claustro de San Zoilo. Se hace referencia a los fragmentos sepulcrales y estatuas que se hallan abandonadas en Benevívere y se ruega inmediato traslado a San Zoilo por ser punto más próximo que la capital palentina. Propone asimismo la conservación de las portadas de Santiago y Santa

\footnotetext{
${ }^{221}$ PERAL VILLAFRUELA, Santiago. Estudio...Op.cit, pág. 37.

${ }^{222}$ RAMÍREZ DE HELGUERA, Martín. El Libro...Op.cit, pág. 236.

${ }^{223}$ PERAL VILLAFRUELA, Santiago. Estudio...Op.cit, pág. 38.

${ }^{224}$ Se reconoce que Villalcázar y Husillos no forman parte del grupo de conventos suprimidos, pues se trata de iglesias, pero por el interés que presenta las obras artísticas que albergan, se solicita su conservación.
} 
María así como la elaboración de dibujos detallados de todos los monumentos por si desaparecieran, pues muchos de ellos se encontraban en evidente estado de ruina ${ }^{225}$.

A pesar de esta actitud pasiva del gobierno, reacio a destinar capital para la conservación de monasterios y conventos exclaustrados, la comisión no desiste en sus intentos. Vicente Carderera, como miembro de la misma, propone diversas alternativas en 1847 destinadas a preservar los sepulcros de la abadía:

“...Como el transporte desde Benevívere hasta Palencia quizá sería muy costoso, podrían llevarse al inmediato monasterio de San Zoilo y colocarse en su célebre claustro hasta que pudiera formarse el museo provincial...Por lo pronto, y hasta que esto pueda verificarse, con cuidado e inteligencia es de suma urgencia que el Gefe político designe algún vecino de Carrión o guarda de aquella comarca de Benevívere, para que custodie los citados sepulcros de la iglesia y sala capitular, así como los restos del bello pórtico que da entrada a ésta, o bien se cierre la entrada o levante una pequeña pared con beneplácito del dueño del edificio o por algún otro medio análogo, debiendo entender dicha autoridad que todos estos objetos de arte jamás han entrado en el contrato de venta de estos monasterios 226 ".

Ante la insistencia, el gobierno central decidió conceder en 1850 ocho mil reales para la recuperación de bienes artísticos que la Comisión de monumentos palentinos determinase. Ésta propuso a través de reiterados escritos que Benevívere era uno de los monumentos dignos de ser conservados; sin embargo, no se obtuvo respuesta. En 1854 tuvo lugar una situación parecida. El gobierno decidió ceder la misma cantidad para el traslado de sepulcros procedentes de este convento, pero finalmente, con la excusa de no tener local para disponerlos, se deniega la concesión ${ }^{227}$.

Una evidencia gráfica del estado de deterioro de la abadía lo constituye una aguatinta de la iglesia que Carderera realizó en su visita de 1858, cuyo título, "Ruinas de la abadía de Benevívere", basta para ilustrar el desolador panorama que se

\footnotetext{
${ }^{225}$ ARASF. Palencia, Comisión de Monumentos, Leg. 2-7-7, Monumentos en general.

${ }^{226}$ PERAL VILLAFRUELA, Santiago. Estudio...Op.cit, pág. 40.

${ }^{227}$ Ibídem.
} 
encontró $^{228}$. En ella apreciamos que tan sólo se conserva un fragmento del ábside, por cuyas ventanas penetra la vegetación, las cubiertas han desaparecido por completo y el suelo está poblado por entero de una espesa masa de arbustos y matorrales. En aquel viaje le acompañaba otro dibujante, Parcerisa, quien también dejó un valioso testimonio en una vista general del recinto ${ }^{229}$. En la litografía observamos cómo parte del lienzo de muralla ha caído, del acceso no se conserva más que el arranque de un arco y el suelo es ahora pasto para el ganado. Al fondo se vislumbra la portada del templo pero se han perdido los muros que le flanqueaban.

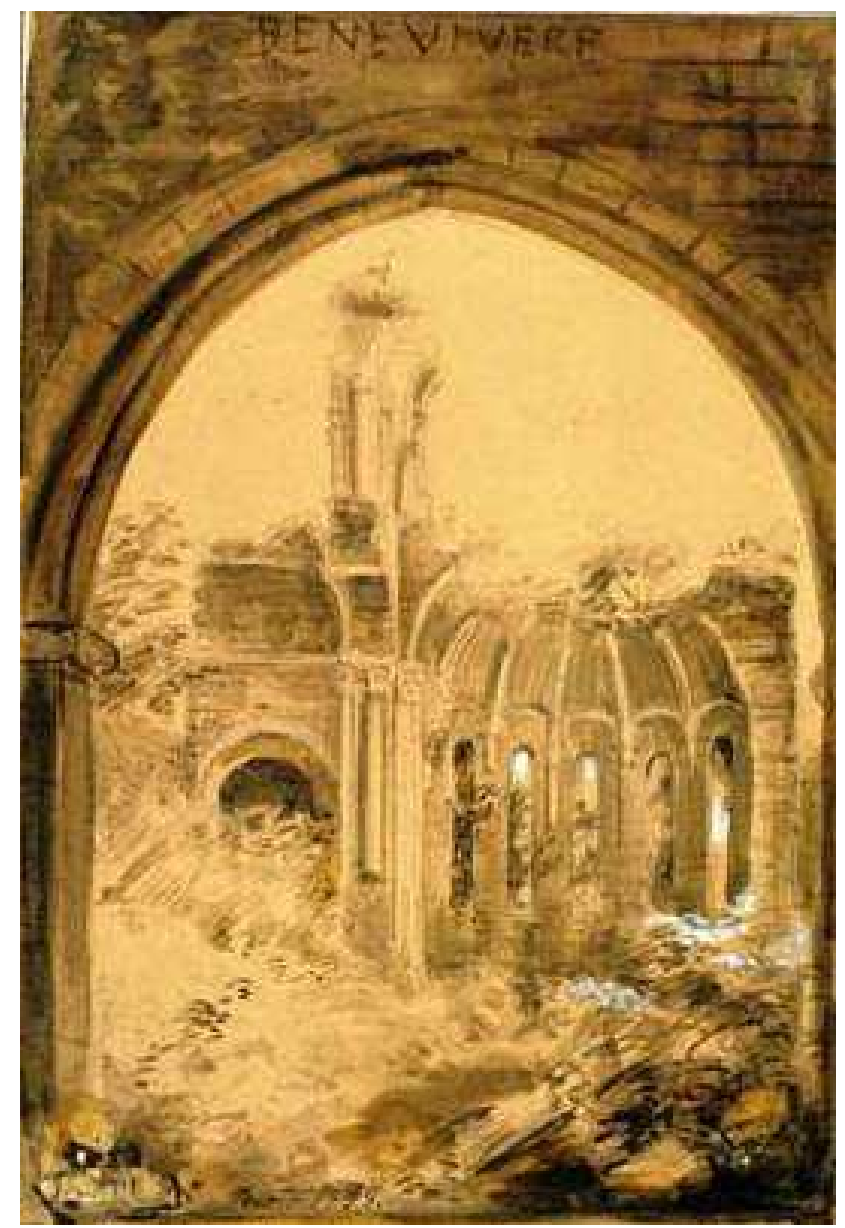

Ruinas de Benevívere. Aguatinta de 1858.

Fundación Lázaro Galdiano. Fondo Carderera 9814.

\footnotetext{
${ }^{228}$ FLG. Ruinas de la abadía de Benevívere. Fondo Carderera. № 9814.

${ }^{229}$ La reproducción de Parcerisa y el comentario de Quadrado "Lamentable es el estado que ofrecen sus informes restos, a los cuales como despropósito se ha dejado la forma de almenas” en QUADRADO; José María y PARCERISA, Francisco J. Op.cit, pág. 141.
} 
Dos años después, Carderera remite un informe sobre sus impresiones de aquella visita, del cual extraemos un fragmento que confirma todo lo expuesto con anterioridad: “...apenas hubiéramos encontrado el sitio en que tal edificio existía, al no conservar un trozo del ápside de su iglesia y cerca de él un precioso arco sepulcral del estilo Rrenacimiento lastimosamente mutilado. Este es el único resto de tantas curiosidades históricas y artísticas como encerraba aquel recinto en su iglesia, claustro y capítulo... ${ }^{230 "}$.

En lo que se refiere a los bienes muebles de la abadía, algunos fueron repartidos por la provincia de Palencia para evitar que se perdieran para siempre entre las ruinas. En el año 1894, la sillería del coro bajo de la abadía de Benevívere fue trasladada a la iglesia de San Andrés de Carrión, donde allí se conserva actualmente. El encargado de inventariar los bienes de la provincia, don Bernardino Martín Mínguez, comprobó desolado el alcance del desastre que presenció en 1907: “...Parece que las tierras se mueven solas destrozando relieves, sepulturas y estatuas. Y no hay una alma, ni piadosa artísticamente que mande recoger lo que por obligación hacerse debe... ${ }^{231}$ ".

Gracias a su intervención, y previa aceptación del fundador del Hospital Municipal, don Acisclo Piña Merino, consiguió que algunas piezas, entre ellas capiteles, se trasladasen a la huerta de los jesuitas de Carrión. En una de las capillas de la epístola de la iglesia palentina de Santo Tomás de Villotilla se conservan una escultura de la Asunción del siglo XVIII y un San Juan Bautista del siglo XVI que seguramente también procedan del templo ${ }^{232}$. En la iglesia del priorato de San Torcuato, junto a la antigua abadía, se conserva, como indicamos, un fragmento del monumento funerario del abad Juan Sarmiento. Un sepulcro del siglo XIII procedente de la sala capitular fue trasladado al Museo Arqueológico de Palencia y finalmente la estela de la época fundacional se halla en la colección del Museo Diocesano de la capital.

Respecto al edificio conventual, gran parte de sus sillares fueron utilizados en edificaciones $^{233}$, como había sucedido con el convento de San Francisco en 1867, cuya

\footnotetext{
${ }^{230}$ PERAL VILLAFRUELA, Santiago. Estudio...Op.cit, pág. 42.

${ }^{231}$ MARTÍN MÍNGUEZ, Bernardino. Catálogo... Op.cit, volumen 3, pág. 55-57.

${ }^{232}$ PERAL VILLAFRUELA, Santiago y GÓMEZ PÉREZ, Enrique. Op.cit, $2^{\text {a }}$ Edición, pág. 83.

${ }^{233}$ RAMÍREZ DE HELGUERA, Martín. El Libro...Op.cit, pág. 236.
} 
piedra fue usada en la construcción del consistorio y el reparo del puente ${ }^{234}$. Actualmente se ha convertido en una granja agrícola y ganadera con vivienda para sus dueños. En el exterior, se puede apreciar algunos muros de ladrillo medio ocultos entre la maleza. Además subsiste una especie de torreón circular al que le falta un escudo, como así se deduce del hueco cuadrangular que falta, procedente del recinto cercado que poseía la abadía.

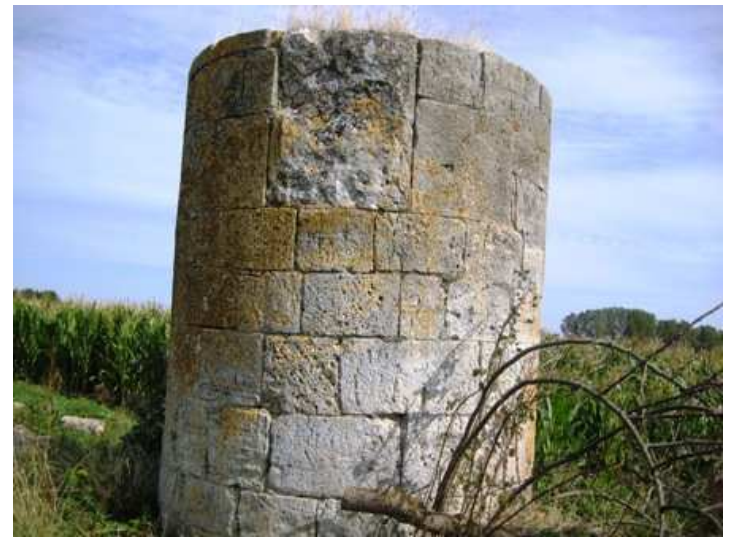

\section{Baluarte de la muralla que rodeaba la abadía.}
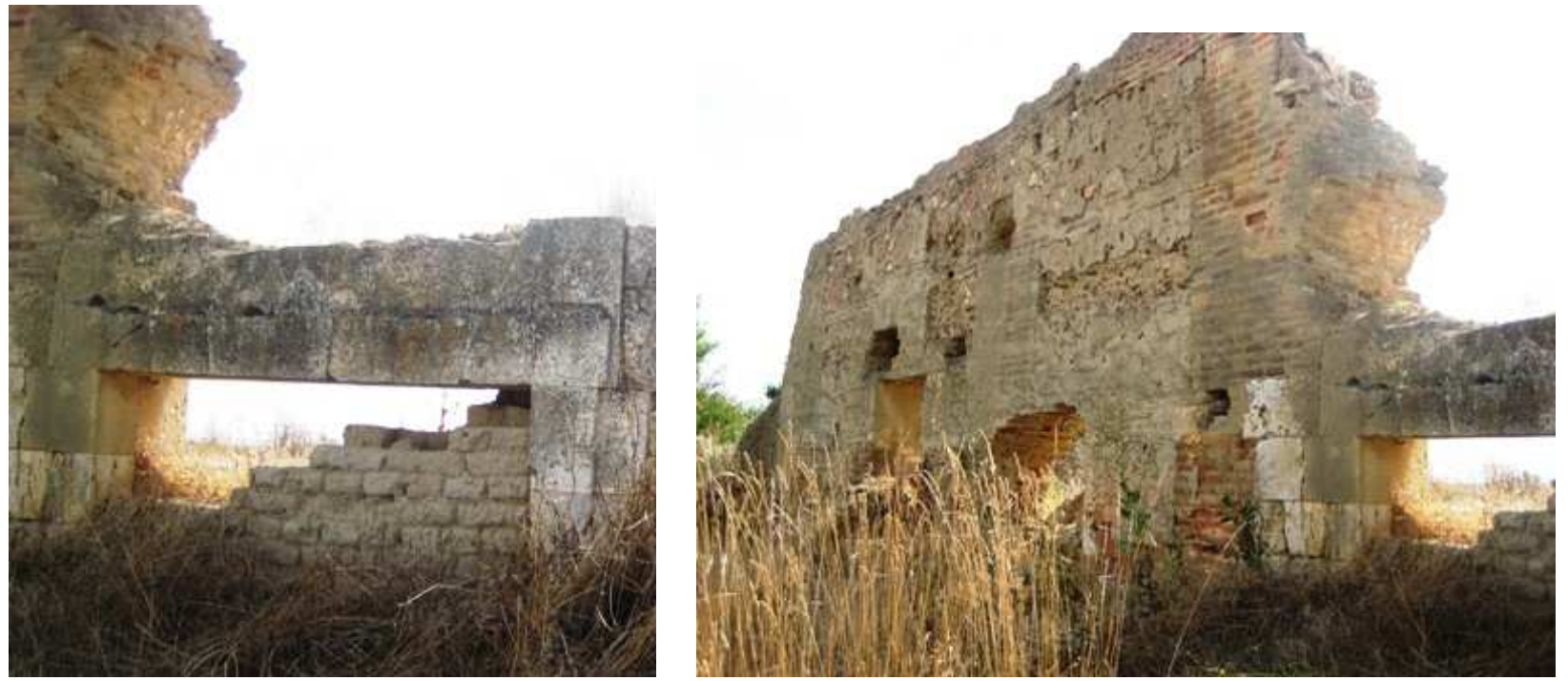

Escasos restos que se conservan de la abadía de Benevívere.

${ }^{234}$ Sobre la utilización de la piedra de San Francisco para las obras municipales se habla en Sesiones de 31 de marzo, de 6 de septiembre y de 20 septiembre de 1867. AMCC. Libro 7, Sesiones municipales (1863-1867), s/f. Sin embargo no figura en las Actas que Benevívere también fuese usado como cantera. 


\subsubsection{EL CONVENTO DE SAN FRANCISCO}

\section{LOS SIGLOS XIII Y XIV}

\subsection{EL PROCESO FUNDACIONAL}

Actualmente es poco perceptible este convento situado a las afueras de Carrión, en su parte oriental, junto al de monjas de Santa Clara ${ }^{235}$. Es necesario indicar la influencia de personalidades relevantes de la villa o del reino que posibilitasen la implantación de una congregación en un determinado asentamiento, como así sucedería en el convento de clarisas con Mencía De Haro o Aldonza de Vivero. En el caso de San Francisco, se trató de un patronato regio, pues fue nada menos que Alfonso IX quien favoreció la fundación de este cenobio y de otros asentamientos franciscanos, como dádiva por los servicios que el santo de Asís había prestado al rey ${ }^{236}$.

Su fecha de fundación es harto discutida. Si se remonta al año 1218, como afirma el analista Lucas Wadding, nos hallaríamos ante uno de primeros conventos de la orden franciscana en España ${ }^{237}$. Por ser la fuente más antigua que poseemos, se ha considerado tradicionalmente como la más fiable, recurriendo a ella un sinfín de estudiosos y eruditos $^{238}$. La experiencia nos dice que debemos, no obstante, manejar con cierta cautela ciertas fuentes, pues en algunos casos los cronistas tratan de otorgar más antigüedad de la que le corresponde a los cenobios con el fin de ligar directamente sus orígenes con la figura del Santo, que pisa suelo hispano por vez primera en 1214, con su peregrinación a Santiago de Compostela ${ }^{239}$. En cualquier caso, esta temprana fecha se correspondería con la llegada de los frailes a Carrión y su asentamiento a las afueras de

\footnotetext{
${ }^{235}$ No es un caso aislado el asentamiento de franciscano junto a sus compañeras terciarias, así ocurre en la capital palentina.

${ }^{236}$ Novedoso y documentado estudio sobre el convento al que haremos referencia en repetidas ocasiones es PERAL VILLAFRUELA, Santiago. "San Francisco de Carrión...Op.cit, pág. 231.

237 "In Hispania aliud, circa Ibídem tempus [1218], acquisitum intra opp.idum quod Carrion de los Condes nuncupatur..." WADDING, Lucas. Annales Minorum in quibus res omnes trium ordinum a $S$. Francisco institutorum ex finde ponderosius asseruntur, calumnias refelluntur, praeclara quaequa monumenta ab oblivione vendicantur, I. Roma, 1587, pág. 187.

238 “...Poco después que San Francisco viniese a España, que fue el de 14 antecedente de 1214 como queda dicho en varias ocasiones en aquella célebre peregrinación a Santiago de Galicia..." CALDERÓN, Padre Francisco. Primera parte de la Chrónica de la Santa Provincia de la Purísima Concepción de Nuestra Señora de la Regular Observancia. (1667-69). APFV. Carpeta 1.Caja 1, Legajo 1, III. Capítulo XIII Fol. 235 y ss. MARTÍNEZ GONZÁLEZ, Rafael. "Aproximación al estudio de los conventos franciscanos en la provincia de Palencia" en Jornadas sobre el de las Órdenes Religiosas en Palencia. Palencia, 1989, pág. 132.

${ }^{239}$ CUADRADO SÁNCHEZ, Marta. "Arquitectura franciscana...Op.cit, pp. 26-27.
} 
la villa, siendo el rasgo definitorio de este primer momento el carácter provisional de sus residencias sin ocupar edificios propios ${ }^{240}$.

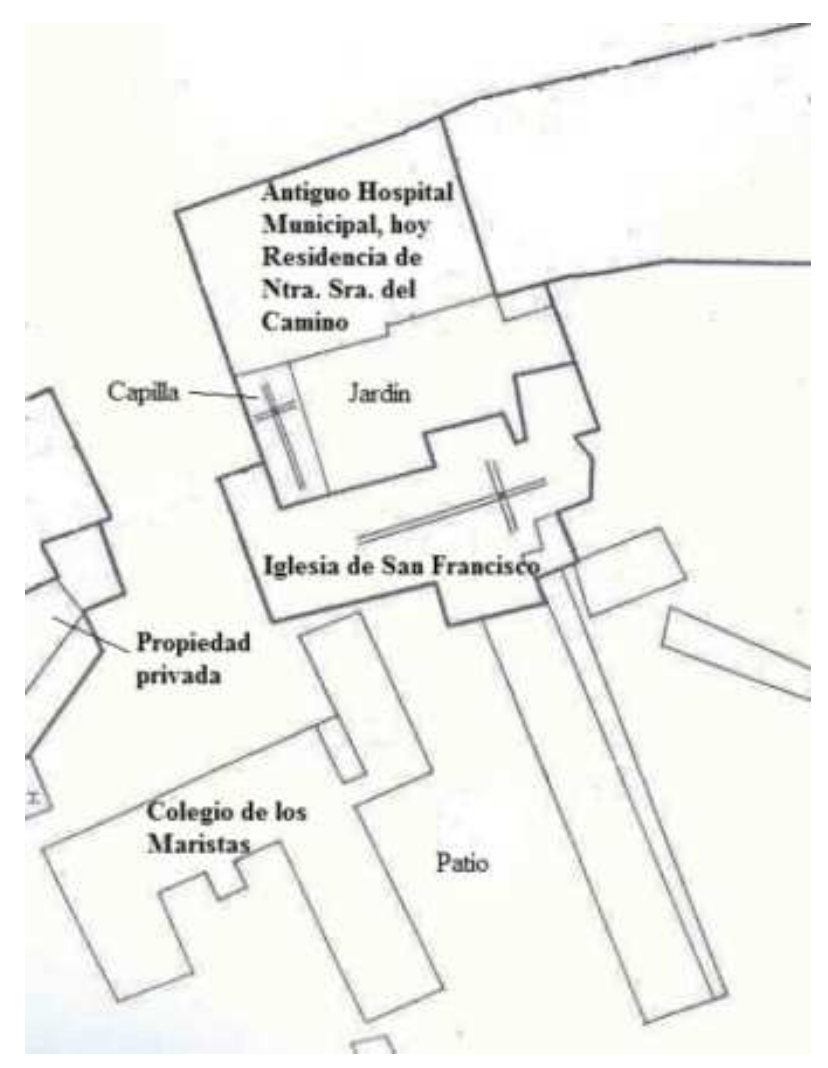

\section{Plano del terreno en el que se asentaba el convento de San Francisco.}

Extrañamente aunque González Dávila no establece una fecha fundacional concreta, aproxima el proceso constructivo a una época demasiado temprana, pues previamente, como indicamos, tuvo que darse un asentamiento inicial. Así indica: “...se edificó poco después que San Francisco pasó en romería a visitar el cuerpo del Apóstol Santiago... ${ }^{241}$ ”. Por su parte, don Juan Cisneros y Tagle, regidor perpetuo de Carrión y patrono de la capilla de San Diego del convento franciscano en el último tercio del siglo

\footnotetext{
${ }^{240}$ Sobre las primeras fundaciones franciscanas ROJAS, Francisco de (OFM). Anales de la orden de los Menores: donde se tratan las cosas más memorables de personas insignes de santidad y letras de las tres órdenes que institvyó sv gran fundador San Francisco. 3 tomos. Málaga, 1652.

${ }^{241}$ GONZÁLEZ DÁVILA, GIL. Teatro eclesiástico de las Iglesias metropolitanas y Catedrales de los Reynos de las dos Castillas: Vidas de sus Arzobispos, y Obispos, y cosas memorables de sus sedes Tomo 2: Iglesias de Sevilla, Palencia, Ávila, Zamora, Coria, Calahorra y Plasencia Imprenta de Francisco Martínez, Pedro de Horma y Villanueva, Diego Díaz de la Carrera. Madrid, 1697, pág. 137.
} 
XVI, considera que 1236 marca el inicio de su prolongada andadura ${ }^{242}$. Ambos postulados pueden resultar ciertos si tomamos la datación más antigua como el año en que el ministro provincial o pontífice concede la solicitud pertinente para el establecimiento del cenobio y la fecha posterior como la cesión de los terrenos necesarios para la creación de un edificio con carácter permanente.

Por tanto, la discrepancia de la mayoría de estudiosos oscila en un abanico que abarca el primer tercio del siglo XIII ${ }^{243}$, correspondiendo este margen cronológico a las diversas fases del proceso fundacional. En sus inicios se indica que la comunidad franciscana estaría compuesta por una treintena de frailes ${ }^{244}$.

La rápida consolidación de la orden hizo necesaria la sistematización de las comunidades, por lo que en los años treinta la Provincia de España se escindió en tres Aragón, Santiago y Castilla- regidas por un Ministro Provincial ${ }^{245}$. Desde 1260 en que San Buenaventura convocó la celebración de Capítulo General en Narbona, las provincias quedaron subdivididas en custodias, otorgando a la de Palencia los conventos de Valladolid, Sahagún, Carrión de los Condes y lógicamente, la capital palentina ${ }^{246}$.

Desde su establecimiento en la villa, los frailes ejercieron docencia en la villa, constituyendo así una pieza clave de la educación carrionesa que contribuyó a su rápida aceptación entre los vecinos, así como eficaz instrumento de la Santa Sede para llegar a todas las capas sociales ${ }^{247}$. Sin embargo no fueron tan bien acogidos por el clero secular, con el que se crearon numerosas desavenencias. Fue un fenómeno generalizado en territorio hispano que los cabildos, obispado y clérigos no viesen con buenos ojos a

\footnotetext{
${ }^{242}$ RAH. CISNEROS Y TAGLE, Juan. Historia de las grandezas...Op.cit, pág. 184.

${ }^{243}$ En Palencia, salvo el convento de Castromocho, todos los conventos se fundaron en la Edad Media, haciéndolo en el siglo XIII Palenzuela, Palencia y el Corpus, siendo el resto del siglo XV. Todos ellos presentan ciertos rasgos generales comunes como el favorecimiento de los Manrique, los patronatos nobles, la rápida aceptación de la orden en la villa y la devoción por la Inmaculada y la Pasión dem Cristo, entre otros. MARTÍNEZ GONZÁLEZ, Rafael.“Aproximación...Op.cit, pág. 116.

${ }^{244}$ CALDERÓN, Padre Francisco. Primera parte de la Crónica..Op.cit,fol 306.

245 CUADRADO SÁNCHEZ, Marta. “Arquitectura franciscana... Op.cit, pp. 22-27.

${ }^{246}$ PERAL VILLAFRUELA, Santiago. "San Francisco..." Op.cit, pág. 233. Posteriormente se incluirían dentro de la misma los conventos de Villalvín, Peñafiel y Nuestra Señora de Viarce, en Liébana, ésta última dependiente de San Francisco de Carrión. MARTÍNEZ GONZÁLEZ, Rafael. "Aproximación..." Op.cit, pág. 120.

${ }^{247}$ GARCÍA ORO, José. Francisco de Asís en la España medieval. C.S.I.C. Santiago de Compostela, 1988, pp. 53-59. Un estudio sobre la instalación de las órdenes mendicantes en Castilla PEÑA PÉREZ, Javier. "Expansión de las órdenes conventuales en León y Castilla: franciscanos y dominicos en el siglo XIII” en III Semana de Estudios medievales. Instituto de Estudios Riojanos. Logroño, 1993, pp. 179-198.
} 
unos frailes que, además de gozar de privilegios y exenciones, contaran con el apoyo del papado $^{248}$. A esto se suma la preferencia de los fieles por la el tipo de predicación establecida por franciscanos, debida a la cotidianeidad en los temas y el uso pionero de la lengua romance que volvía comprensible el mensaje que deseaban transmitir al pueblo $^{249}$.

Además es importante saber que antes de crear un establecimiento definitivo, los frailes ejercerían la liturgia en Santa María del Camino o Santiago interfiriendo de este modo en la rutina diaria de las parroquias, de ahí la incomodidad añadida. La férrea oposición entre ambos bandos se prolongó a lo largo de los siglos, si bien el problema de la celebración de culto quedó solucionado con la erección de un templo propio. Veamos cómo sucedió.

\subsection{LA ERECCIÓN DEL CONJUNTO CONVENTUAL}

El largo proceso evolutivo de la arquitectura franciscana en España, sin constituir el de Carrión de los Condes una excepción, corre paralelo a la transformación ideológica que la orden experimenta progresivamente. Es decir, desde el expreso rechazo de las residencias fijas de San Francisco hasta la construcción de las imponentes fábricas posteriores, transcurren varias décadas e incluso casi un siglo. Este hecho justifica la prolongación en el tiempo del mecanismo fundacional, que nos obliga a establecer varias fases dentro del mismo. Partimos, por tanto, de una etapa inicial itinerante entre 1220 y 1230 , caracterizada por la ausencia de actividad constructiva, basándose la religiosidad por entonces en la pobreza, el trabajo manual y la ayuda a enfermos y leprosos. Con el incremento de adeptos, los franciscanos buscarán asentamientos estables y sencillos de madera, próximos a una capilla y ubicados extramuros de la ciudad. Entre los años treinta hasta mediados del siglo XIII, los franciscanos se olvidan paulatinamente del principio nómada del fundador y buscan una mayor estabilidad a través de los privilegios de los pontífices, quienes concedían

\footnotetext{
${ }^{248}$ LINEHAN, Peter. La Iglesia Española y el Papado en el siglo XIII. Universidad Pontificia de Salamanca. Salamanca, 1975, pp. 222-281.

${ }^{249}$ DELCORNO, G. "Origini de la predicazione franciscana" en Francesco de Assisi e Francescanesimo dal 1216 al 1226. Atti del IV Convegno Internazionale, 15-17 ottobre di 1976. Asís 1977, pp. 146-147.
} 
permisos para levantar conventos, trasladándose a las proximidades de los núcleos poblacionales $^{250}$.

\section{El templo}

De los testimonios conservados podemos colegir el momento de consagración del templo conventual que oscilaría entre mediados del siglo XIII y principios de la centuria siguiente. La prueba de la temprana erección del templo se manifiesta a través de una abertura en la parte central del presbiterio que alberga una semicolumna adosada a un pilar compuesto, éste a su vez empotrado en un muro más profundo de la cabecera. Este soporte se encuentra a dos metros escasos sobre el suelo, medida muy corta para un soporte gótico que con toda seguridad tendría su continuación hacia la parte inferior. Es por ello que Peral Villafruela apunta lógicamente a la existencia de una cripta, o bien que esta diferencia con el nivel actual del templo corresponda a una colmatación del terreno.

La robustez de un capitel corrido situado sobre estos restos apunta hacia una datación comprendida en el abanico mencionado con anterioridad. Así lo constata la existencia de una inscripción sobre la lápida de la capilla mayor que fue descubierta a principios del siglo XVII y que rezaba: “...fabricó la infanta doña Juana, mujer del

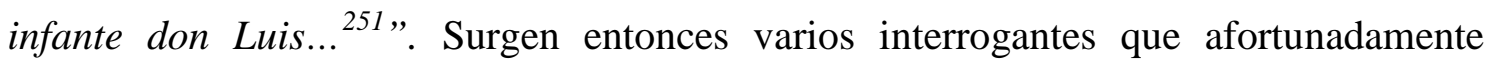
encuentran ahora respuesta. ¿Quién impulsó la construcción de este templo? ¿Qué relación le unía con Carrión? ¿Cómo y cuándo fue descubierta la inscripción de la lápida oculta? ${ }^{252}$.

El infante don Luis al que hace referencia la documentación era el tercer hijo del matrimonio formado por Fernando III y su esposa en segundas nupcias, doña Juana de Ponthieu y de Aumale ${ }^{253}$.

En cuanto a la infanta, se trata de doña Juana Gómez de Manzanedo, poseedora de la encomienda del priorato situado en San Martín de Frómista ${ }^{254}$. Su vida se

\footnotetext{
${ }^{250}$ CUADRADO SÁNCHEZ, Marta. “Arquitectura franciscana...Op.cit, pp. 47-53.

${ }^{251}$ CALDERÓN, Padre Francisco. Primera parte...Op.cit, pág. 132.

252 Para evitar confusiones y dado que seguimos un orden cronológico en las fases constructivas, responderemos a esta cuestión cuando lleguemos al año 1612 de este apartado.

${ }^{253}$ PERAL VILLAFRUELA, Santiago. “San Francisco...”.Op.cit, pp. 258-260.
} 
desarrolló a caballo entre los siglos XIII y XIV, debiéndose a su impulso por tanto la erección de la capilla mayor y por extensión la del templo gótico en el que perviven elementos de este período. Entre los testimonios gráficos de este primer templo se conservan los tres esbeltos baquetones adosados uno a cada ángulo de la cabecera poligonal. Están rematados en capiteles tallados a través de una esquematización de hojas de acanto a modo de formas conopiales de los cuales partirían los nervios de una bóveda radial. Normalmente para la construcción de los templos mendicantes, teniendo en cuenta su pobreza inicial, se recurría al uso de una caliza deleznable, utilizándose la mampostería en lugares específicos. La capilla mayor, sin embargo, por ser que el espacio privilegiado de la iglesia, recibía la cantería, razón por la cual se han conservado estos restos.

La ligereza interior que tendría el origen el templo contrastaría con la presencia de gruesos muros en la nave y los contrafuertes en la cabecera poligonal ${ }^{255}$. En nuestro caso, la base de estos refuerzos adopta la forma rectangular, mientras que en la mayor parte de cenobios franciscanos que han llegado hasta la actualidad, presentan una estructura prismática y escalonada, como en San Francisco de Lugo, de Montblanc, en Tarragona, o de Betanzos, en La Coruña ${ }^{256}$. Entre los contrafuertes se conservan, como en la parte interna, una serie de baquetones estilizados con capiteles esquemáticos en los que se adivina el arranque de los arcos apuntados, seccionados actualmente por la cornisa de remate del templo. El hecho de que se muestren parcialmente, es un dato indicador de la esbeltez original de este espacio. Gracias a estos vanos, seguramente divididos por un mainel central, la cabecera quedaría bañada por una luz natural.

Parece ser que este templo, diáfano a la par que esbelto, estuvo precedido por un pórtico de piedra, como así se deduce de la presencia de una columna en el tramo occidental. La presencia de este tipo de espacios es usual en la arquitectura franciscana, perviviendo hoy día en los cenobios hispanos de Palencia, Tineo, en Asturias o Morella, en Castellón ${ }^{257}$. Lejos de tratarse de espacios con un fin meramente estético, los pórticos

\footnotetext{
${ }^{254}$ Concretamos más datos acerca de este personaje en el apartado relativo a las capillas y sus patrones.

${ }^{255}$ Véase el croquis de la iglesia de San Francisco en el siglo XIV. PERAL VILLAFRUELA, Santiago. "San Francisco...".Op.cit, pág. 321.

${ }^{256}$ CUADRADO SÁNCHEZ, Marta. “Arquitectura franciscana...Op.cit, pág. 485.

${ }^{257}$ Ibídem, 482-483.
} 
desempeñaron una función eminentemente litúrgica, cobijando a la congregación de fieles bajo su cubierta cuando por cualquier motivo no podía hacerse uso del templo ${ }^{258}$.

Por tanto, a lo largo del siglo XIV quedó conformado el templo terciario, que sería de una sola nave y crucero de grandes dimensiones, marcado en planta a través de dos capillas laterales cuadrangulares ${ }^{259}$. Aunque no se conserva ningún soporte original en el templo carrionés, la solución empleada comúnmente en las fábricas mendicantes era el pilar cilíndrico con tres columnas adosadas al mismo, de esbeltos fustes, siendo el central más grueso para sujetar el arco. Este sistema es patente en los cenobios de Santo Domingo y Santa Clara de Pontevedra, o en los templos franciscanos de Palencia y Zamora. Es posible que la nave se cubriera con una techumbre de madera apeada sobre arcos fajones, solución de grandes ventajas técnicas con amplia tradición en la Península Ibérica. Las cubiertas lígneas, aparte de ser más económicas que las pétreas, proporcionaban gran diafanidad debido a su ligereza ${ }^{260}$. La cantería quedaría reservada para las capillas laterales y el crucero, que contaría con una bóveda de nervios octopartita, adaptada a la cabecera poligonal.

\section{Las dependencias conventuales}

En lo que se refiere a la configuración inicial del resto del cenobio, es ineludible advertir la ausencia material de restos que nos ayuden a establecer datos concluyentes sobre su fisonomía. Esta tarea se dificulta aún más si cabe, por la multiplicidad de intervenciones y adiciones que ha experimentado el conjunto en el con el paso de los siglos. A todo ello, se suma además, la ausencia de un plano universal mendicante o de unas directrices arquitectónicas establecidas por San Francisco en sus escritos, conformándose los cenobios de acuerdo a las necesidades litúrgicas. Hay que tener en

\footnotetext{
${ }^{258}$ Remitimos al trabajo de BANGO TORVISO, Isidro. "Atrio y pórtico en el románico español: concepto y finalidad cívico-litúrgica" en BSAA. No XL-XLI, Valladolid, 1975, pp. 175-188.

${ }^{259}$ No existe una tipología única de planta dentro de la arquitectura mendicante en España. A tenor de los templos catalogados puede establecerse una clasificación general con múltiples variantes. Dentro de los templos de una sola nave, los más habituales, existen edificios con nave rectangular sin capillas, como Medina de Pomar y Logroño, de cruz latina con capillas en la cabecera, siendo la Coruña, Robadeo o Vivero ejemplos de ello y templos con capillas entre los contrafuertes y cabecera de un ábside, siendo representativos los cenobios del litoral mediterráneo (Morella, Palma, Valencia). Aparte de estos, figuran los templos de dos naves, como San Francisco de León y de tres naves, como Salamanca o Burgos. CUADRADO SÁNCHEZ, Marta. "Arquitectura franciscana...Op.cit, pág. 494-497.

${ }^{260}$ Ibídem, Op.cit, pp. 489-491.
} 
cuenta que los frailes dedicaban gran parte de su tiempo a la predicación, no cumpliendo unos horarios tan estrictos como los monjes, quedando traducida esta libertad en una mayor flexibilidad en la configuración de las dependencias conventuales

En todo el solar hispano, tan sólo se conserva la sala capitular y el refectorio del cenobio castellonés de San Francisco de Morella, por lo que resulta imposible establecer un criterio que sirva como modelo para el resto de conjuntos mendicantes peninsulares $^{261}$.

\section{El claustro principal}

Por la documentación, sabemos de la existencia paralela de dos claustros en el convento, el principal, que lógicamente se ejecutaría en primer lugar, y el denominado "pequeño", que sería el claustro renacentista ejecutado por Juan de la Cuesta a lo largo del siglo $\mathrm{XVI}^{262}$. Constatamos la existencia de dos claustros en otros cenobios mendicantes como en los conventos franciscanos de Barcelona, y Mallorca o en los dominicos de Vitoria o Mallorca ${ }^{263}$.

El claustro principal, como su propio nombre indica, acogería en su interior las dependencias conventuales más significativas, como la sala capitular, el refectorio, el "De Profundis" y las celdas de los frailes.

Debemos remontar el origen de este espacio al menos al siglo XIV, pudiendo situar las obras del mismo en el período de fiebre edificadora en que, como vimos, la infanta doña Juana remodela el templo, o incluso antes. En cualquier caso, ya estaba construido a finales de dicho siglo como veremos.

\footnotetext{
${ }^{261}$ Ibídem, pp. 524-528.

${ }^{262}$ Identificamos el claustro principal con el más antiguo, pues se indica que en él existía una capilla dedicada al Papa Calixto, que comentamos a continuación. La existencia paralela de ambos claustros figura, por ejemplo en la escritura de contrato entre el convento y Felipe Berrojo para la ejecución de un cuarto nuevo en 1660. Escritura y condiciones del mismo en AHPP. Carr.Prot 5693, Norberto Sandoval y Guevara (1660), fol 481 y ss.

${ }^{263}$ CUADRADO SÁNCHEZ, Marta. “Arquitectura franciscana...Op.cit, pág. 529.
} 
No sabemos nada acerca de su fisonomía, pero las fuentes indican que fue venerado por su hermosa fábrica. Según relata el padre Francisco Calderón, habiendo venido a España el Papa Calixto III en fecha indeterminada (1378-1458) a visitar el cuerpo del Apóstol Santiago, pasó por este convento, dijo misa en una pequeña capilla de este claustro. Quedó tan admirado que otorgó a su guardián el permiso para conceder cuarenta días de indulgencia a sus fieles. Desde aquel momento, en el altar de aquella capilla se colocó un crucifijo con una inscripción conmemorativa en la que extrañamente no figura la fecha:

“En estte santo altar dijo missa el Papa Calixto III quando pasó a Santiago 264 ”.

Podemos determinar la ubicación de este claustro basándonos en los datos resultantes de la documentación. Sabemos que el claustro renacentista se ubicaba en el lado meridional del templo, pues cuando se inicia su construcción se indica su ubicación contigua al muro de la iglesia ${ }^{265}$. Además sabemos que ambos claustros estaban separados por un tabique, por lo que todo apunta a que este se situara a los pies del templo, en su lado occidental ${ }^{266}$.

\section{EL SIGLO XV. CREACIÓN DE NUEVOS ESPACIOS}

La primera remodelación del templo en este período corresponde al año 1436, en que Eugenio IV emite una bula destinada a la intervención de los feligreses en las obras de la iglesia, a cambio, eso sí, de la obtención de indulgencias condicionadas a la participación en los trabajos por un tiempo mínimo de cuatro años ${ }^{267}$. La celebración en 1452 del capítulo provincial franciscano es un dato indicativo de que las obras del convento habían quedado concluidas, pues es lógico pensar que el acto no se habría celebrado de no ser así ${ }^{268}$.

A mediados de siglo dicta testamento doña Mencía de Toledo, mujer de don Gonzalo Ruy de Vega. Fechado en 1449, en él la testadora expresa su deseo de reformar

\footnotetext{
${ }^{264}$ CALDERÓN, Padre Francisco. Op.cit, fol 237.

${ }^{265}$ Las condiciones del mismo transcritas en ZALAMA, Miguel Ángel. "Documentos..." Op.cit, pp. 259261, a su vez de AHPP. Carr.Prot 5617. Melchor de la Rúa (1581-1582), s/f.

${ }^{266}$ Así figura en AHPP. Carr.Prot 5693. Norberto Sandoval y Guevara (1660) fol 481 y ss.

${ }^{267}$ WADDING, Lucas. Annales...Op.cit, pág. 187.

${ }^{268}$ Ibídem, pág. 262.
} 
la capilla mayor del convento franciscano con el fin de acoger en un altar bajo la advocación de Santa María, su sepulcro y el de su difunto marido.

Para la dote de dicha sepultura, la condesa depositó en el convento franciscano la heredad de Cigoñera, cerca de Carrión, incluyendo su molino, soto, piélagos, prados, pastos, huertas, tierras e viñas, con todas su pertenencias, según lo ella tenía e poseía.

Para ornamento de la capilla, entre otras piezas, dona a los frailes una custodia de oro “...que podía pesar hasta cinco marcos de oro en que havía muchas perlas gruesas e muchos rrubies y diamantes e esmeraldas e otras piedras preciosas de mucho preçio e valor que podía valer sola la custodia, no las perlas e joias que tenía, hasta tres mil ducados de oro...”. Con tal aportación sería suficiente para obtener un espacio privilegiado en el que descansar en paz como lo era la cabecera del templo franciscano.

A raíz de un incendio que por estas fechas asoló la nave del templo y los dormitorios, los terciarios no estaban dispuesto a hacer obras en la capilla mayor, que al parecer no había resultado perjudicada, pues otras intervenciones urgían con gran premura.

Pasa el tiempo y la voluntad de la testadora sigue sin cumplirse. Detrás de todo hay un arduo pleito que no verá su fin hasta principios del siglo $\mathrm{XVI}^{269}$.

Aunque la reforma de la capilla mayor no llegó a efectuarse, sí que se crearon, no obstante nuevos lugares de culto en el templo. La cesión de juros y otras aportaciones provenientes de familias nobles desde finales del siglo XV lo hicieron posible. Es el caso de la fundación de las dos capillas colaterales del altar mayor, la de los duques del Infantazgo o Mendoza y la de los señores de Camporredondo o Cisneros. Contigua a ésta última e igualmente en la cabecera, se perfilaba la capilla de las Once Mil Vírgenes o de Beltrán de Guevara, que contaba con sacristía propia en el lado meridional.

A esta centuria también corresponderían las primeras capillas de la nave según se accede al templo. Por ser la única que conserva su cubierta original, destaca entre ellas la de la Dolorosa, provista de una bóveda de terceletes como así lo estaba la

\footnotetext{
${ }^{269}$ Véase el apartado relativo al siglo XVI para ver la resolución. El pleito en ARCHV. Pleitos Civiles. Alonso Rodríguez (F). Caja 361.0001. Legajo 62.
} 
mencionada de las Vírgenes. Esta capilla fue edificada sobre el ángulo suroeste de un pórtico precedente como así deduce Villafruela de la presencia de una columna inserta en el lado occidental. Las dos capillas que continúan por este lado de la Epístola en dirección al presbiterio, serían San Buenaventura y la capilla de Nuestra Señora.

En lo que al lado del Evangelio se refiere, tenemos constancia de la existencia de la segunda capilla, denominada de la Resurrección desde 1452, en que don Mosén Rodrigo de Vozmediano accedió a la misma gracias a un traspaso, de lo que deducimos una mayor antigüedad ${ }^{270}$. De ella no se conserva más que su recuerdo. Sin embargo, de la capilla contigua, la primera según se accede al templo, se conservan varios testimonios, algunos ocultos.

El primero de ellos, que precede a la capilla, es un acceso gótico con escudo de los Colmenares, los patronos de la misma, en el centro. Se trata de un arco apuntado de gran amplitud dotado de molduras que apoya en una sucesión de pilares estilizados y que por su tipología, podemos adscribir al siglo XV. De características similares es el arco que hallamos fortuitamente en una visita reciente a Carrión. Paseando por el antiguo hospital municipal, hoy Residencia de Nuestra Señora del Camino, cuyos muros limitan por el lado norte con el convento franciscano, hallamos, según se entra a mano derecha, el oratorio. En la pared coincidente con los pies del templo conserva un retablo neogótico en cuya parte baja, se esconde una especie de portezuela, disimulada por la arquitectura de la pieza.

El propietario del lugar sabía que a través del mismo se accedía a un espacio de reducidas dimensiones en el que esporádicamente reposaban los peregrinos buscando un lugar fresco. Sumida en la más absoluta obscuridad, nos resultó inimaginable que aquel espacio, por otro lado minúsculo, proporcionara descanso a los caminantes. Más sorprendente nos resultó el hallazgo de un acceso tapiado al lanzar a ciegas varias fotografías en el interior del mismo. Se trata de un espacio rectangular de unos dos metros de anchura y poco más de largo. En su parte frontal se destaca un arco apuntado sustentado por gruesos pilares de fuste poligonal que conformaría un antiguo acceso al templo desde el exterior, que tal vez fuera el correspondiente a la portada. Por un lado,

\footnotetext{
${ }^{270}$ Así se indica en el inventario de los bienes de Don Juan Barba de Vozmediano, entre cuyos papeles figura la escritura de traspaso de esta capilla a dicho fundador. AHPP. Carr.Prot 5713. Norberto Sandoval y Guevara (1668), fol 1137 y ss.
} 
la sencillez del arco, sin molduras y los soportes lisos, sin ningún tipo de ornamentación, nos hace pensar que se trate de un acceso del siglo XIV; por otro, el hecho de que estos espacios de culto quedaran conformados a lo largo de la centuria posterior, hace posible su ejecución en estas fechas por un cantero poco avezado.

A finales del siglo $\mathrm{XV}$, por tanto, quedaría conformado el templo con la adhesión de las dos capillas colaterales cuadrangulares y reforzadas con contrafuertes, además de la capilla de las Vírgenes en el lado de la cabecera. A ellas se suman los espacios que se adosan en los tres primeros tramos de la nave ${ }^{271}$.

Desde su fundación, San Francisco acató la claustralidad o conventualidad, alternando en su historia un período de cinco años en que siguió la observancia ${ }^{272}$, establecida por Breve de la santidad de Pío II en 1460, por el cual se autorizaba a los villacrecianos a fundar cuatro casas más de las que enajenarían todos sus bienes para satisfacer sus necesidades. No fue hasta 1463 cuando se anexionó el convento de Carrión a la Vicaría villacreciana de Domus Dei en la Aguilera, Burgos y la de Abrojo, en Valladolid. La instauración de esta tendencia reformista resultó dificultosa ${ }^{273}$. Debido a su condición de pobreza, estos frailes pusieron a la venta casi todas las propiedades que poseía el convento. Cuando los claustrales recuperaron las edificaciones, se encontraron con una situación desoladora, pues hasta las vigas de las estancias habían sido vendidas. Sin cesar en su empeño y gracias a la ayuda de los Reyes Católicos, los observantes recuperaron con grandes esfuerzos la posesión del convento en 1494, eso sí, sin haber esperado la sentencia emanada por la Chancillería vallisoletana ${ }^{274}$. En vano resultó el apoyo del pueblo carrionés, que manifestaba su inconformismo ante la

\footnotetext{
${ }^{271}$ Ibídem, 266. Véase Croquis 3, pág. 322.

${ }^{272}$ La conventualidad o claustralidad implicaba la posesión por parte de los feligreses de bienes propios, ya fueran muebles o inmuebles, al contrario de lo que sucedía a los hermanos que seguían la observancia, que planteaba un rigor y disciplina extremos, en contra de la relajación de costumbres que venía experimentando el clero. El máximo exponente de esta tendencia será el padre Villacreces, quien desde finales del siglo XIV llegó a poner bajo su regla gran cantidad de conventos. Para profundizar en el tema, véase GARCÍA ORO, José. "Conventualismo y observancia” en Historia de la Iglesia en España, no 3, pp. 234-267 y URIBE, Ángel. "Ensayo de reforma franciscana en España" en Archivo Ibero Americano, $t$ XLV. No 179-180 1945 URIBE, Ángel. "Ensayo de reforma franciscana en España” en Archivo Ibero Americano, $\mathrm{t}$ XLV, $\mathrm{n}^{\circ} 179-180$, Madrid, 1985 pp. 217-348.

${ }^{273}$ PERAL VILLAFRUELA, Santiago. "San Francisco...” Op.cit, pp. 238-240.

${ }^{274}$ Los claustrales renegaban de dicho mandamiento hasta el punto de llegar a secuestrar por las armas al regidor de la villa y a destruir mobiliario, además de llevar bienes propios a vecinos que les prestaban apoyo. PERAL VILLAFRUELA, Santiago. "San Francisco..." Op.cit, pp. 247-248.
} 
expulsión de los frailes conventuales, quienes tanto habían trabajado por su convento ${ }^{275}$. Continuando su andadura observante, en 1502, el convento franciscano se independizó de la casa de Domus Dei para adscribirse hasta 1518 a la provincia de Santoyo, momento en que ambas se unen en la Provincia de la Concepción ${ }^{276}$. Así de intempestiva fue la historia de la casa terciaria hasta la creación de este nuevo departamento.

\section{EL SIGLO XVI}

\section{Reconstrucción del templo}

Como hemos explicado, el aspecto definitivo del templo, salvo la sacristía y el pórtico de los pies, ejecutados a posteriori, quedaría conformado a finales del siglo XV. Hacia 1449 estaba prevista una reforma en la capilla mayor para disponer los sepulcros de doña Mencía de Toledo y su marido don Gonzalo Ruy de Vega. Para posibilitar su ejecución, la testadora había legado a los franciscanos una heredad en La Cigoñera y una valiosa custodia de oro, aportaciones con las que la capilla quedaría dotada para la celebración de misas. Sin embargo, sin saber cómo, estos bienes acaban en manos de la condesa de Osorno, doña Aldonza de Vivero y su hijo don Pedro Manrique de Figueroa, a quienes el convento demanda para que los restituyesen. De este modo, los franciscanos podrían vender la propiedad y el apreciado objeto litúrgico y con los fondos obtenidos, sufragar la construcción de las sepulturas. Después de varios años, en 1509 la sentencia se resuelve favorablemente para el síndico y sus frailes ${ }^{277}$. No obstante, no tenemos constancia de que tales obras se llevasen a cabo.

Recordemos que los condes de Osorno siempre colaboraron activamente con los franciscanos, siguiendo la línea mantenida hasta el momento por parte del linaje Manrique de favorecer las Órdenes Menores, aunque en este caso, fue más por obligación que por devoción ${ }^{278}$. Por lo demás, el siglo XVI transcurriría sin grandes intervenciones hasta el año 1580 en que sobrevino la catástrofe. Debido a inestabilidad

\footnotetext{
275 AGS. Cámara de Castilla, Pueblos, Leg.5, nº 218.

${ }^{276}$ PERAL VILLAFRUELA, Santiago. “San Francisco...” Op.cit, pp. 243, 252-253.

${ }^{277}$ ARCHV. Pleitos Civiles. Alonso Rodríguez (F). Caja 361.0001. Legajo 62.

${ }^{278}$ PERAL VILLAFRUELA, Santiago. Los hospitales...Op.cit.
} 
de los soportes, la iglesia sufrió un desplome ${ }^{279}$. Juan de la Cuesta ${ }^{280}$ fue el maestro trasmerano escogido para ejecutar las obras del convento franciscano, su encargo de mayor envergadura y el que más quebraderos de cabeza le acarrearía, llegando incluso a costarle su internamiento en prisión.

El primer contrato con el cantero había sido firmado el 2 de julio de 1581 en que comenzó a trabajar en las obras y se actualizó el 30 de agosto de 1586 prevaleciendo exactamente las condiciones del primero ${ }^{281}$. Además de la obra de la iglesia, campanario y el claustro, debía ejecutar tanto el coro alto como el bajo con un total de tres bóvedas, una para el nivel superior y dos en la parte inferior. Se comprometió a finalizarla en agosto de 1590, recibiendo por todo ello 23.000 reales. No obstante continuó dedicado a la misma hasta su muerte, acaecida en 1592, con períodos de receso en los que estuvo encarcelado por incumplimiento de los plazos estipulados en el contrato.

Al resultar apresado, Juan de la Cuesta cedió en 1588 la obra de albañilería de la iglesia a Francisco de Calzadilla, Marcos Santiago y Diego Estébanez ${ }^{282}$. De las obras de carpintería se hizo cargo el maestro Santiago de Sigüenza quien ese mismo año dio las trazas para rehacer el tejado de madera de la librería, ubicada en la pared contigua al coro y de tres capillas de la iglesia, una de las cuales era la capilla de la Concepción, y con toda seguridad las otras dos serían sus fronteras, en el lado de la Epístola, pues se encuentran inmediatas al coro, parte que se necesita reforzar ${ }^{283}$. Se habla de la existencia de un pórtico que precede a la capilla mencionada, por lo que este espacio existe desde fecha muy antigua, tratándose de un elemento muy característico de los conventos franciscanos castellanos ${ }^{284}$. Mientras tanto Juan de la Cuesta permanece en prisión. La buena relación que mantenía con los maestros que compartían su oficio, lo muestra la fianza que pagaron por él en junio de 1589 Santiago de Sigüenza, Rodrigo de Losada, Antonio de Cuéllar, Marcos de la Torre y Gonzalo de Albear comprometiéndose los mismos a llevarle de nuevo a prisión cuando les fuera

\footnotetext{
${ }^{279}$ Informaciones diversas sobre fundaciones y misas. ADP. Religiosos. Franciscanos (1616-1774), s/f.

${ }^{280}$ Sobre el mismo, véase el apartado dedicado a los maestros de cantería cántabros.

${ }^{281}$ La carta de concierto, obligación y fianza con Juan de la Cuesta en AHN. Clero Secular-Regular Franciscanos, 5355, s/f.

${ }^{282}$ AHPP. Carr.Prot 5648. Pedro Saldaña (1588), s/f.

283 AHPP. Carr.Prot 5620. Melchor de la Rúa (1588), s/f.

${ }^{284}$ Sobre los pórticos de los conventos franciscanos, CASTILLO, Ma José del. "Tipología de la arquitectura franciscana española desde la Edad Media al Renacimiento" en Actas del XXIII Congreso Internacional de $H^{a}$ del Arte. Granada, 1973, pág. 323 y ss.
} 
solicitado $^{285}$. Una vez en libertad, Juan de la Cuesta decide traspasar la obra del sotocoro y coro alto a los maestros de albañilería Antonio de Cuéllar (con dos terceras partes de la obra) y Gonzalo de Albear (la tercera parte restante) ${ }^{286}$. Por la ejecución de los coros recibirían cuarenta mil maravedíes y por toda la obra de albañilería de las nuevas capillas del templo se les pagaría doce mil quinientos reales. Gonzalo de Albear debió ceder su parte de la obra, pues en las siguientes cartas de pago tan solo figura Cuéllar trabajando en las obras del convento.

A finales de 1589 Antonio de Cuéllar recibe de Francisco de la Cuesta como representante de su hermano Juan, quinientos reales por llevar a cabo la bóveda de cañón situada delante del coro $^{287}$, lo cual indica que la ejecución del mismo se estaba llevando a cabo como se precisó. Desde octubre de ese año Juan de la Cuesta había otorgado un poder a favor de su hermano Francisco de la Cuesta y Marcos de la Torre, ambos maestros de cantería, para que revisaran lo ejecutado por él hasta entonces ${ }^{288}$. Una carta de pago de materiales para la obra del convento firmada ese mismo año, confirma que dicho hermano se encargaría de“...sus negoçios y está sobrehestante en ellos en las obras que se açen en el monasterio de San Francisco d'esta villa de Carrión.. $^{289 ", ~ P o r ~ t a n t o ~ J u a n ~ d e ~ l a ~ C u e s t a, ~ a u n q u e ~ t e n i ́ a ~ l a ~ t i t u l a r i d a d ~ d e ~ l a ~ o b r a, ~ n o ~}$ actuaba directamente en la misma como antes, y ni siquiera se hallaba presente, acudiendo tan sólo cuando es reclamado.

En marco de 1590, Antonio de Cuéllar intervenía en la única capilla que quedaba por rehacer “...la que viene, a lugar y ata con la capilla mayor...”, siguiendo para ello las condiciones de Juan de la Cuesta ${ }^{290}$. Aunque no especifica la advocación de la capilla, por los datos que aporta, se refiere a la de los Serna Bañuelos, pues es el espacio de culto que precede a la cabecera y se une directamente con ella. Debía reforzar sus esquinas con cascajo y cal y labrar de nuevo sus pilastras, capiteles y bóveda. Además se especifica que Cuéllar debía reforzar el acceso a la capilla mayor con su arco, pilastras y capiteles, conservando su arco viejo y manteniendo la

\footnotetext{
${ }^{285}$ AHPP. Carr.Prot 4980. Sebastián García (1588-1590), fol 672. Sobre Marcos de la Torre, Santiago de Sigüenza y Antonio de Cuéllar se hablará en el apartado dedicado a los maestros locales.

${ }^{286}$ Ibídem, fol 666.

${ }^{287}$ Ibídem, fol 512.

${ }^{288}$ Ibídem, fol 952 y 953.

${ }^{289}$ Ibídem, fol 511.

${ }^{290}$ AHPP. Carr.Prot 4981. Sebastián García (1590-1592), fol 57 y ss.
} 
uniformidad conforme a lo ejecutado en el resto del templo, por todo lo cual recibiría 50 ducados y ocho cargas de trigo. El mismo año de 1590 Juan de la Cuesta recibía unos 16 mil de los 23 mil reales que se le debían por toda la obra ejecutada en el convento, restándole de esta suma 4.000 reales por una parte de la iglesia que se cayó y que rehízo en junio del año precedente ${ }^{291}$.

A mediados de 1590 Juan de la Cuesta, que estaba concertado con Francisco del Río en la obra de la iglesia y torre de San Mamés, traspasa su parte a Antonio de Cuéllar y a Marcos de la Torre ${ }^{292}$. Esta cesión revela nuevamente que Juan de la Cuesta se estaba desvinculando progresivamente de las obras que le habían encargado, tal vez porque se encontraba cansado y quería evitar más problemas con los comitentes. Además se encontraba en apuros económicos, pues en febrero de 1591 se vió obligado a devolver un préstamo que le había solicitado a Marcos de la Torre para poder proseguir con las mismas ${ }^{293}$. Entonces le quedaban de recibir 1.750 reales de los 23 mil que como ya dijimos se le debían según la escritura firmada en 1586 y reiterada en 1589 por la ejecución de la iglesia, coro y tres capillas colaterales ${ }^{294}$.

Por su parte, el síndico franciscano acusaba a Juan de la Cuesta de haber recibido una suma mayor del valor de lo ejecutado. Por si fuera poco, el mismo año de 1591, se produjo el hundimiento de dos capillas que él mismo había ejecutado, las de San Bernardino y la de los Santos Cosme y Damián, hecho que le costó nuevamente el encarcelamiento a finales de este fatídico año ${ }^{295}$. El Licenciado Díaz Flores, patrón de ambas capillas, le había demandado exigiéndole un abono de mil quinientos ducados por los desperfectos ocasionados. Juan de la Cuesta le sugirió que fuesen dos maestros canteros, el trasmerano Domingo de Cerecedo Pierredonda -nombrado por su parte- y Juan de Celaya -por parte del patrón- quienes tasasen los desperfectos y estableciesen el precio final, que acordaron sería de doscientos ducados ${ }^{296}$. A pesar de que Juan de la Cuesta propuso encargarse de los reparos, la casa conventual rechazó su oferta y optó por enviarlo a la cárcel. Cuando fue puesto en libertad poco después, saldó su deuda con

${ }^{291}$ Ibídem, fol 131 y ss.

${ }^{292}$ Ibídem fol 103 y ss y fol 354 y ss.

${ }^{293}$ Ibídem fol 352.

${ }^{294}$ Ibídem, fol 366 y ss.

${ }^{295}$ AHPP. Carr.Prot 5650. Pedro Saldaña (1591) fol 526 y ss.

${ }^{296}$ Sobre todos ellos, véase el apartado relativo a sus datos biográficos. La carta de poder otorgada por Juan de la Vega, depositario general del Adelantamiento del reino de León así lo explica en fecha de 1 de Enero de 1592. AHPP. Carr.Prot 5651, Pedro Saldaña (1592), fol 881 y ss. 
el maestro Francisco del Río, quien le había prestado cierta cantidad para ayudarle, consciente de los problemas creados con el convento ${ }^{297}$. Y nada más se vuelve a saber de él, dado su fallecimiento en enero de $1592^{298}$. Antonio de Cuéllar retomó la obra y se encargó de reedificar desde finales de 1592 la capilla de San Bernardino, situada junto a la de Pedro de Cisneros. El patrono de la misma, el Licenciado Flores, dispuso que se hiciera una bóveda de arista en ladrillo, guarnecida de yeso con sus molduras ${ }^{299}$.

Santiago de Siguienza, que ya había participado en las obras de reedificación de los tejados de las primeras capillas del templo y de la sacristía, interviene de nuevo en las obras del convento concertándose en 1594 con don García Manrique de la Vega, marqués de Cenete. Debía reparar el tejado de la capilla del Infantazgo, colateral de la capilla mayor en el lado del Evangelio “...sin hacer daño al casco de la capilla...”. Eso significaba intervenir en la parte relativa al maderaje, sustituyendo todas las vigas en mal estado y reutilizando las que fueran de provecho. Para ello no debía modificar en absoluto la bóveda de crucería existente ni el arco apuntado de entrada, debiéndolos tan sólo cincelar. Debía además abrir una claraboya para la entrada de la luz y un orificio para la salida de las aguas ${ }^{300}$.

Por tanto, la mayor parte del templo fue reedificado en el último tercio de siglo. Por lo que a la capilla mayor respecta, también se vio afectada por el derrumbe de algunos de los soportes en 1580, así que se realizó una intervención en la misma por los años en que se intervenía en la nave. Entre 1589 y 1610 los patronos de la capilla, los marqueses de Aguilar, fueron denunciados ante la Chancillería por los frailes porque la capilla no poseía retablo decente y ni siquiera estaba dotada, y por lo tanto, habían acumulado una deuda desorbitada. Además se encontraba en malas condiciones y existía un riesgo de derrumbe, pero no había fondos en el convento, por lo que los marqueses debían elegir entre saldar la cantidad requerida o perder para siempre el patronazgo de la capilla ${ }^{301}$. El síndico era defendido por los maestros ensambladores Hernando Infante y Martín de Colmenares. Sin embargo, en las probanzas a favor de Doña Antonia de la Cerda y su hijo don Juan Fernández Manrique figuraban maestros

\footnotetext{
${ }^{297}$ AHPP. Carr.Prot 4982. Sebastián García (1592-1594), fol 87 y ss.

${ }^{298}$ ZALAMA, Miguel Ángel. La arquitectura...Op.cit, pág. 260.

${ }^{299}$ AHPP. Carr.Prot 4982. Sebastián García (1592-1594), fol 113 y ss.

${ }^{300}$ Contrato y condiciones de la obra en AHPP. Carr.Prot 5623. Melchor de la Rúa (1594), s/f.

${ }^{301}$ ARCHV. Pleitos Civiles. Quevedo (F) 1557. Expediente 1.
} 
de albañilería y carpintería como Antonio de San Miguel, Pedro de Linares, Pedro González o Antonio de Cuéllar, algunos de los cuales habían participado en la fortificación de la capilla, como así lo declaran en el pleito.

El testimonio de todos ellos, como oficiales entendidos en temas de arquitectura que defienden la seguridad de la capilla nos resulta más creíble que el de dos entalladores cuyo juicio puede ser más inexacto. Finalmente los marqueses fueron obligados a abonar los ocho mil ducados que debían y a reparar la capilla. La sentencia nos parece justa pero cabe preguntarse si los frailes no exageraban al tachar de ruinoso el estado de la capilla cuando varios maestros que habían trabajado en ella no dudaban de su estabilidad. La capilla mayor quedaría separada del resto de espacios de culto del templo a través de un encadenado “...para deuidirla e sitiarla, como es cosa suya propia de su señoría...”. Pedro Navero, como mayordomo del marqués de Aguilar, fue quien en su nombre contrató a Marcos de la Torre, el maestro de cantería que la ejecutó en $1598^{302}$.

Otras actuaciones de pequeña entidad finalizaron el siglo, como la realización de la segunda campana del arco bajo del campanario, llevada a cabo en 1591 por Joan Fernández Otero, maestro campanero procedente de Mogro, jurisdicción de Torre ${ }^{303} \mathrm{o}$ la reparación del reloj viejo de la iglesia por Gaspar Seco, quien se comprometió a ajustarlo con la campana mayor y menor por una cuantía de doce ducados ${ }^{304}$.

\section{El claustro renacentista}

Paralelamente a la reedificación del templo, comenzada en 1581, Juan de la Cuesta se encargaba de la realización del claustro ${ }^{305}$. Éste era el segundo que se ejecutaba, pues exístía otro de mayor tamaño, el principal, probablemente construido en el siglo XIV, paralelamente a las tareas de reedificación del templo ${ }^{306}$.

\footnotetext{
${ }^{302}$ AHPP. Carr.Prot 5289. Pascual López (1598) s/f.

303 AHPP. Carr.Prot 4981, Sebastián García (1590-1592) fol 361 y ss.

${ }^{304}$ Ibídem, fol 452 y ss.

${ }^{305}$ Las condiciones transcritas en ZALAMA, Miguel Ángel. "Documentos...” Op.cit, pp. 259-261, a su vez de AHPP., Carr.Prot 5617. Melchor de la Rúa (1581-1582) s/f.

${ }^{306}$ A este respecto véase el apartado relativo a las obras ejecutadas con anterioridad.
} 
Los cimientos comenzarían a realizarse por la panda colindante a la iglesia, disponiéndose cinco arcos de medio punto por cada lado con sus roscas convenientemente labradas y decorados con rosas. Las arcadas, recorridas por un antepecho, vendrían separadas mediante columnas, disponiéndose en las esquinas cuatro semicolumnas. Por encima de ellas una cornisa corrida de un pie de alto ornamentado con una moldura unificaría el conjunto, caracterizado como vemos por el uso de un lenguaje plenamente clásico “...según horden y como lo trayn Vitrubio y Serlio en sus libros de arquitectura, y bien medidas y proporcionadas...”. En el segundo piso, el denominado "sobreclaustro" se seguirían los mismos principios.

Para toda la obra se utilizaría piedra procedente de las canteras palentinas de Palacios de Alcor, Amusco o Monzón excepto en la techumbre, que se construiría en madera. El coste total de la misma ascendía a ochocientos ducados, que debían ser abonados en tres plazos. El claustro se abría a un jardín, en medio del cual se excavó un pozo, no siendo éste el único del convento, pues había otro en la huerta, junto a la hospedería $^{307}$. Al parecer el paño oeste coincidente con el lado del refectorio del claustro principal, se derrumbó en 1591, pues en marzo de dicho año Juan Ortiz se compromete a rehacerlo por 190 ducados $^{308}$. El paño que le seguía, también se encontraba arruinado, pues se indica que es necesario rehacerlo, pero Juan de la Cuesta no puede proseguir las obras, al fallecer en $1598^{309}$.

Será Santiago Díez de Sigüenza, que ya había intervenido en las reparaciones del templo, quien se encargue de cerrar dicha panda ocupándose de las labores de yesería los albañiles Marcos Santiago, Pedro de Linares y Juan de Alarcón ${ }^{310}$. El año precedente estaba realizando la misma labor en el convento franciscano de clarisas aledaño y continuará trabajando en Carrión en los años siguientes.

\footnotetext{
${ }^{307}$ Este dato lo conocemos por las obras del tejado de la iglesia que tuvieron lugar en 1588, para lo cual se debían depositar los materiales en el claustro, tomando agua de este pozo y no del otro. AHPP. Carr.Prot 5620. Melchor de la Rúa (1588), s/f.

${ }^{308}$ Ver documentos de San Francisco, extraído de AHPP. Carrió.n Protocolo 4981, Sebastián García (1590-1592), fol 410 y ss. Este paño coincidía con el lado del refectorio del claustro principal. Se indica además que “...va por delante de las capillas qu'están por azer asta la puerta de la sacristía...”, es decir, las del lado de la Epístola del templo.

${ }^{309}$ Las cuentas y partición de sus bienes se realizó en la villa de Nogal en 1598. Véase AHPP. Carr.Prot 4768. Martín Cisneros (1597-1598) fol 46 y ss.

${ }^{310}$ Las condiciones de la ejecución del último paño y la carta de pago a Santiago en AHPP. Carr.Prot 4768. Martín Cisneros (1597-1598), fol 30 y ss, 92 y ss.
} 
No se conserva ningún testimonio gráfico de este claustro, cuya existencia sabemos gracias a la documentación que venimos de detallar. Con toda seguridad, se ubicaba adosado al lado sur del templo, información que nos aporta la documentación. Además, accediendo por el Colegio de Maristas, observamos el perfil marcado en el muro de tapial de esta panda, de lo que pudieron ser las arcadas de medio punto de este espacio. Probablemente, acogería dependencias conventuales como la biblioteca, almacenes, graneros o bodega.

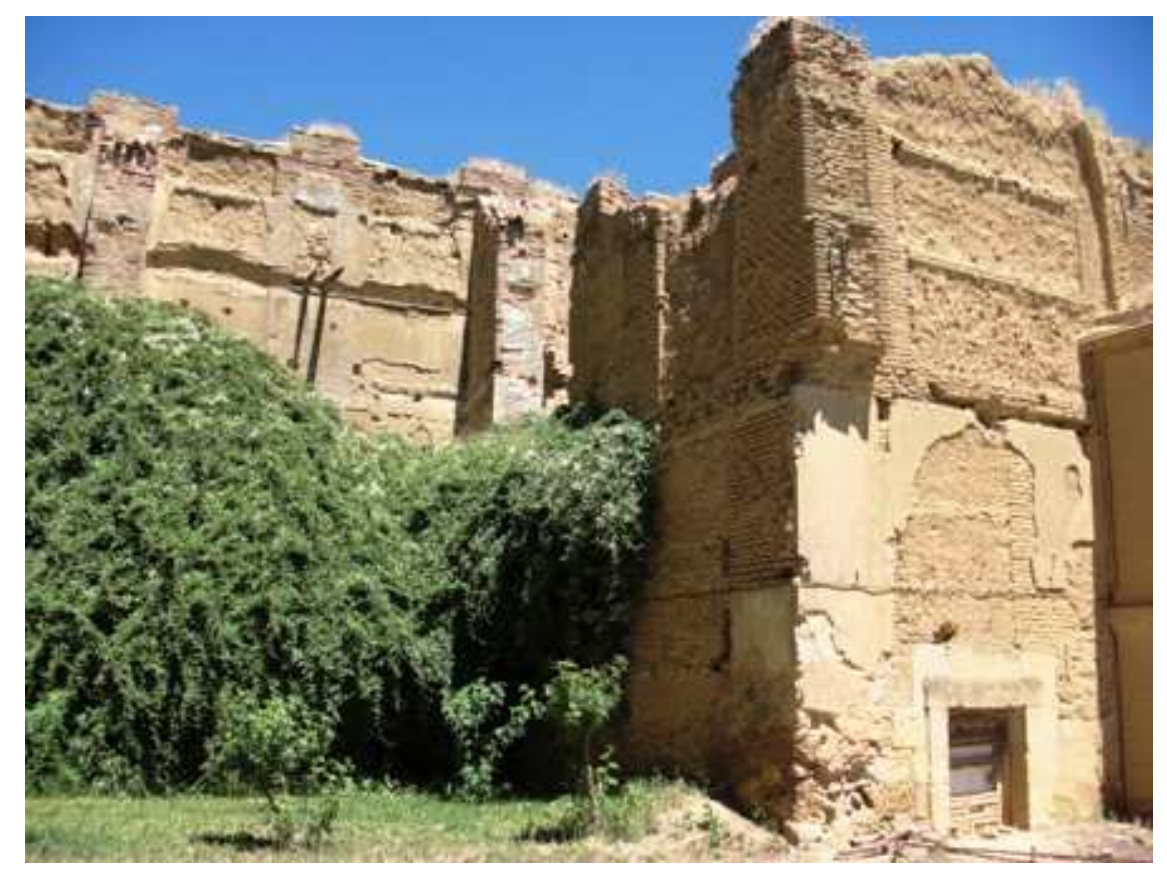

Lado meridional del templo donde se ubicaría el claustro renacentista.

\section{EL SIGLO XVII}

\section{Intervenciones de reedificación y mejoras}

El nuevo siglo se inaugura con el traslado del acceso que comunicaba la iglesia y el claustro, el cual pasa de estar en la capilla de San Diego a ubicarse en la capilla de San Buenaventura ${ }^{311}$.

\footnotetext{
${ }^{311}$ AHPP. Carr.Prot 4709. Pedro Carrión (1606), fol 515.
} 
Desde la última década del siglo anterior se venía arrastrando un pleito entre los frailes y los marqueses de Aguilar que parecía no tener fin. Los que se decían patronos de la capilla mayor, ni siquiera la habían dotado y la tenían en un estado pésimo de conservación, además de sin retablo, ni ornamentos. Finalmente en 1607 quedó resuelto el litigio cuando la sentencia se resolvió favorablemente para el convento, obligando el tribunal a doña Antonia de la Cerda y a su hijo don Juan Fernández Manrique a repararla y dotarla con ocho mil maravedíes anuales ${ }^{312}$. Los marqueses saldaron su deuda y se comprometieron a cumplir con el dictamen emitido, ahora bien, no fueron demasiado diligentes, pues pasarán algunos años hasta que tomen las medidas solicitadas.

El 16 de octubre de 1611 cuando se contrate a Francisco de la Maza, maestro cántabro vecino de Paredes de Nava, para que dirija las obras de la capilla mayor que serán ejecutadas por el maestro albañil Juan González de la Mata ${ }^{313}$. Se trataba, pues, de descomponer la cubierta de la cabecera que estaba quebrada y sustituirla por una bóveda de casco de ochavo, a imitación de la del templo de San Andrés de Carrión, realizándola con ladrillo tabicado y doblado ${ }^{314}$ con sus molduras bien labradas. Esta cubierta se asentaría sobre medias columnas o pilastras con capiteles dóricos. Además se enlucieron todas las ventanas de la capilla mayor a la par que se tapiaron las claraboyas de las capillas colaterales -de los Mendoza y Camporredondo ${ }^{315}$. Las obras estaban muy avanzadas en los tres meses siguiente, al cabo de los cuales de la Maza solicitó a Juan de la Mata que sustituyera el tabique doblado utilizado por ladrillos de media asta ${ }^{316}$ con el fin de igualar la cubierta de la cabecera a la bóveda del templo que estaba así fabricada. Además debía cerrar los arcos de la capilla y reforzar el lindero a la capilla de Guevara, manteniéndose el resto de condiciones anteriores. A los ciento ochenta ducados de la primera obra, se le añadieron trescientos veinte y seis reales por la mejora efectuada. Los plazos y los abonos se cumplen religiosamente, como así lo

\footnotetext{
${ }^{312}$ ARCHV Pl Civiles. Quevedo (F) 1557. Expediente 1.

${ }^{313}$ Contrato de la nueva obra en AHPP. Carr.Prot 5207. Jerónimo López (1611), s/f. Ver datos biográficos de Francisco de la Maza y Juan González en el apartado correspondiente a la procedencia de los artistas.

${ }^{314}$ Aquel superpuesto a otro con el fin de aumentar la rigidez y resistencia del mismo. Para ello, se colocan los ladrillos diagonalmente, desplazándolos de cada hilada la mitad de su longitud en relación con la hilada anterior, para que las llagas de ambas no coincidan.

${ }^{315}$ AHPP. Carr.Prot 5156. Jerónimo Laso (1611), s/f.

${ }^{316}$ Ancho de la pared igual a la de un ladrillo colocado a tizón, es decir, con su largo perpendicular al muro. También se denomina pie y su medida viene a equivaler unos 30 centímetros.
} 
prueba las cartas de pago emitidas por la marquesa de Aguilar entre 1611 y 1612 a Francisco de la $\mathrm{Maza}^{317}$. La actuación favorable del maestro trasmerano en este templo pudo favorecer su intervención posterior en la casa clarisa carrionesa, pues este maestro palentino fue quien ejecutó las segundas trazas del mismo en 1614, mejorando las que se habían dado dos años antes.

A raíz de estas obras que continuaban en 1612 se realiza un descubrimiento de gran trascendencia para la historia del cenobio, pues gracias al mismo se conoce a la promotora de las obras del convento entre los siglos XIII y XIV. Hasta el momento tan sólo sabíamos que fue encontrada una inscripción conmemorativa que rezaba: "mandó

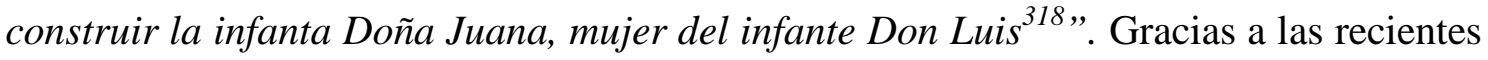
investigaciones de Peral Villafruela, se puede identificar a los personajes con doña Juana Gómez de Manzanedo y don Luis de Ponthieu, hijo de Fernando III ${ }^{319}$. Ahora además podemos contextualizar este hallazgo dentro del conjunto de obras de la cabecera que comenzaron a finales de 1611 y por si fuera poco hemos encontrado una carta ejecutoria a favor de los franciscanos contra el marqués de Aguilar en que se relata el momento preciso en que se realiza el hallazgo del sepulcro de piedra de la difunta ${ }^{320}$. El altar mayor se encontraba por entonces sobreelevado y para bajarlo de nivel se decide excavar esa parte ${ }^{321}$.

La casa franciscana no pasaba por su mejor momento en 1628, por lo que “...considerando su mucha [sic: probeza] y que el dicho monasterio está muy arruynado, caydo e maltratado por ssu antigua fundaçión, y que no tienen con que se poder rreparar y conservar..." un vecino de Carrión, don Diego Arias de Miranda, decide realizar una generosa donación con el fin de que se puedan llevar a cabo las obras pertinentes $^{322}$. Según relata, era duque de Peñaranda y había servido a Felipe IV

\footnotetext{
317 AHPP. Carr.Prot 4579. Juan Aranda Treceño (1610-1611) s/f, y 5208, Jerónimo López (1612), fol 409 y ss.

${ }_{318}$ CALDERÓN, Padre Francisco. Primera parte...Op.cit, pág. 132.

${ }^{319}$ PERAL VILLAFRUELA, Santiago. "San Francisco...”.Op.cit, pp. 258-260.

${ }^{320}$ Para la descripción de este sepulcro, véase la parte relativa a la fundación y los primeros siglos.

${ }^{321}$ Se explica más detalladamente en el apartado relativo a las capillas del templo. El documento al que hacemos referencia está fechado a 29 de agosto de 1612. Se trata de una revisión de las obras que se estaban haciendo en la capilla mayor y que debía abonar el marqués de Aguilar como patrón de la misma tras haber perdido el juicio mantenido con el convento entre 1589-1607.AHPP. Desamortización Legajo 105. Legajo $\mathrm{n}^{\circ} 1$.

${ }^{322}$ Escritura de donación fechada a 23 de mayo de 1628 en AHPP. Carr.Prot 5411. Francisco Moro Saldaña (1628), s/f.
} 
como hombre de armas en las guardas y desempeñado el cargo de Adelantado de Castilla hasta 1625, por lo que su majestad le debía de aquel tiempo unos cuatrocientos mil maravedíes. Dado que el devoto feligrés se hallaba en una situación desahogada, decide invertir esa cuantiosa suma en el convento terciario. A cambio solicita dos sepulturas con estrado para él y sus descendientes junto a la reja de la capilla mayor, en el lado del Evangelio, las correspondientes a don Juan de Vega y Paz y sus herederos, que por entonces se hallaban vacantes. A pesar de la inversión efectuada, no se registra ninguna intervención de entidad por estas fechas.

En 1639 se demanda una intervención de carácter urgente en la primera capilla del Evangelio, dedicada a la cofradía de la Concepción ${ }^{323}$. El regidor y mayordomo de la hermandad, en nombre del patrón y cofrades de la misma se concertaron con Hernando de Inestrosa, maestro de cantería vecino de Carrión, en la reedificación de la capilla desde los cimientos, que al ser demasiado endebles “...an echo gran sentimiento y se teme su peligro si no se rrepara con toda breuedad... ${ }^{324 \text { ”. }}$

La intervención ejecutada tuvo carácter provisional, pues no habían pasado más de seis años y se vuelve a requerir al mismo maestro para que junto al carpintero Bernardo Sánchez, repare enteramente esta capilla y su aledaña de la Resurrección ${ }^{325}$. A finales de 1646, ambos maestros establecen independientemente sus condiciones, unas relativas a la cantería y otras concernientes a la carpintería, firmándose el contrato con ambos en febrero del año siguiente. Se comprometen a tirar la tapia que separa ambas capillas y rehacerlas de nuevo para evitar que el coro situado sobre ambas se derrumbase, ocasionando daños colaterales en la nave. De estas obras, queda un testimonio, hoy oculto, visible desde el Asilo de Nuestra Señora de las Mercedes. A través de la portezuela del retablo, se accede a un espacio de pequeñas dimensiones al que nos referimos con anterioridad que contenía un arco apuntado, fruto de las obras del siglo XV. En su pared lateral se conserva un arco cegado de medio punto ornamentado con una imposta de placa, que se adecuaría perfectamente a las obras realizadas a mediados del XVII en esta capilla.

\footnotetext{
${ }^{323}$ De este espacio de culto se hablará en el apartado relativo.

${ }^{324}$ Escritura de concierto y condiciones firmadas a 15 de octubre de 1639 en AHPP. Carr.Prot 5422. Francisco Moro de Saldaña (1639), s/f.

${ }^{325}$ AHPP. Desamortización, Legajo 105, s/f.
} 


\section{Obras en el claustro principal}

Entre 1660 y 1662 Felipe Berrojo se encarga de ejecutar un cuarto nuevo de dos pisos en el claustro principal, en la misma panda de la cocina, "de profundis" y refectorio, los cuales debía demoler por estar afectados por las aguas, pero manteniendo sus dimensiones. En el nivel superior, debía rehacer las nueve celdas de los frailes que antes había con su corredor ${ }^{326}$. Por entonces Berrojo residía en Carrión, lo cual deducimos del cargo de mayordomo de la cofradía de Santa Brígida que desempeñó durante estos dos años, así como de diversos trabajos que llevó a cabo en diferentes iglesias y conventos de la villa por estos años, en calidad de maestro de albañilería ${ }^{327}$. La obra se estaba ejecutando conforme a lo previsto según se indica en la partida de madera que, para la misma, se trae al convento en agosto de $1661^{328}$. En marzo de 1662 , prosiguen los trabajos como se había acordado en el contrato, pues el convento recibe la herencia de don Rodrigo de Herrera y Rojas, caballero que fue de la Orden de Alcántara, indicándose que tal suma se destinase “...para la reedificación de sus casas $y$ habitación de sus religiosos... ${ }^{329}$ ". Berrojo recibirá en agosto de dicho año, doce mil reales de los quince mil en que se remató la obra, tal y como figuraba el contrato de 1660, abonándose los tres mil reales a la finalización de las mismas ${ }^{330}$.

En el último cuarto de siglo, el cenobio atravesaba una buena situación, llegando a contar con un total de 28 religiosos ingresados en el mismo, aparte de legos y criados, como así se registra en la carta de pago correspondiente a la refacción de las cuatro especies -vino, vinagre, aceite y carnes consumidas por el convento en $1681^{331}$. Además, contaba con el apoyo no sólo moral sino monetario de la monarquía, pues ésta otorga provisiones reales colaborando activamente con el cenobio. Sirva como muestra

\footnotetext{
${ }^{326}$ CASADO IZQUIERDO, $\mathrm{M}^{\mathrm{a}}$ de los Ángeles. El arquitecto...Op.cit, pág. 62. A su vez de AHPP. Carr.Prot 5693. Norberto Sandoval y Guevara (1660), fol 481 y ss.

${ }^{327}$ Véanse datos biográficos de ambos maestros en el apartado relativo a los maestros locales.

${ }^{328}$ AHPP. Carr.Prot 5532. Tomás Pérez (1661), fol 284.

${ }^{329}$ Por la posesión de dicha herencia se establece un pleito con la hermana del difunto, religiosa del convento de Santa Úrsula de Toledo. AHPP. Carr.Prot 5696, Norberto de Sandoval y Guevara (1662), fol 590 y ss.

${ }^{330}$ AHPP. Carr.Prot 5695. Norberto de Sandoval y Guevara (1662), fol 516.

${ }^{331}$ La refacción consistía en una restitución que se hacía al estado eclesiástico de la porción con que había contribuido a los derechos reales, de los cuales estaba exento. AHPP. Carr.Prot 5004. Diego García de la Llana (1679-1685), s/f.
} 
que el 12 de junio de 1686 Carlos II libra 500 ducados de limosna procedentes de las tercias partes de vacantes de Obispados ${ }^{332}$.

\section{EL SIGLO XVIII}

\section{Reedificación general del templo}

Las primeras obras ejecutadas en esta centuria afectaron a la capilla mayor, cuya cubierta se hallaba en mal estado en 1714. El administrador de los bienes del patrón de la capilla, el Marqués de Aguilar y conde de Santiestéban de Gormaz, fue quién en su nombre realizó los trámites necesarios para que dieran comienzo los trabajos. Se concertó con el alarife carrionés Andrés Campero para proceder a la sustitución de su tejado. Paralelamente este carpintero se ocupaba de reparar una de las paredes de la capilla de la Concepción, ubicada la primera según se accede al templo, en el lado del Evangelio, que había resultado dañada por las aguas ${ }^{333}$.

Por entonces también se encontraba en mal estado la capilla colateral de la cabecera, ubicada en el lado de la Epístola, bajo la advocación de Santa Ana. La obra había quedado rematada por cinco mil reales en el maestro trasmerano Francisco de Corrales, quien estableció las condiciones del contrato el 1 de agosto de 1714. Aunque la obra ya estaba adjudicada, los también trasmeranos Felipe de la Lastra y Francisco Muñoz, excusando no haber participado en la subasta por hallarse ausentes de la villa, fueron escogidos para los trabajos. Habían bajado la obra a tres mil cuatrocientos reales, argumento más que convincente para la nueva adjudicación. Ambos se comprometieron a rehacer la bóveda de crucería de la capilla tal y como se había edificado en origen. De hecho en las condiciones que establecen, muestran un plano de la cubierta octopartita sustentada por pechinas en los ángulos, cuyas claves presentan diversos motivos floreados ${ }^{334}$. Poco después, en 1789 estas cubiertas fueron sustituidas, como veremos, por una bóveda de cañón.

\footnotetext{
${ }^{332}$ AHN. Clero Secular-Regular, 5355. Obras, s/f, En este sentido veremos otra intervención de la realeza, siendo Felipe V quien la concede con motivo de las obras ejecutadas en el convento en 1726.

${ }^{333}$ Escritura y condiciones en AHPP. Carr.Prot 5642. Francisco Ruiz Sandoval (1713-1715), s/f.

${ }^{334}$ Escritura y condiciones en AHPP. Carr.Prot 5643. Francisco Ruiz Sandoval (1715-1718) fol 177 y ss.
} 
Posteriormente, y consecuencia de la ruina general que presentaba el resto del templo, se hizo necesaria la reedificación del mismo, que comenzaría, según Rafael Martínez hacia $1721^{335}$ y su año de finalización consta en la placa conmemorativa situada a los pies del templo: “AÑO 1724. ENPENZO A REYNAR LUIS PRYMERO”.

\section{Placa conmemorativa a los pies del templo.}

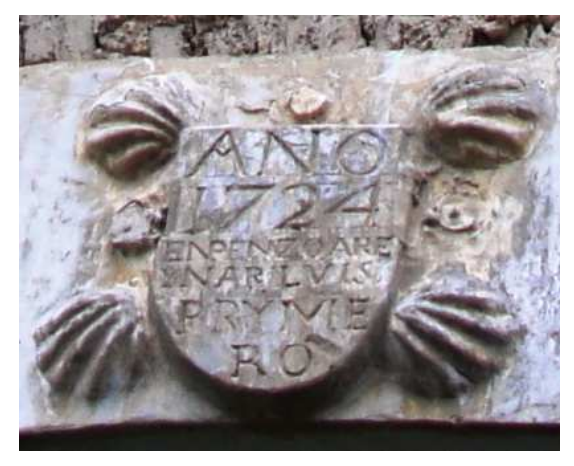

Poco después, en enero de 1726 se encarga una partida de seiscientos carros de piedra procedente bien de Támara, Monzón o Fuentes de Valdepero, e igualmente, a finales de dicho año, se registra un encargo de madera proveniente de Soria, ambos para la obra del convento “...que oy se está fabricando de nueuo... ${ }^{336 ” . ~ . ~ A m b o s ~ e n c a r g o s ~ s o n ~}$ sintomáticos del pésimo estado en que se encontraba el templo desde principios del siglo XVIII. Sin embargo el apoyo de la realeza en estos difíciles momentos se materializa inmediatamente. Felipe $\mathrm{V}$ concederá en febrero de dicho año un privilegio a los frailes por el que los bueyes que portan los materiales desde otras comarcas para la obra del convento puedan pastar libremente por los lugares de paso, responsabilizándose el monarca de los posibles daños que pudieran ocasionarse ${ }^{337}$.

Todas las intervenciones que se llevaron a cabo, siguiendo preceptos neoclásicos confirieron a la iglesia franciscana un aspecto purista y más uniforme acorde a la época. En primer lugar se realizó una sobreelevación de los muros existentes para dotar al templo de una mayor altura y por tanto, esbeltez, conseguida a través del refuerzo de los pilares. En los primeros tramos se dispusieron dos arcos fajones, el primero escarzano y el segundo de medio punto que, además de afianzar este espacio, servirían como soporte

\footnotetext{
${ }^{335}$ MARTÍNEZ, Rafael. "Aproximación al estudio de los conventos franciscanos en la provincia de Palencia" en Jornadas sobre el arte de las Órdenes religiosas en Palencia. Universidad de Verano "Casado de Alisal". Excelentísima Diputación de Palencia. Palencia, 1989, pág. 132 y ss.

${ }^{336}$ AHPP., Carr.Prot 5873, Legajo 1605. Manuel Vega (1725-1727), s/f .

${ }^{337}$ AHN Clero Secular-Regular, 5355. Obras, s/f.
} 
del coro alto que avanzaría hasta la mitad del segundo tramo. De este modo, la estabilidad de los soportes quedó asegurada y el templo protegido de futuros riesgos de derrumbe, como había sido la tónica general hasta el momento desde el siglo XVI. Por otro lado se añadió un friso corrido por encima de las pilastras de la nave en aras de una mayor unidad como así se había hecho en la casa clarisa el siglo precedente. La última reforma afectó a la cubrición del crucero, disponiéndose una bóveda de ladrillo oval en cada una de las capillas colindantes y en el centro se optó por una cúpula sin tambor de grandes dimensiones, todas ellas debidamente enlucidas de yeso.

El lugar donde se sitúa la placa susodicha señala la parte protagonista de esta intervención, consistente en la consolidación del coro alto a través de dos gruesos arcos diafragma, de los cuales el carpanel, situado en el segundo tramo del templo indica el punto hasta el que avanzaba dicho coro ${ }^{338}$. La breve pero clara descripción que del mismo hizo Ramírez de Helguera, constata que era de grandes dimensiones y contaba con una sillería de madera de nogal dividida en dos cuerpos y provista de diversas tallas $^{339}$. El inventario de la desamortización de Mendizábal indica que tenía cuarenta sitiales y por entonces ya se encontraba en mal estado ${ }^{340}$. Una descripción de 1924 aporta información sobre la datación de la sillería del siglo XVII, que fue vendida en aquel año, desconociéndose su paradero actual. En el informe mencionado se señalaba el remate de los sitiales como la única parte provista de ornamentación, a base de imitación de artesonados ${ }^{341}$.

En 1760, la capilla de Nuestra Señora de Mirabueno se encontraba en mal estado a causa de las humedades. Ubicada en el lado del Evangelio contigua al altar mayor, de su reparación se encarga el maestro arquitecto riosecano Melchor García ${ }^{342}$. Las primeras condiciones, dictadas en mayo de 1759 por el propio Melchor, se reiteran en las establecidas un año después con la salvedad que en vez de la media naranja propuesta a priori como cubrición se sustituye finalmente por una bóveda de arista en ladrillo.

\footnotetext{
${ }^{338}$ PERAL VILLAFRUELA, Santiago. “San Francisco...Op.cit, pp. 268-269.

${ }^{339}$ RAMÍREZ DE HELGUERA, Martín. El libro...Op.cit, pág. 179.

${ }^{340}$ ADP, Administración 2, leg.5, Inventario 8.

${ }^{341}$ PERAL VILLAFRUELA, Santiago. "San Francisco...Op.cit, pág. 269, a su vez de ADP. Administración diocesana, VII,1.1, leg 5, nº 57.

${ }^{342}$ Escritura y condiciones de la obra en AHPP., Carr.Prot 4653, Juan Cano Guijelmo (1760-1761), fol 253 y ss. Este artista es el mismo que en 1739 se encarga de ejecutar el Paso de los Azotes para la Cofradía de la Vera Cruz de Carrión. AHPP. Carr.Prot 5046. Santiago Gil Villegas (1738-1744), s/f.
} 
Las goteras habían provocado el hundimiento del tejado; éste a su vez, el desplazamiento de las dos claraboyas de la capilla, y como consecuencia, la aparición de grietas en las paredes, de ahí que se acuerde demoler y fundar todo ex novo. Por encima de la bóveda se dispondrá una doble armadura a tres aguas, bien afianzada con los estribos de la capilla mayor, con el fin de que se mantenga firme por mucho tiempo sin ser afectada por las aguas. Para iluminar este espacio se abriría una ventana con sus pilares y arco de ladrillo de las mismas proporciones que el de su capilla frontera en el lado de la Epístola, esto es, la de San Pedro Regalado. Sobre ella, campearía el escudo del patrón, que por entonces era doña Ana Catalina de Villacid y de la Cueva, VIII Condesa de Amayuelas, en Palencia.

La capilla además se embaldosaría en ladrillo y se fabricarían dos mesas de altar sobre las cuales se dispondrían el retablo que tenía, dedicado a la Virgen milagrera de Mirabueno, y la otra para la urna con Cristo en el sepulcro. Además, para acceder a la misma, se ordenó erigir una reja de madera sobre zócalo pétreo. El 1 de marzo de 1761 la obra estaba finalizada, como así se entiende de la carta de pago de los más de diez mil reales en que se había rematado la obra, dándola por buena Miguel Aranaz, arquitecto riosecano como Melchor García ${ }^{343}$.

Las inclemencias meteorológicas que en forma de lluvias y nieves asolaron Carrión entre los años 1788 y 1789 provocaron inundaciones que afectaron notablemente a la cabecera del templo y otros elementos aledaños. Por ello fue necesario realizar labores de cimentación más profundas, además de reforzar el tramo previo al transepto a través de un arco diafragma de medio punto. Éste precedería a la gran cúpula con pechinas del crucero que iría flanqueada en sus cuatro flancos por bóvedas de cañón, igualmente sobre pechinas. Estas reformas clasicistas correspondieron al arquitecto de Piña de Campos, Juan Monge, quien intervino con seguridad en la capilla que situada en el lado sur, contigua a la capilla mayor estaba bajo la advocación de las Once mil Vírgenes, también denominada del Conde de Sástago, por ostentar su patrón, don Cristóbal de Córdoba, dicho título nobiliario ${ }^{344}$. De este período también debe ser la construcción de la bóveda de cañón con lunetos de la

\footnotetext{
${ }^{343}$ Carta de pago otorgada por Don Juan Monzón, como apoderado de la condesa de Amayuelas, en AHPP. Carr.Prot 4653. Juan Cano Guijelmo (1760-1761), fol 166.

${ }_{344}$ PERAL VILLAFRUELA, Santiago. San Francisco...Op.cit, pág. 270-271, a su vez de ACA, Diversos, Fondo Sástago, Leg. 68, c ${ }^{\mathrm{a}} 10^{\mathrm{a}}$, nº 1 . Carrión de los Condes.1789.Agosto.
} 
capilla Camporredondo ${ }^{345}$. Como indicamos previamente, en 1714 se había realizado ex novo una bóveda de crucería en este espacio de culto, pero debió ser a causa de las inundaciones que la capilla se encontraba en malas condiciones y fue necesaria una temprana restitución.

Tras todas estas intervenciones quedó definitivamente configurado el templo, desde los inicios de su construcción en el siglo XIII. Se trata pues de la típica iglesia franciscana de una sola nave con capillas a ambos lados, amplio crucero y cabecera poligonal con dos capillas laterales rectangulares muy desarrolladas. La iglesia consta de cuatro tramos, de los cuales los tres primeros presentan capillas en el lado de la Epístola que corresponden a época barroca. En la parte superior del segundo tramo se ubicaría el coro, hoy hundido, donde se asentaría la sillería de nogal. La parte correspondiente al presbiterio es la que más elementos de la fábrica original gótica ha conservado, a los que nos referimos con anterioridad, que evidencian la esbeltez original del templo primitivo.

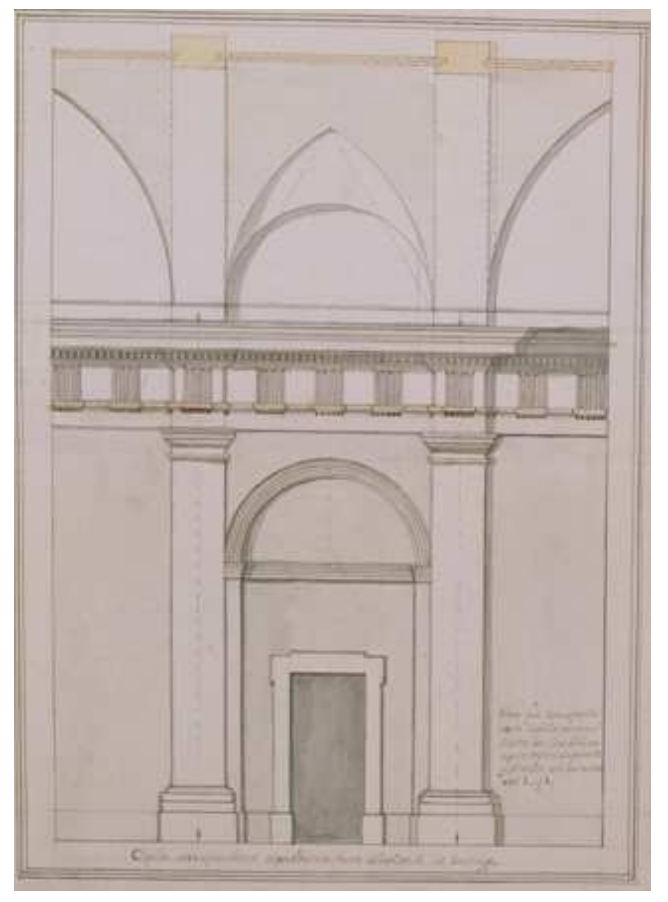

Proyecto de la fachada de la Capilla de las Once Mil Virgenes. 1789. Juan Monje. AGA. Mapas y Plano 409.

\footnotetext{
${ }^{345}$ Así lo constata el diseño de la planta de la capilla del Conde de Sástago y capillas colindantes que se muestra en PERAL VILLAFRUELA, Santiago. "San Francisco...Op.cit, pág. 330.
} 


\section{Renovación de la sacristía}

Por su parte la sacristía, tal y como evidencian los restos conservados hoy día, se debe a una reforma ejecutada en el siglo XVIII, construyéndose la originaria paralelamente a la finalización del templo, hacia el siglo XV. Adosada en el lado de la Epístola, se extendía longitudinalmente desde la capilla de las Vírgenes, junto a la cabecera, hasta la capilla de San Diego, ubicada junto al brazo sur del crucero. Asimismo su lado occidental limitaría con el claustro conventual desaparecido.

Se disponía en cuatro secciones, tres de ellas de iguales dimensiones salvo la colindante a la capilla de las Vírgenes, que era más amplia. En este espacio se combinaban los arcos escarzanos y los de medio punto peraltados en dos niveles comunicados a través de una escalera. Mediante la misma, además de acceder al pasillo que comunicaba con el coro, comunicaba con una especie de tribuna gracias a la cual los patronos de las capillas de la cabecera gozaban de una visión preferente en la celebración de la misa ${ }^{346}$.

Las capillas del templo fueron el lugar de reposo habitual de una sociedad selecta como entorno privilegiado en el que disponer su sepultura. Sin embargo, sabemos que la sacristía también sirvió para tal destino, pues en 1584, el maestro carrionés, Marcos de la Torre $^{347}$ se compromete a labrar una piedra para la sepultura de don Antonio de Velasco Avendaño, dejando la talla de su escudo y la ejecución de los leones sobre los cuales se asentaría la misma al entallador pertinente ${ }^{348}$.

\footnotetext{
${ }^{346}$ Ibídem, pág. 272.

${ }^{347}$ Ver datos biográficos del mismo en el apartado pertinente.

${ }^{348}$ Obligación entre Marcos de la Torre y el Licenciado don Cristóbal Brasas de Reinoso. AHPP. Carr.Prot 5730. Lázaro Santacruz (1585-1590), s/f.
} 

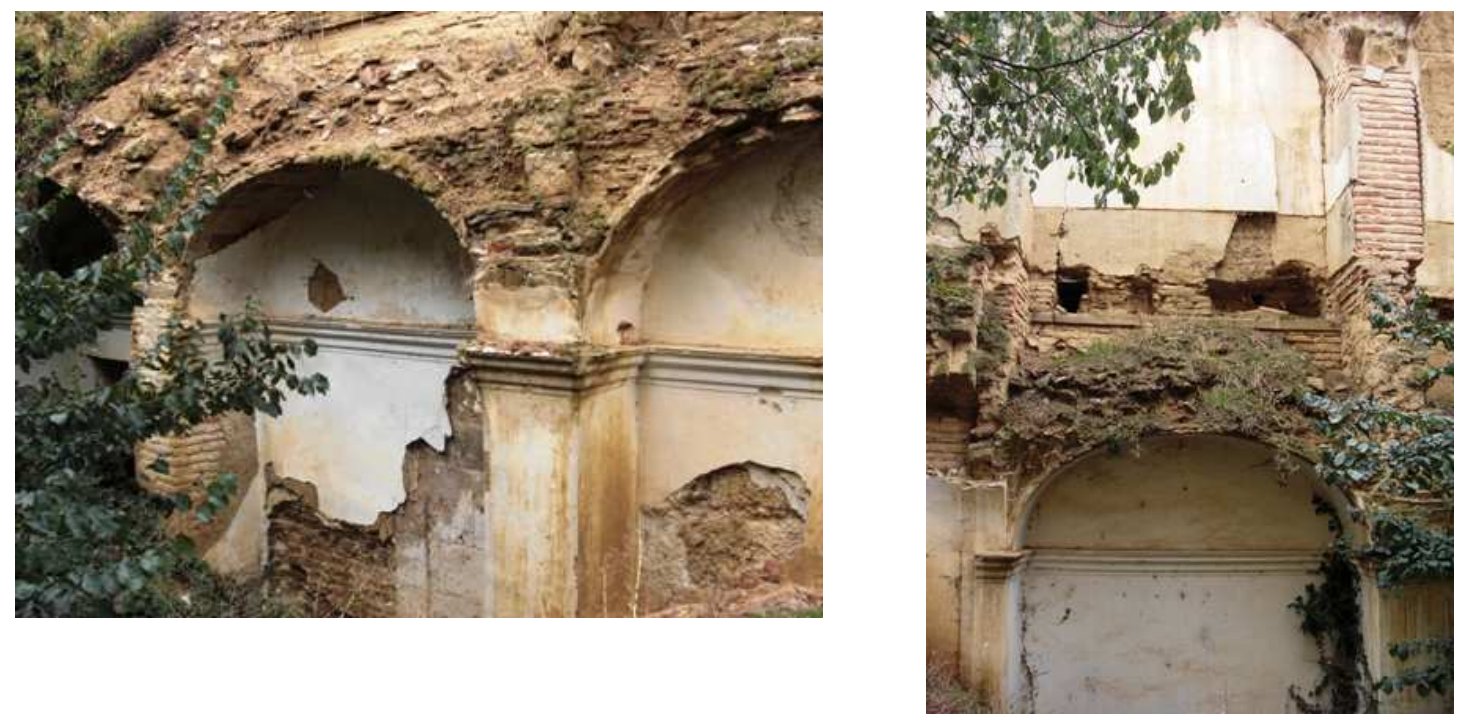

\section{Restos de la sacristía reformada en el siglo XVII}

\section{Otras intervenciones}

A este período de finales del siglo XVIII correspondería también el patio que delimitando con la sacristía albergaba en su interior la fuente inscrita en un dintel de orejetas que hoy se sitúa en la plaza Marcelino Champagnat. Servía como lavadero de manos, y estaba situada inmediata al refectorio.

Por último, en esta centuria se llevó a cabo la ampliación del atrio de entrada a los pies del templo como así se deduce de los muros de ladrillo conservados. Con un acceso en su lado norte, resguardaba la entrada al templo. Esta especie de pórtico adosado en el lienzo occidental era un elemento característico de los conventos franciscanos castellanos cuya erección primigenia se remontaría al período fundacional $^{349}$.

${ }^{349}$ CASTILLO, Ma José del. "Tipología...Op.cit, pág. 323 y ss. 


\section{EL DEVENIR A PARTIR DEL SIGLO XIX}

Sin excepción en la provincia de Palencia, el decreto de 1809 promulgado por José Bonaparte conllevó la expulsión íntegra de todos los miembros pertenecientes a órdenes religiosas ${ }^{350}$. A partir de este momento, los once conventos palentinos -nueve de observantes y dos de descalzos- a excepción del de la capital, se verán avocados a un irrefrenable deterioro. De ahí el semejante estado, fruto del abandono, que presentan por ejemplo los antiguos cenobios de Palenzuela o Paredes de Nava, comparables al de Carrión de los Condes. Si bien no está documentado, se dice que San Francisco se vio muy afectado por el incendio de 1811 provocado por la partida del guerrillero Santos Padilla. Es cierto que en el Inventario de los bienes que el convento poseía en 1810 se contabilizaban tan sólo seis altares, siendo éstos, el mayor, realizado en madera y el resto, de yeso, San Buenaventura, San Antonio, Nuestra Señora del Pilar, San Luis Obispo y San Diego de Alcalá $\hat{a}^{351}$.

Las pérdidas de bienes artísticos no señalan directamente a este indicio, pudiéndose haber producido robos o deterioros en épocas anteriores.

Con la llegada del Trienio Liberal, por ley de 25 de octubre de 1820, los conventos de mendicantes corrieron mejor suerte que los monacales, hospitalarios y canónigos regulares, pues tan sólo fueron reformados. De entre éstos, se prohibió el mantenimiento de la comunidad que no superase los veinticuatro miembros, -si había más de un convento en esa villa- o doce en los pueblos que tan sólo había un convento. De los treinta y dos de la provincia sólo se salvaron nueve de la supresión, entre los cuales figura San Francisco de Carrión, gracias a la adhesión de los miembros pertenecientes a otras casas de la provincia palentina ${ }^{352}$.

\footnotetext{
${ }^{350}$ PERAL VILLAFRUELA, Santiago. “San Francisco...”.Op.cit, pág. 255.

351 "Inventario del Convento de Nuestro Padre San Francisco de esta villa de Carrión (1809-1810)" en AHN. Clero Secular-Regular, 5355 s/f. Cuentas siglos XVII-XIX, Inventarios de bienes y objetos de plata que se hallaron en el convento (s. XIX).

${ }^{352}$ REVUELTA GONZÁLEZ, Manuel. "Origen, ocaso...Op.cit, pp. 64-65.
} 
El golpe más duro lo recibiría el convento con la más drástica de las desamortizaciones, la de 11 de octubre de 1835, por la que se suprimieron todos los conventos que quedaban abiertos ${ }^{353}$. Estos hechos conllevaron la ruina del convento. La Venerable Orden Tercera mantuvo el culto en la iglesia pero ello no evitó el progresivo deterioro del mismo. Del período en que se mantuvieron al cuidado del templo se conserva la imagen titular de la orden, una talla de San Francisco (128cm), donación de la monja Francisca Javiera del Valle, que la regaló en 1904, año en que se puede datar la escultura $^{354}$. En su mano izquierda porta un rosario, mientras con la derecha sostiene un libro en el que se puede leer: "Regla de la Tercera Orde. Penitencia. Obediencia, Pobreza". A pesar de los esfuerzos, la ruina fue inevitable. De hecho, era tal el estado de abandono el que había alcanzado el cenobio que por dicha razón se prohibió que la Corporación para la Intendencia Provincial lo destinase a "objetos de utilidad común ${ }^{355}$.

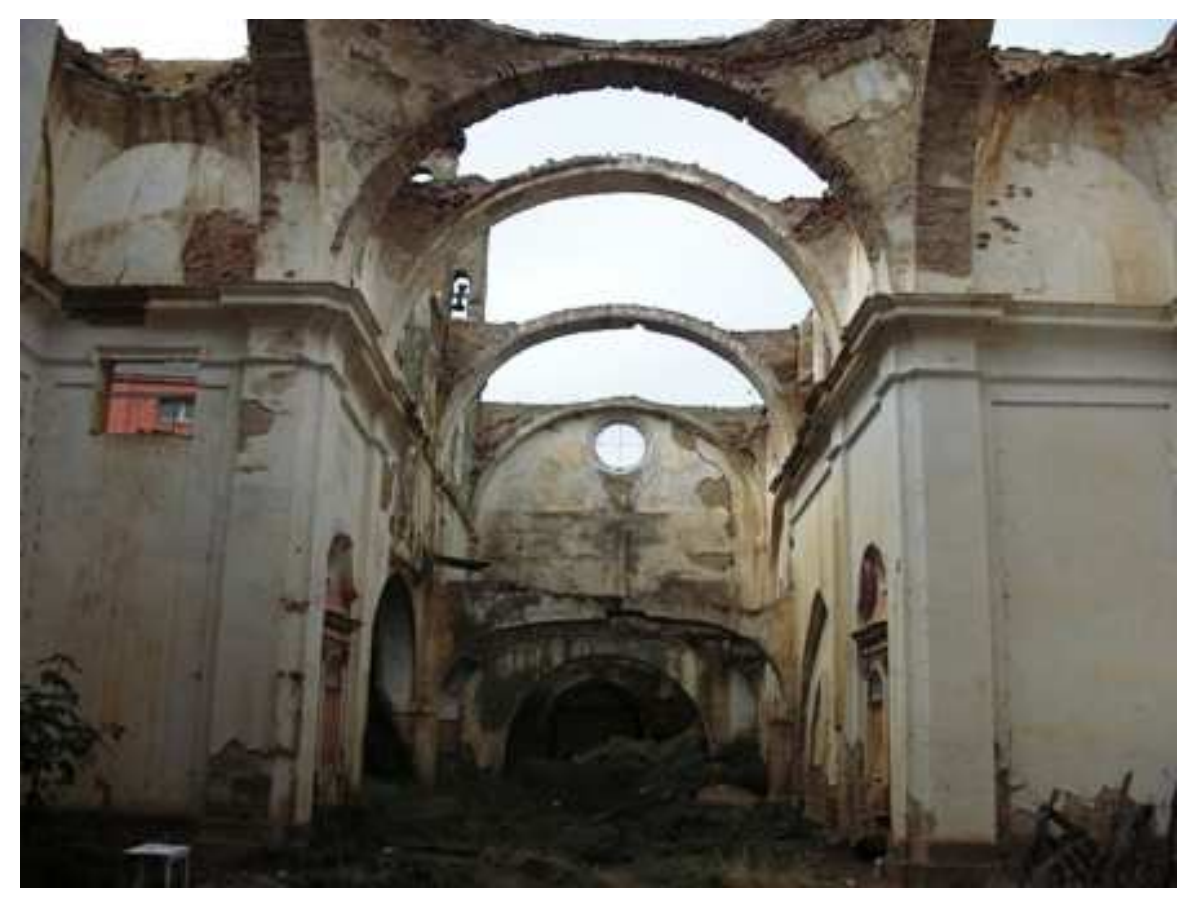

Estado actual del templo en dirección al coro.

\footnotetext{
${ }^{353}$ Ibídem, pp. 63-68.

${ }^{354}$ GÓMEZ PÉREZ, Enrique y MARISCAL ARRANZ, José. Iglesia de Santiago...Op.cit.

${ }^{355}$ Sesión de 11 de enero de 1850. AMCC, Libro 5, Sesiones municipales (1850-1857), fol 5.
} 
Si bien se culpaba a los habitantes de la villa como causantes del deterioro de la casa conventual, seguramente fuesen los vecinos quienes evitaron que se produjera la venta de los altares procedentes de los conventos de San Francisco y Santa Isabel debido a la puesta en marcha de la Real orden de 1842 por la que se permitía subastar estos bienes en los conventos enajenados ${ }^{356}$.

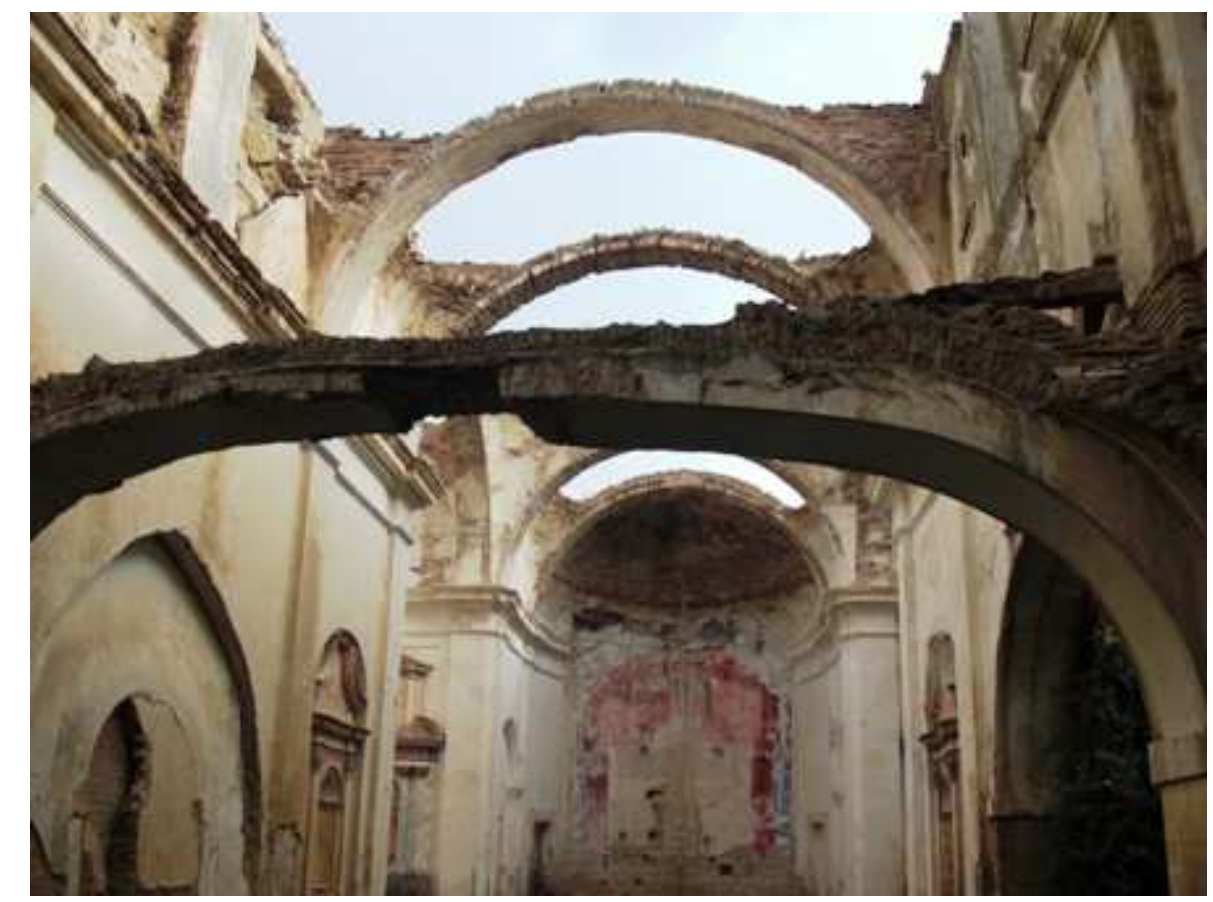

\section{Estado actual del templo hacia la cabecera con los retablos neoclásicos.}

A partir de 1854 en que la Compañía de Jesús adquirió el convento de San Zoilo con el fin de instituir su seminario, se comenzó a extraer material de fábrica del convento franciscano. A consecuencia de ello se desencadenó una disputa entre el Obispo de Palencia, don Jerónimo Fernández Andrés, que creía tener derechos sobre el inmueble, y el administrador de los bienes nacionales de Carrión ${ }^{357}$. Posteriormente, en 1858, fue el concejo quien volvió a solicitar su propiedad con el fin de proceder a extraer materiales necesarios para nuevas edificaciones, argumentando que la hacienda no lo usaba para fin alguno y que sus habitantes lo estaban destruyendo

\footnotetext{
${ }^{356}$ PERAL VILLAFRUELA, Santiago. “San Francisco...”. Op.cit, pág. 256.

${ }^{357}$ Ibídem, pp. 310-311, a su vez de ABAD, P. Camilo María. Historia...Op.cit, pp. 28-29.
} 
paulatinamente ${ }^{358}$. Unos y otros se justificaban y la realidad es que San Francisco estaba siendo utilizado como cantera para todos ellos.

Otro signo evidente de la despreocupación por la conservación del cenobio se manifiesta en los años sesenta. En 1863 el gobernador civil había concedido un permiso para utilizar algunas de sus dependencias como cárcel -cuya aplicación no había llegado en $1866^{359}$ - y posteriormente tramitó su uso como matadero ${ }^{360}$. El tejado de la estancia destinada para este último fin se encontraba un año más tarde totalmente arruinado, hasta tal punto que se hundió poco después. Se plantea entonces volver a utilizar como matadero el antiguo local, abandonado poco antes precisamente por el mal estado de sus tapias, sirviendo desde entonces como almacén. La situación del convento franciscano a la intemperie y la imposibilidad de su custodia nocturna con el fin de evitar robos de materiales, conllevó el paulatino deterioro del mismo ${ }^{361}$.

El convento, o más bien lo que de él quedaba, fue subastado públicamente el 3 de abril de 1867 tasándose su valor en 2500 ducados. El ayuntamiento necesitaba materiales para la construcción del nuevo consistorio. Sabedor de que varios vecinos estaban interesados en la compra, el alcalde gestiona, a través de sus representantes el precio de salida, evitando así la competencia ${ }^{362}$. Además solicita astutamente al gobernador provincial la autoridad competente para establecer tres comisiones en su representación el día de la puja, una por cada sede donde se celebraría la misma a saber: Madrid, Palencia y Carrión de los Condes. La adquisición era segura, pues el gobernador concedió licencia para que se rematara a favor de una de las corporaciones. Al parecer, no se presentaron competidores “...persuadidos que en la subasta de la provincia o de aquí se remataría a favor de las personas nombradas por esta corporación..." De este modo, en la subasta celebrada en Carrión, la obra recayó en el concejal Santiago Doncel, quien en representación del ayuntamiento, la adquirió por 3.100 escudos $^{363}$. Dicha adquisición explica el expolio sufrido por el convento, del que se extrajeron todo tipo de materiales con destino al reparo del puente, el nuevo

\footnotetext{
${ }^{358}$ Sesión de 26 de marzo de 1858. AMCC, Libro 6, Sesiones municipales (1858-1862), fol 11, 11v.

${ }^{359}$ AMCC. Libro 7, Sesiones municipales (1863-1867). Sesión de 16 de enero de 1866. s/f.

${ }^{360}$ Ibídem. Sesión de 27 de marzo de 1863, s/f.

${ }^{361}$ Ibídem. Sesión de 12 de febrero de 1864, s/f.

${ }^{362}$ PERAL VILLAFRUELA, Santiago. "San Francisco...Op.cit, pp. 312-313.

${ }^{363}$ Se acordó solicitar dicho permiso en sesión de 17 de marzo de 1867, 15 días antes de la subasta. El permiso fue concedido el 29 de marzo y la subasta aprobada el 26 de mayo de dicho año. AMCC, Libro 7 , Sesiones municipales (1863-1867), s/f.
} 
consistorio y todas aquellas intervenciones que fueron necesarias en aquel momento ${ }^{364}$. Contrariamente a lo que se pueda creer, los materiales del cenobio no fueron destinados únicamente a las obras municipales sino empleados como moneda de cambio por algún servicio prestado al consistorio ${ }^{365}$ o bien vendidos por resultar necesarios a una determinada comunidad ${ }^{366}$. No obstante, gracias a la solicitud que a mediados de 1867 la Venerable Orden Tercera emitió al consistorio, la iglesia del convento, que por entonces se encontraba en buen estado de conservación, fue respetada ${ }^{367}$. Por ello, es la única parte del convento que ha subsistido hasta la actualidad, si bien desprovista de cubiertas.

Cuando a finales de 1869 ya se habían finalizado las obras del consistorio y de las escuelas, y del convento de San Francisco no quedaban más que escombros, el ayuntamiento decide sacarlo a pública subasta para obtener fondos con los que satisfacer sus deudas ${ }^{368}$. Es patente la despreocupación por la protección y conservación del patrimonio artístico por parte de las autoridades locales, quienes además, durante esta década permitieron impasibles que un panadero de la villa quemara algunos de los altares que quedaban en el templo para avivar su horno ${ }^{369}$. Lo que quedaba del convento fue adquirido en 1871 por Don Daniel Álvarez de Bobadilla. En 1885 fue construido el Hospital Municipal, hoy Residencia de Nuestra Señora del Camino, en el solar que se ubicaba junto al templo, en línea al antiguo pórtico de entrada.

\footnotetext{
${ }^{364}$ Se refiere la utilización de la piedra de San Francisco para las obras municipales y se solicita la misma para el puente en Sesión de 31 de marzo de 1867. AMCC. Libro 7, Sesiones municipales (1863-1867), s/f. La solicitud para el uso de los materiales de San Francisco en el ayuntamiento tiene lugar en Sesión de 6 de septiembre de 1867 y de la concesión se informa en Sesión de 20 septiembre de 1867. AMC, Libro 7, Sesiones municipales (1863-1867), s/f. El proceso se relata igualmente en PERAL VILLAFRUELA, Santiago. "San Francisco...Op.cit, pp. 312-314.

365 Así sucedió en la construcción del balaustre de la escalera del consistorio a finales de 1868, a cuyo ejecutor don Gaspar del Campo se le abonó, “...en recompensa de su trabajo, dos piedras de pequeñas dimensiones y parte de una de las columnas del desmonte de San Francisco, que se halla rota, con lo que se conforma el dicho Campo...". Sesión de 30 de octubre de 1868. AMC. Libro 8, Sesiones municipales (1868-1871), fol 9v

${ }^{366}$ Es el caso de la casa clarisa, a la cual deciden ceder dos columnas de piedra procedentes del desmonte del convento que las hermanas manifestaron iban a necesitar. Sesión municipal de 30 de marzo de 1870. AMC. Libro 8, Sesiones municipales (1868-1871), s/f.

${ }^{367}$ Asunto de la solicitud tratado en sesión de 27 de septiembre de 1867. AMCC. Libro 7, Sesiones municipales (1863-1867), s/f.

${ }_{368}^{36}$ AMC. Libro 8, Sesiones municipales (1868-1871). Sesión municipal de 26 de diciembre de 1869. s/f.

${ }^{369}$ PERAL VILLAFRUELA, Santiago. “San Francisco...Op.cit, pp. 256 y 314.
} 


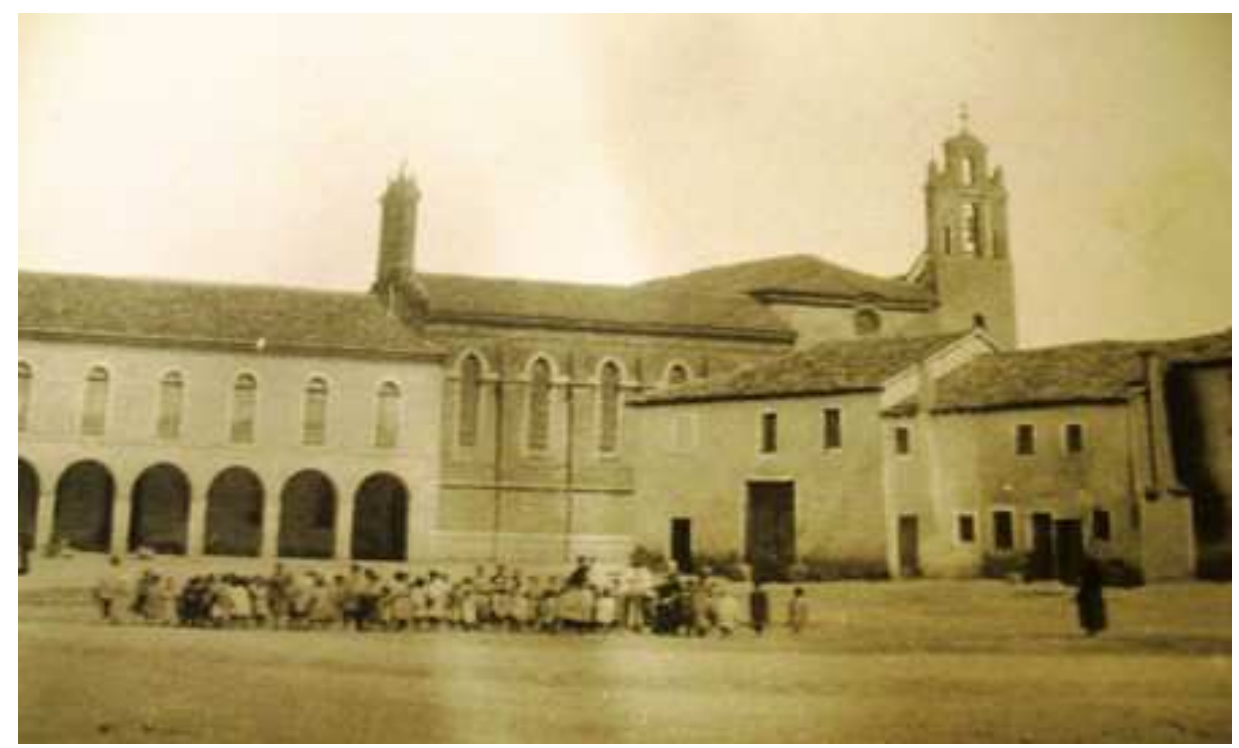

\section{Fachada del antiguo Hospital Municipal, construida en los terrenos del antiguo convento y espadaña de San Francisco al fondo de la imagen. ACJAH. C. 11 FOTOGRAFÍAS.}

Posteriormente, hacia 1895, el senador del reino Don Antonio Jofre de Villegas ${ }^{370}$, natural de Villardefrades, quiso edificar unas escuelas de instrucción primaria en el herrén de San Francisco. Al fallecer en 1897 sin poder acometerlo, fue su mujer, doña Patricia Ruiz de Navamuel, quien dos años después cumpliría con su voluntad solicitando al ayuntamiento una subvención para tal fin ${ }^{371}$. Gracias a la concesión de los permisos y fondos requeridos, las ruinas del ex convento franciscano pasarían a convertirse en Colegio de Los Hermanos de la Doctrina Cristiana. Fue así, cómo la nueva centuria trajo aires renovados a aquel solar abandonado a través de una nueva destinación. En la puerta del colegio campean los escudos del linaje Jofre Villegas ${ }^{372}$ : partido: 1, cortado de cruz floreteada y vacía y dos calderas. 2, del Mendoza de la Vega, en frange, primero y cuarto, una banda, segundo y tercero la leyenda: Ave María. Sobre la barandilla del balcón aparece otros escudo correspondiente a los Ruiz de Navamuel $^{373}$, asentados en Paredes de Nava desde el siglo XVI: 1 y 4, dos calderas. 2 ,

\footnotetext{
${ }^{370}$ Fue además patrón de la capilla de San Nicolás en la iglesia de Santa María de esta villa y caballero de la Orden de Carlos III.

371 AMCC. Sesión de 13 de enero de 1899. Libro 16. Sesiones municipales (1897-1898) fol 10v y ss.

${ }^{372}$ El escudo coincide con el que aparece en el panteón de los Jofre de Villegas en el cementerio de Carrión.

${ }^{373}$ VIGURI, Miguel de. Heráldica...volumen 2. Op.cit, pág. 76.
} 
cinco calderas en sotuer, la central con un pendón. 3, un árbol y dos lebreles atadas al tronco. Bordura de doce calderos y timbre con yelmo.

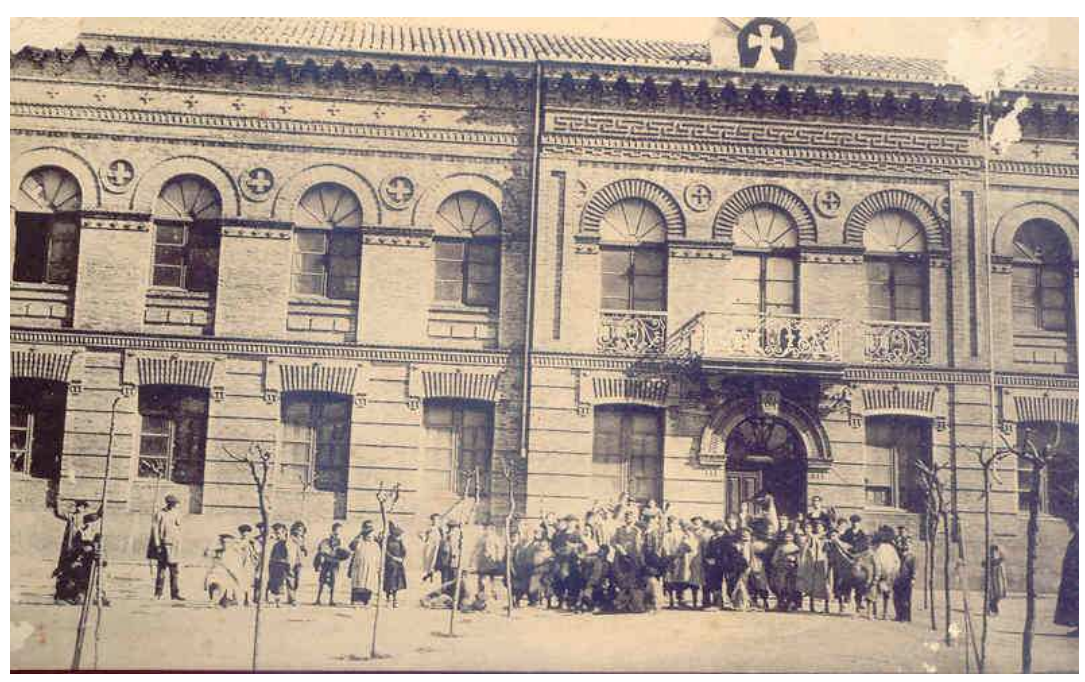

Fachada del Colegio de los Maristas construido sobre las ruinas del convento.

La presencia de la Venerable Orden Tercera en Carrión posibilitó que el templo se mantuviera abierto al culto a lo largo del siglo. Su loable actuación evitó la desaparición del único testimonio vivo del cenobio franciscano, otrora esplendoroso. Sin embargo, la falta de medios impidió que pudieran realizarse intervenciones de imperante necesidad que habrían salvado a la iglesia de su pésimo estado actual. Los hermanos llegaron incluso a vender en 1924 la sillería conventual de cuarenta sitiales para poder hacer frente a la penosa situación que atravesaban, resultando en vano sus esfuerzos $^{374}$.

En el Museo Diocesano de Palencia se conserva un sitial de nogal ornamentado a base de un cordón franciscano enroscado al fuste y varias conchas dispuestas aleatoriamente. Esta sencilla decoración apunta directamente a una procedencia franciscana de una perteneciente al Camino de Santiago. No obstante, en ningún caso puede vincularse, como indica Peral Villafruela, al cenobio terciario de Carrión de los Condes, sino al de San Francisco de Medina de Rioseco, de donde efectivamente procede $^{375}$. Excepto el sitial mencionado, los sitiales restantes del cenobio riosecano

\footnotetext{
${ }^{374}$ GÓMEZ PÉREZ, Enrique. “El real...Op.cit, pág. 164.

375 Este sitial se describe en SANCHO CAMPO Ángel. Guía...Op.cit, pp. 120-121.
} 
fueron trasladados al templo de Santa María de la misma villa el mismo año en que la sillería carrionesa fue vendida ${ }^{376}$. Desconocemos su paradero y ni siquiera se conserva ningún testimonio de la misma.

La celebración de culto en el templo tuvo su fin en el año 1977 en que la VOT abandona el templo, optando por trasladar gran parte de las obras de arte que lo ornamentaban al cercano templo de Santa Clara. Algunas de ellas pasaron a formar parte de los fondos del museo, de otras se desconoce su actual paradero ${ }^{377}$. A lo largo de la década de los años setenta se produjo la pérdida del tejado del templo, consecuencia directa de una actuación insensata por la cual se vendieron las vigas de la armadura del templo. Para ello, previamente se había retirado el tejado de todo el edificio, lo que conllevó el reblandecimiento del mortero que protegía las bóvedas, provocando finalmente su hundimiento. Es por ello que hoy día sólo podemos apreciar los arcos fajones y algunos arranques de las cubiertas en las capillas. Se conserva el enlucido de los paramentos aunque en los tapiales se ha producido algún desprendimiento del mortero. La humedad ha favorecido esta situación, como también la pérdida progresiva de la policromía en las bóvedas más antiguas, así como el reblandecimiento del suelo, lo que podría provocar próximamente el desplazamiento de los soportes ${ }^{378}$. Otros agentes naturales perjudican gravemente la conservación del templo, pues la vegetación lo ha cubierto todo, las zarzas retienen la humedad y los árboles impiden el acceso a ciertos espacios.

Las obras que atesoraba la iglesia fueron trasladadas al cercano monasterio de Santa Clara, las cuales estudiaremos en el apartado de los espacios de culto del convento que las atesoraba originalmente. Otra parte fue reaprovechada para la decoración de los jardines del Mercado Viejo en la actual Plaza Conde de Garay donde se conserva el lavadero de manos que en origen inmediato al refectorio del convento, cumple hoy día la función de fuente. Igualmente se conservan en esta plaza varios escudos, como el la Orden Franciscana y otro cuartelado, perteneciente a los Ríos

\footnotetext{
${ }^{376}$ GÓMEZ PÉREZ, Enrique. El real...Op. cit, pág. 164.

${ }^{377}$ Se explica el proceso de traslado y la oposición del párroco de Santa María que creía tener derecho a la propiedad de las obras. La relación de las mismas, que figura en una carta de 16 de marzo de 1977 es la siguiente: Dos Crucifijos, un Cristo yacente, una Inmaculada, una Dolorosa, un San Antonio de Padua, San Francisco, San Luis Obispo, San Pedro Regalado, San Diego, San Bernardino de Siena, Santo Tomás, San Cristóbal, San Luis rey, Santa Isabel de Hungría, un Vía Crucis, una pila de piedra y un expositor de madera. GÓMEZ PÉREZ, Enrique. "El real...Op.cit, pp. 180-184.
}

${ }^{378}$ PERAL VILLAFRUELA, Santiago. "San Francisco...".Op.cit, pp. 314-315. 
Campoo, de los cuales hemos hablado con anterioridad y el de los Ortega ${ }^{379}$. Aparte de la iglesia, entre los escasos restos que se han conservado de la casa conventual, destaca una espadaña de dos cuerpos perteneciente a $1795^{380}$, la más alta de todos los conventos franciscanos de Palencia, la cual, como sucede en la mayoría de ellos, y generalmente en los cenobios terciarios castellanos, aparece desplazada a la parte derecha del lado occidental del templo ${ }^{381}$.

En marzo de 2007, tras establecer un acuerdo con el Obispado de Palencia, el Ayuntamiento de Carrión compró los restos de San Francisco con el fin de acoger en su templo un auditorio ${ }^{382}$. El acto de donación del inmueble se realizó a finales del año siguiente pero el proyecto no ha sido aún llevado a cabo ${ }^{383}$.
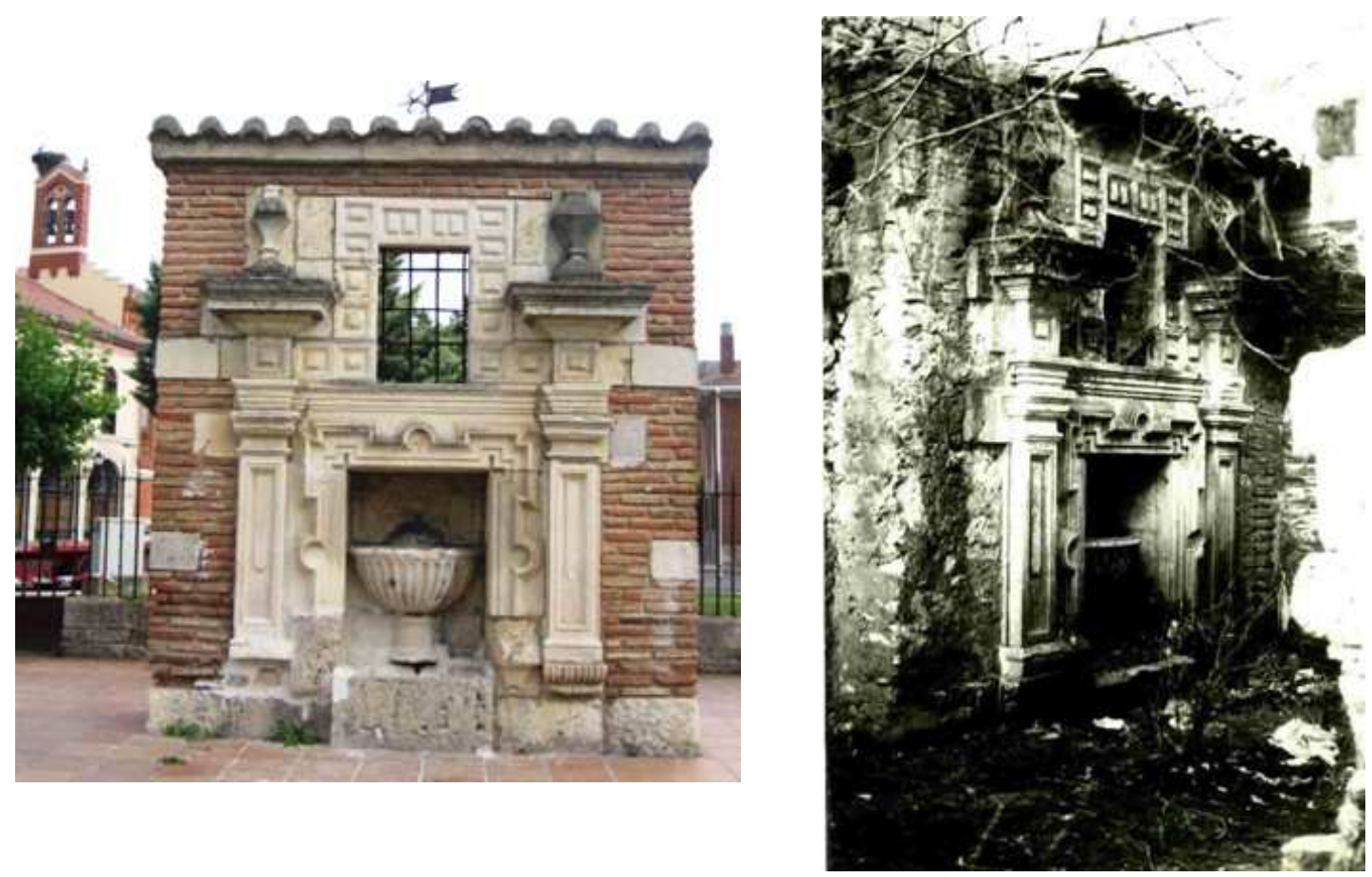

Lavadero de manos de los franciscanos. Estado actual en la Plaza Conde de Garay (arriba) y ubicación original junto al refectorio (derecha).

\footnotetext{
${ }^{379}$ Ver el apartado relativo a los lugares de enterramiento, capilla de la Resurrección.

${ }^{380}$ OSORNO RUIZ, Francisco Javier y Medina Amezúa, Jesús. Op.cit, pág. 10.

${ }^{381}$ PERAL VILLAFRUELA, Santiago. "San Francisco... Op.cit, pág. 272, a su vez de CASTILLO, M ${ }^{a}$ José del "Tipología...Op.cit, pp. 323 y ss.

382 Diario Palentino, 16-03-2007.

${ }^{383}$ Diario Palentino, 6-12-2008.
} 


\section{LAS CAPILLAS, ESPACIOS DE CULTO}

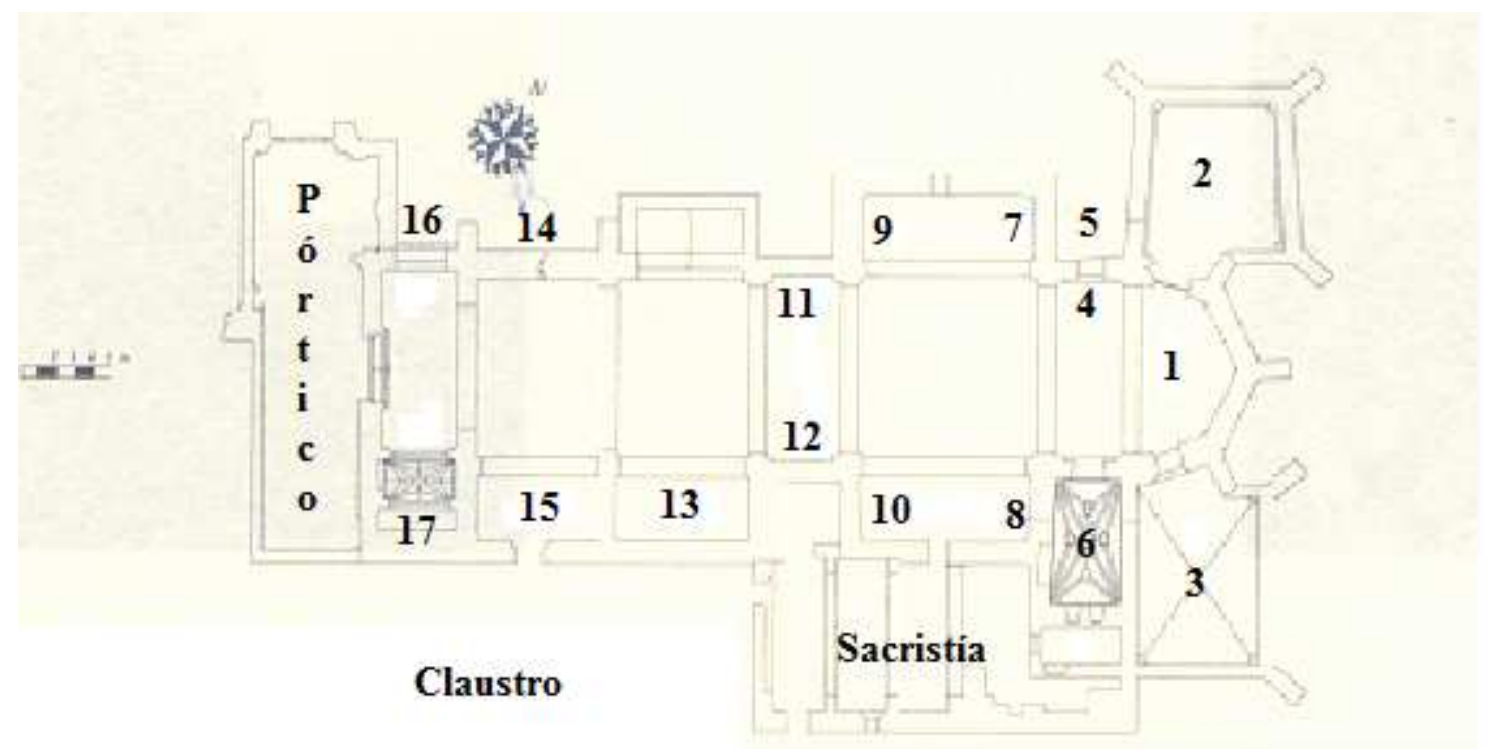

1. La Purísima o los Marqueses de Aguilar

2. Duques del Infantado o Mendozas

3. Señores de Camporredondo o Santa Ana

4. La Purificación o de los Serna

5. La Piedad

6. Las Once Mil Vírgenes, de don Beltrán de Guevara o del conde de Sástago

7. Nuestra Señora de Mirabueno o del Crucifijo y de San Antonio de Padua (a partir de 1789)

8. San Pedro Regalado y San Cristóbal

9. La Virgen del Pópolo, Santa Brígida y San Juan

10. El Crucifijo y de San Antonio (entre 1713 y 1789)

11. San Luis de Anjou

12. San Diego

13. Nuestra Señora

14. La Resurrección o de los Vozmediano

15. San Buenaventura

16. La Concepción, de Santa Catalina o de los Ortega

17. La Dolorosa

Capillas de la iglesia de San Francisco. Croquis extraído de PERAL

VILLAFRUELA, Santiago. "San Francisco de Carrión de los Condes (siglos XIIIXIX)" con las modificaciones pertinentes. 


\subsection{LA CAPILLA MAYOR, DE LOS MARQUESES DE AGUILAR}

Indicamos previamente que la edificación de la misma fue promovida por “...la infanta Doña Juana, mujer del infante Don Luis” como así reza una inscripción que, junto a la pared del presbiterio, fue hallada en 1612, en que la capilla fue bajada de nive $^{384}$. El infante don Luis al que hace referencia la documentación era el tercer hijo del matrimonio formado por Fernando III y su esposa en segundas nupcias, doña Juana de Ponthieu y de Aumale ${ }^{385}$.

La infanta citada era doña Juana Gómez de Manzanedo, hija de Gómez Ruiz, descendiente de una destacada familia castellana oriunda de Campóo y señora de Gatón y Moliellas. Poseía además la encomienda del priorato de San Martín de Frómista, propiedad a su vez del convento de San Zoilo de Carrión. A través de la misma se establecía un acuerdo por el que, a cambio de la protección de los vasallos de la casa conventual, la infanta obtenía algunos privilegios por su arriendo.

Las obras que entre finales del siglo XIII y principios del siguiente impulsó doña Juana en la capilla mayor y seguramente la edificación del resto del templo, justifica su enterramiento en un lugar tan privilegiado. Hemos hallado una descripción de este sepulcro que en 1612, realiza el síndico del convento franciscano a raíz de su descubrimiento: “...ffue allado un sepulcro de piedra al lado derecho del ebanxelio, arrimado a la pared del dicho altar, el qual está puesto sobre unos leones de piedra y labrado y dibuxado en él unas figuras pequeñas que parecen en forma de ffrayles franciscos y con su rrótulo en contorno de la cubierta que pareçe dice estar allí la ynfanta Doña Juana, muger del Ynfante Don Luis que hiço la dicha yglesia y las dichas armas están puestas sobre la cubierta del dicho sepulcro de piedra; y dentro tiene huesos y una calabera... ${ }^{386, "}$.

En el siglo XIX todavía se hallaba este sepulcro en la capilla mayor del templo, como así indica la Comisión de Monumentos en 1860. Hoy día desconocemos su

\footnotetext{
${ }^{384}$ MARTÍNEZ GONZÁLEZ, Rafael. “Aproximación...” Op.cit, pág. 132. Sobre el descubrimiento de la incripción, véase el apartado relativo al siglo XVII.

${ }^{385}$ PERAL VILLAFRUELA, Santiago. "San Francisco...”.Op.cit, pp. 258-260.

3869 de agosto de 1612. AHPP., Carrión, Desamortización, Leg. 105. Legajo n ${ }^{\circ} 1$.
} 
paradero. Descartamos su identificación con el que se ubica en el museo de San Marcos de León. ${ }^{387}$ La pieza que hallamos en este museo, aunque estilísticamente responde a la misma datación que el de doña Juana, no puede corresponder, como señala Peral Villa Fruela, al de la infanta ${ }^{388}$. En uno de los frentes de la urna hallamos una representación del sepulcro abierto donde se ve al difunto, un hombre barbado, frente al cual, lloran sus familiares. Por otro lado, en los laterales, donde figura el cortejo fúnebre, con un desfile de frailes y damas, se repite la representación de la urna. Las figuras más cercanas a la misma son un asistente, con un libro y una mujer de alto rango, con corona y toca que se inclina, con una mano en el pecho, en señal de respeto, probablemente la viuda del difunto. Por tanto, aun desconociendo la identificación del fallecido, las exequias no se celebran en este caso en tributo a una mujer, sino a un hombre.

En el siglo XV la capilla estuvo bajo posesión de Doña Mencía de Toledo, mujer que fue de Gonzalo Ruy de la Vega, quien dispuso en su testamento, dictado en 1449 ser sepultada en la capilla mayor junto a su esposo. Para ello, instaba al convento a reformarla con el fin de disponer en ella sus sepulcros. El desplome producido en la nave de la iglesia unos años más tarde impidió que sus deseos fueran cumplidos, pues era más vital recomponer las partes derruidas del resto del templo que efectuar ciertas mejoras en una zona donde no eran necesarias ${ }^{389}$.

Será el conde de Osorno ${ }^{390}$, don Gabriel Manrique, el encargado de sufragar estas intervenciones, como así constata un pleito mantenido entre su mujer, Aldonza de Vivero y el hijo de ambos, Pedro Manrique, contra el convento de San Francisco durante los primeros años del siglo XVI con el fin de que se cumpliese la última voluntad de doña Mencía ${ }^{391}$.

\footnotetext{
387 Algunos estudiosos apuntan una procedencia de la abadía de Benevívere, pero los monumentos funerarios que allí había, salvo el de Brianda de la Cerda, del siglo XVI, son masculinos. PERAL VILLAFRUELA, Santiago. “San Francisco...”.Op.cit, pp. 274-276.

${ }^{388}$ Sobre un estudio en profundidad de los sepulcros góticos de nuestra región véase FRANCO MATA, Ángela. "Iconografía funeraria gótica en Castilla y León (siglos XIII y XIV) en De arte. Revista de historia del Arte, $\mathrm{n}^{\circ}$ 2. Universidad de León. León, 2003, pp. 47-86.

${ }^{389}$ Explicado en el apartado relativo a las fases constructivas del templo.

${ }^{390}$ Los Osorno, son como vimos, un linaje vinculado desde sus orígenes al convento de clarisas de la misma villa de Carrión. Ver más datos en el apartado relativo a dicho convento.

${ }^{391}$ PERAL VILLAFRUELA, Santiago. “San Francisco...”. Op.cit, pág. 263, a su vez de ARCHV. Pleitos Civiles. Alonso Rodríguez (F). Caja 361.0001. Legajo 62.
} 
El hermano de don Gabriel, don Juan Manrique, conde de Castañeda y sus herederos, los Fernández Manrique, serán quienes tomarán el título de marqueses de Aguilar $^{392}$. Por tanto serán ellos quienes a cambio de la dotación de sumas anuales al convento para sufragar gastos de misas y mantenimiento de la capilla, obtendrán el privilegio perpetuo de sepultarse en dicho espacio, además de gozar de una posición privilegiada en la celebración de la liturgia a través de la ventana abierta en el lado sur del crucero $^{393}$.

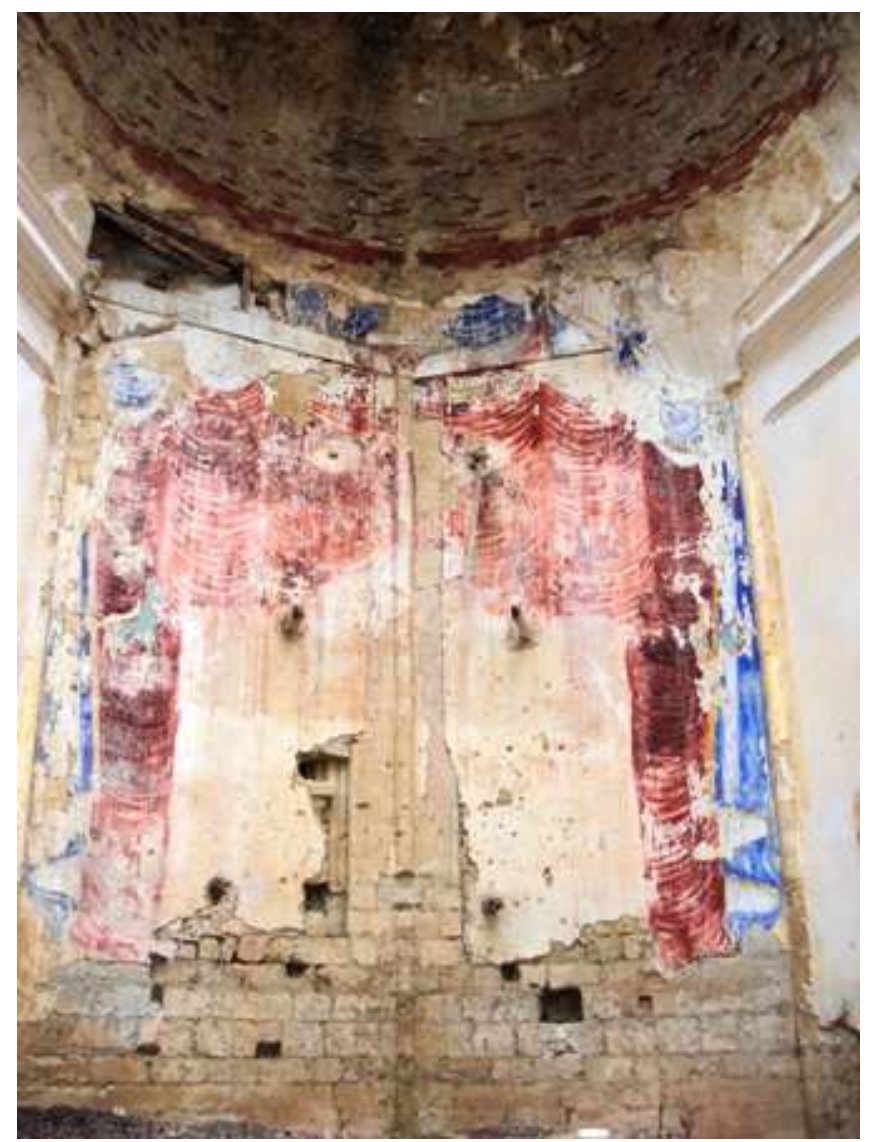

\section{Ábside poligonal de la capilla mayor con restos de pinturas barrocas.}

A mediados del siglo XVI ostentarán el patronazgo de la capilla Don Luis Fernández Manrique y su mujer doña Ana de Aragón. Como venía siendo tradición del resto de miembros del marquesado de Aguilar, ésta dispone su enterramiento en la

\footnotetext{
${ }^{392}$ Recordemos la vinculación del linaje Manrique con los conventos de órdenes menores y la protección otorgada por éstos en Carrión. Véase a este respecto PERAL VILLAFRUELA, Santiago. Los hospitales...Op.cit.

${ }^{393}$ PERAL VILLAFRUELA, Santiago. San Francisco...Op.cit, pág. 290.
} 
capilla mayor cuando dicta testamento el 8 de octubre de $1564^{394}$. Hasta el momento, los frailes no habían tenido quejas de ninguno de ellos, que abonaban sus dotaciones debidamente. Sin embargo, en 1589 llegaron las quejas por la acumulación de impagos. El síndico franciscano interpuso pleito a Bernardo Fernández Manrique, por entonces marqués de Aguilar, para que abonase 3000 ducados de deuda acumulada ${ }^{395}$.

Los franciscanos defendían la propiedad de la capilla pues los marqueses de Aguilar ni la habían fundado ni tan siquiera dotado y de de no ser por su intervención, este espacio estaría en ruinas. Es por ello que reclamaban la renuncia del patronazgo de la capilla o el pago de la suma requerida. Estaban pasando una situación embarazosa pues “...en el altar no hay rretablo, ni paramento, ni frontales ni sauanal, ni capillas ni almáticas, ni libros, ni cossa alguna del seruiçio de la dicha capilla, siendo la capilla mayor y prinçipal de la yglesia, ni hay rrelicario en que se ponga el Sanctíssimo Sacramento, a todo lo qual está obligado el dicho marqués...”396.

El pleito se postergó hasta 1608 en que la sentencia dio la razón a los franciscanos. Se determinó que doña Antonia de la Cerda como marquesa de Aguilar, esposa del ya difunto don Bernardo y curadora de los bienes de Juan Fernández Manrique, se encargase de los arreglos de la capilla abonando 8000 maravedíes anuales, cantidad que fue rebajada tras una apelación.

A pesar de lo dispuesto en la ejecutoria, aún en 1610 no se había saldado la deuda y por tanto, la capilla seguía sin ser reparada en condiciones. No sólo estaba "mal aderezada" sino que existía temor de un derrumbe, ante lo cual los frailes habían efectuado una mejora de carácter provisional a través de un refuerzo de cimbras, sin resultar esta intervención suficiente.

El conflicto se dio por concluido con una nueva sentencia a favor del convento que condenaba a la marquesa a pagar casi seis mil ducados, con lo que al menos se evitó la pérdida del patronazgo de los Aguilar ${ }^{397}$.

\footnotetext{
${ }^{394}$ AHPP. Palencia. Protocolo 7084. Francisco de Herrera (1565-1566), fol 671 y ss.

395 ARCHV. Pleitos Civiles. Quevedo (F) 1557. Expediente 1.

${ }^{396}$ PERAL VILLAFRUELA, Santiago. San Francisco...Op.cit, pág. 291, a su vez de ARCHV, Ejecutorias reales, 2045-71.

${ }^{397}$ A mediados del siglo XVII sigue en poder de los Marqueses de Aguilar, siendo su patrona, doña Isabel Manrique. 1653. Libro de misas, ADP. Religiosos. San Francisco (1616-1774), s/f.
} 


\section{Los diversos retablos}

Del pleito relatado con anterioridad podemos deducir que no existía retablo ya a finales del siglo XV. En cambio, no era así, lo que sucedía es que los frailes actuaban como si no lo tuviesen por lo antiguo que era y el mal estado en que se encontraba, ya que causaba “escándalo" al verlo ${ }^{398}$. De hecho, Hernando Infante, maestro ensamblador, vecino de Carrión, en el testimonio que durante el litigio hizo a favor del convento afirmaba que “...tiene unos tableros lisos con unas imágenes pintadas

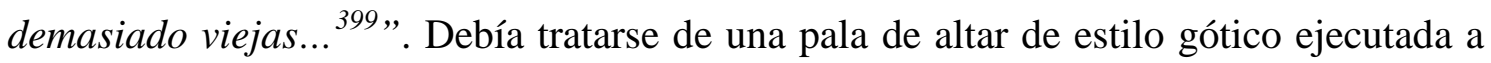
principios del siglo XIV, por la misma época en que la infanta doña Juana reconstruyó la capilla mayor.

Finalmente, en 1633 los frailes consiguieron la sustitución del retablo viejo, pero no se ejecutó una pieza nueva, sino que se trajo del convento de Santa Clara el retablo que hasta entonces ocupaba su capilla mayor. La razón de tal traslado vino motivada por la ejecución de uno nuevo en la casa clarisa. Precisamente los artífices Pedro Santos, Nicolás de Vega y Pedro López que se encargaron de la ejecución de la nueva pieza, fueron los mismos que asentaron el viejo retablo en esta capilla mayor ${ }^{400}$. Probablemente se tratase de un retablo de pequeñas dimensiones en composición triangular, como así señala el espacio que dejan las cartelas halladas en la pared del presbiterio de Santa Clara, visibles a raíz de unas labores de limpieza ejecutadas recientemente. Contendría, según Helguera, las armas de los marqueses de Aguilar ${ }^{401}$, lo cual es lógico dado que el patronazgo de este linaje siempre estuvo presente en la casa clarisa durante los siglos XV y XVI, lo que nos permite acotar su datación.

A mediados del siglo XVIII este retablo fue trasladado a los pies del templo, siendo sustituido por otro, esta vez sí de nueva factura, del que se conocen algunos datos gracias a la descripción realizada por Helguera a finales del siglo XIX: “...albergaba un retablo de madera dorada, con una hermosa imagen de la Purísima en su parte central, -de ahí la advocación de la capilla-, flanqueada por San Fernando y

\footnotetext{
${ }^{398}$ PERAL VILLAFRUELA, Santiago. San Francisco... Op.cit, pág. 294.

${ }^{399}$ ARCHV. Pleitos Civiles. Quevedo (F) 1557. Expediente 1. Probanzas del segundo cosido, pág. 85

${ }^{400}$ AHPP. Carr.Prot 5229. Jerónimo López (1633), s/f. Sobre Nicolás de Vega y Pedro Santos, remítase al capítulo dedicado a los escultores y ensambladores locales.

${ }^{401}$ RAMÍREZ DE HELGUERA, Martín. El libro...Op.cit, pág. 178.
} 
Santo Domingo a su derecha, y, San Francisco y una reina, a su izquierda. Lo coronaba en el remate la figura de San Pedro Telmo ${ }^{402 " . ~ L a ~ l l e g a d a ~ d e ~ l a s ~ r e l i q u i a s ~ d e ~}$ este último santo desde Tuy hasta el Obispado de Palencia no sucedió hasta el año 1742, momento a partir de la cual se comenzarían a difundir las imágenes de este santo y por tanto, fecha aproximativa de este último retablo que albergaría la capilla mayor ${ }^{403}$.

La casa de Aguilar de Campoo mantenía el patronazgo de la capilla mayor en el siglo XVIII, siendo el poseedor en 1774, el Excelentísimo don Pedro de Alcántara Alonso de Guzmán el Bueno Pacheco Manrique Aguilar y Silva, quien además de poseer el marquesado de Aguilar, ostentaba los títulos de duque de Medina Sidonia, conde de Niebla y Castañeda, señor de la villa de Piña de Campos y caballerizo y ballestero real. Al encontrarse su residencia habitual en la villa de Madrid, delega en sus representantes el buen funcionamiento de todo su mayorazgo, entre cuyas posesiones se encontraba la capilla mayor de San Francisco, que mantiene en buenas condiciones con el altar de la Purísima y los blasones del linaje de Aguilar tanto en los laterales de la capilla como sobre la reja de la misma en la parte del Evangelio ${ }^{404}$.

Sin embargo a finales de siglo, en que la capilla se encontraba bastante deteriorada, se pide a sus patronos que se encarguen de repararla, y ya no son los marqueses de Aguilar sino los de Estepa los nuevos propietarios ${ }^{405}$.

Gracias a una fotografía de principios del siglo XX, sabemos que el retablo descrito por Helguera no fue el último que presidió la capilla mayor ${ }^{406}$. En ella observamos una obra clasicista que podemos datar en el segundo tercio del siglo XVII, conformada por un sencillo cuerpo de tres calles y ático, asentado sobre una mesa de altar. En la hornacina central podemos distinguir una imagen de vestir de la Virgen. Se

\footnotetext{
402 Ibídem, pág. 178.

${ }^{403}$ PERAL VILLAFRUELA, Santiago. San Francisco...Op.cit, pág. 294. Sobre la llegada de las reliquias de San Telmo a Palencia FRANCIA LORENZO, Santiago. Anecdotario...Op.cit, pp. 65-67 Hasta entonces, a Fray Pedro González se le conocía en Galicia como "Corpo Santo".FILGUEIRA VALVERDE, José. El "corpo santo" de Fray Pedro González, San Telmo: (c.1194-c.1246) patrón de marineros y navegantes. Pontevedra. Diputación Provincial de Pontevedra, 1983 y ORDAX ANDRÉS, Salvador. "Un patrono para los marineros portugueses": "O corpo Santo" en Las sociedades ibéricas y el mar: Congreso Internacional. Vol 5, 1998, pp. 123-144.

${ }^{404}$ Apeo que de las tierras, herrenes, prados y demás posesiones concernientes marquesado de Aguilar de Campoo se realiza en 1774. AHPP., Carr.Prot 5248, Miguel López (1777-1778), fol 365 y ss.

${ }^{405}$ Carta de notificación al convento de San Francisco de los Marqueses de Estepa a 12 de mayo de 1789 por la que aceptan aportar una dotación para las obras que sean necesarias. AHPP. Desamortización, legajo 105.

${ }^{406}$ ACJAH. Carrión. Fotografías.
} 
trata de una Inmaculada, pues, si observamos con atención, veremos la luna a los pies. A los lados, dispuestos en sendas hornacinas cuadrangulares, se disponen dos santos que no podemos identificar, dada la escasa calidad de la fotografía. La figura ubicada en el extremo izquierdo, porta un hábito blanco, por lo que podría tratarse de un santo dominico, Santo Domingo, tal vez, dada su aparición en el retablo precedente. Al otro lado podemos distinguir una mujer, vestida con una túnica oscura y capa larga, que además está coronada y parece llevar algo entre sus brazos. Cuatro sencillas pilastras de orden compuesto sostienen un entablamento retranqueado en su parte central, sobre el que apea el ático, más estrecho que el cuerpo del retablo. Está conformado por un pequeño templete flanqueado por dos pequeños aletones avolutados y una hornacina central presidida por un santo franciscano sin identificar. Sobre la cúspide del frontón se yergue otra figura de un santo franciscano que porta una cruz con banderola como estandarte. Tal vez este retablo fuese el que, procedente de Santa Clara, fue trasladado a San Francisco, siendo asentado en la capilla mayor, después a los pies del templo, regresando en el siglo XX de nuevo a la cabecera. En la imagen aún se pueden contemplar las pinturas murales que, a modo de telón de teatro en colgaduras muy típicas del barroco, recubrían, y aún hoy día lo hacen, los muros de este sector.

Esta capilla también acogió los restos mortales del ilustre Fray Francisco de Soria, visitador general de la Observancia ${ }^{407}$. Fue una figura relevante en el entorno de la corte, actuando en calidad de consejero para Juan II de Castilla y designado confesor de Juan de Navarra ${ }^{408}$. Había fallecido hacia 1440, antes de que San Francisco pasara a manos de los observantes. Le sorprendió la muerte reformando el convento de clarisas de Carrión y es por ello que probablemente se decidiera su traslado al convento franciscano más cercano, aunque por aquel tiempo siguiera la conventualidad ${ }^{409}$.

\footnotetext{
${ }^{407}$ CALDERÓN, Padre Francisco. Op.cit, fol 236.

${ }^{408}$ Más datos sobre este y otros personajes franciscanos de relevancia en URIBE, Ángel. "Ensayo de reforma franciscana en España" en Archivo Ibero Americano, t XLV, n 179-180, Madrid, 1985 pp. 217 348.

${ }^{409}$ PERAL VILLAFRUELA, Santiago. "San Francisco...".Op.cit, pp. 277.
} 


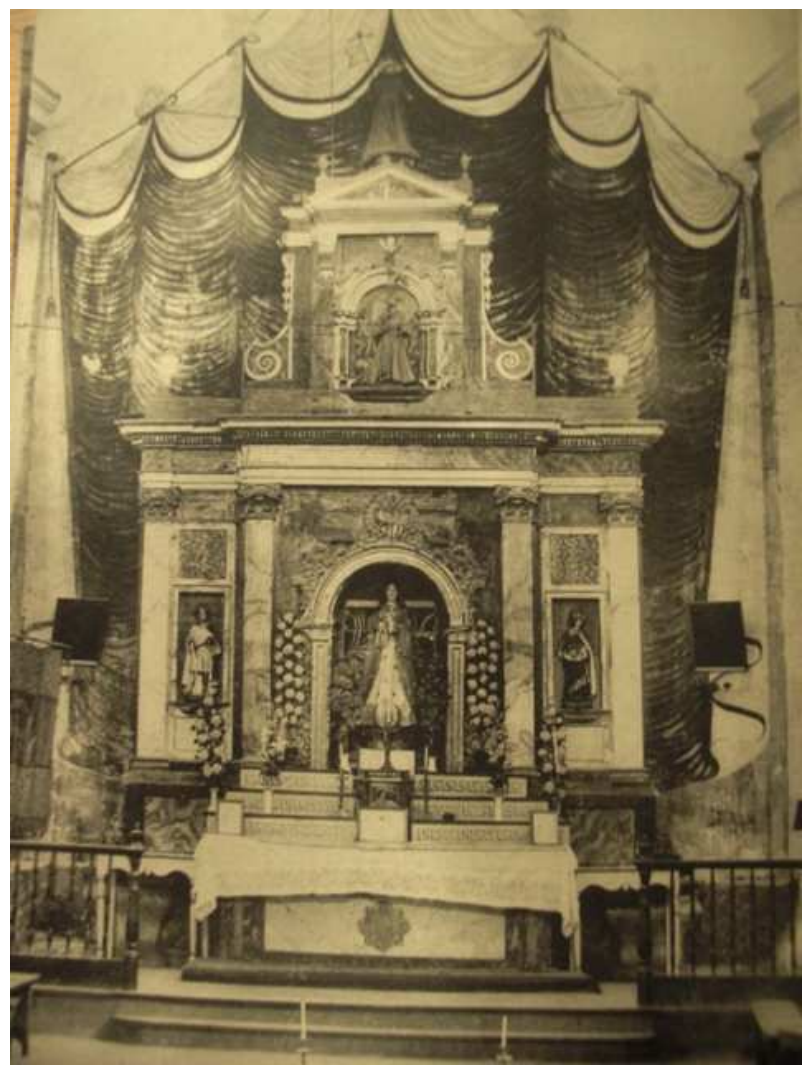

Retablo del siglo XVII que presidió la capilla mayor de San Francisco.

\subsection{CAPILLA DE LOS DUQUES DEL INFANTADO O DE LOS MENDOZA}

Se trata de la otra capilla colateral del altar mayor, situada en el lado del Evangelio $^{410}$. Su perfil es ligeramente irregular, pues a simple vista parece rectangular, pero al examinarla con más detenimiento, hallaremos que sus muros conforman una especie de trapecio al ensancharse hacia el altar mayor. Esta capilla, cuyo patronazgo gracias a las fuentes sabemos que ostentó el linaje de los Mendoza, estaba reforzada en tres de sus ángulos por contrafuertes, como así lo estaban la capilla mayor y la contigua colateral perteneciente a los señores de Camporredondo.

Podemos aproximarnos a su datación a través de los finos arranques de los nervios apuntados que conformarían una sencilla bóveda de crucería y que nos remiten

\footnotetext{
${ }^{410}$ ARCHV. PL Civiles. Quevedo (F) 1557. Expediente 1. fol 88v.
} 
al siglo XV. Según relata Martínez de Helguera, este espacio contenía un retablo con el escudo de sus patronos que a finales del siglo XIX se encontraba a la entrada del templo ${ }^{411}$.

En 1594, siendo patrón don García Manrique de la Vega, marqués de Cenete y duque del Infantazgo, se contrató a Santiago de Sigüenza para que rehiciera los tejados de la capilla que se encontraba algo deteriorada ${ }^{412}$. Se le ordena taxativamente que respete el la cubierta y tan sólo cincele “...aljibas de cruzería y terceletes y rrampantes y firmes y pripiaño de la entrada...", lo cual confirma los restos conservados hoy día en la capilla. Junto al retablo existente, se ordenó disponer un altar guarnecido de yeso para prender frontales.Gracias a esta intervención sabemos además que fue en este momento cuando se realizó el rosetón pétreo de doble moldura en cuyo interior se labró una flor de ocho pétalos calados, a través de los cuales se filtraría la luz al interior de este espacio. Todavía puede verse desde el patio de la residencia de ancianos aledaña al que se adosa el convento por su lado septentrional. En 1611, con motivo de las obras de rehabilitación que se llevaron a cabo en la capilla mayor, se tapió esta claraboya, excepto su orificio central y la otra frontera de la capilla de Camporredondo. Fue Juan González de la Mata, bajo la supervisión de Francisco de la Maza, quien llevó a cabo todas las labores de albañilería ${ }^{413}$.

Restos del arranque de la bóveda y del rosetón de la capilla de los Mendoza.

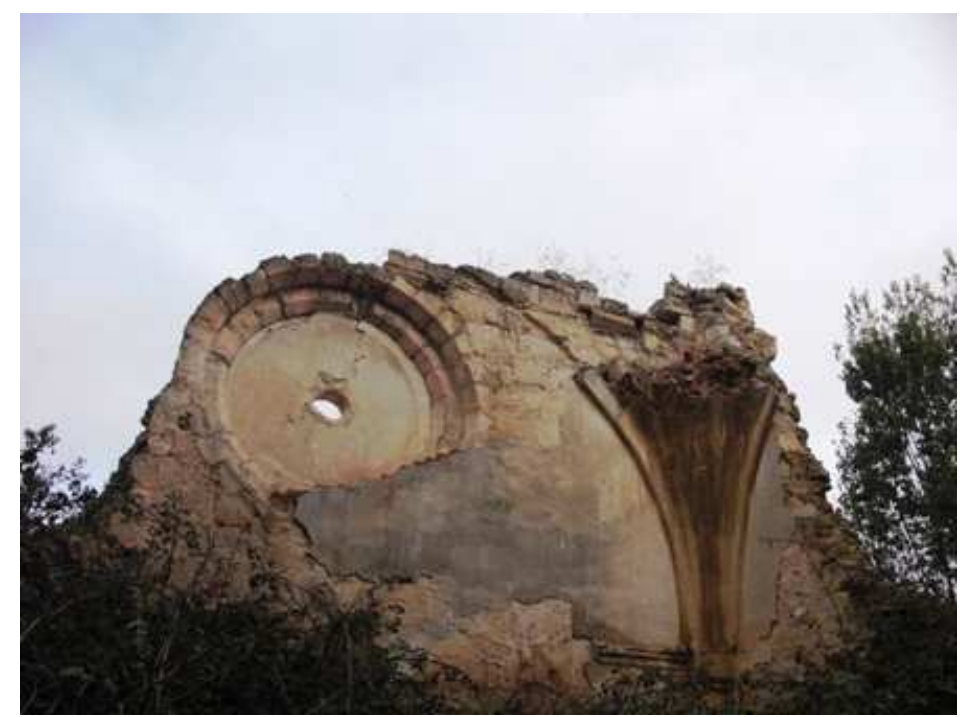

\footnotetext{
411 No se sabe en qué momento se traspasó a aquel lugar. RAMíREZ DE HELGUERA, Martín. El libro...Op.cit, pp. 178-179.

${ }^{412}$ Sobre estas obras, véase el apartado relativo al siglo XVI. Contrato y condiciones de la obra en AHPP. Carr.Prot 5623. Melchor de la Rúa (1594),s/f.

${ }^{413}$ Escritura y condiciones de la obra en AHPP. Carr.Prot 5156. Jerónimo Laso (1611), s/f.
} 


\subsection{CAPILLA DE SANTA ANA O DE LOS SEÑORES DE CAMPORREDONDO}

Era una de las dos capillas colaterales del altar mayor, la primera del lado de la Epístola en la que se situaba un retablo bajo la advocación de Santa Ana. Una inscripción en letras góticas sobre unas lápidas, remite algunos datos acerca de los comitentes de esta capilla: "Esta capilla mandó facer la mui ylustre Señora Doña Mencía de Cisneros, muger que fue del muy ylustre señor García Laso Rroyz de la Uega, señora de la casa de la Uega, padres que fueron de la mui ilustre señora Doña Mencía de Cisneros, muger que fue del ylustre señor Don Pedro Enrríquez, yjo del Ylustrísimo señor Conde Don Tello, señor que fue de Lara y Bizcaya. Y el dicho Conde Don Tello fue yjo del mui alto y poderoso señor, el Rey Don Alfonso el Onceno, que murió sobre Jibratar e el dicho Don Pedro fue su nieto del dicho señor, rrey señor que fue de las uillas de Alua y Canporredondo. Y agora la mandaron rredificar los Ylustres Señores Don Juan Enrríquez de Cisneros y doña Mariana de Castañeda y Solua, sétimos visnietos de los susodichos ${ }^{414, .}$

El poderoso linaje de los Enríquez Cisneros surgió en el siglo XIV. Don Pedro Enríquez Cisneros, primer señor de Camporredondo, era el primogénito de los diez hijos extramatrimoniales que tuvo el poderoso Conde Don Tello, señor de Aguilar, Lara, Vizcaya y Castañeda. Seguramente su devoción franciscana le vino precisamente de su padre, quién se enterró en la iglesia de San Francisco de Palencia ${ }^{415}$.

Biznieto de don Pedro Enríquez y doña María fue don Juan Enríquez de Cisneros, marido de Doña Mariana de Castañeda y Alba, quien dispuso en 1535 que se reedificara por completo su capilla ante el mal estado en que se encontraba, comprometiéndose a correr con los gastos desencadenados de la misma ${ }^{416}$. Mucho

\footnotetext{
${ }^{414}$ En 1614, Antonio de Cisneros solicita a Juan Díaz Pajaza, como escribano de la villa de Carrión, que de fe del rótulo de la capilla santa Ana, perteneciente a su tío Juan Enríquez de Teherán y Peralta, señor de Alba y Camporredondo. AHPP. Carr.Prot 4841.Juan Díaz Pajaza (1614), s/f.

${ }^{415}$ Don Tello (1337-1370) poseía los títulos mencionados porque estaba esposado con Juana Núñez de Lara. Recibió el señorío de Aguilar gracias a su padre Alfonso XI y el de Castañeda por su hermano Enrique II, de ahí el apellido Enríquez que don Pedro heredó. Su sepulcro no fue descubierto hasta 1978, lo que arrojó datos esclarecedores sobre la heráldica familiar. RIVERO SIERRA, Borja del. "Heráldica...Op.cit, pp. 55-56.

${ }^{416}$ La copia de la escritura original de Don Juan de Cisneros en AHN. Clero Secular-Regular Franciscanos 5355. Obras, s/f. La obligación fue firmada el 8 de agosto de 1535. A la misma se hace referencia en Informes varios sobre el templo. ADP. Religiosos. San Francisco (1616-1774), fol 43.
} 
tiempo había transcurrido desde 1518, en que el patrón recibiera provisión real de Don Carlos y su madre, la regente doña Juana para que ejecutase los reparos con la mayor brevedad posible, pues el convento temía que la ruina de la capilla afectara a la capilla mayor y otras dependencias colindantes. Don Juan de Cisneros dispuso sepultarse en la capilla cuando dictó testamento en 1574.

Seguidamente corresponderá el patronazgo a don Pedro Enríquez Cisneros, a quien se le concedió en 1591, a cambio de una dotación y del aderezo de la misma con ornamentos y retablo ${ }^{417}$. En esta fecha se estaba finalizando la obra de reconstrucción de las capillas de la iglesia, como así lo indican las cartas de pago a Antonio de Cuéllar y Juan de la Cuesta ${ }^{418}$. Quedaba por tanto finalizar esta capilla, de ahí que el por entonces mayordomo provincial de los franciscanos, Fray Mateo de Burgos se comprometa a ello con el nuevo patrón: “... se la tienen de dar çerrada y acabada de paredes y bóbeda de ladrillo y blanqueada de yeso”. Además se crearía un acceso hacia el claustro principal.

La pertenencia de dicha capilla a Pedro Cisneros la confirmamos en su testamento, dictado en 1592, el cual la dota a su vez a su mujer, Francisca de Tagle y a su hijo Juan de Cisneros ${ }^{419}$. La novena señora de Camporredondo, doña Juana Enríquez de Cisneros y Peralta se esposa en primeras nupcias con Juan de Mier y Terán, resultando de este matrimonio el patrón de la capilla Don Juan Enríquez de Terán y Peralta, caballero de la orden de Alcántara y señor de las villas de Alba y Camporredondo.

El capitán de la milicia de la villa y familiar suyo, don Antonio Enríquez de Cisneros solicita disponer su enterramiento en esta capilla a don Juan Enríquez por testamento, dictado el 21 de septiembre de 1636, donando para ornamento de la misma un cuadro del ermitaño San Onofre para que se coloque sobre la pila del agua bendita ${ }^{420}$. Sus padres estaban enterrados en la capilla. Así rezaban los letreros:

\footnotetext{
${ }^{417}$ AHPP. Carr.Prot 5621. Melchor de la Rúa (1591-1592), s/f.

${ }^{418}$ Previamente comentadas en el apartado relativo a la construcción del templo.

${ }^{419}$ AHPP. Carr.Prot 5621. Melchor de la Rúa (1591-1592), s/f. El testamento de Luisa Enríquez Cisneros, dictado en 1595 confirma la pertenencia de esta capilla a dicho linaje. AHPP. Carr.Prot 5654. Pedro Saldaña (1595), s/f.

${ }^{420}$ AHPP. Carr.Prot 5232. Jerónimo López (1636-1637) s/f.
} 
“Aquí iaçe sepultado el capitán Don Pedro Enrríquez de Cisneros, falleció a veinte y cinco de agosto de mill y seiscientos y tres".

“Aquí iaçe sepultada Doña Isauel de Loyola, muger que fue del capitán Don Pedro Enrríquez de Cisneros. Murió a nuebe de enero del año de mill y seiscientos y catorce $^{421,}$.

Parece que Don Antonio no había tenido descendencia dejando parte de su hacienda a sus tres sobrinos -Catalina y Juliana, por parte de su hermana Luisa, y Gabriel, hijo de su hermano Pedro-. Como única y universal heredera nombra a su hermana, doña Luisa Enríquez de Cisneros, quien por testamento dictado en 1636 y confirmado posteriormente en 1642 deseará ser enterrada igualmente en esta capilla junto a sus padres don Pedro Enríquez de Cisneros y doña Isabel de Loyola ${ }^{422}$.

El cuñado de don Antonio era el difunto don Pedro de Mendoza, esposo, por tanto, de su hermana Luisa, entroncando así los linajes Enríquez Cisneros y Mendoza en los patronazgos sucesivos de la capilla. Así, una de las dos hijas del matrimonio Catalina de Mendoza Enríquez, ya viuda de Francisco Vijil, dispondrá ser enterrada en esta capilla cuando dicte testamento el 1 de agosto de $1664^{423}$.

En 1715, era patrón de la capilla, Don Juan Antonio Enríquez de Teherán y Peralta, titulado señor de Teherán, Alba, Camporredondo y Carrascal de Gumiel. Dispone se repare la bóveda de la capilla, concertándose la obra un año más tarde. Excusaba su tardanza en las posturas excesivamente elevadas para la obra, proponiendo presentar edictos en Trasmiera y otros parajes para obtener un mayor número de postores y quizá un remate más competitivo.

Era su voluntad que la capilla quedase decente a la par que sencilla "...con vna cruzería regular y no de suerte que se anden buscándolas esquisitas y un blanco bien

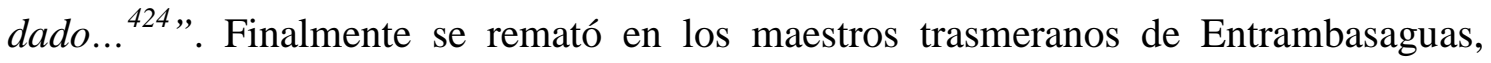

\footnotetext{
${ }^{421}$ Antonio de Cisneros solicita en 1614 que se verifiquen los letreros existentes por entonces en la capilla AHPP. Carr.Prot 4841. Juan Díaz Pajaza (1614) s/f.

${ }^{422}$ AHPP. Carr.Prot 5770. Andrés Simón Aguilar (1664) fol 597 y ss.

${ }^{423}$ AHPP. Carr.Prot 5699. Norberto Sandoval y Guevara (1664), s/f.

${ }^{424}$ AHN Clero Secular-Regular Franciscanos 5355. Obras, s/f.
} 
Felipe de la Lastra y Francisco Muñoz, quienes siguieron las condiciones establecidas por el también trasmerano Francisco de los Corrales. Recibieron carta de pago por 1.200 reales en junio de 1716, lo cual indica la brevedad de las obras ${ }^{425}$.

Las aguas afectan a la capilla mayor y a las contiguas a finales de 1789. Es por ello que el convento conmina a don Francisco Enríquez Calderón, poseedor por entonces de la capilla de Santa Ana e igualmente patrón de la capilla de los Santos Reyes del convento franciscano de Segovia, a que colabore en las labores de reparación. Se necesitaban 600 ducados para la intervención, lo cual le parecía impensable al patrón teniendo en cuenta los casi 7000 reales que, a tal efecto, habían sido invertidos en 1753. A través de la correspondencia mantenida durante tres años entre ambas partes, don Francisco pretende eximirse de dicho pago basándose en el hecho de que: “...ningunos bienes libres goza dicha casa de 3 siglos a esta parte sobre que pudiera averse fundado, y por lo mismo estoy persuadido a que los 4 ducados se señalaren por algún posehedor por razón de dotación... ${ }^{426 ” . ~ P o r ~ s u ~ p a r t e, ~ e l ~ c o n v e n t o ~ l e ~ d e m u e s t r a ~ a ~ t r a v e ́ s ~}$ de una escritura de 1702 que estaba fundada una memoria de misa y sermón por la casa de Camporredondo, para cuya seguridad se hipotecó la casa de Bárcena, situada en la calle de la Rúa.

Bóveda de crucería de la capilla de Camporredondo reparada en 1715. AHPP. Carr.Prot 5643, Francisco Ruiz Sandoval (1715-1718), fol 178.

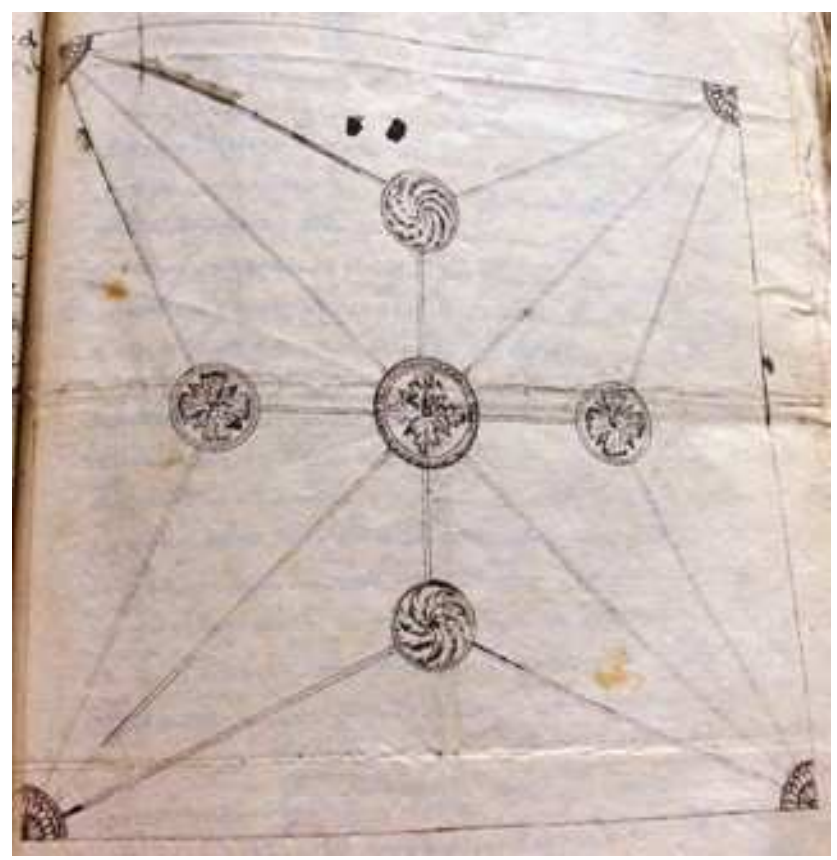

\footnotetext{
${ }^{425}$ La escritura de contrato y condiciones de la obra de la capilla en AHPP. Carr.Prot 5643. Francisco Ruiz Sandoval (1715-1718) fol 177 y ss.

${ }^{426}$ Ibídem.
} 


\subsection{CAPILLA DE LA PURIFICACIÓN}

Situada longitudinalmente en el ámbito contiguo al crucero, esta capilla estaba separada del altar mayor por una reja, de ahí que se le denominase igualmente de la Purificación de Nuestra Señora, por compartir la misma advocación ambos espacios de culto $^{427}$.

Eran los poseedores de la misma los herederos del linaje de los Serna. Así en 1564 dispuso su sepultura don Antonio de la Serna Bañuelos, esposo de Ana de Colmenares e hijo de Diego Bañuelos ${ }^{428}$. Ordena de este modo que sobre su lápida se pongan sus armas en un escudo partido con el jaquelado correspondiente a los Velasco, de quiénes procedía, y la banda de los Serna.

Sin embargo esta capilla no era privativa de la familia mencionada, pues tenemos conocimiento de otros miembros que dispusieron su entierro en este privilegiado lugar como por ejemplo lo hicieron Martín Caldera y su mujer Catalina Ruiz de Colmenares. En su testamento de 1564 que fue confirmado en $1575^{429}$. Al no haber establecido una dotación perpetua de las sepulturas, el dicho testador y su mujer estuvieron a punto de perder el derecho a las mismas de no ser por la actuación de don Alonso Díaz de la Serna, quien en 1619, como patrón de las obras pías, se comprometió a abonar la suma anual acordad, celebrar las misas oportunas y disponer un estrado ${ }^{430}$.

Igualmente estuvieron allí enterrados el regidor carrionés don Francisco de los Ríos Campoo y su mujer Inés de Balboa, al igual que otros antepasados de este linaje, siendo las sepulturas de todos ellos de carácter temporal ${ }^{431}$.

\footnotetext{
${ }^{427}$ AHPP. Carr.Prot 5442. Gregorio Movilla (1563-1564), s/f.

428 “..que mi cuerpo sea sepultado en el monesterio de señor San Francisco estramuros desta dicha villa en la mi capilla que es advocación de la purificación de Nuestra Señora, qu'está dentro de la capilla mayor sobre la mano izquierda y me abran sepultura...” AHPP. Carr.Prot 5442. Gregorio Movilla (15631564), s/f.

${ }^{429}$ Se sabe que dictó testamento en 1564 por un El testamento de 1575 en. AHPP. Carr.Prot 5667. Andrés Sánchez (1575-1576), s/f. PERAL VILLAFRUELA, Santiago. San Francisco... Op.cit, pág. 283284.

${ }^{430}$ AHPP. Carr.Prot 5403. Francisco Moro Saldaña (1620), fol 170 y ss.

${ }^{431}$ Don Francisco de los Ríos Campoo, regidor perpetuo de Carrión, nacería en torno a 1550, pues tenía 57 años cuando en 1607 respondió a un interrogatorio en el pleito entre el convento de San Francisco y el Marqués de Aguilar (1589- 1607) ARCHV. Pleitos Civiles. Quevedo (F) 1557. Expediente 1. fol 169v. Su testamento en AHPP. Carr.Prot 5404. Francisco Moro Saldaña (1621), s/f.
} 
De su lápida se conserva un fragmento en la plaza Conde de Garay que contiene un escudo con sus armas ${ }^{432}$. Su lectura sería la siguiente: 1, de Ríos, ondas y bordura con sierpes. 2, de Balboa ${ }^{433}$, partido de león y dos brazos sujetando una bandera. 3, tronchado por un barra con veneras y ondas $?^{434}, 4$, cruz floronada y bordura de aspas. Este linaje Ríos Campoo era descendiente del solar de Proaño de los Ríos y poseedor de regidurías perpetuas en Carrión ${ }^{435}$.Don Gaspar de Villerías y su mujer María Solórzano dispusieron su enterramiento en esta capilla, pues en agosto de 1614 Pedro Cicero, que había trabajado en la ejecución de parte de la escultura correspondiente al piso alto del claustro de San Zoilo, se encarga de labrar una piedra con el escudo de armas para la sepultura del matrimonio indicándose que ambos están enterrados en esta capilla. El comitente, Francisco de Saldaña le pagó diez ducados por dicho trabajo ${ }^{436}$.

Por último este espacio también fue conocido como la capilla de la Resurrección, como así nos lo indica Miguel de Viguri ${ }^{437}$. No nos parece adecuada dicha mención, pues la primera de las capillas según se entra a mano izquierda también se hallaba bajo dicha advocación ${ }^{438}$.

\footnotetext{
${ }^{432}$ En el apartado relativo al devenir del convento se hace referencia a los restos conservados en este lugar. La piedra quizá fue reaprovechada, como así se deduce de las profundas marcas que tiene para poder ser cargado. PERAL VILLAFRUELA, Santiago. "San Francisco...” Op.cit, pág. 286.

${ }^{433} \mathrm{La}$ certeza de que el segundo cuartelado corresponda al linaje Balboa, lo prueba un documento que las describe: "Los Balboas traen un escudo en palo, a la mano derecha un león, en la otra una bandera amarilla y colorada revuelta, la cual tiene dos brazos de los codos abajo armados en blanco, en campo verde, y esto es que Francisco de Balboa estando en Italia con el Gran Capitán Gonzalo Fernández, gano una bandera amarilla colorada a un alférez de Francia, por lo cual se venció en la batalla". Biblioteca Nacional. Manuscritos, 7757.

${ }^{434}$ La labra casi borrada correspondiente a este cuartelado solo permite hacer conjeturas acerca de lo que en ella se representa.

${ }^{435}$ VIGURI, Miguel de. Heráldica...2. Op.cit, pág. 74.

${ }^{436}$ El contrato entre ambas partes puede verse en AHPP. Carr.Prot 5210, Jerónimo Laso (1614), fol 549

${ }^{437}$ VIGURI, Miguel de. Op. cit, pág. 74, a su vez éste de AHPP. Carr.Prot 5660. Andrés Sánchez (15431558), s/f.

${ }^{438}$ Francisco de los Ríos expresa en su testamento de 1621 su voluntad de disponer su sepultura “... junto a la de mis padres y abuelos que están en ella por vía de depósito, junto a la reja de la capilla mayor del dicho monasterio, como se entra en ella a la mano izquierda, que son tres sepulturas con un lecho y comienzan en la capilla de la Resurrección que es de los herederos de Serna Bañuelos..." AHPP. Carr.Prot 5404. Francisco Moro Saldaña (1621), s/f. Probaremos posteriormente cuando analicemos la capilla que se encuentra a la entrada del templo, cómo recibe el mismo nombre.
} 


\subsection{CAPILLA DE LA PIEDAD}

Se situaba en el lado del Evangelio junto al altar mayor, lindera a la capilla de los Mendoza e inmediata a la capilla del Conde de Peñaflor. Fue fundada a finales del siglo XV por doña Ambrosia de la Carrera ${ }^{439}$.

En la sucesión del patronazgo aparece doña Catalina de la Carrera y su marido don Francisco Pérez de Cisneros, personajes relevantes por el hecho de ser quienes acondicionaron la capilla al encargar en 1575 la ejecución de un retablo donde se dispusieran sus armas ${ }^{440}$.

Los herederos de la capilla de la Piedad serán los sobrinos de la fundadora, el alférez don Fernando o Hernando de la Carrera y su hermana, doña Lucía, mujer del regidor de la villa don Jerónimo González de Saldaña ${ }^{441}$. El deseo de ambos por disponer con decoro su capilla es patente en su aportación de catorce ducados destinados a la ejecución de un cáliz de plata que fuera colocado sobre una peana con sus armas en el año 1590. Ese mismo año además don Hernando contrata al pintor palentino Gregorio de Dueñas para que ejecutase en tres meses un retablo de pintura y reparase la imagen de Nuestra Señora de la Piedad que se encontraba en mal estado ${ }^{442}$. En el banco de este altar se dispondría la escena de la Anunciación con el ángel en el lado izquierdo y la Virgen en el derecho, dejando en medio un jarrón con azucenas. Sobre él se dispondrían dos tablas de San Francisco y San Antonio de Padua de cuerpo entero flanqueados por pilastras doradas. En el remate, un frontispicio con Dios padre portando la cruz. Por tanto, a finales del siglo XVI, la capilla de la Piedad quedaría dotada con dos retablos de reciente factura, uno de escultura y otro de pintura, además de la tabla de la Piedad, que daba nombre a la capilla y los objetos litúrgicos necesarios para celebrar misa en su interior.

\footnotetext{
${ }^{439}$ Así lo constata el traslado de la escritura de concierto entre el abad y síndico del convento franciscano y los patronos de la capilla AHPP. Carr.Prot 4654Juan Cano Guijelmo (1762-1765), s/f.

${ }^{440}$ Dictaron testamento conjunto en dos ocasiones, una en 1556, según se indica en la licencia otorgada en 1764 a Don Juan Antonio Álvarez de Bobadilla como patrón de la capilla de la Piedad, AHPP. Carr.Prot 5682. Bartolomé Sánchez Torres (1762-1767), s/f y otra en 1575, correspondiente al testamento indicado AHPP. Carr.Prot 5615. Melchor de la Rúa (1575-1577), s/f.

${ }^{441}$ Testamento de Jerónimo de Saldaña, 1599. AHPP. Carr.Prot 4702. Pedro Carrión (1599) fol 143 y ss.

${ }^{442}$ Escritura y condiciones firmadas a 3 de diciembre de 1590 en AHPP. Carr.Prot 5851. Nicolás Vallejo (1584-1591), s/f.
} 
Doña Lucía vuelve a dictar testamento el 18 de diciembre de 1591. En él dispone que se rece perpetuamente una misa cantada el día de Nuestra Señora de la O, aportando las limosnas pertinentes su marido don Jerónimo González a la muerte de ésta ${ }^{443}$. A consecuencia de las deudas acumuladas, el síndico franciscano decide interrumpir en 1619 las celebraciones en memoria de la difunta hasta que se abone la suma relativa a los años retrasados. Será en 1628 cuando don Antonio de Paz de la Serna, como hijo político de doña Lucía de la Carrera, se compromete a cumplir los deseos de la testadora. Además, puesto que ya poseía el patronazgo de la capilla de San Nicolás en la iglesia de Santa María, hace cesión al guardián y frailes de San Francisco de una sepultura con estrado de su propiedad en la capilla de la Piedad, junto a la reja de la capilla mayor $^{444}$. Gracias a su intervención, los Carrera continuaron con el patronazgo de este espacio de culto, resultando su mujer, doña Catalina, la detentadora del mismo. Ésta se esposó en segundas nupcias con don Gaspar de Garavito, surgiendo de este matrimonio la sucesiva heredera, doña María Garabito de la Carrera, vecina de Sahagún, que recibirá la posesión en $1674^{445}$. Ese mismo año, había heredado la obra pía fundada por don Melchor Álvarez de Vozmediano en la iglesia de San Andrés, ya que sus padres, doña María de la Carrera y el doctor Castro de Villarroel no habían tenido hijo varón a quien traspasarlo ${ }^{446}$.

Al esposarse doña María Garabito con García Álvarez de Bobadilla, este linaje entronca con el patronazgo de la capilla a través de su hijo don Antonio Álvarez de Bobadilla, esposado con Josefa Rabanal, a quien le sucede su primogénito Félix, marido de doña María de Salas.

\footnotetext{
${ }^{443}$ Se sabe que vuelve a dictar testamento como así manifiesta la escritura de concierto entre el convento y el patrono de la capilla de la Piedad en 1764, don Juan Antonio Álvarez de Bobadilla en el que se incluye el traslado de la escritura de fundación. AHPP. Carr.Prot 4654. Juan Cano Guijelmo (1762-1765), s/f.

${ }^{444}$ Don Antonio de Paz estaba casado con Doña Catalina de la Carrera, hija ésta de doña Lucía. AHPP. Carr.Prot 5411. Francisco Moro Saldaña (1628), s/f.

${ }^{445}$ Así consta en el testamento de Doña Ventura Palacios dictado en 1696, por el cual ésta expresa su deseo de ser enterrada en esta capilla junto a su prima Manuela de Monroy y Lorenzana, si así lo permite la dicha patrona, doña María Garabito de la Carrera. AHPP., Carr.Prot 5018. Agustín García Miranda (1696-1698), s/f. Se sabe con certitud el año en que doña María Garabito adquiere la posesión, pues se hace referencia a ello en el documento de Aceptación del patronazgo de la capilla por parte de don Antonio Álvarez de Bobadilla en 1764. AHPP., Carr.Prot 4654. Juan Cano Guijelmo (1762-1765), s/f.

${ }^{446}$ A este respecto, consúltese el apartado relativo a las capillas de la iglesia de San Andrés.
} 
Una centuria después llegamos en 1764 hasta Don Juan Antonio Álvarez de Bobadilla, vecino de Sahagún, a quien el convento otorga licencia para que continúe ostentando el título de patrón tras el incendio que había asolado la capilla ${ }^{447}$. Fallece el 10 de noviembre de 1796 pero el patronazgo continúa ya que, fruto de su matrimonio con doña María Costilla y Frías, había tenido dos hijos, Gaspar y el primogénito, Don Francisco María Álvarez de Bobadilla Costilla y Garabito, quien había probado su hidalguía en $1788^{448}$. Había desempeñado durante varios años el cargo de mayordomo en la cofradía de Nuestra Señora de la O, perteneciente al hospital homónimo, de ahí que destine una parte de sus bienes a la misma. Tuvo por hijos a Gaspar y Juana Álvarez Bobadilla Ruiz ${ }^{449}$. En su testamento, con fecha de 30 de julio de 1822 decide enterrarse en el cementerio del Pradillo en vez de en la capilla, eso sí, con el hábito franciscano. En pleno Trienio Liberal, es lógico que don Francisco decidiese, ante el riesgo de que el convento franciscano fuese suprimido, escoger un lugar definitivo de descanso ajeno a la política incautadora de estos años.

La Piedad flamenca que se ubicaba en esta capilla, se encuentra hoy día en el Museo Marés de Barcelona. En el catálogo de 1979 se indicaba ya su procedencia carrionesa $^{450}$. Realizada en madera policromada, este grupo de poco más de un metro de altura puede datarse hacia 1500. La túnica y toga de la Virgen era la seña de identidad en la España de los Reyes Católicos no sólo de monja sino de mujer relevante. En la cenefa de su manto se puede leer Mater Dei, palabras que al parecer fueron escritas en fecha posterior a la ejecución de la talla. El rostro contenido y sereno de María contrasta con el tratamiento del cuerpo de Cristo muerto que reposa sobre los brazos de la Virgen, cual muñeco articulado. Su cabeza se desliza hacia atrás, mientras su pecho se hincha y las extremidades se curvan de una manera antinatural. Las manos se cierran casi en un puño a la par que los dedos de los pies se estiran, dando una impresión opuesta a la de un cuerpo ya exánime.

Esta geometrización anatómica se opone al tratamiento suave del paño de pureza, cuyos pliegues convergen anudándose en el centro.

\footnotetext{
447 Se puede deducir que el incendio referido tuviera lugar en una fecha cercana a 1764, de ahí la renovación de la licencia de patronazgo. AHPP. Carr.Prot 5682. Bartolomé Sánchez Torres (1762-1767), s/f.

${ }_{448}$ AHPP. Carr.Prot 5259. Miguel López (1797-1798), fol 330.

449 AHPP. Carr.Prot 12961. Felipe Serna (1821-1824), s/f.

${ }^{450}$ VV.AA. Catàleg d'escultura i pintura medievals. Museo Frederic Marés. Ayuntamiento de Barcelona. Barcelona, 1991, pág. 284.
} 
Piedad de hacia 1500 procedente la capilla homónima. Museo Marés. Barcelona.

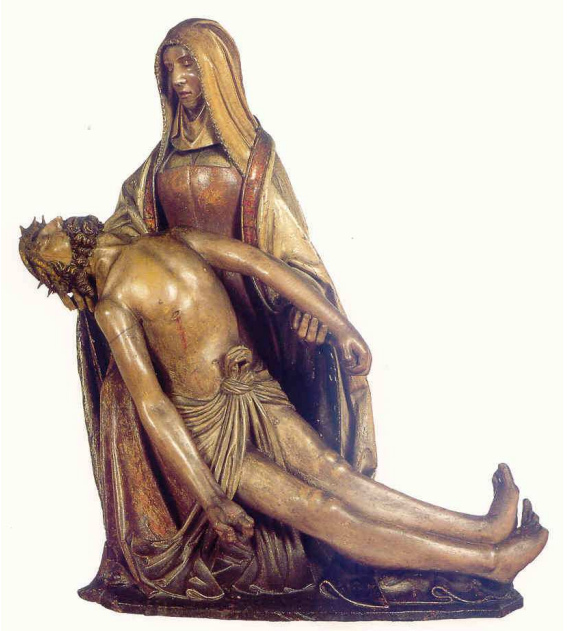

\subsection{CAPILlA DE DON BELTRÁN DE GUEVARA, DE LAS ONCE MIL VÍRGENES}

Esta capilla estaba inmediata a la capilla de los señores de Camporredondo, en el lado de la Epístola, junto a la sacristía. Se componía de dos espacios separados por un par de ventanas abocinadas; uno propiamente el de la capilla y el otro, la sacristía de la misma a la que se accedía por una puerta lateral. Probablemente esta sacristía estuvo ocupada en origen por la capilla de San Bernardino, pues cuando a finales del siglo XVI, Antonio de Cuéllar se encarga de rehacerla, se indica su ubicación junto a la capilla de Pedro de Cisneros, en la misma línea que ésta ${ }^{451}$. Este sería el único espacio posible en que se situaría este espacio de culto que posteriormente perdería su advocación pasando a pertenecer a la capilla de las Vírgenes.

La construcción de esta capilla se debe a los Mújica, quienes la edificaron en el siglo XV, datación a la que pertenece la bóveda de terceletes que cubría este espacio en cuyas claves figuraban varios escudos que se asocian a este linaje. La clave central contenía dragantes de sinople mordiendo una banda de oro, los laterales eran cuartelados: 1 y 3 tres fajas de gules, 2 y 4 tragantes de sinople. Flanqueando el escudo principal por su lado izquierdo se encuentra otro escudo: 1 . cadena de eslabones, 2 y 3 ,

${ }^{451}$ AHPP. Carr.Prot 4982. Sebastián García (1592-1594), fol 87 y ss. 
cruz, 4 objeto sin identificar que podría ser el mismo elemento que aparece en los cuarteles 2 y 4 del blasón derecho, portando castilletes en sus cuarteles 1 y $3^{452}$.

Al esposarse con Isabel de Mújica ${ }^{453}$, el ilustre carrionés Don Beltrán de Guevara adquirió derechos sobre la capilla, disponiendo ser sepultado en la misma el 1 de agosto de 1558. Se encargó de aderezar convenientemente la capilla con la contratación de un retablo al entallador Alejo de Lago y al pintor Juan de Lago el 6 de agosto de $1557^{454}$. El banco contendría tres bustos de las Once mil Vírgenes, en el cuerpo principal se hallaban las imágenes de Nuestra Señora, Santiago, San Cristóbal y otra de San Nicolás y en el remate un Calvario, además de dos escudos de los patronos. Además se ejecutarían...las imágenes de pincel que a nuestros testamentarios les paresçiere...”. . En caso de producirse un incumplimiento del mismo, los Lago, artífices del retablo, recibirían diez mil maravedíes menos de lo establecido; es decir, Beltrán de Guevara les pagaría cuarenta mil reales en lugar de los cincuenta mil establecidos. Se desconoce si se llevaron a cabo dichas condiciones o cual fue la configuración final del retablo, pues de él no se conserva nada.

La prueba fehaciente de la ubicación de esta capilla próxima al altar mayor es el pleito entre el marqués de Aguilar y el convento de San Francisco que, desde 1589 se prolongó hasta 1610. En él figura como declarante Don Gaspar de Guevara, Capitán de caballos, hijo de don Beltrán de Guevara y heredero del patronazgo de la capilla ${ }^{455}$. Solicitaba que se reparase urgentemente la arruinada capilla mayor, pues dada la proximidad con su capilla, temía que si aquella se derrumbaba, se produjeran daños en la suya, recientemente reparada con los treinta mil maravedíes que para tal fin había destinado en $1605^{456}$. En estos términos se expresaba en 1608: “...Digo que yo tengo en la yglesia de San Francisco desta uilla una capilla que llaman de las Vírgenes, la qual está al lado de la Epístola, cerca de la capilla mayor de la dicha yglesia y pareçe una

\footnotetext{
452 PERAL VILLAFRUELA, Santiago. San Francisco...Op.cit, pp. 295-296.

${ }^{453}$ Dictó testamento en 1575 y en él expresa su deseo de ser sepultada en la capilla de las Vírgenes como patrona de tal capilla. AHPP. Carr.Prot 4677. Juan Cantoral (1574-1575), s/f.

${ }^{454}$ GARCÍA CHICO, Esteban. Documentos...Pintores II, Op.cit, pp. 89 y 90, a su vez de AHPP. Carr.Prot 5597. Francisco Rojas (1553-1562), fol 24 y ss. Sobre Alejo de Lago nada se sabe. Acerca de Juan de Lago, remítase al capítulo dedicado a los pintores.

${ }^{455}$ PERAL VILLAFRUELA, Santiago. "San Francisco...Op.cit, pág. 296.

${ }^{456}$ AHPP. Carr.Prot 4771. Martín Cisneros (1604-1606), s/f.
} 
de las paredes de la dicha capilla ha hecho mucho sentimiento y está a peligro de arruynarse y caerse..."

Don Beltrán de Guevara fue quien erigió el arcosolio que aún hoy vemos adosado en uno de los muros laterales para señalar los enterramientos, pero cuando dicta testamento en 1620, aún no estaba finalizado pues como él mismo indica: “...mando se acaue y haga una figura como se acostumbra si yo no la hiçiere, y pongan los letreros necesarios... ${ }^{458, "}$

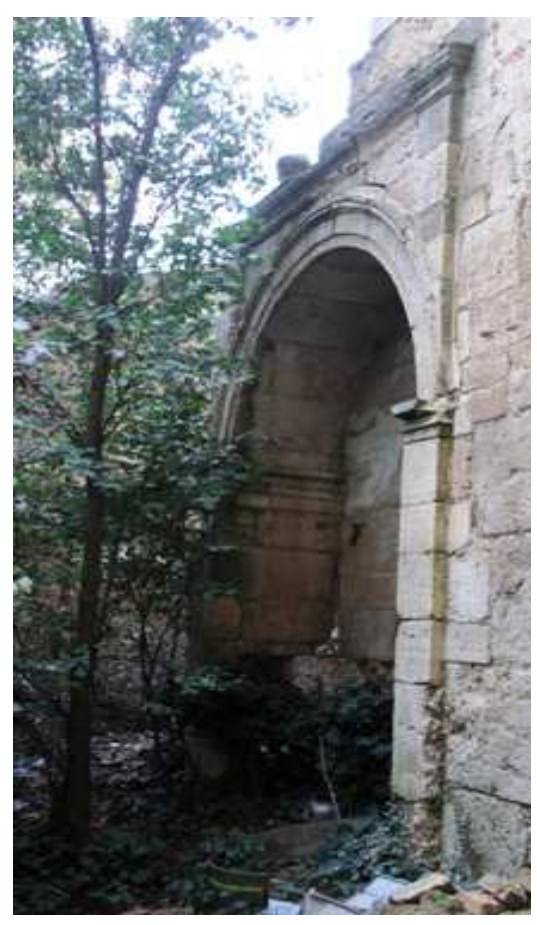

\section{Restos del arcosolio de la capilla de don Beltrán de Guevara.}

Traspasó en 1620 el patronazgo de la capilla de las Vírgenes a su sobrina, doña Constanza de Guevara, pues al parecer no había tenido descendencia. A su hermana doña Mencía de la Serna, le concede el derecho de sepultura en este espacio de culto y la nombra patrona de la capilla de Santa Catalina en la iglesia de Santiago. Al casarse con don Gabriel de Guzmán Herrera, las posesiones de ambos linajes quedaron unidas, sumándose a este mayorazgo el de los Tejada en el siglo XVIII, fruto del matrimonio de Miguel de Córdoba y Alagón y doña Constanza Bazán ${ }^{459}$. A partir de entonces figura como patrón el linaje Córdoba, cuyos miembros ostentaban el título de condes de

\footnotetext{
${ }^{457}$ ARCHV. Pleitos Civiles. Quevedo (F) 1557. Expediente 1. Primer cosido s/f.

${ }^{458}$ Testamento de Don Gaspar de Guevara en AHPP. Carr.Prot 5403. Francisco Moro Saldaña (1620), s/f. ${ }^{459}$ PERAL VILLAFRUELA, Santiago. San Francisco...Op.cit, pág. 296-297 a su vez de ACA, Diversos, Fondo Sástago, L. 68, 10ª . Copia del testamento de Gaspar de Guevara, dictado el 2 de junio de 1618.
} 
Sástago. El deterioro que presentaba a mediados del siglo XVIII el tejado de la capilla conllevó al convento a solicitar del por entonces patrono, don Francisco de Córdoba, una rápida intervención. Ambas partes discrepaban, pues el conde se negaba en un principio a realizarla, basándose en que don Gaspar de Guevara no había fundado ni la capilla ni el mayorazgo ${ }^{460}$. Asumió finalmente su responsabilidad delegando los trámites a su administrador, pues residía en Zaragoza ${ }^{461}$.

El patrón posterior de la capilla de las Vírgenes, don Cristóbal de Córdoba, tuvo que hacer frente al desastre ocasionado en su capilla a consecuencia de las inundaciones que tuvieron lugar entre 1788 y 1789. La valoración de los daños y los nuevos planos fueron proporcionados por el arquitecto Juan Monje, quien estimó que serían necesarios más de diez mil reales. No dispuesto a abonar tan cuantiosa suma, pues los vínculos familiares con los fundadores habían desaparecido- participó no obstante, alegando un fervor por la religión franciscana, con un total de seis mil reales que abonó en los tres años que duraron las obras. Se intervino reforzando el muro colindante con la capilla de los Camporredondo además de rehacer la fachada de las Once Mil Vírgenes.

El diseño de la capilla mezcla el estilo neoclásico imperante con reminiscencias barrocas, pues el acceso rectangular, flanqueado por sendas pilastras toscanas, va enmarcado por unas sencillas orejetas. Entre ambos soportes se disponía un arco de medio punto que cobijaba a su vez la portada ${ }^{462}$. Separado por un entablamento clásico a base de triglifos y metopas se disponía un segundo cuerpo por el que se filtraba la luz a través de lunetos.

Aprovechando las obras de mejora realizadas en la capilla, el convento sugirió en octubre de 1791 la sustitución del viejo retablo además de practicar un acceso desde la sacristía del templo que permitiera el paso directo hacia la capilla mayor. Sólo la primera de las peticiones fue admitida pues la intervención relativa al cambio de acceso habría puesto en peligro la capilla. El nuevo retablo, que quedaría instalado en 1792,

\footnotetext{
${ }^{460}$ Ibídem, pp. 299-300, a su vez de ACA, Diversos, Fondo Sástago, L. 68, 10ª nº2.

46123 de enero de 1761. Escritura de arrendamiento de un prado propiedad de conde de Sástago a don Manuel de la Vega. AHPP., Carr.Prot 4609, Francisco Blanco Manuel (1761-1762), s/f.

${ }^{462}$ ACA, Diversos, Fondo Sástago, L. $68,10^{\mathrm{a}}, \mathrm{n}^{\mathrm{o}} 1$ y 2.
} 
trajo consigo una nueva advocación de este espacio de culto, pues en su hornacina central se dispuso una imagen de San Benito de Palermo, santo negro franciscano ${ }^{463}$.

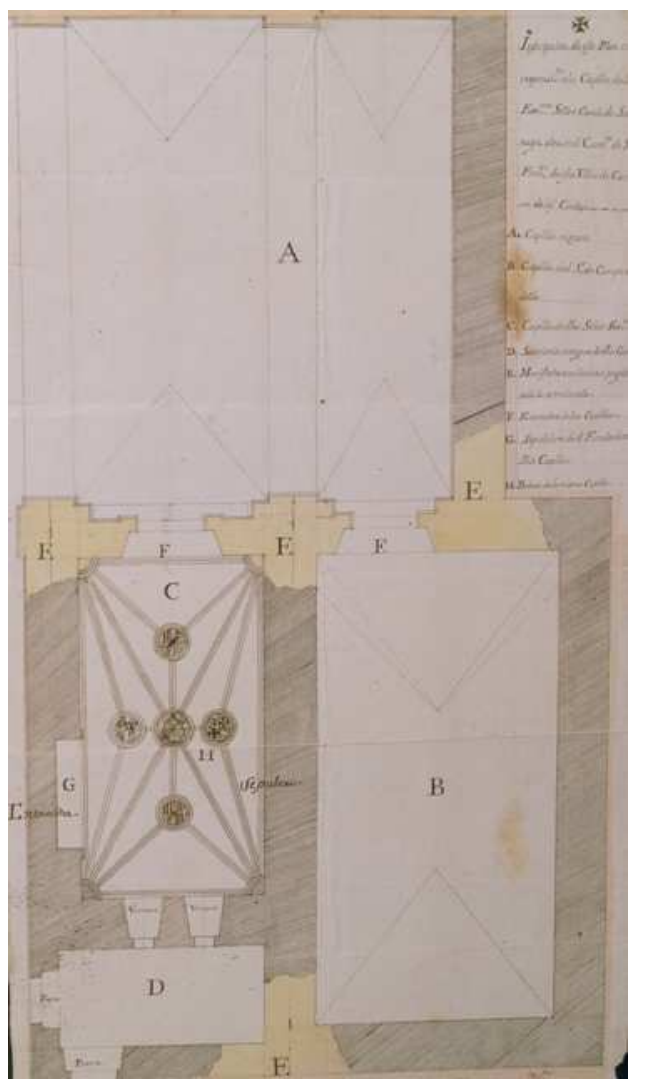

A. Capilla mayor.

B. Capilla de Camporredondo

C. Capilla del conde de Sástago

D. Antigua sacristía de dicha capilla

E. Partes arruinadas

F. Entradas a la capilla

G. Sepulcro del fundador

H. Bóveda

Planta de la capilla de las Once Mil Vírgenes.Juan Monje 1789.

AGA. Mapas y planos 409.

\subsection{NUESTRA SEÑORA DE MIRABUENO O CRUCIFIJO. SAN ANTONIO DE PADUA (desde 1789)}

Fue fundada por el comendador Álvaro de Torres. Hasta 1605 la capilla estaba en manos de la familia del doctor Soto de Acuña y de su difunta mujer Ana de Velasco y de la Serna, año en que decide venderla a Don Álvaro de Torres Quijada, evitando así

\footnotetext{
${ }^{463}$ PERAL VILLAFRUELA, Santiago. San Francisco...Op.cit, pág. 302-303 a su vez de ACA, Diversos, Fondo Sástago, L. 68, 10ª 1 y ACA, Leg. 68, 7ª 4 .
} 
que el patronazgo “salga de su tronco y abolengo del dicho comendador... 464 ”. Más tarde la pertenencia pasó al capitán Nicolás Polanco de Santillana, quien adquirió la titularidad junto su mujer, Dorotea Calderón ${ }^{465}$.

Hasta el año 1789 estuvo bajo la advocación de Nuestra Señora de Las Maravillas, también conocida como Nuestra Señora de Mirabueno, por la Virgen milagrera que allí se custodiaba, traída según se dice por la venerable monja de la orden tercera, Doña Isabel de Colmenares, quién la dotó además de retablo y ornamentos ${ }^{466}$. Posteriormente debió perderse la imagen de la Virgen, pues después figura como capilla del Crucifijo y es la razón más lógica para que Helguera no la mencione al hablar de las capillas $^{467}$.

En 1713 el IV Conde de Peñaflor, Don Ignacio Manuel de Villacid y Manrique de Lara, vecino de Villagarcía de Campos, V conde de Amayuelas, en Palencia, era patrón de la capilla de San Antonio ${ }^{468}$. No se trataba de una capilla al uso, pues ni se ubicaba en la iglesia, sino en el claustro, ni se usaba como tal, pues era la sala capitular del convento. Así figura en un protocolo sobre una reunión de los franciscanos el 20 de julio de 1575 que tuvo lugar en el capítulo para tratar sobre las disposiciones de Don Juan de Vozmediano de ser enterrado en la capilla de la Resurrección de este convento $^{469}$.

El anhelo de don Ignacio era traspasar el patronazgo a este espacio por hallarse en mejores condiciones. Para ello, el síndico franciscano ordena mantener todas las alhajas, ornamentos y demás enseres que allí se conservasen permitiéndole sustituir el retablo del Crucifijo situado en esta capilla, por el suyo propio. Sabemos que los Condes de Peñaflor pasaron desde este momento a ser patronos de la capilla, pues poco

\footnotetext{
${ }^{464}$ AHPP. Carr.Prot 4708. Pedro Carrión (1605), fol 325 y ss.

${ }^{465}$ VIGURI, Miguel de. Heráldica...II. Op.cit, pág. 69.

${ }^{466}$ CALDERÓN, Padre Francisco. Primera parte de la Chrónica...Op.cit, pág. 136.

${ }^{467}$ RAMIREZ DE HELGUERA, Martín. El libro...Op.cit, pág. 179.

${ }^{468}$ El condado de Amayuelas un título nobiliario español creado en 1558por el rey Felipe IV a favor de Bernardino Manrique de Lara y Barrientos que hace referencia a las localidades palentinas de Amayuelas de Arriba y Abajo. Don Ignacio era hijo de Leonor Petronila Manrique de Lara hermana de los tres anteriores condes de las Amayuelas, y de su esposo Gaspar Domingo de Villacís y Quijada, III conde de Peñaflor de Argamasilla. Casó con Manuela de la Cueva y de la Cueva, hija de Melchor Fernández de la Cueva y Enríquez de Ribera, IX duque de Alburquerque, VII marqués de Cuéllar, IX conde de Ledesma y Huelma IX, y Ana Fernández de la Cueva Armendáriz y Ribera, III marquesa de Cadreita y V condesa de la Torre.

${ }^{469}$ AHPP., Carr.Prot 5667, Andrés Sánchez (1575-1576), s/f.
} 
después tomó el relevo su hijo Francisco Antonio Villacid y de la Cueva, el cual falleció poco después en 1723, pasando el mismo a su hija, María de la Concepción, quien murió siendo niña, por lo que la posesión la adquiere su tía, hermana de don Francisco Antonio.

Sin embargo, el nombre de la capilla no varió, manteniéndose el de Virgen de Mirabueno. Así se verifica en las obras que en 1760 ejecuta Melchor García donde se indica que la continúa estando “...ynmediata a el altar maior, a el lado de el

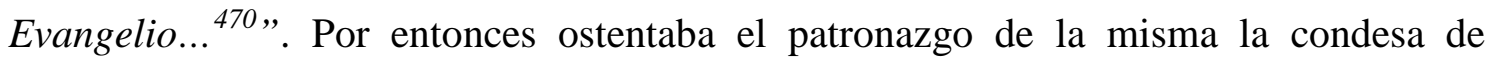
Amayuelas, residente en la villa de Madrid. Sabemos, por las fechas que manejamos, que se trata de Ana Catalina de Villacís y de la Cueva, VII condesa de Peñaflor, quien perdió este último título en 1762, al disputarlo con Francisco de Villacid Menchaca y Torre. No existía en la misma ningún retablo bajo la advocación de San Antonio, pues precisamente a raíz de estas obras se especifica que se coloquen dos mesas de altar, la una para la Virgen de Mirabueno, destinándose la otra, a la urna de Cristo. Este Cristo en el sepulcro podría identificarse con el que se ubica hoy día en el Museo de Santa Clara, que podemos datar hacia 1500. Cristo, aunque exánime, parece estar vivo aún pues su boca y su ojos se muestran entreabiertos, lo que aporta gran realismo al rostro. Este efecto que queda contrarrestado por la presencia de la barba fingida a través de la policromía y los mechones de su cabello demasiado apelmazados. Su dramatismo se acentúa en la policromía posterior a la talla, quizá del siglo XVIII, en la cual es patente el abuso excesivo de la sangre, que empaña incluso el paño de pureza. La urna no se conserva, por eso la que presenta hoy día es moderna.

Continuando con las obras de 1762, la patrona precisa también la colocación de su escudo sobre la ventana de la capilla, que como corresponde al condado Amayuelas, contendría dos calderas jaqueladas puestas en palo con cuatro sierpes a cada lado y el lema: “Nos non venimos de reyes, que reyes vienen de nos 471 ". Cabe preguntarse, ¿dónde fue a parar el antiguo retablo de San Antonio? Pasó a situarse en el brazo sur del

\footnotetext{
${ }^{470}$ Escritura y condiciones de la obra en AHPP., Carr.Prot 4653. Juan Cano Guijelmo (1760-1761), fol 253 y ss., Comentada en el apartado relativo a las obras ejecutadas en el siglo XVIII.

${ }^{471}$ ALONSO DE CADENAS Y LÓPEZ, Ampelio, y CADENAS Y VICENT, Vicente de. Elenco de grandezas y títulos nobiliarios españoles. Hidalguía. Madrid, 1999, pp. 86-87.
} 
crucero, en la capilla del Crucifijo, modificando ésta su nombre por el del santo italiano $^{472}$.

1789 constituye una fecha clave para el templo, pues con la rehabilitación del mismo y la ejecución de nuevos retablos, algunas capillas cambian su nombre. Así, se realizaría un nuevo retablo dedicado a San Antonio de Padua, idéntico a su frontero, dedicado a San Pedro Regalado. Como aquel, es de factura neoclásica, de un solo cuerpo y carece de escultura con la salvedad de que la policromía, si bien imita mármoles como en el otro caso, los colores se disponen de modo diverso. La ejecución de este nuevo retablo tendría dos consecuencias directas y simultáneas:

-En primer lugar, el viejo retablo de San Antonio fue retirado, por lo que la capilla sur del crucero volvió a estar bajo la advocación del Crucifijo.

-Por otro lado, la nueva obra fue colocada en la capilla de Mirabueno, por lo que este espacio de culto pasó desde entonces a situarse bajo la protección de San Antonio de Padua. Es lógico, por tanto, que cuando Ramírez de Helguera hace un repaso de las capillas del templo, mencione al santo italiano y no a la Virgen milagrera, imagen que debió desaparecer en el transcurso de aquellas obras, pues nunca más se supo de ella.

\subsection{CAPILLA DE SAN PEDRO REGALADO Y SAN CRISTÓBAL}

Ubicada en el brazo sur del crucero, junto a la capilla de las Vírgenes, esta capilla pudo situarse en origen bajo la advocación de los Santos Cosme y Damián. Así lo creemos pues a finales de 1591 se produce el hundimiento de dos capillas aledañas ${ }^{473}$. Una de ellas fue la de San Cosme, y la otra, la de San Bernardino, que se ubicaba junto a la capilla de don Pedro de Cisneros, esto es, colateral del altar mayor por el lado de la Epístola. El Licenciado Díaz de Flores poseía el patronazgo de las dos capillas arruinadas que habían sido reedificadas por Juan de la Cuesta, quien es encarcelado por su imprudencia. Ambas partes se comprometen a respetar el veredicto de dos maestros elegidos por ellos que establezcan el valor de la deuda juzgando a partir de los daños

\footnotetext{
${ }^{472}$ Se explica más detalladamente en la capilla del Crucifijo.

473 AHPP. Carr.Prot 5650. Pedro Saldaña (1591), fol 526 y ss.
} 
ocasionados. Confiando en su “...perizia, rretitud y cristiandad...”, el maestro trasmerano escoge a otro maestro cántabro, Domingo de Cerecedo, mientras el patrono se decanta por Juan de Celaya.

Hacia 1789 se produjeron diversas intervenciones de mejora en las capillas colindantes a la de las Once Mil Vírgenes y se modificaron algunos espacios de culto ${ }^{474}$. Seguramente esta capilla no existió con esta advocación de San Pedro y San Cristóbal hasta este momento, pues a mediados de siglo al ubicar la capilla de San Antonio situada junto a ésta en el lado sur del crucero- no se la menciona como hemos visto, indicando que la flanquea la capilla de las Vírgenes, situada en el presbiterio ${ }^{475}$. Cuando Helguera se refiere a esta capilla a finales del siglo XIX, indica que allí se situaba el retablo del santo vallisoletano, en cuyo remate se disponía la imagen de San Cristóbal $^{476}$.
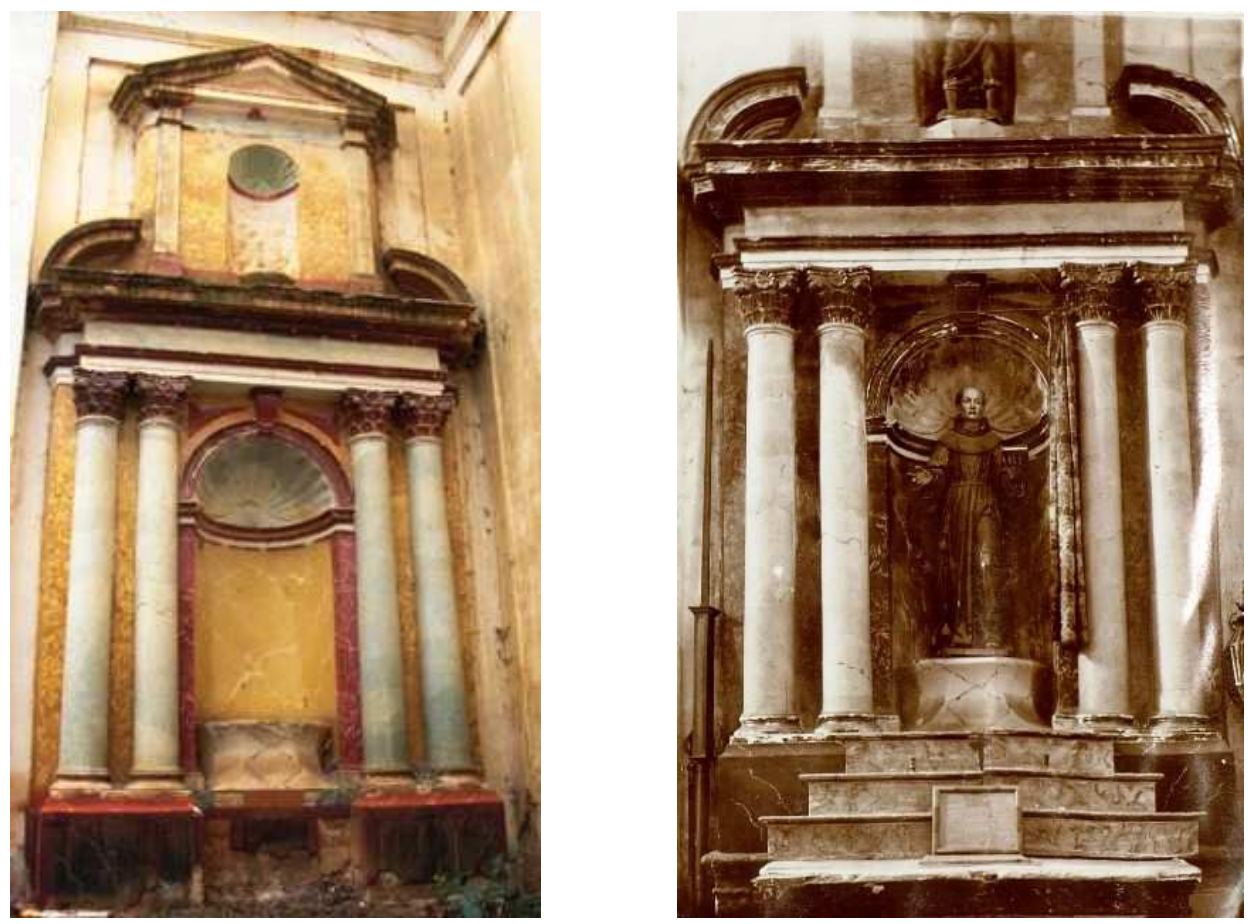

Retablo de San Pedro Regalado y San Cristóbal en la actualidad (izquierda) y en origen (derecha), según la fotografía que tomó Bernardino Martín Mínguez en su Inventario de Palencia de 1907.

\footnotetext{
${ }^{474}$ PERAL VILLAFRUELA, Santiago. “San Francisco...Op.cit, pág. 304.

${ }^{475}$ Permiso concedido a la Cofradía de Sastres para ubicarse en la capilla de San Antonio a 23 de julio de 1751. AHPP. Carr.Prot 5885. Manuel Vega (1749-1751) fol 125 y ss.

${ }^{476}$ RAMÍREZ HELGUERA, Martín. El libro...Op.cit, pág. 179.
} 
Desprovisto hoy día de ambas tallas, éstas pueden identificarse con seguridad con las conservadas en el Museo de Santa Clara de la villa, dada la fotografía de 1907 en que figuran ambos santos presidiendo el retablo. Por entonces figuraba una inscripción con la fecha de la ejecución del retablo, en $1791^{477}$. Presenta una estructura muy similar al del brazo norte del crucero, perteneciente a San Antonio de Padua. Se trata de un sencillo altar de un solo cuerpo alzado sobre un pedestal en cuyo centro figura una hornacina vacía flanqueada de dos pares de semicolumnas corintias. En ella se dispone un plinto cilíndrico destinado a disponer la imagen del titular sobre el mismo. Un grueso entablamento y su cornisa separan este cuerpo del remate, más estrecho, al que se une mediante aletones curvos que acogen un templete clásico en cuyo centro, cobijado por una hornacina, se situaría la imagen de San Cristóbal, trasladada posteriormente al museo de Santa Clara ${ }^{478}$. Presenta, al igual que los otros tres retablos conservados del templo, una viva policromía a base de rojizos y amarillentos semejando jaspes que ha resistido el paso del tiempo gracias a una esmerada preparación de los colores ${ }^{479}$.

La escultura de San Pedro Regalado ubicada según se entra en el museo, es una imagen del siglo XVIII. Enjuto e imberbe, la amplia tonsura de su cabeza se convierte prácticamente en una calvicie, lo que le proporcionaba un aspecto de edad avanzada. Porta el hábito franciscano compuesto por túnica, capilla, capuchón y sandalias de cuero. Si cabía alguna duda de su pertenencia a la orden terciaria, se ha añadido recientemente el cordón franciscano anudado a la cintura. Podría representar también a San Pedro de Alcántara, ya que ambos santos, con idéntica indumentaria, se representan como frailes menores y portan el libro como atributo. Sin embargo nos decantamos por la atribución del Santo vallisoletano, pues en una fotografía antigua preside el retablo homónimo en el convento de San Francisco ${ }^{480}$. Es segura, no obstante su procedencia

\footnotetext{
${ }^{477}$ MARTÍN MÍNGUEZ, Bernardino. Catálogo...Op.cit, inédito, volumen 3, pág. 52

${ }^{478}$ La estudiamos en las obras del museo de Santa Clara.

${ }^{479}$ PERAL VILLAFRUELA, Santiago. "San Francisco...Op.cit, pág. 304.

${ }^{480}$ A este respecto véanse las iconografías de ambos santos en ANDRÉS ORDAX, Salvador. Iconografía de San Pedro Regalado. Junta de Castilla y León, Valladolid, 1991 Del mismo autor, Arte e iconografía de San Pedro de Alcántara. Institución Gran Duque de Alba. Ávila, 2002, GARCÍA MOGOLLÓN, Florencio Javier. "La iconografía de San Pedro de Alcántara. De imagen devocional a signo de identidad" en Ars sacra, n²6-27, Madrid, 2003 pp. 139-146, REDONDO CANTERA, Mª José y ZAPARAÍN YÁÑEZ, Ma José. "San Pedro Regalado. Formación y desarrollo de una iconografía religiosa en el Barroco" en Cuadernos de Arte e Iconografía, tomo 4, nº, Fundación Universitaria Española, 1991, pp. 73-81.
} 
del convento de San Francisco, pues Urrea nos indica que se situaban en el claustro Santa Clara, en $1980^{481}$. Estas y otras esculturas, fueron trasladadas desde el cenobio franciscano cuando su iglesia cerró sus puertas a mediados del siglo XX, pasando posteriormente a formar parte del museo.

También procedente del cenobio franciscano es una imagen de San Cristóbal cuya datación, que estimamos de mediados del siglo XVIII, se convierte en tarea difícil debido a los repintes posteriores. Apoyado en su bastón, el santo recoge su larga túnica para evitar que se moje mientras atraviesa el río ignorando que quien porta en su hombre es el Salvador del mundo. Esta escultura se ubicaría originalmente en el brazo sur del crucero, como remate del retablo de San Pedro Regalado que fue realizado hacia 1789, paralelamente a las obras de renovación de la zona del altar mayor.

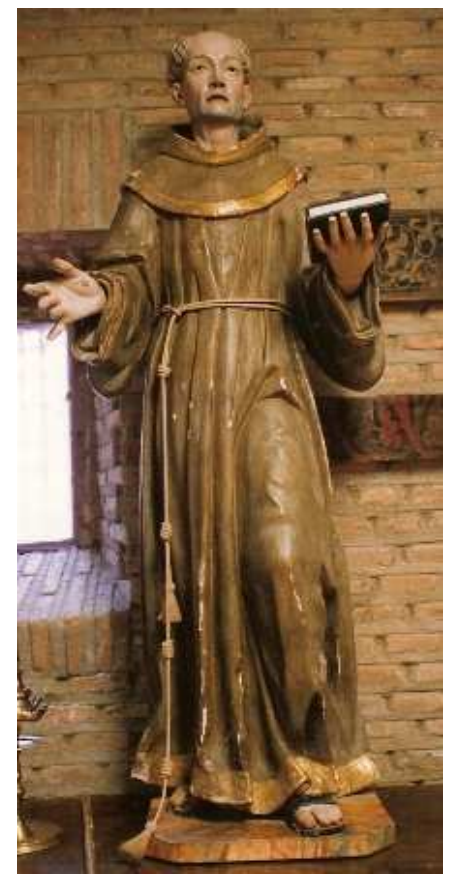

San Pedro Regalado $(161 \mathrm{~cm} \times 67 \mathrm{~cm})$.

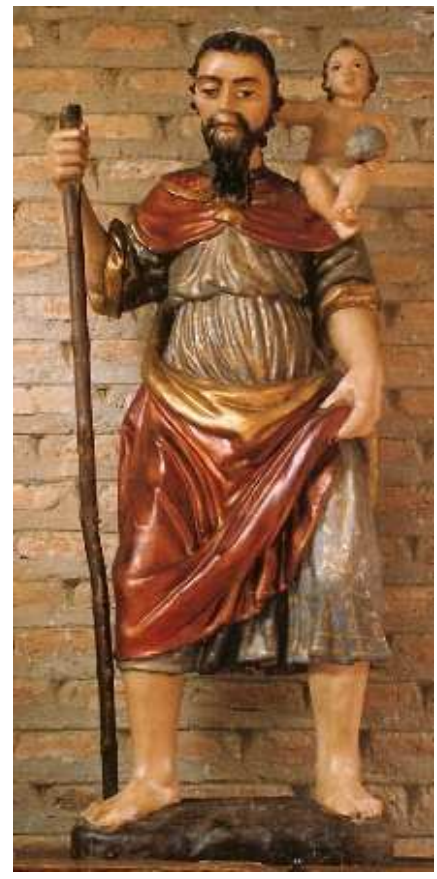

San Cristóbal (109x46cm).

\section{Esculturas procedentes del retablo de San Pedro Regalado del convento franciscano, hoy en el museo de Santa Clara.}

\footnotetext{
${ }^{481}$ Ambas figuran en URREA FERNÁNDEZ, Jesús y MARTÍN GONZÁLEZ, Juan José. Inventario...2, Op.cit, pág. 60, de ahí la duda de identificación, siendo ambas posibles.
} 


\subsection{CAPILLA DE LA VIRGEN DEL PÓPOLO, SANTA BRÍGIDA Y SAN JUAN}

Helguera hace referencia a esta capilla sin precisar con exactitud su ubicación, mencionándola a continuación de la de San Antonio de Padua. Es por ello que, como Santiago Peral, consideramos que se encontraba frontera al altar del Crucifijo y junto a la capilla de San Luis de Anjou ${ }^{482}$. Ignacio Díez de Monroy poseyó esta capilla en 1615. Éste fue el primogénito del matrimonio formado por Alonso Díaz de Monroy e Isabel de Modoya y sus armas figuran en la vivienda de la calle José Antonio Girón, sobre un balcón esquinado. Se trata de un escudo cuartelado, análogo al que probablemente poseería esta capilla: 1, de Díez, cruz flordelisada, 2, castillo, 3, de Modoya, árbol surmontado de dos flores de lis, 4, de Monroy, veros alineados ${ }^{483}$. Este espacio estaba dotado de un retablo de madera con soportes corintios ${ }^{484}$.

\subsection{CAPILLA DEL CRUCIFIJO, DEDICADA A SAN ANTONIO (entre 1713-1789)}

Su existencia se remonta al menos a mediados del siglo XVI, pues figura como su patrona doña Ana Manrique, mujer de don Francisco de Carvajal, cuando dicta testamento en $1561^{485}$. Podemos creer que esta fue la capilla de los Manrique, seguramente fundada en los albores del siglo XV, época de oro de este linaje que en tantas ocasiones favoreció y protegió a las órdenes menores. No es de extrañar, por tanto, que dispusieran de un lugar preferente en este convento, como así lo poseían en la casa clarisa aledaña, donde sus armas campean por doquier.

\footnotetext{
${ }^{482}$ PERAL VILLAFRUELA, Santiago. “San Francisco...Op.cit, pág. 309.

${ }^{483}$ VIGURI, Miguel de. Heráldica...2. Op.cit, pág. 61.

${ }^{484}$ RAMÍREZ HELGUERA, Martín. El libro...Op.cit, pág. 179.

${ }^{485}$ AHPP. Carr.Prot 5662. Andrés Sánchez (1560-1562), s/f.
} 
La capilla del crucifijo se ubicaba, como indica la documentación, “...al salir de la sacristía... ${ }^{486 ”,}$, esto es, en el lado sur del crucero, frontero a la capilla de la Virgen del Pópolo.

Por su parte, la capilla de San Antonio de Padua se ubicaba originalmente en el claustro, como así se indica cuando en 1653 el patronazgo de la misma se transfiere al linaje de los $\operatorname{Tovar}^{487}$. En 1713 la capilla del santo italiano se encontraba en estado total de ruina, pues sus muros eran de tierra. Su patrono, Don Ignacio de Villacid Manrique de Lara, conde de Peñaflor e hijo de don Gabriel Tovar, optó por traspasar el patronazgo a la capilla de las Maravillas o de Mirabueno, ya que sus paredes eran de sillería y por tanto, más duraderas. La capilla de San Antonio había pertenecido al padre de don Ignacio Manrique, don Gaspar Domingo de Villacid Quijada Docampo ${ }^{488}$.

El patronazgo de la capilla a la de Mirabueno- en el crucero norte- pero su retablo, pasó a la Capilla del Crucifijo, adquiriendo esta nueva advocación la capilla. Así se indica en 1751 que la capilla de San Antonio, situada “... a la misma puerta que sale de la sacristía a la yglesia, al costado izquierdo, ymmediata por la parte de arriba a la del sagrario, que se intitula de las Vírgenes, y por abaxo a la de San Diego de Alcalá...", se encontraba vacante por entonces. Hay que pensar que el espacio que fue reformado como sacristía en el siglo XVIII pertenecía por entonces a la capilla de las Once Mil Vírgenes. El espacio que ocupaba esta capilla mientras estuvo bajo la advocación de San Antonio, era mayor que el que delimita Peral Villafruela, por dos motivos: la descripción indica que delimitaba por uno de los lados con la capilla de San

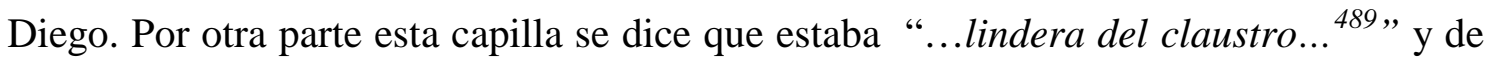
este modo tendría que situarse al menos en el ángulo noreste del mismo para poder limitar con él.

\footnotetext{
${ }^{486}$ Doña Elena de los Ríos Campo, mujer de don Álvaro de Torres e hija de Fernando Bañuelos otorgó una escritura de fundación en la capilla en 1618, que declarada nula por haberse hecho sin facultad real y por haber contraído ciertas deudas. Informes varios sobre el templo. ADP. Religiosos. San Francisco (1616-1774), fol 37.

${ }^{487}$ Así figura en el Libro de las misas perpetuas fechado en 1653. ADP. Religiosos. San Francisco (16161774), s/f.

${ }^{488}$ En la escritura de venta de la capilla se menciona este dato. AHPP. Carr.Prot 5642. Francisco Ruiz Sandoval (1713-1715), s/f.

${ }^{489}$ Escritura de venta de la capilla en AHPP. Carr.Prot 5642. Francisco Ruiz Sandoval (1713-1715), s/f.
} 
El gremio de sastres de la villa solicitó ese año permiso al Ministro Provincial de la Purísima Concepción y visitador general de los conventos franciscanos, don Bartolomé Sarmentero, para establecer allí su cofradía. Concedido el permiso, el gremio pudo hacer uso de lo allí contenido -lámpara de plata, retablo- sin tener derecho de propiedad alguno sobre dichos bienes. A cambio, dicha congregación se comprometía a cumplir con una serie de obligaciones referentes al pago por la cesión de la capilla (misas, sermones, limosnas, uso de cera entre otras) ${ }^{490}$.

No sería hasta 1789 con las obras de mejora realizadas en la iglesia y la modificación de algunos espacios de culto, cuando la capilla de Mirabueno mutó su nombre por el de San Antonio debido al nuevo retablo que de este santo se hizo, volviendo a denominarse esta capilla del Crucifijo, como había sido desde sus orígenes.

\subsection{CAPILLA DE SAN LUIS DE ANJOU}

En el lado del Evangelio, precediendo al crucero y en el ángulo común con la capilla de la Virgen del Pópolo, se situaba esta capilla de la que no se conocen demasiados datos. Encajado en un estrecho nicho del muro, presenta una estructura pareja a su altar frontero dedicado a San Diego. De pequeñas dimensiones y estilo neoclásico, se compone de un solo cuerpo de volúmenes rectilíneos en el cual se enmarca una hornacina vacía sobre pedestal flanqueada por sendas pilastras toscanas. El toque dinámico viene dado por el entablamento quebrado que deja paso a un remate mixtilíneo que a su vez acoge el escudo franciscano.

Al parecer la imagen de San Luis fue trasladada al museo de Santa Clara de la villa, como así se deduce de la existencia de una talla homónima datada en la segunda mitad del siglo XVIII. Se ubicaba en el claustro de Santa Clara antes de ser trasladado al museo $^{491}$. Su aspecto es el de un joven imberbe, con las mejillas rosadas, pues no llegó a alcanzar la madurez. Murió en 1297 cuando tan sólo tenía veintitrés años, unos meses después de ser nombrado Obispo de Tolosa por Celestino V. Presenta el libro en su

\footnotetext{
${ }^{490}$ Permiso otorgado el 23 de julio de 1751. AHPP. Carr.Prot 5885, Manuel Vega, (1749-1751) fol 125 y ss.

${ }^{491}$ Ibídem, pág. 60.
} 
mano izquierda sobre el cual se dispone la mitra, atributo episcopal. Su alto rango eclesiástico también se deduce de las elegantes vestiduras que luce, pero si nos fijamos, debajo de la túnica y la capa pluvial lleva el hábito franciscano, ya que ingresó como fraile en 1296, renunciando a sus derechos sobre la corona de Nápoles a favor de su hermano $^{492}$. Es una imagen adscribible al segundo cuarto del siglo XVIII, que comparte con las tallas de San Diego o San Pedro de Alcántara la elegancia en el rostro del santo y la expresión lánguida que preludia la mentalidad rococó.

\subsection{CAPILLA DE SAN DIEGO}

Frontero al altar de San Luis de Anjou, precediendo por tanto el crucero en el lado de la Epístola se situaba esta capilla. Indica Ramírez de Helguera: "Después del púlpito está el altar de San Diego, con este Santo, de buen tamaño. Es de yeso imitando el orden corintio ${ }^{493}$ ". La fundación de este espacio se debió al impulso de don Pedro de Cisneros, en el año $1598^{494}$. A éste le sucedería su hijo, el regidor y cronista de la villa don Juan de Cisneros y Tagle, como así lo declara en el testamento su mujer, doña Luisa de Benavides, quien en 1627 dispone ser sepultada junto a su difunto marido ${ }^{495}$.

En el siglo XVIII la propiedad pasó a Francisca de los Cuetos, mujer de Andrés de Torres Calderón. A finales de esta centuria debió ser reedificado este espacio y se encargó un nuevo retablo. No cabe duda de que su factura corresponde a la misma época que el de San Antonio, pues son exactamente iguales, incluso en la policromía imitando mármoles. Como sucede en el resto de retablos conservados en este templo, la talla correspondiente al nicho central se identificaría con la homónima que se conserva en el museo de Santa Clara ${ }^{496}$.

Igualmente en el museo de Santa Clara se ubica la imagen de San Diego de Alcalá, obra del siglo XVIII, símbolo de la piedad de la Casa Real Española. De aspecto juvenil e imberbe, se muestra vestido de lego, portando túnica, escapulario y cordón

\footnotetext{
${ }^{492}$ CARMONA MUELA, Juan. Iconografía de los Santos. Madrid, 2003, pág. 298.

${ }^{493}$ RAMIREZ DE HELGUERA, Martín. El libro...Op.cit, pág. 179.

${ }^{494}$ Concierto entre el convento de San Francisco y su síndico sobre la capellanía de la capilla de San Diego. 1598. ACP. Provisorato. Legajo 5, nº505.

${ }^{495}$ AHPP. Carr.Prot 5410. Francisco Moro de Saldaña (1627), s/f.

${ }^{496}$ PERAL VILLAFRUELA, Santiago. San Francisco...Op.cit, pág. 306.
} 
franciscano añadido, no tallado. Sujeta enérgicamente la cruz en la mano, como así se deduce de su puño cerrado, mientras que con la otra, sostiene con delicadeza sus vestiduras mientras adelanta la rodilla para evitar que caigan unas flores que hay sobre el mismo. Esta iconografía se relaciona con el célebre milagro, en el cual el santo fue sorprendido por el guardián del convento cuando se dirigía a repartir comida entre los pobres, los mendrugos de pan que llevaba quedaron convertidos en flores. Procedente, como otras obras que hemos analizado, del aledaño convento de San Francisco, se ubicaba en el claustro del convento de clarisas antes de la apertura del museo ${ }^{497}$. En el cenobio terciario ocuparía la hornacina central del retablo barroco de la capilla de la Epístola que precede al crucero.

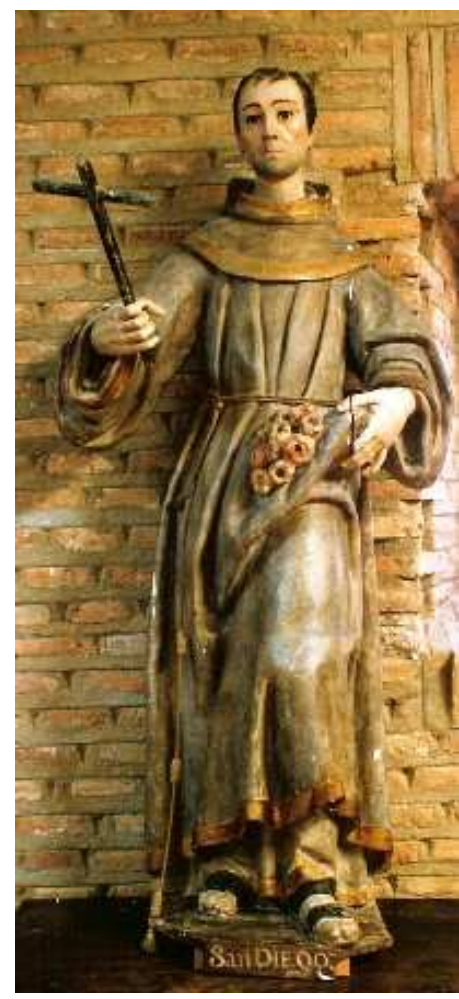

San Diego de Alcalá $(152 \mathrm{~cm} \times 70 \mathrm{~cm})$.

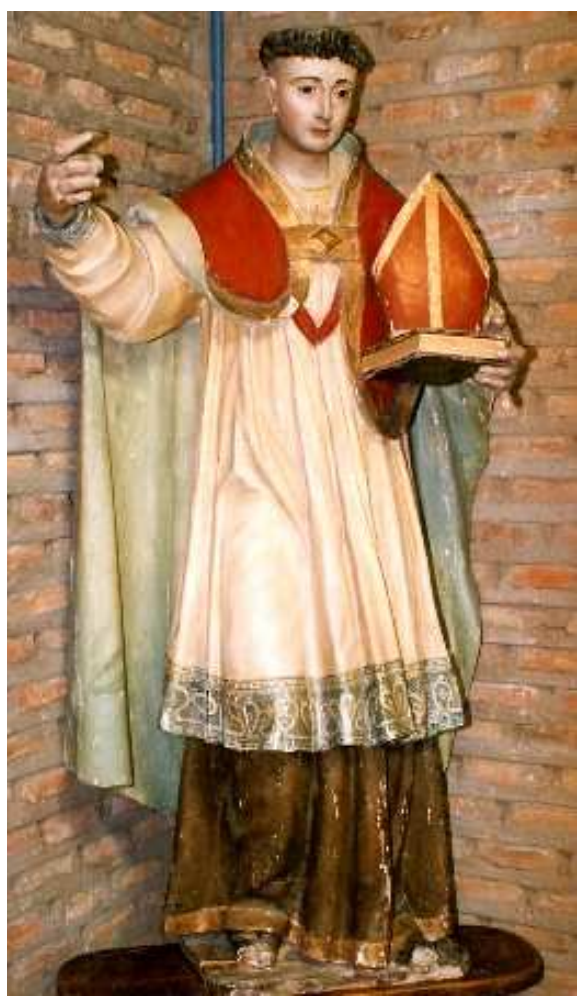

San Luis de Anjou $(185 \mathrm{~cm} \times 83 \mathrm{~cm})$.

Esculturas procedentes del convento de San Francisco ubicadas hoy día en el museo de Santa Clara.

\footnotetext{
${ }^{497}$ URREA FERNÁNDEZ, Jesús y MARTÍN GONZÁLEZ, Juan José. Inventario...2, Op.cit, pág. 60
} 


\subsection{CAPILLA DE NUESTRA SEÑORA}

La existencia de esta capilla se remonta al menos a mediados del siglo XVI, pues Francisco Sánchez de Balbuena era patrono de la capilla de la O en $1560^{498}$.

Los escasos datos que se conocen de este espacio de culto los proporciona Ramírez de Helguera, quien lo sitúa a continuación de la capilla de San Diego. Presentaba una imagen de Jesús en el sepulcro flanqueado por Nuestra Señora de los Ángeles y Nuestra Señora de la $\mathrm{O}^{499}$. Podría identificarse esta última escultura con la Virgen de la Expectación conservada en el Museo de Santa Cruz de Toledo, pues consta que procedía de este convento ${ }^{500}$. Denominada también Virgen de la Esperanza, es una bella imagen de pie, situada en posición de tres cuartos, que mide casi 1.60 metros de altura $^{501}$. Porta el libro en la mano derecha y la izquierda reposa delicadamente sobre su vientre abultado, que junto a la pierna izquierda, son los dos elementos de su anatomía que se adivinan bajo los pliegues de su túnica azul, estofada con ricos brocados. Podemos vincular estilísticamente esta imagen con algunas de las esculturas del retablo de la capilla de San Ildefonso en la Catedral de Palencia. George Weise la atribuye a Juan de Valmaseda y establece para la misma una datación aproximada de hacia 1530, en los mismos años en que el ensamblador palentino estaba a cargo del retablo catedralicio $^{502}$. Dicha afiliación viene justificada por la caída vertical de los pliegues del manto y quebrada en la parte inferior que solía emplear dicho escultor. Gómez Moreno y Portela Sandoval coinciden en que la imagen atiende al estilo de Diego de Siloé estableciéndose una relación con las santas del retablo de Santa Ana en la capilla del Condestable de la Catedral de Burgos, ejecutado en $1522^{503}$. Nosotros nos inclinamos por la atribución a Valmaseda, muy cercano en las facciones alargadas a lo que el artista

\footnotetext{
${ }^{498}$ Diversos informes sobre la iglesia. Religiosos. San Francisco (1616-1774), fol 37.

${ }^{499}$ RAMÍREZ DE HELGUERA, Martín. El libro...Op.cit, pág. 179.

${ }^{500}$ VV.AA. Carolus. Museo de Santa Cruz de Toledo, del 6 de octubre de 2000 a 12 de enero de 2001. Sociedad Estatal para la Conmemoración de los Centenarios de Felipe II y Carlos V. Madrid, 2000, pág. 469 , ficha $\mathrm{n}^{\mathrm{o}} 262$.

${ }^{501}$ REVUELTA TUBINO, Matilde. Museo de Santa Cruz de Toledo. Sección de Bellas Artes.1. Siglos $X I V-X V-X V I$. Consejería de Educación y Cultura de la Junta de Comunidades de Castilla-La Mancha, 1987, pág. 170.

502 AZCÂRATE RISTORI, José María de. Op.cit, pág. 82.

${ }^{503}$ GÓMEZ MORENO, Manuel. Diego Siloé: homenaje en el IV centenario de su muerte. Universidad de Granada, 1963, pág. 20 y PORTELA SANDOVAL, Francisco José. La escultura...Op.cit, pp. 122 y 157.
} 
realiza en el retablo palentino Villamediana ${ }^{504}$ o en la Anunciación de Tordehumos, en Valladolid. De todos modos Valmaseda, en sus tipos femeninos se inspiraba en Siloé y su estela puede seguirse a lo largo del camino jacobeo.

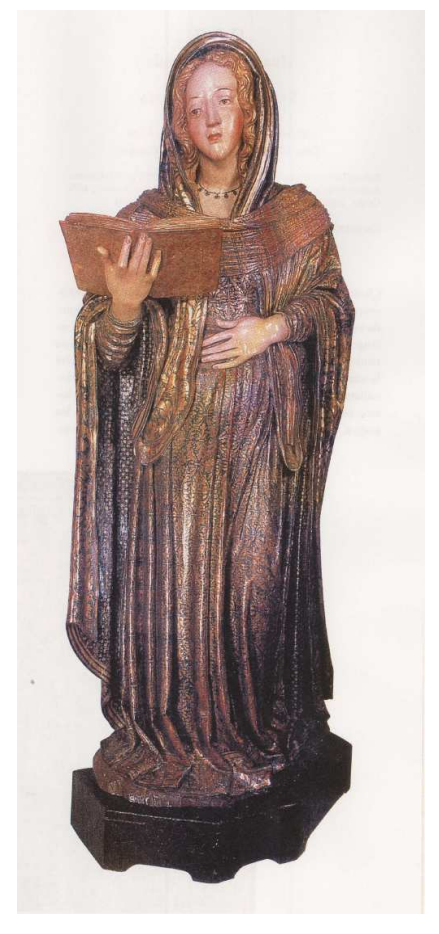

\author{
Virgen de la Expectación procedente \\ del museo de San Francisco, hoy en el \\ Museo de Santa Cruz de Toledo.
}

Cercana a Juan de Valmaseda. Hacia

1522. $(159 \mathrm{~cm} \times 70 \mathrm{~cm} \times 46 \mathrm{~cm})$.

\title{
7.14. CAPILLA DE SAN BUENAVENTURA
}

Contiguo al altar de Nuestra Señora se localizaba esta capilla, dotada de un retablo de madera con la imagen del santo titular en su centro ${ }^{505}$. Era posesión del linaje Barrio, fundándola hacia 1632 doña Manuela Ibáñez Gómez de Barrio, mujer del regidor José de Medina de los Ríos Campoo ${ }^{506}$. Posteriormente, en 1661, año en que don Francisco de Barrio de la Vega dicta testamento, ordena ser sepultado en esta capilla, de la cual era patrono por entonces ${ }^{507}$. El linaje Barrio está directamente

\footnotetext{
${ }^{504}$ LUNA MORENO, Luis. Escultura del siglo XVI en Castilla y León. Ministerio de Cultura, Dirección General de Bellas Artes y Archivos, Madrid, 1987, pág. 42.

${ }_{505}^{505}$ RAMIREZ DE HELGUERA, Martín. El libro...Op.cit, pág. 179.

${ }^{506}$ Así figura en la cesión que de dicha capellanía se hace el 11 de noviembre de 1755 en la persona de don Juan Antonio Olea Castellanos, regidor perpetuo de Carrión AHPP. Carr.Prot 5146. Martín Izquierdo (1755), fol 326 y ss.

${ }^{507}$ AHPP. Carr.Prot 5695. Norberto Sandoval y Guevara (1661), fol 555 y ss.
} 
relacionado con el patronazgo de una capilla en la iglesia San Juan del Mercado, para la cual contrató el retablo de San Juan Bautista ${ }^{508}$.

A mediados del siglo XVIII, concretamente en 1755, el patronato pasa a Juan Antonio Olea Castellanos, regidor perpetuo de Carrión ${ }^{509}$. En 1764 nombra como sucesor del mismo a su hijo Ventura ${ }^{510}$. Este linaje debió ser muy poderoso pues uno de sus miembros, don Francisco Barrio de la Vega, también llegó a poseer una capellanía en el convento de San Zoilo ${ }^{511}$.

\subsection{CAPILLA DE LA RESURRECCIÓN}

Ubicada en el lado del Evangelio junto a la capilla de la Concepción, fue Mosén Rodrigo de Vozmediano, señor de Calzadilla y Bustocirio, quien accedió a su patronazgo por traspaso a su persona el 8 de agosto de 1456, de lo que colegimos una existencia anterior $^{512}$. Don Rodrigo fue un noble bien posicionado, prestando servicios nada menos que a don Álvaro de Luna, maestre de Santiago. Gracias a ello fue premiado con grandes sumas, algunas de las cuales fueron destinadas al convento franciscano, previa aprobación de los Reyes Católicos en 1485, con el fin de perpetuar allí su memoria ${ }^{513}$. Al casarse con doña Constanza Barba, los Vozmediano entroncaron con este nuevo linaje que estará presente en los patronazgos posteriores. Su hijo, don Juan Barba de Vozmediano, primogénito de don Rodrigo, será quien herede la posesión de la capilla, además de los títulos de señor de Calzadilla, Bustocirio, términos éstos situados en Palencia. A su vez, su hijo homónimo toma el relevo de la misma, otorgándose su posesión el 20 de junio de $1576^{514}$.En 1624, siendo patrón don Juan de Vozmediano, la capilla de la Resurrección y la de Santa Catalina, donde igualmente

\footnotetext{
${ }^{508}$ A este respecto ver el apartado relativo a la iglesia de San Juan Bautista o del Mercado

509 AHPP. Carr.Prot 5146. Martín Izquierdo (1755), fol 326 y ss.

${ }^{510}$ Escritura de posesión de la capellanía de San Buenaventura. AHPP. Carr.Prot 5151, Martín Izquierdo (1762-1765), s/f.

${ }^{511}$ Redención de un censo el 18 de noviembre de 1829. AHPP. Carr.Prot 5448. Mariano Navas (18291832), fol 129.

512 Así se indica en el inventario de los bienes de Don Juan Barba de Vozmediano, entre cuyos papeles figura la escritura de traspaso de esta capilla a dicho fundador. AHPP. Carr.Prot 5713, Norberto Sandoval y Guevara (1668), fol 1137 y ss.

${ }_{513}$ PERAL VILLAFRUELA, Santiago. San Francisco...Op.cit, pág. 280.

${ }^{514}$ Así se indica en el inventario de los bienes de Don Juan Barba de Vozmediano, entre cuyos papeles figura la dotación de esta capilla AHPP. Carr.Prot 5713. Norberto Sandoval y Guevara (1668), fol 1137 y ss.
} 
tenía el patronazgo, se encontraban en mal estado y no habían sido reparadas a pesar de la demanda que el convento puso al anterior patrón y padre de éste, don Pedro de Vozmediano $^{515}$.

Gracias a una reedificación de carácter urgente que tiene lugar en 1647, sabemos la ubicación exacta de esta capilla “... a la entrada del dicho conuento a mano d'izquierda, de la advocación, la una de Santa Catalina, la primera, y la segunda, de la Resurrección...". Sabemos que se hallaban una contigua a la otra porque en las condiciones, uno de los maestros al cargo de las obras, indica que va a demoler la tapia que divide ambas para rehacerla de nuevo ${ }^{516}$.Hoy día, el acceso está tapiado por un muro, siendo probable que el espacio ocupado por la capilla continuara hacia el norte, ubicándose en la zona del altar de la Residencia de Nuestra Señora del Camino, como sucede con la capilla de la Concepción o Santa Catalina.

\subsection{CAPILLA DE LA COFRADÍA DE LA CONCEPCIÓN O DE SANTA CATALINA}

Esta capilla está situada a los pies de la iglesia, inmediata a la puerta de acceso occidental, la primera a mano izquierda, junto a la pila del agua bendita ${ }^{517}$.

De su origen, a mediados del siglo XV, se conservan dos arcos apuntados de que ya estudiamos con anterioridad. Uno de ellos se sitúa a la entrada de la capilla, el otro permanece tapiado, pues cuando entre 1892 y 1894 se edificó el asilo contiguo al convento, probablemente se ocultó este espacio para poder aprovecharlo en la nueva edificación ${ }^{518}$. Esta es la razón obvia por la que Ramírez de Helguera, en su descripción de los retablos realizada un año después, no mencionara esta capilla.

\footnotetext{
${ }^{515}$ Informe de 1624 sobre el estado del convento. ADP. Religiosos. Franciscanos (1616-1774), fol 34.

${ }^{516}$ Escritura y condiciones de la obra en AHPP. Desamortización, Legajo 105, s/f

${ }^{517}$ Escritura de concierto y condiciones firmadas a 15 de octubre de 1639 en AHPP. Carr.Prot 5422.

Francisco Moro de Saldaña (1639), s/f.

${ }^{518}$ Sobre el asilo, véase el apartado relativo a los hospitales.
} 
Antiguamente la capilla estaría dedicada a otra advocación que desconocemos, dado que no es hasta 1524 cuando el Emperador Carlos V emite una provisión para fundar en todas las villas y lugares de sus reinos y señoríos la Cofradía de la Concepción ${ }^{519}$.

El nuevo nombre de la capilla vendría acompañado de nuevo patronazgo, el linaje de los Ortega, de ahí la presencia de sus blasones en dos puntos de la capilla. El escudo más destacado se ubicaba al menos hasta 1762 en que se realiza un informe del estado del templo, en medio de la capilla. Se trataba de una “...losa grande leuantada del suelo..." en la que estaban grabadas las armas de los fundadores ${ }^{520}$. Hoy día se sitúa en la plaza Conde de Garay y nos da la clave sobre la familia que adquirió este espacio en las primeras décadas del siglo XVI. Su escudo presenta las armas de los Ortega, esto es: 1, una rueda de carreta cantonada de cuatro flores de lis. 2, un árbol arrancado en la sinistra y un león coronado rampante al tronco a la diestra. El epitafio dice así: "ESTA CAP [ILLA Y COF] FRADIA DE LA CONCEPCION DOTO Y HEDIFICO EL DOTOR NAVARETE Y SV MVG[ ER CAT] ALINA [O] RTEGA QVE [DA] POR SV PATRON JVAN DE ORTEGA Y LOS QVE DEL DESCENDIEREN”.

Igualmente sobre la puerta que precede esta capilla se dispone un arco apuntado que se puede adscribir a los siglos XIV o XV que nos informa sobre la posible antigüedad de la capilla, como así lo hace el acceso tapiado contiguo a la Residencia de Santa María del Camino a la que nos referimos con anterioridad ${ }^{521}$. Sobre este portalón campea un escudo que confirma el patronazgo del linaje mencionado, cuya lectura es la siguiente: 1 y 3 de Ortega: 1, una rueda de carreta cantonada de cuatro flores de lis 3 , un árbol arrancado y un león coronado rampante al tronco a la diestra. 2 y 4 de Colmenares, 2, partido, a la siniestra nueve ruedas de carreta, a la diestra, tres fajas. 4, cinco flores de lis. La familia Ortega poseía el señorío de Gozón y un cargo de regidor perpetuo en Carrión ${ }^{522}$.

El acceso a la capilla se realizaba por un enrejado de madera, que existió al menos hasta mediados del siglo XVIII y tenía un retablo con escultura en el nicho

\footnotetext{
${ }^{519}$ Informaciones diversas sobre fundaciones y misas. ADP. Religiosos. Franciscanos (1616-1774), s/f.

${ }^{520}$ Informe de 1762 sobre las misas de la capilla. ADP. Religiosos. Franciscanos (1616-1774), s/f.

${ }^{521}$ Véase el apartado relativo a la fundación y primeros siglos del templo.

522 Sus armas aparecen también en una casa cercana a la iglesia de San Andrés, concretamente en la bordura de los escudos de Calderón de Ayala.
} 
central de la Inmaculada ${ }^{523}$. Probablemente esta imagen se corresponda con la pieza de hacia 1590 conservada en el Museo de Santa Clara de esta villa, dado que figuraba entre los bienes del convento en $1907^{524}$.
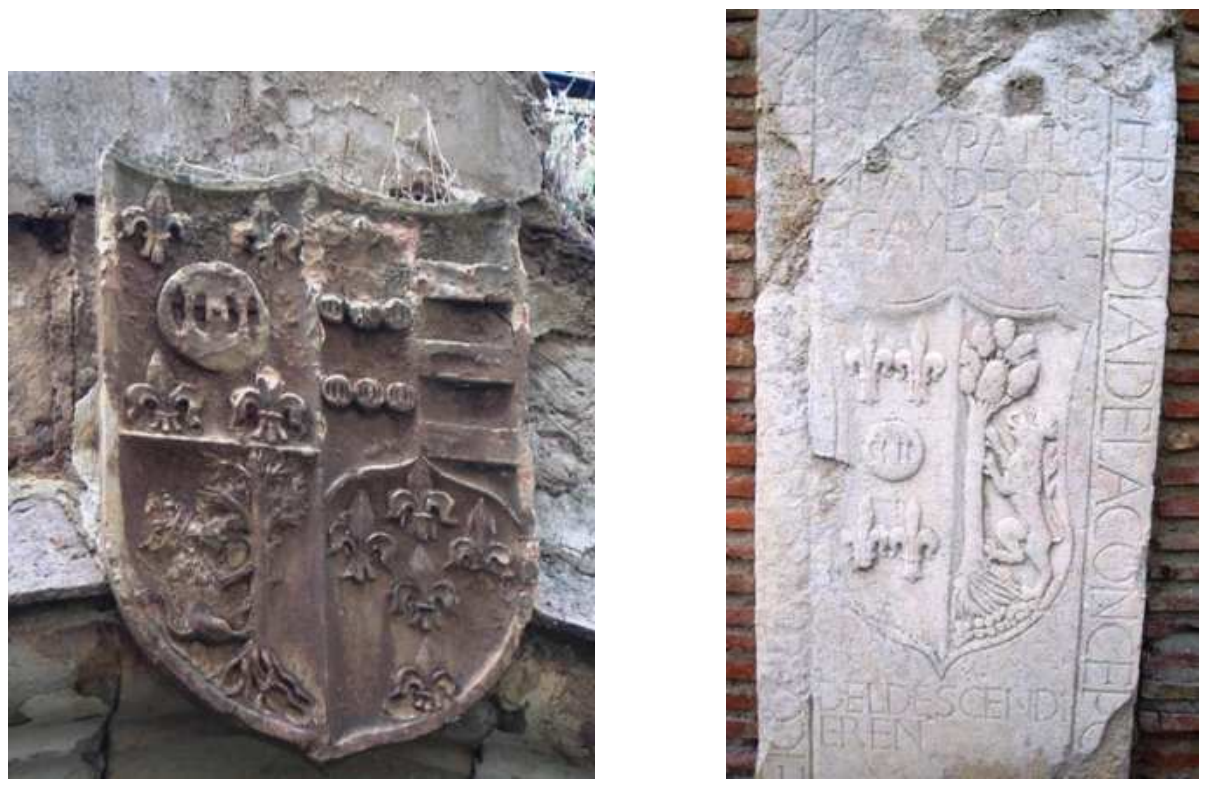

\section{Armas de los Ortega en el acceso a la capilla homónima del convento franciscano}

\section{(izquierda) y en la lauda conservada conservada en la plaza conde de Garay.}

La refundadora por tanto de este espacio ya existente, fue doña Catalina de Ortega. Gracias al hallazgo de su testamento, dictado en 1561, sabemos la fecha en la que sus armas y las de su marido fueron colocadas en la capilla ${ }^{525}$. Dispone ser enterrada en dicha capilla de la Concepción, nombrando como patrón a su hermano Juan Rodríguez de Castañeda, comendador del Hospital de la Herrada. Don Juan, que dicta testamento el mismo año que su hermana encarga que se haga en esta capilla un retablo de pintura con las historias de San Juan Bautista y Evangelista, la Natividad, la Asunción y se ejecute en bulto redondo, la imagen de Santa Catalina, bajo cuya advocación también se sitúa este espacio conventual ${ }^{526}$ Doña Catalina también nombra

\footnotetext{
${ }^{523}$ Informe de 1762 sobre las misas de la capilla. ADP. Religiosos. Franciscanos (1616-1774), s/f.

${ }^{524}$ MARTÍN MÍNGUEZ, Bernardino. Catálogo...Op.cit, volumen 3, pág. 53. Ya comentamos esta imagen entre las piezas relevantes del museo de Santa Clara.

525 AHPP., Carr.Prot 5662. Andrés Sánchez (1560-1562), s/f. El traslado de dicho testamento figura además entre los papeles insertos en el inventario de los bienes de Don Juan Barba de Vozmediano AHPP. Carr.Prot 5713. Norberto Sandoval y Guevara (1668), fol 1137 y ss.

${ }^{526}$ MARTÍN MÍNGUEZ, Bernardino. Catálogo... volumen 3. Op.cit, pág. 54.
} 
patronos al hijo del matrimonio formado por Isabel de Reinoso, y su sobrino Juan de Ortega, homónimo de éste último ${ }^{527}$.

La línea familiar continuará en esta capilla durante la centuria posterior pues doña María Ortega Barahona y Velasco, señora de Gozón, Mañueco y Villojón, había firmado en 1612 las capitulaciones matrimoniales con Don Pedro Barba de Vozmediano, disponiendo sepultarse en esta capilla ${ }^{528}$. Con ella se extinguen los Ortega, adquiriendo los Vozmediano el patronazgo de esta capilla y el del hospital de la Herrada, que habían poseído hasta entonces los ascendientes de doña Catalina ${ }^{529}$. Los Vozmediano, además, poseían por fundación, el patronazgo de la capilla aledaña de la Resurrección ${ }^{530}$. Fruto de este matrimonio fue don Juan Barba de Vozmediano en 15 de julio de 1678 dicta su última voluntad: ser enterrado en esta capilla, donde, por cierto, recientemente había efectuado algunas mejoras de escasa entidad ${ }^{531}$. Siendo soltero, había tenido dos hijos con Josefa Herrero, Juan y Bernarda. Don Juan se había encargado de criarles e inmediatamente después envió al varón a San Llorente del Páramo para que aprendiera a leer y escribir e internó a su hija en el convento de Santa María de Vega. Se casó entonces con doña Manuela de Berrio y Ribera, entroncando así con el linaje fundador de la iglesia de San Julián de la misma villa.

De este matrimonio descienden Mateo Miguel, María y el sucesor legítimo en el patronazgo, don Juan Antonio de Vozmediano, que dictará testamento el 19 de septiembre de $1715^{532}$. Sucede en el mayorazgo su sobrino, Joaquín Teijeiro Vozmediano, vecino de Villafranca del Bierzo y Valladolid, señor de Villasante, Toiriz, Sesmonde, Membribe, Calzadilla de los Hermanillo y Bustocirio. Don Joaquín, se había

\footnotetext{
${ }^{527}$ El vínculo existente entre el linaje Ortega y el de los Colmenares se establece a través del nombramiento como heredero a su sobrino Nicolás de Campoo, hijo éste de doña Isabel Ruiz de Colmenares. Véase un resumen de la genealogía de los Ortega. Explica Viguri que no ha incluido a Catalina de Ortega porque no existe confirmación de que fuese sobrina de Juan de Ortega y Violante de Castañeda, aunque afirma que es casi seguro. VIGURI, Miguel de. Heráldica, volumen 2, Op.cit, pág. 73. ${ }^{528}$ Don Pedro Barba Vozmediano dicta testamento en 10 de junio de 1650 AHPP. Carr.Prot 5193, Jerónimo Laso (1649-50), fol 254 y ss. María Ortega, hija de doña Francisca Ortega y Juan de Ortega, dicta testamento en 8 de julio de 1661 AHPP. Carr.Prot 5200. Jerónimo Laso (1661-1662) fol 79 y ss. Fruto de este matrimonio son Juan, sucesor en el mayorazgo, Clara, Ana y Francisco de Vozmediano.

${ }^{529}$ AHPP. Carr.Prot 5018, Agustín García Miranda (1696-2698), s/f.

${ }^{530}$ Informe de 1624 sobre el estado del convento en ADP. Religiosos. Franciscanos (1616-1774), fol 34.

${ }^{531}$ Así lo indica que debe cien ladrillos que le prestó Don Juan Ibáñez Calderón, cura de San Juan de Mercado, por el reparo de la capilla. AHPP. Carr.Prot 5713, Norberto Sandoval y Guevara (1668) fol 1137 y ss.

${ }^{532}$ El testamento de Don Juan Antonio de Vozmediano en Carr.Prot 5643. Francisco Ruiz Sandoval (1715-1718), fol 351 y ss.
} 
casado con Josefa Enríquez de Quiñones, señora de Cabarcos y Cañedo. Fruto de este matrimonio fue Pedro Teijeiro, primer marqués de Villasante, y heredero del patronato de la iglesia de San Julián, en cuya persona recayeron además, gran número de mayorazgos ${ }^{533}$. Don Joaquín será el último de los patronos conocidos, fallecido en torno a $1762^{534}$.

\subsection{CAPILLA DE LA DOLOROSA}

Es la última de las capillas respecto a la cabecera como así indica Helguera en su descripción que comenzó en la cabecera: “...y por fin el altar de la Dolorosa, también de madera sin pintar, de igual procedencia que el anterior -es decir, se trasladó desde una de las capillas del presbiterio-, con su escudo de armas, de orden corintio. Dicha imagen está en el centro vestida con ropa sin mérito 535 ".

De los ornamentos de esta capilla nada se sabe, pero sí quedan restos arquitectónicos que testimonian su existencia. En estado de completa ruina, conserva, sin embargo, la bóveda de terceletes sujetada por ménsulas en las esquinas, mientras que el arco de acceso, de medio punto moldurado, apoya sobre estilizados pilares que nos remiten a una posible erección en el siglo XV.

Es ésta la única cubierta del templo que conserva restos de policromía, visibles en las claves secundarias, donde podemos apreciar, ya sin su intensidad original, restos rojizos, verdes, negros y amarillentos. En estas claves se representan estrellas de David en cuyo centro se insertan flores.

El escudo de la clave central presenta la cruz de Oviedo con los brazos superiores flordelisados y peana sostenida por dos ángeles. Viguri considera que esta capilla perteneció al inquisidor Don Antonio del Corro Bustamante, basándose para ello

\footnotetext{
${ }^{533}$ Por vía paterna, el mayorazgo de Juan de Ortega, Francisco y Francisca de Vozmediano, Catalina Rodríguez de Cisneros, María de Villarroel, Velasco de Villasante, Catalina y Alonso de Villegas, Álvaro González de Rivadeneira, Rodrigo Lorenzo de Solís. Por parte materna, heredó el mayorazgo de Pedro Pardo de Cabarcos, Sancho Pardo y Juana Manrique de Estrada, Diego Pérez de Veldedo, Catalina Osorio y el licenciado Rengifo. Véase VIGURI, Miguel de. Heráldica...volumen 2. Op.cit, pág. 74.

${ }_{534}$ ADP. Religiosos. San Francisco (1616-1774), s/f.

${ }^{535}$ RAMIREZ DE HELGUERA. El libro...Op.cit, pág. 179.
} 
en el blasón de las mismas características que, situado hoy día en la fachada del Palacio de las Arenas de Santillana del Mar fue trasladado de su ubicación original, la casa que Don Antonio poseía en San Vicente de la Barquera ${ }^{536}$. Aunque falleció en Carrión en 1755 y dispuso su entierro en este convento en la sepultura de su primera mujer Francisca Noreña, no hay prueba documental del patronato de esta capilla, pues don Antonio no especifica ninguna concretamente, y esto es tal vez, indicación, de que el linaje Corro ya no poseía el aposento. Incluso, en 1823, otro miembro de la familia, de nombre José del Corro, dispone su enterramiento en el convento sin hacer referencia alguna a la capilla. Además, ni este escudo ni el del palacio de Santillana, llevan la leyenda que usaban frecuentemente los Corro: "Angelus Pelaio et suis victoriam”.
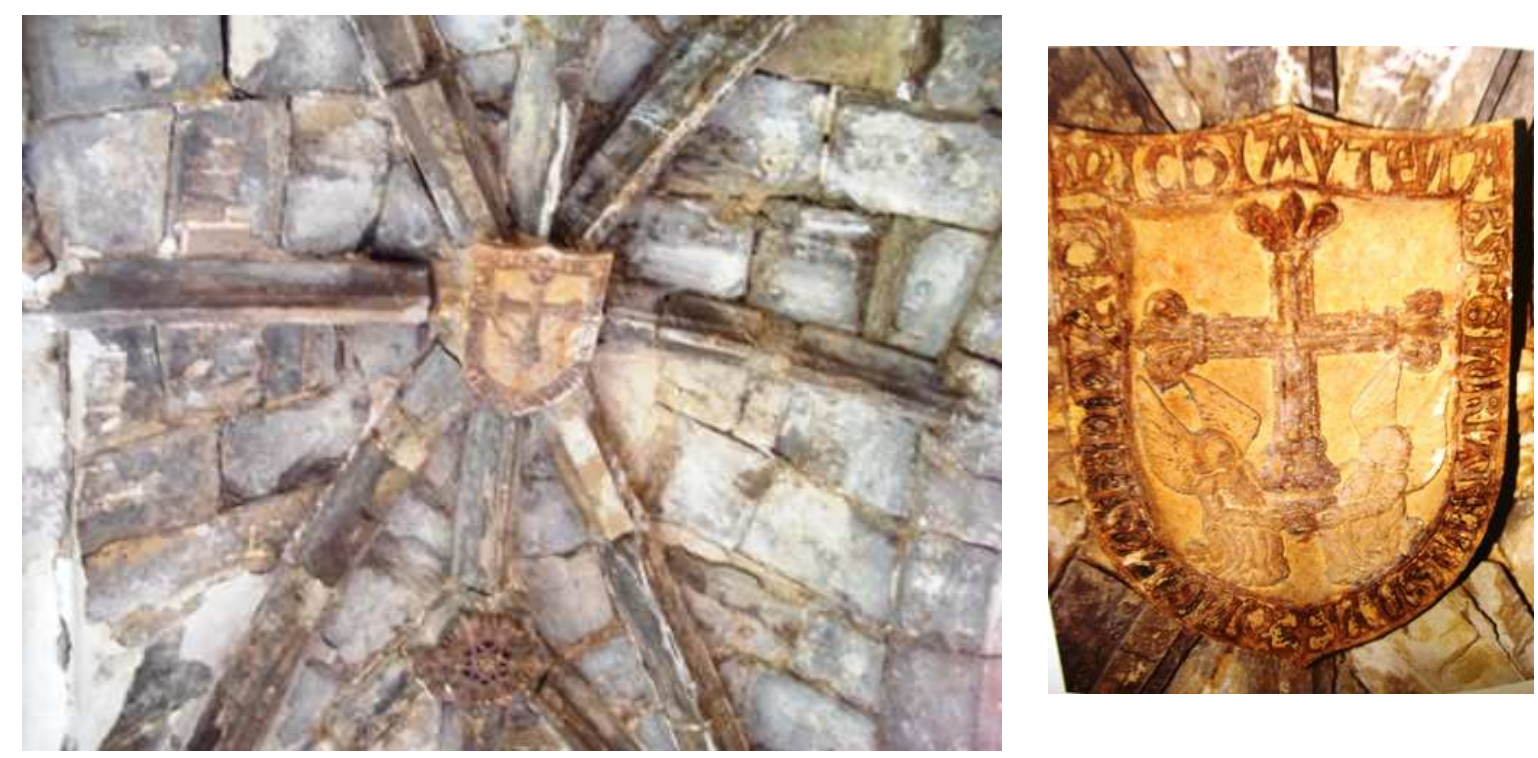

\section{Bóveda de crucería de la capilla de la Dolorosa y detalle del escudo de la clave.}

En este caso la bordura del escudo presenta el lema: MICHI AVTEN ABSIT GLORIARI NISI IN+DO [MI] NUS NOSTRO IHV XPTI ${ }^{537}$, que significa "A mí, sin embargo, nunca me acontezca gloriarme sino en la Cruz de Nuestro Señor Jesucristo”,

\footnotetext{
${ }^{536}$ VIGURI, Miguel de. Heráldica...volumen 2. Op.cit, pág. 70. También en Santillana, en el Museo y Archivo Diocesano del Convento de Regina Coeli de Santillana del Mar, existe un escudo en hueso o marfil sobre un bargueño con las armas de esta familia Véase GONZÁLEZ ECHEGARAY, M ${ }^{a}$. Santillana del Mar a través de su heráldica. Santillana del Mar, 1983, pág. 100.

${ }^{537}$ GONZÁLEZ ECHEGARAY, Ma Carmen.Santillana...Op.cit, 1983, pág. 99.
} 
leyenda que, como indica Villafruela, remite a San Pablo cuyos escritos tuvieron siempre gran vigencia entre los franciscanos ${ }^{538}$. A ello se suma además el hecho de que a finales del siglo XV, datación acorde a la de la capilla, ambos motivos eran usados cotidianamente por los terciarios en sus sellos.

\subsection{OTRAS CAPILLAS}

La capilla de San Andrés pertenecía a Pedro Martínez de Herrera en el s. XVIII $^{539}$. Desconocemos dónde se ubicaba pero su existencia es segura, pues figura en el inventario de la Desamortización, como también lo hacen las capillas de Nuestra Señora de las Candelas y de la Soledad ${ }^{540}$.

\footnotetext{
538 De hecho, en la Vida segunda de San Francisco, de Tomás Celano, se recoge esta misma frase. PERAL VILLAFRUELA, Santiago. San Francisco.... Op.cit, pp. 307-308.

${ }^{539}$ VIGURI, Miguel de. Op.cit, pág. 69.

540 PERAL VILLAFRUELA, Santiago. "San Francisco...Op.cit, pp. 310, a su vez de ADP, Administración 2, Inventario 8.
} 


\subsubsection{EL CONVENTO DE SAN MIGUEL Y SANTA ISABEL}

\section{EL ORIGEN: EL HOSPITAL DE SAN MIGUEL}

La orden terciaria franciscana contó desde sus inicios con gran aceptación dentro de la villa carrionesa. En este caso, y como sucedió en la inmensa mayoría de la Península Ibérica, la instalación de los frailes menores precedió al asentamiento de clarisas, las cuales se vincularon a aquellos estableciéndose en las proximidades ${ }^{541}$. Así la fundación del convento de San Francisco de Carrión oscila entre los años 1217 y $1236^{542}$, mientras que las damianitas se asentaron provisionalmente en la ermita de Santa María del Páramo hasta establecerse definitivamente en la ciudad condal fundando el convento de Santa Clara en $1256^{543}$. Ambos cenobios, institucionalizados por tanto antes de la primera mitad del siglo XIII, se ubican en la parte sureste de la villa, extramuros de la misma, a los pies del camino jacobeo que enlaza con Frómista.

Una tercera fundación franciscana fue el convento de San Miguel y Santa Isabel, cuyo origen y ubicación es bien diferente al de sus compañeros terciarios. Los escasos datos que se conocen del mismo provienen del cronista franciscano, el Padre Francisco Calderón ${ }^{544}$.

\footnotetext{
${ }^{541}$ RODRÍGUEZ NÚÑEZ, C.C; "El conventualismo femenino: las clarisas" en Espiritualidad y franciscanismo, VI Semana de Estudios Medievales: Nájera, 31 de julio a 4 de agosto de 1995. Logroño, 1996, pp.. 99-100. Algunos datos publicados sobre este convento en GARCÍA GARCÍA, Lorena. "El convento franciscano de San Miguel y Santa Isabel de Carrión de los Condes (Palencia)" en BSAA, nº75, Universidad de Valladolid. Valladolid, 2009, pp. 173-180.

${ }^{542} \mathrm{La}$ fecha de fundación es muy discutida. Acerca de este convento las fuentes bibliográficas más significativas son WADDING, L; Annales minorum. Lion, 1625; GONZÁLEZ DÁVILA, G; Teatro eclesiástico de las Iglesias metropolitanas y Catedrales de los Reynos de las dos Castillas: Vidas de sus Arzobispos, y Obispos, y cosas memorables de sus sedes t. segundo. Imprenta de Francisco Martínez, Pedro de Horma y Villanueva, Diego Díaz de la Carrera. Madrid, 1645-1700; MARTíNEZ GONZÁLEZ, R; "Aproximación al estudio de los conventos franciscanos en la provincia de Palencia" en Jornadas sobre el arte gótico en la provincia de Palencia. Palencia, 1989, pp..113-149; REVUELTA GONZÁLEZ, M; "Orígenes, ocaso y renovación de los conventos palentinos" en Publicaciones de la Institución Tello Téllez de Meneses, 63, Palencia, 1992, pp.50-83.

${ }^{543}$ En lo que concierne a Santa Clara, son fundamentales ANDRÉS GONZÁLEZ, P; Los monasterios de las clarisas en la provincia de Palencia, Palencia, 1997; OMAECHEVARRÍA, I; Santa Clara en Carrión de los Condes. t. 10, Zamora, 1986; ROYO ABRIL, A; Real Convento y Museo de Santa Clara de Carrión de los Condes (Palencia), Palencia, 1990; LÓPEZ, A; "Los monasterios de clarisas en España en el siglo XIII" en El eco franciscano, 29. Madrid, 1912, pp..185-190.

${ }^{544}$ APFV. caja 1, carpeta 1, Leg. 1, III. CALDERÓN, F; Primera parte de la Chrónica de la Santa Provincia de la Purísima Concepción de Nuestra Señora de la Regular Observancia. (1667-69), fol 322 y ss.
} 
Tanto la documentación como los escasos restos conservados, confirman la ubicación del hospital de San Miguel en la plaza de San Andrés, en su lado occidental, frente a las casas que denominan "las Mantillonas". Poseemos asimismo un testimonio gráfico muy valioso para el conocimiento del patrimonio existente en la villa a comienzos del siglo XIX. Se trata de una plumilla de hacia 1800 que realiza el grabador Guillermo Orejón en el que se retrata la "Vista de la antigua villa de Carrión de los Condes por la parte del mediodía, desde el sitio llamado de las Vargas". Actualmente este espacio se correspondería con la Avenida Rizo San Millán, entrando por la parte sur de la villa. En el dibujo constatamos la ubicación del convento de San Miguel y Santa Isabel a través de una sencilla espadaña que emerge tímidamente junto a la imponente torre de San Andrés ${ }^{545}$. En algunas fotografías antiguas realizadas desde el río, en la zona noroccidental de la ciudad, se aprecian las tapias del convento, linderas a la ribera.

No debe confundirse este hospital con el homónimo desaparecido de origen medieval, ubicado en la Plaza de Santiago, bajo el control del prior de San Salvador del Nogal $^{546}$. Nuestro hospital en cambio es una fundación del siglo XVI cuyo principal benefactor fue Don Gonzalo Gallo, camarero del conde de Benavente, don Alonso Pimentel, lo cual nos sitúa ante un carrionés de prestigio social considerable ${ }^{547}$. Afirmación que se constata con la autorización que obtuvo en 1510 de Julio II para edificar un hospital bajo la advocación del arcángel San Miguel ${ }^{548}$. Para ello donó en 1515 “libre y desembarazadamente" las casas en las que vivía a la Cofradía de los Veinte y cinco Clérigos, además de ornamentos, cálices y libros para "dar misas y enterrar muertos”. Será en julio de 1522 cuando el Regimiento carrionés acepte los capítulos presentes en la obra pía de don Gonzalo confirmando así mismo su patronazgo 549 .

\footnotetext{
${ }^{545}$ Se trata de un dibujo sobre papel verjurado con aguadas de tinta china y lápiz realizado por el grabador Guillermo Orejón (1777-i?), en una fecha incierta del siglo XIX. BN. Sala Goya, DIB 18/1/616.

${ }^{546}$ PERAL VILLAFRUELA, S y GÓMEZ PÉREZ, E; Los hospitales de Carrión y los Condes de Castañeda en la Edad Media, Palencia, 2003, p.18.

${ }^{547}$ ASCC. Santa Isabel. Legajo XIV. Documentos diversos. Cofradías de la iglesia de San Miguel (15291567), $\mathrm{n}^{\circ} 1$.

${ }^{548}$ La fecha que figura es el año séptimo del Pontificado de Julio VII, cuyo mandato comenzó en 1503, por tanto, sucedió en 1510. ASCC. Santa Isabel. Pergaminos (1475-1715), Legajo 1.

549 ASCC. Santa Isabel. Legajo XIV. Documentos diversos. Cofradías de la iglesia de San Miguel (15291567), nº1. 1529.
} 
Don Gonzalo había testado por vez primera el 26 de abril de 1507, y dispuso ser sepultado en San Francisco de Carrión, junto al Licenciado Castañeda o en caso de que falleciese fuera de la villa, en el monasterio franciscano más cercano a la misma. Para que se cumpliese su voluntad, realiza dotaciones generosas en concepto de misas, derechos de sepultura e incluso limosna para pobres ${ }^{550}$.

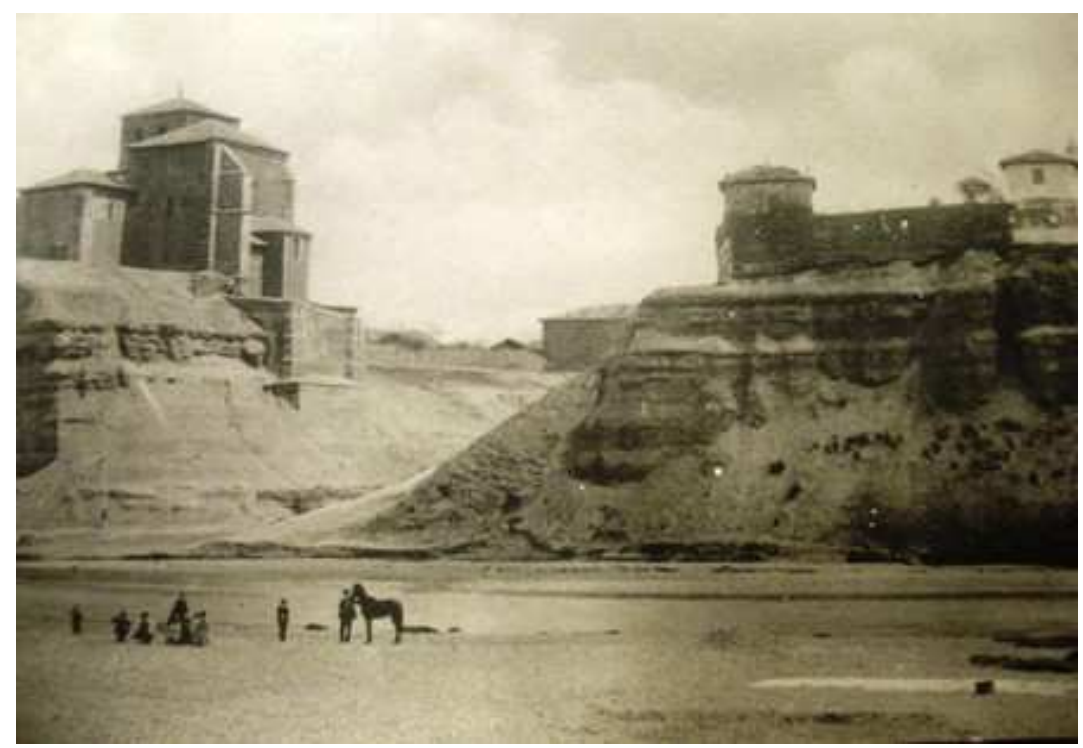

\section{Vista desde el río Carrión sin caudal, con la iglesia de Belén en la margen izquierda y las tapias del convento de Santa Isabel, a la derecha.} ACJAH. Carrión. Fotografías.

No será San Francisco el lugar en el que reposarán sus restos, pues en su testamento posterior, dictado en Cigales el 22 de marzo de 1532, invalida el anterior, ordenando ser enterrado en la capilla de su hospital con el hábito de San Francisco, bajo una losa donde figurase el siguiente epitafio: "A merçed delante de mi señor Dios, según la tu gran misericordia, en ti mesmo dormiré e descansaré en paz e creo ver los bienes y gloria de Dios en tierra de aquellos que viuen" ${ }^{551}$. De su testamento podemos extraer algunos caracteres de la personalidad del fundador. Don Gonzalo era un hombre

\footnotetext{
${ }^{550}$ PERAL VILLAFRUELA, Santiago. San Francisco...Op.cit, pág. 281, a su vez de ASCC, Santa Isabel, leg. $1, \mathrm{n}^{\circ} 1$.

${ }_{551}$ Traslado del testamento de Don Gonzalo Gallo dictado en 1532. ACP. Provisorato. Legajo 31. No3477. 1609. Otro traslado de este testamento en CISNEROS Y TAGLE, Juan. Historia de las grandezas...en AHN. Códices, Libro 336, fol 156 y ss.
} 
sencillo y humilde, por eso rechazó pompas y ceremonias tumultuosas, prefería que se le enterrase “...como mиy pecador e provemente...”. Ordenó que se diere alimento y se obsequiara con dos maravedíes a todos los pobres que asistiesen a su entierro, gesto que ilustra su generosidad con los más necesitados. Además dispuso que se destinasen cuatro mil maravedíes para vestir a los pobres que considerase oportuno su heredero. Concedió asimismo medio real a los diáconos que recitasen los responsos correspondientes a los cincuentas días posteriores al entierro.

Para asegurar no sólo la salvación de su alma sino la de sus familiares, el finado dispuso otras cien misas en el convento de San Francisco, rezadas frente a la sepultura de su difunto padre y quinientos maravedíes anuales para las misas de sus abuelos en la capilla de San Juan de la iglesia de San Andrés, que poseyó posteriormente su madre. Sus donaciones se extendieron a los conventos de la Trinidad y San Antón en Palencia, Santa Olalla de Barcelona y el Hospital de Nuestra Señora de Benavente, a cada uno de los cuales dispensó seis reales. Todas estas dádivas, además del mantenimiento de varios criados, nos sitúan ante un personaje que gozaba de una holgada situación económica, debida en gran parte a "las mercedes" concedidas por don Alonso Pimentel, con las que afirma haber dotado el hospital. Don Gonzalo nunca se esposó y al fallecer sin descendencia, deja como patrón de la capilla de San Juan a su sobrino, Alejo de Colmenares, y a Juan, el hijo de éste. Además le cede dos pares de casas que poseía en el barrio de la Morería.

En este testamento refiere los tres contratos que firmó y cumplió con la Cofradía de los veinticinco clérigos. El primero de ellos data de 1515, por el cual, como indicamos, donaba sus casas para el hospital, donde disponía se sirviese con ocho camas, seis para hombres y dos para mujeres, capilla para confesar y camposanto. Además concedía perpetuamente mil doscientos maravedíes de censo. En otra escritura, firmada en 1522, otorgó algunos juros y encargó una misa diaria por su ánima. La última fue redactada en 1529 y por la misma aumentaba la cifra de censo en seis mil maravedíes: dos mil para asistir a los enfermos con comida, medicamentos y ropa, dos mil para los pobres y dos mil para las misas y las reparaciones que se consideren necesarias. Lo más relevante es la nueva fundación que realiza, por la cual deja renta para que cinco beatas de la Orden Tercera de San Francisco cuiden a los pobres y enfermos. Antepone la función asistencial a la espiritual, pues precisa que el objetivo de 
su donación no estriba en “...rreçcar muchos salmos ni pater nostes...”. Fue así como dio comienzo la andadura del centro con la doble función hospitalaria y conventual. Es precisamente su origen nosocomial el que justifica la ubicación de este convento integrado dentro del casco urbano. Se situaba en la plaza de San Andrés, en su parte derecha si tomamos como referencia la torre de la iglesia homónima, extendiéndose sus posesiones por los terrenos en dirección al río Carrión.

Debió fallecer en 1533, un año después de haber dictado testamento, pues su sobrino Alejo de Colmenares figura a partir de esta fecha como heredero de sus posesiones $^{552}$. Dejó como heredera universal a su prima María de Abanades, por lo que no es de extrañar que ésta dispusiera ser sepultada en la capilla del hospital ${ }^{553}$. Don Gonzalo lo había previsto todo para que el centro funcionase correctamente. Designó tanto a su sobrino Alejo como a dos de los regidores de la villa como patronos, reservando la gestión del mismo a los miembros de la cofradía de los 25 clérigos $^{554}$. Por último, las atenciones religiosas y asistenciales recaerían en las monjas a las que deja cincuenta mil maravedíes de juro para dotar todos los años una doncella huérfana, pagar a la Cofradía de los clérigos, aparte de correr con los gastos relativos a la indumentaria, alimentación y donativos extraordinarios ocasionados por el convento.

Al principio las religiosas tuvieron que adaptarse al espacio general habilitado por el fundador a la espera de una nueva edificación dotada de celdas e iglesia para sus usos comunes. A mediados del siglo XVI, los hospitales experimentan un proceso municipalizador por el cual el concejo se hace con el control de los mismos. En el año 1579, todos los Hospitales existentes en Carrión se fusionan en el Hospital de Santa María, excepto el de San Miguel y Santa Isabel que continúa su andadura como hasta entonces $^{555}$. En 1583, casi finalizando su pontificado, Gregorio XIII concede a todos los cofrades de San Miguel indulgencia plenaria y remisión de sus pecados ${ }^{556}$.

\footnotetext{
${ }^{552}$ ASCC. Santa Isabel. Legajo III. Escrituras III. No 4.

${ }^{553}$ Dictó testamento en 1524 y volvió a testar varios años después. ASCC. Santa Isabel. Legajo XIV. Testamentos, $\mathrm{n}^{\circ} 2$.

${ }^{554}$ Desde el siglo XVII denominada "de los 20 clérigos".

555 Para los hospitales de Carrión, además del volumen previamente citado, consúltese PALACIO SÁNCHEZ IZQUIERDO, M. L; "Hospitales de peregrinos en Carrión de los Condes" en El Camino de Santiago, la hospitalidad monástica y las peregrinaciones, Salamanca, 1992, pp.. 127-133.

${ }^{556}$ ASCC. Santa Isabel. Pergaminos (1475-1715), Legajo 3.
} 


\section{EL SIGLO XVII}

\subsection{DECRETO DE CLAUSURA}

Por decreto apostólico de 1580 se ordenaba a las monjas guardar clausura; no obstante, las isabeles opusieron resistencia justificándola en la ocupación requerida por el hospital. Sí es cierto que a partir de entonces "vivieron con más encerramiento, acudiendo solo al hospital y a misa al conuento de Nuestro Seráfico Padre San Francisco, iendo y boluiendo vía recta, que antes no guardaban”.

El siglo XVII se inaugura con la ejecución de obras de diversa índole en el convento. En primer lugar, se procede a la construcción de varias celdas y un corredor de comunicación entre todas ellas por parte de los carpinteros carrioneses Alonso Cidrón y Francisco de Rojas entre 1601 y $1602^{557}$. Dos años después los trasmeranos Hernando Cidrón y Pedro Ruiz de Solano ${ }^{558}$, igualmente dedicados a la carpintería, son contratados por las beatas para la ejecución de unos cuartos linderos a las tapias del convento, obra por la que recibirían veintinueve ducados ${ }^{559}$. No será ésta la única intervención conjunta de estos dos carpinteros, pues en 1618 ejecutan los reparos correspondientes a la capilla mayor y torre de la iglesia así como del granero del monasterio palentino de Santa María de Arconada ${ }^{560}$. Estos maestros procedentes del valle de Hoz, en Tasmiera, debían ejecutar dos gradas, una mayor y otra menor provistas de rejas con celosías y una ventana para dar luz a la portería y al torno. El contrato incluía la construcción de una casa de horno con las paredes de postes y adobes y provista de chimenea. Esta dependencia, que se ubicaría junto a la letrina, debía dotarse una puerta al exterior y una ventana hacia la huerta.

\footnotetext{
${ }^{557}$ El contrato de “...varias celdas y un corredor con sus celosías, puertas, ventanas y demás obra de carpintería, albañilería y tapería...” se firma el 15 de marzo de 1601, AHPP. Carr.Prot 5675 Andrés Sánchez (1599-1602), s/f. La carta de pago se otorga en 5 de mayo de 1602 en AHPP. Carr.Prot 4705. Pedro Carrión (1602), fol 262 y ss.

${ }^{558}$ La presencia de canteros, maestros oficiales y carpinteros procedentes de la Junta del Voto, Trasmiera, constatada en gran parte de las obras tanto de carácter eclesiástico como civil, ejecutadas en la villa de Carrión de los Condes, se confirma una vez más en este caso. Al respecto SOJO Y LOMBA, F; Los maestros...Op.cit, ZALAMA, Miguel Ángel. La arquitectura...Op.cit; VV.AA; Artistas cántabros...Op.cit; ALONSO RUIZ, Begoña. El arte...Op.cit, entre otros.

${ }^{559} \mathrm{El}$ contrato y las condiciones son firmadas el 21 de junio de 1604.AHPP. Carr.Prot 5387. Francisco Moro Saldaña (1604), s/f.

${ }^{560}$ AHPP. Carr.Prots 5401, Jerónimo López (1618), s/f.
} 
Entretanto, se mantenía la doble función espiritual y asistencial, hasta que el doce de febrero de 1604, don Pedro de Espinosa y don Pedro López de Mendoza, como regidores de la villa de Carrión, solicitan al nuncio la licencia para que las monjas “...se

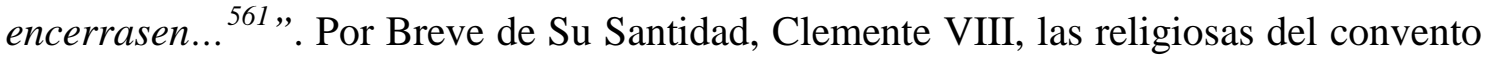
fueron obligadas a guardar clausura corriendo la misma suerte que los centros de su $\operatorname{orden}^{562}$. La cofradía de los Veinte Clérigos, patronos de la obra pía, firmaron una serie de capitulaciones por las que establecían la instalación de una reja en la enfermería que favoreciera la intimidad de las religiosas; se reservaban la elección de las internas en lo sucesivo con el pago obligado de la dote correspondiente a diez mil maravedíes, con independencia de si en adelante aumentaban en número. Además, los miembros de la cofradía dejaban el señorío de la iglesia, siendo las monjas quienes debían encargarse de mantenerla en buenas condiciones. En caso de que se edificase otro templo o capilla nueva, tal y como ocurrió poco después, las monjas debían encargarse del traslado de los huesos de Gonzalo Gallo, reservando un espacio privilegiado con el fin de erigir un monumento en bulto redondo con sus armas en el que se hiciera constar la fundación del hospital. Exclusivamente él y sus descendientes podrían ser sepultados en la nueva iglesia a excepción de alguna personalidad a quien ocasionalmente $\mathrm{Su}$ Santidad concediera tal derecho.

En marzo de 1605, Fray Nuño Daza, Obispo de Palencia, favorece y aprueba cada una de las capitulaciones relativas a la clausura; si bien puntualiza algunas cuestiones, como la de señalar el coro bajo como el lugar más apropiado para disponer la lápida del fundador y, sobre la reja, una piedra en la que se graben sus armas, incluyendo un epitafio ${ }^{563}$. Ese mismo año, las beatas de San Miguel se conciertan con Gabriel Mantilla, alférez mayor de Carrión, en la adquisición de unos terrenos aledaños de su propiedad “...para poderse ençerrar...con mayor comodidad y seruicio...” ${ }^{564}$. La vivienda de don Gabriel se hallaba en la plaza de San Andrés, frente al convento. Su hacienda comprendía parte del prado denominado de "Peña", un lugar de recreo para los vecinos “...por berse y goçarse desde él más de diez y seis leguas de Rriuera...”. Una

\footnotetext{
${ }^{561} \mathrm{La}$ escritura de capitulación y concierto de la clausura entre el regimiento de Carrión y las beatas del convento en RAH. Colección Salazar, H-14.

${ }^{562}$ Escritura de 1734 que relata los pasos dados por las religiosas desde la creación del convento. ASCC. Santa Isabel. Legajo XI. Papeles sobre pleitos (1728-1833).

${ }^{563}$ ASCC. Santa Isabel. Legajo XIV. Documentos diversos. Capitulaciones firmadas en 1605. nº 3, fol 26 y ss.

${ }^{564}$ AHPP. Carr.Prot 4708, Pedro Carrión (1605), s/f.
} 
porción de este campo era utilizado por las monjas como cementerio de aquellos enfermos que fallecían en el hospital. Dado que necesitaban ampliarlo, ansiaban encarecidamente la propiedad lindera. Adquirieron las casas de la Cofradía de las Ánimas para extenderse hacia el río y obtuvieron el beneplácito de don Gabriel a cambio de una suma de cuatrocientos reales que incluía la erección de una tapia que sirviese de límites entre ambos fincas.

Hallamos un comportamiento muy generoso en don Gabriel, no sólo en este caso sino en la cesión de todas sus propiedades de Carrión que hizo a las monjas cuando falleció. En el testamento de 1611 disponía ser sepultado en el convento de Santo Domingo de Carrión ${ }^{565}$. Sin embargo, después lo revocó, como así se deduce de un pleito que dio comienzo en 1689 entre el convento de San Miguel y la nieta de don Gabriel, María Mantilla por el mayorazgo que había fundado su abuelo en $1603^{566}$. Entre los papeles hallamos las cláusulas del testamento y en él don Gabriel solicita su sepultura en la capilla mayor con cuatro escudos que contuviesen sus armas, otorgando a cambio sus propiedades en Carrión a las monjas de San Miguel "por el afecto que les profesa”. La cesión de las mismas no implicaba en ningún caso la pertenencia a las monjas del resto de posesiones del finado carrionés en otros territorios, de ahí que el fallo se resolviese en 1715 a favor de la heredera legítima de los Mantilla ${ }^{567}$. La reclusión de las monjas dio mucho que hablar en Carrión. La oposición férrea del Regimiento de la villa y de la Cofradía de los Veinte Clérigos a la clausura de las monjas fue en vano, confirmándose la misma por Bula de Paulo V el 28 de julio de $1608^{568}$. Las monjas adoptarán desde entonces el nombre de su fundadora, Santa Isabel de Hungría, de ahí que se las denomine coloquialmente como hermanas isabelas.

\footnotetext{
565 AHPP. Carr.Prot 5156. Jerónimo Laso (1611), s/f.

${ }^{566}$ ASCC. Santa Isabel. Mayorazgos (1624-1689), $\mathrm{n}^{\circ}$ 2, 1689.

${ }_{567}^{56}$ El fallo es de 3 de abril de 1715. ASCC. Legajo XI. Papeles sobre pleitos (1728-1833).

568 ASCC. Santa Isabel. Pergaminos (1475-1715), Legajo 4.
} 


\subsection{EL NUEVO TEMPLO}

Ante la nueva situación, se hace necesaria una estructuración del convento adaptada a las nuevas necesidades de la clausura. Así en 1611 el convento compró a la cofradía de los Veinte Clérigos la sala capitular, cuarto, corredor, escalera y cocina de las que había hecho uso hasta entonces sin poseer su titularidad, comprometiéndose a abonar la cantidad acordada antes de 1614. Dado el incumplimiento del contrato por falta de fondos, los Veinte clérigos presentan a las monjas ante la justicia y sólo un año después la venta se hizo efectiva ${ }^{569}$.

A pesar de estas pequeñas adquisiciones, seguía siendo de vital necesidad la construcción de nuevos espacios, por lo que a comienzos del año 1614 las isabelas confían la ejecución de algunos cuartos sin especificar a un maestro de albañilería y cantería carrionés de reconocido prestigio en la villa, Juan González de la Mata. En principio, el remate ascendió a ocho mil reales, reducidos posteriormente "por le hacer mal y daño y de su oficio, por no les haber querido dar parte de la obra le quieren hacer baja en ella”. A finales de dicho año la obra debía estar avanzada pues el convento emite carta de pago por 6.284 reales, suma en que había quedado estipulada toda la intervención ${ }^{570}$. Esta actuación revela por qué Juan de Cisneros y Tagle establece la fecha de fundación del convento en 1614 , pues se puede decir que es desde esta fecha cuando comienza su andadura como centro exclusivamente religioso ${ }^{571}$.

En 1618, Francisco de Colmenares, mayordomo y fiscal del rey presenta pleito contra las monjas por el patronazgo del convento. Considera que parte de las casas propiedad de don Gonzalo Gallo habían sido incorporadas contra la voluntad de dicho fundador. Por ello solicita las bulas apostólicas en las que constase dicho permiso de clausura. Las isabelas, por su parte exponen que, el litigante no es patrón ni parte para pedir nada y las bulas sobre las que se litiga “...no son en perjuicio de patronazgo de legos, porque si algún patrón ay de la dicha memoria es el concexo y clerecía de la dicha uilla de Carrión, con cuyo consentimiento se expiden dichas bulas...”. Por otro

\footnotetext{
${ }^{569}$ ASCC. Santa Isabel. Legajo III. Escrituras III. N ${ }^{\circ} 5$.

${ }^{570}$ No se especifica en qué consistió su actuación dentro del convento, pues tan sólo se conserva una carta de pago. AHPP. Carr.Prot 5397. Francisco Moro de Saldaña (1614), s/f. Sobre Juan González de la Mata, véase el apartado dedicado a los maestros locales.

${ }^{571}$ CISNEROS Y TAGLE, Juan. Historia...op.cit, pág. 84.
} 
lado defienden que Su Santidad posee la facultad plena para conmutar la voluntad del fundador reduciendo la hospitalidad a clausura ${ }^{572}$. Urbano VIII confirmaría en 1623 la bula antecedente de la clausura, aplicando la renta depositada por Gonzalo Gallo para sus obras pías y exonerando a las isabelas de todas las cargas impuestas por el fundador ${ }^{573}$.

En realidad, la primera actuación de envergadura en el convento no se efectúa hasta el año 1620, en que se realiza una reconstrucción del hospital, para cuyas trazas es reclamado Juan González de la Mata ${ }^{574}$. En agosto de 1619 tienen lugar los pregones para subastar la obra, en los que, tras rechazar como postores a los trasmeranos Domingo del Río y Francisco de Buega, se remata finalmente en Juan de Santiago, maestro de carpintería avecindado en Heras, en la merindad de Trasmiera por ciento treinta ducados ${ }^{575}$. Su padre, maestro de albañilería como él, le enseñó seguramente el oficio y con él trabajó en la torre de la iglesia de Autillo de Campos en $1586^{576}$.

Con toda probabilidad fuese gracias a la experiencia avalada por su padre, que se había encargado de las obras de Santa Clara, que él tuvo acceso a esta obra. Hasta mayo de 1620 no se firma el acuerdo con el convento y la razón de la tardanza hay que buscarla en que Santiago necesitaba un fiador para la obra. De modo que en noviembre de 1619, el trasmerano Francisco Martínez de Bálcava se erige como tal. Lo que sucede es que residía en Herrera de Pisuerga, desde donde emite un poder a su primo, Domingo del Río, que residía en Carrión, para que actúe en su nombre. En realidad, la intervención efectuada por Juan de Santiago consistió tan sólo en fundar los cimientos correspondientes a la parte nueva tal y como colegimos de una carta de pago por valor de 585 reales en noviembre de $1621^{577}$. En efecto, a comienzos de dicho año había

\footnotetext{
${ }^{572}$ AHN. Consejo de Castilla, Leg. 27997, no 5.

${ }^{573}$ Escritura de 1734 que relata los pasos dados por las religiosas desde la creación del convento. ASCC. Santa Isabel. Legajo XI. Papeles sobre pleitos (1728-1833), s/f.

${ }^{574}$ AHPP. Carr.Prots 5403. Francisco Moro Saldaña (1620), fol 194 y ss.

${ }^{575}$ VIGURI, Miguel de y SÁNCHEZ, José Luis. Arquitectura...Op.cit, pp. 197-199, a su vez de AHPP., Carr.Prots, leg. 5403, Francisco Moro Saldaña (1620), fol 194 y ss.

${ }^{576}$ ZALAMA RODRIGUEZ, Miguel Ángel. La arquitectura...Op.cit, pág. 70. Se conocen otros datos de Juan de Santiago. Efectúa los reparos de la iglesia de San Lorenzo de Revenga, Palencia, por lo cual recibe carta de pago en 1621, AHPP. Carr.Prot 5484 Antonio Orejón, El joven (1617-1621), s/f. En 1623 fue condenado por la justicia a que reedificase las casas pertenecientes al mesonero Francisco González o le diese cuatrocientos reales en concepto del coste de tales reparos. AHPP. Carr.Prots 5219. Jerónimo Laso (1623) s/f.

577 Así se indica: “...las çinco çepas de cantería que se an plantado para fundar el dicho hospital...” AHPP. Carr.Prot 4848, Juan Díaz Pajaza (1621) s/f.
} 
abandonado la obra “...rrespeto de tener otras cosas forzosas a que acudir fuera d'ella..." cediéndola a los maestros de carpintería cántabros Pedro de Evedia, de Trasmiera y Toribio de la Teja, de Pontejos en la Junta de Cudeyo. Previa compensación de ochenta reales, ambos maestros podían disponer de los materiales existentes además de recibir los 788 reales que hubiesen correspondido a Juan de Santiago en caso de que hubiera efectuado lo convenido ${ }^{578}$.

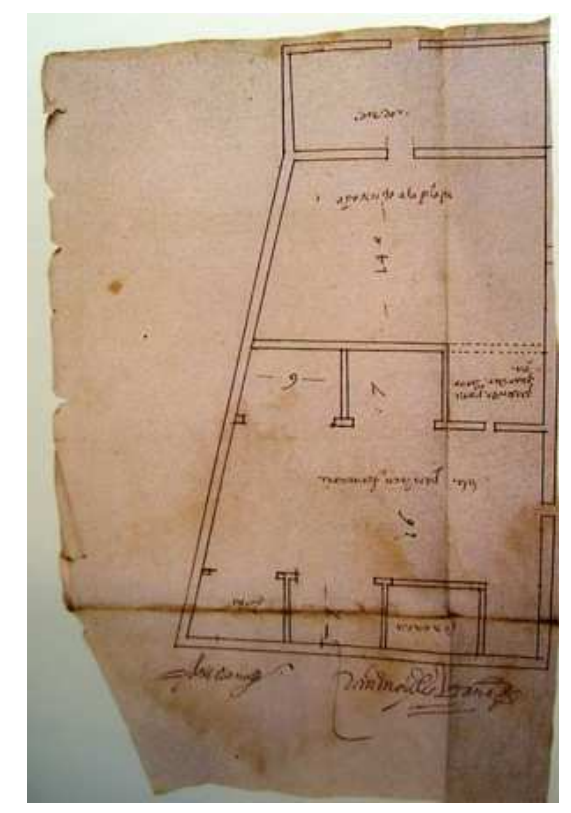

Planta del nuevo hospital de San Miguel dentro del convento. Juan González de la Mata. 1619. AHPP. Mapas y planos.

En las condiciones mencionadas para la ejecución del centro, se ordena el derribo del antiguo edificio de las monjas terciarias para edificar el nuevo hospital sobre su solar ${ }^{579}$. Los cimientos del nuevo nosocomio de dos plantas serían de piedra. La portería se ubicaría en la plaza de San Andrés con un acceso en madera de pino y otro portal alternativo en el extremo oriental. Detrás del portal, hacia el norte, se ubicaría la cocina con su chimenea, ambas estancias realizadas con vigas de la vieja fábrica tramadas con chilla nueva. A ambos lados de la misma, dos grandes aposentos para enfermos y por último, el ángulo suroccidental del piso bajo estaba destinado a la caja de escalera. Sobre estas dependencias se dispondría una gran sala de enfermería con acceso a cuatro alcobas de madera de pino guarnecidas de yeso. En el lado oriental y

\footnotetext{
${ }^{578} \mathrm{La}$ escritura de cesión de la obra se encuentra en AHPP. Carr.Prot 5403. Francisco Moro Saldaña (1620), fol 194 y ss.

579 Ver la planta del hospital. AHPP. Planos y dibujos. Hospital de San Miguel de Carrión de los Condes. publicado en VIGURI, Miguel de y SÁNCHEZ, J. L; Arquitectura...2, Op.cit, pp. 195-196.
} 
coincidente con el portal secundario del piso principal, se ubicaría un corredor alargado. Para las cubiertas se emplearían alfarjes de vigas de olmo con labor ornamental " $a$ la morisca”. Aunque el contrato disponía una duración de las obras inferior a un año, pues debían ser finalizadas en junio de 1620, estas se retrasan hasta 1621.

A comienzos de 1621 el convento, y en su nombre la abadesa por entonces, doña Inés de Colmenares, vuelve a requerir la intervención de Juan González de la Mata para que repare el cerco por la calle lindera al río “...por estar avierto, caydo y arruynado,

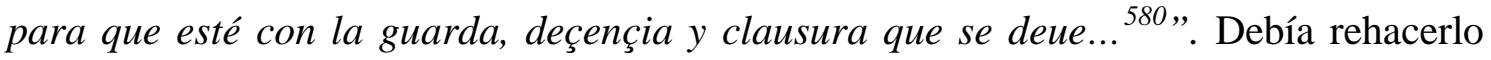
con cuatro pies de grueso, labrados a picón con un zócalo de mampostería ${ }^{581}$. A finales de 1622 se remata en Juan González la ejecución de unas “casas secretas” con tejado de roble y una casa del horno lindera a la iglesia ${ }^{582}$. La obra sería reconocida en 1623 por el maestro de cantería Simón de Inestrosa ${ }^{583}$, quien tan sólo objetó la ausencia de empedrado en el desagüe del alcantarillado ${ }^{584}$. Una década después se refuerzan las tapias correspondientes a la iglesia, ubicada en el extremo oriental del conjunto ${ }^{585}$. De las obras se encarga Hernando de Inestrosa, maestro de cantería vecino de Carrión, posiblemente familiar del anterior ${ }^{586}$. Debía socalzar toda la parte correspondiente a la puerta de la iglesia en adelante, en dirección a la iglesia de Belén, es decir, la actual avenida de Leopoldo Castro.

\footnotetext{
${ }^{580}$ La escritura y condiciones del cerco en AHPP. Carr.Prot 5404. Francisco Moro Saldaña (1621), fol 56 y ss. Se puede ver un dibujo en AHPP. Sección de Mapas, planos y dibujos. Cerca del convento de San Miguel y Santa Isabel de Carrión de los Condes. 1621.

581 Para labrar la piedra se utilizaba una herramienta llamada pico de metal, utilizado para eliminar las irregularidades producidas al escuadrar los bloques, de ahí la denominación "a picón". LOSADA VAREA, M ${ }^{a}$ Celestina. La arquitectura en el otoño...Op.cit, pág. 44.

${ }^{582} \mathrm{La}$ escritura y condiciones de las casas secretas en AHPP. Carr.Prot 5405, Francisco Moro Saldaña (1622) s/f.

583 Procedente de Trasmiera, este maestro es el tracista del hospital de Nuestra Señora del Camino de Carrión, que diseña en 1620. AHPP. Carr.Prot 5403. Francisco Moro de Saldaña (1620),s/f.

${ }^{584}$ VIGURI, Miguel de y SÁNCHEZ, J. L; Arquitectura...2. Op.cit, pág. 201.

585 AHPP. Carr.Prot 5416. Francisco Moro Saldaña (1633), s/f.

${ }^{586}$ En 1635 se le abonan 850 reales por la ejecución de unos pilares en la iglesia del convento de Santo Domingo de Carrión. AHPP., Carr.Prot 5181, Jerónimo Laso (1635), fol 773 y ss. Interviene con carácter urgente en la reedificación de la capilla de la Concepción en el convento de San Francisco de Carrión, en 1639. AHPP. Carr.Prot 5422, Francisco Moro de Saldaña (1639), s/f. En esta capilla y en la aledaña, bajo la advocación de la Resurrección vuelve a intervenir en 1646.AHPP., Desamortización, Legajo 105, s/f. En 1641 se comprometió a reforzar la torre de la iglesia de San Andrés de Carrión con esquinas de cantería, así como la parte en que se ubicarían las campanas y el reloj. AHPP. Carrión .Protocolo 4828. Francisco Cuetos (1640-1641), fol 321 y ss. En 24 de marzo de 1642 se le pagan a 3000 reales por la obra AHPP. Carr.Prot 5188. Jerónimo Laso (1642), fol 297. En abril de 1642, Jerónimo de Avendaño le cede la quinta parte del puente de Astudillo. AHPP. Carr.Prot 5188. Jerónimo Laso (1642), fol 369 y ss.
} 
La obra se la debían haber abonado en 1633, pero aún figuran pagos en marzo de $1637^{587}$. Cuando en noviembre de 1634 el Ministro Provincial de la Concepción, Fray Luis Fernández, visita el convento, determina que en la siguiente dote que se recibiese, fuesen reparadas las cercas que limitan con la vivienda de don Gaspar Mantilla de la Vega, heredero del mencionado don Gabriel Mantilla. Siendo abadesa doña Inés Robles Quijada, en marzo de 1635, el convento se concierta con Juan González de la Mata para la ejecución de las veinticinco tapias necesarias “...para seguridad, rrecoximiento y guarda del dicho convento... ${ }^{588, "}$

Juan Tejedor se encargó de aderezar las gradas, el coro alto y el púlpito en 1655 y en los años siguientes se arregla una esquina deteriorada de la ermita, además de otros costosos reparos sin especificar, salvo un retejo, en el sexenio de 1661 a 1667 durante los cuales se adquieren materiales ${ }^{589}$.

En 1669 se abona el nuevo retablo de la iglesia, por el que se pagan al escultor 900 reales y 970 al dorador, sin que conozcamos sus identidades ni el aspecto de la pieza $^{590}$. Sabemos de la existencia de una capilla dedicada a Nuestra Señora de la Soledad por los reparos que en ella fueron efectuados en $1699^{591}$.

Durante este período fue cuando el conjunto debió quedar completamente conformado. Gracias al diseño que, por orden del $2^{\circ}$ Cabo del distrito, realiza el cuerpo Nacional de Ingenieros de Hacienda Civil conocemos la distribución de las distintas dependencias monásticas en $1838^{592}$. Las tapias del convento conformaban un perímetro rectangular con ciertas irregularidades que se extendía exactamente hasta la pendiente que baja al río Carrión y se ensanchaba más allá de la actual plaza de San Andrés, hacia el norte. En la parte más oriental del conjunto se hallaba un atrio columnado, las gradas o locutorios. Seguidamente se hallaba el templo, precedido de un coro de gran amplitud,

\footnotetext{
${ }^{587}$ ASCC. Santa Isabel Leg XII. Cartas de pago (1493-1797), s/f y también en AHPP. Carr.Prot 5183. Jerónimo Laso (1637), s/f.

588 De los cuatrocientos ducados que el ministro provincial ordenó que se destinasen para la obra, las monjas utilizaron unos doscientos cincuenta. (25 tapias a 110 reales cada una). AHPP. Carr.Prot 5418. Francisco Moro de Saldaña (1635), s/f.

${ }^{589}$ ASCC. Santa Isabel. Libro 6. Libro de caja de Santa Isabel de la villa de Carrión, 1655- ¿ ?, fol 12v, 65, $134,174 \mathrm{v}, 239$.

${ }^{590}$ Ibídem, fol 240.

${ }^{591}$ ASCC. Santa Isabel. Libro de cuentas que comienza en 1672, fol 435.

${ }^{592}$ Ver croquis en AMS. Proyecto del fuerte de Carrión. Sección $3^{\text {a }}$, División $3^{\text {a }}$, Leg 99, nº 11 . Sobre el tema del fuerte hablaremos en la desamortización.
} 
dado que este espacio tiene un gran protagonismo para las comunidades terciarias. Los restos de la iglesia conventual se conservan en el patio de una propiedad particular situada frente a la ermita de la Cruz. Subsisten tres pilastras adosadas a un muro de tapial que permiten suponer un templo de una única nave de doble largura que anchura precedida de un amplio coro, ubicado a los pies $^{593}$. Sobre estos soportes persisten milagrosamente los arranques de los arcos de medio punto correspondientes a la amplia bóveda de cañón que se habría empleado como cubrición de la iglesia. Uno de dichos arranques presenta sendos filetes clasicistas acordes al estilo de la primera mitad del siglo XVII y correspondientes, por tanto, a la traza original. Adosado en su lienzo occidental, se ubicaba la sacristía que lindaba en el lado opuesto con un gran patio rectangular, ocupando su lado oriental y el resto de estancias en torno al mismo.

Al norte se adosaba la leñera, el pajar y la panera, al sur, las celdas de dos pisos, de diversas formas y tamaños y en el lado occidental, el refectorio y otras celdas. En esta parte, extendiéndose hacia el oeste se hallaban además las cocinas, el horno, las estancias comunes y en el extremo más occidental, el gallinero y colmenar. Las únicas dependencias aisladas del conjunto las conformaban una vivienda de dos pisos que se hallaba en el ángulo noroeste; adosado a las tapias e igualmente junto a las mismas, pero en su parte sur, un cobertizo destinado a panera. La zona no construida la constituía una gran superficie que se extendía por los lados meridional, occidental y parte del septentrional utilizada como corrales y huerta. Las tapias estaban realizadas de tierra calicostrada, es decir cubierta por ambas caras de cal y arena de tres pies de grueso y quince de altura ${ }^{594}$.

\footnotetext{
${ }^{593}$ Así podemos apreciar en AMS. Proyecto del fuerte de Carrión. Sección 3a , División 3a , Leg 99, nº 11 .

${ }^{594}$ Iblbídem, fol $2 \mathrm{v}$ y 3.
} 


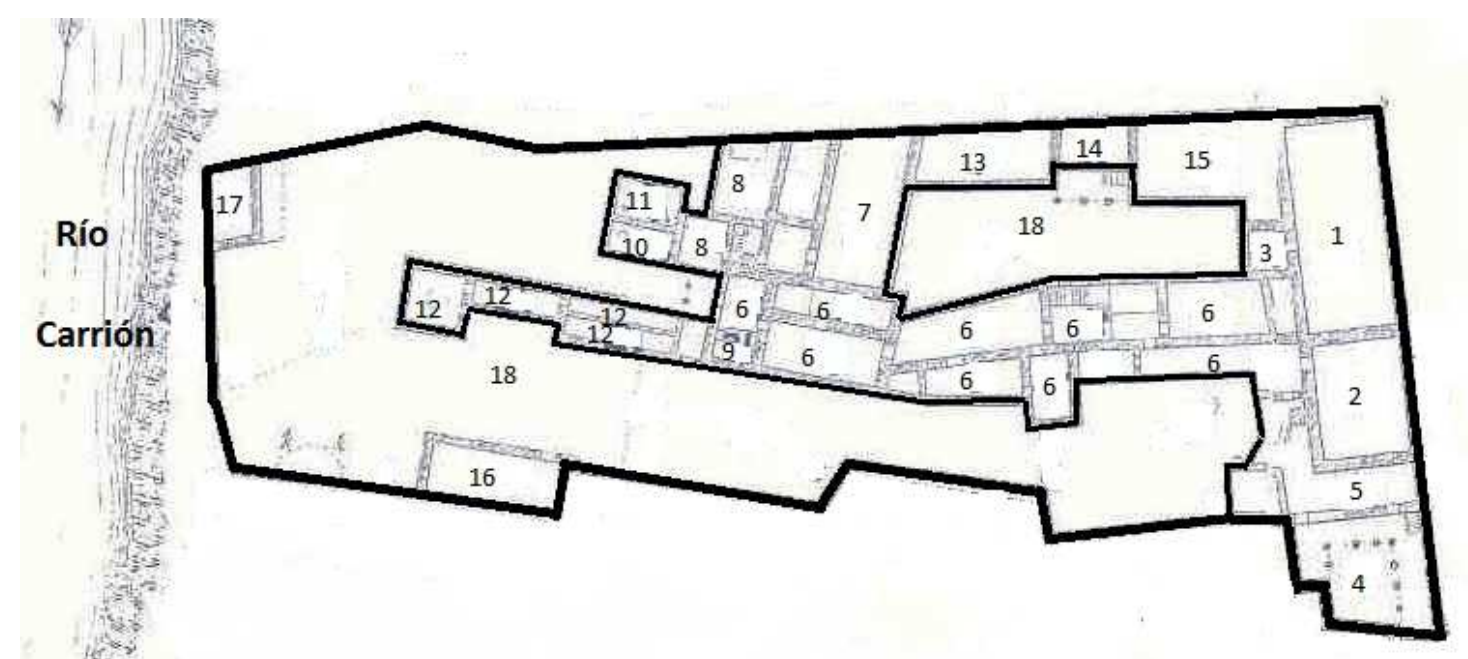

1. Nave de la iglesia

2. Coro

3. Sacristía

4. Portal de entrada

5. Gradas o locutorios

6. Celdas

7. Refectorio

8. Escalera

9. Cocinas
10.Horno

11. Salas comunes

12. Gallinero y colmenar

13. Leñera

14. Pajar

15. Panera principal

16. Otra panera

17. Vivienda de dos pisos

18. Patios y corrales descubiertos

Planta del convento de San Miguel y Santa Isabel. 


\section{EL SIGLO XVIII}

Un dato interesante acerca del progreso experimentado por la congregación a finales de siglo, se obtiene de la carta de pago correspondiente a la refacción de las cuatro especies -vino, vinagre, aceite y carnes- consumidas en 1681. En ella se registra un total de treinta y cuatro religiosas profesas, dos novicias, dos legas, dos criadas de cocina y un sacristán, cifra modesta si se equipara a las casi cincuenta profesas de Santa Clara, pero nada desdeñable habida cuenta los veintiocho de la casa terciaria franciscana, los dieciséis del convento dominico o sencillamente, las cinco internas que eran en sus comienzos ${ }^{595}$. Entre 1712 y 1713 fue el maestro Francisco de Cabria quien se encargó de efectuar los reparos generales de la casa conventual recibiendo por su trabajo 1600 reales $^{596}$.

Dentro de este convento, destacó por su erudición un personaje: Sor Clara Inés de Linares Agüero, quien adquirió gran renombre en la villa a raíz del milagro acaecido en la festividad de Santa Isabel de 1780. Sin apenas poder moverse desde 1775 por una enfermedad que la había dejado en un estado semi-paralítico, y habiendo recibido incluso la extremaunción, la monja sanó improvisadamente durante la adoración del Santísimo en la misa de aquel glorioso día. La firma del acta del suceso por varios testigos, entre ellos el médico y la abadesa, confirman la veracidad del mismo ${ }^{597}$.

\section{EL DEVENIR A PARTIR DEL SIGLO XIX}

La llegada del siglo XIX supondría el fin de la casa isabela. A comienzos de 1812 y debido a la escasez de medios, las monjas trataron encarecidamente de subsistir a través de la venta pública de heredades, solución que no resultó de gran ayuda ${ }^{598}$.

\footnotetext{
${ }^{595}$ La refacción consistía en una restitución que se hacía al estado eclesiástico de la porción con que había contribuido a los derechos reales, de los cuales por ley estaba exento. AHPP. Carr.Prot 5004, Diego García de la Llana (1679-1685) s/f.

${ }^{596}$ ASCC. Santa Isabel. Libro de cuentas que comienza en 1672, fol 626.

${ }^{597}$ PERAL VILLAFRUELA, Santiago y GÓMEZ PÉREZ, Enrique. Carrión...Op.cit, pág. 31.

${ }^{598}$ ASCC. Legajo XIV. Documentos diversos. Correspondencia. $\mathrm{n}^{\circ}$ 10. Carta emitida al obispo de Palencia en 29 de mayo de 1812 por la entonces abadesa María Teresa Ompanera.
} 
El decreto de exclaustración anunciado el 8 de marzo de 1836 manifestó gran comprensión con los conventos femeninos, pues los conventos de monjas tan sólo fueron reducidos. Sin embargo algunos cenobios puntuales no corrieron la misma suerte, como resultó con las isabelas, que fueron trasladadas al convento de Santa Clara de Carrión, reagrupando de este modo ambas casas terciarias en una sola ${ }^{599}$. A partir de entonces el convento fue abandonado.

\section{La construcción del fuerte carlista}

No obstante poco después, en 1838, recobraría el protagonismo, en el contexto de la primera guerra carlista (1833-1840). Si bien esta guerra civil no alcanzó en Castilla la repercusión de las provincias vasco navarras y de las regiones de Aragón, Cataluña y Valencia, sí se sucedieron alzamientos de menor cohesión entre ciertos miembros partidarios carlistas ${ }^{600}$. Ante eventuales ataques que pudiera sufrir Carrión, por junta extraordinaria de 15 de octubre de 1838, el comandante general de la provincia de Palencia, ruega se decida con prontitud el edificio más adecuado para proceder a su fortificación provisional y se lleve a cabo una abastecimiento de víveres para al menos seis días. El comandante de armas responde al respecto que por aprobación de las autoridades militares y jefes de artillería, el lugar más adecuado era el de Santa María ${ }^{601}$.

Sin embargo en noviembre se aceptó el proyecto de un fuerte en las iglesias de San Andrés, Belén y el convento de Santa Isabel conformando así un eje defensivo triple por la parte del río ${ }^{602}$. De este modo, se dominaba todo Carrión desde cualquier punto por el que avanzase el enemigo. Por motivos de economía y rapidez, las labores de fortificación en la mayor parte del territorio español consistían en la incorporación de elementos pertenecientes a la arquitectura militar en edificios ya existentes. La ciudad condal no constituyó una excepción, ya que así sucedió en otros enclaves palentinos

\footnotetext{
${ }^{599}$ REVUELTA GONZÁLEZ, Manuel. “Origen, ocaso...Op.cit, pág. 75.

${ }^{600}$ Existe un gran número de bibliografía referente al conflicto carlista, sin embargo son escasas las fuentes que se refieren al protagonismo de la zona castellana en el mismo. A este respecto, es muy ilustrativo, RODRÍGUEZ DURANTEZ, Lorenzo. "El fuerte de Cervera de Pisuerga y su tiempo: escenarios palentinos en la guerra carlista" en PITTM, $\mathrm{n}^{\circ}$ 79. Diputación Provincial. Palencia, 2008, pp. 395-419.

${ }^{601}$ AMCC. Libro 4, Sesiones municipales (1838-1848), fol 55 y 56.

${ }^{602}$ AMS. Proyecto del fuerte de Carrión. Sección $3^{\text {a }}$, División $3^{\text {a }}$, Leg 99, nº 11.
} 
como Cervera de Pisuerga o Aguilar de Campoo. La adaptación de los edificios conventuales para acuartelar el contingente de tropas durante una contienda es un hecho constatado en Palencia ${ }^{603}$.

En lo que concierne específicamente al área del convento, el proyecto entrañaba el derribo de la propiedad de los Mantilla, que lindaba en su lado sureste con el portal de entrada. En su lugar se plantea la construcción de una muralla de las mismas dimensiones que se una a la línea del cenobio en diagonal, creando así un semi baluarte. Toda esta parte meridional era la más vulnerable a los ataques por estar abierta a una gran plaza, de ahí que se proponga la construcción de un gran foso de diez pies de profundidad y un terraplén con la tierra que salga de la fortificación. En las tapias de este lado deben abrirse aspilleras y otras tantas en el lado occidental, hacia el puente y en el lado norte. Si bien estos dos últimos lienzos no deben ser fortificados por el gran desnivel hacia el río del primero, que la hace inexpugnable y la pendiente escarpada que se extiende hasta la iglesia de Belén por la parte septentrional, donde por otra parte, los muros presentan mayor elevación. En esta sección se practicarían algunos huecos para arrojar granadas de mano y un puente levadizo precedido de una plaza de armas circular en la que las tropas se reúnan y se retiren en caso de ataque por el puente o por un camino cubierto que se construya en aquel punto. Quedarían defendidos por la guarnición ubicada en los corrales, donde se ubicaría, de trecho en trecho varias filas de estacas. En cuanto al lado oriental del convento, se construirían dos lienzos de muralla para enlazar con la iglesia de San Andrés por ambos lados, creando así un único bloque reforzado por el sur con un foso y un puente de acceso. Para ello habría que desmontar parte de las viviendas que se sitúan en la parte intermedia de los dos monumentos, empleándose la madera extraída en la construcción del fuerte. La iglesia de Santa Isabel, que quedaba al margen de la misma iría provista de aspilleras para proporcionar una defensa de fuegos rasantes sirviendo de flanco a la cerca mencionada. Para la construcción de todo lo mencionado, los materiales serían extraídos de la demolición de la casa de las Mantillas y del derruido convento de Santo Domingo.

\footnotetext{
${ }^{603}$ Por ejemplo, durante la guerra de la Independencia, el convento de San Pablo de Palencia fue convertido en hospital y cárcel y los cenobios del Carmen, San Francisco y San Buenaventura se usaron como cuarteles. Sobre este tema RODRIGUEZ SALCEDO, Severino. "Palencia en 1808" en PITTM, $n^{\circ} 14$. Palencia, 1953, pp. 3-125.
} 


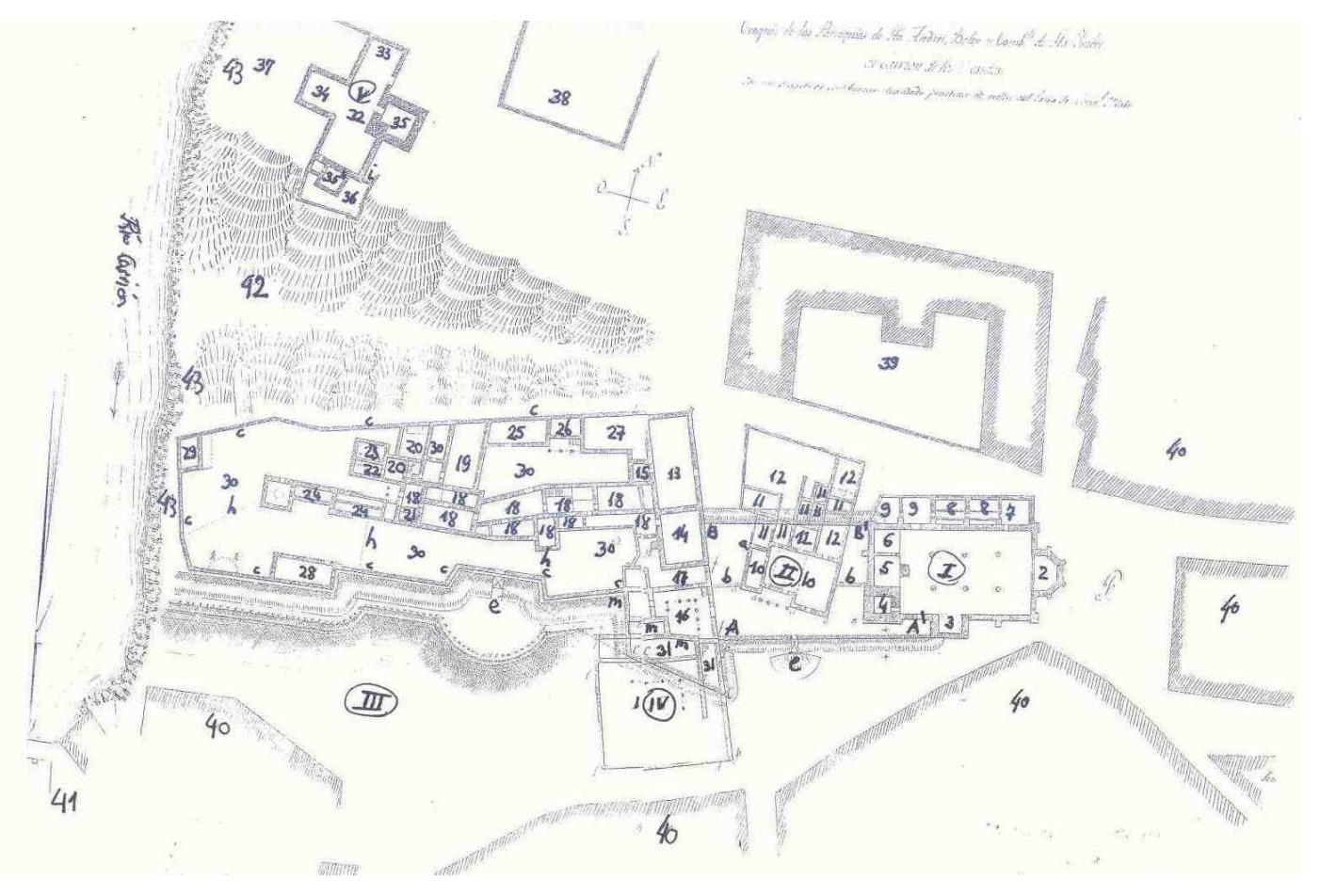

\section{BLOQUE I: SAN ANDRÉS}

2. Presbiterio

3. Capilla de la Herrada

4. Torre

5. Coro

6.Pila y órgano

7. Sacristía

DERRUIRÁ

8. Pasadizo

9. Pequeño corral

BLOQUE III: CTO DE SANTA ISABEL

13. Iglesia

14. Coro

15. Sacristía

16. Portal de entrada

17. Locutorios o gradas

18. Piezas bajas

19. Refectorio

20. Escalera

21. Cocinas

22. Horno

23. Salas comunes

altura

24. Gallinero y colmenar

25.Leñera

26. Pajar

27 y 28. Panera

29. Vivienda de dos pisos

30. Corrales y patio
BLOQUE II: VIVIENDAS A DESMONTAR

10. Casas de dos pisos

11. Cobertizos

12. Corrales

\section{BLOQUE IV: CASA DE LAS MANTILLAS QUE SE}

31. Crujías de la casa, ya en ruinas

\section{BLOQUE V: IGLESIA DE BELÉN}

32. Iglesia y capilla mayor

33. Coro

34. Capilla de San Gregorio.

35. Sacristía y planta de la torre

35'. Camarín de la Virgen

36. Terraplén bajo el edificio 41. Puente mayor

37. Otros precipicios

\section{OTROS EDIFICIOS INDEPENDIENTES}

38. Camposanto 39 y 40. Propiedades particulares

41. Puente 42. Terraplén hacia el río 43. Precipicios de mucha

\section{CONSTRUCCIONES PENDIENTES}

A A'. Lienzo de muralla de San Andrés a Santa Isabel (parte sur) B B'. Lienzo de muralla de San Andrés a Santa Isabel (parte norte)

b . Refuerzo de muralla para proteger B B'

c. refuerzo de la cerca de tapial de Santa Isabel

e. puentes levadizos de los fosos

h. filas de estacas en los patios de Santa Isabel

m. semibaluarte

Plano del fuerte de $\mathbf{1 8 3 8}$ en la zona noroeste de la ciudad. AMS. Proyecto del fuerte de Carrión. Sección $3^{\mathrm{a}}$, División $3^{\mathrm{a}}$, leg 99, n⿳11. 
El edificio desempeñaría a partir de entonces una función militar. Así las celdas serían empleadas como habitaciones de las tropas y oficiales, destinándose a este uso el refectorio y la panera, en caso de que no hubiese cabida para todos. La cuadra se ubicaría en la leñera o en el gallinero, y los almacenes en los coros alto y bajo de la iglesia. Para su defensa, el fuerte se abastecería, dada la escasez con una guarnición de doscientos hombres -serían precisos seiscientos- repartidos del siguiente modo: 22 en San Andrés -12 en el piso bajo y 10 en las bóvedas-, 30 repartidos entre las dos murallas que unen San Andrés y Santa Isabel, 15 en el baluarte de los Mantilla, 68 en Santa Isabel -40 en las parte meridional, 8 en la occidental y 12 en la sección norte. Todos ellos suman un total de 135 hombres, a los que se añaden 65 de reserva para dispersarse por las calles o rotar a los centinelas.

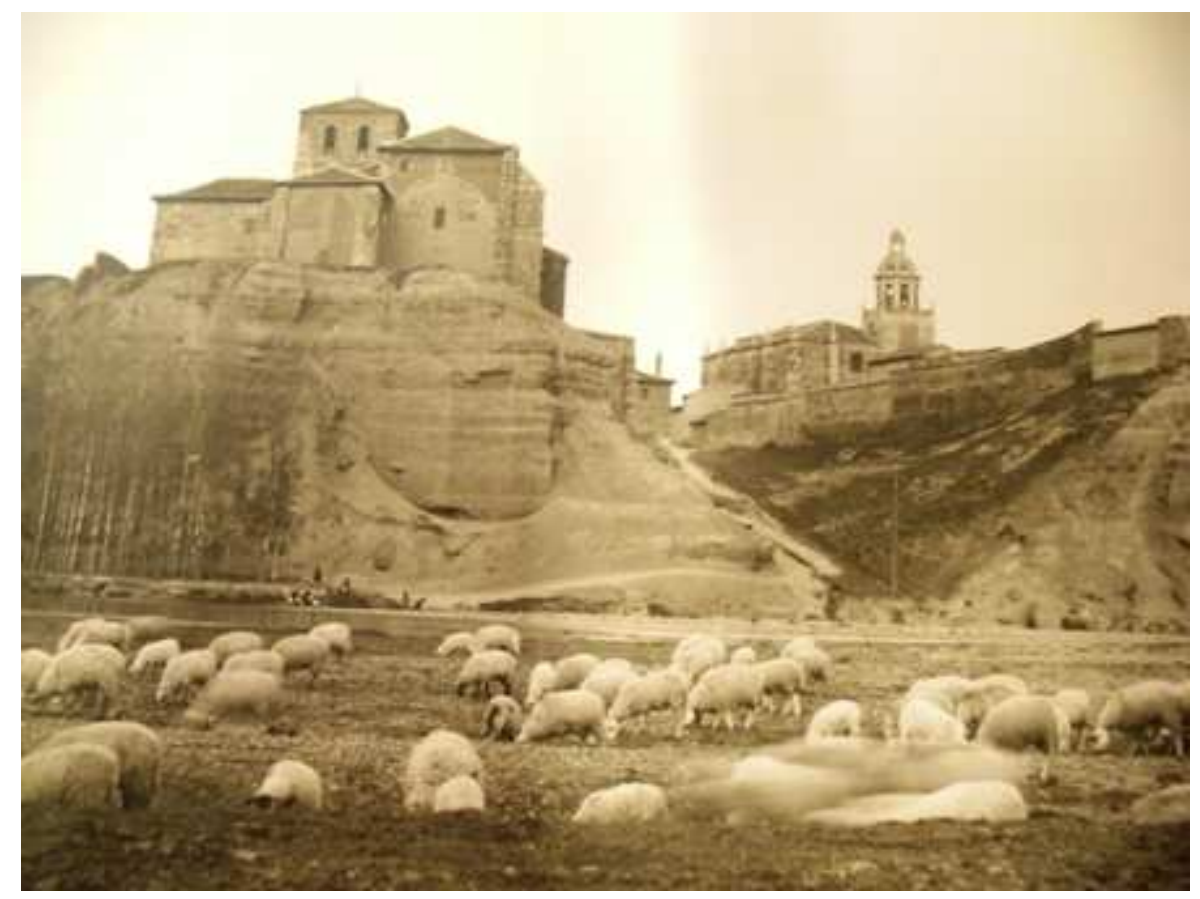

Situación del fuerte en el sector conformado por la iglesia de Belén (izq), la iglesia de San Andrés y el convento de Santa Isabel, del que son visibles las tapias (dcha).ACJAH. C 11. Carrión. Fotografías. 
En 1843, dado que no resultaba de utilidad alguna y que había sufrido algunos desprendimientos, se plantea la demolición del fuerte ${ }^{604}$. Aún en 1856 quedaban algunos restos del mismo, pues se extraen piedras del mismo para reparar el puente ${ }^{605}$. Es por ello que no existen restos físicos de este fuerte, cuyas piedras reutilizaron los vecinos para fortalecer sus viviendas.

\section{La ruina posterior}

En 1860, tras un intento fallido del ayuntamiento por adquirir el solar de la casa del Águila para construir el nuevo edificio de la cárcel, se probó con el convento de Santa Isabel, que por entonces pertenecía a Don Manuel Merino Pérez. La tentativa resultaría fallida, pues su propietario no estaba dispuesto a negociar una cantidad que fuese inferior a tres mil ducados y la municipalidad no contaba con dichos fondos ${ }^{606}$.

Del convento tan sólo subsisten unas tapias a las que nos referimos con anterioridad y algunas obras procedentes de su iglesia se exponen hoy día en el Museo Sacro de la casa clarisa, ubicado en el claustro de la portería. Destaca entre estos objetos el cantoral realizado por Fr. Pedro Gutiérrez dedicado a Doña Ana Pimentel en $1698^{607}$.

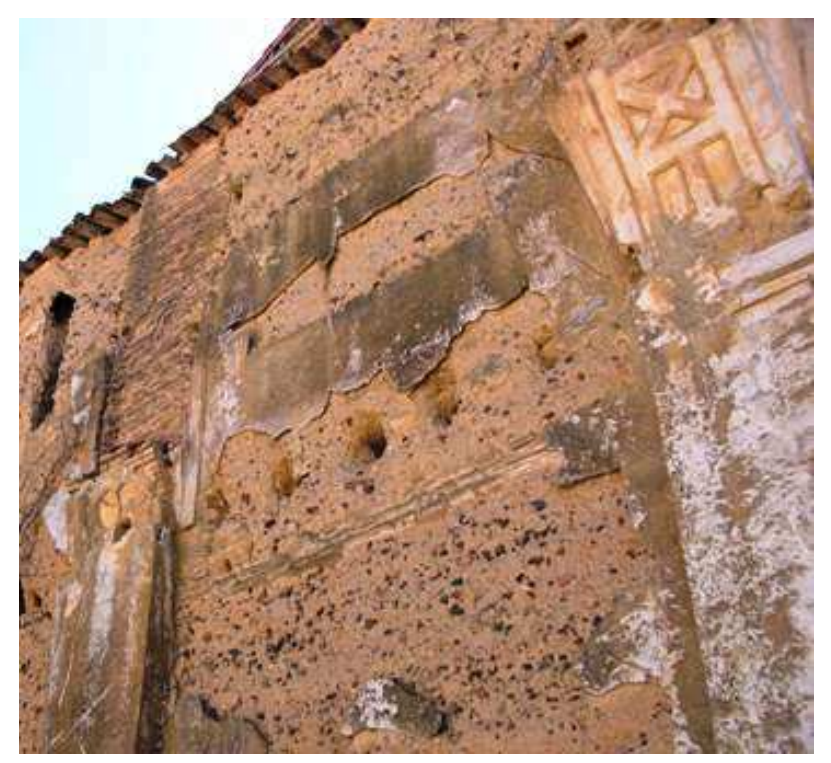

\section{Restos de los pilares y arranques} de los arcos fajones del templo.

\footnotetext{
${ }^{604}$ AMCC. Libro 4.Sesiones municipales (1838-1848). Sesión de 5 de agosto de 1843, s/f. ${ }^{605}$ AMCC. Libro 5.Sesiones municipales (1850-1857), Sesión de 30 de octubre de 1856, fol 67 v. ${ }^{606}$ AMCC. Libro 6. Sesiones municipales (1858-1862), Sesión de 26 de octubre de 1860, s/f. ${ }^{607}$ ANDRÉS GONZÁLEZ. Patricia. Los conventos...Op.cit, pp.. 183-185.
} 


\subsubsection{EL CONVENTO DE SANTO DOMINGO}

\section{LA FUNDACIÓN}

La escritura de fundación de este monasterio relata que el 30 de abril de 1525, Fray Martín de Nieva había iniciado los trámites para el asentamiento de la orden dominica, tomando posesión de la iglesia de San Pedro ${ }^{608}$.

La tradición ubica este templo, y por tanto nuestro cenobio, a corta distancia de la iglesia de San Andrés, en la calle de Santo Domingo, en las proximidades de la plaza de $\operatorname{toros}^{609}$. Se sabe además, que la iglesia San Pedro, y por tanto el convento que se asentó sobre la misma, se ubicaba, como es habitual en los mendicantes, extramuros de la villa ${ }^{610}$.

Gracias a un grabado de Guillermo Orejón y Llamas en el que se muestra la villa desde su lado sur, en el sitio que llaman de "las Vargas", podemos ratificar dicha ubicación $^{611}$. En principio, descartábamos dicha situación, dado que en el dibujo, la torre de Santo Domingo figura entre dos edificios hoy día desaparecidos, la iglesia de San Juan del Mercado, asentada en la plaza homónima y el hospital de Santa María, en la plaza del mismo nombre. Sin embargo, dado el pequeño tamaño de la espadaña del convento, debemos pensar que Santo Domingo se hallaba en un plano más lejano,

\footnotetext{
${ }^{608}$ La documentación general nombra la iglesia que tomaron los dominicos bajo la avocación de San Pedro. García Chico la denomina de San Pablo y Quadrado mantiene ambas advocaciones para el mismo templo. Véase GARCÍA CHICO, Esteban. "El claustro de Santo Domingo de Carrión de los Condes" en BSAA, $\mathrm{N}^{\circ} 10$, pág. 212 y QUADRADO; José María y PARCERISA, Francisco J. Op.cit, pág. 131. En las probanzas contenidas en el pleito mantenido en 1567 entre el convento de Santo Domingo y el Consulado de Sevilla por los bienes del carrionés Bautista Lomas, un testigo declara que: “...el dicho monasterio es más de quarenta años a esta parte, el qual solía ser parroquial e se llamaua San Pedro...” AGI. Justicia.1150.N.4.R.1. Nada se sabe del templo de San Pedro, más que obtenía buenas rentas en el siglo XIV, por lo que se deduce que estaría bien dotado. FRANCIA LORENZO, Santiago. Gentes...Op.cit, pág. 160.

${ }^{609}$ RAMÍREZ HELGUERA, Martín. El libro...Op.cit, pág. 179 y PERAL VILLAFRUELA, Santiago y GÓMEZ PÉREZ, Enrique. Carrión...Op.cit, Edición 2003, pág. 82.

${ }^{610}$ GÓMEZ CASADO, Pantaleón. Defensa de la subsistencia.... Op.cit, pág. 14.

${ }^{611}$ El nombre completo del grabado es "Vista de la antigua villa de Carrión de los Condes por la parte del mediodía, desde el sitio llamado de las Vargas" en BN. Sala Goya. DIB/18/1/616. El dibujo no está fechado pero el burilista, Guillermo Orejón se sabe que vivió a caballo entre los siglos XVIII y XIX. La fiabilidad del grabado radica en el origen carrionés de nuestro grabador, quien conocería de primera mano los monumentos de su villa natal. GARRIDO MORENO, Antonio. "La traducción española de la Iconología de M.M. Gravelot y Cochin: Madrid 1801-1802" en Revista Virtual de la Fundación Universitaria Española. tomo IV-8.1991.
} 
posiblemente donde las fuentes indican y donde precisamente se han hallado restos pétreos en lo que hoy es una finca privada ${ }^{612}$.

La cesión del templo fue realizada por el Obispo de Palencia, Don Pedro Ruiz Sarmiento, el 19 de marzo de 1527, fundando en ella un monasterio de la Orden de Predicadores. Este ilustre personaje fue Obispo de Tuy, Badajoz, Palencia y cardenal de Compostela. Era hijo de Diego Pérez de Sarmiento, segundo conde de Salinas y doña María de Villandrando, segunda condesa de Ribadeo. Cursó sus estudios de derecho en Salamanca y Valladolid. Aparte de los cargos ya citados, fue capellán de los Reyes Católicos, sacristán mayor de Carlos V y cardenal por disposición de Paulo III. Detentó el cardenalato hasta que murió en Luca el 13 de octubre de 1541. Su cadáver fue depositado en el convento de Santo Domingo de esta ciudad italiana, para ser posteriormente trasladado a la abadía de Benevívere por Juan Sarmiento, abad del convento y deudo suyo ${ }^{613}$.

Los clérigos de San Pedro para compensar la pérdida de propiedad del templo recibieron una dotación económica por trasladarse a San Andrés, que sería el templo más cercano ${ }^{614}$. Pasarían a dicha iglesia toda la fábrica, luminaria y bienes muebles de la misma, quedando algunos enseres que los dominicos debían pagar a los clérigos de San Pedro. Quadrado y Parcerisa creen que esta iglesia podría identificarse con la que en 1095 había sometido el Conde Ansúrez a Santa María de Valladolid ${ }^{615}$.

La escritura episcopal de fundación se firmó el 3 de abril de 1527, y solamente dos meses más tarde, los religiosos tomaron posesión de la iglesia y demás propiedades

\footnotetext{
${ }^{612}$ A este respecto, me retracto sobre la ubicación del convento que expuse en un artículo anterior, afirmando que el hecho de que en una vista frontal se sitúe entre la iglesia de San Juan y el hospital de Santa María, no impide que Santo Domingo se ubicara al noreste de Carrión, donde lo sitúa la tradición. GARCÍA GARCÍA, Lorena. "Aportaciones a un convento palentino desaparecido: Santo Domingo en Carrión de los Condes, Palencia" en PITTM, nº0. Diputación Provincial de Palencia, 2009, pp. 465-466.

${ }^{613}$ ORTEGA GATO, Esteban. "Blasones...Op.cit, pp. 204-206. Acerca de la abadía de Benevívere, véase el apartado correspondiente.

${ }^{614} \mathrm{La}$ trascripción de la documentación referida a la licencia del obispo de Palencia y a los acuerdos entre el cura de San Pedro D. Juan de la Serna y el de San Andrés, Don Pedro de la Casera para llevar a cabo la fundación en la iglesia parroquial, la llevó a cabo Salvador y Conde, extrayendo la documentación del Archivo del convento de San Pablo de Palencia. Véase SALVADOR Y CONDE, P.J Los conventos de Dominicos en la provincia de Palencia (Carrión de los Condes s. XVI- XIX). Palencia, 1997, pp. 502-508.

${ }^{615}$ PERAL VILLAFRUELA, Santiago y GÓMEZ PÉREZ, Enrique. Carrión....Op.cit, pág. 13.
} 
en un breve lapso de tiempo, el 23 de junio del mismo año ${ }^{616}$. En este acta de toma de posesión, Fray Martín de Nieva, fraile de la Orden de Predicadores, presentó una donación y transacción firmada por Don Pedro de Sarmiento requiriendo de Juan de la Rúa y Pedro de la Carrera, curas de la iglesia de San Pedro y San Andrés respectivamente, que se le diese posesión de la dicha iglesia de San Pedro a lo cual respondieron afirmativamente, según consta en la documentación.

El Acta del Capítulo Provincial que tuvo lugar en el convento dominicano de Santa Cruz de Segovia el 24 de enero de 1529, atestigua la aceptación oficial del convento de Santo Domingo ${ }^{617}$. Como vemos, la fundación del cenobio se retrasa en más de dos centurias respecto a la inmensa mayoría de los cenobios dominicos en territorio castellano ${ }^{618}$. De hecho, se cree que el convento de San Pablo de Palencia fue fundado por el propio Domingo de Guzmán, quien había cursado en el Estudio de esta ciudad, en 1219, convirtiéndose en el segundo convento de predicadores de la Península, detrás del de Segovia ${ }^{619}$.

Generalmente en las provincias, existe una tendencia generalizada de retraso respecto a las fundaciones dominicas de las capitales. Así sucede en Palencia, pues Santa Catalina de Cisneros no existió hasta 1467; Santa María de la Piedad de Villada

\footnotetext{
${ }^{616} \mathrm{El}$ acta de toma de posesión del convento dominico fue trascrita por el fecundo historiador Monópoli. Véase LÓPEZ, Juan, Obispo de Monópoli. Historia de Syto Impresión Juan de Rueda. Valladolid, $16224^{\text {a }}$ parte. Cap 66, pp. 205-206 y SALVADOR Y CONDE. $O p$, cit, pp. 509-510.

${ }^{617}$ HOYOS, Manuel María, O. P. Registro...Op.cit, pág. 207. Todas las actas de la orden constan en HERNÁNDEZ MARTÍN, Martín. "Actas de los Capítulos Provinciales de la provincia dominicana de España del siglo XVI (I)" en Archivo dominicano. n³. Salamanca 1982, pp. 13-84. Del mismo autor, "Actas de los Capítulos Provinciales de la provincia dominicana de España del siglo XVI (II)"en Archivo dominicano. $\mathrm{n}^{\circ} 7$, Salamanca, 1986, pp. 5-47, "Actas de los Capítulos Provinciales de la provincia dominicana de España del siglo XVI (III)"en Archivo dominicano. nº, Salamanca, 1988, pp. 5-53.

${ }^{618}$ Las fundaciones dominicas en Castilla se dieron fundamentalmente durante el siglo XIII. A este respecto véanse HOYOS, Manuel María de los. Registro documental: material inédito dominicano español. Editorial Sever Cuesta. Valladolid, 1961-1963 y PEÑA PÉREZ, Javier. "Expansión de las órdenes conventuales en León y Castilla: franciscanos y dominicos en el siglo XIII" en III Semana de Estudios medievales. Instituto de Estudios Riojanos. Logroño, 1993, pp. 179-198 y GARCÍA SERRANO, Francisco. "Mundo urbano y dominicos en la Castilla medieval" en Archivo Dominicano. n ${ }^{\circ} 18$. Salamanca. 1997, pp. 255-274. Para la historia de la orden de Santo Domingo CASTILLO, Fray Hernando del (O.P). Primera parte de la historia general de Santo Domingo y de su orden de predicadores. Madrid, 1584. Del mismo autor Segunda parte de la historia general de Santo Domingo y de su orden de predicadores. Valladolid, 1592.

${ }^{619}$ SARABIA Y LEZANA, Joseph. Anales de la sagrada religión de Santo Domingo, erario ascético en las legendas de los Santos y Santas y personas de ylustre virtud de la Orden de Predicadores. Tomo 1. Madrid, 1709, pág. 97.
} 
recibió la aprobación papal en 1486, estableciéndose nuestro cenobio carrionés en último lugar ${ }^{620}$.

Es preciso señalar en este caso, la concurrencia de circunstancias favorables que tuvieron lugar entonces. Con su establecimiento se ponía fin al problema de tener dos parroquias muy próximas- San Pedro y San Andrés- sin demasiados feligreses cada una, y por otro, proporcionaban a la villa un centro de predicadores volcados en la enseñanza. Aunque la adquisición de San Pedro y sus posesiones resultó costosa, a los dominicos no les importó demasiado, pues encontraron muy ventajoso el hecho de no encontrar oposición de otros clérigos o religiosos a su establecimiento en la ciudad condal.

\section{EL SIGLO XVI}

Como indicamos, los predicadores no se establecieron en Carrión hasta 1527, escogiendo la iglesia de San Pedro como su nueva morada. A falta de documentación y de testimonios arqueológicos que aporten una pista sobre este templo, nada se sabe del mismo aparte de su advocación. En él se asentaron provisionalmente los dominicos, quienes durante los primeros años de su andadura, debieron salir adelante no sin grandes esfuerzos, en parte gracias a las limosnas de los vecinos de la villa, como mendicantes que eran.

Así se deduce del hecho de que no se realizan obras para acoger a la nueva orden hasta el año 1565, como veremos posteriormente. Un año después, ante la necesidad de ampliar los espacios, el convento compra a la iglesia de Santa Eulalia toda la piedra, madera, teja y ladrillo procedente de la demolición de la iglesia de San Vicente por ciento cincuenta ducados. Los parroquianos del ruinoso templo habían sido anexionados recientemente al templo de Santa Eulalia por presentar el suyo gran deterioro ${ }^{621}$. El

\footnotetext{
${ }^{620}$ ANDRÉS ORDAX, Salvador. "Los dominicos en Palencia: el convento de San Pablo" en Jornadas sobre el arte de las Órdenes religiosas en Palencia. 24-28 julio 1989. Palencia, 1989, pp. 73- 74.

${ }^{621}$ Escritura de venta a 14 de junio de 1566. AHPP. Carr.Prot 5664. Andrés Sánchez (1565-1568), s/f. La iglesia de San Vicente se situaba a extramuros de Carrión, en lugar despoblado, siendo éste otros de los motivos para el desplazamiento de feligreses a la iglesia de Santa Olalla o Santa Eulalia, de cuyo recuerdo queda hoy día el nombre de la calle. De ambos templos la documentación recoge escasos datos. San Vicente debió desaparecer en 1595 cuando su torre, último resto que quedaba en pie, fue adquirido por Santa Eulalia. AHPP. Carr.Prot 4984. Sebastián García (1595-1597), s/f. Por su parte, Santa Eulalia fue
} 
hallazgo de esta escritura de venta ilustra la precaria situación del cenobio dominico desde su fundación, pues al no poder permitirse la adquisición de materiales nuevos, los frailes recurrieron al aprovechamiento de los que se hallaban en la villa, procedentes de templos derruidos.

\section{El templo}

No se conoce ningún dato sobre la iglesia de San Pedro sobre la que se asentaría la orden dominica, salvo que figura como parroquia en el censo del año $1345^{622}$. Por ello no sabemos si se trataría de una fábrica románica o gótica. Gracias a la documentación se conocen algunas de los espacios de culto con los que contaba el templo y las reformas que sufrieron las mismas. Debió constar de una sola nave y modestas dimensiones, a juzgar por el tamaño del retablo de la capilla mayor que iría adosado al presbiterio y que comentamos más adelante.

La orden de Predicadores aprovechó el traslado de los feligreses de San Pedro para establecerse en el espacio que este templo les brindaba, de ahí que no se registren intervenciones relativas a este espacio a lo largo del siglo XVI. En efecto, se usaba ya como lugar de enterramiento para destacadas figuras, como se verá.

\section{El refectorio}

Las primeras referencias documentales relativas a los espacios del cenobio dominico son del refectorio. Probablemente las obras se llevaron a cabo poco antes de 1565, pues dicho año se contrata a un carpintero carrionés, llamado Hernando de Vegas, para tallar los escaños de esta sala “...con sus respaldares y asientos y estrados...”, además de las puertas levadizas de entrada y salida de la misma, todo en madera de pino. Este contrato señalaría claramente el proceso final correspondiente a una nueva obra, siendo prior del convento Fray Ambrosio de la Serna ${ }^{623}$.

declarada en estado de ruina en 1721 y nunca más volvió a mencionarse. AHN. Clero Secular-Regular 5358. Expediente 3. Santa Eulalia. Obras, s/f.

${ }^{622}$ SAN MARTÍN PAYO, Jesús. "La más antigua estadística...Op.cit, pp. 10-13.

${ }^{623}$ Escritura y condiciones firmadas a 12 de junio de 1565. AHPP. Carr.Prot 5670. Andrés Sánchez (1585-1586) s/f. 


\section{El claustro renacentista}

Las trazas del claustro fueron dadas por el maestro de cantería trasmerano Juan de la Cuesta ${ }^{624}$, quien firmó la que sería su primera obra carrionesa con el prior de la casa dominica, Juan de Salvatierra, el 31 de enero del año $1579^{625}$. El claustro adoptaría forma cuadrangular de dos pisos de sencilla arquitectura. En el primer nivel se disponían siete arcos rebajados con el dovelaje marcado hasta la línea de impostas, separados por recias columnas de orden dórico con un antepecho. Desde la base, hasta la cornisa donde apeaba el piso superior, existía una distancia de dieciocho pies, es decir, un total de cinco metros. Para el sobreclaustro, de cuatro metros de altura, se optó por la disposición de siete arcos carpaneles de la misma luz que los anteriores, sustentados por idénticos soportes salvo por el menor diámetro de su fuste para aligerar la estructura, de forma que “... la garganta de la coluna inferior sea el diámetro della superior...”. Las columnas de este piso se hallaban jalonadas por un antepecho de piedra de un metro de altura completamente desornamentado que recorría todo el perímetro. En los ángulos se dispondrían medias columnas.

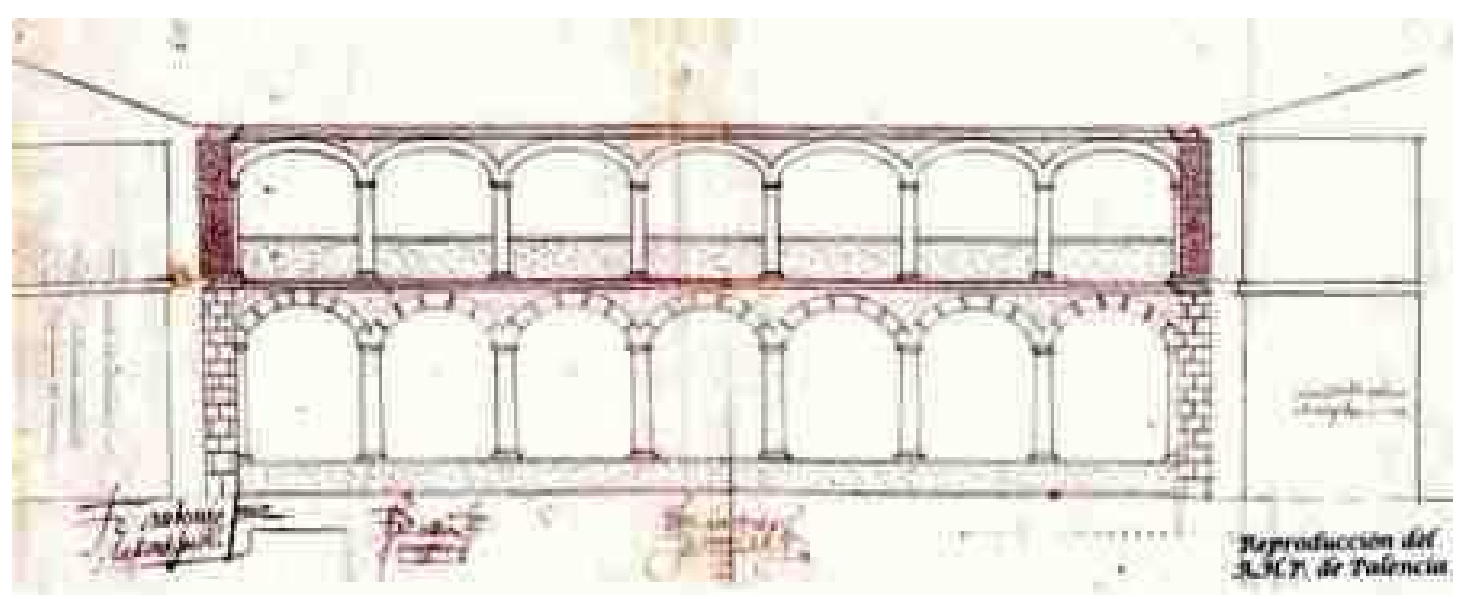

Proyecto del claustro. 1579. Juan de la Cuesta. AHPP. Mapas y planos. Carrión.

\footnotetext{
${ }^{624}$ Datos biográficos en el apartado correspondiente.

${ }^{625}$ Capítulos y condiciones firmados el 30 de enero de 1579. AHPP. Carr.Prot 5668. Andrés Sánchez (1577-1579) s/f.
} 
En el contrato que firmó con el prior, Juan de la Cuesta se comprometía a realizar dos terceras partes de la obra, cediendo un tercio a otro maestro trasmerano, Francisco del Vado. Juan de la Cuesta, a pesar de haber demostrado el conocimiento de los principios de los tratadistas italianos, como refiere en la ejecución del claustro de San Francisco, se muestra reticente a aplicarlos de una manera general. Respecta las proporciones y emplea elementos clásicos como los órdenes, cornisas y arquitrabes pero aún se mantiene a la tradición a través de la elección de arcos de raigambre medieval.

Debido a los elevados costes y la dedicación simultánea de Cuesta en la realización de otro claustro en el convento de San Francisco de la misma villa, la fábrica de la obra dominica marcha con lentitud ${ }^{626}$. Tal es así, que siendo prior Fray Antonio de San Pablo, en diciembre de 1585, tan sólo habían sido ejecutados dos paños del claustro, los correspondientes al refectorio y a la iglesia. Sin embargo, parece que la parte realizada no respondía a las expectativas conventuales por carecer de una buena cimentación. En las nuevas condiciones redactadas ese año Juan de la Cuesta y Francisco del Vado declaran que se les debe abonar lo que costasen “...los despojos de los dos paños que se han de derribar del dicho claustro... ${ }^{627, " . ~ E s ~ c u r i o s o ~ o b s e r v a r ~ l a ~}$ gran diferencia del precio final de la obra entre el primer contrato, en que se pactaron 1.600 ducados, que equivalen aproximadamente a 17.600 reales y los 47.832 reales que se establecieron en el contrato de 1585, que doblaba con creces la cifra anterior. Tal vez fuera este el aliciente que necesitaban los artistas para erigir una obra. Ambos maestros obtienen el permiso para ejecutar la obra de Fray Juan de las Cuevas, provincial de la orden dominica en España; sin embargo, no fue rematada en los maestros mencionados sino en Pedro de Naveda ${ }^{628}$, vecino de Rada, en la merindad de Trasmiera y Juan Pérez de Rozpe, residente en Carrión, pues pujaron a la baja por la cuarta parte de la suma estipulada en diciembre de $1586^{629}$.

\footnotetext{
${ }^{626}$ Véase a este respecto la construcción del claustro de San Francisco.

${ }^{627}$ Nuevamente las condiciones son realizadas por Juan de la Cuesta, quien se concierta igualmente con Francisco del Vado para la ejecución. AHPP. Carr.Prot 5670. Andrés Sánchez (1585-1586) s/f.

${ }^{628}$ Datos de su biografía en VV.AA. Artistas cántabros Op.cit, pág. 461.

${ }^{629}$ VIGURI, Miguel de y SÁNCHEZ, José Luis. Arquitectura en Tierra de Campos...Op.cit, pp. 221-223, a su vez de AHPP. Carr.Prot 5670. Andrés Sánchez (1585-1586), fol 300 y ss.
} 
Las condiciones establecidas por Juan de la Cuesta, que se mantiene al mando de la obra, resultan análogas a las del primer contrato, salvo en los puntos siguientes:

-El antepecho del primer piso no se contempla y será sustituido por un zócalo pétreo.

-Se especifican los materiales a utilizar: la piedra de Villaescusa en los arcos, columnas y cornisa del piso inferior y piedra de los Alcores para las esquinas. En el piso superior, las columnas debían ser de piedra de Villaescusa, y el resto de ladrillo. Las cubiertas deberán ser realizadas en madera, y el suelo de yeso.

-En el lienzo correspondiente al templo, se dispondrán cuatro rafas de ladrillo ligadas con las tapias “...nezesarias para la fortificazión de la dicha pared... ${ }^{630 ” .}$

El claustro debía estar finalizado por los maestros en seis años, es decir, en 1592, por cuyos trabajos se abonarían cuatrocientos ducados anuales, prorrateados trimestralmente. En caso de que tardasen cinco años, se les compensaría la premura con quinientos ducados anuales.

La obra marchaba tan lenta que en 1591, el convento decide apartar a Juan de la Cuesta de la misma y contratar a otro maestro de cantería más fiable, pues llegado este año, tan sólo se había finalizado uno de los paños del claustro. De modo que el prior se concierta con el carrionés Marcos de la Torre, quien se compromete a realizar las tres pandas restantes tomando como modelo el lado ya ejecutado ${ }^{631}$. En 1596 Fray Lorenzo de Valcázar, prior del convento, requiere la intervención del maestro carrionés Santiago de Sigüenza para rehacer la cubierta correspondiente al paño de la sacristía que se había desplomado poco antes ${ }^{632}$. Esto indica que al menos la parte relativa a la cantería de ese paño sí que lo había finalizado Marcos de la Torre. Sin embargo, como Juan de la Cuesta, no cumplirá con lo acordado, ya que uno de los lienzos, aún se está realizando en el siglo XVII. Tampoco esta intervención será la última que Sigüenza realice en el claustro, ya que, como veremos, a principios del siglo siguiente concluyen los trabajos de este sector.

\footnotetext{
${ }^{630}$ GARCÍA CHICO, ESTEBAN. "El claustro de Santo Domingo...Op.cit, pp. 212-215 y también en VIGURI, Miguel de y Sánchez, José Luis. Heráldica...II. Op.cit, pp. 221-224.

${ }^{631}$ Sobre Marcos de la Torre, dirigirse al apartado relativo a su biografía. Escritura y condiciones de la obra en AHPP. Carr.Prot 5650. Pedro Saldaña (1591), fol 564 y ss.

${ }^{632}$ Escritura de contrato y condiciones en AHPP. Carr.Prot 5655. Pedro Saldaña (1596) s/f. Sobre Santiago de Sigüenza, véase el capítulo dedicado al mismo.
} 


\section{La sala capitular}

Paralelamente a las obras del claustro se llevaron a cabo otras piezas del convento por los mismos maestros, además de la sala capitular ${ }^{633}$.

De la misma sabemos que estaba reservado para el enterramiento de personajes ilustres de cierta entidad en la villa y alrededores, como es el caso del linaje de los Ordóñez de la Real. Así, por citar algunos de sus miembros, Laurencio Ordóñez fue un prestigioso abogado que tuvo cuatro hijos, Andrés Ordóñez era clérigo presbítero e igualmente abogado y había sido gobernador de Valencia de Don Juan desde 1645 a 1652; Alonso Ordóñez, dignidad en la Santa Iglesia de Pamplona, capellán de honor de Su Magestad, cura de su palacio y juez apostólico de la Real Capilla; Pedro Ordóñez, caballero de la orden de Santiago y colegial del colegio mayor de Oviedo de Salamanca y del Consejo de Su Majestad; y Martín Ordóñez, maese de campo ${ }^{634}$.

\section{EL SIGLO XVII}

Por los datos hasta ahora recogidos, deducimos que se trataba de un cenobio modesto; de hecho, en el siglo XVII, su época de máximo apogeo, no superaba la veintena de internos ${ }^{635}$. A finales de siglo la cifra desciende, pues en la carta de pago correspondiente a la refacción de las cuatro especies -vino, vinagre, aceite y carnesconsumidas por el convento en 1681, se registra un total de 16 religiosos y tres mozos, a saber, uno de labranza, uno de sacristía y otro de cocina ${ }^{636}$. A mediados del siglo XVIII

\footnotetext{
${ }^{633}$ El provincial de la orden dominica en España otorga el permiso para todas las obras del convento en 1585. AHPP. Carr.Prot 5670. Andrés Sánchez (1585-1586) s/f.

${ }^{634}$ Estos datos se revelan en el testamento de don Andrés Ordóñez de la Real, marido de doña Floriana Santos Regalado. Muestra de su situación acomodada es el hecho de contar con una criada desde hacía más de veinte años. María de Mediavilla, a quien deja muchos de sus bienes e incluso una casa para que viva en ella. Fue dictado el 15 de agosto de 1659. AHPP. Carr.Prot 5771. Andrés Simón Aguilar (1665), fol 179 y ss. Dicho testamento se recoge en el protocolo referido porque el 14 de mayo de 1665 don Andrés decide modificar alguna de las cláusulas a través del codicilo, como la adición de testamentarios y la anulación de la donación de una de sus casas para el Licenciado Vargas, cura de Santa María de Carrión. AHPP. Carr.Prot 5771. Andrés Simón Aguilar (1665), fol 189 y ss.

${ }^{635}$ En 1615 se contabilizaban justamente veinte. VV.AA. Entre Castilla y Filipinas...Op.cit, pág. 27.

${ }^{636}$ Carta de pago correspondiente a la refacción restitución que se hacía al estado eclesiástico de la porción con que había contribuido a los derechos reales, de los cuales estaba exento. AHPP. Carr.Prot 5004. Diego García de la Llana (1679-1685), s/f.
} 
se recupera nuevamente, pues el censo del Catastro del Marqués de la Ensenada recoge dieciocho frailes y a partir de ese momento la cifra decrecerá paulatinamente ${ }^{637}$.

Un dato que ilustra a la perfección el carácter asistencial de las órdenes mendicantes es el que nos transmite Becerro de Bengoa, quien afirma que cuando una epidemia de fiebres contagió a gran parte de la comunidad benedictina en 1640 obligando a la paralización de las obras del nuevo templo, fueron los dominicos quienes les asistieron con sus cuidados hasta que se recuperaron ${ }^{638}$.

En 1664 el convento movió pleito contra el de Santa Clara de la misma villa en razón de la posesión de una escritura de censo otorgada en 1620 a los dominicos por el matrimonio formado entre don Andrés de Valderrábano y Doña Bernardina de Osorio que ascendía a un total de 5.486 maravedís anuales. Éstos habían acumulado una deuda de 375 reales correspondientes al impago de cuatro meses. Por su parte, la casa clarisa, a quien pertenecía por entonces el mayorazgo, alegaba que dicho censo era nulo “...supuesto que en él no había fee de paga ni se auía cunplido con las solenidades que se rrequerían para su fundaçión...”, siendo las monjas quien debían recibir la suma correspondiente a dicho censo. Finalmente, en 1666, la sentencia se resolvió favorablemente para los frailes predicadores ${ }^{639}$.

\section{Reedificación del templo}

Desde principios del siglo XVII la iglesia presenta enormes deficiencias y es necesario proceder a su reedificación. La reforma primordial parte de la capilla de Nuestra Señora del Rosario, la principal de la capilla mayor. Su patrono, el deán de Cuenca, don Juan Bautista de Espinosa, será quien envíe en septiembre de 1616, desde la ciudad manchega en la que residía, una memoria con la traza que había de seguirse ${ }^{640}$. Contrata para la obra al maestro de albañilería y cantería de Carrión, Juan González de

\footnotetext{
${ }^{637}$ AHPP. Catastro del Marqués de la Ensenada. Respuestas dadas a las preguntas generales por los nombrados en dicha villa para la operación de única contribución en la Villa de Carrión, provincia de Toro. 12 de febrero de 1753. Microfilm 335, Libro 629, fol $224 \mathrm{v}$.

${ }^{638}$ BECERRO DE BENGOA, Ricardo. "El monasterio... Op.cit, pp. 88-89.

${ }^{639}$ AHN Clero Secular-Regular, Libro $9597 \mathrm{~s} / \mathrm{f}$.

${ }^{640}$ Escritura de 5 de septiembre de 1616. AHPP. Carr.Prot 5161. Jerónimo Laso (1616), s/f.
} 
la Mata ${ }^{641}$ y le insta a que utilice la cantería para la bóveda y el arco principal, en piedra labrada de Palacios de Alcor, y la mampostería en los muros internos, cubiertos de yeso, cal y arena. Visto el informe, de la Mata objeta que únicamente recurrirá al ladrillo en los muros y la arcada, debido a la resistencia del material y a que en la zona no se encuentra la piedra toba que requiere el comitente y aplicará la mampostería solamente en la cimentación.

En mayo de 1617 recibe 350 ducados para compra de materiales y envía las condiciones de la nueva fábrica, la cual se compromete a finalizar en un año por la generosa suma de mil ducados ${ }^{642}$. Del cumplimiento de las respectivas pagas, en los plazos señalados, se encargaría el hermano de Juan de Espinosa en su nombre, Fray Baltasar de Espinosa, prior del convento por entonces. En el nuevo contrato se pliega a los deseos del canónigo respecto a los materiales a utilizar. Debía, eso sí, dejar la capilla en perfecto estado, debidamente enlosada y lucida y dotada de gradas, ventana y cornisa, recurriendo para ello a un lenguaje de raigambre clasicista, a base de un sencillo zócalo, pilastras con una cornisa "encapitelada", es decir un capitel que recorra toda la superficie del testero. Se trata de una cornisa moldurada con un bocel, muy recurrente en el clasicismo vallisoletano. El arco triunfal que separaba la cúpula “...de media naranxa..." de la capilla mayor, debía ser de medio punto con su rosca bien labrada y como cubrición de este espacio se emplearía una bóveda con lunetos. La capilla debía proveerse de un altar y una grada de cuatro pies de altura, con una molduración de filetes y boceles "labrados y trinchantados ${ }^{643}$ ". El acabado final consistiría en enlosar toda la capilla de piedras cuadradas procedentes de Palacios y guarnecerla íntegramente de yeso.

Para las labores de cantería, de la Mata subcontrata en 1619 al trasmerano Juan de Cajigosa ${ }^{644}$, quien se encargará de componer cuatro pilares, dos en la capilla mayor acompañados de una rafa de refuerzo, uno en la capilla de San Ildefonso y otro en la de

\footnotetext{
${ }^{641}$ Datos biográficos del mismo en el apartado correspondiente.

${ }^{642}$ AHPP. Carr.Prot 5437, fol 30 y ss. Pedro Moro Solórzano (1614-1619)

${ }^{643}$ El trinchante era un martillo con filos rectos y paralelos al mango que se usaba para allanar los sillares, y de ese modo se denominaba así a la labor ejecutada. LOSADA VAREA, Celestina. La arquitectura...Op.cit, pág. 45.

${ }^{644}$ Sobre el mismo, véase el apartado dedicado a su biografía.
} 
San Sebastián, junto al altar mayor, además de algunas pilastras orientadas hacia el cuerpo de la iglesia, todo ello por ciento veinte ducados ${ }^{645}$.

Los trabajos se dilatan irremediablemente. El también trasmerano Hernando del $\mathrm{Arco}^{646}$ se encarga de rehacer un pilar de la capilla de San Ildefonso en 1622 por encargo del prior Fray Domingo Sánchez ${ }^{647}$. Sin embargo estos reparos no frenan el imparable y progresivo deterioro de la capilla, lo que conduce al convento a intervenir, optando por su demolición para evitar daños colaterales. La cofradía homónima de la capilla reunida en cabildo solicita que no se derribe y en caso de ser el último recurso, pueda recoger el despojo de la misma ${ }^{648}$. Al final se llega a un acuerdo con el cabildo: será un miembro de la cofradía, precisamente Juan González de la Mata, quien se encargue de rehacerla, recibiendo por ello “...lo que quatro cofrades de los más antiguos de la dicha cofradía declararen merecer, con que no exceda todo de duçientos ducados...”. Se comprometió a finalizarla en 1624 y así lo cumplió, como así confirman las cartas de pago de 1625 por valor de sesenta ducados correspondientes a los tres años precedentes $^{649}$.

Diez años después de contratar las obras de la capilla mayor, éstas siguen sin concluirse, pues por carta de pago de 8 de julio de 1625 se le abonan a de la Mata 1500 reales correspondientes a “...la capilla de Nuestra Señora del Rosario que por orden del dicho Deán de Cuenca se açe en el dicho monasterio... ${ }^{650 " . ~ S i n ~ e m b a r g o, ~ p a r e c e n ~}$ haberse finalizado poco después, según indica la carta de pago emitida en enero de 1626 por la que Juan González recibe 3350 reales en concepto de lo que quedaba por pagar del tejado de la iglesia y la intervención en la capilla mayor ${ }^{651}$.

\footnotetext{
${ }^{645}$ La escritura de contrato en AHPP. Carr.Prots 5164. Jerónimo Laso (1619), fol 387.

${ }^{646}$ En Carrión, figura en 1622 como testigo de Diego de Mazarredonda y Juan González de la Mata en la firma del contrato de la sacristía, librería y noviciado del convento de San Zoilo AHPP. Carr.Prot 5405, Francisco Moro Saldaña (1622), s/f.

${ }^{647}$ Escritura de contrato y condiciones de la obra el 11 de enero de 1622. AHPP. Carr.Prot 4822. Francisco Cuetos (1621-1622) s/f.

${ }^{648}$ ASMC. Libro de la Cofradía de San Pedro y San Ildefonso (1600-1641) s/f. El requerimiento de los cofrades para que no se derribe la capilla se firma el 2 de febrero de 1622 en AHPP. Carr.Prot 5405. Francisco Moro de Saldaña (1622), s/f.

${ }^{649}$ AHPP. Carr.Prot 5408. Francisco Moro de Saldaña (1625), s/f.

${ }^{650}$ AHPP. Carr.Prot 5491. Antonio Orejón, el Viejo (1624-1625), fol 294.

${ }^{651}$ El 12 de enero de 1626 se le pagan 3348 reales de los cuales 2150 en concepto del tejado del cuerpo de la iglesia conventual y 1198 reales de la capilla mayor que tiene hecha con los que se le acaban de pagar los 11.378 reales de dicho encargo. Carta de pago en AHPP. Carr.Prot 5409, Francisco Moro Saldaña (1626), fol 851.
} 
Los problemas se suceden, pues la capilla de San Ildefonso presenta daños al poco tiempo y es entonces cuando los regidores y mayordomo de la cofradía presentan pleito al maestro albañil ${ }^{652}$. En 1630 se recurre de nuevo a Juan de Cajigosa y al también trasmerano Domingo del Río, nombrados por parte de Juan González de la Mata para que tasen las obras así como al ensamblador Juan Bautista Pérez y otros miembros pertenecientes a la cofradía, por parte del cenobio, para que lleguen a un acuerdo ${ }^{653}$. En tanto se resuelve el litigio continúan las obras en el templo, pues a finales de 1632 el convento abona doscientos ducados en concepto de "...la obra y capilla del cuerpo de la iglesia...” a los maestros albañiles Bartolomé Alejo ${ }^{654}$ y Francisco Rodríguez quedando ajustada la obra en 2.850 reales $^{655}$. Juan González de la Mata, en contra de lo que podríamos pensar, prosigue con los trabajos en la iglesia. Así acuerda en 1635 con Hernando de Inestrosa la ejecución de dos pilares, por lo que le abonará 850 reales ${ }^{656}$. Finalmente, en julio de 1638, la resolución del litigio condena a Juan González de la Mata a abonar a la cofradía 300 ducados, la cual le queda debiendo aún 500 reales de los 2.850 en que se remató la obra, que irá abonando en los dos años siguientes. No termina aquí la participación de Juan González de la Mata, ya que en 1642 se compromete a intervenir en el coro con el objetivo de “...levantar los pilares y hazer el tejado al niuel del nuevo y deshazer el biejo que llegue hasta la torre... ${ }^{657, .}$

Finalizadas las intervenciones, el prior del convento, no conforme con la obra realizada por Juan de la Mata en la capilla mayor, dispone en 1645 que cada uno busque maestros que tasen y vean si se han cumplido las condiciones estipuladas en el contrato. Francisco del Río Pontecillas será nombrado por el convento, y Juan de Trujeda de la

\footnotetext{
${ }^{652}$ AHN. Clero Secular-Regular 5352. Obras, s/f.

653 Sobre todos ellos, remítase al capítulo dedicado a las biografías de los maestros de cantería o ensambladores, en cada caso.

${ }^{654} \mathrm{Su}$ primera obra documentada data de 1584 en que junto al maestro carpintero Juan Antonio González repara la torre de la iglesia de San Andrés de Carrión. AHPP. Carr.Prot. 5600 Francisco Rojas (15801589), s/f. En 1592 Pedro Gutiérrez concluye un cuarto del convento de Benevívere que había dejado inacabado. El contrato y condiciones de esta obra en AHPP. Carr.Prot 4681, Juan Cantoral (1589-1594), s/f. En 1622 puja en la obra del casco de la capilla mayor de la iglesia de Belén con 18 ducados, pero finalmente se remata en Bartolomé del Campo por 11 ducados. AHPP. Carr.Prot 4849. Juan Díaz Pajaza (1622-1623), s/f. Junto a Antonio del Tejo repara en 1636 la iglesia de Santiago de Calzada de los Molinos. AHPP. Carr.Prot 5182, Jerónimo Laso (1636), s/f.

${ }^{655}$ AHN. Clero Secular-Regular 5352 s/f Santo Domingo, Obra y también en AHPP. Carr.Prots 4858. Juan Díaz Pajaza (1632-1633), fol 230.

${ }^{656}$ AHPP. Carr.Prot 5181. Jerónimo Laso (1635), fol 773 y ss. Sobre Inestrosa y Juan González de la Mata, remítase al apartado dedicado a los maestros locales.

${ }^{657}$ AHPP. Carr.Prot 5188. Jerónimo Laso (1642), fol 62.
} 
parte del albañil carrionés ${ }^{658}$. Ambos maestros valoran positivamente la obra, pues además de lo concertado, de la Mata había realizado una serie de mejoras a las que no estaba obligado, como los dos nichos laterales de la cabecera, la ventana del mediodía para aportar diafanidad al espacio, o la disposición de cinco gradas para acceder a la capilla mayor, en lugar de las tres acordadas en principio ${ }^{659}$.

Concluidas las obras de rehabilitación, los priores se encargan de dotar al templo de ornamentos litúrgicos, y además encargan en 1652 la ejecución de una "custodia", es decir un sagrario a los ensambladores Juan Bautista Pérez y Nicolás de Vega ${ }^{660}$. Para determinar si la pieza cumplía con lo establecido, se escogieron dos maestros peritos: Manuel de Salceda, de parte del convento y Juan de Inestrosa, a favor del artífice. Las modificaciones que deberán aplicarse se refieren fundamentalmente a las dimensiones de las diversas partes que conforman la custodia para lograr que sea armónica ${ }^{661}$.

Lo más interesante sin duda es que gracias a las mismas podemos deducir que se trataba de una especie de tabernáculo clasicista estructurado en dos pisos con columnas, separados por una cornisa. El primero de ellos se asentaba sobre un zócalo y sobre este nivel existía un corredor, que podemos interpretar como una balaustrada, al modo de las que presenta el tabernáculo de la capilla del Relicario de la Colegiata vallisoletana de Villagarcía de Campos, o tipo pretil, como el sagrario del retablo mayor de la Catedral de Palencia ${ }^{662}$. El otro cuerpo, dispuesto sobre un pedestal, estaba rematado en una cúpula de media naranja con linterna rematada con motivos de bolas. La doble estructuración sobre amplios zócalos y remate cupulado nos remite al sagrario del retablo mayor de San Zoilo, cuya fisonomía pudo ser semejante.

Como analizamos con anterioridad, Juan González de la Mata se había encargado de la edificación del coro en 1642. La capilla que se hallaba debajo de éste,

\footnotetext{
${ }^{658}$ Sobre ambos artistas, remitirse al apartado relativo a sus biografías

${ }^{659}$ Vista de la obra de la capilla mayor por Juan González de la Mata. 1645. AHN. Clero secular-regular 5352. Obras, s/f.

${ }^{660}$ Sobre ambos artistas, remítase al capítulo dedicado a los escultores y ensambladores locales.

${ }^{661}$ Informe de los veedores de la custodia de Santo Domingo en AHPP. Carr.Prot 5525. Tomás Pérez (1652), s/f. Sobre Manuel de Salceda, remítase al capítulo dedicado a los escultores locales.

${ }^{662}$ Estudios específicos sobre estas obras en REVILLA VIELVA, Ramón. "Retablo mayor de la Santa Iglesia Catedral de Palencia" en PITTM, n5, Palencia, 1950, pp. 91-104, GARCIA CHICO, Esteban. "El retablo mayor de la Colegiata de Villagarcía de Campos" en BSAA, no19. Valladolid, 1952-1953, pp. 1522, SAN MARTÍN PAYO, Jesús. "El retablo mayor de la Catedral de Palencia: Nuevos datos" en PITTM, nº10, Palencia, 1953, pp. 273-312.
} 
aledaña a la torre, experimenta una reparación en 1663, cuando el maestro de albañilería Julián de León junto al maestro de carpintería Francisco Reinaldos se encargan de su reedificación previo acuerdo tomado con el prior Fray Domingo Rubio ${ }^{663}$. Para ello se siguen las condiciones redactadas por el maestro de cantería trasmerano Jerónimo de Avendaño ${ }^{664}$. Por entonces, las dos capillas de la nave de la iglesia contiguas a ésta poseían una bóveda de cañón con lunetos que el mismo Julián de León había realizado. Análoga a aquéllas debía ser la situada bajo el coro, enlucida posteriormente. También debía realizarse un acceso en el medio, consistente en una puerta de madera de cuatro pies de ancho con un arco en chaflán.

Las deficiencias estructurales en el templo son incesantes, pues como indicamos, la falta de medios justificaba una menor calidad en las intervenciones. Efectivamente, en julio de 1698 se ordena demoler, debido a su ruinoso estado, la capilla de Nuestra Señora de la Piedad, colateral del lado del Evangelio, para reedificarla seguidamente ${ }^{665}$. El arquitecto encargado de estas obras será el maestro cántabro Juan de Solana, vecino de Liaño ${ }^{666}$. Para su reedificación, Solana debía tomar como modelo la capilla mayor del Rosario, igualando sus dimensiones y disposición, con su pedestal de mampostería y blanquearla posteriormente. Además debía disponer una puerta nueva en la sacristía ubicada junto a la capilla, para de este modo acceder al templo. Solana contaba con cinco meses para llevar a cabo estos trabajos pero estaban excluidos de los mismos el enlosado de la capilla.

\section{Conclusión del claustro}

En 1600, el convento, en nombre del prior Fray Alonso de Arellano, vuelve a requerir la intervención del maestro carrionés Santiago Díez de Sigüenza en el claustro. En esta ocasión debía encargarse de finalizar el tejado del sobreclaustro correspondiente al refectorio “...açiendo en él su alar de cauezas añadidas enzima de los machones y el

\footnotetext{
${ }^{663}$ Recibiría por su trabajo 1500 reales. Escritura y condiciones firmadas a 10 de enero de 1663 en AHPP. Carr.Prot 5201. Jerónimo Laso (1663-1664), fol 643 y ss. Sobre Julián de León, consúltese el apartado relativo a los maestros locales.

${ }^{664}$ Sobre el mismo, véase el apartado dedicado a los maestros cántabros.

${ }^{665}$ La escritura de orden de demolición de dicha capilla está en AHPP. Carr.Prot 5018. Agustín García Miranda (1696-1698), s/f.

${ }^{666}$ Sobre el artista, véase el apartado relativo a los maestros de otras procedencias.
} 
alar guarneçido con sus canes como lo demás... ${ }^{677 " . ~ P o r ~ l a ~ o b r a, ~ q u e ~ d e b i ́ a ~ f i n a l i z a r ~ e n ~}$ junio de 1601 , recibiría 1.275 reales.

Finalmente, en 1605, el maestro cántabro Toribio de la Cuesta ${ }^{668}$ se compromete a realizar la panda del lado de la iglesia que quedaba por hacer, que comprendía la ejecución de ambos pisos desde sus cimientos “...por la misma orden y labor que trae todo lo demás... ${ }^{669 " . ~ A d e m a ́ s ~ d e b i ́ a ~ p r a c t i c a r ~ u n a ~ p u e r t a ~ d e ~ a c c e s o ~ a ~ l a ~ i g l e s i a ~ d e ~ p i e d r a ~}$ procedente de Palacios de Alcor, formada por un arco de medio punto labrado a golpe de escoda y el resto a picón ${ }^{670}$ y unas escaleras para subir de la iglesia al claustro. Simultáneamente trabajaba en la obra de la bóveda de la cripta de la iglesia del convento de Santa María de Benevívere ${ }^{671}$. Esto podría justificar la dilación de las obras hasta el año 1607, pues Sigüenza figura en una carta de pago recibiendo quinientos reales por una obra que acababa de realizar en el paño del templo ${ }^{672}$. Sabemos que ya habían finalizado porque a mediados de 1608 Toribio de la Cuesta afirmaba no haber recibido aún la suma que se le debía ${ }^{673}$. El remate de esta obra en el maestro cántabro, la primera que realiza en Carrión, se justifica por su participación previa en el convento dominico de Santa Cruz de la Real, del que probablemente llegaría recomendado ${ }^{674}$.

Se concluía así la obra del claustro renacentista, paralelamente a las del monasterio de San Zoilo. Si bien el empeño les valió gran parte de sus ingresos, los frailes dominicos consiguieron acabar la gran empresa que habían comenzado en 1579

\footnotetext{
${ }^{667}$ Escritura de obligación en AHPP. Carr.Prot 4769. Martín Cisneros (1600-1601), s/f.

${ }^{668}$ Sobre el artista, véase el apartado relativo a su biografía.

${ }^{669}$ Escritura y condiciones en AHPP. Carr.Prot 4832. Francisco Moro Saldaña (1605), fol 521 y ss.

${ }^{670}$ La escoda era una herramienta de cuerpo metálico y mango de madera con la que se efectuaban golpes profundos que daba lugar a una talla muy fina. El pico servía para eliminar las irregularidades al escuadrar los bloques. LOSADA VAREA, Celestina. La arquitectura...Op.cit, pág. 44-45.

${ }^{671}$ AHPP. Carr.Prot 4708. Pedro Carrión (1605), s/f y 4832.

${ }^{672}$ AHPP. Carr.Prot 4772. Martín Cisneros (1607-1609), s/f

${ }^{673}$ AHPP. Carr.Prot 4835. Juan Díaz Pajaza (1608) fol 521 y ss.

${ }^{674}$ AHPP. Carr.Prot 4832. Juan Díaz Pajaza (1605), fol 223 y ss.
} 


\section{EL DEVENIR A PARTIR DEL SIGLO XIX}

Tras un siglo XVIII que podríamos denominar fantasma, dada la inexistencia de noticias sobre el convento, en el siglo venidero se observa cómo la comunidad se desenvuelve con precariedad, si bien llevando una vida aparentemente normal ${ }^{675}$.

De este monasterio no se conserva nada, pues las sucesivas exclaustraciones motivaron la desaparición de todos los edificios que conformaron esta casa dominica. La primera desamortización se produjo en 1809, con José I, y en 1811, un grupo de guerrilleros al mando de Santos Padilla, quemó el convento para desalojar a las tropas napoleónicas de Carrión, afectando a sus estancias más significativas ${ }^{676}$. Para la reconstrucción del tejado incendiado de la iglesia de Santa María se extrajeron los materiales de este convento ${ }^{677}$.

También los vecinos de Carrión aprovecharon el estado de debilidad y deterioro para extraer sin permiso piedra, madera y otros efectos para uso personal hasta tal punto que en 1814 el concejo emitió una orden por la que se sancionaban este tipo de acciones, no sólo hacia éste sino hacia otros conventos de la zona que se habían visto avocados a la ruina, con seis ducados de multa. Un informe emitido sobre el estado de los conventos de la provincia de Palencia el 13 de diciembre de 1813 revela que seis de ellos se hallaban completamente en ruina, a saber: el agustino de Cervera, el de mínimos de Saldaña, el de franciscanos de Reinosa, el de benedictinos de Frómista y los dominicos de Cisneros y Carrión ${ }^{678}$. Así lo confirman el consistorio de Carrión, afirmando que se hallaba "prácticamente demolido ${ }^{679, "}$.

\footnotetext{
${ }^{675}$ SALVADOR Y CONDE, P.J Op.cit, pp. 511-515, a su vez de AHPP. Carr.Prot 5670. Andrés Sánchez (1585-1586), fol 300 y ss.

${ }^{676}$ REVUELTA GONZÁLEZ, Manuel. "Origen, ocaso...Op.cit, pp. 62-63, a su vez de AHN. Consejos. Leg. 12027.

${ }^{677}$ El 24 de diciembre de 1811 se abonan 975 reales a Lorenzo Bahíllo por recoger los escombros del templo de Santa María y traer los materiales de Santo Domingo. Los religiosos de Santo Domingo recibirán 3.800 reales por los materiales extraídos. ASMC. Libro $3^{\circ}$ de Fábrica (1805-1850), fol 70v, $124 \mathrm{v}$ y 132.

${ }^{678}$ REVUELTA GONZÁLEZ, Manuel. "Origen, ocaso...Op.cit, pp. 62-63, a su vez de AHN. Consejos. Leg. 12027.

${ }^{679}$ AMCC. Libro 2, Sesiones municipales (1759-1814), s/f.
} 
En 1830, nombrado Presidente el P. Tomás Cañas, entregó al comisionado del gobierno lo que quedaba de la casa conventual ${ }^{680}$. A partir de ese momento, los frailes dominicos pasaron a vivir a unas casas en la Calle Castillería, al noroeste de la villa, abandonándola con la llegada de la ley de exclaustración de $1836^{681}$. Por entonces, del convento ya no quedaba más que el título y la posesión de sus ruinas ${ }^{682}$.

Todos sus materiales fueron reaprovechados para la construcción del fuerte militar que se construyó en 1838 con el fin de proteger la villa ante posibles ataques del sector liberal $^{683}$.

En 1842, el general Espartero lo subastó por 13.600 reales a favor de Don Manuel Gutiérrez Gurrea. El mal estado del edificio desde el incendio de 1811, justifica la baratura del mismo ${ }^{684}$. Desde entonces no se volvió a mencionar el cenobio dominico, del cual no queda más que su recuerdo en la documentación.

\section{LAS CAPILLAS, ESPACIOS DE CULTO}

\subsection{LA CAPILLA MAYOR}

Algunos miembros de diversos linajes adquirieron sepulturas bajo el altar de la capilla mayor con el deseo de asegurarse un trato privilegiado en la otra vida. Así lo hicieron la familia de los Serna, uno de cuyos miembros, Baltasar de la Serna, decidió ser sepultado junto a su padre, cuyos restos allí reposaban, cuando dictó testamento en $1575^{685}$. Idéntica fue la última voluntad del matrimonio formado por don Juan de la Serna y su mujer Mariana, quienes en 1587 dotaron una capellanía con trescientos ducados para la casa dominica ${ }^{686}$.

\footnotetext{
${ }^{680}$ SALVADOR Y CONDE, J. Op.cit, pp. 526-529.

${ }^{681}$ RAMÍREZ DE HELGUERA, Martín. El libro...Op.cit, pág. 179.

${ }^{682}$ VV.AA. Entre Castilla...Op.cit, pág. 27.

${ }^{683}$ AMS. Proyecto del fuerte de Carrión. Sección $3^{\mathrm{a}}$, División $3^{\mathrm{a}}$, Leg 99, nº 11, fol 7.

${ }^{684}$ REVUELTA GONZÁLEZ, Manuel. “Origen, ocaso...Op.cit, pp. 73-75.

${ }^{685}$ AHPP. Carr.Prot 5615. Melchor de la Rúa (1575-1577) s/f.

${ }^{686}$ El testamento de Juan de la Serna se encuentra inserto en un documento en ARCHV. Pleitos Civiles la Puerta (Olvidados) Caja 350 Exp.4 s/f.
} 
Sin duda el caso más anecdótico de sepultura fue la de don Antonio Doro Campoo, próspero comerciante que hizo fortuna en las Américas y a quien se debe la realización de la custodia del Corpus Christi de Carrión ${ }^{687}$. En su testamento, dictado en 1591 dispuso como preferencias de enterramiento, la capilla mayor de San Julián o la del convento de Santo Domingo y si no fuese posible, “...en cualquier iglesia de la villa... ${ }^{688 \% .}$. Cuando falleció en 1602, su viuda, doña Constanza Enríquez solicitó al cenobio dominico una sepultura para su difunto marido, respondiéndole su prior Fray Juan Cisneros que aceptaba, pero que para ello “...saque d'ella los huesos de los que en ella están enterrados y dexe desembarazada la capilla... ${ }^{69}$ ". Sin embargo Doña Constanza rechazó la propuesta y el cadáver fue trasladado a la capilla que bajo la advocación de Nuestra Señora había fundado doña Constanza en marzo de 1602 en el monasterio de San Zoilo, donde reposa el difunto desde entonces ${ }^{690}$.

También el alférez mayor de Carrión, don Gabriel Mantilla, se reservó en 1611 un espacio en la capilla mayor de Santo Domingo, según se entra a mano izquierda, junto a la de su mujer María de la Vega, ordenando además el traslado de la sepultura de su madre doña Mencía Díez de Campoo y el de un hijo suyo fallecido precozmente, desde la capilla mayor de Nuestra Señora de Belén ${ }^{691}$. Revocó el testamento a posteriori, pues en una copia del mismo realizada en 1689, hallamos que en una de las cláusulas expresa su deseo de poseer una sepultura con cuatro escudos en la capilla mayor del convento de San Miguel y Santa Isabel “...por el afecto que les profesa... ${ }^{62, ", ~ d o n d e ~ f u e ~ f i n a l m e n t e ~ s e p u l t a d o . ~}$

\footnotetext{
${ }^{687}$ Sobre el mismo, URREA FERNÁNDEZ, Jesús. "La custodia...Op.cit. pp. 766-767 y LORENZO SANZ, E. "Palentinos...Op.cit , pág. 454.

688 AHN. Clero Secular-Regular Legajo 5331 s/f. Documentos eclesiásticos y papeles de carácter religioso.

689 AHPP. Carr.Prot 5077. Pedro Guerra Cervantes (1602), s/f.

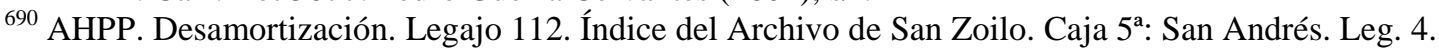
Capilla de doña Constanza. No 2 . Para esta capilla, véase San Zoilo en el siglo XVII.

${ }^{691}$ Este personaje fue un ilustre carrionés que poseía varias casas junto a San Andrés, razón por la cual hoy día a esa zona se le conoce como "Las Mantillonas". El testamento de Gabriel Mantilla en AHPP., Carr.Prot 5156. Jerónimo Laso (1611). Otro ejemplo de la aceptación para la disposición de sepulturas en la capilla mayor es la de don Antonio Doro Campoo. Su viuda, doña Constanza Enríquez, tras un litigio con el convento, consigue trasladar los restos de su difunto marido en 1602. AHPP., Carr.Prot 5077. Pedro Guerra Cervantes (1602) s/f.

${ }^{692}$ ASCC. Santa Isabel. Mayorazgos (1624-1689), $\mathrm{n}^{\circ} 2$, 1689. Sobre este tema, véase el convento de Santa Isabel.
} 


\section{Capilla de la Virgen del Rosario}

Dada la vinculación entre la orden dominica y el rosario, esta advocación era una de las más frecuentes ${ }^{693}$. Por un documento de 1698 en el que se derriba la capilla de la Piedad, colateral del lado del Evangelio, se indica que la capilla del Rosario se halla “...en su correspondencia...”, por lo que entendemos que se trataría de la capilla colateral de la Epístola ${ }^{694}$. Este dato cuadra con las medianas dimensiones del retablo, que, ubicado desde 1810 en la iglesia de San Andrés, no resultaría demasiado acorde para centrar la capilla mayor de una iglesia conventual.

Este retablo completamente dorado, presenta una sencilla estructura de un solo cuerpo y ático, a la cual flanqueaban dos esculturas, la de San Antón y la de San Pedro. En el ático, incluido en una especie de frontón semicircular, se sitúa un gran lienzo de la Virgen entregando el rosario a Santo Domingo y Santa Catalina. Atendiendo a la exuberante ornamentación de la pieza, donde la hojarasca se despliega cubriéndolo todo a modo de tapiz, podemos datarla a principios del siglo XVIII ${ }^{695}$.

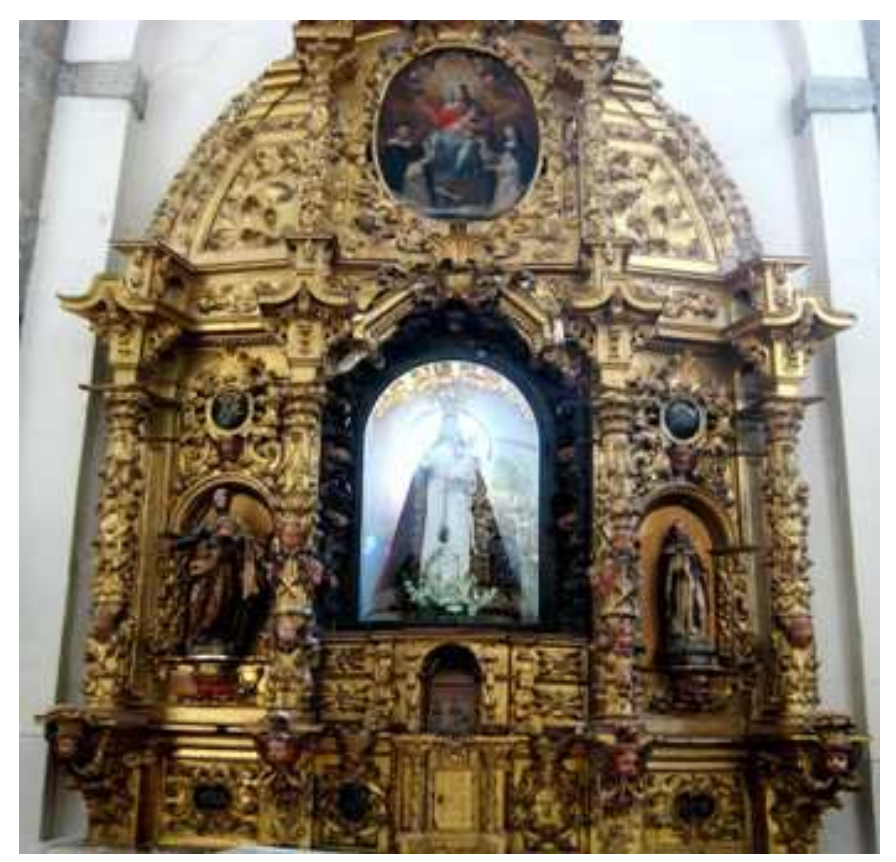

Retablo de la Virgen del Rosario, actualmente en la iglesia de San Andrés. $(6,75 \mathrm{mtrx} 5 \mathrm{mtrx} 1,4 \mathrm{mtr})$.

\footnotetext{
${ }^{693}$ LAVARGA GARCÍA. "La devoción del rosario: datos para la historia” en Archivo dominicano, no 24. Salamanca, 2003, pp. 225-277.

${ }^{694}$ AHPP. Carr.Prot 5018. Agustín García Miranda (1696-1698), s/f.

${ }^{695}$ Sobre este retablo se hablará con detenimiento en las capillas de la iglesia de San Andrés.
} 
El primer patrono conocido de esta capilla y también del templo fue el clérigo Jacques de la Vega, quien por testamento dictado en 1565, ordenó se colocara su sepultura según se entra en la capilla mayor, en la margen derecha “...junto al altar de Nuestra Señora...”. Precisa que se realice un sencillo arcosolio en piedra de Amusco y sin bulto alguno, con tan sólo una inscripción en su memoria ${ }^{696}$. Uno de los primos del difunto fue don Juan Díez de Loyola, patrón de la capilla de San Gregorio en la iglesia de Belén. Al morir sin descendencia, y por la buena relación que mantenía con él, Jacques le concede la posesión de unas casas heredadas de su tío y hermano de su madre, María Díez. A otro de sus primos, Antonio Díez de Modoya, le traspasa el patronazgo de la capilla y además dispone que si éste quisiera realizar una capilla propia, que se construya la misma en lugar de su arcosolio, abonando el generoso finado la mitad de su coste. Tenemos constancia documental de que finalmente Jacques de la Vega se dispuso el nicho y arco en el lado de la Epístola, dentro de la capilla mayor ${ }^{697}$.

Siendo prior del convento Fray Baltasar de Espinosa, los huesos de Jacques de la Vega fueron retirados sin permiso de la capilla mayor y dispuestos en una arquilla de la sacristía. Con toda seguridad este hecho se produjo en 1616, cuando tenemos constancia de que detentaba el cargo y cuando además fue reedificada por completo la capilla mayor por Juan González de la Mata con el fin de acondicionarla para su hermano, el deán y clérigo de Cuenca, don Juan Bautista de Espinosa ${ }^{698}$. Éste ilustre personaje, había adquirido el patronato de este espacio de culto en $1580^{699}$.

Para comprender la presencia de las autoridades eclesiásticas de la sede manchega en Carrión y por extensión en otros territorios de Castilla, es necesario remontarse a los orígenes de la Diócesis de Cuenca. Desde su fundación a finales del siglo XII, y de forma más acentuada en los siglos XIV y XV, la monarquía castellana, secundada por el Papado, ha ejercido una influencia decisiva -cabría decir, incluso manipulación- en la elección del Obispo y su cúpula. Dado el control político que

\footnotetext{
${ }^{696}$ Por la sepultura abonó doce ducados y para la ejecución del arco ordenó que no excediera de cuarenta ducados. Testamento otorgado a 13 de agosto de 1565 en AHPP. Carr.Prot 5443. Gregorio Movilla (1564-1567), s/f.

${ }^{697}$ AHPP. Carr.Prot 5410. Francisco Moro Saldaña (1627) s/f.

${ }^{698}$ Condiciones de la construcción en AHPP. Carr.Prot 5161. Jerónimo Laso (1616), s/f. El tema aparece desarrollado en la parte relativa a la construcción del templo dominico.

${ }^{699}$ AHPP. Carr.Prot 5461. Lázaro Santa Cruz (1579-1584), s/f.
} 
revestía esta institución, la realeza se aseguraba un apoyo incondicional al situar en las altas esferas a miembros de la nobleza castellana ${ }^{700}$. Esto explica que, algunos de los miembros del linaje Espinosa, aun siendo oriundos de Carrión, hubieran detentado el rango de deanes de Cuenca regresando a su villa natal con el fin de precisar los detalles concernientes a su eterno descanso ${ }^{701}$.

Diversos miembros de la familia de los Paz de la Serna, como testamentarios perpetuos de Jacques de la Vega y regidores de la villa, indignados ante la “...poca estimaçión de persona noble de tan sancto celo y bienhechora del dicho conbento y pobres d'esta uilla..." solicitan en 1627 del Obispo de Palencia su intervención para la inmediata restitución de la sepultura del finado ${ }^{702}$. Sin embargo, su petición no debió ser atendida, pues el conflicto continúa en los años posteriores, como así lo confirma la petición que en 1646 solicita el convento de Santo Domingo para comprobar la legalidad del testamento de Jacques de la Vega ${ }^{703}$.

\section{Capilla de los Mendoza o la Piedad}

Los duques del Infantazgo mostraron gran devoción por las órdenes mendicantes a través de sus mandas piadosas y su enterramiento en lugares de culto adquiridos a tal efecto en el interior de los templos. En el caso del convento franciscano de Carrión, poseían capilla propia, colateral al altar mayor, en el lado del Evangelio. En el caso del cenobio dominico, también se ubicarían en un espacio dentro de la cabecera del templo. Lo sabemos porque en 1596 se están efectuando obras de restructuración de los tejados de la panda del claustro correspondiente a la sacristía y se indica que las obras iban a afectar a la cubierta de la capilla de Pedro López de Mendoza, ubicada junto a ella ${ }^{704}$.

\footnotetext{
${ }^{700}$ De hecho no se registra ningún Obispo de procedencia local, debido precisamente a que los intereses pontificios y monárquicos eran bien diferentes. DÍAZ IBÁÑEZ, Jorge. "El poder episcopal en la Diócesis de Cuenca durante la Edad Media" en Espacio, tiempo y forma, serie III. Historia Medieval, t.9. Madrid, 1996, pp. 41-45.

${ }^{701}$ De hecho hay otro miembro del mismo linaje que ostentó el cargo de deán de Cuenca que aparece en estrecha conexión con Carrión. Hablamos de don Andrés de Espinosa, camarero de Clemente VIII, quien donó al convento de Santa Clara de dicha villa la cantidad correspondiente para la ejecución de los retablos de San Blas y Santo Espíritu en 1596. Con toda probabilidad, también éste decidió sepultarse en la villa que le vió nacer. ROYO ABRIL, Alfredo. Real Convento...Op.cit, pág. 11.

${ }^{702}$ AHPP. Carr.Prot 5410. Francisco Moro Saldaña (1627) s/f.

703 ACP. Sección Histórica. Armario IX, Legajo 5,29.

${ }^{704}$ AHPP. Carr.Prot 5655. Pedro Saldaña (1596) s/f.
} 
Por tanto podemos deducir que este espacio era una de las capillas colaterales, situada en el lado de la Epístola.

En el siglo XVII se indica que estaba dedicada a Santa Catalina y se señala su ubicación en el lado del Evangelio de dicha capilla mayor. Don Álvaro de Diguza Carvajal ostentaba el patronazgo de la misma, como así lo atestigua el testamento dictado en 1616 por su mujer, doña María Brasa de Reinoso ${ }^{705}$. Varios años después figura como patrona Doña Ana de Heredia y Mendoza, hija de Ana María de Mendoza, viuda de Francisco Robles y vecina de Navarrete, hasta que decide venderla en $1659^{706}$. Es posible que esta capilla se identifique con la capilla de la Piedad, pues cuando en 1698 se demuele para proceder a su reedificación, se señala su ubicación colateral del Evangelio $^{707}$. La fisonomía de este espacio se rehizo tomando como modelo la capilla mayor, tanto en sus dimensiones como en su forma.

\subsection{CAPILLA DEL CRUCIFIJO}

Situada “...al lado yzquierdo de la Epístola, denttro de la rreja de la capilla mayor... era patronazgo del linaje Calderón Ayala ${ }^{708, " . ~ L a ~ v e n e r a c i o ́ n ~ d e ~ e s t a ~ f a m i l i a ~ p o r ~}$ el Crucifijo no debe ser casual, pues bajo esta advocación poseyó una capilla en la iglesia de Santa María.

Don Marcos Calderón Galarza Ayala, un comerciante carrionés que hizo fortuna en las Indias, ordenó en su testamento, realizado en Lisboa en 1601, la fundación de obras pías en su villa natal, Carrión de los Condes $^{709}$. Designó como administradores de las capellanías que pensaba fundar a Damián de Caviedes Calderón, su hermano, a Gaspar de la Fuente, esposo de su sobrina Francisca Velarde de Santillana, y a

\footnotetext{
${ }^{705}$ AHPP. Carr.Prot 4774. Martín Cisneros (1613-1616) s/f.

${ }^{706}$ Dicha capilla se situaba en el lado derecho de la capilla mayor. AHPP. Carr.Prot 5199. Jerónimo Laso (1659), fol 368.

${ }^{707}$ La escritura de orden de demolición de dicha capilla está en AHPP. Carr.Prot 5018. Agustín García Miranda (1696-1698) s/f.

${ }^{708}$ Nombramiento de iglesias por los patronos del Capitán Marcos Calderón de Galarza e Ayala. AHPP., Carr.Prot 5385, Francisco Moro de Saldaña (1602) s/f.

${ }^{709}$ La emigración a las Indias en busca de fortuna fue un fenómeno generalizado durante la Edad Moderna. A Este respecto, véase ESPINOSA MORO, María José. "Expedientes de bienes de difuntos de palentinos en el Archivo de Indias (siglos XVI-XVIII)" en AIICHP, tomo IV. Palencia, 1990, pp. 501-509
} 
Francisco de los Ríos Campoo, regidor perpetuo de Carrión. Como albaceas testamentarios dejó a sus socios el General Francisco de Novoa Feijoo y al escribano público de Sevilla Simón Pineda, quienes debían administrar su hacienda y enviar a Carrión el numerario que fuese necesario para llevar a cabo las obras pías.

El comerciante no determina el lugar exacto donde desea fundar las capellanías. Teniendo en cuenta que había ordenado ser enterrado en el convento de Santo Domingo de Lisboa con el hábito de dicha orden y que de las cuatro órdenes que manda le acompañen en el entierro sea la primera la de santo Domingo, sus testamentarios decidieron establecer la fundación de las obras pías en el convento de Santo Domingo de su villa natal $^{710}$.

\subsection{CAPILLA DE LA COFRADÍA DE SAN PEDRO Y SAN ILDEFONSO}

Se ubicaba en el lado de la Epístola, frente al púlpito y cercana al presbiterio. Nos consta su existencia por las obras que en 1622 realiza el trasmerano Fernando del Arco, maestro procedente de Villaverde, en la junta de Riva ${ }^{711}$. Se encarga de rehacer un pilar desde los cimientos que presentaba grietas, por lo que los miembros de la cofradía, temiendo daños colaterales, requirieron al prior que si se decidiera rehacer por entero la capilla, se les tuviera al corriente de las nuevas obras ${ }^{712}$.

En este espacio de culto tan sólo poseían licencia para sepultarse los miembros de la cofradía, no sus hijos ni deudos; si bien es cierto que se había dado algún caso en que habían sido enterrados algunos descendientes de cofrades, como fue el de Santiago de Lomas $^{713}$, lo cual, había despertado gran revuelo en la hermandad ${ }^{714}$.

\footnotetext{
${ }^{710}$ LORENZO SANZ, Eufemio. "Carrioneses en el comercio con América en los siglos XVI y XVII" en AIICHP, tomo 4. Palencia, 1990, pp. 387- 399.

${ }^{711}$ Escritura de contrato y condiciones de la obra el 11 de enero de 1622. AHPP. Carr.Prot 4822.

Francisco Cuetos (1621-1622) s/f.

${ }^{712}$ Requerimiento de los cofrades firmado a 2 de febrero de 1622 en AHPP. Carr.Prot 5405. Francisco Moro de Saldaña (1622) s/f.

${ }^{713}$ El testamento dictado por Santiago de Lomas en 1637, en el que expresa su voluntad de ser enterrado en esta capilla AHPP. Carr.Prot 5420. Francisco Moro de Saldaña (1637) s/f.

${ }^{714}$ ASMC. Libro de la Cofradía de San Pedro y San Ildefonso (1600-1641) s/f.
} 


\subsection{CAPILLA DEL DULCE NOMBRE DE JESÚS}

Originalmente bajo la advocación de San Sebastián, tenía acceso al claustro. Esta cofradía fue fundada el 3 de septiembre de 1631, según testamento dictado por su patrón Rodrigo Ortiz de Avecia, marido en primeras nupcias de doña María de Pedrosa y doña Josefa de Mendoza, su segunda mujer. Fruto del matrimonio con esta última fue Martín Fernández de Mendoza, quien ostentaría el patronazgo poco después. Don Rodrigo dotó la capilla con doce cofrades legos y un abad y mayordomo para el cuidado de las advocaciones, festividades y alimentos de los cofrades. Se concertó con el albañil Bartolomé Alejo para que luciera la capilla, rehiciera la bóveda y cegara la puerta sobredicha. Dispuso así mismo que se ornamentara con retablo pero murió en 1632. Se encargaría de cumplir su voluntad su hermano Don Miguel Ortiz de Avecia, tutor de su primogénito Martín Ortiz y cura de la iglesia de San Bartolomé. ${ }^{715}$. Éste dispuso en 1633 que Alonso Álvarez, artista palentino procedente de Renedo de Valdavia, pintase los cuatro tableros del retablo “...al olio con buenos colores y finos de las figuras que el dicho cura quisiere...” y dorar las partes pertinentes del mismo. Además debía pintar cinco escudos con las armas del fundador y de su mujer doña María de Pedrosa, repartidos por la capilla, de modo que dos de ellos a los lados del nicho que compartían, uno sobre el mismo y otros dos en el arco de acceso de la capilla, recibiendo por todo un total de 1.100 reales $^{716}$.

En esta capilla se veneraba el Dulce Nombre de Jesús, una pequeña escultura $(52 \mathrm{~cm})$ del siglo XVII, convertida en imagen de vestir que fue trasladada tras la desamortización de Mendizábal a la iglesia de San Andrés, a donde fue trasladada la sede de la cofradía y donde se ubica hoy día, en una hornacina lateral del cuerpo principal en el retablo del Santo Ángel de la Guarda. El niño Jesús bendice con una mano mientras sostiene el orbe con la otra. Está coronado por un resplandor de alpaca cuyo tamaño, demasiado grande para la cabeza de la imagen, manifiesta que ha sido reaprovechado. Viste una túnica larga de raso blanca decorada con una puntilla

\footnotetext{
${ }^{715}$ Estos y otros datos se recogen en el pleito al que se enfrentó entre 1670 y 1672 Don Manuel Fernández de Mendoza, hijo legítimo de Martín Fernández de Mendoza y nieto, por tanto del fundador don Rodrigo Ortiz, por el impago de 163.920 reales de las fundaciones de la capilla, reparos y ornamentos de la misma. AHN. Clero Secular-Regular 5352. Papeles judiciales, s/f.

${ }^{716}$ AHPP. Carr.Prot 5416. Francisco Moro de Saldaña (1633) s/f.
} 
metalizada. La elección de los cofrades de esta hermandad se celebraba en este convento, salvo en ocasiones en que se realizaba en la sede de la Cofradía de la Vera $\mathrm{Cruz}^{717}$.

En 1663, quien por entonces ostentaba el cargo de patrón de la capilla, Don Martín de Avecia Enríquez y Mendoza encarga al ensamblador Pedro López la ejecución de una reja de madera que sirviera de acceso a la misma ${ }^{718}$.

${ }^{717}$ GÓMEZ PÉREZ, Enrique. "Dulce Nombre de Jesús" en Entre Castilla...Op.cit, pág. 34.

${ }^{718}$ AHPP. Carr.Prot 5534, Tomás Pérez (1663-1666) fol 293 y ss. 


\subsection{IGLESIAS CONSERVADAS}




\subsection{IGLESIAS CONSERVADAS}

En este extenso capítulo estudiaremos los templos parroquiales, siguiendo para ello el orden cronológico de su construcción de los que actualmente existen para finalizar con aquellas iglesias que han desaparecido, por lo que es difícil determinar a qué período data su construcción, por lo que nos basaremos en las fuentes y los testimonios gráficos, en el caso de que existan.

\subsubsection{SANTA MARÍA DEL CAMINO}

\section{SANTA MARÍA DE LAS VICTORIAS. SU NOMBRE ORIGINAL}

La tradición remonta el origen de este templo a la leyenda del "Tributo de las Cien Doncellas" de la cual, según cada historiador posee diferentes protagonistas. Siguiendo a Huidrobo y Serna, Salvador Ordax considera que el nombre se creó por el triunfo de Vermudo I sobre los musulmanes, lo que nos situaría a finales del siglo VIII $^{719}$. Ramírez de Helguera, en cambio, asocia la victoria a Alfonso III, quien derrotaría a los moros en Zamora en el 901 y acudiría a Carrión de los Condes a celebrarlo $^{720}$. La historia que goza de mayor popularidad la protagoniza el rey Alfonso I en su victoria del año 787 contra el rey Mauregato, hijo ilegítimo del monarca con la mora Sisandra, aliado a su vez con el emir cordobés Abdherramán I ${ }^{721}$.

En cualquier caso la historia que se narra para remontarse a los orígenes del templo primigenio es común a todos ellos. Los cristianos debían abonar anualmente un tributo a los nobles musulmanes consistentes en la entrega de cien doncellas cristianas. Un buen día, cuando la comitiva de doncellas iba camino de tierras de los moros, se encomendaron a la Virgen y gracias a su intervención, que dispuso unos toros para que atacaran a los musulmanes, las doncellas se vieron finalmente libres.

\footnotetext{
${ }^{719}$ HUIDROBO Y SERNA, Luciano. Las peregrinaciones jacobeas. Tomo 2. Instituto de España. Madrid, 1950, pág. 528, ORDAX ANDRÉS, Salvador. La iglesia...Op.cit., pág. 43.

${ }^{720}$ RAMIREZ DE HELGUERA, Martín. El libro...Op.cit, pp. 25 y 26 y PERAL VILLAFRUELA, Santiago y GÓMEZ PÉREZ, Enrique. Carrión... Op.cit, pág. 4.

${ }_{721}$ GORDALIZA APARICIO, F. Roberto. Historias y leyendas palentinas. Saber Palencia, Volumen 5. Cáñamo. Palencia, 2001, pp. 115-116.
} 
Si bien basada en una leyenda, con esta historia, conocida por todos los carrioneses, se ha pretendido explicar la presencia de las dos cabezas de toro de la fachada del templo y el lienzo que narra este acontecimiento situado en el altar de la Epístola de este templo de Santa María ${ }^{722}$. Respecto a las testas de bóvidos, forman parte del repertorio iconográfico románico que cuenta, como veremos, con varios exponentes en la Península. En cuanto a la imagen, es una simple plasmación de la creencia popular que se fue transmitiendo a lo largo de los siglos, cobrando protagonismo en la villa ${ }^{723}$.

Antiguamente, para conmemorar este suceso, se celebraba el sábado dentro de la octava de Pentecostés una procesión denominada "las bodas de Nuestra Señora". Con asistencia del Cabildo clerical y el corregidor como figurantes principales, la comitiva partía de la iglesia de Belén y pasaba por las demás iglesias de Carrión hasta llegar al hospital de Santa María donde la comunidad de la parroquia homónima les esperaba para incensar las cruces parroquiales. En Santa María se cantaban las Vísperas, culminándose la celebración en el templo de Santiago ${ }^{724}$.

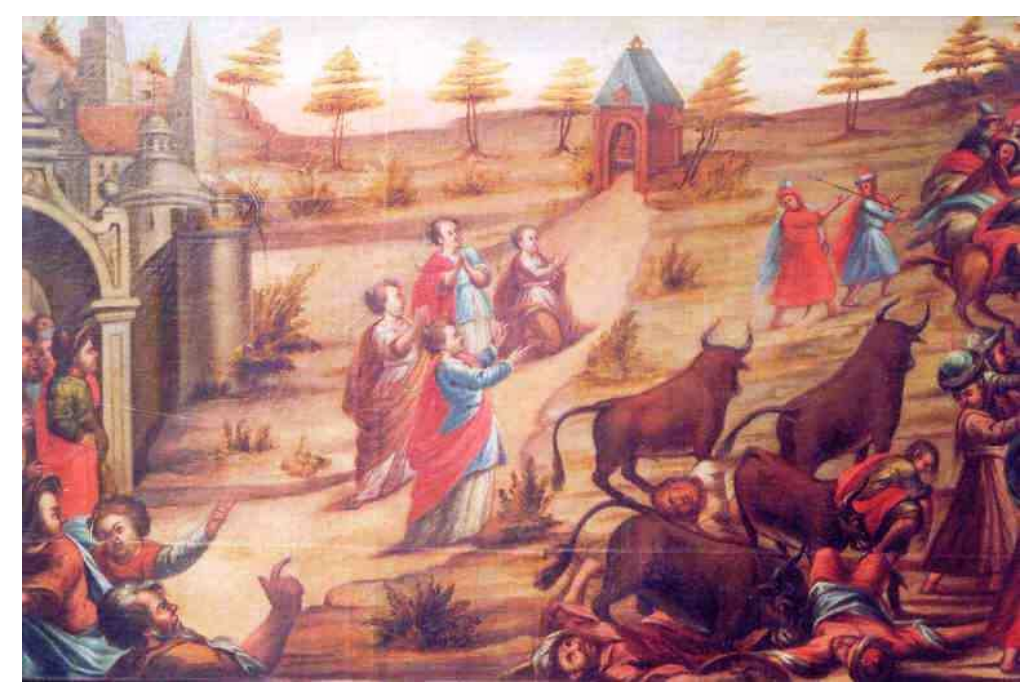

Pintura votiva del templo de Santa María que ilustra el Milagro de las Doncellas.

\footnotetext{
${ }^{722}$ Las crónicas, que suelen ser más dadas a la aceptación de las leyendas, confirman su falsedad. En estos términos se expresa Federico Villalba: "Este cuento, en que ya sólo afecta creer algún novelista utilitario...”. VILLALBA, Federico. Crónica de la provincia de Palencia, I. Rubio y Compañía. Madrid, 1867 , pág. 46.

${ }^{723}$ Nos referiremos a las testas de bóvido y del lienzo posteriormente.

${ }^{724}$ LORENZO, Santiago. Gentes...Op.cit, pág. 193.
} 


\section{EL TEMPLO}

Se trata de un templo románico, sobradamente estudiado, al que se superponen sucesivas reformas por disposiciones patronales o necesidades de estabilidad estructural. La iglesia de Santa María está situada al sureste de Carrión, junto a los restos de la antigua muralla que rodeaba la villa. El edificio románico tiene sus antecedentes en otra iglesia del siglo X dedicada a Santa María de donde se cree que proviene el originario nombre de la población de Carrión de "Santa María in Carrionem" ${ }^{725 " . ~ S u ~ n o m b r e ~ a c t u a l, ~}$ Santa María del Camino, es debido a que es zona de paso en la ruta jacobea.

Consta de una planta de tres naves, de mayor anchura la central con ábsides semicirculares y crucero que no sobresale en planta. Esta tipología se vincula directamente con San Martín de Frómista o la desaparecida iglesia de San Isidro de Dueñas, de finales del siglo $\mathrm{XI}^{726}$.

\section{Capilla mayor}

2. Capilla de Don Antonio Pastor

3. Capilla de San Nicolás o de los Paz

4. Capilla del Cristo del Amparo o de "los Calderones"

5. Sacristía

6. Pórtico

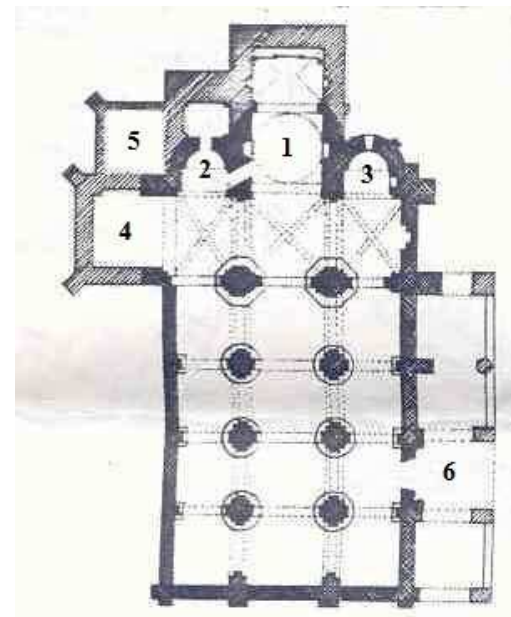

Planta del templo de Santa María. MOPU. Dirección General de Arquitectura y Edificación. Contenido en el plano de Carrión de 1986.

\footnotetext{
${ }^{725}$ RUIZ SALCES, Roberto y PEÑIL MINGUEZ, Javier. "La excavación de la iglesia románica de Santiago: Aportaciones al urbanismo medieval de Carrión de los Condes" en XX Congreso Nacional de Arqueología. Zaragoza, 1991 pp. 483-490.

${ }^{726}$ SENRA GABRIEL Y GALÁN, José Luis. "La realidad material de la iglesia de San Martín de Frómista en el siglo XII: de 1066 a 1904 en Actas de las Jornadas celebradas en Frómista: San Martín de Frómista, ¿paradigma o historicismo? Fundación del Patrimonio Histórico de Castilla y León. Valladolid, 2005, pág. 45.
} 
En la nave central, de mayor anchura y altura que las laterales, se disponen cuatro bóvedas de arista, una por cada tramo, jalonadas por arcos fajones de medio punto apeados sobre pilastras. Sobre los arcos de separación de las mismas se abrieron dos ventanas por cada tramo que permiten iluminar el templo. Las dos naves laterales presentan una cubrición de bóveda de cañón reforzada están desplazadas hacia fuera y los arcos fajones dispuestos sobre pilares cruciformes, han ido deformándose a lo largo del tiempo por el peso de la estructura. El acceso desde las naves laterales al crucero y a la nave central se practica a través de sencillos arcos apuntados con la rosca dovelada que apean sobre pilares cuyo capitel presenta palmetas inscritas en roleos talladas a trépano La recurrencia al arco ojival en este templo constituye una de las manifestaciones más tempranos de Castilla y León, con el precedente en la iglesia de San Benito de Sahagún, iniciada en $1121^{727}$.

Pueden establecerse paralelismos entre este templo con modelos aragoneses, como es el caso de la iglesia de San Pedro el Viejo de Huesca, de la primera mitad del siglo XII. Las coincidencias son varias: mismo tipo de planta, uso de bóveda de cañón, separación de naves por medio de pilares sin columnas, mismo número de tramos y, por último, portada en el muro meridional. No faltan los nexos con la arquitectura provenzal concretados en Saint Sernin de Toulouse a través del uso de pilares cruciformes sin columnas adosadas ${ }^{728}$.

El templo, datado en la primera mitad del siglo $\mathrm{XII}^{729}$, habría sido edificado en el período de paz que iniciado en 1127 con Alfonso VII, tras las férreas luchas entre su madre, doña Urraca, y su padrastro, Alfonso I el Batallador. De los tres ábsides, los dos laterales conservan su estructura románica original, son de planta semicircular precedidos de un tramo recto de acceso. Ambos se cubren con bóveda de cuarto de esfera seguida de otra bóveda de cañón. En el del lado de la Epístola, donde hoy se ubica la capilla de San Nicolás, se dispone una ventana de doble moldura e imposta de billetes y esta disposición de la ventana se repite en el exterior. El ábside del lado norte ha sufrido alteraciones en el siglo XVII para servir de paso a la capilla del clérigo

\footnotetext{
${ }^{727}$ GÓMEZ MORENO, Manuel. El arte románico español: esquema de un libro. Madrid, 1934. pp. $157-$ 158.

${ }^{728}$ GARCÍA GUINEA, Miguel Ángel. El arte románico...Op.cit, Edición actualizada, Palencia, 1990, pág. 118.

${ }^{729}$ URREA, Jesús y MARTÍN GONZÁLEZ, Juan José. Inventario...2. Op.cit, pág. 58.
} 
Pastor, en el mismo eje del ábside, a continuación del mismo. Conserva la policromía hoy día en la imposta de billetes, fileteada de negro y en el muro cóncavo del ábside. En el nicho de este ábside se sitúa una imagen de la Virgen con el niño del siglo XIII, que muestra bastantes signos de deterioro y que estuvo en la portada occidental del templo, frontera a la plaza homónima hasta los años setenta. La talla ha sufrido variaciones considerables, pues no conserva la policromía que seguramente tuvo y sus brazos han sido mutilados ${ }^{730}$. El ábside central fue sustituido entre 1682 y 1683 por una capilla barroca ejecutada por Felipe Berrojo ${ }^{731}$.

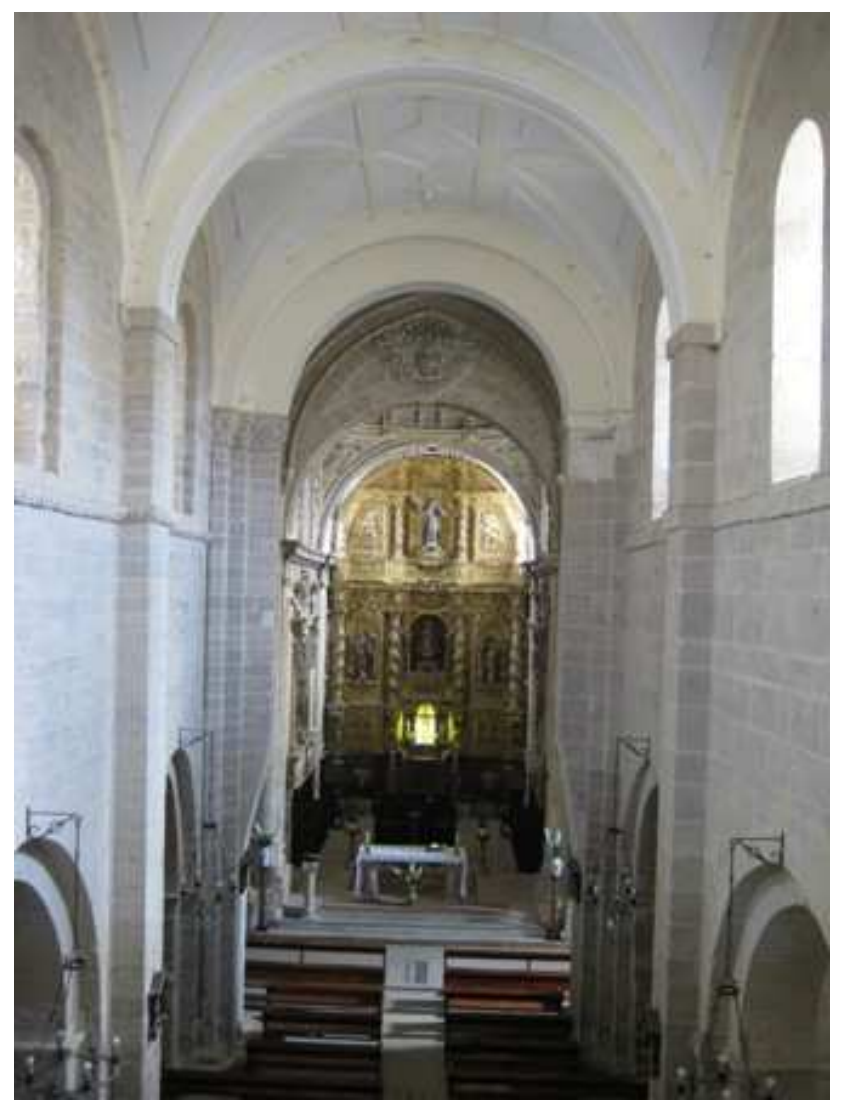

Interior del templo de Santa María hacia la capilla mayor.

\footnotetext{
${ }^{730}$ Delegación Diocesana de Patrimonio Cultural. Carrión de los Condes. Carpeta I.

731 Véase MARTÍNEZ, Rafael Ángel. “El Obispo de Palencia...Op.cit, pp. 251-269. Esta capilla será analizada en el apartado pertinente, dedicado a los espacios de culto.
} 
El crucero originalmente no se acusaba en planta pero la adición en el siglo XVI de la capilla del Cristo del Amparo modificó su disposición original. De modo que en el lado norte del transepto se adosa este espacio cuadrangular de idéntica altura y anchura que el mismo. Presenta una cubrición de bóveda de crucería cuadripartita cuyos nervios moldurados, en número de cinco, apean en los ángulos de donde parte una cornisa corrida. Junto a la capilla del Cristo y construida en la misma centuria, hacia 1500, se adosa, en su lado oriental, la sacristía, a la que se accede desde el ábside del Evangelio. Se trata de una estancia cuadrada de reducidas dimensiones que se cubre con una bóveda de crucería de terceletes con dos nervios espinazos perpendiculares, cuya plementería ha sido blanqueada de yeso. La clave principal representa un jarrón de azucenas, alusivas a la advocación mariana del templo y las cuatro restantes, motivos florales de diversa índole. Los muros laterales son lisos salvo el oriental, que presenta dos hornacinas conformadas por dos arcos rebajados de ladrillo, unidas por un pilar pétreo. En su interior, la sacristía alberga algunas obras, de las que hablaremos posteriormente.

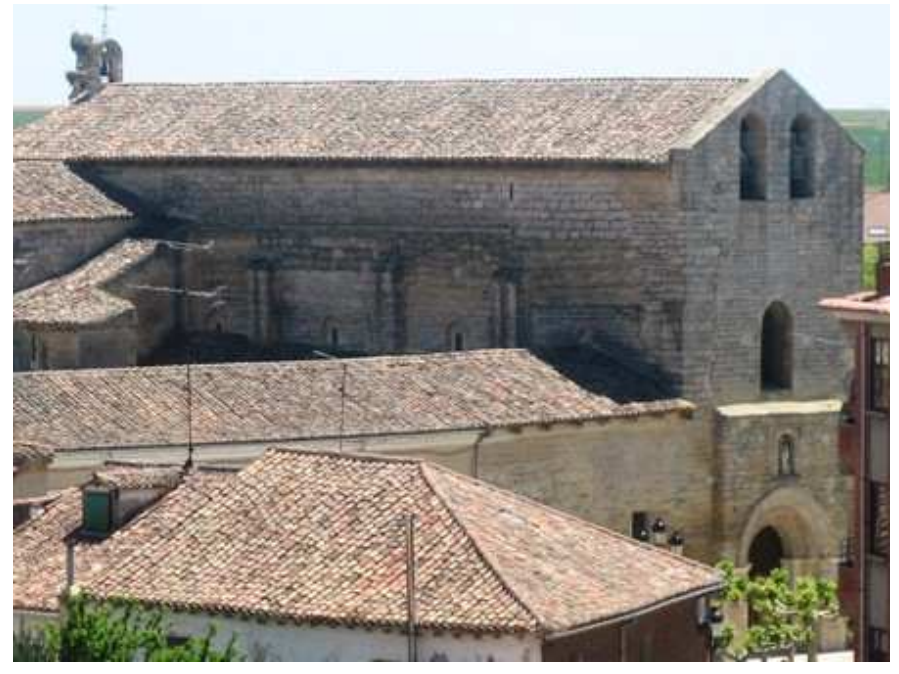

\section{Vista externa del lado septentrional y meridional del templo.}

Externamente todo el templo está provisto de piedra de sillería y en algunos sectores, como la nave del Evangelio y el crucero meridional, conservan tres tipos de paramentos correspondientes al proceso en varias etapas de la fábrica románica. En la parte inferior, al nivel de las ventanas abocinadas, los sillares son de pequeño tamaño, 
se agrandan en el sector intermedio, volviendo a reducirse en el sector donde se ubican las saeteras, lindando con los tejados.

Como consecuencia de los problemas de estabilidad del templo se adosaron contrafuertes jalonando todo el perímetro y se construyó el pórtico que flanquea el muro sur, que supuso la modificación del programa iconográfico de la portada ${ }^{732}$. El costado norte es inaccesible debido a la hospedería y las dependencias parroquiales. En el interior de las mismas subsiste aún en buen estado el muro original del templo, correspondiente al exterior, ornamentado en su parte superior con una imposta de billetes y unas ménsulas zoomorfas que encuentran su equivalente en el lado sur. De los dos ábsides románicos que se conservan, tan sólo se trasdosa el del lado sur, correspondiente a la capilla de San Nicolás, con dos ventanas abocinadas y contrafuertes adosados. En el ábside del lado del Evangelio se ubica, como indicamos, la capilla del Licenciado Antonio Pastor, siendo este espacio cuadrangular el que se trasdosa exteriormente al lado oriental.

A occidente, presenta una sencilla portada románica, con un arco de medio punto con dos arquivoltas y dos capiteles con representaciones animales. En la parte superior se abre una espadaña con dos campanas.

\section{La portada románica}

A continuación analizaremos brevemente la portada románica de Santa María, objeto de estudio de muchos historiadores. En el lado meridional se abre la portada principal del templo, integrada en un pórtico con arbotantes del siglo XVII que modificaron el programa iconográfico de la misma, ya que al descansar directamente sobre el muro meridional, algunas esculturas tuvieron que ser suprimidas o cambiadas de lugar. La fachada presenta claras relaciones hispano-languedocianas que gracias al Camino de Santiago, se prestaron a la imitación. Fue precisamente la calzada de peregrinos situada en el lado sur de la iglesia, la que justificó la colocación de la portada principal en este flanco.

\footnotetext{
${ }^{732}$ CUADRADO LORENZO, Ma Flora. “La iglesia de Santa María de Carrión...”. Op.cit, pág. 220-221.
} 
Cuadrado Lorenzo ofrece una datación de hacia 1150 coincidente con el asentamiento de escultores con una formación dentro de la órbita hispanolanguedociana, precedente del taller de estirpe borgoñona que hacia 1180 se encontraría trabajando en las tallas de la cercana iglesia de Santiago ${ }^{733}$. Esta portada consiste en un arco de medio punto, carente de tímpano, con cuatro roscas entre las que destaca la tercera, por contener una arquivolta figurada en sentido radial, solución utilizada en Santiago de Carrión y en otros templos palentinos como la Asunción de Perazancas y Arenillas de San Pelayo. En ella se disponen treinta y siete dovelas figuradas que parecen representar actividades profesionales, algunas de las cuales podrían interpretarse como los vicios y los castigos. Alguna de las dovelas, parecen contener personajes con instrumentos, en consonancia con la importancia que tenía la música en el Camino de Santiago ${ }^{734}$. Las figuras se caracterizan por una tendencia al estereotipo, donde los personajes presentan un plegado acartonado que hace pensar que la autoría de la arquivolta se deba a un taller más arcaico que los maestros del friso.

Las arquivoltas se asientan sobre columnas con basas de tipo ático sobre las que apoyan cuatro capiteles figurados en sus lados externos. En el lado izquierdo el capitel exterior representa cinco personajes masculinos desempeñando algún tipo de ceremonial. El capitel interior de este lado lleva dos figuras femeninas en cada cara y entre cada pareja, la cabeza de un animal. Estas figuras aparecen en actitud de caminar y portando objetos en conexión con la ceremonia que se desarrolla en el anterior capitel. El capitel del lado derecho interior se compone de una pareja de grifos afrontados en cada cara entrelazados bajo una voluta. El capitel exterior decora sus caras con dos personajes sobre un león al que abren las fauces con las manos como aparece en el templo de San Zoilo ${ }^{735}$.

Sobre el arranque del arco de la puerta sobresalen dos ménsulas que representan cabezas de toro, tradicionalmente identificadas con la leyenda del Tributo de las

\footnotetext{
${ }^{733}$ Ibídem, pp. 260-261.

${ }^{734}$ CUADRADO LORENZO, M ${ }^{a}$ Flora. "Iglesia de Santa Ma del Camino...”. Op.cit, pág. 1009. Sobre el tema de la música en la ruta jacobea, VIRGILI BLANQUET, María Antonia. "La música y su iconografía en el Camino de Santiago a su paso por Palencia" en Jornadas sobre el románico en la provincia de Palencia. Departamento de Cultura. Diputación Provincial. Palencia, 1985, pp. 69-75.

${ }^{735}$ GARCÍA GUINEA, M.A. El románico...Op.cit, pág. 121.
} 
doncellas ${ }^{736}$. Sin embargo, la presencia de testas de bóvidos, bien de toros o de bueyes, en forma de ménsulas a la entrada de las iglesias románicas no es infrecuente en las portadas peninsulares, presentes, por ejemplo en los templos castellanos de San Vicente de Ávila, en los leoneses de Santiago de Corullón o San Isidoro como símbolos de protección $^{737}$. En las enjutas del arco, se disponen dos jinetes, identificados tradicionalmente con Sansón y Constantino como símbolos de la defensa de la Cristiandad y la victoria del bien y del mal, respectivamente ${ }^{738}$.

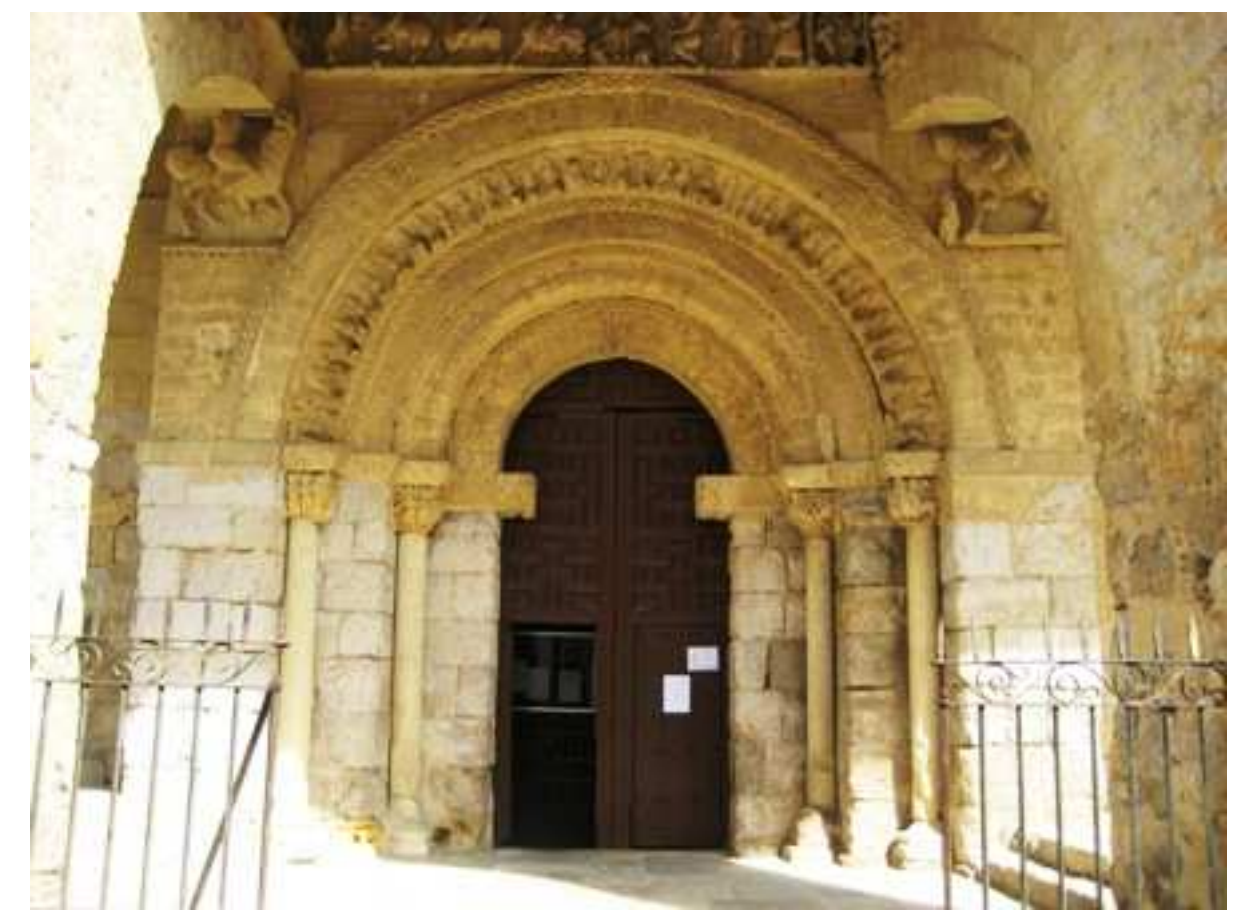

Portada románica de Santa María.

${ }^{736}$ HUIDROBO Y SERNA, Luciano. Las peregrinaciones...Op.cit, pág. 528, ORDAX ANDRÉS, Salvador. La iglesia...Op.cit., pág. 43.

${ }^{737}$ También podemos constatar su presencia en los templos navarros de San Esteban de Otazu, Leire y en la Purificación de Gazolaz. ARAGONÉS ESTELLA, Esperanza. La imagen del mal...Op.cit, pp. 117119.

${ }^{738}$ Sobre el tema del caballero en el Camino de Santiago, es muy interesante el artículo ORDAX ANDRÉS, Salvador. "Exaltación del caballero y su ocaso" en Estudios de Historia del Arte. Homenaje al profesor de la Plaza Santiago. Universidad de Valladolid. Valladolid, 2009, pp. 342-343. Otras interpretaciones sobre estas dos figuras ecuestres en REVILLA VIELVA, R. Camino de Santiago. Pueblos enclavados en la ruta de la provincia de Palencia. Palencia, 1963, pág. 27, RUIZ MALDONADO, Margarita. "El caballero victorioso en la escultura románica española. Algunos consideraciones y nuevos ejemplos" en BSAA, XLV. Valladolid, 1979, pp. 271-286 y CUADRADO LORENZO, Ma Flora. "Iglesia de Santa...Op.cit, pp. 248-249. 
La parte superior de la portada va recorrida por un friso dispuesto entre dos contrafuertes posteriores que alteraron el lugar original de la escultura de la portada, que en principio iría colocado a lo largo del muro. Este friso está formado por once placas de piedra que conforman una representación prolija del ciclo de la Epifanía: la audiencia de los Reyes Magos ante Herodes para informarse del nacimiento del Niño Jesús y más a la derecha, la escena de la Matanza de los Inocentes. Los Reyes Magos eran considerados como patronos de peregrinos en la Edad Media además de figuras del reconocimiento de Jesús como Dios por los Gentiles. En este friso trabajaron al menos dos artistas diversos ${ }^{739}$. Sobre el friso se disponen unos canecillos con representaciones animales y algunas figuras humanas: un portador de un bidón, un músico, un acróbata y una máscara. Las metopas situadas entre los canecillos, igualmente con motivos animales y humanos, podrían evocar los signos zodiacales, como si se tratase de una cristianización simbólica del horóscopo, muy recurrente en el románico ${ }^{740}$.

\section{La torre desaparecida}

Nada se conserva hoy día de la torre que tuvo la iglesia de Santa María pero se tiene constancia gráfica y documental de la existencia de la misma. Una espléndida aguatinta que Valentín Carderera realizó del templo, nos muestra cómo esta torre se ubicaba sobre el crucero, es decir, se trataba de un cimborrio de planta cuadrada que emergía del presbiterio ${ }^{741}$. Constaba de dos cuerpos con cuatro ventanas en cada lado, dos en el inferior y dos en el contiguo. Los vanos se hallaban conformados por arcos de medio punto con arquivoltas que apeaban sobre columnas, lo cual parece remitir a la fábrica románica. En la parte superior, una especie de cupulilla remataba en un chapitel. El dibujo no está fechado pero debió ser realizado en las postrimerías del siglo XVIII o muy a principios del siglo XIX, ya que cuando Quadrado hace referencia a la misma en 1861 nos informa que esta torre pétrea había desaparecido en $1811^{742}$.

\footnotetext{
${ }^{739}$ Las atribuciones de autoría y posibles interpretaciones del tema, véanse CUADRADO LORENZO, M ${ }^{\mathrm{a}}$ Flora. "La iglesia de Santa María...". Op.cit, pp. 260-261.

${ }^{740}$ CUADRADO LORENZO, M ${ }^{\mathrm{a}}$ Flora. "Un posible Zodíaco en las metopas de la parte sur de Santa María de Carrión" en BSAA. Tomo LI. Valladolid, 1985, pp. 439-444. Al mismo tiempo, este tipo de representaciones puede relacionarse con los Reyes Magos del friso, considerados como astrólogos por llegar hasta Jesús siguiendo a una estrella ORDAX ANDRÉS, Salvador. La iglesia...Op.cit., pp. 48-49.

${ }_{741}^{74}$ Museo Lázaro Galdiano. Iglesia de Santa María de las Victorias. Fondo Carderera 9138.

${ }^{742}$ QUADRADO, José María y PARCERISA, Francisco J. Op.cit, pág. 130.
} 
La primera referencia escrita de la torre data de 1586 en que por el peso de la misma, los arcos del crucero del templo debían ser reforzados ante el riesgo de derrumbe $^{743}$. Los problemas de estabilidad fueron una constante a lo largo de los años y una nueva obra de consolidación no se hizo esperar. En mayo de 1613 son contratados Francisco de Reinaldos y Juan González de la Mata, maestros de carpintería y albañilería respectivamente, para reparar la torre “...por la gran ruina y daño que tiene..." siguiendo para ello las trazas aportadas por el segundo ${ }^{744}$. Para ello debían reconstruir el paño que miraba hacia el convento de Santa Clara, en el lado oriental. Debía ser demolido desde el chapitel hasta los cimientos de cantería, asentando cuatro tirantes cruzados sobre los mismos.

Era necesario tener cuidado con los lienzos colindantes que podían sufrir daños, en los cuales debían sustituirse tan sólo las tablas viejas. En los arcos que albergan las campanas, debían retirarse las piedras sueltas y revocar de cal para evitar la filtración de las aguas. Por último tenían la obligación de hacer una caja de vigas asentadas con tornapuntas y grapas de hierro para fijar el chapitel y retejarlo a cuatro aguas, reutilizando las tejas y azulejos existentes e incorporando los que fueren necesarios, no sin antes haber obtenido el beneplácito de los veedores sobre el buen maderaje de la estructura. Como tales, los artífices Ambrosio de Buega, Hernando Infante ${ }^{745}$, Juan de la Maza y Juan Santos, si bien aceptaron las condiciones establecidas, introdujeron pequeñas modificaciones en lo que se refiere al número de tirantes, que por ser cuatro excesivos, establecieron dos, además de refuerzo mayor de las tornapuntas y la colocación de unas cuñas en el primer arco del paño que debía ejecutarse de nuevo. Por las obras, que debían finalizarse en dos años, además de los trescientos ducados en que se remataron, el pago se efectuó en especie, acordándose conveniente por ambas partes un total de treinta cargas de trigo ${ }^{746}$.

En julio de 1614, un año después de que la obra fuera comenzada, Reinaldos y de la Mata, subcontratan a Alonso Serrano "el Viejo", un maestro de carpintería procedente de Cuenca de Campos, para que durante tres meses trabaje en las obras de

\footnotetext{
${ }^{743}$ Se habló de esta obra anteriormente. AHPP. Carr.Prot 5671. Andrés Sánchez (1567-1568), s/f.

${ }^{744}$ De ambos maestros se aportarán algunos datos biográficos en el apartado dedicado a los artistas locales

${ }_{745}$ Sobre el mismo, remítase al capítulo dedicado a los escultores y ensambladores locales.

${ }^{746}$ AHPP. Carr.Prot 5396. Francisco Moro de Saldaña (1613), s/f.
} 
retejo que se realizan. Ambos maestros continúan como responsables de las mismas así que tal vez, necesitaban una inyección de mano de obra para poder acabar a tiempo los trabajos contratados ${ }^{747}$.

Mateo de Arnuero será el maestro campanero oriundo de Trasmiera quien, fiado por Jerónimo de Abendaño, se encargará de sustituir en junio de 1658 la campana quebrada por una nueva, recibiendo por ello 250 reales y en especias, seis cargas de trigo $^{748}$. A mediados de 1665 se ordena la extracción de piedra de Palacios de Alcor destinada al reparo de la torre ${ }^{749}$. Un año después urge una nueva intervención: "para lo cual es preçiso demoler el tejado de la capilla de dicho Don Manuel de Paz y açer andamios para hacer dicho rreparo ${ }^{750}$. La torre lució nuevas campanas en 1701, que fueron fundidas por Antonio Gorgollo ${ }^{751}$. Para comprobar la estabilidad de la torre, en 1771 el síndico general de la villa solicitó un informe de reconocimiento a Gregorio Gutiérrez Bolde sobre el estado de la misma. El arquitecto, maestro de obras del Obispado de Palencia, la declaró totalmente segura ${ }^{752}$.

Durante la guerra de la Independencia, el templo fue víctima de las llamas en un incendio que tuvo lugar los días 30 y 31 de agosto de 1811. La documentación no explica si fueron los guerrilleros castellanos o los soldados franceses los autores de ésta y otras barbaries que se produjeron en Carrión durante el asedio, pero sí indica, al menos en este caso, que el incendio no se produjo por accidente “...sino por caso premeditado según las concurrencias en aquella época...”. La torre quedó en mal estado, por lo que en 1812 fue desmontada, precisándose que no fuese reconstruida ${ }^{753}$. Los materiales procedentes del derrumbe fueron destinados a la cerca del antiguo cementerio y las campanas y el esquilón fueron fundidas ${ }^{754}$.

\footnotetext{
${ }^{747}$ Le abonaron ochocientos reales por su trabajo. AHPP. Carr.Prot 5397. Francisco Moro Saldaña (1614), s/f.

${ }^{748}$ AHPP. Carr.Prot 5691. Norberto Sandoval y Guevara (1658), fol 138 y ss.

${ }^{749}$ Escritura de obligación de 27 de junio de 1665. Felipe Alcalde será el encargado de la extracción de 126 piedras, todo para el 1 de septiembre de dicho año siendo el porte por cuenta de la iglesia abonándose 4 reales y medio por cada pieza. AHPP. Carr.Prot 5700. Norberto Sandoval y Guevara (1665), fol 286.

${ }^{750}$ AHPP. Carr.Prot 5772, Andrés Simón Aguilar (1666), s/f.

${ }^{751}$ ASMC. Libro $1^{\circ}$ de Fábrica (1698-1732), s/f.

${ }^{752}$ ASMC. Libro $2^{\circ}$ de Fábrica (1762-1804), s/f.

${ }^{753}$ AHPP. Carr.Prot 5267 Miguel López (1811-1813), s/f.

${ }^{754}$ ASMC. Libro $3^{\circ}$ de Fábrica (1805-1850), fol 162 y 170.
} 
El cura y mayordomo de la iglesia solicitaron en 1860 al ayuntamiento la cesión de la madera y los fondos necesarios para levantar una nueva torre que sepamos, nunca llegó a reconstruirse ${ }^{755}$.

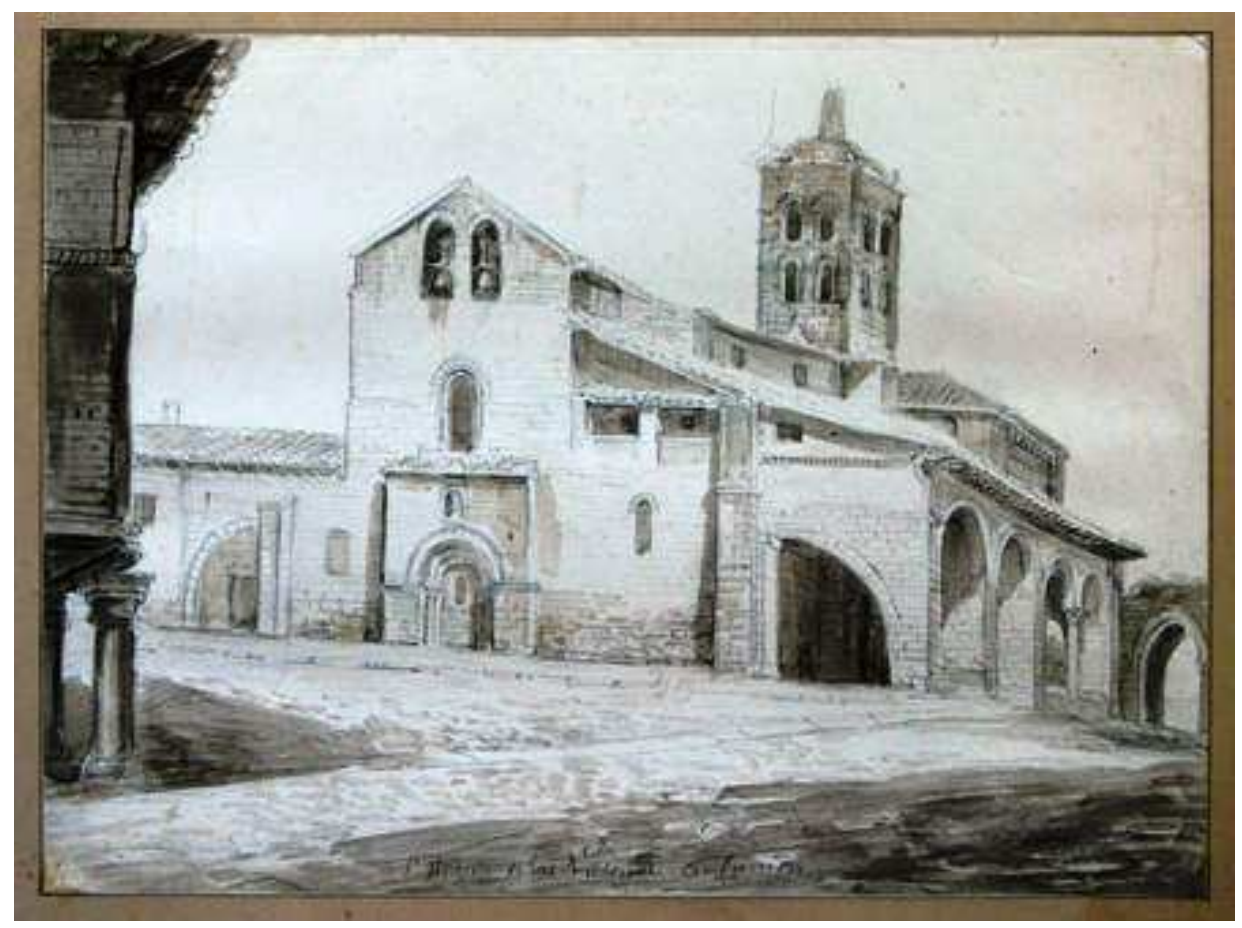

Vista del templo desde su lado meridional con la torre desaparecida del crucero. FLG. Fondo Carderera 9138.

\section{EL SIGLO XVI}

Aparte de las intervenciones que se realizan específicamente en cada una de las capillas del templo en esta centuria ${ }^{756}$, nos centramos ahora en las que tuvo lugar en el último cuarto de siglo y que afectó al presbiterio. A finales de octubre del año 1586 fueron firmadas las condiciones para llevar a cabo una reparación profunda en el pilar toral, base del correcto sustento de la torre, y en las paredes aledañas que se habían desplomado a causa del empuje del cimborrio. La ruina también había afectado al arco de acceso de la capilla absidal de la Epístola, por lo que se dispone la construcción de un arco de medio punto. Se precisa que tan sólo se use piedra procedente de Palacios de

\footnotetext{
${ }^{755}$ AMCC, Libro 6, Sesiones municipales (1858-1862), Sesión extraordinaria de 8 de julio de 1860. s/f.

${ }^{756}$ Sobre cada una de ellas se habla en el apartado dedicado a los espacios de culto.
} 
Alcor, conocida por su óptima calidad ${ }^{757}$. Quedaba por concertar la obra con un maestro, realizándose la puja más de un mes después, el tres de diciembre. El precio de partida fue de 1800 ducados y en ella participaron algunos maestros cántabros como Pedro de la Vega o Francisco de Lado, ambos procedentes de Arganos, en Laredo. Sin embargo, la obra fue finalmente rematada en el maestro de cantería carrionés Marcos de la Torre ${ }^{758}$ y el trasmerano Francisco del Vado, que la aceptaron conjuntamente por 1400 ducados. Si bien, éste último, previa compensación de veinticuatro ducados, le cedió la obra a Marcos de la Torre el 19 de enero de 1587, día de la firma del contrato, por el que se comprometía a concluir los trabajos en dos años.

Marcos de la Torre cumplió los plazos con exactitud, pues en 1588 ya tenía realizadas tres cuartas partes de la obra. Sabemos que la piedra sobrante que se utilizó en esta fábrica, la empleó el maestro en las viviendas que el Hospital de las Tiendas poseía junto al templo, las cuales se comprometió a reedificar dicho año ${ }^{759}$. Por entonces el cura de Santa María, don Juan de Salazar, y los mayordomos no disponían de fondos suficientes para continuar con las obras, por lo que solicitan licencia al vicario de la villa para vender las heredades de la fábrica del templo. Concedido el permiso, optan finalmente por tomar a censo trescientos ducados procedentes de dichas propiedades y del noveno.

El sotocoro, cubierto con bóveda de crucería estrellada podemos fecharlo en el siglo $\mathrm{XV}$, al igual que el amplio arco escarzano que da acceso al mismo del que penden angrelados que cobijan arquillos lobulados. Sin embargo, la talla que contiene la rosca, con decoración de flameros flanqueados por tallos vegetales de filiación renacentista señalan una datación aproximada de hacia 1510.

\footnotetext{
${ }^{757}$ AHPP. Carr.Prot 5671. Andrés Sánchez (1587- 1588), s/f.

${ }^{758}$ Sobre el mismo, remítase al capítulo dedicado a los maestros locales.

759 AHPP. Carr.Prot 5671. Andrés Sánchez (1577-1578), s/f.
} 


\section{EL SIGLO XVII}

La nueva centuria se inaugura con más obras. En este caso se interviene en “...la parte del coro y el paredón sobre la puerta de delante de la dicha yglesia...”. Dada la ubicación del coro y la referencia al acceso, que debe tratarse del occidental, los trabajos que se realizaron en 1600 afectaron al primer tramo del templo, la zona de los pies ${ }^{760}$. No se especifica en qué consistieron las obras, pero dado el montante de ochocientos ducados que se finalizaron de pagar en $1601 \mathrm{y}$ el hecho de que Marcos de la Torre fue el beneficiario de dicho pago, tuvo que tratarse de una importante intervención de cantería. Quizá tuvieron que ser reconstruidos los muros afectados por el peso de la torre, como había sucedido en 1587 en el crucero. Por esta época debió ser edificado el pórtico del templo, conformado por cuatro arcos de medio punto que apean sobre contrafuertes, salvo el tercero de los arcos, que descansa sobre una columna. Los tres estribos del pórtico que descansan directamente sobre el lienzo meridional, se aligeran a través de unos arcos de medio punto seccionados a la mitad practicados en sus muros. Un pretil de piedra de aproximadamente metro y medio de altura recorre la arquería, salvo en el segundo arco, que por ser el que da acceso al templo, carece del mismo.

Las cubiertas existentes hoy día en la nave central del templo, compartimentada en cuatro tramos cubiertos, se deben a las intervenciones que tuvieron lugar entre los años 1603 y $1606^{761}$. Las obras fueron adjudicadas a un maestro de albañilería carrionés, Antonio de Cuéllar ${ }^{762}$, puesto que para la cubrición no se utilizaría piedra, sino madera, ladrillo y yeso. El contrato estipulaba que Cuéllar debía encargarse de reconstruir los tres primeros tramos del templo. El casco del cuarto tramo, lindero a la torre, se hallaba descubierto y no debía intervenirse sobre el mismo hasta que la torre fuese reparada, evitando de este modo, posibles riesgos de derrumbe. En el coro alto se acordó disponer una bóveda de cañón mientras que en los tramos contiguos se optó por la bóveda de arista con lunetos. Todos los cascos de las capillas se cubrirían de yeso, para proporcionar mayor resistencia y de cal, para que con su aspereza proteja la cubierta de goteras. Separando cada tramo se dispondrían dos arcos fajones de medio punto con idéntico grosor y anchura que el de las pilastras sobre las que sustentan. Con

\footnotetext{
${ }^{760}$ La carta de pago fue firmada el 3 de marzo de 1601. AHPP. Carr.Prot 5384. Francisco Moro de Saldaña (1601), s/f.

${ }^{761}$ AHPP. Carr.Prot 5078. Pedro Guerra Cervantes (1603-1604), s/f.

${ }^{762}$ Sobre el mismo se hablará en el apartado dedicado a los maestros locales.
} 
el fin de potenciar la estabilidad y firmeza del edificio, se cuidaría que dichos arcos contuviesen la misma carga en todas sus partes para evitar que se abrieran “...como mostró flaqueza y falta de estribo lo biexo que se quitó...”. A la hora de ejecutar estas obras, debían seguirse las trazas proporcionadas por el maestro de carpintería Santiago de Sigüenza ${ }^{763}$ del que se precisa su presencia tanto en el montaje de los andamios como en la ejecución de las cimbras y “...en lo que conbiniere su maestramiento...”. Por tanto, aparte de tracista, en este caso ejerce de maestro de obras, encargado de supervisar la buena marcha de las mismas. Las cubiertas se ornamentarían con unas “faxas y compartimentos de yeso puro con sus filetes y requadraturas....labadas con su yeso cernido todo bien perfilado...”. Es decir, nos referimos a las sencillas yeserías que se conservan hoy día, en las que hallamos ocho puntas de diamante en cada tramo, distribuidas cuatro en cada extremo, separadas por dos listeles centrales en cuyo centro se ubica un rombo tangente en dos de sus lados. Por último, los muros de la nave central, actualmente desnudos, se guarnecerían de yeso y en tal estado se hallaban al menos hasta 1907, tal y como observamos en una fotografía tomada dicho año.

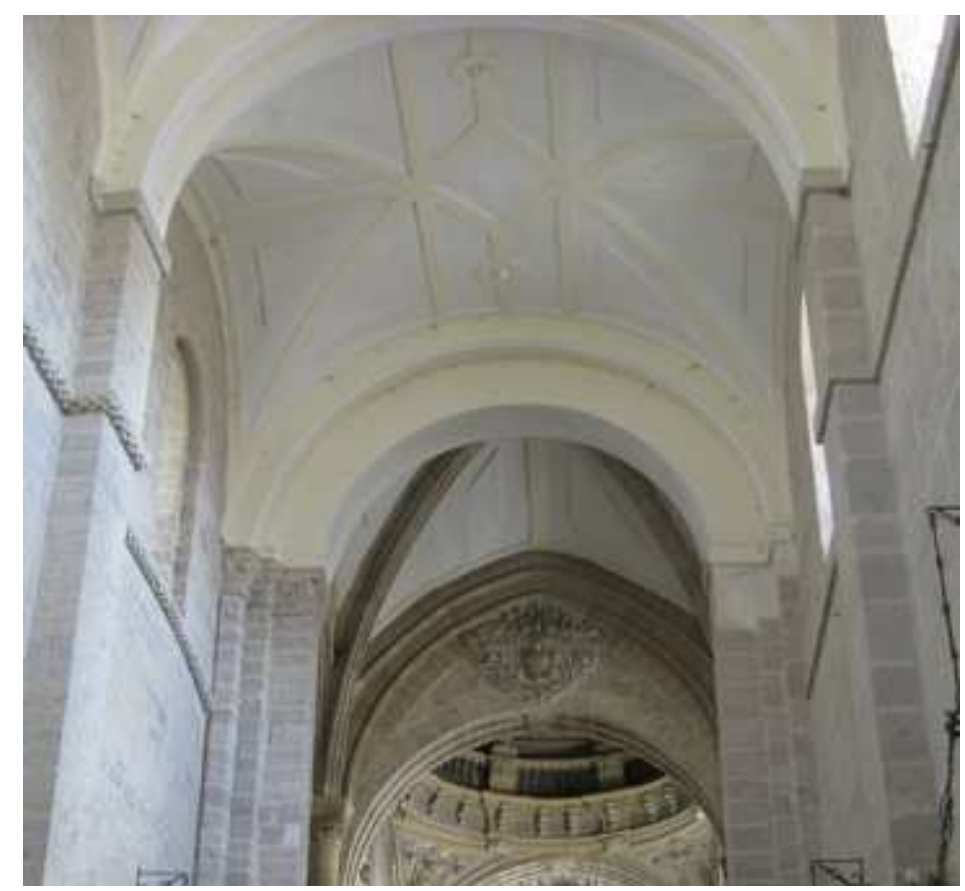

Detalle de las cubiertas de Santa María reedificadas a lo largo del siglo XVII.

${ }^{763}$ Ibídem. 
En lo que respecta al cuarto tramo y al contiguo, correspondiente al crucero, al finalizar la obra precedente, también se había intervenido en este sector, dadas las cartas de pago abonadas en 1606 a Antonio de Cuéllar, por las “...cuatro capillas y el coro...” que había realizado ${ }^{764}$. En el cuarto tramo se repite la estructura de los tres anteriores. En el caso del tramo del presbiterio se entremezclan dos tipos de cubrición, pues existe una bóveda de arista con yeserías en la que se superponen las ojivas diagonales de la bóveda de crucería que existiría previamente. Por tanto se respetaron los nervios pétreos de la anterior cubrición, creando así un vivo contraste con la plementería blanqueada. Estas ojivas de sección cuadrangular presentan una triple compartimentación pues tienen practicadas unas incisiones que recorren el arco en toda su longitud. Así mismo se respetó el arco apuntado que da acceso a la capilla mayor, conformado por cuatro sencillas molduras donde se alternan dos filetes y dos boceles que se sustentan sobre dos columnas cuyos capiteles presentan diversos motivos vegetales. El del lado de la epístola presenta una ramificación en espiral, mientras que en el del lado frontero observamos hojas de acanto muy simplificadas con las terminaciones protuberantes y redondeadas.

Probablemente fue a raíz de esta última reedificación, cuando se quitaron un escudo de armas y una bandera que junto a dos losas de piedra, señalaban la pertenencia de aquel espacio a don Pedro de Villamizar y Tovar. Este pequeño espacio ubicado entre el pilar del crucero y el púlpito, contenía por entonces un pequeño retablo dedicado a Santa Ana, que no tenía “...fundado capellanía ni memoria alguna...”. En dicha argumentación sustentaban el cura y mayordomo de Santa María la eliminación de los blasones cuando en 1607, al regresar a Carrión después de un tiempo, su patrono los denunció a la justicia. El fallo, promulgado en octubre de dicho año determinó la restitución inmediata de los mismos ${ }^{765}$.

Durante las obras de refuerzo de la torre que en 1613 ejecutaron Francisco de Reinaldos y Juan González de la Mata, también se trató de consolidar la estabilidad del templo a través de la construcción de un contrafuerte y un arbotante “...de sillares y

\footnotetext{
${ }^{764}$ AHPP. Carr.Prot 5080. Pedro Guerra Cervantes (1606-1608), fol 160.

765 AHPP. Carr.Prot 4834. Juan Díaz Pajaza (1607), s/f.
} 
buena piedra...” en el ángulo sur-occidental ${ }^{766}$. Por entonces ya se menciona el corredor que podemos contemplar en la aguatinta que Carderera realizó a principios del siglo $\mathrm{XIX}^{767}$. Se trata de una especie de galería que desde los pies del templo y prolongándose hasta el cuarto tramo, se asentaba sobre la nave de la Epístola y el pórtico occidental. Desde este espacio se podían visualizar los oficios divinos, aunque desconocemos el destino real para el que fue concebido. Exteriormente el desnivel existente respecto a la nave central era salvado a través de un tejado de una sola vertiente que caía paralelo al principal. Este corredor poseía un mirador conformado por un antepecho y dos ventanas con vistas a la plaza de Santa María, frente al hospital homónimo. Probablemente desapareció en 1811 cuando también fue derruida la torre.

\section{EL SIGLO XVIII}

Todas las intervenciones documentadas en el templo durante el siglo XVIII afectaron a las cuatro capillas existentes en el mismo. Así, en el primer cuarto de esta centuria se llevó a cabo el retablo de San Nicolás, en la capilla homónima y los retablos de San Antonio y de la Virgen de la Paz de la capilla de los Calderones. Entre 1749 y 1750 se realizaron las pinturas murales de la capilla mayor y por esos años se encargó el retablo del Cristo del Amparo, en la capilla de los Calderones. Finalmente en 1770 se encargaron los retablos colaterales de la capilla de don Antonio Pastor ${ }^{768}$.

En 1797 fueron reconstruidos los arcos de medio que sostienen el pórtico de acceso al templo, y además se realizó un retejo general del mismo ${ }^{769}$. Prueba de esta intervención es la ménsula perteneciente al último de los arcos, el más próximo a la cabecera, que presenta una placa mixtilínea propia del barroco dieciochesco.

\footnotetext{
766 AHPP. Carr.Prot 5396. Francisco Moro de Saldaña (1613), s/f. Sobre ambos maestros, véase el apartado relativo a los maestros locales.

${ }^{767}$ Museo Lázaro Galdiano. Iglesia de Santa María de las Victorias. Fondo Carderera 9138.

${ }^{768}$ Se hablará de todas estas intervenciones en el apartado relativo a los espacios de culto.

${ }^{769}$ ASMC. Libro $2^{\circ}$ de Fábrica (1762-1804), s/f.
} 

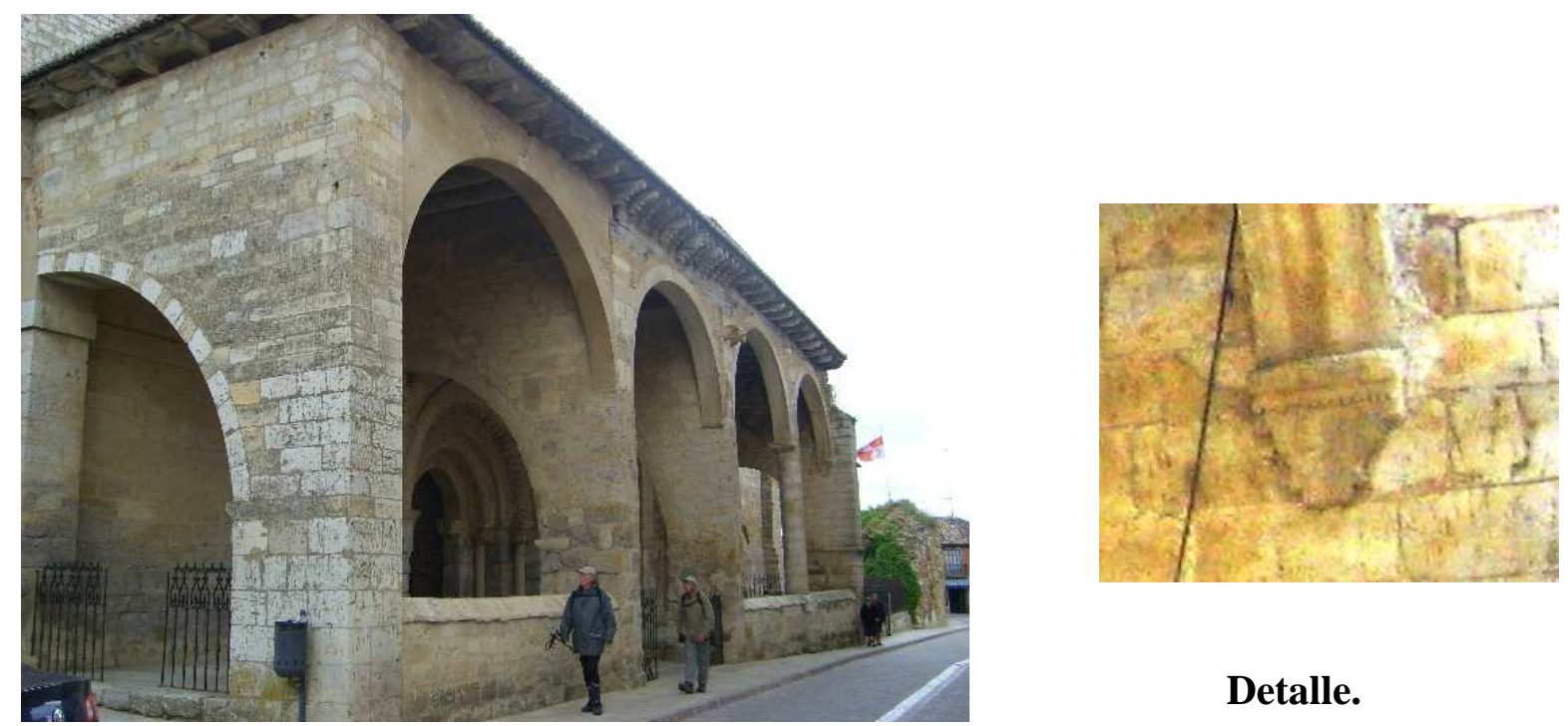

Detalle.

Ménsula dieciochesca.

Pórtico del templo en el lado meridional, reconstruido en el siglo XVIII.

\section{EL DEVENIR A PARTIR DEL SIGLO XIX}

\section{Reconstrucción de los tejados y otras obras}

La invasión napoleónica provocó un ambiente de recelo y desconfianza general que provocó el traslado de las reliquias de los Santos Zoilo y Félix desde el monasterio benedictino al templo de Santa María el 5 de mayo de $1810^{770}$. Aunque las reliquias fueron devueltas sanas y salvas en 1814, tampoco fue esta iglesia un lugar seguro durante el turbulento período. Prueba de ello es el grave incendio provocado de 1811 que afectó a las cubiertas. La iglesia había quedado inutilizada para poder ejercer el culto, por lo que el párroco de Santa María, don Manuel Garrido, se concierta en 1812 con cuatro maestros de carpintería carrioneses: los hermanos Manuel y Martín Martín Carniago, Manuel Gómez y Pablo Salomón ${ }^{771}$, para que reconstruyan el tejado de la

\footnotetext{
${ }^{770}$ VALLE CURIESES, Rafael de. A orillas del Carrión...Op.cit, pág. 102 y también en AHPP. Desamortización 112. Índice del Archivo de San Zoilo. Caja 5a. San Andrés. Legajo 2. Cuaderno A. $\mathrm{n}^{\circ} 25$ y ASMC. Libro $3^{\circ}$ de Fábrica (1805-1850), fol 60v.

${ }_{771}$ Pablo Salomón dictó testamento el 18 de septiembre de 1822, viudo de María Antolinez. Le debía dos mil reales el cura de San Mamés por la barbacana que había hecho. El único hijo de este matrimonio era un varón menor de edad, Francisco Salomón Antolín, de ahí que su padre designe un curador para que se
} 
nave mayor por 5.300 reales $^{772}$. Tenían que rehacer el atirantado y armazón de la misma y disponer dos faldones a par e hilera. El contrato incluía la reposición de los tirantes de la nave de la Epístola, así como el reparo de todos los desperfectos que se hubiesen producido en el resto de tejados del templo. Estos cuatro "maestros de puertas y ventanas", recibieron finalmente siete mil reales ${ }^{773}$. Las trazas fueron proporcionadas por el maestro arquitecto y escultor Francisco Prieto, vecino de Palencia, el 24 de febrero de 1812, quien también intervendrá en las cubiertas de Santiago, igualmente incendiadas $^{774}$.

El 27 de febrero fueron firmadas las condiciones de la obra y en ellas se especifica que debía llevarse a cabo una vez desmontada la torre del templo, de lo cual no debían encargarse los maestros mencionados, ni tampoco de su reedificación. Los materiales para la ejecución de los trabajos fueron extraídos de la demolición del convento de Santo Domingo ${ }^{775}$. Posteriormente, hacia 1824, Salomón y Martín Martín Carniago se encargaron de rehacer la escalera que daba acceso a la torre, que también se hallaba deteriorada por el incendio de $1811^{776}$. En 1834 Manuel Martín Carniago realiza el adoquinado completo del templo ${ }^{777}$.

No volvió a intervenirse sobre el templo hasta el año 1883 en que fue reconstruido el pórtico del templo y se realizó un retejo general, alcanzando los trabajos un coste de 3.600 reales. El encargado de las obras fue el carrionés Nicolás Herrero, quien extrajo los materiales de la cerca del hospital de San Torcuato, junto a Benevívere $^{778}$.

\footnotetext{
encargue de sus cuidados, un tal Manuel Gutiérrez Herrera AHPP. Carr.Prot 4509, Luis Agudo (18221825), fol 138 y ss.

${ }^{772}$ Por la obra recibirían 5.300 reales. Condiciones y contrato en AHPP. Carr.Prot 5267. Miguel López (1811-1813), s/f.

${ }^{773}$ ASMC. Libro $3^{\circ}$ de Fábrica (1805-1850), fol 80v.

${ }_{775}^{774}$ Sobre el mismo, véase el apartado relativo a los maestros locales.

${ }^{775}$ El 24 de diciembre de 1811 se abonan 975 reales a Lorenzo Bahíllo por recoger los escombros del templo de Santa María y traer los materiales de Santo Domingo. Los religiosos de Santo Domingo recibirán 3.800 reales por los materiales extraídos. ASMC. Libro $3^{\circ}$ de Fábrica (1805-1850), fol 70v, $124 \mathrm{v}$ y 132.

${ }^{776}$ Cartas de pago en 1824 y 1829. ASMC. Libro $3^{\circ}$ de Fábrica (1805-1850), fol 171 y 213.

${ }^{777} \mathrm{SE}$ le abonan 1800 reales en 1824. ASMC. Libro $3^{\circ}$ de Fábrica (1805-1850), fol 253.

${ }^{778}$ ASMC. Libro 6º de Fábrica (1883-1908), s/f.
} 


\section{El coro y órgano}

La puerta occidental del templo fue tapiada para colocar la sillería actual cuando en 1859 fue reconstruido el pretil de yesería del coro bajo con una decoración de escamas realizada por el albañil local Pedro Herrero. Los asientos de la obra neorrománica fueron tallados por el maestro carrionés Bonifacio Serrano, el mismo que realizó el San José que existió junto al retablo del Crucifijo en la capilla de los Herrera $^{779}$.

El antiguo órgano que poseía la iglesia fue fabricado en 1735 por el artífice palentino Domingo Galarza siguiendo las condiciones establecidas por el organista mayor del convento de San Pablo de Valladolid, Fray Cipriano Payueta ${ }^{780}$. Del pintado y dorado de su caja se encargó Miguel Pérez Desco ${ }^{781}$. El incendio de 1811 lo destruyó parcialmente, y los seis registros de lengua dañados fueron reconstruidos por Félix Pérez, maestro organista vecino de Frómista ${ }^{782}$. El órgano que preside hoy día el coro alto, fue realizado a finales de siglo y contiene la siguiente inscripción: "Hizo esta obra don Juan Otorel, maestro organero de la Santa Iglesia Catedral de Palencia, año de 1890”. Otorel recibe quince mil reales por este órgano, compuesto por quince registros $^{783}$. Tal vez se trate del último de los órganos realizados por Otorel junto al de la iglesia de San Miguel de Villarramiel, pues no se recoge otro salido de su mano en la documentación ${ }^{784}$.

La presencia de la vidriera situada a los pies ha condicionado la estructura de la pieza, la cual, para permitir el paso de la luz, adquiere forma de $\mathrm{U}$ por cuyos brazos rectilíneos se despliega la tubería. Realizado en madera de pino, manifiesta en su ornamentación un gusto por el neogótico a través de los arcos apuntados albergando a otros polilobulados en los lados, mientras en el centro, el ojival más abierto hace de tránsito entre la crestería que la flanquea. Este tipo de decoración puede observarse

\footnotetext{
${ }^{779}$ ASMC. Libro $4^{\text {o }}$ de Fábrica (1851-1859), s/f.

${ }^{780}$ Escritura y condiciones del contrato firmadas el 28 de diciembre de 1735. AHPP. Carr.Prot 4962. Manuel Gallo Gutiérrez (1735-1738), s/f.

${ }^{781}$ Escritura y condiciones del contrato firmadas el 17 de junio de 1738. AHPP. Carr.Prot 4732, fol 21 y SS.

${ }^{782}$ Se le abonaron 2.060 reales en 1824. ASMC. Libro $3^{\circ}$ de Fábrica (1805-1850), fol 170.

783 ASMC. Libro 6º Fábrica (1883-1908), s/f.

${ }^{784}$ VV.AA. Inventario...Op.cit, pág. 166. Las cartas de pago al maestro organero en ADP. Carrión. Santa María. Papeles y legajos diversos, 85. Cuentas de fábrica 1888-1912, s/f.
} 
igualmente en el órgano de la iglesia conventual de San Pablo, en la capital palentina, realizado poco después, en 1898 por un maestro desconocido ${ }^{785}$. La consola del órgano se conserva junto al altar, mirando al mismo.

\section{3. Últimas actuaciones}

En 1900, el ayuntamiento solicita a la Comisión mixta de las Reales Academias de la Historia y de Bellas Artes de San Fernando que, junto al convento de San Zoilo, sean ambos declarados "Monumento Histórico Artístico Nacional" los pórticos de los templos de Santiago y Santa María ${ }^{786}$. El 3 de junio de 1931 este templo, la iglesia de Santiago y el convento de San Zoilo de la misma villa pasan a formar parte integrante de los bienes inmuebles declarados histórico-artísticos de Castilla y León ${ }^{787}$.

En 1968 se restaura y pavimenta la iglesia, descubriéndose algunas basamentas románicas durante las labores de cimentación. Dos años después todas las imágenes procedentes de Santiago, en estado completo de ruina, fueron acogidas en este templo. En 1971 con la suma recibida de Madrid, se cambió de dirección el tejado en la nave de la Epístola y el pórtico ${ }^{788}$. Por entonces aún existía el cobertizo ubicado entre la nave central y la nave de la Epístola, y se construyó una pequeña espadaña de ladrillo a modo de remate en el lado meridional. Ambos elementos desaparecerían en los años ochenta, según apreciamos en una fotografía tomada hacia esas fechas. Entre 1982 y 1984 se llevó a cabo una restauración del templo relativa a reposiciones estructurales y estéticas de elementos deteriorados en los tejados ${ }^{789}$.

\footnotetext{
${ }^{785}$ Para un estudio de los órganos de la provincia, véase SANTIAGO, Miguel de y GARCÍA MORO, Luis. La organería palentina. Apuntes palentinos, 3.Caja de Ahorros y Monte de la Piedad. Palencia, 1983 y LE BARBIER RAMOS, Elena. La organería en la provincia de Palencia (1500-1800). Institución Tello Téllez de Meneses. Palencia, 2008.

${ }^{786}$ AMCC. Sesión de 26 de enero de 1900. Libro 16. Sesiones municipales (1899-1900) fol 11 y ss

${ }^{787}$ AZCÁRATE RISTORI, José María de. Monumentos españoles: catálogo de los declarados históricoartísticos. Volumen 2. Instituto Diego Velázquez. Madrid, 1954, pp. 443-444. La fecha exacta de la declaración consta en VV.AA. Catálogo monumental de Castilla y León. Bienes inmuebles declarados. Primera Parte. Junta de Castilla y León. Salamanca, 1995, pág. 459-460.

${ }^{788}$ ASMC. Libro Inventario (1861-1953). Hojas sueltas.

${ }^{789}$ AGA. Expedientes de supervisión de contratos de obras y suministros. (3) 126.001.Caja 52/ 18847.
} 

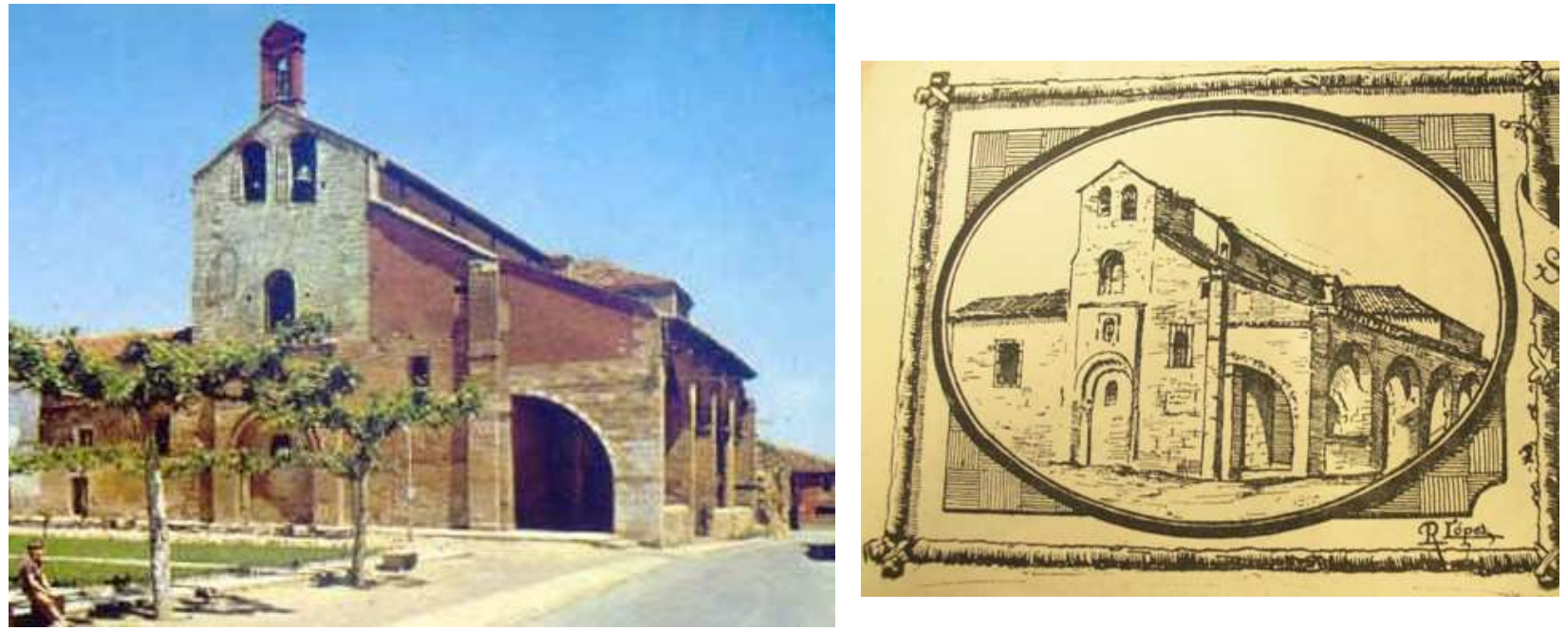

Vista del templo desde el lado meridional donde se observa el acceso tapiado y el cobertizo en la nave de la Epístola. ACJAH. Carrión. C11. Fotografías.

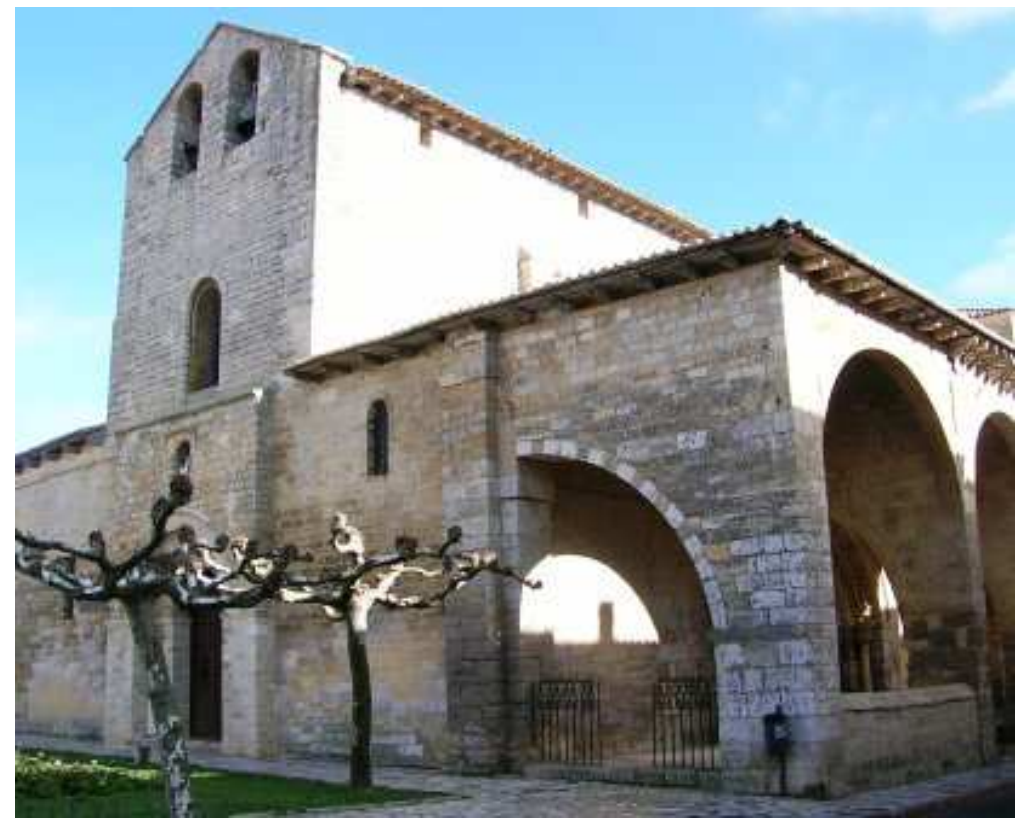

Estado del templo desde los años ochenta. 


\section{LAS CAPILLAS, ESPACIOS DE CULTO}

\subsection{LA CAPILLA MAYOR}

Supone la mayor modificación que sufre el templo románico. Ésta se produjo por iniciativa del obispo de Palencia y natural de la villa, Fray Juan del Molino Navarrete entre 1682 a 1683 , aunque no fallecería hasta el 1 de enero de $1685^{790}$. Hijo de Francisco de Molino y Juana de la Serna, una familia holgada de Socastro, tomó el hábito franciscano en 1631 en el convento de San Francisco de Palencia. Como hechos importantes de su vida, cabe destacar que fue Lector de las Artes en Alcalá de Henares y colegial de San Pedro y San Pablo de la localidad madrileña. En 1666 fue destinado en Alemania como confesor de la hija de Felipe IV, Margarita de Austria. Allí fue nombrado Comisario General de las ocho provincias alemanas, cargo detentado excepcionalmente por un personaje cuyo origen no era germánico. En 1671 le presentaron para la diócesis de Palencia, no sin cierta presión, año a partir del cual detentó el cargo de obispo hasta su muerte en 1685. En esta iglesia había sido bautizado y decidió por ello que se construyera una nueva capilla para su enterramiento. La escritura del patronato, fechada en 1692, fue otorgada en Palencia y firmada por el arcediano del Cerrato, don Manuel Aguado del Molino, sobrino del obispo ${ }^{791}$. Al dejar el obispo libertad a don Manuel Aguado sobre la transmisión del patronato, éste escogió a su hermana mayor, doña Josefa Aguado del Molino, esposa de Don Pedro de Ceballos.

De las trazas de la capilla se encargaron Felipe Berrojo, originario de Paredes de Nava, que por entonces era maestro general de obras del obispado de Palencia y vecino de Medina de Rioseco ${ }^{792}$ ayudado por el maestro local Juan de Páramo, vecino de

\footnotetext{
${ }^{790}$ GARCIA CHICO, Esteban. Documentos...Arquitectos, Op.cit, pp. 203-204. Se finalizó dos años antes de la muerte del Obispo. Boletín Informativo de la Parroquia de Carrión de los Condes. № 7 Carrión de los Condes (Palencia), 1989. Sobre su labor en el obispado palentino, véase MARTIN GONZÁLEZ, Juan José. "La catedral de Palencia entre los Obispados de Axpe Sierra y Molino Navarrete (1594-1685)" en Jornadas sobre la Catedral de Palencia. Palencia 1989, pp. 183-208.

${ }^{791}$ Todos estos datos biográficos en MARTÍNEZ GONZÁLEZ, Rafael. "El Obispo....op.cit, pp. 251-252, a su vez de FERNÁNDEZ DEL PULGAR, Pedro. Teatro clerical apostólico...Parte primera, libro III. Op.cit, $1^{\text {a }}$ Edición, pág. 229.

${ }^{792}$ GARCÍA CHICO, Esteban. "Algunos datos sobre Felipe Berrojo, arquitecto" en BSAA, nº11. Valladolid, 1934-1935, pp. 263-270. Sobre este artista, véase el apartado dedicado a los maestros locales.
} 
Carrión, en $1682^{793}$. El 8 de enero de 1682 hicieron postura de la obra en 7.000 ducados, rematándose en los mismos el 25 de junio de dicho año tras una baja de mil ducados. En la escritura, se precisan pormenorizadamente los pasos que se han de seguir, que implican, entre otros, el desmonte del retablo mayor, la demolición del ábside románico y la construcción de un arco toral cuidando así, la estabilidad de la torre que debía levantarse sobre el crucero. Es importante señalar que la ejecución de esta obra fue posible gracias a la intervención de Pedro Villalón, un buen amigo que Berrojo tenía en Carrión, quien pagó su fianza cuando fue encarcelado en las casas del ayuntamiento de la villa el 2 de noviembre de 1682. Juan de Medina y Berrojo, habían contraído una deuda de cinco mil y setenta y nueve reales con Juan Tejedor, arquitecto vallisoletano con quien trabajaron en la construcción del Archivo de la Chancillería de Valladolid entre 1675 y $1679^{794}$. En junio de dicho año, en que Juan de Medina ya había fallecido, Tejedor reclama esa cantidad a sus herederos y al maestro de Paredes a tenor de “...los gastos y materiales que se gastaron en la fábrica...". El embargo de algunos de sus bienes -una calesa de un asiento de vaqueta, una mula parda de siete años y una yegua castaña de seis años-, no impidieron el internamiento de Berrojo en prisión, de la que por fortuna salió un día más tarde, pudiendo de este modo abordar la obra que sin duda, le catapultó a la fama en la villa carrionesa ${ }^{795}$.

La planta de la capilla es rectangular con dos tramos separados por un arco. El primero va cubierto con cúpula sobre pechinas donde se sitúan los escudos del prelado. En la parte interna de la cúpula se dispone una balaustrada sobre la que se alzan ocho columnas salomónicas de cuatro espiras ornamentadas con hojas de vid entre las cuales se sitúan ocho tableros profusamente ornamentados con cuatro roleos vegetales entremezclados con hojarasca. Todos estos elementos convergen en un gran óculo central tapiado que contiene una yesería que dibuja una estrella de ocho puntas. El otro tramo, de pequeñas dimensiones se halla cubierto por una bóveda de cañón con lunetos que ilumina adecuadamente la capilla y su retablo. Se encuentra ornamentada a base de hojarasca, salvo en el tablero central, donde se dispone un jarrón policromado de azul

\footnotetext{
${ }^{793}$ Sobre estas obras, consúltese el artículo de MARTÍNEZ GONZÁLEZ, Rafael. "El Obispo...Op.cit, pp. 251-269. La referencia documental en AHPP. Carr.Prot 5716 Norberto Sandoval y Guevara (16811682), fol 122 y ss.

${ }^{794}$ GARCIA CHICO, Esteban. Documentos...Arquitectos. Op.cit, pp. 201-202 y 229. Sobre la historia de su construcción SOTERRAÑA .MARTÍN, María de la. Historia del Archivo de la Real Chancillería de Valladolid. Valladolid, 1979.

${ }^{795}$ AHPP. Carr.Prot 5008. Diego García de la Llana (1675-1683), s/f.
} 
cobalto con azucenas de verdes tallos, motivo análogo al que existe en el arco de acceso de esta capilla, alusivo a la advocación del templo a Santa María.

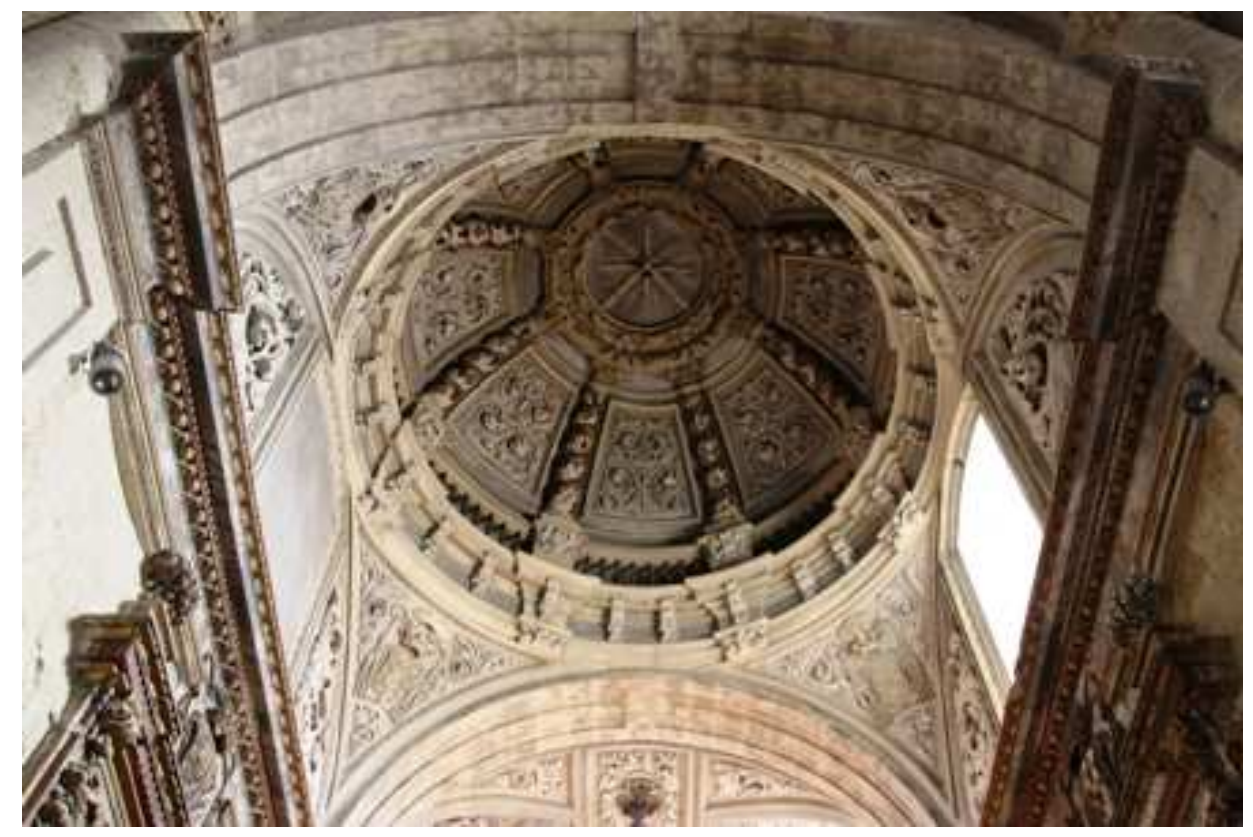

Cúpula del presbiterio construida por impulso del Obispo Juan Molino Navarrete dentro de las obras que promovió entre 1682 y 1685.

\section{El monumento funerario del Obispo Navarrete}

Para su enterramiento, el Obispo dispuso la construcción de dos arcosolios con efigies arrodilladas, tipología funeraria de origen medieval y de gran acogida en el Renacimiento, gracias a la cual los comitentes gozaban de un privilegiado lugar en el que reposar eternamente, a la par que obtenían el reconocimiento de los fieles que admirarían los bultos orantes y sus blasones desde cualquier punto del templo. Esta tipología de origen cortesano, adquiere gran relevancia a lo largo del siglo XVII.

La elevada condición del comitente, hace presuponer la utilización de materiales nobles en el sepulcro, tales como jaspes, mármoles o alabastro. Sin embargo, el Obispo especificó que se usase madera, evitando, de este modo, gastos excesivos. Para proporcionar un acabado más bello, las esculturas se policroman imitando el alabastro, recurso muy usado en época barroca. Éstos se disponen en los muros laterales, en 
arcosolios de medio punto flanqueados por pilastras decoradas con motivos vegetales en su parte superior y rematan con los escudos del patrono. En el muro del Evangelio, se dispone el obispo Molino arrodillado ante un reclinatorio donde apoya la mitra, y tonsurado de acuerdo a su condición franciscana, pero revestido de pontifical. Según testimonio de García Chico, su momia está profanada, sin sus hábitos y sin el anillo y báculo, éste último sustituido por una caña ${ }^{796}$. En el lado derecho, destacan las figuras de sus padres, igualmente arrodillados y ataviados de un modo distinguido como correspondía a su condición. Su padre, don Francisco de Molino, luce armadura, capa y gola. Su madre, doña Juana de la Serna, porta un largo vestido, amplia capa y el cabello recogidos en tres lustrosos moños, uno a cada lado del rostro y el tercero en la parte posterior.

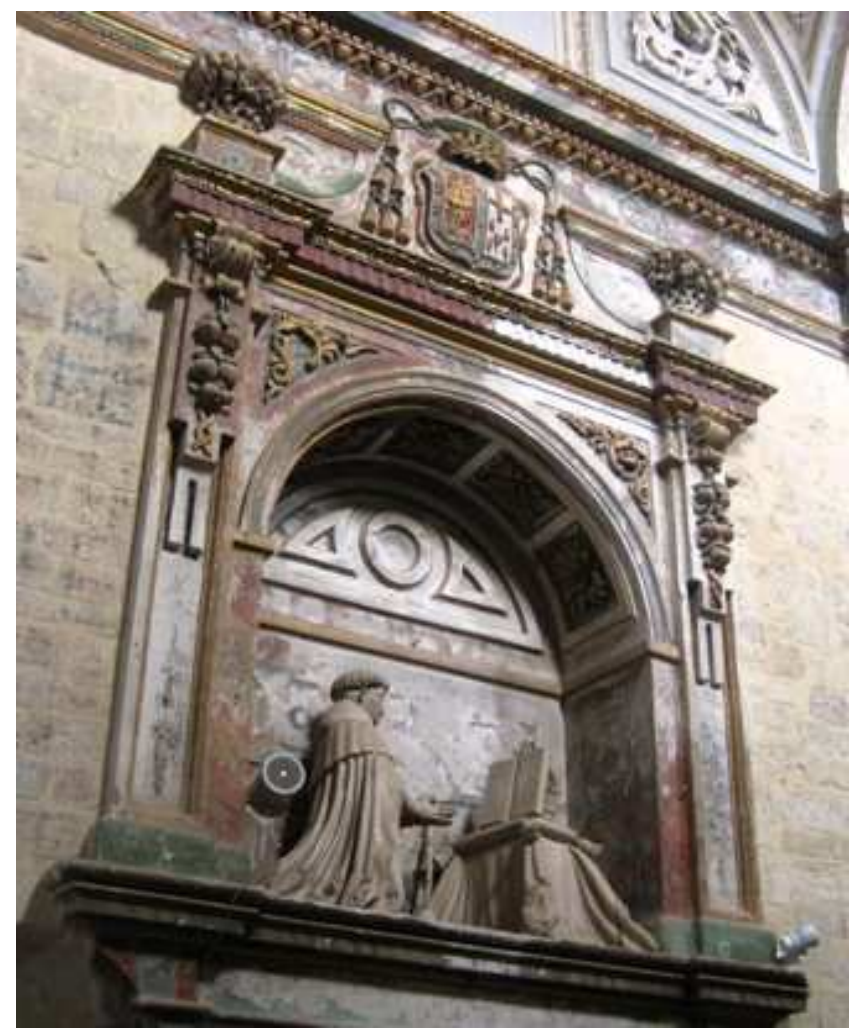

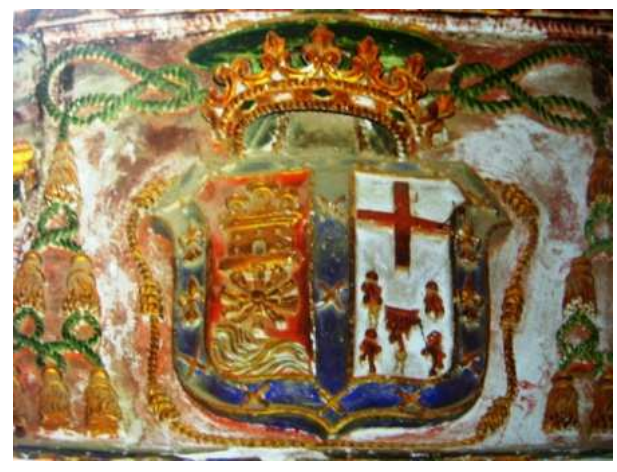

Detalle.

Armas del Obispo.

Monumento funerario del Obispo Juan Molino Navarrete. Madera policromada. $(100 \mathrm{~cm} \times 70 \mathrm{~cm} \times 90 \mathrm{~cm})$.

\footnotetext{
${ }^{796}$ GARCÍA CHICO, Esteban. Documentos...1 Arquitectos. Op.cit, pág. 203.
} 
Las armas personales de Don Juan del Molino están presentes tanto en el arco que se halla sobre los sepulcros, como en las pechinas de la bóveda y en el exterior del templo, en el muro meridional de la cabecera de la capilla central. El escudo se leería de la forma siguiente: partido. 1, de los Molino Navarrete, de gules con un castillo de oro y una rueda de molino de oro sobre ondas de agua. 2, de la Orden Franciscana, de plata con una cruz llana de gules y las llagas de San Francisco. Bordura de azur con trece aspas de oro y en los flancos, cuatro flores de lis de oro rodeado del cordón franciscano. Al timbre, corona, por la posesión del Condado de Pernía, título de los obispos palentinos desde el siglo XV, capelo y cordones episcopales. Así es igualmente, el escudo impreso en las Constituciones sinodales de la diócesis palentina, editadas en 1681 bajo el mandato de nuestro obispo ${ }^{797}$.

Si bien exclusivas de una selecta clientela acaudalada, la provincia de Palencia cuenta con un importante conjunto de sepulturas de este tipo comandadas a lo largo del siglo $\mathrm{XVII}^{798}$. El precedente de todos los monumentos funerarios palentinos lo constituye el sepulcro de los marqueses de Poza, don Francisco de Rojas y doña Francisca Enríquez de Cabrera de la capilla mayor del convento dominico de la capital. Realizado en alabastro, fue encargado en 1609 a Alonso de Vallejo para disponerse frente al sepulcro renacentista ya existente perteneciente a otros miembros del linaje $\mathrm{e}^{799}$. En la iglesia de San Andrés de Carrión, en el lado de la Epístola, figura el sepulcro del Obispo Melchor Álvarez de Vozmediano, fallecido en 1636 bajo un lucillo tallado coetáneamente $^{800}$. Sin duda, un monumento funerario análogo a éste, formado por una pareja de orantes inmersos en arcos de triunfo dispuestos a ambos lados del templo, es el de la familia Guerra en la iglesia de San Miguel de Piña de Campos ${ }^{801}$. Los palentinos Juan de Ochoa, en la cantería y Juan de Rozadilla se concertaron en 1628 con el

\footnotetext{
${ }^{797}$ VIGURI, Miguel de. Heráldica.... II. Op.cit, pág. 46.

${ }^{798}$ CASTRO MARTÍN, Pablo L. “Arte funerario...Op.cit, pp. 601-617.

${ }^{799}$ Finalmente el sepulcro no lo realiza Vallejo, y se contrata a los ensambladores Juan de Muniátegui y Cristóbal y Francisco Velázquez. GARCIA CHICO, Esteban. Documentos...Escultores. Op.cit, pp. 214218. A pesar de todo, la autoría del orante no está clara. Urrea propone, en base a las cláusulas de un testamento y las semejanzas estilísticas, a Antonio de Riera. URREA FERNÁNDEZ, Jesús. "El escultor Antonio de Riera” en BSAA, nº40-41. Valladolid, 1975, pp. 668-672.

${ }^{800}$ Del mismo hablaremos en el capítulo dedicado al templo de San Andrés.

${ }^{801}$ Sobre el mismo, CARLÓN, Concepción, MARTÍNEZ GONZÁLEZ, Rafael Ángel y PRESA, Fabiola. "La capilla funeraria de los Guerra en la iglesia de San Miguel de Piña de Campos (Palencia)" en AIICHP, tomo 5. Palencia, 1990, pp. 181-208 y PARRADO DEL OLMO, Jesús María. Piña de Campos: Iglesia de San Miguel. Colección, Raíces Palentinas. Palencia, 1993, pp. 11-15.
} 
propietario de la capilla colateral del Evangelio, don Diego Guerra para realizar su arcosolio y el de su difunto tío, Fray García Guerra. Un caso palentino en que hallamos representado a un obispo, de Jaén concretamente, compartiendo espacio funerario con sus progenitores ubicados bajo el mismo arcosolio, es el de los sepulcros orantes del prelado Don Antonio Piña, su homónimo padre y doña Magdalena de la Serna, su madre. Se ubican en la iglesia parroquial de San Pedro Apóstol, en Itero de la Vega, igualmente en posición genuflexa ante un atril ${ }^{802}$.

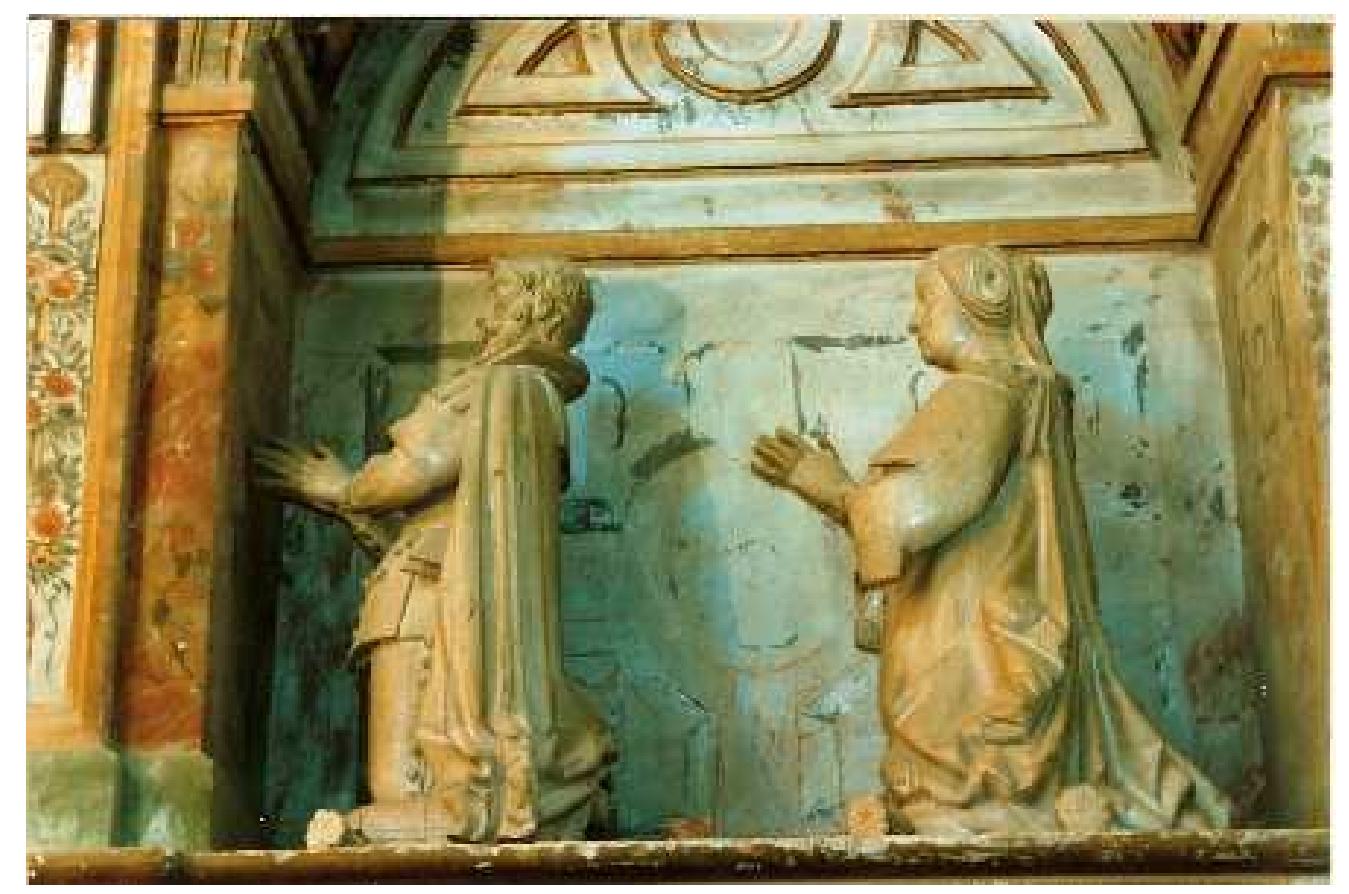

Monumento funerario de Don Francisco del Molino y Doña Juana de la Serna, padres del Obispo don Juan Molino Navarrete en Santa María. Madera policromada. $(146 \mathrm{~cm} \times 70 \mathrm{~cm} \times 90 \mathrm{~cm})$.

\section{El retablo mayor precedente}

Hasta que fue sustituido por el que encargó el Obispo Juan Molino en 1685, existió otro retablo en esta capilla, contratado en 1648 por Juan Bautista Pérez. Dado

\footnotetext{
${ }^{802}$ SALCEDO TAPIA, Modesto. "Noticias y documentos de Itero de la Vega" en PITTM, n 63. Palencia, 1992, pp. 546-557.
} 
que éste se identifica con toda seguridad con el que preside la capilla mayor de la iglesia de San Andrés, estimamos conveniente realizar su estudio en la iglesia mencionada ${ }^{803}$.

La imagen que presidía este retablo era la de Nuestra Señora, dada la advocación del templo a Santa María. El contrato del dorado, ejecutado en 1654 por Gaspar Díaz del $\mathrm{Pozo}^{804}$, indica que se debía realizar un colorido brocado de la caja donde se ubicaba “...la ymajen de Nuestra Señora de bulto qu'está en el dicho rettablo senttada en una silla... ${ }^{805 ” . ~ E s t o s ~ d a t o s ~ s o n ~ c l a v e s ~ p a r a ~ i d e n t i f i c a r ~ e s t a ~ e s c u l t u r a ~ c o n ~ l a ~ V i r g e n ~ g o ́ t i c a ~}$ que, desde los años setenta se ubica en el nicho del crucero de la Epístola y que, presidiría anteriormente el retablo de San Nicolás, hasta los años setenta del siglo XX. Consideramos que puede identificarse con esta imagen dada su posición sedente y la viva policromía de su vestimenta -con un repertorio de capullos florales, estrellas y tetramorfos- que perfectamente puede responder a una intervención de mediados del siglo XVII.

Se trata de una interesante imagen de la Virgen entronizada en disposición frontal, acompañada por el Niño Jesús, en actitud más movida, pues está bendiciendo. Se trata de una obra del tercer cuarto del siglo XIII realizada en piedra, a excepción de la mano derecha con el cetro que porta la Virgen, que es de madera, pues la original debió perderse. Las características formales de la escultura se ajustan perfectamente a esta cronología, pues a partir de esta centuria se advierte una religiosidad más humanizada que se traduce en la expresión más amable del rostro de ambos, con un suave modelado y en las posturas menos rígidas, patente en el giro que se inicia en el Niño Jesús ${ }^{806}$. El traje de la Virgen está compuesto de manto y amplia y larga túnica ceñida por un cinturón bajo y prendedor redondo. Perviven ciertos convencionalismos en la talla como los marcados ángulos de las rodillas o la caída simétrica de la túnica. Desde que fue trasladada a su emplazamiento actual ha permanecido en el mismo sin

\footnotetext{
${ }^{803}$ La escritura y condiciones del retablo en AHPP. Carr.Prot 5238. Jerónimo López (1648), fol 130 y ss. Sobre Juan Bautista Pérez, remítase al capítulo dedicado a los ensambladores locales.

${ }^{804}$ Este artista ya había trabajado en Carrión, dorando 1641 el retablo mayor del convento de Santa Clara AHPP. Carr.Prot 5234 Jerónimo López (1641-1642), s/f.

${ }^{805}$ AHPP. Carr.Prot 5527. Tomás Pérez (1654), fol 108 y ss.

806 ARA GIL, Clementina-Julia. "Imaginería gótica palentina" en Jornadas sobre el gótico en la provincia de Palencia. Diputación Provincial de Palencia. Palencia, 1988, pp. 52.
} 
variaciones, salvo en 1999, que fue tomada en préstamo para formar parte de la Exposición de las Edades del Hombre, celebrada en Palencia ${ }^{807}$.

Ha gozado siempre de gran veneración, pues evoca la victoria sobre los musulmanes al que nos referimos con anterioridad. Es lógico por tanto que se encargasen copias de la misma, como la que pintó en 1614 Bartolomé de Medina. Por este óleo “...con colores finos...”, el pintor recibió ocho ducados y, en especias, tres varas de anjeo ${ }^{808}$. La ubicación final de esta obra es desconocida, pudiendo haber pasado a propiedad particular. El retablo debía estar dorado y estofado para junio de 1655, en que Gaspar Díaz del Pozo recibiría dos mil ciento treinta y seis reales y dos cargas de trigo.

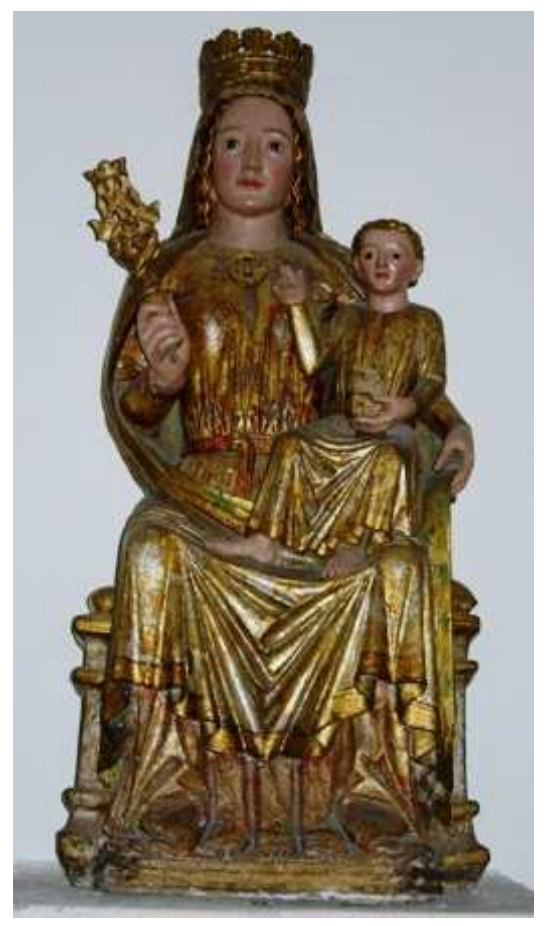

Virgen de Nuestra Señora del Camino que presidía el retablo mayor, actualmente en el lado de la Epístola. Piedra calcárea. Siglo XIII, repintada en el siglo XVI. $(115 \mathrm{~cm} \times 55 \mathrm{~cm})$.

\footnotetext{
${ }^{807}$ FRANCO MATA, Ángela. "Crucifijo", ficha n ${ }^{\circ} 8$ en Memorias y esplendores. Las Edades del Hombre. Catedral de Palencia, 1999, pág. 75.

${ }^{808}$ Anjeo: Especie de lienzo basto cuya terminología procede de la región francesa de Anjou. AHPP. Protocolos Carrión 5397. Francisco Moro Saldaña (1614), s/f. Sobre Bartolomé de Medina, remítase al capítulo dedicado a los pintores locales.
} 


\section{El retablo mayor actual}

El retablo mayor que preside hoy día la capilla mayor fue patrocinado por el obispo Molino Navarrete en 1684, encargándose de la obra el ensamblador Santiago Carnicero $^{809}$. Para su ejecución se trajo en septiembre de 1683 la madera necesaria proveniente de los Pinares de Soria, cuya calidad es sobradamente conocida ${ }^{810}$. Consta de banco, un cuerpo de tres calles separado con columnas salomónicas y remate semicircular que se adapta al presbiterio.

El amplio banco está conformado por dos tableros laterales compartimentados en cuatro cuadrantes, en cuyos ángulos se disponen sendas orejetas, dando cabida, en su parte superior a una tarjeta cactiforme carnosa. Entre éstos se sitúan los netos de los soportes del primer cuerpo, ornamentados a través de una ménsula desarrollada y ornamentada con hojarasca. En el centro se ubica un gran tabernáculo que dados sus dos metros de altura, penetra en el cuerpo principal. Procede de la iglesia de Santiago, donde formaba parte del retablo del ábside de la Epístola hasta que fue desmembrado cuando el templo cerró sus puertas al culto ${ }^{811}$.

De planta octogonal, se encuentra conformado por ocho columnas salomónicas con capiteles corintios sobre los cuales apean amplios cimacios que dan paso a un segundo nivel. Cuatro arcos de medio punto sustentan una estructura cuadrangular rematada en una balaustrada en cuyos ángulos se han colocado cuatro elementos apiñonados. En su interior, el tabernáculo alberga un sagrario de reciente factura en cuya puerta se ha incrustado un bajo relieve de ochenta y siete centímetros de altura, que representa la Resurrección. En el centro de la composición emerge la figura de Cristo, ataviado con el perizonium y una capa atada en su pecho que deja descubrir una prominente anatomía y un correcto modelado que evidencia la proporción de todas sus

\footnotetext{
${ }^{809}$ MARTÍNEZ GONZÁLEZ, Rafael. “El Obispo....op.cit, pág. 260. Sobre Santiago Carnicero, remítase al capítulo dedicado a la biografía de los ensambladores y escultores.

${ }^{810}$ Pedro Gil, carretero de la Cabaña Real se comprometió a traer a Santiago Carnicero la madera siguiente: 37 vigas de pino labrado en vasto de 22 pies de largo y cuarta y sesma de grosor (a 13 reales cada una), 15 del mismo largo pero de tercia y cuarta de grueso (a 26 reales), 36 sesenes de tabla de chilla (a 2 reales el sesén), “...para con ello azer y fabricar el rretablo de la capilla mayor de la yglessia parrochial de Santa María del Camino d'esta dicha uilla que se a de azer por quenta del Ilustrísimo señor Don Fray Juan del Molino Navarrete, Obispo de Palençia, que está a cargo su fábrica de Santiago Carnizero, maestro ensamblador...”AHPP. Carr.Prot 5890, Blas Vela Álvarez (1682-1685), fol 395 y ss. ${ }^{811}$ PERAL VILLAFRUELA, Santiago y GÓMEZ PÉREZ, Enrique. 2003. Op.cit, pp. 52-53.
} 
partes. Bendice con la mano derecha, que eleva al cielo, mientras que con la izquierda sostiene el estandarte de la victoria sobre la muerte.
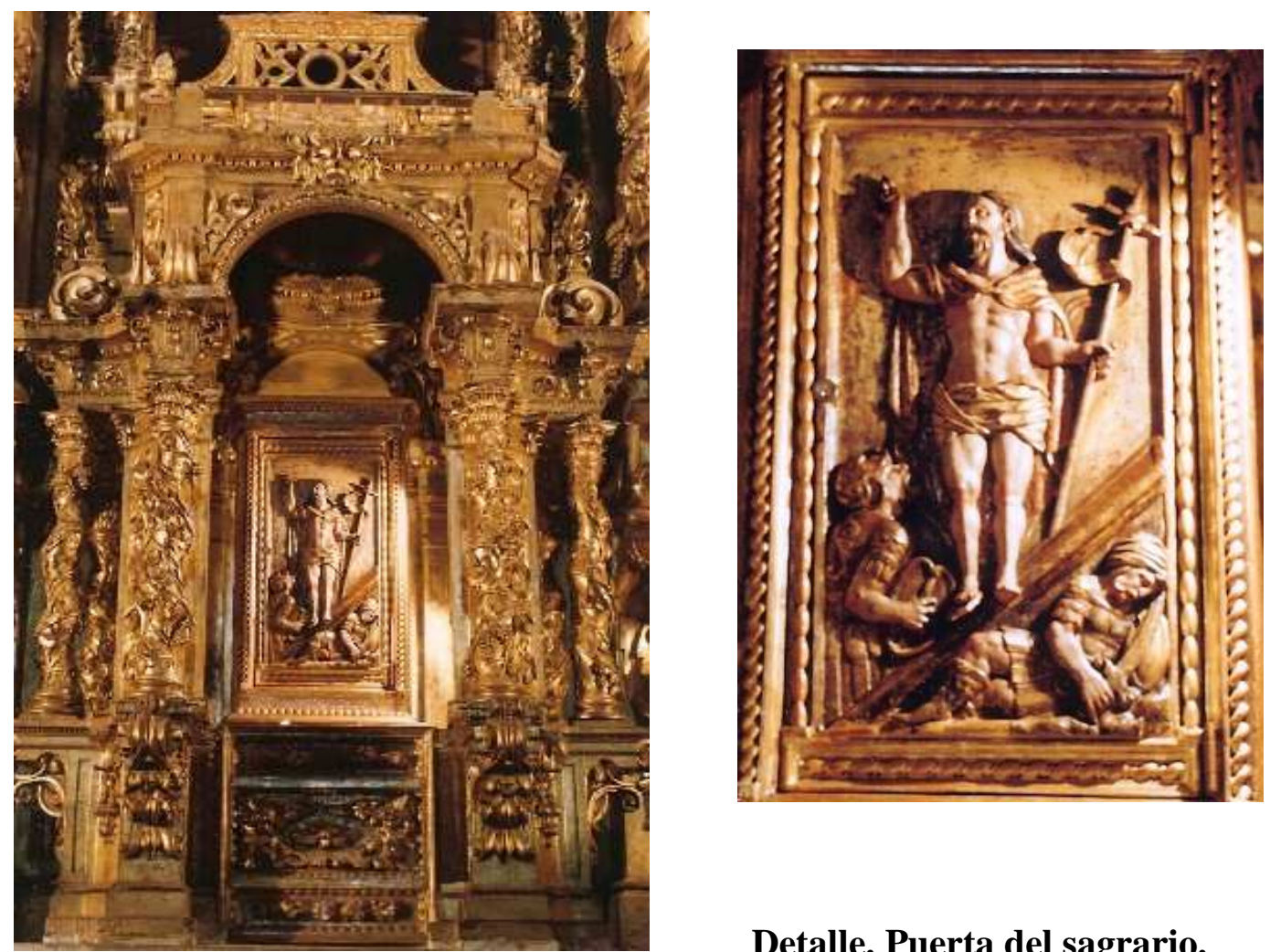

Detalle. Puerta del sagrario.

\section{Cristo resucitado del siglo XVI.}

Tabernáculo del sagrario (2mtrsx1,45mtrsx2mtrs).

En la parte inferior, la tapa del sepulcro dispuesta oblicuamente, divide a los dos soldados romanos encargados de la custodia del cadáver. En la esquina izquierda, uno de los guardias arrodillado, contempla estupefacto el suceso milagroso, mientras que en el ángulo frontero, el otro soldado, recostado sobre su hombro izquierdo y con la espada aún en su mano derecha, se ha quedado dormido, ajeno a lo que sucede a su alrededor. Este relieve hacía pareja con el del Cristo camino del Calvario del museo parroquial que existe hoy en el museo de Santiago ${ }^{812}$. Si bien los soldados pecan de cierta rigidez, pues mantienen cierta contracción violenta, el canon musculoso del Cristo y su pose estática

\footnotetext{
${ }^{812}$ Delegación Diocesana de Patrimonio Cultural de Palencia. Carrión de los Condes. Carpeta 1.
} 
muestran una herencia manierista que nos permite datar el relieve hacia el tercer cuarto del siglo XVI.

El cuerpo principal del retablo se divide en tres calles por medio de cuatro columnas salomónicas de cuatro espiras profusamente decoradas con vistosos ramilletes de vid. Las tres hornacinas existentes están compuestas por un par de columnas salomónicas de tres espiras y cimacios desarrollados sobre los cuales apea un arco de medio punto que se prolonga para cobijar las respectivas imágenes de un metro y medio de altura, conformando una pequeña bóveda de cañón con tres casetones en cada una. Las imágenes de las calles laterales representan a los Santos Juanes, cuya inclusión se justificaría por la alusión al patrón, Fray Juan de Molino y a su madre, llamada Juana ${ }^{813}$.

En el lado izquierdo, San Juan Bautista, es una figura de un hombre dotado de barba y bigote, y pese a ello con apariencia juvenil. Sobre su cabeza se dispone una discreta corona de rayos de cobre sobredorado. La piel de camello que porta atada a la cintura para evitar su caída, permite ver su torso y parte de la pierna derecha que se adelanta, junto a la cual reposa cándidamente el cordero. Se crea de este modo un suave contraposto que traza una diagonal hacia el brazo levantado del santo eremita para sostener el bastón. La composición halla su perfecto equilibrio a través de la segunda línea transversal que desde la pierna que se retrasa confluye en la mano contraria que señala hacia abajo con el dedo índice.

Por su parte, la imagen de San Juan Evangelista presenta a un mancebo imberbe con larga guedejas ondulantes que sostiene con gran elegancia un cáliz dorado. Le acompaña, a su pies, casi oculto por su color negro, el águila, el atributo que lo identifica como evangelista. La capa roja que envuelve su hombro izquierdo presenta una cadencia ondulante en sus perfiles. Ambas tallas han sido adscritas al círculo de Juan de Ávila ${ }^{814}$ de cuyo estilo apreciamos la blandura de los rostros masculinos y los pliegues de las túnicas en suave caída.

\footnotetext{
${ }^{813}$ PERAL VILLAFRUELA, Santiago y GÓMEZ PÉREZ, Enrique. 2003. Op.cit, pág. 53.

${ }^{814}$ URREA FERNÁNDEZ, Jesús y MARTÍN GONZÁLEZ, Juan José. Op.cit, pág. 58. Sobre Juan de Ávila MARTÍN GONZÁLEZ, Juan José. Escultura...Op.cit, pp. 320-324.
} 


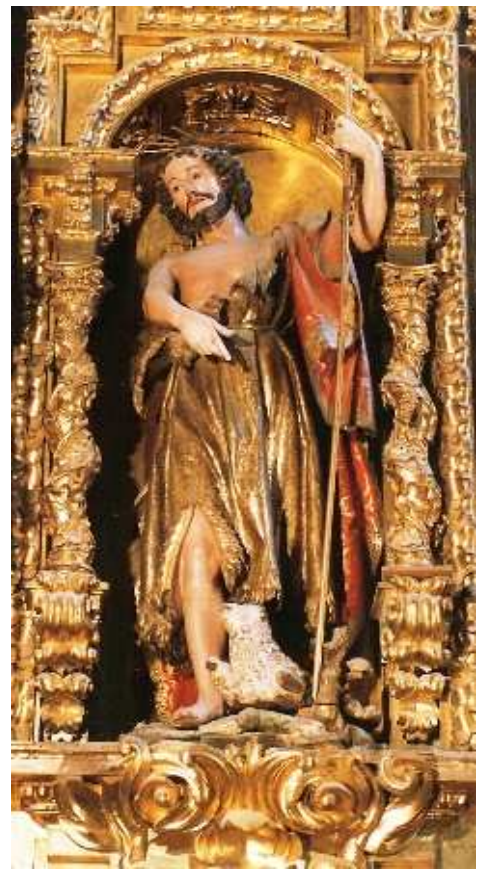

San Juan Bautista.

$(160 \mathrm{~cm} \times 60 \mathrm{~cm} \times 45 \mathrm{~cm})$.

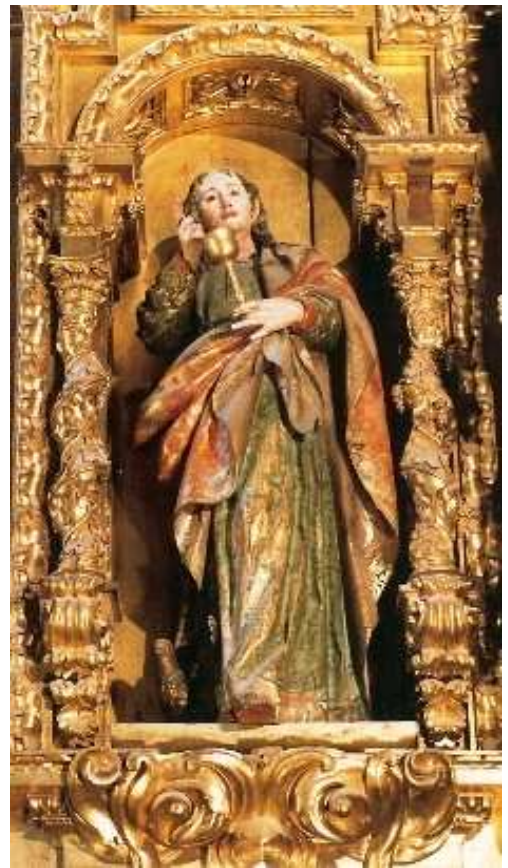

San Juan Evangelista.

$(150 \mathrm{~cm} \times 60 \mathrm{~cm} \times 40 \mathrm{~cm})$.

Esculturas del retablo mayor, cercanas al estilo de Juan de Ávila.

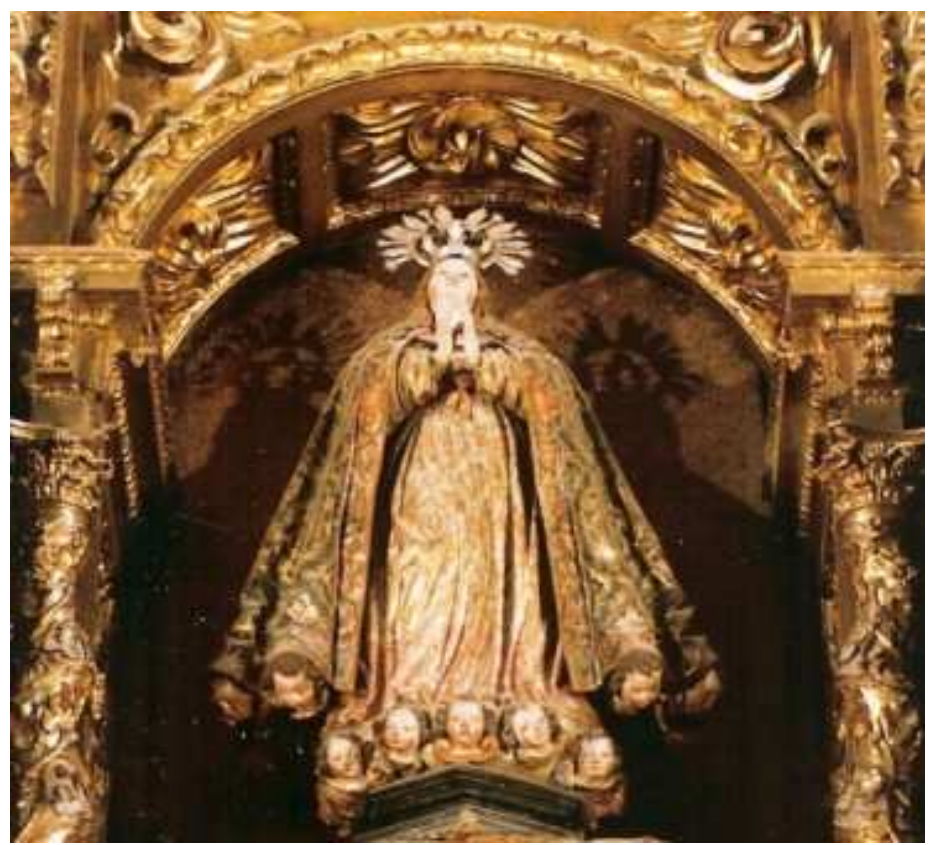

Inmaculada que preside el retablo mayor. Seguidor de Gregorio Fernández $(157 \mathrm{~cm} \times 75 \mathrm{~cm} \times 40 \mathrm{~cm})$. 
Preside el retablo la figura de la Inmaculada, que sigue el prototipo de Gregorio Fernández. Ubicada sobre un pedestal que remata el tabernáculo, la Virgen alza su mirada al cielo mientras dispone sus manos en actitud de oración. La omisión de la luna creciente a sus pies y la presencia de un mayor número de ángeles de los tres habituales en la Inmaculada han llevado a asimilarla con el tema de la Asunción ${ }^{815}$. Cinco testas de angelillos se alinean bajo su túnica blanca mientras que otros cuatro se disponen bajo su verde manto, en los amplios y densos dobleces que crea su caída. Tanto la túnica como el manto se estofan a través de ricos brocados y una orla con motivos vegetales en tonos rojizos y verdes cae por la parte delantera de la imagen. Porta en su cabeza una corona de la que emergen rayos solares, realizada probablemente en plata. La disposición de la cabellera, con mechones anchos y ondulados en caída simétrica y el tratamiento alatonado de drapeado del manto recuerdan el estilo del escultor gallego. Sin embargo la caída suavizada de los pliegues paralelos de la túnica desvincula la talla de la autoría del mismo. La dedicación del templo a Santa María y la vinculación del obispo Molino a esta tipología, como custodio de que fue de la provincia franciscana de la Concepción, motivan su protagonismo en el retablo. La cornisa con dentellones que se ubica sobre el cuerpo principal se retranquea gracias al adelantamiento de los soportes ubicados en los extremos del retablo y además se encuentra partida en su sección central, lo que permite la comunicación directa de la hornacina principal con la que se ubica sobre ella.

El ático semicircular se adapta al arco de medio punto que cierra el testero del templo. Posee un gran desarrollo en altura, por lo que prácticamente se convierte en un cuerpo más del retablo que iguala en altura al principal. Este remate consta de dos tableros laterales cuyo perfil exterior es curvo pues transcurre paralelo al arco y por la parte interior están conformados de un perfil recto. Una inmensa y caprichosa vegetación de fastuosos rameados se extiende por ambos tableros y entre ambos, dos columnas salomónicas de tres espiras acogen la caja central. Su escaso fondo motiva la presencia de una amplia ménsula sobre la cual se ubica una corona -que como indicamos previamente, es símbolo de la ostentación del Condado de Pernía por los obispos palentinos desde el siglo XV- capelo y cordones episcopales. Ambos elementos lo vinculan al obispo Fray Juan del Molino. Preside la hornacina, la imagen de San Francisco. Si bien color oscuro de su hábito, casi negro, puede despistar en su

${ }^{815}$ PERAL VILLAFRUELA, Santiago y GÓMEZ PÉREZ, Enrique. 2003. Op.cit, pág. 53. 
identificación, el cordón franciscano que anuda en su cintura, la llaga visible en su mano izquierda extendida y la cruz en su mano derecha, resultan inconfundibles. Fray Juan de Molino era franciscano y a esto hay que sumar el hecho de que su padre fue bautizado con el nombre de Francisco, de ahí la elección del santo de Asís.

El retablo de Santa María, prototipo de un barroco exuberante que pudo servir como referente para la ejecución de otras obras carrionesas, como el retablo mayor de la iglesia de San Julián, concertado en $1699^{816}$. En ambos casos podemos observar la disposición de un cuerpo tetrástilo y salomónico, la utilización del ático en semicírculo y el uso reiterado de entablamentos partidos.

El dorado y estofado del nuevo retablo fue encargado en mayo de 1685 a Alonso Gómez, vecino de la localidad palentina de Mazuecos de Campos, fiándole en la obra Santiago Carnicero ${ }^{817}$. En toda la obra, sin excepción, debía aplicarse oro limpio, esto es, sin mezclar, y bruñido, recibiendo por la misma, trece mil reales. En los intercolumnios, en los tableros de los nichos, en el pedestal y sobre la ornamentación debía realizarse una exquisita labor de escarchado ${ }^{818}$ “...porque assí conviene para su lucimiento...". En el documento se indica un curioso dato acerca de cómo el oro se entregaba al artista en libros rubricados, y éste los devolvía cuando estaban vacíos. De este modo, el pan de oro se mantenía en buenas condiciones, listo para su uso por el dorador. Cuando se firma el contrato, el sagrario no contenía el relieve reutilizado del Cristo resucitado que vemos hoy día, pues se especifica que Alonso Gómez pinte en su puerta un pelícano o un cordero con los siete sellos. Tampoco habían sido asentadas las esculturas, dada la advertencia del dorador palentino sobre la exención del dorado de los Santos “...que se ubieren de azer, por no sauer qué Santtos son, o si el señor Don Manuel los trairá dorados y estofados de Valladolid o de otra parte...”. Manuel Aguado Molino, sobrino del obispo. Don Juan de Molino, fue quien se mantuvo al cuidado de la capilla y encargado de las obras que se hicieren en la misma, como éste, pero no hereda el patronato de la capilla en $1692^{819}$. Existe además, en esta capilla, un relicario de San Pedro Regalado, que Fray Juan de Molino pudo conseguir por su

\footnotetext{
${ }^{816}$ AHPP. Carr.Prot 5019, Agustín García Miranda (1699-1700), s/f.

${ }^{817}$ Condiciones de la obra en AHPP. Carr.Prot 5890. Blas Vela Álvarez (1682-1685), fol 575 y ss. Sobre Alonso Gómez, remítase al capítulo dedicado a los pintores locales y en el caso de Santiago Carnicero, revísese el que estudia a los ensambladores y escultores locales.

${ }^{818}$ Bordado erudito producido con metales preciosos como oro y plata que van rizados o moteados.

${ }^{819}$ MARTÍNEZ GONZÁLEZ, Rafael. “El Obispo...Op.cit, pág. 260.
} 
elevada condición. Seguramente le interesaría conservarlo especialmente dada la beatificación del Santo un año antes de su muerte, el 17 de agosto de $1683^{820}$.

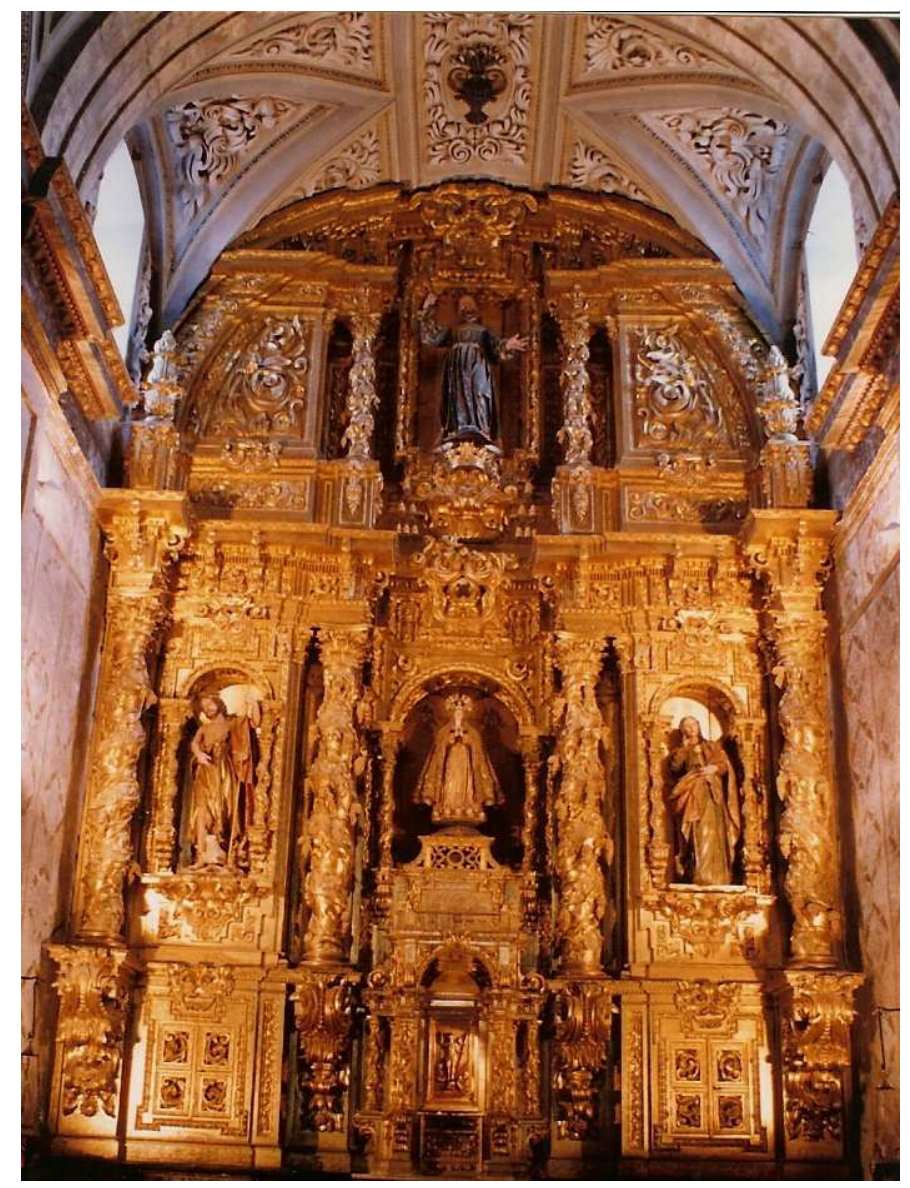

Retablo mayor de la iglesia de Santa María. Santiago Carnicero. 1684.

(8mtrsx6,15mtrsx1,3mtrs).

\section{Las pinturas murales}

La capilla mayor conserva todavía algunos restos de las pinturas murales que recubrieron este privilegiado espacio del templo.

En 1749 la iglesia se concierta con dos maestros doradores, pintores y estofadores para pintar "unas colgaduras" en la capilla mayor ${ }^{821}$. Los encargados de los trabajos son José Cosgaia, oriundo de Carrión y Francisco Gutiérrez, vecino de Cisneros. Del primero de

\footnotetext{
${ }^{820}$ ANDRÉS ORDAX, Salvador. La iglesia..Op.cit, pág. 53-54.

${ }^{821}$ AHPP. Carr.Prot 4735, Gabriel Ceano Vivas (1748-1749), fol 18 y ss.
} 
estos artistas palentinos no se conoce ninguna obra. Caso muy diferente es el de Francisco Gutiérrez, a cuya mano pertenecen varios trabajos en el entorno palentino ${ }^{822}$. Esta pintura debía recubrir por entero la capilla mayor desde la cornisa hasta el piso de la iglesia “...de manera que jueguen ttelas y flores vniformementte...". La ornamentación incluía el panteón del Obispo Fray Juan del Molino y de sus padres, donde se especifica que se pinten “...las fruttas, azafattes y colgantes...” que los adornan, imitando el natural. La documentación se refiere a la policromía de los relieves de los dos cestillos de flores que flanquean el escudo del prelado y las guirnaldas de frutas que ornamentan las pilastras, policromados de vivos verdes y granates. En el fondo de ambos nichos en los mismos tonos pero más apagados, se adivina una decoración de cuadrantes en los que se insertan flores, cubriéndolo todo, a modo de tapiz. La madera con que están realizados ambos monumentos explica la mejor conservación de los pigmentos que en la superficie de los muros pétreos. De igual modo, en la cornisa de yeso que recorre todo el perímetro de la capilla se adhirieron perfectamente los colores. En ella se doró a sisa, es decir, mate, todas las partes talladas como la primera nacela con motivos de hojas, la moldura de dentellones y los gallones situados debajo. El listel ubicado entre éstos va policromado imitando el veteado de los jaspes, y en el filete inferior de la cornisa rubios angelillos que juegan entre la vegetación.

Para realizar toda esta obra, se debían adquirir los mejores materiales que se encontraran en las ciudades de Valladolid o Burgos, recibiendo por la misma dos mil cuatrocientos reales. Sin embargo, en la carta de pago del año 1750, Gutiérrez y Cosgaia reciben más de cuatro mil quinientos reales, ya que además intervinieron en el retablo mayor $^{823}$. Seguramente desde 1685 se habría desprendido alguna parte del dorado y el párroco quería que luciera en perfectas condiciones.

Lo que ha desaparecido por completo es la “...puntilla de encage menudo de oro..." que recubriría la superficie existente entre paño y paño de la colgadura, pues en una intervención posterior que no podemos determinar, parte de las pinturas de este sector fueron sustituidas por otras. Hoy día podemos contemplar hileras de rombos

\footnotetext{
${ }^{822}$ Sobre Francisco Gutiérrez, remítase al capítulo dedicado a los pintores locales.

${ }^{823}$ Así consta que se otorgó carta de pago por valor de 4.641 reales. AHN. Clero Secular-Regular Libro 9606, Cuentas de Fábrica de Santa María desde 1733.
} 
enmarcados de tonos rojizos en la parte más inmediata al retablo mayor. En las paredes aledañas, separadas de aquéllas por dos enormes pilastras cajeadas, percibimos igualmente una serie de trazos negros que conforman un gran ajedrezado y en cada uno de los escaques se inserta un rombo tangente. Aquellos policromados de rojo se sitúan sobre fondo blanco, y aquellos que son negros se sitúan sobre un campo anaranjado. Esta decoración en cuadrícula también la encontramos en el intradós de los arcos que separan la nave mayor de las laterales. Todos estos colores han perdido su intensidad con el paso del tiempo pero a la vista de lo conservado debemos imaginar la viveza que poseían, de manera que, con el intenso contraste que creaba el oro del retablo, creaba en el fiel un referente visual inmediato fruto de una intervención posterior.

\subsection{LA CAPILLA DE SAN NICOLÁS O DE LOS PAZ}

Está situada en lado de la Epístola y es la única que ha conservado exteriormente el ábside semicircular de época románica. El fundador de esta capilla fue el Licenciado don Juan de Paz, hijo de Hernando de Paz. Al casarse con Juana de la Serna, capituló en su nombre la adquisición de la capilla en 1511, ostentando el patronazgo desde entonces los miembros del linaje Paz de la Serna ${ }^{824}$.

\section{Sepulcro de don Juan de Paz}

Su sepulcro se conserva a los pies del templo, en el lado de la Epístola, siendo su ubicación original la capilla de San Nicolás, donde se hallaba al menos hasta 1861, tal y como indica Quadrado ${ }^{825}$. La estatua yacente descansa sobre un doble almohadón acompañado de un paje fiel a sus pies. Los restos de colores rojizos sobre la casulla del difunto y trazos negros en los pliegues de la vestimenta evidencian la policromía original del conjunto. Conserva una inscripción en caracteres góticos que, recorriendo la cama del sepulcro identifica al personaje que reposa sobre el mismo: "Aquí está

\footnotetext{
${ }^{824}$ VIGURI, Miguel de. Heráldica...2. Op.cit, pp. 42-43.

${ }^{825}$ En el informe que realizó la Comisión de monumentos palentinos sobre los monumentos notables de la provincia de Palencia en 1860, remitiéndose al estado en que se encontraban en 1844, se recoge este sepulcro y se indica que por entonces se situaba en la capilla de los Téllez o de las Victorias, es decir, en la capilla de San Nicolás a la que nos referimos. ARASF. Palencia, Comisión de Monumentos, Leg. 2-77, Monumentos en general. Otras fuentes lo corroboran QUADRADO; José María y PARCERISA, Francisco J. Recuerdos...Op.cit, pág. 130.
} 
sepultado el discreto varón licenciado Juan de Paz, el qual acabó su vida, día de Santa Clara, año de MDXIIII'. La fecha del óbito del difunto tuvo que ser coetánea a la de ejecución del sepulcro, pues los pliegues sumarios de su túnica, la planitud de su rostro y la decoración de cardina que bordean sus armas señalan una datación de principios del siglo XVI. Estas características son apreciables igualmente en el sepulcro del abad Husillos, Don Francisco Núñez de Madrid, en la Catedral de Palencia, de 1501, aunque la magnificencia del monumento funerario y la exquisitez de su talla dista bastante de la sencillez del sepulcro de nuestro finado. El escudo de los Paz, apreciable también en la Casa del Cordón de Palencia, se caracteriza por constar de diez bezantes y dos leones dragantes. La diferencia radica en que en este caso concreto, los roeles no se alinean horizontalmente, sino que se disponen en tres palos que cierra su escote, alineación típica del primer gótico ${ }^{826}$. En un documento de 1789 en el que el patrón de la capilla, Francisco José de Villegas nombra un capellán, queda especificado el lugar originario de este sepulcro: "Esta capilla se dize ser de los Pazes, con cuyas armas se halla un sepulcro grande de piedra al lado del Evangelio de dicho altar y en medio una lápida inmediata a su gradilla con las armas de tal ${ }^{827, .}$

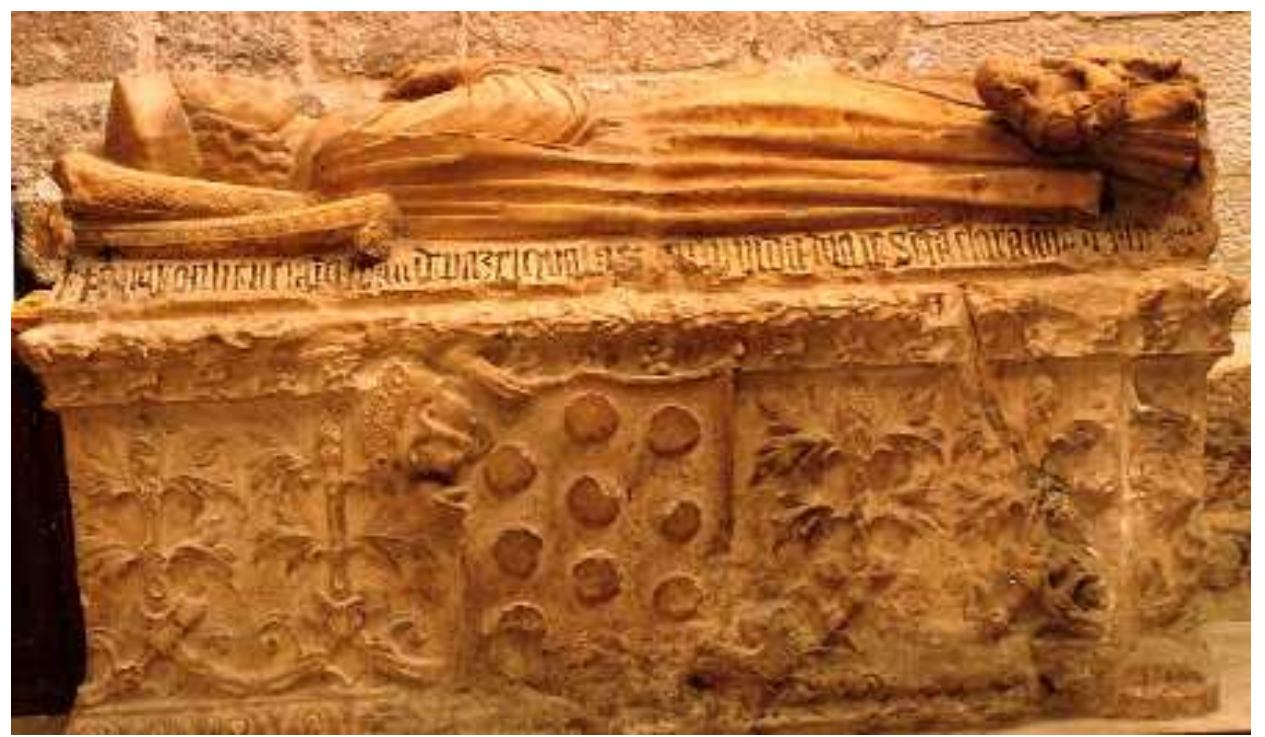

Sepulcro de Don Juan de Paz ubicado a los pies del templo, originalmente en la capilla de los Paz. $(220 \mathrm{~cm} \times 132 \mathrm{~cm} \times 80 \mathrm{~cm})$.

\footnotetext{
${ }^{826}$ PORRAS GIL, M $^{\text {a }}$ Concepción. "Santa María de las Victorias y Santa María del Camino". Ficha no 26 en Memorias y esplendores. Las Edades del Hombre. Catedral de Palencia, 1999, pp. 51 y 52.

${ }^{827}$ VIGURI, Miguel de. Heráldica...2. Op.cit, pág. 42, a su vez de AHPP. Carr.Prot 5626. Isidro Ruiz Colmenares (1783-1790), s/f.
} 
Ya fallecido don Juan de Paz, su mujer Juana de la Serna, dictó testamento el 25 de agosto de 1534. Por él dispone enterrarse junto a su marido en la capilla de San Nicolás, dotándola de ornamentos y cálices para la liturgia y una renta de quince mil maravedíes para su mantenimiento y misas diarias ${ }^{828}$. De los dos hijos del matrimonio, Antonio y Lorenzo de Paz, el patronazgo recayó en Lorenzo, por ser el primogénito. Dispuso en su testamento la ampliación de las fundaciones familiares en Santa María al dictar testamento en 1561. Dejó como heredera a su hija doña Juana de Paz de la Serna, fruto de su matrimonio con la difunta doña María de Tavares, esposada con el susodicho en terceras nupcias. Al morir en edad temprana doña Juana, el patronazgo de la capilla pasa a su madre, la dicha doña María de Tavares, a quien su sobrino don Juan de Vega de Paz demandó con el propósito de que dotara la capellanía para casar huérfanas, tal y como había dispuesto el anterior patrón. A comienzos del siglo siguiente el pleito continuó en manos de diversos consortes, destacándose la figura de unos de los hijos legítimos de don Juan de Vega, don Francisco Paz de la Serna, nieto por tanto del fundador, don Juan de Paz y de su primera esposa Francisca Pacheco ${ }^{829}$.

\section{Lápida sepulcral de don Francisco de Paz}

Fuera de su emplazamiento original, se conserva, en la parte trasera de la iglesia, su lápida sepulcral, que conserva el siguiente epitafio: “AQVI YAZEN LOS SNOS D" FRANco PAZ DE LA SERNA TINENTE QVE FVE DE XVSTICIA DEL ASISTENTE DE SEVILLA CORREGIDOR DE SORIA ALCALDE MAYOR DEL ADELANTAMIENTO DE CAMPOS DEL CONSEXO DE SV MAGESTAD Y SV OIDOR DE LA CORVÑA Y D FRANCISCa DE PACHECO SV PRIMERA MVGER CASO DE SEGVNDO MATRIMONIO CON LA SEÑORA DO XOSEPHA COLON Y TOLEDO MVRIO EN 24 DE SETIENBRE DEL AÑO DE 1634” El escudo que lo acompaña es cuartelado: 1 de los Paz (diez bezantes de oro), 2, partido de castillo y león, 3 de los Serna (banda de sable en sotuer), 4, de los Colón, por ser la segunda esposa de Francisco de Paz, doña

\footnotetext{
${ }^{828}$ ADP. Carrión de los Condes. Santa María. Libro 78. Escrituras antiguas, nº 33.

${ }^{829}$ Este pleito duró hasta 1635, no constando el fallo que determinase a favor de quien se resolvió el litigio. AHN, Consejos Castilla, Leg. 24917, nº 35.
} 
Josefa de Colón y Toledo ${ }^{830}$ (cinco áncoras). Está timbrado a la diestra con yelmo y a la siniestra con el globo terráqueo surmontado de una cruz y siete banderas acoladas a la siniestra.

\section{Reconstrucción de la capilla}

El hermano de don Francisco Paz de la Serna fue el siguiente benefactor de la capilla de San Nicolás. Don Antonio Paz de la Serna, esposado con Catalina de la Carrera Colmenares, ostentaba el cargo de regidor de la villa. Durante su patronazgo se encargó de reconstruir el espacio de culto y para ello contrató en 1619 al cantero cántabro Francisco de Buega ${ }^{831}$. Este artista trasmerano, debía deshacer el tejado y rehacer la armadura existente en el tramo de acceso a la capilla. Cubierta con una bóveda de arista, quedaría blanqueada, respetando los nervios pétreos que cruzan diagonalmente la clave de la antigua bóveda de crucería, como sucedió en el quinto tramo de la nave central, ubicado lindero a éste. También se debían renovar los tejados existentes sobre la bóveda de horno, a la que se adosa el retablo de San Nicolás, que impide hoy día la visibilidad de esta cubierta. Igualmente se guarnecerían los muros de yeso “...cernido de cedazo...” para que el enlucido fuese más fino. Para terminar, Buega debía realizar dos escudos de yeso con las armas del fundador, uno en el pilar de acceso a la capilla y otro en el interior de la misma ${ }^{832}$. Las armas de don Antonio de Paz de la Serna, podemos observarlas en el blasón policromado ubicado en la pared lateral cuya lectura es la siguiente: 1, cortado de Paz (campo de plata, diez bezantes de oro con leones tragantes) y Serna (campo de plata y banda de sable). 2, en sotuer de Mendoza de la Vega (primero y cuarto tres bandas de gules fileteadas de oro, segundo y tercero, campo de oro con la leyenda Ave María ${ }^{833}$.

Con el nieto de don Antonio Paz de la Serna, de nombre Manuel, se registran nuevas obras de cantería, ejecutadas en 1666 por el maestro trasmerano Santiago de la Lastra Díez. Se tiene constancia documental de las mismas por la declaración favorable

\footnotetext{
${ }^{830}$ Es la cuarta nieta de Cristóbal Colón, el famoso navegante. Entre su descendencia se encuentran los Henao, dueños del mayorazgo de Francisco Sánchez de Valbuena y patrones de la capilla de los Contreras en el monasterio de San Francisco de Carrión de los Condes. Sobre la misma, remítase al apartado relativo al convento terciario.

${ }^{831}$ Sobre el mismo, véase el apartado relativo a su biografía.

${ }^{832}$ AHPP. Carr.Prot 4820. Francisco Cuetos (1619), fol 150 y ss

${ }^{833}$ VIGURI, Miguel de. Heráldica...volumen 2. Op.cit, pág. 43.
} 
de los veedores de los trabajos: el arquitecto de Támara, Lucas Ochoa de Garavitar, escogido por parte del patrono y el maestro de cantería cántabro Domingo de Ibarra, por parte del artífice. Reconocen que la obra ha sido realizada según lo acordado, salvo por dos dovelas del arco de la pared que se han descolgado y deben ser fortalecidas ${ }^{834}$.

El patronato de los Paz en esta capilla continuó durante el todo el siglo XVII, pues en 1699, doña María de Paz y Guzmán, hija legítima de Manuel de Paz de Guzmán y de María Bravo y Sobremonte, al dictar testamento confesó su deseo de ser sepultada en la capilla que por entonces pertenecía a su hermano don Juan de Paz y Guzmán ${ }^{835}$.

En 1735 era única patrona doña Lorenza de Soto Manrique y Paz, hija del regidor carrionés don Luis Soto Manrique de Lara $^{836}$ y su primera mujer María de Paz y Guzmán $^{837}$. Su matrimonio con don Francisco Jofre de Villegas permitirá el acceso inmediato de este linaje de regidores perpetuos de Carrión al patronato de la capilla ${ }^{838}$. De los tres vástagos, el primogénito de ambos, José Jofre, hereda el patronazgo a continuación. Su único hijo, Francisco Cándido Jofre de Villegas se convierte en el nuevo patrón, pero al fallecer en 1789 sin descendencia, su tío Francisco, hermano de José Jofre, se encarga de elegir un nuevo patrón, su hijo don Antonio Jofre y Piña, fruto de su enlace con doña Ana Piña del Mazo. Esta prestigiosa familia continuará con el patronato durante el siglo XIX. Así, por ejemplo, Don Antonio Jofre de Villegas, marido de doña Teresa de León, al dictar testamento el 8 de enero de 1820 expresa su deseo de descansar en esta capilla ${ }^{839}$.

\footnotetext{
${ }^{834}$ AHPP. Carr.Prot 5701, Norberto Sandoval y Guevara (1666), fol 514. En agosto de dicho año, Manuel de Paz le abona 3500 reales a Lastra por la nueva obra. Ibídem, fol 662.

${ }^{835}$ Testamento dictado el 12 de octubre de 1699. AHPP. Carr.Prot 5019. Agustín García Miranda (16991700), s/f.

${ }^{836}$ Testamento dictado el 3 de marzo de 1752. AHPP. Carr.Prot 4604. Francisco Blanco Manuel (17501753), fol 161 y ss.

${ }^{837}$ Así lo declara su hermana Úrsula de Soto Manrique al dictar testamento para ser sepultada en la capilla AHPP., Carr.Prot 4597. Francisco Blanco Manuel (1732-1735) fol 199 y ss. La mujer por entonces de don Luis de Soto Manrique era Jerónima Solís de la Viñuela.

${ }^{838}$ El cuadro genealógico del linaje Paz, enlazado con el de Jofre de Villegas en VIGURI, Miguel de. Heráldica...volumen 2. Op.cit, pág. 51.

${ }^{839}$ Testamento de don Antonio Jofre de Villegas. Tuvo dos hijos, de nombre Paula y Diego. AHPP. Carr.Prot 5740. Felipe Serna (1818-1820), fol 1 y ss. Su mujer, Teresa de León, reitera este deseo en su testamento de 22 de marzo de 1832. AHPP. Carr.Prot 5449, Mariano Navas (1829-1832), fol 447 y ss.
} 


\section{El retablo de San Nicolás, antes de Nuestra Señora de las Victorias}

El retablo que da advocación a la capilla es una obra que ha sido datada en el segundo cuarto del siglo XVIII ${ }^{840}$. La documentación nos descubre que se trata de una obra realizada en 1761, momento en el que además se aprovechó para lucir la capilla y abrir la ventana que la ilumina. La obra sigue la tipología impuesta por los Churriguera hacia 1700, resultando ciertamente arcaico para ser de una fecha tan avanzada.

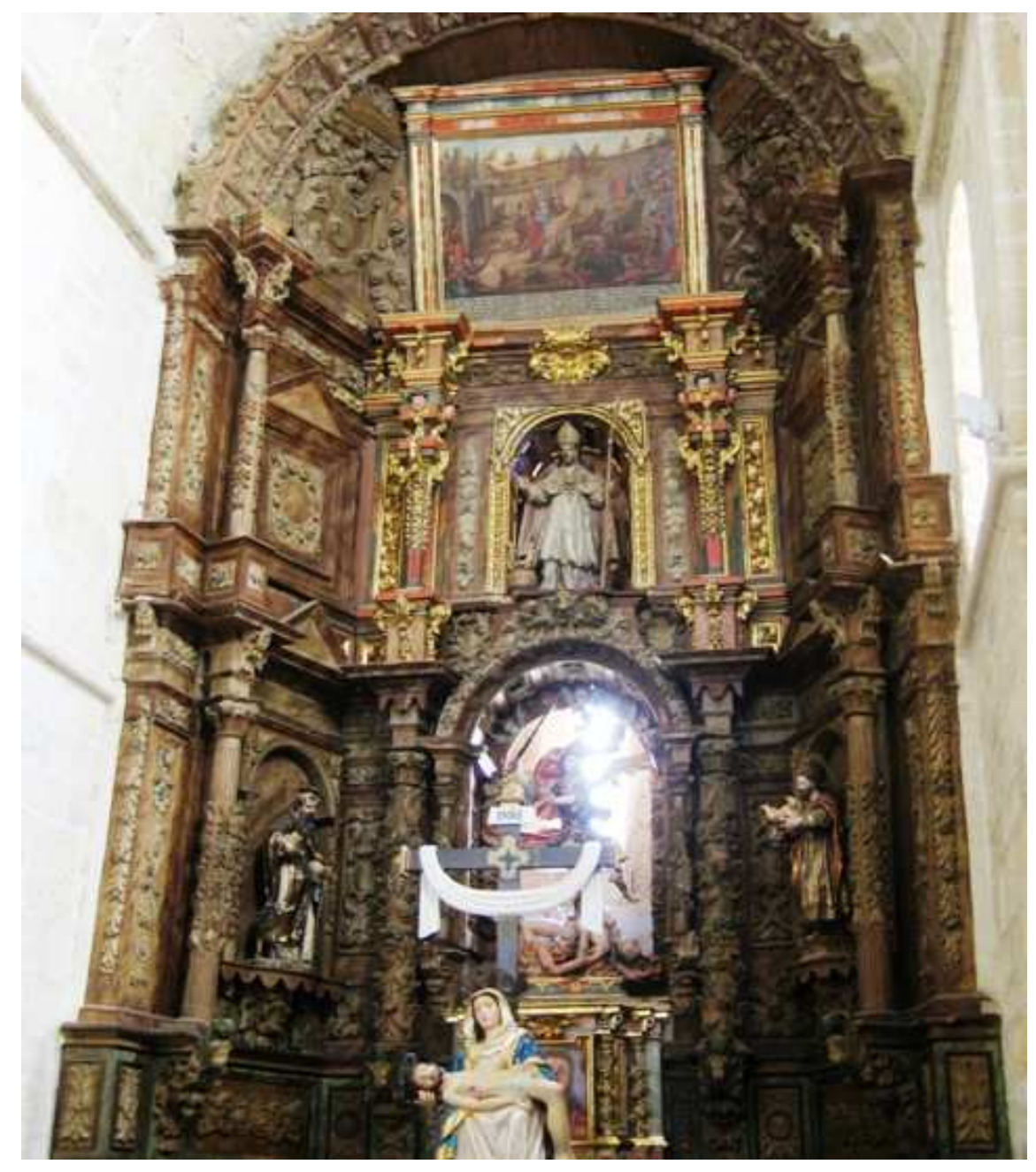

Retablo de la capilla de San Nicolás en la capilla del lado de la Epístola del templo de Santa María. 1761. (6mtrsx4mtrsx2,35mtrs).

${ }^{840}$ URREA FERNÁNDEZ, Jesús y MARTÍN GONZÁLEZ, Juan José. Op.cit, pág. 58. 
Este retablo sustituyó al anterior, vendiéndose sus despojos por entonces ${ }^{841}$. Del retablo sustituido conocemos su existencia por la ejecución del dorado que en 1723 realiza el palentino Manuel de Carrión ${ }^{842}$.

Tanto el retablo anterior como el actual se hallaban bajo la advocación de Nuestra Señora de las Victorias, pues recordemos que la talla gótica que presidió el retablo mayor fue trasladada en 1685 al retablo de esta capilla, donde se mantuvo hasta los años setenta del siglo XX. Fue realizado por José López Mata y Ambrosio de la Cuesta, maestros tallistas carrioneses, que colocaron en el mismo la imagen de Nuestra Señora de las Victorias ${ }^{843}$. Está realizado en madera sin policromar. Podemos observar sin embargo que la calle central del segundo cuerpo, el marco del lienzo del ático y la parte central del banco se hallan policromadas de tonos rojizos y doradas y en los soportes aún se conservan imitación de jaspes, pues esta sección central fue reaprovechada del retablo anterior, que antes de ubicarse en esta capilla, se hallaba junto a la puerta de la iglesia ${ }^{844}$.

El retablo está asentado sobre unos paneles provistos de celosías y se adapta a la forma del ábside, no sólo en su perfil en semicírculo, que acoge parte de los muros laterales, sino en el remate que mantiene la forma de bóveda de horno. Consta de un sencillo banco, dos cuerpos y ático. En el banco se ubica un sencillo tabernáculo compuesto por cuatro columnas salomónicas de tres espiras entre las cuales se halla un lienzo de un Ecce Homo de busto, de mala calidad. Los dos cuerpos se conforman de tres calles en cuyos extremos se ubican cuatro pilastras de sección cuadrada provistas de tallos vegetales. Junto a ellas, en posición avanzada respecto a las pilastras, se ubican cuatro columnas de orden corintio de sencillos acantos y fuste acanalado. Las estrías son interrumpidas en el sector central por una tupida hojarasca. A los lados del primer cuerpo, se disponen dos hornacinas de escaso fondo entre finas pilastras donde se alternan las flores y hojas dispuestas en línea y emparejadas. San Antonio Abad se ubica en la hornacina de la izquierda. Ataviado con el tradicional sayal blanco y la capa marrón, la imagen, que podemos datar en el siglo XVIII, nos presenta un anciano de espesa barba oscura que muestra una gran dignidad en su rostro a pesar de sus humildes

\footnotetext{
${ }^{841}$ ASMC. Libro 2o de Fábrica (1762-1804), fol 9 y 13.

${ }^{842}$ AHPP. Carr.Prot 5872. Manuel Vega (1722-24), fol 14 y ss.

${ }^{843}$ ASMC. Libro $2^{\circ}$ de Fábrica (1762-1804), fol 13 y ss. Carta de pago en 1762, fol 48.

${ }^{844}$ Ibídem, 1772. Inventario de bienes.
} 
vestimentas. Porta una especie de nimbo del que emergen rayos solares, realizado posiblemente en latón. Originalmente, se ubicaba en su lugar la imagen de San Roque $^{845}$

En el lado correspondiente a éste hallamos a San José con el niño, tocado con un nimbo jalonado por estrellas. La rigidez de su cabeza contrata con el suave movimiento de su pierna derecha, levantada del suelo y retrasada respecto a la otra. La inestable posición provoca la cadencia oblicua de los pliegues de su túnica. Presenta una barba corta y cuidada, frente despejada y grandes ojos de mirada perdida que configuran unos rasgos bastante dulcificados. Esta imagen procede del retablo homónimo del lado de la Epístola de la iglesia de San Andrés. La talla a la que sustituyó es una escultura del siglo XVI de San Sebastián que se ubica en la repisa de la ventana del tercer tramo del Evangelio de Santa María ${ }^{846}$. Podemos apreciar que el Niño Jesús que porta San José no se ajusta a la disposición de sus rígidos brazos ya que originalmente el carpintero portaba un niño Jesús reclinado, de unos treinta centímetros de altura, que se ubica en el Museo parroquial de Santiago ${ }^{847}$.

En la calle central, se hallan dos imponentes columnas de orden compuesto decoradas con guirnaldas, motivos florales y testas de querubines entre las cuales se disponen otras dos análogas pero a escala inferior que sustentan un arco de medio punto que se prolonga conformando una bóveda de cañón. En el espacio interior se ubica la figura de San Miguel venciendo al demonio vestido cual soldado romano. Tan solo a través de su espada, podemos deducir que nos encontramos ante una escena de lucha, solapada por el sinuoso vuelo de la falda corta, la pierna elevada como si se tratara de una bailarina y mano izquierda alzada delicadamente, que le confieren un aire de bailarina. A ello se suman las delicadas facciones de su rostro y su melena rizada, que proporcionan un carácter ambiguo al personaje.

La escena representada consigue un efecto decorativo gracias al vuelo en zigzag de los aristados pliegues de la capa del arcángel, reforzado por el brillo que proporcionan el color dorado de las alas desplegadas y de los vistosos lambrequines del

\footnotetext{
${ }^{845}$ Ibídem.

${ }^{846}$ Delegación Diocesana de Patrimonio Cultural de Palencia. Carrión de los Condes. Carpeta 1.

${ }^{847}$ GÓMEZ PÉREZ, Enrique y MARISCAL ARRANZ, José. Iglesia de Santiago...Op.cit, pág. 36.
} 
sombrero. Además en este caso el maligno se reencarna, no en uno, sino en dos figuras antropomorfas provistas de cuernos, que tratan de escapar de las llamas del infierno, consiguiendo un efecto ciertamente teatral, intensificado por la luz que penetra por la parte posterior de la hornacina. Al no tener tallado el fondo, las figuras se hallan justo delante del vano abocinado del ábside, creándose así una especie de transparente, muy recurrente del barroco. La figura de San Miguel no presidía este retablo originalmente, pues a través de una fotografía antigua, podemos observar que la escultura sedente de la Virgen del Camino, ubicada actualmente en el lado de la Epístola, ocupaba este lugar preferente al menos hasta los años setenta.

En las calles laterales del segundo cuerpo, se ubican dos tableros rematados en un frontón triangular dispuestos oblicuamente para adaptarse a la forma del ábside. En ellos se dispone un cuadrante decorado a base de tallas vegetales en cuyo centro hay un espejo ovalado. En la calle central, dos pilastras planas con decoración pictórica de veteado y hojarasca tallada suceden a dos estípites sustentados por amplios pedestales que se retranquean de la línea general del retablo. Sobre los mismos existe un entablamento de gran desarrollo conformado por multitud de molduras dotado de una testa de querubín en cada uno de sus frentes. Bajo un arco de medio punto se dispone la imagen que da nombre a la capilla, San Nicolás de Bari, protector de los peregrinos. De entre los variados atributos del obispo de Asia Menor en este caso se ha optado por los tres niños desnudos sentados sobre el tonel. A pesar de su origen oriental, en Occidente se le representa con los atributos episcopales latinos: tocado con mitra, ataviado con capa pluvial y apoyado en un báculo. La escultura ha perdido íntegramente su policromía original, creando un vivo contraste entre la madera desnuda y el dorado que presenta la rosca del arco, las jambas y las enjutas con vivos rameados. Esta imagen fue donada por la patrona de la capilla por entonces, doña Lorenza de Soto y Paz, quien como apuntamos, adquirió el patronazgo en $1735^{848}$.

Todas las esculturas son obras realizadas por anónimos castellanos en el segundo cuarto del siglo XVIII. Más que por su vinculación con la ruta jacobea, creemos que la presencia de San Nicolás en el retablo radica en su protección sobre las doncellas, a las cuales según su hagiografía, regaló varias bolsas de oro con el fin de que abandonaran la

${ }^{848}$ ASMC. Libro $2^{\circ}$ de Fábrica (1762-1804). 1772. Inventario de bienes. 
miseria que las había conducido a llevar una vida viciosa. Las doncellas protagonizan la escena contenida en el lienzo del remate, rindiéndolas de este modo un homenaje por partida doble.

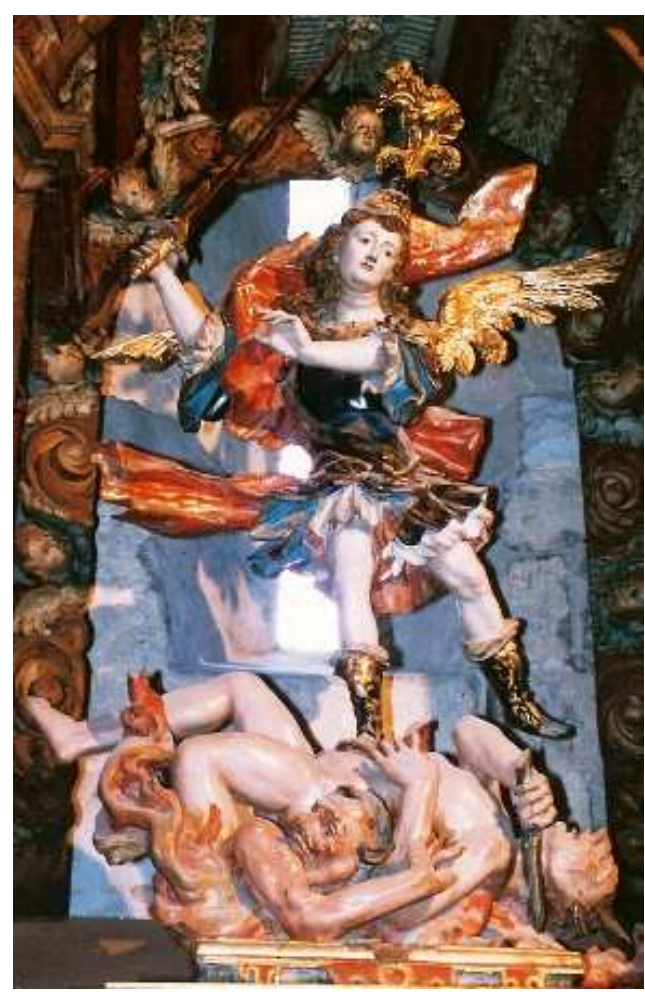

San Miguel Arcángel $(184 \mathrm{~cm} \times 90 \mathrm{~cm})$.

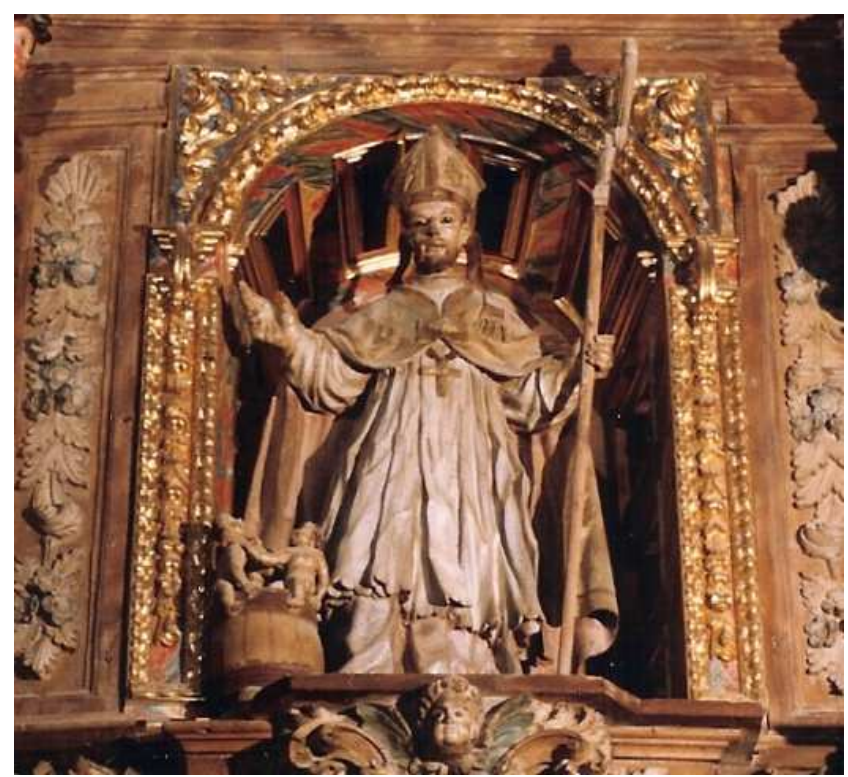

San Nicolás de Bari $(110 \mathrm{~cm} \times 75 \mathrm{~cm})$.

\section{Esculturas que presiden las hornacinas del primer y segundo cuerpo del retablo de la capilla de San Nicolás, en el templo de Santa María.}

Se trata de una pintura de escasa calidad artística pero interesante desde el punto de vista iconográfico por el tema legendario al que hace alusión. El milagro de la liberación del tributo de las doncellas responde, como indicamos en el análisis de la portada, a la leyenda medieval que trataría de justificar la existencia de los toros del acceso, así como la denominación del templo de Nuestra Señora de las Victorias. La proliferación de esta veneración motivó la ejecución de copias del tema, como el lienzo en miniatura ubicado que decora el muro izquierdo de esta capilla. Una inscripción ubicada en la parte inferior del lienzo relata esta leyenda. Dice así: “En tiempo del Rey Miramamolín le fue tributario el Rey Mauregato de quatro doncellas que tocavan a esta 
Villa, y llegando a este sitio con los moros que las llebavan s'encomendaron a esta Ymajen las librase de su cautividad, lo que fue Dios servido por medio de quatro toros que se aparecieron, pues acometiendo furiosos a los moros las quitaron las doncellas y mataron la maior parte d'ellos. Quedaron las doncellas solas y los toros en su guarda asta que los vecinos las recojieron. Con el milagro quedaron las doncellas libres y esta villa esenta del tributto y stizedio por las pascuas d'Espíritv Santo. Ay dos procesiones y sermón del asunto desde el año de 826”. Tenemos constancia de cuales eran estas dos procesiones, que hoy día ya no se celebran. Una de ellas se denominaba la procesión de "las bodas de Nuestra Señora" y es la que propiamente conmemoraba el milagro referido, el sábado dentro de la octava de Pentecostés. Asistían a la misma como figuras principales el cabildo clerical y el corregidor. La comitiva partía de la iglesia de Belén hasta llegar a la plaza de Santa María, donde la comunidad parroquial de este templo les esperaba para incensar las cruces parroquiales y posteriormente cantar unas Vísperas dentro del mismo. La procesión concluía en la iglesia de Santiago. La otra procesión se llamaba del "Arciprestazgo" y se celebraba el 11 de junio, día de San Bernabé. Debían asistir todos los curas del arciprestazgo de Carrión para rezar por el Obispo y agradecer la exención del pago de la moneda forera. La celebración se institucionalizó tras el fallecimiento del prelado don Juan de Castromocho en 1397. A las diez salía la procesión de San Andrés, por ser la sede del arcipreste, después se dirigía a Santa María cantando el Veni Creator y los Salmos, donde finalizaba ${ }^{849}$.

\subsection{LA CAPILLA DEL LICENCIADO PASTOR}

Se sitúa en lado del Evangelio, entre la sacristía y la capilla mayor y a continuación del ábside románico, en cuyo testero se abrió un acceso para disponer esta capilla. Esta capilla fue fundada por el Licenciado Antonio Pastor, un clérigo de menores, nacido en Carrión en 1584. Partiendo de un origen modesto, pues era hijo del labrador, Antonio Pastor "el Alto" y María Magdalena, fue escalando posiciones al establecer su residencia en Sevilla, donde se dedicó al comercio. Sus negocios se extendieron a América, donde logró atesorar una fortuna considerable. Con ella decidió fundar el 10 de julio de 1635, el Monte de Piedad Cristiana en esta iglesia de Santa

${ }^{849}$ LORENZO, Santiago. Gentes...Op.cit, pp. 193-194. 
María de Carrión, dejando como heredera del patronato a la Cofradía de los Veinte Clérigos de la Hermandad de San Pedro y San Pablo de Carrión ${ }^{850}$. Los bienes que poseía se destinarían principalmente para ayudas a los pobres y enfermos de la villa, para la enseñanza y para el casamiento de doncellas. Las funciones principales de estos administradores consistirían básicamente, en cobrar censos, nombrar capellanes, visitadores de pobres, capellanes y celebrar juntas anuales y misas. Serán patronos igualmente de las dos capellanías de misas rezadas, fundadas en Carrión por el dicho Antonio Pastor. Estarán sufragadas con un pago de doscientos ducados por cada una ${ }^{851}$.

Don Antonio Pastor dictó testamento el 25 de abril de 1656 en Sevilla ${ }^{852}$. Por el mismo dispuso ser enterrado en la capilla de José Guerra en el colegio de San Alberto de Nuestra Señora del Carmen de la ciudad andaluza. Posteriormente “...en el tiempo que les paresçiere más a propósito...” deseaba que sus huesos fuesen trasladados a la iglesia de Santa María, donde la cofradía de los veinte clérigos debían erigir una capilla en su nombre. También ordenó que se hiciera un archivo “...para la guarda de los papeles y títulos de la hacienda del dicho patronato..." en el cual nos indica el documento que se ubicaba el testamento original del difunto. La capilla, como veremos seguidamente, fue construida de inmediato, demorándose la erección del archivo hasta 1665 que se emplazaría donde hoy se ubican las dependencias parroquiales ${ }^{853}$.

Su lápida, ubicada en el suelo de la capilla que ordenó erigir, conserva la siguiente inscripción: “AQVI YACEN LOS RESTOS DEL LIC. Dn ANTONIO PASTOR QUE MURIO EN SEVILLA EL $1^{\circ}$ DE MAYO DE 1656 Y FUNDÓ ESTA OBRA PIA”.

Sobre la inscripción figuran las armas del difunto figuran en el escudo partido de la parte superior: 1, campo estrellado, un hombre ascendiendo por una escalera a una torre almenada, 2, busto de perfil de un personaje de rasgos negroides y dos llaves entrelazadas bajo el mismo. La losa del finado fue dispuesta a raíz de las obras que se llevaron a cabo en los meses inmediatos al óbito. El 24 de junio de 1656 fueron redactadas las condiciones de la nueva capilla por el maestro cántabro Jerónimo de

\footnotetext{
850 AHPP. Desamortización 112. Índice del Archivo de San Zoilo. Caja 5a. San Andrés. Legajo 2. Cuaderno C. $\mathrm{n}^{\mathrm{o}} 7$ y en ACP. Provisorato. Carrión. Traslado de 1657.

${ }^{851}$ LORENZO SANZ, Eufemio. "Carrioneses en el comercio con América en los siglos XVI y XVII" en AIICHPTomo 4. Palencia, 1990, pp. 395- 399.

${ }^{852}$ ADP. Carrión. San Andrés. Legajo 94.

${ }^{853} 1$ de noviembre de 1665. AHPP. Carr.Prot 5700. Norberto Sandoval y Guevara (1665), fol 296.
} 
Avendaño, a expensas de la Cofradía de los Veinte Clérigos ${ }^{854}$. El licenciado Lucas de Quintanilla, como abad y regidor de la misma y comisario de la iglesia de Santa María del Camino ordenó demoler la capilla existente, bajo la advocación de San Pedro y con los materiales que pudiera aprovecharse, ejecutar el nuevo espacio de culto para que sirviese de enterramiento al finado ${ }^{855}$. Avendaño declaraba que dicho derribo ponía en riesgo la estabilidad de la torre y la capilla mayor, eximiéndose de cualquier responsabilidad derivada de las obras, pues tan sólo participa como tracista. El compromiso por la ejecución de los trabajos lo adquirieron los carrioneses Bernardo Sánchez y Julián de León ${ }^{856}$, maestros de cantería y albañilería, respectivamente, quienes acordaron concluirlos en noviembre de dicho año. Se debía disponer el zócalo y el arco de acceso a la capilla en piedra, el cual debía separarse del espacio precedente donde se ubicaba el ábside románico a través de una reja ejecutada por Manuel de Salceda ${ }^{857}$ También serían de piedra labrada las esquinas, donde debían ubicarse dos pilastras toscanas y la peana para el altar de piedra “...con su boçel, filette y media caña...". El arco de medio punto del testero y los muros irían guarnecidos de yeso. Los tejados fueron atirantados y su casco cubierto por una bóveda de arista. En el testero de la capilla debían abrir dos ventanas, que son los vanos rectangulares y abocinados que iluminan hoy día este espacio.

La cofradía de los Veinte Clérigos continuó con el patronato de esta capilla a lo largo de varios siglos. Así lo prueban algunos de los pleitos mantenidos por la misma con particulares. Ejemplo de ello es el litigio con los acreedores de los bienes de Don Gabriel Álvarez Grasimo, vecino de Palencia, en $1693^{858}$. Posteriormente en otro proceso sucedido en 1798 con un tal Francisco Martínez Duque, la cofradía se querella por el pago de 2475 reales de vellón de los plazos vencidos de los censos y réditos

\footnotetext{
${ }^{854}$ AHPP. Carr.Prot 5689. Norberto Sandoval y Guevara (1656), s/f. Sobre Avendaño, véase el apartado relativo a los maestros de cantería.

${ }^{855}$ El licenciado Rioja, era además comisario del Santo Oficio de la Inquisición de Valladolid. Tenía dotada una capilla con su retablo en el lado del Evangelio, “...en el estribo del crucero..." con losas para sus familiares, que se hallaba bajo la advocación del Nombre de Jesús. Otro comisario de la Inquisición, el Licenciado Rioja Bustillo, poseía una capilla en el mismo lugar, pero en el lado de la Epístola, dedicado a Nuestra Señora de la Piedad. Ambos solicitan se reparen sus capillas arruinadas, hoy desaparecidas, concediendo en compensación treinta mil maravedíes. AHPP. Desamortización. Legajo 105. Aún existían en 1772 y se indica que se trata de la Soledad, en vez de la imagen de la Piedad. La imagen que presidía el retablo de Bustillo, era un niño Jesús de vestir con una Santa Gertrudis en el remate. ASMC. Libro $2^{\circ}$ de Fábrica (1762-1804). 1772. Inventario de bienes.

${ }^{856}$ Véase el apartado relativo a la biografía de los maestros de cantería y albañilería locales.

${ }^{857}$ Remítase al capítulo dedicado a los escultores y ensambladores locales.

${ }^{858}$ AHPP. Pleitos Civiles Ceballos Escalera (Fenecidos) Caja 2556, Exped 1 s/f.
} 
anuales de dicha obra pía ${ }^{859}$. Estas son sólo dos muestras de todos los procesos en los que se vió metida la cofradía. Esta preocupante situación condujo a la cofradía a contratar en 1770 un representante especialista en materia de pleitos. La persona en quien depositaron su confianza fue don Manuel Pardo Campero, que residía en Madrid “...axente de negocios en los reales consejos de ella... ${ }^{860 ” . ~ L e ~ r u e g a n ~ s e ~ p e r s o n e ~ e n ~ e l ~}$ consejo de Indias para que hiciera constar por escrituras la pertenencia de la capilla a su fundador, Don Antonio Pastor. Recordemos que el prelado había residido durante mucho tiempo en Sevilla, por lo que no debe resultar extraña la solicitud de dichos papeles desde la capital hispalense.

A finales del siglo XIX se ignora quien ostenta el patronazgo de la obra pía, pudiendo haber sucedido en el mismo el párroco de Santa María, como así supone el consistorio carrionés ${ }^{861}$.

\section{El retablo de la Virgen del Pópulo}

Adosado al lado oriental de la capilla se halla un sencillo retablo dorado datado en el primer tercio del siglo XVII ${ }^{862}$. Fue un encargo del fundador de la capilla, don Antonio Pastor. Consta de dos cuerpos sobre un banco conformado por un pedestal con un tablero central y cuatro laterales retranqueados que son los pedestales de los soportes del cuerpo principal. Éste se compone de cuatro columnas de orden corintio, flanqueados en su parte inferior por dos pequeños aletones avolutados. De las cuatro secciones en que se dividen los fustes, la primera y la superior, presentan acanaladuras verticales, mientras que las otras dos las estrías son entorchadas, disponiéndose las del segundo sector en dirección opuesta a las del tercero.

En la parte central se ubica el lienzo de la Virgen del Pópolo. Se trata de una de las innumerables copias del icono de María "Salus Populi Romani" conservada en la iglesia de Santa María Mayor de Roma, dentro de la capilla Paulina. La devoción despertada por la imagen bizantina es patente en Sevilla, lugar de residencia del prelado

\footnotetext{
${ }^{859}$ AHPP. Pleitos Civiles Alonso Rodríguez (Olvidados) Caja 1102, Exped 3 s/f.

${ }^{860}$ La escritura de poder en AHPP. Carr.Prot 4656. Juan Cano Guijelmo (1770-1776), s/f.

${ }^{861}$ AMCC. Sesión de 23 de abril de 1897. Libro 15, Sesiones municipales (1897-1898), fol 70 y 70v.

${ }^{862}$ URREA FERNÁNDEZ, Jesús y MARTÍN GONZÁLEZ, Juan José. Inventario...2. Op.cit, pág. 58.
} 
desde al menos 1628. Precisamente en la catedral de la ciudad hispalense, concretamente en la capilla del Espíritu Santo se localiza una de las copias más tempranas de la célebre advocación romana, fechada en $1508^{863}$.

Todas las copias de época moderna conservadas siguen el prototipo creado por Giusepp.e Valeriano en 1583 y conservado en la Universidad Gregoriana de Roma ${ }^{864}$.

Como corresponde a la iconografía romana, María, es representada de tres cuartos y el niño, que sostiene con su brazo izquierdo, se gira levemente hacia ella. Se mantienen otros convencionalismos presentes en la imagen como el nimbo dorado o el color de las vestimentas de ambos personajes. La Virgen porta una túnica rosada granate, en alusión a la Pasión y un manto azul, en este caso, marino, ribeteado en oro, en clara relación con el ámbito celestial. Por su parte, el niño Jesús va ataviado con una túnica violácea recubierta por un manto amarillento y calzado con sandalias de cuerdas. Persisten igualmente dos de los tres atributos sempiternos de la Virgen del Pueblo: la cruz potenzada sobre la toca de la Virgen y la estrella dorada sobre su hombro derecho, identificada como la "Stella Matutina" que en el Apocalipsis advierte la llegada del Salvador $^{865}$. El libro de los Evangelios que tradicionalmente porta el niño en su mano izquierda ha sido eliminado en esta representación. Se mantiene, no obstante, el acto de bendecir de la mano derecha aunque el rostro, en lugar de mirar al de su madre, se vuelve hacia el espectador como también lo hace ella. Otros cambios significativos respecto a la copia renacentista, los observamos en la Madre, cuyo rostro, frente a la imagen hierática, se torna dulce en nuestra imagen. Su mano derecha descansa sobre su pecho mientras que tradicionalmente lo hacía sobre la otra mano, de la cual otrora pendía el pañuelo bordado, símbolo del imperio romano, hoy eliminado de la presentación. En lo que respecta al fondo, se ha sustituido el campo dorado del icono por uno sombrío y neutro iluminado en su parte superior por potente halo procedente de los nimbos de la madre y el niño. El lienzo de la Virgen fue adquirido en Valladolid, mostrándose cercana al círculo del pintor vallisoletano Diego Valentín Díaz, en el

\footnotetext{
${ }^{863}$ La imagen fue traída por el obsipo de Scala en Nápoles, don Baltasar del Río. Muestra de la devoción que despertó el icono, es que existe otra copia en la catedral, en la capilla de Santiago, fechada a mediados del siglo XVI. VALDIVIESO GONZÁLEZ, Enrique. Catálogo de las pinturas de la catedral de Sevilla. Valladolid, 1978, pág. 47.

${ }^{864}$ Sobre este tema NOREEN, Kirstin. "The icon of Santa Maria Maggiore, Rome: an image and its afterlife" en Renaissance Studies, nº19, 2005, pp. 660-672.

${ }^{865}$ VÉLEZ CHAURRI, José Javier y ECHEVARRÍA GOÑI, Pedro Luis. "Un importante legado de dos clérigos en Estavillo (Álava). Los orantes y un cuadro romano de la Virgen del Pópolo" en Ars bilduma, $\mathrm{n}^{\circ} 1,2011$, pp. 36-37.
} 
primer tercio del siglo XVII ${ }^{866}$. Es probable que Don Antonio Pastor, mandase incluir su retrato orante en dicho lienzo hacia 1640, cuando por entonces residía en Sevilla. La inclusión de esta figura en el lienzo fue encargada a un artista de la ciudad, próximo a Juan del Castillo (1584-1640), según apunta Rafael Martínez ${ }^{867}$. Don Antonio Pastor se ubica de tres cuartos, en actitud orante, dirigiendo su rezos hacia la Virgen. Vestido de clérigo, con una sotana negra y el alzacuellos, muestra un rostro maduro, dotado de una cuidada perilla, espeso bigote y cabello canoso que nos sitúan ante un hombre devoto de edad avanzada, cuyo último deseo era el de perpetuar su memoria en su villa natal. Esta imagen sirvió de inspiración para realizar el lienzo del prelado que se ubica en el Salón de Plenos del consistorio carrionés, pintado por Ramón Canedo. El marco dorado del lienzo presenta una decoración de piedras y gallones propio del primer tercio del silgo XVII, acorde a la datación del retablo.
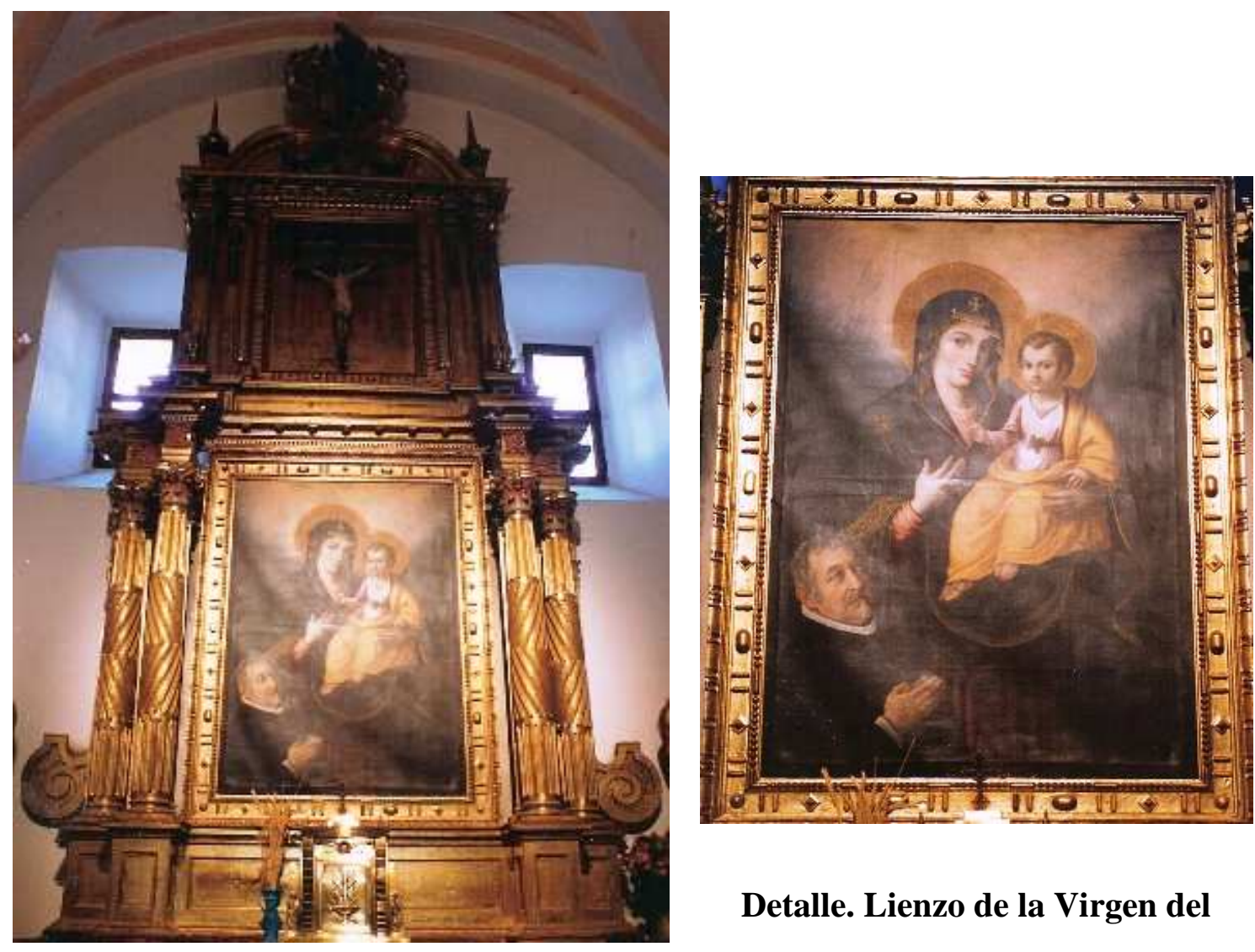

Detalle. Lienzo de la Virgen del Pópolo. $(150 \mathrm{~cm} \times 106 \mathrm{~cm})$.

\section{Retablo de la Virgen del Pópolo en el templo de Santa María (5mtrsx3mtrs).}

\footnotetext{
${ }^{866}$ URREA FERNÁNDEZ, Jesús y MARTÍN GONZÁLEZ, Juan José. Inventario...2. Op.cit, pág. 58. ${ }^{867}$ MARTÍNEZ, Rafael. La pintura...Op.cit, pág. 20.
} 
Separado por una cornisa, en el segundo cuerpo se dispone un tablero cuadrado flanqueado por dos pares de pilastras exentas de molduras en cuyo centro se sitúa una talla de un Crucificado de escayola de pequeñas dimensiones colocada en el retablo en el año 2000 por el párroco de entonces, don José Mariscal ${ }^{868}$. Esta imagen sustituyó a una escultura de San Francisco en actitud contemplativa, hoy ubicada en la nave del Evangelio sobre una de las repisas de la ventana ${ }^{869}$. El santo de Asís porta el hábito estofado de elementos vegetales. Sus manos se cruzan sobre el pecho, mostrando los estigmas, mientras su delicado rostro se eleva hacia los cielos. Podemos datarla en el primer cuarto del siglo XVII y asemeja a los modelos utilizados por el escultor palentino Pedro de Loja en el retablo de San Francisco de la iglesia parroquial Melgar de Yuso, con esa actitud tan manierista y los pliegues voluminosos de la vestimenta ${ }^{870}$. La imagen $(117 \mathrm{~cm} \times 35 \mathrm{~cm} \times 25 \mathrm{~cm})$ ha sido restaurada a principios del siglo $\mathrm{XXI}^{871}$. Corona el conjunto el escudo policromado de Don Antonio Pastor que describimos con anterioridad.

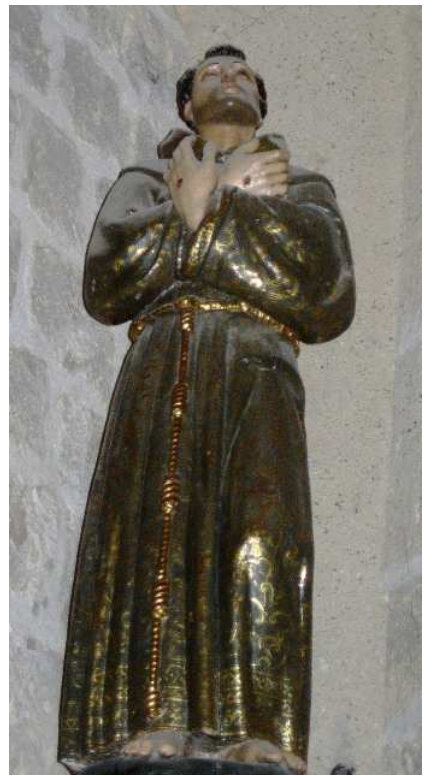

San Francisco de Asís que presidía el ático del retablo de la Virgen del Pópolo, hoy en la nave del Evangelio de la iglesia de Santa María.

\footnotetext{
${ }^{868}$ Debo esta información a mi colega, Enrique Gómez Pérez.

${ }^{869}$ RAMÍREZ DE HELGUERA, Martín. El libro...Op.cit, pág. 150.

${ }^{870}$ Los datos sobre este retablo y algunos del escultor se recogen en PARRADO DEL OLMO, Jesús María. "Retablo de San Francisco en Melgar de Yuso (Palencia)" en BSAA, no 39, Valladolid, 1977, pp. 35-40.

${ }^{871}$ Delegación Diocesana de Patrimonio Cultural. Carrión de los Condes. Carpeta I.
} 
En 1658 se encarga de dorar y estofar esta obra y la reja de la capilla Diego de Avendaño. Además debía dorar una cruz y que había sobre la mesa de altar y pintar el atril del misal imitando “...maderas de la Yndia...”. Tenía que pintar un zócalo con decoración de jaspes y el arco de ingreso debía disponer unos florones o piedras finxidas. En una de las paredes de esta capilla existía un nicho que albergaba una imagen de San Antonio de Padua, que también debía ser dorada ${ }^{872}$. Esta imagen se ubicaba en la parte superior del retablo, al menos hasta $1772^{873}$.

En el remate, sendos pináculos ubicados en los extremos acogen dos aletones avolutados y afrontados en cuya parte central campean las armas de don Antonio Pastor. Su escudo es partido: 1. de gules con una torre de oro por la que asciende un hombre con una espada y en el jefe cuatro estrellas. 2, de sinople con dos llaves de plata en aspa, una cabeza de hombre y una cruz. Timbrado con yelmo y una cruz. Estas armas no formaban parte del retablo originalmente, sino que se añadieron en 1771 cuando fueron realizados los retablos colaterales que ornamentaban esta capilla ${ }^{874}$.

Procedente de esta capilla y probablemente de este retablo, sea el sagrario del siglo XVII que se ubica en el ábside central del museo sacro de Santiago ${ }^{875}$. Es una sencilla obra en cuya puerta se representa una pintura del pelícano alimentando a su polluelos a través de su sangre, célebre referente eucarístico.

\section{Los antiguos retablos colaterales}

En 1771 la cofradía de los Veinte Clérigos encarga a Tomás Prieto, vecino de Palencia, la ejecución de los dos retablos colaterales de la capilla ${ }^{876}$. Este artista realizará tanto el ensamblaje como la escultura de los mismos, ya que desempeñaba paralelamente los oficios de arquitecto como escultor. Ejecuta el retablo mayor de

\footnotetext{
${ }^{872}$ La obra, concertada el 28 de marzo de 1658 debía estar finalizada en septiembre de dicho año. Abendaño recibiría dos mil quinientos reales. AHPP. Carr.Prot 5691. Norberto Sandoval y Guevara (1658), fol 102 y ss.

${ }^{873}$ ASMC. Libro $2^{\circ}$ de Fábrica (1762-1804). 1772. Inventario de bienes.

${ }^{874}$ Hablaremos de dicho retablos seguidamente.

${ }^{875}$ GÓMEZ PÉREZ, Enrique y MARISCAL ARRANZ, José. Iglesia de Santiago...Op.cit, pág. 44.

${ }^{876}$ AHPP. Carr.Prot 4656. Juan Cano Guijelmo (1770-1775), s/f.
} 
Requena de Campos, una obra rococó de $1766^{877}$. Su lugar de residencia fue la capital palentina, concretamente en 1772 figura viviendo en una casa noble de la calle Mayor $^{878}$. Su hijo es el también maestro arquitecto Francisco Prieto que figura trabajando en esta iglesia en $1812^{879}$. Él es quien se encargará de finalizar el retablo barroco de Santo Tomás que le encargó la cofradía de las Ánimas de Autillo de Campos a Tomás Prieto y que dejó inconcluso al fallecer en $1783^{880}$.

Cada retablo, realizado en madera procedente de los pinares de Soria, se ubicaría a un lado de la capilla, uno frente al otro. Serían dos retablos gemelos, uno dedicado a San Andrés y otro bajo la advocación de San Francisco de Paula. Ambos debían contener a los lados, relieves relativos a la vida de cada uno de ellos. Este primer cuerpo estaba flanqueado por aletones decorados con “...los cuatro chicotes...”, es decir, cuatro amorcillos. En el segundo cuerpo se disponía las virtudes cardinales. Además Prieto debía ejecutar tres mesas de altar “...a la romana...”, para cada uno de los retablos de este espacio de culto, entarimar el suelo de roble, abrir dos sepulturas en el suelo “...para enterrar a algún señor hermano...” El contrato incluía la talla de unos bancos de nogal y unos balaustres de haya u olmo para la reja de acceso, lo que indica que ya no existía la que ejecutó Manuel de Salceda. El artífice se comprometió a finalizar los retablos, en paradero desconocido, en abril de 1772, recibiendo por los mismos, cuatro mil reales. Aunque desconocemos cómo serían estos retablos, podemos afirmar con seguridad que eran dos obras barrocas, pues el gusto neoclásico en los retablos, no comienza a imponerse en las obras de arte hasta 1777 con la redacción de las reales órdenes por parte de la Academia de San Fernando, que supervisaría todas las obras a partir de entonces. Prueba de ello, es que en los retablos colaterales de San Benito de Frómista que realizó Tonás Prieto por entonces, promueve la nueva estética emanada de la corte ${ }^{881}$.

Estos retablos aún existían en las postrimerías del siglo $\mathrm{XIX}^{882}$ y en los años ochenta, en que se inventarían los bienes de esta capilla, de los dos, se menciona un

\footnotetext{
${ }^{877}$ URREA FERNÁNDEZ, Jesús y MARTÍN GONZÁLEZ, Juan José. Inventario... 2 Op.cit, pág. 158.

${ }^{878}$ ALARIO TRIGUEROS, Teresa. "La introducción del gusto neoclásico en Palencia. Los proyectos de retablos en la obra de Francisco Prieto" en AIIICHP, tomo IV. Palencia, 1995, pág. 684, nota 5.

${ }^{879}$ AHPP. Carr.Prot 5267 Miguel López (1811-1813), s/f.

${ }^{880}$ ALARIO TRIGUEROS, Teresa. "La introducción...Op.cit, pág. 685.

${ }^{881}$ Ibídem, pág. 686.

${ }^{882}$ RAMÍREZ DE HELGUERA, Martín. El libro...Op.cit, pág. 150.
} 
retablo salomónico en la pared datado en el siglo XVIII, dedicado a San Pedro Telmo que probablemente sea uno de los retablos gemelos referidos y que aún estaba en $1994^{883}$. Constaba de banco, cuerpo principal con la hornacina de San Pedro Telmo, la Asunción y el Niño Jesús y ático decorado con nubes. La imagen se conserva hoy día en el museo Parroquial de Santiago ${ }^{884}$. Se trata de una figura monumental, de amplios ropajes que nos muestra al santo en edad madura, tonsurado y con un rostro cuadrático y serena expresión. El patrón de los marineros está identificado por el casco de barco que porta en la mano izquierda y un cirio fragmentado en la otra. Don Pedro González, conocido como San Telmo, fue canónigo de la Iglesia de Palencia y religioso dominico $^{885}$. Como tal, su indumentaria la constituye el hábito de la orden dominica, aunque en este caso adopta un sentido decorativo, pues el alba y la capa presentan una amplia orla dorada. Su vinculación con los mendicantes apunta hacia una procedencia de esta imagen del desaparecido convento dominico de Santo Domingo de Carrión, donde se veneraría originalmente la imagen hasta la desamortización del cenobio ${ }^{886}$. Dado que por entonces no estaba construido el museo de Santiago, se trasladó eventualmente a la iglesia de Santa María.

\section{Las actuales obras colaterales: La Inmaculada y una lápida moderna}

En la pared del Evangelio de esta capilla se ubica una talla de Nuestra Señora del Amor Hermoso. También denominada Inmaculada de las Congregaciones Marianas, está atribuida al sevillano Manuel Gutiérrez Reyes y $\mathrm{Cano}^{887}$. Esta imagen procede del monasterio de San Zoilo, pues era la imagen titular de la capilla de los jesuitas ${ }^{888}$. Pasó posteriormente al templo de Santa María, donde se conserva hoy día. Se trata de una

\footnotetext{
${ }^{883}$ URREA FERNÁNDEZ, Jesús y MARTÍN GONZÁLEZ, Juan José. Inventario...1, Op.cit, pág. 173. La mención de 1994 en ANDRÉS ORDAX, Salvador. La iglesia... Op.cit, pp. 57-58.

${ }^{884}$ GÓMEZ PÉREZ, Enrique y MARISCAL ARRANZ, José. Iglesia.... Op.cit, pág. 65.

${ }^{885}$ FERNÁNDEZ DEL PULGAR, Pedro. Teatro clerical...Tomo 2, Op.cit, pp. 288-301. Don Pedro González llegó a ser conocido como San Telmo, por su relación con el fuego de San Erasmo, obispo protector de los navegantes, y por derivación, san Ermo, San Elmo, y finalmente San Telmo. Este fuego producido en el mástil por la concentración de energía estática, anunciaba el final de las tormentas, de ahí la representación con un barco y cirio. ANDRÉS ORDAX, Salvador. "Cultura e iconografía: Proyección universal del dominico palentino Pedro González" en AIIICHP, tomo IV. Palencia, 1995, pp. 382-385.

${ }^{886}$ ANDRÉS ORDAX, Salvador. La iglesia de Santa María...Op.cit, pág. 58.

${ }^{887}$ Sobre la misma, LUNA MORENO, Luis. "Madre del Amor...Op.cit, pág. 62. Las ropas que hoy lleva fueron donadas por la célebre mística de Carrión, Francisca Javiera del Valle. DIEGO SÁNCHEZ, Manuel. Fuentes...Op.cit, pág. 171.

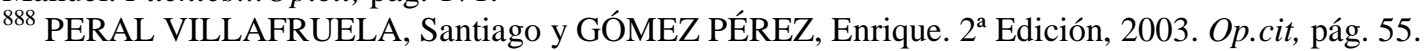


escultura de bastidor que representa la Inmaculada y está datada hacia $1880^{889}$. La Virgen, de facciones amables, porta una túnica, manto y corona dorada y cruza sus brazos en su pecho en actitud de sumisión. Anteriormente esta imagen estaba cobijada por un retablo barroco de principios del siglo XVIII que fue trasladado al museo parroquial de Santiago ${ }^{890}$. La procesión de Nuestra Señora del Amor Hermoso se realiza el último domingo de mayo.

Por su parte, la pared del lado de la Epístola cobija la sepultura de la promotora de la fundación en 1892 del Asilo de Nuestra Señora de las Mercedes, Doña Mercedes Gutiérrez Escribano y sus ascendientes más directos. Sobre la placa conmemorativa figura una hornacina con una escultura de yeso que representa una mujer desconsolada abrazada a una cruz, posible alegoría de la melancolía. En los años setenta se descubrió el sepulcro para adecentarlo. En febrero de 2001 también se adecentó la losa del licenciado Pastor quedando todos los restos en el mismo nicho de piedra, y arrimándose la losa bajo el retablo. Se descubrieron entonces dos arcos correspondientes a la fábrica original del templo, uno románico y otro ligeramente apuntado que fueron trasladados a la Capilla del Cristo para que no entorpeciesen el paso de los feligreses ${ }^{891}$.

\subsection{LA CAPILLA DEL CRISTO DEL AMPARO}

Situada en la parte norte del crucero, debe su nombre a la imagen de madera policromada que preside la misma. Esta capilla también es conocida con el nombre de "los Calderones", porque esta capilla se mantuvo a lo largo de los siglos bajo la protección del linaje Calderón Herrera. Sus escudos se conservan en el arco de ingreso de la capilla, en los dos arranques de los nervios de crucería del lado norte y en el extremo derecho del lado oriental, sobre la cornisa. Se trata de dos calderas y bordura cargada de doce calderas, todas ellas fajadas y gringoladas de sierpes.

La fundación de la capilla corresponde al carrionés Juan de Herrera, alcalde de Medina Sidonia, casado con Bartolina de Tapia y fallecido en 1548. El hijo del matrimonio, Cristóbal de Herrera, fue el encargado de trasladar a esta capilla los restos

\footnotetext{
${ }^{889}$ Delegación Diocesana de Patrimonio Cultural de Palencia. Carrión de los Condes. Caja I.

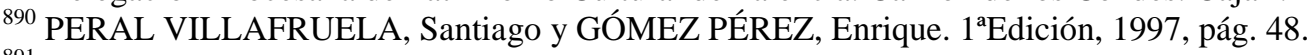

${ }^{891}$ ASMC. Libro Inventario (1861-1953) Papeles sueltos insertos en el mismo.
} 
de sus abuelos paternos desde Sevilla, cumpliendo con la voluntad de su padre. Además fue quien se encargó de hacer las obras pertinentes en la capilla para disponerla con la decencia que merecía la familia. Por ello contrató en 1562 a un maestro carrionés llamado Pedro de la Torre, que por siete mil maravedíes realizó un “...tablero de

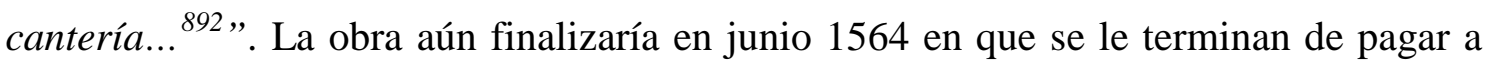
Pedro de la Torre los trescientos ducados en que se había concertado la obra, probablemente la última pues pocos meses después dicta testamento por hallarse gravemente enfermo ${ }^{893}$. Cristóbal de Herrera no dejó al morir más que una hija, Eufrosia de Herrera. Según las exigencias del llamamiento de la fundación, al carecer ésta de descendencia varonil, el patronato pasaba a Don Gaspar de Soto y Acuña, natural de Paredes y vecino de Béjar, el cual, al morir sin sucesión, la capilla pasó a su cuñado Don Hernando Calderón Herrera de Ayala, sucesor del mayorazgo de su padre Juan Calderón, procedente de una fundación que consta en el testamento de 1583. Su hermano Antonio Calderón Herrera de Ayala, intervino en la capilla sepultando en ella a su mujer doña María del Campo en 1635 e igualmente dispuso trasladar a la misma los huesos de la que, durante treinta años había sido su ama, doña María Rojas, pagando todos los costes que ocasionare. Su aportación más importante la constituye la pintura y dorado del retablo del Cristo y el encargo del retablo desaparecido de Nuestra Señora del Socorro, para cuyas obras invirtió un capital de quinientos ducados ${ }^{894}$.

Prueba gráfica de las obras que se realizaron bajo su patronazgo es la inscripción en letras capitales que se ubica en uno de los pedestales en la parte posterior del retablo del Cristo: "RENOVÓ ESTA CAPILLA, AN[S]Í DIO I DORÓ EL RETABLO DEL SANTO CHRISTO. IÇO EL RETABLO I ALTAR DE NVS ${ }^{a}$ SEÑORA DEL SOCOR[R]O I LAS DEMÁS IMÁXINES I ASIENTOS, TODO A SV COSTA, DON ANTONIO CALDERÓN ER[R]ERA Y AIALA, HIJO DE JVAN CALDERÓN I AIALA, HERMANO DE DON ESTEBAN CALDERON DEL [H]ÁBITO DE SAN JVAN I DE DOÑA TERESA DE ERA MAHIÇAO. SVS ANTEPASADOS, LOS HER[R]ERAS FVUERON CONQUISTADORES DE LAS [INDIAS] ${ }^{895,}$

\footnotetext{
${ }^{892}$ AHPP. Carr.Prot 5440. Gregorio Movilla (1561-1562), s/f.

${ }^{893}$ La carta de pago de 15 de junio de 1564 en AHPP. Carr.Prot 5442. Gregorio Movilla (1563-1564), s/f. El testamento de Pedro de la Torre AHPP. Carr.Prot 4675. Juan Cantoral (1563-1568), s/f.

${ }^{894}$ AHPP. Carr.Prot 5231. Jerónimo López (1635), s/f.

895 Debo esta información a mi colega, el historiador Enrique Gómez Pérez, que me avisó de su localización.
} 
A partir de 1637 perpetuamente, el cura y beneficiados del templo de Santa María acordaron con el patrono decir una misa en su honor y el de sus difuntos, rezada tras la celebración de oficios de la capilla mayor. Se finalizaría con dos responsos, uno sobre la sepultura de Don Antonio Calderón y su difunta mujer, doña María de los Ríos Campoo y otro sobre la de su criada, María Rojas ${ }^{896}$.

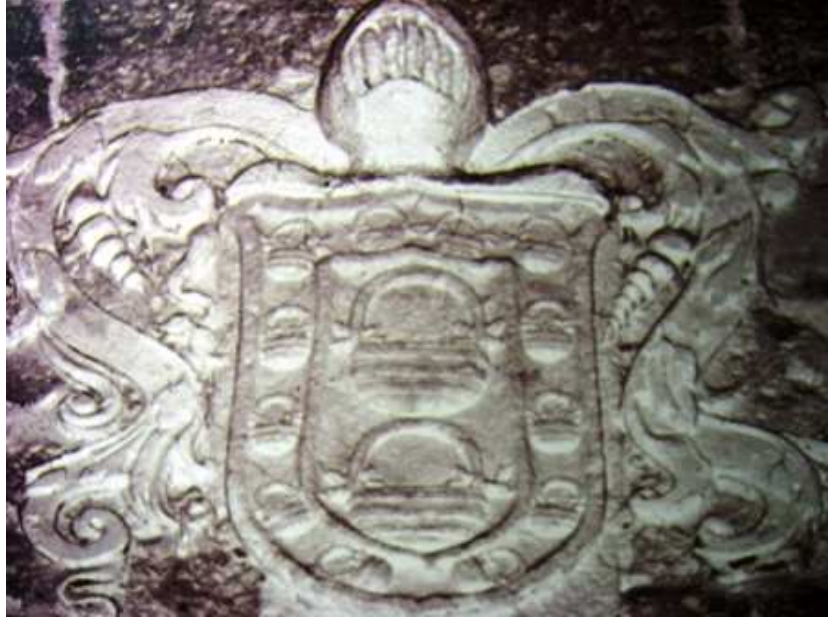

Blasón del acceso a la capilla.

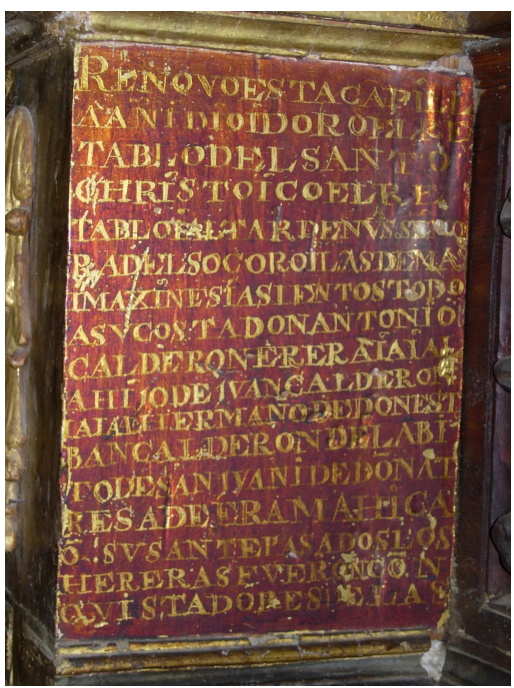

Dedicatoria del plinto del retablo.

\section{Testimonios del patronazgo de los Calderón Herrera en la capilla del Cristo.}

El patronazgo recayó posteriormente en don Manuel Calderón Herrera, vecino de Sahagún. Esposado con doña Ana de Soto y Castro, pidió en 1658 se le cediese el censo del estado del duque de Osuna para que él pudiera dotar la obra pía con dos mil ducados anuales durante los próximos dieciséis años ${ }^{897}$. A mediados del siglo XVIII, el patronazgo de la capilla continúa ostentándolo la misma familia. Así don Joaquín Calderón y Ayala escoge en 1751 dicho aposento como lugar en que descansen sus restos junto a los de su difunta mujer, doña Teresa de Torres ${ }^{898}$. El primogénito de este

\footnotetext{
${ }^{896}$ AHPP. Carr.Prot 5420. Francisco Moro Saldaña (1637), s/f.

${ }^{897}$ AHN. Clero Secular-Regular, Leg, 5358 s/f Expediente 2 Santa María, Papeles judiciales.

${ }^{898}$ Testamento dictado el 6 de enero de 1751. AHPP. Carr.Prot 5845, Diego Val Cornejo (1749-1753), fol 365 y ss.
} 
matrimonio, don Dionisio Joaquín, se encargó de entarimar y enlucir la capilla y encargó un nuevo retablo ${ }^{899}$.

En la centuria posterior "los Calderones" mantienen el título de patronos de la capilla del Cristo. Así consta en el testamento del regidor perpetuo de Carrión, don Juan José Calderón, dictado el 9 de enero de $1825^{900}$.

\section{Retablo del Santo Cristo del Amparo}

Adosado en el lado norte de la capilla, se halla un retablo barroco de madera sin policromar de la segunda mitad del siglo XVIII. Dionisio Joaquín Herrera y Ayala, patrón de la capilla, encargó un nuevo retablo del Santo Cristo, del cual se aprovechó parte del anterior, de la centuria precedente ${ }^{901}$.

Está conformado por un sencillo cuerpo elevado sobre pedestales y flanqueado por sendos estípites y un remate semicircular. La ornamentación consiste en una serie de bajorrelieves de las arma Christi inscritas en óvalos rodeados por una fina hojarasca que se repite en los tableros laterales del ático. Centra la composición del remate un relieve del Sagrado Corazón del que parten rayos solares en todas las direcciones, circunscrito en una corona decorada con testas de querubines de la que parten igualmente rayos.

Integrado en el retablo, se dispone en su parte central un tabernáculo dorado del primer tercio del siglo XVII que fue reaprovechado para la creación del nuevo retablo. Fue dorado en el año 1635 por encargo de don Antonio Calderón Herrera de Ayala, tal y como nos informa la inscripción que se ubica en uno de los pedestales, por la parte posterior, a la que nos referimos anteriormente. El banco está decorado con unos vistosos roleos pintados en tonos verdes rojizos, que confirman la datación del retablo. El cuerpo principal está conformado por un arco central trilobulado donde se sitúa la imagen principal, el Cristo del Amparo. La hornacina está flanqueada por dos columnas estriadas corintias que se asientan sobre un amplio pedestal. En el fondo de la hornacina se representa una imagen de ciudad celestial, con el sol y la luna rematando el conjunto. Sabemos por las fotos antiguas que la ubicación anterior de las dos esculturas de yeso

\footnotetext{
${ }^{899}$ VIGURI, Miguel de. Heráldica, 2, Op.cit ,pág. 49.

${ }^{900}$ AHPP. Carr.Prot 5741. Felipe Serna (1825-1827), s/f.

${ }^{901}$ VIGURI, Miguel de. Heráldica...2, Op.cit ,pág. 49.
} 
de la Virgen y San Juan que se hallan a los lados del retablo, era a los pies del Crucificado. Remata la composición un frontón triangular partido en el que figuran los relieves lígneos de tres cabezas de angelillos.

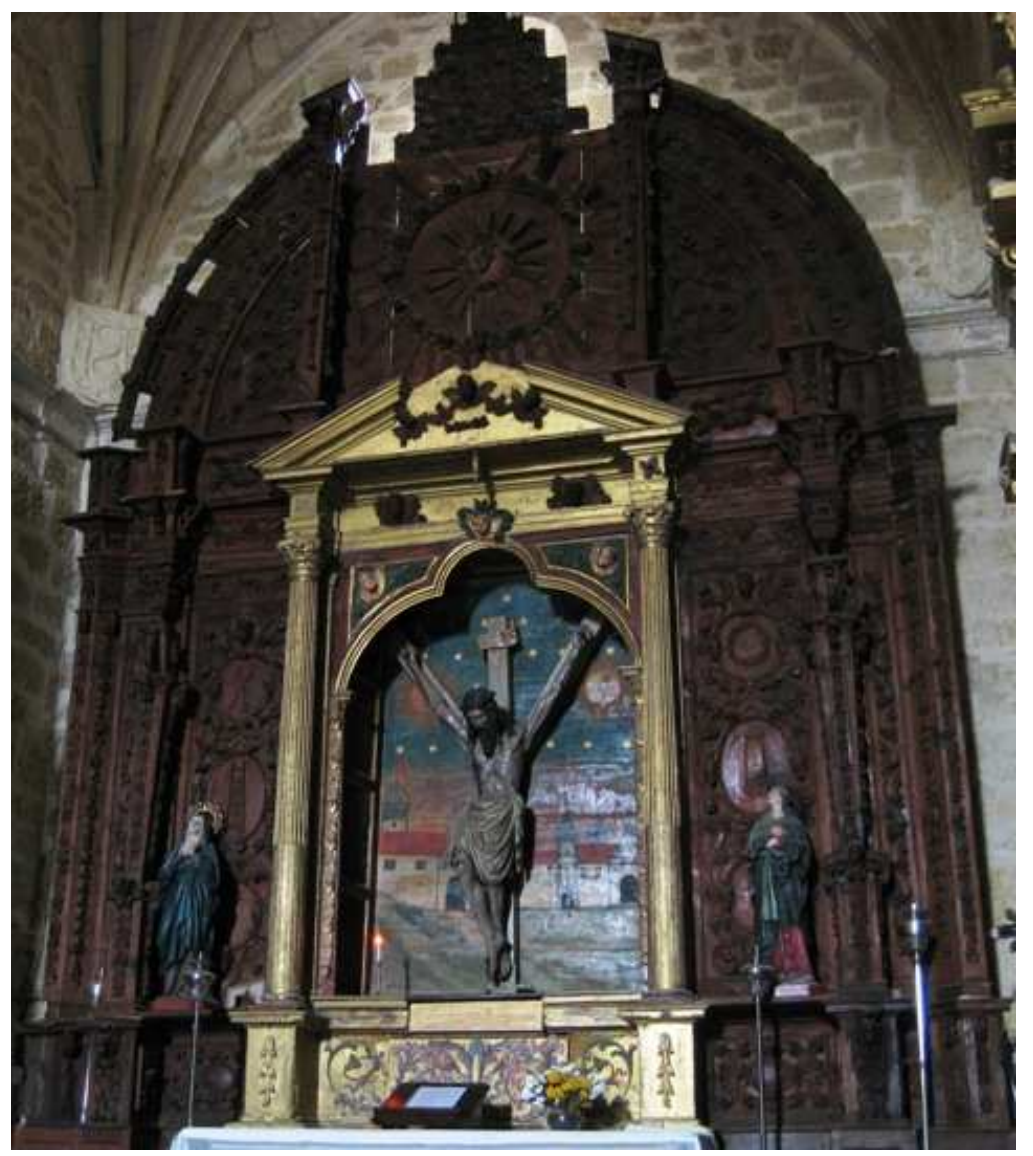

\section{Retablo del Cristo del Amparo en la iglesia de Santa María (7mtrsx4,95mtrsx1mtr).}

El Cristo del Amparo es una grandiosa escultura $-210 \mathrm{~cm}$ de alto x $140 \mathrm{~cm}$ de ancho x $9 \mathrm{~cm}$ de profundidad- que formó parte de la Exposición de las Edades del Hombre celebradas en Palencia en $1999^{902}$. Responde a la tipología de Crucifijo gótico doloroso, con los brazos exageradamente elevados, tórax dilatado y abdomen hundido que se relaciona con modelos alemanes tallados entre 1330 y $1360^{903}$. El dramatismo se

\footnotetext{
902 Delegación Diocesana de Patrimonio Cultural de Palencia. Carrión de los Condes. Caja I.

${ }^{903}$ No vamos a insistir en el tema, pues existen numerosos estudios sobre esta tipología y referencias concretas a nuestra imagen. "L'origine e la diffusione del Crocifisso gótico doloroso"
} 
acentúa en la cabeza que presenta unos cabellos largos y afilados, ojos y boca entreabiertos mostrando los dientes, pómulos muy marcados, rostro alargado costillas señaladas y el abdomen deprimido, todo ello, en consonancia con las visiones de la mística Santa Brígida de Suecia. De similares características dentro del ámbito palentino, hallamos el Cristo de Amusco o el de Paredes de Nava, con la particularidad que el de Carrión conserva la cruz en ípsilon, como en los tipos germanos.

\section{Retablo de San Antonio de Padua}

En el lado del Evangelio de la capilla, se conserva un retablo barroco de madera sin policromar, obra del siglo XVIII ${ }^{904}$. Está compuesto por un banco retranqueado y de gran desarrollo y compartimentado en dos secciones. La parte inferior a su vez está conformada por dos módulos en los que se repite la misma sucesión de molduras: caveto, listel, caveto, listel, gola decorada con roleos y listel. En la parte superior un tablero central da paso a otros tres tableros dispuestos en vertical, todos ellos decorados con una talla de motivos vegetales.

El cuerpo principal va presidido por una escultura de San Antonio de Padua cobijada en un arco de medio punto. En este caso, huyendo de convencionalismos iconográficos, la tonsura ha sido sustituida por una generosa cabellera con un abultado mechón sobre la frente. Presenta unas sonrosadas mejillas en su juvenil rostro que, si bien imberbe, conserva la huella del pelo que originalmente lo cubría. Por otro lado, además se ha añadido un motivo que no suele acompañarle, tres cabezas de angelillos a los pies, cuya presencia, de no ser por el niño que porta en su regazo, nos llevaría a identificar la imagen con San Pedro Regalado. En cuanto a las vestimentas, los pliegues de su hábito franciscano pecan de cierta rigidez, que señalan hacia un escultor de poca pericia, que la realizaría hacia 1750 . La hornacina central se encuentra flanqueada por

Kunstgechichtlichen Jahrbuch der Biblioteca Hertziana, 2, 1938, pp.. 143-26, ARA GIL, Clementina Julia. Escultura gótica en Valladolid y su provincia, Valladolid, Inst. Simancas, 1977, pp.. 88-91, VV. AA. "Cristo Crucificado" en Raíces. El arte en Palencia Diputación Provincial de la Diócesis de Palencia, 1989, pág. 68, FRANCO MATA, Ángela. "Crucifijo”, ficha no 8 en Memorias...Op.cit, pág. 75, del mismo autor "Crucifijos góticos dolorosos en Castilla-León", Travaux offerts à Marcel Durliat "De la création à la restauration”, Toulouse, 1992, pp.. 493-501 y "El Camino de Santiago en Castilla y León: itinerario artístico" en El mundo de los castillos. Ponferrada: templarios, peregrinos y señores. Catálogo de la exposición Castillo de los Templarios del 29 de octubre de 2010 al 8 de enero de 2011. Ponferrada (León), 2011, pp. 88-90.

${ }^{904}$ URREA FERNÁNDEZ, Jesús y MARTÍN GONZÁLEZ, Juan José. Inventario...Op.cit, pág. 58. 
dos robustas columnas estriadas con una decoración de espejos rodeados de cueros recortados en el tercio inferior de sus fustes. Sobre sus capiteles corintios apean sendos cimacios de perfil triangular rematados en dentellones. Le flanquean dos esculturas modernas de escayola de la Virgen con el Niño y San Roque. Son piezas de diversos tamaños, dada su reutilización en el retablo. Puesto que éste no estaba destinado originalmente a asentar esculturas en sus laterales, fue necesario realizar dos peanas de madera reforzadas con unas fijaciones en los muros.

Un frontón partido interrumpido por una cornisa retranqueada precede al ático, donde se ubica un tablero rematado en un frontón curvo en el que se inscribe un bajorrelieve con la escena de la Aparición de Cristo a San Antonio.
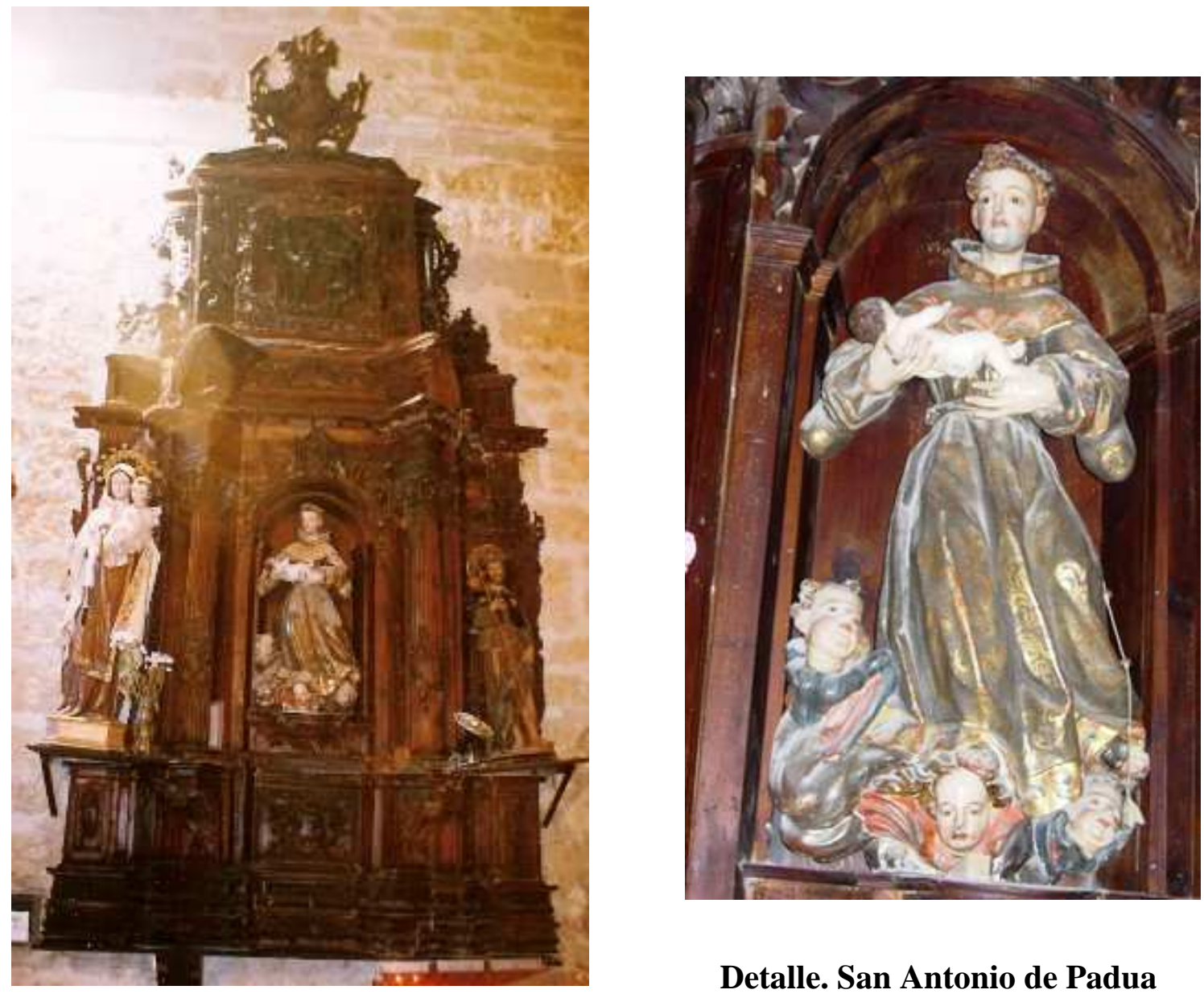

Detalle. San Antonio de Padua

Retablo de San Antonio de Padua en la capilla de los Herrera del templo de Santa María. Mediados del sifglo XVIII. (4,6mtrsx2,5mtrsx0,45mtrs). 


\section{Retablo de la Virgen de la Paz}

En la pared frontera se halla otro retablo barroco, en este caso dorado, datado a principios del siglo XVIII ${ }^{905}$. Consta de banco, un cuerpo y ático. El banco, muy sencillo, está compuesto por dos tableros de perfil cuadrangular y decorados con rocallas que flanquean la puerta lisa del sagrario. A los lados se ubican dos ménsulas avolutadas sobre las cuales apean los soportes centrales del cuerpo principal. En él se disponen cuatro columnas salomónicas de dos espiras y capitel corintio, cuyo fuste se adorna con un profuso rameado de vides. Las ubicadas a los lados se retranquean respecto a las centrales y en el espacio intercolumnar, se halla una pilastra cajeada. A los lados se conservan dos tallas de factura moderna. La de la izquierda representa a Santa Rita, ataviada con el hábito agustino ceñido por correa de la que pende un rosario. Su cándido rostro está marcado por un estigma que señala su frente, en recuerdo de la astilla de la corona de espinas de Cristo que apareció en repetidas ocasiones a la madrugada. Este suceso explica que también lleve un crucifijo entre sus brazos.

En el lado contrario se ubica la Virgen de Fátima sobre las remas de encina, una de las tantas reproducciones que imitan la imagen que se venera en la capilla de las apariciones del santuario homónimo portugués. Porta túnica blanca tachonada con una estrella plateada en la parte inferior, seguramente por el astro que la guiaba en su peregrinación. El manto, también de color blanco está ribeteado con una orla conformada por una línea ondulante. Suele llevar corona, pero en este caso, porta un nimbo plateado tachonado de estrellas. Estas imágenes de escayola podrían pertenecer al taller de Olot, a quien se debe algunas obras de la ermita de la Vera Cruz de Carrión.

En la hornacina principal, bajo arco de medio punto se venera la Virgen de la Paz, una imagen de bastidor también moderna. Policromadas a pulimento, sus manos se hallan juntas, giradas hacia el exterior y sobre su cabeza porta un velo corto fijado con una corona de plata. Lleva túnica y mantos blancos como la Virgen de Fátima, pero en este caso, ornadas de un ribete dorado. Presenta un llamativo postizo, pues de sus orejas agujereadas penden sendos pendientes de piedras de colores.

${ }^{905}$ URREA FERNÁNDEZ, Jesús y MARTÍN GONZÁLEZ, Juan José. Inventario...op.cit, pág. 58. 
Dos aletones avolutados flanquean el remate del retablo, y entre ellos se adosan dos pilastras cajeadas con guirnaldas superpuestas en sus fustes. Sobre las mismas se asienta un frontón curvo rematado en dos bolas que además se encuentra partido para albergar una rocalla y una venera que emergen de la parte central. En el espacio central se hallaba originalmente la imagen de San Francisco de Paula, del siglo XVIII, hoy ubicada en el museo parroquial de la iglesia Santiago. Se trata de una talla de pequeñas dimensiones $(86 \mathrm{~cm} \times 50 \mathrm{~cm})$ procedente a su vez de la iglesia de San Juan del Mercado, que representa al fundador de los Mínimos con el hábito propio de la orden ermitaña, consistente en una túnica de lana negra sin teñir, con mangas anchas, capucho puesto sobre la cabeza y un cíngulo negro fino, de cinco nudos.

La policromía dieciochesca ha sustituido la sobriedad propia del hábito del ermitaño por unos vistosos rameados dorados que recubren toda la vestimenta. Su rostro enjuto, consecuencia de la vida rigurosa de la orden basada en ayunos y penitencia, presenta expresión forzada a través de la boca entreabierta mostrando los dientes, reforzándose su delgadez a través de la disposición rectilínea de su nariz y cejas, extremadamente finas. Provisto de una tupida barba cana, apoya su mano izquierda en un pequeño bastón, como es usual en su iconografía, mientras que en la otra mano, se conserva tan sólo el pie del ostensorio que alzaría originalmente, con el lema "charitas" inscrito en su parte central. La imagen ha sido sustituida por una pintura votiva de escaso valor artístico que representa a la Virgen que se aparece entre nubes acompañada de dos fieles arrodillados a sus pies que la observan, probablemente el matrimonio benefactor del lienzo. El mencionado traslado a otro templo carrionés justificaría la presencia de la ménsula que sobresale en este sector de la línea general del retablo, destinada a acoger una escultura y el hecho de que el bastidor no encaja adecuadamente en el espacio cuadrangular donde se ubica. 


\section{OTRAS OBRAS DEL TEMPLO}

\section{Obras de las naves laterales}

Aparte de las obras mencionadas, repartidas por el templo se hallan una serie de imágenes de pequeño tamaño ubicada en las repisas de las ventanas del lado del Evangelio. En el primer tramo, se ubica San Francisco, a quien ya nos referimos por proceder de la capilla del Licenciado Pastor. En el tramo consecutivo, San Sebastián (115x35x30), una imagen de la primera mitad del siglo XVI ubicada originalmente en el retablo de las Victorias, ubicado en el lado de la Epístola ${ }^{906}$. El contraste entre los cabellos dorados del santo, su piel blanquecina y las gotas de sangre que brotan de sus heridas provocan un juego muy efectista. Presenta una proporcionada anatomía que se conjuga con una pose delicada, con ecos de la escultura burgalesa del primer cuarto de la centuria. A continuación se ubica la talla de San Zoilo, que analizaremos cuando estudiemos el templo de San Julián, dado que procede de uno de sus retablos colaterales.

En el lado de la Epístola podemos mencionar una serie de pinturas del siglo XVII entre las que destacamos un Calvario ubicado en el primer tramo, que podría proceder del convento desaparecido de Santa Isabel. Sobre fondo neutro y oscuro se destacan los cuatro personajes, Cristo, la Virgen, San Juan y la Magdalena, abrazada al crucifijo, que se destacan gracias a la presencia de un foco de luz que se ubica a los pies del santo evangelista. Resulta muy curioso el rostro de Cristo, no sólo por los ojos abiertos sino por el ladeo de la cabeza, como si se hallase ausente. Posee un marco dorado barroco conformado por una moldura interna jalonada de gallones orlada de un espeso follaje y en el remate, un coro de cabezas de angelillos que emergen entre un manto de nubes.

En el cuarto tramo del templo se halla una Sagrada Familia, en la que Santa Ana enseña las Escrituras a la Virgen que ha sido datada en el siglo XVII ${ }^{907}$. El artista anónimo presenta ciertos ecos del lienzo del mismo tema que Murillo pintó hacia 1655, ubicado en el Museo del Prado. La disposición de Santa Ana y la Virgen niña de pie con

\footnotetext{
${ }^{906}$ Delegación Diocesana de Patrimonio Cultural de Palencia. Carrión de los Condes. Caja I.

${ }^{907}$ URREA FERNÁNDEZ, Jesús y MARTíN GONZÁLEZ, Juan José. Inventario, 2, Op.cit, pág. 58.
} 
el libro en las rodillas de la madre es común a ambos lienzos, salvo porque en nuestro caso se invierten los personajes, como una imagen espejo. Por otro lado, el pintor sevillano conjuga armoniosamente dos niveles de realidad, como así sucede en la pintura carrionesa: las labores de costura en la parte inferior nos acercan a ambiente cotidiano mientras que la arquitectura columnada del fondo se desvincula de un ambiente doméstico. Por lo demás, existen elementos diferenciadores, pues en este caso se ha prescindido del rompimiento de gloria que flota sobre la cabeza de la Virgen y se han añadido las figuras de San José y un dócil perrillo a los pies de Santa Ana, concediendo a la pintura un carácter más familiar y cercano. Probablemente la ejecución de este lienzo sea coetánea a la de su sencillo marco dorado, provisto de una finísima talla vegetal en los ángulos, que apuntan hacia la segunda mitad de la centuria. Por último, en este tramo, en el lado del evangelio, hallamos una gran pila bautismal $(94 \mathrm{~cm}$ de alto x $133 \mathrm{~cm}$ de diámetro) datada en el siglo XVI. Asentada sobre un amplio pedestal circular, es muy semejante a la de la iglesia de Santiago, salvo que ésta presenta una sencilla decoración de gallones.

Ubicado en origen en la nave mayor y hoy día en museo sacro de Santiago, concretamente en la zona presbiterial, se hallan dos lienzos, uno de San Buenaventura y otro de San José con el Niño ${ }^{908}$. Su análogo estilo e idénticas dimensiones $(165 \mathrm{~cm} \times 95 \mathrm{~cm})$ apuntan a que fueron ejecutados paralelamente. Son dos obras de buena calidad caracterizadas por su estilo amable y la dulzura de los rostros, patente sobre todo en la pintura de San José. Ambos poseen un marco de gallones y piedras, realizados hacia el segundo tercio del siglo XVII, de corte vallisoletano, que podría indicar la procedencia de las pinturas. En los años ochenta aún se hallaban en Santa María estas imágenes, inventariadas como San José con el Niño y Santo Cardenal y datadas en el siglo XVII ${ }^{909}$. Si observamos con atención, bajo las vestimentas del cardenal asoma el sayo franciscano, confundido con el fondo oscuro del lienzo, lo que señala inconfundiblemente hacia el santo italiano.

\footnotetext{
${ }^{908}$ GÓMEZ PÉREZ, Enrique y MARISCAL ARRANZ, José. Iglesia de Santiago...op.cit. pp. 41 y 45.

${ }^{909}$ URREA FERNÁNDEZ, Jesús y MARTÍN GONZÁLEZ, Juan José. . Inventario, 2.Op.cit, pág. 58.
} 


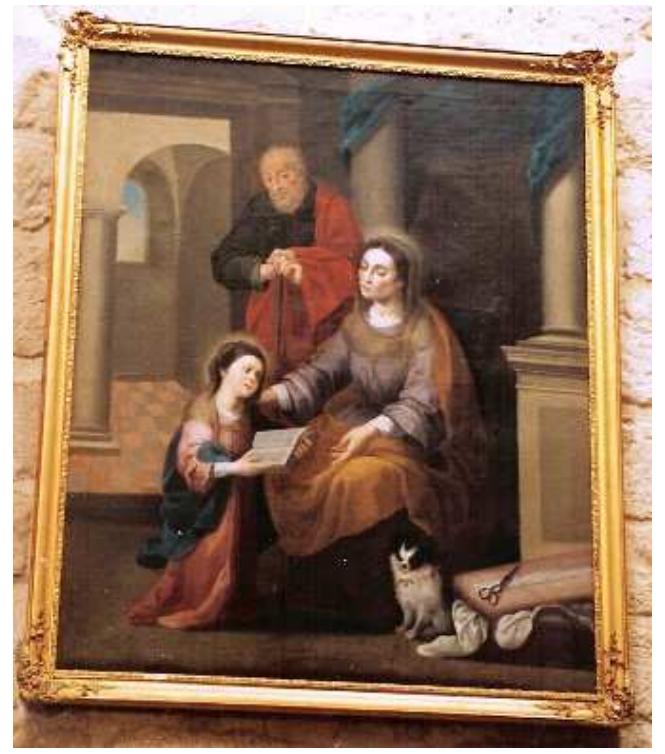

Santa Ana enseñando a leer a la Virgen. Óleo sobre lienzo. Siglo XVII. Iglesia de Santa María $(102 \mathrm{~cm} x 82 \mathrm{~cm})$.

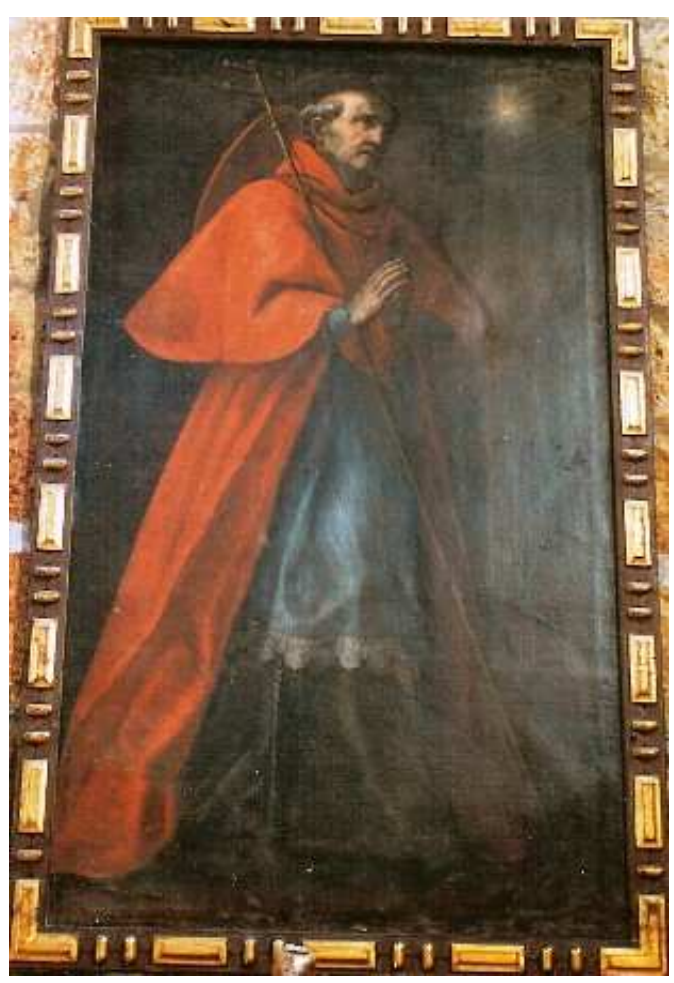

San Buenaventura.

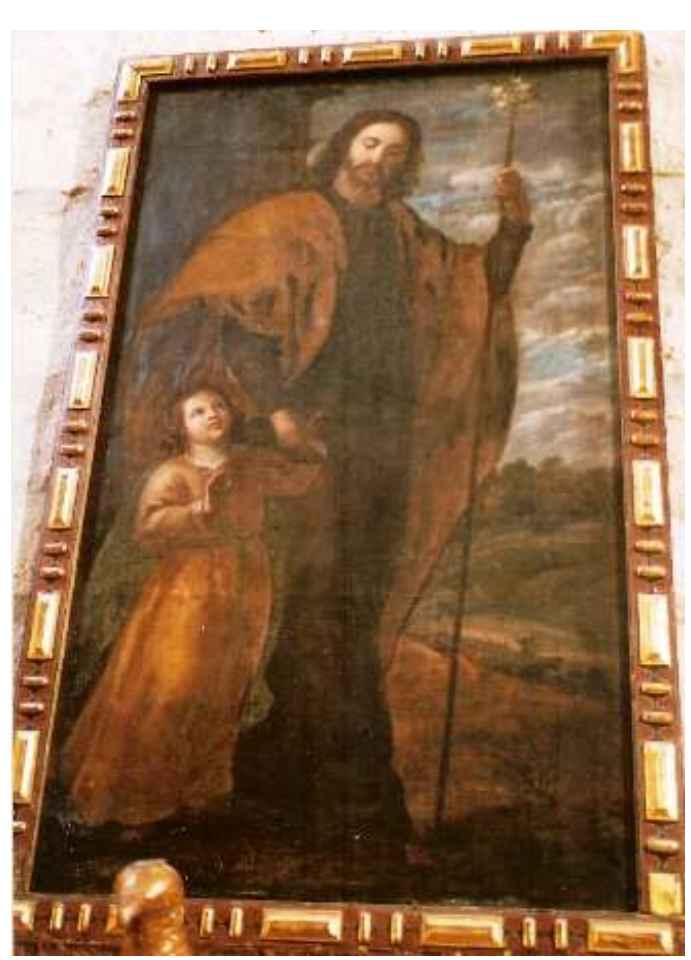

San José con el niño Jesús.

Óleos sobre lienzo del segundo tercio del siglo XVII, procedente de la iglesia de Santa María. Actualmente en el museo de Santiago. $(165 \mathrm{~cm} \times 195 \mathrm{~cm})$. 


\section{Obras destacadas de la sacristía}

La sacristía, espacio erigido como apuntamos, en el siglo XVI, alberga algunas obras, de las cuales destacamos una serie de lienzos dispuestos en pequeños tondos pertenecientes al siglo XIX que representan a diversos Santos como San Francisco Javier, San Francisco de Asís o San Juan Evangelista ${ }^{910}$.

La obra más curiosa por su iconografía es el lienzo de las Ánimas del purgatorio $^{911}$, una pintura popular y de mala calidad artística que impide su datación. Si fue ejecutado contemporáneamente al sencillo marco de madera moldurado, habría que fecharlo a finales del siglo XVIII. La originalidad reside en que las ánimas reciben alivio de la fuente de la misericordia en la que cae la sangre de Cristo, arrodillado a un lado del cuadro. Lo reconocemos tan sólo por su actitud redentora entregando su sangre y por la cruz que le acompaña. Sin embargo su barba blanca y la corona de rayos que porta lo desvinculan de su representación habitual, semejando un dios pagano. Al otro lado está San Francisco, y en dimensiones más reducidas, San Juan Bautista y Santa Clara. Presidiendo el conjunto, dios Padre y el Espíritu Santo y entre ellos una orla de cabezas de querubines que custodia un tabernáculo con una llama en su interior, posible alusión a la morada eterna. Las primeras manifestaciones de esta iconografía pertenecen al siglo XIV, generalizándose a partir del siglo XVI con la Contrarreforma. Los lienzos con esta iconografía son muy difíciles de datar por dos motivos fundamentalmente: el origen popular del tema, que lleva a encargar las obras a artistas locales sin preparación teórica que recurren a grabados y estampas piadosas y por la escasa evolución de la imagen del Purgatorio, recurriendo en la mayor parte de los casos a la tradición medieval $^{912}$. En este tipo de cuadros se busca crear una imagen clara del mensaje de salvación en detrimento de la estética. De ahí que una compartimentación estereotipada de cada lugar -Reino Celestial, infierno, tierra, purgatorio- con el fin de que el fiel comprenda, cual es el camino para llegar a la visión de Dios $^{913}$.

\footnotetext{
${ }^{910}$ Delegación Diocesana de Patrimonio Cultural de Palencia. Carrión de los Condes. Caja I.

${ }^{911}$ Ya refieren su interés iconográfico ANDRÉS ORDAX, Salvador. La iglesia de Santa María...Op.cit, pág. 60 y ANDRÉS GONZÁLEZ, Patricia. "Iconografía franciscana en Palencia" en AIIICHP, vol 4, 1995 , pág. 778.

${ }^{912}$ ARRATIA MARTÍN, $\mathrm{M}^{\mathrm{a}}$ Victoria. Las ánimas del purgatorio en la provincia de Valladolid, una devoción popular. Diputación Provincial de Valladolid. Valladolid, 1999, pág. 68.

${ }^{913}$ Ibídem, pp. 69-72.
} 
Por último, debemos mencionar dos objetos litúrgicos que, procedentes de este espacio, hoy se exponen en el museo de Santiago, en su antigua sacristía. El primero es un cáliz de plata sobredorada $(28 \mathrm{~cm} \times 6,2 \mathrm{~cm}$ diámtetro) en cuya base podemos leer la siguiente inscripción: "FERDINANDUVS VI D.G. HISPANORVM REX VIRTUTE ET PROTECTIONE. EL ILMO. SR. D. ALVARO DE MENDOZA, CARDENAL DE LA SANTA IGLESIA ROMANA, PATRIARCA DE LAS INDIAS, CAPELLAN LIMOSNERO MAYOR DE SU MAJESTAD. AÑO 1754". Al parecer, desde el siglo XVI se estilaba en la corte la costumbre de consagrar tres cálices nuevos en la misa celebrada durante la festividad de Reyes Magos. Estos cálices, símbolo de los presentes que Sus Majestades ofrecieron al Niño Jesús, eran posteriormente regalados a diferentes iglesias, como es el caso que nos ocupa ${ }^{914}$. No presenta ningún tipo de decoración, salvo el bocel que perfila el contorno de la copa por su parte central.

También sobresale por su esmerada ejecución una cruz alzada de plata del siglo XVIII $(55 \mathrm{~cm} \times 57 \mathrm{~cm} \times 5,5 \mathrm{~cm})$ Desde hace varias centurias, este tipo de objetos gozaron de gran protagonismo para toda clase de ceremonias públicas -entierros, letanías, fiestas- pues constituían el estandarte de cada parroquia ${ }^{915}$. Los brazos de la cruz presentan un perfil trebolado y en su frente se ha tallado un crucificado que, junto a los haces solares que parten diagonalmente en la parte posterior, han sido sobredorados. En cada uno de las caras de la macolla existe un bajorrelieve que representan: la Oración en el huerto, la Flagelación ,la Coronación de Espinas y el camino del Calvario, escenas inscritas dentro de templetes con el frontón partido que pudieron ser reaprovechadas de otra cruz más antigua.

\footnotetext{
${ }^{914}$ GÓMEZ PÉREZ, Enrique y MARISCAL ARRANZ, José. Iglesia de Santiago...Op.cit, pp. 58-59. Para la orfebrería en Palencia, consúltese BRASAS EGIDO, José Carlos. La platería palentina. Diputación Provincial de Palencia, 1982.

${ }^{915}$ GÓMEZ PÉREZ, Enrique y MARISCAL ARRANZ, José. Iglesia de Santiago...op.cit, pp. 62-63.
} 


\subsubsection{IGLESIA DE SANTIAGO}

\section{EL TEMPLO}

Se encuentra en la esquina noreste de la plaza mayor, junto a la calle principal antiguamente Calle de la Rúa, hoy calle de José Antonio Primo de Rivera-, que aún cruzan los peregrinos en dirección a Santiago, conectando la iglesia de Santa María del Camino y el barrio de San Zoilo.

La iglesia, que alberga el museo de Arte Sacro desde 1993, consta de una amplia nave con tres ábsides semicirculares precedidos de un tramo recto, el central más amplio que los laterales, que conservan su estructura original románica. En origen se asemejaría a las plantas de los templos palentinos de San Martín de Frómista, Santa Eufemia de Cozuelos, Santa María de Mave o Villamuriel de Cerrato. Adosada al ábside de la epístola, se sitúa la sacristía, la cual con su perfil rectangular, oculta la visión de dicho ábside exteriormente. El templo va precedido por un pórtico cubierto flanqueado por dos estructuras cuadrangulares, que forman parte de la exposición. Una de ellas, la del lado del Evangelio, está parcialmente ocupada por una escalera helicoidal que nos indicaría la ubicación de la antigua torre románica. En cambio, la torre actual se encuentra en el lado frontero, y a la misma se accede a través de una escalera metálica ubicada en el espacio de la primera capilla de la Epístola. Todo este espacio estaría ocupado en origen por el coro.

Una reforma de época moderna propició la estructura irregular existente de las capillas laterales de diversos tamaños. En el lado del Evangelio existen tres, de mayor profundidad conforme nos acercamos hacia el presbiterio. Los muros exteriores de la segunda y tercera capilla desde los pies, presentan su muro externo -en el lado norte del templo - un perfil diagonal dado que linda con una vivienda particular. En el lado de la Epístola se ubican dos capillas de tamaño parejo y escasa profundidad cubiertas mediante una bóveda de cañón. 
A raíz de una excavación arqueológica que tuvo lugar en 1989, se sacaron a la luz interesantes datos acerca de la fisonomía original del templo románico ${ }^{916}$. Dada la amplitud del mismo, se podría pensar que poseería una compartimentación en tres naves. Sin embargo, salvo los pilares cilíndricos del crucero que se hallaron en las excavaciones, no se ha encontrado ningún otro soporte ni muro de descarga hasta el hastial, lo que descartaría la existencia de bóvedas de piedra y apuntaría hacia una nave cubierta con un artesonado.

Los restos cerámicos fueron determinantes para datar la fábrica a principios del siglo XII, coincidiendo con un período de auge económico y demográfico que posibilitó primero un asentamiento en esta zona y posteriormente, la construcción de la iglesia románica con su lado sur adosado a la primera muralla medieval. Las impostas de billetes bajo las ventanas, el aparejo regular de mediana talla y los ábsides embutidos en los tramos rectos que los preceden son indicios suficientes para establecer esta datación $^{917}$.

\section{La portada románica}

La portada principal del templo se ubica en el lienzo occidental, por donde discurre el camino jacobeo. Es fruto de un momento fructífero y de renovación propiciado por la consolidación de la monarquía con Alfonso VIII, la cual, gracias a la prosperidad de la economía, favoreció la renovación y ejecución de monumentos religiosos entre 1160 y 1185 en que oscilaría su ejecución, según comparten la mayor parte de los especialistas ${ }^{918}$.

\footnotetext{
${ }^{916}$ RUIZ SALCES, Roberto y PEÑIL MINGUEZ, Javier. "La excavación...Op.cit, pp. 483-490.

${ }^{917}$ LACOSTE, Jacques. "El Maestro de Carrión de los Condes" en Actas del IV Curso de Cultura Medieval. Seminario Fortificación Medieval (sep 1992). Aguilar de Campoo (Palencia), 2003, pp. 183, nota al pie ${ }^{\circ} 6$. Antes que éstos, habían apuntado la misma datación RAMíREZ DE HELGUERA, Martín. El libro..Op.cit, pág., 154, basándose a su vez en Quadrado.

${ }^{918}$ Ofrece una cronología hacia 1165. PORTER, Arthur Kingley. Spanish Romanesque Sculpture, tomo II. Nueva York, 1928, pp. 27-33, al igual que GÓMEZ-MORENO, Manuel. El arte románico español: esquema de un libro. Madrid, 1934, pág. 80 Como ambos, apoya la cronología de 1165 GOLDSCHMIDT, Werner. "El pórtico de San Vicente en Ávila" en Archivo Español de Arte y Arqueología, nº11, 1935, pp. 259-274. La data entre 1180 y 1185 GARCÍA GUINEA, Miguel Ángel. "Las huellas de Fruchel en Palencia y los capiteles de Aguilar de Campoo" en Goya: Revista de Arte. N $^{\circ}$ 44. Fundación Lázaro Galdiano. Madrid, 1961, pp. 158-67 y del mismo El arte románico...1975 Op.cit, pp. 129 y ss. Por la década de 1160-1170 se decanta D’EMILIO, James. “Tradición local y aportaciones foráneas en la escultura románica tardía: Compostela, Lugo y Carrión" en Actas del Simposio Internacional sobre O Pórtico da Gloria e a arte do seu templo, 3-8 de Outubro de 1988". Santiago de
} 
Se compone de un arco de medio punto con tres arquivoltas radiales y sin tímpano, disposición análoga a la iglesia de Santa María. En la arquivolta central aparecen veintidós personajes pertenecientes a gremios, sedentes la mayoría, con leones en cada extremo, componiendo un total de veinticuatro figuras que encarnan actividades intelectuales y reposadas, como el escribano y el juez o más artesanales y activas, como el acuñador de moneda o la bailarina, conformando un programa con finalidad didáctica $^{919}$. Las dos columnas sobre las que apea la arquivolta principal contienen el fuste decorado con motivos en zig-zag y rosetas intercaladas y en su tercio superior, una representación de sendos ángeles como en las iglesias de Vermenton o Avallon, en Borgoña. El capitel de la izquierda representa un león con las fauces abiertas que trata de acceder al alma del difunto protegido por dos ángeles, alusión a la salvación del alama. En cambio, el capitel del lado derecho, se vincula al castigo del pecador, pues contiene al difunto desnudo ante dos perros que le muerden incesantemente ${ }^{920}$. En la parte superior, sobre la imposta de billetes que recorre la portada, se halla un friso que representa un magnífico Cristo Pantocrátor muy naturalista portando el libro de la palabra divina, acompañado del Tetramorfos, representando el triunfo sobre el pecado $^{921}$. A ambos lados, divididos en dos grupos de seis, se halla un apostolado bajo una arcada de arcos mixtilíneos sobre columnas que separan a cada uno de los santos. Todos ellos han sido restaurados en 1970, sin poderse recuperar las cabezas de los personajes decapitados. En esta portada intervendrían las manos de dos artistas diferentes, siendo el más brillante el autor del Pantocrátor, de los fustes y algunos

Compostela, 1992, pp. 83-94. Cree que fue ejecutada en el último tercio de siglo LACOSTE, Jacques. El Maestro de Carrión de los Condes" en Actas del IV Curso de Cultura Medieval. Seminario Fortificación Medieval (sep 1992). Aguilar de Campoo (Palencia), 2003, pág. 156. El estudio más reciente y profundo sobre los escultores del románico en Palencia HUERTA HUERTA, Pedro Luis. Maestros del románico en el Camino de Santiago. Fundación Santa María la Real. Aguilar de Campoo, 2010.

${ }^{919}$ Estudios sobre la interpretación de los personajes en VIRGILI BLANQUET, María Antonia. "La música y su iconografía...Op.cit, pp.69-75, MARIÑO, Beatriz. "Testimonios iconográficos de la acuñación de moneda en la Edad Media. La portada de Santiago de Carrión de los Condes" en Artistes, artisans et production artistique au Moyen Age. Vol,1, Les hommes. Editorial Picard. París, 1986, pp. 499-513 y de la misma "La portada de Santiago de Carrión" en Palencia en los siglos del románico. Fundación Santa María la Real. Aguilar de Campoó (Palencia), 2002, pp. 49-69, HERNANDO GARRIDO, José Luis. "La fachada de Santiago de Carrión de los Condes, encrucijada de la escultura románica castellana. Estado de la cuestión" en Cluny y el Camino de Santiago en España en los siglos XIXII. Actas del Congreso de Sahagún, 1993 (en prensa), Y del mismo, "Iglesia de Santiago" Enciclopedia del Románico en Castilla y León. Palencia. Aguilar de Campoo. Vol.2, Boedo-La Ojeda, Saldaña-La Valdavia, Tierra de Campos, Cerrato. Aguilar de Campóo, 2002, pp. 1012-1022, LACOSTE, Jacques. "El Maestro...Op.cit, pp. 155-185, del mismo Les maîtres de l'esculpture romane dans l'Espagne du pèllerinage à Compostelle. Burdeos, 2006, pp. 180-190.

${ }_{920}^{92}$ ARAGONÉS ESTELLA, Esperanza. La imagen del mal...Op.cit, pág. 123.

921 RAMOS DE CASTRO, Guadalupe. "Iconografía de la escultura románica palentina" en Jornadas sobre el románico en la provincia de Palencia. Diputación Provincial. Palencia, 1985, pág. 65. 
apóstoles. Este Maestro de Carrión de los Condes o de "los paños mojados" revela un conocimiento de la escultura clásica asimilada por su formación borgoñona que desde principios del siglo XII se inspiraba en modelos romanos ${ }^{922}$.
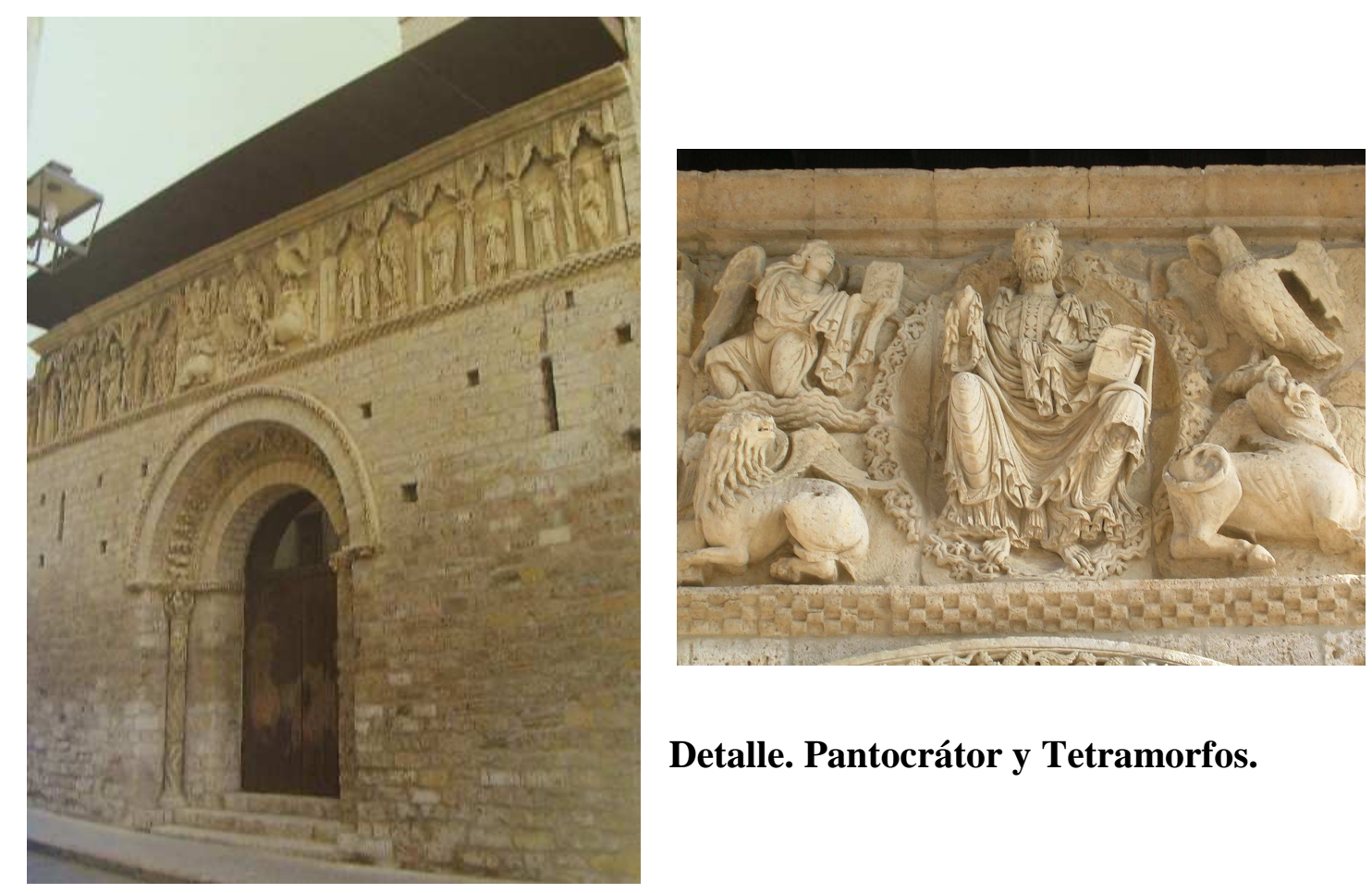

Detalle. Pantocrátor y Tetramorfos.

\section{Fachada occidental del templo.}

\section{EL ANTIGUO CONVENTO DE SANTIAGO}

Algunos historiadores sostienen la creencia de que Santiago perteneció a la Orden del Temple ${ }^{923}$. Los detractores de tal afirmación rechazan esta hipótesis apoyándose en la ausencia de pruebas documentales o en el hecho de que este templo no

\footnotetext{
${ }^{922}$ Esta obra tiene grandes conexiones estilísticas con otras de influencia borgoñona se ha puesto en relación con los autores la portada de San Vicente de Ávila, los capiteles del coro de Aguilar de Campoo o la portada meridional de la catedral de Lugo o las esculturas de la cripta del Pórtico de la Gloria de Santiago. Sobre la autoría, véanse GÓMEZ-MORENO, Manuel. El arte románico español: esquema de un libro. Instituto de las Españas. Madrid, 1934, GARCÍA GUINEA, Miguel Ángel. "Las huellas...Op.cit, pp. 158-67, HERNANDO GARRIDO, José Luis. "Iglesia de Santiago"...Op.cit, pp. 1013-1015, LACOSTE, Jacques. "El Maestro...Op.cit, pp. 157-162 y la aportación más reciente RICO CAMPS, Daniel. "Los maestros de Carrión de los Condes y San Vicente de Ávila: Reflexiones sobre la decantación hispana de la escultura borgoñona" en Maestros del Románico en el Camino de Santiago. Fundación Santa María la Real. Palencia,.2010, pp. 117-150

${ }^{923}$ CARRIÓN GUTIEZ, Manuel. Op.cit, pág. 25, VALLE CURIESES, Rafael de. Op.cit, pág. 95, GARCÍA GUINEA, Miguel Ángel. El románico...Op.cit, pág. 125,CASTÁN LANASPA, Javier. "Las órdenes militares y su arquitectura" en Jornadas sobre el románico en la provincia de Palencia. Diputación Provincial. Palencia, 1985, pp. 51-52.
} 
sigue el patrón de la arquitectura templaría castellano-leonesa de un solo ábside y abovedada $^{924}$. Otro argumento empleado en contra es la referencia de 1118 al prior de Santiago de Carrión, apresado por Alfonso $I^{925}$. Según Salces y Peñil, este dato vincularía el templo a una orden religiosa y descartaría la relación templaria ${ }^{926}$. No creamos que exista óbice para defender una comunidad templaria pudiera estar regida por un prior, pues si bien era una orden militar, estaba compuesta de monjes. A la luz de un testamento de 1575 podemos afirmar que se trataba de un priorato bajo la orden del Temple. Don Antonio de Ribera, caballero de la orden de San Juan de Rodas y tío de Hernando de Berrio Ribera, fundador de la iglesia de San Julián de Carrión expresa como última voluntad ser enterrado en Nuestra Señora de las Capillas, junto a Santiago, separada de la dicha yglesia en el claustro que solía ser de los templarios, quando Santiago fue priorato d'ellos ${ }^{927}$ ”. Parece ser por tanto, que a finales del siglo XVI aún existía este claustro, inutilizado desde la disolución de la orden a principios del siglo XIV, edificándose una capilla en el mismo ${ }^{928}$. Otra prueba documental de un inventario de 1432, refiere la existencia de un molino del Temple en Carrión, ya derribado por entonces ${ }^{929}$.

La iglesia de Santiago formaba parte de un conjunto conventual del que tan solo queda el templo citado -reformado posteriormente- y el portalón adosado al sur que en opinión de Salces y Peñil, se trataba del acceso al hospital de peregrinos: un arco apuntado adovelado ornamentado a través de un bocel. Según ellos, en el lado norte de la iglesia, donde hoy se ubica una vivienda particular, habría estado ubicado el claustro,

\footnotetext{
${ }^{924}$ RUIZ SALCES, Roberto y PEÑIL MINGUEZ, Javier. "La excavación...Op.cit, pp. 484-485. Para Martínez Díez, la única encomienda templaria en Castilla la Vieja al norte del Duero fue Villalcázar de Sirga, cerca de Carrión. Del resto que se decía que existieron en Palencia (Arroyo de los Templarios, Terradillos de los Templarios, Manquillos, Villamuriel de Cerrato, Astudillo o Carrión) niega su existencia a falta de documentación. MARTÍNEZ DÍEZ, Gonzalo. Los templarios en la Corona de Castilla. Colección Piedra Angulares. La Olmeda (Burgos), 1993, pp. 143-147.

${ }^{925}$ Este dato se conoce a través de FLÓREZ, Henrique. España Sagrada, Historia compostelana hasta hoy no publicada. Tomo 20. Libro 2, capítulo IV $1^{\text {a }}$ Edición: Madrid, 1765. Edición facsímil de la Real Academia de Historia. Madrid, 1965.

${ }_{926}^{926}$ RUIZ SALCES, Roberto y PEÑIL MINGUEZ, Javier. "La excavación...Op.cit, pp. 484-485.

${ }^{927}$ Véase AHPP. Carr.Prot 5667. Andrés Sánchez (1575-1576), s/f.

${ }^{928}$ Bajo el reinado de Fernando IV, los templarios castellanos desaparecerán cuando en 1307, Clemente V, presionado por el rey de Francia Felipe IV, extinguió la orden. Sobre el proceso de extinción, VV.AA. DELAVILLE LE ROULX, Joseph Marie. "La supp.ression des templiers" en Revue des questions historisques, $\mathrm{n}^{\circ} 48,1890$, pp. 27-62 o VV.AA. "El proceso de disolución de los templarios: su repercusión en Castilla" en Codex aquilarensis, nº12, Aguilar de Campoo,1996, pp. 87-106.

${ }_{929}$ PÉREZ BUSTAMANTE, Rogelio. "Inventario de los bienes raíces de Leonor de la Vega" en Revista de Archivos, Bibliotecas y Museos, nº1, 1978, pp. 73-104.
} 
dado que hoy día se puede ver un patio enlosado y restos de basas de columnas ${ }^{930}$. Nosotros sin embargo consideramos que este patio es de factura mucho más reciente a la ejecución del claustro medieval y que éste se ubicaría adosado al lado meridional del templo. Nos basamos para ello en el testamento mencionado en el que se indica que sobre el mismo se construyó Nuestra Señora de las Capillas, la cual, aunque no se conserva, sabemos que se ubicaba en este sector. A favor de esta afirmación existe otro documento firmado nuevamente por el mencionado Antonio de Ribera en 1573 por el que vuelve a indicar la ubicación de la capilla, señalando ser entierro de sus predecesores, donde están enterradas sus hermanas Magdalena de Berrio y Ana de Ribera $^{931}$.

La corrupción del nombre de la fundación ha provocado que hoy día a este estrecho espacio ubicado entre la iglesia de Santiago y las viviendas fronteras sea denominado por los vecinos de Carrión como callejón de las Escapillas ${ }^{932}$. El convento dejó de funcionar como tal antes del siglo XV, pues esta capilla había sido edificada en $1462^{933}$.

\section{EL SIGLO XVI}

Exceptuando las referencias a las capillas, a lo largo de todo el siglo XVI apenas hallamos documentación relativa al templo. Sin embargo, a la vista de lo conservado en la nave y capillas laterales, durante el primer cuarto del siglo debieron ser remodeladas, no así la capilla mayor, donde se intervendrá posteriormente. La fábrica románica fue sustituida por un templo de gruesos muros de sillería articulados por pilastras de sección poligonal con capitel moldurado que recorría todo el perímetro de la nave, conformado por un listel entre dos toros. Sobre cada uno apeaban los tres arcos fajones conformados de un bocel entre dos medias cañas y dos listeles. Tan sólo se conserva el arranque de los mismos, por lo que si bien no sabemos con seguridad de qué tipo eran, probablemente serían arcos apuntados que dividirían el espacio en cuatro tramos

\footnotetext{
${ }^{930}$ RUIZ SALCES, Roberto y PEÑIL MINGUEZ, Javier. Op.cit, pág. 484.

931 VIGURI, Miguel de. Heráldica...volumen 2. Op.cit, pág. 62, a su vez de AHPP. Carr.Prot 5446. Gregorio Movilla (1574-1576), s/f

932 Sobre Nuestra Señora de las Capillas véase la iglesia de San Julián, pues fue el lugar de enterramiento previo de la familia Ribera Berrio antes de ostentar el patronazgo del templo.

${ }^{933} 7$ de febrero de 1663. Colación de la capellanía de Nuestra Señora de las Capillas. ACP. Provisorato. Legajo 164, no 26342, s/f.
} 
conformados por sendas bóvedas de crucería. La mayor parte de los accesos a los espacios de culto se realiza por un arco de medio punto cuya prolongación configura bóvedas de cañón de escasa profundidad, de modo que más que parecer capillas, podrían considerarse amplios arcosolios datables por su configuración hacia 1525. La sacristía, adosada al ábside de la Epístola por su lado oriental, debió ejecutarse hacia estas fechas. Se trata de un espacio rectangular conformado por cuatro arcos apuntados sobre los que apean los nervios de la bóveda de crucería, cuya plementería ha sido posteriormente enlucida.

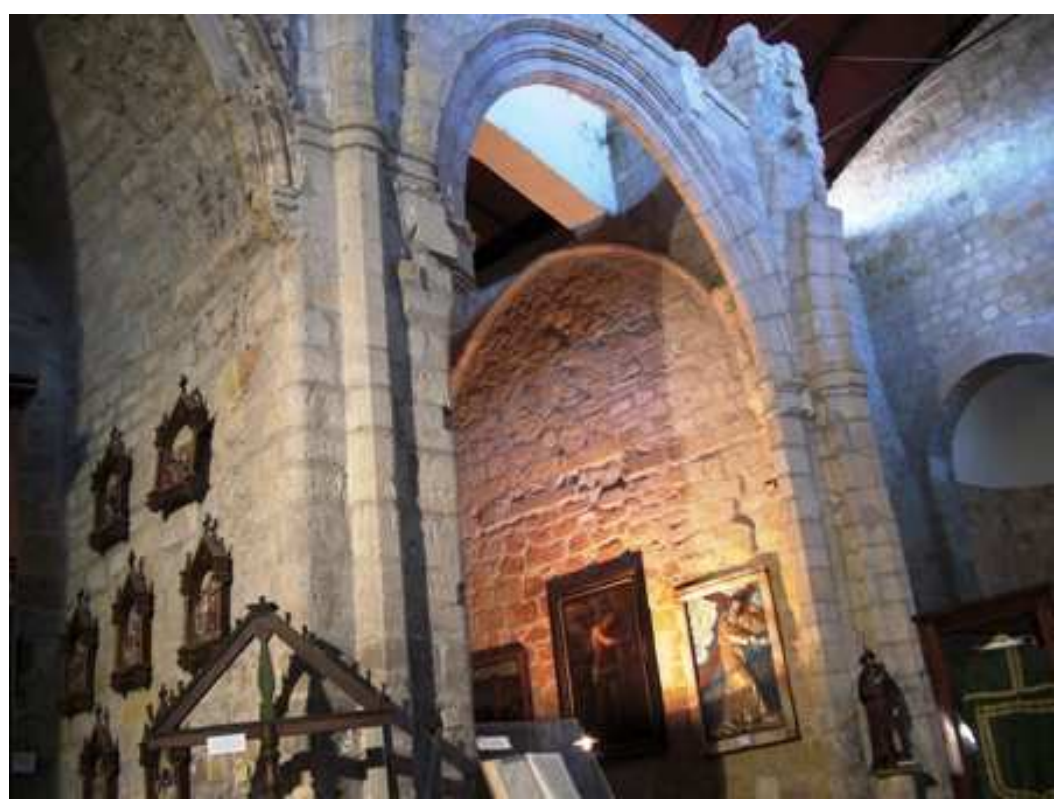

\section{Nave del Evangelio en la que se aprecian las intervenciones del siglo XVI.}

Nos consta que el templo presentaba problemas de cimentación, lo que habría justificado el desplome de parte de la torre románica. La primera noticia sobre la misma data del mayo del año 1580, en que el maestro de albañilería carrionés Antonio de Cuéllar ${ }^{934}$ se compromete a reconstruir su remate. En las condiciones de la obra, por la que recibiría veinte mil maravedíes, se indica que la torre consta de aguja y poseía almenas en la parte contigua, lo que aportaría una apariencia defensiva al templo. Debían abrirse cuatro ventanas de ladrillo policromado de rojo. Al poco tiempo de

\footnotetext{
${ }^{934}$ Sobre el mismo, véase el apartado dedicado a los datos biográficos de los artífices locales.
} 
comenzar las obras, el artista estaba en prisión ${ }^{935}$. El albañil se encontraba realizando paralelamente el reparo de la torre de la iglesia de Santiago de Arconada, que también presentaba daños, por lo que podría estar relacionado el incumplimiento de la obra carrionesa en el plazo establecido dada su ocupación en otros menesteres.

El estado ruinoso del templo motiva la petición de un informe a un maestro experto en 1593 en el que se hicieran constar los daños. Por el mismo, el maestro de cantería trasmerano Juan de la Lastra declaraba que el templo necesitaba una intervención de carácter urgente. El clérigo y el mayordomo de Santiago, al no disponer de fondos, optan por tomar un censo de tres mil maravedíes para cumplir con la recomendación del maestro ${ }^{936}$. Suponemos que sí llegarían a realizarse estas intervenciones, dado que el Obispo de Palencia, don Rodrigo de Guinea, concedió licencia a la iglesia para tomar los réditos del censo solicitado.

\section{EL SIGLO XVII}

En 1607, Alonso de Tejedor, maestro local carrionés, recibe quince ducados por las labores de adecentamiento de la capilla mayor, consistentes en tabicar, enlucir y mesurar el arco de entrada a la misma ${ }^{937}$. Por entonces se abriría probablemente el sencillo arco de medio punto dovelado y sin molduración que da acceso al ábside central, análogo a los que existen en los altares colaterales. En los tres, las bóvedas de horno van precedidas de un tramo recto cubierto con bóveda de cañón, enlucida de blanco hasta el nivel de la imposta. Estas labores se pueden vincular con el encargo de “...rreparar e renovar la dicha capilla..." que refiere su patrón, don Juan Ponce de León, clérigo de Sevilla, que debe hacerse en una carta emitida a finales de 1597 para lo que dona doce mil maravedíes y que no se realizan hasta unos años más tarde ${ }^{938}$.

La siguiente intervención de entidad se produce en la parte correspondiente a los pies del templo “...por estar amenazando muy gran rruina y peligro...”.

\footnotetext{
${ }^{935}$ AHPP. Carr.Prot 5616. Melchor de la Rúa (1578-1580), s/f.

${ }^{936}$ Véanse los datos biográficos de Juan de la Lastra en el capítulo respectivo. AHPP. Carr.Prot 4595. Juan Birtus (1592-1594), s/f.

${ }_{937}^{937}$ AHPP. Carr.Prot 5297. Pascual López (1607), s/f.

${ }^{938}$ La escritura de dotación fue firmada el 24 de noviembre de 1597. AHPP. Carr.Prot 5656. Pedro Saldaña (1597), s/f.
} 
Concretamente se actúa sobre la base de la torre y la parte del coro colindante a la misma, que deben ser fortificadas. Tras varias subastas en las que pujaron Pedro del Arenal y el maestro de cantería oriundo de Penagos, Juan de Cajigosa ${ }^{939}$, la obra quedó rematada en éste último por 3.400 reales en julio de $1618^{940}$. Sin embargo, no se hizo cargo de la misma, ya que se la cedió de inmediato al maestro de albañilería y cantería local Juan González de la Mata ${ }^{941}$. Primeramente debían construir un estribo de ocho pies de anchura en piedra de Palacios del Alcor que subiera hasta el tejado que cubre el cuerpo del templo. Además debían macizar la ventana del coro, retirando las piedras viejas, que no podían ser reutilizadas porque estaban molidas. Debían realizarse dos arcos macizados de buena piedra de modo que el del centro que da acceso al templo, fuese de mayor tamaño para que “...sirua de salida para la gente...” y el de su derecha, ubicado junto a la capilla del Bautismo, sea de la forma y manera que aquél. También debía practicarse una pequeña puerta de acceso al coro, del mismo ancho del pilar que debía construirse. Parece que las obras, que debían finalizarse en un año, proseguían a buen ritmo, pues a principios de 1619, un feligrés de Santiago, don Rodrigo de Avecia, concedía a cambio de unas sepulturas en el templo, una limosna para la ayuda del reparo de la torre “...que se va haciendo... 942 ". La deuda adquirida por el cura y mayordomos de Santiago con Juan González, no fue liquidada completamente hasta el año 1628. Sin embargo, supieron compensar con creces al maestro, abonándole mil ciento cincuenta reales más de lo acordado en el contrato, por “...conbenir en el provecho y brevedad de la dicha obra... ${ }^{943}$ ".

El informe remitido por el consistorio en febrero del año 1636 sobre hundimientos simultáneos en este templo y en los de Nuestra Señora de Belén y San Julián pone de relieve que se produjo alguna catástrofe natural ${ }^{944}$. Efectivamente, a finales de 1635 una “...gran tempestad de aire y aguas...” sobrevino en la villa, según apunta la documentación de la iglesia de San Andrés, que quizá no figure en dicho informe por no resultar entre las más afectadas ${ }^{945}$. El vendaval y las lluvias torrenciales

\footnotetext{
${ }^{939}$ Véanse los datos relativos al mismo en el apartado de datos biográficos de artistas

${ }^{940}$ AHPP. Carr.Prot 5401 Francisco Moro de Saldaña (1618), s/f.

${ }^{941}$ Sobre estos maestros véase el apartado dedicado a los mismos. La escritura de traspaso de la obra en AHPP. Carr.Prot 4756. Gregorio Cisneros (1612-1618), fol 511 y ss.

942 1619. ACP. Provisorato. Legajo 32, no 3622, s/f.

${ }^{943}$ La carta de pago se efectúa el 2 de marzo de 1628, con el cura de Santiago, Juan de Micieces y su mayordomo, Bernardino de Vivriesca. AHPP. Carr.Prot 5411. Francisco Moro de Saldaña (1628), s/f.

944 Sesión de 9 de febrero de 1636. AMC. Libro 1, Sesiones municipales (1618-1637), s/f.

${ }^{945}$ ADP. Carrión. San Andrés. Libro $2^{\circ}$ de Fábrica (1614-1637), fol 179v.
} 
amenazaron notablemente la estabilidad y seguridad de la torre, por lo que se decide derribar los dos cuerpos superiores, el primero con maromas y el segundo a mano, todo a vista nuevamente del maestro Juan González de la Mata. Al hallarse la iglesia sin fondos, los parroquianos de la misma deciden colaborar con "mandas graciosas", sendos donativos personales destinados a reedificar la parte afectada ${ }^{946}$. Hacia 1650 se llevó a cabo la consolidación de su parte inferior a través de un estribo y dos arcos de piedra.

\section{EL SIGLO XVIII}

La bóveda de crucería que cubriría el templo desde el siglo XVI y de la cual sólo perviven los arranques de sus arcos fajones, no se conservaba ya en 1738, cuando el cura y mayordomo de la iglesia, disponiendo de caudales suficientes, deciden “...encascar, luzir y labar la nabe...” por hallarse indecente ${ }^{947}$. El único postor de la obra y por tanto en quien se remató, fue el maestro alarife José Iglesias, perteneciente a una familia de artífices carrioneses que lograron adjudicarse la mayor parte de las obras del momento ${ }^{948}$. En las paredes maestras de los cuatro lados del templo se debían montear arcos de medio punto por su parte interna que sirvieran de base para la cubrición de la nave. En ella se debían disponer cinco bóvedas de arista con dos lunetos a rosca, de modo que se despiezaría una bóveda por cada tramo, incluido el del coro. El casco de la iglesia, sin incluir la capilla mayor ni las laterales, debía ser blanqueado de yeso, ascendiendo la obra a dos mil quinientos reales. Nada se conserva de esta intervención, pues sufrió los avatares de la guerra de la Independencia. Los muros pétreos de la nave dejan hoy paso a una cubrición moderna, a la que nos referiremos posteriormente.

En 1755, el remate de la torre amenaza con derrumbarse pero su reparación no puede costearse debido a la falta de fondos. Estos hechos llevaron al Cabildo y a la comunidad eclesiástica a recurrir a los diezmos, razón por la cual se establece un pleito. Este litigio contiene información sobre la antigua torre, que al parecer en algún tiempo fue íntegramente de piedra, pero un huracán produjo el derribo del último cuerpo y el

\footnotetext{
${ }^{946}$ AHPP. Carr.Prot 5182. Jerónimo Laso (1636), fol 380 y ss.

${ }^{947}$ El contrato y condiciones de la obra se firman el de 1738. AHPP. Carr.Prot 5880. Manuel Vega (17381739), s/f.

${ }^{948}$ Sobre los Iglesias, véase el apartado dedicado a la biografía de los maestros locales.
} 
que le sustituyó fue de madera, ladrillo y adobe ${ }^{949}$. Sólo cuatro año más tarde, en 1759 , se nombran peritos a Manuel de Cieza y José Iglesias para que reconozcan la obra. Éstos, ante el inminente derrumbe, declaran la necesidad de desmontar el último cuerpo de la torre, desde el piso de las campanas hasta su coronación, encargándose del nuevo proyecto el citado José Iglesias, alarife carrionés ${ }^{950}$.

Proyecto de reconstrucción del remate de la torre. José Iglesias. 1759. ACP. Provisorato. Leg. 491.

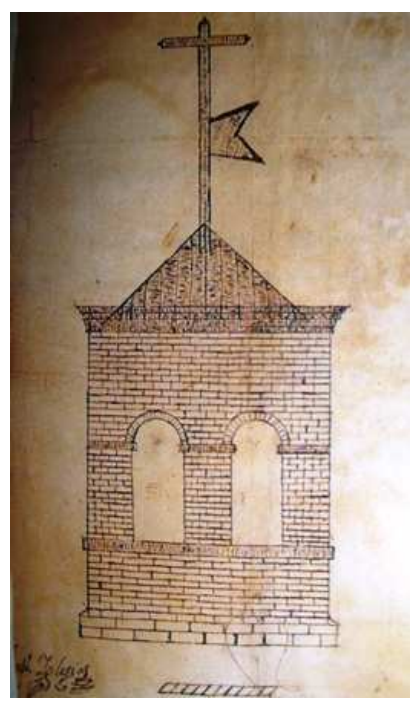

En él se muestra un cuerpo de ladrillo recorrido por varias impostas, una situada en la base de los ventanales, y otra en el arranque de los arcos. Para el cierre de la torre, José Iglesias emplea el mismo recurso que en su diseño de la torre de la ermita de San Juan de Cestillos. Se trata de un remate formado por una cornisa de ladrillos dispuestos en forma de gola, que sobresale de un tejado a cuatro aguas con veleta ${ }^{951}$. Pero no será hasta 1764 cuando el alarife carrionés Leonardo Iglesias ${ }^{952}$ y Manuel Becerril, vecino de Paredes de Nava, firmen la escritura de obligación de su realización por ocho mil reales. Estos últimos seguirán las trazas de los dos maestros citados, salvo en la construcción del tejado propuesto, optando por una cúpula con linterna. Sin embargo esta estructura no evitó la ruina de la torre y tuvo que ser desmontada poco después. Según consta por

\footnotetext{
${ }^{949}$ Estas afirmaciones acerca de los materiales de la torre, vienen confirmadas en la declaración de condiciones de Manuel de Cieza y José Iglesias para la ejecución de la obra. VIGURI, Miguel de y Sánchez, José Luis. Op.cit, pág. 371 y también en GÓMEZ PÉREZ, Enrique y MARISCAL ARRANZ, José. Iglesia...Op.cit, pág. 87.

${ }^{950}$ Las condiciones para la ejecución de la torre, previo examen del estado de la misma se encuentran trascritas en VIGURI, Miguel de y Sánchez, José Luis. Op.cit, pp. 371-373.

${ }^{951}$ El diseño puede verse en ACP. Provisorato. Legajo 491 (1751-1756).

${ }^{952}$ Sobre los Iglesias, remítase al capítulo dedicado a la biografía de los maestros locales.
} 
carta de pago del año 1790, se pagaron más de mil reales al maestro Santiago Sahagún por rehacer el tejado, en el que retomó el modelo de capitel y veleta ${ }^{953}$.

\section{EL DEVENIR A PARTIR DEL SIGLO XIX}

Con la llegada de la Guerra de la Independencia, la iglesia será usada con fines militares por las tropas francesas, resultando incendiada en agosto de 1811, como la iglesia de Santa María. A excepción de la torre, el templo quedó completamente arruinado, por lo que fue cerrado al culto para evitar una catástrofe mayor ${ }^{954}$. Ante el mal estado, la comunidad de Santiago emite en 1813 una petición al ayuntamiento para que le proporcione maderas y de este modo, proceder a la reconstrucción de la techumbre ${ }^{955}$. Se sugiere la extracción del material de la abadía de Benevívere, pues por entonces el cenobio agustino había sido desamortizado por el decreto de Bonaparte de $1809^{956}$. El reconocimiento del templo se hizo en 1814 bajo la supervisión del arquitecto, vecino de Palencia Francisco Prieto Gómez, a quien ya nos referimos al hablar del templo de Santa María, pues en el mismo desempeñó análoga tarea de veedor dado que corrió idéntica suerte en $1811^{957}$.

La iglesia fue de nuevo acondicionada en 1850, con la inversión que realizó el párroco de entonces, don Eleuterio Merino, canónigo de la catedral de Palencia ${ }^{958}$. El mismo encargó en 1855 la construcción de un órgano para el templo, con los restos de las cañerías de los de los conventos desamortizados de Santa Isabel y Benevívere, cuya ejecución corrió a cargo del maestro palentino José Otorel, a quien debemos la ejecución de algunos órganos de la provincia de Zamora, en los alrededores de Toro, y sobre todo de buena parte de los del Obispado de Palencia ${ }^{959}$. Los pagos por el nuevo

\footnotetext{
${ }^{953}$ ADP. Iglesia de Santiago Libro $1^{\circ}$ de Cuentas de Fábrica (1778-1849), fol 89.

954 Ibídem, fol $221 \mathrm{v}$.

${ }^{955}$ RUIZ SALCES, Roberto y PEÑIL MINGUEZ, Javier. Op.cit, pág. 486, a su vez de AMCC, Libro 2 , Sesiones Municipales (1759-1814), fol 23 y v.

${ }_{956}$ Aunque había sido cerrado al culto, se conservaba en buen estado. AGS. Gracia y Justicia. Papeles del Gobierno intruso. Asuntos civiles y eclesiásticos. 1210. Palencia, 7 de julio de 1810.

${ }^{957}$ ADP. Iglesia de Santiago. Libro $1^{\text {o }}$ de Cuentas de Fábrica (1778-1849), fol 246. Una vez que dio su visto bueno, Ramón Iglesias rehízo la escalera, fol 247. Su intervención en Santa María en ASMC. Libro $3^{\circ}$ de Fábrica (1805-1850), fol 80v. Sobre Francisco Prieto, remítase al apartado dedicado a los maestros locales.

${ }^{958}$ ADP. Iglesia de Santiago. Libro $2^{\circ}$ de Cuentas de Fábrica (1850-1894), s/f.

${ }^{959}$ En 1833, José Otorel finaliza el órgano de la Capilla de la Cofradía de la Soledad en Palencia, realizado según el proyecto presentado por Leandro Garcimartín en 1727. Los años cuarenta resulta de un intensa actividad para el artista. Ejecuta el órgano de la iglesia de San Juan Bautista de Villaumbrales en
} 
órgano se realizaron en 1865 en que se acabaron de pagar los cinco mil reales en que se ajustó su construcción ${ }^{960}$.

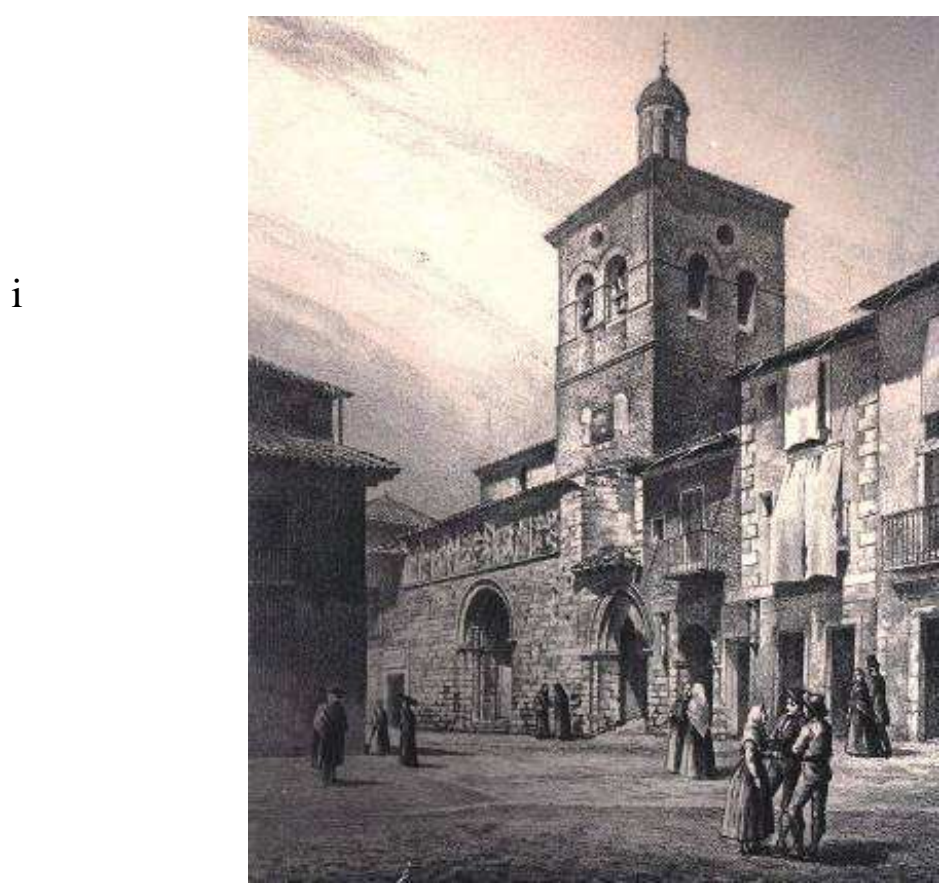

Vista del templo a mediados del siglo XIX con la linterna en la torre. Grabado de Parcerisa extraído de Recuerdos y bellezas de España.

1843 y un año después el de la Nuestra Señora la Blanca de Villalcázar de Sirga, procedente de la ermita de Nuestra Señora del Río. En 1845 Trasladó y asentó desde el monasterio vallisoletano de Palazuelos el órgano que Ramón Guerra había ejecutado en 1831. Fue llevado a la iglesia del Salvador de Monzón de Campos, donde se ubica desde entonces. Se encarga del órgano de Nuestra Señora del Castillo de Torremormojón en 1848 y un año después del de San Martín de Ribas de Campos. Entre 1851y 1852 se hace cargo de la ejecución de los órganos del templo de San Cipriano en Pedraza de Campos y el de la ermita de Torremarte en Astudillo. Reformó el órgano de la ermita de Valdesalce, en Torquemada en 1876, pieza realizada hacia 1739 por Manuel Cuebas. Los órganos de la ermita de la Piedad de Herrera de Pisuerga y el del convento franciscano de Palencia, los lleva a cabo en 1857. En la capital, son de su mano los órganos de Nuestra Señora de la Calle, del Convento de Agustinas Recoletas, realizados en 1864 y 1866, respectivamente, y también el de la iglesia del Carmen, de 1885. En 1877 realiza los de la iglesia de Santa María de Arconada y las clarisas de Calabazanos. De 1882 data el órgano de Santa María de AStudillo y en Aguilar de Campoo, la iglesia de San Miguel le mandó ejecutar el suyo en 1888. VV.AA. Inventario...Op.cit, pp. 66, 91,97, 105, 137, 282, 319, 331,362, 375, 384, 387, 417, 444, 476, 487,505, 528La última obra que consta documentalmente de Otorel es el órgano de Santa María de Carrión, en el año 1890. Además se conserva la inscripción que indica su fecha y autor. Las cartas de pago al maestro organero en ADP. Carr. Santa María. Papeles y legajos diversos, 85. Cuentas de fábrica 1888-1912, s/f y en ASMC. Libro 6º de Fábrica (1883-1908), s/f. El órgano de Villasarracino, si bien no está fechado, se considera también de sus obras más tardías. VV.AA. Inventario...Op.cit, pág. 166.

${ }^{960}$ ADP. Carr. Iglesia de Santiago. Libro $2^{\circ}$ de Cuentas de Fábrica (1850-1894), s/f. 
La ruina que presentaba en 1887 el arco junto a la portada sur de Santiago condujo a plantear su demolición inmediata pero afortunadamente no se llevó a cabo ${ }^{961}$. Desde mayo de 1895, la iglesia de Santiago queda suprimida como parroquia y será agregada a San Andrés, quedando como filial de la misma ${ }^{962}$. Fue declarada Monumento histórico artístico el 3 de junio de $1931^{963}$. En el año 1970 el templo se hallaba desprovisto de bóvedas, el crucero se encontraba cubierto de matorrales y los escombros se acumulaban en los ábsides. Ante semejante estado de ruina y con el fin de proteger sus bienes muebles, queda desprovisto de imágenes, trasladándose éstas a la iglesia de Santa María ${ }^{964}$. Seguidamente se intervino sobre el pórtico recomponiendo algunas cabezas del Apostolado y los arquillos donde se insertan las figuras. Además se cegó la ventana que se ubicaba en la fachada. Por entonces se construye la vivienda con cobertizo para panera y animales frente a los ábsides del templo, dejando solo exenta la fachada y el lado septentrional ${ }^{965}$. Con el fin de evitar que la ruina del edificio avanzase, en 1974 se llevaron a cabo obras urgentes de apuntalamiento y consolidación de sillares. Además se reforzaría la torre y se construiría una escalera de caracol que posibilitase el acceso a las campanas. Estas medidas no eran suficientes, pues se hacía necesario un proyecto de cubrición íntegra del templo que llegaría en 1976. Sin embargo, la escasez presupuestaria conllevó una intervención provisional a base de faldones de uralita revestidos de teja apoyados sobre cerchas metálicas que motivó la reconstrucción del tejaroz tan sólo un año más tarde ${ }^{966}$.

\footnotetext{
${ }^{961}$ AMCC. Sesión de 15 de julio de 1887. Libro 13, Sesiones municipales (1887-1892) fol 31.

962 RAMÍREZ DE HELGUERA, Martín. El libro...Op.cit, pág. 155.

963 AZCÁRATE RISTORI, José María de. Monumentos españoles ... Op.cit, pág. 442, La fecha exacta de la declaración, que omitía el otro manual, figura en VV.AA. Catálogo monumental...Op.cit,, pp. 461-462

${ }^{964}$ Un inventario sin fechar contiene un listado de los retablos que existían en este templo: el retablo mayor estaba dedicado a la Virgen del Carmen, imagen flanqueada por San Roque y San José, y rematando el retablo, la imagen de Santiago flanqueado por Escipión y Escipiniano -debe referirse a San Crispín y San Crispiniano, conservadas hoy día, pues las otras advocaciones son inexistentes-. En el lado del Evangelio, se conservaban tres retablos, uno dedicado a Cristo con San Miguel en su parte superior, otro dedicado a la Virgen de los Dolores y un Cristo sobre el árbol sagrado. Por último existían dos retablillos, uno dedicado a Santa Rosa y otro a la Virgen de la Paz. Estas dos últimas imágenes probablemente sean las que se conservan en la capilla del Crucifijo de Santa María. El resto de las imágenes se hallan en el Museo de Santiago. ASMC, del Libro de Inventario de la parroquia de Santa María (1861-1953), s/f.

${ }^{965}$ Así se indica en unas hojas sueltas de factura reciente y sin firma insertas en el Inventario de Santa María AGA. (3) 115. Caja 26/58. Con parte de la suma restante se llevaron a cabo diversas reparaciones en Santa María. Esta información queda corroborada por el informe que en 1981 realiza el arquitecto Luis Arranz Algueró sobre la historia del edificio. AGA 52/18602.

${ }^{966}$ AGA. (3) 115. Caja 26/105.
} 
La revalorización del patrimonio artístico de Carrión que se estaba dando por aquellos años cuajó en 1981 con la puesta en marcha de un museo de carácter permanente en la villa. El lugar apropiado para su ubicación era el templo de Santiago, dada que no tenía función de culto desde hacía mucho tiempo. Del proyecto de rehabilitación y acondicionamiento se hizo cargo el arquitecto Luis Arranz Algueró, que se decantó por un diseño arquitectónico que aunase funcionalidad y modernidad, evitando cualquier tentativa de imitación a la par que respetara y enfatizara los elementos constructivos originales. Para la bóveda optó por una estructura que por su ligereza respetara los muros sin apoyarse en ellos, es decir, una cubierta en suspensión de aluminio. Ésta iría compartimentada en cuatro tramos -pies del templo, nave y crucero- y tres arcos, correspondientes a la estructura original de triple nave que tendría la iglesia originalmente según el arquitecto. En cuanto al suelo, se diseñó un pavimento que combinaba ladrillo dispuesto de canto y piedra en franjas verticales. Por último se acondicionaría la torre y cámaras anejas a la misma para exponer piezas, de modo que se dispusieron forjados sustentados por vigas metálicas ${ }^{967}$.

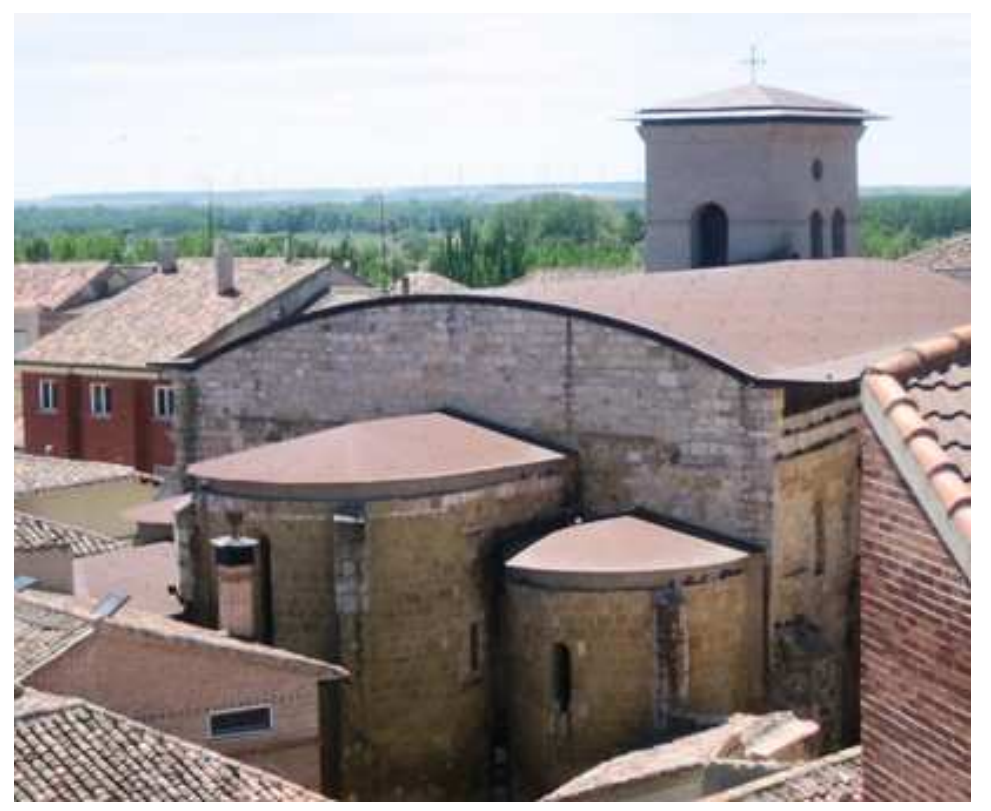

Estado actual del templo con las cubiertas modernas y la torre sin linterna.

\footnotetext{
967 La propuesta de la intervención de Luis Arranz en AGA 52/18602. Podemos verificar esta restauración, que tuvo un coste de diez millones de pesetas en AGA. Expedientes de restauración de monumentos. Caja 51/11328.
} 


\section{LAS CAPILLAS: ESPACIOS DE CULTO}

La mención más antigua de la advocación de las capillas que existieron en el templo de Santiago remonta al siglo XVI, probablemente, cuando, como indicamos, fue renovado el templo románico. Las diversas referencias documentales nos han indicado su posible situación.

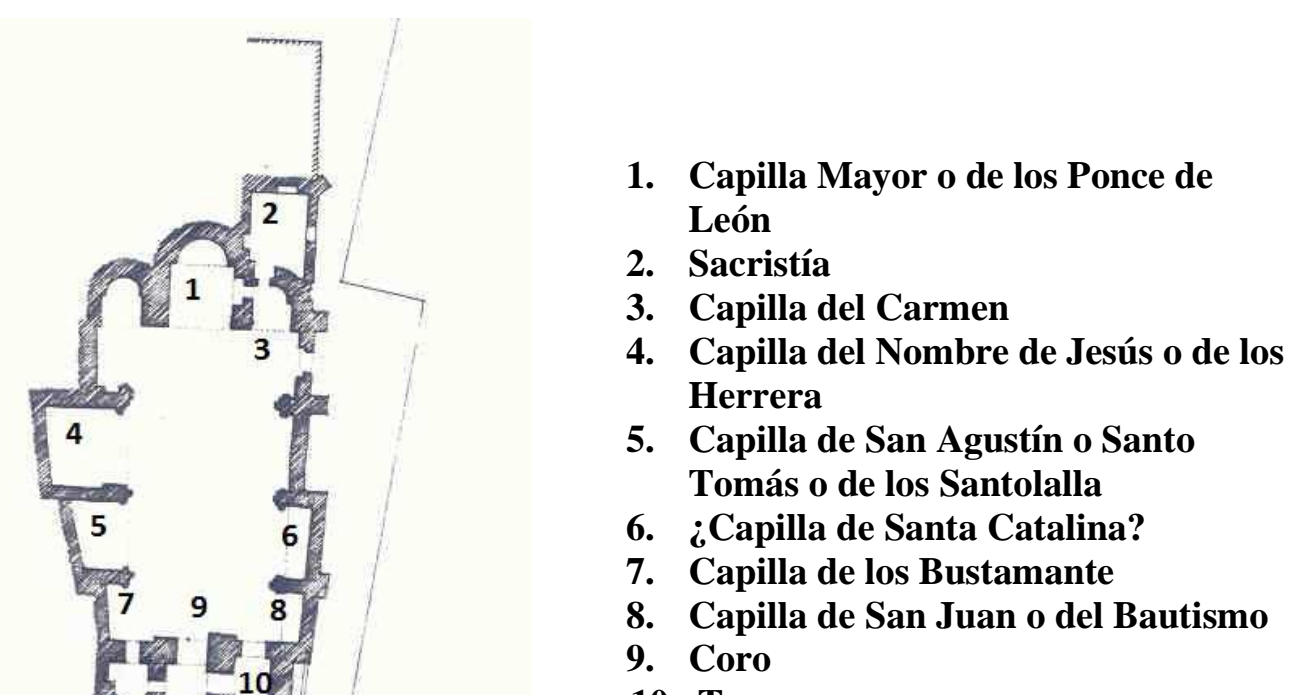

10. Torre

Plano de Santiago con los espacios de culto a partir del siglo XVI.

\subsection{LA CAPILLA MAYOR O DE LOS PONCE DE LEÓN}

Esta capilla perteneció a los Ponce de Léon, un linaje andaluz heredero de la nobleza leonesa cuyos miembros, convertidos en Condes de Arcos, monopolizaron un inmenso patrimonio que hoy se extiende principalmente por las provincias de Málaga, Sevilla y Cádiz ${ }^{968}$. A principios del siglo XVI, e incluso antes, asistimos a la creación de

${ }^{968}$ CARRIAZO RUBIO, Juan Luis. "Dos siglos de estudios...Op.cit, pág. 9. 
una nobleza "sagrada", con los Ponce de León a la cabeza en territorio andaluz - junto a los Sotomayor, Zúñiga, Portocarrero y Téllez Girón- cuyo comportamiento se regía por un patrón eminentemente religioso que reforzaba los lazos con la realeza. En el contexto de engrandecimiento familiar es habitual el recurso de la carrera eclesiástica en los vástagos masculinos ${ }^{969}$. Por ello no resulta extraño que los primeros patrones conocidos de esta capilla, Sebastián y Gaspar Ponce de León, desempeñasen respectivamente los cargos de maestre escuela y canónigo de la iglesia de Sevilla y capellán de Carlos V y el segundo, maestre escuela y canónigo de Sevilla y de Palencia posteriormente. Así nos lo remite el que era patrón de la capilla en 1597, don Juan Ponce de León, clérigo beneficiado del Arzobispado de Sevilla que la había heredado de don Gaspar Ponce, que aún vivía en 1594, cuando encarga a los maestros Santiago de Sigüenza y Marcos de la Torre $^{970}$ que se dispongan uniformemente varias sepulturas para él y sus descendientes $^{971}$.

En cuanto don Juan Ponce de León accedió al patronazgo, supervisó algunas intervenciones que llevó a cabo: ejecución de un altar de azulejos, enlosado de ladrillo, dotación de escaños de nogal y renovación de las imágenes de Nuestra Señora y Santiago que presidirían el retablo de la capilla. Además refería las mejoras que debían practicarse entre las cuales se enumeran: la construcción de la sacristía, la eliminación de las gradas, la bajada del retablo y la renovación de la capilla. Para ello, incorpora en el mayorazgo familiar una renta de doce mil maravedíes de inversión “...para su conservación e maior ornato e dezençia... ${ }^{972 " ~ E s t a s ~ i n t e r v e n c i o n e s ~ f u e r o n ~ r e a l i z a d a s ~}$ poco después, como deducimos de la carta de pago del albañil Alonso de Cuéllar de 1607 en concepto de sus trabajos en la capilla mayor ${ }^{973}$.

El siguiente patrón conocido de la capilla mayor fue don Manuel Ponce de León y Mendoza, que dicta testamento en el año 1627, expresando su voluntad de ser

\footnotetext{
${ }^{969}$ Este proceso de religiosidad de los linajes andaluces es objeto de estudio en PÉREZ GARCÍA, Rafael M. "Espirituales, cortes señoriales y linajes nobiliarios. Construcción y desarrollo de climas sacroespirituales de referencia social en la Andalucía de los siglos XVI y XVII” en Historia y Genaología, nº, 2011, pp. 133-153, especialmente de nuestro interés, pp. 133-139 y 150-152.

${ }^{970}$ Sobre ambos se hablará en el apartado relativo a los maestros.

971 AHPP. Carr.Prot 4595, Juan Birtus (1592-1594), s/f.

${ }^{972} \mathrm{La}$ escritura de dotación fue firmada el 24 de noviembre de 1597. AHPP. Carr.Prot 5656. Pedro Saldaña (1597), s/f.

${ }^{973}$ AHPP. Carr.Prot 5297. Pascual López (1607), s/f. Nos referimos a los mismos en el apartado dedicado al siglo XVII.
} 
sepultado en su capilla ${ }^{974}$. Su esposa, doña Ana de Alarcón Colmenares y Villegas, en su testamento de 1633, indica el mismo deseo y en el que dicta en 1657, refiere la misma voluntad ${ }^{975}$. Como vemos, la redacción de un testamento no indicaba un fallecimiento próximo del testador, sino que de este modo el testador se aseguraba sus bienes en orden por precaución. De hecho, observamos cómo más de veinte años después, don Manuel Ponce de León dispone la ejecución del retablo mayor el 25 de enero de 1655. La obra fue encargada al ensamblador carrionés Juan Bautista Pérez ${ }^{976}$. El retablo, realizado en madera de pino, tendría una anchura aproximada de unos cuatro metros y medio por siete metros y medio de altura, alcanzando el nivel de la ventana abocinada que se ubica en su parte central. Constaba de un banco y dos cuerpos separados por columnas entorchadas de órdenes corintio y compuesto, respectivamente. En la hornacina principal debía situarse la imagen de Nuestra Señora “...que ssolía tener el rrettablo viexo...", es decir, la que Juan Ponce de León refiere en 1597 que había dotado en unas obras anteriores. En las enjutas debían colocarse los escudos del fundador y patrón de la capilla. De haberse conservado las armas familiares en la capilla, el escudo que campearía sería partido con la siguiente lectura: 1, partido de León, en campo de plata un león de gules, 2, de Aragón, en campo de oro cuatro palos o bastones de gules y, bordura del escudo de azur con ocho escudetes de oro con una faja de azur, de Vidaurre, Navarra ${ }^{977} .2$, de Mendoza, cuartelado en sotuer: 1 y 3: banda. 2 y 4: leyenda; “AVE MARÍA GRACIA PLENIS”.Por la obra, que debía finalizar en dos años y tres meses, Juan Bautista Pérez recibiría 2.650 reales y mientras se ocupaba de la misma, ejercía el cargo de mayordomo del templo. Aún se conservaba íntegra en 1890, cuando Ramírez de Helguera visita el templo. Las imágenes que se hallaban a los lados del retablo no eran las originales sino dos obras de factura moderna: un San Antonio y un San Roque, este último adquirido en Barcelona en 1888 y conservado en el museo de este templo ${ }^{978}$.

Aún en 1665, don Manuel Ponce continúa con el patronazgo de la capilla, pues es entonces cuando concierta el dorado y estofado del retablo que él mismo había

\footnotetext{
${ }^{974}$ AHPP. Carr.Prot 5223, Jerónimo López (1627), s/f.

${ }^{975}$ AHPP. Carr.Prot 5229, Jerónimo López (1633), s/f y 5198. Jerónimo Laso (1657-1658), s/f.

${ }^{976}$ AHPP. Carr.Prot 5206. Antonio López (1655-1656), s/f. Sobre Juan Bautista Pérez, remítase al capítulo dedicado a los ensambladores locales.

${ }^{977}$ Esta primera partición corresponde a los Ponce de León. El homónimo tataranieto de Pedro Ponce de León se esposó con la nieta de Jaime Jérica, que era hijo del rey de Aragón, Jaime I y Teresa de Vidaurre, de ahí la aparición en el escudo de Aragón y Navarra.

${ }^{978}$ RAMÍREZ DE HELGUERA, Martín. El libro...Op.cit, pág. 155.
} 
encargado hacía una década ${ }^{979}$. La obra fue encargada al artista Pedro de Guillerón, residente en la ciudad de Valladolid. Debía dorar todo el retablo de oro bruñido y finos colores, disponiendo algunos cogollos en los arbotantes. También tenía que adecentar las tallas de Nuestra Señora y de Santiago y la custodia, que, ubicada en el centro del banco, iría rematada con una pintura del cordero degollado con los siete sellos del Apocalipsis. A ambos lados del mismo, se debían pintar dos lienzos con San Pedro y San Pablo y en los dos tableros laterales del primer cuerpo, la historia de Santiago “...v lo que escoxieren los señores que mandan dorar dicho rretablo...”. Así, entre los dos contratos, el de la ejecución del retablo y el de su dorado, podemos conformarnos una idea bastante precisa de obra de dos cuerpos, probablemente de líneas clasicistas, que presidió la capilla mayor y del que hoy sobrevive tan sólo la talla del Santiago Matamoros, emplazada en el mismo lugar original como pieza del museo. Se trata de una obra anónima del siglo XVII, probablemente ejecutada a mediados de la centuria como corresponde al retablo para el que fue encargada, donde el Apóstol, a pesar de blandir la espada, mantiene una posición que peca de cierto hieratismo. Su rostro resulta igualmente estático, carente de expresión y ajeno a lo que ocurre bajo sus pies, donde dos infieles yacen moribundos confundidos entre el terreno. Igualmente el blanco corcel sobre el que monta Santiago tiene pocos visos de realismo, pues, más bien, parece un caballito de feria.

Don Manuel Ponce de León y Mendoza había transmitido en 1642 la sucesión de su mayorazgo así como las casas de la plaza de Santiago en que vivía y el patronazgo de la capilla mayor de la iglesia a su primo don Manuel Berrio Ribera, patrón éste a su vez de la capilla mayor de la iglesia de San Julián ${ }^{980}$. Berrio adquiriría estos privilegios a la muerte de don Manuel Ponce, que según los datos anteriores, debió producirse hacia 1656. Francisco Antonio Berrio, señor de San Andrés de la Aldea, la Torre y Colmenares y capitán del regimiento de infantería de Granada, heredó la capilla como hijo legítimo de don Manuel Berrio. Bajo su patronazgo, detentado entre 1733 y 1741, se dieron ciertos desajustes en las cuentas que dejó al fallecer a su administrador, siendo

\footnotetext{
${ }^{979}$ Por la obra, el dorador recibiría cinco mil reales. AHPP. Carr.Prot 5771. Andrés Simón Aguilar (1665), fol 488 y ss.

${ }^{980}$ El traslado de la escritura fechada en 1642 en AHPP. Carr.Prot 5773 fol 375 y ss Andrés Simón Aguilar (1667).
} 
posteriormente subsanadas $^{981}$. En 1741, era don Antonio de Berrio Ponce de León ${ }^{982}$, señor de San Andrés de la Aldea, y capitán de infantería en el regimiento de Granada, el poseedor de dicha capilla ${ }^{983}$. La última referencia a esta capilla data de 1794 en que, tras ser derruida la ermita de Nuestra Señora de las Capillas fue trasladado desde allí a este templo el sepulcro del comendador Antonio de Ribera ${ }^{984}$.

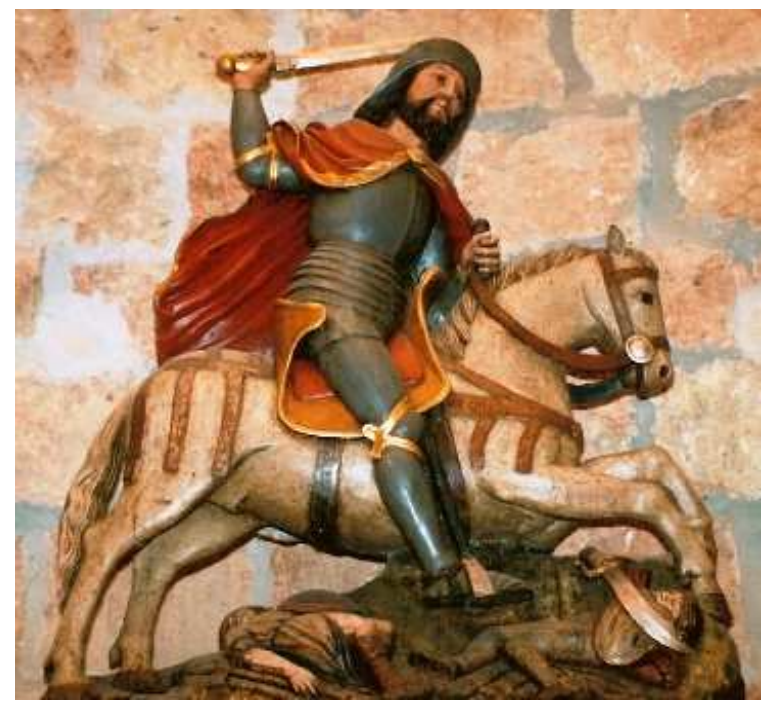

\section{Santiago Matamoros en la capilla mayor. \\ $(118 \mathrm{~cm} \times 105 \mathrm{~cm} \times 31 \mathrm{~cm})$.}

Museo de Arte Sacro.

\section{Estado actual de la capilla mayor de Santiag}

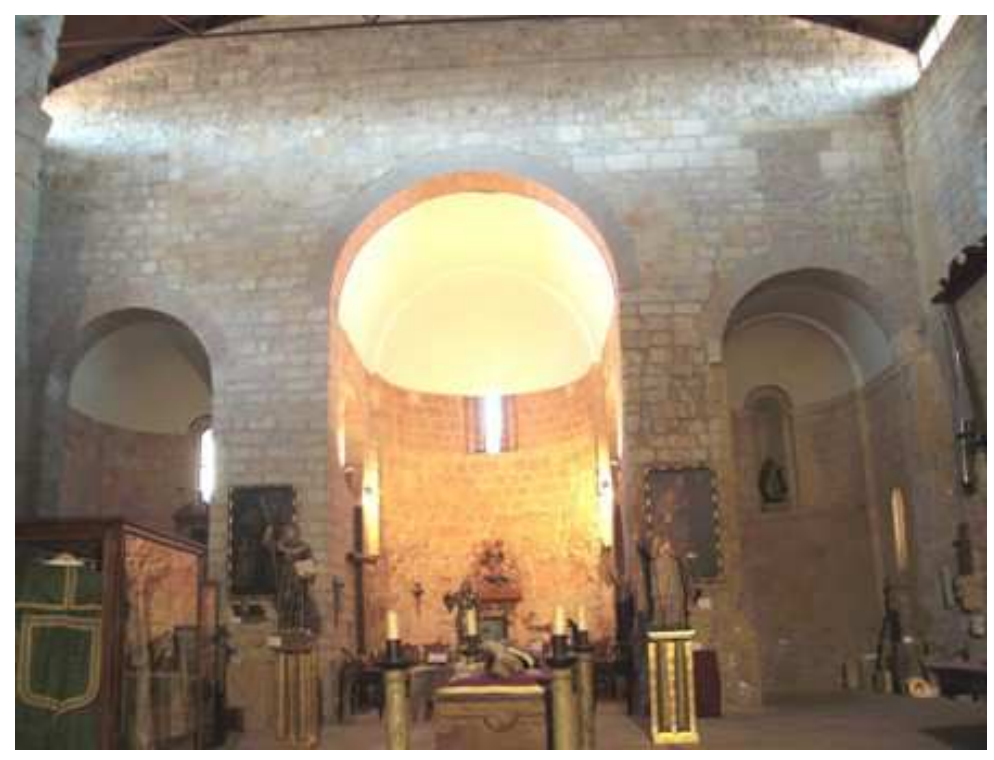

\footnotetext{
981 Entre 1733 y 1741 don Francisco Antonio mantuvo un pleito con la cofradía del Hospital de Santa María del Camino, como heredera de los bienes de Manuel de Hordas, administrador de la capilla mayor de Santiago. ACP. Provisorato. Legajo 399, fol 13 y ss.

982 Conviene recordar la presencia del linaje Berrio en la fundación de la iglesia de San Julián y ostentando el patronazgo compartido con los Alarcón en la capilla mayor de San Andrés, denominada antiguamente de "Libranos de Penis Ynferni".

983 Información extraída de un poder para que dicho patrón cobre las rentas referentes a dicha capilla mayor de Santiago. AHPP., Carr.Prot 4599, Francisco Blanco Manuel (1740-1741) fol 126 y ss.

984 AHPP. Carr.Prot 5091, Ignacio Gutiérrez (1790-1796), s/f.
} 


\subsection{CAPILLA DEL DULCE NOMBRE DE JESÚS}

Era la tercera capilla del lado del Evangelio, la más próxima al retablo mayor. En el acceso a la misma se conserva un escudo con restos de policromía en tonos rojizos. Su lectura es partido: 1. de Herrera, dos calderas fajadas y gringoladas de sierpes. 2, cortado de Troche, tres truchas y Maldonado, cinco flores de lis. Bordura de doce calderas. Estas son las armas de don Rodrigo de Herrera, conquistador de Perú, que a su regreso se hizo vecino de Carrión, convirtiéndose en regidor de la villa. La partición del blasón se explica por su matrimonio con doña Constanza de Troche Maldonado, hija de Francisco Yáñez Troche y doña Leonor de Barrientos. Con los beneficios obtenidos en las guerras en las que participó, Don Rodrigo de Herrera establece una renta anual de 18.000 maravedíes para las memorias de la capilla ${ }^{985}$.

También se denominó capilla de la Concepción por la advocación del retablo que dotaron los testamentarios de don Rodrigo de Herrera en $1569^{986}$. Fallecido el finado, don Antonio de Tovar y el bachiller Antonio de Vega encargaron la nueva obra a Miguel del $\mathrm{Val}^{987}$, pintor vecino de Dueñas, que debía finalizarla en dos años por doscientos ducados. Dado que el hijo primogénito del difunto Rodrigo se hallaba cautivo en Constantinopla, la posesión del patronazgo recayó en su hermano Alonso de Herrera. Los titulares posteriores conservaron la vecindad de Lomas y los parientes próximos se hicieron sepultar en la capilla citada de la iglesia de Santiago ${ }^{988}$. Así lo demuestra, por ejemplo, el testamento de María de Heredia, viuda de Santiago de Herrera, sobrino del fundador. Dictado en 1637, en él dispuso que sus restos fueran dispuestos junto a los de su difunto marido, abonando de sus bienes lo que se debiese de la apertura de la sepultura ${ }^{989}$. Incluso el cura de la iglesia de San Bartolomé y San Juan de Cestillos, Juan de Herrera, dispone que su enterramiento se haga “...en la capilla de los Herrera, en una de las losas de piedra que están en ella... 990 ".

\footnotetext{
${ }^{985}$ Los Troche tenían mayorazgo en Olmedo, Valladolid, de ahí que sus armas estuviesen en el convento de la Merced, donde poseían una capilla y en una casa solariega de la plaza de Ulloa. VIGURI, Miguel de. Heráldica...2. Op.cit, pág. 53.

${ }^{986}$ Escritura de contrato y condiciones en AHPP. Carr.Prot 5444. Gregorio Movilla (1568-1569), s/f.

${ }^{987}$ Sobre Miguel del Val, remítase al capítulo dedicado a los pintores.

${ }^{988}$ VIGURI, Miguel de. Heráldica...2. Op.cit, pp. 53-54. Árbol genealógico de los Herrera en pág. 166.

${ }^{989}$ Testamento de María de Heredia en AHPP. Carr.Prots, 5420. Francisco Moro Saldaña (1637), s/f.

${ }^{990}$ Así figura en el traslado del testamento de Juan de Herrera que se hace en1701. AHPP. Carr.Prot 5020. Agustín García Miranda (1701-1704), s/f.
} 
En el siglo XIX, aún mantienen el patronazgo los Herrera, con la vecindad en Lomas, como así consta en unos retejos generales realizado en 1807, por los que su patrón, don José Herrera debía abonar 124 reales al templo que los había adelantado ${ }^{991}$. Por entonces, esta capilla “...la mejor conservada y cuidada, con sus paredes pintadas alegremente...” se hallaba bajo la advocación de los Dolores, pues poseía una imagen de vestir de la Virgen que presidía un retablo dorado ${ }^{992}$.

\subsection{CAPILLA DEL CARMEN}

La primera mención a la capilla remonta al año 1619 en que Rodrigo Ortiz de Avecia encarga la ejecución de dos sepulturas para disponer bajo su altar. En la escritura se indica que la capilla comparte estribo con la capilla mayor de dicha iglesia “...por su parte izquierda...”, es decir, el lado de la Epístola según miramos desde los pies. Se ubicaría en el tramo recto que precede al ábside, por lo que no se trataba de un espacio independiente. Esto justifica que los cofrades de la Hermandad se reunieran en la capilla del comendador Ribera para tratar los asuntos tocantes a "su capilla"993".

\subsection{CAPILLA DE SAN AgUSTÍN O DE SANTO TOMÁS}

Hasta ahora pensábamos que eran capillas independientes; sin embargo, un retejo general que se realiza en algunos espacios del templo, nos indica que la cofradía de Santo Tomás, como patrona de la capilla de San Agustín, debía abonar veinte reales ${ }^{994}$. Gracias a un testamento de 1591 dictado por un tal Juan de Avendaño "el Viejo" -quizá emparentado con el maestro de cantería trasmerano Jerónimo de Avendaño, avecindado en Carrión- podemos determinar su ubicación, entre las capillas de Blas de Bustamante y de Rodrigo de Herrera, y por tanto de las tres capillas del Evangelio, es la segunda de ellas ${ }^{995}$.

\footnotetext{
991 ADP. Libro $1^{\circ}$ de Cuentas de Fábrica (1778-1849), fol 199.

992 RAMÍREZ DE HELGUERA, Martín. El libro...Op.cit, pág. 156.

993 ACP. Provisorato. Legajo 32, no 3622, s/f.

${ }_{994}$ ADP. Libro $1^{\circ}$ de Cuentas de Fábrica (1778-1849), fol 199.

${ }^{995}$ Basten los testamentos de Baptista Rodrigo de Abendaño, dictado en 1575 y de Juan de Abendaño "El Viejo", de 1591 para su comprobación. AHPP. Carr.Prots 5667. Andrés Sánchez (1575-1576), s/f y 5731. Lázaro Santacruz (1589-1591), s/f.
} 
La capilla de San Agustín fue fundada por Rodrigo de Santaolalla en el siglo XVI, sin saber determinar con precisión cuando, pues el nieto de éste, Rodrigo de Villegas y Santaolalla, canónigo de Guatemala ${ }^{996}$, aporta este dato en su testamento, firmado en $1594^{997}$. En un proceso de 1598 sobre una capellanía vacante por muerte del clérigo Luis de Ayuela, se confirman estos datos, indicándose que junto a Rodrigo de Santaolalla, la capilla fue fundada por Juan de Santaolalla, clérigo de la desaparecida iglesia de Santaolalla y tío de Rodrigo de Villegas ${ }^{998 .}$

A principios del siglo XVII su patronazgo no era detentado por un miembro de un linaje particular sino por la cofradía de las Ánimas. La cofradía encarga en 1602 la pintura de su retablo al pintor Bartolomé de Medina, un artista avecindado en Carrión que desarrolló su actividad en la villa entre finales del siglo XVI y las primeras décadas del siglo siguiente ${ }^{999}$. Por las condiciones del retablo, deducimos que constaba de un solo cuerpo, en cuya hornacina principal se ubicaba una talla de Santo Tomás que el artista debía pintar de azul estofada de oro mate y esmaltes azulados. También debía pintar la peana y la caja donde se ubicaba. La escultura iba flanqueada por columnas que se dorarían y seguidamente dos pinturas: en el lado izquierdo la Purificación, es decir, una Inmaculada, y en el lado frontero el Bautismo de Cristo. En la peana se ubicaban dos pequeños tableros con las imágenes de los Apóstoles y hermanos, Santiago y Juan, entre los cuales figuraría una cartela con las palabras de la Consagración. En la cornisa que separaba el cuerpo principal del ático se pintaría una inscripción en letras doradas y negras que contuviese las siguientes palabras: "Este retablo es de la Confradía de señor Santo Tomás”. Finalmente, el ático del retablo estaría presidido por una pintura del Juicio Final con las “...ánimas del purgatorio...”, que da nombre a la cofradía. Por la obra, Medina recibiría setenta y dos ducados y el privilegio de ser admitido como cofrade de la hermandad ${ }^{1000}$.

Podemos identificar este retablo con el que se encuentra adosado en el ábside del Evangelio del museo sacro de este templo. Así lo creemos por varios motivos: en primer lugar porque estilísticamente se puede encuadrar a tenor de las columnas entorchadas,

\footnotetext{
${ }^{996}$ Aún no había fallecido en 1610, pues dicho año figura en un proceso sobre una capellanía vacante por dejación de don Diego de Cisneros. ACP. Provisorato. Carrión. 1610. Legajo 32, no 3563.

${ }_{997}^{9}$ AHPP. Carr.Prot 4681 Juan Cantoral (1589-1594), s/f. ACP. Provisorato. Legajo 5, no 502.

998 AHPP. Carr.Prot 4701. Pedro Carrión (1598), fol 833 y ss.

${ }^{999}$ AHPP. Carr.Prot 5053. Alonso Gómez Guillén (1595-1603), fol 347 y ss. Acerca de Bartolomé de Medina, remítase al capítulo dedicado a los pintores locales.

1000 AHPP. Carr.Prot 5053. Alonso Gómez Guillén (1595-1603), fol 347 y ss.
} 
dentro del primer tercio del siglo XVII, y por otra parte, conserva las palabras referidas de la Consagración en el banco. Lo que sucede es que la imagen titular de Santo Tomás ha sido sustituida y las pinturas que existían no se conservan. El catálogo del museo de Santiago señala que este retablo fue adquirido a la parroquia de Villotilla en el año 2000 sin embargo, Don José Mariscal, antiguo párroco de Santiago y autor del mencionado catálogo, no recuerda que en la compra de bienes a dicha parroquia se incluyera ningún retablo $^{1001}$. El retablo se compone de banco, en cuyo centro se ubica una inscripción con las palabras latinas de la Consagración, cuerpo dividido en tres calles y ático. El cuerpo principal está compuesto por dos pilastras acanaladas en los extremos que dan paso a unas pinturas florales en las calles laterales realizadas sobre la propia superficie del retablo. En la hornacina central, entre sendas columnas entorchadas, se ubica San Basilio el Grande, también conocido como "el Magno”, o Basilio de Cesarea, pues llegó a detentar el cargo de obispo de dicha localidad de la Capadocia en el siglo IV. Fue uno de los cuatro Padres de la Iglesia Griega y doctor de la Iglesia Católica, al que debemos escritos teológicos como "Moralia y Regulae" o "La divina Liturgia". Es una imagen del siglo XVIII, en la que el santo aparece dotado de báculo y sustentando la mitra, atributos episcopales y el libro en la otra mano, en alusión a su condición de doctor. La estola cruzada bajo la capa pluvial, al modo de los obispos griegos, le identifica como San Basilio. Sobre su hornacina se conserva la siguiente inscripción: "DOROSE ESTE RETABLO, AÑ DE 1679”. Una amplia cornisa da paso al ático, compuesto por un templete rematado en un frontón partido y flanqueado por aletones avolutados en cuyo centro se ubica una pequeña talla de Crucificado, donde originalmente se habría situado el lienzo de las Ánimas. Ha sido objeto de una restauración en el año 2000.

El retablo de la cofradía vuelve a ser dorado y estofado en 1749 y para ello los cofrades se conciertan en febrero de dicho año con el dorador y pintor Francisco Gutiérrez, vecino de Cisneros ${ }^{1002}$. Debía dorarlo siguiendo como modelo del también desaparecido retablo de Nuestra Señora del Carmen de este templo. La talla de Santo Tomás, imagen principal del retablo, debía ser encarnada, sus ropajes estofados y el trono y la peana, pintados de nuevo en la parte visible. La obra debía finalizarla en cuatro meses, pero en abril de dicho año tenía contratada con el párroco de la iglesia de

${ }^{1001}$ GÓMEZ PÉREZ, Enrique y MARISCAL, José. El museo...Op.cit, pág. 37. Don José Mariscal dice no recordar más que la adquisición de un par de pinturas a Villotilla. Él se encargó de trasladarlas en su vehículo propio hasta Carrión y afirma que un retablo no hubiese cabido en el mismo.

${ }^{1002}$ Le abonarán por la obra 1750 reales. AHPP. Carr.Prot 5142. Martín Izquierdo (1748-1749), fol 55 y ss. Sobre Francisco Gutiérrez, remítase al capítulo dedicado a los pintores locales. 
Santa María la pintura de colgaduras del retablo mayor, lo que indica que trabajaba en ambos templos simultáneamente ${ }^{1003}$.

El último dato relativo a este espacio de culto data de 1794, en que, tras disponer la demolición de Nuestra Señora de las Capillas, su patrona doña María Ana de Sierra Salcedo, marquesa de Villasante, ordenó trasladar la imagen de Nuestra Señora de la Paz a la capilla de San Agustín ${ }^{1004}$. Y así sucedió efectivamente, pues esta imagen figura en un inventario sin fechar, realizado a partir de mediados del siglo XIX, figura como una de las obras del templo ${ }^{1005}$.

\subsection{CAPILLA DE SAN JUAN O DEL BAUTISMO}

Es la primera capilla del lado de la Epístola. Junto a la misma, en lo alto de la pared que cierra la nave de la iglesia campea un escudo ovalado timbrado con un yelmo que probablemente ha sido trasladado de su lugar original, el acceso a la capilla. Es un escudo partido que se leería del siguiente modo: 1 , cruz floronada y vacía cantonada de cuatro rosas y en punta tres fajas. Bordura cargada de palos ecotados. No se sabe con certeza qué linaje ostentaba estas armas, que aparecen desglosadas en la iglesia de San Julián vinculadas a las de los Berrio. Según Viguri, en la ascendencia familiar de los Berrio figuran los Pachistre entre sus personajes principales, linaje que a su vez había dotado esta capilla de San Juan, por lo que considera que la cruz floronada se refiere a esta familia ${ }^{1006}$.

Sin descartar la identificación con los Pachistre, consideramos que la cruz mencionada se vincula igualmente a los Saldaña, pues un traslado de una carta emitida 1587 en Ruán traducida del latín y francés, menciona a Carlos Saldaña como único patrón de la capilla. Este ilustre varón, “....señor temporal de los lugares del consexo del christianessimo rei de los franceses y maestro de la cámara de la contaduría de su magestad en el ducado de Normandía, hijo mayor de los nobles Thomás Rodríguez de

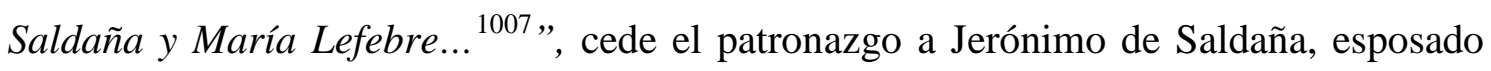

\footnotetext{
1003 AHPP. Carr.Prot 4735, Gabriel Ceano Vivas (1748-1749), fol 18 y ss.

${ }^{1004}$ AHPP. Carr.Prot 5091, Ignacio Gutiérrez (1790-1796), s/f.

1005 ASMC, del Libro de Inventario de la parroquia de Santa María (1861-1953).

1006 VIGURI, Miguel de. Heráldica...2. Op.cit, pág. 54.

1007 AHPP. Carr.Prot5649. Pedro Saldaña (1589-1590), fol 161.
} 
con Lucía de la Carrera ${ }^{1008}$. La madre de Lucía, doña María de Colmenares figura como patrona en 1589 y diez años más tarde adquiere la capilla su hijo, hermano de doña Lucía, el alférez don Hernando de la Carrera que introduciría las fajas del escudo ${ }^{1009}$. Un convenio de ese año de 1599 entre éste y el párroco de Santiago refiere la ubicación exacta de este espacio de culto “...que es como se entra por la puerta principal de la dicha iglesia, que sale a la calle de la Rúa, la primera capilla a la mano derecha como se entra... 1010 ". Por el mismo, don Hernando se compromete a llevar una pila bautismal a la capilla. Este dato, aparentemente baladí, resulta clave para identificar este espacio con la capilla del Bautismo, como así se le denomina en un documento fechado en marzo de 1612, que indica el cambio de advocación en las postrimerías del siglo XVI. La bóveda de la capilla se encontraba en pésimo estado, como así ratificó el obispo de Palencia, don Felipe de Tasis en su visita de octubre del año precedente a la iglesia de Santiago. Juan González de la Mata sería el maestro encargado de su reedificación. Tenía que derribar el estribo ubicado en el callejón de las Escapillas y rehacerlo haciéndolo llegar a la altura del tejado, con el fin de reforzar exteriormente los muros de este espacio. En el interior, las paredes en las que faltare la cantería debían ser rellenadas con postes de madera y adobes y guarnecidos con cal. Igualmente se encargaría de desmontar piedra a piedra el casco de la capilla, colocar unas cimbras y cubrirla con una bóveda de cañón de ladrillo y yeso, tal y como vemos hoy día. Por último, reharía el tejado a la morisca apuntalándolo con la torre, que se ubica junto a la capilla. Respecto a la pila bautismal, se le tenía gran estima, pues se especifica en las condiciones que, en caso de que sufriera algún daño, correría por cuenta de Juan González la Mata.

La pila fue sustituida por otra nueva en 1802, que quedó asentada por el maestro de Saldaña, Damián González ${ }^{1011}$. Hoy día se conserva en la segunda capilla del lado del Evangelio, formando parte de las piezas del museo. Es una obra del siglo XVI, apeada sobre una base circular con un bocel, que no presenta totalmente liso su cuerpo circular.

\footnotetext{
1008 Pidió ser enterrada en la capilla de la Piedad del convento de San Francisco de la que eran patrones los Carrera desde hacía más de cien años. Ver apartado concerniente al convento franciscano.

${ }^{1009}$ VIGURI, Miguel de. Heráldica...2. Op.cit, pág. 54.

${ }^{1010}$ AHPP. Carr.Prot 4768. Martín Cisneros (1598-1599), s/f. Sobre Juan González de la Mata, véanse los datos relativos a su persona en el apartado biográfico dedicado al mismo.

1011 ADP. Libro $1^{\circ}$ de Cuentas de Fábrica (1778-1849), fol 173.
} 
A finales del siglo XIX esta capilla había pasado a dedicarse a Santa Rosa, cuya imagen de yeso presidía una urna, dentro de un retablo moderno de orden jónico ${ }^{1012}$.

\subsection{OTRAS CAPILLAS}

Tenemos constancia de la existencia de otras capillas de las que tan sólo conocemos los datos que a continuación referimos. Algunas seguramente se refieran al mismo espacio, dado que como sabemos, una capilla podía denominarse bien bajo la advocación del santo que se veneraba en su retablo, bien con el patronímico del linaje al que se debía su fundación.

Capilla de los Bustamante. Por una referencia a la misma en un testamento de 1591, sabemos que se ubicaba junto a la capilla de San Agustín o de los Santolalla ${ }^{1013,}$, y por tanto sería la primera capilla del lado del Evangelio. En 1807, en que se realizan algunos retejos generales, era patrón don José Mioño, vecino de Reinosa ${ }^{1014}$.

Capilla de San Martín. Por la documentación, se sabe de la existencia de una capilla dedicada a San Martín, cuyo patronazgo pertenecía a Pedro de Colmenares, según la presentación que se hizo de la misma en 1559 por muerte de su poseedor, continuando la familia con su posesión ${ }^{1015}$.

Capilla de Santa Catalina. En unas obras que se ejecutan en el coro hacia 1618, se menciona esta capilla “...que sale a la pila del Bautismo... 1016”. Fue posesión de don Beltrán de Guevara, quien también ostentó el patronazgo de la capilla de las Once mil Vírgenes del convento de San Francisco. En 1620, en que dicta testamento, se la cede a su hermana doña Mencía de la Serna a condición de que mantenga sus armas y que éstas se restituyan en caso de que estuvieran en mal estado ${ }^{1017}$.

\footnotetext{
${ }^{1012}$ RAMÍREZ DE HELGUERA, Martín. El libro...Op.cit, pág. 155.

${ }^{1013}$ Basten los testamentos de Baptista Rodrigo de Abendaño, dictado en 1575 y de Juan de Abendaño "El Viejo", de 1591 para su comprobación. AHPP. Carr.Prot 5667. Andrés Sánchez (1575-1576), s/f y Protocolo 5731. Lázaro Santacruz (1589-1591), s/f.

${ }_{1014}$ ADP. Libro $1^{\circ}$ de Cuentas de Fábrica (1778-1849), fol 199.

1015 AHPP. Carr.Prot 5660. Andrés Sánchez (1543-1558), s/f.

${ }^{1016}$ AHPP. Carr.Prot 5401. Francisco Moro de Saldaña (1618), s/f.

1017 Testamento de Don Gaspar de Guevara en AHPP., Carr.Prot 5403. Francisco Moro Saldaña (1620), s/f.
} 
Capilla de los Reinoso. Era una fundación de doña Ana López de Cisneros y Reinoso y en 1596 ostentaba el patronazgo don Pedro Ruiz de Reinoso ${ }^{1018}$.

Capilla de los Villasante. Se hallaba en muy mal estado en 1788 pues su patrón no se encargaba de la capilla, por lo que el mayordomo insta a su reparación, o en caso contrario, retirará el retablo en un plazo máximo de dos meses ${ }^{1019}$.

Capilla de Nuestra Señora del Rosario. En el siglo XIX, la capilla más próxima del lado del Evangelio se hallaba bajo la advocación de Nuestra Señora del Rosario, una imagen de vestir que se ubicaba en la parte alta de un retablo "muy antiguo, tal vez el primero que hubo en esta iglesia" y en el centro una talla de San José. Probablemente se conservara el retablo original, realizado seguramente a lo largo del siglo XVI, pero habría perdido las esculturas que fueron concebidas para ocupar sus hornacinas. A partir de 1868, pasó a presidir la capilla el Cristo del Canto, antiguamente ubicado en la puerta homónima de la villa ${ }^{1020}$.

\section{EL MUSEO DE ARTE SACRO}

El templo de Santiago alberga desde el año 1993 el Museo de Arte Sacro, cuya creación fue ideada por un antiguo párroco de Santa María, Don José Mariscal. En él se exponen piezas pertenecientes en su mayor parte a los fondos artísticos de la propia iglesia de Santiago, además de obras procedentes de Santa María y ermitas que están bajo la jurisdicción de ésta última, como San Juan de Cestillos y la Piedad. Otras obras proceden del templo de San Juan del Mercado y de los desaparecidos monasterios de Santa Isabel y San Francisco. Incluso hay piezas obtenidas gracias a particulares, compras, permutas, etc. El análisis de muchas de ellas ya está contenido en las secciones dedicadas a los diferentes monumentos carrioneses por lo que aquí tan sólo reseñaremos aquellas obras más destacadas a las que no nos hallamos referido con anterioridad $^{1021}$.

\footnotetext{
${ }^{1018}$ ACP Provisorato Legajo 5, $\mathrm{n}^{\circ}$ 491, fol 3 Sentenciado en 21 de enero de 1597.

${ }^{1019}$ ADP. Libro $1^{\circ}$ de Cuentas de Fábrica (1778-1849), fol 65.

${ }^{1020}$ RAMÍREZ DE HELGUERA, Martín. El libro...Op.cit, pág. 155.

${ }^{1021}$ Para ello seguiremos la monografía dedicada al museo. GÓMEZ PÉREZ, Enrique y MARISCAL ARRANZ, José. Iglesia de Santiago...Op.cit, pp. 62-63.
} 


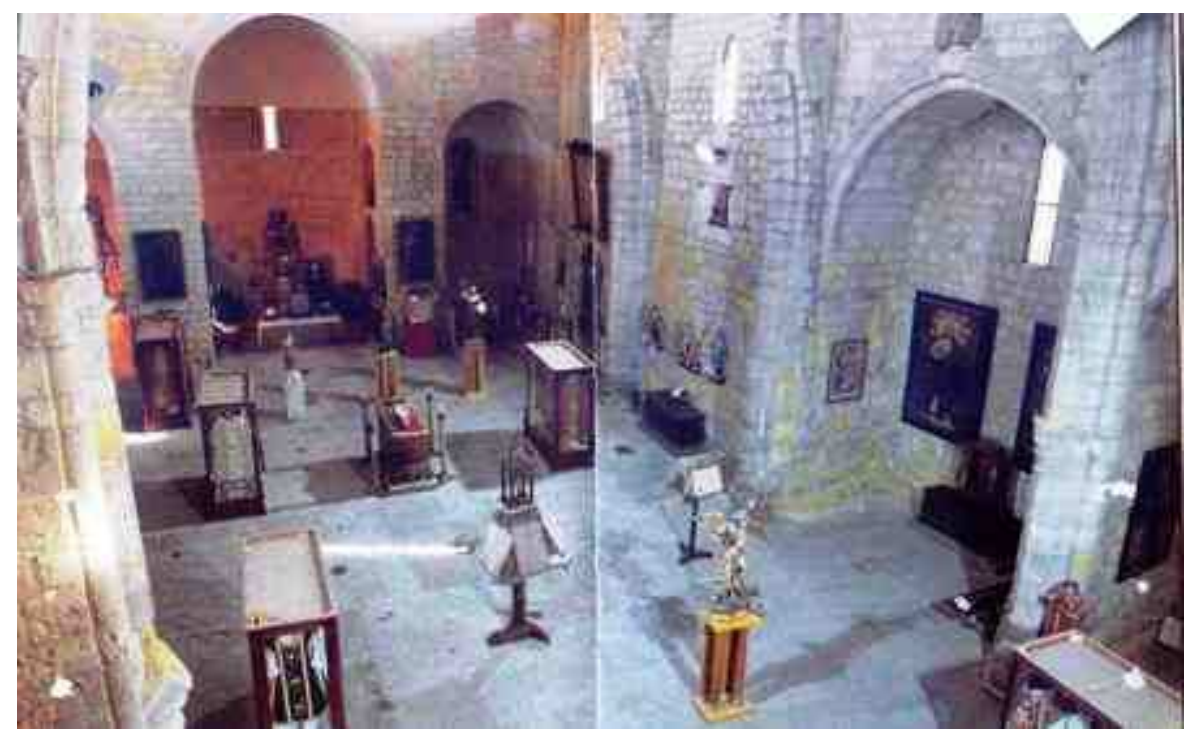

Interior del templo de Santiago, rehabilitado como Museo de Arte Sacro.

En la primera capilla del lado del Evangelio hay una pequeña imagen de poco más de medio metro que representa el Cristo de la Cepa y de la Salud siguiendo la iconografía que según Buenaventura, evoca la Cruz como árbol. Parece pertenecer al siglo XVI, con una marcada herencia berruguetesca patente en el rostro muy expresivo, con la boca entreabierta, el ceño fruncido, los ojos caídos. Su anatomía es musculosa y proporcionada, salvo en la ejecución de las manos y pies, demasiado grandes. Porta un generoso paño de pureza muy pegado al cuerpo con pliegues horizontales sujeto con un gran nudo que pende del lado izquierdo. En un inventario sin fechar del siglo XIX sobre los retablos y altares que poseía la iglesia de Santiago, ya se encontraba esta imagen en el templo, por lo que es probable que sea originaria del mismo y no procedente del monasterio de San Zoilo. Esta hipótesis está basada en la veneración que recibía una imagen de esta temática en el monasterio de San Benito de Valladolid, del que como sabemos, dependió la abadía carrionesa, que pudo tener su propia talla a imitación de la sede vallisoletana ${ }^{1022}$.

Junto a otras obras adquiridas a la parroquia de Villotilla en el año 2000, ingresó en Santiago un cuadro del siglo XVII que representa el Martirio de Santo Tomás de Canterbury, el obispo y mártir, preceptor del hijo del rey de Inglaterra, Enrique II, que

${ }^{1022}$ IbIbídem, pág. 26. 
ocupó el cargo de arzobispo en 1161. Esta obra nos presenta al santo siendo martirizado por los hombres del rey durante el Oficio Divino en diciembre de 1170.

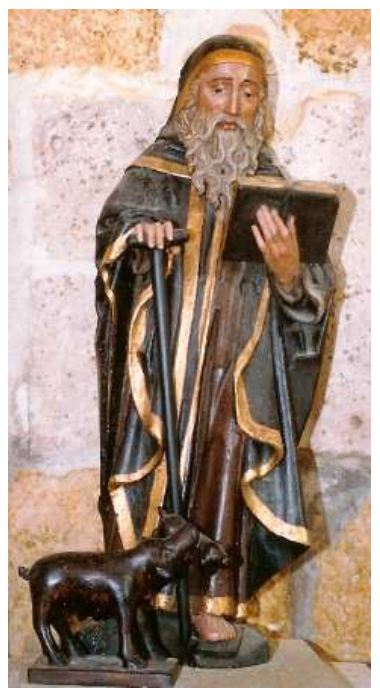

Ubicada en la nave, merece mención un San Antón Abad, atribuido a Alejo de Vahía ${ }^{1023}$, quien la llevaría a cabo en una fecha incierta entre los años 1480 y 1516 en que el entallador tenía su taller en la cercana villa de Becerril. Apoyado en un bastón, el santo porta una barba canosa de mechones ondulados propios de su inequívoco estilo. Los ojos caídos y la nariz alargada con la punta redondeada y la caída trapezoidal de los pliegues nos ubican en la órbita del maestro del Bajo Rin.

\section{San Antón Abad, atribuido a Alejo de Vahía.}

\section{$(76 \mathrm{~cm} \times 32 \mathrm{~cm} \times 20 \mathrm{~cm})$.}

\section{Museo de Arte Sacro.}

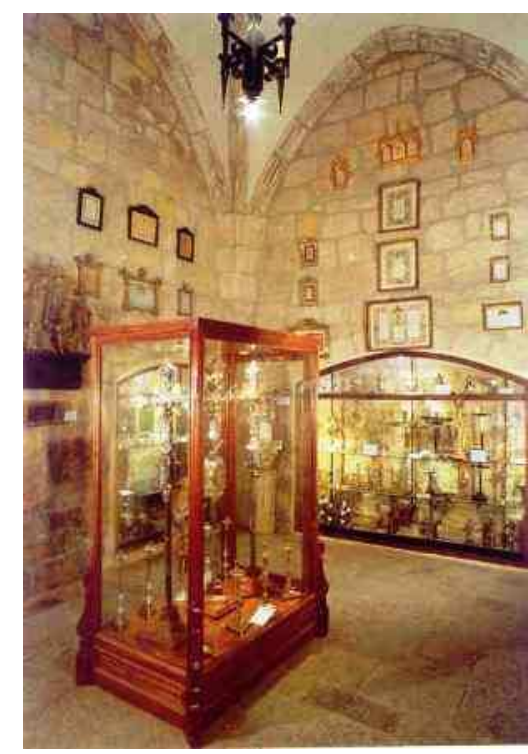

Sacristía donde se ubica

El "Tesoro" de Santiago.

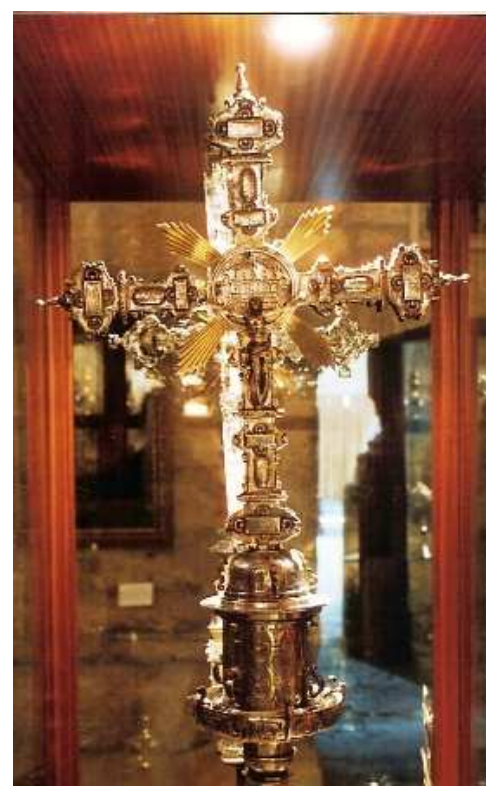

Cruz procesional de Santiago.

$(122 \mathrm{~cm} \times 47 \mathrm{~cm} \times 14 \mathrm{~cm})$. Sacristía.

Museo de Arte Sacro.

\footnotetext{
${ }^{1023}$ Hemos consultado a Clementina Julia Ara Gil, gran conocedora de la obra de Alejo de Vahía y opina que la escultura puede atribuirse al maestro de origen nórdico. Sobre este escultor, véase ARA GIL, Clementina Julia, En torno al escultor Alejo de Vahía (1490-1510), Sever-Cuesta, Universidad de Valladolid, Valladolid, 1974.
} 
El tesoro de Santiago lo constituye la sacristía, situada detrás del ábside de la Epístola. En su interior alberga una serie de piezas de orfebrería, de plata en su mayor parte, dispuestas en vitrinas, tales como rosarios, candeleros, vinajeras, navetas, custodias, cruces, cetros, resplandores, cálices, conchas, etc. Entre las cruces parroquiales conservadas, destaca la cruz alzada de Santiago, realizada en plata y plata sobredorada de la segunda mitad del siglo XVII. Presenta unas marcas una cruz flordelisada y las iniciales "BL", aunque no reconocemos al platero. En esta misma estancia y conservada en el interior de una alacena dieciochesca, destacamos un bajorrelieve del siglo XVI realizado en madera policromada cuya ubicación original era el retablo situado en el lado de la Epístola de este templo de Santiago, el cual se desmontó al cerrarse la parroquia al culto. Representa a Cristo camino del Calvario, ayudado por el Cireneo. Se trata de una composición de carácter horizontalista en la que se aprecia una comitiva que acompaña a Cristo, figurando un soldado romano a la cabeza, que tira de Cristo con una soga y la Virgen desconsolada, en el otro extremo, acompañada por San Juan.

Por último, ubicada originalmente en la iglesia de Santiago, desde 1964 forma parte de la colección de obras del Museo de Navarra una talla de madera policromada que representa un Santo Obispo $(130 \mathrm{~cm} \times 38 \times 31)^{1024}$. Bajo el alba blanca esgrafiada de negro, que le confiere esa tonalidad grisácea, se halla la dalmática y capa pluvial doradas íntegramente, bicromía presente en la mitra blanca orlada de oro que porta el anciano. Esta policromía es fruto de una intervención posterior, probablemente del siglo XVIII. Restaurada en 1966, es una pieza que se ha atribuido al taller de Alonso Berruguete y cuya datación aproximada apunta hacia $1560^{1025}$. Efectivamente, a nuestro juicio, en la cabeza se advierten ecos de la época berruguetesca más temprana, de hacia 1530-1540, visibles en el retablo de San Benito de Valladolid o de la Mejorada de Olmedo, con los característicos rostros alargados y enjutos, dotados de ceños fruncidos que otorgan gran expresividad, muy recurrentes del prolífico artista. En este caso, no obstante, el rostro poco favorecedor del prelado, de ojos saltones y marcadas arrugas difiere del prototipo formalmente bello propio del palentino. Más avanzado sin embargo es el tratamiento de los pliegues, con ese requiebro de la parte inferior, que comienzan a

\footnotetext{
${ }^{1024}$ PORTELA SANDOVAL, Francisco José. Escultura...Op.cit, pág. 293 y también, MEZQUIRIZ DE CATALÁN, María Ángeles. Museo de Navarra: guía. Pamplona, 1978, pág. 69.

${ }^{1025}$ Inventario del Museo de Navarra. Ficha catalográfica número 1.298.
} 
ejecutarse a partir de 1550, fecha en torno a la cual podría haberse ejecutado la escultura. En este sentido, podemos situarla, tal y como precisaba Portela Sandoval dentro del círculo de su discípulo, Francisco Giralte ${ }^{1026}$. Con su mano derecha, que ha perdido uno de sus dedos, sustentaría primitivamente el báculo y en la otra, mutilada, el atributo específico que nos permitiría identificar al personaje representado y su posible procedencia. En cualquier caso, a tenor de la oquedad que la escultura presenta por su parte posterior y que permitiría aligerar su peso, la talla estaría destinada a ser ubicada en algún retablo colateral del templo de Santiago, dado que el principal se hallaría bajo la advocación homónima. En el siglo XVI, entre las capillas de las que se conformaba el templo, existían dos, que por su dedicación a santos Obispos, podrían haber cobijado la talla que nos ocupa en sus retablos: San Martín, que detentó el Obispado de Tours, y San Agustín, designado, como ya sabemos, en Hipona. A juzgar por el considerable tamaño de la imagen, probablemente presidiría una de sus hornacinas principales.
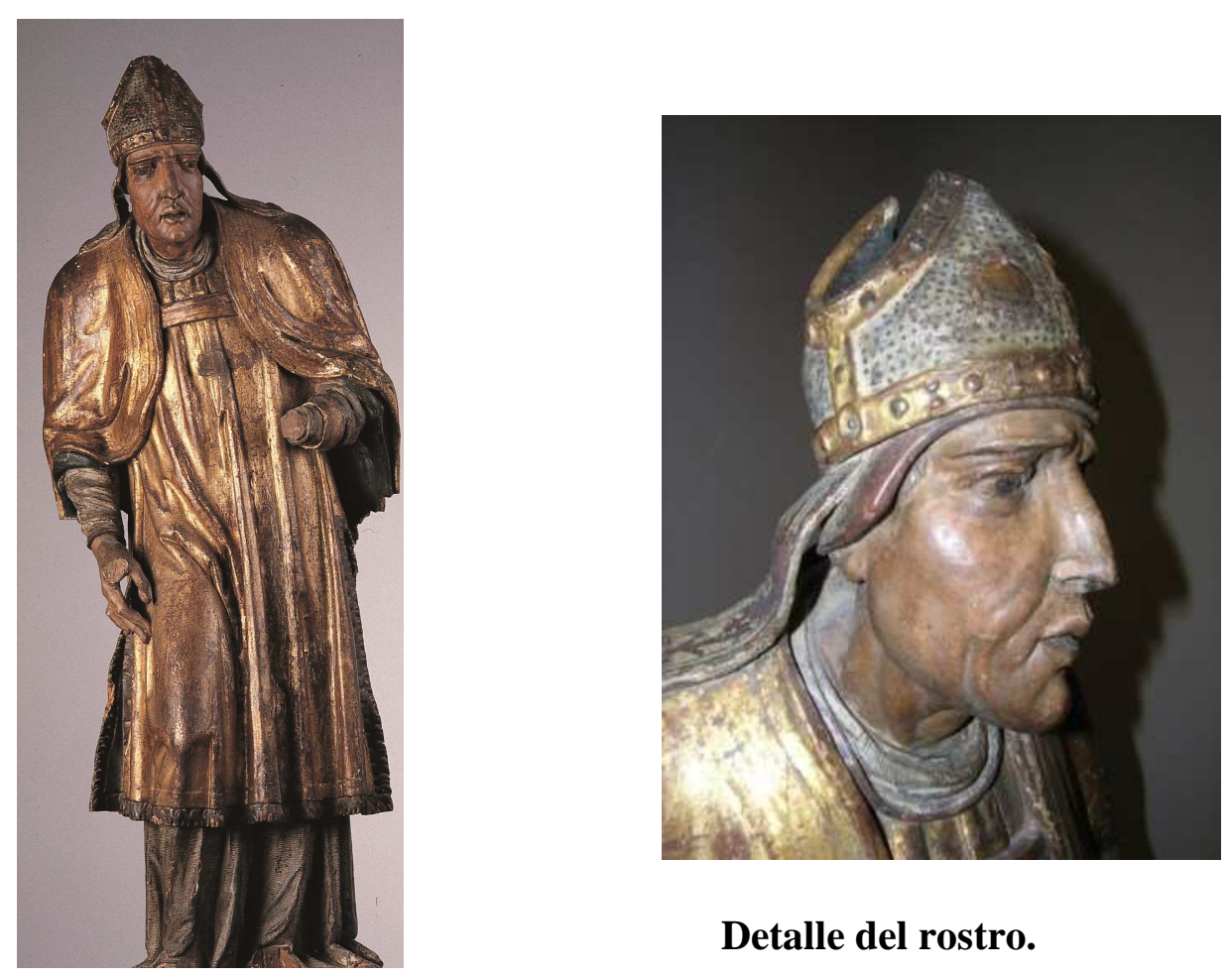

Detalle del rostro.

San Martín o San Agustín, del círculo de Giralte procedente de la iglesia de Santiago. Mediados del siglo XVI. Museo de Navarra. $(130 \mathrm{~cm} \times 38 \mathrm{~cm} \times 31 \mathrm{~cm})$.

${ }^{1026}$ PORTELA SANDOVAL, Francisco José. Escultura...Op.cit, pág. 293. 


\subsubsection{IGLESIA DE NUESTRA SEÑORA DE BELÉN}

\section{ORIGEN MEDIEVAL}

Se asienta sobre la zona del primitivo castillo de Carrión, una fortaleza medieval que construyó Rodrigo de Pimentel, Conde de Benavente hacia 1460 quien la sitió en $1474^{1027}$. Siguiendo a Quadrado, el castillo se mantuvo en pie hasta 1509 , pero dudamos de la fiabilidad de este dato, pues afirma que fue Enrique IV quien lo derruyó con el fin de devolver la independencia a los carrioneses, cuando en realidad el monarca había fallecido hacía varias décadas ${ }^{1028}$. En cualquier caso, esta zona norte de Carrión, antiguamente denominada como barrio de la Castillería, así como la cercana calle de Hortaleza, posible corrupción del término "fortaleza", nos da indicios de la situación de una fortificación en este paraje. También junto a este templo se ubicaría el palacio de los Condes, del que nada sabemos ${ }^{1029}$.

En la estadística de 1345 ya figura “Sancta María de Beldehem” entre los templos existentes en Carrión, que constaba por entonces con dos sacerdotes, un diácono y dos subdiáconos ${ }^{1030}$. Se ubicaba extramuros de la villa, pues dada su situación privilegiada en el lugar más elevado, poseía la protección más valiosa ante el enemigo: el desnivel natural hacia el río Carrión. Otra de sus defensas era su ubicación junto al castillo, binomio arquitectónico muy recurrente en época medieval justificado por las habituales incursiones.

Probablemente fue una de esas iglesias fortificadas, con elementos propios de las construcciones militares como la torre vigía o el camino de ronda. Esta tipología de templo encastillado que se extendió por todo el territorio peninsular, tuvo una gran aceptación en Castilla, donde perviven ejemplos como la iglesia palentina de Vallespinoso de Aguilar o la iglesia del castillo de Turégano, en Segovia ${ }^{1031}$. Estos

\footnotetext{
1027 CISNEROS Y TAGLE, Juan de. Op.cit, fol 226v-230.

${ }^{1028}$ QUADRADO; José María y PARCERISA, Francisco J. Op.cit, pp. 128 y 131.

${ }^{1029}$ RAMÍREZ DE HELGUERA, Martín. El libro...Op.cit, pág. 156.

${ }^{1030}$ SAN MARTÍN PAYO, Jesús. "La más antigua estadística...Op.cit, pág. 12.

${ }^{1031}$ DIMANUEL JIMÉNEZ, Mercedes. "Estructuras y elementos militares en iglesias fortificadas medievales españolas" en Anales de Historia del Arte, vol.16, 2006, pp. 79-102. Sobre este tema véase también BANGO TORVISO, Isidro. "El verdadero significado del aspecto de los edificios. De lo simbólico a la realidad funcional, la Iglesia encastillada" en ADHTA, nº-10, 1997-1998, pp. 53-72.
} 
condicionantes determinaron que el templo de Belén no estuviese integrado en el perímetro de la antigua muralla.
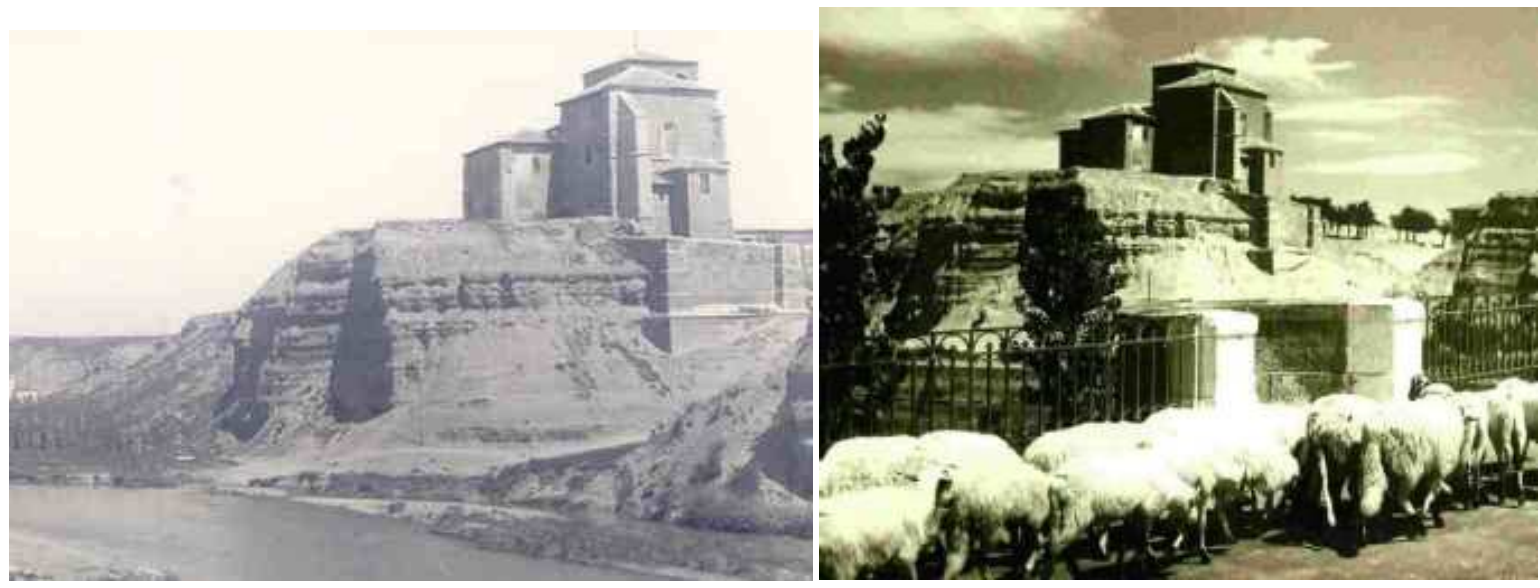

Dos vistas del templo de Belén desde el río y desde el puente donde se observa su situación sobre un altozano.

\section{EL TEMPLO}

Desde sus inicios han estado presentes los riesgos de derrumbes en las paredes del barranco sobre el que se asienta Belén, pues la tierra es fácilmente erosionable por el agua, como atestiguan los desplomes de material que se han sucedido a lo largo de su historia. Esto explica el aspecto de fortaleza que presenta Belén, con sus recios muros y su torre maciza que aporta al conjunto una sensación de pesadez comparable a la de la arquitectura militar. La orografía ha sido, por tanto, el condicionante de la apariencia actual del templo, edificado fundamentalmente en época moderna cuando, pasadas las incursiones medievales, carecía de sentido buscar un carácter defensivo. Belén no es una excepción, pues en muchos templos castellanos existía una situación análoga como en la iglesia burgalesa de Santa María de Sedano, donde se ha primado la estabilidad en detrimento de la estética. La iglesia de Santa María del Castillo en Frómista también se asienta sobre una fortaleza y posee hoy una torre maciza, como ésta.

Las sucesivas transformaciones a lo largo del tiempo han justificado el perfil irregular y asimétrico del templo. Consta de una nave dividida en tres tramos, 
correspondiendo el primero al coro. En la parte superior se dispone el coro alto, con una cubrición de bóveda de cañón y los dos tramos siguientes se cubren con bóvedas de arista separadas por un arco fajón de medio punto, fruto de las reformas del siglo XVII. Adosado al tercero de los tramos del templo se hallan dos espacios, uno a cada lado. En el lado del Evangelio se ubica la torre cuadrangular, de espesos muros, que albergaba en su interior la sacristía, siendo edificada la primigenia en 1570 y la actual una centuria más tarde. En el lado de la Epístola se halla la capilla gótica de San Gregorio. A continuación se desarrolla la cabecera, de gran amplitud, desviado su eje central hacia la izquierda respecto a la nave. La capilla de San Gregorio y la capilla mayor son los dos espacios de culto que se conservan del templo del siglo XVI, ambos cubiertos con bóveda de crucería con nervios combados. Por último, tras la cabecera se ubica el antiguo camarín de la Virgen y actual sacristía, un pequeño cubículo cubierto con cúpula sobre pechinas desde el que se accedía al retablo.

Exteriormente el templo presenta un sentido poco unitario, pues está compuesto por módulos cuadrangulares que se han ido añadiendo a lo largo de los siglos y con una diversidad de materiales que se entremezclan: sillería en los zócalos, en las esquinas del templo y de la torre y en el primer tramo, en el lado oriental y norte, mampostería en el resto de muros de este lienzo y el lado meridional y ladrillo en la parte occidental. El testero, orientado al sur, es completamente plano y reforzado con dos contrafuertes.

El aspecto de solidez que concede la estructura se debe no sólo al espesor de los muros sino al tamaño reducido de los vanos. En la capilla mayor se abren tres ventanas, una a cada lado y otra en la capilla de San Gregorio, en su pared sur. Sobre este vano se ubica un jarrón con azucenas, símbolo de la pureza de la Virgen, que se vincularía con la advocación mariana del templo de Belén. En el lado occidental se abren dos vanos, uno correspondiente al segundo tramo de la nave y otro abierto en el sotocoro. En el cuerpo bajo de la torre, en su lado oriental, asoma una pequeña ventana y el último hueco se ubica a los pies del templo, igualmente en el lienzo este, donde se ha practicado un portalón al que se accede a través de unas escaleras que salvan el desnivel del terreno. Tan sólo preside la portada una minúscula hornacina que cobija imagen pétrea de la Virgen de escaso mérito artístico. En la parte norte del exterior del templo, se conserva un escudo cuartelado de Castilla y León, armas que utilizaron los Condes Beni- Gómez, visibles en el monasterio de San Zoilo. Dado que el palacio condal se 
hallaba próximo al templo, posiblemente su presencia se deba a la fundación de alguna obra pía o al patronazgo de una capilla en la iglesia medieval.

\section{EL SIGLO XVI: RECONSTRUCCIÓN DEL TEMPLO}

La iglesia que se conserva hoy día es fruto de las intervenciones que se llevaron a cabo durante esta centuria y la posterior. Por entonces, indican las fuentes, contaba con tres naves, de estilo gótico, y era de mayores dimensiones que actualmente ${ }^{1032}$. Probablemente todo el templo estaría dividido por bóvedas de crucería, tanto en la nave central, más amplia, como en las laterales.

\section{Planta hipotética del templo en el siglo XVI, correctamente orientada.}

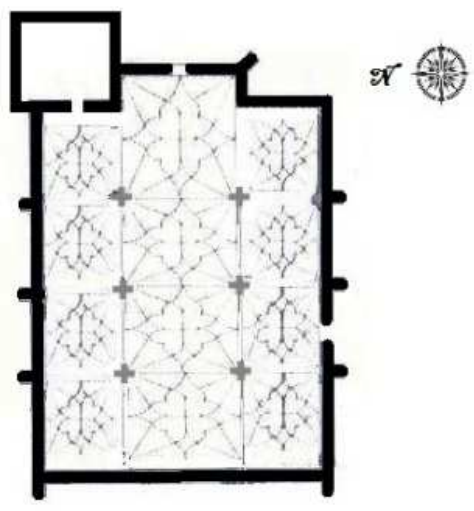

Constaría de un máximo de tres tramos, dado que la presencia del río Carrión impediría una mayor envergadura. Hoy día dicha construcción no sería posible, pues los desprendimientos han ido cediendo terreno al desnivel. Exteriormente iría jalonado por contrafuertes, propios de una fábrica gótica, máxime cuando está asentado sobre un promontorio que presenta cierta inestabilidad ${ }^{1033}$. Siguiendo a Zalama, consideramos que el templo estaba "orientado", de modo que la cabecera actual coincidiría con la primitiva pero modificada su disposición hacia el sur ${ }^{1034}$. Su planta suponemos que sería similar a la que presenta la iglesia palentina de San Pelayo de Salinas de Pisuerga, salvo por la ubicación de la sacristía situada junto a la cabecera, en lugar de adosada al lado del Evangelio.

\footnotetext{
1032 RAMÍREZ DE HELGUERA, Martín. El libro...Op.cit, pág. 156.

${ }^{1033}$ De acuerdo a estos datos hemos elaborado un plano hipotético de la iglesia en el siglo XVI con algunas de las capillas con las que contaba por entonces.

${ }^{1034}$ ZALAMA, Miguel Ángel. Arquitectura...Op.cit, pág. 93.
} 
De acuerdo a las partes conservadas, que a continuación analizaremos, hay que pensar en una reconstrucción total de la antigua fábrica durante la primera mitad del siglo XVI. Externamente en la parte occidental que mira al río, se pueden observar los arranques de los nervios de dos bóvedas de crucería y las ménsulas molduradas. Además el paramento de ladrillo integra un total de tres arcos apuntados de piedra con moldura abocelada que reafirman la continuación del templo hacia el oeste. En el interior se mantienen de este período la capilla de San Gregorio y la capilla mayor, además del arco fajón que da acceso a la misma, dispuesto sobre un zócalo pétreo. Se trata de un arco apuntado de escasa pronunciación y gran luz conformado por un bocel central estructurado en tres prismas, flanqueado por un bocel central entre dos escocias y otros dos boceles. Este arco responde a la misma tipología de los arcos fajones de la iglesia de San Miguel de Piña de Campos, otra iglesia palentina que se estaba construyendo hacia $1540^{1035}$.

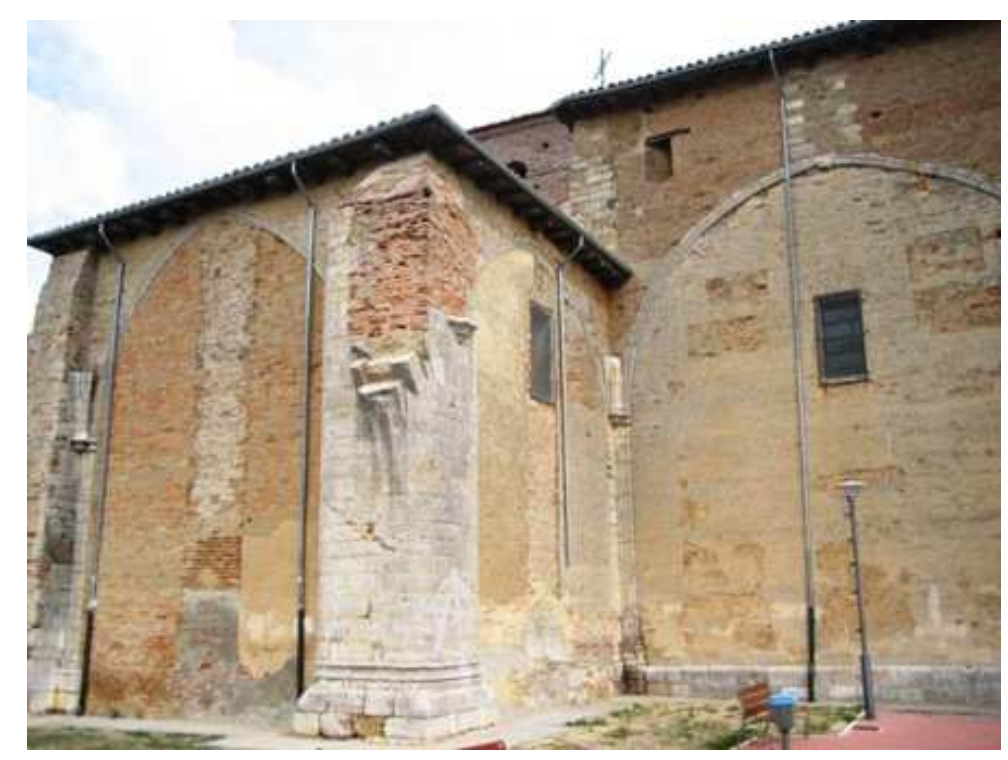

Vista del muro occidental con las arquerías góticas y los arranques de los arcos que señalan la prolongación del templo hacia el río.

\footnotetext{
${ }^{1035}$ Sobre la misma, véase ZALAMA, Miguel Ángel. Arquitectura..Op.cit, pp. 187-188 y PARRADO DEL OLMO, Jesús María. Piña de Campos: Iglesia de San Miguel. Colección, Raíces Palentinas. Diputación Provincial de Palencia. Palencia, 1993.
} 
Respecto a la capilla mayor, ésta se cubre con una bóveda de crucería repleta de nervios combados y terceletes que presentan una molduración de cuatro listeles y un bocel en el extremo. En el centro queda conformada una flor de ocho pétalos en cuyos extremos se disponen, alojados en sus claves, ocho tondos con una decoración de roleos, y en su interior diversos bustos de perfil, posiblemente copiados de grabados renacentistas. Es probable que estas imágenes no se identifiquen con ninguna familia concreta, sino que su presencia tenga una simple finalidad ornamental. Presentan grandes analogías con algunos de los medallones que figuran en Promptuarii Iconum de Guillaume Roville, publicado en 1553. Si bien esta publicación es más tardía que la ejecución de las bóvedas, es probable que, tanto el repertorio de las claves como el de los medallones del manual pudieran tener un referente común. La clave central representa un jarrón con azucenas, de nuevo la alusión a la pureza virginal. No encontramos casual que la imagen se disponga siguiendo un eje este-oeste, acorde a la orientación original del la cabecera. Todas las claves han conservado la policromía original, sobre todo la central, donde observamos una intensa gama cromática de rojos, azules y amarillos y verdosos con algunos toques de blanco que nos ayudan a conformarnos una idea de la prístina intensidad de los mismos. La capilla mayor estaba iluminada a través de vidrieras, una de ellas con la imagen de la Asunción, pues cuando en 1594 se rompe por la fuerza del viento, se ordena su restitución tal y como estaba previamente $^{1036}$. La capilla de San Gregorio, hoy en el lado de la Epístola y en origen en el lado frontero, contiene una bóveda idéntica a la de la capilla mayor pero a menor escala. Muy cerca de Carrión, en Frómista, hallamos una bóveda similar a las mencionadas en el penúltimo tramo de la nave mayor de la iglesia de San Pedro, cuyas cubiertas serían edificadas hacia el segundo cuarto del siglo XVI ${ }^{1037}$.

Las primeras referencias documentales datan de mediados del siglo XVI en que asistimos a la reconstrucción de la fábrica medieval. Al amenazar ruina el edificio, el visitador del Obispo requirió los servicios de Francisco Rabín ${ }^{1038}$ para realizar la torre y sacristía $^{1039}$. No se sabe cuando entró exactamente Rabín al cargo de la obra, pero en 1552 se indica que le han abonado gran cantidad de maravedíes que la tenía tomada

\footnotetext{
${ }^{1036}$ ADP. Carrión. Iglesia de Belén. Libro 15, $3^{\circ}$ de Cuentas de Fábrica (1584-1599), fol 90.

${ }^{1037}$ URREA, Jesús y MARTÍN GONZÁLEZ, Juan José. Tomo I, Op.cit, pág. 163 y ZALAMA, Miguel Ángel. Arquitectura...Op.cit, pp. 133-134.

${ }^{1038}$ Véanse los datos relativos al mismo en el apartado relativo a los maestros de cantería.

${ }^{1039}$ ZALAMA, Miguel Ángel. La arquitectura...Op.cit, pág. 341, a su vez de ADP. Carr. Iglesia de Belén. Libro 13 de Cuentas de Fábrica (1549-1566), fol 24v.
} 
“...ha muchos años...”, probablemente desde 1540 aproximadamente en que fechábamos lo conservado. En 1558 y 1559 recibe otros pagos por estas obras, pero en el último, de 1562 los cobra su mujer, pues Rabín había fallecido ${ }^{1040}$. Paralelamente a la intervención de Rabín, y sin contar con el mayordomo y cura de Belén, los patronos de la capilla de San Gregorio, don Julián y Antonio Díez ordenan levantar el arco apuntado moldurado que da acceso a la misma y lo separa de la nave del templo. Enterado el visitador, en 1557 les compele a que no se entrometan más en ninguna obra del templo bajo pena de excomunión ${ }^{1041}$. La envergadura de la obra que se está llevando a cabo se extrae de una gran partida de piedra de Palacios de Alcor que solicita el párroco de Belén, García de Aguilar en 1565, que abonó cuatro ducados, solamente en concepto de señal $^{1042}$. La insistencia del visitador en que las obras se ejecuten con premura traerá consecuencias desastrosas, pues las prisas repercutieron en la falta de estabilidad de la obra, que como veremos, tuvo que ser demolida ${ }^{1043}$.

El 25 de diciembre de 1570, se encargó un nuevo proyecto de la torre a dos maestros de cantería: Juan de Celaya ${ }^{1044}$, procedente de Vizcaya, que establece las condiciones, y Juan de Aras ${ }^{1045}$, que había trabajado años antes entre 1565 y 1569 en la construcción del templo de San Andrés de esta misma villa ${ }^{1046}$. Las obras dieron comienzo en enero de $1571^{1047}$ y a finales del año siguiente Aras cede su parte a Celaya, a cambio de una obra sin especificar, que tenía contratada por entonces, quedando como único maestro encargado de las obras. Celaya proyecta una alta torre, que desde los pies hasta la base de la cruz del remate mediría 155 pies, nada menos que 43 metros de

\footnotetext{
${ }^{1040}$ ADP. Carr. Iglesia de Belén. Libro 13 de Cuentas de Fábrica (1549-1566), fol 88, 93 y 119.

${ }^{1041}$ Ibídem, fol $25 \mathrm{v}-26$.

${ }^{1042}$ La carta de obligación se firma en Carrión el 15 de junio de 1565. AHPP. Carr.Prot 5664, Andrés Sánchez (1565-1568), s/f y también en ADP. Carr. Iglesia de Belén. Libro 13 de Cuentas de Fábrica (1549-1566), fol 165 .

${ }^{1043}$ Entre 1564 y 1565 ADP.Carr. Iglesia de Belén. Libro 13, $1^{\circ}$ de Cuentas de Fábrica (1549-1566), fol 136,147

${ }^{1044}$ Ya Jesús Ma Parrado había apuntado la posibilidad de que Juan de Celaya participara en las obras de esta iglesia y la de San Andrés de Carrión, debido a que en la carta de pago de la obra del claustro del monasterio de San Zoilo, fechada en 1582, Celaya afirma haber llevado piedra desde estas iglesias, intuyéndose así su participación en las mismas. Véase PARRADO DEL OLMO, Jesús María. "Datos...Op.cit, pp. 391 y 392. Véanse los datos relativos a Juan de Celaya en el apartado relativo a los maestros de cantería.

1045 Sobre el mismo, véase VALDIVIESO GONZÁLEZ, Enrique. Catálogo monumental de la Provincia de Valladolid. Tomo 8. Valladolid, 1975, pp. 26 y 211, PARRADO DEL OLMO, Jesús María. "Datos...Op.cit, pág. 387, VV.AA. Artistas cántabros...Op.cit, pág. 46.

1046 ZALAMA, Miguel Ángel. Documentos...Op.cit, pág. 244 y ss a su vez de AHPP. Carr.Prot 5665, Andrés Sánchez (1569-1572), Segundo Cosido (1353), s/f.

${ }^{1047}$ Así se indica al referirse al gasto de la obra de la torre comenzada ese año. ADP. Carr. Iglesia de Belén. Libro 14, $2^{\circ}$ de Cuentas de Fábrica (1568-1586), fol 82.
} 
altura. La premisa fundamental a la hora de abordar su erección era la ejecución de una buena cimentación, dado que la tierra no era firme y además existían desniveles. Por ese motivo, Celaya decide desbaratar lo existente y hundir los cimientos diez pies, asentando las pilastras y estribos necesarios sobre los mismos para dar firmeza a la obra. En el primer cuerpo de la torre se dispondría la sacristía, pues de este modo, expone Celaya, se optimiza el espacio de la iglesia, sin necesidad de construir una estancia a mayores. El maestro argumentaba además, ser más adecuado dejar libre una capilla construida en la que en principio se había propuesto ubicar la sacristía, pues “...había personas que holgarán de doctarla y será ocasión que la dicha obra se podrá haçer y acabar con brevedad...”. Esto explica una cláusula que señala que por cada capilla del templo que se vendiese, el maestro recibiría cincuenta mil maravedíes de incentivo, obligándole a invertir un año menos en la obra.

En lo que se refiere a la suma pautada en el contrato, la iría cobrando conforme el párroco y mayordomo recibiesen la cuantía de las rentas que proporcionase el trigo extraído del molino que poseían en la ribera de Calzada de los Molinos. Prosiguiendo con la sacristía, se dispone que el suelo se haga necesariamente de piedra, para protegerla del fuego y salvaguardar la plata que se hallará en la misma. Entre algunos ornamentos litúrgicos que se guardaron en la misma de este material figuraban dos cruces de distintos tamaños, cuatro cálices con sus respectivas patenas, un incensario, una naveta, una vinagrera y un portapaz, además de varios cetros y coronas ${ }^{1048}$.

El tejado de la sacristía se ubicaría por encima del de la capilla mayor con el fin de que el peso de los tirantes se distribuyese equitativamente sobre las paredes y no sobre el casco de dicha capilla. Para los muros de la torre, y dado que la iglesia no podía permitirse que toda ella fuese de sillería, se reservaría ésta en las molduras y pilastras y todo el exterior, con sus sillares labrados a picón, pues así se evitaban las irregularidades. En las paredes internas se recurriría a la mampostería, logrando una mayor solidez a través de la mezcla con cal majada entre seis y ocho días antes de su utilización. De este modo se prolongaba su tiempo de secado y se volvía más resistente. Una vez se llegase al cuerpo de las campanas, se dispondría una estructura reforzada de soleras y sobre éstas unas pechinas que sustentasen una cupulilla.

${ }^{1048}$ En 1594, el platero Baltasar de Quijano pesa la plata existente, con lo que hace un inventario de los objetos. ADP. Carr. Iglesia de Belén. Libro 15, 3º de Cuentas de Fábrica (1584-1599), fol 111. 
Juan de Celaya se había comprometido a concluir los trabajos en diez años, esto es, en enero de 1581, durante los cuales su dedicación sería exclusiva. Seducido seguramente por una obra de mayor magnitud que se ejecutaba por entonces, como era el célebre claustro de San Zoilo, Celaya comienza a trabajar en el mismo. Una inscripción existente en la bóveda vigésimo segunda del claustro benedictino anuncia la finalización de su participación en el mismo en 1577, lo que indica, dada la parte ejecutada, que había trabajado paralelamente en Belén y San Zoilo al menos desde hacía un par de años. En 1579, tan sólo había realizado el cuerpo bajo de la torre correspondiente a la sacristía. La iglesia establece un pleito contra él “...por la quiebra de la torre....", logrando que fuse apartado de la misma ${ }^{1049}$.

En 1577, sobre el lugar donde hoy se ubica el tercer tramo de la nave, se estaba edificando una capilla de la que tan sólo se habían hecho los cimientos y algunas paredes. De ella adquiriría plenos poderes el clérigo y doctor carrionés don Zoilo Díez de Loyola, que costearía las obras ${ }^{1050}$. Por tanto deducimos que en el último cuarto del siglo XVI tan sólo existía la capilla mayor y la de San Gregorio y la fábrica gótica restante se hallaba en ruinas ${ }^{1051}$. A partir de estos sectores se había comenzado la nueva obra de la torre, y este espacio de culto que se hallaba junto a la misma. Algunos desprendimientos de la capilla mayor motivaron la intervención del maestro carrionés Marcos de la Torre a partir de 1584, lo que manifiesta, una vez más, la inestabilidad de la fábrica ${ }^{1052}$.

Desde 1585 se encargó Juan de la Cuesta ${ }^{1053}$ del fortalecimiento del templo ocupándose paralelamente de las obras de esta iglesia y del claustro del convento franciscano de la misma villa ${ }^{1054}$. Alonso de Tolosa se encargó entonces de la revisión y modificación de lo realizado por Juan de la Cuesta y tasó, junto a Juan de Nates,

\footnotetext{
${ }^{1049}$ ZALAMA, Miguel Ángel. "Documentos...Op.cit, pág. 245. Entre 1571 y 1575 se le efectúan diferentes pagos a Celaya y en 1579 ya figura pleiteando con la iglesia y en prisión ADP. Carr. Iglesia de Belén. Libro 14, 2 de Cuentas de Fábrica (1568-1586), fol 84, 91v, 102, 126,169, 222.

${ }^{1050}$ FERNÁNDEZ MARTÍN, Luis. "Voces de dentro y de fuera: Familiares de San Ignacio de Loyola...Op.cit, pp. 351-364.

${ }^{1051}$ Tenemos constancia de la existencia de varias capillas, a las que nos referiremos en el apartado correspondiente ADP. Carr. Iglesia de Belén. Libro 15, $3^{\circ}$ de Cuentas de Fábrica (1584-1599), fol 43-45.

${ }^{1052}$ ADP. Carr. Iglesia de Belén. Libro 14 de Fábrica (1584-1599), fol 9. Sobre Marcos de la Torre, véase el capítulo dedicado al mismo.

${ }^{1053}$ Véanse los datos relativos al mismo en el apartado relativo a los maestros de cantería.

${ }^{1054}$ ZALAMA, Miguel Ángel. La arquitectura...Op.cit, pág. 93.
} 
maestro clasicista oriundo de Secadura, la parte ejecutada por Juan Celaya en la iglesia, otorgando carta de pago en $1586^{1055}$. Su hermano, el también arquitecto Juan de Tolosa, participa igualmente como veedor de las obras de Belén en 1587, y un año después Juan Martínez revisa lo que ejecuta Juan de la Cuesta ${ }^{1056}$. La iglesia se vuelve a ver metida en un pleito en 1590, en este caso porque Juan de la Cuesta demandaba setenta y tres ducados que había ganado de prometido junto a Juan Ortega Castañeda al haber pujado a la baja en la obra que se hacía en el templo. De la Cuesta se da por contento con los 422 reales que se le pagan, dando por concluido el litigio ${ }^{1057}$. Entre sus trabajos en la iglesia es segura la terminación de la torre, ya que en 1590 se está aderezando el campanario $^{1058}$. Durante los años en que participa en las obras del templo, hubo breves períodos, entre 1589 y 1590 que los pasó en prisión por incumplimiento del contrato establecido con el síndico de San Francisco ${ }^{1059}$.

La mayor parte de las capillas se encontraban por entonces en mal estado. Aún en 1591 de la Cuesta continuaba trabajando en Belén, pues le pide a Marcos de la Torre que le venda las losas más pequeñas que salieran del puente de la villa, a cuyo cargo estaba por entonces, para emplearlas en la fábrica del templo ${ }^{1060}$. En 1592 tasa la obra realizada por entonces el maestro de Secadura, Juan de Buega, perteneciente a una familia de larga tradición canteril ${ }^{1061}$. Era un artista de prestigio, pues entre otras, a él se debe la portada del Sagrario de la catedral de Sigüenza, donde trabajó como maestro

\footnotetext{
${ }^{1055}$ Ibídem. Los documentos relativos a Alonso de Tolosa dictaminando y tasando la obra, se conservan transcritos en ZALAMA, Miguel Ángel. "Documentos...Op.cit, pp. 245-246. Sobre Celaya, Tolosa y Nates, véanse los datos relativos al mismo en el apartado relativo a los maestros de cantería.

${ }^{1056}$ ADP. Carr. Iglesia de Belén. Libro 15, 3o de Cuentas de Fábrica, (1584-1599), fol 24.

1057 Se conforma más o menos con la mitad, pues se le debían 803 reales. AHPP. Carr.Prot 4981, Sebastián García (1590-1592), fol 79 y ss y también en DP. Carrión. Iglesia de Belén. Libro 15, $3^{\circ}$ de Cuentas de Fábrica, (1584-1599), fol 59.

${ }^{1058}$ ADP. Carr. Iglesia de Belén. Libro 15, $3^{\circ}$ de Cuentas de Fábrica, (1584-1599), fol 54.

${ }^{1059}$ En junio de 1589, los maestros Santiago de Sigüenza, Rodrigo de Losada, Antonio de Cuéllar, Marcos de la Torre y Gonzalo de Albear pagaron la fianza, comprometiéndose los mismos a llevarle de nuevo a prisión cuando les fuera solicitado AHPP. Carr.Prot 4980. Sebastián García (1588-1590), fol 672. En 1590 otorga un poder a su hermano Francisco para que cobre lo que corresponda a la fábrica de San Francisco, probablemente porque había vuelto a ser encarcelado. AHPP. Carr.Prot 8712. Sebastián García (1588-1590), fol 952 y 953. Por eso no es de extrañar que las cartas de pago de la iglesia de Belén en 1590 sean a su hermano. ADP. Carr. Iglesia de Belén. Libro 15, $3^{\circ}$ de Cuentas de Fábrica, (1584-1599), fol 55 .

${ }^{1060}$ AHPP. Carr.Prot 4981, Sebastián García (1590-1592), fol 352-3. Existen cartas de pago desde 1586 hasta 1592, en que se incluyen algunas demasías. ADP. Carrión. Iglesia de Belén. Libro 15, $3^{\circ}$ de Cuentas de Fábrica (1584-1599), fol 21, 30,34, 38v, 39, 60, 69, 71.

${ }^{1061}$ ADP. Carr. Iglesia de Belén. Libro 15, 3º de Cuentas de Fábrica (1584-1599), fol 76, 77.
} 
mayor entre 1573 y 1574 y donde le sobrevino la muerte en $1598^{1062}$. Ese mismo año, en que Juan de la Cuesta dicta testamento, todavía se debían 110 ducados de las obras realizadas en Belén ${ }^{1063}$.

Los problemas estructurales no cesan y en 1593 se caen algunas paredes de tapial que se reconstruyen un año después. Los patronos de la capilla de Santa Lucía, don Gaspar y Antonio de Campoo, habían canalizado el agua desde el río hasta la iglesia para transportarla después a unos molinos que poseían. La corriente había hundido la peña sobre la que se asentaba el templo, ocasionando un peligro de derrumbe inminente $^{1064}$. El siglo termina con nuevos derrumbes de los arcos correspondientes a dos capillas que se hunden en $1599^{1065}$. Como era de prever, se hace necesaria una nueva reconstrucción, más fuerte y sólida que la llevada a cabo hasta el momento.

\section{EL SIGLO XVII}

\section{Continuas intervenciones de refuerzo}

Nada más dar comienzo el siglo, en 1600, la iglesia toma a censo seiscientos ducados para "obra". Se hace acopio de todo tipo de materiales, desde canto tosco, hasta yeso y cal, pasando por ladrillos Parece que la intervención que se hizo por entonces consistió básicamente en labores de "aderezo" como reposición de vidrieras y tapices, y arreglo de campanas ${ }^{1066}$. La ausencia en los libros de Fábrica de los años 1601 a 1615 y el vacío documental sobre este templo en los protocolos en este abanico temporal nos impide desentrañar a ciencia cierta lo que sucedió, si bien creemos que no se llevó a cabo ninguna reforma de entidad hasta más adelante.

\footnotetext{
1062 SOJO Y LOMBA, Fermín. Los maestros...Op.cit, pp. 39-40. En Palencia realiza las trazas de unos corredores en la residencia del obispo junto a Francisco del Río en 1592. Ese mismo año, recibe los pagos como veedor de la obra del templo palentino de San Miguel en Castil de Vela. ZALAMA, Miguel Ángel. Arquitectura...Op.cit, pp. 333-334.

1063 AHPP. Carr.Prot 4768. Martín Cisneros (1598-1599), fol 46 y ss.

${ }^{1064}$ ADP. Carr. Iglesia de Belén. Libro 15, 3º de Cuentas de Fábrica (1584-1599), fol 90.

1065 IbIbídem, fol 158.

${ }^{1066}$ IbIbídem, fol 162v. Aunque el libro dice que acoge hasta el año 1599, en realidad está incluido 1600.
} 
La primera referencia a una obra data de 1614, en que el maestro de carpintería carrionés Francisco Reinaldos se compromete a reconstruir "el telar y ventanaje” de la torre $^{1067}$. Su labor consistía básicamente en recomponer la base estructural del cuerpo de campanas y su armadura y realizar un colgadizo que protegiese de la caída del agua. En 1616 recibe diversas cartas de pago en concepto del campanario de Belén a las que se añaden otros cobros por su ocupación en la obra de un cuérnago y molino en Zerones que poseía el templo, que posiblemente sea despoblado ${ }^{1068}$.

Entre 1616 y 1619 se ejecutan algunos retejos sucesivos en el cuerpo del templo y se refuerza el portal de entrada, lo cual nos indica que persistía la fábrica del siglo $\mathrm{XVI}^{1069}$. La obra del “...aguxero y rrompimiento de la capilla del alto de la capilla mayor...”, que viene a ser el caso de la misma, fue concertada en 1622. Tras varias pujas, la obra es rematada en el maestro de albañilería carrionés Bartolomé del Campo por once ducados, menos de la mitad del precio de salida. En la primera subasta, se ofreció Bartolomé Alejo por veintiséis ducados, Reinaldos la bajó a veintidós, Bartolomé Alejo a dieciocho, Antonio del Valle pujó por catorce, Reinaldos se presentó de nuevo con trece y medio, del Valle lo intentó con trece y finalmente fue adjudicada a Bartolomé del Campo ${ }^{1070}$. Tenemos constancia de que aún en 1627 la cabecera estaba orientada, pues el carpintero carrionés Antonio del Valle recibe carta de pago por el arreglo de la pared de los pies de la iglesia “...sobre la puerta del rrío... ${ }^{1071 ~ ” . ~}$

Los problemas de estabilidad motivados por la débil cimentación se dejan sentir en el templo a partir de entonces. En 1632, tuvieron que ser asentados los retablos de las capillas que se habían caído ${ }^{1072}$. La torre se hallaba por entonces en mal estado y la iglesia decide reedificarla. Por ello recurre a los maestros Bartolomé Lechuga, especialista en cantería, y Juan González de la Mata, dedicado a la albañilería para que se encarguen de las trazas y condiciones de la misma aunque no se intervendrá hasta

\footnotetext{
${ }^{1067}$ Escritura y condiciones de la obra en AHPP. Carr.Prot 4841. Juan Díaz Pajaza (1614), fol 483 y ss.

${ }^{1068}$ La primera carta de pago es de enero AHPP. Carr.Prot 4818, Francisco Cuetos (1616), fol 574 y ss y la otra, en la que se especifica la parte realizada, corresponde al mes de marzo, en la que se le abonan 40.000 maravedíes. AHPP. Carr.Prot 4843. Juan Díaz Pajaza (1616), fol 260.

1069 ADP. Carr. Iglesia de Belén. Libro 16, $4^{\circ}$ de Cuentas de Fábrica (1616-1646), fol 14,68, 69, 78, 87,88. ${ }^{1070}$ AHPP. Carr.Prot 4849. Juan Díaz Pajaza (1622-1623), fol 314 y ss. El primer pago a Bartolomé del Campo de 122 reales fue en el mismo año de 1622, y además se le pagan ocho reales por asentar el retablo de Santa Lucía. ADP. Carrión. Iglesia de Belén. Libro 16, 4º de Cuentas de Fábrica (1616-1646), fol $112 \mathrm{v}, 113$.

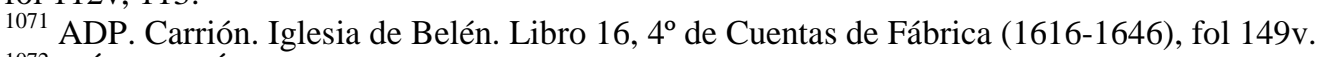

1072 GÓMEZ PÉREZ, Enrique. El Belén...Op.cit, nº V. Cálamo. Palencia, 2009, pág. 16.
} 
1663, como se verá ${ }^{1073}$. Poco después, en 1634 el maestro carpintero Antonio del Tejo repara las cubiertas de una de las naves que se había hundido y el portal de acceso ${ }^{1074}$. A consecuencia de las lluvias torrenciales que cayeron repentinamente en la villa a mediados de 1636, la iglesia de Belén, por ser una de las más vulnerables, resultó muy afectada, corriendo la misma suerte los templos de Santiago y San Juan del Mercado ${ }^{1075}$. Los daños se dejaron sentir en la capilla mayor, cuyas paredes se refuerzan por entonces, se asientan algunos retablos que se habían caído y además interviene Jerónimo de Abendaño ${ }^{1076}$ ejecutando un estribo de refuerzo ${ }^{1077}$.

\section{Reconstrucción de la nave}

La remodelación del templo, tal y como hoy lo conocemos, con la consecuente modificación de la orientación hacia el sur, debe ser fruto, a nuestro parecer, de hacia mediados de esta centuria. Así lo creemos, en base a su estilo y a la existencia de una carta de pago que reciben Juan González de la Mata y el maestro trasmerano Juan de

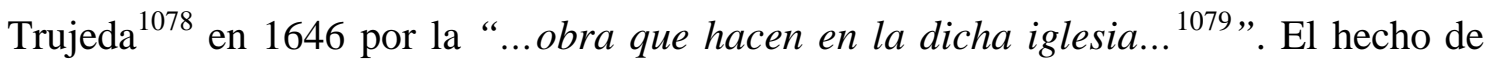
que reciban 35.904 reales, cantidad nada desdeñable para ser recibida de una sola vez y que esta cantidad tan sólo constituya uno de los pagos que deben realizarse a los maestros, puesto que la obra está en proceso, remiten sin duda a una intervención de cierta entidad. Los años que transcurren desde entonces hasta 1652 no aparecen registrados en los libros de Fábrica, pero es probable que continuasen los trabajos durante ese intervalo. Los protocolos sí que avalan la participación de Juan González de la Mata en el templo en 1648, en que repara la capilla de San Gregorio, bajo el patronazgo de Andrés de la Serna y Reinoso ${ }^{1080}$. Como apuntamos, este espacio y la capilla mayor serían los únicos que pervivirían de la fábrica del siglo XVI. De la Mata se encarga de reforzar los cimientos de los muros de sur y oeste de la capilla, levantando una pilastra de ladrillo en el medio de cada una de las paredes que recibiese el arco

\footnotetext{
1073 ADP. Carr. Iglesia de Belén. Libro 16, 4 de Cuentas de Fábrica (1616-1646), fol 183v. Sobre Juan González se hablará en el apartado relativo a los datos biográficos de los maestros.

${ }^{1074}$ ADP. Carr. Iglesia de Belén. Libro 16, 4º de Cuentas de Fábrica (1616-1646), fol 204.

1075 AMC. Libro 1, Sesiones municipales. (1618-1637), Sesión de 9 de febrero de 1636, s/f.

1076 Sobre Abendaño se hablará en el apartado relativo a los datos biográficos de los maestros.

1077 ADP. Carr. Iglesia de Belén. Libro 16, 4º de Cuentas de Fábrica (1616-1646), fol 210v,218, 221, 238.

${ }^{1078}$ Sobre ambos artífices se hablará en el apartado relativo a los datos biográficos de los maestros.

1079 ADP. Carr. Iglesia de Belén. Libro 16, $4^{\circ}$ de Cuentas de Fábrica (1616-1646), fol 301v.

${ }^{1080}$ AHPP. Carr.Prot 5430. Francisco Moro de Saldaña (1648), s/f.
} 
apuntado, cubriendo el resto de hormigón y cascajo, y enluciéndolo de yeso posteriormente. De esta intervención aún perviven las pilastras que trasdosadas al exterior, dividen los muros de ladrillo de este espacio.

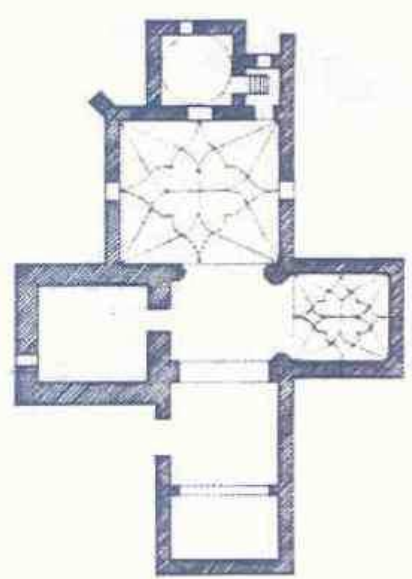

Planta actual del templo.

Mapa MOPU. Dirección de

Arquitectura y Edificación.

Plano de Carrión 1986.
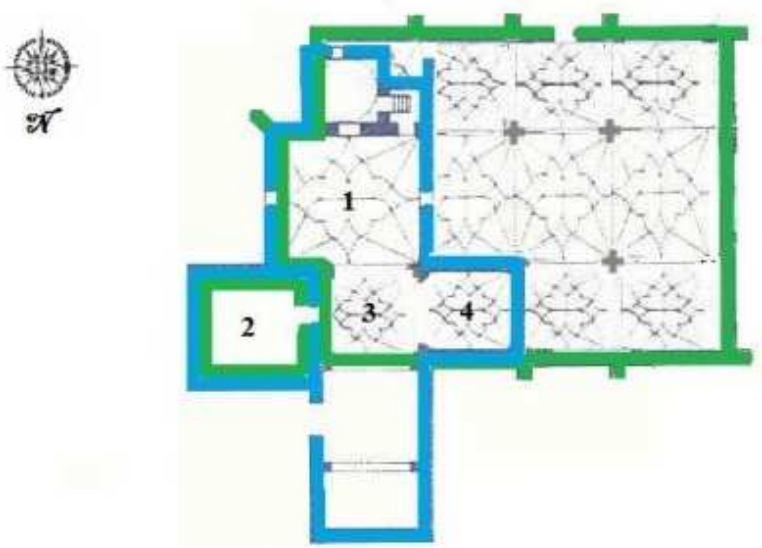

Planta en el siglo XVI (orientación este)

Planta actual del siglo XVII (orientación sur)

Espacios comunes de ambos templos:

1. Capilla mayor

2. Torre

3. Tercer tramo de la nave (antigua capilla de Zoil Díez)

4. Capilla de San Gregorio

Resultado de la intervención de Trujeda y de la Mata sería la configuración de la nave, dividida en tres tramos, el primero correspondiente al coro. Estructurado en dos niveles, el sotocoro está conformado por un sencillo arco escarzano liso. El antepecho pétreo de yesería interrumpido en su parte central para permitir el acceso, debe responder a una intervención del siglo XIX pues el repertorio ornamental se vincula con el neogótico. Se conforma por una sucesión de arcos polilobulados sobre columnas, a los que se yuxtaponen arcos de medio punto invertidos y entrecruzados. En cada una de las intersecciones conformada por tres arcos, hallamos motivos vegetales enroscados y afrontados. Sobre el sotocoro, el coro alto presenta una bóveda de cañón y en los dos tramos siguientes se han empleado bóvedas de arista, todas ellas enlucidas de yeso. La decoración del coro consiste básicamente en una hilera de cinco placas rectangulares, cuatro de las cuales contienen óvalos salvo la del centro, en la que figura un rombo con los perfiles escalonados. La ornamentación de placas de óvalos se repite en los tramos contiguos, pero en este caso conforman una cruz, entre cuyos lados se disponen ocho 
puntas de diamante. Los dos arcos fajones dispuestos entre las cubiertas son de medio punto lisos y apean sobre pilastras pétreas con un sencillo capitel moldurado con un toro entre listeles de diversos grosores. Al nivel de estos capiteles se halla la imposta lisa que recorre toda la nave. El cambio de orientación justifica la falta de armonía respecto a la capilla mayor a la que se adaptó la nave. El nuevo templo tuvo que reducir sus dimensiones originales para evitar inestabilidad y la nave debía ajustarse al espacio existente entre la capilla de San Gregorio y la torre, por lo que no podía desplazarse para alinearse con la cabecera. Todavía en 1658 la iglesia no había abonado a Trujeda lo que le debía, tal y como señala en su testamento: “...cuya quenta no está ajustada y de ella se me está debiendo cantidad de dinero, quiero se juste y se me pague lo que sse me deuiere... ${ }^{1081 ",}$

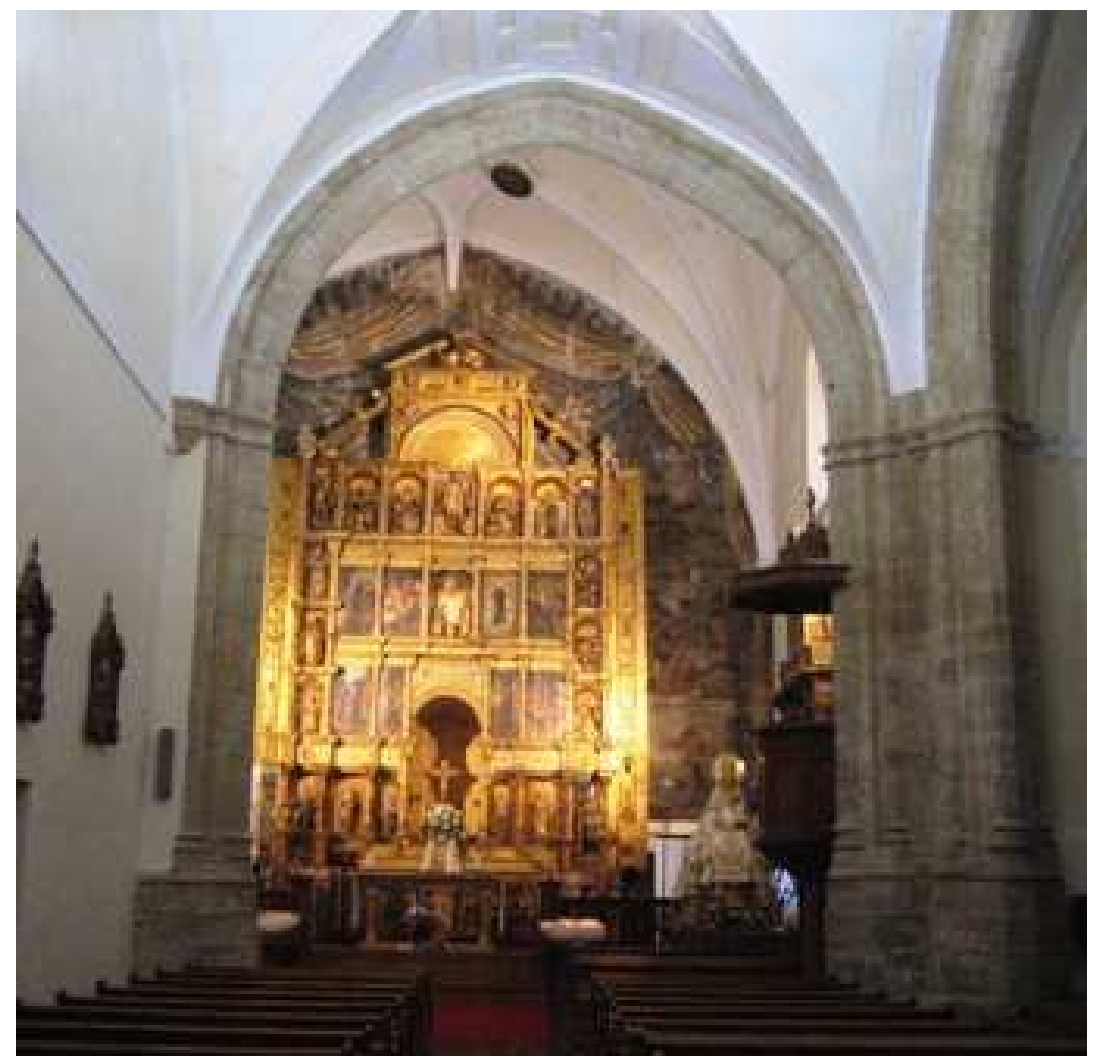

Interior del templo de Belén donde se observa que la nave está descentrada respecto a la capilla mayor debido al cambio de orientación del mismo.

${ }^{1081}$ AHPP. Carr.Prot 5691. Norberto Sandoval y Guevara (1658), fol 495v. 


\section{La nueva torre}

Respecto a la torre, si bien, en 1632 se habían proporcionado nuevas trazas, el proyecto de una reedificación no se materializa hasta junio de 1663. Con la asistencia y aprobación del obispo de Palencia don Enrique de Peralta y Cárdenas, se firman en Carrión las condiciones de la nueva obra con Andrés Díaz de Cabanzo ${ }^{1082}$. Este maestro de cantería, vecino de la localidad de Piña de Campos, se compromete a reedificar la

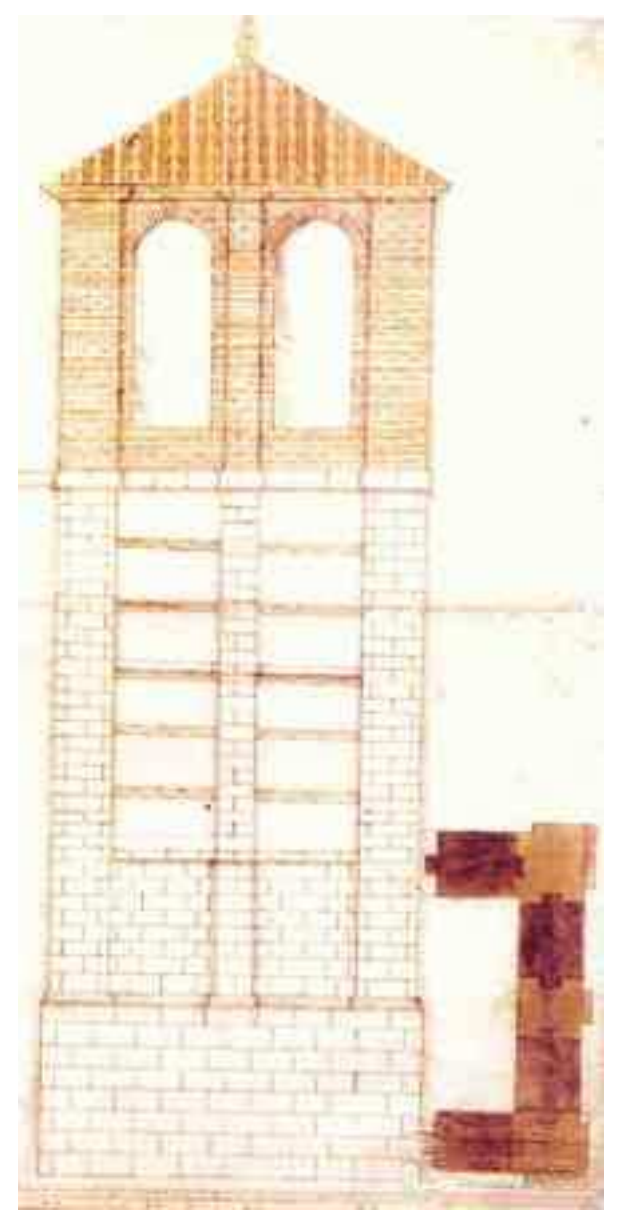
torre, fruto de cuya intervención es la actual, respetando eso sí lo conservado. La cimentación y las primeras tapias eran las únicas partes que permanecían en pie de la fábrica del siglo XVI. A partir de este núcleo Cabanzo estructura la torre en dos niveles y el cuerpo de campanas. Los dos primeros están construidos a través de muros de piedra, pues aunque en la traza el maestro palentino había dispuesto la utilización de tapias de tierra, se decanta ahora por la cantería, desechando un material tan endeble que no resistiría las inclemencias del tiempo. Los cuatrocientos carros de piedra necesarios para la edificación fueron extraídos principalmente de las canteras de Villasabariego y Robladillo de Ucieza, localidades ubicadas al norte de Carrión ${ }^{1083}$.

Proyecto de la nueva torre.

Andrés Díaz Cabanzo (1663).

AHPP. Mapas y Planos. Signatura 45.

\footnotetext{
${ }^{1082}$ La escritura se firma el 14 de junio de 1663 en AHPP. Carr.Prot 5201. Jerónimo Laso (1663-1664), fol 638 y ss. La planta y alzado de la torre que se proyecta se halla en AHPP. Sección de dibujos. Signatura 45.

${ }^{1083}$ ADP. Carrión. Iglesia de Belén. Libro 17, 5º de Cuentas de Fábrica (1653-1783), fol 36v.
} 
Cada cuerpo se halla separado del otro a través de una imposta lisa de unos treinta centímetros de alto y dos dedos de saliente que se ubica al nivel de la de la capilla mayor, tal y como establecen las condiciones, de modo que se consigue un sentido más unitario con el templo. Los muros se refuerzan en las esquinas con pilastrones y en el medio de cada lienzo se dispone una pilastra, sustentándose todos estos soportes sobre un alto zócalo que aparentemente acorta el cuerpo inferior. En los espacios existentes entre la pilastra, “...en la pared que cay frente a la calçada...”, es decir, en el lado oriental, debían abrirse cuatro ventanas de medio metro de ancho y doble de alto, distribuyendo dos por cada piso, cortadas "a regla" en la parte externa y con perfil capialzado al interior. De los cuatro vanos, tan sólo subsiste uno de los del piso inferior, cuya decoración a base de sendas orejetas, remite a la intervención de estos años. Para los suelos y techos de la sacristía y del piso contiguo se harían sus entramados de madera, con sus soleras y se construiría una escalera de tres tiros para comunicarlos. Para el cuerpo de las campanas se determina el empleo del ladrillo y la apertura de ocho ventanas, dos por cada lienzo para alojar una campana en cada una. Hasta la línea de impostas de los arcos de medio punto de estos vanos, los muros están revestidos de sillares, mientras que la parte superior recorrida tan sólo por tejas de pequeño tamaño, remata en una imposta encapitelada que precede al tejado a cuatro aguas. Este cambio de material en el último tramo de la torre, proporciona un aspecto inacabado al templo. La torre debía estar finalizada en el plazo máximo de dos años, es decir, en junio de 1665 pero finalmente se demora más de una década. Andrés Díaz Cabanzo cobra varias partidas en 1665, año en que se había comprometido a finalizar la obra; sin embargo, los trabajos no se hallaban en un estado demasiado avanzado y todavía se adquieren varias partidas de ladrillo para la torre ${ }^{1084}$. A partir de este momento el receptor de las cartas de pago es otro maestro de cantería local, Bernardo Sánchez, quien como maestro, es ayudado de otros oficiales de la comarca, para proseguir con la construcción de la torre, cuyos pagos se prolongan hasta $1670^{1085}$.

Por entonces no se había construido la sacristía, cuyas trazas son proporcionadas por Felipe Berrojo en 1672 y llevadas a cabo por Francisco de Reinaldos, maestro de

\footnotetext{
${ }^{1084}$ Ibídem, fol 46 y la partida de ladrillo figura en AHPP. Carr.Prot 5771. Andrés Simón Aguilar (1665), fol 485 y ss.

${ }^{1085}$ ADP. Carrión. Iglesia de Belén. Libro 17, 5 de Cuentas de Fábrica (1653-1783), fol 50, 62. Sobre Bernardo Sánchez, véase el apartado dedicado a los maestros locales.
} 
carpintería que figura por vez primera en esta obra como maestro de cantería ${ }^{1086}$. Al igual que la primitiva, estaba integrada en el primer cuerpo de la torre. Probablemente el entramado de madera, y las cupulillas de yeso dispuestas entre viga y viga sean fruto de esta intervención. Dos de los lados son lisos, y los dos lienzos, correspondientes a los lados norte y oriental contienen una pareja de arcosolios de medio punto pétreos. Un pequeño cubículo que precede a la sacristía, contiene en el muro del lado derecho la portezuela con la escalera de acceso al piso superior, que también se edificaría por entonces.

\section{El camarín de la virgen}

Se trata de una pequeña estancia cuadrada ubicada tras el retablo mayor que comunica con el mismo a través de la hornacina principal. De este modo, la imagen de la Virgen de Belén es fácilmente trasladada para ser vestida o limpiada en esta cámara sin tener que bajarla del retablo. La apertura de la puerta y ventana y el asentamiento de la cornisa corrieron a cargo del cantero local Jacinto de los Cuetos. Esta ventana debía ser en realidad un balcón, que fue desmontado en 1744 “...por rreconozer trazar nottable daño a la iglesia..." y vendido por 8.500 maravedíes, colocándose otra más pequeña con una reja en $1772^{1087}$. Las construcción de este espacio corrió a cargo del maestro de albañilería Julián de León, artífice que trabaja en varias ocasiones junto a Felipe Berrojo, que la ejecuto entre 1683 y $1684^{1088}$. En las paredes se disponen adosados a la pared cuatro arcos de medio punto sobre los que apea una cúpula sobre pechinas. Ésta va decorada con un repertorio geométrico de círculos y puntas de flecha que convergen hacia la clave central. A finales del XIX el camarín estaba incomunicado con el retablo por la presencia de una cajonería, volviéndose a abrir posteriormente. Desde este espacio, por una portezuela que conduce a una escalera de piedra, se desciende al cuarto "del carnero", utilizado antiguamente para eximir a los miembros del Arciprestazgo de las penas canónicas ${ }^{1089}$.

\footnotetext{
1086 IbIbídem, fol 84 y 88 Sobre ambos artífices, véase el apartado relativo a sus datos biográficos. ${ }^{1087}$ IbIbídem, fol 371-372 y 375 y 601.

1088 IbIbídem, fol 130,131. Sobre Julián de León, véase el apartado relativo a sus datos biográficos. ${ }^{1089}$ RAMÍREZ DE HELGUERA, Martín. El libro...Op.cit, pág. 158.
} 


\section{EL SIGLO XVIII}

Dado que en durante los siglos XVI y XVII se levantó el templo que hoy conocemos, durante esta centuria son escasas las noticias referentes al mismo. Recogemos algunas de estas intervenciones de menor entidad en las que ni siquiera se recogen los artífices que intervienen. En 1711 se arreglaron unas goteras que afectaban a la capilla mayor y se recompuso una parte de la cantería del atrio, llamado así al espacio delimitado por un cerco de piedra que delante de la cabecera, se asienta sobre el terraplén ${ }^{1090}$. Entre 1735 y 1738 se desmontó el tejado de la capilla mayor y además Esteban Guerra, perteneciente a una familia de alarifes carrioneses, recompuso el aguilón de la torre ${ }^{1091}$. En 1748 José Felipe Campero, también alarife, retejó toda la nave, operación que repiten Cristóbal González en 1766 y Juan Antonio Gómez en 1769 y $1770^{1092}$. Además de los Guerra, los Iglesias son otra de las familias de alarifes que se adjudican las obras de la villa. Así, en 1772 Lorenzo Iglesias se encargará de construir el antepecho del atrio y las gradas del camarín y del portal de entrada que vemos hoy día, además de efectuar un blanqueamiento general del templo. Unos años después, en 1780, Leonardo y Juan Iglesias rellenan los huecos existentes en los muros de las capillas $^{1093}$.

Entre la larga lista de pequeñas mejoras que realiza en 1793 enumeramos: la construcción de un estribo en la capilla mayor, la renovación de su tejado y el del camarín de la Virgen, el derribo de una parte del atrio que se hallaba en mal estado, el revestimiento de una de las paredes del presbiterio con tapias de piedra y ladrillo, acortamiento de los arcos de la bóveda de crucería que se quebró al hundirse el tejado, construcción de la escalera pétrea del coro en sustitución de la precedente de adobe, ejecución de mesas de altar y vidrieras. Todas ellas las llevó a cabo el carrionés, Manuel Fernández, que empleó casi cinco meses en llevarlas a cabo, ayudado por algunos oficiales y peones de la localidad ${ }^{1094}$. Dos años después fue requerido por el mayordomo para embaldosarla ${ }^{1095}$. El siglo se cierra con la intervención de 1799 sobre

\footnotetext{
${ }^{1090}$ ADP. Carrión. Iglesia de Belén. Libro 17, 5 de Cuentas de Fábrica (1653-1783), fol 244.

1091 IbIbídem, fol 353, 354.

1092 IbIbídem, fol 392v, 548, 574.

${ }^{1093}$ IbIbídem, fol 600v, 601 y 658v. Sobre los Iglesias, véase el apartado dedicado a la la biografía de los maestros locales.

1094 ADP. Carrión. Iglesia de Belén. Libro 18, 6º de Cuentas de Fábrica (1784-1852), fol 82-89.

1095 IbIbídem, fol 105.
} 
el tejado de la torre por parte del alarife Manuel Merino, quien además coloca una veleta en su remate, sustituida posteriormente por la cruz de aspas metálicas que existe hoy día ${ }^{1096}$.

\section{EL DEVENIR A PARTIR DEL SIGLO XIX}

El paso de las tropas de Bonaparte no se dejó sentir tanto en este templo como en otros de la villa carrionesa, donde se registran bastantes destrozos. En este caso, tan sólo fue necesario recomponer las vidrieras de la capilla mayor, coro y sacristía en 1813, que precisamente se habían renovado un año antes debido a la caída de un rayo que las partió. Al parecer, los franceses las arrancaban porque les interesaba el marco de hierro que tenían para fundirlo en armamento ${ }^{1097}$.

\section{La construcción del fuerte}

Con motivo de la primera guerra carlista, el cuerpo Nacional de Ingenieros, por orden del $2^{\circ}$ Cabo del distrito diseña un fuerte en 1838 para defender la ciudad ante un posible ataque del sector liberal ${ }^{1098}$. Éste se ubicó en la zona norte de la ciudad, en el eje que conforman los templos de Belén y San Andrés y el antiguo convento de Santa Isabel $^{1099}$. En lo que respecta a nuestro templo, la idea inicial era realizar un camino cubierto para unirlo con Santa Isabel pero la hondonada entre ambas impedía su construcción, además dejaba ocultas algunas partes a los fuegos de los fuertes. Salvando el terraplén se aproximaría demasiado a la manzana de pisos aledaña por lo que se plantea que sea un fuerte aislado. Se propone realizar obras en las bóvedas y tejados sin aspilleras pues sus paredes son de sillería. Además se tapiaría el acceso de entrada dejando una puerta estrecha y un foso aprovechando el terraplén y la protección que ofrecen los muros espesos, sobre todo los de la torre. En las escuadras de los tejados, fueron construidos unos parapetos de adobes colocando al efecto dos filas de tablas sobre el macizo de barro con que están asentadas las tejas para hacer otro piso. Entre las bóvedas, de trecho en trecho, se practicarían unas buhardillas para hacer fuego frontal,

\footnotetext{
1096 IbIbídem, fol 126.

1097 IbIbídem, fol 193,200.

1098 AMS. Proyecto del fuerte de Carrión. Sección 3 $3^{\mathrm{a}}$, División 3 ${ }^{\mathrm{a}}$, Leg 99, nº 11.

${ }^{1099}$ Respecto a las actuaciones que se llevaron a cabo en estos lugares, consúltense los mismos.
} 
con el perfil volado para arrojar granadas de mano y proyectiles. Además se pueden lanzar trozos de leña ardiendo, preparados con aguarrás y otros mixtos incendiarios en caso de un ataque por escala y si se hace una brecha, se usarán barriles de pólvora. Los materiales para la edificación fueron extraídos de la demolición de la casa de las Mantillas y del derruido convento de Santo Domingo. El ayuntamiento debió sufragar los gastos de la intervención pues entre 1842 y 1845, la iglesia de Belén recibe cartas de pago de la Comisión “de culto y clero" para gastos de fábrica ${ }^{1100}$. En 1843 el empedrado de la muralla había sufrido diversos desprendimientos por lo que el consistorio propone su derribo ${ }^{1101}$. Todavía en 1856 quedaban algunos restos de dicho fuerte, pues se extraen piedras del mismo para reparar el puente y reparar viviendas particulares ${ }^{1102}$.

32. Iglesia y capilla mayor 33. Coro 34. Capilla de San Gregorio 35. Sacristía y planta de la torre

35'. Camarín de la Virgen

36. Terraplén

37. Meseta rodeada de precipicios

38. Camposanto.

i. Nuevo acceso

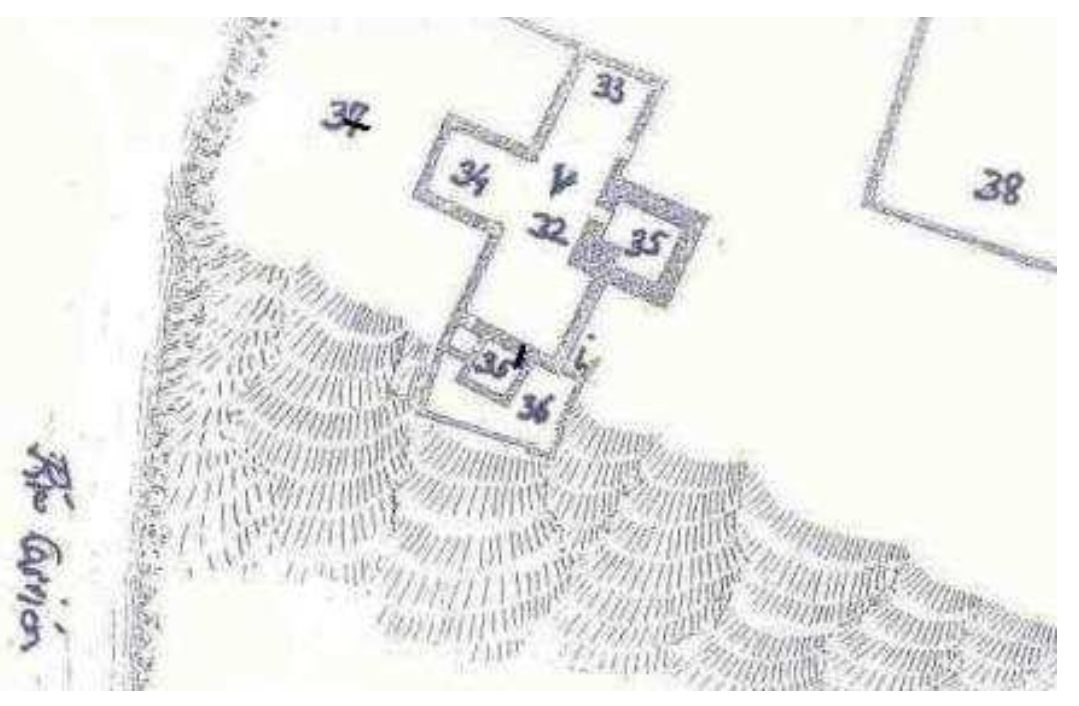

Proyecto del fuerte de Carrión. Puntos sobre los que se debe actuar en el eje defensivo de Belén. 1838. AMS. Sección $3^{\text {a }}$, división $3^{\text {a }}$, legajo 99.

\footnotetext{
${ }^{1100}$ ADP. Carrión. Iglesia de Belén. Libro 18, 6º de Cuentas de Fábrica (1784-1852), fol 268v, 271.

1101 AMCC. Libro 4. Sesiones municipales (1838-1848). Sesión de 5 de agosto de 1843, s/f.

1102 AMCC. Libro 5. Sesiones municipales (1850-1857). Sesión de 30 de octubre de 1856, fol 67 v.
} 


\section{Otras intervenciones}

Tras la obra del fuerte no se registra ninguna otra de consideración salvo algunos retejos generales que llevan a cabo los maestros albañiles carrioneses del momento como Laureano Rojo, entre 1854 y 1860 y Nicolás Herrero entre 1878 y $1883^{1103}$. En 1890 fue fundida la campana denominada "la Goda", para hacer otra más pequeña. Era de grandes dimensiones y recibía este nombre por ser de época de los godos. En torno a la misma existía una inscripción en la figuraba el año $598^{1104}$.

Según el arreglo parroquial de 1895 este templo quedó suprimido pero todos los sábados se reza el Rosario. En el siglo XX, la única referencia relativa a una intervención en el templo recoge un final trágico. A consecuencia de las lluvias torrenciales del invierno de 1912, las tapias del corral se habían caído, permitiendo así el robo de piedras de la iglesia. Por otra parte, los tejados de la torre tampoco se hallaban en buen estado. El año posterior, en que se procede a recomponer la cerca y la cubierta, uno de los oficiales de la obra, al mando de la cual estaba Prudencio Díez, cayó desde lo alto, falleciendo poco después ${ }^{1105}$.

Por último, no podemos eludir en la historia del templo, el acto de coronación canónica de la Virgen de Belén el 28 de agosto de 1960, presidido por el arzobispo don Pedro Cantero Cuadrado y la asistencia de honor de doña Encarna Polo. En 2010 se recordó este acontecimiento a través de la conmemoración de su quincuagésimo aniversario. La devoción de los carrioneses por la Virgen de Belén ha propiciado que la imagen haya sido procesionada en numerosas ocasiones con rogativas para acabar con la sequía, constatadas documentalmente en $1629,1638,1791$ y $1844^{1106}$.

\footnotetext{
${ }^{1103}$ ADP. Carrión. Iglesia de Belén. Libro 19, $7^{\circ}$ de Cuentas de Fábrica (1850-1884), fol 9v, 17, 27, 72, $73 \mathrm{v}$.

${ }^{1104}$ RAMÍREZ DE HELGUERA, Martín. El libro...Op.cit, pág. 159.

1105 ADP. Carrión. San Andrés. Legajo 121. Cuentas de Fábrica de la iglesia de Belén (1908-1947), s/f.

${ }^{1106}$ Otra muestra de la veneración por la santa titular es la creación de la Cofradía de los Pastores de Nuestra Señora de Belén, cuya regla fue redactada en 1757. GÓMEZ PÉREZ, Enrique. Belenes...V, Op.cit, pp. 16-17.
} 


\section{LAS CAPILLAS, ESPACIOS DE CULTO}

\subsection{LA CAPILLA MAYOR}

A pesar de las modificaciones experimentadas por el templo a lo largo de su evolución, la capilla mayor se ha mantenido inalterable desde el siglo XVI, salvo por su cambio de orientación del este al sur. Durante todo este tiempo, este privilegiado espacio no ha estado bajo la protección de ningún patrono particular.

\section{El retablo mayor}

El retablo mayor es fruto de dos épocas y estilos diferentes, de ahí que sea una obra de difícil interpretación. Como apuntamos, hacia 1540 se comenzó a edificar la capilla que hoy conocemos, por lo que el retablo existente, datado en el primer tercio de siglo, fue desmontado ${ }^{1107}$. Cuando este sector quedó finalizado, suponemos que a mediados de siglo en que se ajustan las pinturas, el primitivo retablo volvió ser asentado Sin embargo no creemos que a mediados de siglo, fuesen añadidos el banco, guardapolvos y ático, pudiendo ser fruto del segundo cuarto de siglo, en que ya se utilizaba el repertorio de grutescos y las columnas balaustradas que observamos en este sector $^{1108}$.

\footnotetext{
${ }^{1107}$ En los años ochenta en que el retablo fue datado en el siglo XVI, fue señalado con tres estrellas dada su calidad artística. URREA FERNÁNDEZ, Jesús y MARTÍN GONZÁLEZ, Juan José. Inventario...2, Op.cit, pág. 56. Dada su calidad, algunas de sus tallas, como los tres Reyes Magos y las imágenes de la Anunciación participaron en las Edades del Hombre de 1999, celebradas en Palencia.

${ }^{1108}$ VASALLO TORANZO, Luis. “Anunciación”, ficha n $\mathrm{n}^{\circ} 22$ en Memorias y esplendores. Las Edades del Hombre. Catedral de Palencia, 1999, pág. 158.
} 


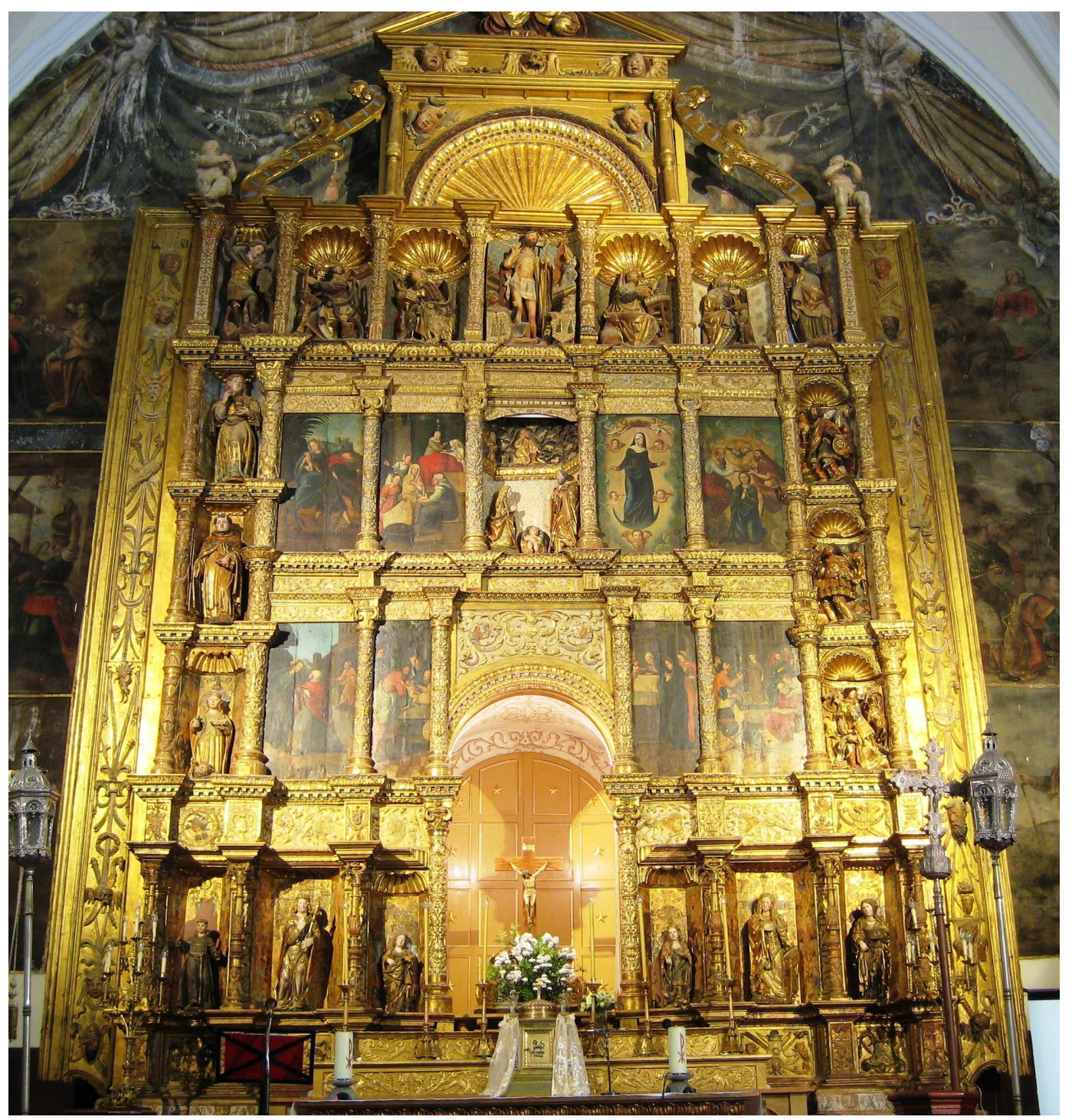

Retablo mayor de Belén. (9mtrsx6,5mtrsx0,6mtrs).

De lo que no hay ninguna duda al respecto es que en algún momento que desconocemos, se introdujeron algunas modificaciones en el retablo, en cualquier caso posteriores a la ejecución de las pinturas de 1553 que se vieron afectadas, desvirtuando la obra original. La intervención tuvo que producirse entre dicho año y finales de siglo, en que la talla de la Virgen de Belén fue adaptada como imagen de vestir ${ }^{1109}$, y por ende, necesitaba una hornacina de mayores dimensiones. Esto justificaría que las dos tablas que la flanquean estén hoy día incompletas, dado que debieron reducir sus

${ }^{1109} \mathrm{Al}$ parecer se convirtió en imagen de vestir en un momento indeterminado del siglo XVI. GÓMEZ PÉREZ, Enrique. El belén...V. Op.cit, pág. 16. 
dimensiones para emplazar las columnas, que al desplazarse, no se ajustan a los pedestales del cuerpo siguiente. Otra incongruencia destacable es el perfil diferente de las hornacinas de las calles laterales -poligonal, las del lado izquierdo, semicircular, las del derecho- y la variación en el tipo de venera utilizada en cada caso. Las hornacinas de los Reyes Magos, semejantes a las del ático, parecen ser las originales, por lo que las del lado izquierdo tendrían una disposición análoga. A esto se suma el hecho de que los soportes de este sector difieren no sólo en cuanto al diámetro de su fuste sino al diverso tratamiento de sus capiteles, de mayor desarrollo los del lado derecho.

Estas modificaciones señalan directamente hacia una intervención de la obra original, ya que es inconcebible que un retablo de tipología plateresca, como éste, en el que impera el orden y la simetría, tuviera esta disposición tan poco armónica en origen. Por otro lado, puesto que las tallas de Melchor, Gaspar y Baltasar oscilan entre los $60 \mathrm{y}$ $68 \mathrm{~cm}$ de altura, debemos pensar que en el lado frontero serían de unas dimensiones semejantes, por lo que Santa Catalina de Alejandría $(70 \mathrm{~cm})$ del lado izquierdo se mantendría en la misma hornacina que hoy día -la Santa Catalina del banco, no formaría parte del retablo original, como veremos-.

En la hornacina de San Pedro Mártir, figura que, como indicaremos, no pertenecería al retablo original, hemos ubicado a Santa Lucía $(68 \mathrm{~cm})$, que se adecúa mejor a este espacio que en el banco, donde se halla hoy día. Respecto a la Magdalena $(92 \mathrm{~cm})$, su altura nos ha llevado a situarla en el banco, donde las hornacinas laterales son de gran tamaño, en el lugar donde estaba San Antonio de Padua, que tampoco pertenece a la obra primitiva. En el banco además se ubicarían San Miguel y San Andrés dado su mejor adaptación a las hornacinas de este espacio. Ocuparían en origen el lugar donde se ubicaban el arcángel Gabriel y la Virgen de la Anunciación, que, como vemos en una fotografía de 1907 se ubicaban junto a los Evangelistas del último cuerpo, figuras que por cierto, originalmente miraban al Salvador, no al lado contrario como actualmente. 


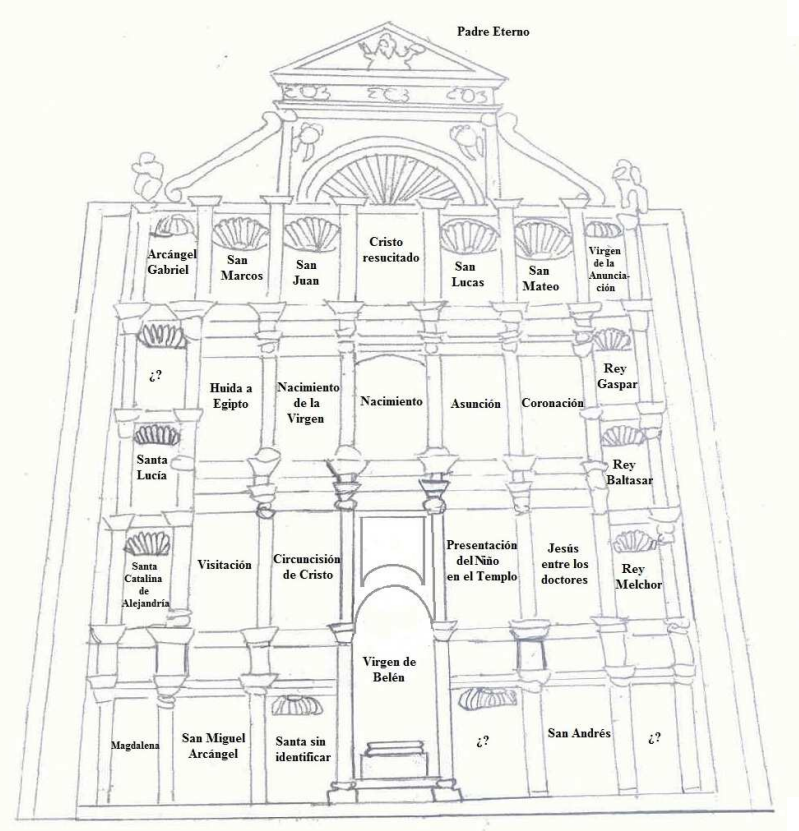

Esquema hipotético del retablo en 1553.

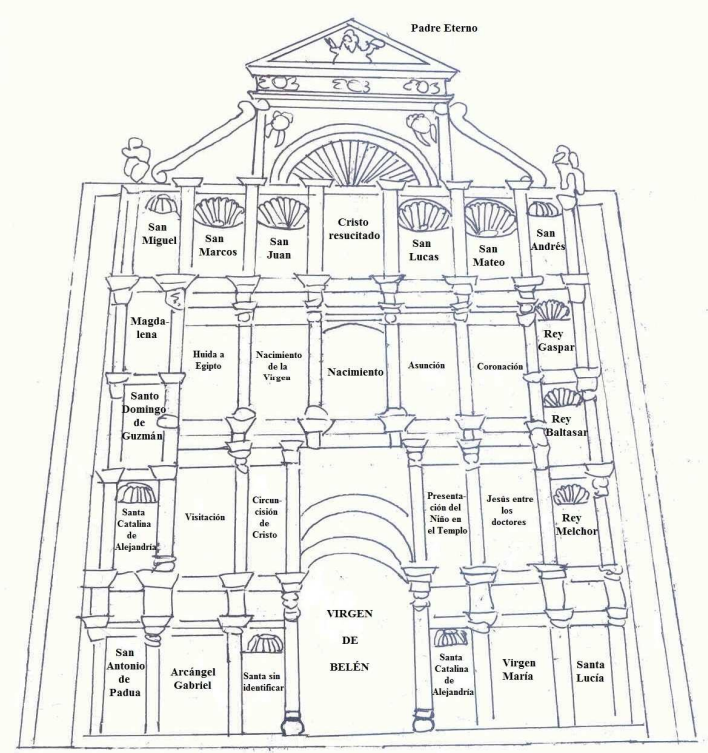

Retablo en la actualidad.

El retablo, de tipo plateresco, consta de amplio banco, tres cuerpos divididos en siete calles, pulseras y ático, conformando una obra de gran magnitud. El banco está conformado por un pedestal de siete tableros en los que se disponen bajorrelieves con motivos de grutescos muy caprichosos. Entre los tableros sobresalen de la línea del retablo los plintos que sustentan los soportes del nivel superior -el banco propiamente dicho-, con análoga ornamentación. Sobre el pedestal, a los lados de la imagen titular, se disponen seis hornacinas separadas por pilastras precedidas de finos balaustres, cuya caja presenta el remate rectangular, salvo las más próximas a la hornacina principal que poseen sendas veneras. Todas las cajas presentan un perfil poligonal de tres lados, con los dos laterales convergentes hacia el centro. Son de mayor tamaño que las esculturas que cobijan, lo cual nos indica que éstas no se ubicaban originalmente en este sector. De izquierda a derecha, divergentes en dimensiones y estilos se ubican San Antonio de Padua, el ángel Gabriel, una Santa sin identificar, Santa Catalina, la Virgen María y Santa Lucía ${ }^{1110}$. Comenzando por el Santo del extremo $(60 \mathrm{~cm})$, se trata de un fraile franciscano dado su hábito y el amplio cordón dorado que lo sujeta. Su mano derecha ha sido mutilada, por lo que desconocemos el atributo que portaba. Los otros objetos que le

\footnotetext{
1110 Comenzaremos por un análisis descriptivo de todas las figuras para después hacer un estudio estilístico de las mismas, agrupándolas entre sí. Las medidas de todas ellas están extraídas de las dichas del Inventario de la Delegación Diocesana de Patrimonio de Palencia. Carpetas de Carrión.
} 
acompañan, un libro cerrado, dado su carácter general, y un rosario, añadido seguramente a posteriori, tampoco resultan concluyentes para su atribución. Probablemente se trate de San Antonio de Padua, que antaño sostendría el lirio o el niño Jesús, dado que el libro en este caso no serviría de asiento al mancebo debido a su disposición vertical. De su estilizado cuello emerge el rostro de un hombre joven, imberbe y tonsurado, de tez pálida. Su frente escasa, sus ojos grandes, su nariz alargada y ancha, los pómulos sonrosados y sus labios carnosos proyectan una apacible expresión en el espectador. Los finísimos esgrafiados de motivos vegetales que decoran las orlas nos sitúan ante una imagen datable hacia 1540.

A continuación se sitúa el arcángel Gabriel $(78 \mathrm{~cm})$, una imagen de gran elegancia que porta una túnica larga en la que asoman sus rodillas y un largo manto abrochado sobre el pecho. En torno a su cabeza, porta una sencilla diadema verde de la que emergen los bucles ensortijados de su rubia cabellera. El cuerpo, desplazado hacia la izquierda en dinámica actitud, corresponde al momento del anuncio, patente a través de sus dedos índice y corazón apuntando hacia el cielo, en señal de divina providencia. Con la otra mano, protegido con su brazo, porta un cetro dorado cuya parte superior se desgaja en cuatro formando los pétalos de una flor de lis. La figura ubicada junto al arcángel corresponde a la de una Santa $(54 \mathrm{~cm})$ de difícil atribución, ya que tan sólo porta un libro abierto en su mano derecha. Los dedos de su mano derecha están doblados, en actitud de sujetar un objeto ligero, tal vez, una palma de martirio. A sus pies se ubicaría su principal atributo, como se deduce de la madera sin tallar en este sector, como si algún objeto adosado a la escultura hubiera sido arrancado.

En el lado derecho, figura Santa Catalina de Alejandría $(57 \mathrm{~cm})$, inconfundible por la figura del infiel que se retuerce a sus pies. La imagen, de dócil expresión, es la de una doncella romana, vestida con túnica, amplio manto y corona. Sostiene en su mano izquierda un libro abierto, mientras que en la otra mano porta un objeto fraccionado que podría ser una cimitarra, pues adivinamos la empuñadura dorada y el filo negro y curvado, alusivo a su decapitación. La repetición de esta figura en el retablo y su estilo divergente al resto, confirma que no formaba parte del conjunto original. Junto a ella, la Virgen María (78cm), una imagen de idénticas dimensiones y estilo al ángel de la Anunciación, con el que formaría pareja originalmente. A pesar de la inexpresividad de su rostro, su espontánea actitud denota la sorpresa que desencadena la feliz noticia de la 
concepción. Su lectura acaba de ser interrumpida, como se deduce del libro que, apoyado en un reclinatorio, está a punto de cerrar y la mano posada en su pecho revela el desconcierto del instante representado. El ángel y la Virgen se ubicaban anteriormente en el último cuerpo del retablo, flanqueando a los Evangelistas, tal y como apreciamos en una fotografía de 1907. Por último, Santa Lucía $(68 \mathrm{~cm})$, ubicada en el extremo derecho, porta un vestido amplio, ceñido a la cintura, de donde cuelgan varias borlas y un manto, abierto por delante, que cubre sus hombros. A simple vista parece que su cuello lo adorna un ajustado collar de colores rojizo y dorado. Sin embargo, si observamos más de cerca, se trata de una sucesión de rayos solares que irradian milagrosamente de una herida sangrante, en alusión al puñal que atravesó su garganta. Realmente sí que porta un collar del que pende una pequeña cruz, que se confunde con la orla dorada que filetea el escote de la túnica.

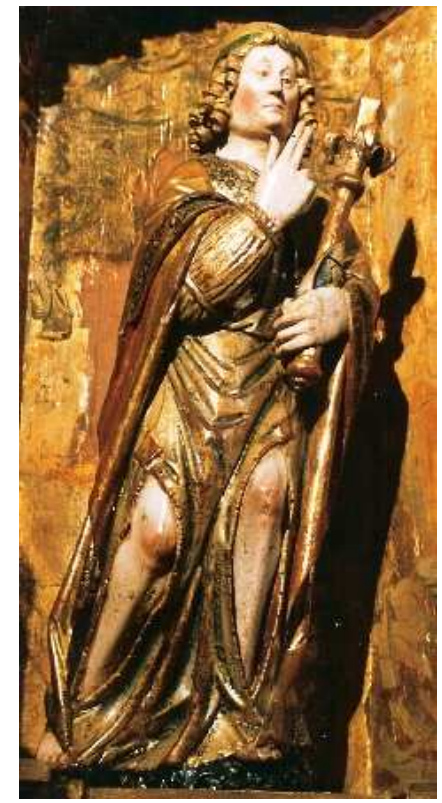

Arcángel Gabriel.

$(78 \mathrm{~cm} \times 32 \mathrm{~cm} \times 30 \mathrm{~cm})$.

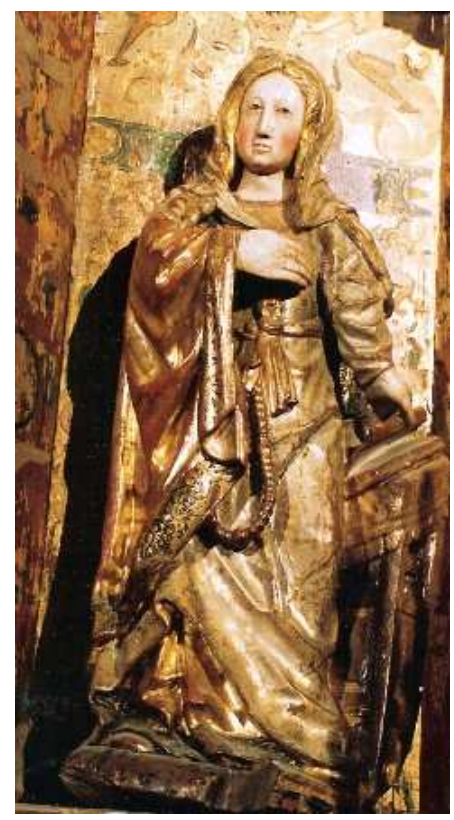

Virgen María.

$(78 \mathrm{~cm} \times 34 \mathrm{~cm} \times 24 \mathrm{~cm})$.

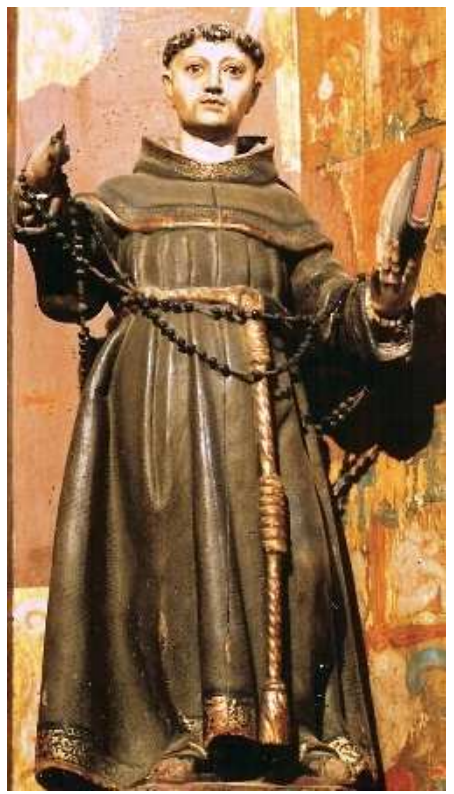

San Antonio de Padua.

$(60 \mathrm{~cm} \times 30 \mathrm{~cm} \times 22 \mathrm{~cm})$.

\section{Esculturas ubicadas en el banco del retablo mayor de Belén.}

El espacio central está conformado por un arco de medio punto moldurado a través de ovas, dentellones y elementos vegetales, sobre el cual se extiende un tablero con decoración a candelieri. Se prolonga a lo largo del banco y el primer cuerpo, por lo 
que, en virtud de su altura, está flanqueado por dos columnas superpuestas a cada lado, decoradas a candelieri. La imagen principal es Nuestra Señora de Belén, patrona de Carrión de los Condes. Tradicionalmente, se ha venido admitiendo que se trata de una talla de época medieval muy mutilada que remonta a finales del siglo XIII o principios del XIV ${ }^{1111}$. En realidad lo que queda de época gótica es el trono, los pies y el tronco, pues las manos y los pies corresponden a una datación posterior, difícil de determinar a tenor de los repintes posteriores. Adaptada como imagen de vestir en el siglo XVI ${ }^{1112}$, luce una túnica y velo blancos con finos bordados florales y un manto granate provisto de ramilletes dorados. Sobre su cabeza porta una pesada corona de plata de ley con incrustaciones que fue costeada por todos los carrioneses, quienes, con motivo de la coronación de la Virgen en 1960, donaron sus joyas más preciadas. Se sabe que tenía corona desde al menos el siglo XVI, pues en 1571 el platero Baltasar Pérez se encargó de fundir la antigua para realizar una nueva con la plata que saliese de la misma ${ }^{1113}$. La Virgen sostiene un cetro dorado en su mano derecha, mientras que con la otra sujeta al Niño Jesús, provisto de corona y túnica larga, a juego con la de su madre. Es una pequeña imagen, tallada íntegramente -sus piernas asoman por la vestimenta- y adaptada igualmente para vestir que tan sólo conserva el tronco de época gótica, habiendo sido tallados las manos y el rostro durante el período barroco ${ }^{1114}$. De su anatomía tan sólo vemos su rostro mofletudo con una espesa cabellera castaña y sus rechonchas manitas con las que bendice y sostiene el orbe. Hasta 1684 en que fue edificado el camarín que hay por detrás del retablo en que se abrió este espacio de comunicación $^{1115}$, la imagen se ubicaba en una hornacina, dato constatado por el hecho de que en 1618 pinta su caja el pintor Bartolomé de Medina, autor de obras de Carrión como el lienzo de San Miguel ubicado en San Andrés o la Virgen de la Misericordia en el convento de Santa Clara ${ }^{116}$. La policromía a pulimento que presenta hoy día es fruto de varias intervenciones: una que tuvo lugar en 1796 a cargo de los maestros doradores

\footnotetext{
${ }^{1111}$ Aldaba: Boletín Informativo de la Parroquia de Carrión de los Condes. № 5. Carrión de los Condes (Palencia), 1997-8, PRIETO SARRO, Marta. Carrión de los Condes. Palencia. Trobajo del Camino, León 1999, pág. 54 y PERAL VILLAFRUELA, Santiago y GÓMEZ PÉREZ, Enrique. Edición 2003, Op.cit, pp. 65-66.

${ }^{1112}$ GÓMEZ PÉREZ, Enrique. El Belén...V. Op.cit, pág. 16.

1113 ADP. Belén. ADP. Carrión de los Condes. Iglesia de Belén. Libro 14 de Fábrica (1568-1586), fol 183.

${ }^{1114}$ Estos datos han sido proporcionados por Enrique Gómez Pérez, gran conocedor del patrimonio carrionés, aunque no existen constancia documental de los mismos.

${ }^{1115}$ Consúltese a este respecto la evolución del templo.

1116 ADP. Carrión. Iglesia de Belén. Libro 16, 4º de Fábrica (1616-1646), fol 43v. Sobre Bartolomé de Medina, remítase al capítulo dedicado a los pintores.
} 
Francisco Ruiz de Muñar y Juan de Mata, vecinos de Carrión y otra de hace seis o siete años que le confirió una carnación más oscura ${ }^{1117}$.

Entre 1847 y 1848 fue construido el tabernáculo para alojar la imagen de Nuestra Señora, ejecutado por el carrionés Manuel Martín Carniago. Aunque el coste de la obra ascendió a más de dos mil reales, parte de la misma fue financiada gracias a las limosnas de los fieles. Casi la misma suma tuvo de coste el dorado y jaspeado de la pieza, actuación de la que se encargó Carlos Laíz ${ }^{1118}$. Una litografía realizada por Heraclio Fournier y una fotografía tomada en 1907 nos permiten visualizar la apariencia de este tabernáculo que se ubicaba por delante del retablo. Estaba conformado por una predela dividida en tres tableros moldurados en cuyo centro se hallaba una cruz inscrita en una corona vegetal. Sobre la misma se ubicaba un tabernáculo asentado sobre cuatro columnas salomónicas de tres espiras entre las cuales se halla una pintura del Agnus Dei con el estandarte de la cruz. La escena se enmarca en un teatro cuya cortina se abre a los lados, recurso decorativo muy típico del barroco. La tarjeta cactiforme que remata el conjunto, plana y movida, apunta una datación del último cuarto del siglo XVII y por ende, es una obra reutilizada para ornamentar este camarín. Hoy día se le ha añadido un óleo sobre tabla con la escena de María Magdalena implorando el perdón de Cristo. Todos los apóstoles se hallan reunidos en torno a Cristo, salvo Judas, frente a ellos. En el respaldo de su asiento figura su nombre y la fecha de 1546 correspondiente a la ejecución de la pintura. Por detrás de este pequeño baldaquino, conservado hasta el año 2009 en Belén y desde entonces en San Andrés ${ }^{1119}$, se levantan los pedestales veteados correspondientes a las cuatro columnas de orden corintio que se alzan sobre ellos. En el centro se abre el arco de medio punto moldurado que albergó la imagen titular. El arquitrabe retranqueado se divide en tres partes: una banda decorada con motivos que imitan piedra fragmentada y dos cornisas provistos de dentellones de diversos tamaños. Dos angelotes sentados sobre la cornisa sustentan una cinta donde figura una de las letanías a la Virgen: “CAUSA NOSTRÆ LÆTITIÆ, ORA PRO NOBIS”. En el remate, se hallaba un medallón adornado con dos ramas de laurel que contenía las iniciales de Ave María entrelazadas. A los lados de este tabernáculo existían varias urnas que

\footnotetext{
${ }^{1117}$ ADP. Carr. Iglesia de Belén. Libro 18, 6º de Cuentas de Fábrica (1784-1852), fol 111.

1118 IbIbídem, fol 289v.

${ }^{1119}$ Mi colega, Enrique Gómez Pérez me informa del traslado hace tres años de esta pieza a la iglesia de San Andrés para decorar el Monumento. El primer año después de Semana Santa, lo volvieron a llevar a la sacristía vieja de Belén, pero ya hace dos años, lo dejan en san Andrés, un año guardado bajo la escalera de subida al coro y otro en el antiguo cuarto del Carro Triunfante.
} 
contenían reliquias de San Zoilo y Santa Lucía, entre otros ${ }^{1120}$. Probablemente se eliminaron al mismo tiempo que el tabernáculo, en 1960, con motivo de la coronación, pero existían desde hacía siglos, ya que en 1703 se hace alusión a estas reliquias, momento en que se doran sus urnas y el frontal del altar ${ }^{121}$.

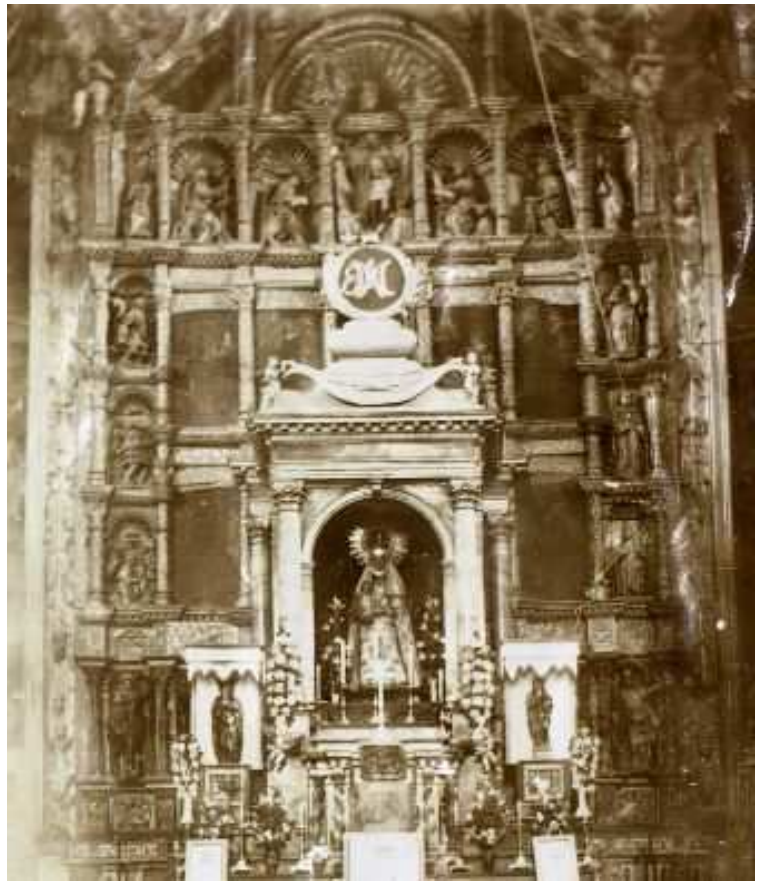

Retablo en 1907 con el camarín.

Imagen contenida en el Inventario

de Palencia y provincia de Bernardino

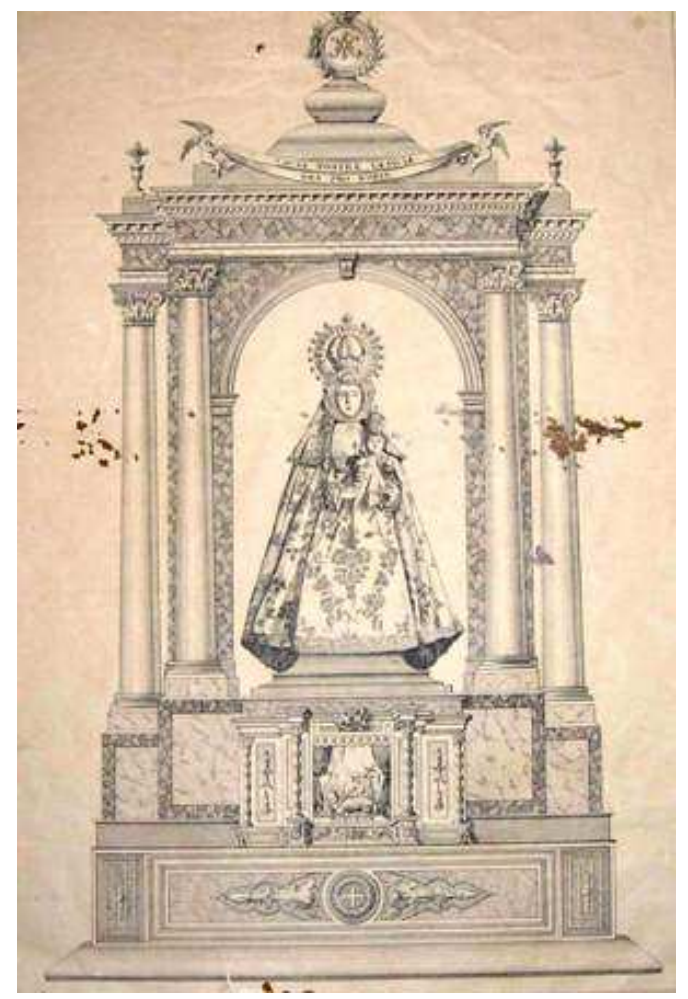

\section{Litografía de Heraclio Fournier con el camarín neoclásico y el tabernáculo.}

\section{Martín Mínguez.}

A continuación una amplia cornisa de grutescos precede al primer y segundo cuerpo, donde se disponen ocho tablas pintadas por Antonio Calderón, quien en 1553 se traslada desde Palencia para asentarlas ${ }^{1122}$. Recibe pagos por las mismas desde 1554, en que se tasa a obra en 323.500 maravedíes, hasta 1561, en que se le abona la última

\footnotetext{
${ }^{1120}$ RAMÍREZ DE HELGUERA, Martín. El libro...Op.cit, pág. 158.

${ }^{1121}$ ADP. Carr. Iglesia de Belén. Libro 17, 5º de Cuentas de Fábrica (1653-1783), fol 231.

1122 VASALLO TORANZO, Luis. "Anunciación", Op.cit, pág. 158. No se conoce nada de su actividad artística, pero se conservan dos pleitos en los que fue protagonista por la posesión de unas casas. En el primer caso litiga en 1550 con el monasterio leonés de San Llodio. ARCHV. Pleitos Civiles (OLV), Caja 673, 6. El otro pleito, comenzado en 1552, se establece contra los clérigos de la iglesia de San Andrés. ARCHV. Pleitos Civiles (Fernando Alonso), Caja 1380, 3 y la ejecutoria está fechada el 6 de octubre de 1556. ARCHV. Registro de ejecutorias. Caja 860,38.
} 
cantidad en su nombre a su mujer, Beatriz Castrillo ${ }^{1123}$. En todas las escenas, salvo en una, contamos con la presencia de la Virgen María, figurando en algunas, como protagonista. Situándose de izquierda a derecha, observamos en el segundo cuerpo la Huída a Egipto, el Nacimiento de la Virgen, la Asunción, y Coronación. Debajo se ubican la Visitación, Circuncisión de Cristo, Presentación del niño en el templo y Cristo con los doctores.

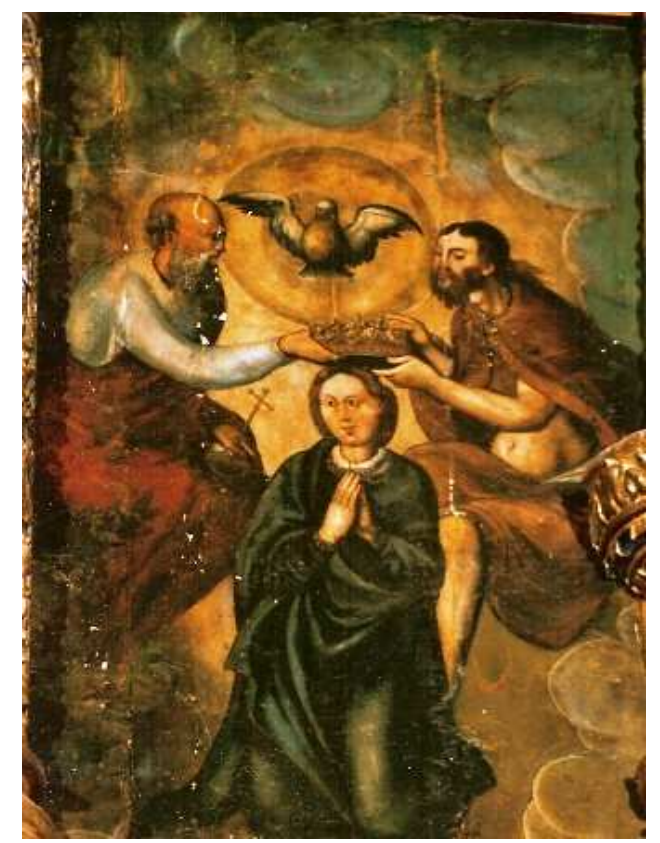

Coronación $(115 \mathrm{~cm} \times 62)$.

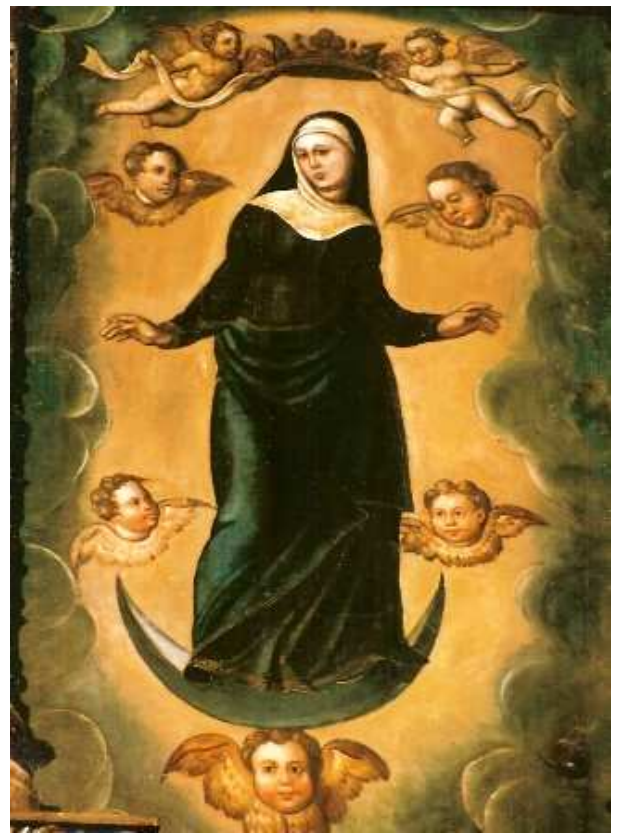

Asunción (115cmx63cm).

Pinturas de la vida de la Virgen de Antonio Calderón. 1553.

Se trata de un pintor de calidad mediocre del que no se conocen más obras en la provincia, lo que apunta que se tratase de un maestro local. Podemos observar cómo el pintor emplea una ambientación muy somera de sencillos paisajes y arquitecturas de líneas rectas en los que no logra el efecto de espacialidad deseado. En cuanto a las figuras, existe una tipificación de los rostros, que pecan de cierta planitud y reiteran su posición ladeada en la mayoría de las pinturas. Se ha relacionado el estilo de las mismas con Juan de Borgoña ${ }^{124}$; sin embargo el gusto por el naturalismo y los detalles, el

\footnotetext{
${ }^{1123}$ ADP. Carr. Iglesia de Belén. Libro 13 de Cuentas de Fábrica (1549-1566), fol 64, 65, 69, 75, 88,100. 1124 UNAMUNO, Fernando. "Retablo de Nuestra Señora de Belén en Carrión de los Condes (Palencia)" en Academia. Boletín de la Real Academia de Bellas Artes de San Fernando. № 11. Madrid, 1960, pág. 75.
} 
protagonismo de las arquitecturas fingidas y el dominio de la perspectiva, patentes en la producción del prolífico artista borgoñón no aparecen en la obra de este pintor artesanal, mucho menos avezado. Centrando el segundo cuerpo preside la escena del Nacimiento de Cristo, cobijada en una hornacina rectangular a la que se accede por un arco rebajado. El fondo de este espacio tan sólo está tallado a partir de la cornisa, por encima de los personajes principales, donde se ha representado muy someramente unos prados salpicados de ovejas y unos pastores que, aludiendo al anuncio bíblico, ambientan la escena que hay bajo ellos. El artista ha omitido a la mula y al buey tradicionales, concentrando en la escena tan sólo a los tres personajes imprescindibles. La Virgen María, genuflexa $(61 \mathrm{~cm})$ aparece situada a la izquierda, de perfil, orante ante el niño Jesús, en actitud de adoración. El recién nacido $(35 \mathrm{~cm})$, de rubios cabellos, reposa desnudo en el pesebre, que el escultor nos presenta inclinado para que pueda apreciarse desde abajo. Por su parte San José, es una figura de mirada ausente, gesto a través del cual el artista ha podido buscar restarle protagonismo dentro de la escena, afianzando así el de los otros dos personajes. Sus manos, que otrora se apoyaban en un firme bastón, sostienen hoy día un pequeño fragmento del mismo. Estas figuras, de carácter retardatario, remontan al momento de ejecución del primitivo retablo, como veremos.

En los extremos, alineados verticalmente, se hallan seis esculturas cobijadas en hornacinas aveneradas, de diferente perfil, como señalamos previamente. En el lado izquierdo, se superponen las tallas de Santa Catalina de Alejandría, San Pedro Mártir y María Magdalena. La efigie de Santa Catalina $(70 \mathrm{~cm})$, repetida en el banco, porta una indumentaria propia del siglo XVI, como la saya dorada de mangas acuchilladas, propias de la moda flamenca que dejan entrever la camisa que lleva debajo. Encima lleva una especie de cota decorada con plumas ajustada por debajo del pecho a través de un fajín anudado en la parte delantera. Un amplio manto cae por sus hombros, que recoge firmemente con el brazo derecho. Presenta los atributos clásicos de su iconografía, como el libro abierto, la espada y el busto barbado del emperador al que pisa enérgicamente, identificado por su corona y cetro en forma de flor de lis. Probablemente, a sus pies, en unos de sus lados, se sitúe además la rueda dentada, que no llegamos a ver por la altura a la que se sitúa la imagen, oculta esta parte por la cornisa. Es sorprendente la semejanza estilística que hallamos entre esta pieza y la talla homónima de la iglesia de la Asunción de Quintanilla de la Cueza, atribuida al círculo 
de Vigarny ${ }^{1125}$, además de la idéntica pose, el mismo tratamiento de los pliegues y el rostro mofletudo y nariz fina. La vestimenta y el modo de disponer los pliegues pone de relieve que una pieza sirvió de inspiración a la hora de ejecutar la otra, muy probable dada la cercanía de ambas localidades palentinas. Incluso, aunque se trate de un detalle baladí, el azar ha querido que hoy día, ambas figuras empuñen tan sólo el pomo y la empuñadura de la espada que portaban. Seguramente la de Quintanilla, de mayor tamaño $(106 \mathrm{~cm})$ fue realizada por un artista del mismo taller pero algo más desenvuelto, patente en la mayor proporción del canon y el tratamiento de los mechones de la melena más trabajado.

Sobre la mártir de Alejandría se ubica la imagen de San Pedro Mártir, una figura de canon corto y cándida expresión. Se presenta sin barba, con la tonsura monacal y el rostro ensimismado. Le falta su mano derecha, la cual estaría alzada con un bastón y en la otra porta un libro, probablemente la Biblia, dado que era un gran conocedor de sus escritor y predicaba sus contenidos. Si bien ha sido identificado como Santo Domingo de Guzmán, la herida que presenta en la parte trasera de su cabeza, aún faltándole el cuchillo clavado $^{1126}$, nos permite identificar la figura con la del santo de Verona. La capa y esclavina del santo dominico está provisto de un rico estofado a base de finos roleos vegetales que remite a una datación de hacia 1540. En lo que respecta a la figura siguiente, descartamos su atribución como San Juan Evangelista ${ }^{127}$, dado que aunque el apóstol suela presentar un carácter bastante ambiguo, nos parece que la rotundidad de la figura y la largura de los cabellos hasta el pecho vinculan a la imagen con la de una mujer, que identificamos como María Magdalena $(92 \mathrm{~cm})$. En este caso no presenta la iconografía tradicional de penitente sino que viste como una mujer de elevada condición, patente en el vistoso vestido que recubre su cuerpo, cuyo volumen es transmitido a través de la pierna izquierda que avanza. Con la mano izquierda sostiene el pomo de los ungüentos, que destapa delicadamente con la otra mano, atributo que fue identificado como el cáliz, propio de San Juan. Es una figura que denota mayor naturalismo que otras por sus pliegues abultados y su rostro de perfil más redondeado.

\footnotetext{
${ }^{1125}$ PORTELA SANDOVAL, Francisco José. La escultura...Op.cit, pp. 45-61.

${ }^{1126}$ GÓMEZ PÉREZ, Enrique. "Santo Domingo de Guzmán” en Entre Castilla y Filipinas, 400 años. Ayuntamiento de Carrión de los Condes. Palencia, 2006, pág. 30

${ }^{1127}$ URREA FERNÁNDEZ, Jesús y MARTÍN GONZÁLEZ, Juan José. Inventario...2, Op.cit, pág. 56
} 


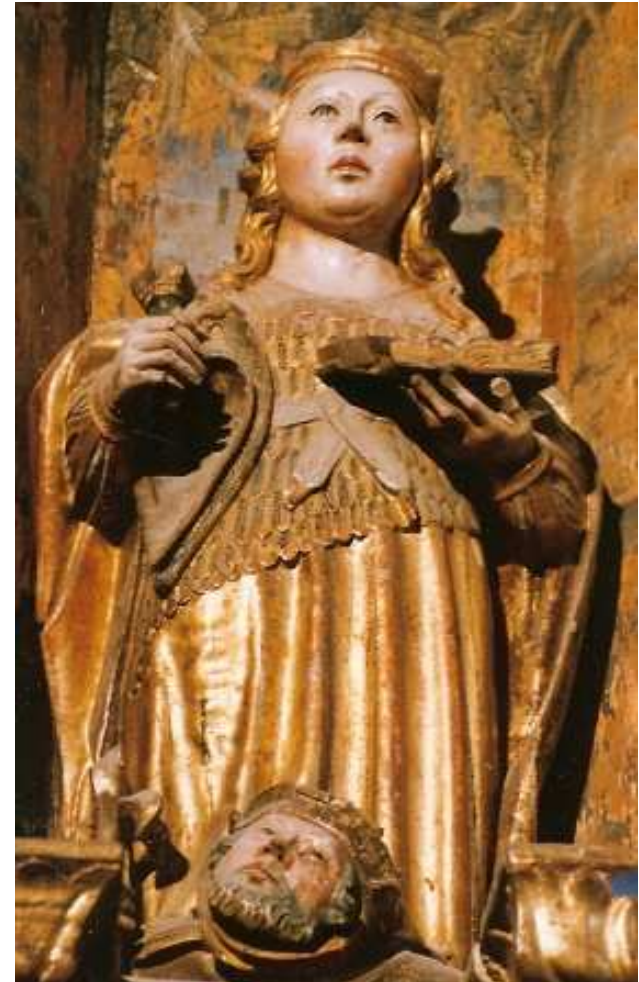

Santa Catalina $(70 \mathrm{~cm} \times 32 \mathrm{~cm} \times 24 \mathrm{~cm})$.

Retablo mayor de Belén.

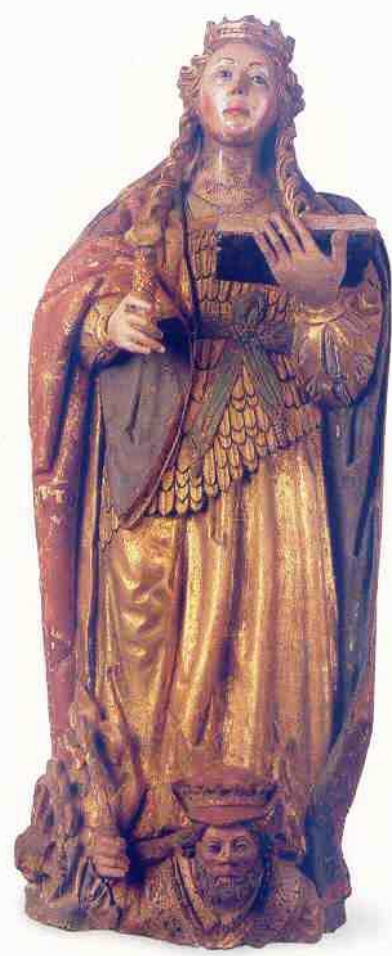

Santa Catalina en la iglesia de la Asunción de Quintanilla de la Cueza.

Obras del primer cuarto del siglo XVI atribuibles al taller de Carrión.
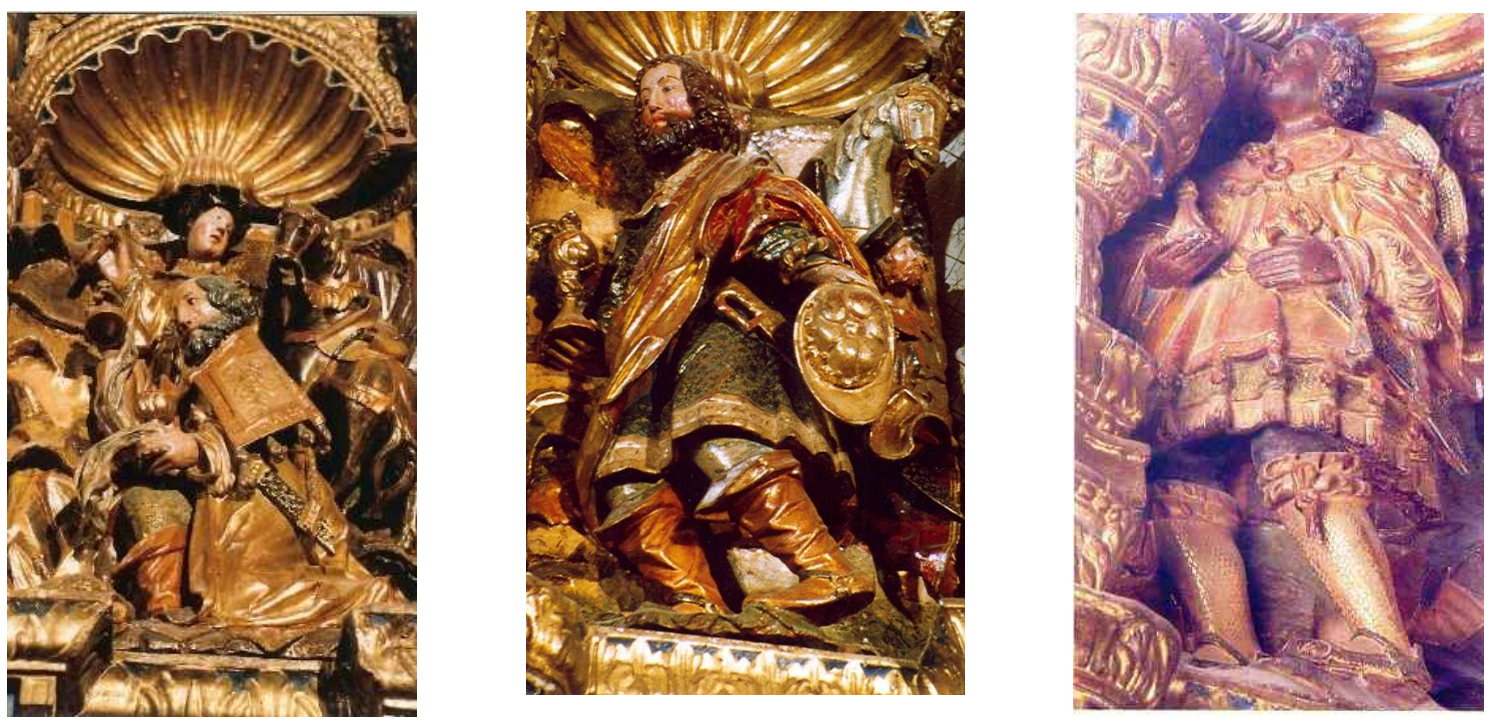

Melchor $(68 \mathrm{~cm} \times 45 \mathrm{~cm} \times 25 \mathrm{mc})$. Gaspar $(60 \mathrm{~cm} \times 45 \mathrm{~cm} \times 25 \mathrm{~cm})$. Baltasar $(60 \mathrm{~cm} \times 42 \mathrm{~cm} \times 25 \mathrm{~cm})$.

Esculturas de los Reyes Magos ubicadas en la calle lateral derecha del retablo. 
En el lado opuesto se superponen las imágenes de los Reyes Magos, dispuestos en dirección hacia la escena del Nacimiento, conformando en la distancia, la escena de la Epifanía. De acuerdo a su condición, lucen suntuosos ropajes y ninguno porta su corona, rindiendo así el respecto debido a la majestad del recién nacido. Los tres aparecen secundados por sus respectivos pajes y corceles que conceden un gran decorativismo a la escena, mientras ofrecen sus dones al niño. El rey Melchor $(68 \mathrm{~cm})$, calvo y de barba cana, por ser según la tradición, el más anciano, es el único que se presenta arrodillado. Porta una larga túnica y sus hombros van cubiertos por una especie de capa pluvial orlada de rojo. Destapa con la mano derecha el cáliz que porta en la otra, para mostrar el oro que ha traído como ofrenda. Gaspar y Baltasar $(60 \mathrm{~cm})$, en cambio, están iniciando la genuflexión, indicando de este modo el artista su inmediata llegada. Además ambos lucen una túnica hasta las rodillas, que les confiere un aspecto más juvenil que a Melchor, y ofrecen sus dones con su mano derecha. El primero está identificado por su barba y cabellera castañas, retratando a un hombre de mediana edad y el segundo, de espesa cabellera oscura y piel negra -si bien no presenta los caracteres propios de esta raza sino los del estilo del autor-, es el más joven de todos.

El arcángel San Miguel, los cuatro Evangelistas, Cristo Resucitado y San Andrés son las siete figuras que presiden el último cuerpo del retablo, separados de nuevo por columnas decoradas mediante grutescos. San Miguel $(100 \mathrm{~cm})$, dotado del escudo y empuñando su espada, lucha contra el demonio, que, a sus pies, trata de liberarse inútilmente arañando con sus garrar las piernas del arcángel. Su dinámica actitud se contrapone a la expresión lánguida de su rostro, de párpados caídos, sin fuerza vital. A continuación se sitúan los cuatro Evangelistas en hornacinas con veneras muy desarrolladas, semejantes a las que cobijan a los Reyes Magos. Resulta muy extraño comprobar cómo San Marcos y San Juan, a la izquierda de Cristo y San Lucas y San Mateo, en su margen derecha, miran hacia el exterior del retablo, de modo que ninguno de ellos converge hacia el Redentor. Gracias a la existencia de una fotografía de 1907, constatamos que originalmente, o al menos por entonces, se agrupaban en torno a él. Probablemente en 1960, con las modificaciones que sufrió el retablo, cambiaron de posición tal y como las vemos actualmente. Tampoco es muy común situar a los Evangelistas en la parte superior del retablo, sino en el banco, donde podrían haber estado situados en la concepción inicial del mismo. Todos ellos, aparecen sentados frente a una escribanía, redactando las Escrituras con el rostro elevado, como si 
estuvieran esperando recibir la inspiración divina. Poseen idénticas dimensiones $(60 \mathrm{~cm})$ y características estilísticas, como veremos, y están acompañados de sus respectivos Tetramorfos. En el centro, preside este cuerpo Cristo resucitado $(105 \mathrm{~cm})$, porta un perizonium estampado con listas verticales decoradas con un filo dorado y sobre sus hombros luce una capa larga y dorada con una orla esgrafiada en azul. A su lado, sobre la tapa rota del sepulcro, un angelillo contempla cómo Cristo bendice mientras sujeta el estandarte de la victoria. Sentados a los pies de Cristo figuran dos soldados portando escudos ornamentados con sendas borlas. El soldado de la izquierda, cubierto con un casco, permanece dormido, ajeno a lo que sucede, en tanto que su compañero, tocado con un turbante, contempla estupefacto la escena. En el extremo derecho, figura un santo barbado asiendo un tronco nudoso que identificamos con San Andrés $(93 \mathrm{~cm})$, dado que parece que en la parte inferior se entrecruza otro tronco. El otro atributo que porta, el libro en su mano derecha, tampoco aporta nada concluyente a este respecto. Sus manos son muy potentes y volumétricas y su rostro, con la barba de mechones movidos guarda cierto aire berruguetesco.

Sobre la cornisa del último cuerpo, sentados en los extremos, figuran dos rechonchos amorcillos tañendo instrumentos. Entre ambos se extiende el ático, añadido a mediados del siglo XVI para adaptarse a la nueva capilla. En el centro una gran venera flanqueada por dos balaustres en los que apoyan dos eses avolutadas que conforman los aletones. Las enjutas y la cornisa situada encima contienen relieves de testas de querubines alados, salvo en el centro de dicha cornisa, donde el dulce motivo ha sido sustituido por el de una calavera alada. Inserto en el frontón del remate se dispone un altorrelieve que representa el busto del Padre Eterno, bendiciendo con una mano y acogiendo el orbe con la otra. Su rostro denota gran expresividad a través de la boca abierta y las cejas ligeramente fruncidas, los pómulos salientes y las mejillas muy hundidas. El trabajo de las guedejas onduladas del cabello denota un avance en el tiempo respecto al resto de esculturas del retablo.

Desde el punto de vista arquitectónico esta obra plateresca presenta grandes analogías estructurales y ornamentales con otros retablos palentinos, como el retablo mayor de la catedral de Palencia. Se trata de una obra muy plana, ortogonal, con una articulación en casillero columnas y entablamentos decorados con grutescos y remates 
en frontón ${ }^{1128}$. Como el retablo de la capital palentina, el de Belén fue concebido a la manera lombarda, con la bóveda de las hornacinas talladas en forma de venera y con grutescos en las pilastras que separan cada calle. Sin salir de este templo, la capilla del Sagrario se encuentra presidida por un retablo atribuido al círculo de Vigarny encargado en 1528 , y por tanto contemporáneo al nuestro, que posee algunos elementos afines ${ }^{1129}$. La disposición de hornacinas aveneradas que combinan la concha dispuesta normalmente o de forma invertida y el empleo de pilastras con candelieri son recursos comunes a ambas piezas.

También se asemeja al retablo plateresco de la iglesia de Santa María de Montealegre de Campos, localidad vallisoletana perteneciente al Partido de Medina de Rioseco. Ambos se distribuyen en cuerpos ortogonales, los cuales presentan como soporte columnas abalaustradas y poseen una fina talla que las ornamenta. Presenta además gran similitud con el retablo mayor del convento de San Pablo de Palencia, realizado hacia 1520 posiblemente por el taller de Vigarny ${ }^{1130}$. Aparte de la composición reticular, en ambos casos el artista ha empleado la hornacina avenerada para acoger las esculturas, repitiéndose este elemento en grandes dimensiones como remate. En Santo Domingo se presenta exento, flanqueado por bolas escurialenses añadidas posteriormente, mientras en Belén, acompaña a un frontón triangular. La presencia de pulseras con grutescos, el banco muy desarrollado y las columnas estilizadas con decoración a candelieri del retablo mayor de Arroyo, realizado probablemente por el taller de Carrión, del que hablaremos a continuación, señala la traslación de un mismo esquema, demostrable también en la disposición de la hornacina de medio punto en el primer cuerpo y la caja poligonal en el segundo ${ }^{1131}$.

En lo que se refiere a las esculturas del retablo, dos artistas de un mismo taller pero diferente estilo se encargarían de realizar la mayor parte de las esculturas en torno al primer tercio del siglo XVI y otro ejecutaría las más avanzadas hacia 1540, las cuales no formarían parte del retablo original. El primero de los escultores se ocuparía de las imágenes de Santa Lucía, la Anunciación, el Nacimiento de Cristo, los Reyes Magos, los Evangelistas, el Cristo resucitado y la Santa Catalina del primer cuerpo. Este

\footnotetext{
${ }^{1128}$ VASALLO TORANZO, Luis. “Anunciación”, Op.cit, pág. 158.

${ }^{1129}$ Sobre el mismo, PORTELA SANDOVAL, Francisco José. La escultura...Op.cit, pp. 82-113.

${ }^{1130}$ Ibídem y también ANDRÉS ORDAX, Salvador. "Los dominicos en Palencia...Op.cit, pág. 92.

${ }^{1131}$ CUESTA SALADO, Jesús. Jacques Bernal...Op.cit, pág. 21.
} 
maestro estaría familiarizado con los modelos del último gótico burgalés, influencia muy posible dado que Carrión se halla en el camino entre Burgos y León caracterizado por el empleo de rostros de gran planitud y tratamiento alargado. La expresión de todos ellos evoca una sensación de aletargamiento a través de los ojos minúsculos y levemente rasgados y los párpados caídos. La nariz en estas figuras es fina y alargada y la boca es bastante pequeña, con los labios pegados y la comisura marcada. Las ejecución de las manos peca de cierta torpeza, resultan anómalamente grandes y muy planas, característica apreciable en el arcángel Gabriel o en Cristo resucitado. Las figuras no se mueven demasiado en el espacio, los ropajes suelen ser suntuosos y los pliegues en ocasiones adoptan forma de $\mathrm{V}$, de raigambre goticista ${ }^{1132}$.

Otro maestro ejecutaría por los mismos años las figuras de la Magdalena, San Miguel, San Andrés y la Santa sin identificar del banco. Son figuras de canon corto pero guardan mayor proporción en sus manos que las anteriores. En todas ellas, la cadencia de los pliegues se desenvuelve de forma redondeada, creando un suave dinamismo al dejar adivinar una rodilla que se adelanta.

Ambos maestros serían miembros de un prolífico taller de escultura asentado en Carrión en las primeras décadas del siglo XVI que abastecía a los pueblos colindantes a la villa palentina. Regido en principio por Juan de Salinas, a la muerte del mismo hacia 1522, tomó el relevo Jacques Bernal, maestro francés bajo cuya supervisión debieron realizarse las tallas carrionesas, dada su vinculación con otras obras documentadas y atribuidas al maestro francés. De su taller salieron las figuras de José de Arimatea y Nicodemo del retablo de la capilla de los Santander en Saldaña, cuyas túnicas presentan unos pliegues muy marcados en las rodillas, muy semejantes a los de la vestimenta de Baltasar o las caras alargadas, de ojos pequeños y nariz recta, características de San José o del ángel Gabriel. La Santa sin identificar de nuestro retablo presenta grandes analogías con la santa sin identificar que preside el retablo mayor de Arroyo, no sólo en el rostro de generosos carrillos, frente reducida e incipiente papada sino en los plegados suaves de las túnicas ${ }^{1133}$.

\footnotetext{
${ }^{1132}$ VASALLO TORANZO, Luis. "Rey Baltasar", ficha no 25 en Memorias y esplendores. Las Edades del Hombre. Catedral de Palencia, 1999, pp. 160-161.

${ }^{1133}$ CUESTA SALADO, Jesús. Aportaciones...Op.cit, pp. 13-21 y sobre obras de Jaques Bernal documentadas y atribuidas, consúltense pp. 23-94.
} 
Por su parte, las figuras de San Miguel y el San Andrés del último cuerpo se relacionan por su belleza formal con una obra documentada de Jaques Bernal: el retablo zamorano de Santo Tomás Cantuariense de Toro. El rostro del arcángel es similar al San Juan del retablo toresano y los personajes barbados del mismo recuerdan al apóstol ${ }^{1134}$.

Por último, hallaríamos tres figuras que no formarían parte del retablo original. Una de ellas es la Santa Catalina del banco, que no se asemeja estilísticamente al estilo de los artistas precedentes y dada su repetición en el retablo, no formaría parte del primitivo. También serían esculturas reaprovechadas las imágenes de San Antonio y San Pedro mártir, a tenor de su desvinculación iconográfica con el resto del programa. Son además, tallas que podemos adscribir hacia 1540, pues denotan un avance en el rostro, más naturalista, de ojos más grandes y el trabajo de los pliegues es más suavizado, pudiendo proceder de retablos pertenecientes a capillas del templo de Belén que, como sabemos, se hallaban arruinadas por esta época.

El 4 de julio de 1960 el retablo queda declarado como Monumento HistóricoArtístico previa solicitud de la Hermandad de Caballeros de Nuestra Señora de Belén y posterior dictamen favorable de la Academia de Bellas Artes de San Fernando. Ésta, tras describir brevemente la pieza, concluye que “...el retablo, en conjunto, es bueno, de arquitectura serena y bien proporcionada, de buena escuela y con estucos y dorados de buena calidad...”. Así mismo insta a la realización de obras de consolidación, limpieza y saneamiento ${ }^{1135}$. El retablo fue desmontado para limpiarlo y al asentarlo nuevamente se eliminó el tabernáculo del siglo XIX y algunas esculturas cambiaron de lugar, como la Anunciación y los Evangelistas. Además fue cambiado el orden cronológico de los episodios, por lo cual su lectura resulta ilógica.

\footnotetext{
${ }^{1134}$ CUESTA SALADO, Jesús. “El escultor Benito Elias” en BSAA, nº 71, Valladolid, 2005, pág. 136

${ }^{1135}$ Archivo Central del Ministerio de Cultura. Iglesia de Santa María de Belén. Carrión de los Condes (Palencia). Retablo del altar mayor. Declaración de monumento histórico Caja 88829, Expediente 5.
} 


\section{Las pinturas murales}

El fondo del presbiterio está cubierto con pinturas murales que han sido datadas en siglo XVII ${ }^{1136}$. Estas pinturas son sin embargo del siglo XVIII. En 1711 la iglesia invirtió 60.282 maravedíes en pintar “...el pabellón, historias y demás pinturas...” de la capilla mayor, momento en que además se retocaron las del retablo y se pusieron en el mismo las piezas que faltaban, lo que indica que se habían perdido imágenes y se reaprovechan otras ${ }^{\mathbf{1 1 3 7}}$. Pendientes de un dosel y en suave cadencia hacia los extremos se despliega dos grandes cortinones recogidos de tramo en tramo, acorde a la teatralidad barroca. A los lados del retablo se ubican tres pinturas de formato rectangular fileteadas de oro y colgados de cintas que presentan la policromía ennegrecida por la humedad y el paso del tiempo. En la parte inferior y de izquierda a derecha se representan Santa Ana con la Virgen en sus brazos y San José con el Niño Jesús de la mano. Seguidamente la Adoración de los Pastores y de los Reyes Magos y, en la parte superior La Anunciación y La Huida a Egipto, temas que se repiten en las pinturas del retablo. Flanqueando el remate se ubican dos angelillos que sostienen en una mano ramilletes de flores mientras que con la otra tiran de dos borlas que permiten la apertura de las bambalinas. Desde el punto de vista artístico, son pinturas de carácter artesanal y calidad mediocre.

Del mismo período deben ser las pinturas murales del presbiterio a las que probablemente se refiere la documentación de 1711 cuando habla de “...demás pinturas de la capilla mayor...”. En enero de 2012 se produjo el hallazgo fortuito de las mismas, cuando, por efecto de la humedad, la capa de yeso que cubría la pared lateral se desprendió, dejando al descubierto unas pinturas con motivos florales en los que predominan los verdes, ocres y amarillos ${ }^{1138}$. Hemos encontrado una fotografía fechada en 1907 que nos permite comprobar cómo las pinturas revestían toda la superficie de las paredes laterales a modo de tapiz. El patrón ornamental estaría conformado por un estilizado jarrón que contiene tres flores carnosas y dos ramilletes de hojas que emergiendo del mismo, cobijan un capullo en flor. A los pies del jarrón, se ubican dos florecillas a cada lado. Estos jarrones se superponen verticalmente y aparecen

\footnotetext{
${ }^{1136}$ URREA FERNÁNDEZ, Jesús y MARTÍN GONZÁLEZ, Juan José. Inventario...2, Op.cit, pág. 56.

1137 ADP. Carrión. Iglesia de Belén. Libro 17, 5º de Cuentas de Fábrica (1653-1783), fol 244-245.

${ }^{1138}$ La noticia apareció en prensa el 30 de enero.
} 
flanqueados por estrechas franjas que contienen motivos de aspas entrecruzadas conformando infinidad de rombos.

\section{El retablo de San José}

En el lado del Evangelio, dentro de la capilla mayor, existe un retablo de pequeñas dimensiones que posiblemente perteneciese a una de las capillas derruidas del siglo XVI. Su traza plateresca podría vincularse con algún miembro del taller carrionés, pero no del período en el que Juan de Salinas estaba al mando hasta 1522 en que falleció $^{1139}$, sino que se trata de una obra más avanzada, del segundo cuarto de la centuria, cuando Jacques Bernal había tomado el relevo en el mismo. Está conformado por banco, dos sencillos cuerpos divididos en tres calles y ático. En el banco se ubican los pedestales de los soportes del primer cuerpo, conteniendo los dos de los extremos medallones con bustos inspirados en grabados renacentistas. Los espacios intermedios se completan con dos tablas de mediocre calidad que representan a los Evangelistas $(21 \times 42 \mathrm{~cm})$. Sobre un fondo muy somero provisto de rocosidades, forman pareja, los cuatro santos, representados por parejas, de medio cuerpo. Están acompañados de sus atributos más característicos (ángel, león, toro y águila) y dotados de nimbo. Portan túnica y manto de vistosos y planos colores, destacando los rojos, verdes y amarillos, que se contraponen a rosa pastel.

En el lado izquierdo, se encuentran San Marcos, que juega con sus manos, resuelta tan precariamente la izquierda que nos parece irreal, y San Juan, en actitud de escribir, cuyo rostro de amplia frente y ojos saltones ponen de relieve las carencias técnicas de un pintor local. Mejor resueltos, dispuestos de medio lado, se representan a San Mateo y San Lucas, redactando las escrituras. El banco está partido para dar paso al grupo de mediocre calidad, que representa a San José con el niño. Están cobijados bajo un arco de medio punto entre pilastras, fruto de una reforma de la caja original para acoger a las esculturas, que tampoco son las primitivas, pues pertenecen al siglo XVII, siendo su policromía del XVIII. Esta escultura procede del retablo de San José de la iglesia de San Andrés de donde fue traída en 1913 cuando se trajo de Valencia una nueva escultura del Santo patriarca ${ }^{1140}$.

${ }^{1139}$ CUESTA SALADO, Jesús. Aportaciones...Op.cit, pág. 18.

1140 ADP. San Andrés. Libro 43 del inventario de todos los ornamentos y alhajas. (1833-1930), fol 41v. 
La imagen sigue el prototipo josefino creado por Gregorio Fernández: el hombre maduro, pero no anciano, con barbas castañas, aunque un poco calvo en este caso, túnica hasta las rodillas y botas altas. Su rostro es alargado y los ojos adolecen de un acentuado estrabismo que pone de manifiesto las carencias del anónimo escultor. El infante es tomado de la mano por su padre, a quien dirige su mirada. Posee unos generosos carrillos, al contrario que su progenitor, y está vestido con una larga túnica florida atada con un fajín dorado. De su brazo derecho pende un cestillo que le confiere un carácter cotidiano a la escena, como si se tratara de un niño cualquiera que sale a pasear.

A lo lados de estas tallas se disponen dos pilastras cajeadas con decoración de candelieri, idéntica a la que campean sobre las columnas superiores y sobre la dos grandes columnas de orden gigante que en los extremos engloban los dos cuerpos. Los capiteles de todos estos soportes están conformados por una mezcla de volutas y elementos vegetales que no siguen ninguno de los órdenes clásico, fruto no sabemos si del desconocimiento o del capricho. La hornacina avenerada del segundo cuerpo va presidida por una imagen de identificación compleja $(108 \mathrm{~cm})$ ya que, si bien se trata de un santo diácono -reconocible por el alba, manípulo y dalmática que porta- no posee ningún atributo específico que lo identifique con San Vicente o con San Lorenzo, como indican algunas fuentes ${ }^{1141}$. Probablemente le acompañaría originariamente la parrilla, objeto común a los santos citados. Sin embargo, hoy día porta una maza, añadida aleatoria y recientemente dado que este atributo ni se ajusta a la posición de la mano, ni se vincula a ningún santo diácono conocido. Esta escultura, realizada en torno a 1560, tampoco pertenecería al primitivo retablo, como vemos a través de la peana que sobresale de la hornacina donde se ubica. Nos inclinamos a pensar que se trata de la imagen de San Vicente, a tenor de la existencia de la iglesia homónima carrionesa, cuya última referencia documental data de 1595, pudiéndose haber trasladado la imagen tras su desaparición ${ }^{1142}$. Las duras facciones del santo tonsurado conformadas mediante un

\footnotetext{
${ }^{1141}$ La atribución a San Vicente es de RAMÍREZ DE HELGUERA, Martín. El libro... Op cit, pág. 158 y MARTÍN MÍNGUEZ, Bernardino. Catálogo...Op.cit, pág. 87. Este último indica que la imagen procedería de la iglesia homónima que efectivamente existió en Carrión. La identificación con San Lorenzo en URREA FERNÁNDEZ, Jesús y MARTÍN GONZÁLEZ, Juan José. Inventario...tomo 2.Op.cit, pág. 56.

${ }_{1142}$ En 1595 es cuando se vende la torre de la iglesia de San Vicente, único elemento que sobrevivía en buen estado de la fábrica. AHPP. Carr.Prot 4984. Sebastián García (1595-1597), s/f.
} 
rostro de perfil cuadrado, ceño fruncido, ojos y orejas grandes le confiere un aspecto recio, que podemos vincular con el círculo de Juan Ortiz Fernández. A los lados de las tallas comentadas se ubican cuatro pinturas que no son las originales dado que no se adaptan en absoluto al marco que las contiene. Sobre todo llama la atención los frontones triangulares del segundo cuerpo que son de menor anchura que los dos lienzos de la parte superior. Representan a San Antonio de Padua y San Antón Abad en el primer cuerpo, correspondiendo la Anunciación y la Inmaculada, sobre las mismas, obras de escasa calidad artística. Las deficiencias del pintor son apreciables en mayor medida en estos dos últimos lienzos, de atmósfera absolutamente irreal. En el primer caso, el ángel Gabriel resulta una figura demasiado pequeña y en la pintura de la Inmaculada, se ha desvirtuado la iconografía tradicional, pues el animal que yace a los pies de la Virgen es un gran dragón de cola enroscada.

La cornisa del segundo cuerpo, moldurada con decoración de ovas, al igual que en el cuerpo precedente, da paso al ático, resuelto mediantes dos aletones curvos que acogen una pequeña hornacina entre dos columnas balaustradas. Bajo un arco de medio punto se dispone una talla del arcángel San Miguel que ha perdido casi la totalidad de su policromía. Se trata de una obra mediocre datada en el siglo XVII, que igualmente habría sido añadida con posterioridad como las otras dos tallas ${ }^{1143}$.

\section{El retablo de San Isidro labrador}

En el lado de la Epístola se ubica un retablo que podríamos fechar en el segundo tercio del siglo XVII, época en la que el culto de San Isidro había proliferado notoriamente a raíz de la canonización de San Isidro en 1622. Por otro lado, la devoción popular al santo madrileño se ha mantenido vigente por la dedicación tradicional a la labranza de sus vecinos, que ha motivado la salida de la imagen en rogativas para pedir lluvias y la celebración de una procesión anual en su honor el 15 de mayo.

El retablo dorado presenta una sencilla estructura a través de banco, cuerpo dividido en tres calles y ático. En el centro del banco figura un sencillo sagrario en cuya puerta se hallaba una pintura, prácticamente borrada donde aún se puede apreciar la

${ }^{1143}$ URREA F., Jesús y MARTÍN GONZÁLEZ, Juan José. Inventario... 2.Op.cit, pág. 56. 
huella de una custodia. A los lados figuran cuatro pequeñas pinturas (39 $\mathrm{cm}$ de altura) dedicadas a la vida y milagros de San Isidro labrador: San Isidro saca del pozo a su hijo Illán, San Isidro aventando, la cura del caballo y el brote de agua cuando su señor estaba sediento. El cuerpo principal se configura a través de cuatro columnas de fuste estriado y ondulante y capitel corintio sobre el cual apean cimacios moldurados de gran desarrollo. En el centro, la hornacina se halla orlada por una decoración de gallones y en la parte superior un motivo cactiforme que se repite sobre la caja del ático. El santo titular es una imagen que no corresponde al primitivo retablo, no sólo por su desmesurado tamaño respecto al hueco donde que lo cobija, sino porque estilísticamente es una obra más tardía, del siglo XIX. A pesar de su modernidad, la imagen, a la que se le ha colocado un nimbo de latón dorado, sigue la iconografía tradicional: barbado y de mediana edad, porta la indumentaria de labriego -sayo, camisa, jubón- y la reja de arado en su mano derecha. A sus pies un ángel conduciendo un arado manejado por dos bueyes, cuya peana se dispone oblicuamente, pues de otro modo no habría cabida para ubicar estas figurillas en la hornacina.

A los lados de la imagen principal continúa la hagiografía del santo madrileño a través de cuatro pinturas: San Isidro ayudado por los bueyes en el arado y el milagro de la olla vacía que se colma de víveres en el lado izquierdo, figurando en el lado derecho las palomas alimentándose del trigo que les ofrece San Isidro y Santa María de la Cabeza, su esposa, cruzando el río sobre su manto. Sobre un pedestal pintado con motivos florales se levanta el ático, conformado por un tabernáculo rematado en un frontón partido sustentado por pilastras cajeadas entre pináculos clasicistas. En la caja de formato cuadrangular se ubica una imagen identificada erróneamente con Santa María de la Cabeza ${ }^{1144}$, pues no porta ninguno de los atributos que suelen acompañar a la esposa de San Isidro, como la vela encendida, la jarra de aceite o la mantilla a sus pies. También ha sido inventariada como la Inmaculada ${ }^{145}$, dada la presencia de las tres cabezas de angelillos sobre las que se ubica, pero la ausencia de la luna a los pies, nos hace inclinarnos a vincularla con la Asunción, pensando que los ángeles que la rodearían en origen se habrían perdido.

\footnotetext{
${ }^{1144}$ RAMÍREZ DE HELGUERA, Martín. El libro...Op.cit, pág. 157.

${ }^{1145}$ URREA FERNÁNDEZ, Jesús y MARTÍN GONZÁLEZ, Juan José. Inventario...2, Op.cit, pág. 56.
} 

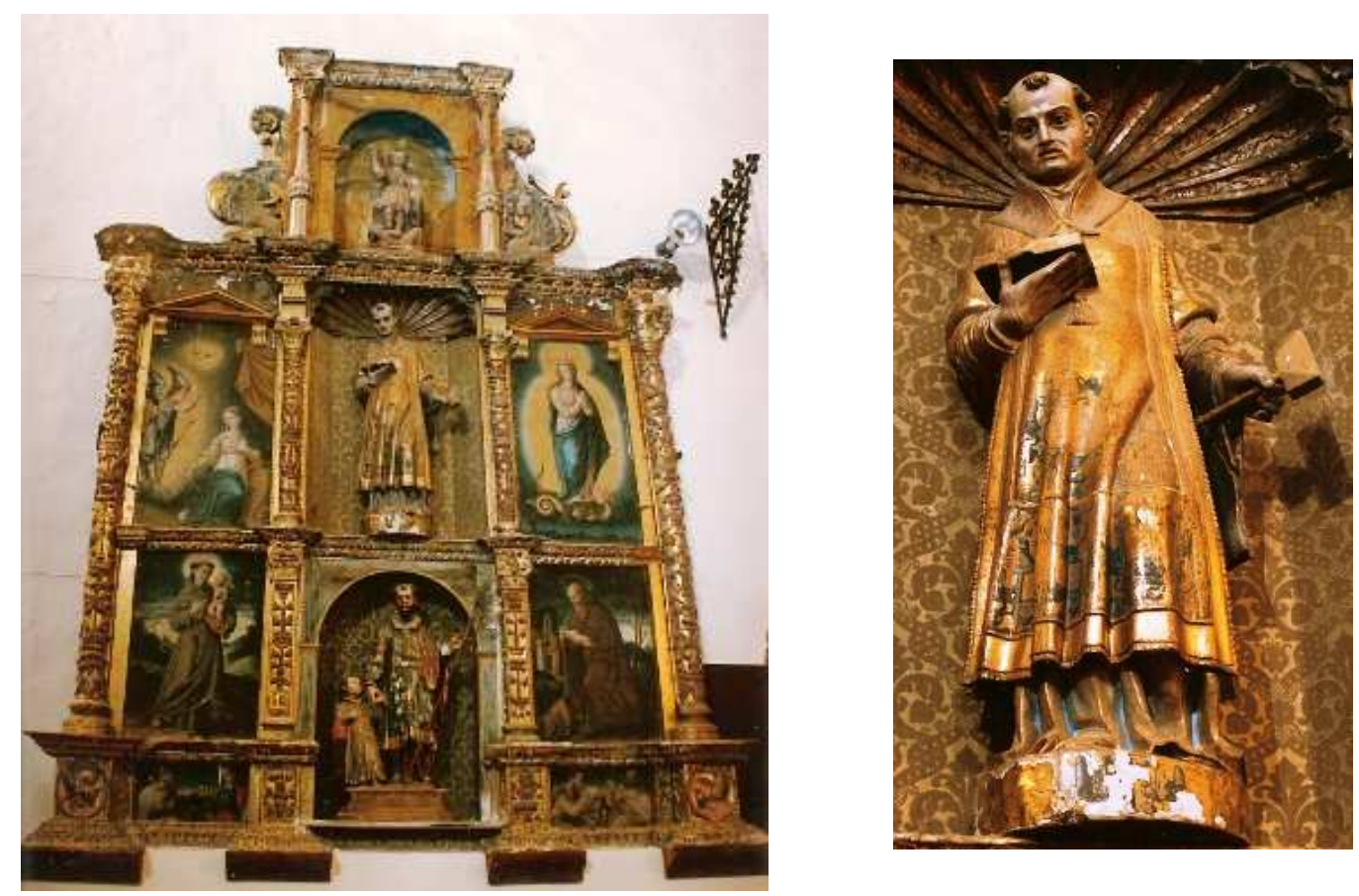

Santo diácono, probablemente San Vicente $(108 \mathrm{~cm} \times 44 \mathrm{~cm} \times 34 \mathrm{~cm})$.

Retablo de San José y el Niño en el lado del Evangelio de la iglesia de Belén. Primer tercio del siglo XVI. (3,7mtrsx2,75x0,50mtrs).
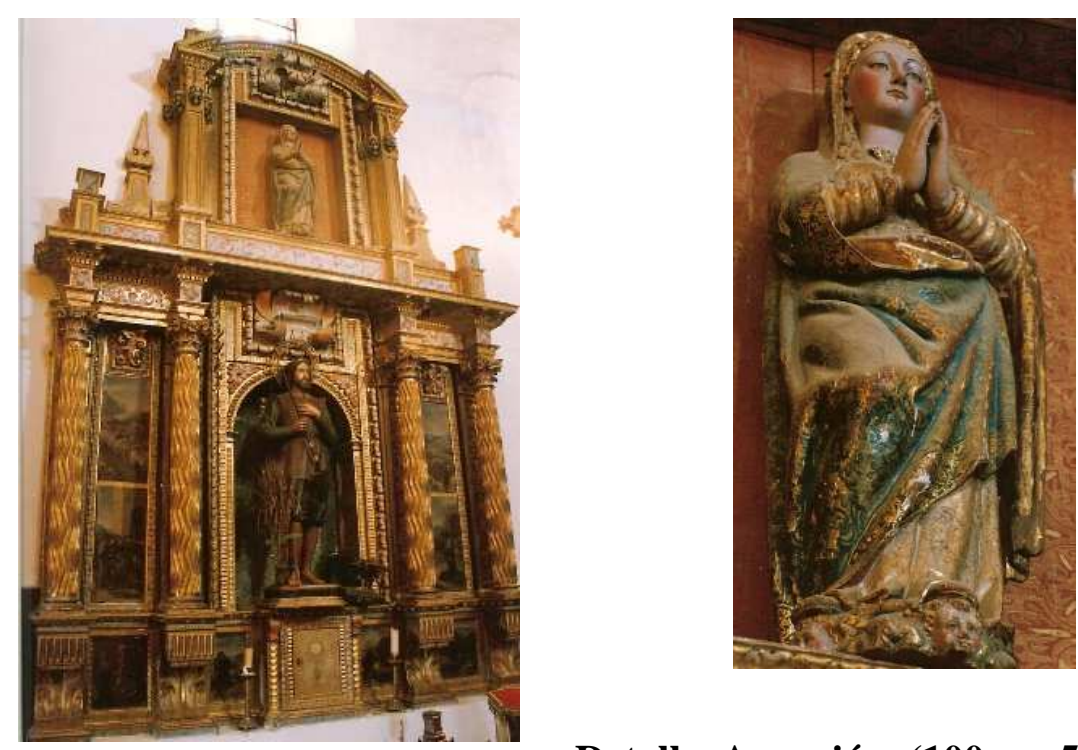

Detalle. Asunción $(100 \mathrm{~cm} \times 50 \mathrm{~cm} \times 30 \mathrm{~cm})$. Último tercio del siglo XVI.

Retablo de San Isidro Labrador en el lado de la Epístola de la iglesia de Belén. Segundo tercio del siglo XVII. (5mtrsx3,5mtrsx0,5mtrs). 
La Virgen $(100 \mathrm{~cm})$, de rubios cabellos ondulados, porta una túnica marfil y un manto verde oscuro esgrafiado y orlado de oro, que recoge entre sus manos, juntas en el pecho, en actitud de oración. Es una pieza del último tercio del siglo XVI, con cierta herencia romanista, cuyo rostro ha sido objeto de un repinte posterior, como se aprecia en sus carrillos sonrosados.

\section{2. CAPILLA DE SAN GREGORIO}

En el tercer tramo de la nave, adosado en el lado de la Epístola se encuentra la capilla de San Gregorio, el único espacio del templo que, junto a la capilla mayor, es fruto de la reedificación del siglo XVI.

El primer poseedor de la capilla fue el Licenciado Fernando Díez, cuyo sepulcro, conservado en este lugar, estudiaremos a continuación. Este doctor de Teología, fallecido en 1556 dispuso en su testamento que su sepelio se celebrase en el convento de San Francisco para después trasladar sus restos a esta capilla ${ }^{1146}$. Compartía el patronazgo de la misma con sus dos hermanos, Antonio y Julián Díez, quienes figuran como tales hacia 1552 en que ordenan ejecutar el arco apuntado que da acceso a la capilla sin licencia del provisor, lo que les granjea una seria amenaza de excomunión por parte del templo ${ }^{1147}$.

El sobrino de Fernando Díez, don Juan Díez de Loyola, hereda el patronazgo de la capilla. Hijo del referido, Julián Díaz y María Pérez de Loyola, le unían lazos de sangre por línea materna con San Ignacio de Loyola. Es difícil determinar el grado de parentesco que vinculaba al regidor carrionés con el santo vasco, pero dada la abundancia del patronímico Pérez entre su ascendencia paterna, su madre pudo ser su prima carnal o segunda. Su holgada posición económica estaba sustentada en las cuantiosas inversiones sobre juros y rentas en ciertas localidades palentinas. Además era administrador de la obra pía que Jacques de la Vega poseía en el convento de Santo

\footnotetext{
${ }^{1146}$ VIGURI, Miguel de. Heráldica...2.Op. cit, pág. 58, a su vez de ADP. Carrión. 116.

1147 ADP. Iglesia de Belén. Libro 13, $1^{\text { }}$ de Cuentas de Fábrica (1549-1566), fol 25.
} 
Domingo, desde su fallecimiento en $1567^{1148}$. En su testamento, dictado en 1586, Juan Díez de Loyola dispone ser sepultado en la capilla ${ }^{1149}$. Del matrimonio de Juan Díaz de Loyola y doña Petronila de Mendoza y de la Serna nacieron Alonso y Gregorio Díez de la Serna, convirtiéndose el primogénito, Antonio, en el heredero del patronazgo, que lo ostentaba todavía en $1619^{1150}$. Desde 1582 y hasta que Alonso de la Serna fuese mayor de edad, su tío y hermano de su padre, don Zoil Díaz de Loyola como su tutor, se haría cargo de administrar la capilla y al mismo tiempo adquiriría el patronazgo de otra junto a ésta, como enseguida veremos ${ }^{1151}$. Don Zoil, sin embargo, no atendía el culto como era debido, pues en vez de dar las misas diarias correspondientes en la capilla, las decía en un oratorio particular de su casa. El descontento del cura y mayordomos de Belén se hace patente en una disposición de 1589 por la que le obligan a cumplir la voluntad de los fundadores bajo pena de excomunión y una multa de cincuenta ducados ${ }^{1152}$.

A mediados del siglo XVII ostentaba el patronazgo Andrés Bernardo de la Serna y Reinoso, habiéndose perdido ya la línea de los Díez. El nuevo patrono se concierta en 1648 con Juan González de la Mata para que ejecute algunos reparos ${ }^{1153}$. Por descendencia la capilla llegó a manos de los marqueses de Villasinda y Auñón y a los condes de San Rafael. De un miembro de éstos últimos, Don Rafael María Curiel Pérez de la Torre Álamos y Serna, señor de Zurita, se conserva un documento de 1774, por el que dicha persona toma posesión de la capilla. Por entonces, el sepulcro del Licenciado Fernando Díez no había sido trasladado a un lado de la capilla, pues estaba en medio de

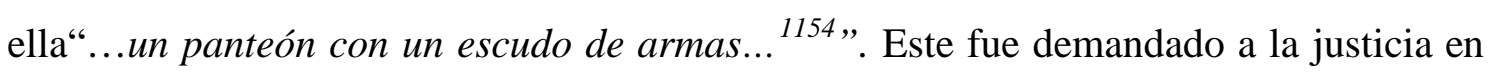
1796 por tener descuidada la capilla, instándole a que invirtiera siete mil reales para su recomposición ${ }^{1155}$. A mediados del siglo XIX los condes de San Rafael mantenían el patronazgo de la capilla, como así nos indica una donación generosa que concede su administrador en 1843 para hacer unas tapias en el huerto que había tras la iglesia ${ }^{1156}$.

\footnotetext{
${ }^{1148}$ FERNÁNDEZ MARTÍN, Luis. "Voces...Op.cit, pp. 353-355.

1149 AHPP., Carr.Prot 5670. Andrés Sánchez (1585-1586), fol 326 y ss.

${ }^{1150}$ Así consta en una escritura de cesión de un censo al dicho Alonso Díaz de la Serna, otorgado el 6 de febrero de 1619.AHPP. Carr.Prot. 4775 Martín Cisneros (1617-1620), s/f.

${ }^{1151}$ FERNÁNDEZ MARTÍN, Luis. "Voces...Op.cit, pp. 358- 359.

1152 ADP. Carrión. Iglesia de Belén. Libro 15, $3^{\circ}$ de Cuentas de Fábrica (1584-1599), fol 45v.

1153 AHPP. Carr.Prot 5430. Francisco Moro de Saldaña (1648), s/f.

${ }^{1154}$ VIGURI, Miguel de. Heráldica...2, Op.cit, pág. 61.

1155 ADP. Carrión. Iglesia de Belén. Libro 18, $6^{\circ}$ de Cuentas de Fábrica (1784-1852), fol 75v.

${ }^{1156}$ Ibídem, fol 285.
} 


\section{Retablo del Santo Cristo}

En la pared principal de la capilla, correspondiente al lienzo occidental del templo, se ubica un retablo sin dorar datado en el siglo XVIII ${ }^{1157}$, probablemente de la segunda mitad de la centuria. La pieza, tallada en madera de pino, se estructura en un cuerpo y ático asentados sobre un banco completamente liso. La hornacina central, conformada por un arco trilobulado, presenta una ornamentación de bajorrelieves que representan las arma christi: a los lados, las tenazas y el martillo y en la parte superior la escalera. Preside este espacio una talla del siglo XIV que representa un crucificado conocido como Cristo de la Salud $(180 \mathrm{~cm})$. La imagen presenta el canon alargado, la anatomía adelgazada, los tres clavos, el perizonium largo de duros pliegues y el tronco nudoso de filiación gótica. Posee algunos rasgos comunes a los Cristos patéticos, coetáneos a éste, como la caja torácica muy marcada y el abdomen prominente; sin embargo la escasez de sangre recorriendo su cuerpo o la disposición normal de los brazos lo alejan del prototipo bohemio. El rostro cubierto con una corona trenzada, muestra una expresión apacible a través de un rictus relajado y ojos cerrados, dulzura que tampoco apreciamos en los Cristos dolorosos. Esta imagen probablemente proceda de una antigua capilla del templo bajo la advocación de San Lorenzo cuya única mención relativa a la misma es que la presidía la imagen del Santo Cristo ${ }^{158}$. Al desaparecer dicha capilla con la reedificación del templo, la imagen pudo ser trasladada a este espacio de culto y posteriormente asentada en el retablo que nos ocupa.

Sobre una cornisa de perfil ochavado en su centro se dispone el ático donde se ubica una pequeña hornacina de medio punto que cobija una imagen del siglo XVI que representa a San Gregorio ${ }^{1159}$. La datamos más concretamente hacia mediados de la centuria y podría ser una obra salida de la mano de algún artista del taller asentado en Carrión, algunos de cuyos miembros, tal y como ya explicamos, habrían trabajado en el retablo mayor. Como atributos de su condición porta la tiara, la cruz papal y la capa pluvial que recoge con su mano izquierda, sobre la que sostiene un templete gótico con un ánima del purgatorio en su interior, objeto específico del magno pontífice. Esta pequeña imagen $(75 \mathrm{~cm})$ procede seguramente de un retablo edificado coetáneamente a

\footnotetext{
${ }^{1157}$ URREA FERNÁNDEZ, Jesús y MARTÍN GONZÁLEZ, Juan José. Inventario...2, Op.cit, pág. 56.

1158 ADP. Carrión. Iglesia de Belén. Libro 16, $4^{\circ}$ de Cuentas de Fábrica (1616-1646), fol 103.

${ }^{1159}$ Ibídem, pág. 56.
} 
la capilla, que albergaría una escultura de mayor tamaño del Padre de la iglesia occidental que habría dado la advocación a la capilla. Remata la composición el escudo de los Díez, compuesto a través de una cruz flordelisada, emblema que se repite en la bóveda y en el sepulcro del fundador. A ambos lados del retablo, en 1883 se colocaron las imágenes de la Piedad y la Soledad, dos tallas que por la datación debían ser de escayola, recogidas en la visita de 1895 de Helguera como la Piedad y la Virgen de los Dolores $^{1160}$.
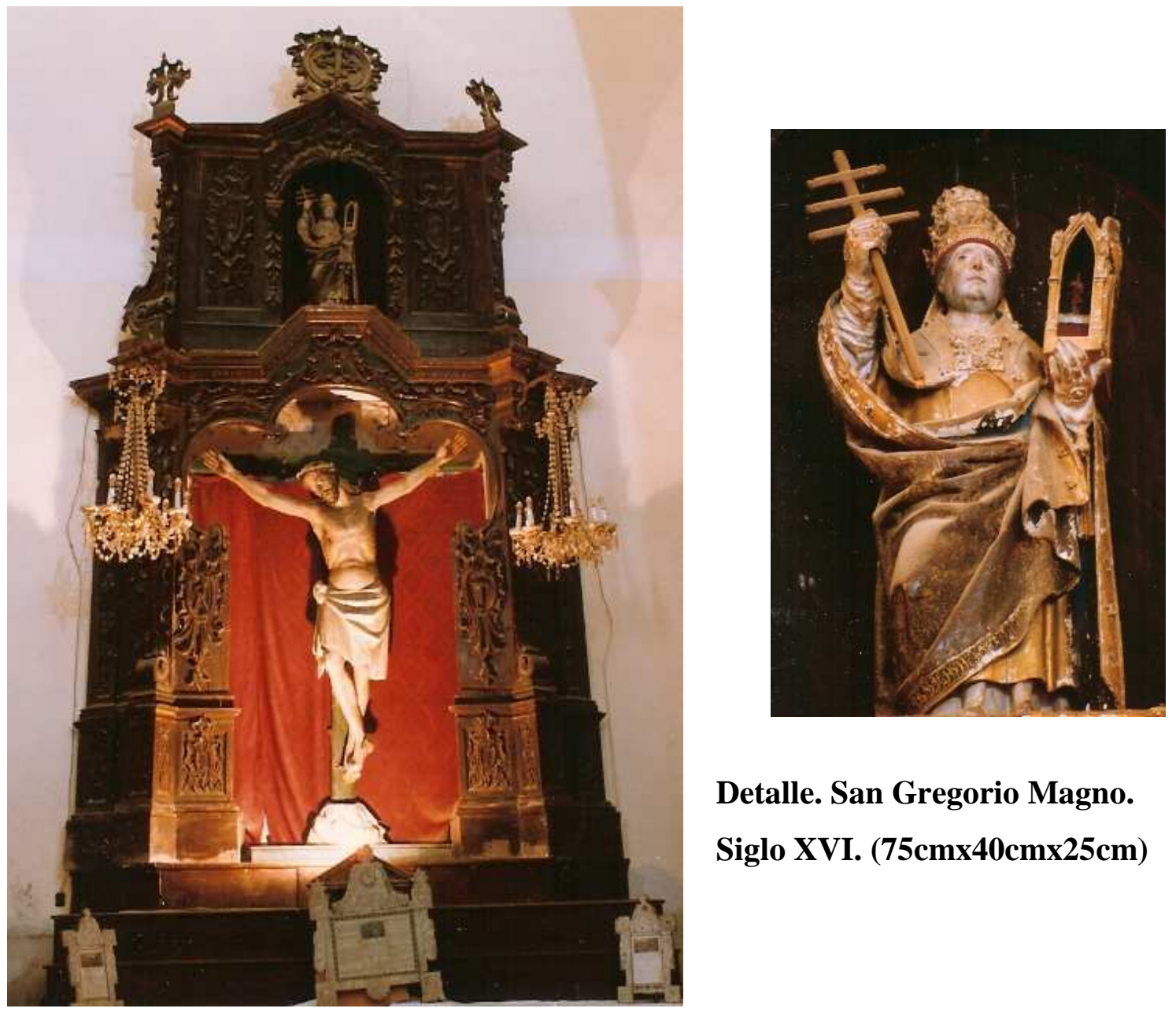

Detalle. San Gregorio Magno.

Siglo XVI. $(75 \mathrm{~cm} \times 40 \mathrm{~cm} \times 25 \mathrm{~cm})$

Retablo del Cristo de la Salud en la capilla de San Gregorio de la iglesia de Belén. Siglo XVIII. (5mtrx3,1mtrx06mtr).

Escultura del Cristo de la Salud. Siglo XIV. $(180 \mathrm{~cm} \times 55 \mathrm{~cm} \times 26 \mathrm{~cm})$.

${ }_{1160}$ ADP. Carrión. Iglesia de Belén. Libro 19, $7^{\circ}$ de Cuentas de Fábrica (1850-1884), fol 72 y RAMÍREZ DE HELGUERA, Martín. El libro...Op.cit, pág. 157. 


\section{Sepulcro de arcosolio del doctor Fernando Díez}

Según se entra en la capilla a mano derecha, es decir, en el muro norte, se ubica el monumento funerario del doctor Fernando Díez (208cm, 161 cmx87cm). El arcosolio, labrado a pulimento, posee una sencilla estructura de arco de medio punto moldurado a través de una mediacaña entre dos listeles que apea sobre dos pilastras cajeadas. En las enjutas del arco se ubica el emblema del linaje Díez, en este caso con la variante de que la cruz es floronada y vacía cantonada de cuatro estrellas. Sobre la cornisa situada a continuación se yerguen dos querubines muy propios del lenguaje renacentista que portan una tarjeta. Se pueden leer las siguiente leyendas relativas a la muerte: "Hic est gloria” y a la cruz: "In hoc signo vincitur".

Sobre la tapa del sepulcro se halla la imagen yacente del finado, que, reposando sobre un doble almohadón con una fina talla vegetal, une sus manos sobre el pecho en señal de perpetua oración. En su rostro, de serena expresión, destacan la nariz mutilada y las cuencas oculares hundidas. Luce el bonete, el alba y roquete, propios de su condición canónica, además de una capa larga que cubre sus hombros, con unos pliegues bastante trabajados. En el frente del sepulcro, se conserva una tarjeta con decoración de cintas, inscrita en un marco cuadrangular que contiene el siguiente epitafio:

“AQUÍ ESTÁ SEPULTADO EL MUY REVERENDO SEÑOR DOCTOR FERNANDO DÍEZ, MAESTRO EN ARTES, DOCTOR EN LA SAGRADA TEOLOGÍA, CANÓNIGO DE ALCALÁ. FALLECIÓ EL PRIMERO DE MAYO DE 1556”.

La ejecución del sepulcro podría datarse a mediados del siglo XVI, cuando efectivamente fallece el finado, a tenor de los cueros recortados de los escudos y de la inscripción referida. Los volúmenes marcados y la naturalidad empleada en el tratamiento de los ropajes se vinculan estilísticamente con un escultor de gran calidad y formación ajena al entorno carrionés. 


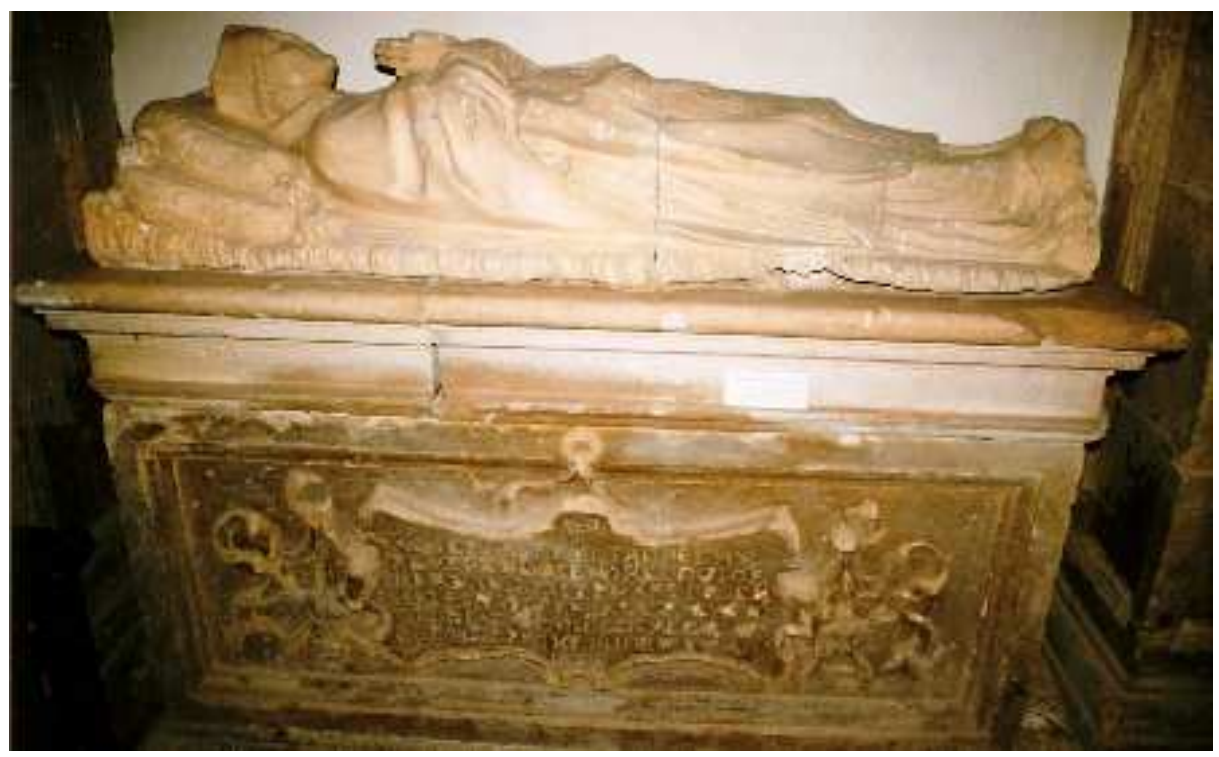

Sepulcro del canónigo Fernando Díez (1,61 mtrsx2,08mtrsx87cm).

\subsection{ANTIGUAS CAPILLAS DEL TEMPLO EN EL SIGLO XVI}

\section{Capilla de Nuestra Señora de Montserrat y de los Santos Reyes}

Era una de las capillas colaterales del altar mayor, ubicada en el lado del Evangelio $^{1161}$. Su fundador fue don Zoil Díaz, hermano de don Juan Díaz de Loyola, patrón de la capilla de San Gregorio. Don Zoilo residió y probablemente nació, dado su nombre, en la villa carrionesa, donde fue clérigo y doctor, probablemente de Derecho, que era lo más habitual en la época ${ }^{1162}$. Decidió adquirir una capilla propia que se hallaba en construcción, pues tan sólo se hallaba construido uno de sus arcos. En la escritura de cesión, firmada el 26 de julio de 1577, se confirma la ubicación de la capilla, entre la torre y la capilla de San Gregorio. En ella podía levantar enterramientos, vidrieras o lo que dispusiera con total libertad. Incluso podía unir dicha capilla con la de San Gregorio si así lo desease, mientras que se continúen haciendo las memorias señaladas. En 1582, Zoil Díaz se había convertido en tutor de Gregorio Díaz de la Serna, su sobrino, pues su hermano Juan Díaz había fallecido. Como su albacea

\footnotetext{
${ }^{1161}$ Así se indica en un documento de 1638 por el que el retablo de Santa Lucía es trasladado a esta capilla. AHPP. Carr.Prot 5233. Jerónimo López (1638-1640), s/f.

1162 FERNÁNDEZ MARTÍN, Luis. "Voces...Op.cit, pp. 357-358.
} 
testamentario, otorgó poder en 1583 a Pedro de Campoo, residente en la corte, para que cobrase cualquier deuda del mismo ${ }^{1163}$. Suponemos que con motivo de responsabilizarse del encargo, don Pedro Campoo trasladó poco después su residencia a Carrión, pues en 1589 es regidor de la villa y además ejerce de patrón de la nueva capilla junto a Zoil Díaz.

Por entonces, la bóveda, que suponemos fuera de crucería, se había resquebrajado. En su interior no se podía ya celebrar ninguna misa “...si no es con mucho peligro y osadía temeraria por las piedras de arriba...”, por lo que se insta a los poseedores de este espacio a que se hagan cargo de su reparación en el plazo máximo de un mes ${ }^{1164}$. Una vez más, la inclinación del terreno y la mala cimentación van a provocar la ruina de un espacio del templo. No sabemos si llegó a intervenirse sobre la cubierta, lo que sí es seguro es que en 1599 estaba otra vez arruinada, por lo que se hace preciso un nuevo requerimiento a su patrón para que repare la capilla o la venda, en caso contrario $^{1165}$.

\section{Capilla del Alférez Carrera}

Se hallaba en un estado indecente en 1589. Ya se había instado en varias ocasiones a su patrón a que se encargase de su reparación pero hizo caso omiso. Le compelen entonces a que la adecente en el plazo de un mes, amenazándole con apartarle de los oficios divinos y prohibirle cualquier sepultura en la misma. El cura y mayordomo estaban tan avergonzados que solicitan a los párrocos del resto de templos de Carrión que no le permitan tampoco hacerlo en los suyos, ya que “...más parece un pradal la dicha capilla, no parte de yglesia ni lugar sagrado... ${ }^{1166 ”, .}$

\section{Capilla de los Modoya o de la Asunción}

Inmediato a uno de los pilares de la capilla de San Gregorio estaban enterrados don Gonzalo Ortega y sus descendientes. La viuda, doña Mencía Díaz, hija de don Antonio Díaz y doña María de Modoya y sobrina del mencionado Fernando Díez, testó

\footnotetext{
1163 Ibídem, pp. 358-359.

${ }^{1164}$ ADP. Carrión. Iglesia de Belén. Libro 15, 3 de Cuentas de Fábrica (1584-1599), fol 43v.

1165 IbIbídem, fol 158.

${ }^{1166}$ IbIbídem, fol 43v.
} 
en (26 sep) 1599 con el deseo de ser sepultada junto a su difunto marido, disponiéndose para ello un estrado sobre el cual fuera asentado un pequeño retablo dedicado a la Asunción ${ }^{1167}$. La imagen de Nuestra Señora centraría la composición flanqueada por dos tablas con imágenes de Santos. La de la izquierda dispone que figuren San Catalina de Siena y San Jerónimo y para la de la derecha opta por San Juan Bautista. De su hermano Francisco Díez de Modoya, fallecido en las Indias, recibió una cuantiosa herencia que traspasaba, en caso de fallecer sin herederos, a su sobrino Ignacio Díez de Monroy. Cedía, además del derecho de sepultura en la iglesia de Belén. Ruega que en caso de que éste no tuviese herederos, el patronazgo de la capilla pasase a manos del patrón que lo fuese de la de San Gregorio. Tenía además una hermana, clarisa profesa en Astudillo, a la que dona parte de su hacienda.

\section{Capilla de Santa Lucía}

Se conoce su existencia desde 1569, incluso antes, pues en 1589 el cura y mayordomos de Belén reclaman a Don Antonio Campoo un retablo “...grande y bueno de talla..." que se había llevado de esta capilla hacía más de veinte años con la excusa de querer dorarlo y aún no lo había devuelto. Por ello le compelen a que lo restituya en el plazo de seis meses y así se cumple ${ }^{1168}$. Sin embargo no se vuelve asentar en la capilla hasta el año $1622^{1169}$. Don Antonio Francisco Enríquez Doro Campoo es conocido por deberse a él el encargo de la custodia del Corpus Christi a finales del siglo XVI. Este comerciante enriquecido en la Américas, fue designado Alférez Mayor y Regidor perpetuo de Carrión, títulos concedidos por Felipe III en 1578, a tenor de las generosas donaciones del mercader a la Corona ${ }^{1170}$. No se sabe en qué lugar de la villa condal residía, sí se sabe en cambio, que en 1585 contrató a Marcos de la Torre para que reforzara un paredón y dos arcos de su casa que amenazaban ruina. Para ello se siguieron las trazas del trasmerano Juan de la Cuesta rematándose la obra en sesenta ducados $^{1171}$. Procedía de una familia ilustre, de ahí que probase su hidalguía a través de

\footnotetext{
${ }^{1167}$ Doña Mencía Díaz dictó testamento el 26 de septiembre de 1599. AHPP., Varios, Protocolo 5858 (1520-1654) s/f.

${ }_{1168}$ ADP. Carrión. Iglesia de Belén. Libro 15, $3^{\circ}$ de Cuentas de Fábrica (1584-1599), fol 45 y 71.

1169 ADP. Carrión. Iglesia de Belén. Libro 16, 4 de Cuentas de Fábrica (1416-1646), fol 113.

${ }^{1170}$ URREA FERNÁNDEZ, Jesús. "La custodia de Carrión de los Condes (Palencia): una obra del siglo XVI hecha con dinero americano" en Homenaje al Profesor Hernández Perera. Madrid, 1992, pág. 767

1171 Ver condiciones de la obra en AHPP. Carr.Prot 5619. Melchor de la Rúa (1585-1587), s/f. Sobre Juan de la Cuesta, véase el apartado relativo a su biografía.
} 
un largo pleito que duró entre 1571 y 1576 que finalmente le dio la razón ${ }^{1172}$. Señor de las villas de Brecianos y Santa Cruz de Buedo, don Antonio Doro, si bien era el poseedor de esta capilla, no se enterró en la misma. En 1591, Antonio Doro dictó testamento declarando su deseo de construir la capilla mayor de la Iglesia de San Julián para servir de panteón familiar y edificar junto a ésta una casa desde la que acceder al templo a través de una tribuna. Si esta edificación no se llevaba a cabo, deseaba construir la capilla mayor del monasterio de Santo Domingo. Ninguno de los dos llegó a convertirse en su lugar de sepultura, pues su cuerpo sería depositado en la iglesia de Santa María del Camino ${ }^{1173}$. Su viuda, doña Constanza Enríquez, consiguió fundar en 1602 una capilla en la iglesia monasterial de San Zoilo, ubicada junto a la capilla mayor, en el lado del Evangelio, donde ella misma trasladó los restos óseos de su difunto marido. Este espacio de culto pasó posteriormente a ubicarse a los pies del templo, bajo la torre románica, derruyéndose en $1773^{1174}$.

Este espacio continuó perteneciendo a los miembros del linaje Doro Campoo en el siglo XVII. Así se indica en 1638, en que se ha hundido la cantería y por ello, se solicita el traslado de los huesos de sus ascendientes y del nicho y retablo a la capilla de los “Santos Reyes” pagando en compensación ochenta reales de limosna cada año ${ }^{1175}$. En 1793 se realiza una mesa de altar y un cancel para esta capilla, ambos realizados en madera, dorados por José Gallego, maestro carrionés ${ }^{1176}$

\section{OTRAS OBRAS DEL TEMPLO}

Entre los lienzos de la iglesia podemos mencionar una pintura del primer tercio del siglo XVII que representa a la Virgen con el niño sentada $(135 \mathrm{~cm} \times 104 \mathrm{~cm})$ sobre un copioso manto de nubes. Es una figura monumental que evoca a través de su

\footnotetext{
1172 ARCHV. Sala de Hijosdalgo. Caja 110 Leg 1 s/f.

1173 Testamento de Don Antonio Doro Campoo en AHN. Clero Secular-Regular Legajo 5331 s/f. Documentos eclesiásticos y papeles de carácter religioso y según informa el profesor Urrea, también en AGS. Contaduría de Mercedes, legajo 228, fol 110 y ss. Otros datos biográficos de Don Antonio Campoo pueden consultarse en LORENZO SANZ, E. "Palentinos en el nacimiento y formación de América" en AICHP, T.IV. Palencia, 1987, pág. 454.

1174 A este respecto, véase el capítulo dedicado a la capilla conocida como "doña Constanza" o "de Nuestra Señora” en las obras del siglo XVII y XVIII del monasterio de San Zoilo.

1175 AHPP. Carr.Prot 5233. Jerónimo López (1638-1640), s/f.

${ }^{1176}$ ADP. Carrión. Iglesia de Belén. Libro 18, $6^{\circ}$ de Cuentas de Fábrica (1784-1852), fol 82v, 87.
} 
monumentalidad a las madonas renacentistas. A sus pies, arrodillados en actitud orante, los donantes del lienzo, un matrimonio acomodado, posiblemente de noble estirpe, dada la vestimenta que lucen. Al fondo, entre el paisaje se adivina una procesión a las afueras de una ciudad, señalando la devoción mariana del lugar. A juzgar por la presencia de los mecenas y la romería del fondo, debe tratarse de un exvoto que ha perdido la dedicatoria tradicional, típica de todas las obras de carácter devocional. Si bien de escaso mérito artístico resultan interesantes por su iconografía dos lienzos del siglo XVII de Nuestra Señora de la Soledad que muestran la extensión de la devoción madrileña en territorio hispano, pues sin ir más lejos, existe otra pintura de esta temática en el museo de Santiago. Se denomina popularmente Virgen de la Paloma, pues preside un retablo de la iglesia homónima de la capital, que a su vez recibe este nombre de la calle donde se ubica el templo. El modelo representa a la Virgen ataviada con toca blanca y manto negro, a imitación de las viudas castellanas. Una de las imágenes $(158 \mathrm{~cm} \times 100 \mathrm{~cm})$ muestra a la Virgen orando arrodillada sobre un cojín ante los clavos de Cristo. Está flanqueada por dos jarrones de flores, alusivos a su pureza y en los extremos, cortinones propios de la teatralidad barroca. La otra imagen $(103 \times 75)$ muestra a la Virgen, de pequeño tamaño, orando de pie sobre un orbe donde figura una cruz con la inscripción "Virgo Maria". A sus pies se ubican las arma christi y sobre ella una paloma que emerge del cielo, aludiendo a su advocación.

En el antiguo camarín y actual sacristía destacaremos dos obras. Una es un grabado al aguafuerte que representa a San Pedro Regalado ${ }^{1177}$ envuelto en una gloria y transportado por ángeles. Es una pieza de pequeño formato $(46 \mathrm{~cm} \times 30 \mathrm{~cm})$ datada en el tercer cuarto del siglo XVIII, con un marco dorado de rocalla coetáneo a la misma. Esta es una de las tantas imágenes demandadas del santo vallisoletano a partir de mediados del siglo XVIII, a raíz de su canonización en 1746 y su nombramiento de patrono de la capital castellana un año después ${ }^{1178}$. Carrión contaba con tres cenobios de la orden franciscana y su pertenencia a la Provincia de la Concepción justifica la devoción que este santo despertó en la villa. La otra obra del camarín es una escultura de un Cristo del siglo $\mathrm{XVI}^{1179}$. El crucificado $(93 \mathrm{~cm})$ presenta una potente anatomía, tangible en la

\footnotetext{
1177 Aparece citado en ANDRÉS ORDAX, Salvador. La iglesia...Op.cit, pp. 25-26.

1178 REDONDO CANTERA, Ma José y ZAPARAÍN YÁÑ̃EZ, Ma José. "San Pedro Regalado. Formación y desarrollo de una iconografía religiosa en el Barroco" en Cuadernos de Arte e Iconografía, tomo 4, n8, Fundación Universitaria Española, 1991, pag 78.

${ }^{1179}$ URREA FERNÁNDEZ, Jesús y MARTÍN GONZÁLEZ, Juan José. Op.cit, pág. 56.
} 
musculatura marcada de su abdomen y sus fuertes gemelos. Tan sólo peca de cierta desproporción en los pies respecto al cuerpo. Su rostro, muy expresivo, refuerza la agonía del momento a través de la lengua visible en su boca entreabierta. Porta un paño de pureza policromado a base de listas verticales que, anudado en su lado izquierdo, presenta unos finos pliegues que se adaptan a la forma de sus piernas.

Por último, en el sotocoro se ubica un lienzo de San Miguel venciendo al dragón del siglo XVII, $(158 \mathrm{~cm} \times 118 \mathrm{~cm})$, copia de una imagen del mismo tema de Guido Reni ${ }^{1180}$. La figura del Arcángel está colocada diagonalmente sobre la superficie del cuadro, con las extremidades en perfecto equilibrio. El brazo derecho lo tiene levantado en acto de blandir la espada, mientras que con el pie izquierdo, en claro equilibrio compositivo, aplasta la cabeza del demonio, ya vencido. Nuestro lienzo, sin embargo, no posee las veladuras de la falda del arcángel ni la riqueza cromática del lienzo de los Capuchinos de Roma. No obstante, el rostro de San Miguel, posee una dulzura y serenidad y belleza propia de los prototipos italianos.
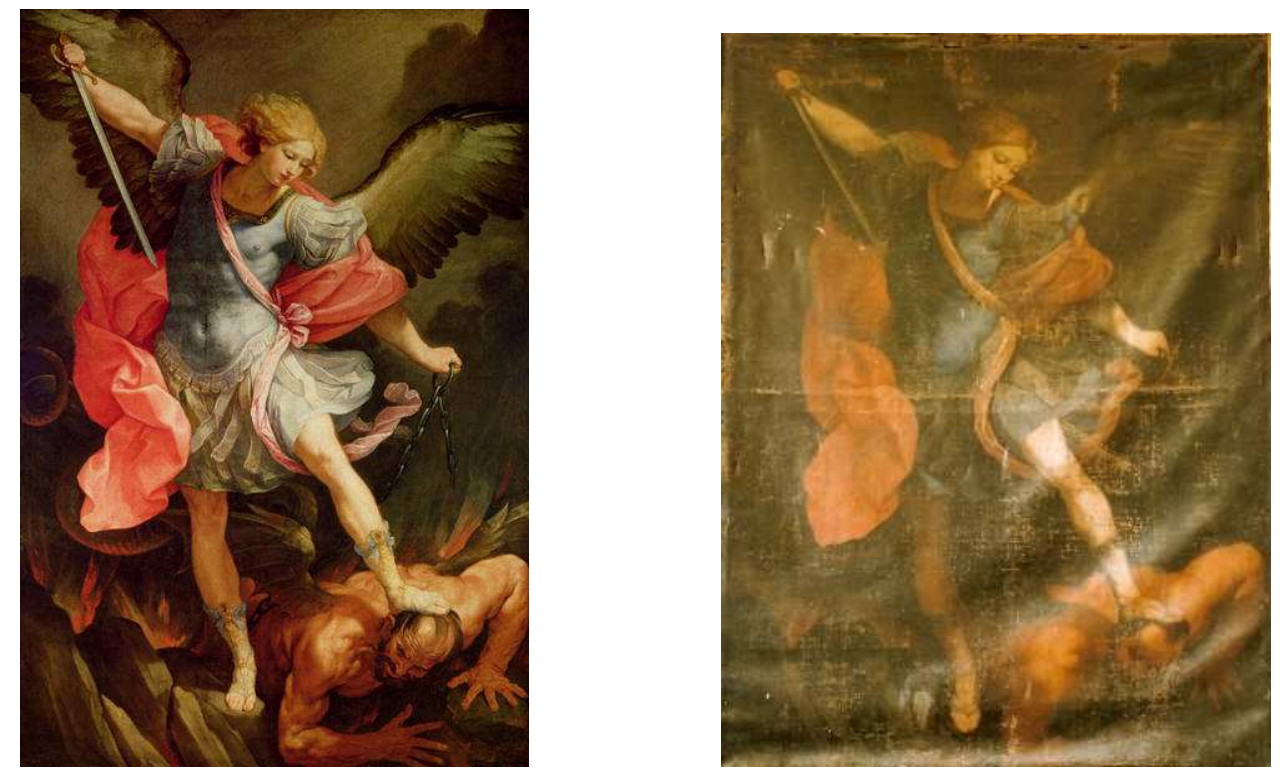

San Miguel venciendo al demonio. Obra de Guido Reni. Iglesia de los Capuchinos de Roma (izq). Copia del lienzo conservado en la iglesia de Belén (dcha).

${ }^{1180}$ Ibídem, pág. 56. 


\subsubsection{IGLESIA DE SAN ANDRÉS}

\section{EL TEMPLO}

Denominada como la catedral de Carrión de los Condes por su claridad interna, su esbeltez y la monumental torre visible desde prácticamente cualquier punto de la villa, la iglesia de San Andrés es una de las parroquias más antiguas de Carrión. Figura ya en 1345 como una de las iglesias parroquiales pertenecientes al arciprestazgo de la villa, abastecida con cuatro prestes, dos diáconos, cuatro subdiáconos y seis $\operatorname{graderos}^{1181}$.

Si bien se creía que el edificio actual, al menos hasta el arranque de las cubiertas, respondía a una reedificación del siglo $\mathrm{XVI}^{1182}$ impulsada por Rodrigo Gil de Hontañón ${ }^{1183}$, del siglo XVI sólo se mantiene en pie la capilla mayor, correspondiendo la totalidad del templo a las reformas llevadas a cabo a lo largo del siglo posterior. Hasta su reedificación definitiva, el templo se derrumbó al menos en dos ocasiones, como así explica en una carta de venta de una capilla a don Juan Cid, fechada en 1477, por la que dona una generosa suma para las obras que se ejecuten a cambio de ser sepultado en el templo ${ }^{1184}$. Es una iglesia salón de tres naves divididas en cuatro tramos y crucero que no se marca en planta. En el lado del Evangelio se adosa la sacristía del siglo XVII, un sencillo espacio cuadrangular recubierto con bóveda de arista que, desde el transepto norte se prolonga hasta el tercer tramo, inclusive, del templo. Adosado al tercer tramo del lado de la Epístola se encuentra la única capilla lateral del templo, denominada de la Herrada. En el ángulo suroccidental, ocupando el primer tramo de la nave de la Epístola se halla la torre, la más elevada de todo Carrión.

Nos hallamos ante un ejemplo de iglesia columnaria, como diría Chueca Goitia, pues las tres naves del templo se hallan separadas por ocho columnas dóricas de basa octogonal con un filete a modo de collarino y decoración de ovas en el equino. Su fuste está formado por sillares labrados sobre los cuales apean las bóvedas de arista que

\footnotetext{
${ }^{1181}$ MARTÍN PAYO, Jesús. "La más antigua... Op.cit, pp. 11-12.

1182 URREA FERNÁNDEZ, Jesús y MARTÍN GONZÁLEZ, Juan José. Inventario...2. Op.cit, pág. 54.

${ }^{1183}$ ZALAMA RODRÍGUEZ, Miguel Ángel. La arquitectura...Op.cit, pág. 90. Sobre el arquitecto, véase el capítulo dedicado a los artistas.

${ }^{1184}$ ADP. Carrión. San Andrés. Pergamino 126.3.
} 
cierran cada sección del templo, fruto de las reformas del siglo XVII. La sección central del crucero es la única que presenta una cubrición diferente al resto, una cúpula sobre pechinas, realizada probablemente en la última década de la centuria.

Exteriormente todo el perímetro, incluida la cabecera ochavada, se articula a través de contrafuertes. Resulta curiosa la aparición de unas arcadas de medio punto ciegas en los muros de la cabecera y del tramo siguiente, que, a juicio de Miguel Ángel Zalama se explica en función del material utilizado: las llamadas tapias de tierra que obligaban a hacer una estructura entre los estribos para impedir el desplome de los paños $^{1185}$. Sin descartar esa posibilidad, consideramos que tal vez se deba al primer planteamiento de la cabecera con articulación de ventanas, posteriormente cegadas en el siglo XVII para reforzar la fábrica y permitir la colocación de un gran retablo.

A continuación se analiza la evolución del edificio.

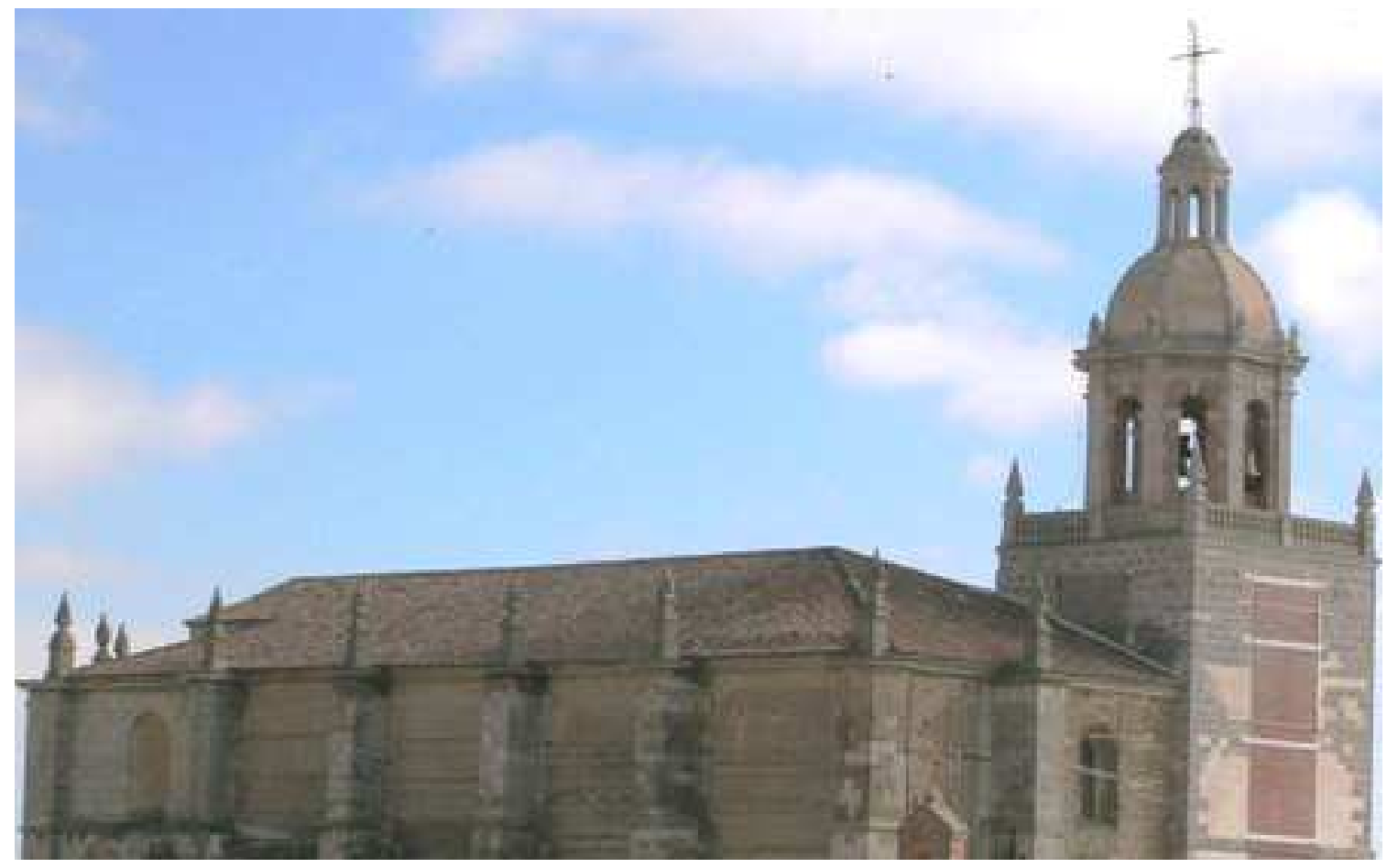

Exterior del templo de San Andrés. Vista tomada desde la iglesia de Belén.

${ }^{1185}$ ZALAMA RODRÍGUEZ, Miguel Ángel. La arquitectura...Op.cit, pág. 91. 


\section{EL SIGLO XVI}

La inmensa mayoría de las capillas del templo se hallaban deterioradas desde las primeras décadas de siglo, por lo que se insta a sus patronos respectivos a que las reparen. La capilla mayor no era una excepción, pues se ordena derribar su bóveda en 1516. La cabecera debía poseer gran altura, a juzgar por la presencia de una tribuna de yeso con el retablo de San Miguel sobre la que se ubicaba el retablo mayor, que se propone bajar, unificando ambos espacios ${ }^{1186}$.

Desde 1527 y durante todo el siglo XVII, el templo figura con la doble advocación de San Pedro y San Andrés, dada la instalación de los dominicos en aquel templo, que conllevó el traslado de los parroquianos y los enseres de San Pedro a San Andrés, recibiendo sus clérigos una compensación económica a cambio ${ }^{1187}$. A medida que el nuevo templo se edifica, van remitiendo las referencias a San Pedro, quedando con la única advocación, tal y como existe hoy día. No obstante, se mantiene el recuerdo de la doble advocación en la cúpula del crucero.

\section{El proyecto de Rodrigo Gil de Hontañón}

Las trazas de este templo fueron dadas por Rodrigo Gil de Hontañón, de cuya intervención tenemos noticia gracias a una referencia indirecta por lo que no podemos saber en qué fecha exacta las proporcionó ${ }^{1188}$. Sin embargo, creemos que su intervención tuvo lugar en el abanico oscilante entre los años 1529 a 1540 en que, salvo la iglesia de los Santos Juanes en Nava del Rey, de ejecución más tardía, proyectó sus iglesias de tres naves con bóveda de crucería a igual altura, como en el caso de Santiago de Cigales ${ }^{1189}$. Hontañón se decantó por la iglesia de tres naves, de largo doblado y más ancha la central que las laterales con crucero que no sobresale en planta. El templo iría sustentado por los tradicionales pilares fasciculados con o sin baquetones, optando en las cubiertas por las bóvedas de crucería en cualquiera de sus variantes: combados,

\footnotetext{
1186 ADP. Carrión. San Andrés. Libro antiguo de Cuentas de Fábrica, mandatos, visitas e inventarios (1511-1528), fol 10-29v.

${ }^{1187}$ GARCÍA CHICO, Esteban. "El claustro...Op.cit, pág. 212 y SALVADOR Y CONDE, P.J Los conventos...Op.cit, pp. 502-508.

1188 ZALAMA RODRÍGUEZ, Miguel Ángel. La arquitectura...Op.cit, pág. 89.

${ }^{1189}$ CASASECA CASASECA, Antonio. "Rodrigo Gil...Op.cit, pp. 44-48.
} 
estrelladas con cuadrifolios, por ser ésta la solución más usual, similar por tanto, en su tipología, al templo segoviano de San Sebastián de Villacastín. El contrapunto de los estilizados soportes del interior vendría creado por los contrafuertes de refuerzo que circundarían el exterior. Creemos que la planta original seguiría el patrón uniforme que el arquitecto madrileño tomaba para las iglesias de pueblos de gran vecindad, como es el caso de Carrión de los Condes. La referencia gráfica de este modelo figura en "Compendio de Arquitectura" de Simón García, manual que recoge, entre otras, las enseñanzas de Hontañón ${ }^{1190}$.

En lo que se refiere a la cabecera observamos una voluntad de introducción de formas novedosas, pues Hontañón plantea dos soluciones para cerrar la capilla mayor, la tradicional ochavada, que se escoge finalmente, u otra que considera más bella, de forma redondeada y más acorde a la tendencia pujante ${ }^{1191}$, como sucede en Santiago de Medina de Rioseco. Para su ejecución, recomienda encarecidamente el uso de piedra de Amusco para los pilares torales, y de Villaescusa, para los casquetes de las bóvedas ${ }^{1192}$. El maestro hace uso de los principios del gótico, en los que se había formado junto a su padre y gran maestro Juan Gil; no obstante asimila sin reticencias el lenguaje renacentista, no sólo en la concepción espacial sino en los motivos decorativos. En este sentido utiliza un modelo de gran aceptación en la Castilla de su tiempo, la iglesia salón o hallenkirche, tipología que cuenta con más de un centenar de ejemplos en territorio hispano, repartidos en su mayoría entre la dos Castillas y Madrid ${ }^{193}$. Esta disposición, frente a la compartimentación anterior, creaba un espacio diáfano a la par que unitario. Aún así, la difusión de este modelo no se produjo tanto por su deleite estético como por la seguridad que aportaba al conjunto como así asegura Simón García ${ }^{1194}$. La altura debía llegar a más de 17 metros, incidiéndose en la utilización de motivos clásicos:

\footnotetext{
${ }^{1190}$ GARCÍA SIMÓN, Agustín. Compendio...op.cit, pág. 52.

${ }^{1191}$ ZALAMA, Miguel Ángel. La arquitectura...Op.cit, pp. 89-91, a su vez de AHPP. Carr.Prot 5663, Andrés Sánchez (1562-1564), s/f.

${ }^{1192}$ Ibídem, pp. 249-252, a su vez de AHPP. Carr.Prot 5663, Andrés Sánchez (1562-1564), s/f.

${ }^{1193}$ Parece que la génesis de esta tipología en las iglesias parroquiales se encuentra en Alemania, siendo importada por artistas extranjeros al foco burgalés desde donde se expandiría. Concretamente en Palencia se encuentran ejemplos en Autilla del Pino, Baltanás, Becerril, Bohadilla, Torquemada, Palenzuela y Villahán. AÚREA DE LA MORENA, Bartolomé. "Reflexiones...Op.cit, pp. 165-168.

1194 “....yendo así a un alto, el edificio es más fuerte porque todo se ayuda uno a otro, lo cual no se hace cuando el central sube mas porque es menester que la colateral le de fuerzas a la mayor y desde la hornacina a la colateral lo cual se da con arbotantes...”. GARCÍA SIMÓN, Agustín. Compendio...Op.cit, pp. 54 y 55.
} 
capiteles, entablamentos, letreros con molduras y mostrando suma atención a las proporciones.

\section{El mantenimiento de los principios de Rodrigo Gil}

A mediados de siglo se puso al frente de las obras Pedro de Castrillo ${ }^{1195}$, maestro de cantería que trabajaría contemporáneamente en el claustro de San Zoilo desde 1552. Nada innovó este maestro, que como indicamos, siguió las trazas de Rodrigo Gil de Hontañón. En 1561 intervino el maestro de cantería cántabro Juan de Escalante ${ }^{1196}$, quien, como veedor de las obras del Obispado de Palencia, introdujo diversas modificaciones en el proyecto de Hontañón ${ }^{1197}$. Por entonces, habían sido erigidos los brazos del crucero y los estribos hasta una altura de 35 pies, además de la capilla mayor. A partir de estas intervenciones, Escalante recomendaba encarecidamente:

- dar mayor altura al templo elevando la clave a 65 pies y prolongarlo hacia los pies para conseguir mayor amplitud y sensación de diafanidad.

-ensanchar los pilares torales de la capilla mayor utilizando la mejor piedra tosca de la comarca, haciendo las basas sencillas y capiteles "al romano".

-estrechar los cuatro pilares torales del templo, que pasarían de seis a cuatro pies de grosor.

-realizar los muros restantes de mampostería en vez de tapias de tierra como se venía haciendo, dado que hacerlos de sillería no resulta posible por la lejanía del material. -construir dos accesos, uno al norte y otro a occidente.

\footnotetext{
1195 ANDRÉS ORDAX, Salvador. La iglesia...Op.cit, pág. 21.

${ }^{1196}$ No fue ésta la primera vez que Escalante revisaba una obra de Hontañón, pues en 1549 lo hace con la de la iglesia parroquial de Frechilla. En 1541 se encargar de la finalización de la torre de la iglesia de San Miguel de Ampudia. No recibirá el pago por este trabajo hasta veinte años más tarde, puesto que se dedica a ella de forma intermitente mientras realiza en otros lugares intervenciones como la traza no aceptada de San Juan Bautista en Cardeñosa en 1550 y algunas tasaciones como la de la torre de la Asunción de Villacuende realizada por Francisco Rabín y la de dos capillas de San Miguel en Piña de Campos, ambas en 1554. A él se atribuye las fachadas de la iglesia palentina de Tudela de Duero (Valladolid) hacia 1561 y la del Salvador de Valladolid, además del proyecto de la torre de la iglesia de Santa María de fuentes de Nava. Éstos y otros datos en LLAGUNO Y AMIROLA, E. Noticias de los arquitectos y arquitectura de España desde su restauración. Tomo 3. Madrid, 1829, pp. 39-40, HERAS GARCÍA, Felipe. Arquitectura religiosa del siglo XVI en la primitiva diócesis de Valladolid. Valladolid, 1975, pp. 276-279, VV.AA. Artistas...Op.cit, pág. 208.

${ }^{1197}$ Las modificaciones introducidas en la obra por Juan de Escalante están trascritas en ZALAMA, Miguel Ángel. "Documentos... Op.cit, pág. 252-256, a su vez de AHPP. Carr.Prot 5663. Andrés Sánchez (1562-1564), s/f.
} 
Las obras se interrumpieron en 1563 debido al fallecimiento de Pedro de Castrillo durante el transcurso de las mismas. El entonces Obispo de Palencia, Don Cristóbal de Valtodano concede la licencia oportuna para que continuase las obras Juan de Aras $^{1198}$, que se comprometió a finalizarla en 1569 siguiendo las condiciones establecidas por Rodrigo Gil de Hontañón y las modificaciones de Escalante ${ }^{1199}$. Aún en 1577 Juan de Aras no había recibido el total de la suma estipulada por su intervención, que se prolongó al menos hasta finales de $1572^{1200}$.

La iglesia había quedado sin maestros, por lo que Juan de Celaya ${ }^{1201}$ solicita tomar el relevo de Aras en las obras, tal y como había sucedido en la iglesia de Belén un par de años antes. La respuesta del provisor de Palencia se hace esperar y no es hasta junio de 1574 cuando le concede licencia para intervenir en el templo, firmándose el contrato de obra con el maestro cántabro en agosto de $1575^{1202}$. Desde que las obras fueron comenzadas, habían avanzado muy lentamente, pues sólo estaban levantados los pilares torales y las paredes del templo, y aún estaba sin cerrar la capilla mayor. Celaya debía fijar los soportes así como labrar sus capiteles en piedra de Becerrilejo o Villaescusa, material que también se emplearía para cerrar la bóveda de crucería de la capilla mayor. Después debía asentar seis arcos perpiaños y un tejado a tres aguas sobre los mismos pero no se comprometía a realizar la cubrición interna. Para los muros laterales planteó un friso de orden dórico que recorriera todo el perímetro del templo, pero sin triglifos ni metopas.

\footnotetext{
${ }^{1198}$ Sobre el mismo, véase el apartado relativo a los maestros de cantería.

1199 ZALAMA, Miguel Ángel. "Documentos... Op.cit, pp. 247-248, a su vez de AHPP. Carr.Prot 5663, Andrés Sánchez (1562-1564), s/f. Como aparejador de las obras intervendría un maestro cántabro natural de Ruesga llamado Bartolomé García, quien además fiaría en 1565 la entrega de piedra destinada a la iglesia de Belén de la misma villa. ZALAMA, Miguel Ángel. La arquitectura... Op.cit, pág. 345, a su vez de AHPP. Carr.Prot 5664, Andrés Sánchez (1565-1568), s/f.

${ }^{1200}$ En 1577 los mayordomos de San Andrés abonan 18750 maravedíes a Gregoria de la Rúa, por una deuda contraída por Juan de Aras con ésta. Como la iglesia aún no le había pagado por las obras, se lo abonan directamente a ella. AHPP. Carr.Prot 5668. Andrés Sánchez (1577-1579), s/f. Existen además cartas de pago en los años precedentes de 1574, 1575. ZALAMA, Miguel Ángel. La arquitectura... Op.cit, pág. 90, a su vez de ADP. Carrión. Iglesia de San Andrés. Libro $1^{\circ}$ de Cuentas de Fábrica, mandatos e visitas e inventarios (1573-1578), fol 18,19, 28.

${ }^{1201}$ Sobre el mismo, véanse los datos biográficos del apartado correspondiente.

${ }^{1202}$ Se le abonarán doce mil reales por la obra que acabará el día de San Andrés (30 de noviembre) dentro de un año y medio contado desde el 4 de agosto de 1575. AHPP. Carr.Prot 5667. Andrés Sánchez (15751576), s/f. Hay cartas de pago desde dicho año. ZALAMA, Miguel Ángel. La arquitectura... Op.cit, pág. 90, a su vez de ADP. Carrión. Iglesia de San Andrés. Libro $1^{\circ}$ de Cuentas de fábrica, mandatos e visitas e inventarios (1573-1578), fol 29,32, 34.
} 
La capilla mayor y las colaterales no se habían finalizado aún en 1577, a pesar de que Celaya se había comprometido a concluirlas por entonces. Era necesario pagar al maestro para poder proseguir con las obras pero la iglesia no tenía fondos suficientes, ante cuya necesidad el regidor de la villa, Rodrigo Meléndez, concede un préstamo de ciento cincuenta ducados destinados a tal efecto ${ }^{1203}$. La falta de seriedad de Celaya desencadena en julio de 1578 un litigio ante la Chancillería de Valladolid, tal y como le sucedió en la obra de Belén, pues como apuntamos, desatendió su primer compromiso para trabajar en las bóvedas del claustro de San Zoilo, lo que justifica que tampoco cumpliera con lo acordado en este caso. Los mayordomos de San Andrés instan a Celaya a “...acabar toda la dicha obra de la dicha iglesia qu'es la capilla cabecera de arcos y bóveda y el tejado y echar los arcos en toda la dicha capilla...” y a sus fiadores, Julián de Calzadilla y el entallador Mateo Lancrín, a que devuelvan 150 ducados abonados por la iglesia. El fallo emitido en noviembre de 1581 dictamina que Celaya continúe con las obras hasta su finalización y compele a la iglesia a que reserve la suma acordada en un principio y se abone cuando sea tasada la obra ${ }^{1204}$. No sabemos si Celaya llegó a levantar los pilares de las naves tal y como Hontañón había proyectado; que, en cualquier caso, no se han conservado. De lo que tenemos certeza es de que no llegó a construir la bóveda de crucería de la capilla mayor aunque al menos es segura la realización de su armadura, encargada a dos maestros de carpintería oriundos de Carrión, Rodrigo de Losada y Santiago de Sigüenza, que la concluyeron en $1584^{1205}$. Todavía en 1593 la capilla mayor estaba sin cubrir y el templo se encontraba en malas condiciones debido a un hundimiento, pues la cimentación siempre había sido pésima $^{1206}$. El mayordomo de San Andrés se ve obligado a solicitar un préstamo para llevar a cabo una reconstrucción completa ${ }^{1207}$. Así llegamos a fin de siglo con la iglesia en ruinas, de modo que todo el trabajo de este siglo, excepto la capilla mayor ha sido en vano, pues será necesario un proyecto de nueva planta.

\footnotetext{
1203 AHPP. Carr.Prot 5668, Andrés Sánchez (1577-1579), s/f.

${ }^{1204}$ La ejecutoria que lo condena el 4 de noviembre de 1581 en ARCHV. Registro de Ejecutorias. Caja 1439,7 .

${ }^{1205}$ Sobre Santiago de Sigüenza se hablará en el apartado dedicado a los artífices que trabajan en Carrión. En cuanto a Rodrigo de Losada, tan sólo se sabe que trabajó en la iglesia de la Magdalena de Zamora y que en su testamento, dictado el 14 de febrero de 1590, dispone ser enterrado en la iglesia de Santa María de Carrión. AHPP. Carr.Prot 4981. Sebastián García (1590-1592), fol 224 y ss. La carta de pago a ambos maestros, fechada en 20 de abril de 1584. AHPP. Carr.Prot 5729. Lázaro Santacruz (1579-1584), s/f.

${ }^{1206}$ ACP. Provisorato. Legajo 5. n449. De hecho, según nos informa ex alcalde de Carrión, don José Ramón Blanco, durante unas labores de excavación realizadas junto al templo se comprobó que todo el terreno era de arena.

${ }^{1207}$ AHPP. Carr.Prot 5673. Andrés Sánchez (1594), s/f.
} 


\section{El fortalecimiento de la torre}

La primera mención documental de la torre data del año 1512, pero ya existía previamente, porque estaba arruinada pero no había fondos para su reedificación ${ }^{1208}$. Seguía en mal estado en 1584; un colgadizo peligraba con derrumbarse sobre la pescadería, ubicada junto al templo y se decide reconstruir ese fragmento y toda la parte circundante $^{1209}$. La intervención afecta principalmente al cuerpo de campanas, que tenía su propio reloj, y a su chapitel, donde había que renovar los telares de madera de las paredes occidental y sur, que se hallaban“...arruinadas y comidas del agua...”. Los otros dos lienzos también debían ser reparados a través de dos pedazos de soleras que reforzarían este sector. También se debían abrir cuatro ventanas a cada lado para alojar los esquilones, de una altura de tres pies, su arco de ladrillo, y entre los vanos, un pilar. El mayordomo del templo recurre nuevamente a Santiago de Sigüenza, para que redacte las condiciones, consideradas a juicio del maestro albañil Alonso de Santiago, las más adecuadas de entre las dos trazas que le entregaron ${ }^{1210}$. Entre las modificaciones que propone se halla el empleo de soleras enteras, no fragmentadas, para reforzar los lienzos y la apertura de una sola ventana en lugar de dos, en cada cuerpo, suficiente para que se escuche con claridad el sonido de las campanas.

Las obras fueron adjudicadas a Juan Antonio González, un maestro de carpintería carrionés del que no se conoce ninguna obra y a Bartolomé Alejo ${ }^{1211}$, maestro albañil también de la villa, que debía ser bastante joven por entonces, pues esta es su primera participación documentada ${ }^{1212}$. Como sucedió para las obras del templo,

\footnotetext{
${ }^{1208}$ ADP. Carrión. San Andrés. Libro antiguo de Cuentas de Fábrica, mandatos, visitas e inventarios (1511-1528), fol 21.

1209 AHPP. Carr.Prot 5600. Francisco de Rojas (1580-1589), fol 387-392.

${ }^{1210}$ Sobre Sigüenza y Alonso de Santiago consúltese el apartado dedicado a los mismos.

1211 Bartolomé Alejo participó en la ejecución de un cuarto del convento de Benevívere que concluyó Pedro Gutiérrez en 1592. El contrato y condiciones de esta obra en AHPP. Carr.Prot 4681. Juan Cantoral (1589-1594), s/f. En 1622 puja en la obra del casco de la capilla mayor de la iglesia de Belén con 18 ducados, pero finalmente se remata en Bartolomé del Campo por 11 ducados. AHPP. Carr.Prot 4849. Juan Díaz Pajaza (1622-1623), s/f. En 1632 se le abona una carta de pago por participar con Francisco Rodríguez, en la ejecución de la nave del templo de Santo Domingo de Carrión. AHN. Clero SecularRegular 5352 s/f Santo Domingo, Obra. Allí además se encargó de lucir y rehacer la bóveda de la capilla del nombre de Jesús. AHN. Clero Secular-Regular 5352 s/f. Papeles judiciales. Junto a Antonio del Tejo repara en 1636 la iglesia de Santiago de Calzada de los Molinos. AHPP. Carr.Prot 5182. Jerónimo Laso (1636), s/f.

1212 En la carta de obligación, firmada el 5 de agosto de 1584, se precisa que Juan González recibirá 30.000 maravedíes y Alejo 3.000 menos. AHPP. Carr.Prot 5600. Francisco Rojas (1580-1589), s/f.
} 
en el caso de la torre, también los clérigos y mayordomos de Belén se vieron obligados a solicitar un préstamo para llevar a cabo su reparación, en este caso de 90.000 maravedíes $^{1213}$. Tampoco sirvieron de nada todas estas reparaciones, pues en el siglo XVII se levantará una nueva torre.

\section{EL SIGLO XVII}

\section{Finalización de la capilla mayor}

A finales del siglo precedente la capilla mayor era la única parte del templo que se hallaba en buen estado. Faltaba tan sólo realizar las cubiertas, que se llevan a cabo recién comenzado el siglo XVII. En 1606 estaba ya finalizada, cuando Juan González de la Mata se encarga de lucir la cubierta y enladrillar el suelo de la misma ${ }^{1214}$. Quedaba así conformada una cabecera muy singular, dado que presenta un perfil ochavado pero su cubrición es una bóveda de arista sustentada por cuatro medias columnas entorchadas adosadas en los ángulos de los tres paños. Estos soportes descansan sobre una fina cornisa que recorre la capilla, iluminada por dos grandes ventanales practicados en los lados oblicuos. Salvo por las columnas adosadas que tienen el fuste liso, esta solución es similar a la cabecera de la iglesia parroquial de Cigales, en que se sigue precisamente el proyecto d Rodrigo Gil de Hontañón ${ }^{1215}$.

\section{Reconstrucción íntegra del resto del templo}

\subsection{El proyecto de 1608: Francisco de Bálcava y Toribio de la Cuesta}

Excepto la capilla mayor, el resto del templo debía hacerse nuevamente desde su planta. Los artistas cántabros Francisco Bálcava, arquitecto, y Toribio de la Cuesta ${ }^{1216}$, maestro de cantería, realizan la traza y redactan las condiciones de la nueva obra el 18 de febrero de $1608^{1217}$. El 9 de marzo salió al pregón por 19.000 ducados y tras seis días de pujas, el maestro Alonso Tejedor la puso en 11.500 ducados pero, al no presentar

\footnotetext{
1213 AHPP. Carr.Prot 5669. Andrés Sánchez (1581-1584), s/f.

1214 AHPP. Carr.Prot 4833. Juan Díaz Pajaza (1606), s/f. Sobre Juan González, véase el capítulo dedicado a los maestros locales.

1215 BUSTAMANTE GARCÍA, Agustín. LA arquitectura...Op.cit, pág. 295.

1216 Véase el apartado relativo a los datos biográficos de ambos artistas.

${ }^{1217}$ AHN. Clero Regular-Secular, Legajo 5356, Expediente 2, Iglesias de San Andrés y San Pedro, Obras.
} 
fiadores en las dos horas que se le concedieron, fue apresado hasta que diese las fianzas. El corregidor determinó que puesto que Bálcava había sido el último postor, la obra quedaba adjudicada en su persona por doce mil ducados, suma con la que había pujado. Debía haber pactado con Toribio de la Cuesta la repartición de la misma, pues a los pocos días después de que se le adjudicase, le transfiere la mitad, estrategia que se repite en junio del mismo año con otra obra de la villa, cuando Bálcaba le traspasa una tercera parte del reparo del puente ${ }^{1218}$.

Las obras darían inicio con el derrumbe del viejo templo y la apertura de la cimentación en la parte consecutiva a la capilla mayor, con cinco pies de profundidad (más de un metro) o algo menos si se tocaba tierra firme. Se añadirían “...cuatro capillas a la larga..." prolongándose 84 pies (casi seis metros cada tramo), lo que indica que el crucero, esto es, uno de los tramos estaba realizado, aunque sin cubrición, a tenor de los cinco tramos que posee el templo.

Los muros, realizados con tapias de tierra mezclados con guijarros, irían jalonados por estribos de piedra al exterior y medios pilares adosados al interior rematados en una cornisa, como figura actualmente. Se levantarían cinco pilares torales, “...según y de la manera e forma que los que al presente están fechos...”, de modo que los soportes cilíndricos que separan las naves actualmente siguen la tipología de los que existían en el templo arruinado del siglo XVI proyectado por Hontañón. El material a emplear en estos soportes se especifica que sea el ladrillo, aunque finalmente se emplee piedra como posteriormente veremos. Todas las capillas, terminología que designaba en la documentación a un sector o tramo del templo, se cubrirían con bóvedas de arista guarnecidas con sus filetes.

\footnotetext{
${ }^{1218}$ La mitad de la obra asciende a seis mil ducados. AHPP. Carr.Prot 4835. Juan Díaz Pajaza (1608), fol 240 y ss y 288 y ss.
} 


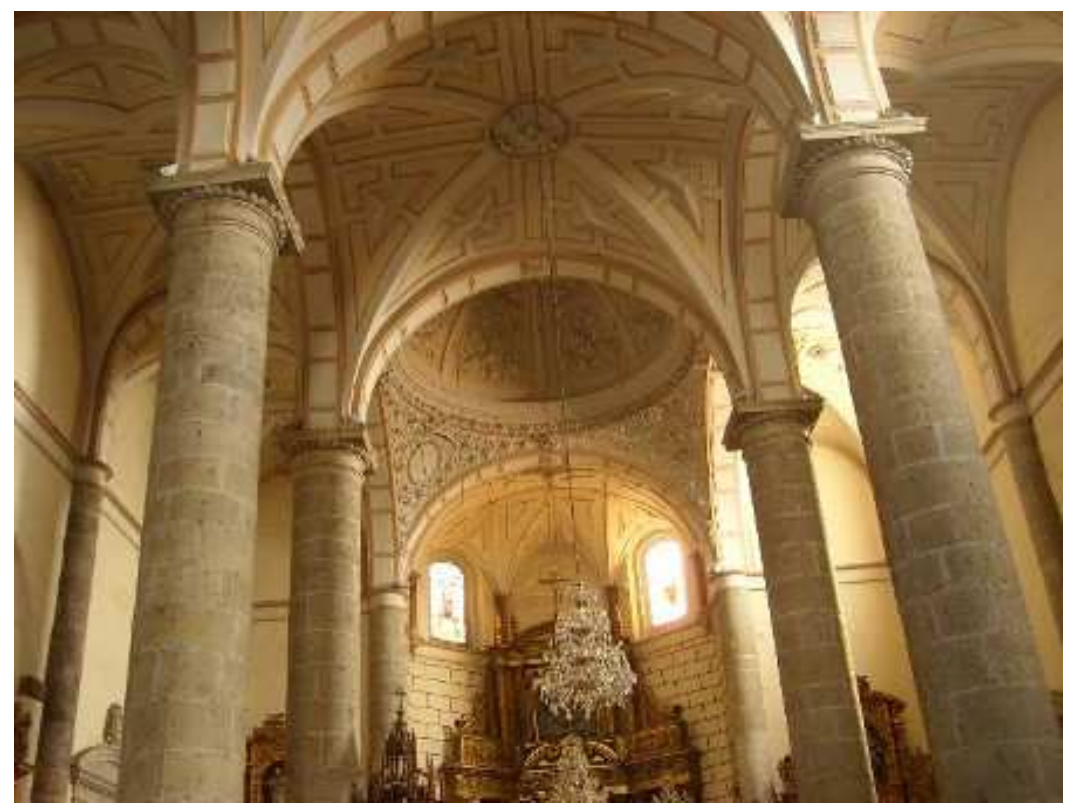

\section{Interior del templo de Belén realizado en el siglo XVII sobre los principios de Rodrigo Gil de Hontañón.}

La sacristía, que se construiría por entonces, se adosaría en el lado del Evangelio, con catorce pies de ancho y diecisiete de largo (4mtrx4,7metros), mucho más reducida de lo que resultó posteriormente. Además se ubicaba junto a la capilla mayor desde donde se accedía, “...por la pared del ochauo...”. Las esquinas de este espacio se realizarían en mampostería, mientras que para los intervalos se emplearían tapias de tierra. Para dar luz a la sacristía se abrirían dos ventanas, practicadas en el muro septentrional. Al igual que en el resto del templo, se establece que las cubiertas sean bóvedas de arista. En el lado de la plaza, es decir, en el lienzo occidental, se abriría la fachada principal en piedra de Villaescusa o Palacio “...con sus colunas y adornos ansí de pedernales como de capiteles, cornixamento y frontispiçioss...” y se abriría otro puerta en el sitio que se determinase. Con el paso del tiempo la puerta principal se abrió en el lado meridional y la otra no se conserva.

En lo que se refiere a la torre, se proyecta una estructura de tres cuerpos y remate de 31 metros de altura, razón por la cual los maestros plantean una cimentación fuerte de cinco pies de profundidad y ocho de grosor. El material empleado para los muros del primer cuerpo, de 38 pies de altura (10,5mtrs), sería mampostería “...asentado muy vien a punta y cordel...", de manera que aunque los sillares fuesen de diversos tamaños, el 
efecto visual resultaría bastante uniforme. El segundo cuerpo se realizaría con tapias de tierra y alcanzaría una altura de 32 pies (9mtrs). Ambos cuerpos, separados por una cornisa pétrea, darían paso al tercer cuerpo, de 21 pies (5.85mtrs), realizado en ladrillo, donde se abrirían las ventanas, jalonadas por pilastras. El perfil iría recorrido por un antepecho decorado con bolas. A continuación, sobre otra cornisa se asentaría el remate de 24 pies (6,6mtrs), conformado por un chapitel donde se colocaría el reloj, coronado por una bola con cruz y veleta. Se debía abrir una puerta para acceder al coro y a la escalera, cuyos peldaños debían ser de piedra de Palacios del Alcor. No debía derruirse la vieja torre hasta que la nueva se hallase bastante avanzada, lo que indica que se asentaba en un lugar diferente a la actual.

En el coro alto se concibe un antepecho de balaustres torneados rematados en una sencilla cornisa. Incluso se prevé como última actuación, la ejecución del retablo mayor que se llevaría a cabo con los últimos mil ducados correspondientes al último pago de la obra, algo que como veremos no sucedió, pues se reutilizó un retablo procedente de la iglesia de Santa María. Todos estos trabajos, dada la escasez de fondos del templo, se financiarían con las limosnas de los parroquianos por lo que no resulta extraño que los ocho años previstos en principio para la conclusión de los trabajos, esto es, 1616, se prolongaran mucho más.

Efectivamente, tal y como se planteó, las obras de reedificación comenzaron por el tramo del crucero, dado que la capilla mayor ya estaba hecha. Los tejados de este sector y el arco de cantería que daban acceso al presbiterio se derrumban y los rehace en 1611 un maestro perito en el arte de la carpintería, Francisco Reinaldos, cuya actuación indica que en los tres años previos, las obras no habían avanzado demasiado ${ }^{1219}$.

\subsection{Renovación del proyecto de 1608}

A la vista de la lentitud de los trabajos, en 1613 Francisco Bálcava renueva el contrato con el templo “...en los mismos términos...” que el anterior, salvo por el hecho de se le da de plazo el año 1616 para tener concluidas cuatro capillas -entiéndanse 4 de los 16 sectores- comenzando por los cimientos de los arcos torales, de modo que se

\footnotetext{
${ }^{1219}$ Se concierta el 27 de enero de 1611 con el bachiller Diego Pérez, cura de San Andrés y su mayordomo Roque de Pedrosa. AHPP. Carr.Prot 4838. Juan Díaz Pajaza (1611), s/f.
} 
debía ir derruyendo el templo conforme se construya la nueva edificación. A partir de entonces, contaba con otra década para concluir las obras, esto es, el plazo se cumpliría el día de San Juan de $1626^{1220}$. Con la firma del nuevo acuerdo, constatamos cómo Bálcava actúa ya sólo, sin la colaboración de Toribio de la Cuesta, encargándose de subcontratar a otros artistas para que lleven a cabo tareas en las que él no está especializado. Es importante señalar que desde entonces, para la ejecución de los pilares, solicita partidas de piedra del Alcor en lugar de ladrillo como se concibió en el primer contrato, por ello hoy día vemos que los pilares cilíndricos poseen sus sillares labrados y sus basas octogonales, pues se precisa que se deben hacer “...con baibel y todas ellas muy vien entregadas y todas las piedras que an de llebar los pedestales las desbaratarán ochavadas... ${ }^{1221}$ ”.

A partir de 1616, Bálcaba dirige paralelamente las obras del nuevo templo del convento de Santa Clara de la misma villa, lo que explica que la solicitud de materiales para ambos templos sean realizados bajo un único pedido ${ }^{1222}$. Las paredes laterales del templo estaban ya levantadas en 1617 en que el trasmerano Domingo del Río ${ }^{1223}$, en nombre de Bálcaba, contrata a un maestro albañil procedente de Revenga, Juan Ruiz de la Calleja, para que se encargue de realizar todas las tapias ubicadas entre los cuatro estribos del templo, con lo que los muros del lado del Evangelio estaban ya levantados ${ }^{1224}$. Sin embargo, las capillas, aunque arruinadas, se mantenían en pie en 1618, momento en que el párroco de San Andrés insta a cada uno de sus patronos a que colaboren en la reedificación de las mismas o se desprendan de su patronazgo en caso de negativa. La capilla mayor estaba finalizada por completo, como se deduce de la colocación del retablo mayor en 1619 por parte del ensamblador carrionés Santiago Infante $^{1225}$.

\footnotetext{
${ }^{1220}$ AHPP. Carr.Prot 4840. Juan Díaz Pajaza (1613), fol 290 y ss.

${ }^{1221}$ En 1616, Bálcaba ordena a Pedro del Arenal que en su nombre compre piedra suficiente para poder llevar a cabo dos pilares nuevos en el templo. AHPP. Carr.Prot 5509. Sebastián Peláez (1611-1613), fol 432 y ss. Domingo del Río, en nombre de Bálcaba compra piedra desbastada procedente de las canteras del Alcor para hacer otros tres pilares. AHPP. Carr.Prot 4842. Juan Díaz Pajaza (1615), fol 163 y ss.

${ }^{1222}$ La primera vez que se menciona a Bálcaba al cargo la obra de Santa Clara es en AHPP. Carr.Prot 4843 Juan Díaz Pajaza (1616), fol 592. Domingo del Río, en nombre de Bálcaba, solicita cuatrocientas fanegas de trigo para ambas iglesias. AHPP. Carr.Prot 5485. Antonio Orejón (el Viejo) (1616-1617), s/f.

${ }^{1223}$ Sobre este maestro dedicaremos un apartado biográfico

${ }^{1224}$ AHPP. Carr.Prot 4844. Juan Díaz Pajaza (1617), fol 530.

${ }^{1225}$ ADP. San Andrés. Libro $2^{\circ}$ de Cuentas de Fábrica (1614-1637), s/f. Acerca de Santiago Infante, remítase al capítulo dedicado a los ensambladores locales.
} 
De nuevo en 1620 aparece en escena Domingo del Río actuando en nombre de Bálcaba, en la contratación de los maestros de cantería trasmeranos Diego de Mazarredonda y Juan de Cagijosa ${ }^{1226}$ para que ejecute los medios pilares del lado del Evangelio, entre los cuales se ubicaría la sacristía, cuyo acceso se precisa que se ejecute

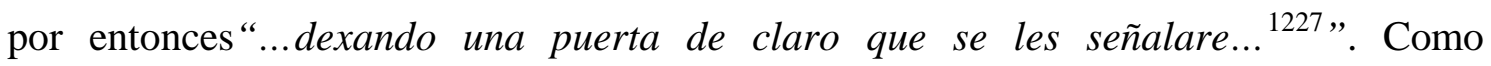
podemos apreciar, Bálcaba, que estaba muy ocupado en la dirección de las obras, encarga en varias ocasiones a Domingo del Río la subcontratación de maestros, la adquisición de materiales y otros menesteres. La confianza existente entre ambos maestros hay que buscarla en los lazos de parentesco que les unían, ya que eran primos. Además Domingo del Río, residía en Carrión por lo que conocía de primera mano a los artífices que contrataba o algún vecino podía facilitarle el contacto oportuno ${ }^{1228}$.

\subsection{El lento transcurrir de las obras}

El tiempo pasa y las obras continúan ${ }^{1229}$, pero no al ritmo debido, dado que en 1626 debían haberse finalizado. El mayordomo y párroco se quejan de que Bálcaba aún no ha construido la sacristía y de que la torre está arruinada. Además hacen constar que el templo no posee “... la firmeça y fortaleça que ha menester para sobre ella poder haçer y fundar las capillas...”. Tampoco el maestro está del todo satisfecho, ya que la iglesia le adeuda varios pagos en 1629, que reclama en su nombre, Domingo del Río y que se le abona poco después ${ }^{1230}$. La iglesia decide encargar una tasación antes de que se edifiquen las capillas que contenga un informe de lo que está hecho y lo que queda por realizar $^{1231}$. Sin embargo la valoración de la obra no se produce hasta el año 1634 en que Bálcava ya había fallecido. Se nombran como maestros peritos en la cantería a Juan González de la Mata, por parte de la iglesia, y a Andrés Gómez de Cisniega ${ }^{1232}$, vecino

\footnotetext{
${ }^{1226}$ Sobre el mismo, véase el apartado dedicado a los maestros de cantería.

${ }^{1227}$ Nuevamente constatamos cómo todos los soportes del templo se hacen de piedra y no ladrillo. AHPP. Carr.Prot 4821.Francisco Cuetos (1620), s/f.

1228 AHPP. Carr.Prot 4855. Juan Díaz Pajaza (1629), s/f.

${ }^{1229}$ Las cartas de pago sucesivas entre los años 1613 y 1625 prueban que la obra continúa, aunque a marchas forzadas. ADP. Carrión. San Andrés. Libro $2^{\circ}$ de Cuentas de fábrica (1614- 1637).

${ }^{1230}$ En 1629 Domingo del Río reclama 178.122 maravedíes correspondientes al noveno de los años atrasados por la obra que aún ejecuta en el templo. AHPP. Carr.Prot 4855. Juan Díaz Pajaza (1629), s/f. La carta de pago de esta cantidad en ADP. Carrión. San Andrés. Libro $2^{\circ}$ de Cuentas de Fábrica (16141637), fol 126v.

1231 ADP. Carrión. San Andrés. Libro $2^{\circ}$ de Cuentas de fábrica (1614- 1637), fol 94v y ss.

1232 Pertenece a una familia de artífices trasmeranos dedicados a la cantería que figuran trabajando en Castilla la Vieja. Oriundo de San Mamés, es hijo de Domingo González de Cisniega y sobrino de Juan González de Cisniega, el miembro más prolífico de esta familia. Junto a su hermano Miguel, está
} 
de Medina del Campo, por parte del corregidor de la villa ${ }^{1233}$. Ambos artífices declaran que estaban realizadas cuatro columnas con sus pedestales y capiteles -probablemente las correspondientes al transepto- y cuatro semicolumnas con sus estribos correspondientes, lo que indica que el crucero estaba edificado hasta el nivel de la cornisa. Además estaban edificados otros dos pilares a los pies de la iglesia. Por tanto la mayor parte de los soportes del templo ya estaban erigidos, pero faltaban por cubrir de tapias de tierra gran parte de los muros, cerrar el tramo completo de los pies, con su respectiva portada, la sacristía, realizar la cornisa corrida y las cubiertas, algunos de cuyos tejados, los más próximos al crucero, ya se habían levantado. En lo que respecta a la torre se habían asentado cuatro pilares hasta una altura de cincuenta pies, es decir, que el segundo cuerpo aún no se había completado.

El cómputo estimado de los trabajos de cantería, albañilería y carpintería que quedaban por hacer en el templo ascendía a 119.000 reales frente a la tasación de la parte ejecutada hasta entonces, valorada en casi 58.000 reales. Estos datos revelan que la mitad de las obras estaban aún por hacer, lo cual, sumado a que la iglesia no disponía de fondos para agilizar los trabajos y que se había quedado sin maestro de obras, justifica el descontento de su mayordomo y párroco, que en julio de 1635 deciden reclamar a los fiadores y herederos de Bálcaba los daños y perjuicios desencadenados por el incumplimiento del contrato ${ }^{1234}$. Por si fuera poco, en 1636, a consecuencia de “...tempestad de aire y aguas..." que asoló la villa, afectando sobre todo a los templos de Belén y Santiago, motivó en San Andrés la retirada masiva de tierra y madera para cuya tarea fueron necesarios más de medio centenar de operarios ${ }^{1235}$.

enterrado en la iglesia de Santa Cruz de Medina de Rioseco, en la que trabajó cuando su tío falleció. Participa en la obra del pórtico de la iglesia de Nava del Rey en 1625. Un año después figura trabajando en los templos vallisoletanos de Villavieja del Cerro y la colegiata de Medina del Campo. Un dato que no es cierto es que ya había fallecido en 1630, pues como vemos, aquí trabaja en 1634. BUSTAMANTE GARCÍA, Agustín. La arquitectura...Op.cit pág. 503-504.

${ }_{1233}$ También se nombran maestros peritos en la albañilería y carpintería para que elaboren sus respectivos informes. De la primera especialidad, se eligen a Francisco Arias, vecino de Sahagún por el corregidor y Julián de la Vega, por parte del templo y en la carpintería nombran a Pedro Álvarez, vecino de Torre y Francisco Rodríguez, respectivamente. AHN. Clero Regular-Secular, Legajo 5356, Expediente 2, Iglesias de San Andrés y San Pedro, Obras. Las cartas de pago en ADP. Carrión. San Andrés. Libro $2^{\circ}$ de Cuentas de Fábrica (1614-1637), fol 159.

${ }^{1234}$ AHN. Clero Regular-Secular, Legajo 5357, Expediente 1, Iglesias de San Andrés y San Pedro, Obras. ${ }^{1235}$ ADP. Carrión. San Andrés. Libro $2^{\circ}$ de Cuentas de Fábrica (1614-1637), fol 179. Tenemos constancia de esta lluvia torrencial en AMC. Libro 1, Sesiones municipales. (1618-1637), Sesión de 9 de febrero de $1636, \mathrm{~s} / \mathrm{f}$. 


\subsection{Conclusión de los trabajos}

Pasados los años, prosiguen las obras al mismo ritmo que en años anteriores. En lo que a la torre se refiere, en 1642 ya se había finalizado el segundo piso, en cuyas labores intervinieron los maestros locales Juan Vicente González y Jerónimo de Linares en las labores de carpintería y albañilería, respectivamente, y Hernando de Inestrosa en la cantería, quien inició el refuerzo del cuerpo de campanas ${ }^{1236}$. Del templo no se vuelve a tener mención hasta 1656 en que se adquiere una partida de piedra procedente de Palacios para un pilar toral que debía rehacerse y para la ventana del coro, que indica el avance de las obras en el tramo de los pies ${ }^{1237}$. Manuel de Salceda y Francisco de Reinaldos, maestros de carpintería, llevarán a cabo desde mediados de 1671 todas las cubiertas a par y nudillo que faltaban de ejecutar en las naves ${ }^{1238}$. No es la primera vez que trabajan juntos, pues ya intervinieron en las reparaciones del desaparecido hospital de la Herrada, ubicado a las afueras de Carrión ${ }^{1239}$. El montante por las obras ascienden a cinco mil reales que se abonan en mayo del año siguiente, incluyéndose en el pago las demasías que tasaron Domingo Lovizera y Santiago de Pedrosa en 330 reales, de los cuales Salceda y Reinaldos cedieron cincuenta como limosna ${ }^{1240}$. Parece que en 1674 las obras estaban bastante avanzadas, lo cual colegimos de la demolición de la torre vieja, que probablemente se hallaba en el lado del Evangelio ${ }^{1241}$. La vinculación entre ambos hechos radica en que en una de las condiciones del contrato de 1608, que es el que, renovado en 1613, prevalece para la edificación del templo, se señala que no se

\footnotetext{
${ }^{1236} \mathrm{El}$ contrato con Hernando de Inestrosa, por tres mil reales en AHPP. Carr.Prot 4828. Francisco Cuestos (1640-1641), fol 321 y ss. Las cartas de pago a Jerónimo Linares y Hernando de Inestrosa, fechadas el 12 y 24 de marzo de 1642, respectivamente en AHPP. Carr.Prot 5188, Jerónimo Laso (1642), fol 255 y 297. La obra de carpintería en AHPP. Carr.Prot 4829 Francisco Cuetos (1641-1642), fol 268 y ss. Sobre Inestrosa, remítase al capítulo dedicado a los maestros locales.

${ }^{1237}$ AHPP. Carr.Prot 5765. Andrés Simón Aguilar (1656), s/f.

${ }^{1238}$ Las condiciones, firmadas el 14 de marzo de 1671 en ACP. Provisorato. Legajo 164. El concierto de la obra entre ambos maestros se firma el 24 de mayo de 1671, fijándose una cantidad por el total de la misma que ascendía a 4800 reales. AHPP. Carr.Prot 5775. Andrés Simón Aguilar (1670-1671), fol 649 y SS.

${ }^{1239}$ Escritura y condiciones de la obra en AHPP. Carr.Prot 5775. Andrés Simón Aguilar (1670-1671), fol 655 y ss. Sobre Manuel de Salceda, remítase al capítulo dedicado a los ensambladores locales.

${ }^{1240}$ La carta de pago es de 29 de mayo de 1672, correspondiente a la obra "... de cantería y carpintería el año passado de setenta y vno..." en que se abonan 5034 reales en que se incluyen las demasías. AHPP. Carr.Prot 5776. Andrés Simón Aguilar (1672), fol 326 y ss.

${ }^{1241}$ ADP. Carrión. San Andrés. Libro $3^{\circ}$ de Cuentas de Fábrica (1672-1718), fol 17v.
} 
derruya la antigua torre “...hasta en todo el cuerpo de la yglessia y ttexados esttén fechos y leuantada la torre y lo demás al pesso de la capilla mayor... ${ }^{1242, .}$

El mismo año de 1674 se ejecutaba el coro, indicio de que se había llegado a los pies, cuya factura se debe al maestro de cantería local Domingo de Solaesa ${ }^{1243}$. Ocupa la parte central del primer tramo del templo y se encuentra dividido en dos niveles: el sotocoro y el coro alto. El coro bajo se encuentra iluminado por una ventana abocinada de perfil rectangular ubicada en el lienzo occidental. Cobija la sillería procedente del convento de Benevívere, de la que hablaremos posteriormente. Se encuentra separado del coro alto a través de una cubierta bastante extraña, compuesta por una bóveda de cañón rebajado en la parte más profunda, mientras que el resto adopta una cubrición de tipo mixtilíneo motivada por la gran concavidad del perfil en el centro que da paso a dos sectores cóncavos en los extremos. A esta curiosa forma se adaptaba el antepecho de madera, realizado por un entallador local, de nombre Gabriel Martínez en 1678, que volvió a rehacerse un siglo después y después nuevamente en el siglo XIX ${ }^{1244}$. Adosado a su lado norte se encuentra el órgano barroco, que tendremos oportunidad de estudiar, este espacio se ilumina como el coro bajo, mediante una ventana abocinada, en este caso de medio punto. De este período debe ser la ejecución de la única de las capillas del templo, la denominada de "la Herrada", un espacio cubicular que sobresale del perfil del templo adosado en el tercer tramo de la Epístola y provisto de una bóveda de arista. Para la cubrición de las naves, también realizadas entonces, se siguen los presupuestos del contrato mencionado, a través de sendas bóvedas de arista. La decoración que presentan es bastante sencilla en la nave central: una punta de diamante en cada uno de los ocho plementos con un capullo pinjante circundado por hojas en la clave. Las naves laterales, además de las puntas de diamante en los extremos, se ornamentan a través de un tablero rectangular que se retranquea en el centro de cada uno de sus lados.

\footnotetext{
1242 AHN Clero Regular-Secular, Legajo 5356, Expediente 2, Iglesias de San Andrés y San Pedro, Obras. ${ }^{1243}$ ADP. Carrión. San Andrés. Libro $3^{\circ}$ de Cuentas de Fábrica (1672-1718), fol 19.

${ }^{1244}$ IbIbídem, fol 39.
} 


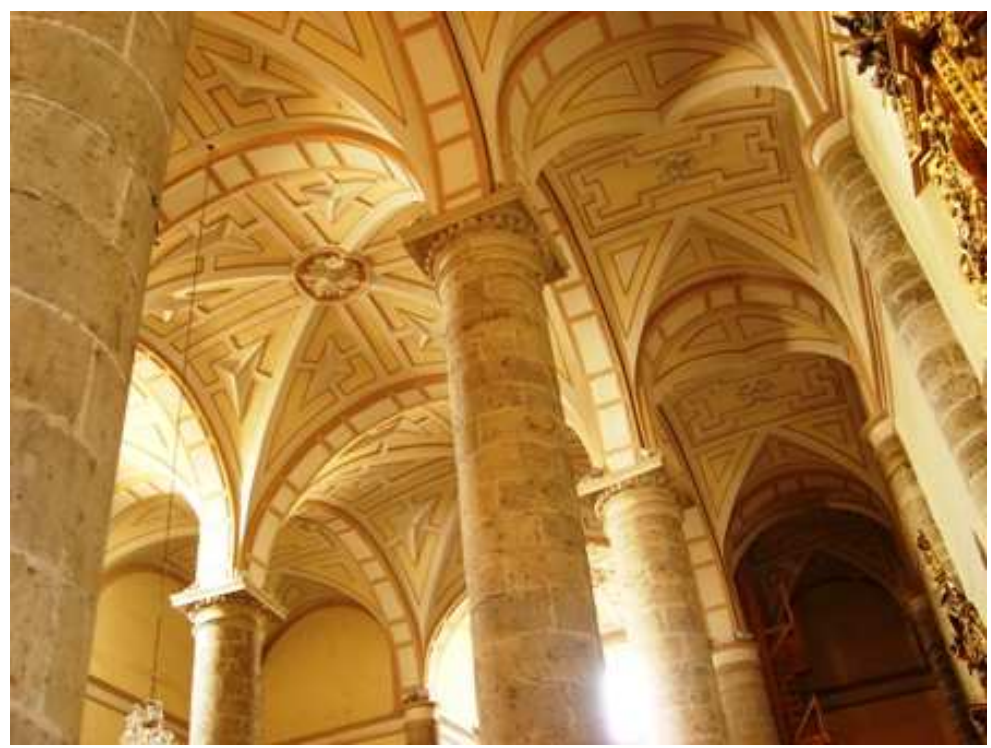

Vista del interior de San Andrés con las cubiertas del siglo XVII.

En el crucero se realizó una gran cúpula que, a juzgar por su decoración, presenta un estilo más avanzado que el resto de las cubiertas, pivotando entre las décadas de los setenta y noventa del siglo XVII. Está decorada a través de ocho gajos recubiertos de rameados vegetales tallados a trépano, que inundan las pechinas. En ellas, inscritas en óvalos timbrados de corona se ubican dos motivos que se repiten: la cruz aspada, alusiva a San Andrés y la tiara con las llaves, emblema del Papado, referente a San Pedro. La presencia de estos elementos se debe a la doble advocación bajo la que estuvo el templo desde 1527 en que, como ya señalamos, los feligreses de la parroquia de San Pedro fueron agregados a la de San Andrés para ubicar en su solar el convento de Santo Domingo. En lo que respecta a la torre, también debía haberse finalizado, siguiendo igualmente las cláusulas de 1608 y así lo manifiestan los arreglos que se efectúan en su tejado en 1690 , dado que éste cubriría el último cuerpo ${ }^{1245}$. Sin embargo este sector se renovó por completo en el siglo XIX, como posteriormente veremos.

Así, tras un largo proceso de dos siglos, queda configurado el templo de San Andrés, cuyo interior conjuga elementos que ya figuraban en el proyecto de Hontañón, recuperados en la traza de 1608, con soluciones típicamente clasicistas. El recurso de las

${ }^{1245}$ IdIbídem, fol 99v. 
columnas cilíndricas, la disposición de las naves a igual altura y el sistema de ochavos en la cabecera iluminada por ventanas rasgadas, remiten a los procedimientos del maestro de Rascafría. Igualmente se asimila la molduración que recorre el templo formada por la integración del fuste en el entablamento, sistema propio del lenguaje de Hontañón. En la cubrición se empleó sin embargo, las bóvedas de arista con decoración de puntas de diamante propias del momento en que se construyen. Esta fusión armónica entre mecanismos de diversas épocas y estilos adaptados a las nuevas corrientes nos remite a un templo clasicista vallisoletano donde se emplean este tipo de soluciones estructurales: la iglesia parroquial de Cigales. En ella Diego de Praves, al frente de la obra desde 1591, respeta las condiciones otorgadas precisamente por Rodrigo Gil de Hontañón. Incluso cuando los religiosos, Fray Antonio de Jesús y Fray Juan Gil proporcionaron nuevas trazas en 1606, Praves continúa los trabajos hasta 1620 en que fallece $^{1246}$, fiel a las direcciones del maestro segoviano, salvo en las cubiertas y su decoración, observándose así el mismo resultado que en nuestro templo.

\section{EL SIGLO XVIII}

\section{La fachada}

A comienzos de siglo, en 1701, un tal Francisco de Viñas Octavilla y Juan de Solana, vecino de Liaño, aparecen concertados en la fabricación de 30.000 ladrillos para la obra de San Andrés ${ }^{1247}$. A juzgar por algunas expresiones del documento - "ambos juntos”, “...nos obligamos con nuestras personas...”- y la ausencia de referencias al oficio de Juan de Solana, parece que éste participa activamente en dicha fabricación pero, en base a su trayectoria como maestro de cantería entendemos que en ese momento se encontraba al cargo de una obra y es quien subcontrata a los operarios necesarios para la misma. Denominado en ocasiones, maestro arquitecto, Juan de Solana Quintanilla aparece trabajando en el entorno palentino entre finales del siglo XVII y principios del siguiente ${ }^{1248}$. Volviendo a la escritura de concierto inicial, si bien no se indica para qué se requiere esa gran partida de ladrillo, una carta de pago de 1704 al

\footnotetext{
${ }^{1246}$ BUSTAMANTE GARCÍA, Agustín. La arquitectura... Op.cit, pp. 295-297.

1247 AHPP. Carr.Prot 5020. Agustín García Miranda (1701-1704), s/f.

1248 Sobre Juan de Solana dedicamos un apartado relativo a sus datos biográficos.
} 
citado Solana, alude, entre otras intervenciones, a las ampliaciones de la sacristía y la panera, estancias adosadas en el lado del Evangelio, por las cuales se abonaron tres mil reales. Además se pagan a Solana otros cuatro mil reales en concepto de la ejecución de la portada principal del templo. Al parecer, la obra fue comenzada en $1702^{1249}$, una vez que la iglesia había sido lucida enteramente por el maestro de albañilería Antonio Ruiz Canales Escalena, de origen trasmerano ${ }^{1250}$.

Parte de esta fachada está realizada con la piedra extraída del despojo de la parroquia de Santa Eulalia ${ }^{1251}$. Ubicada en el lado meridional, coincidente con el segundo tramo de la nave de la Epístola, la fachada se concibe a través de un gran arco de triunfo que cobija el acceso bajo la bóveda de cañón creada por su intradós. En la línea de imposta se hallan dos ménsulas, una a cada lado, cuyo perfil escalonado es propio, efectivamente del barroco dieciochesco. En el acceso se abre un arco de medio punto cuya rosca está interrumpida a los lados por sendas pilastras de capitel dórico. Entre ellas, las pechinas lucen unas discretas puntas de diamante, una de las pocas concesiones ornamentales de esta sobria fachada. Separada por una cornisa estructurada en dos niveles escalonados, se halla el ático, precedido por un amplio pedestal en cuyos extremos se yerguen dos plintos cajeados que sustentan peanas cuadrangulares rematadas en una medias bolas, ya que al estar adosadas al muro, tan sólo están talladas la mitad de las esferas, a modo de altorrelieves. En el centro se yergue un templete clásico estructurado en un frontón triangular donde, a modo de acroteras se despliegan nuevamente dos medias bolas.

El frontón apea sobre dos pilastras de fuste liso entre las cuales se dispone una pequeña hornacina provista de una bóveda de horno fileteada por una imposta y presidida por el santo titular. La escultura se ubica sobre un pedestal donde se ha tallado

\footnotetext{
1249 PERAL VILLAFRUELA, Santiago y GÓMEZ PÉREZ, Enrique. Carrión...2003, Op.cit, pág. 62.

${ }^{1250}$ La carta de pago, que asciende a 13.600 reales, está fechada el 7 de agosto de 1702 , por lo que la iglesia tuvo que ser guarnecida de yeso poco antes. AHPP. Carr.Prot 5020. Agustín García Miranda (1701-1704), s/f. Antonio Ruiz Canales Se encargó de realizar la iglesia del convento de las Agustinas Recoletas de Palencia a partir de 1693 RAMOS DE CASTRO, Guadalupe. El convento de las Agustinas Recoletas de Palencia" en AIIICHP, vol 4, 1995, pág. 628. En 1701, se hace nombrar maestro arquitecto en un pleito contra Catalina Miguel, que le acusaba de haberla dado su palabra de matrimonio “...y en virtud d'ella la abía desflorado y quitado su birjinidad y otras cosas..." El 14 de abril de 1701, el arquitecto trasmerano otorga poder a Pedro Fernández de Mier, procurador de Carrión, para que el defienda en el pleito AHPP. Carr.Prot 5636 Francisco Ruiz Sandoval (1700-1701), fol 211.

${ }^{1251}$ Así figura en la carta de pago otorgada a Solana en 1704. AHPP. Carr.Prot 5020. Agustín García Miranda (1701-1704), s/f.
} 
una palmeta flanqueada por roleos. Ubicada a gran altura, es difícil identificar la figura con San Andrés, pues la cruz aspada propia de su iconografía, además de disponerse de lado, parte de la misma permanece oculta por el manto y brazo derecho del Apóstol. Se trata de una imagen de canon corto, de figura rotunda y rostro de duras facciones que luce bigote y barbas de guedejas ondulantes en simétrica caída.

\section{Obras de pequeña entidad}

Exceptuando la portada, la primera intervención de cierta relevancia afectó a la torre, en la cual se recompusieron su esquilón, campanas y la escalera de acceso en 1731 y no se vuelve a actuar sobre la misma, más que para someterla a un reconocimiento en 1750, en que Manuel Campoo, maestro de albañilería, se cerciora de su seguridad. Más tarde, entre 1739 y 1740 fueron desmontados los tejados de la iglesia, vueltos a armar y se recompusieron las cornisas y ventanas de la capilla mayor y las colaterales, que recordemos, era el sector más antiguo del templo, renovando por completo los de la capilla del Obispo de Guadix, esto es, la del lado de la Epístola ${ }^{1252}$.

Desde 1753 a 1757, se llevan a cabo algunas labores de albañilería consistentes en la reedificación del muro occidental del templo, lindero a la plaza y un retejo general para quitar las goteras existentes. En las obras participan José Iglesias y sus hijos, una familia de gran tradición en el oficio de alarifes dentro de la villa ${ }^{1253}$. Unos años después, en 1763, vuelve a intervenir para reforzar el piso de campanas de la torre donde se colocó un nuevo esquilón fundido por Juan Sierra, campanero del Obispado de Palencia $^{1254}$.

Con motivo de la ejecución del órgano en 1766, que estudiaremos posteriormente, fue necesario realizar previamente, a partir de 1765, obras de adecuación en el coro alto para asentarlo en el lugar donde hoy se ubica. Es entonces cuando Bernardo de Triana, maestro tallista, realiza el entablado, la escalera de acceso al mismo y la balaustrada mixtilínea que delimita este sector irregular, rematada por una cornisa lisa y un bocel, tal y como se había estipulado que se construyese en las

\footnotetext{
1252 ADP. Carrión. San Andrés. Libro $4^{\circ}$ de Cuentas de Fábrica (1718-1752), fol 154, 241, 259.

1253 ADP. Carrión. San Andrés. Libro $5^{\circ}$ de Cuentas de Fábrica (1753-1795), fol 7v, 97v, 102. Sobre los Iglesias, véase el apartado relativo a la biografía de los maestros locales.

${ }^{1254}$ Ibídem, fol 157v y 191.
} 
condiciones redactadas en 1608. Pero la escalera y el piso del coro volverán a renovarse en 1780 “...por estar podridas las maderas...” y la balaustrada también estaba rota, por lo que se rehace en 1791, en este caso por el carrionés Fabián Martín ${ }^{1255}$.

Ambrosio Blanco y Juan de Zerunetes, maestros de albañilería italianos procedentes del Obispado de Milán, se ocupan en 1771 de blanquear las naves del templo y la sacristía y un año después, el dorador y pintor local José Gallego Hierro se encarga de realizar el trampantojo de sillares del ochavo de la capilla mayor ${ }^{1256}$. El empedrado de mampostería de diversos tamaños del atrio de entrada fue ejecutado entre 1784 y 1785 por los maestros de albañilería local, Mateo Santos y Manuel Fernández. Éste último se ocupará de rehacer el arco de entrada en 1794 y reforzar el castillete que cerraba la torre $^{1257}$. Por último, Ramón Iglesias, se encargará de embaldosar la nave mayor del templo en $1797^{1258}$.

\section{EL DEVENIR A PARTIR DEL SIGLO XIX}

\section{Incendio de la torre y reconstrucción}

En virtud de los 11.581 reales que en 1804 fueron abonados a los maestros de cantería Gaspar Rodríguez, Luis del Hierro y Benigno de Montana, se realizó una obra de cierta entidad en la torre con piedra procedente de Palacios del Alcor, probablemente de fortalecimiento. El encargado de proporcionar las trazas fue el maestro arquitecto Francisco Prieto, académico de San Fernando ${ }^{1259}$. De poco sirvieron estas intervenciones pues en 1811, fue derribado el segundo cuerpo de la torre “...por estar amenazando una mui próxima ruina... ${ }^{1260 " . ~ S o s p e c h a ́ b a m o s ~ q u e ~ e s t e ~ d e r r u m b e ~ f u e ~}$ motivado por los daños que sufrió con la invasión napoleónica, como sucedió con otros templos como Santa María y Santiago, y así nos lo confirma una referencia a la misma

\footnotetext{
${ }^{1255}$ Bernardo Triana, maestro ensamblador, se encarga de llevar a cabo todos los trabajos de madera. ADP. Carrión. San Andrés. Libro $5^{\circ}$ de Cuentas de Fábrica (1753-1795), fol 244v-246, 405v y 519v.

${ }^{1256}$ Ibídem, fol 326v, 336.

${ }^{1257}$ Ibídem, fol 446 y 455v, 546v.

${ }^{1258}$ ADP. Carrión. San Andrés. Libro 6º de Cuentas de Fábrica (1796-1850), fol 20.

${ }^{1259}$ Ibídem, fol 104 y 105. Sobre Francisco Prieto, remítase al apartado dedicado a los maestros locales. ${ }^{1260}$ IbIbídem, fol $165 \mathrm{v}$.
} 
de 1837 en que se indica que su escalera estaba derribada “...desde el tiempo de la independencia... ${ }^{1261, "}$

El tiempo transcurre y hasta el 11 de junio de 1862, la torre no es sometida a un reconocimiento peritado por los maestros Laureano Rojo y Pedro Herrero, que declaran el cuerpo superior en estado de inminente ruina ${ }^{1262}$. La comunicación llegó al Obispo de Palencia pero fueron escasas las intervenciones llevadas a cabo. No fue hasta febrero de 1885 cuando Nicolás Herrero, siguiendo el proyecto de Domingo Picallo, emprende las obras, finalizadas el 7 de julio de $1887^{1263}$ con la construcción de un templete octogonal pétreo con un vano de medio punto en ladrillo, abierto en cada sector, jalonado por ocho pilastras y rematado en una cornisa decorada con sendos pináculos. Por encima se eleva una cúpula con linterna que repite el esquema del templete, coronada por una cruz de piedra. Probablemente en este momento también se refuerzan los cuerpos de la torre a través de rafas de ladrillo, que vemos en los frentes de cada muro, a juego con los arcos del templete. La linterna resultó dañada por una centella en 1896, por lo que tuvo que intervenirse sobre la misma ${ }^{1264}$. En el año 1900 se realizan los últimos pagos de la intervención, revisada y declarada conveniente por Domingo Picallo $^{1265}$. En el año 2000, la Consejería de Cultura de la Junta de Castilla y León, realizó importantes reformas en la torre y colocó una escalera monumental de hierro.

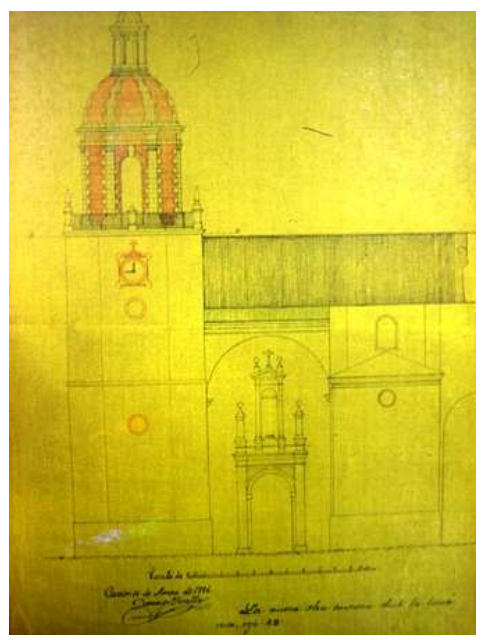

Proyecto del remate de la torre. Domingo Picallo. 1886. Aldaba. 1997.

\footnotetext{
1261 IbIbídem, fol 307.

${ }^{1262}$ En sesión municipal de 17 de octubre de 1862 el concejo insta al cura y mayordomo del templo que actúen lo antes posible. AMCC, Libro 6, Sesiones municipales (1858-1862), s/f y también en ADP. Carrión. San Andrés. Libro $7^{\circ}$ de Cuentas de Fábrica (1851-1929), fol 44.

1263 Aldaba: Boletín Informativo de la Parroquia de Carrión de los Condes. № 2. 1997. Puede verse el dibujo del proyecto en el mismo.

${ }^{1264}$ ADP. Carrión. San Andrés. Libro $7^{\circ}$ de Cuentas de Fábrica (1851-1928), fol 113.

1265 IbIbídem, fol 119.
} 


\section{La construcción del fuerte}

Con motivo de la primera guerra carlista y ante eventuales incursiones de liberales que pudieran darse en la villa, el Cuerpo Nacional de Ingenieros proyectó un fuerte en noviembre de 1838 en su zona noroeste dada su situación elevada sobre el resto de la villa y su natural protección hacia el río Carrión ${ }^{1266}$. La defensa de este sector la integraron las parroquias de San Andrés y Belén y el convento de Santa Isabel. Nos ceñiremos en este caso a las intervenciones realizadas en la parroquia de San Andrés, a cuyos pies se construyeron dos murallas para ser unidas con el cenobio terciario, formando un único bloque y por tanto una menor vulnerabilidad. Para ello se debía derruir parte de los corrales ubicados entre ambos centros, respetando, eso sí, las viviendas allí ubicadas, que pasarían a ser utilizadas como oficinas de recaudación de Hacienda Civil. Estas cercas de piedra asentadas con mortero, tenían una altura de 16 a 18 pies y en ellas fueron practicadas unas aspilleras para defender por ambos lados esa zona. Delante de la muralla meridional se situaría un foso de unos cinco pies de profundidad, con un puente levadizo para acceder a este sector. Entre las dos murallas mencionadas, se ubicaría otra, unida a las tapias de la vivienda que se deja en pie, con el fin de servir de retaguardia a la guarnición que se ubicara en la parte sur. A lo largo de todo el templo debían realizarse aspilleras jalonadas de trecho en trecho por unas buhardillas voladas para arrojar granadas y otros proyectiles. Además en el presbiterio debían practicarse unos parapetos de adobe sobre el tejado con el objetivo de poder dominar desde allí las casas y plazas del pueblo, obteniendo así una posición ventajosa. A pesar de que no se conserva nada del fuerte carlista, no hay duda de que llegó a ser construido y utilizado, por las obras reflejadas en los libros de Fábrica encargadas por la Junta de fortificación de la villa entre 1838 y 1839 y las obras de rehabilitación de la panera en 1840 “...después que zesó la guerra, mediante haver estado destinada para fuerte... ${ }^{1267}$ ". El párroco del templo, a pesar de la carestía pero dada la necesidad, aceptó colaborar con su construcción proporcionando los maestros, mientras que la Junta se haría cargo de la adquisición de materiales. También se hace mención al tapiado de la puerta de 1842 que se abrió en el presbiterio para acceder al fuerte, “...construido para

\footnotetext{
${ }^{1266}$ AMS. Proyecto del fuerte de Carrión. Sección 3a , División 3 $3^{\text {a }}$, Leg 99, nº 11.

1267 ADP. Carrión. San Andrés. Libro 6º de Cuentas de Fábrica (1796-1850), fol 307.
} 
la defensa de las tropas nacionales... ${ }^{1268 ” . ~ E n ~} 1856$ permanecía en pie parte del mismo, siendo parte de sus materiales destinados al reparo del puente ${ }^{1269}$. El resto desapareció paulatinamente, al ser utilizados los materiales de la edificación en las viviendas particulares carrionesas. Todavía en 1865, se hace alguna mención, pues se repintan algunas zonas del presbiterio, como el zócalo y friso, por “...los deterioros que había sufrido durante la guerra civil pasada... ${ }^{1270, "}$

\section{3. Últimas intervenciones}

En 1894 fue finalizado el coro alto, con su perfil de herradura, momento en el que se abrió la vidriera que vemos actualmente ${ }^{1271}$. Las del presbiterio, que representan a San Andrés, fueron colocadas en 1913 y costeadas con las limosnas de los feligreses $^{1272}$. Bajo la dirección de la arquitecta Ana Iglesia González, el templo de San Andrès experimenta su restauración más reciente, en 1977, paralelamente a la del templo de Santiago de la misma villa ${ }^{1273}$. La intervención consistió en la sustitución de las cubiertas de madera por estructuras metálicas, bajando la pendiente primitiva con el fin de salvar la bóveda del crucero a través de un tablero de hormigón. En la sacristía se crearía un forjado para permitir el uso de su piso superior como salón parroquial ${ }^{1274}$.

\section{PRINCIPALES OBRAS DEL TEMPLO}

De todas las iglesias de Carrión, la de San Andrés, es con diferencia, la que más obras de arte atesora, a tenor de sus dimensiones y de su relevancia dentro de la villa. Dado que en muchos casos desconocemos a qué capillas pertenecían los retablos y monumentos conservados, hemos decidido estudiarlos en un apartado independiente. Existen otras piezas, de las que, si bien es sabido el espacio de culto que ocupaban, como los retablos del testero o el monumento funerario del Obispo Vozmediano, hemos estimado pertinente agruparlo en este capítulo con el fin de que todas las obras estén

\footnotetext{
${ }^{1268}$ Ibídem, fol 321.

1269 AMCC. Libro 5, Sesiones municipales (1850-1857). Sesión de 30 de octubre de 1856, fol 67 v.

${ }^{1270}$ ADP. Carrión. San Andrés. Libro $7^{\circ}$ de Cuentas de Fábrica (1851-1928), fol $52 \mathrm{v}$.

${ }^{1271}$ RAMÍREZ DE HELGUERA, Martín. El libro...Op.cit, pág. 160.

1272 ADP. Carrión. San Andrés. Libro 43 del Inventario de todos los ornamentos y alhajas de San Andrés (1833-1930), s/f.

1273 AGA. Expedientes de restauración de monumentos.(3) 5. Caja 51/11328.

1274 AGA. Expedientes de restauración de monumentos. (3) 5 Caja 51/11372. Planos, condiciones y presupuesto en Caja 26/1586.
} 
analizadas conjuntamente, para mejor comprensión y claridad. El retablo mayor y el monumento del Obispo Vozmediano, serán cuando nos refiramos a las capillas. Hemos seguido un orden estrictamente espacial, desde la cabecera a los pies, comenzando por el retablo mayor y testero, prosiguiendo a continuación por el lado del Evangelio, seguidamente por el lado de la Epístola, después el coro y concluimos por la sacristía.

\author{
1. Retablo mayor \\ 2. Retablo de San Francisco Javier \\ 3. Retablo de San José \\ 4. Sepulcro de don Pedro Cantero \\ 5. Sepulcro de don Melchor Álvarez de \\ Vozmediano \\ 6. Púlpito neogótico \\ 7. Retablo de la Adoración de los Reyes \\ 8. Retablo de la Virgen del Rosario \\ 9. Retablo del Santo Ángel \\ 10. Virgen de la Herrada (antigua capilla \\ homónima) \\ 11. Lienzo del Juicio Final \\ 12. Lienzo de San Miguel \\ 13. Sillería y órgano
}

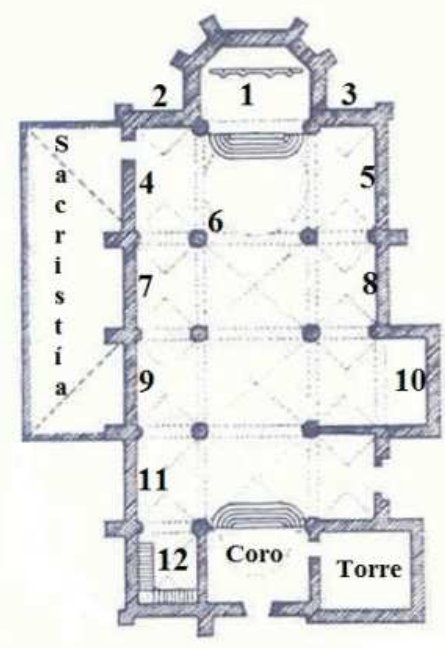

Esquema de la ubicación de las obras artísticas del templo de San Andrés.

\title{
1. El retablo mayor
}

Antes de que la capilla mayor fuese reedificada, presidía este espacio un retablo dorado bajo la misma advocación que el actual, que ya existía en $1511^{1275}$. Con la reconstrucción del templo bajo las órdenes del arquitecto Francisco Bálcava a partir de 1608, se previó la ejecución de un retablo, para el cual se destinarían mil ducados de los doce mil invertidos para las obras generales ${ }^{1276}$. Los trabajos del templo se prolongaron, como ya referimos, hasta los años setenta del siglo XVII, en que quedó configurado. Por entonces no existían fondos suficientes para costear un nuevo retablo y se opta por habilitar este espacio con el retablo procedente de la capilla mayor de Santa María, adquirido en 1685, que sería asentado por Manuel Salceda y Gabriel Martínez.

\footnotetext{
1275 ADP. Carrión. San Andrés. Libro antiguo de Cuentas de Fábrica, mandatos, visitas e inventarios (1511-1528), fol 1.

${ }^{1276}$ AHN. Clero Regular-Secular, Legajo 5356, Expediente 2, Iglesias de San Andrés y San Pedro, Obras.
} 
Precisamente éste artista carrionés fue quien talló las cajas de las reliquias que formarían parte del retablo a partir de entonces, doradas por Alonso Gómez ${ }^{1277}$.

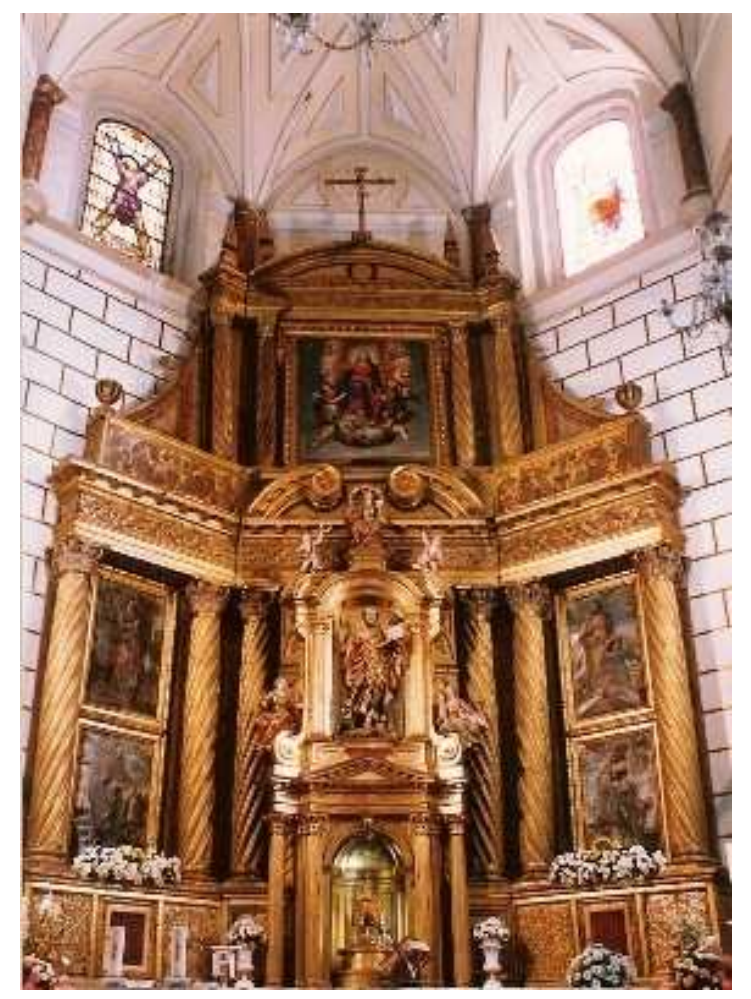

Retablo mayor de San Andrés procedente de la iglesia de Santa María.

Juan Bautista Pérez. 1648. (8,5mtrx6,4mtrx2mtr).

Podemos asegurar con firmeza, en base a otros datos que aportamos, que dicho retablo es, efectivamente, el que hoy preside la capilla mayor de San Andrés. Recordemos que dicho año, el obispo Molino Navarrete encarga el retablo que preside actualmente la capilla de Santa María, resultando éste desplazado, a pesar de que era prácticamente nuevo. En segundo lugar, dado el gran tamaño de la obra, sólo podía haber estado ubicado en la capilla mayor. Por otra parte las dimensiones semejantes en ambos retablos mayores, de ocho metros de altura, y poco más de seis metros de anchura, proporcionan otro argumento favorable de la asimilación de estas dos piezas. Eso explica que el retablo que hoy preside la iglesia de San Andrés se adaptara a la perfección en el templo de Santa María y sin embargo aquí, al ser una obra

1277 ADP. Carrión. San Andrés. Libro $3^{\circ}$ de Cuentas de Fábrica (1672-1718), fol 75. Sobre Manuel de Salceda, véase el capítulo dedicado a los ensambladores locales y acerca de Alonso Gómez, remítase al apartado en que estudiamos a los pintores. La procedencia de Santa María aparece confirmada en RAMÍREZ DE HELGUERA, Martín. El libro...Op.cit, pág. 160. 
reaprovechada, queda demasiado pequeño para la capilla. Por último, resulta clave la descripción que figura en la escritura de contrato, que referimos a continuación, coincidente con la fisonomía de nuestro retablo, salvo por la sustitución de la figura de la Virgen de las Victorias, como es lógico, por la imagen del Apóstol titular.

El retablo, compuesto por un cuerpo dividido en tres calles, fue contratado con el ensamblador Juan Bautista Pérez en 1648, quien debía concluirla en dos años por quinientos ducados ${ }^{1278}$. Todo el retablo se realizaría con madera de pino traída expresamente de Quintanar de la Sierra, salvo el sagrario, realizado en olmo y nogal, materiales procedentes del término de la villa. Se precisa que se realice el banco con un pedestal conformado por basa y sotobasa toscana ensamblados a inglete y un cuerpo con columnas entorchadas con capiteles corintios. Entre estos soportes se ubicaban cinco marcos italianos en cuyo hueco se dispondrían posteriormente varios lienzos. La finalización de los trabajos se cumplieron en los plazos establecidos, ya que el 26 de julio de 1650 se contrata a Juan de la Inestrosa, maestro ensamblador y arquitecto, como veedor del retablo. El artista declara que se ha cumplido con la traza y condiciones excepto en que la custodia ha de bajar dos dedos y en la guarnición de los tres tableros mayores del retablo ha de disponer unos barrotes para fortalecerlos. En octubre de 1654, el artista vallisoletano Gaspar Díaz del Pozo $^{1279}$ es contratado para dorar el nuevo retablo. El contrato que la iglesia establece con el artista proporciona información adicional sobre la fisonomía del mismo ${ }^{1280}$. Así en las condiciones se determina que no se dorasen los tableros ubicados en los pedestales, los de los lados del retablo y el principal porque en ellos debían realizarse cinco imágenes realizadas por un pintor perito en el arte, a ser posible, uno de los mejores de la villa, que debían representar los santos o santas que el párroco determinase.

Nos hallamos ante una obra clasicista que sigue "el orden de Vignola", demasiado sencilla quizá, para un obispo como Navarrete, que, dotado de suficiente caudal, prefería una obra barroca más avanzada, acorde al gusto imperante por entonces. En el banco del retablo se conservan varios relicarios protegidos por sus respectivas

\footnotetext{
${ }^{1278}$ El contrato del retablo en AHPP. Carr.Prot 5238. Jerónimo López (1648), fol 130 y ss. Sobre Juan Bautista Pérez, remítase al capítulo dedicado a los escultores y ensambladores locales.

${ }^{1279}$ Este artista ya había trabajado en Carrión, dorando 1641 el retablo mayor del convento de Santa Clara. AHPP. Carr.Prot 5234 Jerónimo López (1641-1642), s/f.

1280 AHPP. Carr.Prot 5527. Tomás Pérez (1654), fol 108 y ss.
} 
rejas. Sabemos a quienes corresponden gracias al inventario llevado a cabo en 1770, en el que un cirujano se encargó de examinar los huesos que contenía cada uno. El primero y tercero alojan bustos de la Virgen con reliquias de las Once Mil Vírgenes, el segundo, un busto de San Sebastián y San Fabián y el último, una pequeña escultura de cuerpo entero de un Santo Obispo, identificado según inscripción, San Traquilino, mártir ${ }^{1281}$.

En el cuerpo principal, a los lados, se disponen cuatro lienzos con pinturas de los Evangelistas entre sendas columnas entorchadas, situándose San Juan y San Marcos en el lado del Evangelio y San Mateo y San Lucas, en el lado frontero. Son obras de escasa calidad artística que representan a los santos de pie, con sus respectivos atributos a los pies, y con la pluma en la mano, en actitud de redactar las Escrituras. Dotados de nimbo, se hallan ladeados en dirección al centro del retablo y tras sus figuras se delinea un sencillo paisaje salpicado de arbolillos dispersos. Las pinturas de San Juan y Sn Lucas se hallan en pésimo estado de conservación, totalmente ennegrecidas, al contrario que sus compañeras, que parecen haber sido objeto de alguna restauración. El marco de gallones señala una ejecución dentro del segundo tercio del siglo XVII, es decir, paralelo a la firma del contrato, y una posible procedencia vallisoletana.

La calle central está oculta por un tabernáculo que se superpone al mismo, datado en la segunda mitad del siglo XVIII, con escultura de San Andrés, coetánea al mismo $^{1282}$. En efecto, no formaban parte del retablo original, pues en 1782, Juan Manuel Becerril, que se hace llamar "maestro arquitecto de Palencia" y cuatro oficiales, reciben 4.318 reales por el tabernáculo, la custodia, y las esculturas que los contienen, para cuyos trabajos emplearon dos meses ${ }^{1283}$. La ejecución del tabernáculo y sus esculturas fueron ocasionadas con motivo de la visita del Obispo de Palencia, don José Luis de Mollinedo el 27 de septiembre de 1781, en que halló muy deteriorado el tabernáculo existente, por lo que juzgó precisa su restitución, al igual que una nueva

${ }^{1281}$ ADP. Carrión. San Andrés. Libro $5^{\circ}$ de Cuentas de Fábrica (1753-1795), fol 312 y también en Legajo 93.3. Papeles diversos. Inventario 1770 , s/f.

${ }^{1282}$ URREA FERNÁNDEZ, Jesús y MARTÍN GONZÁLEZ, Juan José. Inventario...2, Op. cit, pág. 54. 1283 ADP. Carrión. San Andrés. Libro $5^{\circ}$ de Cuentas de Fábrica (1753-1795), fol 424v. Sobre Manuel Becerril, remítase al capítulo dedicado a los ensambladores y escultores locales. 
imagen que presidiera el retablo “...por no ttener la yglesia de su tittular señor Andrés más que el pecho, caueza y espalda de su ymagen ${ }^{1284, "}$

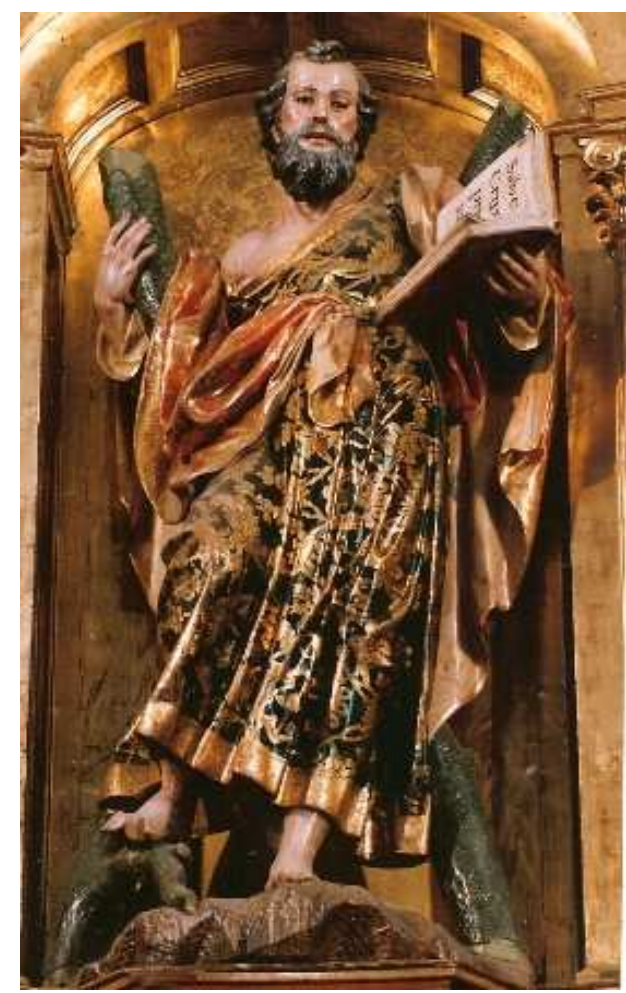

San Andrés. Escultura que preside el

Retablo mayor de San Andrés.

Juan Manuel Becerril. 1782.

$(149 \mathrm{~cm} \times 70 \mathrm{~cm} \times 40 \mathrm{~cm})$.

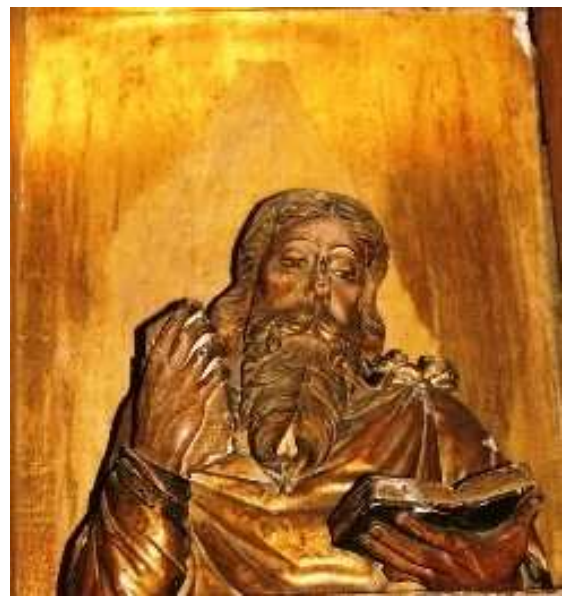

San Andrés. Busto ubicado en la sacristía que presidía el retablo anteriormente. Cercana a Juan de Valmaseda. Hacia 1540. $(50 \mathrm{~cm} \times 40 \mathrm{~cm} \times 20 \mathrm{~cm})$.

Lógicamente, de la iglesia de Santa María, el retablo llegó sin escultura en la hornacina central, puesto que la imagen de Nuestra Señora permaneció en dicho templo. La iglesia debió aprovechar para el nuevo retablo la que existía en el anterior. Probablemente el busto del Santo del siglo XVI conservado en la sacristía del templo $(50 \mathrm{~cm} \times 40 \mathrm{~cm})$, se corresponda con la imagen de San Andrés que presidía el retablo primitivo. La efigie representa a un anciano barbado que porta un libro en la mano

\footnotetext{
${ }^{1284}$ La custodia fue dorada por José Gallego en 1782 y el tabernáculo fue dorado en 1784, cuando además se estofaron las Virtudes. ADP. Carrión. San Andrés. Libro $5^{\circ}$ de Cuentas de Fábrica (1753-1795), fol 425 y $447 \mathrm{v}$.
} 
izquierda y en la otra, un objeto fragmentado que podría corresponder con la cruz aspada a la que suele agarrarse el Apóstol, lo que permitiría suponer que dicha cruz se prolongaría en origen al igual que la imagen, que debió tallarse de cuerpo entero, o cual es lógico si pensamos que presidiría el retablo. Se trata de una obra de buena calidad artística, fechable hacia 1540 y cercana al círculo de Juan de Valmaseda por la ejecución de las venas marcadas en las manos y los cabellos filamentosos y simétricos de las barbas.El tabernáculo, de perfil cóncavo, está compuesto de dos cuerpos de igual altura. El primero está conformado por un templete rematado en un frontón triangular sustentado por columnas estriadas de orden corintio. En su interior, cobijado por una cúpula y elevada sobre una peana hallamos el sagrario, reproducción en miniatura de un templete, abierto por sus cuatro frentes y rematado en un chapitel por cada lado. El cuerpo superior lo preside la imagen titular dispuesta bajo hornacina de medio punto rebajado entre columnas estriadas.

San Andrés $(149 \mathrm{~cm})$ es una imagen de buena calidad, encarnada a pulimento y dotada de vistosos ropajes. Porta una túnica negra esgrafiada de rameados dorados, ajustada a su cintura, que descubre el hombro derecho y sobre ésta, un manto rojo orlado de oro sujeta por el cinturón en la parte delantera. El Apóstol, barbado y de mediana edad, sostiene un libro abierto donde puede leerse unas palabras de adoración al instrumento de su martirio: "Salve crux praetiosa". La figura presenta un elegante dinamismo motivado por la elevación de la pierna derecha del santo, apoyada sobre una rama nudosa que emerge de la cruz aspada casi oculta por su figura. Es por ello que la espalda se arquea ligeramente hacia atrás, la mano derecha se aferra al tronco y los pliegues de la túnica se deslizan en una suave caída lateral. Esta disposición pendular de la figura la observamos en la figura de San José de la hornacina lateral del retablo de Frechilla, que también es obra de Manuel Becerril. En el nivel de la imposta del arco, a ambos lados, arranca un frontón curvo partido, que sirve de asiento para dos querubines. A los lados, en la parte inferior, se despliegan dos volutas sobre las que se ubican, sedentes, las figuras de la Caridad $(74 \mathrm{~cm})$, a la derecha, con dos mancebos sobre su regazo, uno de los cuales ha perdido la pierna. A la izquierda, con los dedos mutilados, hallamos a la Esperanza $(80 \mathrm{~cm})$. No porta ningún atributo que le identifique, pues todos sus dedos han sido mutilados pero su identificación resulta inequívoca porque la tercera de las Virtudes Teologales, la Fe $(90 \mathrm{~cm})$, corona el remate, flanqueada por un frontón curvo partido de remate circular. Sentada majestuosa en un trono y con los ojos 
vendados, porta el cáliz y la ostia en su mano izquierda, símbolos de la Eucaristía, mientras que con la otra parece sujetar un objeto que ha desaparecido, posiblemente la cruz.

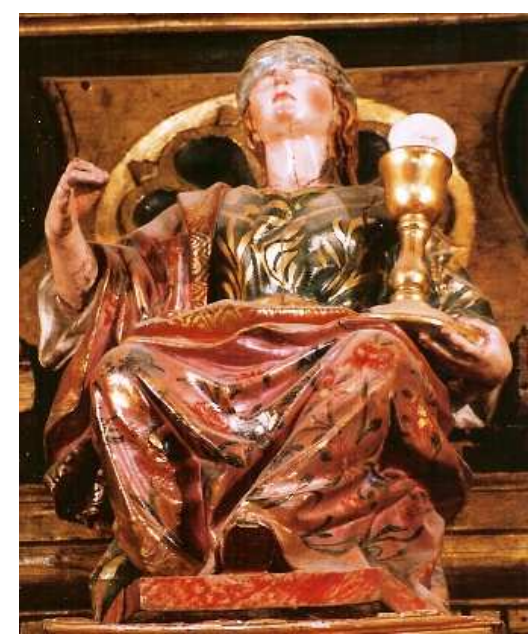

La Fe. $(90 \mathrm{~cm} \times 40 \mathrm{~cm} \times 30 \mathrm{~cm})$.

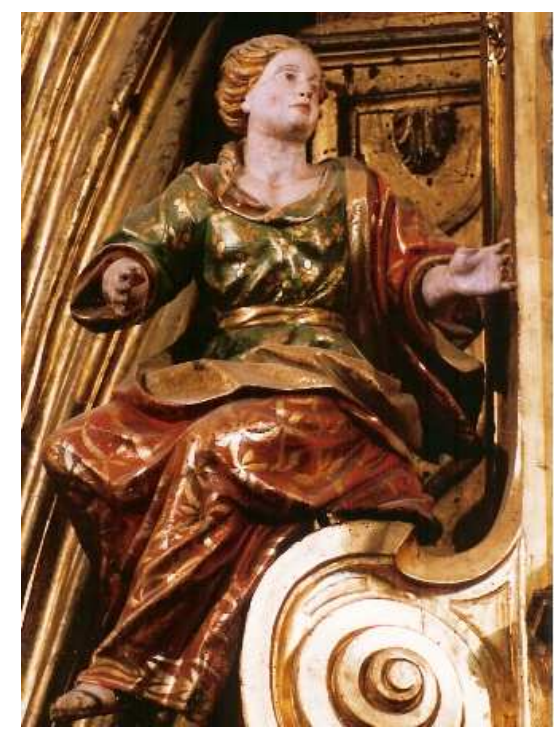

La Esperanza $(80 \mathrm{~cm} \times 43 \mathrm{~cm} \times 37 \mathrm{~cm})$.

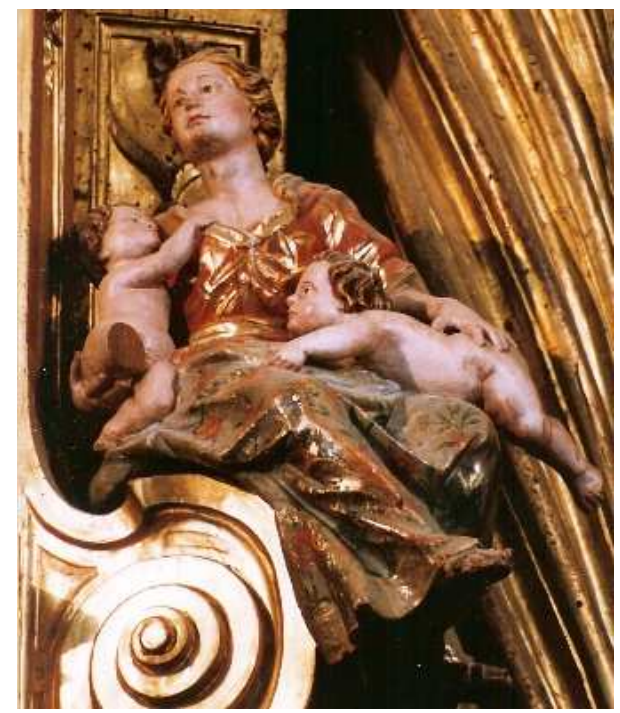

La Caridad $(74 \mathrm{~cm} \times 48 \mathrm{~cm} \times 33 \mathrm{~cm})$.

Virtudes teologales del retablo mayor de San Andrés. Juan Manuel Becerril. 1782.

El ático del retablo se yergue sobre un gran pedestal sobre el que se han pintado roleos vegetales muy dispares en llamativos tonos rojizos y verdes. Sobre el mismo, cuatro columnas entorchadas flanqueadas por aletones curvos enmarcan el lienzo central, en el que se representa la Asunción $(170 \mathrm{~cm} \times 160 \mathrm{~cm})$. Dispuesta sobre un marco 
dorado decorado con motivos de ovas, se trata de una pintura datada en el siglo $\mathrm{XVII}^{1285}$, pues fue ejecutada paralelamente al retablo original, por lo que podemos precisar que fue realizada a mediados de la centuria por el mismo autor de las pinturas de los Evangelistas. La Virgen es una figura monumental, que, sentada sobre un copioso manto de nubes, extiende sus brazos en lugar de presentarlos en la clásica actitud de oración. Los ángeles que le circundan son de lo más variopinto: cabecillas aladas dispuestas en grupos de tres o individualmente que flotan en el aire, dos amorcillos desnudos que elevan a la Virgen por los pies y dos ángeles vestidos con túnica roja la sostienen por ambos flancos. Remata el conjunto un frontón curvo coronado por un crucifijo y cuatro pináculos en los lados.

En 1875, paralelamente a la ejecución del entarimado de la capilla mayor, el retablo fue desarmado y limpiado y al ser colocado, se eleva una vara y media (1,20metros aproximadamente) para su mejor visualización por detrás de la mesa de $\operatorname{altar}^{1286}$. Las imágenes que flanquean el presbiterio, ubicadas sobre hornacinas, representan los Sagrados Corazones de Jesús y María. Son dos esculturas modernas, donadas al templo por un devoto, don Pedro Girón y Arenillas en $1913^{1287}$.

\section{Retablos del testero de las naves}

Los retablos adosados a la pared oriental de las naves laterales fueron realizados por Pedro Alvo Cavada, vecino de Laredo, siguiendo las trazas proporcionadas por el maestro vecino de Palencia, Pablo Villazán, en septiembre de $1714^{1288}$. Ambos se declaraban maestros arquitectos entendiéndose este término sinónimo de retablistas. Pedro Alvo procedía probablemente de Santander, a tenor de su patronímico, pero no se conocen datos de su actividad artística ${ }^{1289}$.

\footnotetext{
1285 URREA FERNÁNDEZ, Jesús y MARTÍN GONZÁLEZ, Juan José Inventario...2, op. cit, pág. 54.

1286 ADP. Carrión. San Andrés. Libro $7^{\circ}$ de Cuentas de Fábrica (1851-1928), fol 86v.

1287 ADP. Carrión. San Andrés. Libro 43 del Inventario de todos los ornamentos y alhajas de San Andrés (1833-1930), s/f.

${ }^{1288}$ AHPP. Carr.Prot 5023. Francisco Ruiz Sandoval (1713-15), s/f.

${ }^{1289}$ Sobre Pablo Villazán, remítase al capítulo dedicado a los ensambladores y escultores locales.
} 


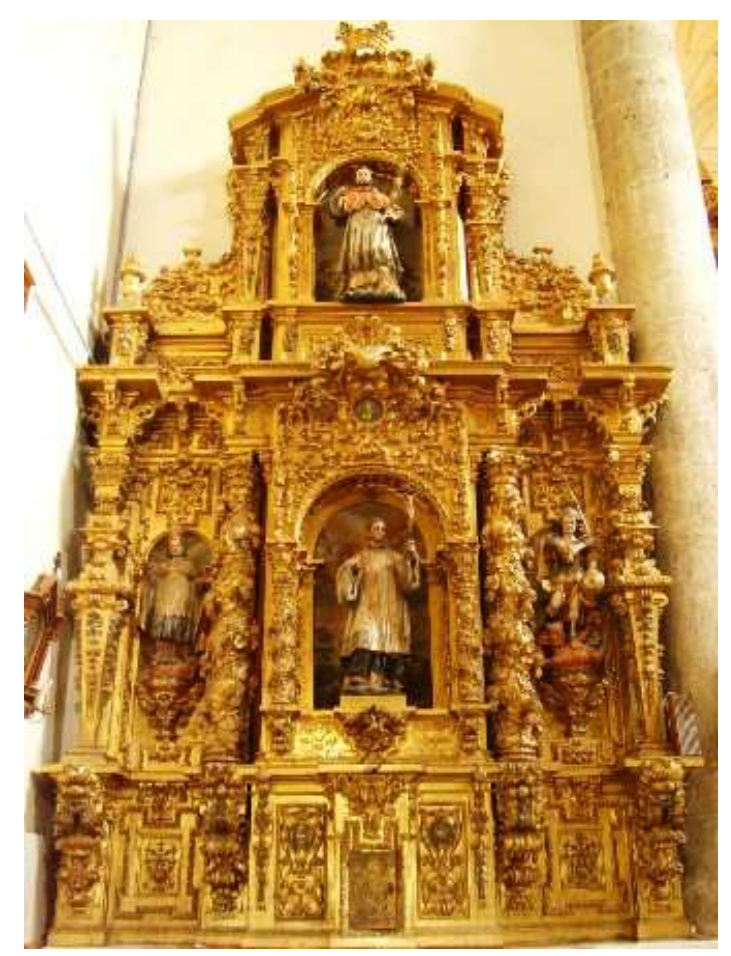

Retablo de San Francisco Javier, originalmente de Santa Catalina.

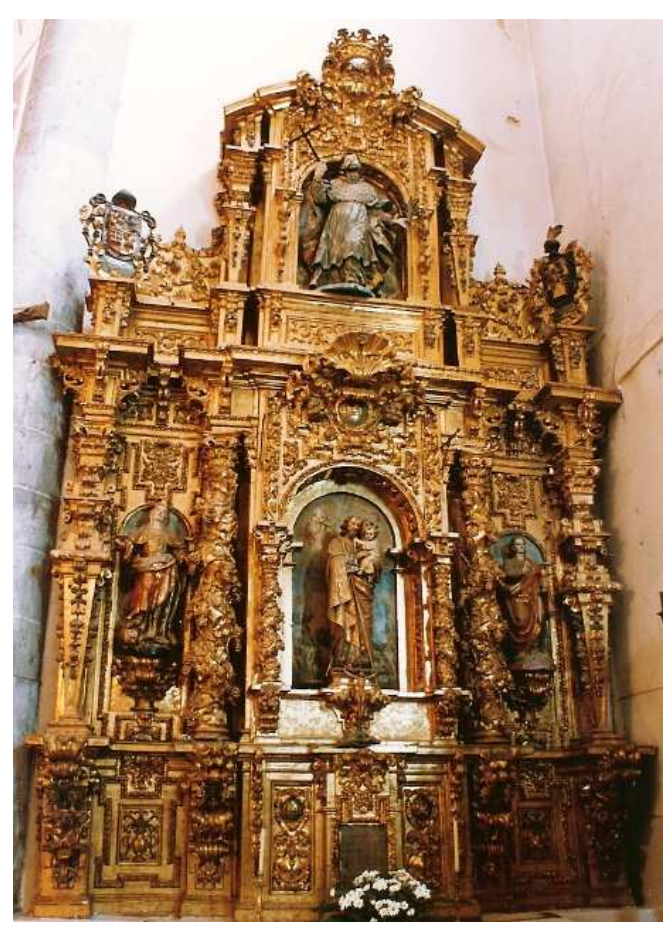

Retablo de San José, originalmente de Nuestra Señora.

\section{Retablos gemelos del crucero en San Andrés.}

Ensamblados por Pedro Alvo Cavada 1714. (6,5mtrx4mtrx0,7mtr).

En las condiciones se precisa en multitud de ocasiones que se siga como modelos los de Santa Gertrudis y San Gregorio que se hallaban en la capilla mayor del monasterio de San Zoilo ${ }^{1290}$. Estos retablos se situarían bajo la advocación de Santa Catalina y Nuestra Señora, esculturas que hoy día no presiden la hornacina principal, de las que tan sólo se conserva la de la santa de Alejandría. A pesar de que no se precisa donde se ubicaría cada imagen titular, sabemos por las referencias documentales que en el testero del lado de la Epístola, se ubicaba antiguamente la capilla de Nuestra Señora de las Velaciones y en el Evangelio, la capilla de Santa Catalina, como más adelantes estudiaremos. Otro indicio de estas advocaciones es que sobre la hornacina principal de cada retablo existe un espejo en la que se han inscrito unas letras doradas. En el retablo del lado derecho es clara la alusión a la Virgen, con las iniciales "AM" entrecruzadas.

\footnotetext{
${ }^{1290}$ Estos retablos no se conservan actualmente. Tan sólo pervive la imagen de Santa Gertrudis, aunque
} ubicada en un retablo neoclásico. 
En el lado del Evangelio, hallamos una $\mathrm{S}$ entrelazada con una espada, posible referencia a Santa Catalina.

Se trata de dos retablos gemelos $(6,5$ metrsx4metros) realizados en madera de pino y de estilo churrigueresco. Constan de un banco, cuerpo dividido en tres calles y ático de gran desarrollo. El banco, profusamente decorado, se halla compartimentado en tres sectores correspondientes a las respectivas calles, separados por cuatro pedestales de gran altura provistos de caprichosa hojarasca enroscada tallada a trépano. Inscritos en dos tableros decorados con orejetas en sus ángulos, se hallan dos jarrones de azucenas, de clara vinculación mariana. En el centro se ubica la puerta del sagrario, desnuda completamente, flanqueada por los anagramas de Cristo y la Virgen María: IHS y AM.

El cuerpo principal se halla flanqueado por dos estípites abalaustrados de forma tronco piramidal invertida con un motivo avolutado en la parte superior de cada frente del que penden cintas y frutos variados. A continuación, se ubica a cada lado una hornacina de medio punto sin fondo que motiva el marcado desarrollo de una ménsula a sus pies para asentar las esculturas laterales y sobre dicha hornacina, se ha tallado un motivo cactiforme muy movido que se extiende hasta el comienzo del friso. Dos grandes columnas salomónicas de cuatro espiras y fuste completamente ornamentado de vides entrelazadas enmarcan el cuerpo central, destacado por su avance respecto a la línea general del retablo. Tanto las columnas salomónicas como los estípites, cuya presencia fue precisada en las condiciones del retablo, poseen un capitel toscano sobre los cuales se yergue una cornisa retranqueada que aporta gran dinamismo al conjunto. La hornacina central, dada su profundidad, crea en su interior una bóveda de cañón decorada con cinco casetones floreados. El arco de medio punto apea sobre dos columnas salomónicas que, de escala inferior respecto a las anteriores, presenta análoga decoración a sus compañeras. Un manto de hojarasca recubre la superficie de las enjutas y en la parte central se despliega un motivo cactiforme muy desarrollado.

Por último, elevado sobre un pedestal retranqueado, se ubica el ático, flanqueado por dos flameros campaniformes asentados sobre altos plintos cajeados con varios frutos adosados en sus frentes. Seguidamente, se sitúan dos aletones curvos provistos de hojarasca, pues tal y como se había estipulado “...los arbotantes hayan de ser tallados por fachada y perfil para mayor hermosura del remate...". En la hornacina central se 
repiten los elementos de la principal, como el arco de medio punto con casetones en el intradós, las enjutas con profusa decoración vegetal y el motivo cactiforme coronando el conjunto, salvo que en este caso, se prolonga hacia los lados y va timbrado de corona. El ático posee un remate curvo y retranqueado, que se sustenta mediantes dos estípites análogos a los anteriores, pues en virtud de las condiciones, han de ser “...correspondientes a las del cuerpo principal, guarneciéndolos según y conforme están los de abajo...”. La única diferencia entre ambos retablos, la constituye, lógicamente las cuatro esculturas que la conforman, tres en el cuerpo principal y una en el ático, además de los dos escudos que fueron añadidos a posteriori en el retablo de San José, de los que carece el de San Francisco Javier.

El abono de los retablos, que se remataron en 6.600 reales se produjo a la conclusión de los trabajos, en $1715^{1291}$. Por encargo de don Juan Manuel Álvarez de Bobadilla, patrón de la capilla de Nuestra Señora, ambos retablos fueron dorados y estofados en $1753^{1292}$. Es el momento en que se pinta el fondo de todas las hornacinas: la principal con una gloria y árboles y las restantes mediante nubes y “...rrompimiento de luminar...", conservados actualmente. Los encargados de estos trabajos fueron Juan López y Francisco Gutiérrez, quienes ya trabajaron juntos en 1749 en la ejecución de las colgaduras de la pintura mayor de la iglesia de Santa María ${ }^{1293 .}$

\subsection{Retablo de Santa Catalina, hoy San Francisco Javier}

Originalmente el retablo estuvo presidido por la imagen de Santa Catalina, como indica el contrato del retablo en $1714^{1294}$. Junto a la imagen de la santa, es seguro que también formaba parte del retablo original la escultura de San Miguel pues cuando a mediados del siglo se dora y estofa, se indica que se encarnen a pulimento las dos esculturas del mismo ${ }^{1295}$. No sabemos las otras dos imágenes que conformaban el retablo pues ese mismo año en que se doran las imágenes de San Severo y San Francisco Javier, se señala que ambas formaban parte de un retablo dedicado al santo

\footnotetext{
${ }^{1291}$ ADP. Carrión. San Andrés. Libro $3^{\circ}$ de Cuentas de Fábrica (1672-1718), s/f.

1292 AHPP. Carr.Prot 4605. Francisco Blanco Manuel (1753-1754), fol 19 y ss.

${ }^{1293}$ El contrato de la obra de Santa María en AHPP. Carr.Prot 4735, Gabriel Ceano Vivas (1748-1749), fol 18 y ss. Sobre Francisco Gutiérrez, remítase al capítulo dedicado a los pintores locales.

${ }^{1294}$ AHPP. Carr.Prot 5023. Francisco Ruiz Sandoval (1713-15), s/f.

1295 AHPP., Carr.Prot 4605, Francisco Blanco Manuel (1753-1754), fol 19 y ss.
} 
jesuita en la capilla homónima ${ }^{1296}$, espacio del que no teníamos constancia documental, pues tal vez comienza a situarse bajo esta advocación cuando se realiza la escultura en el siglo XVIII. En un inventario de 1771 San Francisco Javier ha desplazado a Santa Catalina de la hornacina principal a la calle lateral, junto a San Severo, ocupando San Miguel el ático ${ }^{1297}$. El arcángel será posteriormente desplazado del ático por San Ramón Nonato, tal y como testimonian las fuentes entre 1895 y los años ochenta de la centuria siguiente $^{1298}$. A partir de los años ochenta, la Santa de Alejandría será trasladada a la calle lateral del retablo frontero de San José, donde se ubica desde entonces, ocupando su lugar, esto es, la calle lateral derecha, San Miguel. Ambas obras fueron ejecutadas por Pedro Martínez del Mazo, que otorgó carta de pago por las mismas en 1726, lo que apuntaría a una ejecución poco anterior a este año ${ }^{1299}$.

San Miguel $(134 \mathrm{~cm})$, de rostro afeminado y lánguida expresión, blande la espada, que levanta con su mano derecha, a punto de asestar el golpe definitivo al demonio que parece reposar plácidamente a sus pies, recostado sobre una de sus patas. Con la otra mano se protege con su escudo circular, orlado de la célebre inscripción:“Qvis Sicut Deus”.

Respecto a San Francisco Javier y San Severo, ubicados en la calle lateral izquierda y central, respectivamente, San Francisco Javier $(136 \mathrm{~cm})$, es la imagen de mayor calidad del retablo y en ella podemos reconocer al santo jesuita gracias a su hábito negro de cuello alto, el sobrepelliz con una orla pintada imitando encaje y la estola amarilla que luce por encima. El Apóstol de las Indias se nos muestra aquí, dialogando con el crucifijo, que alza con su mano izquierda. Los pliegues de su vestimenta están muy trabajados, con una suave caída en el roquete y con un tratamiento más duro en las bocamangas. En el lado izquierdo se halla San Severo $(134 \mathrm{~cm})^{1300}$, de inferior calidad, que ha perdido parte de la policromía del rostro. Hoy día tanto sólo podríamos identificarlo como un Santo Obispo pues aparte de su

\footnotetext{
${ }^{1296}$ ADP. Carrión. San Andrés. Libro $5^{\circ}$ de Cuentas de Fábrica (1753-1795), fol 7v.

${ }^{1297}$ ADP. Carrión. San Andrés. Libro $5^{\circ}$ de Cuentas de Fábrica (1753-1795), fol 312.

${ }^{1298}$ San Francisco presidía el retablo y a los lados se ubicaban Santa Catalina y San Severo y en la parte superior San Ramón Nonato. RAMÍREZ DE HELGUERA, Martín. El libro...Op.cit, pág. 161 y URREA, Jesús y MARTÍN GONZÁLEZ, Juan José Inventario...2, Op. cit. pág. 54.

${ }^{1299}$ ADP. Carrión. San Andrés. Libro $5^{\circ}$ de Cuentas de Fábrica (1753-1795), fol 105

${ }^{1300}$ RAMÍREZ DE HELGUERA, Martín. El libro...Op.cit, pág. 161.
} 
indumentaria episcopal, los guantes y la mitra, no porta ningún atributo que nos permita vincularlo con el prelado de Barcelona.

Presidiendo el ático se encuentra San Ramón "Nonato” (140cm), escultura que, como indicamos, fue introducida en este retablo tardíamente, ya que presidía el retablo homónimo hasta el siglo XIX. El apelativo "nonato" deriva del relato que recoge la tradición de que el santo fue extraído del vientre de su madre tras haber fallecido ésta, convirtiéndose a raíz de este hecho milagroso en patrón de las matronas y de los recién nacidos. El santo catalán, vestido de cardenal por su nombramiento por Gregorio IX, sujeta en la mano izquierda la palma del martirio con tres coronas, alusiva a sus tres virtudes: castidad, elocuente predicación y martirio. Mantiene la otra cerrada en un puño, como si en origen sustentase la custodia, otros de sus clásicos atributos en razón de la devoción que profesó a este objeto litúrgico. La escultura fue realizada en 1766 por el tallista Miguel Feliz, mientras que del dorado de la misma se encargó el carrionés Cayetano Bodigos ${ }^{1301}$. Miguel Feliz es un escultor carrionés al que se debe, por ejemplo, el San Roque del retablo de Villamorco, localidad muy próxima a Carrión, ejecutado en $1791^{1302}$. Al observar estas dos imágenes hallamos algunos rasgos comunes, tales como uso de un canon corto, rostros ovalados de ojos grandes y expresivos y una caída ondulante de los pliegues. El retablo de San Ramón, ubicado junto a la sacristía, fue desplazado en 1769 cuando el lienzo de las Ánimas de Ramón Canedo pasó a ocupar su lugar, aunque continuó en el muro del lado del Evangelio ${ }^{1303}$. Este retablo estaba compuesto además por una pintura de Nuestra Señora de la Merced $^{1304}$.

\footnotetext{
${ }^{1301}$ ADP. Carrión. San Andrés. Libro 5 ${ }^{\circ}$ de Cuentas de Fábrica (1753-1795), fol 241 y 244. Bodigos participará junto a Francisco Gutiérrez en 1762 en el retablo de Nuestra Señora de la Asunción de la iglesia de Villamuriel de Cerrato. AHPP. Carr.Prot. 4722, Antonio Ceano Vivas (1759-1762), fol 29. En 1767 estofa las imágenes de los retablos colaterales de la iglesia de San Julián de Carrión. ADP. San Julián. Libro 17 de Cuentas de Fábrica (1747-1849), fol 60v.

${ }_{1302}$ CUADRADO TAPIA, Ricardo. Villamorco: su historia, su arte y sus gentes. Burgos, 2001, pág. 148.

${ }^{1303}$ ADP. Carrión. San Andrés. Libro $5^{\circ}$ de Cuentas de Fábrica (1753-1795), fol 282.

${ }^{1304}$ ADP. Carrión. San Andrés. Legajo 93.3. Papeles diversos. Inventario 1770, s/f.
} 


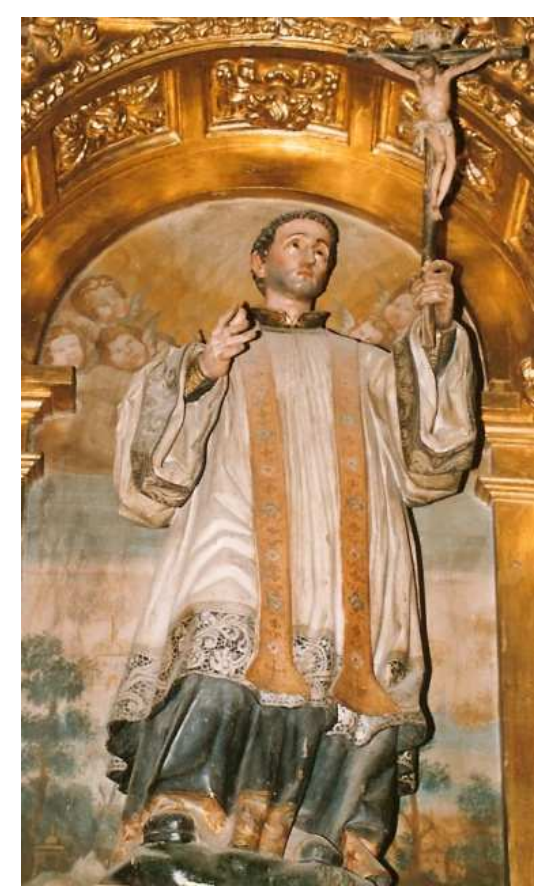

San Francisco Javier. Siglo XVIII. $(136 \mathrm{~cm} \times 55 \mathrm{~cm} \times 50 \mathrm{~cm})$.

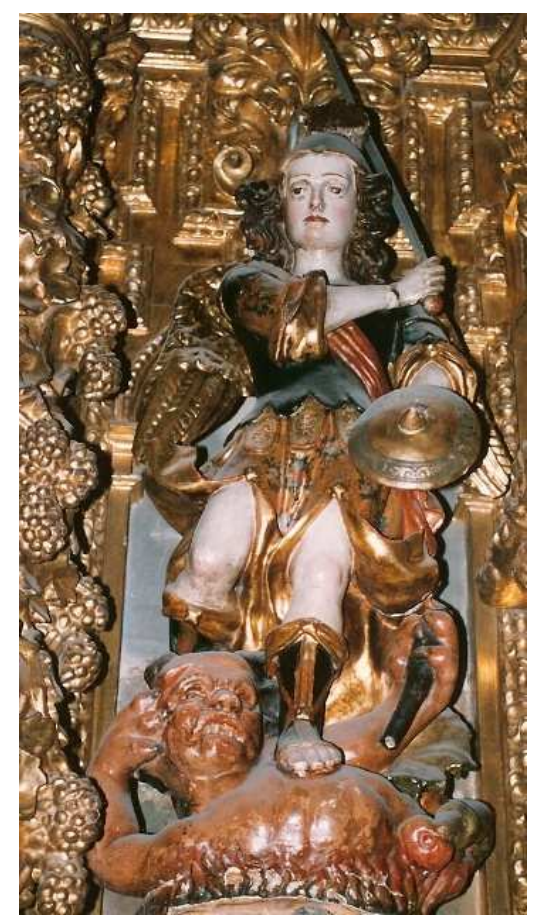

San Miguel Arcángel. Pedro Martínez del Mazo. Primer tercio del siglo XVIII. $(136 \mathrm{~cm} \times 56 \mathrm{~cm} \times 25 \mathrm{~cm})$.

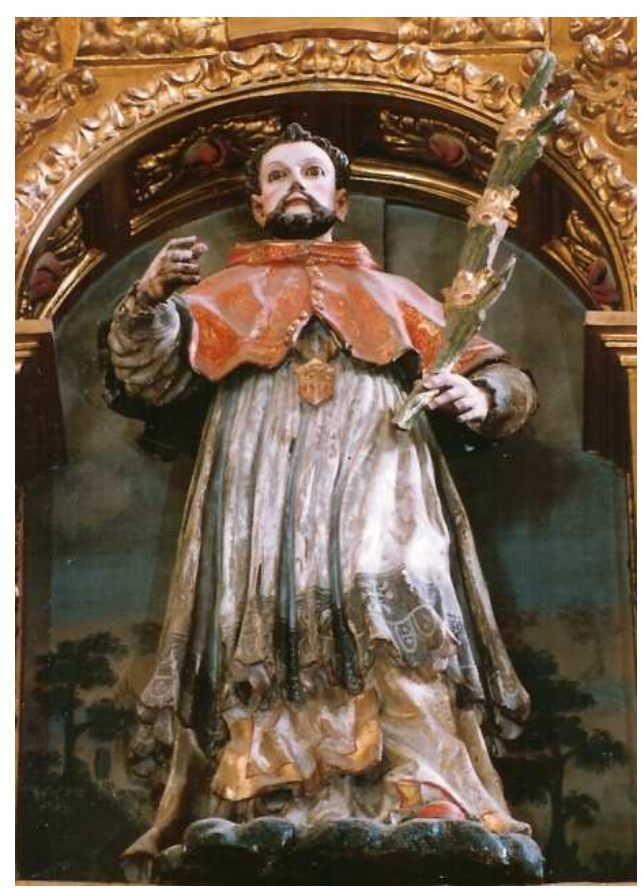

San Ramón Nonato. Miguel Feliz. 1766. $(140 \mathrm{~cm} \times 70 \mathrm{~cm} \times 50 \mathrm{~cm})$.

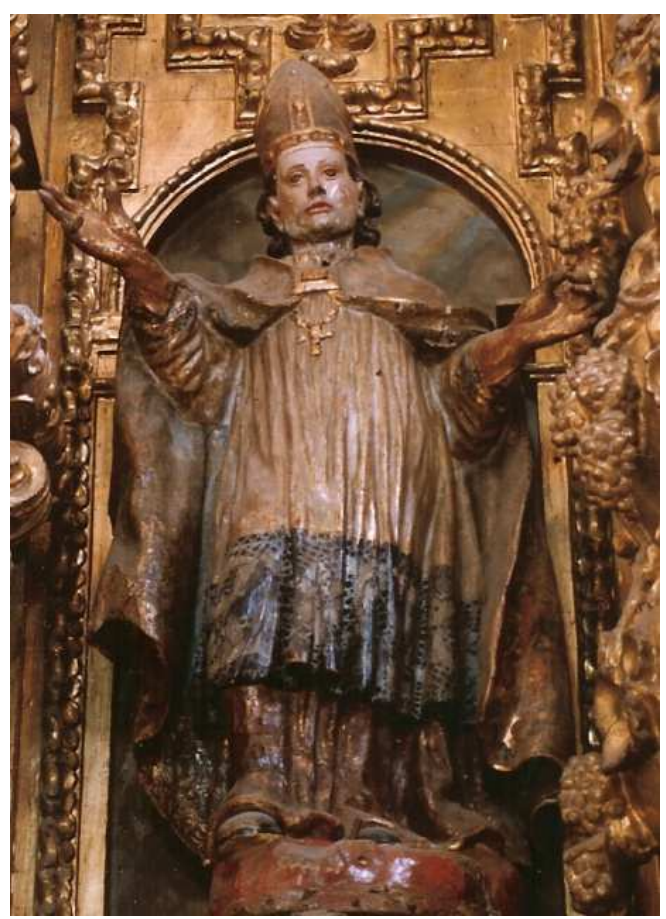

San Severo. Siglo XVIII. (134x52x27).

Esculturas del retablo de San Francisco Javier en el crucero norte de San Andrés. 


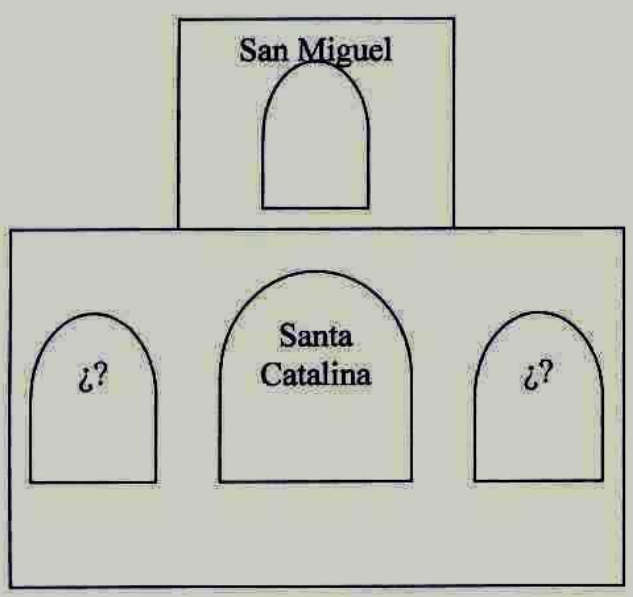

RETABLO ORIGINAL

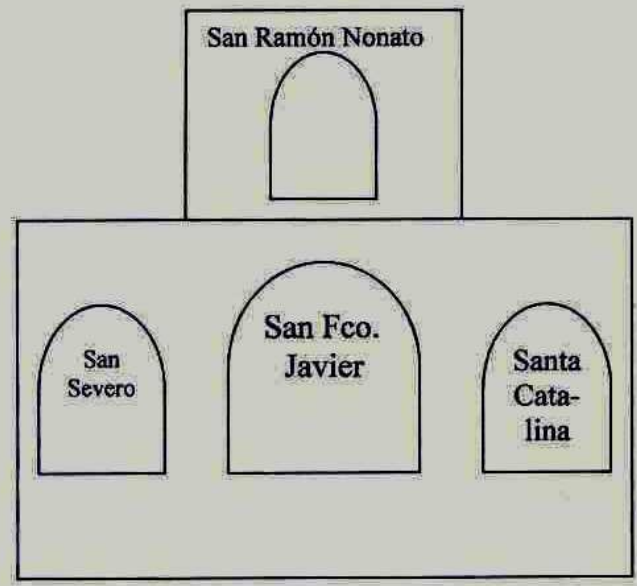

RETABLO 1895

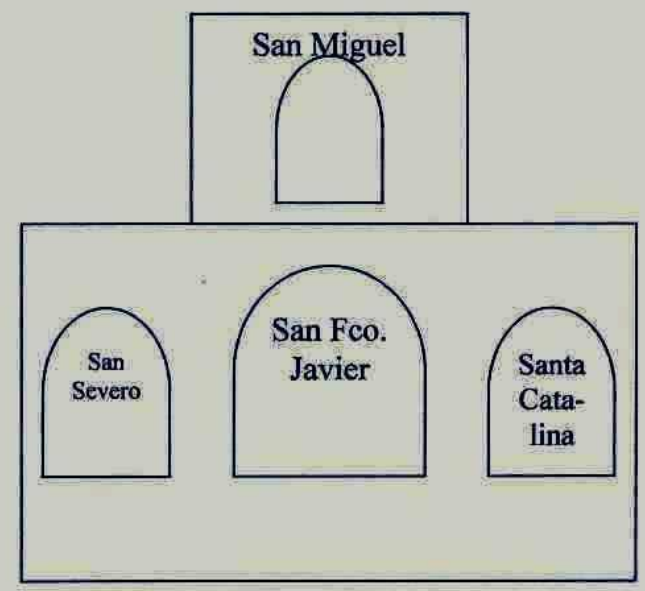

RETABLO EN 1771

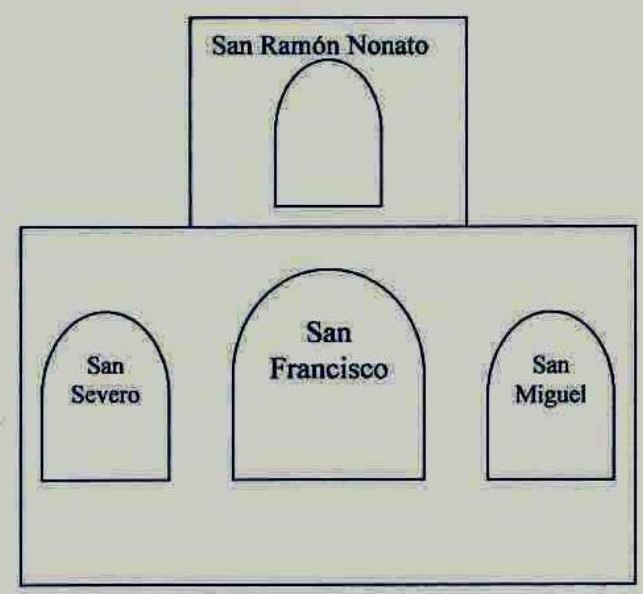

RETABLO ACTUAL

Esquema del retablo de Santa Catalina, hoy de San Francisco Javier, donde figura el trasiego de imágenes que ha sufrido la pieza. 


\subsection{Retablo de Nuestra Señora, hoy de San José}

Este retablo, ubicado en el testero de la Epístola, donde antiguamente se hallaba la capilla de Nuestra Señora de las Velaciones, fue costeado por los patrones y administradores de la obra pía que fundó el obispo de Guadix, a quienes se les facturó la obra en $1721^{1305}$. Por entonces probablemente era patrón don Antonio Álvarez de Bobadilla, pues había adquirido la posesión en $1702^{1306}$.

Dedicado originalmente a la Virgen, cuya imagen desapareció, cambió su advocación por la de San José pero desconocemos exactamente cuando, pues la imagen actual, sustituyó a la anterior del Santo patriarca en 1913, que fue llevada a la iglesia de Belén. La imagen actual pertenece a los talleres del escultor valenciano José Gerique, donada por un feligrés del templo dicho año ${ }^{1307}$. La cadencia ondulante del manto y la suavidad de los rostros de ambos personajes, confiere a la imagen un carácter delicado.

En lo que respecta al resto del retablo, también se ha producido un "trasiego de imágenes", dado que en el inventario de las obras del templo de 1771, a los lados de Nuestra Señora figuraban San Antón y San Pedro, ubicándose en lo alto San Juan Evangelista $^{1308}$. Las imágenes de San Antón y San Pedro fueron trasladadas al retablo de la Virgen del Rosario de este templo, de modo que las estudiaremos posteriormente. En 1895 se hallaban en su lugar San Félix y San Juan Evangelista y en el ático, San Juan Nepomuceno ${ }^{1309}$. En el inventario del año 1980, se mantiene imagen de San Juan, inventariándose el San Juan Nepomuceno como un Santo Rey y la imagen de San Félix es sustituida por San Blas ${ }^{1310}$. En el retablo actual, la imagen de San José se halla flanqueada por Santa Catalina y San Juan, y en el ático hallamos a San Juan Nepomuceno.

\footnotetext{
1305 ADP. Carrión. San Andrés. Libro $5^{\circ}$ de Cuentas de Fábrica (1753-1795), fol 28v.

${ }^{1306}$ AHPP., Carr.Prot 5020, Agustín García Miranda (1701-1704), s/f.

1307 ADP. Carrión. San Andrés. Libro 43 del Inventario de todos los ornamentos y alhajas de San Andrés (1833-1930), s/f

1308 ADP. Carrión. San Andrés. Libro 5º de Cuentas de Fábrica (1753-1795), fol 303 y también en Legajo 93.3. Papeles diversos. Inventario 1770, s/f.

${ }^{1309}$ RAMÍREZ DE HELGUERA, Martín. El libro...Op.cit, pág. 160.

${ }^{1310}$ URREA, Jesús y MARTÍN GONZÁLEZ, Juan José. Inventario...2. Op.cit. pág. 54.
} 
La imagen de Santa Catalina de Alejandría $(160 \mathrm{~cm})$ fue trasladada por tanto a este retablo en algún momento a partir de los años ochenta. La mutilación de ambos brazos nos impide saber si originalmente blandía la espada y portaba el libro, característicos de su iconografía. Sin embargo, podemos reconocer a la mártir por su vestimenta y atributos de princesa con rica túnica y capa de vistosos colores, ambos tachonados de flores y corona en su cabeza, y sobre todo, por la cabeza del emperador vencido a sus pies. Esta imagen del siglo XVIII, contemporánea a la ejecución de los retablos, presidiría, como ya indicamos, el retablo del Evangelio cuando fue comenzado en 1714. La imagen fue ejecutada en 1726, en que se abonan al escultor Pedro Martínez del Mazo las esculturas de los “...retablos colaterales...”, precisándose su autoría de ésta y de las tallas de San Miguel San Antón Abad y San Pedro ${ }^{1311}$. No poseemos datos que nos acerquen a la figura de Pedro Martínez del Mazo. Quizá estuviese emparentado con Pedro del Mazo Vélez, escultor trasmerano que ejecuta a partir de 1706 las esculturas del retablo mayor y colaterales de la iglesia de San Julián, que pudo ser su contacto para ser contratado en Carrión. Familiar o no de Pedro del Mazo Vélez, no cabe duda de que nuestro artista se formó con el escultor cántabro, a tenor de las semejanzas que presenta esta imagen con la Asunción del retablo mayor de San Julián. En ella apreciamos una herencia en la tipología del rostro, caracterizado por los ojos pequeños, barbilla marcada e incipiente papada, además del tratamiento similar de recoger los paños horizontalmente al nivel de la cintura, si bien en el caso de Vélez, con una caída más naturalista.

En el lado derecho, está San Juan Evangelista $(100 \mathrm{~cm})$ que, si bien formaba parte del retablo original, se ubicaba en origen en el ático, pasando posteriormente a la calle lateral. Es una escultura reaprovechada, ya que se trata de una obra del último tercio del siglo XVI, de corte romanista. Los amplios mantos que envuelven por completo la figura, son recogidos en el brazo izquierdo, con el cual ase el cáliz envenenado del que emerge la serpiente. Se trata de una figura de gran rotundidad y aspecto ambiguo, dada la largura de su cabellera y la suavidad de sus facciones, aspectos propios de las representaciones de figuras masculinas juveniles. Se halla muy cercana al estilo de Pedro de Torres en la Catedral de Palencia ${ }^{1312}$.

\footnotetext{
1311 ADP. Carrión. San Andrés. Libro 4º de Cuentas de Fábrica (1718-1752), fol 105.

1312 Sobre Pedro de Torres, remítase al capítulo dedicado a los escultores.
} 
Por su parte, San Juan Nepomuceno $(140 \mathrm{~cm})$, preside el ático. Es una obra de la primera mitad del siglo XVIII y por tanto contemporánea al ensamblaje del retablo, pero no formaba parte del mismo originalmente. La imagen fue adquirida al abad de San Zoilo, don Leandro Pérez en 1804, pero no se asentó por entonces en este retablo sino en el de San Ramón, que existía por entonces, en el lado del Evangelio ${ }^{1313}$. Aunque porta la cruz y la palma del martirio, atributos de carácter general, su esclavina de armiño, sobrepuesta al roquete y sotana, despejan cualquier duda acerca de la identificación del santo confesor de Bohemia. Sus sencillas vestimentas de canónico, contrastan vivamente con el manto de vistosas flores que envuelve la figura creando un toque efectista a través de la artificiosidad con que se desenvuelven sus pliegues.

A los lados de esta escultura se encuentran dos escudos añadidos en 1753, por encargo de don Juan Álvarez de Bobadilla, poseedor por entonces de la capilla, quien, como indicamos, costeó el dorado y estofado de ambos retablos ${ }^{1314}$. Tan sólo incluyó sus armas en el retablo de Nuestra Señora dado que era el que se ubicaba en la capilla de su propiedad. El escudo mantelado del benefactor contiene una inscripción que identifica efectivamente a su benefactor: “Don Juan Antonio Bobadilla y Vozmediano”. $\mathrm{Su}$ lectura es la que sigue: 1, de oro con águila explayada de amarillo, 2, de azur con león de oro lampasado de gules, 3 , de sinople con castillo de oro. Bordura negra de seis armiños y timbrado de yelmo y plumas acolado de banderines de dos pendones.

En el lado opuesto se hallan las armas de don Melchor Álvarez de Vozmediano, fundador de la capilla, identificado con otra cartela en la que figura como Obispo de Guadix. Su escudo cuartelado es idéntico al que figura en su monumento funerario, salvo por la policromía y por la ausencia de bordura general en el caso del sepulcro: 1. Partido de león y flor de lis dorados y bordura aspada, 2, de azur, león de oro cargado con escudete bandado, 3 , de gules con unas correas o forja cruzada de oro, 4 , de oro con águila explayada de oro y al timbre capelo y cordones episcopales, propios de la condición del prelado ${ }^{1315}$.

\footnotetext{
${ }^{1313}$ ADP. Carrión. San Andrés. Libro 6º de Cuentas de Fábrica (1796-1850), fol 103v.

${ }^{1314}$ Francisco Gutiérrez y Juan López pintaron los escudos pero no los hicieron. AHPP. Carr.Prot 4664, Francisco Cano Núñez (1750-1756), fol 64 y ss.

${ }^{1315}$ VIGURI, Miguel de. Herádica...2, Op.cit, pp. 56- 57.
} 


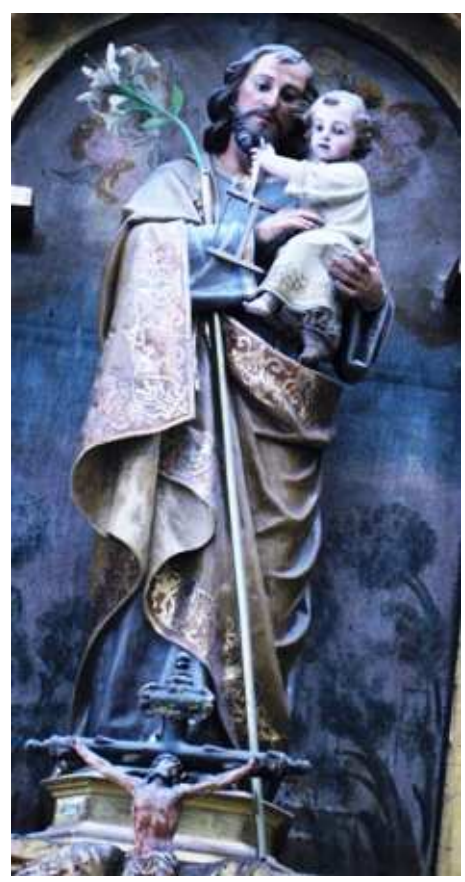

San José con el Niño.

Taller de José Gerique.1913. $(145 \times 55 \mathrm{~cm} \times 30 \mathrm{~cm})$.

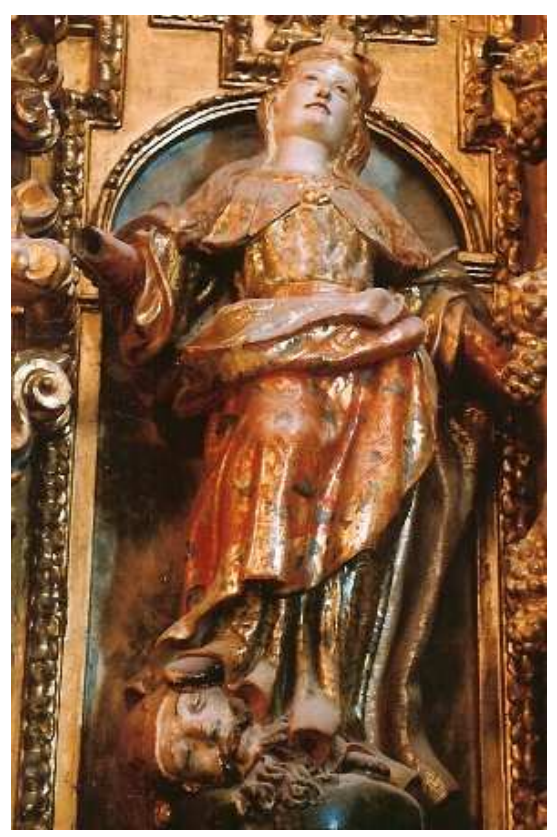

Santa Catalina. Pedro Martínez del Mazo. Primer tercio del siglo XVIII. $(160 \mathrm{~cm} \times 114 \mathrm{~cm} \times 36 \mathrm{~cm})$.

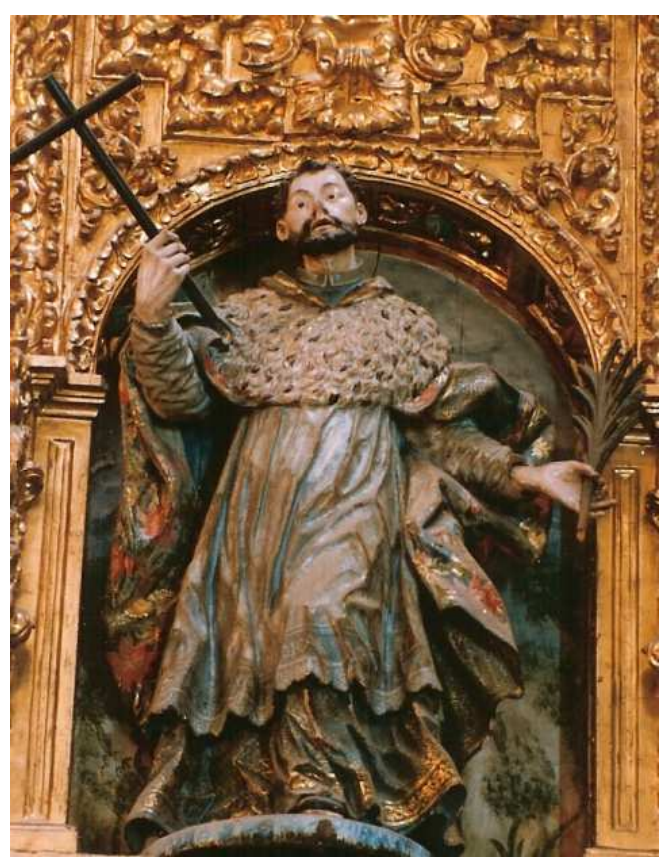

San Juan Nepomuceno.

Primera mitad del siglo XVIII.

$(140 \mathrm{~cm} \times 110 \mathrm{~cm} \times 35 \mathrm{~cm})$.

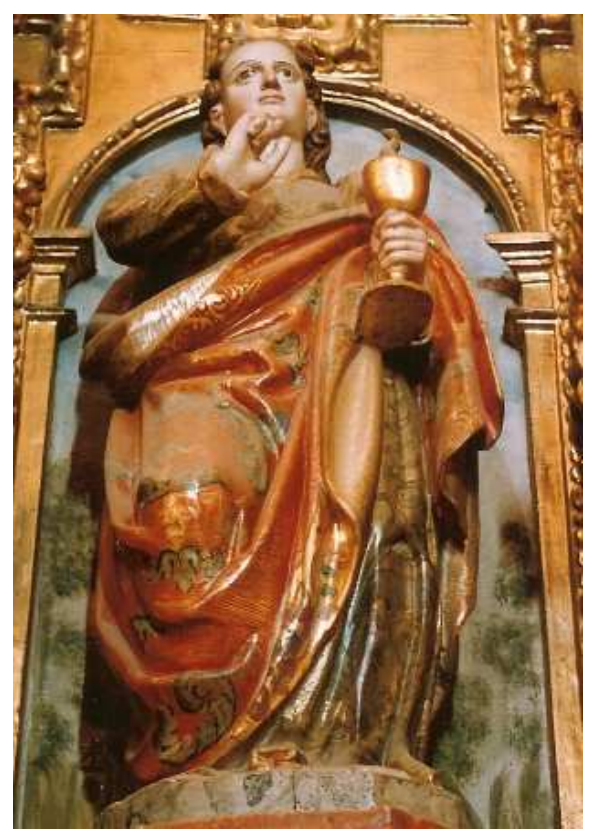

San Juan Evangelista.

Primer tercio del siglo XVI. $(100 \mathrm{~cm} \times 35 \mathrm{~cm} \times 30 \mathrm{~cm})$.

Esculturas del retablo de San José en el crucero sur de San Andrés. 


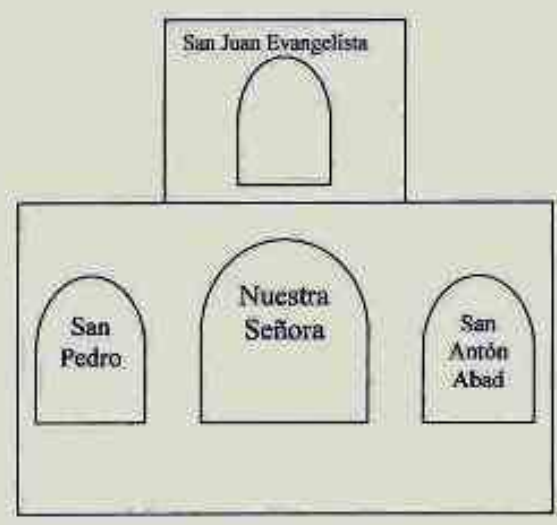

RETABLO ORIGINAI

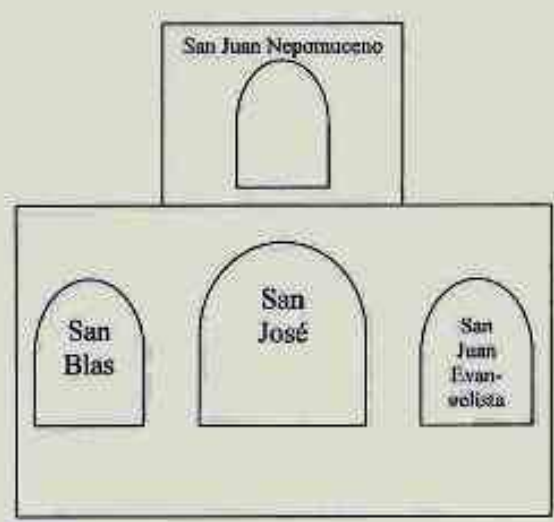

RETABLO EN 1980

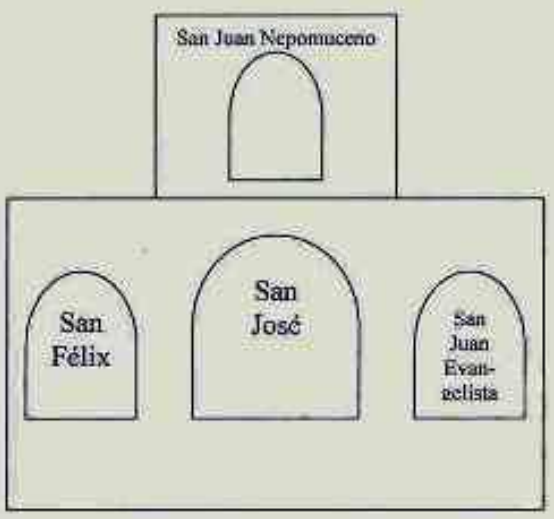

RETABLO EN 1895

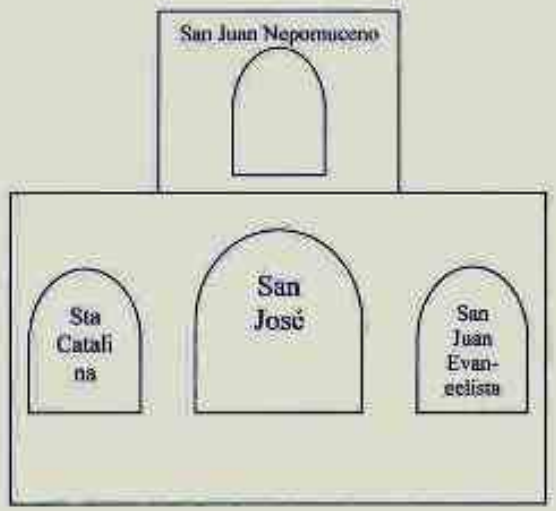

RETABLO ACTUALMENTE

Esquema del retablo de Nuestra Señora de las Velaciones, hoy de San José, donde figura el trasiego de imágenes que ha sufrido la pieza. 


\section{El monumento del Obispo don Pedro Cantero}

Junto a este retablo, en el lado del Evangelio del templo, se ubica también el nicho del Obispo Don Pedro Cantero Cuadrado, arzobispo de Santiago. Este sepulcro fue ejecutado en 1978 por el escultor Mariano Timón ${ }^{1316}$ y su escudo como obispo de Barbastro: cuartelado. 1, casa de Loreto de Madrid -en la cual fue rector- ${ }^{1317}$ y estrella de Belén, patrona de Carrión. 2, dos manos estrechadas surmontadas de una cruz, vinculadas a la unidad cristiana. 3 , dos columnas rotas sobre ondas ${ }^{1318} .4$, del concejo de Carrión: cuartelado, 1, castillo.2 y 3, carro 4, león. Escusón en abismo con la figura de Cristo entregando las llaves a San Pedro. Timbrado de mitra, báculo, capelo y cordones de arzobispo. En el pedestal, figura “M. Timón”, haciendo alusión a Manuel Timón, el maestro que ejecutaría el lucillo. También puede leerse la inscripción: "Don Pedro Cantero Cuadrado, arzobispo, 23-II- 1902/ 19- XII-1978”.

\section{El púlpito}

Antes del púlpito que se conserva hoy día, existió otro ejecutado en 1780 por el ensamblador carrionés Fabián Martín y rematado por una pintura del Espíritu Santo encargada a Ramón Canedo en $1784^{1319}$. El único púlpito del templo, ubicado en el primer tramo del Evangelio, es obra neogótica de Timoteo Martín y su hijo Bernardo, de $1952^{1320}$ con relieves de evangelistas y San Andrés en el antepecho. El pie está formado por un ramillete de columnillas que sustentan el ambón. Éste se encuentra dividido en cuatro paneles, uno para la representación de un Evangelista y en el antepecho central, San Andrés, dada la advocación del templo. Remata la composición el tornavoz con un castillete con arbotantes y pináculos, rememorando la arquitectura gótica.

\footnotetext{
${ }^{1316}$ PERAL VILLAFRUELA, Santiago y GÓMEZ PÉREZ, Enrique. Carrión...Op.cit, pág. 64

${ }^{1317}$ VIGURI, Miguel de. Herádica...2, Op.cit, pág. 57.

1318 Se puede interpretar con el sentido religioso de que la iglesia supera el límite de las columnas de Hércules. Ibídem, pág. 57.

${ }^{1319}$ ADP. Carrión. San Andrés. Libro 5 de Cuentas de Fábrica (1753-1795), fol 405 y 447. Sobre Ramón Canedo, remítase al capítulo dedicado a los pintores.

${ }^{1320}$ Debo esta información a don José Ramón Blanco, ex alcalde de Carrión.
} 


\section{Retablo de la Epifanía}

En el primer tramo de la nave del Evangelio se conservan el retablo más significativo de este lado, que ocupa la que fue capilla de los Bobadilla. Nos referimos al retablo de la Adoración de los Reyes Magos o de la Epifanía (277cmx282), así denominado por su pintura protagonista, obra del siglo XVII considerada como copia de Rubens $^{1321}$. Ésta había sido donadas en junio de 1756 por Doña Ana de Guardo y Páramo, viuda por entonces del regidor de Carrión, Don Agustín Díaz de Castro ${ }^{1322}$. En 1732, cuando contaba con 30 años de edad, se casó con Alonso González de Villegas. Esta relación ocasionó un gran revuelo, llegando incluso a ser llevada a juicio, pues no estaba bien visto que dos parientes en segundo grado de afinidad "se tratasen" sin estar casados, pues de otro modo la mujer quedaría difamada ${ }^{1323}$.

La ilustre devota corrió con los gastos de un retablo para asentar sus pinturas, solicitando como compensación, una sepultura para su entierro a los pies del mismo, como así había sucedido con sus parientes. Este deseo fue confirmado al dictar testamento el 18 de marzo de $1766^{1324}$. Cuando, como apuntamos, en 1756 Ana de Guardo dona los lienzos, precisó que el retablo donde se asentasen fuese colocado en la capilla de los Santos Juanes, inmediato a la entrada del templo, a su mano derecha ${ }^{1325}$. En enero de 1758, doña Ana se retracta respecto al lugar de ubicación de la nueva obra “...que a mi costa se halla quasi concluido...”, optando por ubicarlo donde se hallaba el retablo de San Antonio Abad, lindero a la sacristía. Doña Ana se compromete a sufragar los gastos derivados del desmonte de este retablo desaparecido, a otro lugar que el cura

\footnotetext{
${ }^{1321}$ RAMÍREZ DE HELGUERA, Martín. El libro...Op.cit, pág. 160.

${ }^{1322}$ La donante no se llamaba Juana como se había venido afirmando sino Ana, probado por el testamento de su marido en terceras nupcias, don Agustín Díaz de Castro. MARTíNEZ, Rafael. "La Adoración de los Magos de la Escuela de Rubens de la iglesia de San Andrés de Carrión de los Condes (Palencia)" en PITTM n ${ }^{\circ}$ 78. Diputación Provincial de Palencia, 2007, pp. 429-446, a su vez de AHPP. Carr.Prot 5146, Martín Izquierdo, (1755), s/f.

${ }^{1323}$ La prima por parte de padre de Ana de Guardo, doña Juana del Páramo, había estado casada con Don Alonso. ACP. Provisorato. Legajo 318, $\mathrm{n}^{\circ}$ 54622, s/f.

${ }^{1324}$ Expresa además su deseo de ser enterrada con el hábito del Carmen y que la caja fuera forrada de negro.

Debía encontrarse muy enferma en el momento de dictar testamento, pues tan sólo tres días después, el 21 de marzo de 1766, se dio noticia de su fallecimiento. No tenía hijos, dejando como heredero universal a su nieto, don Francisco Jofre y Guardo. AHPP., Carr.Prot 5152, Martín Izquierdo (1766-1766), s/f.

${ }^{1325}$ Traslado de la escritura otorgada por doña Ana de Guardo el 21 de junio de 1756. AHPP. Carr.Prot 4608, Leg 139, Francisco Blanco Manuel (1758-1760) fol 232.
} 
y mayordomo considerasen pertinente ${ }^{1326}$. Es entonces cuando dispone que la capilla se sitúe a partir de entonces bajo la advocación de los Santos Reyes, por el protagonismo del lienzo, que ocupa la totalidad del cuerpo principal del retablo.

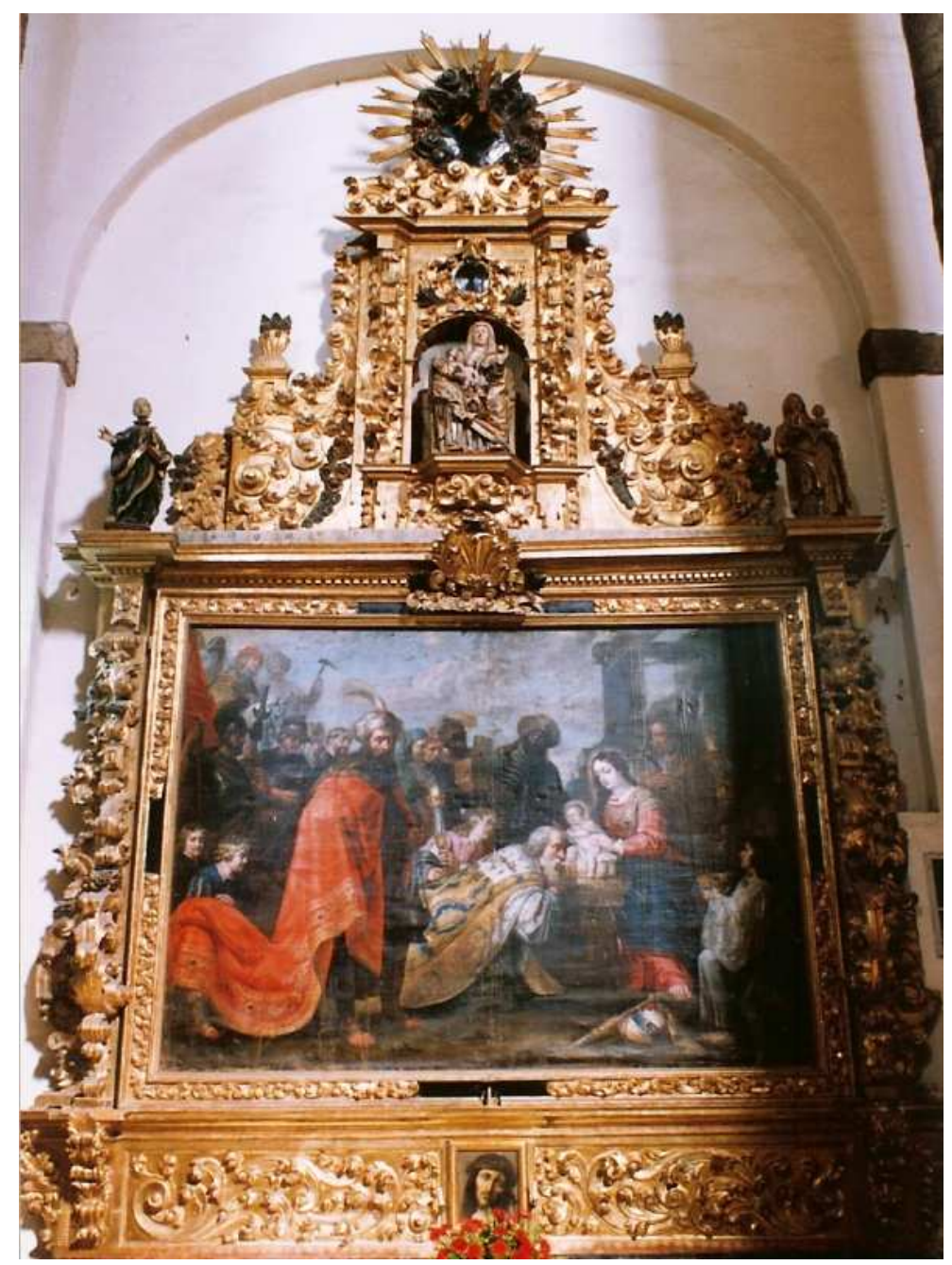

Retablo de la Epifanía (6,5mtrx4,85mtrx0,47mtr).

Obra de 1766 destinada a albergar el lienzo de la Epifanía, del siglo XVII, copia de Rubens $(2,43 m t r s x 3,28 m t r s)$.

Nave de la Epístola de la iglesia de San Andrés.

\footnotetext{
${ }^{1326} \mathrm{El} 21$ de enero de 1758 se firma la escritura de contrato entre doña Ana de Guardo y los mayordomos de San Andrés. AHPP., Carr.Prot 4608, Leg 139, Francisco Blanco Manuel (1758-1760), fol 234 y ss. Otra referencia a esta escritura en ADP. Carrión. San Andrés. Libro $5^{\circ}$ de Cuentas de Fábrica 1753-1795), fol $125,125 \mathrm{v}$
} 
El retablo conserva la mesa de altar original, costeada por Doña Ana, decorada con arquerías donde figuran elementos como el sol, la luna, simbolismo del dominio de Cristo sobre el día y la noche y en el medio una alusión mariana a través del jarrón de azucenas, inscrita en un cortinaje propio del lenguaje barroco. El retablo se asienta sobre el frontal referido y está compuesto por banco, un cuerpo y ático. Compuesto por una banda de hojarasca, el banco se encuentra presidido por una pintura que representa un busto de Ecce Homo, donada junto a la Epifanía por doña Ana de Guardo ${ }^{1327}$. Se trata de un pequeño óleo sobre lienzo $(33 \mathrm{~cm} \times 29 \mathrm{~cm})$ provisto de un sencillo marco dorado moldurado que representa la efigie de Cristo coronado de espinas y apenas asoman los hombros, provistos de una túnica roca. Es una imagen bastante conmovedora, pues la mirada se dirige al espectador, para impactarle a través de su contemplación. Presenta el rostro ladeado, la boca entreabierta y los párpados levemente caídos, rasgos en los que se hace patente su sufrimiento. Esta estética puede vincularse a la de Juan de Juanes, con cuyo círculo podría relacionarse al autor de esta obra, muy cercana, por ejemplo, a la pintura del mismo tema que se conserva del artista en la iglesia valenciana de San Andrés de Alcudia.

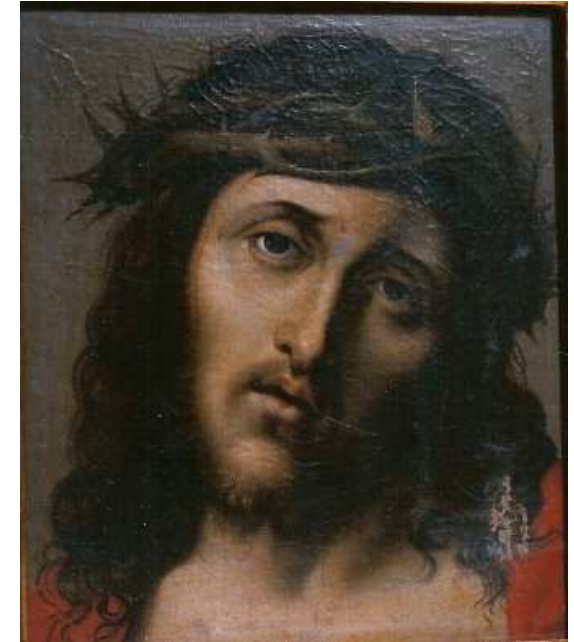

Ecce Homo del retablo de la Epifanía. San Andrés de Carrión. (33,5cmx29cm). Círculo de Juan de Juanes.

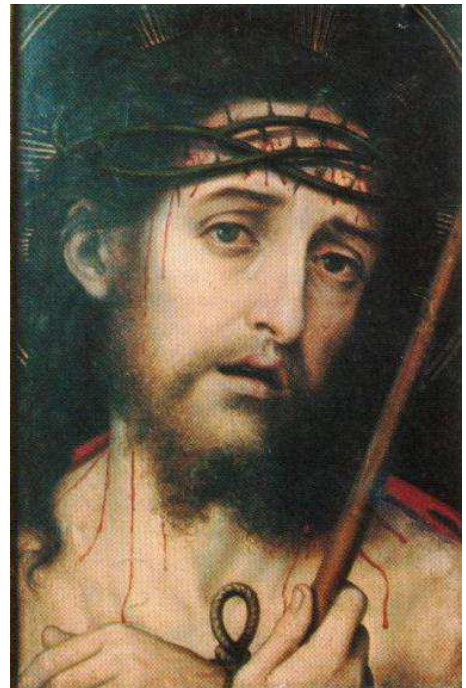

Ecce Homo del retablo de la iglesia de San Andrés de Alcudia, Valencia. Juan de Juanes.

${ }^{1327}$ GARCÍA, Albano. "Sobre el cuadro de la Adoración de los Reyes en la iglesia de San Andrés" en Diario Palentino. Viernes, 13 de diciembre de 1913, pág. 18. 
En el cuerpo central hallamos la pintura referida de la Epifanía, de calidad notable y merecedora del reconocimiento de eruditos e historiadores como Madoz,

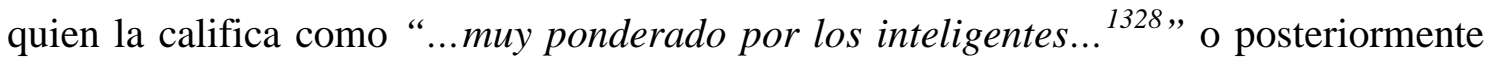
Urrea Fernández, quien también destaca su valor ${ }^{1329}$. Los recientes trabajos de restauración de 2007 han permitido a Rafael Martínez González extraer nuevas e interesantes conclusiones acerca del la pintura, como el relacionado con la autoría, pues aunque no se ha conseguido descifrar el nombre del artista, al menos se conocen sus iniciales: "ABW. fecit". Por otro lado, las marcas del reverso de la obra señalan que la obra estuvo plegada, quizá para ser trasladada desde los Países Bajos, con cuya pintura se establecen claros paralelismos, siguiendo a su vez estilísticamente la huella de Rubens. Si bien es cierto que la escena no se puede considerar como copia fiel de ninguno de los cuadros del pintor flamenco, parece que, si se invierte la composición, la fuente directa de la que bebe el pintor sería el lienzo de los Museos Reales de Bruselas $^{1330}$.

El ático está compuesto por dos aletones avolutados que flanquean dos soportes recubiertos de hojarasca de un modo tan profuso que no resulta posible dilucidar si se trata de pilastras o estípites. En la hornacina central, sobre una peana de perfil mixtilíneo, destaca el grupo escultórico de Santa Ana Triple $(70 \mathrm{~cm})$, datada en el siglo $\mathrm{XVI}^{1331}$, probablemente del primer cuarto de la centuria. Su presencia viene justificada por la onomástica de la donante, doña Ana de Guardo, tal y como ella precisaba que la iglesia dispusiese una imagen “...de la gloriosa Santa Ana de mi nombre... ${ }^{1332, .}$ Repintada hacia el siglo XVIII, Santa Ana es una figura monumental y hermética, dotada de toca de viuda, propia de la moda del siglo XVI, y sentada en un trono de respaldo alto. En su regazo sustenta a la Virgen, ciertamente hierática, mientras ésta sostiene en sus piernas a su vez al niño Jesús desnudo, que intenta desprenderse de los brazos de su madre. Con la otra mano, uno de cuyos dedos está mutilado, muestra una pera, vinculada con el amor de Cristo encarnado en la humanidad. La aparición de este fruto, si bien no demasiado recurrente en la iconografía, tiene su precedente más inmediato en una obra del mismo tema conservada en el museo de la Catedral de

\footnotetext{
${ }^{1328}$ MADOZ, Pascual. Diccionario...Op. cit, pág. 69.

${ }^{1329}$ Se le concede dos asteriscos. URREA FERNÁNDEZ, Jesús y MARTín GONZÁLEZ, Juan José. Inventario...2, Op. cit, pág. 54.

${ }^{1330}$ MARTÍNEZ, Rafael. La adoración...Op.cit, pp. 436-437.

${ }^{1331}$ URREA FERNÁNDEZ, Jesús y MARTÍN GONZÁLEZ, Juan José. Inventario...2, Op. cit, pág. 54.

${ }^{1332}$ AHPP., Carr.Prot 4608, Leg 139, Francisco Blanco Manuel (1758-1760), fol 234 y ss.
} 
Palencia y atribuida a Alejo de Vahía, que la llevaría a cabo en torno a 1510. Algunos de los rasgos del maestro asentado en Becerril, como los ojos caídos y la nariz alargada de punta redondeada están presentes en nuestra escultura.

\section{Santa Ana Triple. Grupo que preside el ático del retablo de la Epifanía de la iglesia de San Andrés. Primer cuarto del siglo XVI.}

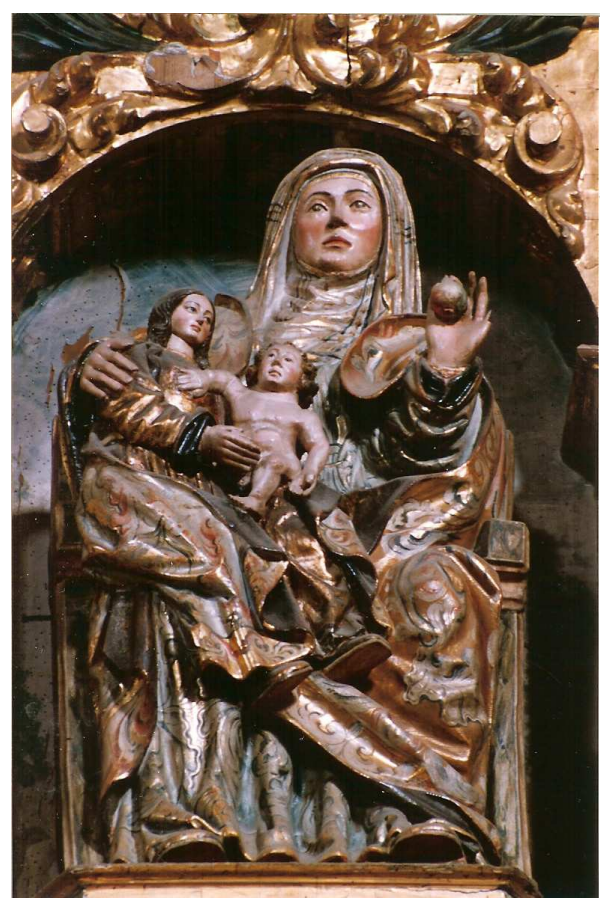

A los lados del ático se ubican dos pequeñas imágenes cuya inclusión no fue precisada por doña Ana, sino que fueron añadidas con posterioridad. En el lado izquierdo se ubica una escultura del siglo XVIII que ha sido identificada como San Ignacio de Loyola $(70 \mathrm{~cm}){ }^{1333}$, a pesar de que en la peana figura la inscripción de "San Félix". Efectivamente se trata de un santo jesuita, a tenor de su sotana negra de cuello alto, orlada de oro en este caso; sin embargo resulta imposible determinar hoy día si se trata del fundador de la Compañía, pues no porta más atributo que un libro cerrado. En el lado derecho contrario hallamos a la Virgen con el Niño $(75 \mathrm{~cm})$, ambos de rubios cabellos, que aunque datada en el siglo XVII ${ }^{1334}$, la consideramos anterior, del siglo XVI, como señala Rafael Martínez ${ }^{1335}$. Podríamos identificar la escultura como la Virgen de la Paz, en virtud del portapaz que enseña la Virgen en su mano derecha. Es una imagen que ha sido repintada posteriormente, como muestra el brillo desmesurado de la carnación a pulimentos de ambos rostros. Coronando el conjunto se halla una

\footnotetext{
${ }^{1333}$ URREA FERNÁNDEZ, Jesús y MARTÍN GONZÁLEZ, Juan José. Inventario...2, Op. cit, pág. 54. 1334 IbIbídem, pág. 54.

${ }^{1335}$ MARTÍNEZ, Rafael. La adoración...Op.cit, pág. 430
} 
paloma rodeada de una corona de nueves y testas de querubines de la que emergen haces de rayos solares, alusión al Espíritu Santo.

\section{Retablo del Santo Ángel de la Guarda}

En el segundo tramo del Evangelio si partimos desde la cabecera, se ubica un retablo procedente, al parecer, de la antigua abadía de Benevívere que estaba dedicado originalmente a San Antonio de Padua y que poseía una imagen de San Juan Bautista en el ático ${ }^{1336}$. La imagen del Santo de Padua fue sustituida en 1922 por una escultura de yeso del Santo Ángel de la Guarda adquirida en Barcelona ${ }^{1337}$. La escultura de San Antonio con su hornacina correspondiente fue trasladada al banco, pues el cuerpo principal del retablo fue reformado para acoger la nueva obra, por lo que es probable que este sector, con la cupulilla, que además es más brillante que el resto del retablo, fuese ejecutado a raíz de la colocación de la figura del Ángel en el retablo. De hecho podemos observar cómo la hornacina principal está flanqueada por dos soportes diminutos, cuya presencia no tendría sentido si no fuera por la antigua ubicación de una escultura que se adaptase a sus dimensiones. En cuanto a la imagen de San Juan Bautista, se encuentra hoy día en la sacristía, donde fue trasladada a partir de 1977, dado que no figura en el inventario realizado por entonces. Podría proceder de la iglesia de San Juan Bautista, demolida en 1937, haber permanecido en algún lugar que desconocemos hasta su emplazamiento definitivo en este templo. Se trata de una escultura sedente, que nos muestra al santo predicador descansando sobre una roca y cubierto con un llamativo manto rojo, más propio del homónimo Evangelista. Es una escultura policromada a pulimento datable a principios del siglo XVIII, probablemente coetánea a la imagen de San Antonio, atribuible a un seguidor de Tomás de Sierra. Se puede vincular estilísticamente a la escultura homónima conservada en la Colegiata vallisoletana de Villagarcía de Campos, salvo que en este caso, la imagen se presenta de pie $^{1338}$.

\footnotetext{
${ }^{1336}$ RAMÍREZ DE HELGUERA, Martín. El libro...Op.cit, pág. 160.

1337 ADP. Carrión. San Andrés. Libro 43 del Inventario de todos los ornamentos y alhajas de San Andrés (1833-1930), s/f.

${ }^{1338}$ Sobre el mismo, remítase al capítulo dedicado a la biografía de los escultores.
} 
Datado en el siglo XVIII ${ }^{1339}$, probablemente en el segundo tercio de siglo, se estructura en banco y cuerpo mixtilíneos, dividido éste en tres calles y ático. En el banco, que se retranquea caprichosamente, se ubican nueve hornacinas de pequeño tamaño, de las cuales tres vacías, que cobijan imágenes de yeso modernas. De izquierda a derecha se trata de Santa Gertrudis, la Virgen y el Niño, El Salvador y el Sagrado Corazón. En la hornacina central se ubica la única talla del banco, la imagen de San Antonio de Padua $(64 \mathrm{~cm})$, coetánea a la ejecución del retablo, presidiría originalmente el mismo, por lo que debemos pensar que el hueco original sería de menores dimensiones hasta la ubicación del Ángel de la guarda. El santo franciscano, de generosos carrillos e incipiente papada, no luce más atributo que un libro en posición horizontal sobre el que se ubicaría originalmente el Niño Jesús, a tenor del soporte metálico conservado para sostener la imagen. Los paños están trabajados con gran naturalismo en contraste con la caída rígida del cordón.

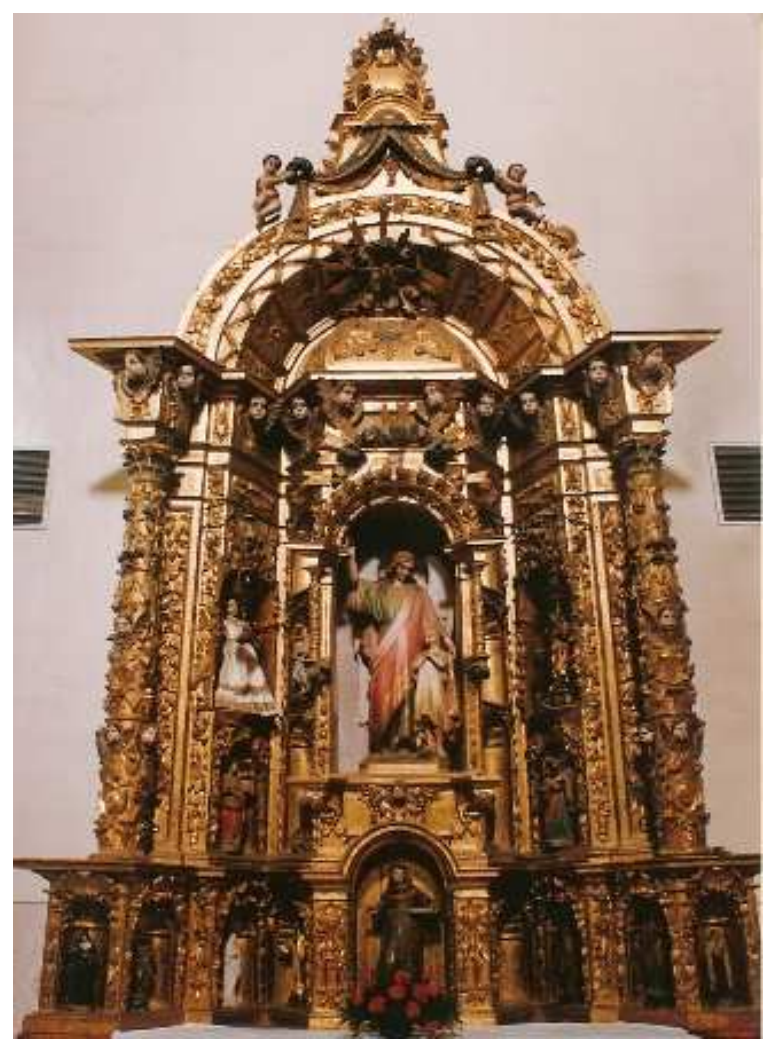

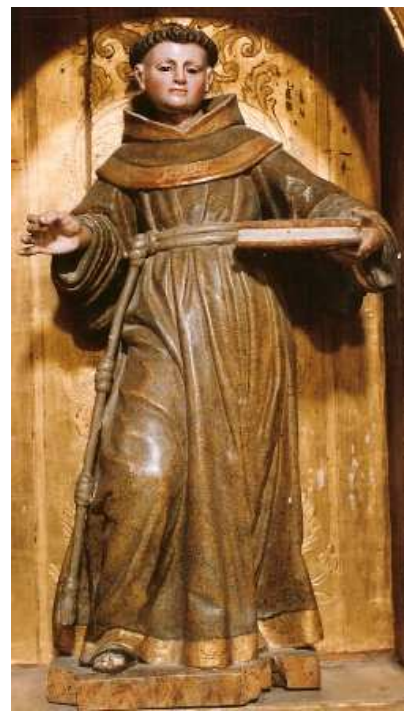

San Antonio de Padua

Segundo tercio del siglo XVIII.

$(64 \mathrm{~cm} \times 36 \mathrm{~cm} \times 22 \mathrm{~cm})$.

Retablo del Santo Ángel de la guarda. (5,2mtrsx3,43mtrsx0,86mtrs). Segundo tercio del siglo XVIII.

Nave del Evangelio de la iglesia de San Andrés.

${ }^{1339}$ URREA FERNÁNDEZ, Jesús y MARTÍN GONZÁLEZ, Juan José. Inventario...2, op. cit, pág. 54. 
El cuerpo principal se encuentra flanqueado por dos pilastras cajeadas a las que se superponen dos columnas cuyo fuste, decorado profusamente con cabezas de querubines y cintas, se adelgazan en el tercio superior. Entre ellas y ubicadas en las cuatro hornacinas de los lados oblicuos, se halla una talla de Niño Jesús de hacia 1600, convertido en imagen de vestir que procede del convento de Santo Domingo, donde le rendía culto la cofradía del Dulce Nombre de Jesús ${ }^{1340}$. También encontramos imágenes modernas de la Virgen del Carmen, un busto relicario sin identificar y la Purísima Concepción. En la calle central, flanqueando a la imagen del santo Ángel, se ubican dos hornacinas a cada lado, superpuestas, de las cuales las inferiores vacías. En las cajas superiores se conservan dos pequeñas tallas de escasa calidad que representan Santa Águeda y Santa Bárbara $(45 \mathrm{~cm})$. Datadas en el siglo XVIII ${ }^{1341}$, pertenecen con toda probabilidad al retablo original. El ático probablemente fuese ejecutado hacia 1920, cuando el Santo Ángel fue adquirido. Está compuesto por una cupulilla que recubre la calle central, protegida bajo un arco de medio punto abocinado cuyo intradós está decorado a través de casetones. De este sector, consideramos original del retablo primitivo, esto es, del siglo XVIII, el copete que cierra de teatralmente el conjunto mediante un cortinaje recogido por dos querubines sedentes, así como la corona de angelillos en la que se inscribe la paloma del Espíritu Santo.

Junto a este retablo se ubica una puerta que da acceso a una estancia moderna donde se guarda el carro triunfante del Corpus Christi.

\section{El lienzo de las Ánimas}

A continuación hallamos el lienzo de las Ánimas, datado en el XVIII y atribuido a Ramón Canedo ${ }^{1342}$. Efectivamente, esta imagen, fue abonada en 1769 al artista asentado en Valladolid, pero ya estaba terminado el ocho de agosto de 1768 en que se ejecutó un arco de medio punto “...para coger la circunferencia de dicho cuadro... ${ }^{1343}$ ".

${ }^{1340}$ GÓMEZ PÉREZ, Enrique. "Dulce Nombre de Jesús" en Entre Castilla y Filipinas: 400 años. Carrión de los Condes, 2006, pág. 34.

${ }^{1341}$ URREA FERNÁNDEZ, Jesús y MARTÍN GONZÁLEZ, Juan José. Inventario...2, Op. cit, pág. 54.

${ }^{1342}$ PERAL VILLAFRUELA, Santiago y GÓMEZ PÉREZ, Enrique. Carrión...Op.cit, pág. 63. Sobre Ramón Canedo, remítase al capítulo dedicado a los pintores.

${ }^{1343}$ ADP. Carrión. San Andrés. Libro 5 de Cuentas de Fábrica (1753-1795), fol 282. 
El lienzo $(352 \mathrm{~cm} \times 187 \mathrm{~cm})$ que presenta una forma de hornacina, está estructurado, como es usual en la iconografía de las pinturas de Ánimas en dos partes claramente diferenciadas: la dimensión celeste y la terrenal ${ }^{1344}$. Preside el conjunto Cristo triunfante, sobre el orbe, sostiene la cruz de su martirio, flanqueado por la Virgen y un santo franciscano, probablemente San Francisco dada su recurrencia en esta temática, ambos en genuflexión, sobre un manto de nubes. En el centro de la composición, San Miguel pesa las almas mientras es ayudado por dos querubines a seleccionar a aquellos bienaventurados que obtendrán primero la salvación. Todas las almas aguardan impacientes su pronta liberación, redimiendo sus pecados entre las llamas del purgatorio. Este sector inferior del lienzo recuerda mucho en la representación del fuego y en la tipificación de los rostros a otra obra de análoga temática ubicada en el museo de Santiago, que pertenecía al estandarte de este templo y que ha sido precisamente atribuida al pintor ${ }^{1345}$. Ambas obras, probablemente coetáneas, manifiestan la escasa creatividad del artista, que repite esquemas compositivos en los que las figuras, algo envaradas, pecan de cierta inexpresividad.

La imagen fue colocada junto a la sacristía, donde hasta entonces se ubicaba el retablo de San Ramón y se realizó una mesa de altar a la romana ${ }^{1346}$. A los lados del lienzo se dispusieron las esculturas de San José y San Antonio Abad y en la parte alta un Santísimo Cristo que donó don Félix de Modoya, miembro del linaje poseedor de la capilla de Santa Catalina ${ }^{1347}$. Por tanto, aunque hoy el lienzo se halla exento en origen formaba parte de un retablo, que, a juicio de Helguera en 1895, era una obra “... sin mérito en la pintura ni en el gusto... ${ }^{1348, "}$

\section{El lienzo de San Miguel}

En la subida al coro alto, podemos observar un gran lienzo de Bartolomé de Medina que representa a San Miguel venciendo al demonio, fechado en $1617^{1349}$. Este artista carrionés desarrolló su actividad entre finales del siglo XVI y las primeras

\footnotetext{
${ }^{1344}$ Para iconografía de las Ánimas, véase ARRATIA MARTÍN, Ma Victoria. Op.cit. pp. 59-65.

${ }^{1345}$ GÓMEZ PÉREZ, Enrique y MARISCAL, José. Iglesia de Santiago...Op.cit, pág. 45.

${ }^{1346}$ ADP. Carrión. San Andrés. Libro 5º de Cuentas de Fábrica (1753-1795), fol 282.

${ }^{1347}$ ADP. Carrión. Legajo 93.3. Papeles diversos. Inventario 1770, s/f.

${ }^{1348}$ RAMÍREZ DE HELGUERA, Martín. El libro...Op.cit, pág. 160.

${ }^{1349}$ PERAL VILLAFRUELA, Santiago y GÓMEZ PÉREZ, Enrique. Carrión...Op.cit, pág. 63. Acerca de Bartolomé de Medina, remítase al capítulo dedicado a los pintores.
} 
décadas del siglo siguiente en esta villa. Este gran lienzo (2,70 metros x 1.93 metros) procede de la abadía de Benevívere y se ubicaba antiguamente junto al retablo de San José, en la capilla de los Bobadilla ${ }^{1350}$. La elegancia del rostro de San Miguel y el tratamiento musculado de sus piernas, nos remite instantáneamente a la pintura italiana. Efectivamente, encontramos un lienzo del mismo tema de Rafael, realizado en 1518 en el que pudo hallar la inspiración para la figura del arcángel, cuya lanza está a punto de clavarse en su objetivo. Al mismo tiempo su pierna derecha pisa enérgicamente al ser monstruoso mientras la izquierda se mantiene en el aire, en un plano posterior. Sin embargo, este modesto artista que dista por otro lado de alcanzar la maestría y calidad técnica del maestro de Urbino. Es probable que Bartolomé Medina, a pesar de ser un artista local, tomara como fuente grabados italianos para inspirar sus obras, posiblemente de Raimondi o Guisi.

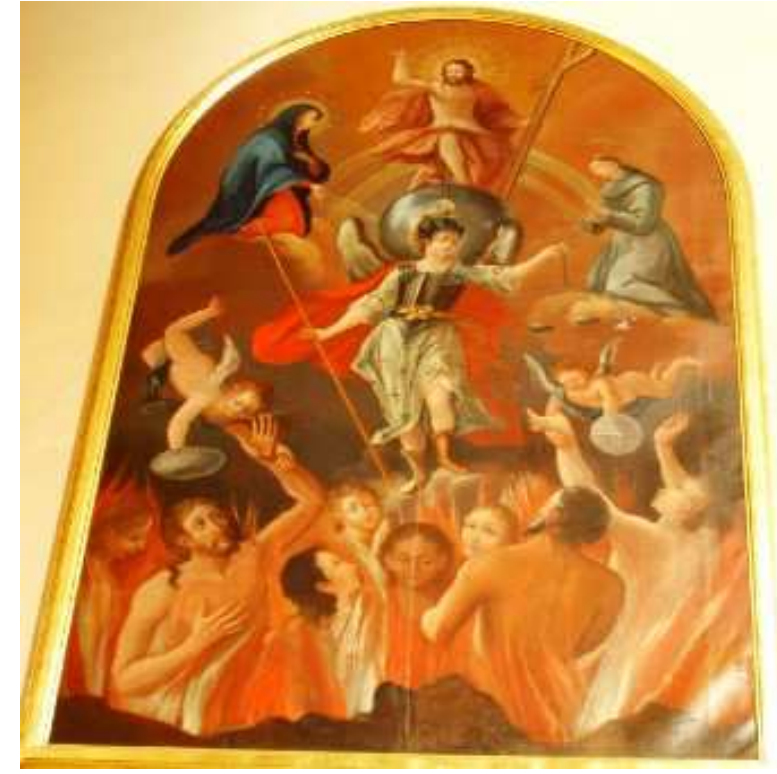

Las Ánimas del Purgatorio. Ramón Canedo. 1768.

$(352 \mathrm{~cm} \times 187 \mathrm{~cm})$.

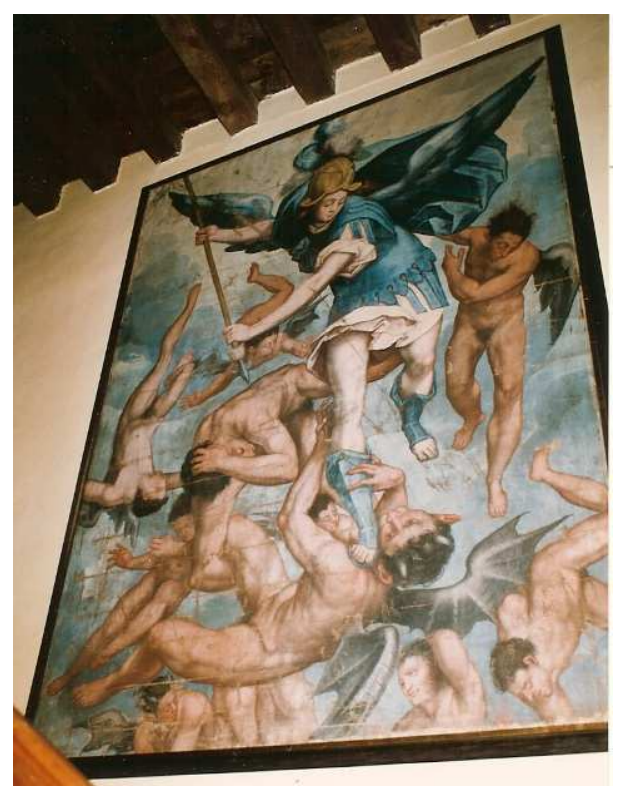

San Miguel luchando contra los demonios Bartolomé Medina. 1617. $(270 \mathrm{cmx} 193 \mathrm{~cm})$.

Lienzos ubicados a los pies del templo de San Andrés, en la nave del Evangelio.

\footnotetext{
${ }^{1350}$ ADP. Carrión. San Andrés. Libro 43 del Inventario de todos los ornamentos y alhajas de San Andrés (1833-1930), fol 14.
} 


\section{El monumento de Melchor Álvarez de Vozmediano}

Junto al retablo de San José, en el lado de la Epístola se adosa el lucillo sepulcral de don Melchor Álvarez de Vozmediano (4m x 3m), obispo de Guadix y fundador de la capilla de Nuestra Señora de las Velaciones, donde instituyó dos capellanías en $1581^{1351}$. El monumento con escultura orante del finado se indicaba que fue realizada en $1630^{1352}$. En realidad la fecha debió de ser mal leída, pues en la inscripción que figura del pedestal se puede leer:

"SIENDO PATRONOS EL DOCTOR CASTRO DE VILLARROEL I EL LDO PEDRO DE HERERA, CVRA DESTA IGLA Y EL PE FR P ${ }^{\mathrm{O}}$ DE VILLALOVO, PROR DE SANTO DOMINGO, SE COLOCARON EN ESTE NICHO LOS GVUESOS DEL MVI ILLVSTRE SEÑOR D MELCHOR ALBAREZ DE BIOZMEDIANO, OBISPO DE GVUADIX, EN 11 DE SEPTIEMBRE, AÑO 1636”.

A continuación, entre dos pilastras jónicas que contienen ovas entre las volutas, hallamos la hornacina de medio punto bajo cuya bóveda de cañón se ubica la escultura de bulto redondo de don Melchor de Vozmediano (136 $\mathrm{cm} \times 94 \mathrm{~cm})$. La efigie nos muestra un hombre maduro, de duras facciones -nariz aguileña y mandíbula muy acentuadagenuflexo y en actitud orante ante un reclinatorio sobre el que descansa un mullido almohadón decorado con borlas. De acuerdo a su condición de Obispo, el prelado va ataviado con el alba, el roquete y una capa pluvial corta, mientras que ha dejado la mitra a un lado del reclinatorio, en señal de respeto y humildad para sus rezos. Sobre el friso de orden jónico se dispone el arquitrabe que contiene una inscripción latina en memoria del fundador, que según podemos leer, fue añadida por don Juan Álvarez de Bobadilla en 1754, como fundador consanguíneo de la obra pía ${ }^{1353}$. Ese mismo año, Don Juan Bobadilla encargó que se dorasen las molduras y remates del panteón dejando el resto

\footnotetext{
${ }^{1351}$ VIGURI, Miguel de. Heráldica...2, Op.cit, pp. 54-55. Sobre el fundador y sus sucesores se hablará en el apartado relativo a los espacios de culto.

${ }^{1352}$ URREA FERNÁNDEZ, Jesús y MARTÍN GONZÁLEZ, Juan José. Inventario...2, Op. cit, pág. 54.

${ }^{1353}$ La inscripción dice lo siguiente: "Hoc opus tan altaris deaurati quam conopaei, ac sepulcri depictorum pertectum fuit, anno MDCCLIV, pie fundationis a Domino Illmo. Domino Melchore ab Alvarez Bodmediano, Acci (nunc Guadix) Episcopo institutae, Patrones esxistentibus. $\mathrm{R}^{\text {mo }}$ P. F. Blasio ad Hevia Dominici Conventus hujus villae priore D. Ioanne a Bobadilla Yll ${ }^{\text {mo }}$ fundatoris consanguíneo et D. Roderico ab Artacho, Beneficiario et Paroeciae Sancti Andreae dictae villae Parrocho”.
} 
jaspeado ${ }^{1354}$. Esto nos indica que en el siglo XVIII el monumento funerario presentaba unos vivos colores, suprimidos por el color hueso del enlucido aplicado posteriormente, quedando tan sólo la policromía en las armas del prelado. Recordemos que además, fue quien introdujo sus armas y las de Don Melchor en el retablo de Nuestra Señora, hoy de San José que se hallaba en su capilla ${ }^{1355}$.

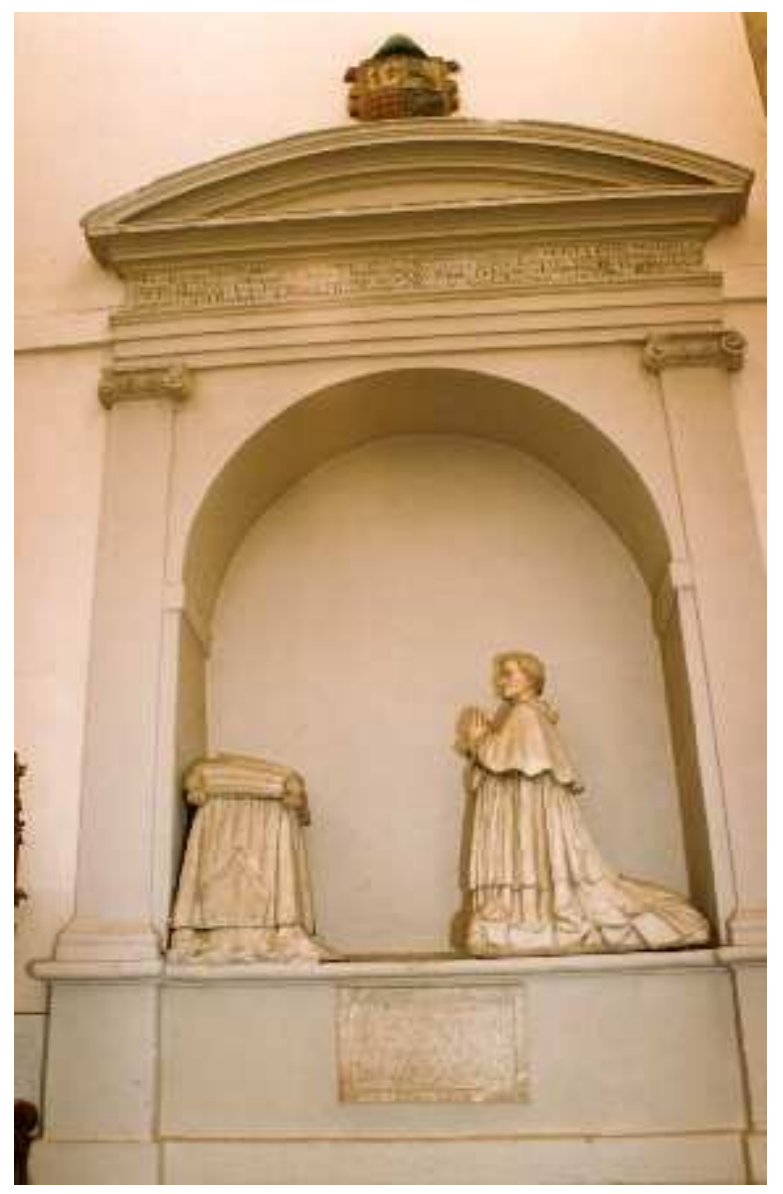

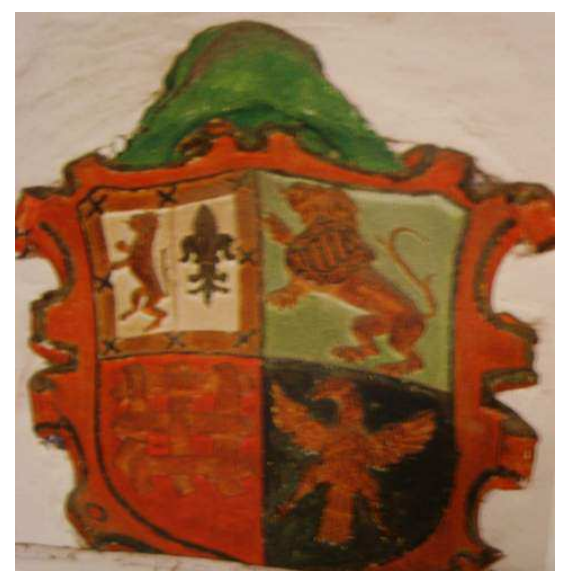

Detalle. Armas del obispo.

\section{Sepulcro del Obispo don Melchor Álvarez de Vozmediano. 1630. Efigie $(136 \mathrm{~cm} \times 94 \times 61 \mathrm{~cm})$. Reclinatorio $(87 \mathrm{~cm} \times 65 \mathrm{~cm} \times 69 \mathrm{~cm})$.}

A modo de remate, sobre un frontón curvo, se ubican las armas de Melchor Álvarez de Vozmediano. El escudo, decorado con cueros recortados, es cuartelado y su lectura es la siguiente: 1, partido de león dorado y flor de lis de sinople, bordura aspada

\footnotetext{
${ }^{1354}$ Francisco Gutiérrez y Juan López pintaron los escudos pero no los hicieron. AHPP. Carr.Prot 4664, Francisco Cano Núñez (1750-1756), fol 64 y ss.

${ }^{1355}$ Véase su análisis en el capítulo dedicado a las obras del templo.
} 
2, de sinople con un león de oro cargado de un escudo bandado, 3, de gules con unas correas. 4 , de sinople con un águila de oro. Timbrado de capelo y cordones episcopales. Este escudo se repite en el retablo referido, con algunas diferencias en cuanto a los colores empleados y en la ausencia de bordura aspada en este caso.

El precedente más inmediato de monumento funerario en la provincia de Palencia y que marcó la pauta en la arquitectura de esta tipología en la provincia, fue el sepulcro de los Marqueses de Poza, encargado en 1609 a Alonso de Vallejo ${ }^{1356}$. Con una sola efigie orante bajo arco triunfal, hallamos los sepulcros del presbiterio de la iglesia del Salvador de Quintanadiez de la Vega, que efigian a Miguel Santos de San Pedro, fallecido en 1633 y a Andrés Santos de San Pedro, fallecido en 1585 pero trasladado a este templo en 1646, momento a partir del cual se edificaría su mausoleo. También de esta tipología es el sepulcro del obispo de Lugo, Astorga y Sevilla, don Matías Moratinos, del templo de San Fructuoso, en Villada, que murió en $1682^{1357}$.

Por su semejanza estilística, conformados por un arco de medio punto entre pilastras y coronados en un frontón curvo, son los monumentos gemelos de Don Juan Santos de San Pedro, canónigo de la Santa Iglesia de Toledo y del Consejo de Felipe IV, fallecido en 1663 y de Bartolomé Santos de Resobar, obispo de Sigüenza, de 1647, ubicados en el presbiterio de la iglesia de Santervás de la Vega ${ }^{1358}$. Por su proximidad y magnificencia, no podemos eludir el monumento funerario del Obispo Navarrete de la capilla mayor de la iglesia de Santa María, realizado a partir de 1682. En todos ellos se repite el clásico esquema del devoto genuflexo bajo nicho de medio punto con las armas en el remate. Mirando al altar, e orante, con las manos en actitud de plegaria, se dispone frente a un atril sobre el que reposa la mitra, aunque en nuestro caso, ésta se ha tallado en bajorrelieve en un lateral del reclinatorio.

\footnotetext{
${ }^{1356}$ Finalmente el sepulcro no lo realiza Vallejo, y se contrata a los ensambladores Juan de Muniátegui y Cristóbal y Francisco Velázquez. GARCIA CHICO, Esteban. Documentos...Escultores. Op.cit, pp.. 214218. A pesar de todo, la autoría del orante no está clara. Urrea propone, en base a las cláusulas de un testamento y las semejanzas estilísticas, a Antonio de Riera. URREA FERNÁNDEZ, Jesús. "El escultor Antonio...Op.cit, pp. 668-672.

${ }^{1357}$ CASTRO MARTÍN, Pablo L. "Arte funerario...Op.cit, pp. 608 y 611.

${ }^{1358}$ URREA FERNÁNDEZ, Jesús y MARTÍN GONZÁLEZ, Juan José. Inventario...2, Op. cit, pp. 202203
} 


\section{El retablo de la Virgen del Rosario}

En el segundo tramo desde la cabecera, a continuación del monumento funerario al Obispo Melchor de Vozmediano, se ubica el retablo de la Virgen del Rosario $(6,75 \mathrm{mtrsx} 5 \mathrm{mtrs})$. Procede del desaparecido convento de Santo Domingo ${ }^{1359}$ y seguramente pasó a este templo porque la sede de la cofradía del Rosario fue trasladada a San Andrés. En el cenobio dominico, esta imagen se ubicaba concretamente en la capilla colateral de la mayor, lo que explicaría que, al no tratarse del retablo principal, no posea unas dimensiones mayores. Fue adquirido por el templo de San Andrés en el año 1810, en que el maestro "puerta-ventanista" Pedro de Rojas lo asentó en el lugar donde se ubica actualmente ${ }^{1360}$. Seguramente se trasladó a San Andrés ante el temor de perder la pieza, pues sólo un año antes había tenido lugar la exclaustración de José I. Gracias a esta actuación, el retablo se salvó de la quema que sufrió el convento con la llegada de las huestes de Padilla en 1811.

Si bien este retablo ha sido datado en el siglo XVII ${ }^{1361}$, lo consideramos obra del segundo cuarto del siglo XVIII, pues, al igual que el retablo del Santo Ángel, posee una ornamentación propiamente churrigueresca. De un solo cuerpo y dorado, el retablo se sitúa por delante de un transparente, tipología propia del barroco. En el banco se ubican los cuatro plintos correspondientes a los soportes del cuerpo principal, en los que se adosan graciosas cabezas de querubes bajo las cuales hallamos dos cuernos de la abundancia, en los de los extremos y motivos de cintas en los del centro. Entre ellos se ubican dos tableros con decoración de espejos en los que figuran las siglas de GRATIA PLENA, alusivas a la dedicación mariana del retablo. En el centro, flanqueado por dos relieves del sol y la luna, referentes del dominio celeste, hallamos la puerta del sagrario, lisa, sin más ornamentación que las dos diminutas columnas salomónicas que lo flanquean.

El cuerpo principal se encuentra dividido en tres calles a través de cuatro columnas de orden toscano cuyo tercio inferior es liso y separado por un bocel, los dos

\footnotetext{
${ }^{1359}$ RAMÍREZ DE HELGUERA, Martín. El libro...Op.cit, pág. 160.

${ }^{1360}$ ADP. Carrión. San Andrés. Libro $6^{\circ}$ de Cuentas de Fábrica (1796-1850), fol 152.

${ }^{1361}$ URREA FERNÁNDEZ, Jesús y MARTÍN GONZÁLEZ, Juan José. Inventario...2, Op. cit, pág. 54.
} 
tercios restantes son acanalados. Todos los fustes presentan una abigarrada ornamentación de bajorrelieves con un variado repertorio de testas de angelillos, cintas, frutos y cueros recortados. En las hornacinas laterales, donde otrora se ubicarían santos dominicos, hallamos las imágenes de San Pedro y San Antón Abad, trasladadas desde el retablo de Nuestra Señora de las Velaciones, hoy de San José, del que formarían parte originalmente. Se deben a la mano del escultor Pedro Martínez del Mazo, que las realizaría hacia 1726, año en que se le otorga carta de pago por estas esculturas y las de San Miguel y Santa Catalina del retablo de San Francisco Javier ${ }^{1362}$. De las dos, la de mejor calidad es la de San Pedro, que recuerda el estilo de Pedro del Mazo Vélez, autor de las esculturas de los retablos de San Julián, quien, como ya apuntamos, pudo ser maestro de nuestro escultor.

A este respecto, hallamos grandes similitudes entre la imagen de San Pedro y dos esculturas del retablo de Julián: la imagen de San Pedro, hoy exenta, y el San Juan Bautista del retablo mayor. Aunque nuestra talla se presenta desvirtuada por su nariz mutilada, podemos observar el mismo rostro enjuto, de párpados caídos, nariz alargada y fina y pómulos levemente hundidos. La indumentaria es idéntica en el caso de las dos imágenes de San Pedro, con la túnica larga con solapas en el cuello y ajustada a la cintura, salvo por los botones que presenta la nuestra. El manto recubre el hombro izquierdo, envuelve la figura desde la cintura a los pies y es recogido con en el brazo del mismo lado, cayendo en sentido oblicuo hasta el pie contrario. Igualmente la pose es idéntica, con la pierna derecha adelantada, el brazo homónimo con los dedos abiertos de los que penden las llaves y la mano contraria extendida para sostener el libro abierto. Probablemente el artista acudió al templo de San Julián para servirse de este modelo en su escultura. Sobre las dos hornacinas laterales hallamos dos espejos entre rocalla, con el anagrama: AVE MARÍA, que completaría con los de la parte inferior, el mensaje bíblico de la Anunciación. En la hornacina central de perfil mixtilíneo y protegida por una vitrina, se halla la imagen de vestir de la Virgen del Rosario, que data de finales del siglo XIX o principios del XX y sustituye a la imagen anterior, denominada "la Antigua", de hacia $1600^{1363}$.

\footnotetext{
${ }^{1362}$ ADP. Carrión. San Andrés. Libro 4 de Cuentas de Fábrica (1718-1752), fol 28v y 105.

${ }^{1363}$ Sobre la misma, véase GÓMEZ PÉREZ, Enrique. "La Virgen del Rosario" en Entre Castilla y Flipinas, Carrión de los Condes, 2006, pág. 32.
} 
De perfil semicircular, el ático está compuesto por dos columnas sostenidas por arquitrabes de gran desarrollo sobre los que apea un frontón curvo que está roto, como es usual en el barroco, para alojar la cruz dominica inscrita en una corona de angelillos de la que emergen haces solares. Preside este sector un lienzo de la Virgen sedente entregando el Rosario a Santo Domingo y a Santa Catalina de Siena, del siglo XVIII.

\section{La Virgen de la Herrada y los Santos Juanes}

En el tercer tramo de la Epístola, sobresaliendo del perfil del templo, se conserva la única capilla del templo. En el inventario de 1771, se menciona en este sector un retablo presidido por los Santos Juanes y rematado por la imagen de la Piedad ${ }^{1364}$. El retablo existente hoy día es una sencilla obra neoclásica del siglo XIX, con columnas corintias veteadas rematada en un gran tondo con el anagrama "AM" flanqueado por dos querubines sedentes realizados en yeso sin policromar. Alberga en su hornacina una escultura moderna del Sagrado Corazón de Jesús. Las tres tallas, sin embargo, sí que se han conservado y pertenecen al siglo XVII ${ }^{1365}$. San Juan Evangelista $(150 \mathrm{~cm})$ y San Juan Bautista $(146 \mathrm{~cm})$, bastante deterioradas por la mutilación de algunos dedos y la pérdida de su policromía, se encuentran flanqueando el retablo. De las dos, destaca por su ejecución la imagen del Bautista, cercana al estilo de Tomás de Sierra ${ }^{1366}$.

En lo que respecta a la imagen mariana, desplazada a un lateral, es conocida con el sobrenombre de Virgen la Herrada $(194 \mathrm{~cm})$, por su posible su procedencia del hospital homónimo desaparecido que existía a las afueras de Carrión ${ }^{1367}$. Aunque ha sido datada en el siglo XVII ${ }^{1368}$, no sería ejecutada hasta un siglo después, a tenor de los pliegues acuchillados de la túnica.

\footnotetext{
1364 ADP. Carrión. San Andrés. Legajo 93.3. Papeles diversos. Inventario 1770, s/f.

1365 URREA FERNÁNDEZ, Jesús y MARTÍN GONZÁLEZ, Juan José. Inventario...2, Op. cit, pág. 54

1366 Sobre Tomás de Sierra, remítase al capítulo dedicado a la biografía de los escultores.

${ }^{1367}$ RAMÍREZ DE HELGUERA, Martín. El libro...Op.cit, pág. 160.

${ }^{1368}$ URREA FERNÁNDEZ, Jesús y MARTÍN GONZÁLEZ, Juan José. Inventario...2, Op. cit, pág. 54
} 

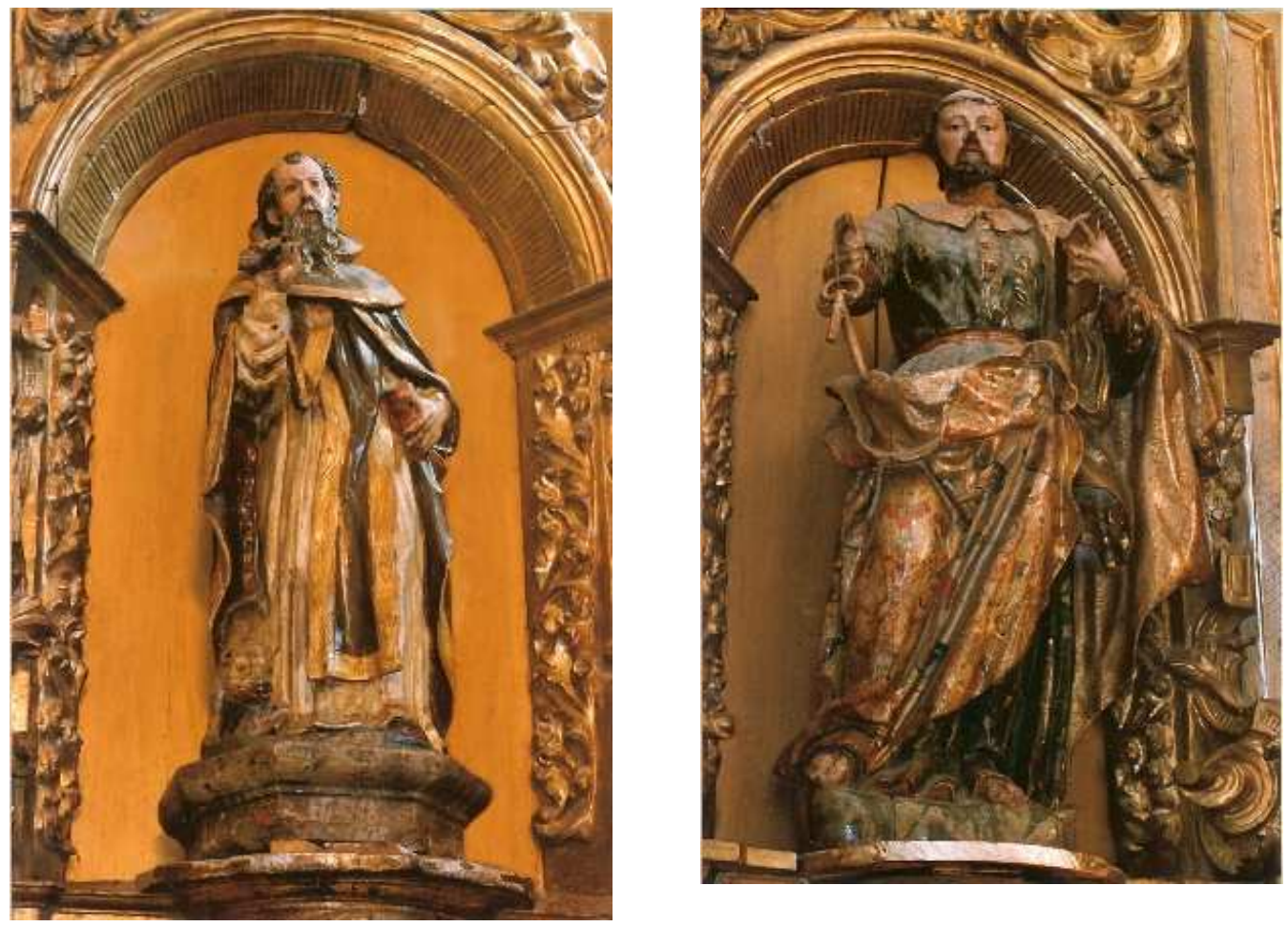

San Antonio Abad (92cmx32cmx33cm). San Pedro $(108 \mathrm{~cm} \times 64 \mathrm{~cm} x 32 \mathrm{~cm})$.

Esculturas del retablo de la Virgen del Rosario, ubicado en el lado de la Epístola de la iglesia de San Andrés, procedentes del retablo de Nuestra Señora de las Velaciones, hoy de San José. Pedro Martínez del Mazo. 1726.

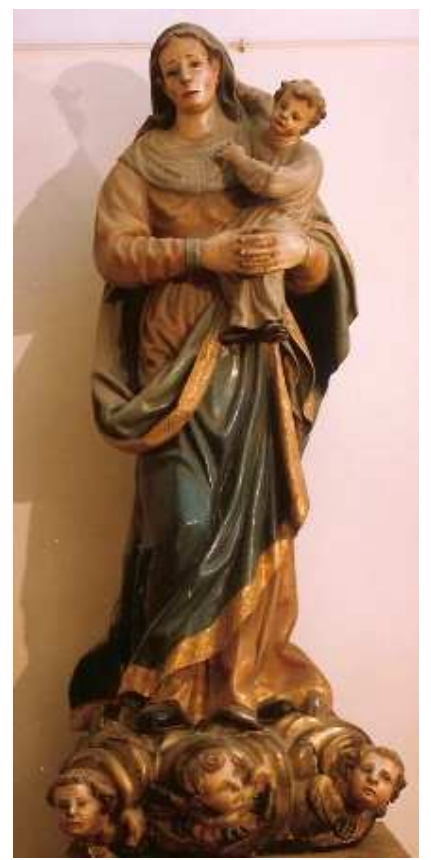

Virgen de la Herrada.

Anónimo castellano. Siglos XVIII.

$(194 \mathrm{~cm} \times 80 \mathrm{~cm} \times 73 \mathrm{~cm})$. 


\section{El coro: la sillería coral y el órgano}

En el año 1740 el cura y mayordomos gastaron casi 11.000 reales por la adquisición de ochenta y ocho tablas de pino para realizar una sillería de coro, pero dada la falta de fondos del templo, se deshicieron de las mismas un año después, vendiéndolas por el mismo precio por el que las compraron ${ }^{1369}$. La sillería que posee el templo, ubicada en el coro bajo procede de la extinta abadía de Benevívere, obra perteneciente al primer tercio del siglo XVII ${ }^{1370}$. Fue traída a la iglesia en 1840, una vez que había pasado la guerra carlista ${ }^{1371}$. Los sitiales del presbiterio, que imitan a éstos, son de factura moderna. En el coro se ubican un total de veintidós sitiales dispuestos en U: siete en los lados y ocho en la parte central.

El escudo de la silla central corresponde a un abad cuyo nombre se desconoce: Partido. 1. Fuselado de quince piezas, las pares cargadas de fajas, las impares, vacías. 2 , de Castilla, tronchado de castillo y león por una banda engolada de leones dragantes ${ }^{1372}$. En una cátedra, quizá destinada al patrono o delegado del abad, se disponen las armas de los condes de Salinas y Duques de Híjar. El resto de sitiales, incluidos los del presbiterio, alternan la mitra y corazón atravesado de la orden agustina los trece bezantes de los Sarmiento, linaje benefactor de la abadía ${ }^{1373}$. En la sacristía se ubican los sitiales del abad y del prior de claustra, que además de contar con el emblema agustino, contienen las representaciones de San Pedro y San Pablo, dada la vinculación de la abadía con la Santa Sede ${ }^{1374}$.

A los pies de la iglesia, sobre el coro alto, existe un interesante órgano barroco de 1766 en óptimo estado de conservación ${ }^{1375}$. Fue construido por el maestro Don Juan Francisco Toledo, organero del Obispado palentino por la suma 14800 reales $^{1376}$. La

\footnotetext{
${ }^{1369}$ ADP. Carrión. San Andrés. Libro 4º de Cuentas de Fábrica (1718-1752), fol 263.

${ }^{1370}$ RAMÍREZ DE HELGUERA, Martín. El libro...Op.cit, pág. 160. La datación de la obra corresponde a URREA FERNÁNDEZ, Jesús y MARTÍN GONZÁLEZ, Juan José, Inventario...2, Op.cit, pág. 54.

${ }^{1371}$ ADP. Carrión. San Andrés. Libro 60 de Cuentas de Fábrica (1796-1850), fol 315.

1372 VIGURI, Miguel de. Heráldica...2. Op.cit, pág. 58

${ }^{1373}$ La leyenda sobre el origen del escudo, además de la información pertinente de la familia Sarmiento consta en el capítulo referido al convento agustino de Benevívere.

${ }^{1374}$ PERAL VILLAFRUELA, Santiago. Estudio...Op.cit, pág. 14.

1375 RAMÍREZ DE HELGUERA, Martín. El libro...Op.cit, pág. 160.

${ }^{1376} \mathrm{La}$ escritura de contrato para la ejecución del órgano se firma el 15 de marzo de 1765. AHPP., Carr.Prot 4610, Francisco Blanco Manuel (1763-1765), s/f.
} 
inscripción situada en el escudo existente sobre los teclados confirma los datos de la documentación: "Siendo cura de esta iglesia don Antonio Pérez, hizo este órgano don Juan Francisco de Toledo y su primer organista Domingo Ramos, año de 1766”. Dicho año se instalaría en Carrión y acogería a Tadeo Ortega como su discípulo, al que comenzaría a instruir en el oficio mediante la ejecución de este órgano ${ }^{1377}$. Precisamente su pupilo fue quien finalizaría el órgano de la iglesia del convento de clarisas de la villa, pues le dejo inconcluso Toledo al sobrevenirle la muerte y quien añadió en 1776 tres caños mayores del registro de la trompeta de este órgano ${ }^{1378}$.
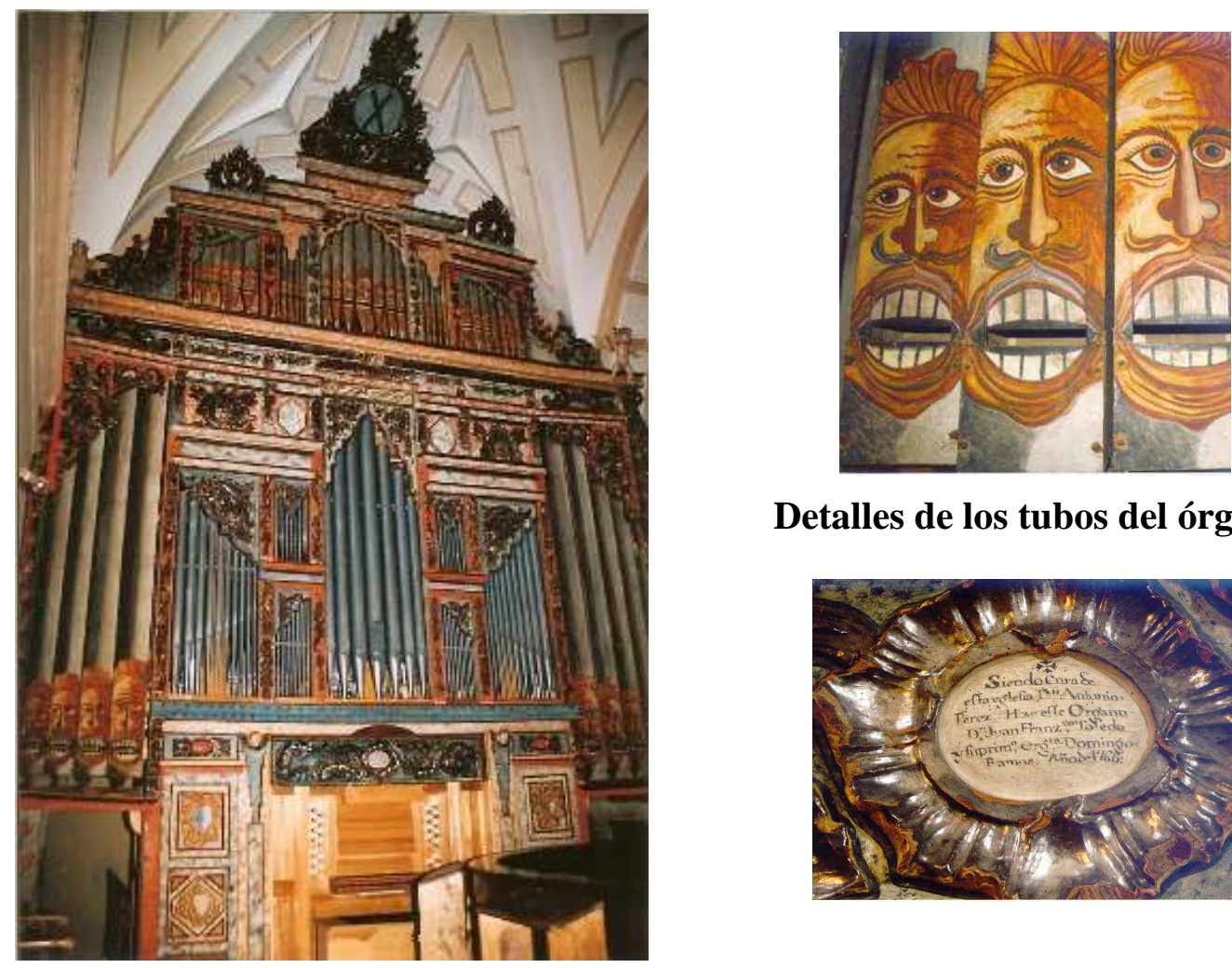

Detalles de los tubos del órgano.

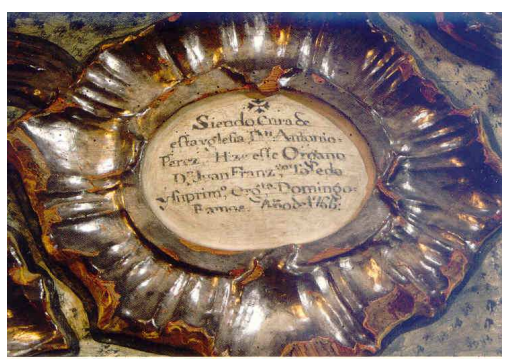

Detalle de la inscripción donde consta la fecha y autor.

\section{Órgano de la iglesia de San Andrés en el coro alto. Juan Francisco de Toledo. 1766. (7mtrsx6mtrsx1,35mtr).}

\footnotetext{
${ }^{1377}$ Un estudio profundo sobre la vida y obra de Tadeo Ortega en CASTRO MATÍA, Santiago de y BIROUSTE, Daniel. La organería...Op.cit, Palencia, 1979. Para un estudio de los órganos de la provincia, véase SANTIAGO, Miguel de y GARCÍA MORO, Luis. La organería palentina. Apuntes palentinos, 3.Caja de Ahorros y Monte de la Piedad. Palencia, 1983 y LE BARBIER RAMOS, Elena. La organería en la provincia de Palencia (1500-1800). Institución Tello Téllez de Meneses. Palencia, 2008 ${ }^{1378}$ VV.AA. Inventario de los...Op.cit, pp. 148-152 y ADP. Carrión. San Andrés. Libro $5^{\circ}$ de Cuentas de Fábrica (1753-1795), fol 383.
} 
Las condiciones fueron redactadas un año antes por el organero titular del Arzobispado de Burgos, don Francisco Javier de Betolaza, quien con motivo de una visita a Carrión para reparar el órgano de San Zoilo, recomendó la ejecución del mismo a su amigo Toledo, pues éste se veía imposibilitado de aceptar dicha tarea pues la multiplicidad de encargos que tenía se lo impedían ${ }^{1379}$. Juan Francisco era natural de las Ventas de Peñaguilera, en Toledo, pero residió la mayor parte de su vida en Palencia, trasladándose después a Carrión, dados los encargos que le surgieron en el entorno ${ }^{1380}$. En su testamento, dictado el 17 de enero de 1768, dispuso ser enterrado en este templo, de donde era feligrés, junto a su mujer, María González de la Cruz Aguirre ${ }^{1381}$.

Presenta una estructura en dos cuerpos, siendo el inferior de mayor envergadura. Ambos contienen una fina talla de filigrana en color plata dispuesta sobre paneles policromados en tonos rojizos imitando el jaspe en los cuales se inserta toda la tubería. La particularidad de los tubos radica en la pintura que se despliega en su parte inferior: un coro de máscaras alargadas dotadas todas ellas de bigote y prominente nariz que parecen entonar al unísono un canto mostrando orgullosamente su dentadura al compás de la música emitida por el órgano. La presencia de mascarones en los tubos, si bien original, no es exclusiva de este órgano en la provincia de Palencia, pues en los templos parroquiales de Santa Cruz de Grijota y San Pedro de Astudillo se disponen formando cartuchos dorados. Complementan la ornamentación dos ángeles portando trompetas a ambos lados del mismo y la cruz de San Andrés, santo titular del templo, remata el conjunto. La ejecución de esta caja del órgano, con su talla, la debemos a Bernabé López y José López Mata ${ }^{1382}$, maestros arquitectos, que la ejecutaron en 1765 ,

\footnotetext{
${ }^{1379}$ IbIbídem, pp. 157-158. Las condiciones para el órgano redactadas por Betolaza y revisadas por Juan Francisco Toledo, así como las de la caja, firmadas por Bernabé López, figuran transcritas en las pp. 158160 de este manual, y fueron extraídas de AHPP. Carr.Prot 4610, Manuel Francisco Blanco (1763-1765), s/f. Así mismo en las cuentas de la iglesia de 1767 figuran varias partidas correspondientes a la ejecución. VV.AA. Inventario de los órganos... Cálamo. Palencia, 2008, pp. 161, a su vez de ADP. Carrión. San Andrés. Libro 5º de fábrica (1753-1795), fol 303.

${ }^{1380}$ Es autor de los órganos palentinos de la iglesia de la Asunción de Villasarracino, de 1761, de San Miguel de Piña de Campos, de 1766, como éste de San Andrés o el de la Asunción de Lantadilla, de 1767. VV.AA. Inventario de los...Op.cit, pp. 154, 297, 524, 424-426.

${ }^{1381}$ FRANCIA LORENZO, Santiago. Por tierras...Op.cit, pp. 152-154, a su vez de ADP. Carrión. San Andrés. Libro 24 de defunciones, 1742-1774.

${ }^{1382}$ Este ensamblador era vecino de Carrión de los Condes, pero en la villa apenas se registra su actividad y figura trabajando mayoritariamente en Burgos, desarrollando su actividad entre 1744 y 1775 . A su mano se deben los retablos de la iglesia parroquial de Amaya de 1744, el de Nuestra Señora del Rosario de Tapia de Villadiego, de 1750, el de la iglesia de Santa María de Grijalba o el de San Pedro de Melgar de Fernamental de hacia 1764. En todos ellos se muestra muy decorativista, incluso en los más tardíos, ya está empapado de la estética rococó. PAYO HERNÁN, Jesús. El retablo barroco en Burgos y su comarca durante los siglos XVII y XVIII. Diputación Provincial de Burgos, 1997, tomo 2, pp. 273-283.
} 
dorándola posteriormente Francisco Gutiérrez, quien había dorado los retablos colaterales de este templo y a quien debemos otros trabajos en Santa María y el entorno palentino $^{1383}$.

En 1880, el órgano fue desmontado por el maestro Miguel Díez para afinarlo y añadirle algunos caños ${ }^{1384}$. Por último, en el 2001 fue restaurado por el taller de los hermanos Desmottes, de escuela alemana. Los expertos afirman que se trata de un instrumento capacitado para tocar la inmensa mayoría del repertorio europeo ${ }^{1385}$.

\section{La sacristía}

Entre los ornamentos de carácter litúrgico, podemos destacar un cáliz de plata, con gallones en la subcopa perteneciente al siglo XVI. Lleva la firma del orfebre: A Grez (Alonso Gutiérrez el Viejo) y P/ Miguel ${ }^{1386}$. También hay un lienzo de la Inmaculada, del siglo XVIII ${ }^{1387}$, siguiendo el tipo de las de Murillo y un Cristo Varón de Dolores, de hacia 1700. La obra más destacada de este espacio es una talla de Crucificado que datamos en el tercer cuarto del siglo XVI $(65 \mathrm{~cm} \times 68 \mathrm{~cm})$, a tenor de su plácida expresión y su corona tallada, propias de este período. Se trata de una escultura de buena calidad, de armónicas proporciones en la que Cristo ha expirado, pues sus ojos permanecer cerrados y su boca entreabierta. La cabeza descansa sobre su lado derecho, sin vida. El torso presenta la caja torácica un tanto pronunciada pero las formas son bastante suavizadas y el canon muy proporcionado.

La cajonería (1.05mtrs de altura x 5.35mtrs de anchura x $1.2 \mathrm{mtrs}$ de profundidad) data de la segunda mitad del siglo XVIII y se ubica en el lado oriental de la sacristía, ocupando todo el muro. En el frente, sobre los cajones, se dispone una fila de sencillos tableros rectangulares cajeados y sobre éstos, una banda de roleos y motivos vegetales. En el copete la decoración se hace más profusa, donde se despliega un repertorio de hojarasca y rameados que flanquean un Crucifijo entre aletones. En la pared, hallamos

\footnotetext{
${ }^{1383}$ ADP. Carrión. San Andrés. Libro $5^{\circ}$ de Cuentas de Fábrica (1753-1795), fol 246. Sobre Francisco Gutiérrez, véanse algunos datos biográficos recopilados en la iglesia de Santa María, cuando realiza las colgaduras de la capilla mayor.

${ }^{1384}$ ADP. Carrión. San Andrés. Libro $7^{\circ}$ de Cuentas de Fábrica (1851-1928), fol 85v.

1385 IbIbídem, pp. 154 y 157.

1386 BRASAS EGIDO, José Carlos. La platería...Op.cit, pág. 70.

${ }^{1387}$ URREA FERNÁNDEZ, Jesús y MARTÍN GONZÁLEZ, Juan José, Inventario...2, Op.cit, pág. 54.
} 
dos lienzos del siglo XVII que representa al Ángel de la Guarda y hace pareja con el Martirio de San Lorenzo, de escaso valor artístico.

\section{LAS ANTIGUAS CAPILLAS, ESPACIOS DE CULTO}

En 1511 en que se efectúa un inventario de los retablos del templo, constatamos la existencia de un gran número de capillas. Señalar su lugar exacto se convierte en una tarea harto complicada, teniendo en cuenta que las referencias a las mismas se hacen en función de la torre y la puerta principal del templo, que no se correspondían con las actuales pero tampoco podemos determinar su ubicación. Con las reedificaciones del templo, llegamos al año 1634 y tan sólo se conservan seis: la de Fernando de Carrión, El Alférez Carrera, Sánchez, Alarcón, del obispo de Guadix, Modoya, el Cura Cid de Herrera $^{1388}$.

1. Capilla Mayor, de San Miguel $y$ de los Reinoso

2. Capilla de San Antolín

3. Capilla de San Juan

4. Capilla de Santa Catalina

5. Capilla de Nuestra Señora de las Velaciones

6. Capilla de la Asunción

7. Capilla de la Magdalena o de "Líbranos de Penis Inferni"

8. Capilla de Juan Cid

9. Capilla de San Julián

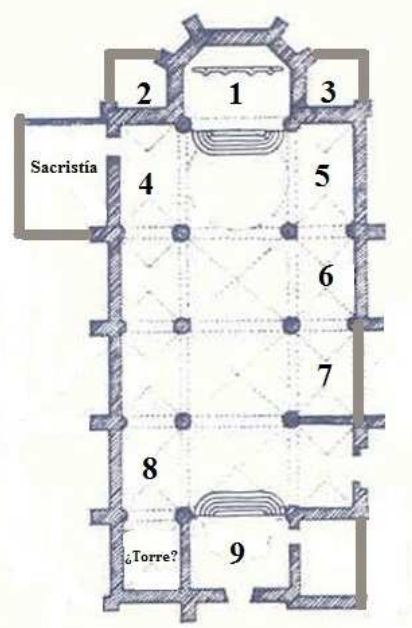

Hipótesis de las capillas del templo de San Andrés en el siglo XVI.

${ }^{1388}$ AHN. Clero Regular-Secular, Legajo 5356, Expediente 2, Iglesias de San Andrés y San Pedro, Obras. 


\subsection{LA CAPILLA MAYOR}

Dado que la capilla mayor poseía bastante altura, el retablo mayor se ubicaba en la parte superior y debajo, donde había una tribuna, se ubicaban la capilla de San Miguel y junto a ella, la de los Reinoso, esta última al parecer sólo poseía sepulturas, no estaba dotada de retablo. En 1516 se ordena derribar la bóveda y se plantea la unificación de todos estos espacios, respetando su extensión en la medida de lo posible $^{1389}$. Lo que sucede con la reedificación del templo es que los Reinoso permanecen en la capilla mayor y la capilla de San Miguel se traslada al lado del Evangelio. Aún a finales del siglo XIX Helguera confirma que al presbiterio se accedía por una escalera con verjas a los lados que contenían atriles ${ }^{1390}$.

\section{Capilla de los Reinoso}

Este linaje de los Reinoso poseía un espacio privilegiado en la capilla mayor para disponer las sepulturas de sus miembros desde al menos el siglo XV, pues cuando en 1511 acudió el visitador a la iglesia para mediar sobre el derecho que poseía el linaje de enterrarse en este espacio, se indica que pertenecía a Juan de Reinoso, quien “...de mucho tiempo la poseya...". Por entonces se fijan los límites bajo su posesión, estableciendo el lado del Evangelio hasta el retablo de San Miguel y el espacio que se ubica según se desciende por la escalera del altar mayor, lo que señala la ubicación de este espacio bajo la capilla mayor ${ }^{1391}$. En 1579 , cuando se está reedificando la capilla mayor, se indica que corre por cuenta de Nicolás de Reinoso como patrón de la misma los gastos ocasionados a los maestros de carpintería ${ }^{1392}$. En 1623 se menciona un estrado de esta capilla que pertenecía a los Reinoso ${ }^{1393}$. También poseías lápidas en este

\footnotetext{
${ }^{1389}$ ADP. Carrión. San Andrés. Libro antiguo de Cuentas de Fábrica, mandatos, visitas e inventarios (1511-1528), fol 27.

${ }^{1390}$ RAMÍREZ DE HELHUERA, Martín. El libro...Op.cit, pág. 160.

1391 ADP. Carrión. San Andrés. Libro antiguo de Cuentas de Fábrica, mandatos, visitas e inventarios (1511-1528), fol 10.

1392 AHPP. Carr.Prot 5729. Lázaro Santacruz (1579-1584), s/f.

${ }^{1393}$ VIGURI, Miguel de. Heráldica...2, Op.cit, pág. 55.
} 
privilegiado espacio el Doctor Gaspar de Aguilar y su esposa María de Guzmán y Sandoval ${ }^{1394}$.

\section{Capilla de San Miguel}

La existencia de la capilla se remonta al menos a principios del siglo XVI, pues en 1511 estaba asentado el retablo homónimo, ubicado “...debajo del altar mayor... ${ }^{1395 \%,}$, pues como indicamos con anterioridad, estaba sobrelevado por una tribuna. Fue dotada por Don Hernando de Carrión, comendador del hospital de la Herrada, disponiendo en la misma un monumento funerario como así consta en su testamento, dictado el 11 de febrero de 1527. Dejó el patronazgo y sus posesiones a Bartolomé de Cisneros, contador del marqués de Astorga ${ }^{1396}$. Después le sucedería don Álvaro de Cisneros, vecino de Manganeses de la Polvorosa, en la villa de Benavente. A falta de descendientes, concede en 1563 un poder a Alonso de Modoya y a su mujer, María Ponce, como patronos en su nombre de dicha capilla ${ }^{1397}$.

A consecuencia de las obras que se realizaban en la capilla mayor, el patrono siguiente, Don Juan de la Serna propone a los clérigos un cambio de ubicación para que no se obstaculizase el culto en este espacio ${ }^{1398}$. La capilla de Don Hernando de Carrión se mantuvo sin embargo, a tenor de las labores de rehabilitación del arco de entrada que se realizan en $1627^{1399}$. Parece que el traslado se hizo efectivo, a la zona del presbiterio, ya que en 1677 en que se hacen unas tapias, se señala su ubicación junto a la capilla de Santa Catalina ${ }^{1400}$.

\footnotetext{
${ }^{1394}$ María de Guzmán y Sandoval, exige en su testamento, dictado el 4 de septiembre de 1622, que se le entierre junto a su marido y su hija Ana de Guzmán en dicha capilla. AHPP. Carr.Prot 5243 Laurencio López (1620-22), s/f.

${ }^{1395}$ ADP. Carrión. San Andrés. Libro antiguo de Cuentas de Fábrica, mandatos, visitas e inventarios (1511-1528), fol 1.

${ }^{1396}$ Traslado con fecha 1571 del testamento original de don Fernando de Carrión en ASCC. Santa Isabel. Legajo XIV. Testamentos, s/f. Más información sobre la fundación de capellanías en ADP. Carrión. San Andrés. Libro 55. Cuentas de la capellanía que dotó Don Fernando de Carrión (1535-1577).

${ }^{1397}$ Poder de Álvaro de Cisneros en ASCC. Santa Isabel. Legajo XIV, fol 5 y ss.

${ }^{1398}$ ARCHV. Pleitos Civiles la Puerta (Olvidados), Caja 350, Exped. 4 s/f.

${ }^{1399}$ ADP. Carrión. San Andrés. Libro $2^{\circ}$ de Cuentas de Fábrica (1614-1637), fol 104.

${ }^{1400}$ ADP. Carrión. San Andrés. Libro $3^{\circ}$ de Cuentas de Fábrica (1672-1718), fol 26v.
} 


\subsection{CAPILLA DE SAN ANTOLÍN}

El retablo que se ubicaba en esta capilla, ornamentado con las tablas de San Antolín y San Sebastián, se menciona en el inventario de 1511, por lo que hay que presuponer la existencia previa de este espacio. Se ubicaba “...a par de la capilla principal al lado del Ebangelio..." y se encontraba deteriorado por entonces, por lo que la iglesia insta a Gregorio Ponce y Ponce Martínez que erijan un arco de cantería o ladrillo como el que poseía la capilla de San Juan, ubicada frente a ésta. En 1516 se les da un nuevo aviso y aún en 1525, su patrón, Hernán Ponce, seguía sin cumplirlo ${ }^{1401}$. Julián Ponce de León fue el siguiente patrón y en 1593 su hijo Gaspar entabla un pleito contra la iglesia pues se había derribado su capilla y en recompensa quería disponer de tres sepulturas para sus familiares que allí tenían para que se les adjudicaran junto al pilar toral del Evangelio en la obra nueva. El fallo sentencia que cuando se finalice la obra que se hace en la capilla mayor así se ejecute ${ }^{1402}$.

\subsection{CAPILLA DE SAN JUAN}

Frente a la capilla de San Antolín, en el lado de la Epístola, se ubicaba la capilla de San Juan. De la misma fue patrón don Gonzalo Gallo, camarero del Conde de Castañeda y fundador del hospital y convento de Santa Isabel. Su última voluntad fue que su sucesor más directo, su sobrino Alejo de Colmenares heredara el patronazgo y así figura desde $1533^{1403}$. No volvemos a tener más referencias de la misma, porque con la reedificación de la capilla mayor desde mediados de siglo desaparecieron las capillas colaterales.

\subsection{CAPILLA DE SANTA CATALINA}

Ubicada en el lado del Evangelio, es la primera capilla de la nave desde la cabecera. Al menos existía desde 1511 en que se menciona el retablo dorado con la

\footnotetext{
${ }^{1401}$ ADP. Carrión. San Andrés. Libro antiguo de Cuentas de Fábrica, mandatos, visitas e inventario. (1511-1528), fol 1, 10-11, 27v,28, 51v.

${ }_{1402}$ ACP. Provisorato. Legajo 5. $\mathrm{n}^{\mathrm{O}} 449$.

${ }^{1403}$ ASCC. Santa Isabel. Legajo III. Escrituras III. N ${ }^{\circ} 4$.
} 
imagen titular de bulto que poseía la capilla, ubicada “...a par de la sobredicha

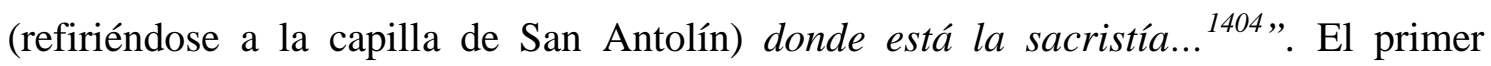
patrón conocido fue Don Francisco de Modoya, quien por su testamento, dictado el 22 de julio de 1660 , dispuso ser enterrado junto a sus familiares en este espacio ${ }^{1405}$. Poseía, según indica, el patronazgo de la capilla de la Asunción de Nuestra Señora, ubicada la segunda al lado de la Epístola, entre la de Melchor de Vozmediano y el cura Juan Cid. Estaba cubierta con una bóveda de ladrillo y se accedía a la misma a través de una reja. De su reedificación debía hacerse cargo en 1618, al igual que los patronos del resto de capillas, pues al hallarse el templo en pésimas condiciones se decidió reconstruirlo, derribando consecuentemente las capillas por estar en mal estado. Los materiales resultantes del despojo podrían ser utilizados en la nueva edificación. Francisco de Modoya considera que su capilla no debía haber sido derribada por estar en óptimas condiciones. En cualquier caso, se compromete a rehacerla sin responsabilizarse de los cimientos ni estribos “...porque mi capilla no se aprouecha del pilar sobre que ha de estriuar la fábrica de la dicha yglesia..." Sin embargo, el mayordomo de San Andrés no está de acuerdo y se establece un pleito entre ambas partes ${ }^{1406}$.

\subsection{CAPILLA DE NUESTRA SEÑORA DE LAS VELACIONES}

Se ubicaba frente a la capilla de Santa Catalina, en el testero de la nave del Evangelio, donde se hallan dos importantes obras previamente estudiadas: el retablo de Nuestra Señora de las Velaciones y el monumento del Obispo don Melchor Álvarez de Vozmediano, el fundador de esta capilla. Detentó el cargo de Obispo de Guadix y prior de la localidad onubense de Aroche, y fue uno de los teólogos escogidos de España para asistir al Concilio de Trento ${ }^{1407}$. En 1581 fundó dos capellanías, para cuyo mantenimiento otorgó veinte mil maravedíes de dote. Como patrón de las mismas

\footnotetext{
${ }^{1404}$ ADP. Carrión. San Andrés. Libro antiguo de Cuentas de Fábrica, mandatos, visitas e inventarios (1511-1528), fol 1.

${ }^{1405}$ AHPP., Carr.Prot 5693 Norberto Sandoval y Guevara (1660), fol 655 y ss. Era hijo de Martín Ruiz de Modoya y de Isabel Ruiz, marido de doña Beatriz de Hermosa, fruto de cuyo matrimonio fue Don Francisco de Modoya y Hermosa, regidor perpetuo de la villa y doña Isabel, esposa de Francisco de Mendoza. El inventario de los enseres que se hallaban en su vivienda particular de la Calle de la Rúa, así como la relación de sus bienes raíces vinculados nos dan una idea del alcance de las posesiones de este personaje.

${ }_{1406}$ ACP. Provisorato. Carrión. 4 de diciembre de 1618. Legajo 32, no 3621.

${ }^{1407}$ MADOZ, Pascual. Diccionario...Palencia, 1984, Op.cit, pág. 69.
} 
designa a su sobrino, el Licenciado Diego Álvarez de Solórzano, gobernador del Señorío de Vizcaya, y a éste le sucedió su hijo, Antonio Álvarez de Solórzano. Las condiciones de la escritura establecían que se debía levantar un pretil para colocar una reja, que actualmente no se conserva, además de disponer un arco y nicho para disponer los restos del finado, del que hablaremos a continuación ${ }^{1408}$. Por si no resultaba suficiente, en 1587 don Melchor realiza una nueva donación de cuatrocientos ducados para la reedificación de la capilla ${ }^{1409}$. Francisco Álvarez de Solórzano, hermano de don Antonio, fue quien se encargó de culminar los trámites de su adquisición en $1623^{1410}$. En 1626 la capilla experimenta una reedificación, probablemente con el fin de adecuarla para disponer el sepulcro de don Melchor. La gestionaba por entonces el mayordomo de las Huelgas de Burgos, don Pedro de los Ríos, que es denunciado por el templo para que abone los gastos correspondientes a las obras que se ejecutaban ${ }^{1411}$.

Al no tener sucesión Francisco Álvarez de Solórzano, el patronato recayó en el doctor Castro de Villarroel por ser el marido de doña María de la Carrera, la pariente más cercana de don Francisco. El único hijo varón del matrimonio falleció prematuramente por lo que tomó el relevo en el patronazgo la sobrina de ambos, María Garabito de la Carrera, que la adquirió en 1674, cuando la capilla poseía una imagen de Nuestra Señora ${ }^{1412}$. Al esposarse con García Álvarez de Bobadilla, poseedor de la capilla de la Piedad del convento de San Francisco de Carrión, éste adquirió derechos sobre este espacio, quien además poseía un mayorazgo en Sahagún que permanecerá unido al de Carrión ${ }^{1413}$. En 1702 la capilla pertenece a Antonio Álvarez de Bobadilla, abogado de los Reales Consejos y vecino de la villa de Sahagún ${ }^{1414}$.

Este linaje mantiene el patronazgo durante la centuria posterior, pues en 1753, es don Gaspar Álvarez de Bobadilla, presbítero de Sahagún, quien ostenta el cargo, delegando en su hermano y apoderado, don Juan Antonio Álvarez de Bobadilla, los trámites ligados al contrato para proceder a dorar el retablo de Nuestra Señora, hoy de

\footnotetext{
${ }^{1408}$ VIGURI, Miguel de. Heráldica...2, Op.cit, pp. 54-55.

${ }^{1409}$ AHPP. Carr.Prot 5620. Melchor de la Rúa (1588), s/f.

${ }^{1410}$ VIGURI, Miguel de. Heráldica...2, Op.cit, pp. 54-55.

${ }^{1411}$ ARCHV. Pleitos Civiles Varela (F) Caja 1182. Exp 3, fol 9 y ss.

${ }^{1412}$ VIGURI, Miguel de. Heráldica...2, Op.cit, pág. 56, a su vez de AHPP. Carr.Prot 5887. Blas Vela Álvarez (1673-1675), s/f.

${ }^{1413}$ VIGURI, Miguel de. Heráldica...2, Op.cit, pág. 56.

${ }^{1414}$ AHPP., Carr.Prot 5020, Agustín García Miranda (1701-1704), s/f.
} 
San José ${ }^{1415}$. Su recuerdo se mantiene hoy día gracias a la inclusión de su escudo en dicho retablo y la inscripción dedicatoria a don Melchor Vozmediano en su monumento funerario $^{1416}$. Gracias a esta intervención sabemos que desde esta capilla se accedía al archivo, el cual disponen se ornamente adecuadamente con una orla. El primogénito de don Juan, Francisco María Álvarez de Bobadilla Costilla y Garabito, que había probado hidalguía en $1783^{1417}$, accede al patronazgo en 1796, tras el fallecimiento de su progenitor $^{1418}$.

\subsection{CAPILLA DE JUAN CID}

En el lado de la Epístola, entre dos columnas de mármol, se hallaba la capilla del cura de Santa María, don Juan Cid. Gracias a una referencia indirecta, sabemos que se hallaba a continuación de la capilla de la Asunción de don Francisco de Modoya, de la cual, por cierto, no existen más referencias ${ }^{1419}$. Don Juan Cid la había comprado en 1477 para ayudar con dicho dinero a la reedificación del templo que se había caído dos veces $^{1420}$. El patronazgo continuaba en la centuria siguiente, pues en 1589 Antonio Cid dispone ser enterrado en dicha capilla si el por entonces patrón Francisco Cid no tenía inconveniente ${ }^{1421}$.

\subsection{CAPILLA DE LOS SANTOS JUSTO Y PASTOR}

En 1511, en que se menciona por vez primera, poseía un viejo retablo con tabernáculo. Hasta el momento había pertenecido a doña María Herrero Heligón, adquiriéndola seguidamente don Diego Sánchez. La cofradía del Santo Justo rezaba aquí la misa de la Transfiguración “...desde cinquenta años o más tiempo a esta

\footnotetext{
${ }^{1415}$ La escritura y condiciones de dorar el retablo de San Francisco Javier fueron firmadas por Juan López y Francisco Gutiérrez el 9 de abril de 1753. AHPP. Carr.Prot 4605, Francisco Blanco Manuel (17531754), fol 19 y ss.

${ }^{1416}$ Francisco Gutiérrez y Juan López pintaron los escudos pero no los hicieron. AHPP. Carr.Prot 4664, Francisco Cano Núñez (1750-1756), fol 64 y ss.

1417 VIGURI, Miguel de. Heráldica...2. Op.cit, pág. 56.

1418 AHPP., Carr.Prot 5259, Miguel López (1797-1798), fol 330.

1419 AHPP., Carr.Prot 5693 Norberto Sandoval y Guevara (1660), fol 655 y ss.

${ }^{1420}$ ADP, San Andrés. Pergamino 126.3.

${ }^{1421}$ AHPP., Carr.Prot 5852, Nicolás Vallejo (1588-1590), s/f.
} 
parte...”, dato que prueba una larga andadura de este espacio de culto ${ }^{1422}$. Sus hijos y sucesores en el patronazgo, Hipólito y Ana Sánchez, junto a sus cónyuges respectivos, doña Beatriz García Pachistre y don Francisco de Castro, son denunciados ante la justicia por el mayordomo de San Andrés, pues desde 1536 en que se convierten en sus dueños, no se habían ocupado de hacer frente a las reparaciones necesarias y su mal estado perjudicaba el culto, pues era una capilla muy visible desde la entrada.

Tampoco habían cumplido con la voluntad del primer benefactor, pues no la habían dotado ni con retablo, ni cáliz, ni esculturas orantes, tal y como el finado solicitaba, para lo cual había destinado una generosa dotación. La Chancillería de Valladolid resuelve en mayo de 1556 que en el plazo de nueve días los descendientes de Diego Sánchez se encarguen de reedificar la capilla, invirtiendo a partir de entonces 500 maravedíes anuales para su sustento ${ }^{1423}$.

\section{8. CAPILLA DE SAN JULIÁN}

Don Juan de la Serna, clérigo que poseía el patronazgo de la capilla de San Miguel, también poseía otro espacio bajo el coro. Su sobrino, Guión de Colmenares hereda la capilla y encarga un nuevo retablo el 3 de junio de $1589^{1424}$. Para la pintura, dorado y estofado del mismo contrata a Miguel del Val ${ }^{1425}$, artista de Dueñas, que se encargaría de pintar la escultura de San Julián, cuya mitra, báculo y casulla, irían de oro bruñido, con el envés encarnado, el alba blanca con la orla de oro y el rostro encarnado a pulimento. El retablo poseía columnas estriadas de orden corintio, según colegimos de las “...ojas de esmaltes verdes y colorados...” y “...las estrías de azul...” y se remataba con dos escudos con las armas de Guión de Colmenares. Sospechamos que quien se encargó de la talla del santo titular fue Martín de Colindres, un escultor originario de la localidad cántabra homónima, pues en las condiciones que redacta el pintor, deja a elección de Colindres la ejecución de los pedestales, lo que señala que probablemente se había subcontratado con él la parte escultórica. En 1611, a

\footnotetext{
${ }^{1422}$ ADP. Carrión. San Andrés. Libro antiguo de Cuentas de Fábrica, mandatos, visitas e inventarios (1511-1528), fol 1 y 12.

${ }^{1423}$ ARCHV. Registro de ejecutorias. Caja 859, 46.

1424 AHPP. Carr.Prot 4980. Sebastián García (1588-1590), fol 651 y ss.

1425 Sobre el mismo, remítase al capítulo dedicado a los pintores locales.
} 
consecuencia de la inminente ruina que sufría el templo “...y considerando que ay pocas hesperanças de que se rreydifique ni buelua a estar en estado conuiniente...", Guión de Colmenares modificó una cláusula de su testamento, disponiendo su sepultura en la iglesia de Santiago, junto al púlpito situado a la entrada de la misma ${ }^{1426}$. El retablo de San Julián fue demolido dado su pésimo estado en el año 1733, siendo tal vez este hecho, síntoma de que la capilla había quedado vacante ${ }^{1427}$.

\subsection{CAPILLA DE “LIBRANOS DE PENIS INFERNI”}

Se encontraba “...en fin de la dicha yglesia a par de la torre...” pero hay que tener en cuenta que la antigua torre no se encontraba donde está la actual, pues cuando ya estaba terminada, se decidió entonces derribar la vieja. Por ello, es difícil precisar dónde se ubicaba este espacio, siendo probable que ocupara el primer tramo desde los pies. En 1511, doña María de Berrio, mujer del fundador, del que no conocemos más que el patronímico Alarcón, se comprometió a lucir la capilla y dotarla de un artesonado, así como de reparar sus tejados en 1516, aunque no sabemos si lo llevó a cabo, ya que en 1525 el visitador se queja de que no estaba decente ${ }^{1428}$. La capilla de La Magdalena y de Santa María "de libranis de penis ynfernii”, como así se llamaba, perteneció después al comendador Pedro Ruiz de Alarcón, cuyo patronazgo había heredado su esposa, doña María Zúñiga, quien lo poseía al menos desde $1559^{1429}$. Se hallaba vacante en 1567, cuando el capellán de la capilla hace dejación de la misma para que se ocupen de ella los familiares del fundador ${ }^{1430}$. A principios del siglo siguiente ostentaba el patronato el biznieto de los fundadores, don Juan de Colmenares y Alarcón, quien en 1603 encargaría a Pedro de Pedrosa dorase el retablo de la capilla y encarnase las figuras que fueran necesarias por cuarenta ducados ${ }^{1431}$.

Con motivo de la obras de reconstrucción del templo que se llevaban a cabo desde 1608, Don Juan de Berrio Colmenares solicita en 1610 que el retablo y reliquias

\footnotetext{
${ }^{1426}$ AHPP. Carr.Prot 4838. Juan Díaz Pajaza (1611) s/f.

${ }^{1427}$ ADP. Carrión. San Andrés. Libro 4º de Cuentas de Fábrica (1718-1752), fol 188v.

${ }^{1428}$ ADP. Carrión. San Andrés. Libro antiguo de Cuentas de Fábrica, mandatos , visitas e inventarios (1511-1528), fol 10, 27v, 51v.

${ }^{1429}$ AHPP. Carr.Prot 5660. Andrés Sánchez (1543-1558), s/f.

${ }^{1430}$ La escritura se firma el 6 de mayo de 1657. AHPP. Carr.Prot 5598. Francisco Rojas (1562-1567), s/f.

1431 AHPP. Carr.Prot 5910. Alonso Zapata (1603-1604), fol 90 y ss.
} 
custodiadas en esta capilla sean trasladadas a la capilla mayor “... a causa d'estar la dicha capilla en lo viejo de la dicha yglesia donde no se puede goçar ni visitar ni ganar los jubileos que en ella están concedidos, ni menos decirse misa en ella y hauerse de derribar... ${ }^{1432}$ ". Es lógico que quisiese que fueran guardadas en este sector, pues era el único de todo el templo que, como indicamos previamente, ya había sido reconstruido. En dicho lugar se mantuvieron desde entonces, pues así se indica en el acto de posesión que tuvo lugar en 1700, cuando Manuel Antonio de Berrio Colmenares y Alarcón, hijo de don Antonio de Berrio y Rivera y doña Josefa María de Colmenares ${ }^{1433}$ inauguró la nueva centuria con un nuevo patronato ${ }^{1434}$.

\subsection{CAPILLA DE SANTA MARTINA LA VIEJA}

En 1511 debían hacerse reparos leves en ella para que estuviese más decente pero en 1527 aún no se habían llevado a cabo por lo que la iglesia insta a Diego y Juan Ruiz de Colmenares a que lo cumplan, apartándoles de los oficios divinos hasta entonces $^{1435}$. La última referencia a la misma es de mediados del siglo XVI, en que figura bajo la advocación de Nuestra Señora la Vieja ${ }^{1436}$.

\footnotetext{
${ }^{1432}$ AHPP. Carr.Prot 4966. Alonso García (1610-1613), s/f.

${ }^{1433}$ El poderoso linaje Berrio Colmenares está íntimamente ligado a la iglesia de San Julián, pues el origen de su fundación corresponde a Don Hernando de Berrio Rivera y el posterior patronazgo del templo correspondió a los Berrio Colmenares. Véase al respecto dicho capítulo.

${ }^{1434}$ La presentación de la capellanía tuvo lugar el 8 de octubre de 1700. AHPP. Carr.Prot 5019. Agustín García Miranda (1699-1700), s/f.

${ }^{1435}$ ADP. Carrión. San Andrés. Libro antiguo de Cuentas de Fábrica, mandatos, visitas e inventarios (1511-1528), fol 13 y $27 \mathrm{v}$.

${ }^{1436}$ Así aparece en el testamento de doña Constanza Ruiz Guadiana, mujer de don Juan de Castañeda, dictado en 1554. En él expresa su deseo de sepultarse en dicha capilla, o de no ser posible, en la de su tío, el Comendador (la capilla de San Miguel). ASCC. Santa Isabel. Legajo XIV. Testamentos, nº 6.
} 


\subsubsection{IGLESIA DE SAN JULIÁN}

\section{EL TEMPLO}

En medio de la villa de Carrión y situada en la plaza homónima, se halla la iglesia de San Julián, que ya existía en 1345, cuando todos los diezmos eran entregados por su capellán al Obispo, bajo cuya jurisdicción se hallaba el templo ${ }^{1437}$. La siguiente mención a San Julián data de principios del siglo XVI, en que un vecino de Carrión, don Juan Campo, decide en su testamento, dictado en 1503, obsequiar a la iglesia con un cáliz, una casulla de damasco y otros ornamentos y encarga al párroco que sustituya el retablo dedicado a San Leonardo por otro que contuviera en el cuerpo central a Cristo Crucificado, sin olvidar una representación de los doce Apóstoles en parejas, seis a cada lado y Cristo en medio, representando la Última Cena y la Anunciación en el lugar que se estimase conveniente ${ }^{1438}$. En 1590 se registra un acopio de madera procedente de Quintanar de la Sierra, conocida por sus pinares, destinada probablemente a la reparación de las cubiertas ${ }^{1439}$. La última referencia al templo antes de que fuese reconstruido, data de 1594 en que Hernando Infante, maestro ensamblador, ejecuta un escriptorio de nogal para el templo ${ }^{1440}$.

De todo lo mencionado, nada se conserva, dado que el modesto templo que vemos hoy día es fruto del siglo XVII ${ }^{1441}$. Es la única iglesia de Carrión, junto a Belén, que no está orientada, pues su cabecera mira hacia el norte. Tal vez esto se deba a que cuando el templo fue edificado de nueva planta, planteándose una ampliación de la fábrica anterior, este era el único modo de disponerla que respetara las edificaciones colindantes.

Posee una planta de cruz latina de una nave con cabecera plana y crucero sobre el que descansa una sobria cúpula, que al interior está sostenida por pechinas, la cual no

\footnotetext{
${ }^{1437}$ MARTÍN PAYO, Jesús. "La más antigua estadística...Op.cit, pág. 10.

${ }^{1438}$ El traslado de su testamento fue realizado en 1603. ACP. Documentación de Santa María. Legajo 1, $\mathrm{n}^{\mathrm{o}} 307$.

1439 AHPP. Carr.Prot 4981. Sebastián García (1590-1592), fol 439 y ss.

${ }^{1440}$ Esta obra sería tasada posteriormente por el maestro de carpintería Santiago de Sigüenza. AHPP. Carr.Prot 4595. Juan Birtus (1592-1594), s/f. Sobre Hernando Infante, remítase al capítulo dedicado a los ensambladores y escultores locales.

${ }^{1441}$ RAMIREZ DE HELGUERA, Martín. El libro...Op.cit, pág. 164.
} 
se trasdosa exteriormente, ya que la recubre un cimborrio cúbico con cubierta a cuatro aguas cuyas esquinas vienen reforzadas por sendas pilastras. La nave, con tres tramos de capillas, se cubre con bóveda de cañón con lunetos que flanquean arcos termales ciegos apoyados en pilastras planas. El capitel de éstas está formado por el arquitrabe que recorre el interior del templo. De acuerdo al espíritu clasicista con que fue concebido el templo, no existen concesiones a la decoración.

\author{
Planta de la iglesia de San Julián. \\ Extraída de MARTÍN GONZÁLEZ, Juan \\ José y URREA FERNÁNDEZ, Jesús, Inventario \\ artístico de Palencia y su provincia ,2.
}

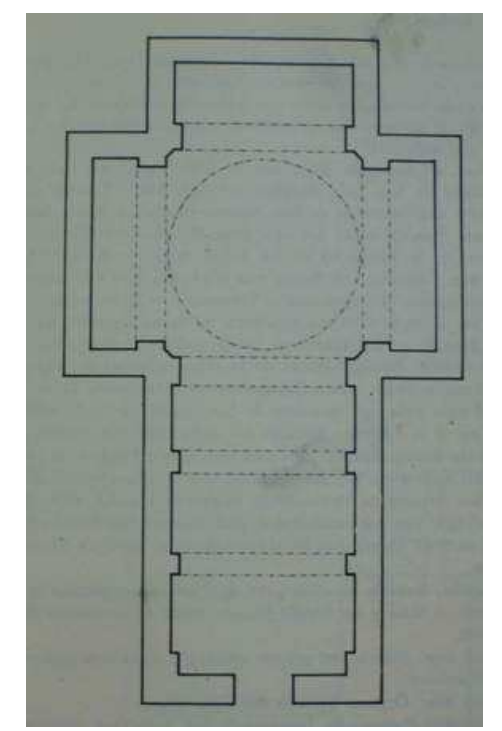

Exteriormente toda la fábrica es de ladrillo visto, reforzado por pilastras en cada tramo y rafas de tapial en los muros del transepto y presbiterio. Los arcos termales cegados se trasdosan a través de rafas de tapial. Incluso la torre, maciza y de escasa altura, es de este mismo material. Se ubica en el ángulo que conforman la capilla mayor y el crucero, adosándose en el lado del Evangelio. Bajo la misma se encuentra la sacristía, edificada paralelamente a la torre y conformada por dos estancias de pequeñas dimensiones cubiertas con vigas de madera y bovedillas de yeso. Se accede a la misma desde un pequeño acceso practicado en el lado del Evangelio del crucero.

No se trata de un templo exento, sino que se halla flanqueado por edificaciones a ambos lados. En el lado del Evangelio hallamos una vivienda y negocio particular que sustituyó a la casa del párroco en la década de los noventa. Se accedía a la misma desde el templo a través de un acceso ubicado en el descansillo del coro, tapiado pero aún visible. La estancia alargada de ladrillo que extendiéndose hasta el presbiterio, se adosa 
en el lado de la Epístola, es un espacio construido en el siglo XIX para la Adoración Nocturna $^{1442}$.

\section{ORIGEN DEL PATRONAZGO}

\section{El fundador: don Hernando de Berrio}

La figura protagonista del templo de San Julián, fue miembro insigne de los Berrio, linaje de procedencia vasca con gran número de residentes en el Obispado de Jaén desde el siglo XIV y extendido al resto de la Península posteriormente ${ }^{1443}$. Hablamos de don Hernando Berrio de Ribera, regidor perpetuo de Panamá natural, al parecer, de la localidad palentina de Villanueva de los Nabos ${ }^{1444}$, a quien debemos la reedificación y patronazgo de la iglesia. Era hijo de Ana María y Berrio, natural de Carrión y Antón González de la Torre, oriunda de Frómista ${ }^{1445}$. Poco se sabe de los años juveniles del fundador, pero se presume su dedicación militar pues, según refiere un documento del Archivo de Indias, a su llegada a América en 1540, “...es soldado viejo $y$ de buen entendimiento y buen consejo y hombre de experiencia por haber seguido la guerra sirviendo a su majestad en España...”. Sus primeras actividades en territorio hispanoamericano, le muestran como pacificador de Veragua junto al gobernador Rafael de Figuerola y combatiente contra el tirano Lope de Aguirre en 1561 por la defensa de la ciudad del Nombre de Dios ${ }^{1446}$.

Como maestre de campo, se encarga de las defensas de las costas de Cartagena de Indias y Nombre de Dios, atacadas por los piratas ingleses. En esta última ciudad, además, apaciguó a los negros cimarrones sublevados, acción que le valió el nombramiento de capitán el 13 de abril de 1578. Desde este año detentó el cargo de regidor de Panamá, pero no recibió gratificación alguna por parte de la corona por los

\footnotetext{
${ }^{1442}$ Debo esta información a mi colega e historiador, Enrique Gómez Pérez.

1443 TORAL PEÑARANDA, Enrique. Los Berrio...Op.cit, pág. 9.

1444 Siguiendo las palabras de Don Santiago Francia, era natural de Villanueba de los Nabos, véase Aldaba: Boletín Informativo de la Parroquia de Carrión de los Condes. $\mathrm{N}^{\mathrm{o}} 9$ Carrión de los Condes (Palencia), 1990.

${ }^{1445}$ GARCÍA CARRAFA, Alberto y Arturo. Diccionario heráldico y genealógico de los apellidos españoles americanos. Apellido: Berrio. Imprenta Antonio Marzo. Madrid, 1920, pág. 140.

${ }^{1446}$ Para una biografía más detallada consúltese FRANCIA LORENZO, Santiago. Aportación palentina a la gesta indiana. Colección Pallantia. Palencia, 1992 y CARVAJAL IBÁÑEZ, Teresa. "Un palentino en Panamá: Hernando de Berrio" en AIICHPTomo 4. Palencia, 1990, pp. 445- 451.
} 
servicios prestados. Simultáneamente, Don Hernando se dedica al comercio con las distintas ciudades de Tierra Firme: Cartagena, Guayaquil, Lima y la propia Panamá, además de ejercer como prestamista. Cuenta incluso, con un agente en Sevilla, Alonso Martínez de Herrera, que se encargará de las operaciones comerciales en la capital andaluza. Bartolomé de Reinoso, su sobrino, residente en Perú, y Juan Ponce de León, gran amigo, serán los albaceas de Hernando de Berrio en América y Sevilla, respectivamente ${ }^{1447}$.

\section{La voluntad testamentaria de don Hernando}

En su testamento, abierto en Panamá el 19 de febrero de 1598 y llegado a Sevilla en los galeones de Luis Fajardo un año más tarde, Hernando de Berrio precisaba las condiciones de su enterramiento y gran cantidad de donaciones que ponen de relieve la generosidad del finado y la vida opulenta que ostentó ${ }^{1448}$.

\subsection{Principales disposiciones del testador}

Su primer deseo fue ser sepultado en la capilla mayor del convento de Santo Domingo de Panamá, al que cede su vivienda, disponiendo a sus albaceas la gestión de los gastos necesarios para el entierro -cera, ornato, asistencia de cofradías- y las misas en que en su honor debían cantarse en los días siguientes dentro de las iglesias principales de la ciudad, como el convento de la Merced o el de San Francisco. La casa en la que residía se la cede a los dominicos pero igualmente concede otras viviendas de su propiedad al hospital de Panamá. Instituye una capellanía en su catedral y designa como patronos a los regidores más antiguos de la ciudad. Para el mantenimiento del hospital y la fábrica de la iglesia de la localidad panameña de Portovelo, concede 250 pesos de limosna.

${ }^{1447}$ FRANCIA LORENZO, Santiago. Palencia en América. Palencia, 1989 pág. 117-122 y CARVAJAL IBÁÑEZ, Teresa. "Un palentino en Panamá: Hernando de Berrio" en AIICHPTomo 4. Palencia, 1990, pp. 445- 451.

${ }^{1448}$ Nos informa del paradero del testamento de don Hernando de Berrio FERRERO MAESO, Concepción. "El mecenazgo de la familia Berrio...Op.cit, pág. 587. 
En lo que respecta a las donaciones personales, Don Hernando nunca se esposó ni tuvo descendencia, lo que explica la repartición de sus bienes entre sus familiares y amigos más allegados. La primera mención se refiere a la hija gitana de un matrimonio necesitado a la que don Hernando había criado: María de la Torre, patronímico de adopción, no real, a tenor del gran cariño que le profesaba. A ella le cede 375 ducados para su sustento y alimento “...por todos los días de su vida...”. También había criado a un mulato al que bautizó con otro de sus apellidos como Juan de Ribera. Le envió a estudiar a Castilla, invirtiendo dos mil ducados en su beneficio, pero éste decidió emplearlos en otros menesteres menos provechosos. A pesar de ello y “...aunque conforme d'esto no me deuiera de acordar d'el..." le dona otros dos mil ducados a condición de que no le reclame nada de sus bienes en adelante, en cuyo caso dispone que sus herederos le obliguen a restituirle los cuatro mil ducados y "...lo que mas paresçiere auerme gastado en estas Yndias” de su cuidado. La magnificencia del comendador se extiende a sus esclavos, Magdalena y Juanico, a quienes concede la libertad; a sus sobrinos, Francisca de Reinoso y Diego de Modoya, y como no, a su pariente más cercano, su hermana Antonia de Rivera, a quienes destina generosas sumas, sin olvidarse de quedar un remanente para redimir cautivos cristianos y repartir entre las viudas y huérfanas pobres y los presos de la villa.

\subsection{Deseo frustrado: Las capellanías en Nuestra Señora de las Capillas}

En Carrión de los Condes don Hernando de Berrio manifestó su deseo de fundar dos capellanías en Nuestra Señora de las Capillas, con la consecuente ampliación del espacio con una capilla propia. Era éste el panteón de los Berrio, donde descansaban su tío Antonio González de la Torre, caballero del hábito de San Juan y su madre, dado que los restos de su padre descansaban en Villanueva de los Nabos ${ }^{1449}$.

Nuestra Señora de las Capillas, también conocida como Nuestra Señora de la Paz, se ubicaba en la margen derecha de la iglesia de Santiago, según se mira su fachada occidental, en el antiguo claustro de templarios de la orden de Santiago y limitaba por el otro lado con la vivienda de don Gaspar Ponce de León, poseedor de la capilla mayor

${ }^{1449}$ FERRERO MAESO, Concepción. “El mecenazgo...Op.cit, pág. 587. 
del templo de Santiago. Su fundador fue el esposo de doña Leonor de Berrio, don Hernán García Pachistre, alcalde de Carrión en 1462 y camarero de la reina Doña María, esposa de Juan $\mathrm{II}^{1450}$. El monarca de Castilla, entre otros títulos, poseyó el de Gran maestre de la Orden de Santiago, por lo que no es extraño que su siervo fuese miembro integrante de la misma y ordenase levantar su panteón sobre esta antigua edificación militar. La iglesia o llamémosla ermita de las Capillas, medía tan sólo ocho metros de largo por cinco de ancho (30 pies x 20 pies) y su ubicación en una callejuela angosta le limitaba espacialmente, impidiéndole cualquier tipo de ampliación.

Como capellanes de la nueva fundación, Don Hernando designó a su sobrino Juan Berrio y a Juan Ponce de León, y en adelante ocuparía este cargo un clérigo perteneciente a cualquiera de los dos linajes, o en su defecto, dos clérigos hijosdalgo de Carrión. En calidad de patrón, designa al dicho Juan Ponce de León, dotándole con setecientos ducados de renta anuales, más doscientos para la fábrica de la iglesia. En caso de fallecimiento de éste, como efectivamente sucedió, su lugar lo ocuparía el sucesor en el mayorazgo de los Ribera, su sobrino Antonio de Berrio y Ribera, vecino de Medina de Rioseco, hijo de don Manuel de Berrio y Ribera y de doña Isabel de Alameda y nieto por vía paterna de Hipólito de Berrio y María Ponce de León.

El ocho de diciembre de 1599, don Antonio de Berrio designa a dos maestros de la villa, Santiago de Sigüenza y Marcos de la Torre ${ }^{1451}$, para que redacten un informe en el que determinen la adecuación de la nueva capilla en el lugar escogido, opción que resultará inmediatamente desestimada. Nuestra Señora de las Capillas lindaba por el sur con la puerta del corral y con la caballeriza de Gaspar Ponce y por oriente con una plaza donde los vecinos vertían residuos y estiércol. El nuevo emplazamiento quedaba descartado no solo por su pésima ubicación sino “...porque demás que no tiene sitio capaz para poderse hazer coro ni sacristía, ni poderse alargar ni ensanchar quando se pudiera... ${ }^{1452, "}$. Tan es así que incluso recomiendan su derribo. Sin embargo éste no llegará hasta el año 1794, en que la fachada estaba desplomada y sin más retablo que los indispensables para poder celebrar misa dignamente. Por entonces era patrona doña María Ana de Sierra, primera marquesa de Villasante, quien, como tutora de su hijo,

\footnotetext{
${ }^{1450}$ VIGURI, Miguel de. Heráldica... 2. Op.cit, pág. 62, a su vez de AHPP. Carr.Prot 5446. Gregorio Movilla (1574-1576), s/f.

${ }^{1451}$ Sobre los mismos se hablará en el apartado relativo a los maestros.

1452 FERRERO MAESO, Concepción. "El mecenazgo...Op.cit, pág. 587.
} 
Miguel de los Santos Tejeiro y Sierra, obtiene permiso del Obispo de Palencia para llevarlo a cabo, trasladando la imagen de Nuestra Señora de la Paz y el sepulcro del comendador Ribera a la iglesia de Santiago ${ }^{1453}$. Si bien no fue construida la capilla de don Hernando, este espacio siguió utilizándose desde entonces al citado año de su demolición como capilla de culto por el linaje Berrio Ribera ${ }^{1454}$. El estrechísimo callejón donde originalmente se ubicaría parte de la iglesia de Nuestra Señora de las Capillas es hoy día conocido popularmente como "las Escapillas", a tenor de la corrupción del término.

\section{EL SIGLO XVII}

\section{El origen de San Julián}

La reacción del nuevo patrón, Don Antonio de Berrio, no se hizo esperar y una semana después de la emisión del informe desfavorable, el 15 de diciembre de 1598, redacta las capitulaciones referentes a la prohibición respecto a la incorporación de las capellanías en Nuestra Señora de las Capillas, comprometiéndose a erigir la capilla en otra iglesia de la villa que debía edificarse con las rentas de cuatro años de las susodichas capellanías, tal y como determinaba don Hernando de Berrio si no era posible la ubicación precedente ${ }^{1455}$.

La ingente labor desempeñada por don Antonio de Berrio es digna de mención, pues se enfrentó a muchas dificultades para poder cumplir con la voluntad de su tío. Tuvo que probar su hidalguía en 1598, pues, según se indicaba“...es menester para pasar en Yndias y otros usos... ${ }^{1456 ” . ~ D e s p u e ́ s ~ t u v o ~ p r o b l e m a s ~ p a r a ~ r e c i b i r ~ l a ~ d o t e ~ d e ~ d o n ~}$ Hernando, debiendo acudir en tres ocasiones a Sevilla -en los años de 1599,1600 y 1603- a realizar trámites de diversa índole, además de probar ante la justicia en 1605 que era el destinatario de la herencia en calidad de patrón y testamentario del maese de

\footnotetext{
1453 AHPP. Carr.Prot 5091. Ignacio Gutiérrez (1790-1796), s/f.

${ }^{1454}$ En 1663 son patronos de la capilla, Bernabé Berrio y doña Josefa Colmenares y Alarcón, viuda de Antonio Berrio Ribera, tutora y madre de Manuel Berrio. ACP. Provisorato. 7 de febrero de 1663.Colación de la capellanía de Nuestra Señora de las Capillas. Legajo 164, s/f. En 1699 era patrón su hijo, Manuel Antonio de Berrio y Ribera. ACP. Provisorato. Legajo 5.

${ }^{1455}$ Capítulos hechos por Don Antonio de Berrio en 1599, patrón de las capellanías del maestre de campo. Pleitos Civiles Pérez Alonso Rodríguez. Caja 0304.0010 Leg. 70, s/f.

${ }^{1456}$ El traslado de las probanzas de este pleito en AHPP. Carr.Prot 5773. Andrés Simón Aguilar (1667), fol 387 y ss.
} 
campo. Se dudaba de su persona porque aun siendo noble caballero, era hombre pobre y no se entendía que Don Hernando, teniendo "deudos parientes muy prinçipales riquezas" en la villa de Carrión, hubiese honrado con el patronazgo de las obras pías a alguien con tan escasos medios. Los testigos presentados por su parte justificaron la elección basándose en que se trataba de un buen cristiano que cumpliría con exactitud las mandas legadas ${ }^{1457}$. Llegó incluso a obtener una bula de Pío V el 19 de enero de 1606 que certificaba la veracidad de todo lo expuesto, que aprobada en 1608 le proporcionó finalmente, el fallo favorable ${ }^{1458}$.

Sin embargo, pasan los años y la herencia no llega. Aún así, en 1611, por evitar una mayor dilación, con las rentas que don Hernando de Berrio poseía en Carrión, Antonio de Berrio decide, previa obtención de licencia del Obispado de Palencia, suscribir con la iglesia de San Julián el patronazgo de don Hernando de Berrio sobre la capilla mayor, crucero, sacristía y torre. Sin embargo, los mayordomos y feligreses del templo reclaman nuevamente su restitución en 1615 mediante pleito judicial, basándose en la falta de cobros y en el hecho de que habían transcurrido demasiados años desde la muerte de don Hernando y no se habían comenzado las obras. Es por ello que Don Antonio desiste de su intención en San Julián, probando suerte en el convento de Santa Isabel para establecer la fundación. Sorprendentemente, en 1622, Don Antonio solicita que se anulen las escrituras firmadas con la abadesa, doña Isabel de Modoya Ponce de León y monjas de la casa terciaria, otorgándoles un poder “...para que acepten el patronazgo que el mayordomo, cura y parroquianos de San Julián de la villa de Carrión de nuevo me ofrecen...”.

Es probable que la fortuna del finado llegase por entonces de Panamá, lo cual suscitaría el interés de San Julián por el patronazgo. Para ellos resultaba muy beneficioso dado que la iglesia se encontraba “...muy arruynada y menoscabada...”. Por el nuevo contrato se ampliaba el patronazgo a todo lo que edificase, de manera que en cualquier lugar del templo, podría poner sus armas ${ }^{1459}$.

\footnotetext{
1457 Información y autos hechos a petición de Don Antonio Berrio de Rivera, por comisión del señor provisor de este Obispado de Palencia, para lo enviar a Roma. 1605. ACP. Provisorato. Carrión. Legajo $32, \mathrm{n}^{\circ} 3545$.

${ }_{1458}$ ACP. Provisorato. Carrión. 1608. Legajo 32, nº 3558.

${ }^{1459}$ FERRERO MAESO, Concepción. "El mecenazgo... Op.cit, pp. 588-589.
} 


\section{Construcción del nuevo templo}

\subsection{Trazas de Juan Gutiérrez Del Pozo}

Escogido el emplazamiento definitivo para la fundación de capellanías en la iglesia de San Julián, se realiza un proyecto de reedificación desde los cimientos, cuyas trazas fueron otorgadas en 1623 por el arquitecto Juan Gutiérrez del Pozo, veedor del Obispado de Palencia, con algunas modificaciones del carmelita Fray Antonio de Jesús. El artista palentino desarrolló su labor en Palencia, Burgos y Valladolid, en torno a la corriente clasicista, estética que condicionará decisivamente esta obra ${ }^{1460}$. Las condiciones del proyecto de Juan Gutiérrez, no las conocemos de primera mano, sino que figuran en el contrato que se compromete a cumplir el maestro de cantería Pedro Quintana, en quien se remató la obra tras bajar la puja de Bartolomé de Cabanzo ${ }^{1461}$. Pedro Quintana, que residía en Valladolid, logró adjudicarse los trabajos por 4.700 ducados, que daría concluidos en un plazo de cuatro años.

Entre las condiciones se determina que los zócalos del templo se realicen con piedra de cantería del término de la villa, reforzando las esquinas con piedra de Palacios o Monzón de Campos. La iglesia sería de ladrillo, jalonada por pilastras que subirían hasta el nivel de la cornisa, también en ladrillo, sin friso ni arquitrabe. Sobre los muros, asentaría los tejados con nudillos y soleras de pino procedentes de Quintanar o Canicosa, perteneciente a la comarca de Pinares, conocida por la calidad de su madera. A lo largo de la nave se optó por abrir huecos de media hasta de ladrillo, esto es, arcosolios destinados a cobijar altares. A los pies del templo, en la parte correspondiente al coro se haría un arco de ladrillo "a buelta de cordel”, y en la parte superior una bóveda de lunetos y un antepecho de balaustres de madera para asomarse al templo.

En el presbiterio se estipula el asentamiento de cuatro pilares de ladrillo de dos pies y medio de grosor para sustentar una cúpula central, trasdosada exteriormente con cuatro muros de ladrillo rematados con un sardinel, es decir con una sencilla moldura. La torre, realizada al igual que el templo en ladrillo, se ubicaría sobre la sacristía. En cuanto a la portada, debía ser de piedra de Villaescusa, con la esquinas de sillería

\footnotetext{
${ }^{1460}$ Sobre el mismo, véanse los datos relativos al mismo en el apartado de los maestros de cantería.

${ }^{1461}$ FERRERO MAESO, Concepción. "El mecenazgo... Op.cit, pp. 589-590, a su vez de AHPV. Protocolo 148, José de Frías Sandoval (1623) fol 819 y ss.
} 
procedente de Monzón o Palacios “...bien labrada a golpe de escoda y trinchantada...” haciendo el resto de muro de tapias revestidas de ladrillo dispuesto a tizón revocado posteriormente.

Como cabe esperar, transcurridos varios años, apenas habían avanzado las obras y la razón principal del lento avance, debemos buscarla en los problemas con la justicia de Don Antonio de Berrio ante la falta de pagos. En 1627 se enfrenta al concejo de Carrión por haber nombrado administrador de la obra pía a su hijo, Manuel de Berrio, quien debía seis mil ducados, según proveía la Real ejecutoria ${ }^{1462}$. En 1637 figura ya como patrón de la obra pía Don Manuel de Berrio ${ }^{1463}$. No obstante don Antonio de Berrio no debía haber fallecido aún, pues desde dicho año hasta 1640, los monasterios calzados de Nuestra Señora de la Merced y de la Santísima Trinidad de Valladolid incoan pleito contra él por el pago de doscientos ducados que Hernando de Berrio había dispuesto en su testamento para destinarlos a la redención de cautivos ${ }^{1464}$. Aquí no acaban los problemas, pues en 1638, el concejo de Carrión vuelve a denunciar a don Manuel de Berrio para que se anulase su nombramiento como mayordomo y se cobrasen las deudas contraídas. El corregidor Don Lope García Tovar, sugirió que dicho cargo debía nombrarlo él, bajo jurisdicción del obispo de Palencia y en cuanto a la falta de pagos, don Manuel se defendía de que no era culpa suya que la obra no estuviese aún afianzada, pues ya había tomado “...las delixencias conuenientes...” contra el maestro de la misma ${ }^{1465}$.

\subsection{Nuevas trazas de 1641}

El once de agosto de 1641, ante el lento transcurrir de las obras, don Manuel de Berrio y Ribera encarga nuevas trazas para el templo. Los responsables de las mismas son los maestros de cantería Jerónimo de Buega ${ }^{1466}$, vecino de San Mamés de Aras, en

\footnotetext{
${ }^{1462}$ ARCHV. Registro de Ejecutorias. Leg, 1263 Expediente 57 F.

${ }^{1463}$ Así figura en una obligación por la que se compromete a ingresar 1.200 reales en la caja del archivo que debía. AHPP. Carr.Prot 5420. Francisco Moro Saldaña (1637), s/f.

1464 ARCHV. Pleitos Civiles Pérez Alonso Rodríguez. Caja 304 Exp. 10 Leg. 70.

1465 FERRERO MAESO, Concepción. "El mecenazgo... Op, cit, pág. 589, a su vez de ARCHV. Fenecidos. Masas. Leg. 1584 (4).

${ }^{1466}$ Era hijo de un maestro de cantería, Domingo de Zorlado, y se esposó con Catalina de Naveda, hermana de Juan de Naveda, también dedicado al mismo oficio, VV.AA. Artistas...Op.cit, pág.. 96. Siguiendo las trazas de Fray Alberto de la Madre de Dios, en 1625 se adjudica en su persona la obra de las Carmelitas Descalzas de Guadalajara. MUÑOZ JIMÉNEZ, José Miguel. "Maestros de obras montañeses en la provincia de Guadalajara durante los siglos XVI y XVII” en Altamira, nº44 1983-1984,
} 
Cantabria y Bartolomé Fernández Lechuga ${ }^{1467}$. No poseemos las trazas originales con sus treinta y cuatro condiciones para saber cómo era el proyecto planteado, pero se refieren algunas de ellas en el contrato firmado en 1642 con el maestro Jerónimo de Avendaño. En él se rematan las obras por 7.550 ducados, tras superar en su oferta a los postores Miguel de la Vega, Francisco de Venero y Hernando de Hinestrosa ${ }^{1468}$. Natural de San Pantaleón de Aras, en Cantabria, Avendaño era vecino de Carrión de los Condes, por entonces, pues tiene varias obras documentadas en la villa por estos años. Hasta el momento no habían dado comienzo prácticamente las obras, pues el punto de partida para emprenderlas lo constituye la cimentación, que debe ahondarse una sexta parte de la medida de lo que se levante en superficie. A cada lado del templo debían abrirse seis ventanas y una vez hechas "se han de zerrar con emplenta de ladrillo".

Gracias a esta cláusula se explica la disposición de los seis vanos de la nave, dos por cada tramo, que fueron cegados inmediatamente después de haber sido realizados, y no como fruto de una reforma posterior, como era lógico pensar. El templo sólo se ilumina a través de la ventana del coro alto, colindante con la fachada, y a través de los vanos del transepto norte y sur. En el crucero se disponía una cúpula ornamentada con sus filetes “... a lo romano...”.

Jerónimo de Avendaño se había comprometido a finalizar los trabajos en un plazo de cuatro años: los dos años y medio primeros para ejecutar la obra hasta el nivel de las cornisas y el año y medio restante para darla concluida. En caso de incumplimiento, se acuerda que “...le pueda compeler y apremiar por justicia por presentación y enbargo de uienes..."de todos sus fiadores, que eran todos maestros dedicados a la construcción: Andrés de Zorlado, Juan de Trujeda y Francisco del Río,

pág. 209. En 1629, Juan de Naveda, a cuyo cargo estaba la obra de la capilla del Rosario de la Catedral de Santander, le otorga poder para que aclare sus cuentas con Juan de Hontañón. MUÑOZ JIMÉNEZ, José Miguel. "Juan de Naveda y la arquitectura del manierismo clasicista en la villa de Santander (16001630)" en Altamira, nº45, 1985, pág. 210. En 1636 se encontraba en Madrid, participando en la cárcel de Corte, colocando unas figuras y escudos. TOVAR MARTÍN, Virginia."La Cárcel de corte Madrileña: revisión de su proceso constructivo" en Revista de la Biblioteca, Archivo y Museo municipal, nº, 1980, pág. 16.

${ }^{1467}$ En 1632, junto a Juan González de la Mata, Lechuga realiza las nuevas trazas de la torre de Belén. ADP. Carrión. Iglesia de Belén. Libro 16, 4º de Cuentas de Fábrica (1616-1646), fol 183v.

${ }^{1468}$ FERRERO MAESO, Concepción. "El mecenazgo... Op.cit, pp. 591, a su vez de AHPP. Carr.Prot 4829. Francisco Cuetos (1641-1642), fol 279 y ss donde figuran la escritura y condiciones del contrato. Sobre Jerónimo de Avendaño y Hernando Inestrosa, véase el apartado relativo a los maestros de cantería cántabros y locales, respectivamente. 
maestros de cantería y Juan González de la Mata, maestro albañil ${ }^{1469}$. Desde 1642 en que comienzan las obras hasta 1656, en que deberían haber sido finalizadas, Avendaño recibe varias cartas de pagos anuales. En uno de los abonos de 1654, se pagan 1.632 maravedíes por revisar lo ejecutado a un maestro trasmerano, que por las fechas, probablemente fue el hijo del homónimo Juan de la Cuesta. En el pago se hace constar “...ser lustrosamente fabricada la dicha yglesia y tan zerca de perfeción con que sse logra el intento del fundador...", señal del avance de las obras ${ }^{1470}$. Durante todo este período ejerce como patrón el citado Don Manuel de Berrio, quien, por ser el primo de Don Manuel Ponce de León y Mendoza, adquiere en 1642 la sucesión del mayorazgo de éste, incluyendo las casas de la plaza de Santiago, donde residía, además del patronazgo de la capilla mayor de la iglesia homónima ${ }^{1471}$. Por entonces, el linaje había incorporado además los mayorazgos de Pedro Ruiz de Alarcón, de Colmenares y Villanuño de Valdavia $^{1472}$.

Aún en 1658 las obras no se habían concluido, dado que Avendaño es requerido por la justicia y denunciado por el patrón de San Julián, que a la sazón era don Antonio de Berrio y Ribera, primogénito de Don Manuel Berrio. Desde la cárcel, Avendaño otorga un poder al curador Pedro Pérez de Fresneda para que le defienda en el pleito ${ }^{1473}$. Parece que entre los vecinos de Carrión no había encontrado un fiador pues en 1659, solicita a su hijo Andrés, por entonces estudiante en la Universidad de Valladolid, que viajase a San Pantaleón, su villa natal, con el fin de buscar “...abonadores legos llanos, de que no saldré d'esta dicha uilla y de que estaré a derecho y de que pagaré lo juzgado y senttenciado... sobre que fenezca y acaue la obra y edeficio de la dicha yglessia... ${ }^{1474,}$. La falta de seriedad de Avendaño no fue óbice para que don Antonio de

\footnotetext{
${ }^{1469}$ Sobre todos ellos, véase el apartado relativo a sus datos biográficos.

${ }^{1470}$ Relación de pagos entre 1642 y 1647 en ADP. San Andrés. Fundaciones. Libro 68. Obra pía del libro de acuerdos (1633-66). Entradas y salidas de dinero (1635-1808), fol 426 y ss. En 1653 y 1654 recibe otras dos cartas de pago. AHPP. Carr.Prot 5436. Francisco Moro Saldaña (1654), s/f. Existe otra carta de pago de 1656 por 6.217 reales. AHPP. Carr.Prot 5468. Francisco Ochoa (1651-1657), s/f.

${ }^{1471}$ El traslado de la escritura fechada en 1642 en AHPP. Carr.Prot 5773.Andrés Simón Aguilar (1667) fol 375 y ss.

1472 VIGURI, Miguel de. Heráldica...2.Op.cit, pág. 63.

1473 AHPP. Carr.Prot 5767. Andrés Simón Aguilar (1658), fol 1.

${ }^{1474}$ FERRERO MAESO, Concepción. "El mecenazgo... Op.cit, pág. 591, a su vez de AHPP. Carr.Prot 5531, Tomás Pérez (1659), s/f.
} 
Berrio continuase concediéndole los pagos acordados, en tanto se resolvía el litigio, con el fin de que sus oficiales no se vieran afectados por su actuación ${ }^{1475}$.

De la colocación de las campanas y la ejecución del telar quedaba eximido Avendaño, por lo que estos trabajos fueron encomendados en noviembre de 1659 al maestro de cantería carrionés Bernardo Sánchez por ser el postor más bajo, pues aunque en la misma había pujado Francisco de Reinaldos ofreciendo 770 reales, éste la bajó a $500^{1476}$. Realizada completamente en ladrillo y de poca elevación, la torre está conformada por dos cuerpos separados por una amplia cornisa, también de ladrillo. En el último cuerpo, cubierto con un tejado a cuatro aguas, se abren cuatro vanos con su campana correspondiente, flanqueados por dos tableros de ladrillo que animan la superficie lisa del paramento.

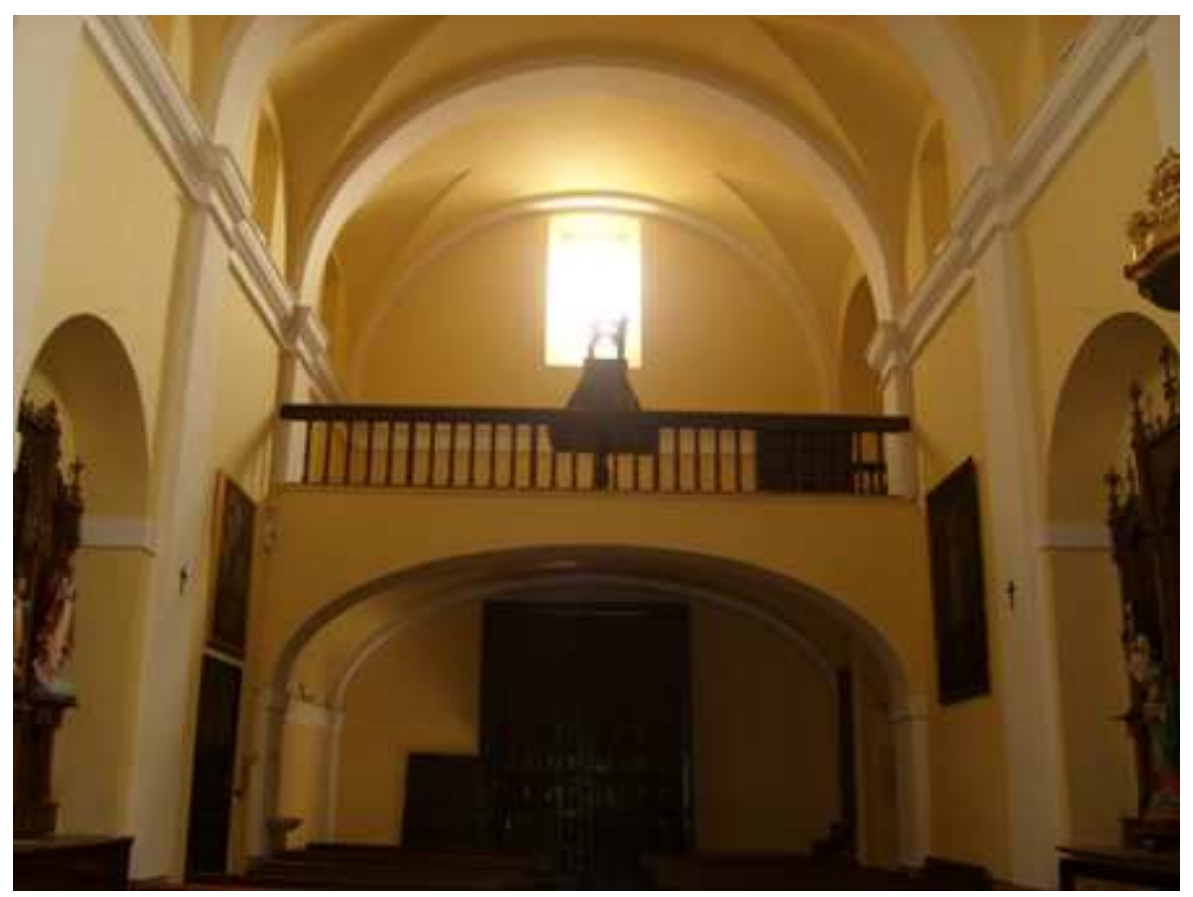

Interior del templo de San Julián hacia el coro.

\footnotetext{
${ }^{1475}$ El 20 de marzo de 1658 se otorga carta de pago y se desglosan los 63.282 reales abonados hasta el momento. AHPP. Carr.Prot 5767. Andrés Simón Aguilar (1658), fol 85 y 85v. El 20 de agosto de 1658 se indica haber abonado 1245 reales, con los cuales Avendaño da 400 para Francisco Cillero por ver la torre y 150 a Felipe Berrojo por el mismo cometido, 100 reales al escribano por los derechos del pleito y 500 reales para el socorro de los oficiales. AHPP. Carr.Prot 5767. Andrés Simón Aguilar (1659), fol 861 y ss.

${ }^{1476}$ FERRERO MAESO, Concepción. "El mecenazgo...Op, cit, pp. 591-592. La requisitoria en la que Avendaño se exime de la obligación de las campanas tiene fecha de 6 de septiembre de 1659. AHPP. Carr.Prot 5767. Andrés Simón Aguilar (1659), s/f. Las condiciones, postura y remate para hacer el telar y colocar las campanas en AHPP. Carr.Prot 5767. Andrés Simón Aguilar (1659), fol 1002 y ss. Sobre Bernardo Sánchez, véase el apartado dedicado a los maestros locales.
} 
Si bien tan sólo nos ha llegado una pequeña parte de las condiciones relativas a las dos trazas que tuvo el templo, podemos concluir, a tenor de su fisonomía, que la idea primitiva de Juan Gutiérrez del Pozo, siguiendo postulados clasicistas, fue retomada por Lechuga y Buega en 1641, pues todos sus principios fueron mantenidos. La iglesia fue realizada en ladrillo y cubierta con bóveda de cañón con vanos termales cegados. Tal y como se señalaba, la iglesia es de una sola nave, con pequeñas hornacinas de medio punto en los lados de sus tres tramos, cobijando el segundo de ellos, un pequeño retablo a cada lado, de moderna factura y escaso valor artístico. Los arcos fajones de medio punto que dividen la nave apean sobre pilastras y una cornisa encapitelada perfila el templo. En el presbiterio se empleó, como señalamos, una cúpula asentada sobre cuatro arcos de medio punto que, prolongándose en los brazos del transepto y en la capilla mayor, crean sendas bóvedas de cañón de escasa profundidad con lunetos cegados.

En la clave de la bóveda se hallan las armas de los fundadores, escudo idéntico a los que presiden la portada, salvo que en este caso los cuarteles se invierten a modo de imagen espejo y conserva aún la policromía original. La lectura de este escudo cuartelado y decorado con cueros recortados sería: 1, de Berrio, en campo de plata tronchado por una banda de sable acompañada de una cruz floronada de sable y de un águila de sable $\mathrm{e}^{1477}, 2$, de Torre, de blanco, castillo sable de tres torres de gules, pues el padre del fundador, don Hernando de Berrio, es Antón González de la Torre, 3, puede ser de Pachistre ${ }^{1478}$, cruz de sable floronada y cantonada de cuatro rosas y 4, de Ribera, de plata, tres fajas de sable. Bordura de armiños de sable y timbrado de yelmo.

En las cuatro pechinas de la cúpula del crucero figuran desglosadas estas armas en cuatro escudos timbrados con yelmo y lambrequines y con bordura de palos ecotados: Berrio, Torre, Ribera y Pachistre. Los colores que lucen los escudos de las pechinas con el campo de oro y el resto de motivos en blanco son producto de un enlucido moderno que se extendió sobre los antiguos sin ninguna contemplación.

\footnotetext{
${ }^{1477}$ En realidad sería en campo de plata, una banda de gules, en lo alto una cruz de Calatrava de sable, y en lo bajo, un águila explayada y coronada. GARCÍA CARRAFA, Alberto. "Berrio" en Diccionario heráldico y genealógico de los apellidos españoles americanos. Imprenta Antonio Marzo. Madrid, 1920, pp. 128-144.

${ }^{1478}$ VIGURI, Miguel de. Heráldica...2. Op.cit, pág. 53.
} 


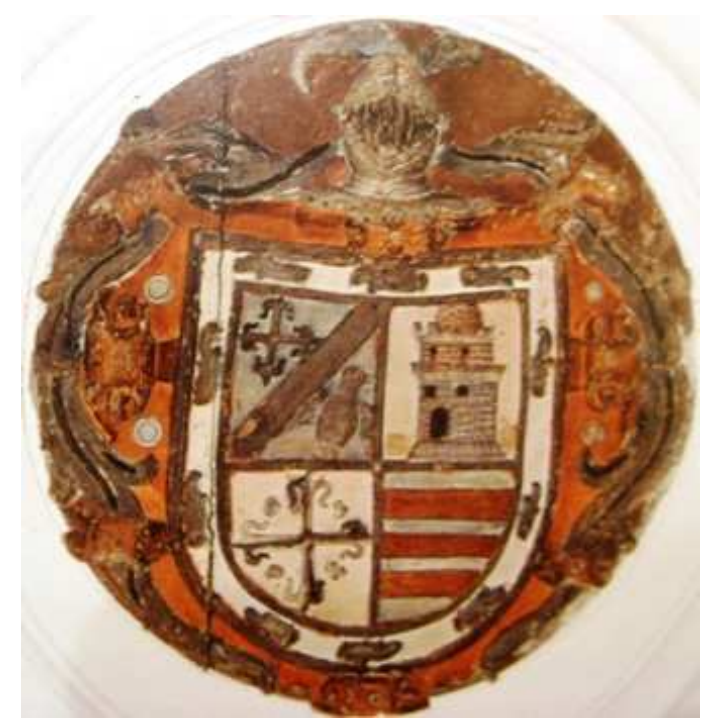

\section{Armas de Don Manuel de Berrio y Ribera, promotor de las obras del templo en la clave de la cúpula.}

En cuanto a la planta del templo, su tipología con la cruz latina de testero plano y capillas hornacina, responde al prototipo clasicista irradiado desde el foco vallisoletano, muy recurrente en la arquitectura conventual, como es el caso de las Agustinas Recoletas de Palencia.

Tal y como precisaba Gutiérrez del Pozo, en la fachada, ubicada en el lado sur, se empleó el ladrillo, aunque no está dispuesto a tizón sino que existe una alternancia con las hiladas a soga. Para la portada se reservó la piedra de sillería, tal y como se especificaba. Acorde a la estética imperante, en que la arquitectura prevalece sobre la ornamentación, una estructura adintelada con las dovelas marcadas, flanqueada por pilastras con un estrechísimo cajeado. Sobre la puerta sobresale una sencilla cornisa compuesta por un filete y un fino bocel y a partir de ésta, todo el muro es de ladrillo, exceptuando la hornacina y los escudos gemelos que se hallan sobre la misma. La escultura de San Julián, preside la portada, dispuesta sobre un basamento cajeado decorado con un motivo floreado. Lo flanquean dos escudos provistos de cueros recortados correspondientes al linaje de los Berrio y Ribera: 1, de Torre, 2, de Berrio, 3, de Ribera, y 4, posiblemente de Pachistre ${ }^{1479}$. Bordura de palos ecotados y timbrado de yelmo y lambrequines. En un nivel superior, en la parte central se abre una ventana que ilumina el coro alto y sobre la misma, remata la fachada en un frontón triangular de

${ }^{1479}$ Ibídem. 
ladrillo. La estructuración de esta fachada guarda a nuestro juicio, grandes analogías con otra portada clasicista: la el convento de Agustinas canónigas de Palencia, datada en la primera mitad del siglo XVII ${ }^{1480}$. Si bien resulta aquélla de mayor complejidad, por las orejetas de la portada, la presencia de bolas escurialenses o la prolongación de las pilastras cajeadas al segundo cuerpo.
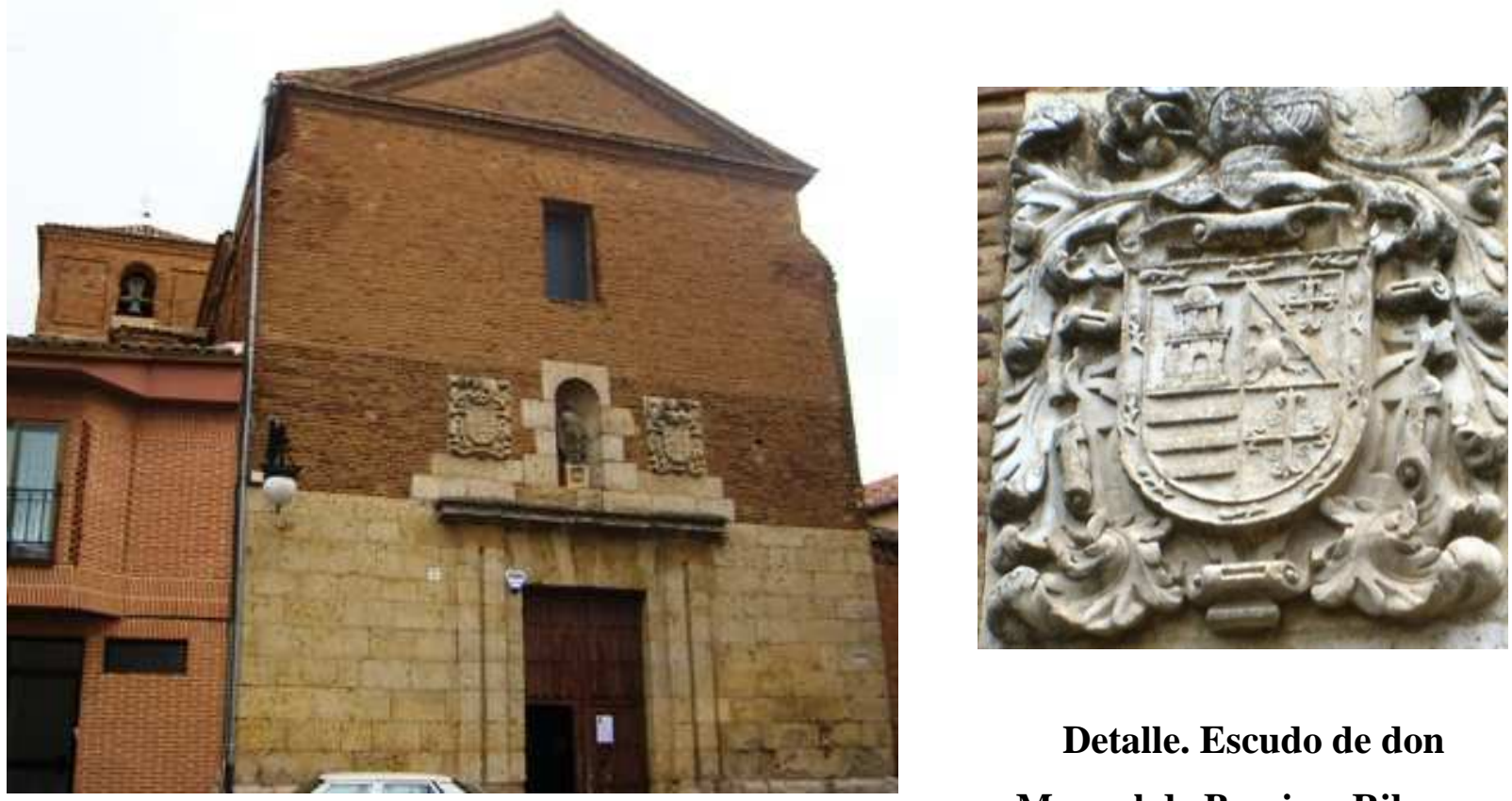

Detalle. Escudo de don Manuel de Berrio y Ribera.

Fachada del templo de San Julián con la torre al fondo.

Don Antonio de Berrio y Ribera continúa como patrón de San Julián hasta 1662 en que fallece, heredando sus bienes y patronazgo su viuda, doña Josefa María de Colmenares y Alarcón, dado que su primogénito era menor de edad ${ }^{1481}$. El hijo de ambos, don Manuel de Berrio y Ribera contrajo matrimonio con Isabel Ana de Villarroel Cabeza de Vaca, adquiriendo así los bienes del Marquesado de San Vicente, pertenecientes al padre de aquélla, Francisco de Villarroel. Don Manuel se convierte en el tutor de su sobrino Juan Antonio de Vozmediano, a quien administra los bienes a

\footnotetext{
${ }^{1480}$ URREA FERNÁNDEZ, Jesús y MARTÍN GONZÁLEZ, Juan José. Inventario...1. Op.cit, pág. 31.

${ }^{1481}$ En una carta de pago con fecha 7 de abril de 1662 para cobrar los bienes, juros y rentas relativos a la obra pía en la que la dicha doña Josefa declara la posesión judicial de dicho patronato AHPP. Carr.Prot 5772. Andrés Simón Aguilar (1666), fol 299.
} 
partir de 1692 por ser aún menor ${ }^{1482}$. Durante su patronato, el ensamblador y carpintero carrionés Manuel de Salceda, debió realizar algunas intervenciones como así consta en su testamento, dictado en 5 de mayo de 1679, en el que asegura que se le habían abonado 1.929 reales “...en quenta de la obra del altar mayor y colaterales de la dicha yglessia... ${ }^{1483}$ ". Dado que los retablos no se comienzan hasta las postrimerías de siglo, probablemente debió tratarse de una reja de madera, como realizaría en la capilla del Licenciado Antonio Pastor, en Santa María, unos años antes, o una labor del estilo. Su muerte le impidió finalizarlos, de ahí que en 1682 sus herederos se vean obligados a devolver una suma que ya tenía recibida: “...se bajan del cuerpo de bienes nuebeçientos y veinte y seis rreales que se están debiendo a la yglesia de San Julián d'esta uilla por los mismos que tenía rresçiuidos de más ${ }^{1484}$. Unos años después, en 1696, se registra una adquisición de madera procedente de Osorno, destinada, tal vez, para la ejecución de los retablos ${ }^{1485}$.

\section{EL SIGLO XVIII}

\section{La ejecución de los retablos}

Cuando en 1699 se concierta la ejecución del retablo mayor y los dos adosados en el brazo norte, seguía siendo patrón de San Julián, don Manuel Antonio de Berrio y Ribera, que al menos lo ostentará hasta 1736 , en que dicta testamento ${ }^{1486}$. Los tres retablos fueron contratados por el maestro vallisoletano Blas Martínez de Obregón y Pedro de Solana por 11.000 reales $^{1487}$. A consecuencia del fallecimiento de este último “...al principiar de dicha obra...”, Obregón se hizo cargo de la misma, la cual finalizó en 1701, tal y como había estipulado, emitiendo carta de pago el 26 de diciembre de

\footnotetext{
1482 AHPP. Carr.Prot 5017. Agustín García Miranda (1691-1695), s/f.

${ }^{1483}$ Sobre Manuel de Salceda, remítase al capítulo dedicado a los maestros y ensambladores locales.

${ }^{1484}$ El testamento de Manuel de Salceda en AHPP. Carr.Prot 5889, Blas Vela Álvarez (1679-1681), fol 274 y ss. Bajas del cuerpo de hacienda en AHPP., Carr.Prot 5897. Blas Vela Álvarez (1686-1705), s/f.

1485 AHPP. Carr.Prot 5018. Agustín García Miranda (1696-1698), s/f.

${ }^{1486}$ Véase el árbol genealógico de los Berrio Colmenares en VIGURI, Miguel de. Heráldica...2. Op.cit, pp. 71-72.

${ }^{1487}$ FERRERO MAESO, Concepción. "El mecenazgo...Op, cit, pp. 594, a su vez de AHPP. Carr.Prot 5019. Agustín García Miranda (1699-1700), s/f. Pedro de Solana estaba avecindado en la localidad trasmerana de Ajo. Sólo se le conoce una obra, el retablo mayor de la iglesia parroquial de Lantadilla, que realizó junto a Lorenzo Zuibelos en 1697. URREA FERNÁNDEZ, Jesús y MARTÍN GONZÁLEZ, Juan José. Inventario...I, Op.cit, pág. 187.
} 
dicho año. Finalmente recibió 13.996 reales, precio más elevado que el convenido, en concepto de las mejoras ejecutadas sobre los mismos ${ }^{1488}$.

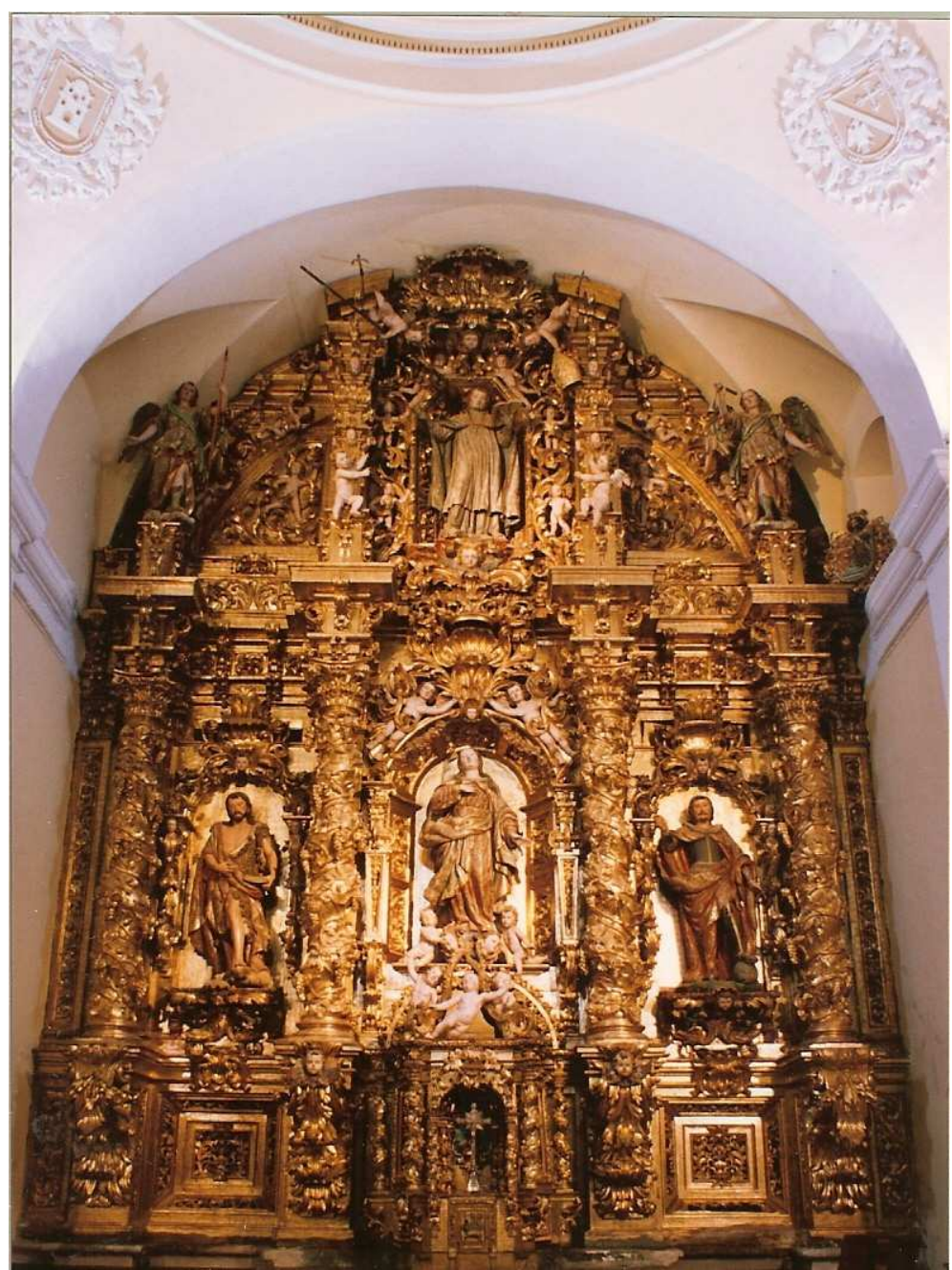

Retablo mayor de la iglesia de San Julián. 1699. Trazado por Diego de Suano y ejecutado por Blas Martínez de Obregón (8mtrx7mtrx2mtr).

Los retablos estaban terminados en lo que a su arquitectura se refieren, pero aún carecían de escultura, pues esta no se incluía en el contrato. La ejecución de la misma se contrató en mayo de 1706 con Pedro del Mazo Vélez, vecino de Entrambasaguas como autor de los treinta bultos “...de diferenttes santos y ánjeles pequeños y grandes...” que habrían de finalizarse en año y medio. Era condición sine qua non la ejecución de todas

${ }^{1488}$ IbIbídem, pág. 594, a su vez de AHPP. Carr.Prot 5020, Agustín García Miranda (1701-1704), s/f. Sobre Blas Martínez Obregón, véase el capítulo dedicado a la biografía de los escultores. 
ellas en madera de Soria, probablemente de pino, salvo los rostros y manos, en madera de peral. Las cabezas se determinó que fuesen huecas “...para mayor duración...” y “...para que en ningún tiempo venttee la madera...” y en ellas se incrustarían los ojos de cristal. También los cuerpos debían ser ahuecados, aunque eso no significa que no estuviesen tallados por la parte posterior, sino al contrario, pues “...de todas dichas hechuras, ha de ir también hecha espaldas como fachadas... ${ }^{1489}$ ". De Pedro del Mazo apenas se conocen datos, pero es segura su procedencia cántabra, a tenor de la abundancia del patronímico en la región, propia de maestros de cantería y doradores, que pudieron estar vinculados familiarmente ${ }^{1490}$. Una vez realizadas y asentadas todas las esculturas, habría que someterlas a juicio del escultor Juan Antonio de la Peña, vecino de Valladolid o de Tomás de Sierra ${ }^{1491}$, vecino de Rioseco, el que prefiriese don Manuel Antonio de Berrio, para que diesen su aprobación. El informe resultaría positivo, dada que en julio de 1711, Pedro del Mazo recibe los 9.000 reales estipulados $^{1492}$.

Para evitar repeticiones innecesarias acerca del estilo del escultor, avanzamos que recurre a unos tipos físicos con un rostro de perfil cuadrado, caracterizado por la expresión lánguida a través de los párpados ligeramente caídos. La nariz suele ser larga y fina y la barbilla marcada con incipiente papada. En lo que respecta al modo de trabajar las vestimentas, éstas suelen tener un gran volumen y un tratamiento artificioso, pues en ocasiones parecen flotar al nivel de la cintura de los personajes. La ampulosidad de los mantos confiere gran elegancia a sus figuras, incluso en el caso de figuras de condición humilde. Todas ellas están dotadas de un suave dinamismo a través de la disposición adelantada de una de las piernas, ya sea insinuada por la túnica, como en la

1489 IbIbídem, pp. 596-598. La escritura para la realización de estas esculturas en 1706 la encontramos en AHPP. Carr.Prot 5021. Agustín García Miranda (1705-1709) s/f.

${ }^{1490}$ Aparte de esta obra, en 1722 está documentada su participación en la escultura del retablo de la capilla mayor de Santa María de Bárcena de Cicero, en Santander, ensamblado por Bartolomé de la Bodega. POLO SÁNCHEZ, Julio J. Arte barroco en Cantabria: retablos e imaginería (1660-1790). Santander, 1991, pág. 197 y 293. Posiblemente, junto a él se formó Pedro Martínez del Mazo, a tenor de la semejanza que presentan algunas de las esculturas de este retablo con las que Vélez ejecuta en la iglesia de San Andrés. Véase el capítulo dedicado a las obras de arte del templo mencionado.

${ }^{1491}$ No es la primera vez que Tomás de Sierra y Blas Martínez de Obregón intervienen en una misma obra. En la iglesia vallisoletana de Villalba de los Alcores, perteneciente antiguamente al Obispado de Palencia Martínez de Obregón se encarga del ensamblaje del retablo desde 1691 y Sierra lleva a cabo el relieve de Santiago Matamoros del ático en 1692-3. Del resto de la escultura se encargaron Antonio Vázquez y Manuel Ordóñez. Por su parte Cristóbal de Honorato interviene en ciertos aspectos de la traza del cascarón del retablo. PARRADO DEL OLMO. Jesús María. "La colaboración entre ensambladores... Op.cit, pp. 401-420. Sobre Tomás de Sierra, remítase al capítulo dedicado a las biografías de los escultores.

${ }^{1492}$ FERRERO MAESO, Concepción. "El mecenazgo...Op, cit, pp. 597-598. 
Asunción, en San Antonio Abad o en el santo titular del templo, ya mostrada directamente, como en los ángeles trompeteros o en San Juan Bautista.

En 1751 el visitador del Obispado determina la necesidad de que los tres retablos sean dorados con la hacienda que dejó el principal benefactor del templo, Don Hernando de Berrio. Para ello se concertó con el dorador y pintor palentino Francisco Gutiérrez, quien, dicho año realizaría el dorado de la custodia e imágenes del retablo mayor y de los colaterales ${ }^{1493}$. En 1755 prosiguió por el dorado de la parte arquitectónica del retablo mayor y finalmente, en 1759 doró “...los quattro tronos y guarniziones..." de los retablos colaterales ${ }^{1494}$.

Entretanto, en 1757, se otorga carta de pago al dorador carrionés Cayetano Bodigos por estofar las cuatro imágenes de los retablos laterales y encarnar los serafines ubicados en los mismos ${ }^{1495}$. Bodigos participará junto a Gutiérrez en 1762 en el retablo de Nuestra Señora de la Asunción de la iglesia de Villamuriel de Cerrato ${ }^{1496}$. En Carrión está documentada su intervención en el dorado de la escultura de San Ramón Nonato del retablo de San Francisco Javier de la iglesia de San Andrés en 1766, realizada por el carrionés Miguel Feliz ${ }^{1497}$. Por estos años, don Manuel de Berrio había fallecido y ahora ostentaba el patronazgo el segundo de sus hijos varones, don Raimundo de Berrio, presbítero de profesión. Éste lo había adquirido por la defunción de su hermano y primogénito de don Manuel, don Francisco Antonio de Berrio Rivera y Villarroel, capitán del Regimiento de infantería de Granada y señor de San Andrés de la Aldea, la Torre y de las casas de Colmenares, quien lo ostentaba al menos desde $1740^{1498}$.

Tan sólo faltaban de dorar los retablos colaterales, labor de la que se encarga el carrionés José Gallego en 1781. Para ello, fueron traídos 28.050 panes de oro desde Valladolid, con los que además se repararon algunos desprendimientos del retablo

\footnotetext{
${ }^{1493}$ Ibídem, pág. 598, a su vez de ADP. San Julián, libro nº17.

${ }^{1494}$ Escritura y contrato firmado el 16 de marzo de 1755. AHPP. Carr.Prot 4606, Francisco Blanco Manuel (1755), fol 112 y ss y los diferentes pagos por la obra, por valor de 5.700 reales en ADP, San Julián. Libro 17 de Cuentas de Fábrica (1747-1849), fol 12,12v y 44 y 79. Sobre Francisco Gutiérrez, remítase al capítulo dedicado a los pintores locales.

${ }^{1495}$ También se contrata al ensamblador Bernardo de Triana, vecino de Carrión para que ejecutara dos alas y dedos de los ángeles que se habían desprendido y otras partes quebradas. ADP. San Julián. Libro 17 de Cuentas de Fábrica (1747-1849), fol 60v.

${ }^{1496}$ AHPP. Carr.Prot. 4722. Antonio Ceano Vivas (1759-1762), fol 29.

1497 ADP. Carrión. San Andrés. Libro 5º de Cuentas de Fábrica (1753-1795), fol 241 y 244.

1498 AHPP. Carr.Prot 4599.Francisco Blanco Manuel (1740-1741), fol 211.
} 
mayor $^{1499}$. Por entonces era patrona doña Manuela Antonia de Berrio, hermana de don Manuel Antonio de Berrio y tía de don Raimundo, pues éste, dada su condición religiosa, había fallecido sin heredero. Su enlace en 1673 con Don Juan Barba de Vozmediano, señor de Calzadilla y Bustocirio, va a suponer el acceso de este linaje al patronazgo, perdiéndose a partir de entonces el apellido Berrio ${ }^{1500}$.

\subsection{El retablo mayor}

Si bien el retablo fue llevado a cabo, como indicamos, por Blas Martínez de Obregón, la traza del mismo correspondió al ensamblador cántabro Diego de Suano, trabajo previo a su obra maestra, el retablo de Santiago de Medina de Rioseco ${ }^{1501}$. El retablo mayor (8mtrs x $7 \mathrm{mtrs} \times 2 \mathrm{mtrs}$ ), ofrece la estructura típica del retablo plenamente barroco con banco desarrollado, un cuerpo con cuatro columnas salomónicas con cornisa muy volada $\mathrm{y}$, por último, remate semicircular que se adapta al muro presbiterial.

El banco está conformado por dos tableros cuadrangulares provistos de una decoración muy plana con labores vegetales a trépano. Entre ellos se ubican los pedestales de los soportes del cuerpo principal, con hojarasca enroscada de gran volumen, presididos los dos centrales por cabezas de querubines. Esta exuberante ornamentación de los plintos es idéntica a la empleada en los retablos colaterales de la iglesia de San Andrés, ejecutados en 1714, de análogo estilo.

En el centro se ubica el tabernáculo $(222 \mathrm{~cm}$ x $160 \mathrm{~cm}$ x $120 \mathrm{~cm})$, cuya ejecución se debe al ensamblador Santiago Carnicero, que no respetó la planta estipulada de doce columnas $^{1502}$. No se trata de una estructura independiente, sino que se adosa al mismo, de modo que, aunque el artista ha tallado tan sólo tres de sus lados, el efecto visual logrado a través de su contemplación frontal, es el de un templete hexástilo. Sustentado

\footnotetext{
${ }^{1499}$ ADP. Carrión. San Andrés. Libro $5^{\circ}$ de Cuentas de Fábrica (1753-1795), fol 196.

1500 Las capitulaciones matrimoniales entre ambos en AHPP. Carr.Prot 5708. Norberto Sandoval y Guevara (1673), fol 444.

${ }^{1501}$ Sobre Diego de Suano, remítase al capítulo dedicado a la biografía de los escultores y ensambladores.

${ }^{1502}$ FERRERO MAESO, Concepción. "El mecenazgo en Actas...Op.cit, pág. 595, a su vez de AHPP. Carr.Prot 5019. Agustín García Miranda (1699-1700), s/f. Sobre Santiago Carnicero, remítase al capítulo dedicado a la biografía de los escultores y ensambladores.
} 
por cuatro columnas salomónicas de tres espiras, los lados oblicuos están recubiertos por bajorrelieves con jarrones de azucenas, alusiones marianas por excelencia. En el frente del baldaquín, se encuentra el sagrario en la parte baja, decorada con un relieve del Agnus Dei en la puerta y sobre el mismo, cobijado bajo arco de medio punto, el expositor, que alberga una cruz de pie, realizada en plata, con un relieve del Crucifijo adosado en su parte frontal y cuatro haces de rayos emergiendo de la parte posterior. Ha debido sustituir a una cruz de madera de peral de media vara de alto (unos $40 \mathrm{~cm}$ ) que se incluyó entre las esculturas que debía ejecutar Pedro del Mazo, destinada a la custodia $^{1503}$. El copete del tabernáculo está conformado por cuatro finos roleos que, desde los ángulos se elevan convergiendo en el centro y en los huecos existentes entre ellos, se encaraman cuatro amorcillos en posturas diversas con los brazos extendidos.

Dividido en tres calles, el cuerpo central está compartimentado, tal y como establecen las condiciones en “...quattro colunas salomónicas rebestidas de ojas y rrazimos y vastagos con capiteles corintios compuestos..." y dos pilastras cajeadas que cierran el conjunto por los extremos, cuyos frentes están decorados con una profusa talla vegetal.

A los lados se disponen dos hornacinas de escaso fondo que motivan la presencia de peanas de amplio desarrollo para disponer las imágenes de bulto. Están conformadas por un nutrido follaje coronado por una diminuta cabeza de querubín. En las jambas se adosa una espesa hojarasca envuelta caprichosamente sobre sí misma, rematada con una testa humana al nivel de las impostas, a modo de termes.

En la rosca continúan los rameados, interrumpidos en su parte central para alojar una cabeza alada sobre la cual se abre un motivo cactiforme que se prolonga hasta el friso. En el contrato se determina que en los extremos del retablo se dispongan las figuras de San Juan Bautista y San Fernando, de unas dos varas de altura, dimensiones que fueron respetadas. En el lado izquierdo hallamos a San Juan $(166 \mathrm{~cm} \times 75 \mathrm{~cm})$, barbado y de larga y lamida melena, cubierto con su “...zamarra peloteada...” y un manto que cubre su hombro derecho. No obstante ambas prendas dejan al descubierto una parte importante de su cuidada anatomía, mostrando los brazos, el torso y el muslo

${ }^{1503}$ AHPP. Carr.Prot 5021. Agustín García Miranda (1705- 1709) s/f. 
izquierdo, que emerge entre la piel de camello para apoyarse en una pequeña roca. Sobre el libro, que porta en su mano izquierda, se ubicaba un cordero desaparecido, al que señalaba el santo eremita con su dedo índice y también ha perdido la caña, que recogía con su brazo izquierdo. Su rostro hierático y cuadrado, de lánguida expresión encuentra su gemelo en la representación del lado frontero, donde hallamos al rey San Fernando $(167 \mathrm{~cm} \times 110 \mathrm{~cm})$, aunque en este caso ha sustituido la barba por un fino bigote y elegante perilla. Responde a una devoción que despertó en territorio hispano, notablemente en la zona andaluza, a raíz de su canonización en 1671. La estampa editada en Roma por el artista francés Claude Audran fijó el modelo iconográfico del monarca de Castilla, con ejemplos tan representativos como los de las seos de Valladolid, Zamora o Palencia. Para ello recurrió a una representación acorde a la moda de Felipe II: armadura completa como indumentaria de índole guerrera, gola, puños almidonados y manto real ${ }^{1504}$.

Efectivamente, en nuestro caso, el rey santo mantiene todos esos elementos salvo los puños que han sido suprimidos y la gola, aunque existente, carece del desarrollo habitual. En las condiciones se dispone que se disponga con su “...mundo, cetro y corona... ${ }^{1505 ",}$, habiendo perdido ésta última. En las manos porta el cetro y la empuñadura de una espada y en cuanto al orbe, que suele sustentarse en la mano izquierda, ha sido trasladado a los pies del santo, donde descansa bajo su pie alzado, confiriéndole un suave dinamismo. La rigidez de la armadura, fileteada de oro, se contrapone al ampuloso manto de tonalidades rojas que envuelve la figura dotándole de un gran volumen.

En el centro, sobre dos estípites de forma tronco piramidal invertida, apea un arco de medio punto abocinado, del que penden sendas guirnaldas, con su intradós provisto de rameados, motivo que se repite en las jambas dispuestas oblicuamente. La imagen que preside esta hornacina es la Asunción $(200 \times 90 \mathrm{~cm})$, para la que se dispuso un acompañamiento de siete ángeles: dos en la parte superior coronándola, dos en el medio, con atributos de la Virgen y tres a los pies “...como que le tienen en el ayre vien

\footnotetext{
${ }^{1504}$ REVILLA VIELVA, Ramón. “San Fernando en el arte palentino” en PITTM, nº, Palencia, 1952, pp. 141-142 y URREA FERNÁNDEZ, Jesús. "San Fernando en Castilla y León” en BSAA, n52, Valladolid, 1986, pp. 484-487.

${ }^{1505}$ FERRERO MAESO, Concepción. "El mecenazgo en Actas...Op.cit, pág. 596, a su vez de AHPP. Carr.Prot 5021. Agustín García Miranda (1705- 1709) s/f.
} 


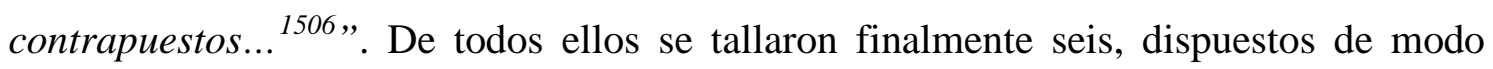
diferente al acordado, lo cual está justificado por la adaptación al hueco de la hornacina, de modo que los ángeles del medio se ubican en la parte inferior, sentados en la repisa y entre ellos les acompañan dos cabezas de querubines a modo de peana. Los ángeles que debían situarse en la parte superior han sido desplazados a la rosca del arco, dado su tamaño y se aferran a un motivo cactiforme de colosales dimensiones que remata efectivamente en una gran corona imperial, que llega al nivel de la cornisa. La Virgen presenta una imagen muy propia del barroco, con la melena larga y ondulante cayendo por delante, la pose delicada a través de la mano señalando al pecho y las telas muy movidas que envuelven su figura. Rasgos inherentes a Pedro del Mazo los hallamos en el mentón marcado, la papada emergente y los ojos pequeños de afable expresión.

Sobre el cuerpo principal se retranquea la cornisa en tres sectores, correspondientes a las calles respectivas sobre las que se sitúa, de manera que sobresalen de la línea general del retablo los cuatro cimacios correspondientes a los soportes. En el frente de la cornisa se han tallado florones en alternancia con modillones de tallos enroscados. El ático, de perfil semicircular está conformado por dos tableros laterales de perfil curvo en los que se han esculpido “...vnos niños enrredados entre la talla... ${ }^{1507, " . ~ E n ~ l o s ~ e x t r e m o s, ~ s o b r e ~ e l e v a d o s ~ p l i n t o s, ~ s e ~ e s t i p u l o ́ ~ l a ~ u b i c a c i o ́ n ~ d e ~ d o s ~}$ ángeles “...con sus túnicas y vandas y deferencia en la planta y vestir” que sostuviesen

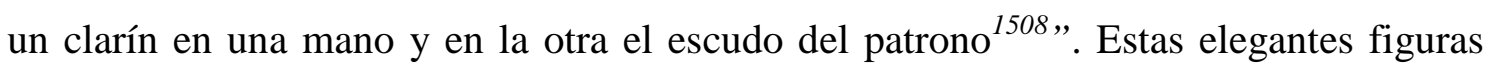
$(150 \mathrm{~cm} \times 100 \mathrm{~cm})$ de amplias alas desplegadas, adelantan una de sus piernas dejando entrever sus rodillas entre los paños de la túnica y las botas altas que calzan.

Finalmente se decidió que sólo una portase el instrumento, asiendo la otra una lanza, dejando la otra mano libre. Las armas del patrono fueron ubicadas en los extremos del retablo, descansando junto a los plintos. Tan sólo se ha conservado uno de los escudos, perteneciente a don Manuel de Berrio y Ribera. Eso explica que experimente cierta variación respecto a los escudos de la fachada y la cúpula. El escudo cuartelado posee la lectura que detallamos: 1, de Pachistre, campo de gules, cruz de oro cantonada de cuatro rosas de oro. 2, de Berrio, de sable tronchado por una banda de

\footnotetext{
${ }^{1506}$ IbIbídem.

${ }^{1507}$ AHPP. Carr.Prot 5019. Agustín García Miranda (1699-1700), s/f.

${ }^{1508}$ FERRERO MAESO, Concepción. "El mecenazgo en Actas...Op.cit, pp. 596-597, a su vez de AHPP. Carr.Prot 5021. Agustín García Miranda (1705-1709), s/f.
} 
plata acompañada de una cruz floronada de plata y de un águila de oro. 3, de Mendoza, de gules con una banda de oro ${ }^{1509}$. 4, de Colmenares, cinco flores de lis de oro. Escusón en abismo de Torre, una torre, entado en punta de sinople, fajado de azur. Bordura cargada de palos ecotados de sinople. Timbrados con yelmo y lambrequines dorados. En el centro, sobresale el cuerpo principal, formado por dos estípites apeados sobre altos pedestales en los que reposan dos angelillos desnudos. En la hornacina central, de perfil poligonal e intradós abocinado hallamos la imagen titular rodeada por un coro de ángeles envueltos entre rameados que ocultan sus partes púdicas. La indumentaria de San Julián $(160 \mathrm{~cm} \times 120 \mathrm{~cm})$ con el alba, estola, capa pluvial y guantes, como corresponde a dignidad episcopal.

Tal y como se estipuló, dos ángeles aparecen volando, en posición invertida, para hacerle entrega de su mitra y báculo. Se trata por tanto del Obispo de Cuenca y doctor en teología y filosofía de la Universidad de Palencia, lo que explicaría su veneración en la provincia castellana. En este caso, la caída de la vestimenta del santo del siglo XII es mucho más naturalista que en el resto de esculturas de este retablo, con un despiece paralelo de los pliegues. Por encima de la hornacina del santo titular, un motivo cactiforme similar al de las calles laterales pero de mayor tamaño irrumpe, rompiendo el frontón curvo que emerge de los laterales.

Este grandioso y abigarrado retablo podríamos situarlo en la etapa intermedia de la producción de Diego de Suano, dentro de un barroco avanzado, prácticamente churrigueresco, en la que abandona los rígidos esquemas de su época precedente, patentes en el retablo burgalés de la Asunción de Villasandino, para presentar innovaciones estructurales como los entablamentos partidos que dotan a la obra de un sentido ascensional y unitario, y el uso del estípite como soporte combinado con la columna salomónica, que Suano emplea por vez primera en el retablo de la iglesia de San Pedro de Lerma.

En lo que a ornamentación se refiere, aquí se conjugan los tradicionales motivos cactiformes o los festones del cuerpo principal con otros más innovadores como los ángeles atlantes de las ménsulas. En este sentido, observamos grandes analogías con los

${ }^{1509}$ El apellido procede del abuelo de don Manuel: Francisco de Colmenares Hurtado de Mendoza, por vía materna, de su madre doña Josefa de Colmenares. VIGURI, Miguel de. Heráldica...2, Op.cit, pág. 65. 
retablos burgaleses de Villalmanzo, de hacia 1693 y el de la iglesia parroquial de Villalbilla, abonado en $1699^{1510}$, que constituyen, a nuestro parecer, la antesala de la realización carrionesa.

El ejecutor del retablo, Obregón, también estaría familiarizado con retablos de similar tipología arquitectónica al nuestro, como el de la capilla mayor de la iglesia de San Quirce de Valladolid, ejecutado por Francisco Billota entre 1689 y 1691, pues Obregón realizaría poco después los retablos colaterales. Ambos son tetrástilos y salomónicos, con remate semicircular y entablamentos partidos, en la línea de lo que Billota venía ejecutando en otros retablos coetáneos vallisoletanos los de la iglesia parroquial de Pozaldez, San Felipe Neri o las Brígidas ${ }^{1511}$.

La calidad técnica de este retablo dejó una impronta perpetua en la memoria de algunos historiadores. Un detractor del barroco como Madoz que criticó la abigarrada

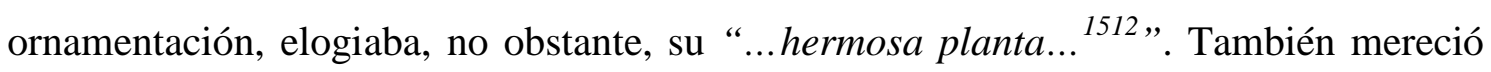
la admiración de Ramírez Helguera, quien llegó a afirmar que probablemente el retablo mayor fuese uno de los mejores de Carrión, por “...sus efigies de bulto y gran tamaño... ${ }^{1513, "}$

\footnotetext{
${ }^{1510}$ Sobre estas obras PAYO HERNÁN, Jesús. "El retablista barroco...Op.cit, pp. 170, 173-174 y del mismo, El retablo barroco en Burgos...volumen 2.Op.cit, pp. 149 y 154-155.

${ }^{1511}$ Sobre la familia Billota, véase MARTÍN GONZÁLEZ, Juan José. Escultura...Op.cit, pp. 305-313.

${ }_{1512}^{12}$ MADOZ, Pascual. Diccionario...Palencia. 1984. Op.cit, pág. 69.

${ }^{1513}$ RAMIREZ DE HELGUERA. El libro...Op.cit, pág. 165.
} 


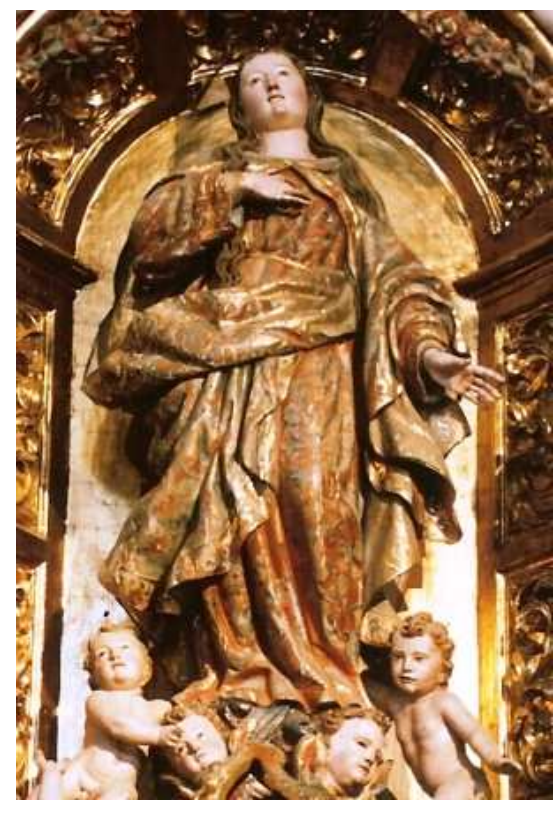

Asunción. (200cmx90cmx75cm).

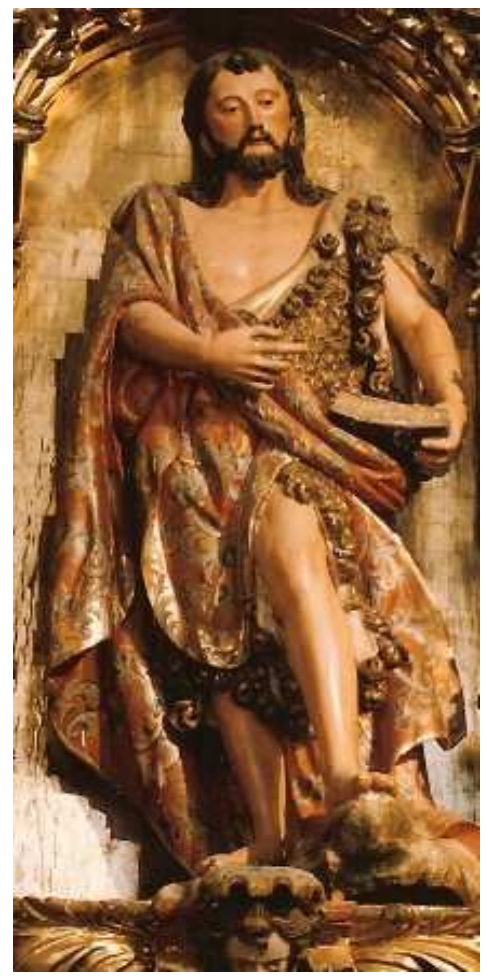

San Juan Bautista $(166 \mathrm{~cm} \times 75 \mathrm{~cm} \times 59 \mathrm{~cm}) . \quad$ San Fernando $(167 \mathrm{~cm} \times 110 \mathrm{~cm} \times 65 \mathrm{~cm})$.

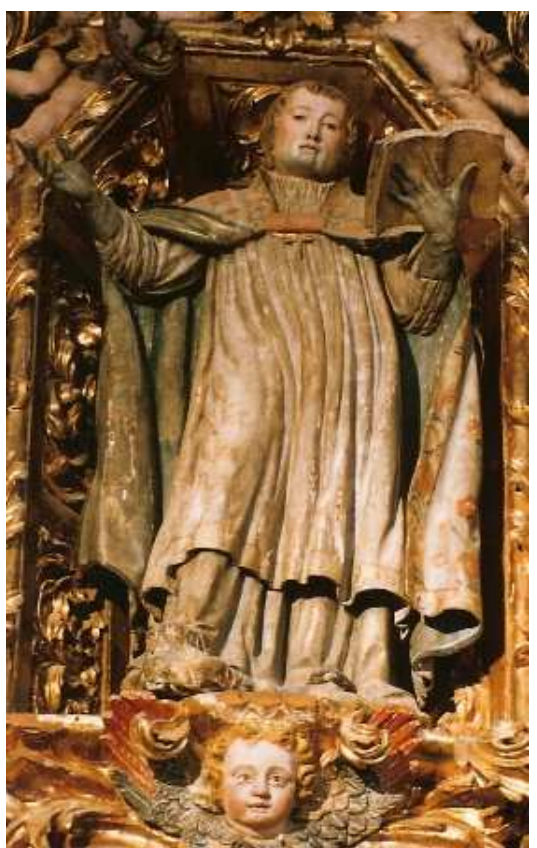

San Julián $(160 \mathrm{~cm} \times 120 \mathrm{~cm} \times 65 \mathrm{~cm})$.

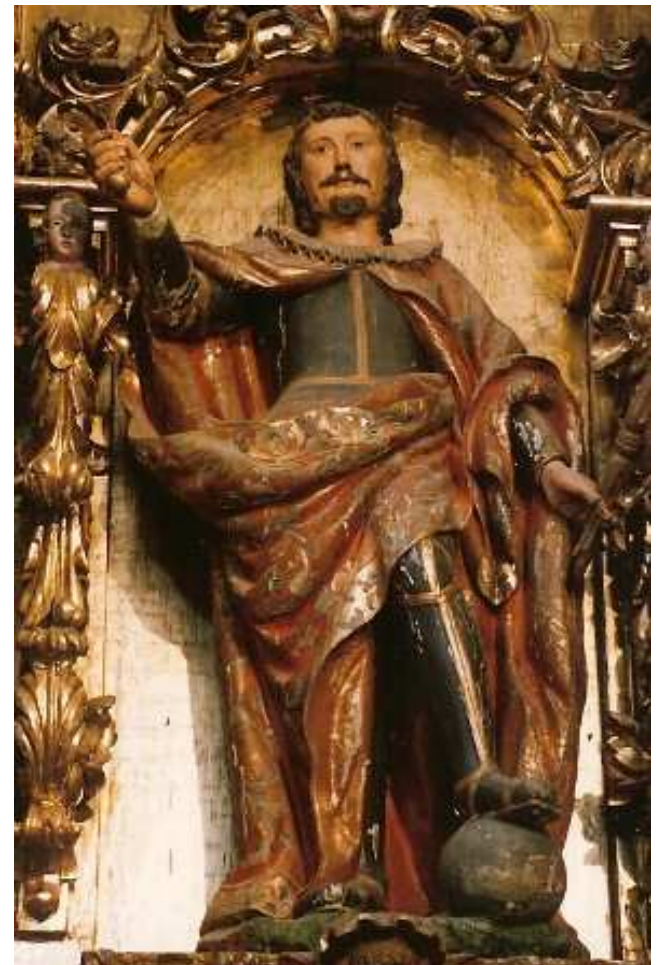

Esculturas del retablo mayor de la iglesia de San Julián.

1703. Pedro del Mazo Vélez. 


\subsection{Los retablos colaterales}

Estos retablos fueron labrados conforme a la traza del ensamblador Santiago Carnicero, vecino de la localidad palentina de Villada ${ }^{1514}$. Se trata de dos retablos gemelos, tanto en dimensiones, (5mtrs x 2,45mtrs) como en estructura, que resultan bastante estrechos respecto a su altura para adaptarse al espacio existente en el muro norte del crucero. Constan de banco, cuerpo principal de una sola calle y ático desarrollado, siendo una reproducción, a escala reducida, del retablo mayor. Comenzado por el banco, está conformado por un tablero central provisto de minuciosa talla de roleos a trépano, flanqueado por cuatro pedestales que sustentan los soportes del cuerpo principal. Los plintos de los extremos poseen labores de hojarasca enroscada mientras que los centrales son completamente lisos, constituyendo los únicos elementos del retablo completamente desnudos. El cuerpo principal, tetrástilo, está conformado por cuatro columnas salomónicas de tres espiras pobladas de racimos que desdibujan el perfil helicoidal de los fustes. Las que se hallan situadas en los lados están retranqueadas respecto a sus compañeras, aportando sensación de profundidad y un efecto de claroscuro al conjunto. La hornacina central, como en el retablo mayor, está conformada por un arco de medio punto abocinado, cuyo intradós está decorado a través de hojarasca inscrita en cuadrantes, ornamentación que se prolonga en las jambas del arco, dispuestas oblicuamente. En la parte central de la rosca hallamos una cabeza de querubín de la que emerge una nutrida hojarasca que cobija un gran espejo policromado de negro. Está sustentando por una pareja de angelillos cuyas cabezas afrontadas, miran hacia la imagen cobijada en la hornacina sobre la que se hallan, mientras sus cuerpos rollizos flotan en el aire horizontalmente. Sobre los capiteles, de orden compuesto, se dispone un entablamento pronunciado que se retranquea nuevamente, dando paso al ático, donde dos estípites piramidales alzados sobre altos plintos, flanquean la hornacina ochavada y abocinada provista de la misma ornamentación que la caja principal. De nuevo, en la rosca del arco hallamos una testa de ángel, a partir del cual se prolonga un motivo cactiforme que se despliega entre los arranques de un frontón curvo.

A los lados, sentados sobre los pedestales de los extremos, se disponen otros dos querubines con los brazos extendidos hacia el santo de la hornacina superior, como si lo

${ }^{1514}$ AHPP. Carr.Prot 5019. Agustín García Miranda (1699-1700), s/f. 
presentaran al espectador. Con éstos son cuatro los querubines repartidos por ambos retablos, dos menos de los previstos inicialmente ${ }^{1515}$. Probablemente, en un principio, Pedro del Mazo no hallara impedimento para asentar seis querubines en los retablos que iban a realizarse, pero debió cambiar de opinión cuando ya estaban ensamblados, cerciorándose de que en aquel reducido espacio no lucirían demasiado provocando cierto agobio visual. La prueba de que esos dos querubines de cada retablo nunca se llegaron a realizar es la carta de pago ya referida al dorador Cayetano Bodigos de 1757 “...por encarnar los ocho ángeles que están puestos en sus retablos... ${ }^{1516 ” .}$

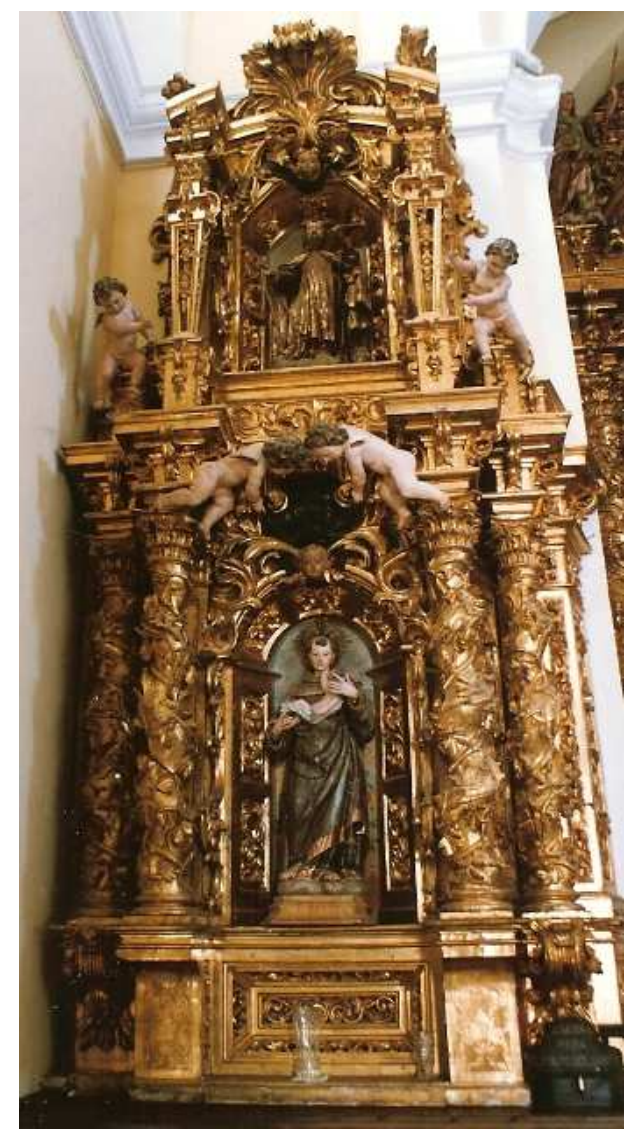

Retablo de San Antonio de Padua.

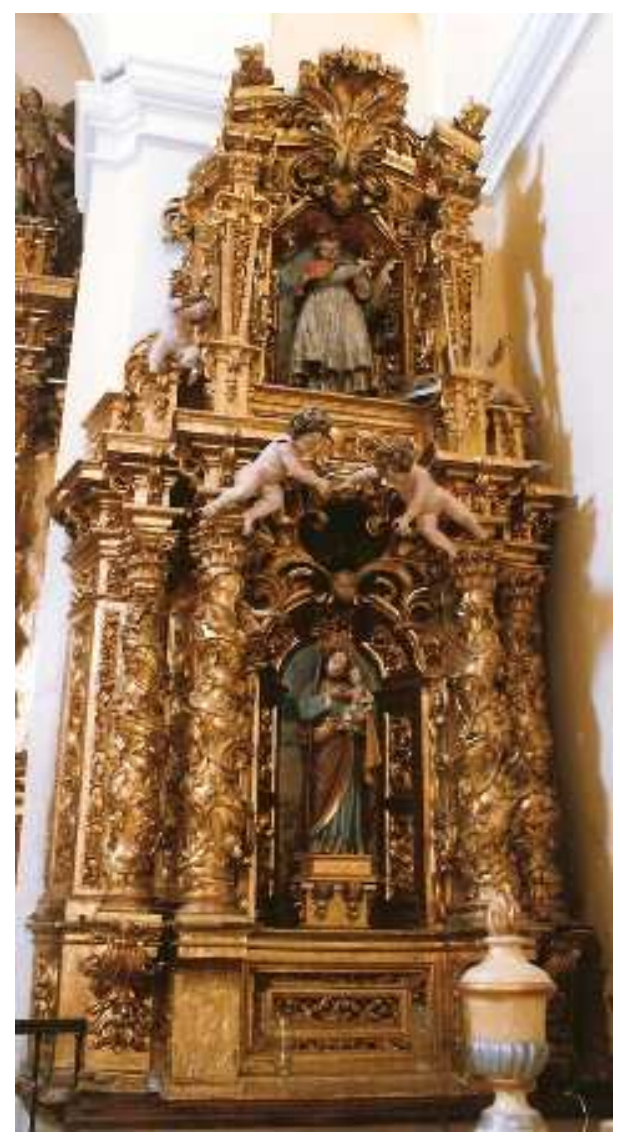

Retablo de San José.

\section{Retablos colaterales de la iglesia de San Julián. Trazado por Santiago Carnicero y ejecutado por Blas Martínez de Obregón. 1699. (5mtrx2,45mtrx2,1mtr).}

\footnotetext{
1515 “...en los mazizos de las colunas de dichos colatterales se han de poner seis niños sentados con sus alas que estén algo ynclinados a las hechuras de los referidos colaterales en la conformidad de los dos que al presentte están puestos; y todos con los atributos que combiniere...”.AHPP. Carr.Prot 5021. Agustín García Miranda (1705-1709), s/f.

${ }^{1516}$ ADP. Carrión. San Julián. Libro 7 de Cuentas de Fábrica (1747-1849), fol 60v.
} 


\section{Retablo de San Pedro, hoy de San Antonio}

El retablo del crucero del lado del Evangelio estaba dedicado en origen a San Pedro ${ }^{1517}$, imagen que ha sido desplazada a una repisa del vano del crucero de la Epístola, donde figura aisladamente. Porta una túnica larga con cuello ajustada a la cintura y un espeso manto que recubre el hombro izquierdo, envuelve la figura desde la cintura a los pies y es recogido con en el brazo del mismo lado, cayendo en sentido oblicuo hasta el pie contrario. Presenta un suave movimiento a través de la pierna derecha adelantada, el brazo homónimo con los dedos abiertos de los que penden las llaves y la mano contraria extendida para sostener el libro abierto. Como ya apuntamos, esta imagen debió servir de inspiración en la realización de la escultura homónima ubicada en el retablo del Rosario de la iglesia de San Andrés a Pedro Martínez del Mazo, posible pupilo y quizá familiar directo de Pedro del Mazo Vélez.

Sin duda, esta escultura formaba parte del retablo primitivo a tenor no solo de su tamaño (140cm, esto es, la vara y media estipulada) sino de sus características estilísticas, en sintonía a las de las esculturas del retablo mayor. El rostro alargado, la mandíbula marcada del Apóstol, con los ojos pequeños y la nariz alargada responden al prototipo de Pedro del Mazo Vélez. No hay más que observar la imagen de San Juan Bautista de la hornacina lateral, para darse cuenta de que emplean idénticos recursos en el modo de disponer el cabello. El mechón abultado en la frente, así como la barba corta y fina unida al bigote conformando un pequeño triángulo equilátero en el que se inscribe la boca, de pequeñas dimensiones y labios plegados, es común en ambas figuras. Incluso comparten un detalle curioso: la franja central supralabial rasurada, particularidad del artista, también presente en la escultura del rey San Fernando. En cuanto al modo de disponer los mantos, cuyos pliegues se recogen artificiosamente en la zona de la cintura, constituye un recurso patente en otras obras como la Asunción o el rey San Fernando.

La imagen que preside la hornacina principal es la de San Antonio de Padua $(121 \mathrm{~cm} \times 48 \mathrm{~cm})$, planteada para ser ubicada en el ático del retablo frontero “...con el

\footnotetext{
${ }^{1517}$ FERRERO MAESO, Concepción. "El mecenazgo en Actas...Op.cit, pág. 597, a s vez de AHPP. Carr.Prot 5021. Agustín García Miranda (1705-1709), s/f.
} 


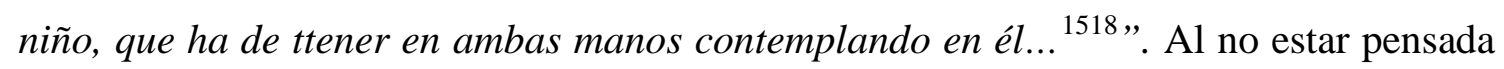
para presidir el retablo, Vélez la talló de menores dimensiones que la imagen de San Pedro. De todas las esculturas, es quizá la de mejor consecución junto a la Asunción. Se identifica el prototipo físico del escultor a través del mechón abultado en el centro de la tonsura del santo y los párpados levemente caídos, pero en este caso el rostro adopta un perfil ovalado, dotado de generosos carrillos, en consonancia a los rostros más delicados del retablo mayor como la Asunción o los ángeles trompeteros del ático. En este caso, la ausencia de mantos ampulosos de los que el escultor hace gala en la mayor parte de sus figuras, refuerzan la sobriedad de sus sandalias de cuero y su hábito franciscano, en vivo contraste con su orla ribeteada de oro. El suave avance de la pierna tensa ligeramente la túnica del santo, provocando unas profundas hendiduras en caída diagonal que animan la superficie de la vestimenta. Además de los ojos de cristal prescritos en las condiciones, la imagen ha sido dotada de otros postizos añadidos a posteriori, como el nimbo de latón dorado de su cabeza y el cordón franciscano rematado en borlas que se superpone, con mayor holgura, al fino y dorado tallado por Vélez.

El ático estaría presidido en origen por la imagen de San Zoilo, patrón de Carrión $^{1519}$. Podemos identificarla con seguridad con la imagen que se halla sobre la repisa de una de las ventanas del lado del Evangelio en la iglesia de Santa María. La imagen está asentada sobre una peana pétrea, que en realidad es un fragmento de una imposta de billetes que se habría desprendido del templo. Aunque lo más fácil es pensar que procede del homónimo monasterio benedictino, su estilo y dimensiones señalan en otra dirección. Por un lado, observamos que la imagen mide 115 centímetros, tan sólo seis menos de lo que mide la escultura de San Antonio de Padua, también destinada en origen al ático del retablo frontero.

Por otro lado, su dulce rostro y sus cabellos ondulantes a los lados, muy lamidos evocan, sin lugar a dudas la figura del ángel trompetero del retablo mayor. El santo cordobés, vestido con falda romana, siguiendo la iconografía tradicional, porta en su mano derecha una palma del martirio postiza, que le supera en altura y en su mano izquierda una bandeja vacía, sobre la que originalmente se dispondrían sus riñones. Esta imagen debió bajarse pronto del retablo para ser procesionada en su fiesta ${ }^{1518}$ Ibídem.
${ }^{1519}$ Ibídem. 
homónima ${ }^{1520}$. Por eso en 1895, el retablo colateral contenía las imágenes de San Pedro en la hornacina principal y San Antón, en el ático, en lugar de San Zoilo. Éste y San Antonio se hallaban por entonces delante del retablo mayor, de "modo provisional ${ }^{1521}$. Ese mismo año, considerando que la imagen de San Zoilo estaba anticuada, el Ayuntamiento de Carrión encarga una nueva escultura de 1.40 metros de altura, a la casa de los Gallego Candela y compañía de Valencia ${ }^{1522}$. La imagen homónima de Pedro Vélez fue trasladada a la ermita de San Juan de Cestillos, para evitar discordias con las parroquias de Santa María y San Andrés que se la disputaban ${ }^{1523}$. En los años ochenta, el párroco, Don José Mariscal la trasladó a Santa María, donde se ubica desde entonces ${ }^{1524}$. La imagen moderna, conservada en San Julián, donde se ubica delante del retablo mayor, es la que se emplea desde entonces para la fiesta patronal.

La escultura que preside el ático hoy día, es una imagen de San Antón abad, del siglo XVIII ${ }^{1525}$. Si bien, no formaba parte del retablo, pudo ser ejecutada coetáneamente por Pedro Vélez, con otro destino inicialmente, a tenor del tipo físico empleado. El rostro cuadrado, la prolongación de los párpados y la disposición triangular de bigote son rasgos identificativos del artista presentes en las imágenes de San Juan Bautista o en San Pedro, si bien en este caso porta una barba larga de mechones ondulantes dispuestos simétricamente. De no ser por el cerdo que lleva a sus pies sería difícil identificar aisladamente al santo eremita, pues aunque porta el sayo con capa y capucha, propia de los Hospitalarios, la policromía -con motivos de eses afrontadas y rameados dorados -es tan rica y detallada que resulta poco acorde a la humilde condición del Santo.

\footnotetext{
${ }^{1520}$ Se celebraba antiguamente el 27 de junio, que continúa hoy día en el calendario litúrgico como San Zoilo. Sin embargo, en 19855, coincidiendo con la celebración del 25 aniversario de la coronación de la Virgen de Belén, la fiesta fue trasladada al lunes anterior al 28 de agosto.

${ }^{1521}$ RAMÍREZ DE HELGUERA, Martín. El libro...Op.cit, pág. 165.

1522 AMCC. Libro 14, Sesiones municipales (1892-1896). Sesión de 18 de enero de 1895, fol 4.

${ }^{1523}$ Sesión municipal de 23 de mayo de 1905. AMCC. Libro 19. Sesiones municipales (1903-1906), fol $87 \mathrm{v}$.

${ }^{1524}$ Debo esta información a mi colega e historiador Enrique Gómez Pérez.

${ }^{1525}$ URREA FERNÁNDEZ, Jesús y MARTÍN GONZÁLEZ, Juan José. Inventario...2. Op.cit, pág. 52.
} 


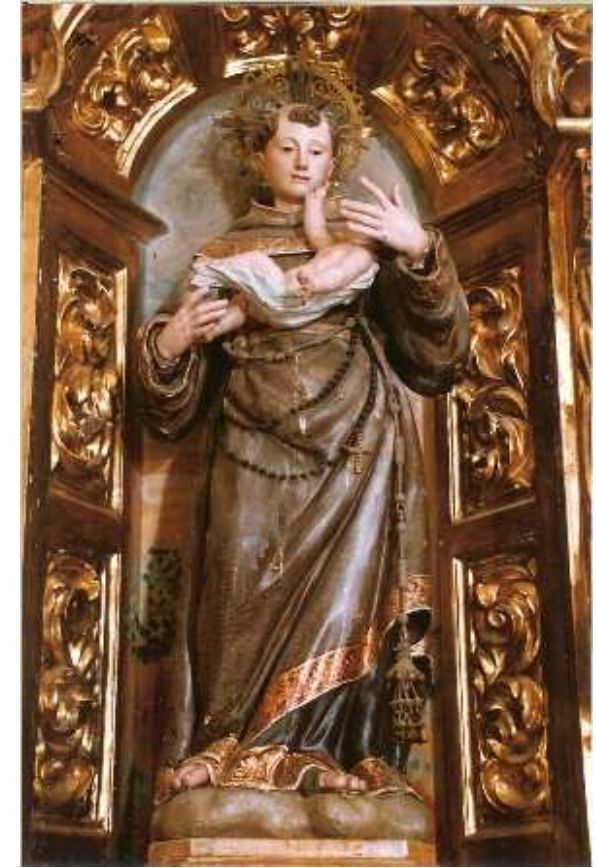

San Antonio $(121 \mathrm{~cm} \times 48 \mathrm{~cm} \times 38 \mathrm{~cm})$. En origen en el retablo frontero.

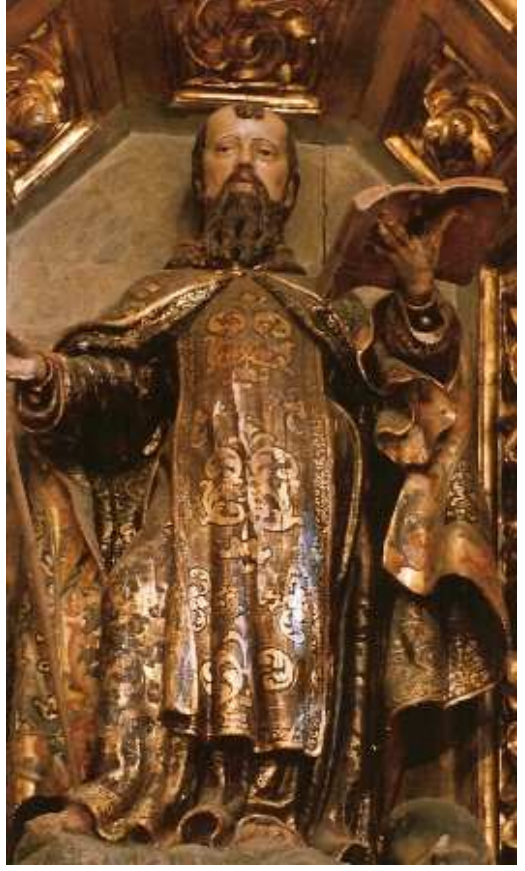

San Antón $(111 \mathrm{~cm} \times 60 \mathrm{~cm} \times 35 \mathrm{~cm})$. En origen no figuraba en el retablo.

Esculturas actuales del retablo del crucero norte de San Julián.

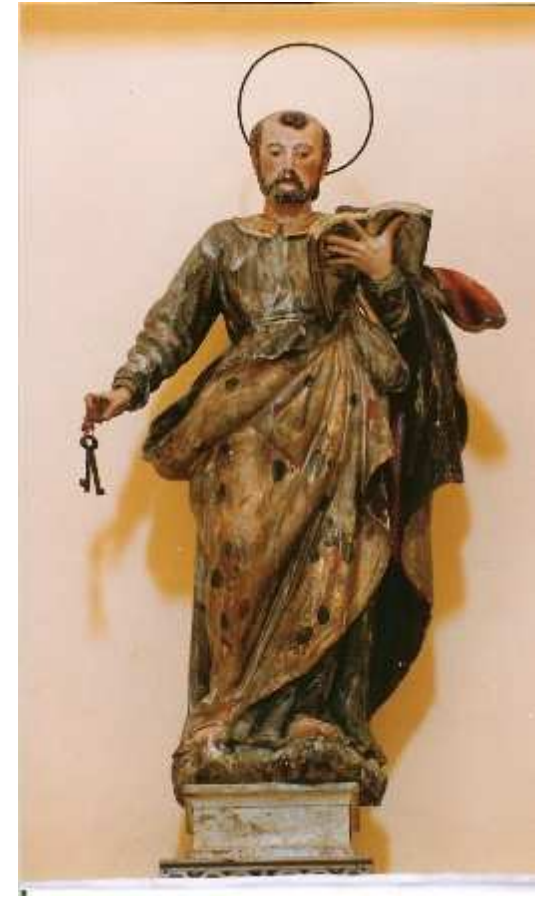

San Pedro $(140 \mathrm{~cm} \times 75 \mathrm{~cm} \times 40 \mathrm{~cm})$.

Crucero de la Epístola en San Julián.

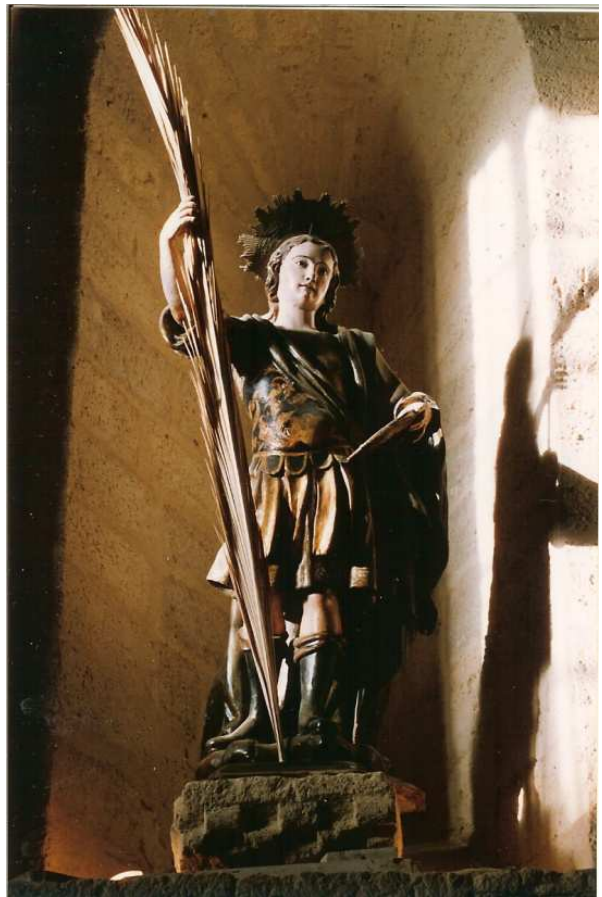

San Zoilo $(115 \mathrm{~cm} \times 56 \mathrm{~cm} \times 27 \mathrm{~cm})$.

Nave del Evangelio de Santa María.

Esculturas originales del retablo del crucero norte de San Julián. 


\section{Retablo de San Jerónimo, hoy de San José}

El retablo ubicado en el muro norte del crucero, en el lado de la Epístola, estaba dedicado originalmente a San Jerónimo, situándose en lo alto San Antonio de Padua ${ }^{1526}$. Éste último, como acabamos de ver, preside el retablo frontero y la imagen de San Jerónimo ha sido trasladada al ático. Está representado con la iconografía de cardenal, no de eremita, aunque carece de capelo. Porta un libro abierto por su erudición y por haber sido proclamado doctor de la Iglesia latina. Su rostro barbado es muy similar a los de San Pedro y San Juan Bautista y la caída lineal de la vestimenta recuerda a la de San Julián, pero no vamos a incidir nuevamente en estos aspectos, sobradamente estudiados.

Por lo que respecta a la hornacina principal, ésta cobija una imagen de moderna factura que representa a San José traído de Valencia por la Hermandad de Josefinas hacia $1890^{1527}$.

\section{EL DEVENIR A PARTIR DEL SIGLO XIX}

Como ya apuntamos, a finales del siglo XVIII se extinguió el linaje de los Berrio Colmenares y a partir de este momento no hallamos menciones de patronazgo del templo. Tampoco hallamos referencias de entidad, salvo retejos y algunos reparos sin importancia durante el siglo XIX. En 1895, la parroquia de San Julián, que tenía el menor número de feligreses de la villa, fue suprimida y pasó a depender de San Andrés, pero no se cerrará por entonces debido a la existencia de las capellanías ${ }^{1528}$.

Experimentó en 1990 un proceso de limpieza, consolidación y desinfección llevado a cabo por la Casa de Oficios de Carrión que devolvió la obra a su estado original $^{1529}$. Entre 1999 y 2000, paralelamente a las obras ejecutadas en el cercano

\footnotetext{
${ }^{1526}$ FERRERO MAESO, Concepción. "El mecenazgo en Actas...Op.cit, pág. 597, a su vez de AHPP. Carr.Prot 5021. Agustín García Miranda (1705-1709), s/f.

${ }^{1527}$ RAMÍREZ DE HELGUERA, Martín. El libro...Op.cit, pág. 164

1528 IbIbídem.

${ }^{1529}$ Boletín Informativo de la Parroquia de Carrión de los Condes. № 8 Carrión de los Condes (Palencia), 1990, pág. 7.
} 
convento de clarisas, se sustituyó el pavimento de madera, carcomido por la humedad por uno de mármol, reparándose además los acabados interiores ${ }^{1530}$.

Hoy día, la iglesia de San Julián está cerrada al culto y tan sólo abre sus puertas para la fiesta patronal referida y la de San Antonio de Padua.

\section{OTRAS OBRAS DEL TEMPLO}

Este templo atesora muy pocas obras de arte si exceptuamos el retablo mayor y los colaterales previamente estudiados. Podemos reseñar, no obstante, dos lienzos ubicados en el segundo tramo de la nave, a continuación del coro. En el lado del Evangelio hallamos una pintura fechada en 1686 que representa el Cristo de Burgos $(200 \mathrm{~cm} \times 137 \mathrm{~cm})^{1531}$. Se llama así por tratarse de devoción propia de la ciudad castellana, en cuya catedral se venera la imagen homónima articulada. La imagen ha tenido una difusión increíble por Europa y América a lo largo de los siglos; tanto su representación escultórica como pictórica, recurriendo en el segundo caso, a un fondo neutro oscuro. Su patética iconografía es muy llamativa, pues Cristo lleva largas melenas, el cuerpo ensangrentado y está cubierto por un faldón blanco que le cubre casi por entero las piernas. A los pies lleva cinco huevos de avestruz, cuyo número varía en función de la representación, donación que un mercader trajo de África ${ }^{1532}$. En nuestro caso, tan sólo aparecen tres, dos de ellos actuando a modo de clavos. Lienzos similares al nuestro en el entorno castellano hallamos en el Museo de Burgos, en la iglesia de Santa María y en la Puerta de San Esteban, ambos en Medina de Rioseco. El hecho de que este lienzo se ubique en la iglesia de San Julián se debe a una razón concreta. Hay

\footnotetext{
${ }^{1530}$ VV.AA. Arquimilenios. Arquitectura entre dos milenios (1999-2000). Junta de Castilla y León. Valladolid, 2000, pág. 69.

1531 PERAL VILLAFRUELA, Santiago y GÓMEZ PÉREZ, Enrique. Op.cit, pág. 68.

1532 Sobre el Cristo de Burgos existe una extensa bibliografía. LOVIANO, Pedro de. Historia del Santísimo Cristo de Burgos. Madrid, 1740. IGLESIAS ROUCO, Lena Saladina. "La capilla del Santo Cristo de la Catedral de Burgos: datos para su estudio" en BSAA, n56. Valladolid, 1990, pp. 542-546, LÓPEZ MARTÍNEZ, Nicolás. El Santísimo Cristo de Burgos. Burgos, 1997, GARCÍA DE GUZMÁN, Miguel y GARCÍA REYES, Miguel Ramón. "Iconografía del Santo Cristo de Burgos o de San Agustín" en Archivo Agustiniano, n²05, 2003, pp. 261-306, MARTÍNEZ MARTÍNEZ, María José. "El Santo Cristo de Burgos. Contribución al estudio de los Crucifijos articulados españoles" en BSAA, n69-70. Valladolid, 2003-2004, pp. 207-246, GILA MEDINA, Lázaro. “Arte e historia del Cristo de Burgos" en Contraluz,n`3, 2006, pp. 143-160 y ITURBE SAIZ, Antonio. "El Cristo de Burgos o de San Agustín en España, América y Filipinas" en Los crucificados, religiosidad, cofradías y arte. Actas del Simposio. San Lorenzo del Escorial, 2010, pp. 683-714.
} 
que tener en cuenta que don Antón González de la Torre, padre del benefactor del templo, don Hernando de Berrio, había fundado la capilla del Santo Cristo en el homónimo convento burgalés para emplearlo como lugar de enterramiento ${ }^{1533}$. Debemos situar esta obra no sólo en un contexto devocional general sino como un homenaje particular a la progenie fundadora.

En el lado del Evangelio se ubica un lienzo que representa el sueño de María Magdalena $(144 \mathrm{~cm}$ x $113 \mathrm{~cm}$ ) perteneciente al siglo XVII. Sobre un fondo neutro se destaca en el ángulo inferior derecho la imagen de la Magdalena dormida, su cabeza apoyada sobre el brazo izquierdo, y éste, a su vez, sobre la calavera, mientras que con la otra sujeta la cruz. Su espesa y larga cabellera oculta su pecho desnudo y un espeso manto recubre su anatomía desde la cintura. En primer plano, el pomo de los ungüentos despeja cualquier duda sobre la identificación del personaje. En la parte superior izquierda se representa el sueño de la Penitente: de la espesa negrura emergen un par de angelillos que descienden del cielo para coronarla y cubrirla de flores. Presenta el mismo esquema compositivo que el lienzo que se ubica en el Museo Parroquial, que copia inequívocamente a éste $(165 \mathrm{~cm} \times 136 \mathrm{~cm})$.
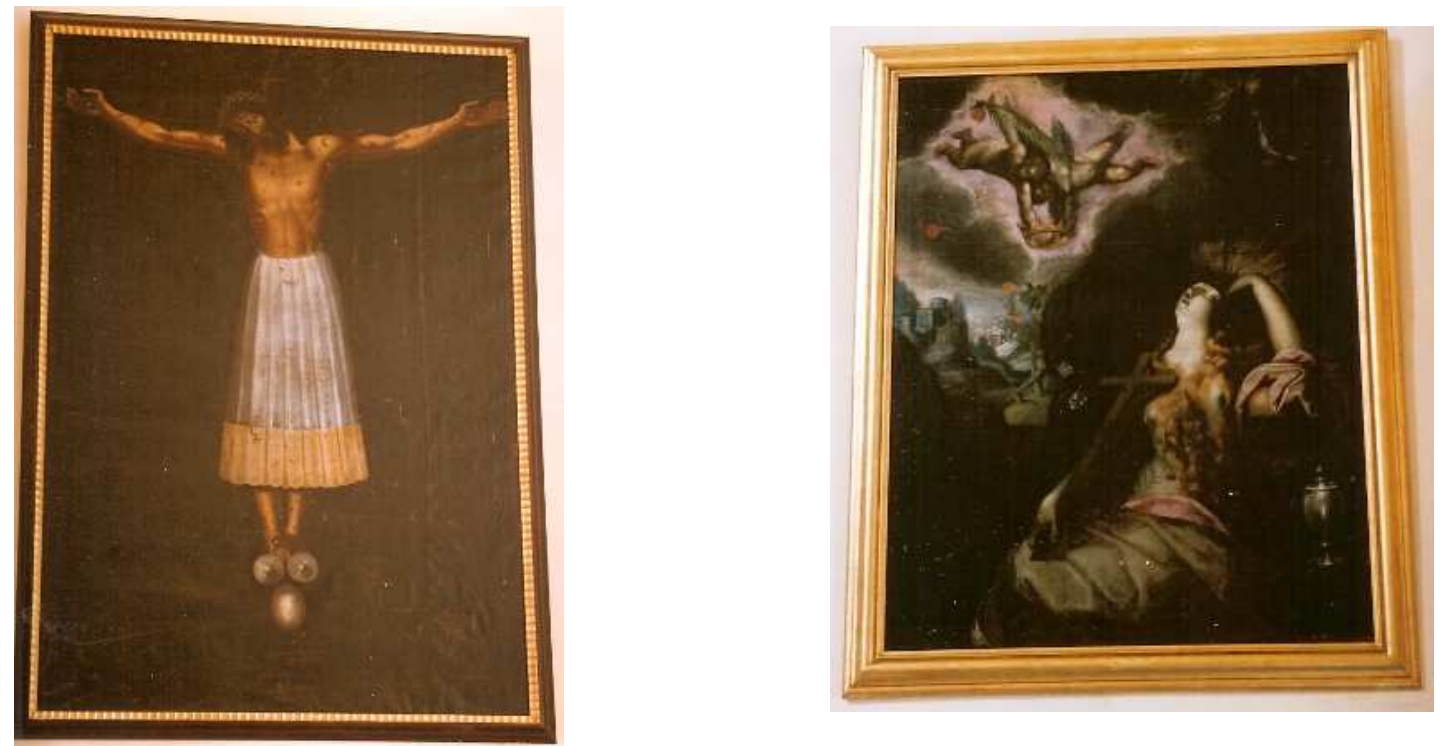

Cristo de Burgos $(200 \mathrm{~cm} \times 127 \mathrm{~cm})$. Sueño de María Magdalena $(144 \mathrm{~cm} \times 113 \mathrm{~cm})$.

Lienzos de la iglesia de San Julián. Anónimos castellanos. Siglo XVII.

${ }^{1533}$ VIGURI, Miguel de. Heráldica...2. Op.cit, pág. 64. 
4.4. IGLESIAS NO CONSERVADAS 


\subsection{IGLESIAS NO CONSERVADAS}

Las referencias documentales y, en algún caso, la existencia de fotografías, prueba la existencia de los templos de San Juan del Mercado, San Bartolomé, San Vicente y Santa Eulalia. El origen de estas cuatro iglesias se remonta al menos, a época medieval, sin que podamos determinar si se trataba de fábricas románicas o góticas, o incluso anteriores, pues figuran por vez primera en la estadística que la Diócesis Palentina realiza por orden de su Obispo, Don Vasco de la Zarza, en 1345. El escaso número de clérigos al cargo de cada una de ellas, parangonándolos con los de otros templos carrioneses, manifiestan la modestia de los mismos ${ }^{1534}$.

\subsubsection{SAN JUAN BAUTISTA o SAN JUAN DEL MERCADO}

Se trataba de un templo de reducidas dimensiones, situado extramuros de Carrión, junto a la desaparecida puerta de San Juan, uno de los accesos a la villa. Se ubicaría en la zona de la actual calle y plaza homónimas. Esta iglesia también se denominó San Juan del Mercado por su proximidad a la plaza del Mercado Viejo.

Fue completamente renovada en el siglo XVI, incluyendo la torre señalada por los arcos menores abiertos en sus cuatro muros ${ }^{1535}$. Construida en ladrillo, con zócalo de piedra, se componía de una nave, cinco altares y entrada principal al sur con soportal $^{1536}$. Quadrado testimonia la existencia de una torre con arcos en sus cuatro lados, lo que constatamos a través de una fotografía antigua ${ }^{1537}$. Maciza y de gran espesor, se situaba a los pies del templo, adosada en el lado del Evangelio. Se componía de tres cuerpos separados por una cornisa lisa. El primero se asentaba sobre un zócalo de sillería y en los dos contiguos se abrían una ventana a cada lado, moldura con orejetas en los ángulos remite a la intervención que tuvo lugar a principios del siglo XVII. Por encima se disponía el cuerpo de campanas, más elevado que el resto y con

\footnotetext{
${ }^{1534}$ San Bartolomé estaba constituida por un preste, un diácono y tres graderos, San Juan, de un preste, un subdiácono y dos graderos, San Vicente, un preste, un diácono, un subdiácono y tres graderos, y Santa Eulalia, un preste, dos subdiáconos y tres graderos. MARTÍN PAYO, Jesús. "La más antigua...Op.cit, pp. 10- 12 .

1535 NAVARRO GARCÍA, Rafael y REVILLA VIELVA, Ramón. Catálogo...2. Op.cit, pág. 10.

${ }^{1536}$ MADOZ, Pascual. Diccionario...Palencia, 1984, Op.cit, pág. 69.

${ }^{1537}$ QUADRADO; José María y PARCERISA, Francisco J. Op.cit, pág. 131.
} 
mayor número de vanos, pues en cada lado se abrían tres arcos de medio punto, de mayores dimensiones el central, y en los ángulos un refuerzo de pilastras. No poseía una fachada principal, pues el acceso se realizaba por una puerta de madera ubicada en el lado meridional y no existía nada más en el muro aparte de un ventanuco. Al norte,

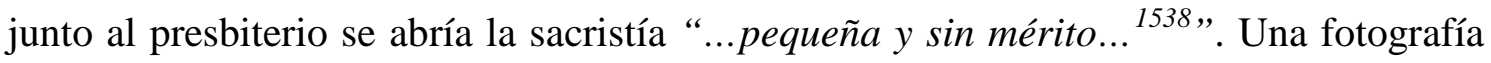
antigua del exterior, tomada cuando la iglesia estaba desprovista de tejados, nos permite observar que poseía en el crucero una cúpula provista de casetones, fruto de una intervención en el siglo XVII.

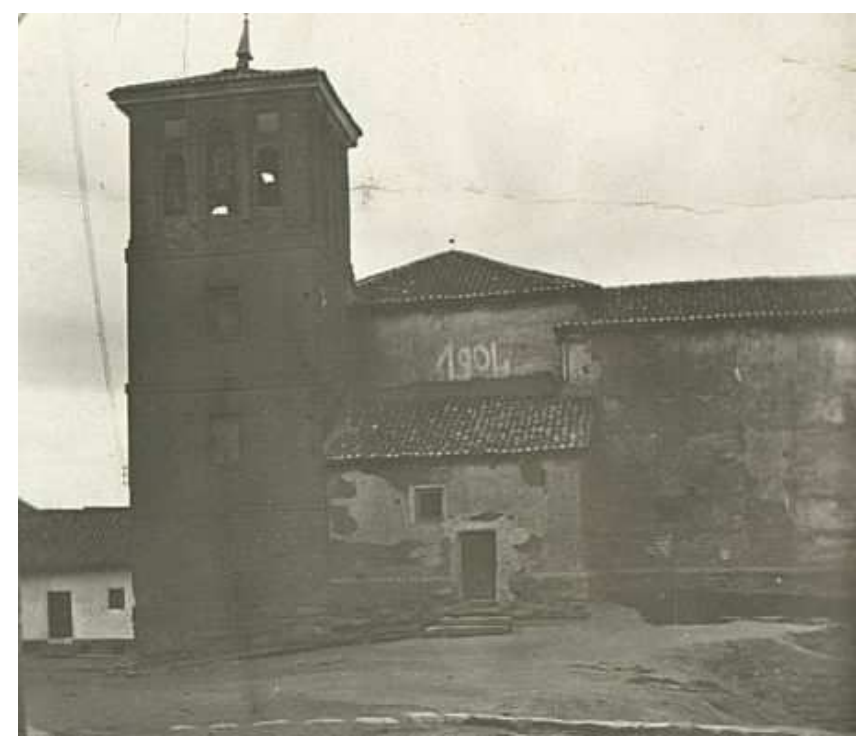

Templo de San Julián. Fotografía de 1904.

El arreglo parroquial de 1895 la suprime como tal reduciéndose a la categoría de ermita. El final de su andadura llegó en 1937 cuando fue demolida ${ }^{1539}$. Hoy día tan sólo se conservan exteriormente algunos muros del zócalo pétreo y tres contrafuertes en la cabecera embutidos en una propiedad particular. De la nave del templo, habilitada como aparcamiento, se conserva el arranque de las pilastras con sus respectivos plintos que recorrían el muro del Evangelio y también se han hallado gran cantidad de restos óseos extraídos de un orificio excavado en el suelo, que testimonian la utilización del lugar como camposanto.

\footnotetext{
${ }^{1538}$ RAMÍREZ DE HELGUERA, Martín. El libro...Op.cit, pág. 162

${ }^{1539}$ Debo esta información al ex alcalde de Carrión, don José Ramón Blanco.
} 


\section{ALGUNOS DATOS DE SU CONSTRUCCIÓN}

\section{La torre}

La primera referencia documental de la iglesia data de 1566 en que su torre se hallaba en proceso de construcción, como así se deduce de la reprimenda del Obispo la Gasca al párroco de San Juan para que avanzase la fábrica ${ }^{1540}$. El albañil carrionés Marcos Santiago se compromete a finalizar la torre en 1598, siguiendo las trazas proporcionadas por Santiago Díaz de Sigüenza ${ }^{1541}$. Le sustituirá en los trabajos Antonio de Cuéllar ${ }^{1542}$, concertado con la iglesia desde principios del año 1600 para ejecutar “...lo que rresta de haçer en la torre...” todo de ladrillo macizo ${ }^{1543}$. Se había comprometido a concluir los trabajos a finales de 1601, no obstante, en 1602 continúan las obras, por lo que la iglesia apremia a Cuéllar ante la inminente llegada de “...las

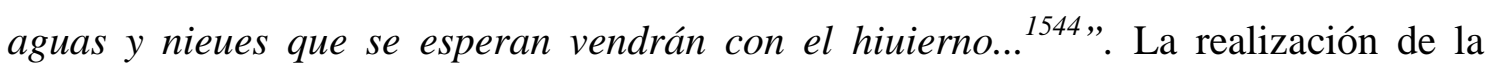
campana mayor en 1620 por el campanero Hernando de Colona, marca la conclusión de la torre ${ }^{1545}$.

\section{Reparos del templo}

La iglesia establece en 1602 un pleito contra Juan de Cantoral para que se encargue de reparar la capilla que posee en la misma, procediéndose a su venta, en caso de negativa, pues ya en 1599 el Doctor Pedro de Arizpicueta, visitador general del Obispado de Palencia había ordenado dicha reparación y aún entonces no se había producido la misma ${ }^{1546}$. En 1662 se registra una adquisición de gran cantidad de madera sin especificar su fin, tal vez fuera destinada al reparo de la techumbre ${ }^{1547}$.

\footnotetext{
${ }^{1540}$ MARTÍN MÍNGUEZ, Bernardino. Catálogo...Op.cit, volumen 3, pág. 85.

${ }^{1541}$ AHPP. Carr.Prot 4701. Pedro Carrión (1598), fol 365 y ss. Sobre Sigüienza, véase el capítulo dedicado a los maestros para obtener algunos datos biográficos.

1542 Sobre el mismo, véase el capítulo dedicado a los maestros.

${ }^{1543}$ El contrato fue firmado el 9 de febrero de 1600 con el párroco del templo, Pedro Santos, el clérigo beneficiado Antonio Vallejo y el mayordomo Esteban Martínez. AHPP. Carr.Prot 5291. Pascual López (1600), s/f.

1544 AHPP. Carr.Prot 5077. Pedro Guerra Cervantes (1602), s/f.

1545 AHPP. Carr.Prot 4847. Juan Díaz Pajaza (1620), fol 27.

1546 AHPP. Carr.Prot 5077. Pedro Guerra Cervantes (1602), s/f.

${ }^{1547} 2$ de enero de 1662. Juan de Martín Serrano vecino de Bilbiestre como principal, fiado por Felipe Berrojo de Isla, maestro de albañilería, vecino de Carrión se comprometen a traer las vigas y machones al templo. AHPP. Carr.Prot 5696, Norberto Sandoval y Guevara (1662) fol 378.
} 
A principios de 1636 se produce un hundimiento de algunas partes en esta iglesia, como también sucede simultáneamente a los templos de Santiago y Nuestra Señora de Belén, a consecuencia de una repentina lluvia torrencial ${ }^{1548}$.

La iglesia se repara nuevamente en 1671, seguramente interviniendo en la cubierta, pues la partida de materiales que se registra correponde a diversos tipos de madera $^{1549}$. En 1700 tiene lugar una obra de cantería de cierta entidad pero la laguna existente en los Libros de Fábrica que pivota entre los años 1655 y 1717 nos impide conocer más datos al respecto. El maestro Juan de Solana Quintanilla, avecindado en Carrión, se compromete a reparar el templo por 14.500 reales ${ }^{1550}$. No se conserva ninguna noticia más del templo hasta 1897 en que el consistorio autoriza al mayordomo de San Juan la utilización de los adoquines depositados en el matadero de propiedad municipal para reparar uno de los ángulos de la nave ${ }^{1551}$.

\section{OBRAS DEL TEMPLO}

\section{El retablo mayor}

El primer retablo conocido del templo fue sustituido por otro en 1564, en que se ordena desmontar el antiguo y se encarga otro bajo la advocación de San Juan Bautista que dorará y estofará Juan de Lago ${ }^{1552}$. Las esculturas ya estaban realizadas por entonces. En el banco se hallaban dos bustos, a los que se refieren como "dos ystorias...de media talla”. Presidía la hornacina principal la imagen titular y en la caja del ático se hallaba la Asunción. Los tableros debían ser pintados con las historias que el clérigo dispusiese y toda la obra concluida en dos años ${ }^{1553}$. Sin embargo, aún en 1569, no estaba finalizado. Así lo transmite el párroco del templo, indicando que el año anterior había solicitado al comendador del Hospital de la Herrada para que compeliese

\footnotetext{
1548 AMCC. Libro 1, Sesiones municipales (1618-1637). Sesión de 9 de febrero de 1636, s/f.

${ }^{1549}$ En la escritura de contrato, el serrano Bartolomé Martín se concierta con la iglesia para traer 9 vigas de pino, 116 machones AHPP. Carr.Prot 5775, Andrés Simón Aguilar (1670-1671), fol 452 y ss.

${ }^{1550}$ Sobre Juan de Solana, véase el apartado relativo a los maestros de cantería. El contrato de la obra fue firmado el 21 de abril de 1700. AHPP. Protocolo 5019, Agustín García Miranda, (1699-1700), s/f.

${ }^{1551}$ AMCC. Libro 15, Sesiones municipales (1897-1898) fol 20 y 20v.

${ }^{1552} \mathrm{La}$ escritura de contrato se firma el 4 de enero de 1564. AHPP. Carr.Prot 4675. Juan Cantoral (15631568), s/f. Sobre Juan de Lago, remítase al capítulo dedicado a los pintores.

1553 AHPP. Carr.Prot 4675. Juan Cantoral (1563-1568), s/f.
} 
a Lago a la entrega de la obra. Este año, sin embargo, “...por evitar pleitos...”, habían decidido contratar nuevamente a Lago y a otros dos oficiales y solicitaban 28.000 maravedíes de censo “...por tener de costa lo que está por haçer más de trescientos ducados....”. Esos dos artistas contratados para colaborar con Lago, fueron Gonzalo Gutiérrez, vecino de Melgar y Miguel del Val, vecino de Dueñas, a cada uno de los cuales se comprometió la iglesia a abonar más de cuarenta mil maravedíes ${ }^{1554}$. Ambos habían trabajado juntos, entre 1565 y 1568 en el retablo del desaparecido hospital carrionés de Nuestra Señora de la O, de cuya talla se encargó Martín de Esquicios, posible miembro del taller asentado en Carrión hacia $1520^{1555}$. En 1570 debían haberlo finalizado, pues Gonzalo Gutiérrez y Juan de Lago otorgan un poder al bordador carrionés, Cristóbal de la Serna para que cobre los 88.666 maravedíes que el templo les debe $\mathrm{e}^{1556}$.

Al menos durante el siglo XVII la capilla mayor se situó bajo el patronazgo del linaje Barrio. En 1661, era propiedad de don Juan de Barrio de la Vega, quien al testar dicho año dispuso ser enterrado en la capilla que poseía en el templo de San Francisco, sin olvidar a sus familiares enterrados en San Juan, para los que dispone que se canten cien misas ${ }^{1557}$. Éste había heredado el patronazgo de su padre, también llamado Juan de Barrio, quien en julio de 1617, encargó la ejecución del retablo mayor para la capilla donde se sepultaría a su muerte. El encargado de la ejecución del retablo será el ensamblador Santiago Infante, vecino de Carrión, quien se compromete a finalizarlo el 29 de septiembre de dicho año ${ }^{1558}$. Aunque este retablo desapareció; afortunadamente contamos con el contrato y un bosquejo muy somero del mismo, en el que apreciamos que se trata de una pequeña obra de un solo cuerpo de tres calles, lo cual transmite la modestia del templo. El banco estaba conformado por dos plintos cajeados en los extremos y tres molduras rectangulares, de mayores dimensiones la del centro. El cuerpo principal se hallaba sustentado por cuatro columnas de orden dórico en cuyo centro se hallaba la hornacina principal, que cobijaría la imagen titular. Ésta no se incluía en el contrato de Infante, ni tampoco los cuatro “...tableros para pincel...”

${ }^{1554}$ AHPP. Carr.Prot 4676. Juan Cantoral (1569-1573), s/f. Sobre Miguel del Val, remítase al capítulo dedicado a los pintores.

${ }_{1555}$ ARCHV. Pleitos Civiles. Zarandona y Balboa (Olv) Caja 604, Expediente 3.

${ }^{1556}$ AHPP. Carr.Prot 5665. Andrés Sánchez (1569-1572). Segundo cosido, n ${ }^{\circ} 1353$, s/f.

${ }^{1557}$ AHPP. Carr.Prot 5695, Norberto Sandoval y Guevara (1661), fol 555 y ss.

${ }^{1558}$ Sabemos del contrato porque se realiza un traslado de la escritura original en 1627, cuando se vuelve a contratar a Santiago Infante. AHPP. Carr.Prot 5172. Jerónimo Laso (1627), fol 865 y ss. Sobre Santiago Infante, remítase al capítulo dedicado a los ensambladores y escultores locales. 
dispuestos a ambos lados. La calle central iría retranqueada respecto a la línea general del retablo, al igual que la cornisa situada sobre la misma. Dos aletones avolutados se ubicarían en los extremos del retablo, flanqueando una especie de templete rematado en frontón triangular sustentado por una pareja de pilastras cajeadas. Se desconoce la imagen o pintura que ocuparía este tablero, pues no se precisa en el contrato de 1617. Diez años más tarde, Francisco de Barrio, nieto del fundador, requiere a Santiago Infante para la finalización del retablo, así como para la ejecución de un Calvario en madera de nogal o peral, tal vez destinado al remate de dicha obra ${ }^{1559}$.

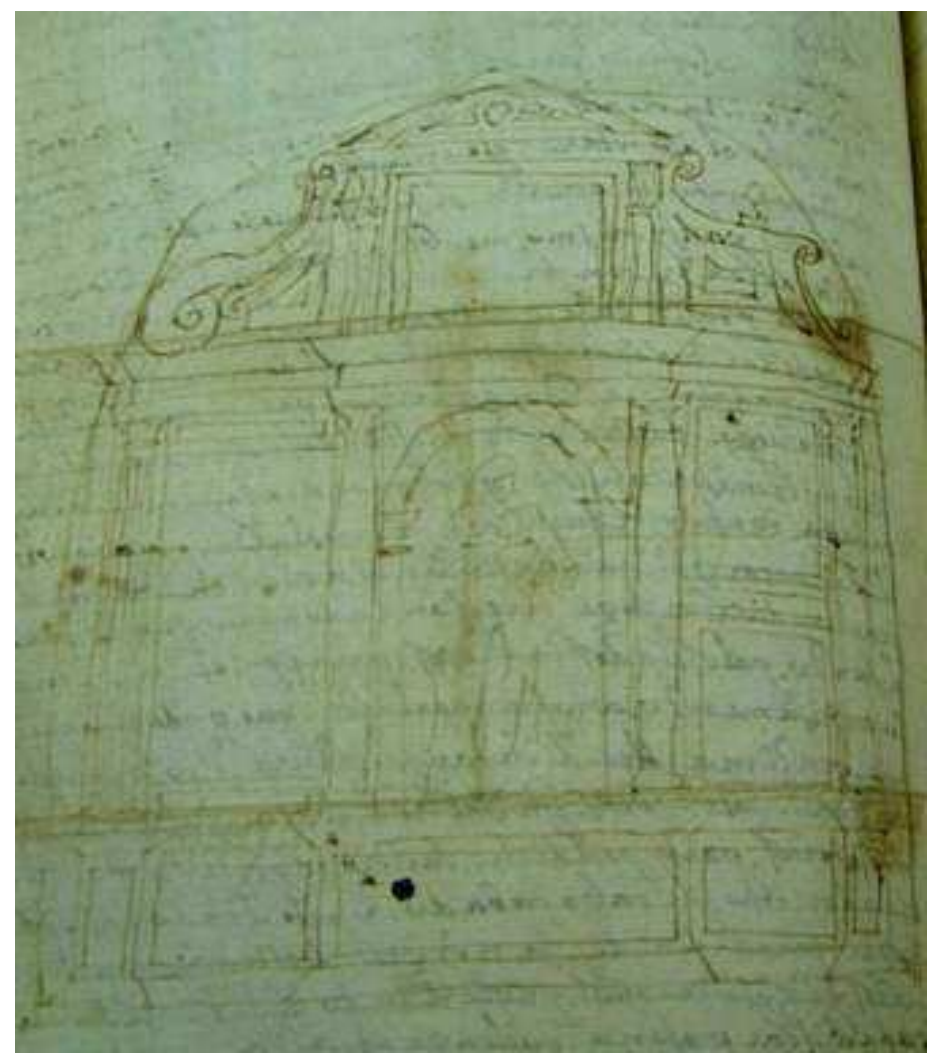

Proyecto del retablo mayor de la iglesia de San Juan del Mercado. Ejecutado por Santiago Infante. AHPP.. Carr.Prot 5172 Jerónimo Laso (1627), fol 868.

${ }^{1559}$ AHPP. Carr.Prot 5172. Jerónimo Laso (1627), fol 865 y ss. 
Este retablo clasicista fue sustituido por otro, de estilo churrigueresco, en cuya parte central aparecía representado San Juan Bautista flanqueado por San Juan Evangelista y la Virgen. y, en el cuerpo superior, la efigie de San Bartolomé, procedente del templo homónimo desaparecido. A los lados del sagrario existían dos urnas con reliquias de los Santos Apóstoles y San Zoilo, y sobre éste, “un disco de mármol...de

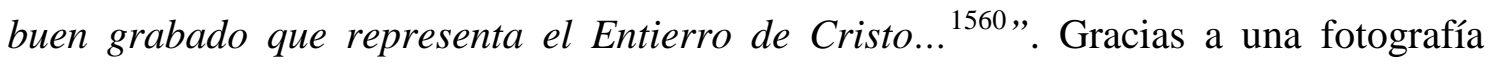
antigua $^{1561}$, podemos determinar que se trataba de un tondo de alabastro, cuyo tema, en realidad, era el Llanto sobre Cristo muerto.

Centrando la composición figura Cristo, semi recostado sobre una especie de grada de dos peldaños, con las piernas cruzadas y la espalda sujeta por una figura masculina que bien podría ser Nicodemo por su turbante y edad madura, a diferencia del anciano que figura a su lado, de amplia barba y tocado con un manto, que identificamos con José de Arimatea. En el medio, la Virgen une sus manos bajo su barbilla, completamente desolada y junto a ella, María Magdalena sostiene el brazo de Cristo. Completan la composición, San Juan, que lleva un paño a sus ojos para enjugarse las lágrimas y una de las Marías, apenas perfilada respecto al resto de relieves, cruza sus manos en el pecho a la par que emite un alarido.

\section{Placa de mármol desaparecida con la escena del Llanto sobre Cristo muerto. \\ Cercana a Diego de Siloé. Primer cuarto del siglo XVI. Extraída de MARTíN MÍNGUEZ, Bernardino. Inventario de Palencia y provincia, 1907.}

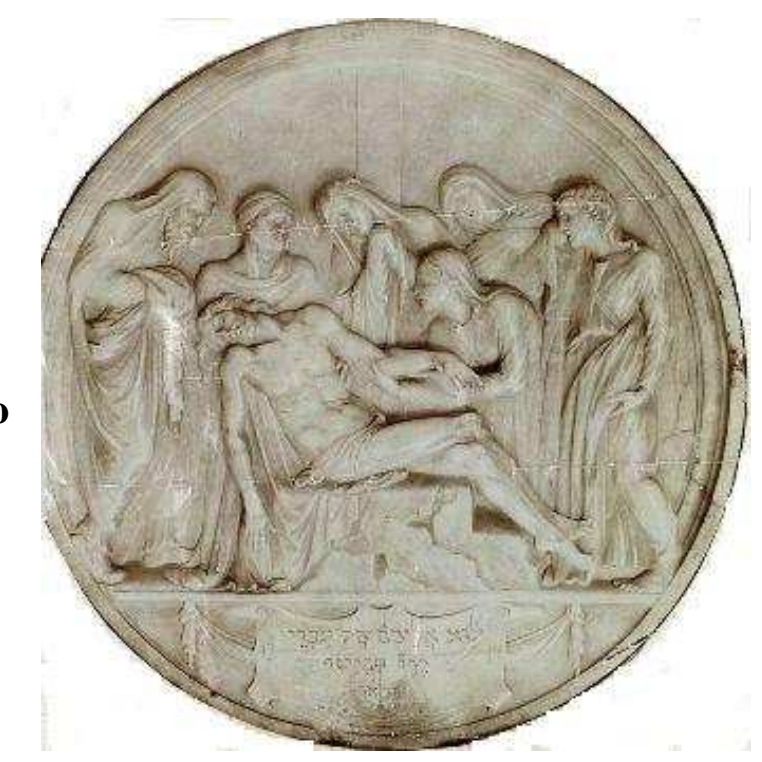

\footnotetext{
${ }^{1560}$ RAMÍREZ DE HELGUERA, Martín. El libro...Op.cit, pág. 163.

${ }^{1561}$ Una fotografía realizada en 1907 en MARTÍN MÍNGUEZ, Bernardino. Catálogo...Op.cit, volumen 3 , pág. 85.
} 
En la parte inferior se conserva una inscripción inscrita en una cartela con cueros recortados sustentados por cintas. Escrita en hebreo, se trata de un pasaje de las Lamentaciones de Jeremías $(1,12)$, que invita a la reflexión del fiel. Su traducción sería la siguiente: “No a vosotros cuantos pasáis por el camino, mirad y ved 1562 ". Es una obra de una gran corrección formal, presente en la cuidada anatomía de Cristo que podemos datar en el segundo tercio del siglo XVI. Recuerda en su delicadeza a algunos de los relieves de la capilla Caraccioli en San Giovanni a Carbonara, en Nápoles, debidos a la mano de dos de las "Águilas del Renacimiento español": Bartolomé Ordoñez y Diego de Siloé. Concretamente el Cristo yacente del frontal, que realizaría éste último hacia $1517^{1563}$, es el que se puede parangonar de forma significativa en relación a la composición del Cristo de nuestro tondo.

\section{Otras obras}

En el lado del Evangelio se situaba el retablo del Cristo del Amparo, con Jesús crucificado en el centro y cinco pinturas sobre tabla que representan a Jesucristo y los Santos Juanes, entre otros. Junto a este podía leerse: “Colocóse siendo patrono D. Antonio Orejón de la Lama y Moro, año 1710”. Igualmente en este lado se hallaban los retablos dedicados a San José y San Antón, que junto al de San Antonio de Padua situado en el lado de la Epístola correspondían a una ejecución tardía, como así mostraba la inscripción del sagrario: "Se pintaron estos tres altares siendo cura D. Manuel Calvo, año1860”. Así mismo, en el lado de la Epístola se custodiaba un retablo dorado de orden corintio con la imagen de vestir de la Virgen de la Paz ${ }^{1564}$.

Procedentes de esta iglesia, hoy día en el museo sacro de Santiago, se han conservado dos obras. Una, es la talla de San Francisco de Paula, anónimo, de hacia 1730, ya estudiada en el capítulo dedicado a las capillas de la iglesia de Santa María, ya que esa imagen fue trasladada a este templo, situándose en el ático del retablo de la

\footnotetext{
${ }^{1562}$ Agradezco sinceramente la traducción de esta inscripción a Alfonso Vives Cuesta, docente del Departamento de Filología Clásica de la Universidad de Valladolid.

${ }^{1563}$ GÓMEZ-MORENO, Manuel. Las águilas del Renacimiento español: Bartolomé Ordoñez, Diego de Siloé, Pedro Machuca, Alonso Berruguete. Instituto Diego Velázquez. Madrid, 1941, pp. 19-20 y 40-41

${ }^{1564}$ RAMIREZ DE HELGUERA, Martín. El libro...Op.cit, pág. 163.
} 
Virgen de la Paz, hasta que en los años ochenta finaliza su andadura en Santiago ${ }^{1565}$. La otra, es una cruz alzada de plata sobredorada del siglo XVII. Se trata de una pieza rococó que representa un Crucificado por uno de los lados y en el otro, el busto de San Juan Bautista señalando el Agnus Dei, referencia que señala su ubicación primitiva en esta $_{\text {parroquia }}{ }^{1566}$.

${ }^{1565}$ GÓMEZ PÉREZ, Enrique y MARISCAL ARRANZ, José. Iglesia de Santiago...op.cit. pág. 78. ${ }^{1566}$ IbIbídem, pág. 63. 


\subsubsection{IGLESIA DE SAN BARTOLOMÉ}

No se conocen demasiados datos acerca de esta iglesia, pues no se conserva ningún resto de la misma y la escasa información recabada en la documentación no esclarece demasiado su historia ${ }^{1567}$. Tan solo permanece el recuerdo de su ubicación gracias a la calle homónima, al sudoeste de la villa, muy próxima a las antiguas tenerías. Se trataría de un edificio de pequeñas dimensiones, dada su condición de parroquia, existente antes de 1345, como así recoge la estadística de la Diócesis de aquel año. Era por entonces un templo modesto, como así se deduce del personal que abastecía la misma, el cura, un preste, un diácono y tres graderos, el menor número en la villa carrionesa $^{1568}$.

Desde finales del siglo XVII el templo se hallaba en ruinas, finalizando su andadura en 1735, en que sus feligreses son agregados a los del templo de San Andrés y los materiales procedentes de su demolición, llevada a cabo por los maestros de albañilería carrioneses José Iglesias y José Pérez, son destinados en parte a la iglesia de San Juan del Mercado ${ }^{1569}$. Su mayordomo vendió por 1200 reales, otros tantos al cura de Santa María con el fin de que se construyese su casa, resultando en vano las súplicas emitidas por el mayordomo de San Andrés, quien los necesitaba para poder reforzar la torre. Fue el receptor del Estudio de Gramática, quien obtuvo finalmente el permiso para hacer uso del resto de los materiales del despojo para reedificar el edificio ${ }^{1570}$.

A mediados del siglo XVIII, tan sólo quedaba el solar, habiéndose eliminado cualquier recuerdo del templo ${ }^{1571}$. Una pequeña parte de los fieles de esta parroquia

\footnotetext{
${ }^{1567}$ Los libros de Fábrica de San Bartolomé que custodia el Archivo de la iglesia de Santa María de Carrión abarcan tan sólo medio centenar de años (1656-1700). A ello se suma la escasa frecuencia con que aparece mencionado en la documentación perteneciente al Archivo Histórico Provincial de Palencia.

${ }_{1568}^{1568}$ SAN MARTÍN PAYO, Jesús. "La más antigua...Op.cit, pág. 10.

${ }^{1569}$ ACP. Provisorato. Legajo 319, $\mathrm{n}^{\circ}$ 54799, s/f

1570 1735. ACP. Provisorato. Legajo 319, $\mathrm{n}^{\circ}$ 54799, s/f

${ }^{1571}$ Así consta en el pregón y remate para proceder a la venta de una casa perteneciente a la obra pía del Estudio de gramática que se encontraba lindero al mencionado solar. AHPP. Carr.Prot 5451, Andrés Núñez Castelo (1754-1755), fol 375.
} 
fueron agregados a la iglesia de Santiago, traspasándose igualmente el patronazgo de la obra pía que allí había fundado su antiguo párroco, don Miguel Ortiz de Avecia ${ }^{1572}$.

\section{ALGUNOS DATOS DE SU CONSTRUCCIÓN}

La primera mención documental relativa a algún tipo de obra en San Bartolomé data del 29 de enero de 1538, en que dicta testamento don Alonso Gómez de San Román, disponiendo la edificación de una capilla para su enterramiento ${ }^{1573}$. Le sucede en el patronazgo su hija, doña Ana de Ulloa, a quien el mayordomo y clérigo reclaman la deuda que había contraído con el templo, al desatender el censo perpetuo a que estaba obligada desde hacía más de ocho años ${ }^{1574}$.

A mediados del siglo se estaba reedificando por entonces la capilla mayor y la iglesia, carente de fondos, decide solicitar en 1561 un censo de mil maravedíes, con el fin de evitar la paralización de la fábrica “...porque a no hacer las tapias prolongaríase

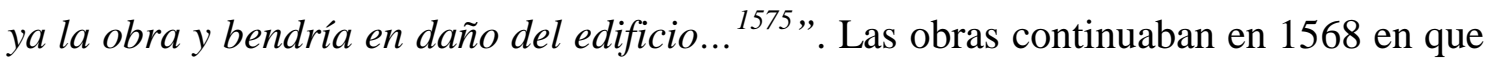
el mayordomo solicita la venta de unas sepulturas en este sector, cuyo beneficio ayudaría a sufragar los gastos de los reparos ${ }^{1576}$. En estas obras intervino el célebre Juan de Celaya, quien, una vez más, se vio envuelto en un pleito con el templo en 1579 por incumplimiento del contrato ${ }^{1577}$. El maestro cántabro era muy dado a concertarse en varias obras paralelamente y verse imposibilitado a dedicarlas el tiempo preciso, lo que le acarrea numerosos contenciosos, como había sucedido en los templos de San Andrés o Belén ${ }^{1578}$. En este caso, la obra de la capilla había sido tasada por los maestros de cantería Juan de Ortega Castañeda y Francisco del Vado en 30.000 maravedíes. El clérigo del templo, Juan Moro, quien además poseía capilla propia en el templo, no estaba satisfecho con lo ejecutado por Celaya, y éste en cambio arguía que había realizado más de lo estipulado. Con el objeto de evitar litigios, ambas partes pactan

\footnotetext{
${ }^{1572}$ Así se muestra en el poder otorgado el 20 de diciembre de 1758 por los patronos de la obra pía de Miguel Ortiz de Avecia a Miguel Santiago. AHPP., Carr.Prot 4652, Juan Cano Guijelmo (1758-1759), fol 206.

${ }^{1573}$ AHPP. Varios, Protocolo 5858 (1520-1654), fol 26 y ss.

1574 1570. AHPP. Carr.Prot 5305. Pedro López de la Vega (1559-1586), s/f

1575 El permiso del censo y la solicitud del mismo en AHPP. Carr.Prot 5440. Gregorio Movilla (15611562), s/f.

${ }^{1576}$ AHPP. Carr.Prot 4675. Juan Cantoral (1563-1568), s/f.

1577 AHPP. Carr.Prot 5729. Lázaro Santacruz (1579-1584), s/f.

1578 Sobre Juan de Celaya, véase el apartado relativo a los maestros de cantería.
} 
“...que agora ni en ningún tiempo del mismo sobre esta causa no se pedirán ninguna cosa el uno al otro, ni el otro al otro....”, concluyéndose así la querella presentada. Al parecer la capilla mayor seguía sin estar finalizada en la primera década del siglo XVII, por lo que la iglesia se concierta en septiembre de 1609 con el maestro de albañilería Antonio de Cuéllar ${ }^{1579}$ para que la socalce desde la capilla de Gaspar de los Ríos Campoo $^{1580}$ hasta la de Juan Moro, ubicados dentro de la capilla mayor. Se había comprometido a finalizarla en junio de 1610 , pero cuando se acercaba la fecha, la obra no estaba finalizada y la iglesia contrata a otro maestro local, Francisco de Arce, para que la finalice ${ }^{1581}$.

En la segunda mitad del siglo XVII los múltiples retejos que sufre el templo y el reparo del colgadizo de la torre que se ejecuta en 1666, verifican su delicado estado al estar aquejado por la filtración de las aguas del río ${ }^{1582}$. En 1695, el visitador describe la ruinosa situación del templo a la par que augura el triste desenlace: “... respecto del peligro imminente que tiene de arruynarse porque las aguas del rrío ban mui arrimadas y tienen casi destruido los fundamentos de el edifizio, por cuia causa ya se alla la torre sin campanas ni serbizio alguno y respecto también del corto caudal de su azienda y pocos y pobres feligreses para ahora y asta ver y determinar si combiene o no rresumir y agregar esta parroquia a otra, se rreserba probeer el Ilmo y Rvmo señor Obispo de Palenzia... ${ }^{1583, "}$.

\section{OBRAS DEL TEMPLO}

Las referencias documentales sobre las obras que atesoraba el templo de San Bartolomé, resultan ciertamente exiguas. Dentro de la capilla mayor, el clérigo y beneficiado de la iglesia, don Juan Moro de Saldaña, había adquirido un espacio propio para él y sus descendientes el 23 de noviembre de 1535. Por disposición testamentaria,

\footnotetext{
1579 Sobre el mismo, véase el apartado relativo a los maestros de obras.

${ }^{1580}$ Este linaje poseía otra capilla propia en la iglesia conventual de San Francisco, bajo la advocación de la Purificación. Véase a este respecto el capítulo de los espacios de culto del templo franciscano. La familia descendía del solar cántabro de Proaño y poseía regidurías perpetuas en Carrión. VIGURI, Miguel de. Heráldica...2. Op.cit, pág. 74.

1581 AHPP. Carr.Prot 5508. Sebastián Peláez (1607-1610), s/f.

${ }^{1582}$ Las reparaciones las realizan diversos carpinteros de la villa carrionesa, destacando entre ellos Juan de Real por sus sucesivas intervenciones. ASMC. Libro de Fábrica (1656-1700), s/f.

${ }^{1583}$ ASMC. Libro de Fábrica (1656-1700) s/f.
} 
el 6 de mayo de 1585, encarga la ejecución de un retablo presidido por la talla de Nuestra Señora que guardaba en su vivienda particular que estaría flanqueada por las imágenes de los Santos Juanes. Además solicitaba que se hiciese un frontal de damasco blanco para las festividades principales. Nombra como herederos de la capilla a su sobrina, Francisca de Saldaña, esposa de Pedro de Saldaña ${ }^{1584}$. La imagen de la Virgen fue dorada por Francisco Valiente, vecino de Guardo en $1649^{1585}$.

A finales de siglo XVI, la precaria situación por la que pasaba el templo, le impedía saldar la deuda contraída en 1595 con Martín de Colindres, entallador cántabro oriundo de la localidad homónima, por la factura de una custodia, esto es, un sagrario para el retablo mayor que probablemente se llevó a cabo en este momento. Al apelar a la justicia, ésta impone establecer un censo mediante el cual se abonen al interesado los siete mil maravedíes que se le deben ${ }^{1586}$. La imagen titular que presidía el retablo fue trasladada al ático del retablo mayor de la iglesia de San Juan del Mercado cuando ésta cerró al culto ${ }^{1587}$. A partir de 1650 , por donación expresa del párroco de entonces, don Miguel Ortiz de Avecia, pasaron a formar parte de los ornamentos del templo dos ángeles turiferarios destinados a la capilla mayor, además de ciertos enseres de carácter litúrgico para el culto ${ }^{1588}$.

\footnotetext{
${ }^{1584}$ ADP. Carrión. San Andrés. Legajo 116, n 19. Traslado del testamento de Juan Moro de Saldaña. 1618

1585 AHPP. Carr.Prot 5193. Jerónimo Laso (1649-1650), fol 154.

${ }^{1586}$ Escritura suelta de 9 de mayo de 1595. AHPP. Varios. Varios años. Protocolo 4695, s/f.

${ }^{1587}$ RAMÍREZ DE HELGUERA, Martín. El libro...Op.cit, pág. 163.

1588 AHPP. Carr.Prot 5432. Francisco Moro de Saldaña (1650), s/f.
} 


\subsubsection{SAN VICENTE Y SANTA EULALIA}

Tratamos ahora dos templos cuya historia presenta nexos comunes y ante la escasez de datos, estudiamos en un mismo capítulo. De todos los templos ubicados en Carrión, estos dos y el de Sancti Espíritus eran los únicos no parroquiales ${ }^{1589}$. Ambos se hallaban en la zona noroeste de Carrión: San Vicente, junto a los depósitos de agua y Santa Eulalia en la actual calle homónima, también denominada Santa Olalla.

A mediados del siglo XVI la iglesia de San Vicente se hallaba en ruinas y se decide anexionarla “...por estar en despoblado e sin parrochianos algunos...” al vecino templo de Santa Eulalia. El párroco de este último, don Antonio de Carrión, propone en 1566 la demolición de San Vicente, ya que con la venta de los materiales extraídos “...se podrá comprar renta para augmento del dicho beneficio...”. El convento de Santo Domingo adquirió en ese año la teja, piedra y ladrillo extraídos por 150 ducados para reutilizarlos en su reciente fundación, ya que no podían costearse nuevos materiales para su fábrica ${ }^{1590}$. En 1595 se decide vender la torre de San Vicente, el único resto que quedaba en buenas condiciones de toda la edificación a la iglesia aneja de Santa Olalla o Santa Eulalia ${ }^{1591}$. Desde entonces no se hace mención alguna en la documentación a este templo, deduciéndose su demolición y la consecuente anexión de los feligreses a Santa Eulalia. De hecho, en el manual de 1619 de Cisneros y Tagle, nuestro regidor elabora una lista con los nombres de los curas de cada una de las parroquias de la villa y no figura ya el templo de San Vicente ${ }^{1592}$. En el museo de Santiago se conserva una imagen de San Vicente de Zaragoza, del siglo XVI $(100 \mathrm{~cm} \times 40 \mathrm{~cm} \times 30 \mathrm{~cm})^{1593}$ que procede probablemente de este templo. La talla nos presenta un hombre de mediana edad, descalzo, vestido de diácono con una dalmática

\footnotetext{
1589 SAN MARTÍ́N PAYO, Jesús. "La más antigua estadística de la Diócesis Palentina (año 1345)" en PITTM, $\mathrm{n}^{\circ}$ 7. Palencia, 1949-1950, pp. 10-13. A su vez de Archivo de la Catedral de Palencia. Armario 8, legajo 1, $\mathrm{n}^{\circ}$ 2, letra A. Este manual lo mandó redactar el Obispo don Vasco (1344-1352) para trazar con exactitud los lugares por donde se extendía la Diócesis palentina. Había un total de 576 parroquias repartidas en cuatro arcedianazgos: Carrión, el más importante de todos por número de parroquias y posesión de privilegios, Campos, Cerrato y Alcor. Sobre este Obispo, véase VACA LORENZO, Ángel. "Don Vasco, el muy buen perlado de Palencia: su vida y obra al frente de este Obispado" en AIIICHP, volumen 2. Palencia, 1995, pp. 437-482

${ }^{1590}$ La petición para derribar el templo y la compra de materiales en AHPP. Carr.Prot 5664. Andrés Sánchez (1565-1568), s/f.

${ }^{1591}$ AHPP. Carr.Prot 4984. Sebastián García (1595-1597), s/f.

1592 CISNEROS Y TAGLE, Juan de. Op.cit, fol 210v.

${ }^{1593}$ GÓMEZ PÉREZ, Enrique y MARISCAL ARRANZ, José. La iglesia...Op.cit, pág. 73
} 
granate y sustentando el libro sobre el que reposa un cuervo, mientras bendice con la otra mano.

La iglesia de Santa Eulalia continúa su andadura y en 1606 el cura de la misma solicita licencia para poder vender un pedazo de tierra y de esta manera poder sufragar los costes ocasionados por el reparo de su torre ${ }^{1594}$. Cuando en 1702 Juan de Solana se encarga de llevar a cabo la portada de la iglesia de San Andrés, señala haber empleado piedra extraída de los despojos de Santa Eulalia, de lo que colegimos que se hallaba en mal estado ${ }^{1595}$. El informe aportado por el carpintero y alarife Francisco García de Cabria en 1721 declaró el templo en estado de ruina. Las aguas habían afectado a la totalidad del edificio: el tejado estaba hundido, la cimentación era endeble, y las tapias y arcos se encontraban resquebrajados. Era necesario tomar una medida urgente, o reparar de inmediato los desperfectos, con un coste equivalente a la realización de nueva fábrica, o bien, proceder a su demolición ${ }^{1596}$. Se optó por la segunda opción, de modo que los feligreses, fueron adheridos a los de la iglesia de San Andrés ${ }^{1597}$. En lo que respecta a sus retablos y bienes muebles, fueron desmontados de inmediato $\mathrm{y}$ trasladados igualmente a dicho templo ${ }^{1598}$. Merece mención un retablo dedicado a Nuestra Señora de la Piedad, el cual originalmente ubicado en el lado de la Epístola de la capilla mayor de Santa Eulalia, pasó a ubicarse junto a la sacristía de San Andrés. Destacamos esta pieza por el litigio que desencadenó en 1738, pues en el nicho de su parte baja se hallaban bajo reja las reliquias de San Antón y San Lorenzo, las cuales fueron extraídas sin permiso por don Félix Barba Dávila y Pimentel, regidor de Carrión de los Condes, bajo pretexto de pertenecerle, pues su mujer era la legítima heredera de los bienes don Juan Herrero Zapata, último cura de Santa Eulalia. Las reliquias se veneraban en el templo de Santa Eulalia desde tiempo inmemorial, mucho antes, por tanto, de la llegada de dicho cura, a quien, en ningún caso pertenecían las reliquias, por lo que el fallo se resolvió a favor de la parroquia de San Andrés ${ }^{1599}$.

\footnotetext{
${ }^{1594}$ AHPP. Carr.Prot 5477. Antonio Orejón El viejo (1606), s/f.

1595 Así figura en la carta de pago otorgada a Solana en 1704. AHPP. Carr.Prot 5020. Agustín García Miranda (1701-1704), s/f.

${ }^{1596}$ AHN Clero Secular-Regular 5358 s/f. Expediente 3. Santa Eulalia. Obras.

1597 ACP. Provisorato. Legajo 318. Cuentas de la iglesia resumida de Santa Eulalia agregada a S. Andrés. 1733 y 1733. Cuenta con el Licenciado don Juan Herrero Zapata de diferentes caudales pertenecientes a la iglesia de Santa Eulalia. ACP. Provisorato. Legajo 318, n 54632, s/f.

1598 ADP. Carrión. San Andrés. Libro $4^{\circ}$ de Cuentas de Fábrica (1718-1752), fol 51.

1599 1738. ACP. Provisorato. Legajo 319, no 54809, s/f.
} 


\subsection{ERMITAS}




\subsection{ERMITAS}

En Carrión existieron un buen número de ermitas: San Juan de Cestillos, dependiente del monasterio de San Zoilo y ubicada en las afueras, la Vera Cruz, junto a San Andrés y otras cuatro que dependían del convento de Santa Clara. De ellas, las ermitas de la Madre Luisa y la de San Juanillo, a las que nos referimos al estudiar la casa clarisa, se ubican en clausura, dentro de la huerta. De las otras dos, una, bajo la advocación de San Cristóbal, ha desaparecido y la otra, situada frente a las tapias del convento, es la ermita de la Piedad. Este tipo de oratorios en conventos de clarisas son muy recurrentes, pudiéndose citar los eremitorios de la huerta de Santa Isabel de los Reyes en Toledo o el del monasterio de La Latina en Madrid. Salvo la ermita de la Cruz, fruto de la devoción popular, el resto de edificaciones pertenecen a órdenes religiosas. Este tipo de edificaciones servían para reproducir en el monasterio una especie de microcosmos sacralizado, de ahí que dispusieran de santos de la devoción particular.

\subsubsection{SAN CRISTÓBAL}

Sobre el lugar que hoy se denomina "cuesta de San Cristóbal" existió una edificación bajo la advocación de San Cristóbal "El Viejo" que Peral Villafruela identifica con un hospital regido por canónigos regulares para los peregrinos que necesitasen su asistencia en el camino que unía Carrión con Arconada ${ }^{1600}$. No podemos determinar donde se remonta el origen del mismo, pero existía con seguridad en 1265 cuando las clarisas adquieren su propiedad junto a la del convento de Sancti Spiritus ${ }^{1601}$. En 1437 en que la fábrica figura bajo la denominación de ermita, se hallaba en estado de ruina y las clarisas conceden su propiedad a los agricultores de la zona. Éstos se

\footnotetext{
${ }^{1600}$ Su posición a la vera del camino y su denominación de San Cristóbal el Viejo por comparación con el hospital nuevo de San Cristóbal señalan, según el autor, esta función de nosocomio. PERAL VILLAFRUELA, Santiago. De Aquitania...Op.cit, pp.148-149.

${ }^{1601}$ ASCC, Leg.3, 123.
} 
comprometen a reedificarla bajo la misma advocación de San Cristóbal, por considerarlo su protector ${ }^{1602}$.

Se hallaba muy deteriorada en 1622, por lo que el mayordomo de la cofradía del mismo nombre asentada en la dicha ermita, don Francisco Moro de Saldaña, decide contratar a un maestro de carpintería con el fin de que renovase todos las cubiertas dañadas y uno de los paredones de ladrillo, material en el que debía estar realizada toda la fábrica. El artífice escogido para acometer las obras fue Pedro Ruiz Solano ${ }^{1603}$, procedente de Trasmiera pero avecindado en Carrión. Los pagos en especie -cargas de trigo- y en dinero obtenido de limosnas, denotan la falta de fondos del templo, a pesar de lo cual, la hermandad no duda en adecentarla “...para que se conserve y continúe y

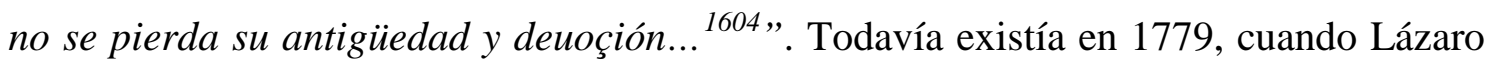
de Castro, cotejándola con la de la ermita de la Piedad, dice “...más distante grandeza es ésta, que en pocas ciudades la alcanzaron en estos tiempos... "1605. Sin embargo se encontraba ya en un estado ruinoso, pues no llegaban hasta este lugar las procesiones de las letanías por no hallarse decorosa para tal acontecimiento ${ }^{1606}$.

1602 GÓMEZ PÉREZ, Enrique. El Real Monasterio...Op.cit, pág. 32, a su vez de ASCCC. Legajo III, $\mathrm{n}^{\circ} 123$.

${ }^{1603}$ Sobre el mismo, véase el apartado relativo a los maestros de cantería.

1604 AHPP. Carr.Prot 5405. Francisco Moro Saldaña (1622), s/f.

1605 CASTRO, Lázaro de. Breve Historia de Carrión. Carrión, Palencia, 1779, s/f.

${ }^{1606}$ BARREDA FERRER, Ángel Luis y GÓMEZ PÉREZ, Enrique. Iter Stelarum. La gran obra de los Caminos de Santiago. Tomo V. Ediciones Hércules. La Coruña, 2004, pág. 270. 


\subsubsection{LA PIEDAD}

En la entrada inmediata a la villa desde la carretera de Frómista, se encuentra la ermita de la Piedad. Está separada del convento de Santa Clara, bajo cuya jurisdicción se mantuvo durante siglos, por una pequeña carretera, paso obligado de la ruta jacobea. Tan celosas de su propiedad fueron las clarisas que en un memorial del siglo XVIII consta que jamás había tenido acceso a la misma ni siquiera el Visitador Provincial ${ }^{1607}$. De hecho sólo se abría públicamente para las procesiones de letanías, en que se ofrecía misa y sermón, siendo los hermanos franciscanos del convento aledaño quienes actuaban en su representación con el fin de que las monjas respetaran la clausura ${ }^{1608}$.

Parece que la ermita fue construida al tiempo del hospital de la Trinidad o de la Condesa doña Aldonza, es decir hacia 1429, pues este espacio conformaría la capilla de dicho nosocomio, situándose bajo la advocación de la Piedad ${ }^{1609}$. Desde el siglo XVI se establecerá en este lugar la cofradía de Nuestra Señora de la Piedad, pasando a ser ermita de devoción incluida en los puntos de paso de las procesiones de las letanías ${ }^{1610}$.

Se trata de un edificio longitudinal de 16 metros de largo y 5,75 metros de ancho $^{1611}$. Consta de una sola nave y testero plano con crucero que no se refleja al exterior. En la fábrica se aprecian claramente dos fases constructivas: la cabecera gótica y el cuerpo del templo reedificado posteriormente. La cabecera es un pequeño espacio cuadrangular conformado por cuatro arcos apuntados muy amplios sobre los que se sitúa una bóveda de arista posterior, del siglo XVII, policromada con un enfoscado azulado de dudoso gusto. En los ángulos del testero, los arcos apean sobre dos ménsulas de sección poligonal ornamentadas a través de motivos vegetales. El arco de ingreso al presbiterio descansa, sin embargo, sobre medias columnas flanqueadas por un baquetón a cada lado, cuyos capiteles presentan análoga decoración a la de las ménsulas. Los fustes de estos soportes están divididos en varios módulos regulares donde se produce una alternancia bícroma de la piedra empleada en los mismos. Este espacio se halla

\footnotetext{
${ }^{1607}$ ASCCC. Legajo XIV. Correspondencia y recibos (1763-1933). Memorial redactado por la comunidad clarisa el 18 de julio de 1788 , s/f.

${ }^{1608}$ GÓMEZ PÉREZ, Enrique. El real Monasterio...Op.cit, pág. 78.

${ }^{1609} \mathrm{Al}$ respecto de los hospitales, véase PERAL VILLAFRUELA, Santiago. Los hospitales...Op.cit.

${ }^{1610}$ GÓMEZ PÉREZ, Enrique. El real Monasterio...Op.cit, pág. 52.

1611 RAMÍREZ DE HELGUERA, Martín. El libro....op.cit, pág. 186.
} 
iluminado por un ajimez de arco ojival y ligeramente abocinado practicado en el muro de la Epístola. Dos arquillos apuntados tangentes al mayor, apean sobre tres finos pilares de capiteles desarrollados con motivos vegetales enroscados. Sobre el mainel, entre la conjunción de ambos arcos, se conserva un rosetón con una cuadrifolia horadada en su interior. Todo este sector, salvo la bóveda de arista mencionada, corresponde a una ejecución temprana que podemos fechar hacia 1400.

En lo que respecta a la nave, su fábrica también debía corresponder primitivamente a una intervención gótica. No obstante, nada queda de aquel período, pues fue reedificada en el siglo XVII. Así consta en la inscripción situada sobre el arco de ingreso al presbiterio. En ella se puede leer sobre el arco de la nave: “ESTA IGLESIA ES DE SANTA CLARA. REEDIFICOLA LA MADRE LVISA DE LA ASCENSIÓN. AÑO DE MIL I SEISCIENTOS I BEINTE I CINCO ANNOS”. Esta fue una de las tantas obras que impulsó la venerable monja de Carrión durante su permanencia en la casa clarisa $^{1612}$. Posteriormente, entre 1646 y 1648, el maestro de carpintería carrionés Antonio del Tejo ${ }^{1613}$ se encarga de reparar y retejar la ermita ${ }^{1614}$.

\section{Nave de la ermita}

2. Sacristía

3. Pórtico

4. Antigua vivienda de la ermitaña

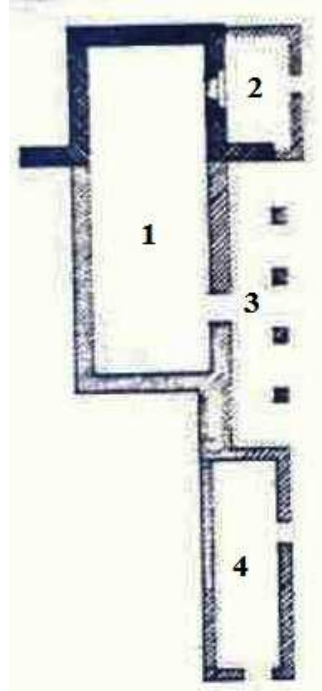

Planta de la ermita de la Piedad. MOPU. Dirección General de Arquitectura y Edificación. Incluida en el mapa de Carrión de 1986.

\footnotetext{
${ }^{1612}$ Respecto a la madre Sor Luisa de la Ascensión, véase el capítulo dedicado a la misma en el apartado de la casa clarisa.

1613 Sobre el mismo, véase el capítulo dedicado a los artífices que trabajan en Carrión.

1614 ASCC. Libro de cuentas 1633-1655, fol 240v.
} 
Exteriormente, el edificio es de ladrillo recubierto de tapial, salvo la cabecera que está realizada en piedra. El elemento de transición entre la nave y el presbiterio es un contrafuerte adosado en el lado meridional que separa a su vez, dos espacios adosados al muro que presentan una cubrición de ladrillo a una vertiente. El primero de ellos es el pórtico de acceso, conformado por cuatro pies derechos que preceden a un sencillo portal de madera. Algunos de los postes fueron reconstruidos en $1816 \mathrm{y}$ reforzados con unos antepechos de madera que los unían, momento en que además se ejecutan algunas labores de refuerzo sobre el muro de la cabecera y se enluce el templo $^{1615}$. Junto al soportal, a los pies de la ermita, existe una pequeña edificación independiente de la ermita pero conectada con la misma por su ángulo sudoccidental. Se trata de la antigua vivienda de la ermitaña que cuidaba del templo ${ }^{1616}$, hoy convertida en cochera.Adosada a la cabecera por el lado de la Epístola, hallamos la sacristía, una estancia rectangular de factura moderna y cubierta de madera. En el lado occidental, adosado a los pies, se encuentra una espadaña moderna de piedra que aloja una sola campana y que sustituyó a la anterior, que, según figura en las cuentas del convento de las clarisas fue construida entre 1756 y $1758^{1617}$.

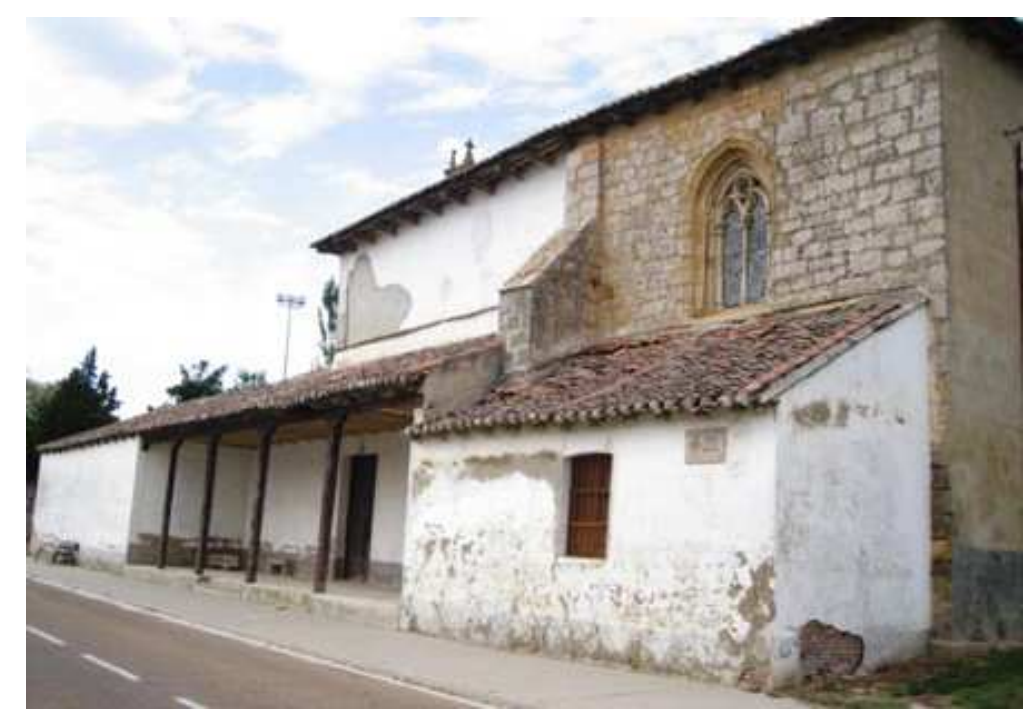

Aspecto exterior de la ermita de la Piedad.

\footnotetext{
1615 ASCC. Libro 30. Cuentas de cargo y descargo. (1815-1817), pp. 50 y 52.

1616 RAMÍREZ DE HELGUERA, Martín. El libro...Op.cit, pág. 186.

${ }^{1617}$ ASCCC. Libro 15. Cuentas Generales (1715-1777), s/f.
} 
Debido al deterioro que sufría uno de los lienzos de la ermita, se creó una comisión en 1879, bajo la supervisión del párroco de Santa María, gracias a la cual se reunirían los fondos suficientes para realizar las reparaciones convenientes ${ }^{1618}$. Fruto de la intervención llevada a cabo por entonces es la inscripción situada en el arco de la capilla mayor, bajo la mencionada con anterioridad de 1625 que reza: "Y EN 1879 SE HIZO OTRA REEDIFICACIÓN A ESPENSAS DE LA DEVOCIÓN". No existen obras de envergadura a lo largo del tiempo, salvando la intervención de refuerzo realizada en 1913 sobre el lienzo oriental, denominado popularmente del "juego de la pelota", donde hoy preside un gran mosaico que representa el Pantocrátor de la iglesia de Santiago ${ }^{1619}$. A mediados del siglo XX, finalizó la andadura de la cofradía de la Piedad asentada en esta ermita ${ }^{1620}$, que fue agregada a la parroquialidad de Santa María.

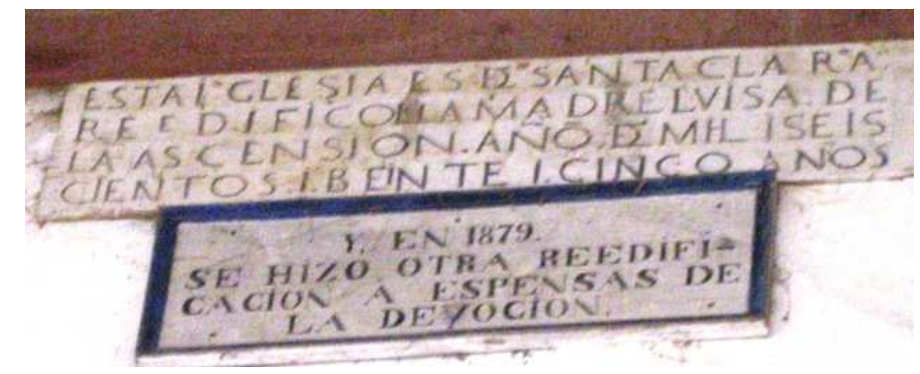

\section{Inscripciones ubicadas en el arco de ingreso a la capilla mayor de la Piedad.}

\section{El retablo mayor}

El retablo anterior “...churrigueresco de mala pintura...” fue sustituido el 22 de mayo de 1895 por el retablo que presidía la capilla del antiguo hospital desaparecido de Santa María, ubicado en la plazuela homónima ${ }^{1621}$. En 1883 fue extraído del viejo nosocomio antes de que fuera demolido y trasladado a la iglesia de Santa María donde se conservó durante poco más de una década, hasta la fecha señalada en que se trasladó a la Piedad, adaptándose a su testero plano. El ayuntamiento permitió el mantenimiento del bien mueble en la ermita, puntualizando la pertenencia de la obra al hospital

\footnotetext{
${ }^{1618}$ AMCC. Libro 11, Sesiones municipales (1879-1885). Sesión de 17 de enero de 1879, fol 4v.

${ }^{1619}$ La autorización del párroco para las obras queda patente en AMCC. Libro 22. Sesiones municipales (1911-1914). Sesión municipal de 13 de abril de 1913, fol 232.

${ }^{1620}$ GÓMEZ PÉREZ, Enrique. El real Monasterio...Op.cit, pág. 52.

${ }^{1621}$ RAMÍREZ DE HELGUERA, Martín. El libro...Op.cit, pág. 184.
} 
municipal, y en su nombre, al concejo y determinando que podrá ser reubicada en el momento que se estime oportuno ${ }^{1622}$. Datado en el siglo XVII ${ }^{1623}$, el retablo $(5,3$ metrosX 6 metros) presenta la estructura propia de una obra de la primera mitad de la centuria, conformada por un solo cuerpo dividido en tres calles y ático desarrollado. En el centro del banco se conserva una pintura muy somera con un cortinaje barroco que serviría de fondo al sagrario, trasladado al crucero del museo Sacro de Santiago ${ }^{1624}$.

En su lugar se hallan enmarcadas las indulgencias concedidas por Bula de Clemente VII de 1527 y confirmada por León X. A los lados se hallaban originalmente ocho óleos sobre tabla: seis de formato alargado, formando parte de los plintos de los soportes que sustentan que representan algunos Apóstoles y dos de ellos, en los espacios intermedios, de carácter apaisado, representando escenas hagiográficas. Han perdido parte de su policromía original y fueron realizadas paralelamente a la ejecución del ensamblaje del retablo, probablemente por un artista local de mediana calidad. De izquierda a derecha, hallamos a Santiago el Mayor, San Jerónimo eremita haciendo penitencia, San Simón, San Felipe, San Andrés y San Bartolomé. Las dos pinturas del lado derecho, que representaban la Aparición de la Virgen a San Bernardo y Santiago Alfeo, fueron robadas en el año 1993, al igual que las imágenes de la Magdalena y San Francisco ubicadas a los lados del cuerpo principal ${ }^{1625}$. Éste se encuentra dividido por seis columnas entorchadas y capitel compuesto que lo dividen en tres calles, estando las laterales ocupadas actualmente por siete pinturas de escaso mérito sobre la vida de Cristo que sustituyeron a las imágenes sustraídas.

La hornacina central está conformada por un arco de medio punto en cuyas enjutas se han tallado puntas de diamante, sobre las que se asienta un frontón curvo decorado a base de dentellones. El arco apea sobre sendas pilastras cajeadas que albergan una Piedad moderna traída de Valencia en $1895^{1626}$. La imagen original, ubicada hoy en el museo de Arte Sacro de Santiago y a la que la que debe su nombre la ermita, es una Piedad horizontal gótica realizada en piedra caliza policromada

\footnotetext{
${ }^{1622}$ AMCC. Libro 14, Sesiones municipales (1892-1896). Sesión de 26 de julio de 1895, fol 56 y ss. ${ }^{1623}$ URREA FERNÁNDEZ, Jesús y MARTÍN GONZÁLEZ, Juan José. Inventario...2.Op.cit, pág. 58. ${ }^{1624}$ GÓMEZ PÉREZ, Enrique y MARISCAL, José. La iglesia...Op.cit, pág. 36.

${ }^{1625}$ Este expolio motivó, como veremos, que algunas obras de esta ermita pasaran a formar parte de los fondos del museo de arte sacro de Santiago. GÓMEZ PÉREZ, Enrique y MARISCAL ARRANZ, José. La iglesia...Op.cit, pág. 36.

${ }^{1626}$ RAMÍREZ DE HELGUERA, Martín. El libro...Op.cit, pág. 185.
} 
$(87 \mathrm{~cm} \times 72 \mathrm{~cm} \times 40 \mathrm{~cm})$. Se trata, de una pieza deudora estilísticamente del prototipo de piedad de origen bohemio que dentro de la corriente cortesana fue creado a lo largo del siglo XIV, continuando su propagación durante el siglo posterior ${ }^{1627}$. El rostro de la Virgen es el de una adolescente compungida, su túnica en los plegados en abanico aportando gran elegancia y el cuerpo de Cristo no muestra el patetismo que, usualmente, presentaban los de las piedades alemanas ${ }^{1628}$. Datada por unos entre 1410 y $1420^{1629}$ y mediados de la centuria, por otros ${ }^{1630}$, muestra a la Virgen con rostro adolescente, con Cristo muerto en su regazo, rígido, según las visiones de Santa Brígida en Suecia, quien afirmó que las extremidades de Cristo no pudieron ser dobladas tras su descendimiento.
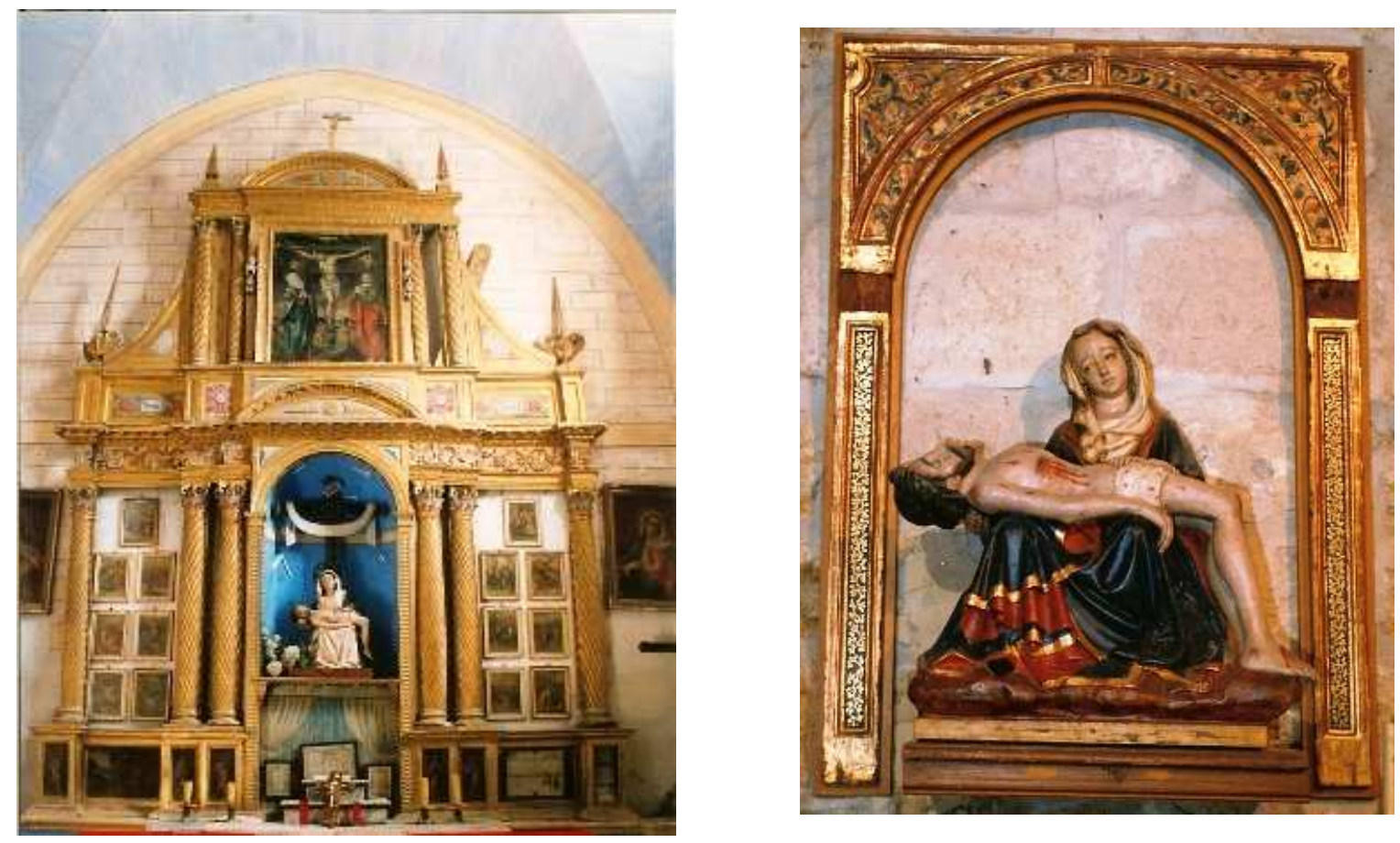

Piedad horizontal procedente del retablo mayor de la ermita de la Piedad. Museo de Arte Sacro. Piedra policromada. Siglo XV. $(87 \mathrm{~cm} \times 72 \mathrm{~cm} \times 40 \mathrm{~cm})$.

\section{Retablo mayor de la ermita de la Piedad procedente del hospital de Santa} María. Mediados del siglo XVII. (5,3mtrx4,6mtrx0,8mtr).

\footnotetext{
${ }^{1627}$ ARA GIL, Clementina-Julia. "Imaginería...”. Op.cit, pág. 56.

${ }^{1628}$ HERNÁNDEZ REDONDO, José Ignacio. "Piedad", ficha $\mathrm{n}^{\circ} 28$ en Memorias y esplendores. Las Edades del Hombre. Catedral de Palencia, 1999, pág. 55.

${ }^{1629}$ Ibídem, pág. 55.

${ }^{1630}$ URREA FERNÁNDEZ, Jesús y MARTÍN GONZÁLEZ, Juan José. Op.cit, pág. 58.
} 
En España se conservan solo cinco piedades góticas reunidas entre las dos Castillas cuyo origen apunta directamente a Praga ${ }^{1631}$. En todas ellas se establece una conexión con la corte real pues las dimensiones de la pieza y el carácter macizo coinciden en todas ellas. En el caso de Carrión, la manera en que los pliegues de los ropajes están tratados pone de relieve la relación con modelos norteños, como es el caso de la Piedad de la Abadía de Santo Tomás en Brno, en la República Checa. Por otro lado, la extensión del brazo de Cristo a lo largo del cuerpo es un rasgo poco común en las piedades góticas. Las semejanzas con modelos centroeuropeos conducen a establecer un criterio de importación de las obras. Si bien, la singularidad en los detalles de ejecución de cada una de ellas lleva a Weninger a barajar la posibilidad de que llegase a existir un taller o artista itinerante en España. No fue, como algunos creen un obsequio de Felipe III a la Madre Ma Luisa, pues, de ser así, existiría algún documento como el que encontramos cuando el monarca donó un Niño Jesús a nuestra monja. Por un documento del Archivo de Simancas, se sabe que $\mathrm{M}^{\mathrm{a}}$ Luisa se gastó cien mil ducados en las obras del convento, entre las que se nombra una ermita con tallas en medio de una huerta. Así es que, sería plausible pensar que una de dichas tallas fuera la Virgen de la Piedad, y que se tratara de una adquisición más que de un regalo. Ha sufrido dos intervenciones, una en 1895 y otra en fechas recientes que han ocultado el aspecto original de la obra ${ }^{1632}$.

El entablamento del cuerpo principal, de perfil retranqueado, presenta una decoración de roleos vegetales en tonos rojos y azulados que destacan sobre la superficie dorada. Encima, se alza el ático, elevado sobre un pedestal pintado con diversos motivos geométricos imitando piedras preciosas. Dos aletones curvos flanquean dos parejas de columnas entorchadas análogas a las del cuerpo principal pero de menores dimensiones. En el intercolumnio del lado izquierdo hallamos un tablero vertical decorado con piedras, habiéndose perdido el del lado opuesto. En el centro, inscrito en un marco de gallones propio del segundo tercio del siglo XVII, hallamos un

\footnotetext{
${ }^{1631}$ Aparte del caso que nos ocupa, éstas están ubicadas en los puntos siguientes: Museo Nacional Colegio San Gregorio y Aniago, ambas en Valladolid, y, en Toledo, contamos con las piedades del convento de dominicas y la de la Catedral. WENIGUER, Matthías, "Las bellas Piedades en Castilla" Actas del I Encuentro europeo de museos con colecciones de escultura. El taller europeo: Intercambios, influjos y préstamos en la escultura europea de la Edad Moderna. Museo Nacional Colegio San Gregorio, Valladolid, 6-8 mayo de 2010.

${ }^{1632}$ HERNÁNDEZ REDONDO, José Ignacio. Op.cit, pág. 56.
} 
óleo sobre lienzo del Calvario, datable hacia esa fecha $(123 \mathrm{~cm} \times 105 \mathrm{~cm})$. Los vivos colores presentes en la túnica de la Virgen y San Juan, se destacan sobre un fondo negro de espesas nubes que acecha la ciudad, de las que emergen el sol y la luna, flanqueando un Cristo exánime, de sinuosa figura. Este retablo clasicista, recuerda en su composición -un cuerpo de tres calles, hexástilo, mismo tipo de soportes, aletones y frontones curvos- al que, procedente de Santa María, preside la capilla mayor de la iglesia de San Andrés. Realizado aquel en 1648 por Juan Bautista Pérez esta obra pudo pertenecer a la mano de este ensamblador carrionés y haber sido realizada por los mismos años ${ }^{1633}$.

\section{Obras conservadas en el Museo de Arte Sacro}

La obra que acabamos de estudiar y otras que seguidamente veremos, fueron trasladadas por el antiguo párroco de Santa María, don José Mariscal en 1993, con motivo del robo de la ermita, para asegurarse su conservación. En primer lugar, hallamos un óleo de un Calvario anónimo del siglo XVI perteneciente, según parece, al retablo anterior de la ermita, que presenta ciertas incorrecciones en el dibujo y un tratamiento un poco tosco de los personajes ${ }^{1634}$. Además existe una talla anónima de Niño Jesús del siglo XVII de pequeño formato, $46 \mathrm{~cm}$. Es de hacia 1625 y realizada en madera policromada, de mano de escuela castellana que procede del sagrario del retablo actual de la ermita. Hoy día está situada en una vitrina ubicada en la pared que servía para acceder al púlpito junto a otras imágenes de Niños Jesús ${ }^{1635}$.

En el lado del Evangelio se hallaba un Cristo yacente “...de buen tamaño y cubierto con ropas regulares... ${ }^{1636 ” . ~ L a ~ i m a g e n ~}(138 \mathrm{~cm}$ largo x $42 \mathrm{~cm}$ ancho x $24 \mathrm{~cm}$ de alto) es en realidad un Crucificado gótico cuyos pies de carácter plano se presentan en rotación externa. Ha sido adaptado como yacente, añadiéndoles los brazos y la cabeza a posteriori, ésta última probablemente de hacia 1500. La policromía a pulimento es fruto del siglo XIX y el perizonium es un postizo de tela encolada ${ }^{1637}$. La urna de Cristal que lo protege fue encargada por las monjas clarisas en $1816^{1638}$.

\footnotetext{
${ }^{1633}$ El contrato del retablo en AHPP. Carr.Prot 5238. Jerónimo López (1648), fol 130 y ss. Sobre Juan Bautista Pérez, remítase al capítulo dedicado a los escultores y ensambladores locales.

${ }^{1634}$ GÓMEZ PÉREZ, Enrique y MARISCAL, José. La iglesia...Op.cit, pág. 31.

1635 Ibídem, pág. 33.

${ }^{1636}$ RAMÍREZ DE HELGUERA, Martín. El libro...Op.cit, pág. 186.

${ }^{1637}$ GÓMEZ PÉREZ, Enrique y MARISCAL, José. La iglesia...Op.cit, pág. 86.

1638 ASCC. Libro 30. Cuentas de cargo y descargo. (1815-1817), pp. 50 y 52.
} 


\subsubsection{SAN JUAN DE CESTILLOS}

Rodeada de huertas, esta ermita se halla a unos dos kilómetros de Carrión, al sur de la misma, en la margen izquierda del río, según se sale de la villa en dirección a Palencia. No podemos precisar el origen de esta ermita, pero sabemos su existencia desde el año 1183, en que establece una concordia con el monasterio de San Zoilo, del que, salvo períodos intermitentes, dependerá jurisdiccionalmente ${ }^{1639}$.

En la Estadística que el Obispo de Palencia realiza de la Diócesis en 1345, la colación e institución pertenecía por entonces al obispado, pero puesto que el arrabal en el que se situaba era posesión de San Zoilo, casi un tercio de los diezmos eran destinados al limosnero del cenobio benedictino ${ }^{1640}$. El abad de San Zoilo acordaba con el Obispo los clérigos que debían custodiar el templo y sus rentas ${ }^{1641}$. A partir de 1478 , la colación del beneficio curado de Cestillos pertenece al Monasterio de San Zoilo, que velará espiritualmente por el mismo desde entonces ${ }^{1642}$.

A principios del siglo XVII la iglesia no se encontraba en muy buen estado, por lo que su mayordomo decide realizar en 1611 algunos arreglos que sólo podían ser de carácter eventual, dado el escaso presupuesto invertido y la brevedad de las obras. Los albañiles de Carrión Alonso Tejedor ${ }^{1643}$ y Pedro de Linares ${ }^{1644}$ socalzaron el muro de la capilla mayor con cimientos más firmes, eliminaron las goteras y retejaron la torre e iglesia $^{1645}$. Como era de prever, unos años después, en 1631, una parte de la nave, la sacristía y una capilla bajo la advocación de San Agustín se hundieron haciéndose cargo

\footnotetext{
${ }^{1639}$ AHPP. Desamortización, 112. Caja 7 . San Felices. Legajo 2. Cuaderno B. Cestillos.

${ }^{1640}$ SAN MARTÍN PAYO, Jesús. "La más antigua....Op.cit, pág. 14.

${ }^{1641}$ PÉREZ CELADA. Julio A. "La explotación de los recursos...Op.cit, pág. 128.

${ }^{1642}$ AHPP. Desamortización, 112. Caja 7 ${ }^{\mathrm{a}}$. San Felices. Legajo 2. Cuaderno B. Cestillos, s/f.

${ }^{1643}$ Este albañil figura como último pujador de la obra de la iglesia y torre de San Andrés de Carrión el 15 de marzo de 1608. Al no presentar fiadores, se le apresó y la obra fue rematada en Francisco Martínez de Bálcava. AHN. Clero regular-secular. Legajo 5356, Expediente 2. Iglesias de San Andrés y San Pedro. Obras, s/f.

${ }^{1644}$ Pedro de Linares aparece trabajando con el también albañil carrionés en 1605 en la obra de la iglesia de San Pedro de Saldaña. AHPP. Carr.Prot 4832. Juan Díaz Pajaza (1605), s/f. Figura como testigo en defensa del marqués de Aguilar en el pleito que éste mantiene con el convento de San Francisco por el estado de la capilla mayor. ARCHV. Pleitos Civiles Quevedo (F) 1557. Expediente 1, fol 119v.

${ }^{1645}$ La debían terminar en agosto y se les abona doscientos ochenta reales. Escritura y condiciones firmadas el nueve de marzo de 1611. AHPP. Carr.Prot 5394. Francisco Moro Saldaña, 1611), s/f.
} 
de la reparación de sus tejados el carpintero carrionés Juan de Viana ${ }^{1646}$. La situación empeora, lo que lleva al párroco de Cestillos, don Juan Marqués, a inventariar los ornamentos y alhajas cedidos por San Zoilo por si había que plantearse su devolución ${ }^{1647}$. La ruina afectó gravemente a la capilla mayor, que sufrió un derrumbe en $1647^{1648}$. Las intervenciones se fueron sucediendo hasta 1682, sin por ello paliar el progresivo deterioro del templo ${ }^{1649}$.

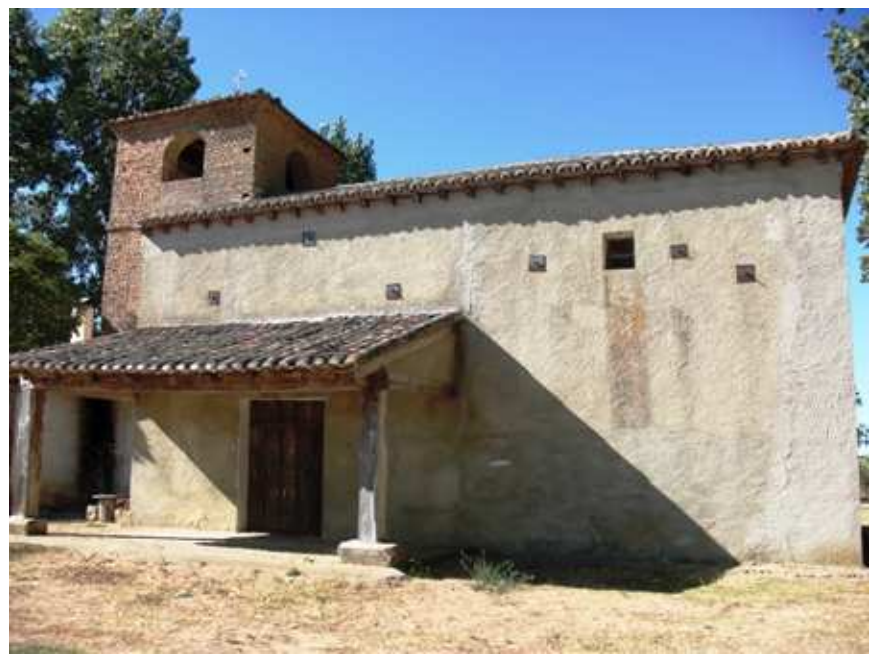

\section{Aspecto actual de la ermita de San Juan de Cestillos.}

Mientras tanto, el monasterio de San Zoilo y el Cabildo eclesiástico se desentendían de responsabilidades y tuvo que ser el Obispo palentino don Laureano Alonso de Pedraza quien ordenase reedificar la iglesia con la torre en el año $1691^{1650}$. Tampoco con esta intervención se logró mitigar el avance del deterioro ya que se actuó parcialmente, incidiendo mayormente en las cubiertas ${ }^{1651}$.

\footnotetext{
${ }^{1646}$ La carta de pago se le abona en 1642. ADP. Carrión. Parroquia de la Magdalena. Libro 16 de Cuentas de Fábrica de San Juan de Cestillos (1603-1795), fol 68 y 95.

${ }^{1647}$ AHPP. Desamortización, 112. Caja 7 ${ }^{\mathrm{a}}$. San Felices. Legajo 2. Cuaderno B. Cestillos, no 10.

${ }^{1648}$ Los carrioneses Antonio del Tejo y Santiago de Pedrosa recibieron 633 reales por el reparo de la iglesia. ADP. Carrión. Parroquia de la Magdalena. Libro 16 de Cuentas de Fábrica de San Juan de Cestillos (1603-1795), fol 104.

${ }^{1649}$ Se constatan reparaciones en 1654, 1660, 1663 y1682. ADP. Carrión. Parroquia de la Magdalena. Libro 16 de Cuentas de Fábrica de San Juan de Cestillos (1603-1795), fol 114,122, 128 y 144v.

${ }^{1650}$ FRANCIA LORENZO, Santiago. Gentes...Op.cit, pp. 285.

${ }^{1651}$ Alonso Reinaldos o Reinaltos, maestro de carpintería como su padre Francisco, muy afamado en Carrión, se hizo cargo de las obras y recibió carta de pago en 1692. ADP. Carrión. Parroquia de la Magdalena. Libro 16 de Cuentas de Fábrica de San Juan de Cestillos (1603-1795), fol 157-158. En los años de 1711, 1719, 1726 y 1728 se dieron sucesivos retejos indicativos de la necesidad de una intervención íntegra en el templo. Ibídem, fol 186v,205v,219v,223v.
} 
Sin embargo no será hasta 1735, cuando, a instancias del obispo de Palencia Don Bartolomé de San Martín y Uribe en su visita a la ciudad, todos los interesados en los diezmos de la iglesia debían colaborar en su necesaria reedificación. El primer reconocimiento del templo lo efectúa el maestro alarife José Iglesias ${ }^{1652}$ en 1739 , momento en que determina urgente una intervención, “...por estar todo el texado quebradas y podridas las maderas, y desunidas todas las juntas del artesonado y las tapias socauadas, y la torre que es toda de tierra en conozido peligro de arruinarse... $^{1653}$ ". Tras firmar en 1740 un segundo informe confirmando el anterior, se aceptan las condiciones de dos alarifes carrioneses, el citado José Iglesias y Eugenio Rodríguez $^{1654}$, para que lleven a cabo las obras en un período de un año por las cuales recibirían una suma de cinco mil cuatrocientos reales ${ }^{1655}$.

La iglesia que vemos hoy día, en su estructura general, es fruto de esta profunda reedificación. El templo quedó conformado en una sola nave dividida en dos tramos cubiertos con bóveda de arista en ladrillo y enlucido de yeso, tal y como establecían las condiciones. En el lado del Evangelio se adosa la sacristía, muy deteriorada y cubierta con una bóveda de cuarto de horno ${ }^{1656}$. La torre de ladrillo es de escasa elevación, pues

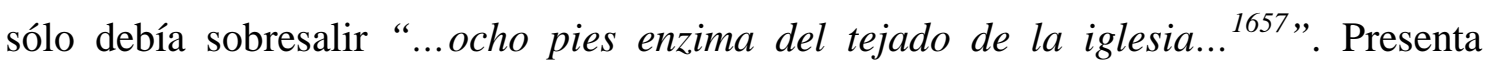
cuatro ventanas de medio punto para alojar las campanas y su tejado a cuatro aguas no sobresale de la línea de cornisa, conforme al gusto de José Iglesias, que lo repite precisamente en la torre de la iglesia de Santiago de Carrión. Siguiendo el diseño original, la cubierta remataba en una veleta con banderola de notables dimensiones.

\footnotetext{
${ }^{1652}$ Sobre los diversos miembros del clan Iglesias, remítase al capítulo dedicado a la biografía de los maestros locales.

${ }^{1653}$ VIGURI, Miguel de. Heráldica...2. Op.cit, pp. 280 y ss, a su vez de AHPP. Carr.Prot 5881, Manuel Vega. (1740-1741), fol 148 y ss.

${ }^{1654}$ Sobre los diversos miembros de las familias de alarifes Iglesias y Rodríguez, remítase al capítulo dedicado a la biografía de los maestros locales.

${ }^{1655}$ Las condiciones y traza para dicha obra se encuentran en VIGURI, Miguel de. Heráldica...2. Op.cit, pp. 280 y ss, a su vez de AHPP. Carr.Prot 5881, Manuel Vega. (1740-1741), fol 148 y ss.

${ }^{1656} \mathrm{La}$ intervención en la sacristía la realiza el alarife carrionés Matías Meciel unos años después de la reedificación del templo, concretamente se abonan cuatrocientos reales en 1746. ADP. Carrión. Parroquia de la Magdalena. Libro 16 de Cuentas de Fábrica de San Juan de Cestillos (1603-1795), fol 245.

${ }^{1657}$ AHPP. Carr.Prot 5881, (Manuel Vega, 1740-1741), fol 155.
} 


\section{Proyecto de la torre de la ermita de San Juan de}

Cestillos. Planta y alzado. José Iglesias.

AHPP.Carr.Prot 5881

Manuel Vega. (1740-1741), fol 155.

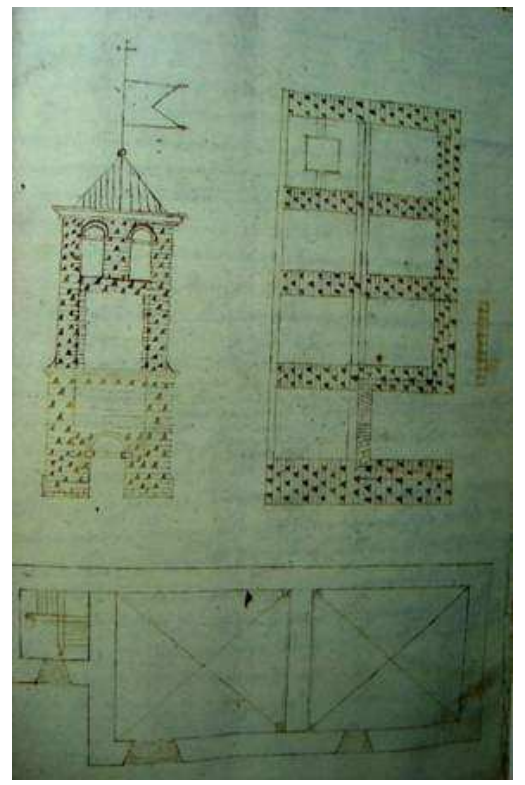

Para el acceso se debía hacer una puerta de medio punto y un portal de resguardo para el mismo ${ }^{1658}$. Este pórtico se desmonta en 1799 por estar demasiado deteriorada la madera y no vuelve a ser construido hasta 1818, resultando ser de 1855 la última intervención, en que el carrionés Laureano Rojo lo desarma para quitar unas goteras ${ }^{1659}$. La apariencia que presenta hoy día debe corresponder a esta última actuación en que se dispone un tejado de ladrillo en vertiente sustentado por dos postes que cobijan una puerta de madera.

San Juan de Cestillos está cerrado al culto y tan sólo abre sus puertas con la celebración de sus dos romerías, la del 24 de junio, por el nacimiento del Santo, y la del 29 de agosto por su degollación.

\section{El retablo mayor}

El retablo del altar mayor se dedica a la advocación de San Juan Bautista y, fue encargado al ensamblador Hernando Infante en $1595^{1660}$. El banco, formado por el sagrario y seis tablas de dos Apóstoles y cuatro Virtudes -suponemos que cardinales

\footnotetext{
1658 “Condizión que se ha de hazer un porttal lo que coje la puertta para ser resguardo della y se ha de hazer de madera toscana..". IboIbídem, fol 155.

1659 ADP. Carrión. Parroquia de la Magdalena. Libro 17 de Cuentas de Fábrica de San Juan de Cestillos (1796-1850), fol 3,33 y 63.

1660 AHPP. Carr.Prot 5382.Francisco Moro Saldaña (1599), s/f. El retablo está documentado en FRANCIA LORENZO, Santiago. Gentes...Op.cit, pp. 284-285. Juan Birtus (1592-1594), s/f.
} 
dado el número-, fue robado en 1993, razón por la cual se decidió trasladar el resto del retablo al Museo de Arte Sacro de la iglesia de Santiago donde se conserva desde entonces $^{1661}$. Se compone de un sencillo cuerpo dividido en tres calles por cuatro columnas estriadas jónicas y ático rematado en un frontón triangular. La mazonería perteneciente a las dos hornacinas del retablo también se ha perdido. El cuerpo central nos presenta la escultura de San Juan Bautista, una talla de buena calidad y casi metro y medio de altura que presenta un elegante contraposto.

El artista nos presenta un hombre barbado de mediana edad con guedejas sueltas y acaracoladas, ataviado con una túnica corta, por encima de las rodillas, en lugar de la clásica piel de camello. Junto a él se dispone un tronco resquebrajado sobre cuya rama se disponen los conocidos atributos del libro y un cordero al que señala el santo con su mano derecha, mientras que la izquierda permanece oculta por la capa que cubre su hombro. En las calles laterales se disponen cuatro tablas al óleo, dos a cada lado, de mediana calidad y reducido formato, que no llegan a los setenta centímetros de altura. Fueron encargadas en julio de 1595 a un pintor vecino de Boadilla del Camino, Pedro de Pedrosa, quien se encargaría además de su dorado y estofado.

Se compromete a finalizarlas dos años después de que se le "entregare el dicho retablo para lo pintar”. No especifica una fecha de finalización concreta porque al parecer, antes de que el artista hiciera las pinturas, el mayordomo tenía intención de hacer "una obra en la dicha pared". Debido a ello y sobre todo a que los bienes y rentas de la iglesia no eran suficientes para abonar el retablo, aún se está realizando en 1603. El último pago efectuado al pintor es de 1618. Por entonces Pedrosa se había mudado a otra población palentina ubicada más al norte, Villanuño de Valdavia. La iglesia de Cestillos había contraído una deuda con el mayordomo de la iglesia de San Julián a quien fue abonando los débitos de un censo hasta $1630^{1662}$.

Las cuatro tablas realizadas relatan la vida de San Juan Bautista: a la izquierda, Salomé bailando en el banquete de Herodes y la promesa de éste de regalarle lo que desee. A mano derecha, la decapitación de San Juan y la entrega de su cabeza en un

${ }^{1661}$ GÓMEZ PÉREZ, Enrique y MARISCAL ARRANZ, José. Iglesia de Santiago...Op.cit, pág. 23.

Sobre Hernando Infante, remítase al capítulo dedicado a los maestros locales.

${ }^{1662}$ Véanse los diferentes pagos en ADP. Carrión. Parroquia de la Magdalena. Libro 16 de Cuentas de Fábrica de San Juan de Cestillos (1603-1795), fol 2,7v y 11-12, 18v, 21, 24v. 
plato. Son obras de mediana calidad repletas de figuras monumentales con un repertorio de prototipos que se repiten y un uso de la perspectiva bastante forzada, visible en la mesa del banquete y la escalinata del palacio. Por su vinculación estilística, es probable que la tabla del Nacimiento de San Juan Bautista conservada en el museo de arte sacro de Santiago $(132 \mathrm{~cm} \times 108 \mathrm{~cm})$ sea de este artista, que la realizaría por entonces.

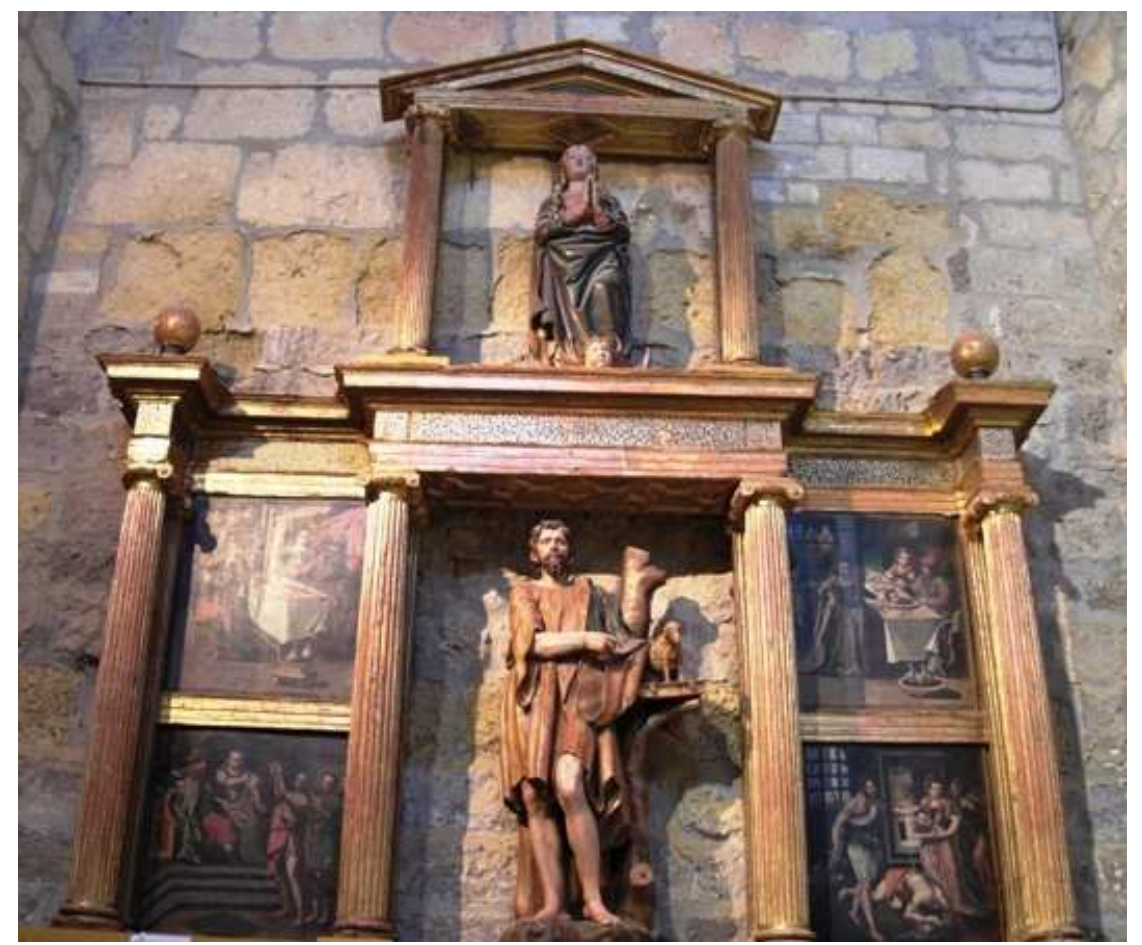

Retablo mayor de la ermita de San Juan de Cestillos, conservado en el Museo de Arte Sacro de la iglesia de Santiago. Hernando Infante. 1595.

Por último, el ático va presidido por una imagen de la Inmaculada con reminiscencias góticas. Su cabellera dorada de suaves ondulaciones se desliza en dos mechones simétricos por encima del pecho donde se sitúan las manos juntas en actitud de oración. La pierna izquierda se adelanta y dota a la figura de cierto dinamismo, evitando así la frontalidad mediante la creación de múltiples hendiduras en los pliegues de su túnica Hoy día el presbiterio está presidido por un tabernáculo moderno sin ningún valor artístico acompañado de las reproducciones de las pinturas del retablo original. 


\section{San Juan "Verde"}

Otra interesante obra que ornamentaba este templo en origen, hoy en el museo parroquial de Santiago, es una talla gótica conocida como "San Juan Verde", una imagen de San Juan Bautista de finales del siglo XIV, que hasta principios del siglo XX, estaba policromada en este color. Estaba sepultada entre el tapial y el tejado de la ermita de San Juan de Cestillos y pasó seguidamente a Santa María. La figura, que adolece de cierto hieratismo y tosquedad, sufrió una drástica restauración que eliminó su policromía original y repuso la mano izquierda de la que carecía, la cual se rehizo colocándose en ella una copa. Esta modificación conllevó un cambio en la advocación pues, desde entonces, la imagen asemeja más a San Juan Evangelista que al Bautista original $^{1663}$.

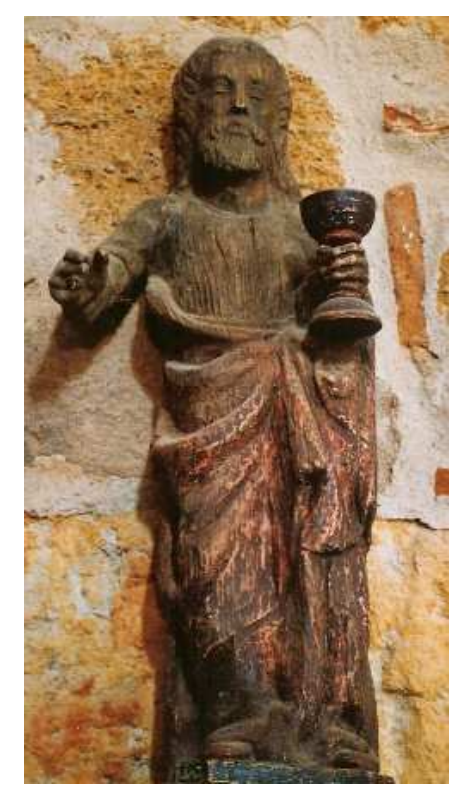

Escultura de San Juan, apodado “el Verde" procedente de la ermita de San Juan de Cestillos. Finales del siglo XIV. Museo de Arte Sacro de Santiago. $(74,5 \mathrm{~cm} \times 24 \mathrm{~cm} \times 20 \mathrm{~cm})$.

${ }^{1663}$ GÓMEZ PÉREZ, Enrique y MARISCAL ARRANZ, José. La iglesia...Op.cit, pp. 65-66. 


\subsubsection{LA VERA CRUZ}

Sede de la Cofradía de la Vera Cruz, la más antigua de Carrión de los Condes, se trata de una modesta fábrica de ladrillo de una sola nave con espadaña en cuyo interior aloja los pasos de esta devoción pertenecientes a los siglos XVI a XIX ${ }^{1664}$. Como sucede con la inmensa mayoría de las cofradías de la Vera Cruz, parece haber sido fundada a finales del siglo XV dentro del recinto del derruido convento de San Francisco de la misma villa. A mediados del siglo XVI la hermandad ya se había establecido en el lugar actual, a medio camino entre las iglesias de Belén y San Andrés, dependiendo su ermita del primero de estos dos templos y perteneciendo sin embargo, la cofradía al segundo de ellos ${ }^{1665}$. Prueba de que la nueva sede estaba construida desde hacía al menos unas décadas, es que en 1568, los mayordomos de la cofradía solicitan establecer un censo de dos mil maravedíes para cubrir "las tapias y pedazo de casa..." que se había derrumbado y en 1576 se adquieren diversas cantidades de madera probablemente para un fin semejante ${ }^{1666}$. Cuatro años más tarde se registra otro censo, en este caso de catorce mil maravedíes, para llevar a cabo una nueva portada con su tejaroz que se hallaba en mal estado “...porque las aguas llobedosas cayan a la puerta de la dicha sala... ${ }^{1667 ”, ~ E l ~ c r e c i m i e n t o ~ e x p e r i m e n t a d o ~ p o r ~ l a ~ c o f r a d i ́ a ~ d u r a n t e ~ e s t a ~}$ centuria condujo a la creación del hospital del mismo nombre para atención de los cofrades y los pobres ${ }^{1668}$.

La tradición ha defendido que esta ermita se asienta sobre parte de la Antigua Sinagoga de los Herreros ${ }^{1669}$. A favor de esta hipótesis destaca la presencia en Carrión

\footnotetext{
${ }^{1664}$ PRIETO SARRO, Marta. Op. cit, pág. 32. El tema de las cofradías de la Vera Cruz en territorio palentino es abordado en TRANCHO PASTOR, José Ángel. "La Cofradía de la Santa Vera Cruz de Palencia a finales del siglo XVI e inicios del siglo XVII: un ámbito de religiosidad y solidaridad urbana" en AIIICHP, volumen 3, 1995, pág.s. 83-94 y VV.AA. La Semana Santa en la Tierra de Campos vallisoletana. Valladolid, 2003.

${ }^{1665}$ Este hecho desencadena algunos conflictos entre ambas iglesias. PÉREZ DE CASTRO, Ramón. "Manifestaciones artísticas...pp. 283-339. Podemos enumerar otros casos en la cofradía de la Vera Cruz, se erige al amparo del convento franciscano de la capital, como sucede en el caso de Palencia capital, donde su templo penitencial se levanta en la Puerta del Campo. MARTín LOZANO, José Enrique. Iglesia Penitencial de la Santa Vera Cruz de Valladolid (1595). Valladolid, 2005, pág. 1

${ }^{1666}$ AHPP. Carr.Prot 5612. Melchor de la Rúa (1569), s/f y Protocolo 5615. Melchor de la Rúa (15751577), s/f.

${ }^{1667}$ AHPP. Carr.Prot 5616. Melchor de la Rúa (1578-1580), s/f.

${ }^{1668}$ GÓMEZ PÉREZ, Enrique. Cofradía Penitencial de la Santa Vera Cruz. Carrión de los Condes. Breve reseña histórico- artística. Palencia, 2004, pág. 4

${ }^{1669}$ MAISO GONZÁLEZ, José y LAGUNILLA ALONSO, J. Ramón. La judería de Carrión. Cálamo. Palencia, 2007,pág. 62.
} 
de una de las dos aljamas más importantes de Castilla ${ }^{1670}$. Ubicada en el barrio "dentro de Castro" esta sinagoga remontaría sus orígenes al año 1020 aproximadamente sobreviviendo hasta finales del siglo XV en que comenzaron las conversiones masivas al catolicismo ${ }^{1671}$. En este sentido la datación recogida por Ramírez de Helguera para la ermita correspondería en verdad a la de la creación de la sinagoga: “...hacia 1180, pero, hoy día, no ocupa el mismo sitio que entonces, que ahora es corral o casa nueva, situándose al oeste de la actual capilla... ${ }^{1672 ” . ~ O t r o ~ a r g u m e n t o ~ q u e ~ j u s t i f i c a r i ́ a ~ l a ~}$ ubicación del templo judío en este lugar es la presencia de inscripciones con caracteres arábigos, que según se asegura, recorría el perímetro interior ${ }^{1673}$.

\section{ESTRUCTURA DE LA ERMITA}

En lo que a su configuración se refiere, se trata de un complejo compuesto por dos edificios en forma de "L", uno de los cuales dispuesto en dirección este-oeste, y otro anejo, norte-sur, abiertos a un patio común. El acceso por puertas muy cercanas con cobertizo común y la estructura similar de las paredes de dichas estancias determinarían la pertenencia de ambos espacios a un único conjunto ${ }^{1674}$.

\footnotetext{
${ }^{1670}$ Burgos, Dueñas o Frómista fueron igualmente centros de asentamientos judíos. Sobre este tema, véase VALDEÓN BARUQUE, Julio. "Judíos y mudéjares en tierras palentinas (siglos XIII-XV)" en AIICHP, volumen 2. Palencia, 1990, pp. 359-376.

Carrión fue por tanto crisol de culturas que vivían pacíficamente, pues en la calle de la Morería, como su nombre indica, vivía una comunidad musulmana Mahomad, moro y su mujer, Marieme, venden unas casas en esta calle en 1376 a la cofradía de San Julián. ACP. Documentación del Hospital de Santa María de Carrión. Legajo 1 (1390-1772), n³

${ }^{1671}$ ALCALDE CRESPO, Gonzalo. La Tierra de Campos palentina. Cálamo. Palencia, 1998, pág. 163

${ }^{1672}$ RAMÍREZ DE HELGUERA, Martín. El libro...Op.cit, pág. 188. Otros autores recogen esta datación. NAVARRO GARCÍA, Rafael. Catálogo monumental de Palencia...Op.cit, pp. 17-18.

${ }^{1673}$ DÍAZ ESTEBAN, Fernando. "La ampliación de la sinagoga de Carrión y sus inscripciones" en Judaísmo Hispano. Vol 2. Madrid, 2002, pp. 519 y ss. También se ha considerado que la cruz de piedra situada fuera del recinto, señalaría un lugar de conversión al cristianismo, aunque a nuestro juicio, la presencia de cruceros no implica necesariamente este hecho. MAISO GONZÁLEZ, José y LAGUNILLA ALONSO, J. Ramón. La judería...Op.cit, pp. 59- 61.

${ }^{1674}$ Sobre el eje septentrión- meridión podría haberse ubicado escuela o salón de baños, presuponiendo un carácter público del edificio basado en las dimensiones del mismo y en el espesor de los muros. En el otro eje, oriental- occidental quizá estaría la antigua sinagoga, cuya cabecera coincidiría con la de la actual ermita, ensanchándose hacia los pies, en el lugar ocupado hoy día por la casa del cuidador y el zaguán MAISO GONZÁLEZ, José y LAGUNILLA ALONSO, J. Ramón. La judería...Op.cit, pp. 58-62.
} 


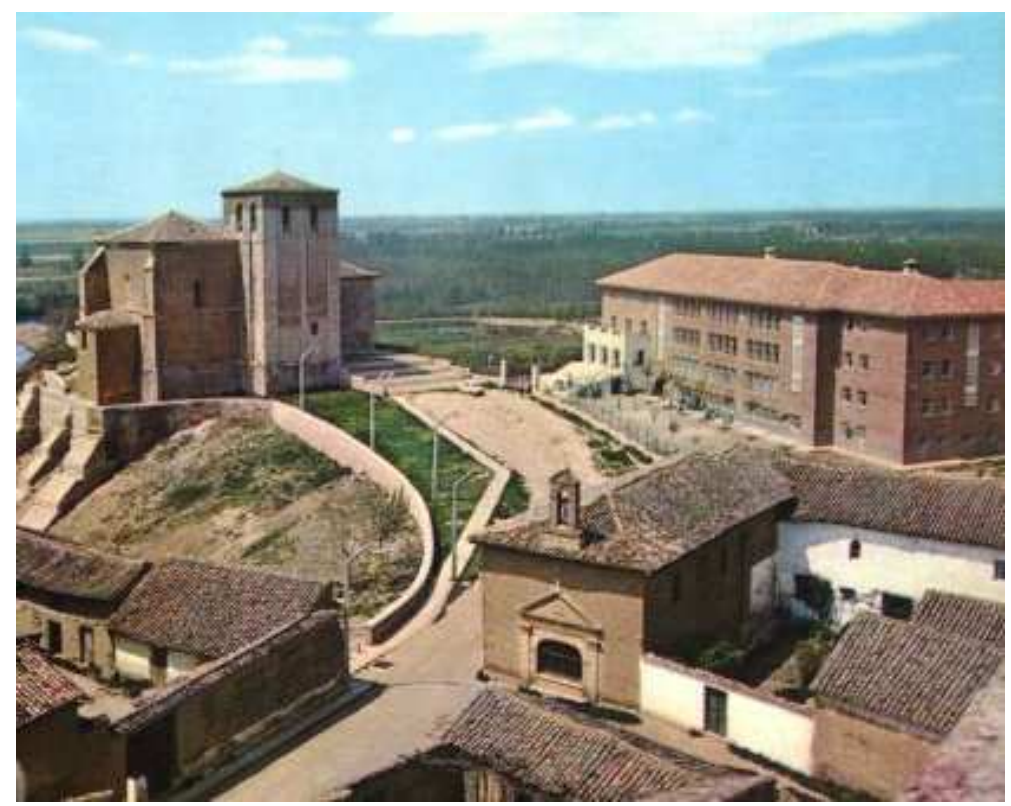

Vista de la ermita de la Vera Cruz en el ángulo inferior derecho de la imagen, donde se aprecian los dos espacios en forma de " $L$ " que la conformaban: la capilla y el salón parroquial, actual vivienda particular.

\section{El salón parroquial}

Formando un ángulo recto respecto a la capilla y ocupando el solar que la tradición considera antigua sinagoga, se dispone un gran espacio longitudinal que comunica directamente con la capilla. Se trata de un salón de tapial cubierto con una armadura sustentada por vigas que apoya sobre canes. En los casetones interiores aparece una decoración de estrellas de ocho puntas biseladas de blanco con un punteado negro. Los sencillos canes dispuestos a modo de cornisa clasicista permiten determinar una datación aproximada de finales del siglo $\mathrm{XVI}^{1675}$. Se presupone el uso de esta dependencia como sacristía o sala de reunión, pudiendo haber desempeñado igualmente otras funciones como fue el caso de otras cofradías de la Vera Cruz: vestidor para los cofrades, depósito de los pasos procesionales, taller para la ejecución de retablos, sede de reunión para otras cofradías e incluso paneras fueron algunos de sus usos ${ }^{1676}$.

1675 PÉREZ DE CASTRO, Ramón. "Manifestaciones...Op.cit, pág. 294.

${ }^{1676}$ IbIbídem, pp. 286 y 290. 


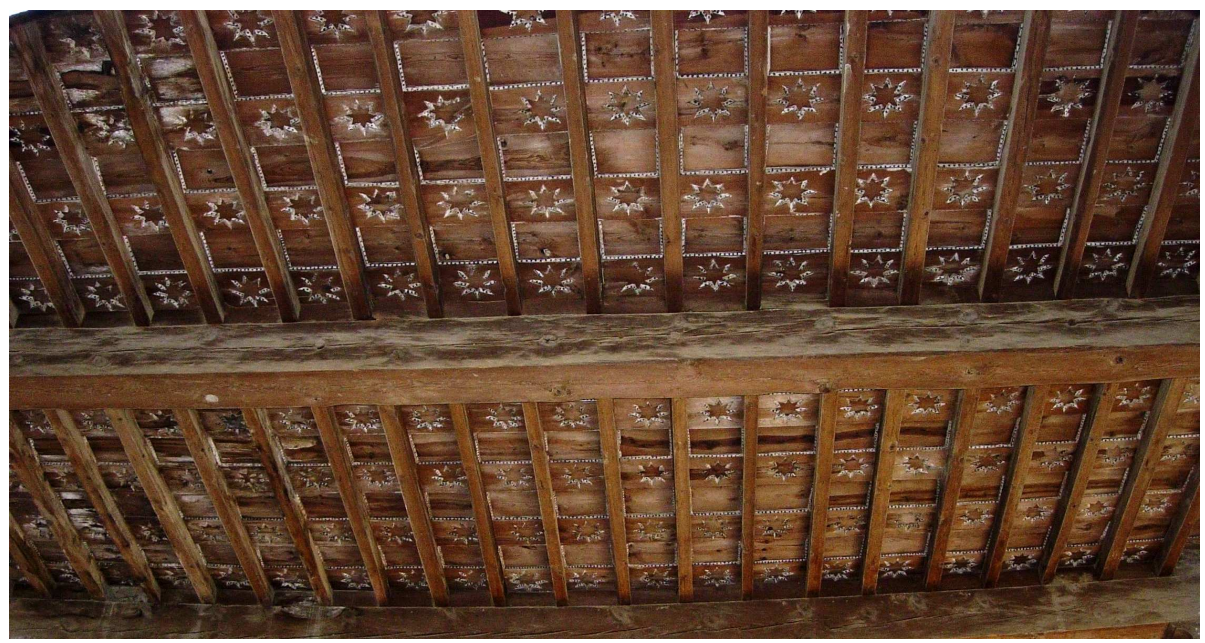

\section{Armadura del antiguo salón parroquial de la ermita de la Vera Cruz. Siglo XVI.}

Las dimensiones originales de esta estancia se han visto reducidas por la construcción de una vivienda cuya techumbre enmascara posiblemente la continuación del alfarje previamente comentado. El espacio descubierto destinado a huerta igualmente de propiedad particular, cerraría el conjunto ${ }^{1677}$. El carácter público de estas salas como lugar de reunión junto a la envergadura de las mismas por su situación en grandes villas, conllevó a denominar a alguna de las sedes de la Vera Cruz con el apelativo de "palacios" o casas de la Cruz. Dicha nomenclatura se hace extensiva a otras cofradías, como fue el caso de Nuestra Señora del Rosario en Palencia ${ }^{1678}$ o la de San Julián de la misma villa de Carrión por ser el lugar donde tratan los asuntos tocantes al buen gobierno de la misma ${ }^{1679}$. La ermita palentina de la Vera Cruz de Paredes de Nava, de afines características cronológicas y compositivas constituye el ejemplo más próximo de análoga tipología a nuestra ermita ${ }^{1680}$.

\footnotetext{
${ }^{1677}$ Mis sinceros agradecimientos a don Urbano, propietario actual de la vivienda que me facilitó el acceso al conjunto.

${ }^{1678}$ Se conserva el contrato para la ejecución del "palacio" -como así expresa el documento- de la Cofradía de Nuestra Señora del Rosario mandó edificar en 1592 y cuyas trazas correspondieron al maestro trasmerano Juan de la Lastra. Declaración favorable de Francisco del Río como veedor de las obras a 25 de mayo de 1594. AHPP. Varios. Protocolo 10895. Varios años y escribanos, s/f.

${ }^{1679}$ Denominan a la cofradía "casa" y "palacio".1602.ACP. Documentación del Hospital de Santa María de Carrión. Legajo 1 (1390-1772), n 47

${ }^{1680}$ PÉREZ DE CASTRO, Ramón. Op.cit, pp. 286-294
} 


\section{La capilla de la Vera Cruz}

Como remitimos con anterioridad, el origen de la ermita se remonta a una fecha incierta del siglo XVI, en que figuran las primeras referencias documentales. También figura una intervención de pequeña entidad en 1616 -dado que el contrato establece una duración de las obras de un mes-, por parte de Mateo Fernández de Menar, un maestro de Amusco, que se hará cargo de hacer unas tapias y revocarlas ${ }^{1681}$. No obstante, la fisonomía actual de la fábrica es fruto de dos fases constructivas bien diferenciadas separadas en el tiempo por más de dos siglos:

La primera, ejecutada a partir de 1658, a consecuencia de una donación de doscientos ducados que el año precedente otorga un particular, Don Eugenio Pérez Esquivel, que permite la reconstrucción del templo sobre el solar de unas casas de reciente adquisición ${ }^{1682}$. La cofradía contrata a los carrioneses Bernardo Sánchez, al cargo de la cantería y a Julián de León, destinado a las labores de albañilería, para la nueva obra de la capilla, situada bajo la advocación del Santo Cristo ${ }^{1683}$. Como referente para las dimensiones del templo se tomó el alto y ancho del relicario de la sacristía del monasterio de San Zoilo, esto es 8,5 metros x 7 metros. Respecto a la longitud, la capilla poseía en origen nueve metros, frente a los diecisiete que alcanzó con la ampliación del siglo XIX.

Para la portada principal, estructurada en un sencillo arco de medio punto en ladrillo, se reaprovechó la del templo anterior, localizada en el lado donde se yergue la cruz pétrea. La capilla se estructuró en principio a través de dos tramos separados por dos arcos fajones de medio punto asentados sobre pilastras dóricas dotadas de una cornisa encapitelada que recorre el perímetro de la estancia. Cubre mediantes sendas bóvedas de cañón rebajado con lunetos. La ornamentación de las mismas es de gran sencillez, resuelta a través de placas geométricas con predominio de motivos triangulares, todo ello blanqueado de yeso. Para albergar las imágenes e insignias de la Vera Cruz se dispusieron en la parte baja de los muros diversas hornacinas flanqueadas

\footnotetext{
${ }^{1681}$ AHPP. Carr.Prot. 5399. Francisco Moro Saldaña (1616), s/f.

${ }^{1682}$ PÉREZ DE CASTRO, Ramón. "Manifestaciones...Op.cit, pág. 292, nota 32, a su vez de AHPP. Carr.Prot 5690, Norberto de Sandoval y Guevara (1657), fol 485 y ss.

${ }^{1683}$ Ibídem, pp. 292 y 327-329, a su vez de AHPP. Carr.Prot 5691. Norberto de Sandoval y Guevara (1658), fol 174 (Escritura del ladrillo para la obra) y fol 176 y ss (Concierto entre Julián de León y Bernardo Sánchez). Sobre ambos artífices, véase el apartado dedicado a los maestros locales.
} 
por pilastras toscanas. Seis serían en total los arcosolios abiertos para tal fin: uno en el testero destinado a la imagen titular, dos a un lado, junto al acceso, y tres en el lienzo frontero. La finalización de la obra, prevista para septiembre de 1660, fue posible, no sólo gracias a la eficiencia y buen hacer de los dos maestros, sino a las múltiples donaciones y mandas de diversos feligreses ${ }^{1684}$. A diferencia del resto de la edificación, que es de tapial, la pared que da al patio está construida a base de hiladas de ladrillo reforzada con contrafuertes del mismo material. Se pueden observar dos filas de ladrillo de diferente tonalidad en la parte superior, que parecen corresponder a esta reforma para ocultar la estructura de la cubierta anterior. En este lado existe un acceso tapiado, que debía ser el único que poseía la ermita en origen ${ }^{1685}$.

La otra intervención que afectaría de una manera determinante a la configuración del templo actual es la que se efectuó en 1895, pues se amplió la capilla ocho metros, desplazándose su cabecera. La capilla pasó entonces a tener tres tramos, empleándose para el tercero de ellos una bóveda de arista con dos lunetos practicados en los extremos. Así se especifica que "se acordó alargar la capilla hacia la pared exterior del salón haciéndose las obras necesarias a tal fin, y se encarga al oficial, maestre de obras Don Nicolás Herrero, para que haga el plano y forme el presupuesto de la dicha obra ${ }^{1686}$. Por otro lado se abrió una pequeña portada en la cabecera, de manera que se invirtió la orientación, quedando este sector como los pies del templo. De este modo, el retablo de madera existente con su Crucificado se colocó al otro extremo. Esta sencilla portada, convertida en ventanón, está compuesta por dos pilastras rematadas en frontón y un pequeño relieve de la Santa Faz en el que consta 1896 como fecha de finalización de esta intervención.

\footnotetext{
${ }^{1684}$ La partida de canto para la obra en el año 1659 y las diversas cartas de pago a Bernardo Sánchez y Julián de León hasta completar los doce mil reales de vellón estipulados, indican un ritmo adecuado de las obras. Véase PÉREZ DE CASTRO, Ramón. "Manifestaciones...Op.cit, pág. 293, notas 35 y 36, a su vez de AHPP. Carr.Prot 5692, Norberto de Sandoval y Guevara (1659), fol 20, 262 y 311,Protocolo 5693, Norberto de Sandoval (1660), fol 552 y Protocolo 5695, Norberto de Sandoval (1661), fol 508. La generosidad de los feligreses y clérigos queda igualmente constatada en el testamento de don Francisco Barrio de la Vega, quien efectúa una donación de 440 reales a cambio de un responso cantado en el convento de San Francisco de Carrión, donde dispuso ser sepultado. PÉREZ DE CASTRO, Ramón. "Manifestaciones...Op.cit, pág. 293, nota 37, a su vez de AHPP. Carr.Prot 5695, Norberto de Sandoval (1661), fol 522.

${ }^{1685}$ Ibídem, pág. 66.

${ }^{1686}$ GÓMEZ PÉREZ, Enrique. Cofradía...Op.cit, pág. 11, a su vez de ACVCCC. Libro de Acuerdos (1830-1961) Acuerdo de 23 de marzo de 1894, folio 40v. El desglose de los gastos correspondientes a estas obras figuran en ACVCC. Libro de Cuentas (1800-1997), pp. 160, 162v,163, 164, 173.
} 


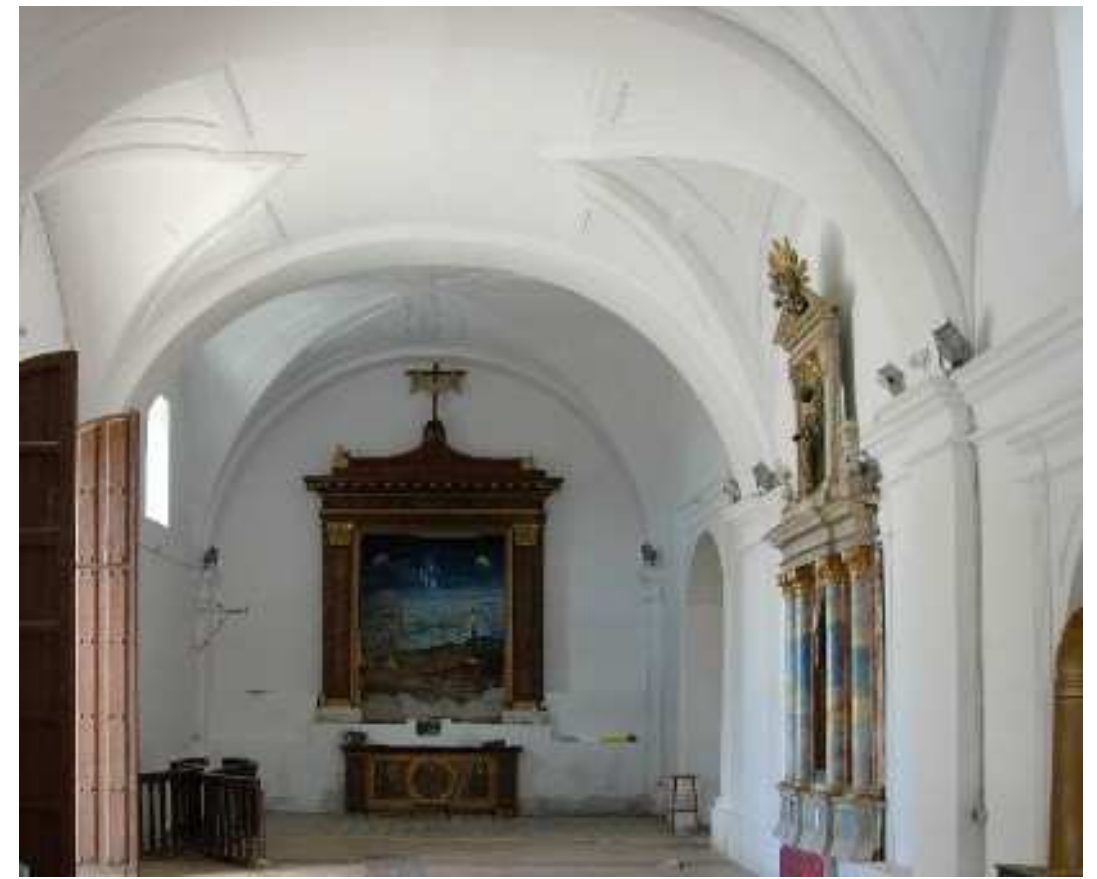

Aspecto actual de la ermita de la Vera Cruz hacia la capilla mayor.

Entre estas dos intervenciones más significativas, separadas en el tiempo por más de dos siglos, se efectúan diversos reparos generales para adecentar el templo que referimos seguidamente, pues, si bien son de menor entidad, resultan ciertamente útiles para trazar una evolución del edificio. Así en 1840 se actúa en el salón, espacio que había sido destinado recientemente como panera, interviniendo concretamente en la fachada, que se encontraba completamente deteriorada ${ }^{1687}$. Cuatro años después se retejó el conjunto, incluyendo capilla, salón y resto de dependencias, reforzando además la espadaña ${ }^{1688}$. El empedrado realizado en la fachada de la capilla corresponde a $1868^{1689}$.

Se constatan ciertos arreglos en la capilla en el año 1920, siendo Prudencio Díez Gil el maestro de obras encargado de ejecutarlos y otras actuaciones de mejora en $1938^{1690}$. Con el traspaso a esta ermita del paso del Descendimiento en 1947, tuvo que abrirse en el lateral una puerta más alta, de dos metros y medio de altura, quedando el

\footnotetext{
1687 ACVCCC. Acuerdo de 13 de enero de 1840. Libro de Acuerdos (1830-1961) fol 6v.

${ }^{1688}$ ACVCCC. Información de 20 de febrero de 1845. Libro de Acuerdos (1830-1961) fol 16.

1689 ACVCCC. Libro de Acuerdos (1830-1961) fol 29v.

${ }^{1690}$ ACVCCC. Libro de Cuentas (1800-1997) pp. 200 y 224.
} 
acceso sur como ventana. Con la creación del nuevo acceso, se derrumbó el paño de la bóveda de esa zona que se reconstruyó inmediatamente ${ }^{1691}$. Por estos años la Cofradía experimentaba un mal momento, pues se había quedado sin presupuesto para el pago del conjunto procesional y de la intervención que la llegada del mismo ocasionó ${ }^{1692}$. En 1973 se restauró el tejado, lo cual provocó una sobrecarga de los arcos de la ermita, que amenazan con derrumbarse ${ }^{1693}$.

El nivel de suelo de la ermita de la Cruz estaba más bajo en origen. La cofradía lo elevó unos 70 centímetros para evitar que se inundara y se ha colocado una bomba para desalojar el agua y evitar humedades ${ }^{1694}$. Asimismo se reforzó la estructura a través de contrafuertes que jalonan su exterior. La intervención más reciente, llevada a cabo en los últimos años, ha sido la recomposición del primer tramo de la capilla, correspondiente a la bóveda de arista cuyo sector central se había hundido.

\section{LAS OBRAS ARTÍSTICAS}

Desde al menos 1920 en que se realiza un inventario de las obras que atesora la cofradía de la Vera Cruz en su capilla, se contabilizan las piezas siguientes ${ }^{1695}$ :

\section{Retablo del Santo Cristo de la Cruz}

El retablo donde se asienta el Cristo de la Cruz lo realiza en 1849 el maestro Manuel Martín Carniago, dorado y pintado por Andrés Diego, Lorenzo Pérez y Joaquín

\footnotetext{
${ }^{1691}$ GÓMEZ PÉREZ, Enrique. "Cofradía. Op.cit, pág. 7, a su vez de ACVCCC. Libro de Acuerdos (1830-1961). Acuerdo de 7 de enero de 1948, fol 80v

${ }^{1692}$ Se hicieron gestiones con el Obispo para la adquisición de un vagón de cemento, indispensable para el reparo de la pared de acceso. Otro signo evidente de la carestía es el hecho de que aún en 1951, cuando se acuerda adquirir un nuevo paso, se indica la deuda contraída por el del Descendimiento. ACVCCC. Libro de Acuerdos (1830-1961). Acuerdo de 7 de enero de 1948 y de 2 de diciembre de 1951, fol 80v y 84 respectivamente.

${ }^{1693}$ GÓMEZ PÉREZ, Enrique. "Cofradía. Op.cit, pág. 7.

${ }^{1694}$ MAISO GONZÁLEZ, José y LAGUNILLA ALONSO, J. Ramón. La judería...Op.cit, pág. 62.

${ }^{1695}$ Inventario de imágenes, ropas y demás efectos pertenecientes a la Hermandad y existentes en la capilla de la Cruz en ACVCCC. Libro de Acuerdos (1830-1961) fol 60v-65. Todas ellas catalogadas por GÓMEZ PÉREZ, Enrique. "Cofradía. Op.cit, pp. 7-17, a quien se seguirá en estas pág.inas.
} 
Baronio un año después ${ }^{1696}$. La escultura que lo preside es la imagen titular de la cofradía. Solo se procesiona en ocasiones especiales, como rogativas, junto a la imagen de Nuestra Señora de Belén y sobre unas andas circulares. Fue traída desde México en 1562 por uno de los cofrades de la compañía, Cristóbal de Carrión, en relación a la promesa de regalar a la cofradía una imagen de Cristo en la Cruz si regresaba de su viaje. Realizada por un artista mexicano cuyo nombre se desconoce, esta imagen, de grandes dimensiones, responde a la tipología de los llamados "Cristos tarascos" que podría relacionarse con El Cristo de papelón de la ermita de la Vera Cruz de la localidad palentina de Paredes de Nava ${ }^{1697}$.

Otra nomenclatura corriente para este tipo de imágenes es la de "Cristos de caña”, pues su armazón se componía de cañas de maíz sobre el que se colocaba una pasta de este mismo material y bulbos de orquídeas, que tras secarse, se pintaba. Su bajo coste y la ligereza de los materiales explican el uso de esta técnica entre los indígenas ${ }^{1698}$. Las esculturas de caña han sido usadas durante siglos en Michoacán por los guerreros, quienes representaban a sus dioses para que les reportaran la victoria, y, en caso de derrota, podían salir huyendo con facilidad ${ }^{1699}$.

La tradición popular se ha hecho eco de un milagro ocurrido en 1629, mediante el cual, el Cristo, al sudar sangre, extinguió la plaga de langosta que asolaba la villa ${ }^{1700}$. Este hecho, recordado en un lienzo conservado en el interior de la cofradía, conllevó un aumento de la devoción y consecuentemente, del número de cofrades de la Vera Cruz $^{1701}$. La imagen sufrió un repinte desafortunado en 1846, siendo encarnada con más acierto un año después por el pintor, dorador y retratista vallisoletano Antonio Saco.

\footnotetext{
${ }^{1696}$ GÓMEZ PÉREZ, Enrique. La Cofradía...Op.cit, pp. 10 y 11, a su vez de ACVCCC. Acuerdo de 21 de enero de 1847. Libro de Acuerdos (1830-1961) fol 17v y fol 19v. El retablo quedó instalado el 6 de junio de 1849 y se acabó de dorar el 17 de septiembre de 1850 .

${ }_{1697}$ La datación, procedencia y su carácter milagrero son comunes a ambas figuras. PÉREZ DE CASTRO, Ramón. "Manifestaciones...Op.cit, pág. 291.

1698 TUDELA, José. “Cristos tarascos en España” en Revista de Indias. 1967 pp. 107-110.

1699 SABAU GARCÍA, M.L. México en el mundo de las colecciones de arte. Nueva España. Tomo 1. Ciudad de México, 1994, pág. 308. Llegaban a ser tan ligeras que una escultura de tamaño natural pesaba tan sólo seis kilogramos, permitiendo así que el "tininiecha" o sacerdote, pudiera llevar las imágenes de regreso. ESTRADA JASSO, Andrés. Imágenes en caña de maíz. San Luis de Potosí, 1996, pág. 12.

${ }^{1700}$ FRANCIA LORENZO, Santiago. Por tierras...Op.cit, pp. 141-142.

${ }^{1701}$ Se procesionó frecuentemente en años sucesivos. ADP. San Andrés no 89, Libro de Acuerdos del cabildo, Fol. 140 y ss.
} 

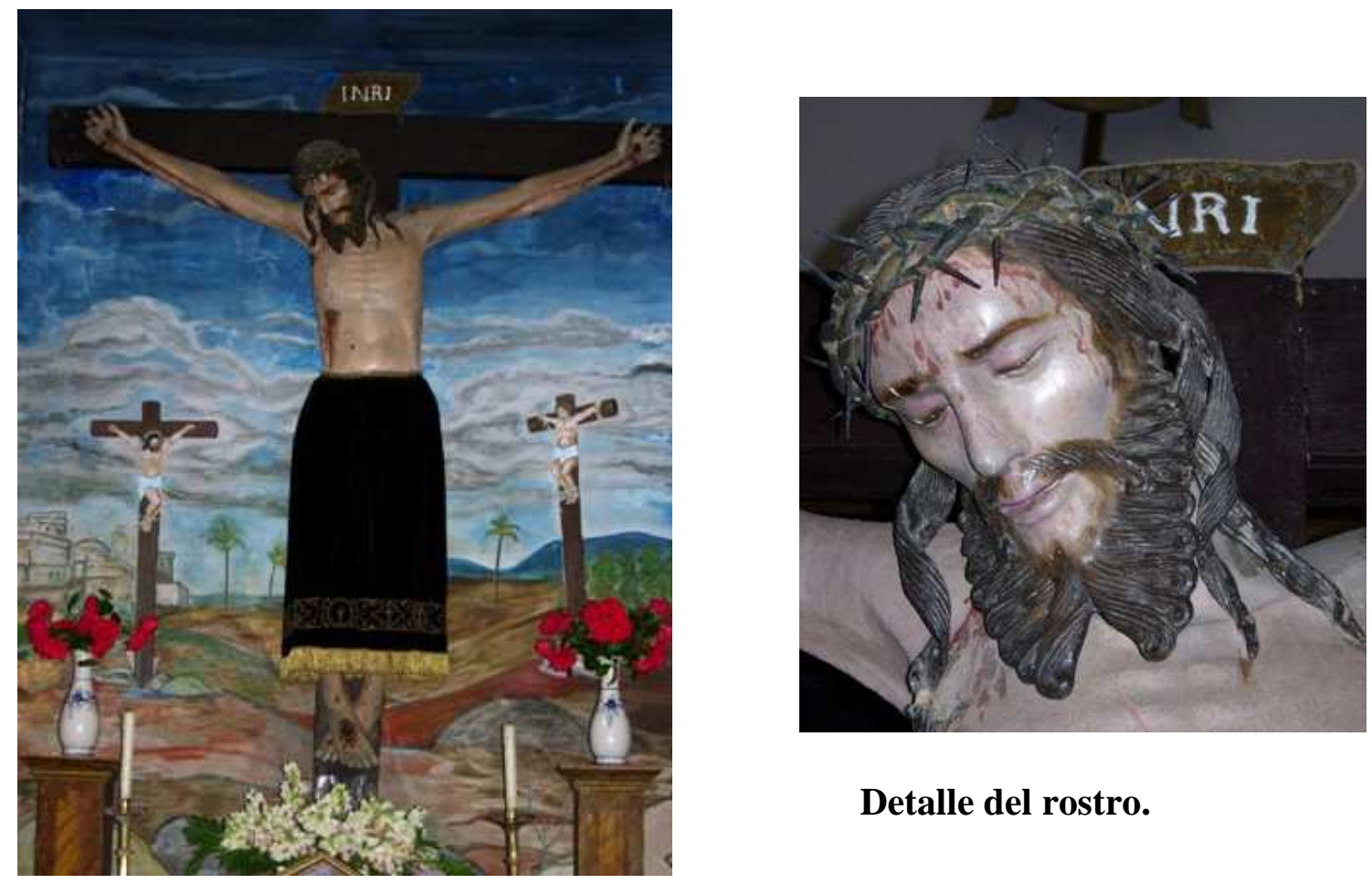

\section{Detalle del rostro.}

\section{Cristo tarasco o “de caña” del retablo mayor de la capilla de la Vera Cruz. Anónimo de 1561. Procedencia mejicana.}

\section{El retablo de la Soledad}

En el segundo tramo de la capilla, adosado en el lado de la Epístola, frente a la puerta, se halla el retablo de la Soledad. De factura moderna, procede de la antigua Abadía de Benevívere de la cual se trajo en $1841^{1702}$. La Virgen de la Soledad, del siglo XVIII, es una de las dos imágenes que se veneran de este retablo. La otra, de San Benito de Palermo podría identificarse con la imagen realizada hacia 1791 para el nuevo retablo de la capilla de las Once Mil Vírgenes del convento de San Francisco de Carrión. Fue un encargo de Don Cristóbal de Córdoba para ser instalada en su recién

\footnotetext{
1702 Ibídem, pág. 10 a su vez de ACVCC. Acuerdo de 13 de enero de 1840. Libro de Acuerdos (18301961) fol 11v.
} 
reformada capilla ${ }^{1703}$. Tiene elementos arriñonados como atributo. Existe en la ermita otra Virgen de la Soledad, de factura moderna realizada por Mariano Lantada Guerra, natural de Lantadilla, que fue regalada por el matrimonio Santiago Delgado y Doña Celestina Fernández en $1896^{1704}$.

\section{Retablo de la Piedad}

Adosado en el lado del Evangelio, en el primer tramo de la capilla, se halla el retablo de la Piedad, una obra de factura moderna conformada por un templete clásico. El grupo escultórico de su hornacina, sigue el prototipo de las Piedades góticas alemanas, con la disposición del Cristo completamente en horizontal. Sin embargo, por el resto, se aparta de las obras de esta tipología, pues no es de piedra, sino madera y no presenta las manchas de sangre en el velo de la Virgen. Es una obra más avanzada, datable a comienzos del siglo XVI y repintada posteriormente. Hasta 1896 se hallaba bajo la advocación de Nuestra Señora de los Dolores, por la imagen que cobijaba, de la que hablaremos a continuación.

\section{Nuestra Señora de los Dolores}

Situada en el lado del Evangelio, es una obra de bastidor anónima realizada hacia 1600. Su rostro y manos están muy reformados a consecuencia de que se incendió involuntariamente el 1 de mayo de 1928. Peor suerte corrieron los ropajes, que quedaron completamente destrozados ${ }^{1705}$, y los que porta hoy día, corresponden a la moda de las viudas españolas del siglo XVII, con toca blanca y manto negro.

\footnotetext{
${ }^{1703}$ PERAL VILLAFRUELA, Santiago. San Francisco...Op.cit, pág. 302-303 a su vez de ACA, Diversos, Fondo Sástago, L. 68, 10ª 1 y ACA, Leg. 68, $7^{\mathrm{a}}, 4$.

${ }^{1704}$ GÓMEZ PÉREZ, Enrique. La Cofradía...Op.cit, pág. 12, a su vez de ACVCC. Acuerdo de 2 de abril de 1896. Libro de Acuerdos (1830-1961) fol 42v.

${ }^{1705}$ Ibídem, pág. 7, a su vez de ACVCCC. Libro de Acuerdos (1830-1961), folio 70.
} 


\section{Vera Cruz}

Se trata de una cruz de madera de la segunda mitad del siglo XVII decorada a través de motivos vegetales enroscados, precedida en la procesión de dos figuras de factura moderna de dos ángeles ceroferarios completamente dorados.

\section{Santo Sepulcro}

Se trata de un Cristo yacente articulado de interesante calidad de hacia 1650, que puede utilizarse como Crucificado gracias a unas bisagras de los brazos. De este modo, serviría para las ceremonias del desenclavo. Imita los modelos creados por Gregorio Fernández para esta tipología. En 1841 se repintó su rostro y se realizó la urna de nogal en la que se encuentra depositado ${ }^{1706}$.

\section{Jesús Nazareno}

Es una imagen de hacia 1730, del mismo tamaño que el Cristo yacente, esto es, 1,58 metros que está dotado de una cabellera tallada hasta el nivel de los hombros. Sin embargo procesiona con una larga melena postiza hasta la cintura. Es una pieza esculpida íntegramente aunque se utilice como imagen de vestir.

\section{Cristo de los Azotes}

Se trata de la única de las cuatro esculturas del paso de los Azotes que se conserva actualmente, ya que los tres sayones que lo acompañaban se perdieron. El conjunto fue encargado en 1739 a Melchor García, perteneciente a la escuela de Medina de Rioseco. Para ello se empleó madera procedente de los pinares de Soria, conocida por su calidad. Las figuras debían tallarse huecas “... a eszemción de las piernas para la seguridad de los tornillos...”, que debían ser fijados a un tablero sobre el que iría asentado el paso. La obra debía estar concluida el Domingo de Ramos de 1740,

1706 GÓMEZ PÉREZ, Enrique. La Cofradía...Op.cit, pág. 10, a su vez de AVCC. Libro de Acuerdos (1830-1961) folio 11. 
recibiendo por la obra el “...maestro archittectto...”, como así se denomina el escultor, mil trescientos reales de vellón ${ }^{1707}$. Se trata de una figura de gran elegancia y dinamismo, proporcionados por el contraposto de la figura, cuya pierna izquierda avanza decididamente mientras ambos brazos se disponen paralelamente atados a la columna baja, tipología tradicional impuesta por Gregorio Fernández. Fue repintada en 1924 por un vecino de la villa, Bernardo Martín García, que aplicó la carnación a pulimento en la figura de Cristo, tal y como era en origen y un veteado rojizo en la columna baja que le acompaña ${ }^{1708}$. También son modernas las potencias de latón dorado que emergen de su cabeza y la cuerda enroscada en su cabeza y muñecas.
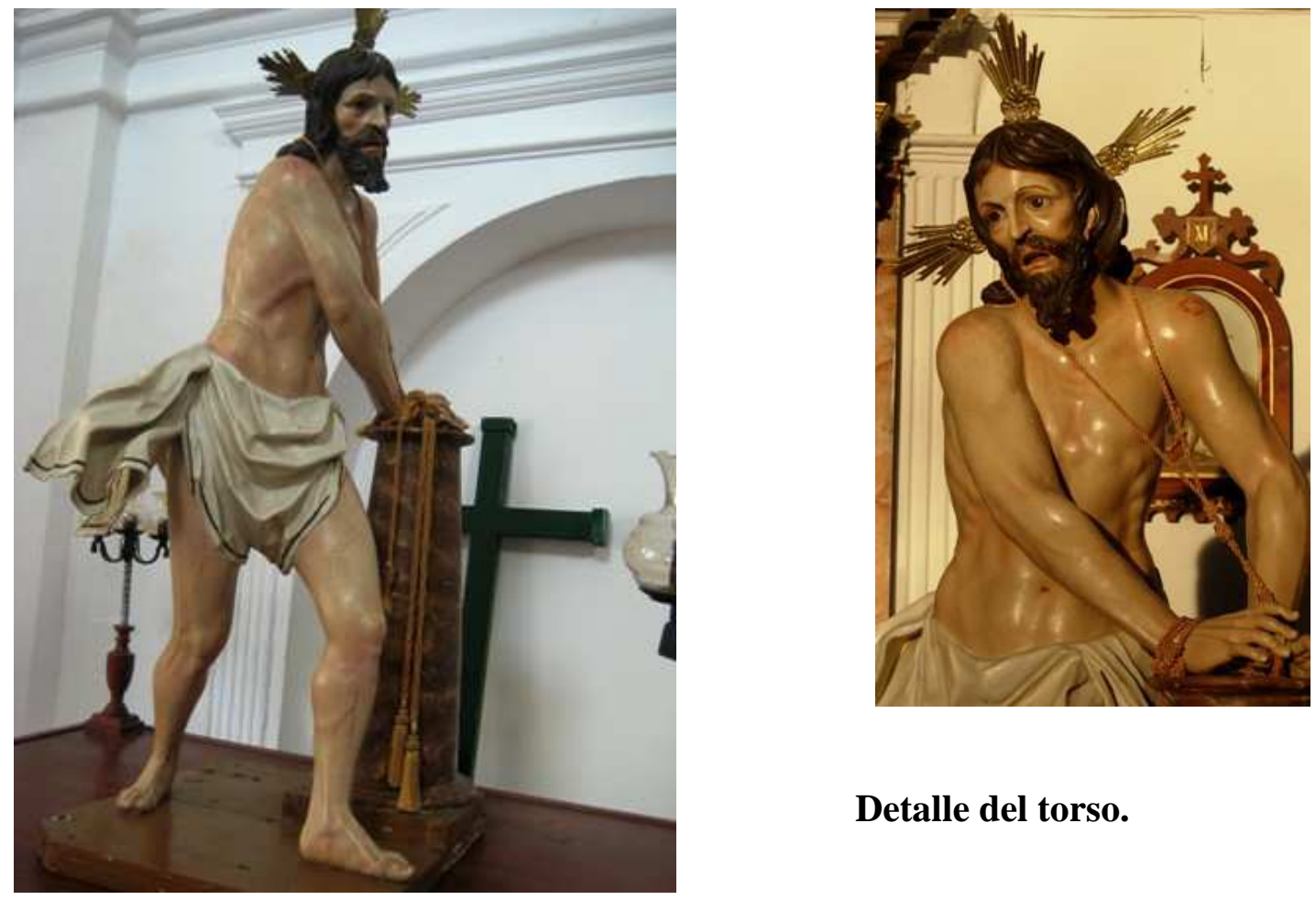

\section{Detalle del torso.}

Cristo de los Azotes en la ermita de la Vera Cruz. Melchor García. 1739.

\footnotetext{
${ }^{1707}$ Escritura de contrato y condiciones fue otorgada en Carrión, el 19 de octubre de 1739. AHPP. Carr.Prot 5046. Santiago Gil Villegas (1738-1744), s/f.

${ }^{1708}$ GÓMEZ PÉREZ, Enrique. La Cofradía...Op.cit, pp. 8 y 9.
} 


\section{Cristo Crucificado}

Es una obra anónima manierista que podemos datar hacia el 1600. De tamaño menor del natural, su procedencia probable es el desaparecido monasterio de Santa María de Benevívere. Posee una corona de espinas tallada y trenzada, dispuesta sobre su cabeza ladeada. Su rostro de decrépita expresión, presenta unas facciones alargadas que enfatizan el dolor, acentuadas por la coloración cetrina del rostro. DE estilizadas proporciones, posee un perizonium tallado y ajustado a su esbelta anatomía, anudado con un cordón postizo.

\section{Virgen de las Angustias}

Es una obra que se puede fechar a principios del siglo XVII que representa a María en actitud de oración sentada sobre una roca que cubre sus ropajes. Procede de la iglesia de San Andrés y fue cedida en 1927 a la cofradía para que fuera procesionada $^{1709}$. Ha sufrido varios repintes de dudoso gusto.

\section{La oración en el Huerto}

La talla del Ángel, muy repintada, es una obra del siglo XVII que nos presenta una figura de generosos carrillos, arrodillada ante Cristo recordándole el sacrificio próximo a través del cáliz. La imagen de vestir de Cristo, coetánea a ésta, se perdió aunque se conservan fotografías antiguas en las que podemos apreciar que poseía una espesa cabellera postiza. Le sustituyó una imagen de vestir de de mayor tamaño, realizada por Olot en 1966.

\section{El descendimiento}

Del mismo taller, de 1947, es el paso del descendimiento, para cuya cabida en la ermita tuvo que practicarse la portada lateral y también de moderna factura es el paso de la Borriquilla, encargada a Inocencio Cuesta en 1952.

\footnotetext{
${ }^{1709}$ Ibídem, pp. 12,13. De ahí que no figure aún entre las obras del inventario de 1920. ACVCC. Libro de Acuerdos (1830-1961) fol 60v-65 y 68.
} 


\section{CONCLUSIÓN}

De entre las villas palentinas surcadas por el Camino de Santiago, Carrión de los Condes fue la más relevante durante la Edad Media. Es este su período de máximo apogeo, cuando por entonces recibía la denominación de Santa María de Carrión. Por entonces, ostentará el Condado de Carrión, con los Beni-Gómez, fundadores del cenobio de San Zoilo a la cabeza del mismo. De este modo, se convertirá en sede de cortes y concilios importantes y foco de referencia de los cuatro arcedianazgos del Obispado de Palencia, elementos que propiciarán un desarrollo económico, cultural, y en consecuencia, artístico, sin parangón en otro período de la historia carrionesa. Basta indicar que la villa contaría con unos tres mil vecinos, esto es, unos doce mil habitantes y un ingente patrimonio religioso, constituido por cuatro centros monásticos, una docena de templos, y tres ermitas a finales de la Baja Edad Media.

No obstante, el largo período medieval, y en especial los siglos XI y XII en los que el románico marca una singular impronta, con ejemplos tan destacados como los templos de Santa María o Santiago, ha sido objeto de numerosos estudios, por lo que el punto de partida de nuestra investigación emerge en las postrimerías de la época medieval para analizar la producción artística que se crea a partir de entonces, adquiriendo nuestro trabajo la originalidad de sus objetivos científicos.

En los albores de la Edad Moderna, Carrión ostenta por primera vez el apelativo condal, a tenor del establecimiento de una destacada clase hidalga de origen castellano, promotora destacada del patrimonio monumental de este período. Una nobleza teñida de una profunda religiosidad, acorde al sentir popular, que, en consecuencia promoverá la construcción de espacios de culto privados debidamente adecentados con con obras de arte donde realizar sus oraciones habituales y asegurarse un lugar privilegiado para el descanso de sus almas. Los marqueses de Aguilar, los Mendoza en sus diversas ramas, los Berrio o los Paz, entre otros muchos, se conviertieron en los grandes promotores de la erección de capillas principalmente en templos parroquiales, y, junto a ellos, el clero regular se erigió en el impulsor de las obras en sus propios cenobios. El siglo XVI se erige paulatinamente como un período de bonanza económica durante el cual, si bien desaparecen algunos templos parroquiales como San Vicente, San Pedro o Sancti 
Espíritus, se producen fundaciones como los cenobios mendicantes de Santo Domingo, Santa Isabel, se construyen nuevas edificaciones como la ermita de la Vera Cruz, y, por supuesto, se levante el celebérrimo claustro de San Zoilo, hito insoslayable del patrimonio carrionés. Esta joya de mérito sin igual, ha merecido el honor de ser declarada Monumento Nacional en 1931, mención obtenida en gran parte gracias a la intervención de artistas de la talla de Miguel de Espinosa que traen a Carrión una impronta clasicista y una pericia técnica heredada de Diego de Siloé.

Durante el período barroco, el progresivo deterioro de algunos templos como Santa Eulalia o San Bartolomé conduce irremediablemente a la ruina de sus fábricas y la consecuente adhesión de sus feligreses a otros templos cercanos. No obstante, y a pesar del receso económico y demográfico que acusa la villa, que se hace extensible a toda Castilla, Carrión experimenta un crecimiento sustancial a nivel artístico, no tanto en su aspecto cuantitativo como cualitativo, que se manifiesta en la renovación íntegra de las edificaciones existentes. El mecenazgo privado y la emigración masiva de artistas de procedencia cántabra, que lograban la adjudicación de las obras a precios competentes, posibilitaron el auge constructivo referido, patente en los templos de San Andrés, Nuestra Señora de Belén, San Julián o los cenobios de Santa Clara y Santa Isabel, entre otros. En ellos se manifiesta la influencia de la corriente clasicista que se origina en el foco vallisoletano.

Dentro de las artes figurativas, la escultura ocupa un papel preeminente en el medio carrionés, con algunas obras documentadas y atribuidas de los grandes genios del barroco castellano como Gregorio Fernández, Juan de Ávila o Tomás de Sierra. No obstante, la mayor parte de la producción escultórica es obra de artistas anónimos de ámbito palentino. En el caso de la pintura carrionesa, y exceptuando los lienzos napolitanos del retablo mayor del convento de Santa Clara, la producción pictórica conservada se encuentra constituida por pinturas votivas e imágenes devocionales de carácter mediocre cuyos autores, de carácter local, se limitan a reproducir grabados y a copiar a otros artistas de reconocido prestigio.

A lo largo de la centuria decimonónica asistimos a una inevitable merma del patrimonio artístico en Carrión, consecuencia directa de la invasión napoleónica, así como de las sucesivas desamortizaciones que provocaron que hoy día tan sólo pervivan 
los templos de Santa María, Santiago, Nuestra Señora de Belén, San Andrés y San Julián, las ermitas de la Piedad, Cestillos y la Vera Cruz y dos de los seis cenobios que existieron: San Zoilo, convertido en Hospedería y Santa Clara, que mantiene actualmente la clausura con una docena de internas.

El estudio del devenir de nuestro patrimonio hasta nuestros días, en que Carrión de los Condes, que ostentaría el título de ciudad a finales del siglo XIX, fue progresivamente transformada en una villa media castellana de poco más de dos mil habitantes, resulta ineludible para comprender las circunstancias específicas de la pérdida de conventos como el de San Francisco o Santa María de Benevívere, de los que tan sólo conservamos las ruinas, o templos como San Juan del Mercado o San Bartolomé, cuyo recuerdo pervive gracias a algún testimonio gráfico o la dedicación de la calle homónima que señala su ubicación original. Lejos queda ya, el esplendor de la que fue "muy noble y leal villa” de Carrión de los Condes. 


\section{ABREVIATURAS DE LAS FUENTES DOCUMENTALES}

Archivo Histórico Provincial de Palencia

AHPP

Archivo Diocesano de Palencia

ADP

Archivo Catedralicio de Palencia

$\mathrm{ACP}$

Biblioteca Tello Téllez de Meneses, Palencia

BTTM

Archivo de la Real Chancillería de Valladolid

ARCHV

Archivo Histórico Provincial de Valladolid

AHPV

Archivo del convento de Padres Franciscanos de Valladolid

APFV

Archivo General de Simancas, Valladolid

AGS

Archivo de la Congregación de San Benito de Valladolid

(en Monasterio de Santo Domingo de Silos, Burgos)

ACSBV

Biblioteca de Santa Cruz de Valladolid

BSCV

Biblioteca Nacional

BN

Archivo Militar de Segovia

AMS

Real Academia de la Historia

RAH

Real Academia de Bellas Artes de San Fernando

ARASF

Archivo Histórico Nacional

AHN

Sección Nobleza de Toledo

SNT

Archivo General de la Administración de Alcalá de Henares

AGA

Archivo de la Compañía de Jesús de Alcalá de Henares

ACJAH

Archivo General Instituto del Patrimonio Cultural de España

IPCE

Archivo Central del Ministerio de Cultura

ACMC

Archivo de la Biblioteca del Instituto de Historia del CSIC

ABIH

Archivo Santa María de Carrión de los Condes, Palencia

ASMCC

Archivo de Santa Clara de Carrión de los Condes, Palencia

ASCC

Archivo de la Cofradía Penitencial de la Vera Cruz de Carrión

ACVCC

Archivo Municipal de Carrión de los Condes

AMCC

Archivo Histórico Regional de Cantabria

AHRC

Archivo de la Corona de Aragón, Barcelona

ACA

Archivo Histórico Provincial de Zaragoza

AHPZ

Archivo General de Indias

AGI 


\section{ABREVIATURAS DE REVISTAS}

Actas del I Congreso de Historia de Palencia

AICHP

Actas del II Congreso de Historia de Palencia AIICHP

Actas del III Congreso de Historia de Palencia AIIICHP

Archivo Español de Arte

AEA

Anuario del Departamento de Historia y Teoría del Arte

ADHTA

Boletín de la Institución Fernán González

BIFG

Boletín del Seminario de Arte y Arqueología

BSAA

Boletín de la Real Academia de la Historia

RAH

Boletín de la Sociedad Castellana de Excursiones

BSCE

Estudios de Historia del Arte

EHA

Publicaciones de la Institución Tello Téllez de Meneses

PITTM

Revista Anual de Historia del Arte

RAHA

Carrión

Carr.

Folio

fol.

Obra citada (opus citata)

Op.cit.

Pág.ina o Pág.inas

pág. o pp.

Protocolo

Prot.

Siguientes

SS.

Varios autores

VV.AA. 


\section{BIBLIOGRAFÍA}

ABAD, P. Camilo María. Historia del Colegio del Sagrado Corazón de Jesús de Carrión de los Condes (1854-1918). Palencia, 1946.

-Una misionera española en la Inglaterra del siglo XVII: Doña Luisa de Carvajal y Mendoza (1566-1614) Universidad Pontificia de Comillas. Santander, 1966.

[D] ABAD MARTíN, Ángel Santos. "Los señoríos en la montaña palentina: El marquesado de Aguilar" en AIIICHP, tomo 2. Palencia, 1995, pp. 527-550.

ADRICOMIO DELFO, Cristiano. Cronicón. Traducido al español por Lorenzo Martínez Marcilla. Zaragoza, 1631.

AGAPITO Y REVILLA, Juan. "Las custodias de plata de Castilla y León" en BSCE, Tomo 1 (1903-1904), pp. 43, 56,61, 337. Tomo 2 (1905-1906), pág. 136. Tomo IV (1909-1910), pág. 142.

-"Retablo de la iglesia de San Pedro en la villa de Cisneros. Obra de Giralte" en BSCE, tomo 2 (1905-1906).

-“Arquitectos de Valladolid" en BSCE, tomo IV (1909-10).

-“Un laborioso arquitecto castellano del siglo XVI" en Boletín de la Real Academia de San Fernando. T.XXXIII. 63. Madrid, 1922, pp. 150-158.

-La obra de los maestros de la escultura vallisoletana: papeletas razonadas para un catálogo. I, Berruguete, Juni, Jordán. Imprenta de E. Zapatero. Valladolid, 1920.

- "Un laborioso arquitecto castellano del siglo XVI: Rodrigo Gil" en Arquitectura, nº7, 1923, pp. 57-63.

- La obra de los maestros de la escultura vallisoletana: papeletas razonadas para un catálogo. II, Fernández - adiciones y correcciones. Casa Santarén. Valladolid, 1929.

-"El escultor en piedra: Miguel de Espinosa en Rioseco y otras partes" en Boletín del Museo Provincial de Bellas Artes de Valladolid, nº16. Valladolid, 1929, pp. 21-32.

AGULlÓ Y COBO, Mercedes. Documentos sobre escultores, entalladores y ensambladores de los siglos XVI al XVIII. Publicaciones del Departamento de historia del Arte. Valladolid, 1978.

[D AÍNSUA SERRANO, Jesús María. "El hospital de Don García” en Peregrino. Revista del Camino de Santiago. Junio-Agosto 2002, pp. 38-39.

[DI ALARIO TRIGUEROS, Teresa. "La imagen urbana de Palencia a finales del reinado de Carlos III" en AIICHP, tomo V. Palencia, 1990, pp. 233-242.

-"La introducción del gusto neoclásico en Palencia. Los proyectos de retablos en la obra de Francisco Prieto" en AIIICHP, tomo IV. Palencia, 1995, pp. 683-690.

[D] ALCALDE CRESPO, Gonzalo. Arquitectura civil de los siglos XVI, XVII y XVIII de la provincia de Palencia (inventario). Diputación Provincial de Palencia. Palencia, 1988. -Palencia. Barro, madera, piedra. Palencia, 1989.

- La Tierra de Campos palentina. Cálamo. Palencia, 1998.

-"Algunas consideraciones sobre las ermitas, oratorios y humilladeros de la Provincia de Palencia: El Cerrato y Tierra de Campos" en PITTM, n 70. Palencia, 1999, pp. 463485. 
-Palencia, pueblo a pueblo. Volúmenes 1, 2 y 3. Diario Palentino. Diputación de Palencia. Palencia, 2003.

D] ALCOLEA GIL, Santiago. Artes decorativas en la España cristiana (s.XI-XIX). Ars Hispaniae, ${ }^{\circ}$ 20. Plus Ultra. Madrid, 1975.

[ㅁ] ALDEA VAQUERO, Quintín, MARÍN MARTÍNEZ, Tomás y VIVES GATELL, José. Diccionario de historia eclesiástica de España. Volúmenes 3 y 4. Instituto Enrique Flórez. Madrid, 1973-1975.

DD ALLENDE SALAZAR, Juan. "Excursión a Cuenca y Uclés" en BSCE, tomo 13, no 149. 1905, pp. 137-152.

DD ALONSO CORTÉS, Narciso. "Datos para la biografía artística de los siglos XVI y XVII" en BRAH. Tomo XXX. Madrid, 1922.

[D] ALONSO DE CADENAS Y LÓPEZ, Ampelio, y CADENAS Y VICENT, Vicente de. Elenco de grandezas y títulos nobiliarios españoles. Hidalguía. Madrid, 1999.

ALONGO GETINO, Luis G. (O.P). Santo Domingo de Guzmán. Bbilioteca Nueva. Madrid,1939.

[D] ALONSO CORTÉS, Narciso. Miscelánea Vallisoletana. 2 volúmenes. Editorial Miñón. Valladolid, 1955.

ALONSO RUIZ, Begoña. El arte de la cantería. Los maestros trasmeranos de la Junta del Voto. Universidad de Cantabria. Asamblea Regional de Cantabria, Universidad de Cantabria, 1991.

- "Datos para el estudio de la organización familiar en los canteros de Trasmiera: Las familias Nates, Vega y Secadura en Príncipe de Viana, nº12, 1991, pp. 111-127.

- "Diego de Riaño y los maestros de la Colegiata de Valladolid" en De arte, n³. Universidad de León. León, 2004, pp. 39-54.

[Q] ÁLVAREZ SANCHÍS, Jesús y CARDITO MARÍA, Luz. Comisión de Antigüedades de la Real Academia de la Historia. Castilla y León. Catálogo e Índices. Madrid, 2000.

DálLVAREZ Y PÉREZ. G. Compendio histórico de las vicisitudes de la Junta de Castilla en esta guerra dividido en dos épocas. Imprenta de Ignacio Boix. Madrid, 1839.

[D] ANDRÉS, Gregorio de. Inventario de documentos sobre la construcción y ornato del Monasterio del Escorial existentes en el Archivo de su Real Biblioteca. Instituto Diego Velázquez. Madrid, 1972.

ANDRÉS GONZÁLEZ, Patricia. "Iconografía franciscana en Palencia” en AIIICHP, vol 4, 1995, pp. 773-790.

-Los monasterios de Clarisas en la provincia de Palencia. Palencia, 1997. 
ANDRÉS ORDAX, Salvador. "Los dominicos en Palencia: el convento de San Pablo" en Jornadas sobre el arte de las Órdenes religiosas en Palencia. 24-28 julio 1989. Diputación Provincial. Palencia, 1989, pp. 71-110.

-Iconografía de San Pedro Regalado. Junta de Castilla y León, Valladolid, 1991.

-"El cristocentrismo franciscano a fines de la Edad Media y su reflejo en la iconografía de los Condestables de Castilla" en Homenaje al profesor Hernández Perera, 1992, pp. 772-782.

-Iconografía jacobea en Castilla y León. Real Academia de Bellas Artes de la Purísima Concepción. Valladolid, 1993.

-Iconografía artística jacobea. Consejería de Relaciones Internacionales. Santiago de Compostela, 1993. Separata del Camino de Santiago, camino de Europa, curso de conferencias, El Escorial. Santiago de Compostela, 1993.

- La iglesia de Santa María de Carrión de los Condes. Diputación Provincial. Palencia, 1994.

-"El pintor Ramón Canedo: Algunos retratos y lienzos religiosos" en $B S A A, N^{o} \mathrm{LX}$. Valladolid, 1994, pp. 515-520.

-Catálogo monumental de Castilla y León. Bienes inmuebles declarados. Primera parte. 1, Avila, Burgos, León, Palencia. Junta de Castilla y León, Consejería de Cultura y Turismo. Valladolid, 1995.

-"Cultura e iconografía: Proyección universal del dominico palentino Pedro González" en AIIICHP,tomo IV. Palencia, 1995, pp. 377-397.

-"Un patrono para los marineros portugueses": "O corpo Santo" en Las sociedades ibéricas y el mar: Congreso Internacional. Vol 5, 1998, pp. 123-144.

-Arte e iconografía de San Pedro de Alcántara. Institución Gran Duque de Alba. Ávila, 2002.

-"Exaltación del caballero y su ocaso" en Estudios de Historia del Arte. Homenaje al profesor de la Plaza Santiago. Universidad de Valladolid. Valladolid, 2009, pp. 342343.

ANDRÉS ORDAX, Salvador, ANDRÉS GONZÁLEZ, Patricia y ZALAMA, Miguel Ángel. Monasterios de Castilla y León. Edilesa. León, 2003.

ANGLES, Higinio. “Antonio de Cabezón, organista de Carlos V y de Felipe II: en el cuarto centenario de su muerte: 1510-1566" en Cuadernos Hispanoamericanos, n²03, 1966, pp. 257-272.

ANGUITA JAÉN, José $\mathrm{M}^{\mathrm{a}}$. "La batalla de Golpejera. Historia, literatura y toponimia" en Iacobus: revista de estudios jacobeos y medievales, n ${ }^{\circ}$ 7-8, 1999, pp. 141-184.

ANGUlO ÍÑIGUEZ, Diego y PÉREZ SÁNCHEZ, Alfonso E. Historia de la pintura española. Escuela toledana de la primera mitad del siglo XVII. Instituto Diego Velázquez. Madrid, 1972.

ANÓNIMO. Aprobación de la regla y orden del gloriosísimo Padre San Benito, maestro de los religiosos, en algunos Concilios, lugares de derecho y letras apostólicas. Prólogo de Fray Juan de Castañiza. Salamanca, 1583. 
D] ANÓNIMO. Memorial Histórico Español. Colección de documentos, opúsculos y antigüedades que publica La Real Academia de la Historia. Volumen 13. Imprenta Nacional. Madrid, 1861.

[D] ANÓNIMO. Historia del Seminario Menor de Palencia en Carrión de los Condes bajo la invocación del Sagrado Corazón de Jesús. Palencia, 1943.

ANÓNIMO. Catálogo de la colección de Don Juan Bautista Muñoz. Documentos interesantes para la historia de América. Volumen II. Real Academia de la Historia. Madrid, 1955.

ANÓNIMO. Cantar del Mío Cid. Edición, prólogo y notas de MONTANER, Alberto; con un estudio preliminar de Francisco Rico. Crítica. Barcelona, 1993.

ANÓNIMO. Liber Sancti Jacobi. Codex Calixtinus. Traducida por MORALEJO, Abelardo, TORRES, Casimiro, FEO, Julio. $1^{\text {a }}$ edición: Instituto Padre Sarmiento de Estudios Gallegos. Santiago de Compostela, 1951. Edición actualizada, Xunta de Galicia. Santiago de Compostela, 2004.

ANTIGÜEDAD DEL CASTILLO-OLIVARES, Dolores. “Aportación documental sobre la enajenación de obras de arte en Palencia durante el gobierno intruso" en AIICHP, tomo 5. Palencia, 1990, pp. 261-276.

D] ARA GIL, Clementina-Julia. "Imaginería gótica palentina" en Jornadas sobre el gótico en la provincia de Palencia. Diputación Provincial de Palencia. Palencia, 1988, pp. 41-64.

-“Un grupo de sepulcros palentinos del siglo XIII: los primeros talleres de Carrión de los Condes, Pedro Pintor y Roi Martínez de Bureva" en II Curso de Cultura Medieval: Alfonso VIII y su época. Aguilar de Campóo (Palencia), 1990, pp. 21-52. - Villamuriel de Cerrato. Iglesia de Santa María la Mayor. Palencia, 1992.

ARAGONÉS ESTELLA, Esperanza. La imagen del mal en el románico navarro. Gobierno de Navarra. Pamplona, 1996.

ARAMBURU- ZABALA HIGUERA, Miguel Ángel. "Los maestros canteros en Palencia (1575-1650)" en AIICHP, tomo V. Palencia, 1990, pp. 163-172.

-"El problema del clasicismo en la arquitectura española de la segunda mitad del siglo XVI" en Príncipe de Viana. Anejo 10-91 Jornadas Nacionales sobre el Renacimiento español, 1991, pp. 119-127.

-La arquitectura de puentes en Castilla y León (1575-1650). 2 tomos. Junta de Castilla y León. Valladolid, 1992.

-Fraude y corrupción en la arquitectura del siglo de Oro. Santander, 2001.

-"De Rodrigo Gil de Hontañón a Juan de Herrera" en El arte de la cantería, Santander, 2003, pp. 91-112.

ARANGUREN ROLDÁN, Jimeno. "Configuración de una identidad hagiográfica popular: la leyenda de San Gregorio Ostiense" en Zainak. Cuadernos de Antropología-Etnografía, no 22. Bilbao, 2003, pp. 89-101. 
[D ARAUJO GÓMEZ, Fernando. Historia de la escultura en España desde principios del siglo XVI hasta fines del siglo XVIII. Librerías Paris. Valencia, 1992.

ARGAIZ, Gregorio de. La soledad laureada por San Benito y sus hijos en las iglesias de España. 6 tomos. Madrid, 1675.

ARIAS ANGLÉS, E. El paisajista romántico Jenaro Pérez Villaamil. CSIC. Madrid, 1986.

[L] ARRATIA MARTÍN, Ma Victoria. Las ánimas del purgatorio en la provincia de Valladolid, una devoción popular. Diputación Provincial de Valladolid. Valladolid, 1999.

[D] ARRIBA CANTERO, Sandra de. "San José en la obra de Gregorio Fernández: un estudio iconográfico" en Gregorio Fernández. Antropología, historia y estética en el Barroco. Valladolid, 2008, pp. 451-463.

[D] ARRIBAS, Miguel María. "Retablo de Juan Correas y Blas Martínez de Obregón en Cuéllar" en Estudios Segovianos, nº 25, 1973, pp. 556-560.

D ARROYO PUERTAS, Carlos. San Martín de Frómista. Editorial Cálamo. Palencia, 2002.

ASCANI, V. "Cisterciensi. Architettura" en Enciclopedia dell'arte medievale, volumen IV. Roma, 1993, pp. 817-835.

ATIENZA HERNÁNDEZ, Ignacio. "La quiebra de la nobleza castellana en el siglo XVII: Autoridad real y poder señorial” en Hispania, nº156, 1984, pp. 49-82.

AUUREA DE LA MORENA, Bartolomé. Rodrigo Gil de Hontañón: un arquitecto entre el gótico y el renacimiento: exposición conmemorativa del quinto centenario de su nacimiento. Madrid, 2000.

-"Reflexiones en torno a la arquitectura religiosa castellana en el siglo XVI" en Arquitectura religiosa del siglo XVI en España y Ultramar. Abril de 2003. Actas del curso de la Cátedra de Goya en abril de 2003. Institución Fernando el Católico. Zaragoza, 2004, pp. 159-188.

AYARZA, Javier. El camino de Santiago en la provincia de Palencia. Cálamo. Palencia, 2004.

[D] AYGUALS DE IZCO, Wenceslao. Galería regia o biografías de los reyes de España desde el primero de los godos hasta Isabel II. Tomo I. $3^{\text {a }}$ Edición. Madrid, 1848.

AZCÁRATE RISTORI, José María de. Monumentos españoles: catálogo de los declarados histórico-artísticos. Volumen 2. Instituto Diego Velázquez. Madrid, 1954.

- Escultura del siglo XVI, Ars Hispaniae, 13. Plus Ultra. Madrid, 1958.

-"El brote del Renacimiento en Palencia" en AICHP, 1. Palencia, 1987, pp. 61-74.

- Arte gótico en España. Cátedra. Madrid, 1990. 
BALMASEDA, Luis Javier. "El territorio palentino en época romana" en Historia de Palencia, I. Palencia, 1990, pp. 67-128.

BALSALOBRE GARCÍA, Juana María. "El aspirante a arquitecto y la Real Academia de Bellas Artes de San Fernando" en Arquitectura y ciudad en España de 1845 a 1898. Actas de la I Jornada de Arquitectura histórica y urbanismo Cádiz, 1998, pp. 135-148.

BANGO TORVISO, Isidro. "Atrio y pórtico en el románico español: concepto y finalidad cívico-litúrgica” en BSAA. No XL-XLI, Valladolid, 1975, pp. 175-188.

-"El espacio para enterramientos privilegiados en la arquitectura medieval española” en ADHTA, n IV, 1992, pp. 93-132.

-"La vieja liturgia hispana y su interpretación funcional del templo prerrománico" en VII Semana de Estudios Medievales, Nájera, 29 julio a 2 de agosto, 1996. Actas, Logroño, 1997, pp. 61-120.

-"El verdadero significado del aspecto de los edificios. De lo simbólico a la realidad funcional, la Iglesia encastillada” en ADHTA, n9-10, 1997-1998, pp. 53-72.

BARÓN FARALDO, Andrés. "Un magnate del siglo XIII: Alvar Fernández Podestat. Problemática y posibilidades sobre su origen y su parentela" en PITTM, $\mathrm{n}^{\circ}$ 73. Palencia, 2005, pp. 243-260.

[d] BARQUERO GOÑI, Carlos. "Los hospitalarios en la Diócesis de Palencia durante los siglos XII y XIII" en AIICHP, vol. 2, Palencia, 1995, pp. 681-691.

BARRIO LOZA, J.A. "Juan de Celaya y el puente mayor de la ciudad de Palencia" en PITTM, n 46. Palencia, 1982, pp. 163-170.

D] BARRIO LOZA, J.A. y MOYA VALGAÑ́n, José G. Los canteros vizcaínos (1500-1800). Diccionario biográfico. Bilbao, 1981.

[Da BARREDA FERRER, Ángel Luis. Carrión de los Condes (Palencia), en el corazón del Camino de Santiago. Artes Gráficas Iglesias. Palencia, 1997.

D] BARREDA FERRER, Ángel Luís y GÓMEZ PÉREZ, Enrique. Iter Stelarum. La gran obra de los Caminos de Santiago. Tomo V. Ediciones Hércules. La Coruña, 2004.

BAYON, Damien. L'architecture en Castille au XVI siècle. Commande et réalisations. Collection Le signe de l'art. Éditions Klincksieck. París, 1967.

BECEIRO PITA, Isabel. "Luchas políticas y nobiliarias y resistencia antiseñorial en el reinado de Enrique IV: los conflictos de Castromocho y Carrión" en El pasado histórico de Castilla y León. Actas del I Congreso de Historia de Castilla y Léón (1-4 de diciembre de 1982), volumen 1. Valladolid, 1983, pp. 151-159.

- "La conciencia de los antepasados y la gloria del linaje en la Castilla Bajo imperial" en Relaciones de poder, de producción y parentesco en la Edad Media y Moderna. Madrid, 1990, pp. 329-350. 
[DI BECERRO DE BENGOA, Ricardo. "El monasterio de Carrión" en La España Moderna, Revista Ibero-Americana, no 7, Madrid, 1889, pp. 55-96.

-El libro de Palencia. Hijos de Gutiérrez. Palencia, 1874. Edición facsímil, Caja España. Palencia, 1993.

BEJARANO, José A. "Cartografía de la estadística de la Diócesis de Palencia (año 1345)" en AICHP, vol II. Diputación Provincial de Palencia, 1985 pp. 197-240.

BEJARANO RUBIO, Amparo y MOLINA MOLINA, Luis. El Monasterio de San Zoilo a finales de la Edad Media: propiedades y rentas. Universidad de Murcia. Murcia, 1999.

BELDA NAVARRO, Cristóbal. Los siglos del Barroco. Akal. Madrid, 1997.

D BELTRÁN DE HEREDIA. Las corrientes de espiritualidad entre los dominicos de Castilla en la primera mitad del siglo XVI. Salamanca, 1941.

D] BÉNÉZIT, Emmanuel. Dictionnaire critique et documentaire des peintres, sculpteurs, dessinateurs et graveurs. 8 tomos. Librairie Grund. París, 1976.

BENITO MARTÍN, Félix. La arquitectura tradicional de Castilla y León. 2 volúmenes. Valladolid, 1998.

DEN BENTO RUANO, Eloy. "Don Pero Sarmiento, repostero mayor de Juan II de Castilla. Datos biográficos documentales" en Hispania, n LXIX. 1957, pp. 483504.

-"El origen del Condado de Salinas" en Hidalguía, V, n²0, 1957, pp. 41-48.

BERAULT-BERCASTEL, Antoine-Henri. Historia general de la Iglesia desde la predicación de los Apóstoles hasta el Pontificado de Gregorio XVI. Tomo III.

Traducida por Epifanio Díez Iglesias. Madrid, 1852.

BERNARD, Auguste. Recueil des chartes de l'Abbaye de Cluny. 6 tomos. $1^{\mathrm{a}}$ Edición, París, 1876. Revisada por BRUEL, Alexandre. Frankfurt, 1988.

BISHKO, Charles Julián. "El abad Radulfo de Cluny y el prior Humberto de Carrión, camerario" de España: tres cartas inéditas de hacia 1174" en Anuario de Estudios Medievales, I. Madrid, 1964, pp. 197-215.

-"Fernando I y los orígenes de la alianza castellano-leonesa con Cluny" en Cuadernos de Historia de España, n 47-48, 1968, pp. 31-135.

BLEYE, Valentín. Guía turística de Palencia y su provincia. Palencia, 1987.

BRASAS EGIDO, José Carlos. La platería vallisoletana y su difusión. Institución Cultural Simancas. Valladolid, 1980.

- La pintura del siglo XIX en Valladolid. Institución Cultural Simancas. Valladolid, 1982.

-La platería palentina. Diputación Provincial de Palencia, 1982.

- "Palencia" en La platería en la época de los Austrias mayores en Castilla y León. Junta de Castilla y León. Valladolid, 1999, pp. 191-202. 
BRAVO LOZANO, Millán. Guía del peregrino medieval: 'Codex Calixtinus'. Centro de Estudios del Camino de Santiago. Sahagún (León), 1989.

BROWN, Jonathan. Imágenes e ideas en la pintura española del siglo XVII. Alianza. Madrid, 1980.

[D] BURRIEZA SÁNCHEZ, Javier. Los milagros de la corte: Marina de Escobar y Luisa de Carvajal en la historia de Valladolid. Valladolid, 2002.

-"Gregorio Fernández: retrato histórico de un escultor en Valladolid" en Gregorio Fernández: antropología, historia y arte en el Barroco. Valladolid, 2008, pp. 245299.

DUSTAMANTE GARCÍA, Agustín. La arquitectura del foco vallisoletano. Institución Cultural Simancas. Valladolid, 1983.

-"El siglo XVII. Clasicismo y barroco" en Manual del arte español. Madrid, 2003, pp. 525-636.

[d BUSTILLO NAVARRO, Ángel. "Toponimia menor del medio rural. Carrión de los Condes. Palencia" en AICHP, tomo IV. Palencia, 1985, pp. 259-270.

CA CAMAÑO MARTÍNEZ, Ma Jesús. "Datos para la historia de la Real Academia de la Purísima Concepción de Valladolid (1786-1797)” en BSAA, n²9, Valladolid, 1963, pp. 89-151.

CABEZA RODRÍGUEZ, Antonio. Clérigos y señores: política y religión en Palencia en el siglo de Oro. Diputación Provincial de Palencia, 1996.

CADENAS Y VICENT, Vicente de. Pleitos de hidalguía que se conservan en el Archivo de la Real Chancillería de Valladolid. Hidalguía. Madrid, 2001.

[D] CADINANANOS BARDECI, Inocencio. "Nuevos datos sobre la Iglesia de San Martín de la Mota del Marqués, obra de Rodrigo Gil de Hontañón” en Academia, n76, 1993, pp. 461-472.

-“Los puentes de la provincia de Palencia en la Edad Moderna" en PITTM, n 69. Diputación de Palencia. Palencia, 1998, pp. 299-367.

-"Fortificación y castillos de los siglos románicos" en Palencia en los siglos del románico. Fundación Santa Ma la Real de Aguilar. Palencia, 2002, pp. 169-199.

[D CALDERÓN, Padre Francisco. Primera parte de la Chrónica de la Santa Provincia de la Purísima Concepción de Nuestra Señora de la Regular Observancia. (166769). Archivo de la Iglesia franciscana de San Antonio de Valladolid. Carpeta 1.Caja 1, Legajo 1, III.

CALLAEY, Eduardo. El otro imperio cristiano. De la Orden del Temple a la francmasonería. Colección Historia Incógnita. México, 2006.

[D] CALLEJA GONZÁLEZ, María Valentina. Guía del Museo Arqueológico provincial de Palencia. Palencia, 1975. 
CALMETTE, Joseph. Charlemagne. Presses Universitaires de France. Paris, 1951.

CÁMARA FERNÁNDEZ, Carmen. "Aportación al estudio de maestros de obras trasmeranos que trabajan en Palencia durante el siglo XVII" en AIICHP, tomo 5, Diputación Provincial de Palencia. Palencia, 1990, pp. 173-179.

-“Arquitectura clasicista en Castilla" en Torno a la figura del trasmerano Pedro de la Torre "Bueras y sus obras de carácter religioso" en Juan de Herrera y su influencia. Actas del simposio. Camargo, 4-7 julio, 1992, pp. 251-257.

[C] CÁMARA FERNÁNDEZ, Carmen, IGLESIAS ROUCO, Lena Saladina y ZAPARAÍN YÁÑEZ, María José. "Juan de Naveda. En torno a su actividad en Burgos (1607-1631) y el ejercicio de la profesión” en BIFG, n 276. Burgos, 1998, pp. 43-59.

[D] CAMÓN AZNAR, José. La arquitectura plateresca. Instituto Diego Velázquez. Madrid, 1945.

-“Juan de Balmaseda" en Goya: Revista de Arte. № 12. Fundación Lázaro Galdiano. Madrid, 1956, pp. 358-369.

-La arquitectura y la orfebrería españolas del siglo XVI. Summa Artis. Volumen 17. Espasa Calpe. Madrid, 1959.

-La escultura y rejería españolas del siglo XVI. Summa Artis. Volumen 18. Madrid, 1961

$\mathbb{E}$ CAMPANY Y DE MONTPALAU, Antonio de. Compendio cronológico- histórico de los soberanos de Europa. Primera parte. Real Compañía de impresores y libreros. Madrid, 1792.

CAMPOS SÁNCHEZ-BORDONA, María Dolores. "Proyectos urbanísticos de Juan de Badajoz y Juan del Ribero Rada para la ciudad de León” en ADHTA, n4, 1992, pp. $145-150$.

- Juan de Badajoz y la arquitectura del Renacimiento en León. Universidad de León. León, 1993.

-"Los órdenes clásicos en la arquitectura de Juan de Ribero Rada" en Los clasicismos en el arte español. Actas del X Congreso Español de Historia del Arte, 1994, pp. 467-474.

- La catedral de León. Colegio de España. Salamanca, 1994.

- “Juan del Ribero Rada y el orden dórico" en Boletín de la Real Academia de Bellas Artes de San Fernando, n81, 1995, pp. 517-542.

-“Juan del Ribero Rada, arquitecto clasicista” en Altamira, n52, 1996, pp. 127-166.

-"La reforma del monasterio de San Benito en la Edad Moderna" en El Patrimonio artístico de San Benito de Sahagún: esplendor y decadencia de un monasterio medieval. León, 2000.

-“Arte y cultura en la biblioteca de Juan del Ribero Rada” en Humanismo y tradición clásica en España y América, Universidad de León, 2002, pp. 311-332.

[D] CAMPOS SÁNCHEZ-BORDONA, María Dolores, HERRÁEZ ORTEGA, Ma Victoria, VALDÉS FERNÁNDEZ, Manuel. "El origen histórico y social de las reformas en los monasterios benedictinos durante el siglo XVI" en Actas del VIII Congreso Nacional de Historia del Arte, II.. Universidad de Extremadura. Editora Regional de Extremadura. Cáceres, 1993, pp. 811-817. 
D] CAÑEDO-ARGUELlES, Cristina. Arte y Teoría: La Contrarreforma y España. Servicio de Publicaciones de la Universidad de Oviedo, 1982.

CAPDEPÓN VERDÚ, Paulino. "Vida y obra de Antonio Cabezón: 1510-1566" en López de Gámiz: Boletín del Instituto Municipal de la Historia, 1986, pp. 59-64.

[D CAPMANY Y DE MONTPALAU, Antonio. Compendio cronológico histórico de los soberanos de Europa. Primera Parte. Madrid, 1784.

CAPUZ LLADRÓ, Rafael. Materiales orgánicos. Maderas. Universidad Politécnica de Valencia, 2005.

CARDERERA Y SOLANO, Valentín. Iconografía española: colección de retratos, estatuas, mausoleos... de reyes, reinas, grandes capitanes... desde el s. XI hasta el XVII. Madrid, 1855-1864.

[d] CARLÓN, Concepción, MARTÍNEZ GONZÁLEZ, Rafael Ángel, PRESA, Fabiola. "La capilla funeraria de los Guerra en la iglesia de San Miguel de Piña de Campos (Palencia)" en AIICHP, tomo 5. Palencia, 1990, pp. 181-208.

D CARNICER, Ramón. Gracias y desgracias de Castilla la Vieja. Plaza y Janés. Barcelona. 1978.

D] CARMONA MUELA, Juan. Iconografía de los Santos. Dirección General del Libro, Archivos y Bibliotecas del Ministerio de Educación, Cultura y Deporte. Madrid, 2003.

CARRAMINANA PELLEJERO, "Proceso de restauración de una obra manierista de la iglesia de San Andrés de Calahorra" en Kalakorikos, nº, Calahorra, 2001, pp. 283-292.

[D] CARRIAZO RUBIO, Juan Luis. La memoria del linaje: los Ponce de León y sus antepasados a fines de la Edad Media. Universidad de Marchena. Sevilla, 2002.

-"Dos siglos de estudios sobre los Ponces de León: historiografía de un linaje medieval" en Historia, instituciones, documentos, n²9, 2002, pp. 9-30.

[d CARRIÓN GUTIEZ, Manuel. "Carrión de los Condes" en Apuntes Palentinos. Villas Palentinas, fascículo 4. Palencia, 1983.

[D] CARVAJAL IBÁÑEZ, Teresa. "Un palentino en Panamá: Hernando de Berrio" en AIICHP, tomo 4. Palencia, 1990, pp. 445- 451.

CASASECA CASASECA, Antonio. "Trazas para la Catedral de Segovia" en AEA, $n^{\circ} 51$. Madrid, 1978, pp. 29-62.

-Rodrigo Gil de Hontañón (Rascafría, 1500-Segovia, 1577). Junta de Castilla y León. Consejería de Cultura y bienestar Social. Salamanca, 1988.

D CASTÁN LANASPA, Guillermo. Documentos del Monasterio de Villaverde de Sandoval (siglos XII-XV). Universidad de Salamanca. Salamanca, 1981. 
-Documentos del Monasterio de Santa María de Trianos: (Siglos XII-XIII). Universidad de Salamanca. Salamanca, 1992.

Q CASTÁN LANASPA, Javier. Arquitectura templaria castellano-leonesa. Universidad de Valladolid. Valladolid, 1983.

-"Las órdenes militares y su arquitectura" en Jornadas sobre el románico en la provincia de Palencia. Departamento de Cultura. Diputación Provincial. Palencia, 1985, pp. 47-55.

-"La arquitectura gótica palentina" en Jornadas sobre el gótico en la provincia de Palencia. Departamento de Cultura. Diputación Provincial. Palencia, 1988, pp. 31-40.

-"Nuevas noticias sobre la iglesia de Nuestra Señora de la Asunción en Cabezón de Pisuerga (Valladolid)"en BSAA, n 54. Valladolid, 1988, pp. 351-360.

-"Una portada románica con capiteles historiados en Carrión de los Condes (Palencia)" en Estudios de Arte. Homenaje al profesor Martín González. Universidad de Valladolid. Valladolid, 1995, pp. 305-310.

CASTELLANOS DE LOSADA, Basilio Sebastián. Biografía eclesiástica completa: vida de los personajes del Antiguo y Nuevo Testamento, de todos los santos que venera la iglesia, Papas y eclesiásticos célebres por sus virtudes y talentos en orden alfabético. Imprenta de Alejandro Gómez Fuentenebro. 30 volúmenes. Madrid, 1848-1867.

CASTILlO, Fray Hernando del (O.P). Primera parte de la historia general de Santo Domingo y de su orden de predicadores. Casa de Francisco Sánchez. Madrid, 1584.

- Segunda parte de la historia general de Santo Domingo y de su orden de predicadores. Impresa por Diego Fernández de Córdoba. Valladolid, 1592.

d] CASTILlO PINTADO, Álvaro. "Population et richesse en Castille durant la seconde moitie du XVI ${ }^{\mathrm{e}}$ siécle" en Anales Economies, Societés, Civilisations, nº, 1965, pp. 719-733.

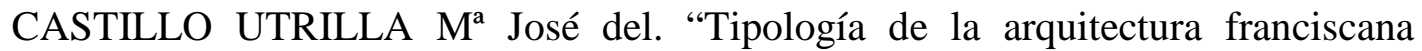
española desde la Edad Media al Renacimiento" en Actas del XXIII Congreso Internacional de $H^{a}$ del Arte. Granada, 1976, pp. 323-327.

- "Reyes y nobles en la iconografía franciscana” en Laboratorio de Arte: Revista del Departamento de Historia del Arte de la Universidad de Sevilla, $\mathrm{n}^{\circ}$ 5, 1. Sevilla, 1992, pp. 25-41.

CASTRO, Lázaro de. Breve Historia de Carrión. Carrión, Palencia, 1779.

CASTRO, Manuel de. El real Monasterio de Santa Clara y los Enríquez: Almirantes de Castilla. Institución Tello Téllez de Meneses. Palencia, 1982.

-"Monasterios hispánicos de clarisas desde el siglo XIII al XVI" en Archivo Iberoamericano. Revista de Estudios Franciscanos, no 193-194, 1989, pp. 79-12

D] CASTRO GARCÍA, Lázaro y ORCAJO DÍEZ, Jesús. "Noticias sobre algunas obras de arte de Villasandino" en BIFG, nº183. Burgos, 1974, pp. 277-299. 
[DCASTRO MARTÍN, Pablo L. “Arte funerario del siglo XVII en Palencia” en AIIICHP, tomo IV. Palencia, 1995, pp. 601-617.

CASTRO MATÍA, Santiago de y BIROUSTE, Daniel. La organería en Tierra de Campos. La obra de Tadeo Ortega. Diputación Provincial de Palencia, 1979.

[D] CASTRO SANTAMARÍA, Ana. "Aportaciones al epistolario de Rodrigo Gil de Hontañón sobre la Catedral de Coria y la catedral de Villafranca del Bierzo" en Norba, $\mathrm{n}^{\circ} 17,1997$, pp. 41-52.

[D] CAVERO DOMINGUEZ, Gregoria. "Monarquía y nobleza: su contribución a las fundaciones de clarisas en Castilla y León (siglos XIII-XV)" en Archivo IberoAmericano. Revista Franciscana de Estudios Históricos. no 213-114, Enero-Junio 1994, pp. 257-280.

[D] CEÁN BERMÚDEZ, Agustín. Diccionario Histórico de los más ilustres profesores de las Bellas Artes en España. 6 volúmenes. Imprenta de la Viuda de Ibarra. Madrid, 1800.

[D] CERVERA VERA, Luis. El convento de Santo Domingo de Lerma. Valencia, 1969 -La iglesia colegial de Lerma. Burgos, 1981.

CDUECA GOITIA, Fernando. Invariantes castizos de la arquitectura española. Madrid, 1947.

- La Catedral Nueva de Salamanca: historia documental de su construcción. Universidad de Salamanca. Salamanca, 1951.

-Arquitectura del siglo XVI. Ars Hispaniae, Tomo XI. Plus Ultra. Madrid, 1953.

-Arquitectura monumental en la provincia de León. Santiago García. León, 1991.

-El plateresco: imagen de una España en tensión. Fundación Cultural Santa Teresa. Ávila, 1998.

CIRIA RAXIS E INOJOSA, Pedro de. Vidas de santas y mugeres ilustres de el orden de San Benito, patriarca de los monges. Tomo 1. Granada, 1684.

-Tomo 2. Granada, 1688.

-Tomo 3. Granada, 1691.

$\mathbb{E}$ CISNEROS Y TAGLE, Juan. Historia de las grandezas y antigüedades de la muy noble villa de Carrión. Frómista, Palencia, 1629.

[D] CLARISA DE CARRIÓN DE LOS CONDES. Algunos apuntes para la historia del convento de Santa Clara y la Virgen de la Piedad de Carrión de los Condes. Gráficas Afrodisio Aguado. Valladolid, 1946.

(d) COLÁS LATORRE, Gregorio y SERRANO MARTÍN, Eliseo. "Nobleza en España en la Edad Moderna" en Manuscrits, nº14, 1996, pp. 15-38.

QD COLLAR DE CÁCERES, Fernando. "El plateresco" en Historia 16. n 8. Madrid, 1992. 
Dd COLOMBÁS GARCÍA, M y ARANGUREN; Iñaki. La Regla de San Benito. $2^{\mathrm{a}}$ Edición. Biblioteca de Autores Cristianos. Madrid, 1993.

[ CORBLET, J. "Étude iconographique sur l'Arbre de Jessé" en Revue de l'art Chretien, $\mathrm{n}^{\circ} 4$. Paris, 1860, pp. 49-61.

[D] CORRAL, Eugenio del. Vida y milagros del dulce doctor y Padre de la iglesia, San Bernardo, abad de Claraval. 3 vol. Imprenta de Isidoro Hernández Pacheco. Madrid, 1782.

DD COSTA Y BORRÁS, Domingo. La leyenda de oro para cada día del año: vidas de todos los santos que venera la Iglesia. Tomo 3. Librería Española. Madrid, 1853.

COVARRUBIAS OROZCO, Sebastián de. Tesoro de la Lengua castellana o española. 2 volúmenes. Madrid, 1673-1674.

[D] CRESPO, Daniel. "Rodrigo Gil de Hontañón y la mirada de la Ilustración" en El arte de la cantería, Santander, 2003, pp. 167-184.

[D] CRESPO, Esteban. "Monumentos españoles. El monasterio de San Zoil" en La esfera. Madrid, 26 de febrero de 1916, nº113, 19

[D] CROISSET, Padre Juan. Año cristiano para todos los días del año. Traducido por ISLA, Padre José Francisco. 12 tomos (enumerados por meses). Barcelona, 18621863

CUADRADO LORENZO, Ma Flora. "Un posible Zodíaco en las metopas de la parte sur de la iglesia de Santa María de Carrión” en BSAA. Tomo LI. CSIC y Universidad de Valladolid. Valladolid, 1985, pp. 439-444.

-"La iglesia de Santa María de Carrión de los Condes y su programa escultórico" en PITTM, no 57. Diputación Provincial. Palencia, 1987, pp. 213-292.

-"Iglesia de Santa Ma del Camino o de las Victorias" en Enciclopedia del Románico en Castilla y León. Palencia. Aguilar de Campoo. Vol.2, Boedo-La Ojeda, Saldaña-La Valdavia, Tierra de Campos, Cerrato. Fundación Santa María la Real, Centro de Estudios del Románico. Aguilar de Campóo, 2002, pp. 1004-1012.

- "Santa María de Carrión y su significación” en Palencia en los siglos del románico. Fundación Santa María la Real. Aguilar de Campoó (Palencia), 2002, pp. 37-47.

[D] CUADRADO SÁNCHEZ, Marta. "Arquitectura franciscana en España" en Archivo Ibero- Americano. Revista de Estudios Franciscanos. no 201-202. Enero-Junio 1991, pp. 15-70.

-"Arquitectura franciscana en España" (Segunda parte) en Archivo IberoAmericano, no 203-204. Julio- Diciembre 1991, pp. 479- 552.

[D] CUESTA SALADO, Jesús. Jacques Bernal, Benito Elías y los Giralte de Villalpando. Aportaciones a la escultura del siglo XVI en el occidente de Tierra de Campos. Maas. Valladolid, 2011.

[D] CUADRADO TAPIA, Ricardo. Villamorco: su historia, su arte y sus gentes. Burgos, 2001. 
DALMAU, Bernabé. Lèxic d'espiritualitat benedictina. Montserrat, Barcelona, 1987.

DE LA FUENTE, Vicente. "La cruz patriarcal o de doble traversa y su antigüedad y uso en España; A propósito de la cruz de Caravaca" en $B R A H, \mathrm{n}^{\circ}$ 9. Madrid, 1886, pp. 177-188.

[D DE LA MADRIZ MANRIQUE, Manuel. Breves reflexiones sobre que es más ventajosa: la dirección del camino de hierro de Palencia a Alar del Rey pasando por Carrión de los Condes que por Frómista. Imprenta y Librería de Mariano García y Gervasio Santos. Palencia, 1856.

DELAVILLE LE ROULX, Joseph Marie. "La supp.ression des templiers" en Revue des questions historisques, $\mathrm{n}^{\circ} 48,1890$, pp. 27-62.

[DI DELCORNO, G. "Origini de la predicazione franciscana" en Francesco de Assisi e Francescanesimo dal 1216 al 1226. Atti del IV Convegno Internazionale, Asís 1977, pp. 127-160.

DD DELICADO BAEZA, José. Historia de la Diócesis de Valladolid. Valladolid, 2006.

[D] D’EMILIO, James. "Tradición local y aportaciones foráneas en la escultura románica tardía: Compostela, Lugo y Carrión" en Actas del Simposio Internacional sobre O Pórtico da Gloria e a arte do seu templo, 3-8 de Outubro de 1988”. Santiago de Compostela, 1992, pp. 83-94.

DIAGO HERNANDO, Máximo. "Política y guerra en la frontera castellano-navarra durante la época de los Trastámara" en Príncipe de Viana, 203, 1994, pp. 525-548.

[D] DÍAZ DÍAZ, Teresa. "Santa María de la Cabeza, única santa nacida en la provincia de Guadalajara (Caraquiz, Úceda), de origen judeoconverso" en El culto a los Santos, 2008, pp. 637-654.

DÍAZ ESTEBAN, Fernando. "La ampliación de la sinagoga de Carrión y sus inscripciones" en Judaísmo Hispano, vol 2. Madrid, 2002, pp. 519 y ss.

\DÍAZ IBÁÑEZ, Jorge. "El poder episcopal en la Diócesis de Cuenca durante la Edad Media" en Espacio, tiempo y forma, serie III. Historia Medieval, no 9. Madrid, 1996, pp. 41-98.

[D] DÍAZ JIMÉNEZ Y MOLLEDA, Eloy. Historia del Museo arqueológico de San Marcos de León. Apuntes para un catálogo. Librería de Victoriano Suárez. Madrid, 1920.

[DI DÍAZ MARTÍN, Luis Vicente. Los oficiales de Pedro I de Castilla. Valladolid, 1987.

[D] DÍAZ NAVA, Adolfo F. "Un claustro plateresco: San Zoilo de Carrión de los Condes" en PITTM, n 23. Diputación Provincial. Palencia, 1963, pp. 89-122. 
DIEGO SÁNCHEZ, Manuel. Fuentes históricas para la biografía de Francisca Javiera del Valle (1856-1930). Palencia, 1991.

Q] DÍEZ, Fray Jacinto (O.S.B). Sermón historial gratulatorio en la entrada de dos urnas de plata para colocar los cuerpos de los gloriosos martyres y patronos de Carrión S. Zoil y S. Félix. Oficina de Eugenio Antonio García. Salamanca, 1707.

DIEZ CANSECO, Vicente. Diccionario biográfico universal de mujeres célebres. Tomos I y II. Madrid, 1844.

[DI] DÍEZ MERINO, Luis. "Pleito eclesiástico de 1764: Monasterio de San Zoilo de Carrión y la Ermita del Santo Cristo de las Heras de la Peña" en PITTM, no 54. Diputación Provincial de Palencia. Palencia, 1986, pp. 281-308.

D] DIMANUEL JIMÉNEZ, Mercedes. "Estructuras y elementos militares en iglesias fortificadas medievales españolas" en $A H A, \mathrm{n}^{\circ} 16,2006$, pp. 79-102

DIMIER, Anselme. Les moines battîsseurs: architecture et vie monastique. París, 1964.

-“Quelques légendes de fondation chez les cisterciennes” en Studia Monastica, nº12, 1 , 1970, pp. 97-105.

[D DOMÍNGUEZ BORDONA, Jesús. Proceso inquisitorial contra el escultor Esteban Jamete. Blass. Madrid, 1933.

DOMINGUEZ CASAS, Rafael. - "Significado de la portada de Felipe Berrojo en el Real Monasterio de San Benito de Sahagún" en Iacobus, no 3,4, 1997 Centro de Estudios del Camino de Santiago. Sahagún, León, 1997.

-"La portada de Felipe Berrojo y la fachada de la portería en el monasterio de San Benito de Sahagún. Estructura e iconografía" en Anales de Arquitectura, nº 8, 1998 pp. 45- 64.

-"El arco de San Benito de Sahagún: Restauración y hallazgos artísticos" en Restaurar la memoria. Congreso Internacional Valladolid ARPA. 2000(actas). Valladolid, 2001 pp. 557-574.

[D] DOMÍNGUEZ ORTIZ, Antonio."La desigualdad contributiva en Castilla durante el siglo XVII' en Anuario de Historia del Derecho Español,1951-1952, pp. 1222-1268. -Crisis y decadencia de la España de los Austrias. Barcelona, 1971.

[D DOSSAT, Yves. "Opp.osition des anciens ordres à l'installation des mendiants" en Cahiers de Fanyeux, nº 8. Fanyeux, 1973, pp. 263-306.

[D] DUBY, Georges. Hombres y estructuras de la Edad Media. Siglo XXI de España Editores. Madrid, 1978.

[D] DUCHET-SUCHAUX, Gaston y PASTOUREAU, Michel. Guía iconográfica de la Biblia y los santos. Alianza Editorial. Madrid, 1996. 
[D] DURO PEÑA, Emilio. El monasterio de San Esteban de Ribas de Sil. Instituto de Estudios Orensanos "Padre Feijoo". Orense, 1977.

ECHEVARRÍA GOÑI, Pedro Luis. Policromía renacentista y barroca. Historia 16. Madrid, 1992.

EGIDO LÓPEZ, Teófanes. "Religiosidad popular y taumaturgia del Barroco. Los milagros de la Monja de Carrión" en AIICHP, tomo 3. Volumen 1. Excelentísima Diputación Provincial de Palencia. Palencia, 1990, pp. 11-39.

ENRÍQUEZ DE SALAMANCA, Cayetano. Palencia. Everest. León, 1972.

ÉPINEY BURGARD, Georgette. Mujeres trovadoras de Dios: una tradición silenciada de la Europa medieval. Paidós. Barcelona, 1988.

[D] ESPINOSA MORO, María José. "Expedientes de bienes de difuntos de palentinos en el Archivo de Indias (siglos XVI-XVIII)" en Actas del II Congreso de Historia de Palencia. Tomo IV. Palencia, 1990, pp. 501-509.

D ESTEBAN LORENTE, Juan Francisco. "La portada de la Piedad de la iglesia de Casalarreina (La Rioja)" en Cuadernos de Investigación, tomo 10, fascículo 2, Universidad de La Rioja, 1984, pp. 95-105.

[D] HERREROS ESTÉBANEZ, Francisco. Historia de Frechilla. Palencia, 1984.

FALQUE, Emma. Historia compostelana. Akal. Madrid, 1994.

FAYA DÍAZ, Ma Ángeles. "Los señoríos eclesiásticos del obispado de Palencia en el siglo XVI" en AIIICHP, tomo 2, Palencia, 1995, pp. 755-772.

[ FERNÁNDEZ ARRIAGA, Inmaculada. El destierro de los jesuitas castellanos (1767-1815). Junta de Castilla y León. Salamanca, 2004.

@] FERNÁNDEZ CANTÓN, José María. Catálogo del Archivo Histórico Diocesano de León, II. León, 1986.

[D] FERNÁNDEZ DE LA CUESTA, Ismael. "Un tiento de Peraza entre papeles de San Zoilo de Carrión” en Anuario Musical, 56. CSIC, Madrid, 2001, pp. 33-45.

[D] FERNÁNDEZ DE MADRID, Alonso. Silva Palentina. 3 volúmenes. Volumen 1 y 2, Palencia, 1932 y volumen 3, Palencia, 1942. Edición actualizada,Valladolid, 1976.

DQ FERNÁNDEZ DEL HOYO, M ${ }^{\mathrm{a}}$ Antonia. Marina de Escobar. Caja de Ahorros Popular de Valladolid. Valladolid, 1984.

-"Juan de Nates y la portada de la Vera Cruz de Valladolid" en BSAA, n52. Valladolid,1986, pp. 396- 401.

-Conventos desaparecidos de Valladolid: patrimonio perdido. Valladolid, 1988.

- "Oficiales del taller de Gregorio Fernández y ensambladores que trabajaron con él” en $B S A A, \mathrm{n}^{\circ}$ 49, Valladolid, 1983, pp. 347-374. 
[D] FERNÁNDEZ DEL PULGAR, Pedro. Teatro clerical apostólico y secular de las iglesias catedrales de España desde la fundación primitiva y predicación del Evangelio por el Apóstol Santiago y sus discípulos y proheminencia de el estado eclesiástico secular al regular. Parte primera Tomo 1 y 2. $1^{\text {a }}$ Edición: Madrid, 1679- 1680. Edición facsímil de Editorial Merino. Palencia, 1981.

FERNÁNDEZ GONZÁLEZ, Rosario. "Niño Jesús dormido" en Catálogo de las Edades del Hombre de Palencia. Salamanca, 1999, pp. 337-338.

FERNÁNDEZ MARTÍN, Luis. La abadía de Santa María de Benevívere durante la Edad Media: su historia, su regla. Universidad Pontifica de Comillas. Santander, 1962.

- Colección diplomática de la Abadía de Santa María de Benevívere (Palencia) 10201561. Escuela Gráfica Salesiana. Madrid, 1961.

-"Un poema latino medieval" en Humanidades, XIII, n³0. Universidad Pontificia de Comillas, 1961, pp. 275-321.

-El movimiento comunero de los pueblos de Tierra de Campos. León, 1979.

-"La diócesis de Palencia durante el reinado de José Bonaparte 1808-1813" en PITTM, nº44. Palencia, 1980, pp. 165-275.

- "La venta de vasallos entre el Pisuerga y el Cea en los siglos XVI y XVII" en Archivos loeneses", n72. Centro de Estudios e Investigación San Isidoro. León, 1982, pp. 293-396.

-"Voces de dentro y de fuera: Familiares de San Ignacio de Loyola en tierras palentinas" en PITTM, n Palencia, 1984, pp. 351-364.

-"La casa de la Inquisición de Valladolid" en Investigaciones Históricas, nº10, 1990, pp. 189-202.

[] FERNÁNDEZ PRIETO DOMÍNGUEZ, Enrique. "El monasterio de religiosas de San Juan de Jerusalén” en Hidalguía, n 274-275, 1999, pp. 337-368.

FERNÁNDEZ RODRÍGUEZ, Manuel. "La lauda sepulcral del infante Alfonso Ansúrez" en BSAA, tomo 1-2, Valladolid, 1932-1933, pp. 140-143.

FERNÁNDEZ SORIANO, Víctor. "Michel Coxcie, pintor grato a la Casa de Hagsburgo" en AEA, tomo 81, n 322. CSIC. Madrid, 2008, pp. 165-196.

[D] FERNÁNDEZ SUÁREZ, Gonzalo Francisco. La nobleza gallega entre los siglos XIVXV: Los Sarmiento Condes de Ribadavia. Santiago de Compostela, 2002.

[D] FERRERO MAESO, Concepción. "El mecenazgo de la familia Berrio en la iglesia de San Julián de Carrión de los Condes" en AIIICHP, n 4. Diputación Provincial. Palencia, 1995, pp. 585-600.

FILGUEIRA VALVERDE, José. El "corpo santo" de Fray Pedro González, San Telmo: (c.1194-c.1246) patrón de marineros y navegantes. Pontevedra. Diputación Provincial de Pontevedra, 1983. 
Dl FLORANES, Rafael. Origen de los estudios de Castilla: especialmente los de Valladolid y Palencia en que se vindica su mayor antigüedad. $1^{\text {a }}$ Edición, Valladolid, 1793. Facsímil. Valladolid, 2002.

FLÓREZ, Enrique. España Sagrada. Historia compostelana hasta hoy no publicada, n ${ }^{\text {2020 }} 1^{\text {a }}$ Edición: Madrid, 1765. Edición facsímil de la Real Academia de Historia. Madrid, 1965.

- Memorias de las Reynas Cathólicas. Historia genealógica de la Casa Real de Castilla y León. Madrid, 1790.

FRANCIA LORENZO, Santiago. Anecdotario para la pequeña historia de un pueblo. Notas de Archivo, 1. Palencia, 1985.

-"El Cabildo palentino en el siglo XV" en PITTM, n 59. Palencia, 1988, pp. 145187.

-Gentes de estas tierras. Notas de Archivo, 2. Palencia, 1987.

-Fuentes eclesiásticas para la historia de Palencia hasta 1500" en AICHP, tomo 2. Palencia, 1987, pp. 51-61.

-Palencia en América. Notas de Archivo, 3. Palencia, 1989.

-Por tierras palentinas. Palencia, 1991.

-Aportación palentina a la gesta indiana. Colección Pallantia. Palencia, 1992.

-"Documentación monástica en la serie Provisorato del Archivo Capitular de Palencia" en AIIICHP, tomo 2. Palencia, 1995, pp. 39-136.

-Apuntes para el estudio de la vida cotidiana en Palencia: cartas a los oficiales de la Audiencia Episcopal (1600-1650). Diputación Provincial de Palencia, 1996.

FRASER, Ronald. La maldita guerra de España. Historia social de la guerra de la Independencia, 1808-1814. Crítica. Barcelona, 2006.

FRANCO MATA, Ángela. Escultura gótica en León y provincia (1230-1530). León, 1998.

-“Crucifijo", ficha $\mathrm{n}^{\circ} 8$ en Memorias y esplendores. Las Edades del Hombre. Catedral de Palencia, 1999, pág. 75.

-“Iconografía funeraria gótica en Castilla y León (siglos XIII y XIV)” en De arte. $\mathrm{n}^{\circ}$ 2. Universidad de León. León, 2003, pp. 47-86.

“El Camino de Santiago en Castilla y León: itinerario artístico" en El mundo de los castillos. Ponferrada: templarios, peregrinos y señores. Catálogo de la exposición Castillo de los Templarios del 29 de octubre de 2010 al 8 de enero de 2011. Ponferrada (León), pp. 79-112.

FRÍAS LESMES, Padre. La provincia de España de la Compañía de Jesús desde 1815 hasta 1863. Madrid, 1914.

-La provincia de Castilla de la Compañía de Jesús desde 1863 hasta 1914: reseña histórica ilustrada. Bilbao, 1915.

FUENTES QUINTANA. "Carrión de los Condes: un lugar para la hospitalidad" en Peregrino, boletín del Camino de Santiago. Nº13, pp. 14-15. Palencia, 1990.

FUIANO, Michelle. La cultura a Napoli ne’ll alto medioevo. Giannini. Nápoles, 1961. 
$\mathbb{E}$ GAILLARD, Georges. Les débuts de la sculpture romane espagnole: León, Jaca, Compostelle. Paul Hartmann. París, 1938.

GALLEGO DE MIGUEL, Amelia. Rejería castellana. Palencia. Institución Tello Téllez de Meneses. Palencia, 1988.

[D] GARCÍA BARRIUSO, Patrocinio. La monja de Carrión: Sor Luisa de la Ascensión Colmenares Cabezón: Aportación documental para una biografía. Madrid, 1986. -Sor Luisa de la Ascensión: una contemplativa del siglo XVII: monja de Santa Clara en Carrión de los Condes. Madrid, 1993.

D GARCÍA CARRAFA, Alberto y Arturo. Diccionario heráldico y genealógico de los apellidos españoles americanos. Imprenta Antonio Marzo. Madrid, 1920.

D GARCÍA CHICO, Esteban. "Algunos datos sobre Felipe Berrojo, arquitecto" en $B S A A, \mathrm{n}^{\circ} 11$. Valladolid, 1934-1935, pp. 263-270.

-Documentos para el estudio del arte en Castilla. 1 Arquitectos. Valladolid, 1940.

-Documentos para el estudio del arte en Castilla. 2. Escultores. Valladolid, 1941.

-"Artistas palentinos" en BSAA, $n^{\circ} 11$. Valladolid, 1944-1945, pp. 197-200.

-Documentos para el estudio del arte en Castilla. 3. Pintores I. Valladolid, 1946.

-Documentos para el estudio del arte en Castilla. 3. Pintores. II. Valladolid, 1946.

-"Celdas y refectorio de la Abadía de San Isidro de Dueñas" en $B S A A, \mathrm{n}^{\circ} 14$.Valladolid, 1947-1948, pp. 238-239.

-Gregorio Fernández. Escuela de Artes y Oficios Artísticos. Valladolid, 1952.

-“Artistas que trabajan en la iglesia de Villamuriel de Cerrato" en BSAA, no 18, Valladolid, 1951 1952, pp. 132-135.

-"El retablo mayor de la Colegiata de Villagarcía de Campos" en BSAA, nº19. Valladolid, 1952-1953, pp. 15-22.

-Documentos para el estudio del arte en Castilla: plateros de los siglos XVI, XVII y XVIII. Valladolid, 1963.

-Documentos para el estudio del arte en Castilla. Maestros rejeros. Valladolid, 1966.

-Palencia: Papeletas para el estudio de historia y arte. Palencia, 1951.

-"El claustro de Santo Domingo de Carrión de los Condes" en BSAA, n¹0. Universidad de Valladolid. Valladolid, 1944, pp. 212-215.

-Medina de Rioseco. Catálogo monumental de la Provincia de Valladolid. Valladolid, 1956. Edición actualizada:Valladolid, 1979.

GARCÍA CUESTA, Timoteo. "La Catedral de Palencia según los Protocolos" en $B S A A, \mathrm{n}^{\circ} 20$. Valladolid, 1952-1953, pp. 67-90.

-"La Catedral de Palencia según los Protocolos" en BSAA, n²0. Valladolid, 19531954, pp. 91-142.

- La cofradía Penitencial de la Santa Vera Cruz. Gráficas Andrés Martín. Valladolid, 1962.

-"Plateros palentinos de los siglos XVII y XVIII" en BSAA, n²9. Valladolid, 1963, pp. 153-208.

-"El primitivo santuario de Nuestra Señora de la Calle" en $B S A A, \mathrm{n}^{\circ} 33$. Universidad de Valladolid. Valladolid, 1967, pp. 115-142.

- "La cofradía de Jesús Nazareno en Palencia" en BSAA, n³6. Valladolid, 1970, pp. 69-146. 
-“Entalladores palentinos del siglo XVII" en BSAA, n³8.Valladolid, 1972, pp. 391399.

-“Entalladores palentinos del siglo XVII (II)” en BSAA, n³9. Valladolid, 1973, pp. 291-316.

-"Plateros palentinos de los siglos XVI y XVII" en BSAA, n52. Valladolid, 1976, pp. 517-526.

[l] GARCÍA CUETOS, P. Arquitectura en Asturias, 1500-1580. La Dinastía de los Cerecedo. Oviedo, 1996.

[D] GARCÍA DE CORTÁZAR, José Ángel. Los grandes monasterios benedictinos hispanos de época románica (1050-1200). Palencia, 2007.

GARCÍA DE GUZMÁN, Miguel y GARCÍA REYES, Miguel Ramón. "Iconografía del Santo Cristo de Burgos o de San Agustín" en Archivo Agustiano, n²05, 2003, pp. 261-306.

[D] GARCIA DE SALAZAR, Lope. Las Bienandanzas e fortunas. Códice del siglo XV, 25 códices. Primera impresión del texto completo, con prólogo, notas e índices por RODRIGUEZ HERRERO, Ángel. E introducción por el Sr. Marqués de Arriluce de Ybarra. Diputación Foral de Vizcaya. Bilbao, 1967.

[D] GARCÍA FLORES, Antonio. Arquitectura de la Orden del Císter en la provincia de Valladolid (1147-1515). Junta de León. Valladolid, 2010.

GARCÍA GARCÍA, Lorena. "Nuevos datos acerca del retablo de San Cristóbal en la iglesia homónima de Lomas (Palencia)" en Estudios de Historia del Arte. Homenaje al profesor De la Plaza Santiago. Valladolid, 2009, pp. 97-100.

-"El convento franciscano de San Miguel y Santa Isabel de Carrión de los Condes (Palencia)" en BSAA, n 75, Valladolid, 2009, pp. 173-180.

-“Aportaciones a un convento palentino desaparecido: Santo Domingo en Carrión de los Condes, Palencia" en PITTM, n80. Diputación Provincial de Palencia, 2009, pp. 465-480.

[D] GARCÍA GONZÁLEZ, Juan José. Vida económica de los monasterios benedictinos en el siglo XIV. Universidad de Valladolid. Valladolid, 1972.

GARCÍA GUINEA, Miguel Ángel. Románico en Palencia. Diputación provincial de Palencia, 1961, Edición actualizada, Palencia, 1990.

-"Las huellas de Fruchel en Palencia y los capiteles de Aguilar de Campoo" en Goya: Revista de Arte, n $^{\text {oo }}$ 44. Fundación Lázaro Galdiano. Madrid, 1961, pp. 158-167.

GARCÍA MOGOLLÓN, Florencio Javier. "La iconografía de San Pedro de Alcántara. De imagen devocional a signo de identidad" en Ars sacra, n²6-27, Madrid, 2003, pp. 139-146.

GARCÍA MORALES, Mª Victoria. La figura del arquitecto en el siglo XVII. Madrid, 1991. 
[D] GARCÍA-MURGA ALCÁNTARA, Juan. "La intervención de Rodrigo Gil de Hontañón en la iglesia de Santa María de Guareña" en Goya, n¹44, 1978, pp. 314323.

-"Documento para la Historia del Arte de Extremadura: directrices de Rodrigo Gil de Hontañón para la iglesia de Santa María de Guareña" en Actas del VII Congreso de Estudios Extremeños, nº1, 1983, pp. 119-128.

GARCÍA ORO, José. Francisco de Asís en la España medieval. C.S.I.C. Santiago de Compostela, 1988.

-"Orígenes de las clarisas en España" en Archivo Ibero-Americano, Enero-Junio 1994, no 213-214, pp. 164-182.

-"El Rey aprueba la elección de Fray Diego de Sahagún como abad de San Zoilo de Carrión” Liceo Franciscano, año 53, nº160-162, 2001, pp. 464-467.

- "Al embajador de Roma para que la abadía de San Zoilo sea trienal” en Liceo Franciscano, año 53, n¹60-162, 2001, pp. 467-468.

GARCÍA SANZ, Ángel. "Auge y decadencia en España en los siglos XVI y XVII: economía y sociedad en Castilla" en Revista de Historia Económica, nº1, 1985, pp. 1127.

DaRCÍA SERRANO, Francisco. "Mundo urbano y dominicos en la Castilla medieval" en Archivo Dominicano. n¹8. Salamanca. 1997, pp. 255-274.

[D] GARCÍA SIMÓN, Agustín. Compendio de architectura y simetría de los templos conforme a la medida del cuerpo humano con algunas demostraziones de geometría, año de 1681. Estudios introductorios, BONET CORREA, Antonio y CHANFÓN OLMOS, Carlos. Valladolid, 1990.

GARCIA TORRELLAS, Julián. "Reflejo social, económico y político de Palencia durante la Restauración (1875-1923)" en Historia de Palencia, 2. Palencia, 1990, pp. 208-222.

[Da GARCÍA VEGA, Blanca. El grabado del libro español: siglos XV-XVI-XVII. Aportación a su estudio con los fondos de las bibliotecas de Valladolid. 2 volúmenes. Valladolid, 1984.

@ GARRACHÓN BENGOA, Ambrosio. Palencia y su provincia. Guía, catálogo prontuario del turista. Biblioteca palentina. Valladolid, 1920.

GARRIDO MORENO, Antonio. "La traducción española de la Iconología de M.M. Gravelot y Cochin: Madrid 1801-1802" en Revista Virtual de la Fundación Universitaria Española. Cuadernos de Arte e Iconografía, tomo IV-8.1991.

GARRIDO REDONDO, Javier. "Introducción histórico-social a los siglos XVI-XVII y XVIII" en Arquitectura civil de los siglos XVI, XVII y XVIII de la provincia de Palencia (inventario). Diputación Provincial de Palencia. Palencia, 1988, pp. 27-34.

Dd GAUTIER DALCHÉ, Jean. Historia urbana de León y Castilla en la Edad Media (siglos IX-XIII). Traducción de PÉREZ SEDEÑO, Encarnación. Madrid, 1979. 
[d] GAYA NUÑO, Juan Antonio. Arquitectura y escultura románicas. Ars Hispaniae, 5. Editorial Plus Ultra Madrid, 1948.

- Luis de Morales. Instituto Diego Velázquez. Madrid, 1961.

-La arquitectura española en sus monumentos desaparecidos. Espasa Calpe. Madrid, 1961.

[D] GEORG MAIER, Franz. Bizancio. Siglo XXI de España Editores. Argentina, 2002.

[D GIL ABAD, Pedro. Quintanar de la Sierra: un pueblo burgalés de la comarca de pinares. Diputación Provincial de Burgos. Burgos, 1980.

GILA MEDINA, Lázaro. "Arte e historia del Cristo de Burgos" en Contraluz,n³, 2006, pp. 143-160.

DI GIORGI, Rosa. Ángeles y demonios. Traducción de CLAVEL, Teresa. Electa. Barcelona, 2004.

GIRONELLA, Gervasio. Semanario pintoresco español, II. Madrid, 1844, pp. 1-2.

GLORIEUX, Paul. "Prélats français contre religieux mendiants" en Revue d'histoire de l'église de France, volumen 11, nº 53, Lion, 1995, pp. 471-495.

GOICOLEA JULIÁN, Francisco Javier. "La influencia de las órdenes mendicantes en la religiosidad de los fieles de la villa de Haro en la Edad Media" en VI semana de Estudios Medievales. Nájera, 31 julio-4 de agosto, 1995. Nájera, 1995 pp. 255-270.

GOLDSCHMIDT, Werner. "El pórtico de San Vicente en Ávila" en Archivo Español de Arte y Arqueología, ${ }^{\circ} 11,1935$, pp. 259-274.

Q] GÓMEZ BÁRCENA, Ma Jesús. "La liturgia de los funerales y su repercusión en la escultura gótica" en La idea y el sentimiento de la muerte en la historia y en el arte de la Edad Media. Ciclo de conferencias celebrado del 1 al 5 de diciembre de 1986, Santiago de Compostela, 1988, pp.. 31-50.

GÓMEZ CASADO, Pantaleón. Defensa de la subsistencia de la parroquialidad única de Carrión mediante el arreglo parroquial en la iglesia matriz de Santa María de la Victoria. Palencia, 1895.

GÓMEZ MARTÍNEZ, Javier. "Canteros trasmeranos en Valladolid en torno a un pleito del Archivo de la Real Chancillería” en BSAA, n57. Valladolid, 1991, pp. 301310.

-"Obras en San Benito el Viejo (Valladolid) y San Zoilo de Carrión (1583-1594). Buenas y malas artes en el foco clasicista" en BSAA, n58. Valladolid, 1992, pp. 333348.

- "Juan Gómez de Nates y Fernández de Albear: Juan de Nates" en Juan de Herrera y su influencia. Actas del simposio de Camargo, 14-1 de julio de 1992, Santander, 1993, pp. 165-182.

-El gótico español de la Edad Moderna. Bóvedas de crucería. Universidad de Valladolid. Valladolid, 1998. 
GÓMEZ-MORENO, Manuel. El Arte en España. Guía del Museo del Palacio Nacional. Barcelona, 1929.

-El arte románico español: esquema de un libro. Instituto de las Españas. Madrid, 1934.

-Las águilas del Renacimiento español: Bartolomé Ordoñez, Diego de Siloé, Pedro Machuca, Alonso Berruguete. Instituto Diego Velázquez. Madrid, 1941.

- El Panteón Real de las Huelgas de Burgos. Instituto Diego Velázquez. Madrid, 1946.

-"La policromía en la escultura castellana" en AEA. Madrid, 1953, pp. 295-311.

- La Inmaculada en la escultura española. Universidad Pontificia de Comillas. Santander, 1955.

-Diego Siloé: homenaje en el IV centenario de su muerte. Universidad de Granada, 1963.

GÓMEZ-MORENO, María Elena. La policromía en la escultura española. Madrid, 1943.

- Gregorio Fernández. Instituto Diego Velázquez. Madrid, 1953.

[D] GÓMEZ PÉREZ, Enrique. El Museo del Real Monasterio de Santa Clara de Carrión. Cálamo. Palencia, 2004.

- "Cofradía penitencial de la Santa Vera Cruz. Carrión de los Condes. Breve Reseña Histórico-Artística”. Carrión de los Condes (Palencia), 2004.

-El Belén, sus personajes y sus símbolos. 7 Volúmenes. Cálamo. Palencia, 2005-2011.

-"Nuestra Señora del Rosario" en Entre Castilla y Filipinas: 400 años. Carrión de los Condes, 2006, pág. 32.

-"Dulce Nombre de Jesús" en Entre Castilla y Filipinas: 400 años. Carrión de los Condes, 2006, pág. 34.

-"La piedad de Gregorio Fernández de las Clarisas de Carrión de los Condes (Palencia)" en Pasos de Arte y Cultura, no5, Madrid, 2008, pp. 32-33.

-El Real monasterio de Santa Clara de Carrión de los Condes. Palencia. Cálamo. Palencia, 2010.

[D] GÓMEZ PÉREZ, Enrique y MARISCAL ARRANZ, José. Iglesia de Santiago de Carrión: un museo en el corazón del camino. Cálamo. Palencia, 2002.

Dd GÓMEZ PÉREZ, Enrique y MARTÍNEZ GONZÁLEZ, Rafael Ángel. Semana Santa en Palencia. Historia, arte y tradiciones. Palencia, 1999.

[D] GÓMEZ PÉREZ, Enrique y SÁNCHEZ GÓMEZ, Juan Carlos. El Belén. Sus personajes y sus símbolos. Vol V. Cálamo. Palencia, 2009.

[D] GÓMEZ PÉREZ, Enrique y SANCHO CAMPO, Ángel. El Real Monasterio de Nuestra Señora de Calabazanos. Palencia. Cálamo. Palencia, 2009.

GONZÁLEZ, Julio. Los sellos concejiles de España en la Edad Media. Instituto Jerónimo Zurita. Madrid, 1945.

-Repartimiento de Sevilla, 2 tomos. Escuela de Estudios Medievales. Madrid, 1951.

-Fijación de la frontera castellano-leonesa en el siglo XII. Valladolid, 1982.

-Historia de Palencia, 1. Edades Antigua y Media. Palencia, 1984.

-Historia de Palencia, 2. Edades Moderna y Contemporánea. Palencia, 1990. 
[DGGONZÁLEZ BALASCH, María Teresa. "San Torcuato, Santa Comba de Bande y Celanova, según el padre La Cueva" en Archivo Español de Arqueología, no 77. Madrid, 2004, pp. 273-318.

GONZÁLEZ BARRIONUEVO, Herminio. El códice polifónico de Santa Clara la Real de Carrión de los Condes. Antología de obras para la misa y el oficio. $1^{\text {a }}$ Edición: 1633. Edición facsímil de Editorial Alpuerto, Madrid, 2004.

[l] GONZÁLEZ CUESTA y ALONSO MARAÑ́́N, Pedro Manuel. "Los arciprestazgos de Palencia" en Memoria ecclesiae, N. 27, Actas del XIX Congreso de la Asociación celebrado en Santa Cruz de Tenerife y Las Palmas (15 al 20 de septiembre de 2003), 2005, pp. 409-434.

GONZÁLEZ DÁVILA, GIL. Teatro eclesiástico de las Iglesias metropolitanas y Catedrales de los Reynos de las dos Castillas: Vidas de sus Arzobispos, y Obispos, y cosas memorables de sus sedes Tomo segundo: Iglesias de Sevilla, Palencia, Ávila, Zamora, Coria, Calahorra y Plasencia Imprenta de Francisco Martínez, Pedro de Horma y Villanueva, Diego Díaz de la Carrera. Madrid, 1645-1700.

[D] GONZÁLEZ DELGADO, José Antonio y HERMOSO NAVASCUÉS, José Luis. Jerónimo Arroyo López, arquitecto. La Editora del Carrión. Palencia, 1999.

[D] GONZÁLEZ ECHEGARAY, Ma Carmen. Escudos de Cantabria. Santander, 1969. -Santillana del Mar a través de su heráldica. Santillana del Mar, 1983.

[C] GONZÁLEZ MÍNGUEZ, César. "Aspectos económicos del espacio palentino en la Edad Media: Estructura productiva, vías de comunicación y ejes mercantiles (siglos XXIII) en AIIICHP, volumen II. Palencia, 1995, pp. 347-369.

[D GONZÁLEZ MUÑOZ, Ma del Carmen. "Algunas notas sobre la cerámica de Talavera" en $A E A$, tomo 53, n² 211. Madrid, 1980, pp. 345-366.

[C] GONZÁLEZ REGLERO, Juan José y CAMPO Y FRANCÉS, Ángel del. "En torno al lenguaje del dedo índice en la iconografía del Bautista" en Cuadernos de Arte e iconografía, tomo 4, n7, 1991, pp. 223-234.

GONZÁLEZ TEJERO, P. "Historia de la estatua de Fray Miguel de Benavides, O.P. en Carrión de los Condes" en Studium, vol. 48, n¹, Madrid, 2008, pp. 133-156.

[d GOOSEN, Louis. De Andrés a Zaqueo. Temas del Nuevo Testamento y la literatura apócrifa en la religión y las artes. Akal. Madrid, 2008.

GORDALIZA APARICIO, F. Roberto. Vocabulario palentino. Caja de Ahorros y Monte de Piedad Cristiana. Palencia, 1988.

-Historias y leyendas palentinas. Saber Palencia, Volumen 5. Cáñamo. Palencia, 2001.

[D] GORDALIZA APARICIO, F. Roberto y CANAL SÁNCHEZ-PAGIN, José Ma Toponimia palentina: nuestros pueblos, sus nombres y sus orígenes. Caja España. Palencia, 1993. 
[D] HALPHEN, Louis. Carlomagno y el imperio carolingio. Traducción de José Almoina. México, 1955.

HANS-JOACHIM, Lope. Antonio Ponz (1725-1792).Coloquio hispano-alemán organizado en la Biblioteca Ducal de Wolffenbütell (diciembre de 1992) con motivo del segundo centenario de su muerte. Frankfurt, 1995.

HEBRERA, Fray José Antonio de. Chrónica real seráfica del reyno y santa provincia de Aragón de la regular observancia de Nuestro Padre San Francisco. Zaragoza, 1705.

HERAS GARCÍA, Felipe. Felipe Berrojo y la portada de la iglesia del Monasterio de Sahagún en BSAA, n³6. Valladolid, 1970, pp. 503-505.

-Difusión de la arquitectura religiosa vallisoletana del siglo XVI en su primitiva diócesis. Tesis Doctoral del Archivo de la Universidad de Valladolid. Valladolid, 1973. -Arquitectura religiosa del siglo XVI en la primitiva diócesis de Valladolid. Valladolid, 1975.

HERDECK, Juan José. Defensa de la religión christiana. Imprenta Real. Madrid, 1797.

[D] HEREDIA, Fray Antonio de. Vidas de santos bienaventurados y personas venerables de la sagrada religión de Nuestro Padre San Benito. Tomo primero. Madrid, 1683.

-Tomo tercero. Madrid, 1685.

-Tomo cuarto. Madrid, 1686.

HERNÁNDEZ DÍAZ, José. Iconografía hispalense de la Virgen-madre en la escultura renacentista. Diputación Provincial de Sevilla. Sevilla, 1944.

- La iconografía mariana en la escultura hispalense de los siglos de Oro. Fundación Universitaria Española. Madrid, 1986.

HERNÁNDEZ MARTÍN, Martín. "Actas de los Capítulos Provinciales de la provincia dominicana de España del siglo XVI (I)" en Archivo dominicano. No3. Salamanca 1982, pp. 13-84.

-“Actas de los Capítulos Provinciales de la provincia dominicana de España del siglo XVI (II)"en Archivo dominicano. N7, Salamanca, 1986, pp. 5-47.

-“Actas de los Capítulos Provinciales de la provincia dominicana de España del siglo XVI (III)"en Archivo dominicano. Nº, Salamanca, 1988, pp. 5-53.

[D] HERMOSO NAVASCÚES, José Luis y GONZÁLEZ DELGADO, José Antonio. "Jerónimo Arroyo López" en Sentir y potenciar Palencia. FUNDEPA. Madrid, 2004, pp. 169-174.

[D] HERNÁNDEZ DÍAZ, José, MARTÍN GONZÁLEZ, Juan José y PITA ANDRADE, José Manuel. La escultura y la arquitectura españolas del siglo XVII. Espasa Calpe. Madrid, 1983.

HERNÁNDEZ REDONDO, José Ignacio. "Piedad", ficha ${ }^{\circ} 28$ en Memorias y esplendores. Las Edades del Hombre. Catedral de Palencia, 1999, pp. 55,56. 
[D] HERNANDO GARRIDO, José Luis. "La fachada de Santiago de Carrión de los Condes, encrucijada de la escultura románica castellana. Estado de la cuestión" en Cluny y el Camino de Santiago en España en los siglos XI-XII. Actas del Congreso de Sahagún, 1993 (en prensa).

-"Iglesia de Santiago" en Enciclopedia del Románico en Castilla y León. Palencia. Aguilar de Campoo. Vol.2, Boedo-La Ojeda, Saldaña-La Valdavia, Tierra de Campos, Cerrato. Fundación Santa María la Real, Centro de Estudios del Románico. Aguilar de Campóo, 2002, pp. 1012-1022.

-"Benevívere" en Enciclopedia del Románico en Castilla y León. Palencia. Aguilar de Campoo. Vol.2, Boedo-La Ojeda, Saldaña-La Valdavia, Tierra de Campos, Cerrato. Fundación Santa María la Real, Centro de Estudios del Románico. Aguilar de Campoo, 2002, pp. 995, 996.

-"Estampas del mundo rural: la imagen del campesino en el arte románico hispano" en Poder y seducción de la imagen románica. Fundación Santa María la Real. Aguilar de Campoo, Palencia, 2006, pp. 159-189.

[D HERNANDO PÉREZ, José. "En las raíces de Europa, San Gregorio Magno: perfiles de su persona” en Salmanticensis, vol 51, fasc, 3. Salamanca, 2004, pp. 579-598.

HERRÁEZ ORTEGA, M ${ }^{\mathrm{a}}$ Victoria. Esplendor y decadencia de un monasterio medieval: el patrimonio artístico de San Benito de Sahagún. Universidad de León. León, 2000.

[D] HERRERO MARCOS, Jesús. Arquitectura y simbolismo del románico palentino. Ars Magna. Barcelona, 1995.

[d HERRERO MARTÍNEZ DE AZCOITIA, Guillermo. La población palentina en los siglos XVI y XVII. Universidad de Valladolid. Valladolid, 1960.

HERREROS ESTÉBANEZ, Francisco. "Las constituciones monásticas de los canónigos regulares de San Agustín de Benevívere, según un libro manuscrito del Archivo Diocesano de Palencia” en Memoria ecclesiae, №. 6, 1995, pp. 177-182.

HEVIA VALLINA, Agustín y MARTÍNEZ VEGA, Andrés. "Reliquias y relicarios en la Archidiócesis de Oviedo" en Memoria Ecclesiae, n XXV, 2004, pp. 493-528.

HOAG, JOHN D. "Rodrigo Gil de Hontañón: gótico y renacimiento en la arquitectura española del siglo XVI”. Traducción: Pilar Navascues Benlloch. Xarait. Madrid, 1985.

[D] HOYOS, Manuel María de los. Registro documental: material inédito dominicano español. Valladolid, 1961-1963.

HUERTA HUERTA, Pedro Luis. Maestros del románico en el Camino de Santiago. Fundación Santa María la Real. Aguilar de Campoo, 2010.

[D] HUIDROBO Y SERNA, Luciano. Las peregrinaciones jacobeas. Tomo 2. Instituto de España. Madrid, 1950.

-"Breve historia de la muy noble villa de Aguilar de Campoo" en AIICHP, tomo 3. Palencia, 1989, pp. 64-67. 
[D HUME, David. Historia de Inglaterra desde la invasión de Julio César hasta el fin del reinado de Jacobo II. Traducida por Eugenio Ochoa. Imprenta de Francisco Oliva. Tomo I. Barcelona, 1842.

[d] IBÁÑEZ FERNÁNDEZ, Javier. "La introducción del ornato al romano en el primer renacimiento aragonés. Las decoraciones pictóricas" en Artigrama, ${ }^{\circ} 18$, Zaragoza, 2003, pp. 293-340.

[D] IBÁÑEZ PÉREZ, Alberto Cayetano. "Rodrigo Gil de Hontañón y la iglesia colegial de Peñaranda de Duero (Burgos), BSAA, n55, Valladolid, 1989, pp. 398-401.

[ IGLESIAS ROUCO, Lena Saladina. "La capilla del Santo Cristo de la Catedral de Burgos: datos para su estudio" en BSAA, n56. Valladolid, 1990, pp. 542-546.

[D] ITURBE SAIZ, Antonio. "Iconografía de San Agustín. Atributos y temas o títulos iconográficos. Sus orígenes literarios. Ciclos principales" en Iconografía Agustiniana. Actas del XI Congreso Internacional de Historia de la Orden de San Agustín. Roma, 2001, pp. 19-126.

-"El Cristo de Burgos o de San Agustín en España, América y Filipinas" en Los crucificados, religiosidad, cofradías y arte. Actas del Simposio. San Lorenzo del Escorial, 2010, pp. 683-714.

[D] ITURGAIZ CIRIZA, Domingo. "Museografía iconográfica dominica. Santo Domingo de Guzmán: palabra e imagen" en Archivo dominicano, n²6. Salamanca 2005, pp. 191-279.

JAGO, Charles. "La crisis de la aristocracia en el siglo XVII en Castilla" en Poder y sociedad en la España de los Austrias. Barcelona, 1982, pp. 248-286.

[1] JANINI, José. "Los fragmentos visigóticos de San Zoilo" en Litúrgica, 3. Montserrat, 1966, pp. 73-83.

JIMÉNEZ HERNÁNDEZ, Emiliano. Isaías, el Profeta de la consolación. Madrid, 2007.

[D] JOVELLANOS, Gaspar Melchor de. Diarios, 2 volúmenes. Instituto de Estudios Asturianos. Oviedo, 1953 y 1954.

[DLEINSCHMIDT, Harald. Comprender la Edad Media. La transformación de ideas y actitudes en el mundo medieval. Akal. Madrid, 2009.

LACAVE, José Luis. Juderías y sinagogas españolas. Madrid, 1992.

LACAVE, José Luis, VALDEÓN, Julio y ATIENZA, Juan G. Los judíos en la España Medieval. Cuadernos Historia 16, nº 38. Grupo 16. Madrid, 1985.

Dd LACOSTE, Jacques. "El Maestro de Carrión de los Condes" en Actas del IV Curso de Cultura Medieval. Seminario Fortificación Medieval (sep 1992). Aguilar de Campoo (Palencia), 2003, pp. 155-185. 
-Les maîtres de l'esculpture romane dans l'Espagne du pèllerinage à Compostelle. Burdeos, 2006.

LAFOND, Paul. La scuplture spagnole. Dirección de Jules Compte. Librairie d'Éducation Nationale. Paris, 1908.

[D] LABAD SASIAÍN, Fernando. "Fundamentos de la estética idealista del románico" en Codex Aquilarensis, n 20. Aguilar de Campoo, 2004, pp. 152-172.

[D] LALANDA CARROBLES, Pablo. "Las vegas de Saldaña y Carrión: antecedentes históricos de sus regadíos" en PITTM, n 36. Palencia, 1975, pp. 142-203.

@] LAMA GUTIÉRREZ, Jesús. El órgano barroco español. Registro I, Registros II. Junta de Castilla y León. Valladolid, 1995.

¿ LAMPÉREZ Y ROMEA, V., Historia de la arquitectura cristiana española en la Edad Media, según el estudio de los elementos. 3 volúmenes. Madrid, Bilbao, Barcelona Espasa-Calpe S.A., 1930.

LAVADO PARADIÑAS, Pedro. "Carpintería y otros elementos típicamente mudéjares en la provincia de Palencia. Partidos judiciales de Astudillo, Baltanás y Palencia" en PITTM no 38. Palencia, 1977 pp. 5-234.

-"Palacios o conventos: Arquitectura en los monasterios de clarisas de Castilla y Léon" en Verdad y Vida, n52. Madrid, 1994, pp. 715-742.

LAVARGA GARCÍA. "La devoción del rosario: datos para la historia" en Archivo dominicano, $\mathrm{n}^{\circ}$ 24. Salamanca, 2003, pp. 225-277.

[D LE BARBIER RAMOS, Elena. La organería en la provincia de Palencia (1500-1800). Institución Tello Téllez de Meneses. Palencia, 2008.

[D] LENTINI, Anselmo. "Alberico di Montecassino nel quadro della Riforma Gregoriana" en Studi Gregoriani, n IV. Roma, 1952, pp. 55-109.

LEÓN, Teresa. "Historia de Paredes de Nava" en PITTM, n 27. Palencia, 1968, pp. 130-132.

[D] LEONARDI, Claudio, RICCARDI, Andrea y ZARRI, Gabriella. Diccionario de los Santos. Volumen 1. Centro Iberoamericano de Editores Paulinos. Madrid, 2000.

LES BLAS, Philipp.e. Historia de la Alemania. Tomo 1. Traducida al castellano por una sociedad literaria. Imprenta del Nacional. Barcelona, 1841.

LINAGE CONDE, Antonio. Los orígenes del monacato benedictino en la Península Ibérica.2. La difusión de la "Regula Benedicti". Centro de Estudios e Investigación San Isidoro. León, 1973.

-"De los monjes a los frailes: notas sobre la implantación de la vida religiosa medieval en el territorio castellano-leonés" en El pasado histórico de Castilla y León. Actas del I Congreso de Historia de Castilla y León celebrado en Valladolid, del 1 al 4 de diciembre de 1982, vol. 1, 1983, pp.. 263-274. 
-"Un caso de sucesión de familias religiosas en una misma sede: benedictinos y jesuitas en San Zoilo de Carrión de los Condes" en AIICHP, tomo 3, 2. Diputación Provincial. Palencia, 1990, pp. 785-794.

-"La presencia palentina en la Congregación benedictina de Valladolid" en AIIICHP, tomo II. Palencia, 1995, pp. 277-286.

@DINEHAN, Peter. La Iglesia Española y el Papado en el siglo XIII. Universidad Pontifica de Salamanca. Salamanca, 1975.

[LLAGUNO Y AMIROLA, Eugenio. Noticias de los arquitectos y arquitectura de España desde su restauración. 4 tomos. Ilustradas y acrecentadas con notas, adiciones y documentos por Juan Agustín Ceán Bermúdez. Editorial Turner. Madrid, 1977.

Dd LLORENTE DE ALCÁZAR Y MENDIZÁBAL, Juan Antonio. Noticias históricas de la villa de Carrión de los Condes esparcidas en diversos historiadores y recopiladas para su instrucción particular. Madrid, 1802.

[C] LÓPEZ, Atanasio. "Los monasterios de clarisas en España en el siglo XIII" en El eco franciscano, 29. Madrid, 1912, pp. 185-190.

LÓPEZ, Juan, Obispo de Monópoli. Historia de Santo Domingo y de su Orden de Predicadores. Impresión Juan de Rueda. Valladolid, 1613-1621.

LÓPEZ AMAT, Alfredo. El seguimiento radical de Cristo. Volumen 1. Madrid, 1987.

LÓPEZ CALO, José. La música en la Catedral de Palencia. II, Actas capitulares (1685-1931), apéndices documentales. Palencia, 1981.

LÓPEZ CASTÁN, Ángel. Los gremios artísticos de Madrid en el siglo XVIII y primer tercio del siglo XIX: oficios de la madera, textil y piel. Universidad Autónoma de Madrid, 1991.

D LÓPEZ DE AYALA, Ignacio. El sacrosanto y ecuménico Concilio de Trento. $1^{\mathrm{a}}$ Edición, Roma, 1564. Traducido al castellano. Madrid, 1785.

LÓPEZ DE HARO, Alonso. Nobiliario genealógico de los Reyes y Títulos de España. 2 volúmenes. 1622. Edición facsímil, Navarra, 1996.

LÓPEZ GARCÍA, José Miguel y VILLA MATEOS, Javier. "Los informes de bienes nacionales y desamortización: una aproximación al estudio del clero regular en las provincias de Valladolid y Palencia a finales del Antiguo Régimen" en Congreso de historia rural: siglos XV-XIX. Actas del coloquio celebrado en Madrid, Segovia y Toledo del 13 al 16 de octubre de 1981. Madrid, 1984, pp. 535-559.

LÓPEZ MARTÍNEZ, Nicolás. El Santísimo Cristo de Burgos. Burgos, 1997.

-"La devoción popular al Cristo de Burgos" en La religiosidad popular: riqueza, discernimiento y retos. Salamanca, 2004, pp. 293-301. 
DO LOPEZ ROJO, M. “Aportación del Corregimiento de Villarcayo a la construcción y arreglos de los puentes palentinos (Carrión. Quintana de la Puente, Astudillo, Melgar de Yuso, Guardo, Lantadilla, Villoldo..) en los siglos XVI, XVII y XVIII" en AICHP, tomo III. Palencia, 1987, pp. 271-336.

LÓPEZ SANTAMARÍA, Justino. Palencia: guía de la ciudad y provincia. Valladolid, 1999.

미 LORENZO SANZ, Eufemio "Palentinos en el nacimiento y formación de América" en AICHP, tomo 4. Palencia, 1987, pp. 447-490.

- "Carrioneses en el comercio con América en los siglos XVI y XVII" en AIICHP, tomo 4. Palencia, 1990, pp. 387- 399.

LOSADA VAREA, Ma Celestina. "El retorno de los maestros canteros de la Junta de Voto" en Altamira: Revista de Estudios Montañeses, n52, Universidad de la Rioja, 1996, pp. 263-284.

-La arquitectura en el otoño del Renacimiento: Juan de Naveda (1590-1638). Universidad de Cantabria. Santander, 2007.

LOVERA, José Rafael. Antonio de Berrio: la obsesión por El Dorado. Caracas, 1991.

LOVIANO, Pedro de. Historia del Santísimo Cristo de Burgos. Madrid, 1740.

$\mathbb{E}[$ LOZANO, Cristóbal. El rey penitente David arrepentido. Historia sagrada autorizada con lugares de escritura, morales y ejemplos. Madrid, 1690.

LUENGAS OTAOLA, Vicente Francisco. "Tierra de Ayala: cómo la Casa de Ayala perdió el Señorío de Ayala y Mayorazgo de Ampudia" en Boletín de la Real Sociedad Bascongada de Amigos del País, tomo 46, no 1-2, 1990, pp. 155-174.

[D] LUNA MORENO, Luis. Escultura del siglo XVI en Castilla y León. Ministerio de Cultura, Dirección General de Bellas Artes y Archivos, Madrid, 1987.

MADOZ, Pascual. Diccionario geográfico-estadístico-histórico de España y sus posesiones de Ultramar. Madrid, 1817.

-Diccionario geográfico-estadístico- histórico de Castilla y León. Palencia. Ámbito. Valladolid, 1984.

[D] MADRIGAL TERRAZOS, Santiago. La eclesiología de Juan de Ragusa O.P (1390/95-1443). Universidad Pontificia Comillas. Madrid, 1995.

MAISO GONZÁlEZ, José y LAGUNILLA ALONSO, J. Ramón. La judería de Carrión. Cálamo. Palencia, 2007.

- "Carrión en el Cantar del Mío Cid: 800 aniversario del manuscrito de Per Abbat" en PITTM, n78 Palencia, 2007, pp. 343-368.

- San Zoilo de Carrión en el origen del románico pleno. El románico de las donnas. Palencia, 2010.

[1] MÂLE, Émile. El barroco. Arte religioso del siglo XVII: Italia, Francia, España, Flandes. Editorial Madrid, 1985. 
MALO CERRO, Mónica. Azulejería en Castilla y León. De la Edad Media al Modernismo. Tomos 1 y 2. Universidad de Valladolid, 2002.

Q MANSELLI, R. "La chiesa e il francescanesimo femminile" en Movimento religioso femminile e francescanesimo nel secolo XIII. Asís, 1980, pp. 230-245.

[d] MAÑANES, Tomás, BALBUENA, Felipe y ALONSO PONGA, José Luis. "La arquitectura militar en la frontera del reino de León con el de Castilla en los siglos XII y XIII” en Tierras de León, n40. León, 1980, pp. 89-114.

[D] MANANES, Tomás y BALBUENA, Felipe. "Torres y fortalezas al sur del Duero en la Provincia de Valladolid" en BSAA, n43. Valladolid, 1977, pp. 111-126.

[D] MANANES, Tomás y SOLANA SAINZ, José María. Ciudades y vías romanas en la Cuenca del Duero (Castilla y León). Valladolid, 1985.

MARCOS MARTÍN, Alberto. Economía, sociedad, pobreza en Castilla. Palencia, 1500-1814. 2 volúmenes. Diputación Provincial de Palencia. Palencia, 1985.

-"Un mapa inacabado: el proceso de señorialización en tierras palentinas durante la época moderna" en AIICHP, tomo 2. Palencia, 1990, pp. 51-118.

MARÍAS, Fernando. "El problema del arquitecto en la España del siglo XVI" en Academia, n'48, 1979, pp. 175-232.

-El siglo XVI: Gótico y Renacimiento. Sílex. Madrid, 1992.

-"Luis de Morales "El Divino" en Historia 16, n68. Madrid, 1992.

-"El ornato en el ámbito del arzobispado toledano" en L'invention de la Renaissance. La réception des formes à l'antique au début de la Renaissance. Actes du Colloque tenu à Tours du 1er au 4 juin 1994, París, 2003, pp.. 187-204.

[D] MARIÑO, Beatriz. "Testimonios iconográficos de la acuñación de moneda en la Edad Media. La portada de Santiago de Carrión de los Condes" en Artistes, artisans et production artistique au Moyen Age. Vol,1, Les hommes. Editorial Picard. París, 1986, pp. 499-513.

-"La portada de Santiago de Carrión" en Palencia en los siglos del románico. Fundación Santa María la Real. Aguilar de Campoó (Palencia), 2002, pp. 49-69.

[D MARQUÉS, Ignacio. Santo Tomás Becket, arzobispo de Canterbury. № 95. Centro de Pastoral Litúrgica. Barcelona, 2004.

[D MARTELL, Carlos. Anales del mundo desde la creación de él y un tratado del origen de las poblaciones de toda la Europa. Iván de Ibar. Zaragoza, 1662.

MARTÍ Y MONSÓ, José. Estudios histórico-artísticos relativos principalmente a Valladolid: basados en la investigación de diversos archivos. $1^{\text {a }}$ Edición: Imprenta, litografía, encuadernación y fábrica de libros rayados de Leonardo Miñón. Valladolid, 1898-1901. Edición facsímil de Editorial Ámbito. Valladolid, 1992.

-"Menudencias biográfico-artísticas" en BSCE, tomo I. 1903-1904. Caja de Ahorros Provincial de Valladolid, 1903-1904 pp. 253-254. 
-"Menudencias biográfico-artísticas" en Boletín de la Sociedad Castellana de Excursiones. Tomo II. Caja de Ahorros Provincial de Valladolid 1905-1906, pp. 172-173, 196-197 y 535-567.

MARTÍN FERNÁNDEZ DE VELASCO, Miguel. Palencia y provincia. Edilesa. León, 2002.

MARTÍN GONZÁLEZ, Juan José. "El relicario de la Colegiata de Villagarcía de Campos" en BSAA, $\mathrm{n}^{\circ} 18$. Valladolid, 1951-1952, pp. 43-52.

-"Miguel de Espinosa, entallador e imaginero" en Goya: Revista de Arte, no 21. Fundación Lázaro Galdiano. Madrid, 1957, pp. 145- 152.

-Escultura barroca castellana. Fundación Lázaro Galdiano. Madrid, 1959.

-“Tipología e iconografía del retablo español del Renacimiento” en BSAA, n³0. Valladolid, 1964, pp. 5-66.

-Arquitectura barroca vallisoletana. Valladolid, 1967.

-Catálogo monumental del Antiguo Partido Judicial de Valladolid. Valladolid, 1973.

-El artista en la sociedad española del siglo XVII. Madrid, 1974.

-El escultor Gregorio Fernández. Ministerio de Cultura. Dirección General del Patrimonio Artístico, Archivos y Museos. Madrid, 1980.

-Escultura barroca en España. 1660-1770. Cátedra. Madrid, 1983.

-"La arquitectura del siglo XVI en Castilla la Vieja y León” en Ciclo de Conferencias sobre el Renacimiento en Castilla y León. Diputación Provincial de Palencia. Palencia, 1985, pp. 5-24.

-"Los patronos del gótico en Palencia" en Jornadas sobre el Gótico en la provincia de Palencia. Diputación Provincial. Palencia, 1988, pp. 31-40.

-"La catedral de Palencia entre los Obispados de Axpe Sierra y Molino Navarrete (1594-1685)" en Jornadas sobre la Catedral de Palencia. Palencia 1989, pp. 183208.

-Imágenes de escultura de la Concepción en Castilla y León, en los siglos XVI al XVIII" en Actas del I Congreso Internacional. La Orden Concepcionista, volumen 2. León, 1990, pp. 15-24.

-"Observaciones sobre la escultura del Renacimiento" en Príncipe de Viana. Anejo 10-91 Jornadas Nacionales sobre el Renacimiento español, 1991, pp. 49-58.

- El retablo barroco en España. Alpuerto. Madrid, 1993.

-"El gusto clásico en los comienzos de la Real Academia de Bellas Artes de San Fernando" en La visión del mundo clásico en el arte español. Madrid, 1993, pp. 305312.

-"Arte y territorio en la provincia de Palencia durante el siglo XVI" en AIIICHP, tomo 4. Palencia, 1995, pp. 399-417.

MARTÍN LOZANO, José Enrique. Iglesia Penitencial de la Santa Vera Cruz de Valladolid (1595). Valladolid, 2005.

[D] MARTÍN MÍNGUEZ, Bernardino. Catálogo monumental de Palencia. 4 volúmenes. 1907-1909 (sin publicar, extraído del CSIC).

[D MARTÍN PRIETO, Pablo. "Sobre la promoción regia de la orden franciscana en la Corona de Castilla durante el primer reinado Trastámara" en Hispania Sacra, vol. 59, nº119. Madrid, 2007, pp. 51-83. 
[D] MARTÍNEZ CAVIRÓ, Balbina. Cerámica de Talavera. Instituto Diego Velázquez. Madrid, 1969.

MARTÍNEZ DÍEZ, Gonzalo. Libro Becerro de las Behetrías. 3 volúmenes. Estudio y texto crítico. Centro de Estudios e Investigación San Isidoro. León, 1981.

-"Palencia en Castilla o la castellanidad de Palencia" en Palencia en la Historia. Caja de Ahorros y Monte de Piedad de Palencia. Palencia, 1982, pp. 67-98.

-"Los Condados de Carrión y Monzón: sus fronteras" en AICHP, tomo 2. Palencia, 1985, pp. 246-274.

-“Curia y Cortes en el Reino de Castilla" en Las Cortes de Castilla y León en la Edad Media. Actas del Congreso sobre la Historia de las cortes de Castilla y León, Burgos, 30 de septiembre a 3 de octubre de 1986, Vol. 1, Burgos, 1988, pp. 105-152.

-“Años de crisis (1252-1369)” en Historia de Palencia, I. Palencia, 1990, pp. 245-272.

-Los templarios en la Corona de Castilla. Colección Piedra Angulares. La Olmeda (Burgos), 1993.

-"La familia condal de Carrión” en AIICHP, tomo 2. Palencia, 1995, pp. 551-603.

-Alfonso VI: señor del Cid, conquistador de Toledo. Madrid, 2003.

-"Los infantes de Carrión del cantar cidiano y su nula historicidad" en Historia, instituciones, documentos, $\mathrm{n}^{\circ}$ 34. Sevilla, 2007, pp. 207-223.

DI MARTÍNEZ DÍEZ, Gonzalo y FRANCIA LORENZO, Santiago. De Itero de la Vega a San Nicolás del Real Camino. Piedra y vida .Diputación Provincial de Palencia. Palencia, 1994.

MARTÍNEZ FERNÁNDEZ, Mateo. "Las aportaciones: técnica financiera de las cooperativas agrícolas de Tierra de Campos (1917-1936)" en El pasado histórico de Castilla y León. Actas del I Congreso de Historia de Castilla y León celebrado en Valladolid, del 1 al 4 de diciembre de 1982, vol. $3 . \quad$ Valladolid, 1983, pp. 215-226.

MARTÍNEZ FRÍAS, José María. El gótico en Soria: arquitectura y escultura monumental. Universidad de Salamanca. Salamanca, 1980.

-“Arquitectura gótica" en Historia del Arte de Castilla y León, volumen 3, 1994, pp 85-218.

[D] MARTÍNEZ GÁZQUEZ, José y FLORIO, Rubén. Antología del latín cristiano y medieval: introducción y textos. Bahía Blanca, Argentina, 2006.

MARTÍNEZ GONZÁLEZ, Rafael. Las cofradías penitenciales de Palencia. Caja de Ahorros y Monte de Piedad. Palencia, 1979.

-La pintura del siglo XVII en Palencia. Caja de Ahorros y Monte de Piedad de Palencia. Palencia, 1986.

-"El Obispo de Palencia Fray Juan del Molino y la capilla mayor de la Iglesia Santa María de Carrión de los Condes" en PITTM, n 56. Diputación Provincial. Palencia, 1987, pp. 251-269.

-"Aproximación al estudio de los conventos franciscanos en la provincia de Palencia" en Jornadas sobre el arte de las Órdenes religiosas en Palencia .Diputación de Palencia. Palencia, 1989, pp. 113-149.

-La arquitectura gótica en la ciudad de Palencia (1165-1516). Diputación de Palencia. Palencia, 1989. 
-"Notas para el estudio del patronazgo de indianos palentinos" en Actas del V Simposio Hispano Portugués de Historia del Arte. Valladolid, 1990, pp. 163-171.

-El Camino de Santiago a su paso por Palencia: una ruta de historia, arte, paisaje, gastronomía e información general: guía del peregrino. Diputación Provincial de Palencia. Palencia, 1992.

-El retablo barroco en España. Alpuerto. Madrid, 1993.

- "Palencia" en Casas y Palacios de Castilla y León. Dirección, Urrea, Jesús. Junta de Castilla y León. Consejería de Educación y Cultura. 2002, pp. 115-149.

-"La escultura del siglo XVI en la antigua diócesis de Palencia" en Boletín de la Real Academia de Bellas Artes de la Purísima Concepción, 41, Valladolid, 2006, pp. 9- 30.

-"La Adoración de los Magos de la Escuela de Rubens de la iglesia de San Andrés de Carrión de los Condes (Palencia)" en PITTM, n ${ }^{\circ}$. Diputación Provincial de Palencia, 2007, pp. 429-446.

MARTÍNEZ JUSTICIA, María José. "La simplificación del Árbol de Jesé y otros temas genealógicos marianos en la escultura granadina" en Cuadernos de Arte iconografía, tomo 2, nº , Valladolid, 1989, pp. 9-19.

MARTÍNEZ MARTÍNEZ, María José. "El Santo Cristo de Burgos. Contribución al estudio de los Crucifijos articulados españoles" en BSAA, n69-70. Valladolid, 2003-2004, pp. 207-246.

[DA MARTÍNEZ SOPENA, Pascual. La tierra de Campos occidental: doblamiento, poder y comunidad del siglo X al XIII. Institución Cultural Simancas. Valladolid, 1985.

-El camino de Santiago en Castilla y León. Junta de Castilla y León. Consejería de Cultura y Bienestar Social. Valladolid, 1990.

-"Fundaciones monásticas y nobleza en los reinos de Castilla y León en la época románica" en Monasterios románicos y producción artística. XVI Seminario sobre historia del monacato. Aguilar de Campoo, 2003, pp. 35-62.

-"Aristocracia, monacato y reformas en los siglos XI y XII" en El monacato en los reinos de León y Castilla (siglos VII-XIII). X Congreso de Estudios Medievales. León, 2007, pp. 67-100.

DI MASOLIVER, Alejandro. Historia del monacato benedictino II. De San Gregorio Magno al siglo XVIII. Traducción del catalán por $\mathrm{M}^{\mathrm{a}}$ Sira Carrasquer. $1^{\mathrm{a}}$ Edición, Barcelona, 1980. Madrid, 1994.

MAURINO, Alonso. El organista ciego de Felipe II: Antonio Cabezón. Madrid, 1977.

MELLADO, Francisco. Enciclopedia moderna. Diccionario universal de literatura, ciencias, artes, agricultura, industria y comercio. Complemento Tomo II. Madrid, 1864.

Dl] MENDIZÁBAL DE LA CRUZ, Nieves y SASTRE RUANO, Ma Ángeles. "Estudio lingüístico de los documentos del Monasterio de San Zoilo de Carrión atendiendo a su tipología" en AIIICHP, tomo 4. Palencia, 1995, pp. 265-296.

MENÉNDEZ PIDAL, Ramón. La España del Cid, II volúmenes. Plutarco, Madrid, 1929. 
[D] MENÉNDEZ PIDAL DE NAVASCÚES, Faustino. Heráldica medieval española, I. La casa Real de León y Castilla. Madrid, 1982.

Qd MERINO REVUELTA, Félix. Por Santa María. Una lección de historia carrionesa. Carrión de los Condes, Palencia, 1911.

[D] MESSEGUER, Juan. "Las cofradías de la Vera Cruz. Documentos y notas para su historia" en Archivo Ibero- Americano, no 109-110. Sevilla, 1968, pp. 201-219.

Dal MEZQUIRIZ DE CATALÁN, María Ángeles. Museo de Navarra: guía. Pamplona, 1978.

[D] MILICUA, José. Palencia monumental. Plus Ultra. Madrid, 1954.

MOGROVEJO, E. Diccionario hispanoamericano de Heráldica, Onomástica y Genealogía. Bilbao, 1995.

MOLINA, Montserrat. "Las tierras de Palencia durante la monarquía goda" en Historia de Palencia, I. Palencia, 1990, pp. 129-155.

[ MOLINER, José María. Espiritualidad medieval: Los mendicantes. Monte Carmelo. Burgos, 1974.

MONTENEGRO DUQUE, Ángel. "La toponimia palentina prerromana y la definición del componente étnico vacceo" en Historia de Palencia, I. Palencia, 1990, pp. 54-66.

[DI MONTERO TEJADA, Rosa María. Nobleza y sociedad en Castilla: el linaje Manrique (siglos XIV - XVI). Caja Madrid. Madrid, 1996.

[C] MORÁIS VALLEJO, E. Aportación Al Barroco en la provincia de León. Arquitectura religiosa. León, 2000, pp. 228-224.

MORAITA, Miguel. Historia General de España. Felipe González Rojas. Madrid, 1887-1890.

MORALEJO ÁLVAREZ, Serafín. "Modelos y copias en el marco de las relaciones hispano-francesas" en Congrés espanyol d'història de l'art. Barcelona, $29 \mathrm{de}$ octubre a 3 de noviembre de 1984. Volumen I. Barcelona, 1987, pp. 89-112.

-“San Martín de Frómista, en los orígenes de la escultura románica europea” en Jornadas sobre el románico en la provincia de Palencia. Palencia, 1985, pp. 27-37.

-“Arte del camino de Santiago y arte de peregrinación” en El Camino de Santiago: curso celebrado en el Monasterio del Poio (Pontevedra), 10-14 de agosto de 1987, 1990, pp. 7-28.

[D] MORALES, Ambrosio de. Viaje de Ambrosio Morales por orden del Rey Felipe II a los reinos de Castilla, León, Galicia y Principado de Asturias. Texto recuperado por Enrique Flórez. $1^{a}$ Edición, Madrid, 1573. Edición facsímil, 1977 y Edición actualizada, Junta de Castilla y León, 2004. 
[D] MORALES TALERO, Santiago de. "Don Fadrique de Castilla y Castro, duque de Arjona” en Boletín del Instituto de Estudios Giennenes, n 40, 1964 pp. 17-36.

MORENO CEBADA, Emilio. Historia de la Iglesia, 2: desde su establecimiento hasta el pontificado de Pío IX. Barcelona, 1867.

[D MORTE GARCÍA, Carmen. La pintura del Renacimiento. Museo Camón Aznar. Zaragoza, 1990.

-"Los retablos de escultura en Aragón: del gótico al renacimiento" en Los retablos: Técnicas, materiales y procedimientos, 2006, pp 1-22.

[D] MOSÁCULA MARÍA, Francisco Javier. Antonio de Berrio: un capitán segoviano en Indias.

$\mathbb{E} d$ MOYA, A. Rasgo heroyco. Declaración de las empresas, armas y blasones con que se ilustran y conocen los principales reynos, provincias, ciudades y villas de España. Madrid, 1756.

MOXÓ, Salvador de. La disolución del régimen señorial en España. Madrid, 1965.

-"De la nobleza vieja a la nobleza nueva. La transformación nobiliaria castellana en la Baja Edad Media” en Anexos de la Revista Hispania, n³, 1969, pp. 5-47.

[DUÑ MUZ JIMÉNEZ, José Miguel. "Maestros de obras montañeses en la provincia de Guadalajara durante los siglos XVI y XVII" en Altamira, n44, 1983-1984, pp. 195-210.

-"Juan de Naveda y la arquitectura del manierismo clasicista en la villa de Santander (1600-1630)" en Altamira, nº45, 1985, pp. 189-210.

-"El orden colosal en el retablo español del Renacimiento" en BSAA, no 51. Universidad de Valladolid. Valladolid, 1995, pp. 315-332.

[D NAVARRO GARCÍA, Rafael y REVILLA VIELVA, Ramón. Catálogo monumental de la provincia de Palencia. 2 Partido de Carrión de los Condes y Frechilla. Diputación de Palencia, 1948.

NARGANES QUIJANO, Faustino. Palencia monumental: monumentos históricoartísticos y bienes de interés cultural de la provincia. Cálamo. Palencia, 1999.

[DU NAVARRETE MARTÍNEZ, Esperanza. "La enseñanza fuera del taller del maestro: la Real Academia de Bellas Artes de San Fernando" en El arte del siglo de las luces. Barcelona, 2010, pp. 255-276.

[D] NAVASCUÉS PALACIO, Pedro. Rodrigo Gil y los entalladores de la fachada de la Universidad de Alcalá en Archivo Español de Arte. n 178, tomo 45 CSIC. Madrid, 1972 pp. 103-118.

-Monasterios en España. Arquitectura y vida monástica. Editorial Lunwerg. Madrid, 2000 .

[D NIETO ALCAIDE, Víctor y CHECA CREMADES, Fernando. Arquitectura del Renacimiento en España: 1488-1599. Cátedra. Madrid, 1989. 
[D] NIPHO, Francisco Mariano. Descripción natural, geográfica y económica de todos los pueblos de España. Tomo 3. Madrid, 1771.

NOREEN, Kirstin. "The icon of Santa Maria Maggiore, Rome: an image and its afterlife" en Renaissance Studies, n¹9, 2005, pp. 660-672.

[DU NÚNEZ MARQUÉS, Vicente. Guía de la S.I. Catedral de Burgo de Osma y breve historia del Obispado de Osma. Soria, 1949.

[D] OCÓN ALONSO, Dulce María. "Ego Sum Ostium" o la puerta del templo como puerta del cielo en el románico navarro-aragonés" en Cuadernos de Arte $e$ Iconografía, tomo 2, n³, 1989, pp. 125-136.

OCAMPO, Florián de. La Coronica general de España / que continuaua Ambrosio de Morales...prosiguiendo adelante de los cinco libros que el Maestro Florian de Ocampo ... dexo escritos... Editado en Casa de Iuan Iñiguez de Lequerica. Alcalá de Henares (Madrid), 1574.

-Los cinco libros postreros de la Coronica General de España / Que continuaua Ambrosio de Morales... prossiguiendo adelante la restauración de España, desde que se començo a ganar de los Moros, hasta el rey don Bermudo, el tercero deste nombre. Impresso por Gabriel Ramos Bejarano, a costa de Francisco Roberte. Córdoba, 1586.

OJEDA, Pablo. Don Antonio de Berrio. Gobernador del Dorado. Biblioteca de Estudios Universitarios. Caracas, 1960.

[D] OLLERO BUTLER, Jacobo. "Michel Coxcie y su obra en España" en AEA, tomo 48, no 190-191. CSIC. Madrid, pp. 165-198.

[D] OLLERO DE LA TORRE, Alfredo. Palencia durante la ocupación francesa (18081814). Repercusiones sociales y económicas. Palencia, 1983.

-"La guerra de la Independencia y la crisis del Antiguo Régimen en Palencia" en Historia de Palencia, 2. Palencia, 1990, pp. 159-186.

OMAECHEVARRÍA, Ignacio. Santa Clara en Carrión de los Condes. Colección Espíritu y vida, 10. Monte Casino. Zamora, 1986.

- Las monjas concepcionistas: notas históricas sobre la Orden de la Concepción fundada por Beatriz de Silva. Burgos, 1973.

OMAN, Charles. The golden age of hispanic silver (1400-1665). Her Majesty's Stationery Office. London,1968.

D ORCASITAS, Miguel Ángel. "Iconografía Agustiniana" en Iconografía Agustiniana. Actas del XI Congreso Internacional de Historia de la Orden de San Agustín. Roma, 2001, pp. 15-18.

[L] ORDUÑA VIGUERA, Emilio. La talla ornamental en madera. Compañía Iberoamericana de Publicaciones. Madrid, 1930

-"Cuestiones de toponimia mayor palentina. Algunos topónimos tradicionalmente mal interpretados” en PITTM, n 70. Palencia, 1999, pp. 519-533. 
OREJÓN CALVO, Anacleto. Historia documentada de la villa de Astudillo. Palencia, 1928.

ORELLA UNZUÉ, José Luis. Partidos politicos en el primer Renacimiento (13001450). Fundación Universitaria Española. Madrid, 1976.

ORLANDIS ROVIRA, José. "Sobre la elección de sepultura en la España medieval" en Anuario de Historia del Derecho español, n²0, 1950, pp. 5-49.

[D OROZCO, Fernando. Gobernantes de México. Desde la época prehispánica a nuestros días. México, 2005.

CD ORTEGA ARAGÓN, Gonzalo. La flor de la palabra: recreación y explicación de vocablos y expresiones populares. Cálamo. Palencia, 2002.

[D] ORTEGA GATO, Esteban. "Blasones y mayorazgos de Palencia" en PITTM, $\mathrm{n}^{\circ} 3$. Diputación Provincial de Palencia. Palencia, 1950, pp. 5- 270.

ORTEGA MATEOS, Lourdes. "Cajita excisa procedente de Carrión de los Condes" en $B S A A, \mathrm{n}^{\circ}$ 48. Valladolid, 1982, pp. 93-96.

Da ORTIZ DE LA TORRE, Elías. "Arquitectos montañeses: Juan y Rodrigo Gil de Hontañón en Boletín Biblioteca Menéndez Pelayo, 1923, pp. 215-240.

-"Sobre los arquitectos Juan y Rodrigo Gil de Hontañón y Juan de Rasines" en AEA, tomo 14,1940-41, pp. 315-317.

OSORNO RUIZ, Fco Javier y Medina Amezúa, Jesús. "Gótico olvidado" en Andar: Revista del Concejo Cultural de Carrión, no 1. Carrión de los Condes, 1984, pp. 10-12.

OSTROGORSKY, Georges. Historia del Estado bizantino. Akal. Madrid, 1983.

PALACIO SÁNCHEZ IZQUIERDO, María Luisa. "Monasterio de San Zoilo y monasterios palentinos" en Palencia en la Historia. Palencia, 1982, pp. 145-166.

-"El monasterio de San Zoilo de Carrión: jurisdicción, franquezas y privilegios" en ACHP, tomo 2. Diputación Provincial de Palencia. Palencia, 1987, pp. 65-73.

-Colección Diplomática del monasterio de San Zoilo de Carrión. 2 vol. (Tesis Doctoral). Madrid, 1988.

-San Zoilo de Carrión (siglo XI-XIV). Diputación Provincial de Palencia. Departamento de Cultura. Palencia, 1990.

-"Hospitales de peregrinos en Carrión de los Condes" en El Camino de Santiago, la hospitalidad monástica y las peregrinaciones. Salamanca, 1992. pp. 127-133.

PALAU, José. La leyenda de oro para cada día del año. Vida de todos los santos que venera la iglesia. Tomo II. Madrid, 1844.

[D] PALENCIA HERREJÓN, Juan Ramón. "Fundación y consolidación del Marquesado de Aguilar de Campoo a través de los pleitos de Garci Fernández Manrique (1401499)" en AIIICHP, tomo 2. Palencia, 1995, pp. 787-794. 
[d] PALOMERO ARAGÓN, Félix. Alfonso VI: del ocaso de lo hispano al mundo romano francés. Dykinson. Madrid, 2009.

PANIAGUA SOTO, José Ramón. Vocabulario básico de arquitectura. Cuadernos de Arte Cátedra. Madrid, 1990.

[ PANO GRACIA, José Luis. "El modelo de planta de salón: origen, difusión e implantación en América" en Arquitectura religiosa del siglo XVI en España y Ultramar. Curso de la Cátedra de Goya en abril de 2003. Institución Fernando el Católico. Zaragoza, 2004 (actas), pp. 38- 84.

PARRADO DEL OLMO, Jesús María. Catálogo monumental del Antiguo Partido Judicial de Mota del Marqués. Valladolid, 1976.

-"Retablo de San Francisco en Melgar de Yuso (Palencia)" en BSAA, no 39, Valladolid, 1977, pp. 35-40

-“Noticias sobre Juan de Nates" en BSAA, n45, Valladolid,1979, pp. 443-448.

-"Nuevos datos sobre el retablo mayor de Santa María de Tordesillas" en BSAA, $\mathrm{n}^{\circ}$ 48, 1982, pp. 435-437.

-Los escultores seguidores de Berruguete en Palencia. Universidad de Valladolid. Valladolid, 1981.

-"El Camino de Santiago a su paso por Palencia" en Jornadas sobre el románico en la provincia de Palencia. Diputación Provincial de Palencia. Departamento de Cultura. Palencia, 1985, pp. 88- 96.

-"Datos para el estudio de la arquitectura del siglo XVI en Palencia" en BSAA, n52. Valladolid, 1986, pp. 384-392.

-"Datos inéditos de entalladores palentinos del siglo XVI" en PITTM. No54. Palencia, 1986, pp. 263-269.

-“Manuel Álvarez" en Jornadas sobre el renacimiento en la provincia de Palencia. Diputación Provincial de Palencia. Departamento de Cultura. Palencia, 1987, pp. 95106.

-"Precisiones sobre escultura palentina del siglo XVI. Nuevas atribuciones al taller vigarnista-siloesco" en AICHP, tomo 1. Valladolid, 1987, pp. 147-159.

-"Estilo de los ensamblajes góticos palentinos" en Jornadas sobre el gótico en la provincia de Palencia. Diputación Provincial de Palencia. Palencia, 1988, pp. 65-83.

-"Sobre el origen de algunas composiciones del arte palentino del siglo XVI. La presencia de la estampa" en AIICHP, tomo 5. Palencia, 1990, pp. 91-116.

-Ampudia: Iglesia de San Miguel. Palencia, 1991.

-"Los talleres castellanos de escultura a mediados del siglo XVI: el diálogo entre las tendencias" en Actas do VI Simpósio Luso-Espanhol de História da Arte. Escola Superior de Tecnologia e Gestao de Tomar. Viseu, 1991, pp. 145-159.

-Piña de Campos: Iglesia de San Miguel. Colección, Raíces Palentinas. Diputación Provincial de Palencia. Palencia, 1993.

-"El renacimiento y la modernización de las formas artísticas en los conventos de Santa Clara de Palencia: Los conventos de Santa Clara en Astudillo y Carrión de los Condes" en Verdad y Vida, tomo 52. Madrid, 1994, pp. 763-772.

-“A propósito del Camino de Santiago palentino. En torno a varias obras de escultura el siglo XVI" en BSAA, n61. Valladolid, 1995, pp. 315-332.

-"La colaboración entre ensambladores en los proyectos de retablos de finales del siglo XVII y unas obras inéditas de Tomas de Sierra" en BSAA, n²42. Universidad de Valladolid. Valladolid, 1996, pp. 401-420. 
-Talleres escultóricos del siglo XVI en Castilla y León: arte como idea, arte como empresa comercial. Colección Serie Arte, arquitectura y urbanismo, 2.Valladolid, 2002.

-"Una atribución a Ramón Canedo en la Universidad de Valladolid" en Memoria Artis, Santiago de Compostela, 2003, pp. 441-444.

-"Sobre algunas esculturas del siglo XVI" 1999 en BSAA, n 69-70. Universidad de Valladolid. Valladolid, 2003-2004, pp. 303-320.

-Antiguo partido judicial de Medina de Rioseco. Diputación Provincial de Valladolid. Valladolid, 2002

- Juanes de Lascoain: un cantero vasco en Castilla. Universidad de Valladolid, 2011.

PARRADO DEL OLMO, Jesús María y ARA GIL, Clementina Julia. Catálogo Monumental del Antiguo Partido Judicial de Tordesillas. Valladolid, 1980.

[D] PARRINO, Domenico Antonio. Teatro eroico e politico de governi de Vicerè del regno di Napoli. Nápoles, 1692.

PASCUAL MOLINA, Jesús Félix. "Rodrigo Gil de Hontañón y el contrato y el contrato para la iglesia parroquial de Laguna de Duero (Valladolid)" en BSAA, $\mathrm{n}^{\circ} 71$. Valladolid, 2005, pp. 89-98.

PASTOR CRIADO, Isabel. Arquitectura purista en Asturias. Oviedo, 1987.

PAULA MELLADO, Francisco de. Diccionario de historia y de geografía. Tomo I. Madrid, 1846.

PAYO HERNÁN, Jesús. "El retablo barroco trasmerano: Diego de Suano" en BIFG, tomo XIV, 206, 1993, pp. 159-182.

-El retablo barroco en Burgos y su comarca durante los siglos XVII y XVIII. Diputación Provincial de Burgos, 1997. 2 tomos.

PELLICER Y OSSAU, J. Informe del origen, antigüedad, calidad y sucesión de la excelentísima Casa de Sarmiento de Villamayor. Madrid, 1663.

[D] PEÑA PÉREZ, Javier. "Expansión de las órdenes conventuales en León y Castilla: franciscanos y dominicos en el siglo XIII" en III Semana de Estudios medievales. Instituto de Estudios Riojanos. Logroño, 1993, pp. 179-198.

PERAL VILLAFRUELA, Santiago. "El convento de Santa Clara de Carrión y su archivo" en Archivo Ibero-Americano. Revista franciscana de estudios históricos. $\mathrm{n}^{\mathrm{o}}$ 213-214. LXIX. Enero-Junio, 1994, pp. 97-103.

-Los hospitales de Carrión y los Condes de Castañeda en la Edad Media. Cálamo. Palencia, 2004.

-"Frómista y San Martín en la Edad Media: una relación conflictiva" en Actas de las Jornadas celebradas en Frómista: San Martín de Frómista,¿̨paradigma o historicismo? Fundación del Patrimonio Histórico de Castilla y León. Valladolid, 2005, pp. 11-36.

-Estudio para la puesta en valor del patrimonio cultural de Carrión de los Condes como fuente de desarrollo rural. Monasterio de Benevivere-San Torcuato. Inédito. Depositado en el Ayuntamiento de Carrión de los Condes, 2007, p. 1- 50. 
-“San Francisco de Carrión de los Condes (siglos XIII-XIX). Aproximación al conocimiento de un convento de menores en la Diócesis de Palencia" en Archivo Ibero-Americano, no 262-263. LXIX. Enero-Agosto 2009, pp. 229-329.

-De Aquitania a Carrión: El priorato de Sancti Spiritus en el camino de Santiago Palentino. Diputación Provincial de Palencia. Palencia, 2011.

[D PERAL VILLAFRUELA, Santiago y GÓMEZ PÉREZ, Enrique. Carrión, la ciudad de los Condes. Cálamo. Palencia, 1997. 2ª Edición actualizada, 2003.

[d PERAL VILLAFRUELA, Santiago, ARROYO PUERTAS, Carlos y GÓMEZ PÉREZ, Enrique. Frómista, la villa del milagro. Cálamo. León, 2002.

PEREDA DE LA REGUERA, Manuel. “Artistas montañeses en la villa de Becerril de Campos" en Altamira: Revista de estudios montañeses, $n^{\circ} 9$. Santander, 1951, pp. 175205.

-Rodrigo Gil de Hontañón. Librería Moderna. Madrid, 1951.

-Juan de Nates. Librería Moderna. Santander, 1953.

[DPÉREZ BUSTAMANTE, Rogelio. "Inventario de los bienes raíces de Leonor de la Vega" en Revista de Archivos, Bibliotecas y Museos, n81, 1978, pp. 73-104.

-El marqués de Santillana: biografía y documentación. Fundación Santillana. Santillana del Mar, 1983.

PÉREZ CELADA, Julio A. Documentación del Monasterio de San Zoilo de Carrión (1047-1300). Fuentes Medievales Castellano-leonesas. Ediciones Garrido Garrido. Palencia, 1985.

-Documentación del Monasterio de San Zoilo de Carrión (1301-1400) Fuentes Medievales Castellano-leonesas. Ediciones Garrido Garrido. Palencia, 1986.

-"Notas sobre la ampliación del patrimonio condal en el siglo XI: Una operación múltiple de compraventa y permuta protagonizada por Don Gómez Díaz y Doña Teresa en 1057" en AIICHP, tomo 2. Excma. Diputación Provincial de Palencia. Palencia, 1990, pp. 415-428.

-El Monasterio de San Zoilo de Carrión. Formación, estructura y decurso histórico de un señorío castellano-leonés (siglos XI al XVI). Universidad de Burgos, 1997.

-"Sobre el origen de Carrión de los Condes y sus funciones en la articulación territorial: Del poblamiento vacceo a la configuración medieval" en Los orígenes de la ciudad en el noroeste hispánico. Actas del Congreso Internacional. Lugo 15-18 de mayo de 1996. vol 2. Lugo, 1999, pp. 1411-1424.

-"La explotación de los recursos hidráulicos en el curso medio del río Carrión en la Edad Media" en PITTM, nº71, Palencia, 2000, pp. 113-133.

PÉREZ DE CASTRO, Ramón. "Un dibujo de Felipe Berrojo para la portada de San Benito de Sahagún” en De arte, nº1, 2002, pp. 75-80.

-"Un retablo en Boadilla de Rioseco (Palencia) de Santiago Carnicero y Tomás de Sierra" en BSAA, $\mathrm{n}^{\circ}$ 71. Valladolid, 2005, pp. 241-258.

-"Manifestaciones artísticas de la Cofradía de la Vera Cruz en Palencia: Palacios, Casas de la Cruz, Ermitas y Humilladeros" en IV Congreso Internacional de Hermandades y Cofradías de la Santa Vera Cruz. 26-28 de septiembre de 2008, Zamora, pp. 283-339. 
-"Precisiones sobre el retablo mayor del monasterio benedictino de Sahagún de Gregorio Fernández: Pedro de Torres, Luis de Llamosa y Mateo Enríquez" en Gregorio Fernández: antropología, historia y arte en el Barroco. Valladolid, 2008, pp. 391-424.

-"Una Inmaculada de Gregorio Fernández en el convento de Santa Clara de Palencia" en Estudios de Historia del Arte. Homenaje al Profesor de la Plaza Santiago. Valladolid 2009.

CD PÉREZ DE URBEL, Fray Justo. Las grandes abadías benedictinas. Su vida, su Arte y su Historia. Ediciones Ancla. Madrid, 1928.

-Historia Silense. Escuela de Estudios Medievales. Madrid, 1959.

PÉREZ EMBID WAMBA, Javier. El Císter en Castilla y León. Monacato y dominios rurales (ss. XII-XIV). Salamanca, 1986.

PÉREZ GARCÍA, Rafael M. "Espirituales, cortes señoriales y linajes nobiliarios. Construcción y desarrollo de climas sacro-espirituales de referencia social en la Andalucía de los siglos XVI y XVII" en Historia y Genaología, nº, 2011, pp. 133153.

PÉREZ GONZÁLEZ, Cesáreo. "Cajitas celtibéricas de la provincia de Palencia. Aportaciones, síntesis y localización” en PITTM, n 48. Palencia, 1983, pp. 7-25.

PÉREZ MONZÓN, Olga. "Iconografía y poder real en Castilla: las imágenes de Alfonso VIII" en ADHTA, n¹4, 2002, pp. 19-41.

-"La procesión fúnebre como tema artístico en la Baja Edad Media" en ADHTA, n 20, 2008, pp. 21-36.

[ PÉREZ RODRÍGUEZ, Estrella. Poema sobre el fundador de Benevívere. Estudio y edición crítica con traducción del poema y de los diplomas relacionados. Universidad de León. León, 2008.

PÉREZ SÁNCHEZ, Alfonso Emilio. El retablo de Morales en Arroyo de la Luz. Salas de Exposiciones de la Dirección General de Bellas Artes. Madrid, 1974.

-"Las colecciones de pintura del conde de Monterrey" en Boletín Academia de la Historia, 1978, pp. 417-459.

-Pintura napolitana. De Caravaggio a Giordano. Museo del Prado. Madrid, 1985.

[D PÉREZ VILLAAMIL, Genaro. España artística y monumental: vistas y descripción de los sitios y monumentos más notables de España. 3 volúmenes. Alberto Hauser, París, 1842-1850.

PERRINO DÍEZ, José Antonio. “San Zoilo (1992-2002). La memoria recuperada” en Sentir y potenciar Palencia. FUNDEPA (Fundación para el desarrollo de Palencia). Madrid, 2004, pp. 285-288.

@ PIFERRER, F. Nobiliario de los reinos y señoríos de España. Vol, I. Madrid, 1860.

@ PINILLOS IGLESIAS, $\mathrm{M}^{\mathrm{a}}$ de los Hoyos. Hilando oro: Vida de Luisa de Carvajal. Laberinto. Madrid, 2000. 
DI PITA GALÁN, Paula. "Monjes capitulares y frailes arquitectos: dos aspectos de la maestría de obras en el monasterio de San Martín Pinario (siglos XVI-XVIII)" en Galica monástica, Santiago de Compostela, 2009, pp. 537-560.

[L] PIZARRO GÓMEZ, Javier. "El Ecce Homo de Luis de Morales del Museo de Bellas Artes del Museo de Chile" en Norba, n 11. Badajoz, 1991, pp. 179-181.

1] PLAZA SANTIAGO, Francisco Javier. Historia del Arte de Castilla y León. 7, Del Neoclasicismo al Modernismo. Ámbito. Valladolid, 1944.

POLANCO MELERO, Carlos. Muerte y sociedad en Burgos en el siglo XVI. Diputación Provincial de Burgos. Burgos, 2001.

[D] POLO SÁNCHEZ, Julio J. Arte barroco en Cantabria: retablos e imaginería (16601790). Santander, 1991.

[D] PONZ, Antonio. Castilla y León en el siglo XVIII a través de los viajes de Antonio Ponz. Selección y prólogo de Julio Valdeón. Valladolid, 1987.

-Viaje de España. $1^{\text {a }}$ Edición. Joaquín Ibarra. Madrid, 1783, Facsímil, Madrid, 1972.

[D] PORRAS GIL, Ma Concepción. "Santa María de las Victorias y Santa María del Camino", ficha no 26 en Memorias y esplendores. Las Edades del Hombre. Catedral de Palencia, 1999, pp. 51 y 52.

PORTELA SANDOVAL, Francisco José. Escultura del siglo XVI en Palencia. Diputación Provincial de Palencia, 1977.

(1) PORTELA SILVA, Ermelindo. La colonización cisterciense en Galicia. Santiago de Compostela, 1981.

[DI PORTER A. Kingsley. La escultura románica en España. Gustavo Gilli. Barcelona, 1929, traducción del original Spanish Romanesque Sculpture, tomo II. Nueva York, 1928.

Dl PRIETO SARRO, Marta. Carrión de los Condes. Palencia. Trobajo del Camino (León), 1999.

PSELO, Miguel. Vida de los Emperadores de Bizancio. Introducción y traducción por Juan Signes Codoñer. Biblioteca universal Gredos. Madrid, 2005.

DD PUENTE, Luis de la. Vida maravillosa de la venerable Virgen Doña Marina de Escobar natural de Valladolid, sacada de lo que ella misma escriuio de orden de sus Padres espirituales. Francisco Nieto. Madrid, 1665-1673.

PUENTE, Ricardo. San Zoilo de Carrión: de la Edad Media al Renacimiento. Albanega. León, 1998. 
[D] QUADRADO, José María y SIMÓN Y NIETO, Francisco. Los antiguos campos góticos: Excursiones histórico-artísticas a la Tierra de Campos. Caja de Ahorros y Monte de Piedad. Palencia, 1971.

[D] QUADRADO; José María y PARCERISA, Francisco J. Recuerdos y bellezas de España. Palencia. $1^{a}$ Edición: Palencia, 1861. Edición facsímil de Editorial Ámbito. Valladolid, 1989.

QUEVEDO, José. Historia del real monasterio de San Lorenzo, llamado comúnmente del Escorial, desde su origen y fundación hasta fin del año de 1848. Madrid, 1849.

[D] RAMOS CRUZ, Guillermina. "La otra cara de Eva: Diosas, sacerdotisas, sibilas, orishas. La mujer y lo sagrado" en Oráfrica: Revista de oralidad africana, n5, abril 2009, pp. 163-180.

D RAMIREZ DE HELGUERA, Martín. El libro de Carrión de los Condes. Establecimiento tipográfico de Abundio Menéndez. Palencia, 1896.

- El Real monasterio de San Zoilo de la muy noble y leal ciudad de Carrión de los Condes ante la Historia y el Arte. 1ªdición: Gutiérrez, Líter y Herrero, 1900. Reproducción facsímil de la Diputación Provincial. Palencia, 1997.

-Ordenanzas municipales de la muy noble y leal ciudad de Carrión de los Condes. Gutiérrez, Líter y Herrero. Carrión, Palencia, 1911.

[D] RAMOS DE CASTRO, Guadalupe. "Iconografía de la escultura románica palentina" en Jornadas sobre el románico en la provincia de Palencia. Departamento de Cultura. Palencia, 1985, pp. 57- 67.-“La iglesia del convento de las Agustinas Canónigas de Palencia" en AICHP, tomo 1, Palencia, 1987, pp. 179-188.

-"El convento de las Agustinas Recoletas de Palencia" en AIIICHP, tomo 4, 1995, pp. 619-635.

RABASCO CAMPO, Jorge. Los plateros españoles y sus punzones. Vitoria, 1975.

REAU, Louis. Iconografía del arte cristiano. Iconografía de la Biblia. Tomo 1, volumen 1, nº4. Barcelona, 1996.

REDONDO AGUAYO, Anselmo. "Monografía Histórica de la villa de Becerril de Campos y noticia biográfica de sus hijos más ilustres" en PITTM. nº, pp. 29-216.

DEDONDO CANTERA, Ma José. "El programa iconográfico del claustro bajo del Monasterio de San Zoilo en Carrión de los Condes (Palencia)" en AIICHP, tomo 5. Palencia, 1990, pp. 129-154.

-El sepulcro en España en el siglo XVI. Tipología e iconografía. Dirección General de Bellas Artes y Archivos. Centro Nacional de Información y Documentación del Patrimonio Histórico. Madrid, 1987.

- "Trazas inéditas de Diego de Praves y de Juan de Nates para el convento de Sancti Spiritus de Valladolid (1592-1596)" en Juan de Herrera y su influencia. Actas del simposio de Camargo, 14-17 de julio 1992. Santander, 1993, pp. 361-370.

- "Juan de Nates, entre las influencias de Ribero Rada y Herrera" en Altamira, no 52, 1996, pp. 167-204 
-"Los arquitectos y canteros del entorno de Rodrigo Gil de Hontañón en Castilla y León: la herencia paterna” en El arte de la cantería, Santander, 2003, pp. 15-76.

REDONDO CANTERA, Ma José y ZAPARAÍN YÁÑEZ, Ma José. "San Pedro Regalado. Formación y desarrollo de una iconografía religiosa en el Barroco" en Cuadernos de Arte e Iconografía, tomo 4, n8, Fundación Universitaria Española, 1991, pp. 73-81.

REGLERO DE LA FUENTE, Carlos. La iglesia de Palencia. Iglesias de Palencia. Valladolid y Segovia. Historia de las Diócesis Españolas, tomo 19. Madrid, 2004.

[D] REVENGA DOMINGUEZ, Paula. Aproximación a la pintura toledana de la segunda mitad del siglo XVII. Caja de Ahorros. Toledo, 1988.

REVILLA VIELVA, Ramón. "Sepulcros de los Beni-Gómez” en PITTM, nº1. Diputación Provincial de Palencia. Palencia, 1949, pp. 39-51.

-"Retablo mayor de la Santa Iglesia Catedral de Palencia" en PITTM, no5, Palencia, 1950, pp. 91-104.

-“San Fernando en el arte palentino” en PITTM, n8, Palencia, 1952, pp. 141-142.

-Camino de Santiago. Pueblos enclavados en la ruta de la provincia de Palencia. Palencia, 1954.

-“Arte románico palentino" en PITTM, nº11. Diputación Provincial de Palencia. Palencia, 1994, pp. 45-60.

REVUELTA GONZÁLEZ, Manuel. Orígenes históricos de la constitución de la provincia de Palencia. Imprenta Provincial. Palencia, 1981.

- La Compañía de Jesús en la España Contemporánea. Supresión y reinstalación (1868-1883). Tomo 1. Universidad Pontificia de Comillas. Comillas, 1984.

-“Un siglo de crisis y restauración en la iglesia palentina" en Historia de Palencia, 2. Palencia, 1990, pp. 223-233.

- La Compañía de Jesús en la España Contemporánea. Expansión en tiempos recios (1884-1906) Tomo 2. Universidad Pontificia de Comillas. Comillas, 1991.

-“Origen, ocaso y renovación de los conventos palentinos" en PITTM, nº63. Diputación Provincial de Palencia. Palencia, 1992, pp. 50-83.

-"Aspectos religiosos en la Guerra de la Independencia y su repercusión en Palencia" en PITTM, no 79. Diputación Provincial de Palencia. Palencia, 2008, pp. 155-178.

REVUELTA TUBINO, Matilde. Museo de Santa Cruz de Toledo. Sección de Bellas Artes.1. Siglos XIV-XV-XVI. Consejería de Educación y Cultura de la Junta de Comunidades de Castilla-La Mancha, 1987.

[D RIAÑO RODRÍGUEZ, Timoteo. "Propósito de Pero abat al escribir el Cantar de Mío Cid: motivaciones geopolíticas" en El Cid, poema e historia: Actas del Congreso Internacional: (12-16 de julio, 1999). Burgos, 2000, pp. 279-282.

[DIBADENEIRA, Pedro de. Flos Sanctorum de la vida de los Santos.(1527-1611) Volúmenes primero, cuarto y sexto, Madrid, 1717. Volúmenes segundo y tercero, Barcelona, 1790. Volumen 5, Madrid, 1716. 
DI RICHE, Denise. L'Ordre de Cluny à la fin du Moyen âge: "le vieux pays clunisien", XIIe-XVe siècles. París, 2000.

[ RICO CAMPS, Daniel. "Los maestros de Carrión de los Condes y San Vicente de Ávila: Reflexiones sobre la decantación hispana de la escultura borgoñona" en Maestros del Románico en el Camino de Santiago. Fundación Santa María la Real. Palencia, 2010, pp. 117-150.

RINCÓN GARCÍA, Wilfredo. "Los varones Apostólicos evangelizadores de España: tradición, culto e iconografía en su dispersión geográfica hispana" en Memoria ecclesiae, $\mathrm{n}^{\circ}$ 28, 2006 Actas del XIX Congreso de la Asociación celebrado en Santa Cruz de Tenerife y Las Palmas (15 al 20 de septiembre de 2003). pp. 737-784.

[D] RIVERA BLANCO, Javier. "Tradición y modernidad en la arquitectura palentina de los comienzos de la Edad Moderna" en Jornadas sobre el renacimiento en la provincia de Palencia. Diputación Provincial de Palencia. Departamento de Cultura. Palencia,1986, pp. 21-38.

-"Palencia" en Catálogo Monumental de bienes inmuebles declarados. Primera parte. Junta de Castilla y León, Consejería de Cultura y Turismo. Valladolid, 1995, pp. 409531.

RIVERA DE LAS HERAS, José Antonio. Imágenes del Niño Jesús. Catálogo de la exposición. Zamora, 1992.

[DIVERA RECIO, Juan Francisco. San Eugenio de Toledo y su culto. Diputación Provincial. Toledo, 1963.

[D RIVERO SIERRA, Borja del. "Heráldica de los Enríquez de Cisneros en Cantabria" en Ascagen: Revista de la Asociación Cántabra de Genealogía, nº ${ }^{\circ}$. Santander, 2009, pp. 54-66.

ROBERTS, Ulysses. "État des monastères espagnols de l'Ordre de Cluny aux XIIIème et XVème siècles, d'après les actes des Chapitres Généreux" en BRAH, n ${ }^{\circ} 20$. Madrid, 1892, pp. 321-431.

DD ROCA Y CORNET, Joaquín. Historia de los hechos y doctrina de Nuestro Señor Jesucristo desde su venida al mundo hasta su gloriosa ascensión al cielo. Biografía Eclesiástica. Barcelona, 1857.

[D RODICIO GARCÍA, Sara. "Osorno y su condado. El señorío y el condado de Osorno" en PITTM, nº 62. Palencia, 1992, pp. 337- 484.

RODRÍGUEZ DURANTEZ, Lorenzo. "El fuerte de Cervera de Pisuerga y su tiempo: escenarios palentinos en la guerra carlista" en PITTM, $\mathrm{n}^{\circ} 79$. Diputación Provincial. Palencia, 2008, pp. 395-419.

[1] RODRÍGUEZ FERNÁNDEZ, Justiniano. Palencia: panorámica foral de la provincia. Merino. Palencia, 1981. 
DOd RODIGUEZ GUTIÉRREZ CEBALLOS, A. "El reflejo de la liturgia visigóticomozárabe en el arte español de los siglos VII al X" en Pontificia Universitas Comillensis, 1965, pp. 3-35.

RODRÍGUEZ MARTÍNEZ, Luis. Historia del Monasterio de San Benito el Real de Valladolid. Valladolid, 1981.

[D] RODRIGUEZ MUÑOZ, Pedro. "Iglesias románicas palentinas" en PITTM, n 13. Diputación Provincial. Palencia, 1955.

[D] RODRÍGUEZ NÚÑNEZ, Clara Cristela. "El conventualismo femenino: las clarisas" en Espiritualidad y franciscanismo, VI Semana de Estudios Medievales: Nájera, 31 de julio a 4 de agosto de 1995. Instituto de Estudios Riojanos, 1996, pp. 87-100.

[C] RODRÍGUEZ PELAZ, Celia. "El grabado barroco en los impresos vasco-navarros" en Ondare, 19, 2000, pp. 151-182.

[DI RODRIGUEZ SALCEDO, Severino. "Historia de los centros palentinos de cultura" en PITTM, no 2. Palencia, 1949, pp. 77-78.

-"Palencia en 1808" en PITTM, n¹4. Palencia, 1953, pp. 3-125.

ROHRBACHER, René François. Storia universale della chiesa cattolica dal principio del mondo sino ai di nostri. Tomo XIII. Traducida al italiano por L. Toccagni. Milano, 1847.

ROJAS, Francisco de (OFM). Anales de la orden de los Menores: donde se tratan las cosas más memorables de personas insignes de santidad y letras de las tres órdenes que institvyó sv gran fundador San Francisco. 3 tomos. Málaga, 1652.

@ ROKISKI LÁZARO, Ma Luz. Arquitectura del siglo XVI en Cuenca. Diputación de Cuenca. Cuenca, 1985.

-Colección de documentos para la historia del arte en España. 2 volúmenes. Real Academia de Bellas Artes de San Fernando. Cuenca, 1988-1989.

-Documentos sobre escultura del siglo XVI en Cuenca. Diputación Provincial de Cuenca. Cuenca, 2001.

-Escultores del siglo XVI en Cuenca. Diputación Provincial de Cuenca. Cuenca, 2010.

[D ROS CARBALLAR, Carlos. San Isidoro de Sevilla: el obispo sabio. Colección Santos y Santas, 115. Barcelona, 2006.

Ql ROYO ABRIL, Alfredo. Real Convento y Museo de Santa Clara de Carrión de los Condes (Palencia). Comunidad de Madres Clarisas. Carrión de los Condes Palencia, 1990.

[C] RUIZ DE ELVIRA, Antonio. "Los “hermanos" de Jesús y la iconografía de Moisés" en Epos: Revista de Filología. No 10, 1994, pp. 51-67.

DU RUIZ LLAMAS, María Gracia. "El arte de enseñar a través del arte: el valor didáctico de las imágenes románicas" en Educatio siglo XXI, n²0-21, Murcia, 2003, pp. 227248. 
RUBIO MAÑÉ, Jorge. Don Luis de Velasco, el virrey popular. México, 1946.

-El virreinato. 1, Orígenes y jurisdicciones, y dinámica social de los virreyes. Instituto de Investigaciones Históricas. $1^{\text {a }}$ Edición, 1963. México, 1983.

[1] RUIZ ASENCIO, José Manuel. "Documentos bajomedievales del monasterio de San Román de Entrepeñas" en AIIICHP, tomo II. Palencia, 1995, pp. 9-38.

[D] RUIZ MALDONADO, Margarita. "El caballero victorioso en la escultura románica española. Algunos consideraciones y nuevos ejemplos" en BSAA, ${ }^{\circ} 45$. Valladolid, 1979, pp. 271-286.

RUIZ MARTÍN, Felipe. "Palencia en el siglo XVII" en AICHP, tomo 3. Palencia, 1987, pp. 9-33.

[D] RUIZ SALCES, Roberto y PEÑIL MINGUEZ, Javier. "La excavación de la iglesia románica de Santiago: Aportaciones al urbanismo medieval de Carrión de los Condes" en XX Congreso Nacional de Arqueología. Zaragoza, 1991 pp. 483-490.

RUPÉREZ ALMAJANO, María Nieves. "El colegio de niños huérfanos: la intervención de Rodrigo Gil de Hontañón y otras aportaciones a la historia de su construcción" en Estudios Históricos Salmantinos: homenaje al P. Benigno Hernández Montes. Salamanca, 1999, pp. 129-156.

[Da SABAU GARCÍA, M.L. México en el mundo de las colecciones de arte. Nueva España. Tomo 1. Ciudad de México, 1994.

SAGREDO, Diego de. Medidas del romano. Toledo. 1526. Edición actualizada a cargo de Fernando Marías. Toledo, 2000.

[D] SAINT-ANDRÉ, Alix de. Archives des anges. Gallimard. Paris, 2000, pág. 88.

[D] SAINZ DE ROBLES, Federico Carlos. Monasterios de España. Su arte, su historia, sus leyendas. Aguilar. Madrid, 1953.

SAINZ GUERRA, José Luis. "El urbanismo medieval en Palencia" en Palencia en los siglos del románico. Aguilar de Campoo, 2002, pp. 203-235.

[ㅁ] SÁINZ SÁIZ, Javier. El gótico rural en Castilla y León. Lancia. León, 1997.

[D] SALAZAR ANDREU, Juan Pablo. Gobierno en la Nueva España del virrey Luis de Velasco, el Joven (1590-1595) y (1607-1611). Valladolid, 1997.

SALAZAR DE MENDOZA, Pedro (1549-1629). Origen de las dignidades seglares de Castilla y Leon: con relacion sumaria de los reyes de estos reynos ..., con un resumen al fin de las mercedes que su magestad ha hecho de marqueses y condes desde el año de 1621 hasta fin del de 1656. Oficina de Don Benito Cano. Madrid, 1794.

[D] SALAZAR Y CASTRO, Luis de. Historia genealógica de la Casa de Silva. Madrid, 1685. 
-Historia genealógica de la Casa de los Lara. 4 vol. Madrid, 1697.

DI SALAZAR Y HACHA, Jaime de. "Contribución al estudio del reinado de Alfonso VI de Castilla: algunas aclaraciones sobre su política matrimonial" en Anales de la Real Academia matritense de heráldica y genealogía. Volumen II. Madrid, 1992, pp. 299335.

[D SALCEDO TAPIA, Modesto. "Noticias y documentos de Itero de la Vega" en PITTM, no 63. Palencia, 1992, pp. 495-612.

SALOMÓN, Nöel. La vida rural castellana en tiempos de Felipe II. Barcelona, 1982.

SALVADOR Y CONDE, P. J. Los conventos de Dominicos en la provincia de Palencia (Carrión de los Condes s. XVI- XIX). Diputación provincial de Palencia, Palencia, 1997.

[D SANABRIA, S.L. "The mechanization of design in the $16^{\text {th }}$ Century: The Structural formulae of Rodrigo Gil de Hontañón" en Journal Society of Architectural Historiadors, 1982, pp. 281-293.

[D SAN MARTÍN PAYO, Jesús. "La más antigua estadística de la Diócesis Palentina (año 1345)" en PITTM, no 7. Palencia, 1949-1950, pp. 1-122.

-"El retablo mayor de la Catedral de Palencia: Nuevos datos" en PITTM, n¹0, Palencia, 1953, pp. 273-312.

[D] SÁNCHEZ AMEIJEIRAS, Rocío. "Un espectáculo urbano en la Castilla medieval: las honras fúnebres del caballero" en El rostro y el discurso de la fiesta. Santiago de Compostela, 1994, pp. 141-158.

[C] SÁNCHEZ BADIOLA, Juan José. "Símbolos locales en los sellos de tinta palentinos durante el siglo XIX” en PITTM, no 79. Palencia, 2008, pp. 375-394.

@D SÁNCHEZ ESTEBAN, Natividad. "Pedro y Alonso de Tolosa, un plano y nuevos datos" en BSAA, n57. Universidad de Valladolid, 1991, pp. 310-324.

SÁNCHEZ LÓPEZ, Juan Antonio. "Iconografía e iconología del pelícano: un ensayo sobre la reconversión del concepto de filantropía" en Boletín de Arte, $\mathrm{n}^{\circ} 12$. Universidad de Málaga. Málaga, 1991, pp. 127-146.

SÁNCHEZ PRIETO, Sara. "El espejo de la justicia: acercamiento a sus principales símbolos e imágenes" en Lex Nova, n59, 2010, pp. 40-41.

Q 1 SÁNCHEZ REY, Agustín. "Los caminos y el transporte terrestre durante el reinado de Isabel La Católica en su quinto centenario" en Revista de Obras Públicas, no 3452 , 2005, pp. 41-52.

[DI SANCHO CAMPO Ángel. El arte sacro en Palencia.4. Santa María y Santiago en el arte palentino. Palencia, 1975.

-"Palencia histórico monumental" en PITTM, n 36. Palencia, 1975, pp. 213-273.

-El arte sacro en Palencia.5. El Museo diocesano de arte de Palencia. Palencia, 1978. 
-Guía del museo diocesano de Palencia. Origen, formación y estado actual. Palencia, 1999.

DANDOVAL, Fray Prudencio de. Crónica del ínclito emperador de España don Alfonso VII. Madrid, 1600.

-Primera parte de las fundaciones de los monasterios del glorioso Padre San Benito. Madrid, 1601

-Historia de los Reyes de Castilla y de León don Fernando el Magno, don Sancho, don Alonso Sexto, doña Urrak., don Alonso Séptimo. Carlos de Labayen. Madrid, 1615. $2^{\text {a }}$ Edición, Madrid, 1792.

SANTIAGO, Miguel de y GARCÍA MORO, Luis. "La organería palentina" Apuntes palentinos, 3.Caja de Ahorros y Monte de la Piedad. Palencia, 1983.

[DANTOS URBANEJA, Fernando. San Zoilo: un mártir cordobés en el Camino de Santiago. Centro de Estudios y Documentación del Camino de Santiago. Carrión de los Condes, Palencia, 2003.

(D) SARABIA VIEJO, María Justina. Don Luis de Velasco: virrey de Nueva España: 1550-1564. Escuela de Estudios Hispano-Americanos. Sevilla, 1978.

DARABIA Y LEZANA, Joseph. Anales de la sagrada religión de Santo Domingo, erario ascético en las legendas de los Santos y Santas y personas de ylustre virtud de la Orden de Predicadores. Tomo 1. Madrid, 1709.

SARANYANA, José Ignacio. La discusión medieval sobre la condición femenina (siglos VIII-XIII). Universidad Pontificia de Salamanca. Salamanca, 1997.

[D] SARAVIA, Crescenciano. "Repercusión en España del decreto del Concilio de Trento sobre las imágenes" en BSAA, n³6. Valladolid, 1960, pp. 129-144.

[D] SCIO DE SAN MIGUEL, don Felipe. (Obispo de Segovia). La Biblia. Vulgata Latina traducida en español. Tomo VIII. Los doce Profetas menores y los libros I y II de los Macabeos. Valencia, 1793.

-Tomo IV del Antiguo Testamento. Josué, Jueces, Ruth y Primero de los Reyes. Imprenta de Don Benito Cano. Madrid, 1795.

-Tomo VIII del Antiguo Testamento. Los Proverbios, el Eclesiastés, el Cantar de los Cantares, la Sabiduría y el Eclesiástico. Imprenta de la Hija de Ibarra. Madrid, 1808.

SCORZA BARCELLONA, Francesco. Enciclopedia dei Papi. Istituto Della Enciclopedia italiana. Roma, 2000.

[D] SEM TOB (rabí de Carrión). Proverbios morales. Edición de DÍAZ-MAS, Paloma y MOTA, Carlos. Cátedra. Madrid, 1998.

DENDÍN CALABUIG, Manuel. El Colegio mayor del arzobispo Fonseca. Universidad de Salamanca. Salamanca, 1977. 
SENRA GABRIEL Y GALÁN, José Luis. "La portada occidental recientemente descubierta en el monasterio San Zoilo de Carrión de los Condes" AEA, tomo 67, nº 265. Dpto de $H^{\mathrm{a}}$ Arte Diego Velázquez. Madrid, 1994, pp. 57-72.

-“Algunas notas sobre la desaparecida iglesia románica del priorato cluniacense de Carrión de los Condes" en AIICHP, tomo 4. Diputación Provincial. Palencia, 1995, pp. 439-452.

-“Alfonso XI y Cluny. La restauración de un vínculo tradicional en la primera mitad del siglo XIV" en Hispania Sacra. XVLII. Madrid, 1995, pp. 537-558.

-“Aproximación a los espacios litúrgicos-funerarios en Castilla y León: pórticos y galileas" en Gesta, no 36. Internacional Center of Medieval Art. New York, 1997, pp. 122-144.

-Arquitectura y escultura en los grandes monasterios benedictinos de Castilla y León (1073-1157). Universidad Autónoma de Madrid. Madrid, 1998.

-"Peregrinaciones y reliquias en las rutas hacia Compostela: héroes y santos a la vera del camino" en Memoria ecclesiae, $\mathrm{n}^{\circ}$ 18, 2001, pp. 277-292.

-"Nuevos hallazgos románicos en el monasterio de San Zoilo de Carrión de los Condes (Palencia)" en AEA, tomo 74, n²93. Diego Velázquez. Madrid, 2001, pp. 88-95.

-"Monasterio de San Zoilo" en Enciclopedia del Románico en Castilla y León. Palencia. Aguilar de Campoo. Vol.2, Boedo-La Ojeda, Saldaña-La Valdavia, Tierra de Campos, Cerrato. Fundación Santa María la Real, Centro de Estudios del Románico. Aguilar de Campóo, 2002, pp. 1023-1032.

- "Dos telas islámicas encontradas en el Monasterio de San Zoilo de Carrión” en Goya, $n^{\circ}$ 303. Summa. S.A. Madrid, 2004, pp. 332-340.

-"La realidad material de la iglesia de San Martín de Frómista en el siglo XII: de 1066 a 1904 en Actas de las Jornadas celebradas en Frómista: San Martín de Frómista, ¿paradigma o historicismo? Valladolid, 2005, pp. 39-68.

-"Mio Cid es de Bivar e nos de los Condes de Carrión. Los Banu-Gómez de Carrión a la luz de sus epitafios" en Quintana, n 5. Santiago de Compostela, 2006, pp. 233-267.

-"La puerta como dogma: A propósito de un nuevo descubrimiento de la iglesia románica de San Zoilo de Carrión de los Condes (Palencia)" en AEA, tomo 81, n³22. Abril-Junio, 2008, pp. 139-150.

-"En torno a las estructuras occidentales de las iglesias románicas: formulación arquitectónica y funcional de las galileas (ca.1030-1150)" en Espacios y estructuras singulares del edificio románico, Aguilar de Campoo, Palencia, 2008, pp. 121-155.

SGARBOSSA, Mario y GIOVANNINI, Luis. Un santo para cada día. Traducida por Justiniano Beltrán. Bogotá, 2007.

[DILVA MAROTO, Ma Pilar. Pintura hispanoflamenca castellana: Burgos y Palencia. Obras en tabla y sarga. 3 vol. Junta de Castilla y León. Valladolid, 1990.

SIMÓN Y NIETO, Francisco. Los antiguos campos góticos: excursiones históricoartísticas a la Tierra de Campos. Región Editorial. Palencia, 2006.

@DOJO Y LOMBA, Fermín. Los maestros canteros de Trasmiera. Editorial Huelves y Compañía. Madrid, 1935.

-La Pantoja: jerga de los maestros canteros de Trasmiera. Segovia, 1947.

SOSPEDRA VILA, Manuel. A un santo desconocido: San Torcuato. Valencia, 1999. 
[DI STRATTON, Suzanne. La Inmaculada Concepción en el arte español. Madrid, 1989.

[D] SUÁREZ FERNÁNDEZ, Luis. Nobleza y monarquía: puntos de vista sobre la historia política castellana del siglo XV. Universidad de Valladolid. Valladolid, 1959.

[D] TENA BELTRÁN, Silvia. "Los antepasados de Cristo en la escalera del coro de la Basílica de Morella" en Ars Longa. Cuadernos de Arte, n³. Valencia, 1992, pp. 153-160.

[D] THOMAS, Werner. Los protestantes y la Inquisición en España en tiempos de Reforma y Contrarreforma. Leuven University Press. Lovaina, 2001.

[D] TORAL PEÑARANDA, Enrique. Los Berrio y sus enlaces. Diputación Provincial de Jaén, 2000.

TORRES PRIETO, Juan Antonio. "El pantocrátor de Carrión" en Tu solus peregrinus: viaje interior por el Camino de Santiago. Santo Domingo de Silos, Burgos, 1996, pp. 329-340.

[D] TORRES AMAT, Félix. La Sagrada Biblia nuevamente traducida de la Vulgata Latina al español. Tomo III del Antiguo Testamento que contiene el libro de los Salmos, Proverbios, Ecclesiastés, Cantar de los Cantares, el Libro de la Sabiduría y la Profecía de Isaías. Imprenta de Miguel de Burgos. Madrid, 1834.

[D] TORRES SÁNCHEZ, Concha. La clausura imposible: conventualismo femenino y expansión contrarreformista. Asociación Cultural Al-Mudayna. Madrid, 2000.

[DI TORRES SEVILLA QUIÑONES DE LEÓN, Margarita. Linajes nobiliarios de León y Castilla. Siglos IX-XIII. Salamanca, 1999.

TOVAR MARTÍN, Virginia. "El arquitecto ensamblador madrileño Pedro de la Torre" en $A E A, \mathrm{n}^{\circ} 183,1973$, pp. 261-297.

-“La cantería en la época de Rodrigo Gil de Hontañón” en El arte de la cantería, Santander, 2003, pp. 77-90.

DI TRANCHO PASTOR, "La Cofradía de la Santa Vera Cruz de Palencia a finales del siglo XVI e inicios del siglo XVII: un ámbito de religiosidad y solidaridad urbana" en AIIICHP, tomo 3, 1995, pág.s. 83- 94.

TRENS, Manuel. Las custodias españolas. Editorial Litúrgica Española. Barcelona, 1952.

[D] TUDELA, José. “Cristos tarascos en España” en Revista de Indias. México,1967, pp.107-110.

[ TURCAT, André. Etienne Jamet, alias Esteban Jamete: sculpteur français de la Renaissance en Espagne condamné par l'Inquisition. Picard. París, 1994. 
[D] UNAMUNO, Fernando. "Retablo de Nuestra Señora de Belén en Carrión de los Condes (Palencia)" en Academia. Boletín de la Real Academia de Bellas Artes de San Fernando. N $^{\circ}$ 11. Madrid, 1960, pp. 74-75.

URCELAY GAONA, Egoy. Los Sarmiento, condes de Salinas: orígenes y elevación de una nueva clase señorial: Siglos XII-XVI. Bilbao, 2009.

[d] URIBE, Ángel. "Ensayo de reforma franciscana en España" en Archivo Ibero Americano, $\mathrm{t}$ XLV, n 179-180, Madrid, 1985 pp. 217-348.

URREA FERNÁNDEZ, Jesús. "En torno a Gregorio Fernández" en BSAA, n³9, Valladolid, 1973, pp. 245-260.

-“El escultor Antonio de Riera” en BSAA, n40-41. Valladolid, 1975, pp. 668-672.

-Catálogo monumental del antiguo Partido Judicial de Valoria la Buena. Valladolid, 1978.

- “Acotaciones a Gregorio Fernández y su entorno artístico” en BSAA, n46, Valladolid, 1980, pp. 375-396.

-La escultura en Valladolid de 1890 a 1936. Real Academia de Bellas Artes de la Purísima Concepción. Valladolid, 1980.

-“Acotaciones a Gregorio Fernández y su entorno artístico" en BSAA, n46. Valladolid, 1980, pp. 375-396

-Gregorio Fernández. Caja de Ahorros Popular de Valladolid. Valladolid, 1983

-"Escultores coetáneos y discípulos de G. Fernández en Valladolid” en BSAA, n50. Valladolid, 1984, pp. 349-370.

-“Ángeles napolitanos” en BSAA, n50. Valladolid, 1984, pp. 442-445.

-La pintura, la rejería y la platería en Valladolid en el siglo XVIII, nº5. Valladolid, 1984.

"La capilla de don Gabriel López de León en la iglesia de San Pedro de Zamora" en $B S A A$, tomo LI. Valladolid, 1985, pp. 500-508.

-Felipe Gil de Mena (1603-1673): del 2 al 21 de noviembre de 1985. Valladolid, 1985.

-“San Fernando en Castilla y León” en BSAA, n52, Valladolid, 1986, pp. 484-487.

-"Blas de Cervera y Felipe Gil de Mena, pintores palentinos" en AICHP, tomo 1. Castillo de Monzón de Campos, 3-5 diciembre de 1985. Palencia, 1987, pp. 241-250.

-"El templo, la torre y el retablo de Matapozuelos" en $B S A A, n^{\circ} 53$, Valladolid, 1987, pp. 259-270.

-"La custodia de Carrión de los Condes (Palencia): una obra del siglo XVI hecha con dinero americano" en Homenaje al Profesor Hernández Perera. Universidad Complutense. Madrid, 1992, pp. 765-770.

-"Escultores coetáneos y discípulos de G. Fernández en Valladolid" en BSAA, n58. Valladolid, 1992, pp. 393-402.

-“Cristo crucificado", ficha nº en Memorias y esplendores. Las Edades del Hombre. Catedral de Palencia, 1999, pp. 337-338.

-“Gregorio Fernández y el modelo icónico de Valladolid” en Juan de Mesa (1627-202). III Jornadas de Historia del Arte celebradas en Córdoba del 28 al 30 de noviembre de 2002. Córdoba, 2003, pp. 169-184.

URREA FERNÁNDEZ, Jesús y BRASAS EGIDO, José Carlos. Catálogo provincial de la provincia de Valladolid. Antiguo Partido judicial de Villalón. Palencia, 1993.

-Pintura y escultura en Valladolid en el siglo XX. Ateneo de Valladolid. Valladolid, 1988. 
URREA FERNÁNDEZ, Jesús y MARTÍNEZ, Rafael. "Construcción, proceso y derribo del arco del Mercado de Palencia (1784-1909)" en BSAA, n44. Valladolid, 1978, pp. 510-516.

URREA FERNÁNDEZ, Jesús y MARTÍN GONZÁLEZ, Juan José. Inventario artístico de Palencia y su provincia.1. Ciudad de Palencia, antiguos partidos judiciales de Palencia, Astudillo, Baltanás y Frechilla. Ministerio de Educación y Ciencia. Madrid, 1977.

-Inventario artístico de Palencia y su provincia. 2, Antiguos partidos judiciales de Carrión de los Condes, Saldaña y Aguilar de Campoo. Ministerio de Cultura, Dirección General de Patrimonio Artístico, Archivos y Museos. Madrid, 1980.

UVION, Arnoldo. Brieve dechiaratione dell'arbore monastico benedictino intitolato Legno della vita.Palermo, 1655.

[ㅁ] VACA GONZÁLEZ, Diodoro y RUIZ DE LUNA ROJAS, Juan. Historia de la cerámica talaverana. Editora Nacional. Madrid, 1943.

VACA LORENZO, Ángel. "La estructura socioeconómica de Tierra de Campos a mediados del siglo XIV. Parte I" en PITTM, n 39. Diputación Provincial. Palencia, 1977, pp. 229-398.

-"La estructura socioeconómica de Tierra de Campos a mediados del siglo XIV. Parte II" en PITTM, n 42. Palencia, 1979, pp. 203-387.

-"La peste negra en Castilla. Aportación al estudio de algunas de sus consecuencias económicas y sociales" en Stvdia Historica. Historia Medieval, n². Salamanca, 1984 pp. 103-107.

-"Recesión económica y crisis social de Castilla en el siglo XIV" en Las crisis en la historia. Salamanca, 1995, pp. 33-56.

-"El Obispado de Palencia desde sus orígenes hasta su definitiva restauración en el siglo XI" en Hispania Sacra, vol.52, n¹05. Madrid, 2000, pp. 21-72.

[D] VALDEÓN BARUQUE, Julio. "Judíos y mudéjares en tierras palentinas (siglos XIII-XV)" AIICHP, tomo 2. Palencia, 1990, pp. 359-376.

-Real Monasterio de Santa Clara de Tordesillas. Ministerio de Educación y Ciencia. Madrid, 2005.

-"La crisis del siglo XIV en la Corona de Castilla" en Homenaje a Marcelo Vigil Pascual: la historia en el contexto de las ciencias humanas y sociales, Salamanca, 1989, pp. 217-236.

[C] VALDÉS FERNÁNDEZ, Manuel y LLAMAZARES RODRÍGUEZ, Fernando. Notas para el estudio del arte en León (VIII): Trazas de los siglos XVI, XVII y XVIII en el Archivo Histórico Provincial de León (II), Juan de Nates y Felipe de la Cajiga en el Monasterio de San Claudio de León” en Tierras de León, n³9, 1980, pp.119-132.

[D] VALDIVIESO GONZÁLEZ, Enrique. La pintura en Valladolid en el siglo XVII. Diputación Provincial de Valladolid. Valladolid, 1971.

-Catálogo monumental de la Provincia de Valladolid. Tomo 8. Valladolid, 1975.

-Catálogo de las pinturas de la catedral de Sevilla. Valladolid, 1978. 
-Historia de la pintura española. Escuela sevillana del primer tercio del siglo XVII. Centro de Estudios Históricos. Madrid, 1985.

VALle CURIESES, Rafael de. A orillas del Carrión. Destellos de un pasado entrañable: acontecimientos históricos, personajes memorables, arte. Caja de Ahorros y Monte de Piedad. Palencia, 1989.

-"El mercado franco de la ciudad de Palencia y sus papeles" en AIICHP, tomo 2. Palencia, 1989, pp. 337-343.

VAQUERIZO GIL, Manuel. "Tipología documental para la Historia del Arte en Protocolos Notariales" en Publicaciones del Instituto de Etnografía y Folclore Hoyos Sainz, vol XII. Santander, 1976, pp. 143-180.

[d VASALLO TORANZO, Luis. "Los Protocolos Notariales como fuente para el estudio social de los canteros trasmeranos" en Fuentes y métodos de la historia local: actas, 1991, pp 233-238.

-"Una nueva obra de Rodrigo Gil de Hontañón en Zamora: la reforma de la iglesia de San Juan de Puerta Nueva" en BSAA, n59, 1993, pp. 313-320.

-“Anunciación”, ficha $\mathrm{n}^{\circ} 22$ en Memorias y esplendores. Las Edades del Hombre. Catedral de Palencia, 1999, pp. 158,159.

-"Nacimiento de Cristo", ficha n²3. Memorias y esplendores. Las Edades del Hombre. Catedral de Palencia, 1999, pág. 159.

-"Rey Melchor, Gaspar y Baltasar", fichas no 24-26 en Memorias y esplendores. Las Edades del Hombre. Catedral de Palencia, 1999, pp. 160-161.

-"La contestación de Juan de Nates y Felipe de la Cajiga al magisterio de Juan del Ribero" en De Arte, no 7. Universidad de León. León, 2008, pp. 113-128.

- "Rodrigo Gil de Hontañón en Valladolid. La iglesia de La Mota del Marqués para Constantino del Castillo y otras obras” en BSAA, n 77. Valladolid, 2011, pp. 39-62.

[C] VÁZQUEZ DE PARGA, LACARRA, J. M. y URÍA RIU, J. Las peregrinaciones a Santiago de Compostela. Tomo II. Pamplona, 1992.

VÁZQUEZ RABANAL, Alfredo. Religión y sociedad en cambio: estudio socioreligioso de Palencia. Palencia, 1974.

[D] VEGA CERNUDA, Daniel S. "La música de Antonio de Cabezón y el repertorio organístico europeo de la época" en Nasarre: Revista aragonesa de musicología, vol 18, nº1-2. 2000. pp. 41-60.

D VEGA GIMÉNEZ, Ma Teresa de. Imágenes exentas del Niño Jesús. Historia, iconografía y evolución. Catálogo de la Provincia de Valladolid. Valladolid, 1984.

VÉLEZ CHAURRI, José Javier y ECHEVARRÍA GOÑI, Pedro Luis. "Un importante legado de dos clérigos en Estavillo (Alava). Los orantes y un cuadro romano de la Virgen del Pópolo" en Ars bilduma, nº1, 2011, pp. 27-38.

VICENTE, Fray Plácido. Vida en compendio de la prodigiosa Virgen Santa Gertrudis la Magna. Imprenta de Espinosa. Madrid, 1807. 
[DICENTE GONZÁLEZ, José de y AZORES TORRES, Mariano. Monasterios, cartujas y conventos en las rutas compostelanas españolas. TresCtres Editores. A Coruña, 2004.

VIGURI, Miguel de. Heráldica palentina. 2 volúmenes. Institución Tello Téllez de Meneses. Diputación de Palencia. Palencia, 2005.

[D] VIGURI, Miguel de y SÁNCHEZ, José Luis. Arquitectura en la Tierra de Campos y el Cerrato. Colegio Oficial de Arquitectos de León. Palencia, 1993.

[d] VILLACORTA BAÑOS, Antonio. El castellano Domingo de Guzmán: (11701221). San Esteban. Salamanca, 1998.

VILLALBA, Federico. Crónica de la provincia de Palencia. 2 volúmenes. Rubio y Compañía. Madrid, 1867.

[1] VILLEGAS, Alonso de. Flos sanctorum: historia general de la vida y hechos de Jesu-christo, Dios y señor nuestro y de los santos. Barcelona, 1794.

VIRGILI BLANQUET, María Antonia. "La música y su iconografía en el Camino de Santiago a su paso por Palencia" en Jornadas sobre el románico en la provincia de Palencia. Departamento de Cultura. Diputación Provincial. Palencia, 1985, pp. 69-75.

[D] VIRGILI BLANQUET, María Antonia y CABEZA RODRÍGUEZ, Antonio. "La música y las órdenes religiosas en Palencia" en Jornadas sobre el de las Órdenes Religiosas en Palencia. Palencia, 1989, pp. 215-230.

[ VON VINGEN, Hildegarda. Vida y visiones de Hildegard von Vingen. Traducción, notas y epílogo de Victoria Cirlot Valenzuela. Madrid, 2009.

VV.AA. "Sepulcro de Doña Aldonza de Mendoza" en Semanario pintoresco español. Dirigido por GIRONELLA, Gervasio. Tomo II. Madrid, 1844, pp. 1, 2.

[D] VV.AA. Diccionario de derecho canónico ajustado a la jurisprudencia eclesiástica. Librería de Rosa y Bouret. París, 1854.

VV.AA. Escuela Apostólica del Sagrado Corazón de Jesús de Carrión de los Condes. Palencia. Palencia, 1919.

[ㅁ] VV.AA. Diccionario de historia eclesiástica de España. 5 vol. Instituto Enríquez Flórez. Madrid, 1972-1987.

[d] VV.AA. "Notas para el estudio del arte en León (IV); Homenaje en el IV centenario de la muerte de Juan de Juni" en Tierras de Léon, n²7. León, 1977, pp. 28-44.

[D] VV.AA Cantabria a través de su historia: la crisis del siglo XVI. Institución cultural de Cantabria. Santander, 1979. 
$\mathbb{1}$ VV.AA. La comunicación en los monasterios medievales: XV centenario de San Benito: exposición itinerante. Dirección General del Patrimonio Artístico, Archivos y Museos. Madrid, 1980.

VV.AA. La desamortización de Mendizábal y Espartero en España. Cátedra. Madrid, 1986.

D] VV.AA. Barocco mediterraneo: Genova, Napoli, Venecia nei musei di Francia. Electa. Napoli, 1989.

VV.AA. Aldaba: Boletín Informativo de la Parroquia de Carrión de los Condes. $\mathrm{N}^{\mathrm{o}}$ 2 a 8 Carrión de los Condes (Palencia), 1986-1990.

[D] VV.AA. El Panteón Real de las Huelgas de Burgos. Los enterramientos de los Reyes de Castilla. Catálogo de la Exposición. Burgos, 1988.

[D] VV.AA. "Cristo Crucificado" en Raíces. El arte en Palencia. Diputación Provincial de la Diócesis de Palencia, 1989, pág. 68.

DV.AA. Catàleg d'escultura $i$ pintura medievals. Museo Frederic Marés. Ayuntamiento de Barcelona. Barcelona, 1991.

[D] VV.AA. Artistas cántabros de la Edad Moderna. Su aportación al arte hispánico. Institución Mazarrasa. Universidad de Cantabria. Salamanca, 1991.

[D] VV.AA. Inventario del patrimonio cultural de la Iglesia en Castilla y León. Salamanca, 1993.

DD V.AA. Catálogo monumental de Castilla y León. Bienes inmuebles declarados. Primera Parte. Junta de Castilla y León. Salamanca, 1995.

[D] VV.AA. "El proceso de disolución de los templarios: su repercusión en Castilla" en Codex aquilarensis, n¹2, Aguilar de Campoo, 1996, pp. 87-106.

VV.A.A. Rodrigo Gil de Hontañón. Un arquitecto entre el gótico y el Renacimiento. Exposición conmemorativa del quinto centenario de su nacimiento. Madrid, 2000.

DI VV.AA. Arquimilenios. Arquitectura entre dos milenios (1999-2000). Junta de Castilla y León. Valladolid, 2000.

[D] VV.AA. Carolus. Museo de Santa Cruz de Toledo, del 6 de octubre de 2000 a 12 de enero de 2001. Sociedad Estatal para la Conmemoración de los Centenarios de Felipe II y Carlos V. Madrid, 2000.

[ ] V. AA. Tratado de genealogía, heráldica y derecho nobiliario. Tercera edición. Instituto Salazar y Castro. Madrid, 2001.

[D] VV.AA. El Marqués de Santillana (1398-1458): los albores de la España Moderna. 5 volúmenes. Nerea. Guipúzcoa, 2001. 
D] VV.AA. Iconografía agustiniana. Actas del XI Congreso Internacional de Historia de la Orden de San Agustín. Institutum Historicum Agustinianum. Roma, 2001.

VV.AA. Jacopo Barozzi da Vignola. Electa. Milán, 2002.

VV.AA. La Semana Santa en la Tierra de Campos vallisoletana. Valladolid, 2003.

VV.AA. Iconografía Mariana: La Inmaculada. Catálogo de la exposición del 31 de octubre al 12 de diciembre en el RR. MM. Clarisas de Carrión de los Condes. Carrión de los Condes, Palencia, 2004.

VV.AA. Entre Castilla y Filipinas, 400 años: Iglesia de San Julián, Carrión de los Condes. Ayuntamiento de Carrión de los Condes. Palencia, 2006.

[] VV.AA. Inventario de los órganos de la Provincia de Palencia. Cálamo. Palencia, 2008.

VV.AA Actas del I Encuentro europeo de museos con colecciones de escultura. El taller europeo: Intercambios, influjos y préstamos en la escultura europea de la Edad Moderna. Museo Nacional Colegio San Gregorio, Valladolid, 6-8 mayo de 2010.

DADDING, Lucas. Annales Minorum in quibus res omnes trium ordinum a $S$. Francisco institutorum ex finde ponderosius asseruntur, calumnias refelluntur, praeclara quaequa monumenta ab oblivione vendicantur, I. Roma, 1587.

WAVE, D. y BETTY, B. Diccionario manual ilustrado de arquitectura con los términos más comunes empleados en la construcción. Gustavo Gili. Barcelona, 1950.

[1] WATTENBERG SAMPERE, Federico. "Algunos retablos de la iglesia de San Miguel de Valladolid" en $B S A A, n^{\circ} 10$. Universidad de Valladolid. Valladolid, 1943-44, pp. 191-97.

-La región vaccea: celtiberismo y romanización en la Cuenca media del Duero. Instituto Español de Prehistoria. Madrid, 1959.

QDWTTENBERG GARCÍA, Eloísa. Medina de Rioseco: ciudad Catálogo monumental de la provincia de Valladolid. Diputación de Valladolid. Valladolid, 2003.

[DA WATEMBERG SAMPERE, Federico. Museo Nacional de Escultura de Valladolid. Aguilar. Madrid, 1966.

YÁÑEZ DE AVILÉS, Fray Pablo. De la era y fechas de España. Chronología española. Tomo segundo. Imprenta de José González. Madrid, 1732.

[D] YÁÑEZ NEIRA, Fray María Damián y TOBÍO CENDÓN, Rafael. San Andrés de Arroyo: ochocientos años de fidelidad. Trobajo del Camino, León, 2001.

[D] YARZA LUACES, Joaquín. "Las clarisas en Palencia" en Jornadas sobre el de las Órdenes Religiosas en Palencia. Palencia, 1989, pp. 151-180. 
[D] YEPES, Fray Antonio. Crónica General de San Benito. 7 volúmenes. Tomos I y II, Irache, Navarra, 1609. Tomo III, Irache, Navarra, 1610. Tomo IV, V, VI y VII. Valladolid, 1613, 1615, 1617 y 1621.

[1] YUN CASALILLA, Bartolomé. "La crisis del siglo XVII en Castilla: indicadores, cronología y factores en la Tierra de Campos (1580-1640)" en El pasado histórico de Castilla y León: [actas del I Congreso de Historia de Castilla y León celebrado en Valladolid, del 1 al 4 de diciembre de 1982, vol. 2, Valladolid, 1983, pp. 257-278.

-“Aristocracia, señorío y crecimiento económico en Castilla. Algunas reflexiones a partir de los Pimentel y los Enríquez (siglos XVI y XVII)" en Revista de Historia Económica, n³, 1985, pp. 443-471.

-Sobre la transición al capitalismo en Castilla: economía y sociedad en Tierra de Campos (1500-1830). Valladolid, 1987.

-"Los señoríos monásticos de Castilla y León en el siglo XVI" en III Reunión Científica de Historia Moderna. Iglesia y sociedad en el Antiguo Régimen, vol 1, 1995, pp. 461-482.

[D ZALAMA, Miguel Ángel. "El retablo mayor de la iglesia de Santa Eulalia en Paredes de Nava (Palencia)" en BSAA, n ${ }^{\circ} 54$, Valladolid, 1988, pp. 361-375.

-Arquitectura del siglo XVI en la provincia de Palencia. Excma. Diputación Provincial de Palencia. Palencia, 1990.

-"Portadas retablo renacentistas en Valladolid y Palencia" en $B S A A, \mathrm{n}^{\circ} 53$, Valladolid, 1987, pp. 312-316.

-"Documentos de Historia del Arte en Palencia, 1. Arquitectos y edificios del siglo XVI” en PITTM, n 66. Diputación Provincial. Palencia, 1995, pp. 165-320.

-"Arquitectura y arquitectos a finales del siglo XVI en Palencia. Juan de la Lastra" en Altamira: Revista del Centro de Estudios Montañeses, n 52. 1996, pp. 205-222.

Cl] ZAPARAIN YÁÑEZ, Ma J. "Aportación a la biografía del arquitecto palentino Juan Gutiérrez del Pozo. Su actuación en la zona de Aranda de Duero (Burgos)" en AIICHP, tomo 5. Palencia, 1990, pp. 155- 161.

-"Maestros palentinos en la comarca occidental burgalesa. Su actividad arquitectónica durante el siglo XVIII" en AIICHP, tomo 4. Diputación Provincial. Palencia, 1995, pp. 691-704.

ZARAGOZA PASCUAL, RAFAEL. Los Generales de la Congregación de San Benito de Valladolid. Los abades trienales. 5 vol. Monasterio de Santo Domingo de Silos, Burgos, 1976-1984.

-"Relación de los daños sufridos por algunos monasterios benedictinos españoles durante el Trienio Constitucional (1820-1823)" en Stvdia Monástica, n³0, fascículo 1. Barcelona, 1988, pp. 121- 162.

-"Abadologio del Monasterio de San Zoilo de Carrión de los Condes (siglos XIXIX). Libro de Gradas de los monjes que profesaron en él (1593-1833)2 en PITTM, nº64. Diputación Provincial de Palencia. Palencia, 1993, pp 273-321.

-"Cuestiones de toponimia mayor palentina" en PITTM, n70. Diputación Provincial. Palencia, 1999, pp. 519-535.

-"Fuentes archivísticas biográficas de benedictinos y benedictinas españoles (siglos XV-XIX)" en Memoria ecclesiae, №. 30, 2007, pp. 251-292. 
[D ZOLA, Ellémire. Los místicos de Occidente II. Místicos medievales. Barcelona, 2000 . 